\title{
CÓdIGO DE LA
}

Administración Gallega

TERCERA EDICIÓN 


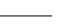




\section{CódIGO DE LA \\ Administración Gallega}

Jaime Rodríguez-Arana Muñoz

Miguel Ángel Sendín García

TERCERA EDICIÓN 


\section{CÓDIGO DE LA ADMINISTRACIÓN GALLEGA. TERCERA EDICIÓN}

Cualquier forma de reproducción, distribución, comunicación pública o transformación de esta obra solo puede ser realizada con la autorización de sus titulares, salvo excepción prevista por la ley. Diríjase a CEDRO (Centro Español de Derechos Reprográficos, www.cedro.org) si necesita fotocopiar o escanear algún fragmento de esta obra.

No está permitida la reproducción total o parcial de este libro, ni su tratamiento informático, ni la transmisión de ninguna forma o por cualquier medio, ya sea electrónico, mecánico, por fotocopia, por registro u otros métodos, sin el permiso previo y por escrito de los titulares del Copyright.

DERECHOS RESERVADOS 2009, respecto a la tercera edición en español, por

(c) Netbiblo, S. L.

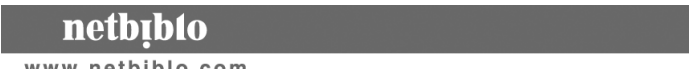

$$
\text { www.netbiblo.com }
$$

NETBIBLO, S. L.

C/. Rafael Alberti, 6 bajo izq.

Sta. Cristina 15172 Oleiros (La Coruña) - Spain

Tlf: +34981915500 • Fax: +34981915511

www.netbiblo.com

editorial@netbiblo.com

Miembro del Foro Europeo de Editores

ISBN: 978-84-9745-425-4

Depósito Legal: C-2935-2009

Directora Editorial: Cristina Seco López

Editora: Lorena Bello

Produción Editorial: Gesbiblo, S. L.

Impreso en España - Printed in Spain 


\section{ÍNDICE GENERAL}

PRÓLOGO A LA TERCERA EDICIÓN

I. NORMAS BÁSICAS.

II. AUTOGOBIERNO Y ORGANIZACIÓN.............................................................. 21

III. ADMINISTRACIÓN LOCAL................................................................................. 105

IV. PROCEDIMIENTO ADMINISTRATIVO, RÉGIMEN JURÍDICO DE LAS ADMINISTRACIONES PÚBLICAS Y FUNCIÓN PÚBLICA

V. RÉGIMEN FINANCIERO

VI. INTERVENCIÓN EN LA ECONOMÍA. 381

VII. BIENES Y PATRIMONIO

VIII. ORDENACIÓN DEL TERRITORIO Y DEL LITORAL, URBANISMO Y VIVIENDA

IX. PROTECCIÓN DEL MEDIO AMBIENTE

X. SEGURIDAD .

XI. MEDIOS E INFRAESTRUCTURAS DE TRANSPORTES

XII. COMUNICACIONES

XIII. ACTIVIDADES AGRARIAS

XIV. CAZA, PESCA, GUARDACOSTAS Y CONTROL DEL MEDIO MARINO........ 999

XV. PROTECCIÓN DE CONSUMIDORES Y USUARIOS 1093

XVI. SERVICIOS SOCIALES, SANIDAD Y VIOLENCIA DE GÉNERO 1109

XVII. EDUCACIÓN, CULTURA, INVESTIGACIÓN, DEPORTES Y TURISMO 1261

XVIII. EMERGENCIAS

ÍNDICE DE CONSELLERIAS 1381

ÍNDICE DE CONCEPTOS. 


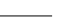




\title{
Prólogo a la tercerea edición
}

Este código de la legislación administrativa gallega comenzó su andadura con el compromiso explícito entre los compiladores y Netbiblo de su actualización permanente y de su edición en las lenguas cooficiales de nuestra Comunidad Autónoma. En estos años transcurridos desde la primera edición son muchas las sugerencias y comentarios recibidos para seguir trabajando en este proyecto de compilación, que por su definición abarca sólo a las principales leyes administrativas gallegas. El profesor Sendín y yo mismo hemos procurado atender las indicaciones con la finalidad de que este código sea sencillo y claro en su manejo para estudiantes y profesionales del Derecho y de otras disciplinas afines.

En esta nueva edición hemos recogido el fruto del trabajo legislativo del Parlamento de Galicia en su última legislatura. Por eso los índices por Consellerías, que hemos variado por mor de la nueva estructura de la Xunta de Galicia, han crecido como consecuencia de las nuevas leyes en materia de residuos, de fiscalidad ambiental, protección del paisaje, vivienda, servicios sociales o pesca. Las nuevas leyes del Parlamento de la Comunidad Autónoma nos han obligado a revisar los índices materiales y a corregir algunas leyes anteriores que resultan modificadas por la actual legislación.

Como director de este código quiero manifestar mi satisfacción por contar con la colaboración del profesor doctor Miguel Angel Sendín, administrativista salmantino que ha trabajado con gran diligencia y profesionalidad en esta ardua tarea de revisar y anotar normas administrativas. Sin su ayuda esta empresa editorial no hubiera sido posible. Muchas gracias Miguel.

Para terminar este breve prólogo a la tercera edición, los compiladores de este código queremos también manifestar nuestro agradecimiento a Netbiblo. Desde el principio, tanto Cristina Seco como Carlos Iglesias, fueron conscientes de la trascendencia de un proyecto de estas características, que necesariamente debe ser sencillo y manejable pues esas fueron las ideas originarias. Desde el principio apostaron por este formato de código y por los lineamientos que les expusimos. También muchas gracias a Lorena Bello, que ha realizado igualmente un brillante trabajo para que las sucesivas ediciones del código hayan visto la luz. Por supuesto que es posible, y deseable, afrontar la compilación sectorial de la Normativa administrativa gallega. Pero este ya es otro proyecto que esperamos se pueda realizar en un futuro no muy lejano.

Ferrol, julio de 2009

\author{
Jaime Rodríguez-Arana Muñoz \\ Catedrático de Derecho Administrativo \\ de la Universidade da Coruña
}




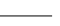




\section{ÍNDICE SISTEMÁTICO}

\section{NORMAS BÁSICAS}

1. Ley Orgánica $1 / 1981$, de 6 de abril, de Estatuto de Autonomía para Galicia (BOE n. ${ }^{\circ} 101,28$. 4. 1981).

2. Ley Orgánica 16/1995, de 27 de diciembre, de Transferencia de Competencias a la Comunidad Autónoma Gallega (BOE nº. 310, 28. 12. 1995).

3. Ley Orgánica $6 / 1999$, de 6 de abril, de Transferencia de Competencias a la Comunidad Autónoma de Galicia (BOE $n^{\circ} .84,8.4$. 1999)

II. AUTOGOBIERNO Y ORGANIZACIÓN

1. Ley $1 / 1983$, de 22 de febrero, Reguladora de la Xunta y su Presidencia (DOGA no. 23, 21. 3. 1983)

2. Ley $9 / 1996$, de 18 de octubre, de Incompatibilidades de los miembros de la Xunta de Galicia y Altos Cargos de la Administracion Autonómica (DOGA n. $\left.{ }^{\circ} 213,30.10 .1996\right)$.

3. Ley $6 / 1995$, de 28 de junio, por la que se crea el Consello

Económico e Social de Galicia (DOGA n. $\left.{ }^{\circ} 133,12.7 .1995\right)$

4. Ley $9 / 1995$, de 10 de noviembre, del Consello

Consultivo de Galicia (DOGA n. $\left.{ }^{\circ} 229,29.11 .1995\right)$

5. Ley $6 / 1984$, de 5 de junio, del Valedor do Pobo de Galicia (DOGA n. ${ }^{\circ} 135,14$. 7. 1984).

6. Ley $4 / 2002$, de 25 de junio, del Estatuto de la Capitalidad de la Ciudad de Santiago de Compostela (DOGA n. ${ }^{\circ} 142,24.7 .2002$ ).

7. Ley $11 / 2001$, de 18 de septiembre, de Colegios Profesionales de la Comunidad Autónoma de Galicia (DOGA n. $\left.{ }^{\circ} 189,28.9 .2001\right)$

8. Ley $5 / 2004$, de 8 de julio, de Cámaras Oficiales de Comercio, Industria y Navegación de Galicia (DOGA n. $\left.{ }^{\circ} 140,21.7 .2004\right)$.

9. Ley 6/1985, de 24 de junio, del Consello de Contas (DOGA n. ${ }^{\circ} 130,9.7 .1985$ ).

\section{ADMINISTRACIÓN LOCAL}

1. Ley $5 / 1997$, de 22 de julio, de Administración Local de Galicia (DOGA n. ${ }^{\circ} 149,5$. 8. 1997).

2. Ley $7 / 1996$, de 10 de julio, de Desarrollo Comarcal (DOGA n. $\left.{ }^{\circ} 142,19.7 .1996\right)$ 


\section{I Índice sistemático}

3. Ley $4 / 2004$, de 28 de junio, para la Aplicación a los Municipios de Ferrol, Lugo, Ourense, Pontevedra y Santiago de Compostela del Régimen de Organización de los Municipios de Gran Población (DOGA n. ${ }^{\circ} 130,7.7 .2004$ )

4. Ley 11/1983, de 29 de diciembre, de Actuación Intensiva en las Parroquias Rurales (DOGA n. ${ }^{\circ} 22,2$. 2. 1984)

IV. PROCEDIMIENTO ADMINISTRATIVO, RÉGIMEN JURÍDICO DE LAS ADMINISTRACIONES PÚBLICAS Y FUNCIÓN PÚBLICA

1. Ley $6 / 2001$, de 29 de junio, de Adecuación de la Normativa de la Comunidad Autónoma de Galicia a la Ley 4/1999, de 13 de enero, de modificación de la Ley 30/1992, de 26 de noviembre, de Régimen Jurídico de las Administraciones Públicas y del Procedimiento Administrativo Común (DOGA n. ${ }^{\circ} 135,12.7 .2001$ )

2. Ley $4 / 2006$, de 30 de junio, de Transparencia y de Buenas Prácticas en la Administración Pública Gallega (DOGA n. $\left.{ }^{\circ} 136,14.6 .2006\right)$

3. Decreto Legislativo $1 / 2008$, de 13 de marzo, por el que se aprueba el Texto Refundido de la Ley de la Función Pública de Galicia (DOGA n. ${ }^{\circ} 114,13.6 .2008$ ).

4. Ley 4/1987, de 27 mayo, de creación de la Escuela Gallega de Administración Pública (DOGA n. ${ }^{\circ} 103,2$. 6. 1987)

1. Decreto Legislativo $1 / 1999$, de 7 de octubre, por el que se aprueba el texto refundido de la Ley de Régimen Financiero y Presupuestario de Galicia (DOGA n. $\left.{ }^{\circ} 214,5.11 .1999\right)$.

2. Ley $12 / 1995$, de 29 de diciembre, del Impuesto sobre la Contaminacion Atmosférica (DOGA n. ${ }^{\circ} 249,30$. 12. 1995)

3. Ley 6/2003, de 9 de diciembre, de Tasas, Precios y Exacciones reguladoras de la Comunidad Autónoma de Galicia (DOGA n. ${ }^{\circ} 240,11.12 .2003$ )

4. Ley 13/1991, de 9 de diciembre, de Tasas, Precios y Exacciones reguladoras de la Comunidad Autónoma de Galicia (DOGA n. $\left.{ }^{\circ} 241,13.12 .1991\right)$

5. Ley $9 / 2007$, de 13 de junio, de Subvenciones de Galicia (DOGA n. ${ }^{\circ} 121,25$ de junio de 2007)

6. Ley $9 / 2008$, de 28 de julio, gallega de medidas tributarias en relación con el impuesto sobre sucesiones y donaciones (DOGA n. ${ }^{\circ} 152,7.8$. 2008)

7. Ley $15 / 2008$, de 19 de diciembre, del impuesto sobre el daño medioambiental causado por determinadoss usos y aprovechamientos del agua embalsada (DOGA n. $\left.{ }^{\circ} 251,29.12 .2008\right) \ldots . .$. 
VI. INTERVENCIÓN EN LA ECONOMÍA

1. Decreto Legislativo $1 / 2005$, de 10 de marzo, por el que se aprueba el texto refundido de las Leyes 7/1985, de 17 de julio, y 4/1996, de 31 de mayo, de Cajas de Ahorros de Galicia (DOGA n. ${ }^{\circ} 101,27.5$. 2005)

2. Ley $5 / 1992$, de 10 de junio, de creación del Instituto Galego de Promoción Económica (DOGA n. ${ }^{\circ} 122,26.6$. 1992).

3. Ley $12 / 2006$, de 1 de diciembre, de Fundaciones de Interés Gallego (DOGA n. $\left.{ }^{\circ} 242,19.12 .2006\right)$

4. Ley 10/1996, de 5 de noviembre, de Actuación de Entes y Empresas en las que tiene participación mayoritaria la Xunta de Galicia, en materia de personal y contratación (DOGA n. $\left.{ }^{\circ} 227,20.11 .1996\right)$

5. Ley $6 / 2004$, de 12 de julio, reguladora de los Órganos de Defensa de la Competencia de la Comunidad Autónoma de Galicia (DOGA n. ${ }^{\circ} 141,22$. 7. 2004)

VII. BIENES Y PATRIMONIO.

1. Ley $3 / 1985$, de 12 de abril, del Patrimonio de la Comunidad Autónoma Gallega (DOGA n. ${ }^{\circ}$ 78, 24. 4. 1985).

2. Ley $13 / 1989$, de 10 de octubre, de Montes Vecinales en Mano Común (DOGA n. ${ }^{\circ} 202,20.10 .1989$ )

3. Ley 8/1993, de 23 de junio, reguladora de la Administracion Hidráulica de Galicia (DOGA n. ${ }^{\circ} 125,2$. 7. 1993).

4. Ley $3 / 1999$, de 11 de marzo, de creación del Instituto Enerxético de Galicia (DOGA n. ${ }^{\circ} 61,30.3$. 1999)

5. Ley $8 / 1995$, de 30 de octubre, del Patrimonio Cultural de Galicia (DOGA nº. 214, 8. 11. 1995).

6. Ley 3/1996, de 10 de mayo, de Protección de los Caminos de Santiago (DOGA n. ${ }^{\circ} 101,23.5$. 1996).

7. Ley $3 / 2008$, de 23 de mayo, de Ordenación de la Minería de Galicia (DOGA n. ${ }^{\circ}$ 109, 6. 6. 2008).

\section{ORDENACIÓN DEL TERRITORIO Y DEL LITORAL,} URBANISMO Y VIVIENDA

1. Ley $10 / 1995$, de 23 de noviembre, de Ordenación del Territorio de Galicia (DOGA n. $.^{\circ} 233,5.12$. 1995).

2. Ley $9 / 2002$, de 30 de diciembre, de Ordenación Urbanística y Protección del Medio Rural de Galicia (DOGA n. ${ }^{\circ}$ 252, 31. 12. 2002).

3. Ley $6 / 2007$, de 11 de mayo, de Medidas Urgentes en Materia de Ordenación del Territorio y del Litoral de Galicia (DOGA n. ${ }^{\circ}$ 94, 15. 5. 2007).

4. Ley $18 / 2008$, de 29 de diciembre, de Vivienda de Galicia (DOGA n. ${ }^{\circ} 13,20.1 .2009$ ).

5. Ley $3 / 1988$, de 27 de abril, de creación del Instituto Galego da Vivenda e Solo (DOGA n. ${ }^{\circ} 88,10.5 .1988$ ).... 
6. Ley 8/1997, de 20 de agosto, de Accesibilidad y

Supresión de Barreras en la Comunidad Autónoma

de Galicia (DOGA n. ${ }^{\circ} 166,29.8$. 1997).

7. Ley $6 / 2008$, de 19 de junio, de Medidas Urgentes en materia de Vivienda y Suelo, por la que se modifica la Ley 9/2002, de 30 de diciembre, de Ordenación Urbanística y Protección del Medio Rural de Galicia (DOGA n. ${ }^{\circ} 125,30$. 6. 2008)

1. Ley $1 / 1995$, de 2 de enero, de Protección Ambiental de Galicia (DOGA n. ${ }^{\circ} 29,10.2$. 1995)

2. Ley $8 / 2002$, de 18 de diciembre, de Protección del Ambiente Atmosférico de Galicia (DOGA n. $\left.{ }^{\circ} 252,31.12 .2002\right)$

3. Ley 7/1997, de 11 de agosto, de Protección Contra la Contaminación Acústica (DOGA n. ${ }^{\circ} 159,20.8$. 1997).

4. Ley 10/2008, de 3 de noviembre, de Residuos de Galicia (DOGA n. $\left.{ }^{\circ} 224,18.11 .2008\right)$

5. Ley $9 / 2001$, de 21 de agosto, de Conservación de la Naturaleza (DOGA n. ${ }^{\circ} 171,4.9 .2001$ ).

6. Ley $8 / 2001$, de 2 de agosto, de Protección de la Calidad de las Aguas de las Rías de Galicia y de Ordenación del Servicio Público de Depuración de Aguas Residuales Urbanas (DOGA n. ${ }^{\circ}$ 161, 21. 8. 2001)

7. Ley 5/1995, de 7 de junio, de Regulacion de las Aguas Minerales, Termales, de Manantial y de los Establecimientos Balnearios de la Comunidad Autónoma de Galicia (DOGA n. ${ }^{\circ} 118$ bis, 21. 6. 1995)

8. Ley $5 / 2006$, de 30 de junio, para la Protección, la Conservación y la Mejora de los Ríos Gallegos (DOGA n. $\left.{ }^{\circ} 137,17.7 .2006\right)$

9. Ley $7 / 2008$, de 7 de julio, de Protección del Paisaje de Galicia (DOGA n. ${ }^{\circ} 139,18.7 .2008$ )

X. SEGURIDAD

1. Ley $8 / 2007$, de 13 de junio, de Policía de Galicia (DOGA n. $\left.{ }^{\circ} 120,22.6 .2007\right)$

2. Ley $4 / 2007$, de 20 de abril, de Coordinación de Policías Locales (DOGA n. ${ }^{\circ} 85,3$. 5. 2007).

3. Ley $1 / 2007$, de 15 de enero, de la Academia Gallega de Seguridad Pública (DOGA n. ${ }^{\circ} 16,23$. 1. 2007)

1. Ley $4 / 1994$, de 14 de septiembre, de Carreteras de Galicia (DOGA n. $\left.{ }^{\circ} 210,31.10 .1994\right)$

2. Ley 6/1996, de 9 de julio, de Coordinación de los Servicios de Transportes Urbanos e Interurbanos por Carretera de Galicia (DOGA n. $\left.{ }^{\circ} 141,18.7 .1996\right)$ 
3. Ley $5 / 1994$, de 29 de noviembre, de Creación del Ente Público Puertos de Galicia (DOGA n. ${ }^{\circ} 243$, 20. 12. 1994).

4. Ley $2 / 2008$, de 6 de mayo, por la que se desarrolla la Libre Prestación de Servicios de Transporte Marítimo de Personas en Aguas Interiores de Galicia (DOGA n. ${ }^{\circ}$ 90, 6. 5. 2008)

XII. COMUNICACIONES

1. Ley $9 / 1984$, de 11 de julio, de Creación de la Compañía de Radio-Televisión de Galicia (DOGA n. ${ }^{\circ}$ 148, 3. 8. 1984)

2. Ley 10/1983, del 9 de diciembre, reguladora del Consello Asesor de RTVE en Galicia (DOGA n. ${ }^{\circ} 148,3.8$. 1984).

3. Ley $6 / 1999$, de 1 de septiembre, del Audiovisual de Galicia (DOGA n. ${ }^{\circ} 174,8$. 9. 1999)

1. Ley $1 / 2006$, de 5 de junio, del Consello Agrario Galego (DOGA n. ${ }^{\circ} 113,14.6 .2006$ ).

2. Ley $7 / 1994$, de 29 de diciembre, por la que se crea el Instituto Lácteo y Ganadero de Galicia (DOGA n. ${ }^{\circ} 4,5.1$. 1995)

3. Ley 10/1985, de 14 de agosto, de Concentración Parcelaria para Galicia (DOGA n. ${ }^{\circ} 160,22.8$. 1985).

4. Ley 7/2007, de 21 de mayo, de Medidas Administrativas y Tributarias para la Conservación de la Superficie Agraria Útil y del Banco de Tierras de Galicia

XIV. CAZA, PESCA, GUARDACOSTAS Y CONTROL DEL MEDIO MARINO

1. Ley $4 / 1997$, de 25 de junio, de Caza de Galicia (DOGA n. ${ }^{\circ} 133,11.7 .1997$ )

2. Ley $11 / 2008$, de 3 de diciembre, de Pesca de Galicia (DOGA n. ${ }^{\circ} 243,16.12 .2008$ ).

3. Ley $7 / 1992$, de 24 de julio, de Pesca Fluvial (DOGA n. ${ }^{\circ} 151$, de 5. 8. 1992)

1078

\section{PROTECCIÓN DE CONSUMIDORES Y USUARIOS}

1. Ley $8 / 1994$, de 30 de diciembre, de creación del Instituto Galego de Consumo (DOGA n. ${ }^{\circ}$ 9, 13. 1. 1995).

2. Ley $11 / 2004$, de 19 de noviembre, de Inspección de Consumo de Galicia (DOGA n. ${ }^{\circ} 235,2.12 .2004$ )

Ley $12 / 1984$, de 28 de diciembre, del Estatuto Gallego del Consumidor y Usuario (DOGA n. $\left.{ }^{\circ} 23,1.2 .2005\right)$. para la Inserción Social (DOGA n.․ 191, 3. 10. 1991).

2. Ley $13 / 2008$, de 3 de diciembre, de Servicios Sociales de Galicia (DOGA n. ${ }^{\circ} 245,18.12 .2008$ ). 
3. Ley $8 / 2008$, de 10 de julio, de Salud de Galicia (DOGA n. $\left.{ }^{\circ} 143,24.7 .2008\right)$

4. Ley $3 / 2001$, de 28 de mayo, reguladora del Consentimiento Informado y de la Historia Clínica de los Pacientes (DOGA n. ${ }^{\circ} 111,8$. 6. 2001)

5. Ley 5/1999, de 21 de mayo, de Ordenación Farmacéutica (DOGA n. ${ }^{\circ}$ 99, 26. 5. 1999)

6. Ley 11/2007, de 27 de julio, Gallega para la Prevención y el Tratamiento Integral de la Violencia de Género (DOGA n. ${ }^{\circ} 152,7.8 .2007$ )

XVII. EDUCACIÓN, CULTURA, INVESTIGACIÓN, DEPORTES Y TURISMO.

1. Ley $14 / 1989$, de 11 de octubre, de Bibliotecas (DOGA n. ${ }^{\circ}$ 204, 24. 10. 1989)

2. Ley $1 / 2003$, de 9 de mayo, de los Consellos Sociais do Sistema Universitario de Galicia (DOGA n. ${ }^{\circ} 104,30.5$. 2003)

3. Ley $7 / 2001$, de 2 de julio, de Control en Materia de Creación y Reconocimiento de Universidades, Centros Universitarios y Autorización de Estudios en la Comunidad Autónoma de Galicia (DOGA n. ${ }^{\circ} 136,13.7 .2001$ )

4. Ley $2 / 2003$, de 22 de mayo, del Consello Galego de Universidades DOGA n. ${ }^{\circ} 106,3$. 6. 2003).

5. Ley $11 / 1989$, de 20 de julio, de Ordenación del Sistema Universitario de Galicia (DOGA n. ${ }^{\circ} 156,16.8$. 1989)

6. Ley $8 / 1983$, de 8 de julio, del Consello de la Cultura Galega (DOGA n. ${ }^{\circ} 146,1.8 .1984$ ).

7. Ley $3 / 1983$, de 15 de junio, de Normalización Lingüística (DOGA n. ${ }^{\circ} 84,14$. 7. 1983).

8. Ley 11/1997, de 22 de agosto, General del Deporte de Galicia (DOGA n. ${ }^{\circ} 170,4.9 .1997$ )

9. Ley $14 / 2008$, de 3 de diciembre, de Turismo de Galicia (DOGA n. ${ }^{\circ} 246,19.12 .2008$ )

10. Ley $4 / 2008$, de 23 de mayo, de creación de la Agencia Gallega de las Industrias Culturales (DOGA n. ${ }^{\circ} 111,10.6 .2008$ )

XVIII. EMERGENCIAS.

1. Ley $5 / 2007$, de 7 de mayo, de Emergencias de Galicia (DOGA n. ${ }^{\circ}$ 94, 16. 5. 2007). 


\section{NORMAS BÁSICAS}

\section{LEY ORGÁNICA 1/1981, DE 6 DE ABRIL, DE ESTATUTO DE AUTONOMÍA PARA GALICIA (BOE N. $\left.{ }^{\circ} 101,28.4 .1981\right)$ TÍTULO PRELIMINAR}

Artículo 1. 1. Galicia, nacionalidad histórica, se constituye en Comunidad Autónoma para acceder a su autogobierno, de conformidad con la Constitución Española y con el presente Estatuto, que es su norma institucional básica.

2. La Comunidad Autónoma, a través de instituciones democráticas, asume como tarea principal la defensa de la identidad de Galicia y de sus intereses y la promoción de solidaridad entre todos cuantos integran el pueblo gallego.

3. Los poderes de la Comunidad Autónoma de Galicia emanan de la Constitución, del presente Estatuto y del pueblo.

Artículo 2. 1. El territorio de Galicia es el comprendido en las actuales provincias de La Coruña, Lugo, Orense y Pontevedra.

2. La organización territorial tendrá en cuenta la distribución de la población gallega y sus formas tradicionales de convivencia y asentamiento.

3. Una ley del Parlamento regulará la organización territorial propia de Galicia, de acuerdo con el presente Estatuto.

Artículo 3. 1. A los efectos del presente Estatuto, gozan de la condición política de gallegos los ciudadanos españoles que, de acuerdo con las leyes generales del Estado, tengan vecindad administrativa en cualquiera de los municipios de Galicia.

2. Como gallegos, gozan de los derechos políticos definidos en este Estatuto los ciudadanos españoles residentes en el extranjero que hayan tenido la última vecindad administrativa en Galicia y acrediten esta condición en el correspondiente consulado de España. Gozarán también de estos derechos sus descendientes inscritos como españoles, si así lo solicitan, en la forma que determine la ley del Estado.

Artículo 4. 1.Los derechos, libertades y deberes fundamentales de los gallegos son los establecidos en la Constitución.

2. Corresponde a los poderes públicos de Galicia promover las condiciones para que la libertad y la igualdad del individuo y de los grupos en que se integran sean reales y efectivas, remover los obstáculos que impidan o dificulten su plenitud y facilitar la participación de todos los gallegos en la vida política, económica, cultural y social ${ }^{1}$.

3. Los poderes públicos de la Comunidad Autónoma asumen, como uno de los principios rectores de su política social y económica, el derecho de los gallegos a vivir y trabajar en su propia tierra.

Artículo 5. 1. La lengua propia de Galicia es el gallego.

\section{Véase:}

- Ley 2/2007, de 28 de marzo, del trabajo en igualdad de las mujeres de Galicia.

- Ley 7/2004, de 16 de julio, gallega para la igualdad de mujeres y hombres.

- Ley 3/1991, de 14 de enero, de creación del Servicio Gallego de Promoción de la Igualdad del Hombre y la Mujer. - Decreto 182/2004, de 22 de julio, por el que se regulan los centros de información a las mujeres y se establecen los requisitos para su reconocimiento y funcionamiento.

- Decreto 33/2007, de 1 de marzo, por el que se crea la Unidad de Mujer y Ciencia de Galicia.

- Decreto 300/2002, de 24 de octubre, por el que se crea y regula el Consello Galego de Personas con discapacidad. - Ley 10/2003, de 26 de diciembre, sobre el acceso al entorno de las personas con discapacidad acompañadas de perros de asistencia. 
2. Los idiomas gallego y castellano son oficiales en Galicia y todos tienen el derecho de conocerlos y usarlos.

3. Los poderes públicos de Galicia garantizarán el uso normal y oficial de los dos idiomas y potenciarán la utilización del gallego en todos los órdenes de la vida pública, cultural e informativa, y dispondrán los medios necesarios para facilitar su conocimiento.

4. Nadie podrá ser discriminado por razón de la lengua 2 .

Artículo 6. 1. La bandera de Galicia es blanca con una banda diagonal de color azul que la atraviesa desde el ángulo superior izquierdo hasta el inferior derecho.

2. Galicia tiene himno y escudo propios ${ }^{3}$.

Artículo 7. 1. Las comunidades gallegas asentadas fuera de Galicia podrán solicitar, como tales, el reconocimiento de su galleguidad entendida como el derecho a colaborar y compartir la vida social y cultural del pueblo gallego. Una ley del Parlamento regulará, sin perjuicio de las competencias del Estado, el alcance y contenido de aquel reconocimiento a dichas comunidades que en ningún caso implicará la concesión de derechos políticos.

2. La Comunidad Autónoma podrá solicitar del Estado español que para facilitar lo dispuesto anteriormente celebre los oportunos tratados o convenios con los Estados donde existan dichas comunidades 4 .

Artículo 8. Una ley de Galicia, para cuya aprobación se requerirá el voto favorable de las dos terceras partes de los

\footnotetext{
2 Véase:

- Ley $3 / 1983$, de 15 de junio, de normalización lingüistica.

- Decreto 58/2006, de 30 de marzo, por el que se crea y regula el funcionamiento de la Comisión de Seguimiento e Impulso del Plan General de Normalización de la Lengua Gallega.

3 Véase:

- Ley 5/1984, de 29 de mayo de 1984, de símbolos de Galicia.

- Decreto 73/1985, de 18 de abril, que regula la bandera y escudo de Galicia.

4 Véase:

- Ley 4/1983, de 15 de junio, de reconocimiento de la galleguidad.

- Decreto 4/1987, de 8 de enero, por el que se aprueba el Reglamento del Consejo de Comunidades gallegas.
}

miembros de su Parlamento, fijará la sede de las instituciones autonómicas 5 .

\section{TÍTULO PRIMERO DEL PODER GALLEGO}

Artículo 9. 1. Los poderes de la Comunidad Autónoma se ejercen a través del Parlamento, de la Xunta y de su Presidente.

2. Las leyes de Galicia ordenarán el funcionamiento de estas instituciones de acuerdo con la Constitución y el presente Estatuto.

\section{Capítulo primero DEL PARLAMENTO}

Artículo 10. 1. Son funciones del Parlamento de Galicia las siguientes:

a. Ejercer la potestad legislativa de la Comunidad Autónoma. El Parlamento sólo podrá delegar esta potestad legislativa en la Xunta, en los términos que establecen los artículos 82, 83 y 84 de la Constitución para el supuesto de la delegación legislativa de las Cortes Generales al Gobierno, todo ello en el marco del presente Estatuto.

b. Controlar la acción ejecutiva de la Xunta, aprobar los presupuestos y ejercer las otras competencias que le sean atribuidas por la Constitución, por el presente Estatuto, por las leyes del Estado y las del Parlamento de Galicia ${ }^{6}$.

c. Designar para cada legislatura de las Cortes Generales a los Senadores representantes de la Comunidad Autónoma gallega, de acuerdo con lo previsto en el artículo 69, apartado 5, de la Constitución. Tal designación se hará de forma proporcional a la representación de las distintas fuerzas políticas existentes en el Parlamento de Galicia.

\footnotetext{
5 Véase Ley $1 / 1982$, de 24 de junio, de fijación de la sede de las instituciones autonómicas de Galicia, que establece en su art. 1 a Santiago de Compostela como sede del Parlamento, de la Xunta, de su Presidente y de las consellerias; y en su art. 2 la ciudad de La Coruña como sede del Tribunal Superior de Justicia. Vease también Ley 4/2002, de 25 de junio, del estatuto de la capitalidad de la ciudad de Santiago de Compostela.

6 Véase Resolución de 12 de mayo 2005 por la que se hace público el Reglamento de las distinciones y condecoraciones del Parlamento de Galicia.
} 
d. Elegir de entre sus miembros al Presidente de la Xunta de Galicia.

e. Exigir, en su caso, responsabilidad política a la Xunta y a su Presidente.

f. Solicitar del Gobierno la adopción de proyectos de ley y presentar ante la Mesa del Congreso de los Diputados proposiciones de ley.

g. Interponer recursos de inconstitucionalidad y personarse ante el Tribunal Constitucional en los supuestos y en los términos previstos en la Constitución y en la Ley Orgánica del Tribunal Constitucional.

2. El Parlamento de Galicia es inviolable.

Artículo 11. 1. El Parlamento estará constituido por Diputados elegidos por sufragio universal, igual, libre, directo y secreto.

2. El Parlamento será elegido por un plazo de cuatro años, de acuerdo con un sistema de representación proporcional que asegure, además, la representación de las diversas zonas del territorio gallego ${ }^{7}$.

3. Los miembros del Parlamento de Galicia serán inviolables por los votos y opiniones que emitan en el ejercicio de su cargo. Durante su mandato no podrán ser detenidos ni retenidos por los actos delictivos cometidos en el territorio de Galicia, sino en caso de flagrante delito, correspondiendo decidir, en todo caso, sobre su inculpación, prisión, procesamiento y juicio al Tribunal Superior de Justicia de Galicia. Fuera de dicho territorio, la responsabilidad penal será exigible, en los mismos términos, ante la Sala de lo Penal del Tribunal Supremo.

4. La circunscripción electoral será, en todo caso, la provincia.

5. Una ley del Parlamento de Galicia determinará los plazos y regulará el procedimiento para elección de sus miembros, fijando su número entre 60 y 80 , y las causas de inelegibilidad e incompatibilidad que afecten a los puestos o cargos que se

7 Véase Ley de 13 de agosto de 1985 de elecciones al Parlamento de Galicia. desempeñen dentro del ámbito territorial de la Comunidad Autónoma ${ }^{8}$.

6. El Parlamento, mediante ley, podrá establecer un sistema para que los intereses del conjunto de los gallegos residentes en el extranjero estén presentes en las decisiones de la Comunidad Autónoma.

7. Los Diputados no estarán sujetos a mandato imperativo.

Artículo 12. 1. El Parlamento elegirá de entre sus miembros un Presidente, la Mesa y una Diputación Permanente. El Reglamento, que deberá ser aprobado por mayoría absoluta, regulará su composición, régimen y funcionamiento 9 .

2. El Parlamento de Galicia fijará su propio presupuesto ${ }^{10}$.

3. El Parlamento funcionará en Pleno y en Comisiones, y se reunirá en sesiones ordinarias y extraordinarias.

4. El Reglamento precisará el número mínimo de Diputados para la formación de Grupos Parlamentarios, la intervención de éstos en el proceso legislativo y las funciones de la Junta de Portavoces de aquéllos. Los Grupos Parlamentarios participarán en todas las Comisiones en proporción al número de sus miembros.

Artículo 13. 1. La iniciativa legislativa corresponde a los Diputados, al Parlamento y a la Xunta. La iniciativa popular para la presentación de proposiciones de ley que hayan de ser tramitadas por el Parlamento de Galicia se regulará por éste mediante ley, de acuerdo con lo que establezca la ley orgánica prevista en el artículo 87.3 de la Constitución ${ }^{11}$.

8 Véase Ley de 13 de agosto de 1985 de elecciones al Parlamento de Galicia. Sobre la elección del primer Parlamento Gallego véase Disposición transitoria primera de este Estatuto.

9 Véase Resolución de 20 junio de 2003 por la que se publica el Reglamento de organización y funcionamiento de la Administración del Parlamento de Galicia. Estatuto de Personal del Parlamento de Galicia (DOGA $n^{\circ} 248,26$ de diciembre de 2007).

10 Véase Resolución de 20 de junio de 2003 por la que se publica el Reglamento de régimen presupuestario y contable del Parlamento de Galicia y del Valedor do Pobo. 11 Véase sobre la iniciativa legislativa popular Ley 1/1988, de 19 de enero, de Iniciativa Legislativa Popular ante el Parlamento de Galicia. 
2. Las leyes de Galicia serán promulgadas en nombre del Rey por el Presidente de la Xunta y publicadas en el "Diario Oficial de Galicia" y en el "Boletín Oficial del Estado". A efectos de su entrada en vigor regirá la fecha de su publicación en el "Diario Oficial de Galicia".

3. El control de la constitucionalidad de las leyes del Parlamento de Galicia corresponderá al Tribunal Constitucional.

Artículo 14. Corresponde a la Comunidad Autónoma la creación y organización mediante ley de su Parlamento y con respeto a la institución del Defensor del Pueblo establecida en el artículo 54 de la Constitución, de un órgano similar que en coordinación con aquélla, ejerza las funciones a las que se refiere el mencionado artículo y cualesquiera otras que el Parlamento de Galicia pueda encomendarle ${ }^{12}$.

\section{Capítulo II \\ DE LA XUNTA Y DE SU PRESIDENTE}

Artículo 15. 1. El Presidente dirige y coordina la acción de la Xunta y ostenta la representación de la Comunidad Autónoma y la ordinaria del Estado en Galicia.

2. El Presidente de la Xunta será elegido por el Parlamento Gallego de entre sus miembros y será nombrado por el Rey.

3. El Presidente del Parlamento, previa consulta con las fuerzas políticas representadas parlamentariamente, y oída la Mesa, propondrá un candidato a Presidente de la Xunta. El candidato presentará su programa al Parlamento. Para ser elegido, el candidato deberá, en primera votación, obtener mayoría absoluta; de no obtenerla, se procederá a una nueva votación veinticuatro horas después de la anterior, y la confianza se entenderá otorgada si obtuviera mayoría simple. Caso de no conseguirse dicha mayoría, se tramitarán sucesivas propuestas en la forma prevista anteriormente.

12 Véase Ley 6/1984, de 5 de junio, del Valedor do Pobo de Galicia.
4. El Presidente de la Xunta será políticamente responsable ante el Parlamento. Una ley de Galicia determinará el alcance de tal responsabilidad, así como el estatuto personal y atribuciones del Presidente.

Artículo 16. 1. La Xunta es el órgano colegiado de Gobierno de Galicia.

2. La Xunta de Galicia está compuesta por el Presidente, Vicepresidente o Vicepresidentes, en su caso, y los conselleiros.

3. Los Vicepresidentes y los Conselleiros serán nombrados y cesados por el Presidente.

4. Una ley de Galicia regulará la organización de la Xunta y las atribuciones y el estatuto personal de su componentes.

Artículo 17. 1. La Xunta de Galicia responde políticamente ante el Parlamento de forma solidaria, sin perjuicio de la responsabilidad directa de cada uno de sus componentes por su gestión.

2. La Xunta cesa tras la celebración de elecciones al Parlamento gallego; en los casos de pérdida de la confianza parlamentaria, dimisión y fallecimiento de su Presidente.

3. La Xunta cesante continuará en funciones hasta la toma de posesión de la nueva Xunta.

Artículo 18. El Presidente y los demás miembros de la Xunta, durante su mandato y por los actos delictivos cometidos en el territorio de Galicia, no podrán ser detenidos ni retenidos sino en caso de flagrante delito, correspondiendo decidir, en todo caso, sobre su inculpación, prisión, procesamiento y juicio al Tribunal Superior de Justicia de Galicia. Fuera de dicho territorio la responsabilidad penal será exigible en los mismos términos ante la Sala de lo Penal del Tribunal Supremo.

Artículo 19. La Xunta de Galicia podrá interponer recursos de inconstitucionalidad y personarse ante el Tribunal Constitucional en los supuestos y términos previstos en la Constitución y en la Ley Orgánica del Tribunal Constitucional. 


\section{Capitulo III \\ DE LA ADMINISTRACIÓN DE JUSTICIA EN GALICIA}

Artículo 20. Corresponde a la Comunidad Autónoma:

1. Ejercer todas las facultades que las Leyes Orgánicas del Poder Judicial y del Consejo General del Poder Judicial reconozcan o atribuyan al Gobierno del Estado ${ }^{13}$.

2. Fijar la delimitación de las demarcaciones territoriales de los órganos jurisdiccionales en Galicia, teniendo en cuenta, entre otros criterios, los límites de los tradicionales partidos judiciales y las características geográficas y de población.

Artículo 21. El Tribunal Superior de Justicia de Galicia, en el que se integrará la actual Audiencia Territorial, es el órgano jurisdiccional en que culminará la organización judicial en su ámbito territorial y ante el que se agotarán las sucesivas instancias procesales, en los términos del artículo 152 de la Constitución y de acuerdo con el presente Estatuto.

Artículo 22. 1. La competencia de los órganos jurisdiccionales en Galicia se extiende:

a. En el orden civil, a todas las instancias y grados, incluidos los recursos de casación y de revisión en las materias de derecho civil gallego.

b. En el orden penal y social, a todas las instancias y grados, con excepción de los recursos de casación y de revisión.

c. En el orden contencioso-administrativo, a todas las instancias y grados, cuando se trate de actos dictados por la Xunta y por la Administración de Galicia, en las materias cuya legislación corresponda en exclusiva a la Comunidad Autónoma y la que, de acuerdo con la ley de dicha jurisdicción, le corresponda

\section{Véase:}

- Decreto 269/2008, de 6 de noviembre, por el que se aprueba el Reglamento de asistencia juridica gratuita de Galicia.

- Orden de 12 de febrero de 2009 por la que se establece el modelo normalizado de solicitud de reconocimiento del derecho a la asistencia juridica gratuita. en relación con los actos dictados por la Administración del Estado en Galicia.

d. A las cuestiones de competencia entre órganos judiciales en Galicia.

e. A los recursos sobre calificación de documentos referentes al derecho privativo gallego que deban tener acceso a los Registros de la Propiedad.

2. En las restantes materias se podrá interponer, cuando proceda ante el Tribunal Supremo, el recurso de casación o el que corresponda, según las leyes del Estado y, en su caso, el de revisión. El Tribunal Supremo resolverá también los conflictos de competencia y jurisdicción entre los Tribunales de Galicia y los del resto de España.

Artículo 23. 1. El Presidente del Tribunal Superior de Justicia de Galicia será nombrado por el Rey a propuesta del Consejo General del Poder Judicial.

2. El nombramiento de los Magistrados, Jueces y Secretarios del Tribunal Superior de Justicia, se efectuará en la forma prevista en las Leyes Orgánicas del Poder Judicial y del Consejo General del Poder Judicial.

Artículo 24. 1. A instancia de la Comunidad Autónoma, el órgano competente convocará los concursos y oposiciones para cubrir las plazas vacantes en Galicia de Magistrados, Jueces, Secretarios Judiciales y restante personal al servicio de la Administración de Justicia, de acuerdo con lo que disponga la Ley Orgánica del Poder Judicial.

2. Corresponde íntegramente al Estado, de conformidad con las leyes generales, la organización y el funcionamiento del Ministerio Fiscal.

Artículo 25. En la resolución de los concursos y oposiciones para proveer los puestos de Magistrados, Jueces, Secretarios Judiciales, Fiscales y todos los funcionarios al servicio de la Administración de Justicia, será mérito preferente la especialización en el derecho gallego y el conocimiento del idioma del país. 
Artículo 26. 1. Los Notarios y los Registradores de la Propiedad y Mercantiles serán nombrados por la Comunidad Autónoma, de conformidad con las leyes del Estado. Para la provisión de notarías, los candidatos serán admitidos en igualdad de derechos, tanto si ejercen en el territorio de Galicia como en el resto de España. En estos concursos y oposiciones será mérito preferente la especialización en derecho gallego y el conocimiento del idioma del país. En ningún caso podrá establecerse la excepción de naturaleza o vecindad.

2. La Comunidad Autónoma participará en la fijación de las demarcaciones correspondientes a los Registros de la Propiedad y Mercantiles para acomodarlas a lo que se disponga en aplicación del artículo veinte, párrafo dos, de este Estatuto. También participará en la fijación de las demarcaciones notariales y del número de Notarios, de acuerdo con lo previsto en las leyes del Estado.

\section{TÍTULO II DE LAS COMPETENCIAS DE GALICIA \\ Capitulo primero \\ DE LAS COMPETENCIAS \\ EN GENERAL ${ }^{14}$}

Artículo 27. En el marco del presente Estatuto corresponde a la Comunidad $\mathrm{Au}$ tónoma gallega la competencia exclusiva de las siguientes materias:

1. Organización de sus instituciones de autogobierno.

2. Organización y régimen jurídico de las comarcas y parroquias rurales como entidades locales propias de Galicia, alteraciones de términos municipales comprendidos dentro de su territorio $\mathrm{y}$, en general, las funciones que sobre el régimen local correspondan a la Comunidad

14 Véase:

- Ley Orgánica 16/1995, de 27 de diciembre, de transferencia de competencias a la Comunidad Autónoma Gallega.

- Ley Orgánica 6/1999, de 6 de abril, de transferencia de competencias a la Comunidad Autónoma de Galicia.
Autónoma al amparo del artículo 149.1.18. ${ }^{a}$ de la Constitución y su desarrollo ${ }^{15}$.

3. Ordenación del territorio y del litoral, urbanismo y vivienda ${ }^{16}$.

4. Conservación, modificación y desarrollo de las instituciones del derecho civil gallego.

5. Las normas procesales y procedimientos administrativos que se deriven del específico derecho gallego o de la organización propia de los poderes públicos gallegos ${ }^{17}$.

6. Estadísticas para los fines de la $\mathrm{Co}$ munidad Autónoma gallega ${ }^{18}$.

7. Obras públicas que no tengan la calificación legal de interés general del Estado o cuya ejecución o explotación no afecte a otra Comunidad Autónoma o provincia.

8. Ferrocarriles y carreteras no incorporados a la red del Estado y cuyo itinerario se desarrolle íntegramente en el territorio de la Comunidad Autónoma y, en los mismos términos, el transporte llevado a cabo por estos medios o por cable.

9. Los puertos, aeropuertos y helipuertos no calificados de interés general por el Estado y los puertos de refugio y puertos y aeropuertos deportivos.

10. Montes, aprovechamientos forestales, vías pecuarias y pastos, sin perjuicio de lo dispuesto en el artículo 149.1.23. ${ }^{a}$ de la Constitución.

15 Véase Ley de 29 de diciembre de 1983, de actuación intensiva en las Parroquias Rurales. 16 Véase:

- Ley 10/1995, de 23 de noviembre, de Ordenación del Territorio de Galicia.

17 Véase Ley 6/2001, de 29 de junio, de adecuación de la Normativa de la Comunidad Autónoma de Galicia a la Ley 4/1999, de 13 de enero, de modificación de la Ley $30 / 92$, de 26 de noviembre, de régimen jurídico de las Administraciones Públicas y del procedimiento administrativo común.

18 Véase:

- Ley 9/1988, de 19 de julio, de estadistica de Galicia.

- Ley 16/2006, de 27 de diciembre, del plan gallego de estadistica 2007-2011.

- Decreto 24/2008, de 21 de febrero, por el que se regulan los órganos estadisticos sectoriales y se establece el procedimiento de designación. 
11. Régimen jurídico de los montes vecinales en mano común ${ }^{19}$.

12. Aprovechamientos hidráulicos, canales y regadíos cuando las aguas discurran íntegramente dentro del territorio de la Comunidad, sin perjuicio de lo dispuesto en el artículo 149.1.22. ${ }^{a}$ de la Constitución.

13. Instalaciones de producción, distribución y transporte de energía eléctrica cuando este transporte no salga de su territorio y su aprovechamiento no afecte a otra provincia o Comunidad Autónoma, sin perjuicio de lo dispuesto en el artículo 149.1.22. ${ }^{a}$ y 25 . de la Constitución.

14. Las aguas minerales y termales. Las aguas subterráneas, sin perjuicio de lo dispuesto en el artículo 149.1.22. a de la Constitución, y en el número 7 del presente artículo.

15. La pesca en las rías y demás aguas interiores, el marisqueo, la acuicultura, la caza, la pesca fluvial y lacustre.

16. Las ferias y mercados interiores.

17. La artesanía.

18. Patrimonio histórico, artístico, arquitectónico, arqueológico, de interés de Galicia, sin perjuicio de lo que dispone el artículo 149.1.28. a de la Constitución; archivos, bibliotecas y museos de interés para la Comunidad Autónoma, y que no sean de titularidad estatal; conservatorios de música y servicios de bellas artes de interés para la Comunidad.

19. El fomento de la cultura y de la investigación en Galicia, sin perjuicio de lo establecido en el artículo 149.2 de la Constitución ${ }^{20}$.

20. La promoción y la enseñanza de la lengua gallega ${ }^{21}$.

19 Véase Ley 13/1989, de 10 de octubre, de Montes Vecinales en Mano Común.

- STC 127/1999, de 1 de julio de 1999. Recurso de inconstitucionalidad 175/1990.

20 Véase Ley $17 / 2006$, de 27 de diciembre, del libro y de la lectura de Galicia.

21 Véase:

- Ley 17/2006, de 27 de diciembre, del libro y de la lectura de Galicia.

- Decreto 342/2009, de 18 de junio, por el que se crea el Registro Administrativo de Librerias de Galicia y se regula su organización y funcionamiento.
21. La promoción y la ordenación del turismo dentro de la Comunidad.

22. La promoción del deporte y la adecuada utilización del ocio ${ }^{22}$.

23. Asistencia social23.

24. La promoción del desarrollo comunitario.

25. La creación de una policía autónoma, de acuerdo con lo que disponga la Ley Orgánica prevista en el artículo 149.1.29. ${ }^{a}$ de la Constitución.

26. El régimen de las fundaciones de interés gallego.

27. Casinos, juegos y apuestas, con exclusión de las Apuestas Mutuas Deportivo Benéficas 24 .

28. Los centros de contratación de mercancías y valores de conformidad con las normas generales de derecho mercantil.

29. Cofradías de Pescadores, Cámaras de la Propiedad Agrarias, de Comercio, Industria y Navegación y otras de naturaleza equivalente, sin perjuicio de lo que dispone el artículo 149 de la Constitución. 30. Normas adicionales sobre proteccíón del medio ambiente y del paisaje en los términos del artículo 149.1.23. ${ }^{\mathrm{a}}$

31. Publicidad, sin perjuicio de las normas dictadas por el Estado para sectores y medios específicos.

32. Las restantes materias que con este carácter y mediante ley orgánica sean transferidas por el Estado.

Artículo 28. Es competencia de la Comunidad Autónoma gallega el desarrollo

22 Véase:

- Ley 11/1997, de 22 de agosto, general del deporte de Galicia.

- Decreto 342/2009, de 18 de junio, por el que se crea el Registro Administrativo de Librerías de Galicia y se regula su organización y funcionamiento.

23 Véase:

- Ley $13 / 2008$, de 3 de diciembre, de servicios sociales.

- Ley 9/1991, de 9 de octubre, de medidas básicas para inserción social.

- Ley 3/1997, de 9 de junio, gallega de la familia, la infancia y la adolescencia.

- Ley 4/2001, de 31 de mayo, reguladora de la mediación familiar.

24 Véase Ley 14/1985, de 23 de octubre, reguladora de los juegos y apuestas de Galicia. 
legislativo y la ejecución de la legislación del Estado en los términos que la misma establezca, de las siguientes materias:

1. Régimen jurídico de la Administración pública de Galicia, y régimen estatutario de sus funcionarios 25 .

2. Expropiación forzosa, contratos y concesiones administrativas en el ámbito de las competencias propias de la Comunidad Autónoma.

3. Régimen minero y energético.

4. Reserva al sector público de recursos o servicios esenciales, especialmente en caso de monopolio e intervención de empresas cuando lo exija el interés general.

5. Ordenación del sector pesquero.

6. Puertos pesqueros.

7. Entidades cooperativas.

8. Establecimientos farmacéuticos.

Artículo 29. Corresponde a la Comunidad Autónoma gallega la ejecución de la legislación del Estado en las siguientes materias:

1. Laboral, asumiendo las facultades, competencias y servicios que en este ámbito, y a nivel de ejecución, ostenta actualmente el Estado respecto a las relaciones laborales, sin perjuicio de la alta inspección de éste. Quedan reservadas al Estado todas las competencias en materia de migraciones interiores y exteriores, fondos de ámbito nacional y de empleo, sin perjuicio de lo que establezcan las normas del Estado sobre estas materias.

2. Propiedad industrial e intelectual.

3. Salvamento marítimo.

4. Vertidos industriales y contaminantes en las aguas territoriales del Estado correspondientes al litoral gallego.

\footnotetext{
25 Véase:

- Ley 6/2001, de 29 de junio, de adecuación de la Normativa de la Comunidad Autónoma de Galicia a la Ley 4/1999, de 13 de enero, de Modificación de la Ley $30 / 92$, de 26 de noviembre, de Régimen Jurídico de las Administraciones Públicas y del Procedimiento Administrativo Común.

- Ley 4/2006, de 30 de junio, de transparencia y de buenas prácticas en la Administración pública gallega. - Decreto Legislativo $1 / 2008$, de 13 de marzo, por el que se aprueba el Texto Refundido de la Ley de la Función Pública.
}

5. Las restantes materias que se atribuyen en el presente Estatuto expresamente como de competencia de ejecución y las que con este carácter y mediante ley orgánica sean transferidas por el Estado.

Artículo 30. 1. De acuerdo con las bases y la ordenación de la actuación económica general y la política monetaria del Estado, corresponde a la Comunidad Autónoma gallega, en los términos de lo dispuesto en los artículos 38, 131 y $149.1 .11 .^{\mathrm{a}}$ y $13 .^{\mathrm{a}}$ de la Constitución, la competencia exclusiva de las siguientes materias:

1. Fomento y planificación de la actividad económica en Galicia.

2. Industria, sin perjuicio de lo que determinen las normas del Estado por razones de seguridad, sanitarias o de interés militar y las normas relacionadas con las industrias que estén sujetas a la legislación de minas, hidrocarburos y energía nuclear. Queda reservada a la competencia exclusiva del Estado la autorización para transferencia de tecnología extranjera ${ }^{26}$.

3. Agricultura y ganadería.

4. Comercio interior, defensa del consumidor y del usuario, sin perjuicio de la política general de precios y de la legislación sobre la defensa de la competencia. Denominaciones de origen en colaboración con el Estado ${ }^{27}$.

5. Instituciones de crédito corporativo, público y territorial y cajas de ahorro.

6. Sector público económico de Galicia, en cuanto no esté contemplado por otras normas de este Estatuto.

7. El desarrollo y ejecución en Galicia de:

a. Los planes establecidos por el Estado para la reestructuración de sectores económicos.

b. Programas genéricos para Galicia estimuladores de la ampliación de actividades productivas e implantación de nuevas empresas.

c. Programas de actuación referidos a comarcas deprimidas o en crisis.

\footnotetext{
26 Véase Ley 9/2004, de 10 de agosto, de seguridad industrial de Galicia.

27 Véase Ley 13/2006, de 27 de diciembre, de horarios
} comerciales de Galicia. 
2. La Comunidad Autónoma gallega participará, asimismo, en la gestión del sector público económico estatal, en los casos y actividades que procedan.

Artículo 31. Es de la competencia plena de la Comunidad Autónoma gallega la regulación y administración de la enseñanza en toda su extensión, niveles y grados, modalidades y especialidades, en el ámbito de sus competencias, sin perjucio de lo dispuesto en el artículo 27 de la Constitución y en las leyes orgánicas que, conforme al apartado $1^{\circ}$. del artículo 81 de la misma, lo desarrollen, de las facultades que atribuye al Estado el número $30 \mathrm{del}$ apartado 1 del artículo 149 de la Constitución, y de la alta inspección necesaria para su cumplimiento y garantía ${ }^{28}$.

Artículo 32. Corresponde a la Comunidad Autónoma la defensa y promoción de los valores culturales del pueblo gallego. A tal fin, y mediante ley del Parlamento, se constituirá un Fondo Cultural Galego y el Consello da Cultura Galega.

Artículo 33. 1. Corresponde a la Comunidad Autónoma el desarrollo legislativo y la ejecución de la legislación básica del Estado en materia de sanidad interior ${ }^{29}$.

2. En materia de Seguridad Social corresponderá a la Comunidad Autónoma el desarrollo legislativo y la ejecución de la legislación básica del Estado, salvo las normas que configuran el régimen económico de la misma.

Corresponde también a la Comunidad Autónoma la gestión del régimen económico de la Seguridad Social en Galicia, sin perjuicio de la Caja Única.

\section{Véase:}

- Decreto 99/2004, de 21 de mayo, por el que se regula la organización y el funcionamiento de la Inspección Educativa y el acceso al cuerpo de inspectores de Educación en la Comunidad Autónoma de Galicia.

- Orden de 13 de diciembre de 2004 por la que se desarrolla el Decreto 99/2004, de 21 de mayo, por el que se regula el funcionamiento de la Inspección Educativa y el acceso al cuerpo de inspectores de Educación en la Comunidad Autónoma de Galicia.

29 Véase Decreto 134/1998, de 23 de abril, sobre policia sanitaria mortuoria.
3. Corresponderá también a la Comunidad Autónoma la ejecución de la legislación del Estado sobre productos farmacéuticos.

4. La Comunidad Autónoma podrá organizar y administrar, a tales fines y dentro de su territorio, todos los servicios relacionados con las materias antes expresadas y ejercerá la tutela de las instituciones, entidades y fundaciones en materia de sanidad y Seguridad Social, reservándose el Estado la alta inspección conducente al cumplimiento de las funciones y competencias contenidas en este artículo.

Artículo 34. 1. En el marco de las normas básicas del Estado, corresponde a la Comunidad Autónoma el desarrollo legislativo y la ejecución del régimen de radiodifusión y televisión, en los términos y casos establecidos en la ley que regule el Estatuto Jurídico de la Radio y la Televisión.

2. Igualmente le corresponde, en el marco de las normas básicas del Estado, el desarrollo legislativo y la ejecución del régimen de prensa y, en general, de todos los medios de comunicación social.

3. En los términos establecidos en los apartados anteriores de este artículo, la Comunidad Autónoma podrá regular, crear y mantener su propia televisión, radio y prensa y, en general, todos los medios de comunicación social para el cumplimiento de sus fines.

Artículo 35. 1. La Comunidad Autónoma podrá celebrar convenios con otras Comunidades Autónomas para la gestión y prestación de servicios propios de la exclusiva competencia de las mismas. La celebración de los citados convenios, antes de su entrada en vigor, deberá ser comunicada a las Cortes Generales. Si las Cortes Generales, o alguna de las Cámaras, manifestaran reparos en el plazo de treinta días, a partir de la recepción de la comunicación, el convenio deberá seguir el trámite previsto en el párrafo siguiente. Si transcurrido dicho plazo no se hubiesen 
manifestado reparos al convenio, entrará en vigor ${ }^{30}$.

2. La Comunidad Autónoma podrá establecer también acuerdos de cooperación con otras Comunidades Autónomas, previa autorización de las Cortes Generales.

3. La Comunidad Autónoma gallega podrá solicitar del Gobierno que celebre y presente, en su caso, a las Cortes Generales, para su autorización, los tratados o convenios que permita el establecimiento de relaciones culturales con los Estados con los que mantenga particulares vínculos culturales o lingüísticos.

Artículo 36. 1. La Comunidad Autónoma gallega podrá solicitar del Estado la transferencia o delegación de competencias no asumidas en este Estatuto.

2. Corresponde al Parlamento de Galicia la competencia para formular las anteriores solicitudes, y para determinar el organismo de la Comunidad Autónoma gallega a cuyo favor se deberá atribuir en cada caso la competencia transferida o delegada.

\section{Capítulo II DEL RÉGIMEN JURÍDICO}

Artículo 37. 1. Las competencias de la Comunidad Autónoma de Galicia se entienden referidas a su territorio.

2. En las materias de su competencia exclusiva le corresponde al Parlamento la potestad legislativa en los términos previstos en el Estatuto y en las leyes del Estado a las que el mismo se refiere, correspondiéndole a la Xunta la potestad reglamentaria y la función ejecutiva.

3. Las competencias de ejecución en la Comunidad Autónoma llevan implícitas la correspondiente potestad reglamentaria, la administración y la inspección. En los supuestos previstos en los artículos veintiocho y veintinueve de este Estatuto,

30 Véase:

- Art. 4. 8 Ley $1 / 1983$, de 22 de febrero, Reguladora de la Xunta y de su Presidencia.

- Decreto 126/2006, de 20 de julio, por el que se regula el registro de convenios de la Xunta de Galicia. o en otros preceptos del mismo, con análogo carácter, el ejercicio de esas potestades por la Comunidad Autónoma se realizará de conformidad con las normas reglamentarias de carácter general que, en desarrollo de su legislación, dicte el Estado.

Artículo 38. 1. En materias de competencia exclusiva de la Comunidad Autónoma, el derecho propio de Galicia es aplicable en su territorio con preferencia a cualquier otro, en los términos previstos en el presente Estatuto.

2. A falta de derecho propio de Galicia, será de aplicación supletoria el derecho del Estado.

3. En la determinación de las fuentes del derecho civil se respetarán por el Estado las normas del derecho civil gallego.

\section{TÍTULO III \\ DE LA ADMINISTRACIÓN PÚBLICA GALLEGA}

Artículo 39. Corresponde a la Comunidad Autónoma la creación y estructuración de su propia Administración Pública, dentro de los principios generales y normas básicas del Estado.

Artículo 40. En los términos previstos en el artículo 27.2 de este Estatuto, por ley de Galicia se podrá:

1. Reconocer la comarca como entidad local con personalidad jurídica y demarcación propia. La comarca no supondrá, necesariamente, la supresión de los municipios que la integren.

2. Crear, asimismo, agrupaciones basadas en hechos urbanísticos y otros de carácter funcional con fines específicos.

3. Reconocer personalidad jurídica a la parroquia rural.

Artículo 41. La Comunidad Autónoma ejercerá sus funciones administrativas por órganos y entes dependientes de la Xunta de Galicia. También podrá delegarlas en las provincias, municipios y demás entidades locales reconocidas en este Estatuto. 


\section{TÍTULO IV DE LA ECONOMÍA Y LA HACIENDA}

Artículo 42. La Comunidad Autónoma gallega contará para el desempeño de sus competencias con hacienda y patrimonio propios.

Artículo 43. 1. El patrimonio de la Comunidad Autónoma estará integrado por:

$1^{\circ}$. El patrimonio de la Comunidad Autónoma en el momento de aprobarse el Estatuto.

$2^{\circ}$. Los bienes afectos a servicios traspasados a la Comunidad Autónoma.

$3^{\circ}$. Los bienes adquiridos por la Comunidad Autónoma por cualquier título jurídico válido.

2. El patrimonio de la Comunidad Autónoma, su administración, defensa y conservación serán regulados por una ley de Galicia.

Artículo 44. La hacienda de la Comunidad Autónoma se constituye con:

1. Los rendimientos de los impuestos que establezca la Comunidad Autónoma.

2. Los rendimientos de los impuestos cedidos por el Estado a que se refiere la Disposición adicional primera y de todos aquellos cuya cesión sea aprobada por las Cortes Generales.

3. Un porcentaje de participación en la recaudación total del Estado por impuestos directos e indirectos, incluidos los monopolios fiscales.

4. El rendimiento de sus propias tasas por aprovechamientos especiales y por la prestación de servicios directos de la Comunidad Autónoma, sean de propia creación o como consecuencia de traspasos de servicios estatales.

5. Las contribuciones especiales que establezca la Comunidad Autónoma en el ejercicio de sus competencias.

6. Los recargos sobre impuestos estatales.

7. En su caso, los ingresos procedentes del Fondo de Compensación Interterritorial.
8. Otras asignaciones con cargo a los Presupuestos Generales del Estado.

9. La emisión de deuda y el recurso al crédito.

10. Los rendimientos del patrimonio de la Comunidad Autónoma.

11. Ingresos de derecho privado, legados y donaciones; subvenciones.

12. Multas y sanciones en el ámbito de sus competencias.

Artículo 45. La Comunidad Autónoma gallega o los entes locales afectados participarán en los ingresos correspondientes a los tributos que el Estado pueda establecer para recuperar los costos sociales producidos por las actividades contaminantes o generadoras de riesgos de especial gravedad para el entorno físico y humano de Galicia en la forma que establezca la ley creadora del gravamen.

Artículo 46. 1. Cuando se complete el traspaso de servicios o al cumplirse el sexto año de vigencia de este Estatuto, si la Comunidad Autónoma gallega lo solicita, la participación anual en los ingresos del Estado citada en el número tres del artículo cuarenta y cuatro y definida en la Disposición transitoria quinta se negociará sobre las siguientes bases:

a. La media de los coeficientes de población y esfuerzo fiscal de Galicia, este último medido por la recaudación en su territorio del impuesto sobre la renta de las personas físicas, es decir, el cociente entre la recaudación efectivamente obtenida y la potencialmente alcanzable habida cuenta del nivel y distribución personal de la renta.

b. La cantidad equivalente a la aportación proporcional que corresponda a Galicia por los servicios y cargas generales que el Estado continúe asumiendo como propios.

c. La relación inversa entre la renta real media de los residentes en la Comunidad Autónoma y la media estatal.

d. Relación entre los índices de déficit en servicios sociales e infraestructuras 
que afecten al territorio de la Comunidad $\mathrm{y}$ al conjunto del Estado.

e. Relación entre los costos por habitante de los servicios sociales y administrativos transferidos para el territorio de la Comunidad y para el conjunto del Estado.

f. Otros criterios que se estimen procedentes.

2. La fijación del nuevo porcentaje de participación será objeto de negociación inicial y será revisable a solicitud del Gobierno o de la Comunidad Autónoma gallega cada cinco años.

Artículo 47. 1. La Comunidad Autónoma, mediante acuerdo del Parlamento, podrá emitir deuda pública para financiar gastos de inversión.

2. El volumen y características de las emisiones se establecerán de acuerdo con la ordenación general de la política crediticia y en coordinación con el Estado.

3. Los títulos emitidos tendrán la consideración de fondos públicos a todos los efectos.

Artículo 48. En el supuesto de que el Estado emita deuda parcialmente destinada a la creación o mejora de servicios situados en Galicia y transferidos a la Comunidad Autónoma gallega, ésta estará facultada para elaborar y presentar el programa de obras y servicios beneficiarios de la emisión.

Artículo 49. 1. Corresponde a la Comunidad Autónoma gallega la tutela financiera sobre los entes locales respetando la autonomía que a los mismos reconocen los artículos 140 y 142 de la Constitución y de acuerdo con el artículo 27.2 de este Estatuto.

2. Es competencia de los entes locales de Galicia la gestión, recaudación, liquidación e inspección de los tributos propios que les atribuyan las leyes, sin perjuicio de la delegación que puedan otorgar para estas facultades a favor de la Comunidad Autónoma gallega.

Mediante ley del Estado se establecerá el sistema de colaboración de los entes locales, de la Comunidad Autónoma gallega y del Estado para la gestión, liquidación, recaudación e inspección de aquellos tributos que se determinen.

Los ingresos de los entes locales de Galicia, consistentes en participación en ingresos estatales y en subvenciones incondicionadas, se percibirán a través de la Comunidad Autónoma gallega, que los distribuirá de acuerdo con los criterios legales que se establezcan para las referidas participaciones.

Artículo 50. La Comunidad Autónoma gallega gozará del tratamiento fiscal que la ley establezca para el Estado.

Artículo 51. Se regularán necesariamente mediante ley del Parlamento gallego las siguientes materias:

a. El establecimiento, la modificación y supresión de sus propios impuestos, tasas y contribuciones especiales y de las exenciones o bonificaciones que les afecten.

b. El establecimiento y la modificación y supresión de los recargos sobre los impuestos del Estado.

c. La emisión de deuda pública y demás operaciones de crédito concertadas por la Comunidad Autónoma gallega.

Artículo 52. Corresponde a la Xunta de Galicia:

a. Aprobar los reglamentos generales de sus propios tributos.

b. Elaborar las normas reglamentarias precisas para gestionar los impuestos estatales cedidos de acuerdo con los términos de dicha cesión.

Artículo 53. 1. Corresponde a la Xunta o Gobierno la elaboración y aplicación del presupuesto de la Comunidad Autónoma gallega, y al Parlamento su examen, enmienda, aprobación y control. El presupuesto será único e incluirá la totalidad de los gastos e ingresos de la Comunidad Autónoma gallega y de los organismos, instituciones y empresas de ella dependientes.

2. Sin perjuicio de lo dispuesto en el artículo 136 y en el apartado d) del artículo 153 de la Constitución, se crea el Consello 
de Contas de Galicia. Una ley de Galicia regulará su organización y funcionamiento y establecerá las garantías, normas y procedimientos para asegurar la rendición de las cuentas de la Comunidad Autónoma, que deberá someterse a la aprobación del Parlamento.

Artículo 54. 1. La gestión, recaudación, liquidación e inspección de sus propios tributos, corresponderá a la Comunidad Autónoma gallega, la cual dispondrá de plenas atribuciones para la ejecución y organización de dichas tareas, sin perjuicio de la colaboración que pueda establecerse con la Administración tributaria del Estado, especialmente cuando así lo exija la naturaleza del tributo.

2. En el caso de los impuestos cuyos rendimientos se hubiesen cedido, la Xunta asumirá por delegación del Estado la gestión, recaudación, liquidación e inspección de los mismos, sin perjuicio de la colaboración que pueda establecerse entre ambas Administraciones, todo ello de acuerdo con lo especificado en la ley que fije el alcance y condiciones de la cesión.

3. La gestión, recaudación, liquidación e inspección de los demás impuestos del Estado recaudados en Galicia corresponderá a la Administración tributaria del Estado, sin perjuicio de la delegación que la Comunidad Autónoma pueda recibir de éste y de la colaboración que pueda establecerse, especialmente cuando así lo exija la naturaleza del tributo.

Artículo 55. 1. La Comunidad Autónoma, de acuerdo con lo que establezcan las leyes del Estado, designará sus propios representantes en los organismos económicos, las instituciones financieras y las empresas públicas del Estado, cuya competencia se extienda al territorio gallego y que por su naturaleza no sean objeto de traspaso.

2. La Comunidad Autónoma podrá constituir empresas públicas como medio de ejecución de las funciones que sean de su competencia, según lo establecido en el presente Estatuto.

3. La Comunidad Autónoma, como poder público, podrá hacer uso de las facultades previstas en el apartado 1 del artículo 130 de la Constitución, y podrá fomentar, mediante una legislación adecuada, las sociedades cooperativas en los términos resultantes del número siete del artículo veintiocho del presente Estatuto. Asimismo, de acuerdo con la legislación del Estado en la materia, podrá hacerse uso de las demás facultades previstas en el apartado 2 del artículo 129 de la Constitución.

4. La Comunidad Autónoma gallega queda facultada para constituir instituciones que fomenten la plena ocupación y el desarrollo económico y social en el marco de sus competencias.

\section{TÍTULO V DE LA REFORMA}

Artículo 56. 1. La reforma del Estatuto se ajustará al siguiente procedimiento:

a. La iniciativa de la reforma corresponderá a la Xunta, al Parlamento gallego, a propuesta de una quinta parte de sus miembros, o a las Cortes Generales.

b. La propuesta de reforma requerirá, en todo caso, la aprobación del Parlamento gallego por mayoría de dos tercios, la aprobación de las Cortes Generales mediante ley orgánica $\mathrm{y}$, finalmente, el referéndum positivo de los electores.

2. Si la propuesta de reforma no es aprobada por el Parlamento gallego o por las Cortes Generales, o no es confirmada mediante referéndum por el cuerpo electoral, no podrá ser sometida nuevamente a debate y votación del Parlamento hasta que haya transcurrido un año.

3. La aprobación de la reforma por las Cortes Generales, mediante ley orgánica, incluirá la autorización del Estado para que la Comunidad Autónoma gallega convoque el referéndum a que se refiere el párrafo b) del apartado uno de este artículo. 
Artículo 57. No obstante lo dispuesto en el artículo anterior, cuando la reforma tuviera por objeto la simple alteración de la organización de los poderes de la Comunidad Autónoma y no afectara a las relaciones de la Comunidad Autónoma con el Estado, se podrá proceder de la siguiente manera:

a. Elaboración del proyecto de reforma por el Parlamento de Galicia.

b. Consulta a las Cortes Generales.

c. Si en el plazo de treinta días, a partir de la recepción de la consulta prevista en el apartado precedente, las Cortes Generales no se declarasen afectadas por la reforma, se convocará, debidamente autorizado, un referéndum sobre el texto propuesto.

d. Se requerirá finalmente la aprobación de las Cortes Generales mediante ley orgánica.

e. Si en el plazo señalado en la letra c) las Cortes se declarasen afectadas por la reforma, ésta habrá de seguir el procedimiento previsto en el artículo anterior, dándose por cumplidos los trámites del apartado a) del número uno del mencionado artículo.

\section{DISPOSICIÓN ADICIONAL PRIMERA}

1. Se cede a la Comunidad Autónoma de Galicia el rendimiento de los siguientes tributos:

a. Impuesto sobre la Renta de las Personas Físicas, con carácter parcial, con el límite del 33 por 100 .

b. Impuesto sobre el Patrimonio.

c. Impuesto sobre Sucesiones y Donaciones.

d. Impuesto sobre Transmisiones Patrimoniales y Actos Jurídicos Documentados.

e. Los Tributos sobre el Juego.

f. El Impuesto sobre el Valor Añadido, con carácter parcial, con el límite del 35 por 100.

g. El Impuesto Especial sobre la Cerveza, con carácter parcial, con el límite del 40 por 100 .

h. El Impuesto Especial sobre el Vino y Bebidas Fermentadas, con carácter parcial, con el límite del 40 por 100. i. El Impuesto Especial sobre Productos Intermedios, con carácter parcial, con el límite del 40 por 100.

j. El Impuesto Especial sobre el Alcohol y Bebidas Derivadas, con carácter parcial, con el límite del 40 por 100.

k. El Impuesto Especial sobre Hidrocarburos, con carácter parcial, con el límite del 40 por 100 .

1. El Impuesto Especial sobre las Labores del Tabaco, con carácter parcial, con el límite del 40 por 100 .

m. El Impuesto Especial sobre la Electricidad.

n. El Impuesto Especial sobre Determinados Medios de Transporte.

ñ. El Impuesto sobre las Ventas Minoristas de Determinados Hidrocarburos.

La eventual supresión o modificación por el Estado de alguno de los tributos antes señalados implicará la extinción o modificación de la cesión ${ }^{31}$.

2. El contenido de esta disposición se podrá modificar mediante acuerdo del Gobierno con la Comunidad Autónoma, que será tramitado por el Gobierno como proyecto de ley. A estos efectos, la modificación de la presente disposición no se considerará modificación del Estatuto.

3. El alcance y condiciones de la cesión se establecerán por la Comisión Mixta a que se refiere el apartado uno de la Disposición transitoria cuarta, que, en todo caso, los referirá a rendimientos en Galicia. El Gobierno tramitará el acuerdo de la Comisión como proyecto de ley, o si concurriesen razones de urgencia, como Decreto-ley, en el plazo de seis meses a partir de la constitución de la primera Xunta de Galicia.

\section{DISPOSICIÓN ADICIONAL SEGUNDA}

El ejercicio de las competencias financieras reconocidas por este Estatuto a la Comunidad Autónoma de Galicia se

31 Disposición adicional primera.1 modificada por Ley 18/2002, de 1 de julio, del régimen de cesión de tributos del Estado a la Comunidad Autónoma de Galicia y de fijación del alcance y condiciones de dicha cesión. 
ajustará a lo que establezca la ley orgánica a que se refiere el apartado 3 del artículo 157 de la Constitución.

\section{DISPOSICIÓN ADICIONAL TERCERA}

1. La Xunta coordinará la actividad de las Diputaciones Provinciales de Galicia en cuanto afecte directamente al interés general de la Comunidad Autónoma, y a estos efectos se unirán los presupuestos que aquéllas elaboren y aprueben al de la Xunta de Galicia.

2. La Xunta podrá encomendar la ejecución de sus acuerdos a las Diputaciones Provinciales. Éstas ejercerán las funciones que la Xunta les transfiera o delegue.

\section{DISPOSICIÓN ADICIONAL CUARTA}

La celebración de elecciones se atendrá a las leyes que, en su caso, aprueben las Cortes Generales con el exclusivo fin de coordinar el calendario de las diversas consultas electorales.

\section{DISPOSICIÓN TRANSITORIA PRIMERA}

El primer Parlamento gallego será elegido de acuerdo con las normas siguientes:

1. Previo acuerdo con el Gobierno, la Xunta preautonómica de Galicia convocará las elecciones en el término máximo de ciento veinte días desde la promulgación del presente Estatuto. Las elecciones deberán celebrarse en el término máximo de sesenta días a partir de la fecha de la convocatoria.

2. La circunscripción electoral será la provincia, eligiéndose un total de 71 miembros, de los que corresponderán a la provincia de La Coruña, 22; a la de Lugo, 15 ; a la de Orense, 15 , y a la de Pontevedra, 19.

3. Los miembros del Parlamento gallego serán elegidos por sufragio universal, igual, directo y secreto, de los mayores de dieciocho años, según un sistema de representación proporcional.

4. Las Juntas Provinciales electorales tendrán, dentro de los límites de su respectiva jurisdicción, la totalidad de las competencias que la normativa electoral vigente atribuye a la Junta Central.

Para los recursos que tuvieran por objeto la impugnación de la validez de la elección y proclamación de los miembros electos será competente la Sala de lo Contencioso-Administrativo de la Audiencia Territorial de La Coruña, hasta que quede integrada en el Tribunal Superior de Justicia de Galicia, que también entenderá de los recursos o impugnaciones que procedan contra los acuerdos de las Juntas electorales provinciales.

Contra las resoluciones de dicha Sala de la Audiencia Territorial, no cabrá recurso alguno.

5. En todo lo no previsto en la presente disposición, serán de aplicación las normas vigentes para las elecciones legislativas al Congreso de los Diputados de las Cortes Generales.

\section{DISPOSICIÓN TRANSITORIA SEGUNDA}

1. En su primera reunión, el Parlamento gallego:

a. Se constituirá, presidido por una Mesa de edad, integrada por un Presidente y dos Secretarios, y procederá a elegir la Mesa provisional, que estará compuesta por un Presidente, dos Vicepresidentes, un Secretario y un Vicesecretario.

b. Elegirá sus autoridades conforme a este Estatuto.

2. Elegidos los órganos de la Comunidad Autónoma gallega, se disolverán las instituciones preautonómicas.

\section{DISPOSICIÓN TRANSITORIA TERCERA}

Mientras las Cortes Generales no elaboren las leyes a que este Estatuto se refiere y el Parlamento de Galicia legisle sobre las materias de su competencia, continuarán en vigor las actuales leyes y disposiciones del Estado que se refieren a dichas materias, sin perjuicio de que su desarrollo legislativo, en su caso, y su ejecución, se 
lleve a cabo por la Comunidad Autónoma gallega en los supuestos así previstos en este Estatuto.

\section{DISPOSICIÓN TRANSITORIA CUARTA}

1. Con la finalidad de transferir a Galicia las funciones y atribuciones que le correspondan con arreglo al presente Estatuto, se creará, en el término máximo de un mes a partir de la constitución de la Xunta de Galicia, una Comisión Mixta paritaria integrada por representantes del Estado y de la Comunidad Autónoma gallega. Dicha Comisión Mixta establecerá sus normas de funcionamiento. Los miembros de la Comisión Mixta representantes de Galicia darán cuenta periódicamente de su gestión ante el Parlamento de Galicia.

La Comisión Mixta establecerá los calendarios y plazos para el traspaso de cada servicio. En todo caso, la referida Comisión deberá determinar en un plazo de dos años desde la fecha de su constitución, el término en que habrá de completarse el traspaso de todos los servicios que corresponden a la Comunidad Autónoma gallega, de acuerdo con este Estatuto.

2. Los acuerdos de la Comisión Mixta adoptarán la forma de propuestas al Gobierno, que las aprobará mediante Decreto, figurando aquéllos como anejos al mismo y serán publicados simultáneamente en el "Boletín Oficial del Estado" y en el "Diario Oficial de Galicia", adquiriendo vigencia a partir de esta publicación.

3. Será título suficiente para la inscripción en el Registro de la Propiedad del traspaso de bienes inmuebles del Estado a la Comunidad Autónoma la certificación por la Comisión Mixta de los acuerdos gubernamentales debidamente promulgados. Esta certificación deberá contener los requisitos exigidos por la Ley Hipotecaria. El cambio de titularidad en los contratos de arrendamiento de locales para oficinas públicas de los servicios que se transfieran no dará derecho al arrendador a extinguir o renovar el contrato.
4. Los funcionarios adscritos a servicios de titularidad estatal o a otras instituciones públicas que resulten afectadas por los traspasos a la Comunidad Autónoma pasarán a depender de ésta, siéndoles respetados todos los derechos de cualquier orden y naturaleza que les corresponda en el momento del traspaso, incluso el de participar en los concursos de traslado que convoque el Estado en igualdad de condiciones con los restantes miembros de su cuerpo, pudiendo ejercer de esta manera su derecho permanente de opción.

Mientras la Comunidad Autónoma de Galicia no apruebe el régimen estatutario de sus funcionarios serán de aplicación las disposiciones del Estado vigente sobre la materia.

5. La Comisión Mixta, creada de acuerdo con el Real Decreto 474/1978, de 16 de marzo, se considerará disuelta cuando se constituya la Comisión Mixta a que se refiere el apartado uno de la presente Disposición transitoria.

\section{DISPOSICIÓN TRANSITORIA QUUINTA}

1. Hasta que se haya completado el traspaso de los servicios correspondientes a las competencias fijadas a la Comunidad Autónoma en este Estatuto, el Estado garantizará la financiación de los servicios transferidos a la Comunidad con una cantidad igual al coste efectivo del servicio en Galicia en el momento de la transferencia.

2. Para garantizar la financiación de los servicios antes referidos la Comisión Mixta prevista en la Disposición transitoria cuarta adoptará un método encaminado a fijar el porcentaje de participación previsto en el apartado tres del artículo cuarenta y cuatro. El método a seguir tendrá en cuenta tanto los costes directos como los costes indirectos de los servicios, así como los gastos de inversión que correspondan.

3. Al fijar las transferencias para inversiones se tendrá en cuenta, en la forma progresiva que se acuerde, la conveniencia de equiparar los niveles de servicios en 
todo el territorio del Estado, estableciéndose, en su caso, las transferencias necesarias para el funcionamiento de los servicios.

La financiación a que se refiere este apartado tendrá en cuenta las aportaciones que se realicen a Galicia, partiendo del Fondo de Compensación a que se refiere el artículo 158 de la Constitución, así como la acción inversora del Estado en Galicia, que no sea aplicación de dicho Fondo.

4. La Comisión Mixta a que se refiere el apartado dos fijará el citado porcentaje, mientras dure el período transitorio, con una antelación mínima de un mes a la presentación de los Presupuestos Generales del Estado en las Cortes.

5. A partir del método fijado en el apartado dos, se establecerá un porcentaje en el que se considerará el coste efectivo global de los servicios transferidos por el Estado a la Comunidad Autónoma, minorado por el total de la recaudación obtenida por ésta por los tributos cedidos, en relación con la suma de los ingresos obtenidos por el Estado en los capítulos I y II del último presupuesto anterior a la transferencia de los servicios.

\section{DISPOSICIÓN TRANSITORIA SEXTA}

En lo relativo a televisión, la aplicación del apartado tres del artículo treinta y cuatro del presente Estatuto supone que el Estado otorgará en régimen de concesión a la Comunidad Autónoma de Galicia la utilización de un tercer canal, de titularidad estatal, que debe crearse específicamente para su emisión en el territorio de Galicia, en los términos que prevea la citada concesión.

Hasta la puesta en funcionamiento efectivo de este nuevo canal de televisión, Radiotelevisión Española (RTVE) articulará a través de su organización en Galicia un régimen transitorio de programación específica para el territorio de Galicia, que Televisión Española emitirá por la segunda cadena (UHF).

El coste de la programación específica de televisión a que se refiere el párrafo anterior, se entenderá como base para la determinación de la subvención que pudiera concederse a la Comunidad Autónoma de Galicia, durante los dos primeros años de funcionamiento del nuevo canal a que se refiere esta Disposición transitoria.

\section{DISPOSICIÓN TRANSITORIA SÉPTIMA}

Las transferencias que hayan de realizarse en materia de enseñanza para traspasar a la competencia de la Comunidad Autónoma los servicios y centros del Estado en Galicia, se realizarán de acuerdo con los calendarios y programas que defina la Comisión Mixta.

\section{LEY ORGÁNICA 16/1995,} DE 27 DE DICIEMBRE, DE TRANSFERENCIA DE

COMPETENCIAS A LA COMUNIDAD AUTÓNOMA GALLEGA

(BOE No. 310, 28. 12. 1995) 32

$(\ldots)^{33}$

\section{TÍTULO PRELIMINAR}

Artículo 1. Objeto de la ley.

La presente ley tiene por objeto transferir, de acuerdo con lo dispuesto en el artículo 150.2 de la Constitución, competencias de titularidad estatal a la Comunidad Autónoma gallega, en los términos recogidos en los artículos siguientes.

\section{TÍTULO PRIMERO TRANSFERENCIAS DE COMPETENCIAS}

\section{Capítulo primero \\ DE LAS COMPETENCIAS QUE SE TRANSFIEREN}

Artículo 2. Transferencia de competencias exclusivas.

Se transfiere a la Comunidad Autónoma de Galicia la competencia exclusiva en las siguientes materias:

a. Cooperativas y mutuas no integradas en el sistema de Seguridad Social, respetando la legislación mercantil.

\footnotetext{
32 Véase Ley Orgánica 9/1992, de 23 de diciembre, de transferencia de competencias a Comunidades Autónomas que accedieron a la autonomía por la vía del artículo 143 de la Constitución.

33 Exposición de motivos omitida.
}

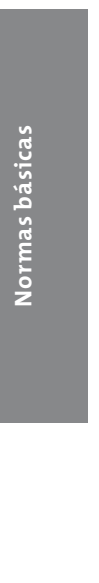


b. Espectáculos públicos.

c. Transporte marítimo, que se lleve a cabo exclusivamente entre puertos o puntos de la Comunidad Autónoma, sin conexión con otros puertos o puntos de otros ámbitos territoriales.

Artículo 3. Transferencia de competencias de desarrollo legislativo y ejecución.

Se transfiere a la Comunidad Autónoma gallega, en el marco de la legislación básica del Estado, el desarrollo legislativo y la ejecución en materia de Corporaciones de derecho público representativas de intereses económicos y profesionales.

Artículo 4. Transferencia de competencias de ejecución.

Se transfiere a la Comunidad Autónoma de Galicia la competencia de ejecución de la legislación del Estado en materia de asociaciones.

\section{Capítulo II \\ DE LA DELIMITACIÓN, CONTENIDO Y CONDICIONES DE EJERCICIO DE LAS COMPETENCIAS}

Artículo 5. Competencia sobre espectáculos públicos.

1. De conformidad con lo dispuesto en el número 29 del apartado uno del artículo 149 de la Constitución, el contenido de la competencia sobre espectáculos públicos se entiende sin perjuicio de la competencia estatal sobre seguridad pública.

2. Queda reservada al Estado la facultad de dictar normas que regulen los espectáculos taurinos.

Artículo 6. Competencia sobre transporte marítimo que se lleve a cabo exclusivamente entre puertos o puntos de la Comunidad Autónoma, sin conexión con otros puertos o puntos de otros ámbitos territoriales.

El ejercicio de la competencia sobre transporte marítimo, que se lleve a cabo exclusivamente entre puertos o puntos de la Comunidad Autónoma, sin conexión con otros puertos o puntos de otros ámbitos territoriales se ajustará, en todo caso, a lo dispuesto por el Estado en el ejercicio de sus competencias, de acuerdo con el número 20 del apartado uno del artículo 149 de la Constitución.

\section{TÍTULO II MODALIDADES DE CONTROL}

Artículo 7. Modalidades de control. La Comunidad Autónoma de Galicia adaptará el ejercicio de las competencias transferidas por la presente ley orgánica a los siguientes principios y controles:

a. La Comunidad Autónoma de Galicia facilitará a la Administración del Estado la información que ésta solicite sobre las materias correspondientes.

b. Las facultades y servicios transferidos mantendrán, como mínimo, el nivel de eficacia que tengan en el momento de la transferencia.

c. En caso de incumplimiento de los requisitos anteriores, el Gobierno requerirá formalmente al respecto a la Comunidad Autónoma y, si persistiere el incumplimiento, podrá suspender a partir de los tres meses las facultades y servicios, dando cuenta de ello a las Cortes Generales, quienes resolverán sobre la procedencia de la decisión del Gobierno, levantando la suspensión o acordando la revocación del ejercicio de la facultad transferida.

\section{TÍTULO III TRASPASO DE SERVICIOS}

Artículo 8. Traspaso de servicios.

Cuando para el ejercicio de las competencias transferidas sea necesario efectuar traspaso de servicios, las Comisiones Mixtas precisarán los medios materiales y financieros, las funciones comprendidas en los ámbitos de la respectiva competencia y, en su caso, concretarán cuáles de estas funciones se llevarán a cabo a través de los órganos de cooperación, o se ajustarán en su ejercicio a planes o programas de carácter general. 


\section{DISPOSICIÓN FINAL ÚNICA}

La presente ley orgánica entrará en vigor el día siguiente al de su publicación en el "Boletín Oficial del Estado".

3. LEY ORGÁNICA 6/1999, DE 6 DE ABRIL, DE TRANSFERENCIA DE COMPETENCIAS A LA COMUNIDAD AUTÓNOMA DE GALICIA (BOE N. 84, 8. 4. 1999)

\section{$(\ldots)^{34}$}

Artículo 1. Objeto de la ley.

La presente ley tiene por objeto transferir, de acuerdo con lo dispuesto en el artículo 150.2 de la Constitución, competencias de titularidad estatal a la Comunidad Autónoma gallega, en los términos recogidos en los artículos siguientes.

Artículo 2. De la competencia que se transfiere.

Se transfiere a la Comunidad Autónoma gallega la competencia de desarrollo legislativo y ejecución en materia de ordenación del crédito, banca y seguros.

Artículo 3. De la delimitación, contenido y condiciones de ejercicio de la competencia.

El ejercicio de la competencia que se transfiere se realizará de acuerdo con la ordenación de la actividad económica general y se ajustará a lo dispuesto por el Estado en el ejercicio de sus competencias, de conformidad con el artículo 149.1.11. ${ }^{a}$ de la Constitución.

Artículo 4. Modalidades de control. La Comunidad Autónoma de Galicia adaptará el ejercicio de las competencias transferidas por la presente ley orgánica a los siguientes principios y controles: a. La Comunidad Autónoma de Galicia facilitará a la Administración del Estado la información que ésta solicite sobre las materias correspondientes.

b. Las facultades y servicios transferidos mantendrán, como mínimo, el nivel de eficacia que tengan en el momento de la transferencia.

c. En caso de incumplimiento de los requisitos anteriores, el Gobierno requerirá formalmente al respecto a la Comunidad Autónoma y, si persistiere el incumplimiento, podrá suspender a partir de los tres meses las facultades y servicios, dando cuenta de ello a las Cortes Generales, quienes resolverán sobre la procedencia de la decisión del Gobierno, levantando la suspensión o acordando la revocación del ejercicio de la facultad transferida.

Artículo 5. Traspaso de servicios. Cuando para el ejercicio de las competencias transferidas sea necesario efectuar traspaso de servicios, las Comisiones Mixtas precisarán los medios materiales, personales y financieros que comporten el coste real del servicio a transferir, las funciones comprendidas en los ámbitos de la respectiva competencia y, en su caso, concretarán cuáles de estas funciones se llevarán a cabo a través de los órganos de cooperación, o se ajustarán en su ejercicio a planes o programas de carácter general.

\section{DISPOSICIÓN FINAL ÚNICA ENTRADA EN VIGOR}

La presente ley orgánica entrará en vigor el día siguiente al de su publicación en el "Boletín Oficial del Estado".

34 Exposición de motivos omitida. 


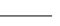




\section{AUTOGOBIERNO Y ORGANIZACIÓN}

\section{LEY 1/1983, DE 22 DE FEBRERO, REGULADORA DE LA XUNTA Y SU PRESIDENCIA $(\text { DOGA No. 23, 21. 3. 1983) })^{35}$}

\author{
$(\ldots)^{36}$ \\ TÍTULO I \\ DE LA XUNTA

\section{Capítulo I \\ DE LA NATURALEZA Y COMPOSICIÓN DE LA XUNTA37}

Artículo 1. La Xunta es el órgano colegiado que, bajo la dirección del Presidente, dirige la política general y la Administración

35 Titulo modificado por Ley $2 / 2007$, de 28 de marzo, del trabajo en igualdad de las mujeres de Galicia.

36 Exposición de motivos omitida.

37 Véase:

- Decreto 324/2009, de 11 de junio, por el que se establece la estructura orgánica de la Conselleria de Economia e Industria.

- Decreto 325/2009, de 18 de junio, de estructura orgánica de los órganos superiores dependientes de la Presidencia de la Xunta de Galicia.

- Decreto 332/2009, de 11 de junio, por el que se establece la estructura orgánica de la Consellería de Educación y Ordenación Universitaria.

- Decreto 335/2009, de 11 de junio, por el que se establece la estructura orgánica de la Conselleria de Trabajo y Bienestar. - Decreto 337/2009, de 11 de junio, por el que se desarrolla la estructura orgánica de la Conselleria de Cultura y Turismo.

- Decreto 318/2009, de 4 de junio, por el que se establece la estructura orgánica de la Consellería del Medio Rural y del Fondo Gallego de Garantía Agraria.

- Decreto 316/2009, de 4 de junio, por el que se establece la estructura orgánica de la Consellería de Medio Ambiente, Territorio e Infraestructuras.

- Decreto 317/2009, de 4 de junio, por el que se establece la estructura orgánica del Instituto Gallego de la Vivienda y Suelo.

- Orden de 2 de junio de 2009 por la que se determina la adscripción de los órganos dependientes de la suprimida Dirección General de Promoción Industrial y Sociedad de la Información, como consecuencia de la entrada en vigor de los decretos 82 y $83 / 2009$, de 21 de abril, por los que se establecen los centros directivos dependientes de la Presidencia de la Xunta de Galicia, y se fija la estructura orgánica de los departamentos de la Xunta de Galicia, respectivamente.

- Decreto 310/2009, de 28 de mayo, por el que se establece la estructura orgánica de la Consellería de Sanidad.

- Decreto 311/2009, de 28 de mayo, por el que se establece la estructura orgánica de los servicios centrales del Servicio Gallego de Salud.

- Decreto 312/2009, de 28 de mayo, por el que se establece la estructura orgánica de la Conselleria del Mar. de la Comunidad Autónoma. A tal fin, ejerce la iniciativa legislativa, la función ejecutiva y la potestad reglamentaria de

- Decreto 307/2009, de 28 de mayo, por el que se establece la estructura orgánica de la Consellería de Hacienda. - Orden de 28 de mayo de 2009 sobre adscripción de órganos como consecuencia de la entrada en vigor de los decretos 82 y $83 / 2009$, de 21 de abril, por los que se establecen los centros directivos dependientes de la Presidencia de la Xunta de Galicia, y se fija la estructura orgánica de los departamentos de la Xunta de Galicia, respectivamente.

- Decreto 303/2009, de 21 de mayo, por el que se establece la estructura orgánica de la Conselleria de Presidencia, Administraciones Públicas y Justicia.

- Orden de 11 de mayo de 2009 sobre adscripción de órganos y delegación de competencias como consecuencia de la entrada en vigor del Decreto 83/2009, de 21 de abril, por el que se fija la estructura orgánica de los departamentos de la Xunta de Galicia.

- Orden de 14 de mayo de 2009 por la que se determina la adscripción de los órganos dependientes de la suprimida Secretaria General de Análisis y Proyección a la Secretaria General de la Presidencia.

- Orden de 8 de mayo de 2009 por la que se determina la adscripción de los órganos dependientes de los centros directivos suprimidos como consecuencia de la entrada en vigor de los decretos 82 y 83/2009, de 21 de abril, por los que se establecen los centros directivos dependientes de la Presidencia de la Xunta de Galicia, y se fija la estructura orgánica de los departamentos de la Xunta de Galicia, respectivamente.

- Orden de 4 de mayo de 2009 sobre adscripción de los órganos suprimidos y atribución de competencias en los órganos superiores de la Conselleria de Trabajo y Bienestar.

- Orden de 30 de abril de 2009 por la que se determina la adscripción de los órganos suprimidos como consecuencia de la entrada en vigor del Decreto 83/2009, de 21 de abril, por el que se fija la estructura orgánica de los departamentos de la Xunta de Galicia.

- Decreto 245/2009, de 30 de abril, por el que se regulan las delegaciones territoriales de la Xunta de Galicia.

- Orden de 24 de abril de 2009 por la que se determina la adscripción de los órganos suprimidos como consecuencia de la entrada en vigor del Decreto 83/2009, de 21 de abril, por el que se fija la estructura orgánica de los departamentos de la Xunta de Galicia, y se encarga el despacho de los asuntos de diversos órganos de la consellería.

- Decreto 82/2009, de 21 de abril, por el que se establecen los centros directivos dependientes de la Presidencia de la Xunta de Galicia.

- Decreto 83/2009, de 21 de abril, por el que se fija la estructura orgánica de los departamentos de la Xunta de Galicia. - Decreto 79/2009, de 19 de abril, por el que se establece la estructura orgánica de la Xunta de Galicia.

- Orden de 3 de julio de 2009 por la que se da publicidad al acuerdo del Consello de la Xunta de Galicia de 2 de julio de 2009 , por el que se crea la comisión de estudio de las vigentes asistencias técnicas, contratos de servicio, consultorias y encomiendas de gestión por las que se prestan servicios a los distintos centros directivos de la Xunta de Galicia). 
conformidad con el Estatuto de Autonomía y las Leyes ${ }^{38}$.

Artículo 2. La Xunta de Galicia está compuesta por el Presidente, Vicepresidente o Vicepresidentes - en su caso-y los Conselleiros.

En el supuesto de que haya varios Vicepresidentes, uno de ellos tendrá la condición de Vicepresidente primero con las facultades que esta ley le atribuye.

Todos ellos constituyen conjunta y colegiadamente el Consello, que ejercerá, conforme a lo establecido en esta ley, las atribuciones de la Xunta, sin perjuicio de las competencias de las Comisiones Delegadas.

En la composición de la Xunta deberá respetarse el principio de equilibrio por sexos, en una proporción entre cada uno de ellos que ha de concretar el Parlamento al inicio de cada legislatura ${ }^{39}$.

Artículo 3. La Xunta de Galicia responde políticamente ante el Parlamento de forma solidaria, sin perjuicio de la responsabilidad directa de cada uno de sus componentes por su gestión.

\section{Capitulo II \\ DE LAS ATRIBUCIONES DE LA XUNTA}

Artículo 4. Corresponde a la Xunta:

1. Establecer las directrices y desarrollar el Programa de gobierno.

2. Elaborar los presupuestos de la Comunidad Autónoma, remitirlo al Parlamento para su aprobación.

3. Aprobar los Proyectos de Ley para su remisión al Parlamento y acordar en su caso su retirada.

4. Dictar Decretos Legislativos en los supuestos de delegación expresa del Parlamento.

5. Otorgar o denegar su conformidad a la tramitación de proposiciones de ley que

38 Art. 1 modificado por Ley $11 / 1988$, de 20 de octubre, de reforma de la Ley 1/1983, de 22 de febrero, reguladora de la Xunta y de su Presidente.

39 Cuarto párrafo del art. 2 añadido por Ley $2 / 2007$, de 28 de marzo, del trabajo en igualdad de las mujeres de Galicia.

supongan aumento de los créditos o disminución de los ingresos presupuestarios, en los términos previstos en el Reglamento del Parlamento.

6. Aprobar los reglamentos para el desarrollo y ejecución de las leyes de Galicia así como los de las leyes del Estado, cuando la competencia de ejecución corresponda a la Comunidad Autónoma en virtud del Estatuto de Autonomía o por delegación o transferencia.

7. Adoptar, en su caso, las medidas reglamentarias que requiriese la ejecución de los tratados y convenios internacionales y el cumplimiento de los Reglamentos y directrices derivadas de aquéllos, en lo que afecte a materias atribuidas a la competencia de la Comunidad Autónoma.

8. Aprobar y remitir al Parlamento los proyectos de convenios y acuerdos de cooperación con otras Comunidades Autónomas para la ratificación o aprobación, en su caso ${ }^{40}$.

9. Acordar la interposición de recursos de inconstitucionalidad, así como el personarse en las cuestiones de inconstitucionalidad que afecten a Galicia y el planteamiento de conflictos de competencias ante el Tribunal Constitucional.

10. Deliberar sobre la cuestión de confianza que el Presidente de la Xunta proponga plantear al Parlamento, así como sobre la disolución de la Cámara, que el Presidente puede decretar, al amparo del artículo 24 de la presente ley ${ }^{41}$.

11. Resolver los recursos en vía administrativa en los casos previstos por las leyes.

12. Resolver mediante Decreto los conflictos de atribuciones que se susciten entre las diversas consellerías.

13. Nombrar y destituir, a propuesta de quien ostente la titularidad de las consejerías respectivas, a los altos cargos de la

\section{Véase:}

- Art. 35.1 del Estatuto de Autonomía.

- Decreto 126/2006, de 20 de julio, por el que se regula el registro de convenios de la Xunta de Galicia.

41 Art. 4.10 modificado por Ley $11 / 1988$, de 20 de octubre, de reforma de la Ley $1 / 1983$, de 22 de febrero, reguladora de la Xunta y de su Presidente. 
Administración pública gallega de rango igual o superior a dirección general, así como a aquellos otros que legalmente se establezca. En los nombramientos se atenderá al principio de equilibrio por sexos, de acuerdo con los porcentajes y estructura que determine la propia Xunta ${ }^{42}$.

14. Crear, modificar y suprimir las Comisiones Delegadas de la Xunta.

15. Determinar la estructura orgánica superior de la Vicepresidencia o Vicepresidencias y de las consellerías de la Xunta de Galicia.

16. Designar a los representantes de la Comunidad Autónoma en los organismos económicos, instituciones financieras y empresas públicas del Estado a que se refiere el artículo 55 del Estatuto de Autonomía. Del mismo modo, supervisar, de acuerdo con la Ley, la gestión de los servicios públicos y de los entes y empresas públicas dependientes de la Comunidad Autónoma, y administrar el patrimonio de la misma con sujeción a lo dispuesto en la Ley ${ }^{43}$.

17. Coordinar la actividad de las Diputaciones Provinciales, en cuanto afecte directamente al interés general de la Comunidad Autónoma, y acordar la transferencia o delegación de funciones en las mismas. Del ejercicio de estas competencias se dará cuenta al Parlamento.

18. Tomar conocimiento de las resoluciones del Parlamento y adoptar, en su caso, las medidas que proceden ${ }^{44}$.

19. Garantizar y promover la aplicación del principio de igualdad por razón de sexo en todas las políticas que corresponda desarrollar a la Xunta de Galicia ${ }^{45}$.

20. Cualquier otra atribución que le venga conferida por alguna disposición legal o reglamentaria y, en general, deliberar

42 Art. 4.13 modificado por Ley 2/2007, de 28 de marzo, del trabajo en igualdad de las mujeres de Galicia.

43 Art. 4.14 , art. 4.15 y art. 4.16 . Ley $11 / 1988$, de 20 de octubre, de reforma de la Ley $1 / 1983$, de 22 de febrero, reguladora de la Xunta y de su Presidente.

44 Art. 4.18 modificado por Ley 11/1988, de 20 de octubre, de reforma de la Ley $1 / 1983$, de 22 de febrero, reguladora de la Xunta y de su Presidente.

45 Art. 4.19 modificado por Ley $2 / 2007$, de 28 de marzo, del trabajo en igualdad de las mujeres de Galicia. acerca de aquellos asuntos cuya resolución deba revestir la forma de Decreto o que, por su importancia y repercusión en la vida de la Comunidad Autónoma, exijan el conocimiento o deliberación de la Xunta ${ }^{46}$.

\section{Capitulo III DEL FUNCIONAMIENTO DE LA XUNTA}

Artículo 5. La Xunta se reúne en Consello, que someterá su funcionamiento a los principios de unidad, colegialidad, participación y coordinación.

Artículo 6. Las atribuciones de la Xunta serán ejercidas por el Consello. El Consello designará de entre sus miembros un Secretario que dará fe de sus acuerdos y de los de las Comisiones Delegadas y librará, cuando proceda, certificación de los mismos ${ }^{47}$.

Artículo 7. 1. El Consello será convocado por el Presidente de la Xunta. A la convocatoria se adjuntará el orden del día, que será conformado por el Secretario de acuerdo con las instrucciones del Presidente.

2. El Consello se entenderá válidamente constituido cuando asista el Presidente, o quien lo sustituya, y, al menos, la mitad de sus miembros.

3. Los miembros del Consello están obligados a guardar secreto sobre las deliberaciones de aquél, las opiniones y, en su caso, los votos emitidos ${ }^{48}$.

Artículo 8. La Xunta podrá crear en su seno Comisiones Delegadas para coordinar la elaboración de directrices y disposiciones, programar la política sectorial, examinar asuntos de interés interdepartamental y preparar las reuniones del Consello.

46 Antiguo art. 4.18 convertido en art. 4.19 por Ley $11 / 1988$, de 20 de octubre, de reforma de la Ley $1 / 1983$, de 22 de febrero, reguladora de la Xunta y de su Presidente, y transformado en art. 4.20 por la Ley 2/2007, de 28 de marzo, de trabajo en igualdad de las mujeres de Galicia. 47 Art. 6 modificado por Ley 11/1988, de 20 de octubre, de reforma de la Ley 1/1983, de 22 de febrero, reguladora de la Xunta y de su Presidente.

48 Art. 7 modificado por Ley 11/1988, de 20 de octubre, de reforma de la Ley 1/1983, de 22 de febrero, reguladora de la Xunta y de su Presidente. 
El régimen general de funcionamiento de las Comisiones, habrá de ajustarse a los criterios establecidos en esta ley para el Consello.

En todo caso el Decreto de creación de una Comisión Delegada deberá contener la composición y Presidencia de la misma y las competencias asignadas.

Artículo 9. El Consello establecerá las normas internas que se precisen para el buen orden de sus trabajos y para la adecuada preparación de los acuerdos que hayan de adoptarse, mediante un Reglamento de Régimen Interior que habrá de ajustarse a los términos de la presente ley ${ }^{49}$.

\section{TÍTULO II DEL PRESIDENTE DE LA XUNTA \\ Capitulo I \\ DEL ESTATUTO PERSONAL, ELECCIÓN Y CESE \\ Sección 1. ${ }^{a}$ \\ Del Estatuto Personal}

Artículo 10. El Presidente de la Xunta ostenta la suprema representación de la Comunidad Autónoma y la ordinaria del Estado en Galicia. Dirige y coordina la acción de la Xunta o Gobierno.

Artículo 11. El Presidente de la Xunta en razón de su cargo tiene derecho a:

1. La preeminencia que, con arreglo a la alta representación de la Comunidad Autónoma y a la ordinaria del Estado en Galicia, le corresponde.

2. Que le sean rendidos los honores que le correspondan con arreglo a lo que se establece en la legalidad vigente y lo que acuerde la Comunidad Autónoma.

3. Recibir el tratamiento de Excelencia.

4. Utilizar la bandera de Galicia como guión.

5. Ocupar la residencia oficial que se establezca, con la correspondiente dotación de personal y servicios.

6. Percibir la remuneración y gastos de representación que se establezcan por el Parlamento de Galicia y figuren en los

49 Véase Decreto 111/1984, de 25 de mayo, Reglamento de régimen interior de la Xunta de Galicia.
Presupuestos Generales de la Comunidad Autónoma.

7. Recibir con carácter vitalicio el tratamiento de excelentísimo señor y los honores protocolarios y las precedencias establecidas en la legislación vigente y en la que, en su caso, dicte la Comunidad Autónoma.

Las ex presidentas y ex presidentes tendrán derecho a percibir, durante dos años desde la fecha de su cese, las compensaciones económicas que se establezcan por decreto de la Xunta de Galicia.

Asimismo, tendrán derecho por un periodo de cuatro años adicionales, si tuvieron la condición de presidenta o presidente durante cuatro o menos años, o por un periodo de diez años adicionales, si tuvieron la condición de presidenta o presidente durante más de cuatro años, a los medios y servicios que se establezcan por decreto de la Xunta. Este derecho será incompatible con la condición de miembro nato del Consejo Consultivo de Galicia o con el ejercicio de un cargo público que otorgue una prestación de medios y servicios de análoga naturaleza.

No obstante, la Xunta de Galicia podrá prestar a las ex presidentas y ex presidentes los medios materiales de apoyo precisos para el ejercicio de las funciones inherentes a su condición por un periodo de tiempo superior a lo establecido en el párrafo anterior 5051 .

Artículo 12. El Presidente de la Xunta no podrá ejercer ninguna función pública que no se derive de su cargo, ni actividad o mercantil profesional o cualesquiera otras que pudiesen menoscabar la independencia y dignidad de su función 52 .

\footnotetext{
50 Párrafo segundo del art. 11.7 modificado y párrafo tercero y cuarto añadidos por Ley 12/2007, de 27 de julio, por la que se modifica la Ley $9 / 1995$, de 10 de noviembre, del Consejo Consultivo de Galicia, y la Ley $1 / 1983$, de 22 de febrero, de normas reguladoras de la Xunta y de su Presidencia.

51 Decreto 211/2007, de 25 de octubre, por el que se establecen las percepciones, medios y recursos asignados y preferencias que les correspondan a las expresidentas y ex-presidentes de la Xunta de Galicia. 52 Véase Ley 9/1996, de 18 de octubre, de incompatibilidades de los miembros de la Xunta de Galicia y altos cargos de la Administración Autonómica.
} 
En cuanto a las funciones representativas propias del mandato parlamentario, habrá que atenerse a lo dispuesto en el artículo 6 de la ley de Galicia 8/1985, de 13 de agosto, de elecciones al Parlamento de Galicia ${ }^{53}$.

Artículo 13. La responsabilidad política del Presidente de la Xunta ante el Parlamento será exigible en los términos establecidos en el Estatuto de Autonomía, en el Reglamento de la Cámara y en la presente ley.

Artículo 14. Durante su mandato y por los actos delictivos cometidos en el territorio de Galicia no podrá ser detenido ni retenido sino en caso de flagrante delito correspondiendo decidir, en todo caso, sobre su inculpación, prisión, procesamiento y juicio al Tribunal Superior de Justicia de Galicia. Fuera de dicho territorio la responsabilidad penal será exigible en los mismos términos ante la Sala de lo Penal del Tribunal Supremo.

\section{Sección 2. \\ De la elección y cese}

Artículo 15. El Presidente de la Xunta será elegido por el Parlamento Gallego de entre sus miembros.

Artículo 16. Constituido el Parlamento y en los demás supuestos en que así proceda, su Presidente, previa consulta con las fuerzas políticas representadas parlamentariamente y oída la mesa, propondrá un candidato a la Presidencia de la Xunta, conforme a lo previsto en el artículo 136.1 del Reglamento del Parlamento de Galicia.

Artículo 17. El candidato presentará su Programa al Parlamento. Para ser elegido el candidato deberá en primera votación obtener mayoría absoluta; de no obtenerla se procederá a una nueva votación 24 horas después de la anterior, y la confianza se entenderá otorgada si obtuviera mayoría

53 Art. 12 modificado por Ley 11/1988, de 20 de octubre, de reforma de la Ley $1 / 1983$, de 22 de febrero, reguladora de la Xunta y de su Presidente. simple. Caso de no conseguir dicha mayoría, se tramitarán sucesivas propuestas en la forma prevista anteriormente.

Si transcurrieran dos meses a partir de la primera votación de investidura sin que ningún candidato propuesto hubiere obtenido la confianza del Parlamento, éste quedará disuelto y se procederá a la convocatoria de nuevas elecciones.

Artículo 18. Si el Parlamento otorga su confianza al candidato, el Presidente lo comunicará al Rey para su nombramiento, mediante Real Decreto que se publicará en el "Boletín Oficial del Estado" y en el "Diario Oficial de Galicia".

Artículo 19. El Presidente elegido tomará posesión de su cargo dentro de los cinco días siguientes al de la publicación de su nombramiento.

Artículo 20. El Presidente prestará juramento en su toma de posesión con la siguiente fórmula:

"Juro o prometo ser fiel a mi mandato como Presidente de la Xunta, observar y hacer cumplir la Constitución y el Estatuto de Autonomía y las demás leyes de Galicia y del Estado y ejercitar mis funciones en el interés supremo y exclusivo de Galicia y de España”.

Artículo 21. El Presidente de la Xunta cesa tras la celebración de elecciones autonómicas, en los casos de pérdida de confianza parlamentaria o por dimisión, fallecimiento o incapacidad para el ejercicio del cargo. Corresponde al Parlamento la apreciación de la incapacidad del Presidente.

Artículo 22. En los supuestos de fallecimiento e incapacidad del Presidente, será sustituido por los Vicepresidentes si los hubiere por su orden, y en su defecto por el Conselleiro que más tiempo lleve perteneciendo ininterrumpidamente a la Xunta y, en caso de igualdad, el de más edad. El mismo orden de sustitución se observará en los casos de ausencia o enfermedad temporal del Presidente de la Xunta, salvo designación expresa del mismo. 
La sustitución habrá de publicarse en el "Diario Oficial de Galicia".

Artículo 23. En los demás casos previstos en el artículo 20 el Presidente continuará el ejercicio de sus funciones hasta la toma de posesión del nuevo Presidente de la Xunta.

\section{Capítulo II DE LAS ATRIBUCIONES}

Artículo 24. Al Presidente de la Xunta, como supremo representante de la Comunidad Autónoma, le compete representar a ésta en las relaciones con otras instituciones del Estado, suscribir los convenios y acuerdos de cooperación con otras Comunidades Autónomas, convocar elecciones al Parlamento de Galicia tras su disolución, promulgar en nombre del Rey las Leyes de Galicia, así como, en su caso, los Decretos Legislativos y ordenar su publicación en el "Diario Oficial de Galicia".

El Presidente, bajo su exclusiva responsabilidad y previa deliberación del Consello de la Xunta, podrá disolver el Parlamento mediante Decreto que fijará la fecha de las elecciones.

Esta facultad en todo caso no se podrá ejercer cuando no hubiese transcurrido al menos un año desde la última disolución de la Cámara ${ }^{54}$.

Artículo 25. Como representante ordinario del Estado en Galicia, corresponde al Presidente de la Xunta mantener relaciones con la Delegación del Gobierno a los efectos de una mejor coordinación de las actividades del Estado en Galicia y las de la Comunidad Autónoma, ordenar la publicación en el "Diario Oficial de Galicia" del nombramiento del Presidente del Tribunal Superior de Justicia, y la de las Leyes y Decretos Legislativos de Galicia en el "Boletín Oficial del Estado".

Artículo 26. Para la dirección y coordinación de las actividades de la Xunta le corresponde:

54 Art. 24 modificado por Ley 11/1988, de 20 de octubre, de reforma de la Ley $1 / 1983$, de 22 de febrero, reguladora de la Xunta y de su Presidente.
1. Crear, modificar o suprimir mediante Decreto la Vicepresidencia o Vicepresidencias, si las hubiere, y las consellerías, siempre que no suponga aumento de gasto público, así como nombrar y disponer el cese de los Vicepresidentes y Conselleiros ${ }^{55}$.

2. Convocar, presidir, suspender y levantar las reuniones del Consello y de las Comisiones Delegadas, así como dirigir sus deliberaciones.

3. Dirigir y coordinar la acción de Gobierno y asegurar su continuidad.

4. Velar por el cumplimiento de las directrices señaladas por la Xunta y promover o coordinar la ejecución de los acuerdos del Consello y de sus Comisiones Delegadas.

5. Asegurar la coordinación entre las distintas consellerías.

6. Coordinar el programa legislativo de la Xunta y la elaboración de normas de carácter general.

7. Encomendar a un Vicepresidente o a un Conselleiro que se encargue del despacho de una Consellería o de la propia Presidencia, en caso de ausencia, enfermedad o impedimento del titular.

8. Plantear ante el Parlamento, previa deliberación del Consello, la cuestión de confianza.

9. Presentar al Parlamento los proyectos de Ley, por sí mismo o a través del miembro de la Xunta designado.

10. Facilitar al Parlamento la información y documentación que éste recabe de la Xunta.

11. Solicitar que el Parlamento se reúna en sesión extraordinaria.

12. Solicitar que se celebre un debate general en el Parlamento.

13. Comunicar al Parlamento la interposición de recursos de inconstitucionalidad y el planteamiento de conflictos de competencias ante el Tribunal Constitucional, así como el acuerdo de la Xunta

55 Art. 26.1 modificado por Ley $11 / 1988$, de 20 de octubre, de reforma de la Ley $1 / 1983$, de 22 de febrero, reguladora de la Xunta y de su Presidente. 
de personarse en los recursos y en las cuestiones de inconstitucionalidad que afecten a Galicia.

14. Ejercer cuantas facultades y atribuciones le correspondan con arreglo a las disposiciones vigentes.

\section{TÍTULO III DE LOS MIEMBROS DE LA XUNTA Capítulo I DEL ESTATUTO PERSONAL, NOMBRAMIENTO Y CESE}

Artículo 27. 1. El Vicepresidente o Vicepresidentes, si los hubiere, y los Conselleiros serán nombrados y cesados por el Presidente de la Xunta, a tenor de lo dispuesto en el artículo 26, y tendrán la alta consideración que corresponde a su condición de miembros del Gobierno autónomo y el tratamiento de excelentísimo señor.

2. Los ex-Vicepresidentes y los exConselleiros mantendrán el tratamiento de excelentísimo señor y recibirán los honores protocolarios que establezca la legislación vigente y la que dicte la Comunidad Autónoma ${ }^{56}$.

Artículo 28. El Vicepresidente o Vicepresidentes, si los hubiere, y los Conselleiros prestarán juramento en su toma de posesión con la misma fórmula prevista en esta ley para el Presidente de la Xunta.

Artículo 29. El cese del Presidente de la Xunta comporta el de todos los miembros de la misma. La Xunta cesante continuará en funciones hasta la toma de posesión de la nueva Xunta.

Artículo 30. Los miembros de la Xunta percibirán la remuneración y gastos de representación que se establezcan por el Parlamento de Galicia y figuren en los Presupuestos Generales de la Comunidad Autónoma.

Artículo 31. El Vicepresidente o Vicepresidentes, si los hubiere, y los

56 Art. 27 modificado por Ley 11/1988, de 20 de octubre, de reforma de la Ley 1/1983, de 22 de febrero, reguladora de la Xunta y de su Presidente.
Conselleiros, no podrán ejercer otras funciones representativas que las propias del mandato parlamentario o, en su caso, del Senado, ni cualquier otra función pública que no derive de su cargo, ni actividad mercantil o profesional $u$ otra que menoscabe la independencia y dignidad de su función ${ }^{57}$.

Artículo 32. En cuanto a la inmunidad se estará a lo dispuesto en el artículo 13 para el Presidente.

\section{Capitulo II \\ DE LAS ATRIBUCIONES}

Artículo 33. El Vicepresidente, o en su caso, el Vicepresidente primero, además de sustituir al Presidente en los supuestos previstos en esta ley ejercerá las funciones que aquél les delegue dentro del ámbito que le confieran las disposiciones de la presente ley.

Asimismo podrán designarse en el seno de la Xunta otros Vicepresidentes encargados de áreas homogéneas con las funciones que le sean asignadas.

Artículo 34. Los conselleiros como jefes de sus consellerías están investidos de las siguientes atribuciones:

1. Ostentar la representación del Departamento de que son titulares.

2. Proponer al Consello los nombramientos y ceses de los cargos de su Consellería que requieran la forma de Decretos para su designación.

3. Ejercer la iniciativa, dirección e inspección de todos los servicios de la Consellería y la alta inspección y demás funciones que les correspondan respecto de los organismos autónomos adscritos a la misma.

4. Proponer para su aprobación por el Consello la estructuración y organización de su Consellería.

5. Proponer al lonsello los proyectos de ley o de Decretos relativos a las competencias atribuidas a su lonsellería.

\footnotetext{
57 Véase Ley 9/1996, de 18 de octubre, de incompatibilidades de los miembros de la Xunta de Galicia y altos cargos de la Administración Autónomica.
} 
6. Ejercer la potestad reglamentaria en las materias de su Consellería.

7. Resolver los recursos administrativos promovidos contra las resoluciones de los Organismos y Entidades de la Consellería, salvo cuando por Ley o reglamentariamente se atribuya esa facultad a otro órgano ${ }^{58}$.

8. Formular el anteproyecto de presupuestos de su Consellería.

9. Disponer los gastos propios de los servicios de su Consellería no reservados a la competencia del Consello, dentro de los límites de la autorización presupuestaria e interesar de los servicios financieros competentes la ordenación de los pagos correspondientes.

10. Firmar en nombre de la Xunta los contratos relativos a asuntos propios de su Consellería.

11. Resolver los conflictos de atribuciones entre autoridades dependientes de su Consellería.

12. Y cuantas facultades le atribuyan las disposiciones en vigor.

Artículo 35. Los miembros de la Xunta podrán designar y cesar libremente al personal colaborador y de asistencia directa dentro de los créditos presupuestarios consignados al efecto. Este personal, de carácter eventual, cesará automáticamente al producirse el cese del miembro de la Xunta que efectuó su nombramiento.

\section{TÍTULO IV ORGANIZACIÓN Y RÉGIMEN JURÍDICO 59}

Artículo 36. 1. La Administración de la Comunidad Autónoma de Galicia, constituida por órganos jerárquicamente ordenados bajo la dirección de la Xunta, tiene personalidad jurídica única y posee

58 Art. 34.7 modificado por Ley 7/2002, de 27 de diciembre, de medidas fiscales y de régimen administrativo.

59 La rúbrica que encabeza el titulo IV ha sido modificada por Ley $11 / 1988$, de 20 de octubre, de reforma de la Ley $1 / 1983$, de 22 de febrero, reguladora de la Xunta y de su Presidente. la capacidad de obrar necesaria para llevar a cabo sus fines ${ }^{60}$.

2. La actuación de la Administración se ajusta a los principios de legalidad, objetividad, servicio al interés general, publicidad, eficacia, jerarquía, economía del gasto público, desconcentración y coordinación entre sus órganos.

Artículo 37. 1. Adoptarán la forma de Decreto:

a. Las disposiciones generales aprobadas por el Consello de la Xunta.

b. Las resoluciones del Consello de la Xunta en los supuestos de los números $6,7,12,13,14,15$ y 16 , primer inciso, y 18 del artículo 4 de la presente ley y los demás casos que establezcan las Leyes.

c. Las resoluciones del Presidente de la Xunta, en los supuestos contemplados en el párrafo 2 del artículo 24, y en los números 1 y 7 del artículo 26 de esta ley.

2. Los Decretos serán firmados por el Presidente de la Xunta y refrendados, salvo en el supuesto c) del apartado anterior, por el conselleiro competente por razón de la materia.

Artículo 38. Las disposiciones y resoluciones de los Conselleiros revestirán la forma de Órdenes, que serán firmadas por el titular del Departamento. Cuando interesen a más de una Consellería, serán firmadas conjuntamente por los Conse1leiros afectados 61 .

Artículo 39. Las normas reglamentarias tendrán el rango del órgano que las

\footnotetext{
60 Véase:

- Orden de 20 de mayo de 2008 por la que se establecen los modelos a los que deberán adaptarse las memorias que editen los distintos departamentos de la Xunta de Galicia, organismos autónomos, agencias, fundaciones, entidades y empresas en las que tiene participación mayoritaria la Xunta de Galicia.

- Decreto 217/2008, de 25 de septiembre, por el que se regula el contenido minimo de las propuestas de creación de nuevas entidades del sector público autonómico.

- Decreto 230/2008, de 18 de septiembre, por el que se establecen las normas de buenas prácticas en la utilización de los sistemas de información de la Administración de la Comunidad Autónoma de Galicia. 61 Actuales art. 36, 37 y 38 añadidos por Ley $11 / 1988$ de 20 de octubre, de reforma de la Ley $1 / 1983$, de 22 de febrero, reguladora de la Xunta y de su Presidente.
} 
hubiere aprobado y se ordenaran jerárquicamente de la siguiente forma:

1. Decretos.

2. Órdenes de las Comisiones Delegadas.

3. Órdenes dictadas por los Conselleiros 62 .

Artículo 40. Serán nulas de pleno derecho las normas reglamentarias que infrinjan otras de rango superior o se opongan a lo establecido por la Ley.

Artículo 41. 1. Las disposiciones reglamentarias no podrán establecer penas ni imponer tributos o exacciones de cualquier naturaleza. Tampoco podrán imponer sanciones sino en el marco de lo dispuesto en la Ley.

2. Serán nulas las disposiciones y resoluciones que infrinjan lo dispuesto en el apartado anterior.

Artículo 42. Las resoluciones administrativas de carácter particular no podrán vulnerar lo establecido en una disposición de carácter general o dispensar singularmente de su cumplimiento, aun cuando aquéllas tengan un rango formal igual o superior a ésta.

Artículo 43. 1. El Consello podrá delegar las funciones administrativas que tenga encomendadas en las Comisiones Delegadas.

2. Sin perjuicio de las competencias delegadas en el Vicepresidente primero de acuerdo con lo dispuesto en el artículo 32 de esta ley, el Presidente podrá delegar funciones puramente ejecutivas en los demás miembros de la Xunta dando cuenta al Parlamento.

3. Los conselleiros podrán delegar competencias administrativas en los órganos inmediatamente inferiores de sus consellerías, cuando las necesidades de funcionamiento así lo aconsejen.

Artículo 44. 1. La delegación de atribuciones a que se refiere el artículo

62 Antiguo articulo 37 modificado y convertido en art. 39 por Ley $11 / 1988$, de 20 de octubre, de reforma de la Ley $1 / 1983$, de 22 de febrero, reguladora de la Xunta y de su Presidente. anterior y su revocación habrán de publicarse en el "Diario Oficial de Galicia".

2. No podrán ser objeto de delegación, salvo que una ley lo autorice expresamente, las competencias que, a su vez, hayan sido delegadas, ni la competencia para resolver recursos administrativos interpuestos contra actos o resoluciones del órgano delegatario.

3. Los actos dictados por delegación se considerarán como propios de órgano delegante que, en cualquier momento, podrá revocar la delegación otorgada ${ }^{63}$.

\section{TÍTULO V \\ DE LAS RELACIONES DE LA XUNTA CON EL PARLAMENTO}

\section{Capitulo I \\ DEL CONTROL PARLAMENTARIO}

\section{Sección $1 .^{\mathrm{a}}$}

\section{De la Moción de Censura}

Artículo 45. 1. El Parlamento puede exigir la responsabilidad política de la Xunta y su Presidente mediante la adopción por mayoría absoluta de la moción de censura.

2. La moción de censura deberá estar firmada al menos por una quinta parte de los miembros del Parlamento, y habrá de incluir un candidato a la Presidencia de la Xunta.

3. La moción de censura no podrá ser votada hasta que transcurran cinco días desde su presentación. En los dos primeros días de dicho plazo podrán presentarse mociones alternativas.

4. Si la moción de censura no fuese aprobada por el Parlamento, sus signatarios no podrán presentar otra durante el mismo período de sesiones.

Artículo 46. Si prosperase la moción de censura la Xunta y su Presidente cesarán y el candidato incluido en ella se entenderá investido de la confianza del Parlamento, procediéndose a continuación

63 Antiguos art. 38, 39, 40, 41 y 42 convertidos en art. $40,41,42,43$ y 44 Ley $11 / 1988$, de 20 de octubre, de reforma de la Ley $1 / 1983$, de 22 de febrero, reguladora de la Xunta y de su Presidente. 
a su designación como Presidente de la Xunta, según lo dispuesto en el artículo 17 de esta ley.

\section{Sección 2.a}

\section{De la Cuestión de Confianza}

Artículo 47. El Presidente de la Xunta, previa deliberación del Consello, puede plantear ante el Parlamento la cuestión de confianza sobre su Programa o sobre una declaración política general. La cuestión de confianza no podrá votarse hasta transcurridas 24 horas desde su presentación. La confianza se entenderá otorgada cuando vote a favor de la misma la mayoría simple de Diputados.

Si el Parlamento negase su confianza al Presidente de la Xunta se entenderá cesado y se procederá a la elección de nuevo Presidente conforme a lo establecido en esta ley ${ }^{64}$.

\section{Sección $3 .^{a}$}

Del impulso y control de la acción política del Gobierno 65

Artículo 48. La Xunta solicitará anualmente del Parlamento, al comienzo de uno de los períodos ordinarios de sesiones, la celebración de un debate de política general ${ }^{66}$.

\section{Sección $4 .^{\text {a }}$}

\section{De otras formas de control 67}

Artículo 49. El Parlamento, sus Comisiones y los Diputados, a través de la Presidencia del mismo, podrán recabar la información y ayuda que precisen la Xunta, de sus Conselleiros y de cualquier otra autoridad de la Comunidad Autónoma.

64 Antiguos art. 43, 44 y 45 convertidos en actuales 45,46 y 47 por Ley $11 / 1988$, de 20 de octubre, de reforma de la Ley $1 / 1983$, de 22 de febrero, reguladora de la Xunta y de su Presidente.

65 Rúbrica modificada por Ley 11/1988, de 20 de octubre, de reforma de la Ley $1 / 1983$, de 22 de febrero, reguladora de la Xunta y de su Presidente.

66 Art. 48 modificado por Ley $11 / 1988$, de 20 de octubre, de reforma de la Ley $1 / 1983$, de 22 de febrero, reguladora de la Xunta y de su Presidente.

67 Sección Tercera convertida en Sección Cuarta por Ley $11 / 1988$, de 20 de octubre, de reforma de la Ley $1 / 1983$, de 22 de febrero, reguladora de la Xunta y de su Presidente.
Artículo 50. El Parlamento y sus Comisiones pueden reclamar la presencia de los conselleiros y demás altos cargos de la Comunidad Autónoma.

Artículo 51. Los conselleiros tienen acceso a las sesiones del Parlamento y a las de sus Comisiones y la facultad de hacerse oír en ellas. Ante las Comisiones podrán hacerse acompañar de altos cargos o funcionarios de sus consellerías y solicitar que éstos informen.

Artículo 52. 1. La Xunta y cada uno de sus miembros están sometidos a las mociones, interpelaciones y preguntas que se le formulen en el Parlamento.

2. Toda interpelación podrá dar lugar a una moción en la que el Parlamento manifieste su posición ${ }^{68}$.

\section{Capitulo II DELEGACIONN LEGISLATIVA}

Artículo 53. 1. El Parlamento podrá delegar en la Xunta la potestad de dictar normas con rango de Ley que recibirán el título de Decretos legislativos.

2. La delegación legislativa deberá otorgarse mediante una ley de bases cuando su objeto sea la formación de textos articulados o por una ley ordinaria cuando se trate de refundir varios textos legales en uno solo.

3. No podrán ser objeto de delegación la regulación del régimen electoral de la Comunidad Autónoma, la aprobación del presupuesto, las leyes institucionales o de desarrollo básico del Estatuto y las que, por su naturaleza, requieran mayoría cualificada para su aprobación.

Artículo 54. La delegación legislativa habrá de otorgarse a la Xunta en forma expresa para materia concreta y con fijación de plazo para su ejercicio, sin que pueda entenderse concedida de forma implícita ni por tiempo indeterminado. Tampoco podrá permitir la subdelegación

68 Antiguos art. 46, 47, 48 y 49 convertidos en actuales art. 49,50,51, 52 por Ley $11 / 1988$, de 20 de octubre, de reforma de la Ley $1 / 1983$, de 22 de febrero, reguladora de la Xunta y de su Presidente. 
en favor de autoridades distintas de la propia Xunta .

Artículo 55. 1. Las leyes de bases delimitarán con precisión el objeto y alcance de la delegación legislativa y los principios y criterios que han de seguirse en su ejercicio. En ningún caso podrán autorizar a la Xunta para modificar la propia ley de bases ni para dictar normas con carácter retroactivo.

2. Las leyes ordinarias de autorización para refundir textos legales, determinarán el ámbito normativo a que se refiere el contenido de la delegación, especificando si se circunscribe a la mera formulación de un texto único o si se incluye la de regularizar, aclarar y armonizar los textos legales que han de ser refundidos.

Artículo 56. El control sobre los Decretos Legislativos se llevará a cabo en los términos previstos en el Reglamento del Parlamento de Galicia, sin perjuicio de lo cual las leyes de delegación podrán establecer, en cada caso, fórmulas adicionales de control parlamentario.

Artículo 57. 1. Cuando una proposición de ley o una enmienda sea contraria a una delegación legislativa en vigor, la Xunta está facultada para oponerse a su tramitación. En este caso podrá presentarse una proposición de ley para la derogación parcial o total de la ley de delegación.

2. La delegación se entenderá agotada con la publicación por la Xunta de la norma correspondiente ${ }^{69}$.

\section{DISPOSICIÓN TRANSITORIA PRIMERA}

Lo dispuesto en el número 7 del artículo 11 de la presente ley será aplicable a todos los efectos, desde la celebración de las primeras elecciones autonómicas gallegas.

Los tratamientos honoríficos establecidos en ese precepto serán también extensibles a los ex-Presidentes de la Preautonomita.

69 Antiguos art. 50, 51, 52, 53 y 54 convertidos en los actuales por $53,54,55,56$ y 57 Ley $11 / 1988$, de 20 de octubre, de reforma de la Ley $1 / 1983$, de 22 de febrero, reguladora de la Xunta y de su Presidente.

\section{DISPOSICIÓN TRANSITORIA SEGUNDA}

En tanto la Xunta no regule por Decreto lo establecido en el párrafo segundo del nímero 7 del artículo 11 de la presente ley, la compensación económica establecida será equivalente al 60 por 100 de la que corresponda al Presidente de la Xunta. Tal compensación será compatible con aquellas otras retribuciones que los exPresidentes puedan percibir, por otros conceptos, con cargo a los Presupuestos Generales de la Comunidad Autónoma.

En ningún caso, la cuantía global puede llegar a ser superior a la retribución total que en cada caso perciba el Presidente de la Xunta de Galicia ${ }^{70}$.

\section{DISPOSICIÓN TRANSITORIA TERCERA}

$$
(\ldots)^{71}
$$

\section{DISPOSICIÓN TRANSITORIA CUARTA}

Mientras el Parlamento de Galicia no adopte la resolución prevista en el artículo 2, párrafo cuarto, de la presente ley, el porcentaje del sexo menos representado en el Consello de la Xunta de Galicia no puede ser inferior al 40 por $100^{72}$.

\section{DISPOSICIÓN FINAL PRIMERA}

Se faculta a la Xunta para dictar sus propios Reglamentos internos conforme a lo establecido en esta ley.

\section{DISPOSICIÓN FINAL SEGUNDA}

La presente ley entrará en vigor el mismo día de su publicación en el "Diario Oficial de Galicia".

70 Disposiciones transitorias 1 y 2 añadidas por Ley $11 / 1988$, de 20 de octubre, de reforma de la Ley $1 / 1983$, de 22 de febrero, reguladora de la Xunta y de su Presidente.

71 Disposición transitoria tercera derogada por Ley 12/1989, de 4 de octubre, de derogación de la Disposición transitoria tercera de la Ley $1 / 1983$, de 22 de febrero, reguladora de la Xunta y de su Presidente.

72 Disposición transitoria cuarta añadida por Ley $2 / 2007$, de 28 de marzo, del trabajo en igualdad de las mujeres de Galicia. 


\section{LEY 9/1996, DE 18 DE OCTUBRE, DE INCOMPATIBILIDADES DE LOS MIEMBROS DE LA XUNTA DE GALICIA Y ALTOS CARGOS DE LA ADMINISTRACIÓN AUTONÓMICA (DOGA N. $\left..^{\circ} 213,30.10 .1996\right)$}

$(\ldots)^{73}$

\section{Capitulo I \\ OBJETO Y ÁMBITO DE APLICACIÓN}

Artículo 1. Objeto.

La presente ley regula el régimen de incompatibilidades de actividades y control de intereses así como de los bienes patrimoniales aplicables a los miembros de la Xunta de Galicia y altos cargos de la Administración autonómica y de las entidades de derecho público vinculadas o dependientes de la misma.

El desarrollo de las funciones de gobierno y administración de la Comunidad Autónoma de Galicia se ejercerá bajo el principio de incompatibilidad de actividades y dedicación absoluta, de conformidad con las disposiciones que se recogen en la presente ley.

Artículo 2. Ámbito de aplicación.

El régimen de incompatibilidades establecido en la presente ley será de aplicación a los siguientes cargos públicos:

a. A los miembros del Gobierno autonómico.

b. A las secretarias y secretarios generales, directoras y directores generales y cargos asimilados.

c. A las delegadas y delegados y representantes del Gobierno gallego en los entes con personalidad jurídica pública.

d. A las presidentas y presidentes, directoras y directores generales y asimilados de los organismos autónomos.

e. A las delegadas y delegados provinciales y territoriales de los departamentos de la Xunta de Galicia.

f. Al personal eventual que, en virtud de nombramiento legal, ejerza funciones

73 Exposición de motivos omitida. de carácter no permanente, expresamente calificadas de confianza y asesoramiento especial, en los gabinetes del Presidente y de los demás miembros del Consello de la Xunta de Galicia.

g. A las presidentas y presidentes, directoras y directores generales, directoras y directores ejecutivos, directoras y directores técnicos y titulares de otros puestos o cargos asimilados, cualquiera que sea su denominación, en entidades de derecho público vinculadas o dependientes de la Administración autonómica, cuyo nombramiento sea efectuado por decisión del Consello de la Xunta de Galicia o por sus propios órganos de gobierno.

h. A las presidentas y presidentes, directoras y directores generales y asimilados de las empresas públicas, sociedades o fundaciones en que la Xunta de Galicia, directa o indirectamente, participe o aporte más del $50 \%$ del capital o del patrimonio, cuando tales cargos sean designados previo acuerdo del Consello de la Xunta de Galicia o por sus propios órganos de gobierno.

i. Al personal eventual que, en virtud de nombramiento legal, ejerza funciones de carácter no permanente, expresamente calificadas de confianza y asesoramiento especial de las presidentas y presidentes y directoras y directores generales de las entidades relacionadas en el artículo 1 de la Ley de transparencia y de buenas prácticas en la Administración pública gallega.

j. A los titulares de cualquier otro puesto de trabajo de la Administración autonómica, cualquiera que sea su denominación, cuyo nombramiento se efectúe por decisión del Consello de la Xunta de Galicia ${ }^{74}$

\section{Capítulo II RÉGIMEN DE ACTIVIDADES}

Artículo 3. Principios generales.

1. Los cargos comprendidos en el ámbito de aplicación de esta ley ejercerán

74 Art. 2 modificado por Ley 4/2006, de 30 de junio, de transparencia y de buenas prácticas en la Administración pública gallega. 
sus funciones con dedicación absoluta y no podrán compatibilizar su actividad pública con:

a. El desarrollo, por sí mismos o mediante sustitución de persona interpuesta, de cualquier otro puesto, profesión o actividad, públicos o privados, por cuenta propia o ajena.

b. El ejercicio de cualquier otra función o actividad pública representativa, incluido el ejercicio de cargos electivos en colegios, cámaras o entidades que tengan atribuidas funciones públicas o coadyuven a las mismas, salvo las autorizadas por esta ley.

c. El desarrollo, por sí mismos o por personas interpuestas, de cargos de todo orden en empresas o sociedades concesionarias, contratistas de obra, servicios o suministros, arrendatarias o administradoras de monopolios o participación del sector público, cualquiera que sea la configuración jurídica de las mismas.

d. El ejercicio de cargos, por sí mismos o por personas interpuestas, que conlleven funciones de dirección, representación o asesoramiento de toda clase de sociedades mercantiles y civiles y consorcios de fin lucrativo, aunque unos y otros no realicen fines de servicios públicos ni tengan relaciones contractuales con las administraciones, organismos o empresas públicas.

e. La gestión, defensa, dirección o asesoramiento de asuntos particulares ajenos cuando, por la índole de las operaciones o asuntos, competa a las administraciones públicas resolverlos o quede implicada en los mismos la realización de algún servicio o fin público.

f. La percepción de pensión de jubilación o retiro por derechos pasivos o por cualquier régimen de seguridad social público y obligatorio.

2. En ningún caso podrá percibirse más de una remuneración, periódica o eventual, con cargo a los presupuestos de las administraciones públicas y de los organismos y empresas dependientes de las mismas, sin perjuicio de las indemnizaciones por gastos de viajes, estancias, traslados y asistencias que en cada caso correspondan por las actividades declaradas compatibles.

3. Quienes desempeñen un cargo de los comprendidos en el ámbito de aplicación de esta ley están obligados a inhibirse del conocimiento de los asuntos en cuyo despacho intervienen o que interesen a empresas o sociedades en cuya dirección, asesoramiento o administración tuvieran alguna parte ellos, su cónyuge o persona de su familia dentro del segundo grado civil. La inhibición se producirá por escrito para su adecuada expresión y constancia, notificándose al superior inmediato del alto cargo u órgano que lo nombró.

4. Las personas que ostenten un cargo de los comprendidos en el ámbito de aplicación de esta ley no podrán poseer la titularidad de participaciones, junto con su cónyuge, persona unida por análoga relación, hijos dependientes y personas tuteladas, superiores al 10 por 100 en empresas que tengan conciertos o contratos de cualquier naturaleza con el sector público estatal, autonómico o local.

En el supuesto de que la persona que sea nombrada para ocupar un puesto de los comprendidos en el artículo 2 de la presente ley poseyera la participación a que se refiere el apartado anterior, tendrá que desprenderse de la misma en el plazo de un mes a contar desde su nombramiento. Si la participación fuera adquirida por sucesión hereditaria en el ejercicio del cargo, tendrá que desprenderse de la misma en el plazo de tres meses desde su adquisición.

5. Durante los dos años siguientes a la fecha de su cese, los cargos comprendidos en el ámbito de aplicación de esta ley no podrán realizar actividades privadas relacionadas con expedientes sobre los que hubieran dictado resolución en el ejercicio del cargo ni firmar contratos de asistencia técnica, de servicios o similares con las administraciones públicas. 
Artículo 4. Compatibilidades con actividades públicas.

1. El ejercicio de las funciones de un cargo de los comprendidos en el ámbito de aplicación de esta ley será compatible con las siguientes actividades públicas:

a. El ejercicio de aquellos cargos que les correspondan con carácter institucional o para los que fueron designados por su propia condición.

b. La representación de la Administración autonómica en los órganos colegiados.

c. El desarrollo de misiones temporales de representación ante organizaciones o conferencias, nacionales e internacionales.

d. La representación de la Administración autonómica en los Consejos de Administración de organismos o empresas con capital público o de entidades de derecho público. No se podrá pertenecer a más de dos Consejos de Administración.

En el supuesto de que concurran razones que lo justifiquen y mediante resolución motivada, el Consello de la Xunta de Galicia podrá autorizar, con carácter excepcional, la pertenencia a un tercero y sucesivos Consejos de Administración de organismos o empresas con capital público o de entidades de derecho público. En estos supuestos no podrá percibirse cantidad alguna en concepto de asistencia.

2. En los supuestos previstos en los apartados anteriores, los cargos comprendidos en el ámbito de aplicación de esta ley sólo podrán percibir, por los indicados cargos o actividades compatibles, las indemnizaciones por gastos de viajes, estancias y traslados que les correspondan de acuerdo con la normativa vigente, así como las cantidades en concepto de asistencia en los supuestos previstos en los apartados b) y d). Las restantes cantidades que, en su caso, se devenguen por el desarrollo de estas funciones y cargos, sea cual fuere el concepto del devengo, serán ingresadas por la empresa, sociedad, organismo o ente pagador directamente en la Tesorería General de la Xunta de Galicia.
Artículo 5. Compatibilidad con el ejercicio de la docencia.

1. Podrá compatibilizarse, cumplidas las restantes exigencias de esta ley, el ejercicio de funciones docentes, de carácter reglado, siempre que no supongan menoscabo de la dedicación en el ejercicio del cargo público y se realice en régimen de dedicación a tiempo parcial.

2. El desarrollo de esa actividad no podrá suponer en caso alguno ningún incremento sobre las cantidades que por cualquier concepto corresponda percibir por el ejercicio del cargo público, con excepción de las indemnizaciones por gastos de viajes, estancias y traslados que les correspondan de acuerdo con la normativa vigente en el área docente y dando idéntico destino a los derechos económicos que, en su caso, pudieran devengarse de acuerdo con lo dispuesto en el artículo 4.2.

3. Para ejercicio de las funciones docentes se requerirá la autorización expresa del Conselleiro de la Presidencia y Administración Pública.

Artículo 6. Compatibilidad con cargos representativos.

Los miembros del Gobierno gallego podrán compatibilizar el desarrollo de su cargo con el de Diputado del Parlamento de Galicia.

Artículo 7. Compatibilidad con actividades privadas.

El ejercicio de un cargo de los comprendidos en el ámbito de aplicación de esta ley será compatible con las siguientes actividades privadas, siempre que con su desarrollo no comprometa la imparcialidad o independencia de sus funciones públicas:

a. Las que se deriven de la mera administración del patrimonio personal o familiar.

b. Las actividades de producción y creación literaria, artística, científica o técnica y las publicaciones derivadas de las mismas, así como la colaboración y asistencia ocasional como ponente a congresos, seminarios, jornadas de trabajo, conferencias o cursos de carácter profesional, siempre 
que no sean consecuencia de una relación de empleo o de prestación de servicios o supongan un menoscabo del estricto cumplimiento de sus deberes.

c. La participación en entidades culturales o benéficas que no tengan ánimo de lucro y siempre que no perciban ningún tipo de retribución o percepción por dicha participación.

\section{Capitulo III OBLIGACIONES DE LOS ALTOS CARGOS}

Artículo 8. Declaraciones de actividades y de bienes patrimoniales.

1. Los cargos a que hace referencia el artículo 2 de esta ley están obligados a formular las siguientes declaraciones:

a. Declaración de actividades que desarrollen por sí mismos o mediante sustitución o apoderamiento ante el Registro de Actividades e Intereses de Altos Cargos. Ésta vendrá referida a cualquier actividad, negocio, empresa o sociedad pública o privada que les proporcione o pueda proporcionar ingresos económicos o en los que tengan participación o intereses.

b. Declaración de bienes patrimoniales ante el correspondiente Registro constituido al efecto, referida a los que integren el patrimonio del interesado, comprensivo de la totalidad de sus bienes, derechos y obligaciones, a la que se adjuntará la copia de la última declaración tributaria correspondiente al Impuesto sobre la Renta de las Personas Físicas (IRPF) y al Impuesto sobre el Patrimonio Neto en caso de que el declarante tuviera obligación de presentarlo ante la Administración tributaria.

Esta declaración deberá incluir las participaciones en todo tipo de empresas y sociedades pertenecientes al cargo de los comprendidos en el ámbito de aplicación de esta ley y a las personas mencionadas en el artículo 3.4.

A esta declaración podrán acompañar la relativa al patrimonio de su cónyuge, o persona vinculada por análoga relación, con su previo consentimiento, y al patrimonio de los hijos dependientes.

2. Las declaraciones mencionadas en los apartados a) y b) se efectuarán en los términos que reglamentariamente se establezcan dentro de los tres meses siguientes a la fecha de toma de posesión y cese, respectivamente, en el alto cargo, así como si se produce modificación de las circunstancias de hecho. A tal efecto se considera modificación de las circunstancias de hecho cualquier alteración en la situación patrimonial de los declarantes por la adquisición o transmisión de bienes o derechos y cualquier alteración en las actividades o causas de posible incompatibilidad declaradas.

Reglamentariamente se determinan las cuantías y características de las adquisiciones y transmisiones de bienes y derechos que han de ser declaradas.

Además, anualmente, durante el mes de julio, se presentará ante el Registro de Bienes Patrimoniales copia de las declaraciones tributarias mencionadas en el apartado b) del presente artículo ${ }^{75}$.

Artículo 9. De otras obligaciones.

1. Las personas incluidas en el ámbito de aplicación de esta ley que tengan competencias reguladoras, de supervisión o control sobre sociedades mercantiles, que emitan valores $y$ otros activos financieros negociables en un mercado organizado y en relación con aquellos de los que sean titulares tales personas, sus cónyuges que presten su conformidad o sus hijos menores de edad no emancipados habrán de encomendar contractualmente la gestión y administración de tales valores o activos a una entidad financiera registrada en la Comisión Nacional del Mercado de Valores. La encomienda de gestión se mantendrá en tanto dure el desarrollo del

75 Orden de 12 de mayo de 2009 por la que se aprueban los modelos oficiales de declaración de actividades y declaración de bienes patrimoniales que deben formular los altos cargos de la Administración autonómica. 
cargo y en los dos años posteriores al cese en el mismo.

La entidad con la que contraten efectuará la administración con sujeción exclusivamente a las directrices generales de la rentabilidad y riesgo establecidas en el contrato sin que pueda pedir ni recibir instrucciones de inversión de los interesados. Tampoco podrán revelárseles la composición de sus inversiones, excepto que se trate de instituciones de inversión colectiva o que, por causa justificada, medie autorización de la Comisión Nacional del Mercado de Valores.

2. Los interesados entregarán copias de los contratos suscritos al Registro de Bienes Patrimoniales para su anotación.

\section{Capítulo IV ÓRGANOS DE GESTIÓN, VIGILANCIA Y CONTROL}

Artículo 10. Registros ${ }^{76}$.

1. Se constituyen el Registro de Actividades de Altos Cargos y el Registro de Bienes Patrimoniales de Altos Cargos de la Xunta de Galicia, en los cuales se inscribirán las correspondientes declaraciones.

2. El Registro de Actividades de Altos Cargos será público. El contenido de las declaraciones inscritas en el mismo, pertenecientes a los titulares de aquellos puestos cuyo nombramiento sea efectuado por decisión del Consello de la Xunta de Galicia, se publicará en el "Diario Oficial de Galicia" y estará disponible en internet.

3. Del contenido del Registro de Bienes Patrimoniales de Altos Cargos de la Xunta de Galicia se dará cuenta anualmente al Parlamento de acuerdo con lo que se establezca en el Reglamento de la Cámara. Asimismo, tendrán acceso al mismo:

a. Los órganos judiciales, para la instrucción o resolución de procesos que requieran el conocimiento de los datos obrantes en el registro, de conformidad con lo dispuesto en las leyes procesales.

76 Decreto 205/2008, de 4 de septiembre, por el que se regulan los registros de actividades y de bienes patrimoniales de altos cargos de la Xunta de Galicia. b. El Ministerio Fiscal, cuando realice actuaciones de investigación en el ejercicio de sus funciones que requieran el conocimiento de los datos obrantes en el registro.

c. El Defensor del Pueblo y el Valedor do Pobo, en los términos previstos en sus leyes de creación.

4. No serán objeto de la publicidad prevista en el párrafo precedente las copias de la última declaración tributaria correspondiente al impuesto sobre la renta de las personas físicas y, en su caso, del impuesto sobre el patrimonio neto recogidas en el artículo 8. 1. b) de la Ley 9/1996, de 18 de octubre, de incompatibilidades de altos cargos.

5. El personal que preste servicios en los registros tiene el deber permanente de mantener en secreto los datos e informaciones que conozca por razón de su trabajo ${ }^{77}$.

Artículo 11. Órgano de gestión.

El órgano competente para la gestión del régimen de incompatibilidades de esta ley será la Inspección General de Servicios de la Xunta de Galicia. Este órgano será el encargado de calificar la declaración de actividades y de la declaración de bienes patrimoniales, en los términos establecidos reglamentariamente.

Asimismo procederá a recordar y, en su caso, requerir a quien sea nombrado o a quien cese en un cargo de los comprendidos en el ámbito de aplicación el cumplimiento de las obligaciones previstas en la presente ley.

Artículo 12. Información al Parlamento de Galicia.

Para asegurar la transparencia del control del régimen de incompatibilidades previsto en esta ley, y sin perjuicio de las competencias atribuidas a las autoridades administrativas señaladas, la Xunta de Galicia, a través de la Inspección General de Servicios, habrá de informar anualmente al Parlamento de Galicia del grado

77 Art. 10 modificado por Ley 4/2006, de 30 de junio, de transparencia y de buenas prácticas en la Administración pública gallega. 
de cumplimiento de las obligaciones de declarar establecidas en esta ley, así como de las conductas contrarias o las obligaciones impuestas en esta ley y a las responsabilidades declaradas.

\section{Capitulo V \\ RÉGIMEN DE RESPONSABILIDADES}

\section{Artículo 13. Conductas.}

1. Las conductas contrarias a las obligaciones impuestas en esta ley darán lugar a la exigencia de responsabilidad muy grave, grave y leve.

2. Darán lugar a la exigencia de responsabilidad muy grave:

a. El incumplimiento de las normas sobre incompatibilidades a que se refieren los artículos 3, 4 y 5 cuando se produjera daño manifiesto a la Administración autonómica de la Xunta de Galicia.

b. La falsedad de los datos y documentos que han de presentarse con arreglo a lo establecido en esta ley.

c. El incumplimiento de las obligaciones a que se refiere el artículo 9 en relación con la gestión de valores bursátiles cuando se produjera daño a la Administración autonómica.

3. Darán lugar a la exigencia de responsabilidad grave:

a. El incumplimiento de las normas sobre incompatibilidades y abstenciones recogidas en los artículos 3, 4 y 5 de esta ley.

b. La omisión de datos y documentos que hayan de ser presentados con arreglo a lo establecido en esta ley.

c. La no presentación de las declaraciones previstas en esta ley, previo el correspondiente apercibimiento.

d. El incumplimiento de las obligaciones a que se refiere el artículo 9 en relación con la gestión de valores bursátiles cuando con arreglo a lo establecido en el artículo anterior no constituya falta muy grave.

e. La comisión de dos infracciones leves en el período de un año.

4. Dará lugar a la exigencia de responsabilidad leve la no presentación en el plazo establecido de las declaraciones previstas en el artículo 8 de la presente ley, cuando se subsane después del requerimiento que se formule al efecto.

Artículo 14. Responsabilidades.

1. Los acuerdos por los que se declare la responsabilidad muy grave o grave serán publicados en el "Diario Oficial de Galicia".

2. Las personas comprendidas en el ámbito de aplicación de esta ley que incurran en responsabilidad leve serán amonestadas por incumplimiento de esta ley.

3. Con independencia de las responsabilidades declaradas, los cargos responsables de las conductas contrarias a las obligaciones impuestas en esta ley deberán, en su caso, restituir las cantidades percibidas indebidamente, en la forma que se determine reglamentariamente.

4. Lo dispuesto en la presente ley se entenderá sin perjuicio de la exigencia de las demás responsabilidades a que hubiera lugar. Si las infracciones pudieran ser constitutivas de delito, la Administración pasará el tanto de culpa al Ministerio Fiscal.

5. Sin perjuicio de lo dispuesto en el apartado 1 del presente artículo, las responsabilidades declaradas se anotarán en el Registro de Actividades o en el Registro de Bienes Patrimoniales, según proceda.

Artículo 15. Imposibilidad de ocupar altos cargos.

1. Las personas que fueran declaradas responsables de alguna de las conductas muy graves de las recogidas en el artículo 13.2 de esta ley no podrán ser nombradas para ocupar un cargo de los relacionados en el artículo 2 durante un período entre tres y diez años.

2. Las personas que fueran declaradas responsables de alguna de las conductas graves de las recogidas en el artículo 13.3 de esta ley no podrán ser nombradas para ocupar un cargo de los relacionados en el artículo 2 durante un período de hasta tres años.

3. En la graduación de las medidas anteriormente previstas se valorará la 
existencia de perjuicio para el interés público, la repercusión de la conducta en los administrados y, en su caso, la percepción indebida de cantidades por el desarrollo de actividades públicas incompatibles.

4. Los cargos comprendidos en el ámbito de aplicación de esta ley responsables de conductas muy graves cesarán por acuerdo del órgano que hubiera procedido a su nombramiento.

5. La responsabilidad del Presidente de la Xunta de Galicia será la regulada en el Estatuto de Autonomía de Galicia, en el Reglamento del Parlamento de Galicia y en la Ley 1/1983, de 22 de febrero, reguladora de la Xunta y su Presidente.

Artículo 16. Prescripción.

Las responsabilidades reguladas en esta ley prescribirán a los cinco años, tres años y seis meses, según se trate de responsabilidades muy graves, graves o leves.

Artículo 17. Procedimiento.

Las responsabilidades reguladas en los artículos precedentes serán declaradas previa instrucción de un expediente en el que dé audiencia al interesado.

Artículo 18. Actuaciones previas.

1. La Inspección General de Servicios de la Xunta de Galicia, con anterioridad a la iniciación de cualquier expediente de responsabilidad, podrá realizar actuaciones previas de carácter reservado al objeto de determinar si concurren circunstancias que justifiquen tal iniciación notificando el inicio de tales actuaciones al interesado.

2. Asimismo la Inspección General de Servicios de la Xunta de Galicia conocerá de las denuncias que sobre los presuntos incumplimientos de esta ley pudieran formularse.

3. Los ficheros, archivos y registros de carácter público proporcionarán a la Inspección General de Servicios de la Xunta de Galicia, cuando le sea requerido, información, datos y colaboración en la forma establecida en la Ley orgánica de regulación del tratamiento automatizado de los datos de carácter personal.
4. Una vez realizada la información previa, la Inspección General de Servicios de la Xunta de Galicia elevará a los órganos previstos en el artículo 19 el informe de las actuaciones previas realizadas.

Artículo 19. Órganos competentes.

1. El órgano competente para la incoación será el Consello de la Xunta de Galicia, a propuesta del Conselleiro de la Presidencia y Administración Pública.

2. La instrucción de los correspondientes expedientes será realizada por la Inspección General de Servicios de la Xunta de Galicia.

3. Corresponde al Consello de la Xunta de Galicia la declaración de las responsabilidades reguladas en la presente ley.

\section{DISPOSICIÓN ADICIONAL PRIMERA}

1. Las entidades de derecho público dependientes de la Administración autonómica y las sociedades y fundaciones en que la Administración autonómica, directa o indirectamente, participe o aporte más del 50 por 100 del capital o patrimonio habrán de informar a la Inspección General de Servicios de la Xunta de Galicia de los nombramientos que efectúen respecto a aquellos puestos de trabajo que con arreglo a esta ley tengan la condición de altos cargos.

2. Las entidades o empresas públicas o privadas con representación del sector público autonómico en sus consejos de administración están obligadas a comunicar a la Inspección General de Servicios de la Xunta de Galicia las designaciones que efectúen para su consejo de administración u órganos de gobierno de personas que con arrreglo a lo dispuesto en la presente ley ostenten la condición de alto cargo.

\section{DISPOSICIÓN ADICIONAL SEGUNDA}

Lo dispuesto en esta ley se entenderá sin perjuicio de las incompatibilidades más rigurosas que se establezcan para determinados altos cargos de acuerdo con la especial naturaleza de su función. 


\section{DISPOSICIÓN TRANSITORIA ÚNICA}

En tanto no se desarrolle reglamentariamente esta ley, permanecerán en vigor los registros de actividades e intereses y de bienes patrimoniales existentes actualmente.

\section{DISPOSICIÓN FINAL PRIMERA}

1. Se autoriza a la Xunta de Galicia, en el marco de sus competencias, para dictar cuantas disposiciones exijan la aplicación y el desarrollo de esta ley.

2. Las obligaciones que establece esta ley serán de aplicación desde su entrada en vigor.

3. En el plazo de tres meses, la Xunta de Galicia dictará las normas reglamentarias que exijan la aplicación y el desarrollo de esta ley.

\section{DISPOSICIÓN FINAL SEGUNDA}

La presente ley entrará en vigor al día siguiente al de su publicación en el "Diario Oficial de Galicia”.

\section{LEY 6/1995, DE 28 DE JUNIO, POR LA QUE SE CREA EL CONSELLO ECONÓMICO E SOCIAL DE GALICIA (DOGA N. $\left.{ }^{\circ} 133,12.7 .1995\right)$}

\section{$(\ldots)^{78}$ \\ TÍTULO I DISPOSICIONES GENERALES}

Artículo 1. Creación y denominación. Se crea el Consello Económico e Social de Galicia, con la finalidad, naturaleza, funciones, composición y estructura que se establecen en la presente ley.

Artículo 2. Finalidad.

La finalidad del Consejo es hacer efectiva la participación de los agentes económicos y sociales en la política socioeconómica de Galicia.

Artículo 3. Naturaleza jurídica.

1. El Consello es un ente institucional de derecho público, consultivo, de la Xunta de Galicia en materia económico y social.

78 Exposición de motivos omitida.
2. El Consello tiene personalidad jurídica propia y plena capacidad y autonomía, orgánica y funcional, para el cumplimiento de sus fines.

3. El Consello queda adscrito a la Consellería de Economía e Facenda.

Artículo 4. Sede.

El Consello tiene su sede en Santiago de Compostela. No obstante, cuando las circunstancias lo aconsejen, podrá celebrar sus sesiones en cualquier lugar del territorio de la Comunidad Autónoma.

Artículo 5. Funciones.

De acuerdo con su finalidad y naturaleza, corresponden al Consello las siguientes funciones:

1. Emitir dictámenes de carácter preceptivo o facultativo.

1) Serán dictámenes de solicitud preceptiva los que versen sobre:

a. Anteproyectos de ley, y proyectos de decretos legislativos y planes generales o sectoriales que regulen materias socioeconómicas directamente vinculadas al desarrollo económico y social de Galicia. Se exceptúan de esta consulta los proyectos de ley de presupuestos generales de la Comunidad Autónoma.

b. Anteproyecto de ley o proyectos de disposiciones administrativas que afecten a la organización, competencias o funcionamiento del Consello.

c. Cualesquiera otros relativos a materias que tengan que consultarse al Consello por precepto expreso de una ley.

El Consello de la Xunta, al comunicar al Parlamento la aprobación de los proyectos de ley y de decretos legislativos, incluirá el dictamen elaborado, en su caso, por el Consello.

2) Son dictámenes de solicitud facultativa los referentes a asuntos o materias no mencionados en el apartado anterior que sean sometidos a consulta del Consejo por el Consello de la Xunta de Galicia o por sus miembros.

3) Los dictámenes requeridos al Consello habrán de ser evacuados en el plazo que se fije por el Consello de la Xunta o por 
cualquiera de sus miembros, en su caso, en la orden de remisión del expediente o en la solicitud de consulta.

En ningún caso dicho plazo será inferior a un mes. Transcurrido aquél, se entenderá cumplido el trámite.

2. Elaborar, a iniciativa propia o a solicitud de la Xunta de Galicia, informes o estudios sobre las reformas que se estimen necesarias en la normativa vigente para favorecer el desarrollo económico y social de Galicia o sobre la elaboración de planes y programas dirigidos a la misma finalidad.

Especialmente, corresponde al Consello elaborar informes o estudios sobre las posibles repercusiones y adaptaciones necesarias que la introducción de las nuevas tecnologías imponga en el sistema económico y social de Galicia.

Igualmente, el Consello podrá dar a conocer al gobierno gallego su opinión sobre la ejecución de los planes o programas de especial trascendencia para el desarrollo económico y social de Galicia.

3. Elaborar y remitir anualmente al Consello de la Xunta, a través de la Consellería de Economía e Facenda, dentro del primer semestre de cada año, una memoria sobre la situación económica y social en Galicia, incluyendo, en su caso, recomendaciones $\mathrm{u}$ orientaciones sobre la política presupuestaria.

4. Elaborar y aprobar el Reglamento de régimen interno del Consejo, de acuerdo con lo previsto en el artículo 20 de la presente ley.

Artículo 6. Facultad de información. Para el ejercicio de sus funciones, el Consejo, a través de su Presidente, podrá recabar de la Xunta de Galicia o de sus Conselleiros la información que precise.

\section{TÍTULO II COMPOSICIÓN}

Artículo 7. Composición y designación.

1. El Consello se compone de los treinta y cinco miembros siguientes: a. Un Presidente.

b. Once miembros designados por las organizaciones sindicales que obtuvieran la condición de más representativas, en proporción a su representatividad, de acuerdo con la Ley Orgánica de Libertad Sindical y el Estatuto de los Trabajadores.

c. Once miembros designados por las organizaciones empresariales que gocen de capacidad representativa, en proporción a su representatividad, de acuerdo con el Estatuto de los Trabajadores.

d. Once miembros con la siguiente distribución: Cuatro representantes del sector agrario, dos del sector marítimo-pesquero (uno de la pesca de bajura y otro del marisqueo), dos de los usuarios y consumidores y tres de las universidades de Galicia.

e. Un Secretario general.

2. Los miembros del Consello indicados en el párrafo d), serán propuestos, en cada caso, por las entidades o asociaciones que a continuación se indican:

1) Sector agrario: Por las organizaciones profesionales con mayor implantación en el sector en Galicia.

2) Sector marítimo-pesquero: Por las Federaciones Provinciales de Cofradías de pescadores.

3) Usuarios y consumidores: Por el Consello Galego de Consumo.

4) Universidades: Uno por cada Junta de Gobierno de las de La Coruña, Santiago y Vigo.

3. En los supuestos a que se refieren los apartados b), c) y d) del punto 1, se designará igual número de suplentes que miembros titulares, asistiendo aquéllos a las sesiones en sustitución de éstos, previa delegación expresa en cada caso.

4. Cada miembro del Consello, salvo el Secretario general, tiene un voto personal y únicamente delegable en su suplente.

Artículo 8. Nombramientos.

El Presidente del Consello será nombrado por el Presidente de la Xunta de Galicia, 
a propuesta conjunta de los Conselleiros de Economía y Hacienda y de Justicia, Interior y Relaciones Laborales, previa consulta a las entidades, organizaciones y asociaciones representadas en el Consello. El Secretario general será designado por el Consello de la Xunta, a propuesta de los Conselleiros de Economía y Hacienda y de Justicia, Interior y Relaciones Laborales, de entre funcionarios del grupo A, previa consulta a las entidades, organizaciones y asociaciones representadas en el Consello. Los demás miembros del Consello, designados en el modo que resulta en el artículo anterior, serán nombrados por el Presidente de la Xunta de Galicia, a quien comunicarán dichas entidades, organizaciones y asociaciones la designación.

Artículo 9. Duración del mandato.

1. El mandato de los miembros del Consello será de cuatro años, renovable por períodos de igual duración, que comenzará a computarse desde el día siguiente al de la publicación del nombramiento en el "Diario Oficial de Galicia".

Los miembros del Consello, salvo el Presidente y el Secretario general, podrán ser sustituidos por las entidades, organizaciones o asociaciones que los hubieran designado, y los así nombrados permanecerán en su cargo, como máximo, por el tiempo que le restara al sustituido para el cumplimiento de su mandato.

2. No obstante, los miembros del Conse1lo, incluido su Presidente, continuarán en el ejercicio de sus funciones hasta la toma de posesión de los nuevos miembros.

Artículo 10. Pérdida de la condición de miembro.

Los miembros del Consello perderán dicha condición por alguna de las siguientes causas:

a. El Presidente y el Secretario general, por cese acordado por el Presidente de la Xunta de Galicia o por el Consello de la Xunta, respectivamente, previa propuesta adoptada en la misma forma en que se señala en el artículo 8. b. Por fallecimiento.

c. Por renuncia expresa ante el Presidente del Consello y, en el caso de éste, ante el Presidente de la Xunta de Galicia.

d. Por expiración del plazo de su mandato, sin perjuicio de lo establecido en el artículo 9.2.

e. Por declaración de incapacidad o inhabilitación para el desempeño de cargo público por sentencia judicial firme.

f. A propuesta de las entidades, organizaciones o asociaciones que promovieron su designación.

Artículo 11. Incompatibilidades.

La condición de miembro del Consello será incompatible con el ejercicio de cualquier cargo o actividad que impida o menoscabe el desempeño de las funciones que le son propias. En particular, será incompatible con la de:

a. Parlamentarios de las Cortes Generales o de los parlamentos autonómicos.

b. Miembros del Gobierno de la Comunidad Autónoma.

c. Miembros de otros órganos previstos en el Estatuto de Autonomía de Galicia o en la Constitución Española.

d. Altos cargos de las administraciones públicas, entendiendo como tales los incluidos en la Ley 12/1995, de 11 de mayo, de incompatibilidades de los miembros del Gobierno de la nación y de los altos cargos de la Administración General del Estado.

e. Miembros electos de las corporaciones locales.

\section{TÍTULO III FUNCIONAMIENTO}

Artículo 12. Órganos del Consejo.

El Consello, para el ejercicio de sus funciones, actuará a través de los siguientes órganos:

1. Colegiados:

El Pleno.

La comisión permanente.

Las comisiones sectoriales.

2. Unipersonales:

El Presidente. 
El Secretario general.

3. Como órgano de apoyo, el Consello contará con un Gabinete Técnico, que actuará bajo la dirección de su Secretario general.

Artículo 13. El Pleno.

1. El Pleno es el órgano de gobierno del Consello.

2. Estará integrado por la totalidad de los miembros mencionados en el artículo 7 de esta ley, bajo la dirección del Presidente y asistido por el Secretario general.

3. El Pleno se reunirá en sesión ordinaria, al menos, cuatro veces al año. Asimismo, podrá reunirse, con carácter extraordinario, a iniciativa del Presidente o de un tercio de sus miembros.

A dichas sesiones podrá asistir un asesor acreditado por cada una de las entidades, organizaciones o asociaciones que integran el Consello. También podrán asistir a las mismas los miembros del Gabinete Técnico del Consejo.

4. Para la válida constitución del Pleno será necesaria la asistencia de la mayoría absoluta de sus miembros en primera convocatoria, y, al menos, de un tercio de los mismos en la segunda.

En todo caso, será necesaria la asistencia a las sesiones del Presidente y del Secretario general, o de los que legalmente los suplan.

5. Los acuerdos del Pleno se adoptarán por mayoría simple de los asistentes, salvo en los supuestos en que legal o reglamentariamente se exija mayoría cualificada, dirimiendo los empates el Presidente mediante el voto de calidad.

6. Son competencias del Pleno:

a. Adoptar los acuerdos que correspondan respecto al ejercicio de las funciones a que se refiere el artículo 5 de esta ley.

b. Las demás que resulten del reglamento del Consello.

7. Los acuerdos o criterios del Consello se expresarán bajo la denominación de "dictámenes", "informes" o "estudios" del Consejo, según proceda, de acuerdo con lo dispuesto en el artículo 5 de esta ley.
Los dictámenes los emitirá el Pleno o, en caso de delegación de éste, la comisión permanente.

Los dictámenes se formularán por separado y en ellos se incluirán los antecedentes, la valoración y las conclusiones. Irán firmados por el Secretario general con el visto bueno del Presidente, y se les adjuntarán los votos particulares, si los hubiera.

Artículo 14. La comisión permanente.

1. La comisión permanente, bajo la dirección del Presidente y asistida por el Secretario general, estará integrada por tres representantes de cada uno de los grupos b), c) y d) con presencia en el Consello a que hace alusión el artículo 7 de esta ley.

Dichos representantes serán designados entre los miembros del Pleno, a propuesta de cada uno de los grupos mencionados en el artículo 7.1 de la presente ley.

2. Corresponderán a la comisión permanente las funciones que específicamente le delegue el Pleno, dentro del ámbito de sus competencias, o que se le atribuyan en el Reglamento de régimen interno.

Artículo 15. Comisiones sectoriales.

1. Por acuerdo del Pleno podrán constituirse, con el carácter de permanentes o para cuestiones específicas, comisiones sectoriales. Formarán parte de las mismas los miembros que designe el Pleno, respetando en cada caso la presencia proporcional de los distintos representados en el Consejo y definidos en el artículo 7.

2. El Pleno podrá adscribir tareas de las comisiones sectoriales a aquellos expertos que considere oportuno para el mejor desarrollo de las mismas.

Artículo 16. El Presidente.

1. Son funciones del Presidente:

a. Formular el orden del día de las sesiones del Pleno de la comisión permanente, en la forma que se establezca en el reglamento del Consejo.

b. Convocar las sesiones del Pleno y de la comisión permanente, presidirlas y moderar el desarrollo de los debates. 
c. Visar las actas, ordenar la publicación de los acuerdos y disponer el cumplimiento de los mismos.

d. Dirigir las actuaciones del Consejo y ostentar la representación del mismo.

e. Remitir los dictámenes, informes y estudios a la Xunta de Galicia y a los Conselleiros.

f. Las demás funciones que le encomienden la presente ley y el reglamento del Consejo.

2. En caso de ausencia, enfermedad o cualquier otra causa justificada, el Presidente será sustituido por el miembro titular del Consejo de mayor edad.

Artículo 17. El Secretario general.

1. El Secretario general, como órgano de asistencia técnica y administrativa del Consejo, es el depositario de la fe pública de los acuerdos del mismo.

2. Son funciones del Secretario general:

a. Ejercer la dirección administrativa y técnica de los distintos servicios del Consejo y velar porque sus órganos actúen con arreglo a los principios generales que informan la actuación de las administraciones públicas.

b. Asistir, con voz pero sin voto, a las sesiones del Pleno y de la comisión permanente. También asistirá a las sesiones de las comisiones sectoriales y de los grupos de trabajo.

c. Extender las actas de las sesiones, autorizarlas con su firma y con el visto bueno del Presidente y dar el curso correspondiente a los acuerdos que se adopten.

d. Custodiar la documentación del Consejo.

e. Expedir certificaciones de las actas, acuerdos, dictámenes e informes con sus votos particulares y otros documentos confiados a su custodia, con el visto bueno del Presidente.

f. Ejercer la Jefatura del personal al servicio del Consejo.

g. Ejercer la dirección del Gabinete Técnico.

h. Ejercer las funciones económicas y presupuestarias del Consejo. i. Elaborar el anteproyecto del presupuesto anual, para someterlo a la consideración del Pleno del Consejo.

j. Cuantas otras le sean atribuidas por el reglamento del Consejo o sean inherentes a su condición de Secretario.

Artículo 18. El Gabinete Técnico.

1. El Gabinete Técnico es el órgano de apoyo al Consejo y actuará bajo la dirección del Secretario general.

2. Estará integrado por cuatro expertos como máximo en materias socioeconómicas, cuya labor realizarán con dedicación plena. El número y cualificación de los mismos serán fijados por acuerdo del Consejo.

3. Serán funciones del Gabinete Técnico la elaboración de bases de datos, informes, estudios y tareas análogas, sobre materias socioeconómicas y técnicas, que recabe el Consejo o el Secretario general.

4. El Gabinete, para el cumplimiento de sus fines, podrá acceder a las bases de datos informáticos existentes, tanto públicas como privadas. Se le garantizará una adecuada prioridad de acceso a los bancos públicos de datos.

5. Los componentes del Gabinete Técnico asistirán a las sesiones del Pleno y de la comisión permanente, en calidad de Asesores, cuando la naturaleza de las materias a tratar así lo aconseje, de acuerdo con lo que disponga el reglamento del Consejo.

6. Cuando el Consejo así lo aprecie, podrá requerir informes de profesionales libres, no vinculados al mismo, que tendrán idéntico tratamiento que los provenientes del Gabinete Técnico.

Artículo 19. Publicidad de las sesiones y trabajos del Consejo.

1. Las sesiones del Consejo no serán públicas.

2. Los dictámenes, estudios e informes del Consejo tendrán la publicidad que en éste se acuerde.

Artículo 20. Reglamento del Consejo. El Consejo, de conformidad con lo dispuesto en el punto 4 del artículo 5 de esta ley, 
elaborará su reglamento de régimen interno, que será aprobado en primera votación por mayoría de dos tercios de los miembros del Pleno del Consello, y en segunda votación por mayoría absoluta de aquéllos. A efectos de general conocimiento se publicará en el "Diario Oficial de Galicia".

\section{TÍTULO IV RÉGIMEN ECONÓMICO Y ADMINISTRATIVO}

Artículo 21. Personal.

El personal propio del Consello se regirá por las normas de derecho laboral. Sus condiciones de trabajo no serán inferiores a las establecidas para el personal laboral de la Xunta de Galicia.

La selección del personal se hará mediante convocatoria pública y de acuerdo con los principios de igualdad, mérito y capacidad.

Artículo 22. Financiación.

Las dotaciones necesarias para el funcionamiento del Consello se cubrirán con las partidas que a tal efecto se consignen en los presupuestos generales de la Comunidad Autónoma de Galicia.

A tal fin, el Pleno del Consello aprobará, anualmente, un anteproyecto de presupuesto, que se remitirá a la Consellería de Economía e Facenda, para que le dé el trámite legalmente establecido.

Artículo 23. Contratación.

El Consello, en cuanto a contratación, se regirá por las normas del derecho privado, pero ésta se ajustará a los principios de objetividad, publicidad y concurrencia, salvaguardia del interés público y homogeneización de comportamientos en el sector público.

Artículo 24. Control y contabilidad. El régimen de su contabilidad y control se adaptará a lo establecido para los entes de su naturaleza en las disposiciones en vigor.

Artículo 25. Patrimonio.

El patrimonio del Consello se integrará en el de la Comunidad Autónoma de Galicia y le será de aplicación lo dispuesto a tal efecto en la Ley 3/1985, de 12 de abril.

\section{DISPOSICIÓN ADICIONAL PRIMERA}

Por acuerdo del Consello se determinarán las asignaciones por asistencias y otras compensaciones que hayan de percibir sus miembros.

\section{DISPOSICIÓN ADICIONAL SEGUNDA}

El Consello, como ente de participación social, podrá proponer a la Xunta de Galicia la convocatoria de mesas sectoriales en las que participen no sólo las organizaciones representadas en el mismo, sino también la Administración autonómica, al objeto de debatir problemas específicos que afecten a sectores estratégicos de Galicia, a fin de definir las posibles líneas de actuación, así como los informes requeridos por la normativa de la Unión Europea.

\section{DISPOSICIÓN ADICIONAL TERCERA}

La Xunta de Galicia remitirá al Consello los proyectos de ley y los proyectos de Decretos legislativos con la antelación suficiente para que la evacuación de los informes correspondientes o de los dictámenes preceptivos sea previa a su remisión por la Xunta de Galicia al Parlamento.

\section{DISPOSICIÓN TRANSITORIA PRIMERA}

Dentro del plazo de los dos meses siguientes a la entrada en vigor de esta ley, las organizaciones, asociaciones y entidades competentes habrán de proceder a la designación de los miembros del Consello, según se establece en la presente ley.

\section{DISPOSICIÓN TRANSITORIA SEGUNDA}

Transcurrido el plazo señalado en la Disposición transitoria anterior, el Presidente de la Xunta de Galicia convocará para su constitución, dentro de los treinta días siguientes, el Pleno del Consello, con fijación del lugar, día y hora en que tenga que celebrarse el acto.

\section{DISPOSICIÓN TRANSITORIA TERCERA}

Se autoriza al Conselleiro de Economía y Hacienda a dotar con cargo a los 
presupuestos generales de la Comunidad Autónoma los gastos necesarios para el funcionamiento del Consello, hasta la aprobación de su presupuesto.

\section{DISPOSICIÓN DEROGATORIA}

Quedan derogadas cuantas disposiciones de igual o inferior rango se opongan a lo establecido en la presente ley.

\section{DISPOSICIÓN FINAL PRIMERA}

Las funciones del Consello dejan a salvo las atribuidas al Consello Galego de Relaciones Laborales por su normativa específica.

\section{DISPOSICIÓN FINAL SEGUNDA}

Se autoriza a la Xunta de Galicia, a propuesta conjunta de los Conselleiros de Economía y Hacienda y de Justicia, Interior y Relaciones Laborales, para dictar las disposiciones necesarias para el desarrollo de la presente ley.

\section{DISPOSICIÓN FINAL TERCERA}

La presente ley entrará en vigor el día siguiente al de su publicación en el "Diario Oficial de Galicia”.

\section{LEY 9/1995, DE 10 DE NOVIEMBRE, DEL CONSELLO CONSULTIVO DE GALICIA (DOGA N. $\left..^{\circ} 229,29.11 .1995\right)$}

\section{$(\ldots)^{79}$ \\ TÍTULO I DISPOSICIONES GENERALES}

Artículo 1. Naturaleza y sede.

1. Se crea el Consello Consultivo de Galicia, como órgano superior consultivo de la Xunta de Galicia.

2. $\mathrm{Su}$ sede radicará en la ciudad de Santiago de Compostela, sede de las instituciones autonómicas.

Artículo 2. Autonomía.

1. En el ejercicio de sus funciones, el Consello Consultivo de Galicia velará

79 Exposición de motivos omitida. por la observancia de la Constitución, del Estatuto de Autonomía y del resto del ordenamiento jurídico.

2. El Consello Consultivo de Galicia, en el ejercicio de sus funciones, gozará de plena autonomía orgánica y funcional, en garantía de su objetividad e independencia.

3. Los asuntos dictaminados por el Consello Consultivo de Galicia no podrán ser remitidos, para informe ulterior, a ningún otro órgano $\mathrm{u}$ organismo de la Comunidad Autónoma.

Artículo 3. Consultas y dictámenes.

1. La consulta al Consello Consultivo de Galicia será preceptiva cuando así lo establezca esta ley u otra norma de igual rango, y facultativa en los demás casos restantes.

2. Salvo que por ley se disponga expresamente lo contrario, su dictamen será no vinculante y de carácter estrictamente jurídico, sin entrar en valoraciones de oportunidad o conveniencia, a no ser que así le sea solicitado expresamente por el órgano consultante.

3. Las disposiciones y resoluciones sobre asuntos dictaminados por el Consello Consultivo de Galicia cuando sea preceptiva su intervención en las mismas, si se tomasen de acuerdo con su dictamen, se expresarán con la fórmula “... de acuerdo con el dictamen del Consello Consultivo de Galicia", y si no se tomasen de acuerdo con el dictamen de aquél, con la de "... oído el Consello Consultivo de Galicia”.

Artículo 4. Miembros natos y miembros electivos del Consejo Consultivo de Galicia.

1. El Consejo Consultivo de Galicia está integrado por consejeras y consejeros natos y consejeras y consejeros electivos.

2. Son consejeras y consejeros natos las ex presidentas y los ex presidentes de la Xunta de Galicia.

3. Son consejeras y consejeros electivos las cinco personas nombradas por decreto de la presidenta o presidente de la Xunta de Galicia, oído el Consello de la Xunta, entre: 
a. Juristas de reconocido prestigio, con más de diez años de experiencia profesional efectiva.

b. Altos cargos y funcionarias y funcionarios de las administraciones públicas, con la licenciatura en derecho, con más de diez años de experiencia.

4. Las consejeras y consejeros natos ejercerán su mandato por un periodo de seis años, si tuvieron la condición de presidenta o presidente durante cuatro o menos años, o por un periodo de doce años, si tuvieron la condición de presidenta o presidente durante más de cuatro años.

El mandato no será renovable excepto en el caso de ser nombrados consejeras o consejeros electivos. Durante el tiempo de su mandato serán inamovibles, excepto en los supuestos establecidos en la presente ley.

5. Las consejeras y consejeros electivos ejercerán su mandato por un periodo de seis años, renovable una sola vez, salvo lo establecido en el apartado 2 del artículo 7 para el supuesto de las vacantes. Durante el tiempo de su mandato serán inamovibles, excepto en los supuestos establecidos en la presente ley.

6. Los miembros natos del Consejo Consultivo de Galicia tienen derecho a los honores y precedencias protocolarias que les correspondan en su condición de ex presidentas o ex presidentes de la Xunta de Galicia.

Los miembros electivos del Consejo Consultivo de Galicia tienen derecho a los honores y precedencias protocolarias que se señalen reglamentariamente.

7. Los miembros natos y electivos tienen derecho a las remuneraciones, por el ejercicio de sus funciones, que se fijen en los presupuestos generales de la comunidad autónoma ${ }^{80}$.

80 Art. 4 modificado por Ley 12/2007, de 27 de julio, por la que se modifica la Ley 9/1995, de 10 de noviembre, del Consejo Consultivo de Galicia, y la Ley $1 / 1983$ de 22 de febrero, de normas reguladoras de la Xunta y de su Presidencia.
Artículo 4 bis. Procedimiento de incorporación de los miembros natos.

1. La incorporación como miembro nato del Consejo Consultivo de quien ocupó la Presidencia de la Xunta de Galicia se producirá dentro del periodo de un año desde la fecha de publicación de su cese como tal. Durante este tiempo la ex presidenta o el ex presidente habrá de formalizar su deseo de incorporarse al Consejo Consultivo y formular declaración de no estar incurso en causa de incompatibilidad ${ }^{81}$.

2. La incorporación podrá demorarse, a petición de la persona interesada, mientras ésta ocupe un cargo público incompatible con la pertenencia al Consejo Consultivo. Producido el cese en dicho cargo, la ex presidenta o el ex presidente dispondrá de un nuevo plazo, de tres meses, para formalizar su incorporación al Consejo Consultivo.

$\mathrm{Si}$ el cese en el cargo incompatible estuviera motivado por la incorporación a otro cargo público igualmente incompatible con la condición de miembro del Consejo Consultivo, el plazo de tres meses para formalizar la referida solicitud de incorporación como miembro nato se computará desde el cese en este último.

3. El mandato de los miembros natos del Consejo Consultivo de Galicia podrá interrumpirse a consecuencia de su nombramiento para un cargo público declarado incompatible. A los efectos de su reincorporación al Consejo Consultivo por el tiempo que le quede de mandato, se estará a lo dispuesto en el apartado anterior ${ }^{82}$.

81 Téngase en cuenta la Disposición transitoria única de la Ley 12/2007, de 27 de julio, por la que se modifica la Ley $9 / 1995$, de 10 de noviembre, del Consejo Consultivo de Galicia, y la Ley $1 / 1983$, de 22 de febrero, de normas reguladoras de la Xunta y de su Presidencia, según la cual:

"Quien, en la fecha de entrada en vigor de la presente ley, tenga la condición de ex presidenta o ex presidente de la Xunta de Galicia podrá ejercer el derecho de incorporación al Consejo Consultivo de Galicia en los plazos y condiciones establecidos en el artículo 4 bis. La entrada en vigor producirá, para el caso, los mismos efectos que el decreto de cese como presidente de la Xunta de Galicia".

82 Art. 4 bis modificado por Ley $12 / 2007$, de 27 de julio, por la que se modifica la Ley $9 / 1995$, de 10 de noviembre, del Consejo Consultivo de Galicia, y la Ley 1/1983, de 22 de febrero, de normas reguladoras de la Xunta y de su Presidencia. 


\section{TÍTULO II COMPOSICIÓN}

Artículo 5. Elección de Presidente y designación de secretario.

1. El Consejo Consultivo de Galicia tendrá un presidente elegido por y entre las consejeras y consejeros electivos en votación secreta y por mayoría absoluta, en la forma prevista en el artículo 10. El presidente o la presidenta ostentará su representación a todos $\operatorname{los}$ efectos ${ }^{83}$.

2. Estará asistido por un secretario general, con voz pero sin voto, perteneciente al cuerpo de letrados del propio Consejo. Ejercerá las funciones que le atribuya el reglamento orgánico.

Artículo 6. Pérdida de la condición.

Los Conselleiros perderán la condición de tales:

a. Por renuncia.

b. Por extinción de su mandato al expirar el plazo.

c. Por incapacidad permanente declarada por resolución judicial firme.

d. Por incompatibilidad sobrevenida.

e. Por inhabilitación judicial para el ejercicio de cargo público declarada en sentencia firme.

f. Por condena por delito doloso en sentencia firme.

g. Por incumplimiento grave de las obligaciones de conselleiro.

h. Por fallecimiento.

Artículo 7. Procedimiento y vacantes.

1. El cese será dictado por el Presidente de la Xunta. En los supuestos previstos en los apartados d) y g) del artículo anterior será preciso el acuerdo favorable del Consejo tomado por mayoría absoluta de sus miembros, previa audiencia del interesado.

2. Las vacantes de miembros electivos del Consejo Consultivo se cubrirán con

83 Art. 5.1 modificado por Ley 12/2007, de 27 de julio, por la que se modifica la Ley 9/1995, de 10 de noviembre, del Consejo Consultivo de Galicia, y la Ley $1 / 1983$, de 22 de febrero, de normas reguladoras de la Xunta y de su Presidencia. arreglo a lo previsto en el artículo 4.3, y por el tiempo que quede de mandato ${ }^{84}$.

Artículo 8. Suspensión.

Los Conselleiros podrán ser suspendidos en sus funciones en caso de inculpación o procesamiento por delito doloso, atendiendo a la gravedad de los hechos, por acuerdo de la mayoría absoluta de los miembros del Consejo.

Artículo 9. Incompatibilidades.

1. La condición de conselleiro será incompatible con:

a. La de diputado del Parlamento de Galicia.

b. La de miembro del Congreso de los Diputados o del Senado.

c. La de magistrado del Tribunal Constitucional.

d. La de defensor del pueblo, valedor y vicevaledor do pobo o cargos homónimos de una Comunidad Autónoma.

e. LademiembrodelConsellodeContas.

f. La de cualquier cargo político o administrativo del Estado, Comunidades Autónomas o entidades locales.

g. Funciones directivas en partidos políticos, sindicatos de trabajadores o asociaciones de empresarios.

h. Cargos de toda índole en empresas concesionarias, contratistas, arrendatarios o administradores de obras o servicios públicos, cualquiera que sea su ámbito territorial.

i. La de miembro de cualquier órgano asesor de la Xunta.

j. El ejercicio de las carreras judicial o fiscal o de la abogacía.

k. Cualquier actividad profesional o mercantil.

2. Será compatible con el ejercicio de la actividad docente o investigadora, previa declaración expresa de compatibilidad por el Presidente del Consejo.

3. Si concurriese alguna causa de incompatibilidad en quien sea designado

84 Art. 7.2 modificado por Ley 12/2007, de 27 de julio, por la que se modifica la Ley $9 / 1995$, de 10 de noviembre, del Consejo Consultivo de Galicia, y la Ley 1/1983, de 22 de febrero, de normas reguladoras de la Xunta y de su Presidencia. 
conselleiro antes de tomar posesión del cargo y no constase su renuncia en lo que motivase la incompatibilidad, se entenderá que renuncia al puesto de conselleiro si no toma una decisión en el plazo de diez días, lo que así decretará el Presidente, cumpliéndose lo dispuesto en el artículo 7.1 para tal evento. En ambos casos se procederá a una nueva designación con arreglo al artículo 7.2.

Artículo 10. Elección de la presidenta o presidente y relevos.

1. En la primera reunión del consejo, cuando esté vacante la Presidencia, sus miembros electivos procederán a la elección de su titular de entre ellos, mediante votación secreta y por mayoría absoluta. En caso de que ésta no se obtuviera, las consejeras y consejeros electivos procederán a una segunda votación, en la cual tan sólo serán elegibles aquellas consejeras y consejeros más votadas y votados en la primera votación. En esta segunda votación resultará elegido quien obtenga mayor número de votos. La propuesta se comunicará a la presidenta o presidente de la Xunta, quien procederá a su nombramiento mediante decreto por un periodo de seis años, a cuyo término sólo podrá ser reelegido para un nuevo mandato.

2. En caso de ausencia o enfermedad, o mientras dure la vacante por cese de la presidenta o presidente, ejercerá sus funciones la consejera o consejero electivo más antiguo, y si la antigüedad fuera la misma, el de más edad ${ }^{85}$.

\section{TÍTULO III COMPETENCIA}

Artículo 11. Consultas y dictámenes preceptivos.

El Consello Consultivo de Galicia será consultado preceptivamente en los supuestos siguientes:

85 Art. 10 modificado por Ley 12/2007, de 27 de julio, por la que se modifica la Ley 9/1995, de 10 de noviembre, del Consejo Consultivo de Galicia, y la Ley 1/1983, de 22 de febrero, de normas reguladoras de la Xunta y de su Presidencia. a. Proyectos de reforma del Estatuto de Autonomía de Galicia.

b. Proyectos de legislación delegada a que se refiere el artículo 10.1.a) del Estatuto de Autonomía de Galicia.

c. Convenios y acuerdos de cooperación con otras Comunidades Autónomas, con arreglo a los artículos 145. 2, inciso primero, de la Constitución y 35.1 y 2 del Estatuto de Autonomía de Galicia.

d. Reglamentos que se dicten en ejecución de leyes, así como sus modificaciones.

e. Conflictos de atribuciones que se susciten entre las diversas consellerías y entre otros altos organismos e instituciones de la Comunidad Autónoma.

f. Recursos administrativos de revisión.

g. Revisión de oficio o a petición del interesado de los actos administrativos en la forma establecida en la Ley de Régimen Jurídico de las Administraciones Públicas y del Procedimiento Administrativo Común.

h. Nulidad, interpretación y resolución de los contratos administrativos en la forma establecida en la Ley de contratos del Estado y de régimen local.

i. Nulidad, interpretación, modificación y extinción de concesiones administrativas cualquiera que sea su objeto, en los casos en que así lo exijan las normas de aplicación.

j. Reclamaciones de responsabilidad patrimonial de cuantía superior a 1.500 euros ${ }^{86}$.

k. La creación o supresión de municipios, así como la alteración de términos municipales.

1. Cese de sus miembros, en todo caso.

m. En general, en todos aquellos supuestos en que así lo establezca una legislación específica.

Artículo 12. Solicitud de dictámenes.

1. En asuntos de competencia de la Xunta de Galicia, el dictamen del Consello Consultivo de Galicia será solicitado por el Presidente de la Xunta.

86 Art. 11.j modificado por Ley 16/2008, de 23 de diciembre, de presupuestos generales de la Comunidad Autónoma de Galicia para el año 2009. 
2. Corresponderá a los presidentes de las entidades locales solicitar el dictamen del Consello Consultivo de Galicia en aquellos supuestos en que la legislación lo requiera.

Artículo 13. Dictámenes facultativos. El Presidente de la Xunta, el Consello, los conselleiros y los presidentes de los organismos y entes públicos podrán solicitar dictamen del Consello Consultivo de Galicia sobre aquellos asuntos no incluidos en el artículo precedente cuando la especial trascendencia del asunto así lo requiera.

Artículo 14. Memoria anual.

El Consello Consultivo de Galicia elevará anualmente una memoria de actividades al Consello de la Xunta en la que se expresará la actividad desarrollada en el período anterior, así como las sugerencias que se consideren oportunas, tendentes a mejorar la actuación administrativa de la Comunidad Autónoma.

\section{TÍTULO IV FUNCIONAMIENTO}

Artículo 15. Atribuciones del Pleno y de las secciones.

1. El Consejo Consultivo de Galicia actuará en pleno y en secciones.

2. Corresponde al pleno emitir dictamen sobre los asuntos comprendidos en los apartados a), b), c), d), e), k) y 1) del artículo 11, y a las secciones sobre los restantes.

3. En caso de los dictámenes facultativos, la competencia se atribuye al pleno, pudiendo éste asignar a una sección la elaboración de una propuesta para su posterior elevación a aquel ${ }^{87}$.

Artículo 16. Número y composición de las secciones.

1. El Consello Consultivo de Galicia, salvo para los asuntos que son competencia del Pleno, funcionará a través de secciones.

87 Art. 15 modificado por Ley 12/2007, de 27 de julio, por la que se modifica la Ley $9 / 1995$, de 10 de noviembre, del Consejo Consultivo de Galicia, y la Ley $1 / 1983$, de 22 de febrero, de normas reguladoras de la Xunta y de su Presidencia.
2. Reglamentariamente, se determinará el número de secciones y la distribución de los asuntos entre ellas procurando la homogeneidad de las materias atribuidas a cada una.

3. Las secciones estarán compuestas por consejeras y consejeros electivos. El número mínimo de miembros de cada sección será de tres, y cada una estará presidida por uno de ellos, con la asistencia de un letrado ${ }^{88}$.

Artículo 17. Adopción de acuerdos.

1. En las reuniones del Pleno del Consello Consultivo de Galicia se requerirá, para la validez de las deliberaciones y de los acuerdos, la presencia del Presidente o de quien legalmente lo sustituya, de un número de miembros que con el Presidente constituyan mayoría absoluta y la del secretario general o de quien lo sustituya.

2. Los acuerdos se tomarán por mayoría absoluta de los miembros que constituyan el Consejo; en caso de empate, decidirá el voto de calidad del Presidente.

3. En caso de discrepancias con el acuerdo adoptado, el o los conselleiros discrepantes podrán formular por escrito, en el plazo que reglamentariamente se determine, su voto particular razonado, que se adjuntará al dictamen.

4. Los miembros natos del Consejo Consultivo de Galicia actuarán con voz pero sin voto, no computándose, en consecuencia, su asistencia a los efectos del quórum de constitución y adopción de acuerdos. No obstante lo anterior, actuarán con voz y voto en la emisión de dictámenes facultativos o en la de aquéllos en que sean solicitadas del órgano consultivo valoraciones de oportunidad o conveniencia, computándose en estos casos su asistencia a efectos de quórum de constitución y adopción de acuerdos.

88 Art. 16.3 modificado por Ley $12 / 2007$, de 27 de julio, por la que se modifica la Ley $9 / 1995$, de 10 de noviembre, del Consejo Consultivo de Galicia, y la Ley $1 / 1983$, de 22 de febrero, de normas reguladoras de la Xunta y de su Presidencia. 
Sin perjuicio de lo establecido en el párrafo anterior, los miembros natos del Consejo Consultivo de Galicia no podrán tomar parte en la discusión y elaboración de los dictámenes preceptivos o facultativos en relación a asuntos que estuvieran en tramitación en el Parlamento de Galicia ${ }^{89}$.

\section{TÍTULO V PROCEDIMIENTO}

Artículo 18. Plazos para la emisión de dictámenes.

1. El Consello Consultivo habrá de emitir sus dictámenes en el plazo de un mes a partir del momento de la recepción de la solicitud; transcurrido este plazo, se entenderá que no existe objeción alguna a la cuestión planteada.

2. Cuando en la orden de remisión del expediente se hiciese constar motivadamente la urgencia del dictamen, el plazo será de quince días, salvo que el Presidente de la Xunta, en atención a la materia y urgencia del asunto, fijase otro menor, que nunca será inferior a diez días.

Artículo 19. Documentación.

1. El órgano consultante habrá de facilitar al Consello cuanta documentación precise para dictaminar sobre la cuestión planteada.

2. El Consello, a través de su Presidente, y por acuerdo de aquél, podrá solicitar al órgano o institución consultante que se complete la documentación con cuantos antecedentes, informes y pruebas considere necesarios, incluso con el parecer de los organismos o personas que tuviesen competencia en las cuestiones relacionadas con el asunto objeto del dictamen; en este supuesto se interrumpirán los plazos previstos en el artículo 18 hasta que sea cubierta la solicitud.

Artículo 20. Audiencias e informes.

1. Pueden ser oídos ante el Consello los directamente interesados en los asuntos

89 Art. 17.4 añadido por Ley 12/2007, de 27 de julio, por la que se modifica la Ley $9 / 1995$, de 10 de noviembre, del Consejo Consultivo de Galicia, y la Ley $1 / 1983$, de 22 de febrero, de normas reguladoras de la Xunta y de su Presidencia. motivadores de la consulta, sea por acuerdo del Consejo a petición de los mismos, sea de oficio.

2. Por conducto del órgano consultante, o directamente, el Consello puede solicitar informe, oral o escrito, de aquellos organismos o personas que tuviesen notoria competencia técnica en las cuestiones solicitadas en las materias relacionadas con el objeto de la consulta.

\section{TÍTULO VI PERSONAL}

Artículo 21. De los letrados y sus funciones.

1. El Consello Consultivo estará asistido por su propio cuerpo de letrados.

2. Los letrados del Consello tendrán como misión el estudio, preparación y redacción de los proyectos de dictamen sobre los asuntos sometidos a la consulta del mismo, así como de aquellos que, siendo adecuados a su carácter, se determinen en el reglamento.

3. El Consello elegirá entre los letrados un secretario general, que será nombrado por su Presidente y tendrá la jefatura del personal, sin perjuicio de las facultades de aquél, y será sustituido, en caso de ausencia, por otro letrado designado por el Presidente.

4. Los letrados tendrán las incompatibilidades establecidas con carácter general para los funcionarios de las administraciones públicas y no podrán ejercer función alguna, salvo la docencia o investigación que se consideren compatibles y cuando no perjudiquen la buena marcha del Consello y siempre previa autorización de su Presidente.

Artículo 22. Selección de letrados. Los puestos de trabajo de letrados serán cubiertos en la forma siguiente:

a. Dos terceras partes, por oposición libre, en la forma que reglamentariamente se determine, entre licenciados en derecho.

b. Un tercio, por concurso entre funcionarios de la escala de letrados de la Xunta 
de Galicia, así como juristas funcionarios de carrera que ejerzan su actividad sometidos a una relación de derecho público.

Artículo 23. De la adscripción de otro personal.

El resto de plazas del personal serán cubiertas por funcionarios de la Administración de la Comunidad, de acuerdo con la plantilla que el Consello Consultivo proponga a la Xunta.

\section{DISPOSICIÓN ADICIONAL PRIMERA}

El Consello Consultivo dispondrá de seis letrados en tanto que la Xunta, a propuesta de aquél, establezca la definitiva plantilla orgánica.

\section{DISPOSICIÓN ADICIONAL SEGUNDA}

1. En el plazo de cuatro meses, siguientes al de la entrada en vigor de esta ley, se procederá al nombramiento de los conselleiros, así como a la constitución del Consello Consultivo de Galicia.

2. Los conselleiros prestarán juramento o promesa de acuerdo con la siguiente fórmula: "Juro (o prometo) cumplir las obligaciones de mi cargo de conselleiro del Consello Consultivo de Galicia y guardar y hacer guardar la Constitución y el Estatuto de Autonomía".

\section{DISPOSICIÓN ADICIONAL TERCERA}

Con arreglo a los principios de esta ley, el Consello Consultivo elaborará su reglamento de organización y funcionamiento y la Xunta procederá a su aprobación en el plazo de seis meses siguientes al de la constitución del Consello Consultivo de Galicia ${ }^{90}$.

\section{DISPOSICIÓN TRANSITORIA ÚNICA}

El Consello de la Xunta habilitará los créditos necesarios para la entrada en funcionamiento del Consello Consultivo de Galicia hasta que éste disponga de su

90 Véase Decreto 282/2003, de 22 de mayo, por el que se aprueba el Reglamento de organización y funcionamiento del Consello Consultivo de Galicia. propia sección en los presupuestos generales de la Comunidad Autónoma.

\section{DISPOSICIÓN FINAL ÚNICA}

Esta ley entrará en vigor el día siguiente al de su publicación en el "Diario Oficial de Galicia".

\section{LEY 6/1984, DE 5 DE JUNIO, DEL VALEDOR DO POBO DE GALICIA (DOGA N. $\left.{ }^{\circ} 135,14.7 .1984\right)$}

\section{$(\ldots)^{91}$ \\ TÍTULO I ESTATUS DE LA INSTITUCIÓN}

\author{
Capítulo I \\ CARÁCTER, ELECCIÓN, \\ NOMBRAMIENTO Y CESE ${ }^{92}$
}

Artículo 1. 1. El Valedor do Pobo es el alto comisionado del Parlamento de Galicia para la defensa, en el ámbito territorial de la Comunidad Autónoma, de los derechos fundamentales y las libertades públicas reconocidos en la Constitución y para el ejercicio de las demás funciones que esta ley le atribuye ${ }^{93}$.

2. La actividad del Valedor do Pobo se extenderá a la tutela de los derechos individuales y colectivos emanados del Estatuto de Autonomía, en especial, los sancionados en su Título Preliminar.

3. A estos fines, y en el ejercicio de las funciones que le encomiendan el Estatuto de Autonomía y la presente ley, el Valedor do Pobo podrá supervisar la actividad de la Administración de la Comunidad Autónoma gallega y de sus entes y empresas públicas o dependientes, así como la de la Administración local en aquellas materias que son competencia de nuestra Comunidad ${ }^{94}$.

\footnotetext{
91 Exposición de motivos omitida.

92 Rúbricas del Título I y del Capitulo I de dicho título modificadas por Ley $3 / 1994$, de 18 de julio, para la modificacion de la Ley $6 / 1984$, de 5 de junio, del Valedor do Pobo.

93 Art. 1.1 modificado por Ley $3 / 1994$, de 18 de julio, para la modificacion de la Ley $6 / 1984$, de 5 de junio, del Valedor do Pobo.

94 Art. 1.3 modificado por Ley 3/1994, de 18 de julio, para la modificacion de la Ley $6 / 1984$, de 5 de junio, del Valedor do Pobo.
} 
Artículo 2. 1. El Valedor do Pobo será elegido por el Parlamento de Galicia para un período de cinco años.

2. La propuesta de candidato o candidatos a Valedor do Pobo será realizada por la Comisión de Peticiones al Pleno del Parlamento de Galicia. A estos efectos será suficiente la mayoría simple para la adopción de acuerdos de la Comisión.

3. Propuesto el candidato o candidatos, se convocará, en un plazo no inferior a 15 días, el Pleno del Parlamento para que proceda a la elección. Será designado quien obtuviese una votación favorable de las tres quintas partes de los miembros del Parlamento.

4. En el supuesto de que ningún candidato alcanzase la mayoría establecida en el apartado anterior, se procederá por la Comisión de Peticiones, en el plazo máximo de un mes, a la formulación de sucesivas propuestas seguidas de las correspondientes votaciones hasta la obtención de la mayoría señalada.

Artículo 3. 1. Podrá ser elegido Valedor do Pobo cualquier ciudadano que goce de la condición política de gallego, se encuentre en pleno disfrute de sus derechos civiles y políticos y conozca los idiomas oficiales de Galicia.

2. El nombramiento del Valedor do Pobo será acreditado por el Presidente del Parlamento y publicado en el Diario Oficial de Galicia.

3. El Valedor do Pobo tomará posesión de su cargo ante la Mesa del Parlamento, dentro de los quince días siguientes a la publicación de su nombramiento. Prestará juramento o promesa de fiel cumplimiento de sus funciones.

Artículo 4. 1. La Comisión de Peticiones del Parlamento de Galicia, será la encargada de las relaciones con el Valedor do Pobo e informará al Pleno en cuantas ocasiones sea necesario.

2. El Valedor do Pobo se dirigirá, de ordinario, al Parlamento a través del Presidente del mismo.
Artículo 5. 1. El Valedor do Pobo de Galicia cesará por alguna de las siguientes causas:

1 . $^{\text {a }}$ Por renuncia.

2. Por expiración del plazo de su nombramiento.

3. ${ }^{a}$ Por muerte o incapacidad sobrevenida.

4. ${ }^{a}$ Por notorio incumplimiento de las obligaciones y deberes de su cargo.

5. ${ }^{a}$ Por ser condenado, mediante sentencia firme, por delito doloso.

2. El Presidente del Parlamento declarará la vacante en el cargo en los supuestos de muerte, renuncia o expiración del plazo del mandato. En los otros casos, decidirá el Pleno del Parlamento por la mayoría establecida de las tres quintas partes de los miembros del Parlamento, mediante debate y previa audiencia del interesado.

3. Vacante el cargo, se iniciará, en plazo no superior a un mes, el procedimiento para la elección de un nuevo Valedor do Pobo.

Si la causa del cese fuese la expiración de su nombramiento, el Valedor do Pobo seguirá en el desempeño de su cargo con prórroga de funciones hasta que se produzca la nueva elección ${ }^{95}$.

4. En los demás supuestos, la Comisión de Peticiones podrá acordar por mayoría simple, en tanto no se cubra vacante, el desempeño de las funciones del Valedor do Pobo por los Vicevaledores, interinamente, en su propio orden ${ }^{96}$.

\section{Capitulo II PRERROGATIVAS E INCOMPATIBILIDADES}

Artículo 6. 1. El Valedor do Pobo de Galicia no estará sujeto a mandato imperativo alguno. No recibirá instrucciones de ninguna autoridad. Desempeñará sus funciones con autonomía y según su criterio.

\footnotetext{
95 Art. 5.3 modificado por Ley 3/1994, de 18 de julio, para la modificacion de la Ley $6 / 1984$, de 5 de junio, del Valedor do Pobo.

96 Art. 5.4 modificado por Ley $3 / 1994$, de 18 de julio, para la modificacion de la Ley $6 / 1984$, de 5 de junio, del
} Valedor do Pobo. 
2. El Valedor do Pobo gozará de las prerrogativas y garantías necesarias para el cumplimiento de su función, de acuerdo con la legislación vigente.

Artículo 7. 1. La condición de Valedor do Pobo es incompatible con todo mandato representativo, cargo político o actividad de propaganda política; con la permanencia en servicio activo de cualquier Administración Pública; con la condición de miembro de Partido Político o con el desempeño de funciones directivas en un Partido, Sindicato, Asociación o Fundación, o con el empleo al servicio de los mismos; con el ejercicio de las carreras judicial y fiscal o de cualquier actividad profesional, judicial, mercantil o laboral.

2. El Valedor do Pobo deberá cesar en la situación de incompatibilidad en la que se encuentre antes de tomar posesión del cargo. En el caso contrario se entenderá que no acepta el nombramiento.

3. En el supuesto de incompatibilidad sobrevenida, se entenderá que renuncia al cargo en la fecha en que se tenga producido aquélla.

\section{TÍTULO II MEDIOS PERSONALES Y MATERIALES}

\section{Capítulo I \\ VICEVALEDORES Y PERSONAL 97}

Artículo 8. 1. El Valedor do Pobo estará auxiliado por hasta un máximo de tres vicevaledores o vicevaledoras, en quienes podrá delegar sus funciones, y que lo sustituirán en el ejercicio de las mismas de acuerdo con el orden que se establezca en su nombramiento, según lo dispuesto en el artículo $5^{\circ} .4$ de la presente ley.

2. Uno de los vicevaledores o una de las vicevaledoras será designado o designada para el ejercicio de las funciones previstas en el capítulo V del título I de la Ley de

97 Rúbrica del Capitulo I del Título II modificada por Ley $3 / 1994$, de 18 de julio, para la modificacion de la Ley 6/1984, de 5 de junio, del Valedor do Pobo. salud de Galicia, teniendo a estos efectos la consideración de vicevaledor o vicevaledora del paciente ${ }^{98}$.

Artículo 9. 1. La Comisión de Peticiones, a iniciativa de los grupos parlamentarios, propondrá al Valedor do Pobo el nombramiento de los Vicevaledores.

Corresponde al Valedor do Pobo el nombramiento y el cese de los mismos ${ }^{99}$.

2. El nombramiento y cese de los Vicevaledores serán publicados en el Diario Oficial de Galicia.

3. Los Vicevaledores habrán de reunir las condiciones establecidas en el artículo 3.1, gozarán durante el ejercicio de sus funciones de todas las prerrogativas y garantías reconocidas en el artículo 6 y estarán sometidos al régimen de incompatibilidades preceptuado en el artículo 7 de la presente ley ${ }^{100}$.

Artículo 10. 1. El personal al servicio del Valedor do Pobo se considerará personal al servicio del Parlamento mientras permanezca en el ejercicio de sus funciones. Dependerá orgánica, funcional y disciplinariamente del Valedor do Pobo y se regirá por las normas de régimen interior previstas en la Disposición adicional y, con carácter supletorio, por el Estatuto de Personal del Parlamento de Galicia.

2. La plantilla será aprobada por la Mesa del Parlamento, a propuesta del Valedor do Pobo. Dentro de dicha plantilla, el Valedor podrá designar libremente a los asesores necesarios para el ejercicio de sus funciones y con sujeción a los límites presupuestarios. El personal restante habrá de reunir la condición previa de funcionario de cualquiera de las Administraciones públicas y podrá ser adscrito a su oficina por

98 Art. 8 modificado por Ley $8 / 2008$, de 10 de julio, de salud de Galicia.

99 Art. 9.1 modificado por Ley 1/2002, de 26 de marzo, por la que se modifica la Ley de Galicia 6/1984, de 5 de junio, del Valedor do Pobo.

100 Art. 9.3 modificado por Ley 3/1994, de 18 de julio, para la modificacion de la Ley $6 / 1984$, de 5 de junio, del Valedor do Pobo. 
Código de la Administración Gallega

libre designación o por concurso público según la relación de puestos de trabajo.

3. Los funcionarios provenientes de las Administraciones públicas gallegas, parlamentaria, local y de la Comunidad Autónoma, adscritos a la Oficina del Valedor do Pobo, tendrán derecho a ser declarados en la situación administrativa de servicios especiales en su Administración de origen, salvo los que se incorporen por concurso público, que pasarán a la situación prevista en el artículo 54 de la Ley de la Función Pública de Galicia ${ }^{101}$.

Artículo 11. Los Vicevaledores y los asesores adscritos a la oficina del Valedor do Pobo cesarán automáticamente en el momento de la toma de posesión de un nuevo Valedor do Pobo nombrado por el Parlamento.

\section{Capitulo II DOTACIÓN ECONÓMICA}

Artículo 12. 1. La dotación económica necesaria para el funcionamiento de la institución constituirá una partida del presupuesto del Parlamento de Galicia y su elaboración corresponde al Valedor do Pobo. Se remitirá a la Mesa del Parlamento para su aprobación e integración en el presupuesto del Parlamento.

2. La autorización de los gastos y la ordenación de los pagos corresponderán al Valedor do Pobo, y podrá delegarlas en un Vicevaledor, y los regímenes de contabilidad, intervención, contratación y adquisición de bienes y derechos serán los que rijan en el Parlamento de Galicia 102103.

$\overline{101}$ Art. 10 modificado por Ley $3 / 1994$, de 18 de julio, para la modificacion de la Ley $6 / 1984$, de 5 de junio, del Valedor do Pobo.

102 Art. 12 modificado por Ley 3/1994, de 18 de julio, para la modificacion de la Ley $6 / 1984$, de 5 de junio, del Valedor do Pobo.

103 Véase Resolución de 20 de junio de 2003 por la que se publica el Reglamento de régimen presupuestario y contable del Parlamento de Galicia y del Valedor do Pobo

\section{TÍTULO III DEL PROCEDIMIENTO}

\section{Capítulo I ATRIBUCIONES Y FACULTADES}

Artículo 13. 1. El Valedor do Pobo, de oficio o a instancia de parte, podrá iniciar y proseguir cualquier investigación sobre:

a. Los actos y resoluciones de la Administración pública de la Comunidad Autónoma y de sus agentes.

b. Los actos y resoluciones de la Administración local, incluidos sus organismos autónomos, así como las empresas y entes públicos o participados que de ella dependan, en el ámbito de las competencias que corresponden a la Comunidad Autónoma, de conformidad con el Estatuto de Autonomía y la legislación vigente.

c. Los servicios gestionados por personas físicas o jurídicas mediante concesión administrativa $y$, en general, cualquier organismo o entidad pública o privada que realice funciones de servicio público y se encuentre sujeta a cualquier tipo de tutela en aquello que afecte a las materias integradas en las competencias de la Comunidad Autónoma, de conformidad con lo establecido en el Estatuto de Autonomía de Galicia y la legislación vigente.

d. En su caso, las materias que sean objeto de transferencia o delegación, al amparo de lo que disponen los apartados primero y segundo del artículo 150 de la Constitución, tanto en el caso de que la Comunidad Autónoma las administre como asunto propio como en el supuesto de administración comisionada ${ }^{104}$.

2. Las facultades del Valedor do Pobo se extenderán a la actividad que realicen los Conselleiros y cualesquiera autoridades administrativas, funcionarios y agentes que actúen al servicio de la Administración de la Comunidad Autónoma y a sus entes o empresas dependientes.

104 Art. 13.1 modificado por Ley 3/1994, de 18 de julio, para la modificacion de la Ley 6/1984, de 5 de junio, del Valedor do Pobo. 
Artículo 14. 1. Toda persona natural o jurídica que invoque un interés legítimo podrá dirigirse al Valedor do Pobo sin restricción ni limitación alguna.

2. Los Diputados, individualmente, y las Comisiones del Parlamento de Galicia relacionadas con la defensa de los derechos y libertades públicas, podrán solicitar la intervención del Valedor do Pobo en todas las cuestiones atribuidas a su competencia.

3. La Comisión de Peticiones podrá además transmitirle las que reciba en los términos del artículo 48 del Reglamento del Parlamento Gallego.

4. Ninguna autoridad administrativa, en el ámbito de su competencia, podrá presentar quejas ante el Valedor do Pobo.

Artículo 15. 1. La actividad del Valedor do Pobo de Galicia no se verá interrumpida en los casos en que el Parlamento no se encuentre reunido, fuese disuelto o expire su mandato. En los citados casos el Valedor do Pobo de Galicia se dirigirá a la Diputación Permanente de la Cámara.

2. La declaración de los estados de excepción o sitio no interrumpirá la actividad del Valedor do Pobo, ni el derecho de los ciudadanos de acceder al mismo, sin perjuicio de lo dispuesto en los artículos 55 y 116 de la Constitución.

Artículo 16. 1. El Valedor do Pobo, de oficio o a instancia de parte, podrá supervisar la actividad de la Administración de la Comunidad Autónoma gallega para garantizar el respeto de los derechos comprendidos en el título I de la Constitución y su sometimiento pleno a la ley y al derecho. Con este mismo fin, podrá además supervisar la actividad de la Administración local en el ámbito de las competencias que el Estatuto de Autonomía y la legislación vigente confieren a la Comunidad Autónoma.

2. Las facultades atribuidas al Valedor do Pobo se extenderán igualmente de manera especial a la defensa de los derechos y principios rectores que dimanan del titulo preliminar del Estatüto de Autonomía de Galicia.

3. Respecto a las demás Administraciones públicas, ejercerá las funciones que le correspondan dentro de los principios de coordinación, cooperación y colaboración establecidos en el artículo 12 de la Ley Orgánica 3/1981, de 6 de abril, y en la Ley $36 / 1985$, de 6 de noviembre.

4. $(\ldots)^{105}$.

\section{Capitulo II TRAMITACIÓN DE LAS QUUEJAS}

Artículo 17. Las quejas que el Valedor do Pobo reciba, referidas al funcionamiento de la Administración de Justicia de Galicia deberá dirigirlas al Ministerio Fiscal y al Consejo del Poder Judicial, sin perjuicio de incluirlas en el informe al Parlamento.

Artículo 18. 1. Toda queja dirigida al Valedor do Pobo habrá de ser formulada por escrito en el que conste la identificación, domicilio o dirección del peticionario y se relate el hecho que la motiva. Irá suscrita o firmada por el solicitante, que puede pedir que su solicitud sea confidencial 106.

2. Se acusará recibo de toda queja que sea registrada.

3. Las quejas al Valedor do Pobo se deberán presentar en el plazo de un año cumplido a partir del conocimiento de los hechos.

4. La actuación del Valedor do Pobo y la de sus colaboradores será gratuita para el interesado.

5. No será preceptiva la intervención o asistencia de Letrado ni Procurador.

Artículo 19. El Valedor do Pobo tramitará o rechazará las quejas recibidas. En este último supuesto, mediante escrito

105 Art. 16.1 y 16.3 modificados y art. 16.4 suprimido por Ley $3 / 1994$, de 18 de julio, para la modificacion de la Ley 6/1984, de 5 de junio, del Valedor do Pobo.

106 Art. 18.1 modificado por Ley 3/1994, de 18 de julio, para la modificacion de la Ley $6 / 1984$, de 5 de junio, del Valedor do Pobo. 
motivado en el que se podrá informar al interesado de lo más oportuno en Derecho a su actuación.

Artículo 20. El Valedor do Pobo de Galicia no entrará en el examen individual de aquellas quejas sobre las que esté pendiente resolución judicial y lo suspenderá si, iniciada la actuación, se interpusiera por persona interesada demanda o recurso ante los Tribunales Ordinarios o el Tribunal Constitucional. Esto no impedirá, sin embargo, la investigación sobre los problemas generales planteados en las quejas presentadas. En cualquier caso velará porque la Administración resuelva expresamente, en tiempo y en forma, las peticiones y recursos que le fueron formulados.

Artículo 21. El Valedor do Pobo de Galicia rechazará las quejas anónimas y podrá rechazar aquéllas en las que se advierta mala fe, carencia de fundamento, inexistencia de pretensión, así como aquellas otras cuya tramitación irrogue perjuicio al legítimo derecho de tercera persona. Sus resoluciones no serán susceptibles de recurso.

Artículo 22. 1. Admitida a trámite una queja, el Valedor do Pobo promoverá la oportuna investigación sumaria e informal. En todo caso, informará al Organismo o Dependencia Administrativa del contenido sustancial de la solicitud, recabando cuantos datos estime pertinentes que tendrán que serle remitidos en el plazo de quince días, a no ser que la complejidad del asunto aconseje, a su criterio, otro mayor.

2. La negativa o negligencia de cualquier organismo, funcionario o de sus superiores responsables al envío de los informes solicitados podrá ser considerada por el Valedor do Pobo de Galicia como hostil y entorpecedora de sus funciones, haciéndola pública de inmediato y destacando tal calificación en su informe anual o especial, en su caso, al Parlamento. También pondrá dichos hechos en conocimiento de su superior jerárquico, informando sobre su comportamiento por si fuese susceptible de corrección disciplinaria ${ }^{107}$.

\section{Capítulo III TRAMITACIÓN DE LA INVESTIGACIÓN}

Artículo 23. En el ejercicio de sus funciones, el Valedor do Pobo, sus adjuntos o persona en que delegue, podrá personarse en cualquier Centro o Dependencia de la Administración Pública de la Comunidad Autónoma Gallega, de sus entes y empresas públicas dependientes de la misma o afectos a un servicio público, para la comprobación de datos, realización de entrevistas personales, estudio de expedientes y documentos relacionados con los motivos de su actuación sin que pueda negársele el examen de la documentación interesada, excepto en los casos taxativamente establecidos por la ley.

Artículo 24. 1. Cuando la queja a investigar afectara la conducta de las personas al servicio de la Administración Pública Gallega, en relación con la función que desempeñan, el Valedor do Pobo de Galicia dará cuenta de la misma al afectado y a su inmediato superior u Organismo de quien aquél dependiera.

2. El afectado responderá por escrito y con la aportación de cuantos documentos y testimonios considere oportunos, en el plazo que le fuera fijado, que en ningún caso será inferior a diez días, pudiendo ser prorrogado a instancia de parte por la mitad del concedido.

El Valedor do Pobo de Galicia podrá comprobar su veracidad y proponer al funcionario afectado una entrevista ampliatoria de datos. Los funcionarios que se negasen a ello podrán ser requeridos por aquél para que manifiesten por escrito las razones que justifiquen tal decisión.

3. El superior jerárquico u Organismo que prohíba al funcionario a sus órdenes

107 Art. 22.2 modificado por Ley $3 / 1994$, de 18 de julio, para la modificacion de la Ley $6 / 1984$, de 5 de junio, del Valedor do Pobo. 
o servicio responder a la requisitoria del Valedor do Pobo de Galicia o entrevistarse con él, deberá manifestarlo por escrito debidamente motivado, dirigido al funcionario y al propio Valedor do Pobo de Galicia. Éste dirigirá en adelante cuantas actuaciones investigadoras sean necesarias al referido superior jerárquico.

4. La información que en el curso de una investigación pueda aportar un funcionario a través de su testimonio personal tendrá el carácter de reservada sin perjuicio de lo dispuesto en la Ley de Enjuiciamiento Criminal sobre la denuncia de hechos que pudiesen revestir carácter delictivo.

Artículo 25. Cuando el Valedor do Pobo, por razón del ejercicio de las funciones propias de su cargo, tenga conocimiento de una conducta o hecho presumiblemente delictivo lo comunicará al Ministerio Fiscal de quien podrá solicitar información sobre el estado de tramitación en que se encuentren las actuaciones iniciadas a su instancia.

\section{Capítulo IV \\ DEBER DE COLABORACIÓN}

Artículo 26. 1. Los poderes públicos de Galicia están obligados a prestar el auxilio y cooperación que les sean demandados por el Valedor do Pobo en sus investigaciones y actuaciones.

2. En los supuestos en que la obtención de datos o la prestación de auxilio resultase preciso obtenerlas fuera del ámbito territorial de la Comunidad Autónoma, el Valedor do Pobo podrá solicitarlos del Defensor del Pueblo o de otras Instituciones similares, de acuerdo con los principios de coordinación y cooperación establecidos en la Ley Orgánica 3/1981, de 6 de abril.

Artículo 27. Si las autoridades, funcionarios o agentes dificultasen o entorpeciesen la actuación del Valedor do Pobo, de sus adjuntos o delegados, aquél dará cuenta al superior jerárquico $\mathrm{y}$, en su caso, al Ministerio Fiscal para el ejercicio de las acciones que puedan proceder, recogiendo tales actitudes en sus informes al Parlamento de Galicia.

\section{Capitulo V GASTOS CAUSADOS A PARTICULARES}

Artículo 28. Los gastos efectuados o los perjuicios materiales, causados a los particulares que no promovieran la queja, al ser llamados a informar por el Valedor do Pobo, serán compensados con cargo a su presupuesto una vez justificados debidamente.

\section{Capítulo VI DE LAS RESOLUCIONES}

Artículo 29. 1. El Valedor do Pobo podrá sugerir a la Administración pública la modificación de los criterios utilizados en la producción de sus actos y resoluciones.

2. Esta actuación de mediación, así como la tramitación de una reclamación, no interrumpirán los plazos establecidos para los diferentes procedimientos administrativos ${ }^{108}$.

Artículo 30. Si el Valedor do Pobo de Galicia, como consecuencia de sus investigaciones, llegase al convencimiento de que el cumplimiento riguroso de una norma puede provocar situaciones injustas o perjudiciales para los administrados, podrá sugerir al Parlamento de Galicia o a la Administración la modificación de la misma.

Artículo 31. El Valedor do Pobo podrá instar de las autoridades administrativas competentes el ejercicio de sus facultades de inspección y sanción si las actuaciones se realizaron con ocasión de servicios prestados por particulares en virtud de acto administrativo habilitante.

Artículo 32. 1. El Valedor do Pobo, con motivo de sus investigaciones, podrá

108 Art. 29 modificado por Ley 3/1994, de 18 de julio, para la modificacion de la Ley $6 / 1984$, de 5 de junio, del Valedor do Pobo. 
formular a las autoridades y funcionarios de las Administraciones Públicas advertencias, recomendaciones, recordatorios de sus deberes legales y sugerencias para la adopción de nuevas medidas.

2. Estos funcionarios y autoridades deberán responder siempre por escrito y en el plazo de un mes.

Artículo 33. 1. Si formuladas sus recomendaciones, no obtuviera respuesta o, en un plazo razonable, no se produjera una medida adecuada a lo sugerido, el Valedor do Pobo podrá poner los antecedentes del escrito y las recomendaciones efectuadas en conocimiento del Conselleiro del Departamento afectado o de la máxima autoridad de la Administración Pública Gallega.

2. Si tampoco obtuviera una justificación adecuada, incluirá tal asunto en su informe anual o especial con mención de los nombres de las autoridades o funcionarios que persistan en aquella actitud, especialmente en los casos en que, considerando el Valedor do Pobo que era posible una solución positiva, ésta no se hubiera conseguido.

\section{Capitulo VII MODIFICACIONES Y NOTIFICACIONES}

Artículo 34. El Valedor do Pobo informará al interesado o, en su caso, al Diputado o Comisiones a que se refiere el artículo 14 de esta ley del resultado de sus investigaciones, así como de la respuesta que le hubiese dado la Administración o los funcionarios implicados, salvo que por su naturaleza aquellas fuesen consideradas, de acuerdo con la Ley, de carácter reservado o declaradas secretas. Asimismo, cuando acuerde no intervenir, informará razonando su decisión ${ }^{109}$.

Artículo 35. Cuando las actuaciones participadas muestren que la queja se originó presumiblemente por abuso,

109 Art. 34 modificado por Ley 3/1994, de 18 de julio, para la modificacion de la Ley $6 / 1984$, de 5 de junio, del Valedor do Pobo. arbitrariedad, discriminación o error, negligencia u omisión de un funcionario, el Valedor do Pobo se dirigirá al interesado, haciéndole constar su criterio al respecto, y a su superior jerárquico, formulando las sugerencias que estime oportunas.

\section{TÍTULO IV DE LOS INFORMES AL PARLAMENTO ${ }^{110}$}

Artículo 36. 1. El Valedor do Pobo dará cuenta anualmente al Parlamento de la gestión realizada en un informe que presentará ante el mismo en el período ordinario de sesiones.

2. Cuando la gravedad o urgencia de los hechos lo aconsejen, podrá presentar un informe extraordinario dirigido a la Diputación Permanente del Parlamento si éste no estuviese reunido o se encontrase disuelto.

3. Los informes anuales y, en su caso, los extraordinarios serán publicados.

Artículo 37. 1. El Valedor do Pobo de Galicia, en su informe anual, dará cuenta del número de tipos de queja presentadas; de aquellas que fueron rechazadas y sus causas, así como de las que fueron objeto de investigación y el resultado de la misma, con especificación de las sugerencias o recomendaciones admitidas por la Administración Pública Gallega.

2. En el informe no constarán datos personales que permitan la pública identificación de los interesados en el procedimiento investigador, sin perjuicio de lo dispuesto en el artículo 27 de la presente ley ${ }^{111}$.

3. En los casos especialmente graves, el Valedor do Pobo podrá destacar en su informe anual la persistencia de una actitud hostil o entorpecedora a su labor de cualesquiera organismos, funcionarios o personas al servicio de la Administración Pública, en su ámbito de competencias.

110 Rúbrica del Título IV modificada por Ley $3 / 1994$, de 18 de julio, para la modificacion de la Ley 6/1984, de 5 de junio, del Valedor do Pobo.

111 Art. 37.2 modificado por Ley 3/1994, de 18 de julio, para la modificacion de la Ley 6/1984, de 5 de junio, del Valedor do Pobo. 
4. El informe contendrá igualmente un anexo, destinado al Parlamento de Galicia, en el que se hará constar la liquidación del presupuesto de la Institución en el período que corresponda.

5. Un resumen del informe será expuesto oralmente por el Valedor do Pobo ante el Pleno del Parlamento.

\section{TÍTULO V DE LAS RELACIONES CON EL DEFENSOR DEL PUEBLO $Y$ LOS COMISIONADOS DE PARLAMENTOS O DE ASAMBLEAS LEGISLATIVAS AUTONÓMICAS 112}

Artículo 38. 1. Le corresponde al Valedor do Pobo el ejercicio de las facultades de investigación en relación con las instituciones y organismos referidos en el artículo 13.1, sin perjuicio de las que puedan corresponder al Defensor del Pueblo, en virtud del artículo 12 de la Ley Orgánica 3/1981, de 6 de abril, y del artículo 2 de la Ley 36/1985, de 6 de noviembre.

2. El Valedor do Pobo podrá concertar con el Defensor del Pueblo acuerdos de coordinación y colaboración entre ambas instituciones, según lo previsto en las mencionadas Leyes.

Para la validez y vigencia de tales acuerdos, será preceptiva su ratificación por la Comisión de Peticiones del Parlamento de Galicia. Estos acuerdos se publicarán en el "Boletín Oficial del Parlamento de Galicia" y en el "Diario Oficial de Galicia".

3. Cuando el Valedor reciba quejas o denuncias referentes a ámbitos de las Administraciones públicas que no son competencia de la Comunidad Autónoma gallega, dará cuenta de las mismas al Defensor del Pueblo. Le notificará igualmente de oficio aquellas infracciones o irregularidades que él hubiese observado.

Artículo 39. El Valedor do Pobo, de oficio o a instancia de parte, podrá

112 Rúbrica del Titulo $V$ modificada por Ley $3 / 1994$, de 18 de julio, para la modificacion de la Ley $6 / 1984$, de 5 de junio, del Valedor do Pobo. dirigirse motivadamente al Defensor del Pueblo solicitándole que éste, en defensa de legítimos intereses de los ciudadanos y siempre que lo considere oportuno:

a. Interponga o ejercite el recurso de inconstitucionalidad o el de amparo.

b. Dirija recomendaciones a los órganos generales del Estado cuando las deficiencias en el funcionamiento de los órganos o entidades a que se refiere el artículo 13 de esta ley se deriven de normas de competencia estatal o sean originadas por el deficiente funcionamiento de la Administración central del Estado.

Artículo 40. El Valedor do Pobo podrá dirigirse a los comisionados parlamentarios de otras Comunidades Autónomas cuando necesite su colaboración para el ejercicio de sus funciones. Asimismo, para coordinar actuaciones conjuntas que excedan del ámbito territorial ${ }^{113}$.

\section{DISPOSICIÓN ADICIONAL}

Se autoriza al Valedor do Pobo para dictar las normas reglamentarias precisas para el desarrollo de la presente ley, de acuerdo con la Mesa del Parlamento y la Comisión de Peticiones.

Estas normas reglamentarias se publicarán en el "Boletín Oficial del Parlamento de Galicia".

\section{DISPOSICIÓN TRANSITORIA}

La Comisión de Peticiones propondrá al Pleno de la Cámara, en el plazo máximo de seis meses computados desde el día de la entrada en vigor de la presente ley, el candidato o candidatos a Valedor do Pobo de Galicia mediante acuerdo adoptado por mayoría simple.

\section{DISPOSICIÓN FINAL}

El Valedor do Pobo, transcurrido un año del ejercicio de sus funciones, podrá

113 Art. 38, 39 y 40 modificados por Ley 3/1994, de 18 de julio, para la modificacion de la Ley $6 / 1984$, de 5 de junio, del Valedor do Pobo. 
proponer al Parlamento en el informe anual, o en otro extraordinario, las modificaciones en el texto de la presente ley que juzgue oportunas a la luz de la aplicación práctica de la misma.

\section{LEY 4/2002, DE 25 DE JUNIO, DEL ESTATUTO DE LA CAPITALIDAD DE LA CIUDAD DE SANTIAGO DE COMPOSTELA (DOGA N. $\left.{ }^{\circ} 142,24.7 .2002\right)$ \\ $(\ldots)^{114}$ \\ TÍTULO I \\ DE LA CIUDAD DE SANTIAGO DE COMPOSTELA}

Artículo 1. Objeto de la ley.

La presente ley tiene por objeto regular el estatuto especial de la ciudad de Santiago de Compostela como sede de las instituciones autonómicas y por su reconocimiento como capital de la Comunidad Autónoma de Galicia, de conformidad con lo previsto en el artículo 89.2 de la Ley 5/1997, de 22 de julio, de Administración local de Galicia.

Artículo 2. Capitalidad.

Santiago de Compostela es la capital de Galicia.

Artículo 3. Régimen jurídico especial y símbolos.

1. La ciudad de Santiago de Compostela gozará del régimen jurídico especial establecido por la presente ley.

2. La Corporación municipal compostelana gozará de la preeminencia honorífica y protocolaria que le corresponda de acuerdo con las leyes.

3. Como distintivo de la capitalidad el escudo de Santiago de Compostela está conformado por dos cuarteles, el derecho con las armas de Galicia, cáliz con Sagrada Hostia con siete cruces periféricas; y el izquierdo con el sepulcro del Apóstol en mármol blanco, con forma de arqueta sobre nubes, y en lo alto una estrella de oro radiante; sobre el escudo, la corona de

114 Exposición de motivos omitida. los Reyes Católicos, por detrás, la Cruz Espada de Santiago.

4. La bandera de Santiago de Compostela es de color granate y lleva bordado, en su centro, el escudo.

5. La ciudad de Santiago de Compostela ostentará los títulos concedidos en atención a su historia y tradición, y en concreto los de muy noble, muy leal y fidelísima ciudad de Santiago de Compostela.

6. El escudo y la bandera de Santiago de Compostela podrán modificarse por acuerdo del Pleno de la Corporación municipal, previo informe de la Comisión de Heráldica de la Xunta de Galicia.

Artículo 4. Término municipal.

El territorio del municipio está constituido por el actual término municipal de Santiago de Compostela.

Artículo 5. Régimen jurídico.

El Ayuntamiento de Santiago de Compostela tiene personalidad jurídica y plena capacidad para el cumplimiento de sus fines y se rige por lo dispuesto en la Ley de bases de régimen local, en la presente ley, en la Ley de Administración local de Galicia y en las normas que las desarrollen.

Artículo 6. Idioma.

1. El gallego, lengua propia de Galicia, lo es también del Ayuntamiento de Santiago de Compostela.

2. El Ayuntamiento de Santiago de Compostela debe normalizar y potenciar el uso del gallego en el ámbito de sus competencias en todos los planos de la vida pública, cultural e informativa.

3. El Ayuntamiento de Santiago de Compostela, dentro del marco constitucional y estatutario, debe garantizar que nadie sea discriminado por causa del uso de las lenguas gallega o castellana.

\section{TÍTULO II ORGANIZACIÓN, COMPETENCIAS E INFORMACIÓN}

Artículo 7. Principios generales. El Gobierno municipal actúa de acuerdo con los principios de eficacia, jerarquía, 
desconcentración y coordinación. Deben ser criterios esenciales de su organización diferenciar las funciones deliberantes de ordenación, programación y control de las ejecutivas de gobierno y administración y fomentar la participación ciudadana.

Artículo 8. Órganos de corporación.

1. El gobierno y la administración municipal de Santiago de Compostela corresponden al Ayuntamiento, integrado por el Alcalde y los concejales.

2. Los órganos de gobierno del Ayuntamiento de Santiago de Compostela son:

a. El Pleno municipal.

b. El Alcalde.

c. Los tenientes de Alcalde.

d. La Comisión de Gobierno.

e. Los demás que establezca el Reglamento orgánico de la corporación de acuerdo, en todo caso, con las disposiciones legales vigentes en materia de régimen local.

3. Las competencias y el funcionamiento de los órganos del Ayuntamiento de Santiago de Compostela se ajustarán a lo dispuesto en la normativa de régimen local y en el Reglamento orgánico de la corporación.

Artículo 9. Áreas de servicios.

1. De acuerdo con lo que establezca el Reglamento orgánico de la corporación, el Alcalde podrá crear áreas funcionales para la gestión de aquellos servicios o competencias que se estimen convenientes, bajo la dependencia de los órganos municipales que se establezcan.

2. Al frente de cada área podrá existir un gerente, nombrado y cesado libremente por el Alcalde, que ejercerá las funciones que se le atribuyan en el Reglamento orgánico.

Artículo 10. Autonomía municipal.

Para la efectividad de la autonomía garantizada constitucionalmente y del régimen de capitalidad reconocido en la presente ley, así como para el cumplimiento de las finalidades establecidas en el artículo 2 de la Ley reguladora de las bases de régimen local y en la Carta europea de autonomía local, el municipio de Santiago de Compostela ostentará las competencias procedentes en atención a las características de su actividad pública y capacidad de gestión.

Artículo 11. Atribución competencial. El Ayuntamiento de Santiago de Compostela tiene las competencias establecidas en la presente ley y en las disposiciones legales en materia de régimen local y podrá ostentar también aquellas otras que las demás administraciones públicas puedan transferirle o delegarle.

Artículo 12. Información a los ciudadanos.

1. Los ciudadanos tienen derecho a ser informados de las actividades municipales, acceder a los archivos públicos y utilizar todos los medios de información general que el Ayuntamiento establezca mediante el uso de cualquiera de las tecnologías al servicio de la comunicación, en los términos y condiciones y con el alcance que determinen la legislación general sobre la materia, el Reglamento orgánico y las ordenanzas.

2. A fin de asegurar la máxima participación, la información municipal puede realizarse de las siguientes formas:

a. Información pública.

b. Información pública individualizada, que debe utilizarse en las actuaciones urbanísticas de singular relevancia y en otros supuestos que se establezcan por el reglamento.

c. Consulta directa de los ciudadanos, mediante sistemas telefónicos y telemáticos, de las bases de datos, ficheros y registros que el Ayuntamiento disponga abrir al acceso público. El Ayuntamiento debe regular los efectos de las comunicaciones enviadas mediante correo electrónico.

3. Los vecinos tienen derecho a ser informados de los resultados de la gestión municipal. A fin de hacer efectivo este principio de transparencia, el Ayuntamiento de Santiago de Compostela debe definir un conjunto de indicadores de actividad, costes, eficacia, eficiencia y calidad, y sus valores deben ser publicados anualmente. 
Esta información se difunde por los medios y redes de comunicación para asegurar su conocimiento general.

4. El Ayuntamiento de Santiago de Compostela debe prestar el servicio de acceso a la información municipal y ciudadana por sistemas telemáticos. Con esta finalidad, el Ayuntamiento puede convenir con otras administraciones, organismos, instituciones o entidades nacionales o internacionales la interconexión de las distintas bases de datos. En cualquier caso, debe especificarse qué información es propiamente municipal y cuál es facilitada por otros organismos, personas o entidades.

5. En el tratamiento específico de la información que se ponga a disposición de quienes quieran consultarla y en la determinación de los procedimientos y protocolos de acceso, debe tenerse en cuenta la normativa que regula el carácter privado de los datos personales.

6. El Ayuntamiento de Santiago de Compostela adoptará las medidas pertinentes para que los procedimientos que se inician a solicitud del interesado se tramiten en soporte informático, así como para que los ciudadanos puedan conocer el estado de tramitación de los procedimientos que les afecten y el acceso a los documentos e información que estén en tal soporte por conducto telemático o informático. Lo anterior se entenderá sin perjuicio de las limitaciones que las leyes establecen en el ejercicio de los derechos de acceso a los archivos y registros administrativos.

Artículo 13. Incorporación de medios técnicos en las relaciones entre el Ayuntamiento de Santiago de Compostela y los ciudadanos.

1. El Ayuntamiento de Santiago de Compostela impulsará el empleo y aplicación de las técnicas y medios electrónicos y telemáticos, para el desarrollo de su actividad y ejercicio de sus competencias, con las limitaciones que para la utilización de estos medios establecen la Constitución y las leyes.

2. Los ciudadanos podrán presentar las solicitudes, escritos y comunicaciones dirigidas a la Xunta de Galicia en cualquiera de los registros públicos de los órganos administrativos del Ayuntamiento de Santiago de Compostela. También podrán presentar en los registros de los órganos dependientes de la Xunta de Galicia cualquier escrito, solicitud o comunicación dirigida al Ayuntamiento de Santiago de Compostela. Las recíprocas obligaciones de ambas administraciones para garantizar el ejercicio de ese derecho de los ciudadanos se regularán mediante la firma del correspondiente convenio de colaboración.

3. Para la presentación de solicitudes, comunicaciones o escritos en los registros de órganos dependientes del Ayuntamiento de Santiago de Compostela, cuando vayan dirigidos a la Administración del Estado, se estará a lo que resulte de los convenios de colaboración que, en su caso, se celebren entre ambas administraciones.

4. El Ayuntamiento de Santiago de Compostela podrá celebrar convenios de colaboración con entidades públicas o privadas para facilitar la presentación de solicitudes, comunicaciones o escritos dirigidos al Ayuntamiento de Santiago de Compostela en las oficinas que dichas entidades tengan abiertas al público.

Artículo 14. Cartas de servicios.

En relación con los servicios públicos de competencia municipal, y de conformidad con lo que establezca el correspondiente reglamento de la corporación, el Ayuntamiento elaborará cartas de servicios en las cuales se establezcan los derechos de los ciudadanos en sus relaciones con la Administración municipal, así como las concretas obligaciones y responsabilidades que esta última asuma para garantizar aquellos derechos y los adecuados niveles de calidad en la prestación de los correspondientes servicios. 


\section{TÍTULO III \\ RELACIONES \\ INTERADMINISTRATIVAS Y EL CONSEJO DE LA CAPITALIDAD} ración.

Artículo 15. Colaboración y coope-

1. Las relaciones de colaboración y cooperación entre el Ayuntamiento de Santiago de Compostela y las demás administraciones públicas se regirán por lo dispuesto en la Ley de Administración local de Galicia, en la legislación que regula el procedimiento administrativo y en las demás normas estatales o autonómicas que resulten de aplicación.

2. En lo que se refiere a las relaciones entre la Comunidad Autónoma y el Ayuntamiento de Santiago de Compostela se observará, además, lo establecido en este título.

Artículo 16. El Consejo de la Capitalidad.

Se crea el Consejo de la Capitalidad como órgano colegiado, de carácter permanente, cuyo objeto es la coordinación entre la Administración autonómica de Galicia y la Corporación municipal de Santiago de Compostela en lo que afecta a sus respectivas competencias y responsabilidades derivadas del hecho de la capitalidad.

Artículo 17. Composición.

1. El Consejo de la Capitalidad estará compuesto por:

El Presidente de la Xunta de Galicia.

Los conselleiros con competencias en las siguientes materias: Presidencia, Relaciones Institucionales y Administración Pública; Justicia, Interior y Relaciones Laborales; Economía y Hacienda; Cultura, Comunicación Social y Turismo; Política Territorial, Obras Públicas y Vivienda; y Educación y Ordenación Universitaria.

El Alcalde de Santiago de Compostela.

Los concejales delegados de las áreas de Presidencia, Casco Histórico, Economía, Cultura y Urbanismo.

Los concejales designados por el Pleno, uno por cada grupo municipal no representado en la Comisión de Gobierno, siempre que hubiera obtenido más del 10 por 100 de los votos en el correspondiente proceso electoral. La Presidencia del Consejo corresponde al Presidente de la Xunta y la Vicepresidencia, al Alcalde de Santiago de Compostela. Actuará como secretario el secretario general del Ayuntamiento de Santiago de Compostela.

2. Por razón de los asuntos que se sometan a consideración del Consejo de la Capitalidad podrán incorporarse a sus sesiones como miembros no permanentes los conselleiros competentes por razón de la materia de que se trate y los concejales del área correspondiente.

Artículo 18. Régimen de funcionamiento.

1. El Consejo de la Capitalidad aprobará su propio reglamento de funcionamiento con observancia de lo establecido en la presente ley, aplicándose supletoriamente las normas sobre funcionamiento de órganos colegiados que establece la legislación sobre régimen jurídico de las administraciones públicas y procedimiento administrativo común.

2. Los acuerdos del Consejo se adoptarán por consenso, a través de la posición manifestada por los titulares de las dos administraciones en el mismo representadas.

3. El Consejo se reunirá, al menos, una vez por año $\mathrm{y}$, en todo caso, antes de la aprobación por la Xunta de Galicia del Proyecto de ley de presupuestos de la Comunidad Autónoma.

4. La convocatoria del Consejo de la Capitalidad la efectuará el secretario, por orden del Presidente, que igualmente fijará el orden del día de sus sesiones.

5. Sin perjuicio de lo establecido en el párrafo anterior, procederá la convocatoria del Consejo siempre que así sea solicitado por la representación del Ayuntamiento de Santiago de Compostela. La solicitud se formulará por conducto de la Alcaldía y en la misma se expresarán los asuntos que la motivan, que se incluirán en el orden del día. 
Artículo 19. La Comisión Ejecutiva.

1. El Consejo dispondrá de una Comisión Ejecutiva, presidida por el Alcalde de Santiago de Compostela y de la que formarán parte:

Un representante, con rango de director general o equivalente, designado por cada una de las consellerías con competencias en materia de Presidencia, Relaciones Institucionales y Administración Pública; Justicia, Interior y Relaciones Laborales; Economía y Hacienda; Cultura, Comunicación Social y Turismo; y Política Territorial, Obras Públicas y Vivienda.

Los concejales delegados de las áreas de Presidencia, Casco Histórico, Economía, Cultura y Urbanismo.

Los concejales designados por el Pleno, uno por cada grupo municipal no representado en la Comisión de Gobierno, siempre que hubiera obtenido más del 10 por 100 de los votos en el correspondiente proceso electoral.

Será secretario de la Comisión un letrado de la Asesoría Jurídica General de la Xunta de Galicia.

2. A la Comisión Ejecutiva podrán incorporarse, en razón de las materias que se traten, como miembros no permanentes, personas representativas de las instituciones que componen el Consejo designadas por el titular respectivo.

3. A la Comisión Ejecutiva le corresponde preparar las sesiones del Consejo de la Capitalidad, velar por la ejecución de sus acuerdos y ejercer cuantas funciones le sean atribuidas por el Reglamento orgánico así como las que le delegue el Consejo de la Capitalidad. Le será de aplicación, en lo que le afecte, el régimen de funcionamiento previsto en el artículo 18 .

Artículo 20. Funciones del Consejo de la Capitalidad.

Al Consejo de la Capitalidad le corresponden las siguientes funciones:

1. La adopción de acuerdos en relación con las materias que el Pleno del propio Consejo declare de interés concurrente para la Administración autonómica y el Ayuntamiento de Santiago de Compostela y que afecten a las funciones que a la ciudad de Santiago de Compostela le correspondan como capital de Galicia.

2. El estudio y valoración de los costes que para la ciudad de Santiago de Compostela conlleva su condición de capital de Galicia y, en su caso, la fijación de los instrumentos de compensación precisos.

Artículo 21. Servicios y actuaciones metropolitanas.

Para la prestación de servicios que exijan una actuación conjunta o coordinada del Ayuntamiento de Santiago de Compostela y de los Ayuntamientos limítrofes podrá constituirse un consorcio en la forma y por el procedimiento regulado en la Ley de Administración local de Galicia. Las iniciativas que a este fin se adopten habrán de ser comunicadas al Consejo de la Capitalidad.

Artículo 22. Patrimonio históricoartístico de Santiago de Compostela.

1. La consellería competente en materia de patrimonio histórico-artístico y el Ayuntamiento de Santiago de Compostela remitirán al Consejo de la Capitalidad una programación anual de las actuaciones tendentes a la conservación y rehabilitación del patrimonio histórico y monumental de la ciudad de Santiago de Compostela.

2. La Administración autonómica y el Ayuntamiento de Santiago de Compostela establecerán los mecanismos de colaboración y cooperación necesarios para determinar y financiar las políticas de recuperación urbana integral del casco histórico de Santiago de Compostela, así como de los entornos monumentales y parajes naturales de interés históricoartístico del Ayuntamiento, en los cuales se indiquen los objetivos que se pretenden alcanzar y los recursos comprometidos.

Artículo 23. Territorio y urbanismo.

1. El Ayuntamiento de Santiago de Compostela reservará en los planes generales de ordenación municipal el suelo necesario 
para dar respuesta a las necesidades de ubicación de edificios de organismos públicos, bien sean autonómicos, estatales o internacionales, que deseen tener sedes permanentes en Galicia.

2. El Ayuntamiento de Santiago de Compostela emitirá informe previo en los casos de diseño de grandes infraestructuras de comunicación que le afecten, de acuerdo con lo dispuesto en la legislación sectorial.

Artículo 24. Seguridad pública.

1. El Ayuntamiento de Santiago de Compostela velará por la seguridad pública en los actos protocolarios oficiales que se celebren en la ciudad, en colaboración y coordinación con las demás fuerzas de seguridad, en los términos previstos en la Ley orgánica de cuerpos y fuerzas de seguridad.

2. En el ámbito de aplicación de la presente ley y a fin de garantizar la seguridad por parte de la Policía Local, la Xunta de Galicia y el Ayuntamiento de Santiago de Compostela firmarán los convenios de colaboración precisos en el marco de la Junta Local de Seguridad, de acuerdo con lo dispuesto en la Ley de coordinación de policías locales de Galicia.

Artículo 25. Transporte.

La Xunta de Galicia y el Ayuntamiento de Santiago de Compostela deberán establecer fórmulas de colaboración y cooperación en el marco de la Ley de coordinación de transportes por carretera para asegurar la prestación del transporte público en el ámbito del área de Santiago de Compostela.

Artículo 26. Turismo.

1. A los efectos previstos en la Ley de Administración local de Galicia y en la Ley de ordenación del turismo de Galicia, Santiago de Compostela tendrá la condición de municipio turístico.

2. De acuerdo con el artículo 91.1 de la Ley 5/1997, de 22 de julio, de Administración local de Galicia, podrán establecerse convenios entre la Administración autonómica y el Ayuntamiento de Santiago de Compostela para la coordinación y apoyo en materia de salubridad y espacios públicos, Protección Civil y seguridad ciudadana, información, atención y promoción turística.

Artículo 27. Relaciones entre el Consejo de la Capitalidad y el Consorcio de la Ciudad de Santiago de Compostela.

El Consejo de la Capitalidad coordinará sus actuaciones con el Consorcio de la Ciudad de Santiago de Compostela, de conformidad con lo dispuesto en sus estatutos.

\section{TÍTULO IV RÉGIMEN DE FINANCIACIÓN}

Artículo 28. Financiación de la capitalidad.

La condición de capital de Galicia de la ciudad de Santiago de Compostela tendrá un apartado específico en los presupuestos de la Comunidad Autónoma. A tal fin, antes de la elaboración del Proyecto de ley de presupuestos, el Consejo de la Capitalidad podrá emitir el correspondiente informe.

\section{DISPOSICIÓN FINAL}

La presente ley entrará en vigor el día siguiente al de su publicación en el "Diario Oficial de Galicia”.

\section{LEY $11 / 2001$, DE 18 DE SEPTIEMBRE, DE COLEGIOS PROFESIONALES DE LA COMUNIDAD AUTÓNOMA DE GALICIA (DOGA N. $\left.{ }^{\circ} 189,28.9 .2001\right)$}

$(\ldots)^{115}$

\section{Capitulo I \\ DISPOSICIONES GENERALES}

\section{Sección $1 .^{\mathrm{a}}$}

Ámbito de aplicación

Ejercicio de las profesiones

Artículo 1. Ámbito de aplicación. La presente ley es de aplicación a los colegios profesionales que desarrollen su actividad exclusivamente en el ámbito territorial de la Comunidad Autónoma de

115 Exposición de motivos omitida. 
Galicia, que se rigen, en el marco de la legislación básica estatal, por la presente ley y sus normas de desarrollo, sus leyes de creación y sus Estatutos y Reglamentos de régimen interior.

Artículo 2. Ejercicio de las profesiones.

1. La Comunidad Autónoma de Galicia, en el ámbito de su competencia, garantiza el ejercicio de las profesiones colegiadas de conformidad con lo dispuesto en las leyes. Se entiende por profesión colegiada aquélla en la cual se requiere la colegiación para su ejercicio.

2. El ejercicio de las profesiones colegiadas se realizará en régimen de libre competencia y estará sujeto, en cuanto a la oferta de servicios y fijación de su remuneración, a la Ley sobre defensa de la competencia y a la Ley sobre la competencia desleal. Los demás aspectos del ejercicio profesional continuarán rigiéndose por la legislación general y específica sobre la ordenación sustantiva propia de cada profesión aplicable.

3. Es requisito indispensable para el ejercicio de las profesiones colegiadas estar incorporado al colegio correspondiente. Cuando una profesión se organice por colegios territoriales, bastará la incorporación a uno solo de los mismos, que será el del domicilio profesional único o principal, sin que pueda exigirse por los colegios en cuyo ámbito territorial no radique dicho domicilio habilitación alguna ni el pago de contraprestaciones económicas distintas de aquéllas que exijan habitualmente a sus colegiados por la prestación de los servicios de que sean beneficiarios y que no se hallen cubiertos por la cuota colegial. Lo anterior se entiende sin perjuicio de que los Estatutos generales o, en su caso, los autonómicos puedan establecer la obligación de los profesionales que ejerzan en un territorio diferente al de colegiación de comunicar a los colegios distintos a los de su inscripción la actuación en su ámbito territorial.
4. Toda persona que esté en posesión de la titulación adecuada y reúna los requisitos establecidos por los correspondientes Estatutos tendrá derecho a ser admitida en el colegio profesional correspondiente.

Artículo 3. Profesionales al servicio de la Administración.

Los profesionales titulados vinculados con la administración pública mediante relación de servicios de carácter administrativo o laboral no precisarán estar colegiados para el ejercicio de funciones puramente administrativas ni para la realización de actividades propias de la correspondiente profesión por cuenta de la administración a que pertenezcan, cuando el destinatario inmediato de las mismas sea esa administración. Sí será obligatoria, en consecuencia, la colegiación para el ejercicio de la actividad privada.

\section{Capitulo II \\ DE LOS COLEGIOS PROFESIONALES}

\section{Sección 1. ${ }^{\mathrm{a}}$ \\ Naturaleza \\ Régimen de funcionamiento}

Ejercicio de competencias administrativas. Artículo 4. Naturaleza jurídica.

Los colegios profesionales y los consejos gallegos de colegios son corporaciones de derecho público, con personalidad jurídica propia y plena capacidad para el cumplimiento de sus fines.

Artículo 5. Estructura interna y régimen de funcionamiento.

La estructura interna y el funcionamiento de los colegios profesionales y de los consejos gallegos de colegios deberán ser democráticos.

Artículo 6. Relaciones con la Administración autonómica.

Los colegios profesionales, en las cuestiones relativas a los aspectos institucionales y corporativos contemplados en la presente ley, se relacionarán con la Administración de la Comunidad Autónoma de Galicia a través de la consellería competente en materia de colegios profesionales, y en las 
cuestiones referentes al contenido de cada profesión, a través de la consellería o consellerías competentes al respecto.

Artículo 7. Ejercicio de competencias y colaboración con la Administración.

1. Los colegios profesionales ejercerán, además de sus funciones propias, las funciones administrativas que les atribuya la legislación estatal y autonómica y las competencias administrativas que les delegue el correspondiente órgano de la administración. El acto de delegación habrá de estar autorizado mediante una disposición legal o reglamentaria.

2. La Comunidad Autónoma de Galicia podrá encomendar a los colegios profesionales, a través del correspondiente convenio, la realización de actividades de carácter material, técnico o de servicios de su propia competencia, según los términos del artículo 15 de la Ley 30/1992, de Régimen Jurídico de las Administraciones Públicas y del Procedimiento Administrativo Común.

3. Asimismo, la Comunidad Autónoma de Galicia podrá celebrar convenios de colaboración con los colegios profesionales para la realización de actividades de interés común y para la promoción de actuaciones orientadas a la defensa del interés público y, en especial, de los usuarios de los servicios profesionales de los colegiados.

\section{Sección 2. \\ Fines y funciones}

\section{Artículo 8. Fines.}

1. Los colegios profesionales regulados por la presente ley tendrán como fines esenciales la ordenación del ejercicio de las profesiones dentro del marco legal respectivo, la representación de las mismas y la defensa de los intereses profesionales de los colegiados.

Además, tendrán los siguientes fines:

a. Velar por la satisfacción de los intereses generales relacionados con el ejercicio de las correspondientes profesiones. b. Lograr la constante mejora del nivel de calidad de las prestaciones profesionales de los colegiados, promoviendo la formación y el perfeccionamiento de los mismos.

c. Cooperar en la mejora de los estudios conducentes a la obtención de títulos habilitantes para el ejercicio de las correspondientes profesiones.

d. Colaborar con las administraciones públicas en el ejercicio de sus competencias, en los términos previstos en la legislación vigente.

2. Lo dispuesto en el apartado anterior se entiende sin perjuicio de la competencia de la administración pública por razón de la relación funcionarial.

Artículo 9. Funciones.

Para el cumplimiento de sus fines, los colegios profesionales ejercerán las funciones encomendadas en la legislación básica del Estado, y como propias las siguientes:

a. Ejercer en su ámbito la representación y defensa de la profesión.

b. Ordenar en el marco de su competencia la actividad de sus colegiados, velando por la ética y dignidad profesional de los mismos así como conciliando sus intereses con el interés social y los derechos de los ciudadanos.

c. Ejercer la potestad disciplinaria sobre los profesionales colegiados, en los términos previstos en la presente ley y sus propios Estatutos.

d. Ejercitar las acciones legales y adoptar las medidas necesarias para evitar el intrusismo profesional y la competencia desleal.

e. Establecer los baremos de honorarios, que tendrán carácter meramente orientativo.

f. Encargarse del cobro de las percepciones, remuneraciones u honorarios profesionales, cuando el colegiado lo solicite libre y expresamente, en los casos en que el colegio profesional tenga creados los servicios adecuados y en las condiciones que se determinen en los Estatutos de cada colegio.

g. Establecer y exigir las aportaciones económicas de los colegiados. 
h. Elaborar y aprobar sus presupuestos anuales de ingresos y gastos, así como sus cuentas y liquidaciones presupuestarias.

i. Visar los trabajos profesionales de los colegiados cuando así se establezca expresamente en los Estatutos.

El visado no comprenderá los honorarios ni las demás condiciones contractuales, que se determinarán por libre acuerdo de las partes.

j. Organizar actividades dirigidas a la formación y perfeccionamiento profesional de los colegiados.

k. Participar de forma activa con las entidades de formación de los futuros titulados en la mejora de los planes de estudio y la preparación de los mismos.

1. Organizar actividades y servicios comunes de carácter profesional, cultural, asistencial, de previsión y análogos que sean de interés para los colegiados, así como de cobertura de posibles responsabilidades civiles contraídas por los mismos en el ejercicio de su profesión.

$\mathrm{m}$. Intervenir como mediador en los conflictos profesionales que surjan entre los colegiados.

n. Relacionarse y coordinarse con otros colegios profesionales, así como con los consejos gallegos de colegios.

o. Informar aquellos proyectos de normas que elabore la Comunidad Autónoma de Galicia que afecten a los profesionales que agrupen o se refieran a los fines o funciones a ellos encomendados.

p. Participar en los órganos consultivos de la Administración de Galicia cuando la misma lo requiera o así se establezca en la normativa vigente y designar representantes en cualquier juzgado o tribunal en que se exijan conocimientos relativos a materias específicas, siempre que sean requeridos para ello en los términos establecidos en la Ley de enjuiciamiento civil.

q. Emitir informes y dictámenes, de carácter no vinculante, en procedimientos judiciales o administrativos en que se planteen cuestiones que afecten a materias de la competencia profesional.

r. Colaborar con las administraciones públicas en materia de sus competencias, de acuerdo con las disposiciones vigentes.

s. Garantizar la prestación de la función por los profesionales colegiados.

t. Actuar como árbitro en los conflictos entre los colegiados y terceros, cuando así se solicite por ambas partes.

u. Cuantas otras funciones repercutan en beneficio de los intereses profesionales de los colegiados y se encaminen al cumplimiento de los fines colegiales.

Artículo 10. Deontología profesional.

1. Los profesionales integrados en los colegios profesionales respectivos deben tener como guía de su actuación el servicio a la comunidad y el cumplimiento de las obligaciones deontológicas propias de la profesión.

2. Constituirá conducta sancionable el incumplimiento de las normas deontológicas de la profesión respectiva. Los colegiados no podrán ser sancionados por acciones $\mathrm{u}$ omisiones que no estén tipificadas como faltas en los correspondientes Estatutos. La imposición de sanciones requerirá la previa instrucción de un procedimiento disciplinario, rigiéndose la tramitación del mismo por lo dispuesto en los Estatutos.

\section{Sección $3 .^{a}$ Creación}

Artículo 11. Constitución.

1. En el ámbito territorial de la Comunidad Autónoma de Galicia, la creación de colegios profesionales se hará por Ley del Parlamento gallego.

2. Cuando el ejercicio de la iniciativa legislativa sea del Consello de la Xunta, el correspondiente anteproyecto de Ley de creación se hará a petición de los profesionales interesados y previa apreciación por parte del Gobierno autonómico del interés público concurrente en la creación del colegio. 
3. Únicamente se podrá crear un nuevo colegio profesional respecto a aquellas profesiones para cuyo ejercicio se exija estar en posesión de un título académico oficial, y también respecto a aquellas actividades profesionales cuyo ejercicio esté condicionado a la posesión de un título oficial que acredite la cualificación y habilite legalmente para su ejercicio.

4. El ámbito territorial mínimo de los colegios de nueva creación será la provincia.

5. No podrá constituirse más de un colegio profesional de idéntica profesión dentro de un mismo ámbito territorial.

Artículo 12. Personalidad jurídica.

Los colegios profesionales tendrán personalidad jurídica desde el momento en que entre en vigor su Ley de creación y capacidad de obrar desde el momento en que se constituyan sus órganos de gobierno.

Artículo 13. Denominación.

1. La denominación de los colegios profesionales habrá de responder a la titulación oficial requerida para la incorporación de sus componentes o a la profesión que desempeñen o puedan desempeñar.

2. La denominación de los colegios profesionales no podrá coincidir ni ser similar a la de otros colegios existentes o susceptible de inducir a error en cuanto a quienes sean los profesionales integrados en ese colegio profesional.

3. El cambio de denominación de un colegio profesional será a iniciativa del propio colegio, de la Administración autonómica o del consejo gallego respectivo, debiendo ser informado por los colegios y consejos gallegos que no hubieran ejercitado la iniciativa y por los que pudieran resultar afectados por el nuevo nombre.

Su aprobación se realizará por medio de Decreto del Consello de la Xunta de Galicia.

\section{Artículo 14. Fusión.}

1. La constitución de un nuevo colegio profesional por fusión de dos o más colegios hasta entonces correspondientes a distintas profesiones o actividades profesionales se aprobará por Ley de la Comunidad Autónoma de Galicia, a propuesta de los colegios afectados, de acuerdo con lo establecido en sus respectivos Estatutos, previo informe de los consejos gallegos respectivos si estuviesen constituidos.

2. La constitución de un nuevo colegio profesional por la fusión de dos o más de ellos de la misma profesión o actividad profesional, siempre que no rebasen el ámbito territorial de la Comunidad Autónoma de Galicia, será acordada por los colegios profesionales afectados, de acuerdo con lo establecido en sus respectivos Estatutos, y se aprobará por Decreto del Consello de la Xunta de Galicia, previo informe, en su caso, del consejo gallego de colegios respectivo.

Artículo 15. Segregación.

1. La segregación de un colegio de otro $\mathrm{u}$ otros en que se exija, para su ingreso, a partir de ese momento, titulación diferente a la del colegio de origen se realizará mediante Ley, siguiéndose los mismos trámites que para su creación.

2. La modificación del ámbito territorial de los colegios profesionales por segregación requerirá el correspondiente acuerdo del colegio afectado, de conformidad con lo establecido en sus respectivos Estatutos, debiendo ser aprobada por Decreto, previo informe del correspondiente consejo de colegios, si existiera.

\section{Sección $4 .^{a}$ \\ Estatutos}

Artículo 16. Elaboración y aprobación. Los colegios profesionales gozarán de autonomía para la elaboración y aprobación de sus Estatutos, sin más límites que los establecidos por el ordenamiento jurídico. Los Estatutos habrán de asegurar que la estructura interna y el funcionamiento de los colegios sean democráticos.

Artículo 17. Contenido.

Los Estatutos de los colegios profesionales contendrán, además de las determinaciones 
exigibles por la legislación básica del Estado, las siguientes:

a. Denominación, domicilio, sede y, en su caso, delegaciones, así como ámbito territorial del colegio profesional.

b. Requisitos para la admisión en el colegio y causas de denegación, debiendo constar en todo caso la titulación oficial exigida.

c. Causas de suspensión o pérdida de la condición de colegiado.

d. Derechos y deberes de los colegiados.

e. Denominación, composición y forma de elección de sus órganos de gobierno, así como requisitos para formar parte de los mismos.

f. Procedimiento para la remoción de los órganos de gobierno por medio de la moción de censura efectuada por la asamblea o junta general.

g. Competencias y régimen de funcionamiento de la asamblea o junta general y de los demás órganos de gobierno, teniendo en cuenta los supuestos en que puedan producirse vacantes en más de la mitad de sus miembros, y forma de adoptar acuerdos.

h. Régimen económico-financiero.

i. Régimen de distinciones y premios.

j. Régimen disciplinario, con tipificación de las infracciones y sanciones en que puedan incurrir los colegiados, así como procedimiento sancionador.

k. Régimen jurídico de los actos de los colegios y recursos contra los mismos en los términos previstos en el artículo 31 .

1. Supuestos y procedimientos para instar la disolución del colegio y régimen de liquidación.

Artículo 18. Deber de inscripción y comunicación.

1. Los colegios profesionales comunicarán a la consellería competente en materia de colegios profesionales los Estatutos aprobados, así como sus modificaciones a los efectos de su aprobación definitiva, previa calificación de legalidad, e inscripción en el registro de colegios.
La aprobación definitiva deberá producirse en el plazo máximo de seis meses; transcurrido el citado plazo sin declaración expresa, la misma se entenderá de carácter favorable. La resolución de carácter desfavorable, que deberá ser motivada, determinará la devolución de los Estatutos.

Aprobados los Estatutos, se publicarán en el "Diario Oficial de Galicia" mediante orden de la Consellería competente en materia de colegios profesionales.

Cuando se trate de colegios profesionales únicos con el ámbito territorial de la Comunidad Autónoma, la aprobación definitiva será competencia del Consello de la Xunta, publicándose en el "Diario Oficial de Galicia" el Decreto aprobatorio y los correspondientes Estatutos y sus modificaciones.

2. Una vez elegidos los miembros de los órganos de gobierno, se comunicará su composición a la consellería competente en materia de colegios profesionales y a la consellería o consellerías competentes por razón de la profesión.

3. Los colegios profesionales comunicarán al consejo gallego de colegios respectivo la composición de sus órganos de gobierno.

\section{Sección $5 .^{a}$ Organización}

Artículo 19. Organización mínima.

1. Son órganos esenciales de la estructura colegial:

a. El órgano plenario.

b. El órgano de gobierno.

c. El órgano presidencial.

2. Los Estatutos podrán crear otros órganos jerárquicamente dependientes de los anteriores.

Artículo 20. Órgano plenario.

1. La asamblea o junta general, integrada por todos los colegiados, es el órgano soberano de decisión de los colegios profesionales.

2. La convocatoria, constitución, funcionamiento y competencias de las asambleas 
o juntas generales se determinarán estatutariamente. Habrá de celebrarse, al menos, una asamblea o junta general al año.

En todo caso, son competencias exclusivas del órgano plenario las siguientes:

a. La aprobación y reforma de los Estatutos y normas deontológicas colegiales.

b. La elección del órgano de gobierno y de su Presidente, y la remoción de los mismos por medio de la moción de censura.

c. La aprobación de los presupuestos y cuentas del colegio.

d. La aprobación de la gestión del órgano de gobierno y de su Presidente.

Artículo 21. Órgano de gobierno.

1. La dirección y administración del colegio corresponderá al órgano de gobierno y su denominación se determinará en los Estatutos.

2. El órgano de gobierno será siempre colegiado y estará compuesto, al menos, por los siguientes miembros:

a. El Presidente, que ostentará la representación legal del colegio profesional, además de las funciones que le encomienden los Estatutos, podrá también recibir la denominación de decano o cualquier otra que le otorguen los Estatutos.

b. El Secretario, que tendrá el carácter de fedatario de los actos y acuerdos del colegio.

c. Los vocales, en número necesario para el desarrollo de las actividades que tenga atribuidas el colegio correspondiente $\mathrm{y}$ en función del número de colegiados adscritos al mismo.

3. La elección de los miembros del órgano de gobierno de los colegios profesionales se hará por sufragio universal, libre, directo y secreto. El voto podrá ejercitarse personalmente o por correo.

4. Las normas sobre elección de los miembros del órgano de gobierno, la convocatoria de reuniones, la composición y funcionamiento, el régimen de acuerdos y sus competencias se determinarán en los respectivos Estatutos, sin perjuicio de la legislación básica del Estado y de la presente ley.

Artículo 22. Órgano presidencial.

1. El órgano presidencial tendrá la denominación que tenga recogida en los Estatutos, ostenta la representación del colegio, ejecuta los acuerdos del órgano de gobierno y ejerce cuantas facultades y funciones le confieren los Estatutos y la normativa vigente.

2. Corresponde la presidencia del órgano de gobierno a quien le corresponda la titularidad del órgano presidencial, salvo que los Estatutos dispongan otra cosa.

\section{Capitulo III CONSEJOS GALLEGOS DE COLEGIOS PROFESIONALES}

\section{Sección $1 .^{\mathrm{a}}$}

Constitución y naturaleza

Artículo 23. Constitución.

Los colegios profesionales de una misma profesión con ámbito territorial circunscrito al de la Comunidad Autónoma de Galicia podrán constituir el correspondiente consejo gallego de colegios.

La creación exigirá el acuerdo favorable de la mayoría de los colegios afectados, siempre que los mismos representen a la mayoría de los colegiados de la profesión en Galicia, realizándose mediante Decreto, que deberá asimismo aprobar los correspondientes Estatutos, de conformidad con lo señalado en el artículo 28.

El plazo para la tramitación del procedimiento administrativo para la creación de un consejo gallego de colegios profesionales no podrá ser superior a seis meses.

Transcurrido dicho plazo sin declaración expresa, se entenderá de carácter favorable.

Artículo 24. Naturaleza.

Los consejos gallegos de colegios son corporaciones de derecho público que adquirirán personalidad jurídica propia desde que entre en vigor su Decreto de creación.

La capacidad de obrar plena se adquirirá desde la constitución de sus órganos de gobierno. 


\section{Sección 2. ${ }^{a}$ \\ Fines y funciones}

\author{
Artículo 25. Fines.
}

Son fines de los consejos gallegos de colegios profesionales los siguientes:

a. La coordinación de los colegios profesionales que los integren y la representación de la profesión en el ámbito territorial de la Comunidad Autónoma de Galicia.

b. Las relaciones con las instituciones y la Administración autonómica, en especial con el Gobierno gallego, para facilitar la mutua colaboración para la mejor satisfacción de los intereses sociales y profesionales cuya defensa tienen encomendada.

c. Todos aquellos que, de acuerdo con la Ley, sus Estatutos generales y Reglamentos establezcan.

Artículo 26. Funciones.

Los consejos gallegos de colegios tendrán, además de las funciones que determinen sus Estatutos, las siguientes:

a. Elaborar sus propios Estatutos e informar los de los colegios de la profesión o actividad de ámbito territorial inferior.

b. Coordinar la actuación de los colegios que lo integren.

c. Representar a la profesión en el ámbito de la Comunidad Autónoma de Galicia y ante los correspondientes consejos generales, cuando así se permita en sus normas reguladoras.

d. Resolver los conflictos que puedan plantearse entre los distintos colegios, sin perjuicio del ulterior recurso contencioso-administrativo.

e. Ejercer las funciones disciplinarias respecto a los miembros de los órganos de gobierno de los colegios que lo integren y los del propio consejo.

f. Elaborar las normas deontológicas comunes a la profesión.

g. Elaborar el presupuesto y fijar la participación de los colegios en los gastos del consejo. h. Informar los proyectos de normas a que se refiere el artículo 9.o) de la presente ley.

i. Ejercer aquellas funciones que les puedan ser delegadas o encomendadas por la Comunidad Autónoma de Galicia y las que puedan ser objeto de los correspondientes convenios de colaboración.

j. Realizar aquellas actividades que se estimen de interés para los profesionales y las demás funciones que les atribuyan la legislación vigente y sus Estatutos.

Artículo 27. Colegios profesionales únicos.

Los colegios profesionales únicos cuyo ámbito de actuación coincida con la Comunidad Autónoma de Galicia desarrollarán las funciones descritas en el artículo anterior, en tanto mantengan dicha naturaleza.

\section{Artículo 28. Estatutos.}

1. Los Estatutos de cada consejo deberán ser elaborados por los colegios profesionales que vayan a integrarlo y aprobados por acuerdo de las juntas de gobierno, que habrá de ser ratificado por las juntas generales de cada colegio. Será necesario el acuerdo favorable de la mayoría de los colegios afectados, siempre que los mismos representen a la mayoría de los colegiados de la profesión en Galicia.

2. Los Estatutos determinarán los órganos de gobierno, la forma de elección de sus integrantes, el régimen de competencias y funcionamiento de cada consejo, que en todo caso será democrático, así como las restantes funciones contempladas en el artículo 9 de la presente ley que fueran de aplicación a las mismas.

3. Su aprobación se efectuará mediante Decreto del Consello de la Xunta de Galicia, previa verificación de su legalidad por la consellería competente en materia de colegios profesionales e informe de la consellería o consellerías cuyo ámbito competencial tenga relación con el contenido de la profesión. 
4. El Decreto aprobatorio y los correspondientes Estatutos se publicarán en el Diario Oficial de Galicia.

5. La modificación de los Estatutos exigirá el mismo procedimiento que su aprobación, correspondiendo la iniciativa, asimismo, a los órganos de gobierno de cada consejo.

\section{Sección $3 .^{\mathrm{a}}$ \\ Extinción}

\section{Artículo 29. Extinción.}

La extinción de los consejos gallegos de colegios tendrá lugar a iniciativa de los propios consejos o de la mayoría de los colegios afectados que representen a su vez a la mayoría de los colegiados de la profesión, y de acuerdo con el procedimiento que se establezca en los Estatutos del respectivo consejo, siendo aprobada mediante Decreto, salvo que medien razones de interés público que impidan tal aprobación.

\section{Capitulo IV \\ DISPOSICIONES COMUNES A COLEGIOS Y CONSEJOS GALLEGOS DE COLEGIOS PROFESIONALES}

Artículo 30. Régimen jurídico. Los colegios profesionales y los consejos gallegos de colegios profesionales, en cuanto corporaciones de derecho público, están sujetos al derecho administrativo en lo relativo a la constitución de sus órganos y en cuanto ejerciten funciones administrativas.

Artículo 31. Recursos.

1. Contra los actos sujetos al derecho administrativo emanados del órgano de gobierno de los colegios profesionales cabrá recurso de alzada ante el correspondiente consejo gallego de los colegios. En defecto de consejo gallego, en los casos de colegios únicos de ámbito autonómico y contra los actos administrativos de los órganos de gobierno de los consejos gallegos, cabrá recurso ante el consejo general nacional solamente si así está contemplado en los Estatutos colegiales.

2. En el supuesto de actos y resoluciones dictados en ejercicio de competencias administrativas delegadas, se estará a los términos de la propia delegación en cuanto al órgano competente para conocer en su caso del recurso correspondiente.

Artículo 32. Medios instrumentales.

1. Cada colegio profesional y consejo gallego de colegios dispondrá de los medios personales y materiales que precise para el desarrollo de su actividad. Los medios personales de los consejos gallegos de colegios serán facilitados por los colegios, salvo que los Estatutos dispusieran otra cosa.

2. Cada colegio profesional y consejo gallego de colegios dispondrá de su propio presupuesto, que tendrá un carácter meramente estimativo y comprenderá todos los ingresos y gastos previstos para cada año natural.

3. Los colegios profesionales y los consejos gallegos de colegios deberán ser auditados, en la forma en que determinen sus Estatutos, cuando se produzca la renovación ordinaria, total o parcial, de sus órganos directivos, sin perjuicio de la función fiscalizadora que corresponde a los organismos públicos legalmente habilitados para ello.

\section{Capítulo V REGISTRO DE COLEGIOS PROFESIONALES Y DE CONSEJOS GALLEGOS DE COLEGIOS PROFESIONALES}

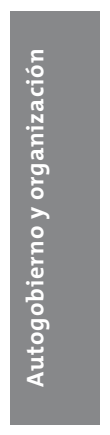

\section{Artículo 33. Registro.}

1. En el registro de colegios profesionales y de consejos gallegos de colegios profesionales se inscribirán, a los meros efectos de publicidad, los colegios profesionales y los consejos gallegos de colegios incluidos en el marco de aplicación de la presente ley, así como sus Estatutos.

2. Sólo podrá denegarse la inscripción en el registro por razones de legalidad, y siempre mediante resolución motivada del titular de la consellería a que está adscrito el registro ${ }^{116}$.

\footnotetext{
116 Decreto 161/1997, de 5 de junio, por el que se regulan los consejos gallegos de colegios profesionales y se crea el registro de colegios profesionales y sus consejos.
} 


\section{DISPOSICIÓN ADICIONAL PRIMERA}

Se consideran colegios profesionales de Galicia aquéllos cuyo ámbito territorial, a la entrada en vigor de la presente ley, no rebase la Comunidad Autónoma.

\section{DISPOSICIÓN ADICIONAL SEGUNDA}

1. Las delegaciones gallegas de los colegios profesionales de ámbito supraautonómico que dispongan de órganos de gobierno elegidos democráticamente podrán solicitar su inscripción en el registro de colegios profesionales y de consejos de colegios de Galicia a los efectos de constancia y publicidad.

2. Una vez inscritas, las delegaciones gallegas de los colegios profesionales de ámbito supraautonómico podrán mantener con la Administración de la Comunidad Autónoma de Galicia las relaciones que procedan en lo que afecte a los intereses profesionales.

\section{DISPOSICIÓN ADICIONAL TERCERA}

No se exigirá la previa incorporación al colegio en el supuesto de libre prestación ocasional de servicios a aquellos nacionales de los estados miembros de la Unión Europea que estén previamente establecidos con carácter permanente en cualquiera de los mencionados estados, de acuerdo, en cada caso, con lo que dispongan las normas comunitarias de aplicación a las profesiones afectadas, todo ello sin perjuicio de la obligación de notificar su actuación al colegio correspondiente mediante la aportación de la documentación exigible según aquellas normas y en los términos que reglamentariamente se establezcan.

\section{DISPOSICIÓN TRANSITORIA}

Los colegios profesionales gallegos y los consejos gallegos de colegios profesionales que estuvieran constituidos a la entrada en vigor de la presente ley adaptarán sus Estatutos a la misma en el plazo de un año. El incumplimiento de la presente obligación supondrá singularmente la denegación de las solicitudes de inscripción en el registro de colegios profesionales y de los consejos gallegos de colegios profesionales. Además, la administración podrá suspender tanto las delegaciones de competencias como la eficacia de los convenios celebrados al amparo del artículo 7 de la presente ley.

\section{DISPOSICIÓN FINAL PRIMERA}

Se autoriza al Consello de la Xunta de Galicia para que desarrolle reglamentariamente la presente ley.

\section{DISPOSICIÓN FINAL SEGUNDA}

La presente ley entrará en vigor a los veinte días de su publicación en el "Diario Oficial de Galicia".

\section{LEY 5/2004, DE 8 DE JULIO, DE CÁMARAS OFICIALES DE COMERCIO, INDUSTRIA Y NAVEGACIÓN DE GALICIA (DOGA N. $\left.{ }^{\circ} 140,21.7 .2004\right)$}

\section{(...) ${ }^{117}$ \\ Capítulo I \\ DISPOSICIONES GENERALES}

Artículo 1. Objeto.

La presente ley tiene por objeto la regulación de las cámaras oficiales de comercio, industria y, en su caso, navegación de la Comunidad Autónoma de Galicia, así como la creación y regulación del Conse1lo Galego de Cámaras.

Artículo 2. Naturaleza jurídica.

Las cámaras oficiales de comercio, industria y, en su caso, navegación de la Comunidad Autónoma de Galicia son corporaciones de derecho público, configurándose como órganos consultivos y de colaboración con las administraciones públicas, especialmente con la Administración de la Comunidad Autónoma de Galicia, sin menoscabo de los intereses privados que persiguen.

Para el cumplimiento de sus fines gozarán de personalidad jurídica propia y plena

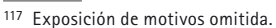


capacidad de obrar. Su estructura y funcionamiento deberán ser democráticos.

Artículo 3. Finalidad.

Las cámaras, de acuerdo con lo establecido en el artículo 1.2 de la Ley 3/1993, de 22 de marzo, básica de las cámaras oficiales de comercio, industria y navegación, además del ejercicio de las funciones de carácter público que les atribuye la presente ley y de las que les puedan encomendar o delegar las administraciones públicas, tienen como finalidad la representación, promoción y defensa de los intereses generales del comercio, la industria y, en su caso, la navegación. Asimismo tendrán como finalidad la prestación de servicios a las empresas que ejerzan las indicadas actividades, sin perjuicio de la libertad sindical y de asociación empresarial y de la representatividad y actuaciones de otras organizaciones empresariales o sociales legalmente constituidas.

Artículo 4. Funciones.

1. A las cámaras les corresponderá el ejercicio de las siguientes funciones:

a. La prestación de servicios de información, formación, asesoramiento y asistencia técnica a su electorado. A estos efectos las cámaras podrán llevar a cabo cualquier clase de actividades que contribuyan a la promoción y defensa del comercio, industria y navegación de Galicia, con especial atención a las microempresas, tanto en lo relativo a su creación como para el desarrollo de su actividad.

b. Las funciones de carácter públicoadministrativo legalmente atribuidas.

c. La gestión de servicios públicos o la realización de funciones que les encomienden o deleguen las administraciones públicas en la forma prevista en las leyes.

2. Asimismo, corresponde a las cámaras el ejercicio de las funciones público-administrativas que se enumeran a continuación, cuyo contenido y procedimiento podrán desarrollarse reglamentariamente. Estas funciones se entenderán sin perjuicio de las actuaciones que desarrollen otras instituciones u organizaciones legalmente constituidas:

a. Elaborar estadísticas del comercio, la industria y la navegación de Galicia y realizar encuestas de evaluación y estudios de los distintos sectores comerciales, industriales y navieros, así como publicarlos y difundirlos, con sujeción, en todo caso, a lo dispuesto en la Ley 12/1989, de 9 de mayo, sobre función estadística pública, en la Ley 7/1993, de 24 de mayo, de modificación de la Ley 9/1988, de 19 de julio, de estadística de Galicia, y demás disposiciones aplicables.

b. Promover y cooperar en la organización de ferias y exposiciones.

c. Difundir e impartir formación no reglamentada referente a la empresa.

d. Colaborar en los programas de formación permanente establecidos por las empresas, por centros docentes públicos o privados y, en su caso, por las administraciones públicas competentes, dentro de los términos que se establezcan.

e. Crear y administrar lonjas de contratación y bolsas de subcontratación, previa autorización de la Administración autonómica.

f. Emitir informe sobre los proyectos de disposiciones generales emanados de la Comunidad gallega que afecten directamente a los intereses generales del comercio, la industria y la navegación, en los supuestos y con las condiciones y alcance que el ordenamiento jurídico determine.

g. Colaborar en la ejecución de los programas públicos de ayudas a las empresas en los términos que se establezcan en cada caso, así como gestionar los servicios públicos relacionados con las mismas, cuando su gestión corresponda a la Administración autonómica y siempre que así se establezca en sus respectivas normas.

h. Colaborar con los órganos competentes de la Comunidad Autónoma de Galicia emitiendo informe sobre los estudios, 
trabajos y acciones que se realicen sobre la ordenación del territorio, medio ambiente y localización industrial y comercial.

i. Designar a las personas que, en su caso, ejerzan las funciones de arbitraje institucional previstas en el artículo 14.1.a) de la Ley 60/2003, de 23 de diciembre, de arbitraje, así como participar en el sistema arbitral de consumo, sin perjuicio de lo establecido en el artículo 2.1.i) de la Ley básica de cámaras.

j. Difundir las actividades y los programas de apoyo dirigidos a las empresas y participar en la elaboración de los mismos, cuando así se determine.

k. Colaborar en la promoción comercial y turística, desarrollar actividades de apoyo y estímulo al comercio exterior, en especial a la exportación, y apoyar y fomentar la presencia de los productos y servicios gallegos en el exterior.

3. Para el adecuado desarrollo de sus funciones, las cámaras podrán, al objeto de conseguir un más eficaz cumplimiento de los fines que tienen encomendados en beneficio de las empresas de su circunscripción, previa autorización del órgano competente de la Administración autonómica en materia de cámaras, promover o participar, junto a otras entidades públicas o privadas, en asociaciones, consorcios, fundaciones, sociedades civiles o mercantiles de carácter público o privado, o entidades de naturaleza análoga, así como establecer los oportunos convenios de colaboración con otras cámaras.

Para el otorgamiento de la citada autorización deberá justificarse la necesidad o conveniencia de la promoción o participación prevista.

4. Las cámaras elaborarán dentro del primer semestre de cada año una memoria que recoja todas las actividades y servicios desarrollados durante el ejercicio anterior, según sus funciones reconocidas, y que deberá ser remitida al órgano competente en materia de tutela de cámaras.
5. En el desarrollo de las funciones público-administrativas descritas en este artículo, así como en su gestión interna, las cámaras normalizarán el uso del idioma gallego.

Artículo 5. Delegación de funciones y encomienda de gestión.

1. El Consello de la Xunta de Galicia, previo informe del Consello Galego de Cámaras, podrá delegar en todas o en alguna de las cámaras el ejercicio de funciones o la gestión de actividades atribuidas a la Administración de la Comunidad Autónoma, siempre que sean plenamente compatibles con su naturaleza y funciones. En la tramitación del expediente, que habrá de acreditar la concurrencia de circunstancias técnicas, económicas, sociales, jurídicas o territoriales que aconsejen la delegación, se dará audiencia a la cámara o cámaras afectadas.

2. La Administración autonómica podrá encomendar a las cámaras la realización de actividades de carácter material, técnico o de servicios de su competencia cuando razones de eficacia o de carencia de medios técnicos idóneos para su desempeño así lo aconsejen.

La encomienda de gestión se formalizará a través de un convenio entre la Administración de la Comunidad Autónoma y la cámara o cámaras afectadas en el cual se hará constar la actividad o actividades objeto de la encomienda, el plazo de vigencia de la misma, la naturaleza y alcance de la gestión encomendada y, en su caso, los medios económicos que se habilitan por ambas partes. Toda encomienda de gestión habrá de ser informada previamente por el Consello Galego de Cámaras.

Artículo 6. Servicios mínimos obligatorios.

La Administración autonómica podrá, previo informe favorable del Consello Galego de Cámaras, declarar servicios mínimos obligatorios para cada cámara respecto a las funciones previstas en el 
artículo 4 de la presente ley, con audiencia de las cámaras afectadas en aquellos casos en que los servicios mínimos no tuvieran carácter general para todas ellas.

\section{Capítulo II ÁMBITO TERRITORIAL}

\section{Artículo 7. Ámbito territorial.}

1. En cada provincia existirá al menos una cámara oficial de comercio, industria y, en su caso, navegación.

Su ámbito competencial se aplicará en su demarcación.

También podrán existir cámaras de distinto ámbito territorial, cuya creación e integración se ajustará al procedimiento establecido en la presente ley.

2. No podrán integrarse ni fusionarse cámaras pertenecientes a distintas provincias. Tampoco podrán existir cámaras cuyo ámbito abarque dos o más provincias, ni cámaras cuya demarcación no coincida, al menos, con un término municipal.

Artículo 8. Requisitos y supuestos de creación de cámaras.

1. La creación de nuevas cámaras sólo podrá realizarse sobre la base de intereses comerciales, industriales o navieros específicos y siempre que la entidad resultante cuente con recursos suficientes para el cumplimiento satisfactorio de sus funciones y no suponga merma en la calidad de los servicios que venían siendo prestados.

2. Podrán crearse nuevas cámaras:

a. Por fusión de dos o más cámaras de ámbito infraprovincial.

El procedimiento se iniciará con los acuerdos, adoptados por la mayoría absoluta de los miembros de los plenos, favorables a la fusión de las distintas cámaras afectadas.

b. Por integración de una o más cámaras de ámbito infraprovincial. Podrá iniciarse el procedimiento cuando una cámara, durante cuatro ejercicios consecutivos, liquide con un déficit superior al $20 \%$ de sus ingresos o no alcance el porcentaje mínimo de autofinanciación, previsto en la Ley básica 3/1993, de 22 de marzo, mediante ingresos no provenientes del recurso cameral permanente, o cuando la administración tutelante, teniendo en cuenta los intereses generales del comercio, industria y navegación de la Comunidad Autónoma de Galicia y previo informe favorable del Consello Galego de Cámaras, lo estime conveniente.

Artículo 9. Disolución de cámaras.

Las cámaras de ámbito infraprovincial podrán disolverse por acuerdo del pleno respectivo adoptado en sesión convocada al efecto. Para la validez del acuerdo se requerirá el voto favorable de dos terceras partes de los miembros del pleno y posterior aprobación por el Consello de la Xunta. La Administración autónoma determinará, previo informe del Consello Galego de Cámaras, la corporación en que haya de integrarse la cámara disuelta, pudiendo incorporarse a varias ya existentes, estableciéndose en este caso las nuevas demarcaciones camerales.

Artículo 10. Modificación de demarcaciones.

El Consello de la Xunta de Galicia podrá alterar la demarcación territorial de las cámaras:

a. Cuando éstas, conjuntamente, así lo acuerden por mayoría de dos tercios de los miembros del pleno.

b. Cuando lo soliciten más de dos tercios del electorado de los términos municipales a segregar de una cámara para agregarlos a otro limítrofe que representen, al menos, el $50 \%$ de las cuotas del recurso cameral permanente de los mismos y cuenten con el acuerdo del pleno de la cámara a la que se agregarían dichos términos municipales.

c. Cuando la administración tutelante, teniendo en cuenta los intereses generales del comercio, industria y navegación de la Comunidad Autónoma de Galicia y previo informe favorable del Consello Galego de Cámaras, lo estime conveniente. 
Artículo 11. Normas comunes para los procedimientos de creación, disolución y modificación de las demarcaciones camerales.

1. La creación, disolución y modificación de las demarcaciones camerales se realizará por decreto del Consello de la Xunta de Galicia.

2. En los supuestos de fusión, disolución y modificación de la demarcación cameral a instancia del pleno o del electorado de acuerdo con lo previsto en el artículo 10.a) y b), se requerirá autorización del órgano tutelar, que podrá denegarla por medio de resolución motivada.

Transcurridos seis meses desde la entrada de la solicitud en el registro del órgano tutelar sin que se haya dictado resolución expresa, ésta se entenderá desestimada. En dichos supuestos, será objeto de publicación en el "Diario Oficial de Galicia" el acuerdo cameral o la solicitud del electorado que promueve el expediente.

3. En los supuestos de creación de una nueva cámara o modificación de su demarcación, promovidas por el órgano tutelar, el procedimiento se iniciará mediante la publicación de la orden correspondiente.

4. En todos los casos, salvo en el supuesto de disolución, será preceptiva la audiencia de la cámara o cámaras afectadas, así como el informe del Consello Galego de Cámaras.

Artículo 12. Creación de delegaciones.

1. En orden a garantizar en todo el territorio de la Comunidad Autónoma de Galicia el eficaz y pleno cumplimiento de las funciones de carácter público-administrativo que se atribuyen a las cámaras, así como la mejor prestación de sus servicios, éstas podrán crear delegaciones en aquellas áreas o zonas en que su importancia económica lo aconseje, dentro de su demarcación territorial.

2. El órgano tutelar podrá recomendar a las cámaras el establecimiento de delegaciones cuando exista un núcleo de empresas suficientemente representativas para justificar la proximidad de los servicios.

3. En cada delegación existirá un delegado que será designado y separado por el pleno de la cámara. El procedimiento de designación y cese y sus funciones se determinarán en el reglamento de régimen interior de cada cámara.

\section{Capitulo III ORGANIZACIÓN}

Artículo 13. Órganos de gobierno de las cámaras oficiales de comercio, industria y, en su caso, navegación de Galicia.

Los órganos de gobierno de las cámaras son el pleno, el comité ejecutivo y la presidencia.

\section{Sección $1 .^{\mathrm{a}}$ Del Pleno}

Artículo 14. El pleno.

1. El pleno es el órgano supremo de gobierno y de representación de la cámara, tiene un mandato de cuatro años y estará compuesto por:

a. Los vocales que, en número no inferior a diez ni superior a sesenta, y que se determinen en el reglamento de régimen interior de cada cámara, serán elegidos mediante sufragio libre, igual, directo y secreto entre todo el electorado de la cámara, clasificado en grupos y categorías, en atención a la importancia económica relativa de los diferentes sectores representados y en la forma que reglamentariamente se establezca.

b. Los vocales que, en número del $15 \%$ de los señalados en el párrafo anterior, serán elegidos por los miembros del pleno señalados en la letra anterior, entre personas de reconocido prestigio en la vida económica gallega, propuestos por las organizaciones empresariales a la vez intersectoriales y territoriales más representativas, en la forma que reglamentariamente se determine. A este fin, dichas organizaciones deberán proponer una lista de candidaturas que supere en un tercio el número de vocales a cubrir. 
2. Siempre que esté previsto en los reglamentos de régimen interior de cada cámara, los plenos de las mismas podrán elegir un número de vocales cooperadores, cuyo número no podrá ser superior a una quinta parte de los y las vocales electos, de entre personas de reconocido prestigio, que no podrán formar parte del comité ejecutivo ni representar a la cámara en entidades u organismos públicos o privados. Podrán asistir al pleno con voz pero sin voto, siempre que hayan sido convocados al efecto.

3. La condición de miembro del pleno es única e indelegable, no teniendo carácter retribuido.

4. Los miembros del pleno tienen el derecho y el deber de asistir, con voz y voto, a las sesiones que el mismo celebre.

5. El pleno cesa tras la convocatoria de elecciones, permaneciendo en funciones hasta la toma de posesión de sus nuevos miembros.

6. La estructura y composición del pleno, en lo referente a su distribución por grupos y categorías, se revisará y actualizará antes de cada período electoral. Para esta revisión y actualización se tendrán en cuenta las variables relacionadas con el crecimiento económico de los diferentes sectores económicos gallegos, todo ello de acuerdo con las directrices establecidas por el órgano tutelar.

7. Reglamentariamente se determinará el régimen de provisión de vacantes en el pleno.

Artículo 15. Atribuciones.

1. Como órgano supremo de la cámara, corresponden al pleno las siguientes atribuciones:

a. La elección y cese de quien ejerza la presidencia.

b. El control y fiscalización de los demás órganos de gobierno de la cámara.

c. La aprobación provisional del reglamento de régimen interior y de sus modificaciones, para su remisión al órgano tutelar a los efectos de su aprobación definitiva. d. La aprobación de los convenios de colaboración y cooperación con las administraciones públicas y con cualquier otra entidad.

e. La adopción de los acuerdos relativos a la creación o participación de la cámara en asociaciones, fundaciones y sociedades civiles o mercantiles, así como de los acuerdos para su supresión o finalización de la participación.

f. La aprobación, a propuesta del comité ejecutivo, de la plantilla de personal, así como de los criterios para su cobertura.

g. La aprobación inicial del presupuesto y de las cuentas anuales de la cámara, así como su sometimiento al órgano tutelar para su aprobación definitiva.

h. La elección y cese de los miembros del pleno que tengan que formar parte del comité ejecutivo.

i. La aprobación inicial de las bases de la convocatoria para la provisión del puesto de quien ocupe la secretaría general.

j. El nombramiento y cese de quien ocupe la secretaría general.

k. El nombramiento y cese del personal de alta dirección al servicio de la cámara.

1. La aprobación de los informes que hayan de remitirse a las administraciones públicas.

m. La adopción de acuerdos sobre el ejercicio de acciones y la interposición de recursos ante cualquier jurisdicción.

n. La enajenación de patrimonio y la concertación de operaciones de crédito.

ñ. La aprobación de los planes anuales de actuación y gestión de la cámara.

o. La constitución de comisiones consultivas y de ponencias.

p. El nombramiento de representantes de la cámara en otras entidades.

q. Cuantas otras atribuciones le confieran las leyes expresamente.

2. Con arreglo al procedimiento previsto en el reglamento de régimen interior, el pleno de la cámara podrá delegar y revocar, sin perjuicio de su comunicación al órgano 
tutelar, el ejercicio de sus atribuciones en el comité ejecutivo, salvo las enumeradas en los apartados a), b), c), e), f), g), h), i), j), k) y n) del punto primero de este artículo. Las delegaciones en materia de gestión financiera decaerán automáticamente con la aprobación de cada presupuesto anual. En cualquier caso, las delegaciones conferidas por el pleno no podrán exceder de su período de mandato, extinguiéndose automáticamente en el momento en que se renueve el pleno de la cámara.

\section{Sección 2. ${ }^{\text {a }}$ Del Comité Ejecutivo}

Artículo 16. Composición.

1. El comité ejecutivo es el órgano permanente de gestión, administración y propuesta de la cámara, que será elegido por el pleno de entre sus vocales con derecho a voto y por un mandato de duración igual al de éstos y estará formado por las personas que ocupen la presidencia, de una a tres vicepresidencias, la tesorería y un número de vocales que no será superior a seis ni inferior a tres, que se fijará en el reglamento de régimen interior de cada cámara. Los cargos del comité ejecutivo no serán remunerados.

2. El órgano tutelar podrá nombrar una persona representante de la Administración autonómica que, sin condición de miembro, tendrá voz pero no voto en las sesiones del comité ejecutivo, a las que deberá ser convocada en las mismas condiciones que sus miembros.

3. En el reglamento de régimen interior de cada cámara, se preverá el ejercicio de las funciones de los miembros del comité ejecutivo en los casos de ausencia, vacante o enfermedad.

Artículo 17. Atribuciones.

Corresponden al comité ejecutivo las siguientes atribuciones:

a. Realizar u ordenar la realización de informes y estudios relacionados con los fines de la corporación. b. Proponer al pleno los planes anuales de actuación y gestión corporativa, así como realizar y dirigir los ya aprobados, dando cuenta a aquél de su cumplimiento.

c.Elaborar los proyectos de presupuestos y presentarlos al pleno para su aprobación.

d. Confeccionar las liquidaciones de presupuestos y las cuentas anuales y presentarlas al pleno para su aprobación.

e. Elaborar los proyectos de la plantilla de personal, así como los criterios para su cobertura, para su aprobación por el pleno.

f. La contratación del personal, salvo el de alta dirección.

g. Aprobar las resoluciones correspondientes a la liquidación, así como las relativas a la recaudación del recurso cameral permanente.

h. Aprobar y revisar el censo electoral y resolver las impugnaciones al mismo.

i. En casos de urgencia debidamente motivada, adoptar acuerdos sobre materias competencia del pleno susceptibles de delegación, dando cuenta a éste para que proceda a su ratificación en la primera sesión que celebre y que tendrá lugar, como máximo, en el plazo de treinta días.

j. Velar por el normal funcionamiento de los servicios de la cámara.

k. Ejercer las competencias que le sean delegadas o encomendadas por el pleno.

1. Ejercer aquellas competencias de la cámara que no estén expresamente atribuidas a otro órgano.

Artículo 18. Pérdida de la condición de miembro del pleno y del comité ejecutivo.

1. Además de por la causa prevista en el artículo 14.5 , la condición de miembro del pleno se perderá, con las garantías y régimen de recursos establecidos en la presente ley, por alguna de las siguientes causas:

a. Cuando desaparezca cualquiera de los requisitos legales de elegibilidad que concurrieron para su elección.

b. Por resolución administrativa o judicial firme que anule su elección o proclamación como miembro de una candidatura.

c. Por la falta de asistencia injustificada a las sesiones del pleno, por tres veces 
consecutivas o cuatro veces no consecutivas, dentro del año natural, previa incoación del expediente administrativo en el que se le dará audiencia ante el pleno.

d. Por dimisión o renuncia, o cualquier causa que incapacite para el desempeño del cargo.

e. Por fallecimiento de los que tengan la consideración de personas físicas o por la extinción de la personalidad jurídica en el caso de los miembros del pleno con forma societaria.

2. Por su parte, y además de la terminación ordinaria de sus mandatos, tanto quien ejerza la presidencia como los cargos del comité ejecutivo cesarán:

a. Por la pérdida de la condición de miembro del pleno.

b. Por acuerdo del pleno, adoptado por mayoría absoluta en la forma que en el reglamento de régimen interior se establezca.

c. Por renuncia al cargo, aunque se mantenga la condición de miembro del pleno.

d. Por falta de asistencia injustificada a las sesiones del comité ejecutivo, por tres veces consecutivas o cuatro veces no consecutivas, dentro del año natural, previa incoación del expediente administrativo en el que se le dará audiencia ante el pleno.

3. El procedimiento para la cobertura de las vacantes será el que se determine en cada reglamento de régimen interior, de conformidad con lo que reglamentariamente establezca la Administración autonómica. Las personas elegidas para ocupar vacantes en el pleno, en el comité ejecutivo o en la presidencia lo serán solamente por el tiempo que reste para cumplir el mandato durante el cual se hubiera producido la vacante.

\section{Sección 3. \\ De la Presidencia}

\section{Artículo 19. Elección.}

1. El Presidente es el órgano de gobierno que tiene la representación de la cámara y ejerce la presidencia de todos sus órganos colegiados. Es responsable de la ejecución de los acuerdos del pleno y del comité ejecutivo.

2. Será elegido por el pleno de entre sus miembros, en la forma que determinen los reglamentos de régimen interior de cada cámara y supletoriamente en la forma que reglamentariamente determine la Administración autonómica. Para resultar elegido, el candidato deberá obtener el voto favorable de la mayoría absoluta de los miembros del pleno. De no obtenerse dicha mayoría, se procederá a una segunda votación, resultando elegido quien obtenga el mayor número de votos. En caso de empate, se procederá en el tercer día hábil siguiente a una nueva votación. De persistir el empate, resultará elegida la empresa que tenga mayor antigüedad en el ejercicio de la actividad empresarial dentro de la circunscripción cameral, salvo que concurra a la elección alguno de los vocales del artículo 14.1.b), en cuyo caso se elegirá por sorteo.

Artículo 20. Cese.

1. Quien ejerza la presidencia cesará, además de por las causas previstas en el artículo 18.2, como consecuencia de:

a. Sustitución de la persona física designada para ostentar la representación de la persona jurídica titular del cargo.

b. Convocatoria de elecciones para la renovación del pleno, actuando en funciones durante dicho período.

c. La aprobación, por mayoría absoluta del pleno, de una moción de censura, que deberá ser propuesta, al menos, por una quinta parte del número de miembros del pleno, en sesión realizada al efecto, y que incluirá necesariamente la propuesta de un candidato a la presidencia de la cámara.

d. Dimisión.

e. Sentencia firme que implique su inhabilitación para el cargo.

f. Fallecimiento.

g. Pérdida de la condición de miembro del pleno.

2. Cuando concurra cualquiera de estos supuestos, la presidencia de la cámara pasará a ser ejercida por quienes desempeñen 
las vicepresidencias, por su orden, hasta la elección de nuevo Presidente o presidenta, de acuerdo con lo previsto en el reglamento de régimen interior.

Artículo 21. Atribuciones.

1. A la presidencia de la cámara le corresponden las siguientes atribuciones:

a. Convocar, presidir y dirigir las sesiones del pleno, del comité ejecutivo y de cualquier otro órgano de la cámara, dirimiendo con su voto de calidad los empates que se produzcan.

b. Ejecutar los acuerdos de los órganos colegiados de la cámara.

c. Disponer gastos dentro de los límites que el pleno establezca y ordenar a la tesorería todos los pagos, debiendo rendir cuentas al pleno.

d. Asumir y llevar la representación de la cámara en los actos oficiales.

e. Presidir los organismos e instituciones que dependan o puedan depender en lo sucesivo de la cámara.

f. Firmar la correspondencia oficial de la cámara.

g. Visar las actas y las certificaciones que de los acuerdos hayan de librarse.

h. Adoptar las medidas disciplinarias que procedan, de acuerdo con lo establecido en el reglamento de régimen interior.

i. Representar a la cámara en todos los actos jurídicos y ejercitar los derechos y las acciones que a ella correspondan.

j. En casos de extrema urgencia, adoptar las resoluciones que sean necesarias para garantizar el adecuado funcionamiento de la cámara y de los servicios camerales, dando cuenta al comité ejecutivo en la primera sesión que éste celebre y que tendrá lugar, como máximo, en el plazo de treinta días.

k. Delegar su representación en los términos previstos en el apartado segundo de este artículo.

1. Disponer el reparto de asuntos, temas o cuestiones a las comisiones consultivas, cuando, a su juicio, hayan de ser objeto de estudio o examen previo a la consideración del pleno. m. Sin perjuicio de las funciones atribuidas a los órganos de gobierno, la presidencia dispondrá sobre los aspectos formales o accesorios que sean necesarios para la buena marcha de la cámara y de las actividades corporativas.

n. Ejercer cuantas otras funciones le encomienden las leyes y el reglamento de régimen interior.

2. La presidencia podrá delegar y revocar el ejercicio de sus atribuciones en las vicepresidencias, salvo la relativa a la presidencia del pleno y del comité ejecutivo, y ello sin perjuicio de los casos de sustitución previstos en los artículos 20.2 y 22.2 de la presente ley, decayendo la delegación automáticamente con la extinción del mandato de quien ejerza la presidencia. El reglamento de régimen interior podrá prever la posibilidad de delegaciones especiales a favor de cualquier miembro del pleno para la dirección y gestión de asuntos determinados.

\section{Sección $4 .^{\mathrm{a}}$ \\ De las Vicepresidencias}

Artículo 22. Designación, cese y funciones.

1. Las personas que ejerzan las vicepresidencias serán elegidas y separadas por acuerdo del pleno de cada cámara, de entre sus miembros, conforme a lo establecido en el reglamento de régimen interior.

2. Quienes ejerzan las vicepresidencias sustituirán, por su orden, a la persona que ocupe la presidencia en los casos de ausencia, enfermedad o vacante.

3. Quienes desempeñen las vicepresidencias ejercerán además aquellas funciones que le sean delegadas por la presidencia, de acuerdo con lo previsto en el artículo 21.2 de la presente ley.

\section{Sección $5 .^{a}$ \\ Del Personal}

Artículo 23. Régimen jurídico.

1. Todo el personal, incluido quien ocupe la secretaría general y el personal 
de alta dirección al servicio de las cámaras, quedará sujeto al derecho laboral, sin perjuicio de lo dispuesto en la Disposición transitoria octava de la Ley 3/1993, de 22 de marzo, básica de las cámaras.

El reglamento de régimen interior de cada cámara establecerá el régimen del personal al servicio de la cámara así como el procedimiento para su contratación, que deberá adecuarse a los principios de igualdad, mérito, capacidad y publicidad de la convocatoria.

2. Asimismo quedarán sometidos al régimen de incompatibilidades que se establezcan en el reglamento de régimen interior de cada cámara. En cualquier caso, el desempeño de un puesto de trabajo al servicio de las cámaras será incompatible con el ejercicio de cualquier cargo, profesión o actividad, pública o privada, que pueda impedir o menoscabar el estricto cumplimiento de sus deberes o comprometer su imparcialidad o independencia.

3. Anualmente, el pleno de cada cámara aprobará una plantilla de personal en la que se relacionarán, debidamente clasificados, todos los puestos de trabajo, con expresión de su denominación, funciones y categoría.

Artículo 24. La secretaría general.

1. Cada cámara tendrá un secretario general retribuido, que cuente con la titulación de licenciatura en derecho.

2. Quien ocupe la secretaría general tiene como funciones, además de aquéllas que expresamente le atribuya el reglamento de régimen interior o que, en su caso, le delegue expresamente la presidencia o el propio comité ejecutivo, velar por la legalidad de los acuerdos de los órganos de gobierno de la cámara, debiendo hacer, cuando proceda, las advertencias pertinentes en tal sentido y dando fe pública de los actos y acuerdos adoptados por las mismas; a estos efectos asistirá a las sesiones de los órganos de gobierno con voz pero sin voto.
3. El nombramiento de la persona que ocupe la secretaría general corresponde al pleno de la cámara, previa convocatoria pública, cuyas bases serán aprobadas por el órgano tutelar. Tanto el acuerdo de nombramiento como el de cese deben ser adoptados de forma motivada por la mitad más uno de los miembros del pleno.

4. Quien ocupe la secretaría dirigirá todos los servicios de la cámara, respondiendo de su funcionamiento ante el comité ejecutivo, salvo en aquellos casos en que las cámaras dispongan la creación de una dirección general. Esta función será desempeñada por una persona vinculada por la relación laboral de carácter especial de alta dirección que dirigirá aquellos servicios de la cámara previstos en el reglamento de régimen interior y de cuyo funcionamiento será responsable ante el comité ejecutivo.

5. El reglamento de régimen interior determinará la forma y los supuestos en que haya de ser sustituido quien ocupe la secretaría general, con ocasión de ausencia temporal, vacante, enfermedad o cualquier otro supuesto de impedimento temporal.

6. La persona que desempeñe la secretaría habrá de ejercer sus funciones con autonomía funcional, imparcialidad y estricto sometimiento a la legalidad. Para el desarrollo de las mismas goza de inmovilidad de acuerdo con lo establecido en el párrafo siguiente.

7. Sin perjuicio de lo establecido en la normativa laboral, quien ocupe la secretaría sólo podrá ser destituido de sus funciones por la comisión de alguna de las faltas que, con carácter objetivo y tasado, estén previstas en el reglamento de régimen interior de cada cámara. Su apreciación compete al pleno, mediante acuerdo motivado, adoptado por la mitad más uno de sus miembros en sesión extraordinaria convocada al efecto y previa instrucción de un expediente en el que se dará audiencia a la persona interesada. 
La instrucción del expediente corresponderá al miembro del comité ejecutivo que éste designe, no pudiendo concurrir a la sesión del pleno en que se adopte la decisión sobre su destitución.

Contra el acuerdo del pleno podrá interponerse recurso administrativo ante el órgano tutelar.

Artículo 25. Personal de alta dirección. Los reglamentos de régimen interior establecerán, con sujeción a la normativa laboral, todas las cuestiones relativas al personal de alta dirección al servicio de la cámara, no siendo de aplicación a este personal la previsión de modificación contractual de la indemnización establecida en el artículo 11.1 del Real decreto 1382/1985, de 1 de agosto.

\section{Sección $6 .^{\mathrm{a}}$}

Reglamento de régimen interior

Artículo 26. Aprobación y modificación del reglamento de régimen interior.

1. Corresponde al órgano tutelar la aprobación de los reglamentos de régimen interior de las cámaras así como de sus modificaciones. Igualmente podrá, de acuerdo con lo establecido en el artículo 7.3 de la Ley 3/1993, promover la modificación de los mismos.

2. Los reglamentos de régimen interior de las cámaras sometidos a aprobación se considerarán aprobados si, transcurridos tres meses desde la entrada de la solicitud en el registro del órgano tutelar, éste no hubiera denegado expresamente su aprobación, formulado objeciones en su contra o promovido su modificación.

3 . En el supuesto de que el órgano tutelar, de oficio o como consecuencia de la presentación de un reglamento de régimen interior, promoviera su modificación, deberá señalar el plazo, no inferior a dos meses, para un nuevo envío del reglamento, su modificación o las alegaciones que se estimen oportunas.

4. Recibidas las alegaciones, o transcurrido el plazo de dos meses sin que se haya recibido la nueva propuesta, o cuando la misma no se ajuste a la modificación requerida, el órgano competente en materia de cámaras dictará la resolución que se estime procedente, incluida una nueva redacción del reglamento de régimen interior.

5. Presentado el texto corregido dentro del plazo establecido o las alegaciones a la modificación propuesta, se entenderán estimadas éstas o aprobada la modificación cuando hubieran transcurrido dos meses desde su presentación en el registro del órgano tutelar.

Artículo 27. Contenido del reglamento de régimen interior.

1. En el reglamento de régimen interior constará, entre otros extremos, la estructura de su pleno, el número y forma de elección de los miembros del comité ejecutivo y, en general, las normas de funcionamiento de sus órganos de gobierno, organización y régimen del personal al servicio de la cámara.

2. Asimismo en el reglamento de régimen interior se establecerán los mecanismos adecuados para asegurar el normal funcionamiento de la cámara, en lo no previsto en la presente ley y en sus normas de desarrollo reglamentario.

3. Se incluirán como anexos al reglamento de régimen interior la estructura y la composición del pleno en lo referente a su distribución por grupos y categorías, elaborado de acuerdo con lo establecido en el artículo 14.6 de la presente ley, así como el régimen de personal al servicio de la cámara.

\section{Capitulo IV RÉGIMEN ELECTORAL}

Artículo 28. Derecho de sufragio activo.

Tendrán la condición de electores las personas naturales o jurídicas, nacionales o extranjeras, que ejerzan actividades comerciales, industriales o navieras en los términos establecidos en el artículo 6 de la Ley 3/1993, de 22 de marzo, básica de 
cámaras oficiales de comercio, industria y navegación.

Artículo 29. Derecho de sufragio pasivo.

1. Las personas que formen parte de las candidaturas a los órganos de gobierno de cada cámara, además de reunir los requisitos necesarios para ser electoras, deberán: a. Tener la nacionalidad española o la de un Estado miembro de la Unión Europea.

b. Llevar, como mínimo, dos años de ejercicio en la actividad empresarial en los territorios citados.

c. No encontrarse en descubierto en el pago del recurso cameral permanente.

d. No estar en situación de inhabilitación por sentencia firme durante el plazo que ésta determine.

2. Para ser candidato a formar parte del pleno será necesario, además, estar incluido en el censo electoral dentro del grupo y categoría por cuya representación se opta.

3. Las personas de otra nacionalidad podrán ser candidatas de acuerdo con el principio de reciprocidad, y siempre que cumplan los requisitos exigidos en los números anteriores, con excepción del apartado 1.a) anterior.

4. Las personas naturales o jurídicas que ejerzan actividades correspondientes a diversos grupos o diversas categorías del mismo grupo del censo de una cámara tienen derecho de sufragio activo y pasivo en cada uno de los mismos. Si resultasen elegidas en más de un grupo o categoría deberán optar por la representación en los órganos de gobierno de sólo uno de ellos.

Artículo 30. Censo electoral.

1. El censo electoral de cada cámara comprenderá la totalidad de su electorado, clasificado por grupos y, en su caso, por categorías.

2. Su revisión será anual y se realizará con fecha del día 1 de enero de cada año.

3. Los grupos comprenderán colectivos formados por sujetos pasivos del impuesto de actividades económicas o tributo que lo sustituya. Cada grupo podrá subdividirse en categorías en atención a la importancia económica relativa de los diversos sectores representados y de acuerdo con lo que reglamentariamente se establezca.

Artículo 31. Publicidad del censo electoral.

1. Abierto el proceso electoral, y dentro de los plazos que reglamentariamente se establezcan, cada cámara deberá exponer su censo al público, en la dirección corporativa, en sus delegaciones y en aquellos otros lugares que estime oportuno.

2. Las reclamaciones sobre la inclusión o exclusión de las empresas en los grupos y categorías correspondientes podrán presentarse desde el momento en que se inicie la exposición de los censos al público hasta el término del plazo que reglamentariamente se establezca.

3. Corresponde al comité ejecutivo de la cámara resolver las reclamaciones a que se hace referencia en el apartado anterior, en los plazos que reglamentariamente se determinen.

4. Contra los acuerdos del comité ejecutivo las personas interesadas podrán interponer recurso administrativo ante el órgano tutelar, en los términos previstos en la Ley de Régimen Jurídico de las Administraciones Públicas y del Procedimiento Administrativo Común.

Artículo 32. Convocatoria de elecciones, publicidad y contenido.

1. Corresponderá al órgano tutelar, previa consulta a las cámaras, la convocatoria de elecciones para la renovación de los miembros de los plenos de éstas.

2. La convocatoria deberá contener:

a. Los días y horas en que cada grupo o categoría debe emitir el voto para la elección de sus representantes.

b. El número de colegios electorales y los lugares en donde hayan de instalarse.

c. Los plazos y el modelo de documento para el ejercicio del voto por correo.

d. Las sedes de las juntas electorales.

3. La convocatoria se publicará en el "Diario Oficial de Galicia" y cada cámara 
le dará publicidad en sus sedes sociales y en sus delegaciones así como mediante la publicación del anuncio en el diario de mayor circulación en su correspondiente demarcación territorial, sin perjuicio de su mayor difusión a través de otros medios de comunicación que estime oportunos.

Artículo 33. Juntas electorales.

1. Publicada la convocatoria, en el plazo que reglamentariamente se establezca, se constituirá en cada cámara una junta electoral que tendrá como finalidad garantizar la transparencia y objetividad del proceso electoral.

2. Cada junta electoral se integrará por tres representantes del electorado de la cámara elegidos por el pleno de la misma de acuerdo con el procedimiento reglamentariamente previsto, y por dos personas designadas por el órgano tutelar, ejerciendo una de ellas las funciones de Presidente. En el supuesto de que alguien designado por el pleno presentara su candidatura al proceso electoral será sustituido por alguna de las personas que previamente deben ser elegidas por el pleno de la cámara a estos efectos.

3. La presidencia nombrará una persona que ocupe la secretaría de la junta electoral con voz pero sin voto entre el funcionariado del órgano tutelar o del personal de la cámara respectiva.

4. El mandato de las juntas electorales se prolongará, tras la celebración de las elecciones, hasta el momento en que proceda su disolución, que se fijará reglamentariamente, y una vez efectuada la toma de posesión de los cargos electos.

5. Las cámaras pondrán a disposición de la junta electoral los medios personales o materiales necesarios para el ejercicio de sus funciones. Igualmente, las juntas electorales podrán solicitar el asesoramiento del secretario o secretaria de la cámara respectiva.

6. Contra los acuerdos de las juntas electorales podrá interponerse recurso de alzada ante el órgano tutelar, que solicitará en todo caso el informe de la comisión de seguimiento del proceso electoral a que se refiere el artículo 35.

7. En lo que resulte compatible con su naturaleza y funciones les será de aplicación a las juntas electorales el régimen de funcionamiento de los órganos colegiados previsto en la Ley de Régimen Jurídico de las Administraciones Públicas y del Procedimiento Administrativo Común.

Artículo 34. Presentación y proclamación de candidaturas.

1. Publicada la convocatoria en el "Diario Oficial de Galicia" procederá la presentación de candidaturas ante la secretaría de la cámara respectiva. Las candidaturas serán avaladas por la firma como mínimo del $4 \%$ del electorado del grupo o, en su caso, de la categoría correspondiente. Si el número de electores del grupo o categoría fuera superior a doscientos, será suficiente con la firma de diez de ellos para la presentación de la candidatura.

2. Corresponde a la junta electoral respectiva, previa comprobación del cumplimiento de los requisitos exigidos para la presentación de las candidaturas, la proclamación de las mismas.

3. La junta electoral reflejará en un acta la proclamación de las candidaturas y las incidencias que hubiera.

De la misma se enviará copia certificada a la delegación provincial del órgano tutelar y se dará publicidad de su contenido mediante anuncio fijado en la dirección de la cámara y en sus delegaciones, que se publicará al menos en uno de los periódicos de mayor circulación de su circunscripción.

4. Los plazos de presentación y proclamación de candidaturas se determinarán reglamentariamente.

Artículo 35. Comisión de seguimiento del proceso electoral.

1. Dentro de la administración tutelante, se constituirá una comisión para el seguimiento del proceso electoral, compuesta por dos representantes de las cámaras designados por el Consello Galego de Cámaras y otros dos designados por el órgano competente en materia de tutela de las cámaras. 
2. La comisión para el seguimiento del proceso electoral emitirá informe sobre todos aquellos asuntos que se le sometan en relación con el proceso electoral y elección y proclamación de los miembros de los órganos de gobierno de las cámaras.

En aquellos casos en que no exista unanimidad dentro de la comisión, los miembros disidentes emitirán voto particular.

3. Dicho informe, con los votos particulares, será remitido a la consideración del órgano competente en materia de cámaras, el cual, a la vista del mismo, dictará una resolución motivada que tendrá carácter vinculante.

Artículo 36. Voto por correspondencia. Los electores que prevean que en la fecha de las elecciones no pueden comparecer en los colegios electorales podrán ejercer su derecho al voto emitiéndolo por correo con sujeción a los requisitos que se establezcan reglamentariamente.

Artículo 37. Funcionamiento de los órganos de gobierno durante el período electoral.

Desde la convocatoria de elecciones hasta la constitución de los nuevos órganos de gobierno, los órganos de gobierno salientes deberán limitar sus actuaciones a la gestión, administración y representación ordinarias de la corporación, adoptando y ejecutando los acuerdos y llevando a cabo las actuaciones que hagan falta para el funcionamiento normal de las cámaras y para el cumplimiento de sus funciones.

\section{Capítulo V RÉGIMEN ECONÓMICO Y PRESUPUESTARIO \\ Sección $1 .^{a}$ \\ Régimen económico}

Artículo 38. Financiación.

Para la financiación de sus actividades, las cámaras dispondrán de los siguientes ingresos:

a. El rendimiento de los conceptos integrados en el denominado recurso cameral permanente, que regula el capítulo III de la Ley 3/1993, de 22 de marzo.

b. El rendimiento, en su caso, derivado de la elevación por la Comunidad Autónoma, de la alícuota cameral girada sobre las cuotas tributarias del impuesto de actividades económicas o tributo que lo sustituya.

c. Los ingresos ordinarios y extraordinarios obtenidos por los servicios que presten y, en general, por el ejercicio de sus actividades.

d. Los recursos que las administraciones públicas destinen a sufragar el coste de los servicios público-administrativos o la gestión de programas que, en su caso, les sean encomendados.

e. Los productos, rentas e incrementos de su patrimonio.

f. Las contribuciones voluntarias de su electorado.

g. Las subvenciones, legados o donativos que puedan recibir.

h. Los procedentes de las operaciones de crédito que se realicen.

i. Cualesquiera otros que les puedan ser atribuidos por ley, en virtud de convenio o por cualquier otro procedimiento de conformidad con el ordenamiento jurídico.

Artículo 39. Elevación del recurso cameral.

En el marco de la legislación básica y dentro de los límites establecidos en la misma, las leyes de presupuestos de la Comunidad Autónoma de Galicia podrán elevar las alícuotas del recurso cameral permanente girado sobre las cuotas del impuesto de actividades económicas o cualquier otro que lo sustituya por encima del tipo general, así como afectar dicho incremento, total o parcialmente, a la realización de funciones de carácter público-administrativo de las cámaras o a la financiación complementaria del Consello Galego de Cámaras.

Artículo 40. Recurso cameral permanente: obligación de pago, devengo y su recaudación. 
En lo referente a la obligación de pago y devengo, así como para la recaudación y en general los demás extremos relativos al recurso cameral permanente, se estará a lo dispuesto en la Ley 3/1993, de 22 de marzo.

Artículo 41. Información sobre recaudación del recurso cameral permanente.

Las cámaras, al enviar la liquidación de los presupuestos anuales, darán cuenta al órgano tutelar del número y cuantía de las cuotas no satisfechas de las distintas exacciones que lo componen, acompañando una memoria explicativa de la situación de dichos expedientes o en su caso los oportunos justificantes.

Artículo 42. Subvenciones y donaciones.

Las cámaras de Galicia solamente podrán conceder subvenciones y efectuar donaciones si se encuentran directamente relacionadas con sus propios fines y no exceden globalmente del 5\% del presupuesto ordinario de ingresos líquidos del recurso cameral permanente de cada ejercicio, salvo autorización expresa del órgano competente en materia de cámaras.

Artículo 43. Porcentaje máximo de financiación con cargo al recurso cameral permanente y fondos de reserva.

1. Los ingresos de cada cámara procedentes del recurso cameral permanente no podrán exceder del $60 \%$ de los totales de la corporación.

A estos efectos, no se computarán, entre los ingresos de la cámara, los procedentes del endeudamiento, ni, entre los que provengan del recurso cameral permanente, los porcentajes del mismo que se encuentren preceptivamente afectados a una finalidad concreta, como el Plan cameral de promoción de las exportaciones y la función de colaboración con las administraciones competentes en tareas de formación señaladas en el artículo 2 de la Ley 3/1993 y 4 del presente texto legal.

2. Cuando los ingresos procedentes del recurso cameral permanente, excluidos los mencionados en el párrafo segundo del apartado anterior, sobrepasen el límite del $60 \%$ señalado, el exceso deberá destinarse a la constitución de un fondo de reserva. De dicha reserva solamente se podrá disponer, en ejercicios sucesivos, para complementar los ingresos procedentes del recurso cameral permanente hasta alcanzar el porcentaje máximo permitido en relación con los ingresos de otra procedencia.

En caso de que, transcurridos cinco años desde la finalización del ejercicio en el que se constituyó la reserva, ésta o sus rendimientos no pudiesen ser aplicados en la forma antes señalada, se destinarán a la financiación de los planes de actuación conjunta del Consello Galego de Cámaras para la promoción e internacionalización de empresas, productos y servicios gallegos, o, alternativamente, se devolverán a quienes hubiesen ingresado las cuotas del recurso cameral permanente en proporción a sus respectivas contribuciones.

3. Cuando la recaudación efectiva de la parte del recurso cameral permanente afectado al Plan cameral de promoción de las exportaciones resulte superior a los gastos e inversiones efectuados para la financiación de dicho plan, la cámara constituirá una reserva patrimonial, materializada en disponible a corto plazo, de la que únicamente se podrá disponer en los ejercicios siguientes para financiar las actividades incluidas en el mencionado plan.

4. Además de los fondos de reserva, regulados en el párrafo anterior, y para hacer frente a bajas de recaudación en ejercicios sucesivos o a gastos urgentes o imprevistos, las cámaras deberán constituir, con el superávit de los presupuestos ordinarios, una reserva obligatoria materializada en disponible a corto plazo hasta que alcance el $50 \%$ del presupuesto total de ingresos liquidados en el último ejercicio cerrado.

Artículo 44. Sujeción al régimen de contabilidad y presupuesto. 
1. La actividad financiera de las cámaras está sujeta al régimen de contabilidad y presupuesto, por lo que su estructura presupuestaria y contable se someterá a los principios contenidos en la normativa en vigor.

2. Las cámaras están obligadas a reflejar en el libro diario el movimiento de sus ingresos y gastos, así como las variaciones de su situación patrimonial, confeccionando, al menos trimestralmente, un estadillo que refleje la ejecución presupuestaria de los ingresos y gastos, y a realizar con igual periodicidad el correspondiente balance que exprese la situación patrimonial, económica y financiera de la corporación. Los fines de la contabilidad cameral serán los siguientes:

a. Facilitar el análisis económico de las actividades de la cámara.

b. Conocer el movimiento y situación de su tesorería.

c. Registrar diariamente el movimiento de sus ingresos y gastos y poner de manifiesto la composición y valoración de su patrimonio.

d. Determinar los resultados de las actividades de la cámara.

e. Permitir el establecimiento de las previsiones presupuestarias y la anotación diaria de la ejecución del presupuesto.

f. Permitir la comparación de la información con las del resto de las cámaras de Galicia y con los ejercicios anteriores.

3. El órgano tutelar podrá dictar las disposiciones oportunas a fin de que el sistema contable y presupuestario aplicado por las cámaras sea único y uniforme para todas ellas y permita conocer en todo momento el patrimonio de cada una de ellas, sus relaciones con terceros y los resultados económicos de su actividad.

4. Las cámaras elaborarán un presupuesto anual ordinario, que coincidirá con el año natural, en el que se consignarán la totalidad de los ingresos que se prevea liquidar y las obligaciones que puedan reconocerse en el período, debiendo, en todo caso, mantenerse el equilibrio presupuestario. Los créditos del estado de gastos se destinarán exclusivamente a la finalidad específica para la que hayan sido autorizados en el presupuesto.

No podrán adquirirse compromisos de gasto por cuantía superior al importe de los créditos autorizados en el correspondiente estado de gastos.

No obstante lo dispuesto en este apartado, podrán efectuarse ampliaciones y transferencias de crédito entre capítulos así como cualquier otra modificación del presupuesto, siempre que se justifiquen debidamente las causas que las motivan y se observe el procedimiento previsto para su aprobación.

5. Para la realización de obras y servicios no previstos en el presupuesto ordinario del ejercicio, y para aquellos gastos, servicios y obras que se realicen con carácter no habitual, deberán formalizarse presupuestos extraordinarios, cuyos proyectos, una vez aprobados por el pleno, se someterán a la aprobación del órgano competente.

Artículo 45. Operaciones especiales. Las cámaras podrán enajenar y gravar sus bienes, si bien para los actos de disposición sobre inmuebles y valores y para la formalización de operaciones de crédito precisan una expresa autorización previa del órgano tutelar, que podrá denegarla mediante resolución motivada.

\section{Sección 2. \\ Régimen presupuestario}

Artículo 46. Elaboración y aprobación de los presupuestos.

1. Las cámaras elaborarán sus presupuestos ordinarios y extraordinarios ordenados por capítulos, artículos, conceptos y partidas.

2. A los efectos económicos y presupuestarios el ejercicio coincidirá con el año natural. El cierre de la contabilidad, la determinación de resultados y la rendición 
de cuentas se referenciarán cada año al 31 de diciembre.

3. La elaboración del proyecto de presupuestos corresponderá al comité ejecutivo, que deberá presentarlos al pleno de la cámara para su aprobación inicial.

4. Los plenos de las cámaras, sobre la base de la propuesta elaborada por el comité ejecutivo, aprobarán el proyecto de presupuesto ordinario para el año siguiente, antes del 1 de noviembre, elevándolo seguidamente al órgano competente.

5. Los presupuestos deberán ser presentados al órgano tutelar para su aprobación definitiva, adjuntando la siguiente documentación:

a. Memoria explicativa del presupuesto.

b. Programa de actuación e inversiones previstas.

c. Programa de financiación y de sus actuaciones.

d. Estado de ejecución de los presupuestos vigentes.

e. Plantilla de personal, especificando las categorías y retribuciones por todos los conceptos de cada puesto de trabajo.

6. Los presupuestos se entenderán aprobados definitivamente si, transcurridos dos meses desde su presentación al órgano tutelar, éste no hubiera manifestado formalmente reparo alguno.

7. $\mathrm{Si}$ el presupuesto no se encontrase aprobado definitivamente al comenzar el ejercicio económico, se entenderá prorrogado automáticamente el presupuesto consolidado del ejercicio anterior.

Artículo 47. Liquidación y fiscalización de los presupuestos y cuentas anuales.

1. Las cámaras elaborarán y aprobarán las cuentas anuales y liquidaciones de presupuestos de su corporación, que contendrán los siguientes documentos:

a. Memoria económica.

b. Liquidación anual del presupuesto ordinario, así como de los presupuestos extraordinarios ya ejecutados, y estado de ejecución de los presupuestos extraordinarios en curso de realización. c. Balance de situación anual y cuenta de pérdidas y ganancias que reflejen la situación patrimonial y financiera de la corporación.

2. El comité ejecutivo deberá formular las cuentas anuales en el plazo máximo de tres meses desde el cierre del ejercicio. Dichas cuentas serán sometidas a un informe de auditoría, presentándose, junto con la liquidación del presupuesto ordinario del ejercicio cerrado, antes del 31 de mayo, al pleno de la cámara para la adopción del acuerdo que proceda. El pleno deberá pronunciarse antes del 30 de junio.

3. Las cuentas anuales, el informe de auditoría, la liquidación del presupuesto ordinario y el certificado del contenido del acuerdo del pleno se remitirán en un plazo máximo de diez días al órgano tutelar para su aprobación definitiva.

4. La aprobación se entenderá concedida si no media objeción alguna en el plazo de tres meses a partir de su recepción.

5. La administración tutelante podrá requerir de la cámara toda aquella documentación complementaria que estime procedente y, en su labor de fiscalización, deberá recibir toda la colaboración que requiera de la cámara y tener libre acceso, si lo considera necesario, a la documentación interior de la auditoría certificante y a recibir de ésta los informes complementarios que recabe.

6. Al amparo de lo previsto en el artículo 23.2 de la Ley 3/1993, la fiscalización superior del destino dado a las cantidades percibidas por las cámaras y por el Consello Galego de Cámaras procedentes de los rendimientos del recurso cameral permanente así como de la elevación de sus alícuotas corresponderá, en los términos previstos en su normativa reguladora, al Consello de Contas de Galicia.

Artículo 48. Responsabilidades. Las personas que gestionen bienes y derechos de las cámaras oficiales de comercio, industria y, en su caso, navegación de Galicia quedarán sujetas a indemnizar los 
daños y perjuicios que puedan causarles por acciones y omisiones realizadas interviniendo dolo, culpa o negligencia grave con infracción de la normativa vigente, con independencia de la responsabilidad penal o de otro orden que les pueda corresponder.

\section{Capítulo VI}

\section{CONSELLO GALEGO DE CÁMARAS}

Artículo 49. Naturaleza.

1. Se crea el Consello Galego de Cámaras como organismo de representación, relación y coordinación de las cámaras y como organismo consultivo y colaborador de la Xunta de Galicia.

2. El Consello Galego de Cámaras se constituye como corporación de derecho público con personalidad jurídica y plena capacidad de obrar para el cumplimiento de sus fines.

3. El Consello Galego de Cámaras está integrado por representantes de la totalidad de las cámaras de la Comunidad Autónoma gallega.

4. El Consello Galego de Cámaras tendrá su dirección en la ciudad sede del Gobierno gallego, sin perjuicio de que sus órganos colegiados puedan celebrar sesiones en cualquier lugar de la Comunidad Autónoma de Galicia, de conformidad con lo que se establezca en su reglamento de régimen interior.

Artículo 50. Funciones del Consello Galego de Cámaras.

Sin perjuicio de las competencias atribuidas a las cámaras, son funciones del Consello Galego de Cámaras:

a. Defender de forma global e integrada los intereses del comercio, de la industria y de la navegación en el ámbito de la Comunidad Autónoma.

b. Promover el arbitraje mercantil.

c. Representar al conjunto de las cámaras de Galicia ante las administraciones públicas y demás entidades, públicas o privadas, sin perjuicio de la competencia propia de cada cámara.

d. Ser el órgano de coordinación e impulso de las actuaciones comunes de las cámaras y de promoción del máximo desarrollo de sus funciones.

e. Potenciar la prestación de servicios mancomunados entre las cámaras.

f. Coordinar la emisión de informes, a requerimiento de las administraciones públicas, en aquellos asuntos de carácter intersectorial que afecten al comercio, la industria o la navegación de la Comunidad Autónoma y cuyo ámbito o repercusión sea superior al de cada una de las cámaras que lo integran.

g. Coordinar la elaboración y actualización de estadísticas del comercio, la industria y la navegación, de acuerdo con las previsiones contenidas en la Ley 9/1988, de 19 de julio, de estadística de Galicia, y normativa que la desarrolle, y realizar las encuestas de evaluación y los estudios necesarios que permitan conocer la situación de los distintos sectores de Galicia, coordinando las actuaciones realizadas por las cámaras en estas materias.

h. Establecer servicios de asesoramiento y apoyo a las cámaras gallegas o acordar convenios de colaboración con éstas, previa autorización del órgano tutelar.

i. Mediar y dirimir en los conflictos o discrepancias que se planteen entre las cámaras gallegas.

j. Establecer convenios con otras entidades públicas y privadas, así como planes de actuación conjunta de las cámaras gallegas y las propuestas de financiación correspondientes, con especial atención a la promoción de los productos, industria y turismo exterior.

k. Informar los proyectos de disposiciones generales emanados de la Comunidad gallega que afecten directamente a los intereses del sector del comercio, la industria o los servicios representados por las cámaras, en los supuestos y con las condiciones y alcance que el ordenamiento jurídico determine.

1. Proponer la aprobación de normas en asuntos que afecten directamente a los intereses generales del comercio, industria y navegación de Galicia. 
m. Colaborar con la Administración autonómica, en los supuestos en que sea requerido por la misma, informando o realizando estudios, proyectos, trabajos y acciones en materia de comercio, industria y navegación que afecten al conjunto de la Comunidad Autónoma o a más de una demarcación cameral.

n. Asesorar a la Administración autonómica en temas referentes al comercio, la industria y la navegación a iniciativa propia o cuando así sea requerido por la misma, así como proponerle cuantas reformas estime necesarias para la defensa y fomento de aquéllos.

ñ. En los supuestos y con las condiciones y alcance que establezca la Administración autonómica, le corresponderá colaborar, en su caso, en la tramitación de programas públicos de ayudas a las empresas, en la gestión de servicios públicos y en el desempeño de las funciones administrativas que se le encomienden y participar en aquellos proyectos de infraestructuras y servicios comunes que afecten al conjunto de la Comunidad gallega.

o. Prestar otros servicios o realizar otras actividades, a título oneroso o lucrativo, que redunden en beneficio de los intereses representados por las cámaras que lo integran.

p. Elaborar anualmente, y de acuerdo con lo realizado por cada una de las cámaras, un censo público de todas las empresas radicadas en el ámbito de la Comunidad Autónoma, así como de sus delegaciones, agencias y establecimientos.

q. Coordinar cualquier otra función de carácter público-administrativo que le encomiende la Administración autonómica.

r. Cuantas otras atribuciones le confieran las leyes expresamente.

Artículo 51. Órganos de gobierno.

1. Los órganos de gobierno y administración del Consello Galego de Cámaras son el pleno, el comité ejecutivo y la presidencia.
2. El Consello Galego de Cámaras contará con una persona que desarrolle las funciones de la secretaría.

Su elección y funciones serán las establecidas en el artículo 24 de la presente ley.

Artículo 52. El Pleno.

El Pleno del Consello Galego de Cámaras, órgano supremo de gobierno y representación del mismo, estará compuesto por:

Los presidentes o presidentas de todas las cámaras oficiales de comercio, industria y, en su caso, navegación de la Comunidad Autónoma de Galicia.

Tres vocales consultores elegidos por los demás miembros del pleno de entre personas de reconocido prestigio en los ámbitos empresariales de Galicia.

La persona que ocupe la secretaría, que actuará con voz pero sin voto.

Un representante del órgano tutelar, con voz pero sin voto.

La composición del pleno se actualizará periódicamente, una vez concluido el proceso electoral en las cámaras gallegas.

Artículo 53. Comité ejecutivo.

El Comité Ejecutivo del Consello Galego de Cámaras es su órgano de gestión, administración y propuesta, y estará compuesto por las personas que ocupen la presidencia del consejo, la secretaría y cuatro miembros del pleno elegidos de la forma que establezca el reglamento de régimen interior, teniendo el Presidente o presidenta voto de calidad en caso de empate.

Artículo 54. La presidencia.

1. Quien ejerza la presidencia será elegido por los miembros del Pleno del Consello Galego de Cámaras, en sesión convocada al efecto, y recaerá en aquel miembro del pleno del consejo que en una primera votación obtenga el mayor número de votos, exigiéndose en todo caso mayoría absoluta; de no alcanzarse dicha mayoría, se procederá a una segunda votación entre el segundo y cuarto día siguientes, quedando elegido quien obtenga mayor número de votos. 
2. La presidencia ejerce la representación del Consello Galego de Cámaras y preside sus órganos colegiados siendo responsable de la ejecución de sus acuerdos. Tendrá las funciones que le asignan la presente ley y el reglamento de régimen interior. Asimismo, ostenta la representación de las cámaras gallegas en aquellos órganos o instituciones en que esta representación sea precisa.

El reglamento de régimen interior podrá contemplar la creación de una vicepresidencia del consejo, que sustituirá a quien ejerza la presidencia como reglamentariamente se determine y que deberá ser miembro del comité ejecutivo.

Artículo 55. Reglamento de régimen interior.

1. El consejo se regirá por un reglamento de régimen interior que se someterá a la aprobación del órgano competente, a propuesta del consejo. La aprobación y modificación de dicho reglamento de régimen interior deberá aprobarse con el voto favorable, al menos, de dos tercios del Pleno del Consello Galego de Cámaras.

2. En el reglamento de régimen interior se establecerán, entre otros extremos, las normas de funcionamiento de los órganos colegiados, la organización y el régimen del personal al servicio del consejo.

3. Las disposiciones que se contemplen en la presente ley relativas a las cámaras y a la normativa vigente en materia de cámaras oficiales de comercio, industria y navegación se aplicarán, con carácter subsidiario, al consejo, a sus órganos de gobierno y a su personal.

Artículo 56. Régimen económico y presupuestario.

1. Los ingresos permanentes del Consello Galego de Cámaras estarán constituidos por las contribuciones de las cámaras en la cuantía que fije anualmente el consejo al aprobar sus presupuestos. La contribución de cada cámara no debe ser inferior al 3\% del rendimiento del recurso cameral permanente que resulte de la última liquidación presupuestaria, una vez deducidos los gastos de recaudación. Este porcentaje será el mismo para todas las cámaras.

2. El consejo también podrá contar con otros recursos eventuales como contribuciones voluntarias, donativos y subvenciones, así como por el rendimiento, en su caso, derivado de la elevación por la Comunidad Autónoma, de la alícuota cameral girada sobre las cuotas del impuesto de actividades económicas o tributo que lo sustituya, o cualesquiera otros previstos por la legislación vigente.

3. El régimen económico y presupuestario, en lo que sea compatible, se regirá por lo dispuesto en el capítulo $\mathrm{V}$ de la presente ley.

\section{Capitulo VII RÉGIMEN JURÍDICO}

Artículo 57. Normativa de aplicación.

1. Las cámaras de Galicia y el Consello Galego de Cámaras se regirán por lo establecido en la presente ley y en sus normas de desarrollo, en los respectivos reglamentos de régimen interior y en la Ley 3/1993, de 22 de marzo, básica de cámaras oficiales de comercio, industria y navegación.

2. Les será de aplicación con carácter supletorio la legislación referente a la estructura y funcionamiento de las administraciones públicas en cuanto sea conforme con su naturaleza y finalidades.

3. La contratación y el régimen patrimonial de las cámaras se regirán por el derecho privado, salvo disposición legal en contrario, con sometimiento a los principios de publicidad, concurrencia y objetividad, salvo que la naturaleza de la operación a realizar sea incompatible con ellos.

Artículo 58. Tutela.

1. Las cámaras de Galicia, así como el Consello Galego de Cámaras, están sujetas en el ejercicio de su actividad a la tutela 
de la Administración de la Comunidad Autónoma de Galicia.

2. La función de tutela comprende las facultades y obligaciones contenidas en la presente ley y en su normativa de desarro1lo, así como el ejercicio de las potestades administrativas de aprobación, fiscalización, resolución de recursos y suspensión y disolución de sus órganos de gobierno.

3. La Administración de la Comunidad Autónoma de Galicia dispondrá de un período de dos meses a partir de la entrada en el órgano competente de las solicitudes formales de las cámaras para la resolución de las mismas, salvo en aquellos casos en que la presente ley prevea plazos distintos.

Artículo 59. Reclamaciones y recursos.

1. Las resoluciones de las cámaras, dictadas en ejercicio de sus competencias de naturaleza público-administrativa, así como las que afecten a su régimen electoral, serán impugnables ante la jurisdicción contencioso-administrativa, previo recurso administrativo formulado ante el órgano tutelar.

2. Las liquidaciones y demás actos relativos a la gestión y recaudación del recurso cameral permanente serán susceptibles de reclamación económico-administrativa.

3. Las actuaciones de la cámara en otros ámbitos $\mathrm{y}$, singularmente, las de carácter laboral se dilucidarán ante los juzgados y tribunales competentes.

4. Las actuaciones de las cámaras podrán ser objeto de queja o reclamación ante el órgano tutelar por parte del electorado. A la vista de la reclamación planteada, se dará traslado de la misma a la cámara respectiva para que en el plazo de quince días formule las alegaciones que considere convenientes. Transcurrido dicho plazo, el órgano competente resolverá lo que estime pertinente.

Artículo 60. Deber de información y de emisión de informes.

1. Las cámaras de Galicia deberán remitir a la Administración de la Comunidad
Autónoma, en los plazos y en la forma que determinen los reglamentos de régimen interior, copia o extracto de todos los acuerdos que adopten sus órganos de gobierno en relación con sus funciones público-administrativas. Los titulares de la presidencia y, en su caso, de la secretaría serán los responsables del cumplimiento del deber de información.

2. La Administración de la Comunidad Autónoma de Galicia podrá solicitar la ampliación o aclaración de la información a que se refiere el apartado anterior, así como cualquier otra que considere de interés relacionado.

3. En los supuestos previstos por la presente ley en los que se exija de modo preceptivo la emisión de informe por parte de las cámaras o del Consello Galego de Cámaras, habrán de remitirlo al órgano competente en el plazo máximo de treinta días. En caso contrario se entenderá que su dictamen es favorable a la pretensión formulada. En aquellos asuntos en que el informe tenga carácter vinculante tanto el consejo como, en su caso, las cámaras habrán de resolver expresamente.

Artículo 61. Suspensión y disolución de los órganos de gobierno de las cámaras.

1. El Gobierno de la Comunidad Autónoma de Galicia podrá suspender la actividad de los órganos de gobierno de las cámaras en caso de que produzcan transgresiones del ordenamiento jurídico vigente que, por su gravedad o reiteración, hagan aconsejable esta medida, así como en los supuestos de imposibilidad de funcionamiento normal de aquéllos.

A estos efectos, se concederá un plazo de quince días a la cámara afectada y al Consello Galego de Cámaras para que efectúen las alegaciones que estimen convenientes, pudiendo reducirse dicho plazo a cinco días en aquellos casos en que el transcurso de aquel plazo pueda conllevar perjuicios de imposible o difícil reparación. 
2. El acuerdo de suspensión determinará su plazo de duración, que no podrá exceder de tres meses, así como el órgano que tendrá a su cargo la gestión de los intereses de las cámaras durante este período.

3. Si, transcurrido el plazo de suspensión, subsistiesen las razones que dieron lugar a la misma, se procederá, dentro del plazo de un mes, a la disolución de los órganos de gobierno, así como a la convocatoria de nuevas elecciones, manteniéndose en sus funciones, hasta la constitución de los nuevos órganos camerales, el órgano designado en el acuerdo de suspensión.

\section{DISPOSICIÓN ADICIONAL PRIMERA}

En el plazo de un año desde la entrada en vigor de la presente ley, las cámaras adaptarán al contenido de la misma sus actuales reglamentos de régimen interior.

\section{DISPOSICIÓN ADICIONAL SEGUNDA}

Cuando la presente ley atribuya competencias a la consellería competente en materia de cámaras, o a la Xunta de Galicia sin especificar el órgano concreto de ésta encargado de ejercerlas, o genéricamente a la Administración autonómica, se entenderá cuando proceda que las menciones se refieren a la dirección general que ostente las competencias en materia de comercio o al órgano administrativo al que las futuras reestructuraciones orgánicas atribuyan con carácter general la tutela sobre las cámaras.

\section{DISPOSICIÓN TRANSITORIA PRIMERA}

En tanto no se produzcan las circunstancias que motiven un procedimiento de modificación de los previstos en el capítulo II de la presente ley, las cámaras seguirán ejerciendo sus funciones en sus respectivas circunscripciones actuales.

\section{DISPOSICIÓN TRANSITORIA SEGUNDA}

La exigencia de licenciatura en derecho prevista en el artículo 24 de la presente ley no se aplicará a los actuales secretarios generales de las cámaras, en tanto se mantengan en la secretaría respectiva y hasta la nueva convocatoria pública de la plaza.

\section{DISPOSICIÓN TRANSITORIA TERCERA}

1. Quien ocupe la Dirección General de Comercio y Consumo de la Xunta de Galicia convocará a los presidentes o presidentas de las cámaras gallegas para la elección de los vocales consultores. Constituido el pleno, la dirección general convocará nuevamente a sus miembros para la elección de la presidencia y del comité ejecutivo. En ambos casos, y en tanto no se designe una persona que ocupe la secretaría general del consejo, actuará como tal el secretario o secretaria de mayor edad de las cámaras gallegas.

2. Mientras no se apruebe el reglamento de régimen interior del Consello Galego de Cámaras, el órgano tutelar dictará las normas necesarias para su buen funcionamiento. Dicho reglamento se presentará para su aprobación en un plazo máximo de seis meses desde la constitución del consejo.

\section{DISPOSICIÓN DEROGATORIA PRIMERA}

Queda derogado el Decreto 14/1980, de 19 de junio, por el que se crea el Consejo Consultivo y Colaborador de las Cámaras Oficiales de Comercio, Industria y, en su caso, Navegación de Galicia.

\section{DISPOSICIÓN DEROGATORIA SEGUNDA}

Quedan derogadas cuantas normas de igual o inferior rango se opongan a lo dispuesto en la presente ley.

\section{DISPOSICIÓN FINAL PRIMERA}

El Reglamento general de cámaras establecido por el Decreto 1291/1974, de 2 de mayo, modificado por los reales decretos 753/1978, de 27 de marzo, y 816/1990, de 22 de junio, y el Decreto 116/1997, de 14 de mayo, por el que se regula el régimen electoral de las cámaras oficiales 
de comercio, industria y navegación de la Comunidad Autónoma de Galicia, serán de aplicación subsidiaria a lo establecido en la presente ley y en sus normas de desarrollo.

\section{DISPOSICIÓN FINAL SEGUNDA}

Se faculta a la Xunta de Galicia para dictar las normas de desarrollo de la presente ley.

\section{LEY 6/1985, DE 24 DE JUNIO, DEL CONSELLO DE CONTAS (DOGA N. $\left.{ }^{\circ} 130,9.7 .1985\right)$}

$(\ldots)^{118}$

\section{TÍTULO I COMPETENCIAS}

Artículo 1. Competencias.

1. El Consello de Contas de Galicia, como órgano de fiscalización de las cuentas y de la gestión económico-financiera y contable, ejercerá su función en relación con la ejecución de los programas de ingresos y gastos del sector público de la Comunidad Autónoma.

2. Depende directamente del Parlamento de Galicia y ejercerá sus funciones con plena independencia y sometimiento al ordenamiento jurídico.

Artículo 2. Ámbito de actuación.

A efectos de esta ley, componen el sector público de la Comunidad Autónoma:

1. La Administración Autonómica y sus organismos autónomos.

2. Las Entidades Locales y sus organismos autónomos, así como las empresas públicas dependientes de las mismas, en el ámbito competencial de las instituciones de autogobierno ${ }^{119}$.

3. Las empresas públicas, cualquiera que sea su forma jurídica, dependientes de la Administración Autonómica.

4. Las Corporaciones a que se refiere el número 29 del artículo 27 del Estatuto de Autonomía de Galicia ${ }^{120}$.

\footnotetext{
118 Exposición de motivos omitida.

119 Véase STC 18/1991, de 31 de enero. FJ. 5.

120 Véase STC 18/1991, de 31 de enero. FJ. 6.
}

Artículo 3. Régimen interior.

Corresponde al Consello de Contas la competencia para todo lo concerniente al gobierno y al régimen interior del mismo y al personal a su servicio.

Deberá elaborar su proyecto de presupuesto, que se integrará en los generales de la Comunidad Autónoma, en una Sección específica diferenciada, para que sea sometido a la aprobación del Parlamento de Galicia.

Artículo 4. Fiscalización.

Son funciones del Consello de Contas de Galicia:

a. Fiscalizar las funciones económicofinanciera del sector público de Galicia, velando para que se ajuste al ordenamiento jurídico y al principio de racionalidad, determinada por criterios de eficiencia y economía.

b. Fiscalizar las subvenciones, los créditos y las ayudas con cargo a los presupuestos de los entes públicos gallegos, así como los avales y exenciones fiscales directas y personales concedidas por aquellos entes, ya sean percibidas por personas físicas o jurídicas.

c. Fiscalizar los contratos celebrados por la Administración Autonómica y otros entes del sector público de Galicia en los casos en que se establezca así o que el Consello de Contas lo considere conveniente.

d. Fiscalizar la situación y las variaciones del patrimonio de la Comunidad Autónoma de Galicia y demás entes públicos gallegos.

e. Fiscalizar los créditos extraordinarios y suplementos de créditos, así como las incorporaciones, ampliaciones transferencias y demás modificaciones de los créditos presupuestarios iniciales.

f. Emitir dictámenes y consultas que en materia de contabilidad pública y de gestión económico-financiera le soliciten las Instituciones y los entes públicos gallegos.

g. Analizar la utilización de los recursos disponibles, atendiendo al menor coste 
en la realización del gasto y formular las propuestas tendentes a mejorar los servicios prestados por el sector público de Galicia.

h. Fiscalizar el grado de cumplimiento de los objetivos propuestos en los diversos programas presupuestarios y en las memorias de las subvenciones, créditos, ayudas y de los avales, e indicar, en su caso, las causas de incumplimiento.

Artículo 5. Enjuiciamiento.

1. Si en el ejercicio de su función fiscalizadora el Consello de Contas advirtiera la existencia de indicios de responsabilidad contable, (...) dará traslado de las correspondientes actuaciones al Tribunal de Contas para que éste efectúe el enjuiciamiento de las mismas ${ }^{121}$.

2. Asimismo, en materia de enjuiciamiento contable, realizará todas las funciones que le delegue el Tribunal de Contas, de acuerdo con lo que prevé la Ley Orgánica 2/82, de 12 de mayo.

\section{TÍTULO II ORGANIZACIÓN Y FUNCIONAMIENTO}

\section{Capitulo I ORGANIZACIÓN}

Artículo 6. Órganos.

Son órganos del Consello de Contas:

1. El Pleno.

2. El Conselleiro Maior.

3. La Comisión de Gobierno.

4. Las Secciones:

a. De fiscalización.

b. De enjuiciamiento.

5. La Secretaría General.

Artículo 7. El Pleno.

1. El Pleno estará integrado por cinco conselleiros, de los que uno será el conse1leiro mayor.

2. El Pleno quedará válidamente constituido cuando estén presentes tres de sus

121 El párrafo del art. 5.1, cuyo texto era "instruirá el oportuno procedimiento jurisdiccional" fue declarado inconstitucional por STC 18/1991, de 31 de enero. FJ. 4. miembros y los acuerdos serán adoptados por mayoría de los presentes ${ }^{122}$.

3. Corresponde al Pleno:

a. Ejercer la función fiscalizadora de acuerdo con las disposiciones de esta ley.

b. Adoptar las disposiciones necesarias para cumplir los fines que esta ley encomienda al Consello de Contas.

c. Aprobar el Proyecto de Presupuesto.

d. Aprobar todos los informes, memorias, propuestas, dictámenes y consultas que formulen los órganos competentes del Consello de Contas.

e. Proponer el nombramiento de uno de sus miembros para el cargo de Conselleiro Maior.

f. Resolver los conflictos de atribuciones y cuestiones de competencia entre los diversos órganos del Consello de Contas.

g. Designar los Presidentes de las Secciones.

h. Nombrar el Secretario General.

i. Plantear los conflictos que afectan a las competencias o atribuciones del Consejo.

j. Decidir sobre la instrucción del procedimiento a que se refiere el no $1 \mathrm{del}$ artículo 5 de esta ley.

k. Las demás funciones que, por ley, se les encomiende.

4. El Pleno será convocado por el Conselleiro Maior, a iniciativa propia o siempre que lo soliciten, por lo menos, dos de sus miembros 123 .

Artículo 8. El Conselleiro Maior.

1. El Conselleiro Maior será nombrado por un período de tres años por el Presidente de la Xunta, a propuesta del Pleno de entre sus miembros.

2. El Conselleiro Maior cesará en su cargo: por expiración del período de su mandato; por renuncia; por invalidez

122 Art. 7.1 y 7.2 modificados por Ley $4 / 1986$, de 26 de diciembre, de modificación de la Ley $6 / 1985$, de 24 de junio, del Consello de Contas.

123 Art. 7.4 modificado por Ley 4/1986, de 26 de diciembre, de modificación de la Ley $6 / 1985$, de 24 de junio, del Consello de Contas. 
permanente, que lo incapacite para el ejercicio de su función; o cuando pierda su condición de conselleiro.

3. El Conselleiro Maior será sustituido provisionalmente en caso de ausencia y enfermedad, así como en el supuesto de vacante, hasta que se produzca el nuevo nombramiento, por el conselleiro de mayor antigüedad de entre los que integran la Comisión de Gobierno, dirimiéndose la sustitución, en caso de empate, en favor del conselleiro de mayor edad.

4. Son atribuciones del Conselleiro Maior:

a. Representar al Consello de Contas.

b. Convocar y presidir el Pleno y la Comisión de Gobierno, así como decidir con su voto de calidad en caso de empate.

c. Ejercer la jefatura superior del personal.

d. Disponer los gastos propios del Consejo y la contratación de obras, bienes, servicios, suministros y demás prestaciones necesarias para su funcionamiento.

e. Resolver las demás cuestiones de carácter interno no asignadas a otros órganos del Consejo.

f. Las demás que le reconozca la ley.

Artículo. 9. La Comisión de Gobierno.

1. La Comisión de Gobierno está constituida por el Conselleiro Maior y los Conselleiros de Cuentas Presidentes de Sección.

2. Corresponde a la Comisión de Gobierno:

a. Establecer el régimen de trabajo del personal.

b. Distribuir los asuntos entre las Secciones.

c. Ejercer las funciones relativas al nombramiento y contratación del personal, gobierno y administración en general.

d. Ejercer la potestad disciplinaria respecto al personal de acuerdo con las normas de régimen interior.

e. Nombrar los Delegados Instructores.

f. Las otras facultades que el Pleno le delegue para la mayor eficacia en el ejercicio de las funciones propias del Consejo.
Artículo 10. Las Secciones.

1. Corresponderá a la Sección de Fiscalización la verificación de la contabilidad de las entidades del sector público de Galicia y el examen y la comprobación de sus cuentas. Se organizará en departamentos sectoriales a cuyo frente estará un conselleiro por cada uno.

2. Corresponde a la Sección de Enjuiciamiento, en el marco establecido por el artículo 5 de esta ley, la instrucción de los procedimientos jurisdiccionales y el enjuiciamiento de las responsabilidades contables de aquellos que tienen a su cargo caudales o efectos públicos conforme a las funciones del Consello de Contas.

3. Los presidentes de las Secciones serán designados por el Pleno, para un período de tres años.

Artículo 11. La Secretaría General.

1. El Secretario General desempeñará las funciones conducentes al adecuado ejercicio de las competencias gubernativas del Pleno, de la Comisión de Gobierno y del Conselleiro Maior en todo lo relativo al régimen interior del Consello de Contas.

2. El Secretario General velará especialmente por la redacción de las Actas de las Sesiones del Pleno y de la Comisión de Gobierno, formará el anteproyecto del presupuesto y el proyecto de memoria anual que se deban someter al Pleno.

\section{Capitulo II FUNCIONAMIENTO}

Sección 1. ${ }^{\mathrm{a}}$ Los miembros del Consejo

Artículo 12. Los Conselleiros.

1. Los Conselleiros, en número de cinco, son designados por el Parlamento mediante votación por mayoría de tres quintas partes, para un período de seis años. Si se produjesen vacantes, se cubrirán de acuerdo con lo establecido anteriormente y por el tiempo que reste de mandato 124 .

124 Art. 12.1 modificado por Ley 4/1986, de 26 de diciembre, de modificación de la Ley 6/1985, de 24 de junio, del Consello de Contas. 
2. Los Conselleiros de Contas son independientes e inamovibies y serán elegidos entre Conselleiros del Tribunal de Contas, Censores Jurados de Cuentas, Magistrados, Fiscales, funcionarios públicos pertenecientes a Cuerpos, que exigen la titulación académica superior, y entre licenciados en Derecho, en Ciencias Económicas, en Ciencias Empresariales e Intendentes Mercantiles, de reconocida competencia, con más de doce años de ejercicio profesional.

3. No podrán ser designados Conselleiros de Cuentas los que, en los dos años anteriores, hayan estado comprendidos en alguno de los supuestos que se citan a continuación:

a. Las autoridades o funcionarios que tienen a su cargo la gestión, inspección o intervención de los ingresos y gastos del sector público de Galicia.

b. Los Presidentes, Directores y miembros de los Consejos de Administración de organismos autónomos y de las empresas integradas en el sector público de Galicia.

c. Los particulares que, excepcionalmente, administren, recauden o custodien fondos o valores públicos.

d. Los perceptores de las subvenciones con cargo a fondos públicos.

e. Cualquier otra persona que tenga la condición de cuentadante ante el Consello de Contas.

f. Los beneficiarios de avales o exenciones fiscales directas y personales, concedidas por cualquiera de los entes indicados en el artículo 2.

Artículo 13. Incompatibilidades.

1. Los miembros del Consello de Contas estarán sujetos a las mismas causas de incapacidad, incompatibilidad y prohibiciones establecidas para los Jueces en la Ley Orgánica del Poder Judicial.

La condición de miembro del Consello de Contas de Galicia es incompatible con:

a. La de Diputado del Parlamento de Galicia o de cualquier otro Parlamento Autonómico. b. La de Diputado del Congreso de los Diputados.

c. La de Senador.

d. La de miembro del Tribunal de Contas.

e. La de Valedor do Pobo.

f. La de Defensor del Pueblo.

g. Cualquier cargo político o administrativo del Estado, de las Comunidades Autónomas y de las Entidades Locales o de sus organismos autónomos, de las empresas públicas, cualquiera que sea su forma jurídica.

h. El ejercicio de funciones directivas o ejecutivas en partidos políticos, centrales sindicales, organizaciones empresariales y Colegios Profesionales.

i. La de miembro de cualquiera de los órganos asesores de la Xunta de Galicia.

j. El ejercicio de su profesión o de cualquiera otra actividad remunerada.

3. Si la designación recayera en alguna de las personas a las que se refiere el apartado anterior, antes de tomar posesión, deberá renunciar a su cargo o función.

4. El nombramiento de los miembros del Consello de Contas implicará, en su caso, la declaración del interesado en la situación de servicios especiales o equivalentes en la carrera o Cuerpo de procedencia.

Artículo 14. Abstención y recusación. Para los Conselleiros rigen las causas de abstención y de recusación siguientes:

a. Tener interés personal en el asunto o en la empresa o entidades interesadas, o tener cuestión litigiosa pendiente o relación de servicio con algún interesado.

b. Tener parentesco de consanguinidad hasta el cuarto grado o de afinidad hasta el segundo grado con cualquiera de los cuentadantes o administradores de las entidades indicadas en el artículo 2.

c. Tener amistad íntima o enemistad manifiesta con algunas de las personas señaladas en el apartado anterior.

Artículo 15. Responsabilidad.

La responsabilidad disciplinaria del Conselleiro Maior y de los conselleiros deberá ser establecida por las normas de régimen interior del Consello de Contas. 
Artículo 16. Pérdida de la condición. Los miembros del Consello de Contas de Galicia pierden su condición por las siguientes causas:

1. Por muerte o por renuncia presentada y aceptada por el Parlamento.

2. Por extinción del mandato al expirar el término.

3. Por incapacidad declarada por decisión judicial fïme.

4. Por inhabilitación para el ejercicio de los derechos políticos declarada por decisión judicial firme.

5. Por condena en sentencia firme a causa de delito.

6. Por incumplimiento de las obligaciones del cargo, conforme a las normas de régimen interior del Consello de Contas.

\section{Sección 2. ${ }^{\mathrm{a}}$}

\section{Personal al servicio del Consejo}

Artículo 17. Régimen general.

1. El personal al servicio del Consello de Contas, integrado por funcionarios con titulación adecuada, sin perjuicio de las normas especiales que le sean de aplicación, estará sujeto al régimen general de la Función Pública y a sus incompatibilidades.

2. El desempeño de la Función Pública en el Consello de Contas será incompatible con cualquiera otra función, destino o cargo, así como con el ejercicio profesional y con la intervención en actividades industriales, mercantiles o profesionales, incluso las consultivas y las de asesoramiento.

Artículo 18. Comisionados.

1. El Consello de Contas podrá comisionar a expertos que tengan titulación adecuada al objeto de inspeccionar, revisar y comprobar documentación, libros, metálico, valores, bienes y existencias de las Entidades del sector público gallego, o para practicar la función prevista en el apartado b) del artículo 4 de esta ley, y, en general, para comprobar la realidad de las operaciones reflejadas en sus cuentas y emitir los informes correspondientes.
2. No podrán ser comisionados los que incurran en alguno de los supuestos a que se refiere el número 3 del artículo 12 .

\section{Sección $3 .^{\mathrm{a}}$}

\section{Documentación y memoria anual}

Artículo 19. Documentación de las actuaciones.

1. El resultado de la fiscalización se hará constar por medio de mociones o notas dirigidas a la Autoridad, Organismo o Entidad a las que afecten y de memorias ordinarias o extraordinarias, que se elevarán al Parlamento de Galicia, con remisión de copias a la Xunta de Galicia y a las indicadas Autoridades, Organismos y Entidades afectadas y se publicarán en el "Diario Oficial de Galicia".

2. El Consello de Contas hará constar cuantas infracciones, abusos o prácticas irregulares haya observado, con indicación de la responsabilidad en que, a su juicio, se haya incurrido y de las medidas para exigirla.

3. El Consello de Contas podrá emitir en cualquier momento, a petición del Parlamento o por iniciativa propia, informes o memorias relativas a las funciones señaladas en esta ley.

Artículo 20. Memoria anual.

1. El Consello de Contas de Galicia deberá elaborar y elevar al Parlamento una memoria de sus actividades, que comprenderá el análisis de la Cuenta General de la Comunidad Autónoma y de las demás del sector público de Galicia. Se extenderá, además, a la fiscalización de la gestión económica de la Comunidad y del sector público gallego y comprenderá, entre otros, los siguientes extremos:

a. Observancia de la Constitución, del Estatuto de Autonomía de Galicia, de las leyes reguladoras de los ingresos y gastos del sector público de Galicia y, en general, de las normas que afectan a la actividad económico-financiera y contable del mismo.

b. Cumplimiento de las previsiones y de la ejecución de los Presupuestos de la Comunidad Autónoma, de las Entidades 
Locales y demás entidades sujetas a su fiscalización.

c. Racionalidad en la ejecución del gasto público basado en criterios de eficacia y economía.

d. Ejecución de los programas de actuación, inversiones y financiación y demás planes o previsiones que rijan la actividad de las empresas públicas y de las empresas vinculadas a la Comunidad Autónoma, así como el empleo o aplicación de subvenciones con cargo al presupuesto de la Comunidad Autónoma y de las exenciones fiscales directas y personales concedidas.

2. El Consello de Contas propondrá las medidas a adoptar, en su caso, para la mejora de la gestión económico-financiera del sector público de Galicia.

3. Asimismo, la memoria anual contendrá un informe de las actividades jurisdiccionales del Consejo durante el ejercicio correspondiente.

\section{Sección $4 .^{a}$}

Relaciones entre el Consejo de Cuentas y el Parlamento

Artículo 21. Comisión parlamentaria. Una Comisión parlamentaria se encargará de las relaciones del Parlamento con el Consello de Contas.

Artículo 22. Las cuentas del Consejo. El examen de las cuentas del Consello de Contas corresponde al Parlamento de Galicia, al que se deberán trasladar con esta finalidad como un anexo en la memoria anual a que se refiere el artículo 20 de la presente ley.

\section{TÍTULO III GARANTÍAS, NORMAS Y PROCEDIMIENTOS PARA ASEGURAR LA RENDICIÓN DE CUENTAS}

Artículo 23. Deber de colaboración.

1. Todas las entidades a que se refiere el artículo 2 colaborarán con el Consello de Contas en el ejercicio de las funciones de éste, estando obligadas a suministrarle cuantos datos, estados, documentos, antecedentes o informes les solicite 125 .

2. El incumplimiento de los requerimientos del Consello podrá suponer la aplicación de las sanciones legalmente establecidas.

Si los requerimientos se refieren a la reclamación de justificantes de inversiones o gastos públicos, y no son cumplidos en el plazo solicitado, se iniciará de oficio el oportuno expediente de reintegro.

El Consello de Contas pondrá en conocimiento del Parlamento de Galicia la falta de colaboración de los obligados a prestarla.

3. Se trasladarán al Consello de Contas las auditorías practicadas por los servicios competentes de la Administración Autonómica o bajo la dirección de la Xunta de Galicia.

Artículo 24. Procedimiento.

1. Los procedimientos para el ejercicio de la función fiscalizadora se impulsarán de oficio en todos sus trámites. La iniciativa corresponde al propio Consejo y al Parlamento de Galicia.

2. Los requerimientos de inhibición hechos al Consello de Contas no producirán la suspensión del respectivo procedimiento.

Artículo 25. Presentación de las cuentas.

1. El Consello de Contas, por delegación del Parlamento de Galicia, procederá al examen y comprobación de la cuenta general de la Comunidad Autónoma dentro del plazo de seis meses, a partir de la fecha en que se haya rendido.

El Pleno dictará la declaración definitiva que le merezca para elevarla al Parlamento, con la oportuna propuesta, dando traslado a la Xunta de Galicia, la cual deberá disponer la publicación de las conclusiones en el "Diario Oficial de Galicia".

2. Las Entidades Locales deberán emitir las cuentas de cada ejercicio, directamente,

125 Véase Circular de 9 de diciembre de 1999, de la Conselleria de Economía e Facenda, de la Xunta de Galicia, de normas relativa a la documentación a rendir al Consello de Contas. 
al Consejo, antes del 31 de julio del año siguiente al del final del ejercicio.

El Consello de Contas debe formar y unir la cuenta general de las Entidades Locales, que debe ser reconocida por el Parlamento.

3. A la cuenta general de la Comunidad Autónoma se acompañará la cuenta general de operaciones realizadas por las corporaciones a que se refiere el número 29 del artículo 27 del Estatuto de Autonomía de Galicia.

Artículo 26. Cuentadantes.

Serán cuentadantes en las que se deban rendir al Consello de Contas:

a. Los funcionarios y demás personal de las Entidades del sector público gallego que tengan a su cargo la gestión de los ingresos y gastos públicos, así como las demás operaciones de administración.

b. Los Presidentes o Directores de los organismo autónomos y empresas públicas a que se refiere el artículo 2 de esta ley.

c. Los particulares que, excepcionalmente, administren, recauden o custodien fondos o valores de la Comunidad Autónoma, sin perjuicio de que sean intervenidas las respectivas operaciones; y

d. Los perceptores de las subvenciones corrientes a que se refiere el artículo 58, apartado 3, y artículo 85, apartado 3, de la Ley 3/1984, de 3 de abril, de la Gestión Económica y Financiera Pública en Galicia.

Artículo 27. Medios de apremio.

1. Los medios de apremio que el Consejo podrá emplear gradualmente para asegurar la rendición de cuentas y el mejor cumplimiento de sus funciones, son:

a. El requerimiento, entendiéndose por tal la orden que se comunique por el Consello, fijando el plazo para el cumplimiento de un servicio.

b. La imposición de multas coercitivas.

c. La formación de oficio de cuenta retrasada y de los estados o documentos que se pidan, a cargo y riesgo del apremiado.

2. En cualquier caso, y sin perjuicio de deducir tanto de culpa por desobediencia a los efectos de instrucción del proceso penal, el Consello de Contas podrá proponer a la autoridad u órgano competente de que dependa el cuentadante la apertura del procedimiento sancionador.

Artículo 28. Multas coercitivas.

1. En el caso de incumplimiento de los requerimientos efectuados, el Consello de Contas podrá imponer multas hasta la cuantía de un mes de sus haberes a los funcionarios, y para los particulares hasta la cantidad de 100.000 pesetas, por la primera vez, y de hasta dos meses o 500.000 pesetas, respectivamente, en caso de reincidencia.

2. Si el requerido al pago fuera personal al servicio de las entidades a que se refiere el artículo 2 y no lo hiciera efectivo, se ordenará al habilitado o pagador que, bajo su responsabilidad, haga efectivo el importe de la misma deduciendo de la primera mensualidad que le corresponda percibir o de las sucesivas, si excediera, en la cantidad que legalmente pueda ser descontada.

3. Cuando el apremiado sea un particular, el Consello, para efectividad de la multa, procederá a su cobro en voluntaria, y, de no efectuarse el pago, en vía ejecutiva, aplicando las normas de la Comunidad Autónoma que regulen la recaudación de sus tributos, y, en su defecto, las normas estatales. A estos efectos, la correspondiente certificación de descubierto será expedida por el Secretario General del Consello de Contas.

4. De toda imposición de multa a altos cargos o personal de las Administraciones Autonómica, Local o Corporativa se dará cuenta a la autoridad de que dependen, exponiendo las causas que hayan determinado dicho medio de apremio, para que, sin perjuicio de la exanción de la multa por el Consello de Contas, adopte aquellas otras medidas que estime convenientes.

\section{DISPOSICIÓN ADICIONAL}

En todo lo no regulado por esta ley será de aplicación, en cuanto fuera conducente, lo establecido en la Ley Orgánica 2/1982, de 12 de mayo, del Tribunal de Contas. 


\section{DISPOSICIÓN TRANSITORIA PRIMERA}

El Parlamento nombrará, en el plazo de tres meses desde la entrada en vigor de esta ley, los miembros del Consello de Contas, de acuerdo con el procedimiento establecido.

\section{DISPOSICIÓN TRANSITORIA SEGUNDA.}

En la primera sesión que se celebre después de constituirse el Consello de Contas, el Pleno debe designar a suertes tres Conselleiros, cuyo mandato durará tres años. Transcurrido el citado plazo, el Pleno del Parlamento designará los nuevos Conselleiros en la forma establecida por la Ley ${ }^{126}$.

\section{DISPOSICIÓN FINAL}

En el término de seis meses a partir de su constitución, el Consello de Contas elaborará un proyecto de normas de régimen interior que presentará al Parlamento para su aprobación ${ }^{127}$.

126 Disposición transitoria segunda modificada por Ley $4 / 1986$, de 26 de diciembre, de modificación de la Ley 6/1985, de 24 de junio, del Consello de Contas.

127 Véase Resolución de 25 de junio de 1992, Reglamento de régimen interior del Consello de Contas de Galicia. 


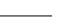




\section{III \\ ADMINISTRACIÓN LOCAL}

\section{LEY 5/1997, DE 22 DE JULIO, DE ADMINISTRACIÓN LOCAL DE GALICIA}

(DOGA N. $\left..^{\circ} 149,5.8 .1997\right)$

(...) 128

\section{TÍTULO PRELIMINAR DISPOSICIONES GENERALES}

Artículo 1. 1. La Comunidad Autónoma de Galicia se organiza en municipios y provincias, que ostentan la condición de Entidades Locales territoriales, a las que se garantiza la autonomía para la gestión de sus respectivos intereses.

2. En los términos que determinará una Ley del Parlamento de Galicia, las parroquias rurales gallegas tendrán la consideración de Entidades Locales territoriales y gozarán de autonomía para la gestión de sus intereses patrimoniales.

Artículo 2. Gozan de la condición de Entidades Locales no territoriales las áreas metropolitanas, las mancomunidades de municipios, los consorcios locales y las Entidades Locales menores.

Artículo 3. La Xunta de Galicia llevará un registro en el que se inscribirán todas las Entidades Locales de Galicia. El contenido, organización y funcionamiento del mismo se determinará reglamentariamente ${ }^{129}$.

Artículo 4. 1. Las Entidades Locales gallegas se regirán conforme a lo dispuesto

\footnotetext{
128 Exposición de motivos omitida.

129 Véanse:

- Decreto 371/1998, de 10 de diciembre, por el que se regula el registro de Entidades Locales de Galicia. - Orden de 8 de marzo de 2000 de desarrollo del Decreto $371 / 1998$, de 10 de diciembre, por el que se regula el registro de Entidades Locales de Galicia.
}

en la presente ley y en la normativa que la desarrolle, sin perjuicio de lo establecido en la normativa básica estatal.

2. Los reglamentos orgánicos y ordenanzas de cada Entidad Local serán de aplicación en todo lo no previsto por la legislación básica y por la presente ley.

Artículo 5. 1. Las Entidades Locales servirán con objetividad a los intereses públicos que se les encomienden y actuarán de acuerdo con los principios de eficacia y servicio a los ciudadanos, descentralización, desconcentración y coordinación, con autonomía propia y sometimiento pleno a la Ley y al derecho.

2. Las Entidades Locales, conforme a los criterios de reciprocidad en sus relaciones entre sí y con las otras administraciones públicas, se regirán por los principios de colaboración, cooperación, auxilio y respeto a los respectivos ámbitos de competencias.

3. La Xunta de Galicia, a través de la Comisión Galega de Cooperación Local, fomentará y promocionará las relaciones de colaboración y cooperación entre las distintas administraciones públicas gallegas.

Artículo 6. 1. En su calidad de administraciones públicas, corresponderán a las Entidades Locales territoriales de Galicia, en el ámbito de sus competencias y en los términos establecidos por la legislación de régimen local:

a. La potestad reglamentaria y de autoorganización.

b. La potestad tributaria y financiera.

c. La potestad de programación o planificación. 
d. Las potestades expropiatoria y de investigación, deslinde y recuperación de oficio de sus bienes.

e. La potestad de legitimidad y ejecutividad de sus actos.

f. La potestad de ejecución forzosa y sancionadora.

g. La potestad de revisión de oficio de sus actos y acuerdos.

h. La inembargabilidad de sus bienes y derechos en los términos previstos en las Leyes, y las de prelación, preferencia y demás prerrogativas reconocidas a la Hacienda Pública en relación con sus créditos, sin perjuicio de las que correspondan a la Hacienda del Estado y de la Xunta de Galicia.

i. La exención de los impuestos del Estado y de la Xunta de Galicia, en los términos establecidos por las Leyes.

2. Las potestades y prerrogativas determinadas por el apartado anterior serán también de aplicación a las demás Entidades Locales no territoriales, de conformidad, en su caso, con lo establecido por sus estatutos, con las siguientes particularidades:

a. La potestad tributaria se referirá, exclusivamente, al establecimiento de tasas, contribuciones especiales y precios públicos.

b. La potestad expropiatoria corresponderá al municipio o provincia, que la ejercerá en beneficio y a instancia de la Entidad Local interesada.

Artículo 7. 1. El gallego, como lengua propia de Galicia, lo es también de su Administración Local.

Las convocatorias de sesiones, órdenes del día, mociones, votos particulares, propuestas de acuerdo, dictámenes de las comisiones informativas, actas, notificaciones, recursos, escrituras públicas, comparecencias judiciales y todos los actos de carácter público o administrativo que se realicen por escrito en nombre de las corporaciones locales se redactarán en lengua gallega 130 .

2. Sin perjuicio de lo dispuesto en el apartado anterior, tales entidades pueden hacerlo, además, en la otra lengua oficial, el castellano.

3. La Xunta de Galicia impulsará el proceso de incorporación de la lengua gallega en la Administración local, especialmente a través de programas de formación de funcionarios de las Entidades Locales en lengua gallega.

Artículo 8. 1. Las competencias de las Entidades Locales son propias o atribuidas por delegación, previa aceptación de la entidad correspondiente.

2. Las competencias propias de municipios, provincias y demás entidades territoriales sólo podrán ser determinadas por Ley y se ejercerán en régimen de autonomía y bajo su propia responsabilidad,

130 Ley 5/1988, de 21 de junio, del uso del gallego como lengua oficial de Galicia por las Entidades Locales $(\ldots)^{*}$

* Exposición de motivos omitida.

Artículo 1.

1. Las convocatorias de sesiones, ordenes del dia, mociones, votos particulares, propuestas de acuerdo, Dictámenes de las Comisiones informativas y Actas de las Entidades Locales de Galicia se redactarán en lengua gallega.

2. Sin perjuicio de lo dispuesto en el apartado anterior, dichas Entidades pueden hacerlo, además, en la otra lengua oficial.

Artículo 2

1. Corresponde a la Xunta de Galicia el impulso del proceso de incorporación de la lengua gallega en la Administración Local, muy especialmente a través de programas de formación de funcionarios en lengua gallega.

2. Sin perjuicio de lo anterior, la Xunta de Galicia adoptará las medidas oportunas para que en los concursos de acceso de funcionarios a la Administración Local se garantice el conocimiento de la lengua gallega.

Disposición transitoria única

1. Las Entidades Locales que no estén en condiciones de incorporar de inmediato el gallego como lengua normal en los actos escritos de la Administración dispondrán de un plazo de dos años, a partir de la publicación de esta ley, para adoptar acuerdo sobre la realización material de lo dispuesto en ella y darle cumplimiento.

2. La Xunta de Galicia elaborará un programa de actuaciones al objeto de garantizar que, al cabo del plazo señalado en el párrafo anterior, todas las Entidades Locales de Galicia están en condiciones de cumplir lo dispuesto en esta ley. 
atendiendo siempre a la debida coordinación, en su programación y ejecución, con las demás administraciones públicas en los términos establecidos por las Leyes.

3. La Xunta de Galicia podrá delegar competencias en las Entidades Locales y encomendarles la gestión ordinaria de sus servicios en los términos establecidos por la presente ley. Para su efectividad será necesaria la aceptación expresa del Pleno de la Corporación.

La delegación no supondrá cesión de la titularidad de la competencia. Las competencias delegadas se ejercerán en los términos de la delegación, que preverá las técnicas de dirección y control y los medios para desempeñarlas, que, en todo caso, tendrán que respetar la potestad de autoorganización de los servicios de la Entidad Local que asuma la delegación.

La encomienda de gestión no supondrá cesión de la titularidad de la competencia ni de los elementos sustantivos de su ejercicio, siendo responsabilidad de la Xunta de Galicia dictar cuantos actos o resoluciones de carácter jurídico den soporte o en los que se integre la concreta actividad material objeto de la encomienda.

4. Las competencias municipales podrán ser ejercidas por las áreas metropolitanas, mancomunidades de municipios o consorcios locales en los supuestos y con los requisitos establecidos por la presente ley y siempre previa delegación de la Entidad Local mediante acuerdo corporativo.

Artículo 9. Siempre que sea posible, y cuando no se opongan razones de interés público debidamente consignadas, se concederá a las asociaciones de municipios y provincias que ostenten la representación y defensa de los intereses de las Entidades Locales gallegas ante los correspondientes poderes públicos la oportunidad de exponer su parecer sobre las disposiciones de carácter general y anteproyectos de Ley que, en materia de régimen local, elabore la Xunta de Galicia. Se hará efectivo mediante un informe razonado y en un plazo mínimo de diez días, a contar desde el siguiente a la remisión del mismo para consulta.

\section{TíTULO I DEL MUNICIPIO}

Artículo 10. 1. Los municipios son Entidades Locales básicas de la organización territorial de la Comunidad Autónoma de Galicia y cauces de participación ciudadana en los asuntos públicos locales.

2. El municipio tiene personalidad jurídica y plena capacidad para el cumplimiento de sus fines.

3. Son elementos del municipio el territorio, la población y la organización.

\section{Capítulo I TERRITORIO}

Artículo 11. 1. El término municipal es el territorio en que el Ayuntamiento ejerce sus competencias.

El ejercicio de competencias fuera del término municipal conllevará la nulidad radical de la actuación por manifiesta incompetencia, salvo en los supuestos en que las potestades municipales puedan, al amparo de una norma específica, exceder el propio término.

2. Todo municipio pertenecerá a una sola provincia.

\section{Sección $1^{\mathrm{a}}$ \\ De las alteraciones de los términos municipales}

Artículo 12. 1. La alteración de los términos municipales sólo podrá producirse entre municipios limítrofes.

2. El término municipal podrá ser alterado:

a. Por fusión de dos o más municipios limítrofes para constituir un nuevo municipio.

b. Por incorporación de uno o más municipios a otro limítrofe. 
c. Por segregación de parte del término de un municipio o de varios municipios para constituir un nuevo municipio.

d. Por segregación de parte del término de un municipio o de varios municipios para agregarse a otro limítrofe.

3. Ninguna alteración podrá dar lugar a un término municipal discontinuo.

4. Los límites territoriales de los términos municipales podrán modificarse con la finalidad de adecuarlos a las iniciativas de corrección de disfuncionalidades territoriales elaboradas por la Comisión Galega de Delimitación Territorial. La modificación será acordada por el Consello de la Xunta de Galicia, a propuesta del conselleiro competente en materia de régimen local, previa audiencia, por plazo de un mes, de los municipios afectados, informe de la respectiva Diputación Provincial y dictamen del Consello Consultivo de Galicia.

5. Las alteraciones de los términos municipales se inscribirán en el Registro de Entidades Locales de Galicia y en el estatal.

Artículo 13. La Xunta de Galicia podrá establecer, entre otras, las siguientes medidas de fomento para la fusión de municipios o para la incorporación voluntaria a otros:

a. Ayudas económicas y técnicas.

b. Criterios prioritarios o especiales en la asignación de subvenciones finalistas.

c. Creación de un fondo especial.

Artículo 14. 1. No procederá la segregación parcial cuando ello suponga:

a. Que el municipio segregado no cuente con recursos suficientes para prestar, en la parte no segregada de su término municipal, los servicios mínimos exigidos por el artículo 81 de la presente ley y por la legislación básica en la materia.

b. Disminución en la calidad media de los servicios que venían siendo prestados por el municipio que se pretende segregar. Por el contrario, deberá suponer una mejora en la calidad de los servicios que pasen a ser gestionados por el municipio agregante. c. Cuando la parte que se trate de segregar estuviese unida por calle o zona urbana a otro núcleo o poblado del municipio originario.

d. Cuando existan datos y evidencias que permitan deducir que los supuestos beneficios de la segregación no pueden alcanzarse con otros mecanismos.

2. La segregación parcial conllevará, además de la división del término, la de bienes, derechos y acciones, deudas y cargas en función del número de habitantes y de la riqueza imponible correspondientes al territorio que se trate de segregar, que se practicarán conjuntamente.

3. La aprobación del expediente de segregación se condicionará a la subrogación formal del nuevo municipio o de aquel en que se integre el territorio segregado en las deudas pendientes y en las cargas financieras derivadas de las inversiones y servicios que venían prestándose en el territorio a segregar, por parte del municipio o municipios originarios.

\section{Subsección 1. ${ }^{a}$ \\ De la Comisión Galega de Delimitación Territorial}

Artículo 15. 1. Se crea la Comisión Galega de Delimitación Territorial como órgano de estudio, consulta y propuesta en relación con las materias que atañen a la determinación, revisión y modificación de los límites territoriales de las Entidades Locales gallegas y de las demarcaciones en que se estructura la Administración de la Comunidad Autónoma de Galicia.

2. Serán funciones de la Comisión:

a. Emitir informe sobre todos los expedientes de alteración de límites municipales.

b. Emitir informe sobre todos los expedientes de cambio de capitalidad.

c. Elaborar, a petición del Consello de la Xunta de Galicia, los estudios y propuestas de revisión para proceder a la aplicación de lo establecido en el artículo 13 de la presente ley. 
d. Estudiar y dictaminar las alegaciones presentadas y los distintos informes emitidos sobre el mapa municipal de Galicia antes de su elevación al Consello de la Xunta de Galicia para su aprobación definitiva.

e. Ejercer las demás que le atribuyen las Leyes.

Artículo 16. El mapa municipal de Galicia se elaborará bajo la responsabilidad de la consellería competente en materia de régimen local, ajustándose en su elaboración y aprobación a lo que resulte de los expedientes de delimitación y deslinde y, en su caso, de las resoluciones definitivas en caso de conflicto, y se aprobará de acuerdo con el siguiente procedimiento:

a. El mapa municipal de Galicia será aprobado inicialmente por la consellería competente en materia de régimen local.

b. Aprobado inicialmente el documento, se remitirá al Instituto Geográfico Nacional para su informe y se someterá a información pública para alegaciones, por plazo de treinta días, mediante su publicación en el "Diario Oficial de Galicia" y en los boletines oficiales de las cuatro provincias gallegas.

c. Simultáneamente se dará traslado del documento a las Diputaciones Provinciales, a los Ayuntamientos interesados y a la Delegación del Gobierno para que, en el mismo plazo, puedan emitir informe, que se entenderá favorable en caso de que, transcurrido dicho plazo, no lo hubiesen remitido.

d. Estudiadas y dictaminadas, por la Comisión Galega de Delimitación Territorial, las distintas alegaciones e informes $\mathrm{y}$ hechas las correcciones que procedan y previo dictamen del Consello Consultivo de Galicia, será elevado el expediente, por el conselleiro competente en materia de régimen local, al Consello de la Xunta de Galicia para su aprobación definitiva.

e. El Decreto por el que se apruebe definitivamente el mapa municipal se publicará en el "Diario Oficial de Galicia" y en el "Boletín Oficial del Estado" y se comunicará a la Administración del Estado, a los efectos previstos en la legislación básica de régimen local.

Artículo 17. La composición, estructura orgánica y funcionamiento de la Comisión Galega de Delimitación Territorial se determinarán reglamentariamente y, en cualquier caso, deberán formar parte de la misma representantes de la Xunta de Galicia y de las Entidades Locales gallegas, designados por sus entidades asociativas más representativas en la forma más adecuada para garantizar una presencia sensiblemente proporcional a los resultados de las últimas elecciones municipales.

Igualmente podrán formar parte de las instituciones públicas y privadas que, en virtud de sus objetivos y finalidades, tengan una relación o incidencia especial sobre la organización territorial de Galicia ${ }^{131}$.

\section{Subsección 2 . $^{\mathrm{a}}$}

\section{De la fusión de municipios}

Artículo 18. 1. Se entiende por fusión de dos o más municipios el resultado de la unión de los mismos, de forma que se produzca la desaparición de todos ellos, creándose uno nuevo cuyo ámbito territorial y población se corresponda con la suma de los municipios fusionados.

2. Como consecuencia de la fusión, el nuevo ente creado podrá mantener la denominación de cualquiera de los municipios originarios o establecer una nueva.

3. El nuevo municipio podrá fijar su capitalidad en cualquier núcleo del término resultante.

4. Tanto la denominación como la capitalidad del municipio resultante de un proceso de fusión deberán ser propuestas desde el comienzo del procedimiento por parte de los municipios originarios.

131 Véase Decreto 370/1998, de diciembre, por el que se establece la naturaleza y funciones de la Comisión Galega de Delimitación Territorial. 
Artículo 19. Podrá realizarse la fusión cuando se dé alguno de los siguientes requisitos:

a. Cuando se confundan núcleos de población que sean capitalidad de los respectivos municipios.

b. Cuando separadamente carezcan los municipios de recursos suficientes para atender los servicios mínimos exigidos por los artículos 81 de la presente ley y 26.1 de la Ley Reguladora de las Bases del Régimen Local o los que en cada momento determine la normativa aplicable.

c. Cuando existan notorios motivos de necesidad o conveniencia económica o administrativa o consideraciones de orden geográfico y demográfico.

d. Cuando del proceso de fusión se deriven importantes ventajas para los municipios afectados en lo que a prestación de servicios se refiere y así sea estimado por los municipios fusionados.

Artículo 20. En el supuesto de concurrir alguna de las circunstancias previstas en los apartados b) y d) del artículo anterior, el expediente de fusión podrá iniciarse a instancia de los municipios interesados o de oficio por parte de la Xunta de Galicia. En el caso del apartado b), la Xunta de Galicia garantizará la inversión para el primer establecimiento de los servicios mínimos.

\section{Subsección 3.}

\section{De la incorporación de municipios}

Artículo 21. 1. Se entiende por incorporación de uno o varios municipios a otro limítrofe la operación consistente en la integración del incorporado o incorporados al incorporante, de forma que aquél o aquéllos desaparezcan pasando a formar parte de éste.

2. El territorio y la población del municipio resultante quedarán constituidos por la suma de todos ellos, manteniéndose la capitalidad y denominación del municipio incorporante, que integrará a todos los efectos la personalidad jurídica de los municipios incorporados.
Artículo 22. Podrá acordarse la incorporación de uno o varios municipios a otro limítrofe cuando se dé alguno de los siguientes requisitos:

a. Cuando resulte imposible la prestación a los vecinos de los municipios a incorporar de los servicios mínimos contemplados en los artículos 81 de la presente ley y 26.1 de la Ley Reguladora de las Bases del Régimen Local o los que en cada momento determine la normativa aplicable, y se opten por esta vía en lugar de la fusión.

b. Cuando resulte gravemente disminuido alguno de los elementos básicos del municipio o municipios que se incorporen.

c. Cuando del proceso de integración se deriven significativas ventajas para los municipios afectados en lo que a prestación de servicios se refiere y así sea estimado por los municipios que se integran y por el receptor.

Artículo 23. 1. En el caso de concurrir alguna de las circunstancias previstas en los apartados a) y c) del artículo anterior, el expediente de incorporación podrá iniciarse a instancia de los municipios interesados o de oficio por parte de la Xunta de Galicia. En el caso del apartado a), la Xunta de Galicia garantizará la inversión para el primer establecimiento de los servicios mínimos.

2. En el caso de concurrir alguna de las circunstancias previstas en el apartado b) del artículo anterior, la Comunidad Autónoma de Galicia deberá iniciar de oficio el expediente de incorporación.

\section{Subsección $4 .^{\mathrm{a}}$}

De la segregación para la creación de municipios independientes

Artículo 24. Se entiende por segregación para la creación de nuevos municipios la operación consistente en separar parte del término de uno o de varios municipios para constituir un nuevo e independiente municipio.

Artículo 25. Para que pueda crearse un municipio nuevo e independiente, por 
segregación, es preciso que se den todos y cada uno de los siguientes requisitos:

a. Que existan motivos permanentes de interés público.

b. Que se trate de uno o varios núcleos de población territorialmente diferenciados y separados de la capitalidad del municipio o municipios originarios en más de 10 kilómetros, o que, sin mediar esta distancia, las vías y medios de comunicación con aquélla resulten manifiestamente insuficientes, y siempre que exista una franja de suelo no urbanizable de, al menos, 5 kilómetros. En todo caso, el nuevo municipio no podrá tener discontinuidades en su territorio y no podrá constituir un enclave dentro de cualquiera de los municipios originarios.

c. Que el núcleo o núcleos a segregar cuenten con una población no inferior a 5.000 habitantes y que el municipio o municipios de los que se segregan no bajen de este límite poblacional al producirse la segregación.

d. Que el nuevo municipio cuente con recursos propios suficientes para la implantación y mantenimiento de los servicios que la Ley le exige y su independencia no suponga en ningún caso disminución en la calidad de los que venían siendo prestados por él o por los municipios originarios.

e. Que en núcleo o núcleos que se pretenden segregar no viniesen siendo prestados, por el municipio o municipios originarios, los servicios mínimos exigidos por la Ley con la calidad media con que se prestan en el resto de su término municipal.

f. Que en cualquier caso no exista otra alternativa que permita solventar los problemas que motivan la segregación.

Artículo 26. En el expediente que al efecto se instruya deberán constar fehacientemente todos los requisitos mencionados en el artículo anterior, así como el proyecto del presupuesto relativo a los gastos e ingresos corrientes, tanto del municipio o municipios originarios como del que se pretende constituir. En el mismo figurarán, de forma especial, los ingresos previstos y los gastos precisos para el mantenimiento de los servicios mínimos con la calidad exigida por la presente ley.

Artículo 27. El nuevo municipio, además de la deudas pendientes y de las cargas financieras que le correspondan, deberá asumir las mismas cargas, funcionarios, personal laboral y servicios que hasta el momento de la segregación viniesen prestando sus actividades al servicio del núcleo o núcleos de población que integrarán el nuevo territorio, debiendo subrogarse en las consiguientes obligaciones.

\section{Subsección 5. ${ }^{\mathrm{a}}$}

De la segregación-agregación

Artículo 28. Se entiende por segregación-agregación la operación consistente en separar parte de un término municipal de su ámbito territorial originario para agregarlo al de otro limítrofe.

Artículo 29. Podrá llevarse a cabo la segregación parcial de un término municipal para su agregación a otro municipio limítrofe cuando concurra alguna de las siguientes causas:

a. En caso de que se confundan núcleos urbanos de dos o más municipios como consecuencia del desarrollo urbanístico y ninguno de estos núcleos sea capital de los municipios afectados o sólo lo sea el del municipio agregante.

b. Cuando existan notorios motivos de necesidad o conveniencia económico-administrativa que así lo aconsejen.

c. Cuando el núcleo de población a segregar esté recibiendo los servicios mínimos, exigidos por los artículos 26.1 de la Ley Reguladora de las Bases del Régimen Local y 81 de la presente ley, del municipio al que pretende agregarse.

Artículo 30. 1. El municipio al que se agregue una parte del término municipal de otro deberá indemnizar económica mente a éste en una cuantía igual a diez veces el valor actual de las cantidades dejadas de percibir por los impuestos sobre bienes inmuebles y actividades económicas que se devenguen en el territorio 
a segregar. Esta valoración deberá figurar en el expediente que se tramite al efecto.

$\mathrm{Si}$ la valoración fuese estimada insuficiente con respecto al beneficio que reportaba al municipio originario la parte del término municipal que se segregó, la indemnización será fijada por el Consello de la Xunta de Galicia, a propuesta del conselleiro competente en materia de régimen local.

2. Si el municipio del que se segrega una porción de territorio no aceptase la valoración señalada, el procedimiento podrá continuar con la consignación del importe de la misma en la Caja General de Depósitos.

\section{Subsección $6 .^{\mathrm{a}}$}

\section{Del procedimiento común para la alteración de los términos municipales}

Artículo 31. Las alteraciones de términos municipales podrán ser iniciadas de oficio por la consellería competente en materia de régimen local o a instancia de:

a. Cualquiera de los municipios interesados.

b. Las Diputaciones Provinciales respectivas.

Artículo 32. 1. Las alteraciones de términos municipales podrán, asimismo, ser tramitadas, con carácter voluntario, por los Ayuntamientos interesados. En tal caso, el expediente será iniciado por los acuerdos de los respectivos Ayuntamientos, adoptados con el voto favorable de las dos terceras partes del número de hecho y, en todo caso, de la mayoría absoluta del número legal de miembros de la corporación.

2. Los acuerdos se someterán a información pública por plazo no inferior a treinta días.

3. Finalizado el período de información pública, los Ayuntamientos adoptarán nuevo acuerdo, con la misma mayoría que en el acuerdo de iniciación, en el que se resolverá sobre la procedencia de la alteración y, en su caso, sobre las reclamaciones presentadas.

4. Si los acuerdos fuesen favorables a la alteración, se elevará el expediente a la consellería competente en materia de régimen local.

Artículo 33. 1. Las alteraciones de términos municipales consistentes en su segregación parcial para la constitución de un nuevo e independiente municipio o en la segregación de parte del término de un municipio para agregarlo a otro limítrofe podrán ser promovidas a instancia de los vecinos residentes en la parte o partes a segregar.

2. En el supuesto de que la segregación fuese promovida a instancia vecinal, se precisará el respaldo de las dos terceras partes de los vecinos residentes, con una residencia mínima de diez años en el territorio a segregar.

3. En el supuesto de iniciación vecinal, se constituirá por los vecinos una Comisión Promotora. Para ello deberán comparecer todos los interesados ante fedatario público, con la finalidad de manifestar su voluntad de designar a los miembros de la Comisión Promotora.

4. La Comisión Promotora deberá incorporar al expediente toda la documentación prevista en los artículos 34 y 35 de la presente ley.

5. Una vez completada la documentación por la Comisión, se elevará a los Ayuntamientos correspondientes, que, tras someterla a información pública por plazo no inferior a treinta días, adoptarán acuerdo sobre la misma, en el plazo de dos meses. Los acuerdos serán adoptados con el voto favorable de las dos terceras partes del número de hecho, y en todo caso de la mayoría del número legal de miembros de la Corporación.

6. Adoptados los acuerdos municipales e incorporada al expediente certificación de los mismos, el Ayuntamiento lo elevará a la consellería competente en materia de 


\section{Administración Local}

régimen local, aun cuando los acuerdos municipales no hubiesen sido favorables. Si transcurrido el plazo de dos meses a que se refiere el párrafo anterior no se ha adoptado acuerdo municipal expreso, la Comisión Promotora elevará el expediente a la consellería competente en materia de régimen local.

Artículo 34. 1. Deberán incorporarse a los expedientes de alteraciones de términos municipales los siguientes documentos, sin perjuicio de cuantos otros se estimen oportunos:

a. Plano del término o términos municipales que vayan a ser objeto de alteración, con señalamiento, en su caso, de los nuevos límites o línea divisoria de los municipios.

b. Informe en el que se justifique que concurren las motivaciones necesarias para llevar a cabo la alteración que se propone.

c. Memoria justificativa de que las alteraciones no merman la solvencia de los municipios a que afectan, en perjuicio de los acreedores, o, en su caso, acta notarial en la que se acredite, por comparecencia de las dos terceras partes de los vecinos de las porciones segregadas, que se comprometen en el nuevo municipio a responder subsidiariamente, en su día, respecto a la parte correspondiente de los créditos que existan, salvo las obligaciones personales de cada uno de aquéllos.

2. Asimismo, se aportarán las estipulaciones jurídicas y económicas que se proponen, entre las que deberán figurar, cuando procedan:

a. La forma de liquidar las deudas o créditos contraídos por cada municipio.

b. Las fórmulas de administración de bienes y gestión de servicios.

c. Cualesquiera otras que convengan a los municipios afectados respecto a las obligaciones, derechos e intereses de cada uno.

Artículo 35. 1. En los supuestos de segregación parcial para constituir un nuevo municipio, se incorporarán al expediente, además de los documentos a que se refiere el artículo anterior, los siguientes documentos:

a. Informe demostrativo de que ni el nuevo municipio ni el originario u originarios carecerán de los medios precisos para el cumplimiento de sus fines.

b. Proyecto de división de bienes, aprovechamientos, usos públicos, créditos y cualesquiera otros derechos y obligaciones entre el Ayuntamiento o Ayuntamientos originarios y el nuevo, y bases que se establezcan para resolver, posteriormente, cualesquiera otras cuestiones que no hubiese sido posible dilucidar.

c. Certificación, expedida por el Secretario, de los bienes, derechos y aprovechamientos comunales del municipio o municipios objeto de la segregación, así como de los que correspondan exclusivamente al vecindario de la parte o partes que se hubiesen de segregar.

d. Certificación del Secretario relativa al número de electores, habitantes y vecinos de los términos municipales y de la porción que se pretenda segregar.

2. En los casos de segregaciones parciales de términos municipales iniciadas a petición de las dos terceras partes de los vecinos, se acreditará, mediante certificación del Secretario del Ayuntamiento respectivo, extendida al final de las firmas que suscriban la solicitud, que han de estar autenticadas notarialmente, que los firmantes figuran como residentes vecinos en el padrón municipal.

Artículo 36. Instruido el expediente de alteración de términos municipales, y a efectos de que emitan el informe que estimen oportuno, se dará audiencia en el plazo de un mes a:

a. Los municipios y demás Entidades Locales interesadas cuando la iniciación haya sido decretada de oficio por la consellería competente en materia de régimen local o a instancia de los municipios o Diputaciones Provinciales respectivas. 
b. Las Diputaciones Provinciales en caso de que las alteraciones de términos municipales hayan sido tramitadas, con carácter voluntario, por los Ayuntamientos interesados o promovidas por los vecinos residentes en la parte o partes que hayan de segregarse.

Artículo 37. 1. Recibidos los informes a que se refiere el artículo anterior o transcurrido el plazo de un mes sin que hayan sido evacuados, la consellería competente en materia de régimen local elevará el expediente a la Comisión Galega de Delimitación Territorial para que emita informe y elaborará propuesta de resolución. A estos efectos, dicha consellería podrá solicitar a todas las administraciones públicas que considere precisas cuantos datos estime necesarios con la finalidad de disponer de los elementos objetivos suficientes para la elaboración de la propuesta de resolución.

2. El informe y la propuesta de resolución a que se refiere el apartado anterior serán remitidos, junto con el expediente, por la consellería competente en materia de régimen local, para dictamen, al Consello Consultivo de Galicia.

Artículo 38. 1. La resolución definitiva del procedimiento se hará por Decreto del Consello de la Xunta de Galicia, del que se dará traslado a la Administración del Estado a los efectos previstos en el artículo 14.1 de la Ley Reguladora de las Bases del Régimen Local.

2. Las resoluciones definitivas de los expedientes de alteración de términos municipales deberán contener, en su caso:

a. Nombre del nuevo municipio.

b. Núcleo en que se ubicará la capitalidad.

c. Nuevos límites de los términos municipales afectados.

d. Población y parroquias de los términos municipales afectados.

e. Aprobación de las estipulaciones jurídicas y económicas acordadas.

3. La resolución se publicará en el "Diario Oficial de Galicia", en el "Boletín
Oficial" de la provincia correspondiente y en el "Boletín Oficial del Estado".

4. En caso de que el expediente haya sido iniciado de oficio por la consellería competente en materia de régimen local y de que en el trámite de informe formulasen oposición uno o más de los municipios afectados, la alteración de términos municipales se aprobará por Ley del Parlamento de Galicia.

Artículo 39. En los casos de creación de nuevos municipios o de alteración de términos municipales durante el período que medie entre elecciones municipales, se observarán las siguientes normas:

1. ${ }^{a}$ En caso de la fusión de dos o más municipios limítrofes, cesarán todos los Alcaldes y Concejales y será designada una Comisión Gestora por la consellería de la Xunta competente en materia de régimen local, integrada por un número de vocales gestores igual al que le correspondiese de Concejales según la población total resultante del nuevo municipio. La designación se hará siguiendo los mismos criterios de reparto utilizados para las elecciones municipales y según los resultados producidos en las mismas en el conjunto de los municipios afectados.

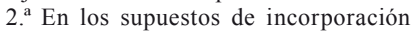
de uno o más municipios a otro limítrofe, cesarán los Alcaldes y Concejales de los Ayuntamientos de los municipios incorporados. Si como consecuencia de la incorporación correspondiese al municipio resultante un mayor número legal de Concejales, de conformidad con lo dispuesto en la legislación electoral, la diferencia se cubrirá por vocales gestores designados por la consellería de la Xunta competente en materia de régimen local entre los Concejales cesados. La designación se hará siguiendo los mismos criterios que se utilizaron para las elecciones municipales, repartiendo el número de Concejales en que resultaría incrementada la nueva Corporación entre 
las candidaturas según los resultados que hubiesen obtenido en el conjunto de los Ayuntamientos que se incorporan.

3. a Cuando se trate de la creación de un nuevo municipio por la segregación de parte de uno o varios municipios o de la segregación de parte de un municipio para agregarlo a otro, aquel del que se segregue la porción de territorio permanecerá con el mismo número de Concejales que tenía. El nuevo municipio procedente de la segregación será regido y administrado por una Comisión Gestora designada por la consellería de la Xunta competente en materia de régimen local con arreglo a los resultados de las elecciones municipales en la mesa o mesas correspondientes al territorio segregado.

Si como consecuencia de la agregación correspondiese al municipio que ha recibido la porción segregada un mayor número de Concejales, la diferencia se cubrirá por vocales gestores designados por la consellería de la Xunta competente en materia de régimen local con arreglo a los resultados de elecciones municipales en la mesa o mesas correspondientes al territorio segregado.

\section{Sección 2. ${ }^{a}$}

De la demarcación, deslinde y amojonamiento

Artículo 40. 1. Los Ayuntamientos tendrán la facultad de promover la demarcación, deslinde y amojonamiento de sus términos municipales.

2. Se entiende por demarcación la operación consistente en la fijación, a una Entidad Local, del término municipal que le corresponde o en la corrección del que hubiese sido fijado.

3. Se entiende por deslinde la operación consistente en la identificación de los límites determinantes del ámbito territorial de dos o más Entidades Locales limítrofes en caso de existir confusión entre ellos.

4. Se entiende por amojonamiento la operación consistente en la colocación de hitos o mojones con los que se señale o haga perceptible la línea divisoria entre los términos municipales pertenecientes a dos o más Entidades Locales limítrofes. Esta operación se realizará de acuerdo con las correspondientes coordenadas GSM.

Artículo 41. 1. Los conflictos que puedan plantearse entre municipios en relación con la demarcación y deslinde de sus términos serán resueltos por el Consello de la Xunta de Galicia, a propuesta del conselleiro competente en materia de régimen local y previo informe de la Comisión Galega de Delimitación Territorial.

2. En el supuesto de que se trate de expedientes que supongan la alteración de términos municipales, será preceptivo, además, el dictamen del Consello Consultivo de Galicia.

Artículo 42. 1. Para la demarcación, deslinde y amojonamiento de los términos municipales, cada uno de los Ayuntamientos a que afecte la línea divisoria nombrará una Comisión compuesta por el Alcalde y tres Concejales, los cuales, con el Secretario de la Corporación y el perito que designe cada Ayuntamiento, verificarán la operación de que se trate.

2. Únicamente asistirán al acto, por cada municipio, además de los miembros de la citada Comisión, dos personas que por su edad y acreditado juicio puedan justificar el sitio en que estuvieron los mojones o señales divisorias y los propietarios de los terrenos afectados por el deslinde.

Artículo 43. Cuando los Ayuntamientos interesados estén conformes con los límites existentes en la actualidad no procederá nueva fijación, salvo en los casos excepcionales en que documentalmente se justifiquen errores materiales o vicios de procedimiento en la delimitación anterior.

Artículo 44. 1. Cuando existiesen divergencias entre los Ayuntamientos implicados, en cuanto a la manera de apreciar el sitio por donde deba pasar la 
línea divisoria o en el que deban colocarse hitos o mojones, cada Comisión levantará acta por separado. En ella se harán constar todos los datos, antecedentes y detalles que se estimen precisos para justificar su apreciación. Con esta actuación se darán por finalizadas las actuaciones previas.

2. Las Alcaldías respectivas remitirán las actas, con todos los demás antecedentes, a la consellería competente en materia de régimen local, que enviará dicho expediente al Instituto Geográfico Nacional para que éste designe técnico o técnicos que deban personarse sobre el terreno en unión de las Comisiones señaladas y de un representante de esta consellería, a fin de llevar a cabo, a la vista y de conformidad con los documentos aportados, el deslinde de los términos municipales, estableciendo su demarcación definitiva y los puntos donde deben situarse los correspondientes mojones.

3. Recibido el informe del Instituto Geográfico Nacional, se remitirá el expediente a informe de la Comisión Galega de Delimitación Territorial y de la Diputación Provincial respectiva, y será resuelto por el Consello de la Xunta de Galicia, a propuesta del conselleiro competente en materia de régimen local, previo dictamen del Consello Consultivo de Galicia.

4. De la fijación de la correspondiente línea límite se dará conocimiento a la Administración Central del Estado, al objeto de su inscripción en el Registro Estatal de Entidades Locales, aunque deberá inscribirse también en el Registro que lleve la Xunta de Galicia.

Artículo 45. Cuando los deslindes afecten a los límites de las provincias, cada una de las Diputaciones interesadas tendrá derecho a integrarse en las Comisiones previstas en el artículo 42 de la presente ley con una representación igual a la de cada Ayuntamiento.

Artículo 46. En los expedientes de señalamiento de la línea de deslinde, la incomparecencia de la representación de alguno de los Ayuntamientos, siempre que hayan sido convocados de forma fehaciente, en las operaciones de campo que se deban realizar llevará implícito el decaimiento de su derecho para impugnar la línea que se fije, con la presencia del Ayuntamiento o Ayuntamientos comparecientes.

Artículo 47. La determinación de los límites de los nuevos municipios constituidos por la segregación de parte del término de uno o varios municipios corresponderá al Consello de la Xunta de Galicia.

\section{Sección $3 .^{\mathrm{a}}$}

\section{Del cambio de denominación y capitalidad del municipio}

Artículo 48. El nombre y la capitalidad de los municipios podrán ser alterados por Decreto del Consello de la Xunta de Galicia, a propuesta del conselleiro competente en materia de régimen local y previo acuerdo del Ayuntamiento interesado e informe de la Diputación Provincial respectiva.

Artículo 49. 1. El acuerdo deberá ser adoptado por las dos terceras partes del número de hecho de la Corporación y, en todo caso, de la mayoría absoluta del número legal de miembros de la misma.

2. El expediente se someterá a información pública por plazo de treinta días, para que los particulares o entidades que se creyesen perjudicados puedan presentar reclamación.

3. Resueltas, en su caso, las reclamaciones presentadas, se elevará el expediente al Consello de la Xunta para su resolución, previo informe de la Comisión Galega de Delimitación Territorial en caso de cambio de capitalidad y de la Comisión Gallega de Toponimia si se tratase de un cambio de denominación.

4. Los cambios de denominación y capitalidad de los municipios serán inscritos en el Registro de Entidades Locales de la Comunidad Autónoma de 


\section{Administración Local}

Galicia y publicados en el "Diario Oficial de Galicia" y en el "Boletín Oficial" de la respectiva provincia.

5. Se dará cuenta de estos cambios a la Administración del Estado, al objeto de su anotación en el Registro de Entidades Locales y de su publicación en el "Boletín Oficial del Estado".

Artículo 50. En los expedientes de cambio de nombre de los municipios se tendrán en cuenta las siguientes reglas:

a. No se autorizará cambio de nombre cuando el propuesto sea idéntico a otro existente o pueda producir confusiones en la organización de los servicios públicos.

b. Cuando la nueva denominación acordada contenga incorrecciones lingüísticas o no se adecue a la toponimia gallega, corresponderá al Consello de la Xunta de Galicia, a propuesta del conselleiro competente en materia de régimen local, la resolución definitiva sobre el cambio de nombre, previo informe de la Comisión Gallega de Toponimia y audiencia del municipio interesado.

Artículo 51. El cambio de capitalidad tendrá que fundarse en alguno de los siguientes motivos:

a. Desaparición del núcleo urbano donde estuviere establecida.

b. Mayor facilidad de comunicaciones.

c. Carácter histórico de la población elegida.

d. Mayor número de habitantes.

e. Importancia económica o beneficios notorios que reporte este cambio a los residentes en el término.

\section{Capítulo II POBLACIÓN}

Artículo 52. 1. La población del municipio está constituida por el conjunto de personas inscritas en el padrón municipal.

2. Toda persona que viva en la Comunidad Autónoma de Galicia está obligada a inscribirse en el padrón del municipio en que resida habitualmente. Quien viva en varios municipios deberá inscribirse únicamente en el que habite durante más tiempo al año.

3. Los inscritos en el padrón municipal son los vecinos del municipio. La condición de vecino se adquiere en el mismo momento de su inscripción en el padrón.

4. Todas las personas que tengan vecindad administrativa en un municipio de Galicia tienen la condición política de gallegos.

Artículo 53. 1. El padrón municipal es el registro administrativo donde constan los vecinos de su municipio. Sus datos constituyen prueba de la residencia en el municipio y del domicilio habitual en el mismo. Las certificaciones que se expidan de estos datos tendrán carácter de documento público y fehaciente a todos los efectos administrativos.

2. La inscripción en el padrón municipal contendrá como obligatorios sólo los siguientes datos:

a. Nombre y apellidos.

b. Sexo.

c. Domicilio habitual.

d. Nacionalidad.

e. Lugar y fecha de nacimiento.

f. Número del documento nacional de identidad o, tratándose de extranjeros, del documento que lo sustituya.

g. Certificado o título escolar o académico que se posea.

h. Cuantos otros datos puedan ser necesarios para la elaboración del censo electoral, siempre que se garantice el respeto a los derechos fundamentales reconocidos en la Constitución.

3. Los datos del padrón municipal se cederán a otras administraciones públicas que lo soliciten sin consentimiento previo del afectado solamente cuado les sean necesarios para el ejercicio de sus respectivas competencias, y exclusivamente para asuntos en que la residencia o el domicilio sean datos relevantes. 
También pueden servir para elaborar estadísticas oficiales sometidas al secreto estadístico, en los términos previstos en la Ley 12/1989, de 9 de mayo, de la función estadística pública.

4. Fuera de estos supuestos, los datos del padrón son confidenciales y el acceso a los mismos se regirá por lo dispuesto en la Ley orgánica 5/1992, de 29 de octubre, de regulación del tratamiento automatizado de los datos de carácter personal, y en la Ley 30/1992, de 26 de noviembre, de Régimen Jurídico de las Administraciones Públicas y del Procedimiento Administrativo Común.

Artículo 54. 1. La formación, mantenimiento, revisión y custodia del padrón municipal corresponden al Ayuntamiento, de acuerdo con lo que establezca la legislación del Estado.

2. La gestión del padrón municipal será llevada por los Ayuntamientos con medios informáticos. Las Diputaciones provinciales gallegas asumirán la gestión informatizada de los padrones de los municipios que, por su insuficiente capacidad económica y de gestión, no puedan mantener los datos de forma automatizada.

3. Los Ayuntamientos realizarán las actuaciones y operaciones que sean necesarias para mantener actualizados sus padrones, de forma que los datos contenidos en los mismos concuerden con la realidad.

Artículo 55. Los Ayuntamientos gallegos remitirán al Instituto Nacional de Estadística y al Instituto Gallego de Estadística los datos de sus respectivos padrones.

Artículo 56. Los Ayuntamientos de la Comunidad Autónoma de Galicia confeccionarán un padrón especial de residentes en el extranjero que hayan tenido la última vecindad administrativa en Galicia y acrediten esta condición en el correspondiente Consulado de España. Se inscribirán también sus descendientes inscritos como españoles, si así lo solicitan. A este efecto, la Xunta de Galicia podrá disponer los fondos precisos y prestar la debida colaboración técnica y administrativa.
Artículo 57. 1. Son derechos y deberes de los vecinos:

a. Ser elector y elegible, de conformidad con lo dispuesto por la legislación electoral.

b. Participar en la gestión municipal, de conformidad con lo dispuesto por las Leyes y por los reglamentos propios del municipio y, en su caso, cuando los órganos de gobierno y administración municipal soliciten la colaboración con carácter voluntario.

c. Utilizar, de acuerdo con su naturaleza, los servicios públicos municipales y acceder a los aprovechamientos comunales de acuerdo con las normas aplicables.

d. Contribuir, mediante las prestaciones económicas y personales establecidas por la Ley, al ejercicio de las competencias municipales.

e. Ser informado, mediante petición razonada, y dirigir solicitud previa a la Administración municipal, en relación con todos los expedientes y la documentación municipal, de conformidad con lo establecido por el artículo 105 de la Constitución, la legislación de régimen local, la Ley 30/1992, de 26 de noviembre, de Régimen Jurídico de las Administraciones Públicas y del Procedimiento Administrativo Común, y los Reglamentos de la Corporación.

f. Pedir la consulta popular en los términos establecidos por la Ley.

g. Exigir la prestación y, en su caso, el establecimiento del correspondiente servicio público, cuando constituya competencia municipal propia de carácter obligatorio.

h. Ejercer los demás derechos y deberes establecidos por las Leyes y, en su caso, por los Reglamentos de la Corporación.

2. La inscripción de los extranjeros en el padrón municipal no constituirá prueba de su residencia legal en España ni les atribuirá ningún derecho que no les confiera la legislación vigente, especialmente en materia de derechos y libertades de los extranjeros en España.

3. Los extranjeros menores de edad emancipados o judicialmente habilitados 


\section{Administración Local}

tendrán los mismos derechos y deberes que los vecinos, a excepción de los de carácter político.

Artículo 58. 1. Para hacer efectivos los derechos establecidos por el artículo precedente de la presente ley, los titulares podrán iniciar los procedimientos administrativos y jurisdiccionales que les correspondan por Ley.

2. Para exigir la prestación o el establecimiento de los servicios obligatorios, podrán formularse, en cualquier caso, reclamaciones contra la aprobación inicial de los presupuestos, cuando éstos no consignen los créditos precisos a tales efectos. Contra los actos que resuelvan definitivamente la reclamación, los interesados podrán interponer recurso contenciosoadministrativo.

\section{Capítulo III ORGANIZACIÓN}

Artículo 59. 1. Los municipios de la Comunidad Autónoma de Galicia tienen la potestad de autoorganización y por ello podrán aprobar sus reglamentos orgánicos sin otro límite que el respeto a las reglas de organización municipal establecidas por la legislación básica del Estado y por la presente ley.

2. La organización municipal se regirá por las siguientes reglas:

a. El Alcalde, los Tenientes de Alcalde y el Pleno existirán en todos los Ayuntamientos.

b. Existirá una Comisión de Gobierno en los municipios cuya población de derecho sea superior a 5.000 habitantes y en los de población inferior cuando lo acuerde el Pleno del Ayuntamiento o lo establezca el reglamento orgánico de éste.

c. La Comisión Especial de Cuentas existirá en todos los Ayuntamientos.

d. Podrán complementar la organización municipal los Alcaldes de barrio, las comisiones de estudio, informe o consulta, los órganos de gestión desconcentrada y de participación ciudadana y cualquier otro órgano establecido por el Ayuntamiento y regulado por su reglamento orgánico.

3. La creación de los órganos complementarios responderá a los principios de eficacia, economía organizativa y participación ciudadana y exigirá el cumplimiento de los siguientes requisitos:

a. Determinación de su forma de integración en la organización municipal y de su dependencia jerárquica.

b. Delimitación de sus funciones y competencias.

c. Dotación de los créditos precisos para su puesta en marcha y funcionamiento.

4. No podrán crearse nuevos órganos que supongan duplicación de otros ya existentes si al mismo tiempo no se suprime o restringe debidamente la competencia de éstos.

Artículo 60. 1. El gobierno y administración municipal corresponden al Ayuntamiento, integrado por el Alcalde y los Concejales.

2. Los Concejales son elegidos mediante sufragio universal, igual, libre, directo y secreto y el Alcalde es elegido por los Concejales o por los vecinos, todo ello en los términos que establezca la legislación electoral general.

\section{Sección 1. \\ Del Alcalde}

Artículo 61. 1. El Alcalde es el Presidente de la Corporación y ostenta las siguientes atribuciones:

a. Representar el Ayuntamiento.

b. Dirigir el gobierno y la administración municipales.

c. Convocar y presidir las sesiones del Pleno, de la Comisión de Gobierno y de cualesquiera otros órganos municipales.

d. Dirigir, inspeccionar e impulsar los servicios y obras municipales.

e. Publicar, ejecutar y hacer cumplir los acuerdos municipales.

f. Dictar bandos y velar por su cumplimiento. 
g. Autorizar y disponer los gastos dentro de los límites de su competencia, ordenar los pagos y rendir las cuentas.

h. Ejercer la dirección superior de todo el personal de la Corporación.

i. Ejercer la jefatura superior de la Policía municipal, así como nombrar y sancionar a los funcionarios que usen armas.

j. Ejercitar acciones judiciales y administrativas en caso de urgencia.

k. Adoptar personalmente y bajo su responsabilidad, en caso de catástrofe o infortunios públicos o de grave peligro de que éstos se produzcan, las medidas precisas y adecuadas, dando inmediata cuenta de las mismas al Pleno de la Corporación.

1. Sancionar las faltas de desobediencia a su autoridad o las infracciones de las ordenanzas municipales, salvo en los casos en que la facultad se atribuya a otros órganos.

m. Contratar obras, servicios y suministros siempre que su cuantía no exceda del 5 por 100 de los recursos ordinarios de su presupuesto ni del 50 por 100 del límite general aplicable al procedimiento negociado.

n. La contratación y concesión de obras, servicios y suministros que excediendo de la cuantía señalada en el punto anterior tengan una duración no superior a un año o no exijan créditos superiores al consignado en el presupuesto anual.

ñ. Decidir los empates con voto de calidad.

o. Otorgar las licencias, salvo en caso de que las ordenanzas o las Leyes sectoriales lo atribuyan expresamente al Pleno o a la Comisión de Gobierno.

p. El desarrollo y la gestión económica conforme al presupuesto aprobado.

q. Presidir las subastas y concursos para ventas, arrendamientos, suministros y toda clase de adjudicaciones de servicios y obras municipales.

r. Solicitar la delegación de competencias para la contratación y ejecución de obras y servicios con otras Administraciones. s. Ejercer las demás que de forma expresa le atribuyan las Leyes y las que la legislación asigne al Ayuntamiento y no atribuya a otros órganos municipales.

2. Corresponderá también el Alcalde el nombramiento de los Tenientes de Alcalde.

3. El Alcalde podrá delegar el ejercicio de sus atribuciones en los miembros de la Comisión de Gobierno y, en caso de que ésta no existiese, en los Tenientes de Alcalde, salvo las de convocar y presidir las sesiones del Pleno y de la Comisión de Gobierno y las mencionadas en las letras b), f), h) j) y k) del apartado 1 de este artículo.

El Alcalde podrá, asimismo, conferir las delegaciones especiales para encargos específicos, a favor de cualquier Concejal, aunque no pertenezca a la Comisión de Gobierno.

4. El acuerdo de delegación determinará los asuntos que ésta comprenda, las potestades que se deleguen y las condiciones concretas de su ejercicio.

\section{Sección 2 . $^{\mathrm{a}}$}

\section{De los Tenientes de Alcalde}

Artículo 62. 1. Los Tenientes de Alcalde serán libremente nombrados y destituidos por el Alcalde de entre los miembros de la Comisión de Gobierno y, donde ésta no exista, de entre los Concejales.

2. En los municipios con Comisión de Gobierno, el número de Tenientes de Alcalde no podrá exceder del número de miembros de aquélla. En aquellos otros en que no exista tal Comisión, el número de Tenientes de Alcalde no podrá exceder del tercio del número legal de miembros de la Corporación. No se tendrán en cuenta, a los efectos del cómputo, los decimales que resulten de dividir por tres el número total de Concejales.

3. La condición de Teniente de Alcalde se pierde, además de por el cese, por renuncia expresa manifestada por escrito y por pérdida de la condición de miembro de la Comisión de Gobierno. 


\section{Administración Local}

Artículo 63. Corresponde a los Tenientes de Alcalde, en cuanto tales, sustituir en la totalidad de sus funciones y por el orden de su nombramiento al Alcalde, en los casos de ausencia, enfermedad o impedimento que imposibilite a éste para el ejercicio de sus atribuciones, así como desempeñar las funciones del Alcalde en los supuestos de vacante en la Alcaldía hasta que tome posesión el nuevo Alcalde.

\section{Sección 3. Del Pleno}

Artículo 64. 1. El Pleno estará integrado por todos los Concejales y presidido por el Alcalde.

2. Corresponderán al Pleno las siguientes atribuciones:

a. Controlar y fiscalizar los órganos de gobierno.

b. Tomar los acuerdos relativos a la participación en organizaciones supramunicipales, la alteración del término municipal, la creación o supresión de municipios y entidades de administración descentralizada, la creación de órganos desconcentrados, la alteración de la capitalidad del municipio, el cambio de nombre del municipio y la adopción o modificación de la bandera, enseña o escudo.

c. Aprobar la iniciación y poner fin a la tramitación municipal de los instrumentos de planeamiento en los términos previstos en la legislación urbanística gallega.

d. Aprobar el reglamento orgánico y las ordenanzas.

e. Crear y regular órganos complementarios.

f. Determinar los recursos propios de carácter tributario, aprobar y modificar los presupuestos, disponer gastos en los asuntos de su competencia y aprobar las cuentas.

g. Contratar obras, servicios y suministros en caso de que su cuantía exceda de la que está permitida al Alcalde o a la Comisión de Gobierno y concertar o modificar operaciones de crédito, así como anticipos de tesorería, cuando la cuantía de éstos exceda del 5 por 100 de los recursos ordinarios del presupuesto municipal.

h. Aprobar las formas de gestión de los servicios y expedientes de municipalización.

i. Aceptar la delegación de competencias hecha por otras Administraciones Públicas.

j. Plantear conflictos de competencia a otras administraciones públicas.

k. Aprobar la plantilla de personal, la relación de los puestos de trabajo, las bases de las pruebas para la selección de personal y para los concursos de provisión de puestos de trabajo, fijar la cuantía de las retribuciones complementarias de los funcionarios y el número y régimen del personal eventual, todo ello en los términos establecidos por la legislación sobre función pública local, así como separar del servicio a los funcionarios de la Corporación, salvo lo establecido por el artículo 99.4 de la Ley Reguladora de las Bases del Régimen Local y ratificar el despido del personal laboral.

1. Ejercitar las acciones administrativas y judiciales.

m. Alterar la calificación jurídica de los bienes de dominio público.

n. Cualquier acto de disposición sobre los bienes, incluida la adquisición, transacción, enajenación y cesión gratuita a otras administraciones o instituciones públicas y a instituciones privadas de interés público sin ánimo de lucro. La concesión, arrendamiento o cesión de uso de bienes por más de cinco años, siempre que su cuantía exceda del 10 por 100 de los recursos ordinarios de su presupuesto, y la regulación del aprovechamiento de los bienes comunales y la cesión, por cualquier título, del aprovechamiento de estos bienes.

ñ. Las demás que deban corresponder al Pleno cuando su aprobación requiera una mayoría especial.

o. Ejercer las demás que de forma expresa le atribuyan las Leyes. 
3. Corresponderá, asimismo, al Pleno la votación sobre la moción de censura al Alcalde, que se regirá por lo dispuesto en la legislación electoral general.

4. No son delegables las atribuciones reservadas al Pleno por los apartados 2, letras a), b), c), d), e), f), h), i), j), k), m) y ñ), y 3 de este mismo artículo.

5. La delegación de atribuciones del Pleno en favor de la Comisión de Gobierno requerirá acuerdo adoptado por la mayoría del número legal de miembros de la Corporación.

El acuerdo de delegación determinará los asuntos que ésta comprenda, las potestades que se deleguen y las condiciones concretas de su ejercicio.

\section{Sección $4 .^{\mathrm{a}}$}

\section{De la Comisión de Gobierno}

Artículo 65. 1. La Comisión de Gobierno estará integrada por el Alcalde y un número de Concejales no superior al tercio del número legal de los mismos, nombrados o separados libremente por el Alcalde, que deberá dar cuenta de ello al Pleno.

2. Corresponderá a la Comisión de Gobierno:

a. La asistencia al Alcalde en el ejercicio de sus atribuciones.

b. Las atribuciones que el Alcalde u otro órgano municipal le deleguen y las que le atribuyan las Leyes.

\section{Sección $5 .^{a}$}

De la Comisión Especial de Contas

Artículo 66. 1. La Comisión Especial de Contas de la Entidad Local estará constituida por los miembros de los distintos grupos políticos de la Corporación.

2. El número de miembros será proporcional a su representatividad en el Ayuntamiento o igual para cada grupo. En el último caso se aplicará el sistema de voto ponderado.

Artículo 67. 1. Corresponderá a la Comisión Especial de Contas el examen, estudio e informe de la cuenta general y de las demás cuentas anuales.

2. Para el ejercicio adecuado de sus funciones, la Comisión podrá requerir, por medio del Alcalde, la documentación complementaria que considere precisa y la presencia de los miembros y funcionarios de la Corporación especialmente relacionados con las cuentas que se analicen.

3. Las competencias de la Comisión Especial de Contas se entenderán sin perjuicio de las que correspondan al Tribunal de Cuentas y al Consello de Contas, de conformidad con su legislación específica.

\section{Sección $6 .^{\mathrm{a}}$}

\section{De las Comisiones de Estudio, Informe o Consulta}

Artículo 68. 1. Se constituirán comisiones de estudio, informe y consulta en todos los municipios de más de 5.000 habitantes. En los demás, podrán constituirse potestativamente, si así lo acuerda el Pleno de la Corporación.

2. Corresponderán a estas comisiones el estudio y dictamen previos de los asuntos que deban someterse a la decisión del Pleno o de la Comisión de Gobierno cuando actúe por delegación de éste. Asimismo, podrán intervenir en relación con los asuntos que deban someterse a la Comisión de Gobierno cuando este órgano les solicite dictamen.

3. Corresponderá al Pleno determinar el número y la denominación de las comisiones de estudio, informe o consulta y sus modificaciones.

4. Estas comisiones podrán constituirse también con carácter temporal para tratar de temas específicos.

5. Las comisiones estarán integradas por los miembros que designen los distintos grupos políticos que forman parte de la Corporación, de conformidad con los criterios a que se refiere el artículo 66.2 de la presente ley. 
Sección 7. ${ }^{\mathrm{a}}$

De los órganos territoriales para la gestión municipal desconcentrada y de participación ciudadana

Artículo 69. 1. En los municipios con más de 20.000 habitantes podrán constituirse, con la finalidad de facilitar la participación ciudadana en la gestión de los asuntos municipales, órganos territoriales de gestión desconcentrada que integrarán a Concejales en número que no podrá ser superior a la mitad del total de sus componentes y representantes de las asociaciones de vecinos, designados por el Alcalde a propuesta de éstas de acuerdo con su efectiva implantación.

2. La presidencia del órgano corresponderá al Concejal que al efecto designe el Alcalde de entre los que figuren en la lista más votada en el territorio de que se trate.

Artículo 70. Los órganos a que se refiere el artículo anterior podrán ejercer las competencias y funciones que cada Ayuntamiento les confiera, atendiendo a las características del asentamiento de la población en el término municipal $\mathrm{y}$, en especial, en los sectores sanitario, asistencial, cultural, deportivo y recreativo, garantizándose, en todo caso, el principio de unidad de gobierno y gestión en el municipio, a cuyo efecto se establecerán en el acuerdo de delegación los sistemas de revisión y control de los actos y acuerdos adoptados por los órganos de participación.

Artículo 71. 1. Asimismo, por acuerdo del Pleno y en municipios con más de 20.000 habitantes, podrán crearse órganos de participación sectorial en relación con los ámbitos de actuación pública municipal que por su naturaleza lo permitan, con la finalidad de integrar la participación de los ciudadanos y de sus asociaciones en los asuntos municipales.

2. Presidirán los órganos de participación sectorial los Concejales en quienes delegue el Alcalde.
Artículo 72. Corresponderán a los órganos de participación sectorial, en relación con el territorio o el sector material correspondiente, las siguientes funciones:

a. Proponer al órgano competente fórmulas encaminadas a resolver los problemas relacionados con el ámbito de sus funciones.

b. Emitir informes, a iniciativa propia o del Ayuntamiento, sobre materias de su competencia.

c. Emitir y formular propuestas y sugerencias en relación con el funcionamiento de los servicios y organismos públicos municipales.

d. Ejercer las demás de naturaleza semejante que determine el acuerdo de creación.

\section{Sección 8. ${ }^{\mathrm{a}}$}

Del Alcalde de Barrio

Artículo 73. 1. En los núcleos de población separados del centro urbano y que no constituyan Entidad Local, el Alcalde podrá nombrar un Alcalde de Barrio para cada núcleo entre los vecinos que residan en éste.

2. El Alcalde también podrá nombrar Alcaldes de Barrio en las ciudades en que los servicios requieran esta designación. Cada Alcalde de Barrio tendrá que ser vecino de aquel en el que ejerza sus funciones.

3. La duración del cargo estará sujeta a la del mandato del Alcalde que lo nombró, quien podrá removerle cuando lo juzgue oportuno.

4. Los Alcaldes de Barrio tendrán carácter de autoridad en el cumplimiento de sus cometidos habituales, en cuanto representantes del Alcalde que los nombró.

\section{Sección 9. ${ }^{a}$ De los Grupos Políticos}

Artículo 74. 1. Los Concejales, a los efectos de su actuación corporativa, se constituirán en grupos, que se corresponderán con los partidos políticos, federaciones, coaliciones o agrupaciones que hayan obtenido puestos en la corporación. 
2. Cada partido político, federación, coalición o agrupación constituirá un único grupo.

3. Nadie puede pertenecer simultáneamente a más de un grupo.

4. Se integrarán, en todo caso, en el grupo mixto los miembros de los partidos políticos, federaciones, coaliciones o agrupaciones que no hubiesen obtenido un mínimo de dos escaños.

En el supuesto de que no existiese grupo mixto, éste quedará constituido por el miembro del partido político, federación, coalición o agrupación que haya obtenido un solo escaño.

5. Durante el mandato de la Corporación, ningún miembro de la misma podrá integrarse en un grupo distinto de aquel en que lo haga inicialmente.

Artículo 75. 1. Los grupos políticos se constituirán mediante escrito dirigido al Presidente y suscrito por todos sus integrantes, que se presentarán en la Secretaría General de la Corporación dentro de los cinco días hábiles siguientes a la constitución de la Corporación. Si algún Concejal no firmase el escrito de constitución del grupo, ello no impedirá su constitución y los no firmantes se integrarán en el grupo mixto.

2. En el mismo escrito de constitución se hará constar la designación del portavoz del grupo, pudiendo designarse también suplentes.

3. De la constitución de los grupos políticos y de sus integrantes y portavoces, el Presidente dará cuenta al Pleno en la primera sesión que se celebre tras cumplirse el plazo previsto anteriormente.

Artículo 76. 1. Los miembros de la Corporación que adquieran su condición con posterioridad a la sesión constitutiva de la misma deberán incorporarse al grupo correspondiente a la lista en que hayan sido elegidos o, en su caso, al grupo mixto. En el primer supuesto, dispondrán de un plazo de cinco días hábiles, que comenzará a contar desde que tomen posesión de su cargo, para acreditar su incorporación al grupo que corresponda mediante escrito dirigido al Presidente y firmado, asimismo, por el correspondiente portavoz.

2. Si no se produce su integración en la forma prevista en el apartado anterior, y salvo que mediase causa de fuerza mayor, se integrarán automáticamente en el grupo correspondiente a la lista en que hayan salido elegidos.

Artículo 77. Corresponde a los grupos políticos designar, mediante escrito de su portavoz dirigido al Presidente, a aquellos de sus componentes que hayan de representarlos en todos los órganos colegiados integrados por corporativos pertenecientes a los diversos grupos.

Artículo 78. Las funciones y atribuciones de los grupos políticos se entenderán, en cualquier caso, sin perjuicio de las que la legislación de régimen local atribuya a los órganos municipales y a los miembros de la Corporación.

Artículo 79. 1. Siempre que sea posible, los diversos grupos políticos dispondrán, en la sede de la Entidad Local, de un despacho o local para reunirse de manera independiente y recibir visitas de los ciudadanos.

2. Los grupos políticos podrán hacer uso de locales municipales de reunión de la Corporación para celebrar reuniones y sesiones de trabajo con asociaciones para la defensa de los intereses colectivos, generales o sectoriales de la población. Estas reuniones no se permitirán si coinciden con sesiones del Pleno o porque la disponibilidad de espacios para otros actos político-administrativos de la Corporación lo impida.

\section{Capitulo IV COMPETENCIAS}

Sección $1 .^{a}$

De las competencias propias

Artículo 80. 1. El municipio, para la gestión de sus intereses y en el ámbito de sus competencias, podrá promover 


\section{Administración Local}

toda clase de actividades y prestar todos los servicios públicos que contribuyan a satisfacer las necesidades y aspiraciones de la comunidad de vecinos.

2. El municipio ejercerá, en todo caso, competencias en los términos de la legislación del Estado y de la Comunidad Autónoma en las siguientes materias:

a. La seguridad en lugares públicos.

b. La ordenación del tráfico de vehículos y personas en las vías urbanas.

c. La Protección Civil y la prevención y extinción de incendios.

d. La ordenación, gestión, ejecución y disciplina urbanística; la promoción y gestión de viviendas; los parques y jardines; la pavimentación de vías públicas urbanas y la conservación de caminos y vías rurales.

e. El patrimonio histórico-artístico.

f. La protección del medio ambiente.

g. Abastos, mataderos, ferias, mercados y la defensa de usuarios y consumidores.

h. La protección de la salubridad pública.

i. La participación en la gestión de la atención primaria de la salud.

j. Los cementerios y servicios funerarios.

k. La prestación de los servicios sociales y la promoción y reinserción sociales.

1. El suministro de agua, el alumbrado público, los servicios de limpieza viaria, la recogida y el tratamiento de residuos, el alcantarillado y el tratamiento de aguas residuales.

$\mathrm{m}$. El transporte público de viajeros.

n. Las actividades e instalaciones culturales y deportivas, la ocupación del tiempo libre y el turismo.

ñ. La participación en la programación de la enseñanza y la cooperación con la Administración educativa en la creación, construcción y mantenimiento de los centros docentes públicos, la intervención en los órganos de gestión de los centros docentes y la participación en la vigilancia del cumplimiento de la escolaridad obligatoria.

o. La ejecución de programas propios destinados a la infancia, juventud, mujer y tercera edad. p. La participación en la formación de activos y desempleados.

\section{Sección 2. ${ }^{\text {a }}$}

\section{De los servicios mínimos}

Artículo 81. Los municipios, independientemente o asociados, prestarán, como mínimo, los siguientes servicios:

a. En todos los municipios: Alumbrado público, cementerio, recogida selectiva, en su caso, de residuos, limpieza viaria, abastecimiento domiciliario de agua potable, alcantarillado, acceso a los núcleos de población, pavimentación y conservación de las vías públicas y control de alimentos y bebidas en todo lo que no sea competencia de otras Administraciones.

En los municipios que cuenten con un núcleo urbano con población superior a los 1.000 habitantes se prestará el servicio de biblioteca pública.

b. En los municipios con una población superior a los 5.000 habitantes, además: Parque público, biblioteca pública, mercado y tratamiento de residuos.

c. En los municipios de población superior a 20.000 habitantes, además: Protección Civil, prestación de servicios sociales, prevención y extinción de incendios e instalaciones deportivas de uso público.

d. En los municipios de población superior a 50.000 habitantes, además: Transporte colectivo urbano de viajeros y protección del medio ambiente.

Artículo 82. 1. La prestación homogénea de los servicios mínimos constituye un objetivo a cuya consecución se dirigirán, preferentemente, las funciones asistenciales y de cooperación municipal de las Diputaciones Provinciales, así como la coordinación y ayuda de la Comunidad Autónoma.

2. El Consello de la Xunta de Galicia establecerá, a propuesta de la consellería competente en materia de régimen local, niveles homogéneos de prestación de los servicios mínimos en los términos que reglamentariamente se determinen.

Artículo 83. 1. Si el establecimiento o prestación de los servicios a que se refiere 
el artículo 81 resultase imposible o de muy difícil cumplimiento, en aplicación del principio de subsidiariedad los municipios podrán solicitar a la Xunta de Galicia la dispensa de la obligación de prestarlos.

2. La tramitación del expediente de dispensa de la obligación de prestar un servicio mínimo se ajustará a las siguientes reglas:

a. Será precisa solicitud formulada por el Ayuntamiento acompañada de los informes que se consideren pertinentes.

b. Informe de la Diputación Provincial correspondiente.

c. Propuesta de resolución del conselleiro competente en materia de régimen local, que, al efecto, solicitará los informes precisos para determinar las características económicas y financieras del servicio y las características técnicas para prestarlo adecuadamente.

d. La resolución corresponderá al Consello de la Xunta de Galicia, y en la misma se determinará necesariamente:

El órgano o la Administración que deberá asumir el servicio.

Las aportaciones económicas municipales para cubrir la totalidad del coste del servicio, cuando la dispensa sea debida a causas técnicas, o para cubrir el coste parcialmente, cuando sea por razones de naturaleza económica.

3. La intervención supletoria a que se refiere el apartado anterior no será necesaria cuando la dispensa se justifique en la innecesariedad de la prestación del servicio, de acuerdo con las características particulares del municipio. En este caso, a la solicitud de dispensa se adjuntará el resultado de la información pública que realizará previamente el municipio.

Artículo 84. 1. No será necesaria la instrucción del expediente de dispensa de prestación de servicios mínimos cuando concurran algunos de los siguientes supuestos:

a. Municipios que, por la insuficiente capacidad financiera, especial infraestructura del territorio y de los asentamientos de la población u otras causas técnicas, no puedan establecer o prestar adecuada o eficientemente los servicios mínimos de su competencia.

b. Municipios donde las partidas presupuestarias para retribuir las funciones públicas necesarias constituyan más del 50 por 100 de su presupuesto.

2. Corresponderá a la Diputación Provincial correspondiente, en relación con los municipios a que se refiere el apartado primero de este artículo, establecer los servicios mínimos deficitarios o asegurar la adecuada prestación de los que lo requieran, así como, en su caso, ejercer las funciones públicas precisas.

Desde la Xunta de Galicia podrán articularse los medios técnicos y económicos precisos para garantizar la cooperación de la Administración autonómica con la provincial en el establecimiento de servicios mínimos deficitarios o en la adecuada prestación de los que lo requieran.

3. La aplicación de lo establecido en el párrafo anterior requerirá la aprobación del Consello de la Xunta de Galicia, a propuesta de la correspondiente Diputación Provincial, y la no oposición del municipio interesado en el trámite de consulta previa que se le otorgue.

Artículo 85. La dispensa de prestación de servicios mínimos tendrá, en todo caso, carácter provisional y la Xunta de Galicia, oídas las Entidades Locales afectadas, establecerá los medios económicos y técnicos necesarios para que en un plazo no superior a dos años garanticen su prestación mediante la utilización de algunas de las modalidades de colaboración previstas en la presente ley.

\section{Sección $3 .^{\mathrm{a}}$}

De las actividades

complementarias de otras

Administraciones Públicas

Artículo 86. 1. Para la gestión de sus intereses y una vez que se garantice la prestación de los servicios mínimos, 


\section{Administración Local}

el municipio también podrá ejercer actividades complementarias de las propias de otras Administraciones Públicas y, en particular, las relativas a:

a. La educación.

b. La cultura, la juventud y el deporte.

c. La promoción de la mujer.

d. La vivienda.

e. La atención primaria a la salud.

f. La ocupación y la lucha contra el paro.

g. Los archivos, museos, conservatorios de música y centros de bellas artes.

h. El fomento de las estructuras agrarias y la prestación de servicios de interés público agrario.

i La protección del medio ambiente.

2. Para la realización de estas actividades, los municipios podrán ejercer las potestades de ejecución que no estén atribuidas por la legislación a otras Administraciones Públicas, incluida, en su caso, la de dictar reglamentos internos de organización de los correspondientes servicios.

\section{Sección $4 .^{\mathrm{a}}$}

De la transferencia y delegación de competencias de la Comunidad Autónoma en los municipios y de la encomienda de gestión

Artículo 87. 1. La Comunidad Autónoma de Galicia, siempre y cuando afecte a los intereses generales de la misma, podrá transferir o delegar competencias en los municipios y, asimismo, podrá encomendar a éstos, siempre que se trate de municipios que sean capitales de provincia o con una población superior a los 70.000 habitantes, la gestión ordinaria de los servicios propios de la Comunidad Autónoma.

2. El régimen de las competencias que la Comunidad Autónoma pueda transferir o delegar en los municipios, mediante Ley del Parlamento de Galicia o Decreto del Consello de la Xunta de Galicia, así como el de la encomienda de gestión de los servicios propios de la Comunidad Autónoma, se acomodarán a las reglas previstas en el título IV de la presente ley.

\section{Capitulo V}

\section{REGÍMENES MUNICIPALES ESPECIALES}

Artículo 88. 1. Por sus singulares características, gozarán de un régimen especial los municipios turísticos, los histórico-artísticos, los industriales, los pesqueros y los rurales.

2. Corresponde tal declaración, conforme al procedimiento que reglamentariamente se establezca, al Consello de la Xunta de Galicia, de oficio o a instancia de los municipios interesados.

3. La aplicación de más de un régimen o tratamiento especial podrá compatibilizarse siempre que el municipio reúna las condiciones y requisitos legales exigidos en cada caso.

4. Además de los regímenes municipales especiales establecidos en la presente ley, podrán regularse, mediante Ley, otros en los que se tengan en cuenta otras particularidades propias de Galicia.

5. Mediante Ley del Parlamento de Galicia se regulará el régimen jurídico específico de las diferentes catalogaciones de los municipios.

Artículo 89. 1. Los municipios con una población superior a los 70.000 habitantes podrán contar con un régimen jurídico especial establecido por Ley.

2. Por Ley del Parlamento de Galicia, se dotará de un estatuto especial a la ciudad de Santiago de Compostela como sede de las instituciones autonómicas.

\section{Sección $1 .^{\mathrm{a}}$}

\section{De los municipios turísticos}

Artículo 90. 1. Podrán ser declarados municipios turísticos aquellos en los que, por la afluencia periódica o estacional, la media ponderada anual de población turística sea superior al 25 por 100 del número de vecinos o cuando el número de alojamientos turísticos y de segundas viviendas sea superior al 50 por 100 del número de viviendas de residencia primaria.

2. También podrá declararse municipios turísticos los que acrediten contar, dentro 
de su territorio, con algún servicio turístico susceptible de producir una atracción turística de visitantes en una cantidad cinco veces superior a su población, computada a lo largo de un año y repartida al menos en más de treinta días.

Artículo 91. 1. Los municipios turísticos y la Xunta de Galicia podrán celebrar Convenios para establecer las fórmulas de asistencia y coordinación destinadas a garantizar la prestación de sus servicios más característicos $\mathrm{y}$, en especial, la protección de la salubridad e higiene en el medio urbano y natural y en las playas y costas, así como también la Protección Civil y la seguridad ciudadana.

2. La Comunidad Autónoma fomentará la constitución de mancomunidades de municipios turísticos para fines de esta naturaleza y coordinará, a petición de los propios Ayuntamientos, las campañas y actividades municipales de difusión y promoción turística. Todos los municipios mancomunados tendrán la consideración de municipios turísticos.

Artículo 92. Los municipios turísticos podrán establecer tributos o recargos específicos, de acuerdo con la legislación de las haciendas locales.

\section{Sección 2. ${ }^{\mathrm{a}}$}

\section{De los municipios histórico-artísticos}

Artículo 93. Podrán tener la consideración de municipios histórico-artísticos los que hayan sido declarados conjunto histórico de acuerdo con la legislación específica o cuenten con un conjunto individualizado de inmuebles a los que haya sido otorgado tal carácter.

Artículo 94. 1. Los municipios histórico-artísticos y la Xunta de Galicia podrán celebrar Convenios por los que se regularán las formas de asistencia y cooperación técnica de proyectos especiales de protección, conservación, restauración y rehabilitación del patrimonio monumental.

2. La Xunta de Galicia asistirá de modo especial a estos municipios en la elaboración del inventario del patrimonio histórico-artístico, mueble e inmueble, y en la defensa del mismo.

\section{Sección $3 .^{a}$}

\section{De los municipios industriales}

Artículo 95. Podrán declararse municipios industriales aquellos en los que la actividad económica predominante corresponda al sector secundario y así sea declarado por el Consello de la Xunta de Galicia.

Artículo 96. Los municipios industriales y la Xunta de Galicia podrán celebrar Convenios mediante los que se regularán las formas de asistencia y cooperación técnica destinadas a dotar a aquéllos de la infraestructura precisa para el asentamiento, en sus términos, de actividades económicas de esta naturaleza y, en especial, de mecanismos eficaces de protección medioambiental y de las singulares condiciones técnicas que las instalaciones industriales imponen para la adecuada prestación de los servicios municipales.

Artículo 97. La Xunta de Galicia potenciará la participación de estos municipios en la elaboración de los instrumentos de planificación física o sectorial que puedan afectar a su ámbito territorial e impulsará tanto el establecimiento, en los mismos, de las dotaciones y equipamientos precisos tendentes a equilibrar las carencias existentes como la realización de operaciones de rehabilitación de las áreas industriales. Igualmente los planes hidráulicos que, de acuerdo con la legislación del Estado, apruebe la Comunidad Autónoma establecerán las determinaciones precisas para el abastecimiento, evacuación y tratamiento de sus aguas.

\section{Sección $4 .^{\mathrm{a}}$ \\ De los municipios pesqueros}

Artículo 98. Podrán declararse municipios pesqueros aquellos en los que la actividad económica predominante corresponda a este sector primario y así sea 


\section{Administración Local}

declarado por el Consello de la Xunta de Galicia.

Artículo 99. Los municipios pesqueros y la Xunta de Galicia podrán celebrar Convenios mediante los que se regularán las formas de asistencia y cooperación técnica destinadas a dotar a aquéllos de la infraestructura precisa, especialmente en materia de puertos; apoyar a las cofradías de pescadores y demás organizaciones de productores, cooperativistas del mar $\mathrm{y}$ asociaciones de productores, y promocionar acuerdos intersectoriales entre las asociaciones y organizaciones señaladas.

\section{Sección 5 . $^{\mathrm{a}}$ \\ De los municipios rurales}

Artículo 100. 1. Podrán declararse municipios rurales aquellos que cumplan las siguientes condiciones:

a. Que la actividad económica predominante se desarrolle en el sector primario de la agricultura.

b. Que tengan menos de 25.000 habitantes.

c. Que el número de Entidades dentro de su término municipal exceda de 10 o la densidad de población sea inferior a la media gallega.

2. Los municipios rurales y la Xunta de Galicia podrán celebrar Convenios mediante los que se regularán las formas de asistencia y cooperación técnica y económica destinadas a dotar a aquéllos de la infraestructura precisa para garantizar la prestación de los servicios mínimos a los ciudadanos.

3. La Xunta de Galicia podrá impulsar planes de actuación respecto a estos municipios a fin de fijar la población en el campo y aprovechar las potencialidades productivas que tengan.

\section{TÍTULO II DE LA PROVINCIA}

Artículo 101. 1. La provincia es una Entidad Local de carácter territorial formada por la agrupación de municipios, con personalidad jurídica propia, autonomía y plena capacidad para el cumplimiento de sus fines propios y específicos.

2. Son fines propios y específicos de la provincia garantizar los principios de solidaridad y equilibrio intermunicipales, en el marco de la política económica y social, y en particular:

a. Asegurar la prestación integral y adecuada en la totalidad del territorio provincial de los servicios de competencia municipal.

b. Participar en la coordinación de la Administración local con la de la Comunidad Autónoma y con la del Estado.

3. El gobierno y la administración de las provincias gallegas corresponde a las Diputaciones Provinciales.

\section{Capítulo I \\ TERRITORIO}

Artículo 102. 1. El término provincial es el ámbito territorial en que la Diputación Provincial ejerce sus competencias.

2. La modificación de los límites provinciales sólo podrá producirse por alteración de los términos municipales y mediante Ley Orgánica conforme a la legislación estatal básica.

\section{Capitulo II ORGANIZACIÓN}

Artículo 103. 1. Formarán parte de la organización provincial:

a. El Presidente, los Vicepresidentes, el Pleno y la Comisión de Gobierno. Será también órgano de la provincia la Comisión Especial de Contas.

b. Son órganos complementarios las comisiones de estudio, informe o consulta, cuya constitución y funcionamiento se acomodará a las mismas reglas que sus homónimas de ámbito municipal. El Pleno de la Diputación, haciendo uso de su potestad de autoorganización, podrá crear cualquier otro órgano de carácter complementario, sin otro límite que el respeto a la organización determinada por la legislación básica y por la presente ley. 
2. Todos los grupos políticos integrantes de la Corporación tendrán derecho a participar, mediante la presencia de Diputados pertenecientes a los mismos, en los órganos complementarios de la Diputación Provincial cuya función sea el estudio, informe o consulta de los asuntos que tengan que ser sometidos a la decisión del Pleno.

Artículo 104. 1. La elección del Presidente se rige por lo dispuesto en la legislación electoral general.

2. Corresponde al Presidente el nombramiento de los Vicepresidentes.

3. El Pleno de la Diputación Provincial estará constituido por el Presidente y los demás Diputados Provinciales.

4. La Comisión de Gobierno estará integrada por el Presidente y un número de Diputados no superior a la tercera parte del número legal de miembros de la Corporación, nombrados y separados libremente por el Presidente, que dará cuenta de ello al Pleno.

Artículo 105. 1. Corresponde, en todo caso, al Presidente de la Diputación:

a. Representar a la Diputación.

b. Dirigir el gobierno y la administración de la provincia.

c. Convocar y presidir las sesiones del Pleno, la Comisión de Gobierno y cualquier otro órgano de la Diputación.

d. Dirigir, inspeccionar e impulsar los servicios y obras cuya titularidad o ejercicio corresponde a la Diputación Provincial.

e. Ordenar la publicación y ejecución y hacer cumplir los acuerdos de la Diputación.

f. Autorizar y disponer gastos, dentro de los límites de su competencia, ordenar pagos y rendir cuentas.

g. Ejercer la dirección y las facultades en materia de personal que no tenga atribuidas el Pleno.

h. Ejercitar acciones judiciales y administrativas en caso de urgencia.

i. Asegurar la gestión de los servicios propios de la Comunidad Autónoma cuya gestión ordinaria esté encomendada por ésta a la Diputación.

j. Adoptar personalmente y bajo su responsabilidad, en caso de catástrofe o infortunios públicos, o de grave peligro de que éstos se produzcan, las medidas precisas y adecuadas, dando inmediata cuenta de las mismas al Pleno de la Diputación.

k. Contratar obras y servicios siempre que su cuantía no exceda del 5 por 100 de los recursos ordinarios de su presupuesto ni del 50 por 100 del límite general aplicable al procedimiento negociado legalmente establecido.

1. Autorizar la contratación y concesión de obras, servicios y suministros que excediendo de la cuantía señalada en el punto anterior tengan una duración no superior a un año o no exijan créditos superiores al consignado en el presupuesto anual.

m. Hacer cumplir las ordenanzas y reglamentos provinciales.

n. Decidir los empates con voto de calidad.

ñ. Otorgar las autorizaciones o licencias, a no ser que las ordenanzas o las leyes sectoriales lo atribuyan expresamente al Pleno o a la Comisión de Gobierno.

o. El desarrollo y la gestión económica conforme al presupuesto aprobado.

p. Presidir las subastas y adjudicar provisionalmente el remate.

q. Ejercer las demás atribuciones que expresamente le atribuyen las leyes.

r. El ejercicio de aquellas otras atribuciones que las leyes asignen a la Diputación y no estén expresamente atribuidas a otros órganos.

2. El Presidente puede delegar en la Comisión de Gobierno el ejercicio de sus atribuciones, a no ser la de convocar y presidir las sesiones del Pleno y de la Comisión de Gobierno y las enumeradas en las letras b), g) y h) del apartado anterior de este mismo artículo, todo ello sin perjuicio de las delegaciones especiales que, para encargos específicos, pueda 


\section{Administración Local}

realizar en favor de cualquier miembro de la Corporación, aunque no pertenezca a la Comisión de Gobierno.

Artículo 106. Corresponde a los Vicepresidentes, en cuanto tales, sustituir en la totalidad de sus funciones y por el orden de su nombramiento al Presidente, en los casos de ausencia, enfermedad o impedimento que imposibilite a éste para el ejercicio de sus atribuciones, así como desempeñar las funciones del Presidente en los supuestos de vacante.

Artículo 107. 1. Corresponden, en todo caso, al Pleno las siguientes atribuciones:

a. La organización de la Diputación.

b. La aprobación de ordenanzas.

c. La aprobación y modificación de los presupuestos, la disposición de gastos dentro de los límites de su competencia y la aprobación de las cuentas.

d. La aprobación de los proyectos de carácter provincial.

e. El control y la fiscalización de la gestión de los órganos de gobierno.

f. La aprobación de la plantilla de personal, la relación de puestos de trabajo, las bases de las pruebas para la selección de personal y para los concursos de provisión de puestos de trabajo, la fijación de la cuantía de las retribuciones complementarias de funcionarios y el número y régimen del personal eventual, todo ello en los términos de la legislación básica y de la presente ley, así como la separación del Servicio de los funcionarios de la Corporación, salvo lo dispuesto en el artículo 99, número 4, de la Ley 7/1985, reguladora de las bases del régimen local, y la ratificación del despido del personal laboral.

g. La alteración de la calificación jurídica de los bienes de dominio público.

h. La enajenación del patrimonio.

i. El planteamiento de conflictos de competencias a otras Entidades Locales y demás Administraciones Públicas. j. El ejercicio de acciones judiciales y administrativas.

k. Aquellas que deben corresponder al Pleno por exigir su aprobación una mayoría especial y a las que se refiere el artículo 215 de la presente ley.

1. La votación sobre la moción de censura al Presidente, que se regirá por lo dispuesto en la legislación electoral general.

$\mathrm{m}$. Ejercer las demás que expresamente le atribuyan las leyes.

2. El Pleno puede delegar en la Comisión de Gobierno el ejercicio de sus atribuciones, salvo las enumeradas en las letras a), b), c), d), e), f), g), i), k) y 1) del apartado anterior.

Artículo 108. Corresponde a la Comisión de Gobierno:

a. La asistencia al Presidente en el ejercicio de sus atribuciones.

b. Las atribuciones que el Presidente u otro órgano provincial le deleguen o que le atribuyan las leyes.

\section{Capitulo III COMPETENCIAS}

\section{Sección $1 .^{a}$}

De las competencias propias

Artículo 109. 1. Serán competencias propias de las Diputaciones Provinciales las que bajo este concepto les atribuyan las leyes. Las competencias propias se ejercerán en régimen de autonomía.

Son competencias propias de las Diputaciones Provinciales, en cualquier caso, las siguientes:

a. Coordinar los servicios municipales entre sí para garantizar la prestación integral y adecuada de servicios públicos en todo el territorio de la provincia, cooperando, especialmente, con los municipios de población inferior a 20.000 habitantes para garantizar su efectividad.

b. Prestar asistencia y cooperación jurídica, económica y técnica a los municipios, especialmente a los que tengan menor capacidad económica y de gestión. 
c. Prestar los servicios públicos de carácter supramunicipal.

d. En general, el fomento y la administración de los intereses peculiares de la provincia.

2. En el ejercicio de las competencias que corresponden a la Comunidad Autónoma, las leyes del Parlamento de Galicia reguladoras de los distintos sectores de la acción pública delimitarán como competencias propias de las Diputaciones Provinciales las que se consideren indispensables para la gestión de los intereses de las mismas.

\section{Subsección $1 .^{\mathrm{a}}$}

De la coordinación de los servicios municipales entre sí para garantizar

la prestación integral y adecuada

de los servicios públicos en todo el territorio de la provincia

Artículo 110. 1. Las Diputaciones Provinciales aprobarán anualmente un Plan provincial de cooperación de obras y servicios de competencia municipal, en cuya elaboración deberán participar los municipios de la provincia.

2. El Plan, que deberá contener una Memoria justificativa de sus objetivos y de los criterios de distribución de los fondos, podrá financiarse con medios propios de la Diputación, las aportaciones municipales y las subvenciones que acuerden la Xunta de Galicia y la Administración General del Estado con cargo a los respectivos presupuestos. La Xunta de Galicia podrá condicionar la utilización o empleo de sus subvenciones al establecimiento de los criterios y condiciones que considere convenientes.

Artículo 111. 1. Las Diputaciones Provinciales participarán activamente en la elaboración y gestión de los planes de desarrollo comarcal, colaborando en el cumplimiento de sus objetivos a través de las unidades técnicas comarcales.
2. Los planes de desarrollo comarcal tendrán el carácter de marco de referencia para la elaboración de los planes de cooperación de obras y servicios.

Artículo 112. 1. Para alcanzar una eficaz coordinación de las inversiones públicas en el territorio gallego, los programas de cooperación económica con las Entidades Locales que elaboren las Diputaciones Provinciales, cualquiera que sea su denominación y naturaleza, serán puestos, antes de su aprobación, en conocimiento de la Xunta de Galicia y de la Comisión Galega de Cooperación Local.

2. Las Administraciones Públicas implicadas procurarán la elaboración de un Plan único en el que se fundan las inversiones públicas provenientes de todas ellas; este Plan se regirá por un criterio de proporcionalidad que facilite el desarrollo de los referidos planes. Será coordinado por la Xunta de Galicia con el apoyo y asesoramiento de la Comisión Galega de Cooperación Local.

\section{Subsección 2. ${ }^{a}$ \\ De la asistencia jurídica}

Artículo 113. La cooperación en la asistencia jurídica en favor de los municipios será prestada por las Diputaciones Provinciales, entre otras, de las formas siguientes:

a. Mediante el informe y asesoramiento en cuantas consultas les sean formuladas por los órganos competentes de tales entidades.

b. Mediante la defensa en juicio cuando así les sea solicitado.

\section{Subsección 3. ${ }^{\mathrm{a}}$ \\ De la asistencia económico-financiera}

Artículo 114. La asistencia económico-financiera será prestada por las Diputaciones Provinciales, entre otras, de las formas siguientes:

a. Mediante el informe y asesoramiento en cuantas consultas les sean formuladas, sobre la gestión económico-financiera, por los órganos competentes. 


\section{Administración Local}

b. Mediante la cesión temporal en uso de material propio de las Diputaciones Provinciales.

c. Mediante la concesión de subvenciones a fondo perdido.

d. Mediante la concesión de créditos y la creación de cajas de crédito para facilitar a los Ayuntamientos operaciones de este tipo.

\section{Subsección $4 .^{a}$}

De la asistencia técnica

Artículo 115. Las Diputaciones Provinciales prestarán asistencia técnica a las Entidades Locales mediante la elaboración de estudios, proyectos y dirección de obras relativas a servicios de su competencia, en especial en el ámbito del urbanismo, gestión tributaria y asesoramiento e impulso de las medidas destinadas a mejorar la organización administrativa con especial atención a los sistemas de trabajo y la mecanización de tareas.

\section{Subsección $5 .^{\mathrm{a}}$}

De la asistencia en materia de

formación y perfeccionamiento en general

Artículo 116. Las Diputaciones Provinciales prestarán asistencia en materia de formación y perfeccionamiento en general directamente o a través de la Escola Galega de Administración Pública en la formación y perfeccionamiento del personal encargado de la gestión económica de las Entidades Locales.

\section{Subsección $6 .^{\mathrm{a}}$}

De la prestación de servicios de carácter supramunicipal

Artículo 117. 1. La prestación de servicios que, por su naturaleza, excedan del ámbito de un Municipio y no sean asumidos por otra Entidad Local será atendida por la Diputación Provincial, previa firma de los oportunos Convenios o acuerdos de cooperación.
2. La prestación de los servicios supramunicipales, cuando fuese asumida por la Diputación Provincial, podrá efectuarse:

a. A través de los servicios de la propia Diputación Provincial, mediante cualesquiera de las formas de gestión previstas en la legislación vigente.

b. Mediante la constitución de consorcios locales.

\section{Subsección 7.}

Del fomento y de la

administración de los intereses peculiares de la provincia

Artículo 118. Compete a las Diputaciones Provinciales regir y administrar los intereses peculiares de la provincia, creando, conservando y mejorando los servicios cuyo objeto sea el fomento de los mismos, y, en especial, los siguientes:

a. Construcción y conservación de carreteras y caminos provinciales.

b. Conservación de monumentos histórico-artísticos.

c. Establecimiento y conservación de bibliotecas.

d. Organización de concursos y exposiciones y de cualquier otra actividad cuya finalidad sea el fomento en materia de cultura, educación y deporte.

e. Realización de obras en todo el territorio provincial.

\section{Sección 2. ${ }^{\mathrm{a}}$}

De la transferencia y delegación de competencias de la Comunidad Autónoma en las provincias y de la encomienda de gestión

Artículo 119. 1. La Comunidad Autónoma de Galicia podrá transferir o delegar competencias en las Diputaciones Provinciales y encomendar a éstas la gestión ordinaria de sus propios servicios.

2. El régimen de las competencias que la Comunidad Autónoma pueda transferir o delegar en las Diputaciones Provinciales mediante Ley del Parlamento de Galicia 
o Decreto del Consello de la Xunta de Galicia, así como el de la encomienda de gestión de servicios propios, se acomodará a las reglas previstas en el título IV de la presente ley.

\section{TÍTULO III OTRAS ENTIDADES LOCALES}

\section{Capítulo I \\ DE LAS ÁREAS METROPOLITANAS \\ Sección 1. ${ }^{\circ}$ \\ De la creación de las áreas metropolitanas}

Artículo 120. Las áreas metropolitanas son Entidades Locales integradas por los municipios donde existan grandes aglomeraciones urbanas y cuando entre sus núcleos de población haya vinculaciones económicas y sociales que hagan precisa la planificación conjunta y la coordinación de determinados servicios $\mathrm{y}$ obras.

Artículo 121. 1. Por Ley del Parlamento de Galicia se podrán crear, modificar o suprimir áreas metropolitanas.

2. Corresponde a la Ley de Creación determinar los órganos de gobierno y administración, el régimen económico y de funcionamiento, los servicios a prestar y las obras a realizar por el área metropolitana, así como las potestades que se le atribuyan y la justa distribución de cargas entre los municipios que la integran.

3. En ningún caso la creación de una área metropolitana puede suponer la pérdida de competencias de los municipios integrados que les hagan perder su condición de tales.

Artículo 122. 1. La iniciativa para la creación del área metropolitana podrá partir de los municipios interesados, y, en este caso, se requerirá acuerdo adoptado con el voto favorable de la mayoría absoluta del número legal de miembros de cada Corporación.

2. Adoptados los acuerdos se elevarán al conselleiro competente en materia de régimen local, quien examinará la regularidad del procedimiento observado.

\section{Sección 2. ${ }^{\mathrm{a}}$}

De la organización y funcionamiento del área metropolitana

Artículo 123. La organización del área metropolitana se regirá por las siguientes reglas:

1. ${ }^{\text {a }}$ Todos los municipios integrados en el área estarán representados en sus órganos de gobierno y administración.

2. ${ }^{\mathrm{a}}$ El gobierno y administración del área metropolitana corresponderán al Consejo Metropolitano. Deberá existir, además, una Comisión de Gobierno, un Director general y un Delegado de la Xunta de Galicia en el área metropolitana. Actuará como Secretario quien lo sea del Ayuntamiento donde radique la capitalidad de la Entidad Local.

3. ${ }^{a}$ Podrán complementar la organización del área metropolitana:

a. El Comité de Cooperación.

b. Los órganos de participación sectorial.

\section{Subsección $1 .^{\mathrm{a}}$ \\ Del Consejo Metropolitano}

Artículo 124. 1. El Consejo Metropolitano estará formado por el número de miembros, representantes de todos los municipios integrados en el área, que especifique la Ley de Creación.

2. El Presidente del Consejo Metropolitano será elegido de entre sus miembros.

3. Los miembros del Consejo serán elegidos por los Ayuntamientos integrados en el área metropolitana garantizando, en todo caso, el pluralismo político existente en sus Corporaciones Locales.

Artículo 125. 1. Corresponderán al Consejo Metropolitano, entre otras, las siguientes atribuciones:

a. Elaborar el inventario de necesidades del área y establecer un orden de prioridades entre ellas.

b. Aprobar el Plan metropolitano cuatrienal de actividades, obras y servicios y su análisis anual. Se someterá a la aprobación 


\section{Administración Local}

definitiva de la Xunta de Galicia en relación con aquellos aspectos que le afecten.

c. Revisar anualmente el Plan y velar por su ejecución.

d. Aprobar la Memoria anual.

e. Adoptar los acuerdos relativos a transferencias o delegación de competencias y los acuerdos de cooperación con los Ayuntamientos del área metropolitana, con la Diputación Provincial, con la Xunta de Galicia y con la Administración Central del Estado.

f. Coordinar las actuaciones de los municipios integrados en el área metropolitana y de las demás Administraciones Públicas que incidan en su demarcación territorial. Las decisiones del Consejo Metropolitano que conciernan solamente a uno de los municipios integrados en el área no podrán adoptarse sin informe previo positivo del Pleno de este municipio.

g. La creación, modificación y disolución de empresas y de entidades de carácter público o mixto, o la participación en otras empresas, cuando ello contribuya a conseguir la máxima eficacia en el cumplimiento de los fines propios del área metropolitana.

h. La aprobación y modificación de los presupuestos.

i. La autorización y la disposición de gastos y la aprobación de las cuentas anuales.

j. La aprobación de la plantilla de personal y la relación de puestos de trabajo.

k. Ejercer las demás facultades que le sean conferidas por Ley o por Decreto de la Xunta de Galicia.

2. El Consejo Metropolitano se reunirá, al menos, trimestralmente y cuantas veces sea preciso, a iniciativa del Presidente o a solicitud de una cuarta parte de sus miembros.

\section{Subsección 2. ${ }^{\text {a }}$}

\section{De la Comisión de Gobierno}

Artículo 126. 1. La Comisión de Gobierno estará integrada por el número de
Vocales que establezca la Ley de Creación del área metropolitana, que serán elegidos por el Consejo Metropolitano.

2. A cada municipio del área deberá corresponderle, al menos, un Vocal en la Comisión de Gobierno.

3. La Comisión de Gobierno estará presidida por el Presidente del Consejo Metropolitano.

Artículo 127. 1. La Comisión de Gobierno es el órgano ejecutivo del área metropolitana y a tal fin tendrá, entre otras, las siguientes atribuciones:

a. Elaborar, de acuerdo con las directrices de la consellería competente en materia de régimen local, de la Consellería de Economía e Facenda en relación con la planificación económica y del Gabinete de Planificación y Desarrollo Territorial, el proyecto del Plan metropolitano cuatrienal, someterlo a información pública en el plazo de un mes y elevarlo al Pleno del Consejo.

b. Ejecutar los acuerdos que adopte el Consejo Metropolitano y la preparación de las decisiones que conciernan a dicho Consejo.

c. Proponer al Consejo Metropolitano la aprobación y modificación de los presupuestos a que se refiere el apartado h) del artículo 125.

d. Solicitar al Consejo Metropolitano la disposición de gastos referentes a las obras y servicios relativos al apartado anterior.

e. Someter al Consejo Metropolitano el proyecto de plantilla de personal y la relación de puestos de trabajo y la propuesta de creación, modificación y disolución de las empresas y entidades a que se refiere el apartado g) del artículo 125.

f. Ejercer las competencias que le sean delegadas por el Consejo Metropolitano.

2. La Comisión de Gobierno se reunirá, al menos, una vez al mes y cuantas veces sea necesario, a iniciativa del Presidente o a solicitud de una tercera parte de los miembros de la Comisión. 


\section{Subsección 3. ${ }^{\mathrm{a}}$ Del Director general}

Artículo 128. El Director general tendrá la consideración de personal eventual y tendrá que reunir las condiciones que se determinarán reglamentariamente.

Artículo 129. El Consejo Metropolitano determinará las atribuciones del Director general, que serán ejercidas bajo la supervisión y control directo del Presidente y que, entre otras, podrán referirse a:

a. Asegurar el cumplimiento de los acuerdos del Consejo Metropolitano y de su Comisión de Gobierno.

b. Impulsar y dirigir los servicios técnicos y administrativos que se creen para el ejercicio de las competencias del área metropolitana.

c. Proponer al Consejo o a la Comisión de Gobierno cuantas medidas considere convenientes en orden al funcionamiento de la entidad metropolitana y al cumplimiento de sus funciones.

d. Desempeñar la jefatura del personal adscrito al área metropolitana.

e. Presentar una Memoria anual sobre la labor realizada.

\section{Subsección $4 .^{\mathrm{a}}$}

Del Delegado de la Xunta de

Galicia en el área metropolitana

Artículo 130. 1. En cada área metropolitana habrá un Delegado de la Xunta de Galicia, que será nombrado por ésta y coordinará los servicios de la Xunta de Galicia con los que asuma el área metropolitana, pudiendo asistir, con voz pero sin voto, a las reuniones del Consejo.

2. El Delegado ejercerá cuantas funciones le atribuya la Xunta de Galicia, debiendo facilitar puntualmente a la misma cuanta información le solicite y elevándole, anualmente, una Memoria explicativa de las actividades realizadas y expresiva de los resultados obtenidos, tanto respecto al desarrollo económico como a la calidad de vida en el área metropolitana.

\section{Subsección $5 .^{\mathrm{a}}$}

De los órganos complementarios

Artículo 131. 1. Podrá crearse el Comité de Cooperación, que tendrá carácter tripartito y estará formado por representantes de la Xunta de Galicia, de la respectiva Diputación Provincial y del área metropolitana.

2. Sus funciones serán, entre otras, las de coordinar las actividades que en el área puedan llevar en común y que estarán financiadas conjuntamente en la proporción que, en cada caso, se establezca.

Artículo 132. 1. Podrán crearse órganos de participación sectorial en relación con los ámbitos de actuación del área metropolitana que por su naturaleza lo permitan, con la finalidad de integrar la participación de los ciudadanos y sus asociaciones en el sector de que se trate.

2. Presidirán los órganos de participación sectorial los miembros de la Comisión de Gobierno a los que haya sido asignado el sector específico de materias de que se trate.

3. Corresponderán a los órganos de participación, en relación con el sector material correspondiente, las siguientes funciones:

a. Informar al Consejo Metropolitano o a su Comisión de Gobierno sobre cuestiones del sector específico en las que tenga atribuidas competencias el órgano complementario, tanto por propia iniciativa como a petición de dicho Consejo o de la Comisión de Gobierno.

b. Formular propuestas y sugerencias en relación con el funcionamiento del sector o servicio concreto de que se trate.

c. Participar en el seguimiento de la gestión de los asuntos metropolitanos del respectivo sector.

d. Ejercer cualesquiera otras análogas que determine el acuerdo de creación.

Sección 3. ${ }^{\mathrm{a}}$

De las competencias

de las áreas metropolitanas

Artículo 133. 1. El objeto del área metropolitana será determinado y no 
podrá incluir todas las competencias de los municipios que la integren.

2. Corresponderá a la Ley de Creación del área metropolitana especificar sus competencias. Podrán corresponderle, entre otras, las siguientes:

a. La coordinación de la planificación urbanística municipal y la gestión urbanística en ámbitos supramunicipales.

b. La prestación de aquellos servicios públicos respecto a los cuales las áreas metropolitanas se convierten en el espacio más idóneo, así:

La planificación hidrológica y la aducción y redes de abastecimiento de agua en alta. Los mercados centrales de abastecimiento y lonjas de pescado y la regulación y autorización de las grandes superficies comerciales. La coordinación de los transportes de viajeros y su infraestructura.

La ordenación del tráfico de vehículos en las vías urbanas que afecten a varios municipios.

La prevención y extinción de incendios.

El tratamiento de la basura y el control de los vertidos, sin perjuicio de la competencia autonómica en la materia.

\section{Sección $4 .^{\mathrm{a}}$ \\ De la Hacienda \\ de las áreas metropolitanas}

Artículo 134. La hacienda del área metropolitana estará constituida por los siguientes recursos:

a. Los ingresos procedentes de su patrimonio y demás de derecho privado.

b. Las aportaciones de los municipios integrados en el área metropolitana.

c. Las subvenciones y auxilios concedidos por otras Administraciones Públicas.

d. Los cánones por la utilización de bienes públicos o las tasas y precios públicos por la prestación de servicios.

e. El producto de las operaciones de crédito.

f. Las donaciones de entidades particulares.

g. Cualesquiera otros que le corresponda percibir de acuerdo con las leyes.

\section{Capitulo II \\ DE LAS MANCOMUNIDADES DE MUNICIPIOS}

Artículo 135. 1. Los municipios de la Comunidad Autónoma de Galicia tendrán derecho a asociarse en mancomunidades para la ejecución o prestación, en común, de obras, servicios y actividades de su competencia.

2. El objeto de la mancomunidad deberá ser determinado y no podrá asumir todas las competencias de los municipios asociados.

Artículo 136. 1. La Xunta de Galicia, a través de la consellería competente en materia de régimen local:

a. Prestará cuanta asistencia técnica y jurídica sea necesaria para la constitución y funcionamiento de una mancomunidad.

b. Consignará en el proyecto de presupuestos una partida destinada al fomento y ayuda de las mancomunidades municipales estimulando el régimen asociativo.

2. Las ayudas a que se refiere la letra b) del apartado anterior serán compatibles con otras que, en función de la naturaleza de la obra o servicio objeto de la mancomunidad, pudiesen ser otorgadas por la propia Comunidad Autónoma.

3. La prestación mancomunada de los servicios municipales o, en su caso, la realización de obras del mismo modo será un criterio a considerar favorablemente a la hora de otorgar cualquier tipo de ayuda o subvención por parte de la Xunta de Galicia.

\section{Sección $1 .^{\mathrm{a}}$}

Del procedimiento de constitución y disolución de las mancomunidades de municipios

Artículo 137. La iniciativa para la constitución de una mancomunidad podrá partir de uno o varios de los municipios interesados.

Artículo 138. 1. Los expedientes para la constitución de mancomunidades municipales, así como para la elaboración y subsiguiente aprobación de sus estatutos, se iniciarán con los acuerdos de los Ayuntamientos promotores, que serán adoptados 
por la mayoría absoluta del número legal de miembros de las Corporaciones.

2. Mediante tales acuerdos cada Ayuntamiento designará un representante de la Corporación que pasará a formar parte de la Comisión Gestora, que ostentará la representación del grupo de municipios hasta la definitiva constitución de los órganos de gobierno de la mancomunidad y que se encargará de la tramitación del correspondiente expediente.

3. De entre los miembros de la Comisión Gestora se elegirá un Presidente y actuará como Secretario el del Ayuntamiento a que pertenezca dicho Presidente.

Artículo 139. La elaboración de los estatutos, cuyo contenido mínimo será el que se señala en el artículo 142 de la presente ley, será competencia de la Comisión Gestora, que los aprobará inicialmente, y su aprobación provisional corresponderá a una asamblea integrada por todos los Concejales de los Ayuntamientos interesados. Esta asamblea será convocada por el Presidente de la Comisión Gestora, y para su válida constitución requerirá la asistencia, al menos, de la mayoría absoluta de los miembros de derecho de la misma, siendo necesaria la presencia, como mínimo, de un representante de cada municipio.

Artículo 140. 1. El proyecto de estatutos, una vez aprobado, será sometido, por plazo de un mes, a informe de la Diputación o Diputaciones Provinciales interesadas, se entenderá favorable si en dicho plazo no hubiese sido emitido y se expondrá a información pública por período de un mes para que sean presentadas, por parte de los interesados, las observaciones o sugerencias que estimen precisas.

2. Finalizado el plazo de información pública y antes de la aprobación definitiva, serán remitidos los estatutos, junto con la resolución de las reclamaciones que hubiesen sido presentadas, a la consellería competente en materia de régimen local para su informe, y ésta podrá formular las observaciones de legalidad, así como las sugerencias y propuestas que considere convenientes.

3. Si del informe a que se refiere el párrafo anterior resultasen modificaciones del proyecto de estatutos provisionalmente aprobado, se someterán las mismas a la consideración de la Comisión Gestora, que, de no aceptarlas, estará obligada a la convocatoria de la asamblea de Concejales para una nueva discusión de las mismas. Tras esta nueva reunión de la asamblea se decidirá si se continúa o no con el procedimiento hasta la aprobación definitiva de los estatutos y la constitución de la mancomunidad.

Artículo 141. 1. Comunicada por el Presidente a la Comisión Gestora la emisión de los informes por parte de la Diputación o Diputaciones Provinciales interesadas o por la consellería competente en materia de régimen local, o transcurrido el plazo legal para ello sin que los mismos hubiesen sido emitidos, los plenos de todos los Ayuntamientos aprobarán, en el plazo de dos meses, los estatutos. Los acuerdos requerirán el voto favorable de la mayoría absoluta del número legal de los miembros de cada una de las Corporaciones.

En el acuerdo de aprobación se designarán los representantes legales de cada Ayuntamiento en la mancomunidad, en el número y condiciones previstas en los estatutos y teniendo en cuenta el pluralismo político existente en las Corporaciones Locales.

2. El Presidente de la Comisión Gestora remitirá copia certificada de los acuerdos de aprobación definitiva de los estatutos y de la constitución de la mancomunidad de municipios a la consellería competente en materia de régimen local, para su íntegra publicación en el "Diario Oficial de Galicia".

3. Dentro del mes siguiente al de la publicación de los estatutos, el Alcalde del municipio en que radique la sede de la mancomunidad convocará a todos los representantes de los municipios mancomunados, 


\section{Administración Local}

al objeto de elegir a los órganos rectores e iniciar el funcionamiento de la misma.

4. El Presidente de la mancomunidad comunicará a la Administración Central del Estado y a la Xunta de Galicia la constitución de la nueva Entidad Local a los efectos de su inscripción en los Registros estatal y autonómico de Entidades Locales.

Artículo 142. 1. La organización y funcionamiento de las mancomunidades se regirá por lo establecido en sus propios estatutos, que se aprobarán de conformidad con las prescripciones de la presente ley y que, en todo caso, deberán contener:

a. Los municipios que la integran.

b. El objeto y fines de la mancomunidad.

c. La denominación y el lugar donde radique la sede de la mancomunidad.

d. Los órganos de gobierno, el número y forma de designación de los representantes de los municipios asociados y la forma de nombrar y revocar a los administradores.

e. Los recursos financieros, las aportaciones y compromisos y los derechos y deberes de los municipios asociados.

f. El plazo de duración y los supuestos de disolución.

g. Las normas de funcionamiento.

h. La forma de liquidación.

i. Las relaciones con los municipios interesados.

2. Los órganos de gobierno de la mancomunidad serán representativos de los Ayuntamientos que la integran, debiendo existir, en todo caso, la figura del Presidente y del Pleno de la mancomunidad.

Artículo 143. 1. La modificación de los estatutos de la mancomunidad o la disolución de la Entidad Local se ajustará al siguiente procedimiento:

a. La iniciativa corresponderá al Pleno de la mancomunidad, de oficio o a instancia de los Ayuntamientos que la constituyen.

b. Adoptado el acuerdo, se someterá a información pública por plazo de un mes y, simultáneamente, se remitirá a la
Diputación o Diputaciones Provinciales respectivas y a la consellería competente en materia de régimen local para su informe, por plazo de un mes.

c. Finalizado el plazo de exposición pública y recibidos los informes a que se refiere el apartado anterior o transcurrido el plazo de un mes sin que hubiesen sido emitidos, se someterá el acuerdo de modificación de los estatutos o de disolución de la mancomunidad a los plenos de los Ayuntamientos mancomunados. La adopción de dicho acuerdo, que resolverá también las alegaciones, en caso de que éstas hubiesen sido presentadas, requerirá el voto favorable de la mayoría absoluta del número legal de miembros de cada una de las Corporaciones.

d. Aprobados los acuerdos de modificación de los estatutos de la mancomunidad o de disolución de la misma por la mayoría de los Ayuntamientos mancomunados, el Presidente de la mancomunidad remitirá copia certificada de los mismos a la consellería competente en materia de régimen local, para su íntegra publicación en el "Diario Oficial de Galicia", y los comunicará a la Administración Central del Estado a los efectos establecidos por la legislación básica de régimen local.

2. Toda incorporación o separación de miembros de una mancomunidad conllevará, necesariamente, la modificación de sus estatutos.

3. En caso de que un municipio decida unilateralmente separarse de la mancomunidad, lo manifestará con un año de antelación, sin dejar de cumplir con los compromisos contraídos en ese plazo.

Artículo 144. En caso de disolución de una mancomunidad, la misma mantendrá su personalidad jurídica en tanto no sea adoptado por el Pleno el acuerdo de liquidación y distribución de su patrimonio, el cual se publicará en el "Diario Oficial de Galicia”, junto con el de disolución. 


\section{Sección 2. ${ }^{\text {a }}$}

De la organización de las mancomunidades de municipios

Artículo 145. 1. Los órganos de gobierno o juntas de mancomunidad estarán integrados por un Presidente, un Vicepresidente que lo sustituya en sus ausencias y el número de Vocales que señalen los estatutos.

2. Los estatutos de la mancomunidad podrán prever, además, la existencia de otros órganos complementarios, ya sean de carácter activo, como la Comisión de Gobierno, o consultivo, como las comisiones informativas, de especial interés cuando sean múltiples los servicios asumidos y gestionados.

Artículo 146. 1. En la Junta de la mancomunidad o asamblea estarán representados, en la proporción que se establezca en los estatutos de la mancomunidad, todos los municipios que la integren.

2. La designación del Presidente y del Vicepresidente concernirá a la Junta de mancomunidad o asamblea, y, si nada dicen los estatutos, la elección se realizará en sesión extraordinaria y por mayoría absoluta de votos.

3. El cargo de Secretario o SecretarioInterventor, así como los de InterventorTesorero, si existiesen, tendrán que ser ejercidos por funcionarios con habilitación de carácter nacional.

\section{Sección 3. ${ }^{\mathrm{a}}$}

De las competencias de las mancomunidades de municipios

Artículo 147. Son competencias de las mancomunidades de municipios:

a. La administración y defensa de su patrimonio.

b. La ejecución de obras y prestación parcial o integral de servicios de su interés.

c. Aquellas otras que les sean delegadas o encomendadas por otras Administraciones Públicas.

\section{Sección $4 .^{\mathrm{a}}$}

De la hacienda de las mancomunidades de municipios

Artículo 148. 1. Las mancomunidades de municipios contarán con una hacienda propia integrada por:

a. Las tasas.

b. Los precios públicos.

c. Las contribuciones especiales.

d. Las aportaciones municipales.

e. Los ingresos procedentes de su patrimonio y demás de derecho privado.

f. Las subvenciones.

g. El producto de operaciones de crédito.

h. El producto de multas y sanciones en el ámbito de su competencia.

2. Los Ayuntamientos mancomunados consignarán en sus presupuestos las cantidades precisas para atender, en los sucesivos ejercicios económicos, las obligaciones derivadas de los compromisos contraídos con la mancomunidad a que pertenezcan. Transcurrido el plazo para el ingreso de las aportaciones de los municipios que integran la mancomunidad, su Presidente podrá dirigirse a la Comunidad Autónoma para la retención de los fondos del municipio deudor y su ingreso en la hacienda de la mancomunidad.

\section{Capitulo III DE LOS CONSORCIOS LOCALES}

Artículo 149. 1. Las Entidades Locales gallegas podrán, con carácter voluntario, constituir consorcios locales entre sí o:

a. Con otras Administraciones Públicas para fines de interés común.

b. Con entidades privadas sin ánimo de lucro que persigan fines de interés público concurrentes con los de las Administraciones Públicas. En este caso en todos los órganos de los que se dote al consorcio deberá garantizarse la presencia mayoritaria del sector público.

2. Los consorcios locales son Entidades Locales dotadas de personalidad jurídica propia y capacidad para el cumplimiento 


\section{Administración Local}

de sus fines específicos, que vendrán definidos en sus respectivos estatutos.

3. Para la gestión de los servicios de su competencia, los consorcios podrán utilizar cualesquiera de las formas previstas en la legislación básica de régimen local y en la presente ley.

Artículo 150. 1. La iniciativa para la constitución de un consorcio local podrá partir de uno o varios Entes Locales interesados.

2. Los expedientes para la constitución de consorcios locales, así como para la elaboración y subsiguiente aprobación de sus estatutos, se iniciarán con los acuerdos de las Entidades Locales promotoras, que deberán ser adoptados por la mayoría absoluta del número legal de miembros de las Corporaciones.

3. Mediante dichos acuerdos cada Entidad Local designará un representante de la Corporación que pasará a formar parte de la Comisión Gestora, que tendrá la representación del grupo de entidades hasta la definitiva constitución de los órganos de gobierno del consorcio, que estarán integrados por representantes de todas las entidades consorciadas en la proporción que se fije en los respectivos Estatutos, y que se encargará de la tramitación del correspondiente expediente y de la elaboración del proyecto de Estatutos.

Artículo 151. 1. Para la elaboración de los Estatutos y para la creación de consorcios locales se seguirán las mismas reglas y el mismo procedimiento que se ha establecido para las mancomunidades de municipios en la legislación estatal básica y en los artículos 137 y siguientes de la presente ley.

2. Del mismo modo, para la modificación de los Estatutos del consorcio local, así como para la disolución del mismo, se seguirán las mismas reglas y el mismo procedimiento que el establecido por la legislación estatal básica y por los artículos 143 y 144 de la presente ley para la modificación de los Estatutos o disolución de las mancomunidades de municipios.

Artículo 152. La Xunta de Galicia, a través de la consellería competente en materia de régimen local:

a. Prestará cuanta asistencia técnica y jurídica sea necesaria para la constitución y funcionamiento de los consorcios locales.

b. Podrá conceder subvenciones a fondo perdido a la constitución de consorcios locales para la prestación de los servicios municipales o, en su caso, realización de obras del mismo carácter.

\section{Capítulo IV \\ DE LAS ENTIDADES LOCALES MENORES}

Artículo 153. 1. Los núcleos de población separados geográficamente del que tenga la condición de capitalidad del municipio y con características peculiares propias podrán constituirse en Entidades Locales Menores, para la gestión descentralizada de sus intereses peculiares, siempre que:

a. Se acredite la posesión de recursos suficientes para tal gestión y el adecuado ejercicio de sus competencias.

b. $\mathrm{Su}$ constitución no suponga una notable disminución de la capacidad económica del municipio, que impida el normal cumplimiento de sus obligaciones o menoscabe la calidad de los servicios que viniese prestando.

2. No podrá constituirse en Entidad Local Menor el núcleo territorial en que radique la capitalidad del municipio.

\section{Sección $1 .^{a}$}

Del procedimiento de constitución y disolución de las Entidades Locales Menores

Artículo 154. 1. La iniciativa para la constitución de una Entidad Local Menor corresponde indistintamente a:

a. Los dos tercios de los vecinos del núcleo de población que pretende su constitución en Entidad Local Menor. 
b. El Ayuntamiento, que adoptará el acuerdo con el voto favorable de las dos terceras partes del número de hecho de la Corporación y, en todo caso, de la mayoría absoluta del número legal de los miembros de la misma.

2. El Ayuntamiento someterá la iniciativa a información pública por plazo de un mes.

3. Transcurrido el plazo de exposición al público, el Ayuntamiento remitirá a la consellería competente en materia de régimen local el expediente, en el que deberán constar, como mínimo:

a. Los motivos de la iniciativa y la imposibilidad de recurrir a otros mecanismos que permitan la participación para la defensa de sus intereses en una gestión descentralizada.

b. En caso de haberse presentado alegaciones, certificación expedida por el Secretario de la Corporación relativa al acuerdo de resolución de las mismas, que deberá ser adoptado con el voto favorable de las dos terceras partes del número de hecho y, en todo caso, de la mayoría absoluta del número legal de miembros de la Corporación.

c. Informe económico-financiero sobre la viabilidad de la Entidad Local Menor, con expresión de los ingresos, debidamente justificados, que integrarán su presupuesto y del importe previsto de gastos.

d. Informe del Ayuntamiento correspondiente.

4. La consellería competente en materia de régimen local requerirá el informe de la Diputación Provincial correspondiente.

5. El Consello de la Xunta de Galicia aprobará, mediante Decreto y a propuesta del conselleiro competente en materia de régimen local, la constitución de la Entidad Local Menor, que será comunicada a la Administración Central del Estado a los efectos de su inscripción en el Registro Estatal de Entidades Locales. El Decreto se publicará en el "Diario Oficial de Galicia" y en el "Boletín Oficial" de la Provincia respectiva.
Artículo 155. 1. Constituida la Entidad Local Menor, se establecerán sus límites territoriales y se hará su segregación patrimonial por acuerdo del Ayuntamiento y previa propuesta de la Junta Vecinal.

2. El acuerdo municipal en esta materia requerirá la ratificación del Consello de la Xunta de Galicia, a propuesta del conselleiro competente en materia de régimen local.

Artículo 156. Procederá la disolución de una Entidad Local Menor cuando se aprecie la insuficiencia de sus recursos o la incapacidad para el ejercicio de sus competencias.

Artículo 157. El procedimiento para la disolución se ajustará a las siguientes reglas:

$1{ }^{a}$ La iniciativa corresponderá indistintamente:

a. Al Ayuntamiento, que adoptará el acuerdo con el voto favorable de las dos terceras partes del número de hecho de la Corporación y, en todo caso, de la mayoría absoluta del número legal de los miembros de la misma.

b. A la Junta Vecinal, mediante acuerdo adoptado por mayoría de dos tercios.

c. A la consellería competente en materia de régimen local, por apreciación de las circunstancias a que se refiere el artículo anterior.

2. ${ }^{a}$ En caso de que la iniciativa proceda del Ayuntamiento o de la Junta Vecinal, se someterá el expediente a información pública por plazo de un mes, transcurrido el cual será remitido a la consellería competente en materia de régimen local, acompañado de la certificación expedida por el Secretario general de la Corporación acreditativa del acuerdo relativo a la estimación o desestimación de las reclamaciones, si éstas hubiesen sido presentadas.

En caso de que la iniciativa proceda de la consellería competente en materia de régimen local, se dará audiencia previa a la Entidad Local Menor y al Ayuntamiento interesado. 


\section{Administración Local}

3. Se requerirá informe a la Diputación Provincial correspondiente, que lo emitirá en el plazo de un mes, y se entenderá favorable si, transcurrido el mismo, no hubiese sido emitido.

4. ${ }^{\text {a }}$ La resolución definitiva, mediante Decreto y a propuesta del conselleiro competente en materia de Régimen Local, corresponde al Consello de la Xunta de Galicia. El Decreto se publicará en el "Diario Oficial de Galicia" y en el "Boletín Oficial" de la respectiva provincia. Se comunicará, además, a la Administración Central, a los efectos de la inscripción de la Entidad Local Menor en el Registro Estatal de Entidades Locales.

\section{Sección 2. ${ }^{\mathrm{a}}$}

De la organización de las Entidades Locales Menores

Artículo 158. 1. Las entidades locales menores contarán con un Alcalde pedáneo, una Junta Vecinal y los otros órganos complementarios de que puedan dotarse con arreglo a su Reglamento orgánico.

2. La Junta Vecinal estará formada por el Alcalde pedáneo, que la presidirá, y por un número de Vocales que no superará el tercio del de Concejales que integren el Ayuntamiento.

3. El Alcalde pedáneo será elegido directamente por los vecinos de la correspondiente entidad local menor, por sistema mayoritario, mediante la presentación de candidatos por los distintos partidos, federaciones, coaliciones o agrupaciones de electores, coincidiendo con las elecciones locales.

4. La designación de los Vocales de la Junta Vecinal se hará de conformidad con los resultados de las elecciones para el Ayuntamiento, en la sección o secciones constitutivas de la Entidad Local Menor, según lo dispuesto en la legislación electoral general.

Artículo 159. 1. El Presidente o Alcalde pedáneo y la Junta Vecinal tendrán las atribuciones que la legislación señale para el Alcalde y el Pleno, respectivamente, circunscritas al área de sus competencias territoriales y de gestión.

2. La Junta Vecinal, órgano colegiado de gobierno, tiene las siguientes atribuciones:

a. La aprobación de los presupuestos, de las ordenanzas y de los acuerdos de establecimiento y modificación de servicios.

b. La administración del patrimonio y la adquisición, enajenación y cesión de bienes.

c. El control y fiscalización de las actuaciones del Alcalde-Presidente y de la gestión económica.

d. En general, cuantas le asigne la Ley o el Pleno del Ayuntamiento con respecto a su administración en el ámbito de la Entidad.

3. El régimen de funcionamiento se ajustará a lo que disponga su propio Reglamento orgánico, si lo hubiese, o a las disposiciones generales que rigen para los Ayuntamientos.

Artículo 160. El Alcalde pedáneo designará, de entre los Vocales de la Junta Vecinal, quien deba sustituirle en los casos de vacante por ausencia o enfermedad.

Artículo 161. 1. En la Entidad de nueva creación y hasta tanto se celebren elecciones locales, el gobierno y administración se encomendará a una Comisión Gestora, integrada por tres miembros, que serán nombrados por la Diputación Provincial respectiva de conformidad con el resultado de las elecciones en la sección o secciones correspondientes, a propuesta de los partidos políticos con representación en el Ayuntamiento.

2. Después de los diez días naturales de su designación, deberá constituirse la Comisión Gestora y elegir de entre sus miembros al Presidente, fijándose la hora de la constitución en la orden de nombramiento.

3. En caso de empate, será Presidente el Vocal de la lista más votada en la sección correspondiente.

Artículo 162. Un miembro de la Junta Vecinal tendrá derecho a asistir, con voz pero sin voto en el punto del orden del 
día correspondiente, a las comisiones informativas existentes en el Ayuntamiento, siempre que en las mismas vaya a determinarse algún asunto que afecte a la Entidad Local Menor.

Para el ejercicio de este derecho, deberá ser citado a la Comisión de referencia, como un miembro más de la misma.

\section{Sección $3 .^{a}$}

De las competencias de las Entidades Locales Menores

Artículo 163. 1. Son competencias de las Entidades Locales Menores:

a. La administración y defensa de su patrimonio.

b. La ejecución de obras y prestación de servicios de su interés, siempre y cuando sean realizados con fondos propios y no estén a cargo del respectivo Ayuntamiento u otra Entidad supramunicipal.

c. La vigilancia, mantenimiento y limpieza de las vías urbanas, caminos rurales, montes, fuentes y lavaderos.

d. Aquellas otras que le delegue el municipio, previa aceptación por la Entidad, y con la asignación de los recursos que sean necesarios para su ejercicio.

2. La Comunidad Autónoma, las Diputaciones Provinciales y los Ayuntamientos podrán prestar la asistencia técnica jurídica y económica precisa para que las Entidades Locales de ámbito territorial inferior al municipal puedan hacer efectivas sus competencias con la mayor economía y evitando la duplicidad de servicios.

\section{Sección $4 .^{\mathrm{a}}$}

De la hacienda de las

\section{Entidades Locales Menores}

Artículo 164. 1. La hacienda de las Entidades Locales Menores estará constituida por los siguientes recursos:

a. Los ingresos procedentes de su patrimonio y demás de derecho privado.

b. Las tasas y precios públicos.

c. Las contribuciones especiales.

d. Los ingresos procedentes de operaciones de crédito. e. El producto de multas y sanciones en el ámbito de su competencia.

f. La participación en los impuestos del Ayuntamiento a que se refiere la legislación sobre haciendas locales en la cuantía que se establezca en el Decreto de Creación. Esta participación no será, en ningún caso, inferior al 25 por 100 de los que se devenguen en el ámbito territorial de la Entidad.

g. Las donaciones, herencias, legados y cesiones aceptadas por la Entidad.

h. Los procedentes de aportaciones de otras entidades públicas supramunicipales, con carácter finalista por la participación en proyectos de actuación e inversiones generales.

i. Cualesquiera otros ingresos de derecho público que la Ley pudiese atribuirles.

2. No obstante lo establecido en el apartado anterior estas entidades deberán contribuir al pago de las cargas generales del Ayuntamiento, en la proporción que se establezca en el Decreto de Creación de las mismas.

\section{Capitulo V \\ DE LAS AGRUPACIONES DE MUNICIPIOS}

\section{Sección $1 .^{\mathrm{a}}$}

De las agrupaciones voluntarias

Artículo 165. 1. Los municipios que, por insuficiencia de recursos económicos, no puedan sostener las plazas reservadas a funcionarios con habilitación de carácter nacional podrán agruparse entre sí a los solos efectos del sostenimiento en común de dicho personal.

2. Las Entidades Locales podrán agruparse, asimismo, al objeto de sostener en común una sola plaza de funcionario técnico de administración especial de personal auxiliar de administración general, su capacidad económica no les permita sostenerla por sí solas.

3. La consellería competente en materia de régimen local prestará especial asesoramiento y apoyo a creación y funcionamiento de este tipo de agrupaciones 


\section{Administración Local}

de municipios, pudiendo serles concedido subvenciones hasta un máximo del 50 por 100 de los costes del personal por el tiempo que establezca y para cuyo sostenimiento se hubiese constituido.

4. Las plazas no se designarán en tanto no estén agrupadas.

Artículo 166. El funcionamiento de estas agrupaciones se regulará por unos estatutos que, al efecto, serán redactados por una Comisión integrada por representantes de municipios afectados, designados por los plenos los mismos. En dichos estatutos se fijará, necesariamente, la participación económica de cada Ayuntamiento, así como el régimen de dedicación del personal a cada uno de ellos.

Artículo 167. El procedimiento de constitución y disolución de estas agrupaciones municipales se ajustará a las siguientes reglas:

a. Iniciación por acuerdo de las Corporaciones Locales interesadas, adoptado por mayoría simple.

b. Sometimiento del expediente a información pública durante el plazo de un mes.

c. Informe de la Delegación del Gobierno de la Comunidad Autónoma Gallega y de la Diputación o Diputaciones Provinciales respectivas. Tales informes deberán ser emitidos en el plazo de un mes a partir de su solicitud, y se entenderán favorables en el caso de no recibirse en el referido plazo.

d. Aprobación definitiva por acuerdo de los Ayuntamientos, que será adoptado con el voto favorable de la mayoría absoluta del número legal de miembros de la Corporación.

e. Remisión del expediente a la consellería competente en materia de régimen local. Formarán parte de este expediente, entre otros:

$1^{\circ}$. Las certificaciones expedidas por los Secretarios de cada Ayuntamiento relativas a los acuerdos a que se refieren los apartados anteriores de este mismo artículo.

$2^{\circ}$.Los informes a que se refiere el apartado señalado con la letra c) de este mismo artículo. $3^{\circ}$. El proyecto de estatutos a que se refiere el artículo 166 de la presente ley.

$4^{\circ}$. Las certificaciones expedidas por los Secretarios de cada Ayuntamiento relativas a la población y presupuestos municipales ordinarios y, en su caso, a la clasificación de la plaza.

Vistos los acuerdos, informes y certificaciones a que se refiere este apartado, la consellería competente en materia de régimen local elevará propuesta de resolución al Consello de la Xunta de Galicia, el cual resolverá.

f. Publicación del Decreto por el que se constituye la agrupación voluntaria de municipios en el "Diario Oficial de Galicia" y en el boletín o boletines oficiales de las respectivas provincias.

g. La constitución de la agrupación será comunicada por la consellería competente en materia de régimen local, a la Administración Central del Estado.

\section{Sección 2.}

\section{De las agrupaciones forzosas}

Artículo 168. 1. El Consello de la Xunta de Galicia deberá acordar la agrupación de aquellos municipios cuya población y recursos ordinarios no superen las cifras que determine la Administración Central del Estado, al objeto de sostener en común un puesto único de Secretario.

2. Asimismo, deberá acordar la agrupación de municipios cuyas Secretarías estén catalogadas como de segunda o de tercera clase, a fin de sostener en común un puesto único de Interventor.

Artículo 169. La constitución de las agrupaciones de municipios a que se refiere el artículo anterior se ajustará al procedimiento siguiente:

a. Iniciación del expediente de oficio por la Xunta de Galicia, dándose audiencia a las Corporaciones Locales afectadas por plazo de un mes.

b. Sometimiento del expediente a información pública durante el plazo de un mes.

c. Resolución del expediente por el Consello de la Xunta de Galicia, a propuesta 
del conselleiro competente en materia de régimen local.

d. Publicación en el "Diario Oficial de Galicia" y en el boletín o boletines oficiales de las respectivas provincias del Decreto de constitución de la agrupación de municipios y remisión del mismo a la Administración Central del Estado.

Artículo 170. En el acuerdo por el que se apruebe la constitución de la agrupación forzosa de municipios para el sostenimiento en común de plazas de funcionarios con habilitación de carácter nacional se determinarán los municipios que deban agruparse y las normas mínimas por las que deberá regirse la agrupación, que podrán ser desarrolladas por acuerdo conjunto de los municipios afectados.

La Xunta de Galicia, atendiendo a cada caso concreto, podrá fijarse una aportación para la atención de esta obligación.

\section{TíTULO IV \\ DE LA TRANSFERENCIA Y \\ DELEGACIÓN DE COMPETENCIAS DE LA COMUNIDAD AUTÓNOMA EN LAS ENTIDADES LOCALES Y DE LA ENCOMIENDA DE GESTIÓN}

\section{Capítulo I \\ DISPOSICIONES GENERALES}

Artículo 171. 1. Con arreglo a la legislación básica del Estado en materia de régimen local y en el marco de la presente ley, las leyes del Parlamento de Galicia reguladoras de los distintos sectores de la acción pública efectuarán la redistribución de las competencias entre la Administración de la Comunidad Autónoma y las entidades locales.

Para hacerla efectiva deberán existir unas circunstancias de índole técnica, económica, social, jurídica o territorial que lo hagan conveniente y, además, garantizar una más eficaz prestación de los servicios.

2. El procedimiento de transferencias se ajustará a lo establecido en los artículos siguientes y las competencias transferidas se convertirán en propias de las Entidades Locales.

Artículo 172. 1. Del mismo modo, la Xunta de Galicia podrá delegar en las Entidades Locales competencias propias siempre que:

a. Se trate de competencias en materias que afecten a los intereses propios de las Entidades Locales.

b. Con la delegación se mejore la eficacia de gestión pública.

c. Se alcance una mayor participación ciudadana.

2. La delegación no supondrá la asunción de titularidad de las competencias delegadas por las entidades locales beneficiarias de la delegación.

3. Para hacer efectiva la delegación de competencia la Administración autonómica tendrá en cuenta la naturaleza y grado de homogeneidad de las competencias y las Entidades Locales destinatarias para que, reuniendo las mismas circunstancias objetivas, puedan asumir su ejercicio en condiciones de igualdad.

Artículo 173. 1. Asimismo, por razones de eficacia o cuando la Xunta de Galicia carezca de los medios técnicos adecuados para su ejercicio, podrá encomendar la realización de actividades de carácter material, técnico o de servicios de su competencia a las Diputaciones Provinciales o a los municipios que sean capital de provincia o cuenten con una población superior a 70.000 habitantes, actuando éstos con sujeción plena a las instrucciones generales y particulares que a tal efecto dicte la Xunta de Galicia.

2. La encomienda de gestión no supondrá la cesión de la titularidad de la competencia, ni de los elementos sustantivos de su ejercicio, siendo responsabilidad del Consello de la Xunta de Galicia dictar cuantos actos o resoluciones de carácter jurídico den soporte o en los que se integre la concreta actividad material objeto de encomienda. 
Artículo 174. 1. En caso de que se transfieran o deleguen competencias en las Diputaciones Provinciales o se les encomiende la gestión de servicios propios de la Comunidad Autónoma, la transferencia, delegación o encomienda de gestión se efectuará, siempre, para la totalidad de las Diputaciones Provinciales comprendidas en el ámbito territorial de la Comunidad Autónoma de Galicia.

2. La Comunidad Autónoma podrá realizar la transferencia o delegación de competencias en favor de uno o varios municipios agrupados entre sí y exigirá que éstos cuenten con capacidad de gestión y medios técnicos suficientes, sin que de ello pueda derivarse trato discriminatorio entre los diferentes municipios gallegos.

3. La encomienda de gestión sólo podrá realizarse en favor de alguna de las Entidades Locales a que se refiere el artículo 173.1 de la presente ley.

Artículo 175. La transferencia o delegación de competencias de la Comunidad Autónoma en las Entidades Locales, así como la encomienda de gestión, tendrán que ser previamente aceptadas por éstas.

Artículo 176. Será requisito imprescindible para que se inicien los procedimientos de transferencia y delegación que las competencias que puedan ser transferidas o delegadas vayan a ejecutarse íntegramente en la circunscripción de la Entidad Local.

Artículo 177. El procedimiento para llevar a efecto la transferencia o delegación será iniciado de oficio por la Xunta de Galicia o a petición razonada de la Entidad o Entidades Locales interesadas o de las asociaciones de municipios más representativas de la Comunidad Autónoma.

Artículo 178. La transferencia o delegación deberá conllevar la de los medios financieros y económicos y, en su caso, personales precisos en favor de las Entidades Locales beneficiarias y fomentará la constitución de mancomunidades o agrupaciones de municipios en los casos en que fuese precisa o conveniente su constitución.

\section{Capitulo II \\ DE LA TRANSFERENCIA}

Artículo 179. 1. La transferencia de la titularidad de competencias en favor de las Entidades Locales se realizará mediante Ley sectorial del Parlamento de Galicia, que establecerá el procedimiento para llevarla a cabo, así como los medios y servicios necesarios para su ejercicio.

En la misma Ley se determinarán los supuestos en que sea posible solicitar la revocación, su procedimiento y los titulares legitimados.

2. Esta transferencia de medios y servicios, salvo lo que disponga la propia Ley sectorial, será propuesta al Consello de la Xunta de Galicia por las comisiones sectoriales que se constituyan, que estarán integradas por un número igual de representantes de la Entidad Local receptora y de la Administración de la Comunidad Autónoma. El número total de representantes no superará el de 10.

La Comisión será presidida por el conselleiro competente en materia de régimen local, formando parte de la misma, siempre, el conselleiro competente en la materia objeto de transferencia y un representante de la Consellería de Economía e Facenda.

Las propuestas de las comisiones contendrán:

a. Relación de las competencias y servicios que se transfieren, así como de los que se reserva la Comunidad Autónoma.

b. Referencia a las normas legales que justifican la transferencia.

c. Medios personales, materiales y financieros que se traspasan, con su valoración y, en su caso, el procedimiento de revisión. Tal valoración se realizará con referencia al 31 de diciembre del año anterior al que se realice la propuesta.

d. Valoración del coste efectivo del servicio, teniendo en cuenta que, cuando se 
traspasen servicios cuya prestación esté gravada con tasas o reporte ingresos de derecho privado, su importe minorará la valoración del coste efectivo del servicio transferido. Se entiende por coste efectivo el que corresponda al gasto corriente, así como, en su caso, al gasto de inversión nueva y de reposición y a las subvenciones condicionadas ${ }^{132}$.

e. Referencia a la documentación administrativa relativa al servicio o competencia transferida.

f. Fecha de efectividad de la transferencia.

3. Elaboradas por consenso de ambas representaciones las propuestas de transferencia por las comisiones a que se refiere el apartado 2 de este mismo artículo, se solicitará, antes de su elevación al Consello de la Xunta de Galicia, informe de la Comisión Galega de Cooperación Local.

Artículo 180. Los recursos económicos precisos para cubrir el coste efectivo del servicio transferido tendrán carácter de recursos propios de la Entidad Local que reciba la transferencia. Tales fondos serán librados por la Consellería de Economía e Facenda, mediante las correspondientes bajas presupuestarias.

Artículo 181. La transferencia podrá ser objeto de revocación, mediante Ley del Parlamento de Galicia. La iniciativa podrá partir de las asociaciones de municipios más representativas de la Comunidad Autónoma.

\section{Capítulo III DE LA DELEGACIÓN}

Artículo 182. 1. La delegación de competencias de la Comunidad Autónoma en favor de las Entidades Locales se realizará mediante Decreto del Consello de la Xunta de Galicia.

2. Para la fijación de los términos de la delegación se constituirá una Comisión

132 Art. 179. 2. d modificado por Ley 8/1999, de 30 de diciembre, de medidas fiscales y presupuestarias y de función pública y actuación administrativa.
Mixta, integrada por tres representantes de la Comunidad Autónoma y tres de las Entidades Locales receptoras de la delegación. Así, formarán parte de esta Comisión Mixta:

a. Por parte de la Administración autonómica, el conselleiro competente en materia de régimen local, que, a su vez, presidirá la Comisión, el Conselleiro de Economía y Hacienda y el conselleiro responsable de la materia o materias objeto de la delegación.

b. Por parte de la Entidad Local beneficiaria de la delegación, el Alcalde o Presidente de la Corporación y dos miembros de la misma designados por el Pleno.

3. La delegación de competencias requerirá aceptación expresa por parte de las Entidades Locales receptoras. Tal aceptación se formulará y remitirá con carácter previo a la deliberación del Consello de la Xunta de Galicia. Además, con carácter previo a dicha deliberación, la Comisión Mixta a que se refiere el apartado 2 de este mismo artículo solicitará informe de la Comisión Galega de Cooperación Local.

4. El Decreto de Delegación se publicará en el "Diario Oficial de Galicia" y en el "Boletín Oficial del Estado" y deberá referirse, entre otros, a los siguientes extremos:

a. Competencias cuya ejecución se delega.

b. Referencia a las normas legales que justifican la delegación.

c. Medios materiales, financieros y, en su caso, personales que se ponen a disposición, así como la valoración y el procedimiento de su revisión.

d. Valoración del coste efectivo de la prestación del servicio, teniendo en cuenta que, cuando se deleguen servicios cuya prestación esté gravada con tasas o reporte ingresos de derecho privado, su importe minorará la valoración del coste efectivo del servicio delegado. Se entiende por coste efectivo el que corresponda al gasto corriente, así como, en su caso, al gasto 


\section{Administración Local}

de inversión nueva y de reposición y a las subvenciones condicionadas ${ }^{133}$.

e. Referencia a la documentación administrativa relativa a la competencia o servicio cuya prestación se delega.

f. Fecha de efectividad de la delegación.

g. Duración de la delegación.

$\mathrm{h}$. Condiciones, instrucciones y directrices que formule la Xunta de Galicia, así como mecanismos de control y requerimientos que puedan ser formulados $y$ supuestos en que procederá la revocación de la delegación.

Artículo 183. Los recursos económicos precisos para cubrir el coste efectivo de la competencia delegada serán librados por la Consellería de Economía e Facenda, mediante las correspondientes bajas presupuestarias.

Artículo 184. 1. Los municipios y demás Entidades Locales que asuman por delegación el ejercicio de competencias propias de la Comunidad Autónoma vendrán obligados, en cuanto a las mismas, a:

a. Cumplir los programas y directrices que la Comunidad Autónoma pueda, en su caso, elaborar.

b. Proporcionar información sobre el funcionamiento de los servicios, así como atenerse a los requerimientos pertinentes para la subsanación de las deficiencias observadas por los órganos de asesoramiento de la Comunidad Autónoma.

c. Mantener el nivel de eficacia en la prestación de los servicios que, como mínimo, tenían antes de la delegación.

d. Cumplir los módulos de funcionamiento y los niveles de rendimiento mínimo que la Xunta de Galicia periódicamente les señale, para lo cual se facilitarán a la Entidad Local los medios financieros y, en su caso, personales y materiales que sean necesarios. Las Entidades Locales podrán mejorar estos módulos o niveles

133 Art. 182.4.d modificado por Ley 8/1999, de 30 de diciembre, de medidas fiscales y presupuestarias y de función pública y actuación administrativa. de rendimiento utilizando sus propias disponibilidades presupuestarias.

2. La Xunta de Galicia estará obligada a respetar la autonomía municipal en el ejercicio de la competencia delegada, en los términos previstos en artículo 182.4.h).

Artículo 185. 1. Si la Entidad Local incumpliese las obligaciones que se derivan del artículo anterior, el Consello de la Xunta de Galicia le advertirá formalmente de ello, y, si mantuviese su actitud, podrá ser revocada la delegación, reasumiendo la Comunidad Autónoma, previo informe de la Comisión Galega de Cooperación Local, el ejercicio de las correspondientes competencias.

2. Por razones de interés público, debidamente justificadas, el Consello de la Xunta de Galicia podrá declarar extinguida la delegación, revisar su contenido o avocar el ejercicio de las competencias que han sido delegadas.

3. El acuerdo de revocación o avocación se publicará en el "Diario Oficial de Galicia" y en el "Boletín Oficial del Estado".

\section{Capitulo IV \\ DE LA ENCOMIENDA DE GESTIÓN}

Artículo 186. 1. La encomienda de gestión de los servicios propios de la Comunidad Autónoma en favor de las Entidades Locales a que se refiere el artículo 174 de la presente ley se realizará mediante Decreto del Consello de la Xunta de Galicia, previo informe de la Comisión Galega de Cooperación Local, y se publicará en el "Diario Oficial de Galicia" y en el "Boletín Oficial" de la provincia respectiva.

2. El acuerdo será adoptado a propuesta de la Comisión Mixta a que se refiere el artículo 182.2 de la presente ley y concretará, al menos, la actividad o actividades a que afecte el plazo de vigencia, la naturaleza y alcance de la gestión encomendada y las facultades de dirección y control que se reserve la Xunta de Galicia. 
3. La efectividad de la encomienda requerirá que ésta vaya acompañada de la dotación o incremento, en favor de las Entidades Locales receptoras, de los medios económicos precisos para llevarla a cabo.

4. En caso de incumplimiento de las directrices y medidas a que se refiere el apartado 2 de este artículo, la Xunta de Galicia podrá, previa advertencia al Ente Local e informe de la Comisión Galega de Cooperación Local, suspender o dejar sin efecto la encomienda y realizar directamente las actividades de carácter material o técnico o la prestación de los servicios que hubiesen sido objeto de la misma.

\section{TÍTULO V RELACIONES \\ INTERADMINISTRATIVAS \\ Capitulo I \\ DISPOSICIONES GENERALES}

Artículo 187. Las Administraciones Públicas gallegas ajustarán sus relaciones a los principios de colaboración, cooperación, auxilio, coordinación y respeto a los correspondientes ámbitos competenciales, garantizándose la máxima eficacia en la gestión administrativa. Asimismo, la Xunta de Galicia ejercerá las funciones de coordinación que prevé el Estatuto de Autonomía de Galicia.

\section{Capítulo II \\ DE LA COMISIÓN GALEGA DE COOPERACIÓN LOCAL}

Artículo 188. La Comisión Galega de Cooperación Local se constituye en el órgano permanente de colaboración para la coordinación entre la Administración autonómica y las entidades locales gallegas.

Artículo 189. 1. La Comisión Galega de Cooperación Local estará integrada paritariamente por representantes de la Comunidad Autónoma y por representantes de las entidades locales gallegas.

El número total de componentes será de 24 :

a. La representación de la Comunidad Autónoma corresponderá al Presidente de la Xunta de Galicia, al conselleiro competente en materia de régimen local y a aquellos otros miembros que designe el Consello de la Xunta de Galicia.

b. Las entidades locales estarán representadas por los Presidentes de las cuatro Diputaciones Provinciales, por dos representantes de los municipios de hasta 5.000 habitantes, por dos representantes de los municipios de 5.001 hasta 20.000 habitantes, por dos representantes de los municipios de 20.001 hasta 50.000 habitantes y por dos representantes de los municipios de más de 50.000 habitantes. Dichos representantes serán designados por la asociación de municipios y provincias más representativa y con mayor implantación en el territorio de la Comunidad Autónoma de Galicia.

2. La presidencia de la Comisión Galega de Cooperación Local será desempeñada por el Presidente de la Xunta de Galicia.

Artículo 190. La Comisión Galega de Cooperación Local elaborará su Reglamento de organización y funcionamiento, y lo remitirá a la consellería competente en materia de régimen local, que lo elevará al Consello de la Xunta de Galicia para su aprobación 134 .

Artículo 191. La Comisión Galega de Cooperación Local podrá ejercer las funciones consultiva y deliberante en las siguientes materias:

a. Emitir informe sobre los anteproyectos de Ley, reglamentos y decretos que conciernan al régimen local.

b. Proponer medidas de asistencia y asesoramiento a los Ayuntamientos, especialmente a través del estudio, información y difusión de las materias que les afecten.

c. Informar de las necesidades e insuficiencias de los municipios gallegos en materia de servicios mínimos y proponer criterios generales para acordar la dispensa de su prestación.

\footnotetext{
134 Véase Decreto 280/1998, de 24 de septiembre, por el que se aprueba el Reglamento de organización y funcionamiento de la Comisión Galega de Coopera-
} ción Local. 
d. Velar por el cumplimiento de los principios de autonomía y suficiencia financiera de las entidades locales.

e. Estudiar y proponer las medidas que crea convenientes en relación con la situación económico-financiera de las entidades locales.

f. Proponer criterios de colaboración y coordinación para que las diferentes Administraciones Públicas ejerzan sus funciones de cooperación económica, técnica y administrativa.

g. Conocer y emitir informe sobre los acuerdos de las comisiones que se creen para la transferencia y delegación de competencias propias de la Comunidad Autónoma en las entidades locales para la encomienda de gestión, así como emitir informe previo en los casos de revocación de la delegación o de la encomienda de gestión.

h. Estudiar y proponer criterios para la distribución del Fondo de Cooperación Local.

i. Conocer y emitir informe sobre los proyectos de planes provinciales de cooperación a las obras y a los servicios de competencia municipal.

j. Proponer y emitir informe sobre los Convenios u otras fórmulas de colaboración interadministrativa que puedan suscribirse entre la Comunidad Autónoma y las Diputaciones Provinciales.

Artículo 192. 1. Además de la Comisión Galega de Cooperación Local, y mediante Ley, podrán crearse otros órganos paritarios de colaboración, cooperación y coordinación. La Ley de Creación determinará:

a. La composición y el funcionamiento del órgano.

b. Las funciones y el ámbito material y territorial de actuación del mismo.

2. Las funciones atribuidas a los órganos de colaboración tendrán carácter deliberante o consultivo.

3. Lo dispuesto en este artículo se entiende sin perjuicio de los órganos específicos que puedan establecer los planes sectoriales de coordinación.

\section{Capítulo III \\ DE LA COLABORACIÓN, COOPERACIÓN Y AUXILIO}

Artículo 193. 1. Las entidades locales gallegas y la Xunta de Galicia adecuarán su actuación a los siguientes principios:

a. La lealtad institucional respecto al ejercicio de las competencias que correspondan a las demás Administraciones Públicas.

b. La colaboración, cooperación y auxilio que pudiesen precisar coyunturalmente para el eficaz cumplimiento de sus tareas.

2. La colaboración se entenderá como:

a. El deber de todas las Administraciones Públicas de ponderar y respetar, en sus respectivas actuaciones, la totalidad de los intereses públicos implicados, y, en concreto, los intereses particulares y legítimos cuya gestión esté encomendada a las demás Administraciones Públicas.

b. El trabajo en común para la solución de aquellos problemas, también comunes, que pudiesen plantearse más allá del concreto reparto competencial en los distintos sectores de la acción pública.

3. Se entenderá por cooperación el coejercicio de competencias, de tal modo que la actuación sometida a este régimen será llevada a cabo de forma mancomunada por las diversas Administraciones Públicas participantes.

4. Por auxilio se entenderá:

a. La obligación que tienen todas las Administraciones Públicas de prestar el apoyo y la asistencia activa precisos a las demás para que éstas puedan ejercer adecuadamente sus competencias.

b. El deber que tienen todas las Administraciones Públicas de facilitarse información recíproca, especialmente cuando la actividad desarrollada pueda tener una especial incidencia sobre el ámbito competencial de otras Administraciones. 


\section{Sección 1. ${ }^{\mathrm{a}}$ \\ De la colaboración y cooperación}

Artículo 194. 1. Las relaciones de colaboración y cooperación económica, técnica y administrativa entre las entidades locales gallegas y la Xunta de Galicia, tanto en los asuntos locales como en los asuntos de interés común se desarrollarán con carácter voluntario, bajo las formas y en los términos previstos en las leyes.

2. De cada acuerdo de cooperación formalizado por alguna de estas Administraciones se dará comunicación a aquellas otras que, resultando interesadas, no hayan intervenido en el mismo, a los efectos de mantener una recíproca y constante información.

Artículo 195. La colaboración y cooperación podrán realizarse mediante:

a. La Comisión Galega de Cooperación Local a que se refieren los artículos 188 y siguientes de la presente ley.

b. Los mecanismos de información a que se refieren los artículos 200 y siguientes de la presente ley.

c. El asesoramiento jurídico-administrativo.

d. La asistencia técnica, que se concretará en la elaboración de estudios y proyectos, prestación de servicios o cualquier otra actividad propia o común.

e. La ayuda financiera, que se llevará a cabo mediante subvenciones eventuales o continuas que se concederán ateniéndose a criterios determinados y a condiciones para su utilización y empleo y para ejecutar obras o prestar servicios locales.

f. La creación de consorcios locales.

g. La creación de sociedades anónimas.

h. La suscripción de Convenios.

i. En general, la delegación de competencias o la encomienda de gestión, técnicas reguladas en el título IV de la presente ley.

\section{Subsección $1 .^{\mathrm{a}}$}

De los consorcios locales

Artículo 196. 1. Las entidades locales gallegas podrán constituir consorcios locales con la Xunta de Galicia y con otras Administraciones Públicas para fines de interés común o con entidades privadas sin ánimo de lucro que persigan fines de interés público concurrentes con los de las Administraciones Públicas.

2. El procedimiento y las reglas que deberán observar las entidades locales para la constitución de los consorcios locales y la elaboración de sus estatutos, así como para su modificación o disolución, serán establecidos en los artículos 150 y siguientes de la presente ley.

3. El Consello de la Xunta de Galicia podrá acordar que la Administración autonómica forme parte del consorcio local. En este caso, y mediante tal acuerdo, designará un representante, que pasará a formar parte de la Comisión Gestora encargada de la tramitación del correspondiente expediente y de la elaboración de los estatutos.

Adoptados sus acuerdos por las demás Administraciones Públicas integrantes del consorcio local, mediante los que se aprueben definitivamente los estatutos y la constitución de la Entidad Local, el Consello de la Xunta de Galicia los aprobará, mediante Decreto, que se publicará en el "Diario Oficial de Galicia", junto con el texto íntegro de los estatutos ${ }^{135}$.

\section{Subsección $2 .^{a}$}

\section{De las sociedades anónimas}

Artículo 197. 1. Para la prestación de servicios cuyo contenido no implique el ejercicio de autoridad y que afecten a los intereses de dos o más Administraciones Públicas podrán constituirse sociedades anónimas cuyo capital pertenezca total o mayoritariamente a las entidades afectadas.

2. Los acuerdos de constitución, participación o adquisición de títulos representativos del capital de las citadas sociedades serán adoptados por las

135 Decreto 62/2009, de 12 de marzo, por el que se aprueba la modificación de los estatutos del Consorcio Provincial contra Incendios y Salvamento de A Coruña. 
Administraciones interesadas en la forma prevista en las normas reguladoras de sus respectivos patrimonios.

\section{Subsección 3. ${ }^{\mathrm{a}}$ \\ De los Convenios de cooperación}

Artículo 198. 1. La Xunta de Galicia y las entidades locales podrán celebrar Convenios de cooperación entre sí para la más eficaz gestión y prestación de servicios de su competencia.

2. A través de los Convenios de cooperación, las partes podrán coordinar sus políticas de fomento dirigidas a un mismo sector, distribuir las subvenciones otorgadas por una de ellas con referencia al ámbito territorial o población de otra, ejecutar puntualmente obras o servicios de la competencia de una de las partes, compartir las sedes, locales o edificios que sean precisos para el desarrollo de competencias concurrentes, ceder y aceptar la cesión de uso de los bienes patrimoniales, desarrollar actividades de carácter prestacional y adoptar las medidas oportunas para alcanzar cualquier otra finalidad de contenido análogo a las anteriores.

3. En especial, las Diputaciones Provinciales podrán suscribir, con todos o alguno de los municipios de la provincia, Convenios para garantizar el acceso de la población al conjunto de los servicios municipales y la mayor eficacia en la prestación de éstos.

Artículo 199. Los instrumentos de formalización de los Convenios de cooperación deberán especificar:

a. Los órganos que suscriben el Convenio.

b. La competencia que ejerce cada Administración.

c. Su financiación.

d. La definición de los mecanismos de asistencia técnica, coordinación o actuación conjunta previstos para hacer efectiva la colaboración-cooperación.

e. La necesidad o no de establecer una organización para su gestión. f. El plazo de vigencia, lo que no impedirá su prórroga si así lo acuerdan las partes firmantes del Convenio, y los mecanismos de denuncia o solución de controversias.

g. La extinción por causa distinta a la prevista en el apartado anterior, así como la forma de determinar las actuaciones en curso para el supuesto de extinción.

h. Cada Convenio deberá ir acompañado de una memoria, donde consten los antecedentes, razones de oportunidad y objetivos perseguidos con su formalización.

\section{Sección 2. ${ }^{\mathrm{a}}$ \\ Del auxilio}

Artículo 200. El auxilio que deben prestarse todas las Administraciones Públicas gallegas encontrará su principal concreción en la obligación de asistencia recíproca para el eficaz ejercicio de sus competencias y en el intercambio mutuo de información.

Artículo 201. 1. A los efectos de lo dispuesto en el artículo anterior, las Administraciones Públicas gallegas podrán solicitar asistencia para la ejecución de sus competencias respectivas.

2. La asistencia requerida sólo podrá negarse cuando el ente del que se solicita no esté facultado para prestarla, o cuando, de hacerlo, causase un perjuicio grave a sus intereses o al cumplimiento de sus propias funciones. La negativa a prestar asistencia se comunicará motivadamente a la Administración solicitante.

Artículo 202. La Xunta de Galicia y las entidades locales gallegas tienen el deber de facilitarse mutuamente la información sobre los datos de su propia gestión que consideren de importancia para el desarrollo de los fines que tienen encomendados:

a. Comunicar o informar, previa petición razonada, todos aquellos datos o extremos sobre la gestión que se realiza o se piensa ejecutar y que pueda incidir en los ámbitos competenciales de otras Administraciones Públicas. 
b. Comunicar, de oficio, los acuerdos de cooperación o Convenios que hayan suscrito a aquellas otras Administraciones que no hayan intervenido pero sean interesadas.

c. Facilitar el libre acceso de las distintas Administraciones Públicas a los registros públicos y exhibir toda clase de documentos y expedientes administrativos, en los términos previstos en las leyes.

d. Facilitar el acceso de las distintas Administraciones Públicas a los instrumentos de planificación, programación y gestión de obras y servicios que elaboren.

Artículo 203. 1. Las entidades locales remitirán a la consellería competente en materia de régimen local, en el plazo de seis días, copia o, en su caso, extracto comprensivo de los actos y acuerdos de los órganos de gobierno municipales que tengan especial relevancia. Los Presidentes de las Corporaciones y, de forma inmediata, los Secretarios serán responsables del cumplimiento de este deber.

2. Con la finalidad de comprobar la efectividad de la aplicación de su legislación, la Xunta de Galicia, a través de la consellería competente en materia de régimen local, podrá solicitar a las entidades locales información concreta sobre su actividad e incluso requerir la exhibición de expedientes y la emisión de informes.

3. La Xunta de Galicia elaborará un plan de informática municipal que estructure los medios precisos para integrar la información local en toda Galicia. Al mismo tiempo, promoverá una red de comunicaciones informáticas entre todas las Administraciones. El deber de información establecido en los apartados 1 y 2 de este artículo podrá cumplirse mediante los servicios de informática, de conformidad con las condiciones y requisitos que se determinen reglamentariamente.

Artículo 204. 1. Las entidades locales que, de conformidad con lo establecido por la presente ley y por la legislación reguladora de los diferentes sectores de la acción pública, tengan atribuida la competencia de formulación y de aprobación de los instrumentos de planificación, facilitarán el acceso de los representantes legales del resto de las Administraciones Públicas afectadas al proceso de elaboración de los planes.

La participación podrá consistir en:

a. El otorgamiento de un plazo de audiencia para poder formular observaciones o sugerencias.

b. La emisión de informes previos.

c. La intervención directa en la realización de los trabajos de elaboración de los planes.

2. La Xunta de Galicia facilitará el acceso de los representantes legales de las entidades locales a los instrumentos de planificación, programación y gestión de obras y servicios que les afecten directamente.

\section{Capitulo IV DE LA COORDINACIÓN}

Artículo 205. 1. Las leyes de la Comunidad Autónoma reguladoras de los diferentes sectores de la acción pública podrán atribuir al Consello de la Xunta de Galicia la facultad de coordinar el ejercicio de las competencias propias de las entidades locales entre sí, y, especialmente, con las de la Comunidad Autónoma, cuando la coherencia de la actuación de las diferentes Administraciones Públicas no pueda alcanzarse por los procedimientos previstos en los artículos anteriores o éstos resulten manifiestamente inadecuados por tratarse de actividades o servicios locales que trasciendan el interés propio de las correspondientes entidades locales, incidan o condicionen relevantemente los de la Administración autonómica o sean concurrentes o complementarios de los de ésta.

2. La coordinación tendrá por finalidad la fijación de medios y sistemas de relación que hagan posible la información recíproca, la homogeneidad técnica 


\section{Administración Local}

en diversos aspectos y la acción conjunta de las distintas Administraciones Públicas en el ejercicio de sus respectivas competencias, de tal modo que se logre la integración en la globalidad del sistema.

3. Las leyes de Galicia que regulen los distintos sectores de la acción pública preverán, en su caso, el correspondiente traspaso de los medios y servicios personales, técnicos y financieros, a través de la constitución de una Comisión sectorial.

4. Las funciones de coordinación no afectarán en ningún caso a la autonomía de las entidades locales.

5. Los instrumentos de coordinación no podrán comprometer los recursos locales de manera obligatoria.

\section{Sección $1 .^{\mathrm{a}}$}

De los planes sectoriales

Artículo 206. 1. De conformidad con lo que establece el artículo anterior, las leyes reguladoras de los diferentes sectores de la acción pública podrán atribuir a la Xunta de Galicia la facultad de coordinar la actividad de las entidades locales por medio de planes sectoriales de coordinación.

2. Las leyes a que se refiere el apartado anterior deberán:

a. Precisar, con suficiente detalle, las condiciones y los límites particulares de la coordinación.

b. Establecer las modalidades de control parlamentario de conformidad con los procedimientos específicos fijados por el Reglamento del Parlamento.

c. Definir, de manera concreta y en relación con una materia, servicio o competencia determinados, los intereses generales o comunitarios que se articularán a través de planes sectoriales, que determinarán los objetivos y prioridades de la acción pública en la materia correspondiente y los medios técnicos, económicos y personales con que se cuente. Estos objetivos y prioridades podrán ser de obligado cumplimiento para la Administración autonómica y para las entidades locales implicadas.

d. Establecer los correspondientes órganos o instrumentos de coordinación, en los que se garantizará la participación de las entidades locales interesadas.

3. En la redacción de los proyectos de planes sectoriales se garantizará la participación de las entidades locales interesadas. Una vez redactados, se someterán a informe de la Comisión Galega de Cooperación Local y se aprobarán por Decreto del Consello de la Xunta de Galicia, a propuesta del conselleiro correspondiente.

4. Las entidades locales ejercerán sus facultades de programación, ordenación y ejecución de los servicios y actividades de su competencia, en el marco de las previsiones de los planes sectoriales de coordinación.

\section{Sección 2. ${ }^{\mathrm{a}}$}

\section{De otras técnicas de coordinación}

Artículo 207. 1. En cumplimiento de la Disposición adicional tercera del Estatuto de Autonomía de Galicia, las Diputaciones Provinciales unirán sus presupuestos al general de la Xunta de Galicia, sin que ello pueda implicar su integración.

2. A los efectos de lo dispuesto en el apartado anterior, las Diputaciones Provinciales, antes de la aprobación de sus presupuestos, remitirán los proyectos a la Xunta de Galicia, que los pondrá en conocimiento de la Comisión Galega de Cooperación Local y del Parlamento de Galicia.

Artículo 208. 1. La Xunta de Galicia podrá adoptar las medidas que sean necesarias para proceder a la ejecución subsidiaria de las competencias locales de ejercicio obligatorio, si la Entidad Local incumple obligaciones impuestas directamente por la ley, siempre que el incumplimiento afecte al ejercicio de competencias de la Administración autonómica y la obligación tenga garantizada legal o presupuestariamente la cobertura económica.

2. El ejercicio de la potestad a que se refiere el apartado anterior corresponderá 
al Consello de la Xunta de Galicia, a instancia de la consellería competente en materia de régimen local, siempre que previamente la Entidad Local no haya cumplido su obligación dentro de un mes, a contar desde el requerimiento que en este sentido le haya hecho dicha consellería.

Artículo 209. Cuando la naturaleza de una actividad hiciese muy difícil o inconveniente una asignación diferenciada de facultades ejecutivas sobre una materia, las leyes sectoriales reguladoras de la acción pública integrarán, en todo caso, el ejercicio de las funciones de las entidades locales en actuaciones o procedimientos conjuntos con los de la Administración autonómica.

\section{TÍTULO VI DISPOSICIONES COMUNES A LAS ENTIDADES LOCALES}

\section{Capítulo I \\ RÉGIMEN DE FUNCIONAMIENTO}

Artículo 210. 1. Los órganos de gobierno colegiados de las Entidades Locales funcionarán en régimen de sesiones ordinarias, de periodicidad preestablecida, y extraordinarias, que pueden ser, además, urgentes.

2. En todo caso, el funcionamiento del Pleno de las Corporaciones Locales se ajustará a las siguientes reglas:

a. El Pleno celebrará sesión ordinaria, como mínimo, cada dos meses y extraordinaria cuando así lo decida el Presidente o lo solicite la cuarta parte, al menos, del número legal de los miembros de la Corporación. En este último caso, el Presidente se verá obligado a convocarla dentro de los cuatro días siguientes al de su solicitud y su celebración no podrá demorarse por más de un mes desde que hubiese sido solicitada.

b. Las sesiones plenarias serán convocadas, al menos, con dos días hábiles de antelación, salvo las extraordinarias con carácter urgente, en las que la convocatoria deberá ser ratificada por el Pleno. La documentación íntegra de los asuntos incluidos en el orden del día, que servirá como base para el debate y, en su caso, la votación, estará a disposición de los Concejales o Diputados, desde el mismo día de la convocatoria, en la Secretaría de la Corporación.

c. El Pleno se constituye válidamente con la asistencia de un tercio del número legal de miembros del mismo, que nunca podrá ser inferior a tres. Este quórum deberá mantenerse durante toda la sesión. En todo caso, se requiere la asistencia del Presidente y del Secretario de la Corporación o de quienes legalmente los sustituyan.

d. La adopción de acuerdos se produce mediante votación ordinaria, a no ser que el propio Pleno acuerde, para un caso en concreto, la votación nominal. El voto puede emitirse en sentido afirmativo o negativo, pudiendo los miembros de las Corporaciones abstenerse de votar.

La ausencia de uno o varios Concejales o Diputados, una vez iniciada la deliberación de un asunto, equivale, a efectos de la votación correspondiente, a la abstención. En caso de votaciones con resultado de empate, se efectuará una nueva votación, $y$, si persistiese el empate, decidirá el voto de calidad del Presidente.

Artículo 211. La Comisión de Gobierno, para ejercer sus competencias resolutorias, tendrá sesiones ordinarias con la periodicidad determinada por el Pleno de la Corporación y sesiones extraordinarias cuando el Presidente lo decida.

Para el ejercicio de sus funciones de asistencia, se reunirá cuando el Presidente de la Corporación lo determine.

Artículo 212. 1. La periodicidad de las sesiones ordinarias de las Comisiones de estudio, informe o consulta y de los órganos de participación será determinada por el Pleno. En todo caso, será preceptiva la reunión de las Comisiones 


\section{Administración Local}

con anterioridad al pronunciamiento del Pleno en asuntos de su materia, salvo cuando tengan que adoptarse acuerdos declarados urgentes.

2. Podrán, sin embargo, celebrar sesiones extraordinarias cuando su Presidente lo decida o cuando lo solicite la cuarta parte, al menos, del número legal de miembros.

3. La Comisión Especial de Contas tendrá que reunirse antes del día 1 de junio de cada año para emitir el informe preceptivo sobre las cuentas anuales de la Entidad Local.

4. Las cuentas y la documentación complementaria estarán a disposición de los miembros de la Comisión para examen y consulta como mínimo quince días antes de la reunión.

Artículo 213. Serán nulos los acuerdos adoptados en sesiones extraordinarias sobre asuntos no comprendidos en su convocatoria, así como los que se adopten en las sesiones ordinarias sobre materias no incluidas en el respectivo orden del día, salvo especial y previa declaración de urgencia hecha por el órgano correspondiente, con el voto favorable de la mayoría absoluta del número legal de miembros de la Corporación.

Artículo 214. Las sesiones de los órganos de las Corporaciones Locales se celebrarán en las sedes de las mismas, salvo en los casos en que, por fuerza mayor, el Presidente crea conveniente celebrarlas en otro lugar del ámbito territorial de la Corporación.

Artículo 215. 1. Los acuerdos de las Corporaciones Locales se adoptarán, como regla general, por mayoría simple de los miembros presentes. Existe mayoría simple cuando los votos afirmativos son más que los votos negativos.

2. Se requerirá el voto favorable de las dos terceras partes del número de hecho $\mathrm{y}$, en todo caso, de la mayoría absoluta del número legal de miembros de las Corporaciones para la adopción de acuerdos en las siguientes materias: a. Creación y supresión de municipios y alteración de términos municipales.

b. Creación, modificación y supresión de las Entidades a que hace referencia el artículo 45 de la Ley reguladora de las Bases del Régimen Local y el título III de la presente ley.

c. Aprobación de la delimitación del término municipal.

d. Alteración del nombre y de la capitalidad del municipio.

3. Será necesario el voto favorable de la mayoría absoluta del número legal de miembros de la Corporación para la adopción de acuerdos en las siguientes materias:

a. Aprobación y modificación del reglamento orgánico propio de la Corporación.

b. Creación, modificación y disolución de mancomunidades $u$ otras organizaciones asociativas, así como aprobación y modificación de sus estatutos.

c. Transferencia y delegación de funciones o actividades a otras Administraciones Públicas.

d. Cesión, por cualquier título, del aprovechamiento de bienes comunales.

e. Concesión de bienes o servicios por más de cinco años, siempre que su cuantía exceda del 10 por 100 de los recursos ordinarios del presupuesto.

f. El ejercicio de actividades económicas y la prestación de servicios esenciales en régimen de monopolio, así como la determinación de la forma concreta de gestión del servicio o actividad.

g. Aprobación de operaciones financieras o de crédito o concesión de quitas y esperas, cuando su importe exceda del 5 por 100 de los recursos ordinarios de su presupuesto.

h. Imposición y ordenación de los recursos propios de carácter tributario.

i. La aprobación que ponga fin a la tramitación municipal de los planes e instrumentos de ordenación previstos en la legislación urbanística.

j. Separación del servicio de los funcionarios de la Corporación y ratificación del despido disciplinario. 
k. Enajenación de bienes, cuando su cuantía exceda del 10 por 100 de los recursos ordinarios de su presupuesto.

1. Alteración de la calificación jurídica de los bienes demaniales o comunales.

$\mathrm{m}$. Cesión gratuita de bienes a otras administraciones o instituciones públicas.

n. Las restantes materias determinadas por la ley.

\section{Capitulo II IMPUGNACIÓN DE ACTOSY ACUERDOS Y EJERCICIO DE ACCIONES}

Artículo 216. 1. Podrán impugnar los actos y acuerdos de las Entidades Locales que incurran en infracción del ordenamiento jurídico en los casos y términos previstos en los artículos 217 y 218 :

a. La Administración gallega, sin perjuicio de los supuestos de legitimación establecidos con carácter general por la legislación reguladora de la jurisdicción contencioso-administrativa.

b. Los miembros de las Corporaciones Locales que votasen en contra de los actos o acuerdos.

2. Asimismo, los Entes Locales podrán impugnar las disposiciones y actos de la Administración de la Comunidad Autónoma que lesionen su autonomía, de conformidad con lo establecido en la legislación básica del Estado en la materia y en la legislación reguladora de la jurisdicción contencioso-administrativa.

Artículo 217. 1. Cuando la Xunta de Galicia considere, en el ámbito de sus competencias, que un acto o acuerdo de alguna Entidad Local infringe el ordenamiento jurídico, podrá requerirla para que anule este acto o acuerdo, invocando expresamente el artículo 65 de la Ley reguladora de las Bases del Régimen Local. El requerimiento, que debe estar motivado y expresar la normativa que considere que es vulnerada, se formulará en el plazo de quince días hábiles a partir de la recepción de la comunicación del acuerdo.
Si hubiese sido solicitada la ampliación de la información, quedará interrumpido el cómputo del plazo, que se reanudará a partir de la recepción de la documentación solicitada.

La Entidad Local, en virtud del requerimiento y en el plazo señalado para ello, podrá anular aquel acto o acuerdo, previa audiencia, en su caso, de los interesados.

2. La Xunta de Galicia podrá impugnar el acto o acuerdo ante la jurisdicción contencioso-administrativa en los dos meses siguientes al día en que venza el plazo señalado en el requerimiento dirigido a la Entidad Local o de la recepción de la comunicación de la misma, en la que se rechaza el requerimiento.

La Xunta de Galicia podrá impugnar el acto o acuerdo ante la jurisdicción contenciosoadministrativa directamente, sin necesidad de formular requerimiento, en los dos meses siguientes al día de la recepción de la comunicación del acto o acuerdo.

Artículo 218. Los actos o acuerdos de las Entidades Locales que menoscaben las competencias de la Xunta de Galicia o interfieran su ejercicio podrán ser impugnados directamente, sin necesidad de requerimiento previo, ante la jurisdicción contencioso-administrativa en el plazo de dos meses, que comenzará a contar desde la recepción de la comunicación del acuerdo.

La impugnación deberá precisar la lesión o, en su caso, la extralimitación competencial que la motiva y las normas legales en que se fundamente.

Artículo 219. Las Entidades Locales territoriales están legitimadas para impugnar las disposiciones y actos de la Administración de la Comunidad Autónoma que lesionen su autonomía.

Artículo 220. 1. Las Entidades Locales tienen la obligación de ejercer las acciones precisas para la defensa de sus bienes y derechos. 


\section{Administración Local}

2. Cualquier vecino que se encuentre en pleno disfrute de sus derechos civiles y políticos podrá requerir su ejercicio a la entidad interesada. Este requerimiento, del que se dará conocimiento a quien pudiese resultar afectado por las correspondientes acciones, suspenderá el plazo para el ejercicio de las mismas por un término de treinta días hábiles.

Si en el plazo de esos treinta días la entidad no acordase el ejercicio de las acciones solicitadas, los vecinos podrán ejercitar esta acción en nombre e interés de la Entidad Local.

De prosperar la acción, el actor tendrá derecho a que la Entidad Local le reembolse las costas procesales y a la indemnización de cuantos daños y perjuicios le siguiesen.

\section{Capítulo III \\ ESTATUTO DE LOS MIEMBROS DE LAS CORPORACIONES LOCALES}

Artículo 221. 1. La determinación del número de miembros de las Corporaciones Locales, el procedimiento para su elección, la duración de su mandato y los supuestos de inelegibilidad e incompatibilidad se regularán por lo dispuesto en la legislación electoral.

2. Los miembros de las Corporaciones Locales gozan, una vez que tomen posesión de su cargo, de los honores, prerrogativas $\mathrm{y}$ distinciones propios de los mismos y estarán obligados al cumplimiento estricto de los deberes y obligaciones inherentes a aquél.

3. El Concejal, Diputado o miembro de cualquier Entidad Local que resulte proclamado electo deberá presentar la credencial ante la Secretaría General de la entidad o Corporación correspondiente.

Artículo 222. Quien ostente la condición de miembro de una Corporación quedará, no obstante, suspendido en sus derechos, prerrogativas o deberes cuando una resolución judicial firme condenatoria lo comporte.
Artículo 223. Quien ostente la condición de miembro de una Corporación Local perderá su condición de tal por las siguientes causas:

1. ${ }^{a}$ Por decisión judicial firme, que anule la elección o proclamación.

2. ${ }^{\text {a }}$ Por muerte o incapacitación, declarada ésta por decisión judicial firme.

3. a Por extinción del mandato, sin perjuicio de que continúe en sus funciones, solamente para la administración ordinaria, hasta la toma de posesión de sus sucesores.

4. ${ }^{\text {a }}$ Por renuncia, que se hará efectiva por escrito ante el Pleno de la Corporación.

5. ${ }^{a}$ Por incompatibilidad, en los supuestos y condiciones establecidos en la legislación electoral.

Artículo 224. 1. Los miembros de las Corporaciones Locales quedan en situación de servicios especiales en los siguientes supuestos:

a. Cuando sean funcionarios de la propia Corporación para la que fueron elegidos.

b. Cuando sean funcionarios de carrera de otras Administraciones Públicas y desempeñen en la Corporación, para la que fueron elegidos, un cargo retribuido y de dedicación exclusiva.

En ambos supuestos, las Corporaciones afectadas abonarán sus cotizaciones a las mutualidades obligatorias correspondientes para aquellos funcionarios que dejen de prestar el servicio que motivaba su pertenencia a ellas, extendiéndose a sus cuotas de clases pasivas.

2. Para el personal laboral rigen idénticas reglas, de acuerdo con lo previsto en su legislación específica.

3. Los miembros de las Corporaciones Locales que no tengan dedicación exclusiva en esta condición tendrán garantizada, durante el período de su mandato, la permanencia en el centro o centros de trabajo públicos o privados en que estuviesen prestando servicios en el momento de la elección y la disposición del tiempo preciso para el ejercicio del cargo, sin que puedan 
ser trasladados $\mathrm{u}$ obligados a concursar a otras plazas vacantes en distintos sitios.

Artículo 225. 1. Los miembros de las Corporaciones Locales tendrán derecho a percibir retribuciones por el ejercicio de sus cargos cuando los desempeñen con dedicación exclusiva. En este caso, serán dados de alta en el Régimen General de la Seguridad Social, asumiendo las Corporaciones el pago de las cuotas empresariales que correspondan, salvo lo dispuesto en el artículo anterior.

En relación con dichas retribuciones, su percepción será incompatible con la de cualquier otra retribución con cargo a los presupuestos de las Administraciones Públicas y de los entes, organismos y empresas que de ellas dependan.

2. Todos los miembros de la Corporación, incluidos los que desempeñan cargos en régimen de dedicación exclusiva, tendrán derecho a recibir indemnización por los gastos ocasionados por el ejercicio de su cargo cuando sean efectivos, y previa justificación documental.

3. Sólo los miembros de la Corporación que no tengan dedicación exclusiva percibirán asistencia por la concurrencia efectiva a sesiones de los órganos colegiados de que formen parte, y en la cuantía que señale el Pleno de la misma.

4. Las Corporaciones Locales consignarán en sus presupuestos las retribuciones, indemnizaciones, compensaciones y asistencias a que se hace referencia en los apartados anteriores de este mismo artículo.

Artículo 226. 1. Todos los miembros de las Corporaciones Locales tendrán derecho a obtener del Alcalde o Presidente de la Comisión de Gobierno cuantos antecedentes, datos o informaciones obren en poder de los servicios de la Corporación y les resulten precisos para el desarrollo de su función. En todo caso, la denegación del acceso a la documentación informativa se hará a través de resolución o acuerdo motivado.
2. Los servicios de la Corporación facilitarán directamente información a los miembros de las Corporaciones en los siguientes casos:

a. Cuando se trate del acceso de los miembros de la Corporación que ostenten delegaciones o responsabilidades de gestión a la información de las mismas.

b. Cuando se trate del acceso de cualquier miembro de la Corporación a la información y documentación correspondiente a los asuntos que deban ser tratados por los órganos colegiados de que formen parte, así como a las resoluciones o acuerdos adoptados por cualquier órgano de la Corporación.

c. Cuando se trate del acceso de miembros de la Corporación a la información o documentación de la Entidad Local que sea de libre acceso para los ciudadanos.

Artículo 227. Todos los miembros de las Corporaciones Locales tienen la obligación de guardar reserva en relación con las informaciones que se les faciliten para hacer posible el desarrollo de sus funciones, singularmente de las que servirán de antecedentes para decisiones que todavía se encuentren pendientes de adopción, así como para evitar la reproducción de la documentación que pueda facilitárseles, en original o copia, para su estudio.

Artículo 228. Los miembros de las Corporaciones Locales tendrán el derecho y la obligación de asistir a todas las sesiones del Pleno y de las comisiones de que formen parte.

Artículo 229. 1. Los miembros de las Corporaciones Locales están sujetos a responsabilidad civil y penal por los actos u omisiones realizados en el ejercicio de su cargo. Las responsabilidades se exigirán ante los Tribunales de justicia competentes y se tramitarán por el procedimiento ordinario aplicable.

Son responsables de los acuerdos de las Corporaciones Locales los miembros de las mismas que los votasen favorablemente. 
2. Las Corporaciones Locales podrán exigir la responsabilidad de sus miembros cuando por dolo o culpa grave causasen daños y perjuicios a la Corporación o a terceros, si éstos tuviesen que ser indemnizados por aquélla.

3. Los Presidentes de las Corporaciones Locales podrán sancionar con multa a los miembros de las mismas por falta no justificada de asistencia a las sesiones o por incumplimiento reiterado de sus obligaciones.

Artículo 230. En el ejercicio de su cargo, los miembros de las Corporaciones Locales observarán, en todo momento, las normas sobre incompatibilidades establecidas en el ordenamiento vigente y se abstendrán de participar en la deliberación, votación, decisión y ejecución de cualquier asunto si concurren en él algunas de las causas a que se refiere la legislación sobre procedimiento administrativo y la de contratos de las Administraciones Públicas.

La actuación de los miembros de las Corporaciones Locales en que concurran las mencionadas causas comportará, si fue determinante, la invalidez de los actos en que intervinieron.

Artículo 230 bis. Los miembros de las corporaciones locales adecuarán su actividad a los siguientes principios éticos y de actuación:

a. Ejercerán los poderes que les atribuye la normativa vigente con la finalidad exclusiva para la que les fueron otorgados y evitarán toda acción que pueda poner en riesgo el interés público, el patrimonio de las administraciones o la imagen que debe tener la sociedad respecto a sus representantes.

b. Usarán las prerrogativas inherentes a sus cargos únicamente para el cumplimiento de sus funciones y deberes, no prevaliéndose de su posición en la entidad local para obtener ventajas personales o materiales, sin que en ningún caso puedan invocar ni hacer uso de su condición en el ejercicio de cualquier actividad mercantil, industrial o profesional propia o de terceras personas, relacionada con la entidad local a que pertenezcan ${ }^{136}$.

\section{Capítulo IV \\ DEL PERSONAL AL SERVICIO DE LAS ENTIDADES LOCALES}

\section{Sección $1 .^{a}$}

\section{Disposiciones generales y comunes}

Artículo 231. El personal al servicio de las Corporaciones Locales estará integrado por:
a. Funcionarios de carrera.
b. Personal interino.
c. Personal laboral.
d. Personal eventual.

Dentro de los funcionarios de carrera se incluyen los funcionarios con habilitación de carácter nacional.

Artículo 232. 1. Cada Corporación Local deberá aprobar anualmente, a través de su presupuesto, la plantilla en la que figuren todos los puestos de trabajo reservados a funcionarios, personal laboral y eventual.

Las Corporaciones Locales formarán la relación de los puestos de trabajo existentes en su organización y en la misma deberán incluirse, en todo caso, la denominación, características esenciales de los puestos, retribuciones complementarias que les correspondan y requisitos exigidos para su ejercicio.

La modificación de las plantillas durante la vigencia del presupuesto requerirá el cumplimiento de los trámites establecidos para la modificación de aquél.

2. Se remitirá copia de la plantilla y de las relaciones de los puestos de trabajo al órgano competente de la Comunidad Autónoma, en el plazo de treinta días desde su aprobación.

3. En cada Corporación Local se constituirá, asimismo, un registro de su

136 Art. 230 bis añadido por Ley 18/2008, de 29 de diciembre, de vivienda de Galicia. 
personal, en el que se inscribirá todo el personal a su servicio y se anotarán todos los actos que afecten a la vida administrativa del mismo.

Artículo 233. 1. Las Corporaciones Locales formularán públicamente su oferta de empleo, de conformidad con los criterios fijados por la normativa básica estatal.

2. El acceso a la condición de funcionarios de carrera o de personal laboral de las Corporaciones Locales se efectuará de conformidad con la oferta pública de empleo, mediante una convocatoria pública y a través del sistema de concurso, concursooposición u oposición libre, en los que se garantizará el cumplimiento de los principios constitucionales de igualdad, mérito y capacidad, así como el de publicidad.

3. Los anuncios de convocatorias de pruebas de acceso a la función pública local y de concursos para proveer puestos de trabajo se publicarán, además de lo dispuesto por la normativa básica del Estado, en el "Diario Oficial de Galicia".

4. La selección se efectuará de conformidad con las reglas básicas, programas mínimos y titulación contenida en la normativa básica del Estado. El Pleno de la Corporación Local aprobará las bases.

Los procedimientos de selección cuidarán especialmente la conexión entre el tipo de pruebas a superar y la adecuación a los puestos de trabajo que se hayan de desempeñar, incluyendo, a tal efecto, las pruebas prácticas que sean precisas.

Artículo 234. 1. Son funciones públicas cuyo cumplimiento queda reservado exclusivamente al personal sujeto al estatuto funcionarial las que impliquen ejercicio de autoridad, las de fe pública y asesoramiento legal preceptivo, las de control y fiscalización interna de la gestión económico-financiera y presupuestaria, las de contabilidad y tesorería $\mathrm{y}$, en general, aquellas que se reserven a los funcionarios para mejor garantizar la objetividad, imparcialidad e independencia en el ejercicio de la función.
2. Son funciones públicas necesarias en todas las Corporaciones Locales, y de las que se responsabilizarán los funcionarios con habilitación de carácter nacional:

a. La de secretaría, comprensiva de la fe pública y asesoramiento legal preceptivo.

b. El control y la fiscalización interna de la gestión económico-financiera y presupuestaria, y la contabilidad, tesorería y recaudación.

Artículo 235. 1. Es personal laboral aquel que, en virtud de contrato de naturaleza laboral, que habrá de formalizarse en todo caso por escrito, ocupa puestos de trabajo clasificados como tales en la relación de puestos de trabajo.

2. Podrán ser desempeñados por personal laboral:

a. Los puestos de naturaleza no permanente y aquéllos cuyas actividades se dirijan a satisfacer necesidades de carácter periódico y discontinuo, incluyendo los auxiliares de la Policía Local.

b. Los puestos de actividades propias de oficios.

c. Los puestos de trabajo de organismos autónomos de carácter comercial, industrial, financiero o análogo, salvo aquellos que impliquen ejercicio de autoridad, inspección o control, que se reservarán a funcionarios.

Artículo 236. 1. Las retribuciones básicas de los funcionarios tendrán la misma estructura e idéntica cuantía que las establecidas con carácter general para toda la función pública.

2. Las retribuciones complementarias se atendrán, asimismo, a la estructura y criterios de valoración objetivos de los del resto de los funcionarios públicos. Su cuantía será fijada por el Pleno de la Corporación dentro de los límites legales.

3. Las Corporaciones Locales reflejarán anualmente en sus presupuestos la cuantía de las retribuciones de los funcionarios en los términos previstos en la legislación básica sobre función pública. 
Artículo 237. La Xunta de Galicia, a través de la Escola Galega de Administración Pública, prestará atención especial al perfeccionamiento, especialización y promoción de los funcionarios al servicio de la Administración Local.

\section{Sección $2 .^{a}$}

De los funcionarios con habilitación de carácter nacional

Artículo 238. El régimen jurídico de los funcionarios de la Administración Local con habilitación de carácter nacional será el establecido por la legislación básica del Estado y por la legislación sectorial de la Comunidad Autónoma en materia de régimen local.

Artículo 239. La Escola Galega de Administración Pública se ocupará de la selección y formación de los funcionarios con habilitación nacional en los términos del Convenio que suscriba con el Instituto Nacional de Administración Pública.

Artículo 240. 1. En el concurso, como sistema normal de provisión de puestos de trabajo, se tendrán en cuenta los méritos generales y también los méritos específicos cuando éstos sean establecidos por la Corporación Local correspondiente.

2. Dentro del porcentaje de baremo reservado a méritos generales corresponde a la Comunidad Autónoma de Galicia el 10 por 100 del total posible para fijar los méritos que correspondan al conocimiento de las especificidades de su organización territorial, normativa autonómica y lengua gallega.

3. Tanto las Corporaciones Locales como la Xunta de Galicia deberán incluir en las bases del concurso aquellos factores ponderados que garanticen un grado suficiente de conocimiento de la lengua gallega para desempeñar las funciones de su puesto de trabajo ${ }^{137}$.

137 Decreto 103/2008, de 8 de mayo, por el que se regula el conocimiento del gallego en los procedimientos para la provisión de puestos de trabajo reservados a funcionarios/as con habilitación de carácter estatal en el ámbito territorial de la Comunidade Autónoma de Galicia.
Artículo 241. 1. La Comunidad Autónoma de Galicia tiene la competencia de ejecución, dentro del marco de la legislación básica del Estado, sobre clasificaciones de puestos, nombramientos provisionales, comisiones de servicio, acumulaciones y permutas, dentro del ámbito territorial de la Comunidad Autónoma.

2. Los nombramientos provisionales se entenderán concedidos en caso de no notificarse lo contrario después de transcurrir treinta días desde la remisión del expediente completo.

\section{Sección 3. ${ }^{\mathrm{a}}$}

\section{De los demás funcionarios de carrera}

Artículo 242. Es competencia de cada Corporación Local la selección de los funcionarios de carrera que no tengan habilitación de carácter nacional; ésta se efectuará de conformidad con las reglas básicas, programas mínimos y titulación contenidos en la normativa básica del Estado ${ }^{138}$.

Artículo 243. 1. Los funcionarios de carrera de la Administración local que no tengan habilitación de carácter nacional se integrarán en las Escalas de Administración General y Administración Especial de cada Corporación, que quedarán agrupadas, con arreglo a lo dispuesto en la legislación básica del Estado sobre función pública, en los grupos que ésta determine, de acuerdo con la titulación exigida para su ingreso.

2. La Escala de Administración general se subdivide en las subescalas siguientes:
a. Técnica.
b. Gestión.
c. Administrativa.
d. Auxiliar.
e. Subalterno.

3. La Escala de Administración Especial se subdivide en las subescalas siguientes:

a. Técnica.

b. Servicios especiales.

138 Decreto 49/2009, de 26 de febrero, sobre el ejercicio de las competencias de la Comunidad Autónoma de Galicia respecto de los/las funcionarios/as con habilitación de carácter estatal. 
Artículo 244. Corresponde a cada Corporación Local determinar los cuerpos, escalas, plazas y categorías de sus funcionarios, que se agruparán de acuerdo con los grupos de titulación establecidos por la legislación básica estatal.

El ejercicio de esta facultad se ajustará a los criterios de coordinación y homologación establecidos para garantizar la movilidad funcional.

Artículo 245. 1. De acuerdo con las ofertas de empleo, las Corporaciones Locales seleccionarán al personal por medio de convocatoria pública y de los sistemas de: Oposición libre.

Concurso-oposición.

Concurso.

En los distintos sistemas deberán estar garantizados los principios de igualdad, mérito, capacidad y publicidad.

2. La selección por oposición consistirá en superar las pruebas teóricas y prácticas exigidas en la convocatoria pública, adecuadas al ejercicio de la función.

3. La selección por concurso-oposición consistirá en superar las correspondientes pruebas, así como poseer determinadas condiciones debidamente valoradas de formación, méritos o grados de experiencia.

4. La selección por concurso consistirá en valorar los méritos de conformidad con el baremo incluido en la convocatoria correspondiente, que será en cualquier caso pública y libre.

5. La prestación de servicios en otras Administraciones Públicas se valorará en méritos, de acuerdo con el principio de reciprocidad.

6. En los sistemas de selección que se realicen para el acceso a las plazas de la Administración Local tendrá que demostrarse el conocimiento de la lengua gallega.

Artículo 246. 1. Previa convocatoria pública y con respeto, en todo caso, a los principios de mérito y capacidad, el Presidente de la Corporación podrá efectuar nombramientos de personal funcionario interino para plazas vacantes siempre que no sea posible, con la urgencia exigida por las circunstancias, la prestación del servicio por funcionarios de carrera. Tales plazas tendrán que estar dotadas presupuestariamente e incluidas en la oferta pública de empleo, salvo en caso de que se trate de vacantes realmente producidas con posterioridad a la aprobación de ésta.

2. El personal funcionario interino deberá reunir los requisitos generales de titulación y demás condiciones exigidas para participar en las pruebas de acceso como funcionario de carrera.

3. Las plazas así cubiertas se incluirán necesariamente en la primera convocatoria de provisión de puestos de trabajo y en la primera oferta pública de empleo que se apruebe.

4. El personal interino cesará cuando la plaza sea cubierta por un funcionario de carrera o la Corporación considere que cesaron las razones de urgencia que motivaron su cobertura.

5. En todo caso, la Corporación correspondiente establecerá con carácter general los mecanismos que deberán seguirse para garantizar la eficaz aplicación de los principios de mérito y capacidad.

Artículo 247. Las pruebas de selección y los concursos para la provisión de puestos se regirán por las bases que apruebe el Pleno de la Corporación.

En las pruebas selectivas, el Tribunal elevará la correspondiente relación de aprobados junto con la propuesta a la autoridad competente para hacer el nombramiento.

Los concursos para la provisión de puestos de trabajo serán resueltos, motivadamente, por la autoridad competente, previa propuesta del Tribunal.

Artículo 248. El Presidente de la Corporación convocará los procesos selectivos para el acceso a las plazas vacantes que deban cubrirse con personal fijo de nuevo ingreso.

En los supuestos de concurso o concursooposición se especificarán los méritos y su correspondiente valoración, así como los medios de acreditación de los mismos. 


\section{Administración Local}

\section{Sección $4 .^{\mathrm{a}}$}

Personal laboral y eventual

Artículo 249. 1. El personal laboral será seleccionado por la propia Corporación, con el máximo respeto al principio de igualdad de oportunidades de cuantos reúnan los requisitos exigidos y de acuerdo con la oferta pública de empleo. Salvo los casos de urgencia, el procedimiento de convocatoria será el concurso.

2. La contratación laboral revestirá las modalidades previstas en la legislación laboral.

3. El régimen de tales relaciones, en su integridad, será el establecido en las normas de derecho laboral.

Artículo 250. 1. El número, características y retribuciones del personal eventual serán determinados por el Pleno de cada Corporación al comienzo de su mandato. Estas determinaciones sólo podrán modificarse con motivo de la aprobación de los presupuestos anuales.

2. Los puestos de trabajo reservados a este tipo de personal deberán figurar en la plantilla de personal de la Corporación.

3. El nombramiento y cese de estos funcionarios es libre y corresponde al Alcalde o al Presidente de la Corporación Local correspondiente. Cesarán automáticamente cuando se produzca el cese o expire el mandato de la autoridad a la que prestan su confianza o asesoramiento.

4. En todo caso, los servicios prestados como personal eventual no podrán constituir mérito para el acceso a la condición de funcionario ni para la promoción interna.

\section{Capítulo V \\ DE LA INFORMACIÓN Y PARTICIPACIÓN CIUDADANA}

Artículo 251. 1. Las Entidades Locales deberán facilitar la más amplia información sobre su actividad y la participación de todos los ciudadanos en la vida local.

2. Las formas, medios y procedimientos de participación que las Entidades Locales establezcan en el ejercicio de su potestad de autoorganización no podrán, en ningún caso, disminuir las facultades de decisión que correspondan a sus órganos representativos.

3. Sin menoscabo de la capacidad de decisión de cada uno de los órganos en que se estructuran los municipios, se podrá complementar, estimular y facilitar otros mecanismos de participación ciudadana en la vida pública y de colaboración en la toma de decisiones por parte del Ayuntamiento.

\section{Sección $1 .^{a}$}

\section{De la información a los ciudadanos}

Artículo 252. 1. La Corporación, por acuerdo del Pleno, determinará los medios precisos para dar publicidad a los acuerdos adoptados y a las convocatorias de los órganos cuyas sesiones sean públicas, al objeto de garantizar el derecho de los ciudadanos a la más amplia información sobre las actividades de la Entidad Local. En todo caso, las convocatorias de las sesiones plenarias se remitirán a los medios informativos.

2. Todos los ciudadanos tienen derecho a:

a. Conocer, en cualquier momento, el estado de la tramitación de los procedimientos en los que ostenten la condición de interesados y obtener copias de documentos contenidos en ellos.

b. Identificar a las autoridades y al personal al servicio de las Corporaciones Locales bajo cuya responsabilidad se tramiten los procedimientos.

c. Obtener copia sellada de los documentos que presenten, aportándola junto con los originales, así como la devolución de éstos, salvo cuando los originales deban obrar en el procedimiento.

d. Utilizar el idioma gallego en sus relaciones con las Corporaciones Locales de la Comunidad Autónoma de Galicia.

e. Formular alegaciones y aportar documentos en cualquier fase del procedimiento en el que ostenten la condición de interesados, anterior al trámite de audiencia, que 
deberán ser tenidos en cuenta por el órgano competente al redactar la propuesta de resolución.

f. Obtener información y orientación acerca de los requisitos jurídicos o técnicos que las disposiciones vigentes impongan a los proyectos, actuaciones o solicitudes que se propongan realizar.

g. Acceder a los registros y archivos de las Corporaciones Locales en los términos previstos en la Constitución y en ésta $u$ otras leyes.

h. Ser tratados con respeto y deferencia por las autoridades y funcionarios, que les facilitarán el ejercicio de sus derechos y el cumplimiento de sus obligaciones.

i. Obtener copias y certificaciones acreditativas de los acuerdos de las Corporaciones Locales y sus antecedentes.

j. Exigir responsabilidades de las Corporaciones Locales.

k. Ejercer cualesquiera otros que les reconozcan la Constitución y las leyes.

\section{Sección 2. ${ }^{\mathrm{a}}$}

\section{Participación ciudadana}

Artículo 253. 1. Las sesiones del Pleno de las Corporaciones Locales serán públicas. Sin embargo, podrán ser secretos el debate y la votación de aquellos asuntos que puedan afectar al derecho fundamental de los ciudadanos a que se refiere el artículo 18.1 de la Constitución, cuando así sea acordado por mayoría absoluta. No serán públicas, sin embargo, las sesiones de las comisiones de gobierno.

Serán también públicas las sesiones de los órganos de participación.

2. Las sesiones de los demás órganos de gobierno serán secretas, salvo que sea dispuesto lo contrario por acuerdo del Pleno.

3. Cuando algunas de las asociaciones o entidades constituidas para la defensa de los intereses generales o sectoriales de los vecinos deseen efectuar una exposición ante el Pleno en relación con algún punto del orden del día en cuya tramitación administrativa intervinieron como interesados, deberán solicitarlo al Alcalde antes de comenzar la sesión. Con la autorización de éste, y a través de un único representante, podrán exponer su parecer durante el tiempo que señale el Alcalde, siempre con anterioridad a la lectura, debate y votación de la propuesta incluida en el orden del día.

4. Terminada la sesión del Pleno, el Alcalde podrá establecer un turno de ruegos y preguntas con el público asistente y sobre temas concretos de interés municipal. Corresponde al Alcalde ordenar y cerrar este turno.

Artículo 254. 1. Los ciudadanos podrán ejercer el derecho de petición ante las autoridades locales solicitando la adopción de actos o acuerdos en materias de su competencia. De su ejercicio no podrá derivarse perjuicio alguno al peticionario, salvo que incurra en delito o falta.

2. En el escrito en que se deduzca la petición, firmado por el peticionario, deberá constar su nombre y domicilio y deberá dirigirse al Alcalde o Presidente de la Entidad Local de que se trate.

3. La autoridad a quien se dirija la petición estará obligada a acusar recibo de la misma.

4. Si la petición se estimase fundada, se adoptarán las medidas oportunas a fin de lograr su plena efectividad. En cualquier caso, deberá comunicarse al interesado la resolución que se adopte.

\section{Sección $3 .^{\mathrm{a}}$}

\section{Asociaciones de vecinos}

Artículo 255. 1. Los Ayuntamientos gallegos favorecerán el desarrollo de las asociaciones que se constituyan para la defensa de los intereses generales o sectoriales de los vecinos.

2. Las asociaciones constituidas con esta finalidad tendrán la consideración de entidades de participación ciudadana.

3. La Xunta de Galicia llevará un Registro General de Asociaciones en el que se inscribirán todas las existentes 
en la Comunidad Autónoma gallega, con los datos que reglamentariamente se establezcan. Los municipios establecerán un Registro propio.

4. En relación con el Ayuntamiento tendrán derecho a:

a. Recibir información directa sobre los asuntos que sean de su interés.

b. Hacer propuestas sobre los asuntos que afecten a los intereses de sus representados en el ámbito de la competencia municipal.

c. Formar parte de los órganos de participación municipal.

d. Intervenir en las sesiones de los órganos del Ayuntamiento cuando sean requeridas y autorizadas.

5. La asignación de medios y la distribución de ayudas, en su caso, se efectuarán con criterios objetivos, de acuerdo con la representatividad de las asociaciones.

La Xunta de Galicia, a través de la consellería competente en materia de régimen local, les prestará la debida asistencia y ayuda.

Artículo 256. Las asociaciones de vecinos podrán federarse dentro de cada municipio y la relación con las mismas será ejercida por el Alcalde o el Concejal delegado.

\section{Sección $4 .^{a}$ \\ Consultas populares}

Artículo 257. 1. Los Alcaldes, previo acuerdo del Pleno, por mayoría absoluta, podrán someter a consulta popular los asuntos de la competencia propia municipal y de carácter local que sean de especial importancia para los intereses de los vecinos, salvo los relativos a las haciendas locales.

2. Se determinarán reglamentariamente los requisitos y condiciones para ejercer este derecho y la celebración de la consulta se ajustará a las disposiciones generales y al procedimiento establecido por la legislación del Estado en materia de referéndum.

3. El procedimiento que se regule al efecto se adecuará a las siguientes reglas:

a. La Corporación Local remitirá a la Xunta de Galicia una copia literal del acuerdo adoptado por el Pleno del Ayuntamiento, precisando los términos exactos de la consulta.

b. El Consello de la Xunta de Galicia enviará la solicitud municipal al Gobierno del Estado, a la que se adjuntará, en su caso, un informe sobre la conveniencia de efectuar la consulta, de conformidad con el interés general de Galicia.

c. Corresponderá al Gobierno del Estado autorizar la consulta.

d. Concedida la autorización, en su caso, y de conformidad con la resolución municipal, el Consello de la Xunta de Galicia convocará la consulta popular mediante Decreto.

Dicho Decreto contendrá el texto íntegro de la disposición o decisión objeto de la consulta, señalará claramente la pregunta o preguntas que haya de responder el cuerpo electoral convocado y determinará la fecha en que deba hacerse la consulta, la cual quedará incluida entre los treinta y los sesenta días posteriores a la fecha de publicación del Decreto.

El Decreto se publicará en el "Diario Oficial de Galicia" y en el "Boletín Oficial" de la provincia correspondiente. Además, se anunciará en uno de los periódicos de mayor difusión de la Comunidad Autónoma y será fijado por el respectivo Ayuntamiento en su tablón de anuncios.

\section{Capitulo VI \\ DE LOS SÍMBOLOS \\ DE LAS ENTIDADES LOCALES}

Artículo 258. Las Entidades Locales de la Comunidad Autónoma de Galicia podrán adoptar escudos heráldicos y banderas propios y privativos, modificar los ya existentes o rehabilitar los que históricamente utilizasen. Se basarán en hechos históricos o geográficos característicos y peculiares de su territorio, conforme a las normas de heráldica.

Artículo 259. Ninguna Entidad Local de Galicia podrá utilizar escudo 
heráldico o bandera que no fuese aprobado por el Consello de la Xunta de Galicia, sin perjuicio de aquellos que fueron aprobados por la Administración del Estado con anterioridad a la transferencia de competencias en esta materia en favor de la Comunidad Autónoma de Galicia.

Artículo 260. 1. La Comisión de Heráldica, adscrita a la consellería competente en materia de régimen local, se constituye en el órgano consultivo de la Xunta de Galicia y le corresponderá emitir informe vinculante en los procedimientos de aprobación, modificación o rehabilitación de escudos heráldicos o banderas de las Entidades Locales gallegas.

2. La Comisión de Heráldica estará facultada para elaborar, sin cargo alguno para la Entidad Local interesada, las correspondientes propuestas para la aprobación, modificación o rehabilitación de escudos heráldicos y banderas.

3. También podrá asesorar, en materia de su competencia, a los órganos dependientes de la Xunta de Galicia, así como a todas aquellas Corporaciones Locales y entidades públicas o privadas que soliciten su dictamen.

Artículo 261. La Comisión de Heráldica estará presidida por el Director general con competencia en materia de régimen local e integrada por un Vicepresidente y cinco Vocales, cuatro de ellos designados por el conselleiro competente en materia de régimen local y el quinto por la asociación de municipios y provincias más representativa y con mayor implantación en el territorio de la Comunidad Autónoma de Galicia.

Será oída, en todo caso, la Corporación Local interesada.

Artículo 262. Las Entidades Locales que deseen aprobar, modificar o rehabilitar su escudo heráldico o bandera seguirán el procedimiento que reglamentariamente se establezca.

\section{TÍTULO VII BIENES, ACTIVIDADES Y SERVICIOS Y CONTRATACIÓN \\ Capítulo I \\ BIENES DE LAS ENTIDADES LOCALES}

\section{Sección $1 .^{\mathrm{a}}$}

Disposiciones comunes

Artículo 263. 1. El patrimonio de las Entidades Locales de Galicia estará constituido por el conjunto de bienes, derechos y acciones que les pertenezcan por cualquier título.

2. Los bienes de las Entidades Locales se clasificarán en bienes de dominio público, bienes comunales y bienes patrimoniales o de propios:

a. Son bienes de dominio público los destinados al uso o servicios públicos.

b. Son bienes comunales aquéllos cuyo aprovechamiento corresponda a una comunidad de vecinos por la normativa legal. Les será de aplicación el régimen jurídico que determine la Ley o, en su defecto, el establecido para los bienes de dominio público.

c. Son bienes patrimoniales los de titularidad de las Entidades Locales que no tienen el carácter de bienes de dominio público o comunal.

Artículo 264. Son bienes de uso público local los caminos, plazas, calles, paseos, parques, aguas de fuentes y estanques, puentes y demás obras públicas de aprovechamiento o utilización general cuya conservación y policía sea competencia de la Entidad Local.

Artículo 265. Son bienes de servicio público los destinados directamente al cumplimiento de fines públicos de responsabilidad de las Entidades Locales, tales como casas consistoriales, palacios provinciales $y$, en general, edificios que sean sede de las mismas, mataderos, mercados, lonjas, hospitales, hospicios, museos, montes catalogados, escuelas, cementerios, elementos de transporte, piscinas y campos de deporte 


\section{Administración Local}

$y$, en general, cualesquiera otros bienes directamente destinados a la prestación de servicios públicos o administrativos.

Artículo 266. Los bienes comunales y demás bienes de dominio público son inalienables, inembargables e imprescriptibles y no están sujetos a tributo alguno.

Artículo 267. 1. Son bienes patrimoniales o de propios los que siendo propiedad de la Entidad Local no estén destinados al uso público ni afectados a algún servicio público y puedan constituir fuentes de ingreso para el erario de la Entidad.

2. Los bienes patrimoniales se rigen por su legislación específica y, en su caso, por las normas de derecho privado.

Artículo 268. 1. Se clasifican como bienes patrimoniales, entre otros, las parcelas sobrantes y los efectos no utilizables.

2. Se conceptuarán como parcelas sobrantes aquellas porciones de terreno propiedad de las Entidades Locales que por la reducida extensión, forma irregular o localización no fuesen susceptibles de uso adecuado.

Para declarar un terreno parcela sobrante se requiere expediente de calificación jurídica, en la forma establecida en el siguiente artículo.

3. Se consideran efectos no utilizables todos aquellos bienes que por su deterioro, depreciación o deficiente estado de conservación resultasen inaplicables a los servicios municipales o al normal aprovechamiento, atendida su naturaleza o destino, aunque los mismos no fuesen dados de baja en el inventario.

Artículo 269. 1. La alteración de la calificación jurídica de los bienes de las Entidades Locales requiere expediente en el que se acrediten su oportunidad y legalidad. El expediente tendrá que ser resuelto por el Pleno, previa información pública por plazo de un mes, mediante acuerdo adoptado con el voto favorable de la mayoría absoluta del número legal de miembros del mismo.
2. En cualquier caso, la incorporación al patrimonio de la Entidad Local de los bienes desafectados, incluso cuando procedan de deslinde de dominio público, no se entenderá efectuada hasta la recepción formal por el órgano competente de la Corporación de los bienes de que se trate, y en tanto la misma no tenga lugar seguirán teniendo aquéllos el carácter de dominio público.

3. No obstante, la alteración se produce automáticamente en los siguientes supuestos:

a. Aprobación definitiva de los planes de ordenación urbana y de los proyectos de obras y servicios.

b. Adscripción de bienes patrimoniales por más de veinticinco años a un uso o servicio público o comunal.

c. Adquisición por usucapión por la entidad, con arreglo al derecho civil, del dominio de una cosa que viniese estando destinada a un uso o servicio comunal.

\section{Sección 2.}

De la adquisición y enajenación de sus bienes por las Entidades Locales

Artículo 270. 1. Las Entidades Locales tendrán capacidad jurídica plena para adquirir y poseer bienes de todas las clases y ejercitar las acciones y recursos procedentes en defensa de su patrimonio.

2. Las Entidades Locales tienen la obligación de ejercer las acciones que sean necesarias para la defensa de sus bienes y derechos.

Artículo 271. Las Corporaciones Locales pueden adquirir bienes y derechos:

a. Por atribución de la Ley.

b. A título oneroso por ejercicio o no de la facultad de expropiación.

c. Por herencia, legado o donación.

d. Por prescripción.

e. Por ocupación.

f. Por cualquier otro modo legítimo conforme al ordenamiento jurídico.

Artículo 272. 1. La adquisición de bienes a título oneroso exigirá el cumplimiento 
de los requisitos contemplados en la normativa reguladora de la contratación. Tratándose de bienes inmuebles se exigirá, además, informe previo pericial, y siendo bienes de valor histórico o artístico se requerirá el informe del órgano autonómico competente, siempre que su importe exceda del 1 por 100 de los recursos ordinarios del presupuesto de la Corporación o del límite general establecido para el procedimiento negociado en materia de suministros.

2. Las adquisiciones de bienes derivadas de expropiaciones forzosas se regirán por su normativa específica.

Artículo 273. 1. La adquisición de bienes a título gratuito no estará sujeta a restricción alguna.

No obstante, si la adquisición llevase aneja alguna condición o modalidad onerosa, sólo podrán aceptarse los bienes previo expediente en el que se acredite que el valor del gravamen impuesto no excede del valor de lo que se adquiere.

2. La aceptación de herencias se entenderá a beneficio de inventario.

Artículo 274. Si los bienes se adquieren bajo la condición o modalidad de su afectación permanente a determinados destinos, se entenderá ésta cumplida y consumada cuando durante treinta años sirviese al mismo y aunque después dejase de estarlo por circunstancias sobrevenidas de interés público.

Artículo 275. 1. Las Entidades Locales prescribirán a su favor con arreglo a las leyes comunes, sin perjuicio de lo establecido en disposiciones especiales.

2. Los particulares podrán prescribir a su favor los bienes patrimoniales de las Entidades Locales de acuerdo con las leyes comunes.

3. La ocupación de bienes muebles por las Entidades Locales se regulará por lo establecido en el Código Civil y en las leyes especiales.

Artículo 276. 1. Toda enajenación, gravamen o permuta de bienes inmuebles tendrá que comunicarse al órgano competente de la Comunidad Autónoma. Si el valor excediese del 25 por 100 de los recursos ordinarios del presupuesto anual de la Corporación, requerirá, además, autorización de aquél.

2. Los bienes inmuebles patrimoniales no podrán cederse gratuitamente a no ser a entidades o instituciones públicas y para fines que redunden en beneficio de los habitantes del término municipal, así como a instituciones o asociaciones privadas de interés público sin ánimo de lucro.

Artículo 277. 1. Las enajenaciones de bienes patrimoniales se realizarán por subasta pública, salvo en el caso de enajenación mediante permuta con otros bienes de carácter inmueble. En los expedientes deberán figurar los correspondientes informes técnicos relativos al valor de los bienes a enajenar.

2. Cuando se trate de enajenaciones o gravámenes que se refieran a monumentos, edificios u objetos de índole artística o histórica, será necesario el informe previo del órgano autonómico competente de acuerdo con la legislación sobre patrimonio histórico y artístico.

3. En ningún caso podrá procederse a la enajenación de bienes patrimoniales para financiar gastos corrientes, salvo que se trate de parcelas sobrantes de vías públicas no edificables o de bienes no utilizables en servicios locales.

Artículo 278. Las Entidades Locales están obligadas a formar inventario valorado de todos los bienes y derechos que les pertenezcan, así como también de los bienes pertenecientes a los organismos autónomos que dependan de ellas. De este inventario se remitirá copia al órgano competente de la Administración de la Comunidad Autónoma y se rectificará anualmente, comprobándose siempre que se renueve la Corporación.

Artículo 279. Las Entidades Locales deberán inscribir en el Registro de la Propiedad sus bienes inmuebles y 
derechos reales, siendo suficiente, a tal efecto, la certificación que, con relación al inventario aprobado por la respectiva Corporación, expida el Secretario, con el visto bueno del Alcalde o Presidente.

\section{Sección 3. ${ }^{a}$}

De las potestades y

prerrogativas de las Entidades

Locales respecto a sus bienes

Artículo 280. 1. Corresponden a las Entidades Locales de carácter territorial las siguientes potestades en relación con sus bienes:

a. La potestad de investigación.

b. La potestad de deslinde.

c. La potestad de recuperación de oficio.

d. La potestad de desahucio administrativo.

2. Para defender su patrimonio y para asegurar la adecuada utilización del mismo, las Corporaciones Locales también podrán establecer e imponer sanciones de acuerdo con lo previsto en la normativa sectorial aplicable.

Artículo 281. Las Corporaciones Locales tienen la facultad de investigar la situación de los bienes y derechos que se presuman de su propiedad, siempre que ésta no conste, con la finalidad de determinar la titularidad de los mismos.

Artículo 282. 1. Las Corporaciones Locales tendrán la facultad de promover y ejecutar el deslinde entre los bienes de su pertenencia y los de los particulares, cuando los límites apareciesen imprecisos o sobre los que existiesen indicios de usurpación.

2. Los propietarios de los terrenos colindantes con fincas pertenecientes a las Entidades Locales o que estuviesen enclavados dentro de aquéllas podrán reclamar su deslinde.

Artículo 283. 1. Las Corporaciones Locales podrán recobrar por sí la posesión de sus bienes de dominio público en cualquier tiempo.

Cuando se trate de bienes patrimoniales, el plazo para recobrarlos será de un año, que comenzará a contar desde el día siguiente a la fecha en que se produjese la usurpación, y, transcurrido ese tiempo, procederá la acción correspondiente ante los tribunales ordinarios.

2. No se admitirán interdictos contra las actuaciones de los agentes de la autoridad en esta materia.

Artículo 284. 1. Las Corporaciones Locales podrán ejecutar en vía administrativa la investigación, el deslinde y la reivindicación de los bienes sitos fuera del término de su jurisdicción mediante exhorto a la entidad del territorio en que radiquen, para que, por su mediación, se desarrollen los actos correspondientes.

2. Las Entidades Locales tendrán plena capacidad para ejercer todo tipo de acciones y recursos en defensa de sus derechos y patrimonio.

Artículo 285. Las Corporaciones Locales no podrán allanarse a las demandas judiciales que afectasen al dominio y demás derechos reales integrantes de su patrimonio.

\section{Capitulo II ACTIVIDADES Y SERVICIOS \\ Sección 1. ${ }^{a}$ \\ Actividades}

Artículo 286. 1. Las Corporaciones Locales podrán intervenir en la actividad de los ciudadanos a través de los siguientes medios:

a. Las ordenanzas y bandos.

b. El sometimiento a previa licencia y otros actos de control preventivo.

c. Las órdenes individuales constitutivas de mandato para la ejecución de un acto o para la prohibición del mismo.

2. La actividad de intervención se ajustará, en todo caso, a los principios de legalidad, igualdad de trato, proporcionalidad y congruencia con los motivos y fines que justifiquen la potestad y respeto a la libertad individual. 
Artículo 287. 1. Las ordenanzas y bandos no podrán contener preceptos contrarios a las leyes y a otras disposiciones generales de superior rango jerárquico.

Las ordenanzas podrán tipificar infracciones y establecer sanciones de conformidad con lo determinado por las leyes sectoriales.

2. Corresponderá al Presidente de la Corporación el ejercicio de la potestad sancionadora, a no ser que la Ley lo atribuya a otro órgano de la Corporación.

Artículo 288. 1. Las licencias y demás actos de control producirán efectos entre la Entidad Local y el sujeto de la actividad a que se refieran y se entenderán otorgadas salvo derecho de propiedad y sin perjuicio de terceros.

No podrán ser invocadas para excluir o disminuir la responsabilidad en que incurran los beneficiarios en el ejercicio de la actividad.

2. Las licencias quedarán sin efecto si se incumplen las condiciones impuestas al beneficiario y cuando termine el plazo por el que fueron otorgadas.

Podrán ser revocadas las licencias cuando desaparezcan las circunstancias que motivaron su otorgamiento o sobreviniesen otras que, de existir en el momento de la concesión, justificarían su denegación. Las licencias podrán ser anuladas, asimismo, cuando resulten otorgadas erróneamente y revocadas cuando se adopten nuevos criterios de apreciación. En estos casos, la anulación y revocación comportará el resarcimiento de los daños y perjuicios efectivamente ocasionados.

3. Serán transmisibles, previa comunicación a la Entidad Local, las licencias otorgadas sin consideración a las cualidades del sujeto beneficiario. En otro caso, se estará a lo dispuesto en su normativa específica y, en su defecto, a lo que se prevea en el acto de otorgamiento.

No serán transmisibles las licencias cuyo número de otorgamiento sea limitado.

Artículo 289. La infracción de las disposiciones generales y el incumplimiento de las obligaciones establecidas mediante actos singulares de intervención determinarán la imposición de la sanción.

La cuantía de la sanción no podrá exceder los límites establecidos en la normativa sobre haciendas locales, a no ser en los casos en que las leyes sectoriales establezcan un régimen sancionador específico que determine una cuantía superior.

Artículo 290. Tendrán la consideración de obras locales todas las de nueva planta, reforma, reparación o mantenimiento que ejecuten las Entidades Locales, tanto con sus propios fondos como con auxilio de otras entidades públicas o particulares, para la realización de servicios de su competencia.

Las obras municipales podrán ser de urbanización u ordinarias. Las primeras se rigen por la legislación urbanística.

Artículo 291. Todo proyecto de obra deberá constar de planos, presupuesto de realización y memoria en que se incluya la relación detallada y la valoración aproximada de los terrenos y construcciones que tienen que ocuparse y, en su caso, expropiarse, así como las condiciones económicas y facultativas que podrán ser ampliadas con anterioridad al anuncio de subasta o concurso.

Artículo 292. Se estimarán expropiables los edificios respecto a los cuales el municipio hubiese adquirido compromiso firme de cederlos en el momento oportuno al Estado, Comunidad Autónoma, provincia o una entidad pública, para destinarlos a fines que redunden en pro de los intereses de la comunidad municipal. La cesión tendrá que ser autorizada, en su caso, por el órgano competente de la Comunidad Autónoma.

Artículo 293. Las obras comprendidas en los planes de obras y servicios locales, incluidos los planes provinciales de cooperación, llevarán anexa la declaración de utilidad pública y la necesidad de ocupación de los terrenos y edificios en ellos comprendidos a los efectos de su expropiación forzosa. 


\section{Administración Local}

Artículo 294. 1. La actividad de fomento se ejercerá de conformidad con los principios de publicidad, objetividad, libre concurrencia e igualdad y con adecuación a la legalidad presupuestaria.

2. Las Corporaciones Locales podrán conceder subvenciones y ayudas de contenido económico u otra naturaleza a entidades, organismos o particulares, en los casos en que los servicios o actividades de los mismos complementen o sustituyan a los atribuidos a la competencia local.

En todo caso la concesión de estas subvenciones o ayudas tendrá en cuenta los criterios, directrices y prioridades que establezcan los planes sectoriales de coordinación.

3. Las Corporaciones Locales comprobarán la aplicación efectiva de los medios de fomento a la finalidad prevista.

\section{Sección 2. ${ }^{a}$ Servicios}

Artículo 295. 1. Son servicios públicos locales cuantos tiendan a la consecución de los fines señalados como de competencia de las Entidades Locales.

2. Los servicios públicos locales podrán gestionarse de forma directa o indirecta; en ningún caso podrán prestarse por gestión indirecta los servicios públicos que impliquen ejercicio de autoridad.

3. La gestión directa adoptará alguna de las siguientes formas:

a. Gestión por la propia Entidad Local, a través de sus órganos ordinarios o mediante órgano especial de Administración.

b. Organismo Autónomo local.

c. Sociedad mercantil cuyo capital social pertenezca íntegramente a la Entidad Local.

4. La gestión indirecta adoptará alguna de las siguientes formas:

a. Concesión.

b. Gestión interesada.

c. Concierto.

d. Arrendamiento.

e. Sociedad de economía mixta en la que participe la Administración, por sí o por medio de una entidad pública, en concurrencia con personas naturales o jurídicas.

Pueden gestionarse indirectamente los servicios de contenido económico que los haga susceptibles de explotación por empresarios particulares.

Artículo 296. 1. Los servicios esenciales que fuesen reservados por Ley a las Entidades Locales podrán prestarse en régimen de libre concurrencia o en régimen de monopolio.

2. La prestación del servicio en régimen de libre concurrencia necesitará de la aprobación definitiva del Pleno. La prestación en régimen de monopolio requerirá, además, la aprobación de la Xunta de Galicia.

3. Para el ejercicio de los servicios esenciales reservados podrá utilizarse cualquiera de las formas de gestión establecidas por la Ley.

Artículo 297. 1. Las Entidades Locales tendrán plena potestad para constituir, organizar, modificar y suprimir los servicios de su competencia, de conformidad con lo establecido por la legislación de régimen local y otras disposiciones aplicables.

2. Las Entidades Locales acordarán de forma expresa la creación de un servicio público local y procederán, en su caso, a su reglamentación antes de empezar a prestarlo. Asimismo, determinarán las modalidades de prestación y el régimen estatutario de los usuarios.

3. Las Entidades Locales podrán constituir consorcios locales con otras Administraciones Públicas para fines de interés común o con entidades privadas sin ánimo de lucro que persigan fines de interés público concurrentes con los de las Administraciones Públicas. El procedimiento para la constitución de los consorcios locales será el regulado por los artículos 149 y siguientes de la presente ley.

Artículo 298. 1. En el acceso a los servicios públicos y en la utilización de los 
mismos se respetará el principio de igualdad en relación con todas aquellas personas que cumplan los requisitos establecidos por la reglamentación del servicio.

2. Si las características o la naturaleza del servicio lo permiten, las Entidades Locales establecerán las técnicas de participación de los usuarios en la prestación de los servicios públicos, con la finalidad de garantizar su adecuado funcionamiento y su mejora.

Artículo 299. La gestión indirecta, en sus distintas formas, no podrá ser otorgada por tiempo indefinido, debiendo fijarse el tiempo del Convenio de acuerdo con las características del servicio, sin que en ningún caso exceda del plazo total de cincuenta años, incluidas las prórrogas.

En los casos de arrendamiento, concesión y empresa mixta, revertirán al patrimonio local, al término del Convenio, los bienes, instalaciones y material afectados al servicio, en condiciones normales de uso.

Artículo 300. En la gestión directa por la Entidad Local, ésta asumirá, en exclusiva, su propio riesgo y ejercerá los poderes de decisión y gestión a través de sus órganos ordinarios o mediante órgano especial instituido a tal efecto. En ambos casos los medios personales y materiales del servicio se adscribirán e integrarán en el presupuesto de la Entidad Local.

Artículo 301. 1. Los organismos autónomos para la gestión directa son entidades de derecho público, con personalidad jurídica pública y patrimonio propio, creadas por las Corporaciones Locales para la gestión descentralizada de sus intereses.

2. Se rigen por su propio estatuto, aprobado por la Entidad Local, que determinará los fines que se les asignen y los bienes y recursos económicos afectados a su cumplimiento, la organización general y régimen de funcionamiento y el sistema de designación de los órganos y personal directivo, así como las facultades de tutela que aquélla se reserve.

3. Los organismos autónomos elaborarán un presupuesto adaptado a la estructura de los presupuestos de las Entidades Locales, que se integrará en el general de la Corporación Local de que dependan.

4. En los procedimientos de contratación y selección de personal los organismos autónomos procurarán adaptar sus procedimientos a los aplicados en la Entidad Local. En particular, en la contratación, garantizarán los principios de publicidad y libre concurrencia, igualdad y no discriminación, y en la selección de personal, los de equidad, publicidad, mérito y capacidad.

Artículo 302. 1. Las sociedades mercantiles con capital social aportado exclusiva o mayoritariamente por la Entidad Local adoptarán una de las formas de responsabilidad limitada.

2. En la escritura de constitución de una sociedad constará el capital aportado por la Entidad Local, la forma de constituir el Consejo de Administración y la determinación de quienes tengan derecho a emitir voto en representación del capital social.

3. En las sociedades mercantiles cuyo capital pertenezca íntegramente a la Entidad Local la Corporación asumirá las funciones de la Junta General.

4. El personal de la sociedad no adquirirá en ningún caso la condición de funcionario. El procedimiento de selección respetará los principios de publicidad, mérito y capacidad.

5. Las sociedades mercantiles locales elaborarán un estado de previsión de gastos e ingresos que se integrará en el presupuesto general de la entidad. También elaborarán un programa de actuación, inversiones y financiación que se unirá, como anexo, al citado presupuesto general.

Artículo 303. En la concesión administrativa, la Entidad Local encomienda a un particular o entidad el establecimiento, 


\section{Administración Local}

a su cargo, de un servicio público, mediante la realización de las obras e instalaciones precisas, y su ulterior gestión, o solamente la prestación de servicio, cuando no requiera obras o instalaciones permanentes o estuviesen ya establecidas.

La gestión del servicio por el concesionario se hará a su riesgo y ventura.

La retribución del concesionario será la establecida en el acuerdo de concesión, pudiendo incluirse en la misma la concesión de tasas, precios de servicio, contribuciones especiales $\mathrm{u}$ otras aportaciones.

Artículo 304. Mediante la gestión interesada, el particular o empresario presta el servicio y la Entidad Local asume en exclusiva el resultado de la explotación o lo comparte con el gestor en la proporción establecida en el contrato.

Corresponderá a la Entidad Local la recepción de las tarifas devengadas por los usuarios. Los gastos de explotación se distribuirán entre el gestor y la Entidad Local en la proporción pactada en el contrato.

La remuneración que el gestor perciba de la Administración podrá consistir, conjunta o aisladamente, en una asignación fija o proporcional a los gastos o beneficios de la explotación.

Asimismo, podrá estipularse un beneficio mínimo en favor de cualquiera de las partes asociadas atendiendo a los resultados de la explotación.

Artículo 305. Las Corporaciones Locales podrán concertar la prestación de servicios con otros entes públicos o privados y con particulares, utilizando los que éstos tengan establecidos mediante el pago de un precio alzado predeterminado e inalterable por la totalidad del servicio, por unidades o actos.

La Entidad Local podrá repercutir en los usuarios el coste de los servicios concertados.

Artículo 306. La prestación de los servicios cuyas instalaciones pertenezcan a las Entidades Locales podrá ser objeto de arrendamiento por canon fijo anual.
Corresponderá al arrendatario la percepción de las aportaciones de los usuarios y serán de su cargo los gastos de explotación y las reparaciones que sean necesarias para el buen funcionamiento del servicio.

Artículo 307. Sin perjuicio de lo establecido en la presente ley y en las disposiciones que la desarrollen, las sociedades mercantiles con participación exclusiva o parcial de las Entidades Locales se regirán por la normativa civil, mercantil o laboral que les sea de aplicación.

Artículo 308. 1. En los casos de gestión indirecta mediante sociedad mercantil con responsabilidad limitada, o cooperativa, la aportación de la Entidad Local podrá ser minoritaria, sin que en ningún caso sea inferior al tercio del capital social, y podrá consistir en la concesión u otra clase de bienes y derechos que tendrán la consideración de patrimoniales y numerarios. El capital social será desembolsado completamente en el momento de la constitución o de la ampliación de capital.

2. Los Estatutos sociales delimitarán el carácter de empresa mixta en cuanto órgano gestor de un servicio público o una actividad económica y, en especial, determinarán las facultades reservadas al ente público o a sus representantes en los órganos directivos de la sociedad y las causas de disolución de éstos. La responsabilidad de la Entidad Local por las obligaciones sociales se limitará a su aportación al capital social.

3. La gestión de la sociedad será compartida por la Corporación Local y los particulares en proporción a la participación respectiva en el capital social. No obstante se requerirá la conformidad de la Entidad Local para la modificación del acto de constitución o de los Estatutos de la sociedad, la concertación de operaciones de crédito y la aprobación de las cuentas y balances.

Artículo 309. 1. El ejercicio por las Entidades Locales de actividades económicas 
requerirá un expediente previo, en el que se acreditará la conveniencia y oportunidad de la iniciativa pública.

2. Para adoptar la iniciativa será necesario:

a. El acuerdo inicial de la Corporación, previa designación de una comisión de estudio compuesta por miembros de la misma y por personal técnico.

b. Una memoria redactada por la comisión, relativa a los aspectos sociales, jurídicos, técnicos y financieros de la actividad económica de que se trate, en la que deberá determinarse la forma de gestión, entre las previstas por la Ley, y los casos en que debe cesar la prestación de la actividad.

c. La toma en consideración de la memoria por el Pleno y la exposición al público por un período de treinta días como mínimo, durante el cual podrán presentarse reclamaciones o alegaciones.

d. La aprobación final por el Pleno de la Entidad Local.

\section{Capítulo III CONTRATACIÓN}

Sección 1. ${ }^{a}$

\section{Disposiciones generales}

Artículo 310. Las Entidades Locales podrán concertar los contratos, pactos o condiciones que consideren adecuados siempre que no sean contrarios al interés público, al ordenamiento jurídico o a los principios de buena administración, y los cumplirán de conformidad con su contenido, sin perjuicio de las prerrogativas establecidas, en su caso, por la legislación básica o por la legislación de la Comunidad Autónoma en favor de las mencionadas entidades.

Artículo 311. 1. Los contratos que celebren las Entidades Locales tendrán carácter administrativo o carácter privado.

2. Los contratos administrativos podrán ser ordinarios o especiales: a. Son ordinarios aquellos cuyo objeto directo, conjunta o separadamente, sea la ejecución de obras, la gestión de servicios públicos y la realización de suministros, los de consultoría y asistencia o de servicios y los que se celebren excepcionalmente con personas físicas para la realización de trabajos específicos y concretos no habituales.

b. Son especiales los de objeto distinto a los anteriormente expresados pero que tengan naturaleza administrativa especial por resultar vinculados al giro o tráfico específico de las Corporaciones Locales, por satisfacer de forma directa o inmediata una finalidad pública de la específica competencia de aquéllas o por declararlo así una Ley.

3. Los restantes contratos celebrados por las Corporaciones Locales tendrán la consideración de contratos privados y, en particular, los contratos de compraventa, donación, permuta, arrendamiento y demás negocios jurídicos análogos sobre bienes inmuebles, propiedades incorporales y valores negociables.

4. Cuando un contrato administrativo contenga prestaciones correspondientes a otro u otros contratos administrativos de distinta clase, se atenderá, para su clasificación y aplicación de las normas que lo regulen, al carácter de la prestación que tenga más importancia desde el punto de vista económico.

Artículo 312. 1. Los contratos administrativos se regirán, en cuanto a su preparación, adjudicación, efectos y extinción, por las leyes de contratos de las Administraciones Públicas y sus disposiciones de desarrollo; supletoriamente se aplicarán las restantes normas de Derecho Administrativo y, en su defecto, las normas de Derecho privado. No obstante, los contratos administrativos especiales, a que se refiere el apartado 2, letra b), del artículo 311 de la presente ley, se regirán por sus propias normas con carácter preferente.

2. Los contratos privados de las Administraciones Públicas se regirán, en cuanto a su preparación y adjudicación, en defecto 


\section{Administración Local}

de normas administrativas específicas, por las leyes de contratos de las Administraciones Públicas y sus disposiciones de desarrollo, y, en cuanto a sus efectos y extinción, por las normas de Derecho privado. Los contratos de compraventa, donación, permuta, arrendamiento y demás negocios jurídicos análogos sobre bienes inmuebles, propiedades incorporales y valores negociables se regirán por la legislación patrimonial de las Administraciones Públicas aplicable a cada caso.

Artículo 313. 1. Los contratos de las Entidades Locales se ajustarán a los principios de publicidad y concurrencia, salvo las excepciones establecidas por la Ley de Contratos de las Administraciones Públicas y, en todo caso, a los de igualdad y no discriminación.

2. Son requisitos necesarios para la celebración de los contratos administrativos, a no ser que expresamente se disponga otra cosa en la presente ley y en la Ley de Contratos de las Administraciones Públicas, los siguientes:

a. La competencia del órgano de contratación.

b. La capacidad del contratista adjudicatario.

c La determinación del objeto del contrato.

d. La fijación del precio.

e. La existencia de crédito adecuado y suficiente, si del contrato se derivan obligaciones de contenido económico para la Entidad Local.

f. La tramitación del expediente, al que se incorporarán los pliegos en los que la Entidad Local establecerá las cláusulas que han de regir el contrato a celebrar y el importe del presupuesto del gasto.

g. La fiscalización previa de los actos administrativos de contenido económico.

h. La aprobación del gasto por el órgano competente.

i. La formalización del contrato.

Artículo 314. 1. La competencia de los órganos de las entidades locales en materia de contratación se regirá por las siguientes reglas:

a. Será competencia del Presidente la contratación de obras, servicios y suministros siempre que su cuantía no exceda del 5 por 100 de los recursos ordinarios de su presupuesto ni del 50 por 100 del límite general aplicable al procedimiento negociado.

b. Será competencia del Pleno la contratación de las obras, servicios y suministros no incluidos en el párrafo anterior.

2. La competencia para suscribir el contrato comportará la facultad de aprobar el proyecto, el pliego de cláusulas administrativas, el pliego de prescripciones técnicas, el expediente de contratación y el gasto, la facultad de adjudicar el contrato y todas las demás facultades que la legislación atribuya al órgano de contratación.

3. El Pleno podrá delegar las facultades de contratación en la Comisión de Gobierno con las siguientes condiciones:

a. El acuerdo de delegación determinará si se refiere a todas las facultades de contratación o no.

b. Para el procedimiento negociado se fijará previamente, por acto general o reglamentariamente, la cuantía máxima de la delegación.

c. No podrán ser objeto de delegación las facultades de contratación cuando por Ley se exija una mayoría cualificada para el establecimiento del contrato.

Artículo 315. Estarán facultadas para contratar con las entidades locales las personas naturales o jurídicas, españolas o extranjeras, que tengan plena capacidad de obrar, no estén comprendidas en ninguno de los supuestos de incapacidad e incompatibilidad determinados por la legislación básica estatal y por las normas que la desarrollan y acrediten su solvencia económica, financiera y técnica o profesional. Este último requisito será sustituido por la correspondiente clasificación en los casos en que, con arreglo a la legislación básica estatal, sea exigible. 
Artículo 316. 1. El objeto del contrato deberá ser determinado y se justificará en el expediente de contratación su necesidad para los fines del servicio público correspondiente.

2. Los contratos tendrán siempre un precio cierto, expresado en moneda nacional, que se abonará al contratista en función de la prestación realmente efectuada y de acuerdo con lo convenido.

\section{Sección 2. \\ De las actuaciones relativas a la contratación}

Artículo 317. 1. Las Entidades Locales podrán aprobar, previo dictamen del Consello Consultivo de Galicia, pliegos de cláusulas administrativas generales. Estos pliegos contendrán las determinaciones jurídicas, económicas y administrativas típicas que se aplicarán a todos los contratos de objeto análogo y las determinaciones exigidas por la legislación aplicable a la contratación local.

2. Los pliegos de cláusulas administrativas generales se referirán necesariamente a los siguientes aspectos:

a. La ejecución del contrato y las incidencias del mismo.

b. Los derechos y obligaciones de las partes y el régimen económico.

c. Las modificaciones del contrato, con indicación de los supuestos y límites.

d. Las causas de resolución del contrato.

e. La conclusión del contrato, las recepciones y el plazo de garantía y la liquidación.

Artículo 318. 1. Las Entidades Locales aprobarán, previa o conjuntamente a la autorización del gasto y siempre antes de la perfección y, en su caso, licitación del contrato, los pliegos de cláusulas administrativas particulares, que incluirán los pactos y condiciones definidoras de los derechos y obligaciones que asumirán las partes contratantes.

2. La aprobación de dichos pliegos corresponderá al órgano de contratación competente y requerirá informe previo del Secretario y del Interventor de la Corporación.

3. El órgano de contratación competente podrá, asimismo, establecer modelos tipo de pliegos particulares de general aplicación a los contratos de naturaleza análoga.

4. Los contratos se ajustarán al contenido de los pliegos particulares y sus cláusulas se considerarán parte integrante de los respectivos contratos.

5. Las Entidades Locales facilitarán las copias de los pliegos o condiciones de los contratos a todos los interesados que lo soliciten.

Artículo 319. Los pliegos y documentos que contengan las prescripciones técnicas particulares que tengan que regir la ejecución de la prestación serán elaborados, de conformidad con los requisitos que para cada contrato establece la legislación estatal básica en materia de contratación, con anterioridad a la autorización del gasto, correspondiendo su aprobación al órgano de contratación competente.

Artículo 320. Los contratos que concierten las Entidades Locales serán inválidos cuando lo sea alguno de los actos preparatorios o el de adjudicación y cuando concurra alguna de las causas de Derecho Administrativo o de Derecho Civil a que se refieren los artículos 62 y siguientes de la Ley de Contratos de las Administraciones Públicas.

Artículo 321. 1. Dentro de los límites y con sujeción a los requisitos y efectos señalados por la legislación básica en materia de contratación, el órgano competente para la contratación tendrá la prerrogativa de interpretar los contratos administrativos y resolver las dudas que presente su cumplimiento. De igual modo, por razones de interés público, podrá modificar los contratos suscritos y acordar su resolución dentro de los límites y con sujeción a los requisitos y efectos establecidos legalmente.

Las facultades otorgadas en el párrafo anterior lo serán sin perjuicio de la audiencia 


\section{Administración Local}

preceptiva del contratista y de las responsabilidades e indemnizaciones que procedan.

2. Los acuerdos dictados por el órgano competente para interpretar, modificar y resolver los contratos pondrán fin a la vía administrativa y serán inmediatamente ejecutivos. Antes de adoptarlos será preceptivo el informe del Secretario y del Interventor de la Corporación.

3 . No obstante lo anterior, será preceptivo el dictamen del Consello Consultivo de Galicia en los casos de:

a. Interpretación, nulidad y resolución, cuando sea formulada oposición por parte del contratista.

b. Modificaciones, cuando la cuantía de las mismas, aislada o conjuntamente, sea superior a un 20 por 100 del precio original del contrato y éste sea igual o superior a mil millones de pesetas.

Artículo 322. 1. Los expedientes de contratación podrán ser ordinarios, urgentes o de emergencia.

2. Podrán ser objeto de tramitación urgente los expedientes de contratos cuya necesidad sea inaplazable o cuya adjudicación sea preciso acelerar por razones de interés público. A tales efectos, el expediente deberá contener la declaración de urgencia, hecha por el órgano de contratación, que estará debidamente motivada. Los expedientes calificados de urgentes seguirán el trámite abreviado establecido por la Ley de Contratos de las Administraciones Públicas.

3. El Pleno y el Presidente de las Entidades Locales podrán ejercer las facultades excepcionales en materia de contratación que sean necesarias cuando las Entidades Locales tengan que realizar obras, servicios, adquisiciones o suministros de emergencia, por causa de acontecimientos catastróficos, situaciones que comporten un grave peligro o necesidades que afecten directamente a la seguridad pública. Si fuese el Presidente quien ejerciese la facultad, dará cuenta de ello al Pleno de la Corporación en la primera sesión que celebre.

Artículo 323. 1. La adjudicación de los contratos podrá llevarse a cabo por procedimiento abierto, restringido o negociado.

2. Tanto en el procedimiento abierto como en el restringido la adjudicación podrá efectuarse por concurso o subasta. La subasta versará sobre un tipo expresado en dinero, con adjudicación al licitador que, sin exceder de aquél, oferte el precio más bajo.

En el concurso la adjudicación recaerá en el licitador que, en su conjunto, haga la proposición más ventajosa, teniendo en cuenta los criterios que hayan sido establecidos en los pliegos, sin atender exclusivamente a su precio y sin perjuicio del derecho de la Corporación a declararlo desierto.

Artículo 324. 1. Los órganos de contratación utilizarán, normalmente, la subasta y el concurso como formas de adjudicación. El procedimiento negociado sólo procederá en los casos determinados por la Ley de Contratos de las Administraciones Públicas para cada clase de contratos.

2. En cualquier caso deberá justificarse en el expediente la elección del procedimiento y forma utilizados.

Artículo 325. 1. Las Entidades Locales podrán ejecutar directamente por administración las obras en que concurran alguna de las circunstancias establecidas en la Ley de Contratos de las Administraciones Públicas, sin perjuicio de las limitaciones que reglamentariamente se establezcan, atendidas las características de la entidad y de la obra a realizar.

2. El procedimiento de adjudicación de los trabajos a ejecutar por terceros se ajustará asimismo a dicha legislación en los supuestos del apartado anterior.

Artículo 326. 1. Todos los procedimientos para la adjudicación de los contratos, con excepción de los procedimientos negociados, se publicarán en 
el "Boletín Oficial" de la provincia y en el "Diario Oficial de Galicia". Además, cuando por razón de su cuantía estén sujetos a publicación en el "Diario Oficial de las Comunidades Europeas", se publicarán en el "Boletín Oficial del Estado".

2. En los procedimientos abiertos, el anuncio se publicará con una antelación mínima de veintiséis días al señalado como último para la recepción de las proposiciones. Este plazo será de catorce días anteriores al último para la recepción de las solicitudes de participación en los procedimientos restringidos y en los negociados con publicidad. En los procedimientos restringidos el plazo para la presentación de proposiciones será de veintiséis días desde la fecha del envío de la invitación escrita.

3. En los anuncios se expresará el plazo y horas en que puedan presentarse las proposiciones en la Secretaría de la Corporación, donde deberá estar a disposición de los futuros proponentes el pliego de condiciones, el lugar, día y hora en que se reunirá la Mesa, el modelo de proposición, el extracto del pliego de condiciones y la garantía provisional exigible para tomar parte en la subasta o concurso, así como la definitiva que se deberá constituir en el caso de adjudicación, para la garantía de las obligaciones que haya que cumplir.

4. Igualmente, se publicará en el "Diario Oficial de las Comunidades Europeas" cuando así proceda, por razón de cuantía y conforme se determine reglamentariamente, de acuerdo con las normas comunitarias vigentes en la materia.

Artículo 327. El procedimiento de adjudicación de los contratos por las Entidades Locales se regirá por las normas generales a que se refiere la Ley de Contratos de las Administraciones Públicas, además de por las siguientes reglas:

1. Será potestativa la constitución de Juntas de Compras en aquellas corporaciones en que la importancia de los suministros lo justifique. El acuerdo de constitución será adoptado por el Pleno, y determinará también su composición.

2. ${ }^{a}$ De la Mesa de Contratación será Presidente el de la Corporación o miembro de ésta en el que se haga delegación, y formarán parte de dicha Mesa el Secretario y el Interventor de la Corporación y, en su caso, los Vocales que se determinen reglamentariamente.

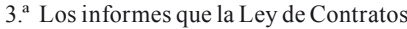
de las Administraciones Públicas asignan a las asesorías jurídicas serán evacuados por la Secretaría de la Corporación.

4. ${ }^{a}$ Los actos de fiscalización serán ejercidos por el Interventor de la entidad.

5. ${ }^{\mathrm{a}}$ El contrato será formalizado en escritura pública o en documento administrativo, dando fe en este caso el Secretario de la Corporación.

6. ${ }^{a}$ Las garantías de los contratistas deberán depositarse en la caja de la Corporación contratante.

7. ${ }^{a}$ Se admitirá el aval bancario como medio de garantía para constituir las fianzas definitivas de los contratistas.

Artículo 328. 1. El objeto de los contratos no podrá fraccionarse en partes o grupos, a no ser que sean susceptibles de utilización independiente o puedan ser sustancialmente definidos, justificándolo debidamente en el expediente.

2. En los contratos en los que el período de ejecución exceda el de un presupuesto anual, podrán redactarse proyectos independientes relativos a cada una de las partes de la obra, siempre que éstas sean susceptibles de utilización independiente en el sentido del uso general o del servicio o puedan ser sustancialmente definidas y proceda autorización concedida por el Pleno de la Corporación adoptada con el voto favorable de la mayoría absoluta legal de sus miembros.

\section{TÍTULO VIII DE LAS HACIENDAS LOCALES}

Artículo 329. La Comunidad Autónoma gallega regulará, mediante Ley 
del Parlamento de Galicia, las haciendas de las Entidades Locales de Galicia en el marco de lo establecido por la legislación básica del Estado.

Artículo 330. Corresponde a la Comunidad Autónoma gallega, de conformidad con el artículo 49 del Estatuto de Autonomía de Galicia, ejercer la tutela financiera sobre las Entidades Locales, respetando la autonomía que a las mismas reconocen los artículos 140 y 142 de la Constitución.

Artículo 331. 1. Para el ejercicio de sus competencias y el cumplimiento de los fines que las Entidades Locales de Galicia tienen confiados éstas serán dotadas de recursos suficientes.

2. Las haciendas de las Entidades Locales gallegas se nutrirán de los tributos propios, de la participación en los tributos del Estado y de la Comunidad Autónoma de Galicia y de aquellos otros recursos que a tal efecto se prevean, de conformidad y con el alcance que se establezca en la Ley a que se refiere el artículo 329 de la presente ley y, en su caso, la legislación general del Estado.

Artículo 332. 1. La Ley a que se refiere el artículo 329 de la presente ley regulará un Fondo de Cooperación Local, y la Ley de Presupuestos de la Comunidad Autónoma de Galicia fijará la cuantía anual de dicho fondo.

2. Este Fondo de Cooperación Local tendrá por objeto compensar los desequilibrios internos de Galicia en infraestructuras básicas de carácter local y, en particular, incrementar éstas, acercando los servicios públicos locales de Galicia a la media del Estado, facilitando, al mismo tiempo, el apoyo a la actividad económica en los núcleos y zonas menos desarrollados de la Comunidad Autónoma.

Artículo 333. La Ley que regule las haciendas locales de Galicia ordenará en especial las siguientes materias:

a. Los ingresos procedentes de su patrimonio y demás de Derecho privado. b. Los tributos propios.

c. Las participaciones en los tributos de la Comunidad Autónoma de Galicia.

d. Las subvenciones, estableciéndose a tal efecto un registro de las subvenciones y ayudas a las entidades locales.

e. El producto de las operaciones de crédito.

f. El producto de las multas y sanciones en el ámbito de sus competencias.

g. Las demás prestaciones de Derecho público.

\section{DISPOSICIÓN ADICIONAL}

En el plazo de seis meses, a partir de la entrada en vigor de esta ley, quedará constituida la Comisión Galega de Cooperación Local, a la que se refieren los artículos 188 y siguientes de la presente ley.

\section{DISPOSICIÓN TRANSITORIA PRIMERA}

Los expedientes relativos a la constitución de mancomunidades de municipios y Entidades Locales menores, así como las alteraciones de términos municipales en tramitación a la entrada en vigor de la presente ley, se ajustarán a lo previsto en la misma.

\section{DISPOSICIÓN TRANSITORIA SEGUNDA}

Los expedientes relativos a planes, programas de inversiones o cualesquiera otros de la misma naturaleza regulados en la presente ley y que se encuentren en tramitación a su entrada en vigor se ajustarán a lo previsto en la misma.

\section{DISPOSICIÓN TRANSITORIA TERCERA}

La Federación Gallega de Municipios y Provincias, reconocida por las Entidades Locales como la entidad asociativa más representativa y mayoritaria, tendrá las facultades establecidas en la presente ley y las derivadas de su representatividad.

\section{DISPOSICIÓN DEROGATORIA}

Quedan derogadas las normas de igual o inferior rango en lo que contradigan o 
se opongan a lo dispuesto en la presente ley, especialmente la Ley 8/1989, de 15 de junio, de Delimitación y Coordinación de las Competencias de las Diputaciones Provinciales Gallegas.

\section{DISPOSICIÓN FINAL PRIMERA}

La organización, funcionamiento y competencias de la parroquia rural se regularán, en su día, por una Ley del Parlamento de Galicia.

\section{DISPOSICIÓN FINAL SEGUNDA}

1. Se autoriza al Consello de la Xunta de Galicia para dictar las disposiciones reglamentarias para el desarrollo de la presente ley.

2. El desarrollo reglamentario a que se refiere el apartado anterior se efectuará en el plazo de un año desde la entrada en vigor de la presente ley.

3. Mientras no se efectúe el desarrollo reglamentario serán de aplicación los $\mathrm{Re}$ glamentos y demás disposiciones del Estado sobre la materia en todo aquello que no se oponga, contradiga o sea incompatible con lo establecido en la presente ley. Aprobados los reglamentos por la Xunta de Galicia, las normas estatales serán de aplicación supletoria, de conformidad con lo establecido por el artículo 149.3 de la Constitución.

Se establece un período de "vacatio legis" de tres meses para la entrada en vigor de la presente ley a contar desde el día siguiente al de su publicación en el "Diario Oficial de Galicia”.

\section{LEY 7/1996, DE 10 DE JULIO, DE DESARROLLO COMARCAL (DOGA N. $\left.{ }^{\circ} 142,19.7 .1996\right)$}

\section{(...) $)^{139}$ \\ TÍTULO I DISPOSICIONES GENERALES}

Artículo 1. Objeto de la ley. Con la finalidad de promover el desarrollo comarcal, la presente ley tiene por objeto

139 Exposición de motivos omitida. establecer el marco normativo de aquél, que se realizará a través de una actuación territorial basada en la dinamización de los recursos endógenos y las iniciativas locales, mediante la implantación gradual y participativa de planes de desarrollo comarcal que permitan la integración de la planificación socioeconómica y la ordenación del territorio, así como la coordinación de las distintas administraciones y las inversiones públicas en los ámbitos comarcales que se configuren y que serían el instrumento para ir dotando de capacidad de actuación a las comarcas.

Artículo 2. Fines.

Los fines del desarrollo comarcal que persigue la presente ley son los siguientes:

1. La coordinación de las diferentes administraciones implicadas para favorecer el desarrollo local, mediante un modelo de cooperación horizontal y vertical que permita una mayor y más eficiente asignación de los recursos.

2. La configuración de las comarcas como unidades supramunicipales, como el ámbito más adecuado para la coordinación e integración de la planificación socioeconómica y la planificación física, y para la protección del medio ambiente en un modelo de desarrollo integrado.

3. La implantación de estrategias de coordinación y planificación integrada sin multiplicar las estructuras administrativas existentes.

4. El fortalecimiento del papel de los agentes socioeconómicos públicos y privados de la comarca como factores dinamizadores del desarrollo.

5. La aplicación de los principios y métodos del modelo de desarrollo local a todo el territorio, mediante una implantación gradual y participativa para diseñar proyectos estratégicos de desarrollo comarcal.

6. La búsqueda de una solución para las situaciones críticas que se derivan de los procesos de despoblamiento demográfico, envejecimiento, descapitalización, infraequipamiento y subutilización de recursos. 


\section{Administración Local}

7. La definición de las especificidades productivas comarcales, que permitan establecer las ventajas comparativas dentro de una oferta de calidad.

8. La reducción de los desequilibrios territoriales existentes.

9. La contribución a la ordenación del territorio, a fin de hacer compatible la protección del medio - entendido como recurso y como calidad de vida - con el desarrollo comarcal.

Artículo 3. Ámbito de aplicación.

1. Subjetivo.

a. El cumplimiento de los objetivos especificados en el artículo anterior es responsabilidad de todas las administraciones públicas implicadas, $\mathrm{y}$, en particular, afectará a:

La Administración autonómica.

La Administración local.

b. Dentro del marco de competencias constitucionalmente establecido el Gabinete de Planificación y Desarrollo Territorial de la Xunta de Galicia procurará la coordinación con las acciones de la Administración General del Estado.

2. Territorial.

La presente ley abarca la totalidad del territorio de la Comunidad Autónoma de Galicia.

\section{TÍTULO II \\ DEL PLAN DE DESARROLLO COMARCAL DE GALICIA \\ Capítulo I PRINCIPIOS Y OBJETIVOS}

Artículo 4. De los planes de desarrollo comarcal.

1. La comarca constituye el ámbito de actuación de los planes de desarrollo comarcal.

2. El Plan de desarrollo comarcal se concibe como un instrumento de coordinación para la concreción de las directrices y normas básicas contenidas en la legislación de ordenación del territorio y en el Plan económico y social para lograr el desarrollo territorial homogéneo y equilibrado de Galicia.

3. Los planes de desarrollo comarcal serán formulados, tramitados y aprobados según el procedimiento establecido en esta ley y normas que la desarrollen. En todo caso, habrá de asegurarse el trámite de información pública y de audiencia de las administraciones implicadas.

Artículo 5. Principios del Plan de desarrollo comarcal.

El Plan de desarrollo comarcal se fundamentará en los siguientes principios generales:

1. Voluntariedad en la incorporación al proceso de desarrollo comarcal.

2. Participación, mediante la colaboración activa y voluntaria, de los agentes económicos y sociales de cada comarca.

3. Coordinación de las acciones de las distintas administraciones en el territorio comarcal.

4. Subsidiariedad, como principio destinado a alcanzar la mayor eficacia en la distribución de las acciones de desarrollo entre las diferentes administraciones territoriales.

5. Adicionalidad, mediante la suma de esfuerzos financieros de las distintas administraciones y agentes socioeconómicos implicados.

6. Complementariedad entre las iniciativas de desarrollo local a través de los planes de desarrollo integrado de cada comarca.

7. Flexibilidad, tanto en el diseño y aplicación de los planes como en el sistema de evaluación abierta y seguimiento continuo.

\section{Artículo 6. Objetivo.}

Para el cumplimiento de los fines señalados en el título anterior, el Plan de desarrollo comarcal estará orientado a la consecución de:

a. La estandarización de los equipamientos públicos.

b. El desarrollo social y económico de la comarca en sus ámbitos formativos, culturales y sociales.

c. La inserción de la comarca en los sistemas generales de comunicación, 
producción, comercialización, promoción y otros relativos al desarrollo económico de la misma.

d. La determinación de las distintas aptitudes y usos del suelo en función de sus capacidades productivas y su valor medioambiental.

e. Crear y mejorar las infraestructuras y servicios locales que favorezcan la descentralización productiva, la capacidad de innovación y el uso de nuevas tecnologías, para competir en un mercado abierto.

f. Articular el sistema de asentamientos, potenciando los niveles intermedios, es decir, los centros y subcentros comarcales de desarrollo, como núcleos de crecimiento.

g. Promover la creación de mancomunidades voluntarias para la prestación de servicios en la totalidad o en parte de los municipios que integran la comarca.

h. Propiciar la creación y potenciación de organizaciones intermedias de dinamización interna.

i. Implantar una estructura territorial descentralizada, adaptada a la dispersión del hábitat, a fin de acercar a la población los servicios que la sociedad moderna demanda.

j. Racionalizar una desconcentración flexible de los servicios administrativos, para conseguir una mejor relación entre los mismos y las necesidades comarcales.

\section{Capítulo II LA ESTRUCTURA DE LOS INSTRUMENTOS DE PLANIFICACIÓN}

Artículo 7. De los instrumentos de planificación.

1. El Plan de desarrollo comarcal se materializa por medio de los planes de desarrollo de cada comarca, que son así los instrumentos específicos de planificación.

2. Los planes de desarrollo comarcal se ajustarán a los planes de ordenación de los recursos naturales, a las directrices de ordenación del territorio y a los planes territoriales integrados que les afecten, y, en su caso, se revisarán para ajustar a los mismos sus determinaciones en el plazo y mediante el procedimiento que reglamentariamente se establezca.

3. Los planes de desarrollo comarcal que se aprueben tendrán la consideración de programas coordinados de actuación previstos en la Ley de ordenación del territorio.

Artículo 8. Estructura y contenido. Los planes de desarrollo de cada comarca tendrán la siguiente estructura y contenido mínimo:

1. Estudio socioeconómico.

2. Estudio del medio físico.

3. Programación de estrategias y acciones de desarrollo comarcal.

Artículo 9. Estudio socioeconómico. El estudio socioeconómico tendrá, al menos, los siguientes contenidos:

1. Un análisis de la cohesión interna y la integración funcional de la comarca, así como su vertebración económica y social con el resto de Galicia.

2. El estudio del marco territorial, a fin de establecer una clasificación del territorio comarcal en áreas y subáreas.

3. Un análisis de los recursos humanos, para determinar la estructura y tendencias en la evolución de la población.

4. Un análisis de la estructura socioeconómica, a fin de detectar las ventajas comparativas y las barreras que afecten al sistema productivo.

5. Un análisis de la calidad de vida, para determinar las debilidades existentes o los problemas de marginalidad que pueden condicionar la habitabilidad y las condiciones de vida de los habitantes de la comarca.

6. El estudio de la red urbana comarcal y de la estructura funcional del territorio, estableciendo, con criterios técnicos, los centros urbanos o núcleos de población que, por sus características y posibilidades, puedan funcionar como centros y subcentros de desarrollo de la comarca.

7. Una síntesis funcional, detectando las oportunidades y debilidades existentes, a fin de fijar los mecanismos alternativos de potenciación o corrección. 


\section{Administración Local}

Artículo 10. El estudio del medio físico.

El estudio del medio físico tiene como fin obtener una síntesis del potencial del territorio, en función de los recursos naturales de la comarca. Ello implica una clasificación del espacio comarcal según sus aptitudes productivas, para compatibilizar el desarrollo socioeconómico con el medio ambiente y la calidad de vida. Dicho estudio incluirá, al menos:

a. Un mapa ambiental, en el cual se localicen áreas con fuerte impacto negativo, áreas de conservación y de protección.

b. Un mapa de recursos naturales de valor estratégico, que contenga los usos y aptitudes del medio físico que, por su potencial natural, sean susceptibles de ser utilizados como recursos para el desarrollo, en particular, en lo relativo a los recursos paisajísticos, cinegéticos, piscícolas o de otras actividades de ocio.

Artículo 11. Programación de estrategias y acciones de desarrollo.

La programación de estrategias y acciones de desarrollo comprenderá, al menos, los siguientes apartados:

1. Los factores diferenciales de la comarca.

Se determinará, a partir de los estudios realizados, un diagnóstico de las potencialidades de la comarca. Comprenderá tanto las debilidades estructurales como las oportunidades existentes, determinando las ventajas diferenciales que constituyen - o pueden constituir - el fundamento para el desarrollo de la comarca.

2. Objetivos estratégicos.

A partir de los factores diferenciales se hará una selección de prioridades y objetivos a fin de establecer una estrategia integrada de desarrollo comarcal.

3. Acciones de desarrollo.

Cada objetivo estratégico se compone de un conjunto de acciones de desarrollo, es decir, actuaciones que se considera necesario realizar en el período de vigencia del plan para la consecución de dichos objetivos.
Artículo 12. Iniciativa.

1. La iniciativa para la inclusión de una comarca en el Plan de desarrollo comarcal corresponderá a los Ayuntamientos integrantes, siempre que lo soliciten al menos dos tercios de los mismos, mediante acuerdo que trasladarán a la Xunta de Galicia.

El Consello de la Xunta de Galicia, a propuesta del conselleiro competente por razón de la materia, adoptará el acuerdo de incluir el área comarcal en el Plan de desarrollo comarcal.

2. Adoptado el acuerdo anterior, se constituirá el Consello Comarcal con arreglo al artículo 22 de esta ley.

Artículo 13. Prediagnóstico.

Una vez que el Consello de la Xunta acuerde la inclusión de una comarca en el Plan de desarrollo comarcal, y constituido el Consello Comarcal, el órgano competente de la Xunta de Galicia elaborará un prediagnóstico, que incluirá el estudio socioeconómico y del medio físico. Su elaboración contempla un sistema participativo que incluye a las corporaciones locales de la comarca y a los agentes socioeconómicos de la misma. Dicho prediagnóstico constituye una primera propuesta de objetivos y acciones, que se someterá a consideración del Consello Comarcal por plazo de un mes.

Con las sugerencias que éste emita se dará traslado a la Comisión de Comarcalización, que emitirá informe en el plazo de un mes sobre su viabilidad, conveniencia y oportunidad.

Artículo 14. Procedimiento de aprobación del Plan de desarrollo comarcal.

1. A la vista de las sugerencias emitidas por el Consello Comarcal y del informe de la Comisión de Comarcalización, se redactará el proyecto del Plan de desarrollo comarcal del área.

Dicho proyecto será sometido, simultáneamente, a informe:

a. De la Consellería de Economía e Facenda, a fin de verificar su adecuación 
a los objetivos del Plan económico y social de Galicia y al Plan de Inversiones.

b. De la Consellería competente en política territorial, para comprobar si sus determinaciones se ajustan a las establecidas en los instrumentos de ordenación del territorio de rango superior.

c. De la Consellería competente en materia de Administración local.

d. De la Consellería de Agricultura.

e. De la Consellería de Pesca en las comarcas pesqueras.

Al mismo tiempo, se someterá a informe de las demás consellerías que se consideren interesadas.

Dichos informes habrán de emitirse en el plazo de dos meses. Transcurrido dicho plazo, se entenderá emitido con carácter positivo.

2. Emitidos e incorporados, en lo que proceda, dichos informes al proyecto, se remitirán los mismos a los Ayuntamientos y diputaciones provinciales afectados, para que en el plazo de un mes formulen las alegaciones que estimen convenientes. Igualmente, se dará traslado a la Delegación del Gobierno en Galicia para que, si lo considera oportuno, los distintos órganos sectoriales de la Administración General del Estado interesados emitan el oportuno informe.

En el mismo período de tiempo se abrirá un trámite de información pública, y con las modificaciones que, en su caso, sean pertinentes se procederá a la aprobación inicial por el Consello Comarcal, que habrá de ser acordada por mayoría de dos tercios de sus miembros.

3. Una vez aprobado inicialmente, se elevará al Consello de la Xunta de Galicia para su aprobación definitiva.

La aprobación definitiva revestirá la forma de Decreto y será objeto de publicación en el "Boletín Oficial del Estado" y en el "Diario Oficial de Galicia".

Artículo 15. Colaboración de las diputaciones provinciales.

Las diputaciones provinciales participarán activamente en la elaboración y gestión de los planes de desarrollo comarcal, colaborando en el cumplimiento de sus objetivos a través de sus unidades técnicas comarcales.

Los planes de desarrollo comarcal tendrán carácter de marco de referencia para la elaboración de los planes provinciales de cooperación de obras y servicios.

\section{Capítulo III EFICACIA DEL PLAN}

\section{Artículo 16. Efectos.}

1. Una vez aprobado el Plan de desarrollo comarcal, las acciones y estrategias contenidas en el mismo serán marco de referencia para las distintas administraciones.

2. Las actuaciones dotacionales que se incluyan en un Plan de desarrollo comarcal tendrán la consideración de utilidad pública a los efectos de la legislación de expropiación forzosa.

Artículo 17. Vigencia.

El Plan de desarrollo de cada comarca tendrá una vigencia de cuatro años, a contar desde su aprobación definitiva. Anualmente, se efectuará una evaluación del grado de cumplimiento de objetivos, de acuerdo con el plazo de ejecución previsto para cada acción.

Artículo 18. Modificación del plan. Coincidiendo con las evaluaciones anuales, el Consello Comarcal podrá proponer los reajustes que se consideren necesarios para adecuar los objetivos y las acciones establecidas en el plan a la cambiante realidad socioeconómica de la comarca.

Estos reajustes podrán tratar acerca de los siguientes puntos:

1. Supresión de aquellos objetivos o acciones que, de acuerdo con la experiencia adquirida, resulten escasamente operativos.

2. Modificación, supresión o sustitución de acciones de desarrollo por otras alternativas que tengan mayor eficacia.

3. Alteraciones en la priorización temporal de las acciones. 
Éstas, y cualquier modificación que se produzca, nunca podrán alterar sustancialmente el contenido estratégico del plan.

Para su inclusión en el plan, estos reajustes habrán de ser, previa información pública de un mes, acordados por las dos terceras partes de los componentes del Consello Comarcal, y aprobados mediante Decreto del Consello de la Xunta.

Artículo 19. Prórroga del plan.

Transcurridos los cuatro años de vigencia del plan, éste podrá prorrogarse a petición del Consello Comarcal y previo informe del Gabinete de Planificación y Desarrollo Territorial. Esta prórroga tendrá carácter excepcional, habrá de ser aprobada por el Consello de la Xunta y no podrá superar los dos años de duración.

\section{TÍTULO III ÓRGANOS DE PLANIFICACIÓN, COORDINACIÓN, GESTIÓN Y PROMOCIÓN}

\section{Artículo 20. Órganos.}

La coordinación del Plan de desarrollo comarcal la llevarán a término el órgano competente en materia de desarrollo comarcal de la Xunta de Galicia, así como el Consejo Comarcal y la Comisión de Comarcalización regulados en la presente ley ${ }^{140}$.

\section{Capítulo I \\ ÓRGANOS DE PLANIFICACIÓN Y COORDINACIÓN}

Artículo 21. Órgano competente en materia de desarrollo comarcal.

La Xunta de Galicia, a través del órgano que tenga asignadas las funciones en materia de desarrollo comarcal, ejercerá las competencias en materia de elaboración,

140 Art. 20 modificado por Ley $12 / 2008$, de 3 de diciembre, por la que se modifican la Ley $7 / 1996$, de 10 de julio, de desarrollo comarcal, y la Ley 5/2000, de 28 de diciembre, de medidas fiscales y de régimen presupuestario y administrativo, y se racionalizan los instrumentos de gestión comarcal y de desarrollo rural. coordinación y seguimiento del Plan de desarrollo comarcal ${ }^{141}$.

En este sentido, son cometidos específicos del mismo:

1. La elaboración de la propuesta de los planes de desarrollo de las comarcas.

2. La propuesta de evaluación anual y el seguimiento de dichos planes.

3. La evaluación de las propuestas de prórroga, revisión y modificación de los planes de desarrollo de cada comarca.

4. La coordinación del Plan de desarrollo comarcal.

Artículo 22. El Consello Comarcal.

El Consello Comarcal tiene como objeto proponer y evaluar los objetivos y acciones de desarrollo comarcal, en cuya elaboración tendrá una participación activa, según lo establecido en esta ley. Asimismo, corresponde al Consello Comarcal la aprobación inicial del Plan de desarrollo de su comarca, participando también en su evaluación anual.

El Consello Comarcal estará facultado para solicitar la prórroga del plan, con arreglo a lo dispuesto en el artículo 19, de acuerdo con el procedimiento establecido en el mismo.

El Consello Comarcal estará integrado por:

1. El conselleiro competente en la materia, que ejercerá la presidencia del Consello Comarcal.

2. Un representante de cada uno de los municipios integrantes de la comarca, que ocuparán, de forma rotatoria, la vicepresidencia del Consejo.

3. Un representante de la Diputación Provincial respectiva.

4. El Director del Gabinete de Planificación y Desarrollo Territorial, que actuará como Secretario.

141 Primer párrafo del art. 21 modificado por Ley $12 / 2008$, de 3 de diciembre, por la que se modifican la Ley $7 / 1996$, de 10 de julio, de desarrollo comarcal, y la Ley $5 / 2000$, de 28 de diciembre, de medidas fiscales y de régimen presupuestario y administrativo, y se racionalizan los instrumentos de gestión comarcal y de desarrollo rural.

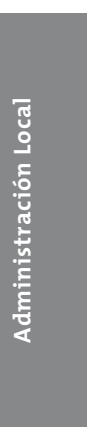


Artículo 23. La Comisión de Comarcalización.

La Comisión de Comarcalización es un órgano colegiado de la Xunta de Galicia, coordinador interconsellerías, cuya finalidad es la evaluación y verificación de los objetivos del plan y el seguimiento de los mismos y de su ejecución. Funcionará en pleno y en grupos de trabajo.

Reglamentariamente se determinará su funcionamiento y composición.

\section{Capitulo II ÓRGANOS DE GESTIÓN Y PROMOCIÓN} $(\ldots)^{142}$

\section{TÍTULO IV \\ EL MAPA COMARCAL DE GALICIA ${ }^{143}$}

Artículo 27. Delimitación territorial de las comarcas.

La aplicación formal y temporal del Plan de desarrollo comarcal se concretará en un mapa comarcal, en el que aparecerá la delimitación territorial de las distintas comarcas, cuya aprobación y sucesivas modificaciones serán efectuadas por Decreto del Consello de la Xunta, por el procedimiento que se establece en los artículos siguientes.

A estos efectos, la comarca se concibe como un ámbito territorial intermedio, formado por un conjunto de municipios colindantes que tienen una cohesión interna entre ellos basada en hechos geográficos, históricos, económicos y funcionales.

142 Art. 24, 25 y 26 derogados por Ley 12/2008, de 3 de diciembre, por la que se modifican la Ley $7 / 1996$, de 10 de julio, de desarrollo comarcal, y la Ley $5 / 2000$, de 28 de diciembre, de medidas fiscales y de régimen presupuestario y administrativo, y se racionalizan los instrumentos de gestión comarcal y de desarrollo rural. 143 Véase:

- Decreto 65/1997, de 20 de febrero, por el que se aprueba definitivamente el mapa comarcal de Galicia. - Decreto 335/1998, de 27 de noviembre, por el que se regulan las áreas funcionales.
Artículo 28. Procedimiento de selección.

La propuesta de configuración de las distintas comarcas en que se divide el territorio de la Comunidad Autónoma de Galicia será llevada a cabo por el Gabinete de Planificación y Desarrollo Territorial, que habrá de tener en cuenta para ello los datos existentes, los criterios que expongan razonadamente las distintas consellerías y la opinión de los distintos entes jurídico-públicos afectados.

Se acompañará a la propuesta un documento justificativo del mapa comarcal que se elevará para su aprobación.

Artículo 29. Aprobación inicial.

El documento a que se refiere el artículo anterior, una vez redactado, se elevará al conselleiro competente, para que acuerde sobre su aprobación inicial.

Artículo 30. Exposición pública. Una vez aprobado, inicialmente, el documento se someterá a exposición pública para alegaciones, por período de un mes, mediante publicación del acuerdo en el "Diario Oficial de Galicia" y en el "Boletín Oficial" de la provincia; también se anunciará en dos de los periódicos de mayor difusión en la Comunidad Autónoma. Simultáneamente, se dará traslado del documento a las diputaciones provinciales y Ayuntamientos de Galicia, para que en el mismo período de tiempo puedan formular, también, alegaciones.

Del mismo modo, se dará traslado del documento a la Delegación del Gobierno en Galicia, para que, si lo considera oportuno, manifieste las alegaciones que estime convenientes.

Artículo 31. Aprobación definitiva. Estudiadas y dictaminadas por el Gabinete de Planificación y Desarrollo Territorial las distintas alegaciones e informes, con las correcciones que procedan, el conselleiro competente elevará el documento al Consello de la Xunta para su aprobación definitiva por Decreto. 
Artículo 32. Publicación.

El Decreto por el que se apruebe definitivamente el mapa comarcal de Galicia se publicará en el "Diario Oficial de Galicia" y en el "Boletín Oficial del Estado" ${ }^{144}$.

Artículo 33. Modificación.

La delimitación comarcal contenida en el documento a que se refiere este título podrá ser objeto de modificación, según el mismo procedimiento establecido en los artículos anteriores, con la salvedad de que únicamente se dará traslado a la Diputación Provincial y Ayuntamientos directamente afectados.

\section{DISPOSICIÓN ADICIONAL PRIMERA}

La Comisión Galega de Cooperación Local propondrá criterios, singularmente en lo referente a la participación del Fondo de Cooperación Local, para el cumplimiento de los objetivos de los planes de desarrollo comarcal.

\section{DISPOSICIÓN ADICIONAL SEGUNDA}

La presente ley deberá interpretarse y aplicarse en coordinación con el contenido de lo dispuesto en las leyes autonómicas de Administración local y ordenación del territorio. A estos efectos, la designación por el Consello de la Xunta de una comarca para su inclusión en el Plan de desarrollo comarcal implicará, si no se hubiese hecho, la tramitación simultánea del Plan territorial integrado correspondiente, según el procedimiento establecido en la Ley de ordenación del territorio.

\section{DISPOSICIÓN TRANSITORIA}

Los planes de desarrollo comarcal vigentes, aprobados por Decreto de la Xunta de Galicia, se adaptarán en su primera revisión al procedimiento establecido en esta ley.

144 Véase Decreto 65/1997, de 20 de febrero, por el que se aprueba definitivamente el mapa comarcal de Galicia.

\section{DISPOSICIÓN FINAL PRIMERA}

Se faculta a la Xunta de Galicia para el desarrollo reglamentario de la presente ley, en lo que proceda.

\section{DISPOSICIÓN FINAL SEGUNDA}

La presente ley entrará en vigor el día siguiente al de su publicación en el "Diario Oficial de Galicia".

\section{LEY 4/2004, DE 28 DE JUNIO, PARA LA APLICACIÓN A LOS MUNICIPIOS DE FERROL, LUGO, OURENSE, PONTEVEDRA Y SANTIAGO DE COMPOSTELA DEL RÉGIMEN DE ORGANIZACIÓN DE LOS MUNICIPIOS DE GRAN POBLACIÓN (DOGA N. ${ }^{\circ} 130$, 7. 7. 2004)}

$(\ldots)^{145}$

Artículo 1. Será de aplicación a los municipios de Ferrol, Lugo, Ourense, Pontevedra y Santiago de Compostela por entender que concurren las circunstancias de carácter objetivo exigidas para ello en el título X de la Ley 7/1985, de 2 de abril, reguladora de las bases de régimen local el régimen de organización de los municipios de gran población contemplado en dicho título.

Artículo 2. Los plenos municipales de Ferrol, Lugo, Ourense, Pontevedra y Santiago de Compostela determinarán la aplicación de la presente ley al régimen de organización de los respectivos municipios.

\section{DISPOSICIÓN ADICIONAL ÚNICA}

Mediante disposición de rango legal podrá procederse, en el marco de lo establecido en la normativa básica estatal, y de acuerdo con lo señalado en el artículo 27 del Estatuto de Autonomía de Galicia, al desarrollo de las previsiones contenidas en el título X de la Ley 7/1985, de 2 de abril, reguladora de las bases de régimen

145 Exposición de motivos omitida. 
local, a fin de adaptarlas a las peculiaridades y circunstancias específicas de los municipios gallegos a las que aquél resulte de aplicación.

\section{DISPOSICIÓN FINAL ÚNICA}

La presente ley entrará en vigor el día siguiente al de su publicación en el "Diario Oficial de Galicia”.

\section{LEY 11/1983, DE 29 DE DICIEMBRE, DE ACTUACIÓN INTENSIVA EN LAS PARROQUIAS RURALES (DOGA N. $\left.{ }^{\circ} 22,2.2 .1984\right)$}

\section{(...) ${ }^{146}$}

Artículo 1. La Xunta de Galicia, por medio de la Consellería de Agricultura, Pesca y Alimentación y con la participación de otras consellerías en lo que afecte a sus competencias, llevará a cabo, en los términos señalados en esta ley, actuaciones intensivas en parroquias rurales.

Artículo 2. 1. Se entiende por actuación intensiva, a los fines de la presente ley, el conjunto de acciones e inversiones previamente estudiadas para aplicación en cada parroquia rural, teniendo en cuenta sus peculiaridades.

2. La actuación intensiva persigue fundamentalmente las siguientes finalidades:

a. La dotación y mejora de la infraestructura y equipamiento de servicios comunitarios, y la mejora del entorno ecológico y la calidad de vida de la población rural.

b. La promoción de explotaciones agrarias de dimensiones suficientes y de características adecuadas en cuanto a su estructura, capitalización y organización empresarial.

Artículo 3. 1. Los programas de actuación intensiva atenderán preferentemente a las actividades agrarias para conseguir su modernización y desarrollo integral.

\footnotetext{
146 Exposición de motivos omitida.
}

2. Los programas de actuación intensiva integrarán las acciones y asignarán los medios tendentes a la consecución de los siguientes objetivos:

a. Dotación y mejora de la infraestructura viaria, abastecimiento de aguas y saneamiento, equipamiento y servicios comunitarios, vivienda rural, electrificación rural y teléfonos.

b. Concentración parcelaria; concesión de auxilios técnico-económicos y financieros para las explotaciones, ordenación de cultivos, transformación en regadíos, construcciones ganaderas, mejora de sanidad pecuaria, y aprovechamiento racional de los recursos forestales.

c. Estímulos a las industrias de elaboración, conservación, transformación y comercialización de productos agrarios.

d. Protección de la caza y pesca fluvial, y del paisaje natural.

e. Capacitación, promoción de la formación profesional y cultural; promoción de las actividades deportivas, recreativas y de ocio de la población rural; estímulo y fomento de las cooperativas y demás modalidades asociativas agrarias.

Artículo 4. 1. El expediente de actuación intensiva podrá iniciarse:

a. Por solicitud de la mayoría de los agricultores de la parroquia.

b. A petición, previo acuerdo corporativo, de las respectivas Cámaras Agrarias Locales.

c. De oficio por la propia Consellería de Agricultura, Pesca y Alimentación.

2. Las solicitudes serán presentadas ante la Delegación provincial correspondiente de la Consellería de Agricultura, Pesca y Alimentación.

3. Recibida la solicitud o petición, la delegación provincial recabará información del Ayuntamiento y de la Cámara agraria local respectiva en orden a la veracidad de los datos consignados, si ésta 


\section{Administración Local}

no se acompañará a la misma, excepto que el expediente se hubiera iniciado de oficio por la consellería.

Asimismo, la delegación provincial de la Consellería emitirá un informe técnico económico sobre la oportunidad de la actuación intensiva.

4. El expediente se hará público a efecto de audiencia de los interesados en el Ayuntamiento y en los lugares parroquiales de costumbre.

Artículo 5. La selección de parroquias que hayan iniciado expediente de actuación intensiva para su inclusión en los programas correspondientes de la consellería de agricultura, pesca y alimentación, se practicará cuando razones de índole técnica o presupuestaria así lo impusieran, atendiendo a los siguientes criterios:

a. Las que promuevan o se encuentren en fase de concretación parcelaria.

b. Aquellas en las que se observen unos índices de depresión económica más acentuados.

c. Las que faculten o promuevan la actuación agrupada o simultánea en varias parroquias limítrofes en función de la corrección de las desigualdades más significativas y una equitativa distribución territorial.

d. El grado de aquiescencia y aceptación por la comunidad.

e. Las ya concentradas.

Artículo 6. 1. El informe técnico-económico sobre la oportunidad de declarar la actuación intensiva se realizará por la Delegación provincial de la Consellería de Agricultura, Pesca y Alimentación, con asesoramiento de la Junta parroquial a la que se refiere el artículo 9 y la colaboración, en su caso, de la Diputación Provincial, Ayuntamiento y cámara agraria local respectivos y, si procediese, de las delegaciones provinciales de otras consellerías.

2. También podrá solicitarse la colaboración de empresas públicas y privadas para la actuación coordinada en orden a la mejora o dotación de servicios demandados por la comunidad.

Artículo 7. 1. La actuación intensiva será acordada por la Xunta de Galicia, a propuesta de la Consellería de Agricultura, Pesca y Alimentación, y el decreto del acuerdo determinará como mínimo:

a. La delimitación del ámbito territorial de la actuación.

b. El programa de actuación intensiva, elaborado conjuntamente por las consellerías implicadas y coordinado por la de Agricultura, Pesca y Alimentación.

c. Los estímulos y ayudas a las explotaciones.

d. Los criterios de calificación de las explotaciones preferentes y protegidas.

e. El plazo de duración, que no será superior a tres años, y podrá ser ampliado por un año más si circunstancias especiales lo requieren para ejecutar las actuaciones programadas.

2. Se establecerá obligatoriamente el programa especial de sanidad animal, que podrá ser mantenido en vigencia después de finalizar el plazo de actuación intensiva.

3. El Decreto podrá declarar de utilidad pública e interés social aquellas acciones del programa de actuación intensiva que lo requieran a efectos de expropiación forzosa.

Artículo 8. Cuando la actuación intensiva conlleve acciones de competencias de varias consellerías, el decreto de declaración se hará a propuesta conjunta de aquellas, y especificará las obras y actuaciones que corresponden a cada una de las mismas.

Artículo 9. 1. A los efectos de esta ley, las Juntas Parroquiales son órganos locales que actúan como portavoces de los intereses generales de la parroquia, informando, asesorando y colaborando en las distintas fases y acciones de la actuación intensiva.

2. Los miembros de las Juntas Parroquiales serán elegidos de entre ellos por los 
Código de la Administración Gallega

agricultores de la parroquia, debiendo fijarse reglamentariamente el número de sus componentes y su régimen de funcionamiento.

3. Las Juntas Parroquiales podrán recabar asesoramiento gratuito e información de la administración.

\section{DISPOSICIÓN FINAL}

La Consellería de Agricultura, Pesca y Alimentación elevará al Consello de la Xunta, en el plazo de seis meses, las disposiciones que sean precisas para el desarrollo y la ejecución de la presente ley. 


\section{PROCEDIMIENTO ADMINISTRATIVO, RÉGIMEN JURÍDICO DE LAS ADMINISTRACIONES PÚBLICAS Y FUNCIÓN PÚBLICA}

\author{
1. LEY 6/2001, DE 29 DE \\ JUNIO, DE ADECUACIÓN DE LA \\ NORMATIVA DE LA COMUNIDAD \\ AUTÓNOMA DE GALICIA A LA \\ LEY 4/1999, DE 13 DE ENERO, \\ DE MODIFICACIÓN DE LA LEY \\ 30/1992, DE 26 DE NOVIEMBRE, \\ DE RÉGIMEN JURÍDICO DE LAS \\ ADMINISTRACIONES PÚBLICAS \\ Y DEL PROCEDIMIENTO \\ ADMINISTRATIVO COMÚN \\ (DOGA N. $\left.{ }^{\circ} 135,12.7 .2001\right)$
}

(... $)^{147}$

Artículo 1. Plazo máximo de duración de los procedimientos.

1. El plazo máximo en que debe notificarse la resolución expresa en los procedimientos administrativos que se indican en el anexo de la presente ley será el establecido para cada uno de los mismos en el anexo citado.

2. El plazo máximo de duración de los procedimientos de concesión de subvenciones o cualquier otra ayuda pública será el establecido en la correspondiente convocatoria o normativa reguladora, sin que pueda exceder en caso alguno de nueve meses, salvo lo dispuesto en la normativa comunitaria europea.

Este plazo se computará desde la fecha de la convocatoria o desde la solicitud del interesado cuando el procedimiento sea iniciado por éste y se indique así en la convocatoria o normativa reguladora.

Artículo 2. Silencio administrativo.

Sin perjuicio de la obligación de la administración de dictar resolución expresa, los interesados podrán entender desestimadas sus solicitudes por silencio administrativo en los procedimientos en que así se establece en el anexo de la presente ley

147 Exposición de motivos omitida. si al vencimiento del plazo máximo establecido en cada caso no se ha notificado resolución expresa.

En los procedimientos de concesión de subvenciones o de cualquier otra ayuda pública que se inicien a solicitud del interesado, la misma se entenderá desestimada por silencio administrativo si al vencimiento del plazo establecido en cada caso no se ha dictado resolución expresa.

Artículo 3. Competencia para la revisión de actos administrativos.

1. Serán competentes para resolver los procedimientos de revisión de oficio de los actos administrativos nulos, declarar la lesividad de los anulables y revocar los de gravamen o desfavorables:

a. El Consello de la Xunta respecto a sus propios actos o los actos de sus comisiones delegadas.

b. Los conselleiros respecto a sus propios actos y los dictados por órganos dependientes de los mismos, así como a los actos de los órganos superiores de gobierno de los organismos autónomos y entes de derecho público que tengan adscritos, salvo que en la respectiva ley de creación se disponga otra cosa.

c. Los órganos superiores de gobierno de los organismos autónomos y entes de derecho público respecto a los actos dictados por órganos dependientes de los mismos.

2. La rectificación de errores materiales, de hecho o aritméticos, corresponderá al propio órgano administrativo que dictó el acto.

3. Será competente para resolver el recurso extraordinario de revisión el propio órgano administrativo que dictó el acto recurrido.

Artículo 4. Fin de la vía administrativa. Ponen fin a la vía administrativa, salvo que por ley especial se establezca lo contrario, las resoluciones de los órganos siguientes: 
a. Las del Consello de la Xunta, las de su Presidente y las de sus Comisiones delegadas.

b. Las de los Conselleiros.

c. Las de los Secretarios generales y $\mathrm{Di}$ rectores generales en materia de personal.

d. Las de los órganos superiores de Gobierno de organismos autónomos y de los entes públicos cuando ejercitan competencias administrativas.

e. Las de las demás autoridades cuando así lo establezca una disposición legal o reglamentaria.

Artículo 5. Responsabilidad patrimonial.

Será competente para resolver los procedimientos de responsabilidad patrimonial el Conselleiro respectivo, salvo que una ley especial atribuya la competencia al Consello de la Xunta.

En caso de los organismos autónomos o entes de derecho público, será competente el titular de la Consellería a que estén adscritos, salvo que su ley de creación disponga otra cosa.

Artículo 6. Reclamación previa a la vía judicial civil.

La reclamación se presentará ante el conselleiro competente por razón de la materia objeto de la reclamación.

\section{DISPOSICIÓN ADICIONAL PRIMERA DETERMINACIÓN DEL REGISTRO DEL ÓRGANO COMPETENTE PARA LA TRAMITACIÓN DE SOLICITUDES ${ }^{148}$}

1. En el ámbito de la Administración de la Comunidad Autónoma de Galicia, a los efectos del artículo 42.3.b) de la Ley $30 / 1992$, de 26 de noviembre, se entiende por registro del órgano competente para la tramitación de una solicitud cualquiera de los registros de la Consellería competente para iniciar su tramitación.

2. A estos efectos, el Registro General de la Xunta de Galicia será considerado

148 Decreto $164 / 2005$, de 16 de junio, por el que se regulan y determinan las oficinas de registro propias 0 concertadas de la Administración de la Comunidad Autónoma de Galicia, se crea el registro telemático de la Xunta de Galicia y se regula la atención al ciudadano. como registro de la Consellería de la Presidencia y Administración Pública y de las Secretarías Generales dependientes del Presidente de la Xunta de Galicia.

3. A los mismos efectos, en caso de organismos autónomos y entes de derecho público, se entiende por registro del órgano competente para la tramitación de una solicitud cualquiera de los registros del órgano o ente competente para iniciar su tramitación.

\section{DISPOSICIÓN ADICIONAL SEGUNDA NORMATIVA DE APLICACIÓN PARA LOS PROCEDIMIENTOS ADMINISTRATIVOS CARENTES DE REGULACIÓN ESPECÍFICA}

Respecto a los procedimientos administrativos que carecen de regulación específica en normas autonómicas, será de aplicación lo que las leyes estatales dispongan respecto a su plazo máximo de duración y al sentido, estimatorio o desestimatorio, que se atribuya a la falta de resolución expresa en el plazo señalado.

\section{DISPOSICIÓN FINAL PRIMERA DESARROLLO NORMATIVO DE LA LEY}

La Xunta de Galicia dictará las disposiciones necesarias para el desarrollo y aplicación de la presente ley.

\section{DISPOSICIÓN FINAL SEGUNDA ENTRADA EN VIGOR DE LA LEY}

La presente ley entrará en vigor el día siguiente al de su publicación en el "Diario Oficial de Galicia"149.

\section{ANEXO I}

Relación de procedimientos de duración superior a seis meses.

Consellería de la Presidencia y Administración Pública.

Tipo de procedimiento: Proceso selectivo de personal funcionario o de personal laboral.

Plazo de duración: Nueve meses.

Normativa reguladora:

Ley 4/1988, de 26 de mayo, de la Función Pública de Galicia.

149 Véanse anexos a continuación. 


\section{Procedimiento administrativo...}

Decreto 95/1991, de 20 de marzo, por el que se aprueba el Reglamento de Selección de Personal de la Administración de la Comunidad Autónoma de Galicia.

Consellería de Economía e Facienda.

Tipo de procedimiento: Cesión gratuita de bienes inmuebles.

Plazo de duración: Doce meses.

Normativa reguladora:

Ley $3 / 1985$, de 12 de abril, del Patrimonio de la Comunidad Autónoma Gallega.

Decreto 50/1989, de 9 de marzo, por el que se aprueba el Reglamento para la ejecución de la Ley 3/1985, de 12 de abril, del Patrimonio de la Comunidad Autónoma Gallega.

Tipo de procedimiento: Deslinde de bienes del patrimonio de la Comunidad Autónoma.

Plazo de duración: Doce meses.

Normativa reguladora: Ley 3/1985, de 12 de abril, del patrimonio de la Comunidad Autónoma gallega.

Decreto 50/1989, de 9 de marzo, por el que se aprueba el Reglamento para la ejecución de la Ley 3/1985, de 12 de abril, del patrimonio de la Comunidad Autónoma Gallega.

Tipo de procedimiento: Concesión del premio previsto en relación con la sucesión intestada a favor de la Comunidad Autónoma.

Plazo de duración: Dieciocho meses.

Normativa reguladora: Decreto 94/1999, de 25 de marzo, sobre Régimen Administrativo de la Sucesión Intestada en favor de la Comunidad Autónoma de Galicia.

Consellería de Política Territorial, Obras Públicas e Vivenda

Tipo de procedimiento: Adjudicación de viviendas de protección oficial de promoción pública.

Plazo de duración: Doce meses.

Normativa reguladora: Decreto 98/1992, de 26 de marzo, por el que se regula la financiación y la adjudicación de viviendas de promoción pública. Tipo de procedimiento: Procedimiento sancionador en materia de vivienda.

Plazo de duración: Doce meses.

Normativa reguladora: Ley de Galicia 13/1996, de 30 de diciembre, de Infracciones y Sanciones en Materia de Vivienda.

Decreto 2114/1968, de 24 de julio, por el que se aprueba el Reglamento para la aplicación de la Ley sobre Viviendas de Protección Oficial, texto refundido aprobado por los Decretos 2131/1963, de 24 de julio, y 3964/1964, de 3 de diciembre.

Tipo de procedimiento: Desahucios administrativos en materia de vivienda.
Plazo de duración: Doce meses.

Normativa reguladora: Decreto 2114/1968, de 24 de julio, por el que se aprueba el Reglamento para la aplicación de la Ley sobre Viviendas de Protección Oficial; texto refundido aprobado por los Decretos 2131/1963, de 24 de julio, y 3964/1964, de 3 de diciembre.

Consellería de Educación e Ordenación Universitaria. Consellería de Industria e Comercio.

Tipo de procedimiento: Otorgamiento de permisos de investigación de las secciones C y D.

Plazo de duración: Doce meses.

Normativa reguladora: Ley estatal 22/1973, de 21 de julio, de Minas, modificada por la Ley $54 / 1980$, de 5 de noviembre.

Reglamento General para el Régimen de la Minería, aprobado por el Real Decreto 2857/1978, de 25 de agosto.

Tipo de procedimiento: Autorización/concesión de aprovechamiento de recursos mineros de la sección B (estructuras subterráneas).

Plazo de duración: Treinta y seis meses.

Normativa reguladora: Ley estatal 22/1973, de 21 de julio, de Minas, modificada por la Ley $54 / 1980$, de 5 de noviembre.

Reglamento General para el Régimen de la Minería, aprobado por el Real Decreto 2857/1978, de 25 de agosto.

Tipo de procedimiento: expediente sancionador o de caducidad en materia de minas.

Plazo de duración: 12 meses.

Normativa reguladora: Ley de ordenación de la minería de Galicia ${ }^{150}$.

Consellería de Agricultura, Ganadería y Política

Agroalimentaria Consellería de Cultura, Comunicación Social y Turismo

Tipo de procedimiento: Concesión de emisoras municipales y comerciales de radiodifusión sonora en ondas métricas con modulación de frecuencia.

Plazo de duración: Tres años.

Normativa reguladora: Ley estatal 31/1987, de 18 de diciembre, de Ordenación de las Telecomunicaciones.

Decreto $156 / 1989$, de 27 de julio, por el que se establece el procedimiento de concesión de emisoras de radiodifusión sonora en ondas métricas con modulación de frecuencia, modificado por el Decreto 35/1992, de 6 de febrero.

Tipo de procedimiento: Concesión de servicios de radiodifusión sonora y televisión digital terrenal.

150 Último procedimiento de la Conselleria de Industria y Comercio añadido por Ley $3 / 2008$, de 23 de mayo, de Ordenación de la Mineria de Galicia. 
Plazo de duración: Tres años.

Normativa reguladora: Ley estatal 66/1997, de 30 de diciembre, de Medidas Fiscales, Administrativas y de Orden Social (disposición adicional 44).

Tipo de procedimiento: Procedimiento de delimitación del Camino de Santiago.

Plazo de duración: Cinco años.

Normativa reguladora: Ley $3 / 1996$, de 10 de mayo, de Protección de los Caminos de Santiago. Consellería de Sanidade e Servicios Sociais; Consellería de Pesca, Marisqueo e Acuicultura; Consellería de Xustiza, Interior e Relacións Laborais.

Tipo de procedimiento: Autorización de alteración del término municipal.

Plazo de duración: Dos años.

Normativa reguladora: Ley 5/1997, de 22 de julio, de Administración Local de Galicia.

Tipo de procedimiento: Resoluciones de las cuestiones de deslindes de términos municipales que se planteen entre municipios.

Plazo de duración: Doce meses.

Normativa reguladora: Ley 5/1997, de 22 de julio, de Administración Local de Galicia.

Consellería de Familia e Promoción do Empleo, Muller e Xuventude; Consellería de Medio Ambiente.

Tipo de procedimiento: Deslinde de montes.

Plazo de duración: Dos años.

Normativa reguladora: Ley de Montes, de 8 de junio de 1957.

Decreto 485/1962, de 22 de febrero, por el que se aprueba el Reglamento de Montes.

Ley 13/1989, de 10 de octubre, de Montes Vecinales en Mancomún.

Tipo de procedimiento: Inclusión en el Registro de Espacios Naturales de Galicia.

Plazo de duración: Un año.

Normativa reguladora: Decreto 82/1989, de 11 de mayo, por el que se regula la figura del Espacio Natural en Régimen de Protección General.

\section{ANEXO II}

Relación de procedimientos en que el silencio administrativo produce efectos desestimatorios. Consellería da Presidencia e Administración Pública.

Tipo de procedimiento: Proceso selectivo de personal funcionario o de personal laboral.

Sentido del silencio: Negativo.

Normativa reguladora: Ley 4/1988, de 26 de mayo, de la Función Pública de Galicia.

Decreto 95/1991, de 20 de marzo, por el que se aprueba el Reglamento de selección de personal de la Administración de la Comunidad Autónoma de Galicia.
Convenio Colectivo para el personal laboral de la Xunta de Galicia.

Tipo de procedimiento: Procedimientos de concursos de traslados de personal funcionario o personal laboral.

Sentido del silencio: Negativo.

Normativa reguladora: Ley 4/1988, de 26 de mayo, de la Función Pública de Galicia.

Decreto 93/1991, de 20 de marzo, por el que se aprueba el Reglamento de Provisión de Puestos de Trabajo, Promoción Profesional y Promoción Interna.

Convenio Colectivo para el personal laboral de la Xunta de Galicia.

Consellería de Economía e Facenda.

Tipo de procedimiento: Autorización a las corporaciones locales de Galicia de las operaciones de crédito en los supuestos del artículo 54 de la Ley 39/1998, de 28 de diciembre, de Haciendas Locales.

Sentido del silencio: Negativo.

Normativa reguladora: Ley 39/1998, de 28 de diciembre, de Haciendas Locales.

Tipo de procedimiento: Cesión gratuita de bienes inmuebles.

Sentido del silencio: Negativo.

Normativa reguladora: Ley 3/1985, de 12 de abril, del Patrimonio de la Comunidad Autónoma Gallega.

Decreto 50/1989, de 9 de marzo, por el que se aprueba el Reglamento para la ejecución de la Ley 3/1985, de 12 de abril, del patrimonio de la Comunidad Autónoma Gallega.

Tipo de procedimiento: Deslinde de bienes del patrimonio de la Comunidad Autónoma.

Sentido del silencio: Negativo.

Normativa reguladora: Ley 3/1985, de 12 de abril, del patrimonio de la Comunidad Autónoma Gallega.

Decreto 50/1989, de 9 de marzo, por el que se aprueba el Reglamento para la ejecución de la Ley 3/1985, de 12 de abril, del patrimonio de la Comunidad Autónoma Gallega.

Tipo de procedimiento: Recuperación de la posesión de los bienes de la Comunidad Autónoma.

Sentido del silencio: Negativo.

Normativa reguladora: Ley 3/1985, de 12 de abril, del patrimonio de la Comunidad Autónoma Gallega.

Decreto 50/1989, de 9 de marzo, por el que se aprueba el Reglamento para la ejecución de la Ley $3 / 1985$, de 12 de abril, del patrimonio de la Comunidad Autónoma Gallega.

Tipo de procedimiento: Concesión del premio previsto en relación con la sucesión intestada a favor de la Comunidad Autónoma. 
Sentido del silencio: Negativo.

Normativa reguladora: Decreto 94/1999, de 25 de marzo, sobre régimen administrativo de la sucesión intestada en favor de la Comunidad Autónoma de Galicia.

Tipo de procedimiento: Autorización para ejercer la actividad de las corredurías de seguros con domicilio y ámbito de operaciones en la Comunidad Autónoma de Galicia.

Sentido del silencio: Negativo.

Normativa reguladora: Ley estatal 9/1992, de 30 de abril, de Mediación en Seguros Privados.

(Normativa autonómica en fase de tramitación.)

Consellería de Política Territorial, Obras Públicas e Vivenda.

Tipo de procedimiento: Autorización de vertidos al mar.

Sentido del silencio: Negativo.

Normativa reguladora: Ley estatal 22/1988, de 28 de julio, de Costas.

Real Decreto 1471/1989, de 1 de diciembre, por el que se aprueba el Reglamento general para el desarrollo y ejecución de la Ley 22/1988, de 28 de julio, de Costas.

Tipo de procedimiento: Otorgamiento de concesiones de utilización del dominio público portuario.

Sentido del silencio: Negativo.

Normativa reguladora: Ley estatal 27/1992, de 24 de noviembre, de Puertos del Estado y de la Marina Mercante.

Ley estatal 22/1988, de 28 de julio, de Costas.

Real Decreto 1471/1989, de 1 de diciembre, por el que se aprueba el Reglamento General para el Desarrollo y ejecución de la Ley 22/1988, de 28 de julio, de Costas.

Tipo de procedimiento: Autorización autonómica previa a la licencia municipal para construcciones e instalaciones en suelo rústico.

Sentido del silencio: Negativo.

Normativa reguladora: Ley 1/1997, de 24 de marzo, del Suelo de Galicia.

Resolución de la COTOP de 14 de mayo de 1991 mediante la que se publican las normas complementarias y subsidiarias de planeamiento de las provincias de A Coruña, Lugo, Ourense y Pontevedra.

Tipo de procedimiento: Autorización de edificaciones en núcleos rurales preexistentes de Ayuntamientos sin planeamiento urbanístico.

Sentido del silencio: Negativo.

Normativa reguladora: Resolución de la COTOP de 14 de mayo de 1991 mediante la que se publican las Normas complementarias y subsidiarias de planeamiento de las provincias de A Coruña, Lugo, Ourense y Pontevedra.
Tipo de procedimiento: Autorización para la utilización o ejecución de cualquier tipo de obras o instalaciones en la zona de servidumbre de las carreteras de competencia de la Comunidad Autónoma.

Sentido del silencio: Negativo.

Normativa reguladora: Ley de Galicia 4/1994, de 14 de septiembre, de Carreteras de Galicia.

Tipo de procedimiento: Acreditación de laboratorios de ensayo para la realización del control de calidad en la edificación con sede en la Comunidad Autónoma de Galicia.

Sentido del silencio: Negativo.

Normativa reguladora: Decreto 441/1990, de 6 de septiembre, por el que se aprueba el sistema para la acreditación de laboratorios de ensayo para el control de la calidad de la construcción, con sede en la Comunidad Autónoma de Galicia.

Tipo de procedimiento: Calificaciones y declaraciones, provisionales y definitivas, de actuaciones protegibles en materia de vivienda y suelo.

Sentido del silencio: Negativo.

Normativa reguladora: Real Decreto 3148/1978, de 10 de noviembre, por el que se desarrolla el Real Decreto-ley 31/1978, de 31 de octubre, sobre Política de Vivienda.

Real Decreto 1186/1998, de 12 de junio, sobre Medidas de Financiación de Actuaciones Protegidas en Materia de Vivienda y Suelo del Plan 1998-2001.

Decreto 345/1998, de 20 de noviembre, por el que se establecen las Ayudas Públicas en materia de Vivienda a cargo de la Comunidad Autónoma de Galicia y se regula la gestión de las previstas en el Real Decreto 1186/1998, de 12 de junio, para el período 1998-2001.

Tipo de procedimiento: Descalificación de viviendas sometidas a algún régimen de protección.

Sentido del silencio: Negativo.

Normativa reguladora: Real Decreto 3148/1978, de 10 de noviembre, por el que se desarrolla el Real Decreto-ley 31/1978, de 31 de octubre, sobre Política de Vivienda.

Decreto 2114/1968, de 24 de julio, por el que se aprueba el Reglamento para la aplicación de la Ley sobre Viviendas de Protección Oficial, texto refundido aprobado por los Decretos 2131/1963, de 24 de julio, y 3964/1964, de 3 de diciembre.

Tipo de procedimiento: Adjudicación de locales de negocio en caso de que no fuesen adjudicados en subasta pública por falta de licitadores.

Sentido del silencio: Negativo.

Normativa reguladora: Decreto 125/1998, de 16 de abril, sobre Normas de Adjudicación de Locales

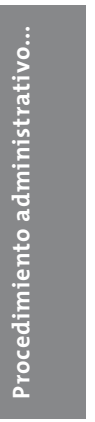


de Negocio del Instituto Galego da Vivenda e Solo.

Tipo de procedimiento: Autorización de cambios de titularidad de viviendas de promoción pública.

Sentido del silencio: Negativo.

Normativa reguladora: Real Decreto 3148/1978, de 10 de noviembre, por el que se desarrolla el Real Decreto-ley 31/1978, de 31 de octubre, sobre Política de Vivienda.

Decreto 2114/1968, de 24 de julio, por el que se aprueba el Reglamento para la aplicación de la Ley sobre Viviendas de Protección Oficial, texto refundido aprobado por los Decretos 2131/1963, de 24 de julio, y 3964/1964, de 3 de diciembre.

Tipo de procedimiento: Regularización de situaciones de ocupantes y cambio de régimen de viviendas de promoción pública.

Sentido del silencio: Negativo.

Normativa reguladora: Decreto 225/2000, de 13 de septiembre, de regularización de situaciones de los ocupantes y cambio de régimen en las viviendas de promoción pública.

Consellería de Educación e Ordenación Universitaria. Tipo de procedimiento: Creación y reconocimiento de Universidades, centros universitarios y autorizaciones de estudios en la Comunidad Autónoma de Galicia.

Sentido del silencio: Negativo.

Normativa reguladora: Real Decreto 557/1991, de 12 de abril, sobre Creación y reconocimiento de Universidades y centros universitarios ("Boletín Oficial del Estado" del 20).

Decreto 259/1994, de 29 de julio, por el que se establece el procedimiento para creación y reconocimiento de Universidades, centros universitarios y autorizaciones de estudios en la Comunidad Autónoma de Galicia.

Consellería de Industria y Comercio.

Tipo de procedimiento: Autorización de explotación e investigación de hidrocarburos.

Sentido del silencio: Negativo.

Normativa reguladora: Ley estatal 34/1998, de 7 de octubre, del Sector de Hidrocarburos.

Real Decreto 2362/1976, de 30 de julio, Reglamento para la aplicación de la Ley sobre Investigación y Explotación de Hidrocarburos, de 27 de junio de 1974.

Tipo de procedimiento: Autorización de aprovechamiento de recursos mineros de la sección A.

Sentido del silencio: Negativo.

Normativa reguladora: Ley estatal 22/1973, de 21 de julio, de Minas, modificada por la Ley $54 / 1980$, de 5 de noviembre.
Real Decreto 2857/1978, de 25 de agosto, Reglamento general para el Régimen de la Minería. Tipo de procedimiento: Declaración de la condición de recursos mineros de la sección B (estructuras subterráneas y yacimientos no naturales) y autorización o concesión de aprovechamiento de dichos recursos.

Sentido del silencio: Negativo.

Normativa reguladora: Ley estatal 22/1973, de 21 de julio, de Minas, modificada por la Ley $54 / 1980$, de 5 de noviembre.

Real Decreto 2857/1978, de 25 de agosto, Reglamento general para el Régimen de la Minería.

Tipo de procedimiento: Concesión de aprovechamiento de recursos mineros de la sección C.

Sentido del silencio: Negativo.

Normativa reguladora: Ley estatal 22/1973, de 21 de julio, de minas, modificada por la Ley $54 / 1980$, de 5 de noviembre.

Real Decreto 2857/1978, de 25 de agosto, Reglamento General para el Régimen de la Minería.

Tipo de procedimiento: Otorgamiento de permisos de exploración y de investigación de las secciones C y D.

Sentido del silencio: Negativo.

Normativa reguladora: Ley estatal 22/1973, de 21 de julio, de minas, modificada por la Ley $54 / 1980$, de 5 de noviembre.

Real Decreto 2857/1978, de 25 de agosto, Reglamento general para el Régimen de la Minería.

Tipo de procedimiento: Autorización de agrupaciones o concentración de concesiones mineras.

Sentido del silencio: Negativo.

Normativa reguladora: Ley estatal 22/1973, de 21 de julio, de minas, modificada por la Ley $54 / 1980$, de 5 de noviembre.

Real Decreto 2857/1978, de 25 de agosto, Reglamento General para el Régimen de la Minería. Tipo de procedimiento: Autorización de Transmisión de Derechos Mineros.

Sentido del silencio: Negativo.

Normativa reguladora: Ley estatal 22/1973, de 21 de julio, de minas, modificada por la Ley $54 / 1980$, de 5 de noviembre.

Real Decreto 2857/1978, de 25 de agosto, Reglamento General para el Régimen de la Minería. Tipo de procedimiento: Declaración de Compatibilidad de Explotaciones Mineras.

Sentido del silencio: Negativo.

Normativa reguladora: Ley estatal 22/1973, de 21 de julio, de minas, modificada por la Ley $54 / 1980$, de 5 de noviembre.

Real Decreto 2857/1978, de 25 de agosto, Reglamento General para el Régimen de la Minería. 


\section{Procedimiento administrativo...}

Tipo de procedimiento: Autorización de Suspensión de Trabajos Mineros.

Sentido del silencio: Negativo.

Normativa reguladora: Ley estatal 22/1973, de 21 de julio, de minas, modificada por la Ley $54 / 1980$, de 5 de noviembre.

Real Decreto 2857/1978, de 25 de agosto, Reglamento General para el Régimen de la Minería.

Real Decreto 863/1985, de 2 de abril, Reglamento General de normas básicas de Seguridad Minera.

Tipo de procedimiento: Aprobación de proyectos de instalaciones mineras.

Sentido del silencio: Negativo.

Normativa reguladora: Real Decreto 863/1985, de 2 de abril, Reglamento General de normas básicas de Seguridad Minera.

Tipo de procedimiento: Declaración de la condición de mineromedicinal o termal de las aguas y reconocimiento del derecho a la utilización de tal denominación.

Autorización o concesión de aprovechamiento de aguas mineromedicinales o termales.

Sentido del silencio: Negativo.

Normativa reguladora: Ley estatal 22/1973, de 21 de julio, de minas, modificada por la Ley $54 / 1980$, de 5 de noviembre.

Real Decreto 2857/1978, de 25 de agosto, Reglamento general para el Régimen de la Minería.

Ley $5 / 1995$, de 7 de junio, de regulación de las Aguas Minerales, Termales, de Manantial y de los Establecimientos Balnearios de la Comunidad Autónoma de Galicia.

Decreto 402/1996, de 31 de octubre, por el que se aprueba el Reglamento de aprovechamiento de aguas mineromedicinales, termales y de los establecimientos balnearios de la Comunidad Autónoma de Galicia.

Tipo de procedimiento: Declaración de las condiciones de mineroindustrial, mineronatural o de manantial de las aguas y reconocimiento a la utilización de tales denominaciones. Autorización o concesión de aprovechamiento de las aguas mineroindustriales, mineronaturales o de manantial. Sentido del silencio: Negativo.

Normativa reguladora: Ley estatal 22/1973, de 21 de julio, de minas, modificada por la Ley $54 / 1980$, de 5 de noviembre.

Real Decreto 2857/1978, de 25 de agosto, Reglamento general para el Régimen de la Minería.

Ley $5 / 1995$, de 7 de junio, de Regulación de las Aguas Minerales, Termales, de Manantial y de los Establecimientos Balnearios de la Comunidad Autónoma de Galicia.
Tipo de procedimiento: Otorgamiento de demasías.

Sentido del silencio: Negativo.

Normativa reguladora: Ley estatal 22/1973, de 21 de julio, de minas, modificada por la Ley $54 / 1980$, de 5 de noviembre.

Real Decreto 2857/1978, de 25 de agosto, Reglamento General para el Régimen de la Minería.

Tipo de procedimiento: Concursos públicos en materia de minas.

Sentido del silencio: Negativo.

Normativa reguladora: Ley estatal 22/1973, de 21 de julio, de minas, modificada por la Ley $54 / 1980$, de 5 de noviembre.

Real Decreto 2857/1978, de 25 de agosto, Reglamento General para el Régimen de la Minería.

Tipo de procedimiento: Intrusiones y deslindes.

Sentido del silencio: Negativo.

Normativa reguladora: Ley estatal 22/1973, de 21 de julio, de minas, modificada por la Ley $54 / 1980$, de 5 de noviembre.

Real Decreto 2857/1978, de 25 de agosto, Reglamento general para el Régimen de la Minería.

Tipo de procedimiento: Autorización de instalaciones de producción, transporte y distribución de energía eléctrica.

Sentido del silencio: Negativo.

Normativa reguladora: Ley estatal 22/1973, de 21 de julio, de minas, modificada por la Ley $54 / 1980$, de 5 de noviembre.

Real Decreto 2857/1978, de 25 de agosto, Reglamento General para el Régimen de la Minería.

Tipo de procedimiento: Reconocimiento de la condición de instalación acogida al régimen especial de producción eléctrica.

Sentido del silencio: Negativo.

Normativa reguladora: Ley estatal 54/1997, de 27 de noviembre, del Sector Eléctrico.

Real Decreto 2818/1998, de 23 de diciembre, sobre Producción de Energía Eléctrica por Instalaciones Abastecidas por Recursos o Fuentes de Energía Renovables, Residuos o Cogeneración. Tipo de procedimiento: Autorización de instalaciones de transporte o de almacenamiento de productos petrolíferos, cuando estas últimas presten servicio a operadores, así como de instalaciones de venta al público de carburantes y combustibles petrolíferos de automoción.

Sentido del silencio: Negativo.

Normativa reguladora: Ley estatal 34/1998, de 7 de octubre, del Sector de Hidrocarburos.

Real Decreto 2085/1994, de 20 de octubre, Reglamento de Instalaciones Petrolíferas.

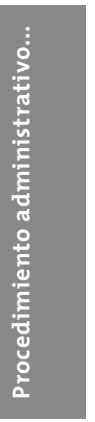


Real Decreto 1905/1995, de 24 de noviembre, Reglamento para la Distribución al por menor de Carburantes y Combustibles Petroliferos en Instalaciones de Venta al Público.

Tipo de procedimiento: Autorización de la actividad de distribución al por menor de productos petrolíferos y de gases licuados del petróleo (GLP) a granel.

Sentido del silencio: Negativo.

Normativa reguladora: Ley estatal 34/1998, de 7 de octubre, del Sector de Hidrocarburos.

Real Decreto 1905/1995, de 24 de noviembre, Reglamento para la Distribución al por menor de Carburantes y Combustibles Petrolíferos en Instalaciones de Venta al Público.

Real Decreto 1085/1992, de 11 de septiembre, Reglamento de la Actividad de Distribución de Gases Licuados del Petróleo.

Tipo de procedimiento: Autorización de instalaciones de almacenamiento, transporte y distribución de gas natural y de almacenamiento y distribución de GLP, combustibles gaseosos manufacturados y sintéticos y de mezcla de gases y aire para suministro por canalización.

Sentido del silencio: Negativo.

Normativa reguladora: Ley estatal 34/1998, de 7 de octubre, del Sector de Hidrocarburos.

Decreto 2913/1973, de 26 de octubre, Reglamento General del Servicio Público de Gases Combustibles.

Tipo de procedimiento: Autorización de la actividad de transporte, distribución y comercialización de gas natural y combustibles gaseosos por canalización.

Sentido del silencio: Negativo.

Normativa reguladora: Ley estatal 34/1998, de 7 de octubre, del Sector de Hidrocarburos.

Decreto 2913/1973, de 26 de octubre, Reglamento General del Servicio Público de Gases Combustibles.

Tipo de procedimiento: Autorización de voladuras tipo y especiales.

Sentido del silencio: Negativo.

Normativa reguladora: Real Decreto 863/1985, de 2 de abril, Reglamento General de Normas Básicas de Seguridad Minera.

Real Decreto 230/1998, de 16 de febrero, Reglamento de Explosivos.

Tipo de procedimiento: Autorización de maquinaria móvil minera.

Sentido del silencio: Negativo.

Normativa reguladora: Real Decreto 863/1985, de 2 de abril, Reglamento General de Normas Básicas de Seguridad Minera.
Tipo de procedimiento: Establecimiento de beneficios mineros.

Sentido del silencio: Negativo.

Normativa reguladora: Ley estatal 22/1973, de 21 de julio, de Minas.

Real Decreto 2857/1978, de 25 de agosto, Reglamento General para el Régimen de la Minería.

Tipo de procedimiento: Carnés profesionales en el ámbito minero.

Sentido del silencio: Negativo.

Normativa reguladora: Real Decreto 863/1985, de 2 de abril, Reglamento General de Normas Básicas de Seguridad Minera.

Tipo de procedimiento: Autorización a las cámaras oficiales de comercio, industria y navegación de Galicia para actos de disposición sobre inmuebles y celebración de operaciones de crédito.

Sentido del silencio: Negativo.

Normativa reguladora: Decreto 1291/1974, de 2 de mayo, Reglamento General de las Cámaras Oficiales de Comercio, Industria y Navegación.

Tipo de procedimiento: Aprobación de planes eólicos estratégicos.

Sentido del silencio: Negativo.

Normativa reguladora: Decreto 205/1995, de 6 de julio, por el que se regula el aprovechamiento de la energía eólica en la Comunidad Autónoma de Galicia.

Tipo de procedimiento: Autorización administrativa de las instalaciones de un parque eólico.

Sentido del silencio: Negativo.

Normativa reguladora: Ley estatal 54/1997, de 27 de noviembre, del Sector Eléctrico.

Real Decreto 1955/2000, de 1 de diciembre, por el que se regulan las actividades de transporte, distribución, comercialización, suministro y procedimientos de autorización de instalaciones eléctricas.

Decreto 205/1995, de 6 de julio, por el que se regula el aprovechamiento de la energía eólica en la Comunidad Autónoma de Galicia.

Consellería de Agricultura, Gandería e Política Agroalimentaria.

Tipo de procedimiento: Inscripción en el Registro de Sociedades Agrarias de Transformación.

Sentido del silencio: Negativo.

Normativa reguladora: Real Decreto 1776/1981, de 3 de agosto, por el que se aprueba el Estatuto que regula las Sociedades Agrarias de Transformación.

Decreto 215/1985, de 10 de octubre, por el que se crea el Registro de Sociedades Agrarias de Transformación. 
Tipo de procedimiento: Peticiones y recursos planteados por los interesados en el procedimiento de concentración parcelaria.

Sentido del silencio: Negativo.

Normativa reguladora: Ley 10/1985, de 14 de agosto, de Concentración Parcelaria para Galicia.

Tipo de procedimiento: Denominaciones de calidad amparadas legalmente.

Sentido del silencio: Negativo.

Normativa reguladora: Ley 25/1970, de 2 de diciembre, del Estatuto de la Viña, el Vino y los Alcoholes.

Reglamento (CEE) 2081/1992, del Consejo, de 14 de julio, relativo a la protección de las indicaciones geográficas y denominaciones de origen de los productos agrícolas y alimenticios.

Reglamento (CEE) 2082/1992, del Consejo, de 14 de julio, relativo a la certificación de las características específicas de los productos agrícolas y alimenticios.

Tipo de procedimiento: Autorización y registro de establecimientos e intermediarios del sector de alimentación animal.

Sentido del silencio: Negativo.

Normativa reguladora: Real Decreto 1191/1998, de 12 de junio, sobre Autorización y Registro de Establecimientos e Intermediarios del Sector de la Alimentación Animal.

Decreto 92/1999, de 25 de marzo, por el que se regula la autorización y registro de establecimientos e intermediarios del sector de la alimentación animal.

Tipo de procedimiento: Asignación de derechos para nuevas plantaciones de viñedo en zonas de producción con denominación de origen.

Sentido del silencio: Negativo.

Normativa reguladora: Real Decreto 1472/2000, de 4 de agosto, por el que se regula el potencial de producción vitícola.

Órdenes anuales de asignación de derechos.

Consellería de Cultura, Comunicación Social y Turismo

Tipo de procedimiento: Donación, depósito y adquisición de obras de arte.

Sentido del silencio: Negativo.

Normativa reguladora: Ley 8/1995, de 30 de octubre, del Patrimonio Cultural de Galicia.

Ley 3/1985, de 12 de abril, del Patrimonio de la Comunidad Autónoma de Galicia.

Decreto 50/1989, de 9 de marzo, por el que se aprueba el Reglamento para la ejecución de la Ley $3 / 1985$, modificado por el Decreto 238/1998, de 24 de julio.
Tipo de procedimiento: Inclusión de bienes en el inventario general del patrimonio cultural de Galicia.

Sentido del silencio: Negativo.

Normativa reguladora: Ley 8/1995, de 30 de octubre, del Patrimonio Cultural de Galicia.

Tipo de procedimiento: Autorización para la realización y dirección de actividades arqueológicas.

Sentido del silencio: Negativo.

Normativa reguladora: Ley 8/1995, de 30 de octubre, del Patrimonio Cultural de Galicia.

Decreto 199/1997, de 10 de julio, por el que se regula la actividad arqueológica en la Comunidad Autónoma de Galicia.

Tipo de procedimiento: Autorización de intervenciones sobre bienes del patrimonio cultural.

Sentido del silencio: Negativo.

Normativa reguladora: Ley 8/1995, de 30 de octubre, del Patrimonio Cultural de Galicia.

Decreto 63/1992, de 19 de febrero, por el que se reestructura la composición y funcionamiento de las comisiones territoriales del patrimonio histórico gallegas.

Tipo de procedimiento: Concesión de emisoras municipales y comerciales de radiodifusión sonora en ondas métricas con modulación de frecuencia. Sentido del silencio: Negativo.

Normativa reguladora: Ley estatal 31/1987, de 18 de diciembre, de Ordenación de las Telecomunicaciones.

Decreto 156/1989, de 27 de julio, por el que se establece el procedimiento de concesión de emisoras de radiodifusión sonora en ondas métricas con modulación de frecuencia, modificado por el Decreto 35/1992, de 6 de febrero.

Tipo de procedimiento: Concesión de servicios de radiodifusión sonora y televisión digital terrenal.

Sentido del silencio: Negativo.

Normativa reguladora: Ley estatal 66/1997, de 30 de diciembre, de Medidas Fiscales, Administrativas y de Orden Social (disposición adicional 44). Tipo de procedimiento: Declaración de fiestas de Galicia de interés turístico.

Sentido del silencio: Negativo.

Normativa reguladora: Decreto 39/2001, de 1 de febrero, de refundición en materia de Consello Galego de Turismo, declaración de municipio turístico gallego y declaraciones de fiestas de interés turístico.

Tipo de procedimiento: Declaración de municipio turístico gallego.

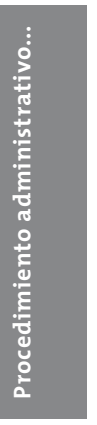


Sentido del silencio: Negativo.

Normativa reguladora: Decreto 39/2001, de 1 de febrero, de refundición en materia de Consello Galego de Turismo, declaración de municipio turístico gallego y declaraciones de fiestas de interés turístico.

Tipo de procedimiento: Autorizaciones provisionales de establecimientos turísticos de alojamiento y restauración.

Sentido del silencio: Negativo.

Normativa reguladora: Orden de 19 de julio de 1968 por la que se dictan normas sobre clasificación de los establecimientos hoteleros.

Orden de 17 de enero de 1967 por la que se aprueba la ordenación de los apartamentos, bungalows y otros alojamientos similares de carácter turístico.

Orden de 28 de octubre de 1968 por la que se aprueba la ordenación turística de las ciudades de vacaciones.

Orden de 2 de enero de 1995 por la que se establece la ordenación de los establecimientos de turismo rural, modificada por Orden de 7 de mayo de 1996.

Decreto 236/1985, de 24 de octubre, sobre Ordenación de los Campamentos Públicos de Turismo en Galicia.

Orden de 17 de marzo de 1965 por la que se aprueba la ordenación turística de restaurantes. Orden de 18 de marzo de 1965 por la que se aprueba la ordenación turística de cafeterías.

Consellería de sanidade e Servizos Sociais

Tipo de procedimiento: Autorización de apertura y funcionamiento de oficinas de farmacia (a instancia de parte).

Sentido del silencio: Negativo.

Normativa reguladora: Ley 5/1999, de 21 de mayo, de Ordenación Farmacéutica.

Decreto 2888/1996, de 12 de julio, sobre Competencia y Procedimiento para la Autorización de Apertura de Oficinas de Farmacia.

Tipo de procedimiento: Traslado de oficinas de farmacia (a instancia de parte).

Sentido del silencio: Negativo.

Normativa reguladora: Ley 5/1999, de 21 de mayo, de Ordenación Farmacéutica.

Tipo de procedimiento: Transmisiones de oficinas de farmacia.

Sentido del silencio: Negativo.

Normativa reguladora: Ley 5/1999, de 21 de mayo, de Ordenación Farmacéutica.

Tipo de procedimiento: Reconocimiento de gastos o indemnizaciones por asistencia médica, asistencia farmacéutica o donación de órganos.
Sentido del silencio: Negativo.

Normativa reguladora: Real Decreto legislativo $1 / 1994$, de 20 de junio, por el que se aprueba el texto refundido de la Seguridad Social.

Tipo de procedimiento: Nombramiento de educadores-becarios del centro Santiago Apóstol.

Sentido del silencio: Negativo.

Normativa reguladora: Orden de 13 de junio de 2000 por la que se convocan plazas de educadores-becarios para el Centro de Asistencia y Educación Especial Santiago Apóstol.

Tipo de procedimiento: Autorización de las unidades, centros, servicios y establecimientos sanitario-asistenciales de tratamiento de las drogodependencias.

Sentido del silencio: Negativo.

Normativa reguladora: Orden de 7 de julio de 1988 sobre autorización de unidades, centros, servicios y establecimientos sanitario-asistenciales de tratamiento de drogodependencias.

Tipo de procedimiento: Certificado de potabilidad de agua para campamentos.

Sentido del silencio: Negativo.

Normativa reguladora: Decreto 236/1985, de 24

de octubre, modificado por el Decreto 53/1989, de 9 de marzo.

Tipo de procedimiento: Autorización de industrias transformadoras de moluscos.

Sentido del silencio: Negativo.

Normativa reguladora: Orden de 29 de febrero de 1996 por la que se regulan las condiciones de autorización a industrias transformadoras de la especie "Acanthocardia tuberculatum".

Tipo de procedimiento: Procedimientos de acreditación de centros de rehabilitación psicosocial y laboral para enfermos mentales crónicos.

Sentido del silencio: Negativo.

Normativa reguladora: Orden de 23 de octubre de 1998, de regulación de los centros de rehabilitación psicosocial y laboral para enfermos mentales crónicos como desarrollo de los dispositivos de apoyo comunitario.

Tipo de procedimiento: Autorización y/o acreditación de centros, servicios y establecimientos sanitarios.

Sentido del silencio: Negativo.

Normativa reguladora: Decreto 147/1994, de 13 de septiembre, sobre Autorización de Centros, Servicios y Establecimientos Sanitarios.

Consellería de Pesca, Marisqueo e Acuicultura Tipo de procedimiento: Autorización para nuevas construcciones y modernización de barcos pesqueros. 


\section{Procedimiento administrativo...}

Sentido del silencio: Negativo.

Normativa reguladora: Real Decreto 1027/1989, de 28 de julio, sobre Abanderamiento, Matriculación de Buques y Registro Marítimo.

Real Decreto 789/1995, de 19 de mayo, por el que se definen los criterios y condiciones de las intervenciones con finalidad estructural en el sector de la pesca, la acuicultura y la comercialización, la transformación y la promoción de sus productos.

Tipo de procedimiento: Permiso de explotación para embarcaciones.

Sentido del silencio: Negativo.

Normativa reguladora: Decreto 425/1993, de 17 de diciembre, por el que se refunde la normativa vigente sobre el permiso de explotación para ejercer la actividad pesquera y marisquera.

Tipo de procedimiento: Permiso de explotación para marisqueo a pie.

Sentido del silencio: Negativo.

Normativa reguladora: Decreto 425/1993, de 17 de diciembre, por el que se refunde la normativa vigente sobre el permiso de explotación para ejercer la actividad pesquera y marisquera.

Tipo de procedimiento: Traslado del permiso de explotación.

Sentido del silencio: Negativo.

Normativa reguladora: Decreto 425/1993, de 17 de diciembre, por el que se refunde la normativa vigente sobre el permiso de explotación para ejercer la actividad pesquera y marisquera.

Tipo de procedimiento: Permiso de explotación para marisqueo a pie con embarcación auxiliar. Sentido del silencio: Negativo.

Normativa reguladora: Decreto 425/1993, de 17 de diciembre, por el que se refunde la normativa vigente sobre el permiso de explotación para ejercer la actividad pesquera y marisquera.

Tipo de procedimiento: Traslado del permiso de explotación por venta.

Sentido del silencio: Negativo.

Normativa reguladora: Decreto 425/1993, de 17 de diciembre, por el que se refunde la normativa vigente sobre el permiso de explotación para ejercer la actividad pesquera y marisquera.

Tipo de procedimiento: Autorizaciones de planes experimentales.

Sentido del silencio: Negativo.

Normativa reguladora: Decreto 424/1993, de 17 de diciembre, por el que se aprueba el Reglamento de la actividad pesquera y de las artes y aparejos de pesca permisibles en Galicia.
Tipo de procedimiento: Autorizaciones de explotación marisquera, extracción, traslados, siembras y limpieza en zonas de libre marisqueo.

Sentido del silencio: Negativo.

Normativa reguladora: Decreto 423/1993, de 17 de diciembre, por el que se refunde la normativa vigente en materia de marisqueo, extracción de algas y cultivos marinos.

Tipo de procedimiento: Autorizaciones de explotación marisquera, extracción, traslados, siembras y limpieza en zonas de autorización y concesión.

Sentido del silencio: Negativo.

Normativa reguladora: Decreto 423/1993, de 17 de diciembre, por el que se refunde la normativa vigente en materia de marisqueo, extracción de algas y cultivos marinos.

Tipo de procedimiento: Concesión de permisos de inmersión de especies marinas.

Sentido del silencio: Negativo.

Normativa reguladora: Decreto 423/1993, de 17 de diciembre, por el que se refunde la normativa vigente en materia de marisqueo, extracción de algas y cultivos marinos.

Tipo de procedimiento: Autorización de explotación de bancos marisqueros en dominio público. Sentido del silencio: Negativo.

Normativa reguladora: Ley 6/1993, de 11 de mayo, de Pesca de Galicia.

Tipo de procedimiento: Concesiones-autorizaciones para instalar establecimientos de acuicultura en la zona marítima y marítimo-terrestre.

Sentido del silencio: Negativo.

Normativa reguladora: Ley 6/1993, de 11 de mayo, de Pesca de Galicia.

Tipo de procedimiento: Concesiones-autorizaciones para remodelar o ampliar establecimientos de acuicultura que supongan modificación de ocupación de dominio público.

Sentido del silencio: Negativo.

Normativa reguladora: Ley 6/1993, de 11 de mayo, de Pesca de Galicia.

Tipo de procedimiento: Autorización temporal para viveros experimentales.

Sentido del silencio: Negativo.

Normativa reguladora: Orden de 17 de septiembre de 1998 por la que se regula el procedimiento para la concesión de autorizaciones temporales de carácter experimental en polígonos de viveros de cultivos marinos.

Tipo de procedimiento: Instalación de centros reguladores de crustáceos en el dominio público.

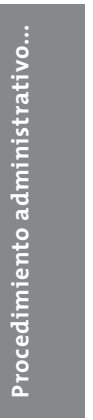


Sentido del silencio: Negativo.

Normativa reguladora: Orden de 16 de octubre de 1996 sobre centros reguladores de crustáceos.

Tipo de procedimiento: Permiso de actividad para establecimientos de acuicultura y auxiliares en la zona terrestre que precisen ocupación de dominio público.

Sentido del silencio: Negativo.

Normativa reguladora: Orden de 27 de marzo de 2000 por la que se regula el procedimiento para el otorgamiento del permiso de actividad a establecimientos de cultivos marinos y auxiliares en la zona terrestre.

Tipo de procedimiento: Autorizaciones para cambios de sistemas de instalaciones (viveros flotantes).

Sentido del silencio: Negativo.

Normativa reguladora: Ley 6/1996, de 11 de mayo, de Pesca de Galicia.

Decreto 406/1996, de 7 de noviembre, por el que se aprueba el Reglamento de viveros de cultivos marinos en las aguas de Galicia.

Tipo de procedimiento: Autorizaciones para cambios de localización de establecimientos de acuicultura.

Sentido del silencio: Negativo.

Normativa reguladora: Ley 6/1996, de 11 de mayo, de Pesca de Galicia.

Decreto 406/1996, de 7 de noviembre, por el que se aprueba el Reglamento de viveros de cultivos marinos en las aguas de Galicia.

Tipo de procedimiento: Autorizaciones para cambios de dominio de establecimientos de cultivos marinos (salvo viveros).

Sentido del silencio: Negativo.

Normativa reguladora: Ley 6/1996, de 11 de mayo, de Pesca de Galicia.

Orden de 21 de julio de 2000 por la que se regula el procedimiento para la transmisión de titularidad del permiso de actividad en establecimientos de cultivos marinos y auxiliares en la zona terrestre. Tipo de procedimiento: Transmisión de la titularidad de las concesiones de las bateas de cultivos marinos.

Sentido del silencio: Negativo.

Normativa reguladora: Orden de 15 de junio de 1999 por la que se regula el procedimiento para la transmisión de titularidad de las concesiones de las bateas de cultivos marinos en las aguas de Galicia. Tipo de procedimiento: Transmisión mortis causa. Autorización temporal de viveros experimentales. Sentido del silencio: Negativo.
Normativa reguladora: Orden de 7 de octubre de 1999 por la que se regula el procedimiento para la transmisión mortis causa de la titularidad de las autorizaciones temporales de carácter experimental de los polígonos de viveros.

Tipo de procedimiento: Autorizaciones para cambios de cultivo.

Sentido del silencio: Negativo.

Normativa reguladora: Ley 6/1996, de 11 de mayo, de Pesca de Galicia.

Decreto 406/1996, de 7 de noviembre, por el que se aprueba el Reglamento de viveros de cultivos marinos en las aguas de Galicia.

Tipo de procedimiento: Autorización para ampliación de las especies autorizadas.

Sentido del silencio: Negativo.

Normativa reguladora: Ley 6/1996, de 11 de mayo, de Pesca de Galicia.

Decreto 406/1996, de 7 de noviembre, por el que se aprueba el Reglamento de viveros de cultivos marinos en las aguas de Galicia.

Tipo de procedimiento: Autorización de plan de extracciones de semilla de mejillón.

Sentido del silencio: Negativo.

Normativa reguladora: Orden de 26 de octubre de 2000 por la que se regula la extracción de especies de mejillones en bancos naturales.

Tipo de procedimiento: Solicitud de título para el gobierno de embarcación de recreo o tarjeta de identidad marina.

Sentido del silencio: Negativo.

Normativa reguladora: Orden de 22 de abril de 1998 por la que se establecen los modelos de las tarjetas acreditativas de las titulaciones para el gobierno de embarcaciones de recreo y el procedimiento para su obtención.

Tipo de procedimiento: Obtención de las tarjetas de identidad profesional náutico-pesquera y sus modelos.

Sentido del silencio: Negativo.

Normativa reguladora: Orden de 8 de junio de 1998 por la que se establece el procedimiento para la obtención de las tarjetas de identidad profesional náutico-pesquera y sus modelos.

Tipo de procedimiento: Obtención o renovación de tarjetas de buceo profesional.

Sentido del silencio: Negativo.

Normativa reguladora: Orden de 23 de abril de 1999 por la que se regula el ejercicio del buceo profesional en la Comunidad Autónoma de Galicia.

Tipo de procedimiento: Expedición del certificado de especialidad de buceo profesional. 
Sentido del silencio: Negativo.

Normativa reguladora: Orden de 23 de abril de 1999 por la que se regula el ejercicio del buceo profesional en la Comunidad Autónoma de Galicia.

Consellería de Justicia, Interior y Relaciones Laborales

Tipo de procedimiento: Declaración de urgente ocupación en expropiaciones forzosas de entidades locales.

Sentido del silencio: Negativo.

Normativa reguladora: Ley de 16 de diciembre de 1954, de Expropiación Forzosa.

Tipo de procedimiento: Autorización de desafectación y enajenación de bienes.

Sentido del silencio: Negativo.

Normativa reguladora: Ley 5/1997, de 22 de julio, de Administración Local de Galicia.

Tipo de procedimiento: Autorización de alteración del término municipal.

Sentido del silencio: Negativo.

Normativa reguladora: Ley 5/1997, de 22 de julio, de Administración Local de Galicia.

Tipo de procedimiento: Resolución de las cuestiones de deslindes de términos municipales que se planteen entre municipios.

Sentido del silencio: Negativo.

Normativa reguladora: Ley 5/1997, de 22 de julio, de Administración Local de Galicia.

Tipo de procedimiento: Dispensa a los municipios de la obligación de prestar los servicios mínimos.

Sentido del silencio: Negativo.

Normativa reguladora: Ley 5/1997, de 22 de julio, de Administración Local de Galicia.

Tipo de procedimiento: Constitución y disolución de las entidades locales menores.

Sentido del silencio: Negativo.

Normativa reguladora: Ley 5/1997, de 22 de julio, de Administración Local de Galicia.

Tipo de procedimiento: Autorización de instalación o apertura de casinos de juego.

Sentido del silencio: Negativo.

Normativa reguladora: Ley 14/1985, de 23 de octubre, Reguladora de los Juegos y Apuestas de Galicia.

Tipo de procedimiento: Procedimiento de autorización, inscripción y modificación en el registro de empresas operadoras, fabricantes, distribuidoras e importadoras de máquinas de juego y recreativas.

Sentido del silencio: Negativo.
Normativa reguladora: Decreto 106/1998, de 12 de febrero, por el que se aprueba el Reglamento de Máquinas Recreativas y de Azar.

Tipo de procedimiento: Autorización de explotación, bajas temporales de autorizaciones de explotaciones, autorizaciones y modificaciones de boletines de instalación estando ya vigente uno, tramitación de autorización de explotación por cambio de titular, autorización y sustitución de máquina recreativa en establecimiento, autorización de cambio de máquina en explotación, autorización de traslado de máquinas entre provincias y habilitación de titular de local y establecimiento, todas ellas respecto a las máquinas recreativas y de azar.

Sentido del silencio: Negativo.

Normativa reguladora: Decreto 106/1998, de 12 de febrero, por el que se aprueba el Reglamento de Máquinas Recreativas y de Azar.

Tipo de procedimiento: Autorización de apertura, instalación y cambio de titularidad en salones recreativos y de juego.

Sentido del silencio: Negativo.

Normativa reguladora: Decreto 106/1998, de 12 de febrero, por el que se aprueba el Reglamento de Máquinas Recreativas y de Azar.

Tipo de procedimiento: Autorización de apertura, instalación y modificaciones de salas de bingo.

Sentido del silencio: Negativo.

Normativa reguladora: Decreto 273/1986, de 31 de julio, del Reglamento del Juego del Bingo.

Tipo de procedimiento: Autorización de apertura, modificación y uso de aparatos auxiliares, en el ámbito de las salas de bingo.

Sentido del silencio: Negativo.

Normativa reguladora: Decreto 273/1986, de 31 de julio, del Reglamento del Juego del Bingo, y Decreto 523/1990, de 29 de noviembre, por el que se prohíbe la instalación de cajeros automáticos en las salas de juego y salas de bingo y se limita la utilización de datáfonos, así como de aparatos auxiliares del juego del bingo.

Tipo de procedimiento: Autorización de rifas, tómbolas y combinaciones aleatorias.

Sentido del silencio: Negativo.

Normativa reguladora: Ley 14/1985, de 23 de octubre, reguladora de los Juegos y Apuestas de Galicia.

Decreto 116/1986, de 4 de junio, por el que se aprueba el Catálogo de Juegos de la Comunidad Autónoma de Galicia.

Tipo de procedimiento: Procedimientos relacionados con la inscripción de actos en el registro de cooperativas.

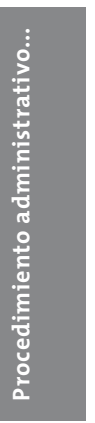


Sentido del silencio: Negativo.

Normativa reguladora: Ley 5/1998, de 18 de diciembre, de Cooperativas de Galicia.

Consellería de Familia y Promoción del Empleo, Mujer y Juventud

Tipo de procedimiento: Solicitud de adopción.

Procedimiento de valoración de la idoneidad.

Sentido del silencio: Negativo.

Normativa reguladora: Decreto 42/2000, de 7 de enero, por el que se refunde la normativa vigente en materia de familia, infancia y adolescencia.

Tipo de procedimiento: Procedimiento de acogimiento familiar.

Sentido del silencio: Negativo.

Normativa reguladora: Decreto 42/2000, de 7 de enero, por el que se refunde la normativa vigente en materia de familia, infancia y adolescencia.

Consellería de Medio Ambiente.

Tipo de procedimiento: Deslinde de Montes.

Sentido del silencio: Negativo.

Normativa reguladora: Ley de Montes, de 8 de junio de 1957.

Decreto $485 / 1962$, de 22 de febrero, por el que se aprueba el Reglamento de Montes.

Ley 13/1989, de 10 de octubre, de Montes Vecinales en Mancomún.

Tipo de procedimiento: Inclusión en el registro de espacios naturales de Galicia.

Sentido del silencio: Negativo.

Normativa reguladora: Decreto 82/1989, de 11 de mayo, por el que se regula la figura de espacio natural en régimen de protección general.

Tipo de procedimiento: Autorización de actividades, obras, instalaciones y usos permitidos en la zona de servidumbre de protección del dominio marítimo-terrestre.

Sentido del silencio: Negativo.

Normativa reguladora: Ley 22/1988, de 28 de julio, de Costas.

Real Decreto 1471/1989, de 1 de diciembre, por el que se aprueba el Reglamento General para el Desarrollo y Ejecución de la Ley 22/1988, de 28 de julio, de Costas.

Tipo de procedimiento: Permisos para la realización de quemas.

Sentido del silencio: Negativo.

Normativa reguladora: Ley $81 / 1968$, de 5 de diciembre, de Incendios Forestales.

Decreto 3769/1972, de 23 de diciembre, por el que se aprueba el Reglamento de Incendios Forestales.
Resoluciones anuales de la Consellería de Medio Ambiente sobre medidas de prevención de incendios forestales.

Tipo de procedimiento: Declaración de prevalencia de servidumbres de utilidad pública o interés sobre montes vecinales.

Sentido del silencio: Negativo.

Normativa reguladora: Ley de Montes, de 8 de junio de 1957.

Ley 13/1989, de 10 de octubre, de Montes Vecinales en Mancomún.

Decreto 485/1962, de 22 de febrero, por el que se aprueba el Reglamento de Montes.

Tipo de procedimiento: Autorización para aprovechamiento de especies de crecimiento lento en montes privados.

Sentido del silencio: Negativo.

Normativa reguladora: Ley de Montes, de 8 de junio de 1957.

Decreto 485/1962, de 22 de febrero, por el que se aprueba el Reglamento de Montes.

Tipo de procedimiento: Solicitudes de certificación de origen de material forestal de reproducción.

Sentido del silencio: Negativo.

Normativa reguladora: Orden de 3 de agosto de 1994, de la Consellería de Agricultura, Ganadería y Montes, de comercialización de materiales forestales de reproducción.

Tipo de procedimiento: Autorización de los centros de acuicultura.

Sentido del silencio: Negativo.

Normativa reguladora: Decreto 130/1997, de 14 de mayo, por el que se aprueba el Reglamento de Ordenación de la Pesca Fluvial y de los Ecosistemas Acuáticos Continentales.

Tipo de procedimiento: Ampliación de cotos privados de Caza-Tecor.

Sentido del silencio: Negativo.

Normativa reguladora: Ley 4/1997, de 25 de junio, de Caza de Galicia.

Ley 1/1970, de 4 de abril, de Caza.

Tipo de procedimiento: Segregación de cotos privados de caza.

Sentido del silencio: Negativo.

Normativa reguladora: Ley 4/1997, de 25 de julio, de Caza de Galicia.

Ley $1 / 1970$, de 4 de abril, de Caza.

Tipo de procedimiento: Autorización para instalación, ampliación, modificación sustancial o traslado de industrias o actividades productoras de residuos peligrosos y de inscripción en el Registro General de Productores y Gestores de Residuos de Galicia. 


\section{Procedimiento administrativo...}

Sentido del silencio: Negativo.

Normativa reguladora: Ley 10/1998, de 21 de abril, de Residuos.

Decreto 298/2000, de 7 de diciembre, por el que se regula la autorización y notificación de productor y gestor de residuos de Galicia y se crea el Registro General de Productores y Gestores de Residuos de Galicia.

Tipo de procedimiento: Autorización de actividades productoras, generadoras o importadoras de productos que por su uso podrán dar lugar a residuos peligrosos y de inscripción en el Registro General de Productores y Gestores de Residuos de Galicia.

Sentido del silencio: Negativo.

Normativa reguladora: Ley 10/1998, de 21 de abril, de Residuos.

Decreto 298/2000, de 7 de diciembre, por el que se regula la autorización y notificación de productor y gestor de residuos de Galicia y se crea el Registro General de Productores y Gestores de Residuos de Galicia.

Tipo de procedimiento: Autorización e inscripción en el Registro General de Productores y Gestores de Residuos de Galicia.

Sentido del silencio: Negativo.

Normativa reguladora: Ley 10/1998, de 21 de abril, de Residuos.

Decreto 298/2000, de 7 de diciembre, por el que se regula la autorización y notificación de productor y gestor de residuos de Galicia y se crea el Registro General de Productores y Gestores de Residuos de Galicia.

Tipo de procedimiento: Solicitud de autorización de construcción de instalaciones de residuos urbanos o municipales.

Sentido del silencio: Negativo.

Normativa reguladora: Ley 10/1998, de 21 de abril, de Residuos.

Decreto 298/2000, de 7 de diciembre, por el que se regula la autorización y notificación de productor y gestor de residuos de Galicia y se crea el Registro General de Productores y Gestores de Residuos de Galicia.

Tipo de procedimiento: Exclusión del catálogo de montes.

Sentido del silencio: Negativo.

Normativa reguladora: Ley de Montes, de 8 de junio de 1957.

Decreto 485/1962, de 22 de febrero, por el que se aprueba el Reglamento de Montes.

Tipo de procedimiento: Autorización para aprovechamiento y utilización de cualquier tipo de vegetación en la orilla de los ríos y en las aguas.
Sentido del silencio: Negativo.

Normativa reguladora: Decreto 130/1997, de 14 de mayo, por el que se aprueba el Reglamento de Ordenación de la Pesca Fluvial y de los Ecosistemas Acuáticos Continentales.

Tipo de procedimiento: Nombramiento de vigilantes jurados de pesca fluvial.

Sentido del silencio: Negativo.

Normativa reguladora: Decreto 130/1997, de 14 de mayo, por el que se aprueba el Reglamento de Ordenación de la Pesca Fluvial y de los Ecosistemas Acuáticos Continentales.

Tipo de procedimiento: Autorizaciones previstas en el artículo 88 del Reglamento de Ordenación de la Pesca Fluvial y de los Ecosistemas Acuáticos Continentales, aprobado por el Decreto 130/1997, de 14 de mayo.

Sentido del silencio: Negativo.

Normativa reguladora: Decreto 130/1997, de 14 de mayo, por el que se aprueba el Reglamento de Ordenación de la Pesca Fluvial y de los Ecosistemas Acuáticos.

Tipo de procedimiento: Autorización para tenencia de animales silvestres autóctonos.

Sentido del silencio: Negativo.

Normativa reguladora: Decreto 153/1998, de 2 de abril, por el que se aprueba el Reglamento que desarrolla la Ley 1/1993, de 13 de abril, de Protección de Animales Domésticos y Salvajes en Cautividad.

Tipo de procedimiento: Autorización para la posesión, exhibición, compraventa, cesión, circulación, donación o cualquier otra forma de transmisión de especies protegidas por la normativa vigente, incluidos los convenios internacionales.

Sentido del silencio: Negativo.

Normativa reguladora: Ley 4/1989, de 27 de marzo, de conservación de los espacios naturales y de la flora y fauna silvestres.

Decreto 153/1998, de 2 de abril, por el que se aprueba el Reglamento que desarrolla la Ley 1/1993, de 13 de abril, de Protección de Animales Domésticos y Salvajes en Cautividad.

Real Decreto 439/1990, de 30 de marzo, por el que se regula el Catálogo Nacional de Especies Amenazadas.

Tipo de procedimiento: Excepciones a las prohibiciones genéricas en materia de caza.

Sentido del silencio: Negativo.

Normativa reguladora: Ley 4/1997, de 25 de junio, de Caza de Galicia. 


\section{LEY 4/2006, DE 30 DE JUNIO, DE TRANSPARENCIA Y DE BUENAS PRÁCTICAS EN LA ADMINISTRACIÓN PÚBLICA GALLEGA} (DOGA N. $\left.^{\circ} 136,14.6 .2006\right)^{151}$ (...) $)^{152}$

\section{Capitulo I \\ ÁMBITO Y PRINCIPIOS GENERALES}

Artículo 1. Ámbito de aplicación.

1. Esta ley será de aplicación:

a. A la Administración de la Comunidad Autónoma de Galicia.

b. A los organismos autónomos, sociedades públicas, fundaciones del sector público autonómico y demás entidades de derecho público vinculadas o dependientes de la Comunidad Autónoma de Galicia.

c. A los órganos con dotación diferenciada en los presupuestos de la Comunidad Autónoma de Galicia que, careciendo de personalidad jurídica, no estén formalmente integrados en la Administración de la Comunidad Autónoma.

d. A los entes y empresas participadas mayoritariamente por la Xunta de Galicia en materia de personal y contratación a que hace referencia la Ley 10/1996, de 5 de noviembre.

2. Sin perjuicio de lo dispuesto en la normativa de general aplicación, los concesionarios de servicios públicos de la Comunidad Autónoma de Galicia someterán su actuación a las disposiciones que en la presente ley regulan expresamente su actividad.

Artículo 2. Principios generales.

Las entidades comprendidas en el ámbito de aplicación de la presente ley y el personal a su servicio, además de cumplir lo

\section{Véase:}

- Decreto 117/2008, de 22 de mayo, por el que se regulan las cartas de servicios de la Xunta de Galicia y el Observatorio da Calidade y de la Administración Electrónica de Galicia.

- Decreto 235/2008, de 18 de septiembre, por el que se regula el Sistema de Calidad de Gestión de la Xunta de Galicia.

152 Preámbulo omitido. dispuesto en la Constitución, el Estatuto de Autonomía y en el resto del ordenamiento jurídico, adecuarán sus actividades a los siguientes principios generales:

a. Procurar la satisfacción del interés general en la toma de decisiones.

b. Garantizar la transparencia, la eficacia y la eficiencia en la organización y en la gestión pública ${ }^{153}$.

c. Proporcionar y difundir información constante, veraz, objetiva y clara sobre la actuación del sector público autonómico.

d. Potenciar su accesibilidad y receptividad al objeto de facilitar el conocimiento por parte de la ciudadanía de las informaciones y gestiones que resulten de su interés.

e. Fomentar y favorecer la participación de la ciudadanía en los asuntos públicos y en el diseño y mejora de los servicios públicos. En particular se fomentará la participación equilibrada de las mujeres y los hombres en los asuntos públicos.

f. Mantener un diálogo abierto, transparente y regular con las asociaciones representativas y con la sociedad civil.

g. Garantizar en sus relaciones con la ciudadanía el principio de no discriminación por razón de género, raza, religión o creencia, ideología, capacidad física o psicológica, o cualesquiera otras circunstancias de índole personal o social. Se buscará especialmente y en los términos contemplados en la Ley 7/2004 la eliminación absoluta de las discriminaciones directas e indirectas.

h. Hacer efectivos los principios de racionalidad, claridad y confianza legítima en la relación de la Administración con los ciudadanos.

i. Impulsar el empleo de las técnicas informáticas y telemáticas para el desarrollo de su actividad y el ejercicio de sus competencias.

j. Promover el uso normal del gallego, oralmente o por escrito, en las relaciones

153 Véase Decreto 217/2008, de 25 de septiembre, por el que se regula el contenido minimo de las propuestas de creación de nuevas entidades del sector público autonómico. 
con la ciudadanía, sin perjuicio del derecho de no discriminación por razones de la lengua.

k. Prestar especial atención a las necesidades de las personas discapacitadas, adoptando las medidas necesarias para facilitar su acceso a la información y sus relaciones con la Administración.

\section{Capítulo II \\ TRANSPARENCIA EN LA ACTIVIDAD ADMINISTRATIVA}

Artículo 3. Derechos de las personas en sus relaciones con la Administración de la Comunidad Autónoma de Galicia.

Sin perjuicio de los derechos reconocidos en la Constitución española, en la legislación europea, en el Estatuto de Autonomía de Galicia y en la legislación básica del Estado, las personas, en sus relaciones con las administraciones públicas gallegas comprendidas en el ámbito de la presente ley, tienen los derechos que en la misma se establecen.

Artículo 4. Derecho de las personas a la información.

1. Las personas tienen derecho a solicitar y obtener información sobre los aspectos de la actividad administrativa de las instituciones y órganos mencionados en el artículo 1 de la presente ley que afecten a sus derechos e intereses legítimos. Dicha información podrá ser de carácter general o particular y comprende asimismo el acceso a los archivos y registros a que se refiere el artículo 37 de la Ley 30/1992, de 26 de noviembre, de Régimen Jurídico de las Administraciones Públicas y del Procedimiento Administrativo Común.

La información recabada se facilitará de forma clara y comprensible, garantizándose la suficiente difusión de la información sobre los derechos y sobre los recursos que, en su caso, sean pertinentes.

2. Para hacer efectivo este derecho, las administraciones y organismos incluidos en el campo de aplicación de la presente ley contarán con los instrumentos de información general sobre los servicios públicos que prestan, su estructura orgánica y funcional y la ubicación de sus unidades administrativas.

3. A través de estos instrumentos se facilitará la información que garantice a las personas su efectivo conocimiento del procedimiento que habrá de seguirse para las solicitudes o actuaciones que se propongan realizar ante aquellas.

4. Todas las personas podrán obtener las informaciones indicadas en las oficinas de atención al ciudadano que se establezcan, bien presencialmente, bien por escrito o bien por cualquier medio electrónico, informático o telemático que permita su debida constancia. También podrán transmitirse dichas informaciones a través de cualquiera de los referidos medios.

5. Cada consellería o unidad administrativa con actuación de relevancia externa, así como todo organismo o ente del sector público autonómico de las mismas características, dispondrá de una página web, en la que podrá accederse a la información general referida en la presente ley y a la necesaria sobre la tramitación de los distintos procedimientos administrativos, de acuerdo con lo que se determine reglamentariamente.

6. Se garantizará el más completo acceso a la información a las personas con cualquier tipo de discapacidad.

7. Reglamentariamente se determinará la articulación de los instrumentos de información a que se refiere este artículo.

Artículo 5. Derecho a la información adicional a las personas interesadas en el procedimiento.

En la notificación de las resoluciones y acuerdos administrativos, incluso referidos a actos de trámite, se identificará siempre la funcionaria o funcionario público o autoridad que los dictó, con indicación de su nombre y del cargo que ostenta. Asimismo, se hará constar la dirección postal, el teléfono y la dirección de correo electrónico a que la persona interesada podrá dirigir sus solicitudes de información adicional en relación con el acto notificado, y que serán contestadas

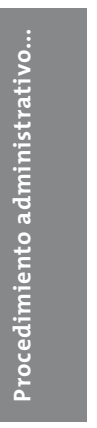


por el medio solicitado por la persona interesada en el procedimiento.

A tal fin, la Administración facilitará una contraseña personal que permita la identificación como interesado en el procedimiento.

Las contestaciones a que se refiere el párrafo anterior tendrán carácter meramente informativo para el solicitante, sin que pueda ser invocada a efectos de interrupción o suspensión de plazos, caducidad o prescripción.

La Administración autonómica adoptará las medidas pertinentes para que en los procedimientos que se tramiten en soporte informático los interesados puedan conocer el estado de tramitación de los procedimientos por conducto telemático o informático.

Artículo 6. Cartas de servicios.

1. Las cartas de servicios son documentos de acceso público a través de los cuales los órganos de la Administración autonómica gallega y sus organismos administrativos informan a las personas sobre sus derechos en sus relaciones con la respectiva entidad, las concretas obligaciones y responsabilidades que éstas asumen para garantizar aquellos derechos y los adecuados niveles de calidad en la prestación de los servicios públicos que tienen encomendados, así como aquellos otros que se entiendan relevantes, a estos efectos, y que se determinarán reglamentariamente.

2. Las cartas de servicios son elaboradas por el órgano competente, según su ámbito, que puede ser el de una consellería o el de unidades inferiores de la misma si se estima más adecuado.

3. La aprobación de las cartas de servicios, que corresponde a la consellería materialmente competente, se publicará en el "Diario Oficial de Galicia" y en la página web de la consellería u órgano correspondiente.

4. Las entidades a que hace referencia este artículo divulgarán por los distintos medios a su alcance las cartas de servicios al objeto de que las personas interesadas conozcan los compromisos y puedan demandar, en su caso, su cumplimiento ${ }^{154}$.

Artículo 7. Publicidad de la programación anual y plurianual.

1. La Administración general de la Comunidad Autónoma establecerá programas anuales y plurianuales en que se definirán los objetivos concretos y las actividades y medios necesarios para ejecutarlos, así como el tiempo estimado para su consecución. Estos programas definirán los objetivos y los plazos fijados por el Consello de la Xunta de Galicia y determinarán las personas o los órganos responsables de su ejecución.

2. Se promoverán fórmulas para que las personas, individualmente o por medio de las organizaciones y asociaciones reconocidas por la ley que las agrupen o representen, puedan participar en el diseño y elaboración de estos programas en los términos en que se determine reglamentariamente.

3. El grado de cumplimiento de los objetivos fijados en los programas a que se refieren los puntos anteriores será evaluado periódicamente por los órganos competentes en el ámbito de la Administración general de la Comunidad Autónoma.

4. La página web correspondiente contendrá la información sobre los programas y sus objetivos, y las formas de participación contempladas en el apartado 2 de este artículo.

Artículo 8. Medios electrónicos, informáticos y telemáticos ${ }^{155}$.

1. La Administración de la Comunidad Autónoma de Galicia impulsará el empleo

154 Véase Orden de 11 de julio de 2008 por la que se aprueba una guia descriptiva de elaboración de cartas de servicios en la Xunta de Galicia y el Manual de identidad gráfica del Programa de cartas de servicios de la Xunta de Galicia. 155 Véase:

- Decreto 255/2008, de 23 de octubre, por el que se simplifica la documentación para la tramitación de los procedimientos administrativos y se fomenta la utilización de medios electrónicos, en lo que respecta a la verificación de datos de identidad y residencia.

- Orden de 7 de julio de 2009 por la que se desarrolla el Decreto 255/2008, de 23 de octubre, por el que se simplifica la documentación para la tramitación de los procedimientos administrativos y se fomenta la utilización de medios electrónicos, en lo que respecta a la verificación de datos de identidad y residencia. 
y la aplicación de las técnicas y medios electrónicos y telemáticos para la realización de su actividad y el ejercicio de sus competencias, con las limitaciones que para la utilización de estos medios establecen la Constitución y las leyes.

2. La tramitación de los procedimientos administrativos se apoyará en la utilización de medios electrónicos, informáticos y telemáticos, respetando las garantías y cumpliendo los requisitos previstos para cada caso en el ordenamiento jurídico.

3. La introducción de medios informáticos y telemáticos en la gestión administrativa estará presidida por los principios de eficiencia y racionalidad de las inversiones realizadas y se ajustará a los criterios establecidos, en su caso, por la consellería competente en materia de tecnologías de la información en la administración pública.

4. La Comunidad Autónoma de Galicia mantendrá un registro telemático en el cual las personas podrán presentar sus solicitudes, escritos y comunicaciones dirigidos a la Administración de la Comunidad Autónoma, a sus organismos autónomos y a los demás entes públicos autonómicos que tramiten procedimientos administrativos.

Artículo 9. Participación en la elaboración de disposiciones de carácter general.

1. Cada consellería de la Administración autonómica publicará en su página web la relación circunstanciada y motivada de los procedimientos de elaboración de disposiciones administrativas de carácter general que estén en curso, indicando su objeto y estado de tramitación, así como la posibilidad que tienen las personas de remitir sugerencias y la forma de hacerlo. En cualquier momento anterior al trámite de audiencia o, en su caso, al informe final de la secretaría general, las personas, individualmente o por medio de asociaciones que las agrupen o representen, podrán remitir sugerencias relativas a aquellos proyectos que les afecten. Las proposiciones, sugerencias o recomendaciones recibidas serán tenidas en cuenta por el órgano encargado de la redacción del texto del proyecto, que podrá asumirlas o rechazarlas a través de un informe final en el cual recibirán una respuesta razonada, salvo las de reconocida y notoria urgencia, que podrá ser común para todas aquellas sugerencias que planteen cuestiones sustancialmente iguales.

2. La presentación de propuestas no atribuye, por sí misma, la condición de persona interesada en el procedimiento.

3. Lo previsto en este artículo no sustituye el trámite de audiencia pública, en los supuestos en que sea preceptivo de acuerdo con la normativa de aplicación.

Artículo 10. Contratos públicos.

1. Los órganos de contratación de las entidades comprendidas en el ámbito de aplicación de la presente ley darán a los operadores económicos un tratamiento igualitario y no discriminatorio y actuarán con transparencia.

2. En los procedimientos de contratación en que, de conformidad con la normativa de contratos públicos, sea preceptiva la publicación de anuncios de licitación, el órgano de contratación publicará, con carácter complementario, un anuncio en su página web en el cual se indicará el objeto del contrato, su precio, la referencia del diario oficial en que se publicó el anuncio, la fecha de finalización del plazo de recepción de ofertas o solicitudes de participación y el lugar donde éstas habrán de ser presentadas, así como los pliegos de cláusulas administrativas y prescripciones técnicas.

Los órganos de contratación podrán publicar en su página web anuncios relativos a contratos públicos que no estén sometidos a una publicidad obligatoria.

3. De conformidad con lo que reglamentariamente se determine, cada órgano 
de contratación publicará en su página web, una vez adjudicado el contrato público, información sobre:

a. Los licitadores.

b. Los criterios de selección y su valoración.

c. El cuadro comparativo de las ofertas económicas.

d. La puntuación obtenida por cada oferta, detallando la otorgada para cada uno de los criterios de valoración.

e. El resumen de la motivación de la valoración obtenida.

f. El adjudicatario.

g. En su caso, las modificaciones del contrato adjudicado que supongan un incremento igual o superior al 20\% del precio inicial del contrato, y éste sea superior a $1.000 .000 \mathrm{~A}$.

No procederá la divulgación de la información facilitada por los operadores económicos que los mismos hayan designado como confidencial. Esta información incluye, en particular, los secretos técnicos o comerciales y los aspectos confidenciales de las ofertas.

Asimismo, podrá no publicarse aquella información relativa a la adjudicación del contrato en caso de que su divulgación constituya un obstáculo para aplicar la legislación, sea contraria al interés público o perjudique los intereses comerciales legítimos de los operadores económicos públicos o privados, o pueda perjudicar la competencia leal entre ellos, debiendo motivarse la concurrencia de estas circunstancias en cada caso.

4. En los supuestos en que se proceda a la cesión de contrato o a la subcontratación, se dará publicidad a estas circunstancias junto con las razones que justifican tal decisión, identificando a los cesionarios y subcontratistas y las condiciones de los acuerdos alcanzados entre el contratista y aquellos, con las excepciones a que se refieren los dos últimos párrafos del punto anterior.

5. En los contratos adjudicados por concurso, y salvo las excepciones que puedan establecerse en resolución motivada del órgano de contratación cuando la relación entre la calidad y el precio así lo exija, la ponderación del precio como criterio de adjudicación del contrato no será inferior al $40 \%$ de la puntuación máxima que pueda atribuirse a las ofertas.

Artículo 11. Convenios de colaboración.

1. Cada consellería o entidad remitirá al "Diario Oficial de Galicia", dentro de los primeros veinte días de los meses de enero, mayo y septiembre de cada año, una relación de los convenios de colaboración, contemplados en el artículo 3.1.c) del texto refundido de la Ley de contratos de las administraciones públicas, suscritos en el cuatrimestre anterior.

A los efectos de su difusión en internet, la consellería o entidad hará pública, en su respectiva página web y dentro de los primeros veinte días de los meses de enero, mayo y septiembre de cada año, una relación de los convenios suscritos referida al cuatrimestre anterior. La información se mantendrá disponible en Internet durante todo el ejercicio presupuestario. Igualmente, se mantendrá disponible en Internet la información referida al ejercicio inmediatamente anterior.

Cuando dichos convenios impliquen obligaciones económicas para la Hacienda autonómica, se señalarán con claridad el importe de las mismas, el objeto del convenio y la persona o entidad destinataria de la prestación.

2. En el expediente administrativo deberá motivarse la utilización de la figura del convenio de colaboración contemplado en el artículo 3.1.d) del texto refundido de la Ley de contratos de las administraciones públicas y las razones que impidan la concurrencia de la oferta y excluyan la celebración de un contrato administrativo. La motivación se publicará en la forma prevista en el párrafo anterior.

3. Los convenios de colaboración plurianuales y los que impliquen la asunción de 
obligaciones económicas para la Hacienda autonómica por importe superior a 150.000 A requerirán la autorización previa del Consello de la Xunta de Galicia.

4. El órgano superior competente en materia de registro de convenios mantendrá un registro central en el cual figuren todos los convenios de colaboración. El registro central podrá contar con secciones, en cada una de las consellerías competentes por razón de la materia, para aquellos convenios que por sus características especiales o por sus contenidos así lo aconsejen. El registro central estará vinculado con sus secciones, que habrán de comunicar a aquel cualquier inscripción o asiento que realicen.

La creación de las secciones deberá ser acordada por el Consello de la Xunta de Galicia.

Artículo 12. Concesiones de servicios públicos.

1. Los concesionarios de servicios públicos deberán regirse en su actuación por el principio de transparencia en la gestión.

2. Los pliegos de cláusulas administrativas contendrán las previsiones necesarias para garantizar, como mínimo, los siguientes derechos de las personas usuarias:

$1^{\circ}$. A presentar quejas sobre el funcionamiento del servicio, que habrán de ser contestadas de forma motivada e individual.

$2^{\circ}$. A obtener copia sellada de todos los documentos que presenten en las oficinas de la concesionaria, en relación con la prestación del servicio.

$3^{\circ}$. A utilizar, a su elección, el gallego o el castellano en sus relaciones con la entidad concesionaria y con sus representantes y trabajadores.

$4^{\circ}$. A acceder a toda la información que obre en poder de la concesionaria y sea precisa para formular quejas o reclamaciones sobre la prestación del servicio. Quedan excluidos los documentos que afecten a la intimidad de las personas y los relativos a materias protegidas por el secreto comercial o industrial, así como, en general, aquellos que estén protegidos por la ley. $5^{\circ}$. A exigir de la Administración el ejercicio de sus facultades de inspección, control y, en su caso, sanción para subsanar las irregularidades en la prestación del servicio.

$6^{\circ}$. A ser tratadas con respeto al principio de igualdad en el uso del servicio, sin que pueda existir discriminación ni directa ni indirecta por razones de sexo.

Artículo 13. Actividad de fomento.

1. Por medio de una ley específica se regulará el régimen aplicable a las subvenciones establecidas o gestionadas por la Comunidad Autónoma de Galicia y, en general, por todo el sector público gallego.

2. La gestión de subvenciones y ayudas públicas se ajustará a los siguientes principios:

Publicidad, concurrencia, objetividad, transparencia, igualdad y no discriminación.

Eficacia en el cumplimiento de los objetivos fijados por la administración otorgante.

Eficiencia en la asignación y utilización de los recursos públicos.

3. El registro y la publicidad de las ayudas, subvenciones y convenios otorgados por la Comunidad Autónoma se someterán a lo dispuesto en la ley presupuestaria correspondiente y demás normativa de aplicación.

4. Cada consellería, organismo o entidad de derecho público vinculada o dependiente de la Administración de la Comunidad Autónoma que realice actividades de fomento mediante el otorgamiento de fondos públicos deberá publicar en su página web oficial:

$1^{\circ}$. Una relación actualizada de las líneas de ayudas o subvenciones que vayan a convocarse durante el ejercicio presupuestario, con indicación de los importes destinados a las mismas, su objetivo o finalidad y la descripción de los posibles beneficiarios.

$2^{\circ}$. El texto íntegro de la convocatoria de las ayudas o subvenciones.

$3^{\circ}$. Las concesiones de dichas ayudas o subvenciones, dentro de los cinco días siguientes al de su notificación o publicación,

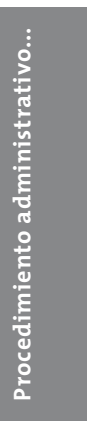


indicando únicamente la relación de los beneficiarios, el importe de las ayudas y la identificación de la normativa reguladora.

5. Se entienden incluidas a los efectos de lo establecido en el párrafo anterior:

a. Las concesiones de créditos oficiales por parte de la Administración de la Comunidad Autónoma, cuando se otorguen sin intereses o con intereses inferiores a los de mercado.

b. Las concesiones de ayudas en que la Administración asuma la obligación de satisfacer a la entidad prestamista todo o parte de los intereses.

c. Las condonaciones de créditos.

d. Cualquier otro acuerdo o resolución de los cuales resulte un efecto equivalente a la obtención de ayudas directas por parte del beneficiario.

e. Las aportaciones dinerarias realizadas por la Comunidad Autónoma a favor de las entidades locales, siempre que no estén destinadas a financiar globalmente actividad de cada ente.

6. Se exceptúan de lo dispuesto en el párrafo 4 , pudiendo ser excluidos de la publicación:

a. Aquellos supuestos en que la publicación de los datos del beneficiario, en razón del objeto de la ayuda, sea contraria al respeto y salvaguarda de la honra e intimidad personal y familiar de las personas físicas, en virtud de lo establecido en la Ley orgánica 1/1982, de 5 de mayo, de Protección Civil del derecho al honor, la intimidad personal y familiar y la propia imagen.

b. Aquellos datos que estén protegidos por el secreto comercial o industrial.

c. Con carácter general, aquellos supuestos, o aquellos datos, en que así lo exijan o aconsejen razones prevalentes por la existencia de un interés público más digno de protección, que, en todo caso, habrá de motivarse expresamente.

\section{Capítulo III \\ MIEMBROS DEL GOBIERNO Y ALTOS CARGOS DE LA ADMINISTRACIÓN}

Artículo 14. Ámbito.

Este capítulo es de aplicación:

a. A los miembros del Gobierno autonómico.

b. A las secretarias y secretarios generales, directoras y directores generales y cargos asimilados.

c. A las delegadas y delegados y representantes del Gobierno gallego en los entes con personalidad jurídica pública.

d. A las presidentas y presidentes, directoras y directores generales y asimilados de los organismos autónomos.

e. A las delegadas y delegados provinciales y territoriales de los departamentos de la Xunta de Galicia.

f. Al personal eventual que, en virtud de nombramiento legal, ejerza funciones de carácter no permanente, expresamente calificadas de confianza y asesoramiento especial, en los gabinetes del Presidente y de los demás miembros del Consello de la Xunta de Galicia.

g. A las presidentas y presidentes, directoras y directores generales, directoras y directores ejecutivos, directoras y directores técnicos y titulares de otros puestos o cargos asimilados, cualquiera que sea su denominación, en entidades de derecho público vinculadas o dependientes de la Administración autonómica, cuyo nombramiento sea efectuado por decisión del Consello de la Xunta de Galicia o por sus propios órganos de gobierno.

h. A las presidentas y presidentes, directoras y directores generales y asimilados de las empresas públicas, sociedades o fundaciones en que la Xunta de Galicia, directa o indirectamente, participe o aporte más del $50 \%$ del capital o del patrimonio, cuando tales cargos sean designados previo acuerdo del Consello de la Xunta de Galicia o por sus propios órganos de gobierno. 
i. Al personal eventual que, en virtud de nombramiento legal, ejerza funciones de carácter no permanente, expresamente calificadas de confianza y asesoramiento especial de las presidentas y presidentes y directoras y directores generales de las entidades relacionadas en el artículo 1 de la presente ley.

j. A los titulares de cualquier otro puesto de trabajo de la Administración autonómica, cualquiera que sea su denominación, cuyo nombramiento se efectúe por decisión del Consello de la Xunta de Galicia.

Artículo 15. Principios de actuación.

1. Las personas comprendidas en el ámbito de aplicación establecido en el artículo 14 de la presente ley observarán, en el ejercicio de sus funciones, lo dispuesto en la Constitución, en el Estatuto de Autonomía de Galicia y en el resto del ordenamiento jurídico, y promoverán el respeto a los derechos fundamentales y a las libertades públicas.

2. Asimismo, adecuarán su actividad a los siguientes principios éticos y de actuación:

$1^{\circ}$. Actuarán con transparencia en la gestión de los asuntos públicos, favoreciendo la accesibilidad y receptividad de la Administración a todos los ciudadanos.

$2^{\circ}$. Observarán un comportamiento ético y dirigido a la satisfacción del interés general.

$3^{\circ}$. Respetarán el principio de imparcialidad, de modo que mantengan un criterio independiente y ajeno a todo interés particular.

$4^{\circ}$. En el ejercicio de sus funciones tratarán de igual forma a todas las personas que se encuentren en idénticas situaciones, sin hacer discriminaciones.

$5^{\circ}$. Promoverán la adopción de medidas de acción positiva para la consecución de la igualdad entre mujeres y hombres y para la protección de los colectivos desfavorecidos.

$6^{\circ}$. Realizarán con lealtad e integridad las funciones o cometidos que tengan asignados. $7^{\circ}$. Usarán normalmente el gallego, oralmente y por escrito, en las relaciones con la ciudadanía.

$8^{\circ}$. Actuarán de buena fe y con la diligencia debida en el cumplimiento de sus obligaciones y fomentarán la calidad en la prestación de servicios públicos.

9. ${ }^{\circ}$ Ejercerán los poderes que les atribuye la normativa vigente con la finalidad exclusiva para la que les fueron otorgados y evitarán toda acción que pueda poner en riesgo el interés público, el patrimonio de las administraciones o la imagen que debe tener la sociedad respecto a sus servidores.

10. Serán responsables de las acciones realizadas en el desarrollo de sus funciones y garantizarán la ausencia de arbitrariedad en la adopción de sus decisiones. Asimismo, están obligados a poner en conocimiento de los órganos competentes cualquier actuación irregular de la cual tengan conocimiento.

$11^{\circ}$. No se implicarán en situaciones, actividades o intereses incompatibles con sus funciones y se abstendrán de intervenir en los asuntos en que concurra alguna causa que pueda afectar a su objetividad.

$12^{\circ}$. No aceptarán regalos que superen los usos habituales, sociales o de cortesía, ni favores o servicios en condiciones ventajosas que puedan condicionar el desarrollo de sus funciones.

$13^{\circ}$. Protegerán y conservarán los recursos públicos y no los utilizarán para actividades que no sean las autorizadas.

$14^{\circ}$. Usarán las prerrogativas inherentes a sus cargos únicamente para el cumplimiento de sus funciones y deberes y no se valdrán de su posición en la Administración para obtener ventajas personales o materiales.

$15^{\circ}$. Mantendrán una conducta digna, tratando a los ciudadanos con esmerada corrección.

$16^{\circ}$. Prestarán especial atención a las necesidades personales y materiales de las personas discapacitadas, adoptando las medidas necesarias para facilitar su 
acceso a la información y sus relaciones con la Administración.

$17^{\circ}$. Sin perjuicio de lo dispuesto en las leyes sobre difusión de la información de interés público, guardarán la debida reserva respecto a los hechos o informaciones de que tengan conocimiento con motivo $\mathrm{u}$ ocasión del ejercicio de sus competencias.

$18^{\circ}$. Observarán estrictamente el régimen de incompatibilidades previstas en la ley reguladora y en su normativa de desarrollo.

Artículo 16. Información previa al Parlamento.

1. El Consello de la Xunta de Galicia, con carácter previo al nombramiento de la directora o director general de la Compañía de Radio-Televisión de Galicia, de las presidentas o presidentes del Tribunal Galego de Defensa de la Competencia, del Consejo Económico y Social, del Consello da Cultura Galega, o de otros órganos que puedan establecerse por ley, y cuyo nombramiento sea realizado por el Consello de la Xunta por un período de tiempo determinado, pondrá en conocimiento del Parlamento de Galicia el nombre de las personas propuestas para estos cargos a fin de que pueda disponer su comparecencia ante la comisión correspondiente de la Cámara.

2. La Comisión Parlamentaria examinará, en su caso, las candidaturas propuestas. Sus miembros formularán las preguntas o solicitarán las aclaraciones que estimen convenientes.

Artículo 17. Información sobre retribuciones.

La página web de la Xunta de Galicia publicará nominalmente las retribuciones públicas percibidas por las personas a que se refiere el artículo 14 de la presente ley, con expresa indicación de los diferentes conceptos retributivos.

Artículo 18. Tratamientos.

El tratamiento oficial de los miembros del Gobierno y de los altos cargos será el de señor/señora, seguido de la denominación del cargo, empleo o rango correspondiente.

\section{DISPOSICIÓN ADICIONAL PRIMERA}

(...) ${ }^{156}$

DISPOSICIÓN ADICIONAL SEGUNDA

(...) ${ }^{157}$

\section{DISPOSICIÓN ADICIONAL TERCERA}

Las publicaciones realizadas en las páginas web a que se refiere la presente ley tendrán carácter meramente informativo y su contenido no vinculará a la administración actuante.

En cualquier caso, los contenidos publicados en el "Diario Oficial de Galicia" tendrán prevalencia sobre los de las referidas páginas web.

A los efectos de cómputo de plazos, se tendrá en cuenta exclusivamente la fecha de publicación en el "Diario Oficial de Galicia" o, en su caso, la fecha de la notificación o publicación a que se refieren los artículos 58 y siguientes de la Ley 30/1992, de 26 de noviembre, de Régimen Jurídico de las Administraciones Públicas y del Procedimiento Administrativo Común.

\section{DISPOSICIÓN TRANSITORIA PRIMERA}

En tanto no se desarrolle reglamentariamente la presente ley, permanecerán en vigor, en todo lo que no se opongan a la misma:

a. El Decreto 164/2005, de 16 de junio, por el que se regulan las oficinas de registro propias o concertadas de la Administración de la Comunidad Autónoma de Galicia, se crea el Registro Telemático de la Xunta de Galicia y se regula la atención al ciudadano.

b. El Decreto 169/1995, de 16 junio, por el que se regulan los registros de Actividades e Intereses y de Bienes de Altos Cargos ${ }^{158}$.

156 Contiene modificaciones a la Ley 9/1996, de 18 de octubre, de incompatibilidades de los miembros de la xunta de Galicia y altos cargos de la Administración Autonómica.

157 Contiene modificaciones a la Ley 9/1996, de 18 de octubre, de incompatibilidades de los miembros de la Xunta de Galicia y altos cargos de la Administración Autonómica.

158 El Decreto 169/1995, de 16 de junio, por el que se regulan los registros de Actividades e Intereses y de Biens de Altos Cargos ha sido derogado por Decreto 205/2008, de 4 de septiembre, por el que se regulan los registros de actividades y de bienes patrimoniales de altos cargos de la Xunta de Galicia. 


\section{DISPOSICIÓN TRANSITORIA SEGUNDA}

El número 1 del artículo 11 entrará en vigor a los seis meses de la publicación de la presente ley en el "Diario Oficial de Galicia”.

\section{DISPOSICIÓN FINAL PRIMERA}

1. Se autoriza a la Xunta de Galicia, en el marco de sus competencias, para dictar cuantas disposiciones exijan la aplicación y el desarrollo de la presente ley.

2. En el plazo de seis meses, a partir de su entrada en vigor, la Xunta de Galicia dictará las normas reglamentarias que exijan la aplicación y el desarrollo de la presente ley.

\section{DISPOSICIÓN FINAL SEGUNDA ENTRADA EN VIGOR}

La presente ley entrará en vigor a los veinte días de su publicación en el "Diario Oficial de Galicia”.

\section{DECRETO LEGISLATIVO \\ 1/2008, DE 13 DE MARZO, POR \\ EL QUE SE APRUEBA EL TEXTO REFUNDIDO DE LA LEY DE LA FUNCIÓN PÚBLICA DE GALICIA (DOGA Nº. 114, 13.6. 2008)}

$$
(\ldots)^{159}
$$

Artículo único. De conformidad con la disposición final primera de la Ley 13/2007, de 27 de julio, de modificación de la Ley $4 / 1988$, de 26 de mayo, de la función pública de Galicia, se aprueba el texto refundido de la Ley $4 / 1988$, de 26 de mayo, de la función pública de Galicia, que se inserta a continuación.

\section{DISPOSICIÓN ADICIONAL. REMISIONES NORMATIVAS A LA LEY 4/1988}

Las remisiones y referencias normativas a la Ley 4/1988, de 26 de mayo, de la función pública de Galicia, se entenderán hechas, en lo sucesivo, al texto refundido de la Ley de la función pública de Galicia.

159 Exposición de motivos omitida.

\section{DISPOSICIÓN FINAL ENTRADA EN VIGOR}

Este decreto legislativo y el texto refundido que se aprueba entrarán en vigor el día siguiente al de su publicación en el Diario Oficial de Galicia.

\section{DISPOSICIÓN DEROGATORIA}

Quedan derogadas todas las disposiciones de igual o inferior rango que se opongan a este decreto legislativo y, en particular, las siguientes:

1. La Ley $4 / 1988$, de 26 de mayo, de la función pública de Galicia.

2. La Ley $4 / 1991$, de 8 de marzo, de reforma de la Ley 4/1988, de 26 de mayo, de la función pública de Galicia.

3. La Ley 8/1992, de 24 de julio, por la que se modifica el artículo 33 de la Ley 4/1988, de 26 de mayo, de la función pública de Galicia, sobre la obligatoriedad de acreditar el conocimiento de la lengua gallega en las pruebas selectivas para el acceso a la función pública de Galicia.

4. La disposición adicional primera de la Ley 4/1993, de 14 de abril, de servicios sociales.

5. La disposición adicional quinta de la Ley 1/1994, de 30 de marzo, de presupuestos generales de la comunidad autónoma para 1994.

6. La Ley $3 / 1995$, de 10 de abril, de modificación de la Ley 4/1988, de 26 de mayo, de la función pública de Galicia.

7. Las disposiciones adicionales novena y décima de la Ley 11/1996, de 30 de diciembre, de presupuestos generales de la Comunidad Autónoma de Galicia para 1997.

8. Los artículos 7 y 8 de la Ley $2 / 1998$, de 8 de abril, de medidas tributarias, de régimen presupuestario, función pública, patrimonio, organización y gestión.

9. El artículo 10 de la Ley $7 / 1998$, de 30 de diciembre, de medidas tributarias, de régimen presupuestario, función pública y gestión. 
10. Los artículos 9, 10, 11, 12, 13 y 14 de la Ley 8/1999, de 30 de diciembre, de medidas fiscales y presupuestarias y de función pública y actuación administrativa.

11. Los artículos $6,7,8,9,10,11$ y 12 de la Ley 3/2002, de 29 de abril, de medidas de régimen fiscal y administrativo.

12. Los artículos 6, 7, 8, 9, 10, 11 y 12 de la Ley 7/2002, de 27 de diciembre, de medidas fiscales y de régimen administrativo.

13. Los artículos 7, 8, 9, 10, 11 y 12 de la Ley 9/2003, de 23 de diciembre, de medidas tributarias y administrativas.

14. La disposición adicional segunda de la Ley 14/2004, de 29 de diciembre, de medidas tributarias y de régimen administrativo.

15. Los números uno, tres, cuatro, cinco, seis, siete, ocho, nueve, diez, once, doce y dieciséis de la disposición adicional segunda de la Ley $2 / 2007$, de 28 de marzo, del trabajo en igualdad de las mujeres de Galicia.

16. La Ley 13/2007, de 27 de julio, de modificación de la Ley 4/1988, de 26 de mayo, de la función pública de Galicia.

\section{TEXTO REFUNDIDO DE LA LEY DE LA FUNCIÓN PÚBLICA DE GALICIA TÍTULO I OBJETO Y ÁMBITO DE APLICACIÓN}

Artículo 1. 1. La presente ley tiene por objeto ordenar y regular todo el personal al servicio de la Administración de la Comunidad Autónoma de Galicia, en desarrollo de su estatuto de autonomía y en el marco de la legislación básica del Estado.

2. Se podrán dictar normas especiales para adaptar esta ley a las peculiaridades del personal docente, investigador y sanitario.

Artículo 2. 1. La función pública de Galicia se desarrollará de acuerdo con el ordenamiento jurídico conforme a los principios de legalidad y eficacia.

2. El personal de la Administración autónoma desempeñará sus funciones al servicio de los ciudadanos y de los intereses generales de Galicia con criterios de objetividad, profesionalidad e imparcialidad.

Artículo 3. 1. Esta ley es aplicable a todo el personal al servicio de la Administración de la Comunidad Autónoma de Galicia y de sus organismos autónomos.

2. En lo que no está reservado a la legislación del Estado, se aplicará esta ley al personal de la Administración local.

3. El personal laboral se regirá por la legislación laboral y por los preceptos de esta ley que le sean aplicables.

4. Al personal que está al servicio del Parlamento de Galicia, regulado por su estatuto de personal previsto en el Reglamento de la cámara, así como al adscrito a órganos creados y dependientes del Parlamento, se le aplicará, con carácter supletorio, la presente ley.

5. Queda excluido de su ámbito de aplicación el personal del Tribunal Superior de Justicia de Galicia.

6. Esta ley y su normativa de desarrollo será de aplicación supletoria al personal de administración y servicios de las universidades gallegas.

Artículo 4. Se le respetarán a la totalidad del personal en régimen funcionarial o estatutario de la Administración pública gallega los derechos reconocidos en el título II de la Ley 7/2004, de 16 de julio, para la igualdad de mujeres y hombres, aunque en la regulación de cada una de las clases de personal no se consideren tales derechos o se consideren en unos términos más restrictivos.

\section{TÍTULO II PERSONAL AL SERVICIO DE LA ADMINISTRACIÓN DE LA COMUNIDAD AUTÓNOMA DE GALICIA}

Artículo 5. El personal al servicio de la Administración pública de la Comunidad Autónoma de Galicia se clasifica en:

a. Personal funcionario.

b. Personal eventual. 
c. Personal interino.

d. Personal laboral.

Artículo 6. Es personal funcionario el que, en virtud de nombramiento legal, esté incorporado a la Administración de la comunidad autónoma de Galicia mediante relación profesional de carácter permanente regulada estatutariamente y sujeta a derecho público, ocupe plazas dotadas en los presupuestos de la comunidad o se encuentre en alguna de las situaciones administrativas previstas en la presente ley.

Artículo 7. 1. Es personal eventual aquel que, en virtud de libre nombramiento de las personas integrantes del Consello de Gobierno de la comunidad autónoma y con carácter no permanente, ocupe un puesto de trabajo expresamente cualificado de confianza o de asesoramiento especial y que no esté reservado a personal funcionario y que figure en las correspondientes relaciones de puestos de trabajo.

El personal eventual realiza tareas de confianza y asesoramiento especial, particularmente de apoyo al desarrollo por las personas integrantes del Consello de Gobierno de su labor política, así como para el cumplimiento de sus tareas de carácter parlamentario y de relación con las instituciones y las organizaciones administrativas. No podrá adoptar, en ningún caso, resoluciones que correspondan legalmente a los órganos de la Administración de la comunidad autónoma o de las organizaciones a ella adscritas.

2. La prestación de servicios en calidad de personal eventual nunca podrá ser considerada como mérito para el acceso a la condición de personal funcionario, de personal interino o laboral ni tampoco para la promoción interna.

3. El Consello de la Xunta de Galicia determinará el número de puestos reservados a personal eventual, con sus características y retribuciones, dentro de los correspondientes créditos presupuestarios consignados al efecto.
La consellería competente en materia de función pública llevará un registro público en el que figuren las titulaciones académicas y las remuneraciones percibidas por el personal eventual.

4. El personal eventual cesará automáticamente cuando cese la autoridad a la que presta su función de confianza o asesoramiento.

5. En el caso de que una funcionaria o funcionario público acceda a un puesto de trabajo de carácter eventual, su nombramiento se realizará cumpliendo los requisitos para el nombramiento de dicho personal.

Este personal funcionario, si no opta por permanecer en servicio activo, será declarado en situación de servicios especiales.

Artículo 8. 1. Es personal interino el que, con carácter transitorio, por razones de necesidad o de urgencia, debidamente justificadas y emitido el informe preceptivo por la Comisión de Personal, es nombrado para prestar servicios en plazas y puestos de trabajo vacantes reservados al personal funcionario y dotados presupuestariamente, mientras no sean ocupados por aquellos.

Como consecuencia de la acumulación de tareas reservadas a personal funcionario, con carácter excepcional y previo informe favorable de las consellerías competentes en materia de función pública y economía, se podrá nombrar personal funcionario interino sin adscripción a la plaza dotada presupuestariamente. Los nombramientos durarán un máximo de seis meses dentro de un período máximo de doce. En caso de las administraciones públicas distintas de la autonómica, el informe favorable previo corresponderá a sus órganos competentes. Los nombramientos por esta causa no podrán superar, en ningún caso, el 20\% del total del personal funcionario del centro directivo, ni el 3\% del personal funcionario de la Xunta de Galicia.

2. La selección de este personal deberá efectuarse observando los principios de

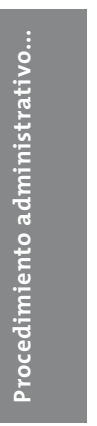


publicidad, mérito y capacidad, a favor de personas que reúnan las condiciones, los requisitos de titulación y los demás exigidos legalmente para participar en la convocatoria pública de los correspondientes procesos selectivos.

3. El personal interino cesará en su puesto cuando su plaza sea cubierta por una funcionaria o funcionario con carácter definitivo o por medio de una adscripción provisional, cuando se amortice dicha plaza, cuando desaparezcan las razones de necesidad o urgencia que motivaron su nombramiento o por el transcurso del plazo máximo de duración del nombramiento, en el supuesto de acumulación de tareas.

4. Los puestos de trabajo ocupados por personal interino deberán figurar en los procedimientos de provisión y en la primera y sucesivas ofertas públicas de empleo, excepto los supuestos de substitución de personal funcionario con derecho a reserva de plaza.

Artículo 9. Será aplicable al personal interino y eventual, por analogía y en cuanto sea adecuado a la naturaleza de su condición, el régimen general del personal funcionario.

Artículo 10. 1. Es personal laboral aquel que, en virtud de contrato de naturaleza laboral, que se deberá formalizar, en todo caso, por escrito, ocupe puestos de trabajo destinados a personal de esta naturaleza o bien, con carácter excepcional, puestos reservados a personal funcionario.

2. La selección del personal laboral se efectuará de acuerdo con la oferta de empleo público, mediante convocatoria pública y a través del sistema de oposición, de concurso o de concurso-oposición libre en el que se garanticen, en todo caso, los principios constitucionales de igualdad, mérito, capacidad y publicidad, sin perjuicio de lo dispuesto en el apartado 1 del artículo 37 de la Ley 7/2004, de 16 de julio, para la igualdad de mujeres y hombres.
3. Para la realización de trabajos de carácter temporal y coyuntural, en el caso de vacante o por razones de necesidad o urgencia, que deberán ser debidamente motivadas, se podrá contratar personal laboral de carácter no permanente de conformidad con la legislación laboral vigente. El contrato se deberá formalizar necesariamente por escrito.

La contratación de este personal no amparado por lo dispuesto en los apartados anteriores dará lugar a la responsabilidad personal de la autoridad o de la funcionaria o funcionario que la autorizase.

4 . La Administración no podrá convertir en fija o indefinida una relación laboral de carácter temporal.

Artículo 11. Ni la prestación de servicios en régimen interino ni la contratación de personal temporal constituirán mérito preferente para el acceso a la condición de personal funcionario o de personal laboral fijo, respectivamente. No obstante, el tiempo de servicios prestados podrá ser computado en los supuestos de concurso oposición y siempre que los servicios correspondan a las plazas convocadas.

\section{TÍTULO III ÓRGANOS DE LA FUNCIÓN PÚBLICA}

Artículo 12. on órganos superiores en materia de función pública:

A. El Consello de la Xunta de Galicia.

B. La conselleira o conselleiro competente en materia de función pública.

C. El Consejo Gallego de la Función Pública.

Artículo 13. Corresponde al Consello de la Xunta de Galicia:

1. Establecer los criterios de la política de personal al servicio de la Administración de la Comunidad Autónoma de Galicia para su coordinación y colaboración con otras administraciones públicas.

2. Aprobar los proyectos de ley en materia de función pública y su remisión al Parlamento. 
3. Determinar las instrucciones a las que deberán atenerse las personas representantes de la Administración de la Comunidad Autónoma de Galicia en la negociación con la representación sindical del personal funcionario público de sus condiciones de trabajo, así como darles validez y eficacia a los acuerdos alcanzados mediante su aprobación expresa y formal, estableciendo las condiciones de trabajo para los casos en que no se produzca acuerdo en la negociación.

4. Establecer las instrucciones a las que debe atenerse la representación de la Administración de la comunidad en la negociación colectiva con el personal laboral.

5. Establecer anualmente los criterios para la aplicación del régimen retributivo del personal funcionario público y del personal al servicio de la Administración de la Comunidad Autónoma de Galicia.

6. Determinar los intervalos de los niveles de puestos de trabajo que les corresponderán a los cuerpos o escalas del personal funcionario.

7. Aprobar las medidas de racionalización de efectivos así como los incentivos a la excedencia voluntaria, regulada en el artículo 57.5 . $^{\circ}$ y a la jubilación anticipada.

8. Aprobar la oferta de empleo público.

9. Aprobar las normas de clasificación y las relaciones de puestos de trabajo de la Administración y acordar su publicación. 10. Aprobar la adscripción de cuerpos o escalas a una determinada consellería, por propuesta de la conselleira o conselleiro competente en materia de función pública, así como la adscripción de puestos de trabajo a un cuerpo o escala.

11. Determinar los requisitos objetivos para la adquisición de los grados superiores dentro de cada cuerpo o escala, que se fundarán exclusivamente en criterios de mérito y capacidad.

12. Establecer las bases del sistema objetivo para el fomento de la promoción interna de todo el personal al servicio de la Administración gallega, de conformidad con los términos previstos en los artículos 63 y 64 de esta ley.

13. Aprobar, cuando proceda, las medidas para garantizar los servicios mínimos en los casos de ejercicio del derecho de huelga por el personal al servicio de la Administración de la comunidad autónoma.

14. Aprobar el Plan de normalización lingüística de la Administración pública de la comunidad autónoma.

15. Decidir las propuestas de resolución de los expedientes disciplinarios que supongan separación del servicio, previos informes y dictámenes preceptivos.

16. Ejercer la potestad reglamentaria y todas las atribuciones en materia de personal que le atribuya la legislación vigente.

Artículo 14. 1. Corresponde a la conselleira o conselleiro competente en materia de función pública el desarrollo general, la coordinación y el control de la ejecución de la política de personal al servicio de la Comunidad Autónoma de Galicia.

2. En particular, le compete:

1) Velar por el cumplimiento de las normas de general aplicación en materia de función pública por todos los órganos de la Administración de la Comunidad Autónoma de Galicia, impulsar, coordinar y desarrollar los planes, métodos de trabajo y medidas tendentes a mejorar el rendimiento de los servicios, la formación y la promoción del personal.

2) Mantener la adecuada coordinación con los órganos de las demás administraciones territoriales competentes en materia de función pública.

3) Ejercer la inspección general de servicios y la de todo el personal de la Administración pública de la comunidad autónoma.

4) Proponer al Consello de la Xunta de Galicia los proyectos de normas de general aplicación a la función pública. Cuando se trate de proyectos normativos referentes al

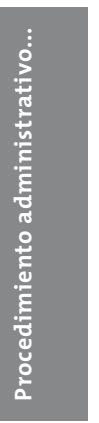


personal funcionario sujeto a un régimen singular o especial, la propuesta será por iniciativa conjunta con la conselleira o conselleiro sectorialmente competente.

5) Elaborar la propuesta de relación de puestos de trabajo y su valoración, así como las plantillas presupuestarias en función de dicha relación y de acuerdo con la política de gastos en materia de personal.

6) Convocar y resolver los concursos de traslados.

7) Proponer, previo informe favorable de la consellería competente en materia de hacienda y con el informe previo de la Comisión Superior de Personal, la oferta de empleo público, que garantizará que no contiene requisitos que determinen un perjuicio para las mujeres o para un colectivo mayoritariamente femenino. Esta garantía tendrá que ser respetada en las correspondientes convocatorias de cobertura de puestos de trabajo.

8) Convocar las pruebas selectivas para el ingreso en los cuerpos o escalas de la Administración de la comunidad, excepto personal docente, investigador o sanitario.

9) Nombrar el personal funcionario e interino, así como expedir los correspondientes títulos, excepto personal docente, investigador o sanitario.

10) Presidir el Consejo Gallego de la Función Pública.

11) Resolver las situaciones del personal funcionario de la Administración de la comunidad y los expedientes de incompatibilidades.

12) Autorizar las adscripciones en comisión de servicios para puestos de trabajo, así como, sin perjuicio del previsto en los artículos 17.7 e) y 65.4 , la adscripción, con carácter provisional, del personal funcionario sin destino definitivo.

13) Autorizar las pruebas selectivas para personal laboral fijo y firmar los correspondientes contratos.

14) Designar la representación de la Administración autonómica en convenios colectivos de ámbito general o que afecten a varias consellerías.

15) Emitir informe, conjuntamente con la Consellería de Economía y Hacienda y con carácter previo a la extensión y adhesión a otros convenios colectivos vigentes, sobre retribuciones salariales y, en general, sobre cualquier autorización de mejoras retributivas individuales o colectivas.

16) Aprobar los planes de empleo.

17) Ejercer las demás competencias que, en materia de personal, le atribuye la legislación vigente.

Artículo 15. Corresponde a la conselleira o conselleiro competente en materia de Administración local:

1. Ejercer las competencias que, respecto del personal funcionario de la Administración local con habilitación de carácter nacional, le correspondan a la Comunidad Autónoma de Galicia.

2. La designación de personas representantes de la comunidad autónoma en los tribunales calificadores de procesos selectivos de personal para las entidades locales.

Artículo 16. Es competencia de la conselleira o conselleiro de Economía y Hacienda:

1. Proponer al Consello de la Xunta de Galicia, dentro de la política general, económica y presupuestaria, las directrices a las que se deberán ajustar los gastos de personal de la Administración autónoma, $\mathrm{y}$, de forma específica, la valoración, a efectos retributivos, de los puestos de trabajo previamente clasificados.

2. Autorizar cualquier medida relativa al personal que pueda suponer modificaciones en el gasto.

Artículo 17. Corresponde a las conse1leiras o conselleiros:

1. Ejercer la jefatura del personal de su departamento y su inspección.

2. El ejercicio de las potestades disciplinarias, excepto la separación del servicio, conforme a las disposiciones vigentes. 
3. Emitir informe sobre la adscripción de los cuerpos y escalas a su consellería.

4. La provisión de puestos de trabajo clasificados como de libre designación, previa convocatoria pública.

5. La propuesta de la relación de puestos de trabajo.

6. Autorizar la asistencia a cursos de formación y perfeccionamiento.

7. En relación con el personal funcionario perteneciente a cuerpos o escalas adscritos a su departamento:

a. La convocatoria y la resolución de los concursos de traslados.

b. El nombramiento de personal interino.

c. El reconocimiento de la adquisición del grado personal y de los trienios.

d. Resolver las situaciones administrativas del personal funcionario.

e. Autorizar la adscripción, con carácter provisional, del personal funcionario sin destino definitivo.

Artículo 18. 1. El Consejo Gallego de la Función Pública es el órgano superior colegiado de asesoramiento y participación en cuestiones comunes de función pública de las distintas administraciones públicas de la Comunidad Autónoma de Galicia.

2. Integran el consejo:

a. La conselleira o conselleiro competente en materia de función pública, que será el presidente.

b. La conselleira o conselleiro de Economía y Hacienda, que será el vicepresidente.

c. La directora o director general que tenga a su cargo la función pública, que será el secretario.

Vocales:

d. La directora o director general de la Escuela Gallega de Administración Pública.

e. La directora o director general de presupuestos.

f. La directora o director general que tenga atribuida el área de la Administración local.

g. Las secretarias o secretarios generales técnicos de las consellerías. h. Cinco personas en representación de las corporaciones locales.

i. Siete personas en representación del personal designadas por las organizaciones sindicales en proporción a su representatividad respectiva.

3. En todo caso, por lo menos el $40 \%$ de los puestos en el Consejo Gallego de la Función Pública se reservan para el sexo menos representado en el propio consejo.

Artículo 19. Corresponde al Consejo Gallego de la Función Pública:

a. Emitir informe, con carácter preceptivo, en el plazo que reglamentariamente se determine, y no superior, en todo caso, a dos meses sobre los anteproyectos de ley y los proyectos de reglamento, en materia de empleo público autonómico.

Con carácter facultativo, emitirá informe sobre los proyectos normativos de rango legal o reglamentario relativos a la función pública a petición de las diferentes administraciones públicas.

b. Emitir informe en el plazo que reglamentariamente se determine, y no superior, en todo caso, a dos meses, sobre aquellas disposiciones o decisiones que tengan relevancia en materia de personal y que le sean consultadas por las distintas administraciones públicas de Galicia.

c. Deliberar, previa consulta, sobre las medidas necesarias para la coordinación de la política de personal y aconsejar la adopción de aquellas dirigidas a mejorar la organización, las condiciones de trabajo, el rendimiento y la consideración social del personal al servicio de las administraciones públicas de Galicia.

d. Estudiar y proponer medidas de homologación de los sistemas de selección, formación y perfeccionamiento para facilitar la movilidad entre las distintas administraciones públicas de Galicia.

e. Estudiar y proponer medidas de homologación de los programas de perfeccionamiento del personal funcionario en la Escuela Gallega de Administración Pública.

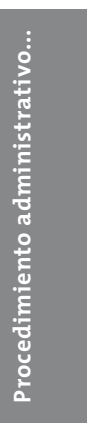


f. Estudiar medidas sobre valoración de puestos de trabajo, niveles y retribuciones.

g. Estudiar y proponer medidas referentes al establecimiento, funcionamiento y coordinación de los registros de personal de las administraciones públicas de Galicia.

h. Estudiar y proponer medidas tendentes a la coordinación de la Administración pública de Galicia con otras administraciones públicas.

i. Estudiar y proponer medidas tendentes a la coordinación de la oferta pública de empleo de las distintas administraciones públicas de la Comunidad Autónoma de Galicia.

j. Conocer y emitir informe sobre cualquier otro asunto que le sea sometido a iniciativa de las administraciones públicas de Galicia.

k. Garantizar, promover y hacer efectivo el principio de igualdad por razón de sexo, así como remover los obstáculos para hacerlo efectivo y combatir las discriminaciones sexistas.

Artículo 20. 1. La Comisión de Personal se configura como un órgano colegiado de coordinación, asesoramiento y documentación para la elaboración de la política de personal al servicio de la Administración de la comunidad autónoma.

2. Tendrá la composición que el Gobierno gallego establezca por decreto, respetándose la misma cuota prevista en el apartado 3 del artículo 18, y ejercerá las siguientes funciones:

1. ${ }^{\circ}$ Como órgano de coordinación, fijar criterios generales en las siguientes materias:

a. Clasificación, valoración y relación de puestos de trabajo.

b. Aplicación del régimen de retribuciones previstas en la Ley 30/1984, de 2 de agosto.

c. Bases de concesión de complementos de productividad y gratificaciones.

d. Condiciones de trabajo y promoción del personal.
2. ${ }^{\circ}$ Como órgano de asesoramiento, emitir informe previo con carácter preceptivo en el plazo máximo de un mes sobre:

a. Los expedientes disciplinarios que impliquen separación del servicio de personal funcionario público de la Administración de la comunidad autónoma.

b. La modificación de la estructura, organización y composición del personal al servicio de la Xunta de Galicia.

3. ${ }^{\circ}$ Como órgano de documentación, ser oído y prestar su apoyo en la elaboración de:

a. Proyectos de disposiciones y actos de carácter general referentes al personal dependiente de la Administración de la comunidad autónoma.

b. Bases generales de las convocatorias de pruebas selectivas de acceso para plazas vacantes y concursos de méritos para provisión de puestos de trabajo.

4. ${ }^{\circ}$ Emitir cualquier otro informe en materia de personal exigido por la normativa vigente o a petición de los órganos superiores de la función pública.

\section{TÍTULO IV ORGANIZACIÓN DE LA FUNCIÓN PÚBLICA \\ Capítulo I \\ CUERPOS DE PERSONAL FUNCIONARIO}

Artículo 21. 1. El personal funcionario se integra en cuerpos y escalas que, de acuerdo con la titulación exigida para su ingreso, se agrupan de la siguiente forma: Grupo A. Titulación de doctorado, licenciatura, ingeniería, arquitectura o equivalente.

Grupo B. Titulación de ingeniería técnica, diplomatura universitaria, arquitectura técnica, formación profesional de tercer grado o equivalente.

Grupo C. Título de bachillerato, formación profesional de segundo grado o equivalente.

Grupo D. Título de graduado escolar, formación profesional de primer grado o equivalente. 
Grupo E. Certificado de escolaridad.

2. Por cada grupo existirá un único cuerpo de Administración general, en el que se podrán establecer diferentes escalas, si así fuese necesario por razones de especialización.

Artículo 22. 1. La creación, refundición, modificación o supresión de los cuerpos y escalas se deberá hacer por ley.

2. La ley de creación deberá contener los siguientes elementos:

a. Denominación del cuerpo y escalas de que, en su caso, se componga.

b. Grupo en el que se clasifica y el sistema de selección aplicable.

c. Funciones que deban desempeñar las personas integrantes, que no se podrán corresponder con las atribuidas a los órganos de la Administración.

d. Nivel de titulación o titulaciones concretas exigidas para el ingreso en los cuerpos y escalas. No obstante lo anterior, cuando el Gobierno apruebe nuevas titulaciones o se produzcan modificaciones en la normativa educativa vigente, el Consello de la Xunta, mediante decreto, podrá establecer las titulaciones equivalentes a las legalmente exigidas.

3. No se podrán crear nuevos cuerpos y escalas cuando su titulación y funciones sean idénticas a las de otros que ya existan.

Artículo 23. Los cuerpos de personal funcionario dependerán orgánicamente de la consellería competente en materia de función pública, sin perjuicio de la que funcionalmente les corresponda.

\section{Capítulo II}

\section{EL REGISTRO DE PERSONAL}

Artículo 24. 1. En la consellería competente en materia de función pública habrá un registro en el que se inscribirá todo el personal al servicio de la Administración de la comunidad autónoma y en el que se anotarán, preceptivamente, todos los actos que afecten a la vida administrativa del mismo.
2. No se podrán incluir en nómina nuevas remuneraciones sin comunicarle previamente al registro de personal la resolución o acto por el que se reconocieron.

3. El funcionamiento del registro de personal estará coordinado con el de las demás administraciones públicas.

4. La utilización de los datos que consten en el registro de personal estará sometida a las limitaciones previstas en el artículo 18.4 de la Constitución. Toda persona funcionaria podrá acceder libremente a su expediente personal, en el que no podrá figurar ningún dato relativo a su raza, religión u opinión.

5. El Consello de la Xunta de Galicia, a propuesta de la conselleira o conselleiro competente en materia de función pública, dictará las normas adecuadas para la organización y funcionamiento del registro de personal.

Artículo 25. Las entidades locales constituirán un registro de personal, sometido al régimen de publicidad que se determine reglamentariamente, conforme a la normativa en materia de protección de datos de carácter personal.

La Administración autonómica cooperará con las entidades locales en la constitución de sus registros de personal cuando aquellas carezcan de suficiente capacidad financiera, y podrá delegar esta función en los órganos de gobierno de las entidades supramunicipales.

Artículo 26. 1. En la Ley de presupuestos de la comunidad figurará la plantilla de todo el personal. La plantilla estará formada por las plazas que figuran dotadas en los presupuestos, clasificadas en grupos de cuerpos y, dentro de ellos, de acuerdo con las escalas de cada cuerpo. Incluirá también al personal eventual y laboral.

2. Los programas de gasto de los presupuestos generales de la comunidad autónoma incluirán el coste de todos los puestos de trabajo asignados a cada una

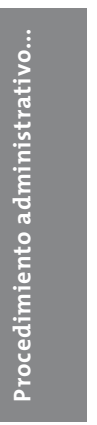


de las consellerías y por cada uno de los centros gestores.

3. La plantilla de los diferentes cuerpos y escalas de la Administración de la comunidad autónoma será la que resulte de los créditos establecidos en la Ley de presupuestos de la comunidad autónoma.

\section{Capítulo III \\ RELACIÓN DE PUESTOS DE TRABAJO, PROVISIÓN, PLANES DE EMPLEOY OFERTA DE EMPLEO PÚBLICO}

Artículo 27. 1. Las consellerías remitirán a la consellería competente en materia de función pública las relaciones de puestos de trabajo correspondientes a su estructura orgánica, que contendrán, necesariamente, los siguientes datos de cada puesto:

a. Órgano o dependencia al que se adscribe.

b. Denominación, tipo y sistema de provisión.

c. Nivel y retribuciones complementarias del personal funcionario y categoría profesional y régimen jurídico aplicable a los puestos a desempeñar por el personal laboral.

d. Requisitos exigidos para su desempeño.

2. Los puestos de trabajo de la Administración de la comunidad autónoma y de sus organismos autónomos de carácter administrativo serán desempeñados por personal funcionario público.

Se exceptúan de la regla anterior y podrán ser desempeñados por personal laboral:

a. Los puestos de naturaleza no permanente y aquellos en los que sus actividades se dirijan a satisfacer necesidades de carácter periódico y discontinuo.

b. Los puestos en los que sus actividades sean propias de oficios.

c. Los puestos correspondientes a áreas de actividades que requieran conocimientos técnicos especializados cuando no existan cuerpos o escalas de personal funcionario en los que las personas integrantes tengan la preparación específica necesaria para su desempeño.

d. Los puestos de carácter instrumental correspondientes a las áreas de mantenimiento y conservación de edificios, equipos e instalaciones, y artes gráficas, así como los puestos de las áreas de expresión artística.

e. Los puestos de trabajo de organismos autónomos de carácter comercial, industrial, financiero o análogo, excepto aquellos que impliquen ejercicio de la autoridad, inspección o control correspondiente a la consellería a la que estén adscritos, que se reservan al personal funcionario.

f. Los de prestación directa de servicios sociales y protección de la infancia.

3. Dichas relaciones serán públicas, y tanto en su elaboración como en las modificaciones posteriores deberán ser sometidas a informe de los correspondientes órganos de representación de las empleadas y empleados públicos, exclusivamente cuando supongan modificación de las condiciones de trabajo de este personal.

Artículo 28. 1. Los puestos de trabajo serán de adscripción indistinta para todo personal funcionario incluido en el ámbito de aplicación de esta ley.

2. La adscripción con carácter exclusivo de determinados puestos a personal funcionario de un cuerpo concreto únicamente se podrá realizar cuando derive necesariamente de la naturaleza del puesto y de las funciones asignadas al mismo para su desempeño. Será acordada por el Consello de la Xunta de Galicia a propuesta de la conselleira o conselleiro competente en materia de función pública.

Artículo 29. Los puestos de trabajo vacantes adscritos a personal funcionario se proveerán por los siguientes procedimientos:

1. Concurso. Constituye el sistema normal de provisión. En él se tendrán en 
cuenta únicamente los méritos exigidos en la correspondiente convocatoria, entre los que figurarán los adecuados a las características de cada puesto de trabajo, así como la posesión de un determinado grado personal, la valoración del trabajo desarrollado en anteriores puestos, los cursos de formación y perfeccionamiento superados que tengan relación con los puestos de trabajo a cubrir y la antigüedad.

Los concursos para la provisión de puestos de personal funcionario deberán ser convocados con una periodicidad anual y serán resueltos en seis meses, desde la publicación de las listas definitivas de personas admitidas y excluidas. La Administración de la Xunta de Galicia garantizará la existencia de los medios materiales y personales propios que hagan posible esta periodicidad y garanticen la agilidad de la resolución de los procedimientos.

A tal efecto, se crearán comisiones de valoración, cuya composición y funcionamiento se determinará reglamentariamente, con la garantía de la presencia de la representación de las trabajadoras y trabajadores en su composición.

Las personas funcionarias deberán permanecer en cada puesto de trabajo de destino definitivo obtenido por concurso un mínimo de dos años para poder participar en los concursos de provisión, a no ser por supresión del puesto de trabajo. En el cómputo de dicho período se incluirá el tiempo de destino provisional que, en su caso, con carácter excepcional, desempeñasen en un puesto las personas funcionarias de nuevo ingreso.

2. Libre designación con convocatoria pública. Por este sistema se cubrirán aquellos puestos que así se determinen en las relaciones de puestos de trabajo.

Para el desempeño de puestos de trabajo de libre designación que así se determinen en las relaciones de puestos de trabajo, atendiendo a la función a desempeñar, será requisito necesario estar en posesión del diploma de directiva o directivo expedido por la Escuela Gallega de Administración Pública o equivalente dado por otras instituciones públicas que habilite para el ejercicio del puesto de trabajo de que se trate.

3. Las convocatorias y resoluciones que se dicten para proveer puestos de trabajo por concurso o por libre designación serán anunciadas en el Diario Oficial de Galicia por la autoridad competente para efectuar los nombramientos.

En las convocatorias de concursos deberán incluirse, en todo caso, los siguientes datos y circunstancias:

Denominación, nivel y localización del puesto.

Requisitos indispensables para desempeñarlo.

Baremo para puntuar los méritos.

Puntuación mínima para la adjudicación de las vacantes convocadas.

Las convocatorias para la provisión de puestos por libre designación incluirán los siguientes datos:

Denominación, nivel y localización del puesto.

Requisitos indispensables para desempeñarlo.

Se concederá un plazo mínimo de quince días hábiles para presentar solicitudes, contado desde la publicación de la convocatoria. Los nombramientos de libre designación requerirán el informe previo de la persona titular del centro orgánico o de la unidad a los que figure adscrito el puesto convocado.

4. Las personas funcionarias adscritas a un puesto de trabajo por el procedimiento de libre designación podrán ser removidas de él con carácter discrecional.

5. Las personas funcionarias que accedan a un puesto de trabajo por el procedimiento de concurso podrán ser removidas por causas sobrevenidas, derivadas de una alteración en el contenido del puesto de trabajo, realizada a través de las relaciones de puestos de trabajo que modifiquen los supuestos 
que sirvieron de base a la convocatoria, o de una falta de capacidad sobrevenida para su desempeño, manifestada por rendimiento insuficiente que no comporte inhibición y que impida realizar con eficacia las funciones atribuidas. La remoción se efectuará previo expediente contradictorio mediante resolución motivada del órgano que realizó el nombramiento, oída la junta de personal correspondiente.

A las personas funcionarias afectadas por lo previsto en este punto les será aplicable lo dispuesto en el artículo $65 .{ }^{\circ} 4$ de la presente ley.

6. Las personas funcionarias que ocupen un puesto que sea objeto de supresión, como consecuencia de un plan de empleo, podrán ser destinadas a otro puesto de trabajo por el procedimiento de reasignación de efectivos.

La reasignación de efectivos como consecuencia de un plan de empleo se efectuará aplicando criterios objetivos relacionados con las aptitudes, formación, experiencia y antigüedad que en él se concretarán.

La adscripción al puesto adjudicado por reasignación tendrá carácter definitivo.

La persona funcionaria que, como consecuencia de reasignación de efectivos en el marco de un plan de empleo, vea modificado su lugar de residencia tendrá derecho a las indemnizaciones que por tal concepto se establecen en el párrafo siguiente. Los mismos derechos se les reconocerán a las personas funcionarias en excedencia forzosa a las que se les asigne destino en el marco de dicho plan.

La indemnización consistirá en el abono de los gastos de viaje, incluidos los de su familia, en una indemnización de tres dietas del titular y cada miembro de su familia que efectivamente se traslade y en el pago de los gastos de transporte de muebles y equipamiento, así como en una indemnización de tres mensualidades de la totalidad de sus retribuciones, excepto el complemento de productividad, cuando se produzca cambio de ayuntamiento. Ello sin perjuicio de otras ayudas que en el propio plan de empleo se puedan establecer. La reasignación de efectivos se producirá en tres fases:

a. La reasignación de efectivos, dentro de la consellería donde estuviese destinada la persona funcionaria, la efectuará la consellería competente en materia de función pública, previo informe de aquella, en el plazo máximo de seis meses, contados a partir de la supresión del puesto. Tendrá carácter obligatorio para puestos en el mismo ayuntamiento y voluntario para puestos que radiquen en distinto ayuntamiento, que serán, en ambos casos, de similares características, funciones y retribuciones. Durante esta fase se percibirán las retribuciones del puesto de trabajo que se desempeñaba.

b. Si en la primera fase las personas funcionarias no obtienen puesto en la consellería donde estuviesen destinadas, podrán ser asignadas por la consellería competente en materia de función pública, en el plazo máximo de tres meses, a puestos de otras consellerías y de sus organismos adscritos, en las condiciones anteriores, percibiendo durante esta segunda fase las retribuciones del puesto de trabajo que desempeñaban.

Durante las dos fases citadas podrán encomendárseles a las personas funcionarias afectadas tareas adecuadas a su cuerpo o escala de pertenencia.

c. Las personas funcionarias que tras las anteriores fases de reasignación de efectivos no obtuviesen puesto se adscribirán a la consellería competente en materia de función pública, a través de relaciones específicas de puestos en reasignación, en la situación de expectativa de destino definida en los artículos 51. g) y 59 de esta ley, y podrán ser reasignadas por ésta a puestos de similares características y retribuciones de otras consellerías y de sus organismos adscritos, con carácter obligatorio cuando estén situadas en el mismo ayuntamiento 
y con carácter voluntario cuando radiquen en distinto ayuntamiento.

7. La Administración de la Xunta de Galicia podrá adscribir a las personas funcionarias a puestos de trabajo en distinta unidad o localidad, previa solicitud basada en motivos de salud o rehabilitación de la funcionaria o funcionario, de su cónyuge o de la persona unida por análoga relación de afectividad, de las hijas e hijos a su cargo o de las personas ascendientes en el primer grado de consanguinidad, cuando concurran los siguientes requisitos:

a. Informe previo favorable del servicio médico oficial legalmente establecido.

b. Existencia de puestos vacantes con asignación presupuestaria.

c. Que el nivel de complemento de destino y específico del puesto de destino no sea superior al del puesto de origen.

d. Que la persona funcionaria reúna los requisitos para su desempeño.

e. En el caso de las personas ascendientes, que la funcionaria o funcionario conviva con ellas.

Esta adscripción tendrá, sin perjuicio de la aplicación de la normativa sobre riesgos laborales, carácter provisional, y el puesto de trabajo de origen de la persona funcionaria, siempre que lo ocupase con carácter definitivo, se le reservará mientras se mantenga la causa que motiva la adscripción. Con la periodicidad que reglamentariamente se determine $y$, en todo caso, cada año, se deberá comprobar que persisten las circunstancias que dieron lugar a la adscripción. La negativa a la adscripción por causa de salud será siempre motivada.

8. En todos los procedimientos de provisión de puestos de trabajo se atenderá especialmente al cumplimiento de lo previsto en el apartado $2 .^{\circ}$ del artículo 34 de la Ley 7/2004, de 16 de julio, para la igualdad de mujeres y hombres.

9. Las mujeres víctimas de violencia de género que se vean obligadas a abandonar el puesto de trabajo en la localidad donde venían prestando servicios, para hacer efectiva su protección o su derecho a la asistencia social integral, tendrán derecho al traslado a otro puesto de trabajo propio de su cuerpo, escala o categoría profesional, de análogas características, sin necesidad de que sea vacante de necesaria cobertura. Incluso así, en tales supuestos, la Administración pública competente estará obligada a comunicar las vacantes radicadas en la misma localidad o en las localidades que las interesadas expresamente soliciten.

Este traslado tendrá la condición de traslado forzoso, a efectos de los derechos que para la trabajadora pudiesen derivar de él. En las actuaciones y en los procedimientos relacionados con la violencia de género se protegerá la intimidad de las víctimas, en especial sus datos personales, los de sus descendientes y los de cualquier persona que esté bajo su guarda o custodia.

Artículo 30. Solamente se podrán cubrir por el sistema de libre designación con convocatoria pública entre personal funcionario los puestos de trabajo de subdirectora o subdirector general, las secretarías de altos cargos así como aquellos otros de carácter directivo o de especial responsabilidad para los cuales, excepcionalmente, así se determine en las relaciones de puestos de trabajo.

Artículo 31. 1. La Xunta de Galicia podrá elaborar planes de empleo, referidos tanto a personal funcionario como laboral, que contendrán, de forma conjunta, las actuaciones que se deben desarrollar para la óptima utilización de los recursos humanos en el ámbito al que afecten, dentro de los límites presupuestarios y de acuerdo con las directrices de política de personal. Las actuaciones previstas para el personal laboral en los planes de empleo se desarrollarán conforme a la normativa específica del ordenamiento jurídico laboral y a lo establecido en los convenios colectivos aplicables. 
2. Los planes de empleo podrán contener las siguientes previsiones y medidas:

a. Previsiones sobre modificación de estructuras organizativas y de puestos de trabajo.

b. Suspensión de incorporaciones de personal externo al ámbito afectado, tanto las derivadas de oferta de empleo como de procesos de movilidad.

c. Reasignación de efectivos de personal.

d. Establecimiento de cursos de formación y capacitación.

e. Autorización de concursos de provisión de puestos limitados al personal de los ámbitos que se determinen.

f. Medidas específicas de promoción interna.

g. Prestación de servicios a tiempo parcial.

h. Necesidades adicionales de recursos humanos, que deberán integrarse, en su caso, en la oferta de empleo público.

i. Otras medidas que procedan en relación con los objetivos del plan de empleo.

Las memorias justificativas de los planes de empleo contendrán las referencias temporales que procedan, respecto de las previsiones y medidas establecidas en ellos.

3. El personal afectado por un plan de empleo podrá ser reasignado voluntariamente en otras administraciones públicas en los términos que establezcan los convenios que, al efecto, se promuevan y subscriban con ellas.

4. Los planes de empleo podrán afectar a una o a varias consellerías, organismos o áreas administrativas concretas y serán aprobados por la consellería competente en materia de función pública, previo informe favorable de la Consellería de Economía y Hacienda.

La iniciativa para su elaboración corresponderá a la consellería o al organismo afectado o, conjuntamente, a las consellerías competentes en materia de función pública y economía.
5. La Xunta de Galicia podrá adoptar, además de planes de empleo, otras medidas de racionalización de efectivos así como incentivos a la excedencia voluntaria y a la jubilación anticipada.

6. Las necesidades de recursos humanos con asignación presupuestaria que no puedan ser cubiertas con los efectivos de personal existentes serán objeto de oferta de empleo público.

La oferta de empleo público será aprobada por el Consello de la Xunta de Galicia a propuesta de la consellería competente en materia de función pública.

7. En el diseño y en la ejecución de los planes de empleo se atenderá, con absoluta prioridad, al principio de igualdad y no discriminación por razón de sexo.

\section{Capítulo IV EL ACCESO A LA FUNCIÓN PÚBLICA}

Artículo 32. Para la admisión a las pruebas selectivas será necesario:

1. Tener nacionalidad española. No obstante, se tendrán en cuenta los siguientes supuestos:

a. La población nacional de los demás estados miembros de la Unión Europea podrá acceder, en idénticas condiciones que las personas de nacionalidad española, a la función pública investigadora, docente, de correos, sanitaria de carácter asistencial y a los demás sectores de la función pública a los que, según el derecho comunitario, les sea aplicable la libre circulación de trabajadoras y trabajadores.

b. La población nacional de aquellos estados a los que, en virtud de tratados internacionales subscritos por la Unión Europea y ratificados por España, sea aplicable la libre circulación de trabajadoras y trabajadores en los términos en que ésta está definida en el tratado constitutivo de la Unión Europea.

Lo previsto en los puntos a) y b) se aplicará de acuerdo con lo dispuesto en la Ley 17/1993, de 23 de diciembre, sobre el acceso a determinados sectores de la función 
pública de los nacionales de los demás estados miembros de la Unión Europea.

2. Estar en posesión de la titulación suficiente o estar en condiciones de obtenerla en la fecha en que finalice el plazo de presentación de las instancias para tomar parte en las pruebas selectivas.

3 . No estar separada o separado del servicio de ninguna Administración pública en virtud de expediente disciplinario ni encontrarse inhabilitada o inhabilitado por sentencia firme para el ejercicio de funciones públicas.

4. Haber cumplido los 18 años de edad o tener la edad que la convocatoria establezca como mínima antes de que finalice el plazo de presentación de instancias, y no exceder la edad establecida como máxima para el ingreso en un cuerpo o escala.

5. Cumplir los requisitos para ejercer las funciones que dentro del cuerpo o escala le puedan ser encomendadas, conforme a lo previsto reglamentariamente.

Artículo 33. 1. Todas las convocatorias de pruebas selectivas se publicarán en el Diario Oficial de Galicia y sus bases, que vinculan al órgano convocante y al tribunal, deberán, en todo caso, contener los siguientes elementos:

a. Número y características de las plazas convocadas.

b. Condiciones y requisitos que deben concurrir en las personas aspirantes.

c. Pruebas y programas de procedimiento selectivo, así como sistemas y formas de calificación de los ejercicios o baremos de puntuación.

d. Composición del tribunal calificador o, en su caso, de la comisión de selección. e. Modelo de solicitud e importe de los derechos de examen.

f. Características, efectos y duración de los cursos o período de prácticas, o ambos, que deban realizar, en su caso, las personas seleccionadas.

2. En las convocatorias se tendrán en cuenta las condiciones especiales de ingreso de las personas con discapacidad en la función pública.

Artículo 34. 1. Las pruebas selectivas serán teóricas y prácticas y deberán adecuarse a los puestos de trabajo que se vayan a ocupar.

2. Los tribunales que juzguen las pruebas selectivas no podrán estar compuestos mayoritariamente por personal funcionario de los cuerpos o escalas de que se trate. Ninguna persona integrante tendrá titulación inferior a la exigida para la admisión a las pruebas. En su composición debe atenderse al artículo 36 de la Ley 7/2004, de 16 de julio, para la igualdad de mujeres $\mathrm{y}$ hombres.

3. El Consello de la Xunta de Galicia, a propuesta de la conselleira o conselleiro competente en materia de función pública, establecerá las bases y contenidos mínimos obligatorios de los programas para el acceso a los distintos cuerpos y escalas de la Administración pública de la comunidad autónoma.

Artículo 35. La Administración garantizará los derechos constitucionales y lingüísticos de las ciudadanas y de los ciudadanos gallegos, tanto respecto del gallego, como lengua propia de Galicia, como del castellano, lengua oficial en Galicia.

Para darle cumplimiento a la normalización del idioma gallego en la Administración pública de Galicia y para garantizar el derecho de las administradas y de los administrados al uso del gallego en las relaciones con la Administración pública en el ámbito de la comunidad autónoma, y la promoción del uso normal del gallego por parte de los poderes públicos de Galicia, que determina el artículo $6.3^{\circ}$ de la Ley de normalización lingüística, en las pruebas selectivas que se realicen para el acceso a las plazas de la Administración de la Comunidad Autónoma de Galicia y de las entidades locales de Galicia se incluirá un examen de gallego, salvo para aquellos que acrediten el conocimiento de la lengua gallega conforme 
a la normativa vigente. Las bases de las convocatorias de los procesos selectivos establecerán el carácter y valoración de este examen.

Todo esto sin perjuicio de aquellas pruebas que tengan que realizarse en gallego para aquellas plazas que requieran un especial conocimiento de la lengua gallega ${ }^{160}$.

Artículo 36. El acceso a la función pública y a sus cuerpos o escalas se realizará mediante concurso, oposición o concurso-oposición libre, convocados públicamente y basados en los principios de igualdad, mérito y capacidad, sin perjuicio de lo que, sobre la carrera administrativa, se dispone en esta ley. En la convocatoria será necesario tener en cuenta lo dispuesto en el artículo 37 de la Ley 7/2004, de 16 de julio, para la igualdad de mujeres y hombres.

Artículo 37. 1. La oposición consistirá en la superación de pruebas teóricas y prácticas exigidas en la convocatoria pública, adecuadas al ejercicio de la función así como, en su caso, en la superación de un curso selectivo de formación.

2. Las pruebas de selección se deberán establecer de manera que puedan manifestarse las condiciones de aptitud y conocimiento que se consideren necesarias según la naturaleza de la función y permitan fijar un orden de prelación de las personas aspirantes seleccionadas.

3. Los programas de las pruebas de selección y, en su caso, de los cursos de formación, deberán procurar especialmente que las materias exigidas se

160 Art. 35 modificado por Ley 2/2009, de 23 de junio, de modificación del texto refundido de la Ley de la función pública de Galicia, aprobado por el Decreto legislativo 1/2008, de 13 de marzo.

Téngase en cuenta Disposición Transitoria Única de Ley $2 / 2009$, de 23 de junio, de modificación del texto refundido de la Ley de la función pública de Galicia, aprobado por el Decreto legislativo $1 / 2008$, de 13 de marzo, que establece que:

"La libertad de elección de lengua gallega y de lengua castellana en las pruebas selectivas les será aplicable a todos los procesos selectivos de la Comunidad Autónoma de Galicia en curso, y que aún non estén finalizados, respecto de aquellos ejercicios no realizados". correspondan con el desarrollo posterior de las tareas a desarrollar.

4. En casos determinados y justificados, las personas aspirantes podrán ser sometidas a un período de prácticas, conforme a la convocatoria.

Artículo 38. 1. La selección por concurso-oposición consistirá en la superación de las pruebas correspondientes $\mathrm{y}$, en su caso, del curso selectivo de formación, así como en la posesión previa, debidamente valorada, de determinadas condiciones de formación, méritos o niveles de experiencia.

2. La valoración de dichos méritos o nivel de experiencia no supondrá, con relación a las pruebas selectivas, más de un $40 \%$ de la puntuación máxima alcanzable en la fase de la oposición. Con el fin de asegurar la debida idoneidad de las personas aspirantes, estas deberán superar, en la fase de oposición, la puntuación mínima establecida para las respectivas pruebas selectivas.

3. En la fase de oposición serán de aplicación los criterios establecidos en el artículo 37.

Artículo 39. El concurso, sistema excepcional de acceso para puestos singulares en atención a la naturaleza de las funciones a desempeñar, valorará los méritos que se señalen en la convocatoria, que, en todo caso, debe ser pública y libre.

Artículo 40. Se podrán celebrar convocatorias de pruebas conjuntas de selección para el ingreso en los distintos cuerpos o escalas.

Artículo 41. Los tribunales no podrán aprobar ni declarar que superaron las pruebas selectivas un número superior de personas aspirantes al de plazas convocadas. La contravención de este principio genera nulidad de pleno derecho en la propuesta del tribunal.

Artículo 42. La adjudicación de puestos de trabajo a las personas aspirantes que superaron el ingreso se deberá realizar de acuerdo con las solicitudes que realicen 
las personas interesadas, siempre según el orden obtenido en las pruebas selectivas.

Artículo 43. 1. Cuando la convocatoria lo establezca y una vez aprobadas las pruebas selectivas, las personas aspirantes al ingreso en la función pública deberán superar un curso de selección o formación en la Escuela Gallega de Administración Pública adaptado a la naturaleza de cada cuerpo o escala o un período de prácticas en una unidad administrativa.

2. Durante este período serán nombradas funcionarias y funcionarios en prácticas con los derechos económicos que se señalen y el tiempo que permanezcan en esta situación se les computará a todos los efectos.

\section{Capitulo V \\ MOVILIDAD DEL PERSONAL FUNCIONARIO DE LAS DIVERSAS ADMINISTRACIONES PÚBLICAS}

Artículo 44. 1. Se garantiza, en el ámbito de la presente ley y de acuerdo con la legislación básica del Estado, el derecho a la movilidad del personal funcionario procedente de otras administraciones públicas, de conformidad con las condiciones y con los requisitos que determine previamente la Xunta de Galicia en las relaciones de puestos de trabajo y de acuerdo con lo que disponga la correspondiente convocatoria.

2. Al personal funcionario de la Administración del Estado, de las comunidades autónomas y de las corporaciones locales que, mediante los procedimientos legalmente establecidos, pase a ocupar puestos de trabajo en la Administración pública de esta comunidad autónoma, le será aplicable la legislación de la función pública de ésta. El mencionado personal que, mediante transferencia, pase a ocupar puestos de trabajo de la Administración de la Comunidad Autónoma de Galicia con carácter definitivo se integrará en el correspondiente cuerpo o escala.

3. En el marco de los acuerdos que las administraciones públicas subscriban con la finalidad de facilitar la movilidad entre el personal funcionario, tendrán especial consideración los casos de movilidad geográfica de las funcionarias víctimas de violencia de género.

4. El personal de otras administraciones en servicio activo en la Administración de la Xunta de Galicia no podrá superar, en ningún caso, el $5 \%$ de los efectivos totales con que ésta cuente.

Artículo 45. El personal funcionario de la Comunidad Autónoma gallega que, mediante concurso o libre designación, pase a ocupar puestos en otras administraciones públicas seguirá perteneciendo a sus cuerpos o escalas de origen en la situación de servicios en otras administraciones públicas, y mientras tanto será de aplicación la legislación de la Administración de destino con la excepción prevista en el artículo 56.

Artículo 46. El personal funcionario transferido a la Comunidad Autónoma gallega que, en virtud de los procedimientos de concurso o libre designación, pase a ocupar puestos de trabajo en otras administraciones públicas seguirá conservando su condición de personal funcionario del Estado y de la Comunidad Autónoma gallega en situación administrativa de servicios en otras administraciones públicas.

\section{TÍTULO V RÉGIMEN JURÍDICO DE LA FUNCIÓN PÚBLICA}

\section{Capítulo I \\ ADOUUISICIÓN Y PÉRDIDA DE LA COÑDICIÓN DE FUNCIONARIA O FUNCIONARIO}

Artículo 47. La condición de funcionaria o funcionario se adquiere por el cumplimiento de los siguientes requisitos:

1. Superar las pruebas selectivas y los cursos de selección o formación que sean procedentes.

2. Nombramiento conferido por la autoridad competente y publicado en el Diario Oficial de Galicia.

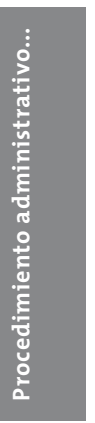


3. Jurar o prometer fidelidad a la Constitución, al Estatuto de autonomía de Galicia y obediencia a las leyes, así como desempeñar con imparcialidad el ejercicio de la función pública.

4. Tomar posesión en el plazo de un mes a partir de la publicación del nombramiento.

Artículo 48. La condición de funcionaria o funcionario se pierde por alguna de las causas siguientes:

1. Renuncia expresa, que no inhabilita para nuevo ingreso en la función pública.

2. Separación del servicio, por resolución firme recaída en expediente disciplinario o inhabilitación absoluta o especial para cargo público acordada como pena principal o accesoria en sentencia judicial de carácter definitivo.

3. Pérdida de la nacionalidad española, teniendo en cuenta, no obstante, la Ley $17 / 1993$, de 23 de diciembre, sobre el acceso a determinados sectores de la función pública de la población nacional de los demás Estados miembros de la Unión Europea.

4. Jubilación forzosa o voluntaria.

Artículo 49. 1. La jubilación forzosa se declarará de oficio al cumplir la funcionaria o funcionario la edad de 65 años.

No obstante lo dispuesto en el párrafo anterior, tal declaración no se producirá hasta el momento en el que las personas funcionarias cesen en la situación de servicio activo, en aquellos supuestos en los que, voluntariamente, prolonguen su permanencia en ella, hasta, como máximo, los 70 años de edad. A tal efecto podrán optar por la prolongación de la permanencia en el servicio activo, mediante escrito dirigido a la conselleira o conselleiro competente en materia de función pública con una anticipación de dos meses, como mínimo, a la fecha en la que cumplan los 65 años de edad, y se entenderá reconocida por la Administración de la Xunta de Galicia dicha prolongación si no notificase a las personas interesadas resolución expresa y motivada en contrario antes de los quince días que preceden a aquella fecha.

Se faculta a la conselleira o conselleiro competente en materia de función pública para dictar las normas complementarias de procedimiento que permitan la aplicación de la medida citada a las personas funcionarias referidas en el párrafo anterior.

De lo dispuesto en el párrafo segundo queda exceptuado el personal funcionario de aquellos cuerpos y escalas que tengan normas específicas de jubilación de acuerdo con lo dispuesto en la normativa básica estatal.

2. Se procederá también a su jubilación, previa instrucción de expediente que podrá iniciarse de oficio o a instancia de la persona funcionaria interesada, cuando se declare la incapacidad permanente para el ejercicio de sus funciones, bien por inutilidad física o psíquica o por disminución apreciable de sus facultades.

En cualquier caso, será preceptiva la audiencia en el expediente de la persona interesada funcionaria.

Artículo 50. 1. La jubilación voluntaria se declarará a instancia de la funcionaria o funcionario conforme la legislación vigente.

2. a. No obstante lo anterior, las personas funcionarias afectadas por un proceso de reasignación de efectivos que se encuentren en las situaciones de expectativa de destino o de excedencia forzosa, como consecuencia de un plan de empleo, podrán solicitar la jubilación voluntaria anticipada, en las condiciones establecidas en el régimen de Seguridad Social en el que estén encuadradas, siempre que hayan cumplido 60 años de edad y reúnan los requisitos exigidos en dicho régimen.

b. Las personas funcionarias que se acojan a esta jubilación tendrán derecho a percibir, por una sola vez, una indemnización cuya cuantía será fijada por el Consello de la Xunta de Galicia según su edad y las retribuciones íntegras correspondientes a la última mensualidad completa percibida, con exclusión, en su caso, del complemento específico y de la productividad, referida a doce mensualidades. 
c. Corresponde a la conselleira o conselleiro competente en materia de función pública acordar la jubilación voluntaria incentivada.

\section{Capítulo II \\ SITUACIONES ADMINISTRATIVAS}

Artículo 51. Las personas funcionarias pueden estar en alguna de las siguientes situaciones:

a. Servicio activo.

b. Servicios especiales.

c. Servicios en otras administraciones públicas.

d. Excedencia voluntaria.

e. Excedencia forzosa.

f. Suspensión de funciones.

g. Expectativa de destino.

h. Excedencia forzosa aplicable a funcionarias y funcionarios en expectativa de destino.

i. Excedencia voluntaria incentivada.

j. Excedencia por razón de violencia sobre la mujer funcionaria.

Artículo 52. Las personas funcionarias están en situación de servicio activo:

1. Cuando ocupen una plaza dotada presupuestariamente de un cuerpo o escala y desempeñen un puesto de trabajo, en virtud de su pertenencia a los mismos.

2. Cuando estén en comisión de servicio de carácter temporal conferida por la consellería competente en materia de función pública.

3. Cuando queden a disposición del órgano que reglamentariamente se determine de acuerdo con lo establecido en el artículo 65. 4.

4. En los supuestos previstos en el artículo 54. en que la persona funcionaria opte por permanecer en esta situación.

Artículo 53. Por necesidad del servicio, debidamente justificada y de acuerdo con los criterios y las condiciones que se determinen reglamentariamente, oída la comisión de personal, los órganos competentes podrán destinar a la funcionaria o funcionario en comisión de servicios de carácter forzoso y por tiempo no superior a tres meses a un puesto de trabajo distinto del de destino y, si supusiese cambio de localidad, la funcionaria o funcionario tendrá derecho a las indemnizaciones establecidas reglamentariamente. Quedan excluidas de esta comisión forzosa las personas que ejerzan los derechos de las letras e) y f) del apartado 1 del artículo 76, así como las funcionarias embarazadas. Reglamentariamente se establecerán derechos de oposición a la comisión forzosa derivados del cuidado de familiares.

Artículo 54. El personal funcionario público pasará a la situación de servicios especiales:

1. Cuando sea autorizado para realizar una misión por período superior a seis meses en organismos internacionales, gobiernos o entidades públicas extranjeras o en programas de cooperación internacional.

2. Cuando adquiera la condición de personal funcionario al servicio de organizaciones internacionales o de carácter supranacional.

3. Cuando sea nombrado integrante del Gobierno o de los órganos de gobierno de las comunidades autónomas o altos cargos de los mismos que no deban ser provistos necesariamente por personal funcionario público.

4. Cuando sea elegido por las Cortes Generales para formar parte de los órganos constitucionales o de otros que corresponda a las cámaras elegir.

5. Cuando sea adscrito a los servicios del Tribunal Constitucional o del Defensor del Pueblo.

6. Cuando acceda a la condición de diputada, diputado, senadora o senador de las Cortes Generales.

7. Cuando acceda a la condición de diputada o diputado del Parlamento gallego, de miembro de las asambleas legislativas de las comunidades autónomas o cuando forme parte de órganos que corresponda elegir al Parlamento gallego, si percibe retribuciones periódicas por el desempeño de la función. 
Cuando no perciba tales retribuciones podrá optar entre permanecer en la situación de servicio activo o pasar a la de servicios especiales, sin perjuicio de la normativa que dicten las comunidades autónomas sobre incompatibilidades de las personas integrantes de asambleas legislativas.

8. Cuando desempeñe cargos electivos retribuidos y de dedicación exclusiva en las entidades locales, cuando desempeñe responsabilidades de órganos superiores y directivos municipales y cuando se desempeñen responsabilidades de personas integrantes de los órganos locales para el conocimiento y la resolución de las reclamaciones económico-administrativas. Se exceptúan las personas funcionarias de la Administración local con habilitación de carácter estatal, cuando desempeñen puestos reservados a ellas, que se regirán por su normativa específica, quedando en la situación de servicio activo.

9. Cuando preste servicio en los gabinetes de la Presidencia del Gobierno, de las ministras y ministros y de las secretarias y secretarios de Estado y no opte por permanecer en la situación de servicio activo en su Administración de origen.

10. Cuando sea nombrado para cualquier cargo de carácter político del que derive incompatibilidad para ejercer la función pública.

11. Cuando cumpla el servicio militar o la prestación substitutoria equivalente.

12. Cuando preste servicio en los gabinetes de la Presidencia de la Xunta de Galicia o de los conselleiros y no opte por permanecer en la situación de servicio activo en su Administración de origen.

13. Cuando desempeñe puestos de trabajo de carácter directivo en el Gabinete de la Presidencia del Parlamento.

14. Cuando sea adscrito a los servicios del Valedor del Pueblo, en los términos previstos en la ley reguladora de dicha institución.

15. Cuando sea nombrado miembro del Consejo de Cuentas de Galicia.
16. Cuando pase a desempeñar los puestos de trabajo de presidenta o presidente, conselleira o conselleiro delegado, directora o director gerente en las sociedades públicas a las que hace alusión el artículo 12 de la Ley 11/1992, de 7 de octubre, de régimen financiero y presupuestario de Galicia, y así lo determine el Consello de la Xunta de Galicia.

17. Cuando sea nombrado como titular de subsecretarías, secretarías generales técnicas o direcciones generales de la Administración general del Estado.

18. Cuando sea nombrado como titular de las subdelegaciones del Gobierno en las provincias o de las direcciones insulares de la Administración General del Estado y no opte por permanecer en la situación de servicio activo en su Administración de origen.

19. Cuando sea nombrado para desempeñar puestos en las áreas funcionales de alta inspección de educación, funcionaria o funcionario de los cuerpos docentes o de las escalas en las que se ordena la función pública docente.

20. Cuando pase a desarrollar cargos directivos en las empresas públicas, en los entes públicos, en las sociedades o en las fundaciones públicas en las que la Xunta de Galicia, directa o indirectamente, participe o aporte más del $50 \%$ del capital o del patrimonio, cuando dichos cargos sean designados previo acuerdo del Consello de la Xunta de Galicia o por sus propios órganos de gobierno.

Artículo 55. 1. A las personas funcionarias en situación de servicios especiales se les computará el tiempo que permanezcan en tal situación a efectos de ascensos, trienios y derechos pasivos y tendrán derecho a la reserva de plaza y destino que ocupasen, que podrá ser desempeñada mientras la persona funcionaria esté en situación de servicios especiales bien en comisión de servicios, bien por personal interino.

En todos los casos percibirán las retribuciones del puesto o cargo efectivo que 
desempeñen y no las que les correspondan como personal funcionario, sin perjuicio del derecho a la percepción de los trienios que pudiesen tener reconocidos como funcionarias o funcionarios.

2. Las diputadas, diputados, senadoras, senadores y personas integrantes de las asambleas legislativas de las comunidades autónomas que pierdan tal condición por disolución de las correspondientes cámaras o finalización del mandato de éstas podrán permanecer en la situación de servicios especiales hasta su nueva constitución.

3. Lo dispuesto en este artículo relativo al cómputo del tiempo de permanencia en la situación de servicios especiales, a efectos de ascensos, trienios y derechos pasivos, no será de aplicación a las funcionarias y funcionarios públicos que, tras ingresar al servicio de las instituciones comunitarias europeas o al de entidades y organismos asimilados, ejerzan el derecho de transferencia establecido en el artículo 11.2 del anexo VIII del Estatuto de los funcionarios de las comunidades europeas, aprobado por el Reglamento 259/1968, del Consejo, de 29 de febrero, modificado por el Reglamento 571/1992, del Consejo, de 2 de marzo, sin perjuicio de los efectos económicos que puedan derivar de los ascensos y trienios consolidables hasta el momento del ejercicio de este derecho.

4. La Administración pública velará para que no haya menoscabo en el derecho a la carrera profesional del personal funcionario público que fuese nombrado alto cargo, miembro del poder judicial o de otros órganos constitucionales o estatutarios o que fuese elegido alcaldesa o alcalde, retribuido y con dedicación exclusiva, presidenta o presidente de diputaciones o instituciones equivalentes, diputada, diputado, senador o senadora de las Cortes Generales y miembro de las asambleas legislativas de las comunidades autónomas. Como mínimo, este personal funcionario recibirá el mismo tratamiento en la consolidación del grado y en el conjunto de complementos que el que se establezca para el que fuese directora o director general y otros cargos equivalentes o superiores de la correspondiente Administración pública.

Artículo 56. Servicios en otras administraciones públicas.

Las personas funcionarias de la comunidad que, por medio de los sistemas de concurso, de libre designación, transferencia o adscripción provisional, en su caso, pasen a ocupar puestos de trabajo en otras administraciones públicas, se someterán al régimen estatutario vigente en la Administración en la que estén destinadas y les será aplicable la legislación en materia de función pública de ésta, pero conservarán su condición de funcionarias o funcionarios de la comunidad en situación de servicio en otras administraciones públicas. En el supuesto de estar incursas en expediente disciplinario, la imposición de la sanción de separación del servicio les corresponderá a los órganos competentes de la comunidad autónoma.

Artículo 57. Excedencia voluntaria.

1. Por incompatibilidad: Procederá declarar, de oficio o a instancia de parte, en situación de excedencia voluntaria a la persona funcionaria cuando esté en situación de servicio activo en otro cuerpo o escala de cualquiera de las administraciones públicas, a no ser que obtuviese la oportuna compatibilidad, o pase a prestar servicios en organismos o entidades del sector público y no le corresponda quedar en otra situación.

2. Por interés particular:

a. Podrá concedérseles igualmente la excedencia voluntaria a las personas funcionarias cuando lo soliciten por interés particular.

Para solicitar el pase a la situación prevista en esta letra será preciso haber prestado servicios efectivos en cualquiera de las administraciones públicas durante los cinco años inmediatamente anteriores y en ella no se podrá permanecer menos de dos años continuados. 
Procederá, asimismo, declarar en excedencia voluntaria al personal funcionario público cuando, finalizada la causa que determinó el pase a una situación distinta a la de servicio activo, incumpla la obligación de solicitar el reingreso en el plazo establecido reglamentariamente.

El personal funcionario público que preste servicios en organismos o entidades que quede excluido de la consideración del sector público a los efectos de la declaración de excedencia voluntaria prevista en el punto 1 de este artículo será declarado en la situación de excedencia voluntaria regulada en este punto, sin que le sean de aplicación los plazos de permanencia en ella.

b. Pasarán también a la situación de excedencia voluntaria por interés particular las personas funcionarias que cesasen en la situación de servicios especiales y no solicitasen el reingreso en el servicio activo en el plazo de treinta días desde tal cese, excepto en el supuesto previsto en el párrafo in fine del artículo 55.

$\mathrm{Al}$ excedente voluntario por interés particular al que, solicitado el reingreso, no se le conceda por falta de puesto vacante con dotación presupuestaria, continuará en la situación de excedencia voluntaria hasta que se produzca éste.

3. Por agrupación familiar: Las personas funcionarias excedentes por alguna de las causas anteriores no percibirán retribuciones ni les será computado el tiempo permanecido en tal situación a efectos de ascensos, trienios y derechos pasivos.

4. Excedencia para el cuidado de hijas, hijos y familiares: Las personas funcionarias de carrera tendrán derecho a un período de excedencia, de duración no superior a tres años, para cuidar cada hija o hijo, tanto cuando sea por naturaleza como por adopción o acogimiento permanente o en proceso de adopción, que se contará desde la fecha de nacimiento o, en su caso, de la resolución judicial o administrativa.

También tendrán derecho a un período de excedencia, de duración no superior a tres años, para el cuidado de una persona familiar que esté a su cargo, hasta el segundo grado inclusive de consanguinidad o afinidad, que por razones de edad, accidente, enfermedad o discapacidad no se pueda valer por si misma y no desempeñe actividad retribuida.

El período de excedencia será único por cada persona causante. Cuando una nueva persona causante diese origen a una nueva excedencia, el inicio del período de ésta pondrá fin al que se viniese disfrutando.

Esta excedencia constituye un derecho individual de las personas funcionarias. En el caso de que dos personas funcionarias generasen el derecho a disfrutarla por la misma persona causante, la Administración podrá limitar su ejercicio simultáneo por razones justificadas relacionadas con el funcionamiento de los servicios.

El tiempo de permanencia en esta situación será computable a efectos de trienios, carrera y derechos en el régimen de la Seguridad Social que sea aplicable. El puesto de trabajo desempeñado se reservará, cuando menos, dos años. Al transcurrir ese período, dicha reserva será a un puesto en la misma localidad y de igual retribución.

Las personas funcionarias en esta situación podrán participar en los cursos de formación que convoque la Administración.

5. Excedencia voluntaria incentivada: Las personas funcionarias afectadas por un proceso de reasignación de efectivos que se encuentren en alguna de las dos fases a las que hace referencia el artículo 29. 6 de esta ley podrán ser declaradas, a solicitud suya, en situación de excedencia voluntaria incentivada.

Las que se encuentren en las situaciones de expectativa de destino o de excedencia forzosa como consecuencia de la aplicación de un plan de empleo tendrán derecho a pasar, a solicitud suya, a dicha situación.

La excedencia voluntaria incentivada tendrá una duración de cinco años e impedirá desempeñar puestos de trabajo en el sector público bajo ningún tipo de 
relación funcionarial o contractual, sea esta de naturaleza laboral o administrativa. Concluido el plazo señalado, se pasará automáticamente, si no se solicita el reingreso, a la situación de excedencia voluntaria por interés particular.

Las que pasen a la situación de excedencia voluntaria incentivada tendrán derecho a una mensualidad de las retribuciones de carácter periódico, excluidas las pagas extraordinarias y el complemento de productividad, percibidas en el último puesto de trabajo desempeñado, por cada año completo de servicios efectivos y con un máximo de doce mensualidades.

Corresponde a la consellería competente en materia de función pública acordar el pase a la situación de excedencia voluntaria incentivada.

No se podrá conceder la excedencia voluntaria cuando la persona funcionaria esté sometida a expediente disciplinario o pendiente del cumplimiento de una sanción.

6. Excedencia por razón de violencia sobre la mujer funcionaria: Las funcionarias víctimas de violencia de género, para hacer efectiva su protección o su derecho a la asistencia social integral, tendrán derecho a solicitar la situación de excedencia durante seis meses sin tener que prestar un tiempo máximo de servicios previos y sin que sea exigible plazo de permanencia en ella.

Durante los seis primeros meses tendrán derecho a la reserva del puesto de trabajo que desempeñasen, y dicho período será computable a efectos de antigüedad, carrera y derechos del régimen de Seguridad Social que sea aplicable.

Cuando las acciones judiciales lo exigiesen, se podrá prorrogar este período por tres meses, con un máximo de dieciocho, con idénticos efectos a los señalados anteriormente, con el fin de garantizar la efectividad del derecho de protección de la víctima.

Durante los dos primeros meses de esta excedencia, la funcionaria tendrá derecho a percibir las retribuciones íntegras y, en su caso, las prestaciones familiares por hija o hijo a su cargo.
Artículo 58. 1. La excedencia forzosa se producirá por las siguientes causas:

a. Cuando se lleve a cabo una reducción de puestos de trabajo de acuerdo con los procedimientos legalmente establecidos y la persona funcionaria afectada por ella no pueda ser adscrita a otro puesto.

b. Cuando, una vez concluido el período de excedencia voluntaria para el cuidado de una hija o hijo, la persona funcionaria solicite el reingreso y no lo pueda obtener por falta de puesto vacante con dotación presupuestaria.

c. Cuando la persona funcionaria procedente de la situación de suspenso en firme, una vez cumplida la suspensión, solicite el reingreso y no fuese posible concederlo por falta de puestos vacantes. Las que estén en la situación a) tendrán derecho a percibir las retribuciones básicas y el complemento de destino inferior en dos niveles a su grado personal, así como al cómputo del tiempo que permanezcan en tal situación a efectos de trienios y derechos pasivos.

Las que estén en las situaciones b) y c) no tendrán derecho al complemento de destino, pero el tiempo que permanezcan en tal situación les será computado a efectos de trienios y derechos pasivos.

2. Excedencia forzosa aplicable a las personas funcionarias en expectativa de destino.

Las personas funcionarias declaradas en expectativa de destino pasarán a la situación de excedencia forzosa, con las peculiaridades establecidas en este apartado, por las causas siguientes:

a. El transcurso del período máximo fijado para ésta.

b. El incumplimiento de las obligaciones determinadas en el artículo 59 de la presente ley.

Las que se encuentren en esta modalidad de excedencia forzosa tendrán derecho a percibir las retribuciones básicas y, en su caso, las prestaciones familiares por hija o hijo a cargo. 
Dichas personas funcionarias estarán obligadas a participar en los concursos convocados a puestos adecuados a su cuerpo, escala o especialidad que les sean notificados, así como a aceptar los destinos que se les señalen en puestos de características similares y a participar en los cursos de capacitación que se les ofrezcan.

No podrán desempeñar puestos de trabajo en el sector público bajo ningún tipo de relación funcionarial o contractual, sea esta de naturaleza laboral o administrativa. Si obtienen puesto de trabajo en dicho sector pasarán a la situación de excedencia voluntaria regulada en el artículo 57.1 de la presente ley.

Pasarán a la situación de excedencia voluntaria por interés particular cuando incumplan las obligaciones a las que se refiere este apartado.

Corresponde a la consellería competente en materia de función pública acordar la declaración de esta modalidad de excedencia forzosa y el pase a la excedencia voluntaria de estos excedentes forzosos, así como la gestión del personal afectado mediante resolución motivada.

Artículo 59. Las personas funcionarias en expectativa de destino percibirán las retribuciones básicas, el complemento de destino del grado personal que les corresponda y el $50 \%$ del complemento específico del puesto que desempeñaban al pasar a esta situación.

Dichas personas estarán obligadas a:

1. Aceptar los destinos en puestos de características similares a los que desempeñaban que se les ofrezcan en la provincia donde estaban destinadas.

2. Participar en los concursos para puestos adecuados a su cuerpo, escala o categoría, situados en la provincia donde estaban destinadas.

3. Participar en los cursos de capacitación a las que sean convocadas.

El período máximo de duración de la situación de expectativa de destino será de un año; transcurrido éste, se pasará a la situación de excedencia forzosa.
A los restantes efectos, esta situación se equipara a la de servicio activo.

Corresponde a la consellería competente en materia de función pública efectuar la declaración y el cese en esta situación administrativa y la gestión del personal afectado por ella.

Artículo 60. 1. La suspensión de funciones puede tener carácter provisorio o firme. La persona funcionaria declarada en tal situación quedará privada temporalmente del ejercicio de sus funciones y de los derechos inherentes a su condición.

2. La suspensión provisoria podrá acordarse preventivamente por un período no superior a seis meses, durante la tramitación del procedimiento judicial o del expediente disciplinario, por posible comisión de faltas graves, que le instruya a la persona funcionaria la autoridad competente.

3. Durante el tiempo de suspensión provisoria la persona funcionaria percibirá las retribuciones básicas que le correspondan.

4. Si la persona funcionaria resultase absuelta en el procedimiento criminal o expediente disciplinario, o si la sanción que se le impusiese fuese inferior a la suspensión, el tiempo de duración de ésta se le computará como servicio activo y deberá reincorporarse inmediatamente a su puesto de trabajo, con reconocimiento de todos los derechos económicos y demás que procedan desde la fecha de efectividad de la suspensión.

5. La suspensión tendrá carácter firme cuando se imponga en virtud de condena criminal o sanción disciplinaria.

6. A las personas funcionarias en situación de suspensión de funciones con carácter firme no se les reservará la plaza ni el destino.

Artículo 61. 1. El reingreso al servicio activo de las personas funcionarias que no tengan reserva de plaza y destino se efectuará mediante su participación en las convocatorias de concurso o de libre 
designación para la provisión de puestos de trabajo.

2. Asimismo, el reingreso podrá efectuarse por adscripción a un puesto, que tendrá necesariamente el carácter de provisional, condicionado a las necesidades del servicio y siempre que se reúnan los requisitos para el desempeño del puesto.

3. El puesto asignado con carácter provisional se convocará para su provisión definitiva en el plazo máximo de un año, y la persona funcionaria reingresada con destino provisional tendrá la obligación de participar en la convocatoria. Si no obtuviese destino definitivo se le aplicará lo dispuesto en el artículo $65 .{ }^{\circ} 4$ de la presente ley.

4. En el supuesto de incumplir la obligación de participar en el concurso en el que se incluya el puesto que ocupa provisionalmente, será declarada de oficio en la situación de excedencia voluntaria.

Artículo 62. Las que estén en situación de excedencia forzosa o de suspensión de funciones en firme, en este caso al cumplir el tiempo de suspensión, están obligadas a solicitar el reingreso, que les será concedido, si existen vacantes, con carácter provisional y hasta que obtengan destino con carácter definitivo, a través de concurso de traslados, estando obligadas a participar en todos los que se convoquen hasta que eso se produzca y, de no hacerlo, serán declaradas en la situación de excedencia voluntaria por interés particular.

\section{Capítulo III LA CARRERA ADMINISTRATIVA}

Artículo 63. 1. La carrera administrativa consiste en la promoción desde el cuerpo o escala de un determinado grupo al de otro inmediatamente superior, o en el ascenso dentro de los grados asignados al mismo cuerpo o escala, o en el acceso a otro cuerpo o escala del mismo grupo.

2. En las convocatorias de las pruebas selectivas se reservará un mínimo de un $25 \%$ de las vacantes convocadas para personal funcionario perteneciente a cuerpos o escalas del grupo inmediatamente inferior que, poseyendo la titulación exigida y los demás requisitos inherentes a la vacante a cubrir, prestase servicios efectivos durante por lo menos dos años en el cuerpo o en la escala de pertenencia.

Dichas pruebas, en las cuales se deberán respetar los principios de igualdad, mérito y capacidad, se podrán llevar a cabo en convocatorias independientes de las de ingreso cuando, por conveniencia de la planificación general de los recursos humanos, así lo autorice el Consello de la Xunta de Galicia.

Podrá participar en los procesos de promoción interna para el acceso al cuerpo administrativo de la Xunta de Galicia (grupo C) el personal funcionario del cuerpo auxiliar de la Xunta de Galicia (grupo D) que, aunque carezca de la titulación exigida para pertenecer al grupo $\mathrm{C}$, acredite una antigüedad mínima de diez años en el grupo $\mathrm{D}$ o bien tenga una antigüedad mínima de cinco años y supere los cursos de formación que reglamentariamente se determinen.

3. Las personas funcionarias que accedan a otros cuerpos o escalas por el sistema de promoción interna tendrán, en todo caso, preferencia para cubrir los puestos vacantes ofertados sobre las personas aspirantes que no procedan de este turno.

Además, las personas funcionarias aspirantes que superen tal proceso selectivo podrán tomar posesión de la plaza que ya viniesen desempeñando con carácter definitivo cuando el nivel de ésta se encuentre incluido en el intervalo de niveles del cuerpo y grupo al que accedan.

Las plazas reservadas a promoción interna que no se cubran por este procedimiento se acumularán a las de provisión libre.

4. Asimismo, estas personas funcionarias conservarán su grado personal que ya consolidasen en el cuerpo o escala de procedencia, siempre que esté incluido en el intervalo de niveles correspondiente 
al nuevo cuerpo o escala, y el tiempo de servicios prestados en aquellos será aplicable, en su caso, para la consolidación del grado personal en éste.

Lo dispuesto en el presente artículo será también aplicable a las personas funcionarias que accedan por integración a otros cuerpos o escalas del mismo grupo o de grupo superior de acuerdo con lo previsto en esta ley.

Artículo 64. Las personas funcionarias podrían acceder a otros cuerpos o escalas encuadradas en el mismo grupo que tengan asignadas funciones substancialmente coincidentes en su contenido profesional y en su nivel técnico, siempre que estén en posesión de la titulación exigida en cada caso y superen las pruebas selectivas.

Podrán ser eximidas de alguna de las pruebas aquellas personas funcionarias que procedan de la misma área de especialización profesional que la correspondiente al cuerpo o escala a la que se pretende ascender.

Artículo 65. 1. Toda persona funcionaria posee un grado personal que corresponderá a uno de los 30 niveles en que se clasifiquen los puestos de trabajo.

2. El grado personal se adquiere por el desempeño de uno o más puestos de nivel correspondiente durante dos años continuados o durante tres con interrupción. Si durante el tiempo en que la persona funcionaria desempeña un puesto se modificase el nivel de estos, el tiempo del desempeño se computará en el nivel más alto con el que tal puesto estuviese clasificado.

No obstante lo dispuesto en el párrafo anterior, las personas funcionarias que obtengan un puesto de trabajo superior en más de dos niveles al correspondiente a su grado personal consolidarán cada dos años de servicios continuados el grado superior en dos niveles al que poseyesen, sin que en ningún caso puedan superar el correspondiente al del puesto desempeñado.

Las personas funcionarias de nuevo ingreso comenzarán a consolidar el grado correspondiente al nivel de complemento de destino del primer puesto al que se les adscriba, de forma provisional o definitiva, tras la superación del proceso selectivo.

3. Las personas funcionarias tendrán derecho, cualquiera que sea el puesto de trabajo que desempeñen, a percibir por lo menos el complemento de destino de los puestos de nivel correspondiente a su grado personal. No obstante, la percepción del complemento específico será siempre la que le corresponda al puesto realmente desempeñado.

4. Las personas funcionarias que cesen en un puesto de trabajo sin obtener otro por los sistemas de provisión previstos en el artículo 27 de la presente ley quedarán a disposición del conselleiro, que les atribuirá el desempeño de un puesto provisional correspondiente a su cuerpo o escala, dentro de la misma localidad.

Sin perjuicio de lo dispuesto en el párrafo anterior, quien cese en un puesto provisto por libre designación o por alteración del contenido o supresión de sus puestos en las relaciones de puestos de trabajo continuará percibiendo mientras no se le atribuya otro puesto, por concurso o por libre designación, y durante un plazo máximo de tres meses, las retribuciones complementarias correspondientes al puesto que venía desempeñando. Las personas funcionarias que cesen en un puesto de trabajo sin obtener otro por los sistemas de provisión previstos en el artículo 27..$^{\circ}$ de esta ley quedarán a disposición del conselleiro, que les atribuirá el desempeño de un puesto provisional correspondiente a su cuerpo y escala, dentro de la misma localidad, no inferior en más de dos niveles al de su grado personal, en tanto no obtengan otro con carácter definitivo, con efectos del día siguiente a la fecha del cese y de acuerdo con el procedimiento que fije la consellería competente en materia de función pública.

5. El tiempo de permanencia en situación de servicios especiales será computado, a efectos de consolidación del 
grado personal, como prestado en el último puesto desempeñado en situación de servicio activo o en el que posteriormente se obtuviese por concurso.

6. La adquisición y los cambios de grado se inscribirán en el registro de personal después de reconocerlos el órgano competente.

7. Los grados superiores de los cuerpos o escalas podrán coincidir con los inferiores en el cuerpo o escala inmediatamente superior.

Artículo 66. En el supuesto de provisión, mediante libre designación, de plazas de la Administración abiertas a personal funcionario docente en las relaciones de puestos de trabajo de la Xunta de Galicia, las funcionarias y funcionarios docentes que prestan servicios en los centros educativos que imparten enseñanzas distintas de las universitarias tendrán derecho a la reserva de la plaza que estuviesen desempeñando si ésta se ocupase con carácter definitivo.

Artículo 67. La adquisición de los grados superiores por las personas funcionarias de los cuerpos y escalas de cada grupo podrá realizarse también mediante la superación de cursos de formación u otros requisitos objetivos que determine la Xunta de Galicia, de conformidad con lo dispuesto en el artículo 13, apartado 11.

Artículo 68. 1. La Administración pública gallega establecerá sistemas que permitan la evaluación del desempeño de sus empleadas y empleados.

La evaluación del desempeño es el procedimiento a través del que se mide y valora la conducta profesional y el rendimiento o el logro de resultados.

2. Los sistemas de evaluación del desempeño se adecuarán, en todo caso, a criterios de transparencia, objetividad, imparcialidad y no discriminación, y se aplicarán sin menoscabo de los derechos de las empleadas y empleados públicos.

3. La Administración pública gallega determinará los efectos de la evaluación en la carrera profesional, en la formación, en la provisión de puestos de trabajo y en la percepción de las retribuciones complementarias correspondientes.

4. La Xunta de Galicia articulará un sistema que, entre otros factores, tendrá en cuenta necesariamente:

a. El grado de satisfacción de la ciudadanía respecto de los servicios que le presten.

b. La buena gestión y organización de la estructura administrativa, para lo cual promoverá la utilización por parte del personal directivo de los datos derivados de la gestión para la toma de decisiones.

c. La implicación en procesos innovadores y de buenas prácticas en aras de la excelencia.

d. La normalización y la racionalización de procesos.

e. El grado de cumplimiento del Plan de normalización lingüística.

5. Se nombrará una comisión de evaluación del desempeño, cuya composición y funcionamiento se regulará por decreto del Consello de la Xunta de Galicia, a propuesta de la consellería competente en materia de función pública. Se podrá nombrar más de una comisión de evaluación del desempeño cuando así se considere necesario.

\section{Capitulo IV \\ RÉGIMEN RETRIBUTIVO}

Artículo 69. 1. Las retribuciones de las personas funcionarias son básicas y complementarias.

2. Son retribuciones básicas:

a. El sueldo, que se fijará en función del índice de proporcionalidad que se le asigne a cada uno de los grupos en que se organizan los cuerpos y escalas de personal funcionario de la comunidad.

b. Los trienios, consistentes en una cantidad igual para cada grupo, por cada tres años de servicio en el cuerpo o escala.

En el caso de que una persona funcionaria preste sus servicios sucesivamente en diferentes cuerpos, escalas, clases o categorías 
de distinto grupo de clasificación, tendrá derecho a seguir percibiendo los trienios percibidos en los grupos anteriores.

Cuando la persona funcionaria cambie de adscripción de grupo antes de completar un trienio, la fracción de tiempo transcurrido se considerará como tiempo de servicios prestados en el nuevo grupo.

c. Las pagas extraordinarias, que serán dos al año por un importe mínimo cada una de ellas de una mensualidad de sueldo y trienios, se percibirán los meses de junio y diciembre.

3. Son retribuciones complementarias:

a. El complemento de destino correspondiente al nivel del puesto que desempeñe. Este complemento figurará en las relaciones de puestos de trabajo y será igual para todos los puestos del mismo nivel.

b. El complemento específico, destinado a retribuir las condiciones particulares de algunos puestos de trabajo en atención a su especial dificultad técnica, dedicación, responsabilidad, incompatibilidad, peligrosidad o penosidad. En ningún caso podrá asignarse más de un complemento específico a cada puesto de trabajo.

c. El complemento de productividad, destinado a retribuir el especial rendimiento, la actividad extraordinaria, el interés o la iniciativa con que la persona funcionaria desempeñe su trabajo.

Su cuantía global no podrá exceder de un porcentaje sobre los costes totales de personal de cada programa y de cada órgano que se determinará en la Ley de presupuestos. El responsable de la gestión de cada programa de gasto, dentro de las correspondientes dotaciones presupuestarias, determinará, de acuerdo con la normativa establecida en la Ley de presupuestos, la cuantía individual que le corresponda, en su caso, a cada persona funcionaria.

Su asignación se realizará conforme criterios objetivos establecidos reglamentariamente con la necesaria información y participación de las personas representantes del personal. Para ello se tendrá especialmente en consideración la cualificación emitida por la comisión de evaluación del desempeño respecto de la unidad administrativa de que se trate, todo ello de acuerdo con lo previsto en el artículo $68 .^{\circ}$ de la presente ley.

En cualquier caso, las cantidades que perciba cada persona funcionaria por este concepto serán de conocimiento público de las demás personas funcionarias del departamento y organismo interesado, así como de las personas representantes sindicales.

d. Las gratificaciones por servicios extraordinarios, fuera de la jornada normal, que en ningún caso podrán ser fijas en su cuantía y periódicas en su percepción.

4. Las personas funcionarias percibirán las indemnizaciones correspondientes por razón de servicio.

Artículo 70. 1. Las cuantías de las retribuciones básicas de las letras a) y b) del apartado 2 del artículo 69 de esta ley serán iguales para cada un de los grupos en los que se clasifican los cuerpos o las escalas. Asimismo, las cuantías de las pagas extraordinarias serán iguales para cada uno de los grupos de clasificación según el nivel del complemento de destino que perciban.

El sueldo de las personas funcionarias del grupo A no podrá exceder en más de tres veces el sueldo de las personas funcionarias del grupo $\mathrm{E}$.

2. La cuantía de las retribuciones básicas, de los complementos de destino asignados a cada puesto de trabajo y de los complementos específicos y de productividad, en su caso, deberá reflejarse para cada ejercicio presupuestario en la correspondiente ley de presupuestos de la comunidad autónoma.

Artículo 71. Los puestos de trabajo que exijan el mismo nivel de titulación y que tengan en su ejercicio similar grado de dificultad tendrán los mismos complementos de destino y específico si son semejantes las condiciones de trabajo. 
Artículo 72. El personal laboral será retribuido conforme a lo previsto en su normativa y en los convenios colectivos, procurándose mediante un conveniomarco $\mathrm{u}$ otros instrumentos la igualdad de retribuciones para las tareas que supongan unas mismas condiciones de preparación y unas mismas funciones.

Artículo 73. En el desarrollo y aplicación de los preceptos incluidos en este capítulo, así como en los de toda la política retributiva de la Xunta de Galicia, se deberán tener en cuenta los artículos 39 y 40 de la Ley 7/2004, de 16 de julio.

\section{Capitulo V \\ LICENCIAS, VACACIONES Y PERMISOS}

Artículo 74. Se podrán conceder licencias en los siguientes casos y condiciones:

1. Por matrimonio, la persona funcionaria tendrá derecho a una licencia retribuida de quince días naturales ininterrumpidos.

2. Por embarazo, en las condiciones y duración previstas en la legislación general.

3. Por asuntos propios se podrán conceder licencias sin retribución de una duración acumulada que no podrá exceder de tres meses cada dos años. La concesión de licencias por asuntos propios se subordinará, en todo caso, a las necesidades del servicio.

4. Las licencias por enfermedad se fijarán de acuerdo con el régimen de la Seguridad Social al que pertenezca la persona funcionaria.

5. Se podrán conceder licencias para la realización de estudios sobre materias directamente relacionadas con la Administración Pública, previo informe favorable de la persona jerárquicamente superior, y la persona funcionaria tendrá derecho a percibir las retribuciones básicas y el complemento familiar.

Artículo 75. 1. El personal funcionario tendrá derecho, por año completo de servicios, a disfrutar de vacaciones retribuidas de un mes natural o de veintidós días hábiles anuales, o a los días que correspondan proporcionalmente al tiempo de servicios efectivos.

2. Asimismo, tendrá derecho a un día hábil adicional al cumplir quince años de servicio, al que le añadirá un día hábil más al cumplir los veinte, veinticinco y treinta años de servicio, respectivamente, hasta un total de veintiséis días hábiles por año natural.

Este derecho se hará efectivo a partir del año natural siguiente al del cumplimiento de los años de servicio señalados en el párrafo anterior.

3. A efectos previstos en este artículo, no se considerarán como días hábiles los sábados, sin perjuicio de las adaptaciones que se establezcan para los horarios especiales.

4. En el caso de que el período de vacaciones coincida con el permiso previsto en el número 4 del artículo 76, la persona interesada tendrá derecho a la fijación de un período alternativo.

5. El calendario de vacaciones se elaborará anualmente, teniendo en cuenta las necesidades de los servicios, oídos los órganos de representación de las personas funcionarias.

Se reconoce el derecho a la elección del período de vacaciones a favor de las mujeres gestantes y la preferencia de elección de mujeres y hombres con hijas o hijos menores de doce años o mayores dependientes a su cuidado.

6. Los permisos de maternidad, paternidad y lactancia, así como los períodos de incapacidad temporal derivados del embarazo, se podrán acumular al período de vacaciones, incluso después de la finalización del año natural al que aquellas correspondan.

Artículo 76. 1. Se concederán permisos por las siguientes causas justificadas:

a. Por el fallecimiento, accidente o enfermedad grave de un familiar dentro del primer grado de consanguinidad o afinidad, tres días hábiles cuando el suceso se produzca en la misma localidad y

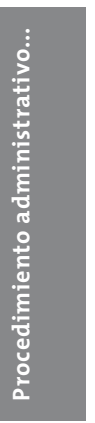


cinco días hábiles cuando sea en distinta localidad.

Cuando se trate del fallecimiento, accidente o enfermedad grave de un familiar dentro del segundo grado de consanguinidad o afinidad, el permiso será de dos días hábiles cuando el suceso se produzca en la misma localidad y de cuatro días hábiles cuando sea en distinta localidad.

b. Por traslado de domicilio sin cambio de residencia, un día en la misma localidad y dos días si hay cambio de localidad. Si la unidad familiar está integrada por dos o más personas miembros, el permiso será de dos días sin cambio de localidad y de cuatro si existe cambio.

c. Para realizar funciones sindicales, de formación sindical o de representación del personal, en los términos legalmente establecidos.

d. Para concurrir a exámenes finales y demás pruebas definitivas de aptitud, durante los días de su realización.

e. Por lactancia de una hija o hijo menor de doce meses, la funcionaria tendrá derecho a una hora de ausencia del trabajo, que podrá dividir en dos fracciones. Este derecho se podrá sustituir por una reducción de la jornada normal en media hora al inicio y al final de la jornada, o bien en una hora al inicio o al final de la jornada. Este derecho podrá ser ejercido indistintamente por las personas progenitoras, en el caso de que ambas trabajen.

Igualmente, se podrá sustituir el tiempo de lactancia por un permiso retribuido que acumule en jornadas completas el tiempo correspondiente, o bien por un crédito de horas, pudiéndose aprovechar, en ambos casos, en cualquier momento, después del disfrute del permiso de maternidad.

La cantidad de horas incluidas en el crédito será el resultado de contabilizar el total de horas a las que se tendría derecho si se dispusiese del permiso de lactación en su modalidad de una hora de ausencia.

Este permiso se incrementará proporcionalmente en los casos de parto múltiple.
En los supuestos de adopción o acogimiento, este derecho se computará durante el primer año desde la resolución judicial o administrativa de adopción o acogimiento.

f. Por nacimiento de hijas e hijos prematuros o que por cualquier otra causa deban permanecer en el hospital a continuación del parto, la funcionaria o funcionario tendrá derecho a ausentarse del trabajo durante un máximo de dos horas diarias y percibirá las retribuciones íntegras.

g. Por razones de guarda legal, cuando el personal funcionario tenga a su cuidado directo algún menor de doce años, una persona mayor que requiera especial dedicación o una persona con discapacidad que no desempeñe actividad retribuida, tendrá derecho a una reducción de un tercio o un medio de la jornada de trabajo, con la disminución proporcional de sus retribuciones.

Tendrá el mismo derecho el personal funcionario que precise encargarse del cuidado directo de un familiar hasta el segundo grado de consanguinidad o afinidad que, por razones de edad, accidente o enfermedad, no se pueda valer por si mismo y que no desempeñe actividad retribuida.

h. Las funcionarias embarazadas tendrán derecho a ausentarse del trabajo para la realización de exámenes prenatales y técnicas de preparación al parto por el tiempo necesario para su práctica y previa justificación de la necesidad de su realización dentro de la jornada de trabajo.

i. El personal funcionario tendrá derecho a un permiso retribuido para tratamientos de fecundación asistida por el tiempo necesario para su práctica, con aviso previo y justificación de la necesidad de realización dentro de la jornada de trabajo. Si fuese necesario el desplazamiento, el permiso será de dos días.

j. Para acompañar a su cónyuge o pareja en análoga relación de afectividad a tratamientos de fecundación asistida, a 
exámenes prenatales y a técnicas de preparación al parto, el personal funcionario tendrá derecho a un permiso retribuido en idénticos términos y condiciones de ejercicio que los previstos para estos permisos.

k. En los supuestos de accidente o enfermedad muy grave del o de la cónyuge, pareja en análoga relación de afectividad, familiares en primer grado, personas acogidas o familiares que convivan en la misma casa, y para atender a su cuidado, el personal funcionario tendrá derecho a un permiso retribuido con una duración máxima de treinta días naturales. Cada accidente o enfermedad generará un único permiso, que, dentro de la duración máxima de treinta días, se podrá utilizar de manera separada o acumulada.

1. Por ser preciso atender al cuidado de un familiar de primer grado, el personal funcionario tendrá derecho a solicitar una reducción de hasta el $50 \%$ de la jornada laboral, con carácter retribuido, por razones de enfermedad muy grave y por el plazo máximo de un mes, prorrogable en circunstancias excepcionales y atendiendo a la extrema gravedad de la enfermedad padecida, hasta un período máximo de dos meses.

Si hubiese más de una persona titular de este derecho por el mismo hecho causante, el tiempo de disfrute de esta reducción se podrá prorratear entre ellas, respetando, en todo caso, el plazo máximo de un mes o, en su caso, el de dos meses.

$\mathrm{m}$. El personal funcionario tendrá derecho a ausentarse para acompañar a las revisiones médicas a las hijas y a los hijos y a las personas mayores a su cargo por el tiempo necesario, con aviso previo y justificación de la necesidad de realización dentro de la jornada de trabajo.

2. Se podrá conceder permiso por el tiempo indispensable para el cumplimiento de un deber inexcusable de carácter público o personal y por deberes relacionados con la conciliación de la vida familiar y laboral.
3. Se podrá disponer de hasta nueve días al año, como máximo, de permiso para asuntos personales sin justificación, atendiendo siempre a las necesidades del servicio. Asimismo, se tendrá derecho al disfrute de dos días adicionales al cumplir el sexto trienio, que se incrementará en un día adicional por cada trienio cumplido a partir del octavo.

4. En todo caso, se concederán los siguientes permisos:

a. Permiso por parto: tendrá una duración de dieciséis semanas ininterrumpidas. Este permiso se ampliará en dos semanas más en el supuesto de discapacidad de la hija o hijo, y por cada hija o hijo a partir del segundo, en los supuestos de parto múltiple. El permiso se distribuirá a la opción de la funcionaria siempre que seis semanas sean inmediatamente posteriores al parto. En el caso de fallecimiento de la madre, la otra persona progenitora podrá hacer uso de la totalidad o, en su caso, de la parte que reste del permiso.

No obstante lo anterior, y sin perjuicio de las seis semanas inmediatas posteriores al parto de descanso obligatorio para la madre, en el caso de que ambos progenitores trabajen, la madre, al iniciarse el período de descanso por maternidad, podrá optar por que la otra persona progenitora disfrute de una parte determinada e ininterrumpida del período de descanso posterior al parto, bien de forma simultánea o sucesiva con el de la madre. La otra persona progenitora podrá seguir disfrutando del permiso de maternidad inicialmente cedido, aunque en el momento previsto para la reincorporación de la madre al trabajo ésta se encuentre en situación de incapacidad temporal.

En los casos de disfrute simultáneo de períodos de descanso, la suma de estos no podrá exceder de las dieciséis semanas o de las que correspondan en el caso de discapacidad de la hija o hijo o de parto múltiple.

Este permiso se podrá disfrutar a jornada completa o a tiempo parcial, cuando las

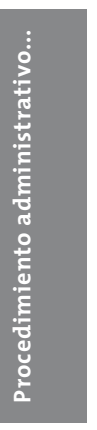


necesidades del servicio lo permitan, y en los términos que reglamentariamente se determinen.

En los casos de parto prematuro y en aquellos en los que, por cualquier otra causa, la neonata o neonato deba permanecer en el hospital a continuación del parto, este permiso se ampliará en tantos días como la neonata o neonato permanezca en el hospital, con un máximo de trece semanas adicionales.

Durante el disfrute de este permiso se podrá participar en los cursos de formación que convoque la Administración.

b. Permiso por adopción o acogimiento, tanto preadoptivo como permanente o simple: tendrá una duración de dieciséis semanas ininterrumpidas. Este permiso se ampliará en dos semanas más en el supuesto de discapacidad de la o del menor adoptado o acogido y por cada hija o hijo, a partir de la o del segundo, en los supuestos de adopción o acogimiento múltiple.

El cómputo del plazo se contará a elección de la persona funcionaria, a partir de la decisión administrativa o judicial del acogimiento o a partir de la resolución judicial por la que se constituya la adopción, sin que un mismo menor pueda dar, en ningún caso, derecho a varios períodos de disfrute de este permiso.

En caso de que ambos progenitores trabajen, el permiso se distribuirá a opción de los interesados, que podrán disfrutarlo de forma simultánea o sucesiva, siempre en períodos ininterrumpidos.

En los casos de disfrute simultáneo de períodos de descanso, la suma de estos no podrá exceder de las dieciséis semanas o de las que correspondan en caso de adopción o acogimiento múltiple y de discapacidad de la o del menor en adopción o en acogida.

Este permiso se podrá disfrutar a jornada completa o a tiempo parcial, cuando las necesidades del servicio lo permitan, y en los términos que reglamentariamente se determinen.
$\mathrm{Si}$ fuese necesario el desplazamiento previo de las personas progenitoras al país de origen de la o del menor en adopción o acogida, en los casos de adopción o acogimiento internacional, se tendrá derecho, además, a un permiso de hasta tres meses de duración, y durante este período se percibirán exclusivamente las retribuciones básicas, pudiendo disfrutar de ellas de forma fraccionada, siempre que no se superen los tres meses.

Con independencia del permiso de hasta tres meses previsto en el párrafo anterior y para el supuesto previsto en el dicho párrafo, el permiso por adopción o acogimiento, tanto preadoptivo como permanente o simple, se podrá iniciar hasta cuatro semanas antes de la resolución judicial por la que se constituya la adopción o la decisión administrativa o judicial del acogimiento.

Durante el disfrute de este permiso se podrá participar en los cursos de formación que convoque la Administración.

Los supuestos de adopción o acogimiento, tanto preadoptivo como permanente o simple, previstos en este artículo serán los que así se establezcan en la normativa aplicable en la Comunidad Autónoma de Galicia, y el acogimiento simple deberá tener una duración no inferior a un año.

c. Permiso por paternidad por el nacimiento, acogimiento o adopción de una hija o hijo: tendrá una duración de veintinueve días naturales, que disfrutará el padre funcionario a partir de la fecha de nacimiento, de la decisión administrativa o judicial de acogimiento o de la resolución judicial por la que se constituya la adopción. En el caso de parto, acogimiento o adopción múltiple, el permiso será de treinta y cinco días naturales.

En los supuestos de adopción o acogimiento, si ambas personas progenitoras fuesen personal al servicio de la Administración pública gallega, el permiso se podrá distribuir a opción de la parte interesada, que podrán disfrutarlo de forma simultánea o 
sucesiva, siempre en períodos ininterrumpidos, respetando en todo caso el plazo de duración.

Este permiso es independiente del disfrute compartido de los permisos previstos en las letras a) y b).

La madre podrá disfrutar de este permiso de paternidad a continuación de los permisos previstos en las letras a) y b) en los siguientes supuestos:

Cuando el padre falleciese antes de la utilización íntegra de dicho permiso.

Si la filiación paterna no estuviese determinada.

Cuando las personas progenitoras no estuviesen casadas ni estuviesen unidas de hecho en análoga relación de afectividad. Cuando en resolución judicial dictada en proceso de nulidad, separación o divorcio, iniciado antes de la utilización del permiso, se le reconociese a la madre la guarda de la hija o del hijo que acaba de nacer.

En el supuesto de matrimonio de mujeres o de uniones de hecho en análoga relación de afectividad, al ser una de ellas la madre biológica, la que no lo sea tendrá derecho al permiso de paternidad en los términos fijados en esta letra.

En los casos previstos en las letras a), b) y c), el tiempo transcurrido durante el disfrute de estos permisos se computará como de servicio efectivo a todos los efectos, garantizándose la plenitud de derechos económicos del personal funcionario durante todo el período de duración del permiso y, en su caso, durante los períodos posteriores al disfrute de este si, de acuerdo con la normativa aplicable, el derecho a percibir algún concepto retributivo se determina en función del período de disfrute del permiso.

Las personas funcionarias que hiciesen uso del permiso por parto o maternidad, paternidad $\mathrm{y}$ adopción o acogimiento tendrán derecho, una vez que finalice el período de permiso, a reintegrarse a su puesto de trabajo en los términos y en las condiciones que no les resulten menos favorables al disfrute del permiso, así como a beneficiarse de cualquier mejora en las condiciones de trabajo a las que pudiesen tener derecho durante su ausencia.

d. Permiso por razón de violencia de género sobre el personal funcionario: las faltas de asistencia del personal funcionario víctima de la violencia de género, totales o parciales, tendrán la consideración de justificadas por el tiempo y en las condiciones en las que así lo determinen los servicios sociales de atención o de salud, según proceda.

Asimismo, el personal funcionario víctima de violencia de género, para hacer efectiva su protección o su derecho a la asistencia social integral, tendrá derecho a la reducción de la jornada con la disminución proporcional de la retribución o a la reordenación del tiempo de trabajo, a través de la adaptación del horario, de la aplicación del horario flexible o de otras formas de ordenación del tiempo de trabajo que le pueda ser aplicable, en los términos que para estos supuestos establezca la Administración de la Comunidad Autónoma de Galicia.

Artículo 77. Las personas funcionarias que ejerzan el derecho de huelga no tendrán derecho a percibir ni percibirán las retribuciones correspondientes al tiempo que permanezcan en esta situación, sin que la deducción de haberes que se efectúe tenga, en ningún caso, carácter de sanción disciplinaria ni afecte al régimen respectivo de sus prestaciones sociales.

\section{Capítulo VI SEGURIDAD SOCIAL}

Artículo 78. El régimen de Seguridad Social y derechos pasivos del personal de la Comunidad Autónoma de Galicia se regulará por la normativa estatal que le resulte de aplicación.

Artículo 79. Se hace extensivo a las personas funcionarias de la Comunidad Autónoma de Galicia el régimen disciplinario establecido por la normativa del Estado. 
A tal fin, un reglamento disciplinario regulará el procedimiento sancionador, en el cual se tendrán básicamente en cuenta los principios de eficacia y garantía.

\section{DISPOSICIÓN ADICIONAL PRIMERA}

Se crean en la comunidad autónoma los siguientes cuerpos de personal funcionario:

A. De Administración general:

1. Cuerpo superior de Administración de la Xunta, del grupo A, que desempeñará funciones de naturaleza administrativa, de dirección, estudio, coordinación, inspección, control y programación.

2. Cuerpo de gestión de Administración de la Xunta, del grupo B que realizará funciones de colaboración en actividades administrativas de nivel superior, así como tareas propias de gestión administrativa que no correspondan al nivel superior y sean propias de la titulación del grupo B.

3. Cuerpo administrativo de la Xunta, del grupo C, que desarrollará actividades administrativas de gestión, tramitación y colaboración preparatorias, complementarias y derivadas de las funciones superiores.

4. Cuerpo auxiliar de la Xunta, del grupo $\mathrm{D}$, que realizará tareas de taquigrafía, mecanografía, registro y despacho de correspondencia, cálculo, manejo de máquinas y otras funciones semejantes. Estas funciones las seguirán desempeñando aquellas personas funcionarias que se acojan a lo dispuesto en la disposición adicional vigésima segunda de la Ley 30/1984, de 2 de agosto.

5. Cuerpo subalterno de la Xunta, del grupo $\mathrm{E}$, que desempeñará funciones ordinarias de vigilancia, custodia, reparto de correspondencia y documentación, transporte manual, centralita, reprografía y otras semejantes.

B. De Administración especial.

1. Cuerpo facultativo superior de la Xunta, del grupo A, que realizará actividades profesionales para cuyo desempeño se precise una titulación específica de índole superior.

2. Cuerpo facultativo de grado medio de la Xunta, del grupo B, que ejercerá funciones profesionales para cuyo desempeño se requiera una titulación específica de grado medio.

3. Cuerpo de ayudantes facultativas y facultativos de la Xunta, del grupo C, que desempeñará funciones de ejecución, colaboración y apoyo a los cuerpos facultativos de grado superior y medio, en el ejercicio de su específica titulación académica o profesión.

4. Cuerpo de auxiliares técnicas y técnicos de la Xunta, del grupo D, que realizará funciones específicas correspondientes a su nivel de titulación que no tengan carácter general o común.

\section{DISPOSICIÓN ADICIONAL SEGUNDA}

Las personas funcionarias transferidas del Estado a la comunidad se integrarán, por acuerdo de la Xunta, en los cuerpos y escalas relacionados en la disposición adicional primera conforme a las siguientes normas:

A. En los cuerpos de Administración general:

1. En el cuerpo superior de Administración de la Xunta, las personas funcionarias pertenecientes a aquellos cuerpos y escalas para cuyo ingreso les fue exigida la titulación académica requerida en esta ley para el ingreso en el grupo A y que tienen o tuvieron atribuidas funciones semejantes o equiparables a las del citado cuerpo.

2. En el cuerpo de gestión de Administración de la Xunta, las personas funcionarias pertenecientes a aquellos cuerpos o escalas para cuyo ingreso les fue exigida la titulación académica requerida en esta ley para el ingreso en el grupo B y que tengan o tuvieron atribuidas funciones semejantes o equiparables a las del citado cuerpo.

3. En el cuerpo administrativo de la Xunta, las personas funcionarias pertenecientes a aquellos cuerpos o escalas para cuyo ingreso les fue exigida la titulación académica 
requerida en esta ley para el ingreso en el grupo $\mathrm{C}$, y que tienen o tuvieron atribuidas funciones semejantes o equiparables a las del citado cuerpo.

4. En el cuerpo auxiliar de la Xunta, las personas funcionarias pertenecientes a aquellos cuerpos y escalas para cuyo ingreso les fue exigida la titulación requerida en esta ley para ingreso en el grupo D y que tienen o tuvieron funciones semejantes o equiparables a las del citado cuerpo.

5. En el cuerpo subalterno de la Xunta, las personas funcionarias pertenecientes a aquellos cuerpos y escalas para cuyo ingreso les fue exigida la titulación académica requerida en esta ley para el ingreso en el grupo y que tienen o tuvieron atribuidas funciones semejantes o equiparables a las del citado cuerpo.

B. En los cuerpos de Administración especial:

1. En el cuerpo facultativo superior de la Xunta, las personas funcionarias a las que les fue exigida, para ingresar en el cuerpo o escala de procedencia, la titulación académica requerida en esta ley para el ingreso en el grupo A y que desempeñen funciones objeto de su profesión específica.

2. En el cuerpo facultativo de grado medio de la Xunta, las personas funcionarias a las que les fue exigida, para ingresar en el cuerpo o escala de procedencia, la titulación académica requerida en esta ley para el ingreso en el grupo B y que desempeñen funciones objeto de su profesión específica.

3. En el cuerpo de ayudantes facultativas y facultativos de la Xunta, las personas funcionarias a las que les fue exigida, para ingresar en el cuerpo o escala de procedencia, la titulación académica requerida en esta ley para el ingreso en el grupo C y que desempeñen funciones objeto de su profesión específica.

4. En el cuerpo de auxiliares técnicas y técnicos de la Xunta, las personas funcionarias a las que les fue exigida, para ingresar en el cuerpo o escala de procedencia, la titulación académica requerida en esta ley para el ingreso en el grupo D y que desempeñen funciones objeto de su profesión u oficio específico.

\section{DISPOSICIÓN ADICIONAL TERCERA}

1. Se declaran a extinguir todas las plazas transferidas no clasificadas en los diferentes cuerpos y escalas de personal funcionario. El Consello de la Xunta de Galicia procederá a integrarlas en los cuerpos o escalas que exijan igual titulación académica y tengan las mismas funciones, previo informe del Consejo Gallego de la Función Pública.

2. El personal transferido como varios sin clasificar será clasificado mediante decreto, que determinará, de acuerdo con la naturaleza de sus funciones y titulación académica exigida, su integración en cuerpos o escalas de personal funcionario de la comunidad autónoma o en plantillas de personal laboral, con reconocimiento de su antigüedad.

3. Se crea en cada cuerpo, escala o especialidad de personal funcionario al servicio de la Administración de la Comunidad Autónoma de Galicia la correspondiente escala o subescala a extinguir, en la que se integrarán las personas funcionarias transferidas a la comunidad autónoma o procedentes de otras administraciones públicas incorporadas a ella en virtud de oferta de empleo público o de concursos permanentes de traslado que, al entrar en vigor esta ley, tengan asignado por su Administración de origen un índice de proporcionalidad correspondiente a un determinado grupo de los establecidos en el artículo 21 y carezcan de la titulación académica exigida para ello.

\section{DISPOSICIÓN ADICIONAL CUARTA}

1. En lo no previsto en esta ley, el personal funcionario transferido de la Administración de la Seguridad Social

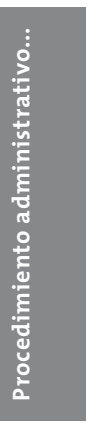


determinado en la disposición adicional decimosexta de la Ley 30/1984, de 2 de agosto, se seguirá rigiendo por sus normas estatutarias, hasta que se establezca el sistema de homologación con el resto de las personas funcionarias.

2. El personal de la Seguridad Social regulado en el Estatuto jurídico del personal médico de la Seguridad Social, en el Estatuto del personal auxiliar sanitario titular y auxiliar de clínica de la Seguridad Social, en el Estatuto del personal no sanitario al servicio de las instituciones sanitarias de la Seguridad Social, así como el de los cuerpos y escalas sanitarias y de asesores médicos a los que se refiere a disposición adicional decimosexta de la Ley 30/1984, de 2 de agosto, se regirán por sus estatutos respectivos mientras no se dicte la correspondiente legislación específica para adaptarlos a esta ley, pudiendo ocupar los puestos de trabajo de ámbito sanitario de conformidad con lo que se determina en las correspondientes relaciones de puestos de trabajo.

\section{DISPOSICIÓN ADICIONAL QUUINTA}

En desarrollo de lo dispuesto en el artículo 17.2 de la Ley 30/1984, de 2 de agosto, los funcionarios de las corporaciones locales de la Comunidad Autónoma de Galicia que, a la entrada en vigor de la presente ley, estuviesen desempeñando puestos de trabajo en la Administración de esta comunidad deberán optar, en el plazo de tres meses desde su vigencia, por integrarse plenamente en la organización de la función pública autonómica y se agruparán en los cuerpos que proceda y, en todo caso, en los grupos establecidos en el artículo 21 de la presente ley. Si tienen la condición de funcionarios con habilitación de carácter nacional, les será de aplicación la legislación vigente.

\section{DISPOSICIÓN ADICIONAL SEXTA}

Los derechos, deberes, responsabilidades y régimen disciplinario del personal funcionario se regularán por su estatuto. Mientras tanto, se aplicará la legislación vigente.

\section{DISPOSICIÓN ADICIONAL SÉPTIMA ${ }^{161}$}

1. En las ofertas de empleo público se reservará una cuota no inferior al $7 \%$ de las vacantes para ser cubiertas entre personas con discapacidad con un grado de minusvalía igual o superior al 33\%, de modo que progresivamente se alcance el $2 \%$ de los efectivos totales de la Administración de la Xunta de Galicia y de sus organismos autónomos, siempre que superen las pruebas selectivas y que, en su momento, acrediten el indicado grado de minusvalía y la compatibilidad con el desempeño de las tareas y funciones correspondientes, según se determine reglamentariamente.

2. La reserva se hará sobre el cómputo total de las vacantes incluidas en la oferta de empleo público, y se podrán concentrar las plazas reservadas para personas con discapacidad en aquellas convocatorias que se refieran a cuerpos, escalas o categorías cuyo desempeño se adapte mejor a las peculiaridades de las personas discapacitadas.

3. Cuando de la aplicación del porcentaje resulten fracciones decimales se redondeará por exceso para su cómputo.

4. Si las plazas reservadas y que fueron cubiertas por las personas con discapacidad no alcanzasen la tasa del 3\% de las plazas convocadas, las plazas no cubiertas se acumularán a la cuota del $7 \%$ de la oferta siguiente, con un límite máximo del $12 \%$.

5. Al alcanzarse el objetivo del $2 \%$ al que se refiere el número 1 de esta disposición, el porcentaje mínimo de reserva será del $5 \%$, y no serán aplicables los números 3 y 4 de esta disposición mientras el porcentaje se mantenga o se incremente.

6. Se podrán realizar convocatorias independientes, no supeditadas a las ordinarias, en las cuales las plazas estarán

161 Véase Decreto 143/2008, de 3 de julio, por el que se crea el Consejo Asesor para la Integración de la Discapacidad en la Función Pública Gallega. 
reservadas a personas con discapacidad con un grado de minusvalía igual o superior al 33\%. Las pruebas tendrán el mismo contenido y grado de exigencia que las que se realicen en las convocatorias ordinarias. En cualquier caso, las personas que participen en la convocatoria deberán acreditar la discapacidad y el grado de minusvalía. Las plazas incluidas en estas convocatorias se computarán, en todo caso, en la cuota reservada en la oferta de empleo público para su cobertura entre personas con discapacidad.

7. En las pruebas selectivas, incluyendo los cursos de formación o los períodos de prácticas, se establecerán para las personas con discapacidad con grado de minusvalía igual o superior al $33 \%$ que lo soliciten las adaptaciones y los ajustes razonables necesarios de tiempo y medios para su realización, para asegurar que las personas con discapacidad participan en condiciones de igualdad.

8. Tras superar el proceso selectivo, las personas que ingresen en cuerpos o escalas de personal funcionario o categorías de personal laboral de la Administración autonómica y de sus organismos autónomos y que fuesen admitidas en la convocatoria ordinaria con plazas reservadas para personas con discapacidad le podrán solicitar al órgano convocante la alteración del orden de prelación para la elección de las plazas dentro del ámbito territorial que se determine en la convocatoria, por motivos de dependencia personal, dificultades de desplazamiento $\mathrm{u}$ otras análogas, que deberán ser debidamente acreditados. El órgano convocante decidirá dicha alteración cuando esté debidamente justificada, y se deberá limitar a realizar la mínima modificación en el orden de prelación necesario para posibilitar el acceso al puesto de la persona discapacitada.

\section{DISPOSICIÓN ADICIONAL OCTAVA}

De acuerdo con lo dispuesto en el artículo 34 de la Ley 31/1991, de 30 de diciembre, de presupuestos generales del Estado para 1992, se le podrá reconocer, de conformidad con lo dispuesto en la Ley 53/1984, de 26 de diciembre, compatibilidad para el ejercicio de actividades privadas al personal que desempeñe puestos de trabajo que comporten la percepción de complemento específico o concepto equiparable siempre que su cuantía no supere el $30 \%$ de su retribución básica, excluidos los conceptos que tengan su origen en la antigüedad. En el supuesto de que la cuantía de tal complemento supere el 30\% referido, podrá concederse la compatibilidad siempre que la persona interesada renuncie a la percepción del complemento específico.

\section{DISPOSICIÓN ADICIONAL NOVENA}

Las personas funcionarias que, como consecuencia de los procesos de reasignación regulados en el apartado 6 del artículo 29 , sean reasignadas por la consellería competente en materia de función pública a puestos de trabajo de menor nivel de complemento de destino del que tuviesen en el último puesto que obtuviesen por concurso tendrán derecho a la percepción de un complemento personal y transitorio equivalente a la diferencia de retribuciones entre ambos puestos, excepto, en su caso, a la productividad.

Esta reasignación a puestos de nivel inferior al que estuviesen desempeñando tendrá carácter de voluntaria para la persona interesada.

El complemento personal y transitorio se percibirá hasta que, de acuerdo con lo previsto en esta ley, obtengan puesto de trabajo por los procedimientos legalmente establecidos, estando, por otra parte, obligadas a participar en los correspondientes concursos que se convoquen.

\section{DISPOSICIÓN ADICIONAL DÉCIMA}

Los planes de empleo serán objeto de negociación con las organizaciones sindicales más representativas, en los términos que establece la Ley 9/1987, de 12 de 
junio, de órganos de representación, determinación de las condiciones de trabajo y participación del personal al servicio de las administraciones públicas, sin perjuicio de lo previsto en su artículo 34.

\section{DISPOSICIÓN ADICIONAL UNDÉCIMA}

Las personas funcionarias de la Xunta de Galicia podrán ocupar un puesto vacante de carácter eventual o de similares o equivalentes características al que desempeñen en la Administración en cualquier ente o empresa pública de la Xunta de Galicia.

En tal caso, la persona funcionaria quedará en la situación de excedencia voluntaria por incompatibilidad, percibiendo los haberes correspondientes al puesto de trabajo que pase a ocupar, y en el supuesto de que reingrese a la Administración autonómica tendrá derecho al reconocimiento de ese tiempo para efectos de antigüedad $\mathrm{y}$ derechos pasivos.

\section{DISPOSICIÓN ADICIONAL DUODÉCIMA}

De conformidad con la letra d) del punto 2 del artículo 22 de esta ley, el Consello de la Xunta, mediante decreto, podrá establecer las titulaciones equivalentes a las requeridas para el acceso a las distintas escalas creadas por el artículo 16 de la Ley $15 / 1991$, de 28 de diciembre, de presupuestos generales de la comunidad autónoma gallega para 1992, y por la Ley 12/1992, de 9 de noviembre, de creación de determinadas escalas de personal funcionario al servicio de la Xunta de Galicia.

\section{DISPOSICIÓN ADICIONAL DECIMOTERCERA}

El personal laboral fijo que preste sus servicios en puestos de trabajo reservados a personal funcionario podrá participar en las pruebas de acceso a los cuerpos y escalas a los que figuren adscritos los puestos correspondientes, siempre que posean la titulación necesaria y reúnan los restantes requisitos exigidos.
Dichas pruebas de acceso se convocarán por el turno de afectados por el artículo 15 de la Ley 30/1984, de 2 de agosto, de medidas para la reforma de la función pública (BOE del 3 de agosto), y por el artículo 27 de esta ley.

Sólo podrá participar en estas pruebas el personal laboral fijo que esté con carácter definitivo en puestos de personal funcionario, así como el personal laboral que, encontrándose en la situación anterior, figure en situación de excedencia con derecho a reserva de puesto de trabajo conforme la normativa laboral aplicable. No podrá participar el personal afectado por las disposiciones transitorias octava y novena de esta ley.

El personal laboral que supere las pruebas de acceso quedará destinado en los mismos puestos de trabajo que venía ocupando y podrá participar en concursos de traslados sin necesidad de permanecer dos años en el puesto en el que está destinado.

\section{DISPOSICIÓN ADICIONAL DECIMOCUARTA}

1. El personal funcionario de carrera al servicio de la Administración de la Comunidad Autónoma de Galicia procedente de cuerpos y escalas de asistentes sociales, integrado en el cuerpo facultativo de grado medio de la Xunta de Galicia, podrá voluntariamente, optar por integrarse en el cuerpo de gestión de Administración general de la Xunta de Galicia, o bien por pasar a personal laboral fijo al servicio de la Administración de la Xunta de Galicia, en la categoría de asistente social (17), del grupo II, del IV convenio colectivo único.

2. El personal funcionario de carrera del cuerpo de conductoras, conductores, conductoras-mecánicas y conductoresmecánicos, grupos E o D, al servicio de la Administración de la Xunta de Galicia que se encuentre desempeñando puestos de trabajo que aparecen reservados al personal laboral en las correspondientes relaciones de puestos de trabajo podrán 
optar por integrarse como personal laboral fijo de la Administración de la Xunta de Galicia en las categorías y en los grupos que correspondan.

3. Mediante orden de la consellería competente en materia de función pública, se regularán los términos y las condiciones a efectos de las opciones de integración previstas en esta disposición.

\section{DISPOSICIÓN ADICIONAL DECIMOQUINTA}

Los convenios colectivos que regulen las condiciones de trabajo de las empleadas y de los empleados públicos tenderán al reconocimiento de los derechos reconocidos en el título II de la Ley 7/2004, de 16 de julio, para la igualdad de mujeres y hombres.

\section{DISPOSICIÓN ADICIONAL DECIMOSEXTA}

El personal que, con efectos anteriores al 7 de octubre de 1996, tuviese reconocida la condición de indefinido en su relación laboral por sentencia judicial firme o por resolución de la Subsecretaría de Trabajo y Asuntos Sociales de 24 de julio de 1997 en virtud de las previsiones contenidas en el Plan de empleo del Instituto Nacional de Empleo tendrá los mismos derechos que el personal laboral fijo.

Este personal será objeto de funcionarización mediante un procedimiento selectivo que respete los principios de igualdad, mérito y capacidad. El personal que no participe o que, participando, no supere el proceso de funcionarización, conservará todos sus derechos como personal laboral de la Xunta de Galicia.

El proceso de funcionarización se deberá iniciar en el plazo máximo de doce meses a partir de la entrada en vigor de esta ley.

\section{DISPOSICIÓN ADICIONAL DECIMOSÉPTIMA}

El personal funcionario de carrera que, a partir de la entrada en vigor de la Ley orgánica 1/1981, de 6 de abril, por la que se aprobó el Estatuto de autonomía para Galicia, desempeñe o hubiese desempeñado durante más de dos años continuados o tres con interrupción puestos de trabajo como directora o director general o persona jerárquicamente superior, directora o director gerente de órganos o entidades públicas o puestos en la Administración pública incluidos en el ámbito de aplicación de la Ley de incompatibilidades de altos cargos, percibirá desde su reincorporación al servicio activo y en cuanto se mantenga esta situación, el complemento de destino correspondiente al puesto de trabajo que desempeñe o, en su caso, al de su grado personal, incrementado en la cantidad necesaria para igualarlo al valor del complemento de destino, o concepto equivalente que la Ley de presupuestos generales del Estado fije para las directoras y directores generales, y la suma de ambos conceptos no podrá ser inferior al importe del complemento de destino que perciban las personas funcionarias que acrediten el nivel máximo establecido legalmente.

\section{DISPOSICIÓN ADICIONAL DECIMOCTAVA}

Las referencias que en esta ley se efectúan a minusválidos y a las personas con minusvalía se entenderán realizadas a personas con discapacidad.

\section{DISPOSICIÓN ADICIONAL DECIMONOVENA}

El personal funcionario o estatutario que acceda al desempeño de puestos directivos será declarado en su puesto de origen en la situación administrativa de servicios especiales. El desempeño de los servicios prestados en los citados puestos será computado para los procesos de selección y provisión como prestados en la plaza de origen, así como a efectos de trienios y determinación del grado de desarrollo profesional. 


\section{DISPOSICIÓN TRANSITORIA PRIMERA}

En el plazo máximo de doce meses desde la entrada en vigor de esta ley, la Xunta de Galicia convocará las pruebas selectivas para la realización de un proceso de funcionarización del personal laboral fijo que ocupe plazas que, por la naturaleza de sus funciones, deban ser ocupadas por personal funcionario, previa valoración, clasificación y determinación de los puestos de trabajo afectados, que será aprobada por el Consello de la Xunta de Galicia.

Las pruebas selectivas que se realicen en el marco del proceso de funcionarización respetarán, en todo caso, los principios de igualdad, mérito y capacidad y valorarán, entre otros méritos, el tiempo de servicios prestados como personal laboral en los puestos objeto de funcionarización.

\section{DISPOSICIÓN TRANSITORIA SEGUNDA}

El personal funcionario que ocupe puestos que antes de la entrada en vigor de esta ley estuviesen clasificados como de libre designación y que, posteriormente, dejen de tener esta forma de cobertura seguirá ocupando los mismos puestos de trabajo hasta la provisión de estos, aunque se podrá disponer discrecionalmente su cese antes de dicha provisión.

En caso de cese al que se refiere el párrafo anterior, se podrá cubrir el puesto de trabajo con otra empleada o empleado público de forma provisional, mediante adscripción o comisión de servicios, que finalizará cuando se provea definitivamente la plaza.

\section{DISPOSICIÓN TRANSITORIA TERCERA}

Lo dispuesto en el artículo 10.4 será aplicable para las declaraciones judiciales de indefinición que se produzcan tras la entrada en vigor de esta ley de reforma. No obstante, en el período máximo de un año a partir de la entrada en vigor de la ley se deberán realizar, en su caso, los procesos de creación de plazas derivadas de declaraciones judiciales anteriores a dicha fecha. Las plazas deberán ser cubiertas, por el oportuno sistema de selección o provisión, en el plazo más breve posible.

\section{DISPOSICIÓN TRANSITORIA CUARTA}

En el plazo de seis meses desde la entrada en vigor de la presente ley se creará una escala específica adscrita a la Consellería de Pesca para la realización de las funciones encomendadas a ésta en el ámbito de las corporaciones de derecho público que tiene tuteladas.

El personal que prestase servicios en estas corporaciones de acuerdo con los requisitos establecidos en la legislación laboral vigente podrá participar en las pruebas selectivas que se convoquen al efecto para cubrir las plazas correspondientes a dicha escala. En las citadas pruebas se tendrán en cuenta los servicios efectivos prestados por dicho personal dentro del respeto a los criterios constitucionales de mérito y capacidad.

\section{DISPOSICIÓN TRANSITORIA QUUNTA}

Las personas funcionarias que, como consecuencia de la aplicación del régimen retributivo establecido en la Ley 30/1984, de 2 de agosto, experimenten una disminución de sus retribuciones anuales tendrán derecho a un complemento personal y transitorio por la diferencia, absorbible en futuras mejoras, según los criterios que señale la Ley de presupuestos de la comunidad.

\section{DISPOSICIÓN TRANSITORIA SEXTA}

1. El personal funcionario adquirirá el grado personal previsto por esta ley a partir de 1 de enero de 1985.

2. Aquellas personas funcionarias que desempeñen durante un plazo de dos años un puesto de nivel superior al del que se les asigne en su cuerpo o escala adquirirán como grado personal el superior de los que le correspondan a su cuerpo o escala. 
3. Cuando un puesto de trabajo resultase clasificado con un nivel superior a aquel con el que fue transferido a la persona funcionaria que lo venía desempeñando desde el 1 de enero de 1985, éste adquirirá el grado con el que se clasifique el citado puesto de trabajo.

4. La persona funcionaria que se considere perjudicada en la asignación de su grado personal podrá solicitar la revisión de tal asignación conforme a criterios objetivos basados en el tiempo de servicios efectivos prestados en su cuerpo o escala y en el nivel de los puestos desempeñados. A tal efecto, el órgano competente resolverá en un plazo máximo de dos meses, previo informe de la Comisión de personal.

\section{DISPOSICIÓN TRANSITORIA SÉPTIMA}

1. El personal contratado laboral fijo que ocupe puestos de trabajo que, por la naturaleza de sus funciones, deben ser desempeñados por personas funcionarias, podrá acceder a la condición de personal funcionario, si voluntariamente optase por ello, a través de la superación de un concurso-oposición libre, en el que se valorarán los servicios efectivos prestados, teniendo en cuenta los criterios de mérito y capacidad.

2. La valoración de los servicios prestados se aplicará en tres convocatorias consecutivas y durante su tiempo de tramitación. La puntuación alcanzada se acumulará a la obtenida en la fase de oposición, y el total constituirá la puntuación final del concurso-oposición. Será condición necesaria que en cada una de las pruebas y en el curso selectivo de formación, en su caso, se obtenga la puntuación mínima, fijada en las bases de la correspondiente convocatoria, que acreditará la idoneidad de la persona candidata.

3. El personal al que se refieren los apartados anteriores que no supere el concurso-oposición en las tres convocatorias mantendrá con la Administración su vínculo laboral que le otorga el derecho al desempeño de un puesto de trabajo de análogas condiciones y en la misma localidad donde venga prestando sus servicios.

\section{DISPOSICIÓN TRANSITORIA OCTAVA}

1. El personal transferido por el Estado, tanto en régimen de contratación administrativa como interino, y el personal interino seleccionado a través de las oportunas pruebas convocadas por la Xunta, así como los contratados administrativos en situación de expectativa de acceso a la función pública conforme al Decreto 57/1983, de 6 de abril, que estuviese en activo a la entrada en vigor de la Ley 4/1988, y el que estuviese al servicio de la Comunidad Autónoma de Galicia el 1 de mayo de 1990, podrá acceder a la condición de personal funcionario mediante la participación y superación de un concurso-oposición libre, y en su convocatoria se deberán respetar los criterios de mérito y capacidad y en él se valorarán los servicios efectivos prestados.

2. El personal que no supere dicha prueba selectiva tendrá derecho a la valoración de los servicios prestados en otras dos convocatorias consecutivas y a continuar prestando servicios en la Administración autonómica mientras no se celebren, manteniendo su situación jurídica anterior. Tal situación no condicionará la consideración de vacante del puesto de trabajo que viniese desempeñando.

3. El personal funcionario de carrera de la Administración autonómica que reúna los requisitos necesarios podrá participar igualmente en las mismas pruebas valorándosele los servicios prestados y otros méritos.

\section{DISPOSICIÓN TRANSITORIA NOVENA}

1. La puntuación obtenida en la valoración de los servicios prestados por todo el personal al que se refieren las disposiciones transitorias novena y décima en ningún caso podrá exceder del $45 \%$ de la

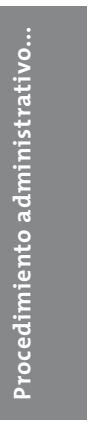


máxima alcanzable en las pruebas selectivas correspondientes, a razón del 0,75\% por mes de servicios, y será aplicable de conformidad con lo establecido en la disposición transitoria séptima, párrafo 2 .

2. A. El personal interino y contratado administrativo que no supere el concurso-oposición en las tres convocatorias permanecerá prestando servicio en la Administración autonómica con la condición de laboral fijo a extinguir y quedará en la misma localidad siempre que en esta exista vacante.

B. A dicho personal y a los laborales que accedan a la condición de personal funcionario les serán reconocidos, a efectos de trienios y antigüedad, los servicios prestados con anterioridad en cualquier Administración pública.

C. El propio personal, al superar las pruebas selectivas, accederá a la condición de personal funcionario en puestos base dentro del grupo en el que se integre. A estos efectos, y sin perjuicio de lo establecido en el artículo 29.3 de esta ley, con posterioridad a la celebración de la primera prueba de acceso, se convocará un concurso interno de traslados en el que se ofertarán todas las vacantes.

3. Para evitar una movilidad contraria a los intereses del servicio en tanto no se resuelva el concurso al que alude el apartado anterior, el personal que acceda a la condición de personal funcionario, así como el que se mantenga en la situación de interino o al que corresponda a tenor de lo establecido en la disposición transitoria octava, párrafo 2, continuará prestando servicio en la misma localidad y en el mismo puesto en el que lo venía haciendo.

\section{DISPOSICIÓN TRANSITORIA DÉCIMA}

El régimen previsto en la disposición transitoria séptima será de aplicación al personal al que se refiere la transitoria cuarta de esta ley.

La no superación del concurso-oposición en las tres convocatorias preceptuadas en dicha ley determinará la vinculación laboral fija de dicho personal con la Administración pesquera gallega en los términos del número 3 de la propia disposición séptima.

\section{DISPOSICIÓN TRANSITORIA UNDÉCIMA}

1. La primera oferta de empleo público, en la que se incluirán las pruebas de acceso a la condición de personal funcionario previstas en las disposiciones transitorias anteriores séptima y octava, se convocará en el plazo máximo de seis meses a partir de la publicación de la relación de puestos de trabajo a la que se alude en la disposición transitoria primera.

2. Con anterioridad a la realización de dicha oferta de empleo público se convocará un concurso para la provisión de todos los puestos de trabajo que, de acuerdo con la relación de estos, no estén ocupados por personas funcionarias, valorándose especialmente los servicios prestados en la Administración autonómica. Sólo podrán participar en el concurso las personas funcionarias que en la fecha de la convocatoria estén desempeñando un puesto de trabajo en la Administración autonómica.

\section{DISPOSICIÓN TRANSITORIA DUODÉCIMA}

A efectos de lo previsto en el artículo 29.2, segundo párrafo, el requisito referido a la exigencia de los diplomas necesarios para acceder a los puestos mencionados en el citado párrafo se aplicará a partir del primero de julio de 1996.

\section{DISPOSICIÓN TRANSITORIA DECIMOTERCERA}

Sin perjuicio de lo dispuesto en el artículo 44.1, durante los cuatro años siguientes a la publicación de la presente ley sólo podrán participar en los concursos de provisión de vacantes los funcionarios de la Comunidad Autónoma de Galicia así como los que estén a su servicio. 


\section{DISPOSICIÓN TRANSITORIA DECIMOCUARTA}

Dentro del marco de las medidas de reducción de la temporalidad y con el objeto de aumentar la estabilidad en el empleo público en la Administración general de la Xunta de Galicia, la comunidad autónoma gallega desarrollará, por una sola vez por plaza, un proceso selectivo de carácter extraordinario para la substitución de empleo interino o temporal por empleo fijo.

Será aplicable a estos procesos lo dispuesto en el artículo 63. 2 de esta ley.

El proceso afectará a aquellas plazas que estén cubiertas, interina o temporalmente, con anterioridad al 1 de enero de 2005 y que continúen, temporal o interinamente, cubiertas en el momento de la convocatoria. Las plazas que en el momento de la entrada en vigor de esta disposición estén en la situación prevista en el párrafo anterior se reservarán para su oferta en los procesos extraordinarios que se realicen.

Los procesos selectivos respetarán, en todo caso, los principios de igualdad, mérito, capacidad y publicidad y se efectuarán por el sistema de concurso-oposición abierto.

El contenido de las pruebas guardará relación con los procedimientos, las tareas y las funciones habituales de los puestos objeto de cada convocatoria. En la fase de concurso se podrán valorar, entre otros méritos, el tiempo de servicios prestados en las administraciones públicas y la experiencia en los puestos de trabajo objeto de la convocatoria.

La valoración de méritos de las personas que superasen la fase de oposición sólo podrá otorgar una puntuación proporcionada, que no determinará, por sí misma, el resultado del proceso selectivo.

\section{DISPOSICIÓN FINAL}

Se autoriza a la Xunta de Galicia para dictar las normas de carácter reglamentario y demás disposiciones que sean necesarias en desarrollo de esta ley.

\section{LEY 4/1987, DE 27 DE MAYO, DE CREACIÓN DE LA ESCUELA GALLEGA DE ADMINISTRACIÓN PÚBLICA (DOGA N. $\left.^{\circ} 103,2.6 .1987\right)^{162}$}

\section{$(\ldots)^{163}$}

Articulo I. 1. La Escuela Gallega de Administración Pública se crea como Organismo autónomo de carácter administrativo, adscrito orgánicameate a la Consellería de la Presidencia.

2. La Escuela Gallega de Administración Pública es una Entidad de Derecho público, con personalidad jurídica y patrimonio propio, que actúa con plena autonomía funcional para el cumplimiento de sus fines, y se regirá por la normativa autonómica que le sea de aplicación y por la reguladora de las Entidades autónomas.

Artículo 2. La Escuela Gallega de Administración Pública tendrá su sede en Santiago de Compostela, y podrá crear delegaciones y centros de estudios especializados, así como desarrollar actividades en otras localidades de Galicia.

Articulo 3. 1. Son fines de la Escuela Gallega de Administración Pública:

a. Colaborar en la realización de las pruebas selectivas para el acceso a la condición de funcionario al servicio de la Administración de esta Comunidad Autónoma convocadas de conformidad con lo dispuesto en la Ley de la Función Pública de Galicia, y de otras Administraciones Públicas que previo Convenio se lo encomienden, con excepción del personal docente y sanitario.

b. Organizar e impartir cursos selectivos de formación y cursos complementarios de formación, de carácter no selectivo,

\section{Véase también:}

- Decreto 306/1990, de 24 de mayo, Reglamento de Régimen Interior de la Escuela Gallega de Administración Pública.

- Decreto 281/1990, Escuela Gallega de Administración Pública, procedimiento de designación de representantes de la Administración Local en el Consejo Rector.

- Decreto 65/2008, de 27 de marzo, por el que se establece la estructura orgánica de la Escuela Gallega de Administración Pública.

163 Exposición de motivos omitida. 
subsiguientes a las pruebas selectivas, con excepción del personal docente y sanitario.

c. Organizar e impartir cursos, seminarios y otras actividades de formación y perfeccionamiento del personal al que se alude en el apartado a) ${ }^{164}$.

d. Realizar las pruebas e impartir los cursos que se establezcan para la promoción interna de los funcionarios.

e. Realizar las pruebas e impartir los cursos selectivos descentralizados para el acceso a la condición de funcionarios locales con "habilitación de carácter nacional", en los términos previstos en el artículo 98.1, de la Ley 7/1985, de 2 de abril, reguladora de las Bases de Régimen Local.

f. Realizar las pruebas selectivas y los cursos selectivos o complementarios de selección de los funcionarios de los Entes locales de Galicia sin habilitación nacional, de acuerdo con los Convenios que se suscriban con las distintas Entidades locales.

g. La investigación, la documentación, el estudio y la realización de trabajos de divulgación en el campo de la Administración Pública, promoviendo su máxima difusión.

h. El establecimiento de Convenios y la celebración de intercambios con organismos semejantes de las Administraciones Públicas, a nivel estatal e internacional.

i. La difusión y normalización del idioma gallego en la Administración Pública, la capacitación lingúistica del personal y la participación en la fijación del lenguaje técnico, administrativo y jurídico gallego.

j. Cualesquiera otros que se le asignen por Ley.

2. La Escuela podrá concenar con Centros universitarios de Galicia y con otros Centros o Entidades de titularidad pública

164 Véase:

- Orden de 19 de mayo de 2008 por la que se regulan las bases para las convocatorias de las acciones formativas en materia de seguridad y salud laboral para el personal funcionario y laboral de nuevo ingreso en la Xunta de Galicia.

- Resolución de 19 de noviembre de 2008 por la que se establecen el procedimiento y los requisitos de homologación de acciones formativas por parte de la Escuela Gallega de Administración Pública. o privada la realización de las actividades a las que se refiere el apartado anterior ${ }^{165}$.

Artículo 4. Las instituciones y órganos de la Comunidad Autónoma de Galicia podrán requerir de la Escuela Gallega de Administración Publica asesoramiento o dictamen para el mejor cumplimiento de sus funciones en relación con los fines enumerados en el articulo antenor.

Artículo 5. Los órganos de gobierno y administración de la Escuela Gallega de Administración Pública son:

1. El Consejo Rector.

2. El Director.

Artículo 6. El Consejo Rector tiene atribuidas las siguientes facultades:

1. Aprobar el anteproyecto del presupuesto anual de la Escuela y sus cuentas.

2. Aprobar el plan anual de actividades, el plan de estudios y la Memoria de la Escuela.

3. Dar la conformidad a los proyectos de convenios con Centros semejantes de otras Administraciones Públicas e instituciones.

4. Proponer la organización administrativa de la Escuela y su correspondiente plantilla.

5. Proponer los programas comunes para el ingreso en la Administración Pública gallega e informar sobre los programas específicos de selección de personal al servicio de la misma, de conformidad con la normativa aplicable en cada caso.

6. Establecer las bases y condiciones generales de participación y acceso a los cursos o actividades que convoque la Escuela Gallega de Administración Pública.

7. Elaborar y aprobar el Reglamento interno de la Escuela Gallega de Administración Pública.

8. Conocer los asuntos que por su relevancia le sean sometidos por el Presidente del Consejo o el Director de la Escuela Gallega de Administración Pública.

165 Art. 3 modificado por Ley 10/1989, de 10 de julio, de modificación de la Ley 4/1987, de 27 de mayo, de creación de la Escuela Gallega de Administración Pública. 
Articulo 7. El Consejo Rector de la Escuela Gallega de Administración Pública estará constituido de la siguiente forma:

1. Presidente: El Consejero de la Presidencia y Administración Pública.

2. Vicepresidente: El Director general de la Funcion Publica.

3. Vocales:

a. El Director de la Escuela Gallega de Administración Pública.

b. Cinco representantes de la Xunta de Galicia, designádos, por razón de su cargo, por el Consejo de la misma de entre aquellos que ostenten la categoría de Director general.

c. Cinco expertos de reconocido prestigio en el campo de la Administración Pública, nombrados por el Consejo de la Xunta de Galicia.

d. Tres representantes de las Universidades gallegas, designados por la Junta de Gobierno.

e. Cuatro representantes de la Administración Local de Galicta, tres elegidos por los Ayuntamientos y uno por las Diputaciones.

Su renovación tendrá lugar cada vez que se celebren elecciones locales generales.

Cinco representantes de los funcionarios, designados por las organizaciones sindicales que hayan obtenido mayor representación en la Administración Autónoma y en la Administración Local de Galicia en las elecciones celebradas de acuerdo con la Ley 9/1987, de 12 de junio.

Su renovación tendrá lugar cada vez que se celebren elecciones sindicales en el ámbito de la Administración Pública.

De estos representantes, tres serán funcionarios de la Administración Autonómica y dos de la Administración Local.

4. El mandato de los Vocales tendrá una duración de cuatro años. En el supuesto de renovación de alguno de ellos antes de finalizar dicho periodo, su sustituto será nombrado para el tiempo que reste para la finalización del mandato.
De lo dispuesto en el párrafo anterior, se exceptúan aquellos Vocales que ocupen el puesto por razón de su cargo.

5. La Xunta de Galicia determinará por Decreto el procedimiento para la designación de los representantes de la Administración Local de Galicia en el Consejo Rector de la Escuela Gallega de Administración Pública.

6. El Secretario general de la Escuela Gallega de Administración Pública actuará, asimismo, como Secretario de su Consejo Rector ${ }^{166}$.

Artículo 8. 1. El funcionamiento del Consejo Rector se ajustará a lo que dispone la Ley de Procedimiento Administrativo en el capitulo II, de su Título I, sobre órganos colegiados.

2. El Secretario, sin voz ni voto en el Consejo, redactará y custodiará las actas.

3. El Consejo Rector se reunirá, por lo menos, una vez al trimestre y, de todos modos, siempre que sea convocado por el Presidente o a petición de una cuarta parte de sus miembros.

4. El orden del día de las sesiones del Consejo Rector será fijado por su Presidente, teniendo en cuenta las peticiones formuladas al respecto por los demás miembros.

Artículo 9. Son competencias del Director de la Escuela Gallega de Administración Pública:

1. Ostentar la representación ordinaria de la Escuela.

2. Preparar y ejecutar los acuerdos del Consejo Rector.

3. Dirigir los servicios y ejercer la jefatura del personal de la Escuela.

4. Ejercer la gestión presupuestaria de la Escuela, disponiendo los gastos y proponiendo la ordenación de los pagos.

5. Elaborar el anteproyecto del presupuesto anual de la Escuela para someterlo a la aprobación del Consejo Rector.

\footnotetext{
166 Art. 7 modificado por Ley 10/1989, de 10 de julio, de modificación de la Ley 4/1987, de 27 de mayo, de crea-
} ción de la Escuela Gallega de Administración Pública. 
6. Proponer al Consejo Rector el plan anual de actividades.

7. Preparar la Memoria de actividades de la Escuela para su sometimiento al Consejo Rector.

8. Coordinar el desarrollo de las actividades de la Escuela.

9. Expedir diplomas y certificados acreditativos de los estudios realizados en la Escuela,

10. Dirigir, impulsar y supervisar el cumplimiento de los fines y actividades de la Escuela.

Artículo 10. El Director de la Escuela Gallega de Administración Pública tendrá categoría de Director general y será nombrado por la Xunta a propuesta del Conselleiro de la Presidencia entre personas con acreditados conocimientos y experiencia en la Administración Pública de Galicia.

Artículo 11. La plantilla de la Escuela será cubierta con funcionarios de carrera destinados en la Comunidad Autónoma de Galicia o en cualquier otra Administración Pública.

2. Los Profesores de la Escuela que no ostenten la condición de funcionanos de carrera que les habilite para el desarrollo de tal función tendrán la condición de colaboradores temporales y devengarán las compensaciones económicas que correspondan por asistencia, horas lectivas, conferencias, seminarios o trabajos determinados.

3. La Escuela podrá encargar trabajos de investigación para el mejor cumplimiento de sus fines, previa correspondiente convocatona pública.

Artículo 12. Para el cumplimiento de sus fines la Escuela Gallega de Administración Pública dispondrá de los siguientes medios económicos:

1. Recursos ordinarios:

1) Las cantidades que se le asignen en los Presupuestos Generales de la Comunidad Autónoma.

2) Los bienes y los valores que constituyen su propio patrimonio y los rendimientos de éste.

2. Recursos extraordinarios:

1) Las subvenciones oficiales y los donativos o aportaciones voluntarias de Entidades o particulares.

2) Las contraprestaciones económicas que generen los convenios que celebre y las actividades de la Escuela.

3) Los ingresos que obtenga por sus publicaciones.

\section{DISPOSICIÓN ADICIONAL}

Sin perjuicio de su valor en la Comunidad Autónoma Gallega, se promoverá el reconocimiento de los diplomas otorgados por la Escuela ante el resto de las Administraciones Publicas.

\section{DISPOSICIÓN FINAL}

Se faculte a la Xunta de Galicia para dictar, en el plazo de los cuatro meses siguientes a la entrada en vigor de esta Ley, las disposiciones que fuesen precisas para su desarrollo y cumplimiento. 


\section{V \\ RÉGIMEN FINANCIERO}

1. DECRETO LEGISLATIVO 1/1999, DE 7 DE OCTUBRE, POR EL QUE SE APRUEBA EL TEXTO REFUNDIDO DE LA LEY DE RÉGIMEN FINANCIERO Y PRESUPUESTARIO DE GALICIA (DOGA N. $\left.{ }^{\circ} 214,5.11 .1999\right)$ (...) ${ }^{167}$

Artículo único. De conformidad con la disposición adicional octava de la Ley 6/1998, de 29 de diciembre, de Presupuestos Generales de la Comunidad Autónoma de Galicia para 1999, se aprueba el texto refundido de la Ley 11/1992, de 7 de octubre, de Régimen Financiero y Presupuestario de Galicia, que se inserta a continuación.

\section{DISPOSICIÓN ADICIONAL ÚNICA REMISIONES Y NORMATIVAS A LA LEY 11/1992}

Las remisiones y referencias normativas a la Ley 11/1992, de 7 de octubre, de Régimen Financiero y Presupuestario de Galicia, se entenderán hechas, en lo sucesivo, al texto refundido de la Ley de Régimen Financiero y Presupuestario de Galicia.

\section{DISPOSICIÓN FINAL ÚNICA ENTRADA EN VIGOR}

El presente Decreto Legislativo y el texto refundido que se aprueba entrarán en vigor el día siguiente al de su publicación en el "Diario Oficial de Galicia".

(...)

\section{TEXTO REFUNDIDO DE LA LEY DE RÉGIMEN FINANCIERO Y PRESUPUESTARIO DE GALICIA TÍTULO PRELIMINAR PRINCIPIOS GENERALES}

Artículo 1. Concepto.

1. La Hacienda Pública de Galicia está constituida por el conjunto de derechos y

167 Exposición de motivos omitida. obligaciones de contenido económico y financiero cuya titularidad le corresponde a la Comunidad Autónoma de Galicia.

2. Constituyen materias propias de la Hacienda Pública de Galicia, con independencia de la normativa que las regule, las siguientes:

a. El procedimiento presupuestario en sus distintas fases de elaboración, gestión y liquidación.

b. El sistema de contabilidad a que debe someterse a la actuación económica de los órganos competentes del sector público gallego.

c. El régimen de su patrimonio.

d. La contratación en régimen de derecho administrativo.

e. La regulación de sus ingresos de derecho público y privado.

f. Las normas de asignación y gestión de los recursos públicos y el control de eficacia y eficiencia en el empleo de los mismos.

g. El endeudamiento y la concesión de avales y otras garantías.

h. La organización y regulación de la Tesorería.

i. Los procedimientos generales de funcionamiento de los órganos responsables de la Hacienda Pública gallega.

j. Las prerrogativas de la Hacienda Pública gallega y las responsabilidades derivadas de la actuación de sus órganos y del personal a su servicio.

$\mathrm{k}$. Cualquier otra que tuviese relación con el contenido de la Hacienda Pública gallega.

Artículo 2. Criterios y fines.

1. La distribución y gestión de los recursos públicos se realizará teniendo en cuenta criterios de eficacia y eficiencia.

2. La acción del Gobierno para la prestación de servicios públicos y la dotación de infraestructuras públicas básicas y sociales de la Comunidad se hará conforme a los 
principios de equidad, solidaridad y equilibrio territorial.

Artículo 3. Normativa reguladora.

1. Constituye el objeto de la presente ley la regulación de la actividad económico-financiera de la Comunidad Autónoma de Galicia, sin perjuicio de lo que se disponga en otras Leyes especiales.

2. La actividad económico-financiera de la Comunidad Autónoma de Galicia se regirá:

a. Por la presente ley y por las demás Leyes especiales y normas concordantes que sobre la materia dicte el Parlamento de Galicia.

b. Por las Leyes de Presupuestos Generales de la Comunidad Autónoma.

c. Por las normas reglamentarias que se dicten en el desarrollo de la presente ley.

3. Tendrán carácter supletorio las demás normas del ordenamiento jurídico administrativo y, en su defecto, el derecho privado, respetando la prelación de normas del derecho civil gallego.

4. Las Leyes anuales de Presupuestos Generales de la Comunidad Autónoma podrán contener normas relacionadas con su actividad económico-financiera con vigencia permanente o con vigencia temporal superior al período anual al que las mismas correspondan.

Cuando en dichas normas legales concurra alguna de estas circunstancias, habrá que tener en cuenta lo siguiente:

a. De tratarse de normas de vigencia permanente, se establecerá así de forma expresa, incluyendo, en su caso, la tabla de derogaciones motivada por la entrada en vigor de la nueva norma legal.

b. De tratarse de normas de vigencia temporal, se definirá con precisión su plazo de vigencia y las normas de ordenamiento jurídico que quedan afectadas, así como los efectos sobre las mismas a la entrada en vigor de la nueva normativa a lo largo del plazo en el que la misma sea aplicable.
Artículo 4. Principios presupuestarios y control.

1. La actividad económica-financiera de la Comunidad Autónoma de Galicia estará sometida al régimen de presupuesto anual y a los principios de control interno, de contabilidad y de unidad de caja que se determinan en la presente ley.

2. Todas las actividades que den lugar al reconocimiento de derechos y obligaciones de contenido económico o al manejo de fondos públicos deberán estar controladas o intervenidas conforme a las normas de esta ley y sometidas al régimen de rendimiento de cuentas al Consello de Contas y al Tribunal de Contas, de acuerdo con las disposiciones que los regulan.

3. La Intervención General de la Comunidad Autónoma será el órgano encargado de la ejecución de las funciones de control interno y de contabilidad reguladas en la presente ley.

4. La Comunidad Autónoma de Galicia, de acuerdo con los procedimientos legales establecidos, podrá exigir las indemnizaciones económicas que sean procedentes a los responsables de la custodia y del manejo de los fondos públicos por los perjuicios que pudiesen ocasionar, con independencia de las demás responsabilidades de carácter civil, penal o disciplinario en que pudiesen incurrir.

Artículo 5. Reserva legal.

Se regularán por Ley del Parlamento de Galicia las siguientes materias:

a. Los Presupuestos Generales de la Comunidad Autónoma y la concesión de créditos extraordinarios y suplementos de créditos de la Xunta de Galicia y de los organismos autónomos en los términos contemplados en esta ley.

b. El establecimiento, la modificación o la supresión de sus propios tributos y de las exenciones y bonificaciones que les afecten.

c. El establecimiento, la modificación y la supresión de los recargos sobre los impuestos del Estado. 
d. La emisión y el régimen de la deuda pública y demás operaciones de crédito.

e. El régimen de patrimonio de la Comunidad Autónoma.

f. La creación y supresión de los organismos autónomos en los términos que se prevén en esta ley.

g. Los Convenios y acuerdos de cooperación con otras Comunidades Autónomas previstos en el artículo $35 \mathrm{del}$ Estatuto de Autonomía.

h. El régimen y la concesión de avales y otras garantías por la Comunidad Autónoma.

i. La coordinación presupuestaria de las Diputaciones Provinciales de Galicia, en concordancia con la Ley 5/1997, de 22 de julio, de Administración Local de Galicia.

j. Las demás materias relativas a la Hacienda Pública gallega que, según las Leyes, se deban regular con este rango.

Artículo 6. Competencia del Consello de la Xunta.

Será competencia del Consello de la Xunta, en el marco de las materias reguladas en esta ley:

a. La determinación de las directrices básicas de política económica y financiera, de acuerdo con el Estatuto de Autonomía de Galicia.

b. La elaboración de los Presupuestos Generales de la Comunidad Autónoma.

c. La autorización de los gastos que según las Leyes requieran su aprobación.

d. La aprobación de los Reglamentos para su aplicación.

e. Cualquier otra que precise conocimiento o aprobación de la Xunta y cuya competencia no esté reservada al Parlamento de Galicia.

Artículo 7. Competencia de la Consellería de Economía e Facenda.

Será competencia de la Consellería de Economía e Facenda:

a. La administración, gestión y recaudación de los derechos de la Hacienda de la Comunidad Autónoma. b. La ordenación de pagos en los términos establecidos en la presente ley.

c. La elaboración del anteproyecto de Ley de Presupuestos Generales de la Comunidad Autónoma.

d. El control de eficacia y eficiencia respecto a los objetivos previstos en los Presupuestos Generales de la Comunidad.

e. El ejercicio directo de las demás funciones de control interno reguladas en esta ley y la dirección y ejecución de la contabilidad pública.

f. La ejecución o dirección de la política económica y financiera aprobada por la Xunta, en la forma que ésta determine.

g. El desarrollo de las actividades inherentes al ejercicio de la tutela financiera sobre los entes locales, que tiene atribuida la Comunidad en el artículo 49 del Estatuto de Autonomía.

h. Las funciones ejecutivas en materia de ordenamiento y control de las instituciones de crédito corporativo público y territorial y de las Cajas de Ahorro que operen en su territorio, en los términos previstos en el artículo 30 del Estatuto de Autonomía.

i. Las demás funciones y competencias que le asigne la normativa legal vigente.

Artículo 8. Competencia de las consellerías.

Será competencia de las consellerías:

a. La elaboración de su anteproyecto de presupuesto.

b. La administración y gestión de los créditos para gastos incluidos en los presupuestos y que estén adscritos a las mismas.

c. La autorización de los gastos propios de la consellería, salvo que la misma esté reservada al Consello de la Xunta.

d. La propuesta del pago de obligaciones a la Consellería de Economía e Facenda.

e. Las demás que les confiera la normativa legal vigente.

Artículo 9. Competencia de los organismos autónomos.

1. Son funciones de los organismos autónomos de la Comunidad Autónoma en el ámbito de sus respectivas competencias: 
a. La elaboración de su anteproyecto de presupuestos de gastos e ingresos.

b. La administración, gestión y recaudación de sus propios derechos económicos.

c. La autorización de los gastos contenidos en sus presupuestos y la ordenación de sus pagos.

d. Las demás que les atribuyan las normas legales vigentes.

2. Lo previsto en el apartado 1 anterior se entiende sin perjuicio de lo que pudiese establecerse en uso de lo dispuesto en el artículo 11.2.

Artículo 10. Prerrogativas.

A la Comunidad Autónoma de Galicia, en el ejercicio de las competencias a las que se refiere la presente ley, le corresponderán en todo momento las mismas prerrogativas e idéntico trato fiscal que la Ley tenga establecidos para el Estado.

Artículo 11. Organismos autónomos.

1. Para el ejercicio de la actividad económico-financiera, la Comunidad Autónoma de Galicia, en el seno de su propia Administración Pública, podrá crear organismos autónomos.

Los organismos autónomos son entes institucionales de derecho público que realizan funciones o actividades de competencia de la Comunidad Autónoma en régimen de descentralización administrativa. Tendrán personalidad jurídica y patrimonio propios, independientes de los de la Xunta de Galicia, y podrán ser de dos clases:

a. Organismos autónomos comerciales, industriales, financieros o análogos, que serán aquellos que realicen de forma principal actividades de esta naturaleza o cualquier otra de carácter mercantil.

b. Organismos autónomos administrativos, que serán todos aquellos en los que no concurra alguna de las circunstancias indicadas en el apartado anterior.

2 . La creación y supresión de los organismos autónomos se realizará por Ley.

3. A los organismos autónomos le serán aplicables los preceptos de esta ley y los demás que se dicten sobre materias no reguladas en la misma, y gozarán de las prerrogativas y de los beneficios fiscales que se establezcan en las Leyes para las entidades públicas de tal naturaleza.

Artículo 12. Sociedades públicas autonómicas.

1. Son sociedades públicas de la Comunidad Autónoma de Galicia a efectos de esta ley:

a. Las sociedades mercantiles en cuyo capital exista participación mayoritaria, directa o indirecta, de la Comunidad o de sus organismos autónomos y las demás entidades de derecho público de la Comunidad Autónoma.

b. Las entidades de derecho público con personalidad jurídica propia que por Ley tengan que adecuar su actividad al ordenamiento jurídico privado.

2. Las sociedades públicas de la Comunidad Autónoma de Galicia se regirán por las normas de derecho mercantil, civil o laboral, salvo en las materias en las que les sea aplicable la presente ley.

3. La creación de las sociedades a las que se refiere la letra a) del número 1 anterior, así como los actos de adquisición o pérdida de la posición mayoritaria, medida ésta en los términos indicados en dicha letra, requerirán acuerdo del Consello de la Xunta.

4. La actividad de las sociedades públicas gallegas la coordinará la Administración de la Hacienda Pública de la Comunidad, en los términos previstos en las Leyes.

Artículo 13. Convenios, acuerdos y transferencias.

1. En los Convenios con otras Comunidades Autónomas para la gestión y prestación de servicios de exclusiva competencia de las mismas, y en los acuerdos de cooperación que se suscriban a tenor de lo dispuesto en los apartados 1 y 2 del artículo 35 del Estatuto de Autonomía, deberán establecerse las cláusulas precisas para asegurar en todo momento la aplicación de la presente 
ley en el caso de que se proceda a comprometer recursos de la Hacienda Pública gallega para el desarrollo de los mismos.

2. En los casos en que, conforme a lo dispuesto en el artículo 36 del Estatuto de Autonomía, se transfieran o deleguen a la Comunidad Autónoma facultades y competencias no asumidas en el mismo, que por su naturaleza den origen al manejo y a la distribución de los fondos públicos, serán aplicables a la gestión financiera de dichos fondos los preceptos de la presente ley, sin perjuicio de las formas de control que se reserve el Estado.

\section{TÍTULO I \\ DEL CONTENIDO DE LA \\ HACIENDA DE LA COMUNIDAD}

\section{Capitulo I \\ DE LOS RECURSOS}

Artículo 14. Recursos de la Hacienda autonómica.

Constituyen derechos económicos de la Hacienda Pública gallega:

1. Los rendimientos de los impuestos, de las tasas y de las contribuciones especiales que establezca la Comunidad Autónoma.

2. Los rendimientos de los tributos cedidos por el Estado.

3. La participación en los ingresos del Estado por impuestos directos e indirectos, incluidos los monopolios fiscales.

4. Las dotaciones para la nivelación de los servicios mínimos.

5. El importe de los precios derivados de los servicios prestados por la Comunidad o por la concesión de cánones por aprovechamientos especiales, ya sean de propia creación o como consecuencia de traspasos de los servicios estatales.

6. Los ingresos procedentes del Fondo de Compensación Interterritorial o de otros fondos de análoga naturaleza.

7. Los recargos sobre impuestos estatales.

8. Cualquier otra asignación a favor de la Comunidad Autónoma contemplada en los presupuestos generales del Estado o en los de otros entes públicos.
9. El producto de la emisión de la deuda pública y del recurso al crédito.

10. Los rendimientos del patrimonio de la Comunidad Autónoma.

11. Los legados, las donaciones y cualquier otro ingreso de derecho privado.

12. El producto de las multas y sanciones impuestas en el ámbito de su competencia.

13. En su caso, las participaciones que establezcan las Leyes en los ingresos por tributos del Estado para recuperar los costes sociales producidos por actividades contaminantes o que deterioren el medio ambiente o que generen riesgos de especial gravedad para el medio físico y humano de Galicia.

14. Las subvenciones que pueda recibir la Comunidad Autónoma.

15. Cualquier otro recurso de derecho público o privado que obtenga o le corresponda a la Comunidad Autónoma.

Artículo 15. Destino.

Los recursos de la Comunidad Autónoma gallega y de cada uno de sus organismos autónomos estarán destinados a satisfacer el conjunto de sus obligaciones respectivas, salvo que por Ley se establezca su afectación para fines determinados.

Artículo 16. Administración de los recursos.

1. La administración general de los recursos de la Hacienda Pública gallega, así como la dirección y la coordinación general de sus procedimientos, corresponde a la Consellería de Economía e Facenda, con los controles que la Ley establezca.

2. En la misma forma, corresponde a los órganos rectores de los organismos autónomos y demás entes públicos con personalidad jurídica propia la administración de los recursos específicos que les correspondan para el cumplimiento de sus fines.

3. Las personas o entidades que tengan a su cargo la administración de los recursos de la Hacienda Pública gallega dependerán de la Consellería de Economía e Facenda o de los órganos de administración de los 
organismos autónomos, y demás entes públicos, en todo lo relativo a su gestión, aplicación y rendimiento de cuentas.

4. Estarán obligadas a la prestación de fianza aquellas personas o entidades que manejen fondos o valores públicos, en la cuantía y forma que determinen las disposiciones reglamentarias.

Artículo 17. Gestión de los tributos.

1. La gestión, incluyendo todas las fases del procedimiento, de los tributos propios de la Comunidad Autónoma, de los impuestos cedidos y de los recargos sobre impuestos del Estado que pueda establecer la Comunidad Autónoma se ajustará:

a. A las disposiciones del Estatuto de Autonomía.

b. A lo dispuesto en la presente ley.

c. A las demás Leyes del Parlamento de Galicia.

d. A las disposiciones reglamentarias aprobadas por la Xunta en desarrollo de esta ley y demás leyes citadas.

e. A las normas de desarrollo que las Leyes o los Reglamentos autoricen dictar al Conselleiro de Economía y Hacienda.

f. A la Ley General Tributaria y a las disposiciones dictadas en su desarrollo, con la consideración de derecho supletorio en los casos en los que sea preceptiva su aplicación.

2. En la gestión de los tributos cedidos por el Estado se tendrá en cuenta, además, lo que disponga la correspondiente normativa.

Artículo 18. Disponibilidad de bienes y derechos.

1. La gestión de los bienes patrimoniales y de sus rendimientos, tanto de la Comunidad Autónoma como de sus organismos autónomos, se ajustará a lo dispuesto en las Leyes del Parlamento de Galicia aplicables en cada caso.

2. No podrán ser enajenados, gravados ni arrendados los derechos de la Hacienda de la Comunidad Autónoma, salvo en los supuestos y en las condiciones previstas en las Leyes.

3. Tampoco se concederán exenciones, condonaciones, rebajas ni moratorias en el pago de los derechos a favor de la Hacienda Pública gallega, salvo en los casos y en la forma que se determinen en las Leyes.

\section{Artículo 19. Garantías.}

1. Para realizar el cobro de los tributos y demás recursos de derecho público que correspondan, la Hacienda Pública gallega estará en posesión de las prerrogativas legalmente establecidas, gozando en todo momento de las mismas facultades y garantías que las demás Administraciones Públicas de ámbito estatal o territorial.

2. Las providencias de apremio acreditativas del descubierto ante la Hacienda de la Comunidad de las deudas por tributos y demás ingresos de derecho público, expedidas por los funcionarios competentes según los reglamentos, serán títulos suficientes para iniciar su cobro por vía de apremio, y teniendo la misma fuerza ejecutiva que la sentencia judicial para proceder contra los bienes y derechos de los deudores ${ }^{168}$.

3. La efectividad de los derechos de la Hacienda de la Comunidad no contemplados en el apartado 1 del artículo 21 se exigirá de acuerdo con las normas de procedimiento aplicables en cada caso.

Artículo 20. Suspensión del procedimiento de apremio.

1. En ningún caso se podrán suspender los procedimientos administrativos de apremio en virtud de recursos interpuestos por los interesados, si no se realiza el pago del débito, se consigna su importe o se garantiza éste en la forma reglamentariamente establecida.

2. Si contra dichos procedimientos se estableciesen reclamaciones en concepto de tercería o por otra acción de carácter civil, por persona que no tenga ninguna responsabilidad con la Hacienda de la Comunidad en virtud de obligación o gestión propia o transmitida, se suspenderán dichos procedimientos sólo en la

168 Art. 19.2 modificado por Ley $14 / 2004$, de 29 de diciembre, de medidas tributarias y de régimen administrativo. 
parte que se refiera a los bienes o derechos controvertidos, una vez que se efectuase su embargo o, en su caso, su anotación preventiva en el registro público correspondiente, y se sustanciará este incidente en la vía administrativa como trámite previo a la judicial.

3. Cuando las reclamaciones formuladas en vía administrativa fuesen denegadas, proseguirá el procedimiento de apremio a no ser que de la ejecución puedan derivarse perjuicios de imposible o difícil reparación; en tal caso la Administración Pública podrá acordar la suspensión de aquél, siempre que se adopten las medidas reglamentarias de aseguramiento de los respectivos créditos.

4. Asimismo, podrá suspenderse el procedimiento de apremio sin los requisitos establecidos en el punto 1 de este artículo si el interesado demuestra que ha existido en su perjuicio error material o aritmético en la determinación de la deuda que se le exija.

5. Podrán aplazarse o fraccionarse las cantidades debidas a la Hacienda de la Comunidad en los casos y con los procedimientos que reglamentariamente se establezcan. Dichas cantidades devengarán intereses de demora y deberán garantizarse excepto en los casos siguientes ${ }^{169}$ :

a. Cuando sean inferiores a la cifra que, por norma jurídica de rango suficiente, fije la Consellería de Economía e Facenda.

b. Cuando el deudor carezca de bienes o créditos suficientes para garantizar la deuda y la ejecución de su patrimonio afectase al mantenimiento de la capacidad productiva y del nivel de empleo de la actividad del sector económico respectivo, o bien produjese graves quiebras para el interés de la Comunidad Autónoma, si así lo acuerda el Conselleiro de Economía y Hacienda.

$\overline{169}$ Orden de 29 de mayo de 2009 reguladora de aplazamientos y fraccionamientos de pago de deudas que correspondan a ingresos de derecho público de la Comunidad Autónoma de Galicia.
Artículo 21. Intereses de demora.

1. Las cantidades adeudadas a la Hacienda de la Comunidad Autónoma devengarán intereses de demora desde el día siguiente al de su vencimiento. Se incluyen en este apartado las cantidades recaudadas a través de entidades colaboradoras, cuentas restringidas, oficinas liquidadoras y demás entidades recaudadoras por cuenta de la Hacienda de la Comunidad que no sean ingresadas por dichas entidades en la Tesorería en los plazos establecidos ${ }^{170}$.

2. Excepto lo establecido en leyes especiales, el interés de demora resultará de la aplicación, para cada año o período de los que integran el período de cálculo, del interés legal fijado en la Ley de presupuestos del Estado para dichos ejercicios 171 .

Artículo 22. Integridad de la Hacienda.

1. No se podrá transigir sobre los derechos de la Hacienda de la Comunidad, ni someter a arbitraje las contiendas que se susciten respecto de los mismos, sino mediante decreto acordado por la Xunta de Galicia.

2. La suscripción por la Hacienda de la Comunidad de los acuerdos de Convenios en procesos concursales previstos en la Ley de Enjuiciamiento Civil y en la Ley de Suspensión de Pagos requerirá únicamente autorización del Conselleiro de Economía y Hacienda.

3. Los actos y contratos realizados en perjuicio de la Hacienda de la Comunidad por los que resulten deudores de la misma serán rescindibles conforme a las disposiciones legales que les sean aplicables.

Artículo 23. Prescripción.

1. Salvo lo establecido por las Leyes reguladoras de los diferentes recursos, prescribirá a los cinco años el derecho de la Hacienda de la Comunidad:

170 Art. 21.1 modificado por Ley 8/1999, de 30 de diciembre, de medidas fiscales y presupuestarias y de función pública y actuación administrativa.

171 Art. 21.2 modificado por Ley 14/2004, de 29 de diciembre, de medidas tributarias y de régimen administrativo. 
a. A reconocer o liquidar créditos a su favor, computándose el citado plazo desde el día en el que el derecho pudo ejercitarse.

b. Al cobro de los créditos reconocidos o liquidados, que se contará desde la fecha de su notificación o, si ésta no fuese preceptiva, desde su vencimiento.

2. En todo caso, el plazo de prescripción a que se refiere el punto anterior será de cuatro años para todos los recursos derivados de los tributos propios de la Comunidad Autónoma.

3. La prescripción quedará interrumpida:

a. Por la interposición de reclamaciones o recursos de cualquier clase, la remisión del tanto de culpa a la jurisdicción penal o la presentación de denuncia ante el Ministerio Fiscal, así como por las actuaciones realizadas con conocimiento formal del beneficiario o entidad colaboradora en el curso de dichos recursos ${ }^{172}$.

b. Por cualquier actuación del obligado conducente al reconocimiento, liquidación o pago de la deuda".

c. Por cualquier acción administrativa, realizada con conocimiento formal del obligado, conducente al reconocimiento, liquidación o cobro de la deuda ${ }^{173}$.

4. Los derechos declarados prescritos serán dados de baja en cuentas, previa tramitación del oportuno expediente, en el que, en su caso, se declarasen las responsabilidades a que hubiese lugar, salvo que procediese su tramitación en pieza separada en la forma dispuesta en el título VI de esta ley.

5. Se autoriza al Conselleiro de Economía y Hacienda para que pueda disponer la no liquidación de deudas o la anulación y baja en contabilidad de deudas ya liquidadas cuando su ejecución resulte antieconómica. A estos efectos, dicha consellería determinará previamente el límite cuantitativo

172 Art. 23.3.a Ley $14 / 2004$, de 29 de diciembre, de medidas tributarias y de régimen administrativo.

173 Art. 23.3 modificado por Ley 7/2002, de 27 de diciembre, de medidas fiscales y de régimen administrativo. en el que se considere que se produce tal efecto 174175 .

\section{Capítulo II DE LAS OBLIGACIONES}

Artículo 24. Nacimiento y exigibilidad.

1. Las obligaciones económicas de la Comunidad y de sus organismos autónomos nacen de la Ley, de los negocios jurídicos y de los actos y hechos que, conforme a derecho, las generen.

2. El pago de las obligaciones sólo será exigible a la Hacienda de la Comunidad en la medida que resulte de la ejecución de sus presupuestos, de sentencia judicial firme o de operaciones de Tesorería legalmente autorizadas.

3. Cuando dichas obligaciones tengan por causa prestaciones o servicios a la Administración de la Comunidad, el pago no podrá realizarse mientras el acreedor no cumpla o garantice, conforme a la Ley, su respectiva obligación.

Artículo 25. Inembargabilidad.

1. Los Tribunales, Jueces y autoridades administrativas no podrán despachar ni dictar mandamiento de ejecución o providencia de embargo contra los derechos, fondos, valores y demás bienes de la Hacienda de la Comunidad.

2. El cumplimiento de las resoluciones que determinen obligaciones a cargo de la Comunidad o de sus organismos autónomos corresponderá exclusivamente a la autoridad administrativa que sea competente. Si no existiese crédito en el presupuesto en vigor o fuese insuficiente el disponible, se solicitará del Parlamento, dentro de los tres meses siguientes a la notificación de la resolución, la concesión de un crédito extraordinario o de un suplemento de crédito.

174 Art. 23 tendrá vigencia permanente según Ley 8/1999, de 30 de diciembre, de medidas fiscales y presupuestarias y de función pública y actuación administrativa.

175 Véase Orden de 22 de diciembre de 2005 que desarrolla el artículo 23.5 del Decreto legislativo 1/1999, de 7 de octubre, por el que se aprueba el texto refundido de la Ley de régimen financiero y presupuestario de Galicia en cuanto a anulación y baja de contabilidad de determinadas deudas. 
Artículo 26. Intereses.

Si el pago de las obligaciones de la Comunidad no se le hiciese efectivo al acreedor en el plazo de los tres meses siguientes al día de la notificación de la resolución judicial o del reconocimiento de la propia obligación, éste tendrá derecho al abono de los correspondientes intereses de demora sobre la cantidad debida al tipo establecido en el apartado 2 del artículo 21 , siempre que reclame por escrito el cumplimiento de la obligación.

Artículo 27. Prescripción.

1. Salvo lo establecido en las Leyes especiales, prescribirán a los cinco años:

a. El derecho al reconocimiento o a la liquidación de toda obligación, computándose el plazo desde el momento en el que ésta sea exigible conforme a derecho.

b. El derecho a exigir el pago de las obligaciones reconocidas o liquidadas. El plazo se contará desde la fecha de notificación del reconocimiento o de la liquidación de la respectiva obligación.

2 . La petición por escrito del reconocimiento o del cumplimiento de la obligación, o de la efectividad de su pago, por parte de los acreedores legítimos, o de los que se subroguen en sus derechos, mediante la presentación de los documentos justificativos de su derecho, interrumpirá la prescripción, según lo dispuesto en el Código Civil, salvo lo establecido en Leyes especiales.

3. Las obligaciones que prescribiesen serán dadas de baja en las cuentas respectivas, previa tramitación del oportuno expediente.

\section{TÍTULO II \\ DE LAS OPERACIONES DE ENDEUDAMIENTO \\ Capitulo I \\ DE LAS OPERACIONES \\ DE ENDEUDAMIENTO}

Artículo 28. Endeudamiento.

Constituyen el endeudamiento público los capitales tomados a préstamo por la
Xunta de Galicia o por sus organismos autónomos. La emisión de Deuda Pública o la concertación de otras operaciones de crédito, su administración, conversión o extinción, así como la prescripción de los capitales y de sus intereses, se regularán por las disposiciones de esta ley.

Artículo 29. Denominación y autorización.

1. Las operaciones de crédito y la emisión de Deuda Pública las podrán llevar a cabo la Comunidad o sus organismos autónomos, recibiendo en el primer caso la denominación de "Deuda de la Comunidad Autónoma de Galicia" y en el segundo la de "Deuda de los organismos autónomos".

2. El endeudamiento, tanto de la Comunidad Autónoma como de sus organismos autónomos, tendrá que ser autorizado por Ley, la cual, sin perjuicio de fijar cualquier otra característica de las operaciones de endeudamiento por realizar, deberá señalar el importe máximo autorizado. La Xunta de Galicia podrá determinar a lo largo del período de autorización límites inferiores a dicho importe si así lo aconsejasen circunstancias de política económica.

Artículo 30. Destino.

1. La deuda y demás operaciones de crédito concertadas por la Comunidad o por sus organismos autónomos por plazo superior a un año se destinarán exclusivamente a la financiación de gastos de capital.

2. La cuantía de las anualidades de amortización, incluido capital e intereses, no podrá exceder del 25 por 100 de los ingresos corrientes previstos en los presupuestos generales de la Comunidad Autónoma en cada año.

Artículo 31. Deuda de Tesorería.

1. En el endeudamiento que la Comunidad Autónoma lleve a cabo con personas físicas o jurídicas para atender necesidades transitorias de Tesorería, cualquiera que sea la forma como se documente, el plazo de reembolso será inferior a un año. En la Ley de Presupuestos de cada año se autorizará el límite máximo de estas operaciones para cada ejercicio. 
2. El producto de la Deuda de Tesorería a que se refiere el apartado anterior se contabilizará independientemente en las cuentas de operaciones del Tesoro. Los gastos e intereses que motive serán imputados al presupuesto de la Comunidad antes del cierre del ejercicio, y a dicha deuda será aplicable, de proceder, lo establecido en los artículos 38 y 39 de esta ley.

3. En todo caso, a partir del momento en el que el montante total anual de estas operaciones transitorias exceda del 5 por 100 del estado de gastos, se deberá dar cuenta trimestralmente al Parlamento de la evolución de las mismas.

Artículo 32. Importe máximo.

1. En las autorizaciones de endeudamiento incluidas en la Ley de Presupuestos Generales de la Comunidad y en otras Leyes especiales, el importe máximo autorizado deberá entenderse, salvo disposición contraria, como variación neta de la posición deudora de la Comunidad o de cada uno de los organismos autónomos a los que dicha autorización se refiera, computada a la finalización del período al que se extienda la autorización.

2. Queda excluido de lo dispuesto en el párrafo anterior la Deuda de Tesorería a que se refiere el artículo 31 .

Artículo 33. Autorización de la emisión o contracción.

1. Las emisiones de Deuda Pública $\mathrm{u}$ operaciones de crédito que realicen la Comunidad o sus organismos autónomos tendrán que ser autorizadas, en todo caso, por el Conselleiro de Economía y Hacienda dentro de los límites señalados por la Ley, al que le corresponderá, asimismo, autorizar las características técnicas de las mismas y su tipo de interés, si éstos no fuesen determinados por su Ley de creación.

Tales actos de endeudamiento, cuando éste tenga un plazo de vencimiento superior a un año, podrán ser formalizados dentro del ejercicio presupuestario en el que la Ley autorice su creación o del ejercicio siguiente.
2. Cuando se trate de conseguir una mejor administración de la Deuda Pública emitida o de las operaciones de crédito formalizadas, la Xunta de Galicia, a propuesta del Conselleiro de Economía y Hacienda, podrá acordar su conversión o renegociación y dará cuenta al Parlamento de Galicia dentro de los treinta días siguientes y siempre que no se altere el equilibrio financiero de aquéllas, ni se perjudiquen, en su caso, los derechos económicos de los poseedores.

Artículo 34. Contabilización.

Sin perjuicio de lo dispuesto en el artículo 36 , el producto de las emisiones continuas de títulos de pago o cualquier otro título emitido por la Comunidad Autónoma con vencimiento igual o inferior a dieciocho meses, así como el importe de las amortizaciones de los mismos, se contabilizarán independientemente en cuentas de Tesorería, aplicándose el saldo neto de dichas operaciones, al final del ejercicio presupuestario, al presupuesto de la Comunidad.

Los gastos por intereses o de cualquier otra naturaleza derivados de su emisión o amortización se aplicarán al presupuesto, siguiendo las normas generales determinadas en esta ley.

Artículo 35. Suscripción y transmisión.

1. La Deuda Pública podrá estar representada por títulos-valores o cualquier otro documento que formalmente la reconozca.

2. En la suscripción y transmisión de la Deuda Pública negociable sólo será preceptiva la intervención de fedatario público cuando aquélla esté representada por títulos-valores y así lo disponga la legislación aplicable a los mismos. No será preceptiva, en todo caso, para las operaciones con títulos de pago o títulos análogos emitidos por la Comunidad o sus organismos autónomos en los que los títulos-valores se extingan por su transformación en anotaciones en cuenta.

Artículo 36. Aplicación presupuestaria. El producto que se obtenga de la Deuda Pública y demás operaciones de crédito, 
así como su amortización e intereses, se aplicará al presupuesto de la Comunidad o de sus organismos autónomos correspondientes, sin perjuicio de lo dispuesto en el artículo 34.

Artículo 37. Competencia y atribuciones del Conselleiro de Economía y Hacienda. Con las limitaciones que se derivan del contenido del presente capítulo, se faculta al Conselleiro de Economía y Hacienda para:

1. Proceder a autorizar la emisión o contracción de Deuda Pública y demás operaciones de crédito de la Comunidad o de sus organismos autónomos respectivos, determinando su representación en títulos-valores, títulos de pago $\mathrm{u}$ otros documentos que formalmente la reconozcan; señalar o concertar su plazo, tipo de interés y demás características, y formalizar, en su caso, en representación de la Comunidad Autónoma, tales operaciones, pudiendo delegar dicha representación en un funcionario de la consellería cuando la formalización de la operación se realice en el extranjero.

2. Utilizar para la colocación de emisiones de Deuda Pública cualquier técnica financiera relativa a su oferta, intereses, plazo o cualquier otra condición de las mismas, siempre que su uso no represente la creación de situaciones distintas a las derivadas de las prácticas usualmente aceptadas en los mercados financieros.

3. Proceder de acuerdo con las condiciones de la emisión o de la contracción, o de mutuo acuerdo con los acreedores, al reembolso anticipado, total o parcial, de la Deuda Pública o de los préstamos concertados o a la modificación de alguna de sus condiciones cuando la situación del mercado u otras circunstancias así lo aconsejen.

4. Cualquier otra operación usual en el mercado financiero, siempre que no perjudique a los acreedores o se realice de común acuerdo con éstos y no esté expresamente excluida por la normativa aplicable.
5. Encomendarles el ejercicio de las facultades expuestas en los números anteriores en relación con la Deuda Pública emitida o contraída por los organismos autónomos a sus correspondientes órganos rectores.

Artículo 38. Beneficios.

1. La Deuda Pública de la Comunidad gozará de los mismos beneficios que la Deuda Pública del Estado y se sujetará a las demás normas que le sean aplicables según su modalidad y características, y conforme a lo previsto por las Leyes.

2. A los títulos al portador de la Deuda Pública que fuesen robados o hurtados, o que sufriesen extravío o destrucción, les será aplicable el procedimiento previsto por la legislación mercantil, salvo que se dictasen procedimientos administrativos especiales que total o parcialmente sustituyesen a aquél.

Artículo 39. Prescripción.

La obligación de reembolso de los capitales de la Deuda Pública y el pago de sus intereses prescribirán de acuerdo con el procedimiento y con los plazos establecidos por la normativa vigente para la Deuda Pública del Estado.

\section{Capitulo II DE LAS GARANTÍAS}

Artículo 40. Garantía por aval.

1. La Comunidad Autónoma podrá afianzar las obligaciones derivadas de créditos concertados por personas naturales o jurídicas, públicas o privadas, con domicilio social en Galicia, mediante el otorgamiento del correspondiente aval de la Tesorería, en la forma establecida en la presente ley.

2. Los citados avales los autorizará la Xunta de Galicia, a propuesta del Conselleiro de Economía y Hacienda, y serán publicados en el "Diario Oficial de Galicia".

Artículo 41. Importe.

El importe máximo de los avales que podrá conceder la Comunidad Autónoma durante el año será determinado en la Ley de Presupuestos Generales de la Comunidad. 
Artículo 42. Beneficiarios.

1. La Comunidad Autónoma podrá avalar las operaciones de crédito que a favor de sus organismos autónomos, sociedades públicas y corporaciones locales sitas en su territorio concedan las entidades de crédito legalmente establecidas.

Asimismo, podrá prestarles un segundo aval a las empresas privadas que tengan fijado su domicilio social o la radicación de sus negocios en Galicia.

2. Los créditos avalados en la forma indicada en el apartado anterior, en el caso de que los beneficiarios sean empresas privadas, solamente podrán tener como finalidad financiar la creación, reconversión y reestructuración de medianas y pequeñas empresas que, mediante la presentación de un plan económico-financiero, demuestren la capacidad y el dimensionamiento necesario para hacer viable su continuidad. En este supuesto cada aval individualizado no podrá exceder del 2 por 100 del límite global autorizado en la Ley de Presupuestos Generales de la Comunidad.

3. La Intervención General de la Comunidad Autónoma controlará la debida aplicación de los créditos avalados.

Trimestralmente se dará cuenta al Parlamento de los avales existentes, de los nuevos avales concedidos y, en su caso, de los riesgos efectivos a los que la Tesorería de la Comunidad tuviese que hacer frente.

Artículo 43. Obligaciones.

1. Los avales otorgados por la Comunidad Autónoma tendrán carácter subsidiario y obligarán a su Tesorería, por el importe del principal y de los intereses, sólo en el caso de no poder satisfacerlos el deudor principal o el primer avalista.

2. Podrá convenirse la renuncia al beneficio de excusión previsto en el artículo 1.830 del Código Civil si se garantizasen créditos concertados por sus organismos autónomos y entes públicos, corporaciones locales existentes en su territorio o, para cada caso, si se autorizase dicha renuncia por Ley del Parlamento de Galicia.
3. Los avales otorgados por la Comunidad Autónoma se documentarán en la forma en la que reglamentariamente se determine y devengarán a favor de su Tesorería la comisión que para cada caso se establezca.

Artículo 44. Autorización legal.

Para la concesión de cualquier otra forma de aval de la no prevista en el presente capítulo será precisa autorización mediante la correspondiente Ley, la que determinará por lo menos la identidad de los avalados y el límite y plazo del correspondiente aval.

Artículo 45. Avales de los organismos autónomos.

1. Los organismos autónomos y entes públicos podrán prestar avales dentro del límite máximo fijado con esta finalidad para cada ejercicio por la correspondiente Ley de Presupuestos Generales, siempre que los beneficiarios sean sociedades públicas o mercantiles en cuyo capital participen. De los avales que concedan, así como de la situación de los existentes, deberán rendirle cuenta anual a la Conse1lería de Economía e Facenda.

Sin embargo, el Instituto Galego de Promoción Económica podrá conceder avales, dentro del límite máximo fijado, a aquellas empresas privadas, participadas o no por este instituto, y para aquellas operaciones que reúnan las condiciones y cumplan los requisitos que se establezcan por acuerdo del Consello de la Xunta de Galicia a propuesta de la Consellería de Economía e Facenda.

El citado acuerdo se publicará en el "Diario Oficial de Galicia".

Asimismo, a los avales concedidos en virtud de este artículo deberá dárseles publicidad en el "Diario Oficial de Galicia".

2. Los avales así concertados cumplirán las condiciones establecidas en el artículo 43.1 de la presente ley, salvo acuerdo de la Xunta autorizando a la renuncia del beneficio de excusión previsto en el artículo 1.830 del Código Civil. 


\section{TÍTULO III \\ DE LOS PRESUPUESTOS GENERALES DE LA COMUNIDAD AUTÓNOMA \\ Capítulo I CONTENIDO Y APROBACIÓN}

\section{Artículo 46. Concepto.}

1. Los Presupuestos Generales de la Comunidad Autónoma constituyen la expresión cifrada, conjunta y sistemática de:

a. Las obligaciones que, como máximo, se podrán reconocer y los derechos que se prevean liquidar por parte de la Comunidad y de sus organismos autónomos durante el ejercicio presupuestario.

b. Los objetivos que se pretendan conseguir con la utilización de los recursos financieros consignados en los mismos.

c. Las estimaciones de los flujos financieros de las sociedades públicas.

d. La totalidad de los gastos e ingresos de los demás entes públicos.

e. Los beneficios fiscales estimados.

2. Los Presupuestos Generales de la Comunidad Autónoma se enmarcarán en un escenario plurianual que contenga las líneas básicas de la actuación a medio plazo del sector público gallego.

3. Los Presupuestos Generales de la Comunidad Autónoma se presentarán y se aprobarán de forma que los estados de gastos no superen los recursos totales previstos en los respectivos estados de ingresos.

4. Previa autorización del conselleiro de Economía y Hacienda podrán gestionarse como operaciones extra presupuestarias aquéllas en que la actividad de la Comunidad, de sus organismos autónomos y de las sociedades públicas autonómicas de carácter no mercantil se limite a la realización de funciones de intermediación en su gestión ${ }^{176}$.

Artículo 47. El ejercicio presupuestario. El ejercicio presupuestario coincidirá con el año natural y a él se imputarán:

176 Art. 46.4 modificado por Ley 9/2003, de 23 de diciembre, de medidas tributarias y administrativas. a. Los derechos liquidados en el transcurso del mismo, cualquiera que sea el período al que correspondan.

b. Las obligaciones reconocidas hasta el 31 de diciembre del correspondiente ejercicio, como consecuencia de adquisiciones, obras, suministros, prestaciones de servicios u otro tipo de gastos realizados con cargo a los créditos respectivos dentro del correspondiente año natural, sin perjuicio de lo dispuesto en el punto 2 del artículo 60.

Artículo 48. Contenido.

1. Los presupuestos generales de la Comunidad Autónoma estarán integrados:

a. Por el presupuesto de la Comunidad.

b. Por los presupuestos de los organismos autónomos.

c. Por los presupuestos de las agencias públicas autonómicas.

d. Por los presupuestos de explotación y de capital de las sociedades mercantiles del artículo 12 de esta ley y de aquéllas en las que concurran los requisitos determinados por el Sistema Europeo de Cuentas para integrarse en el sector de la administración pública autonómica de Galicia.

e. Por los presupuestos de los entes públicos a que hace referencia el artículo 12 de esta ley.

f. Por los presupuestos de explotación y capital de las fundaciones del sector público autonómico en las que concurran los requisitos determinados por el Sistema Europeo de Cuentas para integrarse en el sector de la administración pública autonómica de Galicia.

g. Por los presupuestos de los consorcios en los que concurran los requisitos determinados por el Sistema Europeo de Cuentas para integrarse en el sector de la administración pública autonómica de Galicia.

h. En todo caso, por los presupuestos de las demás entidades que estén clasificadas como administración pública de la Comunidad Autónoma de Galicia de acuerdo con las normas del Sistema Europeo de Cuentas, salvo las universidades públicas. 
2. Los presupuestos generales de la Comunidad Autónoma contendrán:

a. Los estados de gastos, en los que se especificarán en la forma establecida los créditos necesarios para dar cumplimiento a las obligaciones.

b. Los estados de ingresos, en los que se detallarán las estimaciones de los derechos económicos que se liquidarán durante el ejercicio presupuestario.

c. Los estados financieros de los organismos autónomos comerciales, industriales o financieros a que hace referencia el artículo 11 de esta ley.

d. Los estados financieros de las sociedades públicas autonómicas, entes de derecho público y demás entidades con personalidad jurídica propia que formen parte del sector administraciones públicas, según el Sistema Europeo de Cuentas ${ }^{177 .}$

Artículo 49. Estructura.

Los Presupuestos Generales de la Comunidad Autónoma se ajustarán, en cuanto a su estructura, a las siguientes reglas:

Primera:

a. Los estados de gastos se confeccionarán aplicando una clasificación funcional por programas.

Asimismo, las clasificaciones orgánica y económica informarán, respectivamente, sobre el agente que realiza el gasto y la naturaleza del mismo.

b. Para cada programa de gasto se establecerán los objetivos que se pretenden conseguir con los recursos que se le asignen, así como, siempre que sea posible, los indicadores de seguimiento que se consideren adecuados para analizar el grado de consecución de los mismos.

c. Se presentarán con separación los gastos corrientes y los gastos de capital, y su clasificación económica se regirá por los siguientes criterios:

177 Art. 48 modificado por Ley $3 / 2009$, de 23 de junio, por la que se modifica el texto refundido de la Ley de régimen financiero y presupuestario de Galicia, aprobado por el Decreto legislativo 1/1999, de 7 de octubre.
1. En los créditos para gastos corrientes se distinguirán los de funcionamiento de los servicios, los gastos financieros y las transferencias corrientes.

2. En los créditos para gastos de capital se distinguirán los de inversiones reales, las transferencias de capital y las variaciones de activos y pasivos financieros.

Segunda:

Los estados de ingresos presentarán una clasificación económica distinguiendo los correspondientes a operaciones corrientes y a operaciones de capital.

Artículo 50. Competencias de las consellerías.

1. Corresponde a la Consellería de Economía e Facenda determinar, con carácter general, las estructuras básicas de los presupuestos y los demás estados financieros correspondientes a la Comunidad, a sus organismos autónomos y a los demás entes y sociedades públicas.

2. Las distintas consellerías adoptarán dichas estructuras básicas y las desarrollarán en función de sus propias necesidades de gestión y de las de los organismos autónomos, entes y sociedades públicas a ellas adscritas.

3. Los objetivos e indicadores de seguimiento a los que hace referencia el artículo 49.Primera.b) los establecerán las consellerías, los organismos autónomos y demás entes públicos, de acuerdo con la Consellería de Economía e Facenda.

Artículo 51. Elaboración de los Presupuestos Generales.

El procedimiento para la elaboración de los Presupuestos Generales de la Comunidad Autónoma se ajustará a las siguientes normas:

1. Los órganos estatutarios de la Comunidad Autónoma y las consellerías remitirán a la de Economía y Hacienda antes del 1 de julio sus respectivos estados de gastos debidamente documentados y ajustados a las normas que les sean aplicables y a las directrices establecidas por la Xunta. 
2. Dentro del mismo plazo y con las mismas formalidades indicadas en el punto anterior, cada una de las consellerías remitirá:

a. Los anteproyectos de presupuestos de gastos e ingresos de los organismos autónomos que tengan adscritos, formando un sólo presupuesto para cada organismo, incluyendo en los que tengan carácter comercial, industrial o financiero los estados financieros a que hace referencia el artículo 82 de la presente ley.

b. Los anteproyectos de presupuestos de ingresos y gastos de los entes públicos, a los que hace referencia el artículo 12 de esta ley, que le estén adscritos.

c. Los anteproyectos de presupuestos de explotación y capital de las sociedades públicas que tengan adscritas.

3. El anteproyecto de presupuesto de ingresos de la Comunidad Autónoma en el que se recoja la estimación de los recursos derivados de sus fuentes generales de financiación lo elaborará la Consellería de Economía e Facenda.

4. Teniendo en cuenta los estados de ingresos y gastos mencionados y el marco macroeconómico en el que se contenga la previsible actividad económica del ejercicio presupuestario siguiente, la Consellería de Economía e Facenda formulará el anteproyecto de Ley de Presupuestos Generales de la Comunidad Autónoma y lo someterá a acuerdo de la Xunta.

5. Junto con el anteproyecto de Ley de Presupuestos Generales de la Comunidad Autónoma se remitirá al Consello de la Xunta la siguiente documentación:

a. La cuenta consolidada de los Presupuestos Generales de la Comunidad Autónoma.

b. Una memoria explicativa de su contenido y de las principales diferencias existentes en los mismos en relación con el presupuesto en vigor.

c. La liquidación de los presupuestos del año anterior y un avance de los del ejercicio corriente. d. Un informe económico y financiero.

e. Un anexo de inversiones reales, que contendrá la valoración de los proyectos de inversión pública que se van a realizar y su distribución territorial. En el caso de inversiones plurianuales, se indicará la inversión de cada año.

Dentro de dicho anexo de inversiones reales, se distinguirán los proyectos de inversión en vinculantes y no vinculantes. Los créditos destinados a proyectos de inversión a los que se les dé carácter vinculante no podrán destinarse a la financiación de otros proyectos, salvo por autorización del Conselleiro de Economía y Hacienda. Trimestralmente se comunicará a la Comisión 3. ${ }^{\text {a }}$, de Economía, Hacienda y Presupuestos, del Parlamento de Galicia, la relación de las autorizaciones realizadas, en el caso de haberlas.

f. Un anexo de transferencias.

g. Un anexo de personal.

Artículo 52. Remisión al Parlamento.

El Proyecto de Ley de Presupuestos Generales de la Comunidad Autónoma, acompañado de la documentación establecida en el apartado 5 del artículo anterior, se remitirá al Parlamento de Galicia antes del 20 de octubre, a los efectos del artículo 53.1 del Estatuto de Autonomía de Galicia.

Artículo 53. Presupuestos de las Diputaciones Provinciales.

La Xunta remitirá igualmente al Parlamento de Galicia los presupuestos de las Diputaciones Provinciales, a los efectos previstos en la disposición adicional tercera del Estatuto de Autonomía y en la Ley 5/1997, de 22 de julio, de Administración Local de Galicia.

Artículo 54. Prórroga de los Presupuestos Generales.

Si la Ley de Presupuestos Generales no fuese aprobada por el Parlamento de Galicia antes del primer día del ejercicio económico en el que tenga que aplicarse, se considerarán automáticamente prorrogados los del ejercicio inmediato anterior. 
1. La Consellería de Economía e Facenda podrá elaborar, en su caso, los correspondientes estados de gastos en los que se detallarán los importes de los créditos prorrogados. Dichos importes serán el resultado de realizar en los créditos iniciales del presupuesto prorrogado las operaciones siguientes:

a. Se excluirán aquellos gastos que correspondan a actuaciones que deban quedar ultimadas al finalizar el ejercicio cuyos presupuestos se prorrogan, así como aquellos que no se consideren necesarios para el ejercicio que se inicia.

b. En los indicados estados de gastos se incluirán aquellos créditos que correspondan a actuaciones de urgente iniciación o cobertura, siempre que tengan cabida dentro de las bajas motivadas por lo indicado en el apartado a) anterior.

c. El Conselleiro de Economía y Hacienda determinará qué modificaciones presupuestarias de las realizadas durante el ejercicio, cuyos presupuestos se prorrogan, se consolidarán en los estados de gastos a que hace referencia el apartado a).

2. Durante el período de prórroga será aplicable a los estados de gastos resultantes de lo dispuesto en el apartado anterior lo contenido en el capítulo II de este título III.

3. Una vez aprobados los Presupuestos Generales de la Comunidad se procederá a imputarles a los mismos las operaciones realizadas durante el período de prórroga, de acuerdo con las instrucciones que al efecto dicte la Consellería de Economía e Facenda.

En caso de no existir en los presupuestos aprobados créditos a los que imputarles expedientes de gasto tramitados durante el período de prórroga, la consellería o el Organismo Autónomo afectado propondrá a la Consellería de Economía e Facenda aquellos créditos del presupuesto aprobado con cargo a los cuales deberá efectuarse la imputación.

4. La Consellería de Economía e Facenda confeccionará, asimismo, los estados de ingresos que tendrán vigencia durante el período de prórroga y que se elaborarán en función de las previsiones que puedan derivarse bien de la liquidación de los presupuestos de ingresos del ejercicio prorrogado o de cualquier otro dato válido para sustentar dichas previsiones, siempre que no suponga la introducción de ningún cambio en la normativa legal vigente durante cuyo ejercicio se prorroga el presupuesto.

5. El texto de la Ley de Presupuestos correspondiente a los que se prorrogan también se prorrogará en sus propios términos, excepto aquellas disposiciones que por sus propias características sólo pudiesen tener exclusiva vigencia durante el respectivo año natural.

Artículo 55. Derechos y obligaciones reconocidas.

1. Los derechos liquidados y las obligaciones reconocidas se aplicarán a los presupuestos por su importe íntegro, quedando prohibido atender obligaciones mediante minoración de los derechos que se van a liquidar o ya ingresados, a no ser por autorización expresa de una Ley.

2. Se exceptúan de lo dispuesto en el punto anterior las devoluciones de ingresos que se declaren indebidos por tribunal o autoridad competentes y el reembolso del coste de las garantías aportadas por los contribuyentes para obtener la suspensión cautelar del pago de deudas tributarias impugnadas, en cuanto las mismas sean declaradas improcedentes y dicha declaración adquiera firmeza ${ }^{178}$.

3. A efectos de este artículo se entenderá por importe íntegro el que resulte después de aplicar los beneficios fiscales que sean procedentes, los que deberán ser objeto de contabilización independiente. El importe de los beneficios fiscales que afecten a los tributos propios de la Comunidad Autónoma se incluirán en la Ley de Presupuestos Generales de la Comunidad Autónoma.

178 Art. 55.2 modificado por Ley 8/1999, de 30 de diciembre, de medidas fiscales y presupuestarias y de función pública y actuación administrativa. 


\section{Capítulo II DE LOS CRÉDITOS Y DE SUS MODIFICACIONES}

Artículo 56. Autorización de créditos.

1. Los créditos consignados en los estados de gastos se destinarán exclusivamente a las finalidades específicas para las que fueron autorizados por la Ley de Presupuestos o por las modificaciones aprobadas conforme a esta ley.

2. Los créditos autorizados en los programas de gastos tienen carácter limitativo y vinculante a nivel de concepto. Sin embargo, los créditos destinados a gastos de personal, excepto los que se refieren a incentivos al rendimiento, y los gastos en bienes corrientes y servicios tendrán carácter vinculante a nivel de artículo.

3. En el presupuesto correspondiente a los servicios transferidos del INSALUD la vinculación anterior se entenderá referida a sus grupos de programas, atendidos el alcance y grado de pormenor de su estructura en la citada clasificación, en tanto en cuanto dicha estructura difiera de la establecida con carácter general para la Comunidad Autónoma.

4. En todo caso, tendrán carácter vinculante, con el nivel de desglose económico con el que aparezcan en los estados de gastos, los créditos destinados a atenciones protocolarias y representativas y los declarados ampliables conforme al artículo 64 de esta ley.

Artículo 57. Nulidad de obligaciones.

1. No podrán adquirirse compromisos de gastos por cuantía superior al importe de los créditos figurados en los estados de gastos, siendo nulos de pleno derecho los actos administrativos y las disposiciones generales con rango inferior a Ley que infrinjan la expresada norma, sin perjuicio de las responsabilidades a que haya lugar.

2. Se exceptúan de lo dispuesto en el número 1 anterior aquellos compromisos de gastos que reglamentariamente se determinen, cuando la imputación corresponda a créditos ampliables o que se adquieran como consecuencia de las necesidades propias del normal funcionamiento de los servicios y su importe exacto sea de difícil previsión por corresponder a obligaciones de tracto sucesivo.

Artículo 58. Gastos plurianuales.

1. Podrán adquirirse compromisos de gastos de carácter plurianual, aunque su ejecución haya de iniciarse en el ejercicio siguiente, cuando su contenido coincida con los que a continuación se especifican:

a. Inversiones y transferencias de capital.

b. Transferencias corrientes derivadas de normas con rango de ley, o que se concediesen a través de convocatorias o firma de convenios, previa autorización del compromiso plurianual por parte del Consello de la Xunta.

c. Gastos en bienes y servicios cuya contratación bajo las modalidades establecidas en la Ley de contratos del sector público no pudiera ser estipulada o resultase antieconómica por plazo que comprenda un solo ejercicio presupuestario.

d. Arrendamientos de bienes inmuebles que vayan a ser utilizados por organismos o servicios de la comunidad autónoma.

e. Cargas financieras derivadas de operaciones de endeudamiento de la Comunidad o de sus organismos autónomos.

f. Activos financieros.

g. Convenios con universidades y otras instituciones o centros docentes cuando aquellos hayan de ejecutarse durante cursos académicos coincidentes con dos ejercicios presupuestarios ${ }^{179}$.

2. La autorización o realización de los gastos de carácter plurianual se subordinará a los créditos que para cada ejercicio se consignen en los Presupuestos Generales de la Comunidad Autónoma.

3. El número de ejercicios a los que pueden aplicarse los gastos incluidos en las letras a), b), c), f) y g) del número 1 no podrá ser superior a cuatro.

179 Art. 58.1 modificado por Ley $16 / 2008$, de 23 de diciembre, de presupuestos generales de la Comunidad Autónoma de Galicia para el año 2009. 
El gasto que en estos casos se comprometiese con cargo a ejercicios futuros no podrá exceder del resultado de aplicar al crédito inicial, a nivel de concepto, los siguientes porcentajes: en el ejercicio inmediato siguiente el $70 \%$, en el segundo ejercicio el $60 \%$ y en los ejercicios tercero y cuarto el $50 \%$. Tampoco podrá ser inferior al $10 \%$ del importe total del expediente de gasto, en ninguno de los años a los que se extienda su ejecución material, salvo, en su caso, en el último ejercicio.

El total de los importes comprometidos con cargo a ejercicios futuros en el conjunto de los conceptos que definen un nivel de vinculación no podrá sobrepasar los porcentajes arriba indicados, calculados sobre el crédito inicial de ese conjunto de conceptos.

En los contratos de obra de carácter plurianual, con excepción de los realizados bajo la modalidad de abono total del precio, se efectuará una retención adicional de crédito del $10 \%$ del importe de adjudicación, en el momento en que la misma se realizase. Esta retención se aplicará al ejercicio en que finalice el plazo fijado en el contrato para la terminación de la obra o al siguiente, según el momento en que se prevea realizar el pago de la certificación final. Estas retenciones computarán dentro de los porcentajes establecidos en este artículo ${ }^{180}$.

4. También podrá ser diferido el pago del precio de compra de las adquisiciones de bienes inmuebles cuando el importe exceda de 350 millones de pesetas, sin que en ningún caso el desembolso inicial a la firma de la escritura pueda ser inferior al 30 por 100 del precio, pudiendo distribuirse libremente el resto hasta en cuatro anualidades sucesivas a los respectivos vencimientos dentro de las limitaciones del punto anterior.

5. Con independencia de lo establecido en los números anteriores para los programas

180 Art. 58.3 modificado por Ley 16/2008, de 23 de diciembre, de presupuestos generales de la Comunidad Autónoma de Galicia para el año 2009. y proyectos de gastos de capital que se especifiquen en las Leyes de Presupuestos, podrán adquirirse compromisos de gastos que tengan que extenderse a ejercicios futuros hasta el importe que para cada una de las anualidades se determine.

A estos efectos, cuando en los créditos presupuestarios se encuentren incluidos proyectos de las características señaladas anteriormente, los porcentajes a que se refiere el número 3 de este artículo se aplicarán sobre dichos créditos, una vez deducida la anualidad correspondiente a estos proyectos.

6. El Consello de la Xunta, a propuesta del Conselleiro de Economía y Hacienda, podrá modificar los porcentajes señalados en el número 3 de este artículo y los importes que se fijen con arreglo a lo dispuesto en el número 5, así como modificar el número de anualidades en casos especialmente justificados, a petición de la correspondiente Consellería y previos los informes que se estimen oportunos, y, en todo caso, el de la Dirección General competente en materia de presupuestos.

Este procedimiento será igualmente de aplicación en el caso de los contratos de obras que se efectúen bajo la modalidad de abono total de los mismos, según lo previsto en el artículo 99.2 del texto refundido de la Ley de Contratos de las Administraciones Públicas, aprobado por el Real Decreto Legislativo 2/2000, de 16 de junio, bien se pacte el abono total del precio de una sola vez o se fraccione en distintas anualidades, que no podrán ser superiores a diez desde la fecha fijada para la conclusión de las obras ${ }^{181}$.

7. Los compromisos de gastos de carácter plurianual a que hace referencia el presente artículo serán adecuadamente contabilizados de forma independiente.

Artículo 59. Anulación de créditos.

1. Los créditos destinados a atender gastos que en el último día del ejercicio presupuestario no estén afectados al

181 Art. 58.6 modificado por Ley 3/2002, de 29 de abril, de medidas de régimen fiscal y administrativo. 
cumplimiento de obligaciones reconocidas quedarán anulados de pleno derecho, salvo las excepciones contempladas en el artículo 71 de la presente ley.

2. A pesar de lo indicado en el número anterior, la anulación de créditos que por disposición legal tengan el carácter de incorporables no impedirá la continuación de la tramitación en forma provisional de expedientes de gastos con base en los mismos, condicionados a que al dictarse el acuerdo de autorización del compromiso de gasto exista crédito adecuado y suficiente. En ningún caso esta tramitación provisional podrá generar derechos a favor de terceros.

Artículo 60. Regulación de obligaciones.

1. Con cargo a los créditos consignados en los estados de gastos sólo podrán contraerse obligaciones derivadas de adquisiciones, obras, prestaciones de servicios y demás gastos en general que hayan sido realizados en el año natural del correspondiente ejercicio presupuestario.

2. Sin embargo, se aplicarán a los créditos del presupuesto vigente en el momento de la expedición de órdenes de pago las siguientes obligaciones:

a. Las que resulten del reconocimiento y liquidación de atrasos a favor del personal que perciba sus retribuciones con cargo a los Presupuestos Generales de la Comunidad Autónoma.

b. Las derivadas de compromisos de gastos debidamente adquiridos en ejercicios anteriores.

c. Las que tengan su origen en sentencias judiciales.

En aquellos casos en que no exista crédito adecuado en el ejercicio corriente, a iniciativa de la consellería correspondiente, el Conselleiro de Economía y Hacienda podrá determinar los créditos a los cuales habrá de imputarse el pago de estas obligaciones ${ }^{182}$.

182 Art. 60.2 modificado por Ley 5/2000, de 28 de diciembre, de medidas fiscales y de régimen presupuestario y administrativo.
Artículo 61. Normativa aplicable.

1. Las modificaciones de los créditos presupuestarios se ajustarán a lo dispuesto en esta ley y en las Leyes anuales de Presupuestos.

2. Todo acuerdo de modificación presupuestaria deberá indicar expresamente, además de la sección o ente público a que se refiera, el programa, servicio u Organismo Autónomo, artículo, concepto y subconcepto, en su caso, afectados por la misma, incluso en aquellos casos en los que el crédito se consigne o sea vinculante a nivel de artículo.

Las limitaciones establecidas en el artículo 68 de la presente ley se entenderán referidas a nivel de concepto para aquellos casos en los que la vinculación establecida lo sea a nivel de artículo.

La correspondiente propuesta de modificación presupuestaria deberá expresar ineludiblemente la incidencia de la misma en la consecución de los objetivos previstos, así como las razones que la justifican.

Artículo 62. Créditos extraordinarios y suplementos.

1. Cuando deba realizarse algún gasto con cargo a los Presupuestos Generales de la Comunidad Autónoma que no pueda demorarse hasta el ejercicio siguiente y no exista crédito en los estados de gastos, o sea insuficiente y no ampliable el consignado, el Conselleiro de Economía y Hacienda, previo informe de la Dirección General competente en materia de presupuestos, someterá al acuerdo de la Xunta, para su remisión al Parlamento, un Proyecto de Ley de concesión de un crédito extraordinario en el primer caso o de un suplemento de crédito en el segundo, en el que se especificarán necesariamente los recursos con que se financiará el gasto que por estas causas se genera, y el detalle del concepto presupuestario que se debe crear o que es suplementado.

2. A pesar de lo indicado en el punto anterior, si la necesidad de crédito extraordinario o de suplemento de crédito se produce en un Organismo Autónomo y los 
mismos no suponen aumento en los créditos del Presupuesto de la Comunidad Autónoma, se observarán las siguientes normas:

a. Su concesión será facultad del Conselleiro de Economía y Hacienda si su importe no excede del 5 por 100 del presupuesto de gastos del Organismo Autónomo correspondiente, y de la Xunta de Galicia cuando, superando dicho porcentaje, no sobrepasa el 10 por 100 del citado presupuesto de gastos. Dichos porcentajes se aplicarán de forma conjunta y acumulada para ambas clases de modificaciones de crédito y a lo largo del mismo ejercicio presupuestario.

b. En el expediente de modificación presupuestaria emitirá informe la consellería a la que esté adscrito el Organismo Autónomo que lo promueva, justificando debidamente la necesidad y urgencia del gasto y proponiendo los recursos con que se financiará el incremento que se propone.

c. La Xunta de Galicia dará cuenta trimestralmente al Parlamento de Galicia de los créditos extraordinarios y suplementos de crédito concedidos al amparo de lo previsto en el apartado a) del presente número.

Artículo 63. Anticipos de Tesorería. La Xunta de Galicia, a propuesta del Conselleiro de Economía y Hacienda, podrá, excepcionalmente, conceder anticipos de Tesorería para atender gastos inaplazables, hasta un límite del 2 por 100 de los créditos autorizados por la Ley de Presupuestos Generales de la Comunidad, en los siguientes casos:

a. Cuando, dentro de la tramitación del expediente de crédito extraordinario o suplemento de crédito, recayese acuerdo favorable de la Xunta para remitirle al Parlamento el correspondiente Proyecto de Ley.

b. Cuando se promulgue una Ley en la que se establezcan obligaciones para cuyo cumplimiento sea precisa la concesión de un crédito extraordinario o de un suplemento de crédito.

c. Si el Parlamento de Galicia no aprobase el Proyecto de Ley de concesión de crédito extraordinario o del suplemento de crédito, el importe del anticipo de Tesorería será cancelado mediante minoración en los créditos que ocasionen menor trastorno en los servicios públicos de la respectiva consellería u Organismo Autónomo.

Artículo 64. Créditos ampliables.

1. A pesar de lo dispuesto en los artículos 56 y 57 de esta ley, tendrán, excepcionalmente, la condición de créditos ampliables:

a. Aquellos que se especifiquen de manera singular en la Ley de Presupuestos Generales de la Comunidad Autónoma y con las condiciones que en la misma se determinen.

b. Los que se destinen a cubrir los gastos de los servicios traspasados por la Administración del Estado, cuando sean ampliadas las transferencias en las respectivas materias y por el importe del coste efectivo de todas las ampliaciones, mientras éste no se integre en la base de cálculo para obtener el porcentaje de la participación en los ingresos del Estado.

c. Las cuotas de Seguridad Social y la prestación familiar, así como las aportaciones que, en su caso, le corresponda efectuar a la Comunidad Autónoma al régimen de previsión social de sus funcionarios.

d. Los que se destinen al pago de intereses, amortizaciones del principal y gastos derivados de la Deuda Pública emitida por la Comunidad Autónoma o a operaciones de crédito concertadas por ella.

e. Los créditos destinados a la cobertura de necesidades de todo orden motivadas por siniestros, catástrofes u otros de reconocida urgencia, correspondientes a gastos en bienes corrientes y de servicios.

f. Los destinados al pago de productos farmacéuticos procedentes de recetas médicas.

g. Los créditos cuya ejecución corresponda a una consellería y que su cuantía se module por la aportación de otras consellerías u organismos autónomos, previa retención del crédito correspondiente en los estados de gasto afectados. A estos créditos no les serán aplicables 
las limitaciones a que se refiere el artículo 68 de esta ley.

2. El expediente de ampliación de créditos deberá establecer la fuente de financiación de dicha ampliación, distinguiendo si el mismo se financia con retenciones en otros créditos, con mayores recursos que se vayan a obtener, con remanente de Tesorería, con endeudamiento dentro de los límites autorizados o con otras formas de financiación que no entrañen déficit presupuestario.

Artículo 65. Competencias del Consello de la Xunta.

1. Corresponde al Consello de la Xunta, a propuesta del Conselleiro de Economía y Hacienda, y a iniciativa de las consellerías correspondientes:

a. Autorizar transferencias de créditos entre programas incluidos en distinto grupo de función, correspondientes a servicios u organismos autónomos de una misma consellería.

b. Autorizar transferencias de créditos entre uno o varios programas incluidos en la misma función, correspondientes a servicios u organismos autónomos de diferentes consellerías.

c. Autorizar transferencias de crédito entre programas incluidos en distintas funciones, correspondientes a servicios $\mathrm{u}$ organismos autónomos de diferentes consellerías, siempre que se trate de reorganizaciones administrativas o que se produzcan como consecuencia de la aplicación de los recursos procedentes del Fondo Europeo de Desarrollo Regional o del Fondo Social Europeo.

d. Autorizar transferencias de créditos a propuesta del Conselleiro de Economía y Hacienda de las dotaciones no utilizadas en los programas de las distintas secciones del presupuesto a los distintos conceptos del programa de imprevistos y funciones no clasificadas, habilitando los créditos que sean necesarios para su posterior reasignación.

2. De cada modificación acordada en virtud de lo dispuesto en este artículo se dará cuenta de modo singular, en el plazo máximo de treinta días, a la Comisión de Economía, Hacienda y Presupuestos, con remisión de copia del correspondiente expediente.

Artículo 66. Facultades de la Consellería de Economía e Facenda.

Corresponden al Conselleiro de Economía y Hacienda, además de las competencias genéricas atribuidas a los titulares de las consellerías, las siguientes de carácter específico:

a. Resolver los expedientes de modificaciones presupuestarias, en los supuestos en los que éstos estén atribuidos a los titulares de las distintas consellerías y exista discrepancia en la consellería respectiva con el informe de la intervención delegada.

b. Autorizar transferencias de crédito entre uno o varios programas incluidos en la misma o distinta función, dentro del mismo grupo de funciones, correspondientes a servicios u organismos autónomos de una misma consellería, con la creación de nuevos conceptos presupuestarios, si ello fuese preciso.

c. Autorizar transferencias de créditos desde el programa de imprevistos y funciones no clasificadas a los conceptos y artículos de los demás programas de gasto, cualquiera que sea la función o sección a que corresponda.

La consellería o el Organismo Autónomo que solicite la transferencia deberá justificar la imposibilidad de atender las insuficiencias mediante reajuste de sus créditos. A tal efecto, deberá procederse a una revisión de conjunto de los oportunos programas de gasto, poniendo de manifiesto las desviaciones que en la consecución de los objetivos previstos motivaría la modificación presupuestaria propuesta.

d. Introducir, previo informe de la consellería correspondiente, las variaciones que sean precisas en los presupuestos de servicios transferidos del IMSERSO y del INSALUD, al objeto de adaptarlos a los resultantes de la aprobación por las Cortes Generales de los Presupuestos Generales de la Seguridad Social. 
e. Autorizar las incorporaciones de crédito previstas en el artículo 71 de esta ley.

f. Autorizar las generaciones de crédito previstas en los artículos 69 y 70 de esta ley.

g. Autorizar las ampliaciones de crédito cuando éstos tengan tal carácter por disposición de Ley.

h. Introducir en los estados de gastos las modificaciones precisas para adecuar los créditos afectados por transferencias finalistas procedentes de los Presupuestos Generales de la Administración del Estado y de las Comunidades Europeas, y los demás recursos de igual carácter y procedencia. Esta autorización implicará el aumento o la disminución de las consignaciones previstas, así como la incorporación o creación de los correspondientes conceptos presupuestarios si así procede.

Artículo 67. Facultades de los Conselleiros.

1. Los titulares de las consellerías podrán autorizar, previo informe de la Intervención Delegada correspondiente, las transferencias de créditos entre diferentes conceptos del capítulo II, de un mismo programa, correspondientes a un mismo o diferente servicio u Organismo Autónomo dependiente de la consellería, siempre que no afecten a créditos de atenciones protocolarias o representativas, ni supongan desviación en la consecución de los objetivos previstos para el programa respectivo.

En tanto el capítulo II tenga carácter limitativo y vinculante a nivel de artículo, esta autorización comporta la creación, en su caso, de nuevos conceptos presupuestarios de los previstos en la clasificación económica.

2. En caso de discrepancia con el informe emitido por la Intervención Delegada sobre la modificación presupuestaria propuesta, se remitirá el expediente a la Consellería de Economía e Facenda a los efectos previstos en el artículo 66.a) de la presente ley.

3. Los Presidentes de los órganos estatutarios de la Comunidad Autónoma tendrán las mismas competencias establecidas en este artículo en relación con las modificaciones presupuestarias de su respectivo presupuesto, sin perjuicio del principio de autonomía presupuestaria del Parlamento de Galicia.

4. En todo caso, una vez autorizadas las modificaciones presupuestarias incluidas en los números 1 y 3 , se remitirán a la Dirección General competente en materia de presupuestos de la Consellería de Economía e Facenda, para instrumentar su ejecución.

\section{Artículo 68. Limitaciones.}

1. Las transferencias de crédito de cualquier clase estarán sujetas a las siguientes limitaciones:

a. No afectarán a los créditos ampliables ni a los extraordinarios concedidos durante el ejercicio.

b. No podrán minorarse los créditos incorporados como consecuencia de remanentes de ejercicios anteriores, ni los que fuesen incrementados con suplementos o transferencias, salvo cuando afecten a créditos de personal.

c. No podrán incrementarse créditos que como consecuencia de otras transferencias fuesen objeto de minoración, salvo cuando afecten a créditos de personal.

2. Respecto del presupuesto de los servicios transferidos del INSALUD las limitaciones contenidas en los apartados b) y c) anteriores se entenderán referidas a los presupuestos totales de la entidad gestora, aun cuando los mismos se desarrollen de modo descentralizado a través de los distintos centros de gastos.

3. Las anteriores limitaciones no afectarán a las transferencias de créditos que se refieran al programa de imprevistos y funciones no clasificadas o realizadas al amparo del artículo 60.2 de la presente ley, ni serán de aplicación cuando se trate de créditos modificados a consecuencia de reorganizaciones administrativas, de acuerdos de transferencias de servicios o que amparen gastos financiados exclusivamente 
o cofinanciados con transferencias finalistas del Estado o con fondos de la Unión Europea ${ }^{183}$.

4. Los créditos correspondientes a financiación condicionada estarán sujetos a las limitaciones específicas que les sean aplicables; de no existir éstas será aplicable lo determinado en el número 1 de este artículo.

Artículo 69. Generación de crédito.

1. Podrán generar crédito en los estados de gastos de los presupuestos los ingresos efectivos, los derechos liquidados y los compromisos firmes de ingresos derivados de las siguientes operaciones:

a. Aportaciones de otras Administraciones Públicas o de personas físicas o jurídicas para financiar gastos que por su naturaleza estén comprendidos en los fines u objetivos encomendados a la Comunidad Autónoma o a sus organismos autónomos.

b. Enajenación de bienes de la Comunidad o de sus organismos autónomos.

c. Prestación de servicios.

d. Reembolso de los préstamos destinados a atenciones sociales y a la promoción $\mathrm{y}$ al fomento de la actividad económica y cultural de Galicia.

e. Créditos del exterior para financiar inversiones públicas.

2. Las generaciones de crédito a que se hace referencia en el número anterior únicamente podrán realizarse por el exceso de ingresos sobre las cifras inicialmente presupuestadas, y cuando se deriven de operaciones incluidas en el apartado c) se destinarán únicamente a cubrir gastos de la misma naturaleza que los que se originaron por la prestación del servicio ${ }^{184}$.

3. Las generaciones de crédito se efectuarán en el mismo ejercicio en que se ha producido el ingreso, salvo cuando tenga lugar en el último trimestre del año o cuando se trate de fondos procedentes de la Unión Europea o de la Administración

183 Art. 68.3 modificado por Ley 7/2002, de 27 de diciembre, de medidas fiscales y de régimen administrativo.

184 Art. 69.2 modificado por Ley 16/2008, de 23 de diciembre, de presupuestos generales de la Comunidad Autónoma de Galicia para el año 2009.
Central del Estado, casos en que podrá generarse crédito en el ejercicio siguiente, siempre que se justifique la imposibilidad de tener tramitada la generación en el mismo ejercicio en que se ha producido el ingreso. En este caso, el límite a que se refiere el punto anterior se entenderá referido al presupuesto de origen ${ }^{185}$.

Artículo 70. Reposición.

Los ingresos derivados del reintegro de pagos indebidos con cargo a créditos presupuestarios podrán reponer estos últimos en las condiciones que se establezcan reglamentariamente.

\section{Artículo 71. Incorporaciones.}

1. A pesar de lo dispuesto en el artículo 59 de esta ley, podrán incorporarse a los estados de gastos del presupuesto correspondiente al ejercicio inmediato siguiente:

a. Los créditos extraordinarios y los suplementos de crédito, así como las transferencias de crédito, que se concediesen o autorizasen, respectivamente, en el último mes del ejercicio presupuestario y que, por causas justificadas, no pudiesen ser utilizados durante el mismo.

b. Los créditos que contemplen compromisos de gastos anteriores al último mes del ejercicio presupuestario y que no pudiesen ejecutarse al final del ejercicio económico por causas justificadas.

Será preciso que tales compromisos de gastos alcanzasen la fase de disposición en contabilidad antes del último mes del ejercicio.

c. Los créditos destinados a operaciones de capital.

d. Los créditos autorizados en función de la efectiva recaudación de derechos afectados a los mismos.

e. Los créditos generados por las operaciones enumeradas en el artículo 69 de la presente ley.

2. Los remanentes incorporados según lo previsto en el número anterior únicamente podrán ser aplicados dentro del

185 Art. 69.3 modificado por Ley 5/2000, de 28 de diciembre, de medidas fiscales y de régimen presupuestario y administrativo. 
ejercicio presupuestario en el que la incorporación se acuerde, a excepción de los que correspondan a créditos financiados por el Fondo de Compensación Interterritorial $o$ por fondos o subvenciones finalistas procedentes de la Unión Europea o de otras Administraciones públicas, que podrán ser incorporados en tanto persista el derecho a la percepción del ingreso que los financia. En los supuestos a) y b) de dicho número la incorporación se hará para los mismos gastos que motivaron en cada caso la concesión, la autorización y el compromiso.

3. Los créditos correspondientes a financiación condicionada serán incorporables de acuerdo con la normativa que les sea aplicable en cada caso. De no existir ésta, se regirán por las normas de la presente ley.

4. El Conselleiro de Economía y Hacienda podrá acordar, con carácter general, la incorporación automática al ejercicio siguiente de los créditos a que se refiere el apartado d) del número 1 anterior.

5. De las incorporaciones a que se refieren los apartados 1 y 3 se dará cuenta al Parlamento ${ }^{186}$.

\section{Capitulo III EJECUCIÓN Y LIOUUIDACIÓN}

Artículo 72. Autorización de gasto.

1. Corresponde a los órganos estatutarios, salvo lo que establezcan otras Leyes aplicables, a los conselleiros y demás órganos de la Comunidad Autónoma que tuviesen dotaciones diferenciadas en sus estados de gastos autorizar los gastos referentes a los servicios a su cargo, excepto en los casos reservados por las Leyes a la competencia de la Xunta de Galicia, así como autorizar los actos de disposición de créditos y de reconocimiento de obligaciones, y proponer al Conselleiro de Economía y Hacienda la ordenación de los correspondientes pagos.

2. Con la misma reserva legal corresponde a los Presidentes o Directores de los

186 Orden de 20 de diciembre de 2007 por la que se regula el procedimiento para la incorporación automática de remanentes procedentes de ejercicios anteriores. organismos autónomos de la Comunidad la autorización y disposición de gastos y créditos, respectivamente, el reconocimiento de obligaciones y el ordenamiento de los pagos que correspondan a los mismos.

3. Reglamentariamente, el Consello de la Xunta de Galicia podrá establecer las competencias y los trámites que debe realizar directamente la Consellería de Economía e Facenda, respecto de la contabilidad y de la tesorería para los organismos autónomos y entes que por sus características se estime oportuno, sin perjuicio de la normativa que les sea aplicable.

4. Las facultades a las que se hace referencia en este artículo podrán ser objeto de delegación o desconcentración en los términos que reglamentariamente se establezca.

Artículo 73. Fases del gasto.

La gestión económica y financiera de los derechos y créditos incluidos en los presupuestos de la Comunidad Autónoma y de sus organismos autónomos se estructurará de acuerdo con las siguientes fases:

a. Presupuesto de gastos:

1. La autorización del gasto, que es el acto en virtud del cual la autoridad competente acuerda la realización de un gasto, calculado en forma cierta o aproximada, reservando a tal fin la totalidad o una parte del crédito presupuestario legalmente destinado a garantizar el cumplimiento de las obligaciones que puedan ser consecuencia de aquél, teniendo en cuenta la naturaleza económica de las mismas.

2. La disposición, que es el acto en virtud del que se acuerda, concierta o determina, según los casos, después de cumplir los trámites que de acuerdo con el derecho procedan, la cuantía concreta que debe alcanzar el compromiso económico para la realización de todo tipo de prestaciones.

Con los actos de disposición queda formalizada la reserva del crédito por un importe y unas condiciones exactamente determinados.

3. El reconocimiento de la obligación, que es la operación de contraer en cuentas 
los créditos exigibles contra la Comunidad de Galicia que deban acreditarse como contraprestación económica derivada de los acuerdos, de los conciertos o de las normas resolutorias que determinen la disposición de un crédito, una vez realizada y justificada adecuadamente la correspondiente prestación y efectuada la pertinente liquidación.

4. El ordenamiento del pago, que es la operación en virtud de la cual el ordenador competente, previa propuesta de pago realizado por quien ha reconocido la existencia de la obligación, expide la orden de pago contra la Tesorería de la Comunidad a favor del respectivo acreedor.

b. Presupuesto de ingresos:

1. El compromiso de ingresos, que es el acto en base al que se reconoce en cuentas el derecho a liquidar un determinado recurso por una cuantía cierta si se cumplen aquellas condiciones y trámites que se prevean en las normas legales aplicables.

2. El contraído del recurso, que es el acto por el que se liquida el mismo y se reconoce en cuentas el derecho definitivo a su percepción por su exacta cuantía.

3. La recaudación del recurso, que constituye el proceso por el que la Tesorería de la Comunidad hace líquido e ingresa en sus cajas el importe del mismo.

Artículo 74. Ordenación general de los pagos.

1. La ordenación general de pagos de la Comunidad corresponde al Conselleiro de Economía y Hacienda, pudiendo delegar dicha competencia de acuerdo con los procedimientos legales aplicables.

2. Al objeto de facilitar el servicio de ordenamiento de pagos, se podrán establecer ordenamientos secundarios bajo la dependencia del Conselleiro de Economía y Hacienda o de la autoridad en la que delegue sus competencias sobre la materia.

3. Los servicios y las funciones de los ordenamientos de pagos se dispondrán reglamentariamente a propuesta del Conselleiro de Economía y Hacienda.
Artículo 75. Plan de disposición.

La expedición de órdenes de pago con cargo al presupuesto de la Comunidad y de sus organismos autónomos deberá ajustarse al plan que sobre disposición de fondos de la Tesorería establezca anualmente la Consellería de Economía e Facenda.

Artículo 76. Tramitación.

1. Las órdenes de pago se expedirán una vez que se justificase documentalmente ante el órgano competente para reconocer la respectiva obligación, la realización de la prestación o el derecho del acreedor, conforme a los acuerdos por los que en su día se autorizaron y comprometieron los correspondientes gastos.

2. Los ordenadores de pagos podrán recibir las propuestas y librar las correspondientes órdenes de pago mediante la utilización de procesos informáticos. En este supuesto la documentación justificativa del gasto realizado podrá quedar en aquellos centros en los que se reconocieron las correspondientes obligaciones, para su posterior inclusión, en su caso, en la Cuenta General de la Comunidad Autónoma o para su puesta a disposición de los órganos de control competentes.

3. En los casos contemplados en el número anterior, a los ordenadores de pagos no les serán exigibles responsabilidades que procedan de trámites anteriores a su participación en el proceso de gestión presupuestaria, considerándose en estos casos que la referencia que en el artículo 122 y siguientes de la presente ley se hace a las responsabilidades de los ordenadores de pago se entenderá referida a los órganos que reconozcan las obligaciones o propongan el ordenamiento del pago.

Artículo 77. Pagos a justificar.

1. Tendrán el carácter de pagos a justificar los fondos librados para atender gastos que no puedan ir acompañados de la documentación justificativa a que se hace referencia en el artículo anterior.

2. Podrán expedirse órdenes de pago a justificar en los supuestos siguientes: 
a. Cuando los documentos justificativos no puedan adjuntarse antes de efectuar la propuesta de pago.

b. Cuando se considere conveniente la utilización de este sistema para agilizar significativamente la gestión de los créditos.

c. Cuando las órdenes de pago tengan por objeto satisfacer gastos en localidades donde no existan dependencias del Organismo Autónomo de que se trate.

3. La Consellería de Economía e Facenda, oídas las consellerías, previo informe de la Intervención General, establecerá las normas generales que regulen la expedición de órdenes de pago a justificar, así como los límites cuantitativos de las mismas y los conceptos presupuestarios a los que son aplicables.

4. Las órdenes de pago cursadas con el carácter de justificar se aplicarán a los créditos presupuestarios que correspondan y sus perceptores quedarán obligados a justificar la aplicación de las cantidades recibidas en el plazo de tres meses, estando sujetos al régimen de responsabilidades previsto en la presente ley. En los casos excepcionales podrá concederse una prórroga adicional por otro período igual para cumplimentar en todo o en parte la citada justificación.

5. En el curso de los dos meses siguientes a la fecha de recepción de la documentación justificativa a que se refieren los números anteriores, el órgano competente procederá a la aprobación o al reparo de la cuenta rendida.

6. No tendrán la condición de pagos a justificar las provisiones de fondos de carácter permanente que se realicen a pagadurías, cajas y habilitaciones para la atención de gastos periódicos o repetitivos. Estos anticipos de caja fija tendrán la consideración de operaciones extrapresupuestarias y su cuantía global no podrá exceder del 10 por 100 del capítulo destinado a gastos corrientes en bienes y servicios del presupuesto vigente en cada momento. Reglamentariamente se ordenará el procedimiento de concesión de anticipos de caja fija, su justificación e imputación al presupuesto y demás aspectos relacionados con los mismos.

Artículo 78.

$(\ldots)^{187}$.

\section{Artículo 79.}

(...) $)^{188}$.

Artículo 80. Liquidación.

1. El presupuesto de cada ejercicio se liquidará en cuanto a la recaudación de derechos liquidados y al pago de obligaciones reconocidas a 31 de diciembre del año natural correspondiente, y quedarán a cargo de la Tesorería de la Comunidad Autónoma los derechos pendientes de cobro y las obligaciones pendientes de pago según sus respectivas contracciones.

2. No obstante, se aplicarán al ejercicio corriente los ingresos procedentes de derechos liquidados que no sean exigibles en el momento del cierre del ejercicio presupuestario en virtud del aplazamiento, de los fraccionamientos y de las moratorias legalmente concedidos, así como los que se encuentren dentro del plazo legal para realizar el ingreso en período voluntario. En este supuesto, se deberá proceder a dar de baja los indicados derechos en las cuentas justificativas de la gestión de recursos imputables al ejercicio que se cierra, antes de su inclusión en las cuentas del ejercicio siguiente.

3. Los demás ingresos que se realicen una vez cerrado el ejercicio presupuestario respectivo quedarán desafectados del destino específico que, en su caso, les correspondiese, sin perjuicio de su reconocimiento y nueva afectación con cargo al presupuesto del ejercicio en curso, en aquellos otros supuestos que así se determinen.

187 Art. 78 derogado por Ley 9/2007, de 13 de junio, de subvenciones de Galicia.

188 Art. 79 derogado por Ley 9/2007, de 13 de junio, de subvenciones de Galicia. 
Artículo 81. Remanentes de Tesorería.

1. El remanente de Tesorería de la Comunidad o de cada uno de sus organismos autónomos administrativos con referencia a un ejercicio presupuestario determinado estará formado por la suma de las disponibilidades líquidas y los derechos reconocidos pendientes de cobro, menos las obligaciones reconocidas pendientes de pago, según la situación que los mismos presenten a 31 de diciembre del ejercicio anterior.

2. Se entenderá por remanente de Tesorería disponible aquel que no esté afectado a la financiación específica de determinados gastos.

El remanente de Tesorería disponible podrá afectarse en su totalidad o en parte a la financiación del presupuesto inicial de gastos o a la financiación de modificaciones presupuestarias, una vez que sea suficientemente comprobada su disponibilidad.

3. La diferencia que en cada momento exista entre el remanente disponible y el afectado a la financiación del presupuesto inicial o de modificaciones presupuestarias a lo largo del ejercicio constituirá el remanente líquido.

4. En el caso de resultar un remanente de Tesorería negativo a lo largo del ejercicio, el Organismo Autónomo afectado instruirá el oportuno expediente de modificación presupuestaria ante la Consellería de Economía e Facenda, en el que se propondrá la baja en aquellos créditos que considere adecuados para la financiación de aquél.

En el presupuesto que no sea de organismos autónomos el Consello de la Xunta, a propuesta de la Consellería de Economía e Facenda, dará de baja créditos de las distintas consellerías. De no ser posible, en el presupuesto siguiente se enjugarán con menores gastos.

\section{Capitulo IV \\ NORMAS DE ESPECIAL APLICACIÓN PARA LOS ORGANISMOS AUTÓNOMOS DE CARÁCTER COMERCIAL, INDUSTRIAL, FINANCIERO O ANÁLOGO}

Artículo 82. Presupuestos de los organismos autónomos.

1. De los presupuestos de los organismos autónomos comerciales, industriales, financieros o análogos formarán parte los siguientes estados financieros:

a. Cuenta de operaciones comerciales.

b. Cuenta de explotación.

c. Estado demostrativo de la variación del fondo de maniobra.

d. Cuadro de financiación.

2. El resultado que se derive de los estados financieros correspondientes a los apartados a) y c) del número anterior tendrá el adecuado reflejo en el presupuesto de ingresos del Organismo Autónomo respectivo.

3. Las operaciones propias de la actividad específica de estos organismos, recogidas en la cuenta de operaciones comerciales, no estarán sometidas al régimen de limitaciones establecido en el artículo 56 de esta ley para los créditos incluidos en los estados de gastos de sus presupuestos.

4. La Consellería de Economía e Facenda establecerá las estructuras de los estados financieros indicados, adaptados a sus distintas especialidades, así como los criterios generales que se aplicarán para la imputación de gastos a cuenta de operaciones comerciales, según el principio general de que, salvo los gastos generales de personal, se le podrán imputar a la misma todos aquellos gastos que forman parte directa o indirectamente del coste de los productos vendidos, de los servicios prestados o de los bienes producidos.

5. El ejercicio presupuestario coincidirá con el año natural, sin perjuicio de los ajustes necesarios cuando las operaciones que realice el Organismo Autónomo estén vinculadas a un ciclo productivo distinto que no podrá ser superior a doce meses. 


\section{Capitulo V \\ NORMAS DE ESPECIAL APLICACIÓN A LAS SOCIEDADES PÚBLICAS}

Artículo 83. Programas de sociedades públicas.

1. Las sociedades a que se refiere el número 1 del artículo 12 de esta ley elaborarán anualmente un programa de actuación, inversiones y financiación, y su finalidad será la de mostrar la planificación general de su actividad a un nivel de agregación adecuado que permita apreciar los objetivos que va a conseguir la sociedad a medio plazo y en el año económico correspondiente al ejercicio presupuestado.

2. La estructura de los programas de actuación, inversiones y financiación la determinará la Consellería de Economía e Facenda y tendrá, por lo menos, el siguiente contenido:

a. Un estado en el que se recojan las inversiones reales y financieras que se prevean dentro de un marco plurianual.

b. Un estado en el que, para el mismo período, se contengan sus fuentes de financiación, con especificación de las aportaciones de cualquier clase que se prevean recibir de la Comunidad o de sus organismos autónomos.

c. Una exposición de los objetivos que se deben alcanzar en dicho período plurianual y de las características básicas de su actividad económica.

d. Una memoria de la evaluación económica de las inversiones programadas durante el período.

3. Estas sociedades elaborarán además, anualmente, un presupuesto de explotación, que detallará el contenido de su cuenta de explotación, y un presupuesto de capital, en el que se especificarán los orígenes y la aplicación de sus fondos.

4. Los presupuestos de capital mencionados en el número anterior recogerán con un mayor detalle las cifras contenidas en la primera anualidad del programa de actuación, inversiones y financiación, adaptando dichas cifras a las posibilidades reales de financiación que resulten del proceso de elaboración presupuestaria.

Las estimaciones contenidas en los presupuestos de explotación y de capital de las sociedades públicas se remitirán, para su conocimiento y aprobación, al Parlamento de Galicia, formando parte de los Presupuestos Generales de la Comunidad Autónoma.

Las sociedades públicas que se creen a lo largo del ejercicio adaptarán su actividad durante la parte del año natural correspondiente al que prevea su programa de actuación, inversiones y financiación.

5. Las variaciones en los presupuestos a que se refiere el número 3 de este artículo que no afecten a subvenciones de los Presupuestos Generales de la Comunidad Autónoma y que supongan incremento o disminución en los gastos de personal, inversiones reales o financieras y endeudamiento neto sobre las inicialmente previstas serán autorizadas por el Conselleiro de Economía y Hacienda cuando su importe no exceda del 10 por 100 de cada una de las clases de gastos antes indicados que se propongan modificar, y por la Xunta de Galicia en los demás casos.

6. La estructura básica de los presupuestos de explotación y capital la establecerá la Consellería de Economía e Facenda y la desarrollará cada sociedad en función de sus necesidades, siguiendo las directrices del plan de contabilidad aplicable.

Artículo 84. Plazo y tramitación.

1. Las sociedades públicas a las que se refiere este capítulo elaborarán antes del 15 de mayo de cada año el programa de actuación, inversiones y financiación acompañado de una memoria explicativa del contenido del programa y de las modificaciones introducidas en la programación plurianual en relación con los que se encuentren en vigor.

En el caso de las sociedades a que se refiere la letra a) del número 1 del artículo 12 de esta ley, que se encuentren en relación con otra u otras sociedades de las que sean socios 
en cualquiera de los supuestos previstos en el artículo 42 del Código de Comercio, deberán presentar el programa de forma consolidada con dichas sociedades.

En el supuesto de las sociedades a que se refiere la letra b) del número 1 del artículo 12 de esta ley, que sean titulares de la mayoría de las acciones de una o varias sociedades, deberán presentar el programa consolidado con dichas sociedades.

No están obligadas a presentar el programa de actuación, inversiones y financiación aquellas sociedades de las previstas en la letra a) del número 1 del artículo 12 de esta ley que, de acuerdo con la Ley de Sociedades Anónimas, puedan presentar balance abreviado, salvo que reciban subvenciones de explotación o capital con cargo a los Presupuestos Generales de la Comunidad Autónoma.

2. Los programas a que se refiere el número 1 anterior se someterán a la aprobación de la Xunta de Galicia antes del 1 de julio de cada año, a propuesta del Conselleiro de Economía y Hacienda, considerándose condicionadas las aportaciones, figuradas en los mismos con cargo a los Presupuestos Generales de la Comunidad Autónoma, a las resultantes de la tramitación y definitiva aprobación de éstos.

3. La Xunta dará cuenta al Parlamento de Galicia de los principios que informan los programas de actuación de las sociedades públicas gallegas.

Artículo 85. Remisión.

Los presupuestos de explotación y capital que se tengan que elaborar de acuerdo con lo dispuesto en el número 3 del artículo 83 de esta ley serán remitidos por las correspondientes sociedades públicas a la consellería de la que dependan, que los remitirá a la de Economía y Hacienda junto con el resto de la documentación para la elaboración del anteproyecto de Ley de Presupuestos Generales a que hace referencia el artículo 51 de la presente ley. Estos presupuestos de explotación y capital se acompañarán de: a. Una memoria justificativa de su contenido con indicación de objetivos.

b. La liquidación de los del ejercicio anterior y un avance de liquidación de los del corriente.

c. El balance cerrado del ejercicio anterior, el avance del ejercicio corriente y el provisional del ejercicio a que dichos presupuestos correspondan.

Artículo 86. Supuestos macroeconómicos.

1. Los Convenios que la Comunidad Autónoma establezca con las sociedades públicas gallegas o participadas, o con otras que, aun no dependiendo de ella, sean beneficiarias de avales o reciban subvenciones con cargo a sus Presupuestos Generales, incluirán, en cualquier caso, las cláusulas correspondientes a las siguientes materias:

a. Supuestos macroeconómicos y sectoriales que sirvan de base al contenido del Convenio.

b. Objetivos de la política de personal, rentabilidad, productividad o reestructuración técnica de la explotación económica, así como los métodos de evaluación de aquéllas.

c. Aportaciones o avales de la Comunidad o de sus organismos autónomos.

d. Procedimientos para adaptar los objetivos acordados a las variaciones que se produzcan en el respectivo medio económico.

e. Control por la Comunidad Autónoma de la ejecución del Convenio y de la posterior explotación económica.

2. La suscripción del Convenio no excluye la elaboración y ejecución del programa y de los presupuestos de explotación y de capital a que se refiere el artículo 83 de la presente ley.

\section{TíTULO IV DE LA TESORERÍA}

Artículo 87. Concepto.

1. Constituyen la Tesorería de la Comunidad Autónoma de Galicia todos los 
recursos financieros, sean dinero, valores, créditos y los demás productos de las operaciones de endeudamiento de la Comunidad y de sus organismos autónomos que se generen tanto por operaciones presupuestarias como extrapresupuestarias.

2. Las disponibilidades de la Tesorería y las variaciones que puedan sufrir están sujetas al régimen de intervención y deben ser registradas de conformidad con las normas de contabilidad pública. Podrán establecerse procedimientos especiales de anotación en cuenta para aquellos movimientos internos de efectivo entre las distintas cuentas operativas de la Tesorería que determine el Conselleiro de Economía y Hacienda.

Artículo 88. Funciones.

Son funciones propias de la Tesorería:

a. La gestión recaudatoria de los recursos y el pago de las obligaciones de la Comunidad y de sus organismos autónomos.

b. Instrumentar y servir al principio de unidad de caja, mediante la centralización de todos los fondos y valores generados por operaciones presupuestarias y extrapresupuestarias.

c. Distribuir en el tiempo y en el territorio las disponibilidades dinerarias para la satisfacción puntual de las obligaciones de la Comunidad.

d. Velar por la obtención de la adecuada rentabilidad de los recursos disponibles de la Comunidad sin menoscabo de los fines propios de la Tesorería.

e. Responder de los avales contraídos por la Comunidad conforme a las disposiciones de esta ley.

f. Las demás funciones que se deriven o relacionen con las anteriores enumeradas.

Artículo 89. Situación de los fondos de la Comunidad Autónoma.

1. Con carácter general la Tesorería de la Comunidad situará los fondos públicos en el Banco de España o en las entidades de crédito y ahorro gallegas o que operen en Galicia, en cuentas de las que, en todo caso, poseerá la titularidad.
2. La Tesorería de la Comunidad podrá instrumentar todas aquellas operaciones activas que considere convenientes para mantener la adecuada rentabilidad de los fondos a su cargo, guiada en todo caso por el principio de seguridad en su colocación.

3. El régimen general de autorizaciones para la situación y colocación de fondos, la naturaleza de las cuentas, el control y la disposición de los fondos y de los servicios de colaboración que se vayan a concertar con las entidades financieras indicadas en el párrafo anterior lo establecerá la Consellería de Economía e Facenda.

Artículo 90. Situación de los fondos de los organismos autónomos.

1. Los fondos de los organismos autónomos se situarán en cuentas diferenciadas con la autorización expresa de la Consellería de Economía e Facenda y bajo el control de la Tesorería, utilizando rúbricas que contengan la denominación general de "organismos autónomos de la Comunidad Autónoma de Galicia", teniendo la consideración, a todos los efectos, de fondos de la propia Tesorería.

2. Dichos fondos podrán estar situados en el Banco de España o en otras entidades de crédito y ahorro gallegas o que operen en Galicia, necesitando autorización expresa de la Consellería de Economía e Facenda para la apertura de cada cuenta y para la determinación de sus condiciones de funcionamiento, previa solicitud motivada, que podrá ordenar su cancelación o suspender su utilización si se comprobase que no subsisten las condiciones que motivaron la autorización de apertura.

3. Las entidades financieras indicadas en el punto anterior tienen para con la Tesorería de la Comunidad Autónoma, a su solicitud, las mismas obligaciones de información que para con las consellerías y con los organismos autónomos titulares de las cuentas abiertas en las mismas.

4. La Consellería de Economía e Facenda podrá proponerle al Consello de la Xunta que las operaciones de ingreso y de ordenación y realización material del 
pago de los organismos autónomos y de los entes públicos, a que hace referencia el apartado b) del punto 1 del artículo 12 de la presente ley, se realicen por la Tesorería de la Xunta, para lo cual se establecerá el correspondiente procedimiento.

Artículo 91. Ingresos y medios de pago.

1. Los ingresos a favor de la Tesorería podrán realizarse en el Banco de España, en las cajas de la propia Tesorería o en las que se habiliten en los organismos autónomos y en las entidades colaboradoras de la misma.

2. Los medios de pago admisibles por las cajas de la Tesorería podrán consistir en dinero de curso legal, cheques nominativos, giros, transferencias o cualquier otro medio de pago legalmente establecido. La Consellería de Economía e Facenda establecerá las condiciones que tendrán que cumplir los mismos y el momento en el que en cada caso se producirá la liberación de la deuda.

3. La Tesorería podrá darles cumplimiento a sus obligaciones por cualquiera de los medios de pago a que se hace referencia en el párrafo anterior.

Artículo 92. Flujos financieros.

Para una mejor gestión de la Tesorería y un adecuado análisis de su funcionamiento, se deberá elaborar trimestralmente un cuadro de seguimiento de los flujos financieros derivados de la actividad de la Comunidad y de sus organismos autónomos, en el marco de las previsiones de un presupuesto monetario.

\section{TÍTULO V \\ DEL CONTROL INTERNO Y DE LA CONTABILIDAD}

\section{Capítulo I \\ DEL CONTROL INTERNO \\ Sección $1 .^{a}$ Aspectos generales}

Artículo 93. Control interno de la actividad económico-financiera.

1. El control interno de la actividad económico-financiera de la Comunidad, de sus organismos autónomos y entes públicos y de las sociedades públicas lo ejercerá la Intervención General, sin perjuicio de las competencias del Consello de Contas de Galicia y, en su caso, del Tribunal de Contas.

2. La Intervención General de la Comunidad Autónoma ejercerá sus funciones de control interno con plena autonomía respecto a los órganos responsables de la gestión controlada.

Artículo 94. Su ejercicio.

1. El ejercicio del control interno se realizará a través de la función interventora y del control financiero.

2. La función interventora tiene por objeto controlar todos los actos, documentos y expedientes de la Comunidad y de sus organismos autónomos de los que pudiesen derivarse derechos y obligaciones de contenido económico, así como los ingresos y pagos que de ellos se deriven y, en general, la recaudación, la inversión o la aplicación de los fondos públicos, a fin de asegurar que la gestión de los órganos controlados se ajuste a las disposiciones aplicables a cada caso.

3. El control financiero lo ejercerá la Intervención General de conformidad con lo prevenido en cada caso y en la forma que reglamentariamente se establezca respecto de los servicios de la Comunidad, de los organismos autónomos, de los entes públicos y de las sociedades públicas para comprobar su adecuado funcionamiento tanto en el aspecto organizativo como en el económico-financiero.

Asimismo, se ejercerá el control financiero respecto a las sociedades mercantiles, empresas, entidades y particulares por razón de las subvenciones, créditos, avales y demás ayudas de la Comunidad o de sus organismos autónomos, concedidos con cargo a los Presupuestos Generales de la Comunidad. En este caso el control financiero tendrá por objeto comprobar la adecuada y correcta obtención y utilización de las 
indicadas subvenciones y ayudas y el cumplimiento de los objetivos que con ellas se pretenden alcanzar.

4. A pesar de lo dispuesto en el apartado 3 de este artículo, por acuerdo de la Xunta de Galicia, a propuesta del conselleiro de Economía y Hacienda, podrá establecerse el control interno realizado a través de la función interventora en organismos autónomos, sociedades y entes públicos.

\section{Sección 2. ${ }^{\mathrm{a}}$}

\section{De la función interventora}

\section{Artículo 95. Fases.}

1. La función interventora se ejercerá a través de las siguientes fases:

a. La fiscalización o intervención previa de todo acto, documento o expediente susceptible de producir derechos y obligaciones de contenido económico o movimiento de fondos y valores.

b. La intervención formal del ordenamiento del pago.

c. La intervención material del pago.

d. La intervención de la aplicación de las cantidades destinadas a obras, suministros, adquisiciones y servicios, que comprenderá el examen documental y, en su caso, la comprobación material.

2. Son inherentes a la función interventora las siguientes competencias:

a. Interponer recursos y reclamaciones en los supuestos contemplados en las disposiciones vigentes.

b. Solicitar de los órganos competentes el asesoramiento jurídico o los informes técnicos que se precisen en función de la naturaleza del acto, documento o expediente intervenido, así como los antecedentes y documentos necesarios para el ejercicio de dicha función.

\section{Artículo 96. Principios.}

1. La función interventora se ejercerá conforme a los principios de autonomía funcional, ejercicio desconcentrado, jerarquía interna y actuación contradictoria.

2. El ejercicio de la función interventora se organizará de forma desconcentrada a través de las intervenciones delegadas situadas o próximas a los órganos sometidos a control. El Interventor general de la Comunidad podrá avocar el ejercicio de la función respecto a cualquier acto o expediente que estime oportuno.

Reglamentariamente se establecerá la competencia de los Interventores delegados del Interventor general de la Comunidad.

Artículo 97. Intervención limitada.

1. No estarán sometidos a intervención previa:

a. Los gastos de obras, de gestión de servicios públicos, de suministro, de consultoría y asistencia y de servicios, por importe inferior al que en su caso se establezca en la Ley de presupuestos de cada año ${ }^{189}$.

b. Los gastos de carácter periódico y demás de tracto sucesivo, una vez intervenido el gasto correspondiente al período inicial del acto o contrato de que se deriven, o sus modificaciones, así como aquellos otros gastos que de acuerdo con la normativa vigente se hagan efectivos a través del sistema de anticipos de caja fija.

c. La autorización y disposición de las subvenciones que figuren en los presupuestos con asignación nominativa ${ }^{190}$.

2. La Xunta de Galicia podrá acordar, previo informe de la Intervención General de la Comunidad Autónoma, que la intervención previa en cada una de las consellerías o en sus distintos servicios, organismos autónomos o sociedades y entes públicos se limite a comprobar los extremos siguientes:

a. La existencia de crédito presupuestario y que éste es el adecuado a la naturaleza del gasto o de la obligación que se propone contraer.

En los casos en que se trate de contraer compromisos de gastos de carácter plurianual se comprobará, además, si se cumple lo preceptuado en el artículo 58 de esta ley.

189 Art. 97.1.a modificado por Ley 9/2003, de 23 de diciembre, de medidas tributarias y administrativas. 190 Art. 97.1 modificado por Ley $5 / 2000$, de 28 de diciembre, de medidas fiscales y de régimen presupuestario y administrativo. 
b. Que las obligaciones o gastos se generan por órganos competentes.

c. Aquellos otros extremos que, por su transcendencia en el proceso de gestión, determine el Consello de la Xunta, a propuesta del Conselleiro de Economía y Hacienda, previo informe de la Intervención General de la Comunidad Autónoma. Los Interventores delegados podrán formular las observaciones complementarias que consideren convenientes, sin que las mismas tengan, en ningún caso, efectos suspensivos en la tramitación de los expedientes correspondientes.

3. Lo dispuesto en el apartado anterior no será de aplicación respecto a las obligaciones o de los gastos de cuantía indeterminada y de aquellos otros que deban ser aprobados por el Consello de la Xunta.

4. Las obligaciones o los gastos sometidos a la fiscalización limitada a que se refiere el apartado 2 de este artículo serán objeto de otra plena con posterioridad, ejercida sobre una muestra representativa de los actos, documentos o expedientes que dieron origen a la referida fiscalización, mediante la aplicación de técnicas de muestreo o auditoría, a fin de verificar que se ajustan a las disposiciones aplicables en cada caso y determinar el grado de cumplimiento de la legalidad en la gestión de los créditos.

Los Interventores delegados que realicen las fiscalizaciones con posterioridad deberán emitir informe escrito en el que hagan constar cuantas observaciones y conclusiones se deduzcan de las mismas. Estos informes se remitirán al titular de la consellería para que formule, en su caso, y en el plazo de quince días, las alegaciones que considere oportunas, y posteriormente se elevarán a la Intervención General de la Comunidad Autónoma.

La Intervención General de la Comunidad Autónoma dará cuenta al Consello de la Xunta y a los centros directivos que resulten afectados de los resultados más importantes de la fiscalización realizada con posterioridad y, en su caso, propondrá las actuaciones que resulten aconsejables para asegurar que la administración de los recursos públicos se ajuste a las disposiciones aplicables en cada caso.

5. Con independencia de lo dispuesto en el número anterior, el Conselliero de Economía e Facenda, a propuesta del Interventor general de la Comunidad Autónoma, podrá acordar en qué casos la función interventora será ejercida sobre una muestra y no sobre el total de actos, documentos o expedientes sujetos a la intervención previa.

La Intervención General determinará en estos casos los procedimientos que se deban aplicar para la selección, la identificación y el tratamiento de la muestra de procedimiento ${ }^{191}$.

6. La fiscalización previa de los derechos será substituida por la inherente a la toma de razón en contabilidad y se establecerán las actuaciones comprobatorias posteriores que determine la Intervención General de la Comunidad Autónoma.

Artículo 98. Documentación y plazo.

1. La Intervención ejercerá la función interventora a la vista del expediente original completo una vez reunidos todos los justificantes y emitidos los informes preceptivos y que esté, por lo tanto, en disposición de que se dicte acuerdo por quien corresponda.

2. El expediente será fiscalizado en el plazo de diez días contados a partir del siguiente a la fecha de recepción, que se reducirá a cinco días computados de igual forma cuando se declarase urgente la tramitación del expediente o se aplicase el régimen especial de fiscalización previsto en el número 2 del artículo 97.

3. Cuando la Intervención haga uso de la facultad a que se refiere el apartado b) del número 2 del artículo 95, se suspenderá el plazo mencionado en el número 2

191 Véase Orden de 23 de noviembre de 1999 sobre el ejercicio de la función interventora por procedimiento de muestreo. 
anterior, debiendo darle cuenta de dicha circunstancia al órgano gestor proponente del gasto.

Artículo 99. Reparos y reclamaciones.

1. Si la Intervención se manifestase en desacuerdo con el fondo o con la forma de los actos, expedientes o documentos examinados, deberá formular sus reparos por escrito. Dichos reparos deberán ser motivados con razonamientos fundados en normas que apoyen el criterio sustentado y deberán contener todas las objeciones realizadas al expediente.

2. Cuando la disconformidad se refiera al reconocimiento o a la liquidación de derechos a favor de la Hacienda de la Comunidad Autónoma, las observaciones se formularán en notas de reparos y, en caso de subsistir la discrepancia, mediante la interposición de los recursos o de las reclamaciones que procedan.

Artículo 100. Suspensión del expediente.

1. Si los reparos afectan a la autorización y disposición de gastos, al reconocimiento de obligaciones o al ordenamiento de pagos, se originará la suspensión de la tramitación del expediente, hasta que aquéllos no sean subsanados en los siguientes casos:

a. Cuando se basen en la insuficiencia o inadecuación del crédito al que se proponga imputar el gasto, la obligación o el pago.

b. Cuando se aprecien graves irregularidades en la documentación justificativa de las órdenes de pago o no se acredite suficientemente el derecho del perceptor.

c. Cuando el gasto se proponga a un órgano que carezca de competencia para su aprobación.

d. Cuando se omitan en el expediente requisitos o trámites que se consideren esenciales a juicio de la Intervención o cuando ésta estime que la continuación del procedimiento pudiese causar quiebras económicas a la Comunidad Autónoma o a un tercero.

e. Cuando el reparo sea consecuencia de comprobaciones de materiales de obras, suministros, adquisiciones y servicios.
2. La Intervención podrá fiscalizar favorablemente, a pesar de los defectos que se observen en el expediente, siempre que los requisitos o los trámites incumplidos no sean esenciales.

En estos supuestos la eficacia de la fiscalización quedará condicionada a la reparación de aquellos defectos con anterioridad a la aprobación del expediente. El órgano gestor remitirá a la Intervención la documentación justificativa de que se repararon dichos defectos.

De no reparar el órgano gestor los defectos indicados, para la continuación del expediente se considerará formulado el correspondiente reparo.

Lo previsto en este número no será aplicable en aquellos supuestos en los que la fiscalización previa se realice de forma limitada, de conformidad con lo dispuesto en el número 2 del artículo 97 de la presente ley.

Artículo 101. Discrepancia.

1. Cuando el órgano al que se dirija el reparo lo acepte, deberá reparar las deficiencias observadas y remitir de nuevo las actuaciones a la Intervención.

2. Cuando el órgano gestor no acepte el reparo deducido, formulará discrepancia, que deberá ser motivada con citas de los preceptos legales en los que sustente su criterio.

La discrepancia se resolverá de la siguiente forma:

a. Si el reparo fuese formulado por una Intervención Delegada, corresponderá a la Intervención General de la Comunidad conocer de la discrepancia y su resolución será obligada para aquélla.

b. Si el reparo fuese formulado por la Intervención General de la Comunidad o ésta confirmase en todo o en parte el de una Intervención Delegada y subsista la discrepancia, corresponderá a la Xunta de Galicia adoptar una resolución definitiva.

Artículo 102. Omisiones.

1. En los supuestos en los que, de acuerdo con lo dispuesto en este capítulo, 
la fiscalización previa de la aprobación del gasto o del reconocimiento de la obligación fuesen preceptivas y se omitiesen, no se podrá reconocer la obligación, ni tramitar el pago ni intervenir favorablemente estas actuaciones hasta que se conozca o resuelva dicha omisión en los términos previstos en este artículo.

2. Si el Interventor general de la Comunidad o sus delegados al conocer un expediente observasen alguna de las omisiones indicadas en el número anterior lo manifestarán a la autoridad que iniciase aquél y emitirán al mismo tiempo su opinión respecto de la propuesta, con el fin de que, uniendo este informe a las actuaciones, pueda el titular de la consellería de que aquélla proceda someter lo actuado a la decisión de la Xunta de Galicia para que adopte la resolución a que hubiese lugar.

Este informe, que no tendrá naturaleza de fiscalización, pondrá de manifiesto, como mínimo, los siguientes extremos:

Las infracciones del ordenamiento jurídico que, a juicio del Interventor, se produjeran en el momento en el que se adoptó el acto de aprobación del gasto sin fiscalización o intervención previa.

Las prestaciones que se realizasen como consecuencia de dicho acto.

La posibilidad y conveniencia de revisión de los actos dictados con infracción del ordenamiento.

Los Interventores delegados darán cuenta de su informe a la Intervención General de la Comunidad Autónoma en el momento de su emisión.

3. Si el titular de la consellería acordase someter el expediente a la decisión de la Xunta de Galicia, lo comunicará al Conselleiro de Economía y Hacienda, por conducto de la Intervención General de la Comunidad, con diez días de antelación a la reunión del Consejo en el que se conozca el asunto.

Al expediente se unirá una memoria que incluya una explicación de la omisión de la preceptiva fiscalización o intervención previa y, en su caso, las observaciones que estime convenientes respecto del informe de la Intervención.

La Secretaría del Consejo comunicará a la consellería correspondiente, a la de Economía y Hacienda y a la Intervención General de la Comunidad el acuerdo adoptado sobre el expediente para su toma de razón y cumplimiento en sus propios términos.

\section{Sección 3.}

Del control financiero

Artículo 103. Finalidad y principios.

1. El control financiero al que se refiere el artículo 94 de la presente ley tiene por finalidad procurar que la gestión económico-financiera del sector público gallego se adecue a los principios de legalidad, economía, eficacia y eficiencia.

2. El control financiero se ejercerá con plena autonomía e independencia respecto a las autoridades y entidades de las que se controle su gestión, y podrá realizarse en régimen ordinario o en régimen permanente.

3. El control financiero se ejercerá mediante la realización de auditorías u otros tipos de control de conformidad con el que se establezca reglamentariamente.

Artículo 104. Auditorías y clases.

1. Las auditorías a que se refiere el artículo anterior consistirán en la comprobación posterior de la actividad económico-financiera del ente controlado, realizada de forma sistemática y mediante la aplicación de determinados procedimientos de revisión a operaciones o actos singulares seleccionados al efecto.

2. Dichas auditorías, en función de los objetivos y del alcance que para cada control se establezcan, podrán ser de las siguientes clases:

a. Auditoría financiera, que tendrá por objeto la emisión de un dictamen sobre si la información contable del órgano controlado se presenta de acuerdo con los principios, con los criterios y con las normas contables que sean aplicables. 
b. Auditoría de cumplimiento, que tiene por objeto determinar si en la gestión de las operaciones que den lugar a derechos y obligaciones de contenido económico, en la gestión de los ingresos y pagos y en la recaudación, custodia, inversión o aplicación en general de los recursos se ha cumplido con la legalidad y con las normas y directrices, internas o externas, que resulten aplicables.

c. Auditoría operativa, cuyo objeto es la evaluación de la eficacia y la eficiencia alcanzadas en la gestión de los recursos públicos adscritos a una entidad para el cumplimiento de sus objetivos. Este sistema de auditoría será el utilizado para la evaluación del grado de cumplimiento de los objetivos físicos y financieros previstos en los programas de gasto.

d. Auditorías de sistemas y procedimientos, cuya finalidad es recomendar y proponer mejoras y modificaciones parciales o generales, en los procedimientos de gestión económico-financiera, sobre la base de las posibles debilidades o disfuncionalidades detectadas en su revisión.

Artículo 105. Iniciación y desarrollo.

1. El control financiero ordinario se iniciará por acuerdo del Interventor general de la Comunidad, quien delimitará la clase y el alcance del control que se va a efectuar, y se desarrollará directamente por medio de funcionarios o equipos de control destacados temporalmente al efecto y dirigido por Interventores dependientes del Interventor general.

2. El control financiero permanente se realizará de acuerdo con las siguientes características:

a. Lo ejercerá la Intervención General de la Comunidad a través de las Intervenciones Delegadas en los servicios, organismos, sociedades y entes públicos en los que se encuentre establecido este régimen de control, sin perjuicio de las actuaciones de control ordinario que, con carácter excepcional y alcance limitado, pueda realizar directamente el citado centro directivo. b. Las actuaciones y los trabajos necesarios para su desarrollo se efectuarán de forma permanente y continuada a lo largo de los diferentes ejercicios, y no se requerirá acuerdo expreso de la Intervención General de la Comunidad Autónoma para su iniciación.

c. Dichas actuaciones se realizarán, como regla general, sobre la base del principio de proximidad temporal respecto a la actividad o de los actos objeto de control.

d. La Intervención Delegada encargada del control financiero permanente deberá recibir información permanente, actualizada y detallada de la actividad objeto de control, de sus objetivos y del avance en su cumplimiento, en la forma y con la periodicidad que dicha oficina determina, a fin de tener un conocimiento completo de la misma.

Artículo 106. Ámbito de aplicación.

1. El control financiero permanente será aplicable en los siguientes entes del sector público de Galicia, siempre que, de conformidad con lo dispuesto en el apartado 4 del artículo 94 de esta ley, no esté establecida la función interventora:

a. Los organismos autónomos de la Comunidad de carácter industrial, comercial, financiero o análogo.

b. El Ente Público Radiotelevisión de Galicia.

c. Las consellerías, servicios, organismos autónomos de carácter administrativo, sociedades y entes públicos, cualquiera que sea su denominación y forma jurídica, en que así se determine, de conformidad con lo previsto en el punto siguiente.

2. La aplicación del régimen de control financiero permanente a las consellerías, servicios, organismos, sociedades y entes en los que actualmente no se encuentre establecido se efectuará:

a. Mediante orden del Conselleiro de Economía y Hacienda a propuesta de la Intervención General de la Comunidad, en los supuestos de consellerías, servicios u organismos autónomos en los que ya exista Intervención Delegada. 
b. Mediante acuerdo de la Xunta a propuesta del Conselleiro de Economía y Hacienda, en los supuestos de servicios, sociedades o entes públicos en los que no exista Intervención Delegada de la Intervención General de la Comunidad.

3. La relación de dependencia y las condiciones de funcionamiento de los Interventores delegados en el ejercicio del control financiero permanente serán las mismas que las vigentes para la función interventora.

4. Para la aplicación de lo dispuesto en este artículo las Intervenciones Delegadas encargadas del control financiero permanente podrán requerir información referida a:

a. Derechos y obligaciones, compras y ventas.

b. Inversiones y otros contratos.

c. Cobros y pagos.

d. Composición y detalle de saldos en contabilidad.

e. Operaciones que se vayan a realizar o en curso de especial significación o importancia.

f. Existencias de fondos, de materiales y de bienes de cualquier naturaleza.

g. Cualquier otro aspecto financiero $u$ organizativo que se considere de interés en atención a las características del ente controlado.

Las Intervenciones Delegadas deberán recibir un ejemplar de las cuentas y de otros estados anuales, así como de los que se elaboren con otra periodicidad, y tendrán acceso directo a los sistemas de información de los que se deriven dichas cuentas y estados.

5. Si en el ejercicio del control financiero permanente se pusiesen de manifiesto graves irregularidades, se dará cuenta a la Intervención General, proponiendo, en su caso, la sustitución de ese procedimiento de control por el ejercicio de la función interventora.

6. Los Interventores delegados deberán elaborar para cada ente un plan anual de actuación, que se someterá a la aprobación de la Intervención General de la Comunidad.
Dicho plan contendrá el detalle de las actuaciones que se van a realizar y su calendario de ejecución, así como la periodicidad de los informes y de las fechas previstas de emisión.

Los planes de actuación incluirán, en todo caso, la realización de:

a. Auditoría permanente de cumplimiento.

b. Revisiones de registros y procedimientos contables y de las existencias y de los movimientos de fondos.

c. Auditoría financiera de las cuentas anuales.

d. Auditoría de programas sobre el nivel de realización de objetivos y análisis de las causas de las desviaciones.

Los citados planes incluirán, además, si procede, la realización de otras auditorías operativas, de sistemas y procedimientos u otros tipos de control de los previstos en el artículo 104 de esta ley, en los casos y con el alcance en los que así se determine.

Artículo 107. Plan anual de auditorías.

1. El control financiero ordinario enmarcará su actuación en un plan anual de auditorías que se debe realizar en cada ejercicio, cuya elaboración corresponde a la Intervención General de la Comunidad.

2. El plan comprenderá las entidades sobre las que se realizarán controles financieros de carácter ordinario en el ejercicio económico a que se refiera, con indicación, en cada caso, del tipo de control que se debe realizar y del alcance del mismo.

3. El plan tendrá carácter abierto y podrá ser modificado para la realización de controles específicos, en atención a los medios disponibles y por otras razones debidamente ponderadas.

4. Para el desarrollo del control financiero ordinario, la Intervención General de la Comunidad podrá solicitar la colaboración de empresas privadas de auditorías, que deberán ajustarse a las normas e instrucciones que determine dicho centro directivo. 
Para solicitar dicha colaboración será necesaria una orden del Conselleiro de Economía y Hacienda, en la que se especificará la insuficiencia de los servicios de la Intervención General de la Comunidad que justifique dicha colaboración.

Artículo 108. Resultado e informes.

1. Del resultado de las actuaciones de control financiero ordinario o permanente se emitirá informe con la estructura, con el procedimiento y con el contenido que reglamentariamente se determine.

2. Los informes derivados de las actuaciones de control financiero ordinario se elevarán a la Intervención General de la Comunidad para su remisión al Conselleiro de Economía y Hacienda y a los órganos responsables y de tutela de los servicios u organismos controlados.

3. Los informes que tengan su origen en actuaciones de control financiero permanente se remitirán al titular de la gestión y, además, a la Intervención General de la Comunidad cuando éstos tengan un carácter general o hayan sido realizados por alguna circunstancia especial.

\section{Capitulo II DE LA CONTABILIDAD}

Artículo 109. Régimen.

1. La Administración de la Comunidad Autónoma, de sus organismos autónomos y de las sociedades públicas de Galicia queda sometida al régimen de contabilidad pública en los términos previstos en esta ley.

2. La sujeción al régimen de contabilidad pública comporta la obligación de rendir cuentas de las respectivas operaciones y transacciones económicas, cualquiera que sea su naturaleza, al Tribunal de Contas y al Consello de Contas de Galicia.

3. Lo dispuesto en el párrafo anterior es aplicable al empleo de los fondos a justificar y al de las transferencias corrientes y de capital con cargo a los Presupuestos Generales de la Comunidad Autónoma, cualquiera que sea el perceptor de las mismas.

4. Las obligaciones que se determinen en el presente artículo se entenderán sin perjuicio de las facultades que la Constitución le confiere al Tribunal de Contas.

Artículo 110. Competencias de la Consellería de Economía e Facenda.

Es competencia de la Consellería de Economía e Facenda la organización de la contabilidad pública al servicio de los siguientes fines:

a. Registrar la ejecución de los Presupuestos Generales de la Comunidad en sus distintas fases.

b. Conocer el movimiento y la situación de la Tesorería.

c. Reflejar las variaciones, la composición y la situación del patrimonio de la Comunidad y del inventario de bienes afectados a los fines de los organismos autónomos y de las sociedades públicas.

d. Proporcionar los datos necesarios para la formación y el rendimiento de la Cuenta General de la Comunidad, así como de las demás cuentas, estados y documentos que deban elaborarse o remitirse al Consello de Contas de Galicia y al Tribunal de Contas.

e. Facilitar los datos y otros antecedentes necesarios para la confección de las cuentas económicas del sector público estatal.

f. Rendir la información económica y financiera que sea necesaria para la toma de decisiones tanto en el orden político como en el de gestión.

Artículo 111. Funciones de la Intervención General como centro directivo. La Intervención General de la Comunidad Autónoma es el centro directivo de la contabilidad pública de Galicia y le corresponden las siguientes funciones:

a. Someter a la decisión del Conselleiro de Economía y Hacienda el Plan de Contabilidad Pública de Galicia, al que se adaptarán los organismos, las corporaciones y las demás entidades comprendidas en el sector público de Galicia, manteniendo la debida coordinación con el Plan General de Contabilidad Pública. 
b. Promover el ejercicio de la potestad reglamentaria en lo tocante a la determinación de la estructura, justificación, tramitación y rendimiento de cuentas, informes y demás documentos relativos a la contabilidad pública, pudiendo dictar al efecto circulares e instrucciones por los procedimientos que se determinen en las Leyes y en los Reglamentos.

c. Aprobar los planes parciales o especiales de contabilidad pública que se elaboren conforme al Plan de Contabilidad Pública de Galicia, o al Plan General de Contabilidad del Sector Privado, respecto a las sociedades públicas.

d. Inspeccionar la contabilidad de toda clase de organismos públicos de la Comunidad Autónoma.

Artículo 112. Funciones como centro gestor.

1. Como centro gestor de la contabilidad pública, corresponde a la Intervención General:

a. Formar la Cuenta General de la Comunidad Autónoma y elaborar la memoria que acompaña a la misma.

b. Preparar y examinar las cuentas que se deban rendir al Consello de Contas de Galicia y al Tribunal de Contas, y formular las observaciones que, en su caso, se estimen necesarias.

c. Solicitar la presentación de cuentas, estados y otros documentos sujetos a examen crítico.

d. Centralizar la información deducida de la contabilidad de las corporaciones, organismos, entidades y demás agentes que integran el sector público de Galicia.

e. Elaborar las cuentas económicas del sector público de Galicia, de acuerdo con el sistema de cuentas en vigor para todo el Estado.

f. Vigilar e impulsar las actividades de las oficinas de contabilidad de todos los organismos y servicios de la Comunidad.

2. Todos los informes y dictámenes económico-contables que deban evacuar las entidades sometidas al régimen de contabilidad pública deberán ser solicitados a través de la Intervención General de la Comunidad Autónoma.

3. A los efectos previstos en este artículo, el rendimiento de toda clase de cuentas por los procedimientos ordinarios se deberá realizar a través de la Intervención General.

Artículo 113. Soporte documental.

La contabilidad pública se llevará en libros, registros y cuentas, según los procedimientos técnicos establecidos que sean más convenientes por la índole de las operaciones y de las situaciones que en ellos deban anotarse, sin perjuicio de que las sociedades públicas se ajusten a las disposiciones del Código de Comercio, a las que se dicten en su desarrollo y al Plan General de Contabilidad vigente para las empresas españolas.

Artículo 114. Cuentadantes.

Serán cuentadantes de las cuentas que tengan que rendirse al Consello de Contas de Galicia y, en su caso, al Tribunal de Contas:

a. Los funcionarios que tengan a su cargo la gestión de los ingresos y la realización de los gastos, así como las demás operaciones de la Administración de la Comunidad.

b. Los Presidentes o Directores de los organismos autónomos, sociedades públicas y demás entes que conforman el sector público de Galicia.

c. Los particulares que, excepcionalmente, administren, recauden o custodien fondos o valores de la Comunidad, sin perjuicio de que sean intervenidas las respectivas operaciones.

d. Los perceptores de las transferencias a que se refieren los artículos 78 y 109.3 de esta ley.

Artículo 115. Forma y plazos.

Las cuentas y la documentación que se les deban rendir al Consello de Contas de Galicia y al Tribunal de Contas se formarán y se cerrarán por períodos trimestrales, excepto las correspondientes a los organismos autónomos, sociedades públicas y demás entes que conforman el sector público de Galicia, que lo serán anualmente. 
Artículo 116. Sociedades públicas, entes y organismos.

La contabilidad pública de las sociedades públicas, entes y organismos queda sometida a la verificación ordinaria y extraordinaria a cargo de los funcionarios dependientes del Interventor general de la Comunidad y de los que, en su caso, designe el Tribunal de Contas o el Consello de Contas.

Artículo 117. Publicidad e información.

1. La Consellería de Economía e Facenda publicará en el "Diario Oficial de Galicia" los siguientes datos trimestrales:

a. Del movimiento del tesoro por operaciones presupuestarias y extrapresupuestarias, y de su situación.

b. De las operaciones de ejecución del Presupuesto de la Comunidad Autónoma $\mathrm{y}$ de sus modificaciones.

c. De las demás que se consideren de interés.

2. Los organismos autónomos, las entidades públicas y las sociedades mercantiles con participación mayoritaria de la Xunta remitirán trimestralmente a la Consellería de Economía e Facenda un estado de su situación financiera, de acuerdo con la estructura que ésta determine.

3. Trimestralmente, el Conselleiro de Economía y Hacienda dará cuenta a la Comisión 3.a, de Economía, Hacienda y Presupuestos, del estado de ejecución presupuestaria.

\section{Capítulo III DE LA CUENTA GENERAL DE LA COMUNIDAD}

Artículo 118. Documentación.

1. La Cuenta General de la Comunidad Autónoma de Galicia comprenderá todas las operaciones presupuestarias, patrimoniales y de Tesorería llevadas a cabo durante el ejercicio y constará de los siguientes documentos:

a. Cuenta de la Administración de la Comunidad. b. Cuenta de los organismos autónomos de carácter administrativo.

c. Cuenta de los organismos autónomos de carácter industrial, comercial, financiero o análogo.

d. Cuenta de las sociedades públicas y demás entes públicos.

e. Cuenta del patrimonio de la Comunidad y de sus organismos autónomos.

2. Se aportará a la Cuenta General un estado en el que se refleje el movimiento y la situación de los avales concedidos por la Comunidad Autónoma y por sus sociedades públicas.

Artículo 119. Formación.

La Cuenta de la Administración de la Comunidad se formará en base a los estados y documentos que determine la Consellería de Economía e Facenda y, en particular, por los siguientes:

1. La liquidación del presupuesto, especificando los créditos iniciales y sus modificaciones, así como la liquidación de los estados de ingresos y gastos en sus distintas fases de gestión presupuestaria.

2. Un estado demostrativo de los compromisos de gastos adquiridos con cargo a ejercicios futuros, haciendo uso de lo dispuesto en el artículo 58 de la presente ley.

3. Un estado demostrativo de la evolución y situación de los valores que se deben cobrar y de las obligaciones que se deben pagar procedentes de ejercicios anteriores.

4. La Cuenta General de Tesorería que ponga de manifiesto su situación y las operaciones realizadas durante el ejercicio.

5. La Cuenta General del endeudamiento público.

6. El resultado del ejercicio económico, que recogerá la determinación del superávit, el déficit o nivelación de la liquidación del presupuesto, el remanente de Tesorería resultante y la variación de los activos y pasivos financieros.

Artículo 120. Organismos autónomos.

1. Con las cuentas rendidas por los organismos autónomos y demás documentos que se le deban rendir al Consello de Contas 
de Galicia y al Tribunal de Contas, la Intervención General de la Comunidad elaborará estados anuales agregados que permitan ofrecer una visión global de la gestión realizada en el ejercicio por la totalidad de aquéllos.

2. A la Cuenta General de la Comunidad Autónoma se unirá una memoria en la que se demuestre el grado de cumplimiento de los objetivos previstos para cada uno de los programas de gasto.

3. La Consellería de Economía e Facenda establecerá la estructura y el contenido de las cuentas y estados a que hace referencia el número 1 anterior, así como de las cuentas que deban rendir los demás entes del sector público de Galicia.

Artículo 121. Revisión y aprobación.

1. La Cuenta General de la Comunidad de cada año se formará antes del 31 de agosto del año siguiente al que se refiere y se remitirá previo acuerdo de la Xunta al Consello de Contas de Galicia y al Tribunal de Contas dentro de los dos meses siguientes a su formación.

2. La Cuenta General de la Comunidad Autónoma deberá ser aprobada por el Parlamento de Galicia a efectos de dar cumplimiento a lo dispuesto en el apartado b) del artículo 10 del Estatuto de Autonomía.

\section{TÍTULO VI DE LAS RESPONSABILIDADES}

Artículo 122. Sujetos responsables.

1. Las autoridades, los funcionarios y los empleados de la Comunidad Autónoma en cualquiera de sus servicios, organismos autónomos, entes públicos o sociedades públicas que, por dolo, culpa o negligencia adopten resoluciones, ejecuten acciones o incurran en omisiones con infracción de las disposiciones de esta ley, estarán obligados a indemnizar a la Hacienda de la Comunidad por los daños y perjuicios que sean consecuencia de aquéllos, con independencia de la responsabilidad penal o disciplinaria que les pueda corresponder.
2. Estarán sujetos a la obligación de indemnizar a la Hacienda de la Comunidad, además de las autoridades, de los funcionarios y de los empleados a los que se hace referencia en el número 1 anterior, los Interventores, Tesoreros y ordenadores de pagos que, con dolo, culpa, negligencia o ignorancia inexcusable, no salvasen su actuación en el correspondiente expediente mediante observación escrita acerca de la improcedencia o ilegalidad del acto o resolución.

Ello dejando a salvo lo dispuesto en el artículo 76.3 de la presente ley.

3. La responsabilidad de quien participe en la resolución o en el acto será mancomunada, excepto cuando concurra dolo, en el que será solidaria.

Artículo 123. Tipificación de las infracciones.

Constituyen infracciones que dan origen a la obligación de indemnizar según determina el artículo anterior:

a. Incurrir en el alcance o malversación en la administración de fondos de la Comunidad.

b. Administrar los recursos y demás derechos de la Hacienda de la Comunidad incumpliendo las normas reguladoras de su gestión, liquidación, inspección, recaudación o ingreso en las cajas de la Tesorería.

c. Comprometer gastos y ordenar pagos sin crédito suficiente o infringiendo de otro modo las disposiciones legales aplicables a la ejecución y gestión de los presupuestos y de las operaciones de Tesorería.

d. Dar lugar a pagos indebidos al liquidar las obligaciones o al expedir documentos en virtud de las funciones que se tengan encomendadas.

e. No rendir cuentas reglamentarias exigidas o presentadas con graves defectos.

f. No justificar la aplicación de los fondos a que se refiere el artículo 77 de esta ley.

g. Cualquier otro acto o resolución dictada con infracción de lo dispuesto en la presente ley o de la normativa aplicable a la gestión y administración del patrimonio. 
Artículo 124. Instrucción y resolución.

1. Sin perjuicio de las competencias y del conocimiento de los hechos por parte del Consello de Contas de Galicia y del Tribunal de Contas, la responsabilidad por los actos, omisiones y resoluciones tipificados en el artículo anterior será determinada y exigida mediante expediente administrativo instruido al interesado.

2. El acuerdo de incoación, el nombramiento de Juez instructor y la resolución del expediente corresponderán a la Xunta cuando se trate de personas que, de conformidad con el ordenamiento vigente, tengan la condición de autoridad y al Conselleiro de Economía y Hacienda en los demás casos.

3. En la tramitación del expediente se dará audiencia a los interesados y su resolución contendrá el pronunciamiento sobre los daños y perjuicios causados a los bienes y derechos de la Hacienda de la Comunidad, imponiéndoles a los responsables la obligación de indemnizar en la cuantía y en el plazo que se determine.

Artículo 125. Ejecución.

1. Los daños y perjuicios declarados en la resolución del expediente a que se refiere el artículo anterior tendrán la consideración de derechos de la Hacienda de la Comunidad, gozarán del régimen previsto en el artículo 19 de esta ley y podrá procederse a su cobro, en su caso, por la vía de apremio.

2. La Hacienda de la Comunidad tendrá derecho a exigir el interés previsto en el artículo 21 de la presente ley sobre el importe de los alcances, malversaciones, daños y perjuicios a sus bienes y derechos, desde el día en el que éstos se hubiesen causado.

3. Cuando, a consecuencia de la insolvencia de los obligados que deben indemnizar, haya que proceder contra los responsables subsidiarios declarados como tales en el expediente, los intereses a que hace referencia el punto anterior serán exigidos desde la fecha en la que fuesen requeridos para realizar el pago.
Artículo 126. Diligencias previas.

Tan pronto como se tenga noticia de un alcance, malversación, daño o perjuicio a la Hacienda de la Comunidad, o transcurriesen los plazos señalados en el artículo 77 de la presente ley sin que se justificasen las órdenes de pago a las que el mismo se refiere, los superiores jerárquicos de los presuntos responsables y los ordenadores de pagos, respectivamente, instruirán las diligencias previas oportunas y adoptarán, con igual carácter, las medidas necesarias para asegurar los derechos de la Hacienda de la Comunidad, dando cuenta inmediata al Consello de Contas de Galicia, al Conselleiro de Economía y Hacienda y, en su caso, al Tribunal de Contas, para que procedan de acuerdo con sus competencias y conforme a los procedimientos establecidos.

\section{DISPOSICIÓN ADICIONAL PRIMERA DEFINICIÓN DE EMPRESA PÚBLICA}

A los efectos de esta ley, la definición que en la normativa autonómica se hace de la empresa pública se entenderá referida, en lo sucesivo, a las sociedades públicas establecidas en ésta.

\section{DISPOSICIÓN ADICIONAL SEGUNDA RENDICIÓN DE CUENTAS AL PARLAMENTO}

La Consellería de Economía e Facenda, dentro de los primeros quince días hábiles de cada mes, dará cuenta a la Comisión de Economía, Hacienda y Presupuestos de todas las modificaciones que se realicen de acuerdo con lo previsto en esta ley.

\section{DISPOSICIÓN ADICIONAL TERCERA VIGENCIA DEL ARTÍCULO 23 , APARTADO $_{2}$}

El apartado 2 del artículo 23 de esta ley, en la redacción dada por el artículo 8 de la Ley $7 / 1998$, de 30 de diciembre, de Medidas Tributarias, de Régimen Presupuestario, Función Pública y Gestión, tendrá la vigencia determinada en la disposición final 
primera de esa Ley, sin perjuicio de la que establezcan Leyes futuras.

\section{DISPOSICIÓN ADICIONAL CUARTA FUNDACIONES DEL SECTOR PÚBLICO}

$$
(\ldots)^{192}
$$

\section{DISPOSICIÓN ADICIONAL OUINTA. AGENCIAS PÚBLICAS AUTONÓMICAS193}

1. Las agencias públicas autonómicas son entidades instrumentales de derecho público, dotadas de personalidad jurídica pública, patrimonio propio $\mathrm{y}$ autonomía en su gestión, facultadas para ejercer potestades administrativas, que son creadas por el Consello de la Xunta para el cumplimiento de los programas correspondientes a las políticas públicas que desarrolle la Administración de la Comunidad Autónoma de Galicia en el ámbito de sus competencias.

La creación de las agencias públicas autonómicas requiere autorización por ley y se produce con la aprobación de su estatuto por decreto del Consello de la Xunta a propuesta de la Consellería de Economía y Hacienda, previa iniciativa de la consellaría competente por razón de la materia.

La consellería competente por razón de la materia que desee ejercer la iniciativa contemplada en el apartado anterior elaborará una memoria y un proyecto de estatutos.

La memoria habrá de precisar el objeto de la agencia a crear, justificando los objetivos que se persiguen con su creación y las consecuencias organizativas y económico-financieras derivadas de su creación. Además, la memoria habrá de incorporar el plan inicial de actuación de la agencia. El proyecto de estatutos habrá de indicar, en todo caso, las funciones y facultades

192 Disposición adicional cuarta derogada por Ley 9/2007, de 13 de junio, de subvenciones de Galicia.

193 Véase Orden de 20 de mayo de 2008 por la que se establecen los modelos a que deberán adaptarse las memorias que editen los distintos departamentos de la Xunta de Galicia, organismos autónomos, agencias, fundaciones, entidades y empresas en que tienen participación mayoritaria la Xunta de Galicia. atribuidas a la agencia, su estructura orgánica, los medios que se le adscriben y su duración temporal.

La supresión de las agencias públicas autonómicas y la modificación de sus estatutos se llevarán a cabo por decreto del Consello de la Xunta a propuesta de la Consellería de Economía y Hacienda, previa iniciativa de la consellaría competente por razón de la materia.

2. El marco básico de gestión y tratamiento presupuestario de las agencias públicas autonómicas se regirá por lo que se establece a continuación.

La actuación de las agencias públicas autonómicas se producirá conforme a su contrato de gestión. Este contrato de gestión habrá de contener en todo caso: su período de vigencia; los objetivos a conseguir y los resultados a obtener; los planes temporales para alcanzar los objetivos y proyectos asociados a las estrategias definidas así como los indicadores de la evaluación; los efectos asociados al grado de cumplimiento y/o incumplimiento de los objetivos con indicación de los mecanismos que permitan la exigencia de responsabilidad de los órganos de gestión ejecutivos y, en su caso, del personal directivo, y el procedimiento a seguir en la cobertura de los déficits económico-patrimoniales que en su caso pudieran producirse y las consecuencias de la responsabilidad en la gestión que se deriven de los mismos.

El contrato de gestión será aprobado por orden conjunta de la consellaría de adscripción y de la Consellería de Economía y Hacienda, a propuesta del órgano competente de cada agencia.

El primer contrato de gestión se hará como máximo en el plazo de tres meses desde la constitución de la agencia; mientras tanto la agencia actuará según el plan inicial contenido en la memoria de creación. Los posteriores contratos serán aprobados en el último trimestre de vigencia del anterior. 
Las agencias públicas autonómicas se financian con los siguientes recursos:

a. Las transferencias consignadas en los presupuestos generales de la Xunta.

b. Los ingresos propios que perciban como contraprestación por las actividades que puedan realizar, en virtud de contratos, convenios o disposición legal, para otras entidades públicas, privadas o personas físicas.

c. La enajenación de los bienes y valores que constituyan su patrimonio, de acuerdo con lo establecido en la legislación patrimonial de la Comunidad Autónoma.

d. El rendimiento procedente de sus bienes y valores.

e. Las aportaciones voluntarias, donaciones, herencias y legados y demás aportaciones a título gratuito de entidades privadas y particulares.

f. Los ingresos recibidos de personas físicas y jurídicas como consecuencia de patrocinio de actividades o instalaciones.

g. Los demás ingresos de derecho público o privado que estén autorizadas a percibir.

h. Cualesquiera otros recursos que pudieran serles atribuidos.

Los recursos que se deriven de los apar$\operatorname{tados}$ b), e), f) y g) que no estuvieran previstos inicialmente en el presupuesto de las agencias públicas podrán destinarse a financiar mayores gastos por acuerdo del órgano competente de las mismas, con arreglo a lo establecido en sus estatutos.

El recurso al endeudamiento a largo plazo está prohibido en las agencias públicas autonómicas, salvo disposición legal en contra. Por la Ley de presupuestos de cada ejercicio se autorizará el límite del endeudamiento a corto plazo.

El órgano competente, de acuerdo con lo establecido en sus estatutos, de las agencias públicas autonómicas elaborará y aprobará el anteproyecto de presupuesto.
El anteproyecto será remitido para examen a la consellaría de adscripción, que posteriormente lo hará llegar en tiempo y plazo a la Consellería de Economía y Hacienda, para su consolidación dentro del sector público gallego, aprobación por el Consello de la Xunta y posterior elevación al Parlamento de Galicia.

La estructura del presupuesto de las agencias públicas y la documentación que acompañará al mismo se establecerán por la Consellería de Economía y Hacienda.

Los presupuestos de las agencias públicas autonómicas que se constituyan de conformidad con lo establecido en la normativa de aplicación a las mismas tendrán carácter limitativo por su importe global y carácter estimativo para la distribución de los créditos en categorías económicas, salvo los correspondientes a gastos de personal, que en todo caso tienen carácter limitativo y vinculante por su cuantía total.

Corresponde al conselleiro de Economía y Hacienda, a propuesta de los órganos competentes de las agencias, la autorización de las variaciones de la cuantía global del presupuesto así como las que afecten a gastos de personal. La autorización de las restantes variaciones, incluso en la cuantía global cuando sean financiadas con recursos derivados de las letras b), e), f) y g) de este número, por encima de los inicialmente presupuestados y siempre que existan garantías bastantes de su efectividad y del correspondiente equilibrio presupuestario, corresponderá al órgano competente de la agencia conforme a su estatuto, y posteriormente se dará cuenta a la Consellería de Economía y Hacienda.

Los déficits derivados del incumplimiento de las estimaciones de ingresos anuales se compensarán de la forma prevista en el contrato de gestión.

Corresponde a la Intervención General de la Comunidad Autónoma establecer los criterios que precise la aplicación de la 
normativa contable a las agencias públicas autonómicas, en los términos establecidos por la legislación presupuestaria para las entidades del sector público gallego.

El control externo de la gestión económicofinanciera de las agencias públicas corresponde al Consejo de Cuentas de Galicia, de acuerdo con su normativa específica.

El control interno de la actividad económico-financiera de las agencias públicas autonómicas corresponde a la Intervención General de la Comunidad Autónoma, y se realizará bajo las modalidades de control financiero permanente y de auditoría pública, en las condiciones y los términos establecidos en la presente ley.

Sin perjuicio del control establecido en el párrafo anterior, las agencias públicas estarán sometidas a un control de eficacia por parte del departamento de adscripción.

Su régimen económico-financiero, en lo no previsto en esta disposición adicional, se regirá por el de las disposiciones de la presente ley. La contratación de las agencias públicas autonómicas se regirá por la normativa de aplicación al sector público ${ }^{194}$.

\section{DISPOSICIÓN DEROGATORIA ÚNICA}

Quedan derogadas las Leyes que se citan en las tablas adjuntas y cuantas disposiciones de igual o inferior rango se opongan a lo establecido en esta ley.

1. En virtud de su incorporación al texto refundido de la Ley de Régimen Financiero y Presupuestario de Galicia, quedan derogadas las siguientes normas: Ley 11/1992, de 7 de octubre, de Régimen Financiero y Presupuestario de Galicia. Disposición adicional tercera de la Ley 14/1992, de 29 de diciembre, de Presupuestos Generales de la Comunidad Autónoma de Galicia para 1993

Artículos 8, 23, 38, 39 y 40 de la Ley 1/1994, de 30 de marzo, de Presupuestos

194 Disposición adicional quinta añadida por Ley 16/2007, de 26 de diciembre, de presupuestos generales de la Comunidad Autónoma de Galicia para el año 2008.
Generales de la Comunidad Autónoma de Galicia para 1994.

Disposiciones adicionales novena, décima y undécima de la Ley 11/1995, de 28 de diciembre, de Presupuestos Generales de la Comunidad Autónoma de Galicia para 1996

Artículos 4 y 5 de la Ley 2/1998, de 8 de abril, de Medidas Tributarias, de Régimen Presupuestario, Función Pública, Patrimonio, Organización y Gestión.

Artículos 3, 4, 5, 6 y 8 de la Ley 7/1998, de 30 de diciembre, de Medidas Tributarias, de Régimen Presupuestario, Función Pública y Gestión.

2. En virtud de lo establecido en la Disposición derogatoria de la Ley 11/1992, de 7 de octubre, de Régimen Financiero y Presupuestario de Galicia, está derogada la Ley 30/1984, de 3 de abril, de Gestión Económica y Financiera Pública de Galicia.

\section{LEY 12/1995, DE 29 DE DICIEMBRE, DEL IMPUESTO SOBRE LA CONTAMINACIÓN ATMOSFÉRICA (DOGA N. ${ }^{\circ} 249$, 30. 12. 1995)}

(...) 195

\section{Capitulo I \\ DISPOSICIONES GENERALES}

Artículo 1. Fin del tributo.

Al objeto de contribuir a regular la utilización de los recursos naturales de Galicia, y de forma específica, la emisión de sustancias contaminantes, se crea un Impuesto sobre la Contaminación Atmosférica.

Artículo 2. Normativa de aplicación. El Impuesto sobre la Contaminación Atmosférica se regirá, además de por las disposiciones de la presente ley, por lo establecido en las normas tributarias que sean de aplicación.

Artículo 3. Ámbito del tributo.

El Impuesto sobre Contaminación Atmosférica recaerá sobre las emisiones cuyos

195 Exposición de motivos omitida. 
focos se hallen ubicados dentro del ámbito territorial de la Comunidad Autónoma.

Artículo 4. Afectación de los ingresos.

1. Los ingresos provenientes del Impuesto sobre la Contaminación Atmosférica, deducidos los costes de gestión, se destinarán a financiar las actuaciones de la Comunidad en materia de protección medioambiental y conservación de los recursos naturales de Galicia.

2. Con un 5 por 100 de los ingresos obtenidos en cada ejercicio se dotará un fondo de reserva para atender a daños extraordinarios y situaciones de emergencia provocados por catástrofes medioambientales hasta alcanzar la cuantía de 1.000.000.000 de pesetas, cantidad que será repuesta a medida que sea utilizada mediante nuevas dotaciones anuales en porcentaje no superior a la citada.

Las prestaciones del fondo tendrán el carácter de anticipo reintegrable.

El funcionamiento y demás aspectos concretos del fondo se regularán por Decreto.

3. Del destino de los recursos a que se refiere el apartado 1 anterior será informado el Consello Galego de Medio Ambiente, a los efectos de sus funciones.

Artículo 5. Órganos competentes.

1. La gestión, inspección y recaudación del Impuesto sobre la Contaminación Atmosférica corresponde a la Consellería de Economía e Facenda.

2. La modificación de las tarifas impositivas, con arreglo a lo establecido en el artículo 11.2 de esta ley, se efectuará previo informe de la Comisión Gallega del Medio Ambiente.

\section{Capitulo II ELEMENTOS DEL IMPUESTO}

Artículo 6. Hecho imponible.

1. Constituye el hecho imponible la emisión a la atmósfera de cualquiera de las siguientes sustancias:

a. Dióxido de azufre o cualquier otro compuesto oxigenado del azufre. b. Dióxido de nitrógeno o cualquier otro compuesto oxigenado del nitrógeno.

2. Se presumirá realizado el hecho imponible en tanto las instalaciones emisoras no cesen en su actividad y tal circunstancia sea puesta en conocimiento de la Administración.

Artículo 7. Sujeto pasivo.

Serán sujetos pasivos en calidad de contribuyentes las personas o entidades que sean titulares de las instalaciones o actividades que emitan las sustancias contaminantes gravadas.

Artículo 8. Base imponible.

1. Constituye la base imponible la suma de las cantidades emitidas de cada una de las sustancias contaminantes por un mismo foco emisor.

A estos efectos:

a. Las cantidades emitidas de dióxido de azufre y de dióxido de nitrógeno se expresarán en toneladas.

b. Las cantidades emitidas de compuestos oxigenados de azufre se expresarán en toneladas equivalentes de dióxido de azufre.

c. Las cantidades emitidas de compuestos nitronegados se expresarán en toneladas equivalentes de dióxido de nitrógeno.

2. La cuantificación de la base imponible se referirá al año natural.

Artículo 9. Foco emisor.

1. A los efectos de la presente ley constituye un foco emisor el conjunto de instalaciones de cualquier naturaleza que emitan a la atmósfera sustancias contaminantes gravadas.

2. La Administración establecerá el registro obligatorio de los focos emisores así como de sus características e incidencias.

Artículo 10. Determinación de la base imponible.

1. La base imponible se determinará:

a. Por estimación directa, deducida de la declaración del sujeto pasivo y verificada por la Administración, en los casos en que las instalaciones incorporen sistemas 
de medida de la cantidad de sustancias contaminantes emitidas.

b. En los demás casos, mediante estimación objetiva, deduciendo la cantidad de contaminantes emitida de indicadores objetivos vinculados a la actividad o proceso de producción de que se trate.

2. Mediante Decreto, la Xunta determinará los supuestos en que sea de aplicación el régimen de estimación objetiva, los índices o módulos a utilizar en cada caso así como su valoración.

Artículo 11. Determinación de oficio. La Administración podrá señalar de oficio, con la información disponible, la base que corresponda a aquel sujeto pasivo que, incumpliendo las normas fiscales, hiciese imposible su determinación a través de las vías ordinarias previstas en la presente ley.

Artículo 12. Cuota tributaria.

1. La cuota tributaria vendrá determinada por la aplicación de la siguiente tarifa impositiva por tramos de base:

2. La tarifa impositiva podrá ser modificada por la ley de presupuestos de cada año ${ }^{196}$.

Artículo 13. Devengo.

El gravamen se devenga en el momento de la emisión de cualquiera de las sustancias contaminantes gravadas.

\section{Capítulo II GESTIÓN DEL TRIBUTO}

Artículo 14. Normas de gestión.

A propuesta de la Consellería de Economía e Facenda, y mediante Decreto, la Xunta aprobará las normas de gestión y liquidación del tributo.

Artículo 15. Liquidación e ingreso. Los sujetos pasivos están obligados, en la forma y plazos que se establezcan

196 Art. 12 modificado por Ley 16/2008, de 23 de diciembre, de presupuestos generales de la Comunidad Autónoma de Galicia para el año 2009. reglamentariamente al efecto, a liquidar e ingresar el impuesto que corresponda a cada uno de los focos de emisión de los que sean titulares.

La consejería competente en materia de hacienda podrá disponer que las declaraciones y autoliquidaciones se efectúen mediante los programas informáticos de ayuda que, en su caso, se aprueben.

Asimismo, podrá disponer la obligación de su presentación y pago mediante medios telemáticos ${ }^{197}$.

\section{Artículo 16. Reclamaciones.}

Los actos de gestión, liquidación, inspección y recaudación del tributo serán reclamables ante los órganos económicoadministrativos de la Comunidad Autónoma, sin perjuicio de la vía contenciosa.

Artículo 17. Infracciones y sanciones. Las infracciones tributarias del Impuesto sobre la Contaminación Atmosférica serán calificadas y sancionadas con arreglo a lo establecido en la Ley General Tributaria.

\section{DISPOSICIÓN ADICIONAL}

El tramo regulador previsto en el artículo 12.2 de esta ley no se establecerá con anterioridad al año 2000. Su determinación se llevará a cabo por Ley del Parlamento de Galicia, y en ese momento se fijará el tipo de gravamen que sea de aplicación.

\section{DISPOSICIÓN FINAL PRIMERA}

Se autoriza a la Xunta de Galicia para proceder al desarrollo reglamentario de la presente ley dentro de los seis meses siguientes a su entrada en vigor 198 .

\section{DISPOSICIÓN FINAL SEGUNDA}

La presente ley entrará en vigor el día 1 de enero de 1996.

197 Art. 15 modificado por Ley 16/2008, de 23 de diciembre, de presupuestos generales de la Comunidad Autónoma de Galicia para el año 2009.

198 Véase Decreto 29/2000, de 20 de enero, por el que se aprueba el Reglamento del impuesto sobre la contaminación atmosférica. 
3. LEY 6/2003, DE 9 DE DICIEMBRE, DE TASAS, PRECIOS Y EXACCIONES REGULADORAS DE LA COMUNIDAD AUTÓNOMA DE GALICIA $\left(\text { DOGA N. }{ }^{\circ} 240,11.12 .2003\right)^{199}$

\section{$(\ldots)^{200}$ \\ TíTULO I DISPOSICIONES GENERALES}

Artículo 1. Contenido de la ley. La presente ley regula los aspectos financieros de la actividad de la Administración pública de la Comunidad Autónoma de Galicia, en cuanto dicha actividad pretenda determinar o influir en el consumo o consista en la entrega de ciertos bienes o la prestación de ciertos servicios, en ambos casos individualizables.

A estos efectos, se entenderá que el consumo de un bien o servicio es individualizable cuando exista una demanda definida de éste, tanto si la misma es de carácter voluntario como si tiene su origen en una obligación legal.

Artículo 2. Tipo de instrumentos.

En la presente ley se desarrollan dos tipos de instrumentos:

a. Los instrumentos financieros, que son las contraprestaciones percibidas a consecuencia del suministro o utilización de bienes o de la prestación de servicios demandados por los sujetos. Son instrumentos de tipo financiero los contemplados en el título II de esta ley.

b. Los instrumentos reguladores, que son los medios utilizables para alterar las contraprestaciones exigidas por aquellos bienes o servicios ofrecidos por los sujetos activos a que se refiere el artículo siguiente. Son instrumentos reguladores los contemplados en el título III de esta ley.

Artículo 3. Ámbito de aplicación.

Los instrumentos a que se refiere el artículo anterior podrán ser aplicados por los órganos de la Administración general,

199 Véase Decreto 61/2005, de 7 de abril, por el que se dictan las normas para la aplicación de las tasas y precios de la comunidad autónoma de Galicia. 200 Exposición de motivos omitida. sus organismos autónomos y las entidades de derecho público dependientes o que estén vinculadas a cualquiera de los mismos, enmarcables todos ellos dentro de la Administración pública de la Xunta de Galicia.

Artículo 4. Régimen presupuestario y aplicación obligatoria.

1. Los ingresos derivados de la aplicación de los instrumentos regulados en la presente ley y percibidos por los sujetos a que se refiere el artículo 3 estarán destinados a satisfacer el conjunto de sus obligaciones respectivas, salvo que excepcionalmente y mediante ley se establezca su afectación a fines determinados.

2. El rendimiento proveniente de los mismos se aplicará íntegramente al presupuesto de ingresos que corresponda, debiendo realizarse su ingreso en las cajas del tesoro de la Hacienda gallega o, a través de las entidades financieras colaboradoras, en las cuentas autorizadas por la Consellería competente en materia de hacienda.

3. Cuando los sujetos referidos en el artículo 3 entreguen bienes o presten servicios para los que exista demanda, habrán de aplicarse los instrumentos financieros que sean utilizables conforme a las normas de la presente ley.

4. A este fin, todo proyecto de creación de una entidad o inclusive de oferta de un nuevo bien o servicio, independientemente de otros requisitos, deberá adjuntar una memoria económica elaborada por la Consellería correspondiente, en la cual, además de valorar la conveniencia del proyecto, se propondrán los instrumentos financieros que, en su caso, sean de aplicación. Idéntico procedimiento se exigirá para los supuestos de modificación de las cuantías de los instrumentos a que se refiere la presente ley. Sobre dicha memoria emitirá informe la Consellería competente en materia de hacienda.

Artículo 5. Responsabilidades.

1. Las autoridades, funcionarios públicos, agentes o asimilados que de forma 
voluntaria y culpable exijan indebidamente un instrumento financiero de los contemplados en la presente ley o que lo hagan en cuantía superior a la establecida incurrirán en falta disciplinaria muy grave, sin perjuicio de las responsabilidades de otro orden que pudieran derivarse de su actuación.

2. Cuando adopten en la misma forma resoluciones o realicen actos que infrinjan la presente ley y demás normas que reglamentan esta materia, estarán obligados además a indemnizar a la Hacienda pública por los perjuicios causados.

Artículo 6. Normativa aplicable.

1. Los instrumentos financieros regulados en la presente ley se regirán por las normas contenidas en la misma y las normas reglamentarias dictadas en su desarrollo.

2. Serán de aplicación el texto refundido de la Ley de Régimen Financiero y Presupuestario de Galicia y la Ley General Tributaria y demás disposiciones generales en materia tributaria, así como aquellas disposiciones dictadas en desarrollo de las mismas, en cuanto resulten de aplicación, con arreglo al régimen jurídico establecido en la presente ley para cada instrumento financiero en concreto.

3. Los instrumentos financieros transferidos en el marco de la transferencia de competencias del Estado a la Comunidad Autónoma o de las corporaciones locales gallegas a la Comunidad Autónoma se regirán por lo dispuesto en las disposiciones transitorias de los decretos de traspaso. En caso de silencio de las normas de traspaso, serán de aplicación las normas autonómicas en todos sus términos, a excepción de lo dispuesto en el párrafo siguiente, desde el momento en que tenga efectividad el traspaso de las competencias, servicios o bienes que den lugar al instrumento financiero correspondiente.

En los supuestos de prestaciones de servicios, realizaciones de actividades o entrega de bienes en virtud de transferencia de competencias del Estado o de las corporaciones locales gallegas a la Comunidad Autónoma se exigirá, caso, la cuantía establecida en la correspondiente normativa estatal o local en el momento de la transferencia hasta el momento en que la misma sea establecida por el correspondiente acto normativo de la Comunidad Autónoma de Galicia.

\section{TÍTULO II INSTRUMENTOS FINANCIEROS \\ Capítulo I TASAS}

\section{Sección $1 .^{a}$}

Disposiciones generales

Artículo 7. Concepto.

Son tasas de la Comunidad Autónoma de Galicia los tributos creados por ley o transferidos por sus corporaciones locales o el Estado en el marco de la transferencia de servicios y competencias a ésta, cuyo hecho imponible consiste en la utilización privativa, ocupación o aprovechamiento especial del dominio público de la Comunidad Autónoma de Galicia o en la entrega de bienes, prestación de servicios o realización de actividades en régimen de derecho público por parte de los sujetos activos a que se refiere el artículo 3 de la presente ley, que se refieran, afecten o beneficien de modo particular al sujeto pasivo, siempre y cuando se produzca cualquiera de las circunstancias siguientes:

Primera. Que la entrega de bienes, prestación de servicios o realización de actividades no sean de solicitud voluntaria para los administrados. A estos efectos no se considerará voluntaria la solicitud por parte de los administrados:

Cuando venga impuesta por las disposiciones legales o reglamentarias, o Cuando los bienes, servicios o actividades requeridos sean imprescindibles para la vida privada o social del solicitante.

Segunda. Que no se entreguen, presten o realicen por el sector privado, esté o no establecida su reserva a favor del sector público conforme a la normativa vigente. 
Artículo 8. Normativa aplicable.

1. Las tasas de la Comunidad Autónoma de Galicia se regirán por las normas de la presente ley, las disposiciones legales de cada tasa, en su caso, y las normas reglamentarias dictadas en desarrollo de las mismas.

2. Serán de aplicación el texto refundido de la Ley de Régimen Financiero y Presupuestario de Galicia y la Ley General Tributaria y demás disposiciones generales en materia tributaria, así como aquellas disposiciones dictadas en desarrollo de las mismas.

Artículo 9. Reserva de ley.

1. El establecimiento de las tasas y la regulación de sus elementos esenciales se harán mediante norma con rango de ley del Parlamento de Galicia.

2. A los efectos previstos en el apartado anterior son elementos esenciales de las tasas: el hecho imponible, el sujeto pasivo, la base imponible, la cuota tributaria y el devengo.

3. Asimismo, la ley regulará el establecimiento, supresión y prórroga de exenciones $\mathrm{y}$ bonificaciones.

4. La aplicación de una tasa establecida a supuestos concretos de utilización privativa, ocupación o aprovechamiento especial del dominio público de la Comunidad Autónoma de Galicia, venta de bienes, realización de actividades o prestación de servicios podrá hacerse en la Ley de presupuestos de cada año.

Asimismo, en dicha ley, se podrán modificar y actualizar las cuotas tributarias correspondientes a las tasas vigentes.

5. No podrán establecerse tasas que no sean consecuencia de la utilización privativa, ocupación o aprovechamiento especial del dominio público de la Comunidad Autónoma de Galicia o del suministro o entrega, prestación o realización de algún bien, servicio o actividad, respectivamente.

6. Sin perjuicio de lo establecido en el apartado 2, la cuota tributaria podrá ser fijada reglamentariamente cuando así esté contemplado en norma de rango legal y siempre dentro de los límites dispuestos por la misma.

Artículo 10. Principio de capacidad económica.

En cuanto las características del tributo lo permitan, se tendrá en cuenta, para la fijación de la cuota tributaria de las tasas, la capacidad económica del sujeto pasivo, en especial cuando se establezcan consumos o impongan actividades susceptibles de afectar a todos los ciudadanos.

Artículo 11. Principio de equivalencia.

1. El rendimiento total previsible de la tasa no podrá exceder, en su conjunto, del coste total de producción del bien, servicio o actividad.

2. En el caso de la tasa por la utilización privativa, ocupación o aprovechamiento especial del dominio público de la Comunidad Autónoma de Galicia se tomará como referencia el valor de mercado correspondiente o el de la utilidad derivada de la misma.

Artículo 12. Supuestos de no sujeción. No se exigirán tasas a los sujetos a que se refiere el artículo 3 de la presente ley.

Artículo 13. Clases de tasas.

1. Por la presente ley se establecen las tasas siguientes:

a. La tasa por servicios administrativos.

b. La tasa por servicios profesionales.

c. La tasa por venta de bienes.

d. La tasa por utilización privativa, ocupación o aprovechamiento especial del dominio público de la Comunidad Autónoma de Galicia.

2. Cuando las actuaciones solicitadas o que se realicen acerca de un mismo sujeto pasivo conlleven el devengo de diferentes tasas, deberán aplicarse todas las tasas y modalidades que correspondan.

3. Asimismo, la aplicación de una tasa que autorice o permita una actividad al sujeto pasivo se exigirá sin perjuicio de la del precio público o privado que, conforme a las normas de la presente ley, pudiera implicar el ejercicio efectivo de la actividad autorizada. 
Artículo 14. Devengo.

1. Las tasas se devengarán según la naturaleza del hecho imponible:

a. Cuando se conceda la utilización privativa, ocupación o aprovechamiento especial del dominio público de la Comunidad Autónoma de Galicia o cuando se inicie la prestación del servicio, realice la actividad o entregue el bien, sin perjuicio de la posibilidad de exigir su depósito previo.

b. Cuando se presente la solicitud que inicie la actuación o expediente, que no será realizada o tramitado sin que se efectúe el pago correspondiente.

2. Cuando las tasas se devenguen periódicamente, una vez notificada la liquidación correspondiente al alta en el respectivo registro, padrón o matrícula, podrán notificarse colectivamente las sucesivas liquidaciones mediante anuncios en el "Diario Oficial de Galicia".

Artículo 15. Cuota tributaria.

1. La cuota tributaria podrá:

Consistir en una cantidad fija señalada al efecto, determinarse por aplicación de un tipo de gravamen sobre una base imponible, establecerse por aplicación de ambos métodos conjuntamente.

2. Las cuotas tributarias de las tasas establecidas por alguno de los métodos contenidos en el apartado anterior atenderán al coste medio real o previsto para la entrega del bien, prestación del servicio o realización de la actividad de que se trate, o, en su defecto, al valor de la prestación recibida, excepto en la tasa por utilización privativa, ocupación o aprovechamiento especial del dominio público de la Comunidad Autónoma de Galicia, la cual se fijará tomando como referencia el valor de mercado correspondiente o el de la utilidad derivada de aquélla. En otro caso, deberá señalarse la correspondiente subvención reguladora.

3. Para la determinación de las cuotas tributarias de las tasas contempladas en las letras a), b) y c) del apartado $1 \mathrm{del}$ artículo 13 se tomarán los costes directos e indirectos, inclusive los de carácter financiero, amortización del inmovilizado, costes de inversión y, en su caso, los necesarios para garantizar el mantenimiento, expansión y desarrollo razonable del bien, servicio o actividad gravada por la tasa, más una normal rentabilidad de los recursos invertidos.

4. Cuando se establezca un nuevo supuesto de aplicación de una tasa en el ejercicio de lo establecido en el artículo 9.4 de la presente ley o se modifiquen las cuotas tributarias vigentes, siempre que no se trate de la actualización anual a que se refiere el apartado 6 siguiente, deberá elaborarse una memoria económico-financiera que habrá de contener como mínimo información relativa a los costes directos e indirectos que contribuyan a la formación del coste total del servicio o actividad, con arreglo a lo dispuesto en el punto anterior, así como una previsión acerca del coste unitario que al mismo corresponde y una propuesta de la cuota tributaria aplicable.

5. Cuando la utilización privativa, ocupación o aprovechamiento especial del dominio público de la Comunidad Autónoma de Galicia conlleven una destrucción o deterioro del mismo no previstos en la memoria económico-financiera, el beneficiario, sin perjuicio del pago de la cuota tributaria correspondiente, estará obligado al reintegro del coste total de los respectivos gastos de reconstrucción o reparación. Si los daños resultaran irreparables, la indemnización consistirá en una cuantía igual al valor de los bienes destruidos o al importe del deterioro de los dañados.

6. Las cuotas tributarias se revisarán como mínimo cada cinco años, en base a en los registros de gastos e ingresos y a la correspondiente memoria económico-financiera sobre el coste y actividad realizada. No obstante, estas cuotas tributarias podrán ser objeto de actualización anual en la Ley 
de presupuestos en función de las variaciones del coste económico motivadas por la fluctuación de los índices de los precios al consumo e incrementos de las retribuciones del personal adscrito a los mencionados órganos, organismos autónomos o entidades de derecho público.

Artículo 16. Pago.

1. El pago de las tasas podrá exigirse bien en cualquier momento entre la solicitud y el devengo o bien en el momento de la solicitud cuando ésta coincida con el devengo.

También podrá exigirse el anticipo o depósito previo del importe total o parcial de las tasas en la forma que, a propuesta de la Consellería competente en materia de hacienda, se determine reglamentariamente.

2. Los sujetos activos a que se refiere el artículo 3 de la presente ley denegarán la utilización privativa, ocupación o aprovechamiento especial del dominio público de la Comunidad Autónoma de Galicia, la entrega del bien, prestación del servicio o realización de la actividad cuando el sujeto pasivo incumpla el pago.

Asimismo devolverá las cantidades que hubiera percibido cuando, por causas no imputables al sujeto pasivo, no se hubiera llevado a cabo el hecho imponible.

3. El pago de las tasas se efectuará mediante ingreso en el tesoro de la Hacienda gallega, con arreglo a las modalidades reglamentariamente establecidas.

4. Podrá igualmente autorizarse el pago de las tasas mediante el empleo de efectos timbrados de la Comunidad Autónoma de Galicia en los términos que reglamentariamente se determinen.

5. Se podrá aplazar o fraccionar el pago de las tasas, siendo de aplicación lo dispuesto en la Ley 58/2003, de 17 de diciembre, general tributaria 201 .

6. La Administración exigirá por vía apremio las deudas tributarias por las tasas

201 Art. 16.5 modificado por Ley $14 / 2004$, de 29 de diciembre, de medidas tributarias y de régimen administrativo. devengadas y no satisfechas en los plazos establecidos reglamentariamente, conforme a la normativa que sea de aplicación.

\section{Artículo 17. Gestión.}

1. Con carácter general, la gestión y liquidación de cada tasa corresponderá a los sujetos a que se refiere el artículo 3 de la presente ley que concedan la utilización privativa, ocupación o aprovechamiento especial del dominio público de la Comunidad Autónoma de Galicia, suministren el bien, presten el servicio o realicen la actividad gravados.

2. La fiscalización, control contable y funciones de inspección financiera y tributaria, así como la potestad sancionadora en materia tributaria, corresponden a la Consellería competente en materia de hacienda. Las funciones relativas a los procedimientos de recaudación corresponderán a la Consellería competente en materia de hacienda y será llevada por los órganos de recaudación que reglamentariamente y a propuesta de ésta se determinen.

3. Reglamentariamente, a propuesta de la Consellería competente en materia de hacienda, se determinarán los supuestos en que de forma obligatoria los sujetos pasivos deberán practicar la operación de autoliquidación de las tasas y el consiguiente ingreso en el tesoro de la Hacienda gallega.

4. Toda institución o entidad pública que conceda la utilización privativa, ocupación o aprovechamiento especial del dominio público de la Comunidad Autónoma de Galicia, suministre bienes, preste servicios o realice actividades, por los que perciba tasas, estará obligada a llevar registros separados tanto de los gastos en que incurra en la realización de los supuestos anteriores como de los ingresos obtenidos por las tasas.

Artículo 18. Responsables.

La normativa legal reguladora de cada tasa, en su caso, podrá señalar la responsabilidad solidaria o subsidiaria de aquellas personas físicas o jurídicas que, distintas 
del sujeto pasivo, estén interesadas o relacionadas con los supuestos que den lugar al devengo de la tasa.

Artículo 19. Reclamaciones y recursos.

1. Los actos de gestión de las tasas de la Comunidad Autónoma serán recurribles en reposición con carácter potestativo ante el órgano que dictó el acto.

2. Contra la resolución del recurso de reposición o contra los actos de gestión, si no se interpuso aquél, podrá recurrirse ante la Xunta Superior de Facenda, cuyas resoluciones agotan la vía económico-administrativa.

Artículo 20. Prescripción y régimen sancionador.

Todo lo relativo a la prescripción e infracciones y sanciones se regirá por la Ley General Tributaria y demás disposiciones generales en materia tributaria, así como por aquellas disposiciones dictadas en desarrollo de las mismas.

\section{Sección 2. ${ }^{a}$}

\section{Tasa por servicios administrativos}

\section{Artículo 21. Hecho imponible.}

1. Constituye hecho imponible de la tasa por servicios administrativos la prestación, por parte de los sujetos relacionados en el artículo 3 de la presente ley, de cualquier servicio administrativo que se refiera, afecte o beneficie de un modo particular a los sujetos pasivos, en cada una de las modalidades siguientes:

a. Modalidad de autorizaciones: por la concesión de autorizaciones, permisos, licencias, guías, expedición de títulos, diligenciado de libros y, en general, documentos que faculten al sujeto pasivo para realizar una actividad sometida legalmente a dicha condición previa.

b. Modalidad de registro: por la inscripción en registros, matrículas o relaciones mantenidas por la administración en tanto resulte obligado para el desarrollo de una actividad o ejercicio de un derecho por parte del sujeto pasivo.

c. Modalidad de certificaciones: por la verificación de documentos, expedición de certificaciones, copia de archivos y elaboración de documentos acreditativos de información que obre en archivos o registros públicos.

2. No se exigirá la tasa por servicios administrativos cuando se trate de compulsas o cotejos de documentos que hayan de acompañarse a solicitudes, escritos o comunicaciones presentados por el ciudadano y realizados en el ámbito de actuación de los registros según lo dispuesto en el artículo 38.5 de la Ley 30/1992, de 26 de noviembre, de Régimen Jurídico de las Administraciones Públicas y del Procedimiento Administrativo Común.

Artículo 22. Sujetos pasivos.

1. Son sujetos pasivos contribuyentes de la tasa las personas físicas o jurídicas que soliciten o provoquen las actuaciones administrativas que constituyen el hecho imponible.

2. Tendrán también la consideración de sujetos pasivos las herencias yacentes, comunidades de bienes y demás entidades carentes de personalidad jurídica que constituyan una unidad económica o un patrimonio separado susceptible de tributación.

3. En la tarifa 41 contenida en el anexo 1 será sujeto pasivo sustituto del contribuyente la entidad aseguradora en cuyo registro de agentes figure inscrito el agente de seguros exclusivo, el operador de banca-seguros exclusivo o el cargo de administración y de dirección responsable de las actividades de mediación de seguros 202 .

Artículo 23. Exenciones.

Gozarán de exención de la presente tasa:

1. La expedición de certificados de retribuciones satisfechas por la Xunta de Galicia al objeto de justificación con relación al impuesto sobre la renta de las personas físicas.

2. La expedición de certificados y compulsa que el personal de la administración solicite respecto a necesidades propias del puesto de trabajo o relación de servicios.

202 Art. 22.3 añadido por Ley 14/2006, de 28 de diciembre, de Presupuestos Generales de la Comunidad Autónoma de Galicia para el año 2007. 
3. Los alumnos por cualquier actuación en materia de enseñanzas no universitarias.

4. Las compulsas realizadas en las oficinas de empleo para los desempleados en la tramitación de expedientes que sean competencia de dichas oficinas.

5. La inscripción en las convocatorias para selección de personal de la Comunidad Autónoma, previa justificación documental, solicitada por:

Personas con minusvalía igual o superior al 33\%.

Personas que sean miembros de familias numerosas clasificadas en la categoría especial; en caso de miembros de categoría general tendrán una bonificación del $50 \%{ }^{203}$.

6. La expedición de certificados relativos a la situación fiscal.

7. El Estado y demás entes públicos territoriales o institucionales, siempre y cuando los servicios o actividades de que sean beneficiarios se presten o realicen en el marco del principio de colaboración entre administraciones.

8. Las víctimas de actos terroristas así como sus cónyuges e hijos por cualquier actuación en materia educativa realizada en centros oficiales de estudios en todos los niveles de enseñanza.

9. Los miembros de los organismos consultivos de la Administración pública gallega respecto a los certificados emitidos por dichos organismos.

10. La participación en las pruebas para la obtención del certificado de profesionalidad, previa justificación documental, con referencia a las siguientes personas:

- Las que figuren inscritas como desempleadas en las oficinas de empleo.

- Las que tengan una discapacidad en grado igual o superior al $33 \%{ }^{204}$.

203 Art. 23.5 modificado por Ley 13/2004, de 29 de diciembre, de Presupuestos Generales de la Comunidad Autónoma de Galicia para el año 2005.

204 Art. 23.10 añadido por Ley 14/2006, de 28 de diciembre, de Presupuestos Generales de la Comunidad Autónoma de Galicia para el año 2007.

\section{Artículo 24. Devengo.}

La tasa se devengará en el momento en que se presente la solicitud para la prestación de dichos servicios administrativos.

Artículo 25. Tarifas.

La tasa se exigirá con arreglo a tarifas relacionadas en el anexo 1 de la presente ley.

\section{Sección $3 .^{\mathrm{a}}$}

\section{Tasa por servicios profesionales}

Artículo 26. Hecho imponible.

1. Constituye hecho imponible de la tasa por servicios profesionales la prestación, por parte de profesionales facultativos al servicio de los sujetos relacionados en el artículo 3 de la presente ley, de los servicios que se refieran, afecten o beneficien de un modo particular a los sujetos pasivos, previa solicitud de éstos, en cada una de las siguientes modalidades:

a. Modalidad de actuaciones administrativo-facultativas: Servicios administrativos, análogos a los sometidos a la tasa por servicios administrativos, cuando la prestación de los mismos requiere que se lleve a cabo bajo la dirección de un profesional facultativo.

b. Modalidad de actuaciones profesionales:

Servicios de asesoramiento, consulta, dirección técnica de obras, emisión de informes, análisis, dictámenes u opiniones profesionales $\mathrm{y}$, en general, actividades que exigen la cualificación que tiene el profesional que las presta.

2. En el supuesto de las tarifas 08 y 36 de la modalidad de actuaciones administrativo-facultativas, relacionadas en el anexo 2 , constituye el hecho imponible la prestación de las actividades realizadas por los sujetos a que hace referencia el apartado anterior para preservar la salud pública y la sanidad animal, mediante la práctica de inspecciones y controles sanitarios de animales y sus carnes frescas destinadas al consumo, así como de otros productos de origen animal, efectuados por los facultativos de los servicios 
correspondientes, tanto en los locales o establecimientos de sacrificio e inspección sanitaria de mataderos, salas de despiece e instalaciones de transformación de la caza ubicados en territorio de la Comunidad Autónoma de Galicia, como los demás controles y análisis realizados en los centros habilitados al efecto.

A los efectos de la exacción del tributo, las actividades de inspección y control sanitario que se incluyen dentro del hecho imponible de la tarifa 08 de la modalidad de actuaciones administrativo-facultativas se catalogan de la siguiente forma:

a. Inspecciones y controles sanitarios en mataderos.

b. Inspecciones y controles sanitarios en las salas de despiece.

c. Control de las operaciones llevadas a cabo en las instalaciones de transformación de la caza.

A los efectos de la exacción del tributo, las actividades de inspección y control sanitario que se incluyen dentro del hecho imponible de la tarifa 36 de la modalidad de actuaciones administrativo-facultativas se catalogan de la siguiente forma:

Control de determinadas sustancias y residuos en animales y sus productos, en la forma prevista por la normativa vigente ${ }^{205}$.

3. En el supuesto de la tarifa 99 de la modalidad de actuaciones profesionales, relacionada en el anexo 3, el hecho imponible estará constituido, según cada caso, por las siguientes operaciones:

En la tarifa G-1, la utilización de las aguas del puerto, instalaciones de señales marítimas y balizamiento, canales de acceso, esclusas (sin incluir el amarre, remolque o sirga en la misma) y puentes móviles, obras de abrigo y zonas de fondeo, siendo de aplicación en la cuantía y condiciones que se indican en el anexo 3 a todos los barcos que entren en aguas del puerto.

En la tarifa G-2, el uso de las obras de atraque y elementos fijos de amarre y

205 Art. 26.2 modificado por Ley 16/2007, de 26 de diciembre, de presupuestos generales de la Comunidad Autónoma de Galicia para el año 2008. defensa, siendo de aplicación en la cuantía y condiciones que se indican en el anexo 3 a todos los barcos que utilicen las obras y elementos antes señalados que hayan sido construidos total o parcialmente por la Administración portuaria o que sean propiedad de la misma.

En la tarifa G-3, la utilización por las mercancías y pasajeros que se embarquen, desembarquen, transborden o efectúen tránsito marítimo o terrestre de las zonas de maniobra, manipulación y tránsito, accesos y vías de circulación terrestres viarias y ferroviarias y otras instalaciones portuarias fijas. Asimismo, se incluye en el hecho imponible su utilización por las mercancías o pasajeros que accedan o salgan de la zona de servicio del puerto por vía terrestre sin utilizar en ningún momento la vía marítima, excepto que tengan como origen o destino instalaciones fabriles, de transformación, logísticas o de almacenaje ubicadas en la zona de servicio del puerto.

En la tarifa G-4, la utilización por los buques pesqueros en actividad y los productos de la pesca marítima fresca de las aguas del puerto, instalaciones de balizamiento, muelles, dársenas, zonas de manipulación y servicios generales o de policía.

En la tarifa G-5, la utilización por las embarcaciones deportivas o de recreo, y por sus tripulantes y pasajeros, de las aguas del puerto y sus instalaciones de balizamiento, de las ayudas a la navegación, de las dársenas, de los accesos terrestres y viales de circulación de los puertos, de los servicios generales de policía y, en su caso, de las instalaciones de fondeo y atraque en muelles o pantalanes, así como de los servicios específicos disponibles.

En la tarifa E-1, la utilización de las grúas convencionales o no especializadas.

En la tarifa E-2, la utilización de explanadas, cobertizos, tinglados, almacenes, depósitos, locales y edificios, con sus servicios generales correspondientes, no explotados en régimen de concesión. 
En la tarifa E-3, el suministro de productos o energía y la utilización de las instalaciones para la prestación de los mismos.

En la tarifa E-4, cualesquiera otros servicios prestados por Puertos de Galicia, no enumerados en las restantes tarifas y que se establezcan específicamente en cada puerto o se presten previa solicitud por los peticionarios.

En la tarifa por el ejercicio de actividades comerciales, industriales y de servicios, la actividad que realice la Administración portuaria, dirigida a la aplicación del régimen de autorizaciones administrativas para el ejercicio de actividades comerciales, industriales y de servicios en la zona de ámbito portuario.

Artículo 27. Sujeto pasivo.

1. Es sujeto contribuyente de la tasa por servicios profesionales la persona natural o jurídica que solicite o se le preste cualquiera de los servicios que figuran en los anexos 2 y 3 .

2. Tendrán asimismo la consideración de sujetos pasivos las herencias yacentes, comunidades de bienes y demás entidades que, careciendo de personalidad jurídica, constituyen una unidad económica o un patrimonio separado susceptible de tributación.

3. Será sujeto pasivo sustituto del contribuyente:

Uno. En las tarifas 25 y 26 de la modalidad de actuaciones profesionales, que se relacionan en el anexo 3, la entidad encargada de realizar el control metrológico en la fase de instrumentos en servicio que hubiera realizado las labores por cualquiera de las figuras legalmente establecidas $^{206}$.

Dos. En la tarifa 27 de la modalidad de actuaciones profesionales, que se relaciona en el anexo 3, la empresa concesionaria

206 Art. 27.3.Uno modificado por Ley 16/2008, de 23 de diciembre, de presupuestos generales de la Comunidad Autónoma de Galicia para el año 2009. del servicio de inspección técnica de vehículos 207.

4. Uno. Son sujetos pasivos obligados al pago, según la tarifa de que se trate, las siguientes personas o entidades:

1. En la tarifa 08 de la modalidad administrativo-facultativa, relacionada en el anexo 2:

a. En caso de la tarifa relativa a las inspecciones y controles sanitarios en mataderos, los titulares de la explotación de los establecimientos donde se lleve a cabo el sacrificio o se practique la inspección.

b. En la tarifa relativa a las inspecciones y controles sanitarios en las salas de despiece:

1) Las mismas personas o entidades determinadas en la letra a) anterior, cuando las operaciones de despiece se realicen en el mismo matadero.

2) Los titulares de la explotación de los establecimientos dedicados a la operación de despiece de forma independiente, en los demás casos.

c. En la tarifa relativa a los controles en las instalaciones de transformación de la caza, los titulares de la explotación de los citados establecimientos.

2. En la tarifa 36 de la modalidad administrativo-facultativa, relacionada en el anexo 2: En la tarifa relativa al control de sustancias y residuos en animales y sus productos, los titulares de la explotación de los establecimientos donde se lleven a cabo los citados controles y análisis.

Dos. Los sujetos pasivos anteriores deberán trasladar, cargando su importe en factura, la tasa correspondiente a los interesados que hayan solicitado la prestación del servicio o para los que se realicen las operaciones de sacrificio, despiece, transformación de la caza o control de determinadas sustancias y residuos animales y sus productos descritos en el artículo 26.2. . $^{\circ}$ y procederán

207 Art. 27.3 modificado por Ley 14/2006, de 28 de diciembre, de Presupuestos Generales de la Comunidad Autónoma de Galicia para el año 2007. 
posteriormente a su ingreso a favor de la Comunidad Autónoma, en la forma que reglamentariamente se establezca.

En caso de que el interesado, a su vez, hubiera adquirido el ganado en vivo a un tercero, para sacrificio, podrá exigir del mismo el importe de la tasa correspondiente al concepto de la tarifa 36 de la modalidad administrativo-facultativa.

Tres. Se entenderá que son interesados no sólo las personas físicas o jurídicas que soliciten los mencionados servicios, sino también las herencias yacentes, las comunidades de bienes y las demás entidades que, aunque no tengan personalidad jurídica propia, constituyan una unidad económica o un patrimonio separado ${ }^{208}$.

5. En la tarifa 99 de la modalidad de actuaciones profesionales, relacionada en el anexo 3, serán sujetos pasivos las siguientes personas o entidades:

- De las tarifas X-1 y X-2, los armadores o sus representantes o los consignatarios de los barcos que utilicen los servicios gravados.

- De la tarifa X-3, los armadores o los consignatarios de los barcos que utilicen el servicio y los propietarios del medio de transporte cuando la mercancía entre y salga del puerto por medios exclusivamente terrestres.

- De la tarifa X-4, el armador del buque o quien en su representación realice la primera venta.

- El sujeto pasivo habrá de hacer repercutir el importe de la tarifa X-4 sobre el primer comprador de la pesca, si lo hubiere, por lo que éste queda obligado a soportar dicha repercusión, que se hará constar de manera expresa y separada en la factura o documento equivalente. Las controversias que se susciten entre el sujeto pasivo y el comprador repercutido serán de la competencia de la Xunta Superior de Facenda.

208 Art. 27.4 modificado por Ley 16/2007, de 26 de diciembre, de presupuestos generales de la Comunidad Autónoma de Galicia para el año 2008.
- De la tarifa X-5, con carácter solidario, el titular de la embarcación o su representante autorizado y, en su caso, el titular del derecho de uso preferente del amarre o fondeo. En las zonas de concesión en las que el titular de la misma se subrogue en la obligación de los sujetos pasivos, en los términos establecidos en la regla decimoprimera, letra b), de esta tarifa X-5, el concesionario será el sustituto del contribuyente y tendrá que cumplir en su lugar las obligaciones formales y materiales derivadas de la obligación tributaria.

- De la tarifa por el ejercicio de actividades comerciales, industriales y de servicios, el titular de la actividad, cualquiera que sea la naturaleza del título habilitante de la misma ${ }^{209}$.

Artículo 28. Bonificaciones.

Se establece una bonificación de un $25 \%$ del importe de las tarifas de esta tasa a satisfacer cuando estén comprendidas en la solicitud de autorización, ampliación, modificación o traslado de establecimientos industriales y se realicen los trámites a través de las oficinas de tramitación única de industrias (OTUI) de la Consellería competente en materia de industria.

Artículo 29. Responsables.

1. Serán responsables subsidiarios, en los supuestos y con el alcance previsto en el artículo 40 de la Ley General Tributaria, los administradores o liquidadores de quiebras, concursos, sociedades y entidades en general que se dediquen a actividades cuya inspección y control genera el devengo de las tarifas 08 y 36 de la modalidad administrativo-facultativa.

2. En la tarifa 99 de la modalidad de actuaciones profesionales, serán responsables subsidiarios:

Del pago de la tarifa G-3, los propietarios de la mercancía $y$, en su defecto, sus representantes autorizados, salvo que

209 Art. 27.5 modificado por Ley $14 / 2006$, de 28 de diciembre, de Presupuestos Generales de la Comunidad Autónoma de Galicia para el año 2007. 
prueben haber hecho provisión de fondos a los responsables principales.

Del pago de la tarifa G-4, el primer comprador de la pesca, salvo que demuestre haber soportado efectivamente la repercusión, y el representante del armador, en su caso.

Del pago de la tarifa G-5, el capitán de la embarcación y/o el patrón habitual de la misma.

Del pago de la tarifa E-1, los propietarios de las mercancías y, en su defecto, sus representantes autorizados, salvo que prueben haber hecho a éstos provisión de fondos.

Del pago de la tarifa por el ejercicio de actividades comerciales, industriales y de servicios, el titular de la concesión o autorización de ocupación del dominio público cando éste no sea el sujeto pasivo de la tasa ${ }^{210}$.

Artículo 30. Exenciones.

Quedarán exentos de esta tasa los supuestos siguientes:

1. Por los servicios generales contemplados en la tarifa 99 de la modalidad de actuaciones profesionales:

a. Los barcos de guerra y aeronaves militares nacionales. Igualmente los extranjeros que, en régimen de reciprocidad, no realicen operaciones comerciales y siempre y cuando su visita tenga carácter oficial o de arribada forzosa.

b. Las embarcaciones dedicadas por las administraciones públicas a cometidos de vigilancia, investigación, protección y regeneración costera, represión del contrabando, salvamento, lucha contra la contaminación marítima, enseñanzas marítimas y, en general, a misiones oficiales de su competencia.

c. El material y embarcaciones de la Cruz Roja Española dedicadas a los cometidos propios que tiene encomendados esta institución.

2. El Estado y demás entes públicos territoriales o institucionales, siempre y

210 Último apartado del art. 29.2 añadido por Ley 14/2006, de 28 de diciembre, de Presupuestos Generales de la Comunidad Autónoma de Galicia para el año 2007. cuando los servicios o actividades de que sean beneficiarios se presten o realicen en el marco del principio de colaboración entre administraciones.

3. Quedarán exentas de la tarifa 22, "Actuaciones en materia de vivienda", la promoción, cesión y rehabilitación por el Estado de viviendas de protección oficial de interés general, así como las actuaciones de la Comunidad Autónoma y de las corporaciones locales en materia de promoción o rehabilitación.

4. Los informes de evaluación de los ensayos clínicos o estudios postautorización con medicamentos de uso humano o productos sanitarios cuando se solicite la exención de la tarifa 59 de la modalidad de actuaciones profesionales, siempre que cumplan los siguientes criterios, que habrán de ser debidamente acreditados:

a) El promotor del estudio deberá ser un centro del sistema sanitario público, universidad pública, organización científica o institución sin ánimo de lucro, o un/a investigador/a con vinculación laboral a alguna de estas instituciones.

b) El promotor del estudio será responsable del inicio, gestión y presupuesto de un ensayo clínico o estudio postautorización. La propiedad de los datos derivados del estudio pertenecerá al promotor.

c) El estudio no formará parte de un programa de desarrollo clínico que tenga por finalidad la comercialización del medicamento o producto sanitario objeto de la investigación.

d) El promotor deberá garantizar mediante declaración escrita al Comité Ético de Investigación Clínica de Galicia que se cumplen los criterios para ser considerado un estudio de investigación clínica no comercial $^{211}$.

\section{Artículo 31. Devengo.}

1. La tasa se devengará cuando se inicie la prestación del servicio.

211 Art. 30.4 añadido por Ley 16/2008, de 23 de diciembre, de presupuestos generales de la Comunidad Autónoma de Galicia para el año 2009. 
2. La tasa que corresponde satisfacer por las tarifas 08 y 36 de la modalidad administrativo-facultativa se devengará en el momento en que se lleven a cabo las actividades de inspección y control sanitario de animales y sus productos, en los establecimientos o instalaciones en que se desarrollan las mismas, sin perjuicio de que se exija su previo pago cuando la realización del control sanitario se inicie a solicitud del sujeto pasivo o del interesado. En la tarifa 08 de la modalidad administrativo-facultativa, en caso de que en un mismo establecimiento y a solicitud del interesado se realicen en forma sucesiva las operaciones de sacrificio y despiece, el total de la cuantía de la tasa se determinará de forma acumulada al inicio del proceso, con independencia del momento del devengo de las cuotas correspondientes, sin perjuicio de lo previsto en las reglas de acumulación ${ }^{212}$.

3. En la tarifa 99 de la modalidad por actuaciones profesionales, la tasa se devengará, en cada caso:

En la tarifa G-1, cuando el barco entrara en aguas de cualquiera de las zonas del puerto. En la tarifa G-2, cuando el barco atracara en el muelle.

El atraque se contará desde la hora para la que se haya autorizado hasta el momento de largar la última amarra del muelle.

En la tarifa G-3, cuando se inicien las operaciones de paso de las mercancías o pasajeros por el puerto.

En la tarifa G-4, cuando se inicien las operaciones de embarque, desembarque o transbordo de los productos de la pesca en cualquier punto de las aguas o zona terrestre bajo la jurisdicción del organismo portuario. En la tarifa G-5, cuando la embarcación entre en aguas del puerto o el recinto portuario.

En la tarifa E-1, desde el momento de la puesta a disposición de la correspondiente grúa.

212 Art. 31.2 modificado por Ley 16/2007, de 26 de diciembre, de presupuestos generales de la Comunidad Autónoma de Galicia para el año 2008.
En la tarifa E-2, se entenderá que el inicio de la prestación del servicio se produce en la fecha de reserva del espacio solicitado. En la tarifa por el ejercicio de actividades comerciales, industriales y de servicios, se producirá en el momento de la notificación del otorgamiento de la autorización de actividad o de la concesión o autorización de ocupación del dominio público portuario respecto al año en curso. Sin embargo, en el supuesto de que por ejecución de obras y otras causas justificadas se produjera una demora en el inicio de la actividad, el devengo de la tasa no se producirá hasta el momento en que se inicie la misma. En los años sucesivos el devengo se producirá el 1 de enero.

\section{Artículo 32. Tarifas.}

La tasa se exigirá con arreglo a las tarifas contenidas en los anexos 2 y 3 de la presente ley, para las modalidades de actuaciones administrativo-facultativas y actuaciones profesionales, respectivamente, y se entenderá con el impuesto sobre el valor añadido, en su caso, a excepción de la tarifa 99 contemplada en el anexo 3.

\section{Sección $4 .^{\text {a }}$}

Tasa sobre la venta de bienes

Artículo 33. Hecho imponible.

1. Constituye el hecho imponible de la tasa sobre la venta de bienes la entrega por parte de los sujetos relacionados en el artículo 3 de la presente ley de los bienes solicitados.

2. En caso de que el suministro del bien consista en entregas parciales, el hecho imponible se entenderá realizado en cada una de ellas.

Artículo 34. Sujeto pasivo.

1. Es sujeto pasivo de la tasa sobre la venta de bienes la persona física o jurídica solicitante del bien en cuestión.

2. Tendrán asimismo la consideración de sujetos pasivos de esta tasa las herencias yacentes, comunidades de bienes y demás entidades que, careciendo de personalidad jurídica, constituyan una unidad económica 
o un patrimonio separado susceptible de imposición.

Artículo 35. Exenciones.

Quedarán exentos de esta tasa los organismos, entidades y autoridades que conforman la distribución institucional en la venta de las publicaciones del Instituto Gallego de Estadística.

Artículo 36. Devengo.

1. La tasa se devengará en el momento de la entrega del bien.

2. En caso de que la entrega del bien se realice de manera periódica a consecuencia de la realización de una suscripción por el sujeto pasivo, la tasa se devengará en el momento en que se realice dicha suscripción.

Artículo 37. Tarifas.

La tasa se exigirá con arreglo a las tarifas contenidas en el anexo 4 de la presente ley, entendiéndose con el impuesto sobre el valor añadido, en su caso.

\section{Sección $5 .^{a}$}

Tasas por utilización privativa, ocupación o aprovechamiento especial del dominio público de la Comunidad Autónoma de Galicia

Artículo 38. Hecho imponible.

Constituye el hecho imponible de esta tasa la utilización privativa, ocupación o aprovechamiento especial del dominio público de la Comunidad Autónoma de Galicia.

Artículo 39. Sujeto pasivo.

Son sujetos pasivos de esta tasa los titulares de los permisos de ocupación temporal, concesiones administrativas o cualesquiera otras autorizaciones, cuyo objeto sea la utilización privativa, ocupación o aprovechamiento especial del dominio público de la Comunidad Autónoma de Galicia.

Artículo 40. Bonificaciones y exenciones.

A la tarifa 02 contenida en el anexo 5 le serán de aplicación las bonificaciones y exenciones que se relacionan a continuación:

a. Cuando los sujetos pasivos realicen inversiones en obras de relleno, consolidación o mejora de terrenos.
La cuantía de la bonificación se determinará en función de la inversión realizada, conforme a la escala que se establezca reglamentariamente, atendiendo al tipo de obra y coste de la misma, y no podrá rebasar el $50 \%$ de la cuantía correspondiente a la ocupación de las aguas del puerto o, en su caso, de los terrenos.

b. Cuando el objeto de la concesión consista en la urbanización y comercialización de zonas de almacenaje y de actividades logísticas, la cuantía de bonificación se determinará en función de la inversión privada realizada, conforme a la escala que se establezca reglamentariamente, atendiendo al tipo de obra y coste de la misma, y no podrá rebasar el $40 \%$ de la cuantía correspondiente a la ocupación de terrenos. Esta bonificación no podrá aplicarse durante un período superior al establecido para la finalización de cada fase de urbanización en el título concesional.

c. Cuando el titular de la concesión o autorización sea algún órgano de las administraciones públicas y el objeto de éstas sean actividades de interés social y cultural. El importe de esta bonificación será del $50 \%$ de la cuantía correspondiente a la ocupación de terrenos.

d. Cuando la ocupación del dominio público portuario tenga como destino la construcción o la explotación de fábricas de hielo, naves de redes o lonjas con sus correspondientes cámaras de frío, así como la explotación de naves de titularidad de la administración destinadas total o parcialmente a almacenaje de cajas, vestuarios o cámaras de frío, para el sector pesquero o marisquero, la cuantía de la tasa correspondiente a estas ocupaciones para los usos mencionados tendrá una bonificación del $90 \%{ }^{213}$.

e. En las concesiones o autorizaciones de dominio público portuario otorgadas a entidades náuticas o culturales sin ánimo

213 Art. 40.d modificado por Ley 16/2007, de 26 de diciembre, de presupuestos generales de la Comunidad Autónoma de Galicia para el año 2008. 
de lucro para actividades de enseñanza de la náutica deportiva o de conservación o recuperación de embarcaciones tradicionales tendrá una bonificación del $90 \%$ en lo que se refiere exclusivamente a estas actividades, siempre y cuando no sean objeto de explotación económica.

f. Estarán exentos del pago de la tasa por utilización privativa o aprovechamiento especial del dominio portuario:

Los órganos y entidades de las administraciones públicas cuando estén directamente relacionados con actividades de vigilancia, represión del contrabando, Protección Civil de salvamento y lucha contra la contaminación marina o con la defensa nacional.

Las corporaciones locales cuando se trate de actividades enmarcadas entre sus finalidades públicas y no sean objeto de explotación económica.

g. La Cruz Roja Española está exenta del pago de la tasa por utilización privativa o aprovechamiento especial del dominio público portuario respecto a las actividades marítimas propias que tiene encomendadas esta institución.

Por orden de la Consellería competente en materia de puertos y a propuesta del ente público Puertos de Galicia, se concretará las condiciones, escalas y criterios necesarios para la aplicación de las bonificaciones previstas en los anteriores supuestos, partiendo de los elementos esenciales contenidos en los mismos.

\section{Artículo 41. Devengo.}

1. La tasa se devenga en el momento de la notificación del otorgamiento del permiso de ocupación temporal, de la concesión administrativa o de cualquier otra autorización, respecto al año en curso y el 1 de enero en los sucesivos años.

2. En la tarifa 02 contenida en el anexo 5 , en los supuestos de concesiones en que el término inicial se vincule a la fecha de extinción de otra concesión o a la fecha de finalización de obras que ejecuta la autoridad portuaria, el devengo se producirá en esas fechas el primer año y el 1 de enero en los sucesivos años.

\section{Artículo 42. Tarifas.}

1. La tasa se exigirá con arreglo a las tarifas relacionadas en el anexo 5 de la presente ley.

2. Las tarifas se prorratean en función del tiempo de disfrute de la concesión o autorización durante el primer año y el último de duración de las mismas, computándose el tiempo en meses enteros, redondeándose a estos efectos el número de meses al entero inmediatamente superior.

3. En el caso de la tarifa 02 contenida en el anexo 5 será de aplicación lo siguiente:

a. La base sobre la que se aplica el tipo de gravamen establecido se actualizará anualmente en la misma proporción que la variación interanual experimentada por el índice general de los precios al consumo para el conjunto nacional total (IPC) en el mes de octubre. Dicha actualización será efectiva a partir del día 1 de enero siguiente.

b. La tarifa 02 contenida en el referido anexo no alcanza al impuesto sobre el valor añadido correspondiente.

c. La tarifa será exigible por adelantado con las actualizaciones y, en su caso, revisiones que se efectúen, y en los plazos que figuren en las cláusulas de la concesión o autorización, los cuales no podrán ser superiores a un año. Sin embargo, Puertos de Galicia podrá autorizar pagos a cuenta de la tasa por plazos superiores para financiar la ejecución de obras a cargo de ésta.

d. En el supuesto de que Puertos de Galicia convoque concursos para el otorgamiento de las concesiones o autorizaciones, los pliegos de bases podrán contener, entre los criterios para su resolución, el que los licitadores oferten importes adicionales a los establecidos para esta tasa. En este caso, el tipo de tasa estará determinado por la suma de dos componentes:

a. El porcentaje vigente en el momento del devengo.

b. La mejora determinada por el adjudicatario en la proposición sobre la que se realiza la concesión, expresada en puntos porcentuales. 


\section{Capitulo II PRECIOS PÚBLICOS}

Artículo 43. Concepto.

Son precios públicos las contraprestaciones pecuniarias percibidas por los sujetos a que se refiere el artículo 3 de la presente ley por la prestación de servicios o realización de actividades efectuadas en régimen de derecho público cuando, prestándose también tales servicios o actividades por el sector privado, sean de solicitud voluntaria por parte de los administrados; a estos efectos se entiende que los servicios sociales, sanitarios y educativos se prestan en régimen de derecho público.

Artículo 44. Normativa aplicable.

1. En todo lo no previsto en la presente ley los precios públicos objeto de la misma se regularán por lo dispuesto en el texto refundido de la Ley de régimen financiero y presupuestario de Galicia y sus normas de desarrollo.

2. Se aplicará de forma supletoria la Ley general tributaria y demás disposiciones generales en materia tributaria, así como las normas de desarrollo de las mismas.

Artículo 45. Obligados al pago.

Estarán obligados al pago de los precios públicos quienes, en cada caso, determine la norma que los establezca.

Artículo 46. Cuantía de los precios públicos.

1. Los precios públicos se fijarán en la cuantía que cubra como mínimo los costes económicos derivados del servicio o de las actividades prestadas.

2. Cuando existan razones de interés público que lo justifiquen, podrán señalarse precios públicos en cuantía inferior a la indicada en el apartado anterior, previa adopción de las previsiones presupuestarias precisas para la cobertura de la parte del coste subvencionado.

Artículo 47. Fijación de precios públicos.

1. Los precios públicos serán fijados por decreto, a propuesta de la consellería de la que dependa el órgano o entidad oferente. Dicha propuesta incluirá necesariamente una memoria económica que deberá contener como mínimo lo siguiente:

a. Información suficiente respecto al coste de prestación de los bienes o servicios de que se trate.

b. Justificación de la política de precios propuesta, la cual en todo caso habrá de resultar suficiente para cubrir los costes totales, sin perjuicio de la posible subvención reguladora correspondiente.

2. Sobre la propuesta a que se refiere el apartado anterior deberá emitir informe favorable la consellería competente en materia de hacienda.

Artículo 48. Gestión.

1. La gestión de los precios públicos corresponde a los sujetos relacionados en el artículo 3, perceptores de los mismos, que deberán:

a. Llevar registros separados de ingresos $\mathrm{y}$ gastos, de forma que resulte posible su determinación tanto conjuntamente como por el tipo de bien o servicio producido.

b. Poner en conocimiento del órgano de la Administración de la comunidad de que dependan cualquier situación económica adversa que provoque un desequilibrio presupuestario de su gestión.

c. En todo caso, se someterán regularmente a los controles e inspecciones que correspondan por la consellería competente en materia de hacienda.

2. Los ingresos derivados de precios públicos estarán sometidos al régimen presupuestario de la entidad perceptora.

3. Los precios públicos podrán exigirse desde que se efectúe la entrega de los bienes o se inicie la prestación de los servicios que justifican su exigencia.

También podrá exigirse la anticipación o depósito previo del importe total o parcial de los precios públicos en la forma que, a propuesta de la consellería competente en materia de hacienda, se determine reglamentariamente.

4. El pago de los precios públicos se realizará en efectivo o mediante empleo 
de efectos timbrados u otros instrumentos de pago que autorice la consellería competente en materia de hacienda.

5 . Las funciones relativas a los procedimientos de recaudación corresponderán a la consellería competente en materia de hacienda y será llevada por los órganos de recaudación que reglamentariamente y a propuesta de la misma se determinen.

6. Las deudas por precios públicos podrán exigirse mediante el procedimiento administrativo de apremio.

7. Cuando por causas no imputables al obligado al pago del precio no se realice la actividad o no se preste el servicio, procederá la devolución del importe que corresponda.

Artículo 49. Reclamaciones y recursos. Contra los actos de gestión podrá recurrirse en vía económico-administrativa ante de la Xunta Superior de Facenda, sin perjuicio del derecho a interponer previamente, con carácter potestativo, recurso de reposición ante el órgano que dictó el acto. La resolución de las reclamaciones económico-administrativas agotará la vía administrativa.

\section{Capitulo III PRECIOS PRIVADOS}

\section{Artículo 50. Concepto.}

Son precios privados las contraprestaciones que obtengan los sujetos a que se refiere el artículo 3 de la presente ley por la prestación de servicios o la realización de actividades efectuadas en régimen de derecho privado cuando, prestándose también tales servicios o actividades por el sector privado, sean de solicitud voluntaria por parte de los administrados.

Artículo 51. Fijación.

Los precios privados serán fijados por las consellerías correspondientes, previo informe favorable de la de Economía y Hacienda, atendiendo a las condiciones y circunstancias del mercado en que operen, sin perjuicio de que excepcionalmente puedan aplicarse subvenciones reguladoras. A estos efectos, la consellería correspondiente remitirá a la de Economía y Hacienda el proyecto normativo adjunto a la memoria económica en que se justifiquen los aspectos anteriores. La norma que fije estos precios habrá de ser publicada en el "Diario Oficial de Galicia”.

\section{Artículo 52. Gestión.}

La gestión de los precios privados corresponde a los sujetos relacionados en el artículo 3 de la presente ley, quedando asimismo sometidos a las obligaciones enumeradas en el artículo 48.1.

Artículo 53. Régimen jurídico.

Los actos, negocios y, en general, relaciones jurídicas que se deriven de las actuaciones económicas de las entidades oferentes cuya contraprestación haya de calificarse como precio privado con arreglo al artículo 49 se regirán por las normas de ordenación jurídica privada que resulten de aplicación.

\section{TÍTULO III INSTRUMENTOS REGULADORES}

\section{Artículo 54. Concepto.}

1. Son instrumentos reguladores las exacciones o, en su caso, las subvenciones utilizadas al objeto de influir sobre el consumo de determinados bienes o servicios.

2. La aplicación de una exacción reguladora determinará una tarifa para el consumidor o usuario superior al importe normalmente percibido por la institución o entidad oferente del bien o servicio de que se trate.

Al contrario, la utilización de una subvención reguladora permitirá aplicar a los consumidores precios o tarifas inferiores al coste de producción de los bienes o servicios.

Artículo 55. Establecimiento de instrumentos reguladores.

1. El establecimiento de cualquier exacción o subvención reguladoras deberá hacerse mediante norma con rango de ley. En la ley de creación de las exacciones reguladoras se recogerán los elementos esenciales de las mismas así como la finalidad de intervención que se pretende. 
2. En la Ley de presupuestos de cada año podrán modificarse los elementos determinantes de la cuantía de las exacciones reguladoras siempre y cuando no se altere su propósito o naturaleza. En esta misma ley se ofrecerá información global respecto a las compensaciones o subvenciones que pudieran conllevar la venta de bienes y prestación de servicios cuando el oferente sea uno de los sujetos a que se refiere el artículo 3 de la presente ley.

Artículo 56. Reclamaciones y recursos. Las exacciones reguladoras tienen naturaleza tributaria y, en consecuencia, los actos administrativos derivados de su aplicación serán recurribles en vía económico-administrativa como previa a la interposición, en su caso, de los recursos contencioso-administrativos.

\section{DISPOSICIÓN ADICIONAL PRIMERA XUNTA SUPERIOR DE FACENDA}

El Tribunal Económico-Administrativo de la Comunidad Autónoma creado en la Disposición adicional primera de la Ley 13/1991, de 9 de diciembre, de Tasas, Precios y Exacciones de la Comunidad Autónoma de Galicia, pasará a denominarse Xunta Superior de Facenda.

\section{DISPOSICIÓN ADICIONAL SEGUNDA REVISIÓN Y REDUCCIÓN DE LAS TARIFAS DE LAS TASAS}

1. Sin perjuicio de lo dispuesto en el artículo 15.6 de la presente ley y excepto que la Ley de Presupuestos Generales de la Comunidad Autónoma de Galicia disponga otra cosa, en el período quinquenal 2004-2008, las tasas de cuantía fija se elevarán hasta la cantidad resultante de la aplicación de los coeficientes que se relacionan a continuación para cada año a las cuantías exigibles a 31 de diciembre del año inmediatamente anterior:

2004: 1,02

2005: 1,02

2006: 1,01

2007: 1,01

2008: 1,01
Estos coeficientes serán de aplicación a las cuantías que, con carácter mínimo o máximo, se establecen en todo tipo de tarifas cualquiera que sea la forma de establecimiento de su cuota tributaria.

Se consideran tasas de cuantía fija aquéllas que no están determinadas por un porcentaje sobre una base o cuando ésta no se valora en unidades monetarias.

Se exceptúan de este incremento las tarifas de las tasas que se recaudan mediante efectos timbrados.

2. La tarifa portuaria G-5 contenida en el apartado 99 del anexo 3 y aplicable a las embarcaciones deportivas y de recreo tendrá una reducción del $20 \%$ en los puertos ubicados en la comarca de la Costa da Morte.

Esta reducción se aplicará de oficio y será acumulable a las demás reducciones y bonificaciones generales establecidas en las reglas generales de aplicación de esta tasa.

\section{DISPOSICIÓN TRANSITORIA ÚNICA TÍTULOS VIGENTES A LA ENTRADA EN VIGOR DE LA PRESENTE LEY}

Las autorizaciones y concesiones por utilización privativa, ocupación o aprovechamiento especial del dominio público portuario de la Comunidad Autónoma de Galicia o para el ejercicio de actividades comerciales, industriales y de servicios, vigentes a la entrada en vigor de la presente ley, habrán de adaptarse a lo dispuesto en esta ley con respecto a las correspondientes tasas.

Puertos de Galicia, considerando el tiempo transcurrido desde la entrada en vigor de la concesión, la amortización de las obras efectuadas y los resultados económicos de la explotación, podrá efectuar una aplicación lineal del incremento durante un plazo de tres años.

\section{DISPOSICIÓN DEROGATORIA ÚNICA DEROGACIÓN DE DETERMINADAS NORMAS LEGALES}

Quedan derogadas cuantas normas se opongan a lo establecido por la presente 
ley, y, en particular, la Ley 13/1991, de 9 de diciembre, de Tasas, Precios y Exacciones reguladoras de la Comunidad Autónoma de Galicia, excepto sus disposiciones adicionales primera y segunda, así como el Decreto legislativo $1 / 1992$, de 11 de abril, por el que se aprueba el texto articulado de las bases contenidas en el capítulo $3^{\circ}$. del título II de la Ley 13/1991, de 9 de diciembre, de de Tasas, Precios y Exacciones reguladoras de la Comunidad Autónoma de Galicia.

\section{DISPOSICIÓN FINAL PRIMERA}

\section{(...) 214}

\section{DISPOSICIÓN FINAL SEGUNDA}

\section{(...) 215}

\section{DISPOSICIÓN FINAL TERCERA DESARROLLO REGLAMENTARIO}

La Xunta de Galicia, a propuesta del conselleiro de Economía y Hacienda, desarrollará reglamentariamente las normas de la presente ley dentro de los seis meses siguientes a su entrada en vigor ${ }^{216}$.

\section{DISPOSICIÓN FINAL CUARTA ENTRADA EN VIGOR}

La presente ley entrará en vigor al día siguiente al de su publicación. $(\ldots)^{217}$

\section{LEY 13/1991, DE 9 DE DICIEMBRE, DE TASAS, PRECIOS $Y$ EXACCIONES REGULADORAS DE LA COMUNIDAD AUTÓNOMA DE GALICIA}

(DOGA N. $\left.{ }^{\circ} 241,13.12 .1991\right)$

$$
(\ldots)^{218}
$$

214 Disposición final primera contiene modificaciones a la Ley $3 / 1985$, de 12 de abril, del Patrimonio de la Comunidad Autónoma Gallega.

215 Disposición final segunda contiene modificaciones a la Ley $6 / 2002$, de 27 de diciembre, de presupestos generales de la Comunidad Autónoma de Galicia para el año 2003.

216 Véase Decreto 61/2005, de 7 de abril, por el que se dictan las Normas para la Aplicación de las tasas y precios de la Comunidad Autónoma de Galicia.

217 Anexo omitido.

218 Derogada salvo en sus Disposiciones Adicionales 1 y 2 por Ley 6/2003, de 9 de diciembre, de tasas, precios y exacciones reguladoras de la Comunidad Autónoma de Galicia.

\section{DISPOSICIÓN ADICIONAL PRIMERA}

1. Se crea el Tribunal Económico Administrativo de la Comunidad Autónoma de Galicia, como único órgano colegiado competente en el ámbito de la Comunidad Autónoma para la resolución de los recursos y reclamaciones de naturaleza económico-administrativas, tanto si en ellas se plantean cuestiones de hecho como de derecho y que se deduzcan sobre las siguientes materias:

a. La gestión, inspección y recaudación de los tributos propios de la Hacienda de la comunidad y, en general, de todos los ingresos de derecho público que correspondan a la misma.

b. El reconocimiento o liquidación por autoridades u organismos de la Consellería de Economía e Facenda de obligaciones del Tesoro y de la Hacienda gallega y las cuestiones relacionadas con las operaciones de pago por dichos órganos con cargo al mismo.

c. Cualquier otra respecto de la que por precepto legal expreso así se declare.

El tribunal a que se refiere el apartado anterior quedará adscrito a la Consellería de Economía e Facenda y tendrá su sede en la de los órganos centrales de la misma.

2. El Tribunal a que se refiere el apartado anterior quedará adscrito a la Consellería de Economía e Facenda y tendrá su sede en la de los órganos centrales de la misma.

3. Se autoriza al Consello de la Xunta para que, a propuesta del Conselleiro de Economía y Hacienda, dicte las disposiciones reglamentarias necesarias sobre su organización, competencias, composición y funcionamiento.

4. El plazo para su plena reglamentación y aprobación por el Consello de la Xunta será de seis meses, contados a partir de la publicación de la presente ley en el "Diario Oficial de Galicia".

\section{DISPOSICIÓN ADICIONAL SEGUNDA}

Se autoriza al Consello de la Xunta para crear efectos timbrados de la Xunta, destinados al pago de los precios y tasas 
que constituyan tributos propios de la Xunta y a reglamentar su utilización.

\section{LEY 9/2007, DE 13 DE JUNIO, DE SUBVENCIONES DE GALICIA (DOGA N. ${ }^{\circ} 121$, DE 25 DE JUNIO DE 2007) ${ }^{219}$}

$$
(\ldots)^{220}
$$

\section{TÍTULO PRELIMINAR DISPOSICIONES GENERALES}

\section{Capítulo I \\ DEL ÁMBITO DE APLICACIÓN DE LA LEY}

\section{Artículo 1. Objeto.}

La presente ley tiene por objeto la regulación del régimen jurídico propio de las subvenciones cuyo establecimiento y gestión corresponde a la Administración de la Comunidad Autónoma de Galicia, organismos y demás entidades vinculadas o dependientes de la misma, así como también a las entidades locales de Galicia, incluidos los organismos y entidades dependientes de las mismas.

\section{Artículo 2. Concepto.}

1. Se entiende por subvención, a los efectos de la presente ley, toda disposición dineraria realizada por la Administración de la Comunidad Autónoma, o por una entidad vinculada o dependiente de ella, a favor de personas públicas o privadas, y que cumpla los siguientes requisitos:

a. Que la entrega se realice sin contraprestación directa de los beneficiarios.

b. Que la entrega esté sujeta al cumplimiento de un determinado objetivo, la ejecución de un proyecto, la realización de una actividad, la adopción de un comportamiento singular, ya realizados o por desarrollar, o la concurrencia de una situación, debiendo el beneficiario cumplir las obligaciones materiales y formales que se hubieran establecido.

\footnotetext{
219 Véase Decreto 11/2009, de 8 de enero, por el que se aprueba el Reglamento de la Ley 9/2007, de 13 de junio, de subvenciones de Galicia.

220 Exposición de motivos omitida.
}

c. Que el proyecto, la acción, la conducta o la situación financiada tenga por objeto el fomento de una actividad de utilidad pública o interés social o la promoción de una finalidad pública.

2. No tienen el carácter de subvenciones:

a. Las prestaciones previstas en el artículo 2.4 de la Ley 38/2003, de 17 de noviembre, general de subvenciones, destinadas a personas físicas, y las prestaciones autonómicas de naturaleza similar a éstas o de carácter asistencial.

b. Los beneficios fiscales a favor de los usuarios de bienes y de servicios públicos aplicables en los precios correspondientes.

c. Las aportaciones dinerarias a favor de otras administraciones y a favor de organismos y entidades dependientes de la Administración de la Comunidad Autónoma sometidos al ordenamiento autonómico destinadas a financiar global o parcialmente su actividad con carácter indiferenciado.

d. Las aportaciones dinerarias a favor de otras administraciones públicas o de sus entidades dependientes, establecidas mediante norma legal o reglamentaria y destinadas a financiar actividades de su competencia o impuestas por una norma emanada de la administración otorgante.

3. Serán de aplicación los preceptos de la presente ley a los actos o negocios jurídicos que de acuerdo con su verdadera naturaleza impliquen la concesión de subvenciones con arreglo a lo dispuesto en el apartado primero de este artículo, con independencia de la forma o denominación que le hubieran dado las partes.

Artículo 3. Ámbito de aplicación.

1. La ley es de aplicación a las subvenciones establecidas o gestionadas por:

a. La Administración general de la Comunidad Autónoma de Galicia.

b. Los organismos autónomos y entidades de derecho público del artículo 12.1.b) del Decreto legislativo 1/1999, de 7 de octubre, por el que se aprueba el texto refundido de la Ley de régimen financiero y presupuestario de Galicia. 
c. Las entidades locales de Galicia, incluidos los organismos y entes dependientes de las mismas.

2. Serán de aplicación los principios de gestión contenidos en el artículo 5.2 de la presente ley y los de información a que hace referencia el artículo 16 a las aportaciones dinerarias sin contraprestación que realicen los demás entes vinculados o dependientes de la Xunta de Galicia y de las entidades locales gallegas. En todo caso, las aportaciones gratuitas tendrán relación directa con el objeto de la actividad contenido en la norma de creación o en sus estatutos. La concesión de estas aportaciones habrá de ajustarse a las normas de procedimientos elaboradas por las entidades en aplicación de los citados principios.

3. Las subvenciones establecidas por la Unión Europea, el Estado u otro ente público, cuya gestión corresponda, total o parcialmente, a la Administración de la Comunidad Autónoma, así como la financiación complementaria de dichas subvenciones que pueda otorgar esta administración, se regirán por el régimen jurídico del ente que las establezca, sin perjuicio de la aplicación de las normas de organización y procedimiento propios de la Administración de la Comunidad Autónoma. En cualquier caso, la presente ley se aplicará con carácter supletorio respecto a la normativa reguladora de las subvenciones financiadas por la Unión Europea.

Artículo 4. Exclusiones del ámbito material de aplicación.

1. Quedan excluidos del ámbito de aplicación de la presente ley los siguientes supuestos:

a. Los premios que se otorguen sin previa solicitud del beneficiario.

b. Las subvenciones contempladas en la legislación de régimen electoral y en la legislación de financiación de los partidos políticos, las subvenciones a los grupos parlamentarios del Parlamento de Galicia y las aportaciones percibidas por los grupos políticos de las entidades locales, que se regirán por su normativa específica.
2. Los créditos concedidos a particulares sin interés o con interés inferior al del mercado así como las subvenciones a los intereses de los créditos concedidos a particulares se regirán por su normativa específica y en su defecto por las prescripciones de la presente ley que sean acomodadas a la naturaleza de tales operaciones, en particular, los principios generales, requisitos y obligaciones de beneficiarios y entidades colaboradoras y procedimiento de concesión.

\section{Capitulo II \\ DISPOSICIONES COMUNES A LAS SUBVENCIONES PÚBLICAS}

Artículo 5. Principios generales.

1. Los órganos de la administración que propongan el establecimiento de subvenciones, con carácter previo, deberán concretar en un plan estratégico de subvenciones los objetivos y efectos que se pretenden con su aplicación, el plazo necesario para su consecución, los costes previsibles y sus fuentes de financiación, supeditándose, en todo caso, al cumplimiento de los objetivos de estabilidad presupuestaria.

2. La gestión de las subvenciones a que se refiere la presente ley se realizará de acuerdo con los siguientes principios:

a. Publicidad, transparencia, concurrencia, objetividad, igualdad y no discriminación.

b. Eficacia en el cumplimiento de los objetivos fijados por la administración otorgante.

c. Eficiencia en la asignación y utilización de los recursos públicos.

Artículo 6. Requisitos para el otorgamiento de las subvenciones.

1. En aquellos casos en que, de acuerdo con lo dispuesto en los artículos 87 a 89 del Tratado constitutivo de la Unión Europea, deban comunicarse los proyectos para el establecimiento, la concesión o la modificación de una subvención deberán notificarse a la Comisión Europea de 
acuerdo con lo dispuesto en el artículo 10 de la Ley 30/1992, de 26 de noviembre, de régimen jurídico de las administraciones públicas y del procedimiento administrativo común, en los términos que se establezcan reglamentariamente.

2. Con carácter previo al otorgamiento de las subvenciones, deberán aprobarse las bases reguladoras de concesión en los términos establecidos en la presente ley.

3. Las bases reguladoras de cada tipo de subvención se publicarán en el Diario Oficial de Galicia y en la página web del órgano concedente.

4. Adicionalmente, el otorgamiento de una subvención debe cumplir los siguientes requisitos:

a. La competencia para otorgarla del órgano administrativo concedente.

b. La existencia de crédito adecuado y suficiente para atender a las obligaciones de contenido económico que se derivan de la concesión de la subvención.

c. La tramitación del procedimiento de concesión de acuerdo con las normas que resulten de aplicación.

d. La fiscalización previa de los actos de contenido económico, en los términos previstos en el Decreto legislativo 1/1999, de 7 de octubre, por el que se aprueba el texto refundido de la Ley de régimen financiero y presupuestario de Galicia.

e. La aprobación del gasto por el órgano competente.

Artículo 7. Órganos competentes para la concesión de subvenciones.

1. Los consejeros, presidentes o directores de los organismos autónomos y los órganos rectores de los demás entes, de acuerdo con sus leyes de creación o normativa específica dentro de su ámbito de competencia, serán competentes para conceder subvenciones.

2. No obstante, requerirá autorización del Consejo de la Xunta la concesión de subvenciones que superen la cuantía de 3.000 .000 de euros por beneficiario. La autorización no implicará la aprobación del gasto, que corresponderá en todo caso al órgano competente para la concesión de la subvención.

3. Las facultades de los órganos competentes para la concesión de subvenciones podrán ser desconcentradas o delegadas en los términos fijados en las normas sobre la atribución y el ejercicio de competencias.

4. La competencia para conceder subvenciones en las entidades locales corresponde a los órganos que la tengan atribuida en su normativa específica.

Artículo 8. Beneficiarios.

1. Tendrá la consideración de beneficiario de subvenciones la persona que haya de realizar la actividad que fundamentó su otorgamiento o que se encuentre en la situación que legitima su concesión.

2. Cuando el beneficiario sea una persona jurídica, y siempre que así se prevea en las bases reguladoras, los miembros asociados del beneficiario que se comprometan a efectuar la totalidad o parte de las actividades que fundamentan la concesión de la subvención en nombre y por cuenta del primero tendrán igualmente la consideración de beneficiarios.

3. Cuando se prevea expresamente en las bases reguladoras, podrán acceder a la condición de beneficiario las agrupaciones de personas físicas o jurídicas, públicas o privadas, las comunidades de bienes o cualquier otro tipo de unidad económica o patrimonio separado que, aun careciendo de personalidad jurídica, puedan llevar a cabo los proyectos, actividades o comportamientos o se encuentren en la situación que motiva la concesión de la subvención. Cuando se trate de agrupaciones de personas físicas o jurídicas, públicas o privadas sin personalidad, deberán hacerse constar expresamente, tanto en la solicitud como en la resolución de concesión, los compromisos de ejecución asumidos por cada miembro de la agrupación, así como el importe de subvención a aplicar por cada uno de ellos, que tendrán igualmente la 
consideración de beneficiarios. En cualquier caso, deberá nombrarse un representante o apoderado único de la agrupación, con poderes suficientes para cumplir las obligaciones que, como beneficiario, corresponden a la agrupación. No podrá disolverse la agrupación hasta que transcurra el plazo de prescripción previsto en los artículos 35 y 63 de la presente ley.

Artículo 9. Entidades colaboradoras.

1. Será entidad colaboradora aquélla que, actuando en nombre y por cuenta del órgano concedente a todos los efectos relacionados con la subvención, entregue y distribuya los fondos públicos a los beneficiarios cuando así se establezca en las bases reguladoras, o colabore en la gestión de la subvención sin que se produzca la previa entrega y distribución de los fondos recibidos. Estos fondos en ningún caso se considerarán integrantes de su patrimonio. Igualmente tendrán esta condición los que siendo denominados beneficiarios conforme a la normativa comunitaria tengan encomendadas, exclusivamente, las funciones enumeradas en el párrafo anterior.

2. Podrán ser consideradas entidades colaboradoras los organismos y demás entes públicos, las sociedades mercantiles participadas íntegra o mayoritariamente por las administraciones públicas, organismos o entes de derecho público y las asociaciones a que se refiere la disposición adicional quinta de la Ley 7/1985, de 2 de abril, reguladora de las bases del régimen local, así como las demás personas jurídicas públicas o privadas que reúnan las condiciones de solvencia y eficacia que se establezcan.

3. La Administración general del Estado, otras comunidades autónomas y las corporaciones locales podrán actuar como entidades colaboradoras de las subvenciones concedidas por la Comunidad Autónoma de Galicia o sus organismos públicos y demás entes que tengan que ajustar su actividad al derecho público. De igual forma, y en los mismos términos, la
Comunidad Autónoma y sus organismos públicos podrán actuar como entidades colaboradoras respecto de las subvenciones concedidas por la Administración general del Estado, otras comunidades autónomas y las corporaciones locales.

Artículo 10. Requisitos para obtener la condición de beneficiario o entidad colaboradora.

1. Podrán obtener la condición de beneficiario o entidad colaboradora las personas o entidades que se encuentren en la situación que fundamenta la concesión de la subvención o en las que concurran las circunstancias previstas en las bases reguladoras y en la convocatoria.

2. No podrán obtener la condición de beneficiario o entidad colaboradora de las subvenciones reguladas en la presente ley las personas o entidades en las que concurra alguna de las circunstancias siguientes, salvo que por la naturaleza de la subvención se exceptúe por su normativa reguladora:

a. Ser condenadas mediante sentencia firme a la pena de pérdida de la posibilidad de obtener subvenciones o ayudas públicas.

b. Solicitar la declaración de concurso, ser declarados insolventes en cualquier procedimiento, hallarse declarados en concurso, estar sujetos a intervención judicial o ser inhabilitados conforme a la Ley concursal sin que concluya el periodo de inhabilitación fijado en la sentencia de calificación del concurso.

c. Dar lugar, por causa de la que fueran declarados culpables, a la resolución firme de cualquier contrato celebrado con la administración.

d. Estar incursa la persona física, los administradores de las sociedades mercantiles o aquéllos que ostenten la representación legal de otras personas jurídicas en alguno de los supuestos de incompatibilidades que establezca la normativa vigente.

e. No hallarse al corriente en el cumplimiento de las obligaciones tributarias o 
frente a la Seguridad Social o tener pendiente de pago alguna otra deuda con la Administración pública de la Comunidad Autónoma en los términos que reglamentariamente se determinen.

f. Tener la residencia fiscal en un país o territorio calificado reglamentariamente como paraíso fiscal.

g. No hallarse al corriente de pago de obligaciones por reintegro de subvenciones en los términos que reglamentariamente se determine.

h. Haber sido sancionado mediante resolución firme con la pérdida de la posibilidad de obtener subvenciones según la presente ley o la Ley general tributaria.

No podrán acceder a la condición de beneficiarios las agrupaciones previstas en el segundo párrafo del apartado 3 del artículo 8 de la presente ley cuando concurra alguna de las prohibiciones anteriores en cualquiera de sus miembros.

3. En ningún caso podrán obtener la condición de beneficiario o entidad colaboradora de las subvenciones reguladas en la presente ley las asociaciones incursas en las causas de prohibición previstas en los apartados 5 y 6 del artículo 4 de la Ley orgánica 1/2002, de 22 de marzo, reguladora del derecho de asociación.

Tampoco podrán obtener la condición de beneficiario o entidad colaboradora las asociaciones respecto de las que se suspendió el procedimiento administrativo de inscripción por encontrarse indicios racionales de ilicitud penal, en aplicación de lo dispuesto en el artículo 30.4 de la Ley orgánica $1 / 2002$, en tanto no recaiga resolución judicial firme en cuya virtud pueda practicarse la inscripción en el correspondiente registro.

4. Las prohibiciones contenidas en las letras b), d), e), f) y g) del apartado 2 y en el apartado 3 de este artículo se apreciarán de forma automática y subsistirán mientras concurran las circunstancias que, en cada caso, las determinen.
5. Las prohibiciones contenidas en las letras a) y h) del apartado 2 de este artículo se apreciarán de forma automática. El alcance de la prohibición será el que determine la sentencia o resolución firme. En su falta, el alcance se fijará de acuerdo con el procedimiento determinado reglamentariamente, sin que pueda exceder de cinco años en caso de que la prohibición no se derive de sentencia firme.

6. La apreciación y el alcance de la prohibición contenida en la letra c) del apartado 2 de este artículo se determinarán de acuerdo con lo establecido en el artículo 21 en relación con el artículo 20.c) del texto refundido de la Ley de contratos de las administraciones públicas, aprobado por Real decreto legislativo $2 / 2000$, de 16 de junio.

7. La justificación por parte de las personas o entidades de no estar incursos en las prohibiciones para obtener la condición de beneficiario o entidad colaboradora, señaladas en los apartados 2 y 3 de este artículo, podrá realizarse mediante testimonio judicial, certificados telemáticos o transmisiones de datos, de acuerdo con lo establecido en la normativa correspondiente o mediante certificación administrativa, según los casos. Dicho documento podrá ser sustituido por una declaración responsable.

Artículo 11. Obligaciones de los beneficiarios.

Son obligaciones del beneficiario:

a. Cumplir el objetivo, ejecutar el proyecto, realizar la actividad o adoptar el comportamiento que fundamenta la concesión de las subvenciones.

b. Justificar ante el órgano concedente o la entidad colaboradora, en su caso, el cumplimiento de los requisitos y condiciones, así como la realización de la actividad y el cumplimiento de la finalidad que determinen la concesión o disfrute de la subvención.

c. Someterse a las actuaciones de comprobación, a efectuar por el órgano concedente o la entidad colaboradora, en su caso, así 
como a cualquier otra actuación, sea de comprobación y control financiero, que puedan realizar los órganos de control competentes, tanto autonómicos como estatales o comunitarios, aportando cuanta información le sea requerida en el ejercicio de las actuaciones anteriores.

d. Comunicar al órgano concedente o la entidad colaboradora la obtención de otras subvenciones, ayudas, ingresos o recursos que financien las actividades subvencionadas, así como la modificación de las circunstancias que hubieran fundamentado la concesión de la subvención.

Esta comunicación deberá efectuarse en el momento en que se conozca y, en todo caso, con anterioridad a la justificación de la aplicación dada a los fondos percibidos.

e. Acreditar con anterioridad a dictarse la propuesta de resolución de concesión que se encuentra al corriente en el cumplimiento de sus obligaciones tributarias y frente a la Seguridad Social y que no tiene pendiente de pago alguna otra deuda con la Administración pública de la Comunidad Autónoma, en la forma que se determine reglamentariamente, y sin perjuicio de lo establecido en la disposición adicional decimoctava de la Ley 30/1992, de 26 de noviembre, de régimen jurídico de las administraciones públicas y del procedimiento administrativo común.

f. Disponer de los libros contables, registros diligenciados y demás documentos debidamente auditados en los términos exigidos por la legislación mercantil y sectorial aplicable al beneficiario en cada caso, así como cuantos estados contables y registros específicos sean exigidos por las bases reguladoras de las subvenciones, con la finalidad de garantizar el adecuado ejercicio de las facultades de comprobación y control.

g. Conservar los documentos justificativos de la aplicación de los fondos recibidos, incluidos los documentos electrónicos, en tanto puedan ser objeto de las actuaciones de comprobación y control. h. Adoptar las medidas de difusión contenidas en el apartado 3 del artículo 15 de la presente ley.

i. Proceder al reintegro de los fondos percibidos en los supuestos contemplados en el artículo 33 de la presente ley.

Artículo 12. Obligaciones de las entidades colaboradoras.

Son obligaciones de la entidad colaboradora:

a. Entregar a los beneficiarios los fondos recibidos de acuerdo con los criterios establecidos en las bases reguladoras de la subvención y en el convenio celebrado con la entidad concedente.

b. Comprobar, en su caso, el cumplimiento y efectividad de las condiciones o requisitos determinantes para su otorgamiento, así como la realización de la actividad y el cumplimiento de la finalidad que determinen la concesión o disfrute de la subvención.

c. Justificar la entrega de los fondos percibidos ante el órgano concedente de la subvención y, en su caso, entregar la justificación presentada por los beneficiarios.

d. Someterse a las actuaciones de comprobación que respecto de la gestión de dichos fondos pueda efectuar el órgano concedente, así como cualesquiera otras de comprobación y control financiero que puedan realizar los órganos de control competentes, tanto estatales como comunitarios, aportando cuanta información le sea requerida en el ejercicio de las actuaciones anteriores.

Artículo 13. Convenio de colaboración con entidades colaboradoras.

1. Se formalizará un convenio de colaboración entre el órgano administrativo concedente y la entidad colaboradora en el que se regularán las condiciones y obligaciones asumidas por ésta.

2. El convenio de colaboración habrá de contener, como mínimo, los siguientes extremos:

a. Definición del objeto de la colaboración y de la entidad colaboradora. 
b. Identificación de la normativa reguladora especial de las subvenciones que van a ser gestionadas por la entidad colaboradora.

c. Plazo de duración del convenio de colaboración.

d. Medidas de garantía que sea preciso constituir a favor del órgano administrativo concedente, medios de constitución y procedimiento de cancelación.

e. Requisitos que debe cumplir y hacer cumplir la entidad colaboradora en las diferentes fases del procedimiento de gestión de las subvenciones.

f. En caso de colaboración en la distribución de los fondos públicos, determinación del periodo de entrega de los fondos a la entidad colaboradora y de las condiciones de depósito de los fondos recibidos hasta su entrega posterior a los beneficiarios.

g. En caso de colaboración en la distribución de los fondos públicos, condiciones de entrega a los beneficiarios de las subvenciones concedidas por el órgano administrativo concedente.

h. Forma de justificación por parte de los beneficiarios del cumplimiento de las condiciones para el otorgamiento de las subvenciones y requisitos para la verificación de la misma.

i. Plazo y forma de la presentación de la justificación de las subvenciones aportada por los beneficiarios y, en caso de colaboración en la distribución de los fondos públicos, de acreditación por parte de la entidad colaboradora de la entrega de los fondos a los beneficiarios.

j. Determinación de los libros y registros contables específicos que debe llevar la entidad colaboradora para facilitar la adecuada justificación de la subvención y la comprobación del cumplimiento de las condiciones establecidas.

k. Obligación de reintegro de los fondos en el supuesto de incumplimiento de los requisitos y obligaciones establecidas para la concesión de la subvención y, en todo caso, en los supuestos regulados en el artículo 33 de la presente ley.

1. Obligación de la entidad colaboradora de someterse a las actuaciones de comprobación y control previstas en la letra d) del artículo 12 de la presente ley.

m. Compensación económica que, en su caso, se fije a favor de la entidad colaboradora.

3. Cuando la Administración general del Estado, la administración de otras comunidades autónomas o las corporaciones locales actúen como entidades colaboradoras, la Administración de la Comunidad Autónoma o los organismos públicos vinculados o dependientes de la misma suscribirán con aquéllas los correspondientes convenios en los que se determinen los requisitos para la distribución y entrega de los fondos y los criterios de justificación y de rendición de cuentas.

4. Cuando las entidades colaboradoras sean personas sujetas a derecho privado, se seleccionarán previamente mediante un procedimiento sometido a los principios de publicidad, concurrencia, igualdad y no discriminación y la colaboración se formalizará mediante convenio, salvo que por objeto de la colaboración resulte de aplicación plena el texto refundido de la Ley de contratos de las administraciones públicas aprobado por el Real decreto legislativo 2/2000, de 16 de junio.

El contrato, que incluirá necesariamente el contenido mínimo previsto en el apartado 2 de este artículo, así como lo que resulte preceptivo de acuerdo con la normativa reguladora de los contratos administrativos, habrá de hacer mención expresa al sometimiento del contratista al resto de las obligaciones impuestas a las entidades colaboradoras por la presente ley.

Artículo 14. Bases reguladoras de la concesión de las subvenciones.

1. Sin perjuicio de que el Consejo de la Xunta determine los criterios básicos, 
los órganos concedentes establecerán con carácter previo a la disposición de los créditos las bases reguladoras aplicables a la concesión.

Las citadas bases serán objeto de publicación en el Diario Oficial de Galicia y en la página web del órgano concedente, y contendrán, como mínimo, los siguientes extremos:

a. Definición precisa del objeto de la subvención.

b. Requisitos que deberán reunir los beneficiarios para la obtención de la subvención y, en su caso, de los miembros de las entidades contempladas en el apartado 2 y segundo párrafo del apartado $3 \mathrm{del}$ artículo 8, plazo y forma de acreditarlos y plazo y forma en los que deben presentarse las solicitudes.

c. Criterios objetivos de adjudicación de la subvención y, en su caso, ponderación de los mismos.

d. Cuantía individualizada de la subvención o criterios para su determinación.

e. Procedimiento de concesión de la subvención.

f. Órganos competentes para la ordenación, instrucción y resolución del procedimiento de concesión y plazo en el que será notificada la resolución.

g. Composición, en su caso, del órgano colegiado avalador previsto en el artículo 21 de la presente ley.

h. Plazo y forma de justificación por parte del beneficiario del cumplimiento de la finalidad para la que se concedió la subvención o la ayuda pública y de la aplicación de los fondos percibidos.

i. En el supuesto de prever la posibilidad de realizar abonos a la cuenta y anticipados, plazos, modo de pago y régimen particular de garantías que, en su caso, deban aportar los beneficiarios, así como aquellas otras medidas de garantía a favor de los intereses públicos que puedan considerarse precisas.

j. Obligación del reintegro, total o parcial, de la subvención o de la ayuda pública percibida en el supuesto de incumplimiento de las condiciones establecidas para su concesión.

k. Obligación del beneficiario de facilitar toda la información que le sea requerida por la Intervención General de la Comunidad Autónoma, el Tribunal de Cuentas y el Consejo de Cuentas en el ejercicio de sus funciones de fiscalización y control del destino de las subvenciones.

1. En su caso, condiciones de solvencia y eficacia que tengan que reunir las entidades colaboradoras.

$\mathrm{m}$. Circunstancias que, como consecuencia de la alteración de las condiciones tenidas en cuenta para la concesión de la subvención, podrán dar lugar a la modificación de la resolución.

n. Criterios de graduación de los posibles incumplimientos de condiciones impuestas con motivo de la concesión de las subvenciones. Estos criterios resultarán de aplicación para determinar la cantidad que finalmente haya de percibir el beneficiario o, en su caso, el importe a reintegrar, y deberán responder al principio de proporcionalidad.

ñ. Información a los interesados de la existencia del Registro Público de Subvenciones y de los extremos previstos en el artículo 5 de la Ley orgánica 15/1999, de 13 de diciembre, de protección de datos de carácter personal. Asimismo, deberán contemplar la posibilidad de que los interesados hagan constar su derecho a que no se hagan públicos sus datos cuando concurra alguna de las causas previstas en la letra d) del apartado 2 del artículo 15 de la presente ley.

o. Expresión de los recursos que procedan contra la resolución de la concesión, con indicación del órgano administrativo o judicial ante el que tengan que presentarse, plazo para interponerlos y demás requisitos exigidos por la normativa general de aplicación.

p. Compatibilidad o incompatibilidad con otras subvenciones o ayudas para la 
misma finalidad, procedentes de cualquier otra administración o de entes públicos o privados, nacionales, de la Unión Europea o de organismos internacionales.

2. Las bases reguladoras deberán prever el uso y aplicación de medios telemáticos en los procedimientos de concesión y justificación de las ayudas y subvenciones y de presentación y resolución de recursos sobre las mismas. En estos supuestos deberán indicar los trámites que pueden ser cumplimentados por esta vía y los medios electrónicos y sistemas de comunicación utilizables, que deberán ajustarse a las especificaciones establecidas por la consejería competente en materia de economía y hacienda.

Artículo 15. Publicidad de las subvenciones concedidas.

1. Los órganos administrativos concedentes publicarán en el Diario Oficial de Galicia las subvenciones concedidas con expresión de la convocatoria, el programa y crédito presupuestario al que se imputen, beneficiario, cantidad concedida y finalidad o finalidades de la subvención. Igualmente, lo harán en la correspondiente página web oficial en los términos previstos en el artículo 13.4 de la Ley 4/2006, de 30 de junio, de transparencia y buenas prácticas en la Administración pública gallega.

2. No será necesaria la publicación en los siguientes supuestos:

a. Cuando las subvenciones públicas tengan asignación nominativa en los presupuestos.

b. Cuando su otorgamiento y cuantía, a favor de beneficiario concreto, resulten impuestos en virtud de norma de rango legal.

c. Cuando los importes de las subvenciones concedidas, individualmente consideradas, sean de cuantía inferior a 3.000 euros. En este supuesto, las bases reguladoras deberán prever la utilización de otros procedimientos que, de acuerdo con sus especiales características, cuantía y número, aseguren la publicidad de los beneficiarios de éstas y deberán, en todo caso, publicarse en la página web oficial del órgano administrativo concedente en los términos establecidos en la Ley 4/2006, de 30 de junio, de transparencia y buenas prácticas en la Administración pública gallega.

d. Cuando la publicación de los datos del beneficiario en razón del objeto de la subvención pueda ser contraria al respecto y salvaguarda del honor y a la intimidad personal y familiar de las personas físicas en virtud de lo establecido en la Ley orgánica $1 / 1982$, de 5 de mayo, de protección civil del derecho al honor, a la intimidad personal y familiar y a la propia imagen, y sea previsto en su normativa reguladora.

3. Los beneficiarios deberán dar la adecuada publicidad del carácter público de la financiación de programas, actividades, inversiones o actuaciones de cualquier tipo que sean objeto de subvención, en los términos reglamentariamente establecidos.

Artículo 16. Registro Público de Subvenciones.

1. El Registro de Ayudas, Subvenciones y Convenios, y el de Sanciones, creados en los artículos 44 y 45 de la Ley 7/2005, de 29 de diciembre, de presupuestos generales de la Comunidad Autónoma para el año 2006, tendrán el contenido y forma que reglamentariamente se determine.

2. El Registro Público de Subvenciones habrá de servir, por lo menos, para los siguientes fines:

a. La ordenación y conocimiento de la actividad subvencional de la Comunidad Autónoma.

b. La coordinación con las bases de datos establecidas por la Unión Europea, la Administración general del Estado y otras entidades públicas.

c. La elaboración de estudios y análisis sobre la actividad subvencional de la Comunidad Autónoma. 
d. La colaboración con los órganos e instituciones de control de este tipo de actividad.

3. Los sujetos contemplados en el artículo 3 de la presente ley deberán facilitar a la consejería competente en materia de economía y hacienda información sobre las subvenciones por ellos gestionadas en los términos previstos reglamentariamente.

Artículo 17. Financiación de las actividades subvencionadas.

1. La normativa reguladora de la subvención podrá exigir un importe de financiación propia para cubrir la actividad subvencionada. La aportación de fondos propios al proyecto o acción subvencionada tendrá que ser acreditada en los términos previstos en el artículo 28 de la presente ley.

2. La normativa reguladora de la subvención determinará el régimen de compatibilidad o incompatibilidad para la percepción de otras subvenciones, ayudas, ingresos o recursos para la misma finalidad, procedentes de cualquier administración o entes públicos o privados, estatales, de la Unión Europea o de organismos internacionales, sin perjuicio de lo dispuesto en el apartado siguiente.

3. El importe de las subvenciones en ningún caso podrá ser de tal cuantía que, aisladamente o en concurrencia con otras subvenciones, ayudas, ingresos o recursos, supere el coste de la actividad subvencionada.

4. Toda alteración de las condiciones tenidas en cuenta para la concesión de la subvención, y en todo caso la obtención concurrente de otras aportaciones fuera de los casos permitidos en las normas reguladoras, podrá dar lugar a la modificación de la resolución de concesión, en los términos establecidos en la normativa reguladora de la subvención.

5. Los rendimientos financieros que se generen por los fondos librados a los beneficiarios incrementarán el importe de la subvención concedida y se aplicarán igualmente a la actividad subvencionada, salvo que, por razones debidamente motivadas, se disponga lo contrario en las bases reguladoras de la subvención.

Este apartado no será de aplicación en los supuestos en que el beneficiario sea una administración pública.

Artículo 18. Régimen de garantías.

El régimen de las garantías, medios de constitución, depósito y cancelación que tengan que constituir los beneficiarios o las entidades colaboradoras se establecerá reglamentariamente.

\section{TÍTULO I PROCEDIMIENTOS DE CONCESIÓN Y GESTIÓN DE LAS SUBVENCIONES

Capítulo I
DEL PROCEDIMIENTO
DE CONCESIÓN

Artículo 19. Procedimientos de concesión.

1. El procedimiento ordinario de concesión de subvenciones se tramitará en régimen de concurrencia competitiva.

A efectos de la presente ley, tendrá la consideración de concurrencia competitiva el procedimiento mediante el cual la concesión de las subvenciones se realiza a través de la comparación de las solicitudes presentadas, a fin de establecer una prelación entre las mismas de acuerdo con los criterios de valoración previamente fijados en las bases reguladoras y en la convocatoria y adjudicar, con el límite fijado en la convocatoria dentro del crédito disponible, aquéllas que obtuvieran mayor valoración en aplicación de los citados criterios.

2. Las bases reguladoras podrán excepcionar del requisito de fijar un orden de prelación entre las solicitudes presentadas 
que reúnan los requisitos establecidos cuando, por el objeto y finalidad de la subvención, no sea necesario realizar la comparación y prelación de las solicitudes presentadas en un único procedimiento hasta el agotamiento del crédito presupuestario con las garantías previstas en el artículo 31.4 de la presente ley.

3. Excepcionalmente, siempre que así se prevea en las bases reguladoras, el órgano competente procederá al prorrateo, entre los beneficiarios de la subvención, del importe global máximo destinado a las subvenciones.

4. Podrán concederse de forma directa las siguientes subvenciones:

a. Las previstas nominativamente en los presupuestos generales de la Comunidad Autónoma en los términos recogidos en los convenios y en la normativa reguladora de estas subvenciones.

b. Aquéllas cuyo otorgamiento o cuantía vengan impuestos a la administración por una norma de rango legal, que seguirán el procedimiento de concesión que les resulte de aplicación de acuerdo con su propia normativa.

c. Con carácter excepcional, aquellas otras subvenciones en que se acrediten razones de interés público, social, económico o humanitario, $\mathrm{u}$ otras debidamente justificadas que dificulten su convocatoria pública.

\section{Capítulo II \\ DE LOS PROCEDIMIENTOS DE CONCESIÓN EN RÉGIMEN DE CONCURRENCIA COMPETITIVA}

Artículo 20. Iniciación.

1. El procedimiento para la concesión de subvenciones se inicia de oficio, en el caso de concesión en régimen de concurrencia competitiva, salvo en los supuestos que regula el artículo 19.2 de la presente ley.

2. La iniciación de oficio se realizará siempre mediante convocatoria aprobada por el órgano competente, que desarrollará el procedimiento para la concesión de las subvenciones convocadas según lo establecido en este capítulo y de acuerdo con los principios de la Ley 30/1992, de 26 de noviembre, de régimen jurídico de las administraciones públicas y del procedimiento administrativo común, y tendrá necesariamente el siguiente contenido:

a. Indicación de la disposición que establezca, en su caso, las bases reguladoras y del diario oficial en que está publicada, salvo que en atención a su especificidad éstas se incluyan en la propia convocatoria.

b. Créditos presupuestarios a los que se imputa la subvención y cuantía total máxima de las subvenciones convocadas dentro de los créditos disponibles o, en su defecto, cuantía estimada de las subvenciones.

c. Objeto, condiciones y finalidad de la concesión de la subvención.

d. Expresión del régimen en que se efectuará la concesión.

e. Requisitos para solicitar la subvención y forma de acreditarlos.

f. Indicación de los órganos competentes para la instrucción y resolución del procedimiento.

g. Plazo de presentación de solicitudes, a las que serán de aplicación las previsiones contenidas en el apartado 3 de este artículo.

h. Plazo de resolución y notificación.

i. Documentos e informaciones que deben adjuntarse a la petición.

j. En su caso, posibilidad de reformulación de solicitudes de conformidad con lo dispuesto en el artículo 25 de la presente ley.

k. Indicación de si la resolución pone fin a la vía administrativa y, en caso contrario, órgano ante el que se interpondrá recurso de alzada.

1. Criterios de valoración de las solicitudes, en su caso. Se evaluará, en todo caso, el empleo de la lengua gallega en la realización de actividades o conductas para las que se solicita la ayuda.

m. Plazo de justificación de la subvención.

n. Medio de notificación o publicación, de conformidad con lo previsto en el 
artículo 59 de la Ley 30/1992, de 26 de noviembre, de régimen jurídico de las administraciones públicas y del procedimiento administrativo común.

3. Las solicitudes de los interesados acompañarán los documentos e informaciones determinados en la norma o convocatoria, salvo que los documentos exigidos ya estuvieran en poder de cualquier órgano de la administración actuante; en este caso el solicitante podrá acogerse a lo establecido en la letra f) del artículo 35 de la Ley 30/1992, de 26 de noviembre, de régimen jurídico de las administraciones públicas y del procedimiento administrativo común, siempre que se haga constar la fecha y el órgano o dependencia en que fueron presentados o, en su caso, emitidos, y cuando no hayan transcurrido más de cinco años desde la finalización del procedimiento al que correspondan.

En los supuestos de imposibilidad material de obtener el documento, el órgano competente podrá requerir al solicitante su presentación, o, en su defecto, la acreditación por otros medios de los requisitos a que se refiere el documento, con anterioridad al planteamiento de la propuesta de resolución.

La presentación de la solicitud de concesión de subvención por el interesado conllevará la autorización al órgano gestor para recabar las certificaciones que deban emitir la Agencia Estatal de la Administración Tributaria, la Tesorería General de la Seguridad Social y la consejería competente en materia de economía y hacienda de la Xunta de Galicia, cuando así se prevea en las bases reguladoras.

No obstante, el solicitante podrá denegar expresamente el consentimiento, debiendo presentar entonces la certificación en los términos previstos reglamentariamente.

4. A efectos de lo dispuesto en los apartados anteriores, la normativa reguladora de la subvención podrá admitir la sustitución de la presentación de determinados documentos por una declaración responsable del solicitante. En este caso, con anterioridad a la propuesta de resolución de concesión de la subvención se deberá requerir la presentación de la documentación que acredite la realidad de los datos contenidos en la citada declaración, en un plazo no superior a quince días.

5. Si la solicitud no reúne los requisitos establecidos en la norma de convocatoria, el órgano competente requerirá al interesado para que la subsane en el plazo máximo e improrrogable de diez días, indicándole que si no lo hiciera se le tendrá por desistido de su solicitud, previa resolución que habrá de ser dictada en los términos previstos en el artículo 71 de la Ley 30/1992, de 26 de noviembre, de régimen jurídico de las administraciones públicas y del procedimiento administrativo común ${ }^{221}$.

Artículo 21. Instrucción.

1. La instrucción del procedimiento de concesión de subvenciones corresponde al órgano que se indique en la convocatoria.

2. El órgano competente para la instrucción realizará de oficio cuantas actuaciones estime necesarias para la determinación, conocimiento y comprobación de los datos en virtud de los cuales debe formularse la propuesta de resolución.

3. Las actividades de instrucción comprenderán:

a. Petición de cuantos informes estime necesarios para resolver o que sean exigidos por las normas que regulan la subvención. En la petición se hará constar, en su caso, el carácter determinante de aquellos informes que sean preceptivos. El plazo para su emisión será de diez días, salvo que el órgano instructor, atendiendo a las características del informe solicitado

221 Véase Orden de 16 de julio de 2009 reguladora del sistema, formatos y especificaciones de los medios establecidos para la obtención de datos por el módulo Subvenciones, para la formación de los registros de ayudas, subvenciones, convenios y de sanciones, y para la remisión de información a la base de datos nacional de subvenciones. 
o del propio procedimiento, solicite su emisión en un plazo menor o mayor, sin que en este último caso pueda sobrepasar los dos meses.

b. Cuando en el plazo señalado no se emitiera el informe calificado por disposición legal expresa como preceptivo y determinante, o, en su caso, vinculante, podrá interrumpirse el plazo de los trámites sucesivos.

c. Evaluación de las solicitudes o peticiones, efectuada conforme con los criterios, formas y prioridades de valoración establecidos en la norma reguladora de la subvención o, en su caso, en la convocatoria.

La norma reguladora de la subvención podrá contemplar la posibilidad de establecer una fase de preevaluación en la que se verificará el cumplimiento de las condiciones impuestas para adquirir la condición de beneficiario de la subvención.

4. Una vez evaluadas las solicitudes, el órgano instructor deberá emitir informe en el que se concrete el resultado de la evaluación efectuada.

En el supuesto de que las bases hubieran previsto la existencia de un órgano evaluador diferente del instructor, será éste el competente para emitir el informe previsto en el párrafo anterior. El órgano instructor elevará el informe junto con la propuesta de resolución al órgano de resolución.

Cuando las bases reguladoras así lo establezcan, el órgano instructor, a la vista del expediente y, en su caso, del informe del órgano evaluador, formulará la propuesta de resolución provisional, debidamente motivada, que deberá notificarse a los interesados en la forma que establezca la convocatoria, y se concederá un plazo de diez días para presentar alegaciones.

Se podrá prescindir del trámite de audiencia cuando no figuren en el procedimiento ni sean tenidos en cuenta otros hechos ni otras alegaciones y pruebas que las aducidas por los interesados. En este caso, la propuesta de resolución formulada tendrá el carácter de definitiva.
Examinadas las alegaciones aducidas en su caso por los interesados, se formulará la propuesta de resolución definitiva, que deberá expresar el solicitante o la relación de solicitantes para los que se propone la concesión de la subvención, y su cuantía, especificando su evaluación $y$, en su caso, los criterios de valoración seguidos para efectuarla.

El expediente de concesión de subvenciones contendrá el informe del órgano instructor en el que conste que de la información que obra en su poder se desprende que los beneficiarios cumplen todos los requisitos necesarios para acceder a las mismas.

5. La propuesta de resolución definitiva se notificará a los interesados que hubieran sido propuestos como beneficiarios en la fase de instrucción únicamente cuando dicha notificación sea obligada según lo previsto en las bases reguladoras.

Notificada la resolución definitiva por el órgano competente, los interesados propuestos como beneficiarios dispondrán de un plazo de diez días para su aceptación, transcurrido el cual sin que se haya producido manifestación expresa se entenderá tácitamente aceptada.

6. Las propuestas de resolución provisional y definitiva no crean derecho alguno a favor del beneficiario propuesto frente a la administración mientras no se le hubiera notificado la resolución de concesión.

Artículo 22. Procedimiento abreviado.

Las subvenciones cuya concesión se realice por el procedimiento previsto en el artículo 19.2 de la presente ley podrán tramitarse por un procedimiento abreviado en el que la propuesta de concesión se formulará al órgano concedente directamente por el órgano instructor, que únicamente deberá comprobar la concurrencia de los requisitos requeridos para conceder la subvención, por lo que no intervendrá en ningún caso el órgano evaluador a que se refiere el artículo anterior. 
Artículo 23. Resolución.

1. Una vez aprobada la propuesta de resolución definitiva, y de acuerdo con lo previsto en el artículo 89 de la Ley 30/1992, de 26 de noviembre, de régimen jurídico de las administraciones públicas y del procedimiento administrativo común, $\mathrm{y}$, en su caso, en la correspondiente norma o convocatoria, el órgano competente resolverá el procedimiento.

2. La resolución se motivará de conformidad con lo que dispongan las bases reguladoras de la subvención debiendo, en todo caso, quedar acreditados en el procedimiento los fundamentos de la resolución que se adopte.

3. La resolución, además de contener el solicitante o relación de solicitantes a los que se concede la subvención, hará constar, en su caso, de manera expresa, la desestimación del resto de las solicitudes.

4. El plazo máximo para resolver y notificar la resolución del procedimiento no podrá sobrepasar los nueve meses, salvo que una norma con rango de ley establezca un plazo máximo o así venga previsto en la normativa de la Unión Europea. El plazo se computará a partir de la publicación de la correspondiente convocatoria, salvo que la misma posponga sus efectos a una fecha posterior.

En el supuesto de subvenciones tramitadas por otras administraciones públicas en las que corresponda la resolución a la Administración de la Xunta de Galicia o a las entidades de derecho público vinculadas o dependientes de ésta, este plazo se computará a partir del momento en que el órgano otorgante disponga de la propuesta o de la documentación que la norma reguladora de la subvención determine.

5. El vencimiento del plazo máximo sin que sea notificada la resolución legitima a los interesados para entender desestimada por silencio administrativo la solicitud de concesión de la subvención.
Artículo 24. Notificación de la resolución.

La resolución del procedimiento se notificará a los interesados de acuerdo con lo previsto en el artículo 58 de la Ley 30/1992, de 26 de noviembre, de régimen jurídico de las administraciones públicas y del procedimiento administrativo común. La práctica de dicha notificación o publicación se ajustará a las disposiciones contenidas en el artículo 59 de la citada ley.

Artículo 25. Reformulación de las solicitudes.

1. Cuando la subvención tenga por objeto la financiación de actividades a desarrollar por el solicitante y el importe de la subvención de la propuesta de resolución provisional sea inferior al que figura en la solicitud presentada, se podrá instar del beneficiario, si así se prevé en las bases reguladoras, la reformulación de su solicitud para ajustar los compromisos y condiciones a la subvención otorgable.

2. Una vez que la solicitud merezca, si fuera el caso, la conformidad de la comisión de valoración, se remitirá lo actuado al órgano competente para que dicte la resolución.

3. En cualquier caso, la reformulación de solicitudes deberá respetar el objeto, condiciones y finalidad de la subvención, así como los criterios de valoración establecidos respecto de las solicitudes o peticiones.

\section{Capitulo III DEL PROCEDIMIENTO DE CONCESIÓN DIRECTA}

Artículo 26. Concesión directa.

1. La resolución de concesión y, en su caso, los convenios a través de los cuales se canalicen estas subvenciones establecerán las condiciones y compromisos aplicables de conformidad con lo dispuesto en la presente ley.

Los convenios serán el instrumento habitual para canalizar las subvenciones previstas nominativamente.

2. Las propuestas de acuerdo o resolución de concesión, o el instrumento 
del convenio que se autorice a suscribir, habrán de ajustarse a las previsiones contenidas en la presente ley, salvo en lo que afecte a la aplicación de los principios de publicidad y concurrencia, y contendrán como mínimo los siguientes extremos:

a. Definición del objeto de las subvenciones, con indicación del carácter singular de las mismas y las razones que acreditan el interés público, social, económico o humanitario y aquéllas que justifican la dificultad de su convocatoria pública.

b. Régimen jurídico aplicable.

c. Beneficiarios y modalidades de ayuda.

d. Régimen de justificación de la aplicación dada a las subvenciones por los beneficiarios y, en su caso, entidades colaboradoras.

3. La concesión de subvenciones por importe superior a 150.000 euros, o lo que determinen las leyes anuales de presupuestos, requerirá la autorización previa del Consejo de la Xunta de Galicia.

\section{Capitulo IV \\ DEL PROCEDIMIENTO DE GESTIÓN Y JUSTIFICACIÓN DE SUBVENCIONES}

Artículo 27. Subcontratación de las actividades subvencionadas por los beneficiarios.

1. A los efectos de la presente ley, se entiende que un beneficiario subcontrata cuando concierta con terceros la ejecución total o parcial de la actividad que constituya el objeto de la subvención. Queda fuera de este concepto la contratación de aquellos gastos en que tenga que incurrir el beneficiario para la realización por sí mismo de la actividad subvencionada.

2. El beneficiario únicamente podrá subcontratar, total o parcialmente, la actividad cuando la normativa reguladora de la subvención así lo prevea. La actividad subvencionada que el beneficiario subcontrate con terceros no sobrepasará del porcentaje que se fije en las bases reguladoras de la subvención. En el supuesto de que tal previsión no figure, el beneficiario podrá subcontratar hasta un porcentaje que no sobrepase del 50 por ciento del importe de la actividad subvencionada.

En ningún caso podrán subcontratarse actividades que, aumentando el coste de la actividad subvencionada, no aporten valor añadido al contenido de la misma.

3. Cuando la actividad concertada con terceros sobrepase del 20 por ciento del importe de la subvención y dicho importe sea superior a 60.000 euros, la subcontratación estará sometida al cumplimiento de los siguientes requisitos:

a. Que el contrato se celebre por escrito.

b. Que la celebración del mismo se autorice previamente por la entidad concedente de la subvención en la forma que se determine en las bases reguladoras.

4. No podrá fraccionarse un contrato con el objeto de disminuir la cuantía del mismo y eludir el cumplimiento de los requisitos exigidos en el apartado anterior.

5. Los contratistas quedarán obligados solamente ante el beneficiario, que asumirá la total responsabilidad de la ejecución de la actividad subvencionada frente a la administración.

6. A efectos de lo previsto en el apartado anterior, los beneficiarios serán responsables de que en la ejecución de la actividad subvencionada concertada con terceros se respeten los límites que se establezcan en la normativa reguladora de la subvención en cuanto a la naturaleza y cuantía de gastos subvencionables, y los contratistas estarán sujetos al deber de colaboración previsto en el artículo 45 de la presente ley para permitir la adecuada verificación del cumplimiento de dichos límites.

7. En ningún caso podrá concertarse por el beneficiario la ejecución total o parcial de las actividades subvencionadas con:

a. Personas o entidades incursas en alguna de las prohibiciones del artículo 10 de la presente ley.

b. Personas o entidades que hayan percibido otras subvenciones para la realización de la actividad objeto de contratación. 
c. Intermediarios o asesores en los que los pagos se definan como un porcentaje de coste total de la operación, salvo que dicho pago esté justificado con referencia al valor de mercado del trabajo realizado o los servicios prestados.

d. Personas o entidades vinculadas con el beneficiario, salvo que concurran las siguientes circunstancias:

$1 .^{a}$ Que la contratación se realice de acuerdo con las condiciones normales de mercado.

2. ${ }^{\text {a }}$ Que se obtenga la previa autorización del órgano concedente en los términos que se fijen en las bases reguladoras.

e. Personas o entidades solicitantes de ayuda o subvención en la misma convocatoria y programa que no hubieran obtenido subvención por no reunir los requisitos o no alcanzar la valoración suficiente.

Artículo 28. Justificación de las subvenciones.

1. La justificación del cumplimiento de las condiciones impuestas y de la consecución de los objetivos previstos en el acto de concesión de la subvención se documentará de la manera que se determine reglamentariamente, pudiendo revestir la forma de cuenta justificativa del gasto realizado o acreditarse dicho gasto por módulos o mediante la presentación de estados contables, según se disponga en la normativa reguladora.

2. El rendimiento de la cuenta justificativa constituye un acto obligatorio del beneficiario o de la entidad colaboradora, en la que se deben incluir, bajo responsabilidad del declarante, los justificantes de gasto o cualquier otro documento con validez jurídica que permitan acreditar el cumplimiento del objeto de la subvención pública. La forma de la cuenta justificativa y el plazo de rendimiento de la misma vendrán determinados por las correspondientes bases reguladoras de las subvenciones públicas.

A falta de previsión de las bases reguladoras, la cuenta habrá de incluir declaración de las actividades realizadas que fueron financiadas con la subvención y su coste, con el desglose de cada uno de los gastos incurridos, y su presentación se realizará, como máximo, en el plazo de tres meses desde la finalización del plazo para la realización de la actividad.

3. Los gastos se acreditarán mediante facturas y demás documentos de valor probatorio equivalente con validez en el tráfico jurídico mercantil o con eficacia administrativa, en los términos establecidos reglamentariamente.

La acreditación de los gastos también podrá efectuarse mediante facturas electrónicas, siempre que cumplan los requisitos exigidos para su aceptación en el ámbito tributario.

Reglamentariamente, se establecerá un sistema de validación y estampillado de justificantes de gasto que permita el control de la concurrencia de subvenciones.

4. Cuando el beneficiario esté sujeto al régimen de contabilidad empresarial, la presentación de las cuentas del ejercicio donde se reflejen las operaciones relacionadas con la subvención concedida, elaboradas según normas de contabilidad recogidas en las disposiciones aplicables, constituirán un medio de justificación.

5. En las subvenciones concedidas a otras administraciones públicas o entidades vinculadas o dependientes de aquéllas y a las universidades, la justificación podrá consistir en la certificación de la intervención o del órgano que tenga atribuidas las facultades de control de la toma de razón en contabilidad y del cumplimiento de la finalidad para la que fue concedida.

6. Cuando las actividades hubieran sido financiadas, además de con la subvención, con fondos propios u otras subvenciones o recursos, deberá acreditarse en la justificación el importe, procedencia y aplicación de tales fondos a las actividades subvencionadas.

7. En el supuesto de adquisición de bienes inmuebles, además de los justificantes 
establecidos en el apartado 3 de este artículo, debe aportarse certificado de tasador independiente debidamente acreditado e inscrito en el correspondiente registro oficial.

8. Los miembros de las entidades previstas en el apartado 2 y segundo párrafo del apartado 3 del artículo 8 de la presente ley están obligados a cumplir los requisitos de justificación respecto a las actividades realizadas en nombre y por cuenta del beneficiario, del modo que se determina en los apartados anteriores. Esta documentación formará parte de la justificación que viene obligado a rendir el beneficiario que solicitó la subvención.

9. Las subvenciones que se concedan en atención a la concurrencia de una determinada situación en el perceptor no requerirán otra justificación que la acreditación por cualquier medio admisible en derecho de dicha situación previamente a la concesión, sin perjuicio de los controles que hubieran podido establecerse para verificar su existencia.

10. El incumplimiento de la obligación de justificación de la subvención en los términos establecidos en este capítulo o la justificación insuficiente de la misma llevará consigo el reintegro en las condiciones previstas en el artículo 33 de la presente ley.

Artículo 29. Gastos subvencionables.

1. Se consideran gastos subvencionables, a los efectos previstos en la presente ley, aquéllos que de manera indudable respondan a la naturaleza de la actividad subvencionada y se realicen en el plazo establecido por las diferentes bases reguladoras de las subvenciones. En ningún caso el coste de adquisición de los gastos subvencionables podrá ser superior al valor de mercado.

2. Salvo disposición expresa en contrario en las bases reguladoras de las subvenciones, se considerará gasto realizado el que fue efectivamente pagado con anterioridad a la finalización del periodo de justificación determinado por la normativa reguladora de la subvención.

3. Cuando el importe del gasto subvencionable supere la cuantía de 30.000 euros en el supuesto de coste por ejecución de obra, o de 12.000 euros en el supuesto de suministro de bienes de equipo o prestación de servicios por empresas de consultoría o asistencia técnica, el beneficiario deberá solicitar como mínimo tres ofertas de diferentes proveedores, con carácter previo a la contratación del compromiso para la prestación del servicio o la entrega del bien, salvo que por las especiales características de los gastos subvencionables no exista en el mercado suficiente número de entidades que lo suministren o presten, o salvo que el gasto se hubiera realizado con anterioridad a la solicitud de la subvención.

La elección entre las ofertas presentadas, que habrán de aportarse en la justificación, o, en su caso, en la solicitud de la subvención, se realizará conforme a criterios de eficiencia y economía, debiendo justificarse expresamente en una memoria la elección cuando no recaiga en la propuesta económica más ventajosa.

4. En el supuesto de adquisición, construcción, rehabilitación y mejora de bienes inventariables, se seguirán las siguientes reglas:

a. Las bases reguladoras fijarán el periodo durante el cual la persona beneficiaria deberá destinar los bienes al fin concreto para el cual se concedió la subvención, que no podrá ser inferior a cinco años en caso de bienes inscribibles en un registro público, ni a dos años para el resto de bienes.

En el caso de bienes inscribibles en un registro público, deberá hacerse constar en la escritura esta circunstancia, así como el importe de la subvención concedida, debiendo ser objeto estos extremos de inscripción en el registro público correspondiente.

b. El incumplimiento de la obligación de destino referida en la letra anterior, que se producirá en todo caso con la enajenación o el gravamen del bien, será causa de 
reintegro, en los términos establecidos en el artículo 33, quedando el bien afecto al pago del reintegro cualquiera que sea su poseedor, salvo que resulte ser un tercero protegido por la fe pública registral o se justifique la adquisición de los bienes con buena fe y justo título o en establecimiento mercantil o industrial, en caso de bienes muebles no inscribibles.

5. No se considerará incumplida la obligación de destino referida en el anterior apartado cuando:

a. Tratándose de bienes no inscribibles en un registro público, hayan sido sustituidos por otros que sirvan en condiciones análogas al fin para el cual se concedió la subvención y este uso se mantenga hasta completar el periodo establecido, siempre que la sustitución hubiera sido autorizada por la administración concedente.

b. Tratándose de bienes inscribibles en un registro público, el cambio de destino, enajenación o gravamen sea autorizado por la administración concedente. En este supuesto, el adquirente asumirá la obligación de destino de los bienes por el periodo restante y, en el supuesto de incumplimiento de la misma, del reintegro de la subvención.

6. Las bases reguladoras de las subvenciones establecerán, en su caso, las reglas especiales que se consideren oportunas en materia de amortización de los bienes inventariables. No obstante, el carácter subvencionable del gasto de amortización estará sujeto a las siguientes condiciones:

a. Que las subvenciones no hayan contribuido a la compra de los bienes.

b. Que la amortización se calcule de conformidad con las normas de contabilidad generalmente aceptadas.

c. Que el coste se refiera exclusivamente al periodo subvencionable.

7. Los gastos financieros, los gastos de asesoría jurídica o financiera, los gastos notariales y registrales y los gastos periciales para la realización del proyecto subvencionado y los de administración específicos son subvencionables si están directamente relacionados con la actividad subvencionada y son indispensables para la adecuada preparación o ejecución de la misma, y siempre que así se prevea en las bases reguladoras. Con carácter excepcional, los gastos de garantía bancaria podrán ser subvencionados cuando así lo prevea la normativa reguladora de la subvención.

En ningún caso serán gastos subvencionables:

a. Los intereses deudores de las cuentas bancarias.

b. Los intereses, recargos y sanciones administrativas y penales.

c. Los gastos de procedimientos judiciales.

8. Los tributos son gasto subvencionable cuando la persona beneficiaria de la subvención los abona efectivamente. En ningún caso se consideran gastos subvencionables los impuestos indirectos cuando sean susceptibles de recuperación o compensación ni los impuestos personales sobre la renta.

9. Los costes indirectos formarán parte de lajustificación de la subvención, siempre que las bases reguladoras así lo prevean, siempre que se hubieran imputado por el beneficiario a la actividad subvencionada en la parte que razonablemente corresponda de acuerdo con principios y normas de contabilidad generalmente admitidas y, en todo caso, en la medida en que tales costes correspondan al periodo en que efectivamente se realiza la actividad.

Artículo 30. Comprobación de subvenciones.

1. El órgano concedente comprobará la adecuada justificación de la subvención, así como la realización de la actividad y el cumplimiento de la finalidad que determinen la concesión o disfrute de la subvención.

2. En las subvenciones de capital superiores a 60.000 euros, en su cómputo individual, destinadas a inversiones en 
activos tangibles, será requisito imprescindible la comprobación material de la inversión por el órgano concedente, quedando constancia en el expediente mediante acta de conformidad firmada, tanto por el representante de la administración como por el beneficiario.

La comprobación material definida en el párrafo anterior se podrá encomendar a otro órgano distinto del que concedió la subvención.

3. Excepcionalmente, la comprobación material se podrá sustituir por una justificación documental que constate de forma razonable y suficiente la realización de la actividad subvencionada.

4. La entidad colaboradora, en su caso, realizará, en nombre y por cuenta del órgano concedente, las comprobaciones previstas.

5. La administración concedente podrá comprobar el valor de mercado de los gastos subvencionables por uno o varios de los siguientes medios:

a. Precios de mercado.

b. Cotizaciones de mercados nacionales y extranjeros.

c. Estimación por referencia a los valores recogidos en los registros oficiales de carácter fiscal.

d. Dictamen de peritos de la administración.

e. Tasación pericial contradictoria.

f. Cualquier otro medio de prueba admitido en derecho.

\section{Capitulo V \\ DEL PROCEDIMIENTO DE GESTIÓN PRESUPUESTARIA}

Artículo 31. Procedimiento de aprobación del gasto y pago.

1. Con carácter previo a la convocatoria de la subvención o a la concesión directa de la misma, deberá efectuarse la aprobación del gasto en los términos previstos en el Decreto legislativo 1/1999, de 7 de octubre, por el que se aprueba el texto refundido de la Ley de régimen financiero y presupuestario de Galicia.

2. No podrán otorgarse subvenciones por cuantía superior a la que se determine en la convocatoria sin que se realice una nueva convocatoria, salvo que se produzca el incremento de los créditos derivado de:

a. Una generación, ampliación o incorporación de crédito.

b. La existencia de remanentes de otras convocatorias financiadas con cargo al mismo crédito o a créditos incluidos en el mismo programa o en programas del mismo servicio.

3. La resolución de concesión de la subvención llevará consigo la aprobación del compromiso del gasto correspondiente.

4. Cuando el procedimiento administrativo establecido no lleve consigo el agotamiento del crédito en un sólo acto de concesión, sino que su disposición se realice en actos sucesivos, el órgano gestor deberá publicar, en la forma que reglamentariamente se establezca, el agotamiento de la partida presupuestaria asignada y la inadmisión de posteriores solicitudes destinadas a participar del mismo, salvo que proceda lo previsto en el apartado 2 de este artículo.

5. El pago de la subvención se realizará previa justificación, por el beneficiario, de la realización de la actividad, proyecto, objetivo o adopción del comportamiento para el cual se concedió en los términos establecidos en la normativa reguladora de la subvención.

Se producirá la pérdida del derecho al cobro total o parcial de la subvención en el supuesto de falta de justificación o de concurrencia de alguna de las causas previstas en el artículo 33 de la presente ley.

6. Cuando la naturaleza de la subvención así lo justifique, podrán realizarse pagos a cuenta. Dichos pagos a cuenta podrán suponer la realización de pagos fraccionados que responderán al ritmo de ejecución de las acciones subvencionadas, abonándose por cuantía equivalente a la justificación presentada. 
También se podrán realizar pagos anticipados que supondrán entregas de fondos con carácter previo a la justificación, como financiación necesaria para poder llevar a cabo las actuaciones inherentes a la subvención. Sin perjuicio de su desarrollo reglamentario, dicha posibilidad y el régimen de garantías habrán de establecerse, en su caso, expresamente en las bases reguladoras de la subvención.

En ningún caso podrán realizarse pagos anticipados a beneficiarios cuando se haya solicitado la declaración de concurso, hayan sido declarados insolventes en cualquier procedimiento, se hallen declarados en concurso, estén sujetos a intervención judicial o hayan sido inhabilitados conforme a la Ley concursal 22/2003, de 9 de julio, sin que haya concluido el periodo de inhabilitación fijado en la sentencia de calificación del concurso, hayan sido declarados en quiebra, en concurso de acreedores, insolvente fallido en cualquier procedimiento o sujeto a intervención judicial, se hubiera iniciado expediente de quita y espera o de suspensión de pagos o se hubiera presentado solicitud judicial de quiebra o de concurso de acreedores, mientras, en su caso, no fueran rehabilitados. La realización de pagos a cuenta o pagos anticipados, así como el régimen de garantías, deberán preverse expresamente en la normativa reguladora de la subvención.

7. No podrá realizarse el pago de la subvención en tanto el beneficiario no se encuentre al corriente en el cumplimiento de sus obligaciones tributarias y frente a la Seguridad Social y no tenga pendiente de pago ninguna otra deuda con la Administración pública de la Comunidad Autónoma o sea deudor por resolución de procedencia de reintegro.

Las normas reguladoras de las subvenciones podrán establecer un régimen simplificado de acreditación de estas circunstancias en los siguientes casos:

a. Las otorgadas a favor de la Comunidad Autónoma y de sus sociedades públicas y fundaciones del sector público autonómico, así como de los órganos estatutarios de Galicia.

b. Las otorgadas a favor de las universidades.

c. Las otorgadas a favor de las corporaciones locales y de sus organismos autónomos.

d. Las becas y ayudas destinadas expresamente a financiar estudios en centros de formación públicos o privados, cuando las perciban directamente las personas individuales beneficiarias.

e. Las subvenciones con cargo a los créditos presupuestarios del capítulo IV, «Transferencias corrientes», destinadas a familias e instituciones sin fines de lucro.

f. Las que no superen los 3.000 euros individualmente y se concedan con cargo a los créditos presupuestarios del capítulo VII, «Transferencias de capital», destinadas a familias e instituciones sin fines de lucro.

g. Las que se concedan con cargo a los programas presupuestarios en los que así se señale en la correspondiente ley de presupuestos.

h. Aquellas ayudas o subvenciones en las que, por concurrir circunstancias debidamente justificadas, derivadas de la naturaleza, régimen o cuantía de la subvención, así se establezca mediante orden de la consejería competente en materia de economía y hacienda.

i. Las subvenciones destinadas a financiar proyectos o programas de acción social y cooperación internacional que se concedan a entidades sin fines lucrativos, así como a federaciones, confederaciones o agrupaciones de las mismas.

\section{TÍTULO II DEL REINTEGRO DE SUBVENCIONES \\ Capitulo I DEL REINTEGRO}

Artículo 32. Invalidez de la resolución de concesión.

1. Son causas de nulidad de la resolución de concesión: 
a. Las indicadas en el artículo 62.1 de la Ley 30/1992, de 26 de noviembre, de régimen jurídico de las administraciones públicas y del procedimiento administrativo común.

b. La carencia o insuficiencia de crédito, de conformidad con lo establecido en el artículo 57 del Decreto legislativo 1/1999, de 7 de octubre, por el que se aprueba el texto refundido de la Ley de régimen financiero y presupuestario de Galicia.

2. Son causas de anulabilidad de la resolución de concesión las demás infracciones del ordenamiento jurídico y, en especial, de las reglas contenidas en la presente ley, de conformidad con lo dispuesto en el artículo 63 de la Ley 30/1992, de 26 de noviembre, de régimen jurídico de las administraciones públicas y del procedimiento administrativo común.

3. Cuando el acto de concesión incurriera en alguno de los supuestos mencionados en los apartados anteriores, el órgano concedente procederá a su revisión de oficio o, en su caso, a la declaración de lesividad y ulterior impugnación, de conformidad con lo establecido en los artículos 102 y 103 de la Ley 30/1992, de 26 de noviembre, de régimen jurídico de las administraciones públicas y del procedimiento administrativo común.

4. La declaración judicial o administrativa de nulidad o anulación llevará consigo la obligación de devolver las cantidades percibidas.

5. No procederá la revisión de oficio del acto de concesión cuando concurra alguna de las causas de reintegro contempladas en el artículo siguiente.

Artículo 33. Causas de reintegro.

1. También procederá el reintegro de las cantidades percibidas y la exigencia del interés de demora correspondiente desde el momento del pago de la subvención hasta la fecha en que se acuerde la procedencia del reintegro, en los siguientes casos:

a. Obtención de la subvención falseando las condiciones requeridas para ello u ocultando aquéllas que lo hubieran impedido. b. Incumplimiento total o parcial del objetivo, de la actividad o del proyecto o no adopción del comportamiento que fundamentan la concesión de la subvención.

c. Incumplimiento de la obligación de justificación o la justificación insuficiente, en los términos establecidos en el artículo 28 de la presente ley, y en su caso en las normas reguladoras de la subvención.

d. Incumplimiento de la obligación de adoptar las medidas de difusión contenidas en el apartado 3 del artículo 15 de la presente ley.

e. Resistencia, excusa, obstrucción o negativa a las actuaciones de comprobación y control financiero previstas en los artículos 11 y 12 de la presente ley, así como el incumplimiento de las obligaciones contables, registrales o de conservación de documentos cuando de ello se derive la imposibilidad de verificar el empleo dado a los fondos percibidos, el cumplimiento del objetivo, la realidad y regularidad de las actividades subvencionadas, o la concurrencia de subvenciones, ayudas, ingresos o recursos para la misma finalidad, procedentes de cualquier administración o entes públicos o privados, estatales, de la Unión Europea o de organismos internacionales.

f. Incumplimiento de las obligaciones impuestas por la administración a las entidades colaboradoras y beneficiarios, así como de los compromisos por éstos asumidos, con motivo de la concesión de la subvención, siempre que afecten o se refieran al modo en que se consiguen los objetivos, se realiza la actividad, se ejecuta el proyecto o se adopta el comportamiento que fundamenta la concesión de la subvención.

g. Incumplimiento de las obligaciones impuestas por la administración a las entidades colaboradoras y beneficiarios, así como de los compromisos por éstos asumidos, con motivo de la concesión de la subvención, distintos de los anteriores, cuando de ello se derive la imposibilidad 
de verificar el empleo dado a los fondos percibidos, el cumplimiento del objetivo, la realidad y regularidad de las actividades subvencionadas, o la concurrencia de subvenciones, ayudas, ingresos o recursos para la misma finalidad, procedentes de cualquier administración o entes públicos o privados, estatales, de la Unión Europea o de organismos internacionales.

h. Adopción, en virtud de lo establecido en los artículos 87 a 89 del Tratado de la Unión Europea, de una decisión de la cual se derive una necesidad de reintegro.

i. En los demás supuestos contemplados en la normativa reguladora de la subvención.

2. Cuando el cumplimiento por el beneficiario o, en su caso, entidad colaboradora se aproxime de modo significativo al cumplimiento total y se acredite por éstos una actuación inequívocamente tendente a la satisfacción de sus compromisos, la cantidad a reintegrar vendrá determinada por la aplicación de los criterios enunciados en la letra 1) del apartado 1 del artículo 14 de la presente ley.

3 . Igualmente, en el supuesto contemplado en el apartado 3 del artículo 17 de la presente ley procederá el reintegro del exceso obtenido sobre el coste de la actividad subvencionada, así como la exigencia del interés de demora correspondiente.

Artículo 34. Naturaleza de los créditos a reintegrar y de los procedimientos para su exigencia.

1. Las cantidades a reintegrar tendrán la consideración de ingresos de derecho público, resultando de aplicación para su cobro lo previsto en el Decreto legislativo $1 / 1999$, de 7 de octubre, por el que se aprueba el texto refundido de la Ley de régimen financiero y presupuestario de Galicia.

2. El interés de demora aplicable en materia de subvenciones será el interés legal del dinero incrementado en un 25 por ciento, salvo que la Ley de presupuestos generales del Estado establezca otro diferente y del previsto para los fondos procedentes de la Unión Europea en su legislación específica.

3. El destino de los reintegros de los fondos de la Unión Europea tendrá el tratamiento que en su caso determine la normativa comunitaria.

4. Los procedimientos para la exigencia del reintegro de las subvenciones tendrán siempre carácter administrativo.

Artículo 35. Prescripción.

1. Prescribirá a los cuatro años el derecho de la administración a reconocer o liquidar el reintegro.

2. Este plazo se computará, en cada caso:

a. Desde el momento en que venció el plazo para presentar la justificación por parte del beneficiario o entidad colaboradora.

b. Desde el momento de la concesión, en el supuesto previsto en el apartado $9 \mathrm{del}$ artículo 28.

c. En el supuesto de que se hubieran establecido condiciones u obligaciones que debieran ser cumplidas o mantenidas por parte del beneficiario o entidad colaboradora durante un periodo determinado de tiempo, desde el momento en que venció dicho plazo.

3. El cómputo del plazo de prescripción se interrumpirá:

a. Por cualquier acción de la administración, realizada con conocimiento formal del beneficiario o de la entidad colaboradora, que conduzca a determinar la existencia de alguna de las causas de reintegro.

b. Por la interposición de recursos de cualquier clase, por la remisión del tanto de culpa a la jurisdicción penal o por la presentación de denuncia ante el ministerio fiscal, así como por las actuaciones realizadas con conocimiento formal del beneficiario o de la entidad colaboradora en el curso de dichos recursos.

c. Por cualquier actuación fehaciente del beneficiario o de la entidad colaboradora 
conducente a la liquidación de la subvención o del reintegro.

Artículo 36. Obligados al reintegro.

1. Los beneficiarios y entidades colaboradoras, en los casos contemplados en el artículo 33 de la presente ley, deberán reintegrar la totalidad o parte de las cantidades percibidas más los correspondientes intereses de demora, sin perjuicio de lo dispuesto en la letra b) del apartado $5 \mathrm{del}$ artículo 29 de la presente ley. Esta obligación será independiente de las sanciones que, en su caso, resulten exigibles.

2. Los miembros de las personas y entidades contempladas en el apartado 2 y en el segundo párrafo del apartado 3 del artículo 8 de la presente ley responderán solidariamente de la obligación de reintegro del beneficiario en relación con las actividades subvencionadas que se hubieran comprometido a efectuar.

Responderán solidariamente de la obligación de reintegro los representantes legales del beneficiario cuando éste careciera de capacidad de obrar.

Responderán solidariamente los miembros, partícipes o cotitulares de las entidades a que se refiere el apartado 3 del artículo 8 en proporción a sus respectivas participaciones, cuando se trate de comunidades de bienes o cualquier otro tipo de unidad económica o patrimonio separado.

3. Responderán subsidiariamente de la obligación de reintegro los administradores de las sociedades mercantiles, o aquéllos que ostenten la representación legal de otras personas jurídicas, que no hubieran realizado los actos necesarios que fueran de su incumbencia para el cumplimiento de las obligaciones infringidas, adoptaran acuerdos que hicieran posibles los incumplimientos o consintieran los de quienes de ellos dependan.

Asimismo, los que ostenten la representación legal de las personas jurídicas, de acuerdo con las disposiciones legales o estatutarias que les resulten de aplicación, que hayan cesado en sus actividades responderán subsidiariamente en todo caso de las obligaciones de reintegro de éstas.

4. En el caso de las sociedades o entidades disueltas y liquidadas, sus obligaciones de reintegro pendientes se transmitirán a los socios o partícipes en el capital que responderán de ellas solidariamente y hasta el límite del valor de la cuota de liquidación que se les hubiera adjudicado.

5. En el caso de fallecimiento del obligado al reintegro, la obligación de satisfacer las cantidades pendientes de restitución se transmitirá a sus causahabientes, sin perjuicio de lo que establezca el derecho civil común, foral o especial aplicable a la sucesión para determinados supuestos, en particular para el caso de aceptación de la herencia a beneficio de inventario.

\section{Capítulo II \\ DEL PROCEDIMIENTO DE REINTEGRO}

Artículo 37. Competencia para la resolución del procedimiento de reintegro.

El órgano concedente será el competente para exigir del beneficiario o entidad colaboradora el reintegro de subvenciones mediante la resolución del procedimiento regulado en este capítulo, cuando aprecie la existencia de alguno de los supuestos de reintegro de cantidades percibidas establecidos en el artículo 33 de la presente ley, sin perjuicio de las facultades atribuidas a otros órganos para la ejecución del acuerdo.

Artículo 38. Procedimiento de reintegro.

1. El procedimiento de reintegro de subvenciones se regirá por las disposiciones generales sobre procedimientos administrativos contenidas en el título VI de la Ley 30/1992, de 26 de noviembre, de régimen jurídico de las administraciones públicas y del procedimiento administrativo común, sin perjuicio de las especialidades que se establecen en la presente ley y en sus disposiciones de desarrollo.

2. El procedimiento de reintegro de subvenciones se iniciará de oficio por 
acuerdo del órgano competente, bien a propia iniciativa, bien como consecuencia de orden superior, a petición razonada de otros órganos o por denuncia. También se iniciará a consecuencia del informe de control financiero emitido por la Intervención General de la Comunidad Autónoma.

3. En la tramitación del procedimiento se garantizará, en todo caso, el derecho del interesado a la audiencia.

4. Cuando el procedimiento de reintegro se inicie como consecuencia de informe de control financiero de la intervención general y, como consecuencia del trámite de audiencia, el órgano gestor se vaya a separar del dictamen del informe de control, antes de dictar la resolución del procedimiento, formulará discrepancia de acuerdo con el procedimiento que se determine reglamentariamente.

5. El plazo máximo para resolver y notificar la resolución del procedimiento de reintegro será de doce meses desde la fecha del acuerdo de la iniciación. Dicho plazo podrá suspenderse y ampliarse de acuerdo con lo previsto en los apartados 5 y 6 del artículo 42 de la Ley 30/1992, de 26 de noviembre, de régimen jurídico de las administraciones públicas y del procedimiento administrativo común.

Si transcurre el plazo para resolver sin que se haya notificado resolución expresa, se producirá la caducidad del procedimiento, sin perjuicio de continuar las actuaciones hasta su terminación y sin que se considere interrumpida la prescripción por las actuaciones realizadas hasta la finalización del citado plazo.

6. La resolución del procedimiento de reintegro pondrá fin a la vía administrativa.

Artículo 39. Retención de pagos.

1. Una vez acordada la iniciación del procedimiento de reintegro, como medida cautelar, el órgano concedente puede acordar, a iniciativa propia o de una decisión de la Comisión Europea o a propuesta de la Intervención General de la
Comunidad Autónoma, la suspensión de los libramientos de pago de las cantidades pendientes de abonar al beneficiario o entidad colaboradora, sin superar, en ningún caso, el importe que fijen en la propuesta o resolución de iniciación del expediente de reintegro, con los intereses de demora devengados hasta aquel momento.

2. La imposición de esta medida cautelar debe acordarse por resolución motivada, que debe notificarse al interesado, con indicación de los recursos pertinentes. Asimismo, se comunicará al órgano competente para la ordenación de pagos, que hará efectiva la retención del pago hasta el importe objeto de retención.

3. En todo caso, procederá la suspensión si existen indicios racionales que permitan prever la imposibilidad de obtener el resarcimiento, o si éste puede verse frustrado o gravemente dificultado y, en especial, si el perceptor hace actos de ocultación, gravamen o disposición de sus bienes.

4. La retención de pagos estará sujeta, en cualquiera de los supuestos anteriores, al siguiente régimen jurídico:

a. Debe ser proporcional a la finalidad que se pretende conseguir y en ningún caso debe adoptarse si puede producir efectos de difícil o imposible reparación.

b. Debe mantenerse hasta que se dicte la resolución que pone fin al expediente de reintegro, y no puede superar el período máximo que se fije para su tramitación, incluidas prórrogas.

c. No obstante lo dispuesto en el párrafo anterior, debe levantarse cuando desaparezcan las circunstancias que la originaron o cuando el interesado proponga la sustitución de esta medida cautelar por la constitución de una garantía que se considere suficiente.

Artículo 40. Compensación de deudas.

En los supuestos y con los requisitos que se establezcan reglamentariamente, podrán extinguirse total o parcialmente por compensación las deudas de naturaleza 
pública a favor de la hacienda de la Comunidad Autónoma que se encuentren en fase de gestión recaudatoria, tanto voluntaria como ejecutiva, con los créditos reconocidos por la misma en favor del deudor.

\section{TÍTULO III DEL CONTROL FINANCIERO DE SUBVENCIONES}

Artículo 41. Control financiero de subvenciones.

El control financiero de subvenciones se ejercerá sobre:

a. Las subvenciones de la Unión Europea percibidas por la Administración de la Comunidad Autónoma de Galicia o los organismos o entidades vinculadas o dependientes de aquélla.

b. Los beneficiarios y, en su caso, entidades colaboradoras por razón de las subvenciones otorgadas por la Comunidad Autónoma de Galicia y organismos o entidades vinculadas o dependientes de aquélla con cargo a los presupuestos de la Comunidad Autónoma de Galicia o a los fondos de la Unión Europea.

Artículo 42. Competencia para el ejercicio del control financiero de subvenciones.

1. La competencia para ejercer el control de subvenciones corresponde a la Intervención General de la Comunidad Autónoma, sin perjuicio de las funciones que la Constitución española y las leyes otorgan al Tribunal de Cuentas y al Consejo de Cuentas de Galicia y de lo dispuesto en el artículo 3 de la presente ley.

2. Para la realización del control financiero, la Intervención General de la Comunidad Autónoma podrá demandar la colaboración de empresas privadas de auditoría, en las mismas condiciones que las establecidas en el artículo 107.4 del Decreto legislativo 1/1999, de 7 de octubre, por el que se aprueba el texto refundido de la Ley de régimen financiero y presupuestario de Galicia, para el control financiero ordinario, correspondiéndole a la intervención general, en todo caso, la realización de aquellas actuaciones que supongan el ejercicio de potestades administrativas.

Artículo 43. Compatibilidad entre controles realizados por diversos órganos.

1. Las actuaciones de control efectuadas por los diversos órganos competentes en la materia de cualquiera de las administraciones interesadas en el procedimiento de concesión de la subvención serán compatibles entre sí.

2. La Intervención General de la Comunidad Autónoma promoverá cuantas actuaciones estén a su alcance para que las actividades a realizar por los diversos órganos competentes, sin menoscabo de las actuaciones y objetivos del control, se efectúen de la forma más eficaz, evitando duplicidades y actuaciones redundantes, sin valor añadido.

Artículo 44. Objeto del control financiero de subvenciones.

1. El control financiero de subvenciones de la Unión Europea percibidas por la Administración de la Comunidad Autónoma de Galicia o los organismos o entidades vinculadas o dependientes de aquélla verificará el cumplimiento de las normas establecidas en las disposiciones comunitarias.

En el cumplimiento de la normativa comunitaria, los órganos de control podrán llevar a cabo controles y verificaciones de los procedimientos de gestión de los distintos órganos gestores que intervengan en la concesión, gestión y pago de las ayudas cofinanciadas con fondos comunitarios, que permitan garantizar la correcta gestión financiera de los fondos comunitarios.

2. El control financiero de subvenciones tendrá como objeto verificar:

a. La adecuada y correcta obtención de la subvención por parte del beneficiario.

b. El cumplimiento por parte de beneficiarios y entidades colaboradoras de sus obligaciones en la gestión y aplicación de la subvención. 
c. La adecuada y correcta justificación de la subvención por parte de beneficiarios y entidades colaboradoras.

d. La realidad y la regularidad de las operaciones que, de acuerdo con la justificación presentada por beneficiarios y entidades colaboradoras, han sido financiadas con la subvención.

e. La adecuada y correcta financiación de las actividades subvencionadas, en los términos establecidos en el apartado $3 \mathrm{del}$ artículo 17 de la presente ley.

f. La existencia de hechos, circunstancias o situaciones no declaradas a la administración por beneficiarios y entidades colaboradoras y que pudieran afectar a la financiación de las actividades subvencionadas, a la adecuada y correcta obtención, utilización, disfrute o justificación de la subvención, así como a la realidad y regularidad de las operaciones con ella financiadas.

3. El control financiero de las subvenciones podrá abarcar:

a. El examen de registros contables, cuentas o estados financieros y la documentación que los soporte de beneficiarios y entidades colaboradoras.

b. El examen de operaciones individualizadas y concretas relacionadas o que pudieran afectar a las subvenciones concedidas.

c. La comprobación de aspectos parciales y concretos de una serie de actos relacionados o que pudieran afectar a las subvenciones concedidas.

d. La comprobación material de las inversiones financiadas.

e. Las actuaciones concretas de control que deban realizarse conforme con lo que en cada caso establezca la normativa reguladora de la subvención y, en su caso, la resolución de concesión.

f. Cualquier otra comprobación que resulte necesaria en atención a las características especiales de las actividades subvencionadas.
4. El control financiero podrá extenderse a las personas físicas o jurídicas a las que se encuentren asociados los beneficiarios, así como a cualquier otra persona susceptible de prestar un interés en la consecución de los objetivos, realización de las actividades, ejecución de los proyectos o adopción de los comportamientos.

Artículo 45. Obligación de colaboración.

1. Los beneficiarios, las entidades colaboradoras y los terceros relacionados con el objeto de la subvención o su justificación estarán obligados a prestar colaboración y facilitar cuanta documentación sea requerida, en el ejercicio de las funciones de control, a la Intervención General de la Comunidad Autónoma, así como a los órganos que, de acuerdo con la normativa comunitaria, tengan atribuidas funciones de control financiero, a cuyo fin tendrán las siguientes facultades:

a. El libre acceso a la documentación objeto de comprobación, incluidos los programas y archivos en soportes informáticos.

b. El libre acceso a los locales de negocio y demás establecimientos o lugares en que se desarrolle la actividad subvencionada o se permita verificar la realidad y regularidad de las operaciones financiadas con cargo a la subvención.

c. La obtención de copia o la retención de las facturas, documentos equivalentes o sustitutivos y de cualquier otro documento relativo a las operaciones en las que se deduzcan indicios de la incorrecta obtención, empleo o destino de la subvención.

d. El libre acceso a la información de las cuentas bancarias en las entidades financieras donde se pueda efectuar el cobro de las subvenciones o con cargo a las que se puedan realizar las disposiciones de los fondos.

2. La negativa al cumplimiento de esta obligación se considerará resistencia, excusa, obstrucción o negativa a los efectos previstos en el artículo 33 de la presente 
ley, sin perjuicio de las sanciones que, en su caso, pudieran corresponder.

3. Las autoridades, cualquiera que sea su naturaleza, así como los jefes o directores de oficinas públicas, organismos autónomos y otros entes de derecho público y quien, en general, ejerza funciones públicas o desarrolle su trabajo en dichas entidades deberán prestar la debida colaboración y apoyo a los funcionarios encargados de la realización del control financiero de subvenciones.

4. Los juzgados y tribunales deberán facilitar a la administración, de oficio o a requerimiento de ésta, cuantos datos con trascendencia en la aplicación de subvenciones se desprendan de las actuaciones judiciales de las que tengan conocimiento, respetando, en su caso, el secreto de las diligencias sumariales.

Artículo 46. Del personal controlador.

1. En el ejercicio del control financiero, el funcionario encargado de realizar el mismo por la Intervención General de la Comunidad Autónoma será considerado agente de la autoridad.

2. La Asesoría Jurídica de la Xunta deberá prestar la asistencia jurídica que, en su caso, corresponda a los funcionarios que, como consecuencia de su participación en actuaciones de control financiero de subvenciones, sean objeto de citaciones por órgano jurisdiccional.

3. El personal controlador que realice el control financiero de subvenciones deberá guardar la confidencialidad y el secreto respecto de los asuntos que conozcan por razón de su trabajo.

4. Los datos, informes o antecedentes obtenidos en el ejercicio de dicho control solamente podrán utilizarse para los fines asignados al mismo, servir de fundamento para la exigencia de reintegro y, en su caso, para poner en conocimiento de los órganos competentes los hechos que puedan ser constitutivos de infracción administrativa, responsabilidad contable o penal.
5. Cuando en la práctica de un control financiero el funcionario encargado aprecie que los hechos acreditados en el expediente pudieran ser susceptibles de constituir una infracción administrativa o de responsabilidades contables o penales lo deberá poner en conocimiento de la Intervención General de la Comunidad Autónoma a efectos de que, si procede, remita lo actuado al órgano competente para la iniciación de los oportunos procedimientos.

Artículo 47. Del procedimiento de control financiero.

1. El ejercicio del control financiero de subvenciones se adecuará al plan anual de auditorías y sus modificaciones, debidamente motivadas, que apruebe anualmente la Intervención General de la Comunidad Autónoma.

El plan comprenderá a los beneficiarios y, en su caso, entidades colaboradoras sobre las que se realizarán los controles financieros, y su alcance.

No obstante, no será necesario incluir en el plan de auditorías y actuaciones de control financiero de la Intervención General de la Comunidad Autónoma las comprobaciones precisas que soliciten otros estados miembros en aplicación de reglamentos comunitarios sobre beneficiarios perceptores de fondos comunitarios.

2. La iniciación de las actuaciones de control financiero se efectuará mediante su notificación a los órganos, organismos o entidades objeto de control y a los beneficiarios $y$, en su caso, entidades colaboradoras, en la que se indicará la naturaleza y alcance de las actuaciones a desarrollar, la documentación que en un principio debe ponerse a disposición del mismo y los demás elementos que se consideren necesarios. Los beneficiarios $y$, en su caso, entidades colaboradoras deberán ser informados, a la iniciación de las actuaciones, de sus derechos y obligaciones en el curso de las mismas. Estas actuaciones serán comunicadas, igualmente, a los órganos gestores de las subvenciones. 
Si durante el transcurso del control se hubiera producido una modificación que afecte al alcance de las actuaciones, esta modificación será comunicada igualmente a todos los sujetos interesados.

3. Cuando en el desarrollo del control financiero se determine la existencia de circunstancias que pudieran dar origen a la devolución de las cantidades percibidas por causas distintas a las previstas en el artículo 33, se pondrán los hechos en conocimiento del órgano concedente de la subvención, que deberá informar sobre las medidas adoptadas, pudiendo acordarse, por la intervención general, la suspensión del procedimiento de control financiero.

La suspensión del procedimiento deberá notificarse al beneficiario o entidad colaboradora.

4. La finalización de la suspensión, que en todo caso deberá notificarse al beneficiario o entidad colaboradora, se producirá cuando:

a. Una vez adoptadas por el órgano concedente las medidas que, a su juicio, resulten oportunas, las mismas serán comunicadas al órgano de control.

b. Si, transcurridos tres meses desde el acuerdo de suspensión, no se hubiera comunicado la adopción de medidas por parte del órgano gestor.

5. Cuando en el ejercicio de las funciones de control financiero se deduzcan indicios de la incorrecta obtención, destino o justificación de la subvención percibida, la Intervención General de la Comunidad Autónoma podrá acordar la adopción de las medidas cautelares que se estimen precisas al objeto de impedir la desaparición, destrucción o alteración de las facturas, documentos equivalentes o sustitutivos y de cualquier otro documento relativo a las operaciones en que tales indicios se manifiesten.

Las medidas serán proporcionadas al fin que se persiga. En ningún caso se adoptarán aquéllas que puedan producir un perjuicio de difícil o imposible reparación.

6. El órgano que hubiera hecho el control habrá de emitir informe escrito comprensivo de los hechos puestos de manifiesto y de las conclusiones que de ellos se deriven. Este informe tendrá carácter provisional y se remitirá tanto al órgano gestor como al beneficiario de la subvención o entidad colaboradora al fin de que puedan formular durante un plazo de quince días las alegaciones que estimen oportunas.

Transcurrido el plazo se emitirá informe definitivo, que incluirá las alegaciones recibidas del beneficiario o entidad colaboradora y las alegaciones del órgano gestor, así como las observaciones del órgano de control sobre éstas.

Si no se recibieron alegaciones, el informe provisional se elevará a definitivo.

El informe definitivo será remitido al órgano gestor y al beneficiario o entidad colaboradora. El informe enviado al beneficiario o entidad colaboradora no incluirá las conclusiones referentes a la gestión realizada por el órgano gestor, ni las recomendaciones que de ellas se deriven.

7. Cuando el órgano concedente, en aplicación de lo dispuesto en el apartado 4 anterior, comunicara la iniciación de actuaciones que pudieran afectar a la validez del acto de concesión, la finalización del procedimiento de control financiero de subvenciones se producirá mediante resolución de la Intervención General de la Comunidad Autónoma en la que se declarará la improcedencia de continuar las actuaciones de control, sin perjuicio de que, una vez recaída en resolución declarando la validez total o parcial del acto de concesión, pudieran volver a iniciarse las actuaciones.

8. Las actuaciones de control financiero sobre beneficiarios y, en su caso, entidades colaboradoras habrán de concluir en el plazo máximo de doce meses a contar desde la fecha de notificación a aquéllos del inicio de las mismas. Dicho plazo podrá 
ser ampliado, con el alcance y requisitos que se determinen reglamentariamente, cuando en las actuaciones concurra alguna de las siguientes circunstancias:

a. Que se trate de actuaciones que revistan especial complejidad.

b. Cuando en el transcurso de las actuaciones se descubra que el beneficiario o la entidad colaboradora ocultaron información o documentación esencial para un adecuado desarrollo del control.

A los efectos del plazo previsto, no se computarán las dilaciones imputables al beneficiario o a la entidad colaboradora, en su caso, ni los periodos de interrupción justificada que se especifiquen reglamentariamente.

c. En el supuesto del control financiero sobre ayudas de la Unión Europea.

Artículo 48. Documentación de las actuaciones de control financiero.

1. Las actuaciones de control financiero se documentarán en diligencias, para reflejar hechos relevantes que se pongan de manifiesto en el ejercicio del mismo, y en informes que tendrán el contenido y estructura y cumplirán los requisitos que se determinen reglamentariamente.

2. Tanto las diligencias como los informes tendrán naturaleza de documentos públicos y harán prueba de los hechos que motiven su formalización, salvo que se acredite lo contrario.

3. Los informes serán notificados a los beneficiarios o a las entidades colaboradoras objeto de control. Una copia del informe será remitido al órgano gestor que concedió la subvención y se señalará, en su caso, la necesidad de iniciar expedientes de reintegro y sancionador.

Artículo 49. Efectos de los informes de control financiero.

1. Cuando en el informe emitido por la Intervención General de la Comunidad Autónoma se recoja la procedencia de reintegrar la totalidad o parte de la subvención, el órgano gestor deberá comunicar a la
Intervención General de la Comunidad Autónoma en el plazo de un mes a partir de la recepción del informe de control financiero la incoación del expediente de reintegro o la discrepancia con su incoación, que habrá de ser motivada. En este último caso, la Intervención General de la Comunidad Autónoma podrá emitir informe de actuación dirigido al órgano gestor. El procedimiento de tramitación de los informes de actuación será desarrollado reglamentariamente.

2. En caso de que manifestara su conformidad, deberá acordar, en base al referido informe y en el plazo de un mes, la iniciación del procedimiento de reintegro, notificándola así al beneficiario o entidad colaboradora.

3. Durante el mes siguiente al fin de cada trimestre, el órgano gestor informará a la Intervención General de la Comunidad Autónoma de las actuaciones realizadas durante el trimestre respecto a los procedimientos iniciados, así como a aquéllos que en ese periodo fueran terminados. En el mismo plazo, los órganos de recaudación competentes remitirán a cada órgano gestor y a la Intervención General de la Comunidad Autónoma información sobre la gestión recaudadora realizada sobre aquellos expedientes de reintegro que se encontraran pendientes de gestión en dicho periodo y sobre aquellos expedientes que se finalizaron.

4. En caso de que en los informes se ponga de manifiesto la existencia de otras irregularidades no constitutivas de reintegro, el órgano gestor deberá comunicar con periodicidad cuatrimestral las actividades desarrolladas referentes a las mismas.

5. $\mathrm{Si}$ en los informes se ponen de manifiesto otras conclusiones o recomendaciones no constitutivas de irregularidad, el órgano gestor deberá comunicar con periodicidad cuatrimestral las actividades desarrolladas en relación con las mismas. 


\section{TÍTULO IV \\ INFRACCIONES Y SANCIONES ADMINISTRATIVAS EN MATERIA DE SUBVENCIONES}

\author{
Capitulo I \\ DE LAS INFRACCIONES \\ ADMINISTRATIVAS
}

Artículo 50. Concepto de infracción.

Constituyen infracciones administrativas en materia de subvenciones las acciones y omisiones tipificadas en la presente ley y serán sancionables incluso a título de simple negligencia.

Artículo 51. Responsables.

Serán responsables de las infracciones administrativas en materia de subvenciones las personas físicas o jurídicas, públicas o privadas, así como los entes sin personalidad a los que se refiere el apartado 3 del artículo 8 de la presente ley que por acción u omisión incurran en los supuestos tipificados como infracciones en la presente ley $\mathrm{y}$, en particular, las siguientes:

a. Los beneficiarios de subvenciones, así como los miembros de las personas o entidades contempladas en el apartado 2 y segundo párrafo del apartado 3 del artículo 8 de la presente ley, en relación con las actividades subvencionadas que se hubieran comprometido a realizar.

b. Las entidades colaboradoras.

c. El representante legal de los beneficiarios de subvenciones que carezcan de capacidad de obrar.

d. Las personas o entidades relacionadas con el objeto de la subvención o su justificación obligadas a prestar colaboración y a facilitar cuanta documentación sea requerida en cumplimiento de lo dispuesto en el artículo 45 de la presente ley.

Artículo 52. Supuestos de exención de responsabilidad.

Las acciones u omisiones tipificadas en la presente ley no darán lugar a responsabilidad por infracción administrativa en materia de subvenciones en los siguientes supuestos: a. Cuando se realicen por quienes carezcan de capacidad de obrar.

b. Cuando concurra fuerza mayor.

c. Cuando se deriven de una decisión colectiva, para quienes hubieran salvado su voto o no hubieran asistido a la reunión en la que se tomó aquélla.

Artículo 53. Concurrencia de actuaciones con el orden jurisdiccional penal.

1. En los supuestos en los que la conducta pudiera ser constitutiva de delito, la administración pasará el tanto de culpa a la jurisdicción competente y se abstendrá de seguir el procedimiento sancionador mientras la autoridad judicial no dicte sentencia firme, tenga lugar el sobreseimiento o el archivo de las actuaciones o se produzca la devolución del expediente por el ministerio fiscal.

2. La pena impuesta por la autoridad judicial excluirá la imposición de sanción administrativa si se le impuso al mismo sujeto por los mismos hechos e idéntico fundamento a los tenidos en cuenta en el procedimiento sancionador.

3. De no estimarse la existencia de delito, la administración iniciará o continuará el expediente sancionador en base a los hechos que los tribunales hayan considerado probados.

Artículo 54. Infracciones leves.

Constituyen infracciones leves los incumplimientos de las obligaciones recogidas en la presente ley y en las bases reguladoras de subvenciones cuando no constituyan infracciones graves o muy graves y no operen como elemento de graduación de la sanción. En particular, constituyen infracciones leves las siguientes conductas:

a. La presentación fuera de plazo de las cuentas justificativas de la aplicación dada a los fondos percibidos.

b. La presentación de cuentas justificativas inexactas o incompletas.

c. El incumplimiento de las obligaciones formales que, no estando previstas de forma expresa en el resto de párrafos de este 
artículo, sean asumidas como consecuencia de la concesión de la subvención, en los términos establecidos reglamentariamente.

d. El incumplimiento de obligaciones de índole contable o registral, en particular:

1. La inexactitud u omisión de una o varias operaciones en la contabilidad y registros legalmente exigidos.

2. El incumplimiento de la obligación de llevar o conservar la contabilidad, los registros legalmente establecidos, los programas y archivos informáticos que les sirvan de soporte y los sistemas de codificación utilizados.

3. La llevanza de contabilidades diversas que, referidas a una misma actividad y ejercicio económico, no permitan conocer la verdadera situación de la entidad.

4. El empleo de cuentas con significado distinto del que les corresponde, según su naturaleza, que dificulte la comprobación de la realidad de las actividades subvencionadas.

e. El incumplimiento de las obligaciones de conservación de justificantes o documentos equivalentes.

f. El incumplimiento por parte de las entidades colaboradoras de las obligaciones establecidas en la presente ley que no se recojan de forma expresa en el resto de apartados de este artículo.

g. La resistencia, obstrucción, excusa o negativa a las actuaciones de control financiero.

Se entiende que existen estas circunstancias cuando el responsable de las infracciones administrativas en materia de subvenciones, debidamente notificado al efecto, hubiera realizado actuaciones tendentes a dilatar, entorpecer o impedir las actuaciones de los funcionarios de la Intervención General de la Comunidad Autónoma en el ejercicio de las funciones de control financiero.

Entre otras, constituyen resistencia, obstrucción, excusa o negativa las siguientes conductas:

1. No aportar o no facilitar el examen de documentos, informes, antecedentes, libros, registros, ficheros, justificantes, asientos de contabilidad, programas y archivos informáticos, sistemas operativos y de control y cualquier otro dato objeto de comprobación.

2. No atender algún requerimiento.

3. La incomparecencia, salvo causa justificada, en el lugar y tiempo señalados.

4. Negar o impedir indebidamente la entrada o permanencia en locales de negocio y demás establecimientos o lugares en los que existan indicios probatorios para la correcta justificación de los fondos recibidos por el beneficiario o la entidad colaboradora o de la realidad y regularidad de la actividad subvencionada.

5. Las coacciones al personal controlador que realice el control financiero.

h. El incumplimiento de la obligación de colaboración por parte de las personas o entidades a que se refiere el artículo 45 de la presente ley, cuando de ello se derive la imposibilidad de contrastar la información facilitada por el beneficiario o la entidad colaboradora.

i. Las demás conductas tipificadas como infracciones leves en la normativa de la Unión Europea en materia de subvenciones.

Artículo 55. Infracciones graves.

Constituyen infracciones graves las siguientes conductas:

a. El incumplimiento de la obligación de comunicar al órgano concedente o a la entidad colaboradora la obtención de subvenciones, ayudas públicas, ingresos o recursos para la misma finalidad a que se refiere el artículo 11 de la presente ley.

b. El incumplimiento de las condiciones establecidas alterando sustancialmente los fines para los que la subvención fue concedida.

c. La falta de justificación del empleo dado a los fondos recibidos una vez transcurrido el plazo establecido para su presentación.

d. La obtención de la condición de entidad colaboradora falseando los requisitos 
requeridos en las bases reguladoras de la subvención u ocultando los que la hubieran impedido.

e. El incumplimiento por parte de la entidad colaboradora de la obligación de verificar, en su caso, el cumplimiento y efectividad de las condiciones o requisitos determinantes para el otorgamiento de las subvenciones, cuando de ello se derive la obligación de reintegro.

f. Las demás conductas tipificadas como infracciones graves en la normativa de la Unión Europea en materia de subvenciones.

Artículo 56. Infracciones muy graves.

Constituyen infracciones muy graves las siguientes conductas:

a. La obtención de una subvención falseando las condiciones requeridas para su concesión u ocultando las que la hubieran impedido o limitado.

b. La no aplicación, en todo o en parte, de las cantidades recibidas a los fines para los que la subvención fue concedida.

c. La resistencia, excusa, obstrucción o negativa a las actuaciones de comprobación y control previstas, respectivamente, en los artículos 11 y 12 de la presente ley, cuando de ello se derive la imposibilidad de verificar el empleo dado a los fondos percibidos, o el cumplimiento de la finalidad y de la realidad y regularidad de las actividades subvencionadas, o la concurrencia de subvenciones, ayudas, ingresos o recursos para la misma finalidad, procedentes de cualquier administración o ente público o privado, estatal, de la Unión Europea o de organismos internacionales.

d. La falta de entrega, por parte de las entidades colaboradoras, cuando así se establezca, a los beneficiarios de los fondos recibidos de acuerdo con los criterios previstos en las bases reguladoras de la subvención.

e. Las demás conductas tipificadas como infracciones muy graves en la normativa de la Unión Europea en materia de subvenciones.

\section{Capítulo II DE LAS SANCIONES}

Artículo 57. Clases de sanciones.

1. Las infracciones en materia de subvenciones se sancionarán mediante la imposición de sanciones pecuniarias y, cuando proceda, de sanciones no pecuniarias.

2. Las sanciones pecuniarias podrán consistir en multa fija o proporcional. La sanción pecuniaria proporcional se aplicará sobre la cantidad indebidamente obtenida, aplicada o no justificada.

La multa fija estará comprendida entre 75 y 6.000 euros y la multa proporcional puede ir del tanto al triple de la cantidad indebidamente obtenida, aplicada o no justificada o, en el caso de entidades colaboradoras, de los fondos indebidamente aplicados o justificados.

La multa pecuniaria será independiente de la obligación de reintegro contemplada en el artículo 36 de la presente ley, así como de las indemnizaciones por daños y perjuicios que pudieran exigirse. Para su cobro resultará igualmente de aplicación el régimen jurídico previsto para los ingresos de derecho público en el Decreto legislativo $1 / 1999$, de 7 de octubre, por el que se aprueba el texto refundido de la Ley de régimen financiero y presupuestario de Galicia.

3. Las sanciones no pecuniarias, que se podrán imponer en caso de infracciones graves o muy graves, podrán consistir en:

a. La pérdida durante un plazo de hasta cinco años de la posibilidad de obtener subvenciones, ayudas públicas y avales de las administraciones públicas u otros entes públicos.

b. La pérdida durante un plazo de hasta cinco años de la posibilidad de actuar como entidad colaboradora en relación con las subvenciones reguladas en la presente ley.

c. La prohibición durante un plazo de hasta cinco años para contratar con las administraciones públicas. 
Artículo 58. Graduación de las sanciones.

1. Las sanciones por las infracciones a que se refiere este capítulo se graduarán atendiendo en cada caso concreto a:

a. La comisión repetida de infracciones en materia de subvenciones.

Se entenderá producida esta circunstancia cuando el sujeto infractor fuera sancionado por una infracción de la misma naturaleza, ya sea grave o muy grave, en virtud de resolución firme en vía administrativa dentro de los cuatro años anteriores a la comisión de la infracción.

Cuando concurra esta circunstancia en la comisión de una infracción grave o muy grave, el porcentaje de la sanción mínima se incrementará en 20 puntos porcentuales por cada infracción anteriormente sancionada, hasta un máximo de 60 .

b. La resistencia, negativa u obstrucción a las actuaciones de comprobación y control recogidas en la letra c) del apartado 1 del artículo 11 y en la letra d) del apartado 1 del artículo 12 de la presente ley. Cuando concurra esta circunstancia en la comisión de una infracción grave o muy grave, el porcentaje de la sanción mínima se incrementará entre 10 y 75 puntos de la siguiente forma:

1. ${ }^{\mathrm{a}}$ Por no aportar o no facilitar el examen de documentos, informes, antecedentes, libros, registros, ficheros, justificantes, asientos de contabilidad, programas y archivos informáticos, sistemas operativos y de control y cualquier otro dato objeto de comprobación, 15 puntos porcentuales.

$2{ }^{a}{ }^{a}$ Por no atender a requerimientos de la administración, 10 puntos por cada requerimiento desatendido.

3. ${ }^{\text {a }}$ Por la incomparecencia, salvo causa justificada, en el lugar y tiempo señalados, 10 puntos porcentuales.

4. ${ }^{\mathrm{a}}$ Por negar o impedir indebidamente la entrada o permanencia en locales de negocio y demás establecimientos o lugares en los que existan indicios probatorios para la correcta justificación de los fondos recibidos por el beneficiario o la entidad colaboradora o de la realidad y regularidad de la actividad subvencionada, 15 puntos porcentuales.

5. ${ }^{a}$ Por coacciones al personal controlador que desarrolle las actuaciones de comprobación y control, 50 puntos porcentuales.

6. ${ }^{\text {a }}$ Por otras causas establecidas reglamentariamente, hasta 20 puntos porcentuales.

c. La utilización de medios fraudulentos en la comisión de infracciones en materia de subvenciones.

A estos efectos, se considerarán principalmente medios fraudulentos los siguientes:

1. Las anomalías sustanciales en la contabilidad y en los registros legalmente establecidos.

2. El empleo de facturas, justificantes u otros documentos falsos o falseados.

3. La utilización de personas o entidades interpuestas que dificulten la comprobación de la realidad de la actividad subvencionada. Cuando concurra esta circunstancia en la comisión de una infracción grave o muy grave, el porcentaje de la sanción mínima se incrementará entre 20 y 100 puntos.

d. La ocultación a la administración, mediante la falta de presentación de la documentación justificativa o la presentación de documentación incompleta, incorrecta o inexacta, de los datos necesarios para la verificación de la aplicación dada a la subvención recibida. Cuando concurra esta circunstancia en la comisión de una infracción grave o muy grave, el porcentaje de la sanción se incrementará entre 10 y 50 puntos.

e. El retraso en el cumplimiento de las obligaciones formales.

2. Los criterios de graduación son aplicables simultáneamente. El criterio establecido en la letra e) se empleará exclusivamente para la graduación de las sanciones por infracciones leves.

3. Los criterios de graduación recogidos en los apartados anteriores no podrán utilizarse para agravar la infracción cuando 
estén contenidos en la descripción de la conducta infractora o formen parte del propio ilícito administrativo.

4. El importe de las sanciones leves impuestas a un mismo infractor por cada subvención no sobrepasará en su conjunto del importe de la subvención inicialmente concedida.

5. El importe de las sanciones graves y muy graves impuestas a un mismo infractor por cada subvención no sobrepasará en su conjunto del triple del importe de la cantidad indebidamente obtenida, aplicada o no justificada o, en el caso de entidades colaboradoras, de los fondos indebidamente aplicados o justificados.

Artículo 59. Sanciones por infracciones leves.

1. Cada infracción leve será sancionada con multa de 75 a 900 euros, salvo lo dispuesto en el apartado siguiente.

2. Serán sancionadas en cada caso con multa de 150 a 6.000 euros las siguientes infracciones:

a. La inexactitud u omisión de una o varias operaciones en la contabilidad y registros legalmente exigidos.

b. El incumplimiento de la obligación de la llevanza de contabilidad o de los registros legalmente establecidos.

c. La llevanza de contabilidades diversas que, referidas a una misma actividad, no permita conocer la verdadera situación de la entidad.

d. La utilización de cuentas con significado distinto del que les corresponde, según su naturaleza, que dificulte la comprobación de la realidad de las actividades subvencionadas.

e. La falta de aportación de pruebas y documentos requeridos por los órganos de control o la negativa a su exhibición.

f. El incumplimiento por parte de las entidades colaboradoras de las obligaciones establecidas en el artículo 12 de la presente ley.

g. El incumplimiento por parte de las personas o entidades sujetas a la obligación de colaboración y de facilitar la documentación a que se refiere el artículo 45 de la presente ley, cuando de ello se derive la imposibilidad de contrastar la información facilitada por el beneficiario o la entidad colaboradora.

Artículo 60. Sanciones por infracciones graves.

1. Las infracciones graves serán sancionadas con multa pecuniaria proporcional del tanto al doble de la cantidad indebidamente obtenida, aplicada o no justificada o, en el caso de entidades colaboradoras, de los fondos indebidamente aplicados o justificados.

2. Cuando el importe del perjuicio económico correspondiente a la infracción grave represente más del $50 \%$ de la subvención concedida o de las cantidades recibidas por las entidades colaboradoras, y excediera de 30.000 euros, concurriendo alguna de las circunstancias previstas en las letras b) y c) del apartado 1 del artículo 58 de la presente ley, los infractores podrán ser sancionados, además, con:

a. La pérdida durante un plazo de hasta tres años de la posibilidad de obtener subvenciones, ayudas públicas y avales de la administración u otros entes públicos.

b. La prohibición durante un plazo de hasta tres años para celebrar contratos con la administración u otros entes públicos.

c. La pérdida durante un plazo de hasta tres años de la posibilidad de actuar como entidad colaboradora en relación con las subvenciones reguladas en la presente ley.

Artículo 61. Sanciones por infracciones muy graves.

1. Las infracciones muy graves serán sancionadas con multa pecuniaria proporcional del doble al triple de la cantidad indebidamente obtenida, aplicada o no justificada o, en el caso de entidades colaboradoras, de los fondos indebidamente aplicados o justificados.

No obstante, no se sancionarán las infracciones recogidas en las letras b) y d) del artículo 56 cuando los infractores 
hubieran reintegrado las cantidades y los correspondientes intereses de demora sin previo requerimiento.

2. Cuando el importe del perjuicio económico correspondiente a la infracción muy grave exceda de 30.000 euros, concurriendo alguna de las circunstancias previstas en las letras b) y c) del apartado 1 del artículo 58 de la presente ley, los infractores podrán ser sancionados, además, con:

a. La pérdida durante un plazo de hasta cinco años de la posibilidad de obtener subvenciones, ayudas públicas y avales de la administración u otros entes públicos.

b. La prohibición durante un plazo de hasta cinco años para celebrar contratos con la administración $\mathrm{u}$ otros entes públicos.

c. La pérdida durante un plazo de hasta cinco años de la posibilidad de actuar como entidad colaboradora en relación con las subvenciones reguladas en la presente ley.

Artículo 62. Desarrollo reglamentario del régimen de infracciones y sanciones.

Las disposiciones reglamentarias de desarrollo podrán introducir especificaciones o graduaciones al cuadro de las infracciones $o$ sanciones establecidas legalmente que, sin constituir nuevas infracciones o sanciones, ni alterar la naturaleza o límites de las que la ley contempla, contribuyan a la más correcta identificación de las conductas o la más precisa determinación de las sanciones correspondientes.

Artículo 63. Prescripción de infracciones y sanciones.

1. Las infracciones prescribirán en el plazo de cuatro años a contar desde el día en el que la infracción se hubiera cometido.

2. Las sanciones prescribirán en el plazo de cuatro años a contar desde el día siguiente a aquél en que hubiera adquirido firmeza la resolución por la que se impuso la sanción.

3. El plazo de prescripción se interrumpirá de conformidad con lo establecido en el artículo 132 de la Ley 30/1992, de 26 de noviembre, de régimen jurídico de las administraciones públicas y del procedimiento administrativo común.

4. La prescripción se aplicará de oficio, sin perjuicio de que pueda ser solicitada su declaración por el interesado.

Artículo 64. Competencia para la imposición de sanciones.

Las sanciones en materia de subvenciones serán acordadas e impuestas por los titulares de los departamentos concedentes, salvo en relación con aquéllas que para su concesión hubieran necesitado de la autorización del Consejo de la Xunta, caso en el que será competente este último. En caso de subvenciones concedidas por las demás entidades concedentes, las sanciones serán acordadas e impuestas por los titulares de los departamentos a los que hubieran estado e adscritas.

No obstante, cuando la sanción consista en la pérdida de la posibilidad de obtener subvenciones, ayudas públicas y avales de la Comunidad Autónoma, en la prohibición para celebrar contratos con la Comunidad Autónoma o en la pérdida de la posibilidad de actuar como entidad colaboradora en relación con las subvenciones reguladas en la presente ley, la competencia corresponderá al Consejo de la Xunta.

El titular del departamento designará al instructor del procedimiento sancionador cuando dicha función no esté previamente atribuida a ningún órgano administrativo.

Artículo 65. Publicidad de las sanciones.

1. Las resoluciones sancionadoras impuestas por infracciones graves o muy graves que hubieran ganado firmeza en la vía administrativa se publicarán en el Diario Oficial de Galicia. Asimismo, habrán de comunicarse a los registros de subvenciones y de contratistas de la Administración de la Comunidad Autónoma.

2. Todas las sanciones administrativas firmes en materia de subvenciones figurarán en el Registro Público de Sanciones con expresión de las personas físicas o 
jurídicas afectadas, la normativa infringida y el importe de la sanción.

Artículo 66. Procedimiento sancionador.

1. La imposición de las sanciones en materia de subvenciones se efectuará mediante expediente administrativo en el que, en todo caso, se dará audiencia al interesado antes de dictarse el acuerdo correspondiente y que será tramitado de conformidad con lo dispuesto en el capítulo II del título IX de la Ley 30/1992, de 26 de noviembre, de régimen jurídico de las administraciones públicas y del procedimiento administrativo común.

2. El procedimiento se iniciará de oficio, como consecuencia de la actuación de comprobación desarrollada por el órgano concedente o por la entidad colaboradora, así como de las actuaciones de control financiero previstas en la presente ley.

3. Los acuerdos de imposición de sanciones pondrán fin a la vía administrativa.

Artículo 67. Extinción de la responsabilidad derivada de la comisión de infracciones.

La responsabilidad derivada de las infracciones se extingue por el pago o cumplimiento de la sanción o por prescripción o por fallecimiento.

Artículo 68. Responsabilidades.

1. Responderán solidariamente de la sanción pecuniaria los miembros, partícipes o cotitulares de las entidades a que se refiere el apartado 3 del artículo 8 , en proporción a sus respectivas participaciones, cuando se trate de comunidades de bienes o cualquier otro tipo de unidad económica o patrimonio separado.

2. Responderán subsidiariamente de la sanción pecuniaria los administradores de las sociedades mercantiles, o aquellos que ostenten la representación legal de otras personas jurídicas, de acuerdo con las disposiciones legales o estatutarias que les resulten de aplicación, que no realicen los actos necesarios que sean de su incumbencia para el cumplimiento de las obligaciones infringidas, adopten acuerdos que hagan posibles los incumplimientos o consientan los de quienes de ellos dependan.

3. En el caso de sociedades o entidades disueltas y liquidadas en las que la ley limita la responsabilidad patrimonial de los socios, partícipes o cotitulares, las sanciones pendientes se transmitirán a éstos, que quedarán obligados solidariamente hasta el límite del valor de la cuota de liquidación que se les hubiera adjudicado o se les hubiera debido adjudicar.

4. En el caso de sociedades o entidades disueltas y liquidadas en las que la ley no limita la responsabilidad patrimonial de los socios, partícipes o cotitulares, las sanciones pendientes se transmitirán a éstos, que quedarán obligados solidariamente a su cumplimiento.

\section{DISPOSICIÓN ADICIONAL PRIMERA ADAPTACIÓN DE PROCEDIMIENTOS}

Los procedimientos establecidos en la presente ley se adaptarán reglamentariamente a las condiciones de organización y funcionamiento de la Administración local de Galicia.

\section{DISPOSICIÓN ADICIONAL SEGUNDA RÉGIMEN ESPECIAL DE LAS AYUDAS EN MATERIA DE COOPERACIÓN EXTERIOR}

1. Las subvenciones en materia de cooperación para el desarrollo reguladas en la Ley 3/2003, de 19 de junio, se someterán en su concesión a los principios de publicidad y concurrencia, salvo que proceda la aplicación del régimen previsto en el artículo 19.4 de la presente ley.

2. Al objeto de lograr una mayor eficacia y eficiencia en la gestión de los fondos públicos destinados a la cooperación para el desarrollo, las bases reguladoras podrán establecer sistemas específicos de pagos anticipados de hasta el $100 \%$ de la subvención concedida, sin la obligación de presentar garantías, así como regímenes especiales de justificación y control cuando 
la naturaleza de los proyectos o características de los destinatarios lo requieran.

\section{DISPOSICIÓN ADICIONAL TERCERA AYUDAS EN ESPECIE}

Las ayudas consistentes en la cesión de bienes o derechos del patrimonio de la Comunidad Autónoma se regirán por la legislación del patrimonio. No obstante, las entregas de bienes o derechos o la prestación de servicios adquiridos o contratados con la finalidad exclusiva de entregarlos a terceros y que cumplan los requisitos establecidos en las letras a), b) y c) del artículo 2.1 de la presente ley tendrán la consideración de subvenciones en especie y quedarán sujetas a las previsiones de la presente ley, sin perjuicio de las especificidades de la gestión presupuestaria que reglamentariamente se determinen.

\section{DISPOSICIÓN ADICIONAL CUARTA ACTIVIDAD DE PATROCINIO}

La actividad del patrocinio se regirá por su normativa específica y supletoriamente por la presente ley.

\section{DISPOSICIÓN ADICIONAL QUUINTA UNIVERSIDADES}

Las universidades de la Comunidad Autónoma de Galicia se sujetarán a las previsiones de la presente ley sin perjuicio de las peculiaridades derivadas de su propia organización.

\section{DISPOSICIÓN ADICIONAL SEXTA REGISTRO PÚBLICO DE AYUDAS, SUBVENCIONES Y CONVENIOS}

1. Las entidades locales y las universidades de la Comunidad Autónoma de Galicia deberán crear un Registro Público de Ayudas, Subvenciones y Convenios, que permita su consulta pública y la elaboración de la correspondiente información estadística. Este registro deberá ponerse en marcha dentro del plazo de un año a partir de la publicación de la presente ley.
2. En cada un de los registros creados se consignarán las subvenciones concedidas, con expresión de la convocatoria, del programa y del crédito presupuestario al que se imputan, del beneficiario, de la cantidad concedida y de la finalidad o finalidades de la subvención.

3. Este registro es complementario de las obligaciones de publicidad a que están obligadas las entidades y se gestionará teniendo en cuenta, en todo caso, la necesidad de preservación del derecho al honor, a la intimidad persoal y familiar y a la propia imagen.

\section{DISPOSICIÓN ADICIONAL SÉPTIMA \\ ACTUALIZACIÓN DE LAS CUANTÍAS PREVISTAS EN LA PRESENTE LEY}

Se autoriza al Consejo de la Xunta de Galicia para que, a propuesta del consejero competente en materia de economía y hacienda, pueda actualizar, mediante decreto, las cuantías recogidas en la presente ley.

\section{DISPOSICIÓN ADICIONAL OCTAVA AUTORIZACIÓN A LA CONSEJERÍA COMPETENTE EN MATERIA DE ECONOMÍA Y HACIENDA PARA LA REGULACIÓN DE PROCEDIMIENTOS EN MATERIA DE SUBVENCIONES POR MEDIOS TELEMÁTICOS}

Se autoriza a la consejería competente en materia de economía y hacienda para que mediante orden establezca las normas que regulen el empleo de medios electrónicos, informáticos y telemáticos en los procedimientos relativos a las subvenciones previstos en la presente ley.

\section{DISPOSICIÓN TRANSITORIA PRIMERA RÉGIMEN TRANSITORIO DE LOS PROCEDIMIENTOS}

1. A los procedimientos de concesión de subvenciones iniciados a la entrada en vigor de la presente ley les será de aplicación la normativa vigente en el momento de su iniciación. 
2. Sin perjuicio de lo dispuesto en el párrafo anterior, los procedimientos de control financiero, reintegro y revisión de actos previstos en la presente ley resultarán de aplicación desde su entrada en vigor.

3. El régimen sancionador previsto en la presente ley será de aplicación a las personas beneficiarias y a las entidades colaboradoras, en los supuestos previstos en esta disposición, siempre que el régimen jurídico sea más favorable que el previsto en la legislación anterior.

4. La adaptación reglamentaria de los procedimientos establecidos en la presente ley a las condiciones de organización y funcionamiento de la Administración local de Galicia se realizará en el plazo de nueve meses a partir de su entrada en vigor.

\section{DISPOSICIÓN TRANSITORIA SEGUNDA IGAPE}

Los incentivos a la actividad empresarial en la Comunidad Autónoma de Galicia, establecidos al amparo del Decreto 172/2001, de 12 de julio, cuya gestión corresponde al Instituto Gallego de Promoción Económica, se regularán por lo dispuesto en sus bases reguladoras en tanto no se cierre definitivamente el marco de apoyo comunitario establecido para el periodo 2000-2006 por la Comisión Europea, excepto en lo referido al régimen de control financiero y a las infracciones y sanciones administrativas en materia de subvenciones, que se regirán por lo dispuesto en la presente ley.

\section{DISPOSICIÓN TRANSITORIA TERCERA EXONERACIÓN DE LA PRESENTACIÓN DE LOS JUSTIFICANTES DE ACREDITACIÓN DE OBLIGACIONES TRIBUTARIAS, CON LA SEGURIDAD SOCIAL Y DEUDAS CON LA ADMINISTRACIÓN DE LA COMUNIDAD AUTÓNOMA}

La Ley de presupuestos de la Comunidad Autónoma determinará las ayudas y subvenciones en las que se producirá la exoneración de la presentación de los justificantes de acreditación de obligaciones tributarias, con la Seguridad Social y deudas con la Administración de la Comunidad Autónoma en tanto no se aprueben las disposiciones reglamentarias previstas para el desarrollo y aplicación de la presente ley.

\section{DISPOSICIÓN DEROGATORIA ÚNICA DEROGACIÓN NORMATIVA}

1. Quedan derogadas todas las normas de igual o inferior rango en lo que contradigan o se opongan a lo dispuesto en la presente ley.

2. Quedan derogadas las siguientes disposiciones:

a. Del Decreto legislativo 1/1999, de 7 de octubre, por el que se aprueba el texto refundido de la Ley de régimen financiero y presupuestario de Galicia, los artículos 78 y 79 y la disposición adicional cuarta.

b. El Decreto 287/2000, de 21 de noviembre, por el que se desarrolla el régimen de ayudas y subvenciones públicas de la Comunidad Autónoma de Galicia, en cuanto se oponga a lo establecido en la presente ley.

c. El Decreto 21/1992, de 29 de enero, que desarrolla el artículo 31 de la Ley 15/1991, de 28 diciembre, de presupuestos generales de la Comunidad Autónoma para 1992, en materia de subvenciones y ayudas.

d. De la Ley 3/2003, de 19 de junio, de cooperación para el desarrollo, el apartado 5 del artículo 29.

\section{DISPOSICIÓN FINAL ÚNICA DESARROLLO Y ENTRADA EN VIGOR}

1. En el plazo de seis meses a partir de la entrada en vigor de la presente ley se aprobará un reglamento general para su aplicación.

2. La presente ley entrará en vigor tres meses después de su publicación en el Diario Oficial de Galicia. 


\section{LEY 9/2008, DE 28 DE JULIO, GALLEGA DE MEDIDAS TRIBUTARIAS EN RELACIÓN CON EL IMPUESTO SOBRE SUCESIONES Y DONACIONES (DOGA 152. 7.8.2008) 222 $(\ldots)^{223}$ \\ TítULO I ADQUISICIONES POR CAUSA DE MUERTE}

\section{Capítulo único REDUCCIONES DE LA BASE IMPONIBLE}

\section{Sección primera \\ Reducciones subjetivas} tesco.

Artículo 1. Reducciones por paren-

En las adquisiciones por causa de muerte, incluidas las de los beneficiarios de pólizas de seguros de vida, se aplicarán las siguientes reducciones:

Por razón del parentesco con el causante, la que corresponda de las incluidas en los siguientes grupos:

a. Grupo I: adquisiciones por descendientes y adoptados menores de 21 años, 1.000 .000 de euros, más 100.000 euros por cada año menos de 21 que tenga el causahabiente, con un límite de 1.500 .000 euros.

b. Grupo II: adquisiciones por descendientes y adoptados de 21 años o más y menores de 25, 900.000 euros, menos 100.000 euros por cada año mayor de 21 hasta 24; de 25 años o más, cónyuges, ascendientes y adoptantes: 18.000 euros.

c. Grupo III: adquisiciones por colaterales de segundo y tercer grado, y ascendientes y descendientes por afinidad: 8.000 euros.

d. Grupo IV: en las adquisiciones por colaterales de cuarto grado, grados más

$\overline{222}$ Orden de 27 de agosto de 2008 por la que se aprueban los modelos D650, 650 y 651 del impuesto sobre sucesiones y donaciones.

223 Exposición de motivos omitida. distantes y extraños, no habrá lugar a reducción.

Artículo 2. Reducción por discapacidad.

Se aplicarán, además de las que puedan corresponder en función del grado de parentesco con el causante, las siguientes reducciones:

a. Reducción de 150.000 euros a las personas que tengan la consideración legal de personas discapacitadas, con un grado de minusvalía igual o superior al $33 \%$ e inferior al $65 \%$, de acuerdo con el baremo al que se refiere el artículo 148 del texto refundido de la Ley general de la Seguridad Social, aprobada por Real decreto legislativo 1/1994, de 20 de junio.

b. Reducción del $100 \%$ de la base imponible para aquellas personas pertenecientes a los grupos I y II a que hace referencia el artículo 1 de la presente ley que, con arreglo a la normativa anteriormente citada, acrediten un grado de minusvalía igual o superior al $65 \%$, siempre que el patrimonio preexistente del sujeto pasivo no exceda de 3.000 .000 de euros.

c. Reducción de 300.000 euros para aquellas personas que, con arreglo a la normativa anteriormente citada, acrediten un grado de minusvalía igual o superior al $65 \%$ y no tengan derecho a la reducción señalada en la letra anterior.

El grado de minusvalía habrá de acreditarse mediante certificado o resolución expedida por el órgano competente. En particular, se considerará acreditado un grado de minusvalía igual o superior al $33 \%$ en el caso de los pensionistas de la Seguridad Social que tengan reconocida una pensión de incapacidad permanente total, absoluta o gran invalidez y en el caso de los pensionistas de clases pasivas que tengan reconocida una pensión de jubilación o retiro por incapacidad permanente para el servicio o inutilidad. Igualmente, se considerará acreditado un grado de minusvalía igual o superior al $65 \%$ cuando se trate de personas cuya incapacidad sea 
declarada judicialmente, aunque no alcance dicho grado, así como en los casos de dependencia severa y gran dependencia, siempre que estas últimas situaciones fuesen reconocidas por el órgano competente, de acuerdo con lo establecido en el artículo 28 de la Ley 39/2006, de 14 de diciembre, de promoción de la autonomía personal y atención a las personas en situación de dependencia.

Artículo 3. Reducción por la adquisición de las indemnizaciones del síndrome tóxico y por actos de terrorismo.

Cuando en la base imponible de una adquisición mortis causa se integren indemnizaciones satisfechas por las administraciones públicas a las personas herederas de los afectados por el síndrome tóxico, se practicará una reducción del 99\% sobre los importes percibidos, con independencia de las otras reducciones que procedan, teniendo la misma carácter retroactivo, y siendo por tanto de aplicación con independencia tanto de la fecha del devengo del impuesto como del reconocimiento y pago de la indemnización.

Será de aplicación el mismo porcentaje de reducción, y con el mismo carácter, en las prestaciones públicas extraordinarias por actos de terrorismo percibidas por los herederos.

Artículo 4. Incompatibilidad de reducciones.

Las reducciones contempladas en los artículos 1 y 2 suponen una mejora con respecto a las mismas reducciones establecidas por la normativa estatal y sustituyen a éstas. La establecida en el artículo 3 se establece como propia.

\section{sección segunda \\ Reducciones objetivas}

Artículo 5. Reducción por la adquisición de bienes y derechos afectos a una actividad económica y de participaciones en entidades.

En los casos en los que en la base imponible de una adquisición mortis causa estuviese incluido el valor de una empresa individual o de un negocio profesional, o de participaciones en entidades o de derechos de usufructo sobre los mismos, se practicará una reducción del 99\% del mencionado valor cuando concurran las siguientes circunstancias:

a. Que el centro principal de gestión de la empresa o del negocio profesional, o el domicilio fiscal de la entidad, se encuentre situado en Galicia y se mantenga durante los cinco años siguientes a la fecha de devengo del impuesto.

b. Que a la fecha de devengo del impuesto a la empresa individual, al negocio profesional o a las participaciones les fuese de aplicación la exención regulada en el apartado $8 .^{\circ}$ del artículo 4 de la Ley 19/1991, de 6 de junio, del impuesto sobre el patrimonio. A estos efectos, la participación del sujeto pasivo en el capital de la entidad debe ser:

Con carácter general, del 50 por 100 como mínimo, ya sea de forma individual o conjuntamente con su cónyuge, ascendientes, descendientes o colaterales de hasta el cuarto grado de la persona fallecida, ya tenga su origen el parentesco en la consanguinidad, la afinidad o la adopción.

Del 5\% computado de forma individual, o del $20 \%$ conjuntamente con su cónyuge, ascendientes, descendientes o colaterales de hasta el cuarto grado del fallecido, ya tenga su origen el parentesco en la consanguinidad, la afinidad o la adopción, cuando se trate de participaciones en entidades que tengan la consideración de empresas de reducida dimensión de acuerdo con lo dispuesto en el artículo 108 del Real decreto legislativo 4/2004, de 5 de marzo, por el que se aprueba el texto refundido de la Ley del impuesto sobre sociedades.

En caso de que tan sólo se tenga derecho parcial a la exención regulada en el apartado $8 .^{\circ}$ del artículo 4 de la Ley 19/1991, de 6 de junio, del impuesto sobre el patrimonio, también será de aplicación, en la misma proporción, esta reducción. 
c. Que la adquisición corresponda al cónyuge, descendientes o adoptados, ascendientes o adoptantes y colaterales, por consanguinidad hasta el tercer grado inclusive, del causante.

d. Que la persona adquiriente mantenga lo adquirido y cumpla los requisitos de la exención del impuesto sobre el patrimonio durante los cinco años siguientes al devengo del impuesto de acuerdo con lo establecido en los apartados anteriores de este artículo, salvo que dentro de dicho plazo falleciese la persona adquiriente o transmitiese la adquisición en virtud de pacto sucesorio con arreglo a lo previsto en la Ley de derecho civil de Galicia.

e. Que la empresa individual o la entidad haya venido ejerciendo efectivamente las actividades de su objeto social durante un periodo superior a los dos años anteriores al devengo del impuesto.

Artículo 6. Reducción por la adquisición de explotaciones agrarias y de elementos afectos.

1. En los casos en los que en la base imponible de una adquisición mortis causa estuviese incluido el valor de una explotación agraria ubicada en Galicia o de derechos de usufructo sobre la misma, se practicará una reducción del 99\% del mencionado valor cuando concurran las siguientes circunstancias:

a. Que a la fecha de devengo el causante tuviese la condición de agricultor/a profesional.

b. Que la adquisición corresponda al cónyuge, descendientes o adoptados, ascendientes o adoptantes y colaterales, por consanguinidad hasta el tercer grado inclusive, del causante.

c. Que la persona adquiriente mantenga en su patrimonio la explotación agraria durante los cinco años siguientes al devengo del impuesto, salvo que dentro de dicho plazo falleciese la persona adquiriente o transmitiese la explotación en virtud de pacto sucesorio con arreglo a lo previsto en la Ley de derecho civil de Galicia.

d. Que la explotación agraria haya venido ejerciendo efectivamente actividades agrarias durante un periodo superior a los dos años anteriores al devengo del impuesto.

2. Cuando en la base imponible de una adquisición mortis causa estuviese incluido el valor de elementos de una explotación agraria ubicada en Galicia o de derechos de usufructo sobre los mismos, se practicará una reducción del 99\% del mencionado valor cuando concurran las siguientes circunstancias:

a. Que la adquisición corresponda al cónyuge, descendientes o adoptados, ascendientes o adoptantes y colaterales, por consanguinidad hasta el tercer grado inclusive, del causante.

b. Que a la fecha de devengo las personas adquirientes tuviesen la condición de agricultor/a profesional en cuanto a la dedicación de trabajo y procedencia de rentas, y sean titulares bien de una explotación agraria a la cual estén afectos los elementos que se transmiten o bien socios/as de una sociedad agraria de transformación, cooperativa de explotación comunitaria de la tierra o sociedad civil que sea titular de una explotación agraria a la que estén afectos los elementos que se transmiten.

c. Que la persona adquiriente mantenga los elementos adquiridos afectos a la explotación agraria durante los cinco años siguientes al devengo del impuesto, salvo que dentro de dicho plazo falleciese la persona adquiriente o transmitiese los elementos en virtud de pacto sucesorio con arreglo a lo previsto en la Ley de derecho civil de Galicia.

d. Que la explotación agraria haya venido ejerciendo efectivamente actividades agrarias durante un periodo superior a los dos años anteriores al devengo del impuesto. 
3. A efectos de las reducciones contempladas en los apartados 1 y 2 anteriores, los términos de «explotación agraria», «agricultor/a profesional», «elementos de una explotación» y «titular de la explotación» son los definidos en la Ley 19/1995, de 4 de julio, de modernización de las explotaciones agrarias.

Artículo 7. Reducción por adquisición de vivienda habitual.

1. Cuando en la base imponible de una adquisición mortis causa estuviese incluido el valor de la vivienda habitual del causante, y la adquisición corresponda a sus descendientes o adoptados, ascendientes o adoptantes y colaterales, por consanguinidad, se practicará una reducción con un límite de 600.000 euros aplicando el porcentaje de reducción que corresponda en función del valor real total del inmueble:

\begin{tabular}{|l|c|}
\hline \multicolumn{1}{|c|}{$\begin{array}{c}\text { Valor real del } \\
\text { inmueble }\end{array}$} & $\begin{array}{c}\text { Porcentaje de } \\
\text { reducción }\end{array}$ \\
\hline $\begin{array}{l}\text { Hasta } 150.000,00 \\
\text { euros }\end{array}$ & 99 \\
\hline $\begin{array}{l}\text { De } 150.000,01 \text { a } \\
300.000,00\end{array}$ & 97 \\
\hline Más de $300.000,00$ & 95 \\
\hline
\end{tabular}

Cuando la adquisición corresponda al cónyuge, la reducción será del 100\% del valor en la base imponible con un límite de 600.000 euros.

En caso del pariente colateral, éste habrá de ser mayor de 65 años y será necesaria la convivencia con el causante durante los dos años anteriores al fallecimiento.

2. Las personas adquirientes deberán mantener la vivienda adquirida durante los cinco años siguientes al devengo del impuesto, salvo que dentro de dicho plazo falleciese la persona adquiriente o transmitiese la vivienda en virtud de pacto sucesorio con arreglo a lo previsto en la Ley de derecho civil de Galicia.
En caso de que se produjese la venta de la vivienda durante el indicado plazo, y la totalidad de su importe se reinvierta en la adquisición de una vivienda ubicada en Galicia que constituya o vaya a constituir la vivienda habitual de la persona adquiriente, no se perderá la reducción solicitada.

3. Se considerará vivienda habitual, y reinversión en vivienda habitual, la que se ajuste a la definición y a los requisitos establecidos por la normativa del impuesto sobre la renta de las personas físicas.

4. Cuando por un mismo transmitente se produjese la transmisión de varias viviendas habituales en uno o en varios actos, por causa de muerte o por pactos sucesorios, únicamente se podrá practicar la reducción por una sola vivienda habitual.

Artículo 8. Reducción por la adquisición de fincas rústicas incluidas en la Red gallega de espacios protegidos.

1. Cuando en la base imponible de una adquisición mortis causa estuviese incluido el valor de fincas rústicas de dedicación forestal ubicadas en terrenos incluidos en la Red gallega de espacios protegidos, y siempre que la adquisición corresponda al cónyuge, descendientes o adoptados, ascendientes o adoptantes o colaterales, por consanguinidad hasta el tercer grado inclusive del causante, se practicará una reducción del 95\% del mencionado valor.

2. Las personas adquirientes deberán mantener las fincas adquiridas durante los cinco años siguientes al devengo del impuesto, salvo que dentro de dicho plazo falleciese la persona adquiriente o las transmitiese en virtud de pacto sucesorio con arreglo a lo previsto en la Ley de derecho civil de Galicia.

Artículo 9. Incompatibilidad de reducciones.

Las reducciones contempladas en esta sección, salvo la regulada en el artículo 7 , son propias de la comunidad autónoma y serán incompatibles, para una misma 
Código de la Administración Gallega

adquisición, entre sí y con la aplicación de las reducciones reguladas en la Ley 29/1987, de 18 de diciembre, del impuesto sobre sucesiones y donaciones, o con las reguladas en leyes especiales en relación con este impuesto, siempre que hubiesen sido establecidas en consideración a la naturaleza del bien objeto de aquéllas.

Artículo 10. Requisito de mantenimiento e incumplimiento de requisitos.

1. El causahabiente no podrá hacer, en los periodos de mantenimiento establecidos en cada reducción, actos de disposición u operaciones societarias que, directa o indirectamente, puedan dar lugar a una minoración sustancial del valor de adquisición.

2. Si dejasen de cumplir los requisitos establecidos en las anteriores reducciones, deberá pagarse la parte del impuesto que se haya dejado de ingresar como consecuencia de la reducción practicada y los intereses de demora.

Artículo 11. Solicitud de las reducciones.

Las reducciones contempladas en esta sección no se aplicarán de oficio, habiendo de solicitarse por los sujetos pasivos en la presentación de la declaración del impuesto. La solicitud no podrá rectificarse con posterioridad, salvo que la rectificación se presentase en el periodo reglamentario de declaración.

Artículo 12. Base de las reducciones.

El porcentaje de reducción se aplicará sobre el resultado de deducir del valor del bien o derecho el importe de las cargas y gravámenes que contempla el artículo 12 de la Ley 29/1987, de 18 de diciembre, así como la parte proporcional del importe de las deudas y gastos que sean deducibles de acuerdo con los artículos 13 y 14 de la misma ley, siempre que estos últimos se hubieran tenido en cuenta en la fijación de la base imponible individual del causahabiente.

\section{TÍTULO II \\ ADQUISICIONES LUCRATIVAS ENTRE VIVOS}

\section{Capitulo único REDUCCIONES DE LA BASE IMPONIBLE}

\author{
Sección única \\ Reducciones objetivas
}

Artículo 13. Reducción por la adquisición de bienes y derechos afectos a una actividad económica y de participaciones en entidades.

En los casos de transmisión de participaciones inter vivos de una empresa individual o de un negocio profesional o de participaciones en entidades, se aplicará una reducción en la base imponible, para determinar la base liquidable, del $99 \%$ del valor de adquisición, siempre y cuando concurran las siguientes condiciones:

a. Que la persona donante tenga 65 años o más o se encuentre en situación de incapacidad permanente en grado de absoluta o gran invalidez.

b. Que, si la persona donante viniese ejerciendo funciones de dirección, deje de ejercer y percibir remuneraciones por el ejercicio de dichas funciones desde el momento de la transmisión.

A estos efectos, no se entenderá comprendida entre las funciones de dirección la mera pertenencia al consejo de administración de la sociedad.

c. Que el centro principal de gestión de la empresa o del negocio profesional, o el domicilio fiscal de la entidad, se encuentre situado en Galicia y que se mantenga durante los cinco años siguientes a la fecha de devengo del impuesto.

d. Que a la fecha del devengo del impuesto a la empresa individual, al negocio profesional o a las participaciones les fuese de aplicación la exención regulada en el apartado $8 .^{\circ}$ del artículo 4 de la Ley 19/1991, de 6 de junio, del impuesto sobre el patrimonio. A estos efectos, la participación del sujeto pasivo en el capital de la entidad debe ser: 
Con carácter general, del $50 \%$ como mínimo, ya sea de forma individual o conjuntamente con su cónyuge, ascendientes, descendientes o colaterales de hasta el cuarto grado, ya tenga su origen el parentesco en la consanguinidad, la afinidad o la adopción.

Del 5\% computado de forma individual, o del $20 \%$ conjuntamente con su cónyuge, ascendientes, descendientes o colaterales de hasta el cuarto grado, ya tenga su origen el parentesco en la consanguinidad, la afinidad o la adopción, cuando se trate de participaciones en entidades que tengan la consideración de empresas de reducida dimensión de acuerdo con lo dispuesto en el artículo 108 del Real decreto legislativo $4 / 2004$, de 5 de marzo, por el que se aprueba el texto refundido de la Ley del impuesto sobre sociedades.

En caso de que tan sólo se tenga derecho parcial a la exención regulada en el apartado $8 .^{\circ}$ del artículo 4 de la Ley 19/1991, de 6 de junio, del impuesto sobre el patrimonio, también será de aplicación, en la misma proporción, esta reducción.

e. Que la adquisición corresponda al cónyuge, descendientes o adoptados y colaterales, por consanguinidad hasta el tercer grado inclusive, de la persona donante.

f. Que la persona adquirente mantenga lo adquirido y cumpla los requisitos de la exención del impuesto sobre el patrimonio durante los cinco años siguientes al devengo del impuesto de acuerdo con lo establecido en los apartados anteriores de este artículo, salvo que dentro de dicho plazo falleciese la persona adquirente o transmitiese la adquisición en virtud de pacto sucesorio con arreglo a lo previsto en la Ley de derecho civil de Galicia.

g. Que la empresa individual o la entidad haya venido ejerciendo efectivamente las actividades de su objeto social durante un periodo superior a los dos años anteriores al devengo del impuesto.
Artículo 14. Reducción por la adquisición de explotaciones agrarias.

En los casos de transmisiones de participaciones inter vivos de una explotación agraria ubicada en Galicia o de derechos de usufructo sobre la misma, se aplicará una reducción en la base imponible, para determinar la base liquidable, del 99\% del valor de adquisición, siempre y cuando concurran las siguientes condiciones:

a. Que la persona donante tenga $65 \mathrm{o}$ más años o se encuentre en situación de incapacidad permanente en grado de absoluta o gran invalidez.

b. Que a la fecha de devengo la persona donante tenga la condición de agricultor/a profesional y perdiese tal condición a consecuencia de la donación.

c. Que la adquisición corresponda al cónyuge, descendientes o adoptados y colaterales, por consanguinidad hasta el tercer grado inclusive, de la persona donante.

d. Que la persona adquiriente mantenga en su patrimonio la explotación agraria y su condición de agricultor/a profesional durante los cinco años siguientes al devengo del impuesto, salvo que dentro de dicho plazo falleciese la persona adquiriente o transmitiese la explotación en virtud de pacto sucesorio con arreglo a lo previsto en la Ley de derecho civil de Galicia.

e. Que la explotación agraria haya venido ejerciendo efectivamente las actividades de su objeto social durante un periodo superior a los dos años anteriores al devengo del impuesto.

Artículo 15. Reducción por la adquisición de bienes y derechos afectos a una actividad económica, de participaciones en entidades y de explotaciones agrarias en los pactos sucesorios.

En caso de los hechos imponibles contemplados en el apartado a) del artículo 3.1. ${ }^{\circ}$ de la Ley 29/1987, de 18 de diciembre, del impuesto sobre sucesiones y donaciones, en los que no se produjese el fallecimiento 
del transmitente, los requisitos para la aplicación de la reducción por la adquisición de bienes y derechos afectos a una actividad económica, de participaciones en entidades y de explotaciones agrarias serán los establecidos para las adquisiciones inter vivos.

Artículo 16. Reducción por la adquisición de dinero destinado a la adquisición de una vivienda habitual en Galicia.

En las donaciones a hijos y descendientes de dinero destinado a la adquisición de su vivienda habitual se aplicará una reducción del 95\% de la base imponible del impuesto, siempre que se cumplan los siguientes requisitos:

a. La persona donataria deberá ser menor de 35 años o mujer víctima de violencia de género. En el primer caso debe tratarse de la adquisición de su primera vivienda habitual. En el segundo, no debe ser titular de otra vivienda.

b. El importe de la donación no podrá sobrepasar los 60.000 euros. Este límite es único y se aplica tanto en el caso de una sola donación como en el caso de donaciones sucesivas, siempre que se otorgasen a favor de la misma persona donataria, provengan de uno o de distintos ascendientes. En caso de que el importe de la donación o donaciones a que se refiere este artículo sobrepasase esta cantidad, no habrá derecho a reducción alguna.

c. La suma de la base imponible total menos el mínimo personal y familiar a efectos del IRPF del donatario, correspondiente al último periodo impositivo, cuyo plazo reglamentario de declaración estuviese concluido a la fecha del devengo de la primera donación, no podrá ser superior a 30.000 euros.

d. La donación ha de formalizarse en escritura pública en la que se exprese la voluntad de que el dinero donado se destine a la adquisición de la vivienda habitual de la persona donataria. En caso de los menores de 35 años habrá de constar también que se trata de su primera vivienda habitual. Esta declaración de voluntad habrá de ser simultánea a la donación.

e. La persona donataria deberá adquirir una vivienda ubicada en Galicia en los seis meses siguientes a la donación. En caso de haber varias donaciones, el plazo se computará desde la fecha de la primera donación. La reducción no se aplicará a donaciones de dinero posteriores a la compra de la vivienda, salvo en los supuestos de adquisición con precio aplazado o financiación ajena, siempre que se acreditase que el importe del dinero donado se destina al pago del precio pendiente o a la cancelación total o parcial del crédito, con el plazo, límites y requisitos establecidos en los apartados anteriores, salvo en la forma de computar el plazo de seis meses, que se hará para cada donación.

f. Se considerará vivienda habitual la que se ajuste a la definición y a los requisitos establecidos por la normativa del impuesto sobre la renta de las personas físicas. La acreditación de la situación de violencia de género se hará según lo dispuesto en la Ley 11/2007, de 27 de julio, gallega para la prevención y el tratamiento integral de la violencia de género.

Artículo 17. Incompatibilidad de reducciones.

Las reducciones contempladas en esta sección son propias de la comunidad autónoma, siendo incompatibles, para una misma adquisición, entre sí y con la aplicación de las reducciones reguladas en la Ley 29/1987, de 18 de diciembre, del impuesto sobre sucesiones y donaciones, o con las consideradas en leyes especiales en relación con este impuesto siempre que hubiesen sido establecidas en consideración a la naturaleza del bien objeto de aquéllas.

Artículo 18. Requisito de mantenimiento e incumplimiento de requisitos.

1. El causahabiente no podrá hacer actos de disposición u operaciones societarias 
Régimen financiero

que, directa o indirectamente, puedan dar lugar a una minoración sustancial del valor de adquisición.

2. Si dejasen de cumplir los requisitos establecidos en las anteriores reducciones, deberá pagarse la parte del impuesto que se haya dejado de ingresar como consecuencia de la reducción practicada y los intereses de demora.

Artículo 19. Solicitud de las reducciones.

Las reducciones contempladas en esta sección no se aplicarán de oficio, habiendo de solicitarse por los sujetos pasivos en la presentación de la declaración del impuesto, y no podrá rectificarse con posterioridad, salvo que la rectificación se presentase en el periodo reglamentario de declaración.

Artículo 20. Base de las reducciones. El porcentaje de reducción se aplicará sobre el resultado de deducir del valor del bien o derecho el importe de las cargas y gravámenes que contemplan los artículos 12 y 16 de la Ley 29/1987, de 18 de diciembre, así como la parte proporcional del importe de las deudas que sean deducibles de acuerdo con los artículos 13 y 17 de la misma ley, siempre que estos últimos se hubiesen tenido en cuenta en la fijación de la base imponible individual del causahabiente.

\section{TíTULO III DEUDA TRIBUTARIA}

Artículo 21. Tarifa.

La cuota íntegra del impuesto sobre sucesiones y donaciones se obtendrá aplicando a la base liquidable los tipos de gravamen siguientes en función de los grados de parentesco señalados en el artículo 1 :

a. En caso de los hechos imponibles contemplados en los apartados a) y c) del artículo 3.1. ${ }^{\circ}$ de la Ley 29/1987, de 18 de diciembre, del impuesto sobre sucesiones y donaciones, y siempre que los sujetos pasivos estuviesen incluidos en los grupos I y II del artículo 1 de la presente ley, se aplicará la siguiente tarifa:

\begin{tabular}{|c|c|c|c|}
\hline $\begin{array}{c}\text { Base } \\
\text { liquidable } \\
\text { hasta euros }\end{array}$ & $\begin{array}{c}\text { Cuota } \\
\text { integra } \\
\text { Euros }\end{array}$ & $\begin{array}{c}\text { Resto base } \\
\text { liquidable } \\
\text { hasta euros }\end{array}$ & $\begin{array}{c}\text { Tipo } \\
\text { aplicable } \\
\text { Porcentaje }\end{array}$ \\
\hline 0 & 0 & 50.000 & 5 \\
\hline 50.000 & 2.500 & 75.000 & 7 \\
\hline 125.000 & 7.750 & 175.000 & 9 \\
\hline 300.000 & 23.500 & 500.000 & 11 \\
\hline 800.000 & 78.500 & 800.000 & 15 \\
\hline 1.600 .000 & 198.500 & En adelante & 18 \\
\hline
\end{tabular}

b. En caso de los hechos imponibles contemplados en el apartado b) del artículo 3.1. ${ }^{\circ}$ de la Ley 29/1987, de 18 de diciembre, del impuesto sobre sucesiones y donaciones, y siempre que los sujetos pasivos estuviesen incluidos en los grupos I y II del artículo 1 de la presente ley y la donación se formalizase en escritura pública, se aplicará la siguiente tarifa:

\begin{tabular}{|c|c|c|c|}
\hline $\begin{array}{c}\text { Base } \\
\text { liquidable } \\
\text { hasta euros }\end{array}$ & $\begin{array}{c}\text { Cuota } \\
\text { integra } \\
\text { Euros }\end{array}$ & $\begin{array}{c}\text { Resto base } \\
\text { liquidable } \\
\text { hasta euros }\end{array}$ & $\begin{array}{c}\text { Tipo } \\
\text { aplicable } \\
\text { Porcentaje }\end{array}$ \\
\hline 0 & 0 & 200.000 & 5 \\
\hline 200.000 & 10.000 & 400.000 & 7 \\
\hline 600.000 & 38.000 & En adelante & 9 \\
\hline
\end{tabular}

En caso de no cumplirse los requisitos establecidos en esta letra será de aplicación la tarifa señalada en el apartado anterior.

c. En caso de los hechos imponibles contemplados en los apartados a), b) y c) del artículo 3.1. ${ }^{\circ}$ de la Ley 29/1987, de 18 de diciembre, del impuesto sobre sucesiones y donaciones, y siempre que los sujetos pasivos estuviesen incluidos en los grupos III y IV del artículo $1 .^{\circ}$ de la presente ley, se aplicará la siguiente tarifa:

\begin{tabular}{|c|c|c|c|}
\hline $\begin{array}{c}\text { Base } \\
\text { liquidable } \\
\text { hasta euros }\end{array}$ & $\begin{array}{c}\text { Cuota } \\
\text { integra } \\
\text { Euros }\end{array}$ & $\begin{array}{c}\text { Resto base } \\
\text { liquidable } \\
\text { hasta euros }\end{array}$ & $\begin{array}{c}\text { Tipo } \\
\text { aplicable } \\
\text { Porcentaje }\end{array}$ \\
\hline 0,00 & - & $7.993,46$ & 7,65 \\
\hline $7.993,46$ & 611,50 & $7.987,45$ & 8,50 \\
\hline $15.980,91$ & $1.290,43$ & $7.987,45$ & 9,35 \\
\hline $23.968,36$ & $2.037,26$ & $7.987,45$ & 10,20 \\
\hline
\end{tabular}




\begin{tabular}{|c|c|c|c|}
\hline $\begin{array}{c}\text { Base } \\
\text { liquidable } \\
\text { hasta euros }\end{array}$ & $\begin{array}{c}\text { Cuota } \\
\text { integra } \\
\text { Euros }\end{array}$ & $\begin{array}{c}\text { Resto base } \\
\text { liquidable } \\
\text { hasta euros }\end{array}$ & $\begin{array}{c}\text { Tipo } \\
\text { aplicable } \\
\text { Porcentaje }\end{array}$ \\
\hline $31.955,81$ & $2.851,98$ & $7.987,45$ & 11,05 \\
\hline $39.943,26$ & $3.734,59$ & $7.987,45$ & 11,90 \\
\hline $47.930,72$ & $4.685,10$ & $7.987,45$ & 12,75 \\
\hline $55.918,17$ & $5,703,50$ & $7.987,45$ & 13,60 \\
\hline $63.905,62$ & $6.789,79$ & $7.987,45$ & 14,45 \\
\hline $71.893,07$ & $7.943,98$ & $7.987,45$ & 15,30 \\
\hline $79.880,52$ & $9.166,06$ & $39.877,15$ & 16,15 \\
\hline $119.757,67$ & $15.606,22$ & $39.877,16$ & 18,70 \\
\hline $159.634,83$ & $23.063,25$ & $79.754,30$ & 21,25 \\
\hline $239.389,13$ & $40.011,04$ & $159.388,41$ & 25,50 \\
\hline $398.777,54$ & $80.655,08$ & $398.777,54$ & 29,75 \\
\hline $797.555,08$ & $199.291,40$ & En adelante & 34,00 \\
\hline & & & \\
\hline & & & \\
\hline
\end{tabular}

Artículo 22. Cuota tributaria.

La cuota tributaria por el impuesto sobre sucesiones y donaciones se obtendrá aplicando a la cuota íntegra el coeficiente multiplicador que corresponda de los que se indican a continuación, establecidos en función del patrimonio preexistente del contribuyente y del grupo, según el grado de parentesco señalado en el artículo $1 .^{\circ}$ de la presente ley:

\begin{tabular}{|c|c|c|c|}
\hline Patrimonio preexistente Euros & I y II & III & IV \\
\hline $\begin{array}{c}\text { De 0 a 402.678,11 } \\
\text { De más de } 402.678,11 \text { a } \\
2.007 .380,43\end{array}$ & 1 & 1,5882 & 2 \\
\hline $\begin{array}{c}\text { De más de } 2.007 .380,43 \text { a } \\
4.020 .770,98\end{array}$ & 1 & 1,7471 & 2,2 \\
\hline Más de $4.020 .770,98$ & 1 & 1,9059 & 2,4 \\
\hline
\end{tabular}

Artículo 23. Deducción para adquisiciones mortis causa por sujetos pasivos del grupo I.

En las adquisiciones mortis causa por sujetos pasivos incluidos en el grupo I del artículo 1 de la presente ley, incluidas las cantidades percibidas por las personas beneficiarias de seguros sobre la vida, se practicará una deducción del 99\% del importe de la cuota.

Artículo 24. Deducción por parentesco.

1. En las adquisiciones mortis causa por sujetos pasivos incluidos en el grupo II del artículo 1, se aplicará una deducción del $100 \%$ de la cuota tributaria siempre que su base imponible fuese igual o inferior a 125.000 euros.

2. Para el cómputo del límite de 125.000 euros señalado en el apartado anterior, se tendrán en cuenta las bases imponibles de los pactos sucesorios realizados. También se computarán las bases imponibles de las donaciones y demás transmisiones inter vivos equiparables que sean acumulables de acuerdo con lo establecido en el artículo 30 de la Ley 29/1987, de 18 de diciembre, del impuesto sobre sucesiones y donaciones, así como el valor de los usufructos y otras instituciones a que se refiere el artículo 26 de la misma norma que se tengan en cuenta para la determinación del tipo medio de gravamen aplicable.

\section{TÍTULO IV \\ NORMAS COMUNES A LAS ADQUISICIONES POR CAUSA DE MUERTE Y ENTRE VIVOS}

Artículo 25. Tratamiento fiscal de las uniones estables de pareja.

A los efectos de la aplicación de la presente ley, se equiparan al matrimonio las uniones de dos personas mayores de edad, capaces, que convivan con la intención o vocación de permanencia en una relación de afectividad análoga a la conyugal y que la inscriban en el Registro de Parejas de Hecho de Galicia, expresando su voluntad de equiparar sus efectos a los del matrimonio.

\section{DISPOSICIÓN ADICIONAL PRIMERA VALORACIÓN PREVIA DE BIENES INMUEBLES}

En los impuestos sobre sucesiones y donaciones y sobre transmisiones patrimoniales y actos jurídicos documentados, en los casos de solicitud de las valoraciones previas de bienes inmuebles a que se 
refiere el artículo 90 de la Ley general tributaria, será necesaria la presentación de la valoración realizada en el plazo de presentación del impuesto.

\section{DISPOSICIÓN ADICIONAL SEGUNDA SOLICITUD DE VALORACIONES PREVIAS}

En los impuestos sobre sucesiones y donaciones y sobre transmisiones patrimoniales y actos jurídicos documentados, para el ejercicio del derecho reconocido en el artículo 90 de la Ley general tributaria, y siempre que no se solicitase la valoración a través de la página web de la Consellería de Economía y Hacienda, deberá abonarse, en su caso, la tasa correspondiente y presentar el justificante del pago de la misma junto con la solicitud de valoración.

\section{DISPOSICIÓN ADICIONAL TERCERA DEDUCCIÓN EN CUOTA POR SOLICITUD DE VALORACIÓN PREVIA}

Los sujetos pasivos del impuesto sobre sucesiones y donaciones y del impuesto sobre transmisiones patrimoniales y actos jurídicos documentados que hubiesen solicitado valoración previa al amparo del artículo 90 de la Ley general tributaria, pagada la tasa correspondiente y presentada la valoración junto con la declaración del impuesto podrán deducir de la cuota tributaria el importe satisfecho por la tasa.

\section{DISPOSICIÓN TRANSITORIA PRIMERA APLICACIÓN DE LA NORMATIVA SOBRE GESTIÓN DEL IMPUESTO}

A la entrada en vigor de la presente ley, y en tanto no sean aprobados los desarrollos reglamentarios, serán de aplicación las normas reglamentarias vigentes en todo aquello que no se oponga o contradiga a la presente ley.

\section{DISPOSICIÓN TRANSITORIA SEGUNDA PLAZO DE MANTENIMIENTO DE LAS ADQUUISICIONES}

En aquellos casos en los que se estuviese disfrutando de la reducción por adquisición de vivienda habitual del causante en el momento de la entrada en vigor de la presente ley, y no se hubiese incumplido el requisito de permanencia de diez años, el plazo de mantenimiento de la adquisición será de cinco años desde el devengo del impuesto.

\section{DISPOSICIÓN DEROGATORIA PRIMERA}

A la entrada en vigor de la presente ley quedarán derogadas las siguientes disposiciones:

Artículo 2 de la Ley 3/2002, de 29 de abril, de medidas de régimen fiscal y administrativo.

Artículo 1 de la Ley 7/2002, de 29 de abril, de medidas de régimen fiscal y administrativo.

Artículos 1 y 2 de la Ley 9/2003, de 23 de diciembre, de medidas tributarias y administrativas.

Artículo 3 de la Ley 14/2004, de medidas tributarias y de régimen administrativo.

Artículo 53 de la Ley 14/2006, de 28 de diciembre, de presupuestos generales de la Comunidad Autónoma de Galicia para el año 2007.

\section{DISPOSICIÓN DEROGATORIA SEGUNDA}

En general, quedarán derogadas todas aquellas otras disposiciones de igual o inferior rango que contradigan, se opongan o resulten incompatibles con lo que establece la presente ley.

\section{DISPOSICIÓN FINAL PRIMERA ENTRADA EN VIGOR}

La presente ley entrará en vigor el día 1 de septiembre de 2008.

\section{DISPOSICIÓN FINAL SEGUNDA DESARROLLO REGLAMENTARIO.}

Se faculta al Gobierno y al conselleiro o conselleira competente en materia de hacienda para que dicten las disposiciones necesarias para el desarrollo y aplicación de la presente ley. 


\section{DISPOSICIÓN FINAL TERCERA LEYES DE PRESUPUESTOS}

Las leyes de presupuestos generales de la Comunidad Autónoma de Galicia podrán modificar las reducciones de la base imponible, las tarifas, los coeficientes de patrimonio preexistente y las deducciones de la cuota tributaria.

\section{LEY 15/2008, DE 19 DE DICIEMBRE, DEL IMPUESTO SOBRE EL DAÑO MEDIOAMBIENTAL CAUSADO POR DETERMINADOS USOS Y APROVECHAMIENTOS DEL AGUA EMBALSADA (DOGA 251. 29.12.2008) ${ }^{224}$ $(\ldots)^{225}$}

\section{Capítulo I DISPOSICIONES GENERALES}

Artículo 1. Finalidad del impuesto.

El impuesto sobre el daño medioambiental causado por determinados usos y aprovechamientos del agua embalsada tiene como finalidad, por una parte, compensar los efectos negativos a que se encuentra sometido el entorno natural de Galicia por la realización de actividades que afectan a su patrimonio fluvial natural $y$, por otra, reparar el daño medioambiental causado por dichas actividades.

Artículo 2. Naturaleza y objeto.

El impuesto establecido por la presente ley es un tributo propio de la Comunidad Autónoma de Galicia, de naturaleza real y finalidad extrafiscal, que somete a gravamen el daño medioambiental causado por la realización de determinadas actividades que utilizan agua embalsada.

Artículo 3. Ámbito de aplicación.

El impuesto será de aplicación a las actividades y aprovechamientos que utilicen

224 Orden de 27 de febrero de 2009 por la que se aprueban las normas de aplicación del impuesto sobre el daño medioambiental causado por determinados usos y aprovechamientos del agua embalsada. 225 Exposición de motivos omitida. embalses que estén situados en todo o en parte en el territorio de la comunidad autónoma de Galicia.

Artículo 4. Afectación de la recaudación.

Los ingresos efectivamente obtenidos por la recaudación de este tributo, deducidos los costes de gestión, se destinarán a financiar las actuaciones y medidas encaminadas a la prevención y protección de los recursos naturales, así como a la conservación, reparación y restauración del medio ambiente y, en especial, a la conservación del patrimonio natural fluvial gallego directa o indirectamente afectado por los daños medioambientales gravados.

Las leyes de presupuestos de la Comunidad Autónoma de Galicia podrán establecer los criterios de afectación de los ingresos recaudados por este impuesto.

Artículo 5. Normativa de aplicación.

El impuesto sobre el daño medioambiental causado por determinados usos y aprovechamientos del agua embalsada se regirá por las disposiciones de la presente ley y las normas reglamentarias dictadas en su desarrollo y, en lo no previsto en las mismas, por lo dispuesto en las disposiciones generales en materia tributaria.

\section{Capítulo II ELEMENTOS DEL IMPUESTO}

Artículo 6. Hecho imponible.

1. Constituye el hecho imponible la realización de actividades industriales mediante el uso o aprovechamiento del agua embalsada, cuando dicho uso o aprovechamiento altere o modifique sustancialmente los valores naturales de los ríos y, en especial, el caudal y velocidad del agua en su cauce natural.

2. Se entenderá que alteran y modifican sustancialmente los valores naturales de los ríos las actividades industriales que utilicen aguas embalsadas mediante 
presas que reúnan alguna de las siguientes condiciones:

a. que su altura supere los quince metros, medida desde la parte más baja de la superficie general de cimentación hasta la coronación, o

b. que su altura esté comprendida entre quince y diez metros, siempre que reúna alguna de las siguientes características:

b.1. longitud de coronación superior a quinientos metros,

b.2. capacidad de embalsar más de un millón de metros cúbicos de agua, y

b.3. capacidad de vertido superior a 2.000 metros cúbicos por segundo.

Artículo 7. Supuestos de no sujeción.

No estará sujeta a este impuesto la realización de las actividades que, utilizando aguas embalsadas, se enumeran a continuación:

a. abastecimiento de poblaciones,

b. actividades agrarias,

c. acuicultura,

d. actividades recreativas, $y$

e. navegación y transporte acuático.

Artículo 8. Periodo impositivo devengo.

1. El periodo impositivo coincidirá con el trimestre natural.

2. El devengo se producirá el último día del trimestre natural, salvo en caso de extinción de la concesión, que coincidirá con esta fecha.

3. Sin perjuicio de lo dispuesto en el apartado 1, en los casos de nueva concesión o extinción de la misma, el periodo impositivo se entenderá por el periodo existente entre la fecha de la nueva concesión y el devengo, en el primer caso, y entre el primer día del trimestre natural y el devengo, en el segundo.

Artículo 9. Sujeto pasivo.

Serán sujetos pasivos en calidad de contribuyentes las personas físicas o jurídicas y las entidades a que se refiere el artículo $35.4 .^{\circ}$ de la Ley general tributaria que realicen cualquiera de las actividades señaladas en el artículo 6 de la presente ley.

Se presumirá, salvo prueba en contrario, que la actividad industrial es realizada por la persona o entidad que figure como titular de la correspondiente concesión de aprovechamiento para uso industrial.

Si el sujeto pasivo no coincidiera con el titular de la concesión, éste tendrá carácter de responsable solidario.

Artículo 10. Base imponible.

1. Constituye la base imponible la capacidad volumétrica máxima del embalse que esté ubicado en su totalidad o en parte en el territorio de la Comunidad Autónoma de Galicia, medida en $\mathrm{hm}^{3}$.

2. En caso de embalses para los que el agua embalsada se extienda más allá del límite territorial de la Comunidad Autónoma, la base imponible estará constituida por la parte de la capacidad que corresponda a las aguas situadas en el territorio gallego.

3. En el supuesto de que uno o más aprovechamientos gravados compartieran un mismo embalse, la base correspondiente a cada uno de ellos se determinará en proporción a los caudales concedidos.

Artículo 11. Cuota tributaria y tipo de gravamen.

1. La cuota tributaria del impuesto se determinará por aplicación del tipo de gravamen trimestral, $800 €$ por $\mathrm{hm}^{3}$, a la base imponible.

2. La cuota resultante obtenida conforme al apartado anterior se multiplicará por el coeficiente $(1+a-b)$ en función del salto bruto del aprovechamiento y, en su caso, de la potencia instalada del aprovechamiento hidroeléctrico, donde:

$\mathrm{a}=$ será el resultado de aplicar la siguiente escala al salto bruto medido en metros desde la cota de toma y, en su defecto, desde el punto de coronación del embalse hasta el punto de restitución y, en su defecto, hasta el lecho del embalse: 


\begin{tabular}{|c|c|}
\hline Tramos del saldo bruto & Por cada metro \\
\hline Hasta $30 \mathrm{~m}$ & 0,0001 \\
\hline De 30,01 hasta $100 \mathrm{~m}$ & 0,0005 \\
\hline De 100,01 hasta $300 \mathrm{~m}$ & 0,001 \\
\hline De 300,01 hasta $600 \mathrm{~m}$ & 0,01 \\
\hline De $600,01 \mathrm{~m}$ en adelante & 0,04 \\
\hline
\end{tabular}

$\mathrm{b}=$ será el resultado de aplicar, en su caso, la siguiente escala a la potencia instalada del aprovechamiento, medida en MW:

\begin{tabular}{|c|c|}
\hline Tramos de potencia & Por cada MW \\
\hline Hasta 200 MW & 0,0005 \\
\hline De 200,01 MW en adelante & 0,001 \\
\hline
\end{tabular}

La aplicación del coeficiente anterior no podrá suponer, en su caso, una reducción superior al $25 \%$ de la cuota inicial.

\section{Capítulo III GESTIÓN DEL TRIBUTO}

Artículo 12. Normas de aplicación. La consellería competente en materia de hacienda aprobará las normas de aplicación del tributo.

Artículo 13. Declaración inicial.

A los efectos de aplicación del impuesto, los sujetos pasivos están obligados a presentar una declaración inicial mediante los modelos que se aprueben por la consellería competente en materia de hacienda.

Del mismo modo, están obligados a presentar una modificación de declaración inicial cuando varíen los datos declarados a la administración.

Artículo 14. Autoliquidación.

Los sujetos pasivos están obligados a presentar autoliquidación del impuesto, determinando la deuda tributaria correspondiente e ingresando su importe mediante los modelos que se aprueben por la consellería competente en materia de hacienda.

Artículo 15. Plazos y lugar de presentación.

1. La declaración inicial a que se refiere el artículo 13 deberá presentarse junto a la primera autoliquidación que corresponda.
2. La declaración de modificación a que se refiere el artículo 13 deberá presentarse en los veinte primeros días naturales, a contar desde el momento en que se produzca la modificación.

3. Las autoliquidaciones a que se refiere el artículo 14 deberán presentarse en los veinte primeros días naturales, a contar desde la fecha de devengo.

4. Las declaraciones y autoliquidaciones anteriores deberán presentarse ante la delegación competente con arreglo a lo señalado en el artículo 20.

Artículo 16. Utilización de tecnologías informáticas y telemáticas.

La consellería competente en materia de hacienda podrá disponer que las declaraciones y autoliquidaciones del impuesto se efectúen mediante los programas informáticos de ayuda que, en su caso, se aprueben.

Asimismo, podrá disponer la obligatoriedad de su presentación y el pago mediante medios telemáticos.

Artículo 17. Liquidaciones provisionales.

Los órganos de la Administración tributaria podrán dictar la liquidación provisional que proceda de conformidad con lo dispuesto en la Ley general tributaria.

Artículo 18. Potestad sancionadora.

La potestad sancionadora en materia tributaria se ejercerá conforme a los principios reguladores de la misma en materia administrativa y con las especialidades contempladas en la Ley general tributaria, siendo de aplicación las disposiciones generales contenidas en ella.

La clasificación de las infracciones y sanciones tributarias y el procedimiento sancionador tributario se regirán por lo establecido en la Ley general tributaria y demás disposiciones que la desarrollen y complementen.

\section{Artículo 19. Revisión.}

Los actos y actuaciones de aplicación de este tributo, así como los actos de imposición de sanciones tributarias, serán 
revisables con arreglo a las disposiciones contenidas en la Ley general tributaria. El conocimiento de las reclamaciones económico-administrativas corresponderá con exclusividad a los órganos económico-administrativos de la Comunidad Autónoma, sin perjuicio de la vía contenciosa.

Artículo 20. Órganos competentes.

El ejercicio de las funciones de aplicación y de revisión del impuesto, así como el ejercicio de la potestad sancionadora en materia tributaria, corresponderá a los órganos competentes de la Administración tributaria de la consellería competente en materia de hacienda.

La competencia territorial se atribuirá a la delegación territorial de la Administración tributaria en cuyo ámbito territorial se extienda la totalidad o, en su caso, la mayor parte del agua embalsada.

Artículo 21. Órganos de colaboración.

Sin perjuicio de lo establecido en el artículo anterior, los órganos administrativos competentes en las materias de medio ambiente, energía, aguas e industria auxiliarán a los órganos de aplicación de este tributo y colaborarán con los mismos, en el marco de sus respectivas competencias, para la liquidación, comprobación e investigación del tributo, mediante, entre otras actuaciones, la elaboración de informes a petición de éstos, la expedición de certificados oficiales de los datos necesarios para la liquidación del tributo y/o la cesión informática de los datos señalados.

\section{DISPOSICIÓN FINAL PRIMERA HABILITACIÓN PARA LA LEY DE PRESUPUESTOS GENERALES DE LA COMUNIDAD AUTÓNOMA DE GALICIA}

La ley de presupuestos generales de la Comunidad Autónoma podrá modificar cualquier elemento del impuesto.

\section{DISPOSICIÓN FINAL SEGUNDA HABILITACIÓN NORMATIVA}

La Xunta de Galicia dictará cuantas disposiciones sean necesarias para el desarrollo reglamentario de la presente ley, autorizándose a la consellería competente en materia de hacienda para aprobar las disposiciones que sean precisas para la aplicación de este tributo.

\section{DISPOSICIÓN FINAL TERCERA ENTRADA EN VIGOR}

La presente ley entrará en vigor al día siguiente al de su publicación en el Diario Oficial de Galicia y el tributo comenzará a exigirse a partir del primer trimestre natural que dé comienzo tras su entrada en vigor. 


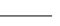




\section{VI \\ INTERVENCIÓN EN LA ECONOMÍA}

1. DECRETO LEGISLATIVO $1 / 2005$, DE 10 DE MARZO, POR EL QUE SE APRUEBA EL TEXTO REFUNDIDO DE LAS LEYES 7/1985, DE 17 DE JULIO, Y 4/1996, DE 31 DE MAYO, DE CAJAS DE AHORROS DE GALICIA (DOGA N. $\left.{ }^{\circ} 101,27.5 .2005\right)$

\section{(...) ${ }^{226}$}

Artículo único. De conformidad con la Disposición final segunda de la Ley $1 / 2004$, de 21 de abril, de modificación de las leyes 7/1985, de 17 de julio, de Cajas de Ahorros Gallegas, y 4/1996, de 31 de mayo, de Cajas de Ahorros de Galicia, para adaptarlas a la Ley 44/2002, de 22 de noviembre, de medidas de Reforma del Sistema Financiero, se aprueba el texto refundido de las Leyes 7/1985, de 17 de julio, y 4/1996, de 31 de mayo, de Cajas de Ahorros de Galicia, que se inserta a continuación.

\section{DISPOSICIÓN ADICIONAL ÚNICA REMISIONES NORMATIVAS}

Las remisiones y referencias normativas a las leyes 7/1985, de 17 de julio, y 4/1996, de 31 de mayo, se entenderán hechas, en lo sucesivo, al texto refundido que se aprueba por el presente decreto legislativo.

\section{DISPOSICIÓN DEROGATORIA}

En virtud de su incorporación al texto refundido quedan derogadas las siguientes normas:

Ley 7/1985, de 17 de julio, de Cajas de Ahorros Gallegas.

Ley 6/1989, de 10 de mayo, de modificación de la Ley 7/1985, de 17 de julio.

Ley 4/1996, de 31 de mayo, de Cajas de Ahorros de Galicia.

226 Exposición de motivos omitida.
Ley $1 / 2004$, de 21 de abril, de modificación de las leyes 7/1985, de 17 de julio, de Cajas de Ahorros Gallegas, y 4/1996, de 31 de mayo, de Cajas de Ahorros de Galicia, para adaptarlas a la Ley 44/2002, de 22 de noviembre, de medidas de Reforma del Sistema Financiero.

Además quedan derogadas las disposiciones de igual o inferior rango que se opongan a lo establecido en texto refundido que se aprueba.

\section{DISPOSICIÓN FINAL PRIMERA DESARROLLO REGLAMENTARIO}

La Xunta de Galicia y el conselleiro de Economía y Hacienda, en el ámbito de sus respectivas competencias, podrán dictar los reglamentos que requiera el desarrollo y la aplicación del texto refundido que se aprueba por el presente decreto legislativo.

\section{DISPOSICIÓN FINAL SEGUNDA ENTRADA EN VIGOR}

El presente decreto legislativo y el texto refundido que se aprueba entrarán en vigor el día siguiente al de su publicación en el Diario Oficial de Galicia.

\section{TEXTO REFUNDIDO DE LAS LEYES DE CAJAS DE AHORROS DE GALICIA TÍTULO I DISPOSICIONES GENERALES}

Artículo 1. Ámbito de aplicación.

1. Las cajas de ahorros con domicilio social en Galicia se regirán por lo establecido en el presente texto refundido y en las demás normas complementarias y de desarrollo emanadas de la Comunidad Autónoma, las cuales serán también de aplicación a las actividades que desarrollen en el territorio de esta comunidad las cajas 
de ahorros con domicilio social fuera de la misma, todo ello sin perjuicio de la normativa básica del Estado.

2. La normativa mercantil reguladora del derecho de sociedades, la estatal de entidades de crédito y la legislación sobre fundaciones, según corresponda por razón de la materia, podrá aplicarse con carácter subsidiario en lo no previsto en el presente texto refundido.

Artículo 2. Concepto de caja de ahorros.

Se entenderá por caja de ahorros, a los efectos de este texto refundido, la entidad financiera de carácter social, de naturaleza fundacional y sin finalidad lucrativa que, bajo el protectorado público ejercido por el Gobierno de la Comunidad Autónoma de Galicia a través de la Consellería de Economía e Facenda, se dedica a la actividad financiera y a la prestación de servicios conexos, destinando parte de sus excedentes a obras de carácter benéfico-social.

Artículo 3. Reserva de denominación.

1. Para las entidades con domicilio en Galicia, las denominaciones caja de ahorros y monte de piedad serán privativas de las instituciones inscritas en el Registro de Cajas de Ahorros Gallegas.

2. Ninguna entidad o empresa no inscrita en el registro utilizará en su denominación marcas, rótulos, modelos, anuncios o expresiones que induzcan a error sobre su naturaleza.

Artículo 4. Registro de Cajas de Ahorros Gallegas.

1. La Xunta de Galicia dispondrá de un registro de Cajas de Ahorros Gallegas, en el que deberá constar, en la forma que reglamentariamente se determine:

a. La denominación de la institución.

b. El domicilio social.

c. La fecha de la escritura de fundación.

d. La corporación, entidad o personas fundadoras.

e. Los estatutos y reglamentos de la caja respectiva. f. La autorización de la admisión en el Registro.

2. Se inscribirán también los acuerdos de la Xunta de Galicia y de la Consellería de Economía e Facenda relativos a la modificación de estatutos, absorción, fusión, disolución o liquidación.

3. El registro será público. Cualquier persona interesada podrá obtener certificación gratuita de los datos inscritos.

4. El registro tendrá una sección dedicada a aquellas cajas de ahorros con domicilio social fuera de Galicia, pero con oficinas en el territorio de esta Comunidad Autónoma, en la que se harán constar aquellos datos que reglamentariamente se determinen. Dichas cajas tendrán que comunicar a la Consellería de Economía e Facenda las aperturas y los cierres de sucursales efectuados en Galicia, de conformidad con la legislación.

5. Todas las altas y bajas de entidades en el Registro se publicarán en el "Diario Oficial de Galicia”, comunicándoselo al Ministerio de Economía y Hacienda y a la comisión Europea.

Artículo 5. Acción de Gobierno.

La acción del Gobierno de la Comunidad Autónoma, en el marco de las bases y de la ordenación de la actividad económica general y de la política monetaria del Estado, se llevará a cabo bajo los siguientes principios:

a. Velar por la independencia de las cajas de ahorros y defender su naturaleza fundacional, prestigio y estabilidad.

b. Vigilar el cumplimiento por parte de las cajas de su función económico-social, de acuerdo con una adecuada política de administración y de inversión del ahorro privado.

c. Procurar la estabilidad económica y financiera de las cajas así como la total transparencia de los mercados donde operan, creando los mecanismos oportunos para que los clientes de las cajas dispongan de toda la información necesaria.

d. Establecer mecanismos de cobertura y protección de los clientes. 
e. Estimular todas las acciones legítimas de las instituciones de ahorro encaminadas a mejorar el nivel socioeconómico de Galicia.

\section{TÍTULO II \\ ORGANIZACIÓN INSTITUCIONAL}

\section{Capítulo I \\ CRITERIOS ORDENADORES}

Artículo 6. Doble dimensión de las cajas.

Las cajas de ahorros tienen un doble carácter: social y fundacional, por su finalidad y aplicación de excedentes, y de entidad financiera, por razón de su actividad.

Artículo 7. Organización democrática. La estructura y la composición de los órganos de gobierno de las cajas serán democráticas y sus miembros velarán por los intereses fundacionales de la caja, por los de sus depositantes y por los del territorio donde éstas desarrollen su actividad, con plena independencia de cualquier otro que les pudiese afectar.

\section{Capítulo II CREACIÓN Y RECURSOS}

\section{Sección $1 .^{\mathrm{a}}$}

Requisitos para la creación

Artículo 8. Fundación.

1. Las cajas de ahorros podrán ser fundadas por personas o entidades, tanto públicas como privadas, en los términos previstos en el presente texto refundido.

2. La condición de fundador no será transmisible por ningún título ni otorgará derechos económicos. Los fundadores, sean públicos o privados, dispondrán exclusivamente de los derechos de representación que se establecen en el presente texto refundido.

3. El patrimonio inicial de las cajas de ahorros estará constituido por la aportación de sus fundadores.

4. Todas las cajas de ahorros con domicilio social en Galicia, cualquiera que sea la persona fundadora, el organismo o la corporación que las patrocine, tendrán la misma naturaleza jurídica y los mismos derechos y obligaciones, así como idéntica consideración por parte del Gobierno de la Comunidad Autónoma.

Artículo 9. Autorización.

1. Corresponderá a la Xunta de Galicia autorizar la creación de cajas de ahorros, observando la normativa básica vigente y lo previsto en presente texto refundido.

2. La solicitud de autorización para la creación de una caja de ahorros se presentará en la Consellería de Economía e Facenda, y se le adjuntarán los siguientes documentos:

a. Proyecto de escritura fundacional.

b. Proyecto de estatutos.

c. Programa de actividades, haciendo constar el género de operaciones que se pretenden realizar y la estructura organizativa de la entidad.

d. Circunstancias personales de las personas físicas, corporaciones o entidades fundadoras.

e. Memoria donde se recojan los objetivos que se propongan conseguir con su creación.

f. Dotación inicial, con la descripción y valoración de los bienes y derechos y las características esenciales de la aportación.

3. La escritura fundacional, los estatutos y sus modificaciones deberán aprobarse por la Consellería de Economía e Facenda.

4. La autorización concedida por la Xunta de Galicia para la creación de una caja de ahorros caducará si no se da comienzo las actividades autorizadas dentro de los doce meses siguientes a la fecha de notificación de la autorización, por causa imputable a los interesados.

Artículo 10. Creación.

1. Concedida la autorización de la Xunta de Galicia, la creación de la nueva caja se deberá hacer mediante escritura pública, que será inscrita en Registro Mercantil y en el Registro de Cajas de Ahorros Gallegas. Sólo después de esta última inscripción la caja podrá iniciar su actividad. 
2. La inscripción en el Registro de Cajas de Ahorros Gallegas sólo podrá ser denegada por incumplimiento de los requisitos establecidos en este texto refundido.

3. La titularidad de las inscripciones concedidas no será transmisible.

Artículo 11. Contenido mínimo de la escritura fundacional.

En la escritura fundacional de la caja se hará constar lo siguiente:

a. Las circunstancias personales de las personas físicas, corporaciones o entidades fundadoras.

b. La voluntad de constituir una caja de ahorros con sumisión a las disposiciones vigentes.

c. Los estatutos que regularán el funcionamiento de la futura caja.

d. La dotación inicial cuantificada, con la descripción de los bienes y derechos que la integren, su título de propiedad, las cargas, si las hubiere, y además el carácter de la aportación.

e. La cuantía total, al menos aproximada, de los gastos de constitución.

f. Las circunstancias personales de las personas que formarán el patronato y se encargarán inicialmente de la administración y representación de la caja. Éstas, en la misma escritura fundacional, nombrarán provisionalmente un director general.

Artículo 12. Contenido mínimo de los estatutos.

En los estatutos de las cajas deberán constar los siguientes extremos:

a. La denominación y la naturaleza de la entidad.

b. El domicilio social y el ámbito de actuación.

c. El objeto y los fines.

d. La fecha de cierre del ejercicio económico.

e. La aplicación o el destino de los excedentes.

f. La estructura, la composición y el funcionamiento de los órganos de gobierno.

g. El número de miembros y el procedimiento de elección de los componentes de los órganos de gobierno. h. Las reglas para la renovación parcial de los órganos de gobierno.

i. Las previsiones para cubrir las vacantes que se produzcan en los órganos de gobierno por la finalización del mandato de sus miembros o cualquier otra causa.

j. Los requisitos para la convocatoria ordinaria y extraordinaria de la asamblea general, los plazos y la publicidad, el quórum exigido en la primera y segunda convocatoria y las mayorías necesarias para la adopción de acuerdos.

k. Los requisitos para la convocatoria de las sesiones del consejo de administración y de la comisión de control.

1. La forma de adopción de los acuerdos en los órganos de gobierno.

m. Las comisiónes delegadas del consejo.

n. La forma de elección, cese y renovación del Presidente.

Artículo 13. Período transitorio.

1. Hasta la constitución de los órganos de gobierno de la caja, el patronato de la fundación tendrá atribuidas las funciones propias del consejo de administración y aprobará sus reglamentos internos.

2. El patronato deberá iniciar el proceso de constitución de la primera asamblea general en un plazo no superior a nueve meses desde el inicio de la actividad de la caja.

3. En las cajas de nueva creación a los representantes de los impositores y del personal no se les exigirá el requisito de antigüedad.

4. En el primer consejo de administración de la caja, además de los vocales elegidos, figurarán con voz y voto los miembros del patronato fundacional, que cesarán a los dos años de la constitución de la primera asamblea general, sin perjuicio de que puedan ser elegidos como vocales.

5. El director general deberá ser ratificado por el primer consejo de administración que se constituya.

6. Las normas que regulan el período transitorio podrán ser objeto de desarrollo reglamentario. 


\section{Sección 2. ${ }^{\mathrm{a}}$}

Los recursos propios de las cajas

\section{Artículo 14. Fondo fundacional.}

1. La creación de una nueva caja de ahorros requerirá de una dotación fundacional mínima de 18.030.363 euros. La Xunta de Galicia, sin perjuicio de la normativa general básica, y atendiendo a los requisitos de solvencia y estabilidad que les son exigibles a las entidades financieras, podrá ajustar periódicamente tal cuantía mínima.

2. El fondo fundacional podrá ampliarse mediante nuevas aportaciones de los fundadores o de otras personas, o de entidades públicas o privadas, que se incorporen con esta misma condición.

3. Las personas o entidades que mediante nuevas aportaciones al fondo fundacional accediesen a la condición de fundadores tendrán, de la misma forma, derecho a estar representadas en los órganos de gobierno de la caja, dentro de la representación prevista para los fundadores, en proporción a sus aportaciones y en los términos en que reglamentariamente se determine.

4. La incorporación de nuevos fundadores requerirá la aprobación de la asamblea general mediante el voto afirmativo de la mayoría de sus miembros y la autorización de la Consellería de Economía e Facenda.

Artículo 15. Situación de déficit patrimonial.

Cuando los recursos propios de una caja resultasen insuficientes para garantizar la solvencia de la entidad, deberán producirse:

a. Nuevas aportaciones de los fundadores, suficientes para cubrir el déficit patrimonial existente.

b. La incorporación de personas o entidades públicas o privadas que, con idéntica consideración jurídica que los fundadores, aporten en concepto de ampliación del fondo fundacional con los recursos suficientes para cubrir el déficit existente.

c. Cualquier otra medida prevista en la normativa básica del Estado.
Artículo 16. Naturaleza de las aportaciones.

1. La dotación del fondo fundacional, así como las ampliaciones del mismo, podrán hacerse tanto en dinero como mediante la aportación de bienes y derechos susceptibles de valoración económica. No obstante, la porción de dinero en el fondo fundacional deberá ser como mínimo de 13.522.772 euros, y, si el fondo se amplía, dicha porción se deberá mantener en todo momento por lo menos en los dos tercios del total del fondo.

2. Cuando las aportaciones sean en bienes y derechos, el registrador mercantil designará dos o más expertos independientes para que procedan a inventariar los bienes y derechos aportados y a comprobar el valor atribuido a éstos por los aportantes. Tal informe pericial se incorporará como anexo a la correspondiente escritura fundacional o de ampliación de la dotación fundacional.

Artículo 17. Emisión de cuotas y financiación subordinado.

De acuerdo con la normativa básica, para ampliar sus recursos propios, las cajas podrán emitir cuotas participativas u otro tipo de financiación subordinada, previa autorización de la Consellería de Economía e Facenda. A estos efectos las cajas estarán obligadas a facilitar a la consellería la información que reglamentariamente se señale.

Artículo 18. Cuotas participativas.

1. Las cuotas participativas son valores nominativos que representan ayudas de dinero a plazo indefinido, que pueden ser aplicadas en igual proporción y a los mismos destinos que los fondos fundacionales y las reservas de la entidad.

2. Podrán emitirse cuotas participativas de distinta clase o serie, determinándose reglamentariamente los derechos correspondientes a cada una de ellas.

3 . Las cuotas confieren a sus suscriptores, como mínimo, el derecho a percibir la retribución que anualmente fije la asamblea general; a obtener, como máximo, el 
reembolso de su valor en el caso de liquidación de la caja; y a suscribir, con carácter preferente, cuotas en las nuevas emisiones.

4. Las cuotas carecen de todo derecho político, y no darán, en ningún caso, derecho a sus suscritores a participar en los órganos de gobierno de la caja emisora.

5. Corresponde a la asamblea general determinar la retribución de las cuotas participativas, previa autorización de la Consellería de Economía e Facenda, que podrá establecer limitaciones a tal retribución.

6. Las cajas que emitan cuotas participativas comunicarán a la Consellería de Economía e Facenda la relación de suscriptores.

Artículo 19. Fondo de estabilización.

1. Si el acuerdo de emisión así lo establece, la asamblea general podrá acordar la constitución de un fondo de estabilización que tenga por finalidad evitar que se produzcan fluctuaciones en la retribución de las cuotas participativas.

2. Reglamentariamente se determinarán los requisitos materiales y formales del fondo de participación, del de reserva de los cuotapartícipes y del fondo de estabilización.

Artículo 20. Financiación subordinada.

Son financiaciones subordinadas las recibidas por la entidad que, a efectos de prelación de créditos, se sitúen tras todos los acreedores comunes, siempre que el plazo original de tales financiaciones no sea inferior a cinco años y el plazo remanente hasta su vencimiento no sea inferior a un año.

\section{Capítulo III LOS ÓRGANOS DE GOBIERNO 227}

\section{Sección 1.}

\section{Normas comunes}

Artículo 21. Órganos de gobierno. La administración, gestión, representación y control de las cajas de ahorros corresponden a los siguientes órganos de

227 Véase Decreto 153/1989 de Galicia, de 27 de julio, de los órganos rectores de las cajas de ahorros gallegas. gobierno, con las competencias que para cada uno de ellos se establecen en el presente texto refundido:

a. Asamblea general.

b. Consejo de administración.

c. Comisión de control.

Artículo 22. Criterios de actuación.

1. Los órganos de gobierno enumerados en el artículo anterior actuarán con carácter colegiado, en su caso, y sus miembros desempeñarán sus funciones, en todo caso, en beneficio exclusivo de los intereses de la caja de ahorros a la que pertenezcan y los de sus depositantes, con plena independencia de cualquier otro que pudiese afectarles.

Los componentes de los órganos de gobierno ejercerán sus funciones en beneficio exclusivo de los intereses de la caja a la que pertenezcan y del cumplimiento de su función social. Asimismo, deberán reunir los requisitos de honorabilidad comercial y profesional que determinen las normas de desarrollo de este texto refundido. En cualquier caso, se entenderá que concurre la honorabilidad comercial y profesional en los que hayan observado una trayectoria personal de respeto a las leyes mercantiles $\mathrm{u}$ otras que regulen la actividad económica y la vida de los negocios, así como las buenas prácticas comerciales y financieras.

2. El cargo de miembro de la asamblea general, de vocal del consejo de administración y de la comisión de control tendrá carácter honorífico y gratuito y no podrá originar percepciones diferentes de las dietas por asistencia y desplazamiento autorizadas con carácter general por el Gobierno de la Comunidad Autónoma.

3. Los reglamentos de cada caja, de acuerdo con las normas legales que sean de aplicación y las de sus estatutos, fijarán los procedimientos de elección de los miembros que vayan a integrar los órganos de gobierno.

Artículo 23. Registro de altos cargos.

1. Se crea en la Consellería de Economía e Facenda el Registro de Altos 
Cargos de las Cajas de Ahorros Gallegas, en el que se inscribirán el nombramiento, reelección y cese de los miembros del consejo de administración, de la comisión de control y del director general. Las altas y las bajas de este registro serán notificadas al Banco de España y podrá emitirse certificación a cualquier persona que justifique el interés.

2. El Registro de Altos Cargos de las Cajas de Ahorros Gallegas sólo tendrá carácter informativo, a no ser que el Gobierno autónomo disponga otra cosa.

3. Los nombramientos, ceses y reelecciones de miembros del consejo de administración y de la comisión de control serán comunicados a la Consellería de Economía e Facenda en un plazo no superior a quince días.

\section{Sección 2. ${ }^{\mathrm{a}}$}

\section{De la asamblea general}

Artículo 24. Definición y composición.

1. La asamblea general es el órgano supremo de gobierno y decisión de las cajas de ahorros. Sus miembros ostentarán la denominación de conselleiros generales y representarán los intereses de los depositantes y los generales en el ámbito de su actuación.

2. Los estatutos de cada caja fijarán el número de conselleiros de la asamblea general, entre un mínimo de sesenta y un máximo de ciento sesenta conselleiros, que representarán a los siguientes sectores.

a. Impositores.

b. Personas, entidades o corporaciones fundadoras de la caja.

c. Corporaciones locales.

d. Empleados de la caja de ahorros.

e. Fundaciones, asociaciones o corporaciones de carácter cultural, científico, benéfico, cívico, económico o profesional de reconocido prestigio en el ámbito territorial de actuación de la caja.

3. La Xunta de Galicia, a propuesta de las cajas de ahorros, aprobará una relación de las entidades mencionadas en la letra e) del número 2 anterior, de entre las que deberá nutrirse la representación que le corresponda en la asamblea general.

Artículo 25. Distribución por sectores. La representación de los mencionados sectores se distribuirá en la forma que reglamentariamente se determine, dentro de los porcentajes que se establecen a continuación:

a. Entre un $15 \%$ y un $25 \%$ del total de los conselleiros generales serán elegidos en representación de las corporaciones locales de los ámbitos territoriales de actuación de cada caja. Ningún Ayuntamiento o corporación podrá absorber más del $80 \%$ de los conselleiros de este apartado y, en todo caso, la designación de los mismos tendrá en cuenta, en cada corporación, el principio de proporcionalidad conforme se determine reglamentariamente.

b. Entre un $25 \%$ y un $35 \%$ serán elegidos en representación de las corporaciones, de las entidades o personas fundadoras, de las entidades de carácter cultural, científico, benéfico, cívico, económico o profesional de reconocido prestigio en el ámbito territorial de actuación de la caja. De no existir entidad o personas fundadoras, o de no resultar posible su identificación, la representación de este apartado será del $25 \%$ de los conselleiros generales.

Se podrá atribuir a la entidad o personas fundadoras un máximo del $70 \%$ de los conselleiros generales de este apartado.

En ningún caso podrán nombrarse más de dos conselleiros generales por entidad de las previstas en la letra e) del apartado 2 del artículo 24.

c. Entre un $30 \%$ y un $40 \%$ será elegido en representación de los impositores de la caja.

d. El personal fijo de la plantilla de la caja accederá a la asamblea general por el grupo de representación del personal, pudiendo hacerlo, excepcionalmente, por el grupo de representación de corporaciones locales. Su representación directa se fija entre un $5 \%$ y un $15 \%$.

La representación de las administraciones públicas y de las entidades y corporaciones de derecho público en los órganos de 
gobierno de las cajas de ahorros, incluida la que corresponda a la entidad fundadora cuando ésta tenga la misma naturaleza, no podrá superar en su conjunto el cincuenta por ciento del total de los derechos de voto en cada uno de tales órganos.

Artículo 26. Requisitos de los conselleiros generales.

Los conselleiros generales deberán reunir los siguientes requisitos:

a. Ser persona física con residencia habitual en la zona de actividad de la caja.

b. Ser mayor de edad y no estar incapacitado.

c. Los representantes de los impositores deberán tener la condición de depositantes con dos años de antigüedad, como mínimo, y con un saldo medio en cuenta en el semestre precedente a su elección no inferior a la cifra que se determine en sus estatutos, dentro de los límites que se establezcan reglamentariamente. Si la elección se hace mediante compromisarios, deberán reunir las condiciones señaladas para los conselleiros generales.

Artículo 27. Causas de inelegibilidad. No podrán ostentar el cargo de conselleiros generales ni actuar como compromisarios:

a. Los quebrados y los concursados no rehabilitados, los condenados a penas que lleven aparejada la inhabilitación de cargos públicos y los que fueran sancionados por infracciones graves. Se consideran infracciones graves:

1. Las que lleven aparejada pena privativa de libertad.

2. Las constitutivas de delito fiscal, las de contrabando de mayor cuantía y las de evasión de capitales.

3. Cualquier otra a la que el ordenamiento jurídico le confiera expresamente carácter grave apreciado por los tribunales u órganos administrativos competentes.

b. Los que con anterioridad a la nueva designación o durante el ejercicio del cargo de conselleiro incurriesen, por ellos mismos o en representación de otras personas o entidades, en incumplimiento de sus obligaciones con la caja con motivo de préstamos o créditos, o por impago a la misma de deudas de cualquier clase.

c. Los administradores o miembros de órganos de gobierno de más de cuatro sociedades mercantiles o cooperativas. A estos efectos no se computarán los puestos ostentados en consejos de administración de sociedades mercantiles o cooperativas en las que los interesados, o su cónyuge, ascendientes o descendientes, juntos o separadamente, sean propietarios de un número de acciones no inferior al cociente de dividir el capital social por el número de vocales del consejo de administración. La misma norma se aplicará a los casos de representación legal de menores, ausentes o incapacitados. En cualquier caso, el número total de conselleiros no será superior a ocho.

d. Los presidentes, conselleiros generales, conselleiros, administradores, directores, gerentes, asesores o empleados de otros establecimientos o instituciones de crédito de cualquier clase, condición o categoría o de empresas dependientes de los mismos o de la propia caja, y de corporaciones o entidades que propugnen, sostengan o garanticen instituciones o establecimientos de crédito.

e. El personal al servicio de las administraciones públicas con funciones a su cargo que se relacionen directamente con las actividades propias de las cajas de ahorros.

f. Los cargos públicos de designación política de las administraciones públicas y el Presidente de la entidad o corporación fundadora de la caja.

Artículo 28. Incompatibilidades.

Los conselleiros generales no podrán estar vinculados a la caja de ahorros o a sociedades en las que la misma participe con más del $25 \%$ del capital, por contratos de obra, servicios, suministros o trabajos retribuidos, por el período en que ostenten esta condición y en los dos años siguientes, contados a partir del cese como conselleiro, salvo la relación laboral, cuando tal condición se ostente por representación directa del 
personal de la caja o excepcionalmente en representación de corporaciones locales.

Artículo 29. Duración del cargo.

1. La duración del ejercicio del cargo de los conselleiros generales será de cuatro años. No obstante, los estatutos podrán prever la posibilidad de reelección, si continuasen cumpliendo los requisitos del artículo 26 de este texto refundido. El cómputo del período de reelección será aplicado cualquiera que sea el tiempo transcurrido entre el cese y el nuevo nombramiento y el grupo o los grupos por los que pudiera haber ejercido la representación.

2. La duración total del mandato no podrá superar los doce años, cualquiera que sea la representación que ejerza. Cumplido el mandato de doce años, de forma continuada o interrumpida, y transcurridos ocho años desde dicha fecha, podrá volver a ser elegido en las condiciones establecidas en este texto refundido.

3. Los estatutos tendrán que prever fórmulas para la renovación parcial de la Asamblea.

4. Cuando se trate de conselleiros generales en representación directa de los impositores, las vacantes que entre ellos se produzcan no se cubrirán hasta que se proceda a la nueva elección general de compromisarios.

Artículo 30. Cese de los conselleiros generales.

1. En tanto no se cumpliese el plazo para el que fueron designados, fuera de los casos de renuncia, defunción o declaración de fallecimiento o ausencia legal, el nombramiento de los conselleiros será irrevocable excepto, exclusivamente, en los supuestos de incompatibilidad sobrevenida, pérdida de cualquiera de los requisitos exigidos para la designación y acuerdo de separación adoptado por la asamblea general si se apreciara justa causa.

Se entenderá que existe justa causa cuando el conselleiro general incumpla los deberes inherentes a su cargo o perjudique notoriamente con su actuación, pública o privada, el crédito, el buen nombre o la actividad de la caja.

2. El cese de los conselleiros generales no afectará a la distribución de puestos en el consejo de administración.

Artículo 31. Funciones de la asamblea general.

La asamblea general es el órgano supremo de gobierno y decisión de las cajas de ahorros, y, en especial, le corresponden las siguientes funciones:

a. El nombramiento de los vocales del consejo de administración.

b. El nombramiento de los miembros de la comisión de control.

c. La apreciación de las causas de separación y revocación de los miembros de los órganos de gobierno antes del cumplimiento de su mandato.

d. La aprobación y modificación de los estatutos y reglamentos.

e. La fusión, liquidación y disolución de la caja.

f. La definición de las líneas generales del plan de actuación anual de la caja, las cuales deberán someterse a los restantes órganos de gobierno.

g. La aprobación de la gestión del consejo de administración, memoria, balance anual y cuenta de resultados, así como la aplicación de éstos a los fines propios de las cajas de ahorros.

h. La creación de obra benéfico-social, así como la aprobación y liquidación de los presupuestos anuales para estos fines.

i. Cualquier otro asunto que se someta a su consideración por los órganos facultados al efecto.

Artículo 32. Requisitos constitutivos de la asamblea general.

1. La asamblea general deberá ser convocada por el consejo de administración con una antelación mínima de quince días, en la forma que establezcan los estatutos de cada institución. La convocatoria deberá expresar la fecha, el lugar de celebración y el orden del día, así como la fecha y hora de reunión en segunda convocatoria, y deberá 
publicarse en el "Diario Oficial de Galicia", en el "Boletín Oficial del Estado" y en diarios de amplia circulación en la zona de actuación de la caja.

2. La asamblea general precisará para su válida constitución de la asistencia de la mayoría de sus miembros, excepto en los supuestos que contemplan los apartados c), d) y e) del artículo 31, en los que se requerirá la asistencia de las dos terceras partes.

3. Cada conselleiro general tendrá derecho a un voto y no lo podrá delegar, y se otorgará a quien presida la reunión voto de calidad. Los acuerdos se tomarán por mayoría simple de votos de los concurrentes, a no ser que los estatutos fijen otros requisitos superiores.

4. La asamblea general será presidida por el Presidente de la caja o, en su caso, por los vicepresidentes, según orden $\mathrm{y}$, en su defecto, por el vocal de mayor edad del consejo de administración que se encuentre presente. Actuará como secretario el que lo sea del consejo de administración.

5. Los acuerdos adoptados se harán constar en acta, que podrá ser aprobada al término de su reunión por la propia asamblea, o por el Presidente y dos interventores designados en la misma, en un plazo máximo de quince días. La mencionada acta tendrá fuerza ejecutiva a partir de la fecha de su aprobación.

Artículo 33. Convocatoria de la asamblea general ordinaria.

1. Con carácter obligatorio, la asamblea deberá ser convocada durante el primer semestre natural de cada ejercicio, con la finalidad de someter a su aprobación la memoria, el balance y la cuenta de resultados, así como el proyecto de aplicación de excedentes, la dotación a la obra benéfico-social y la renovación de cargos del consejo de administración y de la comisión de control.

2. Desde la fecha de la convocatoria hasta la de celebración, los conselleiros generales podrán examinar en la sede de la entidad la documentación justificativa de la memoria, el balance y la cuenta de resultados, el informe de la comisión de control y de las auditorías realizadas.

Artículo 34. Convocatoria de la asamblea general extraordinaria.

1. La asamblea general extraordinaria será convocada y se celebrará en igual forma que la ordinaria pero sólo podrá tratarse en ella el objeto para el que fue expresamente convocada.

2. El consejo de administración convocará asamblea general siempre que lo estime conveniente para los intereses sociales, pudiendo hacerlo también a petición de un tercio de los miembros de la propia asamblea o por acuerdo de la comisión de control, cuando se trate de materias de competencia de ésta. La petición deberá expresar el orden del día de la sesión.

3. En todo caso la convocatoria se hará dentro del plazo de quince días a partir de la presentación de la petición, no pudiendo mediar más de veinte días entre la fecha de la convocatoria y la señalada para la celebración de la asamblea.

\section{Sección $3 .^{\mathrm{a}}$}

\section{Consejo de administración}

Artículo 35. Funciones del consejo de administración.

1. Corresponde al consejo de administración, como órgano delegado de la asamblea general, el gobierno, gestión, administración y representación de la caja, con plenitud de facultades y sin más limitaciones que las expresamente reservadas a la asamblea de la entidad en el presente texto refundido o en los respectivos estatutos particulares.

2. La concesión de créditos, avales y garantías de la caja a los vocales del consejo de administración, a los miembros de la comisión de control, al director general o a sus cónyuges, ascendientes, descendientes, así como a las sociedades en las que las personas mencionadas tengan participación que, aislada o conjuntamente, sea mayoritaria, o en las que desempeñen cargos de alta representación, directivo o asimilado, o la enajenación a la caja 
de bienes o valores de su propiedad o emitidos por tales entidades, deberá ser aprobada por el consejo de administración de la caja y le deberá ser comunicada a la Consellería de Economía e Facenda para que preste autorización expresa ${ }^{228}$.

3. El consejo de administración podrá delegar alguna o algunas de sus facultades de gestión en los órganos de gobierno de las entidades que constituyan y articulen alianzas entre cajas de ahorros o los creados al efecto en el seno de la Confederación Española de Cajas de Ahorros, con la finalidad de reducir los costes operativos de las entidades que la integren, para aumentar la eficiencia sin poner en peligro la competencia en los mercados nacionales o para participar con volumen suficiente en los mercados internacionales de capital. Esta delegación se mantendrá en vigor durante el período de la alianza o mientras las entidades no acuerden su modificación mediante el procedimiento que previamente establecieran al efecto. Esta delegación no se extenderá al deber de vigilancia de las actividades delegadas ni a las facultades que respecto de ellas tenga la comisión de control.

Los acuerdos de delegación requerirán la autorización previa de la Consellería de Economía e Facenda, a los efectos de garantizar que no impliquen menoscabo de la independencia de la caja o peligro para su estabilidad económico-financiera.

Artículo 36. Composición del consejo de administración.

1. El número de vocales del consejo será el que fijen los estatutos, sin que pueda ser inferior a diez ni superior a veintiuno.

2. La presencia en el mismo de los grupos representados en la asamblea deberá ser proporcional a la establecida en el artículo 25 del presente texto refundido, no resultando excluido ningún sector de los integrantes de la asamblea.

228 Véase Orden de 10 de mayo de 2006 sobre autorizaciones previas a determinadas operaciones de las cajas de ahorros gallegas.
En lo previsto en el apartado a) del citado artículo 25 se garantizará como mínimo la presencia en el consejo de administración de dos entidades.

En lo previsto en el apartado b) del ya citado artículo 25 se garantizará igualmente la presencia en el consejo de administración de por lo menos un representante de las entidades no fundadoras. Igualmente, el personal fijo de la plantilla de la caja contará con un representante como mínimo. De resultar fracciones sobrantes en el prorrateo, después de garantizar los mínimos estipulados con anterioridad, éstos se acumularán a los representantes de las entidades no fundadoras previstas en el apartado b) del artículo 25.

Artículo 37. Nombramiento, causas de inelegibilidad e incompatibilidades.

1. Los vocales del consejo de administración serán nombrados por la asamblea general de entre los miembros de cada sector de representación y a propuesta de la mayoría del respectivo sector, del consejo de administración o de un $25 \%$ de los miembros de la asamblea. No obstante lo anterior, el nombramiento de vocales representantes de las corporaciones locales que no tengan la condición de entidad fundadora de la caja de ahorros podrá recaer, como máximo, en dos personas que reúnan los adecuados requisitos de profesionalidad y no sean conselleiros generales. Igualmente el nombramiento de los miembros del consejo de administración representantes de los impositores podrá ser atribuido a un máximo de tres personas que reúnan los anteriores requisitos, siempre que esta cifra no suponga alcanzar el cincuenta por ciento de la representación total del sector.

2. Los vocales del consejo de administración estarán afectados por inelegibilidades idénticas a las establecidas para los conselleiros generales.

Los estatutos de la entidad fijarán la edad máxima que podrán tener en el momento de su toma de posesión, no pudiendo ser esta edad máxima superior a 75 años. 
3. La entidad fundadora, las corporaciones locales o las otras entidades representadas en la asamblea no podrán tener representación en el consejo de administración de más de una caja. Esta incompatibilidad afectará a las personas que, como conselleiros generales, fuesen designadas en representación de la respectiva corporación o entidad.

4. Todos los miembros del consejo de administración asistirán a la asamblea general con voz y voto.

Artículo 38. Duración del mandato y cese.

1. La duración del ejercicio del cargo de vocal del consejo de administración será de cuatro años.

No obstante, los estatutos podrán prever la posibilidad de reelección siempre que se cumplan las mismas condiciones, requisitos y trámites que en el nombramiento.

El cómputo de este período de reelección será aplicado aunque entre el cese y el nuevo nombramiento transcurriesen varios años.

La duración de los sucesivos mandatos no podrá superar los doce años, cualquiera que sea la representación que ejerza.

Cumplido el plazo de doce años, de forma continuada o interrumpida, y transcurridos ocho años desde dicha fecha, podrá volver a ser elegido en las condiciones establecidas en este texto refundido.

2. El nombramiento de los vocales del consejo de administración será irrevocable; tan sólo cesarán en el ejercicio de sus cargos en los supuestos de cese previstos por el artículo 30 de este texto refundido para los conselleiros generales.

Artículo 39. Nombramiento del Presidente.

1. El consejo de administración nombrará de entre sus miembros al Presidente que, a la vez, lo será de la entidad, y uno o más vicepresidentes, que lo sustituirán por orden suya. Nombrará un secretario. El Presidente, vicepresidente y secretario del consejo de administración, lo serán, asimismo, de la asamblea general.
2. En caso de falta de acuerdo sobre el nombramiento del Presidente o en ausencia del mismo y de los vicepresidentes, convocará y presidirá las reuniones y ejercerá las funciones correspondientes el vocal de mayor edad.

Artículo 40. Sesiones del consejo.

1. El consejo se reunirá todas las veces que sea necesario para la buena marcha de la entidad y una vez al mes, como mínimo.

2. La convocatoria le corresponderá al Presidente, quien determinará los asuntos que deben figurar en el orden del día, presidirá la sesión y dirigirá los debates y discusiones.

3. El Presidente convocará, a iniciativa propia o a petición de un tercio, como mínimo, de los miembros del consejo. En este último supuesto, el orden del día estará motivado por el objeto de la petición.

4. Los acuerdos se adoptarán por mayoría de los conselleiros asistentes si los estatutos no exigen otra mayoría. El Presidente podrá tener voto de calidad.

5. A las reuniones del consejo podrá asistir, con voz y voto, el director general de la entidad, excepto para la toma de decisiones que lo afecten.

Artículo 41. Comisiones delegadas. El consejo de administración podrá delegar facultades en una o más comisiones delegadas, entre las cuales será obligatoria la creación de una comisión delegada de la obra benéfico-social.

\section{Sección $4 .^{\mathrm{a}}$ Comisión de control}

Artículo 42. Facultades de la comisión de control.

Serán facultades de la comisión de control:

a. Supervisar la gestión del consejo de administración, velando por la adecuación de sus acuerdos a las directrices y resoluciones de la asamblea general, así como a los fines propios de la entidad.

b. Vigilar el correcto funcionamiento de la auditoría interna.

c. Conocer los informes de auditoría externa y las recomendaciones que formulen los auditores. 
d. Revisar el balance y la cuenta de resultados de cada ejercicio anual, formulando las observaciones que considere oportunas.

e. Elevar a la asamblea general información de su actuación una vez al año, como mínimo.

f. Requerir del Presidente la convocatoria de la asamblea general con carácter extraordinario cuando lo consideren conveniente, por lo menos, los dos tercios de sus miembros.

g. Controlar los procesos electorales de composición de la asamblea.

h. Conocer y dar su opinión sobre los informes de la comisión delegada de la obra benéfico-social.

i. Informar a la Consellería de Economía e Facenda en los casos de nombramiento y cese del director general.

j. Cualquier otra que le atribuyan los estatutos.

2. La comisión de control deberá informar inmediatamente de las posibles irregularidades observadas en ejercicio de sus funciones a la Consellería de Economía e Facenda para que tome las medidas oportunas, sin perjuicio de sus facultades de solicitar la convocatoria de asamblea general y su obligación de comunicar directamente al Banco de España o al organismo estatal que corresponda las cuestiones relacionadas con las competencias que le son propias.

3. La comisión de control elaborará los informes que reglamentariamente se establezcan, que serán remitidos a la Consellería de Economía e Facenda.

4. Para el cumplimiento de estas funciones tendrá derecho al acceso inmediato a toda la documentación precisa para el desarrollo de sus funciones.

Artículo 43. Miembros de la comisión de control.

1. El número de miembros de la comisión de control se fijará como máximo en ocho, elegidos por la asamblea general de entre sus miembros que no ostenten la condición de vocales del consejo de administración, y deberán existir como mínimo en la misma representantes de corporaciones locales, impositores, personas o entidades fundadoras y personal de la caja de ahorros, aplicando criterios de proporcionalidad en lo tocante a los grupos que la integran.

2. De entre sus miembros, la comisión elegirá un Presidente y un secretario.

3. Para el cumplimiento de sus funciones, la comisión de control se reunirá todas las veces que sea convocada por su Presidente a iniciativa propia o a petición de un tercio de sus miembros y, como mínimo, una vez al trimestre. En el ejercicio de sus funciones podrá obtener del consejo de administración y del director general los antecedentes y la información que considere necesarios.

4. El director general asistirá a las reuniones con voz y sin voto, siempre que la comisión así lo requiera.

5. Podrá, además, formar parte de la comisión de control un representante de la Comunidad Autónoma elegido por la Consellería de Economía e Facenda de entre personas con capacidad y preparación técnica adecuada. Asistirá a las reuniones de la comisión con voz y sin voto.

\section{Sección 5. ${ }^{\mathrm{a}}$ \\ El director general}

\section{Artículo 44. Funciones.}

El director general ejecutará los acuerdos del consejo de administración y ejercerá las otras funciones que los estatutos o los reglamentos de cada entidad le encomienden.

Artículo 45. Nombramiento y renovación.

1. El director general será designado por el consejo de administración de la caja entre las personas con capacidad, preparación técnica y experiencia suficiente para realizar las funciones del cargo.

2. Su nombramiento deberá ser ratificado por la asamblea general y comunicado a la Consellería de Economía e Facenda.

3. Podrá ser removido de su cargo:

a. Por el acuerdo de la mitad más uno, como mínimo, de los miembros del consejo 
de administración ratificado por la asamblea general de la caja.

b. En virtud de expediente disciplinario instruido por la Consellería de Economía e Facenda por propia iniciativa o a propuesta del Banco de España.

c. Por jubilación a la edad que fijen los estatutos de la caja.

4. El cese en el cargo de director general no afectará, en su caso, los derechos derivados de su relación laboral con la entidad.

Artículo 46. Dedicación.

El ejercicio del cargo de director general exige dedicación exclusiva, sin perjuicio de las actividades que ejerza en representación de la caja.

\section{Capitulo IV \\ IMPUGNACIÓN DE ACUERDOS, LIBRO DE ACTAS Y RESPONSABILIDAD \\ DE LOS VOCALES DEL CONSEJO DE ADMINISTRACIÓN}

Artículo 47. Impugnación de acuerdos.

1. Podrán ser impugnados los acuerdos tanto de la asamblea general como del consejo de administración que sean contrarios a la ley, se opongan a los estatutos o lesionen los intereses de la caja.

2. Están legitimados para impugnarlos los respectivos miembros que no asistieran a la reunión en la que se adoptó el acuerdo impugnado o que, asistiendo, hicieran constar su oposición a éste.

3. La acción de impugnación de los acuerdos deberá ejercerse dentro del plazo de cuarenta días desde la aprobación del acta correspondiente.

Artículo 48. Libro de actas.

Las discusiones y los acuerdos de cada sesión de la asamblea y del consejo serán recogidos por el secretario en un libro de actas, que serán firmadas por éste y por el Presidente.

Artículo 49. Responsabilidad de los vocales del consejo de administración.

1. Los miembros del consejo de administración responderán frente a la caja, frente a la asamblea general y frente a los depositantes y acreedores del daño que causen por actos contrarios a la ley o a los estatutos o por los realizados sin la diligencia con que deben desempeñar el cargo.

2. Responderán solidariamente todos los miembros del órgano de administración que realizó el acto o adoptó el acuerdo lesivo, menos los que prueben que, no interviniendo en su adopción y ejecución, desconocían su existencia o, conociéndola, hicieron todo lo que convenía para evitar el daño o, por lo menos, se opusieron expresamente a aquél.

\section{Capitulo V FUSIÓN, DISOLUCIÓN Y LIQUUIDACIÓN}

Artículo 50. Clases de fusión. Las cajas de ahorros podrán fusionarse:

a. Mediante creación de una nueva caja de ahorros y extinción de las entidades que se fusionan, que transferirán en bloque sus patrimonios a la entidad de nueva creación.

b. Mediante absorción, en virtud de la cual las cajas absorbidas transferirán en bloque sus patrimonios a la caja absorbente, produciéndose igualmente la extinción de aquéllas.

Artículo 51. Proyecto de fusión.

1. Los consejos de administración de las cajas que pretendan fusionarse deberán elaborar y suscribir un proyecto de fusión.

2. Tal proyecto de fusión deberá contener, por lo menos, los siguientes elementos:

a. La denominación, el domicilio y los datos identificadores de su inscripción en el Registro Mercantil de todas las entidades participantes en la fusión.

b. Las cuentas anuales y el informe de gestión de los tres últimos ejercicios de las entidades participantes en la fusión con los informes correspondientes de los auditores de cuentas.

c. Los estatutos vigentes de las entidades participantes en la fusión, incluido, en 
su caso, el proyecto de los estatutos de la nueva entidad que se pretende crear.

d. La justificación económica del proyecto de fusión, la organización resultante y el programa estratégico de la nueva entidad que suscribirán los administradores de las entidades participantes en el proceso de fusión.

e. Los balances de fusión, el balance resultante y los términos de la transmisión patrimonial que implica la fusión, expresando y justificando las diferencias de valor que pudiesen aparecer respecto del último balance aprobado y al que se le hizo auditoría.

f. El proyecto de la escritura de constitución de la nueva entidad o, si se trata de absorción, el texto íntegro de las modificaciones que se deban introducir en la absorbente.

g. La fecha a partir de la cual ha de tener vigencia la fusión y, por lo tanto, el momento a partir del cual las operaciones efectuadas por las entidades que se extinguen se entenderán realizadas por cuenta de la entidad absorbente o de la nueva entidad que surja de la fusión.

h. Los órganos de gobierno que se hagan cargo de la nueva entidad —o de la absorbente - hasta que se produzcan las correspondientes elecciones.

i. El informe de dos o más expertos independientes sobre el proyecto de fusión y sobre el patrimonio aportado por las entidades que se extinguen.

j. El texto del acuerdo de fusión que se someterá a la consideración de las respectivas asambleas generales.

3. El consejo de administración de cada caja estará obligado a presentar para su depósito en el Registro Mercantil un ejemplar del proyecto de fusión.

Artículo 52. Acuerdo de fusión.

El acuerdo de fusión deberá ser adoptado independientemente por la asamblea general de cada una de las cajas de ahorros que se fusionan. A tal fin será necesaria la presencia, por lo menos, de las dos terceras partes de sus miembros, debiendo votar a favor del acuerdo la mitad más uno de los asistentes.

Artículo 53. Conselleiros generales. Transitoriamente, en los casos de fusión, el número de conselleiros generales podrá alcanzar la suma de los conselleiros de las cajas que se fusionan hasta que, dentro del plazo que señale el acuerdo de fusión, se constituyan los órganos definitivos de la entidad resultante.

Artículo 54. Autorización de las fusiones.

1. Las fusiones deberán ser autorizadas por la Consellería de Economía e Facenda, previa solicitud conjunta de las entidades que pretenden su fusión.

La fusión de una caja de ahorros gallega con otra de fuera de Galicia deberá ser autorizada conjuntamente por los órganos competentes de las Comunidades Autónomas afectadas, determinándose, en el acto de autorización, la proporción que les corresponderá a las administraciones públicas, a las entidades y a las corporaciones de derecho público de cada comunidad en los órganos de gobierno de la caja de ahorros resultante de la fusión.

2. Para conceder la autorización serán requisitos indispensables entre otros:

a. Que la entidad absorbida o las que deseen fusionarse no estén en liquidación.

b. Que no se derive perjuicio para las garantías de los impositores o acreedores de las cajas que pretendan integrarse.

3. Reglamentariamente se determinarán los requisitos, las condiciones y el procedimiento que se deberán cumplir en el proceso de fusión.

Artículo 55. Causas de disolución.

1. Las cajas de ahorros se disolverán:

a. Por acuerdo de la asamblea general adoptado por los dos tercios de sus miembros.

b. Por cumplimiento del plazo fijado en sus estatutos. 
c. Como consecuencia de la revocación de la autorización, según la normativa básica.

d. Por fusión, cualquiera que sea la modalidad.

e. Por cualquier otra causa establecida en los estatutos.

2. La Xunta de Galicia, a la vista de la evolución del neto patrimonial y de la solvencia de la caja, podrá iniciar el oportuno expediente revocatorio de acuerdo con lo previsto en la letra c) anterior.

Artículo 56. Autorización y registro de la disolución.

1. Los acuerdos de disolución deberán ser ratificados por la Consellería de Economía e Facenda, la cual, de juzgarlo necesario, podrá designar un interventor con capacidad suficiente para supervisar todo el proceso hasta la extinción de la caja.

2. Los acuerdos de disolución se inscribirán en el Registro Mercantil y en el Registro de Cajas de Ahorros Gallegas, publicándose además en el boletín oficial del Registro Mercantil, en el "Diario Oficial de Galicia" y por lo menos en uno de los diarios de mayor circulación en el área operativa de la caja que se disuelva.

Artículo 57. Liquidación.

1. Acordada válidamente la disolución de la caja, se iniciará el período de liquidación, durante el cual ésta conservará su personalidad jurídica.

2. Concluida la liquidación, los administradores elaborarán el balance final, que deberá ser suscrito, en su caso, por el interventor y aprobado por la Consellería de Economía e Facenda.

Artículo 58. Adjudicación de los bienes.

1. La adjudicación de los bienes resultantes de la liquidación se ajustará a lo establecido en la Ley de Fundaciones de Interés Gallego.

2. Todo lo anterior se entiende sin perjuicio de lo que establezca la normativa básica sobre el fondo de garantía de depósitos y otros sistemas de colaboración.

\section{TÍTULO III \\ INTERVENCIONES PÚBLICAS}

\author{
Capitulo I \\ PRINCIPIOS GENERALES
}

Artículo 59. Actividad financiera. Las cajas de ahorros desarrollarán su actividad financiera con absoluta libertad e independencia dentro del respeto a las leyes. La Xunta de Galicia velará por la transparencia de los mercados y por la solvencia de las entidades y establecerá los medios necesarios de protección a los clientes.

Artículo 60. Apertura de oficinas. Las cajas de ahorros gallegas podrán abrir oficinas en cualquier parte del territorio del Estado siempre que cumplan las normas de solvencia establecidas y así lo comuniquen a la Consellería de Economía e Facenda. A tal fin y con la suficiente antelación, las cajas pondrán en conocimiento de ella sus planes de expansión.

La apertura de oficinas en el extranjero requerirá la comunicación a la Consellería de Economía e Facenda, sin perjuicio de las competencias del Banco de España.

Artículo 61. Aspectos fundacionales.

La Xunta de Galicia realizará una labor de orientación en materia de obra benéfico-social, indicando las principales necesidades y prioridades, sin perjuicio de la libertad de cada caja en cuanto a la elección de los destinos concretos del gasto.

\section{Capítulo II \\ TRANSPARENCIA DE MERCADO Y PROTECCIÓN A LOS CLIENTES \\ Sección 1. ${ }^{a}$ \\ Solvencia}

Artículo 62. Información de solvencia.

1. Las cajas de ahorros deberán cumplir los coeficientes de solvencia y las limitaciones a la actividad por razón de solvencia, de acuerdo con la normativa estatal de carácter básico y con lo previsto en el presente texto refundido.

2. A estos efectos, la Consellería de Economía e Facenda podrá requerir 
cuanta información sea necesaria para verificar tal cumplimiento por parte de la caja o, en su caso, del grupo consolidable en el que figure ésta en la cabecera. De la misma forma, podrá solicitar información de aquellas personas físicas o jurídicas de las que, por sus relaciones con la caja de ahorros o con su grupo, pueda presumirse una incidencia en la situación jurídica, financiera o económica de la caja de ahorros o de su grupo consolidable.

Artículo 63. Riesgo de solvencia.

1. Sin perjuicio del cumplimiento de la normativa básica, cuando una caja de ahorros o su grupo consolidable no alcance los niveles mínimos de recursos propios exigidos o vulnere las limitaciones por razones de solvencia, tendrá que comunicarlo, con la mayor brevedad posible, al órgano competente de la Comunidad Autónoma de Galicia, debiendo adoptarse, en las condiciones que reglamentariamente se determinen, las medidas necesarias para retornar al cumplimiento de las normas infringidas.

2. En los supuestos del párrafo anterior, la apertura de nuevas oficinas quedará sometida a la autorización del órgano competente de la Comunidad Autónoma, previo informe favorable del Banco de España.

Artículo 64. Coordinación.

A efectos de controlar el cumplimiento de las normas de solvencia, la Comunidad Autónoma de Galicia actuará de forma coordinada con los organismos correspondientes del Estado.

Artículo 65. Autorización de determinadas inversiones.

La Consellería de Economía e Facenda podrá establecer, en función de los recursos propios o totales de la caja de ahorros o en relación con una cantidad determinada, la necesidad de autorización previa para las inversiones en inmuebles, acciones, participaciones $\mathrm{u}$ otros activos monetarios, la concesión de grandes créditos o la concentración de riesgos en una persona o grupo, sin perjuicio de las competencias que la normativa básica atribuye al Banco de España ${ }^{229}$.

\section{Sección 2. ${ }^{a}$}

Transparencia de mercado

Artículo 66. Información pública. La Xunta de Galicia establecerá la información que, como mínimo, y con carácter general, las cajas deben poner a disposición de todo el público, así como la forma de hacerlo. Tal información podrá referirse a:

a. Origen fundacional de la caja y miembros del Consejo de administración.

b. Entidades jurídicas que, en su caso, forman parte del grupo.

c. Operaciones más características que lleva a cabo.

d. Coste efectivo y rendimiento de las operaciones anteriores.

e. Ámbito territorial de actuación.

f. Grado de solvencia de la entidad.

Artículo 67. Publicidad.

1. Requerirá previa y expresa autorización de la Consellería de Economía e Facenda la publicidad realizada por las cajas de ahorros gallegas cuando tenga contenidos económico-financieros.

2. La publicidad carente de tales contenidos será simplemente objeto de comunicación a la referida consellería, y podrá difundirse sin más requisitos ${ }^{230}$.

Artículo 68. Contratos y liquidaciones. De conformidad con lo previsto en la normativa básica, la Consellería de Economía e Facenda podrá:

a. Establecer los requisitos que deban satisfacer los contratos financieros que suscriban con sus clientes las cajas de ahorros para proteger los legítimos intereses de la clientela, tanto activa coma pasiva.

En todo caso, se velará para que su contenido sea claro, transparente y de fácil comprensión.

229 Véase Orden de 10 de mayo de 2006 sobre autorizaciones previas a determinadas operaciones de las cajas de ahorros gallegas.

230 Véase Orden de 31 de mayo de 2006 por la que se regula la publicidad de las cajas de ahorro. 
b. Imponer la entrega al cliente de un ejemplar del contrato, debidamente suscrito por la entidad.

c. Establecer los requisitos que deban satisfacer las liquidaciones periódicas que las cajas efectúan a sus clientes.

\section{Sección $3 .^{a}$}

\section{Protección al cliente}

Artículo 69. Normas de seguridad. Las cajas de ahorros gallegas y las que operen en el territorio de Galicia deberán observar las normas de seguridad en sus instalaciones y formas de operar que establezca la Xunta de Galicia, sin perjuicio de la normativa básica.

Artículo 70. Defensor del cliente.

1. La Federación Gallega de Cajas de Ahorros establecerá la figura del defensor del cliente, que se ocupará de la defensa de los intereses y derechos de éstos en sus relaciones con cualquiera de las cajas de ahorros operantes en Galicia.

2. La Junta de Gobierno de la Federación Gallega de Cajas de Ahorros nombrará el defensor del cliente entre personas de reconocido prestigio e independencia, con residencia habitual en la comunidad gallega. El nombramiento se hará por cuatro años, y podrá ser reelegido una sola vez.

3. El defensor del cliente tendrá las mismas incompatibilidades que las leyes les impongan a los conselleiros generales de las cajas.

4. En las oficinas de las cajas de ahorros se informará convenientemente al público de la existencia del defensor del cliente y del procedimiento que se debe seguir para formular, en su caso, las reclamaciones pertinentes 231 .

Artículo 71. Oficina de reclamaciones. En la oficina de reclamaciones creada en la Consellería de Economía e Facenda los clientes de las cajas de ahorros gallegas podrán presentar sus quejas referidas al incumplimiento por parte de aquéllas de cualquiera de las normas de disciplina.

231 Véase Decreto 240/1998, de 24 de julio, por el que se regula la figura del Valedor del cliente de las cajas de ahorros.
Dichas quejas sólo se podrán formular cuando fuesen desestimadas por el defensor del cliente o no fuesen contestadas en el plazo de dos meses ${ }^{232}$.

\section{Capitulo III POLITICA CREDITICIA}

Artículo 72. Inversión obligatoria. En el marco de la política monetaria y de la ordenación del crédito del Estado, la Consellería de Economía e Facenda calificará los activos en que las cajas de ahorros con domicilio social en la Comunidad Autónoma de Galicia deberán materializar las obligaciones de inversión previstas en cada momento en la legislación vigente.

Artículo 73. Incentivos públicos.

1. La Xunta de Galicia, dentro de sus actuaciones de política regional, podrá suscribir acuerdos con las cajas de ahorros con el fin de favorecer la financiación de aquellos sectores, áreas o grupos económicos que, de acuerdo con los objetivos de tal política autonómica, resulten prioritarios.

2. En la Ley de Presupuestos de cada año la Xunta de Galicia habilitará los créditos necesarios para subvencionar los tipos de interés o asumir, en favor del prestatario, todo o parte del riesgo que comporte la operación que se pretende estimular.

3. Las ayudas que pueda establecer la Xunta de Galicia respetarán, en todo caso, la normativa vigente en materia de defensa de la competencia.

\section{Capítulo IV \\ LA OBRA BENÉFICO SOCIAL 233}

Artículo 74. Cuantía de las dotaciones.

1. De acuerdo con su finalidad y naturaleza fundacional, las cajas destinarán la totalidad de sus excedentes que no tengan que aplicarse a reservas por mandato legal a la dotación de reservas voluntarias y a

232 Véase Decreto 270/1998, de 24 de septiembre, por el que desarrolla la organización y funcionamiento de la Oficina de reclamaciones de clientes de las cajas de ahorros. 233 Véase Decreto 261/1999, de 17 de septiembre, por el que se desarrolla la Regulación de la Obra BenéficoSocial de las cajas de ahorro gallegas. 
la creación y al mantenimiento de obras benéfico-sociales.

2. En el caso de cajas que encabecen un grupo consolidable de entidades de crédito, el excedente de referencia será el que resulte de los estados contables consolidados.

3. Corresponde a la Consellería de Economía e Facenda autorizar los acuerdos aprobados por la asamblea general de las cajas, relativos a la determinación de los excedentes y a su distribución conforme a la normativa aplicable.

4. La Consellería de Economía e Facenda y las cajas podrán acordar el porcentaje de sus excedentes que estas últimas dedicarán, anualmente, a obras benéfico-sociales. En el caso contrario, podrán establecerse por vía reglamentaria, después de ser oída la Federación Gallega de Cajas de Ahorros.

Artículo 75. Destino de la obra benéfico-social.

1. Las dotaciones que las cajas hagan a la obra benéfico-social deberán destinarse a financiar inversiones o a promover actividades que satisfagan alguno de los siguientes requisitos:

a. Que favorezcan el desarrollo cultural, educativo y socioeconómico de Galicia.

b. Que faciliten la integración social de colectivos marginales.

c. Que favorezcan, sobre todo, a grupos con bajos niveles de ingresos.

2. Para identificar aquellos proyectos concretos que pudiesen constituir los destinos de la obra benéfico-social de las cajas se tomarán como referencia los estudios y los análisis existentes sobre la realidad socioeconómica de Galicia y aquellos otros que las propias cajas puedan realizar con especial referencia al territorio que constituye su zona de influencia. En cualquier caso se deberán tener en cuenta también aquellos proyectos que potencien las señas de identidad de cada caja.

3. Las cajas que, no teniendo su sede social en Galicia, cuenten con oficinas en la comunidad gallega deben efectuar inversiones o gastos en obra benéficosocial en Galicia, destinando a tal efecto como mínimo la parte de su presupuesto anual de obra benéfico-social proporcional a los recursos ajenos captados en Galicia con respecto al total de la entidad.

4. Anualmente las cajas evaluarán en qué medida los proyectos realizados contribuyeron a mejorar la situación económico-social de Galicia.

5. A la obra benéfico-social no gestionada directamente por las cajas le serán aplicables los mismos principios y criterios que a la gestionada directamente.

Artículo 76. Proyectos de obras sociales.

1. Las cajas de ahorros realizarán obra benéfico-social propia, en colaboración con otras instituciones públicas o privadas e incluso entre varias cajas.

2. Las cajas deberán justificar el interés y los beneficios sociales de los proyectos de gasto en obras benéfico-sociales que pretendan llevar a cabo, de acuerdo con su naturaleza y finalidad.

Artículo 77. El presupuesto de la obra benéfico-social.

1. El consejo de administración de cada caja, considerando los proyectos que de acuerdo con lo previsto en el artículo 75 deban realizarse, elaborará el presupuesto anual de la obra benéfico-social, que deberá someterse a la asamblea general, y se comunicará seguidamente a la Consellería de Economía e Facenda a los efectos previstos en el artículo 74.3 de este texto refundido.

2. Transcurrido el período presupuestario, el Consejo rendirá cuentas igualmente de su ejecución.

Artículo 78. La gestión de la obra benéfico-social.

Las cajas, a través del consejo de administración y de la comisión de la obra benéfico-social, deberán disponer de una gestión profesionalizada de las inversiones de la obra benéfico-social. 


\section{TÍTULO IV \\ NORMAS DE CONTROL}

\section{Capítulo I}

OBLIGACIONES DE INFORMACIÓN

Artículo 79. Información que hay que suministrar.

1. Las cajas de ahorros estarán obligadas a facilitar a la Consellería de Economía e Facenda, en la forma en que reglamentariamente se determine, toda la información que les sea requerida sobre su actividad y gestión.

2. Asimismo, remitirán, en la forma en que reglamentariamente se determine, copia de:

a. La información que obligatoriamente tengan que ofrecerle al público en general, de acuerdo con las normas de este texto refundido, y de la contenida en su publicidad.

b. Los modelos de los contratos de adhesión que se suscribirán con sus clientes $\mathrm{y}$ de las liquidaciones que practiquen.

c. Las cuentas anuales y demás información exigida por las leyes mercantiles.

d. La información requerida por el Ministerio de Economía y Hacienda y por el Banco de España.

Artículo 80. Informe del defensor del cliente.

El defensor del cliente elaborará anualmente un informe donde se recogerán todas las incidencias de su actividad, así como las propuestas que de éstas se pudiesen derivar, y deberá remitir dicho informe a la Consellería de Economía e Facenda.

\section{Capitulo II MECANISMOS DE CONTROL}

Artículo 81. Coordinación e inspección.

En el marco de las bases aprobadas por el Estado sobre ordenación del crédito y la banca, y de acuerdo con las directrices de la Xunta de Galicia, la Consellería de Economía e Facenda ejercerá las funciones de inspección de las cajas de ahorros domiciliadas en Galicia, sin perjuicio de las funciones que le correspondan al Banco de España.
Artículo 82. Auditorías.

1. Las cajas de ahorros deberán someter a auditoría externa los estados financieros y las cuentas de resultados de cada ejercicio, que remitirán a la Consellería de Economía e Facenda.

2. La Consellería de Economía e Facenda podrá establecer el alcance y el contenido de los informes de la auditoría.

Artículo 83. Inspección financiera.

1. La Xunta de Galicia, a través de la Consellería de Economía e Facenda, controlará el cumplimiento por parte de las cajas del conjunto de las normas legales que les son aplicables, tanto las de carácter básico como las complementarias y de desarrollo que se establecen en el presente texto refundido.

2. A tal efecto la Xunta de Galicia podrá suscribir los convenios oportunos con el Banco de España con objeto de coordinar sus actuaciones y minimizar los costes indirectos del control sobre las entidades afectadas.

Artículo 84. Control de las cajas con domicilio fuera de Galicia.

Sin perjuicio de las competencias del Banco de España la Consellería de Economía e Facenda ejercerá las funciones de disciplina, inspección y sanción de las actividades realizadas en Galicia por cajas de ahorros domiciliadas fuera del territorio de esta Comunidad Autónoma.

Anualmente, las cajas a las que se refiere el párrafo anterior remitirán a la Consellería de Economía e Facenda una memoria explicativa de su actividad económica, administrativa y social.

\section{TÍTULO V RÉGIMEN SANCIONADOR \\ Capítulo I INFRACCIONES}

Artículo 85. Ámbito de aplicación. Las cajas de ahorros sometidas al presente texto refundido, así como las personas que tengan cargos de administración o dirección en ellas, serán sancionadas por las infracciones que pudiesen cometer, de acuerdo con lo dispuesto en este texto refundido. 
Artículo 86. Clases de infracciones. Las infracciones se clasifican en muy graves, graves y leves.

Artículo 87. Infracciones muy graves. Constituyen infracciones muy graves:

a. La realización de los actos que a continuación se relacionan, sin autorización cuando ésta sea preceptiva, sin observar las condiciones básicas fijadas en ella, $\mathrm{u}$ obtenerla por medio de declaraciones falsas o por otro medio irregular:

1. Fusiones, absorciones o escisiones que afecten a las cajas de ahorros.

2. Adquisición, directa o indirecta, de acciones o de otros títulos representativos del capital o cesión de sus derechos políticos de:

a. Entidades de crédito españolas por otras personas físicas o jurídicas españolas o extranjeras, cuando supongan el control, de derecho o de hecho, de aquéllas o el cambio en éste.

b. Entidades de crédito extranjeras, por entidades de crédito españolas o entidad filial o dominante de éstas.

3. Distribución de reservas, expresas u ocultas.

4. Apertura de oficinas operativas en el extranjero.

b. El ejercicio de actividades ajenas a su objeto exclusivo legalmente determinado, excepto que tenga un carácter simplemente ocasional o aislado.

c. La realización de actos u operaciones prohibidas por normas de ordenación y disciplina con rango de ley o con incumplimiento de los requisitos establecidos en ellas, salvo que tenga un carácter simplemente ocasional o aislado.

d. El incumplimiento de la obligación de someter sus cuentas anuales a auditoría de cuentas, conforme a la legislación vigente en la materia.

e. La negativa o resistencia a la actuación inspectora, siempre que medie requerimiento expreso y por escrito al respecto.

f. La falta de remisión al órgano administrativo competente de cuantos datos o documentos deban remitírsele o requiera en el ejercicio de sus funciones, o la falta de veracidad en ellos, cuando con esto se dificulte la apreciación de la solvencia de la entidad. A los efectos de esta letra se entenderá que hay falta de remisión cuando ésta no se produzca dentro del plazo concedido al efecto por el órgano competente al recordar por escrito la obligación o reiterar el requerimiento.

g. El incumplimiento del deber de veracidad informativa debida a los depositantes, prestamistas y al público en general, siempre que por el número de afectados o por la importancia de la información el incumplimiento pueda considerarse como especialmente relevante.

h. La realización de actos fraudulentos o la utilización de personas físicas o jurídicas interpuestas con la finalidad de conseguir un resultado en el que la obtención directa implicaría la comisión de, por lo menos, una infracción grave.

i. Las infracciones graves cuando durante los cinco años anteriores a su comisión le hubiese sido impuesta a la entidad de crédito sanción firme por el mismo tipo de infracción.

Artículo 88. Infracciones graves. Constituyen infracciones graves:

a. La realización de actos u operaciones sin autorización, cuando ésta sea preceptiva, sin observar sus condiciones básicas, u obtenerla por medio de declaraciones falsas o por otro medio irregular, excepto en los casos en que esto suponga la comisión de una infracción muy grave de acuerdo con la letra a) del artículo anterior.

b. La ausencia de comunicación, cuando ésta sea preceptiva, en los supuestos enumerados en la letra a) del artículo anterior y en los casos en que ésta se refiere a la composición de los órganos de administración de la entidad.

c. El ejercicio, incluso ocasional o aislado, de actividades ajenas a su objeto exclusivo legalmente determinado.

d. La realización, incluso ocasional o aislada, de actos o operaciones prohibidas por normas de ordenación y disciplina con 
rango de ley o con incumplimiento de los requisitos establecidos en ellas.

e. La realización de actos u operaciones con incumplimiento de las normas dictadas al amparo del número 2 del artículo 48 de la Ley 26/1988, de 29 de julio.

f. El incumplimiento de las normas vigentes en materia de límites de riesgos o de cualquier otra que imponga limitaciones cuantitativas, absolutas o relativas, al volumen de determinadas operaciones activas o pasivas.

g. La falta de remisión al órgano administrativo competente de los datos o documentos que se deban remitir o que éste requiera en el ejercicio de sus funciones, así como la falta de veracidad en ellos, salvo que esto suponga la comisión de una infracción muy grave. A los efectos de esta letra se entenderá que hay falta de remisión cuando ésta no se produzca dentro del plazo concedido al efecto por el órgano competente al recordar por escrito la obligación o reiterar el requerimiento.

h. La falta de comunicación por parte de los administradores a la asamblea general de aquellos hechos o circunstancias cuya comunicación a aquélla hubiese sido ordenada por el órgano administrativo facultado para ello.

i. El incumplimiento del deber de veracidad informativa debida a los depositantes, prestamistas o al público en general, cuando no concurran las circunstancias a que se refiere la letra g) del artículo anterior.

j. Las infracciones leves cuando durante los dos años anteriores a su comisión le hubiese sido impuesta a la caja de ahorros sanción firme por el mismo tipo de infracción.

k. La efectiva administración o dirección de las cajas de ahorros por personas que no ejerzan de derecho en ellas un cargo de dicha naturaleza.

Artículo 89. Infracciones leves. Constituyen infracciones leves aquellas infracciones a las normas de ordenación y disciplina que no constituyen infracción grave o muy grave conforme a lo dispuesto en los artículos anteriores.

Artículo 90. Prescripción.

1. Las infracciones muy graves y las graves prescribirán a los cinco años y las leves a los dos años.

2. En ambos casos, el plazo de prescripción se contará desde la fecha en que la infracción fue cometida. En las infracciones derivadas de una actividad continuada, la fecha inicial del cómputo será la de finalización de la actividad o la del último acto con que la infracción se consume.

3. La prescripción se interrumpirá por la iniciación, con conocimiento del interesado, del procedimiento sancionador, volviendo a correr el plazo si el expediente permaneciera paralizado durante seis meses por causa no imputable a aquellos contra los que se dirigía.

\section{Capítulo II SANCIONES}

Artículo 91. Sanciones a la entidad. En los supuestos a que se refieren los artículos de la sección anterior serán aplicables una o más de las siguientes sanciones a la caja de ahorros:

1. Por la comisión de infracciones muy graves:

a. Multa por importe de hasta el 1 por 100 de sus recursos propios o hasta 300.000 euros, si aquel porcentaje fuese inferior a esta cifra.

b. Revocación de la autorización de la entidad, con exclusión del Registro de Cajas de Ahorros de Galicia.

c. Amonestación pública con publicación en el "Diario Oficial de Galicia".

2. Por la comisión de infracciones graves:

a. Amonestación pública con publicación en el "Diario Oficial de Galicia".

b. Multa por importe de hasta 0,5 por 100 de sus recursos propios o hasta 
150.000 euros, si aquel porcentaje fuese inferior a esta cifra.

3. Por la comisión de infracciones leves:

a. Amonestación privada.

b. Multa por importe de hasta 60.000 euros.

Artículo 92. Otras sanciones.

Además de las sanciones previstas en el artículo anterior que corresponda imponer a la caja de ahorros por la comisión de infracciones muy graves, se le impondrá a quien, ejerciendo cargos de administración de hecho o de derecho en ella, sea responsable de la infracción una de las siguientes sanciones:

a. Multa a cada responsable por importe no superior a 150.000 euros.

b. Suspensión en el ejercicio del cargo por plazo no superior a tres años.

c. Separación del cargo, con inhabilitación para ejercer cargos de administración o dirección en la misma entidad de crédito, por un plazo máximo de cinco años.

d. Separación del cargo, con inhabilitación para ejercer cargos de administración o dirección en cualquier entidad de crédito o del sector financiero, por un plazo máximo de diez años.

No obstante lo dispuesto en el apartado anterior, en el caso de imposición de las sanciones previstas en las letras c) o d) podrá imponerse simultáneamente la sanción prevista en la letra a).

Por la comisión de infracciones graves se le impondrá a quien, ejerciendo cargos de administración o dirección en la caja, sea responsable de la infracción una de las siguientes sanciones:

a. Amonestación privada.

b. Amonestación pública con publicación en el "Diario Oficial de Galicia".

c. Multa a cada responsable por importe no superior a 90.000 euros.

d. Inhabilitación para ejercer cargos de administración o dirección en cualquier entidad de crédito o del sector financiero, por plazo no superior a un año.
No obstante lo dispuesto en el apartado anterior, en el caso de imposición de la sanción prevista en la letra d) podrá imponerse simultáneamente la sanción prevista en la letra c).

Artículo 93. Criterios de graduación.

1. Las sanciones aplicables a cada caso por la comisión de infracciones muy graves, graves o leves se determinarán atendiendo a los siguientes criterios:

a. La naturaleza y entidad de la infracción.

b. La gravedad del peligro ocasionado o del perjuicio causado.

c. Las ganancias obtenidas, en su caso, como consecuencia de los actos u omisiones constitutivos de la infracción.

d. La importancia de la entidad de crédito correspondiente, medida en función del importe total de su balance.

e. Las consecuencias desfavorables de los hechos para el sistema financiero o la economía nacional.

f. La circunstancia de que se hubiese procedido a la reparación de la infracción por propia iniciativa.

g. La conducta anterior de la entidad en relación con las normas de ordenación y disciplina que la afecten, atendiendo a las sanciones firmes que le hubiesen sido impuestas durante los últimos cinco años.

2. Para determinar la sanción aplicable entre las previstas en el artículo anterior, se tomarán en consideración, además, las siguientes circunstancias:

a. El grado de responsabilidad en los hechos que concurra en el interesado.

b. La conducta anterior del interesado en la misma o en otra entidad de crédito en relación con las normas de ordenación y disciplina, tomando en consideración al efecto las sanciones firmes que le hubiesen sido impuestas durante los últimos cinco años.

c. El carácter de representación que el interesado posea. 


\section{Capitulo III RESPONSABLES}

Artículo 94. Responsables.

1. Quien ejerza en la caja de ahorros cargos de administración o dirección será responsable de las infracciones muy graves o graves cuando éstas sean imputables a su conducta dolosa o negligente.

2. No obstante lo señalado en el apartado anterior, serán considerados responsables de las infracciones muy graves o graves cometidas por las entidades de crédito los administradores o miembros de sus órganos colegiados de administración, excepto en los siguientes casos:

a. Cuando quien forme parte de órganos colegiados de administración no asistiese por causa justificada a las reuniones correspondientes, o votase en contra o salvase su voto en relación con las decisiones o acuerdos que diesen lugar a las infracciones.

b. Cuando tales infracciones sean exclusivamente imputables a comisiones ejecutivas, directores generales u órganos asimilados, o a otras personas con funciones directivas en la entidad.

Artículo 95. Competencia sancionadora.

1. De conformidad con lo dispuesto en el artículo 42 de la Ley 26/1988, de 29 de julio, de Disciplina e Intervención de las Entidades de Crédito, la Xunta de Galicia ejercerá la potestad sancionadora sobre las infracciones definidas en este texto refundido.

2. La imposición de sanciones por infracciones leves y graves corresponderá a la Consellería de Economía e Facenda. La imposición de sanciones por infracciones muy graves corresponderá a la Xunta de Galicia.

3. La propuesta de resolución de los expedientes será objeto de informe por el Banco de España cuando se trate de infracciones graves o muy graves.
4. Cuando los órganos competentes de la Comunidad Autónoma de Galicia tengan conocimiento de hechos sancionables exclusivamente por la Administración del Estado, lo pondrá en conocimiento del Banco de España.

Artículo 96. Suspensión e intervención.

1. La suspensión de los órganos de gobierno y de la dirección de las cajas de ahorros y la intervención de éstas serán decretadas por el Consello de la Xunta de Galicia, a propuesta de la Consellería de Economía e Facenda o del Banco de España, en su caso, cuando así lo aconsejen situaciones de grave irregularidad administrativa o económica. Por motivo de urgencia podrá decretarlas el conselleiro de Economía y Hacienda, quien someterá el acuerdo a la ratificación del Gobierno de la Comunidad Autónoma.

2. También podrá decretarse la intervención previa petición fundamentada de los órganos de gobierno de la propia caja de ahorros.

3. El acuerdo de intervención contendrá las razones y el alcance y limitaciones de éste, será publicado en el "Diario Oficial de Galicia" y en el "Boletín Oficial del Estado" y se inscribirá en los registros correspondientes.

4. En caso de intervención los gastos causados por ésta serán a cargo de la caja afectada.

Artículo 97. Procedimiento sancionador.

El procedimiento y el régimen sancionador serán desarrollados reglamentariamente, teniendo en cuenta los principios básicos de la Ley 30/1992, de 26 de noviembre, de Régimen Jurídico de las Administraciones Públicas y del Procedimiento Administrativo Común 234 .

234 Véase Decreto 241/2000, de 29 de septiembre, por el que se regula el procedimiento sancionador aplicable a las cajas de ahorros de galicia. 


\section{TÍTULO VI ÓRGANOS ASOCIATIVOS}

\section{Capítulo único \\ FEDERACIÓN GALLEGA \\ DE CAJAS DE AHORROS}

Artículo 98. Federación Gallega de Cajas de Ahorros.

Las cajas de ahorros con domicilio social en Galicia se agruparán en una federación que tendrá personalidad jurídica y con las siguientes finalidades:

a. Tener la representación de las cajas ante los poderes públicos.

b. Procurar la captación, la defensa y la difusión del ahorro y orientar las inversiones de las cajas de ahorros conforme las normas generales sobre inversión territorial.

c. Promover y coordinar la prestación de servicios técnicos y financieros.

Artículo 99. Junta de Gobierno y secretaría general.

1. La Federación Gallega de Cajas de Ahorros estará regida por una Junta de Gobierno y por la secretaría general.

La Junta de Gobierno estará integrada por dos representantes de cada una de las cajas federadas, que serán sus respectivos Presidente y director general. El Gobierno de la Comunidad Autónoma, a propuesta de la Consellería de Economía e Facenda, podrá además nombrar un representante en tal junta, con voz y voto.

2. Los acuerdos serán vinculantes y se tomarán por mayoría de votos presentes o representados, en la forma que determinen los estatutos, los cuales podrán prever también la necesidad de voto unánime para determinadas materias. Los estatutos podrán prever la emisión de votos ponderados.

\section{Artículo 100. Estatutos.}

1. Los estatutos de la Federación Gallega de Cajas de Ahorros serán aprobados por la Consellería de Economía e Facenda.

2. Los estatutos fundacionales de la Federación Gallega de Cajas de Ahorros tendrán que ser propuestos por las cajas, previo acuerdo que represente como mínimo la mayoría de dos tercios de sus depósitos de clientes referidos al último balance anual cerrado.

\section{DISPOSICIÓN TRANSITORIA RÉGIMEN TRANSITORIO DE LOS ÓRGANOS DE GOBIERNO DE LAS CAJAS DE AHORROS GALLEGAS}

Los conselleiros generales y los miembros del consejo de administración y de la comisión de control que en la fecha de entrada en vigor de la Ley $1 / 2004$, de 21 de abril, estuvieran ejerciendo el cargo, aunque cumplieran ya el período máximo de doce años o lo cumplan en el transcurso de su mandato, podrán permanecer en el ejercicio de sus cargos el presente mandato y uno más, siempre que sean reelegidos; además, exclusivamente para estos supuestos, no les será de aplicación lo previsto en el artículo 37.2 de este texto refundido en lo referente a la limitación de edad.

\section{LEY 5/1992, DE $10 \mathrm{DE}$ JUNIO, DE CREACIÓN DEL INSTITUTO GALEGO DE PROMOCIÓN ECONÓMICA (DOGA N. $\left.{ }^{\circ} 122,26.6 .1992\right)^{235}$}

$$
(\ldots)^{236}
$$

\section{TíTULO I \\ NATURALEZA, FINES Y FUNCIONES}

Artículo 1. En el ámbito de la Comunidad Autónoma de Galicia y al amparo de su Estatuto de Autonomía, se crea el Instituto Galego de Promoción Económica (IGAPE), como ente de derecho público con personalidad jurídica y patrimonio propios. En los casos en que así proceda, su

235 Véase Decreto 317/1992, de 12 de noviembre, por la que se aprueba el Reglamento del Instituto Galego de Promoción Económica.

236 Exposición de motivos omitida. 
actividad estará sujeta a la Ley de Gestión Económica y Financiera Pública de Galicia y demás normas de aplicación.

En sus relaciones externas, en la administración patrimonial y en la contratación, el IGAPE estará sujeto al derecho privado.

Artículo 2. El IGAPE se adscribe a la Consellería de Economía e Facenda de la Xunta de Galicia.

Artículo 3. El IGAPE se crea como un instrumento básico de actuación de la Xunta de Galicia, para impulsar el desarrollo competitivo del sistema productivo gallego, promoviendo actividades que contribuyan a la creación de empleo en Galicia y a un desarrollo económico armónico, equilibrado y justo, basado en un tejido industrial moderno y competitivo.

$\mathrm{Su}$ acción incidirá tanto en el sistema productivo como en la mejora de los procesos de producción, gestión y comercialización.

Artículo 4. Son funciones del IGAPE:

a. Potenciar las actividades económicas que favorezcan el desarrollo equilibrado e integrado de las distintas comarcas.

b. Promover la creación de empresas en los distintos sectores de la actividad económica que tengan mayor impacto $\mathrm{y}$ ventajas comparativas para el desarrollo de la economía gallega.

c. Promover actividades creadoras de empleo y que utilicen más racionalmente recursos internos.

ch. Favorecer la modernización e innovación tecnológica y organizativa de las Empresas gallegas, en particular de las pequeñas y medianas.

d. Fomentar la prestación de servicios a Empresas especialmente a las pequeñas y medianas, promoviendo Sociedades de servicios.

e. Fomentar el desarrollo de la relación científica y tecnológica entre los Centros universitarios, técnicos de investigación y las empresas productivas. Potenciar el desarrollo de parques tacnológicos que materialicen esta relación. f. Promover acciones de divulgación de los instrumentos y fondos de que disponen las administraciones públicas españolas y la Comisión de las Comunidades Europeas para apoyo a las actividades económicas.

g. Proporcionar información sobre los mercados y favorecer el desarrollo de las exportaciones y acuerdos con Empresas extranjeras.

h. Impulsar la realización de estudios que promuevan el desarrollo económico de Galicia.

i. Divulgar los fines y las actividades que justifican su creación entre los distintos sectores económicos y agentes sociales.

1. Promover, fomentar y potenciar actividades económicas que favorezcan el desarrollo equilibrado e integrado tanto en términos sectoriales como territoriales.

11. Creación de un fondo de documentación básica para la promoción económica. m. En general, apoyar y promover cualquier tipo de actividades que contribuyan a la mejora del sistema productivo de Galicia, especialmente las de mayor importancia estratégica.

Artículo 5. A fin de apoyar y promover las acciones que favorezcan el desarrollo económico de Galicia, el IGAPE podrá realizar toda clase de actividades económicas y financieras, sin más limitación que lo dispuesto en esta ley y en las disposiciones que sean de aplicación.

En particular, podrá constituir Sociedades mercantiles o participar en Sociedades ya constituidas, o en fundaciones que contribuyan al logro de los fines del IGAPE, siendo preceptivo en estos casos el informe del Consejo Asesor a que se refiere el artículo 13 de esta ley.

También podrá obtener subvenciones y garantías de la Xunta de Galicia y de otras Entidades e Instituciones comunitarias, estatales, autonómicas y locales.

Asimismo, podrá promover y establecer acuerdos de todo tipo con empresas, 
Organismos, Instituciones, Asociaciones y expertos que puedan contribuir al logro de sus fines y funciones ${ }^{237}$.

Artículo 6. El IGAPE podrá participar en Sociedades establecidas fuera del territorio de Galicia cuando respondan a procesos de expansión de las empresas gallegas. En este caso la decisión de la participación deberá contar con el acuerdo del Consello de la Xunta.

\section{TÍTULO II \\ ORGANIZACIÓN}

Artículo 7. Los órganos de gobierno del IGAPE serán el Consejo de Dirección, el Presidente y el Director.

Además, el IGAPE contará con un Consejo Asesor.

Artículo 8. El Consejo de Dirección, órgano colegiado de gobierno, estará formado por un mínimo de cinco miembros y un máximo de nueve. Corresponde al Consello de la Xunta, a propuesta del Conselleiro de Economía y Hacienda, su nombramiento y destitución.

El Consejo de Dirección estará compunto por miembros del Gobierno y Administración autonómica, siendo presidido por el Presidente del IGAPE o persona en quien delegue.

El Consejo de Dirección nombrará un Secretario, que actuará con voz pero sin voto. Se determinará reglamentariamente la estructura de dicho órgano.

Artículo 9. Corresponde al Consejo de Dirección ejercer, sin más limitaciones que las establecidas por las leyes, todas las facultades y funciones que sean precisas para alcanzar los fines del IGAPE. En especial:

a. Orientar la actuación del IGAPE, dentro de las líneas marcadas por la Xunta de Galicia.

237 Véase Decreto 133/2002, de 11 de abril, por el que se regula la concesión de préstamos por el Instituto Galego de Promoción Económica. b. Decidir sobre todas las cuestiones relacionadas con la organización, funcionamiento y operaciones que tiene que realizar el IGAPE, sin perjuicio de las facultades y funciones delegadas y atribuidas por esta ley al Director ${ }^{238}$.

c. Aprobar el anteproyecto de presupuesto, que será remitido a la Consellería de Economía e Facenda para ser incluido en el proyecto de presupuesto general de la Comunidad Autónoma.

ch. Acordar la celebración de contratos y convenios que concierte el Instituto.

d. Decidir sobre los asuntos que le someta el Presidente.

e. Aprobar la Memoria anual, el Balance y la Cuenta de Pérdidas y Ganancias, que serán remitidos al Consello de Contas.

Artículo 10. 1. El Consejo de Dirección se reunirá, como mínimo, cuatro veces al año.

2. El Consejo de Dirección podrá delegar en el Presidente cualquier función específica.

Artículo 11. El Presidente del IGAPE será, por razón de su cargo, el Conselleiro de Economía y Hacienda.

El Presdiente desempeñará la representación del IGAPE en toda clase de actos y negocios jurídicos y ejercerá en su nombre acciones y recursos.

Correspondente además al Presidente:

a. Ordenar la convocatoria del Consejo, fijar el orden del día y presidir las sesiones del mismo.

b. Velar por el cumplimiento de las directrices de actuación marcadas por la Xunta de Galicia.

c. Proponer la adopción de las disposiciones reglamentarias necesarias para la organización y funcionamiento del IGAPE.

El Presidente podrá delegar en el Director cualquier función específica.

238 Véase Resolución de 2e de octubre de 2002 por la que se da publicidad al acuerdo del Consejo de Dirección del Instituto Galego de Promoción Económica, IGAPE, que aprueba la reorganización de su personal directivo. 
Artículo 12. El Director del IGAPE será nombrado y, en su caso, destituido por el Consejo de Dirección, a propuesta de su Presidente, siendo su cargo incompatible con cualquier actividad pública o privada, en los términos previstos en la legislación vigente.

Corresponde al Director:

a. Dar cumplimiento a los acuerdos del Consejo de Dirección.

b. Proponer las líneas estratégicas de actuación del IGAPE, el programa anual de actividades y el anteproyecto de presupuestos.

c. Gestionar el IGAPE y rendir cuentas de la gestión ante el Consejo de Dirección y elaborar la Memoria anual, el Balance y la Cuenta de Pérdidas y Ganancias.

ch. Ejercer la dirección administrativa y de personal.

d. Coordinar, inspeccionar y controlar el funcionamiento de los servicios y dependencias.

e. Representar al Instituto en la Sociedades participadas por el mismo.

f. Las funciones que le sean delegadas por el Presidente o Consejo de Dirección.

Artículo 13. Para el mejor ejercicio de las competencias de los órganos a que se refieren los artículos anteriores, se crea el Consejo Asesor como órgano de consulta y asesoramiento, que se reunirá como mínimo una vez cada semestre.

Tendrá a su cargo las siguientes funciones:

a. Asesorar al Consejo de Dirección en la elaboración del plan trianual, antes de su aprobación por los órganos rectores del Instituto.

b. Promover e impulsar todas las actividades que faciliten el cumplimiento de los fines del IGAPE.

c. Informar y asesorar al Consejo de Dirección de todos cuantos asuntos le encomienden.

El Consejo Asesor estará compuesto por representantes de la Administración de la Comunidad Autónoma, de las organizaciones empresariales y sindicales, de las Universidades y de los Centros de investigación, y de otras instituciones y personalidades destacadas por su actividad económica o profesional.

El número de miembros y su funcionamiento se determinarán reglamentariamente.

\section{TÍTULO III}

RECURSOS, RÉGIMEN ECONÓMICO, PERSONAL Y CONTROL

Artículo 14. Los recursos del IGAPE estarán formados por:

1. Las consignaciones presupuestarias que le sean asignadas en los presupuestos generales de la Comunidad Autónoma de Galicia.

2. Los ingresos que pueda percibir por la prestación de los servicios.

3. Las subvenciones o aportaciones voluntarias de Entidades e instituciones públicas o privadas, así como de particulares.

4. Las rentas y productos que generen los bienes y valores que constituyen el patrimonio del IGAPE.

5. Los créditos, préstamos y demás operaciones financieras que concierte.

6. Cualquier otro recurso que se le pudiese atribuir.

Artículo 15. El IGAPE elaborará anualmente un programa de actividades en el que figuren los objetivos anuales, las acciones económicas y de promoción, las inversiones previstas y su evaluación económica.

Este programa se inscribirá en otro trianual en el que se reflejen las directrices estratégicas del IGAPE.

Artículo 16. El régimen financiero, contable y presupuestario se ajustará a las normas que para Sociedades y Entidades de capital público se contienen en la Ley de Gestión Económica y Financiera pública de Galicia.

Artículo 17. El personal del IGAPE podrá ser:

Contratado en régimen de derecho laboral, respetando los principios de publicidad, igualdad, mérito y capacidad. 
Funcionario al servicio de la Admministración de la Xunta de Galicia, adscrito a esta Entidad.

Bajo la dirección y supervisión del Director y del Presidente se definirá su estructura y se dotará del personal suficiente.

Pertenecer al Consejo de Dirección o al Consejo Asesor no generará en ningún caso derechos laborales.

Artículo 18. El control de eficacia será ejercido por la Consellería de Economía e Facenda, basándose en la comprobación del cumplimiento de los objetivos fijados en el plan extratégico trianual y en los respectivos planes anuales.

\section{DISPOSICIÓN ADICIONAL PRIMERA}

El Parlamento de Galicia deberá autorizar, mediante ley, la transformación, modificación, liquidación o extinción del IGAPE. La Comunidad Autónoma de Galicia se hará cargo en estos casos del conjunto de derechos y obligaciones derivados del proceso.

\section{DISPOSICIÓN ADICIONAL SEGUNDA}

La consignación inicial del IGAPE estará constituida por una dotación de 2.000.000.000 de pesetas.

\section{DISPOSICIÓN TRANSITORIA ÚNICA}

Se autoriza al Consello de la Xunta de Galicia para que, una vez constituidos los órganos de gobierno y a propuesta del Consejo de Dirección, a iniciativa del Conselleiro de Economía y Hacienda, apruebe la asignación a las correspondientes cuentas de los estados presupuestarios de la dotación global de 2.000.000.000 de pesetas a que se refiere la Disposición adicional segunda, conforme a lo preceptuado por la Ley de Gestión Económica y Financiera pública de Galicia.

Los estados elaborados pasarán a formar parte del conjunto de presupuestos de Empresas públicas, dentro del presupuesto general de la Comunidad Autónoma de cada ejercicio.
De las actuaciones anteriores se dará cuenta a la Comisión de Economía, Hacienda y Presupuestos del Parlamento.

\section{DISPOSICIÓN FINAL PRIMERA}

Se autoriza al Consello de la Xunta de Galicia, a propuesta del Conselleiro de Economía y Hacienda, para que dicte las disposiciones que sean necesarias para el desarrollo y aplicación de esta ley, dentro de los seis meses siguientes a su entrada en vigor.

\section{DISPOSICIÓN FINAL SEGUNDA}

Esta ley entrará en vigor al día siguiente de su publicación en el "Diario Oficial de Galicia".

\section{LEY 12/2006, DE 1 DE DICIEMBRE, DE FUNDACIONES DE INTERÉS GALLEGO (DOGA N. $\left.^{\circ} 242,19.12 .2006\right)^{239}$ $(\ldots)^{240}$ \\ Capitulo I \\ DISPOSICIONES GENERALES}

Artículo 1. Objeto de la ley.

La presente ley tiene por objeto regular las fundaciones de interés gallego, de competencia de la Comunidad Autónoma de Galicia, con arreglo a lo dispuesto en el artículo 27.26 del Estatuto de Autonomía de Galicia.

Artículo 2. Concepto.

1. Son fundaciones de interés gallego aquellas organizaciones constituidas sin fin de lucro que, por voluntad de sus creadores, tengan afectado de modo duradero su patrimonio a la realización de fines de interés general para Galicia y desarrollen principalmente sus actividades y tengan su domicilio en el territorio de la Comunidad Autónoma.

\footnotetext{
239 Véase:

Decreto 14/2009, de 21 de enero, por el que se aprueba el Reglamento de Fundaciones de Interés Gallego.

Decreto 15/2009, de 21 de enero, por el que se aprueba el Reglamento del Registro de Fundaciones de Interés Gallego.

240 Exposición de motivos omitida.
} 
2. Sin perjuicio de lo dispuesto en el apartado precedente, las fundaciones de interés gallego podrán establecer relaciones instrumentales con terceros en diferente ámbito territorial.

Artículo 3. Régimen jurídico.

Las fundaciones de interés gallego se regirán por la voluntad de la persona fundadora, por sus estatutos y, en todo caso, por la ley.

Artículo 4. Fines y beneficiarios.

1. Las fundaciones a que se refiere la presente ley deberán perseguir fines de interés general, como pueden ser: los de defensa de los derechos humanos, de las víctimas del terrorismo, actos violentos y otros acontecimientos catastróficos, la asistencia social y la inclusión social; fines cívicos, educativos, culturales $-\mathrm{y}$, particularmente, la promoción, fomento y difusión de la lengua y cultura gallegascientíficos, deportivos, sanitarios, laborales, de fortalecimiento institucional de Galicia, de cooperación para el desarrollo, de promoción del voluntariado, de respaldo a la igualdad de oportunidades entre hombres y mujeres, de promoción de la acción social, de defensa del medio natural de Galicia, y de fomento de la economía social y de desarrollo de la economía productiva de Galicia, de promoción y de atención a las personas en riesgo de exclusión por razones físicas, sociales o culturales, de promoción de los valores constitucionales, estatutarios y de defensa de los principios democráticos, de fomento de la tolerancia, de desarrollo de la sociedad de la información, o de investigación científica y desarrollo tecnológico y otros fines de interés general para Galicia que sean de análoga naturaleza.

2. La finalidad fundacional debe beneficiar a colectividades genéricas de personas. Tendrán esta consideración los colectivos de trabajadores de una o varias empresas y sus familiares.

3. En ningún caso podrán constituirse fundaciones cuya finalidad principal sea destinar sus prestaciones al fundador o a los miembros del patronato, a los cónyuges o personas ligadas con análoga relación de afectividad, o a sus parientes hasta el cuarto grado inclusive, así como a personas jurídicas singularizadas que no persigan fines de interés general. No obstante, podrán ser beneficiarios de las actividades de la fundación siempre que formen parte de las colectividades genéricas de personas destinatarias de la finalidad fundacional.

4. No se incluyen en el apartado anterior las fundaciones cuya finalidad exclusiva o principal sea la conservación y restauración de bienes del patrimonio cultural gallego o del patrimonio histórico español, siempre que cumplan las exigencias establecidas por la normativa autonómica y estatal, en particular, respecto a los deberes de visita y exposición pública de dichos bienes.

Artículo 5. Personalidad jurídica.

1. Las fundaciones reguladas por la presente ley tendrán personalidad jurídica desde la inscripción de la escritura pública de su constitución en el Registro de Fundaciones de Interés Gallego de la Comunidad Autónoma de Galicia.

2. La inscripción sólo podrá ser denegada, mediante resolución motivada, cuando la escritura de constitución no se ajuste a las prescripciones de la ley.

3. Sólo aquellas entidades inscritas en el Registro de Fundaciones de Interés Gallego podrán utilizar la denominación de Fundación de Interés Gallego.

Artículo 6. Denominación.

1. La denominación de las fundaciones se ajustará a las siguientes reglas:

a. Deberá figurar la palabra "Fundación", y no podrá coincidir o asemejarse de manera que pueda crear confusión con ninguna otra previamente inscrita en los registros de fundaciones.

b. No podrán incluirse términos o expresiones que resulten contrarios a las 
leyes o que puedan vulnerar los derechos fundamentales de las personas.

c. No podrá formarse exclusivamente con el nombre de España, de Galicia, de las demás Comunidades Autónomas o de las entidades locales, ni utilizar el nombre de organismos oficiales o públicos, tanto nacionales como internacionales, salvo que se trate del propio de las entidades fundadoras.

d. La utilización del nombre o seudónimo de una persona física o de la denominación o acrónimo de una persona jurídica distintos del fundador deberá contar con su consentimiento expreso o, en caso de ser incapaz, con el de su representante legal.

e. No podrán adoptarse denominaciones que hagan referencia a actividades que no se correspondan con los fines fundacionales o induzcan a error o confusión respecto a la naturaleza o actividad de la fundación.

f. Se observarán las prohibiciones y reservas de denominación previstas en la legislación vigente.

2. No se admitirá ninguna denominación que incumpla cualquiera de las reglas establecidas en el apartado anterior o conste que coincide o se asemeja con la de una entidad preexistente inscrita en otro registro público o con una denominación protegida o reservada a otras entidades públicas o privadas por su legislación específica.

Artículo 7. Domicilio.

1. Deberán estar domiciliadas en la Comunidad Autónoma de Galicia las fundaciones de interés gallego que desarrollen principalmente sus actividades dentro de su territorio.

2. Las fundaciones tendrán su domicilio estatutario en el lugar en donde se encuentre la sede de su patronato o bien en el lugar en donde se lleven a cabo principalmente sus actividades.

Artículo 8. Fundaciones extranjeras.

1. Las fundaciones extranjeras que pretendan ejercer sus actividades de forma estable y desarrollen principalmente sus actividades en el territorio de la Comunidad Autónoma deberán inscribirse en el Registro de Fundaciones de Interés Gallego, así como mantener una delegación en su territorio, que constituirá su domicilio a los efectos de la presente ley.

2. La fundación extranjera que pretenda su inscripción deberá acreditar ante dicho registro que ha sido constituida con arreglo a su ley personal.

La inscripción podrá denegarse cuando no se acredite la circunstancia señalada en el párrafo anterior, así como cuando los fines no sean de interés general de acuerdo con el ordenamiento autonómico.

3. Las delegaciones en Galicia de fundaciones extranjeras estarán sometidas al protectorado a que se refiere el capítulo VII de la presente ley, siéndoles de aplicación el régimen jurídico previsto para las fundaciones de interés gallego.

4. Las fundaciones extranjeras que contravengan los requerimientos establecidos en este artículo no podrán utilizar la denominación de "Fundación".

\section{Capitulo II CONSTITUCIÓN DE LA FUNDACIÓN}

Artículo 9. Capacidad para fundar.

1. Podrán constituir fundaciones las personas físicas y las personas jurídicas, sean éstas públicas o privadas.

2. Las personas físicas requerirán de la capacidad para disponer gratuitamente, inter vivos o mortis causa, de los bienes y derechos en que consista la dotación.

3. Las personas jurídicas de índole asociativa requerirán el acuerdo expreso del órgano competente para disponer gratuitamente de sus bienes, con arreglo a sus estatutos o a la legislación que les sea de aplicación. Las de carácter institucional habrán de contar con el acuerdo expreso de su órgano rector.

4. Las personas jurídico-públicas tendrán capacidad para constituir fundaciones, salvo que sus normas reguladoras establezcan lo contrario. 
Artículo 10. Modalidades de constitución.

1. La fundación podrá constituirse por actos inter vivos o mortis causa.

2. La constitución de la fundación por acto inter vivos se realizará mediante escritura pública, con el contenido que determina el artículo siguiente.

3. La constitución de la fundación por acto mortis causa se realizará testamentariamente, cumpliéndose en el testamento los requisitos establecidos en el artículo siguiente para la escritura de constitución.

4. Si en la constitución de una fundación por acto mortis causa el testador se hubiera limitado a establecer su voluntad de crear una fundación y de disponer de los bienes y derechos de la dotación, la escritura pública en que se contengan los demás requisitos exigidos por la presente ley será otorgada por el albacea y, en su defecto, por los herederos testamentarios. En caso de que éstos no existieran o contravinieran esta obligación, la escritura será otorgada por el protectorado a que hace referencia el artículo 47 de la presente ley, previa autorización judicial.

Artículo 11. Escritura de constitución. La escritura de constitución de una fundación habrá de contener, al menos, los siguientes extremos:

a. Nombre, apellidos, edad y estado civil del fundador o fundadora, o de los fundadores o fundadoras, si son personas físicas, y su denominación o razón social, si son personas jurídicas. En ambos casos, su nacionalidad, domicilio y número de identificación fiscal.

b. La voluntad de constituir una fundación.

c. La dotación, valoración y forma y realidad de su aportación.

d. Los estatutos de la fundación, cuyo contenido se ajustará a las prescripciones del artículo siguiente.

e. La identificación de las personas que integran el patronato, así como su aceptación, en caso de que se efectúe en el momento fundacional.
Artículo 12. Estatutos.

1. En los estatutos de la fundación se hará constar:

a. La denominación de la entidad.

b. Los fines fundacionales.

c. Las principales actividades encaminadas al cumplimiento de dichos fines.

d. El domicilio de la fundación y el ámbito territorial en que desarrollará principalmente sus actividades.

e. Las reglas básicas para la aplicación de los recursos a fin de cumplir los fines fundacionales y para determinar las personas beneficiarias.

f. La composición del patronato, las reglas para la designación y sustitución de sus miembros, las causas del cese, sus atribuciones y la forma de deliberar y de adoptar acuerdos.

g. Las causas de su disolución y el destino de los bienes y derechos resultantes de su liquidación.

h. Cualesquiera otras disposiciones y condiciones lícitas que la persona fundadora o las personas fundadoras quieran establecer.

2. Toda disposición de los estatutos de la fundación o manifestación de la voluntad del fundador o fundadora que sea contraria a la ley se considerará por no puesta, salvo que afecte a su validez constitutiva. En este último caso, no procederá inscribir la fundación en el Registro de Fundaciones de Interés Gallego.

Artículo 13. Dotación de la fundación.

1. La dotación, que podrá consistir en bienes y derechos de cualquier clase, tendrá que ser adecuada y suficiente para el cumplimiento de los fines fundacionales. Se presumirá suficiente la dotación cuyo valor económico alcance los 30.000 euros.

Cuando la dotación sea de inferior valor, la persona fundadora deberá justificar su adecuación y suficiencia a los fines fundacionales mediante la presentación del primer programa de actuación, junto con un estudio económico que acredite su viabilidad utilizando exclusivamente dichos recursos. 
2. Si la aportación es dineraria, podrá efectuarse en forma sucesiva. En tal caso, el desembolso inicial será, al menos, del 25 por cien, y el resto deberá hacerse efectivo en un plazo no superior a cinco años, a contar desde el otorgamiento de la escritura pública de constitución de la fundación.

Si la aportación no es dineraria, deberá incorporarse a la escritura de constitución la tasación realizada por un experto independiente.

En uno y otro caso, deberá acreditarse o garantizarse la realidad de las aportaciones ante el notario autorizante, en los términos que reglamentariamente se establezcan.

3. Se aceptará como dotación el compromiso de aportaciones de terceros, siempre que dicha obligación conste en títulos de los que conllevan ejecución.

4. Formarán también parte de la dotación los bienes y derechos de contenido patrimonial que durante la existencia de la fundación se aporten en tal concepto por la persona fundadora o por terceras personas, o que se afecten por el patronato, con carácter permanente, a los fines fundacionales.

5. En ningún caso se considerará dotación el mero propósito de recaudar donativos.

Artículo 14. Fundaciones en proceso de formación.

1. Otorgada la escritura fundacional, y en tanto se procede a la inscripción en el Registro de Fundaciones de Interés Gallego, el patronato de la fundación realizará, además de los actos necesarios para la inscripción, únicamente aquellos otros que resulten indispensables para la conservación de su patrimonio y los que no admitan demora sin perjuicio para la fundación, los cuales se entenderán automáticamente asumidos por ésta cuando obtenga personalidad jurídica.

2. Transcurridos seis meses desde el otorgamiento de la escritura pública fundacional sin que los patronos hubieran instado la inscripción en el Registro de Fundaciones de Interés Gallego, el protectorado dispondrá el cese de los patronos, quienes responderán solidariamente de las obligaciones contraídas en nombre de la fundación y por los perjuicios que ocasione la falta de inscripción.

Asimismo, el protectorado procederá a nombrar nuevos patronos, previa autorización judicial, que asumirán la obligación de inscribir la fundación en el Registro de Fundaciones de Interés Gallego.

\section{Capitulo III GOBIERNO DE LA FUNDACIÓN}

Artículo 15. Patronato.

1. En toda fundación deberá existir, con la denominación de patronato, un órgano de gobierno y de representación de la misma, que adoptará sus acuerdos por mayoría en los términos establecidos en los estatutos.

2. Corresponde al patronato cumplir los fines fundacionales y administrar con diligencia los bienes y derechos que integran el patrimonio de la fundación, manteniendo el rendimiento y utilidad de los mismos.

Artículo 16. Composición del patronato.

1. El patronato es un órgano colegiado que estará integrado por el número de miembros que determinen sus estatutos, con un mínimo de tres. El patronato contará con un Presidente.

2. Al Presidente del patronato, que habrá de ser un miembro del mismo, le corresponde presidir las reuniones del patronato y dirigir los debates, así como representar a la fundación ante todo tipo de personas o entidades, salvo en aquellos supuestos concretos en que el patronato delegue tal representación en alguno de sus miembros u otorgue un poder notarial a tal efecto.

3. Asimismo, el patronato debe nombrar un secretario, cargo que podrá recaer en una persona ajena a aquel, en cuyo caso tendrá voz pero no voto, y a quien corresponderá la certificación de los acuerdos del patronato con el visto bueno del Presidente. 
4. El fundador o fundadores que sean personas físicas podrán reservarse con carácter vitalicio el ejercicio de todas las competencias asignadas al órgano de gobierno de la fundación. En este caso, la persona fundadora deberá ejercer sus funciones dando cuenta previamente al patronato. éste podrá ejercer la acción de responsabilidad frente a aquél en los términos establecidos en el artículo 22. En el supuesto de que sean varias las personas fundadoras, se entenderá que actúan siempre mancomunadamente, a no ser que los estatutos o la escritura de constitución de la fundación mencionen otro sistema de administración.

Artículo 17. Capacidad de los miembros del patronato.

1. Podrán ser miembros del patronato de la fundación tanto las personas físicas como las jurídicas.

2. Las personas físicas que sean miembros del patronato deberán tener plena capacidad de obrar, no pudiendo estar inhabilitadas para el ejercicio de cargos públicos.

3. Los miembros del patronato que sean personas jurídicas deberán nombrar a la persona o personas físicas que los representen, de acuerdo con sus normas de funcionamiento, debiendo dejar constancia de su aceptación en las formas previstas en el artículo 19 de la presente ley.

4. El cargo de miembro del patronato que recaiga en una persona física deberá ser ejercido personalmente. No obstante, podrá actuar en su nombre y representación otro miembro del patronato designado por él. Esta actuación será siempre para actos concretos y habrá de ajustarse a las instrucciones que, en su caso, el representado formule por escrito.

5. En el supuesto de que el miembro del patronato lo sea por razón del cargo que ocupe, podrá actuar en su nombre la persona a la que legalmente corresponda su sustitución.
Artículo 18. Delegación y apoderamientos.

1. Salvo prohibición expresa de los estatutos de la fundación, el patronato podrá delegar sus facultades en uno o más de sus miembros, con funciones mancomunadas, solidarias o colegiadas según se determinen. No serán delegables, en ningún caso:

a. La aprobación de las cuentas anuales y del plan de actuación.

b. La modificación de los estatutos.

c. El acuerdo de fusión, extinción o liquidación de la fundación.

d. Todos aquellos actos que requieran autorización del protectorado.

2. Siempre que el volumen de gestión o cualquier otra circunstancia lo aconseje, el patronato podrá acordar constituir comisiones formadas por el número de miembros del patronato que determine y con la denominación que crea conveniente. En dichas comisiones podrán delegarse las funciones y competencias que el patronato considere oportuno, con las limitaciones previstas en el apartado 1 de este artículo.

3. El patronato, si así lo prevén los estatutos, podrá crear otros órganos, como consejos asesores y de estudio, para el mejor desarrollo de las funciones que le correspondan, con las excepciones previstas en el apartado 1 de este artículo. La constitución de estos órganos deberá notificarse al protectorado.

4. Asimismo, el patronato podrá otorgar o revocar poderes generales y especiales, salvo que los estatutos dispongan lo contrario.

5. En el Registro de Fundaciones de Interés Gallego deberán inscribirse los nombramientos y ceses de los miembros del patronato, las delegaciones, los apoderamientos generales y su revocación, así como los órganos creados al amparo de los apartados segundo y tercero de este artículo, conforme a las condiciones y requisitos que se establezcan reglamentariamente.

Artículo 19. Aceptación.

1. Los miembros del patronato iniciarán su gestión después de haber aceptado 
el cargo. Tal aceptación se formalizará de alguna de las formas siguientes:

a. En la propia carta fundacional o en escritura pública independiente.

b. En documento privado, con firma legitimada por un fedatario público.

c. Mediante comparecencia realizada a tal efecto en el Registro de Fundaciones de Interés Gallego.

d. Ante el patronato, acreditándose mediante certificación expedida por el secretario con el visto bueno del Presidente.

2. En todo caso, la aceptación se notificará formalmente al protectorado y se inscribirá en el Registro de Fundaciones de Interés Gallego.

Artículo 20. Duración del cargo de patrono.

El cargo de patrono tendrá la duración que se establezca en los estatutos o carta fundacional.

Artículo 21. Derechos y deberes de los miembros del patronato.

1. Son derechos de los miembros del patronato:

a. Recibir la convocatoria que contenga el orden del día y asistir a las reuniones de los órganos de que formen parte.

b. Ejercer su derecho de voto.

c. Obtener la información precisa para el cumplimiento de sus funciones.

2. Son deberes de los miembros del patronato, además de los que los estatutos puedan establecer, los siguientes:

a. Cumplir y hacer cumplir fielmente los fines fundacionales, con arreglo a lo dispuesto en la presente ley, la legislación estatal aplicable y los estatutos de la fundación.

b. Administrar los bienes y derechos que integran el patrimonio de la fundación, manteniendo plenamente el rendimiento, la utilidad y la productividad de los mismos, según los criterios económico-financieros de un buen gestor.

c. Asistir a las reuniones del patronato y velar por la legalidad de los acuerdos que en las mismas se adopten. d. Realizar los actos necesarios para inscribir la fundación en el Registro de Fundaciones de Interés Gallego.

Artículo 22. Responsabilidad de los patronos.

1. Los patronos deberán desempeñar su cargo con la diligencia de un representante leal.

2. Los patronos responderán solidariamente frente a la fundación de los daños y perjuicios que causen por actos contrarios a la ley o a los estatutos, o por los actos realizados sin la diligencia con que deben desempeñar el cargo. Quedarán exentos de responsabilidad quienes hayan votado en contra del acuerdo y quienes prueben que, no habiendo intervenido en su adopción y ejecución, desconocían la existencia del mismo o, conociéndola, hicieron todo lo conveniente para evitar el daño o, al menos, se opusieron expresamente a aquel.

3. La acción de responsabilidad se iniciará, ante la autoridad judicial y en nombre de la fundación, por:

a. El propio órgano de gobierno de la fundación, previo acuerdo motivado, en cuya adopción no participará el patrono o patronos afectados.

b. El protectorado, en los términos establecidos en el artículo 47.

c. Los patronos disidentes o ausentes, en los términos del apartado 2 de este artículo, así como la persona fundadora cuando no fuera patrono.

Artículo 23. Gratuidad del cargo de patrono.

1. Los miembros del patronato ejercerán su cargo gratuitamente, sin que puedan percibir retribución alguna, ni en dinero ni en especie, por desempeñar sus funciones. No obstante, tendrán derecho a ser resarcidos de los gastos debidamente justificados que el cargo les ocasione en el ejercicio de su función.

2. Salvo que la persona fundadora dispusiera lo contrario, el patronato podrá fijar una retribución adecuada a aquellos miembros del patronato que presten a la 
fundación servicios distintos de los que implica el desempeño de las funciones que les corresponden como miembros del patronato, dando cuenta de ello al protectorado en el plazo máximo de un mes.

Artículo 24. Sustitución, cese y suspensión del cargo de patronos.

1. La sustitución de los patronos se producirá en la forma prevista en los estatutos. Cuando ello no fuera posible se procederá de conformidad con lo dispuesto en el artículo 41 de la presente ley, quedando facultado el protectorado, hasta que la modificación se produzca, para la designación de la persona o personas que integren provisionalmente el órgano de gobierno y representación de la fundación.

2. Si el número de patronos fuera en algún momento inferior a tres, los subsistentes, en un plazo de treinta días, deberán restablecer el número mínimo de patronos $\mathrm{o}$, en los diez días siguientes a finalizar dicho plazo, deberán comunicárselo al protectorado, que podrá ejercer cualquiera de las siguientes opciones:

a. Concederle un plazo nuevo al patronato para que restablezca el número de sus miembros.

b. Completar por sí mismo el número mínimo de patronos.

c. Instar la extinción de la fundación, sólo si se apreciara su inviabilidad.

3. Si en algún momento de la vida de la fundación faltaran todos los miembros del patronato, por cualquier causa, el protectorado, cuando conozca esto, deberá nombrar nuevos patronos o bien instar la extinción de la fundación.

4. El cese de los patronos de una fundación se producirá en los supuestos siguientes:

a. Por muerte o declaración de fallecimiento de la persona física, así como por extinción de la persona jurídica.

b. Por incapacidad, inhabilitación o incompatibilidad, de acuerdo con lo establecido en la ley.

c. Por cese en el cargo en razón del cual fueron nombrados los miembros del patronato. d. Por no desempeñar el cargo con la diligencia prevista en el apartado $1 \mathrm{del}$ artículo 22, si así se declara por resolución judicial.

e. Por resolución judicial que acoja la acción de responsabilidad por los actos mencionados en el artículo 22.2 de la presente ley.

f. Por haber transcurrido seis meses desde el otorgamiento de la escritura pública fundacional sin que se hubiera instado la inscripción en el Registro de Fundaciones de Interés Gallego.

g. Por haber transcurrido el período de su mandato, si fueron nombrados por tiempo determinado.

h. Por renuncia, que podrá llevarse a cabo por cualquiera de los medios y mediante los trámites previstos para la aceptación.

i. Por las causas establecidas válidamente para el cese en los estatutos.

5. La suspensión de los patronos podrá ser acordada cautelarmente por el juez cuando se interponga contra ellos la acción de responsabilidad.

6. La sustitución, el cese y la suspensión de los patronos se inscribirán en el Registro de Fundaciones de Interés Gallego.

Artículo 25. Gestión de la fundación. Dentro de los límites establecidos en la presente ley, el patronato, si así está previsto en sus estatutos, podrá encargar el ejercicio de la gestión ordinaria o administrativa de sus actividades a un gerente o cargo semejante, que podrá ser una persona física o jurídica, pero siempre con solvencia técnica acreditada al respecto, y con la remuneración ajustada a las funciones desempeñadas.

\section{Capitulo IV RÉGIMEN ECONÓMICO DE LA FUNDACIÓN}

Artículo 26. Patrimonio de las fundaciones.

El patrimonio de la fundación está formado por todos los bienes, derechos y obligaciones susceptibles de valoración económica 
que integren la dotación, así como por aquellos que adquiera la fundación con posterioridad a su constitución, se afecten o no a la dotación.

Artículo 27. Administración y disposición del patrimonio.

La administración y disposición del patrimonio de las fundaciones corresponde al patronato y se hará con arreglo a lo estipulado en sus estatutos y con sujeción a lo establecido en la presente ley y demás disposiciones aplicables.

Artículo 28. Publicidad del patrimonio.

Los bienes o derechos que integran el patrimonio de las fundaciones deberán figurar a su nombre y constar en sus inventarios.

Los que sean susceptibles de inscripción se inscribirán en los registros correspondientes. Los fondos públicos y los valores mobiliarios deberán ser depositados a su nombre en establecimientos financieros.

El órgano de gobierno promoverá, bajo su responsabilidad, la inscripción a nombre de la fundación de los bienes y derechos que integran su patrimonio en los registros públicos correspondientes.

Artículo 29. Enajenación y gravamen.

1. La enajenación y gravamen de los bienes y derechos que formen parte de la dotación o estén directamente vinculados al cumplimiento de los fines fundacionales, así como aquellos cuyo importe, con independencia de su objeto, sea superior al 20 por cien del activo de la fundación que resulte del último balance aprobado, deberán ser comunicados por el patronato al protectorado en el plazo máximo de un mes, a contar desde el día siguiente a su realización.

Se entiende que los bienes y derechos de la fundación están directamente vinculados al cumplimiento de los fines fundacionales cuando tal vinculación está contenida en una declaración de voluntad expresa, ya sea del fundador, del patronato de la fundación o de la persona física o jurídica, pública o privada, que realice una contribución voluntaria a la fundación, y siempre respecto a los bienes y derechos aportados o en que se materialicen las contribuciones percibidas.

Asimismo, la vinculación a que se refiere el párrafo anterior podrá realizarse por resolución motivada del protectorado o de la autoridad judicial.

2. Las restantes enajenaciones o gravámenes se harán constar anualmente en la memoria presentada al protectorado.

3. Las enajenaciones o gravámenes a que se refiere este artículo se harán constar anualmente en el Registro de Fundaciones de Interés Gallego al término del ejercicio económico.

4. El protectorado podrá ejercer las acciones de responsabilidad que correspondan contra los patronos cuando los acuerdos del patronato fueran lesivos para la fundación en los términos previstos en la ley.

Artículo 30. Herencias y donaciones.

1. La aceptación de herencias por la fundación se entenderá hecha siempre a beneficio de inventario. Los patronos serán responsables frente a la fundación de la pérdida del beneficio de inventario por los actos a que se refiere el artículo 1024 del Código Civil.

2. La aceptación de legados con cargas o donaciones onerosas o remuneratorias y la repudiación de herencias, donaciones o legados sin cargas serán comunicadas por el patronato al protectorado en el plazo máximo de los diez días hábiles siguientes, pudiendo éste ejercer las acciones de responsabilidad que correspondan contra los patronos si los actos del patronato son lesivos para la fundación, en los términos previstos en la presente ley.

\section{Capitulo V \\ FUNCIONAMIENTO Y ACTIVIDAD DE LA FUNDACIÓN}

Artículo 31. Principios de actuación de las fundaciones.

Las fundaciones deberán actuar de acuerdo con los principios siguientes:

a. Destinar efectivamente el patrimonio y sus rentas, de acuerdo con esta ley 
y los estatutos de la fundación, a sus fines fundacionales.

b. Dar información suficiente de sus fines y actividades para que sean conocidos por sus eventuales beneficiarios y demás interesados.

c. Actuar con criterios de imparcialidad y no discriminación en la determinación de sus beneficiarios.

d. Respetar el código de conducta de las entidades sin ánimo de lucro.

Artículo 32. Funcionamiento.

1. La organización, funcionamiento y régimen de adopción de acuerdos de las fundaciones se ajustarán a lo dispuesto en sus estatutos y, en su caso, a las normas de régimen interno que a tal efecto apruebe su órgano de gobierno, con sujeción a lo preceptuado en el ordenamiento jurídico vigente.

2. Las fundaciones deberán contar con un libro de actas que recoja las actas de las reuniones del patronato y de las comisiones que tengan delegadas funciones y competencias de éste, firmadas por el secretario y con el visto bueno del Presidente. El libro de actas deberá estar legalizado en los términos establecidos en el apartado 7 del artículo 36.

Artículo 33. Financiación.

1. La fundación podrá ser financiada por cualquier medio lícito.

2. La fundación, para el desarrollo de sus actividades, se financiará con los rendimientos que provengan de su patrimonio y, en su caso, con aquellos otros procedentes de las ayudas, subvenciones, donaciones, herencias y legados, realizados por personas físicas o jurídicas, sean públicas o privadas.

3. Las fundaciones podrán desarrollar actividades económicas cuyo objeto esté relacionado con los fines fundacionales o sean complementarias o accesorias de las mismas, con sometimiento a las normas reguladoras de la defensa de la competencia. Además, podrán intervenir en cualesquiera actividades económicas a través de su participación en sociedades, con arreglo a lo previsto en los apartados siguientes.

4. Las fundaciones podrán participar en sociedades mercantiles en las cuales no se responda personalmente de las deudas sociales. Cuando esta participación sea mayoritaria deberá comunicárselo al protectorado en cuanto tal circunstancia se produzca. Asimismo, las fundaciones con participación igual o superior al 20 por cien en estas sociedades deberán informar al protectorado, a través de la memoria anual, de dicha participación.

5. Si la fundación recibiera por cualquier título, bien como parte de la dotación inicial bien en un momento posterior, alguna participación en sociedades en las cuales deba responder personalmente de las deudas sociales, deberá enajenar dicha participación, salvo que, en el plazo máximo de un año, se produzca la transformación de tales sociedades en otras en que quede limitada la responsabilidad de la fundación.

6. A tal efecto, se entiende por participación mayoritaria aquella que represente más del 50 por cien del capital social o de los derechos de voto, por el que se computarán tanto las participaciones mayoritarias que se adquieran en un único acto como las adquisiciones sucesivas de participaciones minoritarias cuya acumulación dé lugar a que la fundación ocupe una posición dominante en la sociedad de que se trate.

Artículo 34. Obtención de ingresos. Las fundaciones podrán obtener ingresos por las actividades que desarrollen o los servicios que presten a sus beneficiarios, siempre que:

a. No desvirtúe el interés general para la Comunidad Autónoma.

b. No sean contrarios a la voluntad fundacional.

c. No implique una limitación injustificada del ámbito de sus posibles beneficiarios.

Artículo 35. Destino de los ingresos de las fundaciones. 
1. A la realización de los fines fundacionales deberá destinarse al menos el 70 por cien de las rentas e ingresos obtenidos, por cualquier título o causa, después de haber deducido los gastos realizados para la obtención de tales rentas e ingresos.

2. Para calcular los gastos realizados para la obtención de las rentas e ingresos a que se refiere el apartado anterior podrá deducirse, en su caso, la parte proporcional de los gastos por servicios exteriores, de los gastos de personal, de otros gastos de gestión, de los gastos financieros y de los tributos, excluyendo de dicho cálculo los gastos realizados para cumplir los fines estatutarios.

3. Deberá destinarse a incrementar la dotación o las reservas, según el acuerdo del patronato, el resto de rentas e ingresos que no deban destinarse a cumplir la obligación establecida en el apartado 1 de este artículo, una vez deducidos los gastos de administración, cuya cuantía máxima se determinará reglamentariamente.

Los gastos de administración serán aquellos directamente ocasionados a los órganos de gobierno por la administración de los bienes y derechos que integran el patrimonio de la fundación, y a los que los miembros del patronato tienen derecho a ser reembolsados por desempeñar su cargo, según lo dispuesto en la presente ley.

4. Para el cálculo de las rentas e ingresos a que se refiere el apartado 1 de este artículo no se incluirán las contribuciones o donaciones recibidas en concepto de dotación patrimonial, en el momento de la constitución o en un momento posterior, ni las ganancias obtenidas en la transmisión de bienes o derechos afectados a la dotación fundacional, siempre que se reinviertan en bienes dotacionales.

Asimismo, no se incluirán los ingresos obtenidos en la transmisión onerosa de bienes inmuebles en los cuales la entidad desarrolle la actividad propia de su objeto o finalidad específica, siempre que el importe de la citada transmisión se reinvierta en bienes inmuebles en que concurra dicha circunstancia.

5. El plazo máximo previsto para cumplir la obligación contenida en el apartado 1 de este artículo será de cuatro ejercicios económicos a partir del momento de su obtención, siendo el inicial el siguiente a aquel en que se han generado.

Artículo 36. Contabilidad.

1. Las fundaciones llevarán una contabilidad ordenada y adecuada a su actividad, que permita un seguimiento cronológico de las operaciones realizadas. Para ello llevarán necesariamente un libro diario y un libro de inventarios y cuentas anuales.

2. El patronato de la fundación elaborará, en referencia al anterior ejercicio económico, las cuentas anuales, que comprenden el balance de situación, la cuenta de resultados y la memoria. Estos documentos forman una unidad y han de ser redactados con claridad, mostrando la imagen fiel del patrimonio, de la situación financiera y de los resultados de la fundación. El ejercicio económico coincidirá con el año natural, a no ser que en los estatutos se establezca un período anual diferente.

En el balance de situación se expresarán los bienes y derechos que conforman el activo de la entidad y las obligaciones y fondos propios que forman su pasivo.

La cuenta de resultados comprenderá los ingresos y gastos del ejercicio y, por diferencia, su resultado.

La memoria completará, ampliará y comentará la información contenida en el balance de situación y en la cuenta de resultados, relativa al último ejercicio cerrado, debiendo incluir:

a. Una descripción de las actividades fundacionales realizadas, en los términos que reglamentariamente se desarrollen.

b. Un inventario de los elementos patrimoniales, cuyo contenido se desarrollará reglamentariamente, donde conste la valoración de los bienes, los derechos y las obligaciones de la fundación integrantes de su balance. 
c. El detalle del grado de cumplimiento de las reglas establecidas en el artículo 35 de la presente ley.

d. Información relativa a la liquidación del plan de actuación del ejercicio finalizado, donde se especifique el grado exacto de cumplimiento del mismo, diferenciando entre ingresos y gastos, y describiendo los recursos empleados, su procedencia, el número de beneficiarios en cada una de las distintas actuaciones realizadas y los convenios que, en su caso, se hayan llevado a cabo con otras entidades para el cumplimiento de la finalidad fundacional.

e. Información sobre las variaciones patrimoniales y los cambios en los órganos de gobierno, dirección y representación de la fundación durante el ejercicio.

f. El cuadro de financiación.

g. El detalle de las sociedades participadas, con indicación del porcentaje de participación.

3. Los documentos referidos a las cuentas anuales habrán de elaborarse siguiendo los modelos, normas y criterios establecidos en la adaptación sectorial del Plan general de contabilidad para las entidades sin fines lucrativos.

4. Las fundaciones podrán formular sus cuentas anuales en los modelos abreviados cuando cumplan los requisitos establecidos al respecto para las sociedades mercantiles. La referencia al importe neto de la cifra anual de negocios, establecida en la legislación mercantil, se entenderá realizada al importe del volumen anual de ingresos por la actividad propia más, si procede, la cifra de negocios de la actividad mercantil.

5. En los términos que se determinen reglamentariamente podrá establecerse un modelo simplificado de contabilidad de aquellas fundaciones en que, al cierre del ejercicio, se cumplan al menos dos de las siguientes circunstancias:

a. Que el total de las partidas del activo no supere 150.000 euros. A estos efectos se entenderá por total activo el total que figura en el modelo de balance.

b. Que el importe del volumen anual de ingresos por la actividad propia más, en su caso, el de la cifra de negocios de su actividad mercantil sea inferior a 150.000 euros.

c. Que el número medio de trabajadores empleados durante el ejercicio no sea superior a 5 .

6. La contabilidad de las fundaciones se ajustará a lo dispuesto en el Código de comercio, cuando realicen actividades económicas, debiendo formular cuentas anuales consolidadas cuando la fundación se encuentre en cualquiera de los supuestos previstos en el citado código para la sociedad dominante.

7. Los libros que deberán llevar las fundaciones, descritos en el apartado $1 \mathrm{de}$ este artículo, tienen que ser legalizados por el Registro de Fundaciones de Interés Gallego. Estos libros podrán legalizarse antes de ser utilizados o bien después de haber realizado los asientos y anotaciones por procedimientos informáticos y otros pertinentes. En este último caso, tienen que legalizarse dentro del plazo de presentación de las cuentas anuales del año correspondiente.

Artículo 37. Auditoría.

1. Se someterán a auditoría externa las cuentas anuales de las fundaciones cuando, durante dos ejercicios consecutivos, concurran en la fecha de cierre de las mismas, al menos, dos de las siguientes circunstancias:

a. Que el total de las partidas de activo sea superior a 2.400 .000 euros.

b. Que el importe neto del volumen anual de ingresos por la actividad propia más, en su caso, el de la cifra de negocios de su actividad mercantil sea superior a 2.400.000 euros.

c. Que el número de trabajadores empleados durante el ejercicio sea superior a 50 .

d. Que el valor de las ventas y de los gravámenes de bienes y derechos de la fundación realizados durante el ejercicio 
económico supere el 50 por cien del valor total de su patrimonio.

2. Las fundaciones que se encuentren en el primer ejercicio económico desde su constitución o fusión cumplirán lo dispuesto en el apartado anterior si reúnen, en el momento del cierre de dicho ejercicio, al menos dos de las cuatro circunstancias que se especifican.

3. También se someterán a auditoría externa aquellas cuentas que, a juicio del patronato de la fundación o del protectorado, presenten circunstancias especiales que lo aconsejen con relación a la cuantía del patrimonio o al volumen de gestión. En el supuesto de que sea el protectorado el que solicite la realización de la auditoría externa de las cuentas anuales de la fundación, deberá emitir una justificación en donde conste el motivo de la misma, y nombrará auditores de acuerdo con lo establecido reglamentariamente.

4. La auditoría se contratará y realizará conforme establece la Ley 19/1988, de 12 de julio, de Auditoría de Cuentas, y la legislación complementaria, disponiendo los auditores de un plazo mínimo de un mes, a partir del momento en que se les entregaran las cuentas anuales formuladas, para realizar el informe de auditoría.

5. Estos informes se presentarán al protectorado tras su emisión o junto con la presentación de las cuentas anuales. El protectorado, previo examen y comprobación de su adecuación a la normativa vigente, las depositará en el Registro de Fundaciones de Interés Gallego.

Artículo 38. Aprobación y presentación de las cuentas.

1. Las cuentas anuales serán aprobadas por el patronato dentro de los seis meses siguientes a la fecha de cierre del ejercicio, siendo firmadas por el Presidente o persona a la cual, conforme a los estatutos de la fundación o al acuerdo adoptado por sus órganos de gobierno, le corresponda formularlas.
2. Las cuentas anuales se presentarán al protectorado en el plazo de los veinte días hábiles, a contar desde su aprobación por el patronato, acompañadas de certificación del secretario. En su caso, se aportará el informe de la auditoría.

3. No podrán percibir subvenciones ni ayudas públicas de la Xunta de Galicia aquellas fundaciones que no cumplan con la obligación de presentar las cuentas al protectorado.

4. Para comprobar el cumplimiento de los requisitos exigidos en la documentación presentada, el protectorado podrá, en cualquier momento, dirigir requerimientos al patronato de la fundación para que, en el plazo señalado, aporte la documentación acreditativa correspondiente.

5. El protectorado, tras examinar y comprobar su adecuación formal a la normativa vigente, las depositará en el Registro de Fundaciones de Interés Gallego. Cualquier persona podrá obtener información de los documentos depositados, en los términos establecidos reglamentariamente.

6. El protectorado, en la forma establecida en el artículo 50, tiene que solicitar de la autoridad judicial que ordene la intervención temporal de la fundación que no presente las cuentas anuales durante dos ejercicios consecutivos. Mientras que la autoridad judicial no dicte resolución al respecto, el protectorado no puede inscribir documento alguno relativo a la fundación que se le presente, salvo el cese de patronos, la revocación de delegaciones de facultades, la revocación o renuncia de poderes, la extinción de la fundación, los nombramientos de liquidadores y los asientos ordenados por la autoridad judicial.

7. La obligación de presentar las cuentas anuales al protectorado, su anotación posterior y el depósito en el Registro de Fundaciones de Interés Gallego se establecerá, con independencia de la obligación de depositar las mencionadas cuentas en el registro mercantil, en los casos en que así lo disponga la regulación del mismo. 
Artículo 39. Plan de actuación.

1. El patronato elaborará y remitirá al protectorado, en los últimos tres meses de cada ejercicio, un plan de actuación, en el que queden reflejados los objetivos, las actividades que se prevea desarrollar durante el ejercicio siguiente, una previsión de las partidas de ingresos y gastos calculados y una memoria explicativa del mismo plan de actuación.

2. Este plan de actuación deberá presentarse al protectorado acompañado de la certificación de aprobación por parte del patronato de la fundación, que las depositará en el Registro de Fundaciones de Interés Gallego.

Artículo 40. Autocontratación.

Los miembros del patronato podrán contratar con la fundación, ya sea en nombre propio o de un tercero, dando cuenta al protectorado.

\section{Capitulo VI \\ MODIFICACIÓN DE LOS ESTATUTOS. FUSIÓN, ESCISIÓN Y EXTINCIÓN DE LA FUNDACIÓN}

Artículo 41. Modificación de los estatutos.

1. El patronato podrá acordar la modificación de los estatutos de la fundación siempre que resulte conveniente en interés de la misma, salvo que la persona fundadora lo haya prohibido.

2. Cuando las circunstancias que presidieron la constitución de la fundación hayan variado, de manera que ésta no pueda actuar satisfactoriamente con arreglo a sus estatutos, el patronato deberá acordar la modificación de los mismos, salvo que para este supuesto el fundador haya previsto la extinción de la fundación.

3. Si el patronato no da cumplimiento a lo previsto en el apartado anterior, el protectorado lo requerirá para que lo cumpla, solicitando en caso contrario de la autoridad judicial que resuelva sobre la procedencia de la modificación de estatutos requerida.

4. La modificación o nueva redacción de los estatutos habrá de ser formalizada en escritura pública e inscrita en el Registro de Fundaciones de Interés Gallego. La modificación de la nueva redacción de los estatutos acordada por el patronato tendrá que ser comunicada al protectorado, que sólo podrá oponerse por razones de legalidad, en el plazo máximo de tres meses, a contar desde la citada notificación.

Artículo 42. Fusión.

1. Las fundaciones, siempre que no lo haya prohibido el fundador, podrán fusionarse después de haberlo acordado los respectivos patronatos, lo que se comunicará al protectorado, aportando una memoria acreditativa de las circunstancias que aconsejan la fusión frente a otras posibles alternativas e informando de las condiciones pactadas con las fundaciones afectadas.

2. La fusión de fundaciones responderá a la conveniencia de cumplir mejor los fines fundacionales y podrá realizarse por:

a. La absorción de otra u otras que se extinguen.

b. La creación de una nueva fundación, a la que se transmitirán en bloque los patrimonios de las fusionadas que se extinguen.

3. El protectorado podrá oponerse a la fusión por razones de legalidad y mediante un acuerdo motivado, en el plazo máximo de un mes, que comenzará a contar desde la notificación al mismo de los respectivos acuerdos de las fundaciones interesadas. El protectorado podrá comunicar en cualquier momento, dentro de este plazo y de forma expresa, su conformidad al acuerdo de fusión.

4. La fusión requerirá el otorgamiento de escritura pública y la inscripción en el Registro de Fundaciones de Interés Gallego. Dicha escritura pública contendrá los estatutos de la fundación resultante de la fusión, así como la identificación de los miembros de su primer patronato. $\mathrm{Si}$ de la fusión resulta una nueva fundación cuya inscripción constitutiva corresponda inscribir en el Registro de Fundaciones de Interés Gallego, deberán efectuarse simultáneamente las inscripciones de 
extinción por fusión y de constitución de la nueva entidad.

5. Cuando una fundación resulte incapaz de alcanzar sus fines, el protectorado podrá requerirla para que se fusione con otra de fines análogos que haya manifestado ante el protectorado su voluntad favorable a dicha fusión, siempre que el fundador no lo hubiera prohibido. Frente a la oposición de aquélla, el protectorado podrá solicitar a la autoridad judicial que ordene la referida fusión.

\section{Artículo 43. Escisión.}

1. La escisión o creación de otra u otras fundaciones mediante la segregación de una parte o de varias partes de su patrimonio, que se transmite a otra u otras fundaciones, exige que no conste la voluntad contraria del fundador y que se justifique el mejor cumplimiento de los fines fundacionales de la escindida.

2. La escisión con creación de una nueva fundación requerirá el acuerdo motivado del patronato, lo que se comunicará al protectorado, y el cumplimiento de lo previsto en la presente ley para constituir una fundación.

3. La escisión con transmisión de lo escindido a otra $\mathrm{u}$ otras fundaciones ya existentes requiere el acuerdo motivado de los patronatos respectivos, el otorgamiento de la escritura pública, la autorización del protectorado y la inscripción en el Registro de Fundaciones de Interés Gallego.

4. En cualquier caso de escisión, el protectorado podrá oponerse por razones de legalidad y mediante un acuerdo motivado en el plazo máximo de un mes, que comenzará a contar desde que se le haya notificado el acuerdo de escisión. El protectorado podrá comunicar en cualquier momento, dentro de dicho plazo y de forma expresa, su conformidad con el acuerdo de escisión.

Artículo 44. Causas y formas de extinción.

1. La fundación se extinguirá:

a. Cuando expire el plazo por el que fue constituida. b. Cuando se hubiera realizado íntegramente el fin fundacional.

c. Cuando sea imposible realizar el fin fundacional, sin perjuicio de lo dispuesto en los artículos 41 y 42 de la presente ley.

d. Cuando así resulte de la fusión y de la escisión a que se refieren los artículos anteriores.

e. Cuando concurra cualquier otra causa prevista en el acto constitutivo o en los estatutos.

f. Cuando concurra cualquier otra causa establecida en las leyes.

2. En el supuesto del apartado 1.a), la fundación se extinguirá de pleno derecho.

3. En los supuestos de los apartados 1.b), c) y e), la extinción de la fundación requerirá el acuerdo del patronato ratificado por el protectorado. Si no hubiera acuerdo del patronato o éste no fuera ratificado por el protectorado, la extinción de la fundación requerirá la resolución judicial motivada, que podrá ser instada por el protectorado o el patronato, según los casos.

4. En el supuesto del apartado 1.d), se requerirá que se cumplan los requisitos establecidos en los artículos 42 y 43 de la presente ley.

5. En el supuesto del apartado 1.f), se requerirá una resolución judicial motivada.

6. El acuerdo de extinción o, en su caso, la resolución judicial se inscribirán en el Registro de Fundaciones de Interés Gallego.

Artículo 45. Destino de los bienes en caso de extinción.

1. A los bienes y derechos resultantes de la liquidación de una fundación extinguida se les dará el destino previsto por el fundador o decidido por el patronato cuando tenga reconocida esta facultad en la carta fundacional.

2. Si no existiera previsión del fundador ni facultad del patronato, corresponderá al protectorado destinar tales bienes y derechos a las fundaciones, entidades no lucrativas privadas o entidades públicas que persigan fines de interés general, que desarrollen principalmente sus actividades en Galicia y tengan afectados sus bienes, 


\section{Código de la Administración Gallega}

incluso en el supuesto de disolución, a la consecución de tales fines.

Artículo 46. Liquidación.

1. La extinción de la fundación, salvo en los supuestos en que tenga lugar a consecuencia de una fusión, determinará la apertura del procedimiento de liquidación, el cual deberá ser realizado por el patronato con el control y asesoramiento del protectorado. En caso de inexistencia del patronato, el protectorado designará de oficio a los liquidadores.

2. El patronato —como órgano de liquidación — deberá realizar las siguientes actuaciones:

a. Confección del inventario y balance de situación de la fundación en la fecha de inicio del procedimiento de liquidación.

b. Finalización de las operaciones de gestión que estaban iniciadas al acordar la extinción, así como de nuevas que hayan de llevarse a cabo con las limitaciones previstas.

c. Cobro de créditos pendientes, cancelación de deudas con los acreedores de todo tipo y por el orden de prelación establecida.

d. Cualesquiera otras actuaciones que sean convenientes o necesarias para los interesados en el procedimiento.

3. El protectorado podrá solicitar al órgano de liquidación información periódica del proceso e información adicional de la documentación facilitada, debiendo impugnar ante el juez o tribunal competente los actos de liquidación que considere contrarios al ordenamiento o a los estatutos, previo requerimiento de enmienda en los casos en que se dé esta posibilidad.

4. Aprobadas las actuaciones de liquidación por el patronato y adjudicado el haber resultante, de acuerdo con lo previsto en el artículo anterior, éstas serán comunicadas al protectorado, quien verificará las cancelaciones y promoverá las inscripciones que procedan, entre ellas la extinción de la fundación, en el Registro de Fundaciones de Interés Gallego.

\section{Capitulo VII \\ EL PROTECTORADO}

Artículo 47. El protectorado.

1. El protectorado es el órgano administrativo de asesoramiento, apoyo técnico y control de las fundaciones que velará por el ejercicio correcto del derecho de fundación y por la legalidad de su constitución y funcionamiento.

2. El protectorado será ejercido por los departamentos de la Xunta de Galicia que tengan atribuidas las competencias correspondientes a los fines de las fundaciones. Si las competencias sobre los fines fundacionales estuvieran atribuidas a varios departamentos de la Xunta de Galicia, el protectorado será ejercido por el departamento competente en materia de fundaciones.

3. El protectorado ejerce las funciones que le atribuye la presente ley y demás legislación aplicable, respecto a las fundaciones inscritas en el Registro de Fundaciones de Interés Gallego.

Artículo 48. Funciones.

1. Son funciones del protectorado:

a. Asesorar a las fundaciones que se encuentren en proceso de constitución sobre la normativa aplicable a dicho proceso y a las fundaciones ya inscritas sobre aquellas cuestiones que se refieren tanto a su régimen jurídico, económico-financiero y contable como a las actividades que es necesario realizar en cumplimiento de sus fines.

b. Informar sobre la adecuación y suficiencia de la dotación y sobre la idoneidad de los fines de las fundaciones en proceso de constitución.

c. Velar por el cumplimiento adecuado de los fines fundacionales de acuerdo con la voluntad del fundador y teniendo en cuenta la consecución del interés general, así como interpretar, suplir e integrar la voluntad del fundador cuando fuera necesario, conforme a la presente ley.

d. Velar por la integridad, la suficiencia y el rendimiento del patrimonio 
fundacional y verificar si los recursos económicos de las fundaciones han sido aplicados para cumplir los fines fundacionales, en los términos previstos en los estatutos y en la legislación vigente, pudiendo solicitar del patronato la información necesaria a tal efecto.

e. Difundir la existencia y las actividades de las fundaciones.

f. Ejercer provisionalmente las funciones del patronato si por cualquier motivo faltaran todas las personas llamadas a integrarlo, así como en los supuestos de intervención temporal acordados por el órgano judicial competente designar a nuevos miembros del patronato o, en los casos establecidos en la legislación, instar a la extinción de la fundación.

g. Ejercer la acción de responsabilidad de los miembros del patronato en los supuestos establecidos en la presente ley.

h. Garantizar la legalidad de las modificaciones estatutarias, fusiones y extinciones de las fundaciones, instando, en su caso, las acciones judiciales correspondientes.

i. Impugnar los actos y acuerdos del patronato contrarios al ordenamiento jurídico vigente, a lo establecido en los estatutos o al interés general.

j. Controlar el proceso de liquidación de las fundaciones.

k. Procurar la utilización efectiva y adecuada de la denominación "Fundación" y denunciar, en su caso, ante la autoridad competente su utilización por otra clase de entidades.

1. Resolver las solicitudes de autorización o aprobación que, con arreglo a lo dispuesto en la presente ley, la precisen.

$\mathrm{m}$. Cooperar, al servicio del interés general y de la sociedad civil, con las asociaciones de fundaciones u otros entes análogos.

n. Cualesquiera otras funciones que se le atribuya en la presente ley y ordenamiento jurídico vigente.

En el ejercicio de las funciones a que se refieren los apartados anteriores se solicitará asesoramiento al Servicio de Igualdad cuando fuera necesario o conveniente a los efectos de integrar activamente la dimensión de la igualdad de oportunidades entre hombres y mujeres, y, especialmente, cuando las funciones de protectorado se ejerzan respecto a una fundación entre cuyas finalidades se encuentre el respaldo a la igualdad de oportunidades entre hombres y mujeres.

2. En todo caso, el protectorado está legitimado para ejercer la correspondiente acción de responsabilidad por los actos relacionados en el artículo 22.2 y para instar el cese de los miembros del patronato en el supuesto previsto en el apartado d) del artículo 24.4.

Asimismo, está legitimado para impugnar los actos y acuerdos del patronato que sean contrarios a los preceptos legales o estatutarios por los que se rige la fundación.

3. Si el protectorado aprecia la existencia de indicios de ilicitud penal en la actividad de una fundación, remitirá testimonio al ministerio fiscal u órgano jurisdiccional competente, comunicando esta circunstancia a la fundación interesada.

Artículo 49. Régimen de las autorizaciones.

1. Las autorizaciones que, de acuerdo con la presente ley, corresponda efectuar al protectorado se entenderán concedidas si no se recibiera resolución expresa en el plazo de un mes, a contar desde la presentación de la solicitud. El plazo para resolver se interrumpirá cuando la solicitud no reúna los requisitos necesarios o no se presente debidamente documentada y el protectorado así lo considere mediante acto motivado que notificará al patronato. El plazo comenzará a contar de nuevo desde el momento en que tales defectos u omisiones fueran subsanados.

2. Los certificados que deba emitir el protectorado en el curso de los diferentes procedimientos, así como los de acreditación de todo tipo de hechos y circunstancias que soliciten los interesados, deberán expedirse en el plazo de diez días desde la recepción de la solicitud. 
Artículo 50. Intervención temporal.

1. Si el protectorado advirtiera una irregularidad grave en la gestión económica que ponga en peligro la subsistencia de la fundación o una desviación grave entre los fines fundacionales y la actividad realizada, requerirá del patronato, una vez oído este, la adopción de las medidas que considere pertinentes para la corrección de la misma.

2. Si el requerimiento a que se refiere el apartado anterior no fuera atendido en el plazo que al efecto se señale, el protectorado podrá solicitar a la autoridad judicial que acuerde, previa audiencia del patronato, la intervención temporal de la fundación. Autorizada judicialmente la intervención de la fundación, el protectorado asumirá todas las atribuciones legales y estatutarias del patronato durante el tiempo que determine el juez. La intervención quedará alzada al finalizar el plazo establecido, salvo que se acceda a prorrogarla mediante una nueva resolución judicial.

3. La resolución judicial que acuerde la intervención temporal de la fundación se inscribirá en el Registro de Fundaciones de Interés Gallego. Asimismo, será inscrita la demanda que se interponga para solicitar aquélla.

Artículo 51. Recursos.

Los acuerdos del protectorado sujetos a derecho administrativo serán recurribles en vía administrativa y, en su caso, ante la jurisdicción contencioso-administrativa.

\section{Capítulo VIII \\ EL REGISTRO DE FUNDACIONES DE INTERÉS GALLEGO}

Artículo 52. Registro de fundaciones.

1. El Registro de Fundaciones de Interés Gallego será único para toda la Comunidad Autónoma de Galicia y estará adscrito a la consellería competente en materia de fundaciones.

Sin perjuicio de la unicidad a que se refiere el párrafo anterior, el registro contará con tantas secciones como departamentos integren la Xunta de Galicia, en cada uno de los cuales se llevará un registro auxiliar.

2. La estructura y funcionamiento del Registro de Fundaciones de Interés Gallego, así como los plazos de inscripción, serán determinados reglamentariamente.

3. La inscripción de las fundaciones, que deberá contener los requisitos exigidos en el artículo 11 de la presente ley, requerirá, en todo caso, un informe favorable del protectorado, en cuanto a la idoneidad de los fines de interés gallego y a la determinación de la suficiencia de la dotación.

4. Serán funciones del registro:

a. La inscripción de las fundaciones declaradas de interés gallego y de los actos inscribibles descritos en el artículo 54 de la presente ley y demás normativa vigente.

b. El depósito y archivo de la documentación a que se refiere la presente ley y sus normas reglamentarias.

c. La legalización de los libros que hayan de llevar las fundaciones reguladas en la presente ley.

d. Comunicar al registro de fundaciones de competencia estatal, para constancia y publicidad general, las inscripciones de constitución de fundaciones o, en su caso, de extinción de las mismas.

e. Cualesquiera otras funciones que se le atribuyan reglamentariamente.

Artículo 53. Principios registrales.

1. El Registro único de Fundaciones de Interés Gallego será público. La publicidad de los actos inscritos se hará efectiva mediante la certificación de los asientos expedida por el responsable del registro, mediante nota simple informativa o copia compulsada de los asientos y documentos depositados en el registro. Sólo las certificaciones tendrán carácter de documento público.

2. Los documentos originales depositados y los archivados podrán ser consultados previa identificación del solicitante y acreditación de su interés, con arreglo a lo previsto en la normativa vigente en materia de protección de datos. 
3. Los actos inscritos en el registro se presumen válidos y el protectorado los considerará para fundamentar sus decisiones. Respecto a los documentos depositados y a los archivados que no causaran inscripción tan sólo se presumirá su regularidad formal.

4. Los actos sujetos a inscripción en el registro y no inscritos no perjudicarán a terceros de buena fe. La buena fe del tercero se presume mientras no se pruebe que conocía el acto sujeto a inscripción y no inscrito.

5. Todas las actividades registrales podrán hacerse en cualquiera de los dos idiomas oficiales en el territorio de la Comunidad Autónoma de Galicia.

6. Cuando el registro encuentre indicios racionales de ilicitud penal en la constitución de una fundación, éste dictará una resolución motivada, remitiendo toda la documentación al ministerio fiscal u órgano jurisdiccional competente. Asimismo, comunicará esta circunstancia a la fundación interesada, quedando suspendido el procedimiento de inscripción hasta que sea dada una resolución judicial firme.

7. En el registro se llevará una sección de denominaciones, por lo que se informará de las que vayan adoptando las fundaciones inscritas en el Registro Estatal de Fundaciones, con arreglo a lo dispuesto en el artículo 36.3 de la Ley $50 / 2002$, de 26 de diciembre.

8. Lo dispuesto en este artículo se entiende $\sin$ perjuicio de la normativa reguladora de otros registros públicos existentes.

Artículo 54. Actos inscribibles.

En el Registro único de Fundaciones de Interés Gallego debe dejarse constancia de los actos y documentos siguientes:

a. La carta fundacional.

b. Los estatutos y acuerdos de modificación.

c. El nombramiento, suspensión, cese y renuncia de los miembros del patronato y, si procede, de los liquidadores.

d. Las delegaciones de facultades, su revocación y los apoderamientos generales. e. La constitución, modificación, fusión, escisión y extinción de fundaciones.

f. La adquisición, enajenación, gravamen y arrendamiento de bienes en los supuestos establecidos en la presente ley.

g. La delegación de las fundaciones sometidas a otra legislación que actúan en Galicia.

h. Las acciones de responsabilidad contra los miembros del patronato y la resolución judicial correspondiente.

i. Con carácter preventivo, las intervenciones temporales y las solicitudes de intervención temporal sobre las fundaciones, las cuales serán canceladas automáticamente en caso de ser concedidas o denegadas por parte de la autoridad judicial.

j. Cualquier otro que se establezca en la presente ley, su normativa de desarrollo y el ordenamiento jurídico vigente.

$\mathrm{k}$. La prórroga de fundaciones constituidas por un plazo determinado.

Artículo 55. Obligatoriedad de la inscripción.

La inscripción en el Registro de Fundaciones de Interés Gallego es obligatoria para todas las fundaciones definidas en el artículo 2 y para las extranjeras que tengan una delegación abierta en esta comunidad.

\section{Capitulo IX \\ DEL CONSELLO SUPERIOR DE FUNDACIÓNS DA COMUNIDADE AUTÓNOMA DE GALICIA}

Artículo 56. Consello Superior de Fundacións.

1. Se crea el Consello Superior de Fundacións da Comunidade Autónoma de Galicia, adscrito a la consellería competente en materia de fundaciones, como órgano consultivo.

2. Reglamentariamente se establecerá la estructura y composición del Consello Superior de Fundacións da Comunidade Autónoma de Galicia, en el que estarán representadas la Administración de la Xunta de Galicia y las fundaciones objeto de la presente ley, atendiendo a la existencia de asociaciones de fundaciones con implantación en Galicia.

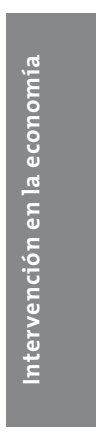


Artículo 57. Funciones.

Serán funciones del Consello Superior de Fundacións da Comunidade Autónoma de Galicia:

a. Asesorar, informar y dictaminar, cuando así se solicite, sobre cualquier disposición legal o reglamentaria que afecte directamente a las fundaciones.

b. Formular las propuestas que considere convenientes, en este ámbito, a la consellería competente en materia de fundaciones.

c. Planificar y proponer las actuaciones necesarias para promover y fomentar las fundaciones de interés gallego.

d. Las demás funciones que puedan atribuirle las disposiciones vigentes.

\section{Capitulo X \\ DE LAS FUNDACIONES DEL SECTOR PÚBLICO DE GALICIA}

Artículo 58. Concepto.

1. Se entiende por fundaciones del sector público de Galicia aquellas fundaciones constituidas mayoritariamente o en su totalidad por aportaciones de la Administración de la Comunidad Autónoma de Galicia, sus organismos públicos y demás entidades o empresas del sector público autonómico o aquellas cuyos ingresos provengan mayoritariamente de subvenciones con cargo a los presupuestos de la Comunidad Autónoma, siempre que en este último caso la Comunidad Autónoma forme parte de sus órganos de gobierno o dirección.

2. Las fundaciones del sector público de Galicia integrarán activamente, en su organización y actividades, la dimensión de la igualdad de oportunidades entre mujeres y hombres en todos los ámbitos y a todos los niveles.

Artículo 59. Creación y extinción.

1. La creación y extinción de las fundaciones del sector público de la Comunidad Autónoma de Galicia, la adquisición y pérdida de la representación mayoritaria, así como la modificación de sus estatutos, deberán ser autorizadas por acuerdo del Consello de la Xunta, que determinará las condiciones generales que han de cumplir todos estos actos y designará a la persona que deba actuar por ella en el acto de constitución y, en su caso, su representante o representantes en el patronato.

2. En el expediente de autorización se incluirá una memoria, que habrá de ser informada por el departamento de la Xunta de Galicia que ejerza las competencias correspondientes a los fines de la fundación, en la cual se justifiquen suficientemente las razones por las que se considera que existirá una mejor consecución de los fines de interés general perseguidos a través de una fundación que mediante otras formas jurídicas previstas en la normativa vigente.

3. Deberá presentarse, igualmente, una memoria económica, que requerirá el informe de la consellería competente en materia de economía, en la que se justificará la suficiencia de la dotación inicialmente prevista para comenzar la actividad de la fundación y, en su caso, los compromisos futuros que garanticen su continuidad.

4. El Parlamento podrá ejercer el control de la creación de este tipo de fundaciones, en los términos establecidos en su reglamento, dentro del control de la acción de la Xunta de Galicia ${ }^{241}$.

Artículo 60. Régimen jurídico.

1. Las fundaciones del sector público de la Comunidad Autónoma no podrán ejercer potestades públicas. Únicamente podrán realizar actividades relacionadas con el ámbito competencial de las entidades fundadoras, debiendo contribuir a la consecución de sus fines, sin que ello suponga la asunción de la titularidad de las competencias de las mismas, salvo previsión legal expresa.

2. El protectorado de estas fundaciones será ejercido por el departamento de la Xunta de Galicia que ejerza las competencias correspondientes a los fines de la fundación.

241 Véase Decreto 217/2008, de 25 de septiembre, por el que se regula el contenido minimo de las propuestas de creación de nuevas entidades del sector público autonómico. 
3. Las fundaciones públicas cuya dotación fundacional fuera totalmente aportada por la Xunta de Galicia, o en las que ésta tenga un control análogo al que ejerce sobre sus propios servicios o unidades, tendrán la consideración de medio propio e instrumental a los efectos previstos en el artículo 3 de la Ley de Contratos de las Administraciones Públicas. En estos casos, la Xunta de Galicia podrá encomendarles la ejecución de obras, suministros o servicios públicos de su competencia. Las encomiendas se instrumentarán a través de encargos de realización obligatoria, cuya ejecución supervisará el ente encomendante. En los casos en que para la efectividad de la encomienda la fundación pública precisara prestaciones por parte de terceros, su adjudicación quedará sometida a la Ley de Contratos de las Administraciones Públicas en los términos previstos en la presente ley.

4. En materia de presupuestos, contabilidad y auditoría de cuentas, las fundaciones previstas en este capítulo se regirán por lo dispuesto en el Decreto Legislativo 1/1999, de 7 de octubre, por el que se aprueba el texto refundido de la Ley de régimen financiero y presupuestario de Galicia.

\section{Artículo 61. Contratación.}

1. A la contratación de personal al servicio de las fundaciones reguladas en este título le serán de aplicación las disposiciones de la Ley de Función Pública de Galicia y de las normas reglamentarias que la desarrollen, relativas a:

a. Composición y funcionamiento de los tribunales o comisiones de selección.

b. Bases de las convocatorias.

c. Pruebas de selección.

En todo caso, se respetarán los principios de igualdad, mérito, capacidad y publicidad de la convocatoria. La consellería competente en materia de función pública deberá informar previamente el contenido de las bases de la convocatoria.

2. En materia de contratación de obras, suministros, servicios o asistencia será de aplicación lo dispuesto en la legislación de contratos de las administraciones públicas.
Artículo 62. Control financiero.

Las fundaciones reguladas en este capítulo estarán sujetas al control financiero que realizará la Intervención General de la Comunidad Autónoma, sin perjuicio de las competencias que en esta materia correspondan al Consello de Contas de Galicia.

Artículo 63. Principios y procedimientos en materia de subvenciones.

Serán de aplicación en su integridad a las fundaciones del sector público de Galicia los principios y procedimientos previstos en la Ley 38/2003, de 17 de noviembre, general de subvenciones.

Será de aplicación a las fundaciones del sector público de Galicia lo previsto en la Disposición adicional decimosexta de la Ley 38/2003, de 17 de noviembre, General de Subvenciones.

\section{DISPOSICIÓN ADICIONAL PRIMERA}

El contenido de los artículos 2.1, 5 al 15, $22,24,26,30,41,42.1 .4$ y $5,44,47.1,48.2$, 50 y 53.8 de la presente ley están redactados en conformidad con los preceptos de aplicación general de la Ley 50/2002, de 26 de diciembre, de Fundaciones.

\section{DISPOSICIÓN ADICIONAL SEGUNDA}

Sin perjuicio de su condición de fundaciones del sector público de Galicia, las fundaciones públicas sanitarias a que se refiere la Ley 7/2003, de 9 de diciembre, de Ordenación Sanitaria de Galicia, seguirán regulándose por su normativa específica, por lo que les será de aplicación lo establecido en el capítulo $\mathrm{X}$ de la presente ley con carácter supletorio.

\section{DISPOSICIÓN ADICIONAL TERCERA}

Los notarios deberán comunicar al protectorado el contenido de las escrituras, en lo referente a la constitución de las fundaciones y a sus modificaciones posteriores, mediante la remisión de copia simple de las citadas escrituras.

En caso de que la fundación se constituyera en testamento, la referida obligación 
será cumplida cuando el notario habilitado conociera el fallecimiento del testador.

\section{DISPOSICIÓN ADICIONAL CUARTA}

Serán de aplicación a las fundaciones reguladas en la presente ley las normas de adaptación del Plan general de contabilidad para las entidades sin ánimo de lucro y las normas de elaboración del plan de actuación de dichas entidades.

\section{DISPOSICIÓN TRANSITORIA ÚNICA}

1. En el plazo de dos años, a contar desde la entrada en vigor de la presente ley, las fundaciones ya constituidas y que se encuentren en el ámbito de aplicación de esta ley deberán adaptar sus estatutos, cuando proceda, a lo dispuesto en dicha ley, salvo lo relativo a lo establecido en el artículo 2, y presentarlos en el Registro de Fundaciones de Interés Gallego. La dotación de dichas fundaciones no se someterá al régimen previsto en el artículo 13 de la presente ley.

De manera excepcional, el protectorado podrá prorrogar hasta un máximo de un año más el citado plazo, previa solicitud razonada del patronato y siempre que consten acreditadas las circunstancias que objetivamente así lo justifiquen.

2. Transcurrido el plazo a que se refiere el apartado anterior sin haberse producido la adaptación de estatutos, cuando sea necesario, no se inscribirá documento alguno de la fundación en el Registro Único de Fundaciones de Interés Gallego hasta que la adaptación sea verificada, y sin perjuicio de lo dispuesto en los artículos 41.3 y 42.5 de la presente ley.

3. El incumplimiento de las obligaciones previstas en esta disposición por alguna fundación provocará que ésta no pueda obtener subvenciones o ayudas públicas de la Xunta de Galicia, sin perjuicio de las responsabilidades en las que, conforme a la legislación vigente, pudiera incurrir.

4. Las condiciones estatutarias contrarias a la presente ley de las fundaciones constituidas a fe y conciencia se considerarán no puestas.

\section{DISPOSICIÓN DEROGATORIA ÚNICA}

Queda derogada la Ley 7/1983, de 22 de junio, de Régimen de las Fundaciones de Interés Gallego, y la Ley 11/1991, de 8 de noviembre, de modificación de la anterior, así como todas las disposiciones de rango igual o inferior en lo que contradigan o se opongan a lo establecido en la presente ley.

\section{DISPOSICIÓN FINAL PRIMERA}

Se autoriza a la Xunta de Galicia para que dicte las disposiciones necesarias para el desarrollo de la presente ley.

\section{DISPOSICIÓN FINAL SEGUNDA}

La presente ley entrará en vigor al mes de su publicación completa en el "Diario Oficial de Galicia".

\section{LEY 10/1996, DE 5 DE NOVIEMBRE, DE ACTUACIÓN DE ENTES Y EMPRESAS EN LAS QUE TIENE PARTICIPACIÓN MAYORITARIA LA XUNTA DE GALICIA, EN MATERIA DE PERSONAL Y CONTRATACIÓN (DOGA N. $\left.^{\circ} 227,20.11 .1996\right)^{242}$}

$$
\text { (... })^{243}
$$

\section{Capitulo I}

\section{ÁMBITO DE APLICACIÓN Y PRINCIPIOS} GENERALES DE ACTUACIÓN

\section{Artículo 1. Principios.}

1. En los términos regulados en los artículos siguientes, habrán de ajustar su actuación en materia de personal y contratación a los principios básicos que regulan la función pública y contratación de las administraciones públicas:

a. Las entidades de derecho público vinculadas a la Administración de la Comunidad Autónoma o dependientes de la misma.

242 Véase Orden de 20 de mayo de 2008 por la que se establecen los modelos a que deberán adaptarse las memorias que editen los distintos departamentos de la Xunta de Galicia, organismos autónomos, agencias, fundaciones, entidades y empresas en que tienen participación mayoritaria la Xunta de Galicia.

243 Exposición de motivos omitida. 
b. Las fundaciones constituidas mayoritariamente o en su totalidad por aportaciones de la Administración de la Comunidad Autónoma de Galicia, por sus organismos autónomos o entidades de derecho público vinculadas o dependientes o cuyos ingresos provengan mayoritariamente de subvenciones con cargo a los presupuestos de la Comunidad Autónoma, siempre que en este último caso la Comunidad Autónoma forme parte de sus órganos de gobierno o dirección.

c. Las sociedades mercantiles en cuyo capital exista participación mayoritaria, directa o indirecta, de la Administración de la Comunidad Autónoma, de sus organismos autónomos y de las demás entidades de derecho público.

2. La actuación en materia de personal y contratación se someterá obligatoriamente a un plan de igualdad para eliminar la discriminación por razón de sexo ${ }^{244}$.

\section{Capítulo II PERSONAL}

Artículo 2. La selección de personal de las entidades, fundaciones y sociedades mencionadas en el artículo 1 será efectuada con respeto a los principios de igualdad, mérito, capacidad y publicidad de la convocatoria.

Artículo 3. La plantilla de los entes enumerados en el artículo anterior habrá de ser aprobada por el órgano superior de dirección.

La contratación de personal será decidida por el órgano correspondiente señalado en sus propios estatutos.

Artículo 4. A estos efectos, para la selección de su personal de plantilla, será necesario un anuncio público de convocatoria, que se efectuará en el "Diario Oficial de Galicia" y, al menos, en un diario de difusión general con una antelación

244 Art. 1.2 añadido por Ley $2 / 2007$, de 28 de marzo, del trabajo en igualdad de las mujeres de Galicia. respecto a las pruebas de, como mínimo, un mes, y la selección será efectuada por una comisión designada al efecto.

Artículo 5. Personal de alta dirección.

1. La contratación de personal de alta dirección se someterá a los principios de mérito y capacidad, entre personas que demostrasen su cualificación profesional.

2. La fijación de sus retribuciones habrá de contar con un informe previo favorable de las consellerías de la Presidencia y Administración Pública y de Economía y Hacienda. De igual modo, se fijarán las indemnizaciones que pudiesen corresponderles, que, en todo caso, habrán de ir acompañadas de una propuesta razonada.

Artículo 6. Indemnizaciones.

Las indemnizaciones máximas que por asistencia pudiesen corresponder a los integrantes de los órganos superiores de dirección se fijarán por acuerdo del Consello de la Xunta.

Artículo 7. Personal temporal.

1. La celebración de contratos laborales de duración determinada debe ser autorizada por el órgano superior de dirección, y en ningún caso podrá dar lugar a contratos indefinidos. La convocatoria podrá efectuarse mediante anuncio público, y la comisión de selección formulará propuesta razonada, entre las personas que se presenten en virtud de dicho anuncio o entre las incluidas en las listas del INEM o de otros servicios de colocación legalmente autorizados.

2. No obstante lo dispuesto en el apartado anterior, las entidades a que se refiere el artículo 1 podrán acogerse a un sistema de listas previo por categorías. Dichas listas se confeccionarán, previo pertinente anuncio público, de conformidad con el baremo aprobado por la entidad respectiva.

Artículo 8. Incompatibilidades.

El personal de las entidades, fundaciones y sociedades a que se refiere el artículo 1 de la presente ley estará sujeto al régimen 
de incompatibilidades que se derive de su condición de acuerdo con el régimen general que le sea de aplicación.

\section{Capítulo III CONTRATACIÓN}

Artículo 9. Principios.

A las fundaciones y sociedades públicas a que se refiere el artículo 1.b) y c) de la presente ley les será de aplicación directa la legislación de contratos de las administraciones públicas en los mismos términos que se establecen en ésta para las sociedades de derecho privado creadas para satisfacer necesidades de interés general.

Las entidades a que se refiere el artículo 1, cuando no les resulte de aplicación directa la legislación de contratos de las administraciones públicas, ajustarán su actividad contractual a los principios de publicidad, concurrencia y objetividad, salvo que la naturaleza de la operación a realizar sea incompatible con estos principios ${ }^{245}$.

Artículo 10. Publicidad y concurrencia. Los principios de publicidad y concurrencia establecidos en el artículo anterior se materializarán en la obligación de publicar anuncios en los medios de comunicación, así como en la concesión de un plazo mínimo de diez días para la presentación de solicitudes. No será necesario cumplir estos trámites en los mismos casos exceptuados por la legislación de contratos de las administraciones públicas.

\section{Capitulo IV FISCALIZACIÓN}

Artículo 11. Auditoría.

Las fundaciones reguladas en el artículo 1.b) estarán sujetas al control financiero de la Intervención General de la Comunidad Autónoma, que lo ejercerá mediante la realización de auditorías en cada ejercicio presupuestario.

245 Art. 9 modificado por Ley 14/2004, de 29 de diciembre, de medidas tributarias y de régimen administrativo.
Artículo 12. Competencia del Conse1lo de Contas.

1. Sin perjuicio de lo dispuesto en el artículo anterior, las fundaciones reguladas en el artículo 1.b) habrán de remitir sus cuentas al Consello de Contas de Galicia, para la fiscalización de las mismas por este órgano. Dicha remisión se realizará independientemente de la Cuenta general de la Comunidad Autónoma.

2. Realizada la tarea fiscalizadora regulada en el apartado anterior, el Consello de Contas de Galicia remitirá un informe con sus conclusiones al Parlamento de Galicia.

\section{DISPOSICIÓN ADICIONAL PRIMERA}

La entidad de derecho público Compañía de Radio-Televisión de Galicia se regirá por su legislación específica.

\section{DISPOSICIÓN ADICIONAL SEGUNDA}

La fiscalización de las fundaciones a que se refiere el capítulo IV se llevará a cabo en relación con las cuentas del ejercicio presupuestario siguiente a la entrada en vigor de esta ley.

\section{DISPOSICIÓN TRANSITORIA}

Las entidades, fundaciones y sociedades mercantiles a que se refiere el artículo 1 de esta ley habrán de adaptar sus estatutos, en cuanto fuera preciso, a lo dispuesto en esta ley, en el plazo de doce meses a partir de su entrada en vigor.

\section{DISPOSICIÓN FINAL PRIMERA}

Se autoriza a la Xunta de Galicia para dictar las normas reglamentarias precisas para el desarrollo de esta ley.

\section{DISPOSICIÓN FINAL SEGUNDA}

La presente ley entrará en vigor el día siguiente al de su publicación en el "Diario Oficial de Galicia”. 
5. LEY 6/2004, DE 12 DE JULIO, REGULADORA DE LOS ÓRGANOS DE DEFENSA DE LA COMPETENCIA DE LA COMUNIDAD AUTÓNOMA DE GALICIA (DOGA N. $\left.{ }^{\circ} 141,22.7 .2004\right)^{246}$

\section{$(\ldots)^{247}$ \\ TÍTULO I \\ DEL TRIBUNAL GALEGO DE DEFENSA DE LA COMPETENCIA}

\section{Capítulo I}

NATURALEZA Y FUNCIONES

Artículo 1. Naturaleza jurídica.

1. Se crea el Tribunal Galego de Defensa de la Competencia como Organismo Autónomo de carácter administrativo, dotado de personalidad jurídica y presupuesto propios, con capacidad de obrar y plena independencia en el ejercicio de sus competencias.

2. El Tribunal Galego de Defensa de la Competencia se adscribe a la consellería competente en materia de economía y hacienda.

\section{Artículo 2. Fines.}

El Tribunal Galego de Defensa de la Competencia tiene como fin general preservar el funcionamiento competitivo de los mercados en el ámbito territorial de la Comunidad Autónoma de Galicia, garantizando la existencia en los mismos de una competencia efectiva.

Artículo 3. Funciones.

De acuerdo con el régimen establecido en la Ley de Coordinación de las Competencias del Estado y de las Comunidades Autónomas en materia de defensa de la competencia, corresponde al tribunal:

1. Resolver los procedimientos sancionadores que tengan por objeto:

a. Acuerdos, decisiones o recomendaciones colectivas, o prácticas concertadas o conscientemente paralelas, prohibidas

246 Véase Decreto 20/2005, de 3 de febrero, de desarrollo de la Ley 6/2004, de 12 de julio, reguladora de los órganos de Defensa de la Competencia de la Comunidad Autónoma de Galicia.

247 Exposición de motivos omitida. en el número 1 del artículo 1 de la Ley de Defensa de la Competencia.

b. Conductas de explotación abusiva por una o varias empresas de su posición de dominio en el mercado, o de una situación de dependencia económica, prohibidas ambas en el artículo 6 de la Ley de Defensa de la Competencia.

c. Actos de competencia desleal que por falsear la libre competencia resulten prohibidos con arreglo al artículo 7 de la Ley de Defensa de la Competencia.

Asimismo, el tribunal, a propuesta del Servicio Gallego de Defensa de la Competencia, podrá adoptar, conforme a lo establecido en la legislación estatal, las medidas preventivas necesarias tendentes a asegurar la eficacia de la resolución que se dicte en su momento.

2. Resolver los procedimientos en materia de autorización de acuerdos, decisiones, recomendaciones y prácticas a que se refiere el artículo 1 de la Ley de Defensa de la Competencia, en los supuestos y con los requisitos previstos en el artículo 3 de la mencionada ley.

3. Las siguientes competencias consultivas y de emisión de informes:

a. Emitir informe, preceptivamente, sobre los proyectos de ley por los que se modifique o derogue, total o parcialmente, este texto legal, así como los proyectos de normas reglamentarias que lo desarrollen.

b. Emitir informe en los procedimientos de control de las operaciones de concentración económica regulados en la Ley de Defensa de la Competencia cuando así lo solicite el Tribunal de Defensa de la Competencia de la Administración general del Estado.

c. Enviar al Tribunal de Defensa de la Competencia de la Administración general del Estado la información que le pueda recabar en el marco del procedimiento de control de concentraciones regulado en la Ley de Defensa de la Competencia.

d. Solicitar personarse en los procedimientos de control de las operaciones de 
concentración económica regulados en la Ley de Defensa de la Competencia, cuando el proyecto o la operación afecte a empresas radicadas o con establecimientos abiertos en el territorio de la Comunidad gallega.

e. Emitir, a requerimiento del Servicio de Defensa de la Competencia de la Administración general del Estado, el informe preceptivo, no vinculante, en relación con aquellas conductas que, afectando a un ámbito supraautonómico o al conjunto del mercado nacional, incidan, de forma significativa, en el territorio de la Comunidad Autónoma de Galicia, a que se refiere el artículo 5.4 de la Ley de Coordinación de Competencias del Estado y de las Comunidades Autónomas en materia de defensa de la competencia.

f. Emitir informe con carácter no vinculante sobre la apertura de grandes establecimientos comerciales en el ámbito territorial de la Comunidad Autónoma de Galicia.

g. Realizar las funciones de arbitraje, tanto de derecho como de equidad, que le encomienden las leyes.

h. Elaborar el informe que, a petición del órgano judicial competente, prevé el artículo 13 de la Ley de Defensa de la Competencia sobre las eventuales indemnizaciones de daños y perjuicios derivados de las conductas previstas en los artículos 1, 6 y 7 de la mencionada ley, cuando los procedimientos que tengan por objeto tales conductas prohibidas correspondiesen a la Comunidad Autónoma de Galicia, de acuerdo con los puntos de conexión establecidos en la Ley de Coordinación de las Competencias del Estado y de las Comunidades Autónomas en materia de defensa de la competencia.

i. Emitir informe, con carácter facultativo y no vinculante, sobre los proyectos de concesión de ayudas a empresas con cargo a los recursos públicos, en relación con sus efectos sobre las condiciones de competencia, sin perjuicio de las competencias que en esta materia corresponden al Tribunal de Defensa de la Competencia de la Administración general del Estado y a la Comisión Europea. A estos efectos, el concepto de ayuda pública será el que define el artículo 19.2 de la Ley de Defensa de la Competencia.

j. Elaborar una memoria anual.

k. Remitir anualmente al Parlamento la memoria de actividades y un informe sobre la situación de la competencia en Galicia.

4. Otorgar las autorizaciones singulares previstas en el artículo 4 de la Ley de Defensa de la Competencia, de acuerdo con lo establecido en la Ley de Coordinación de las Competencias del Estado y de las Comunidades Autónomas en la materia.

Asimismo, le corresponderá asumir todas aquellas competencias que le atribuya la legislación aplicable en materia de defensa de la competencia.

\section{Capitulo II ORGANIZACIÓN}

Artículo 4. Composición.

1. El Tribunal Galego de Defensa de la Competencia estará regido por el pleno, integrado por el presidente o presidenta y dos vocales.

2. El presidente o la presidenta y los vocales tienen la consideración de altos cargos y serán nombrados por el Consello de la Xunta de Galicia, a propuesta del conselleiro competente en materia de economía y hacienda, entre juristas, economistas y otros profesionales de reconocido prestigio con más de diez años de ejercicio profesional.

3. El nombramiento del presidente o presidenta y de los vocales será por un período de cinco años, renovable por una sola vez. No obstante, al expirar el plazo de su mandato continuarán en el ejercicio de sus funciones hasta la toma de posesión de los nuevos vocales o, en su caso, del Presidente o presidenta.

El presidente o presidenta, en los casos de vacante, ausencia o enfermedad y salvo 
delegación expresa en alguno de los vocales, será sustituido por el vocal de mayor antigüedad $\mathrm{y}$, a igualdad de antigüedad, por el de mayor edad.

4. Los miembros del tribunal ejercerán su función con dedicación absoluta y estarán sometidos al régimen de incompatibilidades establecido con carácter general para los altos cargos de la Administración autonómica.

5. El tribunal estará asistido por un secretario.

Artículo 5. Causas de cese y suspensión en el ejercicio del cargo.

1. Los cargos de presidente o presidenta y vocal son inamovibles, sin que puedan ser cesados, suspendidos ni declarados incapaces, salvo en los casos y en la forma previstos en las leyes.

2. El presidente o presidenta y los vocales cesarán en su cargo:

a. Por renuncia.

b. Por expiración del término de su mandato.

c. Por incompatibilidad sobrevenida, estimada por decisión administrativa o judicial firme, de acuerdo con el régimen de incompatibilidades de altos cargos.

d. Por haber sido condenados por delito.

e. Por incapacidad permanente.

f. Por destitución, acordada por el Consello de la Xunta de Galicia, a iniciativa, al menos, de algún miembro del tribunal, por incumplimiento grave de los deberes de su cargo.

3. El presidente o presidenta y los vocales del Tribunal Galego de Defensa de la Competencia sólo podrán ser suspendidos en el ejercicio de su cargo:

a. Cuando se hubiera dictado contra ellos auto de procesamiento o de apertura de juicio oral en procedimientos por delito.

b. Cuando se acuerde en expediente disciplinario o de declaración de incapacidad transitoria.

c. Por sentencia firme condenatoria que imponga la suspensión como pena principal o accesoria.

\section{Capitulo III \\ EL PRESIDENTE O PRESIDENTA DEL TRIBUNAL GALEGO DE DEFENSA DE LA COMPETENCIA}

Artículo 6. Funciones.

1. Corresponden al presidente o presidenta del tribunal las siguientes funciones:

a. $\mathrm{Su}$ representación ordinaria y la representación ordinaria de éste y la convocatoria de las sesiones del pleno.

b. Mantener el buen orden y el gobierno del tribunal, velando por el adecuado cumplimiento y la aplicación de sus normas de organización y funcionamiento.

c. Representar a la Comunidad Autónoma de Galicia en el Consejo de Defensa de la Competencia, creado por la Ley 1/2002, de 21 de febrero, de Coordinación de las Competencias del Estado y de las Comunidades Autónomas en materia de defensa de la competencia.

d. La jefatura del personal del organismo.

e. La ordenación del gasto y autorización de ingresos.

f. Presentar la memoria anual del tribunal mediante comparecencia ante la Comisión de Economía del Parlamento de Galicia antes del 30 de junio de cada año, en la que dará cuenta de las actividades del tribunal en el ejercicio anterior y de sus objetivos para el siguiente.

2. El presidente o presidenta del tribunal podrá delegar en cualquiera de los vocales las funciones que estime adecuadas.

\section{Capitulo IV FUNCIONAMIENTO} bunal.

Artículo 7. Funcionamiento del tri-

1. El pleno del tribunal quedará válidamente constituido cuando esté presente el Presidente o presidenta y la mitad al menos de los vocales. En los casos de sustitución del Presidente o presidenta previstos en el artículo 4.3, para la válida constitución del tribunal, deberán estar presentes los dos vocales. 
Los acuerdos se adoptarán por mayoría de votos de los asistentes. En caso de empate decidirá el voto de quien presida.

2. Su funcionamiento se regulará por la presente ley y por la normativa de desarrollo de la misma y, en su defecto, por la legislación aplicable a los órganos colegiados de las administraciones públicas.

3. Actuará como secretario un funcionario del cuerpo superior de la Administración de la Xunta de Galicia adscrito a la consellería competente en materia de economía y hacienda.

\section{Capítulo V \\ Régimen económico y de personal}

Artículo 8. De los recursos del tribunal. Para el cumplimiento de sus fines, el Tribunal Galego de Defensa de la Competencia dispondrá de los siguientes recursos económicos:

a. Las consignaciones presupuestarias que le sean asignadas en los presupuestos generales de la Comunidad Autónoma de Galicia.

b. Los bienes y derechos que constituyan su patrimonio, así como, en su caso, los productos y las rentas de los mismos.

c. Los ingresos propios que esté autorizado a percibir.

d. Cualquier otro recurso que le pueda corresponder, de conformidad con lo previsto en las leyes.

Artículo 9. Del régimen presupuestario y contable.

1. El Tribunal Galego de Defensa de la Competencia elaborará anualmente un anteproyecto de presupuesto con la estructura que señale la consellería competente en materia de economía y hacienda y lo remitirá a ésta para, en su caso, proceder a su elevación al Consello de la Xunta y posterior remisión al Parlamento integrado en los presupuestos generales de la Comunidad Autónoma.

2. Corresponde al tribunal la administración, gestión y recaudación de sus propios derechos económicos así como la autorización de los gastos contenidos en sus presupuestos y la ordenación de sus pagos.

3. Su régimen presupuestario, económico-financiero y de contabilidad será el establecido para los organismos autónomos en la Ley de Régimen Financiero y presupuestario de Galicia.

Artículo 10. Del personal y de la contratación.

El personal al servicio del Tribunal Galego de Defensa de la Competencia será funcionario o laboral en los mismos términos que los establecidos por la normativa aplicable en el ámbito de la Comunidad Autónoma de Galicia.

La contratación del tribunal se regirá por las normas generales de contratación de las administraciones públicas.

\section{TÍTULO II DEL SERVICIO GALLEGO DE DEFENSA DE LA COMPETENCIA}

Artículo 11. Naturaleza.

Se crea el Servicio Gallego de Defensa de la Competencia, dentro de la estructura orgánica de la consellería competente en materia de economía y hacienda de la Xunta de Galicia. Su nivel y estructura interna serán establecidos por la normativa de desarrollo de la presente ley.

Artículo 12. Funciones.

Corresponde al Servicio Gallego de Defensa de la Competencia la investigación y vigilancia de los mercados y la instrucción de los expedientes sancionadores y de autorización en materia de defensa de la competencia.

En concreto, el servicio llevará a cabo las siguientes funciones:

a. Instruir los expedientes por conductas incluidas en el ámbito de aplicación de la presente ley, con arreglo a los procedimientos en materia de acuerdos y prácticas prohibidas y autorizadas establecidos en la Ley de Defensa de la Competencia.

b. Vigilar la ejecución y el cumplimiento de las resoluciones que se adopten en aplicación de la presente ley. 
c. Llevar el Registro Gallego de Defensa de la Competencia.

d. Auxiliar al tribunal en la ejecución de sus competencias consultivas, de estudio y emisión de informes.

e. Promover y acordar la terminación convencional de los procedimientos tramitados como consecuencia de conductas prohibidas por la Ley de Defensa de la Competencia.

f. Colaborar, en el ámbito de sus funciones, con los organismos homónimos de las Comunidades Autónomas y de la Administración general del Estado. En especial, corresponde al servicio la competencia para realizar y recibir las notificaciones a que se refieren los artículos 2.1, párrafo primero, y 2.2 , párrafo primero, de la Ley 1/2002, de 21 de febrero.

Artículo 13. Deber de colaboración y funciones de investigación e inspección.

1. Toda persona natural o jurídica tiene el deber de colaborar con el Servicio de Defensa de la Competencia, según lo establecido en el artículo 32 de la Ley de Defensa de la Competencia.

2. Los funcionarios autorizados por el Servicio de Defensa de la Competencia para realizar funciones de investigación e inspección actuarán de acuerdo con lo dispuesto en los artículos 33 y 34 de la misma ley.

Artículo 14. Del registro.

1. Se crea el Registro Gallego de Defensa de la Competencia, en el que se inscribirán los acuerdos, decisiones, recomendaciones y prácticas autorizadas por el tribunal y los que haya declarado prohibidos total o parcialmente, así como los acuerdos adoptados por el servicio que no hubieran sido recurridos.

2. El registro será gestionado por el servicio. A estos efectos, el tribunal le dará traslado de sus resoluciones.

3. El registro será público. La publicidad se hará efectiva mediante consulta o certificación.

\section{TÍTULO III DISPOSICIONES GENERALES}

Artículo 15. Normas de procedimiento.

Los órganos gallegos de defensa de la competencia aplicarán a los procedimientos que tramiten las normas de procedimiento establecidas en la legislación estatal en la materia y, con carácter supletorio, lo que disponga la normativa sobre procedimiento administrativo común.

Artículo 16. Recursos.

1. Los actos del servicio que decidan directa o indirectamente el fondo del asunto, determinen la imposibilidad de continuar el procedimiento o produzcan indefensión podrán recurrirse en alzada ante el tribunal en los términos que establece la normativa aplicable en materia de defensa de la competencia.

2. La adopción de medidas preventivas y las resoluciones definitivas que dicte el tribunal agotan la vía administrativa y contra las mismas podrán interponerse los recursos establecidos en la normativa sobre procedimiento administrativo común.

Artículo 17. Publicación en el "Diario Oficial de Galicia".

Las resoluciones sancionadoras del Tribunal Galego de Defensa de la Competencia se publicarán en el "Diario Oficial de Galicia”. El tribunal podrá asimismo acordar la publicación de sus resoluciones no sancionadoras.

Artículo 18. Representación en la Xunta Consultiva en materia de conflictos. El conselleiro competente en materia de economía y hacienda de la Xunta de Galicia nombrará a los representantes de la Comunidad Autónoma en la Xunta Consultiva en materia de conflictos de entre los integrantes de los órganos autonómicos de defensa de la competencia.

Artículo 19. Convenios de colaboración.

El Tribunal Galego de Defensa de la Competencia podrá celebrar convenios 
de colaboración con otros órganos con competencia en la materia para la instrucción y la resolución de los procedimientos que tengan por objeto conductas que sean competencia de las partes firmantes. Los convenios establecerán las formas y mecanismos concretos a través de los que se instrumentará esta colaboración.

Artículo 20. Relaciones con las administraciones públicas.

Las administraciones públicas están obligadas a suministrar a los órganos de defensa de la competencia regulados en la presente ley toda la información que requieran para el ejercicio de sus funciones, así como los informes que les recaben. Asimismo, cualquier organismo que tenga conocimiento de hechos que puedan ser contrarios a las previsiones de la presente ley dará traslado al Servicio Gallego de Defensa de la Competencia de toda la información y documentación de que disponga, a fin de que, si procede, se inicie la tramitación de los correspondientes expedientes.

Artículo 21. Deber de secreto.

Todas las personas que tomen parte en la tramitación de los expedientes previstos en la presente ley o que conozcan tales expedientes por razón de su profesión o cargo están obligadas a guardar secreto. La violación de este deber de sigilo se considerará falta disciplinaria muy grave.

\section{DISPOSICIÓN TRANSITORIA NOMBRAMIENTO DEL PRIMER TRIBUNAL}

En el plazo de tres meses desde la publicación de la presente ley en el Diario Oficial de Galicia, el Consello de la Xunta de Galicia nombrará al Presidente o presidenta y a los vocales del tribunal.

\section{DISPOSICIÓN FINAL PRIMERA DESARROLLO REGLAMENTARIO}

Se autoriza al Consello de la Xunta de Galicia, a propuesta del conselleiro competente en materia de economía y hacienda, para dictar las disposiciones necesarias para el desarrollo y ejecución de la presente ley.

\section{DISPOSICIÓN FINAL SEGUNDA ENTRADA EN VIGOR}

La presente ley entrará en vigor a los tres meses de su publicación en el "Diario Oficial de Galicia”. 


\section{VII \\ BIENES Y PATRIMONIO}

\section{LEY 3/1985, DE 12 DE ABRIL, DEL PATRIMONIO DE LA COMUNIDAD AUTÓNOMA DE GALICIA $\left({ }^{2 O G A ~ N} .^{\circ} 78,24.4 .1985\right)^{248}$}

$$
(\ldots)^{249}
$$

\section{TÍTULO PRELIMINAR DISPOSICIONES GENERALES}

Artículo 1. El patrimonio de la Comunidad Autónoma de Galicia o patrimonio de Galicia está constituido por todos los bienes y derechos que le pertenezcan por cualquier título.

Artículo 2. Los bienes y derechos integrantes del patrimonio de la Comunidad Autónoma de Galicia se clasifican en demaniales y patrimoniales.

Artículo 3. 1. Son bienes de dominio público de la Comunidad Autónoma los afectados al uso general o a la prestación directa de servicios públicos propios de la comunidad y los así declarados por normas con rango de ley.

2. También lo son los inmuebles propiedad de la Comunidad Autónoma en que se alojan sus instituciones y órganos estatutarios.

3. Se aplicará el régimen jurídico demanial a los derechos reales de la Comunidad Autónoma siempre que concurra alguna de las circunstancias definidas en el apartado primero.

Artículo 4. Son bienes patrimoniales de la Comunidad Autónoma de Galicia siempre que no concurra alguna de las circunstancias expresadas en el artículo anterior:

a. Los que le corresponden en propiedad.

b. Los bienes y derechos derivados de su titularidad patrimonial.

248 Véase Decreto 50/1989, de 9 de marzo, por el que se aprueba el Reglamento de la Ley de 12 de abril de 1985 de Patrimonio de la Comunidad Autónoma Gallega. 249 Exposición de motivos omitida. c. Los derechos reales y cualquier otro que le corresponda sobre cosa ajena.

d. Los derechos de propiedad inmaterial que le pertenezcan.

e. Los derechos de arrendamiento y otros de carácter personal.

f. Las cuotas, partes alícuotas y títulos representativos del capital que le pertenezcan en concepto de participación, por cualquier título, en empresas constituidas de acuerdo con el derecho privado.

g. Las empresas mercantiles cuya titularidad corresponda a la Comunidad Autónoma.

h. Cualesquiera otros bienes o derechos que pertenezcan a la Comunidad Autónoma y no sean demaniales en virtud de lo dispuesto en el artículo anterior.

Artículo 5. 1. El patrimonio de la Comunidad Autónoma de Galicia se rige por la presente ley y sus disposiciones concordantes y de desarrollo que, con las normas estatutarias, integran el derecho propio de Galicia en la materia. Supletoriamente se aplicará el derecho público y, en su defecto, las normas de derecho privado, civil y mercantil.

2. Las propiedades administrativas especiales se regularán por su legislación específica.

3. Tendrán la consideración de propiedades administrativas especiales, a estos efectos, las aguas terrestres, minas, montes y derechos de propiedad incorporal, cuando su titularidad en concepto de demanio o patrimonio pueda ser otorgada a la Comunidad Autónoma de Galicia.

Artículo 6. 1. Los bienes y derechos demaniales de la Comunidad Autónoma de Galicia son indisponibles y no podrán ser objeto de tráfico jurídico privado mientras ostenten tal condición, aplicándoseles exclusivamente las peculiares modalidades 
de tráfico administrativo reguladas en la presente ley.

2. El tráfico privado de los bienes y derechos patrimoniales exige la previa observancia de las disposiciones de esta ley.

Artículo 7. 1. El ejercicio de las funciones demaniales sobre el patrimonio de la Comunidad Autónoma corresponde a la Consellería de Economía e Facenda, salvo cuando esté atribuido por esta ley al Parlamento o a la Xunta.

2. Lo dispuesto en el apartado anterior se entiende sin perjuicio de las funciones y responsabilidades de otras consellerías y entes públicos gallegos en orden a la administración, gestión y conservación de los bienes y derechos demaniales que les fueran adscritos para el cumplimiento de sus fines.

\section{TÍTULO I \\ TRÁFICO JURÍDICO DEL PATRIMONIO}

\section{Capítulo I FORMAS DE TRÁFICO \\ ADMINISTRATIVO \\ DE LOS BIENES DEMANIALES}

Artículo 8. Los bienes y derechos demaniales de la Comunidad Autónoma de Galicia son inalienables, imprescriptibles e inembargables, y, en consecuencia, no pueden ser objeto de gravamen, carga, afección, transacción o arbitraje.

Artículo 9. 1. La integración de los bienes y derechos demaniales se origina por su afectación expresa o tácita al uso general o a la prestación de los servicios públicos propios de la Comunidad Autónoma de Galicia.

2. La afectación de bienes y derechos patrimoniales a los fines expresados en el párrafo anterior se realizará por cualquiera de los medios siguientes:

a. Resolución expresa del Consello de la Xunta, a propuesta de la Consellería de Economía e Facenda.

b. Utilización de hecho para el cumplimiento de aquellos fines de uso general o de servicio público durante el plazo de un año. c. Aprobación, por el Consello de la Xunta, de planes, programas, proyectos o resoluciones que conlleven, expresa o implícitamente, el destino específico de determinados bienes o derechos al cumplimiento directo de aquellas finalidades de uso general o de servicio público.

d. Resolución del Parlamento de Galicia que se ejecutará en los términos que la misma establezca.

3. La adquisición de bienes y derechos por usucapión, de conformidad con las reglas de derecho privado, equivale a la afectación, sin necesidad de ningún acto formal, cuando los actos posesorios se vinculasen al cumplimiento de los fines determinantes de la integración demanial.

4. La adquisición de bienes y derechos mediante expropiación forzosa significa su afectación a los fines que fueron determinantes de la declaración de utilidad pública o de interés social sin necesidad de ningún otro acto expreso.

Artículo 10. 1. Cuando los bienes y derechos no fuesen necesarios para el cumplimiento de los fines determinantes de su afectación, cesará su naturaleza demanial y adquirirán la condición de patrimoniales, sin perjuicio, en su caso, del derecho de reversión en los términos de la legislación de expropiación forzosa, respecto de aquellos bienes adquiridos por este título.

2. La desafectación de los bienes de dominio público de la Comunidad Autónoma debe hacerse mediante acuerdo del Consello de la Xunta, previa instrucción de expediente por la Consellería de Economía e Facenda, a instancia de la consellería interesada y siempre que se acredite la desaparición de las causas justificativas de la afectación.

3. La desafectación exige norma con rango de ley o resolución del Parlamento, cuando los actos de afectación habiesen revestido tales formalidades.

4. Las pertenencias o porciones sobrantes en operaciones de deslinde de bienes de dominio público se entienden desafectadas, 
adquiriendo naturaleza patrimonial, sin necesidad de ulterior requisito formal.

Artículo 11. La desafectación y ulterior destino de los bienes transferidos por el Estado a la Comunidad Autónoma deberá hacerse de acuerdo con lo establecido por las leyes.

Artículo 12. 1. Los cambios de afectación por novación de la causa determinante de la integración demanial de los bienes y derechos originan la mutación de destinos de los mismos.

2. La mutación demanial implica alteración de la adscripción orgánica de los bienes o derechos y modificación de competencia funcional y fines específicos a que aquellos se vinculan, sin transferencia de titularidad ni cambio de su calificación jurídica.

3. Los bienes y derechos demaniales, sin mutación del destino determinado por su afectación principal, podrán ser objeto de una o más afectaciones secundarias, siempre que los diversos fines y competencias concurrentes no resulten incompatibles. La concurrencia de diversas afectaciones respecto de un mismo bien o derecho no altera la adscripción orgánica exigida por la afectación principal, sin perjuicio del ejercicio de sus competencias accesorias por las consellerías titulares de un interés específico.

Si surgieran discrepancias entre las consellerías cotitulares en orden a la gestión, administración y conservación de bienes o derechos demaniales objeto de diversas afectaciones, decidirá el Consello de la Xunta, o, en su caso, el Parlamento, previa audiencia de los órganos interesados.

4. La mutación de destino de bienes y derechos demaniales o la imposición de afectaciones secundarias sobre los mismos requiere acuerdo del Consello de la Xunta, previa instrucción del expediente por la Consellería de Economía e Facenda, a instancia de las consellerías interesadas. La resolución motivada de tales aprobaciones expresará los fines a que se afecta el uso de los bienes, la consellería a la que se adscribe y, en su caso, las facultades de otras consellerías titulares de afectaciones accesorias.

5. Las mutaciones o ampliaciones del destino de los bienes y derechos demaniales exigen norma con rango de ley o resolución del parlamento cuando los actos de afectación hayan revestido tales formalidades.

6. Las modificaciones del destino de los bienes y derechos transferidos por el Estado a la Comunidad Autónoma de Galicia se sujetarán a lo dispuesto en el artículo 11 de esta ley.

Artículo 13. 1. Se podrán adscribir bienes y derechos demaniales a entidades públicas u organismos autónomos dependientes de la administración de la Comunidad Autónoma cuando sean necesarios para el cumplimiento directo de los fines atribuidos a su competencia.

2. La adscripción transfiere facultades de uso, gestión y administración, vinculadas al ejercicio de una finalidad competencial concreta sin cambio en la titularidad o calificación jurídica de los bienes o derechos cedidos.

3. La consellería de la que dependa la entidad pública u Organismo Autónomo cesionario adoptará, como titular de la competencia y en ejercicio de funciones de tutela, las medidas que estime oportunas para la adecuada conservación de los bienes y su efectiva aplicación a los fines expresados en el acuerdo de adscripción.

4. Cuando los bienes y derechos adscritos dejen de ser necesarios para el cumplimiento directo de los fines determinantes de cesión, revertirá su uso a la consellería cedente.

5. El acuerdo aprobatorio de la reversión del uso de los bienes y derechos demaniales adscritos a entidades públicas u organismos autónomos origina la desafectación, sin necesidad de ningún otro acto formal, cuando la consellería cedente u otro organismo de la administración de la Comunidad Autónoma, central o institucional, no asuman, simultáneamente, la gestión y ejercicio de las competencias expresadas en el acuerdo de adscripción. 
Los acuerdos de reversión surten eficacia de mutación demanial de los bienes y derechos, en los términos de los párrafos 1 y 2 del artículo anterior, cuando, con ocasión de los mismos, se impusiera una nueva afectación.

6. Los acuerdos de adscripción y reversión de uso regulados por este artículo observarán las formalidades que establecen los párrafos 4 y 5 del artículo 12 de esta ley, en sus respectivos casos.

Artículo 14. La sucesión entre organismos públicos en los supuestos de creación, supresión o reforma de departamentos de la administración de la Comunidad Autónoma y organismos y entidades públicas dependientes de la misma en virtud de norma legal o reglamentaria no supone novación de las causas determinantes de la integración demanial de los bienes y derechos, que continuarán afectos al ejercicio de las competencias y funciones objeto de traspaso o subrogación, sin necesidad de declaración expresa.

Artículo 15. 1. La utilización y aprovechamiento de bienes o derechos demaniales por personas o entidades determinadas se sujetarán a previa licencia, permiso o concesión administrativa, en los términos establecidos por el Título Primero de esta ley

2. Las licencias, permisos o concesiones a que se refiere el párrafo anterior ostentan la naturaleza de los títulos legitimadores de la utilización por los particulares de los bienes y derechos de dominio público.

\section{Capitulo II \\ REQUISITOS ESPECIALES DEL TRÁFICO DE LOS BIENES PATRIMONIALES}

\section{Sección $1 .^{\mathrm{a}}$ Adquisición}

Artículo 16. La Comunidad Autónoma tiene plena capacidad para adquirir y poseer bienes y derechos por los medios establecidos por el ordenamiento jurídico, así como para ejercitar las acciones y recursos que procedan en orden a la defensa y tutela de su patrimonio.
Artículo 17. 1. La adquisición pura y simple de bienes a título gratuito o lucrativo requerirá Decreto del Consello de la Xunta de Galicia, a propuesta de la Consellería de Economía e Facenda.

2. La aceptación de herencias se entenderá siempre a beneficio de inventario.

Artículo 18. 1. La adquisición de bienes inmuebles a título oneroso será realizada por la Consellería de Economía e Facenda y se exigirá el cumplimiento de las normas previstas en la contratación administrativa, especialmente las relativas a publicidad y concurrencia.

2. No obstante, a petición de la consellería interesada, la Consellería de Economía e Facenda o el Consello de la Xunta a propuesta de ésta podrá prescindir del trámite de concurso y autorizar la adquisición directa, en función de la cuantía que reglamentariamente se determine, cuando así lo requieran las peculiaridades de los bienes, las necesidades del servicio o función a satisfacer, la urgencia extrema de la adquisición y afectación a las limitaciones del mercado inmobiliario en la localidad en donde estén situados.

En todo caso, las razones que justifiquen la adquisición directa deberán publicarse en el Diario oficial de Galicia.

2 bis. El ejercicio de los derechos de tanteo y retracto tendentes a la adquisición de bienes que se incorporen al patrimonio de la Comunidad Autónoma corresponde a la Consellería de Economía e Facenda, a propuesta de la Dirección General del Patrimonio y previo informe de Intervención General 250 .

3. Para la efectividad de las adquisiciones previstas en este artículo podrán adquirirse compromisos de gastos de carácter plurianual en los términos de la Ley de Gestión Económica y Financiera Pública para inversiones reales.

La adquisición de inmuebles (u otros bienes patrimoniales) podrá hacerse por medio de

250 Art. 18.2 bis añadido por Ley $13 / 1988$, de 30 de diciembre, de Presupuestos Generales de la Comunidad Autónoma Gallega para 1989. 
"leasing" y aplazamiento de pagos, cuando las circunstancias así lo aconsejen y por razones de economicidad y oportunidad, previo informe favorable de la Consellería de Economía e Facenda a través de la Dirección General del Patrimonio.

En estos casos, la compra se conceptuará como un proyecto plurianual, debiéndose de realizar el correspondiente contrato con arreglo a los trámites establecidos en el presente artículo.

En todo caso, la Dirección General del Patrimonio será la competente para la formalización notarial de los correspondientes contratos 251 .

Artículo 18 bis. La adquisición a título oneroso de bienes muebles será realizada por la consellería u organismo que haya de utilizarlos y se someterá a las normas de contratación administrativa vigentes. En todo caso, el Consello podrá acordar la adquisición centralizada de determinados bienes muebles, por una sola consellería u organismo, de acuerdo con la normativa contractual aludida ${ }^{252}$.

Artículo 19. 1. Las adquisiciones realizadas en el marco del procedimiento expropiatorio observarán las normas específicas del mismo.

2. Estas adquisiciones llevarán implícita la afectación de los bienes a los fines que determinaron su declaración de utilidad pública o interés social, así como su adscripción.

Artículo 20. A la Consellería de Economía e Facenda corresponderá la cuantificación, tasación pericial y formalización, en su caso, de las operaciones de escrituración, registro e inventario de los bienes y derechos que, como consecuencia de procedimientos judiciales o administrativos, resulten adjudicados a la Comunidad Autónoma de Galicia.

251 Art. 18 modificado por Ley 2/1988, de 5 de marzo, de Presupuestos Generales de la Comunidad Autónoma Gallega para el año 1988.

252 Art. 18 bis añadido por Ley 2/1988, de 5 de marzo, de Presupuestos Generales de la Comunidad Autónoma Gallega para el año 1988.
Artículo 21. 1. La adquisición a título oneroso de cuotas, partes alícuotas o títulos representativos del capital de empresas constituidas conforme al derecho privado deberá ser realizada mediante compra o suscripción, a propuesta de la Consellería de Economía e Facenda y oída la consellería competente por razón de la materia.

2. Cuando se trate de empresas mercantiles, la participación de la Comunidad Autónoma resultante de la adquisición no podrá ser inferior al 10 por ciento del importe del capital social.

3. La compra o suscripción de obligaciones, bonos o cuotas u otros títulos acreditativos de deuda emitida por empresas mercantiles exigirá que el porcentaje de participación en el capital social no resulte inferior a un 10 por ciento del mismo en la eventual circunstancia de su conversión en acciones o títulos con análogo carácter.

4. La adquisición de propiedades incorporales corresponde al Consello de la Xunta, a propuesta de la Consellería de Economía e Facenda ${ }^{253}$.

Artículo 22. 1. La Consellería de Economía e Facenda realizará los arrendamientos de bienes inmuebles necesarios para el desarrollo de las funciones de la Xunta, concertándolos mediante concurso público, salvo cuando concurra alguna de las circunstancias previstas en el artículo 18. 2, en cuyo caso la citada Consellería podrá acudir a la concertación directa mediante resolución motivada y pública.

2. Es competencia de la Consellería de Economía e Facenda disponer la resolución voluntaria de los contratos de arrendamientos de inmuebles en favor de la Comunidad Autónoma.

3. El arrendamiento de bienes muebles será concertado de acuerdo con lo previsto en este artículo por la consellería y organismo interesado 254 .

253 Art. 21.4 modificado por Ley 2/1988, de 5 de marzo, de Presupuestos Generales de la Comunidad Autónoma Gallega para el año 1988.

254 Art. 22 modificado por Ley 2/1988, de 5 de marzo, de Presupuestos Generales de la Comunidad Autónomá Gallega para el año 1988. 
Artículo 23. 1. No se podrán adquirir bienes y derechos a título lucrativo cuando el valor global de los gravámenes, cargas y afecciones impuestos sobre los mismos rebase su valor intrínseco.

No se considerarán carga, gravamen o afección las inversiones que haya de realizar la Comunidad Autónoma para dar el destino de uso general o servicio público de su competencia que fije el cedente o donante ${ }^{255}$.

2. Las adquisiciones de bienes y derechos a título oneroso se efectuarán libres de toda carga, gravamen o afectación, si así lo exigiera el cumplimiento directo de los fines determinantes de su adquisición. Sin embargo, podrán subsistir aquellas limitaciones a título de licencia, permiso o concesión administrativa cuyo ejercicio resulte compatible con el fin de la afectación.

3. La subsistencia de cargas, gravámenes, derechos o afecciones sobre bienes objeto de expropiación forzosa se decidirá en el marco del procedimiento expropiatorio.

4. Cuando los bienes o derechos se hubieran adquirido bajo condición o carga de vinculación permanente a determinados destinos, se entenderán cumplidos y consumados si durante treinta años hubieran estado afectos a los mismos y dejasen de estarlo por circunstancias sobrevenidas de interés público.

\section{Sección 2. ${ }^{\text {a }}$}

Enajenación y cesión

\section{Apartado A Bienes inmuebles}

Artículo 24. 1. La enajenación o gravamen por cualquier título de bienes inmuebles del patrimonio de la Comunidad Autónoma de Galicia o de derechos impuestos sobre los mismos requiere la previa declaración de su alienabilidad, que será dictada por el Conselleiro de

255 Art. 23.1 modificado por Ley $2 / 1988$, de 5 de marzo, de Presupuestos Generales de la Comunidad Autónoma Gallega para el año 1988.
Economía y Hacienda previo informe de la consellería interesada.

2. No podrán ser objeto de declaración de alienabilidad:

a. Los bienes que se encontrasen en litigio.

b. Los bienes no deslindados o no inscritos previamente en el Registro de la Propiedad.

c. Los bienes o derechos cuya titulación no suministre los datos relativos a su identidad.

3. La declaración de alienabilidad será publicada en el "Diario Oficial de Galicia", con expresión de sus circunstancias.

Artículo 25. Cuando el valor de los bienes y derechos, según la declaración de alienabilidad, no exceda de 3.005.000 euros, corresponderá acordar la enajenación a la Consellería de Economía e Facenda. A partir de esa cantidad y hasta 12.020.000 euros al Consello de la Xunta de Galicia, a propuesta de la Consellería de Economía e Facenda, y cuando exceda de 12.020.000 euros al Parlamento de Galicia, mediante ley.

La Consellería de Economía e Facenda, el Consello de la Xunta y el Parlamento de Galicia podrán autorizar, en los respectivos acuerdos de enajenación, la celebración de contratos de alquiler o de alquiler financiero de los bienes a enajenar, cuando se considere procedente que temporalmente sigan siendo utilizados por los servicios administrativos. En todo caso, los citados acuerdos habrán de ser adoptados previo informe de la Dirección General de Presupuestos 256 .

Artículo 26. La enajenación se hará mediante subasta pública, salvo cuando la Consellería de Economía e Facenda, si el valor es inferior a 1.502.600 euros, o el Consello de la Xunta, en los demás casos, a propuesta de la Consellería de Economía e Facenda, autoricen expresamente la

256 Art. 25 modificado por Ley 7/2002, de 27 de diciembre, de medidas fiscales y de régimen administrativo. 
enajenación directa mediante acuerdo motivado $^{257}$.

Artículo 27. No podrá promoverse la venta de los bienes que se hallaren en litigio. Si se suscitase después de iniciado el procedimiento de enajenación, éste quedará provisionalmente suspendido.

Salvo en dicho supuesto, una vez anunciada la subasta, sólo podrá suspenderse por orden de la Consellería de Economía e Facenda fundada en documentos fehacientes que prueben la improcedencia de la venta.

Artículo 28. 1. Los propietarios colindantes podrán adquirir directamente con preferencia a cualquier otro solicitante, una vez publicada la declaración de alienabilidad, las parcelas sobrantes, los solares inedificables y las fincas rústicas que no alcancen una superficie económicamente explotable o susceptible de prestar utilidad acorde con su naturaleza. A estos efectos, la clasificación de las fincas se regulará por las leyes, reglamentos $\mathrm{u}$ ordenamientos especiales aplicables a la materia, y, en su caso, por los planes de ordenación, debidamente aprobados.

2. Cuando solicite dicha adquisición más de un propietario colindante, será preferido el del inmueble de menos superficie de los que, mediante su agrupación con el que se pretende adquirir, lleguen a constituir, según los casos, un solar edificable o una superficie económicamente explotable o susceptible de prestar acorde con su naturaleza.

Cuando no concurran tales circunstancias será preferido el propietario del inmueble colindante de mayor superficie.

257 Art. 26 modificado por Ley 1/1986, de 29 de octubre, de Presupuestos Generales de la Comunidad Autónoma de Galicia para 1986.

- La cantidad fijada en el art. 26 ha sido modificada por Decreto 180/2003, de 27 de febrero, por el que se modifican las cuantias establecidas en los articulos 26 , $34.1^{\circ}$ e $2^{\circ}, 35.2^{\circ}$ y 36 de la Ley $3 / 1985$, de 12 de abril, del patrimonio de la Comunidad Autónoma de Galicia, asi como varios artículos de reglamento que la ejecuta, aprobado por el Decreto 50/1989, de 9 de marzo.
Artículo 29. 1. Los bienes inmuebles de la Comunidad Autónoma podrán ser permutados por otros, previa tasación pericial y justificación de su conveniencia, siempre que la diferencia en su valor no fuese superior al 50 por $100 \mathrm{del}$ que lo tenga más alto.

2. Corresponderá autorizar la permuta a quien, por razón de la cuantía, fuese competente para acordar la enajenación.

3. La disposición que autorice la permuta llevará implícita, en su caso, la desafectación del inmueble de que se trate y la declaración de alienabilidad ${ }^{258}$.

Artículo 30. 1. Los bienes patrimoniales inmuebles de la Comunidad Autónoma de los que no se estime previsible su afectación demanial o aprovechamiento por la propia administración podrán ser cedidos gratuitamente por el Consello de la Xunta, a propuesta de la Consellería de Economía e Facenda, en favor de instituciones y corporaciones públicas o sin ánimo de lucro, que deberán destinarlos a fines de utilidad pública o de interés social.

2. El acuerdo de cesión, que se publicará en el "Diario Oficial de Galicia", expresará la finalidad concreta a la que las entidades beneficiarias deben destinar los bienes, así como sus condiciones.

3. Si los bienes cedidos no se aplicasen al fin señalado dentro del plazo inicialmente fijado en el acuerdo o dejasen de estarlo con posterioridad, se descuidasen o utilizasen con grave quebranto, o se incumpliesen las condiciones del acuerdo, se considerará resuelta la cesión y los bienes revertirán a la Comunidad Autónoma, que tendrá derecho a percibir, previa tasación pericial, el valor de los detrimentos o deterioros que hubiesen experimentado.

4. La Consellería de Economía e Facenda podrá comprobar el cumplimiento de las obligaciones que conlleva la cesión

258 Art. 29 modificado por Ley 2/1998, de 8 de abril, de medidas tributarias, de régimen presupuestario, función pública, patrimonio, organización y gestión. 
e iniciará los expedientes de reversión que procedan ${ }^{259}$.

Artículo 31. Los bienes patrimoniales de la Comunidad Autónoma, sus rentas, frutos o productos podrán ser adscritos a organismos autónomos $\mathrm{u}$ otros entes dependientes de su administración para el cumplimiento de los fines específicos que determine el acuerdo de adscripción ${ }^{260}$.

Artículo 32. Cuando por la Comunidad Autónoma se transfieran competencias a entes territoriales de su circunscripción o se deleguen funciones administrativas en éste o en otros entes institucionales localizados en su territorio, podrá adscribirse a los mismos el uso de los bienes precisos con sujeción a las condiciones que establezca la norma de transferencia o delegación, que habrá de determinar el procedimiento de vigilancia en orden al cumplimiento de los fines de la cesión así como prever su reversión en el caso de no ser necesarios para la prestación de la función o servicio, o el supuesto de su reasunción.

Artículo 33. 1. Las entidades autónomas dependientes de la administración de la Comunidad Autónoma no podrán enajenar o gravar los bienes o derechos patrimoniales de que sean titulares, que se incorporarán al patrimonio de la Comunidad Autónoma cuando no sean necesarios para el cumplimiento directo de los fines atribuidos a su específica competencia. La entrega de los citados bienes o derechos se efectuará a través de la consellería a la que estén adscritos los respectivos organismos o entidades, mediante acta que suscribirán el titular de aquélla y el de la Consellería de Economía e Facenda.

2. Podrán, no obstante, enajenarse los bienes adquiridos por sí mismos con el propósito de devolverlos al tráfico jurídico privado, de acuerdo con los fines peculiares,

259 Art. 30 modificado por Ley $2 / 1998$, de 8 de abril, de de medidas tributarias, de régimen presupuestario, función pública, patrimonio, organización y gestión.

260 Art. 31 modifidado por Ley 2/1998, de 8 de abril, de de medidas tributarias, de régimen presupuestario, función pública, patrimonio, organización y gestión. o para garantizar la rentabilidad de las reservas que tengan que constituir en cumplimiento de las disposiciones por las que se rigen.

3. Las enajenación de los bienes o derechos a que se refiere el párrafo anterior se regulará por las normas que le sean de aplicación y, en su defecto, por las reglas de la presente ley.

A tales efectos, dichas entidades se relacionarán con la Consellería de Economía e Facenda a través de la consellería a la que están adscritas o de la que dependan.

\section{Apartado B \\ Bienes muebles}

Artículo 34. 1. La enajenación de bienes muebles de la Comunidad Autónoma corresponderá al titular de la consellería que los viniera utilizando cuando el valor de los mismos, previa tasación pericial, no excediera de 60.200 euros. Si superara dicha cantidad, la enajenación se acordará por el Consello de la Xunta, a propuesta de la Consellería de Economía e Facenda y previa petición de aquélla que los viniera utilizando.

En todo caso, cuando se trate de bienes calificados como de interés tecnológico o informático, la enajenación será acordada por el Consello de la Xunta a propuesta de la Consellería de Economía e Facenda ${ }^{261}$.

2. Cuando se trate de obras de arte o de objetos de interés arqueológico, histórico o artístico cuyo valor, según tasación pericial, exceda de 50.000 .000 de pesetas, corresponderá al Parlamento mediante ley aprobar su enajenación.

3. El acuerdo de enajenación, que será publicado en el "Diario Oficial de Galicia", implicará en todo caso la desafectación de los bienes de que se trate ${ }^{262}$.

261 Art. 34.1 modificado por Ley $1 / 1986$, de 29 de octubre, de Presupuestos Generales de la Comunidad Autónoma de Galicia para 1986.

262 Cantidades de los art. 34.1 y 34.2 modificadas por Decreto 180/2003, de 27 de febrero, por lo que se modifican las cuantías establecidas en los artículos 26 , $34.1^{\circ}$ y $2^{\circ}, 35.2^{\circ}$ y 36 de la Ley $3 / 1985$, de 12 de abril, de patrimonio de la Comunidad Autónoma de Galicia, asi como varios artículos del reglamento que la ejecuta, aprobado por el Decreto 50/1989, de 9 de marzo. 
Artículo 35. 1. La enajenación de bienes muebles se llevará a efecto mediante subasta pública por el procedimiento previsto para los inmuebles.

2. Se aplicará el procedimiento de contratación directa cuando el departamento que los viniera utilizando, si el valor es inferior a 60.200 euros, o el Consello de la Xunta, en los demás casos y a propuesta de la Consellería de Economía e Facenda, así lo autoricen expresamente mediante acuerdo motivado 263 .

Si concurrieran varias solicitudes será preferible la que ofrezca un precio más elevado, atendiéndose a la prioridad, si existiera igualdad de condiciones ${ }^{264}$.

3. La celebración de subastas podrá demorarse si la cuantía de los bienes para enajenar no aconsejase su realización de modo inmediato.

Artículo 35 bis. La Consellería que adquiriera o que tuviera adscritos bienes muebles de la Comunidad Autónoma de Galicia, previo informe favorable de la Consellería de Economía e Facenda, podrá cedérselos a Entidades Públicas o sin ánimo de lucro en el marco de relación de colaboración, cooperación y coordinación, para ser destinados a fines de utilidad pública o interés social. Si los bienes cedidos no se aplicaran al fin señalado se considerará resuelta la cesión y revertirán a la Administración de la Comunidad Autónoma.

El acuerdo de cesión llevará implícita, en su caso, la desafectación de los bienes de que se trate ${ }^{265}$.

263 Cantidad del art. 35 modificada por Decreto 180/2003, de 27 de febrero, por el que se modifican las cuantias establecidas en los articulos $26,34.1^{\circ}$ e $2^{\circ}, 35.2^{\circ}$ y 36 de la Ley $3 / 1985$, de 12 de abril, de patrimonio de la Comunidad Autónoma de Galicia, asi como varios artículos del reglamento que la ejecuta, aprobado por el Decreto 50/1989, de 9 de marzo.

264 Art. 35.2 modificado por Ley $1 / 1986$, de 29 de octubre, de Presupuestos Generales de la Comunidad Autónoma de Galicia para 1986.

265 Art. 35 bis añadido por Ley 11/1996, de 30 de diciembre, de Presupuestos Generales de la Comunidad Autónoma de Galicia para 1997. Art. 35 bis modificado por Ley $7 / 2002$, de 27 de diciembre, de medidas fiscales y de régimen administrativo.
Artículo 36. Los bienes muebles adjudicados a la Comunidad Autónoma de Galicia en procedimientos judiciales o en aplicación de la normativa recaudatoria por la vía de apremio, podrán ser enajenados por subasta o contratación directa, mediante resolución del Conselleiro de Economía y Hacienda a propuesta de la Dirección General del Patrimonio, si su valoración no excediese de 6.100 euros 266 .

Artículo 37. 1. La enajenación de bienes muebles propiedad de entidades autónomas dependientes de la Administración de la Xunta, se regulará por lo dispuesto en los artículos 35 y 36 de esta ley.

2. Se exceptúan de lo previsto en el párrafo anterior, rigiéndose por las reglas del derecho privado sin necesidad de previo procedimiento administrativo, las enajenaciones que, de acuerdo con las normas específicas reguladoras de su organización, funcionamiento y régimen jurídico, lleven a cabo aquellas entidades cuando desarrollen actividades empresariales, comerciales o industriales.

\section{Apartado C \\ Propiedades incorporales}

Artículo 38. La enajenación de propiedades incorporales o derechos de exclusiva de que sean titulares la Comunidad Autónoma o entidades autónomas dependientes de la misma, cuando su explotación por la propia administración no se juzgue conveniente, será acordada por el Consello de la Xunta a propuesta de la Consellería de Economía e Facenda.

Artículo 39. 1. La enajenación habrá de verificarse, por la regla general, mediante subasta pública, a menos que el Consello de la Xunta autorice la contratación directa por motivos de interés público debidamente acreditados.

266 Cantidad del art. 36 modificada por Decreto $180 / 2003$, do 27 de febrero, por la que se modifican las cuantias establecidas en los artículos $26,34.1^{\circ}$ e $2^{\circ}$, $35.2^{\circ}$ y 36 da Ley $3 / 1985$, de 12 de abril, de patrimonio de la Comunidad Autónoma de Galicia, asi como varios artículos del reglamento que la ejecuta, aprobado por el Decreto 50/1989, de 9 de marzo. 
2. Serán aplicables a esta clase de subastas las normas contenidas en esta ley para las de los bienes inmuebles en cuanto sean compatibles con la naturaleza de aquellos derechos.

\section{Apartado D \\ Títulos representativos del capital o deuda emitida por sociedades y empresas}

Artículo 40. 1. La enajenación de títulos representativos del capital propiedad de la Comunidad Autónoma en empresas mercantiles o de los derechos de suscripción que le correspondan se acordará, aun cuando implique directa o indirectamente la pérdida de la condición mayoritaria o extinga la participación, por el Consello de la Xunta a propuesta de la Consellería de Economía e Facenda.

2. Los títulos se enajenarán en Bolsa. Si no tuviesen cotización en la misma serán objeto de subasta pública, excepto en los casos en que el Consello acuerde la enajenación directa como consecuencia de las especiales características de aquéllos 267.

Artículo 41. En todo caso constituirá requisito previo del acuerdo de enajenación la declaración de alienabilidad, que será adoptada por la Consellería de Economía e Facenda.

La declaración, que se acompañará a la propuesta de enajenación, certificará la conveniencia, oportunidad y procedimiento de enajenación aplicable, así como el cumplimiento de las circunstancias a que se refiere el artículo anterior.

Artículo 42. 1. El régimen establecido en los artículos precedentes se aplicará también, en lo que fuese posible, a la enajenación de obligaciones, bonos, cuotas u otros títulos análogos representativos de participación de la Comunidad Autónoma en la deuda emitida por empresas mercantiles.

267 Art. 40 modificado por Ley 13/1988, de 30 de diciembre, de Presupuestos Generales de la Comunidad Autónoma Gallega para 1989.
2. Si los títulos-valores no fuesen objeto de cotización en Bolsa y el procedimiento de subasta no fuese el adecuado a su naturaleza o especiales características, podrá aplicarse mediante acto motivado el sistema de enajenación directa.

Artículo 43. 1. La enajenación de títulos-valores que se regula en los precedentes artículos se ajustará, en todo caso, a las bases y a la ordenación del mercado de capitales que establezca la planificación de la actividad económica de Galicia, dentro del marco de la planificación económica general.

2. Cuando dadas las características de la operación fuese preceptiva o aconsejable la intervención de algún instituto de crédito o cuando en los términos del apartado anterior no fuese procedente o conveniente acudir a la Bolsa, el Consello de la Xunta determinará el procedimiento a seguir, en cada caso, a propuesta de la Consellería de Economía e Facenda.

\section{Sección 3. ${ }^{\mathrm{a}}$}

\section{Actividad empresarial del sector público de Galicia}

Artículo 44. Constituye el sector público económico de Galicia toda actividad empresarial de orden comercial, industrial, financiera o análoga llevada a cabo por la Comunidad Autónoma mediante la creación de empresas públicas y la participación en el capital, deuda emitida o gestión de empresas integradas en los sectores privados, estatal o local, dentro del ámbito de interés comunitario y en el marco de la Constitución y del Estatuto de Autonomía.

Artículo 45. 1. Las empresas públicas creadas por la Comunidad Autónoma adoptarán la forma de organismos autónomos o de sociedad privada.

2. Los organismos autónomos se regirán por su ley de creación, que constituirá su estatuto y determinará:

a. Su competencia y funciones.

b. Consellería que orgánicamente han de quedar adscritos en atención al objeto de la institución. 
c. Las bases generales de su organización, régimen de acuerdos y designación de sus órganos directivos.

d. Los bienes que constituyan su patrimonio $\mathrm{y}$, en su caso, los bienes y medios económicos que se les adscriban o asignen para el cumplimiento de sus fines específicos.

e. El destino a que hayan de afectarse sus beneficios y reservas que tengan que constituir.

3. Las sociedades privadas podrán ser creadas directamente por la Xunta de Galicia a través de un Organismo Autónomo dependiente de la misma y adoptarán la forma de sociedades de responsabilidad limitada o anónima, rigiéndose por las normas del derecho mercantil, civil o laboral, salvo lo establecido por las disposiciones especiales que resulten aplicables y las siguientes reglas de carácter general:

a. Las sociedades anónimas se constituirán, en todo caso, por el sistema de fundación simultánea.

b. El capital de estas empresas habrá de estar íntegramente desembolsado en el momento de su constitución y no se podrá transferir ni destinar a otras finalidades, salvo en los supuestos de transformación y extinción regulados por las leyes mercantiles y especiales que resulten de aplicación.

c. La participación en el capital de la Xunta de Galicia o de los organismos autónomos dependientes de la misma habrá de ser siempre mayoritaria.

d. Los estatutos de la empresa serán aprobados por el Consello de la Xunta y determinarán, con observancia de la proporcionalidad en la participación del capital, la composición, competencia, funcionamiento y forma de designación de la junta general, consejo de administración y gerencia.

e. El Consello de la Xunta, a propuesta de la Consellería de Economía e Facenda, podrá acordar la aportación de bienes inmuebles patrimoniales, cualquiera que fuese su valor, con objeto de cubrir el importe de su participación en el capital social.
Artículo 46. 1. Sin perjuicio de las facultades de vigilancia y control de la consellería competente por razón de la materia sobre los organismos autónomos que le fuesen adscritos en orden a su gestión administrativa, organización y funcionamiento, será en todo caso competencia de la Consellería de Economía e Facenda el ejercicio de las funciones relativas a su tutela financiera, de conformidad con lo prescrito en la Ley de Gestión Económica y Financiera Pública de Galicia.

2. En el supuesto de empresas públicas que adopten las formas de sociedades privadas o en el caso de empresas participadas, será competencia de la Consellería de Economía e Facenda el ejercicio de los derechos que correspondan a la Xunta como partícipe. A este fin podrá impartir a los representantes del capital comunitario en los consejos de administración de las citadas empresas las instrucciones que considere oportunas para el adecuado ejercicio de los derechos.

Artículo 47. 1. La Xunta de Galicia podrá participar en el capital de empresas mercantiles, cooperativas o sociedades laborales, cualquiera que sea su forma u objeto social, con sujeción a lo dispuesto en el artículo 45 de esta ley, cuando el Consello de la Xunta, previo informe de la Consellería de Economía e Facenda, lo estime conveniente para el cumplimiento de finalidades concretas de política económica.

2. Salvo lo dispuesto por normas especiales la participación de la Xunta no será inferior al 10 por ciento, ni superior al cincuenta por ciento, del capital social de las sociedades o empresas.

\section{TÍTULO II UTILIZACIÓN Y APROVECHAMIENTO DEL PATRIMONIO \\ Capitulo 1 \\ FORMAS DE UTILIZACIÓN \\ DE LOS BIENES DEMANIALES}

Artículo 48. 1. La utilización de los bienes de dominio público por la propia

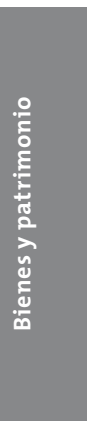


administración se regirá por la presente ley y disposiciones que la desarrolle. $\mathrm{Si}$ estuviesen afectos a un servicio público, se ajustará además a sus reglas específicas y a las instrucciones dictadas por las autoridades responsables de su funcionamiento.

2. Excepcionalmente, con fundamento en el fomento y planificación de la actividad económica de Galicia, y, en todo caso, con fines de estudio, investigación o explotación, la Comunidad Autónoma de Galicia podrá reservar, mediante ley de Galicia, el uso exclusivo de bienes de uso público, o declarados de dominio público por normas con rango de ley, siempre que concurran los siguientes requisitos:

a. Que la reserva no afecte a recursos previamente reservados por el Estado.

b. La potestad de la reserva se ajustará a los términos de la legislación del Estado y a las bases de planificación económica general.

c. No podrá establecerse en perjuicio de derechos adquiridos por las particulares en orden al uso de los bienes. Si su motivación consistiese en un deficiente o irracional explotación de un recurso determinado, la ley que declare la reserva dispondrá la previa expropiación e indemnización de los afectados por la medida.

d. Determinación del plazo de su duración, que en ningún caso será superior al máximo previsto para la concesión demanial del recurso de que se trate.

3. El uso privativo excluido que retiene la Administración, Una vez establecidas las reservas a que se refiere el párrafo anterior, será objeto de explotación con arreglo a las normas que regulan la utilización de los bienes patrimoniales de la presente ley.

4. En ningún caso se podrán establecer reservas demaniales por motivos fiscales o de orden o seguridad pública.

Artículo 49. El uso general de los bienes de dominio público no está sujeto a licencia, correspondiendo a todos los ciudadanos sin mas limitaciones que las siguientes:

a. El impedimento del mismo derecho a los demás ciudadanos. b. El respeto a la naturaleza del bien.

c. Las que imponga el ordenamiento jurídico por razón de su conservación, adscripción u orden público.

Artículo 50. El uso común especial de los bienes demaniales realizado por personas o entidades determinadas de modo que no impida el de otros, deberá sujetarse al otorgamiento de previa licencia con el fin de garantizar la continuidad del uso común general si concurriesen en él las circunstancias singulares de peligrosidad, intensidad de uso u otras semejantes.

Artículo 51. El uso privativo por personas o entidades de los bienes de dominio público mediante la ocupación de una porción de los mismos, de modo que limite o excluya la utilización por los demás interesados, requerirá el previo otorgamiento de un título adecuado a su naturaleza, de conformidad con las siguientes reglas:

a. El uso normal, conforme a las disposiciones o afectación de los bienes, que no impliquen la realización de obras permanentes o instalaciones fijas, requerirá tan solo permiso de ocupación temporal.

b. Los usos consistentes en estacionamiento de materiales o instalaciones de carácter accesorio y no permanente exigirán también permiso de ocupación temporal.

c. Los usos anormales, no conformes con el destino de los bienes, y aquellos que requieran una ocupación permanente mediante obras e instalaciones de carácter fijo, se otorgarán mediante concesión administrativa.

Artículo 52. 1. Las licencias habilitantes de usos comunes especiales se otorgarán directamente a los peticionarios salvo si, por cualquier circunstancia, se limitase el número de las mismas. En este caso se otorgarán por licitación $\mathrm{y}$, si no fuese posible por tener que reunir todos los interesados las mismas condiciones, mediante sorteo.

2. No serán transmisibles las licencias que se refieran a las cualidades personales del sujeto y aquellas cuya normativa específica así lo determine. La transmisión 
cuando proceda requerirá acto expreso aprobatorio para su eficacia frente a la administración otorgante.

Artículo 53. 1. Los permisos de ocupación temporal llevan implícita la cláusula de precariedad y podrán revocarse libremente en cualquier momento por la administración sin que el interesado tenga derecho a ninguna indemnización.

2. Si hubiese varios solicitantes, se observarán siempre las reglas de publicidad y concurrencia, otorgándose los permisos previa licitación.

Artículo 54. 1. Las concesiones de disfrute o uso privativo de bienes de dominio público, serán de otorgamiento discrecional por la administración, y tendrán el plazo de duración que determine su legislación específica. Si no existiese plazo determinado en ésta, su duración no podrá exceder de cincuenta años, sin perjuicio de su prórroga por mutuo acuerdo.

2. Las concesiones se otorgarán para una finalidad concreta, determinando el objeto y límites de las mismas, siendo exigible como contraprestación la cuantía de la tasa que resulte vigente en el momento de su devengo ${ }^{268}$.

3. Las concesiones se otorgarán, a salvo el derecho de propiedad y sin perjuicio de tercero, llevando implícita la facultad de rescate antes de su vencimiento, mediante indemnización, si lo justificasen circunstancias sobrevenidas de interés público.

Artículo 55. 1. Las concesiones se otorgarán por el procedimiento de competencias, su ejercicio será obligatorio por el interesado y llevarán anexas las facultades administrativas de inspección, vigilancia y resolución.

2. El régimen de otorgamiento de las concesiones se ajustará a la legislación sobre contratación administrativa para la gestión de servicios públicos.

268 Art. 54.2 modificado por Ley 6/2003, de 9 de diciembre, de tasas, precios y exacciones reguladoras de la Comunidad Autónoma de Galicia.
Artículo 56. Son causas de extinción de las concesiones:

1. El transcurso del plazo o de su prórroga.

2. El rescate.

3. La renuncia y el no ejercicio del derecho en los casos en que proceda.

4. La caducidad o resolución de la relación concesional.

5. La desaparición o agotamiento de la cosa.

6. La degradación del título concesional por desafectación del bien demanial.

7. Y cualquier otra causa admitida en derecho.

Artículo 57. 1. En los supuestos de degradación del título concesional, por desafectación del demanio que le sirve de fundamento, los titulares de autorizaciones, licencias o concesiones otorgadas legalmente continuarán en la posesión de sus derechos.

No obstante, será declarada la caducidad de las concesiones cuyo plazo hubiera vencido o la de aquellas en las que la administración se hubiera reservado la facultad de libre rescate, sin perjuicio de que la Consellería de Economía e Facenda pueda acordar la expropiación de estimar que el mantenimiento de la concesión habría de perjudicar el ulterior destino de los bienes o que los harían desmerecer notoriamente en caso de enajenación.

2. Los permisos de ocupación temporal se estimarán revocados "ipso iure", en virtud de la resolución que acuerda la desafectación de los bienes sobre los que recaigan.

Artículo 58. 1. En la enajenación de bienes desafectados, los titulares de derechos sobre ellos, resultantes de una concesión, tendrán la facultad de adquirirlos con preferencia a cualquier otra persona que no tenga a su favor un derecho de retracto legalmente establecido.

2. Los derechos de adquisición preferente regulados en el párrafo anterior, no tendrán lugar en los supuestos a que hacen referencia los artículos 30 y 31 de la presente ley. 
3. Las entidades que, conforme a los artículos 30 y 31 , hubiesen recibido bienes sobre los que recaigan los derechos anteriormente establecidos en favor de beneficiarios de concesiones y autorizaciones, podrán liberarlos con cargo exclusivo a sus fondos propios en igualdad de términos con la Comunidad Autónoma, pudiendo instar, en su caso, el ejercicio de potestad expropiatoria.

Artículo 59. 1. La competencia para el otorgamiento de las concesiones que por disposición legal no venga específicamente determinada corresponderá al Consello de la Xunta, a propuesta de la consellería responsable de la gestión, conservación y administración de los bienes demaniales implicados.

2. Las licencias, autorizaciones y permisos de ocupación temporal se otorgarán por los órganos competentes de la consellería titular de las facultades de gestión, conservación y administración del sector demanial de que se trate.

3. La consellería competente por razón de la materia determinará, previo informe del organismo gestor del patrimonio de la Comunidad Autónoma, las condiciones generales que hayan de regir para toda clase de concesiones, autorizaciones o permisos sobre el dominio público, respetándose, en todo caso, las disposiciones contenidas en la presente ley.

Las condiciones generales, una vez aprobadas por el Consello de la Xunta, se publicarán en el "Diario Oficial de Galicia".

\section{Capítulo II \\ EXPLOTACIÓN DE LOS BIENES PATRIMONIALES}

Artículo 60. Corresponde al Consello de la Xunta, a propuesta de la Consellería de Economía e Facenda, disponer el modo de explotación de acuerdo con el criterio de mayor rentabilidad de los bienes patrimoniales que no convenga enajenar en las condiciones usuales de la práctica civil o mercantil.
El oportuno expediente, que incoará la dirección general competente en materia de gestión patrimonial, lo informarán previamente los servicios jurídicos y la Intervención General de la Xunta de Galicia.

Artículo 61. La explotación podrá llevarse a cabo directamente por la propia administración de la Comunidad Autónoma, por una entidad autónoma dependiente de la misma, o conferirse a particulares mediante contrato.

Artículo 62. Si el Consello de la Xunta acordase que la explotación se llevase a cabo directamente o por medio de entidad autónoma fijará las condiciones de la misma, adoptándose por la consellería competente en materia de gestión patrimonial las medidas conducentes a la entrega del bien al órgano o entidad a quien se confíe la explotación, y las de vigilancia del exacto cumplimiento de las condiciones impuestas.

Artículo 63. 1. Si el Consello de la Xunta dispusiese que la explotación se encomiende a particulares mediante contrato, aprobará las bases del concurso, que será convocado y resuelto por la consellería titular de la gestión patrimonial. La convocatoria se publicará en el "Diario Oficial de Galicia".

2. No obstante lo establecido en el apartado anterior, el Consello de la Xunta podrá acordar la adjudicación directa de la explotación de bienes patrimoniales cuando concurran circunstancias que así lo aconsejen, previa justificación razonada en el expediente ${ }^{269}$.

Artículo 64. Están facultadas para contratar la explotación de bienes patrimoniales de la Comunidad Autónoma las personas que, ostentando plena capacidad de obrar, la tuviesen de conformidad con la legislación general de contratos del Estado

Artículo 65. La Xunta de Galicia, a través de la consellería competente en

269 Art. 63 modificado por Ley 2/1998, de 8 de abril, de medidas tributarias, de régimen presupuestario, función pública, patrimonio, organización y gestión. 
materia de gestión patrimonial, ejercerá la vigilancia precisa sobre la empresa adjudicataria de la explotación en orden a garantizar la indemnidad del bien de que se trate y, en su caso, la íntegra percepción de las cantidades que haya de satisfacer el adjudicatario, así como, en general, el cumplimiento del contrato.

Artículo 66. A petición del adjudicatario, podrá prorrograrse el contrato si el resultado satisfactorio de la explotación hiciera aconsejable esta medida.

La prórroga la acordará, en su caso, el Consello de la Xunta, a propuesta de la consellería titular de la gestión patrimonial previo informe preceptivo de la Intervención General.

Artículo 67. La subrogación de cualquier persona natural o jurídica en los derechos $\mathrm{u}$ obligaciones de adjudicatario requerirá acuerdo del Consello de la Xunta. La persona subrogada deberá reunir los requisitos para contratar.

Artículo 68. 1. Los frutos, rentas o percepciones de cualquier clase o naturaleza producidos por la explotación, así como por la enajenación de los bienes patrimoniales, previa liquidación, cuando sea preciso, se ingresarán en la tesorería, con aplicación a los pertinentes conceptos del presupuesto de ingresos.

2. No se admitirán otras excepciones a lo dispuesto en el párrafo anterior que las consignadas en una ley.

\section{TÍTULO III PROTECCIÓN Y DEFENSA}

\section{Capítulo I RECUPERACIÓN DE LA POSESIÓN}

Artículo 69. 1. La administración de la Xunta de Galicia podrá recuperar por símisma, en cualquier momento, la posesión de sus bienes de dominio público.

2. Igualmente podrá recuperar la posesión indebidamente perdida sobre los bienes y derechos patrimoniales en el plazo de un año, contado a partir del día siguiente de producirse la usurpación. Transcurrido este tiempo, deberá acudir ante la jurisdicción ordinaria ejercitando las acciones correspondientes.

No se admitirán interdictos contra la administración de la Xunta en esta materia, siempre que aquélla se haya ajustado al procedimiento legalmente establecido.

Artículo 70. La administración de la comunidad tiene la facultad de investigar e inspeccionar la situación de los bienes y derechos que se presuman de su dominio privado, a fin de determinar y probar, cuando no le conste, la propiedad de la Comunidad Autónoma sobre unos y otros.

Artículo 71. 1. La recuperación de la posesión se incoará de oficio o en virtud de denuncia verbal o escrita, que dará lugar a la instrucción del correspondiente expediente por la Dirección General del Patrimonio.

2. Comprobados los hechos que acrediten la usurpación, y siempre que no haya transcurrido un año desde aquélla, la Dirección General del Patrimonio hará que el usurpador cese en su actuación. En el supuesto de resistencia activa o pasiva, se actuará de acuerdo con lo establecido en la Ley de Procedimiento Administrativo.

3. Si hubiera transcurrido más de un año, la Dirección General del Patrimonio instará el ejercicio de las acciones que procediesen en conformidad con lo dispuesto en el artículo 69. 2 de esta ley.

4. En todo caso, si del hecho o hechos que acrediten la usurpación se suscitasen indicios racionales de delito o falta penal, se dará cuenta de los mismos a la autoridad judicial, sin perjuicio de adoptar las medidas a que se refieren los otros apartados de este artículo.

\section{Capitulo II DESLINDE}

Artículo 72. 1. La Xunta de Galicia podrá proceder al deslinde de los bienes de su patrimonio mediante procedimiento administrativo en el que se oiga a los 
afectados por éste. El deslinde se acordará de oficio o a instancia de los propietarios de las fincas colindantes o titulares de derechos reales sobre las mismas.

2. La resolución definitiva del deslinde no podrá efectuar declaraciones de dominio o decidir cuestiones de carácter civil, limitándose a definir un estado posesorio de hecho que se presume integrado con carácter "iuris tantum" en una titularidad preexistente.

Artículo 73. 1. Mientras esté en trámite el procedimiento administrativo de deslinde, no podrá instarse procedimiento judicial con igual pretensión, ni se admitirán interdictos sobre el estado posesorio de las fincas de la Comunidad Autónoma objeto de aquél.

2. Del acto que inicie el procedimiento se dará traslado al registro de la propiedad a fin de que, si la finca estuviese inscrita, se practique anotación marginal al asiento de inscripción de la misma y, en su caso, de las fincas colindantes afectadas o, en defecto de inmatriculación, se extienda anotación de suspensión.

Artículo 74. La orden resolutoria del deslinde, que se notificará a todos los interesados y se publicará en el "Diario Oficial de Galicia”, será ejecutiva. Dicha orden podrá ser impugnada en vía contencioso-administrativa, sin perjuicio de las acciones que correspondan ante la jurisdicción ordinaria.

Artículo 75. Firme la resolución aprobatoria del deslinde, se procederá a la demarcación, con intervención de los interesados. A este efecto se señalará día para su práctica, que será notificada a los mismos y publicada en el "Diario Oficial de Galicia" con la suficiente antelación.

Artículo 76. El deslinde administrativo será objeto de inscripción en el registro de la propiedad. Para ello, en defecto de inmatriculación de la finca, se procederá a la previa inscripción del título adquisitivo de ésta.

Artículo 77. Ningún Tribunal podrá dictar providencia de embargo ni despachar mandamiento de ejecución contra los bienes y derechos del patrimonio de la Comunidad Autónoma de Galicia ni contra las rentas, frutos o productos del mismo, debiendo estarse, a este respecto, a lo dispuesto en la Ley de Gestión Económica y Financiera Pública de Galicia.

Artículo 78. 1. La consellería competente en materia de gestión patrimonial deberá llevar el Inventario General del Patrimonio de la Comunidad Autónoma, que comprenderá:

a. Los bienes inmuebles de la Comunidad Autónoma, cualquiera que sea su naturaleza, demanial o patrimonial, y la forma de su adquisición.

b. Los derechos patrimoniales.

c. Los bienes muebles de carácter histórico-artístico o de apreciable valor económico.

d. Los títulos-valores.

e. Los bienes y derechos atribuidos a organismos autónomos o entidades públicas, dependientes de la Comunidad Autónoma de Galicia, con la única excepción de los que se adquieran para garantizar la rentabilidad de las reservas legales que tenga que constituir o con el propósito de devolverlos al tráfico jurídico patrimonial de acuerdo con sus fines patrimoniales.

El inventario de los bienes y derechos a que se contrae el párrafo anterior podrá elaborarse en relaciones separadas.

2. El servicio de inventario estará asistido por el de contabilidad patrimonial, que dependerá funcionalmente de la Intervención General de la Xunta.

Artículo 79. 1. Será obligatoria para la Comunidad Autónoma la inscripción o anotación de los bienes y derechos de su pertenencia en el registro de la propiedad o en cualquier otro registro de carácter público.

2. Se exceptúan, no obstante, de la inscripción o anotación registral los bienes demaniales de uso público y todos aquellos cuya condición demanial se manifieste de forma ostensible o aparente.

3. La Dirección General del Patrimonio será la encargada de promover la inscripción 
o anotaciones de los bienes en el registro competente.

Artículo 80. Toda persona, natural o jurídica, que tenga a su cargo la gestión de los bienes o derechos a que se refiere esta ley, estará obligada a velar por su custodia, conservación, y, en su caso, explotación racional, debiendo responder ante la administración de la Comunidad Autónoma de los daños y perjuicios sobrevenidos por su pérdida o deterioro cuando concurriese fraude o negligencia.

Artículo 81. Toda persona que por dolo o negligencia cause daño en bienes demaniales de la Comunidad Autónoma o realice sobre ellos actos de usurpación, será sancionada en vía administrativa con multa del tanto a duplo del perjuicio ocasionado, con independencia de la reparación del daño o de la restitución, en su caso.

Artículo 82. Cuando los hechos a que se refiere el artículo anterior pudiesen constituir delito o falta, la Xunta de Galicia lo pondrá en conocimiento de la jurisdicción penal, dejando en suspenso la tramitación del procedimiento administrativo hasta que se acuerde el sobreseimiento de la causa o se dicte sentencia firme.

\section{DISPOSICIÓN TRANSITORIA}

Queda exceptuada de las limitaciones establecidas en el artículo 40 de la presente ley la enajenación por la Xunta de Galicia de las acciones, participaciones, cuotas o cualquier clase de título representativo de participación de capital social en las empresas a que hace referencia el Decreto 123/1983, de 27 de julio, sobre fomento de empleo.

\section{DISPOSICIÓN ADICIONAL PRIMERA}

La Xunta de Galicia dictará en el plazo de seis meses, computados a partir del día en que entre en vigor esta ley, las disposiciones reglamentarias precisas para su desarrollo y ejecución.

\section{DISPOSICIÓN ADICIONAL SEGUNDA}

El Consello de la Xunta de Galicia podrá, a través de Decreto, a propuesta de la Consellería de Economía e Facenda, modificar las cuantías establecidas en los artículos $25,26,34$. 1 y $2,35.2$ y 36 de esta Ley de Patrimonio ${ }^{270}$.

\section{LEY 13/1989, DE 10 DE OCTUBRE, DE MONTES VECINALES EN MANO COMÚN (DOGA N. ${ }^{\circ} 202$, DE 20. 10. 1989) ${ }^{271}$}

\section{$(\ldots)^{272}$}

\section{Título preliminar DISPOSICIONES GENERALES}

Artículo 1. Son montes vecinales en mano común y se regirán por esta ley los que, con independencia de su origen, sus posibilidades productivas, su aprovechamiento actual y su vocación agraria, pertenezcan a agrupaciones vecinales en su calidad de grupos sociales y no como entidades administrativas, y se vengan aprovechando consuetudinariamente en régimen de comunidad sin asignación de cuotas por los miembros de aquéllas en su condición de vecinos.

Artículo 2. Los montes vecinales en mano común son bienes indivisibles, inalienables, imprescriptibles e inembargables, no estando sujetos a ninguna contribución de base territorial ni a la cuota empresarial de la Seguridad Social, de acuerdo con el artículo 2.1 de la Ley 55/1980.

Artículo 3. 1. La propiedad de los montes vecinales en mano común, con independencia de su origen, es de naturaleza privada y colectiva, correspondiendo su titularidad dominical y aprovechamiento, sin asignación de cupos, al conjunto de los vecinos titulares de unidades económicas.

270 Disposición adicional segunda modificada por Ley 13/1988, de 30 de diciembre, de Presupuestos Generales de la Comunidad Autónoma Gallega para 1989.

271 Decreto 260/1992, de 4 de septiembre, por el que se aprueba el Reglamento de la ley 10 de octubre de 1989 de montes vecinales en mano común.

272 Exposición de motivos omitida. 
con casa abierta y residencia habitual en las entidades de población a las que tradicionalmente hubiese estado adscrito su aprovechamiento, y que vengan ejerciendo, según los usos y costumbres de la Comunidad, alguna actividad relacionada con aquéllos.

2. La Comunidad vecinal a que se refiere el apartado anterior se entenderá compuesta por los vecinos que la integren en cada momento.

\section{TÍTULO I RÉGIMEN JURÍDICO}

Artículo 4. 1. La Comunidad de vecinos propietaria de un monte vecinal en mano común tendrá plena capacidad jurídica para el cumplimiento de sus fines y la defensa de sus derechos, sobre el monte y sus aprovechamientos, así como sobre su administración y disposición, en los términos establecidos en la presente ley.

2. Si se extinguiese la Comunidad vecinal titular con independencia de su voluntad, habrá que estar, transitoriamente y hasta tanto no se reconstituya la Comunidad, a lo dispuesto en el artículo 27 de la presente ley.

Artículo 5. Los montes vecinales en mano común, pese a su inalienabilidad, podrán ser objeto de cesión temporal, en todo o en parte, a título oneroso o gratuito, para obras, instalaciones, explotaciones de diversa índole, servicios u otros fines que redunden de modo principal en el beneficio directo de la Comunidad de vecinos, de acuerdo con las mayorías previstas en el artículo 18.1. La cesión podrá ser por tiempo indefinido en favor de cualquiera de las Administraciones Públicas cuando sea destinada a equipamientos a favor de la propia Comunidad, y en tanto se mantenga el fin para el que ha sido hecha la cestón.

Artículo 6. 1. Los montes vecinales sólo podrán ser objeto de expropiación forzosa o imponérsele servidumbres por causa de utilidad pública o interés social prevalentes a los de los propios montes vecinales.

2. El impone de las cantidades abonadas por la expropiación o servidumbre habrá de destinarse a la mejora del monte, al establecimiento de obras o servicios de interés general de la Comunidad de vecinos propietarios, o en su imposibilidad, repartirlo entre los comuneros, de acuerdo con lo que esté previsto en los Estatutos o con lo que decida la Comunidad según las mayorías previstas en el artículo 18.1.

3. Si como consecuencia de la expropiación quedase todo el monte fuera de la titularidad dominical de la Comunidad, ésta subsistirá para el ejercicio de los derechos a que haya lugar y como titular del eventual derecho de reversión.

Artículo 7. 1. La Comunidad de vecinos propietarios podrá establecer derechos de superficie con destino a instalaciones o edificaciones hasta el plazo máximo de treinta años, o a cultivos agrícolas de diez años, pasando a ella, sin indemnización alguna, al caducar el derecho, la propiedad de todo lo instalado, edificado o plantado. En caso de aprovechamientos forestales de arbolado, la Comunidad no podrá concertar plazos superiores a los correspondientes a un único turno de la especie plantada, ni para otra clase de aprovechamientos que el de la corta del arbolado plantado.

2. La constitución de este derecho se fomalizará en escritura pública, que habrá de inscribirse en el Registro de la Propiedad, será transmisible y susceptible de gravamen, y se regirá por el título constitutivo del derecho, por la presente ley y, subsidiarimente, por las normas del Derecho Privado.

3. Si el derecho de superficie afectase sólo a una parte del monte vecinal. habrá de practicarse la correspondiente delimitación a los efectos de inscripción de aquel derecho.

Artículo 8. No obstante lo dispuesto en el artículo 2, cuando razones de utilidad 
o interés social de las comunidades de vecinos así lo aconsejen, podrán éstas, dando cuenta al Jurado Provincial de Clasificación permutar terrenos integrantes de los montes vecinales en mano común, por otros terrenos limítrofes que sean de valor similar.

\section{TÍTULO II DE LA CLASIFICACIÓN Y SUS EFECTOS}

Artículo 9. La clasificación como monte vecinal de los terrenos a que se refiere el artículo 1 se llevará a cabo por los Jurados Provinciales en la forma prevista en esta ley y su reglamento.

Artículo 10. En cada una de las provincias gallegas existirá un Jurado Provincial de Clasificación de Montes Vecinales, con la siguiente composición:

Presidente: El Delegado de la Consellería de Agricultura.

$(\ldots)^{273}$

Vocales: Un Letrado de la Asesoría Jurídica de la Xunta de Galicia, un abogado designado por los Colegios Profesionales de la provincia, un Técnico de la Consellería de Agricultura, un representante de las Comunidades de montes de vecinos de la provincia y dos representantes de la Comunidad propietaria en cada caso implicada.

Secretario: Un funcionario de la Delegación de la Consellería de Agricultura.

Los representantes de la Consellería de Agricultura se nombrarán reglamentariamente en función del puesto de trabajo que desempeñen. Reglamentariamente se determinará todo lo relativo a la organización, régimen de incompatibilidades, excusas, asistencias, dietas, gastos, sanciones, nombramientos y sustituciones de los miembros del Jurado.

Artículo 11. 1. Los expedientes de clasificación de montes vecinales se iniciarán

273 El inciso del art. 10 "Vicepresidente: Un Magistrado de la Audiencia Provincial correspondiente", ha sido declarado inconstitucional por FJ. 2 STC 127/1999, de 1 de julio de 1999. Recurso de inconstitucionalidad $175 / 1990$. de oficio por el Jurado o a instancia de cualquier vecino, de la Consellería de Agricultura, de las Comunidades parroquiales o vecinales afectadas o del Ayuntamiento donde esté comprendido el monte.

2. Reglamentariamente, se determinará el procedimiento de clasificación, habiendo de ser oídos cuantos resulten interesados en el expediente y debiendo notificárseles en la fase inicial a las personas o entidades que tengan a su favor la inscripción en el Registro de la Propiedad de algún título relativo al monte.

3. Cuando se inicie un expediente de clasificación, cuya tramitación no podrá exceder de un año a partir de su comienzo, se le dará publicidad oficial y mediante la fijación de edictos en los lugares públicos de costumbre y en los asentamientos de la Comunidad vecinal interesada.

4. Una vez clasificado el monte se fijará la superficie y lindes del mismo, adjuntando a la resolución planimetría suficiente, con los datos descriptivos precisos, y se procederá a su señalización y deslinde, que llevará a cabo de forma gratuita la Consellería de Agricultura. Asimismo figurará el estado económico de aprovechamiento, usos, concesiones y consorcios.

5. Al mismo tiempo el Jurado remitirá testimonio de la resolución al Registro de la Propiedad, a los efectos de que se proceda a la anotación preventiva de la clasificación del monte.

Artículo 12. Las resoluciones del Jurado provincial podrán ser objeto de recurso de reposición ante el propio Jurado, previo a su impugnación en vía contenciosoadministrativa, de conformidad con la ley reguladora de esta Jurisdicción.

Artículo 13. La resolución firme de clasificación de un terreno como monte vecinal en mano común habrá de contener los requisitos necesarios para su inmatriculación en el Registro de la Propiedad de conformidad con lo dispuesto en la Ley Hipotecaria y su Reglamento, y vendrá acompañada de planimetría suficiente que

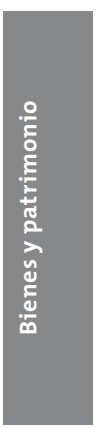


permita la identificación del monte. Dicha resolución, de acuerdo con el artículo 13 de la Ley 55/1980, una vez firme, producirá los siguientes efectos:

a. Atribuir la propiedad a la Comunidad vecinal correspondiente, en tanto no exista sentencia firme en contra, dictada por la jurisdicción ordinaria.

b. Servir de título inmatriculador suficiente para la inscripción del monte en el Registro de la Propiedad y para excluirlo del Catálogo de los de utilidad pública o del inventario de bienes municipales si figurase en ellos, así como para resolver sobre las inscripciones total o parcialmente contradictorias que resulten afectadas.

Si la certificación para la inmatriculación del monte estuviese en contradicción con algún asiento no cancelado, se procederá en la forma prevista en la legislación hipotecaria.

c. Estará exento de los Impuestos sobre Transmisiones Patrimoniales y Actos Jurídicos Documentados, siendo gratuitos la primera inscripción del monte y las cancelaciones que se produzcan por este motivo, de acuerdo con el artículo 13 de la Ley 55/1988.

\section{TÍTULO III \\ DE LA ORGANIZACIÓN DE LAS COMUNIDADES}

Artículo 14. 1. La Asamblea General de la que forman parte todos los comuneros, es el órgano supremo de expresión de la voluntad de la Comunidad vecinal.

2. La Asamblea General ordinaria será convocada una vez al año y siempre dentro de los seis meses siguientes a la fecha de cierre del ejercicio económico. Con carácter extraordinario, podrá convocarse Asamblea General a iniciativa de la Junta Rectora o a petición de un mínimo del 20 por 100 de los comuneros.

3. La Asamblea General quedará válidamente constituida en primera convocatoria cuando estén presentes o representados más de la mitad de los comuneros y en segunda convocatoria cuando estén al menos un 25 por 100 de los mismos. Entre la primera y la segunda convocatoria habrá de transcurrir un mínimo de dos horas.

4. La convocatoria de Asamblea General se hará con un mínimo de diez días de antelación, mediante notificación escrita a todos los comuneros y con el orden del día de los asuntos a tratar, y estará expuesta durante el mismo plazo en los tablones de anuncios del Ayuntamiento, así como en los lugares de costumbre de la Entidad donde radique la Comunidad.

5. Para asistir a la Asamblea General, un comunero podrá delegar su representación en otro comunero, sin que ninguno pueda asumir más de una delegación. En todo caso, la delegación habrá de ser expresa para cada Asamblea General.

Artículo 15. 1. La Junta Rectora es el órgano de gobierno, gestión y representación de la Comunidad. Estará compuesta por un Presidente y el número de Vocales que señalen los Estatutos, sin que en ningún caso puedan ser menos de dos. La Junta Rectora será elegida por la Asamblea General por un período máximo de cuatro años.

El Presidente de la Junta Rectora ostenta la representación legal de la Comunidad.

2. Cuando el número de comuneros no permita la constitución de la Junta Rectora, con arreglo a lo establecido en el apartado 1, asumirá sus funciones la Asamblea General de la Comunidad de vecinos.

3. Las Comunidades de vecinos, previo acuerdo de la Asamblea General, podrán mancomunarse para la mejor defensa de sus intereses y consecución de sus objetivos.

Artículo 16. 1. La Comunidad de vecinos propietaria redactará y aprobará los Estatutos que, siendo la norma reguladora de su funcionamiento, habrán de recoger los usos y costumbres por los que se venía rigiendo la Comunidad y las previsiones de esta ley y contendrán como mínimo los siguientes extremos: 
a. La atribución de la condición de comunero con arreglo a lo dispuesto en el artículo 3.1 de esta ley.

b. La representación por casa y la delegación entre comuneros.

c. Las condiciones de admisión de nuevos comuneros.

d. La manera de ejercitar los derechos derivados de la condición de comuneros.

e. Obligaciones de los comuneros en cuanto a custodia, defensa y conservación del monte.

f. Los órganos a los que se encomienda el gobierno y administración, modo de nombrarlos, sustituirlos y funciones que les corresponden.

g. Porcentaje de reserva en rendimientos económicos para inversiones en mejoras y protección del monte, de acuerdo con el artículo 23 de la presente ley.

h. Criterios a los que se han de adecuar los diversos aprovechamientos del monte.

2. Los Estatutos y sus modificaciones empezarán a surtir efecto al día siguiente de su aprobación, y se remitirá una copia, a efectos de conocimiento, al Registro General de Montes Vecinales en Mano Común.

Artículo 17. Cualquier comunero podrá defender los intereses de la Comunidad de montes en mano común, teniendo que serle reintegrados los gastos que le ocasione tal defensa, siempre que prosperen sus pretensiones o sea aprobado por la Asamblea General.

Artículo 18. 1. La aprobación, reforma o revocación de los Estatutos, así como los acuerdos referidos a actos de disposición, corresponden a la Asamblea General, requiriendo la convocatoria expresa y el voto favorable de la mayoría de los presentes que represente al menos el 50 por $100 \mathrm{del}$ censo de comuneros en primera convocatoria y el 30 por 100 en segunda.

2. Para la aprobación de la gestión y Balance del ejercicio económico, aprovechamientos y actos de administración en general será suficiente la mayoría simple, salvo que en los Estatutos se exija otra mayoría.
Artículo 19. 1. En cuanto no se constituyan los órganos de gobierno, o si por cualquier causa no existiesen, ejercerá las facultades que a éstos corresponda una Junta provisional compuesta, como mínimo, por un Presidente y dos Vocales, elegidos de entre los comuneros y por éstos, dando cuenta de su composición al Registro General de Montes Vecinales en Mano Común.

2. La Junta provisional tendrá la representación de la Comunidad e impulsará la redacción y aprobación de los Estatutos o, en su caso, la elección de los órganos de gobierno. Confeccionará, si no existiese, la lista provisional de vecinos comuneros.

3. Las Juntas provisionales tendrán un plazo máximo de un año para la redacción del proyecto de Estatutos de la Comunidad.

4. La Junta provisional se encargará de la gestión y administración del monte vecinal, pudiendo autorizar, por razones de urgencia o interés general, actos de administración de cuantía económica no superior a 1.000 .000 de pesetas en total.

5. El mandato de la Junta provisional finalizará, en todo caso, con la aprobación de los Estatutos, no pudiendo ser superior a un año. Transcurrido éste y persistiendo las circunstancias señaladas en el apartado 1 del presente artículo, se procederá a una nueva elección.

Artículo 20. En situaciones jurídicas de pendencia por extinción o desaparición de la Comunidad de vecinos titular del monte, la defensa de sus intereses corresponde a la parroquia donde radique el mismo, o subsidiariamente a la Consellería de Agricultura, que regularán en concepto de titulares provisionales el aprovechamiento del monte en beneficio de la Comunidad parroquial.

\section{TÍTULO IV \\ DE LOS APROVECHAMIENTOS}

Artículo 21. 1. El aprovechamiento y disfrute de los montes vecinales en mano común corresponde en origen 
exclusivamente a la Comunidad titular y se hará según las normas recogidas en sus Estatutos, en esta ley y en las disposiciones que la desarrollen.

2. Los rendimientos que produzca el monte, respetando lo dispuesto en el artículo 23 de esta ley, se dedicarán, en todo o en parte y según acuerden los Estatutos o la Asamblea General, a obras o servicios comunitarios con criterios de reparto proporcional entre los diversos lugares, a inversiones en el propio monte o a reparto, total o parcial, en partes iguales entre todos los comuneros. Los rendimientos no individualizables se repartirán, en todo caso, en partes iguales entre todos los comuneros.

3. Los aprovechamientos de los montes vecinales en mano común podrán ser objeto de gravamen, pudiendo en este caso dirigirse la ejecución solamente contra los aprovechamientos o las rentas que se pudiesen derivar de su cesión hecha de conformidad con lo dispuesto en la presente ley.

Artículo 22. 1. La Comunidad de vecinos propietaria podrá acordar para usos ganaderos o agrícolas qué parte del monte se pueda aprovechar de forma individual mediante la distribución entre los vecinos comuneros de lotes, suertes o parcelas cedidos temporalmente a título oneroso o gratuito y por períodos no superiores a los once años.

En la asignación de lotes se procurará qué comuneros que trabajen conjuntamente bajo la fórmula de explotación comunitaria de la tierra tengan los lotes contiguos.

2. Cuando la utilización de tal lote, suerte o parcela, por parte del particular, sea destinada a uso distinto o contradictorio del acordado por la Comunidad, dará lugar a la reversión inmediata de tal lote, suerte o parcela a la situación de aprovechamiento colectivo.

3. Finalizado el período de cesión, la Comunidad de vecinos podrá optar por acometer el aprovechamiento en común o proceder a un nuevo reparto. En este caso, los lotes que se entreguen a los comuneros no pueden coincidir con los que se aprovecharon en el período anterior.

4. La Comunidad de vecinos propietaria velará porque las parcelas cedidas estén adecuadamente cultivadas, y porque se pueda atender la demanda de lotes por parte de los que adquieran la condición de comuneros una vez hecha la distribución.

Artículo 23. De todos los rendimientos económicos que se puedan derivar de los aprovechamientos, se reserva una cantidad, que se debe fijar en los Estatutos, y en todo caso nunca inferior al 15 por 100 de aquéllos, para inversiones en mejora, protección, acceso y servicios derivados del uso social al que el monte pueda estar destinado.

\section{TíTULO V PROTECCIÓN Y GESTIÓN CAUTELAR}

Artículo 24. La Comunidad titular de un monte vecinal en mano común tomará las medidas necesarias para la gestión, explotación, protección y defensa del mismo. Velará especialmente por la prevención y lucha contra los incendios forestales en coordinación con la Administración Pública.

Artículo 25. La Consellería de Agricultura dará a los montes vecinales en mano común carácter preferente en sus actuaciones de fomento y mejora de la producción agraria y en la concesión de ayudas económicas para las mismas finalidades. Además, desempeñará las siguientes funciones:

Proceder al deslinde y señalización de los mismos.

Velar por su conservación e integridad. Asesorar técnicamente a las Comunidades vecinales en la redacción de los planes y proyectos técnicos de transformación, mejora y aprovechamientos agrícolas, pecuarios o forestales. 
Vigilar por el cumplimiento de la ejecución de los planes de mejora que se citan en los artículos 28 y 29.

Realizar convenios dirigidos a un mejor aprovechamiento del monte con aquellas Comunidades de vecinos que así lo soliciten.

Impulsar y promover el aprovechamiento cooperativo del monte.

Velar por el cumplimiento de lo dispuesto en esta ley, aplicando las medidas correctoras y sancionadoras que legalmente se establezcan.

Artículo 26. En la Consellería de Agricultura se creará un Registro General de Montes Vecinales en Mano Común que, en todo caso, será público, con la finalidad de mantener una relación actualizada de los mismos y de su situación estatutaria, así como de los actos de disposición a que se refieren los artículos 5, 6, 7, 8 y 22 de esta ley. En cada Delegación Provincial existirá una sección con los datos registrados de los montes vecinales de su ámbito. Reglamentariamente se desarrollarán las características de este Registro.

Artículo 27. 1. Los montes vecinales en mano común serán gestionados cautelarmente por la consejería competente en materia de montes en las situaciones siguientes:

a. Por extinción o desaparición de la comunidad de vecinos titular del monte de manera provisional hasta que, en su caso, se reconstituya la comunidad, y siempre que la parroquia donde radique el monte no ejerza su derecho conferido en el artículo 20 de la presente ley.

b. Cuando sea declarada la situación de estado de grave abandono o degradación del monte vecinal, de acuerdo con lo contemplado en la presente ley.

2. La consejería competente en materia de montes podrá ejercitar la gestión cautelar prevista en el apartado 1 de este artículo directamente o mediante su encomienda a entes o empresas cuyo capital sea íntegramente público ${ }^{274}$.

$\overline{274}$ Art. 27 modificado por Ley 7/2007, de 21 de mayo, de medidas administrativas y tributarias para la conservación de la superficie agraria útil y del Banco de Tierras de Galicia.
Artículo 28. 1. Se entenderá por monte vecinal en estado de grave abandono o degradación aquél que, de modo manifiesto, sufriese un grave deterioro ecológico, no sea explotado de acuerdo con sus recursos o sufra una extracción abusiva de los mismos.

2. La Xunta de Galicia, a propuesta de la Consellería de Agricultura, será competente para declarar por razones de utilidad pública e interés general el estado de grave abandono o degradación.

3. La declaración en estado de grave abandono o degradación implicará la ejecución de un plan de mejora y aprovechamiento.

4. La Consellería de Agricultura establecerá periódicamente los indicadores objetivos que sirvan para la determinación del estado de grave abandono o degradación de los montes, en base, fundamentalmente, a los siguientes criterios: El grado de aprovechamiento de la extensión superficial; el grado de manifiesto desuso; el grado de acomodación a los aprovechamientos establecidos en planes específicos de ordenación agroganadera o forestal, en su caso; el carácter depredador de las actividades extractivas de los recursos, y el peligro manifiesto de degradación de las tierras.

Artículo 29. La Consellería de Agricultura acomodará la declaración de estado de grave abandono o degradación al siguiente procedimiento:

Primero. Requerirá de oficio a la Comunidad de vecinos para que presente un plan de mejora y transformación integral del monte, en el que se exprese el plazo para su ejecución.

Segundo. Requerida la Comunidad, ésta tendrá un plazo de tres meses, prorrogable por otros tres, para presentar el referido plan.

Tercero. En caso de no presentación del plan por la Comunidad o de no aprobación del presentado, la Consellería de Agricultura procederá a la elaboración de un plan 
de gestión y mejora integral del monte, que será notificado a la Comunidad, en el plazo máximo de tres meses para su conocimiento y aprobación.

Cuarto. Transcurridos tres meses sin que la Comunidad hubiese aceptado el plan ni se hubiese llegado a fórmulas de compromiso, la Consellería de Agricultura elevará la propuesta al Consello de la Xunta de Galicia para que el monte sea declarado en estado de grave abandono o degradación. Contra esta Resolución cabe el correspondiente recurso contencioso-administrativo.

Artículo 30. 1. Decretado un monte en estado de grave abandono o degradación, la consejería competente en materia de montes tomará a su cargo en el plazo de dos años la ejecución del plan de gestión y mejora integral propuesto, debiendo rendir cuenta de su gestión a la junta rectora para información a la asamblea anual de la comunidad.

2. En el supuesto en que, con arreglo a lo previsto en el artículo 27.2 de la presente ley, se haya encomendado la gestión cautelar del monte vecinal a un ente o empresa cuyo capital sea íntegramente público, la ejecución del plan de gestión y mejora integral y la rendición de cuenta a que se refiere el apartado anterior corresponderán al mismo ente o empresa.

3. Los beneficios derivados del plan de mejora y aprovechamiento de los montes gestionados cautelarmente, una vez deducidos los gastos e inversiones en la gestión y mejora del monte, serán para la comunidad. Si no existiera esta, serán para el municipio o municipios en donde radique el monte, que los destinará o destinarán a mejoras de interés general en las parroquias correspondientes ${ }^{275}$.

\section{DISPOSICIÓN ADICIONAL PRIMERA}

Las resoluciones de los Jurados provinciales tendrán eficacia durante el plazo de

275 Art. 30 modificado por Ley $7 / 2007$, de 21 de mayo, de medidas administrativas y tributarias para la conservación de la superficie agraria útil y del Banco de Tierras de Galicia. un año, a partir de su firmeza, para rectificar las inmatriculaciones contradictorias del Registro de la Propiedad, salvo que éstas se hubiesen practicado en virtud de sentencia dictada en juicio declarativo, de acuerdo con la Ley 55/1980, de 11 de noviembre.

\section{DISPOSICIÓN ADICIONAL SEGUNDA}

Las Comunidades propietarias de montes de vecinos consorciados o con convenios con la Administración y con independencia de que en ellos fuesen parte los Ayuntamientos o Diputaciones Provinciales, podrán optar por subrogarse en el consorcio o convenio preexistente, realizar un nuevo convenio o resolver el existente.

Las deudas de los consorcios realizados por la Administración Forestal del Estado serán condonadas por el importe a que ascendía la deuda en el momento de la clasificación del monte como vecinal en mano común.

Si los consorcios con la Administración continúan en vigor, bien en su forma original o transformados en convenios al amparo de la disposición final tercera de la Ley 55/1980, de 11 de noviembre, y la totalidad o parte de la deuda existente en el momento de la clasificación hubiese sido amortizada, el importe de ésta se devolverá a las Comunidades en forma de inversiones a realizar por la Administración en nombre propio.

Cuando el consorcio o convenio fuese resuelto y liquidado, las Comunidades interesadas podrán solicitar la devolución del importe de las amortizaciones realizadas en el momento de la clasificación, que será compensado por la Administración en forma de inversiones materializadas en el propio monte.

Estas inversiones se realizarán con acuerdo expreso de las Comunidades propietarias, en un plazo máximo de cuatro años.

En todo caso, aquellas Comunidades que se beneficien de la condonación de la 
deuda según lo contemplado en esta disposición y quieran rescindir el consorcio o convenio tendrán que presentar siempre un plan de aprovechamientos y gestión del monte, que habrá de ser aprobado por la Administración.

\section{DISPOSICIÓN ADICIONAL TERCERA}

$$
(\ldots)^{276}
$$

\section{DISPOSICIÓN ADICIONAL CUARTA}

Los derechos atribuidos en esta ley a la parroquia se entenderán en el marco de lo dispuesto y previsto en los artículos $40.3 \mathrm{y}$ 27.2 del Estatuto de Galicia.

\section{DISPOSICIÓN ADICIONAL QUUINTA}

La Consellería de Agricultura confeccionará, en un plazo de tres años, un inventario general de los montes en mano común en el que consten individualizados los datos que permitan la perfecta identificación de los mismos, tales como situación geográfica, superficie, lindes, estado económico de aprovechamiento, usos, concesiones, convenios, consorcios y arrendamientos establecidos sobre los mismos.

\section{DISPOSICIÓN ADICIONAL SEXTA}

Concluido el inventario a que hace referencia la Disposición adicional quinta, la Consellería de Agricultura, partiendo de las demandas de las Comunidades propietarias, elaborará un plan de aprovechamiento de montes vecinales en mano común, que tendrá como objetivo el mejor uso de estas tierras atendiendo a su vocación productiva y a las necesidades de las Comunidades.

Este plan, que será debatido en el Parlamento gallego, contará con las previsiones correspondientes de financiación y promoción de aprovechamientos.

La Xunta de Galicia impulsará y promoverá el aprovechamiento cooperativo, o

276 Disposición adicional tercera declarada inconstitucional por FJ. 3-5 STC 127/1999, de 1 de julio de 1999. Recurso de inconstitucionalidad 175/1990. comunitario, de aquellos montes que por sus circunstancias puedan ser susceptibles de aprovechamiento industrial.

\section{DISPOSICIÓN TRANSITORIA PRIMERA}

Al entrar en vigor esta ley los Jurados provinciales de los montes vecinales en mano común se configurarán de acuerdo con lo dispuesto en esta ley sin perjuicio de que aquellos expedientes en trámite sean resueltos de conformidad con la legislación existente en el momento de haberlos comenzado.

\section{DISPOSICIÓN TRANSITORIA SEGUNDA}

Los Estatutos aprobados y las Juntas de Comunidad constituidas de conformidad con la legislación anterior se adaptarán a lo dispuesto en la presente ley en el plazo de un año desde la entrada en vigor de la presente ley.

\section{DISPOSICIÓN TRANSITORIA TERCERA}

Las actuaciones para la declaración de un monte vecinal en estado de grave abandono o degradación no se podrán iniciar antes de que haya transcurrido un año desde la entrada en vigor de la presente ley para los montes ya clasificados o desde la clasificación cuando ésta sea posterior a la misma.

\section{DISPOSICIÓN TRANSITORIA CUARTA}

El Ministerio Fiscal defenderá las Comunidades de vecinos de montes en mano común, cuando éstas se vean afectadas en la propiedad de la que son titulares, al amparo de la Ley 55/1980, de 11 de noviembre.

\section{DISPOSICIÓN FINAL PRIMERA}

La Xunta de Galicia aprobará el Reglamento de la presente ley en el plazo de seis meses, computados desde el día de entrada en vigor de la misma.

\section{DISPOSICIÓN FINAL SEGUNDA}

La presente ley, juntamente con la costumbre, constituyen el derecho propio 
de Galicia en materia de montes vecinales en mano común, que de conformidad con lo dispuesto en el artículo 38.1 del Estatuto de Autonomía será de aplicación, en su ámbito territorial, con preferencia a cualquier otro.

\section{LEY 8/1993, DE 23 DE JUNIO, REGULADORA DE LA ADMINISTRACIÓN HIDRÁULICA DE GALICIA (DOGA N. $\left.{ }^{\circ} 125,2.7 .1993\right)$}

$(\ldots)^{277}$

\section{Capítulo I \\ ORGANIZACIÓN Y COMPETENCIA DE LA ADMINISTRACIÓN HIDRÁULICA}

Artículo 1. La Comunidad Autónoma de Galicia ejerce sus competencias y funciones en materia de aguas y obras hidráulicas a través de los órganos administrativos y Entes públicos que integran su Administración hidráulica.

Artículo 2. 1. A los efectos de esta ley, y de acuerdo con lo que en la misma se prevé, constituyen la Administración hidráulica de Galicia los siguientes órganos administrativos generales:

a. El Consello de la Xunta de Galicia.

b. La Consellería de Ordenación del Territorio e Obras Públicas.

2. Son Entes especiales de dicha Administración hidráulica:

a. El Organismo Autónomo Augas de Galicia.

b. La Empresa pública de Obras y Servicios Hidráulicos.

Artículo 3. En el ejercicio de las competencias de la Comunidad Autónoma en materia de aguas, la Administración hidráulica de Galicia se someterá a los siguientes principios:

1. Unidad de gestión, tratamiento integral, economía del agua, desconcentración, descentralización, coordinación, eficacia y participación de los usuarios.

277 Exposición de motivos omitida.
2. Respecto de la unidad de la cuenca hidrográfica, de los sistemas hidráulicos y del ciclo hidrológico.

3. Compatibilidad de la gestión pública del agua con la ordenación del territorio, la conservación y protección del medio ambiente y la restauración de la naturaleza.

Artículo 4. 1. Corresponde a la Administración Hidráulica de Galicia:

a. La ordenación y concesión de los recursos hidráulicos en todas las cuencas comprendidas íntegramente dentro del territorio de la Comunidad Autónoma, así como el otorgamiento de autorizaciones y el ejercicio del régimen sancionador para el vertido en cauces públicos y desde tierra al litoral gallego, o para la utilización o aprovechamiento del dominio público hidráulico y de la policía de aguas y cauces en dichas cuencas 278 .

b. El ejercicio de todas las funciones de deslinde y defensa del dominio público hidráulico en las cuencas a que se refiere el apartado anterior.

c. La programación, aprobación, ejecución y explotación de aprovechamientos hidráulicos, incluida su policía y, demás obras hidráulicas que se realicen en el territorio de Galicia que no sean de interés general del Estado o cuya realización no afecte a otra Comunidad Autónoma, así como las que sean delegadas por el Estado.

ch. La regulación y el otorgamiento de auxilios económicos a corporaciones locales, entidades particulares para la promoción, ejecución y explotación de las obras y aprovechamientos de las obras y de los aprovechamientos a que se refiere el apartado precedente, de acuerdo con la legislación que les sea de aplicación.

d. La elaboración, de acuerdo con las normas propias de redacción y tramitación, del plan hidrológico de las cuencas hidrográficas comprendidas íntegramente en el territorio de Galicia, así como la participación en

278 Art. 4.1.a modificado por Ley 2/1998, de 8 de abril, de medidas tributarias, de régimen presupuestario, función pública, patrimonio, organización y gestión. 
la elaboración y tramitación de los planes hidrológicos a cargo del Estado que afectan a las cuencas hidrográficas de las que forme parte el territorio de Galicia.

e. La adopción de las medidas excepcionales en los supuestos a que se refiere el artículo 56 de la Ley de Aguas y dentro del ámbito de la competencia de la Comunidad Autónoma de Galicia.

f. En general, el cumplimiento de todas las funciones que se derivan de la Ley de Aguas y de las que le sean delegadas por el Estado, con el ejercicio de las facultades $\mathrm{y}$ atribuciones pertinentes.

2. En particular, el Consello de la Xunta de Galicia y, en su caso, el Conselleiro de Ordenación del Territorio y Obras Públicas ejercerán la potestad reglamentaria de desarrollo de la legislación estatal de aguas, en el ámbito de las competencias de la Comunidad Autónoma, y de la legislación que dicte el Parlamento de Galicia en el ejercicio de sus competencias en materia de aguas y obras hidráulicas.

Artículo 5. A los efectos de lo dispuesto en esta ley, son cuencas hidrográficas comprendidas íntegramente dentro del territorio de Galicia todas las existencias dentro del ámbito territorial de la Comunidad Autónoma, salvo las correspondientes a los ríos Miño, Eo, Navia, Limia y Duero Norte.

Artículo 6. 1. El Consello de la Xunta de Galicia establecerá la división del territorio de Galicia en demarcaciones hidrográficas para la prestación de los servicios hidráulicos de competencia autonómica y que constituirán, asimismo, ámbitos de representación de los usuarios en los órganos colegiados de la Administración hidráulica.

2. En cada demarcación hidrográfica podrá existir un servicio territorial del Organismo Autónomo Augas de Galicia, que ejercerá las funciones que reglamentariamente se determinen.

\section{Capitulo II \\ EL ORGANISMO AUTÓNOMO AUGAS DE GALICIA ${ }^{279}$ \\ Sección $1 .^{\mathrm{a}}$ \\ Disposiciones generales}

Artículo 7. 1. Aguas de Galicia es un Organismo Autónomo de carácter administrativo, adscrito a la Consellería de Medio Ambiente, y dotado de plena autonomía para el cumplimiento de las funciones que la presente ley le asigna, con la participación en sus órganos colegiados de los usuarios ${ }^{280}$.

2. Dentro de la competencia de la Administración autonómica, corresponde al ente autónomo Aguas de Galicia:

a. La elaboración, el seguimiento y la revisión de los planes hidrológicos.

b. La administración y el control del dominio público hidráulico.

c. La administración y el control de los aprovechamientos hidráulicos.

ch. El proyecto, la construcción y la explotación de obras hidráulicas.

d. La autorización de las obras e instalaciones de vertidos desde tierra a las aguas del litoral gallego y el ejercicio de las funciones de policía sobre los mismos.

e. El ejercicio de cualquier otra función que le sea atribuida por el Consello de la Xunta de Galicia ${ }^{281}$.

Artículo 8. Aguas de Galicia, como Organismo Autónomo de carácter administrativo, tiene personalidad jurídica y patrimonio propios y plena capacidad de obrar para el cumplimiento de sus fines, de

\footnotetext{
279 Véase:

- Decreto 108/1996, de 29 de febrero, por el que se aprueba el Reglamento del Organismo Autónomo de Augas de Galicia.

- Decreto 84/1997, de 10 de abril, sobre colaboración técnica y financiera de la Administración hidráulica de Galicia con las entidades locales en materia de abastecimiento y saneamiento de aguas.

280 Art. 7.1 modificado por Ley $3 / 2002$, de 29 de abril, de medidas de régimen fiscal y administrativo.

281 Art. 7.2 modificado por Ley 2/1998, de 8 de abril, de medidas tributarias, de régimen presupuestario, función pública, patrimonio, organización y gestión.
} 
acuerdo con la presente ley y la legislación general sobre entidades autónomas que le es de aplicación. En consecuencia, puede adquirir, poseer, reivindicar, permutar, gravar o enajenar cualquier tipo de bienes de su patrimonio, concertar créditos, celebrar contratos, contratar y explotar obras y servicios, obligarse, interponer recursos y ejercitar las acciones previstas por las leyes. Sus actos y resoluciones son susceptibles de ser impugnados mediante la interposición de recurso ordinario ante el Conselleiro de Política Territorial, Obras Públicas y Vivienda, salvo lo previsto en la presente ley 282 .

Artículo 9. El Conselleiro de Ordenación del Territorio y Obras Públicas ejercerá las atribuciones derivadas de la relación orgánica y funcional de adscripción de la Entidad autónoma.

Artículo 10. 1. El gobierno y la administración del Ente autónomo Aguas de Galicia están a cargo de los órganos siguientes:

a. El Presidente del Organismo.

b. La Junta de Gobierno.

2. Son órganos de gestión en régimen de participación las juntas de explotación y las comisiones de desembalse 283 .

3. La constitución de órganos de planificación, su composición y su funcionamiento se establecerán reglamentariamente.

\section{Sección 2. ${ }^{\text {a }}$ Órganos directivos}

Artículo 11. 1.El Presidente de Aguas de Galicia es el Director general competente en materia de obras hidráulicas.

2. El Presidente ostenta la representación legal del Organismo, autoriza las acciones y los recursos que le corresponden en la defensa de sus derechos y ejerce sus funciones directivas y ejecutivas.

282 Art. 8 modificado por Ley 2/1998, de 8 de abril, de medidas tributarias, de régimen presupuestario, función pública, patrimonio, organización y gestión. 283 Véase Orden de 6 de agosto de 2001 por la que se regulan las comisiones de desembalse de aguas de Galicia.
Artículo 12. Son atribuciones del Presidente:

a. Otorgar las autorizaciones y concesiones relativas al uso y aprovechamiento del dominio público hidráulico y también las referentes al régimen de policía de las aguas y sus cauces y de los aprovechamientos hidráulicos de competencia de la Xunta de Galicia, así como las autorizaciones de vertido de aguas residuales desde tierra al litoral gallego 284 .

b. Aprobar definitivamente los proyectos de obras e instalaciones y decidir la prestación de servicios por el Ente autónomo Aguas de Galicia.

c. Ejercer la dirección superior de los servicios del Organismo.

ch. Elaborar el anteproyecto de los presupuestos del Organismo.

d. Autorizar los gastos y ordenar los pagos dentro de los créditos aprobados.

e. Aplicar el régimen económicofinanciero de utilización del dominio público hidráulico.

f. Proponer el nombramiento de los titulares de las unidades administrativas citadas en el artículo 21.

g. Presidir la Junta de Gobierno, sin perjuicio de lo dispuesto en el artículo 13. a), y los órganos colegiados de gestión que se constituyan.

h. Resolver los recursos administrativos de su competencia.

i. Conocer todos los asuntos que no estén atribuidos a la competencia de otro órgano de la Entidad.

j. Velar por que los acuerdos de los órganos colegiados se ajusten a la legalidad vigente.

Artículo 13. 1. La Junta de Gobierno del Ente autónomo Aguas de Galicia estará integrada por:

a. El Presidente, que será el propio Organismo.

284 Art. 12.a modificado por Ley 2/1998, de 8 de abril, de Medidas Tributarias, de Régimen Presupuestario, función pública, patrimonio, organización y gestión. 
b. El Vicepresidente, elegido por los Vocales de la Junta de Gobierno del Ente autónomo que representen a los usuarios del agua.

c. En representación de la Administración de la Xunta de Galicia:

Tres Vocales designados por la Consellería de Ordenación del Territorio e Obras Públicas. Un Vocal por cada una de las consellerías de la Presidencia y Administración Pública, de Economía y Hacienda, de Industria y Comercio, de Agricultura, Ganadería y Montes, de Sanidad y de Pesca, Marisqueo y Acuicultura.

ch. La representación de los distintos tipos de uso, que será proporcional a la importancia de los respectivos aprovechamientos en el territorio de Galicia. En todo caso habrá, al menos, un Vocal representante por cada uno de los usos de abastecimiento de agua y de producción de energía hidroeléctrica.

d. hasta diez Vocales más, designados por el Consello de la Xunta de Galicia en representación de otros intereses y usos relacionados con la política hidráulica.

2. En cualquier caso, la representación de los usuarios, incluido el Vicepresidente, debe significar al menos un tercio del total de los miembros de la Junta.

Artículo 14. La designación de los representantes de los usuarios se efectuará de acuerdo con el procedimiento que se establezca reglamentariamente, que habrá de ajustarse a las determinaciones contenidas en el artículo 13, puntos 1, ch), y 2 . Dicho procedimiento fijará el número de Vocales que se designarán en cada una de las demarcaciones hidrográficas que se delimiten en el desarrollo de lo previsto en esta ley.

Artículo 15. Corresponde a la Junta de Gobierno:

a. Proponer los planes de actuación del Organismo.

b. Elevar el Consello de la Xunta de Galicia, a través de la Consellería de Or- denación del Territorio e Obras Públicas, el plan hidrológico de la cuencas internas y sus ulteriores revisiones.

c. Elevar el anteproyecto de los presupuestos del Organismo.

ch. Emitir informe sobre los proyectos de concertación de operaciones de crédito.

d. Adoptar, de conformidad con la normativa vigente, los acuerdos relativos a actos de disposición sobre bienes del patrimonio del Ente autónomo, así como informar y proponer con carácter previo los actos de desafectación de los bienes de dominio público hidráulico.

e. Emitir informes sobre cuestiones de interés general en materia de aguas y sobre las relativas a la mejor ordenación, explotación y tutela del dominio público hidráulico, incluidas las medidas de carácter excepcional.

f. Conocer las cuestiones que le sean encomendadas por una norma legal o reglamentaria.

Artículo 16. 1. La Junta de Gobierno se reunirá en pleno o por secciones.

2. La Junta de Gobierno consta de dos secciones permanentes:

a. Sección Galicia-costa.

b. Sección cuencas intercomunitarias.

La composición y las funciones de dichas secciones se fijarán reglamentariamente, debiéndose asegurar en todo caso la adecuada representación de los usuarios de las cuencas respectivas y de los beneficiarios de las obras y servicios que presente el Ente autónomo Aguas de Galicia en cada una. Deberán fijarse, asimismo, los asuntos que hayan de quedar reservados a la competencia del Pleno.

3. Por acuerdo del Pleno de la Junta de Gobierno pueden constituirse secciones temporales encargadas del seguimiento, estudio o ejecución de asuntos o cometidos determinados. El acuerdo de constitución habrá de expresar la composición y el procedimiento de actuación de la sección y el plazo de duración de su cometido. 
Artículo 17. 1. Corresponde al Presidente de la Junta de Gobierno asegurar la regularidad de las deliberaciones, fijar el orden del día, convocar, presidir, suspender y levantar las sesiones, dar el visto bueno a las actas y velar por el cumplimiento de los acuerdos.

2. El Vicepresidente de la Junta de Gobierno sustiturá a su Presidente en caso de vacante, ausencia o enfermedad.

Artículo 18. El Pleno de la Junta de Gobierno y sus secciones ajustarán su funcionamiento y el régimen de sus acuerdos a las normas que regulan los órganos colegiados de la Administración de la Xunta de Galicia.

\section{Sección 3. ${ }^{\mathrm{a}}$ Órganos de gestión}

Artículo 19. 1. Las juntas de explotación tienen como finalidad coordinar, respetando los derechos derivados de las correspondientes concesiones y autorizaciones, la explotación de las obras hidráulicas y de los recursos de agua del mismo conjunto de ríos, tramo de río o unidad hidrogeológica que tengan sus aprovechamientos especialmente interrelacionados.

2. La constitución de las juntas de explotación, en las que los usuarios participarán mayoritariamente en relación con sus respectivos intereses en el uso del agua y con el servicio prestado a la comunidad, se determinará reglamentariamente.

Artículo 20. Corresponde a las comisiones de desembalse deliberar y formular propuestas al Presidente del Organismo sobre el régimen adecuado de llenado y vaciado de los embalses, atendidos los derechos concesionales de los distintos usuarios. Su composición y su funcionamiento se determinarán reglamentariamente, atendiendo al derecho de representación adecuada de los intereses afectados.

Artículo 21. 1. Directamente dependientes del Presidente del Ente autónomo Aguas de Galicia existirán en este Organismo las unidades administrativas siguientes: a. La Secretaría General.

b. El Departamento de Gestión del Dominio Público Hidráulico.

c. El Departamento de Régimen Económico-Financiero.

2. El nivel orgánico de cada unidad, la forma de nombramiento de su titular y las funciones respectivas se determinarán, según corresponda, por el reglamento o en las relaciones de puestos de trabajo.

3. En particular, el titular de la Secretaría General actuará como Secretario de los órganos colegiados del Ente autónomo.

\section{Sección $4 .^{\mathrm{a}}$}

\section{Patrimonio y régimen financiero}

Artículo 22. 1. El Organismo Autónomo Aguas de Galicia posee un patrimonio propio integrado por:

a. Los bienes y derechos que adquiera con cargo a los fondos de su presupuesto.

b. Los bienes demaniales y patrimoniales que le sean adscritos o cedidos.

c. Los bienes del dominio público hidráulico sometidos a su administración, una vez que hubiesen sido desafectados de acuerdo con las normas legales aplicables.

ch. Los bienes que por cualquier título jurídico reciba del Estado, de la Comunidad Autónoma, de Entidades públicas y privadas o de los particulares.

2. Se adscriben al Organismo Autónomo Aguas de Galicia los bienes y derechos transferidos por el Estado a la Comunidad Autónoma afectos al servicio público que presta dicho Organismo.

Artículo 23. 1. Los bienes de la Comunidad Autónoma adscritos o cedidos al Ente autónomo Aguas de Galicia para el cumplimiento de sus fines conservan su titularidad y calificación jurídica originarias, correspondiendo a dicho Organismo utilizarlos, administrarlos y explotarlos con sujeción a las disposiciones legales vigentes en esta materia.

2. Se aplicarán las disposiciones de la legislación del patrimonio de la Comunidad Autónoma de Galicia en todo lo que se 
refiere al régimen jurídico de los bienes y derechos patrimoniales o demaniales que le sean cedidos, adscritos o incorporados al patrimonio del Organismo.

Artículo 24. El Organismo Autónomo Aguas de Galicia podrá ceder a las Corporaciones Locales y mancomunidades de municipios interesados el uso, la explotación o la titularidad de las obras e instalaciones afectadas a servicios de competencia local que hayan sido ejecutadas total o parcialmente con cargo a su presupuesto.

Artículo 25. 1. Tendrán la consideración de ingresos del Organismo Autónomo Aguas de Galicia:

a. Los productos y las rentas de su patrimonio y los de la explotación de las obras propias o de las que le sean encomendadas por la Comunidad Autónoma, el Estado, las Corporaciones Locales o los particulares.

b. Las remuneraciones procedentes de la prestación de servicios facultativos y técnicos y por el estudio y redacción de proyectos y por la redacción y ejecución de obras que le encomiende cualquiera de las personas o Entidades citadas en el apartado anterior.

c. Las asignaciones presupuestarias de la Xunta de Galicia, de sus organismos autónomos y Empresas públicas y, en su caso, las del Estado y de las Corporaciones Locales.

ch. Los ingresos procedentes de la recaudación de tasas, exacciones y precios autorizados al Organismo.

d. Las indemnizaciones establecidas como compensación de daños y perjuicios al dominio público hidráulico que administra el Ente autónomo o a sus bienes propios o adscritos.

e. El producto de las aportaciones a cargo de los usuarios para obras o actuaciones específicas y también cualquier otra percepción autorizada por disposición legal.

2. El importe de los anteriores ingresos, así como el derivado de las sanciones impuestas por infracciones al régimen de policía de aguas, se integrarán en la hacienda del Organismo y quedarán afectados al cumplimiento de sus fines propios.

Artículo 26. 1. El Ente autónomo Aguas de Galicia gestionará las tasas y otros ingresos exigibles dentro del ámbito del ejercicio de sus competencias, ajustándose a la legislación reguladora de estos ingresos.

2. En particular, corresponde al Ente autónomo Aguas de Galicia la gestión de los siguientes ingresos:

a. El canon de utilización del dominio público hidráulico con arreglo a lo establecido en el artículo 104 de la Ley 29/1985, de 2 de agosto, de Aguas.

b. El canon de saneamiento regulado en la presente ley, así como el canon de vertidos establecido en la Ley 29/1985, de 2 de agosto, de Aguas, sin perjuicio de lo establecido en el artículo 105, punto 4, de dicha ley.

c. Las exacciones establecidas en el artículo 106 de la Ley 29/1985, de 2 de agosto, de Aguas.

\section{Capitulo III \\ NORMAS DE PROCEDIMIENTO ADMINISTRATIVO}

Artículo 27. La Consellería de Ordenación del Territorio e Obras Públicas, a través de la Dirección General de Obras Públicas, es el órgano administrativo que, sin perjuicio de la atribución de funciones que efectúa esta ley, coordina y confiere unidad a la actuación de los diversos órganos administrativos y Entes públicos, en orden a conseguir la máxima eficacia dentro del respeto a los principios a que se somete la Administración hidráulica, de acuerdo con el artículo 3 de esta ley.

Artículo 28. Todas las autorizaciones y concesiones relativas a aprovechamientos de aguas y, en general, al uso y ocupación del dominio público hidráulico se sustanciarán en cada caso en un expediente único, 
en el que se dictará una sola resolución. La incoación y tramitación de estos expedientes hasta su resolución corresponderá a los órganos y Entes integrados en la Administración hidráulica de Galicia, de acuerdo con lo que dispone esta ley.

Artículo 29. 1. Las mancomunidades, los consorcios y otras Entidades semejantes que se constituyan con la finalidad de administrar el aprovechamiento conjunto de aguas $\mathrm{u}$ otros bienes del dominio público hidráulico dentro del territorio de Galicia tendrán la consideración de comunidades de usuarios a los efectos de su intervención por la Administración hidráulica de Galicia.

2. El Ente autónomo Aguas de Galicia podrá ordenar la agrupación de comunidades de vertidos de las diversas personas o Entidades productoras de los mismos, sean éstos de origen urbano o industrial, a fin de facilitar su tratamiento conjunto. La resolución del otorgamiento de las correspondientes autorizaciones podrá contener dicho mandato, así como plazo para su cumplimiento, con apercibimiento, en su caso, de renovación de la autorización o de imposición de las multas coercitivas que correspondan.

3. El otorgamiento de concesiones y la atribución de auxilios económicos por parte de la Administración autónoma para abastecimiento y saneamiento podrán estar condicionados a la constitución de las Entidades a que se refieren los puntos precedentes.

Artículo 30. 1. Los Entes y Organismos públicos titulares de instalaciones de depuración de aguas residuales habrán de garantizar su correcto funcionamiento para conseguir los objetivos de protección de la calidad de las aguas establecidos en las leyes y en la planificación aprobada en la materia.

2. El Ente autónomo Aguas de Galicia podrá hacerse cargo, por razones de interés público y con carácter temporal, de las instalaciones públicas o privadas de depuración de aguas residuales cuando no fuese procedente o posible la paralización de las actividades que producen el vertido y se derivasen graves inconvenientes del mismo. En ese caso, Aguas de Galicia reclamará al titular de las instalaciones, incluso por vía de apremio:

a. Las cantidades necesarias para modificar o acondicionar las instalaciones en los términos previstos en la autorización o que hagan posible su otorgamiento.

b. Los gastos de explotación, mantenimiento y conservación de las instalaciones.

3. La Xunta de Galicia, en el ámbito de sus competencias, podrá ordenar la suspensión de las actividades que den origen a vertidos no autorizados, sin perjuicio de las responsabilidades civil, penal o administrativas en que pudiesen incurrir los causantes de los mismos.

Artículo 31. 1. En circunstancias de sequías extraordinarias, de sobreexplotación grave de los recursos o en semejantes estados de necesidad, urgencia o concurrencia de situaciones anómalas o excepcionales, la Administración hidráulica de Galicia, oída la Junta de Gobierno del Ente autónomo Aguas de Galicia, podrá adoptar para la superación de dichas situaciones las medidas que sean precisas en relación con la utilización del dominio público hidráulico o con la explotación de los aprovechamientos concedidos sobre el mismo.

2. La aprobación de dichas medidas corresponderá al Consello de la Xunta de Galicia.

Artículo 32. 1. La Administración hidráulica de Galicia sancionará las infracciones administrativas al régimen general del dominio hidráulico de competencia de la Comunidad Autónoma, así como las relativas a los vertidos de aguas residuales efectuados de tierra al mar ${ }^{285}$.

285 Art. 32.1 modificado por Ley 2/1998, de 8 de abril, de Medidas Tributarias, de Régimen Presupuestario, función pública, patrimonio, organización y gestión. 
2. La sanción de las infracciones leves y menos graves corresponde al Ente autónomo Aguas de Galicia. Es competencia del Conselleiro de Ordenación del Territorio y Obras Públicas la sanción de las infracciones graves y se reserva al Consello de la Xunta de Galicia la imposición de multas por infracciones muy graves.

3. El Consello de la Xunta de Galicia podrá, mediante Decreto, proceder a la actualización del importe de las sanciones.

4. Cuando la infracción pudiese, a juicio de la Administración, ser constitutiva de delito, el órgano administrativo dará traslado a las autoridades judiciales para la imposición, en su caso, de las sanciones penales que correspondan.

\section{Capitulo IV CANON DE SANEAMIENTO ${ }^{286}$}

Artículo 33. 1. Se crea un canon de saneamiento, con carácter de ingreso de derecho público, aplicable en el ámbito territorial de la Comunidad Autónoma de Galicia.

2. $\mathrm{Su}$ rendimiento se destinará íntegramente a la financiación de gastos de inversión y de explotación de infraestructuras de evacuación "en alta" y de tratamiento de aguas residuales, de acuerdo con la programación aprobada por el Consello de la Xunta de Galicia.

3. El Ente autónomo Aguas de Galicia realizará la gestión de dicho canon y lo aplicará a las finalidades concretas a las que el mismo se destina.

4. El Ente autónomo Aguas de Galicia está obligado a llevar un registro separado de los recursos obtenidos por este concepto, que podrá ser fiscalizado por la Consellería de Economía e Facenda.

Artículo 34. 1. Constituye el hecho imponible de canon de saneamiento la producción de vertidos de aguas y de

286 Véase Decreto 8/1999, de 21 de enero, por el que se aprueba el Reglamento de desarrollo legislativo del capitulo IV de la Ley 8/1993, reguladora de la Administración hidráulica, relativo al canon de saneamiento. productos residuales, realizados directa o indirectamente. En todo caso, se entiende realizado el hecho imponible por el consumo o por la utilización potencial o real del agua de cualquier procedencia.

2. No darán lugar a la aplicación del canon de saneamiento los usos del agua correspondientes a:

a. Suministro en alta a servicios públicos de distribución de agua potable.

b. Alimentación de fuentes públicas o monumentales, bocas de riego y extinción de incendios a cargo de Entidades públicas.

c. La utilización de agua para el uso de riego agrícola.

d. Los usos domésticos en los núcleos de población que no dispongan de alcantarillado, mientras éste no entre en funcionamiento ${ }^{287}$.

3. Se establece una deducción del 50 por 100 de la cuota tributaria del canon de saneamiento para los usos domésticos del agua de las familias numerosas que acrediten formalmente tal condición, de acuerdo con la normativa de aplicación en la materia ${ }^{288}$.

Artículo 35. 1. Estará exento del canon de saneamiento el consumo o utilización de agua para usos domésticos en las aglomeraciones urbanas de menos de 2.000 habitantes, entendidas éstas como aquellas zonas geográficas formadas por uno o varios municipios, o parte de uno o varios de ellos, que por su población o actividad económica constituyan un foco de generación de aguas residuales que justifique la recogida y conducción a una instalación de tratamiento o a un punto de vertido final.

Reglamentariamente se determinará la relación de aglomeraciones urbanas que, con arreglo a lo antes dispuesto, no estarán

287 Art. 34.2.d añadido por Ley 7/1999, de 29 de diciembre, de Presupuestos Generales de la Comunidad Autónoma de Galicia para el año 2000.

288 Art. 34.3 añadido por Ley 7/1999, de 29 de diciembre, de Presupuestos Generales de la Comunidad Autónoma de Galicia para el año 2000.

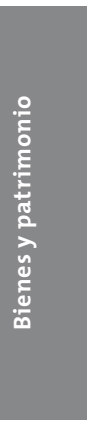


exentas del canon de saneamiento. El límite del número de habitantes podrá ser variado anualmente en la Ley de Presupuestos de la Comunidad Autónoma ${ }^{289}$.

2. Se entiende por habitante la definición de habitante-equivalente contenida en el artículo 2.f) del Real Decreto-ley 11/1995, de 28 de diciembre, por el que se establecen las normas aplicables al tratamiento de las aguas residuales urbanas 290 .

3. $(\ldots)^{291}$

Artículo 36. 1. El canon se devengará en el momento de producirse el vertido o bien en el momento en que se produzca el uso o consumo de agua procedente de Entidades suministradoras o de captaciones propias.

2. A los efectos de lo previsto en esta ley, tienen la condición de Entidades suministradoras de agua las personas físicas o jurídicas de cualquier naturaleza que mediante instalaciones de titularidad pública o privada efectúen un suministro —en baja- de agua potable.

Artículo 37. 1. Son sujetos pasivos en calidad de contribuyentes las personas físicas o jurídicas de cualquier naturaleza y demás Entidades sin personalidad jurídica a las que se refiere el artículo 33 de la Ley General Tributaria que efectúen vertidos o, en su caso, utilicen o consuman agua.

2. Cuando el consumo o la utilización del agua no provenga de captaciones propias del sujeto pasivo y se realice a través de Entidades que efectúen el suministro

289 Art. 35 modificado por Ley 6/1998, de 29 de diciembre, de Presupuestos Generales de la Comunidad Autónoma de Galicia para 1999. Convertido en art. 35.1 por Ley $8 / 2001$, de 2 de agosto, de protección de la calidad de las aguas de las Rías de Galicia y de ordenación del servicio público de depuración de aguas residuales urbanas.

290 Art. 35.2 añadido por Ley 8/2001, de 2 de agosto, de protección de la calidad de las aguas de las Rías de Galicia y de ordenación del servicio público de depuración de aguas residuales urbanas.

291 Art. 35.3 suprimido por Ley 6/1994, de 29 de diciembre, de Presupuetos Generales de la Comunidad Autónoma de Galicia para 1995. —en baja- de agua potable, éstas tendrán la consideración de sujetos pasivos sustitutos del contribuyente.

Artículo 38. 1. Todas las Entidades públicas o privadas suministradoras de agua que desarrollen su actividad en el territorio de Galicia están obligadas a facturar y recaudar de sus abonados el canon de saneamiento. Las cantidades percibidas por este concepto serán ingresadas al Ente autónomo Aguas de Galicia mediante autoliquidación en la forma y plazos que reglamentariamente se establezcan.

2. El canon se liquidará directamente por la Administración a los sujetos pasivos que sean titulares de captaciones propias de aguas superficiales o subterráneas, o que sin serlo y sin recibir agua de una Entidad suministradora efectúen vertidos contaminantes. En este caso, en la forma, plazos y supuestos que reglamentariamente se determinen, podrá establecerse la obligación de realizar declaración-liquidación del canon a cargo del sujeto pasivo.

Artículo 39. 1. La base imponible del canon consiste:

a. En general, en el volumen de agua consumida o utilizada en el período que sea considerado.

b. En los casos en que la Administración, de oficio o a instancia del sujeto pasivo, opte por la determinación por medida directa o por estimación objetiva singular de la carga contaminante, la base consistirá en la contaminación efectivamente producida o estimada expresada en unidades de contaminación.

2. Los parámetros y las unidades de contaminación que se consideran en la determinación de la carga contaminante en el período considerado son los siguientes: Unidades de contaminación. Parámetros:

a. Materias en suspensión (MES)-kg.

b. Sales solubles (SOL)-S/cm.m.

c. Materias oxidables (MO)-kg. 
d. Metales (MT)-kg equimetal.

e. Materias inhibidoras (MI)-Equitox ${ }^{292}$.

3. Reglamentariamente podrán establecerse métodos de estimación singular de la base imponible, que serán de aplicación en los supuestos siguientes:

a. Captaciones superficiales o subteráneas de agua no medida por contador.

b. Cuando la base imponible consista en la carga contaminante del vertido y la misma no fuese objeto de medida directa particularizada 293 .

Artículo 40. 1. El tipo de gravamen se expresará en euros $/ \mathrm{m}^{3}$ o en euros por la unidad de contaminación en función de la base imponible a la que tenga que aplicarse.

Se establecen los siguientes valores del tipo de gravamen del canon:

a. Usos industriales o asimilados:

- Tipo general por volumen: 0,351 euros $/ \mathrm{m}^{3}$.

- Materias en suspensión: 0,205 euros $/ \mathrm{kg}$.

- Sales solubles: 3,296 euros/S/cm m³.

- Materia oxidable: 0,411 euros/kg.

- Metales: 9,261 euros/kg equimetal.

- Materias inhibidoras: 0,043 euros/ equitox.

b. Usos domésticos: 0,209 euros $/ \mathrm{m}^{3294}$.

2. La Ley de Presupuestos Generales podrá modificar para cada ejercicio presupuestario los valores del tipo por unidad de volumen y por cada unidad de contaminación.

3. A los efectos de la aplicación del canon se reputarán como usos domésticos del agua todos aquellos supuestos de utilización

292 Art. 39.2 modificado por Ley 8/2003, de 23 de diciembre, de Presupuestos Generales de la Comunidad Autónoma de Galicia para el año 2004.

293 Art. 39 modificado por Ley 6/1994, de 29 de diciembre, de Presupuetos Generales de la Comunidad Autónoma de Galicia para 1995.

294 Art. 40.1 modificado por Ley 16/2008, de 23 de diciembre, de presupuestos generales de la Comunidad Autónoma de Galicia para el año 2009. del agua que no tengan la consideración de industriales o asimilados, según lo dispuesto en el apartado siguiente.

4. Tendrán la consideración de usos industriales o asimilados del agua los efectuados por los usuarios, cuando el consumo anual de agua sea igual o superior a 3.000 metros cúbicos, o, cuando siendo inferior, origine contaminación de carácter especial en su naturaleza o en su cantidad. A estos efectos, se considerará producida tal contaminación cuando la misma sea superior a la equivalente a una población de 200 habitantes.

5. Se fija como cantidad de contaminación diaria equivalente a un habitante:

a. 90 gramos de materia en suspensión.

b. 57 gramos de materias oxidables.

6. Corresponderá a la Ley de Presupuestos el establecimiento de coeficientes de concentración demográfica que afecten al tipo de gravamen con relación a los usos domésticos del agua. Dichos coeficientes atenderán a la población total y a su grado de dispersión en cada municipio.

7. Coeficiente de vertido al mar:

a. El tipo de gravamen aplicable en los vertidos al mar efectuados mediante instalaciones de saneamiento privadas será el resultado de multiplicar los tipos generales fijados en el punto 1 anterior por los siguientes parámetros y coeficientes:

Parámetro/Coeficiente.

Sales solubles/0.

Materias inhibidoras/1.

Resto de parámetros/Coeficientes de dilución.

b. Los baremos de aplicación del coeficiente de dilución serán los que a continuación se indican:

Valores de dilución inicial/Coeficiente por dilución-(Kd)

11.000 ó más/0,30.

Entre 7.000 y menos de $11.000 / 0,45$.

Entre 4.000 y menos de 7.000/0,60.

Entre 2.000 y menos de $4.000 / 0,70$. 
Entre 1.000 y menos de $2.000 / 0,75$. Entre $100 \mathrm{y}$ menos de $1.000 / 0,80$. Menos de 100/1,00.

La Ley de Presupuestos Generales podrá modificar para cada ejercicio presupuestario los valores de este coeficiente ${ }^{295}$.

8. Coeficiente de piscifactorías:

En los usos industriales del agua procedente de captaciones superficiales del dominio público-hidráulico realizados en piscifactorías, el tipo de gravamen se afecta por el coeficiente siguiente en función de la relación de dimensionamiento.

Siendo la relación de dimensionamiento el valor resultante de multiplicar el volumen anual, cuantificado por alguno de los sistemas referidos en el artículo 39 , expresado en $\mathrm{m}^{3}$, por la superficie de las balsas de cultivo, expresado en $\mathrm{m}^{2}$, y dividido entre la superficie de las balsas de decantación multiplicada por 20.000 , expresado en $\mathrm{m}^{2}$.

En los términos que reglamentariamente se establezcan, cuando la instalación disponga de sistemas de filtración adecuados para el tratamiento del vertido, estos coeficientes se afectarán por un factor de $0,8^{296}$.

Artículo 41. 1. La cuota tributaria será el resultado de multiplicar:

a. En los supuestos a que se refiere el artículo 39.1.a), el volumen de agua consumida en el período considerado, expresado en metros cúbicos, por el tipo de gravamen correspondiente.

b. En los supuestos a que se refiere el artículo 39.1.b), aquellas unidades de contaminación producidas en el período considerado, correspondientes a cada uno de los parámetros definidos en el artículo 39.2, por el tipo de gravamen

295 Art. 40 modificado por Ley 6/1994, de 29 de diciembre, de Presupuetos Generales de la Comunidad Autónoma de Galicia para 1995.

296 Art. 40.8 modificado por Ley $16 / 2008$, de 23 de diciembre, de presupuestos generales de la Comunidad Autónoma de Galicia para el año 2009. correspondiente a cada una de las mismas, modulado, en el caso de vertido al mar, por el coeficiente referido en el artículo 40.7.

2. En los usos industriales y asimilados, la cuota del canon, cuando sea calculada por el procedimiento de medida directa de la contaminación, podrá modificarse en razón de las aportaciones o detracciones de agua que efectúe el contribuyente a lo largo del proceso. Dicha modificación, cuando proceda, se operará mediante la aplicación de un coeficiente corrector de volumen igual a la relación existente entre el caudal de agua vertida y el caudal suministrado o utilizado ${ }^{297}$.

Artículo 42. 1. La gestión, liquidación y recaudación del canon de saneamiento se efectuarán con arreglo a lo dispuesto en esta ley y en su reglamento de desarrollo. Supletoriamente, rige la legislación general tributaria.

2. Las infracciones tributarias del canon de saneamiento regulado en la presente ley serán calificadas y sancionadas de conformidad con lo dispuesto en la Ley General Tributaria.

3. Los efectos de gestión, liquidación y recaudación dictados por el Ente autónomo Aguas de Galicia en relación con el canon de saneamiento serán reclamables ante los órganos económico-administrativos de la Comunidad Autónoma 298.

\section{DISPOSICIÓN ADICIONAL PRIMERA ${ }^{299}$}

Se crea la Empresa pública de Obras y Servicios Hidráulicos, como Entidad de derecho público de la Xunta de Galicia, cuyo objeto es la gestión de aquellas obras

297 Art. 41 modificado por Ley 6/1994, de 29 de diciembre, de Presupuetos Generales de la Comunidad Autónoma de Galicia para 1995.

298 Art. 42 era originariamente art. 41, convertido en art. 42 por Ley 6/1994, de 29 de diciembre, de Presupuetos Generales de la Comunidad Autónoma de Galicia para 1995.

299 Véase Decreto 125/1996, de 7 de marzo, por el que se aprueban los estatutos de la empresa pública de obras y servicios hidráulicos. 
y la prestación de aquellos servicios que por su cuantía o entidad le sean encomendadas, dentro del programa de actuaciones del Ente autónomo Aguas de Galicia. Dicha Entidad tiene personalidad jurídica propia y plena capacidad y autonomía para el cumplimiento de sus fines. Su actividad se adecuará al ordenamiento jurídico privado, sin perjuicio de las relaciones que resulten de su adscripción administrativa.

2. El Consello de la Xunta de Galicia aprobará el estatuto de dicha empresa y determinará el momento del comienzo de su actividad.

3. El órgano colegiado superior de la empresa es su Consejo de Administración. El Presidente del Consejo de Administración, que a su vez ejercerá la presidencia de la empresa, será nombrado de entre sus miembros por el Consello de la Xunta de Galicia a propuesta del Conselleiro de Política Territorial, Obras Públicas y Vivienda. El Presidente tiene la representación legal de la empresa y ejerce sus funciones directivas y ejecutivas superiores.

Formarán parte del Consejo de Administración:

a. El Director general de Obras Públicas de la Consellería de Política Territorial, Obras Públicas e Vivenda.

b. Tres Vocales designados por la Consellería de Política Territorial, Obras Públicas e Vivenda.

c. Un Vocal designado por la Consellería de Economía e Facenda.

d. Hasta dos Vocales más en representación de otros Departamentos de la Administración Autonómica.

Pertenecer al Consejo de Administración no generará derechos laborales 300 .

4. El personal de la Empresa Pública de Obras y Servicios Hidráulicos podrá ser contratado en régimen de derecho laboral o ser funcionario, o asimilado, al

300 Disposición adicional 1.3 modificado por Ley $7 / 2002$, de 27 de diciembre, de medidas fiscales y de régimen administrativo. servicio de la Administración de la Comunidad Autónoma de Galicia, adscrito a la empresa ${ }^{301}$.

\section{DISPOSICIÓN ADICIONAL SEGUNDA}

1. La aprobación de los proyectos de obras hidráulicas que lleve a cabo la Administración hidráulica de Galicia llevará implícita la declaración de utilidad pública y la necesidad de ocupación de los bienes y derechos afectados a los efectos de su expropiación forzosa, de la ocupación temporal y de la imposición o modificación de servidumbres. La declaración de utilidad pública y necesidad de ocupación se refieren también a los bienes y derechos afectados por el replanteo del proyecto y por las modificaciones de obras que puedan aprobarse con posterioridad.

2. Los proyectos correspondientes a obras hidráulica que no agoten su funcionalidad en el término municipal donde se ubiquen no estarán sujetos a licencia municipal ni a cualquier acto de control preventivo municipal a los que se refiere el artículo 84.1.b) de la Ley 7/1985, de 2 de abril, reguladora de las bases del régimen local, y el artículo 286.1.b) de la Ley 5/1997, de 22 de julio, de la Administración local de Galicia. La ejecución de estas obras, siempre que se lleve a cabo de acuerdo con los proyectos aprobados y se haya previamente informado a las administraciones locales correspondientes, no podrá ser suspendida por los órganos urbanísticos competentes 302 .

\section{DISPOSICIÓN TRANSITORIA PRIMERA}

1. El personal funcinario actualmente adscrito a los servicios hidráulicos dependientes de la Consellería de Ordenación

301 Disposición adicional 1.4 añadido por Ley 7/2002, de 27 de diciembre, de medidas fiscales y de régimen administrativo.

302 Disposición adicional 2 añadida por Ley 8/2001, de 2 de agosto, de protección de la calidad de las aguas de las Rias de Galicia y de ordenación del servicio público de depuración de aguas residuales urbanas. 
del Territorio e Obras Públicas podrá integrarse en la plantilla del Ente público Aguas de Galicia sin alteración en su situación administrativa.

Esta integración se ajustará, en todo caso, a las necesidades de personal del Ente público, según la relación de puestos de trabajo que se apruebe.

El personal de esta clase que no se integre en Aguas de Galicia tendrá opción a prestar sus servicios en otros órganos de la Administración autonómica.

2. El personal laboral que actualmente preste sus servicios en la Administración hidráulica quedará integrado en Aguas de Galicia, conservando los derechos laborales de todo tipo que tenga reconocidos; la integración se ajustará a la estructura de la plantilla que en su momento se apruebe.

3. El personal interino y el contratado administrativo que a la entrada en vigor de esta ley prestase sus servicios en la Administración hidráulica de la Consellería de Ordenación del Territorio y Obras Públicas podrá, asimismo, ser integrado en Aguas de Galicia en la forma prevista en el punto 1 anterior. En todo caso, dicho personal podrá acceder a la condición de funcionario de carrera en los términos establecidos por la Ley de la Función Pública de Galicia, en las mismas condiciones que el que no ejercitase la opción de integración.

El personal de esta clase que no se integre continuará prestando sus servicios en la Consellería de Ordenación del Territorio y Obras Públicas.

4. La integración en la plantilla del Ente público Aguas de Galicia se entenderá sin menoscabo de los derechos adquiridos con anterioridad por el personal que la ejercite.

\section{DISPOSICIÓN TRANSITORIA SEGUNDA}

En tanto no sean aprobadas las disposiciones reglamentarias relativas a la composición de los órganos colegiados del
Ente autónomo Aguas de Galicia ni constituidos efectivamente dichos órganos, los actos de la Administración hidráulica de Galicia que, según la presente ley, requieren la intervención de los mismos podrán adoptarse por el órgano competente en cada caso, debiendo contarse con la autorización del Conselleiro de Ordenación del Territorio y Obras Públicas cuando la resolución corresponda a un órgano dependiente o adscrito a la citada consellería. En ningún caso la constitución de tales órganos debe ser superior al año desde la entrada en vigor de esta ley.

\section{DISPOSICIÓN TRANSITORIA TERCERA}

Hasta que no sean aprobados los instrumentos de planificación hidrológica de las cuencas hidrográficas comprendidas íntegramente en el territorio de Galicia, las concesiones de aprovechamiento de bienes de dominio público hidráulico se otorgarán por el órgano competente previa valoración de la solicitud, considerando los recursos disponibles en el área afectada por la misma y su adecuación a las necesidades efectivas del peticionario, de acuerdo con el orden de preferencias que establecen los artículos 58. 3, y 58. 4, de la Ley Estatal de Aguas.

\section{DISPOSICIÓN TRANSITORIA CUARTA}

La exención establecida en la letra d) del punto 2 del artículo 34 de la presente ley y la deducción del punto 3 del mismo artículo sólo producirán efecto a partir de la entrada en vigor de la norma reglamentaria donde se establezcan los requisitos y procedimientos para su aplicación ${ }^{303}$.

\section{DISPOSICIÓN FINAL PRIMERA}

El Organismo Autónomo Aguas de Galicia someterá su régimen económico, financiero y presupuesto a la Ley 11/1992,

303 Disposición transitoria 4 añadida por Ley $7 / 1999$, de 29 de diciembre, de Presupuestos Generales de la Comunidad Autónoma de Galicia para el año 2000. 
de 7 de octubre, de Régimen Financiero y Presupuestario de Galicia, a las leyes de presupuestos de la Comunidad Autónoma y a las demás normativas aplicable.

Aguas de Galicia gozará del mismo tratamiento fiscal que la Comunidad Autónoma, por ser Administración institucional de la misma.

\section{DISPOSICIÓN FINAL SEGUNDA}

Se autoriza al Consello de la Xunta de Galicia para que dicte las disposiciones reglamentarias que sean precisas para el cumplimiento de esta ley.

\section{DISPOSICIÓN FINAL TERCERA}

A través de la Ley de Presupuestos de la Comunidad Autónoma podrán establecerse las modificaciones oportunas en cuanto a la regulación legal del canon de saneamiento establecido en la presente ley.

\section{LEY 3/1999, DE 11 DE MARZO, DE CREACIÓN DEL INSTITUTO ENERXÉTICO DE GALICIA (DOGA N. $\left.{ }^{\circ} 61,30.3 .1999\right)$}

$(\ldots)^{304}$

\section{Capítulo I \\ DISPOSICIONES GENERALES: NATURALEZA, FINES Y FUNCIONES}

Artículo 1. Creación del Instituto Enerxético de Galicia.

1. En el ámbito de la Comunidad Autónoma de Galicia y al amparo de su Estatuto de Autonomía, se crea el Instituto Enerxético de Galicia, como Ente de Derecho Público, con personalidad jurídica y patrimonio propio para el cumplimiento de sus fines.

2. El Instituto Enerxético de Galicia se regirá por la presente ley, por la Ley 11/1992, de 7 de octubre, de Régimen Financiero y Presupuestario de Galicia, y por las demás normas de aplicación.

El Instituto Enerxético de Galicia ajustará su actividad al ordenamiento jurídico privado,

304 Exposición de motivos omitida. salvo cuando ejerza potestades administrativas. En este supuesto estará sometido a la Ley 30/1992, de 26 de noviembre, de Régimen Jurídico de las Administraciones Públicas y del Procedimiento Administrativo Común, y a las demás normas administrativas de general aplicación.

En sus actividades de contratación se aplicará la Ley 13/1995, de 18 de mayo, de Contratos de las Administraciones Públicas, de acuerdo con lo dispuesto en el artículo 1.3 de la misma.

3. El Instituto Enerxético de Galicia se adscribe a la Consellería competente en materia de energía.

Artículo 2. Fines del Instituto.

El Instituto Enerxético de Galicia tiene por finalidad el fomento, impulso y realización de iniciativas y programas de actuación para la investigación, el estudio y apoyo de las actuaciones de conocimiento, desarrollo y aplicación de las tecnologías energéticas, incluidas las renovables, la mejora del ahorro y la eficiencia energética, el fomento del uso racional de la energía y, en general, la óptima gestión de los recursos energéticos en los distintos sectores económicos de Galicia, así como la participación en la gestión y prestación, en su caso, de servicios en otros campos sinérgicos al energético, de acuerdo con las directrices del Gobierno en el ámbito de sus competencias.

Artículo 3. Autonomía funcional.

1. El Instituto estará sujeto, en sus actividades, a los programas y directrices generales de la Xunta de Galicia.

2. Sin perjuicio de lo anterior, el Instituto tendrá autonomía funcional para realizar estudios, dictámenes, peritajes $\mathrm{y}$ actividades formativas y comerciales, dentro de su finalidad básica, para la Administración Pública, las empresas y los particulares.

Artículo 4. Funciones.

Las funciones generales del Instituto serán las siguientes: 
a. Elaborar y proponer a la consellería competente en materia de energía planes y programas en materia energética.

b. Promover y, en su caso, ejecutar los planes y programas indicados, aprobados por la consellería competente en materia de energía.

c. Controlar, vigilar e inspeccionar las instalaciones de producción, conducción, distribución, suministro y consumo de energía, teniendo como objetivo prioritario la seguridad de las instalaciones.

d. Proponer la elaboración de disposiciones para el establecimiento, desarrollo y gestión de la política energética.

e. Fomentar y desarrollar programas de asesoramiento y auditoría energéticos para impulsar actuaciones de ahorro y mejora de la eficacia energética, elaborar programas de racionalización del uso de la energía y promover el aprovechamiento de los recursos energéticos.

f. Fomentar y participar en programas y proyectos de investigación y desarrollo de tecnologías energéticas, bienes de equipo y servicios relacionados con la energía.

g. Fomentar y participar en la evaluación e implantación de sistemas de producción de energía basados en recursos endógenos, con especial promoción de los que utilicen energías renovables y de cogeneración.

h. Elaborar estudios y realizar y emitir informes y recomendaciones en materia energética para entes públicos o privados.

i. Organizar programas de formación y reciclaje profesional, en colaboración con centros de formación de ámbito universitario y profesional.

j. Orientar a los usuarios en los hábitos de consumo energético mediante campañas y actuaciones específicas.

k. Fomentar la participación de las empresas e instituciones gallegas en los programas energéticos estatales e internacionales, principalmente los emprendidos por la Unión Europea, así como emitir informe y asesorar sobre las directrices y programas comunitarios dirigidos al ámbito energético.

1. Podrá ostentar la representación de la Comunidad Autónoma en los organismos previstos por la Ley 54/1997, de 27 de noviembre, del Sector Eléctrico, así como por cualquier otra ley en materia energética.

m. Ejercer cualquier otra función técnica, material o jurídica que, en relación con las materias de su competencia, se le encomiende o competa al Instituto en el marco de la presente ley.

Artículo 5. Actuaciones del Instituto. Para el adecuado ejercicio de sus funciones, el Instituto Enerxético de Galicia podrá, de acuerdo con la legislación autonómica aplicable:

a. Establecer convenios y contratos con instituciones públicas o privadas interesadas en el ámbito de sus funciones.

b. Colaborar con otras Administraciones para favorecer la adopción de medidas de ahorro y de racionalización en la producción, distribución y suministro de energía.

c. Constituir y/o participar en sociedades, cualquiera que sea su forma, cuyo objeto se relacione con los fines del Instituto, previo informe de la Consellería de Economía e Facenda.

d. Promover el establecimiento de líneas de financiación para la realización de proyectos energéticos por cuenta propia o en colaboración con otras instituciones públicas o privadas.

\section{Capitulo II \\ ÓRGANOS DEL INSTITUTO ENERXÉTICO DE GALICIA}

Artículo 6. Órganos de gobierno. Los órganos de gobierno del Instituto serán el Consejo de Administración y el Director. Asimismo, el Instituto contará con la orientación y la asistencia de un Consejo Asesor.

Artículo 7. El Consejo de Administración.

1. El Consejo de Administración es el órgano colegiado de gobierno y ostenta 
las más amplias facultades de dirección, actuación y gestión del mismo.

2. El Consejo de Administración estará constituido por:

a. El Presidente, que será el conselleiro competente en materia de energía.

b. El Vicepresidente, que será el Director general competente en materia de energía.

c. Un mínimo de seis Vocales y un máximo de ocho, de los cuales:

Uno será el Director del Instituto.

Dos Vocales representarán a la consellería competente en materia de energía y serán designadas por la misma.

Un Vocal representará a la consellería competente en materia de economía y hacienda y será propuesto por la misma.

Un Vocal representará a la consellería competente en materia de ordenación territorial y será propuesto por la misma.

Un Vocal representará a la consellería competente en materia de ambiente y será propuesto por la misma.

Un Vocal representará a las Corporaciones

Locales y será propuesto por la Fegamp.

d. Los Vocales del Consejo de Administración serán nombrados y separados por la consellería competente en materia de energía.

El Consejo de Administración, a propuesta del Director del Instituto, nombrará a un Secretario, que actuará con voz pero sin voto, quien será igualmente Secretario del Consejo Asesor.

3. Corresponde al Consejo de Administración ejercer, sin más limitaciones que las establecidas por las leyes, todas las facultades y funciones que sean precisas para lograr los fines del Instituto y, en especial:

a. Fijar las directrices de actuación del Instituto, dentro de las líneas marcadas por la Xunta de Galicia.

b. Decidir sobre todas las cuestiones relacionadas con la organización, el funcionamiento y las operaciones que tiene que realizar el Instituto.

c. Aprobar el anteproyecto de presupuesto, que será remitido a la consellería competente en materia de economía y hacienda, a través de la Consellería competente en materia de energía, para ser incluido en el proyecto de presupuesto general de la Comunidad Autónoma.

d. Aprobar la memoria anual, el balance y la cuenta de pérdidas y ganancias, que serán remitidos al Consello de Contas.

e. Aprobar el programa de actividades, así como su evaluación periódica y sus resultados.

f. Aprobar los convenios de colaboración y los contratos que se celebren para la consecución de sus fines.

g. Cualesquiera otras funciones que, por su importancia o trascendencia, le someta el Presidente, así como todas aquéllas que sean necesarias para lograr los fines del Instituto y no estén expresamente atribuidas a otro órgano del mismo.

h. Fijar los precios y tarifas que el Instituto haya de percibir por la prestación de sus servicios.

i. Decidir la constitución de sociedades filiales o la participación en sociedades cualquiera que sea su forma jurídica.

4. El Consejo de Administración se reunirá, en sesión ordinaria, como mínimo, una vez al trimestre.

Artículo 8. El Director del Instituto.

1. El Director del Instituto será nombrado por el Consello de la Xunta, a propuesta del conselleiro competente en la materia.

2. Correspondiente al Director dirigir la actividad del Instituto bajo las directrices del Consejo de Administración y, en concreto:

a. Representar al Instituto en cualquier acto y contrato en juicio y fuera del mismo.

b. Ejecutar los acuerdos del Consejo de Administración.

c. Dirigir, coordinar, gestionar y controlar todas las dependencias, instalaciones y servicios.

d. Ejercer la dirección de todo el personal.

e. Elaborar y presentar anualmente al Consejo de Administración, para su aprobación, el anteproyecto de presupuestos, 
el programa de actividades a que se refiere el artículo 11, la memoria, el balance y la cuenta de pérdidas y ganancias del Instituto.

f. Realizar las funciones específicas que el Consejo de Administración le delegue.

g. Autorizar los gastos y ordenar los pagos.

Artículo 9. El Consejo Asesor.

1. El Consejo Asesor es un órgano de carácter consultivo y de asesoramiento, en el cual participarán o estarán representadas instituciones o sociedades del ámbito energético gallego, públicas o privadas, a fin de coordinar los esfuerzos conducentes a la consecución de los objetivos básicos del Instituto.

2. El Presidente del Consejo de Administración será el Presidente del Consejo Asesor.

3. Su composición y funcionamiento se determinará reglamentariamente.

\section{Capitulo III \\ RECURSOS, RÉGIMEN ECONÓMICO, PERSONAL Y CONTROL}

Artículo 10. Recursos del Instituto. Los recursos del Instituto Enerxético de Galicia estarán constituidos por:

a. Las consignaciones presupuestarias que le sean asignadas en los presupuestos generales de la Comunidad Autónoma de Galicia.

b. Los ingresos procedentes de la recaudación de tasas y precios que obtenga por la prestación de sus servicios en el ejercicio de sus funciones.

c. Los productos y las rentas de su patrimonio.

d. Los ingresos y beneficios de todo tipo derivados de la participación en las sociedades a que se refiere el apartado c) del artículo 5 de la presente ley.

e. Las subvenciones y aportaciones que, en su caso, concedan a su favor entidades e instituciones públicas o privadas, así como de particulares. f. Los créditos, préstamos y demás operaciones financieras que pueda concertar, de acuerdo con lo previsto en las leyes anuales de presupuestos de la Comunidad Autónoma.

g. Cualquier otra aportación o recurso que pudiese generarse o le sea atribuido.

Artículo 11. Programa de actividades. El Instituto elaborará anualmente un programa de actividades en el que figuren los objetivos anuales, las acciones económicas $\mathrm{y}$ de promoción, las inversiones previstas y su evaluación económica.

Anualmente se remitirá al Parlamento un informe detallado del programa de actividades del Instituto.

Artículo 12. Régimen financiero y presupuestario.

El régimen financiero contable y presupuestario, así como el control de la actividad económica y financiera del Instituto, se regirán por lo dispuesto en la Ley 11/1992, de 7 de octubre, de Régimen Financiero y Presupuestario de Galicia.

Artículo 13. Personal del Instituto.

1. El personal del Instituto podrá ser:

a. Contratado en régimen de derecho laboral, respetando los principios de publicidad, igualdad, mérito y capacidad.

b. Funcionario al servicio de la Administración de la Xunta de Galicia, adscrito a esta entidad.

2. Bajo la dirección del Consejo de Administración y a propuesta del Director del Instituto, se definirá su estructura y se dotará del personal suficiente.

3. Pertenecer al Consejo de Administración o al Consejo Asesor no generará en caso alguno derechos laborales.

\section{DISPOSICIÓN ADICIONAL ÚNICA}

El Parlamento de Galicia deberá autorizar, mediante ley, la transformación, modificación, liquidación o extinción del Instituto Enerxético de Galicia. La Comunidad Autónoma se hará cargo, en 
estos casos, del conjunto de derechos y obligaciones derivados del proceso.

\section{DISPOSICIÓN TRANSITORIA ÚNICA}

Se autoriza al Consello de la Xunta de Galicia, a propuesta de la Consellería de Economía e Facenda, para aprobar los presupuestos de explotación y capital previstos en el artículo 83 de la Ley 11/1992, de 7 de octubre, de Régimen Financiero y Presupuestario de Galicia.

\section{DISPOSICIÓN FINAL PRIMERA}

El Consello de la Xunta de Galicia adoptará cuantas disposiciones sean necesarias para la aplicación y desarrollo de la presente ley dentro de los seis meses siguientes a la entrada en vigor de la misma ${ }^{305}$.

\section{DISPOSICIÓN FINAL SEGUNDA}

Se asignan al Instituto Enerxético de Galicia las funciones que venía desarrollando la Consellería de Industria y Comercio con respecto a las siguientes sociedades: "Gas Galicia"; "SDG, Sociedad Anónima"; "Galioil, Sociedad Anónima"; "Gestión Energética de Galicia, Sociedad Anónima"; "Parque Eólico de Malpica, Sociedad Anónima", y "Energía de Galicia, Sociedad Anónima”.

\section{LEY 8/1995, DE 30 DE OCTUBRE, DEL PATRIMONIO CULTURAL DE GALICIA (DOGA N $\left.{ }^{\circ} .214,8.11 .1995\right)$}

\section{$(\ldots)^{306}$ \\ Título preliminar DISPOSICIONES GENERALES}

\section{Artículo 1. Objeto.}

1. El patrimonio cultural de Galicia está constituido por todos los bienes materiales e inmateriales que, por su reconocido

305 Véase Decreto 280/1999, de 4 de noviembre, por el que se aprueba el Reglamento de organización y funcionamiento del Instituto Enerxético de Galicia. 306 Exposición de motivos omitida. valor propio, hayan de ser considerados como de interés relevante para la permanencia e identidad de la cultura gallega a través del tiempo.

2. La presente ley tiene por objeto la protección, conservación, acrecentamiento, difusión y fomento del patrimonio cultural de Galicia, así como su investigación y transmisión a generaciones futuras.

3. Integran el patrimonio cultural de Galicia los bienes muebles, inmuebles e inmateriales de interés artístico, histórico, arquitectónico, paleontológico, arqueológico, etnográfico, científico y técnico. También forman parte del mismo el patrimonio documental y bibliográfico, los conjuntos urbanos, los lugares etnográficos, los yacimientos y zonas arqueológicas, así como los sitios naturales, jardines y parques que tengan valor artístico, histórico o antropológico.

4. La Administración autonómica procurará el retorno a Galicia de aquellos bienes especialmente representativos de nuestro patrimonio cultural que se encuentren fuera de ella.

Artículo 2. Competencia.

1. Corresponde a la Comunidad Autónoma la competencia exclusiva sobre el patrimonio cultural de interés de Galicia.

2. Las distintas administraciones públicas colaborarán para que las competencias respectivas se ejerzan con arreglo a lo establecido en esta ley.

3. Las instituciones públicas y privadas cooperarán a la mejor consecución de los fines previstos en esta ley.

Artículo 3. De los particulares.

1. Las personas que observasen peligro de destrucción o deterioro de un bien integrante del patrimonio cultural de Galicia habrán, en el menor tiempo posible, de ponerlo en conocimiento de la Administración competente, que comprobará el objeto de la denuncia y actuará con arreglo a lo dispuesto en esta ley. 
2. Cualquier persona física o jurídica está legitimada para actuar en defensa del patrimonio cultural de Galicia ante las Administraciones Públicas de la Comunidad Autónoma y los Tribunales de Justicia, en cumplimiento de lo previsto en esta ley.

Artículo 4. Colaboración de las corporaciones locales.

1. Los Ayuntamientos tienen la obligación de proteger, defender, realzar y dar a conocer el valor cultural de los bienes integrantes del patrimonio cultural de Galicia que se ubiquen en su término municipal.

2. Les corresponde, asimismo, adoptar, en caso de urgencia, las medidas cautelares necesarias para salvaguardar los bienes del patrimonio cultural de Galicia que viesen su interés amenazado.

Artículo 5. Colaboración de la Iglesia católica.

1. La Iglesia católica, propietaria de una buena parte del patrimonio cultural de Galicia, velará por la protección, conservación, acrecentamiento y difusión del mismo, colaborando a tal fin con la Administración en materia de patrimonio.

2. Una Comisión Mixta entre la Xunta de Galicia y la Iglesia católica establecerá el marco de colaboración y coordinación entre ambas instituciones para elaborar y desarrollar planes de intervención conjunta.

Artículo 6. Proyección exterior.

La difusión exterior del patrimonio cultural de Galicia será impulsada por la Xunta de Galicia, que fomentará los intercambios culturales que estime oportunos y promoverá, en el ámbito de sus competencias, la celebración de convenios o acuerdos con las demás Comunidades Autónomas, así como con los estados en que se encuentren bienes integrantes del patrimonio cultural de Galicia.

Artículo 7. Órganos asesores y consultivos.

1. Son órganos asesores de la Consellería de Cultura en materia de patrimonio cultural: a. La Comisión Superior de Valoración de Bienes Culturales de Interés para Galicia.

b. La Comisión Mixta Junta-Iglesia.

c. La Comisión del Patrimonio Histórico de la Ciudad y Camino de Santiago.

d. Las comisiones territoriales del $\mathrm{Pa}$ trimonio Histórico Gallego.

e. La Comisión Técnica de Arqueología.

f. La Comisión Técnica de Etnografía ${ }^{307}$.

g. La Comisión Técnica de Archivos.

h. La Comisión Técnica de Museos.

i. Cuantos otros se considere necesario establecer con carácter general o con carácter específico.

2. Reglamentariamente se establecerá la composición y funcionamiento de los órganos asesores de la Consellería de Cultura ${ }^{308}$.

3. Tendrán la consideración de órganos consultivos de la Consellería de Cultura en materia de bienes culturales:

a. El Consello da Cultura Galega.

b. Las reales academias.

c. Las Universidades de Galicia.

d. El Instituto de Estudios Gallegos Padre Sarmiento.

e. Cuantos otros se considere necesario establecer con carácter general o con carácter específico.

\section{TÍTULO I \\ DE LOS BIENES DECLARADOS, CATALOGADOS Y DEL INVENTARIO GENERAL}

\section{Capitulo I \\ DE LOS BIENES DE INTERÉS CULTURAL}

Artículo 8. Definición y clasificación.

1. Los bienes muebles, inmuebles e inmateriales más destacados del patrimonio cultural de Galicia serán declarados bienes de interés cultural mediante Decreto de la Xunta de Galicia, a propuesta de la

307 Decreto 60/2008, de 13 de marzo, por el que se regula la composición y funcionamiento de la Comisión Técnica de Etnografia.

308 Véase Decreto 39/2007, de 8 de marzo, por el que se regula la composición y funcionamiento de las comisiones territoriales del patrimonio histórico gallego. 
Consellería de Cultura, y se inscribirán en el Registro de Bienes de Interés Cultural de Galicia.

2. Los bienes muebles declarados de interés cultural podrán serlo de forma individual o bien como colección, entendida ésta como el conjunto de bienes agrupados de forma miscelánea o monográfica, previo proceso intencional de provisión o acumulación.

3. Los bienes inmuebles serán declarados de interés cultural atendiendo a las siguientes clases: Monumento, conjunto histórico, jardín histórico, sitio o territorio histórico, zona arqueológica, lugar de interés etnográfico y zona paleontológica.

4. A los efectos de la presente ley, tienen la consideración de:

a. Monumento, la construcción u obra producto de la actividad humana, de relevante interés histórico, arquitectónico, arqueológico, artístico, etnográfico, científico o técnico, con inclusión de los muebles, instalaciones y accesorios que expresamente se señalen como parte integrante del mismo, y que por sí sola constituya una unidad singular.

b. Conjunto histórico, la agrupación de bienes inmuebles que forman una unidad de asentamiento, continua o dispersa, condicionada por una estructura física representativa de la evolución de una comunidad humana, por ser testimonio de su cultura o constituir un valor de uso y disfrute para la colectividad, aunque individualmente no tengan una especial relevancia.

c. Jardín histórico, el espacio delimitado, producto de la ordenación por el hombre de elementos naturales, a veces complementado con estructuras de fábrica, y estimado de interés en función de su origen o pasado histórico o de sus valores estéticos, sensoriales o botánicos.

d. Sitio o territorio histórico, el lugar o paraje natural vinculado a acontecimientos o recuerdos del pasado, creaciones culturales o de la naturaleza, y a obras del hombre que posean valores históricos o técnicos ${ }^{309}$.

e. Zona arqueológica, el lugar o paraje natural en donde existen bienes muebles o inmuebles susceptibles de ser estudiados con metodología arqueológica, tanto si se encontrasen en la superficie como en el subsuelo o bajo las aguas territoriales.

f. Lugar de interés etnográfico, aquel paraje natural, conjunto de construcciones o instalaciones vinculadas a formas de vida, cultura y actividades tradicionales del pueblo gallego.

g. Zona paleontológica, el lugar en que hay vestigios fosilizados o no que constituyan una unidad coherente y con entidad propia.

5. En todos los supuestos anteriormente citados, la declaración de bien de interés cultural afectará tanto al suelo como al subsuelo.

6. De forma excepcional podrá declararse bien de interés cultural la obra de autores vivos, siempre y cuando tres de las instituciones consultivas reconocidas por la Consellería de Cultura emitan informe favorable y medie autorización expresa de su propietario.

Artículo 9. Procedimiento de declaración.

1. La declaración de bien de interés cultural requerirá la previa incoación y tramitación del expediente administrativo por la Consellería de Cultura. La iniciación del expediente podrá realizarse de oficio o bien a instancia de parte por cualquier persona física o jurídica.

2. En caso de iniciarse a instancia de parte, la denegación de la incoación será motivada y habrá de notificarse a los solicitantes.

3. En el expediente que se instruya habrá de constar informe favorable de dos de los órganos consultivos a que se refiere

309 Véase Ley $3 / 1996$, de 10 de mayo, de protección de los Caminos de Santiago. 
el artículo 7 de la presente ley, y se dará audiencia a los interesados.

Artículo 10. Notificación, publicación y efectos de la incoación.

1. La incoación será notificada tanto a los interesados como al Ayuntamiento en que se ubique el bien.

2. Sin perjuicio de su eficacia desde la notificación, la resolución de la incoación será publicada en el "Diario Oficial de Galicia" y en el "Boletín Oficial del Estado". En caso de tratarse de bienes inmuebles se dará audiencia al Ayuntamiento correspondiente y se abrirá un período de información pública por un plazo mínimo de un mes.

3. La incoación de un expediente para la declaración de un bien de interés cultural determinará, respecto al bien afectado, la aplicación inmediata y provisional del régimen de protección previsto en la presente ley para los bienes ya declarados. En caso de bienes inmuebles, además, será de aplicación lo estipulado en el artículo 35.1 de la presente ley.

Artículo 11. Contenido del expediente de declaración.

1. En el expediente de declaración de un bien de interés cultural obrarán las siguientes especificaciones respecto al mismo:

a. Descripción clara y exhaustiva del objeto de la declaración que facilite su correcta identificación $y$, en caso de inmuebles, las partes integrantes, pertenencias, accesorios y bienes muebles y documentales que, por su vinculación con el inmueble, hayan de ser objeto de incorporación en la declaración.

b. En caso de inmuebles, además, habrán de figurar perfectamente definidas sus relaciones con el área territorial a que pertenece, así como la protección de los accidentes geográficos y elementos naturales que conformen su entorno, que aparecerá delimitado también gráficamente, en atención a su adecuada protección, contemplación y estudio.
2. Igualmente habrá de figurar en el expediente la determinación de la compatibilidad del uso con la correcta conservación del bien que se pretende declarar. En caso de que el uso a que viene destinándose el referido bien fuese incompatible con la adecuada conservación del mismo, podrá establecerse su cese o modificación.

3. Asimismo, información exhaustiva sobre el estado de conservación del bien, pudiendo incluirse en la declaración los criterios básicos que regirán las futuras intervenciones.

Artículo 12. Declaración y conclusión.

1. Corresponde al Consello de la Xunta de Galicia, a propuesta del Conselleiro de Cultura, acordar la declaración de bien de interés cultural.

2. El acuerdo de declaración describirá clara y exhaustivamente el bien objeto de la declaración. En caso de los inmuebles describirá su delimitación gráfica, el entorno afectado, las partes integrantes, pertenencias, accesorios y bienes muebles y documentales que por su vinculación hayan de ser objeto de incorporación en la declaración.

3. El expediente habrá de resolverse en el plazo máximo de veinte meses, a contar a partir de la fecha en que fue incoado. Transcurrido éste, se producirá la caducidad del expediente si se solicitase el archivo de las actuaciones o si dentro de los sesenta días siguientes no se dicta resolución. El expediente no podrá volver a iniciarse en los tres años siguientes, salvo que tres de las instituciones consultivas reconocidas por la Comunidad Autónoma lo solicitasen o lo haga el propietario del bien.

Artículo 13. Notificación y publicación de la declaración.

La declaración de bien de interés cultural será notificada tanto a los interesados como al Ayuntamiento en que radique el bien, y será publicada en el "Diario Oficial de Galicia" y en el "Boletín Oficial del Estado". 
Artículo 14. Registro de Bienes de Interés Cultural de Galicia.

1. Los bienes de interés cultural serán inscritos en el Registro de Bienes de Interés Cultural de Galicia. A cada bien se le dará un código para su identificación. En este registro también se anotará preventivamente la incoación de los expedientes de declaración. Corresponde a la Consellería de Cultura la gestión de este registro.

2. El Registro de Bienes de Interés Cultural de Galicia tendrá por objeto la anotación e inscripción de los actos que afecten a su identificación y localización, y reflejará todos los actos que se realicen sobre los bienes inscritos en el mismo cuando afecten al contenido de la declaración y dará fe de los datos en él consignados.

3. Cualquier inscripción relativa a un bien, efectuada de oficio, será notificada a su titular, y será obligación de éste la de comunicar al registro todos los actos jurídicos y técnicos que puedan afectar a dicho bien.

4. El acceso al registro será público en los términos que se establezcan reglamentariamente, siendo precisa la autorización expresa del titular del bien para la consulta pública de los datos relativos a:

a. La situación jurídica y valor de los bienes inscritos.

b. Su localización, en caso de bienes muebles.

5. De las inscripciones y anotaciones en el Registro de Bienes de Interés Cultural se dará cuenta al Registro General de Bienes de Interés Cultural del Estado, a fin de que se hagan las correspondientes inscripciones y anotaciones en el mismo.

Artículo 15. Inscripción en el Registro de la Propiedad.

Cuando se trate de monumentos y jardines históricos, la Consellería de Cultura instará de oficio la inscripción gratuita de la declaración de bien de interés cultural en el Registro de la Propiedad.

\section{Artículo 16. Procedimiento para} dejar sin efecto una declaración.

1. La declaración de un bien de interés cultural únicamente podrá dejarse sin efecto siguiendo los mismos trámites y requisitos necesarios para su declaración.

2. No pueden invocarse como causas determinantes para dejar sin efecto la declaración de un bien de interés cultural las derivadas del incumplimiento de las obligaciones de conservación y mantenimiento recogidas en esta ley.

\section{Capitulo II DE LA CATALOGACIÓN DE LOS BIENES}

Artículo 17. Catálogo del patrimonio cultural de Galicia. Definición.

1. Los bienes del patrimonio cultural de Galicia que, sin llegar a ser declarados de interés cultural, posean especial singularidad, de acuerdo con lo establecido en el artículo 1.3 de la presente ley, serán incluidos en el Catálogo del patrimonio cultural de Galicia y gozarán de la protección para los bienes catalogados en esta ley.

2. Se crea el Catálogo del patrimonio cultural de Galicia como instrumento de protección de los bienes muebles, inmuebles e inmateriales incluidos en el mismo, y con fines de investigación, consulta y difusión. Dicho catálogo, en lo relativo a los bienes inmuebles, incluirá la regulación del régimen de protección previsto en esta ley.

3. La inclusión podrá realizarse de forma individual o como colección, correspondiendo la gestión del catálogo a la Consellería de Cultura.

4. Reglamentariamente se establecerá el régimen de acceso público al Catálogo del patrimonio cultural de Galicia, así como las determinaciones a que se refiere el apartado 2 de este artículo.

Artículo 18. Procedimiento.

1. La inclusión de un bien en el Catálogo del patrimonio cultural de Galicia 
requerirá la previa tramitación del expediente, iniciado de oficio o a instancia del interesado, por la Consellería de Cultura, siéndole de aplicación las normas generales del procedimiento administrativo.

2. La notificación al titular o poseedor de la iniciación de un expediente para la inclusión de un bien en el Catálogo del patrimonio cultural de Galicia determinará la aplicación inmediata y provisional del régimen de protección previsto en la presente ley para los bienes ya catalogados. Al mismo tiempo se abrirá un período de información pública por un plazo mínimo de un mes mediante la publicación del acuerdo de iniciación del expediente en el "Diario Oficial de Galicia".

3. Cuando el expediente de catalogación afecte a un bien inmueble, se dará además audiencia al Ayuntamiento en que se ubique.

4. En caso de iniciarse a instancia de parte, la denegación de la incoación para la inclusión de un bien en el catálogo será motivada y habrá de notificarse a los solicitantes.

5. De la iniciación del expediente para la catalogación de un bien mueble se dará cuenta al Inventario General de Bienes Muebles de la Administración del Estado para la correspondiente anotación preventiva.

Artículo 19. Contenido del expediente de catalogación.

El expediente de inclusión de un bien en el Catálogo del patrimonio cultural de Galicia recogerá al menos:

a. La descripción del bien que facilite su correcta identificación, y en caso de un bien inmueble, además de todos aquellos elementos que lo integran, el entorno afectado, considerado como un territorio gráficamente delimitado en que los elementos geográficos y naturales también gozarán de protección.

b. La determinación de la compatibilidad del uso con la correcta conservación del bien catalogado.
Artículo 20. Catalogación y conclusión.

1. Corresponde al Conselleiro de Cultura, a propuesta del Director general del Patrimonio Histórico y Documental, acordar la inclusión de un bien en el Catálogo del patrimonio cultural de Galicia.

2. El expediente habrá de resolverse en el plazo máximo de veinte meses, contado a partir de la fecha en que fue iniciado. Transcurrido éste, se producirá el archivo del expediente.

3. El acuerdo de catalogación será notificado tanto a los interesados como al Ayuntamiento en que se ubique el bien, y se publicará en el "Diario Oficial de Galicia".

4. De las inclusiones de bienes muebles en el Catálogo del patrimonio cultural de Galicia se dará cuenta al Inventario General de Bienes Muebles de la Administración del Estado para que se hagan las correspondientes inscripciones.

Artículo 21. Exclusión de un bien del catálogo.

La catalogación de un bien únicamente podrá dejarse sin efecto siguiendo los mismos trámites necesarios para su inclusión.

\section{Capitulo III DEL INVENTARIO GENERAL 310}

Artículo 22. El Inventario general del patrimonio cultural de Galicia. Definición.

1. El Inventario general del patrimonio cultural de Galicia lo conforman los bienes declarados de interés cultural, los catalogados y aquellos otros a que hace referencia el artículo 1.3 de la presente ley y que, sin estar incluidos entre los anteriores, merezcan ser conservados.

2. Se crea el Inventario general del patrimonio cultural de Galicia, como instrumento básico de protección adscrito a la Consellería de Cultura.

3. El acceso al Inventario general del patrimonio cultural de Galicia será público,

310 Véase Decreto 232/2008, de 2 de octubre, sobre el Inventario general del patrimonio cultural de Galicia. 
en la forma que reglamentariamente se establezca.

Artículo 23. Procedimiento.

1. La inclusión de un bien en el Inventario general del patrimonio cultural de Galicia requerirá la previa tramitación del expediente por la Consellería de Cultura, siéndole de aplicación las normas generales del procedimiento administrativo. Quedan excluidos de dicha tramitación aquellos bienes declarados de interés cultural y los catalogados que por su condición ya forman parte del Inventario general del patrimonio cultural de Galicia.

2. La inclusión podrá ser realizada de forma individual o colectiva.

3. Corresponde al Director general del Patrimonio Histórico y Documental la inclusión de los bienes en el Inventario general del patrimonio cultural de Galicia.

\section{TÍTULO II \\ RÉGIMEN GENERAL DE PROTECCIÓN Y CONSERVACIÓN DEL PATRIMONIO CULTURAL DE GALICIA \\ Capítulo I \\ RÉGIMEN DE PROTECCIÓN Y CONSERVACIÓN}

Artículo 24. Protección general.

1. Todos los bienes que integran el patrimonio cultural de Galicia gozarán de las medidas de protección establecidas en esta ley.

2. El patrimonio cultural de Galicia, con arreglo a lo dispuesto en el título anterior, se clasifica en:

a. Bienes declarados, que serán aquellos que se consideren como bienes de interés cultural, previa incoación del oportuno expediente.

b. Bienes catalogados, aquellos que se incorporen al Catálogo del patrimonio cultural de Galicia.

c. Bienes inventariados, aquellos que, sin estar incluidos entre los anteriores, merezcan ser conservados y se incluyan en el Inventario general del patrimonio cultural de Galicia.

Artículo 25. Deber de conservar.

1. Los propietarios, poseedores y demás titulares de derechos reales sobre bienes integrantes del patrimonio cultural de Galicia están obligados a conservarlos, cuidarlos y protegerlos debidamente para asegurar su integridad y evitar su pérdida, destrucción o deterioro.

2. Los poderes públicos garantizarán la protección, conservación y enriquecimiento del patrimonio cultural de Galicia.

Artículo 26. El acceso al patrimonio cultural de Galicia.

1. Los propietarios, poseedores y demás titulares de derechos reales sobre los bienes integrantes del patrimonio cultural de Galicia facilitarán el acceso, con fines de inspección, a la Administración competente. Igualmente, estarán obligados a permitir el acceso de los investigadores, previa solicitud motivada, a los bienes declarados o catalogados. El cumplimiento de esta obligación sólo podrá ser dispensado por la Administración cuando, en atención a las circunstancias concurrentes, entienda que existe causa suficientemente justificada para ello.

2. A los efectos previstos en esta ley, la Administración competente podrá solicitar de los titulares de derechos sobre los bienes integrantes del patrimonio cultural de Galicia el examen de los mismos, así como las informaciones pertinentes para su inclusión, si procede, en el Inventario general.

3. Los propietarios, poseedores y demás titulares de bienes declarados de interés cultural habrán de facilitar la visita pública a los mismos en las condiciones que se determinen, que en todo caso será gratuita durante cuatro días al mes, en días y horario prefijado.

Artículo 27. Derechos de tanto y retracto.

1. Toda pretensión de enajenación o venta de un bien declarado o catalogado habrá de ser notificada a la Consellería de 
Cultura, con indicación del precio y las condiciones en que se proponga realizar aquélla, sin perjuicio de lo establecido en el artículo 38 de la Ley 16/1985, del Patrimonio Histórico Español.

Los subastadores habrán de notificar igualmente con un plazo de antelación de dos meses las subastas públicas en las que pretenda enajenarse cualquier bien declarado, catalogado o cualquier otro que, formando parte del patrimonio cultural de Galicia, reglamentariamente se exija.

2. En el plazo de dos meses, el órgano competente de la Xunta de Galicia podrá ejercer el derecho de tanteo para sí o para otras instituciones sin ánimo de lucro, obligándose al pago del precio convenido o del de remate de la subasta.

3. Si la pretensión de enajenación o venta y sus condiciones no fuesen notificadas correctamente, podrá ejercerse, en los términos del apartado anterior, el derecho de retracto, en el plazo de seis meses a partir de la fecha en que se tenga conocimiento fehaciente de la venta.

Artículo 28. Escrituras públicas.

Para la formalización de escrituras públicas de adquisición de bienes declarados o catalogados, o de transmisión de derechos reales de disfrute sobre estos bienes, se acreditará previamente el cumplimiento de lo establecido en el artículo 27 de la presente ley. Esta acreditación también es necesaria para la inscripción de los títulos correspondientes.

Artículo 29. Comercio.

1. Las personas y entidades que se dediquen habitualmente al comercio de bienes muebles integrantes del patrimonio cultural de Galicia llevarán un libro de registro legalizado por la Consellería de Cultura, en el cual constarán las transacciones efectuadas. Se anotarán en el citado libro los datos de identificación del objeto y las partes que intervengan en cada transacción.

2. La Consellería de Cultura creará y llevará un registro de las empresas que se dediquen habitualmente al comercio de los objetos a que se refiere el apartado anterior. Será requisito indispensable estar incluido en el mencionado registro para el ejercicio de esta actividad. Reglamentariamente se determinará el funcionamiento de dicho registro.

Artículo 30. Limitaciones a la transmisión.

1. Los bienes declarados y catalogados que sean propiedad de la Comunidad Autónoma o de las entidades locales serán imprescriptibles, inalienables e inembargables, salvo las transmisiones que puedan efectuarse entre entes públicos territoriales.

2. Cuando estos bienes estén en posesión de las instituciones eclesiásticas, se regirán por las legislación estatal.

Artículo 31. Expropiación.

El incumplimiento de las obligaciones de protección y conservación será causa de interés social para la expropiación forzosa de los bienes declarados y catalogados por la Administración competente.

Artículo 32. Impacto o efecto ambiental.

1. La Consellería de Cultura habrá de ser informada de los planes, programas y proyectos, tanto públicos como privados, que por su incidencia sobre el territorio puedan implicar riesgo de destrucción o deterioro del patrimonio cultural de Galicia.

2. A los efectos previstos en el apartado anterior, la Consellería de Cultura habrá de establecer aquellas medidas protectoras y correctoras que considere necesarias para la protección del patrimonio cultural de Galicia.

3. En la tramitación de todas las evaluaciones de impacto o efecto ambiental, el organismo administrativo competente en materia de medio ambiente solicitará informe de la Consellería de Cultura e incluirá en la declaración ambiental las consideraciones y condiciones resultantes de dicho informe.

4. Habrán de ser incluidas todas las figuras relativas al planeamiento urbanístico. 


\section{Capítulo II \\ PROTECCIÓN DE LOS BIENES DE INTERÉS CULTURAL}

\section{Sección $1 .^{\mathrm{a}}$}

Régimen general de aplicación a los bienes inmuebles y muebles

Artículo 33. Régimen de protección. Los bienes declarados de interés cultural gozarán de la máxima protección y tutela, y su utilización quedará subordinada a que no se pongan en peligro los valores que aconsejan su conservación. Cualquier cambio de uso habrá de ser autorizado por los organismos competentes para la ejecución de esta ley.

\section{Sección 2. ${ }^{a}$}

Régimen de aplicación a los bienes inmuebles

\section{Subsección 1. ${ }^{\mathrm{a}}$ Régimen general}

Artículo 34. Definición.

A los efectos previstos en esta ley tienen la consideración de bienes inmuebles, además de los enumerados en el artículo 334 del Código Civil, todos aquellos elementos que puedan considerarse consustanciales con los edificios y formen parte de los mismos o la hubiesen formado en otro tiempo.

Artículo 35. Incoación y suspensión de licencias.

1. La incoación de un expediente de declaración de bien de interés cultural respecto a un inmueble determinará la suspensión de las correspondientes licencias municipales de parcelación, edificación o demolición en las zonas afectadas, así como de los efectos de las ya otorgadas. La suspensión dependerá de la resolución o caducidad del expediente incoado.

2. Las obras que, por causa de fuerza mayor, interés general o urgencia, hubiesen de realizarse con carácter inaplazable precisarán, en todo caso, autorización de los organismos competentes de la Consellería de Cultura.
Artículo 36. Desplazamiento.

Un inmueble declarado bien de interés cultural es inseparable de su entorno. No podrá procederse a su desplazamiento salvo que resulte imprescindible por causa de fuerza mayor o interés social, previo informe favorable de la Consellería de Cultura, en cuyo caso será preciso adoptar las cautelas necesarias en aquello que pueda afectar al suelo o subsuelo. Para la consideración de causa de fuerza mayor o de interés social, será preceptivo el informe favorable de al menos dos de las instituciones consultivas contempladas en esta ley.

Artículo 37. Autorización de las intervenciones.

Cualquier intervención que pretenda realizarse en un inmueble declarado bien de interés cultural habrá de ser autorizada por la Consellería de Cultura, previamente a la concesión de la licencia municipal, con la salvedad que supone lo previsto en el artículo 47.2 de la presente ley.

Artículo 38. Proyectos de intervención.

1. Cualquier proyecto de intervención en un bien inmueble declarado bien de interés cultural habrá de incorporar un informe sobre su importancia artística, histórica y/o arqueológica, elaborado por técnico competente en cada una de las materias. Del mismo modo, habrá de incluirse en dicho informe una evaluación de la intervención que se propone.

2. Una vez concluida la intervención, la dirección facultativa realizará una memoria en la que figure, al menos, la descripción pormenorizada de la obra ejecutada y de los tratamientos aplicados, así como la documentación gráfica del proceso seguido.

Artículo 39. Criterios de intervención en inmuebles.

1. Cualquier intervención en un inmueble declarado bien de interés cultural habrá de ir encaminada a su conservación y mejora, de acuerdo con los siguientes criterios:

a. Se respetarán las características esenciales del inmueble, sin perjuicio de 
que pueda autorizarse el uso de elementos, técnicas y materiales actuales para la mejor adaptación del bien a su uso y para valorar determinados elementos o épocas.

b. Se conservarán las características volumétricas y espaciales definidoras del inmueble, así como las aportaciones de distintas épocas. En caso de que excepcionalmente se autorice alguna supresión, ésta quedará debidamente documentada.

c. Se evitarán los intentos de reconstrucción, salvo en los casos en que la existencia de suficientes elementos originales así lo permitan.

d. No podrán realizarse adiciones miméticas que falseen su autenticidad histórica.

e. Cuando sea indispensable para la estabilidad y el mantenimiento del inmueble, la adición de materiales habrá de ser reconocible.

f. Se impedirán las acciones agresivas en las intervenciones sobre los paramentos.

2. En los monumentos, jardines, sitios o territorios históricos, zonas arqueológicas situadas o no en suelo urbano, lugares de interés etnográfico y zonas paleontológicas no podrá instalarse publicidad, cables, antenas y todo aquello que impida o menoscabe la apreciación del bien dentro de su entorno.

Artículo 40. Licencias.

1. La obtención de las autorizaciones necesarias según la presente ley no altera la obligatoriedad de obtener licencia municipal ni las demás licencias o autorizaciones que fuesen necesarias.

2. No podrán otorgarse licencias para la realización de obras que, con arreglo a la presente ley, requieran cualquier autorización administrativa, hasta que ésta fuese concedida.

3. Las obras realizadas sin cumplir lo establecido en el apartado anterior serán ilegales, y los Ayuntamientos y, en su caso, la Consellería de Cultura ordenarán, si fuese preciso, su reconstrucción o demolición con cargo al responsable de la infracción.
Artículo 41. Declaración de ruina.

1. Si a pesar de lo establecido en el artículo 33 llegase a incoarse expediente de declaración de ruina de algún inmueble declarado bien de interés cultural, la Consellería de Cultura podrá intervenir como interesada en dicho expediente, debiendo serle notificada la apertura y las resoluciones que en el mismo se adopten. En ningún caso podrá procederse a la demolición sin autorización de la Consellería de Cultura.

2. En el supuesto de que la situación de ruina conlleve peligro inminente de daños a personas, la entidad que incoase expediente de ruina habrá de adoptar las medidas oportunas para evitar dichos daños. Se tomarán las medidas necesarias que garanticen el mantenimiento de las características y elementos singulares del edificio, que no podrán incluir más demoliciones que las estrictamente necesarias, y se atendrán a los términos previstos en la resolución de la Consellería de Cultura.

3. La situación de ruina producida por incumplimiento de lo previsto en el apartado anterior conllevará la reposición, por parte del titular de la propiedad, del bien a su estado primigenio.

Artículo 42. Suspensión de intervenciones.

La Consellería de Cultura impedirá los derribos y suspenderá cualquier obra o intervención no autorizada en un bien declarado.

\section{Subsección $2 .^{\mathrm{a}}$}

Régimen de los monumentos

Artículo 43. Intervención en monumentos.

En ningún monumento podrá realizarse obra interior, exterior, señalización, instalación o cambio de uso que afecte directamente al inmueble o a cualquiera de sus partes integrantes, pertenencias o a su entorno delimitado, sin autorización expresa de la Consellería de Cultura.

Artículo 44. Entorno de los monumentos.

1. El entorno de los monumentos estará constituido por los inmuebles y espacios 
colindantes inmediatos y, en casos excepcionales, por los no colindantes o alejados, siempre que una alteración de los mismos pueda afectar a los valores propios del bien de que se trate, su contemplación, apreciación o estudio.

2. El volumen, tipología, morfología y cromatismo de las intervenciones en el entorno de los monumentos no pueden alterar el carácter arquitectónico y paisajístico de la zona, ni perturbar la contemplación del bien.

3. Podrán expropiarse, y proceder a su derribo, los inmuebles que impidan o perturben la contemplación de los monumentos o den lugar a riesgos para los mismos.

4. Para cualquier intervención que pretenda realizarse, la existencia de una figura de planeamiento que afecte al entorno de un monumento no podrá excusar el informe preceptivo y vinculante de la Consellería de Cultura.

5. En caso del entorno de un monumento declarado de interés cultural, integrado en un conjunto histórico que cuente con un plan especial de protección, se regirá por lo establecido en el artículo 47.2 de la presente ley.

\section{Subsección $3 .^{\mathrm{a}}$}

\section{Régimen de los conjuntos históricos}

Artículo 45. Conjuntos históricos. Planeamiento.

1. La declaración de un conjunto histórico determinará la obligación para el Ayuntamiento en que se encuentre de redactar un plan especial de protección del área afectada. La aprobación definitiva de este plan requerirá el informe favorable de la Consellería de Cultura, que se entenderá positivo transcurridos tres meses desde su presentación.

La obligatoriedad de dicha normativa no podrá excusarse en la preexistencia de otro planeamiento contradictorio con la protección ni en la inexistencia previa de planeamiento general.
2. Cualquier otra figura de planeamiento que incida sobre el área afectada por la declaración de un conjunto histórico precisará, igualmente, informe favorable de la Consellería de Cultura, en los términos previstos en el apartado anterior.

Artículo 46. Contenido del planeamiento.

1. El plan especial a que se refiere el artículo anterior establecerá para todos los usos públicos el orden prioritario de su instalación en los edificios y espacios que fuesen aptos para ello. Igualmente contemplará las posibles áreas de rehabilitación integrada que permitan la recuperación del área residencial y de las actividades económicas adecuadas.

También contendrá los criterios relativos a la conservación de fachadas y cubiertas e instalaciones sobre las mismas, así como de aquellos elementos más significativos existentes en el interior.

2. Se mantendrán igualmente la estructura urbana y arquitectónica del conjunto histórico y las características generales del ambiente y de la silueta paisajística. No se permitirán modificaciones de alineaciones, alteraciones de la edificabilidad, parcelaciones ni agregaciones de inmuebles, salvo que contribuyan a la conservación general del carácter del conjunto.

3. Contendrá un catálogo exhaustivo de todos los elementos que conforman el conjunto histórico, incluidos aquellos de carácter ambiental, señalados con precisión en un plano topográfico, en aquellos casos en donde fuese preciso.

4. En el planeamiento se recogerán normas específicas para la protección del patrimonio arqueológico, que contemplarán, al menos, la zonificación de áreas de fertilidad arqueológica, soluciones técnicas y financieras.

5. En la redacción del plan especial se contemplarán específicamente las instalaciones eléctricas, telefónicas o cualesquiera otras, que deberán ir bajo tierra. Las antenas de televisión, pantallas de recepción de 
ondas y dispositivos similares se situarán en lugares que no perjudiquen la imagen urbana o del conjunto. Sólo se autorizarán aquellos rótulos que anuncien servicios públicos, los de señalización y comerciales, que serán armónicos con el conjunto, quedando prohibidos cualquier otro tipo de anuncios o rótulos publicitarios.

Artículo 47. Conjuntos históricos. Autorización de obras.

1. En tanto no se apruebe definitivamente la normativa urbanística de protección a que se hace referencia en el artículo 45.1 de la presente ley, la concesión de licencias o la ejecución de las ya otorgadas antes de la declaración de conjunto histórico precisará resolución favorable de la Consellería de Cultura. No se admitirán modificaciones en las alineaciones y rasantes existentes, incrementos o alteraciones del volumen, parcelaciones ni agregaciones y, en general, cambios que afecten a la armonía del conjunto.

2. Una vez aprobado definitivamente el plan especial de protección, los Ayuntamientos serán competentes para autorizar las obras que lo desarrollan, incluidas las de los entornos de los monumentos declarados, debiendo dar cuenta a la Consellería de Cultura de las licencias concedidas en un plazo máximo de diez días. En todo caso, las intervenciones arqueológicas requerirán la autorización de la Consellería de Cultura.

3. Las obras que se realicen al amparo de licencias contrarias al plan especial aprobado serán ilegales y la Consellería de Cultura habrá de ordenar su reconstrucción o demolición con cargo al Ayuntamiento que las hubiese otorgado, sin perjuicio de lo dispuesto en la legislación urbanística.

\section{Subsección $4 .^{\text {a }}$}

\section{Régimen de los otros bienes} inmuebles declarados

Artículo 48. Protección de las otras clases de bienes inmuebles declarados.

1. Los sitios o territorios históricos, las zonas arqueológicas y los lugares de interés etnográfico se ordenarán mediante planes especiales de protección u otro instrumento de planeamiento que cumpla las exigencias establecidas en esta ley.

2. Los jardines históricos y las zonas paleontológicas podrán ordenarse mediante las figuras de planeamiento previstas en el apartado anterior.

3. Cualquier remoción de tierras de una zona arqueológica o zona paleontológica habrá de ser autorizada por la Consellería de Cultura, con independencia de que exista o no un instrumento urbanístico de protección.

\section{Sección $3 .^{a}$ \\ De los bienes muebles}

Artículo 49. Definición.

A los efectos previstos en esta ley, además de los enumerados en el artículo $335 \mathrm{del}$ Código Civil, tienen la consideración de bienes muebles aquellos de carácter y valor histórico, tecnológico o material susceptibles de ser transportados, no estrictamente consustanciales con la estructura de inmuebles, cualquiera que sea su soporte material.

Artículo 50. Conservación.

1. A todos los bienes que formen parte de un museo, colección visitable o fondos de un archivo, así como a aquellos que integren el patrimonio bibliográfico de Galicia, les será de aplicación el sistema de protección establecido en la presente ley para los bienes declarados de interés cultural.

2. Cualquier modificación, restauración o alteración de otro tipo sobre bienes muebles declarados requerirá autorización previa de la Consellería de Cultura.

Artículo 51. Traslados.

1. El traslado de bienes muebles declarados se comunicará a la Consellería de Cultura para su anotación en el Registro de Bienes de Interés Cultural, indicando su origen y destino, y si aquel traslado se hace con carácter temporal o definitivo. 
2. Los bienes muebles que fuesen reconocidos como inseparables de un inmueble declarado estarán sometidos al destino de éste, y su separación, siempre con carácter excepcional, exigirá la previa autorización de la Consellería de Cultura.

\section{Capitulo III DE LOS BIENES CATALOGADOS}

Artículo 52. De la protección de los bienes inmuebles catalogados.

1. Los bienes inmuebles catalogados, así como su entorno, gozarán de la protección prevista en el artículo 17 de la presente ley a través del correspondiente catálogo, al que habrá de ajustarse la planificación territorial o urbanística, cuya aprobación precisará el informe favorable y vinculante de la Consellería de Cultura.

2. Cualquier intervención en un bien inmueble catalogado y en su entorno precisará la autorización previa de la Consellería de Cultura. En caso de tratarse de un conjunto histórico con plan especial de protección, regirá para el entorno lo establecido en el artículo 47.2 de la presente ley.

3. La Consellería de Cultura podrá suspender cautelarmente cualquier obra o intervención no autorizada en un bien inmueble catalogado para el cumplimiento de los fines previstos en la presente ley.

Artículo 53. Protección de los bienes muebles catalogados.

1. Cualquier actuación sobre un bien mueble catalogado se regirá por lo establecido en el artículo 50.2 de la presente ley.

2. Con carácter general, los bienes muebles catalogados podrán ser objeto de comercio de acuerdo con las normas que reglamentariamente se establezcan y, en todo caso, con lo previsto en el artículo 29 de la presente ley.

3. A los efectos de su posible inclusión en el Catálogo del patrimonio cultural de Galicia, los propietarios, poseedores y personas o entidades que ejerzan habitualmente el comercio de bienes muebles habrán de comunicar a la Consellería de Cultura la existencia de los mismos antes de proceder a su transmisión a terceros, haciendo constar el precio convenido o valor de mercado, siempre que éste sea igual o superior a lo dispuesto por la legislación estatal.

\section{Capitulo IV DE LOS BIENES INVENTARIADOS}

Artículo 54. Protección.

Los bienes inventariados a que se refiere el artículo 22.1 gozarán de una protección basada en evitar su desaparición, y estarán bajo la responsabilidad de los Ayuntamientos y de la Consellería de Cultura, que habrá de autorizar cualquier intervención que les afecte.

\section{TíTULO III DEL PATRIMONIO ARQUEOLÓGICO ${ }^{311}$}

\section{Artículo 55. Definición.}

Integran el patrimonio arqueológico de Galicia los bienes muebles e inmuebles de carácter histórico suceptibles de ser estudiados con método arqueológico, fuesen o no extraídos, y tanto si se encuentran en la superficie como en el subsuelo o en las aguas. Forman parte asimismo de este patrimonio los elementos geológicos y paleontológicos relacionados con la historia humana, sus orígenes, sus antecedentes y el desarrollo sobre el medio.

Artículo 56. Bienes arqueológicos de dominio público.

1. A los efectos de la presente ley, tienen la consideración de dominio público todos los objetos y restos materiales de interés arqueológico descubiertos como consecuencia de excavaciones arqueológicas o cualquier otro trabajo sistemático, remoción de tierras, obras de cualquier índole o de forma casual.

311 Decreto 199/1997, de 10 de julio, por el que se regula la actividad arqueológica en la Comunidad Autónoma de Galicia. 
2. La Consellería de Cultura deberá ordenar la ejecución de intervenciones arqueológicas en cualquier terreno público o privado en donde se constate o presuma la existencia de un yacimiento o restos arqueológicos. A efectos de la correspondiente indemnización, regirá lo dispuesto en la legislación vigente sobre expropiación forzosa.

3. Como medida precautoria, la Consellería de Cultura deberá ordenar el control arqueológico, entendido como la supervisión por un arqueólogo de un proceso de obras que afecten o puedan afectar a un espacio en donde se presuma la existencia de restos arqueológicos. $\mathrm{Si}$ así fuese, la Administración competente determinará si procede paralizar las obras o remociones y ordenar algún tipo de intervención arqueológica.

Artículo 57. Actividades arqueológicas. Será necesaria la autorización previa de la Consellería de Cultura para la realización de las siguientes actividades arqueológicas:

a. La prospección arqueológica, entendida como la exploración superficial y sistemática sin remoción, tanto terrestre como subacuática, dirigida al estudio e investigación para la detección de restos históricos o paleontológicos, así como de los componentes geológicos y ambientales relacionados con los mismos. Esto engloba la observación y el reconocimiento sistemático de superficie y también la aplicación de las técnicas que la arqueología reconoce como válidas.

b. El sondeo arqueológico, entendido como aquella remoción de tierras complementaria de la prospección, encaminado a comprobar la existencia de un yacimiento arqueológico o reconocer su estratigrafía. Cualquier toma de muestras en yacimientos arqueológicos se considerará dentro de este apartado.

c. La excavación arqueológica, entendida como la remoción, en el subsuelo o en medios subacuáticos, que se realice a fin de descubrir e investigar toda clase de restos históricos o paleontológicos relacionados con los mismos.

d. El estudio del arte rupestre, entendido como el conjunto de tareas de campo orientadas a la investigación, a la documentación gráfica por medio de calco y a cualquier manipulación o contacto con el soporte de los motivos representados.

e. Las labores de protección, consolidación y restauración arqueológica, entendidas como las intervenciones en yacimientos arqueológicos encaminadas a favorecer su conservación y que, en consecuencia, permitan su disfrute y faciliten su acrecentamiento.

f. La manipulación con técnicas agresivas de materiales arqueológicos.

Artículo 58. Urgencias arqueológicas.

1. Las actuaciones serán consideradas de urgencia cuando exista riesgo de destrucción inmediata del yacimiento y se agotasen todas las posibilidades para evitar su desaparición o afectación.

2. La Consellería de Cultura, mediante procedimiento simplificado, podrá ordenar o autorizar la realización de las intervenciones necesarias siempre que concurran las circunstancias previstas en el apartado anterior.

Artículo 59. Hallazgos casuales.

1. A los efectos de la presente ley, tendrá la consideración de hallazgo casual el descubrimiento de objetos y restos materiales que posean los valores que son propios del patrimonio cultural gallego y fuesen descubiertos por azar o como consecuencia de cualquier tipo de remociones de tierra, demoliciones u obras de cualquier índole.

2. El descubridor de un bien que tenga la consideración de hallazgo casual habrá de comunicar inmediatamente su descubrimiento a la Consellería de Cultura.

3. En caso de bienes muebles, una vez comunicado el descubrimiento, y hasta que los objetos sean entregados a la Consellería de Cultura, se aplicarán al descubridor las normas de depósito legal, salvo que los 
entregue en un museo público, institución que habrá de ponerlo, asimismo, en conocimiento de la Consellería de Cultura, que decidirá su ubicación definitiva.

4. La Consellería de Cultura o, en su caso, los Ayuntamientos respectivos, podrán ordenar la interrupción inmediata de las obras en el lugar objeto de un hallazgo casual por un plazo máximo de un mes, a fin de llevar a cabo los trabajos arqueológicos que considerasen necesarios. Dicha paralización no conllevará derecho a indemnización alguna. En caso de considerarlo necesario, podrá disponerse la prórroga de la suspensión de las obras por tiempo superior a un mes, quedando en este caso sujetos a lo dispuesto en la legislación vigente sobre expropiación forzosa.

Artículo 60. Derecho a premio.

1. El descubridor y el propietario del terreno en que se encontrase un hallazgo casual tendrán derecho a percibir de la Xunta de Galicia en concepto de premio una cantidad igual a la mitad del valor que en tasación legal se atribuya, que se distribuirá entre ellos a partes iguales. La valoración será realizada por la Comisión Superior de Valoración de Bienes Culturales de Interés para Galicia. En lo relativo a bienes inmuebles, éstos no devengarán derecho a premio.

2. El incumplimiento de las obligaciones previstas en el artículo anterior privará al descubridor $\mathrm{y}$, en su caso, al propietario del terreno del derecho a premio, y los objetos quedarán depositados en el museo que determine la Consellería de Cultura, con independencia de las sanciones que procedan.

Artículo 61. Requisitos y autorizaciones.

1. Los requisitos para realizar y dirigir las actividades arqueológicas se ajustarán a lo establecido reglamentariamente. Se requerirá la presentación de un proyecto que contenga un programa detallado y coherente, que acredite la conveniencia e interés científico de la intervención y avale la idoneidad técnica del arqueólogo director. Asimismo, las solicitudes presentadas por personas físicas extranjeras habrán de estar avaladas por una institución científica en materia de arqueología radicada en su país.

2. Las solicitudes habrán de acompañarse de la autorización del propietario del terreno.

3. En la resolución por la que se concede la autorización se indicarán las condiciones a que han de atenerse los trabajos, así como el museo en que habrán de depositarse los materiales y la documentación escrita o gráfica complementaria correspondiente, y se concederá sin perjuicio de otras autorizaciones o licencias que fuesen necesarias por aplicación de la legislación urbanística.

4. La responsabilidad por los daños y perjuicios que pudiesen resultar de la ejecución de actuaciones arqueológicas recaerá sobre el solicitante de la autorización para la realización de las mismas y, en su caso, sobre otros posibles implicados.

Artículo 62. Responsabilidad en la dirección y destino de los hallazgos arqueológicos.

1. El arqueólogo director de los trabajos asumirá personalmente la dirección de los mismos.

2. Los bienes materiales procedentes de las actuaciones arqueológicas autorizadas, así como toda la documentación escrita y gráfica que permita el adecuado tratamiento museográfico de los fondos, habrán de ser depositados en los museos que designe la Consellería de Cultura. Hasta que los objetos sean entregados en dichos centros, serán de aplicación al titular de la autorización las normas de depósito legal.

3. Una vez depositados los materiales y presentada la memoria correspondiente a cada actuación, éstos quedarán a disposición del público en general, a fin de facilitar otros estudios e investigaciones. 
Artículo 63. Intervenciones arqueológicas por obras en conjuntos históricos, zonas arqueológicas o yacimientos catalogados o inventariados.

1. Cuando, como requisito previo para la realización de cualquier tipo de obra que afecte a un conjunto histórico, zona arqueológica o yacimientos catalogados o inventariados, la Consellería de Cultura o la figura de planeamiento vigente determine la necesidad de realizar intervenciones arqueológicas, el promotor presentará un proyecto arqueológico de acuerdo con lo que se establece en el artículo 61 de la presente ley.

2. Si se trata de un particular, la Consellería de Cultura colaborará en la financiación del coste de la ejecución del proyecto. Si el promotor de la obra es una Administración pública o concesionario, el coste de las intervenciones arqueológicas será asumido íntegramente por la entidad promotora.

\section{TíTULO IV DEL PATRIMONIO ETNOGRÁFICO}

Artículo 64. Definición.

Integran el patrimonio etnográfico de Galicia los lugares y los bienes muebles e inmuebles, así como las actividades y conocimientos que constituyan formas relevantes o expresión de la cultura y modos de vida tradicionales y propios del pueblo gallego en sus aspectos materiales e inmateriales.

Artículo 65. Protección de los bienes inmateriales.

Tienen valor etnográfico y gozarán de protección aquellos conocimientos, actividades, prácticas, saberes y cualesquiera otras expresiones que procedan de modelos, técnicas, funciones y creencias propias de la vida tradicional gallega.

Cuando estén en previsible peligro de desaparición, pérdida o deterioro, la Consellería de Cultura promoverá y adoptará las medidas oportunas conducentes a su estudio, documentación científica y a su recogida por cualquier medio que garantice su transmisión y puesta en valor.

Artículo 66. Bienes inmuebles de carácter industrial.

A todos los bienes de carácter etnográfico que constituyan restos físicos del pasado tecnológico, productivo e industrial gallego que sean susceptibles de ser estudiados con metodología arqueológica les será de aplicación lo dispuesto en esta ley para el patrimonio arqueológico.

\section{TíTULO V DE LOS MUSEOS}

Artículo 67. Definición y funciones de los museos.

1. Los museos son instituciones de carácter permanente, abiertas al público y $\sin$ finalidad de lucro, orientadas a la promoción y desarrollo cultural de la comunidad en general, por medio de la recogida, adquisición, inventario, catalogación, conservación, investigación, difusión y exhibición, de forma científica, estética y didáctica, de conjuntos y colecciones de bienes patrimoniales de carácter cultural que constituyen testimonios de las actividades del ser humano o de su entorno natural, con fines de estudio, educación, disfrute y promoción científica y cultural.

2. Son funciones de los museos:

a. La conservación, catalogación, restauración y exhibición ordenada de las colecciones.

b. La investigación en el ámbito de sus colecciones, de su especialidad o de su respectivo entorno cultural.

c. La organización periódica de exposiciones científicas y divulgativas de carácter temporal.

d. La elaboración y publicación de catálogos y monografías de sus fondos.

e. El desarrollo de una actividad didáctica respecto a sus contenidos.

f. Cualesquiera otras funciones que en sus normas estatutarias o por disposición legal o reglamentaria se les encomienden. 
Artículo 68. Colección visitable. Aquella colección que no reúna todas las características y condiciones que constituyen los requisitos necesarios para su reconocimiento como museo se calificará como colección visitable siempre que sus titulares faciliten, mediante un horario accesible y regular, la visita pública y el acceso de los investigadores, gozando sus fondos de las atenciones básicas que garanticen su custodia y conservación.

Artículo 69. Creación y reglamentación.

1. La creación, autorización y calificación de un museo o de una colección visitable se hará por acuerdo del Consejo de Junta, en el cual se delimitará su ámbito territorial y contenido temático.

2. Los organismos públicos y las personas físicas o jurídicas interesadas en la creación de museos o colecciones visitables promoverán ante la Consellería de Cultura la iniciación del oportuno expediente, en el cual se incorporará la documentación y el inventario sobre los fondos y patrimonio con que cuenta el promotor, así como el programa y proyecto museográfico, que incluirá un estudio de las instalaciones, medios y personal, de la forma que reglamentariamente se determine.

3. Se crea en la Consellería de Cultura un registro general administrativo en el que se inscribirán los museos y colecciones autorizadas en virtud de lo dispuesto en la presente ley, y en el que se hará constar la calificación y la delimitación establecidas para cada centro.

4. Corresponde a la Consellería de Cultura, a través de sus órganos específicos, la reglamentación, inspección y control de todos los museos y colecciones visitables de Galicia.

Artículo 70. Sistema gallego de museos.

1. Constituye el sistema gallego de museos la estructura organizativa y funcional que regula la integración de los centros y redes museísticas de Galicia en un programa de vínculos institucionales que articulen de forma operativa la gestión cultural y científica de los museos de la Comunidad Autónoma. Sus órganos rectores y su funcionamiento se establecerán reglamentariamente por la Consellería de Cultura.

2. Forman parte del sistema gallego de museos todos los museos y colecciones visitables que se encuentren en el territorio de la Comunidad Autónoma de Galicia.

Artículo 71. Red de museos.

A los efectos de la presente ley, se entiende por red de museos la trama diversa de titularidades, ámbitos territoriales o contenidos temáticos que afectan a los diferentes museos y colecciones de Galicia, y será establecida reglamentariamente por la Consellería de Cultura.

Artículo 72. Instrumentos y medios de los museos.

Todos los museos radicados en la Comunidad Autónoma de Galicia contarán con un registro para el tratamiento administrativo de los fondos, que se reflejará en un libro de inscripción. Del mismo modo contarán con un inventario y un catálogo para el tratamiento técnico-científico y la identificación, control, estudio y difusión del patrimonio mueble albergado en los mismos.

Todos los museos integrados en el sistema gallego contarán con los medios humanos y técnicos suficientes para poder desarrollar sus funciones de acuerdo con la estructuración en áreas y dotaciones que reglamentariamente se establezcan.

Artículo 73. Acceso a los museos.

1. La Consellería de Cultura promoverá y garantizará el acceso de todos los ciudadanos a los museos públicos, sin perjuicio de las restricciones que, por causa de la conservación de los bienes custodiados en los mismos, puedan establecerse.

2. La Consellería de Cultura establecerá las condiciones que regirán el acceso y la visita pública a los museos del sistema 
gallego $\mathrm{y}$, de acuerdo con los titulares de las diferentes redes, a otros museos y colecciones visitables, y regulará los horarios de apertura al público, para facilitar el conocimiento y disfrute de los bienes culturales expuestos en los mismos, o para su investigación, con arreglo a los objetivos y funciones determinados en esta ley.

Artículo 74. Reproducciones.

1. La Consellería de Cultura, respecto a los museos del sistema gallego, establecerá las condiciones para autorizar la reproducción por cualquier procedimiento de los objetos custodiados en los mismos.

2. Toda reproducción total o parcial con fines de explotación comercial o de publicidad de fondos pertenecientes a colecciones de museos de titularidad estatal gestionados o de titularidad autonómica habrá de ser formalizada mediante convenio entre las Administraciones implicadas.

\section{TÍTULO VI DEL PATRIMONIO BIBLIOGRÁFICO}

\section{Artículo 75. Definición.}

1. Constituyen el patrimonio bibliográfico de Galicia los fondos y colecciones bibliográficas y hemerográficas, y las obras literarias, históricas, científicas o artísticas, impresas, manuscritas, fotográficas, cinematográficas, fonográficas y magnéticas de carácter unitario o seriado, en cualquier tipo de soporte e independientemente de la técnica utilizada para su creación o reproducción, de las cuales no conste la existencia de, al menos, tres ejemplares en bibliotecas o servicios públicos.

2. Asimismo, forman parte del patrimonio bibliográfico de Galicia las obras con más de cien años de antigüedad, incluidos los manuscritos, así como los fondos que por alguna circunstancia formen un conjunto unitario, independientemente de la antigüedad de las obras que lo conforman.

\section{TÍTULO VII \\ DEL PATRIMONIO DOCUMENTAL Y DE LOS ARCHIVOS}

Artículo 76. Definición.

1. Constituyen el patrimonio documental de Galicia todos los documentos, fondos y colecciones de cualquier época, reunidos o no en archivos existentes en Galicia y fuera de ella, procedentes de las personas o instituciones de carácter público y privado, que se consideren integrantes del mismo en el presente título.

2. Se entiende por documento, a los efectos de la presente ley, todo testimonio de funciones y actividades humanas recogido en un soporte perdurable y expresado en lenguaje oral o escrito, natural o codificado. Se excluyen los ejemplares no originales de obras editadas o publicadas.

3. Se entiende por archivo el conjunto orgánico de documentos producidos o acumulados por las personas físicas o jurídicas, públicas o privadas, en el ejercicio de sus funciones y actividades, y conservados como testimonio y garantía de los derechos y deberes de la Administración y de los ciudadanos y como fuente de información general para la gestión administrativa y para todo tipo de investigación. Esta noción corresponde también a la del fondo del archivo. Igualmente, se entiende por archivo la institución que reúne, custodia, comunica y difunde los fondos de archivo y las colecciones documentales por medio de los métodos y técnicas que le son propios.

4. Se entiende por colección documental, a los efectos de la presente ley, el conjunto no orgánico de documentos reunido artificialmente en función de criterios subjetivos o de conservación.

Artículo 77. Contenido del patrimonio documental.

1. Integran el patrimonio documental de Galicia:

a. Los documentos de cualquier época generados, conservados o reunidos en el 
ejercicio de su función por cualquier organismo de carácter público existente en Galicia, así como por personas privadas, físicas o jurídicas, gestoras de servicios públicos.

b. Los documentos con una antigüedad superior a los cuarenta años generados, conservados o reunidos en el ejercicio de sus actividades por las entidades e instituciones de carácter público, sindical o religioso y por las entidades, fundaciones y asociaciones culturales y educativas de carácter privado.

c. Los documentos con una antigüedad superior a los cien años generados, conservados o reunidos por cualquier otra entidad o persona física.

2. La Consellería de Cultura podrá declarar constitutivos del patrimonio documental de Galicia aquellos documentos que, sin alcanzar la antigüedad indicada en los apartados anteriores, merezcan esa consideración.

Artículo 78. Sistema de Arquivos de Galicia.

1. El Sistema de Arquivos de Galicia se configura como el conjunto de órganos, centros y servicios encargados de la protección, custodia, enriquecimiento, comunicación y difusión del patrimonio documental de Galicia. Sus órganos rectores y su funcionamiento se establecerán reglamentariamente por la Consellería de Cultura.

2. Todos los archivos integrados en el sistema gallego contarán con los medios humanos y técnicos suficientes para poder cumplir sus funciones propias establecidas en la presente ley.

Artículo 79. Red de archivos.

A los efectos de la presente ley, se entiende por red de archivos la trama diversa de titularidades o ámbitos territoriales que afecten a los diferentes archivos de Galicia, y será establecida reglamentariamente por la Consellería de Cultura.

Artículo 80. Ciclo vital de los documentos.

1. La Consellería de Cultura regulará el ciclo vital de los documentos de las distintas Administraciones públicas de
Galicia, así como la circulación de documentos, las transferencias y la selección de los mismos, su valoración y la posterior destrucción de los no llamados a la conservación permanente.

2. Los documentos de los archivos integrados en el Sistema de Arquivos de Galicia serán objeto de la pertinente selección para, una vez finalizado el plazo de vigencia administrativa, determinar su eliminación o, al contrario, su conservación definitiva en un archivo, de acuerdo con sus valores administrativos, jurídicos, históricos y legales.

3. Bajo ningún concepto podrán destruirse documentos en tanto subsista su valor probatorio de derechos y obligaciones de las personas y entes públicos.

Artículo 81. Circulación de los documentos.

1. El procedimiento para el caso de entradas extraordinarias de documentos por cualquier título en alguno de los archivos del sistema y su adscripción en cada caso al más adecuado serán establecidos reglamentariamente.

2. La salida de los documentos depositados en estos archivos habrá de comunicarse a la Consellería de Cultura como órgano competente en materia de archivos y patrimonio documental.

Artículo 82. Acceso a la documentación.

Todas las personas tienen derecho a la consulta de los documentos constitutivos del patrimonio documental de Galicia y a la obtención de información sobre el contenido de los mismos, de acuerdo con la legislación aplicable en la materia.

\section{TÍTULO VIII DE LAS MEDIDAS DE FOMENTO}

Artículo 83. Normas generales.

1. Las ayudas de las Administraciones públicas para la investigación, documentación, conservación, recuperación, restauración y difusión de los bienes 
integrantes del patrimonio cultural de Galicia se concederán de acuerdo con los criterios de publicidad, concurrencia y objetividad y dentro de las previsiones presupuestarias.

2. En el otorgamiento de las medidas de fomento a que se refiere este título, se fijarán las garantías necesarias para evitar la especulación con bienes que se adquieran, conserven, restauren o mejoren con ayudas públicas.

3. Las personas y entidades que no cumplan el deber de conservación establecido por esta ley no podrán acogerse a las medidas de fomento.

4. La Xunta de Galicia puede propiciar la participación de entidades privadas y de particulares en la financiación de las actuaciones de fomento a que se refiere este título. Si se tratase de un particular, la Consellería de Cultura podrá colaborar en la financiación del coste de la ejecución del proyecto, estableciéndose reglamentariamente el porcentaje y las fórmulas de colaboración convenientes.

5. Cuando se trate de obras de reparación urgente, la Consellería de Cultura podrá conceder una ayuda con carácter de anticipo reintegrable que será inscrita en el Registro General de Bienes de Interés Cultural, en el Catálogo del patrimonio cultural de Galicia o en el inventario general del patrimonio cultural de Galicia, según corresponda, y en caso de tratarse de bienes inmuebles, en el Registro de la Propiedad, en los términos que reglamentariamente se establezcan.

Artículo 84. Investigación, conservación y difusión.

La Xunta de Galicia facilitará la financiación de la conservación, acrecentamiento y rehabilitación, así como las actividades de estudio y difusión de su patrimonio cultural, dando prioridad en todo caso a aquel que esté declarado de interés cultural o catalogado.

Artículo 85. Adquisición.

La Xunta de Galicia podrá adoptar las medidas necesarias para la financiación de la adquisición de bienes declarados de interés cultural y catalogados, a fin de destinarlos a un uso general que asegure su protección. Asimismo, adoptará las medidas necesarias para que tales bienes tengan acceso preferente al crédito oficial.

Artículo 86. Inversiones culturales.

1. A los efectos de concretar las obligaciones establecidas en esta ley, se destinará un mínimo del 0,15 por 100 de los presupuestos generales de la Comunidad Autónoma para fines de conservación, restauración y rehabilitación del patrimonio cultural de Galicia, el cual será gestionado por la Consellería de Cultura.

2. Las inversiones culturales que el Estado haga en Galicia en aplicación del 1 por 100 cultural determinado por la Ley del Patrimonio Histórico Español se harán con informe previo de la Consellería de Cultura sobre los sectores y ámbitos culturales que se consideren prioritarios en cada momento.

Artículo 87. Pagos con bienes culturales.

El pago de tributos con bienes del patrimonio cultural de Galicia en los impuestos de sucesiones y donaciones, y en los del patrimonio, se llevará a cabo a través del régimen previsto en la legislación estatal.

Artículo 88. Beneficios fiscales.

Los bienes declarados de interés cultural gozarán de los beneficios fiscales que establezca la legislación correspondiente.

\section{TÍTULO IX DEL RÉGIMEN SANCIONADOR}

Artículo 89. Infracciones. Clases.

1. Constituyen infracciones administrativas en materia de protección del patrimonio cultural de Galicia las acciones u omisiones que supongan incumplimiento de las obligaciones establecidas en esta ley.

2. Las infracciones en materia de protección del patrimonio cultural de Galicia se clasificarán en leves, graves y muy graves. Artículo 90. Infracciones leves. Constituyen infracciones leves: 
a. La simple falta de notificación a la Consellería de Cultura de actos o traslados que afecten a los bienes inscritos en el Registro de Bienes de Interés Cultural o incluidos en el Catálogo del patrimonio cultural de Galicia.

b. La obstrucción de la capacidad de inspeccionar que tiene la Administración sobre los bienes del patrimonio cultural de Galicia, salvo los bienes declarados de interés cultural.

c. El incumplimiento del deber de permitir el acceso de los investigadores a los bienes declarados de interés cultural, catalogados o inventariados.

d. El incumplimiento de cualquier obligación de carácter formal contenida en esta ley.

e. El otorgamiento de licencias municipales sin la autorización preceptiva de la Consellería de Cultura para obras en bienes inventariados, incluido su entorno.

f. El incumplimiento de la suspensión de obras acordada por la Consellería de Cultura.

g. La realización de cualquier intervención en un bien inventariado sin la preceptiva autorización de la Consellería de Cultura.

Artículo 91. Infracciones graves. Constituyen infracciones graves:

a. No poner en conocimiento de la Consellería de Cultura, en los términos fijados en el artículo 27, la transmisión onerosa de la propiedad o de cualquier derecho real sobre bienes declarados de interés cultural.

b. La obstrucción a la facultad de inspeccionar que tiene la Administración sobre los bienes declarados de interés cultural.

c. El incumplimiento del deber de conservación de los propietarios o poseedores de bienes declarados de interés cultural.

d. La inobservancia del deber de llevar el libro de registro a que hace referencia el artículo 29.1, así como la omisión o inexactitud de datos que deben constar en el mismo.

e. La retención ilícita o el depósito indebido de documentos objeto de protección en esta ley. f. La separación no autorizada de bienes muebles vinculados a bienes inmuebles declarados de interés cultural.

g. El incumplimiento de las obligaciones de comunicación del descubrimiento de restos arqueológicos y de la entrega de los bienes hallados.

h. La realización de cualquier intervención en un bien declarado o catalogado sin la preceptiva autorización de la Consellería de Cultura.

i. El incumplimiento de la suspensión de obras con motivo del descubrimiento de restos arqueológicos y de las suspensiones de obras acordadas por la Consellería de Cultura.

j. El otorgamiento de licencias municipales sin la autorización preceptiva de la Consellería de Cultura para obras en bienes declarados no catalogados, incluido su entorno, o aquellas otorgadas que contraviniesen lo especificado en los planes especiales de protección y el incumplimiento de lo establecido en el apartado 2 del artículo 47 de la presente ley.

k. La realización de actividades arqueológicas sin la preceptiva autorización de la Consellería de Cultura o las realizadas contraviniendo los términos en que fue concedida ésta.

1. No poner en conocimiento de la Consellería de Cultura la realización de subastas que afecten a los bienes integrantes del patrimonio cultural de Galicia, salvo los bienes declarados de interés cultural.

$\mathrm{m}$. El incumplimiento de los deberes establecidos en el artículo 29.1 para los comerciantes de bienes integrantes del patrimonio cultural de Galicia.

Artículo 92. Infracciones muy graves. Constituyen infracciones muy graves:

a. El derribo o la destrucción total o parcial de inmuebles declarados bienes de interés cultural sin la preceptiva autorización.

b. La destrucción de bienes muebles declarados de interés cultural o catalogados. 
c. Todas aquellas acciones u omisiones que conlleven la pérdida, destrucción o deterioro irreparable de los bienes declarados de interés cultural o catalogados.

Artículo 93. Las infracciones en función del daño causado.

Se consideran como infracciones leves, graves o muy graves, en función del daño potencial o efectivo al patrimonio cultural de Galicia:

a. El cambio de uso en monumentos sin la previa autorización de la Consellería de Cultura.

b. La realización de obras con remoción o demolición en un lugar en que se hubiese realizado un hallazgo casual.

c. La utilización sin la debida autorización de sistemas, técnicas y métodos de detección de bienes integrantes del patrimonio cultural, tanto en el suelo como en el subsuelo, en medio terrestre o acuático.

Artículo 94. Responsabilidad.

Serán responsables de las infracciones previstas en la presente ley:

a. Los considerados de acuerdo con la legislación penal como autores, cómplices o encubridores, así como los que incumplan las obligaciones que establece esta ley, para obtener un beneficio.

b. Los promotores de las intervenciones u obras que se realicen sin autorización o incumpliendo las condiciones de la misma.

c. El director de las intervenciones u obras que se realicen sin autorización o incumpliendo las condiciones de la misma.

d. Los funcionarios o responsables de las Administraciones públicas que por acción u omisión permitan las infracciones.

Artículo 95. Sanciones. Clases.

1. En los casos en que el daño causado al patrimonio cultural de Galicia pueda ser valorado económicamente, la infracción será sancionada con multa de tanto al cuádruplo del valor del daño causado.

2. En los demás casos procederán las siguientes sanciones:

a. Infracciones leves: Sanción de hasta 10.000.000 de pesetas. b. Infracciones graves: Sanción desde 10.000 .001 pesetas hasta 25.000.000 de pesetas.

c. Infracciones muy graves: Sanción desde 25.000.001 pesetas.

3. Sin perjuicio de lo dispuesto en los apartados anteriores, la cuantía de la sanción no podrá ser en caso alguno inferior al beneficio obtenido como resultado de la actuación infractora.

4. La graduación de las multas se realizará en función de la gravedad de la infracción, de las circunstancias atenuantes o agravantes que concurran, de la importancia de los bienes afectados, de las circunstancias personales del sancionado, del perjuicio causado o que hubiese podido causarse al patrimonio cultural de Galicia y del grado de malicia del interviniente.

5. Las multas que se impongan a distintos sujetos como consecuencia de una misma infracción tendrán carácter independiente entre sí.

Artículo 96. Órganos competentes.

1. La competencia para la imposición de las sanciones previstas en el artículo anterior corresponde:

a. Al Director general del Patrimonio Histórico y Documental: Sanciones de hasta 10.000 .000 de pesetas.

b. Al Conselleiro de Cultura: Sanciones comprendidas entre 10.000 .001 pesetas y 25.000.000 de pesetas.

c. Al Consello de la Xunta de Galicia: Sanciones superiores a 25.000.001 pesetas.

2. La Consellería de Cultura, sin perjuicio de lo dispuesto en el presente artículo, emprenderá ante los órganos jurisdiccionales competentes las acciones penales que correspondiesen por los actos delictivos en que pudiesen incurrir los infractores.

Artículo 97. Procedimiento.

1. La iniciación del procedimiento sancionador, sin perjuicio de la superior autoridad del conselleiro, se realizará por resolución de la Dirección General del Patrimonio Histórico y Documental, de oficio o previa denuncia de parte. 
2. La tramitación del expediente sancionador, en el cual, en todo caso, se dará audiencia al interesado, se regirá por lo dispuesto en el título IX de la Ley 30/1992, de 26 de noviembre, de Régimen Jurídico de las Administraciones Públicas y del Procedimiento Administrativo Común y en su normativa de desarrollo.

Artículo 98. Reparación y decomiso.

1. Las infracciones de las que se deriven daños al patrimonio cultural de Galicia conllevarán, siempre que sea posible, la obligación de reparación y restitución de las cosas a su debido estado, así como, en todo caso, la indemnización de los daños y perjuicios causados.

2. En caso de incumplimiento de dicha obligación, la Consellería de Cultura realizará, siempre que sea posible, las intervenciones reparadoras necesarias a cargo del infractor.

3. El órgano competente para imponer una sanción podrá acordar como medida cautelar el decomiso de los materiales y útiles empleados en la actividad ilícita, así como acordar el depósito cautelar de los bienes integrantes del patrimonio cultural que se hallen en posesión de personas que se dediquen a comerciar con ellos si no pueden acreditar su adquisición lícita.

Artículo 99. Prescripción.

Las infracciones administrativas de lo dispuesto en la presente ley prescribirán a los diez años de haberse cometido o descubierto en el caso de las muy graves, y a los cinco años en los demás supuestos.

\section{DISPOSICIÓN ADICIONAL PRIMERA}

Todos aquellos bienes muebles e inmuebles sitos en el ámbito territorial de la Comunidad Autónoma de Galicia que hubiesen sido declarados de interés cultural con anterioridad a la entrada en vigor de esta ley pasarán a tener la consideración de bienes de interés cultural y quedarán sometidos al mismo régimen jurídico de protección aplicable a éstos.

\section{DISPOSICIÓN ADICIONAL SEGUNDA}

En virtud de esta ley se incluyen en el inventario general del patrimonio cultural de Galicia todos aquellos bienes recogidos en los catálogos de las normas complementarias y subsidiarias de planeamiento de las provincias de A Coruña, Lugo, Ourense y Pontevedra, aprobadas por la Orden de la Consellería de Ordenación del Territorio y Obras Públicas de 3 de abril de 1991, así como los contenidos en los catálogos de cualquier otra figura de planeamiento.

\section{DISPOSICIÓN ADICIONAL TERCERA}

La Consellería de Cultura promoverá la preparación adecuada de los funcionarios encargados de la administración y custodia del patrimonio cultural de Galicia.

\section{DISPOSICIÓN ADICIONAL CUARTA}

El conocimiento del patrimonio cultural de Galicia será valorizado dentro del sistema educativo obligatorio en sus diferentes niveles.

\section{DISPOSICIÓN ADICIONAL QUUINTA}

La cuantía de las sanciones previstas en esta ley habrá de actualizarse por decreto de la Xunta de Galicia, de acuerdo con el índice de precios al consumo.

\section{DISPOSICIÓN ADICIONAL SEXTA}

1. Para el ejercicio de la actividad de vigilancia e inspección del patrimonio cultural se crea, dentro del Cuerpo Facultativo Superior de la Xunta de Galicia, grupo A, la Escala de Vigilancia e Inspección del Patrimonio Cultural de Galicia, cuya estructura, dependencia y funcionamiento orgánico serán establecidos reglamentariamente.

2. La titulación deberá ser de Arquitecto superior, Licenciado en Geografía e Historia o en Historia (Arqueólogo), Licenciado en Historia del Arte o Licenciado en Humanidades. El sistema de 
selección será por concurso-oposición, siendo sus funciones:

a. Vigilancia del cumplimiento de la ordenación urbanística municipal a través de los planes de ordenación y planes operativos en lo que se refiere al patrimonio cultural de Galicia.

b. Comprobación del cumplimiento de las normas, resoluciones y dictámenes emanados de la autoridad competente en materia de protección del patrimonio cultural.

c. Control de los obligatorios libros de registro, en donde han de constar las transacciones realizadas por las personas y entidades dedicadas al comercio de bienes integrantes del patrimonio cultural.

d. Todas aquellas otras que por disposición legal o reglamentaria puedan serle atribuidas ${ }^{312}$.

\section{DISPOSICIÓN TRANSITORIA PRIMERA}

La tramitación y los efectos de los expedientes de declaración de bienes de interés cultural incoados con anterioridad a la entrada en vigor de la presente ley quedarán sometidos a lo dispuesto por ésta.

\section{DISPOSICIÓN TRANSITORIA SEGUNDA}

Cuando, a la entrada en vigor de esta ley, el entorno de un inmueble catalogado no esté delimitado expresamente por una figura de planeamiento, será determinado por la Consellería de Cultura de acuerdo con la incidencia del bien en las áreas afectadas por el mismo. En todo caso, se tendrá en cuenta la legislación general aplicable.

\section{DISPOSICIÓN DEROGATORIA}

Quedan derogadas cuantas disposiciones de igual o inferior rango se opongan a lo dispuesto en esta ley.

\section{DISPOSICIÓN FINAL PRIMERA}

Se autoriza al Consello de la Xunta para dictar las normas necesarias para el desarrollo y ejecución de esta ley.

312 Disposición adicional sexta modificada por Ley $7 / 2002$, de 27 de diciembre, de medidas fiscales y de régimen administrativo.

\section{DISPOSICIÓN FINAL SEGUNDA}

La presente ley entrará en vigor al día siguiente de su publicación en el "Diario Oficial de Galicia".

6. LEY 3/1996, DE 10 DE
MAYO, DE PROTECCIÓN DE
LOS CAMINOS DE SANTIAGO
(DOGA N. $\left.^{\circ} 101,23.5 .1996\right)^{313}$

(...) $)^{314}$

\section{TÍTULO PRELIMINAR OBJETO DE LA LEY}

Artículo 1. 1. La presente ley tiene por objeto la delimitación y regulación de la conservación, uso y diferentes niveles de protección de los tramos de los caminos de Santiago que discurren por Galicia.

2. A los efectos de la presente ley, se entiende como Camino de Santiago todas las rutas históricas reconocidas documentalmente.

3. La ruta principal, dentro del marco de la presente ley, es el "Camino francés", bien de interés cultural, según la delimitación de su territorio histórico, recogida en la Resolución de 12 de noviembre de 1992 de la Dirección General del Patrimonio Histórico y Documental.

4. Las otras rutas que se enmarcan en la denominación general de "Camino de Santiago" se corresponden con las actualmente conocidas como "Camino portugués", "Ruta de la plata", "Camino del norte", "Camino de Fisterra", "Camino inglés" y "Ruta del mar de Arousa y Ulla”. Su delimitación y deslinde se realizará con arreglo a lo dispuesto en la presente ley. Una vez deslindadas, les será de aplicación la protección prevista en la Ley del Patrimonio Cultural de Galicia para los bienes catalogados.

\section{TÍTULO I}

\section{DE LA NATURALEZA DEL CAMINO}

Artículo 2. 1. El Camino de Santiago está constituido por vías de dominio y

313 Véase Decreto 45/2001, de 1 de febrero, de refundición de la normativa en materia del Camino de Santiago. 314 Exposición de motivos omitida. 
uso público, delimitadas con arreglo a lo establecido en la presente ley.

2. La naturaleza demanial del Camino se extiende a los terrenos que ocupa y a sus elementos funcionales. Con independencia del proceso de delimitación del Camino previsto en esta ley, su anchura vendrá constituida por una franja de, al menos, tres metros en los casos en que fuese necesaria su recuperación. Cuando el Camino discurra por puentes formará parte del mismo el terreno ocupado por los soportes de la estructura.

3. Adquirirán igualmente naturaleza demanial los tramos que vayan recuperándose del Camino histórico que estén aún en manos privadas. En tanto no se recuperen se constituye una servidumbre pública para el paso del Camino sobre propiedad privada de una anchura de tres metros.

Artículo 3. 1. En los casos de ejecución de obras de infraestructura en que fuera indispensable, por causa de fuerza mayor o interés social, ocupar algún tramo del Camino, habrá de contemplarse en los respectivos proyectos un trazado alternativo al mismo, que adquirirá naturaleza demanial. En el supuesto de construcción de una carretera dicho tramo alternativo discurrirá de forma paralela y próxima a la misma, y reunirá semejantes características al tramo ocupado.

2. La necesidad de ocupación de un tramo del Camino por los motivos expuestos en el apartado anterior necesitará, previamente, la incoación del correspondiente expediente administrativo, en donde habrá de acreditarse la existencia de dicha necesidad.

Artículo 4. El Camino de Santiago constituye un bien de dominio público de carácter cultural incluido en la categoría de territorio histórico. Como tal le será de aplicación la legislación general autonómica en esta materia.

\section{TÍTULO II \\ DE LA DELIMITACIÓN, DESLINDE Y RÉGIMEN URBANÍSTICO DEL CAMINO}

Artículo 5. 1. La delimitación del Camino se llevará a cabo mediante expediente incoado al efecto, en donde se definirá la anchura de acuerdo con el artículo 2.2 de la presente ley y se concretarán sus pertenencias, accesorios y características, así como las correspondientes zonas de protección.

2. Corresponde a la Consellería de Cultura la incoación de los procedimientos de delimitación y deslinde de los tramos del Camino de Santiago. La incoación del expediente de delimitación habrá de ser notificada a los Ayuntamientos por cuyos términos discurra el Camino y anunciada en el "Diario Oficial de Galicia".

3. En el procedimiento de delimitación del Camino habrá de intervenir preceptivamente el Comité Asesor do Camiño de Santiago previsto en la presente ley. Antes de su aprobación, la delimitación del trazado del Camino habrá de ser sometida a información pública por un plazo de dos meses.

4. La delimitación del Camino será aprobada mediante Decreto de la Xunta de Galicia, a propuesta del Conselleiro de Cultura.

5. La delimitación del Camino, una vez aprobada, llevará implícita la declaración de interés social y la de necesidad de ocupación de los bienes y adquisición de derechos a los fines de expropiación forzosa, de ocupación temporal o de imposición o modificación de servidumbres.

Artículo 6. 1. Igualmente, y siguiendo el procedimiento previsto en el artículo anterior, habrán de delimitarse las correspondientes zonas laterales de protección del Camino, que consistirán en dos franjas de terreno a ambos lados del mismo de una anchura mínima de tres metros a partir de su línea exterior, salvo en aquellos tramos en que discurra 
tangencialmente a una carretera. En este caso la zona lateral de protección de tres metros se establecerá para la orilla del Camino opuesta a la carretera.

2. Las zonas laterales de protección del Camino están sometidas a las limitaciones establecidas en la presente ley.

3. En los tramos urbanos del Camino, los instrumentos de ordenación urbanística se someterán a las normas específicas que la presente ley establece para las zonas laterales de protección. Se consideran tramos urbanos aquellos que discurran por el suelo calificado de urbano por el correspondiente instrumento de planeamiento.

Artículo 7. La Xunta de Galicia regulará por vía reglamentaria el procedimiento de deslinde.

\section{TÍTULO III DE LA CONSERVACIÓN Y PROTECCIÓN DEL CAMINO}

Artículo 8. 1. Los poderes públicos gallegos, dentro de sus respectivas competencias, garantizarán la recuperación, conservación, mejora y protección del Camino y de todos sus elementos funcionales.

2. Las administraciones locales cooperarán con los órganos de la Xunta de Galicia en la conservación y protección de los tramos del Camino que discurran por sus respectivos territorios, adoptando las medidas oportunas que eviten su deterioro o destrucción. En todo caso, los Ayuntamientos notificarán a la Consellería de Cultura cualquier peligro de daño que se produzca en el Camino.

3. La Xunta de Galicia podrá delegar en las entidades locales por las que discurra el Camino funciones de conservación y protección del mismo, asignando las dotaciones oportunas.

4. En aquellas acciones que se realicen en el patrimonio arquitectónico y monumental situado en el Camino de Santiago se tendrá en cuenta la garantía del ulterior mantenimiento de los monumentos restaurados, cuando no sean la titularidad pública, en función de su uso.
5. En el caso de los bienes citados en el punto anterior, una vez restaurados esos bienes, la Consellería de Cultura garantizará su utilización pública para el uso de los peregrinos que recorran el Camino, previo acuerdo con los propietarios de los mismos cuando los hubiese.

Artículo 9. 1. El destino del Camino será el de un sendero peatonal, destino que será compatible con su utilización como vía ecuestre o como vía para vehículos sin motor. En ningún caso tanto la utilización del Camino como la de sus elementos funcionales podrán suponer un peligro de destrucción o deterioro ni realizarse de forma incompatible con los valores que encierra.

2. Constituyen elementos funcionales del Camino los afectos a la conservación o servicio del mismo, tales como áreas de descanso, áreas de auxilio y atención médica de urgencia, señalizaciones, albergues de peregrinos y, en general, todos aquéllos que sean complementarios a su utilización.

Artículo 10. 1. El Camino, en sus tramos no urbanos, no podrá ser utilizado para el tráfico rodado de vehículos de motor, cualquiera que sea su naturaleza.

2. La prohibición contenida en el apartado anterior no será de aplicación en aquellos casos en que el Camino sea el vial directo de acceso a fincas y viviendas. En todo caso, y a través de los correspondientes procedimientos de concentración parcelaria o expropiación forzosa, habrán de irse arbitrando paulatinamente accesos a fincas y viviendas que eviten la utilización de tramos del Camino para el tráfico rodado.

Artículo 11. 1. En las zonas laterales de protección previstas en el artículo 6.1 de la presente ley no se permitirán más usos que los que sean compatibles con la conservación del Camino, previa autorización expresa, en cualquier caso, de la Consellería de Cultura.

2. En particular, en las zonas laterales de protección quedará prohibido: 
a. El establecimiento de campamentos $\mathrm{y}$, en general, cualquier tipo de acampada colectiva o individual.

b. Todo tipo de actividad constructiva, salvo las infraestructuras previstas en el artículo 3.

c. Las explotaciones propias de las carreteras.

d. La tala de arbolado. Con la autorización expresa de la Consellería de Cultura, podrá permitirse la tala aislada de árboles, con la obligación de compensar la tala con la plantación inmediata de especies autóctonas.

Artículo 12. El resto de las actividades en las zonas laterales de protección requerirá la autorización de la Consellería de Cultura, previo informe preceptivo del Comité Asesor do Camiño de Santiago.

Artículo 13. 1. La Consellería de Cultura ordenará la paralización de toda actividad u obra no autorizada o que no se ajuste a las condiciones establecidas en la autorización.

2. En el plazo de dos meses a partir de la orden de paralización de toda actividad, la Consellería de Cultura habrá de adoptar, previo informe preceptivo del Comité Asesor do Camiño de Santiago, algunas de las resoluciones siguientes:

a. Demoler las obras o impedir definitivamente las actividades no autorizadas o no ajustadas a las condiciones establecidas en la autorización.

b. Ordenar la instrucción del oportuno expediente para la eventual legalización de las obras o autorización de las actividades, siempre que fueran compatibles con lo dispuesto en la presente ley y demás legislación aplicable.

Artículo 14. En las zonas laterales de protección podrá procederse a la expropiación forzosa de los bienes existentes, entendiéndose implícita la declaración de interés social siempre que la expropiación sea condición necesaria para la conservación, reparación, ampliación o servicio del Camino.
Artículo 15. El incumplimiento de las obligaciones y prohibiciones previstas en la presente ley para las zonas laterales de protección del Camino implicará la declaración de interés social a los efectos de aplicación de la expropiación forzosa a los bienes a que se refiere el artículo anterior.

Artículo 16. 1. A fin de salvaguardar el Camino, en cuanto bien de interés cultural, se establece una zona de protección del entorno, compuesta por dos franjas de 30 metros de ancho, contados a partir de los límites exteriores del mismo, en la que el uso del suelo quedará sometido a la autorización de la Consellería de Cultura, previo informe preceptivo del Comité Asesor do Camiño de Santiago.

2. La autorización a que se refiere el párrafo anterior únicamente podrá otorgarse cuando las actuaciones respondan a las características tradicionales de la zona y respeten los valores del Camino.

3. En cualquier caso, en la zona de protección del entorno queda prohibido:

a. Todo tipo de publicidad.

b. La explotación minera.

c. La extracción de grava y arena.

4. En las zona de protección, la Consellería competente podrá llevar a cabo una ordenación espacial incluso de las explotaciones agrarias afectadas por el Camino.

5. Para cualquier actuación sobre el Camino de Santiago se tendrá en cuenta lo dispuesto en la legislación de evaluación de impacto ambiental.

Artículo 17. 1. La Consellería de Cultura redactará, en el marco de la presente ley, un plan especial de protección y promoción del Camino de Santiago, y en el mismo se dará audiencia a todos los Ayuntamientos por los que discurra. Dicho plan habrá de ser previamente informado por el Comité Asesor do Camiño de Santiago previsto en la presente ley y será aprobado por el Consello de la Xunta.

2. La obligatoriedad del plan especial de protección y promoción del Camino 
no podrá excusarse en la preexistencia de otro planeamiento, cualquiera que sea su naturaleza.

Los planes especiales que los Ayuntamientos afectados puedan redactar con vistas a la ordenación del tramo del Camino de Santiago que discurra por su territorio habrán de adaptarse al plan especial de protección y promoción previsto en el presente artículo.

Artículo 18. 1. El planeamiento municipal y, en su caso, las normas subsidiarias provinciales de planeamiento deben incorporar en sus determinaciones y documentos lo dispuesto en la presente ley y en el plan de protección y promoción del Camino de Santiago.

2. El otorgamiento de licencias municipales para actividades autorizables que afecten al Camino de Santiago, a sus zonas laterales de protección y a la zona de protección del entorno precisará de la resolución previa de la Consellería de Cultura, previo informe preceptivo del Comité Asesor do Camiño de Santiago. Por tanto, no podrá otorgarse la licencia hasta que la autorización sea notificada al Ayuntamiento.

3. En todo caso, no se permitirán en las zonas laterales de protección ni en la de protección del entorno nuevas alineaciones ni aumentos de edificabilidad.

Artículo 19. Será pública la acción para exigir ante los órganos administrativos competentes el cumplimiento de lo previsto en la presente ley y en el plan especial de protección y promoción.

\section{TÍTULO IV \\ DE LAS INFRACCIONES Y SANCIONES}

Artículo 20. 1. Sin perjuicio de lo previsto en la legislación sobre patrimonio cultural, la vulneración de las obligaciones y prohibiciones contenidas en la presente ley y en el plan especial de protección y promoción tendrá la consideración de infracción administrativa. Conllevará la imposición de las correspondientes sanciones a los responsables, así como la obligación de resarcimiento de daños y perjuicios, todo ello con independencia de las responsabilidades penales que pudieran derivarse y de la obligación de restauración del Camino o de sus zonas laterales de protección.

2. Las infracciones cometidas en el Camino o en sus zonas laterales de protección se sancionarán con multas cuya cuantía se graduará teniendo en cuenta la gravedad del daño, la entidad económica de los hechos constitutivos de la infracción, la reiteración, las circunstancias concurrentes y el grado de responsabilidad de la persona o personas infractoras. Los límites cuantitativos son los establecidos en la Ley del Patrimonio Cultural de Galicia.

Artículo 21. Las infracciones se clasifican en muy graves, graves y leves.

1. Tienen el carácter de infracciones muy graves:

a. Toda actuación que suponga la destrucción de parte del Camino o de sus elementos funcionales, incluido el arbolado.

b. La falta de autorización preceptiva o el incumplimiento de las condiciones previstas en la misma, en aquellas actividades que se realicen en el Camino o en sus zonas de protección. Todo ello, con independencia de lo previsto en el artículo 13.2.b) de la presente ley.

c. La realización de actividades prohibidas en las zonas laterales de protección del Camino previstas en el artículo 11.2 de la presente ley.

d. La infracción de las prohibiciones establecidas en el artículo 16.

e. La reincidencia en la comisión de infracciones graves.

2. Tienen el carácter de infracciones graves:

a. La utilización del Camino para el tráfico rodado fuera del supuesto previsto en el artículo 10.2 de la presente ley.

b. La reincidencia en la comisión de infracciones leves. 
3. Tienen el carácter de infracciones leves:

a. El vertido o abandono en el Camino $o$ en sus zonas de protección de objetos, residuos y otros desperdicios fuera de los lugares autorizados, así como la quema de los mismos.

b. La utilización del Camino que atentase al uso y disfrute pleno y pacífico del mismo por las demás personas.

c. La realización de actividades contrarias a los valores del Camino.

Artículo 22. A los efectos de lo dispuesto en el artículo anterior se entiende que hay reincidencia cuando en el período de un año se hubiesen cometido dos o más infracciones graves o leves, y así hubiese sido declarado por resolución firme.

Artículo 23. Las faltas a que se refieren los artículos anteriores prescribirán:

a. Las muy graves, a los tres años.

b. Las graves, a los dos años.

c. Las leves, a los seis meses.

Estos plazos se contarán desde que se ha tenido conocimiento del hecho.

Artículo 24. Los órganos competentes para la imposición de multas serán los siguientes:

a. El Director general del Patrimonio en cuanto a las faltas leves.

b. El Conselleiro de Cultura en las graves.

c. El Consello de la Xunta en las muy graves.

Artículo 25. En lo no previsto en este artículo será de aplicación lo dispuesto en el título IX de la Ley 30/1992, de 26 de noviembre, de Régimen Jurídico de las Administraciones Públicas y del Procedimiento Administrativo Común, y en la normativa autonómica de desarrollo de la misma.

\section{TÍTULO V DE LA PROMOCIÓN DEL CAMINO}

Artículo 26. Corresponde a la Consellería de Cultura la realización de todo tipo de actividades de promoción cuyo objeto sea el conocimiento y difusión del patrimonio histórico-cultural ligado al Camino de Santiago.

Artículo 27. 1. En el marco de la promoción del Camino de Santiago, la Consellería de Cultura y, en su caso, el Consello de la Xunta procurarán el establecimiento de los oportunos mecanismos de colaboración y coordinación de programas con las Comunidades Autónomas por donde discurra el mismo.

2. El Consello de la Xunta podrá acordar beneficios e incentivos a favor de los Ayuntamientos y particulares afectados por la política protectora y de promoción del Camino, y constituir consorcios y celebrar convenios con otras Administraciones Públicas.

3. A través de los mecanismos de cooperación con otras Comunidades, se procurará una señalización uniforme del Camino siguiendo las directrices del Consejo de Europa, teniendo en cuenta los siguientes criterios:

a. La rotulación dentro del territorio de Galicia se hará en gallego. En el caso de utilización de varios idiomas, aquél tendrá lugar preferente en el orden de colocación y mayor relevancia en la dimensión tipográfica.

b. Fuera del territorio gallego, se promoverán los acuerdos oportunos para que nuestro idioma figure en la rotulación y se expresen de forman correcta los topónimos.

Artículo 28. La Consellería de Cultura elaborará anualmente unas directrices de actuación que recojan las actividades de promoción del Camino que pretenda llevar a cabo.

Artículo 29. Es competencia de la Consellería de Cultura:

a. El establecimiento, conservación y mantenimiento de toda clase de servicios para la peregrinación a lo largo de los tramos gallegos del Camino de Santiago.

b. El establecimiento de la señalización adecuada del Camino. 
c. El establecimiento, organización y gestión de una red de albergues destinados a la peregrinación. Podrá igualmente establecerse un sistema de apoyo a albergues y hospederías que tengan carácter privado $^{315}$.

\section{TÍTULO VI DEL COMITÉ ASESOR DO CAMIÑO DE SANTIAGO ${ }^{316}$}

Artículo 30. 1. Se crea, como órgano consultivo de la Consellería de Cultura, el Comité Asesor do Camiño de Santiago para que emita los informes que se señalan en los artículos 3, 5, 12, 13, 16 y 17 de la presente ley y cuantos otros se le soliciten.

2. El Comité Asesor, compuesto por diez miembros como máximo, será designado entre personas de reconocida competencia en la materia.

\section{DISPOSICIÓN ADICIONAL}

Dentro del plazo máximo de dos años a partir de la entrada en vigor de la presente ley, la Xunta de Galicia aprobará el plan especial de protección y promoción del Camino de Santiago a que se refiere el artículo 17 de la presente ley.

\section{DISPOSICIÓN TRANSITORIA PRIMERA}

En tanto no se apruebe el expediente de delimitación del Camino, y sin perjuicio de las zonas de protección establecidas por la presente ley, seguirá estando vigente la delimitación establecida por la Resolución de la Dirección General del Patrimonio Histórico y Documental de 12 de noviembre de 1992 .

\section{DISPOSICIÓN TRANSITORIA SEGUNDA}

El Comité Asesor do Camiño de Santiago previsto en el título VI de la presente ley habrá de constituirse dentro de un plazo

315 Art. 29.c modificado por Ley 14/2004, de 29 de diciembre, de medidas tributarias y de régimen administrativo.

316 Véase Decreto 46/2007, de 8 de marzo, por el que se regula la composición y funcionamiento del Comité Asesor do Camiño de Santiago. máximo de un año a partir de la entrada en vigor de la misma. Mientras tal constitución no se lleve a cabo, las funciones que la presente ley atribuye a dicho Comité Asesor serán desempeñadas provisionalmente por la Comisión del Patrimonio Histórico de la ciudad y Camino de Santiago.

\section{DISPOSICIÓN TRANSITORIA TERCERA}

En tanto no se apruebe el plan especial de protección y promoción previsto en la presente ley, en las zonas laterales de protección y en las de protección del entorno no se permitirán nuevas alineaciones, aumentos de edificabilidad, parcelaciones ni agregaciones.

\section{DISPOSICIÓN DEROGATORIA}

Queda derogado el Decreto 32/1991, de creación del Centro Coordinador Jacobeo, y cuantas disposiciones de igual o inferior rango se opongan a lo establecido en la presente ley.

\section{LEY 3/2008, DE 23 DE MAYO, DE ORDENACIÓN DE LA MINERÍA DE GALICIA (DOGA N. ${ }^{\circ} 109,6.6 .2008$ ) $(\ldots)^{317}$ TítULO I DISPOSICIONES GENERALES}

Artículo 1. Objeto.

La presente ley tiene por objeto el desarrollo del régimen jurídico de las actividades mineras en Galicia en condiciones de sostenibilidad y seguridad promoviendo un aprovechamiento racional compatible con la protección del medio ambiente.

Artículo 2. Ámbito de aplicación.

1. La presente ley es de aplicación a las siguientes actividades:

a. A la exploración, investigación, explotación y aprovechamiento de los recursos minerales y demás recursos geológicos situados en Galicia.

317 Exposición de motivos omitida. 
b. Al aprovechamiento de recursos geotérmicos y de formaciones geológicas superficiales o subterráneas.

c. A la preparación para la entrega a los mercados de los minerales y recursos extraídos.

d. A la gestión de los residuos producidos en las actividades extractivas.

e. A la recuperación ambiental de los terrenos afectados por labores mineras, así como a las condiciones y requisitos del abandono de la actividad minera.

f. A la actividad administrativa de apoyo para la mejora e innovación en las actividades mineras, a fin de disminuir el impacto sobre los recursos naturales y la valorización integral de los recursos producidos en la búsqueda del cierre del ciclo productivo en Galicia.

2. Están excluidas del ámbito de aplicación de la presente ley las siguientes materias:

a. La exploración, investigación, explotación y almacenamiento subterráneo de hidrocarburos líquidos y gaseosos.

b. La extracción ocasional y de escasa importancia de recursos minerales, cualquiera que sea su clasificación, siempre que se lleve a cabo por el propietario de un terreno para su uso exclusivo y no exija la aplicación de técnica minera alguna.

c. Las aguas reguladas en la Ley 5/1995, de 7 de junio, de regulación de las aguas minerales, termales, de manantial y de los establecimientos balnearios de la Comunidad Autónoma de Galicia.

Artículo 3. Principios. ley:

Son principios que inspiran la presente

a. La planificación minera en el marco de la ordenación de la economía y del territorio.

b. La gestión sostenible de los recursos mineros.

c. La innovación tecnológica orientada a la sostenibilidad y la valorización plena de los recursos mineros. d. La mejora de las condiciones de seguridad y salud laborales.

e. La colaboración y cooperación de las diferentes administraciones públicas.

f. La participación en la política minera de los sectores sociales y económicos implicados, los cuales integrarán activamente la dimensión de la igualdad de oportunidades entre mujeres y hombres.

\section{TÍTULO II}

\section{ORGANIZACIÓN ADMINISTRATIVA Y COMPETENCIAS}

\section{Capítulo I}

\section{LA ADMINISTRACIÓN DE LA XUNTA DE GALICIA}

\section{Artículo 4. El Consejo de la Xunta.}

Al Consejo de la Xunta, como órgano superior de dirección y coordinación de la política minera de la Comunidad Autónoma de Galicia, corresponde:

a. Aprobar el Plan sectorial de actividades extractivas de Galicia, así como sus modificaciones o revisiones, a propuesta de la consejería competente en materia de minas.

b. Garantizar la coordinación de los distintos departamentos autonómicos con incidencia en la minería.

c. Acordar con carácter excepcional, previa justificación del interés público, el otorgamiento de derechos mineros en caso de existencia de informes preceptivos desfavorables, si fuera el caso.

d. Establecer las líneas de cooperación con las demás administraciones públicas. e. Resolver sobre la prevalencia de utilidades públicas incompatibles cuando se vean afectadas competencias atribuidas a distintas consejerías.

f. Aprobar la declaración de municipios mineros.

Artículo 5. La consejería competente en materia de minas.

Corresponderá a la consejería que tenga atribuida la competencia en materia de minería: 
a. Promover y planificar la actividad minera en Galicia elaborando el Plan sectorial de actividades extractivas de Galicia y aquellos otros planes que sean precisos para un desarrollo sostenible de esta actividad.

b. Otorgar las concesiones, permisos y autorizaciones, en los términos de la legislación básica estatal, necesarios para el desarrollo de actividades extractivas.

c. Ejercer las competencias relativas a la seguridad minera.

d. Inspeccionar el cumplimiento de las condiciones técnicas, de seguridad y ambientales de las actividades extractivas o de cualquier otra actividad que utilice técnicas mineras.

e. Impulsar la mejora de las explotaciones mineras potenciando sus competencias técnicas, medioambientales, comerciales y organizativas.

f. Ejercer la potestad sancionadora en los términos establecidos en la presente ley.

g. El desarrollo competitivo y sostenible del tejido empresarial minero gallego.

\section{Capitulo II \\ EL CONSEJO DE LA MINERÍA DE GALICIA}

Artículo 6. Creación y régimen jurídico.

1. Se crea el Consejo de la Minería de Galicia como órgano colegiado de participación, consulta y asesoramiento de la administración competente en materia de minería.

2. El consejo estará adscrito a los efectos administrativos a la consejería competente en materia de minería. La organización y régimen jurídico del consejo, así como el carácter de sus informes, se determinarán reglamentariamente garantizando un funcionamiento transparente, una periodicidad adecuada y la participación activa de todos sus miembros.

Artículo 7. Funciones.

Corresponden al Consejo de la Minería de Galicia las siguientes funciones: a. Emitir informe sobre los anteproyectos de ley, sobre los proyectos de reglamentos con incidencia en la minería y sobre el Plan sectorial de actividades extractivas de Galicia.

b. Asesorar sobre los planes y programas que la presidencia le proponga en razón a la importancia de su incidencia sobre la minería.

c. Emitir informes y efectuar propuestas en materia de minería, a iniciativa propia.

d. Proponer medidas para un mejor desarrollo de la política minera.

e. Impulsar la coordinación entre la iniciativa pública y privada en materia de minería.

f. Informar sobre cuantos asuntos en materia minera sean sometidos a su consideración por la consejería competente en materia de minería y las que reglamentariamente se le atribuyan.

g. Conocer de la evolución del empleo en el sector de la minería, de las sanciones firmes derivadas de los incumplimientos de la presente ley y de las estadísticas de siniestrabilidad del sector y subsectores de la minería.

h. Efectuar el seguimiento del grado de cumplimiento de todas las iniciativas encaminadas a mejorar la calidad del empleo en la minería de Galicia, incrementar la seguridad laboral e impulsar la formación de los trabajadores y trabajadoras del sector en nuestra Comunidad.

i. Ser informado anualmente respecto a los expedientes administrativos tramitados con arreglo al procedimiento dispuesto en el título IV de la presente ley.

j. Todas aquellas funciones que le sean atribuidas por una ley.

Artículo 8. Composición.

1. El Consejo de la Minería de Galicia estará presidido por la persona titular de la consejería competente en materia de minería o persona en quien delegue.

La composición y organización del Consejo de la Minería de Galicia se regirá por 
el principio de paridad y tratará de garantizar una representación proporcionada entre mujeres y hombres.

Reglamentariamente se determinará la composición del consejo, en el que estarán integrados representantes de las administraciones, de las organizaciones sindicales y empresariales más representativas del sector, de las asociaciones de defensa de la naturaleza, de las comunidades de montes en mano común, de los municipios mineros, de los colegios profesionales competentes en materia minera y de la Cámara Oficial Minera de Galicia.

2. Sus miembros serán nombrados por la persona titular de la consejería competente en materia de minería a propuesta de las organizaciones representativas. El nombramiento de los miembros electivos del consejo y de sus suplentes será por un periodo de cuatro años, que podrá ser renovado por periodos iguales de dos años. Los miembros del consejo cesarán a propuesta de las organizaciones o entidades que propusieron su nombramiento.

\section{Capítulo III REGISTRO MINERO DE GALICIA}

Artículo 9. Registro Minero de Galicia.

1. Se crea el Registro Minero de Galicia, en el que se inscribirán todos los derechos mineros autorizados o concedidos en el territorio de la Comunidad Autónoma de Galicia. La inscripción se practicará de oficio e incluirá, con el suficiente desglose, el tipo de derecho minero, su titular, extensión, delimitación y plazo de vigencia.

2. Los datos reflejados en el Registro Minero de Galicia se incorporarán al Catastro Minero de Galicia, constituyendo información de apoyo para la gestión interna y la definición de la política minera de la comunidad autónoma.

3. El Registro Minero de Galicia será público, según las condiciones que se establezcan reglamentariamente.
Artículo 10. Registro de Solicitudes de Derechos Mineros.

1. La consejería competente en materia de minas llevará un registro de solicitudes de permisos, autorizaciones y concesiones de derechos mineros.

2. En este registro, que se articulará como una sección independiente dentro del Registro Minero de Galicia, se inscribirán las solicitudes en el orden en el que fueron presentadas.

3. La prioridad para la tramitación de los derechos mineros se determinará por el orden de inscripción en el Registro de Solicitudes de Derechos Mineros.

\section{TÍTULO III \\ PLANIFICACIÓN DE LA MINERÍA}

Artículo 11. Plan sectorial de actividades extractivas de Galicia.

1. El Plan sectorial de actividades extractivas de Galicia se configura como un plan sectorial de incidencia supramunicipal de los regulados en la Ley 10/1995, de 23 de noviembre, de ordenación del territorio de Galicia. Como máximo instrumento de planificación de la política minera tiene por objeto establecer los principios y directrices para la ordenación minera de Galicia, basada en criterios de estabilidad y sostenibilidad, así como la normativa necesaria para desarrollar los ejes básicos de actuación administrativa en Galicia en el sector propiciando la coordinación de las acciones, su desarrollo sostenible, la mejora tecnológica y la diversificación económica.

2. Las determinaciones del Plan sectorial de actividades extractivas de Galicia serán directamente aplicables y prevalecerán de forma inmediata sobre las del planeamiento urbanístico, que habrá de ser objeto de adaptación.

3. El procedimiento de aprobación del Plan sectorial de actividades extractivas de Galicia se ajustará a lo dispuesto en el artículo 25 de la Ley 10/1995, de 23 de

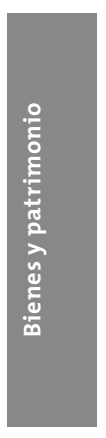


noviembre, de ordenación del territorio de Galicia.

Artículo 12. Criterios orientadores. Los criterios que inspirarán el Plan sectorial de actividades extractivas de Galicia serán los siguientes:

a. El establecimiento de las bases del desarrollo de una minería sostenible.

b. La identificación de zonas con potencial minero.

c. La mejora de la seguridad de las explotaciones mineras y de sus establecimientos de beneficio.

d. La armonización de la actividad extractiva con el resto de los usos del suelo dentro del marco de la ordenación territorial, agraria y ambiental.

e. El aprovechamiento ordenado y sostenible de los recursos mineros de manera compatible con la protección del medio natural y el patrimonio cultural.

f. La racionalización del empleo de recursos naturales y de residuos a través de la implantación de las mejores técnicas disponibles y la valorización.

g. La promoción de la investigación, el desarrollo y la innovación en las propiedades y aplicaciones de los materiales, así como en los procesos de producción, tratamiento y aprovechamiento de subproductos.

h. La búsqueda de una mayor vinculación de la minería con la mejora de la economía de las zonas en que se sitúen las explotaciones y el fomento de la creación de empleo.

i. El asesoramiento, información y colaboración con las administraciones locales, entes privados y organizaciones empresariales y sindicales en cuestiones relacionadas con las actividades mineras y el desarrollo empresarial.

j. La mejora de la productividad de las empresas del sector minero y el apoyo a la implantación de industrias que permitan el cierre de todos los ciclos de transformación de los materiales mineros extraídos en Galicia. k. La máxima simplificación administrativa en la tramitación de los expedientes mineros.

1. El carácter temporal de la explotación minera respecto a la ordenación del territorio y los usos del suelo.

Artículo 13. Contenido del Plan sectorial de actividades extractivas de Galicia.

Sin perjuicio del contenido establecido en el artículo 23 de la Ley 10/1995, de 23 de noviembre, de ordenación del territorio de Galicia, el Plan sectorial de actividades extractivas de Galicia contendrá, en todo caso:

a. Un diagnóstico de la minería en Galicia que incluya referencias a los recursos existentes y en investigación, a los derechos mineros, a los efectos de la minería sobre el entorno económico, social y ambiental, a la localización de las explotaciones, al empleo en el sector con indicación de las condiciones laborales existentes y a las repercusiones ambientales más relevantes de las explotaciones existentes.

b. La coordinación con los instrumentos de protección ambiental y patrimonio cultural con la determinación de los ámbitos incompatibles con actividades extractivas por las necesidades de preservación de dichos bienes sociales.

c. La fijación de objetivos de desarrollo del sector teniendo en cuenta los condicionamientos territoriales, agrarios y ambientales y el objetivo de diversificación y cierre del ciclo productivo.

d. Las líneas de actuación y los programas específicos, destacadamente los destinados a municipios mineros, de acuerdo con los principios de actuación de la presente ley.

e. Los instrumentos financieros y de gestión para la ejecución del plan y las líneas directrices de las medidas de fomento de la minería que deberán estar presididas por los objetivos que fija la presente ley.

f. Las bases de la investigación minera para alcanzar una extracción, preparación 
y puesta en mercado eficiente y sostenible de los recursos minerales.

g. Las acciones encaminadas a mejorar la calidad del empleo en el sector, incrementando la seguridad y potenciando la formación de los trabajadores y trabajadoras, así como la incorporación de mujeres a un sector en el que están infrarrepresentadas a través de políticas de acción positivas.

h. La valoración económica de las actuaciones previstas.

Artículo 14. Participación de la consejería competente en materia de minas en instrumentos de planificación.

1. Para la elaboración de instrumentos de planificación con incidencia en la minería se tendrán en cuenta las solicitudes y los derechos mineros otorgados o concedidos en el territorio de la Comunidad Autónoma de Galicia, para lo cual será obligatorio solicitar de la consejería competente en materia de minas un informe de los datos reflejados en el Registro Minero de Galicia.

2. Cualquier prohibición contenida en los instrumentos de ordenación sobre actividades incluidas en la Ley 22/1973, de 21 de julio, de minas, y en la presente ley habrá de ser motivada y no podrá ser de carácter genérico.

\section{TíTULO IV DERECHOS MINEROS}

\section{Artículo 15. Derechos mineros.}

1. Los derechos mineros que se otorguen o se soliciten en el territorio de la Comunidad Autónoma de Galicia se ajustarán a lo dispuesto en el presente título.

2. Son derechos mineros regulados en la legislación específica minera:

a. Las autorizaciones de aprovechamiento de recursos de la sección A).

b. Las autorizaciones y concesiones de recursos de la sección $\mathrm{B}$ ).

c. Los permisos de exploración, permisos de investigación y concesiones mineras de los recursos C) y D).

3. Con las especialidades previstas en la presente ley, se establece un procedimiento unitario e integrado para el otorgamiento de todos los derechos mineros en el territorio de la comunidad autónoma, con independencia del tipo de recurso y de la actividad minera desarrollada.

Artículo 16. Órgano minero competente.

1. Sin perjuicio de las funciones atribuidas al Consejo de la Xunta de Galicia en el artículo 4 de la presente ley, el órgano minero competente es la persona titular de la consejería competente en materia de minas de la Comunidad Autónoma de Galicia, a quien corresponde otorgar los derechos mineros, autorizar sus modificaciones, transmisiones, renovaciones y prórrogas, declarar su caducidad, así como realizar la convocatoria y la resolución de los concursos para la adjudicación de terrenos no registrables.

2. El órgano minero competente velará para que el otorgamiento de los derechos mineros respete las prescripciones de la normativa minera, ambiental, agraria y de ordenación del territorio, y cualquier otra que resulte de aplicación.

3. En caso de aprovechamientos inmediatos directamente asociados a proyectos de obras públicas y que no impliquen beneficio de recursos en el territorio de la Comunidad Autónoma de Galicia corresponderá al órgano competente para la aprobación del correspondiente proyecto de construcción, cualquiera que sea el sistema de ejecución, su autorización, mediante el cumplimiento de las prescripciones de la presente ley.

Dichos órganos notificarán a la consejería competente en materia de minas el inicio y finalización de los trabajos referidos, así como, anualmente, informarán de las cantidades de materiales extraídos.

\section{Capítulo I \\ PROCEDIMIENTO DE OTORGAMIENTO DE LOS DERECHOS MINEROS}

Artículo 17. Solicitudes de derechos mineros.

1. Toda solicitud de derechos mineros incluirá, al menos, la siguiente documentación: 
a. Un modelo normalizado de solicitud.

b. Una memoria, que comprenderá el proyecto de exploración, investigación o explotación y los proyectos de instalaciones mineras y procesos productivos, cuyo contenido se establecerá reglamentariamente.

c. Un informe de viabilidad y solvencia, que acredite que la persona solicitante reúne los requisitos exigidos en la legislación minera para poder ser titular de derechos mineros, especialmente su solvencia económica y técnica.

La justificación de la solvencia económica del solicitante podrá acreditarse por uno o varios de los medios siguientes:

Un informe de instituciones financieras.

Tratándose de personas jurídicas, una presentación de las cuentas anuales o extracto de las mismas.

Una declaración relativa a la cifra de negocios global y de los trabajos mineros realizados por el solicitante en el curso de los cinco últimos años.

Cualquier otra documentación considerada como suficiente por el órgano minero competente.

La solvencia técnica de la persona solicitante podrá acreditarse por uno o varios de los medios siguientes:

Titulaciones académicas y profesionales y experiencia de las plantillas de la empresa. Una declaración de los medios materiales y equipo técnico del que dispondrá el solicitante para la ejecución de su programa minero.

Una declaración sobre los efectivos personales de la empresa, indicando, en su caso, grado de estabilidad en el empleo de los mismos e importancia de sus equipos directivos durante los últimos cinco años. Cualquier otra documentación establecida reglamentariamente.

d. En caso de los derechos mineros sometidos a la evaluación ambiental, un estudio ambiental con el contenido establecido en la legislación vigente para su remisión al órgano ambiental autonómico.

e. Un plan de seguridad y salud laboral. f. Un plan de restauración del espacio afectado por las actividades mineras.

g. Un plan de cese de actividades mineras.

h. Un calendario de ejecución y presupuesto.

i. Planos.

j. Anexos.

$\mathrm{k}$. Cualquier otra documentación e información acreditativa del cumplimiento de requisitos establecidos en la legislación sectorial de aplicación.

2. A la solicitud de los derechos mineros se adjuntará un resumen no técnico de todas las indicaciones especificadas en los párrafos anteriores, para facilitar su comprensión a efectos del trámite de información pública.

Artículo 18. Condiciones especiales de la solicitud de derechos mineros de la sección A).

Además de la documentación exigida en el artículo 17 de la presente ley, a la solicitud de derechos mineros de la sección A) se adjuntará la documentación que acredite el derecho al aprovechamiento cuando el yacimiento se encuentre en terrenos de propiedad privada, de conformidad con la legislación específica de minas. Cuando el yacimiento se encuentre en terrenos de propiedad pública, será necesario el oportuno título habilitante de la administración titular.

Artículo 19. Condiciones especiales de la solicitud de derechos mineros de la sección B).

Además de la documentación exigida en el artículo 17 de la presente ley, la solicitud de derechos mineros sobre yacimientos de origen no natural, estructuras subterráneas y huecos resultantes de canteras exigirá la declaración previa de su calificación como recursos de la sección B), realizada por el órgano minero competente.

Artículo 20. Enmienda de las solicitudes.

Si la solicitud de iniciación no reúne los requisitos señalados en la presente ley, 
se requerirá al interesado para que, en un plazo de diez días, enmiende la falta o acompañe los documentos preceptivos, con indicación de que, si así no lo hiciera, se le tendrá por desistido de su petición, previa resolución motivada.

Artículo 21. Información pública.

1. Una vez completada la documentación, de acuerdo con lo establecido en los artículos anteriores, se abrirá un periodo de información pública que no será inferior a treinta días.

2. Simultáneamente, el órgano minero competente remitirá copia del expediente a las demás administraciones públicas para que puedan pronunciarse sobre las diferentes materias de su competencia.

Artículo 22. Informe municipal preceptivo.

1. El municipio que tenga ubicado el derecho minero en su término municipal emitirá un informe sobre las cuestiones de competencia municipal. Dicho informe deberá emitirse en el plazo de dos meses desde la recepción del expediente.

2. En caso de no emitirse el informe en el plazo señalado, podrán proseguirse las actuaciones. Si el informe es emitido fuera de plazo pero recibido antes del otorgamiento de los derechos mineros, deberá ser valorado en su resolución por el órgano minero competente.

3. Si el informe municipal fuera desfavorable, con independencia del momento en que se emitió, el órgano minero competente, en caso de disconformidad con el mismo y excepcionalmente, elevará al Consejo de la Xunta el expediente para su resolución motivada. La resolución adoptada por el Consejo de la Xunta determinará, en su caso, el contenido de los derechos mineros y adoptará las disposiciones necesarias en relación al planeamiento urbanístico y la protección ambiental.

Artículo 23. Informes autonómicos preceptivos.

El órgano minero competente remitirá a los órganos ambiental, urbanístico y agrario de la comunidad autónoma la solicitud de derechos mineros para que emitan informe preceptivo y determinante que acredite una gestión minera compatible con el medio ambiente y el patrimonio cultural y con la planificación urbanística y territorial, así como con la ordenación agraria. Dichos informes deberán emitirse en el plazo de dos meses desde la recepción del expediente.

Artículo 24. Compatibilidad de derechos mineros y con usos de interés público.

1. Si la solicitud de un derecho minero afectara a un derecho minero preexistente o a otros usos de interés público, el órgano minero competente se pronunciará sobre su compatibilidad o incompatibilidad, así como sobre su prevalencia, a través del procedimiento que reglamentariamente se establezca.

2. Para ello tendrá en cuenta los siguientes criterios:

a. La viabilidad e interés económico de la solicitud, de acuerdo con la memoria presentada.

b. Su incidencia en el entorno natural y social, el paisaje y el medio rural.

c. Su repercusión sobre otras infraestructuras de interés público existentes en el territorio afectado (parques eólicos, líneas eléctricas, gaseoductos.).

3. Si considera que la solicitud es incompatible con otro derecho minero preexistente, el órgano minero competente dictará resolución motivada, poniendo fin al procedimiento.

Artículo 25. Trámite de audiencia.

1. Una vez emitidos los informes preceptivos a que se refieren los artículos anteriores, se dará audiencia a los interesados e interesadas para que formulen las alegaciones o aporten las informaciones y documentos que estimen oportunos, en el plazo máximo de quince días.

2. Si antes del vencimiento del plazo los interesados e interesadas manifiestan su decisión de no efectuar alegaciones ni 
aportar nuevos documentos o justificaciones, se tendrá por realizado el trámite.

Artículo 26. Resolución.

1. El órgano minero competente dictará la resolución que ponga fin al procedimiento en el plazo máximo de doce meses, incorporando, en su caso, los condicionamientos que resulten de los informes preceptivos.

2. La resolución otorgará o denegará el derecho minero solicitado. Los derechos mineros podrán denegarse motivadamente en los siguientes casos:

a. La inadecuación de la memoria y demás documentos presentados a los requisitos y condiciones exigidos por la legislación minera.

b. La falta de acreditación de la viabilidad de un aprovechamiento racional de los recursos mineros, en función de la existencia de recurso natural mineral en cantidad y calidad.

c. El incumplimiento de los requisitos subjetivos, o la insuficiente acreditación de la solvencia económica o técnica del solicitante.

d. La inadecuación a la normativa sectorial, de carácter urbanístico, ambiental, agraria $u$ otra, debidamente acreditada en el expediente.

e. La incompatibilidad y la no prevalencia con otro derecho minero preexistente, o con infraestructuras de interés público en el territorio de la comunidad autónoma.

3. La resolución que otorgue el derecho minero podrá imponer las condiciones necesarias para su adecuación o compatibilidad con otros intereses dignos de protección.

Dicha resolución podrá incluir también, con los condicionamientos que en su caso procedan, la autorización de escombreras y de establecimientos de beneficio, siempre y cuando exista una unidad productiva y de ubicación física de las instalaciones.

4. Transcurrido el plazo máximo de doce meses sin que se hubiera notificado resolución expresa, podrá entenderse desestimada la solicitud.

Artículo 27. Notificación y publicidad.

1. El órgano minero competente notificará la resolución a los interesados, al municipio en el que se ubique el proyecto minero, a los distintos órganos que hubieran emitido informes preceptivos y, en su caso, a los demás órganos administrativos que resulten competentes.

2. El otorgamiento de los derechos mineros se publicará en el Diario Oficial de Galicia.

\section{Capitulo II CONTENIDO DE LOS DERECHOS MINEROS}

Artículo 28. Contenido de los derechos mineros.

1. La resolución de otorgamiento de un derecho minero tendrá el siguiente contenido mínimo:

a. Las condiciones impuestas por el órgano minero competente para el ejercicio de las actividades de exploración, investigación y explotación, así como para los establecimientos de beneficio.

b. Su extensión y delimitación. En caso de permisos de exploración, el órgano minero competente valorará que, dentro de los límites fijados por la legislación específica de minas, su extensión no supere las cuatrocientas cuadrículas mineras, teniendo en cuenta las peculiaridades del territorio de la comunidad autónoma, por razones ambientales, agrarias, urbanísticas u otras de su competencia.

En caso de permisos de investigación, la autoridad minera no otorgará extensiones superiores a quince cuadrículas mineras, salvo supuestos excepcionales debidamente justificados y motivados por razón de la tipología del recurso a investigar, de las mejoras técnicas disponibles, de su naturaleza estratégica o de su interés para la economía gallega.

c. Su plazo de vigencia y condiciones de renovación, en su caso. 
d. La constitución de las garantías obligatorias y del seguro de responsabilidad civil regulados en la presente ley.

e. Las prescripciones que garanticen, en su caso, la protección de los recursos naturales.

f. Las medidas relativas al cierre definitivo y abandono de la explotación.

g. Cualquier otra medida o condición determinada por la legislación sectorial de aplicación.

2. Los derechos mineros contendrán, además, cuando así sea exigible en la normativa que resulte de aplicación:

a. La declaración de impacto ambiental $\mathrm{u}$ otras figuras de evaluación ambiental.

b. Las condiciones preventivas y de control necesarias en materia de accidentes graves en los que intervengan sustancias peligrosas.

c. La gestión de los residuos de actividades extractivas y su transporte, cuando se realicen dentro de la propia explotación. d. Las condiciones de actividad de los establecimientos de beneficio vinculados a las actividades mineras.

Artículo 29. Vigencia temporal de los derechos mineros.

Las autorizaciones mineras para recursos de las secciones A) y B) se otorgarán por el periodo previsto en el proyecto de explotación correspondiente, con un límite máximo de revisión de las condiciones de su otorgamiento cada diez años. En el caso de la sección A), el tiempo de la duración de la autorización no podrá exceder de aquél para el que el peticionario tenga acreditado el derecho de aprovechamiento.

Los permisos de exploración se otorgarán por un plazo máximo de un año.

Los permisos de investigación se otorgarán por un periodo máximo de tres años.

Las concesiones de explotación mineras se otorgarán por un periodo de treinta años, pudiendo prorrogarse hasta un máximo de setenta y cinco años.
Artículo 30. Renovación y prórroga de derechos mineros.

1. Transcurrido el plazo máximo de vigencia de los permisos de exploración y de los permisos de investigación, éstos podrán ser renovados y prorrogados por periodos sucesivos, conforme a lo dispuesto en la legislación general. Las concesiones de explotación mineras no podrán ser prorrogadas una vez transcurrido el plazo máximo establecido en el artículo anterior.

2. Con una antelación mínima de un mes antes del vencimiento del plazo de vigencia de los derechos mineros, salvo en el supuesto de concesiones de explotación en el que el plazo será de doce meses, el titular de derechos mineros solicitará su renovación y prórroga, que se tramitará por el procedimiento que se establezca reglamentariamente.

3. El titular de un permiso de investigación podrá prorrogar los trabajos por el periodo que dure la tramitación del expediente de otorgamiento de la concesión derivada prevista en la legislación minera. Con todo, el órgano minero competente podrá acordar la paralización temporal de los trabajos mediante resolución motivada, hasta que se resuelva definitivamente el expediente.

Artículo 31. Derechos de prioridad.

1. Los derechos de prioridad que la legislación minera reconoce a las personas titulares de determinados derechos mineros no suponen el reconocimiento de derechos consolidados a su otorgamiento, mientras no se acredite la viabilidad de su aprovechamiento racional y la concurrencia de los requisitos exigidos en la legislación de aplicación.

2. El órgano minero competente podrá limitar o condicionar motivadamente el ejercicio de tales derechos de prioridad por razones urbanísticas y de ordenación del territorio, agrarias, ambientales u otras que sean de su competencia.

3. Los derechos de prioridad deberán ejercitarse, en su caso, dentro de los 
plazos máximos regulados en la legislación minera.

Artículo 32. Garantías financieras.

1. La persona titular de un derecho minero deberá constituir una garantía suficiente en el plazo de un mes, a contar desde la notificación de su otorgamiento, siendo responsable de su mantenimiento en los términos señalados en los epígrafes siguientes.

2. La cuantía de la garantía corresponderá a la suma de dos conceptos, uno fijo y otro variable. En todo caso, su importe deberá ser actualizado según se determine reglamentariamente.

3. La garantía fija responderá del cumplimiento de las obligaciones de financiación y viabilidad de los trabajos mineros. Su importe será del $4 \%$ del presupuesto de financiación, en caso de una autorización de aprovechamiento o de una concesión de explotación, y de un $20 \%$ para los permisos de exploración o investigación.

4. La garantía variable responderá del cumplimiento del Plan de restauración ambiental, determinándose su cuantía de acuerdo con los siguientes criterios:

a. Coste real de todos los trabajos de restauración.

b. Área afectada en cada año de investigación o de explotación. ción.

c. Calendario y programa de ejecu-

d. Uso actual y previsto del suelo.

El plazo de la garantía se fijará en función de criterios técnicos derivados de los trabajos mineros y de la ejecución del plan de restauración.

5. La garantía podrá constituirse por cualquiera de las siguientes formas:

a. Depósito en metálico o en títulos de emisión pública, constituido en la Caja de Depósitos de la Comunidad Autónoma de Galicia.

b. Mediante aval solidario e incondicionado prestado por alguno de los bancos, cajas de ahorro, cooperativas de crédito o establecimientos financieros de crédito autorizados para operar en España.
Artículo 33. Seguro de responsabilidad civil.

La persona titular de cualquier derecho minero deberá suscribir un seguro de responsabilidad civil en el plazo de treinta días, a contar desde la notificación de la resolución de otorgamiento, para hacer frente a los daños que puedan causar a las personas, los animales, los bienes o el medio ambiente.

Si la persona titular de un derecho minero contrata las labores que éste implica, en todo o en parte, con un tercero, podrá subrogar en todo o en parte el contrato de seguro de responsabilidad civil al explotador, dando cuenta a la Administración minera.

La cuantía de los seguros será fijada y revisada por el órgano minero competente, de acuerdo con los riesgos derivados de las labores de exploración, investigación o explotación y, especialmente, de la gestión de los residuos generados por la explotación.

Reglamentariamente se establecerán los riesgos, criterios y condiciones para fijar la cuantía que habrá de cubrir dicho seguro de responsabilidad civil y su revisión.

Artículo 34. Plan anual de labores.

Los titulares de derechos mineros de las secciones A), C) y D) habrán de presentar anualmente un plan de labores para su aprobación por el órgano minero competente.

El plan de labores habrá de ser cumplimentado y firmado por el director facultativo. Reglamentariamente se establecerá el procedimiento para la aprobación del plan de labores y su alcance, contenido y efectos ${ }^{318}$.

\section{Capitulo III CONCURSOS DE DERECHOS MINEROS}

Artículo 35. Convocatoria de concursos de derechos mineros.

1. Los terrenos francos resultantes del levantamiento de una zona de reserva o la

318 Véase Resolución de 22 de diciembre de 2008 por la que se aprueba y se hace público el nuevo modelo del Plan de labores de actividades mineras. 
declaración de caducidad de un permiso de exploración, un permiso de investigación o una concesión minera podrán ser declarados registrables una vez celebrado el necesario concurso público previsto en la legislación específica minera.

2. Las convocatorias tendrán el siguiente contenido mínimo:

a. La documentación a presentar por el solicitante, que será, al menos, la siguiente: La que acredite que reúne los requisitos establecidos para ser titular de derechos mineros. La que acredite la constitución de una fianza provisional.

b. La designación del terreno que se pretende, lugar y superficie del yacimiento o recurso minero objeto del concurso.

c. Los requisitos de viabilidad y solvencia técnica.

d. La metodología y técnica minera requeridas.

e. La inversión mínima necesaria.

f. El plazo de ejecución de los trabajos.

3. El concurso se adjudicará al solicitante que, en su conjunto, formule la propuesta más ventajosa a juicio del órgano minero competente, pudiendo declararse desierto.

4. Si después de celebrado el concurso quedaran aún terrenos no adjudicados, podrán ser declarados francos y registrables por la Administración minera, debiéndose publicar esa declaración en el Diario Oficial de Galicia.

\section{Capitulo IV \\ COORDINACIÓN CON OTRAS LEGISLACIONES SECTORIALES}

Artículo 36. Coordinación administrativa.

El otorgamiento de los derechos mineros se hará en coordinación con las demás autorizaciones sustantivas o licencias que sean obligatorias, entre otras, la licencia municipal de actividades clasificadas y las autorizaciones o concesiones que deban exigirse para la ocupación o utilización del dominio público, de conformidad con la normativa que resulte de aplicación.
Artículo 37. Coordinación con el procedimiento de evaluación ambiental.

1. No podrán otorgarse derechos mineros sin que previamente se tenga dictada la declaración ambiental, cuando sea necesaria de conformidad con la legislación vigente.

2. A estos efectos, el órgano ambiental competente, en cuanto formule la declaración ambiental, remitirá una copia de la misma al órgano minero, que habrá de incorporar su condicionado al contenido de los derechos mineros.

Artículo 38. Coordinación con el régimen de aplicación en materia de licencias urbanísticas y actividades clasificadas.

1. El ejercicio de los derechos mineros estará condicionado al otorgamiento de las licencias municipales urbanísticas y de actividades clasificadas, de conformidad con la normativa de aplicación.

2. A estos efectos, el municipio en que esté ubicado el derecho minero habrá de pronunciarse sobre la viabilidad del proyecto minero en el informe que deberá remitir al órgano minero competente durante la tramitación de los derechos mineros.

\section{TÍTULO V \\ FOMENTO DE LA MINERÍA}

\section{Capitulo I \\ INVESTIGACIÓN, FORMACIÓN, DIFUSIÓN SOCIAL DE LA ACTIVIDAD MINERA Y PATRIMONIO GEOMINERO}

\section{Artículo 39. Investigación.}

1. La Xunta de Galicia, en el marco del Plan gallego de investigación, desarrollo e innovación tecnológica, promoverá el desarrollo de la investigación científica y técnica, la experimentación y los estudios en materia minera y de recursos mineros que permitan disponer de los conocimientos científicos y técnicos necesarios para la mejora del aprovechamiento de los recursos mineros, la minimización de los residuos, la protección ambiental y el cierre de los ciclos productivos, así como

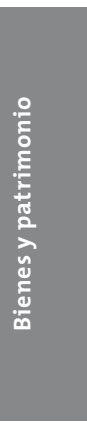


la mejora de las condiciones de seguridad y salud en el trabajo.

2. De conformidad con lo establecido en el apartado anterior, la Xunta de Galicia establecerá directamente o en colaboración con entidades públicas o privadas los mecanismos que conduzcan a alcanzar los fines de investigación señalados.

Artículo 40. Formación.

La Xunta de Galicia fomentará, en colaboración con las empresas, organizaciones sindicales y entidades representativas del sector minero de Galicia, el reciclaje y el perfeccionamiento de los trabajadores y trabajadoras del sector, mediante las medidas y actuaciones que reglamentariamente se establezcan, que contemplarán la participación de los agentes sociales en su diseño, ejecución y evaluación.

Artículo 41. Difusión social de la actividad minera y patrimonio geominero.

1. La Xunta de Galicia impulsará, en colaboración con los agentes científicos, organizaciones sindicales y entidades representativas del sector minero de Galicia, la difusión de la actividad minera entre la sociedad.

2. La Xunta de Galicia promoverá las medidas adecuadas para garantizar la conservación, mantenimiento y recuperación de la documentación minera.

\section{Capítulo II INCENTIVOS ECONÓMICOS}

Artículo 42. Principios generales.

1. La consejería competente en materia de minería, de acuerdo con las orientaciones y prioridades del Plan sectorial de actividades extractivas de Galicia, concretará en un plan estratégico previo los incentivos económicos, los objetivos y efectos que se pretenden con su aplicación, el plazo necesario para su consecución y los costes previsibles.

2. La gestión de los incentivos económicos se realizará de acuerdo con los principios de publicidad, transparencia, concurrencia, objetividad, igualdad y no discriminación, eficacia en el cumplimiento de los objetivos y eficiencia en la asignación de recursos públicos.

3. Las ayudas a la minería deberán ir dirigidas a la mejora de las condiciones de trabajo y a la formación de los trabajadores y trabajadoras, a conseguir un aprovechamiento eficiente de los recursos, a la reducción del impacto sobre el medio y a la valorización endógena de los recursos territorializando la cadena de valor.

4. Serán objeto de las ayudas:

a. La innovación e investigación tecnológica.

b. El mantenimiento del empleo y la mejora de las condiciones de seguridad laboral y de la formación de los trabajadores y trabajadoras, así como de la calificación del empleo.

c. La protección ambiental y la reducción del consumo de recursos y de la producción de residuos.

d. El cierre de los ciclos productivos, la diversificación económica y el impulso de las redes de comercialización e internacionalización de las empresas mineras.

e. La investigación geológica minera.

5. La cooperación entre agentes interesados en la realización o promoción de cualquiera de estas actividades será objeto de atención preferente.

Artículo 43. Beneficiarios.

1. Podrán ser beneficiarias de las ayudas tanto las personas titulares de los derechos mineros como aquellas personas naturales o jurídicas a las que aquéllos hubieran cedido su explotación en las condiciones que reglamentariamente se establezca, así como los organismos de investigación y tecnológicos especializados en campos científicos y tecnológicos relevantes para la actividad minera, las asociaciones y cooperativas de los sectores productivos relacionados con la minería y los particulares o empresas que realicen estudios o presten servicios en el sector de la minería.

2. No podrán obtener la condición de beneficiarias aquellas personas o entidades 
que incurran en alguna de las causas de prohibición previstas en la legislación vigente en materia de ayudas públicas ni las empresas que carezcan de los permisos administrativos pertinentes para el ejercicio de su actividad.

Artículo 44. Exclusiones.

No serán objeto de ayudas los trabajos, obras o estudios que vengan impuestos como consecuencia de la obligación de restauración, ni los que se deriven de la reparación de los daños causados por una actuación que hubiera sido objeto de una sanción.

\section{Capitulo III}

\section{MUNICIPIOS MINEROS}

Artículo 45. De los municipios mineros.

1. El Consejo de la Xunta de Galicia, a solicitud de los municipios afectados, podrá declarar como municipios mineros aquéllos en los que exista o haya existido una dependencia de la minería para su economía.

2. Los municipios mineros serán objeto de medidas y planes de actuación específicos, de acuerdo con las previsiones del Plan sectorial de actividades extractivas de Galicia, de adaptación de las infraestructuras a sus necesidades, de mejora ambiental y seguridad y de diversificación del tejido productivo. La Xunta de Galicia impulsará la celebración de convenios con los municipios mineros, que regularán las formas de asistencia y cooperación técnica y financiera.

\section{TÍTULO VI DISCIPLINA MINERA \\ Capítulo I \\ INSPECCIÓN MINERA 319}

Artículo 46. Inspección de minas.

1. Corresponde a la Xunta de Galicia, a través de la consejería competente en

319 Orden de 17 de octubre de 2008 por la que se aprueba el Plan de inspección de seguridad minera para el periodo 2008-2009 de la Comunidad Autónoma de Galicia. materia de minas, realizar las comprobaciones necesarias y pedir la documentación e información necesaria para el seguimiento y vigilancia de las declaraciones ambientales, así como comprobar el cumplimiento de la normativa minera aplicable a las actividades incluidas en el ámbito de aplicación de la presente ley, de oficio o a instancia de parte interesada, así como de las condiciones de seguridad de cualquier otra actividad que utilice técnicas mineras, sin perjuicio de lo establecido en la normativa vigente en materia de riesgos laborales.

2. La inspección de las actividades incluidas en el ámbito de aplicación de la presente ley, así como de la normativa en materia de prevención de riesgos laborales respecto a las actividades que impliquen el empleo de técnica minera, será realizada por funcionarios o funcionarias que ocupen puestos de trabajo que tengan atribuido el ejercicio de las funciones de inspección y que estén adscritos a órganos administrativos con competencia para el control o inspección en materia minera.

3. Para el desempeño de la función inspectora, la autoridad minera podrá establecer mecanismos de colaboración con órganos o administraciones que tengan atribuidas competencias y responsabilidades en el ámbito laboral.

\section{Artículo 47. Facultades.}

El funcionario o funcionaria que, de conformidad con lo establecido en el artículo anterior, realice la inspección de minas tiene en el ejercicio de sus funciones el carácter de autoridad pública y estará autorizado para:

a. Acceder libremente, en cualquier momento, acreditándose adecuadamente, a las explotaciones mineras, a sus establecimientos de beneficio o lugares en los que se realice algún tipo de actividad minera y a permanecer en ellos, debiendo comunicar al empresario o a sus representantes su presencia, salvo que éstos estén abandonados o presenten signos, a criterio 
del actuante, que manifiesten la falta de utilización habitual.

b. Practicar todas las diligencias y requerir la información y documentación necesarias para comprobar que se cumplen las disposiciones legales y reglamentarias, así como obtener copias y extractos de la misma.

c. Tomar muestras u obtener cualesquiera otras evidencias en el soporte que sea adecuado en la presencia del empresario o empresaria o persona responsable del establecimiento, salvo que la apreciación motivada de las circunstancias pueda requerir su obtención en su ausencia.

Artículo 48. De las actas.

1. Las actividades inspectoras se documentarán mediante actas que estarán dotadas de presunción de certeza respecto a los hechos reflejados en las mismas que hubieran sido constatados por el inspector $\sin$ perjuicio de las pruebas en contrario. Su contenido se ajustará a lo previsto en la presente ley y a los modelos reglamentarios.

2. Las actas se extenderán por duplicado y habrán de firmarse por el funcionario o funcionaria actuante, $y$, cuando lo desee, por el titular, explotador o responsable del establecimiento. La negativa a firmar se hará constar en el acta. La firma acreditará el conocimiento del acta y de su contenido.

3. En las actas de infracción habrán de reflejarse, en todo caso, los siguientes extremos:

a. La identificación de los sujetos actuantes, la fecha y el lugar de las actuaciones.

b. Los hechos constatados por el funcionario actuante, destacando los relevantes a efectos de tipificación de las infracciones y de graduación de las sanciones.

c. Las manifestaciones de los interesados.

d. Los medios y las muestras obtenidos para la comprobación de los hechos.

e. Las medidas adoptadas.

f. La infracción o infracciones supuestamente cometidas, con expresión del precepto vulnerado.

g. La propuesta de sanción, su graduación y cuantificación.

h. El órgano competente para imponer la sanción y la norma que le atribuya tal competencia.

Artículo 49. Medidas derivadas de la actividad inspectora.

Finalizada la actividad de comprobación, el funcionario o funcionaria que hubiera realizado la inspección podrá adoptar las siguientes medidas:

a. Requerir a la persona responsable, cuando las circunstancias así lo aconsejen, para que adopte, en el plazo que se señale, las medidas correctoras oportunas; dando cuenta de esta actuación al órgano competente en materia de seguridad minera.

b. Proponer la iniciación del procedimiento sancionador, mediante la extensión de las actas de infracción.

c. Ordenar, por escrito, la suspensión inmediata de los trabajos o tareas que se estuvieran desarrollando en caso de concurrir grave e inminente riesgo para la seguridad o salud de los trabajadores. Dicha medida, que será inmediatamente ejecutiva, será comunicada tanto a las personas responsables como al órgano competente en materia de seguridad minera y a la autoridad laboral.

La orden de suspensión, que habrá de ser ratificada, en el plazo máximo de dos días hábiles, en el seno del correspondiente procedimiento sancionador y por la autoridad que tenga competencia para acordar su iniciación, podrá ser levantada por la autoridad minera tan pronto como se corrijan las deficiencias que la motivaron.

\section{Capítulo II RÉGIMEN SANCIONADOR}

Artículo 50. Responsables.

1. Serán sujetos responsables de las infracciones las personas físicas o 
jurídicas que incurran en las mismas, $y$, en particular:

a. La persona explotadora efectiva del recurso minero y, en su caso, el titular de los derechos de aprovechamiento minero.

b. El subcontratista del explotador efectivo.

c. La dirección facultativa, en el ámbito de sus respectivas funciones.

2. En caso de existir más de una persona responsable de la infracción, las sanciones que se impongan tendrán entre sí carácter independiente.

3. Cuando en aplicación de la presente ley dos o más personas resulten responsables de una infracción y no hubiera sido posible determinar su grado de participación, serán solidariamente responsables a los efectos de las sanciones que se deriven.

Artículo 51. Competencia sancionadora.

1. Los expedientes sancionadores se incoarán por las delegaciones provinciales de la consejería competente en materia de minas.

2. La competencia para sancionar las infracciones en materia de minería corresponderá:

a. En las infracciones leves: al titular de la delegación provincial competente.

b. En las infracciones graves: al titular de la dirección general competente en materia de minas.

c. En las infracciones muy graves: al titular de la consejería competente en materia de minas.

Artículo 52. Procedimiento sancionador.

1. El procedimiento para la imposición de sanciones se ajustará a las normas generales aplicables sin perjuicio de que reglamentariamente se establezcan especialidades de procedimiento.

2. El plazo para resolver y notificar el procedimiento sancionador será de doce meses, a contar desde la fecha de la notificación de su iniciación. Transcurrido el plazo máximo para resolver sin que se hubiera dictado resolución, se producirá la caducidad del procedimiento. En caso de que la infracción no hubiera prescrito, deberá iniciarse un nuevo procedimiento sancionador.

Artículo 53. Medidas cautelares.

1. En los supuestos en que exista un riesgo grave o inminente para las personas, bienes o medio ambiente, el órgano competente para la incoación del expediente podrá ordenar motivadamente en cualquier momento la adopción de cuantas medidas cautelares resulten necesarias. En particular, podrán acordarse las siguientes:

a. Medidas de corrección, seguridad o control que impidan la continuidad en la producción del daño.

b. Precintado de aparatos, equipos o vehículos.

c. Prestación de fianzas.

d. Suspensión temporal de la autorización para el ejercicio de la actividad.

e. Limitación o prohibición de la comercialización de productos.

2. La adopción de las medidas cautelares se llevará a cabo, previa audiencia del interesado, en un plazo de cinco días, salvo en los casos que requieran una actuación inmediata, en los que podrán ser adoptadas por los inspectores de minas debiendo ser ratificadas por el delegado provincial con audiencia a las partes.

3. Las medidas de suspensión temporal de la actividad de la empresa se entenderán sin perjuicio de los intereses de los trabajadores y trabajadoras, en los términos previstos en la legislación laboral y de Seguridad Social, y de la obligación de la empresa de realizar un mantenimiento eficaz de la explotación minera.

Artículo 54. Prescripción.

1. Las infracciones a que se refiere la presente ley prescribirán en los siguientes plazos:

Dos años, en caso de infracciones leves. 
Tres años, en caso de infracciones graves. Cinco años, en caso de infracciones muy graves.

2. El cómputo del plazo de prescripción de las infracciones se iniciará en la fecha en que se hubiera cometido la infracción o, si se trata de una actividad continuada, en la fecha de su cese.

3. Las sanciones a que se refiere la presente ley prescribirán en los siguientes plazos:

Un año, en caso de sanciones por infracciones leves.

Tres años, en caso de sanciones por infracciones graves.

Cinco años, en caso de sanciones por infracciones muy graves.

Artículo 55. Concurrencia de sanciones.

1. Cuando las conductas constitutivas de infracción supongan incumplimiento de la normativa en materia de seguridad industrial o de prevención de riesgos laborales se sancionarán de acuerdo con la misma.

2. Las vinculaciones del procedimiento sancionador en materia minera con el orden jurisdiccional penal se ajustarán a lo dispuesto en el Real decreto 1398/1993, de 4 de agosto, por el que se aprueba el Reglamento del procedimiento para el ejercicio de la potestad sancionadora.

\section{Capitulo III INFRACCIONES, SANCIONES Y MEDIDAS ACCESORIAS}

Artículo 56. Infracciones.

Sin perjuicio de las infracciones tipificadas en la Ley 22/1973, de 21 de julio, de minas, constituyen infracciones administrativas, en el ámbito de la Comunidad Autónoma de Galicia, las acciones u omisiones que contravengan las obligaciones establecidas en la presente ley.

Artículo 57. Infracciones leves. Son infracciones leves:

a. El incumplimiento de las obligaciones de carácter formal o documental previstas en la normativa de seguridad minera del que no se derive riesgo laboral o ambiental.

b. La inobservancia de los requerimientos de la inspección de minas, siempre que se refirieran a condiciones de seguridad minera que no hubieran supuesto daño derivado del trabajo o daños ambientales.

c. Cualesquiera otras que supongan inobservancia de las obligaciones comprendidas en la presente ley y que no estén tipificadas como infracción grave o muy grave en los artículos siguientes.

Artículo 58. Infracciones graves. Son infracciones graves:

a. El incumplimiento de obligaciones de carácter formal o documental que impidan conocer las condiciones de seguridad existentes en el establecimiento o del que se derive riesgo laboral grave para la salud y seguridad de los trabajadores o para el medio ambiente.

b. La inobservancia de los requerimientos realizados o la demora en la instalación de los elementos correctores impuestos por la inspección de minas o por los órganos competentes en la materia, referidas a condiciones de seguridad minera, que hubieran ocasionado daño a las personas, las cosas o el medio ambiente.

c. La demora en el cumplimiento total de las condiciones de seguridad exigibles.

d. El incumplimiento de los deberes inherentes a su función por parte de los directores facultativos.

e. No dar cuenta, en tiempo y forma, al órgano competente en materia de seguridad minera de los accidentes de trabajo graves, muy graves o mortales o de incidentes que comprometan gravemente la seguridad de los trabajos o de las instalaciones ocurridos en éstas.

f. La obstrucción o negativa a colaborar con la inspección de mina.

g. El incumplimiento de las condiciones de otorgamiento de los derechos mineros, sin perjuicio de su caducidad, revocación o suspensión. 
h. La utilización de instrumentos, maquinaria o materiales que no cumplan las normas exigibles.

i. La expedición, de forma intencionada, de certificados o informes que no se ajusten a los resultados de las comprobaciones o inspecciones realizadas.

j. El incumplimiento de las obligaciones de reacondicionamento del espacio natural afectado por actividades mineras.

$\mathrm{k}$. El incumplimiento de las previsiones contenidas en el plan de restauración del derecho minero.

1. La denegación de la información solicitada por la autoridad minera competente cuando su entrega sea preceptiva.

$\mathrm{m}$. La sanción por tres infracciones leves, ya sea por el mismo hecho o por hechos diferentes, cualquiera que sea su naturaleza en el plazo de un año.

Artículo 59. Infracciones muy graves. Son infracciones muy graves:

a. La exploración, investigación y explotación de recursos mineros o la apertura de establecimientos de beneficio sin la obtención de la correspondiente autorización, permiso o concesión.

b. Las tipificadas como infracciones graves en el artículo anterior, cuando de las mismas resulte un daño muy grave o un riesgo alto e inminente para la seguridad de las personas, los bienes o el medio ambiente.

c. La concurrencia en la comisión de tres infracciones graves, ya sea por el mismo hecho o por hechos diferentes, cualquiera que sea su naturaleza.

Artículo 60. Sanciones.

1. Las infracciones tipificadas en los artículos anteriores serán sancionadas:

a. Las infracciones leves, con multa desde 1 hasta 30.000 euros.

b. Las infracciones graves, con multa desde 30.001 hasta 300.000 euros.

c. Las infracciones muy graves, con multa desde 300.001 hasta 1.000.000 de euros.

2. No obstante lo expresado en el apartado anterior, cuando a consecuencia de la infracción se obtenga un beneficio económico cuantificable, la multa podrá alcanzar hasta el cuádruple del beneficio obtenido, con el límite, en caso de las infracciones leves y graves, de la máxima sanción correspondiente al grado inmediatamente superior.

3. La cuantía de las sanciones se graduará atendiendo a criterios de proporcionalidad.

4. La comisión de una falta muy grave por el director facultativo podrá llevar aparejada la inhabilitación para el ejercicio de las funciones de director o directora facultativo de actividades mineras, por un periodo máximo de un año en el ámbito territorial de Galicia.

En el supuesto de reincidencia por la comisión de infracciones muy graves, la sanción podrá consistir en la inhabilitación para el ejercicio de esas funciones por un periodo de cinco años en el ámbito territorial de Galicia.

5. La comisión de una infracción grave o muy grave podrá llevar aparejada la imposibilidad de obtención de ayudas o subvenciones de la Comunidad Autónoma de Galicia en materia de minería durante los siguientes plazos:

Infracciones graves: hasta tres años.

Infracciones muy graves: hasta cinco años.

Artículo 61. Graduación de las sanciones.

Sin perjuicio de los criterios de graduación de sanciones establecidos en la legislación de procedimiento administrativo de aplicación, las sanciones se graduarán, además, considerando los siguientes criterios:

a. El riesgo resultante de la infracción para la vida y la seguridad de las personas, los bienes y el medio ambiente.

b. El carácter permanente o transitorio de los riesgos inherentes a dichas actividades.

c. La gravedad de los daños y perjuicios producidos y su naturaleza. 
d. El grado de participación y el beneficio obtenido.

e. La intencionalidad en la comisión de la infracción.

f. El número de trabajadores o trabajadoras afectados.

g. Las medidas de protección individual o colectiva adoptadas por el empresario y las instrucciones impartidas por éste en aras a la prevención de los riesgos.

h. El incumplimiento de advertencias o requerimientos previos de la inspección de minas.

i. La inobservancia de las propuestas realizadas por los delegados o delegadas o los comités de seguridad de la empresa o el centro de trabajo para la corrección de las deficiencias existentes.

Artículo 62. Reparación de daños.

Sin perjuicio de la sanción administrativa que se imponga, la persona infractora estará obligada a reparar los daños y perjuicios causados al objeto de restaurar y reponer los bienes alterados a su estado anterior.

Artículo 63. Multas coercitivas.

1. Cuando la persona infractora no cumpla con la obligación impuesta en el artículo anterior o lo haga de forma incompleta, podrán serle impuestas multas coercitivas. La cuantía de cada una de dichas multas no superará el $20 \%$ de la sanción fijada para la infracción correspondiente, sin perjuicio de la posible ejecución subsidiaria por la propia administración a cargo de aquélla.

2. Las multas coercitivas serán independientes y compatibles con las que se hubieran impuesto o hubieran podido imponerse como sanción por la infracción cometida.

Artículo 64. Suspensión temporal o caducidad.

1. La comisión de una falta grave podrá llevar aparejada la suspensión temporal con clausura de la explotación por un plazo no superior a dos meses.
2. La comisión de una falta muy grave, o de las faltas graves en las que expresamente así se indica, podrá llevar aparejada la suspensión temporal de las actividades de la empresa por un plazo entre dos meses a un año o el inicio del expediente de caducidad del derecho minero. Estas medidas habrán de ser ejecutadas, en todo caso, mediante resolución motivada por la autoridad competente para otorgar los derechos mineros.

Artículo 65. Publicidad.

El órgano que ejerza la potestad sancionadora hará constar en la resolución correspondiente la necesidad de proceder a la publicación en el Diario Oficial de Galicia y a través de los medios de comunicación social que considere oportunos de las infracciones graves y muy graves cometidas, así como de las sanciones impuestas, incluyendo los nombres y apellidos o la razón social de las personas físicas o jurídicas responsables, siempre que hubieran adquirido ya el carácter de firmes en vía administrativa o judicial.

\section{DISPOSICIÓN ADICIONAL PRIMERA ATRIBUCIÓN DE COMPETENCIAS}

La Xunta de Galicia dictará las normas de organización administrativa para atribuir a los órganos administrativos idóneos las competencias que ejerza la Comunidad Autónoma de Galicia en materia de minas, respecto a las cuales la legislación minera estatal de aplicación atribuya de forma explicita a órganos de la administración estatal las funciones para la realización de las mismas.

\section{DISPOSICIÓN ADICIONAL SEGUNDA NORMAS DE PROCEDIMIENTO}

En todos aquellos aspectos no regulados en la presente ley y sus normas de desarro1lo, los procedimientos en materia minera se regirán por las normas contenidas en la Ley 30/1992, de 26 de noviembre, de régimen jurídico de las administraciones 
públicas y del procedimiento administrativo común.

\section{DISPOSICIÓN ADICIONAL TERCERA INSPECCIÓN}

Los funcionarios o funcionarias que desempeñen la función inspectora en materia de prevención de riesgos laborales deberán poseer formación en esta materia.

\section{DISPOSICIÓN ADICIONAL CUARTA FIANZA AMBIENTAL}

Las garantías financieras previstas para las actividades mineras sometidas a la presente ley sustituyen a la fianza ambiental regulada en el Decreto 455/1996, de 7 de noviembre.

\section{DISPOSICIÓN TRANSITORIA ÚNICA EXPEDIENTES ADMINISTRATIVOS DE REGULARIZACIÓN NO RESUELTOS}

Los expedientes administrativos de regularización de explotaciones mineras, actividades extractivas de recursos minerales y de establecimientos de beneficio vinculados a las actividades mineras iniciados y no resueltos en la fecha de entrada en vigor de la presentes ley habrán de ser remitidos, en el plazo máximo de dos meses, a contar desde esa fecha, a la consejería competente en materia de minas para continuar su tramitación con arreglo a lo dispuesto en la disposición transitoria duodécima de la Ley 9/2002, de 30 de diciembre, de ordenación urbanística y protección del medio rural de Galicia, que se modifica en la disposición final segunda de la presente ley.

\section{DISPOSICIÓN DEROGATORIA ÚNICA}

Quedan derogadas cuantas disposiciones de igual o inferior rango se opongan, contradigan o resulten incompatibles con lo dispuesto en la presente ley, y, en especial, el Decreto 56/1985, de 21 de marzo, por el que se crea el Comité Consultivo de la Minería de Galicia.

\section{DISPOSICIÓN FINAL PRIMERA}

$$
(\ldots)^{320}
$$

\section{DISPOSICIÓN FINAL SEGUNDA}

$$
(\ldots)^{321}
$$

\section{DISPOSICIÓN FINAL TERCERA APROBACIÓN DE LAS NORMAS Y PLANES PREVISTOS EN LA PRESENTE LEY}

La Xunta de Galicia aprobará en el plazo de un año las normas de desarrollo precisas para la aplicación de la presente ley.

\section{DISPOSICIÓN FINAL CUARTA DESARROLLO REGLAMENTARIO}

1. Se autoriza a la Xunta de Galicia para dictar las disposiciones de aplicación y desarrollo de la presente ley. 2. Queda igualmente facultada la Xunta de Galicia para actualizar por decreto la cuantía de las sanciones fijadas en la presente ley.

\section{DISPOSICIÓN FINAL QUINTA ENTRADA EN VIGOR}

La presente ley entrará en vigor a los veinte días de su publicación en el «Diario Oficial de Galicia»».

320 Contiene modificaciones a la Ley 6/2001, de 29 de junio, de adecuación de la normativa de la Comunidad Autónoma de Galicia a la Ley 4/1999, de 13 de enero, de modificación de la Ley 30/1992, de 26 de noviembre, de régimen juridico de las administraciones públicas y del procedimiento administrativo común.

321 Contiene modificaciones a la Ley 9/2002, de ordenación urbanística y protección del medio rural de Galicia. 


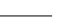




\section{VIII \\ ORDENACIÓN DEL TERRITORIO Y DEL LITORAL, URBANISMO Y VIVIENDA}

\section{LEY 10/1995, DE 23 DE NOVIEMBRE, DE ORDENACIÓN DEL TERRITORIO DE GALICIA (DOGA N. $\left.{ }^{\circ} 233,5.12 .1995\right)$ \\ $(\ldots)^{322}$ \\ Capítulo I \\ DISPOSICIONES GENERALES}

Artículo 1. Finalidad de la ley. La presente ley tiene como finalidad establecer los objetivos fundamentales y crear los instrumentos necesarios para la coordinación de la política territorial y la ordenación del espacio de la Comunidad Autónoma de Galicia, al objeto de favorecer la utilización racional del territorio gallego y proteger el medio natural, mejorar la calidad de vida y contribuir al equilibrio territorial.

Artículo 2. Contenido de la ordenación del territorio.

A los efectos de lo previsto en la presente ley, se entiende por ordenación del territorio el conjunto de criterios expresamente formulados, que regulen las actuaciones y los asentamientos sobre el territorio, a fin de conseguir una adecuada interrelación entre población, actividades, servicios e infraestructuras con el territorio gallego en que se implantan, coordinando las actuaciones sobre el territorio de los distintos órganos y diferentes administraciones públicas.

Artículo 3. Objetivos fundamentales. Los instrumentos de ordenación del territorio regulados en la presente ley estarán destinados a la consecución de los siguientes objetivos fundamentales:

a. Disposición de una adecuada estructura espacial tendente a conseguir un equilibrado desarrollo de la Comunidad

322 Exposición de motivos omitida.
Autónoma de Galicia procurando el máximo bienestar de su población al tiempo que se garantiza la protección y mejora del medio ambiente.

b. Definición de los criterios a seguir en los asentamientos favoreciendo la accesibilidad de la población al medio natural, mejorando sus condiciones de vida.

c. Compatibilización del proceso de desarrollo del sistema productivo, de la urbanización y de la ordenación turística como la racional utilización de los recursos naturales, sobre todo en lo referente al litoral, a los recursos hidráulicos y al paisaje.

d. Perfeccionamiento y corrección, en su caso, de la distribución espacial de las instalaciones productivas propias de los sectores primario y secundario mediante la utilización de procedimientos de fomento o disuasión en relación con las existentes o futuras.

e. Fijación de los núcleos de población que, por sus características y posibilidades, hayan de constituirse en impulsores del desarrollo socioeconómico de una zona.

f. Definición de las áreas territoriales que, por su idoneidad actual o potencial para la explotación agrícola, forestal o ganadera, o por su riqueza paisajística o ecológica, hayan de ser objeto de especial protección.

g. Adecuación de los planes sectoriales de infraestructuras, instalaciones o equipamientos y servicios a su función vertebradora de una política territorial, definiendo los criterios de diseño, características funcionales y localización, que garanticen la accesibilidad e inserción de la totalidad del territorio en una racional disponibilidad de dichos elementos estructurantes. 
h. Establecimiento de los criterios y procedimientos necesarios para asegurar la coordinación de las acciones con la incidencia territorial que corresponda desarrollar a las diferentes administraciones públicas, así como de las diferentes políticas sectoriales de los diversos órganos de la Administración autonómica, que aseguren su integración en una visión de conjunto de los problemas territoriales.

i. Regulación de la participación de la sociedad en el proceso de ordenación territorial para conseguir que ésta sea auténticamente democrática y responda a las aspiraciones y necesidades de la población.

Artículo 4. Instrumentos de ordenación del territorio.

La ordenación territorial de Galicia se realizará a través de los siguientes instrumentos: Directrices de ordenación del territorio. Planes territoriales integrados.

Programas coordinados de actuación. Planes y proyectos sectoriales.

Planes de ordenación del medio físico. Las disposiciones normativas de los instrumentos de ordenación del territorio se publicarán en el "Diario Oficial de Galicia" para su entrada en vigor ${ }^{323}$.

Artículo 5. Aplicación de la ley. Los instrumentos previstos en la presente ley son complementarios y no excluyentes de los que respecto a la ordenación urbanística del suelo se regulan en su legislación específica.

Artículo 5 bis. Suspensión motivada por la formulación de un instrumento de ordenación del territorio.

1. Acordada por el Consello de la Xunta la iniciación del procedimiento de elaboración de cualquier instrumento de ordenación del territorio, la persona titular de la consellería competente en materia de urbanismo y ordenación del territorio, de forma motivada, podrá suspender cautelarmente los procedimientos

323 Último párrafo del art. 4 añadido por Ley 6/2007, de 11 de mayo, de medidas urgentes en materia de ordenación del territorio y del litoral de Galicia. de aprobación del planeamiento urbanístico, de los instrumentos de gestión o ejecución del planeamiento y de otorgamiento de licencias para ámbitos o para usos determinados, con la finalidad de elaborar el instrumento de que se trate.

Esta suspensión habrá de publicarse en el "Diario Oficial de Galicia".

2. La suspensión a que se refiere el número 1 anterior se extinguirá con la aprobación definitiva del instrumento de ordenación del territorio que motivó la adopción de la medida cautelar de suspensión y, en todo caso, por el transcurso del plazo de dos años a contar desde la fecha del acuerdo de suspensión, prorrogable por un año más. Extinguidos los efectos de la suspensión por aplicación de este artículo, no podrán acordarse nuevas suspensiones en el mismo ámbito y por idéntica finalidad en el plazo de cuatro años ${ }^{324}$.

\section{Capítulo II DE LAS DIRECTRICES DE ORDENACIÓN DEL TERRITORIO}

Artículo 6. Funciones.

Con la finalidad de establecer las pautas espaciales de asentamiento de las actividades, de acuerdo con las políticas sociales, económicas y culturales emanadas de la Comunidad, corresponden a las directrices de ordenación del territorio las siguientes funciones:

a. Formular con carácter global e interrelacionado, y en el marco del Plan económico-social de la Comunidad Autónoma, el conjunto de criterios y normas que orienten y regulen los procesos de asentamiento en el territorio de las distintas actividades económicas y sociales de los agentes públicos y privados que operen en dicho territorio.

b. Construir un marco general de referencia para la formulación de los restantes instrumentos de ordenación territorial, así

324 Art. 5 bis añadido por Ley 6/2007, de 11 de mayo, de medidas urgentes en materia de ordenación del territorio y del litoral de Galicia. 
como de los planes de ordenación previstos en la legislación urbanística, y para la formulación y ejecución de las distintas políticas sectoriales de la Comunidad, al que habrán de acomodarse los planes, programas y acciones con incidencia en el territorio que puedan desarrollar las administraciones públicas de carácter autonómico o local, a fin de garantizar una adecuada coordinación y compatibilización de todas ellas.

c. Suministrar las previsiones y criterios básicos que vayan a actuar como marco de referencia para la formulación de las políticas sectoriales, así como para la programación de los recursos de las administraciones públicas que deban aplicarse en el territorio de la Comunidad Autónoma.

d. Proponer las acciones territoriales que requiera la actuación conjunta con otras Comunidades Autónomas y restantes administraciones públicas, ofreciendo las bases suficientes para celebrar los convenios o acuerdos de colaboración que resulten necesarios.

Artículo 7. Contenido.

1. Las directrices de ordenación del territorio tendrán el siguiente contenido:

a. Descripción e interpretación de las características propias del territorio de la Comunidad Autónoma, formulando un diagnóstico de los problemas existentes, en relación con los asentamientos urbanos y productivos, el medio físico y los recursos naturales y las pautas de desarrollo territorial manifestadas o previsibles.

b. Definición de los criterios a adoptar, en relación con los problemas objeto de diagnóstico, de acuerdo con los objetivos sociales, culturales y económicos diseñados por la Comunidad Autónoma.

c. Formulación, a partir de los distintos elementos de las políticas sectoriales, de propuestas de ordenación del territorio destinadas a reorientar o, en su caso, regular las actuaciones públicas y privadas en el ámbito comunitario, de acuerdo con los objetivos señalados en el apartado precedente, como marco de referencia pública para la actuación de los agentes sociales y económicos que operen en dicho ámbito.

d. Proposición de las relaciones entre las distintas administraciones y organismos públicos que intervengan en el territorio de la Comunidad Autónoma, formulando las propuestas relativas a los procedimientos e instancias a través de los que deban ser resueltos los conflictos que puedan surgir en la fijación o ejecución de las actividades a desarrollar, dejando a salvo en todo caso las facultades que al Estado reconoce la legislación urbanística vigente.

e. Señalamiento de las causas y supuestos que vayan a determinar la adaptación o modificación de las directrices de ordenación del territorio, en función de la aparición de necesidades no contempladas en las mismas o de los cambios introducidos en la política económica o social a desarrollar por las administraciones públicas implicadas.

f. Delimitación de las áreas de protección que queden sustraídas al desarrollo de las actividades urbanas, para ser destinadas a la preservación o explotación de los recursos naturales, atendiendo a su valor cultural, social o económico y estableciendo la prioridad de dicho destino.

g. Delimitación de áreas homogéneas de carácter supramunicipal, con arreglo a su potencial desarrollo y situación socioeconómica.

h. Fijación de los criterios para la localización y ejecución de las infraestructuras y equipamientos de carácter comunitario, regional o subregional. En el supuesto de que dichas infraestructuras y equipamientos tengan carácter reestructurante y su ejecución se programe a corto plazo, las directrices de ordenación territorial podrán definir su localización y los criterios para su diseño.

i. Señalamiento de las condiciones a que deban someterse las propuestas de 
desarrollo urbano, industrial, terciario o agrícola, en función de las disponibilidades de los recursos energéticos, hidráulicos y de saneamiento correspondientes.

j. Definición de los ámbitos en que sea necesario elaborar planes de ordenación del medio físico previsto en la presente ley, con señalamiento, en su caso, de las condiciones y plazos a que deba someterse la formulación de los mismos.

k. Criterios para establecer las condiciones a que deberá sujetarse la localización de viviendas de protección oficial o promoción pública directa o de las que se incorporen a programas de rehabilitación, tomando en consideración las previsiones que en este orden se contengan en el planeamiento local.

2. Las determinaciones previstas en el punto anterior tendrán carácter enunciativo y no limitativo, por lo que las directrices de ordenación del territorio podrán contener cuantas otras fuesen congruentes con las funciones previstas en el artículo anterior. En todo caso, las directrices de ordenación del territorio respetarán la autonomía de las administraciones locales para la gestión de sus intereses propios.

Artículo 8. Documentación.

Las directrices de ordenación del territorio contendrán los documentos gráficos y escritos que reflejen adecuadamente los contenidos expuestos en el artículo anterior, con el grado de precisión apropiado a sus funciones.

Artículo 9. Eficacia.

Las determinaciones contenidas en las directrices de ordenación del territorio tendrán, en todo caso, la fuerza vinculante que sea congruente con su función de instrumento directriz. A este efecto, expresarán de forma clara e inequívoca el alcance concreto con que habrán de operar todas y cada una de sus determinaciones y que podrá manifestarse en cualquiera de las siguientes formas:

a. Excluyente de cualquier otro criterio, localización, uso o diseño territorial o urbanístico. b. Alternativa entre varias propuestas contenidas dentro de las mismas directrices de ordenación del territorio.

c. Orientativa, debiendo la Administración competente concretar la propuesta contenida en las directrices de ordenación territorial.

Artículo 10. Procedimiento.

La formulación y aprobación de las directrices de ordenación del territorio se ajustará al siguiente procedimiento:

1. Corresponde al Consello de la Xunta de Galicia acordar la iniciación del procedimiento de su elaboración. El acuerdo, que habrá de ser publicado en el "Diario Oficial de Galicia", será motivado, señalará las causas que los justifiquen y determinará el plazo de formulación del correspondiente avance.

2. Corresponde a la Consellería competente en materia de política territorial la dirección y preparación del avance de directrices de ordenación del territorio.

Las consellerías con competencias de proyección territorial formularán las previsiones y determinaciones que les correspondan respecto a los contenidos sectoriales de las directrices descritos en el artículo 7 a los efectos de su integración efectiva en el avance. Dicha formulación se hará en el plazo de tres meses, a contar desde su petición por el departamento director del procedimiento.

Con la misma finalidad, se recabará de la Administración del Estado y de las administraciones locales informe sobre sus propias previsiones en las materias de su competencia, que evacuarán en el mismo plazo que el expresado en el párrafo anterior.

3. En cualquier caso, para la elaboración del avance de directrices, la consellería directora del procedimiento recabará de los órganos y entidades mencionados cuantos datos e informaciones sean necesarios para la más correcta redacción de dicho documento, que habrán de ser aportados en el plazo de dos meses a partir del momento en que sean solicitados. 
Asimismo, dichos órganos y entidades podrán aportar cuantas informaciones y sugerencias estimen convenientes para los mismos fines.

4. El avance de las directrices será remitido, con los informes evacuados, a las administraciones citadas en los apartados anteriores y a las entidades públicas y privadas que se estimen interesadas, para que en el plazo de tres meses aporten cuantas observaciones, propuestas y alternativas estimen oportunas.

5. Analizadas las observaciones y sugerencias formuladas, la consellería citada realizará las modificaciones que procediesen, en vista de lo cual, previo informe de la Consellería de Economía e Facenda, aprobará inicialmente, si procediese, las directrices de ordenación del territorio.

6. El acuerdo de aprobación inicial será publicado en el "Diario Oficial de Galicia", en el "Boletín Oficial del Estado" y al menos, en dos periódicos de los de mayor circulación en la Comunidad Autónoma, y su texto íntegro será remitido a la Delegación del Gobierno en la Comunidad Autónoma y a las diputaciones provinciales, así como a los Ayuntamientos.

Desde el momento de la publicación del acuerdo de aprobación inicial en el "Diario Oficial de Galicia" quedará abierto un plazo de audiencia de dos meses, dentro del cual las distintas administraciones y entidades públicas y privadas podrán exponer cuantas observaciones y sugerencias estimen convenientes, quedando expuesta la documentación de las directrices en los lugares que al efecto se señalen.

7. Concluido el plazo a que hace referencia el número anterior y a la vista del resultado del trámite de audiencia, se realizarán, en su caso, las modificaciones que procediesen, tras lo cual el conselleiro competente en la dirección del procedimiento procederá, previo informe de la Consellería de Economía e Facenda, a otorgar la aprobación provisional a las directrices, que elevará al Consello de la Xunta de Galicia y de las que dará traslado al Parlamento de Galicia para su tramitación de acuerdo con lo dispuesto para los planes y programas remitidos por la Xunta en el Reglamento del Parlamento de Galicia.

8. Finalizado el procedimiento previsto en el artículo anterior, el Parlamento remitirá el documento a la Xunta de Galicia, que lo aprobará con la forma de Decreto y que será publicado en el "Diario Oficial de Galicia" y en el "Boletín Oficial del Estado".

9. Las modificaciones de las directrices de ordenación del territorio que no supongan revisión general o sustancial de tal instrumento tendrán lugar mediante el procedimiento que al efecto establezca el Consello de la Xunta. En todo caso, conservará los trámites establecidos para la aprobación inicial y definitiva, pudiéndose reducir los plazos previstos para los mismos.

10. Asimismo, por Decreto del Consello de la Xunta de Galicia se determinará el procedimiento que regule el seguimiento y puesta al día de los objetivos y determinaciones de las directrices de ordenación del territorio.

Artículo 11. Control.

La Xunta de Galicia, una vez al año, presentará al Parlamento una memoria en la que se plasmará el estado en que se encuentran las directrices de ordenación del territorio.

\section{Capitulo III DE LOS PLANES TERRITORIALES INTEGRADOS}

Artículo 12 Funcionalidad.

1. En desarrollo de las directrices de ordenación del territorio podrán formularse planes territoriales integrados dirigidos a la organización de áreas geográficas supramunicipales de características homogéneas o de aquellas que, por su tamaño y relaciones funcionales, precisen de una planificación infraestructural, de equipamientos y recursos de ámbito comarcal, y de carácter integrado. 
2. Cuando circunstancias no previstas en las directrices lo aconsejen, el Consello de la Xunta de Galicia podrá acordar la elaboración de un plan territorial integrado, señalando su ámbito territorial y los objetivos principales a alcanzar.

Artículo 13. Contenido.

Los planes territoriales integrados contendrán los documentos gráficos y escritos que sean necesarios para reflejar las siguientes determinaciones:

a. Diagnóstico territorial del área, en especial en lo referente a los recursos naturales, población, planeamiento vigente y situación socioeconómica.

b. Definición de los objetivos de la ordenación, con especial atención al estudio de las posibilidades de desarrollo socioeconómico.

c. Señalamiento de los espacios aptos para servir de soporte a las grandes infraestructuras, determinando la ubicación y características de aquellas que deban crearse o modificarse para potenciar el desarrollo socioeconómico comarcal.

d. Definición de la ubicación de los equipamientos de interés común para el área o zona objeto del plan.

e. Criterios, principios y normas generales que constituyan el referente para la ordenación urbanística municipal.

f. Recomendaciones y propuestas relativas a los espacios que deban ser objeto de remodelación, regeneración o rehabilitación, a fin de evitar su degradación o conseguir su recuperación para usos, total o parcialmente, distintos.

g. Estimación ponderada de las superficies de suelo que deban reservarse con destino a alguna de las siguientes finalidades:

Construcción de viviendas de protección oficial, tanto de promoción pública como privada, o de cualesquiera otras que en el futuro pudiesen ser limitadas en su precio final mediante regulación específica.

Promoción pública de suelo industrial al objeto de posibilitar la formación de polígonos urbanizados. h. Determinación de aquellos servicios que deban o puedan crearse para común utilización de los municipios incluidos en el ámbito del plan.

i. Determinaciones tendentes a evitar desequilibrios funcionales en zonas limítrofes de distintos municipios.

j. Creación de medidas de apoyo encaminadas a incentivar actuaciones que favorezcan la consecución de los objetivos fijados en las directrices de ordenación del territorio y en el propio plan.

k. Criterios, normas y principios necesarios para el desarrollo de sus determinaciones.

Artículo 14. Eficacia.

1. Las determinaciones de los planes territoriales integrados tendrán, en todo caso, la fuerza vinculante que sea congruente con su funcionalidad y expresarán de forma clara e inequívoca el alcance con que habrán de operar.

2. Los planes de desarrollo comarcal se ajustarán a las directrices de ordenación del territorio y a los planes territoriales integrados que total o parcialmente les afecten y, en su caso, se revisarán para ajustar a éstos sus determinaciones en el plazo y mediante el procedimiento que reglamentariamente se establezca.

3. Cuando los planes territoriales integrados incidan sobre planes urbanísticos ya existentes, el acuerdo de aprobación definitiva de aquéllos precisará, necesariamente, los puntos concretos en los que éstos quedan modificados, sin perjuicio de que los municipios afectados puedan incoar los procedimientos precisos para adaptarlos a las determinaciones de aquéllos.

Artículo 15. Procedimiento.

1. Corresponde al Consello de la Xunta acordar la iniciación del procedimiento de su elaboración. El acuerdo será motivado, señalará las causas que lo justifiquen y determinará la consellería competente para la elaboración y dirección del procedimiento, así como aquellos otros departamentos que tengan que participar en el mismo.

El acuerdo, que habrá de ser publicado en el "Diario Oficial de Galicia" y, al menos, en 
dos periódicos de los de mayor circulación en la Comunidad Autónoma, se notificará, además, a los Ayuntamientos afectados y a la diputación provincial respectiva.

2. Redactado el plan territorial y antes de su aprobación inicial por el departamento director del procedimiento, se someterá a informe de las corporaciones locales referidas en el número anterior y de las entidades de carácter supramunicipal con incidencia en el área, que lo evacuarán en el plazo máximo de dos meses.

3. Con el acuerdo de aprobación inicial se adoptará el de apertura del trámite de información pública por un período de dos meses, y se solicitará informe de la Delegación del Gobierno, que habrá de evacuarlo en igual plazo.

4. La consellería que hubiese otorgado su aprobación inicial, a la vista del resultado de la información pública y de los informes producidos, acordará la aprobación provisional con las modificaciones que, en su caso, procedan. Si con motivo de las alegaciones formuladas o de los informes evacuados tuviesen que introducirse modificaciones sustanciales en relación con el documento aprobado inicialmente, podrá disponer un nuevo período de información y consulta de igual duración que el anterior.

5. Después de la aprobación provisional, corresponde al departamento que la hubiese otorgado su elevación al Consello de la Xunta de Galicia para su aprobación definitiva mediante Decreto.

\section{Capitulo IV DE LOS PROGRAMAS COORDINADOS DE ACTUACIÓN}

Artículo 16. Funciones.

Son funciones de los programas coordinados de actuación:

a. Formular un programa plurianual, referido a la totalidad del ámbito comunitario o a algunas de las áreas del mismo, de carácter sectorial o intersectorial, integrando las actuaciones propuestas por las distintas administraciones u organismos públicos que operen en el ámbito de la Comunidad Autónoma.

b. Determinar, conjuntamente y de acuerdo con el régimen de competencias establecido por la legislación vigente, las administraciones u organismos responsables de su ejecución y, en su caso, los criterios para establecer los necesarios acuerdos o convenios entre las administraciones públicas que deban proceder a su desarrollo conjunto.

Artículo 17. Relación con los planes de desarrollo comarcal.

Cuando los programas coordinados de actuación tengan por objeto un ámbito comarcal específico, su regulación y ejecución se llevará a cabo a través de planes de desarrollo comarcal, que se regirán por su legislación específica.

Artículo 18. Documentación y determinaciones.

1. Los programas coordinados de actuación constarán de los documentos escritos y gráficos necesarios para reflejar el siguiente contenido:

a. Objetivos que se persiguen en la formulación del programa.

b. Análisis de los aspectos sectoriales a que se refieran sus propuestas, formulando un diagnóstico sobre su eficacia en relación con el sistema general de asentamientos residenciales o productivos y con el medio natural.

c. Relación y localización de las obras y actuaciones integradas en los mismos.

d. Estimación ponderada de los costes de dichas obras y actuaciones.

e. Los recursos, directos o indirectos, con que se proyecte financiar dichas obras $\mathrm{y}$ actuaciones.

f. Prioridades para su ejecución y, en su caso, programación temporal para la iniciación de las obras y actuaciones incluidas en el programa.

g. Medidas de articulación, en su caso, entre los programas coordinados de actuación, las directrices de ordenación del 
territorio y demás instrumentos de ordenación urbanística y del territorio vigentes.

h. Relación con los planes o programas de obras de los distintos organismos públicos que intervienen en el territorio de la Comunidad Autónoma.

i. Causas y procedimientos para su actualización continua.

2. El contenido de los programas coordinados de actuación podrá, asimismo, referirse a la ejecución de infraestructuras básicas, instalaciones productivas, industriales o agrícolas, equipamientos y viviendas.

\section{Artículo 19. Carácter.}

1. Los programas coordinados de actuación, por su carácter de instrumento de programación plurianual, constituirán referencia para la actuación de las administraciones y organismos públicos a los que corresponda la ejecución y gestión de las obras y actuaciones incluidas en los mismos y, en consecuencia:

a. Servirán de marco de referencia para la elaboración, por el Consello de la Xunta de Galicia, de los proyectos de presupuestos de la Comunidad Autónoma.

b. Constituirán la base para la celebración de convenios y acuerdos de cooperación con las entidades locales y urbanísticas especiales.

c. Constituirán, asimismo, la base para la celebración de convenios y acuerdos con la Administración del Estado, en cuanto a las obras o actuaciones de su competencia que tengan que realizarse en el ámbito de Comunidad Autónoma, así como con otras Comunidades Autónomas.

2. La formulación de estos contenidos respetará el ámbito de competencias municipales, teniendo en cuenta la autonomía municipal para la gestión de sus intereses propios.

Artículo 20. Eficacia.

1. Los programas coordinados de actuación no podrán modificar directamente las determinaciones de las figuras de planeamiento general reguladas en la legislación urbanística ni de los planes de ordenación del medio físico regulados en la presente ley.

2. Cuando las obras o actuaciones de interés estatal o que afecten al conjunto de la Comunidad o a ámbitos supramunicipales de la misma previstas en un programa coordinado de actuación exijan una modificación de las determinaciones de los planes generales o normas complementarias o subsidiarias de planeamiento y planes que los desarrollen y dicha modificación no haya sido incorporada como consecuencia de la adecuación del planeamiento a las directrices de ordenación territorial, se procederá, con carácter excepcional y una vez definida la obra o actuación de que se trate, a la adaptación de dichos planes al programa coordinado de actuación, en los plazos que se señalen en el mismo.

Artículo 21. Procedimiento.

1. La formulación y aprobación de los programas coordinados de actuación se ajustará al siguiente procedimiento:

a. Corresponde al Consello de la Xunta de Galicia, a propuesta de una o varias consellerías, que podrán actuar a instancia de una entidad local o urbanística especial o por propia iniciativa, acordar la formulación de un programa coordinado de actuación.

El acuerdo, que habrá de publicarse en el «Diario Oficial de Galicia», será motivado, señalará las causas que lo justifiquen y finalidades que se persigan, determinará la consellería encargada de su formulación y las consellerías, entidades u organismos que han de colaborar en la misma, así como el plazo dentro del cual habrá de ser redactado el documento a que se refiere el apartado siguiente.

b. Adoptado dicho acuerdo y dentro del plazo que en el mismo se señale, se procederá a la redacción de un documento previo, en el que se expongan los objetivos y propuestas básicas que haya de desarrollar el programa coordinado de actuación. 
c. El documento previo será remitido por la consellería encargada de su elaboración a las corporaciones locales afectadas que, dentro de los dos meses siguientes a su recepción, habrán de remitir los programas de actuación o actividades que desarrollen los instrumentos de ordenación general, al tiempo que podrán efectuar las propuestas de programación $\mathrm{u}$ observaciones $\mathrm{y}$, en su caso, alternativas que estimen convenientes.

Igualmente, se remitirá a las corporaciones y organismos públicos así como a las empresas prestadoras de servicios públicos que se estime necesario para que, dentro de los dos meses siguientes a su recepción, aporten los proyectos o programas cuya ejecución tengan prevista.

d. La consellería que lo hubiese elaborado acordará, después de ello, la aprobación inicial del programa coordinado de actuación, que será publicado en el "Boletín Oficial del Estado", en el "Diario Oficial de Galicia" y en un periódico de los de mayor difusión en la Comunidad Autónoma, y se someterá a los trámites de información pública y audiencia de los Ayuntamientos, entidades, corporaciones y organismos públicos afectados, por el plazo de dos meses.

e. A la vista del resultado del trámite de información pública y audiencia, procederá a su aprobación provisional incorporando las modificaciones que, en su caso, procediesen.

f. Después de la aprobación provisional, el programa coordinado de actuación será elevado por el departamento que la hubiese otorgado al Consello de la Xunta de Galicia, para su aprobación definitiva. La aprobación definitiva revestirá la forma de Decreto y será objeto de publicación en el "Boletín Oficial del Estado" y en el "Diario Oficial de Galicia".

2. Cuando circunstancias no previsibles en el momento de la aprobación de un programa coordinado de actuación requieran la inclusión en el mismo de obras o actuaciones no previstas inicialmente, el Consello de la Xunta de Galicia, mediante Decreto, dispondrá la inclusión de éstas en el programa.

\section{Capitulo V \\ DE LOS PLANES Y PROYECTOS SECTORIALES 325}

\section{Artículo 22. Finalidad.}

1. Los planes y proyectos sectoriales de incidencia supramunicipal tienen por objeto regular la implantación territorial de suelo destinado a viviendas protegidas, infraestructuras, dotaciones e instalaciones de interés público o utilidad social cuando su incidencia transcienda del término municipal en el que se localicen, por su magnitud, importancia, demanda social o especiales características, o que se asienten sobre varios términos 326 .

2. A los efectos de lo previsto en el presente artículo, se consideran infraestructuras las construcciones y conducciones destinadas a las comunicaciones, la ejecución de la política hidráulica, la lucha contra la contaminación y protección de la naturaleza y la ejecución de la política energética; se consideran dotaciones las construcciones que sirvan de soporte a las actividades y servicios de carácter sanitario, asistencial, educativo, cultural, comercial, administrativo, de seguridad y Protección Civil, recreativo y deportivo; se consideran instalaciones las destinadas a la realización de actividades económicas primarias, secundarias y terciarias que cumplan las condiciones señaladas en el número anterior.

Y se considera suelo destinado a viviendas protegidas los ámbitos o sectores que sean objeto de actuaciones de transformación

325 Vease Decreto $80 / 2000$, de 23 de marzo, por el que se regulan los planes y proyectos sectoriales de incidencia supramunicipal.

326 Art. 22.1 modificado por Ley 6/2007, de 11 de mayo, de medidas urgentes en materia de ordenación del territorio y del litoral de Galicia. 
urbanística promovidas y desarrolladas por la consellería competente en materia de vivienda a través del Instituto Galego da Vivenda e Solo y las sociedades públicas de él dependientes con destino mayoritario a la construcción de viviendas sometidas a algún régimen de protección pública, por la necesidad demostrada de fuerte demanda social 327 .

3. Los planes y proyectos sectoriales de incidencia supramunicipal pueden ser promovidos y desarrollados por iniciativa pública o privada.

4. Corresponde al Consello de la Xunta de Galicia calificar, a efectos de lo previsto en la presente ley, un plan o proyecto sectorial como de incidencia supramunicipal, así como la determinación de la consellería a la que corresponda su impulso y, en su caso, aquellas que tendrían que colaborar en el mismo.

Artículo 23. Documentación y determinaciones.

Los planes y proyectos sectoriales constarán de los documentos necesarios para reflejar con claridad y suficiencia las siguientes determinaciones:

1. Descripción del espacio en que se asiente la infraestructura, dotación o instalación objeto del plan o proyecto, y ámbito territorial de incidencia del mismo.

2. Organismo, entidad o persona jurídica o física promotor y titular de la infraestructura, dotación o instalación.

3. Justificación del interés público o utilidad social de la infraestructura, dotación o instalación.

4. Descripción, con la especificación suficiente de las características de la infraestructura, dotación o instalación objeto del plan o proyecto, duración temporal estimada de su ejecución y recursos económicos afectados a la misma.

5. Incidencia sobre el territorio físico, afecciones ambientales y medios de corrección o minimización de las mismas.

327 Segundo párrafo del art. 22 añadido por Ley 6/2007, de 11 de mayo, de medidas urgentes en materia de ordenación del territorio y del litoral de Galicia.
6. Adecuación con el planeamiento local vigente en el término o términos municipales en que se asiente la infraestructura, dotación o instalación o, en su caso, determinaciones de dicho planeamiento local que han de ser modificadas como consecuencia de la aprobación del plan o proyecto sectorial, así como el plazo para realizar la correspondiente adecuación.

7. Los proyectos sectoriales que impliquen la transformación y parcelación urbanística del suelo deberán contener, además de las determinaciones exigidas en este artículo, las que se indican en el artículo 66 de la Ley 9/2002, de 30 de diciembre, de Ordenación Urbanística y Protección del Medio Rural de Galicia. Dichos proyectos no podrán afectar a terrenos que, de conformidad con la legislación urbanística, deban ser clasificados como suelo rústico de especial protección ${ }^{328}$.

Artículo 24. Eficacia.

Las determinaciones contenidas en los planes y proyectos sectoriales de incidencia supramunicipal vincularán el planeamiento del ente o entes locales en que se asienten dichos planes o proyectos, que habrán de adaptarse a ellas dentro de los plazos que a tal efecto determinen.

Artículo 25. Procedimiento.

La formulación y aprobación de los planes y proyectos sectoriales de incidencia supramunicipal se ajustará al siguiente procedimiento:

1. El organismo o entidad que lo promueva lo remitirá a la consellería competente por razón del contenido del proyecto o plan de que se trate para su tramitación, si procediese, en los casos en que no correspondiese a ésta la iniciativa de su formulación.

2. El Consello de la Xunta de Galicia, a propuesta del conselleiro competente por razón de la materia, declarará dicho plan o proyecto como de incidencia supramunicipal a los efectos previstos en esta ley.

328 Art. 23.7 añadido por Ley 6/2007, de 11 de mayo, de medidas urgentes en materia de ordenación del territorio y del litoral de Galicia. 
3. Los planes o proyectos que el Consello de la Xunta declare como de incidencia supramunicipal se someterán por un plazo mínimo de un mes a los trámites de información pública mediante el correspondiente anuncio en el "Diario Oficial de Galicia", y de audiencia a las entidades locales sobre las que incida el plan o proyecto.

4. El Consello de la Xunta de Galicia, previo informe de la consellería competente sobre las alegaciones presentadas en el trámite de exposición pública y audiencia, aprobará definitivamente el plan o proyecto, y dicha aprobación se publicará en el "Diario Oficial de Galicia".

En la aprobación definitiva por el Consello de la Xunta de Galicia podrá acordarse, en su caso, la declaración de utilidad pública a los efectos expropiatorios.

\section{Capítulo VI \\ DE LOS PLANES DE ORDENACIÓN DEL MEDIO FÍSICO}

Artículo 26. Funciones.

1. Los planes de ordenación del medio físico tienen por objeto desarrollar las directrices de ordenación del territorio en los ámbitos que aquéllas delimiten en función de sus características morfológicas, agrícolas, ganaderas, forestales, paisajísticas o ecológicas diferenciadas, que exijan una consideración y tratamiento unitarios, bajo presupuestos que excedan de los propios de cada uno de los términos municipales afectados por la ordenación.

2. Cuando circunstancias singulares no previstas en las directrices lo aconsejen, podrá el Consello de la Xunta de Galicia acordar la elaboración de un plan de ordenación del medio físico, señalando su ámbito territorial y los objetivos principales a alcanzar, previo informe de los Ayuntamientos cuyos términos municipales estén incluidos, total o parcialmente, dentro del ámbito objeto del plan.

3. Las determinaciones de los planes de ordenación del medio físico que regulen las materias contempladas en la Ley 4/1989, de 27 de marzo, de Conservación de los Espacios Naturales y de la Flora y Fauna Silvestres, se ajustarán a lo dispuesto en la misma y, en su virtud, prevalecerán sobre los instrumentos de ordenación territorial o física existentes.

En todo caso, la regulación y gestión de los recursos naturales se regirán por su legislación específica.

Artículo 27. Contenido.

Los planes de ordenación del medio físico contendrán las siguientes determinaciones:

1. Descripción del ámbito objeto de ordenación y de sus características diferenciales destacando sus valores naturales y potencialidades como soporte de actividades de carácter agropecuario, forestal, ecológico, recreativo, cultural o científico.

2. Diagnóstico sobre los problemas suscitados por los usos existentes en el ámbito de ordenación y las tendencias previsibles de los mismos, analizando su adecuación o inadecuación a las exigencias de uso, protección o explotación de los recursos naturales.

3. Señalamiento de las zonas que presenten características homogéneas para su destino, exclusivo o compatible, a usos recreativos, científicos, agropecuarios, forestales u otros que se establezcan, y establecimiento de las relaciones de complementariedad recíproca entre las mismas y en relación con los asentamientos de desarrollo urbano comprendidos en su ámbito.

4. Establecimiento de las medidas y normas de protección y de las actuaciones públicas o privadas necesarias para la preservación, restauración o mejora de las diferentes zonas para su adecuación a las funciones y usos correspondientes, y evaluación de su incidencia ambiental.

5. Señalamiento de la localización, magnitudes y carácter de los asentamientos vinculados al disfrute y explotación de los recursos naturales y definición de las infraestructuras y equipamientos vinculados 
al disfrute y explotación de los usos y actividades reguladas.

6. Normativa reguladora de las actividades productivas o recreativas, así como de la parcelación y construcciones vinculadas a la explotación, disfrute y estudio de los recursos naturales.

7. Estudio económico, en el que se analice la coherencia entre las normas y actuaciones propuestas y la disponibilidad de los recursos hidráulicos y energéticos, así como sus efectos sobre el sistema productivo, agrícola, ganadero, forestal y extractivo.

8. Formulación, en su caso, de los programas de inversiones públicas vinculados al desarrollo de las actuaciones de preservación, restauración o mejora de las diferentes zonas, estableciendo las prioridades de las distintas actuaciones previstas.

9. Análisis de la relación del contenido del plan con el planeamiento municipal vigente, exponiendo las posibles discrepancias y justificando las determinaciones que impliquen la necesaria modificación de dicho planeamiento.

10. Constitución de los órganos de gestión a los que se atribuya la tutela o fomento de las actividades propias de la totalidad del ámbito ordenado o de partes del mismo, así como el desarrollo de los programas correspondientes.

En dichos órganos de gestión estarán representados los Ayuntamientos incluidos total o parcialmente en el ámbito objeto de ordenación.

Artículo 28. Documentación.

Los planes de ordenación del medio físico contendrán los documentos gráficos y escritos necesarios para reflejar los contenidos expuestos en el artículo anterior y, en todo caso, los siguientes:

Memoria con análisis de la situación actual, descripción de problemas, objetivos y medidas de actuación.

Documentación gráfica con planos de información y propuesta.
Normativa que defina el grado de vinculación de cada contenido.

Artículo 29. Eficacia.

1. Las determinaciones contenidas en los planes de ordenación del medio físico vincularán el planeamiento local en sus propios términos, y a tal efecto el acuerdo de aprobación definitiva precisará los puntos concretos de dicho planeamiento que quedan modificados desde ese mismo momento, sin perjuicio de que las entidades afectadas puedan incoar los procedimientos precisos para incorporar dichas determinaciones.

2. Sin perjuicio de lo dispuesto en el artículo 26.3, los planes de ordenación del medio físico no podrán contener determinaciones para el suelo clasificado como urbano o urbanizable que esté en ejecución.

Artículo 30. Procedimiento.

La formulación y aprobación de los planes de ordenación del medio físico se ajustará al siguiente procedimiento:

1. Corresponde al Consello de la Xunta de Galicia acordar la iniciación del procedimiento de su elaboración. El acuerdo será motivado, señalará las causas que lo justifiquen y determinará la consellería competente para su elaboración y dirección del procedimiento, así como aquellos otros departamentos que tengan que participar en el mismo.

El acuerdo, que habrá de ser publicado en el "Diario Oficial de Galicia" y, al menos, en dos periódicos de los de mayor circulación en la Comunidad Autónoma, se notificará, además, a los Ayuntamientos afectados y a la Diputación Provincial respectiva.

2. Redactado el plan y antes de su aprobación inicial por el departamento director del procedimiento, se someterá a informe de las corporaciones locales referidas en el número anterior y entidades de carácter supramunicipal con incidencia del área, que evacuarán en el plazo máximo de dos meses. 
3. Con el acuerdo de aprobación inicial se adoptará el de apertura del trámite de información pública por un período de dos meses, y se solicitará informe de la Delegación del Gobierno. Transcurrido el plazo de dos meses sin que éste se evacuase, podrán proseguir las actuaciones.

4. La consellería que hubiese otorgado su aprobación inicial, a la vista del resultado de la información pública y de los informes producidos, acordará la aprobación provisional con las modificaciones que, en su caso, procedan. Si con motivo de las alegaciones formuladas o de los informes evacuados tuviesen que introducirse modificaciones sustanciales en relación con el documento aprobado inicialmente, podrá disponer un nuevo período de información y consulta de igual duración que el anterior.

5. Después de la aprobación provisional, corresponde al departamento que la hubiese otorgado su elevación al Consello de la Xunta de Galicia para su aprobación definitiva mediante Decreto.

Artículo 31. Instituto de Estudios del Territorio.

Se creará el Instituto de Estudios del Territorio, con la naturaleza, fines y medios que se establezcan en su ley reguladora.

\section{DISPOSICIÓN ADICIONAL PRIMERA}

1. La aprobación definitiva de los instrumentos de ordenación del territorio llevará implícita la declaración de utilidad pública o interés social de las obras, instalaciones y servicios proyectados, así como la necesidad de la ocupación de los bienes y derechos necesarios para la ejecución de las obras, instalaciones y servicios previstos de forma concreta en aquéllos, a los efectos de expropiación forzosa o de imposición de servidumbres, siempre que conste la descripción física y jurídica individualizada de los bienes y derechos afectados.
2. Las obras promovidas directamente por la Administración Pública o sus Organismos Autónomos previstas en un proyecto sectorial y calificadas como de marcado carácter territorial no estarán sujetas a licencia urbanística municipal.

No obstante, una vez aprobados los proyectos de las citadas obras públicas, la Administración competente lo pondrá en conocimiento de los Ayuntamientos afectados ${ }^{329}$.

\section{DISPOSICIÓN ADICIONAL SEGUNDA}

El acuerdo de la Xunta de Galicia para iniciar el procedimiento recogido en el artículo 10.1 de la presente ley se realizará dentro de los dos meses siguientes a la entrada en vigor de la misma.

\section{DISPOSICIÓN DEROGATORIA}

Quedan derogadas cuantas disposiciones se opongan a lo dispuesto en la presente ley.

\section{DISPOSICIÓN FINAL}

Se autoriza al Consello de la Xunta de Galicia para dictar cuantas disposiciones sean necesarias para el desarrollo y aplicación de esta ley.

\section{LEY 9/2002, DE 30 DE DICIEMBRE, DE ORDENACIÓN URBANÍSTICA Y PROTECCIÓN DEL MEDIO RURAL DE GALICIA (DOGA N. $\left.{ }^{\circ} 252,31.12 .2002\right)$}

\section{(...) ${ }^{330}$ \\ Título preliminar PRINCIPIOS GENERALES}

Artículo 1. Objeto de la ley.

1. Es objeto de la presente ley la ordenación urbanística en todo el territorio de Galicia, así como la regulación, ordenación y protección del medio rural,

329 Disposición adicional 1 modificada por Ley $9 / 2002$, de 30 de diciembre, de ordenación urbanistica y protección del medio rural de Galicia.

330 Exposición de motivos omitida. 
de los núcleos rurales de población que se ubiquen en él y del patrimonio rural.

2. El régimen urbanístico del suelo y la regulación de la actividad administrativa con él relacionada vendrán determinados por lo establecido en la presente ley o, en su virtud, por los instrumentos de ordenación previstos en la misma.

Artículo 2. Actividad urbanística. Por actividad urbanística en la Comunidad Autónoma de Galicia se entiende la que tiene por objeto la organización, dirección y control de la ocupación y la utilización del suelo, incluidos el subsuelo y el vuelo, su transformación mediante la urbanización, la edificación y la rehabilitación del patrimonio inmobiliario, así como la protección de la legalidad urbanística y el régimen sancionador.

Artículo 3. Ámbito de la competencia urbanística.

1. La competencia urbanística concerniente al planeamiento comprenderá las siguientes facultades:

a. Formular los planes e instrumentos de ordenación urbanística previstos en la presente ley.

b. Emplazar las infraestructuras, equipamientos, centros de producción y residenciales del modo más conveniente para la población.

c. Dividir el territorio municipal en áreas de suelo urbano, de núcleo rural, urbanizable y rústico.

d. Establecer zonas de distinta utilización según la densidad de la población que haya de habitarlas, porcentaje de terreno que pueda ser ocupado por construcciones, volumen, forma, número de plantas, clase y destino de los edificios, con arreglo a las ordenaciones generales uniformes para cada especie de los mismos en toda la zona.

e. Determinar el trazado de las vías públicas y medios de comunicación.

f. Establecer espacios libres para parques y jardines públicos en proporción adecuada a las necesidades colectivas. g. Señalar el emplazamiento y características de los centros y servicios de interés público y social, centros docentes y análogos.

h. Calificar terrenos para la construcción de viviendas sujetas a los diferentes regímenes de protección pública.

i. Determinar la configuración y dimensiones de las parcelas edificables.

j. Determinar el uso del suelo, del subsuelo y de las edificaciones.

k. Orientar la composición arquitectónica de las edificaciones y regular, en los casos en que fuera necesario, sus características estéticas.

2. La competencia urbanística, en lo que atañe a la ejecución del planeamiento, confiere las siguientes facultades:

a. Realizar, conceder y controlar la ejecución de las obras de urbanización.

b. Fomentar la iniciativa de los particulares, apoyando y promoviendo su participación en los procesos de ejecución.

c. Expropiar los terrenos y construcciones necesarios para efectuar las obras y cuantos convengan a la economía de la urbanización proyectada.

3. La competencia urbanística en lo que se refiere a la intervención en la regulación del mercado del suelo confiere las siguientes facultades:

a. Transmitir terrenos edificables y establecer derechos de superficie sobre los mismos.

b. Constituir y gestionar patrimonios públicos de suelo.

c. Ejercitar los derechos de tanteo y retracto.

d. Regular los terrenos urbanos y urbanizables como garantía de derecho a una vivienda digna.

4. La competencia urbanística en orden a la intervención en el ejercicio de las facultades dominicales relativas al uso del suelo y edificación comprenderá las siguientes facultades:

a. Intervenir en la parcelación de terrenos. 
b. Someter a previa licencia la construcción y uso de las fincas.

c. Prohibir los usos que no se ajusten a la ordenación urbanística.

d. Exigir a los propietarios el cumplimiento de las obligaciones impuestas por la presente ley.

5. La competencia en materia de disciplina urbanística comprenderá las siguientes funciones:

a. Inspeccionar las obras, edificaciones y usos del suelo para comprobar el cumplimiento de la legalidad urbanística.

b. Adoptar las medidas necesarias para la restauración del orden urbanístico vulnerado y reponer los bienes afectados al estado anterior a la producción de la situación ilegal.

c. Sancionar a los responsables de las infracciones urbanísticas.

6. Las mencionadas facultades tendrán carácter enunciativo y no limitativo, y la competencia urbanística comprenderá cuantas otras fueran congruentes con la misma, para ser ejercidas con arreglo a la presente ley y las demás que resulten de aplicación.

7. La gestión pública canalizará y fomentará, en la medida más amplia posible, la iniciativa privada y la sustituirá cuando ésta no alcanzase a cumplir los objetivos necesarios, con las compensaciones que la presente ley establece.

Artículo 4. Fines de la actividad urbanística.

Son fines propios de la actividad urbanística, en desarrollo de los principios rectores enunciados en los artículos 45, 46 y 47 de la Constitución, los siguientes:

a. Asegurar que el suelo se utilice en congruencia con la utilidad pública y la función social de la propiedad, garantizando el cumplimiento de las obligaciones y cargas legalmente establecidas.

b. Impedir la desigual atribución de los beneficios y cargas del planeamiento entre los propietarios afectados e imponer la justa distribución de los mismos. c. Asegurar la participación de la Comunidad en las plusvalías que genere la acción urbanística de los entes públicos.

d. Preservar el medio físico, los valores tradicionales, las señas de identidad y la memoria histórica de Galicia.

e. Armonizar las exigencias de ordenación y conservación de los recursos naturales y del paisaje rural y urbano con el mantenimiento, diversificación y desarrollo sostenible del territorio y de su población, para contribuir a elevar la calidad de vida y la cohesión social de la población.

f. Velar para que la actividad urbanística se desarrolle promoviendo la más amplia participación social, garantizando los derechos de información y de iniciativa de los particulares, asegurando, en todo caso, la participación de los ciudadanos y asociaciones por éstos constituidas para la defensa de sus intereses y valores.

g. Conseguir la integración armónica del territorio y proteger los valores agrarios, forestales y naturales y la riqueza y variedad arquitectónica fomentando el empleo de las formas constructivas propias de las diversas zonas y garantizando su integración en el medio rural.

h. Fomentar la ordenación y mejora de los núcleos rurales, evitando la degradación y la pérdida de las construcciones tradicionales, favoreciendo el uso y disfrute del medio rural.

i. Ejercer las competencias de las Administraciones públicas con arreglo a los principios de cooperación, coordinación, asistencia activa e información recíproca, con el objetivo de garantizar la plena aplicación y eficacia de la normativa urbanística.

Artículo 5. Dirección de la actividad urbanística.

1. La dirección y control de la gestión urbanística corresponde, en todo caso, a la administración urbanística competente.

2. La gestión de la actividad urbanística puede desarrollarse directamente por aquélla o a través de las formas previstas 
por esta ley y de las autorizadas por la legislación reguladora de la Administración actuante.

En todo caso, las facultades que impliquen el ejercicio de autoridad sólo podrán desarrollarse a través de una forma de gestión directa y en régimen de derecho público.

3. Cuando el mejor cumplimiento de los fines y objetivos del planeamiento urbanístico así lo aconseje, se suscitará la iniciativa privada en la medida más amplia posible, a través de los sistemas de actuación o, en su caso, mediante concesión. En este sentido, podrán celebrarse convenios urbanísticos con particulares con la finalidad de establecer los términos de colaboración para el mejor y más eficaz desarrollo de la actividad urbanística.

4. En la formulación, tramitación y gestión del planeamiento urbanístico las administraciones urbanísticas competentes deberán asegurar la participación de los interesados y, en particular, los derechos de iniciativa o información por parte de las entidades representativas de los intereses que resulten afectados y de los ciudadanos.

Artículo 6. Reglas de interpretación. Las dudas en la interpretación del planeamiento urbanístico producidas por imprecisiones o por contradicciones entre documentos de igual rango normativo se resolverán teniendo en cuenta los criterios de menor edificabilidad, de mayor dotación para espacios públicos y de mayor protección ambiental y aplicando el principio general de interpretación integrada de las normas.

\section{TÍTULO I \\ RÉGIMEN URBANÍSTICO DEL SUELO \\ Capitulo I \\ DISPOSICIONES GENERALES}

Artículo 7. Régimen de la propiedad.

1. Las facultades urbanísticas del derecho de propiedad relativas al uso del suelo, subsuelo y vuelo, y en especial su urbanización y edificación, se ejercerán dentro de los límites y con cumplimiento de los deberes establecidos en la presente ley y, en virtud de la misma, por los planes de ordenación, con arreglo a la clasificación urbanística de las fincas, asegurando que el suelo se utilice en congruencia con la utilidad pública y función social de la propiedad, garantizando el cumplimiento de las obligaciones y cargas legalmente establecidas y coordinadamente con la legislación sectorial.

2. La ordenación del uso de los terrenos y construcciones establecida en la legislación y en el planeamiento urbanísticos no confiere a los propietarios ningún derecho a exigir indemnización por implicar meros límites y deberes que definen el contenido normal de la propiedad según su calificación urbanística, salvo en los supuestos previstos en las leyes. Los afectados tendrán, no obstante, derecho a la distribución equitativa de los beneficios y cargas derivados del planeamiento en los términos previstos en la presente ley.

Artículo 8. Subrogación real.

La transmisión de fincas no modificará la situación del titular de las mismas respecto a los deberes establecidos por la legislación urbanística o a los exigibles por los actos de ejecución derivados de la misma. El nuevo titular quedará subrogado en el lugar y puesto del anterior propietario en sus derechos y deberes urbanísticos, así como en los compromisos que éste hubiese contraído con la administración urbanística competente y hayan sido objeto de inscripción registral, siempre que tales compromisos se refieran a un posible efecto de mutación jurídico real y sin perjuicio de la facultad de ejercitar contra el transmitente las acciones que procedan.

Artículo 9. Deberes de uso, conservación y rehabilitación.

1. Los propietarios de toda clase de terrenos, construcciones, edificios e instalaciones deberán:

a. Destinarlos a los usos permitidos por el planeamiento urbanístico. 
b. Mantenerlos en condiciones de funcionalidad, seguridad, salubridad, ornato público y habitabilidad según su destino, y con arreglo a las normas de protección del medio ambiente, del patrimonio histórico y de la rehabilitación.

2. (...) ${ }^{331}$.

3. El deber de conservación a cargo de los propietarios alcanza hasta el importe de los trabajos correspondientes que no rebasen el límite del contenido normal de aquél que, en el caso de las construcciones, está representado por la mitad del coste de reposición del bien o de nueva construcción con características similares, excluido el valor del suelo.

4. Los propietarios de tierras conservarán y mantendrán el suelo natural y en su caso la masa vegetal en las condiciones precisas que eviten la erosión y los incendios, impidiendo la contaminación de la tierra, el aire y el agua.

\section{Capítulo II CLASIFICACIÓN DEL SUELO}

Artículo 10. Clasificación del suelo. Los planes generales de ordenación municipal deberán clasificar el territorio municipal en todos o algunos de los siguientes tipos de suelo: Urbano, de núcleo rural, urbanizable y rústico.

Artículo 11. Suelo urbano.

1. Los planes generales clasificarán como suelo urbano, incluyéndolos en la delimitación que a tal efecto establezcan, los terrenos que estén integrados en la malla urbana existente siempre que reúnan alguno de los siguientes requisitos:

a. Que cuenten con acceso rodado público y con los servicios de abastecimiento de agua, evacuación de aguas residuales y suministro de energía eléctrica, proporcionados mediante las correspondientes redes públicas con características adecuadas

331 Art. 9.2 derogado por la Ley 15/2004, de 29 de diciembre, de modificación de la Ley $9 / 2002$, de 30 de diciembre, de ordenación urbanistica y protección del medio rural de Galicia. para servir a la edificación existente ya la permitida por el planeamiento.

A estos efectos, los servicios construidos para la conexión de un sector de suelo urbanizable, las vías perimetrales de los núcleos urbanos, las vías de comunicación entre núcleos, las carreteras y las vías de la concentración parcelaria no servirán de soporte para la clasificación como urbanos de los terrenos adyacentes, salvo cuando estén integrados en la malla urbana.

b. Que, aún careciendo de algunos de los servicios citados en al apartado anterior, estén comprendidos en áreas ocupadas por la edificación, al menos en las dos terceras partes de los espacios aptos para ella, según la ordenación que el plan general establezca.

2. A los efectos de la presente ley se consideran incluidos en la malla urbana los terrenos de los núcleos de población que dispongan de una urbanización básica constituida por unas vías perimetrales y unas redes de servicios de las que puedan servirse los terrenos y que éstos, por su situación, no estén desligados del entramado urbanístico ya existente.

Artículo 12. Categorías de suelo urbano.

Los planes generales diferenciarán en el suelo urbano las siguientes categorías:

a. Suelo urbano consolidado, integrado por los solares así como por las parcelas que, por su grado de urbanización efectiva y asumida por el planeamiento urbanístico, puedan adquirir la condición de solar mediante obras accesorias y de escasa entidad que pueden ejecutarse simultáneamente con las de edificación o construcción.

b. Suelo urbano no consolidado, integrado por la restante superficie de suelo urbano y, en todo caso, por los terrenos en los que sean necesarios procesos de urbanización, reforma interior, renovación urbana u obtención de dotaciones urbanísticas con distribución equitativa de beneficios y cargas, por aquéllos sobre 
los que el planeamiento urbanístico prevea una ordenación sustancialmente diferente de la realmente existente, así como por las áreas de reciente urbanización surgida al margen del planeamiento.

Artículo 13. Suelo de núcleo rural.

1. Constituyen el suelo de núcleo rural los terrenos que sirven de soporte a un asentamiento de población singularizado en función de sus características morfológicas, tipología tradicional de las edificaciones, vinculación con la explotación racional de los recursos naturales o de circunstancias de otra índole que manifiesten la imbricación racional del núcleo con el medio físico donde se sitúa y que figuren diferenciados administrativamente en los censos y padrones oficiales, así como las áreas de expansión o crecimiento de estos asentamientos.

2. El planeamiento urbanístico deberá realizar un análisis detallado de la formación y evolución de los asentamientos, de sus peculiaridades urbanísticas, morfológicas, de su grado de consolidación por la edificación y de sus expectativas de desarrollo, así como de las tipologías edificatorias, forma de los huecos y de las cubiertas, y características de los materiales, colores y formas constructivas empleadas en las edificaciones y construcciones tradicionales de cada asentamiento.

3. El planeamiento delimitará el ámbito de los núcleos rurales en atención a la proximidad de las edificaciones, los lazos de relación y coherencia entre lugares de un mismo asentamiento con topónimo diferenciado, la morfología y tipologías propias de dichos asentamientos y del área geográfica en que se encuentran (casal, lugar, aldea, rueiro u otro), de modo que el ámbito delimitado presente una consolidación por la edificación de, al menos, el 50 por 100 , de acuerdo con la ordenación propuesta y trazando una línea perimetral que encierre las edificaciones tradicionales del asentamiento siguiendo el parcelario y las huellas físicas existentes (caminos, ríos, regatos, cómaros y otros) y, como máximo, a 50 metros de dichas edificaciones tradicionales.

Igualmente delimitará el área de expansión de dichos núcleos, de acuerdo con los criterios de crecimiento que el planeamiento urbanístico contemple. Dicha área estará comprendida por los terrenos delimitados por una línea poligonal paralela a la de circunscripción del núcleo existente y como máximo a 200 metros lineales de la misma sin que, en ningún caso, pueda afectar a suelo rústico especialmente protegido.

Los núcleos rurales ubicados en la franja de 200 metros desde el límite interior de la ribera del mar no podrán ser ampliados en dirección al mar salvo en los casos excepcionales en que el Consello de la Xunta lo autorice expresamente, por la especial configuración de la zona costera donde se encuentren o por motivos justificados de interés público, justificando la necesidad de la iniciativa, la oportunidad y su conveniencia en relación con el interés general.

Artículo 14. Suelo urbanizable.

1. Constituirán el suelo urbanizable los terrenos que no tengan la condición de suelo urbano, de núcleo rural, ni rústico y puedan ser objeto de transformación urbanística en los términos establecidos en esta ley.

2. En el suelo urbanizable el plan general diferenciará dos categorías:

a. Suelo urbanizable delimitado o inmediato, que es el comprendido en sectores delimitados que tengan establecidos los plazos de ejecución y las condiciones para su transformación y desarrollo urbanístico ${ }^{332}$.

Se incluirán en esta categoría los terrenos contiguos al suelo urbano que el plan general estime adecuados para ser urbanizados.

b. Suelo urbanizable no delimitado o diferido, integrado por los demás terrenos que el plan general clasifique como suelo urbanizable.

332 Art. 14.2. a modificado por Ley 15/2004, de 29 de diciembre, de modificación de la Ley $9 / 2002$, de 30 de diciembre, de ordenación urbanistica y protección del medio rural de Galicia. 
Artículo 15. Suelo rústico.

Constituirán el suelo rústico los terrenos que hayan de ser preservados de los procesos de desarrollo urbanístico y, en todo caso, los siguientes:

a. Los terrenos sometidos a un régimen específico de protección incompatible con su urbanización, de conformidad con la legislación de ordenación del territorio o con la normativa reguladora del dominio público, las costas, el medio ambiente, el patrimonio cultural, las infraestructuras y de otros sectores que justifiquen la necesidad de protección.

b. Los terrenos que, sin estar incluidos entre los anteriores, presenten relevantes valores naturales, ambientales, paisajísti$\cos$, productivos, históricos, arqueológicos, culturales, científicos, educativos, recreativos u otros que los hagan merecedores de protección o cuyo aprovechamiento deba someterse a limitaciones específicas.

c. Los terrenos que, habiendo sufrido una degradación de los valores enunciados en el apartado anterior, deban protegerse a fin de facilitar eventuales actuaciones de recuperación de dichos valores.

d. Los terrenos amenazados por riesgos naturales o tecnológicos, incompatibles con su urbanización, tales como inundación, erosión, hundimiento, incendio, contaminación o cualquier otro tipo de catástrofes, o que simplemente perturben el medio ambiente o la seguridad y salud.

e. Los terrenos que el plan general o los instrumentos de ordenación del territorio estimen inadecuados para el desarrollo urbanístico en consideración a los principios de utilización racional de los recursos naturales o de desarrollo sostenible ${ }^{333}$.

Artículo 16. Solares.

1. Tendrán la condición de solar las superficies de suelo urbano legalmente divididas y aptas para la edificación que, en todo caso, cuenten con acceso por vía

333 Art. 15.e añadido por Ley 15/2004, de 29 de diciembre, de modificación de la Ley $9 / 2002$, de 30 de diciembre, de ordenación urbanistica y protección del medio rural de Galicia. pública pavimentada y servicios urbanos de abastecimiento de agua potable, evacuación de aguas residuales a la red de saneamiento, suministro de energía eléctrica, alumbrado público, en condiciones de caudal y potencia adecuadas para los usos permitidos. Si existiera planeamiento, además de lo anterior deberán estar urbanizadas de acuerdo con las alineaciones, rasantes y normas técnicas establecidas por éste.

2. Los terrenos incluidos en el suelo urbano no consolidado y en el suelo urbanizable sólo podrán alcanzar la condición de solar después de ejecutadas, conforme al planeamiento urbanístico, las obras de urbanización exigibles para la conexión con los sistemas generales existentes y, en su caso, para la ampliación o refuerzo de los mismos.

\section{Capitulo III \\ RÉGIMEN DE LAS DISTINTAS CLASES Y CATEGORÍAS DE SUELO \\ Sección 1. \\ Suelo urbano}

Artículo 17. Derechos de los propietarios.

Los propietarios de suelo urbano tienen el derecho de completar la urbanización de los terrenos para que adquieran la condición de solares y a edificar éstos en las condiciones establecidas en la presente ley y en el planeamiento aplicable.

Artículo 18. Aprovechamiento urbanístico.

El aprovechamiento urbanístico de los propietarios del suelo urbano será:

a. En los terrenos incluidos por el plan en la categoría de suelo urbano consolidado, el aprovechamiento real que resulte de la aplicación directa de las determinaciones del plan sobre la parcela.

Los propietarios materializarán su aprovechamiento directamente sobre sus parcelas o previa normalización de fincas.

b. En los terrenos incluidos en la categoría de suelo urbano no consolidado, el 
aprovechamiento resultante de referir a su superficie el $90 \%$ del aprovechamiento tipo del área de reparto correspondiente.

No obstante, los propietarios tienen derecho al $100 \%$ del aprovechamiento tipo en los siguientes supuestos:

Polígonos para los que el plan imponga cargas especialmente onerosas relativas a la rehabilitación integral o restauración de bienes inmuebles de interés cultural o edificios catalogados.

Polígonos para los que el nuevo plan no contempla el incremento de la superficie edificable respecto a la preexistente lícitamente realizada ni incorpora nuevos usos que generen plusvalías.

Los propietarios materializarán su aprovechamiento urbanístico sobre las parcelas que resulten de la nueva ordenación o mediante compensación económica ${ }^{334}$.

Artículo 19. Deberes de los propietarios de suelo urbano consolidado.

En suelo urbano consolidado, los propietarios tienen los siguientes deberes:

a. Completar por su cuenta la urbanización necesaria para que los mismos alcancen, si aún no la tuvieran, la condición de solar.

A tal efecto, deberán costear los gastos de urbanización precisos para completar los servicios urbanos y regularizar las vías públicas, ejecutar las obras necesarias para conectar con las redes de servicios y viaria en funcionamiento y ceder gratuitamente al municipio los terrenos destinados a viales fuera de las alineaciones establecidas en el planeamiento, sin perjuicio de lo dispuesto en el artículo 122 de esta ley.

b. Regularizar las fincas para adaptar su configuración a las exigencias del planeamiento cuando fuera preciso por ser su superficie inferior a la parcela mínima o su forma inadecuada para la edificación.

c. Edificar los solares en los plazos que en su caso señale el planeamiento urbanístico.

334 Art. 18.b modificado por Ley 15/2004, de 29 de diciembre, de modificación de la Ley $9 / 2002$, de 30 de diciembre, de ordenación urbanistica y protección del medio rural de Galicia. d. Conservar y, en su caso, rehabilitar la edificación a fin de que ésta mantenga en todo momento las condiciones establecidas en el apartado 1.b) del artículo 9 de esta ley.

Artículo 20. Deberes de los propietarios de suelo urbano no consolidado.

1. En suelo urbano no consolidado, los propietarios tienen los siguientes deberes:

a. Ceder obligatoria y gratuitamente a la Administración municipal todo el suelo necesario para los viales, espacios libres, zonas verdes y dotaciones públicas de carácter local al servicio predominantemente del polígono en el que sus terrenos resulten incluidos.

b. Ceder obligatoria, gratuitamente y sin cargas el suelo necesario para la ejecución de los sistemas generales que el plan general incluya o adscriba al polígono en el que estén comprendidos los terrenos, así como ejecutar la urbanización únicamente de los incluidos en el polígono en las condiciones que determine el plan.

c. Ceder obligatoria, gratuitamente y sin cargas el suelo correspondiente al aprovechamiento urbanístico del Ayuntamiento, por exceder del susceptible de apropiación privada, en los términos establecidos por el apartado b) del artículo 18 de esta ley.

La Administración actuante no tendrá que contribuir a los costes de urbanización de los terrenos en que se ubique este aprovechamiento, que deberán ser asumidos por los propietarios.

d. Proceder a la distribución equitativa de los beneficios y cargas del planeamiento con anterioridad al inicio de la ejecución material del mismo.

e. Costear y, en su caso, ejecutar o completar las obras de urbanización del polígono, así como las conexiones con los sistemas generales existentes, en los plazos establecidos por el planeamiento.

f. Edificar los solares en el plazo que, en su caso, establezca el planeamiento.

2. No podrá ser edificado terreno alguno que no reúna la condición de solar, salvo 


\section{Ordenación del territorio y...}

que se asegure la ejecución simultánea de la urbanización y de la edificación mediante aval que habrá de alcanzar el coste estimado de las obras de urbanización y las demás garantías que se determinen reglamentariamente.

\section{Sección 2. ${ }^{a}$ Suelo urbanizable}

Artículo 21. Régimen del suelo urbanizable.

1. Los propietarios de suelo clasificado como urbanizable tendrán derecho a usar, disfrutar y disponer de los terrenos de su propiedad de acuerdo con la naturaleza rústica de los mismos, debiendo destinarlos a fines agrícolas, forestales, ganaderos o similares.

Además, tendrán el derecho de promover su transformación solicitando al Ayuntamiento la aprobación del correspondiente planeamiento de desarrollo, de conformidad con lo establecido en la presente ley y en el plan general de ordenación municipal, o proceder a su desarrollo si ya estuviera ordenado directamente en el plan general.

2. La transformación del suelo urbanizable a través del plan parcial podrá ser también promovida por la Administración municipal o autonómica.

3. En el suelo urbanizable delimitado, en tanto no se apruebe la correspondiente ordenación detallada, no podrán realizarse obras ni instalaciones, salvo las que vayan a ejecutarse mediante la redacción de planes especiales de infraestructuras y las de carácter provisional en las condiciones establecidas en el artículo 102 de esta ley.

4. En el suelo urbanizable no delimitado, en tanto no se apruebe el correspondiente plan de sectorización, se aplicará el régimen establecido para el suelo rústico en esta ley.

Artículo 22. Deberes de los propietarios de suelo urbanizable.

Una vez aprobado el planeamiento que establezca la ordenación detallada, la transformación del suelo urbanizable comportará para sus propietarios los siguientes deberes:

a. Ceder obligatoria y gratuitamente a la Administración municipal todo el suelo necesario para los viales, espacios libres, zonas verdes y dotaciones públicas de carácter local al servicio del sector en el que los terrenos resulten incluidos.

b. Ceder obligatoria, gratuitamente y $\sin$ cargas el suelo necesario para la ejecución de los sistemas generales que el plan general o el plan de sectorización incluya o adscriba al sector en el que estén comprendidos los terrenos, y ejecutar su urbanización únicamente de los incluidos en el sector en las condiciones que determine el plan.

c. Costear y, en su caso, ejecutar las infraestructuras de conexión con los sistemas generales existentes, así como las obras necesarias para la ampliación y refuerzo de los citados sistemas, de forma que se asegure su correcto funcionamiento en función de las características del sector y de conformidad con los requisitos y condiciones que establezca el plan general.

d. Ceder obligatoria, gratuitamente y libre de cargas a la Administración municipal el suelo correspondiente al 10 por 100 del aprovechamiento tipo del área de reparto. La Administración actuante no tendrá que contribuir a los costes de urbanización de los terrenos en que se ubique este aprovechamiento, que deberán ser asumidos por los propietarios.

e. Proceder a la distribución equitativa de los beneficios y cargas derivados del planeamiento, con anterioridad al inicio de la ejecución material del mismo.

f. Costear y, en su caso, ejecutar las obras de urbanización del sector, incluidas las conexiones con los sistemas generales existentes y en funcionamiento, en los plazos establecidos por el planeamiento, sin perjuicio del derecho a reintegrarse de los gastos de instalación de las redes de suministros con cargo a las empresas que presten los correspondientes servicios. 
g. Edificar los solares en el plazo que, en su caso, establezca el planeamiento.

h. Ceder obligatoria, gratuitamente y sin cargas a la Administración autonómica los terrenos destinados a la dotación autonómica para la construcción de viviendas de promoción y titularidad pública ${ }^{335}$.

Artículo 23. Aprovechamiento urbanístico.

El aprovechamiento urbanístico de los propietarios de suelo urbanizable será el resultado de aplicar a la superficie de sus fincas respectivas el 90 por 100 del aprovechamiento tipo del área de reparto correspondiente.

\section{Sección $3 .^{a}$} Núcleos rurales

\section{Subsección 1 . $^{\mathrm{a}}$ Derechos y deberes}

\section{Artículo 24. Régimen.}

1. Los terrenos que los planes generales incluyan en las áreas delimitadas como núcleos rurales de población serán destinados a los usos relacionados con las actividades propias del medio rural y con las necesidades de la población residente en dichos núcleos.

Los propietarios de esta clase de suelo tienen derecho a su uso y edificación en las condiciones establecidas en esta sección.

2. Cuando se pretenda construir nuevas edificaciones, o sustituir las existentes, los propietarios deberán ceder gratuitamente al Ayuntamiento los terrenos necesarios para la apertura o regularización del viario preciso y ejecutar, a su costa, la conexión con los servicios existentes en el núcleo.

3. En el supuesto de ejecución de planes especiales de protección, rehabilitación y mejora del medio rural que contemplen actuaciones de carácter integral en los núcleos rurales y delimiten polígonos, los propietarios de suelo están obligados a:

335 Art. 22.h añadido por Ley 6/2008, de 19 de junio, de medidas urgentes en materia de vivienda y suelo, por la que se modifica la Ley $9 / 2002$, de 30 de diciembre, de ordenación urbanistica y protección del medio rural de Galicia. a. Ceder gratuitamente a los Ayuntamientos los terrenos destinados a viales, equipamientos y dotaciones públicas.

b. Costear y ejecutar las obras de urbanización previstas en el plan especial.

c. Solicitar la licencia de edificación y edificar cuando el plan especial así lo establezca.

4. El plan general establecerá las limitaciones necesarias para impedir que la edificación en el área de expansión pueda dificultar la aprobación del futuro plan especial de protección, rehabilitación y mejora del medio rural.

En todo caso, antes de la aprobación del plan especial no se permitirán segregaciones o división de parcelas en el área de expansión salvo en el supuesto previsto en el párrafo cuarto del artículo 206.1 de la presente ley.

Una vez aprobado el plan especial de protección, rehabilitación y mejora del medio rural, podrá obtenerse licencia municipal con sujeción a las condiciones establecidas por el plan y sin necesidad de previa autorización autonómica ${ }^{336}$.

5. En el supuesto de ejecución de planes especiales que desarrollen operaciones de carácter integral sobre un área de expansión del núcleo rural, además de las obligaciones establecidas en el apartado anterior, los propietarios del suelo estarán obligados a ceder obligatoria, gratuitamente y libre de cargas a la administración municipal el suelo correspondiente al $10 \%$ del aprovechamiento urbanístico de dicha área. La administración actuante no tendrá que contribuir a los costes de urbanización de los terrenos en que se ubique dicho aprovechamiento, que habrán de ser asumidos por los propietarios ${ }^{337}$.

336 Art. 24.4 añadido por Ley 15/2004, de 29 de diciembre, de modificación de la Ley 9/2002, de 30 de diciembre, de ordenación urbanistica y protección del medio rural de Galicia.

${ }^{337}$ Art. 24.5 añadido por Ley 15/2004, de 29 de diciembre, de modificación de la Ley 9/2002, de 30 de diciembre, de ordenación urbanistica y protección del medio rural de Galicia. 


\section{Ordenación del territorio y...}

\section{Subsección 2. ${ }^{\text {a }}$ Condiciones de uso}

Artículo 25. Tipos de actuaciones.

En los núcleos rurales delimitados de conformidad con la presente ley se permitirán, previa licencia municipal y sin necesidad de autorización autonómica previa, las siguientes actuaciones:

a. Obras de conservación y restauración de las edificaciones existentes, siempre y cuando no supongan variación de las características esenciales del edificio, ni alteración del lugar, volumen y tipología tradicional.

En todo caso, se ajustarán a lo dispuesto en el artículo 29 de esta ley.

b. Obras de rehabilitación y ampliación en planta o altura de las edificaciones existentes que no impliquen variación de su tipología, siempre que se cumplan las condiciones establecidas en el artículo 29 de esta ley.

c. Nuevas edificaciones de acuerdo con las reglas establecidas en el artículo 29 de esta ley.

d. Obras de conservación, restauración, rehabilitación y reconstrucción de las edificaciones tradicionales o de especial valor arquitectónico existentes en el núcleo rural, siempre que no supongan variación de las características esenciales del edificio ni alteración del lugar, de su volumen ni de la tipología originaria, sin necesidad de cumplir todas las condiciones exigidas por el artículo 29338 .

Artículo 26. Obras de derribo y demolición.

1. Queda prohibido el derribo o demolición de las construcciones existentes, salvo en los siguientes supuestos:

a. Aquellas construcciones sin interés arquitectónico alguno en las que, por su reducido tamaño o imposibilidad de acceso, no sea posible su recuperación,

338 Art. 25.d añadido por Ley 15/2004, de 29 de diciembre, de modificación de la Ley $9 / 2002$, de 30 de diciembre, de ordenación urbanistica y protección del medio rural de Galicia. restauración o reconstrucción para cualquier uso de los autorizados en esta ley.

b. Las edificaciones de escaso valor histórico o etnográfico de las que, estando en ruina material de acuerdo con la legislación urbanística, con evidente peligro para las personas o cosas, no sea viable su recuperación total o parcial.

c. Todos los añadidos que desvirtúen la tipología, forma y volumen de cualquier edificación primitiva, o que por los materiales en ellos empleados supongan un efecto distorsionador para la armonía y estética del conjunto edificatorio. Igualmente todos los alpendres, almacenes y edificaciones auxiliares que estén en las mismas condiciones.

2. En los supuestos previstos en el número anterior, se solicitará licencia de demolición acompañando al proyecto técnico un estudio justificado y motivado del cumplimiento y veracidad de las circunstancias que concurren de acuerdo con lo especificado anteriormente.

Artículo 27. Usos permitidos en los núcleos rurales.

El uso característico de las edificaciones en los núcleos rurales será el residencial. Asimismo, se podrán permitir usos comerciales, productivos, turísticos y tradicionales ligados a la vida rural, así como pequeños talleres, siempre que no se altere la estructura morfológica del asentamiento y el nuevo uso contribuya a revitalizar la vida rural y mejorar el nivel de vida de sus moradores y que, en todo caso, resulten compatibles con el uso residencial.

Artículo 28. Actuaciones prohibidas. Dentro del núcleo rural no se permitirán:

a. Las edificaciones, ya sean de vivienda, auxiliares o de otro uso, cuya tipología no responda a las del asentamiento en el que se ubiquen.

b. Viviendas adosadas, proyectadas en serie, de características similares y colocadas en continuidad en más de tres unidades.

c. Naves industriales de cualquier tipo. 
d. Aquellos movimientos de tierras que supongan una agresión al medio natural o que varíen la morfología del paisaje del lugar.

e. La apertura de pistas, calles o caminos que no estén contemplados en el planeamiento, así como la ampliación de los existentes y el derribo, de manera injustificada, de muros tradicionales de los rueiros o corredoiras.

f. $(\ldots)^{339}$.

g. Las nuevas instalaciones destinadas a la producción ganadera, salvo las pequeñas construcciones destinadas a usos ganaderos para el autoconsumo ${ }^{340}$.

h. Aquellos usos que, ya sea por el tamaño de las construcciones, por la naturaleza de los procesos de producción, por las actividades a desarrollar o por otras condiciones, aun cumpliendo con los requisitos de la legislación medioambiental, no sean propios del asentamiento rural.

\section{Subsección 3 . $^{\mathrm{a}}$}

\section{Condiciones de edificación}

Artículo 29. Condiciones de edificación.

1. Las nuevas edificaciones que se pretendan emplazar en los núcleos rurales se identificarán con las características propias del lugar y estarán encaminadas a consolidar la trama rural existente. Todas ellas cumplirán las siguientes condiciones:

a. La parcela mínima edificable no será inferior a 300 metros cuadrados, salvo casos excepcionales debidamente justificados de parcelas inferiores ubicadas entre otras ya edificadas que imposibiliten alcanzar la parcela mínima.

En el área de expansión del núcleo delimitada según lo dispuesto por el artículo 13, la parcela mínima de edificación no será inferior a 600 metros cuadrados.

339 Art. 28.f derogado por Ley $15 / 2004$, de 29 de diciembre, de modificación de la Ley $9 / 2002$, de 30 de diciembre, de ordenación urbanistica y protección del medio rural de Galicia.

340 Art. 28.g modificado por Ley $15 / 2004$, de 29 de diciembre, de modificación de la Ley $9 / 2002$, de 30 de diciembre, de ordenación urbanistica y protección del medio rural de Galicia. b. Las características estéticas y constructivas y los materiales, colores y acabados serán acordes con el paisaje rural y con las construcciones tradicionales del asentamiento. En tal sentido, para el acabado de las edificaciones, se empleará la piedra o los materiales tradicionales y propios de la zona. En casos justificados por la calidad arquitectónica de la edificación, podrán emplearse otros materiales que armonicen con los valores naturales, el paisaje rural y las edificaciones tradicionales del entorno.

c. El volumen máximo de la edificación será similar al de las edificaciones tradicionales existentes en el núcleo rural. En caso de que resulte imprescindible sobrepasarlo por exigencias del uso o actividad, habrá de descomponerse en dos o más volúmenes conectados entre sí, a fin de adaptar las volumetrías a las tipologías tradicionales propias del medio rural. En todo caso, habrán de adoptarse las medidas correctoras necesarias para garantizar el mínimo impacto visual sobre el paisaje y la mínima alteración del relieve natural de los terrenos ${ }^{341}$.

d. La altura de la edificación no excederá de planta baja y piso, ni de un máximo de 7 metros medidos en la forma establecida en el artículo 42, apartado 1, letra c), de esta ley.

e. La cubierta tendrá una pendiente igual o inferior a la media de las existentes en el asentamiento, nunca superior a 400 , y estará formada por planos continuos sin quiebras en sus vertientes. En el supuesto de que el planeamiento urbanístico permita el aprovechamiento bajo cubierta, éste deberá ser como prolongación de la vivienda inferior, recibiendo su iluminación y ventilación por los testeros y por ventanas inclinadas situadas en el plano de las vertientes de las cubiertas. Salvo en casos debidamente justificados y previa autorización preceptiva del

341 Art. 29.a, b y c modificados por Ley 15/2004, de 29 de diciembre, de modificación de la Ley $9 / 2002$, de 30 de diciembre, de ordenación urbanistica y protección del medio rural de Galicia. 


\section{Ordenación del territorio y...}

Ayuntamiento, los materiales a utilizar en la terminación de la cubrición serán teja cerámica y/o pizarra, según la tipología propia de la zona. Quedan prohibidas las mansardas o buhardillas, salvo en aquellas zonas en que se justifique que formen parte de las tipologías tradicionales y cuenten con la previa autorización preceptiva del Ayuntamiento.

f. Para las nuevas construcciones, serán obligatorios, salvo en alineaciones estables o consolidadas, los retranqueos mínimos con respecto a las vías de acceso, que en todo caso deberán separarse un mínimo de 4 metros del eje de la vía, y 3 metros con respecto al lindero posterior. En caso de que se desease retranquear una edificación a los linderos laterales, este retranqueo deberá ser, como mínimo, de 3 metros.

g. Para autorizar las edificaciones se exigirá tener resueltos, con carácter previo y a costa del promotor, al menos los servicios de acceso rodado, abastecimiento de agua, evacuación y tratamiento de las aguas residuales y suministro de energía eléctrica o, en otro caso, garantizar la ejecución simultánea con la edificación.

2. Reglamentariamente podrán establecerse condiciones adicionales específicas de edificación y uso del suelo aplicables a cada área del territorio.

3. El plan especial de protección, rehabilitación y mejora del medio rural, con fundamento en el estudio detallado e individualizado del núcleo rural, podrá establecer condiciones de edificación distintas de las fijadas en los apartados a), d) y f) del número 1 de este artículo.

4. La instalación de invernaderos con destino exclusivo al uso agrario que se instalen con materiales ligeros y fácilmente desmontables no estará sujeta a las condiciones de edificación establecidas en este artículo ${ }^{342}$.

342 Art. 29.3 y 29.4 añadidos por Ley $15 / 2004$, de 29 de diciembre, de modificación de la Ley $9 / 2002$, de 30 de diciembre, de ordenación urbanistica y protección del medio rural de Galicia.
Artículo 30. (...) $)^{343}$.

\section{Sección $4 .^{a}$}

Suelo rústico

\section{Subsección $1 .^{\mathrm{a}}$ \\ Régimen}

Artículo 31. Facultades y deberes de los propietarios en suelo rústico.

1. Los propietarios de terrenos clasificados como suelo rústico tendrán el derecho a usar, disfrutar y disponer de ellos de conformidad con la naturaleza y destino rústico de los mismos. A estos efectos, los propietarios podrán llevar a cabo:

a. Acciones sobre el suelo o subsuelo que no impliquen movimiento de tierras, tales como aprovechamientos agropecuarios, pastoreo, roturación y desecación, así como vallados con elementos naturales o de setos.

b. Acciones sobre las masas arbóreas, tales como aprovechamiento de leña, aprovechamiento maderero, entresacas, mejora de la masa forestal, otros aprovechamientos forestales, repoblaciones y tratamiento fitosanitario, de conformidad con la legislación aplicable en materia forestal.

Además, podrán llevar a cabo las actuaciones complementarias e imprescindibles para el aprovechamiento maderero, tales como la apertura de vías de saca temporales, los cargaderos temporales de madera y el estacionamiento temporal de maquinaria forestal, siempre que los propietarios se comprometan a reponer los terrenos a su estado anterior en el plazo que se determine. A estos efectos, el Ayuntamiento podrá exigir la prestación de las garantías necesarias ${ }^{344}$.

c. Otras acciones autorizadas en los términos previstos en esta ley.

343 Art. 30 derogado por Ley 15/2004, de 29 de diciembre, de modificación de la Ley $9 / 2002$, de 30 de diciembre, de ordenación urbanistica y protección del medio rural de Galicia.

344 Segundo párrafo del art. 31.1.b añadido por Ley $15 / 2004$, de 29 de diciembre, de modificación de la Ley 9/2002, de 30 de diciembre, de ordenación urbanistica y protección del medio rural de Galicia. 
2. Los propietarios de suelo rústico deberán:

a. Destinarlos a fines agrícolas, forestales, ganaderos, cinegéticos, ambientales o a otros usos vinculados a la utilización racional de los recursos naturales dentro de los límites que, en su caso, establezcan esta ley, el planeamiento urbanístico y los instrumentos de ordenación del territorio.

b. Solicitar autorización de la Comunidad Autónoma para el ejercicio de las actividades autorizables en los casos previstos en esta ley, sin perjuicio de lo dispuesto en la legislación sectorial correspondiente.

c. Solicitar, en los supuestos previstos en la legislación urbanística, la oportuna licencia municipal para el ejercicio de las actividades contempladas en el artículo 33 de esta ley.

d. Realizar o permitir realizar a la Administración competente los trabajos de defensa del suelo y la vegetación necesarios para su conservación y para evitar riesgos de inundación, erosión, incendio, contaminación o cualquier otro riesgo de catástrofe o simple perturbación del medio ambiente, así como de la seguridad y salud públicas.

e. Cumplir las obligaciones y condiciones señaladas en esta ley para el ejercicio de las facultades que correspondan según la categoría de suelo rústico, así como las mayores restricciones que sobre ellas imponga el planeamiento urbanístico y la autorización autonómica otorgada al amparo de esta ley.

Artículo 32. Categorías.

En el suelo rústico se distinguirán las siguientes categorías:

1. Suelo rústico de protección ordinaria, constituido por los terrenos que el planeamiento urbanístico o los instrumentos de ordenación del territorio estimen inadecuados para su desarrollo urbanístico, en razón a sus características geotécnicas o morfológicas, el alto impacto territorial que conllevaría su urbanización, los riesgos naturales o tecnológicos o en consideración a los principios de utilización racional de los recursos naturales o de desarrollo sostenible ${ }^{345}$.

2. Suelo rústico especialmente protegido, constituido por los terrenos que por sus valores agrícolas, ganaderos, forestales, ambientales, científicos, naturales, paisajísticos, culturales, sujetos a limitaciones o servidumbres para la protección del dominio público o de otra índole deban estar sometidos a algún régimen especial de protección incompatible con su transformación, de acuerdo con lo dispuesto en este apartado.

Dentro de este tipo de suelo rústico especialmente protegido se distinguirán las siguientes categorías:

a. Suelo rústico de protección agropecuaria, constituido por los terrenos de alta productividad agrícola o ganadera, puesta de manifiesto por la existencia de explotaciones que la avalen o por las propias características o potencialidad de los terrenos o zonas donde se enclaven, así como por los terrenos objeto de concentración parcelaria a partir de la entrada en vigor de la Ley 9/2002 y por los terrenos concentrados con resolución firme producida en los diez años anteriores a esta fecha, salvo que hayan de ser incluidos en la categoría de suelo rústico de protección forestal.

No obstante, el plan general podrá excluir justificadamente de esta categoría los ámbitos colindantes sin solución de continuidad con el suelo urbano o con los núcleos rurales que resulten necesarios para el desarrollo urbanístico racional, que serán clasificados como suelo urbanizable o incluidos en el área de expansión de los núcleos rurales, respectivamente.

b. Suelo rústico de protección forestal, constituido por los terrenos destinados a explotaciones forestales y los que sustenten masas arbóreas que deban ser protegidas por cumplir funciones ecológicas,

345 Art. 32.1 modificado por Ley 15/2004, de 29 de diciembre, de modificación de la Ley $9 / 2002$, de 30 de diciembre, de ordenación urbanistica y protección del medio rural de Galicia. 


\section{Ordenación del territorio y...}

productivas, paisajísticas, recreativas o de protección del suelo, e igualmente por aquellos terrenos de monte que, aun cuando no sustenten masas arbóreas, deban ser protegidos por cumplir dichas funciones $\mathrm{y}$, en todo caso, por las áreas arbóreas formadas por especies autóctonas, así como por aquéllas que sufriesen los efectos de un incendio a partir de la entrada en vigor de la presente ley o en los cinco años anteriores a la misma. Igualmente se consideran suelo rústico de protección forestal aquellas tierras que declare la administración competente como áreas de especial productividad forestal, los montes públicos y los montes vecinales en mancomún.

No obstante, los montes vecinales en mancomún podrán ser calificados como suelo rústico de protección forestal o incorporados por el plan a cualquier otra categoría de suelo rústico especialmente protegido que se estime más adecuada.

Excepcionalmente, el plan general podrá excluir de esta categoría las áreas sin masas arboladas merecedoras de protección, colindantes sin solución de continuidad con el suelo urbano o con los núcleos rurales, que resulten necesarias para el desarrollo urbanístico racional ${ }^{346}$.

c. Suelo rústico de protección de infraestructuras, constituido por los terrenos rústicos destinados al emplazamiento de infraestructuras y sus zonas de afección no susceptibles de transformación, como son las de comunicaciones y telecomunicaciones, las instalaciones para el abastecimiento, saneamiento y depuración del agua, las de gestión de residuos sólidos, las derivadas de la política energética o cualquier otra que justifique la necesidad de afectar una parte del territorio, conforme a las previsiones de los instrumentos de planeamiento urbanístico y de ordenación del territorio.

346 Art. 32.2.a y 32.2.b modificados por Ley $15 / 2004$, de 29 de diciembre, de modificación de la Ley $9 / 2002$, de 30 de diciembre, de ordenación urbanistica y protección del medio rural de Galicia. d. Suelo rústico de protección de las aguas, constituido por los terrenos, situados fuera de los núcleos rurales y del suelo urbano, definidos en la legislación reguladora de las aguas continentales como cauces naturales, riberas y márgenes de las corrientes de agua y como lecho o fondo de las lagunas y embalses, terrenos inundados y zonas húmedas y sus zonas de servidumbre.

Asimismo, se incluirán en esta categoría las zonas de protección que a tal efecto delimiten los instrumentos de planeamiento urbanístico y de ordenación del territorio, que se extenderán, como mínimo, a la zona de policía definida por la legislación de aguas, salvo que el plan justifique suficientemente la reducción. Igualmente tendrán dicha consideración los terrenos situados fuera de los núcleos rurales y del suelo urbano con riesgo de inundación, y aquéllos bajo los cuales existan aguas subterráneas que deban ser protegidas.

No obstante lo anterior, las corrientes de agua de escasa entidad que discurran dentro del ámbito de un sector de suelo urbanizable quedarán debidamente integradas en el sistema de espacios libres públicos, con sujeción al régimen de suelo urbanizable ${ }^{347}$.

e. Suelo rústico de protección de costas, constituido por los terrenos, situados fuera de los núcleos rurales y del suelo urbano, que se encuentren a una distancia inferior a 200 metros del límite interior de la ribera del mar.

Excepcionalmente, previo informe favorable de la Comisión Superior de Urbanismo de Galicia, el plan general de ordenación municipal podrá reducir por razones debidamente justificadas, la franja de protección hasta los 100 metros a contar desde el límite interior de la ribera del mar.

f. Suelo rústico de protección de espacios naturales, constituido por los terrenos

347 Art. 32.2.d modificado por Ley 15/2004, de 29 de diciembre, de modificación de la Ley $9 / 2002$, de 30 de diciembre, de ordenación urbanistica y protección del medio rural de Galicia. 
sometidos a algún régimen de protección por aplicación de la Ley 9/2001, de Conservación de la Naturaleza, o de la legislación reguladora de los espacios naturales, la flora y la fauna. Igualmente tendrán dicha consideración los terrenos que los instrumentos de ordenación del territorio, las normas provinciales de planeamiento o el planeamiento urbanístico estimen necesario proteger por sus valores naturales, ambientales, científicos o recreativos.

g. Suelo rústico de protección paisajística, constituido por los terrenos que determine el planeamiento urbanístico o los instrumentos de ordenación del territorio con la finalidad de preservar las vistas panorámicas del territorio, el mar, el curso de los ríos o los valles, y de los monumentos o edificaciones de singular valor ${ }^{348}$.

h. Suelo rústico especialmente protegido para zonas con interés patrimonial, artístico o histórico, que estén contempladas en el planeamiento o en la legislación sectorial que les sea de aplicación.

i. Las demás que se determinen reglamentariamente.

3. Cuando un terreno, por sus características, pueda corresponder a varias categorías de suelo rústico, se optará entre incluirlo en la categoría que otorgue mayor protección o bien incluirlo en varias categorías, cuyos regímenes se aplicarán de forma complementaria; en este caso, si se produce contradicción entre dichos regímenes, prevalecerá la que otorgue mayor protección.

4. Sin perjuicio de mantener su clasificación como suelo rústico especialmente protegido, podrán adscribirse los terrenos como sistema general de espacios libres y zonas verdes públicas a los nuevos desarrollos urbanísticos que estén previstos en los terrenos colindantes, sin que se tenga en cuenta su superficie a los efectos de cómputo de edificabilidad ni densidad.

\footnotetext{
348 Art. 32.2.g modificado por Ley 15/2004, de 29 de diciembre, de modificación de la Ley $9 / 2002$, de 30 de diciembre, de ordenación urbanistica y protección del medio rural de Galicia.
}

5. En los municipios con más del $40 \%$ de la superficie del término municipal clasificada como suelo rústico de especial protección de espacios naturales, en aplicación del artículo 32 de la presente ley, el plan general de ordenación municipal podrá otorgar otra clasificación en ámbitos colindantes sin solución de continuidad con el suelo urbano y con los núcleos rurales que resulten imprescindibles para el desarrollo urbanístico sostenible, siempre que el plan contenga las medidas necesarias para la integración de la ordenación propuesta con el paisaje y los valores merecedores de protección ${ }^{349}$.

\section{Subsección 2.a Condiciones de uso}

Artículo 33. Usos y actividades en suelo rústico.

Los usos y actividades posibles en suelo rústico serán los siguientes:

1. Actividades y usos no constructivos:

a. Acciones sobre el suelo o subsuelo que impliquen movimientos de tierra, tales como dragados, defensa de ríos y rectificación de cauces, abancalamientos, desmontes, rellenos y otras análogas.

b. Actividades de ocio, tales como práctica de deportes organizados, acampada de un día y actividades comerciales ambulantes.

c. Actividades científicas, escolares y divulgativas.

d. Depósito de materiales, almacenamiento de maquinaria y estacionamiento de vehículos al aire libre.

e. Actividades extractivas, incluida la explotación minera, las canteras y la extracción de áridos o tierras.

2. Actividades y usos constructivos:

a. Construcciones e instalaciones agrícolas, tales como las destinadas al apoyo de las explotaciones hortícolas, almacenes agrícolas, viveros e invernaderos.

\footnotetext{
349 Art. 32.5 añadido por Ley 15/2004, de 29 de diciembre, de modificación de la Ley $9 / 2002$, de 30 de diciembre, de ordenación urbanistica y protección del
} medio rural de Galicia. 
b. Construcciones e instalaciones destinadas al apoyo de la ganadería extensiva e intensiva, granjas, corrales domésticos e instalaciones apícolas.

c. Construcciones e instalaciones forestales destinadas a la extracción de la madera o la gestión forestal y las de apoyo a la explotación forestal, así como las de defensa forestal.

d. Instalaciones vinculadas funcionalmente a las carreteras y previstas en la ordenación sectorial de éstas, así como, en todo caso, las de suministro de carburante.

e. Construcciones y rehabilitaciones destinadas al turismo rural y que sean potenciadoras del medio donde se ubiquen.

f. Instalaciones necesarias para los servicios técnicos de telecomunicaciones, la infraestructura hidráulica y las redes de transporte y distribución de energía eléctrica, gas, abastecimiento de agua y saneamiento, siempre que no impliquen la urbanización o transformación urbanística de los terrenos por los que discurren.

En todo caso, las edificaciones necesarias para el funcionamiento de las infraestructuras y servicios técnicos en suelo rústico que sobrepasen los 50 metros cuadrados edificados precisarán autorización autonómica previa a la licencia urbanística municipal, con arreglo al procedimiento establecido por el artículo 41 de la presente ley.

g. Construcciones e instalaciones para equipamientos y dotaciones que hayan de emplazarse necesariamente en el medio rural, como son: los cementerios, las escuelas agrarias, los centros de investigación y educación ambiental y los campamentos de turismo.

Además, mediante la aprobación de un plan especial de dotaciones regulado por el artículo 71 de la presente ley, podrán permitirse equipamientos sanitarios, asistenciales y educativos, públicos o privados, que en ningún caso podrán situarse a una distancia superior a 1.000 metros del suelo urbano ${ }^{350}$.

h. Construcciones destinadas a usos residenciales vinculados a la explotación agrícola o ganadera.

i. Cierres o vallado de fincas en las condiciones establecidas por el artículo 42.1.c) de la presente ley.

j. Actividades de carácter deportivo, cultural y recreativo que se desarrollen al aire libre, con las obras e instalaciones mínimas e imprescindibles para el uso de que se trate ${ }^{351}$.

k. Construcciones destinadas a actividades complementarias de primera transformación, almacenamiento y envasado de productos del sector primario, siempre que guarden relación directa con la naturaleza, extensión y destino de la finca o explotación del recurso natural.

1. Construcciones e instalaciones destinadas a establecimientos de acuicultura ${ }^{352}$.

$\mathrm{m}$. Infraestructuras de abastecimiento, saneamiento y depuración de aguas, de gestión y tratamiento de residuos sólidos urbanos o de producción de energía ${ }^{353}$.

3. Otras actividades análogas que se determinen reglamentariamente y coordinadas entre la legislación sectorial y la presente ley.

Artículo 34. Usos en suelo rústico.

1. Los usos en suelo rústico relacionados en el artículo anterior se determinan en los artículos siguientes, para cada categoría de suelo, como:

350 Art. 33.2.f y 33.2.g modificados por Ley $15 / 2004$, de 29 de diciembre, de modificación de la Ley 9/2002, de 30 de diciembre, de ordenación urbanistica y protección del medio rural de Galicia.

351 Art. 33.2.i y 33.2.j modificados por Ley $15 / 2004$, de 29 de diciembre, de modificación de la Ley 9/2002, de 30 de diciembre, de ordenación urbanistica y protección del medio rural de Galicia.

352 Art. 33.2.I añadido por Ley 15/2004, de 29 de diciembre, de modificación de la Ley $9 / 2002$, de 30 de diciembre, de ordenación urbanistica y protección del medio rural de Galicia.

353 Art. 33.m añadido por Ley 6/2007, de 11 de mayo, de medidas urgentes en materia de ordenación del territorio y del litoral de Galicia. 
a. Usos permitidos: Los compatibles con la protección de cada categoría de suelo rústico, sin perjuicio de la exigibilidad de licencia urbanística municipal y demás autorizaciones administrativas sectoriales que procedan.

b. Usos autorizables: Los sujetos a autorización de la Administración autonómica, previamente a la licencia urbanística municipal y en los que deban valorarse en cada caso las circunstancias que justifiquen su autorización, con las cautelas que procedan.

c. Usos prohibidos: Los incompatibles con la protección de cada categoría de suelo o que impliquen un riesgo relevante de deterioro de los valores protegidos.

2. En el suelo rústico especialmente protegido para zonas con interés patrimonial, artístico o histórico, antes del otorgamiento de la licencia municipal será necesario obtener el preceptivo informe favorable del organismo autonómico competente en materia de patrimonio cultural.

3. Serán nulas de pleno derecho las autorizaciones y licencias que se otorguen para usos prohibidos, así como las licencias municipales otorgadas para usos autorizables sin la previa y preceptiva autorización autonómica o en contra de sus condiciones.

4. No necesitarán autorización autonómica previa, a los efectos de la presente ley, las infraestructuras, dotaciones e instalaciones previstas en un proyecto sectorial aprobado al amparo de la Ley 10/1995, de Ordenación del Territorio de Galicia.

Artículo 35. Limitaciones de apertura de caminos y movimientos de tierras.

1. No está permitida la apertura de nuevos caminos o pistas en el suelo rústico que no estén expresamente contemplados en el planeamiento urbanístico o en los instrumentos de ordenación del territorio, salvo los caminos rurales contenidos en los proyectos aprobados por la Administración competente en materia de agricultura, de montes o de medio ambiente y aquellos que obtuvieran la correspondiente autorización autonómica de conformidad con lo dispuesto en el artículo 41 de la presente ley.

En todo caso, la ejecución de nuevas pistas o caminos que afecten a suelo rústico de protección de espacios naturales y de interés paisajístico estará sujeta a la evaluación de efectos ambientales que prevé la Ley 1/1995, de 22 de enero, de Protección Ambiental de Galicia.

2. Las nuevas aperturas de caminos o pistas que se puedan realizar deberán adaptarse a las condiciones topográficas del terreno, con la menor alteración posible del paisaje y minimizándose o corrigiéndose su impacto ambiental.

3. Con carácter general quedan prohibidos los movimientos de tierra que alteren la topografía natural de los terrenos rústicos, salvo en los casos expresamente autorizados por la presente ley.

Artículo 36. Suelo rústico de protección ordinaria.

El régimen del suelo rústico de protección ordinaria tiene por finalidad garantizar la utilización racional de los recursos naturales y el desarrollo urbanístico sostenible. Estará sometido al siguiente régimen:

Usos permitidos por licencia municipal: los relacionados en el apartado 1, letras b, c y e, y en el apartado 2, letras f e i, del artículo 33 de la presente Ley.

Usos autorizables por la comunidad autónoma: el resto de los usos relacionados en el artículo 33 de la presente Ley, así como los que puedan establecerse a través de los instrumentos previstos en la legislación de ordenación del territorio, siempre que no impliquen la transformación urbanística del suelo.

Usos prohibidos: todos los demás.

3. Usos prohibidos: Todos los demás ${ }^{354}$.

354 Art. 36 modificado por Ley $3 / 2008$, de 23 de mayo, de Ordenación de la Minería de Galicia. 
Artículo 37. Suelos rústicos de especial protección agropecuaria, forestal o de infraestructuras.

El régimen de los suelos rústicos de protección agropecuaria $\mathrm{y}$ forestal tiene por finalidad principal preservar los terrenos de alta productividad y garantizar la utilización racional de los recursos naturales y el desarrollo urbanístico sostenible. El régimen del suelo rústico de protección de infraestructuras, sin perjuicio de lo establecido en su específica legislación reguladora, tiene por objeto preservar las infraestructuras existentes o de nueva creación.

Estará sometido al siguiente régimen:

Usos permitidos por licencia municipal: los relacionados en el apartado 1 , letras b y c, y en el apartado 2, letras f e i, del artículo 33 de esta Ley. Además, en el suelo rústico de protección forestal se permitirá lo relacionado en el apartado 1, letra e.

En suelo rústico de protección de infraestructuras se permitirán las instalaciones necesarias para la ejecución y funcionamiento de la correspondiente infraestructura.

Usos autorizables por la comunidad autónoma:

En suelo rústico de protección agropecuaria serán autorizables los usos relacionados en el apartado 1, letras a y d, y en el apartado 2, letras a, b, d, e, h, j, k y l, del artículo 33 de la presente Ley, así como los que puedan establecerse a través de los instrumentos previstos en la legislación de ordenación del territorio, siempre que no impliquen la transformación urbanística de los terrenos ni lesionen los valores objeto de protección.

En suelo rústico de protección forestal podrán autorizarse los usos relacionados en el apartado 1, letras a y d, y en el apartado 2, letras a, b, c, d, e, g, h, j, k y l, del artículo 33, siempre que no impliquen la transformación urbanística del suelo ni lesionen los valores objeto de protección, y los que puedan establecerse a través de los instrumentos de ordenación del territorio.

En suelo rústico de protección de infraestructuras únicamente serán autorizables los usos relacionados en el apartado 1 , letra a, y en el apartado 2, letras d y f, del artículo 33, así como los que puedan establecerse a través de los instrumentos de ordenación del territorio.

Usos prohibidos: todos los demás, especialmente los usos residenciales e industriales ${ }^{355}$.

Artículo 38. Suelos rústicos de protección de las aguas, las costas, de interés paisajístico y de patrimonio cultural.

El régimen general de los suelos rústicos de protección de las aguas, las costas, de interés paisajístico y del patrimonio cultural, sin perjuicio de lo establecido en su legislación reguladora, tiene por objeto preservar el dominio público hidráulico y marítimo y su entorno, así como los espacios de interés paisajístico y el patrimonio cultural, quedando sujetos al siguiente régimen:

1. Usos permitidos por licencia municipal:

Los relacionados en el apartado 1, letras b) y c), y en el apartado 2, letras f) e i), del artículo 33 de la presente ley.

2. Usos autorizables por la Comunidad Autónoma:

Los relacionados en el apartado 1, letra a), y en el apartado 2, letras e) y 1), del artículo 33 de la presente ley, así como las actividades vinculadas directamente con la conservación, utilización y disfrute del dominio público, del medio natural y del patrimonio cultural, y los que puedan establecerse a través de los instrumentos previstos en la legislación de ordenación del territorio, siempre que no conlleven la transformación de su naturaleza rústica y quede garantizada la integridad de los valores objeto de protección.

En el suelo rústico de protección de costas y de protección de aguas, además de los usos anteriormente indicados, podrán autorizarse específicamente las construcciones e instalaciones necesarias para actividades

355 Art. 37 modificado por Ley $3 / 2008$, de 23 de mayo, de Ordenación de la Mineria de Galicia. 
de talasoterapia, aguas termales, sistemas de depuración de aguas, astilleros e instalaciones mínimas necesarias para la práctica de los deportes náuticos.

3. Usos prohibidos:

Todos los demás, especialmente los usos residenciales e industriales ${ }^{356}$.

Artículo 39. Suelo rústico de especial protección de espacios naturales.

El régimen general de los suelos rústicos de protección de espacios naturales, sin perjuicio de lo establecido en su legislación reguladora, tiene por objeto preservar sus valores naturales, paisajísticos y tradicionales, quedando sujetos al siguiente régimen:

1. Usos permitidos por licencia municipal:

Los relacionados en el apartado 1 , letras b) y c), y en el apartado 2, letra i), del artículo 33 de la presente ley.

2. Usos autorizables por la Comunidad Autónoma:

Los relacionados en el apartado 1, letra a), y en el apartado 2, letras e), f) y 1), del artículo 33 de la presente ley, así como las actividades vinculadas directamente con la conservación, utilización y disfrute del medio natural, y los que puedan establecerse a través de los instrumentos previstos en la legislación de ordenación del territorio, siempre que no conlleven la transformación de su naturaleza rústica y quede garantizada la integridad de los valores objeto de protección.

Para autorizar los usos señalados por el apartado 2, letra 1), del artículo 33 sobre suelo rústico de especial protección de espacios naturales, será necesario obtener el previo informe favorable de la Consellería competente en materia de conservación de espacios naturales.

356 Art. 38 modificado por Ley $15 / 2004$, de 29 de diciembre, de modificación de la Ley $9 / 2002$, de 30 de diciembre, de ordenación urbanistica y protección del medio rural de Galicia.
En los municipios con más del 40\% de la superficie del término municipal clasificada como suelo rústico de especial protección de espacios naturales, podrán autorizarse, con carácter excepcional, los usos relacionados en el apartado 2, letras a), b), c) y d), siempre que quede garantizada la integración de las edificaciones con el paisaje y los valores objeto de protección.

3. Usos prohibidos:

Todos los demás, especialmente los usos residenciales e industriales ${ }^{357}$.

Artículo 40. Edificaciones existentes de carácter tradicional o de singular valor arquitectónico.

Se permitirá en cualquier categoría de suelo rústico, previa autorización autonómica con arreglo al procedimiento establecido por el artículo 41, la reconstrucción y rehabilitación de las edificaciones tradicionales o de singular valor arquitectónico, que podrán ser destinadas a vivienda y usos residenciales, a actividades turísticas y artesanales o a equipamientos de interés público. La reconstrucción o rehabilitación habrá de respetar el volumen edificable preexistente y la composición volumétrica original.

Asimismo, previa autorización autonómica, podrá permitirse por razones justificadas su ampliación, incluso en volumen independiente, sin sobrepasar el 10\% del volumen originario de la edificación tradicional. Excepcionalmente, la ampliación podrá alcanzar el $50 \%$ del volumen de la edificación originaria cumpliendo las condiciones establecidas por los artículos 42 y 44 de la presente ley ${ }^{358}$.

357 Art. 39 modificado por Ley $15 / 2004$, de 29 de diciembre, de modificación de la Ley 9/2002, de 30 de diciembre, de ordenación urbanistica y protección del medio rural de Galicia.

358 Art. 40 modificado por Ley $15 / 2004$, de 29 de diciembre, de modificación de la Ley $9 / 2002$, de 30 de diciembre, de ordenación urbanistica y protección del medio rural de Galicia. 


\section{Ordenación del territorio y...}

\section{Subsección 3. ${ }^{a}$ \\ Procedimiento para el otorgamiento de autorizaciones}

Artículo 41. Procedimiento para el otorgamiento de la autorización autonómica en suelo rústico.

1. La competencia para el otorgamiento de la autorización autonómica prevista en la presente ley corresponde al Director general competente en materia de urbanismo.

2. El procedimiento para la tramitación de las autorizaciones autonómicas en suelo rústico se ajustará a las siguientes reglas:

a. El promotor deberá presentar la solicitud ante el Ayuntamiento acompañada de anteproyecto redactado por técnico competente, con el contenido que se detalle reglamentariamente, y, como mínimo, la documentación gráfica, fotográfica y escrita que sea suficiente para conocer las características esenciales del emplazamiento y de su entorno en un radio mínimo de 500 metros, de la titularidad de los terrenos y superficie de los mismos, del uso solicitado y de las obras necesarias para su ejecución, conservación y servicio, sus repercusiones territoriales y ambientales y las que sean necesarias para justificar el cumplimiento de las condiciones establecidas en la presente ley.

b. El Ayuntamiento someterá el expediente a información pública por un plazo mínimo de veinte días, mediante anuncio que habrá de publicarse en el tablón de anuncios del Ayuntamiento y en uno de los periódicos de mayor difusión en el municipio. El anuncio deberá indicar, como mínimo, el emplazamiento, el uso solicitado, la altura y ocupación de la edificación pretendida, y el lugar y horario de consulta de la documentación completa 359 .

c. Concluida la información pública, el Ayuntamiento remitirá el expediente

359 Art. 41.2.b modificado por Ley $15 / 2004$, de 29 de diciembre, de modificación de la Ley $9 / 2002$, de 30 de diciembre, de ordenación urbanistica y protección del medio rural de Galicia. completo tramitado a la Consellería competente en materia de ordenación del territorio y urbanismo, incluyendo las alegaciones presentadas y los informes de los técnicos municipales y del órgano municipal que tenga atribuida la competencia para otorgar la licencia de obra.

Transcurrido el plazo de tres meses sin que el Ayuntamiento haya remitido el expediente completo a la Consellería, los interesados podrán solicitar la subrogación de esta última, que reclamará el expediente al Ayuntamiento y proseguirá la tramitación hasta su resolución.

d. La Consellería podrá requerir del promotor la documentación e información complementaria que estime necesaria o bien la subsanación de las deficiencias de la solicitud para adaptarse a lo dispuesto en la presente ley.

Asimismo, podrá recabar de los organismos sectoriales correspondientes los informes que se estimen necesarios para resolver.

e. El Director general competente en materia de urbanismo examinará la adecuación de la solicitud a la presente ley y a los instrumentos de ordenación del territorio y resolverá en el plazo de tres meses, a contar desde la entrada del expediente completo en el Registro de la Consellería competente, concediendo la autorización simplemente o condicionándola justificadamente a la introducción de medidas correctoras, o bien denegándola motivadamente. Transcurrido dicho plazo sin resolución expresa, se entenderá denegada la autorización por silencio administrativo.

\section{Subsección $4 .^{\text {a }}$}

\section{Condiciones de edificación}

Artículo 42. Condiciones generales de las edificaciones en el suelo rústico.

1. Para otorgar licencia o autorizar cualquier clase de edificaciones o instalaciones en el suelo rústico deberá justificarse el cumplimiento de las siguientes condiciones:

a. Garantizar el acceso rodado público adecuado a la implantación, el abastecimiento de agua, la evacuación y 
tratamiento de aguas residuales, el suministro de energía eléctrica, la recogida, tratamiento, eliminación y depuración de toda clase de residuos y, en su caso, la previsión de aparcamientos suficientes, así como corregir las repercusiones que produzca la implantación en la capacidad y funcionalidad de las redes de servicios e infraestructuras existentes. Estas soluciones habrán de ser asumidas como coste a cargo exclusivo del promotor de la actividad, formulando expresamente el correspondiente compromiso en tal sentido y aportando las garantías exigidas al efecto por la Administración en la forma que reglamentariamente se determine y que podrán consistir en la exigencia de prestar aval del exacto cumplimiento de dichos compromisos por importe del 10 por 100 del coste estimado para la implantación o refuerzo de los servicios.

b. Prever las medidas correctoras necesarias para minimizar la incidencia de la actividad solicitada sobre el territorio, así como todas aquellas medidas, condiciones o limitaciones tendentes a conseguir la menor ocupación territorial y la mejor protección del paisaje, los recursos productivos y el medio natural, así como la preservación del patrimonio cultural y la singularidad y tipología arquitectónica de la zona.

c. Cumplir las siguientes condiciones de edificación:

La superficie máxima ocupada por la edificación en planta no excederá del $20 \%$ de la superficie de la finca. No obstante, las edificaciones destinadas a explotaciones ganaderas y los establecimientos de acuicultura podrán ocupar hasta el $40 \%$ de la superficie de la parcela. Excepcionalmente, los instrumentos establecidos por la Ley 10/1995, de Ordenación del Territorio de Galicia, podrán permitir una ocupación superior para estas actividades, siempre que se mantenga el estado natural, al menos, en un tercio de la superficie de la parcela.
El volumen máximo de la edificación será similar al de las edificaciones tradicionales existentes en el suelo rústico del entorno. En caso de que resulte imprescindible sobrepasarlo por exigencias del uso o actividad autorizable, procurará descomponerse en dos o más volúmenes conectados entre sí a fin de adaptar las volumetrías a las tipologías propias del medio rural. En todo caso, habrán de adoptarse las medidas correctoras necesarias para garantizar el mínimo impacto visual sobre el paisaje y la mínima alteración del relieve natural de los terrenos.

Las características tipológicas de la edificación habrán de ser congruentes con las tipologías rurales tradicionales del entorno, en particular, las condiciones de volumetría, tratamiento de fachadas, morfología y tamaño de los huecos, y soluciones de cubierta, que, en todo caso, estarán formadas por planos continuos sin quiebras en sus vertientes. Salvo en casos debidamente justificados por la calidad arquitectónica del proyecto, los materiales a utilizar en la terminación de la cubrición serán teja cerámica y/o pizarra, según la tipología propia de la zona.

En los suelos rústicos de protección ordinaria, agropecuaria, forestal o de infraestructuras, la altura máxima de las edificaciones no podrá sobrepasar las dos plantas ni los 7 metros medidos en el centro de todas las fachadas, desde la rasante natural del terreno al arranque inferior de la vertiente de cubierta. Excepcionalmente, podrá sobrepasar los 7 metros de altura cuando las características específicas de la actividad, debidamente justificadas, hicieran imprescindible sobrepasarlos en alguno de sus puntos. En los demás suelos rústicos protegidos, las edificaciones no podrán sobrepasar una planta de altura ni 3,50 metros medidos de igual forma.

Las características estéticas y constructivas y los materiales, colores y acabados serán acordes con el paisaje rural y las 
construcciones tradicionales del entorno. En tal sentido, para el acabado de las edificaciones se empleará la piedra u otros materiales tradicionales y propios de la zona. En casos justificados por la calidad arquitectónica de la edificación, podrán emplearse otros materiales acordes con los valores naturales, el paisaje rural y las edificaciones tradicionales del entorno.

Los cierres y vallados serán preferentemente vegetales, sin que los realizados con material opaco de fábrica sobrepasen la altura de 1 metro, salvo en parcelas edificadas, donde podrán alcanzar 1,50 metros. En todo caso, deben realizarse con materiales tradicionales del medio rural en que se emplacen, no permitiéndose el empleo de bloques de hormigón u otros materiales de fábrica, salvo que sean debidamente revestidos y pintados en la forma que reglamentariamente se determine ${ }^{360}$.

d. Cumplir las siguientes condiciones de posición e implantación:

La superficie mínima de la parcela sobre la que se emplazará la edificación será la establecida en cada caso por esta ley, sin que a tal efecto sea admisible la adscripción de otras parcelas.

Los edificios se ubicarán dentro de la parcela, adaptándose en lo posible al terreno y al lugar más apropiado para conseguir la mayor reducción del impacto visual y la menor alteración de la topografía del terreno.

Los retranqueos de las construcciones a las lindes de la parcela habrán de garantizar la condición de aislamiento $\mathrm{y}$, en ningún caso, podrán ser inferiores a 5 metros.

Las condiciones de abancalamiento obligatorio y de acabado de los bancales resultantes deberán definirse y justificarse en el proyecto, de modo que quede garantizado el mínimo impacto visual sobre el paisaje y la mínima alteración de la topografía natural de los terrenos.

360 Art. 42.1.c modificado por Ley 15/2004, de 29 de diciembre, de modificación de la Ley 9/2002, de 30 de diciembre, de ordenación urbanistica y protección del medio rural de Galicia.
Se mantendrá el estado natural de los terrenos o, en su caso, el uso agrario de los mismos o con plantación de arbolado o especies vegetales en, al menos, la mitad de la superficie de la parcela.

e. Se hará constar obligatoriamente en el Registro de la Propiedad la vinculación de la total superficie real de la finca a la construcción y uso autorizados, expresando la indivisibilidad y las concretas limitaciones al uso y edificabilidad impuestas por la autorización autonómica.

f. En todo caso, el plazo para el inicio de las obras será de seis meses a contar desde el otorgamiento de la licencia municipal correspondiente, debiendo concluirse las obras en el plazo máximo de tres años, a contar desde el otorgamiento de la licencia.

g. Transcurridos dichos plazos, se entenderá caducada la licencia municipal y la autorización autonómica, previo expediente tramitado con audiencia del interesado, y será de aplicación lo dispuesto en el artículo 203 de la presente ley.

h. Las que se fijen reglamentariamente.

2. A las obras de derribo y demolición que se pretendan realizar en suelo rústico les será de aplicación lo dispuesto en el artículo 26 de la presente ley.

Artículo 43. Condiciones adicionales que deben cumplir las edificaciones destinadas a usos residenciales vinculados a las explotaciones agrícolas o ganaderas.

Las edificaciones destinadas a uso residencial complementario de la explotación agrícola o ganadera, además de las condiciones generales especificadas en el artículo 42 de la presente ley, cumplirán las siguientes:

a. $(\ldots)^{361}$.

b. La edificación deberá estar íntimamente ligada a la explotación agrícola o ganadera del solicitante. A tal efecto, deberá acreditarse fehaciente e imprescindiblemente que el

361 Art. 43.a derogado por Ley 15/2004, de 29 de diciembre, de modificación de la Ley $9 / 2002$, de 30 de diciembre, de ordenación urbanistica y protección del medio rural de Galicia. 
solicitante es titular de una explotación de las señaladas y que la misma cumple los requisitos que reglamentariamente se determinen.

c. Que la edificación tenga la condición de aislada, prohibiéndose la construcción de varias edificaciones residenciales sobre una misma parcela y las edificaciones destinadas a usos residenciales colectivos o no vinculados a la explotación.

d. En todo caso, la superficie mínima exigible para poder edificar nunca será inferior a 4.000 metros cuadrados, la superficie ocupada por la edificación no superará el 5 por 100 de la superficie neta de la parcela.

e. La edificación residencial no podrá emplazarse a una distancia inferior a 100 metros de cualquier otra edificación emplazada en suelo rústico, salvo las de la propia explotación agrícola o ganadera.

Artículo 44. Condiciones adicionales para otras actividades constructivas no residenciales.

1. Las construcciones en suelo rústico distintas de las señaladas en el artículo anterior, además de las condiciones generales especificadas en el artículo 42 de la presente ley, cumplirán las siguientes:

a. La superficie de la parcela en la que se ubique la edificación no será inferior a 5.000 metros cuadrados.

b. Habrá de justificarse cumplidamente la idoneidad del emplazamiento elegido y la imposibilidad o inconveniencia de ubicarlas en suelo urbano o urbanizable con calificación idónea.

2. Excepcionalmente, podrá otorgarse licencia, sin necesidad de autorización autonómica previa, para la ejecución de pequeñas construcciones e instalaciones destinadas a explotaciones agrícolas, ganaderas, cinegéticas y forestales o al servicio y funcionamiento de las infraestructuras y obras públicas, siempre que quede justificada la proporcionalidad de la construcción o instalación con la naturaleza, extensión y destino actual de la finca en que se emplace y no se sobrepasen los 25 metros cuadrados de superficie total edificada ni la altura máxima de una planta ni 3,50 metros. En todo caso, la tipología de la edificación y los materiales de construcción serán los determinados en el artículo 42 de la presente ley.

Igualmente, podrá permitirse, sin sujeción a lo dispuesto por los artículos 42 y 44 de la presente ley, la instalación de invernaderos con destino exclusivo al uso agrario que se instalen con materiales ligeros y fácilmente desmontables.

Este régimen excepcional sólo será de aplicación en el ámbito del suelo rústico de protección ordinaria y de especial protección agropecuaria, forestal o de infraestructuras.

3. Las obras de simple conservación y las obras menores a que hace referencia el artículo 195.3 de la presente ley no precisarán autorización autonómica con anterioridad a la obtención de la preceptiva licencia urbanística municipal cuando se realicen en edificaciones que fueron construidas al amparo de las preceptivas licencias urbanísticas y autorización autonómica.

4. Las nuevas explotaciones ganaderas sin base territorial no podrán emplazarse a una distancia inferior a 1.000 metros de los asentamientos de población y $250 \mathrm{me}$ tros de la vivienda más próxima. Cuando se trate de nuevas explotaciones con base territorial, la distancia mínima a los asentamientos de población y a la vivienda más próxima será de 200 metros.

El planeamiento urbanístico o los instrumentos de ordenación del territorio podrán reducir o aumentar estas distancias dentro de su ámbito territorial de aplicación, respetando en todo caso lo establecido por la legislación sectorial que sea de aplicación ${ }^{362}$.

$$
\text { 5. }(\ldots)^{363} \text {. }
$$

362 Art. 44.2, 44.3 y 44.4 modificados por Ley $15 / 2004$, de 29 de diciembre, de modificación de la Ley $9 / 2002$, de 30 de diciembre, de ordenación urbanistica y protección del medio rural de Galicia.

363 Art. 44.5 derogado por Ley $15 / 2004$, de 29 de diciembre, de modificación de la Ley $9 / 2002$, de 30 de diciembre, de ordenación urbanistica y protección del medio rural de Galicia. 


\section{Ordenación del territorio y...}

\section{TÍTULO II \\ PLANEAMIENTO URBANÍSTICO}

\section{Capítulo I \\ CLASES DE INSTRUMENTOS DE ORDENACIÓN}

Sección $1 .^{a}$

Disposiciones generales

Artículo 45. Instrumentos de ordenación.

1. La ordenación urbanística se llevará a cabo a través de normas subsidiarias y complementarias de planeamiento y de planes generales de ordenación municipal que se desarrollarán a través de los instrumentos urbanísticos previstos en la sección cuarta de este capítulo.

2. Los planes de ordenación urbanística están vinculados jerárquicamente a las determinaciones de las directrices de ordenación del territorio y a los demás instrumentos establecidos por la Ley 10/1995, de Ordenación del Territorio de Galicia, y habrán de redactarse en coherencia con todos ellos.

Artículo 46. Límites de sostenibilidad.

1. El planeamiento urbanístico tendrá como objetivo en el suelo urbano consolidado favorecer la conservación y recuperación del patrimonio construido, de los espacios urbanos relevantes, de los elementos y tipos arquitectónicos singulares, de las formas tradicionales de ocupación del suelo y de los rasgos diferenciales o distintivos que conforman la identidad local.

En tal sentido, se procurará mantener la trama urbana existente, y las construcciones de nueva planta, así como la reforma, rehabilitación o ampliación de las existentes, serán coherentes con la tipología arquitectónica característica del entorno, en particular en cuanto a la altura, el volumen y el fondo edificables.

2. En suelo urbano no consolidado de uso residencial, hotelero o terciario, el planeamiento no podrá contener determinaciones de las que resulte una superficie edificable total superior a los siguientes límites:

a. En municipios con población superior a 50.000 habitantes: 1,50 metros cuadrados edificables por cada metro cuadrado de suelo.

b. En municipios con población superior a 20.000 habitantes e inferior a 50.000 habitantes: Un metro cuadrado edificable por cada metro cuadrado de suelo.

c. En municipios con población superior a 5.000 habitantes e inferior a 20.000 habitantes: 0,85 metros cuadrados edificables por cada metro cuadrado de suelo.

d. En municipios con población inferior a 5.000 habitantes: 0,50 metros cuadrados edificables por cada metro cuadrado de suelo.

3. En suelo urbanizable delimitado de uso residencial, hotelero o terciario contiguo al suelo urbano, la superficie edificable total de cada sector no podrá superar los siguientes niveles de intensidad:

a. En municipios con población superior a 50.000 habitantes: Un metro cuadrado edificable por cada metro cuadrado de suelo.

b. En municipios con población superior a 20.000 habitantes e inferior a 50.000 habitantes: 0,85 metros cuadrados edificables por cada metro cuadrado de suelo.

c. En municipios con población superior a 5.000 habitantes e inferior a 20.000 habitantes: 0,60 metros cuadrados edificables por cada metro cuadrado de suelo.

d. En municipios con población inferior a 5.000 habitantes: 0,40 metros cuadrados edificables por cada metro cuadrado de suelo.

El planeamiento justificará la edificabilidad asignada en cada ámbito, según los criterios establecidos por el artículo 52.3 de esta ley, valorando el parque de viviendas existente.

4. En el resto del suelo urbanizable delimitado y en el no delimitado de uso residencial, hotelero o terciario, la superficie 
edificable total en cada sector no podrá sobrepasar los 0,30 metros cuadrados edificables por cada metro cuadrado de suelo.

5. En suelo urbano no consolidado y suelo urbanizable de uso industrial, no se permitirá una ocupación del terreno por las construcciones superior a las dos terceras partes de la superficie del ámbito ${ }^{364}$.

6. Para la determinación de la superficie edificable total deberán tenerse en cuenta las siguientes reglas:

a. Se computarán todas las superficies edificables de carácter lucrativo, cualquiera que sea el uso a que se destinen, incluidas las construidas en el subsuelo y los aprovechamientos bajo cubierta, con la única excepción de las superficies construidas en el subsuelo con destino a trasteros de superficie inferior a 10 metros cuadrados vinculados a las viviendas del edificio, a aparcamientos o a instalaciones de servicio como las de calefacción, electricidad, gas o análogas 365 .

b. El índice de edificabilidad se aplicará sobre la superficie total del ámbito, computando los terrenos destinados a nuevos sistemas generales incluidos en el mismo, y con exclusión, en todo caso, de los terrenos reservados para dotaciones públicas existentes que el plan mantenga, y de los destinados a sistemas generales adscritos a efectos de gestión que se ubiquen fuera del ámbito.

7. Las directrices de ordenación del territorio y los planes territoriales integrados aprobados al amparo de la Ley 10/1995, de Ordenación del Territorio de Galicia, podrán establecer los límites de edificabilidad para determinadas áreas del territorio, sin sujeción a lo dispuesto en los números 2 y 3 de este artículo ${ }^{366}$.

364 Art. 46.4 y 46.5 modificados por Ley $15 / 2004$, de 29 de diciembre, de modificación de la Ley 9/2002, de 30 de diciembre, de ordenación urbanistica y protección del medio rural de Galicia.

365 Art. 46.6 a modificado por Ley 15/2004, de 29 de diciembre, de modificación de la Ley 9/2002, de 30 de diciembre, de ordenación urbanistica y protección del medio rural de Galicia.

366 Art. 46.7 añadido por Ley 15/2004, de 29 de diciembre, de modificación de la Ley $9 / 2002$, de 30 de diciembre, de ordenación urbanistica y protección del medio rural de Galicia.
Artículo 47. Calidad de vida y cohesión social.

1. El plan general deberá contemplar las reservas de suelo necesarias para la implantación de los sistemas generales o conjunto de dotaciones urbanísticas al servicio predominante del conjunto de la población, de su asentamiento, movilidad y empleo, en proporción adecuada a las necesidades de la población, y teniendo en cuenta la capacidad máxima residencial derivada del plan $\mathrm{y}$, como mínimo, los siguientes:

a. Sistema general de espacios libres y zonas verdes de dominio y uso públicos, en proporción no inferior a 15 metros cuadrados por cada 100 metros cuadrados edificables de uso residencial.

b. Sistema general de equipamiento comunitario de titularidad pública, en proporción no inferior a 5 metros cuadrados por cada 100 metros cuadrados edificables de uso residencial.

2. Con independencia de los sistemas generales, el plan que contenga la ordenación detallada establecerá en el suelo urbano no consolidado y en el suelo urbanizable las reservas mínimas de suelo para las siguientes dotaciones urbanísticas:

a. Sistema de espacios libres públicos destinados a parques, jardines, áreas de ocio, expansión y recreo de la población:

En ámbitos de uso residencial u hotelero: 18 metros cuadrados de suelo por cada 100 metros cuadrados edificables y como mínimo el 10\% de la superficie total del ámbito.

En ámbitos de usos terciario o industrial: el $10 \%$ de la superficie total del ámbito.

b. Sistema de equipamientos públicos destinados a la prestación de servicios sanitarios, asistenciales, educativos, culturales, deportivos y otros que sean necesarios:

En ámbitos de uso residencial u hotelero: 10 metros cuadrados de suelo por cada 100 metros cuadrados edificables.

En ámbitos de uso terciario o industrial: el $2 \%$ de la superficie del ámbito.

c. Plazas de aparcamientos de vehículos: En ámbitos de uso residencial y hotelero: 2 plazas de aparcamiento por cada 100 metros cuadrados edificables, de las que, 
como mínimo, la cuarta parte debe ser de dominio público.

En ámbitos de uso terciario: 2 plazas de aparcamiento por cada 100 metros cuadrados edificables, de las que, como mínimo, la quinta parte debe ser de dominio público.

En ámbitos de uso industrial: 1 plaza de aparcamiento por cada 100 metros cuadrados edificables, de las que, como mínimo, la cuarta parte será de dominio público ${ }^{367}$.

3. El planeamiento efectuará las reservas de suelo para dotaciones urbanísticas en los lugares más adecuados para satisfacer las necesidades de la población, en orden a asegurar su accesibilidad, funcionalidad e integración en la estructura urbanística, de modo que no se ubiquen en zonas marginales o residuales.

4. El Ayuntamiento pleno, por mayoría absoluta legal y sin necesidad de seguir el procedimiento de modificación del plan, podrá acordar el cambio de uso de los terrenos reservados para equipamientos públicos por otro uso dotacional público distinto, siempre que se mantenga la titularidad pública o se destine a incrementar las zonas verdes y espacios libres públicos.

5. El plan general calificará como suelo dotacional los terrenos que hayan sido destinados efectivamente a usos docentes o sanitarios públicos, elementos funcionales de las infraestructuras de transportes e instalaciones adscritas a la defensa nacional. No obstante lo anterior, mediante convenio entre la administración titular del bien, la consellería competente en materia de urbanismo y ordenación del territorio y el Ayuntamiento, podrán ser destinados por el plan general a otros usos distintos y atribuirse a los propietarios el $100 \%$ del aprovechamiento tipo, de conformidad con lo establecido en la presente ley, con

367 Art. 47.2 modificado por Ley 15/2004, de 29 de diciembre, de modificación de la Ley 9/2002, de 30 de diciembre, de ordenación urbanistica y protección del medio rural de Galicia. la finalidad de facilitar la financiación de infraestructuras públicas ${ }^{368}$.

6. Reglamentariamente se precisarán las dimensiones y características, así como, en su caso, el destino de las reservas de suelo dotacional público.

7. Las cesiones de suelo obligatorias establecidas por esta ley comprenderán el suelo, el subsuelo y el vuelo. En ningún caso podrá renunciar la administración a las cesiones correspondientes a las reservas mínimas de suelo para dotaciones públicas establecidas por esta ley.

8. El plan que contenga la ordenación detallada podrá regular el uso del subsuelo de los espacios de dominio público con la finalidad de contemplar la implantación de infraestructuras, equipamientos y aparcamientos de titularidad pública.

El reglamento de desarrollo de la presente ley podrá establecer los supuestos y condiciones en que se permita la utilización del subsuelo de los espacios públicos para aparcamientos privados 369 .

9. El planeamiento urbanístico determinará el trazado y las características de las redes básicas de distribución de energía eléctrica, abastecimiento de agua, evacuación y saneamiento de aguas residuales, telefonía y otras redes, galerías o canalizaciones de servicios necesarios.

Para las nuevas redes de ámbito supramunicipal no previstas en el planeamiento urbanístico, será necesario aprobar previamente el correspondiente proyecto sectorial al amparo de la Ley 10/1995, de Ordenación del Territorio de Galicia ${ }^{370}$.

368 Art. 47.5 modificado por Ley 15/2004, de 29 de diciembre, de modificación de la Ley 9/2002, de 30 de diciembre, de ordenación urbanistica y protección del medio rural de Galicia.

369 Art. 47.8 modificado por Ley 15/2004, de 29 de diciembre, de modificación de la Ley $9 / 2002$, de 30 de diciembre, de ordenación urbanistica y protección del medio rural de Galicia.

370 Art. 47.9 añadido por Ley 15/2004, de 29 de diciembre, de modificación de la Ley $9 / 2002$, de 30 de diciembre, de ordenación urbanistica y protección del medio rural de Galicia. 
10. Los planes establecerán en aquellos sectores de suelo urbanizable para los que se contemplen usos residenciales, aun cuando estos usos no fueran los predominantes, una reserva de suelo con el carácter de dotación autonómica para construcción de viviendas de promoción y titularidad pública en cuantía de 2,5 metros cuadrados de suelo por cada 100 metros cuadrados edificables de uso residencial.

La edificabilidad que se asigne a estos terrenos vendrá justificada por el plan después de estudiar las rentas de la población municipal y la demanda de viviendas prevista para la población de las rentas más bajas. En todo caso, la edificabilidad total no podrá sobrepasar el $2,5 \%$ de la establecida para el uso residencial en la totalidad del sector de que se trate, teniéndose en cuenta para el cálculo de las demás dotaciones, equipamientos y espacios libres locales.

11. Con independencia de lo dispuesto en el apartado anterior, los planes generales habrán de contemplar también las reservas de suelo para vivienda sujeta a algún régimen de protección pública. En los municipios que en el momento de la aprobación inicial de su plan general contasen como mínimo con 20.000 habitantes inscritos en el padrón municipal, estas reservas no podrán ser inferiores al $40 \%$ de la edificabilidad residencial contemplada por el plan general para el conjunto del suelo urbano no consolidado y urbanizable delimitado, no pudiendo ser inferiores al 30\% de dicha edificabilidad en el resto de los municipios.

El plan general distribuirá discrecionalmente las reservas entre el suelo urbano no consolidado y el urbanizable delimitado de conformidad con las siguientes reglas:

a. Como mínimo, el $20 \%$ de la edificabilidad residencial del suelo urbano no consolidado será para vivienda sujeta a algún régimen de protección pública.

b. Las reservas que localice el plan en suelo urbano no consolidado no podrán ser superiores a las que fije para el suelo urbanizable delimitado.

c. En suelo urbano no consolidado el porcentaje de edificabilidad residencial que se fije como reserva será el mismo para todos los distritos, y en cada sector de suelo urbanizable delimitado será como mínimo del $20 \%$ de la edificabilidad residencial, excepto en aquellos sectores cuya edificabilidad total no sobrepase los 0,20 metros cuadrados edificables por cada metro cuadrado de suelo, en cuyo caso la reserva podrá reducirse o suprimirse, siempre que el planeamiento general compense esta reducción en el resto de los sectores.

Las reservas para la construcción de viviendas sujetas a algún régimen de protección pública habrán de localizarse evitando la concentración excesiva de viviendas de dicho tipo, para favorecer la cohesión social y evitar la segregación territorial de los ciudadanos en razón a su nivel de renta.

12. Los planes de sectorización habrán de contemplar también las reservas de suelo necesarias para atender las demandas de vivienda sujeta a algún régimen de protección pública. Estas reservas no podrán ser inferiores a las necesarias para localizar el $40 \%$ de edificabilidad residencial contemplada en el plan de sectorización.

13. No obstante lo dispuesto en los apartados 11 y 12, el plan general llevará a cabo una estimación de la demanda potencial de vivienda $y$, en particular, de la sujeta a los diferentes regímenes de protección, en función de las circunstancias relativas a los precios del suelo y de la vivienda, la evolución de la población, la expectativa de creación de nuevos hogares y las necesidades de reposición y/o rehabilitación del parque inmobiliario en razón a su estado y antigüedad, de tal forma que, teniendo presente la estimación así elaborada, si dicha demanda no pudiera ser atendida con los porcentajes fijados en dichos apartados, incrementará la reserva hasta cubrir esa demanda. 
Sin embargo, si el plan general acredita que la reserva contemplada en los apartados 11 y 12 es excesiva para atender la demanda potencial de vivienda protegida en atención a las circunstancias antes expuestas y que un elevado porcentaje de la edificabilidad residencial que contemple el planeamiento general para el conjunto del suelo urbano no consolidado y urbanizable delimitado no está dirigido a satisfacer la demanda de primera residencia, podrá reducirse el porcentaje de reserva hasta el $20 \%$, siempre y cuando el municipio contase con menos de 20.000 habitantes inscritos en el padrón municipal en el momento de la aprobación inicial del planeamiento.

Estarán exentos de las reservas de terrenos reguladas en los apartados 11 y 12 aquellos ayuntamientos que, en el momento de la aprobación inicial de su planeamiento general, contasen con menos de 5.000 habitantes inscritos en el padrón municipal, cuando dicho plan general no contenga previsiones para nuevos desarrollos urbanísticos, en suelos clasificados como urbanos no consolidados y urbanizables, que sobrepasen las 5 viviendas por cada 1.000 habitantes y año, tomando como referencia el número de años que se fije como horizonte del planeamiento ${ }^{371}$.

Artículo 48. Normas de calidad urbana.

1. El planeamiento urbanístico garantizará las condiciones de habitabilidad, salubridad y funcionalidad de las viviendas y usos residenciales, respetando las condiciones mínimas que se fijen reglamentariamente. En todo caso, se prohíbe el uso residencial en sótanos y semisótanos ${ }^{372}$.

371 Apartados 10, 11, 12 y 13 del art. 47 añadidos por Ley $6 / 2008$, de 19 de junio, de medidas urgentes en materia de vivienda y suelo, por la que se modifica la Ley $9 / 2002$, de 30 de diciembre, de ordenación urbanistica y protección del medio rural de Galicia.

372 Véase:

- Decreto 262/2007, de 20 de diciembre, por el que se aprueban las normas del hábitat gallego.

- Orden de 7 de abril de 2008 por la que se regula la composición y el funcionamiento del Comité Asesor de Habitabilidad.
2. Los viarios principales de nueva apertura en suelo urbano no consolidado y en suelo urbanizable no podrán tener un ancho inferior a 16 metros.

3. El planeamiento urbanístico procurará una razonable y equilibrada articulación de usos, actividades y tipologías edificatorias compatibles, evitando también la repetición de soluciones urbanísticas y tipologías edificatorias idénticas.

4. El planeamiento que establezca la ordenación detallada contemplará las previsiones necesarias para evitar barreras arquitectónicas y urbanísticas, de manera que las personas con movilidad reducida vean facilitado al máximo el acceso directo a los espacios públicos y edificaciones públicas y privadas, con arreglo a la normativa vigente sobre accesibilidad y supresión de barreras arquitectónicas.

5. El planeamiento urbanístico deberá fijar la altura máxima de las edificaciones en proporción al ancho de las vías y espacios libres, de modo que queden garantizadas las mejores condiciones posibles de soleamiento y ventilación natural de las viviendas.

6. El planeamiento podrá prohibir los tendidos aéreos y prever el soterramiento de los existentes. En todo caso, deberán soterrarse las redes de servicios de las nuevas urbanizaciones ${ }^{373}$.

Artículo 49. División del suelo urbano y urbanizable.

1. La totalidad del suelo urbano se dividirá por el plan general en distritos, atendiendo a la racionalidad y calidad de la ordenación urbanística y a la accesibilidad de la población a las dotaciones, utilizando preferentemente como límites los sistemas generales y los elementos estructurantes de la ordenación urbanística, y coincidiendo en la mayor parte de su extensión con los barrios, parroquias o unidades territoriales con características homogéneas.

373 Art. 48.6 añadido por Ley $15 / 2004$, de 29 de diciembre, de modificación de la Ley $9 / 2002$, de 30 de diciembre, de ordenación urbanistica y protección del medio rural de Galicia. 
Dentro de cada distrito el plan general habrá de incluir la totalidad de los terrenos correspondientes a las categorías de suelo urbano consolidado y no consolidado.

El plan general habrá de justificar que en el conjunto del suelo urbano no consolidado de cada distrito se cumplen los estándares de reserva mínima para dotaciones urbanísticas locales y de limitación de intensidad establecidos en la presente ley.

A los efectos de aplicar los estándares de reserva mínima de suelo para dotaciones públicas de carácter local y de los límites de edificabilidad, no se tendrán en cuenta aquellos ámbitos de suelo urbano no consolidado que se sometan a operaciones de reforma interior con la finalidad de obtener nuevas dotaciones públicas, siempre que de la ordenación establecida por el plan no resulte incrementada la superficie edificable respecto a la preexistente lícitamente realizada ni se incorporen nuevos usos que generen plusvalías; en este caso, será necesario obtener el informe favorable de la Comisión Superior de Urbanismo de Galicia ${ }^{374}$.

2. El suelo urbanizable se dividirá en sectores a los efectos de su ordenación detallada y de aplicación de los estándares establecidos en la presente ley, que deberán tener una extensión mínima de 20.000 metros cuadrados o la superior que fije el planeamiento. Los sectores se delimitarán utilizando preferentemente los límites de los sistemas generales y los elementos naturales determinantes, de forma que se garantice una adecuada inserción del sector dentro de la estructura urbanística del plan general. En el suelo urbanizable delimitado inmediato al suelo urbano, el plan general podrá delimitar sectores de menor superficie, siempre que resulte viable técnica y económicamente el cumplimiento de los estándares urbanísticos.

374 Último párrafo del art. 49.1 añadido por Ley 15/2004, de 29 de diciembre, de modificación de la Ley 9/2002, de 30 de diciembre, de ordenación urbanistica y protección del medio rural de Galicia.
Artículo 50. Normas técnicas de planeamiento.

1. Las normas técnicas del planeamiento urbanístico tendrán por objeto la determinación de los siguientes extremos:

a. Los requisitos mínimos de calidad, sustantivos y formales de los distintos instrumentos de planeamiento urbanístico.

b. Los modelos indicativos de regulación de las diferentes zonas de ordenación urbanística más usuales, con determinación para cada una de ellas de los elementos tipológicos definitorios de las construcciones en función de su destino o referidos a ámbitos territoriales determinados. Los planes de ordenación podrán establecer el régimen urbanístico de las zonas resultantes de las operaciones de calificación que realicen por simple remisión al pertinente modelo de regulación.

c. Las obras y servicios mínimos de urbanización y sus características técnicas.

d. Las prescripciones técnicas para elaborar la documentación de los diferentes instrumentos de planeamiento.

e. Cualesquiera otras cuestiones precisadas de orientación técnica en materia de planeamiento urbanístico.

2. La aprobación de las normas técnicas corresponde al conselleiro competente en materia de urbanismo y ordenación del territorio, previa audiencia a la Federación Gallega de Municipios y Provincias.

\section{Sección 2. ${ }^{a}$ Normas subsidiarias y complementarias de planeamiento}

Artículo 51. Objeto y contenido.

1. Las normas subsidiarias y complementarias de planeamiento establecerán las disposiciones que habrán de ser aplicadas en los municipios que carezcan de plan general de ordenación municipal.

2. Asimismo, serán de aplicación, con carácter complementario, para suplir las indeterminaciones y lagunas del planeamiento 
municipal vigente, sin modificar la calificación del suelo ni alterar las determinaciones del planeamiento que complementan.

3. Las normas subsidiarias y complementarias de planeamiento contendrán las siguientes determinaciones:

a. Fines y objetivos de su promulgación.

b. $(\ldots)^{375}$.

c. Relaciones e incidencias con las directrices de ordenación territorial.

d. Regulación de los usos del suelo y de la edificación.

e. Medidas de protección urbanística del medio rural, el patrimonio y el paisaje.

f. Definición del ámbito y condiciones de desarrollo de sectores de suelo urbanizable delimitado para actuaciones previstas por el Instituto Galego da Vivenda e Solo, con destino a la creación de suelo empresarial público o a la construcción de viviendas de promoción pública.

4. Las normas subsidiarias y complementarias incluirán los siguientes documentos:

a. Memoria justificativa de sus fines, objetivos y determinaciones.

b. Planos de información.

c. Planos de delimitación del suelo.

d. Ordenanzas de edificación y uso del suelo.

e. Normativa de protección del medio rural, el patrimonio cultural y el paisaje.

f. Cualesquiera otros documentos que sean procedentes para el cumplimiento de las determinaciones de las propias normas.

Sección 3 . $^{\text {a }}$

Plan general de ordenación municipal rales.

Artículo 52. Consideraciones gene-

1. Los planes generales de ordenación municipal, como instrumentos urbanísticos de ordenación integral, abarcarán uno o varios términos municipales completos,

375 Art. 51.3.b derogado por Ley 15/2004, de 29 de diciembre, de modificación de la Ley 9/2002, de 30 de diciembre, de ordenación urbanistica y protección del medio rural de Galicia. clasificarán el suelo para el establecimiento del régimen jurídico correspondiente, definirán los elementos fundamentales de la estructura general adoptada para la ordenación urbanística del territorio y establecerán las determinaciones orientadas a promover su desarrollo y ejecución.

2. El contenido de los planes generales de ordenación municipal deberá ser congruente con los fines que en los mismos se determinen y adaptarse a las características y complejidad urbanística del territorio que sea objeto de la ordenación, garantizando la coordinación de los elementos fundamentales de los respectivos sistemas generales.

3. Asimismo, el plan general deberá garantizar la coherencia interna de las determinaciones urbanísticas, la viabilidad técnica y económica de la ordenación propuesta, el equilibrio de los beneficios y cargas derivados del plan entre las distintas áreas de reparto, la proporcionalidad entre el volumen edificable y los espacios libres públicos de cada ámbito de ordenación y la participación de la Comunidad en las plusvalías generadas en cada área de reparto.

Artículo 53. Determinaciones de carácter general.

1. Los planes generales de ordenación municipal contendrán las siguientes determinaciones de carácter general:

a. Objetivos generales y criterios de la ordenación compatibles con la normativa sectorial y ambiental, con los instrumentos de ordenación del territorio y con el planeamiento de los municipios limítrofes.

b. Clasificación del suelo de todo el término municipal en todos o alguno de los distintos tipos y categorías establecidos en esta ley.

c. División del suelo urbano en distritos de acuerdo con lo dispuesto en el artículo 49 de esta ley.

d. Delimitación de los sectores en suelo urbanizable delimitado. 
e. Estructura general y orgánica del territorio integrada por los sistemas generales determinantes del desarrollo urbano $\mathrm{y}$, en particular, por los sistemas generales de comunicaciones y sus zonas de protección, de espacios libres y zonas verdes públicas, de equipamiento comunitario público y de servicios urbanos.

En cualquier caso, se indicará para cada uno de sus elementos no existentes sus criterios de diseño y ejecución y el sistema de obtención de los terrenos.

f. Catálogo de los elementos que por sus valores naturales o culturales, o por su relación con el dominio público, hayan de ser conservados o recuperados, con las medidas de protección que procedan.

g. Delimitación de las cuencas de interés paisajístico en el término municipal y medidas para su adecuada protección y recuperación.

h. Delimitación de áreas de reparto en suelo urbano no consolidado y en suelo urbanizable delimitado, con fijación del aprovechamiento tipo, en su caso.

i. Carácter público o privado de las dotaciones.

j. Determinación, en su caso, de los plazos para la aprobación del planeamiento de desarrollo y, en general, para el cumplimiento de los deberes urbanísticos.

2. Asimismo, los planes generales deberán contener las determinaciones necesarias para que las construcciones e instalaciones cumplan las condiciones de adaptación al ambiente establecidas por el artículo 104 de esta ley.

Artículo 54. Determinaciones en suelo urbano consolidado.

Los planes generales de ordenación municipal contendrán en suelo urbano consolidado las siguientes determinaciones:

a. Delimitación de su perímetro.

b. Calificación de los terrenos, entendida como la asignación detallada de usos pormenorizados, tipologías edificatorias y condiciones de edificación correspondientes a cada zona. c. Delimitación de los espacios libres y zonas verdes destinados a parques y jardines públicos, zonas deportivas, de recreo y expansión, indicando su carácter público o privado.

d. Emplazamientos reservados para dotaciones, equipamientos y demás servicios de interés social, señalando su carácter público o privado y las condiciones de edificación, garantizando su integración en el entorno en que se deban emplazar.

e. Regulación detallada de los usos, volumen y condiciones higiénico-sanitarias de los terrenos y construcciones, así como las características estéticas de la edificación y de su entorno.

f. Trazado y características de la red viaria pública, con señalamiento de alineaciones y rasantes.

g. Previsión de aparcamientos de titularidad pública, que podrán ubicarse incluso en el subsuelo de los sistemas viarios y de espacios libres, siempre que no interfieran el uso normal de estos sistemas ni supongan la eliminación o traslado de elementos físicos o vegetales de interés.

h. Características y trazado de las redes de abastecimiento de agua, alcantarillado, energía eléctrica y aquellos otros servicios que, en su caso, prevea el plan.

i. En su caso, establecimiento de plazos para la edificación.

Artículo 55. Determinaciones en suelo urbano no consolidado.

1. En el suelo urbano no consolidado, cuando el plan general contenga su ordenación detallada, incluirá, además de las determinaciones establecidas en el artículo anterior, la delimitación de los polígonos necesarios para la ejecución del plan y la determinación del sistema de actuación de cada polígono.

2. Cuando el plan general remita la ordenación detallada a un plan especial de reforma interior, contendrá las siguientes determinaciones:

a. Delimitación del ámbito del plan especial de reforma interior. 


\section{Ordenación del territorio y...}

b. Determinación de los usos globales, tipologías edificatorias, altura máxima y superficie total edificable.

c. Fijación de la cuantía de las reservas mínimas de suelo para dotaciones urbanísticas que habrá de prever el plan especial.

d. Previsión de los sistemas generales necesarios, en su caso, para el desarrollo del plan especial.

\section{$(\ldots)^{376}$}

Artículo 56. Determinaciones en suelo de núcleo rural.

Los planes generales de ordenación municipal contendrán la ordenación detallada de los núcleos rurales con arreglo a lo dispuesto en la presente ley y, a tal efecto, incluirán las siguientes determinaciones:

a. Delimitación de su perímetro y estudio del componente parroquial actual.

b. En su caso, emplazamiento reservado para dotaciones y equipamientos, señalando su carácter público o privado.

c. Trazado de la red viaria pública.

d. Reglamentación del uso pormenorizado de los terrenos y construcciones, así como de las características estéticas de la edificación.

e. Cuantas otras resulten convenientes para la conservación y recuperación de la morfología del núcleo y la salvaguarda de los cauces naturales, las redes de caminos rurales, la estructura parcelaria histórica y los usos tradicionales.

f. Fijación de los indicadores que deban dar lugar a la necesidad de redactar un plan especial de protección, rehabilitación y mejora del medio rural para hacer frente a la complejidad urbanística sobrevenida.

Artículo 57. Determinaciones en suelo urbanizable delimitado.

1. Los planes generales de ordenación municipal contendrán, en todo caso, en suelo urbanizable delimitado las siguientes determinaciones:

376 Art. 55.3 derogado por Ley 6/2008, de 19 de junio, de medidas urgentes en materia de vivienda y suelo, por la que se modifica la Ley 9/2002, de 30 de diciembre, de ordenación urbanistica y protección del medio rural de Galicia. a. Delimitación de sectores para su desarrollo en planes parciales.

b. Desarrollo de los sistemas de la estructura general de la ordenación urbanística del territorio con la precisión suficiente para permitir la redacción de planes parciales o especiales, determinando los sistemas generales incluidos o adscritos a la gestión de cada sector.

c. Trazados de las redes fundamentales de abastecimiento de agua, alcantarillado, energía eléctrica y demás servicios que, en su caso, prevea el plan.

d. Determinación de las conexiones con los sistemas generales existentes y exteriores al sector y, en su caso, previsión de las obras necesarias para la ampliación y refuerzo de dichos sistemas en función de las necesidades generadas por la actuación y de forma que se asegure su correcto funcionamiento.

A estos efectos, el plan deberá incluir un estudio que justifique la capacidad de las redes viarias y de servicios existentes y las medidas procedentes para atender las necesidades generadas y, en su caso, la implantación del servicio público de transporte, recogida de residuos urbanos y cuantos otros resulten necesarios.

Asimismo, el plan general establecerá obligatoriamente las características, dimensiones y capacidad mínima de las infraestructuras y servicios necesarios para el desarrollo del sector y determinará con precisión los terrenos necesarios para la conexión con el sistema general viario y de infraestructuras y servicios urbanos existentes que deberán incluirse o adscribirse al desarrollo del sector.

Cuando proceda, se establecerán los mecanismos que permitan la redistribución de los costes entre los sectores afectados.

e. Asignación de los usos globales de cada sector y fijación de la edificabilidad y las tipologías edificatorias.

2. Además de las determinaciones del número anterior, los planes generales podrán ordenar detalladamente, con el mismo contenido y determinaciones exigibles a 
un plan parcial, aquellos sectores de desarrollo urbanístico preferente, de manera que se puedan ejecutar directamente sin necesidad de planeamiento de desarrollo. En estos casos, será necesario que se garantice la ejecución del plan a través de actuaciones públicas programadas o privadas concertadas con la Administración.

Artículo 58. Determinaciones en suelo urbanizable no delimitado.

En suelo urbanizable no delimitado, el plan general establecerá los criterios para delimitar los correspondientes sectores, tales como los relativos a magnitud, usos, intensidad de uso, dotaciones, equipamientos, sistemas generales que deban ejecutarse y conexiones con los mismos, así como prioridades para garantizar un desarrollo urbano racional. En particular, podrá condicionarse la delimitación de nuevos sectores al desarrollo de los ya delimitados en el plan general.

Artículo 59. Determinaciones en suelo rústico.

Los planes generales de ordenación municipal, con arreglo a lo dispuesto en la presente ley, contendrán las siguientes determinaciones:

a. Delimitación de las distintas categorías de suelo rústico.

b. Determinación de las condiciones estéticas y características de diseño de las construcciones, incluyendo los materiales y colores a emplear en la fachada y cubierta de las edificaciones.

c. Normas y medidas de protección del suelo rústico para asegurar el mantenimiento de la naturaleza rústica de los terrenos y la conservación, protección y recuperación de los valores y potencialidades propios del medio rural.

Artículo 60. Estrategia de actuación y estudio económico.

1. Los planes generales de ordenación municipal contendrán la estrategia para el desarrollo coherente del plan y, en particular, determinarán la ejecución de los sistemas generales que hayan de crearse necesariamente para el desarrollo de las áreas de suelo urbano no consolidado y de los sectores de suelo urbanizable delimitado.

2. Asimismo, determinarán los ámbitos de actuación preferente en suelo urbano no consolidado y en suelo urbanizable delimitado, para los que habrán de fijarse los plazos y condiciones en que tengan que ser ejecutadas las actuaciones públicas programadas o privadas concertadas con los particulares, así como las determinaciones de la ordenación detallada sin necesidad de remisión al planeamiento de desarrollo.

3. El plan general de ordenación municipal contendrá una evaluación del coste de ejecución de los sistemas generales y de las actuaciones previstas, con indicación del carácter público o privado de la iniciativa de financiación, justificando las previsiones que hayan de realizarse con recursos propios del Ayuntamiento.

En el supuesto de que se atribuya la financiación a administraciones o entidades públicas distintas del municipio, deberá acreditarse la conformidad de las mismas.

Artículo 61. Documentación.

1. Las determinaciones del plan general de ordenación municipal a que se hace referencia en esta sección se desarrollarán en los siguientes documentos, con el contenido que se fije reglamentariamente:

a. Memoria justificativa de sus fines y objetivos, así como de sus determinaciones.

b. Estudio del medio rural y análisis del modelo de asentamiento poblacional.

c. $(\ldots)^{377}$

d. Planos de información.

e. Planos de ordenación urbanística del territorio.

f. Normas urbanísticas.

g. Estrategia de actuación y estudio económico.

377 Art. 61.1.c derogado por Ley 6/2007, de 11 de mayo, de medidas urgentes en materia de ordenación del territorio y del litoral de Galicia. 


\section{Ordenación del territorio y...}

h. Catálogo de elementos a proteger o recuperar.

i. Aquellos otros que se estimen necesarios para reflejar adecuadamente sus determinaciones.

2. El estudio del medio rural servirá de base para establecer las medidas tendentes a la conservación y mejora de sus potencialidades intrínsecas $\mathrm{y}$, en particular, para la protección de sus valores ecológicos, ambientales, paisajísticos, históricos, etnográficos, culturales o con potencialidad productiva. A estos efectos, analizará detalladamente los usos del suelo, los cultivos, el paisaje rural, la tipología de las edificaciones y construcciones tradicionales de la zona, las infraestructuras existentes, los caminos y vías rurales, el planeamiento urbanístico de los municipios limítrofes y cualquier otra circunstancia relevante para la justificación de las determinaciones en suelo rústico.

3. El análisis del modelo de asentamiento poblacional tendrá por objeto determinar las medidas a adoptar para la preservación y mejora del medio rural, definiendo los elementos que lo constituyan y su inserción en el marco comarcal y destacando la división parroquial, el sistema de núcleos de población y su relación con el medio natural o productivo.

A fin de fundamentar la delimitación de los núcleos rurales, deberá analizar individualizadamente cada núcleo, su morfología, infraestructuras y dotaciones urbanísticas existentes, consolidación edificatoria, patrimonio arquitectónico y cultural y cualquier otra circunstancia urbanística relevante para justificar las determinaciones sobre el suelo de núcleo rural. El estudio incluirá una ficha, plano y fotografía aérea individualizada para cada núcleo rural, en cuyos documentos se recogerá la información urbanística anteriormente indicada.

$$
\text { 4. (...) })^{378} \text {. }
$$

378 Art. 61.4 derogado por Ley 6/2007, de 11 de mayo, de medidas urgentes en materia de ordenación del territorio y del litoral de Galicia.

\section{Sección $4 .^{\mathrm{a}}$ \\ Planeamiento de desarrollo \\ Subsección 1. ${ }^{\mathrm{a}}$ \\ Disposición común}

Artículo 62. Disposición común a los planes de desarrollo.

1. Los planes parciales y planes especiales podrán modificar la ordenación detallada establecida por el plan general de ordenación con arreglo a las siguientes condiciones:

a. Que tengan por objeto la mejora sustancial de la ordenación urbanística vigente, la mejora de la articulación de los espacios libres públicos y los volúmenes construidos, la eliminación de usos no deseables o la incorporación de otros necesarios, la previsión de nuevas dotaciones públicas, la resolución de problemas de circulación y otros fines análogos.

b. Que no afecten ni alteren de ningún modo a las determinaciones del plan general señaladas en los artículos 53, 55.2 y 57 de esta ley, sin perjuicio de los ajustes necesarios para garantizar las conexiones.

c. Que no impliquen un incremento de la superficie edificable total ni la alteración de los usos globales.

d. Que no supongan una disminución, fraccionamiento o deterioro de la capacidad de servicio y de la funcionalidad de los espacios previstos para las dotaciones locales.

2. Los planes parciales y especiales podrán reajustar, por razones justificadas, la delimitación de los sectores y áreas de reparto, siempre que el reajuste no afecte a suelo rústico de especial protección ni a dotaciones públicas y que no suponga una alteración igual o superior al 5 por $100 \mathrm{del}$ ámbito delimitado por el plan general. En todo caso, será necesaria la previa audiencia a los propietarios afectados.

\section{Subsección 2 . $^{\mathrm{a}}$ Planes parciales}

Artículo 63. Planes parciales: Objeto. 1. Los planes parciales tendrán por objeto regular la urbanización y la edificación del 
suelo urbanizable, desarrollando el plan general mediante la ordenación detallada de un sector.

2. En municipios sin planeamiento general también podrán aprobarse planes parciales para el desarrollo de sectores de suelo urbanizable delimitado por las normas subsidiarias y complementarias de planeamiento.

Artículo 64. Determinaciones de los planes parciales.

Los planes parciales contendrán en todo caso las siguientes determinaciones:

a. Delimitación del ámbito de planeamiento, que abarcará un sector completo definido por el plan general.

b. Calificación de los terrenos, entendida como la asignación detallada de usos pormenorizados, tipologías edificatorias y niveles de intensidad correspondientes a cada zona.

c. Señalamiento de reservas de terrenos para dotaciones urbanísticas en proporción a las necesidades de la población y de conformidad con las reservas mínimas establecidas en el artículo 47 de esta ley.

d. Trazado y características de la red de comunicaciones propias del sector y de su enlace con el sistema general de comunicaciones previsto en el plan general, con señalamiento de alineaciones, rasantes y zonas de protección de toda la red viaria.

e. Características y trazado de las redes de abastecimiento de agua, alcantarillado, energía eléctrica, alumbrado público, telecomunicaciones, gas y de aquellos otros servicios que, en su caso, prevea el plan.

\section{$(\ldots)^{379}$}

g. Determinaciones necesarias para la integración de la nueva ordenación con los elementos valiosos del paisaje y la vegetación.

379 Art. 64.f derogado por Ley 6/2008, de 19 de junio, de medidas urgentes en materia de vivienda y suelo, por la que se modifica la Ley $9 / 2002$, de 30 de diciembre, de ordenación urbanistica y protección del medio rural de Galicia. h. Medidas necesarias y suficientes para garantizar la adecuada conexión del sector con los sistemas generales exteriores existentes y, en su caso, la ampliación o refuerzo de dichos sistemas y de los equipamientos y servicios urbanos a utilizar por la población futura.

Igualmente deberá resolver los enlaces con las carreteras o vías actuales y con las redes de servicios de abastecimiento de agua y saneamiento, suministro de energía eléctrica, telecomunicaciones, gas, residuos sólidos y otros.

Los servicios técnicos municipales y las empresas suministradoras deberán informar sobre la suficiencia de las infraestructuras y servicios existentes y previstos antes de iniciar la tramitación del plan parcial.

i. Ordenación detallada de los suelos destinados por el plan general a sistemas generales incluidos o adscritos al sector, salvo que el municipio opte por su ordenación mediante plan especial.

j. Plan de etapas para el desarrollo de las determinaciones del plan, en el que se incluya la fijación de los plazos para dar cumplimiento a los deberes de los propietarios, entre ellos los de urbanización y edificación.

Los plazos que se fijen para cumplir los deberes de edificación de las viviendas con protección pública no podrán ser superiores a los que se fijen para edificar las viviendas libres ${ }^{380}$.

k. Delimitación de los polígonos en que se divida el sector y determinación del sistema de actuación de acuerdo con lo dispuesto en esta ley.

1. Evaluación económica de la implantación de los servicios y de la ejecución de las obras de urbanización, incluyendo la conexión a los sistemas generales y, en su

380 Último inciso del art. 64.j añadido por Ley $6 / 2008$ de 19 de junio, de medidas urgentes en materia de vivienda y suelo, por la que se modifica la Ley $9 / 2002$, de 30 de diciembre, de ordenación urbanistica y protección del medio rural de Galicia. 


\section{Ordenación del territorio y...}

caso, las obras de ampliación o refuerzo de los mismos.

Artículo 65. Documentación de los planes parciales.

Los planes parciales comprenderán los planos de información, incluido el catastral, memoria justificativa de sus determinaciones, estudio de sostenibilidad ambiental, impacto territorial y paisajístico, evaluación económica de la implantación de los servicios y ejecución de las obras de urbanización, incluidas las conexiones con los sistemas generales existentes y su ampliación o refuerzo, planos de ordenación urbanística y ordenanzas reguladoras necesarias para su ejecución, todos ellos con el contenido que se fije reglamentariamente.

Si el plan parcial fue sometido a la evaluación ambiental estratégica no será necesario el estudio de sostenibilidad ambiental, impacto territorial y paisajístico ${ }^{381}$.

\section{Subsección 3. ${ }^{\mathrm{a}}$}

\section{Planes de sectorización}

Artículo 66. Planes de sectorización.

1. Los planes de sectorización son los instrumentos mediante los cuales se establecen las determinaciones estructurantes de la ordenación urbanística necesarias para la transformación de los terrenos clasificados como suelo urbanizable no delimitado.

2. Los planes de sectorización deben resolver la adecuada integración del ámbito delimitado en la estructura de ordenación municipal definida por el plan general.

3. Los planes de sectorización deben contener las siguientes determinaciones:

a. La delimitación del sector que será objeto de transformación, de acuerdo con los criterios básicos establecidos por el plan general.

b. Las determinaciones de ordenación básica propias del plan general para el suelo urbanizable delimitado, señaladas en el artículo 57 de esta ley.

381 Último párrafo del art. 65 añadido por Ley 6/2007, de 11 de mayo, de medidas urgentes en materia de ordenación del territorio y del litoral de Galicia. c. La previsión de suelo para nuevas dotaciones de carácter general, en la proporción mínima establecida por el número 1 del artículo 47, con independencia de las dotaciones locales. Los nuevos sistemas generales habrán de emplazarse dentro del ámbito del sector, salvo en el caso de que el plan general determine específicamente su ubicación concreta en otro lugar 382 .

d. Las determinaciones establecidas en el artículo 64 para los planes parciales.

4. En todo caso, la aprobación del plan de sectorización implicará la declaración de utilidad pública y la necesidad de la ocupación, a efectos de expropiación forzosa, de los terrenos necesarios para el enlace de la zona de actuación con los correspondientes elementos de los sistemas generales.

Artículo 67. Documentación de los planes de sectorización.

Los planes de sectorización comprenderán los planos de información, incluido el catastral, memoria justificativa de sus determinaciones, estudio de sostenibilidad ambiental, impacto territorial y paisajístico, evaluación económica de la implantación de los servicios y ejecución de las obras de urbanización, incluidas las conexiones con los sistemas generales existentes y su ampliación o refuerzo, planos de delimitación del nuevo sector, planos de ordenación urbanística y ordenanzas reguladoras necesarias para su ejecución, todos ellos con el contenido que se fije reglamentariamente.

Si el plan de sectorización fue sometido a la evaluación ambiental estratégica no será necesario el estudio de sostenibilidad ambiental, impacto territorial y paisajístico $^{383}$.

382 Art. 66.3.c modificado por Ley 15/2004, de 29 de diciembre, de modificación de la Ley 9/2002, de 30 de diciembre, de ordenación urbanistica y protección del medio rural de Galicia.

383 Último párrafo del art. 67 añadido por Ley 6/2007, de 11 de mayo, de medidas urgentes en materia de ordenación del territorio y del litoral de Galicia. 


\section{Subsección $4 .^{\mathrm{a}}$ \\ Planes especiales}

Artículo 68. Finalidades de los planes especiales.

1. En desarrollo de las previsiones contenidas en los planes generales de ordenación municipal, podrán formularse y aprobarse planes especiales con la finalidad de proteger ámbitos singulares, llevar a cabo operaciones de reforma interior, coordinar la ejecución de dotaciones urbanísticas, proteger, rehabilitar y mejorar el medio rural u otras finalidades que se determinen reglamentariamente.

2. En ausencia de planeamiento general municipal, o cuando éste no contuviese las previsiones detalladas oportunas, podrán aprobarse planes especiales únicamente con la finalidad de proteger ámbitos singulares, rehabilitar y mejorar el medio rural o establecer infraestructuras y dotaciones urbanísticas básicas, siempre que estas determinaciones no exijan la previa definición de un modelo territorial.

3. Los planes especiales contendrán las determinaciones necesarias para el desarrollo del planeamiento correspondiente $\mathrm{y}$, en todo caso, las propias de su naturaleza y finalidad, debidamente justificadas y desarrolladas en los estudios, planos y normas correspondientes.

4. En ningún caso los planes especiales podrán sustituir a los planes generales, en su función de instrumentos de ordenación integral del territorio, por lo que no podrán modificar la clasificación del suelo, sin perjuicio de las limitaciones de uso que puedan establecerse.

Artículo 69. Planes especiales de protección.

1. Los planes especiales de protección tienen por objeto preservar el medio ambiente, las aguas continentales, el litoral costero, los espacios naturales, las áreas forestales, los espacios productivos, las vías de comunicación, los paisajes de interés, el patrimonio cultural y otros valores de interés.
2. Con tales fines podrán afectar a cualquier clase de suelo e incluso extenderse a varios términos municipales, a fin de abarcar ámbitos de protección completos, y podrán establecer las medidas necesarias para garantizar la conservación y recuperación de los valores que se deban proteger, imponiendo las limitaciones que resulten necesarias, incluso con prohibición absoluta de construir.

3. En particular, los planes especiales cuyo objeto sea proteger los ámbitos del territorio declarados como bienes de interés cultural contendrán las determinaciones exigidas por la legislación sobre patrimonio cultural y el catálogo previsto en el artículo 75 de esta ley.

4. El plan general podrá remitir la ordenación detallada del suelo urbano consolidado a un plan especial de protección. En este caso, antes de la aprobación definitiva del plan especial, deberá recabarse el informe preceptivo y vinculante de la consellería competente en materia de urbanismo y ordenación del territorio en los términos señalados por el artículo 86.1.d) ${ }^{384}$.

Artículo 70. Planes especiales de reforma interior.

1. Los planes especiales de reforma interior tienen por objeto la ejecución de operaciones de reforma en suelo urbano no consolidado previstas en el plan general para la descongestión de esta clase de suelo, la mejora de las condiciones de habitabilidad, la creación de dotaciones urbanísticas, el saneamiento de barrios insalubres, la resolución de problemas de circulación, la mejora del ambiente o de los servicios públicos, la rehabilitación de zonas urbanas degradadas u otros fines análogos.

2. Los planes especiales de reforma interior en suelo urbano no consolidado contendrán las determinaciones adecuadas a su finalidad e incluirán, al menos, las

384 Art. 69.4 añadido por Ley 15/2004, de 29 de diciembre, de modificación de la Ley $9 / 2002$, de 30 de diciembre, de ordenación urbanistica y protección del medio rural de Galicia. 
determinaciones y documentación propias de los planes parciales.

Artículo 71. Planes especiales de infraestructuras y dotaciones.

1. Los planes especiales de infraestructuras y dotaciones tienen por objeto el establecimiento y ordenación de las infraestructuras básicas relativas al sistema de comunicaciones, transportes, espacios libres públicos, equipamiento comunitario, y de las instalaciones destinadas a los servicios públicos y suministros de energía y abastecimiento, evacuación y depuración de aguas.

2. Los planes especiales de infraestructuras y dotaciones contendrán las siguientes determinaciones:

a. Delimitación de los espacios reservados para infraestructuras y dotaciones urbanísticas y su destino concreto.

b. Las medidas necesarias para su adecuada integración en el territorio y para solventar los problemas que genere en el viario y demás dotaciones urbanísticas.

c. Medidas de protección necesarias para garantizar la funcionalidad y accesibilidad de las infraestructuras y dotaciones urbanísticas.

Artículo 72. Planes especiales de protección, rehabilitación y mejora del medio rural.

1. Estos planes especiales tendrán por finalidad la protección, rehabilitación y mejora de los elementos más característicos de la arquitectura rural, de las formas de edificación tradicionales, de los conjuntos significativos configurados por ellas y de los núcleos rurales.

2. El ámbito de cada plan especial abarcará los terrenos comprendidos en uno o varios núcleos rurales completos, así como los terrenos clasificados como suelo rústico pertenecientes a uno o varios términos municipales.

No obstante, podrá redactarse el plan especial con la exclusiva finalidad de desarrollar una operación de carácter integral sobre un área de expansión del núcleo rural que constituya una unidad urbanística homogénea y completa. En este caso, el plan especial deberá garantizar la integración de la actuación con la morfología, el paisaje, los servicios y las características del núcleo rural, contener las determinaciones señaladas por las letras d), e), f), g) y h) del número 3 de este artículo y prever las reservas de suelo para dotaciones públicas y para aparcamientos, en la proporción mínima establecida por el artículo 47.2385.

3. El plan especial contendrá las siguientes determinaciones:

a. Delimitación de las áreas geográficas homogéneas en razón a la morfología de los asentamientos de población, tipología de las edificaciones, valores y potencialidades del medio rural merecedoras de protección y otras circunstancias relevantes.

b. Estudio de las parroquias y delimitación de las áreas geográficas homogéneas en razón a la morfología del asentamiento de población, tipología de las edificaciones, valores y potencialidades del medio rural merecedoras de protección y otras circunstancias relevantes.

c. Delimitación de los núcleos rurales incluidos en su ámbito.

d. Determinación de las condiciones de volumen, forma, tipología, características estéticas, materiales a emplear y técnicas constructivas, condiciones de implantación y aquellas otras que se estimen necesarias para garantizar la conservación y preservación de las características propias del medio.

e. Identificación de los elementos que deban ser objeto de protección específica para su conservación y recuperación, que habrán de incluirse en el correspondiente catálogo, así como aquellos cuya demolición o eliminación sea procedente.

f. Actuaciones previstas para la conservación, recuperación, potenciación y

385 Art. 72.2 modificado por Ley $15 / 2004$, de 29 de diciembre, de modificación de la Ley $9 / 2002$, de 30 de diciembre, de ordenación urbanistica y protección del medio rural de Galicia. 
Código de la Administración Gallega

mejora de los asentamientos tradicionales y su entorno.

g. Cualesquiera otras determinaciones necesarias para el cumplimiento de sus fines.

h. Previsión de las áreas en que sea necesaria la realización de actuaciones de carácter integral, para las que deberán delimitarse los correspondientes polígonos. En estos casos, la densidad máxima no podrá superar las 25 viviendas por hectárea, sin perjuicio del cumplimiento obligado de las condiciones de uso y edificación establecidas en la presente ley.

\section{Subsección $5 .^{\mathrm{a}}$}

Estudios de detalle

Artículo 73. Estudios de detalle.

1. En desarrollo de los planes generales, planes parciales y especiales podrán redactarse estudios de detalle para manzanas o unidades urbanas equivalentes completas con los siguientes objetivos:

a. Completar o reajustar las alineaciones y rasantes.

b. Ordenar los volúmenes edificables.

c. Concretar las condiciones estéticas y de composición de la edificación complementarias del planeamiento.

2. Los estudios de detalle en ningún caso podrán:

a. Alterar el destino urbanístico del suelo.

b. Incrementar el aprovechamiento urbanístico.

c. Reducir o modificar las superficies destinadas a viales, espacios libres o dotaciones públicas.

d. Prever la apertura de vías de uso público que no estén previamente contempladas en el plan que desarrollen o completen.

e. Aumentar la ocupación del suelo, las alturas máximas edificables o la intensidad de uso.

f. Parcelar el suelo.

g. Desconocer o infringir las demás limitaciones que les imponga el correspondiente plan.

h. Establecer nuevos usos y ordenanzas.

\section{Subsección $6 .^{\mathrm{a}}$}

Planes de iniciativa particular

Artículo 74. Planes de iniciativa particular.

Los planes de iniciativa particular o que tengan por objeto actuaciones urbanísticas de iniciativa particular deberán, además de las determinaciones establecidas en este título:

a. Determinar la obligación de conservación de la urbanización, expresando si correrá por cuenta del municipio, de los futuros propietarios de las parcelas o de los promotores de la urbanización.

b. Prestar las garantías del exacto cumplimiento de los deberes de ejecución del plan, por importe del $20 \%$ del coste estimado para la implantación de los servicios y la ejecución de las obras de urbanización y de conexión con los sistemas generales existentes, así como, en su caso, las obras de ampliación y refuerzo necesarias.

Estas garantías podrán constituirse mediante cualquiera de los mecanismos previstos en la legislación de contratos de las administraciones públicas, deberán prestarse en el plazo máximo de tres meses desde la aprobación definitiva del proyecto de urbanización y han de cancelarse, a petición de los interesados, una vez recibida la urbanización en los términos establecidos por el artículo 110.5 de la presente ley.

c. Acreditar, en caso de planes elaborados por iniciativa particular, la aceptación por los propietarios que representen más del $50 \%$ de la superficie del ámbito de planeamiento 386 .

\section{Subsección 7. ${ }^{\mathrm{a}}$ Catálogos}

\section{Artículo 75. Catálogos.}

1. Los catálogos son instrumentos complementarios de los planes cuyo objeto es identificar las construcciones, recintos,

386 Art. 74 modificado por Ley 15/2004, de 29 de diciembre, de modificación de la Ley $9 / 2002$, de 30 de diciembre, de ordenación urbanistica y protección del medio rural de Galicia. 
jardines, monumentos, inmuebles u otros elementos que, por sus singulares características o valores culturales, históricos, artísticos, arquitectónicos o paisajísticos, se estime conveniente conservar, mejorar o recuperar.

2. Los instrumentos de planeamiento contendrán obligatoriamente un catálogo en el que se identificarán los núcleos rurales, inmuebles, construcciones, instalaciones $\mathrm{u}$ otros elementos existentes de carácter tradicional en suelo rústico, o conjuntos de éstos, que merezcan ser objeto de especial protección en razón a sus valores culturales, históricos, artísticos, arqueológicos o etnográficos, tales como viviendas, hórreos, fuentes, cruceros, molinos, pazos, iglesias, puentes, yacimientos arqueológicos y otros.

3. El planeamiento habrá de contemplar las medidas necesarias para la protección, conservación, recuperación y aprovechamiento social y cultural de los bienes incluidos en el catálogo.

4. El catálogo contendrá una ficha individualizada de cada elemento catalogado en la que se recogerán, como mínimo, sus datos identificativos, ubicación y delimitación de su ámbito de protección, descripción gráfica de sus características constructivas, estado de conservación y determinaciones para su conservación, rehabilitación, mejora o recuperación.

\section{Capítulo II \\ ELABORACIÓN Y APROBACIÓN \\ DE LOS INSTRUMENTOS DE ORDENACIÓN}

\section{Sección $1 .^{\mathrm{a}}$ Actos preparatorios}

Artículo 76. Elaboración del plan. Los organismos públicos, los concesionarios de servicios públicos y los particulares prestarán su concurso a la redacción de los planes de ordenación y, al efecto, facilitarán a los organismos encargados de su redacción los documentos e informaciones necesarias.
Artículo 77. Suspensión de licencias.

1. Los órganos competentes para la aprobación inicial de los instrumentos de planeamiento urbanístico podrán acordar la suspensión del procedimiento de otorgamiento de licencias de parcelación de terrenos, edificación y demolición para áreas o usos determinados, a fin de estudiar su formación o reforma.

Dicho acuerdo habrá de publicarse en el "Diario Oficial de Galicia" y en uno de los periódicos de mayor difusión de la provincia.

2. El acuerdo de aprobación inicial de los instrumentos de ordenación determinará, por sí solo, la suspensión del procedimiento de otorgamiento de licencias en aquellos ámbitos del territorio objeto de planeamiento cuyas nuevas determinaciones supongan la modificación de la ordenación urbanística vigente; a estos efectos, determinará expresamente las áreas afectadas por la suspensión.

3. La suspensión a que se refiere el número 1 anterior se extinguirá, en todo caso, en el plazo de un año.

Si dentro de este plazo se hubiera producido acuerdo de aprobación inicial, la suspensión se mantendrá para las áreas cuyas nuevas determinaciones de planeamiento supongan modificación de la ordenación urbanística. La suspensión determinada por la aprobación inicial tendrá una duración máxima de dos años a contar de dicha aprobación y en cualquier caso se extinguirá con la aprobación definitiva del planeamiento.

4. Extinguidos los efectos de la suspensión, en cualquiera de los supuestos previstos, no podrán acordarse nuevas suspensiones en el plazo de cuatro años por idéntica finalidad.

5. Los peticionarios de licencias solicitadas con anterioridad a la publicación de la suspensión tendrán derecho a ser indemnizados del coste oficial de los proyectos y a la devolución, en su caso, de los tributos municipales, siempre que su otorgamiento no sea posible, por resultar incompatible con la nueva ordenación establecida. 
Artículo 78. Propuestas de planeamiento.

Las entidades, organismos y particulares interesados podrán remitir al Ayuntamiento propuestas de planeamiento y anteproyectos parciales que sirvan de orientación para la redacción del planeamiento. La aceptación de dichas propuestas o anteproyectos por el órgano al que corresponda la aprobación del planeamiento sólo tendrá efectos administrativos internos.

\section{Sección 2.a}

Iniciativa y colaboración en el planeamiento

Artículo 79. Planes de iniciativa particular.

1. Los particulares podrán redactar y elevar a la Administración competente para su tramitación los instrumentos de desarrollo del plan general.

2. Los propietarios afectados deberán presentar dichos instrumentos, cuando así se contemplase en el plan general, dentro de los plazos establecidos al efecto.

3. Si hubiesen obtenido la previa autorización del Ayuntamiento, les serán facilitados por los organismos públicos cuantos elementos informativos precisaren para llevar a cabo su redacción, y podrán efectuar en fincas particulares las ocupaciones necesarias para la redacción del plan, con arreglo a la Ley de Expropiación Forzosa.

4. Los propietarios podrán consultar a la Administración urbanística municipal y autonómica sobre los criterios de ordenación y las obras que habrán de realizarse con cargo a los promotores para asegurar la conexión con los sistemas generales exteriores a la actuación, con arreglo a lo dispuesto por la presente ley.

La contestación habrá de producirse en el plazo de cuatro meses a partir de la fecha de entrada de la consulta en el registro del órgano competente para resolverla.

Cuando la consulta se presente acompañada de un anteproyecto técnico, cuyo contenido mínimo se determinará reglamentariamente, el transcurso del plazo sin resolución expresa determinará la aceptación por la administración consultada de los criterios de ordenación y de la solución propuesta para asegurar la conexión con los sistemas generales exteriores a la actuación, con arreglo al anteproyecto técnico presentado ${ }^{387}$.

\section{Sección $3 .^{\mathrm{a}}$}

\section{Competencia para su formulación}

Artículo 80. Formulación de las normas subsidiarias y complementarias de planeamiento.

Las normas subsidiarias y complementarias de planeamiento serán formuladas por el conselleiro competente en materia de urbanismo y ordenación del territorio.

Artículo 81. Formulación del planeamiento general.

1. Los planes generales de ordenación municipal serán formulados por los Ayuntamientos respectivos.

2. En los supuestos en que algún Ayuntamiento no llegara a formular y aprobar el correspondiente plan general, el conselleiro competente en materia de urbanismo y ordenación del territorio podrá requerir su formulación, señalando el plazo máximo para iniciar su tramitación. En el supuesto de que el municipio no cumpla este requerimiento o paralice injustificadamente su tramitación, podrá el conselleiro disponer que se proceda, por subrogación, a la formulación del plan general por el órgano de la Administración autonómica que corresponda. En este caso, la tramitación se realizará dando audiencia al Ayuntamiento respectivo, por plazo de dos meses, antes de la aprobación inicial y de la aprobación definitiva.

Artículo 82. Ordenación urbanística que afecte a varios municipios.

1. Si las necesidades urbanísticas de un territorio que afecte a varios municipios

387 Art. 79.4 añadido por Ley 15/2004, de 29 de diciembre, de modificación de la Ley 9/2002, de 30 de diciembre, de ordenación urbanística y protección del medio rural de Galicia. 
aconsejasen la ordenación conjunta del mismo, el conselleiro competente en materia de urbanismo y ordenación del territorio podrá declarar su procedencia, de oficio o a petición de todos o alguno de los municipios afectados.

2. Igual medida será de aplicación cuando resultase procedente ordenar urbanísticamente alguna comarca.

3. En ambos supuestos, el conselleiro competente en materia de urbanismo y ordenación del territorio resolverá sobre la procedencia de la actuación propuesta y determinará su ámbito y a quién corresponde su formulación.

4. Los Ayuntamientos interesados participarán activamente en el proceso de elaboración y tramitación del plan y en la financiación de los costes en la forma en que determine la resolución del Conselleiro.

Artículo 83. Formulación del planeamiento de desarrollo.

1. Los planes parciales, planes especiales, planes de sectorización y estudios de detalle podrán ser formulados por los Ayuntamientos, por otros órganos competentes en el orden urbanístico y por los particulares legitimados para hacerlo.

2. Los planes especiales de protección, rehabilitación y mejora del medio rural podrán ser formulados por el conselleiro competente en materia de urbanismo y ordenación del territorio o por los municipios afectados.

\section{Sección $4 .^{\mathrm{a}}$ \\ Procedimiento para la aprobación de los \\ instrumentos de planeamiento \\ Subsección 1. ${ }^{\mathrm{a}}$ \\ Elaboración del planeamiento}

Artículo 84. Elaboración del planeamiento municipal.

1. La redacción de los instrumentos de planeamiento urbanístico se efectuará por facultativos con titulación universitaria de segundo o tercer ciclos.
2. La redacción del proyecto de plan general habrá de realizarse por un equipo multidisciplinar formado por un mínimo de tres especialistas con titulación universitaria de segundo o tercer ciclos, de los que, al menos, uno de ellos tendrá que ser arquitecto o ingeniero de caminos, canales y puertos.

3. Acordada la redacción de cualquier instrumento de ordenación urbanística, podrá formularse potestativamente un avance del plan que sirva de orientación a su redacción, en el que se contengan la estrategia, directrices y objetivos generales del plan. A continuación se abrirá un período de información pública por plazo mínimo de un mes, mediante anuncio que se publicará en el "Diario Oficial de Galicia" y en uno de los periódicos de mayor circulación de la provincia, durante el cual las entidades y los particulares podrán sugerir lo que estimen oportuno y presentar propuestas y convenios urbanísticos que estimen procedentes.

\section{Subsección 2 . $^{a}$}

\section{Tramitación del planeamiento}

Artículo 85. Procedimiento de aprobación del plan general.

1. Terminada la fase de elaboración del planeamiento, e inmediatamente antes de su aprobación inicial, el expediente completo será remitido al conselleiro competente en materia de urbanismo y ordenación del territorio para su informe, que habrá de ser emitido en el plazo de tres meses. Transcurrido este plazo, podrá continuar la tramitación del plan.

2. El Ayuntamiento que lo formuló procederá a su aprobación inicial y seguidamente será sometido al trámite de información pública, como mínimo durante un mes y como máximo durante dos meses, mediante anuncio que se publicará en el Diario Oficial de Galicia y en dos de los periódicos de mayor difusión en la provincia. Simultáneamente y durante el mismo plazo, se dará audiencia a los municipios 
limítrofes. No será precisa la notificación del trámite de información pública a los propietarios de terrenos afectados.

3. Al mismo tiempo que el trámite de información pública, la Administración municipal deberá recabar de las administraciones públicas competentes los informes sectoriales que resulten necesarios, que habrán de ser emitidos en el plazo máximo de un mes, salvo que la legislación sectorial señale otro plazo ${ }^{388}$. $(\ldots)^{389}$

4. Los servicios técnicos y jurídicos municipales deberán emitir informe respecto a la conformidad del plan con la legislación vigente y la calidad técnica de la ordenación proyectada.

5. Cumplidos los trámites señalados en los apartados precedentes, el pleno del Ayuntamiento aprobará provisionalmente el contenido del plan con las modificaciones que fueran pertinentes y lo someterá, con el expediente completo debidamente diligenciado, al órgano autonómico competente que haya de otorgar la aprobación definitiva.

La Consellería, en el plazo de un mes, examinará con carácter previo la integridad documental tanto del proyecto de plan como del expediente y de las actuaciones administrativas realizadas. De apreciarse la omisión o defectuosa celebración de algún trámite, o la existencia de alguna deficiencia en la documentación del proyecto, requerirá la subsanación de las deficiencias observadas, fijando plazo al efecto. Hasta el cumplimiento efectivo de requerimiento no comenzará el cómputo del plazo legal para la resolución sobre la aprobación definitiva.

Una vez completado el expediente, el Conselleiro adoptará motivadamente alguna de las siguientes decisiones:

\footnotetext{
388 Art. 85.2 y 85.3 modificados por Ley 15/2004, de 29 de diciembre, de modificación de la Ley $9 / 2002$, de 30 de diciembre, de ordenación urbanistica y protección del medio rural de Galicia.

389 Párrafo segundo del art. 85.3 derogado por Ley $6 / 2007$, de 11 de mayo, de medidas urgentes en materia de ordenación del territorio y del litoral de Galicia.
}

a. Aprobar definitivamente el plan. La aprobación podrá ser parcial cuando las deficiencias sólo afecten a áreas o determinaciones tan concretas que, prescindiendo de ellas, el planeamiento se pueda aplicar con coherencia. La parte objeto de reparos quedará en suspenso hasta que el Ayuntamiento subsane las deficiencias y remita el documento corregido a la consellería para su aprobación definitiva.

b. Si no procede otorgar la aprobación definitiva, el órgano competente señalará las deficiencias y subsiguientes modificaciones que procede introducir, al objeto de que, una vez subsanadas y aprobadas por el Ayuntamiento, se eleve de nuevo el documento para su aprobación definitiva, salvo que hubiese quedado relevado de hacerlo por la escasa importancia de las modificaciones.

c. Denegar la aprobación definitiva en el supuesto de que el plan en tramitación se estime inviable porque las deficiencias constatadas no sean susceptibles de enmienda.

6. En caso de que pretenda introducirse, en el momento de la aprobación provisional por el pleno municipal, modificaciones que signifiquen un cambio sustancial del documento inicialmente aprobado, por la adopción de nuevos criterios respecto a la clasificación y calificación del suelo, o en relación con la estructura general y orgánica del territorio, se abrirá un nuevo trámite de información pública con anterioridad al referido acuerdo del pleno municipal y de la remisión de la documentación oportuna a la Consellería para resolver sobre su aprobación definitiva.

7. Para resolver sobre la aprobación definitiva, la Consellería competente en materia de urbanismo y ordenación del territorio analizará:

a. La integridad y suficiencia de los documentos que integran el plan.

b. La conformidad del plan con la legislación urbanística vigente y la adecuación de sus determinaciones a la protección del medio rural. 
c. La coherencia del plan con las directrices de ordenación del territorio y los demás instrumentos previstos en la Ley 10/1995, de Ordenación del Territorio de Galicia, así como con las normas técnicas de planeamiento.

d. La incidencia del plan sobre las materias de competencia autonómica y sobre las políticas autonómicas de desarrollo sostenible y la articulación de las infraestructuras de carácter local con los elementos vertebradores del territorio de alcance supramunicipal.

En todo caso, dado el valor del litoral como recurso natural y ambiental no renovable, se entenderá que la ordenación urbanística de los terrenos situados en la franja de 500 metros desde la ribera del mar afecta a los intereses autonómicos.

8. El plan general se entenderá aprobado definitivamente si transcurren tres meses desde la entrada del expediente completo en el registro del órgano competente sin que éste hubiera comunicado la resolución, siempre que el plan contenga los documentos y determinaciones preceptivos.

9. Los instrumentos de planeamiento son disposiciones de carácter general, por lo que su aprobación definitiva no podrá recurrirse en vía administrativa, sino tan sólo a través del correspondiente recurso contencioso-administrativo en los términos previstos en la legislación aplicable.

Artículo 86. Tramitación de planeamiento de desarrollo.

1. La tramitación de los planes parciales, planes especiales y planes de sectorización se ajustará al siguiente procedimiento:

a. El órgano municipal competente procederá a su aprobación inicial y lo someterá a información pública como mínimo durante un mes y como máximo durante dos meses, mediante anuncio que se publicará en el "Diario Oficial de Galicia" y en dos de los periódicos de mayor difusión en la provincia. Simultáneamente se notificará individualmente a todos los propietarios de los terrenos afectados. A estos efectos, únicamente será obligatoria la notificación a los titulares que figuren en el catastro, debiendo figurar la relación en la documentación del plan.

b. Durante el mismo tiempo en que se realiza el trámite de información pública, la Administración municipal deberá recabar de las administraciones públicas competentes los informes sectoriales que resulten preceptivos, que habrán de ser emitidos en el plazo máximo de un mes, salvo que la legislación sectorial señale otro plazo.

En caso de tramitación de planes parciales o planes de sectorización, habrá de obtenerse también de la consellaría competente en materia de vivienda el informe sobre el cumplimiento y la adecuada localización de la dotación autonómica a la que hace referencia el artículo 47.10 en relación con su accesibilidad, funcionalidad e integración en la estructura urbanística, que será emitido en igual plazo. Transcurrido el mismo sin que se comunicase el informe obtenido, podrá continuarse el procedimiento de aprobación del plan ${ }^{390391}$.

(...) 392393 .

c. Los servicios técnicos y jurídicos municipales deberán emitir informe respecto a la conformidad del plan con la legislación vigente y la calidad técnica de la ordenación proyectada.

390 Corrección de errores. Ley 6/2008, de 19 de junio, de medidas urgentes en materia de vivienda y suelo, por la que se modifica la Ley $9 / 2002$, de 30 de diciembre, de ordenación urbanistica y protección del medio rural de Galicia.

391 Último inciso del art. 86.b añadido por Ley 6/2008, de 19 de junio, de medidas urgentes en materia de vivienda y suelo, por la que se modifica la Ley $9 / 2002$, de 30 de diciembre, de ordenación urbanistica y protección del medio rural de Galicia.

392 Párrafo segundo del art. 86.1.b derogado por Ley 6/2007, de 11 de mayo, de medidas urgentes en materia de ordenación del territorio y del litoral de Galicia.

393 Art. 86.1.a y art. 86.1.b modificados por Ley $15 / 2004$, de 29 de diciembre, de modificación de la Ley $9 / 2002$, de 30 de diciembre, de ordenación urbanistica y protección del medio rural de Galicia. 
d. La aprobación de planes de sectorización y de planes especiales no previstos en el plan general requerirá en todo caso la previa emisión del informe preceptivo y vinculante en lo que se refiera al control de la legalidad, la tutela de los intereses supramunicipales, así como el cumplimiento de las determinaciones establecidas en las directrices de ordenación del territorio y de los planes territoriales y sectoriales.

A estos efectos, cumplidos los trámites señalados en los apartados precedentes, el órgano municipal competente aprobará provisionalmente el contenido del plan con las modificaciones que fueran pertinentes y lo someterá, con el expediente completo debidamente diligenciado, al conselleiro competente en materia de urbanismo y ordenación del territorio para su informe preceptivo, que habrá de ser emitido en el plazo de tres meses, a contar desde la entrada del expediente completo en el Registro de la Consellería.

La Consellería, en el plazo de un mes, examinará con carácter previo la integridad tanto del proyecto de plan como del expediente y de las actuaciones administrativas realizadas. De apreciarse la omisión o defectuosa celebración de algún trámite o la existencia de alguna deficiencia en la documentación del proyecto, requerirá la subsanación de las deficiencias observadas, fijando plazo al efecto. Hasta el cumplimiento efectivo del requerimiento no comenzará el cómputo del plazo legal para la emisión del informe autonómico.

En los demás casos, no será necesario el informe de la Consellería ni la aprobación provisional del plan.

e. Cuando, con posterioridad al trámite de información pública, se pretendan introducir modificaciones que supongan un cambio sustancial del documento inicialmente aprobado, se abrirá un nuevo trámite de información pública.

f. Cumplidos los trámites señalados en los apartados precedentes, el Ayuntamiento procederá a su aprobación definitiva.
2. Los estudios de detalle serán aprobados inicialmente por el órgano municipal competente y sometidos a información pública por el plazo mínimo de veinte días mediante anuncio que se publicará en el "Diario Oficial de Galicia" y en uno de los periódicos de mayor circulación en la provincia. A la vista del resultado de la información pública, el órgano municipal los aprobará definitivamente con las modificaciones que resulten pertinentes.

Artículo 87. Tramitación de los planes especiales de protección, rehabilitación y mejora del medio rural.

1. La tramitación de los planes especiales de protección, rehabilitación y mejora del medio rural corresponde al conselleiro competente en materia de urbanismo y ordenación del territorio o al municipio que lo hubiera formulado.

2. La aprobación inicial se adoptará por el órgano que lo hubiera formulado, sometiéndolo a información pública por el plazo mínimo de un mes, mediante anuncio que será publicado en el "Diario Oficial de Galicia" y en dos periódicos de mayor circulación en el ámbito de la Comunidad Autónoma, con audiencia a los Ayuntamientos afectados en los supuestos de que no lo hubieran formulado.

3. Cuando el plan sea tramitado por la Administración municipal, serán de aplicación los apartados 3, 4, 5 y 6 del artículo 85 de esta ley.

4. (...) ${ }^{394}$.

Artículo 88. Tramitación de las normas subsidiarias y complementarias de planeamiento y de otros instrumentos que afecten a varios municipios.

1. Las normas subsidiarias y complementarias de planeamiento y los instrumentos de ordenación urbanística que afecten a varios municipios serán tramitados por el conselleiro competente

\footnotetext{
394 Art. 87.4 derogado por Ley 15/2004, de 29 de diciembre, de modificación de la Ley $9 / 2002$, de 30 de diciembre, de ordenación urbanistica y protección del
} medio rural de Galicia. 
en materia de urbanismo y ordenación del territorio, siguiendo el procedimiento previsto en este capítulo.

2. Antes de la aprobación definitiva se dará traslado del documento elaborado a los municipios afectados a fin de que puedan examinarlo y pronunciarse sobre el mismo mediante acuerdo adoptado por el pleno de la corporación en el plazo máximo de un mes.

\section{Sección $5 .^{a}$}

Otras disposiciones

Artículo 89. Competencia para la aprobación definitiva.

1. Corresponde al conselleiro competente en materia de urbanismo y ordenación del territorio la aprobación definitiva de las normas subsidiarias y complementarias de planeamiento, de los planes generales de ordenación municipal, de los planes de protección, rehabilitación y mejora del medio rural y de los instrumentos de planeamiento que afecten a varios términos municipales.

2. La aprobación definitiva de los planes parciales, especiales y de sectorización y de los estudios de detalle corresponderá al órgano municipal competente.

Artículo 90. Plazos para la aprobación definitiva de instrumentos de planeamiento de desarrollo de iniciativa particular.

1. El plazo máximo para resolver sobre la aprobación inicial de planes de desarrollo del plan general de iniciativa particular será de tres meses, a contar a partir de su presentación en el registro general del Ayuntamiento. Transcurrido este plazo sin que haya recaído resolución expresa, podrá entenderse otorgada la aprobación inicial del correspondiente instrumento de planeamiento.

2. El plazo para la aprobación definitiva por el Ayuntamiento de planes de desarrollo de los planes generales será de seis meses, y para la aprobación definitiva de estudios de detalle será de tres meses, a contar desde el acuerdo de aprobación inicial. Transcurrido este plazo sin que se procediese a la notificación de la resolución, podrá entenderse aprobado definitivamente el plan, siempre que se hubiera realizado el trámite de información pública y obtenido los informes preceptivos en sentido favorable, de conformidad con la legislación aplicable, o, en su caso, hubiesen sido recabados los informes y hubieran transcurrido los plazos para emitirlos ${ }^{395}$.

3. No se aplicará el silencio administrativo estimatorio cuando los planes o instrumentos contuviesen determinaciones contrarias a la Ley, a los planes de superior jerarquía o a las directrices de ordenación del territorio de Galicia.

Artículo 91. Regla especial de tramitación.

El Consello de la Xunta de Galicia podrá acordar la declaración de urgencia en la tramitación de los planes de desarrollo del plan general tramitados a iniciativa de las administraciones públicas o de empresas con capital exclusivo o mayoritariamente público cuyo fin principal sea la urbanización, creación de suelo o construcción de viviendas de promoción pública.

En este caso, se reducirán los plazos a dos meses para la aprobación inicial y a cuatro meses para la aprobación definitiva, computados según dispone el artículo anterior. Transcurrido cualquiera de estos plazos sin que el Ayuntamiento hubiera comunicado la resolución procedente, el conselleiro competente en materia de urbanismo y ordenación del territorio actuará por subrogación en la tramitación y aprobación definitiva del plan.

\section{Sección $6 .^{a}$}

Vigencia y revisión de los planes

Artículo 92. Vigencia de los planes.

1. Los planes de ordenación tendrán vigencia indefinida, sin perjuicio de su modificación y revisión.

395 Art. 90.1 y 90.2 modificados por Ley 15/2004, de 29 de diciembre, de modificación de la Ley $9 / 2002$, de 30 de diciembre, de ordenación urbanistica y protección del medio rural de Galicia. 
2. El acuerdo de aprobación definitiva del planeamiento habrá de publicarse, en el plazo de un mes desde su adopción, en el "Diario Oficial de Galicia" y el documento que contenga la normativa y las ordenanzas, en el "Boletín Oficial" de la provincia.

3. Cuando la competencia para la aprobación definitiva corresponda al Ayuntamiento, ésta será comunicada a la Consellería competente en materia de urbanismo y ordenación del territorio, a la vez que se le dará traslado de una copia autenticada de dos ejemplares del instrumento aprobado definitivamente con todos los planos y documentos que integran el plan sobre los que hubiera recaído el acuerdo de aprobación definitiva, debidamente diligenciados por el Secretario del Ayuntamiento, haciendo constar dicho extremo.

En el anuncio de aprobación definitiva se hará constar la remisión de la documentación a la Consellería.

4. La eficacia del acto de aprobación definitiva y la entrada en vigor del plan aprobado quedan condicionadas al cumplimiento de lo dispuesto en este artículo y a lo que disponga al efecto la legislación reguladora de la Administración actuante.

5. En las materias reguladas por la presente ley, será la Consellería competente en materia de urbanismo y ordenación del territorio la que tenga la competencia para proceder al requerimiento de anulación de los actos y acuerdos de las Corporaciones locales, regulado por el artículo 217 de la Ley 5/1997, de Administración Local de Galicia, y por los artículos 65 y 66 de la Ley 7/1985, reguladora de las Bases del Régimen Local.

Es asimismo esta Consellería a la que habrá de efectuarse la comunicación de los actos y acuerdos municipales según lo previsto en la legislación del régimen local.

Los plazos a que hacen referencia los preceptos citados comenzarán a contar desde la recepción de la documentación en el
Registro de la Consellería, correspondiendo al Conselleiro formular, en su caso, el correspondiente requerimiento.

Artículo 93. Alteración del planeamiento.

1. La alteración del contenido de los instrumentos de planeamiento urbanístico podrá llevarse a cabo mediante la revisión de los mismos o a la modificación de alguno o algunos de los elementos que los constituyan.

2. Se entiende por revisión del planeamiento general la adopción de nuevos criterios respecto a la estructura general y orgánica del territorio o a la clasificación del suelo, motivada por la elección de un modelo territorial distinto o por la aparición de circunstancias sobrevenidas, de carácter demográfico o económico, que incidan sustancialmente sobre la ordenación, o por el agotamiento de su capacidad. La revisión podrá determinar la sustitución del instrumento de planeamiento existente y se observarán las mismas disposiciones enunciadas para su tramitación y aprobación.

3. En los demás supuestos, la alteración de las determinaciones del plan se considerará como modificación del mismo, aun cuando dicha alteración conlleve cambios aislados en la clasificación, calificación del suelo o delimitación del ámbito de los polígonos.

4. La revisión del planeamiento y las modificaciones de cualquiera de los elementos de los planes, proyectos, normas y ordenanzas se sujetarán a las mismas disposiciones enunciadas para su tramitación y aprobación, sin perjuicio de lo dispuesto en el artículo 62 de la presente ley.

Las modificaciones del planeamiento general que no impliquen ni la reclasificación de suelo ni el incremento de la intensidad de uso de una zona ni alteren los sistemas generales previstos en el planeamiento vigente no precisarán obtener el informe previo a la aprobación inicial 
a que hace referencia el artículo 85.1 de la presente ley ${ }^{396}$.

Artículo 94. Modificación de los planes.

1. Cualquier modificación del planeamiento urbanístico deberá fundamentarse en razones de interés público debidamente justificadas encaminadas a la mejora sustancial de la ordenación urbanística vigente, al descongestionamiento urbano, a la mejora de la articulación de los espacios libres públicos y de los volúmenes construidos, a la eliminación de usos no deseables o a la incorporación de otros necesarios, a la creación de nuevas dotaciones urbanísticas públicas, a la resolución de problemas de circulación y a otros fines públicos.

2. No podrán formularse nuevas modificaciones del planeamiento urbanístico durante la tramitación de un plan general de ordenación municipal o de su revisión; esto es, desde su aprobación inicial hasta su aprobación definitiva, salvo en ejecución de sentencias.

3. Cuando la modificación tendiera a incrementar la intensidad del uso de una zona, se requerirá para aprobarla la previsión de las mayores dotaciones públicas, de acuerdo con los estándares establecidos en el apartado 2 del artículo 47, debiendo emplazarse las nuevas dotaciones en el mismo distrito o sector, según se trate de suelo urbano o urbanizable.

4. Si la modificación de los planes urbanísticos afectase a terrenos calificados como zonas verdes o espacios libres públicos, su aprobación requerirá el previo informe favorable de la Comisión Superior de Urbanismo de Galicia, que habrá de ser emitido en el plazo de tres meses, a contar desde la entrada del expediente completo en el Registro de la Consellería competente

396 Segundo párrafo del art. 93.4 añadido por Ley $15 / 2004$, de 29 de diciembre, de modificación de la Ley 9/2002, de 30 de diciembre, de ordenación urbanistica y protección del medio rural de Galicia. en materia de urbanismo y ordenación del territorio. Transcurrido el citado plazo sin que se emita informe, se entenderá emitido en sentido desfavorable.

5. $(\ldots)^{397}$.

Artículo 95. Modificación de los planes en suelo rústico.

1. Se prohíbe toda modificación del planeamiento urbanístico que conlleve la conversión o inclusión directa de suelo rústico en la clase de suelo urbano.

2. Sólo será admisible el cambio de clasificación del suelo rústico en urbanizable cuando se justifique de modo fehaciente y manifiesto la pérdida de los valores rurales, tradicionales, paisajísticos, etnográficos, culturales y, en general, las razones determinantes de su inclusión en el suelo rústico. En este caso, será necesario obtener el previo informe favorable de la Comisión Superior de Urbanismo de Galicia, que habrá de ser emitido en el plazo de tres meses, a contar desde la entrada del expediente completo en el Registro de la Consellería competente en materia de urbanismo y ordenación del territorio. Transcurrido el citado plazo sin que se emita informe, se entenderá emitido en sentido desfavorable.

3. No se podrá clasificar o reclasificar como suelo urbanizable el suelo rústico que hubiera sufrido los efectos de un incendio forestal a partir de la entrada en vigor de la presente ley o en los cinco años anteriores a la misma, salvo autorización expresa del Consello de la Xunta de Galicia y en la forma que reglamentariamente se determine.

4. La competencia para la aprobación definitiva de las modificaciones del planeamiento cuyo objeto sea la reclasificación de suelo rústico de especial protección corresponde al Consello de la Xunta de Galicia, previo informe favorable de la

397 Art. 94.5 derogado por Ley 15/2004, de 29 de diciembre, de modificación de la Ley $9 / 2002$, de 30 de diciembre, de ordenación urbanistica y protección del medio rural de Galicia. 
Comisión Superior de Urbanismo de Galicia. El plazo para la aprobación definitiva será de seis meses, a contar desde la entrada del expediente completo en el Registro de la Consellería competente en materia de urbanismo y ordenación del territorio. Transcurrido dicho plazo sin resolución expresa, se entenderá denegada la aprobación de la modificación.

Artículo 96. Suspensión del planeamiento.

1. El Consello de la Xunta, a instancias del conselleiro competente en materia de urbanismo y ordenación del territorio, y previa audiencia del Ayuntamiento afectado, podrá suspender para su revisión, en todo o en parte del ámbito a que se refieran, la vigencia de los instrumentos de ordenación urbanística.

2. El acuerdo de iniciación del expediente corresponde al Conselleiro y determina por sí solo la suspensión automática del procedimiento de otorgamiento de licencias hasta la entrada en vigor de la ordenación provisional.

3. Con el acuerdo de suspensión, que habrá de ser adoptado por el Consello de la Xunta en el plazo de tres meses desde el acuerdo de iniciación, se aprobará la ordenación provisional, que se publicará en el "Diario Oficial de Galicia" y estará vigente con carácter transitorio hasta la entrada en vigor del nuevo planeamiento.

\section{Capitulo III EFECTOS DE LA APROBACIÓN DE LOS PLANES}

Artículo 97. Ejecutividad del planeamiento.

Los instrumentos de ordenación urbanística serán inmediatamente ejecutivos tras su entrada en vigor según lo dispuesto en el artículo 92 de la presente ley.

Artículo 98. Declaración de utilidad pública.

1. La aprobación de los instrumentos de ordenación urbanística conllevará la declaración de utilidad pública y la necesidad de ocupación de los bienes y derechos afectados a los fines de expropiación o imposición de servidumbres.

2. Cuando para la ejecución del planeamiento no fuese necesaria la expropiación del dominio y bastase la constitución de alguna servidumbre sobre el mismo, prevista por el derecho privado o administrativo, podrá imponerse, si no se alcanzase acuerdo con el propietario, con arreglo al procedimiento de la Ley de Expropiación Forzosa.

Asimismo, cuando hayan de modificarse o suprimirse servidumbres privadas por estar en contradicción con las determinaciones del planeamiento, podrá expropiarse con arreglo al procedimiento de la citada Ley.

Artículo 99. Iniciación de expropiaciones por ministerio de la Ley.

Cuando transcurran cinco años desde la entrada en vigor del plan sin que se lleve a efecto la expropiación de los terrenos que estén destinados a sistemas generales o dotaciones públicas locales que no hayan de ser objeto de cesión obligatoria por no resultar posible la justa distribución de beneficios y cargas, el titular de los bienes advertirá a la Administración de su propósito de iniciar el expediente de justiprecio, que podrá llevarse a cabo por ministerio de la Ley si transcurren otros dos años desde el momento de efectuar la advertencia.

Para ello, el propietario podrá presentar la correspondiente hoja de aprecio, y, si transcurrieran tres meses sin que la Administración la acepte, podrá aquél dirigirse al Jurado de Expropiación de Galicia, que fijará el justiprecio.

\section{Artículo 100. Publicidad.}

1. Los instrumentos de ordenación urbana, con todos sus documentos, tanto si se encuentran aprobados como durante su tramitación, serán públicos y cualquier persona podrá, en todo momento, consultarlos, obtener copias de los mismos previo pago del precio correspondiente y recabar información sobre los mismos en el Ayuntamiento. 
2. Toda persona tendrá derecho a que el municipio correspondiente le informe por escrito sobre el régimen y condiciones urbanísticas aplicables a un terreno concreto o al sector, polígono o ámbito de planeamiento en que se encuentre incluido.

Esta información deberá facilitarse por la Administración municipal en el plazo más breve posible y, como máximo, en el de tres meses, a contar desde la presentación de la solicitud en el Registro municipal.

3. Los Ayuntamientos deberán regular, mediante la correspondiente ordenanza, la cédula urbanística de los terrenos o edificios existentes en suelo urbano y urbanizable.

Al expedir la cédula, si el plan estuviese en proceso de modificación o revisión, se hará constar expresamente esta circunstancia en la misma.

Artículo 101. Obligatoriedad.

1. Los particulares, al igual que la Administración, quedarán obligados al cumplimiento de las disposiciones sobre ordenación urbana contenidas en la presente ley, en las normas que la desarrollan y en los instrumentos de ordenación aprobados con arreglo a la misma.

2. Serán nulas de pleno derecho las reservas de dispensación que se contuviesen en los planes u ordenanzas, así como las que, con independencia de los mismos, se concediesen.

Artículo 102. Usos y obras provisionales.

No obstante la obligatoriedad de la observancia de los planes, si no hubiesen de dificultar su ejecución, podrán autorizarse usos y obras justificadas de carácter provisional en suelo urbano no consolidado, suelo urbanizable delimitado y terrenos afectados a sistemas generales en tanto no se haya iniciado el procedimiento de gestión correspondiente, siempre que no se hallen expresamente prohibidos por la legislación urbanística o sectorial ni por el planeamiento general, que habrán de demolerse cuando lo acordase el Ayuntamiento, sin derecho a indemnización. La autorización aceptada por el propietario se hará constar bajo las indicadas condiciones en el Registro de la Propiedad.

Las obras ejecutadas para usos provisionales habrán de ser las mínimas imprescindibles para permitir unas instalaciones fácilmente desmontables. No se admiten como usos provisionales los residenciales ni los industriales.

Artículo 103. Edificios fuera de ordenación.

1. Los edificios e instalaciones erigidos con anterioridad a la aprobación definitiva del planeamiento urbanístico que resultasen disconformes con el mismo quedarán sometidos al régimen de fuera de ordenación.

2. En las construcciones y edificaciones que queden en situación de fuera de ordenación por total incompatibilidad con las determinaciones del nuevo planeamiento sólo se podrán autorizar obras de mera conservación y las necesarias para el mantenimiento del uso preexistente.

3. En las construcciones sólo parcialmente incompatibles con el nuevo planeamiento se podrán autorizar las obras de mejora, ampliación o reforma que se determinen en el plan.

4. El Ayuntamiento comunicará al Registro de la Propiedad, a efectos de su constancia, las limitaciones y condiciones especiales en la concesión de licencias en edificaciones fuera de ordenación.

\section{TÍTULO III NORMAS DE APLICACIÓN DIRECTA \\ Capítulo I DISPOSICIONES GENERALES}

Artículo 104. Adaptación al ambiente. Las construcciones e instalaciones habrán de adaptarse al ambiente en que estuviesen emplazadas, y a tal efecto:

a. Las construcciones en lugares inmediatos o que formen parte de un grupo de edificios de carácter artístico, histórico, típico o tradicional deberán armonizar 
con el mismo. Igualmente cuando, sin existir un conjunto de edificios, hubiera alguno de gran importancia o calidad de los caracteres indicados.

b. En los lugares de paisaje abierto o natural, sea rural o marítimo, o en las perspectivas que ofrezcan los conjuntos urbanos de características histórico-artísticas, típicos o tradicionales y en las inmediaciones de las carreteras o caminos de trayecto pintoresco, no se permitirá que la ubicación, masa o altura de las construcciones, muros y cierres, o la instalación de otros elementos, limiten el campo visual para contemplar las bellezas naturales, rompan la armonía del paisaje, desfiguren la perspectiva propia del mismo o limiten o impidan la contemplación del conjunto.

c. La tipología de las construcciones habrá de ser congruente con las características del entorno y los materiales empleados para la renovación y acabado de fachadas y cubiertas de las edificaciones y los cierres de parcelas habrán de armonizar con el paisaje en que vayan a emplazarse.

d. Queda prohibida la publicidad estática que por sus dimensiones, emplazamiento o colorido no cumpla las anteriores prescripciones.

e. Las construcciones deberán presentar todos sus parámetros exteriores y cubiertas totalmente terminados, con empleo en los mismos de las formas y materiales que menor impacto produzcan así como de los colores tradicionales en la zona o, en todo caso, los que favorezcan en mejor medida la integración en el entorno inmediato y en el paisaje.

f. En las áreas amenazadas por graves riesgos naturales o tecnológicos como inundación, hundimiento, incendio, contaminación, explosión u otros análogos, no se permitirá ninguna construcción, instalación o cualquier otro uso del suelo que sea susceptible de padecer estos riesgos ${ }^{398}$.

398 Art. 104.e y 104 ff añadidos por Ley 15/2004, de 29 de diciembre, de modificación de la Ley $9 / 2002$, de 30 de diciembre, de ordenación urbanística y protección del medio rural de Galicia.
Artículo 105. Altura de las edificaciones.

En municipios sin planeamiento general, no podrá edificarse con una altura superior a dos plantas ni sobrepasar los 7 metros de altura medidos desde la rasante del terreno al arranque inferior de la vertiente de cubierta.

Artículo 106. Protección de las vías de circulación.

1. Las construcciones y cierres que se construyan con obra de fábrica, vegetación ornamental u otros elementos permanentes, en zonas no consolidadas por la edificación, tendrán que desplazarse un mínimo de 4 metros del eje de la vía pública a la que den frente, salvo que el instrumento de ordenación establezca una distancia superior.

Únicamente se excluye de esta obligación la colocación de mojones y cierres de postes y alambre destinados a delimitar la propiedad rústica.

En todo caso, deberá cumplirse lo dispuesto por la legislación sectorial de aplicación.

2. No se podrán realizar obras de construcción de nuevas vías de circulación de vehículos automóviles que no estén previstas en los planes generales $\mathrm{u}$ otros instrumentos de planeamiento urbanístico o de ordenación del territorio, sin perjuicio de lo dispuesto en la legislación sectorial de aplicación.

\section{TÍTULO IV \\ EJECUCIÓN DE LOS PLANES DE ORDENACIÓN \\ Capítulo I DISPOSICIONES GENERALES}

Artículo 107. Finalidad.

1. Las normas que regulan la gestión urbanística tienen como finalidad garantizar la ejecución de las previsiones del planeamiento, el reparto equitativo de las cargas y beneficios derivados del mismo y establecer los cauces para garantizar que la comunidad participe en las plusvalías que genera la habilitación de suelo para usos urbanísticos. 


\section{Ordenación del territorio y...}

2. La ejecución del planeamiento se desarrollará por los procedimientos establecidos en la presente ley.

Artículo 108. Competencias.

1. La ejecución de los planes de ordenación urbanística corresponde a los municipios.

La Comunidad Autónoma podrá también ejecutar el planeamiento urbanístico en desarrollo de sus competencias y siempre que concurra un interés supramunicipal.

2. La ejecución de los planes por el sistema de expropiación puede ser objeto de concesión administrativa o ser asumida por los órganos o entidades de la Administración autonómica o del Estado.

3. Los particulares podrán participar en la ejecución del planeamiento a través de los procedimientos previstos por la presente ley.

4. En caso de actuaciones urbanísticas promovidas por otras administraciones públicas con destino exclusivamente a la construcción de viviendas de promoción pública o de equipamientos públicos o a la creación de suelo para facilitar la implantación de industrias y otras actividades económicas, la totalidad del aprovechamiento urbanístico es atribuido a la administración pública actuante.

5. Los proyectos sectoriales de incidencia supramunicipal, aprobados al amparo de la Ley 10/1995, de Ordenación del Territorio de Galicia, que impliquen la urbanización o transformación urbanística del suelo deberán cumplir los límites de sostenibilidad y las reservas mínimas para dotaciones públicas establecidos para el suelo urbanizable por la presente ley, garantizando en todo momento el equilibrio en la estructura territorial de las dotaciones y equipamientos públicos.

En caso de proyectos sectoriales promovidos por la Administración autonómica con la finalidad de crear suelo urbanizado con destino a infraestructuras, dotaciones o instalaciones, podrán ser ejecutados mediante el sistema de expropiación establecido por los artículos 140 a 149 de la presente ley ${ }^{399}$.

Artículo 109. Presupuestos de la ejecución.

1. La ejecución del planeamiento requiere la aprobación del planeamiento que contenga la ordenación detallada.

2. En suelo urbano no consolidado será suficiente la aprobación del planeamiento general, si éste contuviera su ordenación detallada. En su defecto, se precisará la aprobación del correspondiente plan especial, de acuerdo con lo que se establezca en el planeamiento general.

3. En suelo urbanizable delimitado se requerirá la previa aprobación del plan parcial del sector correspondiente, salvo que el plan general hubiera establecido la ordenación detallada.

4. En suelo urbanizable no delimitado se exigirá previamente la aprobación del correspondiente plan de sectorización.

5. La ejecución de los sistemas generales exigirá la aprobación previa de un plan especial cuando su delimitación y ordenación detallada no estuviera contenida en el plan general.

Artículo 110. Ejecución y conservación de obras de urbanización.

1. Los proyectos de urbanización son proyectos de obras cuya finalidad es ejecutar los servicios y dotaciones establecidos en el planeamiento.

2. Los proyectos de urbanización no podrán modificar las previsiones del planeamiento que desarrollan, sin perjuicio de que puedan efectuar las adaptaciones exigidas por la ejecución material de las obras.

3. Los proyectos de urbanización comprenderán una memoria descriptiva de las características de las obras, plano de situación debidamente referenciado

399 Art. 108.4 y 108.5 añadidos por Ley $15 / 2004$, de 29 de diciembre, de modificación de la Ley $9 / 2002$, de 30 de diciembre, de ordenación urbanistica y protección del medio rural de Galicia. 
y planos de proyecto y de detalle, pliego de prescripciones técnicas, mediciones, cuadros de precios y presupuesto.

4. Los proyectos de urbanización serán aprobados inicialmente por el órgano municipal competente y sometidos a información pública por el plazo mínimo de veinte días mediante anuncio que se publicará en el "Boletín Oficial" de la provincia y en uno de los periódicos de mayor circulación en la provincia. A la vista del resultado de la información pública, el órgano municipal los aprobará definitivamente con las modificaciones que resulten pertinentes.

5. La recepción por el Ayuntamiento de las obras de urbanización en ejecución del planeamiento se regirá por lo dispuesto en la legislación de contratos de las Administraciones públicas.

En caso de que la Administración no resuelva expresamente sobre la recepción de las obras de urbanización en el plazo de tres meses, a contar desde que se inste la recepción, bastará el ofrecimiento formal de cesión de las mismas por la persona responsable de la ejecución, a los efectos de entender recibidas las obras.

6. La conservación de la urbanización corresponderá al Ayuntamiento. El planeamiento urbanístico podrá prever la obligación de los propietarios de los solares resultantes de la ejecución de la urbanización de constituirse en entidad urbanística de conservación, y, en este caso, la conservación de la urbanización corresponderá a esta entidad por el plazo que señale el plan.

Las entidades urbanísticas de conservación son entidades de derecho público, de adscripción obligatoria y personalidad y capacidad jurídica propias para el cumplimiento de sus fines. Los requisitos para su constitución e inscripción en el Registro administrativo correspondiente y el contenido mínimo de los estatutos se establecerán reglamentariamente.

Las cuotas de conservación que corresponda satisfacer a los miembros de la entidad urbanística de conservación serán obligatorias y exigibles por la vía de apremio.

Contra los acuerdos de la entidad urbanística de conservación cabrá formular recurso de alzada ante el órgano municipal competente.

7. El pleno de la corporación, a petición de los propietarios de al menos el $50 \%$ de la superficie del ámbito, podrá acordar la constitución obligatoria de una entidad urbanística que se haga cargo de la conservación de la urbanización de un ámbito de suelo industrial o terciario.

La entidad urbanística de conservación tendrá personalidad jurídica propia para el cumplimiento de sus fines. Los estatutos por los que se regirá la entidad urbanística y la delimitación del ámbito de conservación a su cargo serán aprobados en expediente que se tramitará con arreglo a los trámites establecidos por el artículo 117 de la presente ley.

Los propietarios de los solares incluidos en el ámbito que se delimite quedarán incorporados obligatoriamente a la entidad urbanística de conservación y deberán contribuir a los gastos de conservación en proporción a su aprovechamiento urbanístico ${ }^{400}$.

\section{Capitulo II ÁREAS DE REPARTO}

\section{Artículo 111. Determinación.}

1. Los planes generales de ordenación municipal deberán delimitar áreas de reparto de beneficios y cargas en el suelo urbano no consolidado y en el suelo urbanizable delimitado.

2. En suelo urbano consolidado, los planes generales no podrán definir áreas de reparto ni ningún otro instrumento o técnica de distribución de cargas y beneficios, sin perjuicio del contenido de los derechos y obligaciones de los propietarios

400 Art. 110.7 añadido por Ley $15 / 2004$, de 29 de diciembre, de modificación de la Ley $9 / 2002$, de 30 de diciembre, de ordenación urbanistica y protección del medio rural de Galicia. 
de esta clase de suelo recogidos en el artículo 19 de la presente ley.

3. Las áreas de reparto podrán ser discontinuas tanto en suelo urbano no consolidado como en suelo urbanizable.

4. En el suelo urbanizable delimitado, las áreas de reparto incluirán uno o varios sectores completos y los sistemas generales que se integren en ellos o que se les adscriban a efectos de su gestión.

5. En suelo urbanizable no delimitado, las áreas de reparto se definirán por medio de los planes de sectorización que las ordenen y desarrollen, conforme a los criterios señalados al efecto en el plan general, incluyendo obligatoriamente los terrenos necesarios para sistemas generales y dotaciones públicas así como los enlaces del sector con los sistemas generales viarios y sistemas generales de infraestructuras existentes.

Artículo 112. Reglas para la delimitación.

1. La delimitación de áreas de reparto se efectuará teniendo en cuenta el equilibrio de beneficios y cargas entre las distintas áreas así como la proporcionalidad entre la edificabilidad resultante y las cargas y dotaciones previstas.

2. Serán incluidos en las áreas de reparto los terrenos destinados a sistemas generales, salvo cuando su propia magnitud determine la improcedencia de que sean obtenidos a través de los sistemas de reparto de cargas y beneficios.

3. Dentro de cada área de reparto deberán delimitarse polígonos que permitan el cumplimiento conjunto de los deberes de cesión, de distribución de cargas y beneficios y de urbanización que fueran procedentes.

\section{Capitulo III APROVECHAMIENTO TIPO}

Artículo 113. Cálculo en suelo urbano no consolidado.

1. En suelo urbano no consolidado, el aprovechamiento tipo de cada área de reparto se obtendrá dividiendo el aprovechamiento lucrativo total, incluido el dotacional privado correspondiente a la misma, expresado siempre en metros cuadrados edificables del uso y tipología edificatoria característicos, por su superficie total, excluidos los terrenos afectos a dotaciones públicas, de carácter general o local, ya existentes en el momento de aprobación del plan general que se mantengan. El resultado reflejará siempre, unitariamente, la superficie edificable del uso y tipología característicos por cada metro cuadrado de suelo del área respectiva.

2. En los supuestos en que el plan general no establezca la edificabilidad por medio de un coeficiente, el aprovechamiento tipo habrá de deducirse de la edificabilidad resultante por aplicación de las condiciones generales de la edificación establecidas por el propio planeamiento.

3. Para que el aprovechamiento tipo pueda expresarse por referencia al uso y tipología edificatoria característicos, el planeamiento fijará justificadamente los coeficientes de ponderación relativa entre dicho uso y tipología, al que siempre se le asignará el valor de la unidad, y los restantes, a los que corresponderán valores superiores o inferiores, en función de las circunstancias concretas del municipio y área de reparto.

4. No será necesario que el plan general determine el aprovechamiento tipo cuando, efectuada la distribución de los sistemas generales y la atribución de usos e intensidades, se puedan estimar suficientemente equilibrados los aprovechamientos.

A estos efectos, el plan general deberá justificar la equivalencia y la nivelación del aprovechamiento de los distintos polígonos en razón a la proporción de sistemas que se habrán de incluir o adscribir en cada uno de ellos y al valor relativo de los usos e intensidades previstos.

Artículo 114. Cálculo en suelo urbanizable.

En suelo urbanizable el aprovechamiento tipo de cada área de reparto se determinará dividiendo el aprovechamiento lucrativo total, expresado en metros cuadrados 
edificables del uso característico, por la superficie total del área, incluyendo los sistemas generales pertenecientes a la misma, con exclusión de los terrenos afectos a dotaciones públicas de carácter general o local existentes en el momento de aprobación del plan general que se mantengan.

\section{Capitulo IV REGLAS GENERALES PARA LA EQUUDISTRIBUCIÓN \\ Sección 1. ${ }^{\mathrm{a}}$ Principios y criterios}

Artículo 115. Objeto.

1. La equidistribución tiene por objeto distribuir justamente las cargas y beneficios de la ordenación urbanística, regularizar la configuración de las fincas, situar su aprovechamiento en zonas aptas para la edificación con arreglo al planeamiento y ubicar sobre parcelas determinadas y en esas mismas zonas el aprovechamiento que, en su caso, corresponda al municipio.

2. Se entenderá por instrumento de equidistribución o reparcelación la agrupación de fincas comprendidas en el polígono para su nueva división ajustada al planeamiento, con adjudicación de las parcelas resultantes a los interesados en proporción a sus respectivos derechos.

3. La reparcelación comprende también la determinación de las indemnizaciones o compensaciones necesarias para que quede plenamente cumplido, dentro de su ámbito espacial, el principio de la justa distribución entre los interesados de las cargas y beneficios de la ordenación urbanística.

4. La distribución justa de las cargas y beneficios de la ordenación será necesaria siempre que el plan asigne desigualmente a las fincas afectadas el volumen o superficie edificable, los usos urbanísticos o las limitaciones y cargas de la propiedad.

Artículo 116. Contenido del instrumento de equidistribución.

1. El instrumento de equidistribución tendrá en cuenta los siguientes criterios: a. El derecho de los propietarios será proporcional a la superficie de las parcelas respectivas.

En suelo urbano no consolidado, el derecho de los propietarios afectados será proporcional al valor urbanístico de la superficie de sus respectivas fincas.

No obstante, los propietarios, por unanimidad, podrán adoptar un criterio distinto.

b. La valoración de las parcelas aportadas y de las resultantes habrá de referirse al momento de presentación del instrumento de equidistribución para su aprobación o tramitación por el municipio.

c. Las plantaciones, obras, edificaciones, instalaciones y mejoras que no puedan conservarse se valorarán con independencia del suelo, y su importe habrá de satisfacerse al propietario interesado con cargo al proyecto, en concepto de gastos de urbanización.

d. Las obras de urbanización no contrarias al planeamiento vigente al tiempo de su realización que resulten útiles para la ejecución del nuevo plan serán consideradas igualmente como obras de urbanización con cargo al proyecto, satisfaciéndose su importe al titular del terreno sobre el que se hubieran realizado.

e. Toda la superficie susceptible de aprovechamiento privado del polígono no destinada a un uso dotacional público deberá ser objeto de adjudicación entre los propietarios afectados, en proporción a sus respectivos derechos en la equidistribución.

f. Para la determinación del valor de las parcelas resultantes se considerará el valor de repercusión en parcela, determinado en la forma que señale la normativa sobre fijación de valores catastrales.

Si el valor de repercusión en parcela no estuviese fijado por la Administración tributaria conforme a las determinaciones del plan en ejecución, o hubiera perdido su vigencia, se calculará aplicando los valores de repercusión obtenidos por el método residual. 


\section{Ordenación del territorio y...}

Las compensaciones económicas sustitutivas o complementarias por diferencias de adjudicación que, en su caso, procedan se fijarán de conformidad con lo establecido en los párrafos anteriores.

g. Se procurará, siempre que sea posible, que las fincas adjudicadas estén situadas en lugar próximo al de las antiguas propiedades de los mismos titulares.

h. Cuando la escasa cuantía de los derechos de algunos propietarios no permita que se adjudiquen fincas independientes a todos ellos, los solares resultantes se adjudicarán en pro indiviso a tales propietarios. No obstante, si la cuantía de esos derechos no alcanzase el 15 por 100 de la parcela mínima edificable, la adjudicación podrá sustituirse por una indemnización en metálico.

2. En ningún caso podrán adjudicarse como fincas independientes superficies inferiores a la parcela mínima edificable o superficies que no reúnan la configuración y características adecuadas para su edificación con arreglo al planeamiento.

3. No serán objeto de nueva adjudicación, conservándose las propiedades primitivas, sin perjuicio, cuando fuese necesario, de la regularización de lindes y de las compensaciones económicas que procedan:

a. Los terrenos edificados con arreglo al planeamiento.

b. Los terrenos con edificación no ajustada al planeamiento, cuando la diferencia, en más o en menos, entre el aprovechamiento que le corresponda con arreglo al plan y el que correspondería al propietario en proporción a su derecho en la equidistribución sea inferior al 15 por 100 de este último, siempre que no estuvieran destinados a usos incompatibles con la ordenación urbanística.

c. Los inmuebles que hubieran iniciado expediente de declaración de bien de interés cultural o estén incluidos en los catálogos a que se refiere el artículo 75 .
Artículo 117. Procedimiento de aprobación.

1. El expediente de aprobación del instrumento de equidistribución se entenderá iniciado al aprobarse la delimitación del polígono.

2. La iniciación del expediente de equidistribución implica, sin necesidad de declaración expresa, la sus pensión del otorgamiento de licencias de parcelación y edificación en el ámbito del polígono.

3. Una vez aprobado inicialmente por el órgano municipal competente, se someterá el proyecto a información pública por plazo mínimo de veinte días a través de la correspondiente publicación en el "Boletín Oficial" de la provincia, con notificación individualizada a los interesados.

A estos efectos, el municipio deberá tener a disposición del público un ejemplar del expediente administrativo, con toda la documentación obrante.

4. La aprobación definitiva deberá recaer en el plazo máximo de dos meses desde la conclusión del trámite de información pública. Transcurrido este plazo sin resolución expresa, el instrumento de equidistribución se entenderá aprobado por silencio salvo en los supuestos en los que en la fase de información pública o durante la instrucción del expediente se hubieran formulado alegaciones por los propietarios o titulares de derechos afectados, en cuyo caso el silencio tendrá efectos desestimatorios.

5. El procedimiento establecido en el presente artículo se aplicará con carácter supletorio a los sistemas de actuación indirectos previstos en la Ley.

Artículo 118. Efectos.

1. El acuerdo aprobatorio del instrumento de equidistribución surtirá los siguientes efectos:

a. Transmisión al municipio, en pleno dominio y libre de cargas, de todos los terrenos de cesión obligatoria para su incorporación al patrimonio del suelo o su afectación a los usos previstos en el planeamiento. 
b. Subrogación, con plena eficacia real, de las antiguas por las nuevas parcelas, siempre que quede establecida su correspondencia.

c. Afectación real de las parcelas adjudicadas al cumplimiento de las cargas y pago de los gastos inherentes al sistema de actuación correspondiente.

2. La aprobación definitiva del instrumento de equidistribución habilita a la Administración para proceder, inmediatamente y sin ulterior trámite, a la ocupación de los terrenos y bienes que, por su calificación urbanística, hayan de ser objeto de cesión obligatoria y gratuita, y de aquellos otros incluidos en el ámbito que resulten necesarios para la ejecución material de las obras de urbanización.

Artículo 119. Extinción o transformación de derechos y cargas.

1. Cuando no tenga lugar la subrogación real, el acuerdo aprobatorio del instrumento de equidistribución producirá la extinción de los derechos reales y cargas constituidos sobre la finca aportada, corriendo a cargo del propietario que la aportó la indemnización correspondiente, fijándose su importe en el mencionado acuerdo.

2. En los supuestos de subrogación real, si existiesen derechos reales o cargas que se estimen incompatibles con el planeamiento, el acuerdo aprobatorio de la equidistribución declarará su extinción y fijará la indemnización correspondiente a cargo del propietario respectivo.

3. Existiendo subrogación real y compatibilidad con el planeamiento urbanístico, si la situación y características de la nueva finca fuesen incompatibles con la subsistencia de los derechos reales o cargas que habrían de recaer sobre ellas, las personas a que estos derechos o cargas favorecieran podrán obtener su transformación en un derecho de crédito con garantía hipotecaria sobre la nueva finca, en la cuantía en que la carga se valorara.

El Registrador de la Propiedad que aprecie tal incompatibilidad lo hará constar así en el asiento respectivo.
En defecto de acuerdo entre las partes interesadas, cualquiera de ellas podrá acudir al Juzgado competente del orden civil para obtener una resolución declarativa de la compatibilidad o incompatibilidad y, en este último caso, para fijar la valoración de la carga y la constitución de la mencionada garantía hipotecaria.

4. No obstante lo dispuesto en los números 1 y 2, las indemnizaciones por la extinción de servidumbres o derechos de arrendamiento incompatibles con el planeamiento o su ejecución se considerarán gastos de urbanización, correspondiendo a los propietarios en proporción a la superficie de sus respectivos terrenos.

Artículo 120. Inscripción.

Una vez firme en vía administrativa el acuerdo de aprobación definitiva del instrumento de equidistribución, se procederá a su inscripción en el Registro de la Propiedad, en la forma que se establece en la legislación aplicable.

Artículo 121. Efectos tributarios y supletoriedad de las normas de expropiación forzosa.

1. Las adjudicaciones de terrenos a que dé lugar la equidistribución, cuando se efectúan en favor de los propietarios comprendidos en el correspondiente polígono y en proporción a sus respectivos derechos, gozarán de todas las exenciones tributarias que establezca la legislación aplicable. Respecto a la incidencia de estas transmisiones en el Impuesto sobre el Incremento del Valor de los Terrenos de Naturaleza Urbana se estará a lo dispuesto en la normativa estatal.

2. Supletoriamente se aplicarán a la equidistribución las normas de la expropiación forzosa.

\section{Sección $2 .^{\mathrm{a}}$}

Operaciones de reorganización de la propiedad en suelo urbano consolidado

Artículo 122. Objeto.

1. Cuando fuera necesario adaptar la configuración física de las parcelas en 
suelo urbano consolidado, en aplicación de las determinaciones del planeamiento urbanístico, el municipio podrá delimitar zonas de normalización de fincas sin que ello produzca minoración de los aprovechamientos atribuidos por el plan ni imposición de cesión de aprovechamiento lucrativo a favor del municipio.

Las eventuales variaciones en el valor de las fincas se compensarán en metálico o en la forma en que cada caso se establezca en el correspondiente procedimiento.

2. El procedimiento para delimitar las zonas de normalización de fincas, si no se contuviera en el planeamiento de ordenación detallada, se iniciará de oficio o a instancia de parte, y deberá incluir una memoria y planos justificativos, sometiéndose a audiencia de los interesados por plazo de veinte días. La competencia para la resolución del procedimiento corresponde al órgano municipal competente.

\section{Capítulo V POLÍGONOS DE EJECUCIÓN Y OTROS INSTRUMENTOS DE LA GESTIÓN URBANÍSTICA}

\section{Artículo 123. Polígonos.}

1. Los polígonos se configuran como los ámbitos territoriales que comportan la ejecución integral del planeamiento y serán delimitados por el plan que contenga la ordenación detallada, de forma que permitan el cumplimiento conjunto de los deberes de cesión, urbanización y justa distribución de cargas y beneficios en la totalidad de su superficie. En suelo urbano no consolidado, los polígonos podrán ser discontinuos a los solos efectos de incluir terrenos destinados a sistemas generales.

2. La ejecución del planeamiento se realizará por polígonos completos, salvo cuando se trate de ejecutar directamente los sistemas generales o las actuaciones aisladas previstas en el artículo 124 de la presente ley.

3. La delimitación de polígonos habrá de garantizar el equilibrio entre los beneficios y cargas dentro de cada área de reparto. A estos efectos, no podrán delimitarse polígonos que tengan una diferencia de aprovechamiento superior al $15 \%$ en relación con el aprovechamiento tipo del área de reparto correspondiente ni que impliquen una desproporcionada diferencia de las cargas de urbanización o de asignación de reservas para viviendas sometidas a algún régimen de protección pública $^{401}$.

4. La delimitación de los polígonos definidos por el plan podrá ser reajustada, de oficio o a instancia de parte, con arreglo a los trámites procedimentales señalados por el artículo 117 de la presente ley, sin alterar en ningún caso la ordenación urbanística establecida por el plan ni implicar una variación de la superficie superior al $20 \%$ del ámbito delimitado 402 .

Artículo 124. Actuaciones aisladas. El municipio podrá promover actuaciones aisladas en suelo urbano para hacer posible la ejecución de elementos concretos previstos por el planeamiento. La obtención de los terrenos necesarios se realizará mediante la aplicación de los mecanismos previstos en el artículo 166.1 de la presente ley.

Artículo 125. Sociedades mercantiles para la ejecución del planeamiento.

1. Las entidades locales y demás Administraciones públicas podrán constituir sociedades mercantiles cuyo capital social pertenezca íntegra o mayoritariamente a las mismas, con arreglo a la legislación aplicable, para la ejecución de los planes de ordenación.

2. La participación de la iniciativa privada en el capital social deberá realizarse con arreglo a los principios de publicidad y concurrencia inherentes a la contratación

401 Art. 123.3 modificado por Ley 6/2008, de 19 de junio, de medidas urgentes en materia de vivienda y suelo, por la que se modifica la Ley 9/2002, de 30 de diciembre, de ordenación urbanistica y protección del medio rural de Galicia.

402 Art. 123.4 añadido por Ley 15/2004, de 29 de diciembre, de modificación de la Ley $9 / 2002$, de 30 de diciembre, de ordenación urbanistica y protección del medio rural de Galicia. 
administrativa. No obstante, la Administración podrá ofrecer la suscripción de una parte del capital de la sociedad a constituir a todos los propietarios afectados sin licitación. La distribución de dicha parte del capital entre los propietarios que aceptasen participar en la sociedad se hará en proporción a la superficie de sus terrenos.

3. La Administración podrá encomendar a estas sociedades instrumentales, de forma directa, la ejecución de las obras de urbanización y las operaciones de gestión y ejecución del polígono, cualquiera que sea el sistema de actuación elegido.

\section{Capítulo VI \\ SISTEMAS DE ACTUACIÓN}

\section{Sección $1 .^{a}$}

\section{Disposiciones generales}

Artículo 126. Clases de sistemas de actuación.

1. Los polígonos se desarrollarán por el sistema de actuación que la Administración determine en cada caso.

2. Los sistemas de actuación son los siguientes:

a. Sistemas de actuación directos:

1. Cooperación.

2. Expropiación.

b. Sistemas de actuación indirectos:

1. Concierto.

2. Compensación.

3. Concesión de obra urbanizadora.

3. La expropiación forzosa podrá aplicarse, además, para la ejecución de los sistemas generales de la ordenación urbanística del territorio o de alguno de sus elementos, o para realizar actuaciones aisladas en suelo urbano.

Artículo 127. Elección del sistema de actuación.

1. El municipio elegirá el sistema de actuación aplicable, teniendo en cuenta las características y complejidades de la iniciativa a desarrollar, los medios con que cuente, la colaboración de la iniciativa privada y las demás circunstancias que concurran.
2. La determinación del sistema de actuación deberá incluirse obligatoriamente en los instrumentos de planeamiento que contengan la ordenación detallada del suelo urbano no consolidado y del suelo urbanizable.

La modificación del sistema de actuación podrá ser aprobada por el municipio, de oficio o a instancia de los particulares interesados, previa información pública por plazo de veinte días mediante anuncio que se publicará en el "Boletín Oficial" de la provincia y con notificación individualizada a los propietarios afectados.

Cuando los propietarios sean desconocidos, se ignore el lugar de notificación o intentada la notificación no pudiera practicarse, la notificación se hará por medio de anuncios en el tablón de edictos del municipio y en el "Boletín Oficial" de la provincia.

3. Cuando se hubiera fijado un sistema de gestión indirecta y no se ejecutara conforme a los plazos o planes de etapas establecidos, o hubiera transcurrido más de un año desde la aprobación definitiva del planeamiento urbanístico detallado sin que se hubiere iniciado el proceso de desarrollo y ejecución, el municipio podrá sustituir el sistema de ejecución por el procedimiento establecido en el número anterior. El cambio de sistema no se materializará si los afectados ofrecen en el trámite de información pública garantías bastantes de los gastos de urbanización pendientes y las formalizan en el plazo que acuerde el municipio.

Artículo 128. Cumplimiento de las previsiones de urbanización establecidas.

1. Las previsiones de urbanización y el cumplimiento de los deberes de cesión y equidistribución deberán ser desarrolladas en los plazos establecidos al efecto en el planeamiento detallado.

2. Los deberes a que se refiere el número anterior se considerarán cumplidos en la siguiente forma:

a. El deber de cesión y de distribución de cargas y beneficios, con la aprobación definitiva del instrumento de equidistribución. 
b. El deber de ejecutar la urbanización, con la recepción por el Ayuntamiento de las obras previstas en el correspondiente proyecto de urbanización.

3. El incumplimiento de estas obligaciones, cuando se apliquen sistemas indirectos, dará lugar a que la administración pueda sustituir de oficio el sistema de actuación y optar por un sistema de actuación directo, con independencia de las restantes consecuencias que, en su caso, pudieran derivarse del incumplimiento.

El incumplimiento de la obligación de urbanizar faculta al municipio para sustituir el sistema de actuación por el de expropiación. Asimismo, el conselleiro competente en materia de urbanismo y ordenación del territorio podrá acordar la actuación pública directa del Instituto Galego da Vivenda e Solo a través del sistema de expropiación forzosa por el procedimiento de tasación conjunta, que se adoptará previa audiencia al Ayuntamiento y a los propietarios incumplidores.

4. El incumplimiento de los propietarios de las obligaciones señaladas en el apartado primero de este precepto provocará la incautación de la garantía prestada para satisfacer las responsabilidades derivadas de la ejecución de las obras de urbanización.

5. Los propietarios que antes de finalizar el plazo establecido manifiesten su interés en desarrollar la actuación y garanticen el cumplimiento de sus deberes mediante los correspondientes compromisos y garantías ante el municipio conservarán con plenitud sus derechos y se integrarán en el proceso de ejecución que se desarrolle.

6. Si la falta de ejecución del plan fuese imputable a la Administración, los propietarios afectados conservarán sus derechos a iniciar o proseguir el proceso urbanizador y edificatorio.

Artículo 129. Polígonos con exceso de aprovechamiento real.

1. Cuando los aprovechamientos permitidos por el planeamiento en un polígono excedan de los susceptibles de apropiación por el conjunto de propietarios incluidos en el mismo, los excesos corresponderán al municipio.

2. Dichos excesos deberán destinarse a compensar a propietarios con aprovechamiento real inferior al susceptible de apropiación en el área de reparto en que se encuentren. Si tras esta compensación existiera aprovechamiento excedentario, deberá destinarse a cualquiera de los fines del patrimonio municipal del suelo.

Artículo 130. Polígonos con aprovechamiento real inferior al susceptible de apropiación.

Cuando los aprovechamientos permitidos por el planeamiento fueran inferiores a los susceptibles de apropiación por el conjunto de los propietarios, se compensará la diferencia con los excesos de aprovechamiento en otros polígonos del área de reparto que se encuentren en situación inversa.

Artículo 131. Distribución justa de cargas y beneficios.

1. Los deberes y cargas inherentes a la ejecución serán objeto de distribución justa entre los propietarios afectados, junto con los beneficios derivados del planeamiento, en la forma prevista en la presente ley.

2. Cuando en el polígono existan bienes de dominio público obtenidos por expropiación anticipada en ejecución del plan, el aprovechamiento urbanístico correspondiente a su superficie pertenecerá a la Administración titular de aquéllos. Cuando las superficies de los bienes de dominio y uso público anteriormente existentes fuesen iguales o inferiores a las que resulten como consecuencia de la ejecución del plan, se entenderán sustituidas unas por otras. Si tales superficies fuesen superiores, la administración percibirá el exceso, en la proporción que corresponda, en terrenos edificables.

Artículo 132. Gastos de urbanización.

1. La totalidad de los gastos de urbanización y los generales de la gestión 
serán sufragados por los afectados en proporción a los aprovechamientos que respectivamente les correspondan.

2. En los gastos se comprenderán, al menos, los siguientes conceptos:

a. El coste de las obras de infraestructuras, servicios y mobiliario urbano que estén previstos en los planes y proyectos y sean de interés para el polígono, sin perjuicio del derecho a reintegrarse de los gastos de instalación de las redes de suministros con cargo a las entidades, titulares o concesionarias que prestasen sus servicios, salvo en la parte en que hayan de contribuir los propietarios según la reglamentación de aquéllos.

b. Las obras de urbanización de las instalaciones e infraestructuras consideradas sistemas generales incluidos en los correspondientes sectores o polígonos, en las condiciones fijadas en el planeamiento.

c. Las indemnizaciones procedentes por el cese de actividades, traslados, derribo de construcciones, destrucción de plantaciones, obras e instalaciones que exijan la ejecución de los planes.

d. Las indemnizaciones procedentes por la extinción de arrendamientos o derechos de superficie referidos a edificios y construcciones que hayan de ser demolidos con motivo de la ejecución del planeamiento.

e. El coste de los planes de ordenación detallada y de los proyectos de urbanización y los gastos originados por la compensación y reparcelación.

f. La canalización e instalación de las redes de telecomunicaciones.

g. Los gastos de control de calidad de la urbanización.

h. Cualesquiera otros asumidos en el proyecto de equidistribución.

3. El pago de estos gastos podrá realizarse, previo acuerdo con los propietarios interesados, cediendo éstos, gratuitamente y libres de cargas, terrenos edificables en la proporción que se estime suficiente para compensarlos.
Artículo 133. Régimen de contratación de las obras de urbanización.

La contratación de las obras de urbanización se realizará siempre con arreglo a los principios de publicidad y concurrencia. Cuando el organismo contratante sea la Administración tendrá que respetar además las prescripciones de la legislación de contratos de las administraciones públicas.

\section{Sección 2. ${ }^{\mathrm{a}}$}

Sistemas de cooperación

Artículo 134. Determinaciones generales.

1. En el sistema de cooperación los propietarios aportan el suelo de cesión obligatoria y la Administración ejecuta las obras de urbanización con cargo a los mismos.

2. La aplicación del sistema de cooperación exige la aprobación del proyecto de reparcelación de los terrenos comprendidos en el polígono, como instrumento de equidistribución, salvo que ésta sea innecesaria por resultar suficientemente equitativa la distribución de las cargas y beneficios.

3. Podrán constituirse asociaciones administrativas de propietarios, bien a iniciativa de éstos o del propio municipio, con la finalidad de colaborar en la ejecución de las obras de urbanización, debiendo integrar, al menos, el 25 por 100 de la propiedad de la superficie afectada.

4. El procedimiento, contenido y demás normativa aplicable a la reparcelación se ajustará a lo dispuesto en el capítulo IV del título IV de la presente ley.

Artículo 135. Cargas de la urbanización.

1. La distribución de los costes de urbanización se hará en proporción al valor de las fincas que les sean adjudicadas en la reparcelación o, en caso de innecesariedad de ésta, en proporción al aprovechamiento de sus respectivas fincas.

2. El municipio actuante podrá exigir a los propietarios afectados el pago de cantidades a cuenta de los gastos de urbanización. Estas cantidades no podrán 
exceder del importe de las inversiones previstas para los próximos seis meses.

3. El municipio podrá, asimismo, cuando las circunstancias lo aconsejen, convenir con los propietarios afectados un aplazamiento en el pago de los gastos de urbanización de conformidad con lo previsto en la legislación de Haciendas locales.

Artículo 136. Reservas de terrenos para gastos de urbanización.

1. El proyecto de reparcelación determinará las parcelas resultantes destinadas a compensar, en su caso, los gastos de urbanización previstos y sus posibles rectificaciones.

2. La Administración podrá enajenar los terrenos reservados para atender los gastos de urbanización o contratar con empresas urbanizadoras la ejecución material de las obras, a cambio de determinado aprovechamiento lucrativo con cargo a dichos terrenos.

3. En todo caso, las enajenaciones y obras se realizarán con arreglo a las prescripciones de la legislación de contratos de las Administraciones públicas relativas a capacidad de las empresas, publicidad, procedimientos de licitación y formas de adjudicación.

4. Concluidas las obras, el aprovechamiento urbanístico sobrante, tras atender a los gastos de urbanización, se distribuirá entre los propietarios, en la proporción que corresponda a sus respectivos bienes originarios.

Artículo 137. Colaboración de los propietarios.

1. Los propietarios que representen, al menos, el 25 por 100 de la superficie total del polígono podrán ofrecer su colaboración al municipio, que se concretará en la entrega de planos, documentos y cualquier tipo de antecedentes, así como en la elaboración y presentación del proyecto de reparcelación, con el alcance que se determine en el compromiso que se formalice.

2. En el supuesto de que los propietarios llegasen a presentar el proyecto de repar- celación, el municipio estará obligado a efectuar su tramitación de acuerdo con las reglas establecidas a tal efecto por la presente ley.

\section{Artículo 138. Iniciativa.}

El proyecto de reparcelación será formulado de oficio por el municipio o por los propietarios que representen, al menos, el 25 por 100 de la superficie del polígono.

Artículo 139. Reparcelación voluntaria.

1. Los propietarios de terrenos que tengan que ser sometidos a un proceso de distribución de cargas y beneficios podrán utilizar el procedimiento abreviado de la reparcelación voluntaria.

2. En estos casos, la propuesta de reparcelación formulada por los propietarios afectados y formalizada en escritura pública, en la que harán constar la aceptación de todos ellos, será sometida a información pública durante veinte días mediante anuncio publicado en el "Boletín Oficial" de la provincia e informada por los servicios municipales correspondientes, siendo elevada al municipio para que se pronuncie sobre la aprobación definitiva.

3. Cuando recaiga la aprobación definitiva no será necesaria ninguna nueva formalización, bastando, para la inscripción en el Registro de la Propiedad, con la presentación de la citada escritura y de la certificación del acuerdo de su aprobación.

4. El proyecto se entiende aprobado si transcurre un mes desde la finalización de la información pública sin que se haya producido acuerdo expreso de aprobación y no se hubieran formulado alegaciones u objeciones en el trámite de información pública.

\section{Sección 3. ${ }^{\mathrm{a}}$}

\section{Sistema de expropiación}

Artículo 140. Determinaciones generales.

1. La Administración actuante podrá optar por utilizar el sistema de expropiación cuando razones de urgencia o necesidad lo justifiquen. 
2. La expropiación se aplicará por polígonos completos y comprenderá todos los bienes y derechos incluidos en los mismos, sin perjuicio de lo dispuesto en los artículos 146 y siguientes de la presente ley.

3. Mediante este sistema, la Administración expropiante obtiene la propiedad de todos los bienes y derechos incluidos en el polígono, ejecuta las obras de urbanización $\mathrm{y}$, posteriormente, enajena las parcelas resultantes o susceptibles de edificación.

Artículo 141. Formas de gestión.

Cuando se fije la expropiación como sistema de actuación para un polígono, podrán utilizarse las formas de gestión que permita la legislación de régimen local aplicable y que resulten más adecuadas a los fines de urbanización y edificación previstos en el planeamiento.

\section{Artículo 142. Justiprecio.}

1. El justiprecio expropiatorio de los terrenos se determinará de acuerdo con lo establecido en la legislación básica del Estado. Su pago efectivo podrá realizarse en metálico o, mediante acuerdo con el expropiado, en especie asignándole aprovechamiento lucrativo de titularidad municipal en correspondencia con el valor fijado como justiprecio, y previa valoración técnica del aprovechamiento transmitido.

2. La Administración actuante podrá aplicar el procedimiento de tasación conjunta conforme a lo dispuesto en el artículo siguiente o seguir el expediente de valoración individual de acuerdo con lo establecido en la legislación general de expropiación forzosa.

Artículo 143. Tasación conjunta.

1. En los supuestos del procedimiento de tasación conjunta, el expediente contendrá los siguientes documentos:

a. Delimitación del ámbito territorial, con los documentos que lo identifiquen en cuanto a situación, superficie y lindes, con la descripción de bienes y derechos afectados y la relación de sus titulares. b. Fijación de precios con la valoración razonada del suelo, según su calificación urbanística.

c. Hojas de justiprecio individualizado de cada finca, en las que se contendrá no sólo el valor del suelo, sino también el correspondiente a las edificaciones, obras, instalaciones y plantaciones.

d. Hojas de justiprecio que correspondan a otras indemnizaciones.

2. El proyecto de expropiación con los documentos señalados será expuesto al público por plazo de un mes, para que quienes puedan resultar interesados formulen las observaciones y reclamaciones que estimen convenientes, en particular en lo que concierne a la titularidad o valoración de sus respectivos derechos.

3. La información pública se efectuará mediante la inserción de anuncios en el "Diario Oficial de Galicia" y en un periódico de los de mayor circulación de la provincia.

4. Asimismo, las tasaciones se notificarán individualmente a los que aparezcan como titulares de bienes o derechos en el expediente, mediante traslado literal de la correspondiente hoja de aprecio y de la propuesta de fijación de los criterios de valoración, para que puedan formular alegaciones en el plazo de un mes, a contar a partir de la fecha de notificación.

5. Cuando el órgano expropiante no sea el municipio, se oirá a éste por igual plazo de un mes. El período de audiencia a la Administración municipal podrá coincidir en todo o en parte con el de los interesados.

6. Informadas las alegaciones, se someterá el expediente a la aprobación del órgano municipal competente o, de ser tramitada por la Administración autonómica, al conselleiro competente en materia de urbanismo.

7. La resolución aprobatoria del expediente se notificará a los interesados titulares de bienes y derechos que figuran en el mismo, confiriéndoles un plazo de veinte días, durante el cual podrán manifestar por escrito ante el órgano expropiante su 
disconformidad con la valoración establecida en el expediente aprobado.

En tal caso, se dará traslado del expediente y la hoja de aprecio impugnada al Jurado de Expropiación de Galicia, a efectos de fijar el justiprecio, que, en todo caso, se hará de acuerdo con los criterios de valoración establecidos en la legislación vigente.

8. Si los interesados no formulasen oposición a la valoración en el citado plazo de veinte días, se entenderá aceptada la que se fijó en el acto aprobatorio del expediente, entendiéndose determinado el justiprecio definitivamente y de conformidad.

9. Los errores no denunciados y justifícados en el plazo señalado en el número 2 de este artículo no darán lugar a la nulidad o reposición de actuaciones, sin perjuicio de que los interesados conserven su derecho a ser indemnizados en la forma que corresponda.

Artículo 144. Aprobación y efectos del procedimiento de tasación conjunta.

1. El acuerdo de aprobación definitiva del expediente de tasación conjunta implicará la declaración de urgencia de la ocupación de los bienes y derechos afectados.

2. El pago o depósito del importe de la valoración establecida producirá los efectos previstos en los números 6,7 y 8 del artículo 52 de la Ley de Expropiación Forzosa, sin perjuicio de que continúe la tramitación del procedimiento para la definitiva fijación del justiprecio.

3. El pago del justiprecio sólo se hará efectivo, consignándose en caso contrario su importe, en la forma determinada por la legislación básica del Estado.

Artículo 145. Procedimiento individual de expropiación.

En caso de que no se utilice el procedimiento de tasación conjunta, se seguirá el que establece la legislación del Estado para la expropiación individualizada.

Artículo 146. Exclusión de la expropiación.

1. En la aplicación del sistema de expropiación el órgano expropiante podrá excluir de la misma determinados bienes, a petición de sus titulares, cuando esta determinación no dificulte los objetivos de la actuación y el propietario se comprometa a participar en el proceso de ejecución del plan, observando las condiciones que establezca la Administración.

2. En ningún caso podrá acordarse la exclusión si la expropiación viene motivada por el incumplimiento de deberes urbanísticos.

3. En los supuestos previstos en el artículo 148, será requisito imprescindible para que pueda acordarse la exclusión de la expropiación la presentación de la escritura de reparcelación voluntaria.

4. Asimismo, el órgano expropiante, previa audiencia del propietario e información pública por plazo de veinte días mediante anuncio en el "Diario Oficial de Galicia”, podrá acordar de oficio la exclusión siempre que se trate de terrenos edificados destinados al uso establecido por el plan que se ejecuta. En este caso, la Administración fijará las condiciones, términos y proporción en que el propietario habrá de vincularse a la gestión urbanística.

Artículo 147. Requisitos.

1. Para resolver la petición de exclusión, la Administración deberá tener especialmente en cuenta que las características de los terrenos no entorpezcan el proceso de ejecución. A este fin, podrá exigirse una superficie mínima que permita la realización de una actuación edificatoria independiente.

2. Si la Administración estimase justificada la petición de exclusión y que es posible acceder a la misma, señalará al propietario de los bienes afectados las condiciones, términos y proporción en que el mismo habrá de vincularse a la gestión urbanística. Se fijarán, asimismo, las garantías para el supuesto de incumplimiento.

En todo caso, el beneficiario quedará sujeto al cumplimiento de los deberes urbanísticos básicos establecidos por la presente ley. 
3. Aceptadas por el propietario las condiciones fijadas, el órgano expropiante, previa apertura de un período de información pública de veinte días, dictará la correspondiente resolución, que se publicará en el "Diario Oficial de Galicia".

Artículo 148. Adjudicación de parcelas excluidas de la expropiación.

Cuando en los terrenos a excluir de la expropiación resulte necesario efectuar una nueva distribución de parcelas para, en el ámbito excluido, hacer posible el reparto de cargas y beneficios, se utilizará el procedimiento de la reparcelación voluntaria, en el que en ningún caso podrán incluirse bienes o derechos no excluidos de aquélla.

Artículo 149. Incumplimiento del propietario de bienes excluidos.

El incumplimiento de los deberes establecidos en la resolución por parte de los propietarios de los bienes excluidos determinará la expropiación por el incumplimiento de la función social de la propiedad o, en su caso, el ejercicio de la vía de apremio.

\section{Sección $4 .^{a}$}

Sistema de concierto

\section{Artículo 150. Características del sistema.}

1. El sistema de concierto podrá utilizarse cuando todos los terrenos del polígono, excepto los de uso y dominio público, en su caso, pertenezcan a un único propietario, o bien cuando todos los propietarios del polígono garanticen solidariamente la actuación.

2. En el sistema de concierto asumirá el papel de urbanizador el propietario único, o bien el conjunto de propietarios que garanticen solidariamente la actuación.

Artículo 151. Formas de gestión del sistema.

1. En el sistema de concierto la gestión de la actividad de ejecución podrá ser realizada: a. Mediante la constitución en escritura pública por todos los propietarios de una entidad urbanística de gestión, que tendrá naturaleza administrativa y duración limitada a la de la actuación, salvo que asuma también la conservación de la urbanización realizada. A estos efectos, la escritura pública de constitución deberá contener los estatutos por los que se regirá la entidad así como una propuesta de equidistribución.

b. A través de sociedad mercantil constituida al efecto, siempre que en su capital participen todos los propietarios.

c. Directamente por el único propietario de la totalidad de los terrenos afectados.

2. Tanto a la entidad urbanística de gestión como a la sociedad constituida por los propietarios podrán incorporarse, como miembros o socios, personas o entidades que aporten financiación o asuman la realización de las obras de urbanización y edificación precisas en los términos fijados por los particulares, que deberán ser aprobados por el municipio competente.

Artículo 152. Sociedad mercantil.

1. Los propietarios deberán, en todo caso, aportar a la sociedad mercantil que constituyan para la gestión y ejecución de la actuación la totalidad de los terrenos, edificaciones y construcciones de que sean titulares en el ámbito del polígono de actuación.

2. El municipio estará representado, al menos, por un Conselleiro o Administrador, que ostentará el derecho de veto suspensivo, por tiempo máximo de un mes, de cualquier acuerdo social, ejercitable en el acto de votación, si estuviera presente, o en los cinco días hábiles siguientes a la fehaciente notificación del mismo si no asistiese a la reunión social.

En todo caso, el procedimiento habrá de ser resuelto dentro del plazo de un mes desde la formulación del veto suspensivo $y$, durante el tiempo de vigencia de aquél, el municipio y la sociedad podrán llegar a una solución acordada. 
Artículo 153. Procedimiento.

1. La propuesta de equidistribución formulada por los propietarios afectados y formalizada en escritura pública será sometida a información pública durante veinte días mediante anuncio publicado en el "Boletín Oficial" de la provincia e informada por los servicios municipales correspondientes, siendo elevada al municipio para que se pronuncie sobre la aprobación definitiva.

2. El proyecto de equidistribución se entiende aprobado si transcurre un mes desde la finalización de la información pública sin que se haya producido acuerdo expreso de aprobación, siempre que no se hubieran formulado reparos $\mathrm{u}$ objeciones por los afectados.

\section{Sección 5. ${ }^{\mathrm{a}}$}

\section{Sistema de compensación}

Artículo 154. Concepto.

En el sistema de compensación, los propietarios aportan los terrenos de cesión obligatoria, realizan a su costa la urbanización en los términos y condiciones que se determinen en el plan y se constituyen en Junta de Compensación.

Artículo 155. Constitución de la Junta de Compensación.

1. Cuando el sistema de compensación venga establecido en el planeamiento para un determinado polígono, su efectiva aplicación requerirá que los propietarios presenten el proyecto de estatutos y de bases de actuación, y que en el momento de aprobación definitiva de aquéllos superen el 50 por 100 de la superficie del polígono. Dicha iniciativa habrá de presentarse en el plazo máximo de tres meses, a contar desde la aprobación definitiva del planeamiento detallado.

2. La Administración procederá a su aprobación inicial, salvo que infringieran las normas legales aplicables, publicará el acuerdo de aprobación en el "Boletín Oficial" de la provincia y en uno de los periódicos de mayor circulación, y lo someterá a información pública por plazo de veinte días. Simultáneamente lo notificará de forma individual a los propietarios o titulares de derechos de contenido patrimonial en el polígono, a fin de que, por idéntico término, formulen las alegaciones pertinentes sobre el proyecto de las bases de actuación y de los estatutos, rechazando cualquier otra objeción o reparo, y soliciten su incorporación. Concluida la fase de información pública, el órgano municipal competente habrá de otorgar la aprobación definitiva en el plazo máximo de un mes, transcurrido el cual se entenderá aprobado por silencio administrativo.

Se podrá prescindir de este procedimiento de aprobación de bases y estatutos de la Junta de Compensación si el Ayuntamiento previamente hubiera aprobado, con carácter general, un modelo de bases y estatutos, con información pública y publicación en el "Boletín Oficial" de la provincia, y los propietarios que representaran, al menos, el 70 por 100 de la superficie del polígono hubieran consentido su aplicación, en escritura pública o documento administrativo fehaciente en el plazo establecido en el número 1.

3. La Junta de Compensación habrá de constituirse en el plazo máximo de un mes, desde la aprobación definitiva de estatutos y bases de actuación o, en su caso, desde que los propietarios hubieran consentido la aplicación del modelo general de bases y estatutos aprobado por el municipio.

A estos efectos se requerirá a todos los propietarios, mediante notificación individualizada, para que constituyan la Junta de Compensación en el plazo indicado.

4. La Junta de Compensación tendrá naturaleza administrativa, personalidad jurídica propia y plena capacidad para el cumplimiento de sus fines.

5. Un representante del municipio formará parte del órgano rector de la Junta 
de Compensación en todo caso, siendo designado en el acuerdo de aprobación definitiva de las bases y estatutos.

6. Los acuerdos de la Junta de Compensación se adoptarán por mayoría simple de las cuotas de participación, salvo el de aprobación del proyecto de compensación, que requerirá la mayoría absoluta de cuotas, y aquellos otros para los cuales los estatutos exijan una mayoría cualificada.

7. Los acuerdos de la Junta de Compensación serán recurribles ante el municipio.

Artículo 156. Incorporación de propietarios a la Junta de Compensación.

1. Los propietarios del polígono que no hubiesen solicitado el sistema podrán incorporarse con igualdad de derechos y obligaciones a la Junta de Compensación, si no lo hubieran hecho en un momento anterior, dentro del plazo de un mes, a partir de la notificación del acuerdo de aprobación definitiva de los estatutos y bases de actuación de la Junta de Compensación o de la certificación administrativa de aplicación a este polígono concreto de las bases y estatutos aprobados con carácter general por el municipio. Transcurrido dicho plazo, la incorporación sólo será posible si no entorpece el desarrollo del proceso y lo aprueba la Junta de Compensación, de conformidad con sus estatutos. $\mathrm{Si}$ algunos propietarios del polígono no se hubieran incorporado a la Junta de Compensación, ésta podrá solicitar del municipio o bien la expropiación de dichas fincas, teniendo la condición de beneficiaria de la misma, o bien la ocupación de dichas fincas en favor de la Junta de Compensación a fin de posibilitar la ejecución de las obras de urbanización previstas, reconociéndose a sus titulares el derecho a la adjudicación de terrenos edificables en proporción a la superficie aportada con la reducción adecuada para compensar los gastos de urbanización correspondientes. En este último caso, aun cuando los terrenos hubieran quedado directamente afectados al cumplimiento de las obligaciones inherentes al sistema, la Junta de Compensación sólo actuará como fiduciaria con pleno poder dispositivo sobre las fincas que pertenezcan a los propietarios incorporados voluntariamente a la misma.

En todo caso, si los propietarios afectados por la ocupación hubieran demostrado que sus terrenos constituyen la única o predominante fuente de ingresos con que cuentan, tendrán derecho a percibir una indemnización equivalente a la rentabilidad demostrada durante el período que medie entre la ocupación efectiva y la adjudicación que les corresponda, o a la expropiación de su derecho.

2. Podrán también incorporarse a la Junta de Compensación empresas urbanizadoras que vayan a participar con los propietarios en la gestión del polígono.

Artículo 157. Proyecto de compensación.

1. Con arreglo a lo establecido en las bases de actuación, la Junta de Compensación formulará el correspondiente proyecto de compensación. Para la definición de derechos aportados, valoración de las fincas resultantes, reglas de adjudicación, aprobación, efectos del acuerdo aprobatorio e inscripción en el Registro de la Propiedad del mencionado proyecto se estará a lo dispuesto en el capítulo IV de este título. No obstante lo anterior, por acuerdo unánime de todos los afectados pueden adoptarse criterios diferentes, siempre que no sean contrarios a la Ley o al planeamiento aplicable, ni lesivos para el interés público o de terceros.

2. En el proyecto de compensación deberá incluirse la valoración y correspondiente indemnización de los derechos que se extingan. Podrá acudirse ante el Jurado de Expropiación de Galicia en caso de discrepancia con la valoración aprobada en el proyecto de compensación.

Sin embargo, la aprobación definitiva del proyecto de compensación constituirá 


\section{Ordenación del territorio y...}

título suficiente para la ocupación de los inmuebles que correspondan, una vez que se constituya en depósito o se efectúe el pago de las indemnizaciones a que se refiere este número.

3. El proyecto de compensación será aprobado con arreglo al procedimiento establecido por el artículo 117 de la presente ley, con la salvedad de que la aprobación inicial corresponderá a la Junta de Compensación y la aprobación definitiva al Ayuntamiento ${ }^{403}$.

Artículo 158. Junta de Compensación y transmisión de terrenos.

1. La incorporación de los propietarios a la Junta de Compensación no presupone, salvo que los estatutos dispusieran otra cosa, la transmisión a la misma de los inmuebles afectados a los resultados de la gestión común.

En todo caso, los terrenos quedarán directamente afectados al cumplimiento de las obligaciones inherentes al sistema, con anotación en el Registro de la Propiedad en la forma que determina la legislación estatal.

2. Las Juntas de Compensación actuarán como fiduciarias con pleno poder dispositivo sobre las fincas pertenecientes a los propietarios miembros de aquéllas, sin más limitaciones que las establecidas en los estatutos.

3. La transmisión a la Administración correspondiente de todos los terrenos de cesión obligatoria, en pleno dominio y libre de cargas, tendrá lugar por ministerio de la Ley con la aprobación definitiva del proyecto de compensación.

4. A las transmisiones de terrenos que se realicen como consecuencia de la constitución de la Junta de Compensación por aportación de los propietarios del polígono, en caso de que así lo dispusieran los

403 Art. 157.3 modificado por Ley $15 / 2004$, de 29 de diciembre, de modificación de la Ley 9/2002, de 30 de diciembre, de ordenación urbanistica y protección del medio rural de Galicia. estatutos, y a las adjudicaciones de solares que se realicen a favor de los propietarios en proporción a los terrenos incorporados por aquéllos se les aplicarán las exenciones tributarias que establece la legislación estatal o autonómica correspondiente, en especial, las previstas en el artículo 159.4 del Real Decreto Legislativo 1/1992, de 26 de junio.

Artículo 159. Responsabilidad de la Junta de Compensación y obligaciones de sus miembros.

1. La Junta de Compensación será directamente responsable, frente a la administración competente, de la urbanización completa del polígono y, en su caso, de la edificación de los solares resultantes, cuando así se hubiese establecido.

2. El incumplimiento por los miembros de la Junta de Compensación de las obligaciones y cargas impuestas por la presente ley habilitará al municipio para expropiar sus respectivos derechos en favor de la Junta de Compensación, que tendrá la condición jurídica de beneficiaria.

3. Las cantidades adeudadas a la Junta de Compensación por sus miembros podrán ser exigidas por vía de apremio, previa petición de la Junta de Compensación al municipio.

Artículo 160. Sustitución del sistema de compensación.

1. En el supuesto de que no se consiga la participación voluntaria de propietarios que representen la superficie requerida para la determinación del sistema de compensación y aprobación de estatutos, bases de actuación y proyecto de compensación, quienes estén dispuestos a promover la ejecución podrán solicitar del municipio la sustitución del sistema por alguno de los sistemas de actuación directos o el de concesión de obra urbanizadora.

2. Los propietarios que formulen esta petición y se comprometan a hacer efectivas sus obligaciones conservarán la plenitud de sus derechos y podrán realizar las 
operaciones de colaboración previstas en los sistemas de actuación directos siempre que cumplan las condiciones establecidas para cada supuesto.

\section{Sección $6 .^{\mathrm{a}}$}

Sistema de concesión de obra urbanizadora

Artículo 161. Características del sistema.

1. El sistema de concesión de obra urbanizadora es un sistema de actuación indirecta en el que el municipio otorga al agente urbanizador o concesionario la realización de las obras de urbanización, procediendo éste a la distribución de los beneficios y cargas correspondientes, obteniendo su retribución en terrenos edificables o en metálico conforme a lo convenido con el municipio.

2. Sin perjuicio de lo dispuesto en el artículo 160 de la presente ley, una vez transcurrido el plazo de dos años a contar desde la aprobación definitiva del planeamiento detallado que ordene el polígono, la aplicación efectiva de este sistema podrá acordarse de oficio por el municipio o por iniciativa de cualquier persona aunque no sea propietaria de suelo en el ámbito de actuación.

Artículo 162. Procedimiento.

1. En caso de iniciativa pública, el municipio aprobará las bases que regirán el concurso para la selección de la oferta, que deberán incluir como mínimo los extremos previstos en el apartado $2 \mathrm{del}$ presente artículo.

El procedimiento de selección y adjudicación de la concesión se regirá por las disposiciones contenidas en la legislación de contratos de las Administraciones públicas.

2. En los supuestos de iniciativa privada, la propuesta de los particulares para participar de la acción urbanizadora deberá contener los siguientes documentos:

a. Proposición jurídico-económica que habrá de incluir los compromisos adquiridos voluntariamente por el promotor de la iniciativa, las garantías financieras y reales, los plazos de inicio y conclusión de las obras de urbanización y, en su caso, de edificación, además de las cláusulas penales previstas para el supuesto de incumplimiento.

b. Las condiciones económicas dirigidas a los propietarios de suelo, que incluirán la oferta de compra de terrenos, por precio determinado, y la oferta de incorporación al proceso urbanizador, especificando la retribución que corresponda al urbanizador en terrenos edificables o en metálico a través de las cuotas de urbanización. En caso de no existir acuerdo, la valoración se realizará con arreglo a lo dispuesto en la legislación básica estatal.

c. Un anteproyecto de urbanización detallado, que permita evaluar correctamente las calidades y ofertas económicas presentadas, así como las cesiones y compensaciones que estime oportunas superiores a las previstas en la Ley.

3. Presentada la iniciativa, el municipio en un plazo de dos meses podrá desestimarla por causas justificadas, incluidas las referidas al ejercicio de la potestad de planeamiento.

4. En caso de asumir la iniciativa privada, se procederá a tramitar un procedimiento de concurrencia, con las siguientes particularidades:

a. Durante el período de información pública, que no podrá ser inferior a un mes, podrán ser presentadas mejoras o alternativas a la iniciativa formulada.

b. El Pleno de la Corporación elegirá entre las proposiciones presentadas la que estime más adecuada a los intereses públicos, otorgando el título concesional donde deberán figurar las cláusulas, obligaciones y derechos del concesionario.

5. Los propietarios que rechacen la oferta de compra y de incorporación al proceso urbanizador serán expropiados y se procederá a la ocupación urgente de los terrenos. 
Artículo 163. Responsabilidad.

El coste de las inversiones, instalaciones, obras y compensaciones necesarias para ejecutar el planeamiento será garantizado en forma y proporción suficientes y financiado por el urbanizador responsable de la actuación, quien podrá repercutirlo en la propiedad de los solares resultantes.

Artículo 164. Retribución.

1. El urbanizador obtendrá su retribución a costa de los propietarios, en terrenos edificables o en metálico, en los términos establecidos en la concesión.

2. La retribución en terrenos se hará efectiva mediante la reparcelación.

3. La retribución en metálico se hará efectiva mediante cuotas de urbanización acordadas entre urbanizador y propietarios o, en su defecto, aprobadas por el municipio, que habrán de satisfacer los propietarios, quedando sujetos los terrenos al pago de tales cuotas, como carga real, que figurará en el proyecto de reparcelación. El urbanizador podrá solicitar del municipio la exacción por vía de apremio de las cuotas adeudadas por los propietarios.

\section{Capítulo VII \\ OBTENCIÓN DE TERRENOS \\ DE SISTEMAS GENERALES \\ Y DE DOTACIONES PÚBLICAS}

Artículo 165. Definiciones.

1. Se entiende por terrenos destinados a dotaciones públicas los de titularidad del municipio o, en su caso, de la Comunidad Autónoma que tienden a satisfacer necesidades colectivas e implantar usos o servicios públicos, teniendo el carácter de bienes de dominio público.

2. Son terrenos de sistemas generales los dotacionales públicos que están diseñados o previstos para el servicio de la totalidad del municipio y, en especial, para implantar las infraestructuras básicas del modelo de ciudad.

3. No tendrán el carácter de sistemas generales los terrenos, instalaciones e infraestructuras de titularidad estatal o autonómica de carácter supramunicipal que no estén contemplados en el plan general, y cuya vocación exceda del servicio al municipio, sin perjuicio de lo dispuesto en la legislación sectorial de aplicación.

4. Son terrenos destinados a dotaciones locales los dotacionales públicos de titularidad del municipio, que están diseñados o previstos predominantemente para el servicio del polígono o sector, en su caso.

Artículo 166. Obtención de los sistemas generales.

1. Los terrenos destinados a sistemas generales que hayan de implantarse sobre suelo rústico o urbano consolidado se obtendrán mediante expropiación forzosa, por convenio entre la Administración y el propietario o por permuta forzosa con terrenos del patrimonio municipal del suelo. Tanto en el supuesto del convenio como en el caso de la permuta forzosa se tasará previamente por los técnicos municipales el valor de los terrenos a obtener y el de los aprovechamientos o suelos municipales conforme a los criterios de valoración establecidos en la legislación estatal aplicable.

2. La expropiación de los terrenos de sistemas generales deberá realizarse dentro de los cinco años siguientes a la aprobación del planeamiento detallado que legitime su ejecución.

3. Los terrenos destinados por el planeamiento a sistemas generales en suelo urbano no consolidado y en suelo urbanizable o, en su caso, suelo rústico incluido en un área de reparto se obtendrán:

a. Por cesión obligatoria derivada de su inclusión o adscripción en un área de reparto y en el correspondiente polígono.

b. Por ocupación directa.

c. Por permuta forzosa.

d. Mediante expropiación forzosa.

e. Por convenio urbanístico, debiendo incluirse entre sus cláusulas las previsiones necesarias para compensar a los propietarios, bien en metálico o bien 
mediante aprovechamiento lucrativo de titularidad municipal.

4. La obligación de cesión gratuita de los terrenos destinados a sistemas generales incluye también la realización de las obras de urbanización, de las instalaciones e infraestructuras, en las condiciones que establezca el plan general.

Artículo 167. Obtención de terrenos destinados a dotaciones locales.

1. Los terrenos destinados por el planeamiento a dotaciones locales en suelo urbano consolidado se obtendrán mediante expropiación forzosa, por convenio entre la Administración y el propietario o por permuta forzosa con terrenos del patrimonio municipal del suelo.

2. Los terrenos destinados a dotaciones locales en suelo urbano no consolidado y en suelo urbanizable se obtendrán mediante cesión obligatoria y gratuita a través del sistema de actuación que se adopte o por expropiación, ocupación directa o permuta forzosa.

3. La obligación de cesión gratuita de los terrenos destinados a dotaciones de carácter local incluye también su urbanización, a costa de los propietarios incluidos en el correspondiente polígono.

Artículo 168. Permuta forzosa.

1. Los terrenos destinados a sistemas generales o dotaciones públicas locales podrán obtenerse mediante permuta forzosa con terrenos pertenecientes al patrimonio público de suelo y que sea de características adecuadas para servir de soporte al aprovechamiento urbanístico que corresponda subjetivamente a su propietario, salvo que por éste se acepte voluntariamente la entrega de terrenos que no cumplan este requisito.

2. La permuta forzosa de terrenos requiere que previamente se haya determinado:

a. El aprovechamiento urbanístico que corresponde al propietario afectado.

b. Los terrenos pertenecientes al patrimonio público de suelo que van a ser permutados. c. De no poder ser materializada la totalidad del aprovechamiento, la indemnización a satisfacer en metálico por la parte de aprovechamiento no materializable en los mismos.

3. La permuta forzosa de terrenos se llevará a cabo por el procedimiento previsto en el artículo 170, debiendo incluirse en el acta la descripción de los terrenos del patrimonio público de suelo objeto de la permuta y, en su caso, la indemnización complementaria y el momento de su abono.

Artículo 169. Ocupación directa.

1. Se entiende por ocupación directa la obtención de terrenos destinados a sistemas generales y dotaciones públicas locales mediante el reconocimiento a su titular del derecho al aprovechamiento en el polígono al que se vincule.

2. La ocupación directa requiere que esté aprobada la ordenación pormenorizada, tanto de los terrenos a ocupar, con determinación del aprovechamiento que corresponda a sus propietarios, como del polígono en que hayan de integrarse.

Artículo 170. Procedimiento para la ocupación directa.

1. El procedimiento de aplicación de la ocupación directa se ajustará a las disposiciones reglamentarias que se dicten y, en todo caso, a las siguientes reglas:

a. La Administración actuante publicará en el "Boletín Oficial" de la provincia la relación de los terrenos y propietarios afectados, los aprovechamientos urbanísticos correspondientes a cada uno de ellos y el polígono donde habrán de hacerse efectivos sus derechos.

Asimismo y de modo simultáneo se notificará a los propietarios y titulares de derechos de contenido económico sobre los terrenos la ocupación prevista y el resto de circunstancias relevantes.

b. Se abrirá un período de información pública durante un plazo de veinte días para efectuar alegaciones. Simultáneamente se 
solicitará por el municipio certificación de dominio y cargas al Registro de la Propiedad, así como la práctica de los asientos que procedan.

c. La ocupación sólo podrá llevarse a cabo transcurrido el plazo de veinte días a contar desde la notificación o publicación, levantándose acta en la que se harán constar al menos:

$1^{\circ}$. Lugar y fecha de otorgamiento.

$2^{\circ}$. Identificación de los titulares de los terrenos a ocupar o de derechos sobre éstos y su situación registral.

$3^{\circ}$. Superficie a ocupar y aprovechamiento urbanístico que le corresponda.

$4^{\circ}$. Polígono donde se hará efectivo este aprovechamiento.

d. En caso de propietarios desconocidos, no comparecientes, incapacitados sin persona que les represente, o cuando se trate de propiedad litigiosa, se entenderán las actuaciones con el Ministerio Fiscal.

e. El municipio expedirá a favor de cada uno de los propietarios de terrenos ocupados certificación de los extremos señalados en el apartado c) de este artículo, remitiendo a la vez una copia de dicha certificación, acompañada del correspondiente plano, al Registro de la Propiedad para inscribir la superficie ocupada a favor del municipio, en los términos que resulten de la legislación estatal aplicable.

f. Transcurridos cuatro años sin que se haya procedido a la ejecución del planeamiento en el polígono donde los propietarios hubieran sido integrados, éstos tendrán derecho a exigir de la Administración que se inicie el expediente expropiatorio de sus terrenos, en los términos y con el procedimiento establecido en el artículo 99 de la presente ley.

2. Los propietarios y titulares de derechos de contenido patrimonial afectados por las ocupaciones reguladas en este artículo tendrán derecho a ser indemnizados en los términos establecidos en la legislación estatal sobre expropiación forzosa que resulte aplicable, por el período que medie desde la ocupación hasta la aprobación definitiva del instrumento de equidistribución.

\section{Capítulo VIII \\ INSTRUMENTOS DE EJECUCIÓN DE LOS PLANES EN SUELO DE NÚCLEO RURAL}

Artículo 171. Sistema de cesión de viales.

El sistema de cesión de viales en el suelo de núcleo rural se aplicará conforme a las siguientes reglas:

a. Los propietarios deberán ceder al municipio los terrenos destinados por el planeamiento a viales, fuera de las alineaciones, que resulten necesarios para que la parcela sea edificable con arreglo a las determinaciones de la presente ley y del planeamiento.

b. El cumplimiento efectivo del deber de cesión tendrá lugar con la solicitud de la licencia. Esta cesión se formalizará en documento público, acompañado de plano o documento gráfico en donde se exprese con precisión la superficie objeto de cesión conforme a las alineaciones establecidas.

c. Los propietarios deberán urbanizar su parcela en los términos del artículo siguiente.

Artículo 172. Conexiones y urbanización en la cesión de viales.

1. La ejecución de las actuaciones integrales previstas por un plan especial de protección, rehabilitación y mejora del medio rural se llevará a cabo por alguno de los sistemas de actuación regulados en el capítulo VI del título IV de la presente ley.

2. Para edificar en el ámbito de los núcleos rurales, incluida su área de expansión, deberá ejecutarse la conexión con las redes de servicio existentes en el núcleo rural o sus proximidades. De no existir, deberán resolverse por medios individuales con cargo al promotor de la edificación y con el compromiso de conexión cuando se implanten los servicios. 
Una vez aprobado definitivamente el plan especial de protección, rehabilitación y mejora del medio rural, deberán implantarse las redes de servicios e instalaciones que resulten necesarias para el suministro de agua y de energía eléctrica y para la evacuación y depuración de las aguas residuales y, en su caso, realizarse la conexión con las redes existentes en el núcleo rural o sus proximidades 404 .

3. Podrá autorizarse la ejecución simultánea de las obras de acometida, urbanización y edificación. El municipio deberá exigir garantías suficientes del cumplimiento de esta obligación.

Artículo 173. Obtención de dotaciones en los núcleos rurales.

Los terrenos destinados a dotaciones públicas podrán obtenerse mediante expropiación forzosa, convenio urbanístico entre la Administración y los propietarios o permuta forzosa.

En el supuesto previsto en el apartado 3 del artículo 24, por cesión obligatoria y gratuita o por ocupación directa.

\section{TÍTULO V INSTRUMENTOS DE INTERVENCIÓN EN EL MERCADO DEL SUELO}

\section{Capitulo I \\ PATRIMONIOS PÚBLICOS DEL SUELO}

\section{Artículo 174. Constitución.}

1. Los ayuntamientos habrán de constituir el patrimonio municipal del suelo con la finalidad de obtener reservas de suelo para actuaciones de iniciativa pública, facilitar la ejecución de la ordenación territorial y urbanística y contribuir a la reglamentación del mercado de terrenos destinados al desarrollo urbanístico.

2. También habrá de constituir su propio patrimonio de suelo la Administración autonómica en colaboración con los

$\overline{404}$ Art. 172.1 y 172.2 modificados por Ley $15 / 2004$, de 29 de diciembre, de modificación de la Ley $9 / 2002$, de 30 de diciembre, de ordenación urbanistica y protección del medio rural de Galicia. ayuntamientos, al objeto de atender la demanda de vivienda de protección pública y de suelo para el desarrollo de actividades empresariales.

3. La Administración autonómica habrá de constituir también un inventario de suelo para vivienda pública, en el que se incluirán los terrenos dotacionales obtenidos por la Administración autonómica en virtud de lo dispuesto en los artículos 22.h) y 47.10 de la presente ley ${ }^{405}$.

Artículo 175. Reservas de terrenos.

1. El plan general podrá establecer, en cualquier clase de suelo con excepción del rústico, reservas de terrenos de posible adquisición para la constitución o ampliación por la administración correspondiente de su patrimonio público de suelo.

2. El establecimiento o la delimitación de las reservas de terrenos con la finalidad expresada en el número 1 comporta:

a. La declaración de la utilidad pública y la necesidad de la ocupación a efectos de expropiación forzosa por un tiempo máximo de cuatro años, prorrogable una sola vez por otros dos años. La prórroga deberá fundarse en causa justificada y acordarse, de oficio o a instancia de parte, previa información pública $\mathrm{y}$ audiencia de los propietarios afectados por plazo común de veinte días.

La eficacia de la prórroga requerirá la publicación en el "Diario Oficial de Galicia".

b. La sujeción de todas las transmisiones que se efectúen en las zonas de reservas a los derechos de tanteo y retracto previstos en la presente ley en favor de la Administración correspondiente.

3. Los plazos de vigencia de la declaración de la utilidad pública y la necesidad de ocupación, y de su eventual prórroga, cuando se trate de suelo urbano, serán la mitad de los expresados en el apartado anterior.

405 Art. 174 modificado por Ley 6/2008, de 19 de junio, de medidas urgentes en materia de vivienda y suelo, por la que se modifica la Ley $9 / 2002$, de 30 de diciembre, de ordenación urbanistica y protección del medio rural de Galicia. 
Artículo 176. Bienes que integran el patrimonio municipal del suelo.

1. Los bienes del patrimonio municipal del suelo constituyen un patrimonio diferenciado de los restantes bienes municipales y los ingresos obtenidos mediante la enajenación de parcelas, o del aprovechamiento que corresponda a terrenos de titularidad municipal, se destinarán a los fines previstos en el artículo 177 de la presente ley.

2. Integrarán el patrimonio municipal del suelo:

a. Los bienes patrimoniales que resultasen clasificados por el planeamiento urbanístico como suelo urbano o urbanizable.

b. Los terrenos y las edificaciones o construcciones obtenidas en virtud de las cesiones correspondientes a la participación de la Administración en el aprovechamiento urbanístico, así como las adquisiciones de bienes o dinero obtenidos con ocasión de la gestión urbanística.

c. Los terrenos y las edificaciones o construcciones adquiridos, en virtud de cualquier título y en especial mediante expropiación, por la Administración titular con el fin de su incorporación al correspondiente patrimonio de suelo y los que lo sean como consecuencia del ejercicio de los derechos de tanteo y retracto previstos en la presente ley.

d. Cesiones en especie o en metálico derivadas de deberes u obligaciones, legales o voluntarias, asumidos en convenios, concursos públicos o plasmadas en instrumentos de gestión urbanística.

e. Los ingresos obtenidos mediante enajenación de terrenos incluidos en los patrimonios públicos de suelo.

Artículo 177. Destino de los patrimonios públicos del suelo y del inventario del suelo para vivienda pública ${ }^{406}$.

406 Rúbrica del art. 177 modificada por Ley 6/2008, de 19 de junio, de medidas urgentes en materia de vivienda y suelo, por la que se modifica la Ley $9 / 2002$, de 30 de diciembre, de ordenación urbanistica y protección del medio rural de Galicia..
1. Los bienes del patrimonio municipal del suelo deberán ser destinados a alguno de los siguientes fines:

a. Construcción de viviendas sujetas a algún régimen de protección pública.

b. A la propia planificación y gestión urbanística, en especial al pago en especie, mediante permuta, de los terrenos destinados a sistemas generales y dotaciones públicas.

c. Actuaciones públicas dotacionales, sistemas generales u otras actividades de interés social.

d. Conservación y mejora del medio ambiente, del medio rural y del patrimonio cultural construido.

e. Creación de suelo para el ejercicio de actividades empresariales compatibles con el desarrollo sostenible.

f. Conservación y ampliación del propio patrimonio.

2. La enajenación o permuta de los bienes de carácter patrimonial que constituyen el patrimonio público del suelo de la Administración autonómica o local se realizará, de acuerdo con lo contemplado en la normativa sectorial correspondiente, mediante concurso público por procedimiento abierto, en la forma establecida en la legislación de contratos de las administraciones públicas y patrimonial.

No podrán enajenarse o permutarse bienes del patrimonio público de suelo hasta tanto éste y el registro de solares se hayan constituido formalmente.

En el pliego de condiciones se determinará, como mínimo, lo siguiente:

a. Plazos máximos de edificación y, en su caso, de urbanización.

b. Precios finales máximos de venta o alquiler de las futuras edificaciones.

c. Condiciones que impidan ulteriores enajenaciones por precio superior al de adquisición.

d. Índices de referencia para la actualización de los precios señalados en las letras b) y c) anteriores. 
Si el concurso quedase desierto, podrá enajenarse directamente dentro del plazo máximo de un año, en las mismas condiciones ${ }^{407}$.

3. Cuando exista demanda de viviendas sujetas a algún régimen de protección pública, al menos, el 50 por 100 de los bienes y derechos obtenidos con cargo al 10 por 100 de cesión obligatoria serán destinados preferentemente a cubrir dicha necesidad.

4. Los municipios podrán ceder gratuitamente los bienes incluidos en el patrimonio municipal del suelo, en los supuestos previstos en la legislación vigente y cumpliendo los requisitos establecidos en la misma, observando su finalidad urbanística con destino a la vivienda de promoción pública o para equipamientos comunitarios, debiendo constar en documento público la cesión y el compromiso de los adquirentes.

5. Si transcurriesen dos años desde que los terrenos integrantes del patrimonio municipal de suelo a que hace referencia el apartado tres adquirieran la condición de solar, o el plazo menor que pueda establecer el planeamiento para la edificación, sin que dicho proceso haya concluido por causas imputables a la administración titular, el Consello de la Xunta de Galicia, previo requerimiento exigido por el artículo 208 de la Ley 5/1997, de Administración local de Galicia, podrá promover la construcción de viviendas sujetas a algún régimen de protección hasta la finalización completa del proceso.

6. Los terrenos del inventario de suelo para vivienda pública al que hace referencia el apartado 3 del artículo 174 tendrán la condición de bienes demaniales, y se adscribirán al Instituto Gallego de la Vivienda y Suelo (IGVS), organismo autónomo adscrito a la Consellería de Vivienda y Suelo. Una vez obtenidos dichos terrenos y alcanzada la condición de solar, se procederá

407 Art. 177.2 modificado por Ley 6/2008, de 19 de junio, de medidas urgentes en materia de vivienda y suelo, por la que se modifica la Ley 9/2002, de 30 de diciembre, de ordenación urbanistica y protección del medio rural de Galicia.. a la construcción de tales viviendas a través del Instituto Gallego de la Vivienda y Suelo o de los organismos o entidades dependientes del mismo.

Una vez construidas y recepcionadas por la administración, estas viviendas se destinarán a uso y aprovechamiento de aquéllos que, mediante los procedimientos y con el cumplimiento de las condiciones que exija la legislación aplicable, resultasen adjudicatarios. El uso y el aprovechamiento se llevarán a cabo de forma que se garantice en todo caso la titularidad pública de las viviendas por tiempo indefinido ${ }^{408}$.

\section{Capítulo II DERECHO DE SUPERFICIE}

Artículo 178. Derecho de superficie. 1. Las Entidades Locales y las demás personas públicas podrán constituir el derecho de superficie en terrenos de su propiedad o integrantes del patrimonio municipal del suelo, con destino a la construcción de viviendas sujetas a algún régimen de protección pública o a otros usos de interés social, cuyo derecho corresponderá al superficiario.

2. En estos supuestos, se aplicará el régimen establecido en la legislación del Estado.

3. El derecho de superficie se extinguirá si no se edifica en el plazo fijado en la licencia o, en todo caso, en el establecido supletoriamente en la presente ley.

\section{Capítulo III DERECHOS DE TANTEO Y RETRACTO}

Artículo 179. Delimitación de áreas. 1. A efectos de garantizar el cumplimiento de las previsiones temporales del planeamiento, incrementar el patrimonio de suelo y, en general, facilitar el cumplimiento de los objetivos de aquél, los

408 Art. 177.5 y 177.6 añadidos por Ley 6/2008, de 19 de junio, de medidas urgentes en materia de vivienda y suelo, por la que se modifica la Ley $9 / 2002$, de 30 de diciembre, de ordenación urbanistica y protección del medio rural de Galicia. 
municipios podrán delimitar áreas en las cuales las transmisiones onerosas de terrenos quedarán sujetas al ejercicio de los derechos de tanteo y retracto por la Corporación respectiva.

2. Al delimitarse estas áreas habrá de establecerse si las transmisiones sujetas al ejercicio de tales derechos son sólo las de terrenos sin edificar, tengan o no la condición de solares, o se incluyen también las de terrenos con edificación que no agote el aprovechamiento permitido por el plan, con edificación en construcción, ruinosa o disconforme con la ordenación aplicable.

3. Podrá igualmente disponerse en el acuerdo de delimitación de áreas la sujeción al ejercicio de los expresados derechos de las transmisiones de viviendas en construcción o construidas, siempre que el transmitente hubiera adquirido del promotor $\mathrm{y}$, en el segundo caso, la transmisión se proyecte antes de transcurrido un año desde la terminación del edificio.

4. Si el ámbito delimitado estuviese previamente declarado, en todo o en parte, como área de rehabilitación integrada, podrá también establecerse en el correspondiente acuerdo que el ejercicio de los derechos de tanteo y retracto abarcará incluso las fincas edificadas conforme a la ordenación aplicable, tanto en el supuesto de que la transmisión se proyecte o verifique en conjunto como fraccionadamente, en régimen o no de propiedad horizontal.

5. El plazo máximo de sujeción de las transmisiones al ejercicio de los derechos de tanteo y retracto será de diez años, salvo que, al delimitarse el área, se hubiera fijado otro menor.

Artículo 180. Procedimiento para la delimitación.

1. La delimitación de dichas áreas podrá efectuarse en el plan general o en el planeamiento de desarrollo.

En su defecto, podrá delimitarse previa información pública por plazo de veinte días en el "Boletín Oficial" de la provincia y notificación individualizada a los propietarios afectados.

2. En cualquier caso, entre la documentación específicamente relativa a la delimitación deberá figurar una memoria justificativa de la necesidad de someter las transmisiones a los derechos de tanteo y retracto, los objetivos a conseguir, la justificación del ámbito delimitado en relación con el conjunto del ámbito territorial no afectado y una relación de los bienes afectados y de sus propietarios, siendo preceptiva la notificación a éstos previa apertura del trámite de información pública.

3. Los municipios remitirán a los Registros de la Propiedad correspondientes copia certificada de los planos que reflejen la delimitación y relación detallada de las calles o sectores comprendidos en aquellas áreas y de los propietarios y bienes concretos afectados, mediante traslado de copia del acuerdo de delimitación.

Artículo 181. Notificación de la transmisión.

Los propietarios de bienes afectados por estas delimitaciones habrán de notificar al municipio la decisión de enajenarlos, con expresión del precio y forma de pago proyectados y restantes condiciones esenciales de la transmisión, a efectos del posible ejercicio del derecho de tanteo, durante un plazo de sesenta días naturales, a contar desde el siguiente al de la notificación.

Artículo 182. Ejercicio del derecho de retracto.

1. El municipio podrá ejercitar el derecho de retracto cuando no se le hubiese hecho la notificación prevenida en el artículo precedente, se omitiesen en la misma cualesquiera de los requisitos exigidos o resultase inferior el precio efectivo de la transmisión o menos onerosas las restantes condiciones de ésta.

2. Este derecho habrá de ejercitarse en el plazo de sesenta días naturales a contar desde el siguiente al de la notificación de la transmisión efectuada, que el adquirente 
deberá hacer, en todo caso, al municipio mediante entrega de copia de la escritura o documento en que se formalizase.

3. El derecho de retracto a que se refiere la presente ley tendrá carácter preferente a cualquier otro.

Artículo 183. Caducidad de la notificación.

1. Los efectos de la notificación para el ejercicio del derecho de tanteo caducarán a los tres meses siguientes a la misma.

2. La transmisión realizada transcurrido este plazo se entenderá efectuada sin dicha notificación, a los efectos del ejercicio del derecho de retracto.

Artículo 184. No inscripción registral. No podrán inscribirse en el Registro de la Propiedad las transmisiones efectuadas sobre los inmuebles incluidos en las expresadas delimitaciones, si no aparece acreditada la realización de las notificaciones contempladas en los artículos precedentes.

Artículo 185. Transmisiones de viviendas sujetas a protección pública.

1. Al objeto de garantizar el cumplimiento efectivo de las limitaciones sobre precios máximos de venta de las viviendas sujetas a cualquier régimen de protección pública que imponga dicha vinculación, los municipios podrán delimitar áreas en las cuales tanto las primeras como las ulteriores transmisiones onerosas de aquéllas queden sujetas a las notificaciones prevenidas en los artículos 181 y 182, a efectos del posible ejercicio de los derechos de tanteo y retracto en los plazos establecidos en los mismos.

2. La falta de acreditación del cumplimiento de estos requisitos de notificación impedirá la inscripción en el Registro de la Propiedad de la transmisión efectuada.

3. La tramitación de la delimitación de estas áreas se ajustará a lo prevenido en el artículo 180, siendo aplicable también, a los efectos previstos en el número anterior, lo dispuesto en el apartado 3 del citado artículo.

4. La Comunidad Autónoma, subsidiariamente o por acuerdo con el municipio implicado, podrá ejercer la delimitación de áreas o el derecho de tanteo y retracto a que se refiere este artículo.

Artículo 186. Adjudicación de viviendas.

Las viviendas adquiridas en el ejercicio del tanteo y retracto por la Administración serán adjudicadas mediante concurso entre quienes, no poseyendo otra vivienda, reúnan los demás requisitos establecidos por el régimen de protección pública aplicable.

Artículo 187. Derechos de tanteo y retracto en el suelo de núcleo rural.

1. Las transmisiones onerosas de terrenos, edificaciones y construcciones incluidas en el ámbito de los núcleos rurales catalogados de acuerdo con la presente ley quedarán sujetas al ejercicio de los derechos de tanteo y retracto por la Comunidad Autónoma de Galicia y el Ayuntamiento donde aquéllas se ubiquen. En cualquier caso, el ejercicio de estos derechos por la Comunidad Autónoma será preferente sobre el de la Administración Municipal.

2. El ejercicio de los derechos de tanteo y retracto se ajustará a lo dispuesto en este capítulo, debiendo en este caso efectuarse las notificaciones de la transmisión, además de al Ayuntamiento, al conselleiro competente en materia de urbanismo y ordenación del territorio.

\section{TÍTULO VI INTERVENCIÓN EN LA EDIFICACIÓN Y USO DEL SUELO Y DISCIPLINA URBANÍSTICA ${ }^{409}$ \\ Capítulo I \\ FOMENTO DE LA EDIFICACIÓN}

Artículo 188. Deber de edificar los solares.

1. Los propietarios de solares y de construcciones en ruina o inadecuados

409 Véase Decreto 28/1999, de 21 de enero, por el que se aprueba el Reglamento de disciplina urbanistica para el desarrollo y aplicación de la Ley del Suelo de Galicia. 
deberán emprender la edificación en los términos establecidos en la presente ley.

2. En el suelo urbanizable y en el suelo urbano no consolidado, el plazo para el cumplimiento del deber de edificar comenzará a contarse desde la conversión de los terrenos en solares.

3. Por lo que respecta al suelo urbano consolidado, el plazo para el cumplimiento del deber de edificar comenzará a contarse desde la aprobación definitiva del planeamiento urbanístico que contenga su ordenación detallada, aunque los terrenos no reúnan la condición de solar. En este último caso, el deber de edificar abarca también la obligación de dotar a la parcela de los elementos de urbanización necesarias para que se convierta en solar.

4. El deber de edificar y las disposiciones contenidas en el presente capítulo afectan igualmente a los propietarios de las fincas en las que existieren construcciones paralizadas, ruinosas, derruidas o inadecuadas al lugar en que radiquen, quienes deberán emprender la edificación en los plazos señalados en la presente ley. En caso de que el planeamiento prohíba la sustitución total o parcial de las edificaciones existentes o imponga la conservación de determinados elementos o su rehabilitación integral, el deber de edificar se entenderá como deber de rehabilitar, respetando, al materializarse los correspondientes aprovechamientos urbanísticos, los elementos dotados de protección.

Artículo 189. Plazos para edificar o rehabilitar.

1. Los plazos aplicables para el cumplimiento del deber de edificar o rehabilitar serán los fijados por el planeamiento general o de desarrollo en función de la clasificación y calificación del suelo y de las circunstancias específicas que concurran en determinadas áreas o solares, que serán apreciadas de forma motivada, siendo el plazo, en su defecto, de dos años.

Los plazos que se fijen para cumplir los deberes de edificación de las viviendas con protección pública no podrán ser superiores a los que se fijen para edificar las viviendas libres.

2. La administración podrá conceder prórrogas con una duración máxima conjunta de un año, a petición de los interesados, por causas justificadas y de forma motivada. No obstante lo anterior, no podrán concederse prórrogas para construcción de viviendas sujetas a algún régimen de protección si ya se hubieran otorgado licencias para construir la mitad de la edificabilidad residencial destinada a vivienda libre prevista en el polígono en que se ubique el solar ${ }^{410}$.

Artículo 190. Consecuencias del incumplimiento de los deberes de edificar o rehabilitar.

1. Si venciese el plazo concedido para cumplir los deberes de edificar o rehabilitar, incluidas sus eventuales prórrogas, el ayuntamiento decretará la inscripción obligatoria en el registro de solares. Transcurridos dos años desde la inscripción sin que se haya dado cumplimento al deber de edificar o, en su caso, de rehabilitar, el ayuntamiento decretará la edificación forzosa del solar, la rehabilitación forzosa del inmueble o, en su caso, su expropiación, bien de manera directa o a través de un particular, denominado agente edificador, de conformidad con las reglas establecidas en los artículos siguientes.

2. Si el ayuntamiento no adoptase las medidas a las que hace referencia el apartado anterior transcurrido un año desde que tuviera dicha obligación, el Consello de la Xunta de Galicia, previo requerimiento exigido por el artículo 208 de la Ley 5/1997, de Administración local de Galicia, podrá decretar, según corresponda, la inscripción obligatoria en el registro de solares, la edificación forzosa del solar, la rehabilitación forzosa del inmueble

410 Art. 189 modificado por Ley 6/2008, de 19 de junio, de medidas urgentes en materia de vivienda $y$ suelo, por la que se modifica la Ley $9 / 2002$, de 30 de diciembre, de ordenación urbanistica y protección del medio rural de Galicia. 
o, en su caso, su expropiación, bien de manera directa, a través de la consellaría que tenga las competencias en materia de vivienda o mediante los organismos o entidades dependientes de la misma, bien a través de un particular, denominado agente edificador, de conformidad con las reglas establecidas en los artículos siguientes ${ }^{411 .}$

Artículo 191. Actuación directa y a través de una sociedad urbanística.

1. La Administración Urbanística podrá aprobar programas de edificación forzosa, de forma simultánea al planeamiento que contenga la ordenación detallada, en los que se delimiten áreas prioritarias a los efectos de la edificación forzosa.

La Comunidad Autónoma podrá celebrar convenios con los Ayuntamientos a fin de colaborar en la gestión de los programas de edificación forzosa.

También se podrán aprobar programas de rehabilitación con el mismo contenido y determinaciones, en los que se regule la gestión de edificios que, de acuerdo con el planeamiento, deban ser objeto de rehabilitación integral o en los que deban conservarse algunos elementos.

2. Cuando se incumpla el deber de edificar en algún terreno incluido en dichas áreas, la Administración podrá expropiarlo a fin de asumir la edificación, o bien encomendar a una sociedad urbanística pública el desarrollo de la actuación. En este último caso, la sociedad urbanística actuará como beneficiaria de la expropiación y asumirá frente a la Administración el deber de edificar en los plazos que se fijen en el convenio que regule la actuación, que en ningún caso podrán ser más largos que los otorgados inicialmente al propietario.

3. La Administración notificará al propietario del terreno la iniciación del

411 Art. 190 modificado por Ley 6/2008, de 19 de junio, de medidas urgentes en materia de vivienda y suelo, por la que se modifica la Ley 9/2002, de 30 de diciembre, de ordenación urbanistica y protección del medio rural de Galicia. procedimiento, concediéndole un plazo de veinte días para formular alegaciones, y a la vez ordenará su anotación en el Registro de la Propiedad, en los términos de la legislación aplicable.

4. Concluido el trámite de audiencia, el Ayuntamiento aprobará, en su caso, la actuación o el convenio que la regule, en caso de que vaya a asumirla una sociedad urbanística pública.

5. La expropiación podrá tramitarse por el procedimiento de tasación conjunta.

6. Una vez ocupado el inmueble, comenzarán a computarse los plazos fijados para solicitar licencia y para proceder a la edificación. Asimismo, se inscribirá la transmisión en el Registro de la Propiedad, aplicándose lo previsto en su normativa específica para la inscripción de las adjudicaciones de solares en régimen de venta forzosa.

Artículo 192. Actuación a través de un agente edificador.

1. Cualquier particular con capacidad suficiente para asumir las responsabilidades previstas en este precepto podrá colaborar con la Administración en la garantía del cumplimiento del deber de edificar e instarla a que ejercite la expropiación para adquirir el solar no edificado, siempre que asuma la obligación de solicitar licencia de obra en el plazo máximo de tres meses a contar desde la fecha en que esté resuelta la disponibilidad del terreno.

2. Si el Ayuntamiento entiende que la solicitud reúne los requisitos formales exigibles, la notificará al propietario del terreno, concediéndole un plazo de veinte días para efectuar alegaciones, y ordenará su anotación en el Registro de la Propiedad en los términos de la legislación aplicable.

3. Transcurrido el citado plazo, el Ayuntamiento deberá resolver en el plazo de un mes acerca de la aprobación de la solicitud de edificación forzosa. Si en dicho plazo no se notifica resolución expresa, se podrá entender desestimada la solicitud. 
4. Se aplicarán los apartados 5 y 6 del artículo anterior.

Artículo 193. Concurrencia de distintas iniciativas.

Cuando un particular presente una solicitud al amparo de lo previsto en el artículo anterior, la Administración podrá optar por gestionar ella misma la actuación, aplicando el artículo 191 de la presente ley, o convocar concurso público en plazo no superior a tres meses desde la solicitud. La Administración valorará las distintas propuestas teniendo presente entre otros factores el precio y el régimen de las viviendas resultantes. A este efecto, se podrá otorgar un plazo a los solicitantes para que mejoren su solicitud o hagan proposiciones acerca de los factores que la Administración estime más importantes. La Administración Urbanística decidirá acerca de las solicitudes presentadas en el plazo de un mes, salvo que se haya optado por permitir su mejora o nuevas proposiciones, en cuyo caso se ampliará a un mes más.

\section{Capítulo II INTERVENCIÓN EN LA EDIFICACIÓN Y USO DEL SUELO \\ Sección $1 .^{\mathrm{a}}$ Licencias}

Artículo 194. Licencias urbanísticas.

1. La licencia urbanística tiene por finalidad comprobar que los actos de ocupación, construcción, edificación y uso del suelo y del subsuelo proyectados se ajustan al ordenamiento urbanístico vigente. Asimismo, para la concesión de la licencia se verificará si el aprovechamiento proyectado se ajusta al susceptible de apropiación y si las obras y usos proyectados reúnen las condiciones exigibles de seguridad, salubridad, habitabilidad y accesibilidad.

2. Estarán sujetos a previa licencia municipal, sin perjuicio de las autorizaciones que fuesen procedentes de acuerdo con la legislación aplicable, los actos de edificación y uso del suelo y del subsuelo, tales como las parcelaciones urbanísticas, los movimientos de tierra, las obras de nueva planta, la modificación de la estructura o aspecto exterior de las edificaciones existentes, la primera utilización de los edificios y la modificación del uso de los mismos, la demolición de construcciones, la colocación de carteles de propaganda visibles desde la vía pública, los cierres y vallados de fincas y los demás actos que se señalen reglamentariamente.

3. Las empresas suministradoras de energía eléctrica, agua, gas y telecomunicaciones exigirán para la contratación de los respectivos servicios las licencias que en cada caso resulten precisas.

Artículo 195. Procedimiento de otorgamiento de licencias.

1. Las licencias se otorgarán de acuerdo con las previsiones de la legislación y planeamiento urbanísticos.

En ningún caso se entenderán adquiridas por silencio administrativo licencias en contra de la legislación o planeamiento urbanístico.

2. La competencia para otorgar las licencias corresponderá a los municipios según el procedimiento previsto en la legislación de régimen local. Para el otorgamiento de la licencia solicitada serán preceptivos los informes técnicos y jurídicos sobre su conformidad con la legalidad urbanística.

3. Las solicitudes de licencias que se refieran a ejecución de obras o instalaciones deberán acompañarse de proyecto técnico completo redactado por técnico competente, con ejemplares para cada uno de los organismos que hayan de informar la solicitud.

Se exceptúa de la necesidad de presentación de proyecto técnico la ejecución de obras o instalaciones menores. A estos efectos, se considerarán como menores aquellas obras e instalaciones de técnica simple y escasa entidad constructiva y económica que no supongan alteración del volumen, del uso, de las instalaciones 
y servicios de uso común o del número de viviendas y locales, ni afecten al diseño exterior, la cimentación, la estructura o las condiciones de habitabilidad o seguridad de los edificios o instalaciones de toda clase.

En ningún caso se entenderán como tales las parcelaciones urbanísticas, los muros de contención, las intervenciones en edificios declarados bienes de interés cultural o catalogados y los grandes movimientos de tierra.

4. Se entiende por proyecto técnico el conjunto de documentos que definan las actuaciones a realizar con el suficiente contenido y detalle para permitir a la Administración conocer el objeto de las mismas y decidir si se ajusta o no a la normativa urbanística aplicable y al resto de las condiciones señaladas en la presente ley.

Dicho proyecto técnico contendrá una memoria urbanística, como documento específico e independiente, en la que se indicará la finalidad y uso de la construcción o actuación proyectada, razonándose su adecuación a la ordenación vigente, con expresa indicación de la clasificación y calificación del suelo objeto de la actuación y de la normativa y ordenanzas aplicables al mismo.

La memoria desarrollará los argumentos necesarios para justificar el cumplimiento de lo preceptuado en el artículo 104 de la presente ley y se acompañará de los correspondientes planos de situación a escala adecuada, así como de cualquier otra información gráfica que resulte precisa en orden a respaldar su contenido.

Igualmente contendrá una memoria justificativa del cumplimiento de las condiciones previstas en la normativa autonómica de accesibilidad y supresión de barreras arquitectónicas.

Una vez presentado ante el Ayuntamiento, el proyecto adquiere el carácter de documento público, y de la exactitud y veracidad de los datos técnicos consignados en el mismo responde su autor a todos los efectos.

5. Las peticiones de licencia se resolverán en el plazo de tres meses a contar desde la presentación de la solicitud con la documentación completa en el Registro del Ayuntamiento. En caso de obras menores, el plazo será de un mes.

Transcurrido dicho plazo sin haberse comunicado ningún acto, se entenderá otorgada por silencio administrativo, de conformidad con lo dispuesto en los artículos 43 y 44 de la Ley 30/1992, de 26 de noviembre, de Régimen Jurídico de las Administraciones Públicas y del Procedimiento Administrativo Común.

6. Para otorgar la licencia de primera ocupación de edificaciones se exigirá certificado final de obra de técnico competente en el que conste que las obras están completamente terminadas y se ajustan a la licencia otorgada y la previa visita de comprobación de los servicios técnicos municipales.

Artículo 196. Prelación de licencias y otros títulos administrativos 412 .

1. Cuando los actos de edificación y uso del suelo y del subsuelo fuesen realizados en terrenos de dominio público, se exigirá también licencia municipal, sin perjuicio de las autorizaciones o concesiones que sea pertinente otorgar por parte de la organización jurídico-pública titular del dominio público. La falta de autorización o concesión demanial o su denegación impedirá al particular obtener la licencia y al órgano competente otorgarla.

2. Los supuestos que exijan licencia de actividad clasificada o de apertura y, además, licencia urbanística serán objeto de una sola resolución, sin perjuicio de la formación y tramitación simultánea de piezas separadas para cada intervención administrativa.

\footnotetext{
412 Véase Decreto 158/2005, de 2 de junio, por el que se regulan las competencias autonómicas en la zona de servidumbre de protección del dominio público
} maritimo-terrestre. 
La propuesta de resolución de la solicitud de licencia de actividad clasificada o de apertura tendrá prioridad sobre la correspondiente a la licencia urbanística. $\mathrm{Si}$ procediera denegar la primera, así se notificará al interesado y no será necesario resolver sobre la segunda.

En cambio, si procediera otorgar la licencia de actividad clasificada o de apertura, el órgano municipal competente pasará a resolver sobre la licencia urbanística, notificándose lo pertinente en forma unitaria al interesado.

3. En el supuesto de que los actos de edificación y uso del suelo y del subsuelo sujetos a licencia urbanística requirieran previa evaluación de impacto ambiental, no se podrá otorgar la licencia municipal con anterioridad a la declaración de impacto o efectos ambientales dictada por el órgano ambiental competente, o cuando hubiera sido negativa o se incumplieran las medidas correctoras determinadas en la misma.

4. No podrá concederse licencia sin que se acredite el otorgamiento de la autorización de la Comunidad Autónoma cuando fuere procedente de acuerdo con lo dispuesto en la presente ley.

5. En los restantes supuestos en que el ordenamiento jurídico exija, para la ejecución de cualquier actividad, autorización de otra Administración Pública en materia medioambiental o de protección del patrimonio histórico-cultural, la licencia municipal urbanística sólo podrá solicitarse con posterioridad a que haya sido otorgada la referida autorización.

Artículo 197. Caducidad de las licencias.

1. En el acto de otorgamiento de la licencia se determinarán los plazos de caducidad de las licencias de edificación por causa de demora en la iniciación y finalización de las obras, así como por causa de interrupción de las mismas.

En su defecto, el plazo de iniciación no podrá exceder de seis meses y el de terminación de tres años, desde la fecha de su otorgamiento, no pudiendo interrumpirse las obras por tiempo superior a seis meses.

2. Los municipios podrán conceder prórroga de los referidos plazos de la licencia por una sola vez y por un nuevo plazo no superior al inicialmente acordado, previa solicitud expresa formulada antes de la conclusión de los plazos determinados y siempre que la licencia sea conforme con la ordenación urbanística vigente en el momento de concesión de la prórroga.

3. La caducidad será declarada por la Administración Municipal previo procedimiento con audiencia del interesado. No obstante, transcurridos tres años desde el otorgamiento de la licencia sin que se hubiesen iniciado las obras se entenderá caducada automáticamente por ministerio de la Ley y no podrán iniciarse las obras sin obtener nueva licencia ajustada a la ordenación urbanística en vigor.

Artículo 198. Actos promovidos por las Administraciones Públicas.

1. Los actos relacionados en el artículo 194 que promuevan órganos de las Administraciones Públicas o Entidades de Derecho Público estarán igualmente sujetos a licencia municipal, salvo en los supuestos exceptuados por la legislación aplicable.

2. Cuando razones de urgencia o excepcional interés público lo exijan, el conselleiro competente por razón de la materia podrá acordar la remisión al Ayuntamiento correspondiente del proyecto de que se trate, para que en el plazo de un mes notifique la conformidad o disconformidad del mismo con el planeamiento urbanístico en vigor.

En caso de disconformidad, el expediente será remitido por la Consellería interesada al conselleiro competente en materia de urbanismo y ordenación del territorio, quien lo elevará al Consello de la Xunta, previo informe de la Comisión Superior de Urbanismo de Galicia. El Consello de la Xunta decidirá si procede ejecutar el 
proyecto y, en su caso, ordenará la iniciación del procedimiento de modificación o revisión del planeamiento, conforme a la tramitación establecida en la presente ley.

3. El Ayuntamiento podrá, en todo caso, acordar la suspensión de las obras a que se refiere el número 1 de este artículo cuando se pretendiesen llevar a cabo en ausencia o contradicción con la notificación de conformidad con el planeamiento y antes de la decisión de ejecutar la obra adoptada por el Consello de la Xunta, y comunicará dicha suspensión al órgano redactor del proyecto y al conselleiro competente en materia de urbanismo y ordenación del territorio, a los efectos previstos en el mismo.

4. El mismo régimen será de aplicación a la Administración del Estado, con intervención de sus correspondientes órganos competentes.

5. Las obras públicas municipales se entenderán autorizadas por el acuerdo de aprobación del proyecto previa acreditación en el expediente del cumplimiento de la legislación urbanística y de protección del medio rural, así como del planeamiento en vigor.

\section{Sección 2. ${ }^{\mathrm{a}}$}

Deber de conservación y ruina

Artículo 199. Deber de conservación y órdenes de ejecución.

1. Los propietarios de toda clase de terrenos, urbanizaciones de iniciativa particular, edificaciones y carteles deberán mantenerlos en las condiciones establecidas en el artículo 9 de la presente ley.

2. Los Ayuntamientos ordenarán, de oficio o a instancia de cualquier interesado, mediante el correspondiente expediente y previa audiencia de los interesados, la ejecución de las obras necesarias para conservar aquellas condiciones, con indicación del plazo de realización.

Cuando la entidad de las obras lo requiera, el Ayuntamiento exigirá al obligado la solicitud de licencia acompañada del proyecto técnico correspondiente.
3. También podrán ordenar las obras necesarias para adaptar las edificaciones y construcciones al entorno, con arreglo a lo establecido en el artículo 104 de la presente ley, tales como acabado, conservación, renovación o reforma de fachadas o espacios visibles desde la vía pública, limpieza y vallado de terrenos edificables, y retirada de carteles u otros elementos impropios de los inmuebles.

Las obras se ejecutarán a costa de los propietarios que estuviesen dentro del límite del deber de conservación que les corresponde, y con cargo a los fondos de la entidad que la ordene cuando la sobrepasase para obtener mejoras de interés general ${ }^{413}$.

4. En caso de incumplimiento de la orden de ejecución de obras, la Administración Municipal procederá a la ejecución subsidiaria de la misma o a la ejecución forzosa mediante la imposición de multas coercitivas de 300 a 6.000 euros, reiterables hasta lograr la ejecución de las obras ordenadas.

Artículo 200. Inspección periódica de construcciones.

1. Los Ayuntamientos deberán regular mediante ordenanza municipal el deber de inspección periódica de las edificaciones para determinar su estado de conservación.

Esta ordenanza establecerá las edificaciones que quedan sujetas a esta obligación en función de su antigüedad y, en todo caso, incluirán todas las edificaciones catalogadas o de antigüedad superior a cincuenta años, los plazos y las condiciones en que haya de realizarse la inspección técnica de las edificaciones a cargo de facultativo competente.

2. Dicho facultativo consignará los resultados de su inspección expidiendo un informe que describa los desperfectos apreciados en el inmueble, sus posibles causas y las medidas prioritarias recomendables para asegurar su estabilidad,

413 Art. 199.3 modificado por Ley 15/2004, de 29 de diciembre, de modificación de la Ley $9 / 2002$, de 30 de diciembre, de ordenación urbanistica y protección del medio rural de Galicia. 
seguridad, estanqueidad y consolidación estructurales o para mantener o rehabilitar sus dependencias en condiciones de habitabilidad o uso efectivo según el destino propio de las mismas. Asimismo, dejará constancia del grado de realización de las recomendaciones expresadas con motivo de la anterior inspección periódica. La eficacia del informe exige remitir copia del mismo al Ayuntamiento y al colegio profesional correspondiente.

El Ayuntamiento podrá exigir de los propietarios la exhibición de los informes actualizados de inspección periódica de construcciones y, si descubriera que las mismas no se han efectuado, podrá realizarlas de oficio a costa de los obligados ${ }^{414}$.

Artículo 201. Declaración de ruina.

1. Cuando alguna construcción o parte de ella estuviese en estado ruinoso, el Ayuntamiento, de oficio o a instancia de cualquier interesado, la declarará en situación de ruina y acordará la total o parcial demolición, previa tramitación del oportuno expediente contradictorio con audiencia del propietario y de los moradores, salvo inminente peligro que lo impidiera.

2. Se declarará el estado ruinoso en los siguientes supuestos:

a. Cuando el coste de las obras necesarias exceda de la mitad del coste de reposición de la edificación o de nueva construcción con características similares, excluido el valor del suelo ${ }^{415}$.

b. Cuando el edificio presente un agotamiento generalizado de sus elementos estructurales fundamentales.

c. Cuando se requiera la realización de obras que no pudieran ser autorizadas

414 Art. 200.2 modificado por Ley 15/2004, de 29 de diciembre, de modificación de la Ley $9 / 2002$, de 30 de diciembre, de ordenación urbanistica y protección del medio rural de Galicia.

415 Art. 201.2.a modificado por Ley 15/2004, de 29 de diciembre, de modificación de la Ley $9 / 2002$, de 30 de diciembre, de ordenación urbanistica y protección del medio rural de Galicia. por encontrarse el edificio en situación de fuera de ordenación.

3. En caso de incumplimiento de la orden de demolición, la Administración Municipal procederá a la ejecución subsidiaria de la misma a costa del obligado, o a la ejecución forzosa mediante la imposición de multas coercitivas de 300 a 6.000 euros, reiterables hasta lograr la ejecución de las obras ordenadas.

4. Si existiese urgencia y peligro en la demora, el Alcalde, bajo su responsabilidad, por motivos de seguridad dispondrá lo necesario respecto a la habitabilidad del inmueble y desalojo de los ocupantes.

5. En los bienes declarados de interés cultural y en los núcleos históricos se estará a lo dispuesto en la legislación del patrimonio histórico aplicable.

Cuando por cualquier circunstancia resulte destruida una construcción o edificio catalogado, el terreno subyacente permanecerá sujeto al régimen propio de la catalogación. El aprovechamiento subjetivo de su propietario no excederá del preciso para la fiel restitución, que podrá ser ordenada en los términos que reglamentariamente se determinen.

\section{Sección 3. ${ }^{\mathrm{a}}$}

Fomento de la conservación y rehabilitación de las edificaciones tradicionales

Artículo 202. Subvenciones.

Los Proyectos de Ley de Presupuestos de la Comunidad Autónoma deberán incluir las partidas presupuestarias oportunas destinadas a acciones o subvenciones de conservación, mejora o recuperación de construcciones, edificaciones y elementos de carácter tradicional, así como a la rehabilitación de asentamientos y espacios protegidos de especial interés, atendiendo a las finalidades de la presente ley, cuya gestión corresponderá al conselleiro competente en materia de ordenación del territorio y urbanismo. 
Artículo 203. Órdenes de ejecución en suelo rústico y de núcleo rural.

1. En el supuesto de que los propietarios incumplieran los deberes de conservación y rehabilitación establecidos en la presente ley, el Alcalde o el conselleiro competente en materia de ordenación del territorio y urbanismo podrá ordenar la ejecución de las obras necesarias que garanticen el deber de conservación definido en el artículo 9 de esta ley y, en especial, las siguientes:

a. Las obras necesarias para adaptar los inmuebles a las condiciones de su entorno, tales como la conservación y reforma de fachadas o espacios visibles desde las vías públicas y la retirada de carteles u otros elementos impropios de los inmuebles rústicos.

b. Las obras de rehabilitación de inmuebles y edificios de acuerdo con lo establecido en el planeamiento urbanístico.

c. Las obras que garanticen el destino rústico o características de la finca, incluyendo la eliminación de elementos impropios de su finalidad o que supongan un riesgo de deterioro del medio ambiente, del patrimonio cultural o del paisaje.

2. La orden de ejecución deberá contener obligatoriamente la determinación concreta y detallada de las obras a realizar conforme a las condiciones establecidas en la presente ley o en el planeamiento urbanístico.

Asimismo deberá fijar el plazo para el cumplimiento voluntario por el propietario de lo ordenado, que se determinará en razón directa de la importancia, volumen y complejidad de las obras a realizar. De igual modo, la orden de ejecución resolverá si la entidad de las obras exige proyecto técnico y, en su caso, dirección facultativa.

3. El incumplimiento de la orden de ejecución facultará al Alcalde o a la Consellería, en su caso, para ejecutar subsidiariamente las obras con cargo a los obligados y para la imposición de multas coercitivas, hasta un máximo de diez sucesivas, con periodicidad mínima mensual, y por importe cada una de 300 a 6.000 euros. Se denunciarán además los hechos a la jurisdicción penal cuando el incumplimiento pudiera ser constitutivo de delito o falta.

4. El Alcalde o la Consellería competente en materia de ordenación del territorio y urbanismo podrán ordenar en cualquier momento la demolición o eliminación de las obras, construcciones, edificaciones o instalaciones inacabadas o inadecuadas al medio rural, efectuadas sin licencia o al amparo de una licencia que hubiera sido declarada caducada, sin que ello produzca derecho a obtener indemnización.

5. Se declara la utilidad pública, a efectos expropiatorios, de los terrenos, construcciones, edificaciones e instalaciones inacabadas o inadecuadas que se estime necesario demoler para la protección del medio rural o conservación del entorno y morfología de los núcleos rurales de población.

A estos efectos, la Administración deberá incoar el oportuno procedimiento, con audiencia de los interesados, en el que se constate la incompatibilidad o inadecuación de las obras o instalaciones con la protección del medio rural o con las determinaciones estéticas y tipológicas establecidas en el planeamiento urbanístico.

\section{Sección $4 .^{\text {a }}$ \\ Parcelaciones}

Artículo 204. Parcelaciones urbanísticas.

Se considerará parcelación urbanística, a los efectos de la presente ley, la división de terrenos en dos o más lotes o porciones a fin de su urbanización o edificación, ya sea en forma simultánea o sucesiva. Toda parcelación urbanística deberá acomodarse a lo dispuesto en la presente ley o, en virtud de la misma, en los planes de ordenación.

Artículo 205. Indivisibilidad de parcelas.

1. Serán indivisibles:

a. Las parcelas determinadas como mínimas en el correspondiente planeamiento, a fin de constituir fincas independientes. 
b. Las parcelas cuyas dimensiones sean iguales o menores a las determinadas como mínimas en el planeamiento, salvo si los lotes resultantes fueran adquiridos simultáneamente por los propietarios de terrenos colindantes, con el fin de agruparlos y formar una nueva finca.

c. Las parcelas cuyas dimensiones sean menores que el doble de la superficie determinada como mínima en el planeamiento, salvo que el exceso sobre dicho mínimo pueda segregarse con el fin indicado en el apartado anterior.

d. Las parcelas edificables con arreglo a una relación determinada entre superficie del suelo y superficie construible, cuando se edificase la correspondiente a toda la superficie del suelo, o, en el supuesto de que se edificase la correspondiente sólo a una parte de ella, la restante, si fuera inferior a la parcela mínima, con las salvedades indicadas en el apartado anterior.

e. Las parcelas de suelo rústico en el supuesto establecido en los artículos 42.1.e) y 206.1 de esta ley.

2. Los Notarios y Registradores harán constar en la descripción de las fincas su cualidad de indivisibles, en su caso.

Artículo 206. División y segregación de fincas en suelo rústico.

1. En el suelo rústico no podrán realizarse ni autorizarse parcelaciones, divisiones o segregaciones, excepto aquéllas que se deriven de la ejecución, conservación o servicio de infraestructuras públicas, de la ejecución de equipamientos públicos, de la realización de actividades extractivas o energéticas, de la ejecución del planeamiento urbanístico o que tengan por objeto la mejora de las explotaciones agropecuarias existentes.

En todo caso, se respetará la superficie mínima e indivisible que determine la legislación agraria.

Sin embargo, podrá autorizarse la división de parcelas vacantes de edificación por razón de partición de herencias, siempre que se haga constar el compromiso expreso de no edificar los lotes resultantes y que la superficie de cada lote tenga una extensión mínima de 15.000 metros cuadrados. Esta condición de inedificabilidad de los terrenos debe hacerse constar expresamente en el registro de la propiedad y en todos los actos de transmisión de la propiedad.

También podrá autorizarse, con la exclusiva finalidad de regularizar la configuración de parcelas colindantes, la segregación y simultánea agregación en unidad de acto. En ningún caso esta regulación podrá implicar el aumento o la disminución de más del 5\% de la superficie de las parcelas originarias.

2. Los actos de segregación o de división de la propiedad que pudieran permitirse por aplicación de lo dispuesto en los números anteriores estarán sujetos en todo caso a licencia municipal. Para la tramitación y obtención de la misma, habrá de solicitarse con la documentación escrita y gráfica necesaria para la identificación precisa del acto que se instó ${ }^{416}$.

Artículo 207. Régimen de parcelaciones.

1. No podrá efectuarse ninguna parcelación urbanística sin que previamente haya sido aprobado el planeamiento urbanístico exigible según la clase de suelo de que se trate. Queda prohibida en suelo rústico la realización de parcelaciones urbanísticas.

2. Toda parcelación urbanística quedará sujeta a licencia o a la aprobación del proyecto de compensación o reparcelación que la contenga.

3. En ningún caso se considerarán solares, ni se permitirá edificar en ellos, los lotes resultantes de una parcelación efectuada con infracción de las disposiciones de la presente ley.

416 Art. 206 modificado por Ley 15/2004, de 29 de diciembre, de modificación de la Ley $9 / 2002$, de 30 de diciembre, de ordenación urbanistica y protección del medio rural de Galicia. 
4. Los Notarios y Registradores de la Propiedad exigirán para autorizar e inscribir, respectivamente, escritura de división de terrenos que se acredite previamente el otorgamiento de la licencia municipal, que deberá testimoniarse en el documento.

\section{Capítulo III DISCIPLINA URBANÍSTICA \\ Sección 1. Inspección urbanística}

Artículo 208. De la inspección urbanística.

1. La inspección urbanística es la actividad que los órganos administrativos competentes en materia de edificación y uso del suelo han de realizar con la finalidad de comprobar que una y otro se ajustan al ordenamiento urbanístico.

2. El personal adscrito a la inspección y vigilancia urbanística, en el ejercicio de sus funciones, tendrá la consideración de agente de la autoridad y estará capacitado, con dicho carácter, para requerir y examinar toda clase de documentos relativos al planeamiento, para comprobar la adecuación de los actos de edificación y uso del suelo a la normativa urbanística aplicable y para recabar de todas las partes relacionadas con cualquier actuación urbanística y de los Colegios Profesionales y cualesquiera otros Organismos oficiales con competencia en la materia cuanta información, documentación y ayuda material precise para el adecuado cumplimiento de sus funciones.

3. Los Inspectores urbanísticos están autorizados para entrar y permanecer libremente y en cualquier momento en fincas, construcciones y demás lugares sujetos a su actuación inspectora. Cuando para el ejercicio de esas funciones inspectoras fuera precisa la entrada en un domicilio, se solicitará la oportuna autorización judicial.

4. Los hechos constatados por el personal funcionario de la inspección y vigilancia urbanística en el ejercicio de las competencias propias en materia de disciplina urbanística gozan de valor probatorio y presunción de veracidad, sin perjuicio de las pruebas que en defensa de los respectivos derechos o intereses puedan señalar o aportar los propios administrados 417 .

\section{Sección 2. ${ }^{\mathrm{a}}$ \\ Protección de la legalidad urbanística}

Artículo 209. Obras sin licencia en curso de ejecución.

1. Cuando se estuvieren ejecutando obras sin licencia u orden de ejecución o sin ajustarse a las condiciones señaladas en las mismas, el Alcalde dispondrá la suspensión inmediata de dichos actos y procederá a incoar el expediente de reposición de la legalidad, comunicándoselo al interesado.

2. Con el acuerdo de suspensión se adoptarán las medidas cautelares necesarias para garantizar la total interrupción de la actividad. A estos efectos el Alcalde podrá:

a. Ordenar la retirada de los materiales preparados para ser utilizados en la obra o actividad suspendida y la maquinaria afecta a la misma.

b. Ordenar el precintado de las obras, instalaciones y elementos auxiliares de las actividades objeto de suspensión.

c. Ordenar la suspensión de suministros de agua, electricidad, gas y telecomunicaciones de las actividades y obras cuya paralización se haya ordenado.

d. Proceder a la ejecución forzosa mediante la imposición de multas coercitivas por importe de 600 a 6.000 euros, reiterables hasta lograr el cumplimiento de la orden de paralización.

e. Adoptar cualquier otra medida que sea conveniente en orden a la efectividad de la suspensión.

3. Instruido el expediente de reposición de la legalidad y previa audiencia

417 Véase Orden de 20 de febrero de 2006, por la que se aprueba el plan de inspección urbanistica autonómica. 
del interesado, se adoptará alguno de los siguientes acuerdos:

a. Si las obras no fueran legalizables por ser incompatibles con el ordenamiento urbanístico, se acordará su demolición a costa del interesado y se procederá a impedir definitivamente los usos a que dieran lugar o, en su caso, a la reconstrucción de lo indebidamente demolido.

b. Si las obras fueran legalizables por ser compatibles con el ordenamiento urbanístico, se requerirá al interesado para que en el plazo de tres meses presente la solicitud de la oportuna licencia, manteniéndose la suspensión de las obras en tanto ésta no sea otorgada.

c. Si las obras no se ajustan a las condiciones señaladas en la licencia u orden de ejecución, se ordenará al interesado que las ajuste en el plazo de tres meses, prorrogables por otros tres a petición del interesado, siempre que la complejidad técnica o envergadura de las obras a realizar haga inviable su acomodación a las previsiones de la licencia en el plazo previsto.

4. El procedimiento a que se refiere el número anterior deberá resolverse en el plazo de un año a contar desde la fecha del acuerdo de iniciación.

5. Si transcurrido el plazo de tres meses desde el requerimiento el interesado no solicitara la oportuna licencia o, en su caso, no ajustara las obras a las condiciones señaladas en la misma o en la orden de ejecución, el Alcalde acordará la demolición de las obras a costa del interesado y procederá a impedir definitivamente los usos a que dieran lugar. De igual modo se procederá en el supuesto de que la licencia fuese denegada por ser su otorgamiento contrario a la legalidad.

6. En caso de incumplimiento de la orden de demolición, la Administración Municipal procederá a la ejecución subsidiaria de la misma o a la ejecución forzosa mediante la imposición de multas coercitivas, reiterables mensualmente hasta lograr la ejecución por el sujeto obligado, en cuantía de 1.000 a 10.000 euros cada una.

7. Lo dispuesto en los números anteriores se entenderá sin perjuicio de la imposición de las sanciones que procedan y de las facultades que correspondan a las autoridades competentes, en virtud del régimen específico de autorización o concesión a que estén sometidos determinados actos de edificación y uso del suelo.

Artículo 210. Obras terminadas sin licencia.

1. Si se hubiesen terminado las obras sin licencia o incumpliendo las condiciones señaladas en la misma o en la orden de ejecución, el Alcalde, dentro del plazo de seis años, a contar desde la total terminación de las obras, incoará expediente de reposición de la legalidad, procediendo según lo dispuesto en los números $3,4,5$, 6 y 7 del artículo anterior.

2. Transcurrido el plazo de seis años sin que se hubieran adoptado las medidas de restauración de la legalidad urbanística, no se podrán realizar otras obras que las pequeñas reparaciones exigidas por razones de seguridad e higiene y en ningún caso las de consolidación, aumento de valor o modernización ni cambio del uso existente, excepto las necesarias para la adecuación a la legalidad urbanística vigente.

Artículo 211. Otros actos sin licencia.

1. Cuando algún acto distinto de los regulados en el artículo anterior y precisado de licencia se realizase sin ésta o en contra de sus determinaciones, el Alcalde dispondrá la cesación inmediata de dicho acto e incoará expediente de reposición de la legalidad.

2. Instruido el expediente de reposición de la legalidad, y previa audiencia del interesado, se adoptará alguno de los siguientes acuerdos:

a. Si la actividad se realizara sin licencia o sin ajustarse a sus determinaciones, se requerirá al interesado para que solicite la oportuna licencia o ajuste la actividad a la ya concedida. 
b. Si la actividad no fuera legalizable por ser incompatible con el ordenamiento urbanístico, se procederá a impedir definitivamente la actividad y a ordenar la reposición de los bienes afectados al estado anterior al incumplimiento de aquélla.

3. Si transcurrido el plazo de tres meses desde el requerimiento el interesado no solicitara la oportuna licencia o, en su caso, no ajustara la actividad a las condiciones señaladas en la misma, el Alcalde adoptará el acuerdo previsto en el apartado b) del número anterior.

De igual modo se procederá en el supuesto de que la licencia fuese denegada por ser su otorgamiento contrario a la legalidad.

4. Para la ejecución forzosa de las medidas adoptadas por el Alcalde será de aplicación lo dispuesto en el artículo 209.6 de la presente ley.

Artículo 212. Suspensión y revisión de licencias.

1. El Alcalde dispondrá la suspensión de los efectos de una licencia u orden de ejecución $\mathrm{y}$, consiguientemente, la paralización inmediata de las obras iniciadas a su amparo cuando el contenido de dichos actos administrativos constituya una infracción urbanística grave o muy grave, cualquiera que sea la fecha de otorgamiento de la licencia, y en el plazo de diez días deberá darse traslado directo del acto suspendido al órgano jurisdiccional competente, en la forma y con los efectos previstos en al legislación reguladora de la jurisdicción contencioso-administrativa.

2. En todo caso, las licencias u órdenes de ejecución contrarias al ordenamiento urbanístico deberán ser revisadas a través de alguno de los procedimientos de revisión de oficio contemplados en los artículos 102 y 103 de la Ley 30/1992, de 26 de noviembre, de Régimen Jurídico de las Administraciones Públicas y del Procedimiento Administrativo Común, o por el procedimiento del artículo 127 de la Ley de la Jurisdicción Contencioso-Administrativa.
3. Lo dispuesto en los números anteriores se entiende sin perjuicio de las sanciones que pudiesen imponerse.

Artículo 213. Protección de la legalidad en zonas verdes, espacios libres, dotaciones y equipamientos públicos.

1. Los actos de edificación y uso del suelo relacionados en el artículo 194 que se realicen sin licencia $u$ orden de ejecución sobre terrenos calificados por el planeamiento como zonas verdes, espacios libres, dotaciones o equipamientos públicos quedarán sujetos al régimen establecido en el artículo 209 mientras estuviesen en curso de ejecución, y al régimen previsto en el artículo 210 cuando hubieran finalizado sin que tenga aplicación la limitación del plazo que establece dicho artículo. En estos supuestos, la competencia corresponderá al conselleiro competente en materia de urbanismo.

2. Las licencias u órdenes de ejecución que se otorgasen con infracción de la zonificación o uso urbanístico de las zonas verdes, espacios libres, dotaciones o equipamientos públicos previstos en el planeamiento serán nulas de pleno derecho. En estos casos, el conselleiro competente en materia de urbanismo requerirá al Alcalde para que proceda según lo dispuesto en el artículo anterior.

Artículo 214. Protección de la legalidad en el suelo rústico.

1. Corresponderá al conselleiro competente en materia de urbanismo y ordenación del territorio la competencia para la adopción de las medidas precisas de protección de la legalidad respecto de las obras y actividades realizadas en suelo rústico, en cualquiera de sus categorías, sin la preceptiva autorización autonómica o sin ajustarse a las condiciones de la autorización otorgada, así como en los supuestos de actividades prohibidas, sin que resulte de aplicación la limitación de plazo establecida en el artículo 210.

En los restantes supuestos la competencia corresponderá al Alcalde. 
2. El Alcalde, en cualquier caso, adoptará las medidas necesarias para la paralización de las obras y actividades en ejecución sin autorización autonómica previa, sin licencia municipal o sin ajustarse a las condiciones de cualquiera de ellas, dando cuenta, en su caso, y de forma inmediata al conselleiro competente en materia de urbanismo.

\section{Artículo 215. Subrogación.}

Si la Consellería competente en materia de urbanismo y ordenación del territorio apreciase que las obras o usos del suelo constituyen infracción urbanística grave o muy grave, lo pondrá en conocimiento del Alcalde a la mayor brevedad posible a fin de que proceda según lo dispuesto en este capítulo.

Si el Alcalde no adoptase las medidas señaladas en el párrafo anterior en el plazo de un mes, el conselleiro competente en materia de urbanismo y ordenación del territorio podrá subrogarse en el ejercicio de las competencias municipales adoptando las medidas pertinentes para la reposición de la legalidad y la sanción de los infractores.

Iniciado el correspondiente expediente por la Consellería, el municipio deberá abstenerse de toda actuación en el mismo asunto desde el momento en que reciba la oportuna comunicación, remitiendo a la citada Consellería cuantas actuaciones hubiese practicado.

\section{Sección 3. ${ }^{\mathrm{a}}$}

\section{Infracciones y sanciones}

Artículo 216. Definición de las infracciones urbanísticas.

1. Son infracciones urbanísticas las acciones $\mathrm{u}$ omisiones que vulneren las prescripciones contenidas en la legislación y el planeamiento urbanístico, tipificadas y sancionadas en aquélla.

2. Toda infracción urbanística conllevará la imposición de sanciones a los responsables, así como la obligación de resarcimiento de los daños e indemnización de los perjuicios a cargo de los mismos, todo ello con independencia de las medidas previstas en la sección anterior.

3. En ningún caso podrá la Administración dejar de adoptar las medidas tendentes a restaurar el orden urbanístico vulnerado o a reponer los bienes afectados al estado anterior a la producción de la situación ilegal.

Artículo 217. Tipificación de las infracciones urbanísticas.

1. Las infracciones urbanísticas se clasifican en muy graves, graves y leves.

2. Son infracciones muy graves:

a. Las acciones y omisiones que constituyan incumplimiento de las normas relativas al uso y edificación que afecten a terrenos calificados como zonas verdes, espacios libres, dotaciones o equipamientos públicos.

b. Las obras y actividades realizadas en suelo rústico que estén prohibidas por la presente ley y en todo caso las parcelaciones urbanísticas.

c. La realización de obras de urbanización sin la previa aprobación del planeamiento y proyecto de urbanización exigibles.

3. Son infracciones graves:

a. Las acciones y omisiones que constituyan incumplimiento de las normas relativas a parcelaciones, aprovechamiento urbanístico, uso del suelo, altura y número de plantas, superficie y volumen máximo edificables, emplazamiento de las edificaciones, distancias mínimas de separación a lindes y otros elementos y ocupación permitida de la superficie de las parcelas o de habitabilidad de las viviendas, cuando no tengan el carácter de muy graves.

b. El incumplimiento de las condiciones de uso y edificación establecidas en la presente ley para el suelo rústico y el suelo de núcleo rural y la realización de actividades sin la preceptiva autorización de la Comunidad Autónoma, cuando ésta sea exigible de acuerdo con esta ley, o incumpliendo sus condiciones. 
c. El incumplimiento de la orden de corte de suministro de los servicios de agua, electricidad y otros.

d. El incumplimiento del régimen establecido por la presente ley para las edificaciones fuera de ordenación y para las edificaciones ilegales a que hace referencia el artículo 210.

e. El incumplimiento de los deberes de urbanización y edificación en los plazos establecidos por el plan.

4. Se considerarán infracciones leves las infracciones del ordenamiento urbanístico que no tengan el carácter de graves o muy graves y, en todo caso, la ejecución de obras o instalaciones realizadas sin licencia $\mathrm{u}$ orden de ejecución cuando sean legalizables por ser conformes con el ordenamiento urbanístico, así como el incumplimiento de las órdenes de ejecución o demolición o de la obligación de la inspección periódica de las edificaciones.

5. En los supuestos en que se instruyese expediente sancionador por dos o más infracciones tipificadas entre las que exista conexión de causa a efecto, se impondrá una sola sanción, y será la correspondiente a las actuaciones que supongan el resultado final perseguido, en su cuantía máxima. En los demás casos, a los responsables de dos o más infracciones urbanísticas se les impondrán las multas correspondientes a cada una de ellas.

Artículo 218. Prescripción.

Las infracciones urbanísticas muy graves prescribirán a los quince años, las graves a los seis años y las leves a los dos años, a contar desde la finalización de las obras o de la actividad.

Artículo 219. Personas responsables.

1. En las obras que se ejecutasen sin licencia o con inobservancia de sus condiciones serán sancionadas por infracción urbanística las personas físicas o jurídicas responsables de ellas en calidad de promotor de las obras, propietario de los terrenos o empresario de las obras, y los técnicos redactores del proyecto y directores de las obras.

2. En las obras amparadas en una licencia, pero constitutivas de infracción urbanística grave o muy grave, serán igualmente sancionados el técnico que hubiese informado favorablemente el proyecto y las autoridades o miembros de la Corporación que hubiesen resuelto o votado a favor del otorgamiento de la licencia $\sin$ los informes previos exigibles o cuando éstos fueran desfavorables en razón de aquella infracción.

3. Aquellos que, como consecuencia de una infracción urbanística, sufriesen daños o perjuicios podrán exigir de cualquiera de los infractores, con carácter solidario, el resarcimiento y la indemnización.

4. Las sanciones que se impongan a los distintos sujetos por una misma infracción tendrán entre sí carácter independiente.

5. Si la persona jurídica autora de una infracción contemplada en la presente ley se extinguiera antes de ser sancionada, se considerarán autores a las personas físicas que, desde sus órganos de dirección o actuando a su servicio o por ellas mismas, determinaron con su conducta la comisión de la infracción.

6. En caso de extinción de la persona jurídica responsable, los socios o partícipes en el capital responderán solidariamente, y hasta el límite del valor de la cuota de liquidación que les hubiera adjudicado, del pago de la sanción o, en su caso, del coste de reposición de la realidad física alterada.

Artículo 220. Reglas para determinar la cuantía de las sanciones.

1. Las infracciones urbanísticas serán sancionadas de la siguiente forma:

a. Las infracciones leves, con multa de 300 a 6.000 euros y como mínimo el 2 por 100 del valor de la obra, instalación o actuación realizada.

b. Las infracciones graves, con multa de 6.001 a 60.000 euros y como mínimo el 


\section{Ordenación del territorio y...}

$20 \%$ del valor de la obra, terrenos, exceso de edificación o actuación realizada.

c. Las infracciones muy graves, con multa de 60.001 a 1.000 .000 de euros y como mínimo el $30 \%$ del valor de las obras, terrenos, edificaciones o actuaciones realizadas. En los supuestos de escasa entidad de la infracción, la administración podrá aplicar la sanción prevista en la letra b) anterior ${ }^{418}$.

2. Para graduar las multas se atenderá primordialmente a la gravedad de la materia, la entidad económica de los hechos constitutivos de infracción, su reiteración por parte de la persona responsable y el grado de culpabilidad de cada uno de los infractores.

Se considerará como circunstancia atenuante la paralización de las obras o el cese en la actividad o uso, de modo voluntario, tras la inspección y la pertinente advertencia por agente de la autoridad, y como circunstancia agravante el incumplimiento de los requerimientos efectuados por la Administración para la paralización de las obras y la restauración del orden urbanístico, la obstrucción a la función inspectora y aquellas otras que se determinen reglamentariamente.

3. Cuando concurra alguna circunstancia agravante, la sanción se impondrá siempre en cuantía superior a la tercera parte de su máximo. Si concurre alguna circunstancia atenuante y ninguna agravante, se impondrá en su cuantía mínima.

4. El responsable de la infracción tendrá derecho a una reducción del $80 \%$ de la multa que haya de imponerse en caso de que reponga por sí mismo la realidad física alterada antes de la resolución del procedimiento sancionador ${ }^{419}$.

418 Art. 220.1.b y 220.1.c modificados por Ley $15 / 2004$, de 29 de diciembre, de modificación de la Ley 9/2002, de 30 de diciembre, de ordenación urbanistica y protección del medio rural de Galicia.

419 Art. 220.3 y 220.4. modificados por Ley $15 / 2004$, de 29 de diciembre, de modificación de la Ley 9/2002, de 30 de diciembre, de ordenación urbanistica y protección del medio rural de Galicia.
5. En ningún caso la infracción urbanística puede suponer un beneficio económico para el infractor.

Cuando la suma de la sanción impuesta y del coste de las actuaciones de reposición de los bienes y situaciones a su primitivo estado arrojase una cifra inferior a dicho beneficio, se incrementará la cuantía de la multa hasta alcanzar el montante del mismo.

Artículo 221. Sanciones accesorias. Los sujetos responsables de infracciones muy graves, cuando las acciones que las motivaron no sean legalizables, podrán ser sancionados, según los casos, además de con las multas previstas en este título, con las siguientes sanciones accesorias:

a. Inhabilitación durante un plazo de hasta cinco años de la posibilidad de obtener subvenciones públicas o crédito oficial y del derecho a gozar de beneficios o incentivos fiscales.

b. Prohibición durante un plazo de hasta cinco años para celebrar contratos con la Administración Autonómica y con las Administraciones Locales de Galicia.

c. Publicación en un diario de mayor circulación de la provincia de las sanciones firmes en vía administrativa y de la identidad de los sancionados.

Artículo 222. Órganos competentes.

1. Las autoridades competentes para la imposición de las sanciones serán:

a. Por infracciones muy graves, a partir de 600.000 euros, el Consello de la Xunta.

b. Por infracciones muy graves, hasta 600.000 euros, el conselleiro competente en materia de urbanismo y ordenación del territorio.

c. Por infracciones graves cometidas en suelo rústico sin la preceptiva autorización de la Comunidad Autónoma, cuando ésta sea exigible con arreglo a la presente ley, o incumpliendo sus condiciones, el Director general competente en materia de urbanismo.

d. En los demás supuestos, por infracciones graves y leves, el Alcalde. 
2. La Axencia de Protección dla Legalidade Urbanística será competente para la imposición de sanciones cuando ésta le haya sido delegada o transferida voluntariamente por el titular de la competencia.

Artículo 223. Procedimiento sancionador.

1. La potestad sancionadora se ejercerá mediante el procedimiento establecido en la legislación del procedimiento administrativo.

2. El plazo para resolver el procedimiento sancionador será de un año a contar desde la fecha de su iniciación.

Transcurrido el plazo máximo para resolver sin que se dictase resolución, se producirá la caducidad del procedimiento. En el supuesto de que la infracción no hubiese prescrito, deberá iniciarse un nuevo procedimiento sancionador.

\section{TíTULO VII ORGANIZACIÓN \\ Capitulo I DISPOSICIÓN GENERAL}

Artículo 224. Administraciones competentes.

En el desarrollo de las actividades reguladas en la presente ley entenderán específicamente los órganos pertenecientes a la Administración de la Comunidad Autónoma y a las Administraciones Locales.

\section{Capitulo II ÓRGANOS URBANÍSTICOS EN EL ÁMBITO DE LA COMUNIDAD AUTÓNOMA}

Artículo 225. Órganos urbanísticos de la Comunidad Autónoma.

1. Son órganos de la Comunidad Autónoma con competencia urbanística:

a. El Consello de la Xunta.

b. El conselleiro competente en materia de urbanismo y ordenación del territorio.

c. El Director general competente en materia de urbanismo. d. La Comisión Superior de Urbanismo de Galicia ${ }^{420}$.

2. Son Organismos Públicos con competencias urbanísticas:

a. La Axencia de Protección dla Legalidade Urbanística, en materia de disciplina urbanística, adscrita a la Consellería competente en materia de urbanismo y ordenación del territorio.

b. El Instituto Galego da Vivenda e Solo, en materia de gestión urbanística.

3. Los órganos urbanísticos de la Xunta de Galicia podrán delegar el ejercicio de sus competencias en los términos previstos en los artículos 43 y 44 de la Ley 1/1983, de 22 de febrero, Reguladora de la Xunta y su Presidente, y la Ley 30/1992, de Régimen Jurídico de las Administraciones Públicas y del Procedimiento Administrativo Común.

Artículo 226. Axencia de Protección dla Legalidade Urbanística.

1. La Axencia de Protección dla Legalidade Urbanística es un ente público de naturaleza consorcial, dotado de personalidad jurídica, patrimonio y presupuesto propios y plena autonomía en el cumplimiento de sus funciones, para el desarrollo en común por la Administración autonómica y los municipios que voluntariamente se integren en la misma de las funciones de inspección, restauración de la legalidad y sanción en materia de urbanismo y el desempeño de cuantas otras competencias le asignen sus estatutos.

2. Son miembros de la agencia la Administración autonómica y los municipios que voluntariamente se integren en la misma.

La incorporación se realizará a través del correspondiente convenio de adhesión, que deberá obtener la aprobación del pleno de la corporación y del Consello de la Xunta de Galicia y que será publicado en el "Diario Oficial de Galicia".

420 Véase Decreto $119 / 1998$, de 16 de abril, por el que se regula la composición y el funcionamiento de la Comisión Superior de Urbanismo de Galicia. 
El convenio habrá de contener, entre otros extremos, la determinación de las competencias que se atribuyen a la agencia, el plazo de vigencia, las causas de resolución y las demás condiciones.

3. La agencia estará adscrita orgánicamente a la consellería competente en materia de urbanismo y ordenación del territorio. Sus estatutos serán aprobados por el siguiente procedimiento:

a. Aprobación inicial del proyecto de estatutos por el conselleiro competente en materia de urbanismo y ordenación territorial.

b. Audiencia a los Ayuntamientos durante el plazo de un mes.

c. Dictamen de la Comisión Superior de Urbanismo de Galicia y del Consello Consultivo de Galicia.

d. Aprobación definitiva por el Consello de la Xunta mediante decreto, que será publicado en el "Diario Oficial de Galicia".

4. Corresponden en todo caso a la Axencia de Protección dla Legalidade Urbanística las siguientes competencias:

a. La inspección y vigilancia urbanística sobre los actos de edificación y uso del suelo.

b. La adopción de las medidas cautelares previstas en la presente ley, en especial las de suspensión de los actos de edificación y uso del suelo que se realicen en suelo rústico sin la preceptiva autorización autonómica o incumpliendo las condiciones de la autorización otorgada.

c. La instrucción de los expedientes de reposición de la legalidad y de los expedientes sancionadores por infracciones urbanísticas, cuando la competencia para su resolución corresponda a la Comunidad Autónoma o le haya sido atribuida por los Ayuntamientos consorciados.

d. La formulación a las distintas administraciones de toda clase de solicitudes que estime pertinentes para asegurar el mejor cumplimiento de la legalidad urbanística. e. La denuncia ante el Ministerio Fiscal y los órganos del orden jurisdiccional penal de los hechos que, a resultas de las actuaciones practicadas, se consideren constitutivos de delito.

f. Las demás competencias que en materia de disciplina urbanística le sean atribuidas por sus estatutos. En todo caso, se atribuyen a la agencia, una vez constituida, las competencias inicialmente asignadas a los órganos autonómicos para restaurar la legalidad urbanística (artículos 213, 214 y 215) y para imponer las sanciones por infracciones urbanísticas graves o muy graves hasta 600.000 euros (artículo 222.1).

g. Asumirá, de conformidad con sus estatutos, el ejercicio de la potestad sancionadora y de reposición de la legalidad en el ámbito de la servidumbre de protección del dominio público marítimo-terrestre, según lo establecido en la legislación aplicable en materia de costas ${ }^{421}$.

5. Los órganos directivos de la agencia son:

a. El consejo ejecutivo, órgano de dirección y control de la agencia que estará presidido por el director general competente en materia de urbanismo e integrado por ocho vocales, cuatro en representación de los Ayuntamientos incorporados a la agencia y otros cuatro en representación de la Comunidad Autónoma. Todos los miembros del consejo habrán de ser licenciados en derecho, arquitectos o ingenieros de caminos, canales y puertos con más de cinco años de experiencia profesional en materia de urbanismo.

b. El director, que será nombrado por el Consello de la Xunta, oído el consejo ejecutivo. Le corresponderá la representación ordinaria de la agencia, la dirección de todos los servicios de la misma y la jefatura de su personal, y asistirá a las 421 Art. 226.4.g modificado por Ley 6/2007, de 11 de mayo, de medidas urgentes en materia de ordenación del territorio y del litoral de Galicia. 
reuniones del consejo ejecutivo con voz pero sin voto.

6. De conformidad con lo dispuesto por el ar-tículo 109 de la Ley 30/1992, de Régimen Jurídico de las Administraciones Públicas y del Procedimiento Administrativo Común, los actos y resoluciones dictados por la Axencia de Protección dla Legalidade Urbanística ponen fin a la vía administrativa.

7. La contratación de la agencia se rige por las normas generales de la contratación de las administraciones públicas, y su régimen económico y presupuestario se ajustará a las prescripciones de la Ley de Régimen Financiero y Presupuestario de Galicia.

8. El personal al servicio de la agencia estará integrado por funcionarios públicos ${ }^{422423}$.

Artículo 227. Competencias.

1. A los órganos de la Administración Autonómica les corresponden la dirección de la política urbanística, el establecimiento de directrices de ordenación y la aprobación de los instrumentos de ordenación urbanística, en los supuestos establecidos en la presente ley.

2. También les corresponde ejercer el control de legalidad sobre la actividad urbanística, la tutela de los intereses supramunicipales y actuar por subrogación en los supuestos previstos en la presente ley.

\section{Capitulo III ÓRGANOS URBANÍSTICOS EN EL ÁMBITO LOCAL}

Artículo 228. Competencia de los municipios.

1. La competencia urbanística de los municipios comprenderá todas las facultades que, siendo de índole local, no

422 Art. 226 modificado por Ley 15/2004, de 29 de diciembre, de modificación de la Ley 9/2002, de 30 de diciembre, de ordenación urbanística y protección del medio rural de Galicia.

423 Véase:

- Decreto 213/2007, de 31 de octubre, por el que se aprueban los estatutos de la Agencia de Protección de la Legalidad Urbanistica.

- Decreto 51/2008, de 6 de marzo, por el que se establece la estructura orgánica de la Agencia de Protección de la Legalidad Urbanistica. estuvieran expresamente atribuidas por la presente ley a otros Organismos.

2. Los municipios podrán utilizar las distintas formas de gestión que establece la legislación del régimen local para el desarrollo de la actividad urbanística.

3. También podrán constituir mancomunidades y establecer formas de colaboración interadministrativa con otras Entidades Locales o con la Administración Autonómica.

Específicamente, podrán constituir Consorcios mediante convenio en el que podrán participar los órganos de la Administración Autonómica, las Diputaciones Provinciales y los municipios, para el ejercicio en común de competencias urbanísticas, así como para la realización de obras o prestación de servicios públicos.

Artículo 229. Sociedades urbanísticas.

1. Las Entidades Locales y los Consorcios a que se refiere el artículo anterior podrán constituir sociedades mercantiles de capital íntegramente público o mixtas, exigiéndose en este último caso que el capital público represente, al menos, el 51 por 100 .

2. Estas sociedades podrán tener por objeto el estudio, la promoción, la gestión o la ejecución de cualquier tipo de actividad urbanística, siempre que no implique ejercicio de autoridad.

3. La creación de estas sociedades se realizará de acuerdo con la legislación mercantil y con observancia de las normas administrativas que reglamentariamente se determinen.

Artículo 230. Incumplimiento de obligaciones.

1. Cuando una Entidad Local incumpliese gravemente las obligaciones que directamente le incumban por disposición de la presente ley o dejase de adoptar las medidas necesarias para la protección de la legalidad urbanística, el conselleiro competente en materia de urbanismo y ordenación del territorio le requerirá su cumplimiento con indicación de plazo, nunca inferior a un mes. 
En el supuesto de inactividad o incumplimiento del requerimiento en el plazo indicado, la Consellería podrá subrogarse en la correspondiente competencia, de conformidad con lo dispuesto en la legislación de régimen local.

2. Si la Administración Autonómica ejecuta subsidiariamente las competencias urbanísticas locales, con los requisitos y presupuestos establecidos en la legislación de régimen local, el Consello de la Xunta puede designar, para un plazo concreto, a un gerente, o bien puede transferir las atribuciones necesarias de la Corporación Municipal a la Comisión Superior de Urbanismo de Galicia, que ha de ejercerlas mediante una comisión especial en la cual ha de tener representación el Ayuntamiento.

Artículo 231. Competencia de las Diputaciones Provinciales.

1. Las Diputaciones Provinciales deberán ejercer funciones de asistencia y cooperación con los municipios de la provincia, especialmente con los de menor capacidad económica y de gestión, para colaborar en el cumplimiento de sus obligaciones urbanísticas.

2. También podrán participar en funciones de gestión urbanística en colaboración con el resto de las administraciones con incidencia en el territorio de su provincia.

\section{Capítulo IV \\ JURADO DE EXPROPIACIÓN DE GALICIA}

Artículo 232. Jurado de Expropiación de Galicia.

1. El Jurado de Expropiación de Galicia es un órgano colegiado permanente de la Comunidad Autónoma de Galicia especializado en los procedimientos para la fijación del justiprecio en la expropiación forzosa, cuando la Administración expropiante sea la Comunidad Autónoma o las Entidades Locales de su ámbito territorial.

Estará adscrito a la Consellería competente en materia de urbanismo y ordenación del territorio, actuando en el cumplimiento de sus funciones con plena autonomía funcional y sin estar sometido a instrucciones jerárquicas.

2. La resolución del Jurado se adoptará en el plazo máximo de tres meses a contar desde el día siguiente al de entrada en el registro del expediente completo.

De no adoptarse acuerdo en el plazo señalado, se entenderán desestimadas las reclamaciones por silencio negativo. Sus acuerdos serán siempre motivados y fundamentados en lo que se refiere a los criterios de valoración seguidos para cada uno de los casos en concreto, de conformidad con las disposiciones legales que sean de aplicación. Los actos que dicte el Jurado pondrán fin a la vía administrativa.

3. El jurado de expropiación se compone de los siguientes miembros:

a. Presidente: un licenciado en derecho, arquitecto o ingeniero de reconocido prestigio con más de diez años de experiencia profesional en el sector público o privado o en el ejercicio libre de la profesión.

b. Vocales:

Un asesor jurídico, que deberá pertenecer a la escala de letrados de la Xunta de Galicia. Tres vocales pertenecientes al cuerpo facultativo superior al servicio de la Xunta de Galicia.

Un vocal, a propuesta del conselleiro competente en materia de hacienda.

Un técnico facultativo superior, del grupo A, a propuesta de la Federación Galega de Municipios e Provincias.

Un técnico competente en la materia, a propuesta del Consello Galego de Consumidores e Usuarios.

Tres profesionales libres colegiados competentes en la materia, en representación de los colegios profesionales, dependiendo de la naturaleza de los bienes o derechos objeto de la expropiación.

c. Cuando se trate de expropiaciones de las corporaciones locales, podrá nombrarse a un representante, designado a 
propuesta de éstas, quien actuará con voz y sin voto en las sesiones del jurado.

d. Secretario: Un funcionario del cuerpo superior de administración de la Xunta de Galicia, con voz pero sin voto.

Reglamentariamente se establecerá la organización, funcionamiento y régimen interior del jurado de expropiación ${ }^{424}$.

4. $(\ldots)^{425}$.

\section{TÍTULO VIII CONVENIOS URBANÍSTICOS}

Artículo 233. Concepto, alcance y naturaleza.

1. La Administración Autonómica y los municipios, así como sus organizaciones adscritas y dependientes y las demás organizaciones por ellos creadas conforme a esta ley, podrán celebrar, conjunta o separadamente, y siempre en el ámbito de sus respectivas esferas de competencias, convenios urbanísticos entre sí y con personas públicas o privadas, en orden a su colaboración y más eficaz desarrollo de la actividad urbanística.

2. La negociación, celebración y cumplimiento de los convenios urbanísticos a que se refiere el número anterior se regirá por los principios de transparencia y publicidad.

3. Serán nulas de pleno derecho las estipulaciones de los convenios que contravengan, infrinjan o defrauden objetivamente, en cualquier forma, normas imperativas legales o reglamentarias, incluidas las del planeamiento urbanístico, en especial las reguladoras del régimen urbanístico del suelo y de los deberes de los propietarios del mismo.

424 Art. 232.3 modificado por Ley $15 / 2004$, de 29 de diciembre, de modificación de la Ley 9/2002, de 30 de diciembre, de ordenación urbanistica y protección del medio rural de Galicia.

Véase Decreto 223/2005, de 16 de junio, por el que se aprueba el Reglamento de organización y funcionamiento del Jurado de Expropiación de Galicia.

425 Art. 232.4 derogado por Ley 15/2004, de 29 de diciembre, de modificación de la Ley $9 / 2002$, de 30 de diciembre, de ordenación urbanistica y protección del medio rural de Galicia.
4. Los convenios regulados en esta sección tendrán a todos los efectos carácter jurídico-administrativo y las cuestiones relativas a su celebración, cumplimiento, interpretación, efectos y extinción serán competencia del órgano jurisdiccional contencioso-administrativo.

Artículo 234. Objeto.

Los convenios urbanísticos se diferenciarán por su contenido y finalidad en:

a. Convenios Urbanísticos de Planeamiento: Aquéllos que incluyan o puedan tener como consecuencia o resultado posibles modificaciones del planeamiento urbanístico, bien directamente, bien por ser éstas precisas en todo caso para la viabilidad de lo estipulado.

b. Convenios Urbanísticos para la Ejecución del Planeamiento: Aquéllos que no afectando en absoluto a la ordenación urbanística se limiten a la determinación de los términos y condiciones de la gestión y ejecución del planeamiento y demás instrumentos existentes en el momento de su celebración. Del cumplimiento de estos convenios en ningún caso podrá derivarse o resultar modificación, alteración, excepción o dispensa del planeamiento.

Artículo 235. Convenios Urbanísticos de Planeamiento.

1. La Administración Autonómica y los municipios, así como los Organismos adscritos o dependientes de una y otros, podrán celebrar entre sí y con otras Administraciones convenios para definir de común acuerdo y en el ámbito de sus respectivas competencias:

a. Los criterios de ordenación a que deba ajustarse el planeamiento urbanístico y sus modificaciones y revisiones.

b. Los términos en que deba preverse en el planeamiento urbanístico, o sus modificaciones o revisiones, la realización de los intereses públicos que gestionen.

2. Cuando se tramiten los procedimientos de aprobación de los planes de ordenación 
urbanística o de sus modificaciones o revisiones a los que se refieran los convenios previstos en el número anterior, éstos deberán ser incluidos, para conocimiento general, como anexo a la memoria del proyecto o entre la documentación sometida al preceptivo trámite de información pública, si son posteriores a la aprobación inicial.

3. Con ocasión del ejercicio de la potestad de planeamiento, la Administración Autonómica y los municipios, en el ámbito de sus respectivas competencias y conjunta o separadamente, podrán celebrar con cualesquiera personas, públicas o privadas, convenios urbanísticos relativos a la formación, modificación o revisión de un plan de ordenación urbanística.

4. Los convenios a que se refiere el número anterior:

a. Sólo podrán negociarse y suscribirse con el carácter de preparatorios de la resolución y hasta el momento en que el procedimiento de aprobación del planeamiento o, en su caso, de su modificación o revisión sea sometido al preceptivo trámite de información pública.

b. Sus estipulaciones sólo tendrán, en esta fase, el efecto de vincular a las partes para la iniciativa y tramitación del pertinente procedimiento sobre la base del acuerdo respecto a la oportunidad, conveniencia y posibilidad de concreta o concretas soluciones de ordenación. En ningún caso vincularán o condicionarán en cualquier otra forma el ejercicio por las Administraciones Públicas, incluidas las que sean parte en ellos, de la potestad de planeamiento.

c. Deberá incluirse, entre sus estipulaciones, la cuantificación de todos los deberes legales de cesión y determinarse la forma en que éstos serán cumplidos.

d. La ordenación urbanística derivada del convenio celebrado deberá incorporarse a las correspondientes determinaciones y documentos del plan.
Artículo 236. Convenios Urbanísticos para la Ejecución del Planeamiento.

1. La Administración Autonómica y los municipios, así como las Entidades Públicas adscritas o dependientes de una y otros y los Consorcios creados por tales Administraciones, podrán celebrar, en el ámbito de sus respectivas competencias y conjunta o separadamente, convenios con personas públicas o privadas para determinar las condiciones y los términos de la gestión y ejecución del planeamiento urbanístico en vigor en el momento de la celebración del convenio.

$(\ldots)^{426}$

Artículo 237. Celebración y perfeccionamiento.

1. Una vez negociados y suscritos, los convenios se someterán al trámite de información pública, mediante anuncio publicado en el "Diario Oficial de Galicia" y en, al menos, uno de los periódicos de mayor difusión en la provincia, por un período mínimo de veinte días.

2. Cuando la negociación de un convenio coincida con la tramitación del procedimiento de aprobación del instrumento de planeamiento con el que guarde directa relación, deberá incluirse el texto íntegro del convenio en la documentación sometida a información pública propia de dicho procedimiento, sustituyendo ésta a la prevista en el número anterior.

3. Tras la información pública, el órgano que hubiera negociado el convenio deberá, a la vista de las alegaciones, elaborar una propuesta de texto definitivo del convenio, de la que se dará vista a la persona o personas que hubieran negociado y suscrito el texto inicial para su aceptación, reparos o, en su caso, renuncia.

4. El texto definitivo de los convenios habrá de ratificarse por el órgano competente, debiendo firmarse dentro de los

426 Art. 236.2 derogado por Ley 6/2008, de 19 de junio, de medidas urgentes en materia de vivienda y suelo, por la que se modifica la Ley $9 / 2002$, de 30 de diciembre, de ordenación urbanistica y protección del medio rural de Galicia. 
quince días siguientes a la notificación de la aprobación del texto definitivo por la persona o personas interesadas, privadas o públicas. Transcurrido dicho plazo sin que tal firma haya tenido lugar, se entenderá que renuncian a aquél.

\section{DISPOSICIÓN ADICIONAL PRIMERA ACTUACIONES PÚBLICAS EN MUNICIPIOS SIN PLANEAMIENTO}

1. En municipios con población inferior a 5.000 habitantes y sin planeamiento general, podrán formularse planes especiales cuyo objeto sea la ejecución de actuaciones públicas para crear suelo urbanizado con destino a usos industriales, terciarios, de equipamientos públicos o la construcción de viviendas de promoción pública.

2. $(\ldots)^{427}$

3. El contenido del plan especial será determinado reglamentariamente $\mathrm{y}$, en todo caso, serán de aplicación los estándares de reserva de suelo para dotaciones y las limitaciones de intensidad exigidas para el suelo urbanizable no delimitado.

4. El plan especial deberá incluir entre su documentación el estudio del medio rural circunscrito a su ámbito e incidencia de la nueva actuación en su entorno y el estudio de sostenibilidad ambiental, impacto territorial y paisajístico a que se refiere el artículo 61.4 de la presente ley.

\section{DISPOSICIÓN ADICIONAL SEGUNDA RÉGIMEN DEL SUELO EN LOS MUNICIPIOS SIN PLANEAMIENTO}

1. En los municipios sin planeamiento general únicamente podrá edificarse en los terrenos que merezcan la condición de suelo urbano consolidado por reunir los requisitos establecidos en el artículo 12.a) de la presente ley y se garantice previamente las obras necesarias para cumplir la condición de solar.

427 Disposicion adicional 1.2 derogado por Ley $15 / 2004$, de 29 de diciembre, de modificación de la Ley 9/2002, de 30 de diciembre, de ordenación urbanistica y protección del medio rural de Galicia.
2. Para edificar en los núcleos rurales existentes en los municipios sin planeamiento, será necesaria la previa aprobación del expediente de delimitación del suelo de núcleo rural, en el que se acreditará el cumplimiento de los requisitos establecidos por el artículo 13 de la presente ley. El expediente contendrá el estudio individualizado del núcleo rural, con arreglo a lo señalado por el artículo 61.3 de la presente ley, así como los planos de delimitación del perímetro del núcleo rural y, en su caso, de su área de expansión. También quedarán reflejados el trazado de la red viaria pública existente y los espacios reservados para dotaciones y equipamientos públicos. En el área de expansión la superficie mínima de la parcela edificable no será inferior a 2.000 metros cuadrados y la superficie de la edificación en planta no sobrepasará los 200 metros cuadrados.

El expediente será tramitado por el Ayuntamiento con información pública por plazo máximo de un mes, mediante anuncio que habrá de publicarse en el "Diario Oficial de Galicia" y en dos de los periódicos de mayor difusión en la provincia. El expediente será aprobado provisionalmente por el órgano municipal competente para la aprobación del planeamiento general y remitido al director general competente en materia de urbanismo para que resuelva sobre la aprobación definitiva en el plazo de tres meses contados a partir de la recepción del expediente completo en el registro de la consellería. Transcurrido este plazo sin resolución expresa, se entenderá aprobado por silencio administrativo ${ }^{428}$.

3. En el resto de los terrenos se aplicará el régimen del suelo rústico establecido en la presente ley.

\footnotetext{
428 Disposición adicional 2.2 modificado por Ley $15 / 2004$, de 29 de diciembre, de modificación de la Ley $9 / 2002$, de 30 de diciembre, de ordenación urba-
} nistica y protección del medio rural de Galicia. 
DISPOSICIÓN ADICIONAL TERCERA NÚCLEOS RURALES PREEXISTENTES DE CARÁCTER TRADICIONAL AFECTADOS POR LA LEGISLACIÓN DE COSTAS

1. A los núcleos rurales preexistentes de carácter tradicional contemplados en la Ley 11/1985, de 22 de agosto, de adaptación de la del suelo a Galicia, les será de aplicación el régimen previsto en el apartado 3 de la disposición transitoria tercera de la Ley $22 / 1988$, de 28 de julio, de costas, así como lo establecido en el apartado 3 de la disposición transitoria séptima y en los apartados 1 y 3 de la disposición transitoria novena del Reglamento general para el desarrollo y ejecución de dicha Ley de costas, cuando, a la entrada en vigor de esta última, concurría en los mismos alguno de los siguientes supuestos:

a. En municipios con planeamiento, los terrenos clasificados de suelo urbano de núcleo rural, así como aquellos que reunían alguno de los siguientes requisitos:

- Que contaban con acceso rodado, abastecimiento de agua, evacuación de aguas residuales y suministro de energía eléctrica.

- Que, aun careciendo de alguno de los servicios citados en el guión anterior, estaban comprendidos en áreas consolidadas por la edificación como mínimo en dos terceras partes de su superficie, de conformidad con la ordenación de aplicación.

b. En municipios sin planeamiento, los terrenos que reunían alguno de los siguientes requisitos:

- Que contaban con acceso rodado, abastecimiento de agua, evacuación de aguas residuales y suministro de energía eléctrica.

- Que, aun careciendo de alguno de los servicios citados en el guión anterior, estaban comprendidos en áreas consolidadas por la edificación como mínimo en la mitad de su superficie.

2. Reglamentariamente se establecerá la documentación y el procedimiento para determinar las áreas en que concurren los requisitos señalados en el apartado anterior.

3. En los deslindes del dominio público marítimo-terrestre el límite interior de su zona de servidumbre de protección habrá de ajustarse a la realidad urbanística preexistente reconocida expresamente por la Administración urbanística autonómica429 430.

\section{DISPOSICIÓN ADICIONAL CUARTA ACCIÓN PÚBLICA}

1. Cualquier ciudadano, en ejercicio de la acción pública en materia de urbanismo, puede exigir ante los órganos administrativos y ante la jurisdicción contencioso-administrativa el cumplimiento de la legislación y del planeamiento urbanístico.

2. La acción pública a que se hace referencia en el número anterior, si es motivada por la ejecución de obras que se estimen ilegales, puede ejercerse mientras se prolongue su ejecución $\mathrm{y}$, posteriormente, hasta el vencimiento de los plazos de prescripción determinados en la presente ley.

\section{DISPOSICIÓN ADICIONAL OUINTA PAGO VOLUNTARIO DE MULTAS Y SANCIONES}

Las multas y sanciones impuestas al amparo de la presente ley se reducirán en

429 Disposición adicional tercera modificada por Ley 18/2008, de 29 de diciembre, de vivienda de Galicia. 430 Téngase en cuenta Providencia del 5 de mayo de 2009 del Tribunal Constitucional, por la que se establece que:

"El Pleno del Tribunal Constitucional por providencia de 5 mayo actual, ha admitido a trámite el recurso de inconstitucionalidad número 3644-2009, promovido por el Presidente del Gobierno, contra la disposición adicional segunda de la Ley de la Comunidad Autónoma de Galicia 18/2008, de diciembre, de Vivienda. Y se hace constar que por el Presidente del Gobierno se ha invocado el articulo 161.2 de la Constitución, lo que produce la suspensión de la vigencia y aplicación del precepto impugnado desde la fecha de interposición del recurso -20 de abril de 2009- para las partes del proceso, y desde la publicación del correspondiente edicto en el "Boletin Oficial del Estadon para los terceros". 
su cuantía en un 30 por 100 si son abonadas en el plazo de quince días a partir de la notificación de la multa o sanción, y el infractor muestra por escrito su conformidad con éstas y renuncia expresamente al ejercicio de toda acción de impugnación en el referido plazo.

\section{DISPOSICIÓN ADICIONAL SEXTA CONSTITUCIÓN DE LA AGENCIA DE PROTECCIÓN DE LA LEGALIDAD URBANÍSTICA}

Se habilita al Consello de la Xunta de Galicia, a propuesta del conselleiro competente en materia de ordenación del territorio y urbanismo, para adoptar todas las medidas precisas para la constitución y puesta en funcionamiento de la Axencia de Protección dla Legalidade Urbanística creada en virtud de la presente ley.

\section{DISPOSICIÓN TRANSITORIA PRIMERA RÉGIMEN DE APLICACIÓN A LOS MUNICIPIOS CON PLANEAMIENTO NO ADAPTADO}

1. Los planes de ordenación aprobados definitivamente con anterioridad a la entrada en vigor de esta ley conservarán su vigencia hasta su revisión o adaptación a los preceptos de la presente ley, con arreglo a las siguientes reglas:

a. Al suelo urbano de los municipios con plan general de ordenación municipal aprobado al amparo de la Ley 1/1997, del suelo de Galicia, se le aplicará lo dispuesto en esta ley para el suelo urbano, sin perjuicio de respetar la ordenación establecida en el planeamiento en vigor.

b. Al suelo urbano de los municipios con planeamiento general no adaptado a la Ley 1/1997, del Suelo de Galicia, que reúna las condiciones establecidas en el artículo 12.a) de esta ley, se le aplicará lo dispuesto en la misma para el suelo urbano consolidado, sin perjuicio de respetar la ordenación establecida en el planeamiento vigente. c. Al resto del suelo urbano y, en todo caso, al incluido en polígonos, unidades de ejecución o de actuación de los municipios con planeamiento no adaptado a la Ley 1/1997, del Suelo de Galicia, se le aplicará lo dispuesto por la presente ley para el suelo urbano no consolidado y podrá ejecutarse de acuerdo con la ordenación establecida por el planeamiento vigente en el plazo de tres años a partir de la entrada en vigor de la Ley 9/2002, de Ordenación Urbanística y Protección del Medio Rural de Galicia. Transcurrido este plazo sin que haya sido aprobado definitivamente el instrumento de equidistribución, serán de aplicación los límites de edificabilidad establecidos por la presente ley para el suelo urbano no consolidado, siendo el ámbito de referencia para la aplicación de esta limitación el polígono o unidad de ejecución o de actuación.

En caso de que los terrenos no estén incluidos en polígonos y merezcan la condición de suelo urbano no consolidado según la presente ley, deberá procederse a la delimitación del polígono con arreglo al procedimiento establecido por el artículo 117.

d. Al suelo urbanizable de los municipios con plan general adaptado a la Ley 1/1997, del Suelo de Galicia, se le aplicará lo dispuesto en la presente ley para el suelo urbanizable delimitado; y, al resto del suelo urbanizable, apto para urbanizar o rústico apto para el desarrollo urbanístico, se le aplicará lo dispuesto en la presente ley para el suelo urbanizable no delimitado.

En todo caso, los sectores con plan parcial aprobado definitivamente deberán ser ejecutados con arreglo a la ordenación y en los plazos establecidos en el propio plan parcial y, como máximo, en el plazo de tres años contados a partir de la entrada en vigor de la Ley 9/2002, de Ordenación Urbanística y Protección del Medio Rural de Galicia. Transcurrido este plazo sin que haya sido aprobado definitivamente el instrumento de equidistribución, deberá 
revisarse íntegramente el plan para adaptarlo a lo dispuesto en la presente ley.

En los municipios con plan general de ordenación municipal adaptado a la Ley 1/1997, del Suelo de Galicia, los planes parciales y planes de sectorización que se aprueben deberán acomodarse íntegramente a lo dispuesto en la presente ley, con la particularidad de que serán de aplicación los usos e intensidades fijados por el vigente plan general, en su caso.

En el resto de los municipios con planeamiento general no adaptado a la Ley 1/1997, del Suelo de Galicia, ni a la presente ley, se aplicará íntegramente la Ley $9 / 2002$, con la particularidad de que a los sectores contiguos sin solución de continuidad con el suelo urbano se les aplicarán los límites establecidos por el artículo 46.3, y a los demás sectores se les aplicarán los límites establecidos por el artículo 46.4, sin perjuicio de las mayores limitaciones establecidas por el planeamiento vigente. Al mismo tiempo, en estos municipios, para la aprobación definitiva de planes parciales y de sus modificaciones, será necesario obtener el informe favorable del director general competente en materia de urbanismo, en los términos establecidos por el artículo 86.1.d).

En todo caso, a los ámbitos sin plan parcial aprobado definitivamente antes de la entrada en vigor de la Ley 9/2002 que se encuentren en el ámbito de la servidumbre de protección establecida por la Ley 22/1988, de Costas, o en el ámbito sometido a algún régimen de protección de la Ley 9/2001, de conservación de la naturaleza, se les aplicará el régimen establecido por la presente ley para el suelo rústico de protección de costas o de espacios naturales, respectivamente.

e. Al suelo incluido en el ámbito de los núcleos rurales tradicionales delimitados al amparo de la Ley 11/1985, de adaptación de la del suelo a Galicia, o clasificado como suelo de núcleo rural según la
Ley 1/1997, del Suelo de Galicia, se le aplicará íntegramente lo dispuesto en la presente ley para el suelo de núcleo rural, sin perjuicio de las mayores limitaciones establecidas por el planeamiento.

No obstante lo anterior, a los terrenos incluidos en polígonos en ejecución por contar con instrumento de equidistribución aprobado definitivamente con anterioridad a la entrada en vigor de la Ley 9/2002, les será de aplicación el régimen de suelo urbano no consolidado, sin perjuicio de respetar la ordenación establecida por el plan especial.

A los terrenos incluidos en el ámbito del núcleo rural delimitado que no presenten un grado de consolidación por la edificación superior al 50\% se les aplicará el régimen establecido por la presente ley para las áreas de expansión del suelo de núcleo rural.

A través del procedimiento de modificación del planeamiento general, se podrá delimitar o revisar la delimitación individualizada de los núcleos rurales existentes, según los criterios establecidos por el artículo 13 de la presente ley.

El planeamiento general modificado o revisado podrá incluir dentro del área de expansión aquellos terrenos que fueron clasificados como suelo de núcleo rural al amparo de lo establecido por la Ley 1/1997, del Suelo de Galicia, aunque no cumplan todos los requisitos establecidos por el artículo 13 de la presente ley ${ }^{431}$.

f. Al suelo clasificado por el planeamiento vigente como no urbanizable o rústico se le aplicará íntegramente lo dispuesto en esta ley para el suelo rústico, sin perjuicio de las mayores limitaciones establecidas en el planeamiento vigente.

g. En todo caso, las modificaciones y revisiones del planeamiento vigente a la

431 Disposición transitoria 1.1.c, Disposición transitoria 1.1.d y Disposición transitoria 1.1.e modificadas por Ley 15/2004, de 29 de diciembre, de modificación de la Ley $9 / 2002$, de 30 de diciembre, de ordenación urbanistica y protección del medio rural de Galicia. 
entrada en vigor de la presente ley deben ajustarse a lo dispuesto en la misma.

2. Los Decretos autonómicos de suspensión del planeamiento urbanístico que fueron dictados antes de la entrada en vigor de la presente ley mantendrán su plena eficacia hasta la aprobación definitiva del correspondiente Plan General de Ordenación Municipal, con las siguientes especificaciones:

a. Al suelo urbano se le aplicará el régimen establecido por esta ley para el suelo urbano y la ordenación provisional establecida en los correspondientes Decretos.

b. En el suelo apto para urbanizar y en el suelo no urbanizable será de aplicación íntegramente lo dispuesto en esta ley para el suelo rústico.

c. En los núcleos rurales tradicionales delimitados será de aplicación lo dispuesto en esta ley para el suelo de núcleo rural.

\section{DISPOSICIÓN TRANSITORIA SEGUNDA ADAPTACIÓN DEL PLANEAMIENTO}

1. El planeamiento urbanístico vigente en la actualidad deberá adaptarse a lo dispuesto en la presente ley en cualquiera de los siguientes supuestos:

a. En el plazo de tres años.

b. Cuando se proceda a su revisión.

c. Cuando concurriesen circunstancias objetivas en el Ayuntamiento afectado que lo aconsejen y así lo determine el conselleiro competente en materia de ordenación del territorio y urbanismo. En caso de incumplimiento del requerimiento autonómico será de aplicación lo dispuesto en el artículo 81.2 de la presente ley.

2. En todo caso, los Ayuntamientos podrán adaptar sus planes generales o normas subsidiarias en cualquier momento.

\section{DISPOSICIÓN TRANSITORIA TERCERA PLANES EN TRAMITACIÓN}

El planeamiento aprobado inicialmente y en tramitación antes de la entrada en vigor de esta ley podrá, durante el plazo máximo de seis meses, continuar su tramitación hasta su aprobación definitiva con arreglo a lo dispuesto en la Ley 1/1997, del Suelo de Galicia, en cuyo caso será de aplicación lo establecido en la Disposición transitoria primera de esta ley, o adaptarse íntegramente a la presente ley. La simple adaptación del contenido del plan en tramitación a las disposiciones establecidas en la presente ley no implicará, por sí solo, la necesidad de someterlo a nueva información pública, salvo cuando se pretendan introducir otras modificaciones que alteren sustancialmente la ordenación proyectada y no sean consecuencia de la adaptación, extremo que será informado por el Secretario municipal.

Transcurrido el plazo de seis meses desde la entrada en vigor de la presente ley, el planeamiento obligatoriamente deberá adaptarse íntegramente a lo dispuesto en esta ley.

\section{DISPOSICIÓN TRANSITORIA CUARTA RÉGIMEN DE AUTORIZACIONES Y LICENCIAS OTORGADAS EN SUELO RÚSTICO Y SUELO DE NÚCLEO RURAL}

1. Las autorizaciones y licencias otorgadas en suelo rústico y en suelo de núcleo rural antes de la entrada en vigor de esta ley en las que no se hubiera iniciado la edificación se podrán declarar extinguidas por el órgano que las hubiese otorgado, previa audiencia del interesado, en cuanto sean contrarias o disconformes con el nuevo régimen establecido en la presente ley, sin perjuicio de los eventuales derechos de indemnización que pudieran corresponder, en cuyo caso deberán fijarse en el mismo expediente.

En el supuesto de que ya hubieran transcurrido los plazos para la iniciación, se entenderán automáticamente caducadas por ministerio de la ley.

2. En el supuesto de que las obras ya se hubiesen iniciado antes de la entrada en vigor de la presente ley y resultaran incompatibles o disconformes con el nuevo régimen del suelo rústico o de núcleo rural, 
el conselleiro competente en materia de ordenación del territorio y urbanismo o el Ayuntamiento podrán modificar, dejar sin efecto o revocar, respectivamente, la autorización o licencia, sin perjuicio de los eventuales derechos de indemnización, que, en su caso, deberán fijarse en el mismo expediente.

3. Las construcciones ejecutadas en suelo rústico al amparo de la licencia urbanística y de la preceptiva autorización autonómica podrán mantener el uso autorizado, y podrán ejecutarse en las mismas obras de mejora y reforma de las instalaciones sin incrementar la superficie edificada legalmente, aun cuando no cumplan las condiciones de uso y de edificación establecidas por la presente ley.

Asimismo, previa autorización autonómica, con arreglo a lo establecido por el artículo 41, podrán ejecutarse obras de ampliación de la superficie edificada lícitamente, cumpliendo los siguientes requisitos:

a. Que no se trate de terrenos que hayan de ser incluidos en el suelo rústico de protección de espacios naturales, de aguas, de costas o de interés paisajístico de acuerdo con la presente ley.

b. Que cumpla las condiciones de edificación establecidas por los artículos 42 y 44 de la presente ley por el planeamiento urbanístico.

En caso de viviendas en suelo rústico, sólo podrán ampliarse hasta un máximo del $10 \%$ de la superficie edificada autorizada.

c. Que se mantengan el uso y la actividad autorizados originariamente, no permitiéndose el cambio de uso.

d. Que se adopten las medidas correctoras necesarias para minimizar la incidencia sobre el territorio y todas aquellas medidas, condiciones o limitaciones tendentes a conseguir la menor ocupación territorial y la mejor protección del paisaje, los recursos productivos y el medio natural, así como la preservación del patrimonio cultural y de la singularidad y tipología arquitectónica de la zona ${ }^{432}$.

\section{DISPOSICIÓN TRANSITORIA QUINTA EDIFICACIONES ILEGALES EN SUELO RÚSTICO}

1. Las edificaciones y construcciones situadas en terrenos clasificados como suelo rústico sin la preceptiva autorización autonómica o sin licencia municipal podrán ser objeto de expediente de legalización siempre que se cumplan las siguientes condiciones:

a. Que en el momento de la entrada en vigor de la Ley 9/2002 hubiera transcurrido el plazo legalmente establecido sin que la administración haya adoptado ninguna medida dirigida a la restauración de la legalidad urbanística.

b. Que los terrenos en que se emplaza la edificación no merezcan la condición de suelo rústico de protección de espacios naturales, de costas o de interés paisajístico, según lo establecido en la presente ley.

2. Para la legalización de las edificaciones, construcciones e instalaciones será necesario obtener, previamente a la licencia urbanística municipal, la preceptiva autorización autonómica con arreglo al procedimiento establecido por el artículo 41 de la presente ley.

El anteproyecto de legalización deberá contemplar las medidas correctoras necesarias para dar cumplimiento a lo dispuesto por las letras a) y b) del número 2 del artículo 42 y por el artículo 104 de la presente ley.

La solicitud de autorización para legalizar las construcciones e instalaciones deberá presentarse en el plazo máximo de tres años a contar desde la entrada en vigor de la Ley de modificación de la Ley 9/2002.

432 Disposición transitoria 4.3 modificado por Ley 15/2004, de 29 de diciembre, de modificación de la Ley 9/2002, de 30 de diciembre, de ordenación urbanistica y protección del medio rural de Galicia. 
3. El promotor de la licencia deberá abonar en concepto de canon de legalización del aprovechamiento urbanístico una parte del aprovechamiento que se legalice. El importe del canon se distribuirá atribuyendo el $80 \%$ al municipio en que se emplaza la edificación o construcción y el $20 \%$ restante a la Comunidad Autónoma.

La cuantía del canon será de 10 euros por cada metro cuadrado de superficie edificada, incluida en su caso la superficie que se pretende ampliar, debiendo ser abonado al municipio en el plazo de un mes desde que le sea notificado el otorgamiento de la licencia de legalización.

El municipio será responsable de la gestión y recaudación del canon y deberá transferir a la Comunidad Autónoma la parte proporcional de los ingresos obtenidos por este canon.

4. En las edificaciones y construcciones legalizadas podrán autorizarse obras de mejora y reforma y, en casos justificados, obras de ampliación cumpliendo las condiciones de edificación establecidas por los artículos 42 y 44 de la presente ley por el planeamiento urbanístico. En caso de viviendas en suelo rústico, sólo podrá ampliarse hasta un máximo del $10 \%$ de la superficie edificada originaria.

En ningún caso se autorizará el cambio de uso o actividad preexistente.

5. Las edificaciones y construcciones existentes en suelo rústico sin la preceptiva licencia urbanística municipal o sin la preceptiva autorización autonómica que no resulten legalizadas deberán ser demolidas por sus propietarios. En caso de que el propietario no proceda a la demolición, el Alcalde o el conselleiro competente en materia de urbanismo y ordenación del territorio podrán ordenar la demolición a costa del obligado, previa audiencia al interesado. Para la ejecución de la orden de demolición podrán imponerse multas coercitivas en la forma y cuantía señalada por el artículo 209.6 de la presente ley ${ }^{433}$.

\section{DISPOSICIÓN TRANSITORIA SEXTA DISPOSICIONES COMPLEMENTARIAS} A ESTA LEY

Hasta que entren en vigor las disposiciones reglamentarias de desarrollo de esta ley, se aplicarán las que se contienen en los reglamentos de planeamiento urbanístico, gestión urbanística, disciplina urbanística de Galicia y edificación forzosa y registro municipal de solares, en todo lo que no se opongan a la presente ley o resulten afectadas por la misma.

\section{DISPOSICIÓN TRANSITORIA SÉPTIMA JURADOS PROVINCIALES DE EXPROPIACIÓN}

El Reglamento previsto en el artículo 232.3 de la presente ley se aprobará en el plazo máximo de un año desde su entrada en vigor y, mientras, seguirán ejerciendo estas funciones los actuales Jurados Provinciales de Expropiación Forzosa.

\section{DISPOSICIÓN TRANSITORIA OCTAVA DIRECTRICES DE ORDENACIÓN DEL TERRITORIO Y PLANES SECTORIALES}

Con arreglo a lo dispuesto en la Ley 10/1995, de Ordenación del Territorio de Galicia, la Xunta remitirá al Parlamento en el plazo de un año desde la entrada en vigor de la presente ley el documento de aprobación provisional de las directrices de ordenación del territorio.

Asimismo, la Xunta remitirá al Parlamento en el plazo de dos años desde la entrada en vigor de la presente ley el Plan Sectorial de Ordenación del Litoral en donde se recogerán las condiciones específicas de este ámbito territorial.

433 Disposición transitoria 5 modificado por Ley 15/2004, de 29 de diciembre, de modificación de la Ley 9/2002, de 30 de diciembre, de ordenación urbanistica y protección del medio rural de Galicia. 


\section{DISPOSICIÓN TRANSITORIA NOVENA INSTRUMENTOS DE GESTIÓN URBANISTICA EN TRAMITACIÓN}

Los instrumentos de gestión urbanística en tramitación a la entrada en vigor de la presente ley podrán continuar tramitándose de acuerdo con lo dispuesto en la Ley 1/1997, de 24 de marzo, del Suelo de Galicia.

\section{DISPOSICIÓN TRANSITORIA DÉCIMA PROCEDIMIENTOS SANCIONADORES}

En todo caso, los procedimientos sancionadores y de reposición de la legalidad por infracciones cometidas con anterioridad a la entrada en vigor de la presente ley se regirán por la legislación vigente en el momento de su comisión, sin perjuicio de aplicar a los expedientes sancionadores la norma más favorable al sancionado.

\section{DISPOSICIÓN TRANSITORIA DÉCIMO PRIMERA \\ EXPLOTACIONES AGROPECUARIAS Y ASERRADEROS EXISTENTES}

1. Las construcciones e instalaciones ubicadas en suelo rústico o en suelo de núcleo rural que estando destinadas exclusivamente a actividades agrícolas, ganaderas y aserraderos de madera existían en el momento de la entrada en vigor de la presente ley podrán mantener su actividad aunque no estuvieran amparadas en la preceptiva licencia urbanística municipal.

En estas construcciones podrán permitirse, previa obtención de licencia urbanística municipal, las obras de conservación y de reforma necesarias siempre que mantengan su actividad agropecuaria o de aserradero, adoptando las medidas correctoras oportunas para garantizar las condiciones sanitarias y medioambientales.

2. Asimismo, podrá permitirse, previa obtención de licencia urbanística municipal, la ampliación de las construcciones destinadas a explotaciones agrícolas y ganaderas, incluso en volumen independiente, cumpliendo las condiciones de edificación establecidas en el artículo 42 de la presente ley y en el planeamiento urbanístico vigente, salvo en lo referente a las condiciones de parcela mínima edificable, ocupación y volumen máximos y distancias mínimas a viviendas y a asentamientos de población.

En caso de las construcciones destinadas a aserraderos también se permitirá su ampliación siempre que cumpliesen las condiciones de edificación establecidas en el artículo 42 de la presente ley y en el planeamiento urbanístico, salvo en lo referente a la superficie máxima ocupada por la edificación sin sobrepasar el límite del $40 \%$ de la superficie de la parcela.

En todo caso, habrá de mantenerse el estado natural del terreno, o con plantación de arbolado o especies vegetales, como mínimo, en la mitad de la superficie de la parcela.

3 . Este mismo régimen será de aplicación a las edificaciones, construcciones e instalaciones destinadas a explotaciones agropecuarias y aserraderos amparadas en licencia urbanística otorgada antes de la entrada en vigor de la presente ley ${ }^{434}$.

\section{DISPOSICIÓN TRANSITORIA DUODÉCIMA EXPLOTACIONES MINERAS EXISTENTES}

Las explotaciones mineras, las actividades extractivas de recursos minerales y los establecimientos de beneficio vinculados a las actividades mineras en activo en el momento de la entrada en vigor de la Ley 9/2002, de 30 de diciembre, ubicados en suelo rústico especialmente protegido podrán continuar su actividad en los ámbitos para los que disponen de licencia urbanística municipal.

Las explotaciones mineras, las actividades extractivas de recursos minerales y los establecimientos de beneficio vinculados a las actividades mineras en activo en el momento de la entrada en vigor de la Ley

434 Disposición Transitoria Décimo primera modificada por Ley 6/2008, de 19 de junio, de medidas urgentes en materia de vivienda y suelo, por la que se modifica la Ley $9 / 2002$, de 30 de diciembre, de ordenación urbanistica y protección del medio rural de Galicia. 
9/2002, de 30 de diciembre, ubicados en suelo rústico de protección ordinaria y de especial protección forestal que no cuenten con la preceptiva licencia urbanística municipal para continuar su actividad deberán obtenerla, previa acreditación de su existencia con anterioridad a la entrada en vigor de dicha Ley. Para ello, bastará con el reconocimiento administrativo de la dirección general con competencia en materia de minas. Para la obtención de la licencia urbanística municipal se presentará en el ayuntamiento la solicitud de regularización a la que se adjuntará el reconocimiento administrativo anteriormente señalado.

Las explotaciones mineras, las actividades extractivas de recursos minerales y los establecimientos de beneficio vinculados a las actividades mineras en activo en el momento de la entrada en vigor de la Ley 9/2002, de 30 de diciembre, ubicados en cualquier categoría de suelo rústico especialmente protegido, salvo los mencionados en el párrafo anterior, que no cuenten con la preceptiva licencia urbanística municipal para continuar su actividad deberán obtenerla, previa autorización del Consejo de la Xunta, oída la Comisión Superior de Urbanismo de Galicia y la propuesta de la consejería competente en materia de minas. El Consejo de la Xunta valorará la compatibilidad o no de la explotación con los valores naturales, ambientales, paisajísticos y de patrimonio cultural existentes o con su vinculación a pactos ambientales.

La implantación de nuevas explotaciones y actividades extractivas así como la ampliación de las existentes en cualquier categoría de suelo rústico especialmente protegido no podrán realizarse en tanto no sea aprobado definitivamente el Plan sectorial de actividades extractivas de Galicia previsto en el título III de la Ley de Ordenación de la Minería de Galicia, que será formulado y tramitado por el consejero o consejera competente en materia de minas; todo ello sin perjuicio de la posibilidad de otorgar licencia para actividades extractivas en suelo rústico de protección ordinaria y de especial protección forestal, según lo dispuesto por los artículos 36 y 37 de la presente Ley. 435 .

\section{DISPOSICIÓN TRANSITORIA DECIMOTERCERA ASENTAMIENTOS SURGIDOS AL MARGEN DEL PLANEAMIENTO}

Los asentamientos de viviendas surgidos al margen del planeamiento urbanístico antes de la entrada en vigor de la presente ley que no estén integrados en la malla urbana ni reúnan las características propias de un núcleo rural tradicional se clasificarán como suelo urbanizable, cumpliendo los siguientes requisitos:

a. El ámbito del sector deberá estar ocupado por la edificación, al menos, en dos terceras partes de los espacios aptos para la misma, de acuerdo con la ordenación que el plan establezca. En ningún caso podrá afectar a terrenos que hayan de incluirse en suelo rústico de protección de costas, de aguas o de espacios naturales, según la presente ley.

b. La tipología de las edificaciones será la de vivienda unifamiliar con una altura máxima de dos plantas.

c. El plan podrá reducir o eliminar justificadamente las reservas de suelo para dotaciones públicas y para viviendas sujetas a algún régimen de protección pública establecidas por la presente ley.

d. El aprovechamiento urbanístico de los propietarios será el correspondiente al $100 \%$ del aprovechamiento tipo ${ }^{436}$.

\footnotetext{
435 Disposición Transitoria décimo segunda modificada por Ley $3 / 2008$, de 23 de mayo, de Ordenación de la Mineria de Galicia.

436 Disposición transitoria 13 modificada por Ley 15/2004 de 29 de diciembre, de modificación de la Ley 9/2002, de 30 de diciembre, de ordenación urbanistica y protección del medio rural de Galicia.
} 


\section{DISPOSICIÓN DEROGATORIA DEROGACIÓN DE LAS LEYES 7/1995 Y 1/1997}

Quedan derogadas la Ley 1/1997, de 24 de marzo, del Suelo de Galicia, y la Ley 7/1995, de 29 de junio, de Delegación y Distribución de Competencias en Materia de Urbanismo.

Asimismo, quedan derogados cuantos preceptos de igual o inferior rango, incluidas las determinaciones del planeamiento urbanístico, se opongan a lo dispuesto en la presente ley.

\section{DISPOSICIÓN FINAL PRIMERA} $(\ldots)^{437}$

\section{DISPOSICIÓN FINAL SEGUNDA DESARROLLO REGLAMENTARIO DE LA LEY}

Se autoriza al Consello de la Xunta para dictar las disposiciones para el desarrollo reglamentario de la presente ley.

\section{DISPOSICIÓN FINAL TERCERA ENTRADA EN VIGOR}

La presente ley entrará en vigor al día siguiente de su publicación en el "Diario Oficial de Galicia".

\section{LEY 6/2007, DE 11 DE MAYO, DE MEDIDAS URGENTES EN MATERIA DE ORDENACIÓN DEL TERRITORIO Y DEL LITORAL DE GALICIA (DOGA N. $\left.{ }^{\circ} 94,15.5 .2007\right)$}

\section{(...) 438 \\ Capítulo preliminar OBJETO DE LA LEY}

Artículo 1. Objeto.

Es objeto de la presente ley la adopción de medidas urgentes en materia de ordenación del territorio y del litoral de Galicia, con la finalidad de:

437 Disposición final primera contiene modificaciones a la Ley de ordenación del territorio de Galicia. 438 Preámbulo omitido. a. Garantizar la preservación del litoral en tanto no sea aprobado el Plan de ordenación del litoral o el planeamiento urbanístico adaptado a la legislación vigente y a los criterios de sostenibilidad económica, social y ambiental.

b. Integrar los procedimientos de aprobación de los instrumentos de ordenación del territorio y del planeamiento urbanístico con el proceso de evaluación ambiental estratégica.

c. Crear el Instituto de Estudios del Territorio.

d. Fomentar la creación de suelo destinado a viviendas protegidas.

\section{Capítulo I}

MEDIDAS URGENTES EN MATERIA

DE ORDENACIÓN DEL TERRITORIO Y DEL LITORAL

Artículo 2. Plan de ordenación del litoral.

1. El Plan sectorial de ordenación del litoral a que hace referencia la Disposición transitoria octava de la Ley 9/2002, de 30 de diciembre, de Ordenación Urbanística y Protección del Medio Rural de Galicia, tendrá la naturaleza de un plan territorial integrado regulado en la Ley 10/1995, de 23 de noviembre, de Ordenación del Territorio de Galicia, al objeto de establecer los criterios, principios y normas generales para la ordenación urbanística de la zona litoral basada en criterios de perdurabilidad y sostenibilidad, así como la normativa necesaria para garantizar la conservación, protección y puesta en valor de las zonas costeras.

2. Las determinaciones del Plan de ordenación del litoral serán directamente aplicables y prevalecerán de forma inmediata sobre las del planeamiento urbanístico, que habrá de ser objeto de adaptación.

3. El procedimiento de aprobación del Plan de ordenación del litoral se ajustará 
a lo dispuesto en los artículos 5 bis y 15 de la Ley 10/1995, de 23 de noviembre, de Ordenación del Territorio de Galicia ${ }^{439}$.

Artículo 3. Suspensión de nuevos desarrollos urbanísticos en la zona litoral.

1. Se suspende la tramitación y aprobación de los planes especiales de reforma interior, planes parciales, planes de sectorización e instrumentos de equidistribución que tengan por objeto la transformación urbanística de terrenos situados a una distancia inferior a 500 metros, medidos en proyección horizontal tierra adentro, desde el límite interior de la ribera del mar de los municipios que se relacionan en el anexo.

2. Esta suspensión será de aplicación en las siguientes clases de suelo:

a. En todos los municipios costeros, en los terrenos clasificados como suelo urbanizable, apto para urbanizar o rústico apto para el desarrollo urbanístico.

b. En los municipios costeros con población inferior a 50.000 habitantes, en los terrenos clasificados como suelo urbano que, en el momento de la entrada en vigor de la presente ley, no reúnan los requisitos establecidos en los artículos 11 y 12.a) en relación con el artículo 16.1 de la Ley 9/2002, de 30 de diciembre, de Ordenación Urbanística y Protección del Medio Rural de Galicia, y, en todo caso, en los incluidos en polígonos, unidades de actuación o de ejecución.

Artículo 4. Alcance de la suspensión.

1. Las medidas de suspensión a que se refiere el artículo 3 de la presente ley serán de aplicación en los municipios con planeamiento general no adaptado a la Ley 9/2002, de 30 de diciembre, de Ordenación Urbanística y Protección del Medio Rural de Galicia, durante el plazo de dos años a contar desde la entrada en vigor de la presente ley, o hasta la aprobación del Plan de ordenación del litoral o del Plan general

439 Orden de 14 de mayo de 2009 por la que se acuerda la suspensión cautelar previa a la aprobación inicial del Plan de ordenación del litoral de Galicia. de ordenación municipal adaptado íntegramente a la Ley 9/2002, de 30 de diciembre.

2. La suspensión abarca a todos los planes especiales de reforma interior, planes parciales y planes de sectorización que, en el momento de la entrada en vigor de la presente ley, no estén aprobados definitivamente. Asimismo, la suspensión comprende todos los instrumentos de equidistribución del planeamiento urbanístico respecto a los que, en el momento de la entrada en vigor de la presente ley, hubiera transcurrido el plazo establecido en el instrumento de planeamiento que contenga la ordenación detallada para su aprobación definitiva o ya hubiesen transcurrido tres años a contar desde la aprobación de dicho plan que se ejecuta.

\section{Capítulo II EVALUACIÓN AMBIENTAL ESTRATÉGICA DE INSTRUMENTOS DE ORDENACIÓN DEL TERRITORIO Y DE PLANEAMIENTO URBANÍSTICO}

Artículo 5. Instrumentos de ordenación del territorio y de planeamiento urbanístico objeto de evaluación ambiental estratégica. De conformidad con lo dispuesto en los artículos 3 y 4 de la Ley 9/2006, de 28 de abril, sobre evaluación de los efectos de determinados planes y programas del medio ambiente, serán objeto de evaluación ambiental estratégica los siguientes instrumentos de ordenación del territorio y de planeamiento urbanístico:

a. Los instrumentos de ordenación del territorio regulados en la Ley 10/1995, de 23 de noviembre, de Ordenación del Territorio de Galicia, excepto los proyectos sectoriales de incidencia supramunicipal que desarrollen las previsiones de un plan sectorial previamente sometido a evaluación ambiental estratégica según la Ley 9/2006, de 28 de abril.

b. Los planes generales de ordenación municipal.

c. Todos los instrumentos de ordenación del territorio o de planeamiento urbanístico 
que afecten a espacios naturales incluidos en la Red ecológica europea Natura 2000 o sometidos a algún régimen de protección establecido en la Ley 9/2001, de 21 de agosto, de conservación de la naturaleza.

d. Los planes parciales, los planes de sectorización y los planes especiales cuando así lo decida el órgano ambiental en cada caso, excepto que el planeamiento general que desarrollen fuera sometido a evaluación ambiental estratégica según la Ley 9/2006, de 28 de abril. La decisión, que deberá ser motivada y pública, se ajustará a los criterios establecidos en el anexo II de la Ley 9/2006, de 28 de abril.

e. Las modificaciones de cualquiera de los instrumentos relacionados en las letras anteriores cuando así lo decida el órgano ambiental en cada caso. La decisión, que deberá ser motivada y pública, se ajustará a los criterios establecidos en el anexo II de la Ley 9/2006, de 28 de abril.

Artículo 6. Administraciones competentes.

1. A los efectos establecidos en la Ley 9/2006, de 28 de abril, ejercerá las funciones correspondientes al órgano ambiental la consellería competente en materia de medio ambiente.

2. Las funciones correspondientes al órgano promotor serán ejercidas:

a. Respecto a los instrumentos de ordenación del territorio y del planeamiento urbanístico supramunicipal, por el departamento autonómico responsable de su tramitación.

b. Respecto a los demás instrumentos de planeamiento urbanístico, por el municipio responsable de su tramitación.

Artículo 7. Integración de procedimientos.

1. El proceso de evaluación ambiental estratégica de los instrumentos de ordenación del territorio o de planeamiento urbanístico se tramitará simultáneamente con el procedimiento legalmente establecido para su aprobación.
2. El promotor comunicará al órgano ambiental el inicio de la tramitación del instrumento de ordenación del territorio o del planeamiento urbanístico, acompañando un documento de inicio que incluirá los aspectos recogidos en el artículo 18 de la Ley 9/2006, de 28 de abril.

3. El órgano ambiental, en el plazo de tres meses desde la recepción de la documentación necesaria, trasladará al órgano promotor el documento de referencia de conformidad con lo dispuesto en el artículo 9 de la Ley $9 / 2006$, de 28 de abril.

4. El órgano promotor elaborará el informe de sostenibilidad ambiental de acuerdo con lo dispuesto en el artículo 8 de la Ley 9/2006, de 28 de abril, y según los criterios contenidos en el documento de referencia redactado por el órgano ambiental.

5. El plan aprobado inicialmente con todos los documentos que lo integran, incluido el informe de sostenibilidad ambiental, se someterá simultáneamente a las consultas previstas en el documento de referencia y a información pública durante el plazo mínimo de dos meses, mediante anuncios que se publicarán en la forma que determine la legislación reguladora del procedimiento de aprobación del plan.

6. Finalizado el período de consultas e información pública, y con carácter previo a la aprobación provisional o la definitiva cuando aquélla no sea preceptiva, el órgano promotor enviará al órgano ambiental la documentación completa del plan que tome en consideración el informe de sostenibilidad, las alegaciones y los informes presentados en el período de consultas, así como una propuesta de memoria ambiental de conformidad con lo dispuesto en el artículo 12 de la Ley 9/2006, de 28 de abril. Deberá también enviar los informes sectoriales y un informe sobre el proceso de participación pública.

7. El órgano ambiental, en el plazo de tres meses desde la recepción de la documentación, elaborará la memoria ambiental cuyas determinaciones tendrán 
carácter vinculante y deberán quedar reflejadas en el documento del plan que se apruebe provisional y definitivamente.

Si transcurre el plazo para elaborar la memoria ambiental sin que le hubiera sido comunicado al órgano promotor, se entenderá aceptada la propuesta de memoria ambiental enviada al órgano ambiental y se podrá continuar la tramitación del plan.

8. El cumplimiento de los trámites a que se refieren los anteriores números 6 y 7 interrumpirá el cómputo de los plazos que para la aprobación de los planes se establece en la legislación urbanística o de ordenación del territorio.

Artículo 8. Seguimiento.

El órgano promotor deberá realizar el seguimiento de los efectos en el medio ambiente de la aplicación o ejecución del plan, para identificar con prontitud los efectos adversos no previstos y permitir llevar a cabo las medidas adecuadas para evitarlos, con arreglo a lo dispuesto en el artículo 15 de la Ley $9 / 2006$, de 28 de abril.

El órgano ambiental podrá participar en el seguimiento de dichos planes y podrá recabar la información y realizar las comprobaciones que considere necesarias para verificar la información que figure en el informe de sostenibilidad ambiental.

\section{Capitulo III \\ EL INSTITUTO DE ESTUDIOS DEL TERRITORIO}

\section{Sección $1 .^{a}$}

Disposiciones generales

Artículo 9. Naturaleza y objeto.

1. De conformidad con lo dispuesto en el artículo 31 de la Ley 10/1995, de 23 de noviembre, de Ordenación del Territorio de Galicia, se crea el Instituto de Estudios del Territorio como Organismo Autónomo de carácter administrativo que tiene por objeto el análisis, estudio y asesoramiento en materia de urbanismo y ordenación del territorio.

2. Para el cumplimiento de sus fines el Instituto de Estudios del Territorio dispone de patrimonio propio y goza de personalidad jurídica propia, autonomía funcional y plena capacidad de obrar.

Artículo 10. Funciones.

1. Las funciones del Instituto de Estudios del Territorio serán las siguientes:

a. Realizar trabajos de investigación, análisis, estudio y difusión sobre urbanismo y ordenación del territorio.

b. Prestar asistencia y asesoramiento a los municipios de Galicia para la elaboración del planeamiento urbanístico y la gestión y ejecución del planeamiento.

c. Prestar apoyo a la consellería competente en materia de urbanismo y ordenación del territorio.

2. Las funciones atribuidas al Instituto de Estudios del Territorio se entenderán sin perjuicio de las que correspondan a los órganos urbanísticos de la Comunidad Autónoma.

Artículo 11. Régimen jurídico.

1. El Instituto de Estudios del Territorio se rige por lo dispuesto en esta ley y por las normas aplicables a los organismos autónomos dependientes de la Administración autonómica.

2. Los actos del Consejo Rector del Instituto de Estudios del Territorio, dictados en ejercicio de sus competencias, ponen fin a la vía administrativa.

3. El Instituto de Estudios del Territorio estará adscrito orgánicamente a la consellería competente en materia de urbanismo y ordenación del territorio.

\section{Sección 2. ${ }^{a}$ Órganos de gobierno}

\section{Artículo 12. Órganos.}

Los órganos de gobierno y administración del Instituto de Estudios del Territorio son el consejo rector y la dirección.

Artículo 13. El consejo rector.

1. El consejo rector está formado por:

a. La presidencia, que será ejercida por la persona titular de la consellería competente en materia de urbanismo y ordenación del territorio. 
b. La vicepresidencia, que corresponde a la persona titular de la dirección general de urbanismo.

c. Un mínimo de cuatro y un máximo de ocho vocales, en los que tendrán representación los Ayuntamientos, designados en la forma que se determine reglamentariamente.

d. El director o directora del instituto.

e. La secretaría, que será ejercida por quien designe el consejo rector entre el personal adscrito al Instituto de Estudios del Territorio, que podrá intervenir en las deliberaciones con voz pero sin voto.

2. El consejo rector es el órgano superior de dirección del Instituto de Estudios del Territorio, al que corresponden las siguientes funciones:

a. Aprobar las directrices de actuación del instituto.

b. Aprobar el anteproyecto de presupuesto anual de ingresos y gastos.

c. Proponer la estructura orgánica y el cuadro de personal del instituto.

d. Supervisar la actividad del instituto y la gestión de su director o directora.

e. Aprobar el reglamento de régimen interior del instituto.

f. Aquellas otras que reglamentariamente se determinen.

3. El funcionamiento del consejo se regirá por lo dispuesto en el reglamento de régimen interior $\mathrm{y}$, en lo no previsto, por lo dispuesto en los artículos 22 a 26 de la Ley 30/1992, de 26 de noviembre, de Régimen Jurídico de las Administraciones Públicas y del Procedimiento Administrativo Común.

Artículo 14. La dirección.

1. La directora o director del Instituto de Estudios del Territorio será nombrado por decreto de la Xunta de Galicia, a propuesta del conselleiro o conselleira competente en materia de urbanismo y ordenación del territorio.

2. Corresponde a la directora o director del Instituto de Estudios del Territorio:

a. La representación ordinaria del instituto.

b. La dirección e impulso de la actividad del instituto. c. La ejecución de los acuerdos del consejo rector.

d. La gestión económica del instituto.

e. La dirección de los servicios administrativos y la jefatura del personal del instituto.

f. El ejercicio de las competencias que, correspondiendo al Instituto de Estudios del Territorio, no se encuentren atribuidas legal o reglamentariamente a otro órgano del mismo.

\section{Sección 3. \\ Del régimen financiero y del personal}

Artículo 15. Régimen financiero.

1. El Instituto de Estudios del Territorio dispone, para el cumplimiento de sus fines, de los siguientes recursos:

a. Las cantidades que se le asignen en los presupuestos generales de la Comunidad Autónoma para garantizar el funcionamiento del instituto.

b. Las subvenciones y otras aportaciones públicas o privadas.

c. Las contraprestaciones derivadas de los convenios en los que sea parte.

d. Los rendimientos de su patrimonio.

e. Los rendimientos percibidos como contraprestación por la prestación de servicios de publicaciones y de cualquier otro servicio retributivo del instituto.

f. Los demás ingresos que pueda percibir de acuerdo con la legislación vigente.

2. Tendrán el carácter de patrimonio adscrito los bienes que le adscriba la Comunidad Autónoma.

Artículo 16. Régimen del personal.

1. Los puestos de trabajo del Instituto de Estudios del Territorio serán cubiertos por personal funcionario de la Comunidad Autónoma de Galicia o de otras administraciones públicas de acuerdo con lo dispuesto en la Ley de la Función Pública de Galicia.

2. El Instituto de Estudios del Territorio podrá encargar trabajos de investigación, estudio y documentación para el mejor 
cumplimiento de sus fines, con sujeción a la Ley de Contratos de las Administraciones Públicas.

\section{DISPOSICIÓN ADICIONAL PRIMERA LICENCIAS EN SUELO URBANO NO CONSOLIDADO}

1. Para el otorgamiento de licencias urbanísticas en terrenos en los que, estando clasificados como suelo urbano, no reúnan los requisitos del suelo urbano consolidado que establece el artículo 12 de la Ley 9/2002, de 30 de diciembre, de Ordenación Urbanística y Protección del Medio Rural de Galicia, será necesario que previamente esté aprobado el planeamiento que contenga la ordenación detallada, el proyecto de urbanización y el instrumento de equidistribución, de conformidad con lo dispuesto en los artículos 109.2, 110, 115 y siguientes de dicha Ley $9 / 2002$.

2. Serán nulas de pleno derecho las licencias para nuevas edificaciones que se hubieran otorgado en contra de lo dispuesto en el número 1 de esta disposición.

\section{DISPOSICIÓN ADICIONAL SEGUNDA} $(\ldots)^{440}$

\section{DISPOSICIÓN ADICIONAL TERCERA}

$$
(\ldots)^{441}
$$

\section{DISPOSICIÓN DEROGATORIA ÚNICA}

1. Quedan derogados los siguientes preceptos de la Ley 9/2002, de 30 de diciembre, de Ordenación Urbanística y Protección del Medio Rural de Galicia, modificada por la Ley 15/2004, de 29 de diciembre: la letra c) del número 1 del artículo 61; el número 4 del artículo 61; el párrafo segundo del número 3 del artículo 85 , y el párrafo segundo de la letra b) del número 1 del artículo 86 .

\footnotetext{
440 Contiene modificaciones de la Ley 10/1995, de 23 de noviembre, de ordenación del territorio de Galicia 441 Contiene modificaciones de la Ley $9 / 2002$, de 30 de diciembre, de ordenación urbanistica y protección del medio rural de Galicia.
}

2. Quedan derogadas aquellas disposiciones de igual o inferior rango que se opongan a lo dispuesto en la presente ley.

\section{DISPOSICIÓN FINAL PRIMERA HABILITACIÓN NORMATIVA}

Se facultan al Consello de la Xunta de Galicia y a la persona titular de la consellería competente en materia de urbanismo y ordenación del territorio para dictar las disposiciones necesarias para el desarrollo y aplicación de la presente ley.

\section{DISPOSICIÓN FINAL SEGUNDA ENTRADA EN VIGOR}

La presente ley entrará en vigor al día siguiente de su publicación en el "Diario Oficial de Galicia”.

$(\ldots)^{442}$

\section{LEY 18/2008, DE 29 DE DICIEMBRE, DE VIVIENDA DE GALICIA (DOGA 13. 20. 1. 2009)} $(\ldots)^{443}$

\section{TÍTULO PRELIMINAR EL DERECHO A LA VIVIENDA}

\section{Capítulo I DISPOSICIONES GENERALES}

\section{Artículo 1. Objeto}

La presente ley tiene por objeto la regulación del derecho a la vivienda en la Comunidad Autónoma de Galicia y, en particular:

a. El establecimiento del régimen jurídico de las viviendas, libres y protegidas. b. La definición de las políticas públicas en materia de vivienda, con la concreción de los instrumentos de desarrollo para su promoción y fomento.

c. La fijación de las medidas de protección de las personas adquirentes o usuarias de las viviendas.

442 Anexo suprimido.

443 Preámbulo omitido. 
d. La regulación de las potestades de intervención atribuidas a las administraciones públicas con la finalidad de garantizar el derecho a la vivienda y el cumplimiento de las exigencias de calidad previstas en la normativa vigente.

Artículo 2. Principios rectores de la política de vivienda de la Comunidad Autónoma de Galicia.

1. El diseño, programación y ejecución de las políticas públicas de vivienda en la Comunidad Autónoma de Galicia se regirá por los siguientes principios:

a. La efectividad del derecho constitucional a la vivienda y la mejora de la calidad de vida, adoptando las medidas de discriminación positiva que resulten necesarias para favorecer la igualdad social y eliminar los obstáculos que impidan su plenitud.

b. La consecución de un parque de viviendas suficiente, con una oferta significativa de viviendas protegidas derivadas de acciones de nueva construcción, de recuperación o de rehabilitación de las edificaciones existentes.

c. El fomento del alquiler como modalidad de acceso a la vivienda.

d. La puesta en valor del medio ambiente, el paisaje y la cultura en las acciones constructivas, que habrán de estar regidas por criterios de sostenibilidad y calidad, de acuerdo con la legislación sectorial de aplicación.

e. La garantía del ejercicio de los derechos lingüísticos en el acceso a la vivienda, ya sea alquiler o compraventa, en el marco de la promoción del idioma gallego.

2. Las administraciones públicas prestarán especial atención a los colectivos vulnerables de la sociedad y orientarán sus actuaciones a la consecución de los objetivos de cohesión social, lucha contra la exclusión social y solidaridad.

3. El ejercicio de las potestades reconocidas en la presente ley tendrá por finalidad favorecer la transparencia del mercado inmobiliario, garantizar la seguridad jurídica de las personas adquirentes y usuarias y adoptar medidas frente a prácticas ilegales o fraudulentas.

Artículo 3. Acción pública.

Cualquier persona, en ejercicio de la acción pública en materia de vivienda, podrá exigir ante los órganos administrativos y la jurisdicción contencioso-administrativa el cumplimiento de la normativa de vivienda, de acuerdo con la legislación aplicable.

Artículo 4. Servicios de interés general.

Las actuaciones dirigidas a garantizar el derecho a la vivienda tendrán la consideración de servicios de interés general, a los efectos previstos en la normativa de contratación pública.

Artículo 5. Definiciones.

A los efectos de la presente ley, se entiende por:

a. Edificio: el inmueble proyectado, construido, reformado o rehabilitado cuyo uso principal sea residencial, sin perjuicio de otros usos complementarios o accesorios.

b. Vivienda: la construcción destinada a residencia, con carácter permanente o temporal.

c. Superficie útil de la vivienda: la superficie del suelo de la vivienda, delimitada por la cara interna de los elementos de cierre con el exterior o de separación con otras viviendas o locales colindantes, de acuerdo con las siguientes reglas:

- Se incluirá en la superficie útil la mitad de la que corresponda a espacios exteriores como balcones, terrazas, galerías o tendederos que sean de uso privativo del titular de la vivienda, hasta un máximo del $10 \%$ de la superficie útil cerrada.

- Quedan excluidas de la superficie útil las zonas en que la altura libre de construcción no alcance 1,50 metros.

- No se computarán en la superficie útil la que ocupen en el interior de la vivienda los elementos divisorios entre estancias, 
ni los pilares, columnas y otros elementos estructurales verticales, cualquiera que sea la función arquitectónica o estética que cumplan en la misma. Cuando se trate de viviendas iguales y dispuestas en columna vertical dentro de un mismo edificio, para el cómputo de las superficies ocupadas en planta por los elementos estructurales verticales, se tomará el promedio aritmético de los valores correspondientes a las viviendas emplazadas en las plantas inferior y superior de la columna, siempre que la divergencia entre aquellos valores no sea superior al $100 \%$.

d. Vivienda desocupada: la vivienda en que sus usuarios legítimos están ausentes de modo transitorio, intermitente o provisional, presumiéndose dicha situación en la ausencia en tiempo de vacaciones o por razón de trabajo, enfermedad o similar.

e. Vivienda vacía: la vivienda en que sus usuarios legítimos están ausentes de modo no transitorio, intermitente o provisional, presumiéndose dicha situación por la ausencia ininterrumpida por más de veinticuatro meses, certificada de acuerdo con los criterios de comprobación que se establezcan reglamentariamente.

f. Agente de la edificación: la persona, física o jurídica, que interviene en el proceso de la edificación:

- Agente promotor: la persona física o jurídica, pública o privada, que decide, impulsa, programa y financia, con recursos propios o ajenos, las obras de edificación, para su posterior venta, entrega o cesión a terceros bajo cualquier título o para satisfacer su necesidad de vivienda.

- Agente proyectista: el agente técnico que, por encargo del agente promotor y contando con la titulación profesional habilitante establecida en la normativa de edificación, redacta el proyecto, prestando con su firma la garantía de seguridad, habitabilidad y ornato público de las obras edificatorias proyectadas.

- Agente constructor: la persona física o jurídica que asume contractualmente ante el agente promotor el compromiso de ejecutar con medios humanos y materiales, propios o ajenos, las obras o parte de las mismas con sujeción al proyecto y contrato y bajo las órdenes de la dirección facultativa.

- Agente industrial colaborador: la persona física o jurídica que asume la realización de una parte específica y detallada del proceso constructivo bajo la coordinación del agente constructor.

- Dirección facultativa: el agente o los agentes que, estando en posesión de la titulación académica y profesional habilitante establecida en la normativa de la edificación, asumen la función de dirección de la obra en los aspectos técnicos, estéticos, urbanísticos y medioambientales (director/a de la obra), así como la dirección de la ejecución material de la obra, el control cualitativo y cuantitativo de la construcción y la calidad de lo edificado (director/a de la ejecución de la obra).

- Agente de control de calidad: la persona física o jurídica, pública o privada, capacitada para prestar asistencia técnica a los restantes agentes de la edificación que así lo recaben respecto a la calidad de la edificación:

1) Entidad de control de calidad de la edificación: el agente de control de calidad capacitado para prestar asistencia técnica en la verificación de la calidad del proyecto, los materiales y la ejecución de la obra y sus instalaciones de acuerdo con el proyecto y normativa de aplicación.

2) Laboratorio de ensayos para el control de calidad de la edificación: el agente de control de calidad capacitado para prestar asistencia técnica mediante la realización de ensayos o pruebas de servicio de los materiales, sistemas o instalaciones de una obra de edificación.

g. Agente inmobiliario: la persona física o jurídica que se dedica en el desarrollo de su actividad empresarial o profesional a la prestación de servicios de mediación, asesoramiento y gestión en transacciones 
inmobiliarias en relación con operaciones de compraventa, alquiler, permuta o cesión de viviendas.

\section{Capitulo II \\ ORGANIZACIÓN Y COMPETENCIAS EN MATERIA DE VIVIENDA}

Artículo 6. Las administraciones públicas de vivienda.

Las administraciones públicas que tengan competencias en materia de vivienda las ejercerán de acuerdo con los principios de programación, objetividad, transparencia, eficacia, imparcialidad, responsabilidad y servicio a la ciudadanía.

Artículo 7. Competencias autonómicas.

1. La Administración de la Comunidad Autónoma de Galicia, a través de la consellaría competente en materia de vivienda y del Instituto Gallego de la Vivienda y Suelo, ejercerá las siguientes competencias:

a. La elaboración y aprobación, en su caso, de las normas por las que se establece la política de la Xunta de Galicia en materia de vivienda y suelo.

b. La iniciativa en la elaboración, impulso y tramitación de planes y proyectos sectoriales de incidencia supramunicipal en materia de vivienda.

c. La elaboración de programas y el establecimiento de acciones que promuevan la calidad de la vivienda, bajo el principio de sostenibilidad.

d. La programación y la ejecución del gasto público en vivienda, salvo el destinado por otras administraciones públicas a las entidades locales, así como el sufragado por estas con cargo a sus presupuestos.

e. El establecimiento de medidas de promoción y fomento de la renovación y rehabilitación del parque de viviendas existente, atendiendo a las singularidades del territorio, la cultura y la arquitectura de Galicia, así como a criterios de calidad, innovación y sostenibilidad de la edificación.

f. La aprobación de medidas que favorezcan el acceso a la vivienda, especialmente a los colectivos sociales con más dificultades.

g. El ejercicio de la potestad expropiatoria y las restantes que le sean atribuidas en la presente ley para asegurar la efectividad del derecho a la vivienda.

h. La coordinación con las entidades locales en la ejecución de la política autonómica de vivienda, en los términos previstos en la legislación vigente.

i. El ejercicio de la potestad de inspección para garantizar el cumplimiento de las disposiciones vigentes en materia de vivienda, sin perjuicio de las competencias atribuidas a los ayuntamientos.

j. El ejercicio de la potestad sancionadora, sin perjuicio de las que correspondan a otros órganos de las administraciones locales o autonómica.

k. Cualesquiera otras competencias que le atribuya la presente ley o sus normas de desarrollo.

2. La Xunta de Galicia contará con un Laboratorio de Sostenibilidad de la Edificación, orientado a programar y desarrollar las actuaciones de control de calidad de la edificación en la Comunidad Autónoma de Galicia, especialmente:

a. Elaborar propuestas de implantación del código técnico de la edificación.

b. Proponer estándares técnicos de calidad y el reconocimiento de distintivos.

c. Emitir informe sobre la acreditación de las/los agentes de control de la calidad.

d. Realizar estudios, informes y dictámenes sobre la calidad de la edificación.

e. Elaborar documentos básicos de gestión de la calidad.

f. Ofrecer a los agentes de la edificación bases de datos, guías, modelos, dibujos y criterios de diseño.

g. Asesorar a los usuarios de las edificaciones sobre el cumplimiento de estándares de calidad.

h. Llevar a cabo tareas de control e inspección del cumplimiento de la normativa de calidad de las edificaciones. 
El Laboratorio de Sostenibilidad de la Edificación constituirá una unidad administrativa dependiente de la consellaría competente en materia de vivienda. En la consecución de sus fines procurará la colaboración y participación de las entidades públicas y privadas relacionadas con el sector de la edificación.

Artículo 8. Competencias municipales.

1. Los ayuntamientos ejercerán competencias en materia de vivienda a través de la planificación urbanística, en la forma y con la intensidad que resulte de lo dispuesto en la legislación urbanística y en la presente ley.

2. Además de las competencias en materia de planificación urbanística, corresponde a los ayuntamientos la ejecución de las políticas públicas de vivienda en sus respectivos términos municipales, y especialmente:

a. La ejecución de las competencias que en materia de promoción y gestión de viviendas les reconoce la legislación de régimen local.

b. La programación y ejecución del gasto público en materia de vivienda de la propia entidad local.

c. El control de la calidad de las viviendas en los diversos momentos del proceso edificatorio y, especialmente, en la resolución de la licencia de primera ocupación, sin perjuicio de los instrumentos de coordinación y colaboración establecidos en la presente ley.

d. La aprobación de programas específicos de promoción y fomento del acceso a la vivienda, así como las medidas de fomento de la renovación y rehabilitación del parque de viviendas existente, en los términos previstos en la presente ley y sus normas de desarrollo.

e. El ejercicio de la potestad de inspección para garantizar el cumplimiento de la normativa de edificación y utilización de viviendas, sin perjuicio de las potestades que les puedan corresponder según lo dispuesto en la normativa urbanística. f. El ejercicio de la potestad sancionadora, en los términos establecidos en el título V de la presente ley.

g. El ejercicio de la potestad expropiatoria y las restantes que les sean atribuidas por la legislación vigente.

h. Las competencias que, siendo de índole local, no estén atribuidas por la presente ley a otros órganos.

i. Cualesquiera otras competencias en materia de vivienda que les correspondan con arreglo a lo previsto en la legislación de régimen local, sin perjuicio de las que puedan asumir otras entidades de ámbito supramunicipal.

\section{Capitulo III FONDO SOCIAL DE VIVIENDA}

Artículo 9. Fondo social de vivienda. 1. Se crea el Fondo Social de Vivienda, con una dotación que formará parte de los créditos anuales de los presupuestos de la consejería competente en materia de vivienda y suelo.

2. El fondo estará al servicio del desarrollo de las políticas públicas de vivienda $y$, en particular, a:

a. Procurar el derecho a la vivienda digna y adecuada de los sectores con mayores dificultades de acceso de la sociedad gallega.

b. Favorecer la integración social, con especial atención a los colectivos más desfavorecidos de la sociedad, y luchar contra la segregación y la infravivienda.

c. Fomentar la sostenibilidad urbana, especialmente con relación a la eficiencia energética, el ahorro de consumo de agua y el reciclaje de residuos.

d. Desarrollar programas que conlleven una mejora económica y social de las poblaciones rurales y urbanas.

e. Fomentar medidas, en el marco de la programación pública de la vivienda, orientadas a la búsqueda de la cohesión social y la solidaridad, entre otras, la subsidiación de la actualización de las rentas de alquiler para los inquilinos 
que ejerzan el derecho de retorno a una vivienda rehabilitada.

\section{TÍTULO I \\ EL ESTATUTO GALLEGO DE LA VIVIENDA}

\section{Capítulo I \\ EL PROCESO DE EDIFICACIÓN}

\section{Sección primera \\ Disposiciones generales}

Artículo 10. Normativa aplicable y ámbito de aplicación.

1. El proceso de edificación de las viviendas ubicadas en el territorio de la Comunidad Autónoma de Galicia se regulará por las disposiciones de la presente ley y sus normas de desarrollo, la normativa básica de ordenación de la edificación, la normativa urbanística y cualquier otra de carácter sectorial que resulte de aplicación.

2. El proceso de edificación comprende todas las actuaciones que se llevan a cabo desde que se inicia la promoción hasta la declaración de obra nueva, en los supuestos contemplados en el artículo 2.2. ${ }^{\circ}$ de la Ley 38/1999, de 5 de noviembre, de ordenación de la edificación.

Artículo 11. Calidad de las edificaciones.

1. En orden a garantizar la seguridad de las personas, el bienestar de la sociedad y la protección del medio ambiente, los edificios habrán de proyectarse, construirse, mantenerse y conservarse de tal forma que se satisfagan los requisitos establecidos por la normativa básica de ordenación de la edificación y la reglamentación técnica de desarrollo, de acuerdo con la normativa de la edificación de aplicación.

2. El proceso de edificación deberá perseguir la reducción del impacto medioambiental producido por el edificio, atendiendo a los siguientes principios informadores:

a. La optimización en la utilización de los recursos disponibles, mediante la adecuada reutilización, reciclaje y uso eficiente de los mismos, así como el empleo de recursos renovables.

b. La conservación del medio ambiente, mediante un adecuado uso del terreno, la gestión eficiente de los residuos generados y la prevención de emisiones y contaminación.

c. La obtención y el mantenimiento de ambientes saludables en el interior del edificio, mediante la prevención de las emisiones nocivas, especialmente las de gas radón, y de la contaminación del aire, y la protección contra el ruido, así como la adecuada ventilación de los espacios habitables.

d. El ahorro energético y la eficiencia térmica, de tal manera que se consiga un uso racional de la energía y la utilización de fuentes de energía renovables, en especial la solar.

e. La integración paisajística de la edificación, de modo que guarde armonía con el entorno natural y cultural, mediante la implantación de la arquitectura bioclimática y el uso de materiales de construcción autóctonos y ecológicos acreditados.

3. Reglamentariamente se determinarán las condiciones de reconocimiento de las marcas, sellos, certificaciones de conformidad y otros distintivos de calidad voluntarios que faciliten el cumplimiento de las exigencias de calidad de la edificación.

Artículo 12. Las/los agentes de control de calidad.

1. En el ejercicio de las funciones de acreditación de la calidad de la edificación que les atribuye la Ley 38/1999, de 5 de noviembre, de ordenación de la edificación, la/el agente de control de calidad y el personal a su servicio deben mantener la debida objetividad, independencia e imparcialidad respecto a los restantes agentes que intervienen en la edificación. En particular, no tendrán efecto los resultados de las asistencias técnicas de las/los agentes de control de calidad:

a. Cuando las personas que promuevan las obras sean propietarias de las empresas 
de control, formen parte de sus órganos de dirección o tengan participación en el capital de la persona jurídica o de la entidad titular de las mismas, o cuando pertenezcan a su mismo grupo empresarial.

b. Cuando el personal al servicio de las/los agentes de control preste la asistencia técnica en obras que promueva o en las que actúe como dirección facultativa.

2. Las/los agentes de control de calidad deberán obtener la correspondiente acreditación de la Administración autonómica como requisito previo para el ejercicio de su actividad en el territorio de la Comunidad Autónoma de Galicia.

La acreditación será individual e intransferible y se otorgará con carácter específico para el área de acreditación en que se inscriba la/el agente.

3. Reglamentariamente se determinarán las condiciones, áreas, procedimiento de acreditación y cualesquiera otras medidas que resulten necesarias para la efectividad de esta disposición.

Artículo 13. Registros de agentes de la edificación.

La consejería competente en materia de vivienda podrá poner en funcionamiento registros de homologación de los/las agentes de la edificación que desempeñen profesionalmente su actividad en el territorio de la Comunidad Autónoma de Galicia.

\section{Sección segunda}

\section{Fases del proceso de edificación}

Artículo 14. Fase preparatoria.

Conforman la fase preparatoria del proceso de edificación la promoción y el proyecto, así como la obtención de las autorizaciones y la realización de las actuaciones previas a la ejecución de la obra que tuvieran por finalidad garantizar la adecuación de la futura construcción a las exigencias normativas y constructivas.

Artículo 15. El proyecto.

1. El agente proyectista redactará el proyecto de acuerdo con las normas técnicas y urbanísticas vigentes.
2. La Administración autonómica establecerá reglamentariamente:

a. Las determinaciones que, junto con las contempladas en la normativa técnica de la edificación, hayan de contemplarse en el proyecto, con carácter general o referidas a determinados tipos de edificios.

b. El sistema de gestión de calidad y de verificación de los proyectos, así como su justificación documental.

Artículo 16. Actuaciones previas.

1. Con carácter previo a la construcción, se exigirá un estudio geotécnico y el replanteo de las obras sobre el terreno.

2. El estudio geotécnico tiene por objeto conocer las características geotécnicas de los terrenos donde vaya a emplazarse la edificación. Dicho estudio será necesario para la realización de obras nuevas y las de reforma y de rehabilitación que afecten a la cimentación o modifiquen, significativamente, los empujes que la estructura haya de transmitir al terreno. En caso de viviendas unifamiliares autopromovidas será suficiente con una mención expresa en el proyecto sobre la viabilidad geotécnica de la obra proyectada, en los términos que se establezcan reglamentariamente.

3. El replanteo consistirá en la verificación por la/el agente director de la obra de la realidad geométrica de la misma y de la disponibilidad de los terrenos para su normal ejecución. El replanteo se formalizará en un acta firmada por la/el agente constructor y suscrita por la/el agente director de la ejecución de la obra.

4. Para la supervisión de los proyectos se exigirá la constancia de una certificación de la/el agente proyectista en la cual conste la viabilidad geotécnica de la obra proyectada así como el acta de replanteo sobre el terreno.

Artículo 17. Licencia urbanística.

Para llevar a cabo cualquier obra de edificación destinada a vivienda será preceptiva la correspondiente licencia urbanística de conformidad con la normativa urbanística vigente, sin perjuicio de otros permisos, 
licencias o autorizaciones exigidos por la legislación general o sectorial aplicable.

Artículo 18. Ejecución de la obra.

1. La ejecución de la obra será llevada a cabo por la/el agente constructor de acuerdo con los términos del contrato que hubiese celebrado con la/el agente promotor, cuando sea una persona distinta a este.

Será de aplicación la Ley 30/2007, de 30 de octubre, de contratos del sector público, cuando se tratase de una promoción pública de viviendas.

2. La/el agente constructor ejecutará las obras con sujeción al proyecto y bajo la dirección facultativa de la obra. Le corresponderá, en su caso, la contratación de las/ los agentes industriales colaboradores y la adquisición o asignación de los materiales que requiera la ejecución, en los términos señalados en el contrato celebrado con la/el agente promotor.

3. Corresponde a la dirección facultativa la expedición del certificado final de obra, con el contenido y efectos que le atribuye la normativa de ordenación de la edificación.

4. Reglamentariamente se determinará la documentación del seguimiento de la ejecución de la obra, que, junto con la que se establezca de la normativa técnica de la edificación, permitirá verificar el cumplimiento de las exigencias de calidad de la edificación durante el proceso constructivo.

Artículo 19. Recepción de la obra ejecutada.

1. Una vez redactado y suscrito el certificado final de la obra por la dirección facultativa de la obra, la/el agente constructor notificará a la/al agente promotor la finalización de la misma, a fin de que se proceda a formalizar su recepción.

2. La/el agente promotor podrá rechazar la recepción por considerar que la obra no está terminada o que no reúne las condiciones contractuales.
3. La recepción se formalizará en un acta de recepción. Sin embargo, y salvo pacto en contrario, la recepción de la obra se entenderá tácitamente producida si, una vez pasados treinta días desde la recepción de la notificación de la/del agente constructor de que la obra está terminada, la/el agente promotor no pusiera de manifiesto reservas o rechazo motivado por escrito.

Artículo 20. Licencia de primera ocupación.

1. La licencia de primera ocupación es el acto administrativo que acredita que el edificio o vivienda cumple los requisitos exigidos para ser destinado a uso residencial, especialmente que la obra está completamente ejecutada y se ajusta a la licencia urbanística otorgada.

2. Una vez concluidas las obras de ejecución del edificio o vivienda, y previa recepción, la/el agente promotor solicitará la licencia de primera ocupación en el ayuntamiento en que radique el inmueble, acompañando a su solicitud la certificación final de obra y el acta de recepción, si se hubiera otorgado expresamente, o la acreditación de la recepción tácita.

3. La Administración, previa visita de comprobación de los servicios técnicos municipales, habrá de resolver expresamente la solicitud y notificar a la persona interesada la resolución en el plazo máximo de dos meses, a contar a partir de la fecha en que la solicitud tuvo entrada en el registro general del ayuntamiento.

Una vez transcurrido dicho plazo sin que recaiga resolución expresa, la licencia de primera ocupación se entenderá concedida por silencio administrativo.

En ningún caso se entenderán otorgadas por silencio las licencias de primera ocupación en contra de la legislación o del planeamiento urbanístico.

4. En la resolución de la licencia de primera ocupación se hará constar la fecha del acta de recepción de la obra ejecutada o, en su caso, la de recepción tácita. 
5. Las administraciones autonómica y municipales pondrán en funcionamiento un sistema de información que permita conocer los datos de ocupación de las viviendas, a fin de mantener actualizado el seguimiento del parque autonómico.

Artículo 21. Servicios.

1. La licencia de primera ocupación es el único documento que permite la conexión del abastecimiento de agua potable, electricidad, telecomunicaciones y otros servicios comunitarios.

2. La Administración municipal, previa audiencia concedida al promotor del edificio o vivienda, podrá ordenar el corte del suministro contratado sin la existencia de previa licencia de primera ocupación.

Artículo 22. Declaración de obra nueva.

Las notarias y notarios y las registradoras y registradores de la propiedad exigirán para autorizar o inscribir, respectivamente, escrituras de declaración de obra nueva terminada que se acredite el otorgamiento de la licencia urbanística, la expedición de la certificación final de la obra y el otorgamiento, expreso o por silencio administrativo, de la licencia de primera ocupación.

\section{Sección tercera}

El libro del edificio

Artículo 23. Exigibilidad, objeto y contenido del libro del edificio.

Los usuarios finales tendrán a su disposición el libro del edificio, que estará constituido por la documentación completa de la obra finalizada que refleje la historia constructiva del edificio y la documentación relativa a su uso, mantenimiento y conservación, especialmente:

a. Los documentos que permitan identificar el edificio, entre ellos el plano de su emplazamiento y una fotografía de su fachada principal.

b. Los documentos del proceso de la edificación, al menos la licencia urbanística otorgada expresamente o la acreditación de su otorgamiento por silencio administrativo, la certificación final de la obra, el acta de recepción o la acreditación de su recepción tácita y la licencia de primera ocupación otorgada expresamente o la acreditación de su otorgamiento por silencio administrativo.

c. Los datos identificativos de las/los agentes que han intervenido en el proceso de edificación.

d. La información sobre la situación jurídica del inmueble, en la cual figurará una nota informativa del registro de la propiedad sobre la titularidad del edificio así como su régimen de protección, en su caso.

e. Los datos técnicos de la edificación, especialmente el certificado de eficiencia energética, las garantías de los elementos e instalaciones y los seguros.

f. El plan de mantenimiento y conservación del edificio, que contendrá, además de las instrucciones de uso y mantenimiento, las restantes directrices que se establezcan reglamentariamente para planificar las operaciones de mantenimiento del edificio y sus instalaciones.

g. Los restantes documentos que se determinen reglamentariamente.

Artículo 24. Elaboración, entrega y gestión del libro del edificio.

1. Corresponde al/a la director/a de la obra elaborar el libro del edificio y entregarlo a la/al agente promotor una vez finalizada.

2. La/el agente promotor deberá hacer entrega del libro a las personas adquirentes. En caso de propiedad horizontal, la/el agente promotor entregará el libro a la persona que ostente el cargo de administrador/a de la comunidad de propietarios de conformidad con lo establecido en la normativa sobre propiedad horizontal.

3. Sin perjuicio de lo anterior, todas las personas propietarias recibirán de forma individualizada e independiente un manual de su vivienda, con los documentos que se determinen reglamentariamente, 
que habrán de ser los suficientes para garantizar el uso adecuado de la misma y cumplir con los deberes de mantenimiento y conservación.

4. El libro del edificio habrá de estar a disposición de todas las personas copropietarias y usuarias. Las administraciones autonómica y municipal podrán establecer sistemas de depósito o registro del libro del edificio, a los efectos del ejercicio de sus funciones inspectoras previstas en la presente ley.

5. Corresponde a las personas propietarias, de forma individual o formando parte de una comunidad de propietarios, conservar y, en su caso, transmitir el libro del edificio y, especialmente:

a. Completar y actualizar la documentación que lo integra y registrar los incidentes y las actuaciones de mantenimiento acometidas, así como las obras de conservación, reforma y rehabilitación en los términos previstos en el plan de mantenimiento y conservación del edificio.

b. En su caso, poner a disposición de la persona arrendataria o usuaria de la vivienda la documentación que le permita hacer un uso responsable de la misma y conocer las instrucciones para actuar en caso de emergencia.

6. Se determinarán reglamentariamente el modelo y las formalidades a que habrá de ajustarse el libro del edificio.

\section{Capitulo II LA UTILIZACIÓN DE LA VIVIENDA}

Artículo 25. Uso adecuado y mantenimiento.

Las personas usuarias de las viviendas están obligadas a realizar un uso adecuado de las mismas y a llevar a cabo las obras de mantenimiento previstas en el plan de mantenimiento y conservación del edificio del libro del edificio.

Artículo 26. Deberes de conservación y rehabilitación.

1. Las personas propietarias de las viviendas tienen el deber de conservar sus condiciones normales de funcionalidad, seguridad, salubridad, ornato público y habitabilidad, de acuerdo con las determinaciones del proyecto técnico que haya servido de base para el otorgamiento de la licencia urbanística, lo establecido en el plan de mantenimiento y conservación del edificio y las exigencias de la normativa urbanística, medioambiental y técnica de la edificación.

2. Las personas propietarias habrán de llevar a cabo las obras de rehabilitación que resulten necesarias sobre los elementos comunes o privativos de los edificios y viviendas, cuando el incumplimiento del deber de conservación o la insuficiencia de las medidas adoptadas supongan un deterioro de las condiciones normales de funcionalidad, seguridad, salubridad, ornato público y habitabilidad.

3. En los términos previstos en el título III de la presente ley, las administraciones públicas competentes en materia de vivienda fomentarán actuaciones de conservación y rehabilitación del patrimonio inmobiliario de Galicia, para favorecer la efectividad del derecho a una vivienda digna y adecuada.

Artículo 27. Sujeto pasivo de los deberes de conservación y rehabilitación.

1. Los deberes de conservación y rehabilitación recaen sobre la persona propietaria de la vivienda. La persona que adquiere una vivienda queda subrogada en la posición de la anterior en el cumplimiento de dichos deberes, así como en los derechos que pudiera tener frente a la Administración, salvo los de carácter personalísimo.

En el instrumento público mediante el que se transmita, por cualquier título, la vivienda, la persona transmitente deberá declarar estar al corriente en el cumplimiento de los deberes de conservación y rehabilitación o expresar los que tenga pendientes de cumplimiento.

2. Cuando la persona propietaria de una vivienda fuese desconocida, corresponderá a la administración competente en materia 
de vivienda realizar las obras que sean necesarias para la adecuada conservación y rehabilitación del edificio, sin perjuicio de las acciones de repetición que procedan.

Artículo 28. Administración competente.

1. Corresponderá a la Administración municipal velar por el cumplimiento de los deberes de conservación y rehabilitación. A estos efectos, podrá ejercitar las potestades administrativas que se señalan en este capítulo y las que regula la normativa urbanística, especialmente la inspección técnica de los edificios, las órdenes de ejecución y las medidas de ejecución forzosa.

2. La Administración autonómica, a través de la consellaría competente en materia de vivienda, podrá actuar por sustitución en los supuestos de inactividad municipal, en orden a garantizar la adecuada conservación y rehabilitación de las viviendas.

Artículo 29. Derecho de retorno.

Cuando las personas usuarias de viviendas desalojadas como consecuencia de la ejecución de obras de conservación y rehabilitación tuvieran derecho de retorno con arreglo a lo establecido en la legislación de arrendamientos urbanos, la Administración autonómica podrá establecer programas de subsidiación de la actualización de las rentas de alquiler para adecuar el precio de alquiler al del mercado, con el límite máximo de la renta señalada para el alquiler de viviendas protegidas y en atención a la situación económica de la unidad familiar o de convivencia del retornado.

Artículo 30. Expropiación por incumplimiento de la función social de la propiedad.

1. Existirá causa de interés social para la expropiación forzosa por incumplimiento de la función social de la propiedad de los edificios, viviendas o parte de los mismos cuando estén vacíos y presenten condiciones de deterioro grave en sus requisitos básicos de funcionalidad, seguridad y habitabilidad, siempre que, al dictarse la correspondiente orden de ejecución de obras, esta fuera desatendida por la persona propietaria.

Se entenderá que existe deterioro grave de los requisitos básicos de funcionalidad, seguridad y habitabilidad cuando el coste de las obras necesarias exceda de la cuarta parte del coste de reposición del edificio o vivienda de nueva construcción con características similares, excluido el valor del suelo.

2. Las viviendas expropiadas serán destinadas a usos residenciales, preferentemente en régimen de alquiler para sectores desfavorecidos.

3. Sin perjuicio de lo establecido en la normativa de expropiación forzosa, tendrán la condición de beneficiarias las personas jurídicas que ostenten la condición de promotoras públicas de vivienda protegida con arreglo a lo dispuesto en el artículo $38^{\circ}$ de la presente ley. Igualmente, podrán ser beneficiarias las comunidades de propietarios, cuando la realización de obras de rehabilitación o el establecimiento de condiciones adecuadas de utilización de un edificio en régimen de propiedad horizontal requiera la expropiación de elementos privativos o comunes.

Artículo 31. Declaración de inhabitabilidad, orden de ejecución de obras, suspensión y archivo del procedimiento expropiatorio.

1. La expropiación forzosa por incumplimiento de la función social de la propiedad requerirá la previa declaración de inhabitabilidad del inmueble afectado, el incumplimiento de la correspondiente orden de ejecución y la notificación de la intimación de expropiación forzosa.

2. Procederá la declaración de inhabitabilidad de un edificio o vivienda cuando concurran las circunstancias contempladas en el artículo 30.1 de la presente ley, previa tramitación de un procedimiento en los términos que se determinen reglamentariamente. En todo caso, será preceptiva 
la audiencia de la persona interesada así como, si la misma lo solicitase, la apertura de un periodo de prueba para la defensa de sus intereses.

La declaración de inhabitabilidad será notificada a la persona propietaria, junto con la orden de ejecución de las obras de rehabilitación. Simultáneamente, la declaración de inhabitabilidad se remitirá al registro de la propiedad para su constancia mediante nota marginal.

3. Desatendida la orden de ejecución, y sin perjuicio de la imposición de las multas coercitivas que correspondan, la Administración podrá iniciar el procedimiento expropiatorio.

4. El procedimiento expropiatorio quedará en suspenso cuando la persona propietaria, dentro del mes siguiente a la recepción de la notificación de la intimación, presente una garantía suficiente de realización de las obras de adecuación del inmueble, proceda a ocuparla habitualmente o se comprometa a ponerla en alquiler una vez que la vivienda reúna los requisitos de habitabilidad exigidos por la normativa vigente.

Realizadas las obras de adecuación y puesta la vivienda en alquiler, la administración archivará el expediente expropiatorio. En otro caso, levantará la suspensión y proseguirá las actuaciones, de acuerdo con la legislación de expropiación forzosa.

Artículo 32. Ocupación temporal.

1. A los efectos previstos en este capítulo, la Administración podrá ocupar de modo temporal una vivienda para realizar por su cuenta los trabajos que no hubiera realizado por sí la persona propietaria y que resulten necesarios para el cumplimiento del deber de rehabilitación.

2. La ocupación temporal requerirá la declaración de inhabitabilidad y la intimación prevista en el artículo anterior.

3. Será de aplicación a la ocupación temporal lo dispuesto para las comunidades de propietarios respecto a su condición de beneficiarias de la expropiación forzosa de elementos privativos o comunes.

\section{TÍTULO II LA VIVIENDA PROTEGIDA}

\section{Capítulo I \\ DISPOSICIONES GENERALES}

\section{Sección primera \\ Concepto de vivienda protegida}

\section{Artículo 33. Definición.}

1. Es vivienda protegida aquella que, cumpliendo las exigencias de destino, superficie, condiciones edificatorias, diseño, calidad y precio establecidos en la presente ley y sus normas de desarrollo, recibe dicha calificación por la consellaría competente en materia de vivienda.

2. También tendrán esta condición los alojamientos que sean calificados como protegidos por la consellaría competente en materia de vivienda. En todo caso habrán de tener características adecuadas a personas usuarias con circunstancias específicas definidas, siempre que tales alojamientos persigan su integración social y cumplan los requisitos que establezca la Xunta de Galicia.

\section{Artículo 34. Destino.}

1. Las viviendas protegidas se destinarán a residencia habitual y permanente, salvo los supuestos excepcionales establecidos en la presente ley.

2. Las viviendas protegidas no podrán destinarse a usos distintos del residencial. No obstante lo anterior, la consejería competente en materia de vivienda podrá autorizar el ejercicio en la vivienda de una profesión u oficio por cualquier miembro de la familia o unidad convivencial, siempre que dicha actividad sea compatible con el uso residencial y su desarrollo no requiera un espacio superior a los tres quintos de la superficie útil de la misma. La autorización autonómica no exime a la persona interesada de recabar los restantes permisos, licencias o autorizaciones contemplados en la normativa vigente. 


\section{Artículo 35. Superficie útil y anexos.}

1. Las viviendas protegidas habrán de tener una superficie útil comprendida entre los 40 y los 140 metros cuadrados, de acuerdo con lo dispuesto en el artículo $5 .^{\circ}$ de la presente ley.

2. Podrán tener la condición de anexos vinculados a la vivienda protegida el trastero de superficie útil total no superior a 15 metros cuadrados y una plaza de garaje por vivienda.

Artículo 36. Precio máximo.

1. La calificación como vivienda protegida determina la sujeción de cualquier acto de disposición, alquiler o adquisición a un precio máximo tasado.

2. Corresponde al Consello de la Xunta de Galicia, a propuesta de la persona titular de la consejería competente en materia de vivienda, fijar la cuantía máxima de los precios de venta y renta de las viviendas protegidas, así como de sus anexos, teniendo en consideración la fecha de calificación definitiva de las mismas.

3. Queda prohibida la percepción de cualquier sobreprecio, prima o cantidad distinta a la que corresponda satisfacer a la persona compradora o arrendataria de una vivienda protegida. Serán nulas las cláusulas y disposiciones que establezcan precios superiores a los máximos autorizados.

\section{Sección segunda}

Promoción de viviendas protegidas privada.

Artículo 37. Promoción pública y Las viviendas protegidas pueden ser de promoción pública o de promoción privada.

Artículo 38. Promoción pública.

1. Son de promoción pública las viviendas protegidas sufragadas con cargo a los presupuestos de una administración pública o de una entidad de derecho público vinculada o dependiente de aquella.

Tienen esta misma condición las viviendas protegidas promovidas por: a. Sociedades mercantiles en que la Administración pública o las entidades de derecho público participen mayoritariamente, financien mayoritariamente su actividad o nombren a más de la mitad de los miembros de sus órganos de administración, dirección o control.

b. Otras personas jurídico-privadas constituidas o integradas mayoritariamente por administraciones públicas o entidades de derecho público, o cuya actividad sea mayoritariamente financiada por las mismas.

2. La promoción pública podrá llevarse a cabo mediante la construcción de viviendas nuevas, la adquisición de viviendas nuevas o usadas y la renovación o rehabilitación de viviendas, sin ánimo de lucro, para la realización de los principios rectores contemplados en la presente ley.

3. Las viviendas de promoción pública construidas sobre terrenos del inventario autonómico de suelo para vivienda pública serán de titularidad pública y se regirán, en lo relativo a su uso y aprovechamiento, por la normativa de patrimonio, salvo en lo expresamente dispuesto para las mismas en la presente ley.

Artículo 39. Promoción privada.

1. Son de promoción privada las viviendas protegidas construidas, renovadas o rehabilitadas por personas físicas o jurídicas distintas de las establecidas en el artículo anterior, cuando la/el agente promotor cuente con ayudas públicas o financiación calificada en cualquiera de las fases del proceso de la edificación.

2. La promoción privada podrá llevarse a cabo mediante la construcción de viviendas nuevas o la renovación y rehabilitación de viviendas usadas para destinarlas a venta o alquiler, en ejecución de las políticas públicas de vivienda.

Artículo 40. Autopromoción.

1. Podrán ser calificadas como viviendas protegidas las promovidas para uso propio por la persona propietaria cuando 
haya recibido ayudas públicas o financiación cualificada con cargo a los fondos asignados a la consejería competente en materia de vivienda para construir una nueva vivienda o para renovar o rehabilitar su residencia habitual y permanente.

2. Se entenderán autopromovidas las viviendas promovidas por comunidades de propietarios, cooperativas de vivienda o asociaciones legalmente constituidas, en los términos establecidos en el apartado anterior.

\section{Capitulo II \\ CALIFICACIÓN DE LAS VIVIENDAS PROTEGIDAS}

Artículo 41. La calificación.

1. La calificación constituye el procedimiento administrativo por el cual se comprueba si una vivienda satisface los requisitos exigidos para las viviendas protegidas y, si procede, se declara dicha condición.

2. Las viviendas de promoción pública construidas sobre terrenos del inventario de suelo para vivienda pública tendrán la condición de viviendas protegidas sin necesidad de calificación.

Artículo 42. Calificación provisional.

1. La/el agente promotor presentará ante la administración competente en materia de vivienda la solicitud de calificación provisional de vivienda protegida, acompañada de la documentación que se establezca reglamentariamente.

2. La Administración habrá de dictar resolución expresa sobre la calificación provisional y notificarla a la persona interesada en el plazo máximo de dos meses, a contar a partir de la fecha en que la solicitud hubiera entrado en un registro de la consellaría competente en materia de vivienda. Transcurrido dicho plazo sin que se haya notificado resolución expresa, podrá entenderse desestimada por silencio la calificación provisional.
Si se advirtiesen deficiencias subsanables que impidan el otorgamiento de la calificación provisional, la Administración podrá señalar plazo y condiciones para proceder a su subsanación, quedando entre tanto interrumpido el plazo para resolver.

3. La calificación provisional es condición suficiente y necesaria para que el agente promotor solicite ayudas públicas o financiación cualificada para acometer las actuaciones de promoción.

Artículo 43. Calificación definitiva.

1. Finalizadas las obras de construcción o rehabilitación, la/el agente promotor solicitará la calificación definitiva ante la consejería competente en materia de vivienda, acompañando la documentación que se establezca reglamentariamente.

2. La Administración habrá de dictar resolución expresa sobre la calificación definitiva y notificarla a la persona interesada en el plazo máximo de dos meses, a contar a partir de la fecha en que la solicitud hubiera entrado en un registro de la consellaría competente en materia de vivienda. Transcurrido el mismo sin que se haya notificado resolución expresa, podrá entenderse desestimada por silencio la calificación definitiva.

En caso de advertirse deficiencias subsanables que impidan el otorgamiento de la calificación definitiva, la Administración podrá señalar plazo y condiciones para proceder a su subsanación, quedando entre tanto interrumpido el plazo para resolver. En estos casos, para la fijación del precio de venta de la vivienda se tendrá en cuenta la fecha de comunicación a la/al agente promotor de las deficiencias observadas.

3. La concesión o denegación de la calificación definitiva es reglada.

La denegación de la calificación definitiva por causa imputable a la/al agente promotor supondrá la devolución, en su caso, de las ayudas percibidas con los intereses legales desde la fecha de su percepción. Las personas adquirentes de las viviendas podrán optar por resolver los contratos o 
solicitar a la Administración autonómica la rehabilitación del expediente a su favor, comprometiéndose a subsanar las deficiencias que motivaron la denegación. En este caso, se deducirán del precio que haya de abonarse a la/al agente promotor las cantidades invertidas por las personas adquirentes en la subsanación de las deficiencias.

4. Las notarias y notarios no podrán autorizar escrituras públicas que documenten la transmisión de viviendas protegidas con anterioridad al otorgamiento de la calificación definitiva.

Las/los agentes promotores estarán obligados a elevar a escritura pública, en el plazo de tres meses desde la concesión de la calificación definitiva, los contratos de compraventa formalizados con anterioridad a la concesión de la calificación.

Artículo 44. Registro de la propiedad.

1. Las calificaciones provisional y definitiva de la vivienda protegida se harán constar en el registro de la propiedad por nota marginal de la inscripción de la obra nueva, con expresión de sus circunstancias esenciales, especialmente el plazo de duración del régimen de protección.

2. Respecto a las viviendas protegidas de promoción y titularidad pública construidas sobre terrenos del inventario de suelo para vivienda pública, la nota marginal dejará constancia de su titularidad pública, de su condición de protegida y de la duración indefinida del régimen de protección.

Artículo 45. Duración del régimen de protección y descalificación.

1. La duración del régimen de protección de las viviendas protegidas será de treinta años, sin perjuicio del plazo distinto que establezca la presente ley o sea aprobado por decreto del Consello de la Xunta de Galicia para atender a programas específicos de vivienda dirigidos a sectores de la población desfavorecidos o con circunstancias especiales.
2. Será de duración indefinida el régimen de protección de las viviendas protegidas de promoción y titularidad públicas construidas sobre terrenos del inventario de suelo para vivienda pública.

3. El régimen de protección de las viviendas protegidas se extinguirá:

a. Por el transcurso del plazo de duración del régimen de protección.

b. Por descalificación de la vivienda.

4. El transcurso del plazo de duración del régimen de protección determinará, sin necesidad de declaración administrativa, la extinción del régimen de protección de la vivienda, que se considerará libre a todos los efectos si, transcurridos seis meses desde el cumplimiento del plazo de duración del régimen de protección, no consta en el registro de la propiedad ningún asiento contradictorio. En esos casos, las registradoras o registradores cancelarán de oficio las notas marginales relativas al régimen de protección.

5. Por razones excepcionales y a instancia de los propietarios o cuando quede acreditada la ausencia de demanda real de vivienda, la administración competente en materia de vivienda podrá declarar la descalificación de las viviendas protegidas antes del transcurso del plazo de duración del régimen de protección, previo reintegro de las ayudas o beneficios recibidos y siempre que no se deriven perjuicios a terceros o al interés general. La resolución de descalificación, que deberá estar motivada, será adoptada por la persona titular de la consejería competente en materia de vivienda, siendo elevada al registro de la propiedad para la cancelación de las notas marginales relativas al régimen de protección.

6. La administración competente en materia de vivienda, previa instrucción del oportuno expediente, podrá descalificar de oficio la vivienda protegida como medida complementaria derivada de un procedimiento sancionador, en los términos establecidos en el artículo 113.b) de la presente ley. 
Durante el plazo de cinco años a contar desde la fecha de la descalificación, y en todo caso en tanto no transcurran quince desde la fecha de la calificación definitiva, los usuarios de buena fe de la vivienda protegida conservarán los derechos derivados del régimen legal de protección, quedando los propietarios vinculados a los precios máximos de renta y venta establecidos para las viviendas protegidas.

La resolución de descalificación será elevada al registro de la propiedad para la cancelación de las notas marginales relativas al régimen de protección y la anotación de las condiciones establecidas en el párrafo anterior.

\section{Capitulo III \\ ACCESO A LAS VIVIENDAS PROTEGIDAS}

\section{Sección primera \\ Personas beneficiarias}

Artículo 46. Requisitos.

Podrán resultar beneficiarias de viviendas protegidas las personas físicas en que concurran los requisitos siguientes:

a. Que la persona beneficiaria reúna los requisitos de capacidad económica que se determinen para cada tipo de viviendas, incluyendo los ingresos ponderados y el patrimonio de los miembros de la unidad familiar o de convivencia.

b. Que la persona beneficiaria, o cualquier otro miembro de la unidad familiar o de convivencia, no sea propietaria de otra vivienda. Se exceptúa el caso de que la vivienda resulte inadecuada o insuficiente para las necesidades de la unidad familiar o de convivencia, en los términos establecidos en el artículo siguiente. En este caso, la persona propietaria habrá de ofrecer la vivienda a la consejería competente en materia de vivienda. Para la determinación de su precio se aplicará el módulo vigente en promoción pública en el momento de la puesta a disposición, pudiendo aplicarse coeficientes de depreciación en función del estado de conservación de la vivienda.

c. Que la persona beneficiaria resida o desarrolle su actividad laboral en un municipio de la Comunidad Autónoma de Galicia.

Artículo 47. Vivienda inadecuada o insuficiente.

En relación con lo previsto en el apartado b) del artículo anterior, se tendrán en cuenta las siguientes situaciones:

a. Se presumen inadecuados los edificios y viviendas que no tengan un fin propiamente residencial y los que se encuentren en situación de ruina, así como las viviendas que tengan deficiencias, no imputables a la falta de mantenimiento por la persona solicitante, que afecten de forma notoria a la habitabilidad, debidamente acreditadas por técnico competente.

b. Se considera que una vivienda tiene una superficie insuficiente para la composición de la unidad familiar o de convivencia cuando a cada ocupante le correspondan menos de 10 metros cuadrados de superficie útil, no computándose al efecto la dedicada a baños, pasillos y tendederos.

En el supuesto de que habiten la vivienda dos unidades familiares o de convivencia distintas, y siempre que dicha circunstancia se produzca con una antelación de al menos un año a la fecha de la adjudicación de las viviendas, el límite de superficie útil señalado en el párrafo anterior se incrementará hasta 20 metros cuadrados por ocupante, con idénticas minoraciones a efectos de cómputo.

c. Se entiende que una vivienda es inadecuada por causa de movilidad cuando su configuración arquitectónica, distribución espacial, emplazamiento o accesos supongan una grave pérdida de funcionalidad para el miembro de la unidad familiar o de convivencia con movilidad reducida.

Artículo 48. Situaciones excepcionales.

Excepcionalmente, podrán acceder a una vivienda protegida las personas que sean 
propietarias de otra vivienda cuando esté sujeta a expediente de expropiación forzosa o desahucio judicial o administrativo no imputable a ellas, y las que ocupen alojamientos provisionales como consecuencia de operaciones de emergencia o remodelación que impliquen la pérdida de su vivienda o cualquier otra situación excepcional declarada por los servicios sociales del ayuntamiento competente o por la consejería competente en materia de vivienda.

Artículo 49. Unidad familiar o de convivencia.

1. A los efectos de la presente ley se entiende por unidad familiar o de convivencia:

a. La formada por los cónyuges no separados legalmente $\mathrm{y}$, si los hubiera, por sus descendientes y ascendientes que convivan con ellos y estén a su cargo.

b. Las uniones de hecho que estén inscritas en el registro correspondiente.

c. En los casos de separación legal, viudedad o familia monoparental, la formada por los respectivos titulares de dichas uniones familiares o de convivencia y, si los hubiera, por sus descendientes y ascendientes que convivan con ellos y estén a su cargo.

d. Las personas mayores de edad o menores emancipadas integradas en una unidad familiar o de convivencia que manifiesten su deseo de independizarse.

2. No tendrán la condición de miembros de la unidad familiar o de convivencia las personas que figuren como titulares o miembros de otras unidades que formulen solicitud separada en el mismo procedimiento.

3. La separación temporal motivada por razones de estudios, trabajo, tratamiento médico u otras causas semejantes debidamente justificadas no rompe la convivencia entre familiares, a los efectos establecidos en la presente ley.

\section{Sección segunda}

Registro único de demandantes de vivienda

Artículo 50. Objeto, contenido y características del registro.

1. La consejería competente en materia de vivienda mantendrá actualizado un Registro Único de Demandantes de Vivienda, que, centralizando todos los datos relativos a la demanda de vivienda, contribuya a la gestión y seguimiento de las políticas públicas de vivienda y garantice los principios de publicidad, concurrencia y transparencia en los procedimientos de adjudicación.

2. El registro tendrá carácter administrativo y será público. Reglamentariamente se determinarán el procedimiento y los requisitos para la inscripción, modificación y cancelación de los datos del registro.

3. La inscripción en el registro es requisito necesario para participar en los procedimientos de adjudicación de las viviendas protegidas, salvo en los casos de adjudicación directa contemplados en la presente ley.

4. Será obligación de la persona demandante comunicar cualquier cambio que se hubiera producido en sus circunstancias durante el período de inscripción.

\section{Sección tercera Modos de acceso}

Artículo 51. Títulos.

1. El acceso a las viviendas protegidas se realizará por compraventa, alquiler $u$ otras formas de transmisión o cesión del uso previstas en la legislación vigente.

Las viviendas protegidas de promoción y titularidad públicas construidas sobre terrenos del inventario de suelo para vivienda pública se destinarán preferentemente a alquiler.

2. Reglamentariamente se establecerán los ingresos mínimos y máximos para el acceso a las viviendas protegidas, según su modalidad de acceso. 
Artículo 52. Adjudicación por sorteo.

1. Para cada promoción de viviendas protegidas se realizará un sorteo ante notario entre las personas demandantes inscritas en el registro.

2. Realizado el sorteo, la Administración formalizará la adjudicación de las viviendas, previa comprobación de que las personas beneficiarias cumplen con los requisitos para ser adjudicatarias de las viviendas.

3. El procedimiento del sorteo se fijará reglamentariamente.

Artículo 53. Adjudicación directa.

1. Podrán adjudicarse directamente las viviendas protegidas para satisfacer necesidades urgentes de vivienda derivadas de realojos motivados por expedientes expropiatorios o en ejecución de desarrollos urbanísticos, procesos de rehabilitación pública, situaciones de violencia de género, situaciones de emergencia que impliquen pérdida de vivienda o cualquier otra situación que se establezca reglamentariamente.

2. Reglamentariamente se determinarán las especificidades de este procedimiento, de tramitación preferente y sumaria, que se garantizará en todo caso para las mujeres víctimas de violencia de género, y en el cual podrá establecerse, con carácter provisional o definitivo, la exención de algunos de los requisitos exigibles con carácter general según el artículo 52 y siguientes de la presente ley, en función de los bienes jurídicos a proteger. Se tendrá en cuenta, asimismo, lo previsto por la Ley para la prevención y el tratamiento integral de la violencia de género.

Artículo 54. Excepciones.

No estarán sometidas al procedimiento de adjudicación previsto en los artículos anteriores:

a. Las viviendas autopromovidas para uso propio, incluyendo las promovidas por comunidades de propietarios, cooperativas de vivienda o asociaciones legalmente constituidas, cuando el número de viviendas coincida con el número de demandantes. En otro caso, habrán de solicitar el correspondiente sorteo entre las personas demandantes inscritas en el registro.

b. Las viviendas adquiridas en los supuestos de permuta de suelo por vivienda, siempre que las personas beneficiarias cumplan con los requisitos exigidos para el acceso a la vivienda protegida.

Artículo 55. Reservas.

1. En cada procedimiento de adjudicación, la consejería competente en materia de vivienda podrá reservar viviendas para ser adjudicadas a las unidades familiares o de convivencia que se encuentren en alguna de las siguientes situaciones:

a. Alguna de las personas integrantes de la unidad familiar o convivencial tiene movilidad reducida.

b. Familias numerosas o unidades convivenciales de tres o más hijos.

c. Familias o unidades convivenciales monoparentales.

d. Familias o unidades convivenciales cuya persona titular tenga menos de 35 años o más de 65 .

e. Otras situaciones consideradas de atención preferente por la administración competente en materia de vivienda, entre las que se incluye la atención a las mujeres víctimas de violencia de género.

2. La suma de todas las reservas no podrá sobrepasar el $30 \%$ de las viviendas ofertadas, salvo supuestos especiales derivados de programas específicos de interés público o integración social, que se regirán por lo dispuesto en su reglamentación propia, así como las excepciones derivadas de la atención a las mujeres víctimas de violencia de género.

Artículo 56. Adjudicación de viviendas vacantes.

Las viviendas protegidas adjudicadas que queden vacantes serán adjudicadas a las personas que figuren en los primeros lugares de la lista de espera correspondiente, debiendo acreditar las mismas, 
en el momento de la adjudicación, que continúan reuniendo los requisitos para ser beneficiarias.

Artículo 57. Eficacia de la adjudicación.

La resolución de adjudicación se notificará a las personas interesadas en las formas previstas por la Ley 30/1992, de 26 de noviembre, de régimen jurídico de las administraciones públicas y del procedimiento administrativo común.

En la notificación se les advertirá del plazo establecido para la aceptación de la adjudicación y la formalización del contrato de compraventa o alquiler, así como de las consecuencias de la falta de aceptación y formalización.

Artículo 58. Régimen de recursos.

Las resoluciones de adjudicación serán susceptibles de recursos administrativos en los términos previstos en la Ley 30/1992, de 26 de noviembre, de régimen jurídico de las administraciones públicas y del procedimiento administrativo común.

Artículo 59. Aceptación de la adjudicación y formalización del contrato.

1. Notificada la adjudicación o resueltos, en su caso, los recursos administrativos, la persona adjudicataria habrá de aceptar la adjudicación y proceder a la formalización del contrato de compraventa o alquiler, según los modelos autorizados por la consejería competente en materia de vivienda. El plazo para la aceptación y formalización del contrato será el que se determine en las convocatorias correspondientes, o, en su defecto, un mes. Incumplido el plazo por causa imputable a la persona interesada, será advertida de que, si no diera cumplimiento a los referidos trámites en el plazo que se señale al efecto, no inferior a quince días ni superior a un mes, se entenderá que renuncia al derecho sobre la vivienda, que pasará a la situación de vacante.

2. Los actos por los que se transmite la propiedad de las viviendas habrán de formalizarse en escritura pública. Para su otorgamiento, las notarias y notarios, y para su inscripción las registradoras y registradores, deberán dejar constancia del documento privado visado por la consellaría competente en materia de vivienda con las siguientes menciones, que habrán de figurar también en la escritura pública:

a. La limitación del precio de venta.

b. El plazo de duración del régimen de protección.

c. Las condiciones legales.

d. Las limitaciones que afecten a la vivienda.

Reglamentariamente se determinarán las condiciones de formalización de los contratos de alquiler de las viviendas protegidas.

3. La persona compradora o arrendataria de la vivienda estará obligada a ocupar la vivienda en el plazo de dos meses, a contar desde la formalización del contrato, salvo que, mediando justa causa, sea autorizada por la Administración para su ocupación posterior.

Artículo 60. Fallecimiento de la persona adjudicataria y subrogación.

En el supuesto de que la persona titular solicitante falleciese después de haberse producido la adjudicación y antes de la firma del contrato, podrán subrogarse en la condición de persona adjudicataria los miembros de la unidad familiar o de convivencia que figuren en la solicitud formulada, aplicando, en su caso, y a los efectos de designar persona adjudicataria, el orden de prelación establecido para los arrendamientos rústicos en la Ley 2/2006, de 14 de junio, de derecho civil de Galicia.

\section{Capitulo IV \\ UTILIZACIÓN Y DISPOSICIÓN DE LAS VIVIENDAS PROTEGIDAS}

Artículo 61. Uso y conservación. Las personas adjudicatarias de viviendas protegidas asumirán los deberes de uso, mantenimiento y conservación establecidos en el título I de la presente ley y su normativa de desarrollo. 


\section{Ordenación del territorio y...}

Artículo 62. Administración.

Reglamentariamente se determinarán las condiciones de administración de las viviendas protegidas en régimen de alquiler y de las restantes formas de cesión del uso.

Artículo 63. Limitaciones a la facultad de disposición.

1. El régimen de disposición de las viviendas protegidas queda sujeto a las limitaciones establecidas en la presente ley y en las normas que la desarrollen.

2. Las viviendas protegidas solo podrán transmitirse inter vivos transcurrido el plazo de cinco años desde la fecha de formalización de la escritura pública contemplada en el artículo 59.2 o de la fecha de la resolución de calificación de las viviendas en los supuestos del artículo 54 de la presente ley. En cualquier caso, la persona adquirente deberá cumplir los requisitos establecidos para ser persona adjudicataria de viviendas protegidas.

En situaciones excepcionales debidamente justificadas, la Administración competente en materia de vivienda podrá autorizar la transmisión de la vivienda antes del transcurso del plazo de cinco años. En su caso, se exigirá la cancelación previa del préstamo y el reintegro de las ayudas económicas directas recibidas de la Administración, con los intereses legales correspondientes.

3. Las viviendas protegidas para alquiler podrán ser vendidas, individualizadamente o por promociones completas, en cualquier momento del período de vinculación a dicho régimen de uso, previa autorización y en las condiciones fijadas reglamentariamente por la consejería competente en materia de vivienda.

Las nuevas personas propietarias, que tendrán que destinar las viviendas a alquiler, se subrogarán en los derechos y obligaciones de las anteriores propietarias, e incluso en la financiación cualificada que obtuvieron estas.
Artículo 64. Segundas y ulteriores transmisiones de viviendas protegidas de promoción pública en régimen de compraventa.

1. Las personas propietarias de viviendas protegidas de promoción pública que deseen venderlas habrán de comunicarlo a la consellaría competente en materia de vivienda, con expresión del precio. Dicha comunicación es vinculante para la persona oferente, teniendo la consideración de promesa de venta a los efectos de la normativa vigente.

2. La Administración autonómica, a través de la consejería competente en materia de vivienda, podrá ejercitar, para sí o en beneficio de otra administración pública, el derecho de adquisición preferente en el plazo de un mes a partir del día siguiente a aquel en que se produjese la comunicación prevista en el apartado anterior.

Si dicha comunicación fuera incompleta o defectuosa, el plazo se suspenderá desde la fecha de requerimiento de corrección o complemento de datos hasta que estén correctos o completos a disposición de la Administración.

Si no se efectuase la comunicación, la Administración tendrá derecho de retracto en los términos establecidos en la normativa civil.

3. Si no se ejercitase el derecho de adquisición preferente, la Administración autonómica ofertará las viviendas, con expresión del precio y condiciones que deben reunir las personas demandantes.

4. La persona adquirente se elegirá por sorteo público realizado entre las demandantes con el mismo procedimiento contemplado en el artículo 52 de la presente ley, salvo que concurra alguno de los supuestos de adjudicación directa.

5. Los modelos de contratos de compraventa serán facilitados a las partes contratantes por la consejería competente en materia de vivienda y serán visados una vez firmados, previa verificación del 
cumplimiento por la persona adquirente de los requisitos establecidos en las disposiciones vigentes para la adquisición de la vivienda protegida.

6. Si la venta de las viviendas protegidas se produce como consecuencia de un procedimiento de ejecución patrimonial, corresponde al organismo que realice la ejecución ponerla a disposición de la Administración autonómica.

7. La formalización de las transmisiones en escritura pública se regirá por lo dispuesto en el artículo 59 de la presente ley.

8. Los apartados anteriores no serán de aplicación a las transmisiones entre personas con parentesco hasta el segundo grado en línea recta siempre que la persona adquirente cumpla los requisitos establecidos en las disposiciones vigentes para la adquisición de la vivienda protegida.

Artículo 65. Derechos de tanteo y retracto.

1. Las personas adjudicatarias de viviendas protegidas de promoción privada y las personas propietarias de viviendas protegidas autopromovidas habrán de comunicar a la consejería competente en materia de vivienda, por cualquier medio que permita tener constancia de su recepción, la decisión de venderlas, con expresión del precio de venta y la acreditación del cumplimiento por la persona interesada en adquirir la vivienda de los requisitos establecidos en las disposiciones vigentes para la adquisición de la vivienda protegida.

La comunicación caducará a los seis meses, debiendo procederse a una nueva comunicación si transcurriera dicho plazo sin que se hubiese formalizado la transmisión.

2. Los modelos de contratos de compraventa serán facilitados a las partes contratantes por la consejería competente en materia de vivienda y serán visados una vez firmados, previa verificación del cumplimiento por la persona adquirente de los requisitos establecidos en las disposiciones vigentes para la adquisición de la vivienda protegida.
3. La consejería competente en materia de vivienda tendrá derecho de tanteo sobre la vivienda protegida, a su favor o al de otra Administración o entidad del sector público, en tanto dure el régimen de protección, salvo en los casos de compraventa entre personas con parentesco hasta el segundo grado en línea recta siempre que la persona adquirente cumpla los requisitos establecidos en las disposiciones vigentes para la adquisición de la vivienda protegida.

El derecho de tanteo podrá ser ejercido durante el plazo de un mes a partir del día siguiente a aquel en que se haya producido la comunicación previa prevista en el apartado 1 de este artículo.

Si la consejería no se manifestase al respecto, podrá llevarse a cabo la transmisión en los términos de la comunicación.

4. El incumplimiento de las condiciones establecidas en los apartados anteriores por parte de la persona transmitente conferirá a la consellaría competente en materia de vivienda el derecho de retracto, que podrá ejercitarse en el plazo de dos meses a partir de la fecha en que tuviera conocimiento de la transmisión y de sus condiciones.

5. El ejercicio de los derechos de tanteo y retracto se realizará por el precio máximo legalmente aplicable para las viviendas protegidas, o por el convenido si fuese inferior.

6. Las disposiciones establecidas en los apartados anteriores son de aplicación a las segundas y ulteriores transmisiones de viviendas protegidas en régimen distinto del de compraventa, cualquiera que fuese su modalidad de promoción, salvo las transmisiones entre personas con parentesco hasta segundo grado en línea recta o en los casos de liquidación de la sociedad de gananciales, siempre que la persona adquirente cumpla los requisitos establecidos en las disposiciones vigentes para la adquisición de la vivienda protegida. 
Artículo 66. Escrituración e inscripción.

Las limitaciones establecidas en los artículos anteriores se harán constar expresamente en las escrituras de transmisión, de préstamo y de declaración de obra nueva en el supuesto de autopromoción, así como en el registro de la propiedad, por medio de nota marginal.

\section{Artículo 67. Desahucio.}

1. Las personas propietarias de las viviendas protegidas, sin perjuicio de las sanciones que procedan, podrán instar el desahucio de las personas ocupantes de estas viviendas por las mismas causas y con arreglo a los procedimientos establecidos en el ordenamiento jurídico.

2. La consejería competente en materia de vivienda podrá acordar, previa tramitación del correspondiente expediente administrativo, el desahucio administrativo y, en su caso, el lanzamiento de las personas ocupantes de las viviendas de su propiedad en los supuestos previstos en la legislación común y, en particular, cuando concurran las siguientes causas:

a. El impago de las rentas pactadas en el contrato de arrendamiento o de las cantidades a que esté obligada la persona cesionaria en el acceso diferido a la propiedad.

b. La ocupación de la vivienda sin título legal.

c. Haber sido sancionada la persona ocupante por infracción grave o muy grave de las tipificadas en la presente ley.

\section{TÍTULO III \\ POLÍTICAS DE FOMENTO DEL DERECHO A LA VIVIENDA}

\section{Capítulo I \\ ACCIONES EN MATERIA DE VIVIENDA}

Artículo 68. Derecho a la vivienda. Las administraciones públicas de la comunidad autónoma promoverán y desarrollarán, en el ámbito de sus competencias, cuantas acciones contribuyan a garantizar el derecho a disfrutar de una vivienda, en los términos del artículo 47 de la Constitución española, y, entre otras, las siguientes:

a. La creación de un parque de viviendas estable, suficiente y de calidad, a través de la promoción pública y privada de viviendas protegidas.

b. La recuperación de los parques de viviendas existentes, mediante acciones de renovación y rehabilitación.

c. La dinamización del mercado de vivienda en alquiler, con la consiguiente ocupación de las viviendas vacías.

d. La mejora de la calidad de las viviendas, con medidas de fomento orientadas a favorecer la innovación y la sostenibilidad de la edificación.

\section{Artículo 69. Medidas.}

1. Con el objetivo prioritario de facilitar el acceso a la vivienda, las administraciones públicas podrán establecer medidas de carácter fiscal, económico o financiero en los términos previstos en las leyes.

2. A estos efectos, la Administración autonómica y los entes locales podrán establecer, dentro del ámbito de sus respectivas competencias, exenciones, deducciones o cualquier otra acción de fomento.

3. Las medidas económicas y financieras en materia de vivienda podrán adoptar las siguientes modalidades:

a. Medidas de financiación cualificada, a través de préstamos cualificados y descuentos bancarios de certificaciones de obra.

b. Ayudas económicas directas, especialmente subvenciones a fondo perdido, subsidiaciones totales o parciales del tipo de interés de los préstamos cualificados y de las operaciones de descuento de certificaciones de obra y subsidiaciones de préstamos no cualificados.

c. Cualesquiera otras medidas económicas o financieras que contribuyan a facilitar la financiación del coste de la vivienda. 


\section{Capítulo II FOMENTO DE LA RENOVACIÓN Y REHABILITACIÓN}

Artículo 70. Actuaciones.

1. Las administraciones públicas competentes en materia de vivienda fomentarán la renovación y rehabilitación del parque de viviendas de Galicia, mediante políticas de ayudas y subvenciones y la ejecución de actuaciones directas sobre dicho patrimonio.

2. Son actuaciones de renovación y rehabilitación las constituidas por una o varias intervenciones sobre el patrimonio edificado o urbanizado al objeto de conservar, recuperar y poner en valor el parque inmobiliario residencial existente en el medio rural y urbano.

3. Las políticas públicas de renovación y rehabilitación tendrán como objetivos prioritarios:

a. Los inmuebles de valor arquitectónico, para su recuperación y utilización, preferentemente en régimen de alquiler.

b. Los núcleos tradicionales de costa e interior, con la finalidad de contribuir a la conservación y puesta en valor del patrimonio construido, la fijación de su población y revitalizar su entorno.

c. Los cascos históricos y, en particular, la conservación del patrimonio histórico y la mejora de la calidad de vida de la población asentada tradicionalmente en esos espacios.

d. Las áreas urbanas degradadas, procurando la superación de las carencias y deficiencias urbanas, medioambientales e incluso sociales a través de una intervención global sobre la edificación, las infraestructuras, las dotaciones y los espacios libres.

e. Mejoras de la accesibilidad de los edificios y viviendas.

4. La consellaría competente en materia de vivienda podrá aprobar programas de renovación o rehabilitación dirigidos a planificar, coordinar y ejecutar las acciones orientadas a los objetivos señalados en el apartado anterior. Dichos programas, que respetarán las disposiciones contenidas en el planeamiento urbanístico, conllevarán la declaración de interés social a los efectos de expropiación forzosa por incumplimiento de la función social de la propiedad, en los términos previstos en la presente ley.

Artículo 71. Recuperación aislada de inmuebles de valor arquitectónico.

1. La Administración autonómica podrá promover la recuperación de los inmuebles de reconocido valor arquitectónico que estén vacíos y deteriorados, para ser destinados preferentemente a alquiler.

2. Sin perjuicio de las ayudas y subvenciones que establezcan los programas específicos de vivienda, las actuaciones de recuperación podrán llevarse a cabo bajo el régimen de promoción pública para su puesta en alquiler sobre los edificios o viviendas catalogados en los planes municipales y siempre que exista una demanda real de viviendas en alquiler en dicho municipio, de acuerdo con los datos del Registro Único de Demandantes de Vivienda.

3. Las/los agentes promotores podrán convenir con las personas propietarias de los edificios o viviendas la cesión del uso por plazo determinado, a fin de llevar a cabo las obras de renovación o rehabilitación de las viviendas para destinarlas preferentemente a alquiler. En cualquier caso, la duración del derecho de uso habrá de ser suficiente para costear con las rentas del alquiler al menos el $70 \%$ del coste de las obras de renovación o rehabilitación proyectadas, salvo que la persona propietaria financie parcialmente las mismas.

4. Las viviendas renovadas o rehabilitadas recibirán la calificación de protegidas, siéndoles de aplicación lo dispuesto en el título II de la presente ley.

Dicha calificación tendrá la duración que la/el agente promotor y la persona propietaria convengan para la duración del derecho de uso, que en ningún caso será inferior a cinco años. 
Artículo 72. Renovación y rehabilitación de edificios y viviendas en núcleos de costa e interior.

1. La finalidad de contribuir a la conservación y puesta en valor del patrimonio construido de los núcleos de costa e interior, la fijación de su población y la revitalización de su entorno se llevará a cabo preferentemente mediante ayudas y subvenciones destinadas a actuaciones de renovación y rehabilitación de los edificios y viviendas construidas, de acuerdo con criterios de sostenibilidad, ahorro energético, mejora de la calidad y conservación de los elementos singulares de las construcciones tradicionales.

2. Las poblaciones afectadas por dichas actuaciones, las personas beneficiarias, las condiciones de las viviendas afectadas y el procedimiento de actuación se establecerán reglamentariamente.

3 . Las viviendas renovadas o rehabilitadas recibirán la calificación de viviendas protegidas, siéndoles de aplicación lo dispuesto en el título II de la presente ley.

El régimen de protección tendrá una duración de cinco años, salvo que en el programa específico se fije otro plazo distinto en atención a las ayudas y subvenciones percibidas por los interesados.

Artículo 73. Renovación y rehabilitación de cascos históricos.

1. La recuperación de los cascos históricos de los núcleos urbanos y, en particular, la mejora de la calidad de vida de sus habitantes se llevarán a cabo preferentemente mediante subvenciones de actuaciones de renovación y rehabilitación del patrimonio edificado o urbanizado.

2. La determinación de los cascos históricos afectados por dichas actuaciones, las personas beneficiarias, las condiciones de los edificios y viviendas y el procedimiento de actuación se determinarán reglamentariamente.

3. Las viviendas renovadas o rehabilitadas recibirán la calificación de viviendas protegidas, siéndoles de aplicación lo dispuesto en el título II de la presente ley.
El régimen de protección tendrá una duración de cinco años, salvo que en el programa específico se fije otro plazo distinto en atención a las ayudas y subvenciones percibidas por los interesados.

4. Sin perjuicio de lo dispuesto en el título II de la presente ley, se adjudicarán directamente las viviendas en régimen de alquiler a las personas arrendatarias que hubiesen sido desalojadas de las mismas como consecuencia del proceso de renovación o rehabilitación.

Artículo 74. Renovación y rehabilitación de áreas urbanas degradadas.

1. Las administraciones públicas promoverán actuaciones de renovación y rehabilitación de los espacios urbanos con graves deficiencias urbanas o medioambientales o significativo deterioro o decadencia funcional de la edificación, las infraestructuras, las dotaciones y los espacios libres que los sirvan.

2. Corresponde a la consellaría competente en materia de vivienda la declaración de áreas de rehabilitación, a los efectos de coordinar y programar las actuaciones de las administraciones públicas y fomentar actividades privadas de rehabilitación, a través de ayudas de carácter técnico, económico, de gestión y de información.

3. La renovación o rehabilitación de las áreas urbanas degradadas se llevará a cabo por las administraciones municipales a través de planes especiales. Sin perjuicio de lo anterior, la consellaría competente en materia de vivienda podrá acordar la declaración de un área urbana degradada de rehabilitación obligatoria, disponiendo un plazo para que la Administración municipal tramite el correspondiente Plan Especial de reforma interior. La inactividad municipal facultará a la Administración autonómica para adoptar las medidas necesarias en sustitución de la Administración local, en los términos previstos en el artículo 91 de la Ley 9/2002, de ordenación urbanística y protección del medio rural de Galicia. 
Artículo 75. Medidas financieras.

1. Las actuaciones de rehabilitación podrán llevarse a cabo a través de medidas de financiación cualificada y subvenciones a fondo perdido, en los términos que se establezcan reglamentariamente, sin perjuicio de su compatibilidad con cualquier otra ayuda que pudiera concederse para la misma finalidad, siempre que el conjunto de todas ellas no sobrepase el $75 \%$ del coste del presupuesto protegible definido reglamentariamente.

2. Los titulares de las actuaciones de rehabilitación previstas en este capítulo podrán acceder a préstamos cualificados, en las condiciones que se dispongan reglamentariamente. La cuantía máxima del préstamo podrá alcanzar la totalidad del presupuesto protegible, deducidas, en su caso, las subvenciones a fondo perdido concedidas.

3. Para llevar a cabo las actuaciones de rehabilitación contempladas en este capítulo, la comunidad autónoma podrá conceder subvenciones personales a fondo perdido, en los términos que se establezcan en las correspondientes normas de desarrollo.

\section{Capitulo III FOMENTO DEL ACCESO A LA VIVIENDA EN RÉGIMEN DE ALQUUILER}

Artículo 76. Actuaciones.

1. Constituye un marco de actuación preferente de la Administración autonómica el fomento del acceso a la vivienda en régimen de alquiler.

2. Las administraciones públicas adoptarán medidas dirigidas a impulsar la puesta en el mercado de viviendas en alquiler, con los objetivos prioritarios de movilizar las viviendas vacías y favorecer el acceso a la vivienda a sectores con dificultades, en particular las personas jóvenes que deseen acceder a la vivienda por primera vez, las personas mayores y los colectivos sociales especialmente desfavorecidos o en situación de exclusión social y las mujeres víctimas de violencia de género.

Artículo 77. Programa de vivienda en alquiler.

1. La Administración autonómica desarrollará un programa de vivienda en alquiler en el cual se concretarán la puesta en el mercado de las viviendas vacías y las bases reguladoras de las subvenciones y ayudas que se dispongan con cargo a los presupuestos públicos. Las líneas de acción de dicho programa se concretarán en las convocatorias periódicas realizadas mediante orden de la persona titular de la consellaría competente en materia de vivienda.

2. Las viviendas que se incorporen al programa habrán de estar ubicadas en municipios con demanda real de vivienda en alquiler, de acuerdo con los datos que se deriven del Registro Único de Demandantes de Vivienda.

3. La Administración autonómica podrá gestionar, por sí o a través de una entidad colaboradora, los contratos de alquiler que se celebren al amparo del programa. A estos efectos, se formalizará con las personas propietarias el contrato que corresponda, de al menos cinco años de duración, subrogándose la entidad gestora en los derechos y acciones que corresponden a la persona propietaria sobre la vivienda a los efectos de arrendamiento.

Artículo 78. Otras acciones, planes y programas.

Sin perjuicio de lo dispuesto en el artículo anterior, las administraciones públicas podrán impulsar las acciones, planes y programas orientados a favorecer el acceso a la vivienda en régimen de alquiler. Su régimen de compatibilidades y los límites cuantitativos de los mismos habrán de regularse expresamente en las respectivas convocatorias.

Artículo 79. Medidas financieras. La Administración autonómica favorecerá la ejecución de las acciones orientadas a 
favorecer el acceso a la vivienda en régimen de alquiler con medidas financieras dirigidas a:

a. La adecuación de las viviendas vacías a las condiciones de habitabilidad, mediante subvenciones de las obras y actuaciones de renovación o rehabilitación.

b. La asignación de subvenciones a los arrendatarios de rentas bajas, en los términos establecidos en la convocatoria respectiva.

c. El establecimiento de ayudas dirigidas a personas jóvenes mayores de edad y menores de 35 años o menores de edad emancipadas y a personas mayores de 65 años para acceder a una vivienda en régimen de alquiler, así como a las mujeres víctimas de violencia de género.

\section{Capítulo IV \\ FOMENTO DE LA CALIDAD, LA INNOVACIÓN Y LA SOSTENIBILIDAD}

\section{Artículo 80. Actuaciones.}

1. Las administraciones públicas fomentarán la calidad del parque de viviendas de Galicia y promoverán las actuaciones dirigidas a incorporar medidas de calidad por encima de los mínimos exigidos en las normas de calidad vigentes, emplear criterios de sostenibilidad en la ejecución, uso y conservación de las viviendas e introducir experiencias innovadoras.

2. La Administración autonómica desarrollará, entre otras, las siguientes medidas:

a. El impulso de acciones $\mathrm{I}+\mathrm{D}+\mathrm{i}$ en lo referente a la calidad de la edificación.

b. El fomento de la profesionalidad y la transparencia en el sector de la edificación, la identificación de los agentes y su idoneidad.

c. El impulso de la información de los agentes y usuarios, mediante la elaboración de estudios, bases de datos y guías orientados a la mejora de la calidad.

d. El reconocimiento de la excelencia en el proceso edificatorio, mediante el reconocimiento oficial de distintivos de calidad y su promoción en las edificaciones de la Comunidad Autónoma de Galicia.

e. El fomento de acciones que contribuyan a mejorar la eficiencia energética de los edificios y viviendas.

f. El desarrollo de acciones formativas de los agentes de la edificación.

g. Cuantas acciones estén orientadas a la mejora de la calidad de la edificación. Artículo 81. Eficiencia energética.

La Administración autonómica podrá adoptar medidas de fomento que contribuyan a mejorar la eficiencia energética de los edificios y viviendas. Entre otras, podrá llevar a cabo las siguientes actuaciones:

a. Apoyar la implantación de soluciones técnicas que mejoren el rendimiento energético de las viviendas existentes.

b. Potenciar las viviendas de consumo energético bajo.

c. Fomentar la implantación de la arquitectura bioclimática, así como el uso de materiales y productos de la construcción autóctonos y ecológicos acreditados.

d. Promover planes de renovación de electrodomésticos y del alumbrado de bajo consumo de edificios y viviendas.

e. Promover la utilización de fuentes de energía renovables o la producción combinada de calor y electricidad en los edificios nuevos y usados.

f. Estimular las empresas de construcción a utilizar sistemas integrados de gestión medioambiental, especialmente el sistema comunitario de gestión y auditoría medioambiental.

g. Desarrollar programas de auditoría energéticos para impulsar actuaciones de ahorro y mejora de la eficacia energética.

h. Desarrollar acciones que permitan extender la utilización de etiquetas ecológicas y energéticas a toda la equipación del hogar.

Artículo 82. Medidas financieras.

1. Las administraciones públicas establecerán medidas financieras para 
contribuir a la mejora de la calidad, la innovación y la sostenibilidad de edificios $\mathrm{y}$ viviendas.

2. Las medidas financieras concedidas a estos fines podrán ser préstamos cualificados, subsidiación del tipo de intereses de los mismos, subvenciones a fondo perdido o cualquier otra que determine la Administración.

3. Podrán acceder a dichas ayudas, en los términos en que se determine reglamentariamente, las/los agentes promotores de viviendas de nueva construcción o de rehabilitación y las personas usuarias de las viviendas.

\section{TÍTULO IV PROTECCIÓN DE LOS ADQUIRENTES Y ARRENDATARIOS DE VIVIENDA \\ Capitulo I PUBLICIDAD E INFORMACIÓN \\ Sección primera \\ Publicidad en la oferta de venta}

Artículo 83. Características de la publicidad.

1. La publicidad en la oferta de venta se ajustará a los principios de buena fe y veracidad, no conteniendo informaciones ni omitiendo datos esenciales que puedan inducir a error a sus destinatarios.

2. Las características, condiciones, prestaciones y garantías de las viviendas, anexos, servicios e instalaciones comunes ofrecidas en la publicidad serán exigibles por la persona compradora, aun cuando no figuren expresamente en el contrato de compraventa firmado.

Artículo 84. Contenido mínimo de la publicidad.

1. La publicidad en la oferta de venta deberá señalar, en su caso, la condición de protegida de la vivienda $\mathrm{y}$, en caso de viviendas en construcción, la fecha de concesión de la licencia urbanística y especialmente los usos y el número de plantas y de viviendas autorizadas.
2. Cuando se trate de viviendas integradas en un complejo inmobiliario, se hará constar expresamente esta circunstancia en la publicidad, indicándose si las instalaciones o servicios a que se hace referencia corresponden a un solo edificio, a varios o a elementos comunes a todo el complejo.

3. Las alusiones publicitarias a la superficie de las viviendas se entenderán referidas a la superficie útil, en los términos contemplados en el artículo 5 de la presente ley.

Cuando se ofrezcan viviendas con anexos, tales como trasteros, plazas de garaje u otros espacios análogos, la publicidad indicará su superficie útil, emplazamiento $\mathrm{y}$, en su caso, el carácter inseparable o independiente de la vivienda.

Artículo 85. Publicidad sobre el precio.

1. La publicidad sobre el precio de venta de una vivienda destacará con claridad el importe de su precio final total, especificándose que el IVA está incluido.

El precio de los anexos, cuando sean inseparables de la vivienda, se entenderá comprendido en el precio de venta. En los restantes casos, la publicidad indicará su precio, haciéndose constar con claridad que no está incluido en el precio final de la vivienda.

Si se omitiese la referencia expresa al IVA o al precio de los anexos, se entenderá que el precio publicitado incluye todos los conceptos.

2. Si se incluye en la publicidad información sobre formas de pago aplazado del precio, habrá de indicarse si se exige una entrada inicial, así como el número total de plazos y su vencimiento.

\section{Sección segunda}

Información en la oferta de venta

Artículo 86. Deber de información por escrito.

La/el agente promotor y las/los agentes inmobiliarios deberán proporcionar a las 
personas interesadas en la adquisición información básica sobre sus características, por escrito y antes de celebrar el contrato.

Artículo 87. Contenido de la información.

1. La información incluirá, además de las menciones a que hace referencia el artículo 84 de la presente ley, las siguientes:

a. La identificación de la/el agente promotor y el constructor.

b. El régimen jurídico de la vivienda, si se tratase de vivienda protegida, especificando las condiciones para el acceso a la propiedad de las viviendas y, en su caso, para obtener ayudas financieras.

c. El emplazamiento del edificio.

d. La indicación de si la vivienda está terminada, en construcción o simplemente proyectada, señalando, en su caso, el plazo de construcción y la fecha de entrega de la vivienda.

e. La descripción de la vivienda y, en su caso, de los elementos vinculados a la misma, haciéndose mención expresa a la etiqueta de eficiencia energética.

f. La superficie útil de la vivienda, en los términos previstos en la presente ley.

g. El precio de venta y las condiciones básicas de financiación.

h. La entidad financiera que garantice las cantidades entregadas a cuenta.

2. En caso de previsión de subrogación en el préstamo hipotecario, se incluirá en la información la parte de gravamen que corresponde a cada una de las viviendas en la distribución de la responsabilidad hipotecaria, así como la indicación del número de plazos, importe de cada uno de ellos y fecha de su vencimiento.

3. Si se trata de una vivienda protegida, la información habrá de hacer referencia, además, al régimen de protección a que está acogida la vivienda, a la fecha de la calificación provisional o, en su caso, definitiva y a la expresión de que la vivienda habrá de dedicarse a residencia habitual y permanente del titular.
4. En todo caso habrá de ofrecerse información separada de la superficie útil de los anexos y de su emplazamiento.

Artículo 88. Examen de la documentación antes de la perfección del contrato. Antes de celebrar el contrato, el futuro adquirente de una vivienda podrá exigir la exhibición ante él de la documentación justificativa de la información contemplada en el artículo anterior, al objeto de que pueda examinarla.

\section{Sección tercera Información en la oferta de arrendamiento}

Artículo 89. Deber de información por escrito.

En la oferta de viviendas en régimen de arrendamiento, el arrendador o el oferente que se dedique en el desarrollo de su actividad empresarial o profesional al arrendamiento de viviendas habrá de proporcionar a las personas interesadas en arrendar una vivienda información básica sobre las características de la misma, por escrito y antes de la celebración del contrato.

Artículo 90. Contenido de la información.

En la oferta de viviendas en régimen de arrendamiento habrán de especificarse los siguientes extremos:

a. Las características, servicios e instalaciones de que dispone la vivienda y las condiciones de uso.

b. La renta contractual y su fórmula de actualización.

c. La duración del contrato.

d. Los gastos repercutibles.

\section{Capítulo II VENTA DE VIVIENDAS}

Sección primera

VEnta de viviendas en proyecto o en construcción

Artículo 91. Requisitos previos.

1. La/el agente promotor podrá vender las viviendas en fase de proyecto o en 
construcción siempre que reúna los siguientes requisitos:

a. Tener sobre el suelo sobre el que se va a emplazar el derecho de propiedad o de superficie inscrito en el registro de la propiedad sin cargas o gravámenes que impidan su libre disponibilidad.

b. Disponer de la licencia urbanística y de las demás autorizaciones precisas por la normativa aplicable.

c. Otorgar la escritura de declaración de obra nueva en construcción.

2. El incumplimiento de estos requisitos permitirá a la persona compradora la resolución del contrato si llegara a celebrarse, con las indemnizaciones que procedan, sin perjuicio de la imposición a la persona vendedora de las sanciones pertinentes.

Artículo 92. Contrato de compraventa en proyecto o en construcción.

1. El contrato de compraventa en proyecto o en construcción habrá de contener las siguientes especificaciones:

a. El régimen de protección a que, en su caso, está acogida o pretende acogerse la vivienda.

b. El plazo previsto de finalización de la obra y entrega de las viviendas, así como las penalizaciones que correspondan por su incumplimiento.

c. Las condiciones económicas y financieras de la venta.

d. La superficie de la vivienda y sus correspondientes anexos.

e. La cuota de participación que corresponda en relación con el total del valor del inmueble.

f. Las servidumbres, cargas y gravámenes que recaigan sobre la vivienda y sus anexos o sobre los elementos comunes del edificio.

g. Las cláusulas obligatorias establecidas por disposición legal.

2. Una vez firmado el contrato, se entregarán a la persona compradora:

a. Los estatutos de la comunidad de propietarios, si los hubiera. b. La documentación en que se especifiquen los materiales y las calidades a emplear en la construcción de la vivienda y elementos comunes del edificio.

3. Cuando exista discrepancia en perjuicio de la persona compradora entre la información suministrada con anterioridad a la venta y el contrato, aquella tendrá derecho a una rebaja proporcional del precio o a una indemnización equivalente, sin perjuicio de su facultad de resolver el contrato, cuando sea procedente, en los términos establecidos en la legislación civil.

Artículo 93. Correspondencia entre la construcción y el proyecto.

1. La construcción de la vivienda y del edificio o complejo inmobiliario en que se emplace habrá de ajustarse a las especificaciones contenidas en el proyecto, sin perjuicio de las modificaciones que, por exigencias técnicas, sea necesario realizar durante el proceso constructivo, en los términos dispuestos en los apartados siguientes.

2. Cuando, por circunstancias no previsibles en el momento de elaborar el contrato, sea necesario realizar modificaciones en los materiales de la construcción, se sustituirán los inicialmente descritos por otros de calidad análoga, sin variación en el precio, salvo consentimiento expreso de la persona compradora.

3. Será necesario igualmente el consentimiento expreso de la persona compradora para realizar modificaciones que consistan en:

a. Suprimir servicios.

b. Imponer nuevas cargas o gravámenes.

c. Alterar la distribución de espacios en elementos de aprovechamiento común o privativo.

d. Crear nuevos espacios constructivos o cambiar de naturaleza jurídica los ya configurados.

e. Constituir ámbitos de comunidad distintos de los contemplados en el pro- 


\section{Ordenación del territorio y...}

yecto técnico de obra, con edificios con que se forme un complejo inmobiliario.

4. El incumplimiento de las disposiciones contenidas en este artículo facultará a la persona compradora a resolver el contrato, con las indemnizaciones a que hubiera lugar, sin perjuicio de la imposición a la persona vendedora de las sanciones que procedan.

Artículo 94. Pago de cantidades anticipadas a cuenta del precio total de la vivienda.

1. La/el agente promotor podrá percibir de las personas compradoras cantidades anticipadas a cuenta del precio total convenido de las viviendas.

2. Las cantidades anticipadas serán depositadas en una cuenta bancaria abierta a esos efectos por la/el agente promotor.

3 . Cuando se trate de viviendas protegidas, la/el agente promotor habrá de obtener una autorización de la consellaría competente en materia de vivienda, previa solicitud, en que se acredite o garantice que se cumplen los siguientes requisitos:

a. La previa obtención de la calificación provisional.

b. La acreditación mediante una certificación registral de la titularidad y libertad de cargas del solar, salvo las constituidas en garantía de devolución de los préstamos cualificados concedidos para la construcción de las viviendas.

Artículo 95. Garantía de devolución de cantidades anticipadas.

1. La entrega de cantidades anticipadas a cuenta del precio total de la vivienda obligará a la/al agente promotor a garantizar su devolución, junto con los intereses legales del dinero incrementado en dos puntos hasta el momento de hacerse efectiva la devolución, para el caso de que, por cualquier causa, la construcción no llegue a iniciarse o a concluirse en los plazos establecidos en el contrato, sin perjuicio de que la persona compradora que pretenda la resolución del contrato reclame, además, en su caso, la indemnización de daños y perjuicios que proceda.
2. Se admitirá la constitución de cualquier forma de garantía admitida en derecho.

3. Las garantías solo se extinguirán cuando la/el agente promotor pruebe la entrega de las viviendas ya terminadas y tras la obtención de la correspondiente licencia de primera ocupación expresamente o por silencio administrativo.

Artículo 96. Entrega de viviendas.

1. Las viviendas terminadas no podrán ser entregadas en tanto no se otorgue, expresamente o por silencio administrativo, la licencia de primera ocupación y la calificación definitiva, si se tratase de viviendas protegidas.

2. En el momento de la entrega de la vivienda, el comprador recibirá la documentación que corresponde al comprador de vivienda de nueva construcción terminada que no haya recibido de modo anticipado, en los términos contemplados en el artículo 99 de la presente ley.

\section{Sección segunda}

\section{Venta de viviendas terminadas}

Artículo 97. Requisitos previos.

La/el agente promotor que pretenda vender viviendas de nueva construcción terminadas habrá de disponer de la licencia de primera ocupación concedida expresamente o por silencio positivo y la calificación definitiva si se tratase de viviendas protegidas.

Artículo 98. Contrato de compraventa e información.

Cuando exista discrepancia en perjuicio de la persona compradora entre la información suministrada con anterioridad a la venta y el contrato, aquella tendrá derecho a una rebaja proporcional del precio o a una indemnización equivalente, sin perjuicio de su facultad de resolver el contrato, cuando sea procedente, en los términos establecidos en la legislación civil.

Artículo 99. Entrega de documentación al comprador.

1. Simultáneamente a la firma del contrato, la/el agente promotor habrá de 
entregar al comprador de vivienda de nueva construcción terminada la siguiente documentación:

a. El libro del edificio, salvo que obre en poder de la comunidad de propietarios, caso en que bastará con la entrega del manual de la vivienda.

b. Los estatutos que regirán la comunidad de propietarios, si los hubiera.

c. La documentación relativa a la hipoteca, si se constituyese.

Igualmente, si la vivienda pertenece a un edificio en régimen de propiedad horizontal en que se hubieran designado los órganos de gobierno de la comunidad, se hará entrega al comprador de una certificación expedida por el secretario, con el visto bueno del presidente, de que se halla al corriente en el pago de los gastos generales o, en su caso, una certificación indicativa de los que se adeudan, salvo que el vendedor hubiera sido expresamente exonerado de esta obligación por el comprador.

2. La documentación comprendida en el apartado anterior habrá de ser entregada en las segundas y sucesivas transmisiones de la vivienda, salvo la relativa a la hipoteca, si hubiera sido cancelada.

\section{Capitulo III ARRENDAMIENTO DE VIVIENDAS}

\section{Sección primera}

Requisitos para el arrendamiento

Artículo 100. Requisitos previos.

Sin perjuicio de los requisitos establecidos por la legislación de arrendamientos urbanos, toda vivienda que pretenda arrendarse debe disponer de la licencia de ocupación, otorgada expresamente o por silencio, y la calificación definitiva si se tratase de vivienda protegida.

Artículo 101. Entrega de documentación.

Simultáneamente a la firma del contrato, la persona arrendadora habrá de entregar a la persona arrendataria la siguiente documentación: a. Copia de la licencia de primera ocupación, o del recibo de la presentación de su solicitud, y copia de la calificación definitiva si se tratase de vivienda protegida.

b. Copia de los estatutos de la comunidad de propietarios, si existiesen.

c. La documentación de la vivienda que le permita hacer un uso responsable de la misma y, especialmente, el certificado de eficiencia energética y las instrucciones para actuar en caso de emergencia.

\section{Sección segunda}

Depósito de las fianzas de los arrendamientos de viviendas

Artículo 102. Establecimiento de fianza.

1. En los términos establecidos en la legislación de arrendamientos urbanos, para llevar a cabo el contrato de arrendamiento de vivienda será obligatoria la prestación por la persona arrendataria de una fianza en metálico, sin perjuicio de cualquier otra garantía que las partes establezcan para garantizar el cumplimiento de las obligaciones arrendaticias.

2. La fianza equivaldrá a una mensualidad de renta. En los arrendamientos de temporada la cuantía de la fianza se calculará proporcionalmente al plazo de duración del contrato, si bien teniendo en cuenta que la base del cálculo será de dos mensualidades por año de duración, en los términos establecidos en la legislación de arrendamientos urbanos.

3. Durante los cinco primeros años de duración del contrato, la fianza no estará sujeta a actualización. Sin embargo, cada vez que el arrendamiento se prorrogue, la persona arrendadora podrá exigir que la fianza sea incrementada o la persona arrendataria que disminuya, hasta hacerse igual a una mensualidad de la renta vigente al tiempo de la prórroga.

La actualización de la fianza durante el periodo de tiempo en que el plazo pactado para el arrendamiento exceda de los cinco años se regirá por lo que estipulen las 
partes al efecto. A falta de pacto específico, se aplicará a la fianza lo acordado sobre actualización de la renta.

4. El saldo de la fianza que haya de ser restituido a la persona arrendataria al final del arrendamiento devengará el interés legal después de haber transcurrido un mes desde la entrega de las llaves sin que se haya hecho efectiva dicha restitución.

5. Las partes podrán pactar cualquier tipo de garantía adicional del cumplimiento por la persona arrendataria de sus obligaciones.

6. Quedan exceptuadas de la obligación de prestar fianza las administraciones públicas, sus organismos autónomos, las entidades de derecho público y los demás entes públicos dependientes de las mismas, cuando la renta haya de ser satisfecha con cargo a sus respectivos presupuestos.

Artículo 103. Depósito.

1. Las personas arrendadoras depositarán las fianzas y sus actualizaciones en el Instituto Gallego de la Vivienda y Suelo o en las entidades gestoras concertadas, en los términos que se determinen reglamentariamente.

2. Las empresas, entidades o administraciones públicas que presten suministros o servicios habrán de depositar en el Instituto Gallego de la Vivienda y Suelo las fianzas que exijan a los abonados por cualquier concepto en la celebración de los contratos que afecten a los edificios y viviendas.

3. $\mathrm{Si}$ se incumpliese la obligación de depósito, se reclamará su importe, incrementado en el interés legal hasta el momento en que se realice el mismo, sin perjuicio de las sanciones administrativas que procedan.

El Instituto Gallego de la Vivienda y Suelo podrá utilizar la vía ejecutiva para el ingreso de las fianzas no depositadas y de las sanciones que se deriven del incumplimiento.

4. El importe de las fianzas depositadas podrá ser destinado a la promoción pública de viviendas protegidas y al cumplimiento de las políticas de fomento del derecho a la vivienda contempladas en la presente ley, siempre que quede garantizada la devolución de fianzas que sean reclamadas en tiempo y forma.

Artículo 104. Responsabilidades.

La Administración autonómica no resultará afectada por las controversias y exigencia de responsabilidades que puedan plantearse entre los contratantes por causa de arrendamiento, que quedarán reservadas a la jurisdicción ordinaria.

\section{Capítulo IV ARBITRAJE}

Artículo 105. Arbitraje de vivienda.

1. La resolución de las quejas o reclamaciones de las personas adquirentes o usuarias de la vivienda podrá someterse al sistema arbitral de resolución de conflictos.

2. La Xunta de Galicia creará organismos arbitrales especializados que resolverán los conflictos que los afectados acuerden someter a su conocimiento, con los efectos previstos en la normativa general de arbitraje.

Por decreto del Consello de la Xunta se determinarán el ámbito territorial de dichos organismos, su composición, organización y funciones, el procedimiento de tramitación y resolución de conflictos y cuantas cuestiones sean necesarias para el cumplimiento de sus fines.

\section{TÍTULO V \\ INSPECCIÓN Y RÉGIMEN SANCIONADOR}

\section{Capítulo I INSPECCIÓN}

Artículo 106. Competencias y actividad inspectora.

1. Las administraciones municipales realizarán las actividades de inspección que fuesen necesarias para garantizar el control de la calidad de las viviendas en 
los diversos momentos del proceso edificatorio.

Igualmente, regularán el deber de inspección periódica de los edificios y viviendas y llevarán a cabo las actuaciones de control necesarias para verificar el estado de conservación de los mismos, en los términos previstos en la normativa vigente.

2. Sin perjuicio de las competencias que corresponden a las administraciones municipales, la consellaría competente en materia de vivienda llevará a cabo actividades de investigación y la comprobación del cumplimiento de la normativa de vivienda con arreglo a lo establecido en la presente ley y sus normas de desarrollo.

3. El personal al servicio de la Administración pública competente en materia de vivienda al que se le encomiende expresamente el ejercicio de la actividad inspectora ostenta la condición de agente de la autoridad. Las actas levantadas en el ejercicio de su función tendrán valor probatorio de los hechos que se reflejan en las mismas y hayan sido comprobados por el personal de inspección, sin perjuicio de las pruebas que en defensa de sus derechos e intereses pudieran señalar o aportar las personas interesadas.

4. Las/los agentes inspectores pueden realizar cuantas actuaciones resulten imprescindibles para comprobar el cumplimiento de la normativa de vivienda. Asimismo, están autorizados para entrar y permanecer en inmuebles sujetos a la actividad inspectora, respetando, en todo caso, el derecho a la intimidad personal y familiar y la inviolabilidad del domicilio de los interesados.

5. Corresponde a las/los agentes inspectores de vivienda el ejercicio de las siguientes funciones:

a. La investigación y comprobación del cumplimiento de la presente ley y sus disposiciones de desarrollo, practicando las pruebas que resulten necesarias a tal fin.

b. La propuesta de adopción de medidas provisionales y definitivas para asegurar el cumplimiento de la legislación vigente, incluidas las de protección y restauración de la legalidad.

c. La propuesta de incoación de los expedientes sancionadores y de medidas de protección y restablecimiento de la legalidad que procedan.

Artículo 107. Información y colaboración.

1. Las administraciones territoriales y las personas físicas y jurídicas, públicas o privadas, estarán obligadas a proporcionar a las/los agentes inspectores los datos, informes, antecedentes y justificantes que fuesen determinantes para verificar el cumplimiento de las obligaciones contempladas en la presente ley, con los límites establecidos en la normativa de protección de datos de carácter personal.

2. Las administraciones municipales aportarán los datos relativos al empadronamiento, certificado de convivencia o cualquier otro que resulte necesario para la investigación de presuntas infracciones, así como en la investigación del grado de ocupación de las viviendas en los respectivos términos municipales.

3. Las compañías suministradoras de los servicios de agua, energía eléctrica, gas y cualquier otro servicio de suministro facilitarán los datos de los consumos de los edificios y viviendas así como los relativos a las fianzas de los contratos de suministro celebrados.

4. Las empresas, sociedades y agencias dedicadas a la compraventa de bienes inmuebles o gestión de alquileres proporcionarán los datos relativos a las condiciones de la transmisión o alquiler de las viviendas protegidas.

5. Las personas propietarias pondrán a disposición de las/los agentes inspectores el plan de mantenimiento y conservación del edificio a los efectos de verificar su grado de cumplimiento.

6. La aportación de los datos a que se refieren los apartados anteriores no requerirá el consentimiento de los afectados. 


\section{Ordenación del territorio y...}

\section{Capitulo II \\ RÉGIMEN SANCIONADOR}

Sección primera

Infracciones de la normativa de vivienda

Artículo 108. Infracciones graves.

1. Son infracciones muy graves de las normas de edificación:

a. La vulneración de las normas de calidad vigentes en la Comunidad Autónoma de Galicia que afecten a la seguridad de los edificios y viviendas.

b. La negligencia de las/los agentes de la edificación durante el proceso constructivo cuando diese lugar a vicios o defectos graves que afecten a la seguridad de la edificación o causen daños a los destinatarios de la vivienda de más de 12.000 euros.

c. La falsedad en los documentos o certificaciones expedidos por las/los agentes de la edificación durante el proceso constructivo, en su favor o de terceros.

d. El incumplimiento por las/los agentes de la edificación de las condiciones o limitaciones al ejercicio de su actividad establecidas en la presente ley.

e. La transmisión o la cesión del uso de la vivienda de nueva construcción sin la preceptiva licencia de primera ocupación, salvo en los supuestos contemplados expresamente en la presente ley.

f. El suministro por parte de las compañías de agua, gas, electricidad, telecomunicaciones $y$ otros servicios comunitarios sin la existencia de licencia de primera ocupación y, en su caso, sin la resolución de calificación definitiva de vivienda protegida.

2. Es infracción muy grave de las normas de utilización de las viviendas el incumplimiento de los deberes de uso, mantenimiento, conservación o rehabilitación de la vivienda, cuando se ponga en riesgo la seguridad o habitabilidad del edificio o vivienda.
3. Son infracciones muy graves de las normas de viviendas protegidas, además de las previstas en el apartado anterior:

a. La falsedad en los hechos, documentos o certificaciones que resulten esenciales para obtener la calificación provisional o definitiva.

b. No obtener la calificación definitiva por no ajustarse la construcción al proyecto aprobado en la calificación provisional.

c. El incumplimiento de la obligación de destinar la vivienda protegida a residencia habitual y permanente, salvo los supuestos excepcionales admitidos en la presente ley.

d. Tener la vivienda vacía, en los términos establecidos en la presente ley.

e. El destino de la vivienda protegida a usos distintos al residencial sin contar con la preceptiva autorización autonómica.

f. El destino de la vivienda protegida a usos distintos de los establecidos en la resolución de calificación definitiva.

g. El establecimiento de precios de venta y renta de las viviendas protegidas superiores a los fijados por la Xunta de Galicia.

h. La percepción de sobreprecios, primas o cantidades distintas al precio en la transmisión o arrendamiento de viviendas protegidas.

i. La falsedad de hechos, documentos o certificaciones que hayan sido tomados en consideración por la Administración para la adjudicación de la vivienda protegida.

j. La utilización de más de una vivienda, salvo en los casos expresamente previstos en la presente ley.

k. El subarrendamiento, de modo oculto o manifiesto, o la cesión de la totalidad o parte de la vivienda adjudicada, incluso a título no oneroso.

1. La transmisión de la vivienda protegida inter vivos, en segunda o sucesivas transmisiones, antes del transcurso del plazo de cinco años desde la fecha de elevación a escritura pública del contrato 
de compraventa sin la preceptiva autorización administrativa.

m. La transmisión de las viviendas protegidas sin seguir el procedimiento establecido en los artículos 64 y 65 de la presente ley.

4. Son infracciones muy graves en materia de protección de las personas consumidoras y usuarias:

a. El incumplimiento reiterado de los principios de buena fe y veracidad, así como la inducción a confusión en la publicidad dirigida a la venta o arrendamiento de viviendas.

b. La omisión reiterada en la información de la oferta de venta de los datos de contenido obligatorio previstos en la presente ley.

5. Asimismo, son infracciones muy graves:

a. La falsedad de los datos exigidos para obtener los préstamos, subvenciones y ayudas previstos en la presente ley.

b. El destino de los préstamos, subvenciones y ayudas previstos en la presente ley a finalidades diferentes de las determinantes de su otorgamiento.

Artículo 109. Infracciones graves.

1. Son infracciones graves de las normas de edificación:

a. La vulneración de las normas de calidad vigentes en la Comunidad Autónoma de Galicia que no afecten a la seguridad de los edificios y viviendas.

b. La negligencia de las/los agentes de la edificación durante el proceso constructivo cuando diese lugar a vicios o defectos graves que no afecten a la seguridad de la edificación o causen daños a los destinatarios de la vivienda superiores a 1.200 euros e iguales o superiores a 12.000 euros.

c. La inexactitud de los documentos o certificaciones expedidos por las/los agentes de la edificación durante el proceso constructivo, cuando de la misma se deriven perjuicios a terceros.

d. El incumplimiento por la/el agente de la obligación de registrarse en el registro de agentes de la edificación que se crease al amparo de la presente ley.

e. El incumplimiento de los deberes de elaboración, entrega y gestión del libro del edificio.

f. No visar los contratos de compraventa o arrendamiento de las viviendas protegidas en su primera transmisión.

2. Es infracción grave de las normas de utilización de las viviendas:

a. El incumplimiento de los deberes de uso y mantenimiento de las viviendas cuando se causen daños a las mismas superiores a 1.200 euros.

b. El incumplimiento de los deberes de conservación o rehabilitación de la vivienda, cuando no se ponga en riesgo la seguridad o habitabilidad del edificio o vivienda.

c. El incumplimiento del deber de realojo o el impedimento del derecho de retorno por parte del arrendador de la vivienda.

3. Son infracciones graves de las normas de viviendas protegidas, además de las previstas en el apartado anterior:

a. La falsedad en los hechos, documentos o certificaciones no esenciales para obtener la calificación provisional o definitiva.

b. Dejar la vivienda desocupada sin justa causa reconocida por la Administración.

c. La inadecuación entre el proyecto de ejecución de obras calificado provisionalmente y la obra efectivamente realizada que no impida la obtención de la calificación definitiva, salvo en el caso de modificaciones autorizadas previamente por el órgano competente.

d. El incumplimiento por la/el agente promotor de la obligación de formalizar la compraventa de viviendas protegidas en escritura pública, o el incumplimiento de la obligación de hacer constar en la escritura pública las prohibiciones y limitaciones a la facultad de disponer de las viviendas. 
e. El incumplimiento por la/el agente promotor de la obligación de elevar a escritura pública en plazo los contratos de compraventa celebrados con anterioridad a la calificación definitiva.

f. No comunicar al Registro Único de Demandantes de Vivienda los cambios esenciales o determinantes para la adjudicación de una vivienda protegida que se hayan producido en las circunstancias de la unidad familiar o convivencial durante el período de inscripción.

g. La falsedad de los hechos, documentos o certificaciones que no fueron tomados en consideración por la administración para la adjudicación de la vivienda protegida.

h. No ocupar la vivienda protegida en el plazo establecido en el artículo 59.3. ${ }^{\circ} \mathrm{sin}$ justa causa declarada por la Administración.

i. No desocupar la vivienda en el plazo fijado en el correspondiente requerimiento de la Administración.

j. La venta de las viviendas protegidas para alquiler sin contar con la autorización administrativa exigida en el artículo $63.3 .^{\circ}$ de la presente ley o la alteración de las condiciones fijadas por la consellaría competente en materia de vivienda.

$\mathrm{k}$. La utilización de una vivienda protegida sin título legal para ello.

4. Son infracciones graves de las normas de protección de las personas consumidoras y usuarias:

a. El incumplimiento de los principios de buena fe y veracidad, así como la inducción a confusión en la publicidad dirigida a la venta o al arrendamiento de viviendas.

b. La omisión en la información de la oferta de venta de los datos de contenido obligatorio previstos en la presente ley.

c. El incumplimiento de los requisitos exigibles para proceder al arrendamiento de la vivienda o a su venta en proyecto, en construcción o terminada, y especial- mente el incumplimiento de las exigencias relativas al depósito de las fianzas.

d. La no adecuación de la vivienda, edificio o complejo inmobiliario a las especificaciones del proyecto, cuando se trate de viviendas adquiridas en proyecto o construcción y no concurran las circunstancias señaladas en el artículo 93 de la presente ley.

5. Asimismo, es infracción grave la obstrucción u omisión de colaboración con las administraciones públicas competentes para realizar las actividades de inspección previstas en la presente ley.

Artículo 110. Infracciones leves.

1. Son infracciones leves de las normas de edificación:

a. La negligencia de las/los agentes de la edificación durante el proceso constructivo cuando diese lugar a vicios o defectos leves que no afecten a la seguridad de la edificación o causen daños a los destinatarios de la vivienda iguales o inferiores a 1.200 euros.

b. La inexactitud de los documentos o certificaciones expedidos por las/los agentes de la edificación durante el proceso constructivo, cuando de la misma no se deriven perjuicios a terceros.

c. Las omisiones o incorrecciones relevantes en cualquiera de los datos o documentos que deben figurar en el libro del edificio.

2. Es infracción leve de las normas de utilización de las viviendas el incumplimiento de los deberes de uso y mantenimiento, cuando no se ponga en riesgo la seguridad o habitabilidad de la edificación.

3. Son infracciones leves en materia de viviendas protegidas, además de las previstas en el apartado anterior:

a. No visar los contratos de compraventa de las segundas o sucesivas transmisiones de viviendas protegidas.

b. Incumplir las obligaciones de gestión y administración de las viviendas protegidas. 
4. Son infracciones leves en materia de protección de las personas consumidoras y usuarias:

a. No incluir en el contrato de compraventa o arrendamiento de vivienda protegida las cláusulas legales o el contenido obligatorio establecido en la presente ley.

b. El incumplimiento del deber de entregar al comprador o arrendatario de la vivienda la documentación exigible con arreglo a la presente ley.

c. El incumplimiento de las condiciones legales establecidas para el pago de cantidades anticipadas a cuenta del precio total de la vivienda.

d. El incumplimiento de las formalidades establecidas en la presente ley para el depósito de las fianzas.

e. La falta de actualización del importe de la fianza, en caso de prórroga del contrato de arrendamiento, o de actualización de su renta inicial.

f. La constitución del depósito de la fianza fuera del plazo establecido al efecto.

5. Tendrán «asimismo» la calificación de infracciones leves los restantes incumplimientos de las disposiciones contempladas en la presente ley no previstos en los artículos precedentes.

Artículo 111. Responsabilidad.

1. Serán sancionadas por los hechos constitutivos de las infracciones previstas en la presente ley las personas físicas o jurídicas que resulten responsables de las mismas, aun a título de simple inobservancia.

Cuando la responsabilidad de los hechos constitutivos de infracción corresponda a una persona jurídica, podrán considerarse responsables, además, las personas físicas integrantes de sus órganos de dirección que hubieran autorizado o consentido la comisión de la infracción. Dichas personas físicas serán consideradas responsables, en todo caso, si la persona jurídica se extinguiese antes de ser sancionada.

2. Cuando un mismo sujeto resultase responsable de hechos constitutivos de infracciones de diversa naturaleza, las sanciones impuestas tendrán entre sí carácter independiente. Igualmente, tendrán carácter independiente las sanciones impuestas a varios sujetos por la comisión de la misma infracción.

3. Cuando una infracción afecte a varias viviendas, aunque pertenezcan al mismo edificio, podrán imponerse tantas sanciones como infracciones se hayan cometido en cada vivienda.

4. La responsabilidad de las/los distintas/os agentes de la edificación se exigirá de acuerdo con el reparto de funciones y atribuciones realizado en la presente ley y en la normativa de ordenación de la edificación.

\section{Sección segunda}

Sanciones

Artículo 112. Multas y graduación.

1. Las infracciones tipificadas en la presente ley serán sancionadas con multas en las siguientes cuantías:

a. Las infracciones leves, con multa de 300 hasta 6.000 euros.

b. Las infracciones graves, con multa de 6.001 hasta 60.000 euros.

c. Las infracciones muy graves, con multa de 60.001 hasta 1.000 .000 de euros.

2. Cuando la infracción cometida sea la tipificada en el apartado h) del artículo $108.3^{\circ}$, la cuantía de la sanción no resultará inferior al quíntuplo de la diferencia entre el sobreprecio, prima o cantidad percibida y el precio máximo legal cuando se trate de arrendamiento, y al doble de dicha diferencia en caso de compraventa.

3. Cuando la infracción cometida sea no haber depositado la fianza o sus actualizaciones en los arrendamientos de viviendas o en los contratos de suministros y servicios, la multa no podrá ser inferior al depósito adeudado. En el supuesto de regularización de la demora en el ingreso de las fianzas de forma voluntaria y sin requerimiento por parte de la Administración, no se impondrá sanción alguna, sin perjuicio del abono 
de los intereses legales por el tiempo en que se haya demorado el ingreso.

4. Si de la comisión de una infracción resultase un beneficio para la persona infractora superior al importe de la sanción, se incrementará dicho importe en la cuantía necesaria para alcanzar la equivalente al beneficio obtenido.

5. En la graduación de la cuantía de la sanción se tendrá especialmente en cuenta el perjuicio causado, el enriquecimiento injusto, la existencia de intencionalidad o reiteración y la reincidencia por la comisión en el término de un año de más de una infracción de la misma naturaleza cuando así hubiera sido declarada por resolución firme.

Se considerará circunstancia atenuante el cese de la conducta de modo voluntario tras la oportuna inspección o advertencia, así como la realización de obras de subsanación antes de la resolución del procedimiento sancionador. Serán circunstancias agravantes el incumplimiento de los requerimientos efectuados por la Administración o la obstrucción de la función inspectora.

Las circunstancias previstas en este apartado no se tendrán en cuenta a los efectos de graduación de la sanción cuando su concurrencia sea exigida para la comisión de las conductas típicas.

\section{Sección tercera Otras medidas} tarias.

Artículo 113. Medidas complemenA los autores de infracciones graves y muy graves declaradas por resolución o sentencia firme podrá aplicárseles las siguientes medidas:

a. La inhabilitación para participar en promociones de viviendas protegidas de la Comunidad Autónoma de Galicia durante el plazo máximo de seis años, para las infracciones graves, y de diez años, para las infracciones muy graves.

Si la inhabilitación recae sobre una persona jurídica, resultarán también inhabilitadas las personas físicas integrantes de sus órganos de dirección que hubieran autorizado o consentido la comisión de la infracción. Si la persona jurídica se extinguiese antes de cumplir el plazo de inhabilitación, la misma se extenderá a las empresas o sociedades en que aquellas personas físicas ostenten cargos de toda índole o participen en su capital social, por sí o por persona interpuesta.

b. La descalificación de la vivienda, con la pérdida de los beneficios percibidos, cuando se trate de infracciones muy graves al régimen de viviendas protegidas, con los efectos contemplados en el artículo 45.6. ${ }^{\circ}$ de la presente ley.

c. La pérdida de las ayudas económicas y financieras recibidas, con la consiguiente devolución, con los intereses legales que correspondan, de las cantidades percibidas, en caso de infracciones al régimen de financiación protegida en la promoción y acceso a las viviendas, sin perjuicio de lo que establezca la normativa de subvenciones de Galicia.

d. En las viviendas protegidas de promoción pública, la resolución del contrato de compraventa o de arrendamiento.

Artículo 114. Reposición, indemnización, reintegro y reparación.

1. Las responsabilidades administrativas que se deriven del procedimiento sancionador regulado en la presente ley serán compatibles con la exigencia a la persona infractora de la reposición a su estado originario de la situación alterada, así como con la indemnización por los daños y perjuicios causados.

2. En las resoluciones de los procedimientos sancionadores podrá imponerse a las personas infractoras, en su caso, la obligación de reintegrar las cantidades indebidamente percibidas, así como la realización de las obras de reparación y conservación que sean procedentes y las necesarias para acomodar la edificación al proyecto aprobado o a la normativa vigente, sin perjuicio de las obligaciones 
de indemnización de daños y perjuicios que pudiesen tener lugar.

\section{Sección cuarta}

Competencias, procedimiento y ejecución forzosa

Artículo 115. Competencias.

Los órganos competentes para la imposición de sanciones serán los siguientes:

a. Las personas que ostenten el cargo de alcalde, cuando se trate de la comisión de infracciones leves y graves de las normas de edificación y utilización de las viviendas.

b. Las personas titulares de las delegaciones provinciales de la consellaría competente en materia de vivienda, cuando se trate de la comisión de infracciones leves y graves de las normas de vivienda protegida o de protección de las personas consumidoras y usuarias o de cualquier otra infracción leve o grave prevista en la presente ley no atribuida a otro órgano.

c. La persona titular de la consellaría competente en materia de vivienda, en caso de infracciones muy graves hasta 600.000 euros.

d. El Consello de la Xunta, cuando se trate de infracciones muy graves superiores a 600.000 euros.

Artículo 116. Plazo máximo.

El plazo máximo para la resolución del procedimiento sancionador será de doce meses, a partir de la fecha del acuerdo de incoación.

Artículo 117. Ejecución forzosa.

1. La ejecución de las resoluciones recaídas en los expedientes sancionadores podrá realizarse mediante la aplicación de las medidas de ejecución forzosa previstas en el capítulo V del título VI de la Ley $30 / 1992$, de 26 de noviembre, de régimen jurídico de las administraciones públicas y del procedimiento administrativo común.

2. En caso de imposición de la obligación de realizar obras a que se refiere el artículo 114.2 de la presente ley, en el mismo acto de la notificación de la resolución sancionadora a la persona infractora se le requerirá para la ejecución de las mismas en el plazo máximo señalado, que podrá ser prorrogado por causa justificada y por un periodo no superior a la mitad del inicialmente establecido.

3. Para compeler al cumplimiento por parte de la persona obligada, la Administración, a partir del momento de notificación de la orden de ejecución, podrá imponer multas coercitivas entre $300 \mathrm{y}$ 6.000 euros, con periodicidad mínima mensual, en tanto la persona infractora no subsane la causa que motivó la sanción.

La cuantía global de las multas coercitivas no superará el montante del importe de las obras que hayan de realizarse. Si se superase tal importe, la administración habrá de acudir, en su caso, a la ejecución subsidiaria, en cuyo caso el importe de los gastos, daños y perjuicios se liquidará de forma provisional, exigiéndose por vía ejecutiva antes de la ejecución, salvo que la persona infractora preste garantía suficiente.

Artículo 118. Condonación y mutuo acuerdo.

1. El cumplimiento de las obligaciones impuestas en las resoluciones sancionadoras dentro del plazo establecido podrá dar lugar a que el órgano que dictó la resolución acuerde, a solicitud de la persona interesada, la condonación parcial hasta un $75 \%$ de la multa impuesta.

2. Los procedimientos de ejecución forzosa podrán finalizar por mutuo acuerdo cuando la persona propietaria acepte voluntariamente el programa de actuaciones sobre la vivienda ofrecido por la Administración para su puesta en valor y la adecuación a las exigencias de calidad y habitabilidad exigidas por la normativa vigente.

\section{Sección quinta Prescripción}

Artículo 119. Plazos.

1. Las infracciones tipificadas en la presente ley y las acciones para exigir las 
sanciones prescribirán en los siguientes plazos:

a. Infracciones: las muy graves a los diez años, las graves a los cuatro años y las leves a los dos años.

b. Sanciones: por infracciones muy graves a los tres años, por infracciones graves a los dos años y por infracciones leves al año.

Los plazos establecidos no serán inferiores, en lo referente a la aparición de defectos de obra, a los establecidos en los plazos de garantía de la normativa de ordenación de la edificación.

2. El plazo de prescripción de las infracciones comenzará a computarse desde el día en que fueron cometidas. En caso de incumplimiento de la obligación de depositar las fianzas, el plazo de prescripción de la infracción comenzará a computarse desde la fecha de extinción del contrato.

El plazo de prescripción de las infracciones se interrumpirá mediante la iniciación, con el conocimiento de la persona interesada, del procedimiento sancionador, reanudándose el cómputo del plazo si el expediente sancionador estuviera paralizado durante un mes por causa no imputable a la presunta responsable.

3. El plazo de prescripción de las acciones para exigir las sanciones comenzará desde el día siguiente a aquel en que adquiera firmeza la resolución por la que se impone la sanción o, en caso de que se hubiera recurrido la misma, desde que transcurra el plazo máximo para resolver el recurso procedente sin que se haya dictado y notificado la consiguiente resolución expresa.

Dicho plazo se interrumpirá mediante la iniciación, con el conocimiento de la persona interesada, del procedimiento de ejecución, reanudándose el cómputo del plazo si aquel permanece paralizado durante un mes por causa no imputable a la persona infractora.

\section{DISPOSICIÓN ADICIONAL PRIMERA PLANEAMIENTO URBANÍSTICO}

De conformidad con lo establecido en el artículo 85.3 de la Ley 9/2002, de 30 de diciembre, de ordenación urbanística y de protección del medio rural de Galicia, en la tramitación del Plan General de Ordenación Municipal los ayuntamientos habrán de solicitar de la consellaría competente en materia de vivienda un informe sobre el cumplimiento de los estándares referidos a reservas de suelo para viviendas sujetas a regímenes de protección y sobre la adecuación del plan a la normativa de habitabilidad.

Dicho informe habrá de ser emitido en el plazo de un mes. Transcurrido este plazo sin que se hubiera emitido el mismo, podrá continuarse el procedimiento de aprobación.

\section{DISPOSICIÓN ADICIONAL SEGUNDA MODIFICACIÓN DE LA LEY 9/2002, DE 30 DE DICIEMBRE, DE ORDENACIÓN URBANISTICA Y DE PROTECCIÓN DEL MEDIO RURAL DE GALICIA<smiles>[AsH3]</smiles>

\section{DISPOSICIÓN ADICIONAL TERCERA LICENCIAS DE PRIMERA OCUPACIÓN}

La Xunta de Galicia promoverá la formalización de convenios de colaboración

444 Disposición adicional segunda contiene modificaciones a Ley $9 / 2002$, de 30 de diciembre, de Ordenación Urbanistica y de Protección del Medio Rural de Galicia. 445 Téngase en cuenta Providencia deñl 5 de mayo de 2009 del Tribunal Constitucional, por la que se establece que:

"El Pleno del Tribunal Constitucional por providencia de 5 mayo actual, ha admitido a trámite el recurso de inconstitucionalidad número 3644-2009, promovido por el Presidente del Gobierno, contra la disposición adicional segunda de la Ley de la Comunidad Autónoma de Galicia 18/2008, de diciembre, de Vivienda. Y se hace constar que por el Presidente del Gobierno se ha invocado el artículo 161.2 de la Constitución, lo que produce la suspensión de la vigencia y aplicación del precepto impugnado desde la fecha de interposición del recurso -20 de abril de 2009- para las partes del proceso, y desde la publicación del correspondiente edicto en el "Boletin Oficial del Estadon para los terceros". 
con las administraciones municipales para facilitar la gestión de las licencias de primera ocupación, dotándolas de asistencia y medios materiales y personales cuando sea necesario.

\section{DISPOSICIÓN ADICIONAL CUARTA EMIGRANTES}

Sin perjuicio de las normas que se establezcan reglamentariamente, a las personas emigrantes que residan fuera de Galicia se les aplicarán las siguientes reglas:

a. La obligación de destinar la vivienda a residencia habitual se limitará a la residencia en la vivienda al menos quince días al año.

b. No se exigirá el cumplimiento del requisito de residencia o desarrollo de la actividad laboral en un municipio de la comunidad autónoma.

c. El plazo para la aceptación de la adjudicación de la vivienda protegida y la celebración del contrato correspondiente será de tres meses, si las personas emigrantes viven dentro del territorio del Estado, y seis meses si viven en el extranjero.

d. El plazo para la ocupación de la vivienda protegida será de seis meses, si las personas emigrantes viven dentro del territorio del Estado, y doce meses si viven en el extranjero.

\section{DISPOSICIÓN ADICIONAL OUINTA CUANTIAAS DE LAS SANCIONES}

Las cuantías de las sanciones contempladas en la presente ley podrán ser revisadas y actualizadas por decreto del Consello de la Xunta, de acuerdo con la variación del índice de precios al consumo.

\section{DISPOSICIÓN ADICIONAL SEXTA OBSERVATORIO DE LA VIVIENDA DE GALICIA}

1. Se crea el Observatorio de la Vivienda de Galicia como órgano consultivo y asesor de la consellaría competente en materia de vivienda, que tendrá por objeto contribuir al desarrollo de las políticas de vivienda de Galicia, realizando tareas de investigación, innovación y desarrollo tecnológico en el ámbito de la vivienda y prestando asistencia a las entidades y empresas vinculadas a la vivienda orientada a la mejora de la calidad del sector. Especialmente, el observatorio contribuirá al cumplimiento de los objetivos de sostenibilidad de la edificación y fomento del alquiler.

2. En el ejercicio de sus funciones, el observatorio promoverá la participación de los agentes sociales y económicos, consumidores y usuarios, colegios profesionales, expertos y los departamentos de la Xunta de Galicia con competencias en materia de vivienda y urbanismo.

3. Por decreto se establecerán la composición y el régimen de funcionamiento del observatorio.

\section{DISPOSICIÓN ADICIONAL SÉPTIMA MODIFICACIÓN DE LA LEY 5/1998, DE 18 DE DICIEMBRE, DE COOPERATIVAS DE GALICIA}

$$
(\ldots)^{446}
$$

\section{DISPOSICIÓN ADICIONAL OCTAVA MODIFICACIÓN DE LA LEY 5/1997,} DE 22 DE JULIO, DE ADMINISTRACIÓN
LOCAL DE GALICIA

$$
(\ldots)^{447}
$$

\section{DISPOSICIÓN TRANSITORIA PRIMERA DISPOSICIONES SANCIONADORAS}

1. Las disposiciones sancionadoras contenidas en el título $\mathrm{V}$ de la presente ley serán de aplicación a las infracciones cometidas a partir de su entrada en vigor. No obstante, se aplicarán con carácter retroactivo a las infracciones cometidas con anterioridad a la entrada en vigor de

446 Disposición adicional séptima contiene modificaciones a la Ley $5 / 1998$, de 18 de deciembre, de cooperativas de Galicia.

447 Disposición adicional octava contiene modificaciones a la Ley 5/1997, do 22 de julio, de Administración Local de Galicia. 
la presente ley en cuanto favorezcan a la presunta persona infractora.

2. Los procedimientos sancionadores iniciados con anterioridad a la entrada en vigor de la presente ley se concluirán de acuerdo con lo dispuesto en la normativa vigente en el momento en que se dictó el acuerdo de incoación, salvo en lo que favorezca a la presunta persona infractora.

\section{DISPOSICIÓN TRANSITORIA SEGUNDA POTESTADES ADMINISTRATIVAS}

Las restantes potestades administrativas contempladas en la presente ley serán de aplicación a las viviendas protegidas, cualquiera que fuese el momento de su calificación, siempre que concurran los presupuestos exigidos para su ejercicio.

\section{DISPOSICIÓN TRANSITORIA TERCERA PROCEDIMIENTOS DE CALIFICACIÓN}

1. Los procedimientos de calificación de vivienda protegida iniciados antes de la entrada en vigor de la presente ley se tramitarán y resolverán con arreglo a la normativa vigente en el momento de presentación de la solicitud. Será no obstante de aplicación a las viviendas calificadas lo dispuesto en la presente ley, salvo en lo relativo al plazo de duración del régimen legal de protección, que será el establecido en las respectivas resoluciones de calificación.

2. Las viviendas calificadas definitivamente con arreglo a cualquier régimen de protección pública con anterioridad a la entrada en vigor de la presente ley se regirán por lo dispuesto en su normativa específica. Les serán en todo caso de aplicación los artículos relativos a la utilización de las viviendas protegidas contemplados en el capítulo IV del título II.

\section{DISPOSICIÓN TRANSITORIA CUARTA ACCESO A LA VIVIENDA DE LAS MUJERES VÍCTIMAS DE VIOLENCIA DE GÉNERO}

En tanto no se produzca el desarrollo reglamentario de la presente ley y de los artículos 44, 45 y concordantes de la Ley para la prevención y el tratamiento integral de la violencia de género, mantendrán plena vigencia las normas de rango reglamentario que regulen las condiciones de acceso de las mujeres víctimas de violencia de género a la vivienda, en cualquier modalidad de programa o régimen gestionado por la Xunta de Galicia, sin perjuicio de la aplicación directa de los principios y normas contenidos en estas leyes, si supusieran un trato más favorable.

\section{DISPOSICIÓN DEROGATORIA ÚNICA}

Expresa y genérica.

Quedan derogadas a partir de la entrada en vigor de la presente ley:

a. La Ley 4/2003, de 29 de julio, de vivienda de Galicia.

b. Las disposiciones de igual o inferior rango que se opongan a lo dispuesto en la presente ley.

\section{DISPOSICIÓN FINAL PRIMERA DESCALIFICACIÓN}

Tendrán la condición de viviendas libres a todos los efectos las viviendas sometidas a cualquier régimen de protección con anterioridad al 31 de diciembre de 1977, y habrá de procederse, de oficio, a la cancelación registral de las anotaciones relativas al régimen de protección, haciéndose constar en nota marginal la pérdida de la condición de vivienda protegida.

\section{DISPOSICIÓN FINAL SEGUNDA NORMATIVA DE CALIDAD DE LA EDIFICACIÓN}

Las disposiciones contenidas en el capítulo IV del título III serán de aplicación a todos los edificios de la Comunidad Autónoma de Galicia, cualquiera que sea su uso, residencial o de otro tipo.

\section{DISPOSICIÓN FINAL TERCERA DESARROLLO REGLAMENTARIO}

Se habilita al Gobierno de la Xunta de Galicia para desarrollar el contenido de la presente ley. 


\section{DISPOSICIÓN FINAL CUARTA ENTRADA EN VIGOR.}

1. La presente ley entrará en vigor a los tres meses de su publicación en el Diario Oficial de Galicia.

2. Las disposiciones contenidas en el capítulo I del título I serán exigibles a los edificios y viviendas cuya licencia urbanística de obras se solicite a partir de la entrada en vigor de la presente ley.

\section{LEY 3/1988, DE 27 DE ABRIL, DE CREACIÓN DEL INSTITUTO GALEGO DA VIVENDA E SOLO $\left(\text { DOGA N. }{ }^{\circ} 88,10.5 .1988\right)^{448}$}

\section{$(\ldots)^{449}$}

Artículo 1. Se constituye en el ámbito de la Comunidad Autónoma de Galicia el Instituto Galego da Vivenda e Solo, como Organismo Autónomo de carácter comercial y financiero, adscrito a la consellería de Ordenación del Territorio y Obras Públicas, que se regirá por esta ley.

Artículo 2. El Instituto Galego da Vivenda e Solo tiene personalidad jurídica y patrimonio propios, goza de autonomía administrativa y económica y de plena capacidad de obrar con los instrumentos del derecho público y privado propios de su naturaleza, para el cumplimiento de sus finalidades. Por ello, podrá adquirir, vender, poseer, reivindicar, permutar, ceder gratuitamente o mediante precio, arrendar y administrar su patrimonio. Asimismo, podrá constituir, modificar, posponer y cancelar hipotecas y demás derechos reales; conceder subvenciones, créditos, subsidios, empréstitos; celebrar contratos; establecer y explotar obras y servicios; obligarse; interponer los recursos establecidos y ejercer las acciones previstas por las leyes.

448 Véase Decreto 288/1988, de 29 de septiembre, desarrolla ley de 27 de abril de 1988, de creación del Instituto Galego da Vivenda e Solo. 449 Exposición de motivos omitida.
Artículo 3. Corresponde al Instituto Galego da Vivenda e Solo la realización de la política de suelo y vivienda de la Xunta de Galicia, a fin de garantizar los derechos constitucionales a una vivienda digna y adecuada, especialmente para los sectores con menos capacidad económica, y a una utilización del suelo de acuerdo con el interés general, erradicando la especulación y actuando como elemento de regulación del mercado inmobiliario y de mejora de la calidad ambiental. Asimismo, le corresponde el ejercicio de las funciones ejecutivas de las competencias indicadas, en relación con estas materias, en los términos establecidos en esta ley ${ }^{450}$.

Artículo 4. 1. Son funciones del Instituto Galego da Vivenda e Solo:

a. Elaborar y proponer a la consellería de Ordenación del Territorio y Obras Públicas los planes y programas en materia de vivienda y suelo.

b. La promoción y gestión de los planes y programas indicados, aprobados por la Consellería de Ordenación del Territorio y Obras Públicas.

c. Proponer la elaboración de disposiciones para el establecimiento, desarrollo y gestión de la política de vivienda y suelo.

d. La realización de estudios sobre oferta y demanda de viviendas y suelo, estado del parque inmobiliario y residencial, patrimonio urbano y rural y, en general, cuantos estudios y análisis sean necesarios para el establecimiento de la política de vivienda y suelo, en colaboración con la Consellería de Ordenación del Territorio y Obras Públicas.

e. La redacción y gestión de planes y proyectos técnicos urbanísticos que se

450 Véase:

- Decreto 253/2007, de 13 de diciembre, de régimen juridico del suelo y de las edificaciones promovidas por el Instituto Gallego de la Vivienda y Suelo.

- Orden de 31 de marzo de 2008 por la que se constituye el Registro de Demandantes de Vivienda Protegida de Galicia. 
desarrollen directamente por el Instituto Galego da Vivenda e Solo o con su cooperación mediante cualquiera de los sistemas previstos en la legislación sobre urbanismo aplicable a Galicia. Esta actividad urbanística podrá comprender tanto la promoción del suelo y la renovación o remodelación urbana como la realización de obras de infraestructura y de dotación de servicios.

f. La adquisición del suelo por cualquier título, incluso por expropiación forzosa, de los terrenos destinados a la formación de reservas de suelo, preparación de solares, dotaciones y equipamiento, fomento de la vivienda o cualesquiera otras finalidades análogas de carácter urbanístico, así como para constituir reservas de terrenos para el desarrollo y gestión de la política de vivienda.

g. La promoción pública de viviendas de protección oficial y sus edificaciones complementarias y equipamientos; la redacción y supervisión de proyectos de viviendas de promoción pública; la adquisición de viviendas en proyecto, en ejecución o finalizadas y la rehabilitación pública de viviendas y equipamientos, así como la aplicación de su régimen de uso, conservación y aprovechamiento.

h. La administración, gestión, conservación y disposición de su patrimonio de suelo, viviendas, locales de negocio, edificaciones complementarias y terrenos de su propiedad, urbanizados o no, en los términos señalados en el artículo 2 de esta ley. A tal efecto, los bienes que constituyen el patrimonio del Instituto como consecuencia del cumplimiento de sus funciones no quedarán incorporados a su patrimonio inmovilizado, sino que se adscribirán al mismo con el propósito de devolverlos al tráfico jurídico, independientemente de su cuantía.

i. El arrendamiento de bienes muebles e inmuebles.
1. La constitución de un parque público de vivienda en el ámbito de la Comunidad Autónoma, inventariados y debidamente catalogados los módulos y calidades.

11. Preparar y proponer los planes plurianuales de vivienda. Una vez aprobados por el Consello de la Xunta serán remitidos al parlamento a los efectos previstos en el artículo 142.1 del Reglamento. Las previsiones para la vivienda urbana se referirán a la rehabilitación del parque, la recuperación y protección de los casos históricos y el nuevo crecimiento; establecerá previsiones para la vivienda rural, en colaboración con las entidades locales, teniendo en cuenta las necesidades existentes.

$\mathrm{m}$. El fomento de la adquisición de suelo y su urbanización, de la construcción de viviendas de protección oficial, así como de la rehabilitación y construcción de todo tipo de viviendas, y el impulso del régimen de alquiler.

n. El Instituto Galego da Vivenda e Solo podrá proceder a la revisión de la adjudicación de las viviendas que, por el falseamiento de datos, hayan sido concedidas o a las que se haya otorgado cualquier beneficio.

ñ. La administración y gestión directa, o mediante conciertos, de las finanzas legalmente establecidas en los supuestos de arrendamiento de viviendas y locales de negocio y contratos de suministro.

o. El fomento de la mejora y rehabilitación de la vivienda rural.

p. El fomento y promoción de cooperativas para la construcción de viviendas.

q. La gestión de todos los derechos y obligaciones que por subrogación en las funciones del Instituto para la promoción pública de la vivienda se adscriban a su patrimonio y aquellas que se le encomienden reglamentariamente.

r. La obtención de reservas de suelo para uso público y social. A tal efecto se podrán establecer convenios o instrumentos jurídicos análogos con las entidades 
locales y particulares. Dichos convenios habrán de contener las previsiones urbanísticas de los terrenos a adquirir y los recursos a destinar por el Instituto a tal fin, y el compromiso de la corporación respectiva a hacerlos efectivos a través de los procedimientos establecidos.

s. El estudio de nuevas tecnologías aplicadas a la construcción de viviendas, así como la inspección y el control de calidad de la edificación ${ }^{451}$.

t. El ejercicio de cualesquiera otras funciones técnicas, materiales o jurídicas que, en relación con las materias de su competencia, se encomienden o competen al propio Instituto en el marco de la presente ley.

2. El Instituto Galego da Vivenda e Solo gozará de la potestad de expropiación forzosa. La aprobación de los planes y programas a que hace referencia la presente ley, cualquiera que fuese la fórmula de ejecución, llevará implícita la declaración de utilidad pública de las obras y la necesidad de ocupación de los terrenos y edificios correspondientes a los fines de expropiación o imposición de servidumbre.

Artículo 5. Para el adecuado ejercicio de sus funciones, el Instituto Galego da Vivenda e Solo podrá, de acuerdo con la legislación autonómica aplicable:

a. Suscribir convenios de promoción y gestión con otros organismos y entidades, en especial con las corporaciones locales.

b. Desarrollar las funciones que tiene atribuidas directamente, por órgano $\mathrm{u}$ órganos existentes, o las que al efecto se pueden crear.

c. Formar consorcios con toda clase de entidades públicas para el desarrollo de los fines propios de la gestión y ejecución de actividades urbanísticas.

d. Constituir y participar en asociaciones, sociedades, empresas y consorcios, por sí mismo o en colaboración con corporaciones locales, con otros entes públicos o

451 Decreto 232/1993, de 30 de septiembre, regula el control de calidad de la edificación. de iniciativa privada para el desarrollo de sus fines.

e. Participar en entidades urbanísticas colaboradoras.

Artículo 6. Será competencia del Consello de la Xunta:

a. Autorizar las transmisiones de terrenos a título gratuito que proyecte efectuar el Instituto en favor de entidades públicas, cuyo objeto sea el establecimiento de servicios públicos o la creación de dotaciones y equipamientos.

b. Autorizar la constitución de gerencias y la creación de consorcios y sociedades anónimas y la integración o participación del Instituto en las ya constituidas.

c. Dictar las normas adecuadas para el ejercicio del control de carácter económico-financiero y de eficacia del mismo.

Artículo 7. El Instituto Galego da Vivenda e Solo tendrá la siguiente estructura orgánica:

1. El Consejo del Instituto.

2. El Presidente.

3. El Director general.

Artículo 8. 1. El Consejo del Instituto Galego da Vivenda e Solo ostenta las más amplias facultades de dirección, actuación y gestión del mismo.

2. El Consejo tendrá como funciones elaborar los planes y programas del organismo, sus presupuestos, la memoria de actividades y las cuestiones que por su importancia o trascendencia le someta el Presidente.

Artículo 9. 1. El Consejo del Instituto está constituido por:

a. El Presidente, que será el Conselleiro de Ordenación del Territorio y Obras Públicas.

b. El Vicepresidente, que será el Director general competente en materia de vivienda.

c. Los vocales, que serán:

Dos vocales designados por la Consellería de Ordenación del Territorio e Obras Públicas.

Un Director general representante de la Consellería de Economía e Facenda.

Un Director general representante de la Consellería de la Presidencia e Administración Pública. 
El Director general del Instituto Galego da Vivenda e Solo.

d. El Secretario, que será nombrado por el Consejo a propuesta del Director general del Instituto.

2. Reglamentariamente se determinarán los mecanismos para asegurar la participación de los Ayuntamientos de la Comunidad Autónoma y las tareas del Instituto Galego da Vivenda e Solo.

Artículo 10. El Presidente del Instituto será el Conselleiro de Ordenación del Territorio y Obras Públicas, quien ostentará la representación oficial del mismo, y tendrá las demás facultades que reglamentariamente le sean atribuidas.

Artículo 11. Al Director general del Instituto, que será nombrado por el Consello de la Xunta de Galicia a propuesta del Conselleiro de Ordenación del Territorio y Obras Públicas, le corresponderán las siguientes funciones:

a. Dirigir y coordinar las actuaciones de las unidades que integran el Instituto.

b. Formular el anteproyecto de presupuestos del organismo, así como rendir las cuentas correspondientes.

c. Cuantas facultades le delegue el Presidente del Instituto o le sean encomendadas por el Consejo.

d. Presentar la memoria anual del organismo referente a su gestión.

e. Disponer los gastos propios del organismo dentro de los límites que le correspondan.

f. Ejercer la jefatura superior sobre el personal del Instituto.

Artículo 12. La estructura orgánica del Instituto Galego da Vivenda e Solo será aprobada por el Consello de la Xunta de Galicia, a propuesta del Conselleiro de Ordenación del Territorio y Obras Públicas. El Instituto no tendrá función pública propia. La Xunta de Galicia adscribirá al mismo los funcionarios necesarios para la provisión de los puestos de trabajo previstos en su plantilla presupuestaria. Estos funcionarios continuarán en situación de servicio activo en la administración de la Comunidad Autónoma.

Artículo 13. Los medios económicos con que contará el Instituto Galego da Vivenda e Solo serán los siguientes:

a. Los bienes y valores de transferencia a la Comunidad Autónoma procedentes de los extinguidos Instituto para la Promoción Pública de la Vivienda e Instituto Nacional para la Calidad de la Edificación, de participación en sociedades urbanísticas y de los Patronatos de Mejora de la Vivienda Rural y cualesquiera otros que le puedan ser adscritos por la Xunta de Galicia.

b. Los bienes, valores y derechos que adquieran en el ejercicio de sus funciones.

c. Los productos, rentas e incrementos de su propio patrimonio.

d. Las consignaciones que la Comunidad Autónoma fije en su presupuesto.

e. Las transferencias recibidas en el presupuesto de la Comunidad Autónoma gallega desde los presupuestos generales del Estado, como consecuencia de los traspasos en materia de vivienda y suelo, así como las subvenciones, aportaciones o dotaciones que reciba de cualquier entidad pública o privada o de los particulares.

f. Los ingresos ordinarios y extraordinarios que esté autorizado a percibir.

g. Los beneficios que obtenga en sus operaciones comerciales y análogas.

h. El $70 \%$ del total de las fianzas de alquileres y suministros a que se refiere el apartado $\mathrm{m}$ ) del artículo 4 de la presente ley, que obligatoriamente deben depositar los propietarios y empresas a la disposición del organismo, de acuerdo con las normas reguladoras de las transferencias en materia de vivienda y suelo.

i. Los préstamos que otorguen a su favor las entidades oficiales de crédito, caja postal, cajas de ahorros y bancos inscritos en el registro oficial de bancos y banqueros.

1. Las participaciones o los ingresos que procedan de los conciertos que celebre y de los consorcios, empresas, sociedades 
y entidades en que intervenga, de conformidad con lo establecido en el artículo 5 de esta ley.

11. El producto de la emisión de títulos de la deuda que pueda emitir, de acuerdo con lo determinado en las disposiciones en vigor.

$\mathrm{m}$. Cualesquiera otros recursos ordinarios o extraordinarios que se le puedan atribuir con arreglo a las disposiciones en vigor.

Artículo 14. El Instituto someterá su régimen económico, financiero y presupuestario a la Ley $3 / 1984$, de 3 de abril, del Parlamento de Galicia, de Gestión Económica y Financiera Pública de Galicia, Ley de Presupuestos de la Comunidad Autónoma y demás normativa aplicable.

El Instituto gozará del mismo tratamiento fiscal que la Xunta de Galicia, por ser un ente orgánicamente adscrito a la Consellería de Ordenación del Territorio e Obras Públicas, de acuerdo con lo establecido en el artículo 1 de la presente ley.

Artículo 15. La contratación y ejecución de obras y servicios por el Instituto Galego da Vivenda e Solo en desarrollo de sus funciones se acomodará a la legislación que le sea aplicable en virtud de lo que dispone el Estatuto de Autonomía de Galicia.

Artículo 16. Contra los actos administrativos del Instituto Galego da Vivenda e Solo procederán los recursos previstos en las normas sobre procedimiento administrativo aplicables en Galicia.

Todos los actos administrativos del Instituto podrán ser objeto de recurso de alzada ante el Conselleiro de Ordenación del Territorio y Obras Públicas y, en su caso, los de revisión ante el Consello de la Xunta de Galicia.

La interposición del recurso contenciosoadministrativo procederá según lo que establece la Ley de esta Jurisdicción.

El ejercicio de acciones civiles y laborales se regirá por las normas de general aplicación, y la reclamación previa se dirigirá siempre al Consejo del Instituto Galego da Vivenda e Solo.

\section{DISPOSICIÓN TRANSITORIA}

Hasta que la Xunta de Galicia apruebe la plantilla del Instituto Galego da Vivenda e Solo el Conselleiro de Ordenación del Territorio y Obras Públicas adscribirá al Instituto el personal necesario para el desarrollo de sus funciones, de entre el destinado en su consellería.

\section{DISPOSICIÓN ADICIONAL PRIMERA}

Se declaran extinguidos los Patronatos para la Mejora de la Vivienda Rural de A Coruña, Lugo, Ourense y Pontevedra, integrándose sus funciones, bienes, derechos y obligaciones en el Instituto Galego da Vivenda e Solo.

\section{DISPOSICIÓN ADICIONAL SEGUNDA}

Los bienes transferidos a la Comunidad Autónoma que sean atribuidos al patrimonio del Instituto se considerarán incluidos en la autorización que, para enajenar, establece el artículo 33.2 de la Ley 3/1985, de 12 de abril, del Patrimonio de la Comunidad Autónoma Gallega.

\section{DISPOSICIÓN ADICIONAL TERCERA}

En lo no previsto en esta ley, se estará a lo dispuesto en la Ley 3/1984, de 3 de abril, de Gestión Económica y Financiera Pública de Galicia; en la Ley 3/1985, de 12 de abril, del Patrimonio de la Comunidad Autónoma Gallega, y, supletoriamente, en la Ley de Entidades Estatales Autónomas, de 26 de diciembre de 1985, y en las demás disposiciones de general aplicación.

El Instituto Galego da Vivenda e Solo podrá utilizar para hacer efectivos sus créditos de toda índole el procedimiento de compulsión regulado por la Ley 3/1984, de 3 de abril, de Gestión Económica y Financiera Pública de Galicia.

\section{DISPOSICIÓN FINAL}

La Xunta de Galicia dictará cuantas disposiciones sean necesarias para el desarrollo y ejecución de esta ley. 


\section{DISPOSICIÓN DEROGATORIA}

Queda derogado el Decreto 25/1984, de 23 de febrero, sobre regulación provisional de los Patronatos Provinciales para la Mejora de la Vivienda Rural, así como cuantas disposiciones de igual o inferior rango se opongan a lo dispuesto en la Ley.

6. LEY 8/1997, DE 20 DE AGOSTO, DE ACCESIBILIDAD Y SUPRESIÓN

DE BARRERAS EN LA COMUNIDAD AUTÓNOMA DE GALICIA (DOGA N. $\left.{ }^{\circ} 166,29.8 .1997\right)$

\section{$(\ldots)^{452}$ \\ TÍTULO I \\ DISPOSICIONES PRELIMINARES}

Artículo 1. Objeto de la ley.

Es objeto de la presente ley:

a. Garantizar a las personas con movilidad reducida o cualquier otra limitación la accesibilidad y utilización del entorno urbano, de edificios, medios de transporte y sistemas de comunicación sensorial.

b. La promoción de ayudas técnicas para mejorar la calidad de vida de las citadas personas.

c. El establecimiento de medidas de fomento para conseguir la integración de las personas con limitación.

d. El control del cumplimiento de la normativa de aplicación en la materia y el establecimiento del correspondiente régimen sancionador para las infracciones cometidas.

e. La desaparición de las barreras u obstáculos físicos o sensoriales existentes.

Artículo 2. Ámbito de aplicación.

Están sometidas a las prescripciones de la presente ley todas las actuaciones llevadas a cabo en la Comunidad Autónoma de Galicia por entidades públicas o privadas, así como por las personas individuales, en materia de:

Planeamiento, gestión o ejecución urbanística.

452 Exposición de motivos omitida.
Nueva construcción, rehabilitación o reforma de edificaciones.

Transporte y comunicación.

Artículo 3. Definiciones.

A los efectos de aplicación de la presente ley se establecen las siguientes definiciones:

a. Se entiende por accesibilidad aquellas características del urbanismo, de la edificación, del transporte o de los medios y sistemas de comunicación que le permiten a cualquier persona su utilización y disfrute de manera autónoma, con independencia de su condición física, psíquica o sensorial.

b. Se entiende por barreras cualquier impedimento, traba u obstáculo que limite o impida el acceso, la libertad de movimiento, la estancia, la circulación y la comunicación sensorial de las personas con movilidad reducida o cualquier otra limitación. Las barreras se clasifican en: Barreras arquitectónicas urbanísticas (BAUR): Son aquellas barreras existentes en las vías y espacios libres de uso público. Barreras arquitectónicas en la edificación (BAED): Son aquellas barreras existentes en los accesos y/o en el interior de los edificios, tanto de titularidad pública como privada.

Barreras en el transporte (BT): Son aquellas barreras que existen en los medios de transportes y en sus infraestructuras.

Barreras en la comunicación (BC): Es todo aquel impedimento para la expresión y recepción de mensajes a través de los medios o sistemas de comunicación.

c. Se entiende por personas con limitaciones aquellas que temporal o permanentemente tienen limitada la capacidad de utilizar el entorno o de relacionarse con él.

d. Se entiende por personas con movilidad reducida aquellas que temporal o permanentemente tienen limitada la posibilidad de desplazarse.

e. Se entiende por ayuda técnica cualquier medio que, actuando como intermediario entre las personas con movilidad reducida o que poseen cualquier 
otra limitación y el entorno, facilita su autonomía personal y aminora los efectos de su discapacidad o limitación, mejorando su calidad de vida.

Artículo 4. Niveles de accesibilidad.

1. A los efectos de aplicación de la presente ley, los espacios, instalaciones y servicios se clasificarán en función de su grado de accesibilidad para las personas con movilidad reducida o cualquier otro tipo de limitación.

a. Se entiende por espacio, instalación o servicio adaptado aquel que se ajusta a las exigencias funcionales y de dimensiones que garanticen su utilización autónoma y cómoda por personas con movilidad reducida o poseedoras de cualquier tipo de limitación.

b. Se entiende por espacio, instalación o servicio practicable, sin ajustarse estrictamente a todos los requerimientos antes señalados, aquel cuya utilización de forma autónoma es posible por personas con movilidad reducida o poseedoras de cualquier tipo de limitación.

c. Se entiende por espacio, instalación o servicio convertible aquel cuya transformación es posible como mínimo en practicable, mediante la realización de modificaciones de escasa entidad y bajo coste que no afecten a su configuración esencial.

2. En la presente ley y en las normas que la desarrollan se establecerán los parámetros y demás requisitos exigibles para que un espacio, instalación o servicio posea la condición de adaptado, practicable o convertible.

\section{TÍTULO II DISPOSICIONES GENERALES}

\section{Capítulo I}

DISPOSICIONES SOBRE BARRERAS AROUITECTÓNICAS URBANÍSTICAS

\section{Sección 1. ${ }^{\mathrm{a}}$}

\section{Características de las urbanizaciones}

Artículo 5. Accesibilidad en espacios públicos.

1. Las vías públicas, parques y demás espacios de uso público deberán ser planificados y urbanizados de forma que resulten accesibles para todas las personas, y en especial para aquéllas con movilidad reducida o afectadas por cualquiera de las limitaciones señaladas anteriormente. Para ello, los criterios básicos que se establecen en la presente ley deberán ser recogidos en los planes generales de ordenación urbana, en las normas complementarias y subsidiarias y en aquellos otros instrumentos de planeamiento que puedan ser creados por la legislación urbanística, así como en los demás instrumentos de planeamiento y ejecución que los desarrollen, y en los proyectos de urbanización, de dotación de servicios, de obras y de instalaciones.

2. En los informes de carácter técnico que se emitan con carácter previo a la aprobación definitiva de los instrumentos de planeamiento deberá hacerse constancia expresa, con mención de la presente ley, del cumplimiento de los criterios fijados por ésta.

Las vías públicas, parques y demás espacios de uso público existentes, así como las respectivas instalaciones de servicios y mobiliarios urbanos, deberán ser adaptados gradualmente, de acuerdo con un orden de prioridades que tendrá en cuenta la mayor eficacia y la concurrencia o tránsito de personas y las reglas y condiciones previstas reglamentariamente.

A tal efecto, los entes locales tendrán que elaborar planes especiales de actuación para adaptar las vías públicas, parques y demás espacios de uso público a las normas de accesibilidad. Con esta finalidad, los proyectos de presupuestos de los entes públicos deberán contener, en cada ejercicio presupuestario, las consignaciones necesarias para la financiación de dichas adaptaciones.

3. Los pliegos de condiciones de los contratos administrativos de obras contendrán, con referencia a la presente ley, cláusulas de adecuación a lo que en la misma se dispone. 
Artículo 6. Itinerarios.

Los itinerarios peatonales, así como los mixtos, destinados al tráfico de peatones y vehículos, se diseñarán y realizarán de forma que resulten accesibles a cualquier persona. A estos efectos, reglamentariamente se establecerán los diferentes parámetros y características que los mismos han de tener para ser considerados adaptados o practicables, según los casos, que deberán contemplar, como mínimo, los siguientes aspectos:

Anchura mínima libre de obstáculos.

Pendiente máxima longitudinal.

Pendiente máxima transversal.

Dimensiones de vados e isletas.

Dimensiones de pasos de peatones.

Dimensiones y características de escaleras y rampas destinadas a salvar desniveles.

Artículo 7. Parques, jardines y espacios libres públicos.

1. Los parques, jardines y demás espacios libres de uso público se diseñarán y realizarán de forma que resulten accesibles a cualquier persona. A tal efecto, los itinerarios peatonales se ajustarán a los criterios señalados en el artículo anterior.

2. Los aseos de uso público que se dispongan en estos espacios deberán contar al menos con un aseo adaptado, compuesto como mínimo por un inodoro y un lavabo, que, cumpliendo las características señaladas en la presente ley y en las normas que la desarrollen, puedan ser accesibles a cualquier persona.

\section{Artículo 8. Aparcamientos.}

1. En las zonas destinadas a estacionamiento de vehículos ligeros, sean de superficie o subterráneas, que se sitúen en vías o espacios de uso público se reservarán, con carácter permanente y tan próximo como sea posible de los accesos peatonales, plazas debidamente señalizadas para vehículos que transporten a personas en situación de movilidad reducida.

2. Los accesos peatonales a dichas plazas cumplirán las condiciones exigidas para ser adaptados. Cuando sea preciso salvar desniveles para acceder a dichas plazas, éstos se salvarán mediante rampas o ascensores adaptados o practicables, según los casos.

Las plazas reservadas para uso de personas con movilidad reducida deberán cumplir las especificaciones y poseer las dimensiones que reglamentariamente se establezcan para las plazas adaptadas.

\section{Sección 2. ${ }^{a}$ \\ Características de los elementos de urbanización}

Artículo 9. Elementos de urbanización. Los elementos de urbanización, tales como pavimentos, saneamiento, alcantarillado, alumbrado, redes de telecomunicación y redes de suministro de agua, electricidad, gases y aquellas otras que materialicen las indicaciones del planeamiento urbanístico, poseerán unas características de diseño y ejecución tales que no constituyan obstáculo para la libertad de movimientos de cualquier persona.

\section{Sección 3. ${ }^{\mathrm{a}}$}

Características del mobiliario urbano

Artículo 10. Señales y elementos verticales.

Las señales de tránsito, semáforos, postes de iluminación o cualquier otro elemento vertical de señalización que se emplace en un itinerario o espacio de acceso peatonal se diseñarán y colocarán de modo que no obstaculicen la circulación de cualquier persona y permitan ser usados, en su caso, con la máxima comodidad.

A estos efectos, reglamentariamente se establecerán los diferentes parámetros y características que los mismos han de tener para ser considerados adaptados, que en todo caso deberán contemplar, como mínimo, los siguientes aspectos:

Altura libre mínima bajo las señales.

Colocación en las aceras.

Situación de pulsadores y mecanismos manuales. 
Artículo 11. Otros elementos de mobiliario urbano.

Los elementos de mobiliario urbano, tales como cabinas u hornacinas telefónicas, fuentes, papeleras, bancos y otros análogos, se diseñarán y colocarán de modo que no obstaculicen la circulación de las personas y permitan ser usados con la máxima comodidad.

Iguales condiciones habrán de poseer los elementos salientes que se emplacen en espacio peatonal, tales como marquesinas, toldos y otros análogos, que deberán evitar, en todo caso, ser un obstáculo para la libre circulación de las personas.

A estos efectos, reglamentariamente se establecerán los diferentes parámetros y características que los mismos han de tener para ser considerados adaptados, que en todo caso deberán contemplar, como mínimo, los siguientes aspectos:

Altura de mecanismos y zonas de uso.

Colocación en las aceras.

Situación de pulsadores y mecanismos manuales.

Señalización.

Altura libre mínima bajo salientes.

Artículo 12. Protección y señalización de obras en la vía pública.

1. Todo tipo de obra o elemento provisional, tales como zanjas, andamiajes o análogos, que implique peligro, obstáculo o limitación de recorrido, acceso o estancia peatonal deberá señalizarse y protegerse de modo que garantice la seguridad física de todos los viandantes.

2. Las especificaciones técnicas de señalización serán:

a. La protección se realizará mediante vallas estables y continuas, dotadas de señalización luminosa de color rojo y de señales acústicas intermitentes, cuyos umbrales no perturben al resto de la comunidad, de modo que puedan ser advertidas con antelación por personas con cualquier tipo de limitación. b. Los itinerarios peatonales cortados por obras se sustituirán por otros que permitan el paso a personas con movilidad reducida.

\section{Capítulo II \\ DISPOSICIONES SOBRE BARRERAS AROUITECTÓNICAS EN LA EDIFICACIÓN}

Sección 1. ${ }^{\mathrm{a}}$

Edificios de uso público

Artículo 13. Accesibilidad en edificios de uso público.

1. Se considerarán, a los efectos de la presente ley, edificios de uso público aquellos destinados a un uso que implique la concurrencia de público.

2. La construcción, ampliación o reforma de los edificios de titularidad pública o privada destinados a uso público se efectuarán de forma que garanticen que los mismos resulten adaptados.

3. En las ampliaciones o reformas de los referidos edificios que requieran para su adaptación medios técnicos o económicos desproporcionados se realizarán las modificaciones precisas para garantizar la condición como mínimo de practicables.

4. Se consideran incluidos dentro de este apartado de edificios de uso público, junto a otros de naturaleza análoga, los siguientes:

Edificios públicos y de servicios de las Administraciones Públicas.

Centros sanitarios y asistenciales o cualquier otro centro social.

Estaciones ferroviarias, de metro y de autobuses.

Puertos, aeropuertos y helipuertos.

Centros de enseñanza.

Garajes y aparcamientos colectivos.

Centros de trabajo.

Embarcaciones marítimas y fluviales.

Centros sindicales.

Museos, archivos, bibliotecas y salas de exposiciones.

Teatros, salas de cine y espectáculos.

Casas de cultura. 
Instalaciones deportivas.

Lonjas, mercados, plazas de abastos y establecimientos comerciales y bancarios de superficie igual o superior a 500 metros cuadrados.

Centros religiosos.

Instalaciones hoteleras y hosteleras, a partir del número de plazas que reglamentariamente se determine.

Artículo 14. Reserva de plazas de aparcamientos.

En los aparcamientos que dan servicio a los edificios de uso público reglamentariamente se establecerá el mínimo de plazas que deberán ser reservadas, debidamente señalizadas, para su uso por personas con movilidad reducida, así como su emplazamiento y accesos.

Artículo 15. Accesos al interior de los edificios.

Uno al menos de los accesos peatonales al interior de los edificios de uso público deberá estar diseñado y ejecutado de forma que cumpla las condiciones establecidas para itinerarios adaptados o practicables, según el caso.

Cuando se trate de un conjunto de edificaciones e instalaciones, uno al menos de los itinerarios peatonales que los unan entre sí y con la vía pública deberá cumplir las condiciones establecidas para itinerarios adaptados o practicables, según el caso.

Artículo 16. Comunicación horizontal. La movilidad horizontal entre espacios, instalaciones y servicios comunitarios emplazados en edificios de uso público se realizará mediante itinerarios y rampas que deberán cumplir las condiciones establecidas en la presente ley y en las normas que la desarrollen.

Artículo 17. Movilidad vertical.

Para facilitar la movilidad vertical entre espacios, instalaciones y servicios comunitarios emplazados en edificios de uso público, los desplazamientos entre diferentes niveles se realizarán mediante un elemento - ascensor, escaleras, rampas y tapices rodantes- que deberá cumplir las condiciones establecidas para ser considerado adaptado o practicable, en cada caso.

Artículo 18. Aseos.

Los aseos de uso público que existan en este tipo de edificios deberán disponer al menos de un aseo adaptado para cada sexo, compuesto como mínimo por un inodoro y un lavabo, que, cumpliendo las características señaladas en la presente ley y en las normas que la desarrollen, puedan ser accesibles a cualquier persona.

Artículo 19. Reserva de espacios.

1. Los locales de espectáculos, aulas y otros análogos dispondrán de espacios reservados para personas con movilidad reducida.

2. Los espacios reservados estarán debidamente señalizados.

Artículo 20. Servicios e instalaciones.

1. Todos aquellos elementos de los servicios e instalaciones de general utilización deberán estar diseñados de forma que puedan asegurar el acceso y uso de los mismos a todas las personas.

2. A estos efectos, reglamentariamente se establecerán los diferentes parámetros y características que los mismos han de tener para ser considerados adaptados, que deberán contemplar, como mínimo, los siguientes aspectos:

Altura de mecanismo y zonas de uso. Altura de zonas de atención al público.

Situación de pulsadores manuales.

Señalización.

Características de vestuarios y duchas.

Artículo 21. Controles de ejecución.

Debe establecerse el control pertinente para garantizar que las obras en los edificios de uso público se ajustan al proyecto autorizado y a las condiciones de accesibilidad. En caso contrario, se instruirá el correspondiente procedimiento establecido en la presente ley y en la legislación urbanística de aplicación, y si las obras realizadas no fuesen legalizables por no poder adaptarse a la normativa sobre supresión de barreras, se ordenará el 
derribo de los elementos no conformes y la aplicación de las sanciones previstas.

\section{Sección 2. ${ }^{\text {a }}$ \\ Otros edificios \\ de titularidad privada}

Artículo 22. Accesibilidad en edificios de titularidad privada y uso residencial.

1. Los edificios, instalaciones y servicios de titularidad privada y uso residencial de nueva construcción, en los que sea obligatoria la instalación de ascensor, deberán reunir, como mínimo, los siguientes requisitos:

a. Disponer de un itinerario practicable que una las viviendas y demás dependencias existentes en el edificio con el espacio exterior y con las dependencias de uso comunitario que estén al servicio del mismo, incluyéndose en éstas los garajes vinculados a las viviendas.

b. Disponer de un itinerario practicable que una la edificación con la vía pública, con otras edificaciones o servicios anexos de uso comunitario y con los edificios vecinos.

2. Los edificios de titularidad privada y uso residencial de nueva construcción, en los que no sea obligatoria la instalación de ascensor y posean altura superior a planta baja y un piso, deberán disponer de un itinerario practicable - excepto por lo que se refiere a la exigencia de un ascensor en el mismo- que comunique las viviendas y demás dependencias existentes en el edificio con el espacio exterior y con las dependencias de uso comunitario que estén a su servicio. De esta exigencia se exceptúan, en todo caso, las viviendas unifamiliares.

3. Los proyectos de reforma, rehabilitación o restauración de edificios, servicios o instalaciones de uso privado residencial deberán cumplir los requisitos exigidos a los de nueva construcción, salvo que la adaptación suponga alteración y/o variación del número de viviendas o de la superficie de las mismas respecto al coste total de la obra; en este caso se realizará una propuesta alternativa que requerirá, previamente a la concesión de la licencia, el informe favorable del Consello Autonómico para a Promoción da Accesibilidade e a Supresión de Barreiras. En lo referente a las obras de adaptación que lleven a cabo los propietarios o usuarios de viviendas, se estará a lo dispuesto en la Ley 15/1995, de 30 de mayo, sobre Límites del Dominio sobre Inmuebles para eliminar barreras arquitectónicas a las personas con discapacidad o mayores de setenta años.

Artículo 23. Accesibilidad en otros edificios de titularidad pública y uso residencial.

Los edificios, instalaciones y servicios de titularidad pública y uso residencial de nueva construcción, así como los proyectos de reforma, rehabilitación o restauración de los mismos, deberán, además de ajustarse a la normativa propia de las viviendas de protección oficial de promoción pública, cumplir como mínimo con las exigencias de accesibilidad establecidas en la presente ley para los edificios de uso residencial y titularidad privada.

\section{Sección $3 .^{\mathrm{a}}$}

\section{Rererva de viviendas para} personas con limitaciones

Artículo 24. Reserva de viviendas adaptadas.

1. Como mínimo un 3 por 100 de las viviendas totales previstas en los programas anuales de promoción pública deberán reservarse para personas con movilidad reducida, en la forma que reglamentariamente se establezca.

2. En las promociones privadas de viviendas de protección oficial los promotores deberán reservar la proporción mínima que se establezca reglamentariamente, y en todo caso respetando el mínimo indicado en el apartado anterior. Quedan exceptuadas de dicha reserva aquellas promociones privadas cuyo destino sea la construcción de la vivienda que será el domicilio habitual de sus promotores. 
3. Estas viviendas reservadas para personas con limitaciones deberán estar adaptadas o poseer las dimensiones necesarias para poder ser adaptadas para personas con movilidad reducida, de acuerdo con lo establecido en el artículo siguiente.

4. En los edificios en que, en cumplimiento de lo anteriormente establecido, se proyecten viviendas adaptadas deberá reservarse igual número de plazas de aparcamiento adaptadas, vinculadas a las mismas y debiendo establecerse un itinerario practicable o adaptado, según los casos, que comunique los garajes con las viviendas.

Artículo 25. Garantías para la realización de obras de adaptación.

1. Los promotores privados de viviendas de protección oficial o sometidas a cualquier otro régimen de ayuda pública podrán sustituir las adaptaciones interiores de viviendas reservadas para personas con movilidad reducida, al solicitarse la calificación provisional, por el depósito de un aval suficiente de una entidad financiera legalmente reconocida que garantice la realización de las obras necesarias para las adaptaciones correspondientes, según el tipo de limitación que posea el futuro usuario, en los términos y condiciones que se establezcan reglamentariamente.

2. Estas viviendas serán adjudicadas prioritariamente a personas en situación de movilidad reducida y, en el supuesto de que resultasen vacantes, a entidades públicas o privadas con personalidad jurídica propia y sin finalidad de lucro en el plazo que prevé la legislación vigente, para dedicarlas a minirresidencias, pisos compartidos o cualquier tipo de vivienda destinada a personas con movilidad reducida.

3. En el supuesto de que resultasen vacantes, el promotor, previa justificación de falta de demanda ante el organismo competente y obtenida la correspondiente acreditación, podrá ofertar las viviendas libremente, recuperando el aval si fuese el caso.
Reglamentariamente se establecerá el proceso y órgano responsable de emitir dicha acreditación.

\section{Capitulo III \\ DISPOSICIONES SOBRE BARRERAS EN EL TRANSPORTE}

\section{Sección $1 .^{\mathrm{a}}$}

Accesibilidad en los

transportes de uso público

Artículo 26. Accesibilidad en los transportes públicos.

1. Todos los transportes públicos de viajeros deberán observar lo dispuesto en la presente ley. Deberán además ajustarse progresivamente a las medidas que se dicten y a aquellas otras que resulten como consecuencia del avance tecnológico y cuya eficacia esté debidamente acreditada.

2. Las Administraciones Públicas competentes en materia de transporte público realizarán y mantendrán debidamente actualizado un plan de supresión de barreras y de utilización y adaptación progresiva de los transportes públicos colectivos, así como de los edificios, servicios, instalaciones y mobiliario vinculados a los mismos.

3. Las normas de desarrollo que regulen la construcción o reforma de las infraestructuras del transporte y la adquisición del material móvil deberán garantizar, al menos, las siguientes medidas de accesibilidad:

a. Estaciones de transporte: Las estaciones de transporte público deberán ajustarse a lo dispuesto en la presente ley en todas aquellas cuestiones referidas a construcción, itinerarios, servicios y mobiliario que sean comunes a los edificios de uso público, debiendo contemplar adaptaciones específicas en lo no señalado con anterioridad, tales como señalización, megafonía, sistemas de información y andenes, entre otros.

b. Material móvil: El material móvil de transporte público de viajeros que sea competencia de las Administraciones Públicas gallegas, con adquisición formalizada a 
partir de la entrada en vigor de la presente ley, deberá ser accesible de conformidad con las prescripciones que se establezcan reglamentariamente.

4. En todo caso se observará lo siguiente: En los vehículos de transporte público colectivo, tanto urbanos como interurbanos, deberán reservarse a las personas con movilidad reducida al menos tres asientos por coche, próximos a las puertas de entrada y debidamente señalizados. Se dispondrá junto a ellos de un timbre de aviso de parada en lugar accesible, así como del espacio físico necesario para la ubicación de cuantos utensilios o ayudas técnicas vengan provistas las personas afectadas. El piso de todos los vehículos de transporte será antideslizante.

En los autobuses urbanos e interurbanos de servicio público, las personas con movilidad reducida podrán apearse por la puerta de entrada para evitar su desplazamiento a lo largo del vehículo.

Las puertas de vehículos de transporte público contarán con dispositivos que las abran automáticamente cuando al cerrarse aprisionen cualquier objeto.

5. En las poblaciones en que reglamentariamente se determine, los Ayuntamientos reservarán al menos una licencia para un vehículo especial o taxi acondicionado que pueda ser utilizado por las personas con movilidad reducida en sus desplazamientos. Además, reglamentariamente deberán señalarse las exigencias mínimas que se establezcan en esta materia para atender a la población rural, en función de la dispersión de los núcleos de población, estableciendo las dotaciones mínimas por comarcas, municipios y parroquias en función de la población y extensión.

\section{Sección 2. ${ }^{\mathrm{a}}$}

\section{Tarjetas de accesibilidad}

Artículo 27. Tarjetas de accesibilidad.

1. Por la presente ley se establecen en la Comunidad Autónoma de Galicia dos tipos de tarjetas de accesibilidad.
2. Se crea la tarjeta de estacionamiento para personas con minusvalía, que se concederá a las personas con movilidad reducida, con carácter personal e intransferible, acreditativa de su situación de movilidad reducida, en orden a favorecer el uso y disfrute de los transportes privados y para que su titular pueda disfrutar de las facilidades de estacionamiento relacionadas con la misma.

Los Ayuntamientos tendrán que aprobar normativas que garanticen y favorezcan la accesibilidad de personas con movilidad reducida, y que con respecto a las personas titulares de estas tarjetas serán, como mínimo, las siguientes:

a. Reservas con carácter permanente de plazas de aparcamiento debidamente señalizadas para vehículos que transporten a personas en situación de movilidad reducida. Se situarán próximas a los accesos peatonales dentro de las zonas destinadas a aparcamiento de vehículos ligeros, ya sean exteriores, interiores o subterráneos.

b. Ampliación del límite de tiempo, cuando éste estuviese establecido, para aparcamiento de vehículos de personas con movilidad reducida.

c. Reserva de aparcamiento para titulares de tarjetas, en los lugares donde se estime necesario.

d. Autorización para que los vehículos ocupados por dichas personas puedan detenerse en la vía pública durante el tiempo imprescindible y siempre que no entorpezcan la circulación rodada o peatonal.

3. Se crea la tarjeta de accesibilidad de usuarios, que se concederá a las personas con alguna limitación, con carácter personal e intransferible y con validez en todo el ámbito de la Comunidad Autónoma, acreditativa de su situación de discapacidad, en orden a favorecer el uso y disfrute de los transportes públicos.

Los Ayuntamientos tendrán que aprobar normativas que garanticen y favorezcan la accesibilidad de personas con limitaciones, 
y que con respecto a las personas titulares de tarjetas serán, como mínimo, las siguientes:

a. Reserva de plazas en los transportes colectivos.

b. Condiciones para la bonificación en las tarifas para las personas que dispongan de la tarjeta.

4. En caso de comprobarse el uso indebido de las tarjetas de manera reiterada, éstas serán retiradas por el Ayuntamiento correspondiente.

Artículo 28. Expedición de las tarjetas de accesibilidad.

Las tarjetas de accesibilidad tendrán validez en todo el ámbito de la Comunidad Autónoma y corresponde al Ayuntamiento en que resida el solicitante la expedición de las mismas previa acreditación de su condición de persona con minusvalía. En todo caso, en lo que respecta a las tarjetas de estacionamiento, éstas deberán ajustarse a la estructura y características recogidas en el anexo de la presente ley.

\section{Capítulo IV \\ DISPOSICIONES SOBRE BARRERAS EN LA COMUNICACIÓN}

Artículo 29. Accesibilidad de los sistemas de comunicación y señalización.

1. Las Administraciones Públicas gallegas deberán promover la supresión de barreras en la comunicación y el establecimiento de los mecanismos y alternativas técnicas que hagan accesibles los sistemas de comunicación y señalización a toda la población.

2. Las Administraciones Públicas gallegas fomentarán la formación de profesionales intérpretes de la lengua de signos y guías de sordos-ciegos, facilitando así la comunicación directa al discapacitado auditivo o sordo-ciego, y la existencia en las distintas Administraciones Públicas de este personal especializado.

Los medios de comunicación audiovisuales dependientes de las Administraciones Públicas gallegas realizarán y mantendrán debidamente actualizado un plan de medidas técnicas que permita gradualmente, mediante el uso de la lengua de signos o de subtitulaciones, garantizar el derecho a la información a las personas con limitaciones auditivas.

\section{TÍTULO III MEDIDAS DE FOMENTO}

Artículo 30. Fondo para la supresión de barreras.

Se crea un fondo destinado a subvencionar la supresión de barreras arquitectónicas, urbanísticas, del transporte y de la comunicación sensorial, así como para la dotación de ayudas técnicas.

Artículo 31. Dotaciones del fondo.

1. La Comunidad Autónoma consignará partidas presupuestarias finalistas en cada ejercicio para la dotación de este fondo, que se adscribirá a la consellería competente en materia de servicios sociales.

2. Asimismo, integrarán dicho fondo las donaciones, herencias y legados, que, por voluntad expresamente manifestada, deberán dedicarse a los fines previstos en la presente ley.

Artículo 32. Destino del fondo.

1. Anualmente se destinará una parte del fondo citado a subvencionar los programas específicos de los entes locales para la supresión de barreras en el espacio urbano y rural, en los edificios de uso público y en el transporte de su término municipal.

Estos programas específicos de actuación contendrán, como mínimo:

a. Un inventario o relación de aquellos espacios, edificios, locales, infraestructuras, medios de transporte y comunicación que sean susceptibles de adaptación.

b. Orden de prioridades en que tales adaptaciones vayan a ser acometidas.

c. Fases de ejecución del programa.

d. Dotación económica que la entidad solicitante destinará al programa.

e. Coste estimado del programa.

Tendrán prioridad para acceder a esta financiación los entes locales que asignen 
al programa una partida presupuestaria similar a la de la Comunidad Autónoma.

2. La otra parte del fondo irá destinada a subvencionar los programas presentados por entidades privadas y a particulares para la supresión de barreras y la adquisición de ayudas técnicas.

\section{Título IV Medidas de control}

Artículo 33. Licencias y autorizaciones.

1. Corresponde a los Ayuntamientos y a la Administración autonómica, en el ámbito de sus respectivas competencias, exigir y verificar el cumplimiento de lo dispuesto en la presente ley, en las aprobaciones de instrumentos urbanísticos y en el otorgamiento de licencias, autorizaciones y calificaciones de viviendas sometidas a algún régimen de protección pública.

2. A estos efectos, los distintos instrumentos urbanísticos, así como los proyectos de edificación o construcción, deberán hacer constar expresamente en su memoria el cumplimiento de la presente ley.

3. Los pliegos de condiciones de los contratos administrativos contendrán cláusulas de actuaciones adaptadas a lo dispuesto en la presente ley.

Artículo 34. Visado de proyectos técnicos.

Los colegios profesionales que tengan atribuida la competencia en el visado de los proyectos técnicos necesarios para la obtención de licencias denegarán los visados a los proyectos que contengan alguna infracción de las normas contenidas en la Ley, en las disposiciones que la desarrollen y en las demás normativas de aplicación en materia de accesibilidad y supresión de barreras.

Artículo 35. Barreras en el transporte y en la comunicación.

Las Administraciones competentes en la autorización y regulación de los medios de transporte y comunicación en Galicia velarán por el cumplimiento de lo dispuesto en la presente ley sobre accesibilidad y eliminación de barreras en el transporte y en la comunicación.

\section{TÍTULO V RÉGIMEN SANCIONADOR}

Artículo 36. Infracciones.

1. Las acciones u omisiones que contravengan las normas sobre accesibilidad y supresión de barreras constituyen infracción y serán sancionadas con arreglo a lo establecido en la presente ley.

2. Las infracciones se clasifican en leves, graves y muy graves.

3. Se considera infracción leve el incumplimiento de las normas de condiciones de accesibilidad y supresión de barreras que no impidan la utilización del espacio, el equipamiento, la vivienda, el medio de transporte o el medio de comunicación por personas con limitaciones.

4. Se considera infracción grave el incumplimiento de las normas de condiciones de accesibilidad y supresión de barreras que obstaculicen, limiten o dificulten la utilización del espacio, el equipamiento, la vivienda, el medio de transporte o el medio de comunicación por personas con limitaciones y, en especial, las siguientes:

a. El incumplimiento de las normas sobre supresión de barreras arquitectónicas urbanísticas en obras de urbanización y su mobiliario de nueva construcción, ampliación y reforma de espacios destinados al uso público.

b. El incumplimiento de las normas sobre supresión de barreras arquitectónicas en la edificación, construcción, ampliación o reforma de edificios de propiedad pública o privada destinados a servicios públicos o a un uso que implique la concurrencia de público.

c. El incumplimiento de las normas de condiciones de accesibilidad y supresión de barreras en edificios de nueva construcción o rehabilitados totalmente, que deben ser 
destinados al uso de vivienda, o en edificios de titularidad privada y uso no residencial.

d. El incumplimiento de las normas de accesibilidad establecidas para el transporte público y los medios de comunicación.

e. La reincidencia por comisión de más de una falta leve en el plazo de dos años.

5. Se considera infracción muy grave el incumplimiento de las normas de condiciones de accesibilidad y supresión de barreras que impidan el libre acceso y uso de cualquier espacio o medio, infringiendo la normativa contenida en la presente ley y, en especial, las siguientes:

a. El incumplimiento de las normas sobre supresión de barreras arquitectónicas urbanísticas en obras de urbanización y su mobiliario de nueva construcción, ampliación y reforma de espacios destinados al uso público, y que impidan el libre acceso y uso de cualquier medio o espacio.

b. El incumplimiento de las normas sobre supresión de barreras arquitectónicas en la edificación, construcción, ampliación o reforma de edificios de propiedad pública o privada destinados a servicios públicos o a un uso que implique la concurrencia de público, y que impidan el libre acceso y uso de cualquier medio o espacio.

c. El incumplimiento de la obligación que se establece en la presente ley de reserva de viviendas para su utilización por personas con movilidad reducida.

d. El incumplimiento de las normas de condiciones de accesibilidad y supresión de barreras que supongan grave peligro o afecten gravemente a la seguridad de las personas.

e. La reincidencia por comisión de más de una falta grave en el plazo de dos años.

Artículo 37. Sanciones.

1. Sin perjuicio de la obligación de la reposición del orden jurídico infringido, las infracciones tipificadas en la presente ley darán lugar a la imposición de multas. con la siguiente graduación, para la que se procurará que la sanción no sea inferior al beneficio obtenido:

a. Para infracciones leves: Multa de 100.000 a 1.000 .000 de pesetas.

b. Para infracciones graves: Multa de 1.000 .001 a 10.000 .000 de pesetas.

c. Para infracciones muy graves: Multa de 10.000 .001 a 50.000 .000 de pesetas.

Artículo 38. Graduación de las sanciones.

Para graduar el importe de las multas se tendrá en cuenta la gravedad del hecho constitutivo de infracción, el coste económico derivado de las obras de accesibilidad necesarias, el perjuicio directa o indirectamente causado y la intencionalidad o reiteración de los infractores.

Artículo 39. Responsabilidades.

Son sujetos responsables las personas físicas y jurídicas que incurran en las acciones, comisiones o infracciones tipificadas en la presente ley y, en particular, las siguientes:

a. En las obras y demás actuaciones que se ejecutasen sin la licencia municipal correspondiente o con inobservancia de ésta, el empresario de las obras, el técnico director de las mismas y el promotor.

b. En los actos autorizados o de supervisión de proyectos cuyo contenido sea manifiestamente constitutivo de una infracción de las tipificadas en la presente ley serán responsables los facultativos que los informasen favorablemente, de acuerdo con el ámbito de su intervención.

Asimismo, serán responsables las Administraciones Públicas gallegas actuantes que acordasen el otorgamiento de un acto autorizado sin el informe técnico preceptivo previo o cuando éste fuese desfavorable.

Las multas que se impongan a los diferentes sujetos como consecuencia de una misma infracción tendrán entre sí carácter independiente.

Artículo 40. Órganos competentes para la imposición de las sanciones.

1. Se crea la Comisión Técnica de Accesibilidad como órgano administrativo 
competente para la tramitación de los expedientes sancionadores derivados de la presente ley.

Son funciones de la Comisión Técnica de Accesibilidad la incoación, tramitación y propuesta de resolución a la autoridad competente de los expedientes sancionadores en la materia, así como aquellas otras que reglamentariamente se le atribuyan.

Dicha Comisión estará adscrita a la consellería competente en materia de servicios sociales y su composición se determinará en via reglamentaria.

2. Las autoridades competentes para imponer sanciones son las siguientes:

a. Para las infracciones leves y graves, un órgano colegiado compuesto por el Director general competente en materia de servicios sociales, el Director general en materia de urbanismo y el Director general competente en materia de cooperación con las corporaciones locales.

b. Para las infracciones muy graves, el Consello de la Xunta.

Artículo 41. Procedimiento sancionador.

1. Las infracciones de las normas contenidas en la presente ley y en su normativa de desarrollo serán sancionadas de acuerdo con la normativa vigente sobre el procedimiento sancionador.

2. Las personas protegidas por la presente ley, o las asociaciones y federaciones en que se integran, tendrán siempre la consideración de interesadas en estos procedimientos en los términos previstos en la Ley de Régimen Jurídico de las Administraciones Públicas y del Procedimiento Administrativo Común.

3. Contra el acuerdo de archivo de las actuaciones o resolución desestimatoria expresa o tácita de la denuncia de posibles infracciones, las personas, asociaciones y federaciones antes referidas quedarán legitimadas para interponer los recursos $\mathrm{o}$, en su caso, las acciones judiciales que consideren procedentes.
Artículo 42. Destino de las sanciones. Los ingresos obtenidos por la imposición de las sanciones previstas en la presente ley serán destinados al fondo de supresión de barreras arquitectónicas, urbanísticas, del transporte y de la comunicación, así como para la dotación de ayudas técnicas.

Artículo 43. Prescripción.

Las infracciones muy graves prescribirán a los cuatro años.

Las infracciones graves prescribirán a los dos años.

Las infracciones leves prescribirán al año. El plazo de prescripción comenzará a computarse desde el día en que la infracción se ha cometido.

\section{TÍTULO VI CONSELLO GALEGO PARA A PROMOCIÓN DA ACCESIBILIDADE E A SUPRESIÓN DE BARREIRAS}

Artículo 44. Consello Galego para a Promoción da Accesibilidade e a Supresión de Barreiras.

1. Se crea el Consello Galego para a Promoción da Accesibilidade e a Supresión de Barreiras como órgano de participación y consulta.

2. El Consejo estará adscrito a la consellería competente en materia de servicios sociales y estará compuesto por un número máximo de 15 miembros, en representación de la Comunidad Autónoma, de las corporaciones locales, de las entidades públicas y privadas y de las asociaciones y colegios profesionales con interés en la materia.

3. La organización y el funcionamiento del Consejo se establecerán reglamentariamente.

4. Son funciones del Consejo el asesoramiento, informe, propuestas de criterios de actuación, seguimiento y fomento de lo dispuesto en la presente ley, así como aquellas otras que reglamentariamente se le atribuyan.

\section{DISPOSICIÓN ADICIONAL PRIMERA}

Las correspondientes Administraciones Públicas gallegas elaborarán los planes 
de adaptación y supresión de barreras previstas en la presente ley en un plazo de dos años desde su entrada en vigor. Estos planes serán revisados cada cinco años y el plazo para su realización no superará los diez años.

Las Administraciones Públicas gallegas establecerán, anualmente, un porcentaje de sus partidas presupuestarias de inversión para la supresión de las barreras existentes en los edificios de uso público de su titularidad o sobre las que dispongan, por cualquier título, del derecho de uso.

\section{DISPOSICIÓN ADICIONAL SEGUNDA}

Se determinarán reglamentariamente los planes de evacuación y seguridad de los espacios, edificaciones y servicios de concurrencia o uso público, a fin de garantizar su adecuación a las necesidades de las personas con limitación, movilidad o comunicación reducida.

\section{DISPOSICIÓN ADICIONAL TERCERA}

La Administración autonómica promoverá campañas informativas y educativas dirigidas a la población en general, a fin de sensibilizarla en el problema de la accesibilidad y de la integración de las personas con limitaciones.

Asimismo, fomentará la realización de jornadas, cursos y publicaciones dirigidos a responsables políticos, funcionarios, técnicos y colectivos de personas con limitaciones, al objeto de divulgar el contenido de la presente ley y de la demás normativa de aplicación en materia de accesibilidad y eliminación de barreras.

\section{DISPOSICIÓN ADICIONAL CUARTA}

Lo dispuesto en la presente ley no será de aplicación:

a. A los inmuebles y espacios de uso público que se encuentren declarados bienes de interés cultural o incluidos en catálogos municipales de edificios protegidos, siempre que las modificaciones necesarias afecten a elementos objeto de la protección.

En este supuesto, se procederá a la realización de un programa de accesibilidad, cuyo objeto será mejorar la accesibilidad y la eliminación de aquellas barreras que no precisen la realización de obras que afecte a elementos protegidos. En los casos en que esto no sea posible, se habilitarán las ayudas técnicas necesarias para que estos edificios se adecuen, en la medida de lo posible, para su visita por personas con limitaciones o con movilidad reducida.

b. A los proyectos de edificación y urbanización que fuesen visados por los colegios profesionales competentes en la materia respectiva, antes de su entrada en vigor.

c. A los proyectos de edificación y urbanización que tengan concedida licencia de obra en la fecha de su entrada en vigor.

\section{DISPOSICIÓN ADICIONAL QUINTA}

En el plazo de seis meses desde la entrada en vigor de la Ley, la Xunta de Galicia aprobará el reglamento de desarrollo y el código de accesibilidad que contenga todas las normas técnicas de aplicación en la materia ${ }^{453}$.

\section{DISPOSICIÓN ADICIONAL SEXTA}

En el reglamento y en el código de accesibilidad que se aprueben en el desarrollo de la presente ley deberán adoptarse, como mínimo, para definir la condición de adaptado de un espacio, servicio o instalación, los parámetros de accesibilidad que se definen en el anexo a esta ley.

\section{DISPOSICIÓN TRANSITORIA PRIMERA}

Los planes generales de ordenación urbana, las normas subsidiarias de planeamiento

\footnotetext{
453 Véase Decreto 35/2000, de 28 de enero, por el que se aprueba el Reglamento de desarrollo y ejecución de la Ley de accesibilidad y supresión de barreras en la Comunidad Autónoma de Galicia.
} 
y los demás instrumentos de planeamiento que los desarrollan, que dispongan de aprobación definitiva a la entrada en vigor de la presente ley, se adaptarán a las determinaciones y criterios técnicos contenidos en la misma y en el reglamento de desarrollo en la primera revisión, no superando, en todo caso, el plazo de cinco años.

No obstante lo anterior, las prescripciones contenidas en la presente ley prevalecerán sobre las eventuales determinaciones que se opusiesen a las contenidas en los planes urbanísticos y demás instrumentos de planeamiento, así como en las ordenanzas municipales vigentes, a la fecha de su entrada en vigor.

\section{DISPOSICIÓN TRANSITORIA SEGUNDA}

En cuanto no se apruebe la normativa de desarrollo de la presente ley, todas las actuaciones que se realicen dentro del ámbito de aplicación de la misma deberán ajustarse a los parámetros de accesibilidad contenidos en el anexo.

\section{DISPOSICIÓN DEROGATORIA}

Quedan derogadas las disposiciones de igual o inferior rango que se opongan a lo establecido en la presente ley.

\section{DISPOSICIÓN FINAL PRIMERA}

Se autoriza al Consello de la Xunta para dictar las disposiciones precisas para el desarrollo y ejecución de lo previsto en la presente ley, así como para modificar su anexo.

\section{DISPOSICIÓN FINAL SEGUNDA}

La presente ley entrará en vigor a los tres meses de su publicación en el "Diario Oficial de Galicia”.

\section{(...) ${ }^{454}$.}

454 Anexos omitidos.
7. LEY 6/2008, DE 19 DE JUNIO, DE MEDIDAS URGENTES EN MATERIA DE VIVIENDA Y SUELO, POR LA QUE SE MODIFICA LA LEY 9/2002, DE 30 DE DICIEMBRE, DE ORDENACIÓN URBANÍSTICA Y PROTECCIÓN DEL MEDIO RURAL DE GALICIA (DOGA $\left.N^{\circ} .125,30.6 .2008\right)$

$(\ldots)^{455}$ Artículo único. $(\ldots)^{456}$

\section{DISPOSICIÓN TRANSITORIA PRIMERA ADAPTACIÓN DEL PLANEAMIENTO}

Los planes generales aprobados provisionalmente antes de la entrada en vigor de la presente ley podrán, durante el plazo máximo de un año, continuar su tramitación hasta su aprobación definitiva a tenor de lo dispuesto en la Ley 9/2002, de ordenación urbanística y protección del medio rural de Galicia, en cuyo caso será de aplicación lo establecido en la disposición transitoria segunda de esta ley, o adaptarse íntegramente a la presente ley. La simple adaptación del contenido del plan en tramitación a las disposiciones establecidas en la presente ley no implicará, por sí sola, la necesidad de someterlo a nueva información pública, salvo cuando se pretendieran introducir otras modificaciones que alterasen sustancialmente la ordenación proyectada y no fuesen consecuencia de la adaptación, extremo sobre el que el secretario municipal habrá de emitir informe.

Transcurrido el plazo de un año desde la entrada en vigor de la presente ley, el planeamiento obligatoriamente habrá de adaptarse íntegramente a lo dispuesto en la presente ley.

\footnotetext{
455 Preámbulo omitido.

456 Articulo único contiene modificaciones a la Ley 9/2002, de 30 de diciembre, de Ordenación Urbanistica
} y de Protección del Medio Rural de Galicia. 


\section{DISPOSICIÓN TRANSITORIA SEGUNDA RÉGIMEN TRANSITORIO}

1. Las reservas de terrenos para viviendas sujetas a algún régimen de protección pública y las cesiones para dotación autonómica destinada a vivienda de promoción y titularidad pública establecidas en la presente ley se aplicarán a los nuevos planeamientos que se aprueben tras la entrada en vigor de la misma.

A tales efectos, y en tanto no se modifique o revise el planeamiento general, serán de aplicación directa en aquellos municipios que contasen con una población igual o superior a los 5.000 habitantes las siguientes reservas:

a. En el suelo urbano no consolidado de aquellos municipios con planeamiento no adaptado a la Ley 9/2002 se establece una reserva de terrenos para viviendas sujetas a algún régimen de protección pública de forma que en cada polígono, unidad de actuación o ejecución o ámbito equivalente se localice al menos el $20 \%$ de la edificabilidad residencial.

En los municipios que contasen con planeamiento general adaptado a la Ley 9/2002 se mantendrán las reservas para viviendas sujetas a algún régimen de protección pública que el planeamiento hubiera establecido para el suelo urbano no consolidado.

b. En el suelo urbanizable delimitado se establece directamente una reserva de terrenos o se incrementa la que ya hubiera estado previamente fijada para viviendas sujetas a algún régimen de protección pública de forma que en todos los sectores de suelo urbanizable con previsión de usos residenciales, aun cuando éstos no fueran los predominantes, se localice el $40 \%$ de la edificabilidad residencial del sector en aquellos municipios que en el momento de entrada en vigor de la presente ley contasen al menos con 20.000 habitantes inscritos en el padrón municipal, o el $30 \%$ de dicha edificabilidad en el resto de los municipios de Galicia.
Sin embargo, en los municipios con plan general de ordenación municipal adaptado a la Ley 9/2002, cuando en el conjunto del suelo urbanizable delimitado las reservas de suelo destinado a vivienda protegida sean iguales o superiores a las establecidas en el párrafo anterior, serán de aplicación exclusivamente las determinaciones del plan general.

c. En el suelo urbanizable no delimitado se establece directamente una reserva de terrenos para viviendas sujetas a algún régimen de protección pública de forma que no sea inferior a la necesaria para localizar el $40 \%$ de edificabilidad residencial que contemple el plan de sectorización.

En los municipios que contasen con menos de 5.000 habitantes, se establece únicamente una reserva mínima del $20 \%$ de la edificabilidad residencial prevista para cada sector de suelo urbanizable.

2. No obstante lo dispuesto en el apartado anterior, podrá continuarse la tramitación de los planes de desarrollo ya aprobados inicialmente de acuerdo con la ordenación establecida en el planeamiento vigente, durante un plazo de dos años desde la entrada en vigor de la presente ley. Para ello será necesario que el plan de desarrollo contemple o incorpore durante la tramitación una reserva de terrenos para viviendas sujetas a algún régimen de protección pública para localizar al menos el $20 \%$ de la edificabilidad residencial establecida en el planeamiento de desarrollo. Transcurrido este plazo sin que se haya alcanzado la aprobación definitiva, dichos planes habrán de adaptarse íntegramente a lo dispuesto en la presente ley.

3. En todo caso, los ámbitos que a la entrada en vigor de la presente ley contasen con ordenación detallada o planeamiento de desarrollo aprobado definitivamente, así como aquellos ámbitos que aprobaran su planeamiento de desarrollo durante los plazos y con las condiciones fijados en el apartado anterior, habrán de ser ejecutados 
a tenor de la ordenación y en los plazos establecidos en el propio plan y, como máximo, en el plazo de tres años contados a partir de la entrada en vigor de la presente ley. Transcurrido dicho plazo sin que se haya aprobado definitivamente el instrumento de equidistribución, habrá de revisarse íntegramente el planeamiento para adaptarlo a lo dispuesto en la presente ley.

\section{DISPOSICIÓN TRANSITORIA TERCERA INTEGRACIÓN EN LAS ESCALAS DE INSPECCIÓN Y SUBINSPECCIÓN URBANISTICA}

1. Podrá integrarse en la escala de inspección urbanística el personal funcionario de carrera de la Administración autonómica del grupo A que reúna los requisitos para el acceso a esta escala y que desempeñaba funciones propias de la inspección urbanística en el momento de la entrada en vigor de la Ley 9/2002, de ordenación urbanística y protección del medio rural de Galicia, o un puesto de trabajo reservado a la escala de inspección en el momento de la entrada en vigor del Decreto 213/2007, de 31 de octubre, por el que se aprueban los estatutos de la Agencia de Protección de la Legalidad Urbanística.

2. Podrá integrarse en la escala de subinspección urbanística el personal funcionario de carrera de la Administración autonómica del grupo B que reúna los requisitos para el acceso a esta escala y que desempeñaba funciones propias de esta escala en el momento de la entrada en vigor de la Ley 9/2002, de ordenación urbanística y protección del medio rural de Galicia, o un puesto de trabajo reservado a la escala de subinspección en el momento de la entrada en vigor del Decreto $213 / 2007$, de 31 de octubre, por el que se aprueban los estatutos de la Agencia de Protección de la Legalidad Urbanística.

\section{DISPOSICIÓN DEROGATORIA ÚNICA}

Quedan derogados el apartado $3 \mathrm{del}$ artículo 55, el apartado f) del artículo 64 y el apartado 2 del artículo 236 de la Ley 9/2002, de 30 de diciembre, de ordenación urbanística y protección del medio rural de Galicia.

Asimismo, quedan derogados cuantos preceptos de igual o inferior rango, incluidas las determinaciones del planeamiento urbanístico, se opongan a lo dispuesto en la presente ley.

\section{DISPOSICIÓN FINAL ÚNICA ENTRADA EN VIGOR}

La presente ley entrará en vigor al día siguiente de su publicación en el «Diario Oficial de Galicia». 


\section{IX \\ PROTECCIÓN DEL MEDIO AMBIENTE}

\section{LEY 1/1995, DE 2 DE ENERO, DE PROTECCIÓN AMBIENTAL DE GALICIA}

(DOGA N. $\left.{ }^{\circ} 29,10.2 .1995\right)$

(...) 457

\section{TÍTULO I \\ DISPOSICIONES GENERALES}

Artículo 1. Objeto.

La presente ley tiene como objeto el establecimiento de las normas que, en el ámbito de la competencia de la Comunidad Autónoma, configuran el sistema de defensa, protección, conservación y restauración, en su caso, del medio ambiente en Galicia y aseguran una utilización racional de los recursos naturales.

Artículo 2. Principios y objetivos. Los principios que inspiran la presente ley y que servirán de marco a todo el desarrollo normativo ulterior de protección ambiental son:

a. De clasificación de las actividades de acuerdo con su incidencia ambiental, a fin de evitar y corregir, dentro del procedimiento de autorización previa y de la subsiguiente vigilancia y control, los efectos negativos que éstas pueden tener en el medio ambiente.

b. De prevención, compatibilizando la defensa de los valores ambientales con el desarrollo económico y el progreso técnico.

c. De utilización racional y de defensa de los recursos naturales y el paisaje, que constituyen el patrimonio natural de Galicia, al objeto de que su utilización se realice de manera racional, orientada al aprovechamiento sostenido, al mantenimiento de la diversidad genética y a la conservación de la capacidad de retroalimentación y

457 Exposición de motivos omitida. regeneración del ecosistema, evitando en todo momento los daños irreversibles al equilibro ecológico y contribuyendo a la protección de la salud humana y a la conservación de las especies.

d. De promoción de la investigación científica y tecnológica, orientando la acción investigadora al reciclaje y recuperación de los residuos, a la protección del medio ambiente, a la lucha contra la contaminación y a la defensa de la calidad de los distintos sectores que integran el medio natural y humano.

e. De promoción de la educación ambiental, en todos los niveles educativos, y de la concienciación ciudadana, en todos los sectores sociales, para una eficaz defensa de los valores ambientales, a fin de que, de acuerdo con una información objetiva, completa y actual, pueda participar la totalidad de la población en la defensa de su medio ambiente ${ }^{458}$.

f. De coordinación, tanto en lo que hace referencia a las distintas administraciones y regulaciones, ya sean sectoriales, ya de actividades con incidencia ambiental, como a sus componentes, a fin de asegurar su coherencia, de manera que se facilite su aplicación y gestión administrativa, al objeto de potenciar y agilizar la actividad administrativa.

g. De subsidiariedad, a fin de garantizar la actuación de los Ayuntamientos para que afronten sus problemas ambientales y para asegurar el ejercicio efectivo de la disciplina ambiental, a cuyo objeto se fomentarán las fórmulas consorciales entre municipios, con arreglo a la Ley de

\section{Véase:}

- Decreto 68/2006, de 30 de marzo, por el que se regula el observatorio gallego de educación ambiental. 
Bases de régimen local, para la solución de los problemas ambientales comunes.

h. De corrección del ilícito ambiental mediante un efectivo régimen sancionador que sirva para corregir las conductas manifiestamente insolidarias y atentatorias al bien común que es el medio ambiente.

i. De publicidad, participación y transparencia administrativa, por lo que las actuaciones sobre medio ambiente se basarán en el libre acceso del público a una información objetiva, fiable y concreta, que sirva como base para una efectiva participación de los sectores sociales implicados ${ }^{459}$.

j. De pacto ambiental, como actuación encaminada a obtener acuerdos, tanto en el establecimiento de medidas preventivas y correctoras como, sobre todo, en situaciones con planteamientos ambientales conflictivos que afecten a sectores sociales y económicos, en las que, mediante una estrategia adecuada, se consiga la compatibilización de las medidas correctoras con la viabilidad de las empresas a través de innovaciones tecnológicas en los procesos de fabricación y en los sistemas de eliminación de agentes contaminantes, teniendo presente que la administración no podrá aceptar la pervivencia de situaciones que produzcan agresiones o deterioro grave del medio ambiente.

k. De integración de los requisitos de protección del medio ambiente en las políticas económicas, industriales, agrarias y sociales.

1. De fomento de las actuaciones dirigidas a regenerar los deterioros y degradaciones producidos en el medio ambiente ${ }^{460}$.

Artículo 3. Mandato general.

La presente ley obligará, en el ámbito territorial de la Comunidad Autónoma, a toda persona, natural o jurídica, pública

\footnotetext{
459 Decreto 226/2007, de 22 de noviembre, por el que se crea el Registro de entidades de carácter medioambiental de la Comunidad Autónoma de Galicia.

460 Véase Decreto 208/2005, de 14 de julio, sobre gestión e integración ambiental de huecos ocasionados por antiguas actividades, con excedentes de tierras y rocas procedentes de grandes obras.
}

o privada, que proyecte realizar o efectivamente realice cualquier actividad susceptible de producir un deterioro en el medio ambiente.

Artículo 4. Ámbito de protección.

A los efectos de la presente ley, se considera que son elementos que tienen que protegerse: El medio natural constituido por la población, la fauna, la flora, la diversidad genética, el suelo, el subsuelo, el agua, el aire, el clima y el paisaje, así como la interrelación entre los elementos antes mencionados, los recursos naturales y culturales, incluido el patrimonio arquitectónico y arqueológico, en cuanto pueden ser objeto de contaminación y deterioro por causas ambientales.

\section{TÍTULO II TÉCNICAS Y MEDIDAS DE DEFENSA \\ Capítulo I DISPOSICIONES GENERALES}

Artículo 5. Clasificación del grado de protección y autorización de actividades.

1. A los efectos de lo dispuesto en los artículos 2, a), y 4, todos los proyectos, obras y actividades que fuesen susceptibles de afectar al medio ambiente habrán de obtener una autorización, y su otorgamiento derivará de un previo procedimiento que determinará el órgano de administración ambiental, según la clasificación del grado de protección aplicable a los mismos.

2. La clasificación del grado de protección para determinar el procedimiento podrá ser:

a. De evaluación del impacto ambiental.

b. De evaluación de los efectos ambientales.

c. De evaluación de la incidencia ambiental.

3. Por evaluación se entenderá la actividad del órgano ambiental competente que tenga por objeto determinar la compatibilidad de un proyecto, obra o actividad con el medio ambiente y, en su caso, las medidas correctoras que es preciso incluir en el proyecto y/o en su desarrollo. 
4. La autorización será un requisito previo, preceptivo y vinculante, en cuanto a las medidas correctoras. En ningún caso podrá otorgarse licencia de apertura o actividad sin la previa obtención de la autorización correspondiente.

5. Los particulares podrán solicitar, por escrito y adjuntando la documentación pertinente que estimen precisa, información previa sobre el régimen que según la clasificación se tiene que aplicar a un determinado proyecto, obra o actividad.

6. Cuando la autorización imponga la adopción de medidas correctoras, el órgano administrativo al que corresponda su otorgamiento podrá exigir la prestación de una fianza que cubra la reparación de los posibles daños y el posible coste de la restauración 461 .

Artículo 6. Aplicación a actividades en funcionamiento.

Las técnicas y medidas de defensa previstas en esta ley podrán aplicarse a actividades que estén realizándose o ya realizadas, al objeto de comprobar los posibles efectos nocivos de éstas en el medio ambiente y señalar las medidas correctoras y la determinación y exigencia de responsabilidad, en su caso.

\section{Capítulo II DE LA EVALUACIÓN DE IMPACTO AMBIENTAL}

Artículo 7. Ámbito.

Quedan sometidos a la evaluación de impacto ambiental los proyectos, obras y actividades que se incluyen en la normativa comunitaria, la legislación básica estatal y la de ámbito autonómico.

Artículo 8. Procedimiento.

La Xunta de Galicia elaborará un catálogo de las actividades sujetas al trámite de evaluación y regulará por Decreto el procedimiento para declarar dicha evaluación.

461 Véase Decreto 455/1996, de 7 de noviembre, de fianzas en materia ambiental.
Artículo 9. Efectos de la declaración de impacto.

La declaración de impacto será de carácter vinculante para el órgano de competencia sustantiva si la declaración fuese negativa o impusiese medidas correctoras.

\section{Capitulo III \\ DE LA EVALUACIÓN \\ DE EFECTOS AMBIENTALES}

Artículo 10. Ámbito.

Serán sometidos a evaluación de efectos ambientales todos los proyectos, obras y actividades que se relacionen en la legislación sectorial y sus normas de desarrollo.

Artículo 11. Actividades sujetas y procedimiento.

Las actividades sujetas al trámite de evaluación de efectos ambientales y el procedimiento para su declaración se determinarán por decreto de la Xunta de Galicia.

Artículo 12. Efectos.

La declaración de efectos ambientales tendrá carácter vinculante para el órgano de competencia sustantiva si la declaración fuese negativa o impusiese medidas correctoras.

\section{Capítulo IV \\ DE LA EVALUACIÓN DE INCIDENCIA AMBIENTAL 462}

\section{Artículo 13. Ámbito.}

Están sometidas al procedimiento de previa evaluación de incidencia ambiental todas las actividades que figuren en el nomenclátor que al respecto se apruebe por Decreto de la Xunta de Galicia, así como aquellas otras que, no estando incluidas en el mismo, merezcan la consideración de molestas, insalubres, nocivas o peligrosas, con arreglo a las siguientes definiciones:

a. Molestas: Las que constituyan una perturbación por los ruidos o vibraciones, o que produzcan manifiesta incomodidad por

462 Véase Decreto $133 / 2008$, de 12 de junio, por el que se regula la evaluación de incidencia ambiental. 
los humos, gases, olores, nieblas, polvos en suspensión o sustancias que eliminen.

b. Insalubres: Las que den lugar a desprendimiento o evacuación de productos que puedan resultar directa o indirectamente perjudiciales para la salud humana.

c. Nocivas: Las que por las mismas causas puedan ocasionar daños a la riqueza agrícola, forestal, pecuaria, faunística o piscícola.

d. Peligrosas: Las que tengan por objeto fabricar, manipular, transportar, expender, almacenar o eliminar productos susceptibles de originar riesgos graves por explosiones, combustiones, radiaciones $\mathrm{u}$ otros de análoga naturaleza para las personas o los bienes, con arreglo a la legislación vigente.

Artículo 14. Actividades sujetas y procedimiento.

Las actividades sujetas al trámite de evaluación de incidencia ambiental y su procedimiento se regularán por Decreto de la Xunta de Galicia.

Artículo 15. Delegación.

1. Sin perjuicio de que la competencia para la evaluación de incidencia ambiental corresponde a la administración autonómica, ésta podrá delegar el ejercicio de la misma en los Ayuntamientos, previa solicitud de los mismos.

2. Como presupuesto para otorgar la delegación se exigirá que el Ayuntamiento acredite disponer de medios técnicos, personales y materiales suficientes para el ejercicio de la competencia delegada.

Artículo 16. Contenido y publicidad del acuerdo.

1. El acuerdo en que se otorgue la delegación tendrá los siguientes contenidos mínimos:

a. Determinación de las competencias que se delegan.

b. Fecha del comienzo de la delegación.

c. Condiciones que tienen que seguirse para la instrucción y resolución de los expedientes.

d. Control que del ejercicio de la delegación se reserve la administración autonómica.
2. El acuerdo de delegación se publicará en el "Diario Oficial de Galicia".

Artículo 17. Facultades autonómicas en supuestos de delegación.

1. La administración autonómica podrá establecer instrucciones técnicas de carácter general relativas al ejercicio de las competencias delegadas, solicitar en todo momento información sobre la gestión ambiental del Ayuntamiento y formular los requerimientos pertinentes para la subsanación de las deficiencias observadas.

2. La administración autonómica podrá revocar la delegación conferida, que habrá de estar motivada y se publicará en el "Diario Oficial de Galicia".

Artículo 18. Deber de información. Los Ayuntamientos informarán a la administración autonómica de las peticiones sometidas al régimen de evaluación de incidencia ambiental en que intervengan, así como de las licencias otorgadas en cada caso.

Artículo 19. Efectos.

El dictamen de evaluación de incidencia ambiental tendrá efectos vinculantes para la autoridad municipal que ha de otorgar la licencia cuando fuese negativa o impusiese medidas correctoras que no estuviesen en el proyecto y en la Memoria que adjunten a la solicitud.

\section{Capitulo V OTRAS MEDIDAS DE PROTECCIÓN AMBIENTAL}

Artículo 20. Régimen de registros, catálogos e inventarios.

1. La administración autonómica redactará inventarios de los distintos espacios, sectores ambientales y ecosistemas que haya que proteger, entre ellos el paisaje, como fase previa a una catalogación de los mismos, que los dotará de un estatuto jurídico de protección adecuado a las características singulares del espacio, sector o ecosistema. 
2. Los inventarios y catálogos serán abiertos, y reglamentariamente se determinarán los contenidos obligatorios mínimos de las distintas regulaciones y regímenes de protección, así como del procedimiento de revisión y modificación, a fin de mantenerlos permanentemente actualizados.

Artículo 21. Conexión con los instrumentos de planeamiento.

1. En los instrumentos de planeamiento urbanístico de carácter general, planes generales de ordenación urbana y normas subsidiarias habrá de tenerse en cuenta la defensa del medio ambiente y de los recursos naturales. A este fin se determinarán reglamentariamente las medidas o condiciones tipo de protección de la naturaleza y el paisaje, así como de la calidad ambiental, que habrán de incorporarse al planeamiento.

2. No constituirá causa suficiente para modificar la clasificación original de un suelo como no urbanizable de protección especial el hecho de que el terreno o espacio hubiese sufrido cualquier clase de agresión que afectase a las causas o motivos que han justificado su clasificación.

Artículo 22. Educación ambiental.

1. La educación ambiental estará orientada a la formación de los ciudadanos, especialmente de los más jóvenes, en una mayor aproximación y respeto a la naturale$\mathrm{za}$, con un enfoque interdisciplinario, abarcando el conjunto de los niveles educativos y con carácter eminentemente práctico, que fomente la necesaria conciencia ecológica en la defensa del medio ${ }^{463}$.

2. El órgano de la administración ambiental correspondiente promoverá, en conexión con los demás órganos competentes de la administración autonómica y los medios de comunicación de titularidad pública, la educación y formación ambiental que responda a los anteriores criterios, así como el uso didáctico-recreativo de la naturaleza, la orientación de los jóvenes

463 Decreto 68/2006, de 30 de marzo, por el que se regula el observatorio gallego de educación ambiental. de cara a profesiones nuevas, desaparecidas o minusvaloradas en el mercado de trabajo, prestando una especial atención al medio rural y a los pequeños municipios, fomentando las escuelas-taller ambientales, las aulas y los centros de interpretación de la naturaleza y cualesquiera otras instituciones que faciliten dicha formación integrada.

Artículo 23. Investigación.

1. La administración autonómica potenciará la investigación sobre problemas ambientales y las vías de trabajo y colaboración en esta materia, principalmente a través del plan gallego de investigación y desarrollo y de sus organismos ejecutores.

2. En especial, esta asistencia científica y técnica se orientará a la elaboración de estudios básicos de la contaminación y el medio físico, al establecimiento de laboratorios homologados, a la determinación de la tecnología más adecuada en cada momento para el medio ambiente, el asesoramiento en el establecimiento de redes de control, programas, medidas estándares de calidad y métodos de análisis, entre otros ${ }^{464}$.

Artículo 24. Información y participación ciudadana.

1. Las actuaciones sobre el medio ambiente en Galicia se basarán en el libre acceso del público a una información objetiva, fiable y completa, además de la especial relativa a determinados expedientes sobre asuntos concretos, como base de una efectiva participación de los sectores sociales implicados y los Ayuntamientos. No obstante, en casos justificados, debidamente motivados, y de acuerdo con el derecho comunitario y demás legislación vigente, podrán establecerse restricciones a dicha transparencia informativa por razones de defensa, confidencialidad de la información, secreto industrial, respeto de la intimidad u otra análoga.

\footnotetext{
464 Véase Decreto 164/1999, de 27 de mayo, por el que se establecen las competencias y funciones del laboratorio de medio ambiente de Galicia.
} 
2. Se dará especial relevancia a los trámites de información pública, facilitando la presentación de alegaciones, sugerencias y propuestas alternativas.

Artículo 25. Pacto ambiental 465 .

1. La acción administrativa en esta materia estará orientada a la consecución de un pacto ambiental para las situaciones más conflictivas, así como para acometer aquellas que puedan mejorar la imagen pública de las empresas a través de los instrumentos de participación dispositiva de las mismas y de los ciudadanos en la defensa del medio, pudiendo extenderse a estrategias y acciones de carácter local o comarcal.

2. Este pacto ambiental, que se planteará con los sectores sociales implicados, constará de los siguientes contenidos mínimos: Objetivos que pretenden conseguirse, inconvenientes de las medidas propuestas, compensación, medidas que se van a adoptar y plazo para realizarlas.

3. En aplicación del pacto ambiental, se establecerá un sistema de ecogestión y ecoauditoría que permita la participación voluntaria de las empresas que desarrollen actividades industriales para la evaluación y mejora de los resultados de sus actividades industriales en relación con el medio ambiente y la facilitación de la correspondiente información al público.

El objetivo del sistema será promover la mejora continua de los resultados de las actividades industriales en relación con el medio ambiental mediante:

a. El establecimiento y la aplicación, por parte de las empresas, de políticas, programas y sistemas de gestión medioambientales en relación con sus centros de producción.

b. La evaluación sistemática, objetiva y periódica del rendimiento de dichos elementos.

465 Decreto 295/2000, de 21 de diciembre, por el que se desarrolla la Ley $1 / 1995$, de 2 de enero, de protección ambiental de Galicia, en relación con el pacto ambiental en la Comunidad Autónoma de Galicia. c. La información al público acerca del comportamiento en materia de medio ambiente.

Este sistema se aplicará sin perjuicio de las actuales normas y requisitos técnicos autonómicos, estatales y comunitarios en materia de controles medioambientales, y sin merma de las obligaciones a que están sujetas las empresas en virtud de dichas normas y requisitos.

El Gobierno promulgará la normativa que cree y desarrolle la ecogestión y la ecoauditoría, en el marco de la legislación de la Unión Europea y de la estatal ${ }^{466}$.

Artículo 26. En aplicación de este principio se instituye la ecoetiqueta o etiqueta ecológica como mecanismo voluntario de participación de las empresas y los ciudadanos en la protección del medio ambiente a través de la selección de productos comerciales por criterios ecológicos en el proceso de utilización de los recursos naturales, su fabricación, comercialización, consumo y abandono, respecto a lo cual la Xunta promulgará la normativa correspondiente, adecuada a la normativa general y comunitaria.

\section{TÍTULO III ADMINISTRACIÓN AMBIENTAL}

Artículo 27. Administración ambiental.

1. La Administración ambiental estará constituida por aquellos órganos de la administración con competencias en materia de esta ley ${ }^{467}$.

2. La Administración ambiental tendrá como objetivo ejercer las competencias que correspondan a la Comunidad Autónoma de Galicia, y entre ella:

466 Véase Decreto 185/1999, de 17 de junio, por el que se establece el procedimiento para la aplicación, en la Comunidad Autónoma gallega, de un sistema voluntario de gestión y auditoria medioambiental.

467 Véase Decreto 581/2005, de 15 de diciembre, por el que se crea el Comité Interdepartamental de Desarrollo Sostenible.

- Decreto 306/2004, de 2 de diciembre, por el que se crea el Consello Forestal de Galicia.

- Orden de 23 de mayo de 2008 por la que se crea la Red gallega de ayuntamientos por la sostenibilidad 
a. Velar por el cumplimiento de las normas medioambientales.

b. Desarrollar actuaciones públicas en relación con la protección, conservación, mejora y restauración del medio ambiente.

c. Llevar a cabo las acciones precisas para la utilización racional de los recursos naturales.

d. Asegurar y mejorar la calidad ambiental.

e. En general, las demás que en relación con el medio ambiente se deriven de esta Ley.

3. Su organización, composición, funciones y competencias se desarrollarán reglamentariamente de acuerdo con los principios de integración y coordinación de gestión, eficacia y autonomía.

Artículo 28. Consello Galego de Medio Ambiente.

1. A fin de cumplir el principio de participación pública y de establecer una vía de participación de los estamentos interesados de la sociedad gallega y de su comunidad científica, se crea, como órgano consultivo de la administración ambiental, el Consello Galego de Medio Ambiente.

2. Su organización, composición, funcionamiento y régimen jurídico, así como el carácter de sus informes se determinarán reglamentariamente 468 .

\section{Título IV}

\section{Disciplina ambiental}

\section{Capitulo I \\ INSPECCIÓN Y VIGILANCIA ${ }^{469}$}

Artículo 29. Órganos de inspección.

1. Sin perjuicio de las específicas funciones inspectoras que correspondan a órganos sectoriales competentes en los términos que reglamentariamente se determinen, en el ámbito de la administración

468 Véase Decreto $74 / 2006$, de 30 de marzo, por el que se regula el Consello Galego de medio ambiente y desarrollo sostenible.

469 Véase Decreto 156/1995, de 3 de junio, de inspección ambiental. autonómica corresponderá el ejercicio de la función de control y vigilancia a una inspección ambiental única, coordinada por el órgano de la administración ambiental que reglamentariamente se determine. Para dicho ejercicio podrá servirse del personal adecuado de los órganos que tengan la competencia sustantiva ${ }^{470}$.

2. La administración local desarrollará su propia inspección de cara al correcto ejercicio de su competencia en el marco de la presente ley y demás reguladoras del régimen local.

No obstante, cuando la Administración local se considere imposibilitada para el ejercicio de la competencia de inspección, ésta podrá solicitar a la Administración autonómica el auxilio en tal función.

Artículo 30. Inspección ambiental.

1. La inspección ambiental tiene como función, en el marco de la defensa y protección del medio ambiente de Galicia, la ejecución del control y vigilancia de las actividades e instalaciones de cualquier tipo que fuesen susceptibles de afectarle negativamente.

2. Los funcionarios que ejerzan la inspección ambiental de la Comunidad Autónoma gozarán en el ejercicio de sus funciones de la consideración de agentes de la autoridad, estando facultados para acceder, sin previo aviso y tras ser identificados a las instalaciones en que se desarrollen las actividades objeto de esta Ley.

3. Las demás policías o guarderías municipales o estatales están obligadas a prestar un auxilio administrativo en las funciones de inspección reconocidas en esta ley.

Artículo 31. Clases de inspección. Las inspecciones pueden ser:

a. Previas al otorgamiento de una autorización o licencia.

470 Véase Orden de 30 de mayo de 1996 por la que se regula el ejercicio de la inspección ambiental única y la tramitación de denuncias ambientales. 
b. En virtud de denuncia ${ }^{471}$.

c. Las que puedan acordarse de oficio durante el funcionamiento de una actividad.

Artículo 32. Comprobación.

1. Las inspecciones que se realicen para vigilar el cumplimiento de esta ley adoptarán las medidas necesarias para asegurar el buen resultado de las mismas, en la forma que reglamentariamente se determine.

2. Las actas de inspección que se levanten en dichos términos gozarán de la presunción de veracidad respecto a los hechos que en la misma se declaren probados.

3. Las prescripciones anteriores se entienden sin perjuicio de las establecidas para determinadas inspecciones, tanto por la legislación básica estatal como por la regulación autonómica.

4. Reglamentariamente se establecerá el procedimiento de la inspección y su alcance, contenido y efectos.

\section{Capitulo II INFRACCIONES Y SANCIONES}

Artículo 33. Infracciones.

Constituirán infracción ambiental, a los efectos de esta ley y en el ámbito de la Comunidad Autónoma de Galicia:

a. La iniciación o realización de proyectos, obras o actividades sin obtener la previa autorización o la licencia, cuando se trate de actividades sometidas a este trámite.

b. La descarga en el medio ambiente, bien sea en las aguas marítimas o continentales, suelo o subsuelo y atmófera de productos o sustancias, en estado sólido, líquido o gaseoso o de formas de energía, incluso sonoras, que constituyan un riesgo objetivamente verificable para la salud humana y los recursos naturales, supongan un deterioro o degradación de las condiciones ambientales o afecten negativamente al equilibrio ecológico en general. No tendrán la consideración de infracción los vertidos o emisiones en

471 Véase Orden de 30 de mayo de 1996 por la que se regula el ejercicio de la inspección ambiental única y la tramitación de denuncias ambientales. cantidades o condiciones expresamente autorizados con arreglo a la normativa aplicable en cada caso.

c. La explotación indebida, el abuso o la destrucción de los recursos naturales, entendiendo que la misma se produce cuando se realice contraviniendo los términos de la autorización o de las normas que la regulan.

d. La ocultación de datos o su falseamiento, total o parcial, en el procedimiento de obtención de la autorización o licencia.

e. La transgresión o el incumplimiento de las condiciones impuestas en la autorización o licencia, o el incumplimiento de las órdenes de clausura o de aplicación de medidas correctoras o restauradoras del medio.

f. La negativa o resistencia a facilitar datos que sean requeridos y la obstrucción a la labor inspectora de la Administración.

g. El incumplimiento de las medidas cautelares previstas en esta ley.

h. En general, el incumplimiento de los requisitos, obligaciones y prohibiciones establecidos en esta ley y en la normativa que la desarrolle.

Artículo 34. Clasificación de las infracciones.

1. Las infracciones ambientales reguladas en el artículo anterior se clasificarán en muy graves, graves y leves.

2. Se consideran infracciones leves los incumplimientos de los requisitos, obligaciones o prohibiciones establecidas en esta ley, salvo cuando, de acuerdo con los apartados siguientes constituyan infracciones graves o muy graves.

3. Se consideran infracciones graves las señaladas con las letras desde la a) hasta la g) del artículo anterior.

4. Se consideran infracciones muy graves:

a. Las señaladas en los apartados a), b), c) y e) del artículo anterior, cuando concurra alguna de las circunstancias siguientes: Malicia o intencionalidad.

Coste económico de la restauración superior a los 10.000 .000 de pesetas. 
Irreversibilidad del daño causado.

Repercusión grave o significativa en la salud de las personas o especies o grave deterioro en los recursos naturales.

Cuando el daño afecte a recursos únicos, escasos o protegidos.

Cuando el daño afecte gravemente a los ciclos vitales y ecosistemas básicos.

b. Las señaladas en los apartados d), e) f) y g) del artículo anterior, en caso de reincidencia.

5. La reincidencia en dos infracciones leves o graves conllevará la aplicación del grado inmediatamente superior. Se entenderá que existe reincidencia cuando se cometan dos faltas graves en el período de dos años o leves en el de seis meses.

Artículo 35. Sanciones.

1. Las infracciones en materia ambiental contempladas en esta Ley serán sancionadas según su gravedad:

a. Infracciones leves: Con multa de hasta 1.000 .000 de pesetas.

b. Infracciones graves: Con multa entre 1.000 .001 y 10.000 .000 de pesetas.

c. Infracciones muy graves: Con multa entre 10.000.001 a 50.000.000 de pesetas.

2. Las multas podrán conllevar, simultáneamente:

a. En casos de infracción grave, el cierre del establecimiento o la suspensión de la actividad, total o parcial, por un plazo no superior a dos años. En caso de que se impongan medidas correctoras, el cierre subsistirá hasta que éstas se cumplan.

En caso de ser inviables las aludidas medidas correctoras, podrá decidirse la clausura definitiva, total o parcial del establecimiento o actividad.

b. En casos de infracción muy grave:

a) El cierre del establecimiento o la suspensión de la actividad, total o parcial, por un plazo no superior a cuatro años $\mathrm{y}$, en todo caso, hasta la adopción de las medidas correctoras.

b) La clausura definitiva, total o parcial, del establecimiento o actividad.
3. Las sanciones que supongan la suspensión de actividades o el cierre de establecimientos habrán de ser publicadas en el "Diario Oficial de Galicia".

Artículo 36. Prescripción.

Las infracciones a que se refiere la presente Ley prescribirán en los siguientes plazos a contar desde la comisión del hecho o desde la detección del daño ambiental, si éste no fuese inmediato:

a. Seis meses, en caso de infracciones leves.

b. Dos años, en caso de infracciones graves.

c. Cuatro años, en caso de infracciones muy graves.

Artículo 37. Aplicación de las sanciones.

1. La aplicación de las sanciones se efectuará atendiendo a su repercusión en el medio ambiente y en los recursos naturales, al coste de restitución, al riesgo y trascendencia por lo que respecta a la salud de las personas y en los recursos ambientales a las circunstancias del responsable, al grado de malicia o intencionalidad a los beneficios obtenidos con la agresión, a la irreversibilidad del daño o del deterioro producido a la calidad del recurso o capacidad de retroalimentación y regeneración del ecosistema y a la reincidencia.

2. En el supuesto de sanción que implique el cierre del establecimiento o la suspensión de la actividad se computará, en la sanción definitiva, el tiempo que hubiese estado cerrado o suspendido como medida cautelar.

Artículo 38. Compatibilidad de sanciones.

Cuando un mismo hecho resulte sancionable de conformidad con esta ley y otras de protección ambiental que corresponda aplicar a la Administración autonómica, se resolverán los expedientes sancionadores correspondientes imponiendo únicamente la sanción más elevada de las que resulten. 


\section{Capitulo III RESPONSABILIDAD Y SUSPENSIÓN DE ACTIVIDADES}

Artículo 39. Sujeto responsable.

1. A los efectos de esta ley, tendrán la consideración de responsables de las infracciones ambientales previstas en la misma:

a. Las personas que directamente realicen la actividad infractora o, en su caso, las que ordenen la mencionada actividad, cuando el ejecutor tenga obligación de cumplir dicha orden.

b. Las personas que, de acuerdo con los estatutos o escritura social, sean titulares o promotoras de la actividad o proyecto del que se derive la infracción.

2. Cuando concurra en varias personas la autoría de la infracción o cuando el deterioro ambiental esté ocasionado por una acumulación de infracciones y no fuese posible determinar el grado de participación efectiva de cada una de ellas, la responsabilidad será solidaria.

3. En los casos en que la infracción sea imputable a una administración pública, ésta se someterá a las reglas generales y de carácter disciplinario aplicables a la administración y a sus agentes y funcionarios.

Artículo 40. Suspensión de actividades no autorizadas.

Toda actividad que comenzase a realizarse sin autorización o licencia, o incumpliendo manifiestamente las condiciones establecidas, cuando tales trámites estuviesen impuestos por la legislación vigente, será suspendida en su ejecución a requerimiento del órgano de la administración ambiental competente, sin perjuicio de exigir las responsabilidades a que por ello hubiese lugar.

Artículo 41. Medidas cautelares en el procedimiento sancionador.

1. En aquellos casos en que exista riesgo grave o inminente para el medio ambiente, el órgano competente para la incoación del expediente podrá ordenar motivadamente a la vez que acuerda la apertura del expediente la suspensión inmediata de la actividad o cualquier otra medida cautelar necesaria, sin perjuicio de la iniciación del expediente de disciplina ambiental que, en todo caso, proceda.

2. La adopción de las medidas cautelares previstas en el apartado anterior se llevará a cabo, previa audiencia del interesado, en un plazo de cinco días, salvo en los casos que exijan una actuación inmediata.

3. La administración autonómica y la municipal se comunicarán mutuamente las medidas cautelares que adoptasen.

Artículo 42. Restauración del medio e indemnización.

1. Sin perjuicio de la sanción que en cada caso proceda, el infractor habrá de reparar el daño causado. La reparación y la reposición de los bienes tendrán como finalidad lograr la restauración del medio ambiente a su estado anterior a la Comisión de la infracción. El órgano correspondiente de la administración competente para imponer la sanción lo será para exigir la restauración.

2. Si el infractor no procediese a reparar el daño causado en el plazo que se le señale, la administración que impuso la sanción procederá a la imposición de multas coercitivas sucesivas de hasta 500.000 pesetas cada una o, en su caso, a realizar la ejecución subsidiaria en los términos del artículo 98 de la Ley de Régimen Jurídico de las Administraciones Públicas y del Procedimiento Administrativo Común.

3. En cualquier caso, el promotor del proyecto o titular de la actividad causa de la infracción habrá de indemnizar por los daños y perjuicios ocasionados. La valoración de los mismos se hará por la administración, previa taxación contradictoria cuando el citado responsable no diese su conformidad a aquélla.

4. La utilización de los recursos generados por las sanciones que imponga la administración habrán de destinarse íntegramente a acciones destinadas a la mejora del medio ambiente. 
Artículo 43. Responsabilidad penal y administrativa.

1. En el supuesto de que la infracción pudiese ser constitutiva de delito o falta, la administración que instruye el expediente dará traslado a la jurisdicción competente, quedando en suspenso la actuación sancionadora en vía administrativa. No obstante, la vía penal no paralizará el expediente que se incoase para la restauración $\mathrm{y}$, en su caso, la indemnización de los daños y perjuicios a que hace referencia el artículo 42 de la presente ley.

2. Si la resolución judicial fuese absolutoria, la administración proseguirá las actuaciones para, si procediese, imponer la sanción administrativa correspondiente.

\section{Capitulo IV PROCEDIMIENTO}

Artículo 44. Remisión normativa. El procedimiento sancionador por incumplimiento de las obligaciones establecidas en esta ley se regirá por lo establecido en el capítulo II del título IX de la Ley de Régimen Jurídico de las Administraciones Públicas y del Procedimiento Administrativo Común.

\section{Artículo 45. Competencia.}

1. La incoación y la instrucción de expedientes sancionadores por las infracciones a que se refiere el artículo 32 corresponden:

a. Al órgano autonómico o municipal, en su caso, que tuviese atribuida la competencia por razón de la materia para otorgar la autorización.

b. Al órgano municipal competente, por la falta de licencia de ejercicio de la actividad.

2. La competencia para la resolución de los expedientes sancionadores a que hace referencia el apartado 1.a) anterior, instruidos por el órgano administrativo que a los efectos de esta ley, tenga atribuida la consideración de órgano ambiental sustantivo, corresponderá:

a. En faltas leves, al titular del centro directivo competente por razón de la materia. b. En faltas graves, el conselleiro del ramo.

c. En faltas muy graves, al Consello de la Xunta de Galicia.

Artículo 46. Vía del apremio.

Tanto el importe de las sanciones e indemnizaciones como el coste de la ejecución subsidiaria podrán ser exigibles por la vía de apremio a los infractores. Cuando proceda la ejecución subsidiaria, el órgano que haya de realizar la ejecución valorará el coste de las actuaciones que hayan de realizarse y su importe será exigido cautelarmente con arreglo al artículo 98 de la Ley de Régimen Jurídico de las Administraciones Públicas y del Procedimiento Administrativo Común.

Artículo 47. Recursos contra resoluciones sancionadoras.

1. Las resoluciones de los Alcaldes, que habrán de comunicarse al órgano correspondiente de la Administración autonómica en el plazo de quince días, ponen fin a la vía administrativa.

2. Las resoluciones del órgano correspondiente de la Administración ambiental autonómica serán comunicadas a los Alcaldes del término municipal en el que recaiga la sanción, dentro del plazo de quince días y tendrán el siguiente régimen:

a. En caso de infracciones leves, podrán ser objeto de recurso ordinario ante el conselleiro del ramo.

b. En caso de infracciones graves y muy graves, pondrán fin a la vía administrativa.

Artículo 48. Incumplimiento de medidas cautelares.

Si las medidas cautelares o de sanción, salvo la multa, no fuesen ejecutadas por la autoridad municipal que las hubiese impuesto, el órgano correspondiente de la administración autonómica podrá, previo requerimiento y audiencia al Ayuntamiento y al interesado, adoptar las medidas cautelares pertinentes para la salvaguarda del medio ambiente.

Artículo 49. Resoluciones municipales no ajustables a Derecho.

Cuando el órgano competente de la Administración autonómica considere que un acto o 
acuerdo municipal infringe el ordenamiento jurídico en materia de medio ambiente, podrá proceder con arreglo a las previsiones y requisitos establecidos en el artículo 65 de la Ley 7/1985, de 2 de abril, reguladora de las Bases de Régimen Local.

\section{DISPOSICIÓN ADICIONAL PRIMERA}

A excepción de las que en esta ley tengan establecido otro plazo distinto, en el plazo de un año, a contar desde la entrada en vigor de la presente ley, habrán de aprobarse las normas reglamentarias que la desarrollen.

\section{DISPOSICIÓN ADICIONAL SEGUNDA}

La Xunta de Galicia podrá actualizar la cuantía de las multas para adecuarla a las variaciones del coste de la vida, de acuerdo con el índice general de precios al consumo.

\section{DISPOSICIÓN ADICIONAL TERCERA}

En el plazo de dos años, los Ayuntamientos de Galicia habrán de proceder a adaptar sus ordenanzas ambientales a lo dispuesto en esta ley y en las disposiciones que la desarrollen.

\section{DISPOSICIÓN ADICIONAL CUARTA}

Por las autorizaciones administrativas a que se refiere esta ley, serán exigibles las tasas correspondientes de conformidad con la legislación reguladora.

\section{DISPOSICIÓN TRANSITORIA PRIMERA}

Los expedientes iniciados antes de la entrada en vigor de la presente ley se tramitarán y resolverán de conformidad con las normas vigentes en su iniciación, teniendo en cuenta los criterios establecidos en la misma.

\section{DISPOSICIÓN TRANSITORIA SEGUNDA}

En tanto no se aprueben las normas reglamentarias de desarrollo de esta ley, continúan en vigor:

E1 Decreto 2414/1961, de 30 de noviembre, por el que se apruebe el Reglamento de actividades molestas, insalubles, nocivas y peligrosas.

El Decreto 442/1990, de 13 de septiembre, de evaluación del impacto ambiental para Galicia.

E1 Decreto 327/1991, de 20 de octubre, de evaluación de los efectos ambientales de Galicia.

\section{DISPOSICIÓN DEROGATORIA ÚNICA}

Quedan derogadas cuantas disposiciones, de igual o inferior rango, se opongan a lo dispuesto en esta ley ${ }^{472}$.

\section{DISPOSICIÓN FINAL PRIMERA}

Se autoriza a la Xunta de Galicia para dictar las disposiciones reglamentarias precisas para el cumplimiento de esta ley.

\section{DISPOSICIÓN FINAL SEGUNDA}

La presente ley entrará en vigor al día siguiente de su publicación en el "Diario Oficial de Galicia".

\section{LEY 8/2002, DE 18 DE DICIEMBRE, DE PROTECCIÓN DEL AMBIENTE ATMOSFÉRICO DE GALICIA (DOGA N. $\left..^{\circ} 252,31.12 .2002\right)$}

\section{$(\ldots)^{473}$ \\ Capitulo I \\ DISPOSICIONES GENERALES}

Artículo 1. Objeto de la ley.

1. La presente ley tiene por objeto el establecimiento, en la Comunidad Autónoma de Galicia y dentro del marco de sus competencias, de las normas, criterios y técnicas de ordenación para mantener un alto nivel de calidad del aire ambiente y mejorarla, en su caso, así como para prevenir, vigilar y reducir la contaminación atmosférica.

2. El fin primordial de la presente ley, orientada a la consecución de un desarrollo

472 Disposición derogatoria única modificada por Ley $2 / 1995$, de 31 de marzo, por la que se le da una nueva redacción a la Disposición derogatoria única de la Ley 1/1995, de 2 de enero, de protección ambiental de Galicia. 473 Exposición de motivos omitida. 
sostenible, es evitar la contaminación atmosférica producida por el hombre, directa o indirectamente, mediante la introducción en la atmósfera de contaminantes que, por sí mismos o como consecuencia de su transformación, puedan inducir efectos nocivos, perjudiciales o molestos sobre la salud humana, los ecosistemas y hábitats implantados en suelos o aguas, el paisaje, los recursos naturales, los materiales, incluido el patrimonio histórico, el clima o la propia calidad fisicoquímica del aire.

Artículo 2. Líneas de actuación.

Para alcanzar los fines y objetivos del artículo anterior se procederá al desarrollo de las siguientes acciones:

a. La definición y establecimiento de los objetivos de la calidad del aire para los diferentes contaminantes y la fijación de límites de emisión para las actividades potencialmente contaminantes.

b. La evaluación de la calidad del aire ambiente.

c. La elaboración de información adecuada sobre el estado del medio ambiente atmosférico y su puesta en conocimiento del público en general.

d. El mantenimiento y defensa de un alto nivel de calidad del aire ambiente y la mejora, en su caso.

e. La adopción de las medidas necesarias a fin de contribuir a la solución o mitigación de los problemas ambientales de alcance planetario o internacional como la lluvia ácida, el cambio climático, la destrucción de la capa de ozono y los flujos transfronterizos de contaminantes.

Artículo 3. Principios.

Los principios que inspiran la acción pública en favor de la protección y mejora del ambiente atmosférico en Galicia, y que servirán para el desarrollo de su marco normativo, son:

a. El desarrollo sostenible, que debe constituir un objetivo básico de aplicación a todas las actividades humanas con incidencia sobre el ambiente atmosférico, mediante la utilización racional de todos los recursos, renovables o no, que permita la conservación y regeneración de los ecosistemas y, en su caso, de los propios recursos.

b. El de prevención, mediante la adopción de las medidas que eviten la formación de contaminantes o su emisión, con preferencia al establecimiento de medidas de corrección o de restauración.

c. El de precaución, adoptando medidas cuando existan indicios de riesgos graves para la salud humana o el medio ambiente, aun en caso de que no pueda justificarse claramente el nexo causal sobre la base de las pruebas científicas disponibles.

d. La transparencia de la Administración en la información a la sociedad, relativa al estado del medio ambiente atmosférico, y la participación ciudadana en la adopción de decisiones sobre esta materia.

e. El de integración, incorporando las exigencias de protección del aire ambiente en las diferentes políticas sectoriales gestionadas por la Administración pública de Galicia.

f. La coordinación y la unidad de gestión entre todos los organismos competentes de Galicia en la protección del ambiente atmosférico, así como la colaboración y cooperación con otras Administraciones internacionales, estatales y autonómicas, teniendo en cuenta el carácter transfronterizo de la contaminación atmosférica.

g. El control integrado de la contaminación de manera que, tras el análisis de las circunstancias concurrentes, cualquier actuación de prevención o control de la contaminación atmosférica no suponga una incidencia negativa sobre los otros medios o recursos naturales.

h. La adaptación al desarrollo científico y técnico, haciendo uso de las mejores técnicas disponibles dentro de los condicionantes económicos aceptables, mediante la aplicación, en su caso, del análisis coste-beneficio.

i. La subsidiariedad en la gestión pública, procurando el nivel más adecuado de la Administración para el logro de los objetivos de calidad ambiental. 
j. La solidaridad colectiva y la responsabilidad compartida de todos los agentes económicos y sociales, promoviendo la formación de pactos ambientales $\mathrm{u}$ otro tipo de instrumentos voluntarios, en particular con la industria, a fin de lograr mejoras adicionales en la calidad y gestión del aire ambiente.

k. El principio de "quien contamina, paga", responsabilizando al contaminador mediante la aplicación de instrumentos económicos y con la internalización de los costes ambientales.

Artículo 4. Ámbito de aplicación de la ley.

1. La presente ley obligará, en el ámbito territorial de la Comunidad Autónoma bajo su competencia, a toda persona física o jurídica, pública o privada, que realice o proyecte realizar actividades, permanentes o esporádicas, industriales y agrarias, de tráfico y transportes, de carácter doméstico y servicios, consideradas potencialmente contaminantes por la normativa vigente y que puedan originar emisiones puntuales, fugitivas o difusas.

2. Quedan sujetos a la aplicación de la presente ley los contaminantes atmosféricos de naturaleza química que se relacionan en el anexo, y los que en el futuro puedan incorporarse a requerimiento de la normativa estatal y comunitaria.

3. Quedan excluidos de la aplicación de la presente ley, rigiéndose por su normativa específica:

a. Los ruidos y vibraciones.

b. Las radiaciones ionizantes y no ionizantes.

c. La calidad del aire en el interior de los lugares de trabajo.

d. Los organismos modificados genéticamente.

Artículo 5. Definiciones.

A los efectos de la presente ley se entenderá por:

1. Aglomeración: Área con una concentración de población de más de
50.000 habitantes o cuando, siendo igual o inferior a esta cifra, tiene una densidad de habitantes por kilómetro cuadrado que justifique la evaluación y control de la calidad del aire ambiente.

2. Aire ambiente: El aire troposférico y exterior.

3. Autorización: Decisión escrita por la que se permite explotar la totalidad o parte de una instalación, bajo determinadas condiciones destinadas a garantizar que la instalación responde a los requisitos de la presente ley. Tal autorización podrá ser válida para una o más instalaciones o partes de instalaciones que tengan la misma ubicación y sean explotadas por el mismo titular.

4. Evaluación: Cualquier método utilizado para medir, calcular, predecir o estimar el nivel de un contaminante en el aire ambiente.

5. Carga crítica: Estimación cuantitativa de la exposición a uno o más contaminantes por debajo de la cual, de acuerdo con el actual nivel de conocimientos, no se producen efectos adversos significativos sobre los elementos sensibles específicos del medio ambiente.

6. Contaminación atmosférica: Introducción en la atmósfera por el hombre, directa o indirectamente, de sustancias o formas de energía que, por sí mismas o como consecuencia de su transformación, tengan una acción nociva de tal naturaleza que implique un riesgo sobre la salud humana o el medio ambiente, que cause daños, inmediatos o diferidos, o molestias a las personas, los recursos biológicos, los ecosistemas y los bienes de cualquier naturaleza.

7. Contaminante atmosférico: Cualquier sustancia o forma de energía introducida, directa o indirectamente, por el hombre en el aire ambiente, que pueda tener efectos nocivos sobre la salud humana o el medio ambiente en su conjunto, entendiéndose como sustancia los elementos químicos y 
sus compuestos, con la excepción de los productos radiactivos y los organismos modificados genéticamente.

8. Contorno: Espacio en los alrededores de una instalación industrial en el que previsiblemente serán más acusados los efectos de las emisiones de la planta y en la que, por tanto, habrán de ejercerse una vigilancia y seguimiento más cuidadosos.

9. Emisión: Descarga o vertido a la atmósfera, realizados de forma continua o con carácter irregular, de sustancias o formas de energía procedentes, directa o indirectamente, de instalaciones, equipos y actividades potencialmente contaminantes del aire ambiente.

10. Emisiones difusas: Emisiones producidas por un gran número de pequeños focos puntuales, fijos o móviles, y que tienen lugar en toda una superficie de extensión variable, como son las generadas por el tránsito en una red viaria, las de un centro urbano o las de explotaciones agrícolas.

11. Emisiones fugitivas: Emisiones gaseosas, de olores o de partículas sólidas, producidas con carácter irregular o esporádico, cuya magnitud depende en gran medida de las condiciones meteorológicas y que se generan en algunas actividades industriales como las canteras o minas al descubierto, y en ciertas instalaciones auxiliares que manejan materiales polvorientos, reactivos o combustibles.

12. Foco emisor: Dispositivo, equipo o sistema de vertido fijo o móvil, emplazamiento físico o superficie en los que los gases residuales resultantes de actividades industriales, urbanas, agrarias o del transporte entran en contacto con el aire ambiente, de forma continua o irregular, iniciando a partir de ese punto cualquier eventual proceso de contaminación atmosférica.

13. Gases residuales: Productos en forma gaseosa que pueden contener contaminantes atmosféricos gaseosos, sólidos o líquidos, resultantes de la operación de una instalación o de un equipo y destinados a su vertido final a la atmósfera.

14. Indicador ambiental: Variable que fue socialmente dotada de un significado añadido al derivado de su propia configuración científica, a fin de reflejar de forma sintética una preocupación social con respecto al medio ambiente o insertarla coherentemente en el proceso de toma de decisiones y para información pública en general.

15. Instalación: Unidad técnica fija en la que se llevan a cabo una o más de las actividades de producción industrial, generación de energía, fabricación de productos, tratamiento de materiales o destrucción de residuos, así como cualesquiera otras actividades directamente relacionadas con éstas que puedan tener repercusiones sobre las emisiones y la contaminación de la atmósfera.

16. Instalación existente: Instalación que se encuentre en funcionamiento o esté autorizada, o de la cual se hubiese presentado una solicitud completa de autorización antes de la fecha de entrada en vigor de la presente ley, siempre que su puesta en marcha se realice en el plazo de dos años desde la vigencia de esta ley.

17. Límite de alerta: Nivel de inmisión a partir del cual una exposición de corta duración supone un riesgo para la salud humana ; en dicho caso la Administración habrá de adoptar medidas inmediatas, así como informar a la población.

18. Límite de emisión: Masa expresada en relación con determinados parámetros específicos, la concentración o el nivel de una emisión, con un valor que no debe superarse dentro de uno o de varios períodos determinados.

19. Límite de inmisión: Concentración máxima admisible de un contaminante dado en el aire ambiente, basada en conocimientos científicos y establecida a fin de evitar, prevenir o reducir los efectos nocivos para la salud humana y el medio ambiente en su conjunto, que debe 
alcanzarse en un plazo determinado y no superarse una vez alcanzado.

20. Mapa de cargas y niveles críticos: Aquel conjunto de informaciones sobre los elementos que constituyen el medio y que permiten evaluar la incidencia de las emisiones de contaminantes vertidos a la atmósfera en una zona determinada y dictaminar su influencia.

21. Margen de exceso tolerado: Porcentaje del valor límite de inmisión en el que éste puede excederse temporalmente en las condiciones definidas por la normativa.

22. Mejores técnicas disponibles: La fase más eficaz y avanzada de desarrollo de actividades tecnológicas y de sus formas de explotación, con capacidad demostrada para alcanzar un alto nivel de protección del medio ambiente en su conjunto y accesibles en condiciones económica y técnicamente viables al titular, que podrían constituir, en principio, la base para el establecimiento de los valores límite de emisión.

23. Modificación de una instalación: Cambio de las características, del funcionamiento y de la forma de explotación o ampliación de una instalación que pueden llevar consigo repercusiones perjudiciales o importantes para las personas o el medio ambiente.

24. Nivel crítico: Concentración de contaminantes en la atmósfera por encima de la cual, de acuerdo con el actual nivel de conocimientos, pueden producirse efectos adversos directos sobre las personas, el medio ambiente en su conjunto o los bienes materiales.

25. Nivel de inmisión: Concentración de un contaminante en el aire ambiente o su depósito en superficies en un momento o en un período determinados.

26. Titular: Cualquier persona física o jurídica que explote una instalación o sea propietario de la misma, o que ostente, directamente o por delegación, un poder económico determinante sobre la explotación técnica de aquélla.
27. Valor de referencia objetivo: Nivel de inmisión fijado a fin de evitar a más largo plazo efectos nocivos para la salud humana o para el medio ambiente en su conjunto, que debe alcanzarse, en la medida de lo posible, en un plazo determinado.

28. Zona: Parte del territorio delimitada por la Administración a los efectos de la evaluación del estado del aire ambiente y, en su caso, para la aplicación de medidas de mejora y mantenimiento de la calidad de la atmósfera.

\section{Capítulo II EVALUACIÓN Y PROTECCIÓN DE LA CALIDAD DEL AIRE \\ Sección $1 .^{\mathrm{a}}$}

Parámetros de la calidad del aire

Artículo 6. Criterios generales.

1. La Administración pública gallega adoptará cuantas medidas sean necesarias para mejorar la calidad del aire ambiente y mantenerla dentro de los límites legalmente establecidos, que serán de obligado cumplimiento dentro del ámbito de protección de la Comunidad Autónoma.

2. A los efectos de lo dispuesto en el apartado anterior, serán objeto de control y vigilancia los contaminantes recogidos en los puntos 1.a) y 1.b) del anexo, sin perjuicio de lo previsto en la normativa estatal vigente.

3. También podrán ser objeto de adopción de medidas por parte de la Administración aquellos contaminantes que, en su caso, se estime preciso considerar específicamente en función de las actividades desarrolladas en una determinada zona de la Comunidad Autónoma de Galicia y de conformidad con las directrices recogidas en el punto 2 del anexo.

Artículo 7. Valores de la calidad del aire.

1. Con arreglo a la normativa del Estado y de la Comunidad Europea, los organismos competentes de la Administración pública gallega velarán por el 
cumplimiento de las normas de calidad del aire ambiente, que fijan los valores límite de inmisión y sus márgenes de exceso tolerado, los límites de alerta y los valores de referencia objetivo de los contaminantes seleccionados, así como los procedimientos de evaluación.

2. Sin perjuicio de lo establecido en el apartado anterior, el Gobierno de la Xunta de Galicia, a propuesta de la Consellería de Medio Ambiente, adoptará planes específicos para el saneamiento y mejora de la calidad del aire en aquellas áreas en que se excedan los límites de inmisión o exista un riesgo elevado de que ello suceda y en los casos de alerta atmosférica, y desarrollará planes de acción para el mantenimiento de la calidad de la atmósfera en las zonas en que ésta ya alcanza un alto nivel.

\section{Sección 2. ${ }^{a}$}

Vigilancia y evaluación de la calidad del aire

Artículo 8. Evaluación de la calidad del aire.

Las mediciones de la calidad del aire serán obligatorias en los siguientes supuestos:

1. En las aglomeraciones definidas en el apartado 1 del artículo 5.

2. En las zonas en que se superen los límites de inmisión.

3. En las zonas en que aun no superándose los límites de inmisión sí existe un riesgo potencial de acuerdo con los parámetros técnicos que se determinarán reglamentariamente.

Artículo 9. Red general de vigilancia de la calidad del aire de Galicia.

1. La red general de vigilancia de la calidad del aire de Galicia la integrarán los sistemas de vigilancia y seguimiento de los niveles de inmisión localizados en las zonas y aglomeraciones urbanas en las que exista una obligación de control conforme a lo establecido en la presente ley. A efectos funcionales, estará constituida por todas las estaciones sensoras, de titularidad pública y privada, existentes o de futura instalación en el territorio de la Comunidad Autónoma siempre que se adecuen a los criterios y técnicas reglamentariamente previstas.

La Administración pública gallega definirá los criterios a seguir en cuanto al número y localización de las estaciones de medida con arreglo a la normativa vigente.

2. Para establecer la red general de vigilancia a que se refiere el apartado anterior e instalar los aparatos y estaciones de medición de la contaminación atmosférica en los casos que particularmente se determinen, pueden imponerse las servidumbres forzosas cuando resulten necesarias, con la indemnización previa que corresponda legalmente.

3. La red general de vigilancia establecerá cauces de coordinación a efectos funcionales con la red nacional de vigilancia y previsión de la contaminación atmosférica.

4. En determinados casos, previa resolución motivada, la Administración pública gallega podrá requerir a los titulares de las instalaciones la implantación de redes y estaciones de vigilancia de las inmisiones de los productos que emiten y que cubrirán el contorno de la planta.

5. Los sistemas de muestreo y medición de los contaminantes responderán a procedimientos normalizados que se determinarán reglamentariamente. Se exigirá la medición continua de los contaminantes y de los principales parámetros meteorológicos y su transmisión al centro de recepción de datos de la red general de vigilancia, salvo que razones técnicas impidan su realización.

6. La Administración pública gallega potenciará la mejora y ampliación de los sistemas de medida y predicción meteorológicos de la Comunidad Autónoma y el intercambio permanente de información con organismos nacionales y extranjeros activos en este campo.

Artículo 10. Modelización de la calidad del aire ambiente.

A fin de cubrir al máximo el territorio de la Comunidad Autónoma, y cuando por 
su importancia relativa o porque razones técnicas, económicas u operativas no permitan o justifiquen la instalación de sistemas de medición directa, podrá hacerse uso de otros procedimientos de evaluación de la calidad del aire ambiente y en particular de la modelización. A tal efecto, la Administración pública gallega establecerá reglamentariamente, en cada caso y de acuerdo con los medios tecnológicos existentes en ese momento, los criterios de resolución espacial del modelo, los métodos de evaluación objetiva y las técnicas de referencia para su validación.

Artículo 11. Tratamiento de la información atmosférica.

1. Los datos numéricos obtenidos en el control de la contaminación atmosférica deberán validarse y resumirse por la Consellería de Medio Ambiente como paso previo a cualquier tipo de difusión. En esta operación se seguirán criterios de utilización general establecidos por la normativa comunitaria que permitan el intercambio recíproco de informaciones y datos procedentes de redes y estaciones aisladas que miden la calidad del aire.

2. La información a que se refiere el apartado anterior será la única legalmente válida para:

a. Promover las medidas de mantenimiento y mejora de la calidad del aire.

b. Formular los mapas de cargas y niveles críticos y emprender las actuaciones dirigidas a la corrección de las emisiones.

Artículo 12. Mapa de cargas y niveles críticos de Galicia.

1. Con el objetivo de facilitar la aplicación de la presente ley, la Administración pública gallega elaborará y actualizará periódicamente un Mapa de cargas y niveles críticos de los contaminantes que determine la capacidad y sensibilidad ambiental de todo el territorio de la Comunidad Autónoma. La formulación, los contenidos y las especificaciones del Mapa de cargas y niveles críticos de Galicia, así como su procedimiento de aprobación, se determinarán reglamentariamente. En todo caso, en su redacción participarán las entidades locales a través de los comités de coordinación e integración ambiental.

2. Para su confección se tendrán en cuenta prioritariamente los siguientes datos:

a. La distribución de la población.

b. La información disponible sobre los usos y características del suelo, e inventarios de la vegetación.

c. Las condiciones meteorológicas y fisiográficas.

d. La localización de las principales actividades contaminantes, sus focos de emisiones atmosféricas y la evaluación de las mismas.

e. La calidad del aire existente.

f. La localización de las zonas especialmente sensibles por el valor de su patrimonio cultural y ecológico.

3. La información resultante del citado Mapa se utilizará como referencia en la elaboración y revisión de los instrumentos de ordenación territorial y de las figuras de planeamiento urbanístico previstos por la legislación gallega, y en los procedimientos de autorización de las actividades potencialmente contaminadoras de la atmósfera.

\section{Sección 3. ${ }^{a}$}

Medidas para el mantenimiento y mejora de la calidad del aire

Artículo 13. Zonas y aglomeraciones urbanas.

A la vista de las determinaciones e informaciones contenidas en el Mapa de cargas y niveles críticos a que se refiere el artículo anterior, la Consellería de Medio Ambiente delimitará las aglomeraciones urbanas y zonas de la Comunidad Autónoma en las que tendrán que aplicarse las medidas enunciadas en este capítulo, tales como los planes de saneamiento y mejora de la calidad del aire en zonas de atmósfera contaminada, la situación de alerta atmosférica o los planes de acción para el mantenimiento de la calidad del aire. 
Artículo 14. Planes de saneamiento y mejora de la calidad del aire en zonas de atmósfera contaminada.

1. En aquellas áreas del territorio de la Comunidad Autónoma que hubiesen sido declaradas zonas o aglomeraciones urbanas de acuerdo con lo previsto por el artículo anterior, y cuyos niveles de uno o más contaminantes superen o exista un riesgo potencial muy elevado de superar el valor límite de inmisión, incrementado por el margen de exceso tolerado, se adoptarán planes de saneamiento y mejora de la calidad del aire. Dichos planes contendrán la información incluida en el apartado 5 del anexo.

Cuando los niveles de inmisión de varios contaminantes sean superiores a los valores límite respectivos, se establecerá un plan integrado incluyendo todas las sustancias de que se trate.

2. La aprobación de los planes de saneamiento de la calidad del aire corresponderá al Gobierno de la Xunta de Galicia a propuesta de la Consellería de Medio Ambiente, que actuará a iniciativa propia o a petición de la corporación local o corporaciones locales afectadas.

3. La corporación o corporaciones locales afectadas participarán en la elaboración del plan de saneamiento y mejora de la calidad del aire, que en todo caso será sometido al trámite de información pública por el plazo de un mes.

4. El plan de saneamiento contendrá un programa de las medidas que han de adoptarse, los recursos económicos necesarios y la determinación de las entidades y organismos que han de ejecutarlo y financiarlo, así como el plazo de tiempo en el que habrán de lograrse los niveles admisibles de la calidad del aire. Entre las posibles medidas que pueden aplicarse se incluirán:

a. La prohibición o condicionamiento del ejercicio de las actividades potencialmente contaminantes. b. El establecimiento de valores límite de emisión más rigurosos que los fijados con carácter general para las actividades e instalaciones contaminantes que se encuentren en la zona o aglomeración urbana.

c. La revisión o modificación de las figuras de planeamiento urbanístico existentes en la zona, que podrán implicar la prohibición del establecimiento de actividades potencialmente contaminantes.

d. La suspensión de licencias de instalación o ampliación de actividades contaminantes que puedan deteriorar la calidad del aire de la zona afectada.

e. La adopción de medidas destinadas a reducir la contaminación atmosférica producida por el tráfico urbano y los medios de transporte.

5. En los casos de instalaciones y actividades contaminantes que no puedan asumir en el plazo previsto las medidas contenidas en el plan de saneamiento, en razón del excesivo coste o complejidad técnica de la adecuación, la Administración pública gallega cooperará flexibilizando los plazos de adaptación y facilitando las gestiones para el acceso a créditos o ayudas públicas que puedan ser de aplicación en la resolución de la situación suscitada.

Artículo 15. Situación de alerta atmosférica.

1. En aquellas zonas del territorio de la Comunidad Autónoma donde por causas accidentales o circunstancias meteorológicas excepcionales se supere o haya riesgo grave de superar el límite de alerta en los niveles de inmisión se declarará la situación de alerta atmosférica. Reglamentariamente, se elaborará una lista de los detalles mínimos que han de comunicarse. En todo caso, se tomarán las medidas necesarias para informar debidamente a la población.

2. La declaración de alerta atmosférica corresponderá al Conselleiro de Medio Ambiente, a iniciativa propia o a petición de la corporación o corporaciones 
locales afectadas, y contendrá un plan de medidas urgentes que deben adoptarse con la finalidad de lograr a corto plazo el restablecimiento de los niveles admisibles de inmisión. Entre otras medidas podrán aplicarse las siguientes:

a. Respecto de las actividades industriales, y siempre previo trámite de audiencia al titular de la actividad:

La suspensión total o parcial de la actividad de las instalaciones con focos puntuales fijos de emisión contaminadora o con emisiones difusas y fugitivas.

La modificación del horario de funcionamiento de las instalaciones contaminadoras.

b. Respecto de las actividades domésticas y los servicios, así como las relativas al tráfico y al transporte:

La suspensión total o parcial de las actividades potencialmente contaminadoras.

La reducción o prohibición de la circulación de vehículos y de los demás medios de transporte, facilitando el uso de los transportes públicos.

3. El Alcalde o Alcaldes de las zonas afectadas por una situación de alerta atmosférica podrán adoptar con carácter de urgencia algunas de las medidas previstas en el apartado anterior, comunicándolo inmediatamente al Conselleiro de Medio Ambiente o, en todo caso, en un plazo máximo de veinticuatro horas.

Artículo 16. Planes de acción para el mantenimiento de la calidad del aire.

1. En las zonas donde la calidad atmosférica se mantiene por debajo de los valores límite de inmisión, el Gobierno de la Xunta de Galicia podrá aprobar, a propuesta de la Consellería de Medio Ambiente, planes de acción y las medidas oportunas para preservarlas de todo incremento de la contaminación atmosférica.

Dichas medidas, que se determinarán reglamentariamente, se aplicarán teniendo en cuenta la situación socioeconómica de la zona y sin que puedan impedirse actividades compatibles con el desarrollo sostenible.
2. Se considerarán áreas prioritarias para la aplicación de las acciones previstas en el apartado anterior aquellas zonas de especial interés por sus valores ecológi$\cos$, paisajísticos, históricos, etnográficos y culturales, y, en particular, las zonas donde se encuentren espacios naturales protegidos declarados con arreglo a la legislación vigente.

\section{Capitulo III \\ CONTROL DE LA CONTAMINACIÓN \\ ATMOSFÉRICA PRODUCIDA POR LAS DISTINTAS ACTIVIDADES}

\section{Sección 1. ${ }^{\mathrm{a}}$}

\section{Requisitos generales}

Artículo 17. Inventario de las fuentes de emisión.

1. La Administración pública gallega elaborará el inventario de las fuentes de emisión existentes en la Comunidad Autónoma, determinando, según su naturaleza y cantidad, los contaminantes que se considere prioritario controlar conforme al apartado 3 del anexo.

2. Las fuentes a considerar serán tanto las fijas como las móviles, así como los generadores de contaminaciones difusas y fugitivas situados en el medio terrestre.

3. Cada cinco años se realizará la actualización del inventario de las fuentes de emisión y se preparará la información sobre emisiones requerida por la Unión Europea y otros organismos internacionales. La revisión y actualización del inventario afectarán tanto a las fuentes existentes como a las posibles fuentes nuevas.

Artículo 18. Obligaciones generales para los titulares de actividades potencialmente contaminantes.

1. Los titulares de actividades potencialmente contaminadoras de la atmósfera deberán:

a. Disponer de la preceptiva autorización o licencia, previa realización de la evaluación de impacto, efectos o incidencia ambiental del correspondiente 
proyecto técnico. Esta evaluación se efectuará según los criterios establecidos por la normativa vigente de la Comunidad Autónoma de Galicia, así como de acuerdo con los parámetros previstos para la elaboración del Mapa de cargas y niveles críticos.

b. Cumplir las exigencias mínimas que se establezcan en la presente ley y en sus normas de desarrollo para los proyectos técnicos de las actividades nuevas y de ampliación o modificación de las existentes.

c. Respetar los límites de emisión de los contaminantes recogidos en el apartado 3 del anexo, exigidos por la normativa vigente con carácter general o, en su caso, aquellos que específicamente les hubiesen sido impuestos por las autorizaciones correspondientes.

d. Adoptar las medidas previstas en los planes de saneamiento y mejora de la calidad del aire y las derivadas de los supuestos de alerta atmosférica regulados en la presente ley, así como en los planes de acción para el mantenimiento de la calidad del aire ambiente de Galicia.

e. Facilitar en todo momento los actos de inspección y de comprobación que las corporaciones locales $\mathrm{u}$ organismos competentes de la Administración pública gallega ordenen, y adecuar las instalaciones que lo requieran.

2. Sin perjuicio de lo dispuesto en el apartado anterior, podrán establecerse límites especiales más rigurosos que los de carácter general cuando se superen en los puntos afectados los límites de inmisión. La fijación de dichos límites corresponde al Gobierno de la Xunta de Galicia, a propuesta de la Consellería de Medio Ambiente $o$, a través de ésta, de las corporaciones locales afectadas, teniendo en cuenta la localización geográfica de las actividades en función del Mapa de cargas y niveles críticos y de las emisiones ya existentes, $\mathrm{y}$ el potencial efecto sobre el medio ambiente del contaminante considerado, los avances tecnológicos para su eliminación y la viabilidad económica de su implantación, justificada por un estudio coste-beneficio.

\section{Sección 2. ${ }^{\mathrm{a}}$}

Control de la contaminación atmosférica producida por las actividades industriales

Artículo 19. Condiciones para la autorización de instalaciones industriales.

1. La autorización de una instalación nueva o la modificación de cualquiera existente incluirá los valores límite de emisión de contaminantes exigibles durante su operación normal y los sistemas de control, así como los condicionantes específicos de protección ambiental precisos para respetar las normas de calidad atmosférica en los respectivos contornos, que se determinarán reglamentariamente.

2. No se autorizará la puesta en marcha ni la operación de ninguna instalación nueva potencialmente contaminadora, ni la de los equipos modificados en las existentes sin que se cumplan las condiciones de protección y control a que se refiere el apartado anterior.

No obstante, podrá autorizarse una puesta en marcha provisional, durante un período limitado, para probar o ajustar el funcionamiento de los sistemas de control de la contaminación atmosférica, adoptando todas las precauciones precisas para mantener en el contorno de la instalación los niveles admisibles de la calidad del aire ambiente.

3. La Administración tomará las medidas necesarias para la revisión periódica y, si fuese necesario, la actualización de las condiciones de la autorización.

Artículo 20. Sistemas de control y medida.

1. Los titulares de las actividades deberán instalar y mantener en perfecto 
estado de servicio los sistemas de control y de medida de las emisiones y, en el caso previsto por el artículo 9.4 de la presente ley, de las inmisiones, exigidos de conformidad con las condiciones previstas en este artículo.

2. Se especificarán reglamentariamente, para cada tipo de actividad industrial, todas las condiciones técnicas asociadas a la expresión del valor límite de emisión, la situación de los puntos de medición y los parámetros auxiliares necesarios para obtener medidas representativas, evitar interpretaciones dudosas de los datos, manejar resultados comparables y posibilitar la determinación de las cantidades totales de contaminantes emitidos en un período dado.

3. Con carácter general, se requerirá la medición continua de las emisiones a la atmósfera mediante sistemas normalizados que se determinarán reglamentariamente. Sin embargo, cuando dicha medición resulte inviable o la magnitud de los vertidos no sea significativa, podrá recurrirse a la aplicación de algún sistema alternativo que permita evaluarlas.

4. Con independencia del mantenimiento de los límites de emisión aplicables, deberán respetarse en el contorno de las instalaciones industriales los criterios de calidad del aire reglamentados. En caso de grandes emisores industriales en los que, aunque se cumplan los límites de emisión, las condiciones meteorológicas desfavorables pueden conducir a la superación temporal de los valores límite de inmisión, la Administración pública gallega podrá exigir al titular la aplicación de sistemas de control suplementario, que se determinarán reglamentariamente.

5. En el supuesto previsto en el apartado anterior, la Administración pública gallega establecerá los mecanismos necesarios para que, de forma automática e inmediata, se adopten medidas técnicas sobre la operación de la instalación para reducir sus emisiones hasta el restablecimiento de la situación admisible a nivel del terreno.

6. Los titulares de las actividades potencialmente contaminadoras estarán obligados a poner en conocimiento de la Administración cualquier incidencia que pueda afectar a la calidad del ambiente atmosférico, así como las medidas adoptadas para corregirla. Asimismo, facilitarán periódicamente a la Administración la información precisa para evaluar el comportamiento ambiental de las plantas industriales, en la forma que se determine reglamentariamente, así como los resultados de las auditorías ambientales realizadas que, en su caso, requiera la propia Administración.

Artículo 21. Sistema de control integrado de la contaminación.

1. En el marco de un sistema de control integrado de la contaminación y de conformidad con la normativa específica dictada al efecto, el titular de la instalación adoptará todas las medidas necesarias para garantizar las acciones propuestas para reducir la contaminación atmosférica. Entre estas medidas se recogerán aquellas que no la transfieren ni afecten a la calidad de los otros medios, que eviten la producción de residuos o, de no ser posible, que procuren su recuperación, su reciclado o eliminación segura y que promuevan el uso eficaz de la energía y de otros recursos.

2. Para lo referido con anterioridad, se recurrirá a la utilización de las mejores técnicas disponibles dentro de condicionantes económicos aceptables.

Artículo 22. Emisiones fugitivas y difusas en operaciones industriales.

1. En aquellas actividades que por su naturaleza constituyen focos potenciales de emisiones fugitivas, así como en determinados sistemas auxiliares de otras instalaciones y en las operaciones susceptibles de dar lugar a emisiones difusas, se adoptarán las medidas de prevención y 
protección necesarias para que en su contorno se mantengan los niveles de calidad del aire exigidos por la normativa vigente.

2. Se estudiarán con particular atención las medidas que, juntamente con una reducción de este tipo de emisiones, lleven asociada la mejora del impacto visual de las instalaciones productoras.

\section{Sección $3 .^{a}$}

\section{Control de la contaminación atmosférica urbana y de la derivada del transporte}

Artículo 23. Control de las emisiones urbanas no industriales.

Además de las medidas previstas en los planes de saneamiento y mantenimiento de la calidad del aire, así como las adoptadas en los supuestos de alerta atmosférica, los municipios controlarán las emisiones procedentes de las actividades domésticas y de servicios y las de los vehículos de motor que circulen en el término municipal, pudiendo condicionar su funcionamiento al cumplimiento de los requisitos que se determinen reglamentariamente.

Artículo 24. Control de las actividades de transporte.

En el ámbito de sus competencias, la Comunidad Autónoma velará por la aplicación de las medidas previstas en la legislación de transportes a fin de prevenir y sancionar las actividades perjudiciales para el medio ambiente atmosférico.

\section{Capitulo IV \\ FOMENTO DE LA CALIDAD DEL AIRE AMBIENTE \\ Sección $1 .^{a}$ \\ Instrumentos económicos y de apoyo financiero}

Artículo 25. Ayudas y subvenciones.

1. Los titulares de las actividades potencialmente contaminadoras de la atmósfera, legalmente autorizadas con anterioridad a la aprobación de la presente ley, que resulten afectadas por los planes de saneamiento y mejora, así como por los de mantenimiento de la calidad del aire, y a las que sea particularmente gravosa la adecuación a éstos podrán beneficiarse de las subvenciones y las ayudas que acuerde, en su caso, el Gobierno de la Comunidad Autónoma.

2. Igualmente, podrán beneficiarse de dichas subvenciones y ayudas los municipios para la ejecución de las medidas previstas en la presente ley y en los planes de saneamiento y mejora, así como en los de mantenimiento de la calidad del aire. De conformidad con la legislación de régimen local propia de Galicia, los municipios que hubiesen sido declarados municipios industriales serán objeto de una atención preferente en la dotación y reparto de dichas ayudas.

3. Estas subvenciones y ayudas se otorgarán sin perjuicio de los beneficios que el Gobierno del Estado pueda conceder en aplicación de la legislación vigente.

En ningún caso la totalidad de estas ayudas y subvenciones podrá superar el coste total de las nuevas instalaciones.

Artículo 26. Fondo de Protección del Ambiente Atmosférico de Galicia.

1. Con la finalidad de apoyar la financiación de las actuaciones públicas y privadas encaminadas a mejorar la calidad del aire ambiente y reducir los niveles de emisión, se crea el Fondo para la Protección del Ambiente Atmosférico de Galicia.

2. El fondo se nutre de los créditos presupuestarios habilitados con esta finalidad.

Artículo 27. Contabilidad ambiental. Las empresas habrán de llevar una contabilidad específica de sus costes ambientales a fin de conocer las inversiones y gastos que por este concepto realizan.

Artículo 28. Sistemas de gestión y auditoría ambientales.

A fin de promover la mejora continua de los resultados del control de la contaminación atmosférica e incrementar la calidad 
y transparencia de las actuaciones en éste y en todos los campos de la protección ambiental, la Administración pública gallega potenciará la implantación voluntaria en las industrias radicadas en el territorio de la Comunidad Autónoma de sistemas de gestión y auditoría ambiental.

Artículo 29. Otros instrumentos de gestión.

1. Con arreglo a la normativa vigente, se fomentará el establecimiento de pactos y acuerdos entre la administración y los sectores industriales o las empresas en particular para alcanzar niveles crecientes de protección del ambiente atmosférico más allá del marco meramente normativo y se valorarán la asunción de códigos de conducta, planes de medio ambiente o la adopción de buenas prácticas ambientales.

2. En función de las evoluciones de las políticas ambientales, los futuros desarrollos tecnológicos y los condicionantes económicos aplicables, y cuando las circunstancias lo justifiquen, se podrá contemplar la utilización de otros instrumentos económico-financieros.

\section{Sección 2. ${ }^{\text {a }}$}

Instrumentos horizontales de apoyo

Artículo 30. Investigación y desarro1lo científico y técnico.

1. Teniendo en cuenta la problemática relacionada con la contaminación atmosférica en la Comunidad gallega, se fomentarán las acciones de investigación, desarrollo y demostración destinadas al esclarecimiento y solución de tales cuestiones, al desarrollo de tecnologías y productos más respetuosos con el medio ambiente y a la mejora de los existentes. Asimismo, se prestará especial atención a las repercusiones de la contaminación atmosférica sobre la salud humana.

2. Para las actividades referidas en el apartado anterior deberá contarse con la participación de las universidades gallegas, los centros de investigación y, en general, los especialistas de la Comunidad $\mathrm{Au}$ tónoma, fomentando el intercambio de datos y conocimientos con otros centros especializados.

3. La íntima relación de la contaminación atmosférica con la meteorología y con las ciencias experimentales y de la naturaleza justifica la necesidad de desarrollo de acciones prioritarias encaminadas a un mejor conocimiento de la dinámica de la atmósfera en Galicia, el comportamiento de los contaminantes y la interacción de éstos con el medio natural terrestre, fluvial y marino.

4. En estas actuaciones, se aprovechará la experiencia industrial, de modo que, a través de acuerdos voluntarios con las empresas, se facilite la formación de técnicos e investigadores en ciencias ambientales y otras asignaturas afines, se desarrollen programas específicos y, al mismo tempo, pueda abordarse la solución de determinados problemas propios de las industrias.

Artículo 31. Formación y educación ambiental.

1. A fin de crear y mantener una conciencia ambiental positiva en la sociedad, se incorporarán en las correspondientes planificaciones, y desde los primeros niveles de la enseñanza, asignaturas y programas de formación y sensibilización ambiental con aplicación de los aspectos específicos a la Comunidad gallega.

2. Se potenciará la formación de especialistas de distinto nivel en los diferentes campos de actuación del medio ambiente.

3. Tanto en el núcleo básico de la familia como en la escuela, barrios y todo tipo de asociaciones, se promoverán la realización de actividades de divulgación y sensibilización sobre los problemas ambientales de la Comunidad, la importancia de la colaboración ciudadana en su solución o mitigación y las preocupaciones globales de la humanidad. 


\section{Sección $3 .^{a}$}

Planificación territorial y sectorial

Artículo 32. Planificación sectorial y protección integrada del medio ambiente atmosférico.

La Comisión Delegada de Medio Ambiente aprobará la estrategia o estrategias dirigidas a integrar la política de protección atmosférica de la comunidad en el proceso de elaboración y ejecución de las demás políticas y acciones sectoriales. En particular, fomentará las medidas encaminadas a:

a. El fomento del transporte público, en particular el ferroviario, y de los modos de transporte poco contaminantes y de los modos no motorizados; la aprobación de medidas de planificación, a nivel local y regional, para mejorar la gestión del tráfico y la eficacia de las operaciones de transporte por carretera, y el desarrollo de campañas de concienciación y formación de los conductores.

b. La introducción en los instrumentos de ordenación del territorio de las informaciones disponibles sobre el estado del ambiente atmosférico de Galicia a fin de mejorar la calidad del aire y reducir las fuentes de contaminación atmosférica.

c. El desarrollo de una política forestal y de prevención de incendios forestales que destaque la importancia de los bosques como sumideros de contaminación en la lucha frente al cambio climático, y los preserve, en su caso, de la acción de los contaminantes atmosféricos.

d. La promoción y apoyo a las prácticas agrarias y ganaderas más respetuosas con el medio ambiente.

e. El fomento e incentivación de medidas para la reducción y recuperación de los residuos orgánicos y las operaciones de su aprovechamiento energético.

f. La potenciación de medidas para la eficiencia y ahorro energético y la promoción de la utilización de fuentes de energías renovables e instalaciones de cogeneración de energía, así como la disminución del impacto y las emisiones del sector energético.

\section{Capitulo V \\ INFORMACIÓN Y PARTICIPACIÓN EN LA GESTIÓN DEL AMBIENTE ATMOSFÉRICO}

Artículo 33. Derecho a la información sobre la calidad del aire y las emisiones a la atmósfera.

1. Todos los ciudadanos tienen derecho a acceder a una información objetiva y fiel sobre las materias ambientales de la Comunidad Autónoma en los términos establecidos y con las limitaciones impuestas por la legislación vigente.

2. La Administración pública gallega garantizará que periódicamente se difunda a la población, organizaciones interesadas y organismos sanitarios la información actualizada disponible, que resumirá los datos sobre la calidad del aire y de las fuentes de emisión de forma que puedan ser de fácil acceso. Se elaborarán indicadores de información, sencillos y claros, que se harán públicos a través de los distintos medios de comunicación de las zonas correspondientes o mediante paneles informativos en las áreas urbanas, así como por medio de las redes informáticas. En particular, se establecerán procedimientos de comunicación de las eventuales situaciones de alerta.

3. Asimismo, con arreglo a la normativa vigente, se facilitará información a la población y organizaciones interesadas sobre los planes y programas de medidas aprobados en aplicación de la presente ley.

Artículo 34. Informe anual sobre el estado del ambiente atmosférico de Galicia.

1. La Administración pública gallega elaborará anualmente un informe en el que se recoja la información ambiental relevante sobre la situación de la calidad del aire en la Comunidad Autónoma y sobre las emisiones de los distintos contaminantes, 
incluidas las de los gases con efecto invernadero, y sus fuentes, así como sobre las medidas de prevención adoptadas y los progresos alcanzados. Dicho informe se elaborará de acuerdo con las pautas de información requeridas por la Comunidad Europea para sus informes periódicos y por el Estado español.

2. También anualmente se preparará un informe sencillo, conteniendo la información más destacada, y adecuado para una amplia difusión pública.

Artículo 35. Indicadores ambientales. Al objeto de disponer de una información condensada, coherente y comprensible de la situación y evolución de la gestión ambiental en la comunidad, la Administración implantará, previo informe preceptivo del Consello Galego de Medio Ambiente, el uso de indicadores ambientales reconocidos con carácter general y comparables entre sí.

Artículo 36. Participación ciudadana.

1. Se fomentará la participación ciudadana en la elaboración de los planes y programas de medidas previstos en la presente ley y en el diseño de las estrategias ambientales que afecten a la Comunidad Autónoma, teniéndose en cuenta sus opiniones.

2. En el procedimiento de solicitud de autorización de instalaciones o actividades potencialmente contaminantes de la atmósfera se establecerá un período de información pública que, en todo caso, será previo a su resolución por la autoridad competente. Asimismo, la Administración correspondiente pondrá a disposición de la población la decisión autorizatoria y sus posteriores actualizaciones, así como los resultados de la supervisión y vigilancia de las emisiones de dichas actividades.

Lo previsto en este apartado se aplicará sin perjuicio de las limitaciones previstas en la Ley 38/1995, de 12 de diciembre, sobre el Derecho de Acceso a la Información en Materia Ambiental.
3. Con arreglo a la normativa vigente en la Comunidad Autónoma, corresponderán al Consello Galego de Medio Ambiente el conocimiento e información de los proyectos y planes ambientales, así como la propuesta de medidas, el fomento de iniciativas y la realización de sugerencias que tengan por finalidad facilitar el cumplimiento de los objetivos propuestos en la presente ley.

\section{Capítulo VI FUNCIONES DE LAS ADMINISTRACIONES PÚBLICAS}

\section{Sección $1 .^{\mathrm{a}}$}

Funciones de las Administraciones Públicas de Galicia

Artículo 37. Administración Pública de la Xunta de Galicia.

1. Corresponden a la Consellería de Medio Ambiente, además de las ya señaladas específicamente en la presente ley y sin perjuicio de las atribuciones que le otorga la legislación ambiental, industrial y de actividades, las siguientes funciones:

a. La elaboración del Mapa de cargas y niveles críticos de Galicia previsto en el artículo 12 de la presente ley, cuya aprobación corresponderá al Gobierno de la Xunta de Galicia.

b. El establecimiento de los niveles de emisión o inmisión de los contaminantes atmosféricos y las normas técnicas relacionadas con su aplicación, así como la reglamentación de los métodos de medición y análisis y de los sistemas de control de los niveles de emisión de las actividades potencialmente contaminadoras de la atmósfera. Para la fijación de los límites de inmisión se tendrán en cuenta los factores previstos en el apartado 4 del anexo.

c. La delimitación de las zonas y aglomeraciones con especiales exigencias de vigilancia y control, y la formulación y aprobación, en su caso, de los planes de actuación correspondientes. 
d. El establecimiento y gestión de la red general de vigilancia de la calidad del aire de Galicia.

e. La puesta en marcha de medidas y actuaciones para la aplicación de técnicas de reducción en origen de las emisiones, a fin de lograr un alto nivel de protección del ambiente atmosférico, con especial atención a los gases de efecto invernadero y a las sustancias destructoras de la capa de ozono.

f. El desarrollo de la inspección y control de las actividades potencialmente contaminadoras de la atmósfera. dora.

g. El ejercicio de la potestad sanciona-

2. Corresponden a la Consellería de Sanidade:

a. La vigilancia epidemiológica del impacto de la contaminación atmosférica sobre la población.

b. El análisis y difusión de la información a la población sobre los efectos de la contaminación atmosférica en la salud.

c. La planificación, programación y evaluación de las actividades de protección frente a los factores de riesgo ocasionados por la contaminación atmosférica.

d. La elaboración del informe vinculante que corresponda con respecto a los valores de inmisión de los contaminantes atmosféricos y a las normas técnicas relacionadas con su aplicación.

3. Corresponderá al Comité Galego de Integración e Coordinación Ambiental la coordinación entre los distintos departamentos de la Administración autonómica.

Artículo 38. Municipios.

Corresponde a las corporaciones locales, en su ámbito territorial y sin perjuicio de las atribuciones que les otorga la legislación ambiental, industrial y de actividades:

a. Aprobar las ordenanzas correspondientes, o adaptar las ya existentes, de acuerdo con las finalidades y medidas previstas en la presente ley, previo informe de la Consellería de Medio Ambiente. b. Comprobar y exigir que los proyectos técnicos que acompañen a la solicitud de licencia municipal para ejercer actividades clasificadas potencialmente como contaminadoras de la atmósfera contengan las determinaciones mínimas establecidas reglamentariamente, sin detrimento de lo que determine la Consellería de Medio Ambiente a través de las figuras de protección ambiental.

c. Adoptar provisionalmente medidas en la situación de alerta atmosférica.

d. Implantar y gestionar las estaciones de vigilancia de la calidad del aire, precisas de conformidad con lo establecido en la presente ley, en los núcleos urbanos del término municipal, con la ayuda y asesoramiento técnicos de la Consellería de Medio Ambiente.

e. Imponer las sanciones en los supuestos previstos por la presente ley.

f. Adaptar los planes de ordenación urbanística del municipio a las prescripciones de la presente ley o a las que resulten del Mapa previsto en el artículo 12.

g. Establecer el control sanitario sobre industrias, actividades y servicios y transportes, en relación con la contaminación atmosférica.

h. Participar con la Administración de la Xunta de Galicia en la elaboración de los instrumentos de planificación ambiental, los procedimientos y las acciones previstas en la presente ley, a través del Comité Galego de Integración e Coordinación Ambiental.

\section{Sección 2. ${ }^{\mathrm{a}}$}

\section{Relaciones interadministrativas}

Artículo 39. Colaboración y coordinación.

1. La Xunta de Galicia y las administraciones locales gallegas, en colaboración con la Administración del Estado y otras Comunidades Autónomas, ejercerán sus competencias al objeto de alcanzar los objetivos previstos en la presente ley. 
2. A fin de asegurar la coherencia y efectividad de las acciones destinadas a la protección del ambiente atmosférico de Galicia, se atribuye a la Xunta de Galicia la coordinación de la actividad de las Administraciones locales en el ejercicio de aquellas competencias que trasciendan a los intereses locales y estén comprendidas dentro de los objetivos de la presente ley.

3. A través del Comité Galego de Integración e Coordinación Ambiental, dependiente de la Consellería de Medio Ambiente, se impulsará la coordinación administrativa, se formularán sugerencias y se elaborarán propuestas para la mejora de la protección del ambiente atmosférico de Galicia.

Artículo 40. Comunicación e información.

1. Se instrumentalizarán cauces de comunicación para facilitar de forma normalizada, coherente y rápida la información sobre la calidad ambiental y las incidencias relevantes a los organismos del Estado y, en su caso, de la Unión Europea.

2. La Comunidad Autónoma y los municipios podrán, mutuamente, solicitar y obtener información concreta sobre la actividad de cada administración en materia de contaminación atmosférica. En particular, cuando las corporaciones locales adopten cualquier medida destinada a la protección o mejora de la calidad del aire y cuando inicien un expediente sancionador en aplicación de la presente ley deberán comunicarlo a la Consellería de Medio Ambiente.

Artículo 41. Auxilio. Convenios con los municipios.

En caso de que los municipios no cuenten con los medios técnicos o personales necesarios para cumplir las funciones y competencias que la presente ley les atribuye, podrán reclamar el auxilio de la Administración autonómica. Para formalizar esta colaboración podrá subscribirse, en su caso, un convenio de cooperación entre ambas administraciones.

\section{Capitulo VII DISCIPLINA AMBIENTAL \\ Sección $1 .^{\mathrm{a}}$ \\ Inspección}

Artículo 42. Potestad de inspección.

1. Los alcaldes, en aquellos casos en los que así lo recoja la normativa, y los órganos competentes de la Administración ambiental de Galicia en materia de protección del ambiente atmosférico tienen la potestad de inspección de las actividades potencialmente contaminadoras de la atmósfera radicadas en el ámbito de la Comunidad Autónoma de Galicia. Dicha potestad es ejercida por el personal al servicio de la respectiva Administración debidamente acreditado. Deben establecerse los medios de coordinación necesarios para lograr un eficaz ejercicio de la potestad de inspección de las distintas Administraciones públicas.

2. Para el ejercicio de las funciones de inspección en materia de contaminación atmosférica se estará a lo dispuesto en la Ley 1/1995, de 2 de enero, de Protección del Medio Ambiente, y a la normativa reglamentaria de desarrollo.

3. La Xunta de Galicia podrá otorgar determinadas facultades de auxilio y control a entidades públicas o privadas debidamente acreditadas y habilitadas al respecto por la Consellería de Medio Ambiente, estableciéndose reglamentariamente las funciones que se van a desarrollar y los requisitos para su ejercicio.

Artículo 43. Homologación de los procedimientos de toma de muestras y mediciones.

1. La Consellería de Medio Ambiente establecerá las especificaciones técnicas que deben cumplir los aparatos de toma de muestra, análisis y medición de contaminantes. La contrastación o calibrado periódicos de los mismos deben ser realizados por laboratorios oficialmente acreditados.

2. El análisis de las muestras de gases o de cualquier otro material o producto que 
no pueda ser llevado a cabo en el acto de inspección será realizado por laboratorios debidamente acreditados por la Consellería de Medio Ambiente.

3. El titular o representante de la empresa que participa en el acto de inspección podrá solicitar la acreditación del cumplimiento de los requisitos señalados en los apartados anteriores, así como los datos técnicos del muestreo y la identificación del laboratorio que debe llevar a cabo el análisis y el sistema analítico al que debe someterse la muestra.

4. Los resultados del análisis y medición que se obtengan siguiendo el sistema fijado en los apartados anteriores tienen valor probatorio, sin perjuicio de otras pruebas que pueda aportar el interesado.

\section{Sección 2. ${ }^{\mathrm{a}}$}

Infracciones y sanciones

\section{Artículo 44. Responsabilidades.}

1. Las infracciones cometidas por acción u omisión, que contravengan lo dispuesto en la presente ley, se sancionarán de conformidad con el presente capítulo, siguiendo previamente el procedimiento sancionador que se establezca por ley o reglamento, sin perjuicio de las posibles responsabilidades civiles o penales que puedan derivarse y de la restauración del medio ambiente y los recursos naturales afectados.

2. Cuando no sea posible determinar el grado de participación de las personas, físicas o jurídicas, que hubiesen intervenido en la realización de la infracción, la responsabilidad será solidaria, sin perjuicio de las acciones contra los demás participantes por aquellos que hubiesen hecho frente a la responsabilidad común.

Artículo 45. Infracciones administrativas.

1. Las infracciones administrativas a las disposiciones de la presente ley se clasifican en muy graves, graves y leves.

2. Son infracciones muy graves:

a. Emitir contaminantes a la atmósfera superando los límites de emisión legalmente permitidos cuando se originan daños o perjuicios reales o potenciales para la salud de las personas o el medio ambiente.

b. Poner en funcionamiento actividades o instalaciones potencialmente contaminadoras incumpliendo órdenes de suspensión o clausura o vulnerando los preceptos legales.

c. Reincidir en faltas graves.

3. Son infracciones graves:

a. Ejercer actividades potencialmente contaminadoras de la atmósfera sin disponer de la licencia municipal de actividades o autorización equivalente.

b. Ejercer actividades potencialmente contaminadoras de la atmósfera incumpliendo las condiciones o medidas impuestas en las autorizaciones o licencias ambientales.

c. Emitir contaminantes a la atmósfera superando los límites de emisión legalmente autorizados.

d. Negarse a instalar, a poner en funcionamiento y a mantener en perfecto estado de servicio los aparatos de control y medición de emisiones o inmisiones, o realizarlos con retraso.

e. Impedir u obstaculizar los actos de inspección y control reglamentarios u ordenados por las autoridades competentes.

f. Ocultar o alterar los datos, informes o documentos de aportación obligatoria solicitados por la Administración.

g. Incumplir las medidas específicamente previstas para las actividades contaminadoras contenidas en los diferentes planes de protección del ambiente atmosférico previstos en la presente ley.

h. Reincidir en faltas leves.

4. Son infracciones leves:

a. Incurrir en demora no justificada en la aportación obligatoria de datos, informes o documentos solicitados por la Administración.

b. No someterse a los controles periódicos establecidos por reglamento o fijados en la licencia municipal de actividades o autorización equivalente.

c. Emitir, mediante vehículos de motor o actividades domésticas y de servicios, 
contaminantes a la atmósfera de forma que superen los límites de emisión legalmente establecidos.

d. Incurrir en cualquier otra acción u omisión que infrinja las determinaciones de la presente ley y la reglamentación que la desarrolle y que no sea cualificada como infracción grave o muy grave.

Artículo 46. Medidas cautelares.

1. Simultáneamente a la incoación del procedimiento sancionador o en cualquier momento de su curso, puede acordarse, como medida cautelar, el precintado de generadores de calor y vehículos de motor, la suspensión o clausura de la actividad o cualquier otra medida dirigida a la protección del ambiente atmosférico.

2. Antes de la incoación del procedimiento sancionador el órgano competente, de oficio o a instancia de parte, en los casos de urgencia y para la protección de los intereses implicados, podrá adoptar con carácter provisional las medidas previstas en el apartado anterior.

Artículo 47. Sanciones económicas.

1. Por la comisión de las infracciones administrativas previstas en la presente ley podrán imponerse las siguientes sanciones económicas:

a. Para las infracciones muy graves: Multa de entre 60.001 y 1.200 .000 euros, si se trata de actividades industriales.

Multa de entre 12.001 y 60.000 euros, si se trata de actividades urbanas no industriales y del transporte.

b. Para las infracciones graves:

Multa de entre 6.000 y 60.000 euros, si se trata de actividades industriales.

Multa de entre 301 y 12.000 euros, si se trata de actividades urbanas no industriales y del transporte.

c. Para las infracciones leves:

Multa de entre 301 y 6.000 euros, si se trata de actividades industriales.

Multa de entre 150 y 300 euros, si se trata de actividades urbanas no industriales y del transporte.
2. En caso de que la infracción se produzca en zonas o aglomeraciones sometidas a los planes de saneamiento previstos en la presente ley o bajo la declaración de alerta atmosférica, la cuantía de la multa puede imponerse hasta el doble o el triple, respectivamente.

3. La sanción consistente en una multa impuesta por el incumplimiento de los niveles de emisión establecidos supone el requerimiento de la reducción de las emisiones a los límites admitidos en el plazo que se señale en la resolución sancionadora.

Artículo 48. Graduación de las multas. En la graduación de la multa deberán tenerse en cuenta:

1. La naturaleza de la actividad o instalación de que se trate.

2. Las circunstancias y el grado de culpa del responsable.

3. La reiteración.

4. La participación y el beneficio obtenido.

5. El grado de incidencia o riesgo de daño a la salud humana, al medio ambiente o a los recursos naturales.

Artículo 49. Sanciones accesorias.

1. La imposición de multas será compatible con la imposición de las siguientes sanciones:

a. En caso de infracción muy grave:

El precintado de los generadores de calor y los vehículos y el cierre del establecimiento o la suspensión de la actividad, total o parcial, por un plazo no superior a cuatro años y, en todo caso, hasta la adopción de las medidas correctoras.

La clausura definitiva, total o parcial, del establecimiento o actividad.

b. En casos de infracción grave, el precintado de los generadores de calor y los vehículos y el cierre del establecimiento o la suspensión de la actividad, total o parcial, por un plazo no superior a dos años. En caso de que se impongan medidas correctoras, el cierre o la suspensión subsistirá hasta que éstas se cumplan. 
En caso de ser inviables las aludidas medidas correctoras, podrá decidirse la clausura definitiva, total o parcial, del establecimiento o actividad.

2. En el supuesto de sanción que implique el cierre del establecimiento o la suspensión de la actividad se computará, en la sanción definitiva, el tiempo que estuviese cerrado o suspendido como medida cautelar.

3. El órgano que ejerza la potestad sancionadora podrá acordar la publicación, en el diario oficial correspondiente y a través de los medios de comunicación que considere oportunos, de las sanciones impuestas por la comisión de infracciones graves y muy graves, así como los nombres y apellidos o razón social de las personas físicas o jurídicas responsables, una vez que dichas sanciones adquieran el carácter de firmes. En todo caso, las sanciones que supongan la suspensión de actividades o el cierre de establecimientos habrán de ser publicadas en el "Diario Oficial de Galicia”.

Artículo 50. Prohibición de establecer contratos y de obtener subvenciones.

Las empresas que hubiesen sido sancionadas por faltas graves y muy graves derivadas del incumplimiento de lo dispuesto en la presente ley no podrán contratar ni obtener subvenciones de las administraciones públicas hasta la ejecución de las medidas correctoras pertinentes y hasta la satisfacción de la sanción.

Artículo 51. Competencia para imponer las sanciones.

La competencia para la imposición de sanciones corresponderá:

1. A los alcaldes, si la sanción supone el precintado de generadores de calor domésticos, de oficinas y de servicios, así como el precintado de vehículos de motor.

2. A los alcaldes de municipios de menos de 20.000 habitantes y a los Delegados provinciales de la Consellería de Medio
Ambiente, si la cuantía de la multa no excede de 12.000 euros.

3. A los alcaldes de municipios de más de 20.000 habitantes, si la cuantía de la multa no excede de 60.000 euros.

4. Al Director general de Calidad y Evaluación Ambiental, si la cuantía de la multa excede de 12.000 euros y no pasa de 60.000 euros.

5. Al Conselleiro de Medio Ambiente, si la cuantía de la sanción excede de 60.000 euros o supone la suspensión o clausura temporal de la actividad.

6. Al Consello de la Xunta de Galicia, si la sanción supone la suspensión o clausura definitiva de la actividad.

Artículo 52. Restauración del medio e indemnización.

1. Sin perjuicio de la sanción que en cada caso proceda, el infractor habrá de reparar el daño causado. La reparación y reposición de los bienes tendrán como finalidad lograr la restauración del medio ambiente a su estado anterior a la comisión de la infracción. El órgano correspondiente de la Administración competente para imponer la sanción lo será para exigir la restauración.

2. Si el infractor no procediese a reparar el daño causado en el plazo que se le señale, la Administración que impuso la sanción procederá a la imposición de multas coercitivas sucesivas de hasta un tercio de la sanción económica impuesta cada una o, en su caso, a realizar la ejecución subsidiaria en los términos previstos en la Ley de Régimen Jurídico de las Administraciones Públicas y del Procedimiento Administrativo Común.

3. Cuando la reparación del daño o reposición de los bienes no fuese posible, el órgano sancionador competente podrá ordenar la reparación por su equivalente económico.

4. En el supuesto previsto en el apartado anterior, para fijar la indemnización se tendrán en cuenta los siguientes criterios, 
debiendo aplicarse el que proporcione el mayor valor:

a. Coste teórico de la restitución o reposición.

b. Valor de los bienes dañados.

c. Beneficio obtenido por el infractor con la actividad ilegal.

\section{Sección $3 .^{\mathrm{a}}$}

\section{Régimen de recursos}

Artículo 53. Recursos administrativos.

1. Sin perjuicio de un ulterior recurso ante los órganos de la jurisdicción contencioso-administrativa, contra los actos administrativos sancionadores resultado de la aplicación de este capítulo puede recurrirse, en la forma y plazos establecidos por las disposiciones de procedimiento administrativo vigentes en Galicia, del siguiente modo:

a. Contra las resoluciones de los Delegados provinciales de la Consellería de Medio Ambiente podrá interponerse recurso de alzada ante el Director general de Calidad y Evaluación Ambiental.

b. Contra las resoluciones que no ponen fin a la vía administrativa dictadas por el Director general de Calidad y Evaluación Ambiental podrá interponerse recurso de alzada ante el Conselleiro de Medio Ambiente.

c. Las resoluciones del Consello de la Xunta de Galicia, del Conselleiro de Medio Ambiente y de los alcaldes ponen fin a la vía administrativa.

2. La determinación de las medidas correctoras que haya que imponer a cualquiera de los focos emisores es, en todos los casos, de exclusiva competencia de la Administración, sin perjuicio de que sea objeto de revisión ante la jurisdicción contencioso-administrativa.

Artículo 54. Acción pública.

Será pública la acción para exigir ante los Tribunales la observancia de lo establecido en la presente ley y en las disposiciones que se dicten en su desarrollo y aplicación.

\section{DISPOSICIÓN ADICIONAL PRIMERA}

En lo que no esté regulado en la presente ley será de aplicación lo dispuesto en la Ley $1 / 1995$, de 2 de enero, de Protección Ambiental de Galicia, y el Decreto 156/1995, de 3 de junio, de Inspección Ambiental, así como el capítulo II del título IX de la Ley 30/1992, de 26 de noviembre, de Régimen Jurídico de las Administraciones Públicas y del Procedimiento Administrativo Común, y su Reglamento de desarrollo sobre el ejercicio de la potestad sancionadora.

\section{DISPOSICIÓN ADICIONAL SEGUNDA}

Todas las referencias que realiza la presente ley a la Administración pública gallega deben entenderse hechas a la Consellería de Medio Ambiente.

\section{DISPOSICIÓN ADICIONAL TERCERA}

La red general de vigilancia de la calidad del aire de Galicia será gestionada por el Laboratorio de Medio Ambiente de Galicia, dependiente orgánicamente de la Dirección General de Calidad y Evaluación Ambiental de la Consellería de Medio Ambiente.

\section{DISPOSICIÓN TRANSITORIA PRIMERA}

A fin de facilitar la actuación de control de las emisiones, y para disponer cuanto antes de inventarios actualizados, el órgano competente de la Consellería de Medio Ambiente debe ordenar a los titulares de las empresas con actividades potencialmente contaminantes de la atmósfera existentes a la entrada en vigor de la presente ley que adecuen los sistemas de toma de muestras de sus instalaciones a equipos y procedimientos disponibles comercialmente que permitan una evaluación representativa y fiable de las emisiones a la atmósfera.

\section{DISPOSICIÓN TRANSITORIA SEGUNDA}

Los titulares de las actividades potencialmente contaminadoras de la atmósfera 
existentes en la fecha de entrada en vigor de la presente ley disponen de un plazo de dos años, a partir de dicha fecha, para hacer efectivas las medidas correctoras necesarias para el cumplimiento de los valores límite de emisión exigibles por la normativa.

\section{DISPOSICIÓN TRANSITORIA TERCERA}

La Consellería de Medio Ambiente elaborará en el plazo de dos años el inventario de las fuentes de emisión, conforme a lo establecido en el artículo 17.

\section{DISPOSICIÓN DEROGATORIA ÚNICA}

Queda derogada cualquier norma de igual o inferior rango que contravenga o se oponga a lo establecido en la presente ley.

\section{DISPOSICIÓN FINAL PRIMERA}

En el plazo máximo de un año, la Consellería de Medio Ambiente dictará las normas necesarias para estructurar y regular la gestión y el funcionamiento de la red general de vigilancia de la calidad del aire de Galicia.

\section{DISPOSICIÓN FINAL SEGUNDA}

De forma inmediata y por aplicación del Decreto de creación de la Consellería de Medio Ambiente, la Consellería de Sanidade incorporará a la red general de vigilancia de la calidad del aire de Galicia todas las estaciones sensoras existentes en la actualidad y procederá a la transferencia de los recursos financieros correspondientes.

\section{DISPOSICIÓN FINAL TERCERA}

En el plazo máximo de un año, la Consellería de Medio Ambiente elaborará el Mapa de cargas y niveles críticos de Galicia, conforme a lo establecido en el artículo 12.

\section{DISPOSICIÓN FINAL CUARTA}

Se habilita al Consello de la Xunta de Galicia para adaptar el anexo de la presente ley a las determinaciones que resulten de la normativa básica estatal o de la Unión Europea.

\section{DISPOSICIÓN FINAL QUINTA}

Se habilitan al Consello de la Xunta de Galicia y al Conselleiro de Medio Ambiente para que, en el plazo de un año, dicten las disposiciones necesarias para el desarrollo y aplicación de la presente Ley.

\section{DISPOSICIÓN FINAL SEXTA}

La presente ley entrará en vigor a los treinta días de su publicación en el "Diario Oficial de Galicia".

$(\ldots)^{474}$

\section{LEY 7/1997, DE 11 DE AGOSTO, DE PROTECCIÓN CONTRA LA CONTAMINACIÓN ACÚSTICA (DOGA N. $^{\circ} 159,20.8$. 1997) ${ }^{475}$}

\section{$(\ldots)^{476}$ TÍTULO I DISPOSICIONES GENERALES}

Artículo 1. Objeto de la ley. La presente ley tiene por objeto la protección de las personas contra los ruidos y vibraciones imputables a cualquier causa. Los ciudadanos tienen derecho a disfrutar de su intimidad y de un entorno adecuado para el normal desarrollo de sus actividades, sin ser perturbados por ruidos o vibraciones que puedan dañar su salud u ocasionarles molestias.

Las Administraciones públicas competentes adoptarán las medidas precisas para el cumplimiento de lo dispuesto en la presente ley, de oficio o a demanda de los ciudadanos.

Artículo 2. Ámbito de la ley.

1. Quedan sometidas a las prescripciones establecidas en la presente ley las actividades, instalaciones y comportamientos que

474 Anexo suprimido.

475 Véase Decreto 150/1999, de 7 de mayo, por el que se aprueba el Reglamento de protección contra la contaminación acústica.

476 Exposición de motivos omitida. 
generen ruidos o vibraciones susceptibles de producir molestias, y se encuentren emplazadas o se ejerzan en el territorio de la Comunidad Autónoma de Galicia.

2. Igualmente, las prescripciones establecidas en la presente ley se aplicarán a todos los elementos constructivos constituyentes de la edificación, en tanto en cuanto facilitan o dificultan la transmisión de los ruidos y vibraciones producidos en su entorno.

Artículo 3. Competencia administrativa.

1. Corresponde a los Ayuntamientos dictar ordenanzas sobre ruidos y vibraciones.

2. Corresponde a la Xunta de Galicia:

a. La asistencia y el control de la Administración municipal, en el ejercicio de sus competencias y en los términos previstos en el título $\mathrm{V}$ de la presente ley.

b. Dictar los Reglamentos que sean necesarios para garantizar la aplicación homogénea de la presente ley en todo el territorio de la Comunidad Autónoma de Galicia.

c. Dictar Reglamentos de desarrollo de la presente ley que sean de aplicación en aquellos municipios de la Comunidad Autónoma de Galicia que no tengan aprobadas ordenanzas municipales sobre ruido y vibraciones 477 .

\section{TÍTULO II RÉGIMEN JURÍDICO DE LAS ACTIVIDADES SUSCEPTIBLES DE PRODUCIR RUIDOS Y VIBRACIONES \\ Capítulo I NORMAS GENERALES}

Artículo 4. Regulación del ruido de las actividades relacionadas con los usos productivo y terciario, y con el equipamiento.

1. Todas las actividades susceptibles de producir ruidos y vibraciones quedan sometidas a lo dispuesto en este título.

477 Véase Decreto 320/2002, de 7 de noviembre, por el que se aprueba el Reglamento que establece las ordenanzas tipo sobre protección contra la contaminación acústica.
2. En todo caso, la transmisión de ruidos y vibraciones originados como consecuencia de aquellas actividades deberá ajustarse a los límites establecidos en el título II del anexo de la presente ley. Los titulares de dichas actividades estarán obligados a adoptar las medidas de insonorización de sus fuentes sonoras y de aislamiento acústico de los locales para cumplir en cada caso las prescripciones establecidas.

3. Las actividades que produzcan una perturbación por ruidos o vibraciones deberán someterse al procedimiento de evaluación de incidencia ambiental.

4. A los efectos de lo dispuesto en el párrafo anterior, todos los proyectos de obras o instalaciones industriales, comerciales y de servicios que puedan provocar ruidos o vibraciones se acompañarán de un estudio justificativo del cumplimiento de las medidas establecidas en la presente ley, en sus Reglamentos de desarrollo y en las ordenanzas municipales sobre esta materia. Dicho estudio se ajustará a lo dispuesto en los Reglamentos que desarrolle la presente ley.

En el control del visado los Colegios profesionales comprobarán que los proyectos se ajusten a la presente ley, a su normativa de desarrollo reglamentario y a las ordenanzas municipales correspondientes.

5. La autoridad municipal no otorgará licencia de apertura de las instalaciones, actividades o establecimientos sometidos a lo dispuesto en la presente ley si los proyectos presentados por los interesados no se ajustan a lo dispuesto en la misma. No se podrá iniciar la actividad o poner en funcionamiento las instalaciones en tanto que no esté comprobado, por los órganos inspectores o mediante certificación expedida por empresas o entidades homologadas, que se cumple la normativa sobre contaminación acústica.

6. En las licencias de apertura y en las declaraciones de incidencia ambiental 
deberán señalarse las medidas correctoras y los controles que habrán de cumplir las actividades e instalaciones, indicándose expresamente que el incumplimiento de las mismas puede dar lugar a la revocación de aquellas licencias o autorizaciones.

7. Una vez iniciada la actividad o puestas en funcionamiento las instalaciones, también podrán realizarse inspecciones para comprobar que las actividades e instalaciones cumplen la normativa. Como consecuencia de las mismas, podrán incoarse los correspondientes procedimientos sancionadores o bien acordar medidas correctoras o de control.

Las comprobaciones a que se refiere este artículo se regirán por lo dispuesto en la legislación ambiental de Galicia.

8. Todas las obras, instalaciones o actividades que, de conformidad con lo dispuesto en la normativa estatal básica sobre la materia y en la Ley de Protección Ambiental de Galicia, estén sometidas a un procedimiento de evaluación de impacto ambiental o de evaluación de efectos ambientales deberán contener un estudio acreditativo de su impacto acústico. En la declaración que se dicte, que tendrá carácter vinculante, deberán imponerse las medidas correctoras precisas.

\section{Capitulo II TRÁFICO}

Artículo 5. Regulación del ruido del tráfico.

1. Todo vehículo de tracción mecánica deberá tener en buenas condiciones de funcionamiento el motor, la transmisión, la carrocería y los demás órganos capaces de producir ruidos, a fin de que el nivel sonoro emitido por el vehículo al circular con el motor en marcha no exceda de los límites que establece la presente ley.

2. Los límites máximos admisibles para ruidos emitidos por los distintos vehículos a motor en circulación serán los establecidos para las emisiones de vehículos terrestres, así como para las emisiones de aeronaves, en la legislación estatal vigente.

3. En los casos en que se afecte notoriamente a la tranquilidad de la población, el Ayuntamiento podrá señalar zonas o vías en las que algunas clases de vehículos a motor no puedan circular o deban hacerlo de forma restringida en horario y velocidad. A efectos de lo establecido en el párrafo anterior, se consideran las zonas que soporten un nivel de ruido, debido al tráfico rodado, que alcance valores de nivel continuo equivalente (L) superior a $55 \mathrm{~dB}$ durante el período nocturno y a 65 $\mathrm{dB}$ en el período diurno.

\section{Capítulo III EDIFICACIÓN}

Artículo 6. Regulación del ruido en la edificación.

1. Las condiciones acústicas exigibles a los diversos elementos constructivos que componen la edificación serán las determinadas en el capítulo III de la Norma básica de Edificación sobre Condiciones Acústicas (NBE-CA-88).

2. Se excluyen del apartado anterior los forjados constitutivos de la primera planta de la edificación, cuando dicha planta sea de uso residencial y en la planta baja puedan localizarse, con arreglo al planeamiento, usos susceptibles de producir molestias por ruidos o vibraciones.

En estos casos, el aislamiento acústico bruto a ruido aéreo exigible será de, al menos, $55 \mathrm{~dB}(\mathrm{~A})$.

3. Los aparatos elevadores, las instalaciones de ventilación y acondicionamiento de aire y sus torres de refrigeración, la distribución y evacuación de aguas, la transformación de energía eléctrica y demás servicios de los edificios serán instalados con las precauciones de localización y aislamiento que garanticen un nivel de transmisión sonora a los locales y ambientes próximos que cumpla con lo 
dispuesto en el título II del anexo de la presente ley.

4. A fin de evitar en lo posible la transmisión de ruido a través de la estructura de la edificación, deberán como mínimo tenerse en cuenta las normas establecidas en los siguientes apartados:

1) Todo elemento con órganos móviles se mantendrá en perfecto estado de conservación, principalmente en lo que se refiere a la suavidad de sus rodamientos.

2) No se permitirá el anclaje directo de máquinas o soportes de las mismas en las paredes medianeras, techos o forjados de separación de recintos, sino que se realizará interponiendo los adecuados dispositivos antivibratorios.

3) Las máquinas de arranque violento, las que trabajen por golpes o choques bruscos y las dotadas de órganos con movimiento alternativo deberán estar ancladas en bancadas independientes, sobre el suelo y aisladas de la estructura de la edificación por medio de los adecuados antivibradores.

4) Los conductos por los que circulen fluidos líquidos o gaseosos en forma forzada, conectados directamente con máquinas que tengan órganos en movimiento, dispondrán de dispositivos de separación que impidan la transmisión de las vibraciones generadas en tales máquinas. Las bridas y los soportes de los conductos tendrán elementos antivibratorios. Las aberturas de los muros para el paso de las conducciones se dotarán de materiales antivibratorios.

5) En los circuitos de agua se evitará la producción de los golpes de elevadores hidráulicos, y las secciones y disposición de las válvulas y grifería deberán ser tales que el fluido circule por las mismas en régimen laminar para los gastos nominales.

5. A partir de la presentación del correspondiente certificado de fin de obra, el Ayuntamiento comprobará el cumplimiento de las prescripciones establecidas en este título. Tal cumplimiento podrá acreditarse mediante certificación expedida por empresas o entidades homologadas. Sin el informe favorable sobre el cumplimiento de los requisitos acústicos exigidos no se concederá la licencia de primera utilización.

\section{Capítulo IV ACTIVIDADES VARIAS}

Artículo 7. Regulación del ruido para actividades varias.

1. Con carácter general no se permitirá el empleo de ningún dispositivo sonoro con fines de propaganda, reclamo, aviso o esparcimiento.

Esta prohibición no regirá en los casos de alarma, urgencia o especial significación ciudadana, determinada por los Ayuntamientos.

2. En los trabajos realizados tanto en la vía pública como en la edificación no se autorizará el empleo de maquinaria cuyo nivel de emisión externo (NEE) sea superior a $90 \mathrm{~dB}(\mathrm{~A})$, medido en la forma que se fije reglamentariamente.

3. Los trabajos realizados tanto en la vía pública como en la edificación no podrán realizarse entre las veintidós horas y las ocho horas del día siguiente si producen niveles sonoros superiores a los establecidos con carácter general en el título II del anexo de la presente ley.

4. Se exceptúan de la prohibición anterior las obras urgentes, las que se realicen por razones de necesidad o peligro y aquellas que por sus inconvenientes no puedan llevarse a cabo durante el día. El trabajo nocturno deberá ser expresamente autorizado por el Ayuntamiento, que determinará los límites sonoros que habrá de cumplir en función de las circunstancias que concurran en cada caso, sin perjuicio de lo establecido en la legislación laboral.

5. Cuando el anormal funcionamiento de un sistema de alarma produzca molestias al vecindario y no sea posible localizar al responsable o titular de dicha instalación, el órgano municipal competente, 
en cumplimiento de lo dispuesto en el artículo 20 de la presente ley, procederá a desmontar y retirar el sistema de alarma.

6. Cualquier otra actividad que implique una perturbación por ruidos del vecindario se entenderá incursa en el régimen sancionador de la presente ley.

\section{TÍTULO III RÉGIMEN JURÍDICO \\ Capítulo I DISPOSICIONES GENERALES}

Artículo 8. Remisión normativa.

Será de aplicación a esta materia lo dispuesto en la Ley 1/1995, de 2 de enero, de Protección Ambiental de Galicia, y en el Decreto 156/1995, de 3 de junio, de Inspección Ambiental, así como en el capítulo II del título IX de la Ley 30/1992, de 26 de noviembre, de Régimen Jurídico de las Administraciones Públicas y del Procedimiento Administrativo Común, y en el Real Decreto 1398/1993, de 4 de agosto, por el que se aprueba el Reglamento de Procedimiento para el Ejercicio de la Potestad Sancionadora.

\section{Capitulo II \\ INSPECCIÓN Y VIGILANCIA}

Artículo 9. Inspección.

Corresponde a los Ayuntamientos ejercer el control del cumplimiento de la presente ley, exigir la adopción de medidas correctoras necesarias, señalar limitaciones, realizar cuantas inspecciones se requieran y aplicar las sanciones correspondientes en caso de incumplimiento. Cuando para la realización de inspecciones sea necesario entrar en un domicilio, será preceptiva la correspondiente autorización judicial. En los demás supuestos, los funcionarios municipales a quienes competa la inspección de las instalaciones o establecimientos estarán facultados para acceder, en su caso, a los mismos sin previo aviso y siempre que se identifiquen. La Administración local desarrollará su propia inspección en orden al correcto ejercicio de su competencia en el marco de la presente ley y demás normas reguladoras del régimen local.

No obstante, cuando la Administración local se considere imposibilitada para el ejercicio de la competencia de inspección, ésta podrá solicitar el auxilio en tal función a la Administración autonómica o empresas habilitadas al respecto por la Xunta de Galicia, de acuerdo con lo estipulado en el artículo 25 de la presente ley.

Artículo 10. Denuncias.

Las visitas de inspección podrán llevarse a cabo por propia iniciativa municipal o por solicitud previa de cualquier interesado. Las solicitudes contendrán, además de los datos exigibles en la legislación que regula el procedimiento administrativo, los datos precisos para la realización de la visita de inspección. En los casos de reconocida urgencia, cuando los ruidos resulten altamente perturbadores o cuando sobrevengan ocasionalmente por uso abusivo, deterioro o deficiente funcionamiento de las instalaciones, aparatos o equipos, la solicitud de visita de inspección podrá formularse directamente ante los servicios de inspección, tanto de palabra como por escrito.

Artículo 11. Actas de inspección.

Las visitas de inspección se realizarán teniendo en cuenta las características del ruido y vibraciones, y, a tal fin, las mediciones relativas a ruido objetivo se realizarán previa citación al responsable del foco ruidoso, y las mediciones relativas a ruido subjetivo podrán practicarse sin el conocimiento del titular, sin perjuicio de que en este caso pueda ofrecerse al responsable del foco ruidoso una nueva medición en su presencia para su conocimiento. En todo caso, concluidas las mediciones, se entregará a los interesados una copia del resultado de éstas. Las actas emitidas por los órganos competentes gozan de presunción de veracidad en cuanto a los hechos contenidos en 
las mismas y constituyen prueba suficiente a los efectos del correspondiente procedimiento sancionador. Tal presunción se extiende a las mediciones realizadas con instrumentos que reúnan los requisitos reglamentariamente establecidos. En tales mediciones, tanto la autoridad competente como el responsable sobre el que recaiga la inspección podrán solicitar la asistencia de empresas o entidades debidamente homologadas, de acuerdo con lo que se disponga en los Reglamentos de desarrollo y ordenanzas municipales. Los Ayuntamientos establecerán en sus ordenanzas el tipo de aparatos homologados para la realización de las mediciones.

\section{Capítulo III INFRACCIONES Y SANCIONES}

Artículo 12. Clasificación de infracciones y sanciones.

Se considerarán infracciones administrativas las acciones $\mathrm{u}$ omisiones que contravengan las disposiciones de la presente ley. Las infracciones se clasifican en leves, graves y muy graves, de conformidad con la tipificación contenida en los artículos siguientes.

Artículo 13. Faltas leves.

Constituye falta leve:

a. La superación de los límites admitidos hasta $5 \mathrm{~dB}(\mathrm{~A})$.

b. La transmisión de niveles de vibración correspondientes a la curva base inmediatamente superior a la máxima admitida para cada situación.

c. Cualquier otra infracción a las normas de la presente ley no calificada expresamente como falta grave o muy grave.

d. La realización de las actividades no permitidas por el artículo 7 .

e. La circulación de vehículos a motor con escape libre y con silenciadores ineficaces, incompletos, inadecuados o deteriorados.

f. La no presentación de los vehículos a las inspecciones.

Artículo 14. Faltas graves.

Constituye falta grave:

a. La superación en más de $5 \mathrm{~dB}(\mathrm{~A})$ de los valores límite admitidos. b. La transmisión de niveles de vibración correspondientes a dos curvas base inmediatamente superiores a la máxima admitida para cada situación.

c. La vulneración expresa de los requerimientos municipales para la corrección de las deficiencias observadas.

d. La negativa u obstrucción a la labor inspectora. Se considera, en todo caso, como resistencia a la actuación inspectora impedir a los funcionarios competentes la entrada en los recintos y locales donde deban realizarse las inspecciones, siempre y cuando la Administración actuante hubiese observado los requisitos formales establecidos en la presente ley.

e. La reincidencia en faltas leves en el plazo de doce meses.

f. La iniciación de actividades o la apertura de establecimientos e instalaciones susceptibles de producir ruidos o vibraciones sin obtener la previa autorización o licencia.

g. La transgresión o el incumplimiento de las condiciones impuestas en la autorización o licencia, así como la no adopción, dentro del plazo concedido, de las medidas correctoras señaladas por el órgano competente. En este último supuesto, los sujetos responsables podrán evitar la imposición de la sanción si proceden voluntariamente a la paralización o no iniciación de la actividad.

Artículo 15. Faltas muy graves.

Constituye falta muy grave:

a. La superación en más de $15 \mathrm{~dB}(\mathrm{~A})$ de los valores límite admitidos.

b. La transmisión de niveles de vibración correspondientes a más de dos curvas base inmediatamente superiores a la máxima admitida para cada situación.

c. La reincidencia en faltas graves en el plazo de doce meses.

d. El incumplimiento de las órdenes de clausura de los establecimientos o de paralización de la actividad acordadas por la autoridad competente. 
Artículo 16. Sanciones.

1. Las infracciones a los preceptos de la presente ley se sancionarán de la forma siguiente:

a. Infracciones leves, con multa desde 10.000 hasta 250.000 pesetas.

b. Infracciones graves, con multa de 250.001 hasta 1.500 .000 pesetas, clausura temporal del establecimiento o paralización de la actividad por un espacio de tiempo no superior a seis meses.

c. Infracciones muy graves, con multa de 1.500 .001 hasta 10.000 .000 de pesetas, clausura del establecimiento o paralización de la actividad por espacio superior a seis meses o con carácter definitivo.

2. Siempre que la comisión de la infracción se produjese por primera vez y la corrección de la emisión del ruido que originó la sanción se hiciese en un plazo de cuarenta y ocho horas, reduciéndola al nivel autorizado, la sanción se impondrá en su grado mínimo. En todo caso, el plazo se computará a partir de la comprobación de la comisión de la infracción.

3. La sanción de clausura temporal o definitiva podrá imponerse en aquellas infracciones en que se aprecie reiterada resistencia al cumplimiento de lo ordenado por la alcaldía o manifiesta actitud del titular de la instalación en el sentido de dificultar, falsear o desvirtuar el resultado de la inspección.

Artículo 17. Indemnización de daños. En la resolución que ponga fin al procedimiento sancionador podrá acordarse, aparte de la imposición de la sanción correspondiente, la adopción de medidas correctoras, así como la indemnización de los daños y perjuicios ocasionados como consecuencia de la actividad infractora. Para la ejecución de dichos actos, si el infractor no los cumpliese voluntariamente en el plazo que se le señale, podrán imponérsele multas coercitivas sucesivas de hasta 500.000 pesetas cada una. Igualmente, podrá ordenarse la ejecución subsidiaria en los términos previstos en el artículo 98 de la Ley de Régimen Jurídico de las Administraciones Públicas y del Procedimiento Administrativo Común.

Artículo 18. Solución de conflictos. Los Ayuntamientos podrán crear órganos de mediación para la solución de los conflictos que se deriven de la contaminación acústica, en los cuales también participarán los vecinos.

Artículo 19. Prescripción.

Las infracciones a que se refiere la presente ley prescribirán en los siguientes plazos, desde la comisión del hecho:

a. Seis meses, en caso de infracciones leves.

b. Dos años, en caso de infracciones graves.

c. Cuatro años, en caso de infracciones muy graves.

Artículo 20. Medidas cautelares.

Con independencia de las demás medidas que se adopten para garantizar la eficacia de la resolución que en su momento se dicte, con carácter cautelar el Ayuntamiento podrá acordar la inmediata adopción de medidas correctoras imprescindibles para evitar los daños o molestias graves que estén ocasionándose como consecuencia de las actividades presuntamente infractoras. Igualmente, y con el mismo carácter cautelar, podrá acordarse la paralización de la actividad o la clausura de las instalaciones o establecimientos cuando la producción de ruidos o vibraciones supere los niveles establecidos para su tipificación como falta muy grave, o bien cuando, acordada la adopción de medidas correctoras, el requerimiento municipal resultase incumplido en el plazo que al efecto se señale. También podrá acordarse el precinto de equipos, así como cualquier otra medida que se considere imprescindible para evitar la persistencia en la actuación infractora. Dichas medidas se adoptarán previa audiencia del interesado, por un plazo de cinco días, salvo en aquellos casos que exijan una actuación inmediata. 


\section{TÍTULO IV AUDITORÍAS}

Artículo 21. Definición y objetivos.

1. La auditoría sobre ruidos y vibraciones es un proceso de evaluación sistemática, objetiva, independiente y periódica en materia de ruidos y vibraciones en las actividades susceptibles de control.

2. Los objetivos básicos de las auditorías son el establecimiento y aplicación, por parte de las empresas o instituciones, de sistemas de gestión internos para la protección contra el ruido y las vibraciones, la evaluación sistemática de los resultados obtenidos que permita establecer y adoptar las medidas complementarias para reducir la incidencia ambiental y la información general sobre el comportamiento de las mismas en materia de ruidos y vibraciones.

Artículo 22. Concesión de ayudas. La Comunidad Autónoma de Galicia podrá conceder ayudas económicas, previa convocatoria pública, a las empresas o instituciones para la realización de las mencionadas auditorías, a condición de que posteriormente ejecuten las medidas correctoras recogidas en los correspondientes informes.

\section{TÍTULO V RELACIONES INTERADMINISTRATIVAS Y DE AUXILIO}

Artículo 23. Obligación de informar. La Comunidad Autónoma y los Ayuntamientos podrán mutuamente solicitarse y obtener información concreta sobre la actividad de la otra Administración en materia de contaminación acústica.

Artículo 24. Ejercicio de acciones. Cuando la Administración autonómica considere, en el ámbito de sus competencias, que en un acto o acuerdo de alguna entidad local se infrinja el ordenamiento jurídico, podrá requerirla, invocando expresamente este artículo, para que anule el mencionado acto o acuerdo.

Artículo 25. Convenios con los Ayuntamientos.

En caso de que los Ayuntamientos no cuenten con los medios técnicos o humanos necesarios para cumplir la función de control que la presente ley les atribuye, podrán reclamar el auxilio de la Administración autonómica, que se prestará mediante convenio celebrado entre la misma y los Ayuntamientos, a instancia de éstos. De igual modo, podrán reclamar el auxilio de empresas o entidades especializadas, las cuales habrán de ser previamente homologadas, según los criterios que se fijarán en el correspondiente Reglamento.

\section{DISPOSICIÓN ADICIONAL PRIMERA}

En el plazo de dos años los Ayuntamientos de Galicia deberán proceder a adaptar sus ordenanzas en materia de ruidos a lo dispuesto en la presente ley y en las disposiciones que la desarrollen.

\section{DISPOSICIÓN ADICIONAL SEGUNDA}

En el plazo de un año, a contar desde la entrada en vigor de la presente ley, deberán aprobarse las normas reglamentarias que la desarrollen.

\section{DISPOSICIÓN ADICIONAL TERCERA}

Por las autorizaciones administrativas a que se refiere la presente ley serán exigibles las tasas correspondientes de conformidad con la legislación vigente. En las licencias de primera utilización y primera apertura de establecimientos, la tasa se considerará incluida en la tasa general de apertura de la actividad o primera utilización.

\section{DISPOSICIÓN ADICIONAL CUARTA}

En caso de que el contenido de lo dispuesto en el anexo de la presente ley resulte afectado por normas estatales o de la Unión Europea, se faculta a la Xunta de Galicia 
para dictar las correspondientes normas de adaptación a las mismas.

\section{DISPOSICIÓN ADICIONAL QUUINTA}

En el caso de las infraestructuras viarias y variantes de población preexistentes, el plazo de adaptación a lo establecido en la presente ley se ajustará a las previsiones de los planes aprobados.

Todos los estudios, anteproyectos o proyectos de carreteras sometidos al procedimiento de evaluación del impacto ambiental, así como los de nuevas carreteras, deberán contener un estudio de impacto acústico. Reglamentariamente se determinarán las metodologías de previsión, medición y sistemas de control, en función de las intensidades medias de tráfico.

\section{DISPOSICIÓN ADICIONAL SEXTA}

La Xunta de Galicia, en el ámbito de sus competencias, fijará reglamentariamente de manera armonizada y homologada los métodos de medición de la contaminación ambiental en sus diferentes categorías de fuente y ruidos.

\section{DISPOSICIÓN TRANSITORIA ÚNICA}

Los titulares de las actividades legalmente autorizadas o en trámite en la fecha de entrada en vigor de la presente ley disponen de un período de un año, a partir de su vigencia, para hacer efectivas las medidas correctoras necesarias para el cumplimiento de los niveles máximos de emisión y transmisión sonora y de vibraciones, pudiendo prorrogarse el plazo preceptuado anteriormente por resolución del Alcalde en casos debidamente justificados, en los que deberá señalarse el nuevo plazo para la adaptación, que no será superior a seis meses.

\section{DISPOSICIÓN DEROGATORIA ÚNICA}

Quedan derogadas cuantas disposiciones, de igual o inferior rango, se opongan a lo dispuesto en la presente ley.

\section{DISPOSICIÓN FINAL ÚNICA}

Se faculta al Consello de la Xunta para dictar cuantas disposiciones sean precisas para el desarrollo y ejecución de la presente ley.

4. LEY 10/2008, DE 3 DE NOVIEMBRE, DE RESIDUOS DE GALICIA (DOGA 224. 18.11.2008)

$(\ldots)^{478}$

\section{TÍTULO I DISPOSICIONES GENERALES \\ Capitulo I \\ OBJETO Y ÁMBITO DE APLICACIÓN}

Artículo 1. Objeto.

Constituye el objeto de la presente ley, en el marco de la normativa de la Unión Europea y de la legislación básica del Estado, prevenir la producción de residuos, establecer el régimen jurídico general de la producción y gestión de los residuos, fomentando, por este orden, su reducción, reutilización, reciclaje y otras formas de valorización, y la regulación de los suelos contaminados, en orden a proteger el medio ambiente y la salud humana.

Artículo 2. Objetivos.

El objetivo de la presente ley es el de mejorar la calidad de vida de la ciudadanía de Galicia y alcanzar un alto nivel de protección del medio ambiente, dotando a los entes públicos competentes de los mecanismos de intervención y control necesarios para garantizar una adecuada gestión de los residuos y, en particular:

a. Prevenir los riesgos para la salud y el bienestar de las personas, sin provocar incomodidades por el ruido o los olores.

b. Proteger el medio ambiente sin crear riesgos para el agua, el suelo, la flora y la fauna.

c. Preservar el paisaje y, particularmente, los lugares de especial interés.

d. Reducir la cantidad y nocividad de los residuos generados en Galicia. A tal

478 Preámbulo omitido. 
fin, los planes de residuos y las normas de desarrollo y aplicación de la presente ley fijarán objetivos concretos.

e. Fomentar la recogida selectiva de residuos y la reutilización de productos y materiales usados, la utilización de materiales reciclados y su puesta en el mercado, así como otras formas de valorización. A tal fin, las normas de desarrollo y aplicación de la presente ley fijarán objetivos concretos de reducción cuantitativa y cualitativa.

f. Conseguir que quienes sean responsables de la puesta en el mercado de productos que con su uso se convierten en residuos utilicen en su fabricación tecnologías limpias que permitan el ahorro de recursos naturales y elaboren productos que por sus características favorezcan la prevención de residuos y faciliten su reutilización, reciclaje y valoración.

g. Prohibir el abandono, vertido o eliminación incontrolados de los residuos, así como tender a limitar la eliminación de los residuos a aquellos no valorizables.

h. Regular los suelos contaminados al objeto de prevenir y reparar los daños en el suelo.

i. Promover la participación y colaboración activa de los agentes implicados en la producción y gestión de los residuos en la sensibilización y concienciación social. A este respecto, las administraciones actuarán con la debida transparencia, poniendo a disposición pública toda la información relativa a los residuos.

j. Promover la integración de programas de educación en materia de residuos en todos los ciclos formativos, asegurando la información a la ciudadanía sobre la acción pública en esta materia con el fin de promover su colaboración para la reducción y valorización de los residuos.

k. Desarrollar instrumentos de planificación, inspección y control que favorezcan la suficiencia, seguridad y eficiencia de las actividades de gestión de los residuos.
1. Promover líneas de I+D de cara a la producción limpia en Galicia.

Artículo 3. Ámbito de aplicación.

1. La presente ley es de aplicación a todo tipo de residuos que se originen o gestionen en el ámbito territorial de la Comunidad Autónoma de Galicia, con las siguientes exclusiones:

a. Las emisiones a la atmósfera reguladas en la Ley $34 / 2007$, de 15 de noviembre, de calidad del aire y protección de la atmósfera, y en la Ley $8 / 2002$, de 18 de diciembre, de protección del ambiente atmosférico de Galicia.

b. Los residuos radiactivos regulados en la Ley 25/1964, de 29 de abril, de energía nuclear.

c. Los vertidos de efluentes líquidos a las aguas continentales regulados en el texto refundido de la Ley de aguas aprobado por Real decreto legislativo $1 / 2001$, de 20 de julio; los vertidos desde tierra al mar regulados por la Ley $22 / 1988$, de 28 de julio, de costas, y los vertidos desde buques y aeronaves al mar regulados por los tratados internacionales de que España sea parte.

2. La presente ley se aplicará supletoriamente, en defecto de regulación específica, a las siguientes materias, que se regirán por su legislación específica:

a. La gestión de los residuos resultantes de la prospección, extracción, valorización, eliminación y almacenamiento de recursos minerales, así como de la explotación de canteras, en lo regulado en la Ley 22/1973, de 21 de julio, de minas.

b. La actividad de producción y gestión de subproductos animales no destinados al consumo humano en lo no previsto en la normativa de aplicación.

c. Los residuos producidos en las explotaciones agrícolas y ganaderas consistentes en materias fecales y otras sustancias naturales y no peligrosas cuando se utilicen exclusivamente en el marco de las explotaciones agrarias, con arreglo a lo dispuesto en la disposición 
adicional quinta de la Ley 10/1998, de 21 de abril, de residuos.

d. Los explosivos, cartuchos y artificios pirotécnicos desclasificados, así como los residuos de materias primas peligrosas o de productos explosivos utilizados en la fabricación de los anteriores, en lo regulado en el Reglamento de explosivos, aprobado mediante el Real decreto 230/1998, de 16 de febrero.

e. Las tierras separadas en las industrias agroalimentarias en sus fases de recepción y de limpieza primaria de las materias primas agrícolas, cuando estén destinadas a su valorización como tratamiento de los suelos y produzcan un beneficio a la agricultura o una mejora ecológica de los mismos.

Artículo 4. Definiciones.

A los efectos de la presente ley, y de conformidad con la Ley 10/1998, de 21 de abril, de residuos, se entenderá por:

1. Residuo: cualquier sustancia u objeto perteneciente a alguna de las categorías que figuran en el anexo de la Ley 10/1998, de 21 de abril, de residuos, del cual su poseedor se desprenda o tenga la intención u obligación de desprenderse. En todo caso, tendrán esta consideración aquéllos que figuren en la Lista europea de residuos (LER), aprobada por las instituciones comunitarias.

No tendrán la consideración de residuo:

Los materiales, objetos o sustancias sobrantes de un proceso de producción, transformación o consumo que no tengan modificadas sus propiedades y características originales y que se utilicen de forma directa como producto o materia prima, sin someterse previamente a una operación de valorización o eliminación y sin poner en peligro la salud humana ni causar perjuicios al medio ambiente.

Aquellos materiales, objetos o sustancias defectuosas generadas en un proceso productivo que se reincorporan al mismo.

Los materiales, objetos o sustancias que se obtengan tras la valorización de los residuos que se incorporen al ciclo productivo.

Las tierras y rocas no contaminadas de excavación utilizadas para la restauración, acondicionamiento y relleno, o con fines de construcción.

2. Residuos urbanos o municipales: los generados en los domicilios particulares, comercios, oficinas y servicios, así como todos aquellos que no tengan la calificación de peligrosos y que, por su naturaleza o composición, puedan asimilarse a los producidos en los anteriores lugares o actividades.

Tendrán también la consideración de residuos urbanos los siguientes:

Residuos procedentes de la limpieza ordinaria de vías públicas, zonas verdes, áreas recreativas y playas.

Animales de compañía muertos, así como muebles, aparatos y vehículos abandonados. Se entenderá como animal de compañía los animales que tenga en su poder la persona humana, siempre que su tenencia no tenga como destino su consumo o el aprovechamiento de sus producciones, o no se lleve a cabo, en general, con fines comerciales o lucrativos.

Residuos y escombros procedentes de obras menores de construcción y reparación domiciliaria.

3. Residuos comerciales: residuos municipales generados por la actividad propia del comercio al por menor y al por mayor, la hostelería, los bares, los mercados, las oficinas y los servicios.

A los efectos del régimen de responsabilidades en la gestión, tendrán también esta consideración los residuos no peligrosos generados por la industria que, por su naturaleza o composición, sean asimilables a los residuos urbanos o municipales.

4. Residuos peligrosos: los definidos como tales en el artículo 3.c) de la Ley 10/1998 y en la Decisión 2000/532/CE de la Comisión de 3 de mayo por la que se aprueba la Lista europea de residuos, publicada mediante la Orden MAM/304/2002, de 8 de febrero. 
Los residuos peligrosos generados en los domicilios particulares se regularán de conformidad con lo dispuesto en la normativa de residuos urbanos.

5. Residuos no peligrosos: aquellos residuos no incluidos en la definición anterior que se generan en un proceso de fabricación, transformación, utilización, consumo, limpieza o mantenimiento de una instalación o actividad industrial, sanitaria o ganadera y no tengan la consideración de residuos urbanos o municipales.

6. Residuos de construcción y demolición: aquéllos que se originan en los procesos de ejecución material de los trabajos de construcción tanto de nueva planta como de rehabilitación o de reparación y de las operaciones de desmontaje, desmantelamiento y derribo de edificios e instalaciones y que se encuentran incluidos en la Lista europea de residuos aprobada por la Orden MAM/304/2002, de 8 de febrero, por la que se publican las operaciones de valorización y eliminación de residuos y la Lista europea de residuos. Se excluyen de la definición anterior: Los residuos procedentes de obras menores de construcción y reparación domiciliaria, que se considerarán urbanos y municipales, entendiéndose por tales los de sencilla técnica y escasa entidad constructiva y económica que no supongan alteración del volumen del uso de las instalaciones y servicios de uso común o del número de viviendas y locales ni afecten al diseño exterior, la cimentación, estructura o condiciones de habitabilidad o seguridad de los edificios o instalaciones de todas las clases.

Los residuos de construcción y demolición que tengan la consideración de peligrosos, que se regirán por su normativa específica.

7. Residuos inertes: aquellos residuos no peligrosos que no experimentan transformaciones físicas, químicas o biológicas significativas. Los residuos inertes no son solubles ni combustibles y no reaccionan física ni químicamente, ni de ninguna otra manera, no son biodegradables y no les afectan negativamente otras materias con las que entran en contacto de manera que puedan dar lugar a la contaminación del medio ambiente o perjudicar la salud humana. La lixiviabilidad total, el contenido de contaminantes de los residuos y la ecotoxicidad del lixiviado deberán ser insignificantes y, en particular, no habrán de suponer un riesgo para la calidad de las aguas superficiales y/o subterráneas.

8. Residuos industriales: aquellos residuos que, siendo o no peligrosos, se generan en un proceso de fabricación, transformación, utilización, consumo, limpieza o mantenimiento de una instalación o actividad industrial y de los cuales quienes los producen o poseen tienen voluntad de desprenderse.

9. Prevención: el conjunto de medidas destinadas a evitar la generación de residuos o a conseguir su reducción, o la de la cantidad y nocividad de sustancias peligrosas o contaminantes presentes en ellos.

10. Productor/a de residuos: cualquier persona física o jurídica cuya actividad produzca residuos (productor o productora inicial de residuos), excluida la derivada del consumo doméstico, o que efectúe, previa autorización, operaciones de tratamiento previo, de mezcla o de otro tipo que ocasionen un cambio de naturaleza o de composición de esos residuos.

Tendrán también carácter de productor/a de residuos quienes importen o adquieran residuos en cualquier Estado miembro de la Unión Europea.

11. Productor/a de residuos peligrosos: aquellos/as productores/as que generen o importen residuos peligrosos y aquellas actividades que generen o importen productos que por su uso puedan dar lugar a residuos peligrosos.

12. Poseedor/a: quienes produzcan los residuos o la persona física o jurídica que los tenga en su poder y que no tenga la condición de gestor/a de residuos. 
13. Gestor/a: la persona o entidad, pública o privada, que realice cualquiera de las operaciones que componen la gestión de los residuos, sea o no quien produzca los mismos.

14. Responsable de la puesta en el mercado: el/la fabricante o, en su defecto y por este orden, el/la importador/a, el/la adquirente en otro Estado miembro de la Unión Europea, el/la agente o intermediario/a o los/las agentes económicos dedicados a la distribución de los productos.

15. Gestión: la recogida, clasificación, almacenamiento, transporte, valorización y eliminación de los residuos, incluida la vigilancia de los lugares de depósito o vertido, después de su cierre. A los efectos de la presente ley, la reutilización no se considera una operación de gestión de residuos.

16. Recogida: toda operación, realizada por un gestor o gestora, consistente en recoger, clasificar, agrupar o preparar residuos para su transporte y entrega a gestor/a.

17. Transporte: el traslado de los residuos desde su lugar de producción hasta los centros donde se realizan las operaciones de gestión, así como los traslados de residuos de éstos entre sí.

No se incluye en este concepto el traslado de residuos realizado por quienes los posean o produzcan con sus propios medios hasta los centros de recogida y almacenamiento, cuando la cantidad a transportar sea inferior al límite que se determine reglamentariamente, ello sin perjuicio de las limitaciones que la normativa de transporte de mercancías pueda establecer.

18. Almacenamiento: el depósito temporal de residuos por tiempo inferior a dos años, si su destino fuese la valorización, un año si fuese la eliminación, o seis meses, si se tratase de residuos peligrosos.

No se incluye en este concepto el depósito temporal de residuos en las instalaciones de producción con los mismos fines y por periodos de tiempo inferiores a los señalados o los superiores que hubieran sido previamente autorizados por la consellería competente en materia de medio ambiente.

19. Reciclaje: la transformación de los residuos, dentro de un proceso de producción, para su fin inicial o para otros fines, incluido el compostaje y la biometanización, pero no la incineración con recuperación de energía.

20. Reutilización: el empleo de un producto o material usado para el mismo fin para el que fue diseñado originariamente sin necesidad de someterlo con carácter previo a ninguna de las operaciones que figuran en la lista de operaciones de valorización aprobada por las instituciones comunitarias.

21. Regeneración: procedimiento al que es sometido un producto usado o desgastado a los efectos de devolverle las cualidades originales que permitan su reutilización.

22. Vertedero: instalación de eliminación de residuos mediante su depósito subterráneo o en superficie, por periodos de tiempo superiores a los contemplados en el número 19 anterior.

Se incluyen en este concepto las instalaciones internas de eliminación de residuos, es decir, los vertederos en los cuales quienes los producen eliminan sus residuos en el lugar de producción. No se incluyen las instalaciones en las que se descargan los residuos para su preparación para su transporte posterior a otro lugar para su valorización, tratamiento o eliminación.

23. Valorización: todo procedimiento que permita el aprovechamiento de los recursos contenidos en los residuos sin poner en peligro la salud humana y sin utilizar métodos que puedan causar perjuicios al medio ambiente. Se incluye en este concepto el almacenamiento previo a la valorización, entendiéndose como tal las siguientes operaciones:

El depósito de residuos que, por formar parte del proceso de valorización, se 
realice para facilitar o posibilitar las operaciones de valorización.

El depósito de residuos que se realiza con carácter previo a una actividad de valorización para posibilitar su puesta en marcha.

24. Eliminación: todo procedimiento dirigido bien al vertido de los residuos bien a su destrucción, total o parcial, realizado sin poner en peligro la salud humana y sin utilizar métodos que puedan causar perjuicios al medio ambiente. Se incluyen en este concepto las instalaciones de incineración destinadas al tratamiento de residuos urbanos cuando su eficiencia energética resulte inferior a lo dispuesto en la normativa de residuos; asimismo, se incluye en este concepto el almacenamiento previo a la eliminación, entendiéndose como tal las siguientes operaciones:

El depósito de residuos que, por formar parte del proceso de eliminación, se realice para facilitar o posibilitar las operaciones de eliminación.

El depósito de residuos que se realiza con carácter previo a una actividad de eliminación para posibilitar su puesta en marcha.

25. Planta móvil: instalación de valorización o eliminación destinada a permanecer por un tiempo limitado en un lugar y diseñada para ser desarmada o desmantelada para su traslado.

26. Suelo contaminado: todo aquel cuyas características físicas, químicas o biológicas han sido alteradas negativamente por la presencia de componentes de carácter peligroso de origen humano, en concentración tal que conlleve un riesgo para la salud humana o el medio ambiente, de acuerdo con los criterios estándares y procedimiento que se determine reglamentariamente.

27. Actividades potencialmente contaminantes: aquellas actividades de tipo industrial o comercial que, ya por el manejo de sustancias peligrosas ya por la generación de residuos, puedan contaminar el suelo.
28. Espacio degradado: aquel que ha sido objeto de vertidos incontrolados o de un inadecuado depósito de residuos.

29. Sistema integrado de gestión: sistema establecido y financiado mediante acuerdo de los agentes económicos responsables de la puesta en el mercado de productos que con su uso se convierten en residuos, para garantizar la correcta gestión de los mismos.

30. Empresa gestora del sistema integrado de gestión: entidad sin ánimo de lucro cuya misión es la de realizar las actuaciones necesarias para el correcto funcionamiento del sistema o sistemas integrados de gestión constituidos y la consecución de sus fines.

31. Autodiagnóstico medioambiental: autoanálisis de la actividad de las instalaciones encaminado, entre otros fines, a la optimización de la ecoeficiencia mediante la aplicación de técnicas de producción limpia y de las mejores tecnologías disponibles, a la implantación de la prevención de residuos y otras fuentes contaminantes y a la adopción de medidas preventivas, a los efectos de minimizar los riesgos medioambientales.

32. Auditoría medioambiental: herramienta de control medioambiental que tiene entre sus fines la colaboración con las empresas para la identificación de los puntos críticos medioambientales y la cooperación con las mismas para la adopción de medidas que mejoren su ecoeficiencia, incluida la minimización en la generación de residuos, así como aquellas otras que contribuyan a disminuir los riesgos medioambientales. Asimismo, servirá para verificar los datos suministrados por las empresas tanto en el documento de autodiagnóstico como en la declaración de ecoeficiencia (o declaración de sostenibilidad).

33. Declaración de ecoeficiencia (o declaración de sostenibilidad): documento en el que se incluyen los resultados de la aplicación de un autodiagnóstico. 


\section{Capitulo II} ORGANIZACIÓN Y COMPETENCIAS

Artículo 5. Competencias de las entidades locales en materia de residuos.

1. Las entidades locales serán competentes para la gestión de los residuos urbanos, en los términos previstos en la presente ley y en la Ley 10/1998, de 21 de abril, de residuos.

2. En particular, corresponde a los municipios:

a. Prestar, por sí solos o asociados, los servicios derivados de la gestión de los residuos urbanos o municipales en la forma que se establezca en sus respectivas ordenanzas y, en su caso, planes de gestión de residuos.

Los municipios gestionarán los servicios públicos de recogida, transporte, valorización y eliminación de residuos urbanos o municipales de forma directa o indirecta.

b. Implantar sistemas de recogida selectiva de residuos urbanos o municipales que posibiliten su reciclaje y otras formas de valorización.

c. Llegar a acuerdos con quienes produzcan residuos comerciales para la consecución de su correcta gestión.

d. Elaborar los planes de gestión de residuos urbanos, de acuerdo con lo que, en su caso, se establezca en la presente ley y en los planes de residuos de la Comunidad Autónoma de Galicia.

e. Gestionar adecuadamente los residuos urbanos o municipales abandonados en vías o espacios públicos de titularidad municipal.

f. Vigilar, inspeccionar y sancionar en el ámbito de sus competencias.

g. Ejercer las competencias que, en su caso, les sean atribuidas con carácter temporal o permanente por las administraciones competentes, mediante acuerdos o cualquier otro instrumento administrativo. Dicho ejercicio podrá llevarse a cabo directamente o mediante la constitución y participación en entes supramunicipales o de otra índole de entre los previstos en el ordenamiento jurídico.

Artículo 6. Competencias de las diputaciones provinciales.

Son competencias de las diputaciones provinciales las siguientes:

1. Adoptar las medidas oportunas para asegurar, con arreglo a lo establecido en la legislación vigente en materia de administraciones locales, la colaboración precisa a los ayuntamientos en la prestación del servicio de recogida y gestión de residuos urbanos, incluyendo estos servicios como de carácter preferente en los planes provinciales de obras y servicios.

2. Asimismo, de acuerdo con el contenido de los planes de residuos y en los términos establecidos en la legislación de régimen local, podrán contribuir económicamente a la elaboración y ejecución de planes comarcales y locales de gestión de residuos.

Artículo 7. Competencias de la Comunidad Autónoma de Galicia.

Son competencias de la Comunidad Autónoma de Galicia las siguientes:

a. La autorización, vigilancia, inspección y sanción de las actividades de producción y gestión de residuos.

b. La autorización de los sistemas integrados de gestión de residuos que se constituyan en virtud de acuerdos voluntarios, así como su vigilancia, inspección y sanción.

c. La declaración de suelo contaminado, la realización de un inventario de suelos contaminados y las demás que, en relación con los mismos, le atribuya la normativa básica y la presente ley.

d. La autorización de traslados de residuos desde o hacia países de la Unión Europea, regulados en la normativa comunitaria, así como los traslados en el interior del territorio del Estado que tengan su origen o destino en la Comunidad Autónoma de Galicia, y la inspección y, en su caso, sanción derivada de los citados regímenes de traslados. 
e. Autorizar la eliminación de residuos procedentes de otras comunidades autónomas.

f. La elaboración de los planes autonómicos de residuos.

g. Declarar como servicio público, de titularidad autonómica o municipal, todas o algunas de las operaciones de gestión de determinados residuos.

h. Obligar a quienes sean responsables de la puesta en el mercado de productos que con su uso se conviertan en residuos a elaborar productos que por sus características favorezcan la prevención en la generación de residuos y faciliten su valorización, así como a constituir sistemas integrados de gestión o adoptar las medidas oportunas para garantizar su correcta gestión.

i. Velar por la adecuada prestación de los servicios municipales obligatorios, respetando las competencias locales en la materia.

j. El ejercicio de la potestad expropiatoria para el establecimiento o ampliación de instalaciones de gestión de residuos.

$\mathrm{k}$. Adoptar las medidas excepcionales necesarias para garantizar la gestión de los residuos en caso de cese de actividad de un sistema integrado de gestión.

1. El desarrollo de programas de apoyo a la producción limpia en las empresas e industrias dentro del territorio gallego.

$\mathrm{m}$. Cualesquiera otras que, en relación con la presente ley, le sean atribuidas por el ordenamiento jurídico.

n. Cualquier otra actividad relacionada con los residuos que no venga atribuida por ley a la Administración general del Estado o a los entes locales.

Artículo 8. Órganos competentes de la Comunidad Autónoma de Galicia.

La actuación de la Xunta de Galicia en las materias a que se refiere la presente ley se llevará a cabo a través de la consellería competente en medio ambiente, cuando no hubiese legislación específica que atribuya esa competencia a otra consellería u organismo.
Artículo 9. Coordinación interadministrativa.

1. Las entidades locales gallegas coordinarán sus competencias entre sí, y con la Comunidad Autónoma de Galicia y la Administración del Estado, en orden a realizar las acciones necesarias para la consecución de los objetivos establecidos en la presente ley y de los que puedan estar contemplados en los correspondientes planes de residuos de la Comunidad Autónoma de Galicia.

2. A fin de asegurar la coherencia de actuación de las administraciones públicas, la Xunta de Galicia dispondrá de los procedimientos previstos en la normativa de régimen local. Asimismo, y de conformidad con lo dispuesto en los artículos 205 y siguientes de la Ley 5/1997, de 22 de julio, de Administración local de Galicia, se le atribuye la facultad de coordinar la actuación de las entidades locales y, en especial, de las diputaciones provinciales, cuando las actividades o servicios locales comprendidos dentro de los objetivos de la presente ley transciendan el interés propio de las correspondientes entidades, incidan o condicionen relevantemente los de la Xunta de Galicia o sean concurrentes o complementarios de ésta.

La potestad de coordinación de las entidades locales se ejercerá a través de los planes de residuos de la Comunidad $\mathrm{Au}-$ tónoma de Galicia en materia de residuos, que fijarán los objetivos y prioridades de la acción pública en materia de residuos y la vinculación de las entidades locales al contenido de los mismos, en los términos previstos en la legislación básica y en la presente ley.

\section{Capítulo III DE LA SOCIEDAD GALLEGA DEL MEDIO AMBIENTE}

Artículo 10. Sociedad Gallega del Medio Ambiente.

1. La Sociedad Gallega del Medio Ambiente, S.A., creada por el Decreto 
111/1992, de 11 de abril, es una sociedad pública autonómica dependiente de la consellería competente en materia de residuos, a la cual corresponden las siguientes funciones:

a. La gestión de los residuos urbanos a partir del momento en que son depositados en las estaciones de transferencia o plantas de tratamiento previstas en el plan de gestión de residuos urbanos, con las consiguientes operaciones de transporte, almacenamiento, valorización, tratamiento, comercialización y depósito controlado de los residuos.

b. La gestión de aquellos otros residuos que figuren en su objeto social.

c. La realización de acciones para la mejora de la gestión y prevención de residuos, incluidas las actuaciones de formación y sensibilización.

d. Cualesquiera otras que le sean atribuidas y que tengan relación con su objeto social.

2. Toda la gestión de la Sociedad Gallega del Medio Ambiente, S.A., se realizará de tal forma que se garantice el cumplimiento de todos los objetivos contemplados en la presente ley, y en los correspondientes planes de residuos de la Xunta, para lo cual deberá concertar sus acciones con las de los gestores o gestoras que intervengan en las fases iniciales del proceso.

3. Para el cumplimiento de estos fines la Sociedad Gallega del Medio Ambiente, S.A., podrá desarrollar sus actividades total o parcialmente mediante la titularidad de acciones o de participaciones en sociedades con objeto idéntico o análogo.

\section{Capitulo IV ACCIÓN DE LAS ADMINISTRACIONES PÚBLICAS}

Artículo 11. Principios generales.

1. La Xunta de Galicia y las entidades locales, en colaboración con la Administración del Estado, coordinarán sus competencias para realizar una ejecución conjunta de las acciones necesarias para:

a. Promover entre la ciudadanía patrones de consumo responsables que favorezcan la reducción en origen de los residuos.

b. Alcanzar objetivos concretos de reducción de la cantidad y nocividad de los residuos implementando medidas de fomento de la producción limpia.

c. Alcanzar objetivos concretos de valorización de los residuos a través de su recogida selectiva, reutilización, reciclaje y recuperación energética o cualquier otro procedimiento dirigido al aprovechamiento de los recursos que contienen.

d. Promover la implantación de las instalaciones e infraestructuras adecuadas para la gestión de los residuos de la Comunidad Autónoma de Galicia.

e. Limitar la eliminación de los residuos a los no susceptibles de ser valorizados en las instalaciones ubicadas en la Comunidad Autónoma de Galicia.

f. Impedir la eliminación incontrolada de los residuos y promover la regeneración de los espacios degradados.

g. Potenciar el uso de productos procedentes de la valorización de residuos.

h. Garantizar el traslado de residuos en condiciones seguras.

i. Impulsar el desarrollo de programas de formación medioambiental, información, sensibilización y concienciación social que susciten la participación y colaboración activa de la ciudadanía, así como facilitar el diálogo entre la Xunta de Galicia y los distintos agentes económicos y sociales, asociaciones ecologistas y productores/as y gestores/as, en general, en todo el ciclo de vida del residuo.

2. A fin de asegurar la coherencia y efectividad de estas acciones en materia de gestión de residuos, se atribuye a la Xunta de Galicia la facultad de coordinar la actuación de las entidades locales en el ejercicio de aquellas competencias que 
trasciendan los intereses locales y estén comprendidas dentro de los objetivos de la presente ley.

3. Al objeto de hacer efectivos los principios de eficacia y eficiencia relativos a la actuación de las administraciones públicas, previstos en los párrafos uno y dos del artículo 3 de la Ley 30/1992, de 26 de noviembre, de régimen jurídico de las administraciones públicas y del procedimiento administrativo común, las administraciones con competencias en materia de residuos garantizarán en su ejecución la suficiencia de medios humanos y materiales, tanto para la promoción y fomento como para la información, prevención, vigilancia y control.

Artículo 12. Prevención de residuos. Para la prevención de residuos las administraciones públicas competentes fomentarán:

a. El uso de tecnologías limpias que permitan un mayor ahorro de los recursos naturales.

b. El diseño, fabricación, comercialización y uso de productos que generen el menor impacto medioambiental a lo largo de su ciclo de vida, y que permitan su más idónea valorización, prestando especial atención a los envases compuestos.

c. La utilización de las mejores técnicas disponibles para la eliminación de las sustancias peligrosas contenidas en los residuos destinados a la valorización o eliminación.

d. La adopción y cumplimiento de medidas de prevención por parte de quienes produzcan los residuos en los términos previstos en la presente ley.

e. El desarrollo de programas sectoriales de minimización de residuos y emisiones.

\section{Artículo 13. Valorización.}

1. Al objeto de lograr la valorización adecuada de los residuos las administraciones competentes en materia de residuos fomentarán: a. La recogida selectiva de todos aquellos componentes susceptibles de ser reutilizados o reciclados, incluyendo la puesta en marcha de sistemas de recogida que permitan el mayor aprovechamiento de los recursos contenidos en los residuos.

b. La separación, previamente al comienzo del tratamiento, del resto de componentes que, aun no habiendo sido recogidos selectivamente, puedan ser objeto de reciclaje o recuperación.

c. El reciclaje, así como otras formas de recuperación en los recursos contenidos en los residuos.

2. Los objetivos de la valorización, así como las medidas para su consecución, habrán de estar contemplados en los planes de residuos.

Artículo 14. Optimización en la eliminación.

1. Todo residuo potencialmente valorizable, de acuerdo con las mejores técnicas disponibles en las instalaciones ubicadas en la Comunidad Autónoma de Galicia, deberá ser destinado a este fin.

2. La eliminación de residuos se realizará con la mejor tecnología disponible, respetando los principios de suficiencia, proximidad y responsabilidad compartida.

3. Excepcionalmente, no obstante lo dispuesto en el número 1 del presente artículo, y previa autorización del órgano competente en materia de medio ambiente, podrán ser objeto de las operaciones propias de depósito controlado o vertedero aquellas fracciones valorizables que no resultase posible comercializar por la situación coyuntural del mercado.

Artículo 15. Formación y concienciación.

En el marco de los principios generales de actuación, se desarrollarán acciones de formación y concienciación ciudadana dirigidas a:

a. Promover la participación activa en la mejora de la recogida selectiva $y$, en especial, de la separación en origen de residuos. 
b. Fomentar la disminución del uso de envases y embalajes innecesarios, principalmente los de difícil reutilización o reciclaje.

c. Potenciar la educación medioambiental y la integración de programas de educación en materia de residuos en todos los ciclos formativos.

d. Potenciar la creación de mesas de participación, estudio y trabajo conjunto, a fin de plasmar y realizar un seguimiento de las especificaciones del plan de residuos y del cumplimiento de lo establecido en la presente ley.

e. Facilitar la consecución de acuerdos concretos entre la Xunta de Galicia y quienes ostenten la representación de los sectores productivos y del asociacionismo ecológico y ciudadano.

f. Favorecer el diálogo y el compromiso entre los sectores de la industria y el consumo y las administraciones públicas en el ámbito de la protección del medio ambiente.

g. Informar de las consecuencias nocivas para el medio ambiente que puede tener el uso incorrecto de los productos que generen residuos tóxicos o peligrosos.

\section{TíTULO II \\ PLANIFICACIÓN EN MATERIA DE RESIDUOS \\ Capitulo I \\ DISPOSICIONES GENERALES}

Artículo 16. De la planificación.

Las actividades, tanto públicas como privadas, de gestión de residuos se ejecutarán con arreglo a los planes de residuos aprobados por las administraciones públicas competentes.

Artículo 17. Objetivos del Plan autonómico de gestión de residuos.

1. La planificación de la gestión de los residuos por la Comunidad Autónoma de Galicia persigue la coordinación entre las diferentes administraciones públicas con competencias en este ámbito, habida cuenta de la incidencia económica, social, cultural, ecológica, demográfica y territorial de la gestión integral de los residuos, para lograr el cumplimiento de los siguientes objetivos:

a. Prevenir y reducir la producción de residuos y su nocividad.

b. Garantizar que todo residuo susceptible de ser valorizado se destinará a tales fines.

c. La determinación y distribución en el territorio del conjunto de instalaciones de gestión necesarias para garantizar los principios de autosuficiencia y proximidad en la gestión de residuos generados en la Comunidad Autónoma gallega.

d. Evitar el depósito incontrolado de residuos.

2. Para la consecución de los objetivos definidos en este artículo, se fomentará la aplicación de las mejores técnicas disponibles.

\section{Capitulo II \\ PLANIFICACIÓN AUTONÓMICA}

Artículo 18. Planes de residuos de la Xunta de Galicia.

1. Corresponde a la Xunta de Galicia la elaboración y aprobación de los planes de residuos de conformidad con lo previsto en la normativa básica, la presente ley y sus normas de desarrollo.

2. Los planes de residuos de la Xunta de Galicia contendrán al menos las siguientes determinaciones:

a. Ámbito material, territorial y temporal, así como el procedimiento de revisión.

b. Análisis y diagnóstico de la situación existente y estimación de los residuos objeto del plan: cantidad, tipología y origen, así como operaciones de gestión a que se someten. Especialmente habrán de incluir un análisis y diagnóstico de la situación actual en relación con los núcleos de población, actividad económica y social y medio rural.

c. Principios que han de regir la gestión de los residuos afectados por el plan. 
d. Objetivos específicos de reducción, reutilización, reciclaje, otras formas de valorización y eliminación de los residuos, y las medidas a adoptar para la consecución de estos objetivos.

e. Plan de infraestructuras necesarias para la consecución de los objetivos previstos.

f. Criterios a tener en cuenta para la ubicación de las infraestructuras necesarias.

g. Estimación de los costes de ejecución del plan.

h. Programación temporal de las actuaciones previstas para la ejecución del plan.

i. A efectos de la coordinación interadministrativa prevista en el artículo 9 de la presente ley, procedimiento de integración, en su caso, de las entidades locales en el plan.

j. Directrices básicas a que habrán de adecuarse, en su caso, los planes de las entidades locales.

3. Como documento anexo se formulará un programa financiero de actuación en el que se expresarán y valorarán los costes económico-financieros derivados tanto de la ejecución del plan como del proceso de gestión de los residuos, y se propondrá su reparto entre todas las personas y entidades implicadas en el plan. Igualmente, se establecerá la aportación de la Xunta de Galicia a la financiación del plan, así como las ayudas o subvenciones existentes por parte del resto de las instituciones. Este programa podrá ser revisado independientemente del plan propiamente dicho.

Artículo 19. Procedimiento de elaboración.

1. La elaboración de los planes de la Xunta de Galicia en materia de residuos se ajustará al siguiente procedimiento:

a. La consellería competente en materia de medio ambiente elaborará un documento de referencia para la realización de la evaluación medioambiental estratégica del plan, sobre la base del cual se redactará el informe de sostenibilidad medioambiental y una propuesta del plan. b. La propuesta del plan, que incluye el informe de sostenibilidad, se someterá al trámite de consultas definidas en el documento de referencia, que, en todo caso, incluirá la consulta a todas las administraciones públicas afectadas, incluidas, en su caso, las de otra comunidad autónoma y las de otro Estado miembro. Asimismo, se someterá al trámite de información pública durante un periodo no inferior a cuarenta y cinco días. El periodo de información pública se anunciará en el Diario Oficial de Galicia, a fin de que el público interesado pueda examinarlo y formular las alegaciones que estime oportunas.

c. Finalizada la fase de consultas, se elaborará una memoria medioambiental al objeto de valorar la integración de los aspectos medioambientales en la propuesta del plan. La memoria medioambiental contendrá las determinaciones finales que habrán de incorporarse a la propuesta del plan.

d. Tomando en consideración las alegaciones formuladas en las consultas, el informe de sostenibilidad medioambiental y la memoria medioambiental, la consellería competente en materia de medio ambiente, en un plazo no superior a treinta días, elevará la propuesta del plan al Consello de la Xunta para su aprobación.

e. El plan se aprobará mediante acuerdo del Consello de la Xunta de Galicia y la consellería competente en materia de residuos lo hará público, procediendo a su difusión para garantizar el conocimiento a la ciudadanía y administraciones implicadas. El texto íntegro del plan aprobado será remitido al Parlamento de Galicia.

f. La consellería competente en materia de medio ambiente realizará un seguimiento de los efectos en el medio ambiente de la aplicación o ejecución del plan.

2. El programa financiero de actuación del plan será aprobado directamente por el Consello de la Xunta a propuesta de la persona titular de la consellería competente en materia de medio ambiente, no estando 
sujeto a los trámites procedimentales previstos en los apartados anteriores para el conjunto del plan.

Artículo 20. Publicidad del plan.

La consellería competente en materia de medio ambiente pondrá a disposición de las administraciones públicas consultadas y del público afectado la siguiente documentación:

1. El plan aprobado.

2. Una declaración que resuma cómo se integraron en el plan los aspectos medioambientales, y cómo se ha tomado en consideración el informe de sostenibilidad medioambiental, los resultados de las consultas, la memoria medioambiental y, en su caso, las discrepancias que pudiesen surgir en el proceso, así como las razones de la elección del plan en relación con las alternativas consideradas.

3. Las medidas adoptadas para el seguimiento de los efectos en el medio ambiente de la aplicación del plan.

4. Un resumen no técnico sobre la documentación contemplada en los números 2 у 3 .

Artículo 21. Efectos.

1. Los planes en materia de residuos aprobados por la Xunta podrán declararse de incidencia supramunicipal de acuerdo con la normativa de ordenación del territorio de Galicia.

2. Los planes serán de obligado cumplimiento para administraciones públicas y particulares, y constituyen, en especial, un límite vinculante para cualquier instrumento de plan urbanístico, cuyas determinaciones no podrán modificar, derogar o dejar sin efecto aquéllos.

3. Los instrumentos de plan urbanístico habrán de adaptarse a las determinaciones de los planes de la Xunta en materia de residuos en los plazos que determinen estos planes y, en todo caso, en la primera modificación o revisión del plan urbanístico.

4. Se declaran de interés público, a los efectos de la Ley 10/1995, de 23 de noviembre, de ordenación del territorio de Galicia, las infraestructuras de gestión de residuos contempladas en los planes autonómicos de residuos.

Artículo 22. Revisión.

Los planes de residuos de la Xunta de Galicia se revisarán:

1. En los plazos previstos en los mismos, que no excederán del plazo máximo de diez años.

2. En cualquier caso, cuando concurriesen circunstancias sobrevenidas que lo hagan necesario, $y$, especialmente, para adaptar su contenido a las exigencias que se deriven de las modificaciones que se produzcan en la normativa autonómica, estatal y comunitaria en la materia de que se trate.

Artículo 23. Duración.

Los planes de la Xunta en materia de residuos tendrán la duración prevista en los mismos, prorrogándose automáticamente en tanto no se aprobase un nuevo plan que los sustituya.

\section{Capitulo III PLANIFICACIÓN DE LAS ENTIDADES LOCALES}

Artículo 24. Planes de residuos de las entidades locales.

1. Las entidades locales podrán elaborar y aprobar sus propios planes de gestión de residuos urbanos, de conformidad con lo previsto en la normativa básica, la presente ley, sus normas de desarrollo y los planes autonómicos en materia de residuos.

2. Los planes de residuos urbanos de las entidades locales respetarán las directrices contenidas en los planes de residuos de la Xunta, y contendrán, como mínimo, las determinaciones contempladas en los números 2 y 3 del artículo 18 de la presente ley, si bien referido a su ámbito territorial.

Artículo 25. Elaboración.

1. La entidad local que se proponga elaborar su propio plan en materia de residuos o modificar los ya existentes lo notificará a la Xunta de Galicia. 
2. Al objeto de evitar que se produzca una duplicidad de evaluaciones medioambientales, la consellería competente en materia de medio ambiente determinará, caso por caso, la necesidad de someter el plan o su modificación a una evaluación estratégica medioambiental, de acuerdo con lo establecido en la Ley 9/2006, de 28 de abril, sobre evaluación de los efectos de determinados planes y programas en el medio ambiente, y normativa autonómica de aplicación.

3. A los efectos de lo establecido en el apartado anterior, antes de su aprobación definitiva, la entidad local remitirá a la Xunta el texto íntegro del proyecto y las alegaciones recibidas durante el periodo de información pública, acompañadas de sus correspondientes contestaciones e informes técnicos.

4. Una vez aprobado definitivamente el plan, la entidad local procederá a su publicación y adoptará las medidas pertinentes para asegurar su máxima difusión y su conocimiento por la ciudadanía, debiendo mantener a disposición de la misma y de las entidades públicas y privadas que lo soliciten su texto íntegro.

Artículo 26. Revisión.

Los planes de las entidades locales en materia de residuos se revisarán en el plazo previsto en los mismos y cuando concurriesen circunstancias sobrevenidas que lo hagan necesario, y, en todo caso, cuando necesiten adaptarse a las directrices y objetivos del correspondiente plan autonómico de residuos, así como a las exigencias que se deriven de las modificaciones que se produzcan en la normativa autonómica, estatal y comunitaria en la materia de que se trate.

Artículo 27. Duración.

Los planes de los entes locales en materia de residuos tendrán la duración prevista en los mismos, prorrogándose automáticamente en tanto no se aprobase un nuevo plan que los sustituya.

\section{TÍTULO III MEDIDAS ECONÓMICAS $Y$ FINANCIERAS}

Artículo 28. Garantías financieras de las actividades sometidas a autorización.

1. Las autorizaciones de las actividades de gestión de residuos quedarán sujetas a la constitución por parte de quienes las soliciten de un seguro de responsabilidad civil y/o a la prestación de una fianza u otra garantía equivalente en la forma y cuantía que en cada autorización se determine, de acuerdo con lo que reglamentariamente se establezca.

2. Asimismo, la consellería competente en materia de medio ambiente exigirá, en su caso, a quienes produzcan los residuos la constitución de un seguro de responsabilidad civil y/o la prestación de una fianza u otra garantía equivalente, en la forma que reglamentariamente se establezca.

3. Estas garantías tendrán por finalidad asegurar el cumplimiento, ante las administraciones públicas, de las obligaciones que incumban en virtud de la autorización expedida, y las derivadas, en su caso, de la posible ejecución subsidiaria por parte de la administración competente, así como la reparación de los posibles daños y el coste de la restauración.

Artículo 29. Recursos económicos. La gestión de los residuos podrá financiarse mediante los siguientes recursos:

a. Las tasas y precios públicos obtenidos por la prestación de los servicios de gestión de residuos, recaudados por las administraciones municipal y autonómica.

b. Los precios privados obtenidos por las empresas legalmente autorizadas para intervenir en la gestión.

c. Las subvenciones asignadas a gestores públicos o privados.

d. Cualesquiera otros tributos que puedan establecerse para la financiación de las operaciones de gestión de residuos. 


\section{TÍTULO IV \\ PUESTA EN EL MERCADO DE PRODUCTOS QUE CON SU USO SE CONVIERTEN EN RESIDUOS}

Artículo 30. Obligaciones.

Quienes sean responsables de la puesta en el mercado de productos que con su uso se conviertan en residuos estarán obligados/as, con anterioridad a la puesta en el mercado de los primeros, a:

a. Obtener de quienes los fabricaron información suficiente sobre la cantidad y características de los residuos que, previsiblemente, puedan generarse, y los sistemas de gestión a los que habrían de someterse los mismos, así como, en caso de que contengan sustancias o preparados peligrosos, la ficha de datos de seguridad de los correspondientes productos.

b. Adoptar las medidas pertinentes para asegurar la adecuada gestión de los residuos derivados de sus productos cuando las características de los mismos no permitan su gestión a través de los sistemas e instalaciones en funcionamiento en el territorio de la Comunidad Autónoma de Galicia.

\section{Artículo 31. Régimen general.}

1. Los agentes económicos responsables de la puesta en el mercado de productos que con su uso se conviertan en residuos optarán por una de las siguientes alternativas:

a. Hacerse cargo directamente de la gestión de los residuos derivados de sus productos.

b. Participar en un sistema integrado de gestión de dichos residuos.

c. Contribuir económicamente a los sistemas públicos de gestión de residuos, en medida tal que se cubran los costes atribuibles a su gestión.

d. Aceptar un sistema de depósito, devolución y retorno de los residuos derivados de sus productos.
2. Reglamentariamente, podrá establecerse un listado de productos que con su uso se conviertan en residuos y para los cuales sea obligatorio optar por una de las alternativas previstas en el número anterior.

3. Asimismo, quienes sean responsables de la puesta en el mercado de productos que con su uso se conviertan en residuos habrán de informar anualmente al órgano competente en materia de medio ambiente de la Comunidad Autónoma de los residuos producidos en su actividad de fabricación y del resultado cualitativo y cuantitativo de las operaciones efectuadas para la gestión de los mismos.

Artículo 32. Sistemas integrados de gestión.

1. Para el cumplimiento de todas o algunas de las obligaciones previstas en el número 1 del artículo anterior, quienes sean responsables de la puesta en el mercado de productos que con su uso se conviertan en residuos podrán establecer sus propios sistemas integrados de gestión mediante la celebración de acuerdos voluntarios autorizados por la Comunidad Autónoma de Galicia.

2. La solicitud de autorización de los sistemas a que alude el apartado primero habrá de acompañarse de la documentación acreditativa de los siguientes aspectos:

a. Características de los productos incluidos y de los residuos que puedan generarse por el uso de los mismos.

b. Delimitación de su ámbito territorial de actuación.

c. Medidas a adoptar tanto para la prevención de su generación como, en su caso, para facilitar su reutilización, reciclado o cualquier otro tipo de valorización antes de su eliminación, teniendo en cuenta las particularidades de la distribución de la población y los asentamientos poblacionales en Galicia, así como su orografía.

d. Obligaciones asumidas por quienes sean responsables de la puesta en el mercado de los productos y por los demás agentes económicos que intervienen en el sistema. 
e. Mecanismos de control, seguimiento y revisión.

f. Alternativas de gestión de los residuos resultantes.

g. Estimación de la cantidad de residuos que puedan generarse anualmente en el ámbito de la Comunidad Autónoma de Galicia.

h. Objetivos previstos de reducción, reciclaje y valorización.

i. Designación de una persona representante de la empresa gestora del sistema integrado de gestión que actúe como única interlocutora con la administración.

j. Presupuesto anual, en el ámbito territorial de la Comunidad Autónoma de Galicia, del sistema integrado de gestión.

k. Acuerdo adoptado entre los agentes económicos que operen en los sectores interesados y suscritos por todos y cada uno de ellos.

1. Relación y cantidad de productos puestos en el mercado que con su uso se conviertan en residuos en el ámbito territorial de la Comunidad Autónoma de Galicia.

3. El plazo máximo para resolver y notificar estas autorizaciones es de seis meses. Transcurrido dicho plazo sin haberse notificado la resolución expresa, la autorización se entenderá denegada.

4. Las autorizaciones podrán introducir las condiciones que se estimen necesarias para su efectividad, así como prever la constitución de una garantía que asegure el cumplimiento de las obligaciones asumidas, y el establecimiento de las obligaciones de suministro de información, análisis económico y auditorías sobre la gestión de los residuos.

Artículo 33. Mecanismos de control. Cuando existan varios sistemas integrados de gestión para una misma categoría de residuos según la Lista europea de residuos, éstos están obligados al establecimiento de una oficina de coordinación en la que estén representados todos los sistemas.
Artículo 34. Suspensión o revocación de la autorización.

En caso de incumplimiento de las condiciones y requisitos establecidos en la autorización, y previa audiencia de la parte interesada, el órgano competente en materia de medio ambiente podrá suspender temporalmente o revocar la autorización, sin perjuicio de la responsabilidad administrativa derivada del incumplimiento, que se determinará, cuando proceda, en el expediente sancionador que se iniciase al efecto.

Artículo 35. Convenios de colaboración.

Para el cumplimiento de todas o algunas de las obligaciones señaladas en los artículos anteriores de este título, quienes sean responsables de la puesta en el mercado de productos que con su uso se conviertan en residuos podrán, asimismo, celebrar convenios de colaboración con la Xunta de Galicia.

Artículo 36. Medidas excepcionales en caso de cese de actividad de los sistemas integrados de gestión de residuos.

1. Cuando un sistema integrado de gestión cese en su actividad o su autorización quede suspendida o revocada, la Xunta de Galicia, a propuesta de la consellería competente en materia de medio ambiente, determinará la forma de gestión de los residuos incluidos en el sistema.

2. En los supuestos previstos en el apartado anterior, los agentes económicos participantes en el sistema integrado de gestión quedan obligados a contribuir económicamente a los sistemas públicos de gestión de residuos en la medida necesaria para cubrir los costes atribuibles a la gestión de dichos residuos hasta el momento en que el agente económico correspondiente o bien acreditase su participación en un sistema integrado de gestión debidamente autorizado y en funcionamiento o bien justificase que lo gestiona por sí mismo. 


\section{TíTULO V \\ RÉGIMEN DE INTERVENCIÓN ADMINISTRATIVA $^{479}$}

Artículo 37. Régimen de intervención administrativa de la producción y gestión de residuos.

1. Están sujetas a autorización administrativa previa del órgano competente en materia de medio ambiente de la Comunidad Autónoma las siguientes industrias y actividades:

1.1. Producción de residuos: la instalación de industrias o actividades productoras de residuos peligrosos, la ampliación y modificación sustancial o el traslado de industrias o actividades productoras de residuos peligrosos, así como aquellas industrias o actividades productoras de residuos que no tienen la consideración de peligrosos y figurasen en una lista que, en su caso, se apruebe por razón de las excepcionales dificultades que pudiera presentar la gestión de los residuos producidos.

1.2. Gestión de residuos: el almacenamiento, valorización y eliminación de residuos, así como el transporte de residuos peligrosos cuando quienes los transportan asumiesen la titularidad de los residuos en el momento de la recogida en el lugar de producción.

2. Las autorizaciones habrán de ser solicitadas por quienes sean titulares de las industrias o actividades afectadas.

3. Quienes sean titulares de las actividades de producción y gestión de residuos distintas de las enumeradas en el número 1 habrán de notificarlo al órgano competente en materia de medio ambiente para su inscripción en el Registro de Productores/as y Gestores/as de Residuos.

4. Las actividades de gestión de residuos urbanos realizadas directamente por los ayuntamientos o entes locales y la producción de los mismos por las personas particulares no estarán sometidas al

479 Decreto 59/2009, de 26 de febrero, por el que se regula la trazabilidad de los residuos régimen de control previo previsto en este artículo.

5. Reglamentariamente se establecerá el régimen jurídico de las autorizaciones de gestión y producción y el registro de las actividades previstas en este artículo, así como las actividades de producción de residuos peligrosos y no peligrosos que por su escasa incidencia medioambiental no necesitasen la intervención administrativa prevista en este artículo.

6. Quedarán exentas de las autorizaciones a que se refieren los números anteriores aquellas industrias y actividades a las que resultase de aplicación la normativa sobre prevención y control integrado de la contaminación.

Artículo 38. Obligaciones de quienes produzcan, posean y gestionen residuos.

Quienes produzcan, posean y gestionen residuos habrán de cumplir las siguientes obligaciones generales:

1. Las previstas en la Ley 10/1998, de 21 de abril, de residuos, sin perjuicio de otras obligaciones establecidas en la legislación vigente.

2. Las previstas en la presente ley y normas que la desarrollen, así como en el desarrollo reglamentario.

3. Facilitar a la consellería competente en materia de medio ambiente la información que la misma les requiera en relación con la naturaleza, características y composición de los residuos que posean, así como en las labores de inspección en relación con las materias reguladas en la presente ley.

4. Comunicar al órgano medioambiental competente cualquier cambio que se produzca, en el plazo máximo de un mes, a contar desde dicha fecha, con respecto a los datos y documentos que obren en el Registro General de Productores/as y Gestores/as de Residuos de Galicia.

5. Quienes produzcan residuos, en función de las características de sus procesos productivos, aplicarán tecnologías que originen los menos posibles, así como 
las precisas para el control, tratamiento y, en su caso, eliminación de las sustancias peligrosas que contengan.

6. Los/Las transportistas que asuman la titularidad de los residuos habrán de disponer de una infraestructura adecuada de almacenamiento.

7. Quienes produzcan residuos comerciales estarán obligados/as a entregar sus residuos a un gestor o gestora autorizado para su tratamiento, o bien a acogerse al sistema de recogida y gestión que el ente local competente establezca para este tipo de residuos.

Artículo 39. Importación, adquisición intracomunitaria, intermediación y agencia.

1. Sin perjuicio de lo establecido en la normativa comunitaria y de las actuaciones que, en su caso, fuesen exigibles, quienes sean responsables de importaciones y adquisiciones intracomunitarias, así como de agencias comerciales o intermediaciones que, en nombre propio o ajeno, pongan residuos en el mercado o realicen con los mismos operaciones jurídicas que impliquen cambios de titularidad posesoria incluso sin contenido transaccional comercial, habrán de notificarlo previamente a la consellería competente en materia de medio ambiente para su registro administrativo, indicando, al menos, las cantidades, naturaleza, orígenes y destino de los residuos, así como, en su caso, el método de transporte y el método de valorización o eliminación a emplear.

2. Reglamentariamente podrá establecerse un procedimiento adecuado para el control y supervisión.

\section{TÍTULO VI EXPROPIACIÓN}

Artículo 40. Declaración de utilidad pública.

1. Se declara de utilidad pública e interés social, a los efectos de la legislación de expropiación forzosa, el establecimiento o ampliación de instalaciones de gestión de residuos.
2. La declaración de utilidad pública conllevará en todo caso la necesidad de ocupación de los bienes o la adquisición de los derechos afectados e implicará la urgente ocupación a los efectos del artículo 52 de la Ley de expropiación forzosa de 16 de diciembre de 1954.

Artículo 41. Solicitud de reconocimiento de utilidad pública.

1. Para el reconocimiento de la utilidad pública de las instalaciones a que se refiere el artículo anterior, será necesario que la empresa interesada lo solicite, incluida una relación concreta e individualizada de los bienes o derechos que quien haga la solicitud estimase de necesaria expropiación.

2. La petición se someterá a información pública, recabándose informe de los organismos afectados.

3. Concluida la tramitación, el reconocimiento de la utilidad pública será acordado por la consellería competente en materia de medio ambiente.

\section{TÍTULO VII DE LA CONTAMINACIÓN Y DEGRADACIÓN DEL SUELO}

\section{Capitulo I SUELOS CONTAMINADOS480}

Artículo 42. Declaración de suelo contaminado.

1. La consellería competente en materia de medio ambiente, de acuerdo con la normativa vigente, declarará, delimitará y regulará los suelos contaminados y la creación de su correspondiente registro. El plazo máximo para la notificación de la resolución de declaración de un suelo como contaminado será de un año, a contar desde el inicio del procedimiento para su declaración como tal.

2. La resolución que declare un suelo como contaminado contendrá, al menos, las siguientes determinaciones:

480 Decreto 60/2009, de 26 de febrero, sobre suelos potencialmente contaminados y procedimiento para la declaración de suelos contaminados. 
a. Delimitación del suelo contaminado.

b. Las personas físicas o jurídicas obligadas a llevar a cabo la limpieza y recuperación.

c. Las principales operaciones para su limpieza y recuperación.

d. En su caso, medidas preventivas, de defensa y control y de seguimiento que hayan de adoptarse.

e. Los usos a los que no podrá destinarse el suelo, en tanto subsista la declaración.

f. Requisitos jurídicos y técnicos en los que se sustenta la declaración.

Artículo 43. Efectos de la declaración.

1. La declaración de un suelo como contaminado obligará a realizar las actuaciones necesarias para proceder a su limpieza y recuperación, en la forma y plazos que determine el órgano competente de la Comunidad Autónoma.

2. Tendrán la obligación de realizar las operaciones de limpieza y recuperación quienes causaran la contaminación, y cuando sean varios/as responderán de estas obligaciones de forma solidaria y subsidiariamente, por este orden, los/las poseedores/as de los suelos contaminados y los/las propietarios/as no poseedores/as.

3. Una vez que la declaración de un suelo como contaminado fuese firme en vía administrativa, ésta será objeto de nota marginal en el registro de la propiedad, a iniciativa de la consellería competente en materia de medio ambiente. Dicha nota se cancelará una vez que se declarase que el suelo ha dejado de tener tal consideración.

4. La firmeza de la declaración de un suelo como contaminado implicará su inclusión en el Registro de Calidad de los Suelos de Galicia.

Artículo 44. Acuerdos voluntarios y convenios de colaboración.

1. Las actuaciones para proceder a la limpieza y recuperación de los suelos declarados como contaminados podrán llevarse a cabo mediante:

a. Acuerdos voluntarios celebrados entre quienes tuviesen la obligación de realizar dichas operaciones y autorizados por el órgano correspondiente de la consellería competente en materia de medio ambiente.

b. Convenios de colaboración entre quienes tuviesen la obligación de realizar dichas operaciones y las administraciones públicas competentes, que podrán concretar incentivos económicos que puedan servir de ayuda para financiar los costes de limpieza y recuperación de suelos contaminados.

2. En todo caso, los costes de limpieza y recuperación de suelos contaminados correrán a cargo de quienes tuviesen la obligación, en cada caso, de realizar dihas operaciones.

3. Los acuerdos voluntarios a que alude el apartado primero contendrán, al menos, las siguientes determinaciones:

a. Alcance de las operaciones de limpieza y recuperación a realizar y obligaciones asumidas, por cada una de las partes responsables, en relación con las mismas.

b. En su caso, medidas preventivas, de defensa y control y de seguimiento que hayan de adoptarse.

c. Plazo de ejecución.

d. Presupuesto y mecanismos de financiación.

Artículo 45. Medidas provisionales.

1. Antes de la iniciación del procedimiento de declaración de suelo contaminado, la consellería competente en materia de medio ambiente, de oficio o a instancia de parte, en los casos en que existiese un grave riesgo para la salud de las personas o el medio ambiente, podrá adoptar las medidas provisionales que estime oportunas. Las medidas provisionales deberán ser confirmadas, modificadas o levantadas en el acuerdo de iniciación del procedimiento, que habrá de efectuarse dentro de los quince días siguientes a su adopción.

En todo caso, dichas medidas quedarán sin efecto si no se iniciase el procedimiento en dicho plazo o cuando el acuerdo de 
iniciación no contenga un pronunciamiento expreso acerca de las mismas.

2. Una vez iniciado el procedimiento de declaración de un suelo como contaminado, el órgano correspondiente de la consellería competente en materia de medio ambiente para resolverlo podrá adoptar, de oficio o a instancia de parte, las medidas provisionales que estime oportunas para asegurar la eficacia de la resolución que pudiera dictarse, en los supuestos en que existiese un grave riesgo para la salud de las personas o el medio ambiente.

3. Las medidas provisionales podrán ser alzadas o modificadas durante la tramitación del procedimiento, de oficio o a instancia de parte, en virtud de circunstancias sobrevenidas o que no hubieran podido tenerse en cuenta en el momento de su adopción.

En todo caso, se extinguirán con la eficacia de la resolución administrativa que ponga fin al procedimiento.

Artículo 46. Actividades potencialmente contaminantes de suelos.

1. Quienes tengan la propiedad de fincas en las que se hubiera realizado alguna de las actividades potencialmente contaminantes de suelos tendrán la obligación, con motivo de su transmisión, de declararlo en escritura pública. Este hecho será objeto de nota marginal en el registro de la propiedad.

2. Quienes sean titulares de actividades potencialmente contaminantes habrán de remitir al órgano correspondiente de la consellería competente en materia de medio ambiente un informe de situación, con el contenido y periodicidad que reglamentariamente se establezca.

Artículo 47. Relación con el plan urbanístico.

1. No podrán ejecutarse desarrollos urbanísticos en los ámbitos que incluyan suelos contaminados en tanto la consellería competente en materia de medio ambiente no declarase que los suelos han dejado de tener tal consideración.
2. En relación con dichos suelos y al objeto de determinar la viabilidad de los usos previstos en el ámbito a desarrollar, para la tramitación de los planes urbanísticos deberá presentarse, junto con la documentación exigida por la normativa de aplicación, un informe de la calidad del suelo.

\section{Capitulo II ESPACIOS DEGRADADOS}

Artículo 48. Regeneración de espacios degradados.

Al objeto de subsanar los efectos causados por una deficiente gestión de los residuos, se acometerán las obras e instalaciones necesarias para restituir los terrenos que han sido objeto de vertidos incontrolados o de un inadecuado depósito de los residuos por parte de quienes los gestionen actualmente a las condiciones medioambientales que poseían antes de la iniciación de estas actividades.

Artículo 49. Responsables de la degradación del terreno.

1. Se considerarán responsables de la degradación del terreno, teniendo, por tanto, la obligación en primer lugar de restaurarlo:

a. La persona física o jurídica que efectuó el vertido inadecuado de los residuos $\mathrm{y}$, solidariamente, quienes los produjeran o poseyeran, salvo que estos últimos los hubieran entregado a un gestor o gestora autorizado para dicha actividad.

b. Subsidiariamente, quienes tengan la propiedad del terreno donde se produjo la descarga o, en su caso, la titularidad del dominio público afectado.

2. En aquellos supuestos en los que quien tuviera la responsabilidad de la degradación haya sido un ayuntamiento, las actuaciones de regeneración serán acometidas por la entidad local en cuyo territorio se encuentre el espacio degradado. La Xunta actuará a través de la asistencia y cooperación con las administraciones afectadas. 


\section{TÍTULO VIII FOMENTO}

Artículo 50. Subvenciones.

La Comunidad Autónoma de Galicia, en el ámbito de sus competencias, podrá otorgar subvenciones para incentivar mecanismos de producción limpia y la implantación de las mejores técnicas disponibles en la gestión de los residuos.

Artículo 51. Promoción.

La consellería competente en materia de medio ambiente podrá:

a. Desarrollar, con carácter periódico, campañas de formación y concienciación ciudadana dirigidas a fomentar el cumplimiento de los objetivos de la presente ley.

b. Potenciar la celebración de acuerdos entre la consellería competente en materia de medio ambiente y los sectores productivos, representantes patronales y sindicales y del asociacionismo medioambiental, de las asociaciones de personas consumidoras y de otras organizaciones de participación ciudadana.

c. Promover convenios con entidades públicas o privadas, para la implantación de medidas tendentes a la educación, investigación, información y asesoramiento, orientadas especialmente a pymes, para introducir en las empresas las tecnologías menos contaminantes y prácticas de prevención en materia de residuos.

d. Favorecer, a través de acuerdos con la consellería competente en materia de educación, la integración de contenidos en materia de residuos en los ciclos formativos, a fin de mejorar la conciencia medioambiental del estudiantado y la ciudadanía en general.

\section{TÍTULO IX INSPECCIÓN, VIGILANCIA Y CONTROL}

Artículo 52. Órganos competentes.

La inspección, vigilancia y control del cumplimiento de la presente ley, así como de sus normas de desarrollo, corresponde, en el ámbito de sus respectivas competencias, a la consellería competente en materia de medio ambiente o al ayuntamiento respectivo.

Artículo 53. Servicios de inspección y vigilancia de la Comunidad Autónoma de Galicia.

1. Las funciones de vigilancia e inspección medioambiental de la Comunidad Autónoma de Galicia relativas al cumplimiento de la presente ley se llevarán a cabo:

a. Directamente por personal funcionario debidamente acreditado por la consellería competente en materia de medio ambiente. Dicho personal tendrá el carácter de agente de la autoridad y los hechos constatados por el mismo y formalizados en acta gozarán de la presunción de certeza a efectos probatorios. A tal fin, estará facultado para realizar exámenes, controles, tomas de muestras y recogida de información y para acceder a aquellos lugares e instalaciones donde se desarrollen las actividades mencionadas en la presente ley, previa identificación y sin necesidad de aviso previo.

b. Por organismos de control debidamente autorizados por la consellería competente en materia de medio ambiente en el ámbito de los residuos.

2. Para el desempeño de sus funciones, los/las agentes de la autoridad podrán ir acompañados/as de asesores/as técnicos debidamente identificados y autorizados por quien sea titular del órgano del que dependan los servicios de vigilancia e inspección, que en ningún caso tendrán la consideración de agentes de la autoridad ni gozarán de las potestades de la misma. Este personal asesor estará obligado a guardar secreto respecto a los datos e informaciones de que tuviese conocimiento en el ejercicio de estas funciones.

3. Reglamentariamente se establecerán las funciones que desarrollarán las entidades medioambientales de control, así como los requisitos y procedimiento para 
su ejercicio. Estas entidades de control están obligadas igualmente a guardar secreto respecto a los datos e informaciones de que tuviesen conocimiento en el ejercicio de estas funciones de vigilancia e inspección.

Artículo 54. Actas de inspección.

Los hechos constatados por los/las agentes de la autoridad se formalizarán en un acta y gozarán de la presunción de certeza a efectos probatorios. Dicha acta será firmada por el/la agente de la autoridad y se entregará copia a la parte interesada.

Artículo 55. Costes de los servicios de inspección.

El coste de las inspecciones previas a la concesión de autorización, así como aquellas otras que sean preceptivas, podrá ser imputado a quienes hubiesen solicitado las mismas o a quienes sean titulares de las instalaciones inspeccionadas, respectivamente. También se podrá imputar el coste de las inspecciones facultativas cuando las mismas se realicen como consecuencia de no atender quienes sean titulares de la instalación a los requerimientos de la administración, cuando se realicen en el ámbito de un procedimiento sancionador que finalizase con la imposición de una sanción o cuando se aprecie temeridad o mala fe en quienes sean titulares de la instalación inspeccionada.

Artículo 56. Autodiagnósticos y auditorías.

1. Todas las actividades industriales y/o empresas que generen residuos industriales habrán de realizar autodiagnósticos medioambientales, empleándose como herramienta de control medioambiental la auditoría medioambiental y la declaración de ecoeficiencia o de sostenibilidad en consonancia con las definiciones de la presente ley.

2. Los documentos de autodiagnóstico medioambiental serán aprobados por el órgano de control medioambiental, de modo específico para cada sector cuando ello fuese posible.
3. La declaración de ecoeficiencia o de sostenibilidad tendrá como base los datos obtenidos previamente en el documento de autodiagnóstico medioambiental.

4. La periodicidad de los autodiagnósticos y declaraciones derivadas de los mismos, a que se refieren los números $2 \mathrm{y}$ 3 de este artículo, será anual.

5. Para la verificación de la información contenida en los documentos de autodiagnóstico y en las declaraciones, así como para la revisión de estos documentos, el órgano de control medioambiental llevará a cabo auditorías medioambientales.

Artículo 57. Deber de colaboración.

Quienes sean titulares de las actividades a que se refiere la presente ley que sean objeto de vigilancia, inspección y auditoría tienen la obligación de permitir el acceso, para el ejercicio de sus funciones, a los funcionarios y funcionarias o personal de las entidades medioambientales de control debidamente identificados, así como a los asesores y asesoras técnicos que circunstancialmente acompañasen a dicho funcionariado, y a prestarles la colaboración necesaria para la realización de exámenes, controles, tomas de muestras y recogida de información y cualquier otra operación para el cumplimiento de su misión.

\section{TÍTULO X \\ RÉGIMEN Y PROCEDIMIENTO SANCIONADOR}

\section{Capitulo I RÉGIMEN SANCIONADOR}

Artículo 58. Potestad sancionadora.

1. El ejercicio de la potestad sancionadora sobre las actividades sometidas a lo dispuesto en la presente ley corresponde a los órganos correspondientes de la consellería competente en medio ambiente y a los ayuntamientos, de acuerdo con sus respectivos ámbitos competenciales atribuidos por la legislación vigente.

2. La inobservancia o vulneración de las prescripciones contenidas en la 
legislación básica estatal, la presente ley y normas que la desarrollen, o en las ordenanzas y demás normas municipales, constituye infracción administrativa y será sancionada con arreglo a lo establecido en los siguientes artículos, sin perjuicio, en su caso, de las correspondientes responsabilidades civiles y penales.

Artículo 59. Responsabilidad administrativa.

1. A los efectos de lo establecido en este título, los residuos tendrán siempre un o una titular responsable, calidad que corresponderá a quien los produzca, posea o gestione.

2. La responsabilidad será solidaria en los siguientes supuestos:

a. Cuando quienes posean o gestionen los residuos los entregasen a persona física o jurídica distinta de las señaladas en la presente ley.

b. Cuando fuesen varios/as los/las responsables y no sea posible determinar el grado de participación de cada uno/a en la realización de la infracción.

3. Cuando los daños causados al medio ambiente se produjesen por acumulación de actividades debidas a diferentes personas, la administración competente podrá imputar individualmente esta responsabilidad y sus efectos económicos.

4. Sólo habrá exención de responsabilidad administrativa para quienes cediesen los residuos a gestores/as autorizados para realizar las operaciones que componen la gestión de residuos, y siempre que la entrega de los mismos se realizase cumpliendo los requisitos establecidos en la normativa básica y en la presente ley y sus normas de desarrollo. En todo caso, la cesión constará en documento fehaciente.

5. Igualmente, para quienes posean residuos urbanos habrá exención de responsabilidad por los daños que pudieran derivarse de tales residuos, siempre que los hayan entregado a las entidades locales o a gestores/as autorizados por éstas, observando las respectivas ordenanzas y demás normativa de aplicación.

\section{Artículo 60. Infracciones.}

1. Constituyen infracciones, con arreglo a la presente ley, las acciones y omisiones tipificadas en la misma, sin perjuicio de las correspondientes responsabilidades civiles y penales a que pudiesen dar lugar.

2. Las infracciones a la presente ley se clasifican en muy graves, graves y leves.

Artículo 61. Infracciones muy graves.

Son infracciones muy graves:

a. El ejercicio de una actividad descrita en la presente ley o normativa que la desarrolle sin la preceptiva autorización o con la misma caducada, revocada o suspendida, y el incumplimiento de las obligaciones impuestas en las autorizaciones, así como la actuación en forma contraria a lo establecido en la presente ley, cuando la actividad no estuviera sujeta a autorización específica, todo ello siempre que se hubiera puesto en peligro grave la salud de las personas o el medio ambiente o cuando la actuación tuviese lugar en espacios protegidos en función de su valor ecológico.

b. El abandono, vertido o eliminación incontrolados de residuos peligrosos.

c. El abandono, vertido o eliminación incontrolados de cualquier otro tipo de residuos, siempre que se hubiera producido un daño o deterioro grave para el medio ambiente o se haya puesto en peligro grave la salud de las personas.

d. El incumplimiento de las obligaciones derivadas de las medidas provisionales y cautelares, salvo los supuestos de fuerza mayor o imposibilidad sobrevenida.

e. La ocultación o alteración maliciosa de datos aportados a los expedientes administrativos para la obtención de autorizaciones, licencias, permisos o inscripciones relacionadas con el ejercicio de las actividades reguladas en la presente ley.

f. La elaboración, importación o adquisición intracomunitaria de productos con sustancias o preparados prohibidos por la normativa vigente por la peligrosidad de los residuos que generan. 
g. El incumplimiento por los agentes económicos responsables de la puesta en el mercado de productos que con su uso se conviertan en residuos de las obligaciones señaladas en el artículo 31.1 de la presente ley.

h. La no realización de las operaciones de limpieza y recuperación cuando un suelo fuese declarado como contaminado, tras el correspondiente requerimiento de la consellería competente en materia de medio ambiente, o el incumplimiento, en su caso, de las obligaciones derivadas de acuerdos voluntarios o convenios de colaboración.

i. La mezcla de las diferentes categorías de residuos peligrosos entre sí o de éstos con los que no tengan tal consideración, siempre que se hubiera producido un daño o deterioro grave para el medio ambiente o se haya puesto en peligro grave la salud de las personas.

j. La entrega, venta o cesión de residuos peligrosos a personas físicas o jurídicas distintas de las señaladas en la presente ley, así como la aceptación de los residuos en condiciones distintas de las que aparezcan en las correspondientes autorizaciones o en las normas establecidas en la presente ley y en sus disposiciones de desarrollo.

k. La omisión, en caso de residuos peligrosos, de los necesarios planes de seguridad y previsión de accidentes, así como de los planes de urgencia interior y exterior de las instalaciones, exigibles de conformidad con la normativa de aplicación.

1. El incumplimiento de la obligación de reponer prevista en el artículo 72 .

$\mathrm{m}$. La comisión durante un periodo de tres años de dos o más infracciones graves sancionadas con carácter firme en vía administrativa.

Artículo 62. Infracciones graves. Son infracciones graves:

a. El ejercicio de una actividad descrita en la presente ley o normativa que la desarrolle sin la preceptiva autorización o con la misma caducada, revocada o suspendida, y el incumplimiento de las obligaciones impuestas en las autorizaciones, así como la actuación en forma contraria a lo establecido en la presente ley, cuando la actividad no estuviera sujeta a autorización específica, todo ello siempre que no se hubiera puesto en peligro grave la salud de las personas ni se haya producido un daño o deterioro grave para el medio ambiente.

b. El abandono, vertido o eliminación incontrolados de cualquier tipo de residuos no peligrosos, siempre que no se hubiera puesto en peligro grave la salud de las personas ni se haya producido un daño o deterioro grave para el medio ambiente.

c. El incumplimiento de las condiciones de almacenamiento de cualquier tipo de residuos establecidas en la normativa.

d. El incumplimiento de la obligación de proporcionar documentación o información o la ocultación o falseamiento de datos exigidos por la normativa de aplicación o por las estipulaciones contenidas en la autorización, así como el incumplimiento de la obligación de custodia y mantenimiento de dicha documentación.

e. La falta de constitución de seguros, fianzas u otras garantías, o de su renovación, cuando fuesen obligatorias.

f. El traslado de residuos con origen o destino en el territorio de la Comunidad Autónoma de Galicia de residuos procedentes de otros estados u otra parte del territorio nacional $\sin$ los requisitos previstos en la legislación comunitaria, la presente ley o las normas que la desarrollen.

g. En caso de adquisición intercomunitaria de residuos, el incumplimiento de la obligación de notificar la realización de su valorización o eliminación, de acuerdo con lo establecido en el Reglamento 1013/2006/CE. 
h. La obstrucción a la actividad inspectora o de control de las administraciones públicas.

i. La falta de etiquetado o el etiquetado incorrecto o parcial de los envases que contengan residuos peligrosos.

j. La mezcla de las diferentes categorías de residuos peligrosos entre sí o de éstos con los que no tengan tal consideración, siempre que, como consecuencia de ello, no se hubiera puesto en peligro grave la salud de las personas ni se haya producido un daño o deterioro grave para el medio ambiente.

k. La entrega, venta o cesión de residuos no peligrosos a personas físicas o jurídicas distintas de las señaladas en la presente ley, así como la aceptación de los residuos en condiciones distintas de las que aparezcan en las correspondientes autorizaciones o en las normas establecidas en la presente ley y en sus disposiciones de desarrollo.

1. El incumplimiento por parte de las entidades aseguradoras o del asegurado de la obligación de notificar a la consellería competente en materia de medio ambiente la suspensión de la cobertura o la extinción del contrato de seguro.

$\mathrm{m}$. La comisión de alguna de las infracciones indicadas en el artículo anterior cuando, por su escasa cuantía o entidad, no mereciesen la calificación de muy graves.

n. La comisión durante un periodo de tres años de dos o más infracciones leves sancionadas con carácter firme en vía administrativa.

Artículo 63. Infracciones leves. Son infracciones leves:

a. El ejercicio de una actividad descrita en la presente ley sin la correspondiente inscripción en los registros administrativos pertinentes en su caso.

b. El abandono o vertido de residuos derivados del consumo privado en la vía pública y espacios públicos. c. El retraso en el suministro de la documentación o información que haya de proporcionarse a la administración de acuerdo con lo establecido por la normativa de aplicación o por las estipulaciones contenidas en las autorizaciones.

d. La comisión de alguna de las infracciones indicadas en el artículo anterior cuando, por su escasa cuantía o entidad, no mereciesen la calificación de graves.

e. Cualquier infracción de lo establecido en la presente ley, sus normas de desarrollo o las estipulaciones contenidas en las autorizaciones, cuando no estuviese tipificada como muy grave o grave.

Artículo 64. Prescripción de las infracciones.

1. Las infracciones previstas en la presente ley prescribirán en los siguientes plazos:

a. Las infracciones muy graves, a los cinco años.

b. Las infracciones graves, a los tres años.

c. Las infracciones leves, al año.

2. El plazo de prescripción comenzará a contarse desde el día en que la infracción se hubiera cometido, con las siguientes particularidades:

a. Cuando se tratase de infracciones continuadas, el plazo de prescripción comenzará a contar desde el momento de la finalización o cese de la acción u omisión que constituye la infracción.

b. Cuando no fuesen inmediatamente perceptibles los daños al medio ambiente derivados de las infracciones, el plazo de prescripción comenzará a contar desde el momento de su manifestación o conocimiento.

3. Interrumpirá la prescripción la iniciación, con conocimiento de la parte interesada, del procedimiento sancionador, reanudándose el plazo de prescripción si el expediente sancionador estuviera paralizado durante más de 
un mes por causa no imputable a la parte presuntamente responsable.

Artículo 65. Sanciones.

1. Por la comisión de las infracciones muy graves podrá imponerse alguna de las siguientes sanciones:

a. Multa desde 31.001 hasta 2.000.000 de euros, salvo en residuos peligrosos, que será desde 301.001 hasta 2.000.000 de euros.

b. Inhabilitación para el ejercicio de cualquiera de las actividades previstas en la presente ley por un periodo de tiempo no inferior a un año ni superior a diez.

c. En los supuestos de infracciones tipificadas en los apartados a), d), e), i) y k) del artículo 61, clausura temporal o definitiva, total o parcial, de las instalaciones o aparatos.

d. En los supuestos de infracciones tipificadas en los apartados a), d), e), f), i), j) y k) del artículo 61, revocación de la autorización o suspensión de la misma, o cancelación o suspensión de la inscripción registral, por un tiempo no inferior a un año ni superior a diez.

2. Por la comisión de las infracciones graves podrá imponerse alguna de las siguientes sanciones:

a. Multa desde 603 hasta 31.000 euros, salvo en los residuos peligrosos, que será desde 6.020 hasta 301.000 euros.

b. Inhabilitación para el ejercicio de cualquiera de las actividades previstas en la presente ley por un periodo de tiempo de hasta un año.

c. En los supuestos de infracciones tipificadas en los apartados a), e), f), g), h), i), j) y k) del artículo 62, revocación de la autorización o suspensión de la misma, o cancelación o suspensión de la inscripción registral, por un tiempo de hasta un año.

3. Por la comisión de las infracciones leves podrá imponerse la sanción de multa de hasta 602 euros, salvo en residuos peligrosos, que será hasta 6.019 euros.
En el supuesto de la infracción tipificada en el apartado b) del artículo 63, los ayuntamientos de la Comunidad Autónoma de Galicia podrán establecer en sus ordenanzas, como alternativa a la multa, la posibilidad de que quien cometió la infracción realice, con carácter voluntario, una prestación personal de servicios de limpieza en la vía pública.

4. La sanción de multa será compatible con el resto de las sanciones previstas en los números anteriores.

5. Las personas físicas o jurídicas que hubieran sido sancionadas por faltas graves o muy graves derivadas del incumplimiento de la presente ley no podrán obtener subvenciones ni otro tipo de ayudas de la Comunidad Autónoma de Galicia hasta cumplir la sanción y, en su caso, ejecutar las medidas correctoras pertinentes.

Artículo 66. Equiparación al beneficio.

En ningún caso la multa que se impusiese por la comisión de una infracción tipificada en la presente ley resultará más beneficiosa para quienes cometieron la infracción que el cumplimiento de la disposición infringida, pudiendo incrementarse su cuantía hasta el doble de la misma, aunque ello suponga sobrepasar las sanciones máximas previstas en el artículo precedente. La valoración del beneficio ilícito se realizará con arreglo a valores y precios de mercado.

Artículo 67. Graduación de las sanciones.

1. Habrá de guardarse la debida adecuación entre la gravedad del hecho constitutivo de la infracción y la sanción aplicada, considerándose especialmente los siguientes criterios para la graduación de la sanción a aplicar:

a. La naturaleza del riesgo o daño ocasionado, su repercusión y trascendencia social, el coste de restitución o la irreversibilidad del daño o deterioro producido en la calidad del recurso o bien protegido. 
b. La existencia de intencionalidad o reiteración.

c. La cuantía del beneficio ilícito obtenido y el grado de participación de los sujetos.

d. La comisión de la infracción en espacios naturales protegidos por la normativa vigente, así como en los espacios contemplados en la Red Natura 2000 y en áreas de elevado valor paisajístico, establecidas estas últimas de acuerdo con la normativa vigente en materia de protección del paisaje en Galicia.

e. La reincidencia, por la comisión en el término de un año de más de una infracción de la misma naturaleza cuando así haya sido declarado por resolución firme.

f. La adopción, con antelación a la finalización del procedimiento sancionador, y previo consentimiento del órgano medioambiental competente, de medidas correctoras que minimicen o resuelvan los efectos perjudiciales que sobre el medio ambiente se derivasen de la infracción.

2. Cando la sanción consistiese en el cierre temporal del establecimiento o la suspensión de la actividad, se incluirá en el cómputo de la duración de la sanción el tiempo que el establecimiento hubiera estado cerrado o la actividad suspendida como medida provisional o cautelar.

Artículo 68. Causas modificativas. Podrá tenerse en cuenta como circunstancia atenuante o agravante la disposición de quienes hubieran cometido la infracción para reparar los daños causados.

Artículo 69. Prescripción de las sanciones.

1. Las sanciones previstas en la presente ley prescribirán en los siguientes plazos:

a. Las sanciones impuestas por infracciones muy graves, a los cinco años.

b. Las sanciones impuestas por infracciones graves, a los tres años.

c. Las sanciones impuestas por infracciones leves, al año.
2. El plazo de prescripción de las sanciones comenzará a contarse desde el día siguiente a aquel en que adquiriese firmeza la resolución por la que se impone la sanción.

3. Interrumpirá la prescripción la iniciación, con conocimiento de la parte interesada, del procedimiento de ejecución, volviendo a transcurrir el plazo si aquél estuviera paralizado durante más de un mes por causa no imputable a quien cometió la infracción.

Artículo 70. Publicidad de las sanciones.

1. El órgano competente para resolver el procedimiento sancionador podrá acordar que se dé publicidad a las sanciones impuestas por la comisión de las infracciones graves o muy graves, por razones de ejemplaridad y siempre que concurriese alguna de las circunstancias de riesgo o daño efectivo para el medio ambiente, reincidencia o intencionalidad acreditada, una vez que dichas sanciones adquiriesen firmeza.

2. La publicidad de las sanciones se efectuará en los medios que se estimen oportunos, haciéndose indicación expresa en dicha publicación de las personas físicas o jurídicas responsables y de las infracciones cometidas.

Artículo 71. Compatibilidad de las sanciones.

1. Cuando la misma conducta resultase sancionable con arreglo a la presente ley y otras normas de protección medioambiental, se impondrá únicamente la sanción más grave de las que resultasen aplicables o, a igual gravedad, la de superior cuantía $\mathrm{y}$, en caso de igual cuantía, prevalecerá la norma especial.

2. El apartado anterior no será de aplicación a las acciones u omisiones que infringiesen normas de protección medioambiental y normas de índole sectorial encaminadas a la protección de bienes o valores distintos, o se fundasen en el incumplimiento de diferentes obligaciones formales. 
En estos supuestos, el órgano medioambiental de la Comunidad Autónoma de Galicia habrá de remitir al órgano competente por razón de la materia los antecedentes que obrasen en su poder y que pudieran acreditar dicha infracción.

Artículo 72. Obligación de reponer e indemnización de los daños al medio ambiente.

1. Sin perjuicio de la sanción penal o administrativa que se impusiera, quienes infrinjan la presente ley tendrán la obligación de reponer o restaurar las cosas al ser y estado anteriores a la infracción cometida, en la forma y condiciones establecidas por el órgano que impuso la sanción. A tal fin la resolución sancionadora determinará el contenido de esta obligación, así como el plazo para su ejecución.

2. Quienes sean responsables de las infracciones en materia de medio ambiente deberán indemnizar por los daños y perjuicios causados. La valoración de los mismos se hará por la administración, previa tasación contradictoria cuando quienes sean responsables no hayan prestado su conformidad a la valoración realizada.

3. La prescripción de infracciones y sanciones no afectará a la obligación de reponer o restaurar las cosas a su ser y estado primitivo, ni a la de indemnizar por los daños y perjuicios causados.

Artículo 73. Multas coercitivas y ejecución subsidiaria.

1. Si quienes cometieron la infracción no procediesen a la reposición o restauración en los plazos y términos fijados en la resolución sancionadora, el órgano competente podrá acordar la imposición de multas coercitivas de acuerdo con el artículo 99 de la Ley 30/1992, de 26 de noviembre, de régimen jurídico de las administraciones públicas y del procedimiento administrativo común, que serán reiteradas por lapsos de tiempo suficientes para cumplir lo ordenado. Estas multas serán independientes de las sanciones que se hubieran impuesto por las infracciones cometidas y compatibles con las mismas.

2. La cuantía de cada una de las multas coercitivas no sobrepasará un tercio de la multa fijada por la infracción cometida. La cuantía se fijará teniendo en cuenta los criterios siguientes:

a. El retraso en el cumplimiento de la obligación de reparar.

b. La existencia de intencionalidad o reiteración.

c. La naturaleza de los perjuicios causados y, en concreto, que el daño afectase a recursos o espacios únicos, escasos o protegidos.

d. La reincidencia en el incumplimiento de las obligaciones de reparación de los daños causados al medio ambiente.

3. Asimismo, en estos casos, el órgano sancionador podrá, igualmente, proceder, por sí o a través de las personas que se determinen, a la ejecución subsidiaria por cuenta de quien cometió la infracción y a su costa.

\section{Capitulo II PROCEDIMIENTO SANCIONADOR}

Artículo 74. Procedimiento sancionador y resolución.

1. La imposición de sanciones y la exigencia de responsabilidades con arreglo a la presente ley se realizará mediante la instrucción del correspondiente procedimiento sancionador de acuerdo con lo dispuesto en el título IX de la Ley 30/1992, de 26 de noviembre, de régimen jurídico de las administraciones públicas y del procedimiento administrativo común, y en el Real decreto 1398/1993, de 4 de agosto, por el que se aprueba el Reglamento del procedimiento para el ejercicio de la potestad sancionadora, así como en las normas de desarrollo dictadas por la Comunidad Autónoma de Galicia. 
2. La resolución que ponga fin al procedimiento será motivada, y resolverá todas las cuestiones planteadas en el expediente. La resolución habrá de dictarse en el plazo máximo de un año desde la incoación del procedimiento.

3. En la resolución no podrán aceptarse hechos distintos de los determinados en el curso del procedimiento, con independencia de su diferente valoración jurídica.

4. La resolución será ejecutiva cuando ponga fin a la vía administrativa. En la misma se adoptarán, en su caso, las disposiciones cautelares precisas para garantizar su eficacia en tanto no sea ejecutiva.

Artículo 75. Relación con el orden jurisdiccional penal.

1. En cualquier momento del procedimiento sancionador, cuando el órgano competente estimase que los hechos también pudieran ser constitutivos de ilícito penal, lo comunicará al Ministerio Fiscal, recabándole testimonio sobre las actuaciones practicadas respecto a la comunicación.

En estos supuestos, así como cuando el órgano competente tuviera conocimiento de que se está desarrollando un proceso penal sobre los mismos hechos, recabará del órgano judicial comunicación sobre las actuaciones adoptadas.

2. Recibida la comunicación, y si se estimase que existe identidad de sujeto, hecho y fundamento entre la infracción administrativa y la infracción penal que pudiera corresponder, el órgano competente para la resolución del procedimiento sancionador acordará su suspensión hasta que se dictase resolución judicial.

3. En caso de que la resolución judicial no estimase la existencia de delito o falta, el órgano competente podrá continuar la tramitación del procedimiento sancionador. En todo caso, los hechos declarados probados por resolución judicial penal firme vincularán al órgano administrativo respecto a los procedimientos sancionadores que sustancien.

Artículo 76. Medidas provisionales urgentes.

1. Antes de la iniciación del procedimiento sancionador, quien sea titular del órgano competente, de oficio o a instancia de parte, en los casos en que existiese un grave riesgo para la salud de las personas o el medio ambiente, podrá adoptar las medidas provisionales que estime oportunas.

2. Las medidas provisionales habrán de ser confirmadas, modificadas o levantadas en el acuerdo de iniciación del procedimiento dentro de los quince días siguientes a su adopción. Esta actuación habrá de realizarse previa audiencia a la parte interesada por un plazo de cinco días. En todo caso, tales medidas quedarán sin efecto si no se iniciase el procedimiento en dicho plazo o cuando el acuerdo de inicio no contenga un pronunciamiento expreso acerca de las mismas.

3. Estas medidas provisionales serán independientes de las resoluciones que sobre la solicitud de adopción de medidas provisionales pudieran adoptar los jueces y las juezas de los órdenes civil o penal debidas al ejercicio de acciones de responsabilidad por personas legitimadas.

4. El órgano autonómico competente en materia de medio ambiente para la adopción de las medidas provisionales urgentes y los ayuntamientos que, en su caso, hubieran adoptado medidas provisionales urgentes deberán comunicarse entre sí -cuando éstas hayan sido dictadas-sus respectivas resoluciones en el plazo de diez días desde su adopción.

Artículo 77. Apercibimiento.

Si se comprobase la existencia de infracciones leves como consecuencia de una inspección, el órgano competente para resolver el procedimiento sancionador podrá apercibir a la empresa para que 
subsane los defectos detectados en un plazo determinado, siempre y cuando no hubiera sido apercibida en el último año por un hecho igual o similar.

Artículo 78. Medidas cautelares.

1. Iniciado el procedimiento sancionador, el órgano administrativo competente para resolverlo, de oficio o a instancia de parte, podrá adoptar las medidas cautelares que estimase necesarias para asegurar la eficacia de la resolución que pudiera recaer, si existiesen elementos de juicio suficientes para ello.

2. Las medidas cautelares habrán de ser proporcionadas a la naturaleza y gravedad de las infracciones cometidas. Estas medidas podrán consistir en:

a. Medidas de corrección, seguridad o control que impidan la continuidad en la producción del daño.

b. Precintado de aparatos, equipos o vehículos.

c. Clausura temporal, parcial o total, del establecimiento.

d. Suspensión temporal de la autorización o la inscripción para el ejercicio de la actividad.

e. Cualesquiera otras medidas cautelares tendentes a evitar la continuidad o la extensión del daño medioambiental.

3. Estas medidas cautelares se adoptarán previa audiencia de la parte interesada por un plazo de quince días, salvo que concurriesen razones de urgencia que aconsejen su adopción inmediata, basadas en la producción de un daño grave para la salud humana o el medio ambiente, o que se tratase del ejercicio de una actividad regulada en la presente ley sin la preceptiva autorización o con la misma caducada o suspendida, en cuyos casos la medida provisional impuesta habrá de ser revisada, ratificada o dejada sin efecto tras la audiencia a las partes interesadas.

En el trámite de audiencia previsto en este número se dará a las partes interesadas un plazo máximo de quince días para que puedan presentar cuantas alegaciones, documentos o informaciones estimasen convenientes.

Artículo 79. Órganos competentes.

1. En los casos en que, de acuerdo con lo establecido en la presente ley, la potestad sancionadora correspondiese a la Comunidad Autónoma de Galicia, la incoación e instrucción de los procedimientos sancionadores será competencia de la delegación provincial de la consellería competente en materia de residuos.

La iniciación del procedimiento sancionador se pondrá en conocimiento de la dirección general competente en materia de residuos, que podrá reclamar para sí su tramitación si estimase que la presunta infracción pone en peligro grave de degradación el medio ambiente. La resolución de los expedientes a que se refiere el número anterior corresponderá:

a. En las infracciones leves, a la persona titular de la delegación provincial de la consellería competente en materia de residuos.

b. En las infracciones graves, a la persona titular de la dirección general competente en materia de residuos.

c. En las infracciones muy graves, a la persona titular de la consellería competente en materia de residuos.

2. En el supuesto regulado en los artículos 62 y 63, en sus apartados b), de la presente ley, cuando se trate de residuos urbanos, la potestad sancionadora corresponderá a las personas titulares de las alcaldías.

3. La Comunidad Autónoma de Galicia será competente, en todo caso, para instruir y resolver los procedimientos sancionadores cuando los hechos constitutivos de la infracción afectasen a más de un término municipal, debiendo notificar a los ayuntamientos afectados los actos y resoluciones que se adoptasen en el ejercicio de esta competencia. 
Artículo 80. Coordinación y colaboración interadministrativas.

1. El órgano medioambiental de la Comunidad Autónoma de Galicia pondrá en conocimiento de la administración competente los hechos de los que tuviera conocimiento que puedan afectar al medio ambiente, a fin de que se adopten las medidas necesarias para preservarlo y, en su caso, se incoe el procedimiento sancionador correspondiente.

2. Cuando, en el supuesto anterior, la competencia sancionadora correspondiera a los ayuntamientos, éstos habrán de comunicar a la consellería competente en materia de medio ambiente las resoluciones sancionadoras que adoptasen, en el plazo de quince días desde su firmeza en vía administrativa.

3. Asimismo, cuando los ayuntamientos tuvieran conocimiento de hechos que puedan ser constitutivos de infracciones en materias reguladas en la presente ley respecto a los que no tengan atribuida competencia sancionadora, deberán ponerlos en conocimiento del órgano medioambiental de la Comunidad Autónoma de Galicia inmediatamente, dándole traslado de las actuaciones, documentos y cuanta información obrase en su poder.

\section{DISPOSICIÓN ADICIONAL PRIMERA NORMAS ESPECÍFICAS PARA LOS RESIDUOS DE ESTABLECIMIENTOS SANITARIOS}

1. La gestión extracentro de los residuos generados en áreas de centros sanitarios en que no se realizan actividades específicamente sanitarias, que no presentasen un riesgo para la salud y que, por su naturaleza, son similares a los producidos en los domicilios, corresponde a las entidades locales, siempre de conformidad con lo establecido en los planes autonómicos de residuos. Se incluyen en esta clase los residuos generados en estancias tales como oficinas, almacenes, salas de espera, cafeterías o comedores.
2. La gestión extracentro del resto de residuos sanitarios, salvo disposición específica en contrario, corresponde a quienes los produzcan, debiendo entregarlos a gestores/as autorizados de residuos; en caso de los residuos de la clase II o residuos sanitarios asimilados a urbanos, que son aquellos generados como resultado de la actividad sanitaria propiamente dicha, podrán acogerse al sistema de gestión que estableciese la entidad local competente.

\section{DISPOSICIÓN ADICIONAL SEGUNDA CONTRATACIÓN PÚBLICA}

En los pliegos de condiciones administrativas de los contratos administrativos que realice la Comunidad Autónoma de Galicia o las entidades de derecho público vinculadas a la misma, se desglosará la parte del presupuesto de licitación que habrá de destinarse para sufragar los costes de la correcta gestión de los residuos generados en su ejecución.

\section{DISPOSICIÓN DEROGATORIA ÚNICA}

Queda derogada la Ley 10/1997, de 22 de agosto, de residuos sólidos urbanos de Galicia, así como todas las normas de igual o inferior rango en lo que contradigan o se opongan a lo dispuesto en la presente ley.

\section{DISPOSICIÓN FINAL PRIMERA HABILITACIÓN NORMATIVA}

Se habilita al Consello de la Xunta de Galicia y a la persona titular de la Consellería de Medio Ambiente y Desarrollo Sostenible para que, en el plazo de un año, dicte las disposiciones necesarias para el desarrollo y aplicación de la presente ley.

\section{DISPOSICIÓN FINAL SEGUNDA ENTRADA EN VIGOR}

La presente ley entrará en vigor en el plazo de tres meses desde el día siguiente al de su publicación en el Diario Oficial de Galicia. 


\section{LEY 9/2001, DE 21 DE AGOSTO, DE CONSERVACIÓN DE LA NATURALEZA (DOGA N. $\left..^{\circ} 171,4.9 .2001\right)$}

(...) ${ }^{481}$

\section{Título preliminar OBJETIVO DE LA LEY}

Artículo 1. Objeto.

La presente ley tiene por objeto establecer normas encaminadas a la protección, conservación, restauración y mejora de los recursos naturales y a la adecuada gestión de los espacios naturales y de la flora y fauna silvestres, además de la gea de la Comunidad Autónoma gallega, a la difusión de sus valores, así como a su preservación para las generaciones futuras ${ }^{482}$.

Artículo 2. Principios inspiradores. La presente ley se inspira en los siguientes principios:

a. La conservación de la biodiversidad a través del mantenimiento de los procesos ecológicos esenciales, garantizando la conexión de las poblaciones de fauna y flora silvestres y preservando la diversidad genética.

b. La subsidiariedad y el fomento de la participación pública, a través de la cooperación y colaboración activa de los sectores sociales y económicos implicados, asumiendo una responsabilidad compartida en la conservación.

c. La prevención y planificación para impedir el deterioro ambiental. Las políticas sectoriales integrarán las consideraciones medioambientales en su planificación y pondrán en marcha los mecanismos necesarios para evitar los daños al medio ambiente.

d. La internalización de los costes medioambientales, teniendo en cuenta, en su sentido amplio, el principio de "quien contamina paga". Las medidas compensatorias o actuaciones correctoras deberán ser asumidas y programadas como un elemento más del proceso productivo.

\footnotetext{
481 Exposición de motivos omitida.

482 Véase Decreto 297/2008, de 30 de diciembre, por el que se aprueba el Plan de gestión del lobo en Galicia.
}

e. El desarrollo sostenible, favoreciendo los usos y aprovechamientos respetuosos con el medio. Este uso ha de ser compatible con el mantenimiento de los ecosistemas y no reducir la viabilidad de los otros recursos a que se estuviera asociado, ni mermar las posibilidades de disfrute de los mismos a las generaciones venideras.

Se procurará la puesta en valor de los componentes de la biodiversidad, a veces difícilmente traducibles a valores de mercado, y se tratará de que los beneficios generados por el uso de los recursos reviertan en favor de los agentes implicados.

Artículo 3. Deberes de conservación.

1. Todos tienen el deber de respetar y conservar los espacios naturales y la obligación de reparar el daño que causen.

2. Todas las administraciones, en el ámbito de sus competencias, asegurarán el mantenimiento, protección, preservación y restauración de los recursos naturales, con independencia de su titularidad o régimen jurídico, garantizando que la gestión de los mismos se produzca sin merma de su potencialidad y compatibilidad con los fines de su conservación.

\section{TítULO I DE LOS ESPACIOS NATURALES 483 \\ Capítulo I DEL PLANEAMIENTO DE LOS RECURSOS NATURALES}

Artículo 4. Planes de ordenación de los recursos naturales.

1. A fin de adecuar la gestión de los recursos naturales, y en especial de los espacios naturales y especies a proteger, a los principios inspiradores señalados en el artículo 2 de la presente ley, la Xunta de Galicia planificará los recursos naturales. Las determinaciones de esa planificación tendrán los efectos previstos en esta ley.

\footnotetext{
483 Véase Decreto 64/2009, de 19 de febrero, por el que se aprueba el Plan de ordenación de los recursos naturales del parque natural de A Baixa Limia-Serra do Xurés.
} 
2. Como instrumento de esa planificación se configuran los planes de ordenación de los recursos naturales, cuyos objetivos y contenidos, con independencia de su denominación, serán los establecidos en los artículos siguientes.

Artículo 5. Objetivos.

Los planes de ordenación de los recursos naturales son instrumentos de planificación cuyos objetivos son los siguientes:

a. Definir y señalar el estado de conservación de los recursos naturales y ecosistemas dentro de su ámbito.

b. Establecer la regulación que, en su caso, proceda aplicar en las distintas áreas del espacio.

c. Fijar el marco para la ordenación de los espacios naturales protegidos incluidos en su ámbito.

d. Determinar las limitaciones que deban establecerse y el régimen de ordenación de los diversos usos de los recursos naturales y actividades admisibles en los espacios protegidos.

e. Promover la aplicación de medidas de conservación, restauración y mejora de los recursos naturales.

f. Formular los criterios orientadores de las políticas sectoriales y ordenadoras de las actividades económicas y sociales, públicas y privadas, para que sean compatibles con los objetivos de los planes de ordenación de los recursos naturales.

Artículo 6. Efectos.

1. Los efectos de los planes de ordenación de los recursos naturales tendrán el alcance que establecen sus propias normas de aprobación.

2. Los planes de ordenación de los recursos naturales serán obligatorios y ejecutivos en todo lo que afecte a la conservación, protección o mejora de la flora, la fauna, la gea, los ecosistemas, el paisaje y los recursos naturales.

3. Los planes de ordenación de los recursos naturales a que se refiere la presente ley prevalecerán sobre cualesquiera otros instrumentos de ordenación territorial o física, constituyendo sus disposiciones un límite para éstos, cuyas determinaciones no podrán alterar o modificar aquéllas y se aplicarán, en todo caso, prevaleciendo sobre los instrumentos de ordenación preexistentes.

4. Las previsiones de los planes de ordenación de los recursos naturales tendrán carácter vinculante para cualesquiera otras actuaciones, planes o programas sectoriales en todo lo relativo a las materias a que se refiere el apartado 2 del presente artículo y revestirán carácter indicativo en todo lo demás.

Artículo 7. Formulación y vigencia.

1. Corresponde a la consellería de Medio Ambiente la iniciativa, mediante resolución publicada en el "Diario Oficial de Galicia", la elaboración y la propuesta de aprobación de los planes de ordenación de los recursos naturales.

2. La elaboración del plan de ordenación de los recursos naturales incluirá la consulta previa a las instituciones y sectores sociales directamente afectados.

3. Después de haber elaborado el plan de ordenación de los recursos naturales, éste se someterá a los trámites de información pública y audiencia de los interesados que se hubieran personado en el expediente.

4. A la vista de las observaciones e informes recibidos, y previo informe del Consello Galego de Medio Ambiente, se elevará el plan al Consello de la Xunta de Galicia para su aprobación mediante Decreto.

5. Los planes de ordenación de los recursos naturales tendrán una vigencia indefinida, salvo indicación expresa en contrario.

\section{Capítulo II \\ DEL RÉGIMEN DE LOS ESPACIOS NATURALES PROTEGIDOS}

Artículo 8. Concepto.

Se definen como espacios naturales protegidos aquellos espacios que contengan 
elementos o sistemas naturales de particular valor, interés o singularidad, tanto debidos a la acción y evolución de la naturaleza como derivados de la actividad humana, y que fueran declarados como tales.

Artículo 9. Categorías de espacios naturales protegidos 484 .

1. En función de los bienes y valores a proteger, los espacios naturales protegidos regulados en la presente ley se clasifican en las siguientes categorías:

a. Reserva natural.

b. Parque nacional.

c. Parque natural.

d. Monumento natural.

e. Humedal protegido.

f. Paisaje protegido.

g. Zona de especial protección de los valores naturales.

h. Espacio natural de interés local.

i. Espacio privado de interés natural ${ }^{485}$.

2. En el ámbito territorial de un espacio natural podrán coexistir distintas categorías de protección de las contempladas en el apartado anterior si así lo exigen las particulares características del mismo.

3. La declaración de un espacio natural protegido podrá incluir la delimitación de áreas de amortiguación de impactos — que podrán tener carácter discontinuo-, en las que se aplicarán medidas específicas.

Artículo 10. Red gallega de espacios protegidos.

1. Bajo la competencia de la Comunidad Autónoma de Galicia, se crea la Red gallega de espacios protegidos, en la cual estarán representados los principales ecosistemas, paisajes o hábitats gallegos y que contendrá aquellos lugares necesarios para asegurar su conservación.

484 Véase art. $3,9,12.2,15.3,18.4$ y 20.2 Decreto $105 / 2006$, de 22 de junio, por el que se regulan medidas relativas a la prevención de incendios forestales, a la protección de los asentamientos en el medio rural y a la regulación de aprovechamientos y repoblaciones forestales.

485 Véase Decreto 124/2005, de 6 de mayo, por el que se regula la figura del espacio natural de interés local y la figura del espacio privado de interes natural.
2. La Red gallega de espacios protegidos estará constituida por aquellos espacios protegidos que se declaren en alguna de las categorías del artículo 8.1, excepto las de los apartados h) e i).

\section{Capitulo III DEFINICIONES}

Artículo 11. Reserva natural.

1. Las reservas naturales son espacios naturales cuya declaración tiene como finalidad la protección de ecosistemas, comunidades o elementos biológicos que, por su rareza, fragilidad, importancia o singularidad, merecen una valoración especial.

En las reservas estará limitada la explotación de recursos, salvo en aquellos casos en que esta explotación se considere compatible con la conservación de los valores que pretenden protegerse. Con carácter general, estará prohibida la recolección de material biológico o geológico, con excepción de aquellos casos en que por razones de investigación, educativas o de conservación se permita la misma, previa autorización administrativa.

2. Aquellas reservas naturales que contengan ecosistemas o comunidades en estado de conservación que requieran una protección absoluta podrán ser declaradas reservas naturales integrales. En estas zonas está prohibido cualquier tipo de aprovechamiento y se restringirá el acceso público, funcionando el sistema con la mínima intervención exterior posible, salvo las necesarias medidas de conservación, gestión y, en su caso, investigación.

Artículo 12. Parque.

1. Los parques son áreas naturales, poco transformadas por las actividades humanas, que, en razón de la belleza de sus parajes, de la representatividad de sus ecosistemas o la singularidad de su flora, fauna o formaciones geomorfológicas, poseen unos valores ecológicos, estéticos, 
educativos o científicos cuya conservación merece una atención preferente.

2. En los parques podrá limitarse los aprovechamientos de los recursos naturales, prohibiéndose en todo caso los incompatibles con las finalidades que hubieran justificado su creación.

3. En los parques se facilitará la entrada de visitantes con las limitaciones que sean precisas para garantizar la conservación de los valores naturales.

4. Los parques podrán ser naturales o nacionales ${ }^{486}$.

\section{Artículo 13. Monumento natural.}

1. Los monumentos naturales son espacios o elementos de la naturaleza constituidos básicamente por formaciones de notoria singularidad, rareza o belleza que merecen ser objeto de una protección especial.

Se consideran también monumentos naturales las formaciones geológicas y demás elementos de la gea, así como los yacimientos paleontológicos, que reúnan un interés especial por la singularidad o importancia de sus valores científicos, culturales o paisajísticos.

2. En los monumentos naturales sólo se admitirán los usos o actividades que no pongan en peligro la conservación de los valores que motivaron su declaración.

Artículo 14. Humedal protegido.

1. Se entenderá por humedal protegido las extensiones de marismas, pantanos, turberas o superficies cubiertas de agua, sean éstas de régimen natural o artificial, permanentes o temporales, estancadas o corrientes, dulces, salobres o saladas, incluidas las extensiones de agua marina cuya profundidad en marea baja no exceda de seis metros, que a la vez cumplan una 486 Véase:

- Ley 15/2002, de 1 de julio, por la que se declara el Parque Nacional maritimo-terrestre de las Islas Atlánticas de Galicia.

- Decreto 23/2006, de 16 de febrero, por el que se establecen determinadas medidas de gestión en el Parque Nacional de las Islas Atlánticas de Galicia función de importancia internacional, nacional o autonómica en la conservación de los recursos naturales, y que sean declaradas como tales.

Podrán comprender zonas ribereñas, costeras o adyacentes, así como las islas o extensiones marinas de profundidad superior a los seis metros en marea baja cuando éstas se encuentren dentro del humedal.

2. En los humedales protegidos podrá limitarse los aprovechamientos de los recursos naturales, prohibiéndose en todo caso los incompatibles con las finalidades que hubieran justificado su declaración ${ }^{487}$.

Artículo 15. Paisaje protegido.

1. Los paisajes protegidos son espacios que, por sus valores singulares, estéticos y culturales o bien por la relación armoniosa entre el hombre y el medio natural, sean merecedores de una protección especial.

2. El régimen de protección de los paisajes protegidos estará dirigido expresamente a la conservación de las relaciones y procesos, tanto naturales como socioeconómicos, que han contribuido a su formación y hacen posible su pervivencia.

Artículo 16. Zona de especial protección de los valores naturales.

1. Se considera como zona de especial protección de los valores naturales aquellos espacios por cuyos valores o interés natural, cultural, científico, educativo o paisajístico sea necesario asegurar su conservación y no tengan otra protección específica, sin perjuicio de lo dispuesto en el artículo 9 de la presente ley.

2. En estas áreas podrá seguirse llevando a cabo de manera ordenada los usos y actividades tradicionales que no vulneren los valores protegidos. Para el resto de las actuaciones, incluyendo la realización de edificaciones, será precisa la autorización de la Consellería de Medio Ambiente.

3. Se incluirán también las zonas especiales de conservación que conforman

487 Véase Decreto $127 / 2008$, de 5 de junio, por el que se desarrolla el régimen juridico de los humedales protegidos y se crea el Inventario de humedales de Galicia. 
la Red Natura 2000, creada al amparo de las Directivas CEE 79/409 y 92/43, y que no posean otra figura de protección de las contempladas en la presente ley.

Artículo 17. Espacio natural de interés local.

1. A petición del Ayuntamiento y previo del informe de la Consellería de Política Territorial, Obras Públicas e Vivenda, la Consellería de Medio Ambiente podrá declarar como espacios naturales de interés local a aquellos espacios integrados en su término municipal que por sus singularidades sean merecedores de algún tipo de protección de sus valores naturales.

2. La responsabilidad y competencia en la gestión de estos espacios será municipal, y no se considerarán incluidos en la Red gallega de espacios protegidos.

3. $\mathrm{Su}$ declaración como tales no implicará la asignación de recursos de la Comunidad Autónoma, si bien podrán tener preferencia en la obtención de ayudas para su conservación y gestión.

Artículo 18. Espacio privado de interés natural.

1. Las instituciones y los propietarios particulares de los terrenos en que existan formaciones naturales, especies o hábitats de flora y fauna silvestres cuya protección se considere de interés podrán proponer a la Consellería de Medio Ambiente, mediante la presentación de una memoria suficientemente motivada, su declaración como espacio privado de interés natural.

2. La declaración supone el compromiso formal del promotor de poner en práctica las medidas precisas para la conservación de los valores naturales que lo motivaron.

3. Estos espacios no se incluirán en la Red gallega de espacios naturales protegidos.

4. Su declaración no implicará la obligatoriedad, por parte de la Consellería de Medio Ambiente, de aportar recursos públicos, si bien podrán tener preferencia en la concesión de ayudas y subvenciones.

Artículo 19. Denominaciones.

Las denominaciones de los artículos precedentes se emplearán únicamente para los espacios naturales que cumplan las condiciones y se tramiten a través de los procedimientos establecidos por la presente ley o sus normas reglamentarias.

\section{Capítulo IV \\ DE LA DECLARACIÓN DE ESPACIOS NATURALES PROTEGIDOS \\ Sección 1. ${ }^{\mathrm{a}}$ \\ Procedimiento}

Artículo 20. Propuesta de declaración de parque nacional.

La Comunidad Autónoma de Galicia podrá proponer al Estado la declaración de parque nacional de aquellos espacios naturales de alto valor ecológico y cultural del territorio de Galicia cuya conservación se considere de interés general para la nación, de conformidad con lo que se establece en la Ley 4/1989, de 27 de marzo, de conservación de los espacios naturales y de la flora y fauna silvestres, y la Ley 41/1997, de 5 de noviembre, por la que se modifica.

Artículo 21. Otras figuras de protección de ámbito supraautonómico.

La Xunta de Galicia podrá promover ante los organismos que corresponda la declaración de otras figuras de protección de ámbito supraautonómico.

Artículo 22. Iniciativa.

Corresponde a la Consellería de Medio Ambiente la iniciación de oficio del procedimiento de declaración de un espacio natural protegido. Para las categorías de espacio natural de interés local o espacio privado de interés natural, el procedimiento se iniciará a instancia de parte.

\section{Artículo 23. Tramitación.}

1. Corresponde a la Consellería de Medio Ambiente la tramitación de los procedimientos de declaración de espacios naturales protegidos.

2. La declaración de las reservas naturales y de los parques exigirá la previa elaboración y aprobación del correspondiente plan de ordenación de los recursos 
naturales, según se especifica en el capítulo IV del título I de la presente ley.

Excepcionalmente, podrán declararse reservas naturales y parques sin la previa aprobación del plan de ordenación de los recursos naturales cuando existan razones que lo justifiquen, las cuales se harán constar expresamente en la norma que los declare. En este caso, habrá de tramitarse en el plazo de un año, a partir de la declaración de parque o reserva natural, el correspondiente plan de ordenación.

3. Para los demás espacios incluidos en la Red gallega de espacios protegidos, la Consellería de Medio Ambiente aprobará un plan de conservación en el plazo de dos años desde su declaración.

4. En cualquier caso, los instrumentos de planificación de los espacios naturales protegidos serán sometidos a información pública.

Artículo 24. Declaraciones.

1. Las reservas naturales serán declaradas por Ley del Parlamento de Galicia.

2. Los parques naturales, monumentos naturales, paisajes protegidos, humedales protegidos y zonas de especial protección de los valores naturales serán declarados por Decreto de la Xunta de Galicia, a propuesta de la Consellería de Medio Ambiente.

3. Los espacios naturales de interés local y los espacios privados de interés natural serán declarados por Orden de la Consellería de Medio Ambiente.

\section{Sección 2. ${ }^{a}$}

\section{Protección preventiva}

Artículo 25. Régimen de protección preventiva.

1. La iniciación de un procedimiento de declaración de un espacio natural protegido o del procedimiento para la elaboración de alguno de los instrumentos de ordenación previstos en la presente ley determinará la prohibición de realizar actos que supongan una transformación sensible de la realidad física o biológica que dificulte o imposibilite la consecución de los objetivos de la declaración de espacio natural protegido o suponga un riesgo para sus valores naturales.

2. En cualquier caso, la iniciación del procedimiento de aprobación de un plan de ordenación de los recursos naturales determinará automáticamente la exigencia de informe favorable de la Consellería de Medio Ambiente para cualquier autorización, licencia o concesión que habilite para realizar transformaciones de la realidad física o biológica en el ámbito territorial al que afecta el plan de ordenación de los recursos naturales.

3. Por Orden de la Consellería de Medio Ambiente podrá establecerse un régimen preventivo de protección para cada caso, en el cual se establecerán las medidas cautelares que hayan de aplicarse a partir de la iniciación del expediente de declaración del espacio natural protegido o durante el procedimiento de elaboración de los instrumentos de ordenación previstos en la presente ley.

4. La Consellería de Medio Ambiente podrá aplicar el régimen de zona de especial protección de los valores naturales de forma provisional a los espacios naturales cuando considere que su conservación se hallan en peligro.

5. Las medidas cautelares previstas en el presente artículo tendrán una vigencia máxima de tres años.

\section{Sección 3. ${ }^{\mathrm{a}}$}

Efectos de la declaración de espacios naturales protegidos

Artículo 26. Enumeración de los efectos.

La declaración de espacio natural protegido incluido en la Red gallega de espacios protegidos conllevará los efectos que se mencionan a continuación:

1. Declaración de utilidad pública e interés social a efectos expropiatorios 
de todos los bienes y derechos incluidos dentro de su ámbito.

2. Sometimiento de las transmisiones onerosas e "inter vivos" de terrenos a la facultad de la administración de ejercer los derechos de tanteo y de retracto, con arreglo a lo previsto en el artículo siguiente.

3. Sujeción a la servidumbre de instalación de señales prevista en el artículo 28 de la presente ley.

4. Utilización de los bienes comprendidos en estos espacios con arreglo a lo previsto en la presente ley y en los instrumentos de ordenación establecidos en la misma.

5. Prioridad en el desarrollo de actuaciones de mejora de las condiciones socioeconómicas de la población residente.

6. Cualesquiera otros que reglamentariamente se determine.

Anualmente, la Consellería de Medio Ambiente establecerá las dotaciones presupuestarias específicas para la planificación, ordenación, protección, uso y gestión de la Red de espacios protegidos de Galicia.

Artículo 27. Derechos de tanteo y de retracto.

1. Las transmisiones onerosas "inter vivos" de bienes inmuebles ubicados total o parcialmente en el ámbito de un espacio natural protegido están sujetas a los derechos de tanteo y de retracto por parte de la Administración autonómica. Quedan excluidos los inmuebles sitos en suelo urbano, salvo previsión expresa en contrario de la norma de declaración del espacio natural o de su instrumento de ordenación.

2. El plazo de ejercicio del derecho de tanteo será de tres meses, a contar a partir de la notificación previa expresa de la transmisión a la Consellería de Medio Ambiente. A estos efectos, la persona transmitente notificará fehacientemente a la Consellería de Medio Ambiente las condiciones esenciales de la transmisión pretendida.

3. El derecho de retracto podrá ejercerse en el plazo de un año, a contar a partir del momento en que tenga constancia fehaciente de la transmisión. A estos efectos, la Consellería de Economía e Facenda deberá comunicar a la Consellería de Medio Ambiente, en el plazo de tres meses, las transmisiones de los bienes y derechos a que se refiere el presente artículo.

4. En todo caso, será requisito necesario para inscribir la transmisión en el Registro de la Propiedad el cumplimiento del deber de notificación de que se trata en los apartados anteriores.

Artículo 28. Servidumbre de instalación de señales del espacio natural protegido.

1. Los terrenos ubicados en el interior de los espacios naturales protegidos estarán sujetos a la servidumbre forzosa de instalación de señales indicadoras de esa condición y de su régimen, con arreglo a lo previsto en el presente artículo.

2. Para declarar e imponer las servidumbres será precisa la previa instrucción y resolución del expediente por parte de la Consellería de Medio Ambiente, en el cual, con audiencia de los interesados, se justifique la conveniencia y necesidad técnica de establecimiento de las mismas.

3. La servidumbre conlleva la obligación de los predios sirvientes de dar paso y permitir la realización de los trabajos para el establecimiento y conservación de las mismas.

Artículo 29. Aprovechamiento y uso de los bienes y recursos incluidos en espacios naturales protegidos.

1. El aprovechamiento y uso de los bienes y recursos incluidos en el ámbito de un espacio natural protegido se realizará de manera que resulte compatible con la conservación de los valores que motivaron su declaración, tal y como se dispone en los instrumentos de planeamiento.

2. Las limitaciones al uso de los bienes y recursos derivadas de la declaración de espacio natural protegido o de los instrumentos de ordenación previstos en la presente ley podrán dar lugar a indemnización cuando concurran simultáneamente estos requisitos: 
a. Que incidan sobre derechos efectivamente incorporados al patrimonio del titular.

b. Que afecten a usos o aprovechamientos legal y efectivamente ejercidos en el momento de imposición de la restricción.

c. Que se produzca una lesión patrimonial efectiva, actual y cuantificable en términos monetarios.

d. Que se trate de limitaciones singulares no susceptibles de distribución entre los afectados.

Artículo 30. Áreas de influencia socioeconómica.

1. Los procedimientos de declaración del espacio establecerán, en su caso, las áreas de influencia socioeconómica, en las que podrán preverse las medidas de compensación pertinentes.

2. Para contribuir a las mejoras de calidad de vida de sus habitantes y al desarrollo sostenible en estos ámbitos, la Xunta de Galicia propiciará el desarrollo de actividades tradicionales y fomentará otras compatibles con la conservación del espacio de que se trate.

3. Para una mejor aceptación y participación social se fomentará la integración de los habitantes de los territorios afectados en las actividades generadas por la protección y gestión del espacio natural.

4. Las producciones artesanales de las áreas de influencia socioeconómica, sin perjuicio de la legislación específica, podrán establecer el uso de una etiqueta de calidad de productos referenciada en la denominación del espacio natural protegido de que se trate.

\section{Capitulo V \\ DE LA PLANIFICACIÓN DE LOS ESPACIOS NATURALES PROTEGIDOS \\ Sección $1 .^{a}$ Instrumentos de planificación}

Artículo 31. Clasificación.

1. La planificación de los espacios naturales protegidos se efectuará mediante los siguientes instrumentos, que se enumeran conforme a su prevalencia:

1) Planes de ordenación de los recursos naturales.

2) Planes rectores de uso y gestión.

3) Planes de conservación.

2. En los parques naturales y reservas naturales se requerirá con carácter previo la aprobación de un plan de ordenación de los recursos naturales, cuya gestión se llevará a cabo mediante planes rectores de uso y gestión.

3. En las demás categorías será necesaria al menos la aprobación de planes de conservación, en un plazo no superior a dos años ${ }^{488}$.

\section{Sección 2. ${ }^{\text {a }}$ \\ Planes de ordenación de los recursos naturales}

\section{Artículo 32. Contenido.}

1. Los planes de ordenación de los recursos naturales tendrán al menos el siguiente contenido:

1) Memoria descriptiva y justificativa, en la cual se incluirán, como mínimo, los siguientes extremos:

a. La delimitación territorial del plan y la descripción de sus características físicas y biológicas.

b. El diagnóstico de la situación de los recursos naturales, ecosistemas y paisajes y la previsión sobre su evolución futura.

2) Objetivos.

3) Zonificación.

4) Establecimiento de criterios orientadores en la formulación y ejecución de las diversas políticas sectoriales que inciden en el ámbito territorial.

5) Directrices para la planificación.

6) Normas de aplicación directa para la regulación de usos y actividades, la conservación y la protección de los recursos, espacios y especies a proteger.

488 Véase Orden de 14 de mayo de 2009 por la que se acuerda la suspensión cautelar previa a la aprobación inicial del Plan de ordenación del litoral de Galicia. 
7) Regímenes de protección que, en su caso, deban aplicarse.

8) Análisis de la realidad socioeconómica del área, especificando, en su caso, el área de influencia socioeconómica.

9) En su caso, directrices y criterios para la redacción de planes rectores de uso y gestión.

10) Régimen de evaluación ambiental.

2. Podrán integrarse en un mismo plan de ordenación de los recursos naturales varios espacios naturales cuando existan circunstancias que así lo aconsejen.

\section{Sección 3. ${ }^{\mathrm{a}}$}

\section{Planes rectores de uso y gestión}

\section{Artículo 33. Concepto.}

1. Los planes rectores de uso y gestión desarrollan las directrices emanadas del plan de ordenación de los recursos naturales y establecen las previsiones de actuaciones de la Administración en su ámbito de aplicación, y en particular la investigación, el uso público y la conservación, protección y mejora de los valores ambientales.

2. Estos planes prevalecerán sobre el planeamiento urbanístico y la ordenación del territorio. Cuando sus determinaciones sean incompatibles con las de la normativa urbanística en vigor, ésta se revisará de oficio por los órganos competentes.

Artículo 34. Contenido.

Los planes rectores de uso y gestión tendrán al menos el siguiente contenido:

1. Memoria descriptiva.

2. Zonificación del espacio de acuerdo con el contenido del plan de ordenación de los recursos naturales, delimitando las áreas de diferentes usos.

\section{Objetivos.}

4. Previsiones de uso y aprovechamiento.

5. Normas generales de gestión, incluyendo, como mínimo, las relativas a la vigencia y revisión del plan.

6. Normas de regulación de usos y actividades, así como para la gestión, protección, conservación o mejora de los recursos naturales y valores ambientales, cuando resulte preciso completar o desarrollar las contenidas en el plan de ordenación de los recursos naturales.

7. Normas relativas a las actividades de investigación.

8. Normas relativas al uso público.

9. Programa económico-financiero.

10. Programación de actuaciones a desarrollar en el espacio natural.

Artículo 35. Tramitación.

1. Corresponde a la Consellería de Medio Ambiente la elaboración de los planes rectores de uso y gestión, previo informe de las Consellerías con competencias en relación con el ámbito protegido $\mathrm{y}$, en todo caso, informe de la Administración competente en materia de planificación territorial y urbanismo.

2. Después de haber elaborado el plan rector de uso y gestión, éste será sometido a información pública y audiencia de los interesados que se hubieran personado en el expediente.

3. A la luz de las observaciones e informes recibidos se redactará una propuesta de plan, que se elevará a la Xunta de Galicia para su aprobación mediante Decreto.

4. Los planes rectores de uso y gestión se aprobarán en el plazo máximo de dos años desde la entrada en vigor de la declaración del espacio natural protegido, previo informe, en su caso, de la Junta consultiva correspondiente.

Artículo 36. Vigencia.

Los planes rectores de uso y gestión tendrán una vigencia máxima de seis años. Estos planes habrán de revisarse al término de cada período o antes si fuera necesario.

\section{Sección $4 .^{\text {a }}$}

\section{Planes de conservación}

Artículo 37. Concepto.

1. Los planes de conservación establecerán el régimen de usos y actividades permisibles, así como las limitaciones que se consideren necesarias para la conservación del espacio. 
2. La aprobación de estos planes tendrá lugar en un plazo no superior a los dos años desde la declaración del espacio natural como protegido.

Artículo 38. Contenido.

1. Los planes de conservación incluirán como mínimo:

1) La delimitación de su ámbito de protección, que podrá ser discontinuo cuando resulte necesario.

2) La identificación de los valores a proteger y de los posibles riesgos que puedan afectar a sus valores naturales.

3) Las normas de uso y aprovechamiento del suelo y de los recursos naturales, destinadas a proteger y conservar o mejorar los valores ambientales.

4) Las normas relativas al uso público, así como a las actividades científicas o educativas.

Artículo 39. Efectos.

Los planes de conservación serán vinculantes, tanto para las administraciones públicas como los particulares, prevalecerán sobre el planeamiento urbanístico y su aprobación conllevará la revisión de los planes territoriales o sectoriales incompatibles con los mismos.

\section{Artículo 40. Tramitación.}

El plan de conservación se formulará por la Consellería de Medio Ambiente, que lo someterá a información pública y audiencia de los interesados que se hubieran personado en el expediente. Después de la realización de los trámites referidos se elevará al Consello de la Xunta de Galicia para su aprobación mediante Decreto.

\section{Capítulo VI \\ DE LA GESTIÓN DE LOS ESPACIOS NATURALES PROTEGIDOS}

Artículo 41. Órganos de gestión.

1. La gestión de los espacios incluidos en la Red gallega de espacios naturales protegidos será responsabilidad de la Consellería de Medio Ambiente.

2. Para la gestión de los parques naturales y reservas, la Consellería de Medio Ambiente designará a un director del espacio, a quien le corresponderá la gestión del espacio natural protegido, y, en particular, la elaboración y propuesta de los presupuestos y programas de gestión y la ejecución y desarrollo del plan rector de uso y gestión.

3. La gestión de los espacios de interés local corresponderá a los Ayuntamientos en cuyos términos municipales estén asentados, y la gestión de las áreas privadas de interés natural corresponderá a las entidades o particulares que hayan propuesto su declaración.

En todo caso, la Consellería de Medio Ambiente velará porque aquéllos y éstas cumplan las finalidades recogidas en la declaración.

Artículo 42. Junta consultiva.

1. Para colaborar en la gestión de los espacios naturales protegidos y canalizar la participación de los propietarios y los intereses sociales y económicos afectados se constituirá, para cada parque natural o reserva, una Junta consultiva, órgano colegiado, de carácter asesor y adscrito a la Consellería de Medio Ambiente.

2. La composición y funcionamiento de la Junta consultiva se establecerá en la norma de declaración de cada espacio natural protegido.

3. La Junta consultiva estará compuesta por el Presidente de la misma y el Director del espacio natural protegido, asegurando, en todo caso, la representación de:

1) Los municipios en donde se ubica el espacio natural protegido.

2) Los propietarios de los terrenos incluidos en el espacio natural protegido.

3) Las personas o entidades que representen intereses sociales, institucionales o económicos relevantes implicados.

4) Las entidades cuyos objetivos fundamentales coincidan con la finalidad del espacio natural protegido ${ }^{489}$.

489 Decreto 265/2007, de 28 de diciembre, por el que se modifica la composición de las juntas consultivas de los parques naturales de Galicia. 
Artículo 43. Funciones de la Junta consultiva.

1. Corresponde al órgano colegiado de cada espacio protegido la colaboración en la gestión de los espacios naturales protegidos a través de su función asesora y consultiva mediante:

a. La aprobación y modificación de su Reglamento de régimen interior.

b. La emisión de aquellos informes que le sean solicitados.

c. La propuesta de actuaciones e iniciativas tendentes a la consecución de los fines del espacio natural protegido, incluyendo los de difusión e información de los valores del mismo, así como los programas de formación y educación ambiental.

d. La colaboración en la promoción y proyección exterior del espacio natural protegido y sus valores.

e. En general, la promoción y realización de cuantas gestiones considere oportunas en beneficio del espacio natural protegido.

2. Habrá de ser oído para la adopción de las siguientes decisiones:

a. La aprobación, modificación y revisión de la normativa relativa al espacio natural protegido y de sus instrumentos de planificación.

b. La aprobación del presupuesto de gestión del espacio natural protegido.

\section{TÍTULO II \\ DE LA FAUNA Y FLORA ${ }^{490}$ \\ Capítulo I \\ DISPOSICIONES GENERALES}

Artículo 44. Principios generales.

1. En sus actuaciones, la Xunta de Galicia adoptará las medidas necesarias para garantizar la conservación, protección y recuperación de las especies de flora y fauna que viven en estado silvestre en Galicia, con especial atención a las autóctonas.

490 Decreto 260/2007, de 13 de diciembre, por el que se crea el Observatorio Gallego de la Biodiversidad y se determinan sus funciones, composición y funcionamiento.
2. Se otorgará preferencia a las medidas de conservación de las especies en sus hábitats naturales, considerando cuando fuera necesario la adopción de medidas adicionales de conservación fuera de dichos hábitats.

3. Se adoptarán las medidas precisas para regular la introducción y proliferación incontrolada en el medio natural de especies distintas a las autóctonas, en especial cuando puedan competir con éstas y alterar su pureza genética o los equilibrios y dinámica ecológicos.

4. Se dará prioridad, en las actuaciones y planes de conservación, a las especies endémicas y a aquellas otras cuya área de distribución sea muy limitada o su población muy escasa, así como a las migratorias.

Artículo 45. Conceptos.

A los efectos de la presente ley, se entenderá por:

a. Especies de fauna y flora silvestres: Las especies que mantienen poblaciones establecidas y viables en el medio natural.

b. Especies de fauna y flora autóctonas: Las especies que constituyen poblaciones establecidas en el medio natural de Galicia que forman parte inveteradamente de los ecosistemas naturales del territorio gallego, siendo éste parte de su área de distribución natural.

Se incluyen también aquellas estacionales o de paso y las que habiendo estado en alguna de las situaciones anteriores se hallen actualmente extinguidas en Galicia.

Artículo 46. Competencias.

1. Será competencia exclusiva de la Consellería de Medio Ambiente la cría, repoblación y reintroducción de especies catalogadas en Galicia.

2. La cría para reintroducción o repoblación en el medio natural de especies silvestres no catalogadas necesitará la autorización de la Consellería de Medio Ambiente.

Artículo 47. Preservación de la pureza y diversidad genética.

No podrá autorizarse la liberación en el medio natural de organismos modificados genéticamente bajo condiciones en que puedan alterar la pureza y diversidad genética 
de las poblaciones naturales de las especies autóctonas o poner en riesgo cualquier otro valor natural amparado por la presente ley. En todo caso, se establecerá un control específico para los organismos transgénicos.

\section{Capítulo II DE LA CATALOGACIÓN DE ESPECIES}

Artículo 48. Instrumentos de catalogación.

1. Para la adecuada protección de las especies, subespecies o núcleos poblacionales de Galicia, se crea el Catálogo Gallego de Especies Amenazadas.

2. Se crea el Registro de Especies de Interés Gallego, en el cual podrán incluirse aquellas especies, subespecies o núcleos poblacionales no catalogados, incluso aquellas a que se refiere la disposición adicional segunda y cuyas singularidades científicas, ecológicas o culturales las hagan merecedoras de una atención específica, con especial atención a los endemismos gallegos.

3. Ambos instrumentos, de carácter administrativo y dependientes de la Consellería de Medio Ambiente, serán objeto de desarrollo reglamentario.

4. Podrán incluirse o excluirse de los mismos aquellas especies, subespecies o poblaciones para las que se justifique que su "status" ha variado.

Artículo 49. Catálogo Gallego de Especies Amenazadas.

Las especies, subespecies o núcleos poblacionales que se incluyan en el Catálogo Gallego de Especies Amenazadas habrán de ser catalogados en alguna de las siguientes categorías:

a. En peligro de extinción, reservada para aquellas cuya supervivencia es poco probable si los factores causantes de su actual situación siguen actuando.

b. Sensibles a la alteración de su hábitat, referida a aquellas cuyo hábitat característico está particularmente amenazado, en grave regresión, fraccionado o muy limitado. c. Vulnerables, destinada a aquellas que corren el peligro de pasar a las categorías anteriores en un futuro inmediato si los factores adversos que actúan sobre ellas no son corregidos.

d. De interés especial, aquellas otras merecedoras de catalogación y cuyo grado de amenaza sea insuficientemente conocido $^{491}$.

Artículo 50. Planes de recuperación, protección, conservación y manejo.

1. La Consellería de Medio Ambiente elaborará y aprobará los planes siguientes:

a. Planes de recuperación para las especies en peligro de extinción, en los cuales se definirán las medidas necesarias para eliminar tal peligro.

b. Planes de reintroducción de especies extinguidas en Galicia, siempre y cuando los hábitats naturales y las condiciones socioeconómicas y culturales lo permitan.

c. Planes de protección del hábitat, dirigidos a las especies sensibles a la alteración de su hábitat.

d. Planes de conservación para especies vulnerables, los cuales incluirán, en su caso, la protección de su hábitat.

e. Planes de manejo para las especies de interés especial, los cuales determinarán las medidas necesarias para garantizar la viabilidad de las poblaciones.

2. Cuando proceda, estos planes incluirán entre sus determinaciones la aplicación de alguna de las categorías de espacios naturales protegidos, referida a la totalidad o a una parte del hábitat en que vive la especie, subespecie o población.

3. La consellería adoptará las medidas necesarias para mejorar el conocimiento o conservación de las especies incluidas en el Catálogo Gallego de Especies Amenazadas y en el Registro de Especies de Interés Gallego.

Artículo 51. Efectos de la catalogación.

1. La inclusión de una especie o subespecie en el Catálogo Gallego de Especies Amenazadas o en el Registro de Especies de 491 Véase Decreto 88/2007, de 19 de abril, por el que se regula el catálogo gallego de especies amenazadas. 
Interés Gallego conlleva, salvo autorización expresa de la Consellería de Medio Ambiente, las siguientes prohibiciones:

a. Tratándose de plantas, la de cualquier actuación no autorizada que se lleve a cabo con el propósito de destruirlas, mutilarlas, cortarlas o arrancar ejemplares completos o parte de los mismos, así como la recolección de sus semillas, polen o esporas, y, en general, la destrucción de su hábitat.

b. Tratándose de animales, incluidas sus larvas, crías o huevos, la de cualquiera actuación no autorizada hecha con el propósito de darles muerte, capturarlos, perseguirlos o molestarlos, y en particular en sus nidos, vivares y áreas de reproducción, invernada, muda, paso, reposo y alimentación, así como la destrucción de su hábitat.

c. En ambos casos, la prohibición de poseer, transportar, vender o exponer para la venta, importar o exportar ejemplares vivos o muertos, así como sus propágulos o restos, salvo en los casos que reglamentariamente se determinen.

2. Para las especies catalogadas como en peligro de extinción o sensibles a la alteración de su hábitat queda prohibida, salvo expresa autorización, la observación y filmación mediante el establecimiento de puestos fijos a menor distancia de la que en su caso se determine.

3. Para las especies catalogadas, sólo en situaciones excepcionales y con fines científicos, culturales o de conservación, la Consellería de Medio Ambiente podrá conceder las autorizaciones previstas en el artículo 53.3.

4. Sin perjuicio de los demás requisitos legales exigibles, para que se entienda autorizada la tenencia en cautividad de ejemplares de fauna catalogada, será condición necesaria que su poseedor pueda acreditar fehacientemente el origen legal de los mismos.

Los poseedores de ejemplares en cautividad de fauna catalogada deberán declarar su tenencia a la consellería.
Al efecto de garantizar su identificación individual, podrá marcarse al animal o realizarle los análisis y pruebas precisas para permitir el seguro reconocimiento del mismo en el futuro.

Reglamentariamente, podrán adoptarse las disposiciones precisas para que el medio y las condiciones higiénico-sanitarias y de mantenimiento en cautividad sean las adecuadas.

5. El cultivo en vivero de especies de flora catalogadas únicamente podrá ser autorizado por la Consellería de Medio Ambiente cuando su fin sea la restauración de poblaciones naturales, la conservación de la especie, la educación, la investigación o cualquier otro establecido legal o reglamentariamente.

6. La Consellería de Medio Ambiente podrá autorizar las labores silvícolas y fitosanitarias que precisen las especies catalogadas de flora.

Artículo 52. Catálogo Gallego de Árboles Singulares.

Se crea el Catálogo Gallego de Árboles Singulares de Galicia, en el cual se incluirán aquellos ejemplares o rodales cuya conservación sea necesario asegurar por sus valores o intereses natural, cultural, científico, educativo, estético o paisajístico.

En los ejemplares o rodales incluidos en el Catálogo podrán llevarse a cabo, previa autorización de la Consellería de Medio Ambiente, todo tipo de tratamientos silvícolas y actuaciones encaminadas a su protección, conservación y mejora 492.

\section{Capitulo III \\ DE LA PROTECCIÓN DE LA FAUNA Y FLORA SILVESTRES \\ Sección 1. ${ }^{\mathrm{a}}$ Disposiciones comunes}

Artículo 53. Régimen general de protección.

1. Queda prohibido dar muerte, dañar, molestar o inquietar intencionadamente a

492 Véase Decreto 67/2007, de 22 de marzo, por el que se regula el catálogo gallego de árboles singulares. 
las especies animales objeto de la presente ley, con especial atención a las especies autóctonas, así como capturarlas vivas y recoger sus huevos o crías.

2. Queda igualmente prohibido poseer, traficar y comerciar con ejemplares vivos o muertos o con restos de animales silvestres, así como transportarlos sin el debido cumplimiento de los requisitos exigidos por la legislación vigente.

3. Excepcionalmente, y siempre que ello no suponga perjudicar el mantenimiento, en un estado de conservación favorable, de las poblaciones de la especie de que se trate en un área de distribución natural, podrán quedar sin efecto estas prohibiciones, previa autorización expresa de la Consellería de Medio Ambiente, cuando concurra alguna de las siguientes circunstancias:

a. Si de su aplicación se derivan efectos perjudiciales para la salud y seguridad de las personas.

b. Cuando de su aplicación se derivan efectos perjudiciales para otras especies protegidas o sus hábitats.

c. Para prevenir perjuicios importantes para los cultivos, el ganado, los bosques, las pesquerías y la calidad de las aguas, así como para otros usos de la propiedad.

d. Cuando sea necesario por razón de investigación, educación, repoblación o reintroducción de dichas especies, o cuando se precise para la cría en cautividad.

e. Para prevenir accidentes en relación con la seguridad aérea.

f. Por razones imperativas de interés público de primer orden.

g. Para permitir en condiciones estrictamente controladas y mediante métodos selectivos y tradicionales la captura, retención o cualquier otra utilización discreta de determinadas especies.

Artículo 54. Autorizaciones.

1. Las autorizaciones administrativas a que se refiere el apartado 3 del artículo anterior se otorgarán en el plazo máximo de tres meses desde su solicitud, transcurrido el cual se entenderán denegadas.
2. La solicitud, al menos, especificará:

a. El nombre y documento nacional de identidad de la persona peticionaria (o, en su caso, de la institución a la que representa) y la relación nominal, documentos nacionales de identidad y cualificación de los miembros del equipo encargado de la recogida.

b. El objetivo o razón de la acción.

c. Las especies a que se refiera y el número máximo de ejemplares a recoger y tratar, salvo en el caso de invertebrados.

d. Los medios, sistemas o métodos a emplear.

e. Las condiciones de riesgo y las circunstancias de tiempo y lugar.

f. Los sistemas de control que se ejercerán.

3. La Xunta de Galicia, a través de la Consellería de Medio Ambiente, comunicará al Ministerio de Medio Ambiente, a efectos de su posterior notificación a la Comisión de la Unión Europea, las autorizaciones acordadas según lo previsto en el presente artículo, siempre que afecten a especies de interés comunitario.

Artículo 55. Taxidermia y herborización.

1. Se prohíbe la disecación o cualquier otra clase de conservación de animales pertenecientes a las especies incluidas en el Catálogo Gallego de Especies Amenazadas. Excepcionalmente la Consellería de Medio Ambiente podrá autorizar, con fines científicos o educativos, la disecación de estos ejemplares. Asimismo se requerirá autorización para la exhibición pública de los ejemplares disecados.

2. En todo caso, la disecación, herborización o cualquier otra clase de conservación de los ejemplares de especies incluidas en el Registro de Especies de Interés Gallego, así como de otras especies incluidas en el régimen general de protección, necesitarán autorización de la Consellería de Medio Ambiente.

3. Se crea el Registro de Talleres Taxidermistas, dependiente de la Dirección 
General de Montes y Medio Ambiente Natural, en el cual deberán inscribirse las personas físicas y jurídicas que practiquen estas actividades.

\section{Sección 2. ${ }^{a}$}

\section{De la fauna silvestre}

Artículo 56. Introducción de especies. A fin de garantizar la conservación de la diversidad genética o evitar la alteración de hábitats y equilibrios ecológicos, se prohíbe con carácter general la introducción no autorizada en el medio natural de animales de especies de fauna no autóctona en el territorio de Galicia, excepto para aquellas especies objeto de aprovechamiento cinegético o piscícola excluidas en la disposición adicional segunda.

Artículo 57. Autorizaciones y control de poblaciones.

La Consellería de Medio Ambiente podrá autorizar la tenencia, comercio, tráfico y exhibición pública de especies no autóctonas, vivas o muertas, comprendidas las crías, huevos, partes y derivados de las mismas, incluidas en los tratados y convenios internacionales ratificados por España o en disposiciones de la Unión Europea.

Las poblaciones de especies silvestres podrán ser sometidas a medidas de control e incluso de erradicación cuando afecten de manera negativa a las poblaciones de especies autóctonas, especialmente a las catalogadas, o puedan comprometer su conservación.

Artículo 58. Centros de recuperación de fauna.

1. La Consellería de Medio Ambiente establecerá centros de recuperación de fauna, cuya finalidad será el cuidado y recuperación de los ejemplares de fauna silvestre autóctona que se encuentren incapacitados, al objeto de proceder a su posterior devolución al medio natural con posibilidad de supervivencia.

2. Sin perjuicio de la cooperación y coordinación de la Administración Autonómica de Galicia con la Administración General del Estado en la materia objeto de la presente ley, la Consellería de Medio Ambiente promoverá la coordinación con centros de recuperación de otras Comunidades Autónomas o extranjeros.

3. Del mismo modo, podrá concertar con instituciones públicas o privadas la recuperación de ejemplares de especies silvestres y el mantenimiento de ejemplares irrecuperables.

\section{Sección 3. ${ }^{\mathrm{a}}$}

De la flora silvestre

Artículo 59. Medidas de conservación. La actuación de la Xunta de Galicia en aras de la preservación de los taxones botánicos gallegos se basará en los siguientes criterios:

a. Dar preferencia a las medidas de conservación y preservación de las especies autóctonas en sus hábitats naturales, si bien podrán tomarse medidas complementarias fuera de los mismos.

b. Conceder prioridad a las especies autóctonas cuando se propongan medidas de fomento.

Artículo 60. Bancos genéticos.

La Consellería de Medio Ambiente podrá establecer los viveros y bancos genéticos que considere oportunos para la conservación de la flora silvestre gallega, asegurando el mantenimiento de su acervo genético, los cuales podrán establecerse tanto dentro como fuera de sus hábitats.

La actividad de estos centros habrá de planificarse de acuerdo con las necesidades de conservación de las especies de flora silvestre, tanto "in" como "ex situ".

\section{TÍTULO III DE LAS INFRACCIONES Y SANCIONES \\ Capitulo \\ DE LAS INFRACCIONES}

Artículo 61. Naturaleza de la responsabilidad y calificación de las infracciones.

1. Constituyen infracciones administrativas en materia de conservación de la naturaleza las acciones u omisiones que 
supongan el incumplimiento de las obligaciones establecidas en la presente ley.

2. A los efectos de esta ley, las infracciones se califican en leves, menos graves, graves y muy graves.

Artículo 62. Infracciones leves.

Serán infracciones leves los incumplimientos de los requisitos, obligaciones o prohibiciones establecidas en la presente ley, siempre que no estén calificadas como infracciones menos graves, graves o muy graves.

Artículo 63. Infracciones menos graves.

Serán infracciones menos graves:

1. La captura, tenencia, disecación, destrucción, muerte, deterioro, comercio, tráfico, exhibición o naturalización no autorizados de especies de fauna silvestre no catalogadas y que no sean susceptibles de aprovechamiento.

2. El transporte de los animales silvestres con vulneración de los requisitos establecidos por la legislación vigente.

3. Los daños a las especies de fauna silvestre, fuera de las excepciones previstas en la presente ley.

4. El mantenimiento de ejemplares de fauna silvestre sin cumplir las condiciones adecuadas desde el punto de vista higiénico-sanitario y conforme a sus necesidades etológicas.

5. La producción de ruidos innecesarios que alteren la tranquilidad habitual de las especies de fauna catalogada.

6. El tránsito, acampada y encender fuego en los lugares expresamente prohibidos en los instrumentos de planificación de los espacios naturales protegidos.

7. El incumplimiento de las condiciones impuestas en las autorizaciones y concesiones administrativas a que se refiere la legislación ambiental o la normativa de los instrumentos de ordenación del espacio natural protegido sin perjuicio de su caducidad, revocación o suspensión, cuando exista riesgo o daño para las especies silvestres o para los valores que llevaron a su declaración como espacio.

8. La introducción no autorizada de especies de fauna silvestre.

9. La destrucción, deterioro, sustracción o cambio de emplazamiento de las señales vinculadas a los espacios protegidos regulados por la presente ley.

10. La instalación de carteles de propaganda u otros elementos similares que rompan la armonía del paisaje o desfiguren las perspectivas en espacios naturales o su entorno, en contra de lo dispuesto en los instrumentos de ordenación/planificación ambiental previstos en la presente ley.

11. El comportamiento irrespetuoso que suponga riesgo para la conservación de los valores ambientales o dificulte su disfrute y utilización.

Artículo 64. Infracciones graves. Serán infracciones graves:

1. La destrucción, muerte, deterioro, recolección, comercio, captura o exposición para el comercio o naturalización no autorizados de especímenes protegidos, catalogados como vulnerables a la alteración de su hábitat, o de interés especial o expresamente identificados a estos efectos en los instrumentos de ordenación de espacios naturales, así como de sus propágulos o restos.

2. La destrucción o degradación severa del hábitat de especies vulnerables o de interés especial, en especial de los lugares de reproducción, invernada, reposo o alimentación incluidos en los espacios naturales protegidos.

3. La ejecución de obras, implantación de infraestructuras básicas, usos o actividades en las zonas sujetas legalmente a algún tipo de limitación en su destino o uso conforme a la presente ley, sin la debida autorización administrativa o sin la obtención de los informes previstos por la legislación ambiental o que incumplan las normas de los instrumentos de ordenación de los espacios naturales. 
4. La obstrucción o resistencia a la labor inspectora o vigilante de los agentes de la autoridad en el ejercicio de sus funciones de protección de los espacios naturales y de la flora y fauna silvestres regulados por la presente ley.

5. El incumplimiento de las condiciones impuestas por la Consellería de Medio Ambiente en las autorizaciones previstas en los artículos 51, 53 y 57 de la presente ley, cuando existiera riesgo o daño para las especies, sin perjuicio de su revocación o suspensión de inmediato y de la exigencia de las indemnizaciones que procedan.

6. La introducción no autorizada de especies de fauna silvestre en los espacios protegidos, excepto en los lugares expresamente autorizados.

7. El abandono o depósito de residuos fuera de los lugares destinados al efecto.

8. La circulación de vehículos de motor en las zonas reguladas por la presente ley, excepto que se cuente con autorización administrativa.

Artículo 65. Infracciones muy graves. Serán infracciones muy graves:

1. La utilización cuando estuviera prohibida de productos químicos, la realización de vertidos o el derrame de residuos que alteren las condiciones de habitabilidad de los espacios naturales protegidos de la red gallega con daño para los valores y especies que motivaron su declaración.

2. La destrucción, muerte, deterioro, recolección, comercio, captura o exposición o naturalización no autorizados de especímenes, catalogados como en peligro de extinción o sensibles a la alteración de su hábitat, así como de sus propágulos o restos.

3. La destrucción del hábitat de especies catalogadas en peligro de extinción o sensibles a la alteración de su hábitat, que se encuentren incluidos en los espacios naturales protegidos, en particular sus lugares de reproducción, invernada, reposo o alimentación.

Artículo 66. Circunstancias para la graduación de las sanciones.

1. Serán circunstancias a tener en cuenta para la graduación de las sanciones que puedan imponerse por las distintas clases de infracciones:

a. La existencia de intencionalidad.

b. La naturaleza e irreversibilidad de los perjuicios.

c. La reincidencia por la comisión en un plazo de un año de más de una infracción de la misma naturaleza cuando así fuera declarado por resolución firme.

d. La agrupación u organización para cometer la infracción.

e. El beneficio económico perseguido.

2. Si un solo hecho constituye dos o más infracciones administrativas de las previstas en la presente ley, se impondrá la sanción que corresponda a la de mayor gravedad.

3. La reincidencia en infracciones de la misma categoría en un plazo inferior al de su prescripción se equiparará con la comisión de una infracción de la categoría inmediatamente superior.

Artículo 67. Sujetos responsables.

1. A los efectos de la presente ley tendrán la consideración de responsables de las infracciones previstas en la misma:

1) Los autores materiales de las actuaciones infractoras o, en su caso, las empresas o entidades de que dependen.

2) Los técnicos o profesionales que contribuyan dolosamente a la comisión de una infracción.

3) Cuando se trate de actuaciones amparadas por autorizaciones o licencias manifiestamente ilegales, se considera también responsables:

a. A los funcionarios o empleados de cualquier Administración Pública que informen favorablemente el otorgamiento del correspondiente título, quienes serán sancionados por falta grave en vía disciplinaria tras la tramitación del correspondiente expediente. 
b. A las autoridades y miembros de órganos colegiados de cualquier corporación o entidad pública que resuelvan o voten a favor del otorgamiento del título, desoyendo informes preceptivos y unánimes en que se advierta expresamente de la ilegalidad, o cuando no se hubieran recabado dichos informes. La sanción será de multa en la cuantía que corresponda en cada caso por aplicación de los criterios de la presente ley.

2. Cuando concurran diversas personas en la comisión de una misma infracción, las sanciones se impondrán con carácter solidario, salvo que la actuación de cada una de ellas pueda dar lugar a una infracción separada, en cuyo caso se impondrán sanciones independientes.

\section{Artículo 68. Prescripción.}

1. Las infracciones previstas en la presente ley prescribirán en los siguientes plazos, a contar desde la total consumación del hecho:

a. Las infracciones muy graves a los cuatro años.

b. Las infracciones graves al cabo de dos años.

c. Las infracciones menos graves al año.

d. Las infracciones leves a los seis meses.

2. La obligación de restaurar el medio natural al estado anterior al de la comisión de la infracción no prescribe.

\section{Capítulo II DE LAS SANCIONES}

\section{Artículo 69. Sanciones.}

1. Las infracciones tipificadas en la presente ley se sancionarán con las siguientes multas:

a. Infracciones leves: Multa de 10.000 a 100.000 pesetas.

b. Infracciones menos graves: Multa de 100.001 a 1.000 .000 de pesetas.

c. Infracciones graves: Multa de 1.000 .001 a 10.000 .000 de pesetas.

d. Infracciones muy graves: Multa de 10.000 .001 a 50.000 .000 de pesetas.
2. La infracción podrá conllevar una indemnización, que será como mínimo equivalente al valor del beneficio económico conseguido por la persona infractora, independientemente de la calificación de la infracción o de que la cuantía pueda superar la cantidad máxima prevista para las infracciones muy graves.

3. La imposición de la multa podrá conllevar el decomiso del objeto de la infracción y el de las artes de captura o muerte y los instrumentos con que se haya realizado.

Igualmente podrá conllevar el cierre de locales, establecimientos o instalaciones cuando se incurra en infracciones graves o muy graves.

4. Quienes cacen o pesquen especies catalogadas no susceptibles de aprovechamiento cinegético o piscícola serán sancionados además con inhabilitación para cazar o pescar por un período de tres a ocho años.

5. Tanto el importe de las multas como el de las responsabilidades administrativas podrán ser exigidos por la vía administrativa de apremio.

Artículo 70. Responsabilidad civil.

1. Sin perjuicio de la sanción que en cada caso proceda, la persona infractora deberá reparar el daño causado. La reparación y reposición de los bienes tendrá como finalidad la restauración del medio natural al ser y estado previos al hecho de haberse producido la agresión, siempre que ello sea posible. El órgano competente para imponer la sanción lo será también para exigir la restauración.

2. Si la persona infractora no procediera a reparar el daño causado en el plazo que se le señale, la autoridad sancionadora procederá a la imposición de multas coercitivas reiteradas por lapsos de tiempo suficientes para cumplir lo ordenado, cuya cuantía no podrá exceder del 20 por 100 de la multa fijada para la infracción cometida. 
3. La persona responsable de la infracción deberá indemnizar de los daños y perjuicios ocasionados previa tramitación del correspondiente expediente y con audiencia de la persona interesada. La valoración de los mismos será realizada por la Consellería de Medio Ambiente.

4. La utilización de los recursos generados por las sanciones que imponga la Administración deberán destinarse íntegramente a acciones destinadas a la conservación de los espacios naturales protegidos y de la flora y fauna silvestres.

\section{Capítulo III DEL PROCEDIMIENTO SANCIONADOR}

Artículo 71. Tramitación.

1. La tramitación del expediente sancionador, en el cual, en todo caso, se dará audiencia a la persona interesada, se regirá por lo dispuesto en el título IX de la Ley de Régimen Jurídico de las Administraciones Públicas y del Procedimiento Administrativo Común y en su normativa de desarrollo.

2. La incoación de los correspondientes expedientes sancionadores corresponde al Delegado provincial de la Consellería de Medio Ambiente.

Artículo 72. Competencia sancionadora.

La competencia para la imposición de las sanciones a que se refiere la presente ley corresponderá:

1. En el supuesto de infracciones leves y menos graves, al Delegado provincial de la Consellería de Medio Ambiente.

2. En el supuesto de infracciones graves, al Director general de Montes y Medio Ambiente Natural.

3. En el supuesto de infracciones muy graves, al Conselleiro de Medio Ambiente.

Artículo 73. Ilícito penal.

Cuando a juicio de la Administración las infracciones pudieran ser constitutivas de delito o falta, el órgano administrativo lo trasladará al órgano jurisdiccional competente, absteniéndose de proseguir el procedimiento sancionador mientras la autoridad judicial no se haya pronunciado. La sanción de la autoridad judicial excluirá la imposición de multa administrativa. De no estimarse la existencia de delito o falta, la Administración podrá continuar el expediente sancionador con base en su caso en los hechos que la jurisdicción competente haya considerado probados.

Artículo 74. De la prescripción de las sanciones.

1. Las sanciones previstas en la presente ley prescribirán: A los dos años las impuestas por infracciones leves y menos graves, y a los cuatro años las impuestas por infracciones graves y muy graves.

2. El plazo de prescripción comenzará a contarse desde el día siguiente a aquel en que adquiera firmeza la resolución por la que se imponga la sanción.

3. Interrumpirá la prescripción la iniciación, con conocimiento de la persona interesada, del procedimiento de ejecución.

\section{DISPOSICIÓN ADICIONAL PRIMERA CONFIRMACIÓN}

Los espacios naturales protegidos ya declarados con anterioridad a la entrada en vigor de la presente ley mantendrán el régimen de sus declaraciones respectivas en lo que no se contradiga con lo dispuesto en la misma, beneficiándose del rango normativo que la Ley les otorga.

\section{DISPOSICIÓN ADICIONAL SEGUNDA ÁMBITO}

Salvo indicación expresa en contra, las previsiones contenidas en el título II de la presente ley no serán de aplicación a los animales domésticos o salvajes en cautividad o abandonados, con arreglo a lo establecido en la Ley 1/1993, de 13 de abril, de Protección de los Animales Domésticos y Salvajes en Cautividad; a los animales 
criados para el aprovechamiento de sus producciones o con fines de experimentación científica por organismos acreditados con la debida autorización, así como a la regulación de los aprovechamientos de las especies cinegéticas, piscícolas o cualquier otra objeto de regulación específica, incluyendo aquellos ejemplares de especies objeto de cultivo agrícola o aprovechamiento forestal, que serán reguladas por su propia normativa.

\section{DISPOSICIÓN ADICIONAL TERCERA INSPECCIÓN AMBIENTAL}

1. La inspección, vigilancia y control de la materia objeto de la presente ley corresponderá a la Consellería de Medio Ambiente, la cual promoverá los mecanismos de control necesarios con los demás órganos de la Administración Autonómica de Galicia y el resto de las Administraciones Públicas.

2. En el ejercicio de sus funciones, los agentes forestales y demás cuerpos de inspección, vigilancia y control de la Consellería de Medio Ambiente tendrán la consideración de agentes de la autoridad, siempre y cuando realicen funciones de inspección y control en cumplimiento de la presente ley y acrediten su condición mediante la correspondiente documentación.

\section{DISPOSICIÓN ADICIONAL CUARTA COMPETENCIAS DE OTROS ÓRGANOS Y ADMINISTRACIONES}

Las autorizaciones a que se refiere la presente ley se otorgarán, en su caso, sin perjuicio de las que correspondan a otros organismos o administraciones en el ejercicio de sus propias competencias.

\section{DISPOSICIÓN ADICIONAL OUINTA ACTUALIZACIÓN DE MULTTAS}

La Xunta de Galicia podrá actualizar la cuantía de las multas para adecuarlas a las variaciones del coste de la vida, de acuerdo con el índice general de precios al consumo.

\section{DISPOSICIÓN ADICIONAL SEXTA DURACIÓN MÁXIMA DEL PROCEDIMIENTO}

A los efectos previstos en el artículo 42.2 de la Ley 30/1992, de 26 de noviembre, de Régimen Jurídico de las Administraciones Públicas y del Procedimiento Administrativo Común, el plazo máximo de aplicación a los procedimientos administrativos regulados en la presente ley será de tres años, a excepción del procedimiento sancionador, el cual estará a lo dispuesto en dicha Ley 30/1992 y el Reglamento que la desarrolla.

\section{DISPOSICIÓN ADICIONAL SÉPTIMA DESCALIFICACIÓN DE LOS ESPACIOS NATURALES PROTEGIDOS}

1. Un espacio natural protegido o una zona del mismo solamente podrá ser descalificada, con la consiguiente exclusión de la red, en virtud de una norma de igual o superior rango a la de su declaración, y conforme al procedimiento previsto para ésta.

2. La descalificación sólo podrá realizarse si hubieran desaparecido las causas que motivaron la protección y éstas no fueran susceptibles de recuperación o restauración, siempre y cuando la desaparición de aquéllas no estuviera motivada por una alteración intencionada.

3. En todo caso, no podrá procederse a la descalificación y posterior exclusión de la red de un espacio natural protegido que fuera afectado por un incendio forestal. Serán nulos de pleno derecho los actos administrativos de descalificación y exclusión que fueran en contra de este precepto.

\section{DISPOSICIÓN ADICIONAL OCTAVA COMPATIBILIDAD CON LA DECLARACIÓN DE BIEN DE INTERÉS CULTURAL}

1. La declaración de espacio natural protegido será compatible con la declaración de bien de interés cultural.

2. En estos supuestos, la Consellería de Medio Ambiente y la Consellería de 
Cultura establecerán los medios de coordinación necesarios para conseguir una adecuada planificación y financiación.

\section{DISPOSICIÓN ADICIONAL NOVENA COLABORACIÓN ENTRE LOS CUERPOS DE INSPECCIÓN}

Al objeto de conseguir una protección integral del patrimonio cultural y del medio ambiente, se establecerá la colaboración y cooperación entre los distintos cuerpos de inspección en esta materia.

\section{DISPOSICIÓN TRANSITORIA PRIMERA RECALIFICACIÓN Y ADAPTACIÓN}

1. A los efectos de la debida coordinación en cuanto a la aplicación de la normativa básica, denominación y homologación internacional en su caso, la Consellería de Medio Ambiente procederá en el plazo de un año a recalificar los espacios naturales protegidos que se hubieran declarado con anterioridad a la fecha de entrada en vigor de la presente ley y que se correspondan con las figuras reguladas en aquella legislación y en esta ley.

2. La Consellería de Medio Ambiente propondrá o dictará las normas oportunas para adaptar el régimen de los espacios naturales protegidos ya declarados a lo dispuesto en la presente ley.

\section{DISPOSICIÓN TRANSITORIA SEGUNDA PUBLICACIÓN DEL CATÁLOGO}

En el plazo de dos años, a partir de la entrada en vigor de la presente Ley, la Xunta de Galicia publicará el Catálogo Gallego de Especies Amenazadas de la flora y fauna silvestres de conformidad con lo que determinan los artículos 48 y 49 de la misma.

\section{DISPOSICIÓN TRANSITORIA TERCERA IRRETROACTIVIDAD}

Las infracciones y sanciones se regirán en cuanto a su procedimiento y a los plazos de prescripción por la legislación aplicable en el momento en que se cometió la infracción, sin perjuicio de la retroactividad de la disposición más favorable para la persona infractora.

\section{DISPOSICIÓN DEROGATORIA ÚNICA CLÁUSULA DE DEROGACIÓN}

Quedan derogadas o sin aplicación en el ámbito de la Comunidad Autónoma de Galicia cuantas disposiciones de igual o inferior rango se opongan a lo dispuesto en la presente ley.

\section{DISPOSICIÓN FINAL PRIMERA HABILITACIÓN}

Se autoriza al Consello de la Xunta para dictar cuantas disposiciones sean necesarias para el desarrollo y aplicación de la presente ley.

\section{DISPOSICIÓN FINAL SEGUNDA ENTRADA EN VIGOR}

La presente ley entrará en vigor al día siguiente de su publicación en el "Diario Oficial de Galicia”.

6. LEY 8/2001, DE 2 DE AGOSTO,

DE PROTECCIÓN DE LA CALIDAD DE LAS AGUAS DE LAS RÍAS

DE GALICIA Y DE ORDENACIÓN DEL SERVICIO PÚBLICO DE DEPURACIÓN DE AGUAS RESIDUALES URBANAS (DOGA N. $\left.{ }^{\circ} 161,21.8 .2001\right)$

$(\ldots)^{493}$

\section{TÍTULO I \\ DE LA PROTECCIÓN DE LA \\ CALIDAD DE LAS AGUAS \\ DE LAS RÍAS DE GALICIA}

Artículo 1. Objeto y ámbito.

1. Es objeto de la presente ley prevenir, minimizar, corregir o, en su caso, impedir los efectos perjudiciales que determinadas obras, instalaciones y actividades públicas o privadas puedan tener sobre la calidad de las aguas de las rías de Galicia, a través de las medidas que en ella se establecen.

493 Exposición de motivos omitida. 
2. En particular, la presente ley será de aplicación a los vertidos, tanto líquidos como sólidos, que, de forma directa o indirecta, se realicen desde tierra a las rías de Galicia en el ámbito territorial indicado en el apartado 4 y sin perjuicio de lo dispuesto en el artículo 4.9, así como al planeamiento urbanístico en sus manifestaciones de planes, programas y proyectos, en los supuestos del artículo 5 .

3. Se excluyen del ámbito de aplicación de la presente ley los vertidos efectuados desde buques y otras instalaciones flotantes cuya competencia corresponda a la Administración del Estado.

4. El ámbito territorial al que se extiende el título I de la presente ley es la zona terrestre correspondiente a las cuencas de los municipios ribereños vertientes al interior de las rías de Foz, Viveiro, O Barqueiro, Ortigueira, Cedeira, Ferrol, Ares-Betanzos, A Coruña, Corme-Laxe, Camariñas, Lires, Corcubión, MurosNoia, Arousa, Pontevedra, Aldán, Vigo y Baiona. En el anexo I se indican los límites geográficos exteriores de las mencionadas rías. En todo caso, el límite interior de las rías se sitúa en el extremo interior de la zona de dominio público marítimo-terrestre, según se define en la vigente normativa en materia de costas.

Artículo 2. Vertidos de residuos.

1. Queda prohibido efectuar cualquier tipo de vertido de residuos a las aguas de las rías de Galicia, salvo cuando éstos sean utilizados como rellenos y estén debidamente autorizados, una vez constatada la ausencia de afección a la calidad de las aguas de acuerdo con lo previsto en el anexo II.

2. Cuando los rellenos pudiesen afectar a la conservación y regeneración de los recursos marinos se requerirá informe preceptivo y vinculante de la Consellería competente en materia de pesca.

3. Las autoridades competentes, y en particular los Ayuntamientos y demás entidades locales, denegarán las correspondientes licencias de obras, de apertura y de actividades, respecto de aquéllas que no estén debidamente autorizadas de acuerdo con lo previsto en el apartado anterior.

Artículo 3. Objetivos de calidad de las aguas.

1. Se establecen como objetivos de calidad de las aguas de las rías de Galicia los indicados en el anexo II de la presente ley. Estos objetivos de calidad tendrán el carácter de mínimos.

2. Los métodos de análisis de referencia para la determinación de los parámetros considerados en los objetivos de calidad del punto anterior, así como el procedimiento para su control, serán determinados reglamentariamente.

3. En cualquier caso, los anteriores objetivos de calidad se entenderán modificados en caso de que por parte de la Unión Europea o del Estado se dictasen objetivos de calidad más estrictos, o bien referentes a nuevos parámetros, particularmente en lo relativo a las normas de calidad para las aguas de baño, de calidad de las aguas y de la producción de moluscos y otras especies marinas, o bien en relación con el vertido de sustancias peligrosas desde tierra al mar.

Artículo 4. Normas sobre vertidos de aguas residuales industriales.

1. En el ámbito territorial de la presente ley, queda prohibido efectuar vertidos de aguas residuales industriales a las rías de Galicia sin contar con la previa y preceptiva autorización, que corresponde otorgar a la Administración hidráulica de la Comunidad Autónoma de Galicia, previo informe de la Consellería de Pesca, Marisqueo e Acuicultura.

2. No podrán otorgarse licencias municipales de obras, de apertura y de actividades de naturaleza diferente a la doméstica sin que, previa y expresamente, sus promotores hayan obtenido la autorización a que se refiere el párrafo anterior. 
3. Las mencionadas autorizaciones de vertido se otorgarán con arreglo a la vigente legislación en materia de costas y de protección ambiental y a la presente ley, sin perjuicio de la concesión de ocupación del dominio público marítimo-terrestre si fuese necesaria, y de manera que los límites impuestos a la calidad de las aguas residuales se adecuen a los objetivos de calidad indicados en el artículo anterior.

4. La autorización de vertido no será efectiva, y por tanto éste no podrá llevarse a cabo, sin la comprobación previa de las condiciones impuestas en dicha autorización, entre las que necesariamente se encontrarán las relativas a la adecuación de los sistemas de tratamiento del vertido a los límites que se impongan.

5. Para la nueva instalación o ampliación en el ámbito territorial objeto de la presente ley de las actividades industriales, públicas o privadas, indicadas en el anexo III, se requerirá, además de la autorización de vertido a que se refiere el apartado 1, la necesidad de someter previamente el proyecto a evaluación ambiental, de acuerdo con el procedimiento previsto en la vigente normativa de protección ambiental de Galicia.

6. Para la instalación de las actividades a que se refiere el apartado anterior se requerirá igualmente que sus titulares utilicen las mejores técnicas disponibles económicamente viables para la reducción en el origen de los vertidos de aguas residuales o, en su caso, para su tratamiento y depuración. Los promotores deberán igualmente justificar el cumplimiento de objetivos de calidad para aquellos parámetros que no tengan fijados límites de vertido.

7. En todo caso, la Administración Hidráulica de Galicia podrá prohibir, en el ámbito territorial a que se refiere la presente ley, aquellos procesos industriales cuyos efluentes, a pesar del tratamiento a que sean sometidos, puedan constituir un riesgo de contaminación del dominio público superior al admisible de acuerdo con lo establecido en esta ley, bien sea en su funcionamiento normal o en el caso de situaciones previsibles.

8. Igualmente, no podrán autorizarse vertidos de aguas residuales industriales cuya carga contaminante supere los límites de emisión establecidos en el anexo IV, que en ningún caso podrán ser alcanzados mediante dilución. Las mismas previsiones del artículo 3.3 serán de aplicación para estos límites. Los métodos analíticos de referencia para estos parámetros, así como el procedimiento para su control, serán determinados reglamentariamente.

9. Los límites de emisión establecidos en el punto anterior podrán ser de aplicación, asimismo, a cada uno de los vertidos que, junto con otro u otros vertidos de un mismo u otro establecimiento, puedan conformar un vertido único final, incluso en el caso de que dichos establecimientos se encontrasen fuera del ámbito establecido en el artículo 1 de la presente ley. En este último caso, dichos vertidos quedarán también sujetos al régimen de autorización previsto en este título, previa motivación de su riesgo de afección a la ría de que se trate.

A estos efectos, la medición de la contaminación de los efluentes se realizará en el punto de salida del vertido de cada uno de los establecimientos separadamente.

10. En las autorizaciones de vertido, Aguas de Galicia podrá motivadamente imponer la instalación de sistemas de medición y análisis en continuo de los efluentes, así como de transmisión de datos en tiempo real.

Artículo 5. Aplicación de las técnicas de protección ambiental al planeamiento urbanístico y a las actividades en funcionamiento.

1. En la tramitación del planeamiento urbanístico en el ámbito territorial objeto de la presente ley deberá recabarse un 
informe de la autoridad ambiental. Cuando dicho planeamiento pudiese afectar a los recursos marinos, se requerirá además informe de la Consellería de Pesca, Marisqueo e Acuicultura.

2. Al objeto de comprobar sus posibles efectos nocivos para el medio y señalar las medidas correctoras, y sin perjuicio de lo indicado en la disposición transitoria primera, se aplicarán a las actividades que se estén realizando o a las ya realizadas en dicho ámbito territorial las técnicas de protección ambiental establecidas por la Ley 1/1995, de 2 de enero, de Protección Ambiental de Galicia.

3. Todas aquellas actuaciones, públicas o privadas, susceptibles de producir una alteración física o una pérdida de los valores naturales, culturales, científicos o educativos de los espacios naturales en régimen de protección general incluidos en el Registro General de Espacios Naturales de Galicia ubicados en el ámbito territorial de la presente ley serán sometidas a evaluación de su impacto ambiental de acuerdo con el procedimiento vigente.

\section{TÍTULO II \\ DE LA ORDENACIÓN DEL SERVICIO PÚBLICO DE DEPURACIÓN DE AGUAS RESIDUALES URBANAS}

Artículo 6. Declaración de interés general de la Comunidad Autónoma.

1. Se declara de interés general de la Comunidad Autónoma de Galicia el servicio de depuración de aguas residuales urbanas.

2. El ámbito material del servicio comprende la regulación, la planificación, la aprobación definitiva de proyectos, la construcción y la gestión, explotación y mantenimiento de las estaciones depuradoras de aguas residuales, redes de colectores generales y emisarios submarinos que formen parte de la programación de saneamiento y depuración de la Xunta de Galicia, así como, en su caso, la reutilización de las aguas residuales depuradas.
3. Quedan expresamente excluidas aquellas redes de alcantarillado cuyo proyecto, construcción y gestión corresponda a las Entidades Locales de forma exclusiva.

Artículo 7. Competencias de las Entidades Locales.

Las Entidades Locales, sin perjuicio de lo dispuesto en el artículo 6.3, ejercerán en materia de depuración de aguas residuales urbanas las competencias siguientes:

1. La promoción, redacción y propuesta a la Xunta de Galicia para su aprobación, previa comprobación de su adecuación a la programación a que se refiere el artículo 6.2, de planes y proyectos de obras e instalaciones.

2. La contratación y ejecución de las obras e instalaciones que les correspondan con arreglo a los planes y proyectos aprobados previamente, y aquellas otras que les encomiende la Xunta de Galicia.

3. La gestión y explotación de las obras e instalaciones, por sí mismas o mediante cualquier fórmula asociativa con otras entidades locales.

4. La participación en la elaboración del Reglamento Autonómico Regulador del Servicio de Depuración, en los términos del artículo 10.3.

Artículo 8. Administración gestora del servicio.

1. El servicio de depuración de aguas residuales urbanas de la Comunidad Autónoma será gestionado por la Administración Hidráulica de Galicia, bien a través del Organismo Autónomo Aguas de Galicia o bien a través de la Empresa Pública de Obras y Servicios Hidráulicos, Entidades creadas por la Ley 8/1993, de 23 de junio, Reguladora de la Administración Hidráulica de Galicia.

2. En igualdad de condiciones técnicas y económicas, la Administración Hidráulica de Galicia podrá encomendar a las entidades locales la prestación del servicio, tanto en la construcción como en la explotación de las instalaciones. 
3. La Administración gestora de las instalaciones podrá utilizar al efecto cualesquiera de las formas actualmente vigentes para la gestión de servicios públicos.

Artículo 9. Financiación del servicio.

1. El servicio de depuración de aguas residuales urbanas de la Comunidad $\mathrm{Au}$ tónoma será financiado íntegramente por la Administración Hidráulica de Galicia, a través de los recursos siguientes:

a. El producto del canon de saneamiento creado por la Ley 8/1993.

b. Las transferencias que en su favor ordene la Xunta de Galicia y otras Entidades Públicas.

c. Préstamos y créditos, en los términos que determinen las leyes de presupuestos.

d. El producto de las sanciones que imponga por incumplimientos de la regulación del servicio.

e. Ingresos de derecho privado.

f. Cualesquiera otros recursos que pudiese obtener o serle asignados a este fin.

2. Se declara la incompatibilidad en favor del canon de saneamiento respecto de aquellos tributos y precios que, de acuerdo con la vigente normativa en materia de haciendas locales, las Administraciones Locales tuviesen en vigor para financiar el servicio de depuración de aguas residuales urbanas en los supuestos en que sea asumido por la Comunidad Autónoma, a partir de la asunción efectiva del servicio.

3. El comienzo de la prestación efectiva del servicio por parte de la Administración Hidráulica de Galicia comportará el cese de la recaudación de los instrumentos tributarios y financieros que tuviesen vigentes la correspondiente entidad o entidades locales a las que dé servicio la instalación de depuración de que se trate, sin perjuicio del derecho de éstas al cobro de los créditos pendientes en ese momento.

Artículo 10. Regulación del servicio.

1. El servicio público de depuración de aguas residuales urbanas, con independencia de la Administración que lo preste, se regirá por lo dispuesto en la presente ley y en las disposiciones que la desarrollen, así como por lo dispuesto en la normativa básica vigente sobre tratamiento de aguas residuales urbanas.

2. El Consello de la Xunta de Galicia dictará el Reglamento de Prestación del Servicio Público de Depuración de Aguas Residuales Urbanas, que habrá de desarro1lar, entre otros, los siguientes extremos:

a. Elementos para la protección de las instalaciones de saneamiento y depuración y del medio receptor de sus efluentes.

b. La definición de los vertidos prohibidos y tolerados a los sistemas públicos de depuración de aguas residuales, incluida la prohibición de diluir los vertidos a fin de alcanzar dichos límites.

c. La obligación de someter a autorización los vertidos de naturaleza no doméstica, con carácter previo a su conexión a las redes de saneamiento. $\mathrm{La}$ autorización deberá contener, al menos, los condicionantes cuantitativos y cualitativos del vertido para que éste sea admitido en dichas redes. Procedimiento de autorización de los vertidos.

d. Los vertidos que no alcancen los límites establecidos en el punto b) deberán someterse al tratamiento previo adecuado antes de ser autorizados.

e. El régimen de situaciones de emergencia y de los vertidos accidentales potencialmente peligrosos para la seguridad de las personas o de las instalaciones de saneamiento, referido, como mínimo, a su comunicación, adopción de medidas correctoras y valoración y abono de los daños.

f. El régimen de vertidos mediante camiones cisterna.

g. El régimen de inspección, muestreo, análisis y control de los vertidos, incluyendo la obligación, para los vertidos de naturaleza no doméstica, de disposición de una arqueta de registro que permita a la Administración actuante su inspección en todo momento.

3. El Reglamento será elaborado por el Organismo Autónomo Aguas de Galicia y lo 
propondrá al Conselleiro de Política Territorial, Obras Públicas y Vivienda, quien, tras recabar informe de las Entidades Locales a través de su asociación más representativa en Galicia, lo elevará al Consello de la Xunta de Galicia.

\section{TÍTULO III RÉGIMEN DE INFRACCIONES Y SANCIONES}

Artículo 11. Infracciones y sanciones relativas al título $\mathrm{I}$.

1. Las infracciones a lo prevenido en el título I de la presente ley serán sancionadas con arreglo a la vigente normativa en materia de costas.

2. En todo caso, constituirán infracciones de carácter grave:

a. El vertido no autorizado de aguas residuales industriales a las rías de Galicia.

b. El incumplimiento de las condiciones establecidas en la correspondiente autorización de vertido.

3. La comisión de las infracciones previstas en el apartado anterior será sancionada con la imposición de multas desde 750.000 hasta 75.000 .000 de pesetas.

4. Con independencia de la sanción que les fuese impuesta, los infractores serán obligados a indemnizar los daños y perjuicios causados, en el plazo que determine la resolución del expediente sancionador.

5. Las sanciones por infracciones graves podrán llevar aparejada la obligación del cese de la actividad infractora, en los términos del artículo 35.2 de la Ley 1/1995, de 2 de enero, de Protección Ambiental de Galicia, y sin perjuicio de la declaración de caducidad de las autorizaciones o concesiones correspondientes, si es el caso.

Artículo 12. Infracciones y sanciones relativas al título II.

En relación con lo dispuesto en el título II:

1. Se considerarán infracciones de carácter leve:

a. El vertido al sistema de depuración de aguas residuales de naturaleza doméstica sin contar con la autorización correspondiente. b. El incumplimiento de las condiciones establecidas en la autorización de vertido, siempre que no cause daños al sistema público de depuración, o bien cuando estos daños no superen las 500.000 pesetas.

c. Las acciones y omisiones de las cuales se deriven daños o perjuicios para la integridad o el funcionamiento del sistema público de depuración inferiores a 500.000 pesetas.

d. La obstaculización de las funciones de inspección, vigilancia y control que lleve a cabo la Administración, la desobediencia a sus requerimientos de información o en relación con la adecuación de vertidos o instalaciones a las condiciones reglamentarias.

e. Cualquier incumplimiento de las obligaciones del conjunto normativo de regulación del servicio que no tenga atribuida otra calificación.

2. Se considerarán infracciones graves:

a. El vertido al sistema de depuración de aguas residuales de naturaleza distinta a la doméstica sin contar con la autorización correspondiente.

b. La realización de vertidos prohibidos por el Reglamento a que se refiere el artículo 10.2.

c. El incumplimiento de las condiciones establecidas en la autorización de vertido, siempre que se causen daños al sistema público de depuración superiores a 500.000 pesetas y hasta 2.500 .000 pesetas.

d. Las acciones y omisiones de las cuales se deriven daños o perjuicios para la integridad o el funcionamiento del sistema público de depuración superiores a 500.000 pesetas y hasta 2.500 .000 pesetas.

e. La ocultación o falsificación de datos determinantes para el otorgamiento de la autorización de vertido.

f. La falta de comunicación de las situaciones de emergencia o peligro, o el incumplimiento de las órdenes de la administración derivadas de situaciones de peligro o emergencia. 
g. La reincidencia en la comisión de dos o más infracciones leves en el período de un año.

3. Se considerarán infracciones muy graves:

a. Cualquier conducta indicada en el apartado 2 de la cual se deriven daños o perjuicios para el sistema de depuración superiores a 2.500 .000 pesetas.

b. El incumplimiento de las órdenes de suspensión de vertidos no autorizados.

c. La reincidencia en la comisión de dos o más infracciones graves en el período de un año.

4. Las infracciones tipificadas en los apartados anteriores serán sancionadas con las multas siguientes:

a. Infracciones leves: Multa de hasta 1.000 .000 de pesetas.

b. Infracciones graves: Multa entre 1.000 .001 y 5.000 .000 de pesetas.

c. Infracciones muy graves: Multa entre 5.000 .001 y 25.000 .000 de pesetas.

5. Las sanciones se graduarán en función de la reincidencia del infractor, su intencionalidad, el beneficio obtenido y la afección producida al sistema de depuración, o a la calidad del medio receptor.

Artículo 13. Órganos competentes.

1. Los órganos competentes para la imposición de las sanciones previstas en la presente ley, así como las establecidas en la Ley de Costas de competencia de la Administración Hidráulica de Galicia, serán los previstos en el artículo 32 de la Ley 8/1993, de 23 de junio, reguladora de la Administración Hidráulica de Galicia.

2. No obstante lo anterior, al Presidente del Organismo Autónomo Aguas de Galicia se le atribuye expresamente la competencia para sancionar infracciones de carácter grave previstas en el artículo 11 , siempre qué la multa que se imponga no supere los 50.000.000 de pesetas, y en general para sancionar las infracciones de carácter grave previstas en el artículo 12.
Artículo 14. Procedimiento sancionador.

1. Corresponde la incoación de los expedientes sancionadores previstos en la presente Ley al Organismo Autónomo Aguas de Galicia.

2. El procedimiento para la tramitación de los expedientes sancionadores será el previsto en la vigente normativa general de procedimiento administrativo común.

3. Serán sancionadas por la Comisión de Infracciones las personas físicas y jurídicas que resulten responsables de las mismas aun a título de mera inobservancia.

4. Con independencia de la sanción que se imponga, los infractores serán obligados a reparar el daño causado, pudiendo la Administración, en su caso, ejercitar las facultades de ejecución subsidiaria previstas en la ley.

5. Los plazos de prescripción de las infracciones y de las sanciones serán los previstos en la vigente normativa general de procedimiento administrativo común.

6. El plazo para la resolución de los expedientes sancionadores será de un año a contar desde su incoación.

\section{DISPOSICIÓN ADICIONAL PRIMERA}

En el supuesto de que se produzca la modificación normativa a que se refieren los artículos 3.3 y 4.8 , el Consello de la Xunta de Galicia procederá a actualizar y modificar, mediante Decreto, el contenido de los anexos II y IV, respectivamente, de la presente ley.

\section{DISPOSICIÓN ADICIONAL SEGUNDA}

Los Ayuntamientos y demás Administraciones Locales que se encuentren incluidos, en su totalidad o en parte, dentro del ámbito territorial de esta ley, indicado en el anexo I, deberán, en el plazo de un año a partir de la entrada en vigor de la presente ley, aprobar o, en su caso, revisar sus correspondientes ordenanzas de vertido, a fin de adecuarlas a los objetivos de calidad establecidos en esta ley, para lo 
que podrán contar con el asesoramiento de la Administración Hidráulica de Galicia. El incumplimiento de esta obligación comportará necesariamente la pérdida del derecho a cualquier colaboración financiera de la Xunta de Galicia para la explotación de sus instalaciones de saneamiento y depuración de aguas residuales.

\section{DISPOSICIÓN ADICIONAL TERCERA}

El Consello de la Xunta de Galicia promoverá, de común acuerdo con el Gobierno del Principado de Asturias, la regulación correspondiente para la protección de la calidad de las aguas de la ría de Ribadeo.

\section{DISPOSICIÓN ADICIONAL CUARTA}

\section{(...) ${ }^{494}$}

\section{DISPOSICIÓN ADICIONAL QUINTA}

Se entienden autorizados a los efectos de esta ley los vertidos de aguas residuales municipales de naturaleza urbana o doméstica, producidos en el ámbito territorial previsto en el artículo 5 de la Ley 8/1993 y desde tierra al litoral gallego, que se integren en la programación de actuaciones de saneamiento del organismo autónomo Aguas de Galicia, así como los vertidos industriales conectados a la red de colectores municipales siempre que no afecten a los objetivos de calidad fijados en la presente ley.

Todo ello sin, perjuicio de que Aguas de Galicia, previa audiencia de las correspondientes entidades locales, dicte las condiciones en que hayan de realizarse los mencionados vertidos.

\section{DISPOSICIÓN TRANSITORIA PRIMERA}

1. Los establecimientos industriales instalados en el ámbito territorial definido en el artículo 1.3 en la fecha de la entrada en vigor de esta ley deberán

494 Disposición adicional cuarta contiene modificaciones a la Ley $8 / 1993$, de 23 de junio, reguladora de la Administración Hidráulica de Galicia. acreditar ante Aguas de Galicia, en el plazo de dos meses desde dicha fecha, la posesión de la preceptiva autorización administrativa en vigor de sus vertidos de aguas residuales o bien deberán solicitar la tramitación de la misma de acuerdo con lo previsto en la presente ley y demás disposiciones vigentes.

2. Igualmente, y en el mismo plazo, los titulares de autorizaciones de vertido, otorgadas conforme a la legislación anterior a la Ley 22/1988, de costas, deberán acreditar que se adecuaron a la mencionada ley.

3. Las autorizaciones que resulten acreditadas serán revisadas, de oficio, por parte de Aguas de Galicia, a los efectos de su adecuación a la presente ley, siguiéndose, en su caso, su eventual confirmación, modificación o revocación. En ningún caso podrá concederse un plazo superior a dos años para la adaptación progresiva de los vertidos a los límites establecidos en esta ley.

4. Lo prevenido en esta disposición no dará lugar a indemnización alguna.

\section{DISPOSICIÓN TRANSITORIA SEGUNDA}

En el plazo seis meses a partir de la entrada en vigor de la presente ley quedarán sin efecto los convenios que hayan sido suscritos por la Xunta de Galicia en materia de vertidos de aguas residuales a las rías de Galicia que se opongan al contenido de la misma.

\section{DISPOSICIÓN TRANSITORIA TERCERA}

Los procedimientos de otorgamiento de autorización de vertido de aguas residuales y los de licencia de apertura o de actividades que contemplen la producción de vertidos en el ámbito territorial definido en el artículo 1.3, así como el planeamiento urbanístico — planes, programas y proyectos - en dicho ámbito, que se encuentren en trámite en el momento de la entrada en vigor de la presente ley deberán 
adecuarse al contenido de la misma antes del otorgamiento de aquélla.

\section{DISPOSICIÓN TRANSITORIA CUARTA}

La Administración Hidráulica de Galicia podrá asumir la gestión de las estaciones depuradoras actualmente en servicio en la Comunidad Autónoma en el plazo máximo de tres años, a contar desde la entrada en vigor de la presente ley. A estos efectos, se celebrarán los correspondientes convenios con las administraciones locales gestoras de las mismas, en los que necesariamente se indicará, entre otros extremos, la descripción de las instalaciones del sistema de depuración de que se trate y el balance económico de los tres últimos ejercicios.

La gestión de dichas instalaciones podrá ser encomendada también a las administraciones locales en los términos de la presente Ley, sin perjuicio de la aprobación por parte de la Administración Hidráulica de Galicia de los correspondientes proyectos de explotación.

\section{DISPOSICIÓN TRANSITORIA OUUINTA}

Las ordenanzas municipales sobre uso y vertidos a las redes de alcantarillado que se encuentren vigentes a la entrada en vigor del presente decreto deberán adaptarse a lo que disponga el reglamento a que se refiere el artículo 10.2, en el plazo de un año a contar desde la entrada en vigor de este último.

\section{DISPOSICIÓN FINAL PRIMERA}

Se autoriza a la Xunta de Galicia para dictar las disposiciones que sean necesarias para el desarrollo y aplicación de la presente ley.

\section{DISPOSICIÓN FINAL SEGUNDA}

La presente ley entrará en vigor el día siguiente de su publicación en el "Diario Oficial de Galicia".

(...) ${ }^{495}$

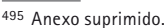

7. LEY 5/1995, DE 7 DE JUNIO, DE REGULACION DE LAS

AGUAS MINERALES, TERMALES, DE MANANTIAL Y DE LOS

ESTABLECIMIENTOS BALNEARIOS DE LA COMUNIDAD AUTÓNOMA DE GALICIA

(DOGA N. ${ }^{\circ} 118$ BIS, 21. 6. 1995) 496

\section{(...) ${ }^{497}$ \\ TítULO I \\ OBJETO Y ÁMBITO DE APLICACIÓN}

Artículo 1. La presente ley tiene como objeto la regulación de las aguas minerales, termales y de manantial cuyo lugar de nacimiento o alumbramiento esté situado dentro del territorio de la Comunidad Autónoma de Galicia.

Igualmente, es objeto de esta ley, dentro del ámbito territorial señalado, la regulación de los establecimientos balnearios.

\section{TÍTULO II}

DE LA CLASIFICACIÓN DE LAS

AGUAS MINERALES, TERMALES Y DE MANANTIAL Y DE SU APROVECHAMIENTO

\section{Capítulo I \\ CLASIFICACION DE LAS AGUAS \\ MINERALES, TERMALES \\ Y DE MANANTIAL}

Artículo 2. A los efectos de la presente ley, las aguas reguladas en la misma se clasifican en tres grupos: Minerales, termales y de manantial.

1. Aguas minerales. Éstas, a su vez, se clasifican en:

a. Aguas minero-medicinales: Las alumbradas natural o artificialmente y que por sus características y cualidades sean declaradas de utilidad pública y sean aptas para tratamientos terapéuticos.

b. Aguas minero-industriales: Las que permiten el aprovechamiento racional de

496 Véase Decreto 402/1996, de 31 de octubre, por el que se aprueba el Reglamento de aprovechamiento de aguas mineromedicinales, termales y de los establecimientos balnearios de la Comunidad Autónoma de Galicia.

497 Exposición de motivos omitida. 
las sustancias que contengan, entendiéndose incluidas las aguas tomadas del mar a estos efectos.

c. Aguas minerales naturales: Aquéllas bacteriológicamente sanas que tengan su origen en un estrato o depósito subterráneo y que broten de un manantial en uno o varios puntos de alumbramiento naturales o perforados. Estas aguas pueden distinguirse claramente de las restantes aguas potables por su naturaleza y pureza original, caracterizadas por su contenido en minerales, oligoelementos y, en ocasiones, por determinados efectos favorables.

2. Aguas termales: Son aquellas aguas cuya temperatura de surgencia sea superior, al menos, en cuatro grados centígrados a la media anual del lugar en que alumbren.

3. Aguas de manantial: Aquéllas de origen subterráneo que emergen espontáneamente en la superficie de la tierra o se captan mediante labores practicadas al efecto, con las características naturales de pureza que permiten su consumo.

\section{Capitulo II \\ APROVECHAMIENTO DE LAS AGUAS MINERALES, TERMALES Y DE MANANTIAL}

\section{Sección $1 .^{a}$}

Declaración de la condición de

mineral o termal de las aguas y

reconocimiento del derecho a la utilización de tales denominaciones

Artículo 3. A los efectos de lo previsto en la legislación básica de minas, el órgano competente para la declaración de mineral o termal y el reconocimiento del derecho a la utilización de las denominaciones, según el caso, de las aguas minerales y termales será la consellería que tenga la competencia en materia de Industria y esta declaración y reconocimiento será requisito previo para la utilización de su aprovechamiento como tal.

Artículo 4. 1. En los expedientes para la declaración o reconocimiento se escuchará a los órganos competentes en cada caso de la Comunidad Autónoma de Galicia.
2. Para el caso de aguas minero-medicinales, minerales naturales o termales para usos terapéuticos, será recabado el informe, que tendrá carácter vinculante, de la consellería competente en materia de sanidad.

Artículo 5. El expediente se iniciará de oficio o a instancia del interesado. Dicha iniciación se notificará al propietario del terreno en donde emerjan las aguas, para su conocimiento y a los efectos oportunos, y será objeto de publicación en el "Diario Oficial de Galicia".

Artículo 6. 1. Una vez efectuada la declaración o reconocimiento, quien hubiera iniciado el expediente dispondrá de un plazo de un año, desde la notificación de la resolución causante, para solicitar la concesión o autorización administrativa de aprovechamiento.

2. Realizados de oficio la declaración o el reconocimiento, o no solicitado el aprovechamiento según se indica en el número anterior, el órgano competente podrá otorgar dicho aprovechamiento mediante concurso público.

Artículo 7. La pérdida de la condición de mineral o termal o del derecho a la utilización de la denominación de las aguas de que se trate se declarará mediante orden motivada del conselleiro competente en materia de industria, previo informe vinculante de la consellería que tenga la competencia en materia de sanidad cuando se trate de aguas minero-medicinales, minerales naturales o termales para usos terapéuticos. Dicha orden motivada será publicada en el "Diario Oficial de Galicia".

\section{Sección 2.}

Reconocimiento del derecho a la utilización de la denominación agua de manantial

Artículo 8. El reconocimiento del derecho de utilización de la denominación agua de manantial se declarará mediante orden del conselleiro competente en 
materia de industria y será requisito previo para la utilización de su aprovechamiento como tal.

Será requisito previo para el reconocimiento de utilización de la denominación de agua de manantial la obtención de la correspondiente autorización o concesión, en su caso, de aprovechamiento de las aguas del órgano competente en materia de dominio público hidráulico, de acuerdo con lo previsto en la Ley 29/1985, de 2 de agosto, de aguas, y en su reglamento.

Artículo 9. 1. En los expedientes para el reconocimiento o declaración de agua de manantial se escuchará a los órganos competentes de la Comunidad Autónoma en la materia, así como a aquéllos a que hace referencia la legislación básica estatal.

2. Igualmente, será recabado informe, que tendrá carácter vinculante, de la consellería competente en materia de sanidad ${ }^{498}$.

Artículo 10. El expediente se iniciará de oficio o a instancia del interesado. Dicha iniciación se notificará al propietario del terreno en donde emerjan las aguas, para su conocimiento y a los efectos oportunos y será objeto de publicación en el "Diario Oficial de Galicia".

Artículo 11. 1. Efectuado el reconocimiento de la denominación, quien hubiera iniciado el expediente tendrá un plazo de un año, desde la notificación de la resolución, para solicitar la concesión o autorización administrativa, en su caso, de aprovechamiento.

2. Realizado de oficio el reconocimiento a la denominación, o no solicitado el aprovechamiento según se indica en el apartado anterior, el órgano competente podrá otorgar dicho aprovechamiento mediante concurso público.

Artículo 12. La pérdida del derecho a la utilización de la denominación aguas de manantial se realizará mediante orden motivada del conselleiro competente

498 Véase Orden de 5 de noviembre de 1996 por la que se regula la autorización sanitaria de los establecimientos balnearios de la Comunidad Autónoma de Galicia. en materia de industria, previo informe vinculante de la consellería que tenga la competencia en materia de sanidad. Dicha orden motivada será publicada en el "Diario Oficial de Galicia”.

\section{Sección 3. ${ }^{\mathrm{a}}$}

\section{Condiciones generales} de aprovechamiento

Artículo 13. 1. Para ejercer el derecho al aprovechamiento de las aguas minerales, termales y de manantial, habrá de solicitarse la oportuna concesión administrativa, presentando un proyecto general de aprovechamiento, compuesto por los documentos que reglamentariamente se establezcan y fijando, además, un perímetro de protección para la conservación del acuífero, definido por coordenadas geográficas referidas al meridiano de Greenwich.

2. Además de otras condiciones que se fijen reglamentariamente, para ejercer el derecho de aprovechamiento de las aguas a que se refiere la presente ley habrá de solicitarse la oportuna concesión administrativa, presentando el proyecto general de aprovechamiento, el presupuesto de las inversiones a realizar y el plan de viabilidad. Asimismo, se solicitará un perímetro de protección tendente a la conservación del acuífero y un estudio justificando la necesidad del mismo y la delimitación propuesta.

Dicho perímetro de protección, definido por coordenadas geográficas referidas al meridiano de Greenwich, estará constituido por tres zonas, que limitarán las actividades que se pretendan llevar a cabo en las mismas: Zona de restricciones máximas, zona de restricciones medias y zona de restricciones mínimas. Las tres zonas se establecerán en función de lo que se denomina "tiempo de tránsito", que se define como el tiempo que transcurre entre la entrada de una sustancia en el seno del acuífero y su extracción por la captación. 
Al inicio del aprovechamiento de las aguas, el titular del derecho deberá disponer de los terrenos que comprendan la zona de restricciones máximas.

Artículo 14. 1. En el caso de que el aprovechamiento sea otorgado mediante concesión administrativa, tendrá un plazo de vigencia de treinta años, prorrogable como máximo por otros dos plazos iguales, salvo que finalice con anterioridad, en los supuestos previstos en la presente ley.

2. El titular de la concesión habrá de solicitar la prórroga con anterioridad mínima de un año a la finalización del plazo de vigencia.

3. Cualquier explotación de las aguas objeto de la presente ley que no obtuviera la necesaria concesión o autorización, en su caso, será considerada ilegal y el organismo competente ordenará la inmediata paralización de la misma, que se mantendrá en tanto no se legalizara su situación, sin perjuicio de las sanciones a que haya lugar.

Artículo 15. La ampliación, restricción, paralización o cualquier otra modificación de un aprovechamiento o de sus instalaciones, bien sea en régimen de concesión o de autorización, requerirá la previa autorización administrativa o nueva concesión, en su caso.

Artículo 16. El titular de un aprovechamiento de las aguas reguladas en la presente ley estará obligado a iniciar la explotación en el plazo de un año, contado a partir de la fecha en que estén debidamente autorizadas las instalaciones.

Asimismo, dentro del mes de enero y con carácter cuatrienal, éste habrá de presentar ante el órgano competente un plan de aprovechamiento.

El primer plan de aprovechamiento se presentará dentro del mes de enero del cuarto año posterior al de la obtención de la concesión o autorización, en su caso, de tal aprovechamiento.
Artículo 17. 1. La concesión o autorización, en su caso, de aprovechamiento de las aguas aquí reguladas otorga a su titular el derecho exclusivo a utilizarlas en las condiciones que reglamentariamente se fijen. El órgano competente, a instancias del titular, proveerá las medidas precisas para impedir que se realicen, en el perímetro de protección autorizado, trabajos o actividades que pudieran perjudicar el normal aprovechamiento de las aguas.

2. Cualquiera de los trabajos o actividades a que se refiere el número anterior habrá de contar, previamente, con la autorización del órgano competente.

3. El titular tendrá derecho al aprovechamiento de las aguas que se encuentren dentro del perímetro de protección autorizado, previa incoación de los oportunos expedientes de declaración o reconocimiento y aprovechamiento.

Artículo 18. 1. Los derechos que otorga una concesión o autorización, en su caso, de aprovechamiento podrán ser transmitidos, alquilados o gravados, en todo o en parte, por cualquier medio admitido en derecho, previa autorización administrativa, a cualquier persona que reúna las condiciones que exige la legislación básica de minas y mediante el procedimiento que en la misma se establece.

2. Las autorizaciones o concesiones de aprovechamientos tendrán únicamente efectos administrativos, dejando a salvo derechos y obligaciones de carácter civil.

Artículo 19. Las concesiones o autorizaciones de aprovechamiento se declararán extinguidas, en su caso, mediante resolución del órgano otorgante en los siguientes supuestos:

1. Por renuncia voluntaria del titular, aceptada por la Administración.

2. Por la pérdida de la condición de mineral o termal o del reconocimiento de aguas de manantial de las aguas de que se trate.

3. Por el agotamiento del recurso.

4. Por la disminución del caudal del acuífero que impida su explotación en las 
condiciones establecidas en la autorización o concesión otorgada.

5. Por la finalización del plazo por el que fue otorgada la concesión o las prórrogas sucesivas.

6. Por la contaminación irreversible del acuífero.

7. Por mantener paralizados los trabajos de aprovechamiento más de un año sin autorización administrativa.

8. Por incumplimiento de las condiciones impuestas en la concesión o autorización, en su caso.

9. Por los restantes supuestos previstos en esta ley que conlleven la extinción.

En los supuestos recogidos en los puntos 2, 4, 6 y 8, se precisará informe de la consellería competente en materia de sanidad, que será vinculante, cuando se trate de aguas minero-medicinales, minerales naturales, termales para usos terapéuticos o aguas de manantial.

En cualquier caso, el órgano competente dará cuenta al de sanidad de las extinciones de aprovechamientos de aguas minero-medicinales, termales para usos terapéuticos y minerales naturales o de manantial.

Artículo 20. 1. Declarada la extinción de una concesión o autorización, en su caso, y siempre que no se debiera a la pérdida de las condiciones o características que sirvieron de base para su aprovechamiento, el órgano competente podrá conceder el aprovechamiento mediante concurso público, de acuerdo con el procedimiento establecido en esta ley y en las normas reglamentarias que la desarrollen.

2. La extinción de un aprovechamiento de aguas destinadas a usos terapéuticos llevará implícita la retirada de las autorizaciones de funcionamiento como establecimiento balneario.

3. Para el abandono de un aprovechamiento se estará a lo dispuesto en la legislación básica de minas.

Artículo 21. En la consellería competente en materia de industria se crea el
Registro de Aguas Minerales, Termales y de Manantial, en el que se inscribirán de oficio las declaraciones o reconocimientos, así como los aprovechamientos legalmente constituidos. Este Registro tendrá carácter público y de las inscripciones practicadas podrá solicitarse certificación, que será medio de prueba del contenido registral.

\section{TÍTULO III \\ DE LOS ESTABLECIMIENTOS BALNEARIOS E INSTALACIONES INDUSTRIALES}

Artículo 22. 1. Los establecimientos balnearios son aquéllos que, estando dotados de los medios adecuados, utilizan las aguas minero-medicinales declaradas de utilidad pública con fines terapéuticos y preventivos para la salud. Se considerarán establecimientos sanitarios y, como tales, quedan sujetos a lo dispuesto en la legislación sanitaria.

2. Corresponde a la consellería competente en materia de sanidad la competencia para establecer los requisitos técnicos y condiciones sanitarias mínimas de apertura de balnearios, así como el procedimiento para otorgar la autorización sanitaria previa en cuanto a su creación, modificación o cierre.

A los efectos de la presente ley, las instalaciones que no cumplan los requisitos establecidos no podrán tener la denominación de balneario.

3. Estos establecimientos podrán disponer de instalaciones de complemento turístico, de ocio e industriales, que quedarán sometidas a sus normativas específicas.

\section{TÍTULO IV DE LA JUNTA ASESORA}

Artículo 23. Se crea la Junta Asesora de Aguas Minerales, Termales, de Manantial y de Establecimientos Balnearios de la Comunidad Autónoma de Galicia, cuya composición y funcionamiento se determinarán reglamentariamente. 
Artículo 24. Las funciones de la Junta Asesora serán las siguientes:

a. Asesorar a la Administración autonómica en lo relativo a las aguas minerales, termales, de manantial, balneoterapia y promoción de los complejos balnearios.

b. Promover estudios y elaborar planes conducentes al mejor y más racional aprovechamiento de las aguas reguladas por la presente ley.

c. Proponer a la Administración autonómica disposiciones y actuaciones dirigidas al fomento, protección, promoción y comercialización de las aguas reguladas por la presente ley.

d. Aquellas otras análogas que reglamentariamente se determinen.

\section{TíTULO V}

\section{Capítulo I \\ DE LA COMPETENCIA ADMINISTRATIVA}

Artículo 25. 1. El ejercicio de la competencia en materia de las aguas reguladas por la presente ley corresponderá a la consellería competente en materia de industria $\mathrm{y}$, según los casos, al órgano competente en materia de dominio público hidráulico, sin perjuicio de las facultades que puedan corresponder a los órganos que la tengan en materia sanitaria y turística.

2. La consellería que tenga la competencia en materia de industria o, en su caso, el órgano competente podrán suspender provisionalmente y mediante resolución motivada la actividad del aprovechamiento, en todo o en parte, en los casos de urgencia en que peligre la salud o seguridad de las personas, la integridad de la superficie, la conservación del recurso en cantidad o calidad o de las instalaciones o la protección del ambiente, sin perjuicio de los derechos económicos y laborales que, frente al titular de la explotación, pudieran corresponder al personal afectado; esta suspensión se mantendrá en tanto persistan las circunstancias que la motivaron o no se adopte resolución definitiva.

\section{Capitulo II \\ DE LAS INFRACCIONES \\ Y SANCIONES}

Artículo 26. 1. Las infracciones a lo contenido en la presente ley se clasifican en leves, graves y muy graves:

1) Son infracciones leves:

a. La presentación del plan cuatrienal de aprovechamiento fuera del plazo establecido, pero dentro del primer semestre del año que corresponda.

b. El incumplimiento de las obligaciones formales derivadas de la presente ley.

c. El incumplimiento de las prescripciones impuestas.

d. En general, cualquier incumplimiento de lo dispuesto en la presente ley que no esté tipificado como falta grave o muy grave.

2) Son infracciones graves:

a. No comenzar el aprovechamiento en el plazo establecido en el artículo 16 de la presente ley.

b. Llevar a cabo modificaciones, ampliaciones, restricciones o paralizaciones del aprovechamiento sin la previa autorización o nueva concesión, en su caso.

c. El incumplimiento de los planes cuatrienales de aprovechamiento.

d. La presentación del plan cuatrienal de aprovechamiento fuera de plazo, pero dentro del segundo semestre del año que corresponda.

e. La utilización de las aguas para fines distintos a los autorizados, salvo lo previsto en el apartado 1.3.d).

f. La transmisión de los derechos que otorga la concesión o autorización, en su caso, de aprovechamiento sin la previa autorización administrativa.

g. La reiteración de infracciones leves.

3) Son infracciones muy graves:

a. El incumplimiento de las condiciones impuestas en el otorgamiento del aprovechamiento.

b. El deterioro significativo en calidad o cantidad del acuífero por causas imputables al titular o explotador. 
c. La falta de presentación del plan cuatrienal de aprovechamiento o su presentación fuera del primer año que corresponda.

d. La utilización de las aguas para fines distintos a los autorizados, cuando pueda afectar a la salud de las personas.

e. La reiteración de infracciones graves.

2. Las infracciones administrativas a que se refiere la presente ley prescribirán en los siguientes plazos, a contar desde la comisión del hecho o desde su detección:

a. Seis meses, en el caso de infracciones leves.

b. Un año, en el caso de infracciones graves.

c. Dos años, en el caso de infracciones muy graves.

3. Se entenderá que existe reiteración cuando se cometieran dos o más infracciones del mismo grado que hubieran sido objeto de sanción antes de finalizar su período de prescripción.

Artículo 27. 1. Las infracciones tipificadas en el artículo anterior serán sancionadas, previa incoación del oportuno expediente, de acuerdo con la siguiente graduación:

a. Infracciones leves: Multa de hasta 100.000 pesetas.

b. Infracciones graves: Multa desde 100.001 hasta 1.000 .000 de pesetas.

c. Infracciones muy graves: Multa desde 1.000 .001 hasta 10.000 .000 de pesetas En estos casos podrá decretarse, además, una suspensión de la concesión o autorización, en su caso, de aprovechamiento de hasta seis meses o la extinción de dicha concesión o autorización.

2. La competencia para imponer las sanciones corresponderá:

a. Infracciones leves: Al Delegado provincial de la consellería competente en materia de industria o al órgano competente en materia de dominio público hidráulico, según el caso.

b. Infracciones graves: Al Director general competente en materia de industria o al órgano competente en materia de dominio público hidráulico, según el caso. c. Infracciones muy graves: Al conselleiro competente en materia de industria o al órgano competente en materia de dominio público hidráulico, según el caso.

Las sanciones superiores a 5.000.000 de pesetas y, en todo caso, la extinción de la concesión o autorización, en su caso, de aprovechamiento las acordará el Consello de la Xunta de Galicia.

Artículo 28. 1. Para la graduación de las sanciones se tendrá en cuenta el grado de repercusión de la infracción en el aprovechamiento autorizado, su trascendencia respecto a personas y bienes, la participación y el beneficio obtenido, la intencionalidad del infractor, así como el deterioro producido en la calidad del recurso.

2. Se tendrá en cuenta, igualmente, en la graduación de la sanción el hecho de que durante la tramitación del expediente y antes de recaer resolución definitiva se hubiera acreditado, por alguno de los medios válidos en derecho, que se han subsanado los defectos que dieron origen a la iniciación del procedimiento de que se trate.

3. La sanción de suspensión de la concesión o autorización, en su caso, de aprovechamiento se entenderá sin perjuicio de los intereses y derechos laborales de los trabajadores, así como de la obligatoriedad de cotizar a la Seguridad Social.

Artículo 29. 1. Las infracciones en materia sanitaria, turística o industrial serán sancionadas con arreglo a lo previsto en la normativa específica que resulte de aplicación.

2. Cuando una misma conducta resulte sancionable conforme a esta ley y otras, que corresponda aplicar a la Administración autonómica, se resolverán los expedientes sancionadores correspondientes, imponiendo únicamente la sanción más gravosa.

\section{DISPOSICIÓN ADICIONAL PRIMERA}

De los informes de los órganos consultivos:

1. Los informes preceptivos que se contemplan en la presente ley habrán de 
ser evacuados en el plazo máximo de un mes, siendo considerados favorables de no ser cumplimentados en el plazo señalado.

2. Los informes vinculantes habrán de ser evacuados en el plazo máximo de dos meses; transcurrido dicho plazo sin ser evacuados, y reiterada la petición, se entenderán favorables de no cumplimentarse en el plazo de un mes.

\section{DISPOSICIÓN ADICIONAL SEGUNDA}

Para que los titulares puedan acogerse a los beneficios y ayudas de cualquier tipo que se establezcan para el fomento del sector, las concesiones o autorizaciones, en su caso, de aprovechamiento deberán estar inscritas en el Registro de Aguas Minerales, Termales y de Manantial a que se refiere la presente ley.

\section{DISPOSICIÓN ADICIONAL TERCERA}

Los servicios administrativos y profesionales relacionados con las aguas minerales, termales y de manantial recogidos en la presente ley darán lugar a la exacción de las tasas que les sean de aplicación en los términos previstos en el Decreto legislativo 1/1992, de 11 de abril, por el que se aprueba el texto articulado de las bases contenidas en el capítulo $3^{\circ}$. del título II de la Ley 13/1991, de 9 de diciembre, de Tasas, Precios y Exacciones Reguladoras de la Comunidad Autónoma de Galicia, y en concreto las previstas para actuaciones sobre derechos mineros y de aguas minerales.

\section{DISPOSICIÓN ADICIONAL CUARTA}

En todo lo que no se contemple en la presente ley será de aplicación lo dispuesto en la legislación estatal de minas.

Se garantizan a los titulares de aprovechamientos de aguas definidas en la presente ley los derechos adquiridos que se acrediten con arreglo a la Ley 22/1973, de minas, al Real Decreto de 25 de abril de 1928, por el que se aprueba el Estatuto de explotación de manantiales de aguas minero-medicinales, y al Real Decreto 1164/1991, de 22 de julio, por el que se aprueba la reglamentación técnico-sanitaria para la elaboración, circulación y comercio de las aguas de bebida envasadas.

\section{DISPOSICIÓN TRANSITORIA PRIMERA}

1. Los titulares de los aprovechamientos que fueran explotados a la entrada en vigor de la presente ley disponen de un plazo de un año para acreditar, ante la consellería competente en materia de industria, los siguientes extremos:

a. La existencia de una declaración de mineral o termal de los caudales aprovechados o bien las características de las aguas, en base a las cuales se otorgó la citada declaración o autorización de aprovechamiento.

b. La existencia de una autorización o concesión de aprovechamiento a favor del interesado, en su caso.

2. Una vez comprobadas y conformes las acreditaciones, la consellería competente en materia de industria verificará las permanencias de las características que motivaron la declaración. En caso de aguas minero-medicinales, termales para usos terapéuticos, minerales naturales y de manantial, se precisará el informe de la consellería competente en materia de sanidad, que será vinculante.

3. Verificada la permanencia de las características de las aguas, la consellería competente en materia de industria comunicará al interesado tal circunstancia e inscribirá de oficio el aprovechamiento en el registro correspondiente.

4. Aquellas explotaciones en que no pueda acreditarse lo recogido en el punto 1 serán declaradas ilegales a los efectos de esta ley.

\section{DISPOSICIÓN TRANSITORIA SEGUNDA}

Si el interesado acreditara la existencia de una declaración de condición de mineral de las aguas, pero no su concesión 
o autorización, en su caso, para el aprovechamiento, habrá de solicitarla con arreglo al procedimiento establecido en la presente ley.

\section{DISPOSICIÓN TRANSITORIA TERCERA}

En los expedientes para la declaración o reconocimiento de denominación también se recabará informe del Instituto Tecnológico Geominero de España, en tanto no exista organismo equivalente en la Comunidad Autónoma de Galicia.

\section{DISPOSICIÓN TRANSITORIA CUARTA}

En tanto que reglamentariamente no se determine otro procedimiento, los expedientes de aprovechamiento de estas aguas se tramitarán y resolverán con arreglo a lo que se establece en la legislación básica de minas, que también le será de aplicación.

\section{DISPOSICIÓN FINAL PRIMERA}

Se autoriza al Consello de la Xunta de Galicia el desarrollo reglamentario de la presente ley, que habrá de efectuarse en el plazo de un año desde su entrada en vigor.

\section{DISPOSICIÓN FINAL SEGUNDA}

La presente ley entrará en vigor al día siguiente al de su publicación en el "Diario Oficial de Galicia”.

\section{LEY 5/2006, DE 30 DE JUNIO, PARA LA PROTECCIÓN, LA CONSERVACIÓN Y LA MEJORA DE LOS RÍOS GALLEGOS (DOGA N. $\left.{ }^{\circ} 137,17.7 .2006\right)$}

(...) $)^{499}$

Articulo 1. Principios generales.

1. Se declara prioridad de interés general de la Comunidad Autónoma de Galicia la conservación del patrimonio natural fluvial, incluyendo la biodiversidad de la flora y la fauna de los ríos gallegos, así

499 Preámbulo omitido. como el patrimonio etnográfico e histórico-cultural relacionado.

2. Se declara, asimismo, obligación de las administraciones públicas gallegas garantizar su protección, conservación y mejora.

3. Con tal finalidad, y en lo que respecta a los valores naturales, se asumen los objetivos más avanzados de la Directiva 2000/60/CE, del Parlamento Europeo y del Consejo, de 23 de octubre de 2000 , por la que se establece un marco comunitario de actuación en el ámbito de la política de aguas, y se aplicarán de forma prioritaria y urgente las medidas contenidas en la misma.

Artículo 2. Planificación hidrológica. La administración competente elaborará los nuevos planes hidrológicos para las nuevas demarcaciones hidrográficas, de conformidad con los criterios básicos contenidos en la Directiva 2000/60/CE, y los previstos por la normativa vigente, incluida la presente ley.

Artículo 3. Contenido de los planes hidrológicos y red de vigilancia y control del estado ecológico de los ríos.

1. Los planes hidrológicos a que hace referencia el artículo anterior incluirán programas o planes de medidas que, como resultado de los estudios técnicos y análisis económicos realizados previamente, permitan alcanzar los objetivos que establece la Directiva 2000/60/CE:

Los programas o planes de medidas incluirán previsiones en materia de:

a. Restauración de los ecosistemas fluviales, especialmente en lo que se refiere a los indicadores de régimen hidrológico y continuidad del río y previendo las necesidades de restauración que lo requieran para garantizar el buen estado de las aguas.

b. Mejora integral de los ecosistemas fluviales, atendiendo a las características morfológicas tales como la evaluación de profundidad y anchura del río, la estructura, el sustrato del cauce, la calidad 
de la zona ribereña y la prevención de la contaminación difusa.

c. Medidas de restauración de humedales y de zonas de inundación de los ríos, y de restauración hidrológico-forestal de las cuencas.

d. Medidas de saneamiento integral de los cursos fluviales y depuración integral de vertidos urbanos e industriales, aplicando las alternativas más eficientes y modernas desde el punto de vista medioambiental.

2. Se creará una red de vigilancia y control del estado ecológico de los ríos, según lo recomendado por la Directiva 2000/60/CE, contando con los diferentes equipos de investigación existentes y promoviendo los estudios encaminados a determinar los valores de referencia para Galicia.

Artículo 4. Protección integral de los ecosistemas fluviales.

1. Se desarrollarán los estudios y análisis que determinen la categorización y la tipificación de las masas de agua, con la indicación de las condiciones de referencia y la inclusión de la catalogación y cuantificación de la biodiversidad fluvial. El programa de medidas resultado de estos estudios integrará:

a. Un plan o programa para el estudio hidrobiológico de los ríos.

b. Un plan o programa para conseguir la protección integral de una parte significativa de los ecosistemas fluviales gallegos, con el objetivo de garantizar la conservación sostenible del paisaje y de la biodiversidad fluvial.

Artículo 5. Gestión del uso del agua.

1. Las diferentes actuaciones relacionadas con el agua y los ríos se basarán en los principios de gestión de la demanda, recuperación de costes y consideración del agua y los ríos como un activo ecosocial. Habrán de establecerse dotaciones de recurso de referencia, atendiendo a criterios de disponibilidad, eficiencia y racionalidad en el uso, y compatibilidad con los objetivos ambientales de no deterioro y recuperación del buen estado de las aguas.

2. Las dotaciones de referencia serán aquéllas que garanticen la satisfacción de las necesidades básicas de las personas y las que se deriven de la aplicación de las mejores tecnologías disponibles en lo referido a los usos agroganadero e industrial. Las futuras infraestructuras hidráulicas, captaciones de recursos, vertidos o usos vendrán definidas por las dotaciones de referencia y el cumplimiento del objetivo del buen estado de los ecosistemas fluviales.

Artículo 6. Participación ciudadana en las políticas del agua.

1. Se garantizará la participación efectiva de la ciudadanía en los procesos de elaboración de los planes hidrológicos.

2. Se garantizará el acceso a la información ambiental, a la participación en la toma de decisiones y el acceso a la justicia en cuestiones ambientales, en la forma que lo establece el Convenio internacional de Aahrus.

3. En aquellas actividades que considere oportuno el organismo competente en materia ambiental impulsará, de acuerdo con el Convenio internacional de Aahrus, un marco efectivo de participación que se articulará al inicio del procedimiento, en el que se prestará especial atención a la participación de las poblaciones locales interesadas.

4. Los organismos de toma de decisiones en lo referido a planes y programas contarán con una representación paritaria de miembros de entidades sociales en relación con la suma de los miembros de administración y de las entidades directamente interesadas en los usos del agua.

Artículo 7. Educación ambiental y capacitación técnica del personal de la Administración.

1. Se elaborará, con arreglo a las líneas y pautas de actuación definidas en la Estrategia gallega de educación ambiental:

a. Un plan de educación ambiental relacionado con los usos doméstico, industrial 
y agroganadero del agua, priorizando la reducción del consumo y la prevención de la contaminación, con atención específica tanto al medio urbano como al rural, con la finalidad de comenzar a construir una nueva cultura del agua.

b. Un plan de educación ambiental para el ahorro energético, con actuaciones particularizadas para cada ámbito de interés, como el consumo doméstico, el transporte y desplazamientos, y el consumo industrial.

c. Programas de concienciación sobre los peligros de las especies invasoras, tanto del público en general como de sectores clave, entre los que se encuentran el turismo, el comercio, el transporte, etc.

2. Se atenderán, de forma prioritaria, las necesidades de capacitación técnica del personal de la Administración hidráulica en particular, y del personal de la Administración autonómica y local relacionado con los diferentes aspectos de la presente ley.

\section{DISPOSICIÓN ADICIONAL PRIMERA DOTACIÓN DE RECURSOS}

La administración se dotará de los recursos necesarios para el desarrollo de la presente ley.

\section{DISPOSICIÓN ADICIONAL SEGUNDA ÁMBITO DE APLICACIÓN}

La presente ley es de aplicación en aquellos ámbitos territoriales y materias en los que la Comunidad Autónoma de Galicia detenta las competencias.

\section{DISPOSICIÓN TRANSITORIA PRIMERA REVISIÓN DE LOS PLANES SECTORIALES}

Se revisarán los planes sectoriales que afecten al contenido de la presente ley y se agilizará la elaboración de los nuevos planes hidráulicos cumpliendo los plazos de la Directiva 2000/60/CE.

\section{DISPOSICIÓN TRANSITORIA SEGUNDA GESTIÓN DE LA PARTICIPACIÓN DE GALICIA EN EL COMITÉ DE AUTORIDADES COMPETENTES EN LAS CUENCAS DE LOS SISTEMAS MIÑO-SIL, LIMIA Y TÁMEGA}

Mientras el Estado detente las competencias en materia de planificación hidrológica en las cuencas de los sistemas Miño-Sil, Limia y Támega, la Xunta de Galicia gestionará su participación como parte integrante en el comité de autoridades competentes en las citadas cuencas, en función del peso específico que en el citado comité deba corresponder a Galicia.

\section{DISPOSICIÓN DEROGATORIA ÚNICA DEROGACIÓN GENERAL}

Se derogan aquellas normas de igual o inferior rango que entren en contradicción con los contenidos de la presente ley.

\section{DISPOSICIÓN FINAL PRIMERA HABILITACIÓN NORMATIVA}

Se autoriza a la Xunta de Galicia para dictar las disposiciones que sean necesarias para el desarrollo y aplicación de la presente ley.

\section{DISPOSICIÓN FINAL SEGUNDA ENTRADA EN VIGOR}

La presente ley entrará en vigor el día siguiente al de su publicación en el "Diario Oficial de Galicia".

\section{LEY 7/2008, DE 7 DE JULIO, DE PROTECCIÓN DEL PAISAJE DE GALICIA (DOGA 139.}

18.7.2008)

$(\ldots)^{500}$

\section{Capítulo I \\ DISPOSICIONES GENERALES}

Artículo 1. Objeto.

La presente ley tiene por objeto el reconocimiento jurídico, la protección, la gestión

500 Exposición de motivos omitida. 
y la ordenación del paisaje de Galicia, a fin de preservary ordenar todos los elementos que la configuran en el marco del desarrollo sostenible, entendiendo que el paisaje tiene una dimensión global de interés general para la comunidad gallega, por cuanto trasciende a los campos ambientales, culturales, sociales y económicos.

A tal fin, la presente ley impulsa la plena integración del paisaje en todas las políticas sectoriales que incidan en el mismo.

Artículo 2. Principios inspiradores.

1. Los principios que inspiran la presente ley y que deben regir las actuaciones de los poderes públicos en materia de paisaje se basan en los contenidos del Convenio europeo del paisaje, firmado en Florencia a propuesta del Consejo de Europa el 20 de octubre de 2000 , y demás convenios internacionales vigentes en la materia.

2. Señaladamente, estos principios inspiradores son:

a. Reconocer jurídicamente el paisaje, como elemento importante de nuestro entorno y del bienestar humano, indicador de la calidad de vida de las personas y componente fundamental del patrimonio natural y cultural de Galicia, expresión de nuestra identidad propia.

b. Defender y preservar el paisaje, favoreciendo una relación armónica y respetuosa entre la gente y su entorno, y promoviendo un uso racional y ordenado del territorio, que tenga en cuenta los valores naturales y culturales de los paisajes.

c. A las personas que viven en las zonas de especial interés paisajístico se les reconoce el derecho a un desarrollo económico, cultural y social, equilibrado y sostenible.

d. Diseñar y aplicar políticas destinadas a la protección, gestión y ordenación del paisaje, integrando estas políticas en las de protección ambiental, de ordenación territorial y urbanística, en materia cultural, turística, agraria, social o económica, y en aquellas otras que puedan tener un impacto directo o indirecto sobre los paisajes. e. Fomentar la coordinación y la colaboración entre las distintas administraciones públicas en materia de paisaje.

f. Establecer mecanismos de participación social en la toma de decisiones y en la definición de las políticas de paisaje, sobre todo con las entidades locales.

g. Fomentar la sensibilización de la sociedad gallega en lo referente al valor del paisaje, de su importancia y funciones, y de los procesos de transformación que están aconteciendo.

h. Promover el estudio y la formación en materia de paisaje, desarrollando actividades específicas sobre la importancia, protección, gestión y ordenación del paisaje.

Artículo 3. Definiciones.

A los efectos de la presente ley, y de conformidad con la terminología internacional definida por el Convenio europeo del paisaje, se entiende por:

a. Paisaje: cualquier parte del territorio tal y como la percibe la población, cuyo carácter sea el resultado de la acción y de la interacción de factores naturales y humanos.

b. Política de paisaje: es la expresión por parte de las autoridades públicas competentes de los principios generales y las estrategias y directrices que permiten la adopción de medidas específicas orientadas a la protección, gestión y planificación de los paisajes.

c. Objetivos de calidad paisajística: el planteamiento por parte de las autoridades públicas competentes, para un paisaje concreto, de las aspiraciones de la colectividad en relación a las características paisajísticas de su entorno.

Artículo 4. Ámbito de aplicación.

Las disposiciones de la presente ley se aplicarán a todo el territorio de Galicia, ya sean áreas naturales, rurales, urbanas y periurbanas, así como aquellas otras áreas de elevado valor ambiental y cultural, e incluso los paisajes degradados, comprendiendo asimismo las zonas terrestres, marítimo-terrestres y las aguas interiores. 


\section{Capitulo II POLITICAS DE PAISAJE}

Artículo 5. Políticas en materia de paisaje.

1. Los poderes públicos velarán para que en el ámbito de su competencia y de la naturaleza de cada territorio se adopten las medidas específicas necesarias para la protección, gestión y ordenación del paisaje.

2. Los poderes públicos integrarán la consideración del paisaje en las políticas de ordenamiento territorial y urbanístico, y en sus políticas ambientales, del patrimonio cultural, agrícolas, forestales, sociales, turísticas, industriales y económicas, así como en cualquier otra política sectorial que pueda producir un impacto directo o indirecto sobre el paisaje.

3. La Xunta de Galicia promoverá acciones de cooperación transfronteriza en los distintos niveles territoriales, para la elaboración de políticas y programas comunes en materia de paisaje, así como con las comunidades autónomas que limiten con Galicia.

Artículo 6. Fines de las actuaciones de las administraciones públicas en materia de paisaje.

Las actuaciones de las administraciones públicas en materia de paisaje deben atender, como mínimo, a los siguientes fines:

1. La protección del paisaje: entendida como todas aquellas acciones que tengan como fin la preservación y conservación de los elementos más significativos y característicos de un paisaje, justificados por su valor patrimonial como resultante de su configuración natural o de la intervención humana sobre el medio.

2. La gestión del paisaje: entendiendo como tal aquellas acciones que desde una perspectiva de uso sostenible del territorio garanticen el mantenimiento regular del paisaje, a fin de guiar las transformaciones inducidas por los procesos sociales, económicos y ambientales.

3. La ordenación del paisaje: que serán todas aquellas acciones que presenten un carácter prospectivo particularmente acentuado con vistas a mantener, mejorar, restaurar o regenerar paisajes.

Artículo 7. Cooperación en materia de paisaje.

La Xunta de Galicia impulsará la cooperación con todas las administraciones públicas con competencia en el territorio, especialmente con las administraciones locales, a fin de promover el desarrollo de políticas comunes, debidamente coordinadas y programadas, que aseguren el cumplimento de los fines que se contienen en la presente ley.

\section{Capítulo III \\ INSTRUMENTOS PARA LA PROTECCIÓN, GESTIÓN Y ORDENACIÓN DEL PAISAJE}

Artículo 8. Instrumentos.

Se establecen los siguientes instrumentos para su desarrollo y aplicación en cuanto a asegurar una idónea protección, gestión y ordenación de los paisajes de Galicia:

1. Catálogos del paisaje de Galicia.

2. Directrices de paisaje.

3. Estudios de impacto e integración paisajística.

4. Planes de acción del paisaje en áreas protegidas.

Artículo 9. Catálogos del paisaje.

1. Son los documentos de referencia que fundamentándose en las distintas áreas geográficas, morfológicas, urbanas y litorales existentes en el territorio gallego deberán delimitar, en base a los diferentes estudios y trabajos existentes en la materia, las grandes áreas paisajísticas de Galicia, identificando los diversos tipos de paisajes existentes en cada una de ellas y sus características diferenciales.

2. Los catálogos del paisaje incluirán:

a. La identificación de los diferentes tipos de paisaje que existen en cada área paisajística.

b. Un inventario de los valores paisajísticos presentes en cada área paisajística, identificando aquellos ámbitos que en cada área presenten un especial estado de 
deterioro y que precisen especiales medidas de intervención y protección.

c. Un análisis de las causas que determinaron la existencia de esos tipos de paisaje, de aquéllas que inciden hoy sobre los elementos del paisaje, y su evolución futura prevista.

d. Una diagnosis del estado actual del paisaje en cada área paisajística.

e. La delimitación de las unidades de paisaje presentes en cada área, entendidas como ámbitos territoriales con valores paisajísticos homogéneos y coherentes.

3. Los catálogos del paisaje podrán, en su caso, identificar determinadas zonas geográficas como «Áreas de especial interés paisajístico», en atención a los valores naturales y culturales allí presentes.

4. Corresponde al Observatorio Gallego del Paisaje la elaboración de los catálogos del paisaje, en la que se tendrán en consideración otros catálogos existentes referidos a la materia paisajística.

5. En el procedimiento de elaboración de los catálogos del paisaje se abrirá un trámite de información pública no inferior a dos meses para que todos los posibles interesados puedan formular las alegaciones que estimen pertinentes.

6. Los catálogos del paisaje serán aprobados por el Consejo de la Xunta de Galicia, a propuesta de la consellería competente en materia de medio ambiente, previa consulta a los departamentos competentes en materia de ordenación del territorio y patrimonio cultural.

Artículo 10. Directrices de paisaje.

1. Las directrices de paisaje son las determinaciones que basadas en los catálogos del paisaje definen y precisan para cada unidad de paisaje los objetivos de calidad paisajística que se pretenden alcanzar.

2. Estos objetivos de calidad paisajística deben expresar las aspiraciones de la ciudadanía en cuanto a la valoración y grado de compromiso de la colectividad en la protección de nuestros paisajes, por lo que la determinación de estos objetivos se hará mediante un proceso de participación pública.

3. Las directrices de paisaje incluirán:

a. La definición de los objetivos de calidad paisajística para cada unidad de paisaje.

b. Una propuesta de medidas y acciones específicas para alcanzar los objetivos de calidad y de recuperación de aquellas áreas en las que existen ámbitos degradados.

c. Una descripción de los indicadores de calidad paisajística para el control y seguimiento del estado y evolución de las unidades de paisaje.

d. Una serie de normas y recomendaciones para la definición de los planes urbanísticos y sectoriales y de las estrategias regionales o locales encaminadas a un desarrollo sostenible del territorio, a fin de integrar en ellos los objetivos de calidad paisajística.

4. Las directrices de paisaje serán congruentes con las determinaciones que en materia de paisaje puedan derivarse de otros instrumentos normativos. Las normas recogidas en las directrices de paisaje, una vez aprobadas, tendrán carácter vinculante para los instrumentos de planificación sectorial y urbanística.

5. La evaluación ambiental de aquellos planes y programas que con arreglo a la Ley 9/2006, de 28 de abril, sobre evaluación de los efectos de determinados planes y programas en medio ambiente, deban someterse a este procedimiento integrarán criterios que tengan como objetivo la protección del paisaje y facilitar su ordenación y gestión. A tal efecto, el documento de referencia previsto en el artículo 19 de la Ley 9/2006, de 28 de abril, no sólo establecerá las pautas y criterios a seguir en la evaluación ambiental del plan y programa, sino que también integrará preceptivamente las normas que se establezcan en las directrices de paisaje.

6. Corresponde a la consellería competente en materia de medio ambiente y desarrollo sostenible la elaboración de las directrices de paisaje, en cuyo 
procedimiento se observarán los siguientes trámites:

a. Información pública, como mínimo, por el plazo de dos meses.

b. Informe preceptivo de los ayuntamientos afectados.

c. Informe preceptivo de las consellerías competentes en materia de ordenación del territorio y patrimonio cultural.

7. La competencia para la aprobación de las directrices de paisaje corresponderá al Consejo da Xunta de Galicia.

Artículo 11. Estudios de impacto e integración paisajística.

1. En todos los proyectos que deban someterse al procedimiento de Declaración de impacto ambiental, según se establece en la legislación sectorial vigente, las entidades promotoras habrán de incorporar en el estudio de impacto ambiental un estudio de impacto e integración paisajística, documento específico en el que se evaluarán los efectos e impactos que el proyecto pueda provocar en el paisaje y las medidas de integración paisajística propuestas por dichas entidades.

2. Los estudios de impacto e integración paisajística deberán contener:

a. Una diagnosis del estado actual del paisaje: principales componentes, valores paisajísticos, visibilidad y fragilidad del paisaje.

b. Las características principales del proyecto.

c. El impacto previsto del proyecto sobre los elementos que configuran el paisaje.

d. La justificación de cómo se incorporaron al proyecto los objetivos de calidad paisajística y las determinaciones de las directrices de paisaje establecidas para la unidad de paisaje en la que se pretende ejecutar la actuación. El contenido de este apartado será preceptivo una vez sean aprobadas las directrices de paisaje.

e. Los criterios y medidas a adoptar para alcanzar la integración paisajística del proyecto.
3. Corresponde a la consejería competente en materia de medio ambiente emitir el informe de impacto e integración paisajística dentro de los procedimientos de declaración y evaluación del impacto ambiental, informe que resultará integrado en la correspondiente declaración de impacto ambiental.

4. El Consejo de la Xunta de Galicia determinará, vía reglamentaria, en las zonas geográficas identificadas como «Áreas de especial interés paisajístico», los supuestos en los que se podrá exigir a las entidades promotoras, no sometidas a los procedimientos de declaración y evaluación de impacto ambiental, incorporar al proyecto un estudio de impacto e integración paisajística, al objeto de considerar las repercusiones que puedan tener sobre el paisaje la ejecución de las actuaciones, obras o actividades que se pretendan desarrollar, así como exponer los criterios para su integración. A tal efecto, en la determinación de estos supuestos se tendrán en cuenta parámetros tales como la existencia de espacios naturales protegidos, la distancia a la línea de costa, el volumen de edificación, la superficie afectada por el proyecto, las afecciones a los recursos naturales y la presencia de elementos valiosos del patrimonio natural y cultural.

Artículo 12. Planes de acción del paisaje en áreas protegidas.

1. La Xunta de Galicia elaborará planes de acción para la protección, gestión y ordenación del paisaje en aquellos territorios declarados como espacios protegidos según lo dispuesto en la normativa gallega vigente en materia de conservación de la naturaleza.

2. El plan de acción se ajustará a las determinaciones contenidas en las directrices de paisaje para el territorio donde se ubique el espacio protegido, de conformidad con los objetivos de calidad paisajística establecidos, e incluirá además una propuesta de medidas para el mantenimiento, mejora, recuperación o regeneración de los paisajes 
presentes en aquella área. Los planes de acción se integrarán en los instrumentos de planificación y ordenación del área protegida, previstos en la normativa gallega vigente en materia de conservación de la naturaleza.

3. La consellería competente en materia de medio ambiente y desarrollo sostenible promoverá que todas las zonas geográficas identificadas en los catálogos del paisaje como "Áreas de especial interés paisajístico» dispongan la protección precisa que permita la preservación de sus valores.

4. En aquellas áreas geográficas transfronterizas o interautonómicas que cuenten con algún espacio natural protegido la administración ambiental promoverá la elaboración de un plan de acción conjunto en materia de paisaje.

\section{Capitulo IV}

INSTRUMENTOS DE ORGANIZACIÓN, SENSIBILIZACIÓN Y CONCERTACIÓN DE LAS POLIITICAS DE PAISAJE

Artículo 13. El Observatorio Gallego del Paisaje.

1. El Observatorio Gallego del Paisaje se configura como entidad de apoyo y asesoramiento a la Xunta de Galicia en materia de paisaje, y de colaboración y coordinación con otras administraciones y sectores de la sociedad.

2. El Observatorio Gallego del Paisaje adoptará la forma que más se adecue a sus funciones.

3. Son funciones del Observatorio Gallego del Paisaje:

a. Delimitar las grandes áreas paisajísticas sobre las que se desarrollarán los catálogos del paisaje.

b. Elaborar los catálogos del paisaje con arreglo a lo establecido en la presente ley.

c. Formar, sensibilizar y concienciar a la sociedad gallega en la necesidad de proteger y gestionar debidamente nuestros paisajes.

d. Evaluar el estado de conservación de los paisajes gallegos y analizar sus transformaciones y previsible evolución. e. Realizar estudios y propuestas en materia de paisaje.

f. Promover la colaboración y la cooperación en materia de paisaje, sobre todo mediante asistencia científica y técnica mutua, e intercambios de experiencias con fines de formación e información.

g. Servir como órgano asesor a las entidades locales a fin de implementar las políticas de paisaje en la planificación urbanística y territorial.

h. Hacer el seguimiento de iniciativas de ámbito estatal, europeo e internacional en materia de paisaje.

i. Participar en las redes de observatorios de paisaje y entidades semejantes, tanto en el resto del Estado como europeos e internacionales, así como en el seguimiento de iniciativas de investigación y difusión de conocimientos que se adopten a escala estatal, europea e internacional.

j. Fomentar el intercambio de información y experiencias, así como la asistencia científica y técnica mutua en materia de paisajes transfronterizos.

k. Elaborar cada cuatro años un informe sobre el estado del paisaje en Galicia, que la Xunta de Galicia presentará en el Parlamento de Galicia.

4. Mediante la norma de constitución del Observatorio Gallego del Paisaje se desarrollarán las funciones, composición, funcionamiento, recursos económicos y otros aspectos organizativos del observatorio. Asimismo, su composición garantizará la presencia equilibrada de hombres y mujeres en este órgano.

Artículo 14. Formación, sensibilización, educación y concertación.

1. La Xunta de Galicia, con arreglo a lo establecido en la presente ley y en la consideración de la importancia ambiental, cultural, social y económica que poseen nuestros paisajes como señal de calidad de vida, promoverá acciones de formación, sensibilización y educación dirigidas a la sociedad gallega en general, y a los gestores y usuarios del territorio en particular, que tengan como finalidad 
la promoción del entendimiento, respeto y salvaguarda de los elementos que configuran nuestros paisajes.

2. La Xunta de Galicia fomentará la incorporación de la materia del paisaje en los distintos ciclos educativos, y promoverá la formación de especialistas en materia de intervención del paisaje.

3. La Xunta de Galicia impulsará la celebración de pactos por el paisaje como instrumentos de concertación entre las administraciones públicas, las entidades locales y otros agentes económicos y sociales de un determinado territorio que de manera voluntaria deseen promover acciones de protección y mejora de los paisajes y de la calidad de vida de los ciudadanos en el marco del desarrollo sostenible. Estos pactos incorporarán en su contenido las actuaciones concretas y específicas que tienen que emprender los diferentes agentes intervinientes para alcanzar los objetivos de calidad paisajística.

4. Los pactos por el paisaje que se establezcan entre la Xunta de Galicia y las administraciones locales, así como con otros agentes económicos y sociales, habrán de tener en cuenta las recomendaciones y determinaciones de los catálogos del paisaje y de las directrices de paisaje para ese ámbito geográfico, así como la existencia de espacios o elementos inventariados del patrimonio natural, artístico o cultural.

5. La Xunta de Galicia favorecerá la realización de acuerdos voluntarios en las áreas de especial interés paisajístico entre las personas propietarias de las tierras y entidades públicas, a fin de colaborar y apoyar la defensa y la conservación de los valores naturales y culturales presentes en estas áreas.

\section{DISPOSICIÓN TRANSITORIA PRIMERA NORMATIVA DE APLICACIÓN EN LOS PROCEDIMIENTOS INICIADOS}

A los procedimientos administrativos iniciados con anterioridad a la entrada en vigor de la presente ley, y cuya regulación sustantiva exija incorporar la dimensión paisajística, les será de aplicación la normativa vigente en el momento de su iniciación.

\section{DISPOSICIÓN TRANSITORIA SEGUNDA ELABORACIÓN DE LOS CATÁLOGOS DEL PAISAJE}

En tanto no se constituya el Observatorio Gallego del Paisaje, corresponderá a la consellería competente en materia de medio ambiente la elaboración de los catálogos del paisaje.

\section{DISPOSICIÓN FINAL PRIMERA DESARROLLO REGLAMENTARIO}

La Xunta de Galicia, en el plazo de seis meses a contar desde la publicación de la presente ley, aprobará las disposiciones reglamentarias de desarrollo de los contenidos previstos en los artículos 11, apartado 4, y 14 de la presente ley, referidos a los supuestos en los que se podrá exigir a las entidades promotoras de proyectos públicos o privados, no sometidas a la declaración y evaluación de impacto ambiental, la presentación de un estudio de impacto e integración paisajística y la constitución, naturaleza jurídica, funciones, composición, funcionamiento y otros aspectos organizativos del Observatorio Gallego del Paisaje, respectivamente.

\section{DISPOSICIÓN FINAL SEGUNDA ENTRADA EN VIGOR}

La presente ley entrará en vigor en el plazo de un mes a contar desde el día de su publicación en el «Diario Oficial de Galicia». 


\section{$X$ \\ SEGURIDAD}

1. LEY 8/2007, DE 13 DE JUNIO, DE POLICÍA DE GALICIA (DOGA N. $\left.{ }^{\circ} 120,22.6 .2007\right)$

\section{$(\ldots)^{501}$ \\ TÍTULO I \\ DISPOSICIONES GENERALES, PRINCIPIOS DE ACTUACIÓN Y FUNCIONES}

\section{Capitulo I}

\section{DISPOSICIONES GENERALES}

Artículo 1. Objeto de la ley.

La presente ley tiene por objeto la creación de la Policía de Galicia.

Asimismo, en la misma se establecerá su estructura y funciones y el régimen jurídico y estatutario de su personal.

Artículo 2. Ámbito territorial.

1. El ámbito de actuación de la Policía de Galicia estará constituido por el territorio de dicha comunidad autónoma.

2. No obstante, de acuerdo con lo establecido en el artículo 42 de la Ley orgánica 2/1986, de 13 de marzo, de fuerzas y cuerpos de seguridad, la Policía de Galicia podrá actuar fuera de dicho territorio:

a. En situaciones de emergencia, previo requerimiento de las autoridades estatales.

b. Cuando ejerza funciones de protección de autoridades públicas de la Comunidad Autónoma de Galicia.

3. En este último supuesto, se precisa autorización previa del Ministerio del Interior y, cuando proceda, comunicación al órgano de gobierno de la comunidad autónoma correspondiente, con las condiciones y requisitos que se determinen reglamentariamente.

Artículo 3. Naturaleza.

La Policía de Galicia es un instituto armado de naturaleza civil, con estructura

501 Exposición de motivos omitida. y organización jerarquizada, que se constituye orgánicamente como un cuerpo único y que se rige, sin perjuicio de lo establecido en la normativa básica reguladora de las fuerzas y cuerpos de seguridad, por lo dispuesto en la presente ley y, supletoriamente, en la Ley de la función pública gallega.

Artículo 4. Uso de armas y uniforme.

1. Dado el carácter de instituto armado de la Policía de Galicia, sus miembros portarán las armas que reglamentariamente se determinen, excepto en los supuestos que por la misma vía se establezcan.

2. Los miembros de la Policía de Galicia vestirán el uniforme reglamentario cuando estén de servicio. No obstante, en determinados puestos de trabajo o por las características del servicio pueden ejercer sus funciones $\sin$ el uniforme. Tales excepciones se determinarán reglamentariamente.

3. Por la misma vía se determinarán las divisas, los distintivos y la documentación policial, así como los saludos y honores.

Artículo 5. Misión de la Policía de Galicia.

1. En el ámbito de sus competencias la Policía de Galicia tiene como misión esencial proteger el libre ejercicio de los derechos y libertades y garantizar la seguridad ciudadana. A estos efectos, deberá velar por la pacífica convivencia y proteger a las personas y sus bienes de acuerdo con el ordenamiento jurídico.

2. Asimismo, como policía al servicio de la comunidad, habrá de contribuir a la consecución del bienestar social y cooperar con otros agentes sociales, especialmente en los ámbitos de la prevención, el civismo, la cohesión social, la lucha contra la violencia de género, la ayuda y la asistencia al ciudadano y la rehabilitación y reinserción social. 


\section{Código de la Administración Gallega}

Artículo 6. Acatamiento a la Constitución y al Estatuto de autonomía de Galicia. Antes de tomar posesión de su cargo, los miembros de la Policía de Galicia jurarán o prometerán acatamiento a la Constitución, como norma fundamental del Estado, y al Estatuto de autonomía de Galicia, como norma institucional básica de esta comunidad autónoma.

Artículo 7. Régimen jurídico.

1. En lo relativo al foro jurisdiccional, régimen de protección penal y régimen penitenciario, los miembros de la Policía de Galicia se rigen por lo establecido por la Ley orgánica 2/1986, de fuerzas y cuerpos de seguridad del Estado.

2. En su aplicación se establece:

a. En el ejercicio de sus funciones, los miembros de la Policía de Galicia tendrán a todos los efectos legales el carácter de agentes de la autoridad.

b. En caso de los delitos de atentado en cuya comisión se empleen armas de fuego, explosivos u otros medios de agresión de peligrosidad análoga que puedan poner en peligro grave la integridad física de los miembros de la Policía de Galicia, éstos tienen, a los efectos de su protección penal, la consideración de autoridad.

c. La jurisdicción competente para conocer de los delitos que se cometan contra miembros de la Policía de Galicia así como los cometidos por éstos en el ejercicio de sus funciones es la jurisdicción ordinaria.

d. Los miembros de la Policía de Galicia cumplirán la prisión preventiva y las penas privativas de libertad en los establecimientos penitenciarios ordinarios. No obstante, se garantiza su separación de los demás detenidos o presos.

e. La iniciación de un procedimiento penal contra un miembro de la Policía de Galicia no impide la tramitación de un expediente disciplinario por los mismos hechos. Sin embargo, la resolución definitiva del expediente tan sólo podrá producirse cuando la dictada en el ámbito penal sea firme, vinculando a la administración la declaración de hechos probados.

\section{Capítulo II PRINCIPIOS DE ACTUACIÓN}

Artículo 8. Disposiciones generales. La Policía de Galicia ejercerá sus funciones con respeto a la Constitución, al Estatuto de autonomía y al resto del ordenamiento jurídico. Asimismo, cumplirá sus deberes sirviendo a la comunidad y observando los principios básicos de actuación del código ético policial, contenidos en la normativa básica de los cuerpos y fuerzas de seguridad y en la presente ley.

Artículo 9. Principios básicos de actuación.

1. Los miembros de la Policía de Galicia actuarán con absoluta neutralidad política, de manera equitativa y con imparcialidad, respetando en todo momento los principios de igualdad y no discriminación por razón de ideología, religión o creencias, situación familiar, pertenencia a etnia o raza, origen nacional, idioma, sexo, orientación sexual, género, enfermedad, discapacidad o cualquier otra condición o circunstancia personal o social.

Asimismo, habrán de observar y acatar todos los demás principios, derechos y libertades que se consignan en la Constitución y en la Declaración universal de derechos humanos.

2. Asimismo, evitarán cualquier práctica abusiva, arbitraria o que entrañe violencia física y/o moral y deberán actuar en todo momento con integridad y dignidad, evitando todo comportamiento que pueda significar pérdida de la confianza y consideración que requieren sus funciones, o comprometer el prestigio o eficacia del servicio o de la administración. En particular, se abstendrán de todo acto de corrupción y se opondrán al mismo.

3. En su actuación profesional se regirán por los principios de jerarquía y subordinación, debiendo respeto y obediencia a las autoridades y superiores jerárquicos. Sin embargo, se abstendrán de cumplir órdenes que entrañen la ejecución de actos 
que manifiestamente constituyan delito o sean contrarios a la Constitución o a las leyes, sin que en tal caso pueda ser adoptada medida disciplinaria alguna contra ellos.

4. Los miembros de la Policía de Galicia respetarán la autoridad de los tribunales, debiendo colaborar y auxiliar a la Administración de justicia en los términos que dispongan las leyes.

Asimismo, en el desempeño de su función como policía judicial, estarán al servicio y bajo la dependencia de dicha administración, en los términos legalmente establecidos.

Artículo 10. Relaciones con la comunidad.

1. En sus relaciones con la ciudadanía los miembros de la Policía de Galicia mantendrán un trato correcto y esmerado, proporcionándoles información cumplida y tan amplia como sea posible sobre las causas y finalidad de sus intervenciones. Asimismo, procurarán su auxilio y protección siempre que las circunstancias lo exijan o sean requeridos para ello.

Además, acreditarán su condición profesional siempre que sea necesario y cuando lo demanden las personas con las que se relacionen en sus actuaciones.

2. En el ejercicio de sus funciones, los miembros de la Policía de Galicia actuarán sin demora y con la decisión necesaria cuando de ello dependa evitar un daño grave, inmediato e irreparable.

3. Sus intervenciones se regirán por los principios de congruencia, oportunidad y proporcionalidad en la utilización de los medios a su alcance, no recurriendo a la fuerza salvo en caso de absoluta necesidad y con el exclusivo fin de conseguir un objetivo legítimo.

4. No deberán utilizar las armas salvo que exista un riesgo racionalmente grave para su vida o integridad física o para la vida e integridad física de terceras personas, así como en aquellas circunstancias en que concurra un grave riesgo para la seguridad ciudadana. Al hacerlo, se regirán por los principios a que se refiere el apartado anterior.

\section{Artículo 11. Tratamiento de los} detenidos.

Los miembros de la Policía de Galicia, en el tratamiento con los detenidos, observarán los siguientes principios:

a. Identificarse debidamente como tales en el momento de efectuar una detención.

b. Dar cumplimiento y observar con la debida diligencia los trámites, plazos y requisitos exigidos por el ordenamiento jurídico.

c. Velar por la vida, integridad física y salud de las personas que detengan o se encuentren bajo su custodia y respetar su honor, dignidad y los demás derechos reconocidos en la Constitución y en el resto del ordenamiento jurídico.

Artículo 12. Dedicación profesional. Los miembros de la Policía de Galicia llevarán a cabo sus funciones con total dedicación. Además, aun estando fuera de servicio, están obligados a observar los deberes inherentes a su función, debiendo intervenir siempre en defensa de la ley y la seguridad ciudadana y prestar auxilio en aquellos casos en que fuese necesario.

Artículo 13. Deber de secreto.

Los miembros de la Policía de Galicia habrán de guardar secreto respecto a todas las informaciones que conozcan por razón o con ocasión del desempeño de sus funciones. Por tanto, no estarán obligados a revelar sus fuentes de información, salvo que se lo imponga el ejercicio de sus funciones o las disposiciones legales.

Artículo 14. Responsabilidad.

Todos los miembros de la Policía de Galicia son responsables, personal y directamente, de los actos que lleven a cabo en su actuación profesional al infringir o vulnerar las normas legales así como las reglamentarias que rigen su profesión y los principios enumerados en el presente capítulo, sin perjuicio de la responsabilidad patrimonial que como consecuencia de los mismos pueda corresponder a la administración pública de la que dependen, de acuerdo con la normativa vigente. 


\section{Capítulo III FUNCIONES DE LA POLICÍA DE GALICIA}

Artículo 15. Funciones.

1. El Cuerpo de Policía de Galicia, con arreglo al artigo 5 de la presente ley, ejercerá las siguientes competencias y funciones:

a. En el ámbito de seguridad ciudadana:

$1 .^{\circ}$ La vigilancia y protección de personas, órganos, edificios, establecimientos y dependencias de la Comunidad Autónoma de Galicia, garantizando el normal funcionamiento de las instalaciones y la seguridad de los usuarios de sus servicios.

2 . $^{\circ}$ Prestar auxilio en los casos de accidente, catástrofe o calamidad pública y participar en la ejecución de los planes de protección civil en la forma en que se determina en las leyes.

3. ${ }^{\circ}$ Prestar auxilio en las actuaciones en materia de salvamento, si es requerido para ello.

4. ${ }^{\circ}$ Las demás funciones legalmente atribuidas, especialmente:

- Proteger a las personas y los bienes.

- Mantener el orden público, de acuerdo con el ordenamiento jurídico.

- Vigilar los espacios públicos.

- Proteger y colaborar en las manifestaciones y mantener el orden público en las grandes concentraciones humanas cuando fuese requerido para ello.

- Prevenir la comisión de actos delictivos e intervenir cuando fueran cometidos.

- Intervenir en la resolución amistosa de conflictos privados si fuese requerido.

- Cumplir las funciones de protección de seguridad ciudadana atribuidas a las fuerzas y cuerpos de seguridad por la Ley orgánica 1/1992.

b. En el ámbito de policía administrativa:

$1{ }^{\circ}$ Velar por el cumplimento de las leyes y disposiciones del Estado aplicables en Galicia y garantizar el funcionamiento de los servicios públicos esenciales.

$2 .^{\circ}$ Velar por el cumplimiento de las leyes de Galicia y de las normas, disposiciones y actos emanados de las demás instituciones y órganos de la Comunidad Autónoma, mediante las actividades de investigación, inspección y denuncia, y la ejecución forzosa de sus resoluciones.

$3 .^{\circ} \mathrm{La}$ inspección de las actividades sometidas a la ordenación o disciplina de la Comunidad Autónoma de Galicia, denunciando toda actividad ilícita.

En la ejecución de este tipo de funciones se prestará especial atención a:

- Velar por el cumplimiento de la normativa vigente sobre medio ambiente, recursos marinos, caza, ganadería, salud pública, incendios forestales, pesca fluvial, ordenación urbanística, protección de caminos, costas y asuntos marítimos, transporte y contaminación acústica.

- Velar por el cumplimiento de la normativa sobre el patrimonio histórico y cultural gallego para evitar su expolio o destrucción y para garantizar su salvaguardia y protección.

- En el marco de las funciones que le atribuya la normativa específica, vigilar y controlar el cumplimiento de la legislación vigente en materia de juego y de espectáculos.

4. ${ }^{\circ}$ Vigilancia y control del tráfico en las vías interurbanas del territorio de la Comunidad Autónoma de Galicia.

$5 .^{\circ}$ Vigilar, inspeccionar y controlar las empresas de seguridad privada, sus servicios y actuaciones y los medios y personal a su cargo, en los términos establecidos en la legislación vigente.

$6 .^{\circ}$ Informar, asistir y orientar a los ciudadanos.

7. ${ }^{\circ}$ Colaborar con las instituciones públicas de protección y tutela de menores en la consecución de sus objetivos, de conformidad con la legislación civil, penal y penitenciaria del Estado.

$8 .^{\circ}$ Colaborar con las instituciones públicas y privadas de protección y tutela de la inmigración y con aquellas otras que tengan como objetivo prevenir y evitar cualquier forma de marginación.

$9 .^{\circ}$ Colaborar con las instituciones públicas de protección y asistencia a las víctimas de violencia de género. 
$10 .^{\circ}$ Las demás funciones que le atribuya la legislación vigente.

c. En el ámbito de policía judicial, aquellas funciones que le correspondan de acuerdo con lo establecido en el artículo 126 de la Constitución, en la Ley orgánica del poder judicial y en la restante normativa vigente.

2. Las funciones enumeradas en el apartado anterior se cumplirán bajo los principios de cooperación, coordinación y mutua colaboración con el resto de fuerzas y cuerpos de seguridad.

3. Además, la Policía de Galicia podrá asumir todas aquellas otras funciones que sean delegadas o transferidas a la Comunidad Autónoma por la vía del artículo 150.2 de la Constitución, así como aquellas otras que le sean encomendadas.

Artículo 16. Convenios de colaboración con las entidades locales.

Las entidades locales y la consejería competente en materia de seguridad podrán celebrar convenios de colaboración para la asistencia de la Policía de Galicia en aquellas funciones de naturaleza técnica y operativa, estrictamente policial, que correspondan a los cuerpos de Policía local, en los casos en que no dispongan del mismo o, aunque dispongan, sus efectivos no alcancen a dar cobertura a la totalidad de los servicios de su competencia. En ningún caso estos convenios de colaboración podrán eximir del ejercicio de competencias que las entidades locales tienen en materia de Policía local.

\section{TÍTULO II ORGANIZACIÓN ADMINISTRATIVA}

\section{Capítulo I ÓRGANOS DE DIRECCIÓN}

Artículo 17. Órganos de dirección.

1. Corresponde al Consello de la Xunta de Galicia, a través de su presidente, el mando supremo de la Policía de Galicia.
Dicho mando se ejerce por la persona titular de la consejería competente en materia de seguridad, según lo contemplado en la presente ley.

2. A dicha consejería, de conformidad con los objetivos generales establecidos por el Consello de la Xunta de Galicia, le corresponde la jefatura y superior dirección de la Policía de Galicia, respecto de la cual ejerce las siguientes competencias:

a. La dirección, coordinación e inspección de los servicios policiales.

b. La elaboración de planes y proyectos de actuación policial, el seguimiento y la ejecución de los mismos.

c. La elaboración de los planes y proyectos de actuación económica y la coordinación y ejecución de los mismos, exceptuando aquéllos que correspondan al Consello de la Xunta de Galicia o a otros órganos, de conformidad con la legalidad vigente.

d. La elaboración de estudios relativos a organización, coordinación y desarrollo que afecten al Cuerpo de Policía de Galicia.

e. La aplicación y supervisión del régimen estatutario de los funcionarios de la Policía de Galicia, con excepción de las competencias que correspondan al Consello de la Xunta de Galicia y las que estén atribuidas a otros órganos de la Administración de la Comunidad Autónoma, en virtud de lo dispuesto en la presente ley y en el resto del ordenamiento jurídico.

f. Las funciones relativas a selección, formación, especialización, promoción, situaciones administrativas y régimen disciplinario de los funcionarios de la Policía de Galicia, sin perjuicio de lo dispuesto en el apartado anterior.

g. La determinación de la representación de la Administración de la Xunta de Galicia en las negociaciones con los representantes de los funcionarios de la Policía de Galicia, de acuerdo con la normativa vigente.

h. Fomentar la coordinación de la Policía de Galicia y de sus servicios de soporte técnico-administrativo con las policías

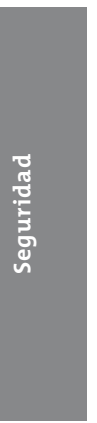


locales, respetando, en todo caso, la autonomía orgánica y funcional de la misma.

i. Promover la creación de los órganos y servicios necesarios para el desarrollo de las tareas policiales referidas a coordinación, información, consulta y asesoramiento de la Policía de Galicia.

j. Las demás previstas en el ordenamiento jurídico.

3. Las competencias previstas en el apartado anterior se entenderán sin perjuicio de cualquier otra que le atribuya la normativa vigente, correspondiendo su ejercicio a los órganos de la consejería competente en materia de seguridad que reglamentariamente se determinen.

\section{Capitulo II ÓRGANOS DE COORDINACIÓN}

Artículo 18. Junta de Seguridad de Galicia.

1. De conformidad con lo dispuesto en el artículo 50 de la Ley orgánica 2/1986, de 13 de noviembre, de fuerzas y cuerpos de seguridad, se constituye la Junta de Seguridad de Galicia, integrada por igual número de representantes del Estado y de la Comunidad Autónoma, con la misión de coordinar la actuación de las fuerzas y cuerpos de seguridad del Estado y de la Policía de Galicia, en los términos que reglamentariamente se determinen.

2. La Junta de Seguridad de Galicia será el órgano competente para resolver las incidencias que pudieran surgir en la colaboración entre los miembros de las fuerzas y cuerpos de seguridad del Estado y los de la Policía de Galicia.

3. A tal efecto, las autoridades competentes de la Comunidad Autónoma de Galicia y la Delegación del Gobierno deberán informar periódicamente a dicha junta acerca de las deficiencias que se observen en la coordinación, mutuo auxilio e información recíproca entre aquéllos, indicando las medidas oportunas para subsanar los problemas planteados.
Artículo 19. Centro de Elaboración y Proceso de Datos para el Servicio Policial.

1. Se crea el Centro de Elaboración y Proceso de Datos para el Servicio Policial, como órgano administrativo encargado de la captación, análisis, clasificación, elaboración, depósito y conservación, en ficheros automatizados con soporte físico, de los datos que les sean precisos a los servicios policiales para el ejercicio de sus funciones. Dicho órgano también llevará a cabo su comunicación a los sujetos autorizados.

2. La organización y funcionamiento de este órgano se determinará reglamentariamente, de acuerdo con lo previsto legalmente sobre el tratamiento automatizado de datos de carácter personal, especificando su dependencia orgánica, su estructuración, las personas autorizadas a acceder al mismo, los mecanismos de control, las condiciones de acceso y seguridad y cuantas cautelas sean necesarias para el correcto uso de la información.

3. El centro se coordinará con la Administración general del Estado en los términos previstos en la legislación vigente.

4. Para facilitar la coordinación policial y mediante el correspondiente convenio, la Policía de Galicia y las policías locales podrán utilizar las bases de datos comunes en lo necesario para el cumplimiento de sus respectivas funciones.

\section{Capítulo III ÓRGANOS CONSULTIVOS}

Artículo 20. Consejo de la Policía de Galicia.

1. Se crea el Consejo de la Policía de Galicia como órgano consultivo y de participación en el que se integran representantes de la consejería competente en materia de seguridad y representantes de los miembros de la Policía de Galicia.

Dicho consejo estará presidido por el titular de la consejería competente en materia de seguridad, que será quien designe y destituya a los representantes de su departamento que han de integrar dicho órgano. 
Los representantes de los miembros de la Policía de Galicia se designarán en la forma que reglamentariamente se determine. Se establecerá también, por la misma vía, todo lo relativo a número de integrantes, organización, estructura y régimen interno.

2. Corresponden al Consejo de la Policía de Galicia las siguientes funciones:

a. Formular propuestas relativas a los criterios de aplicación en el desarrollo de los concursos para la provisión de puestos de trabajo.

b. Evacuar consultas en materias relativas al estatuto profesional.

c. Participar en programas de modernización de los métodos y técnicas de trabajo.

d. Con carácter previo a la adopción de la resolución que proceda, emitir informe en los expedientes disciplinarios que se instruyan por faltas muy graves contra funcionarios de la Policía de Galicia y en todos aquellos que se instruyan contra sus representantes o delegados sindicales. Asimismo, será informado de la incoación de los restantes expedientes disciplinarios que se instruyan, así como de su resolución y de las rehabilitaciones.

e. Informar los anteproyectos de ley y los proyectos de cualquier normativa que afecten al régimen estatutario.

f. Emitir informe en la determinación de las condiciones de prestación del servicio policial.

g. Debatir y proponer medidas en relación con la política de personal y, en especial, en materia de sistemas de ingreso, relaciones de puestos de trabajo, promoción y carrera profesional y aplicación de retribuciones.

h. Aprobar sus normas de organización $\mathrm{y}$ funcionamiento.

i. Las demás que le atribuya la normativa vigente.

Artículo 21. Comisión Gallega de Seguridad.

1. Se crea la Comisión Gallega de Seguridad, como órgano de encuentro e intercambio de ideas y experiencias en orden a favorecer la coherencia en las actuaciones de las diversas entidades e instituciones implicadas y afectadas por la política de seguridad.

2. Podrán formar parte de dicha comisión representantes:

a. De la Administración de la Comunidad Autónoma, a través de la consejería competente en materia de seguridad.

b. De la Administración del Estado.

c. De la Administración local.

d. De la Administración de justicia de Galicia.

Asimismo, podrán participar en sus sesiones aquellas personas físicas o jurídicas, ya sean públicas o privadas, que resulten de interés a los fines de la comisión.

3. Reglamentariamente se establecerán las normas que regirán la constitución, composición y funcionamiento de la Comisión Gallega de Seguridad.

\section{Capitulo IV ÓRGANOS DE PARTICIPACIÓN CIUDADANA}

Artículo 22. Gabinete de Iniciativas Ciudadanas para la Optimización del Servicio Policial.

1. En la consejería competente en materia de seguridad existirá un Gabinete de Iniciativas Ciudadanas para la Optimización del Servicio Policial, que se encargará de estudiar las iniciativas dirigidas a la mejora del funcionamiento de los servicios policiales que se presenten por cualquier administrado con sujeción a los requisitos y límites establecidos por el ordenamiento jurídico.

Además, dicho gabinete propondrá la adopción de aquellas medidas que estime convenientes para el perfeccionamiento del servicio.

2. Las iniciativas podrán ser presentadas en cualquier dependencia policial, estando obligado el funcionario responsable de la misma a su inmediata tramitación. 
3. Quedan excluidas del ámbito de este gabinete las peticiones derivadas de acciones administrativas, penales o de otro orden sujetas a regulación específica.

4. De todas las iniciativas se dará cuenta a la Comisión Gallega de Seguridad.

\section{TíTULO III DEL RÉGIMEN FUNCIONARIAL DE LA POLICÍA DE GALICIA}

\section{Capítulo I DISPOSICIONES GENERALES}

Artículo 23. Regulación.

1. Los miembros del Cuerpo de la Policía de Galicia son funcionarios de carrera de la Administración de la Comunidad Autónoma gallega y se regirán por las normas de aplicación directa de la Ley orgánica 2/1986, de 13 de noviembre, de fuerzas y cuerpos de seguridad, por lo establecido en la presente ley y por las normas que la desarrollen.

2. Será aplicable además, con carácter supletorio, la normativa vigente en materia de función pública gallega y, asimismo, se tendrá en cuenta lo dispuesto en la Ley 7/2004, de 16 de julio, para la igualdad entre mujeres y hombres.

Artículo 24. Escalas y categorías.

1. El Cuerpo de Policía de Galicia se estructura jerárquicamente en las siguientes escalas y categorías:

a. Escala de mando y dirección, que comprende las categorías de comisario, inspector jefe e inspector.

b. Escala ejecutiva, que comprende la categoría de subinspector.

c. Escala básica, que comprende las categorías de oficial y policía.

2. Corresponden a las escalas de la Policía de Galicia los siguientes grupos:

a. A la escala de mando y dirección, grupo A.

b. A la escala ejecutiva, grupo B.

c. A la escala básica, grupo C.

Artículo 25. Funciones.

1. Corresponde a los miembros de la Policía de Galicia, según las respectivas categorías, cumplir con carácter preferente las siguientes funciones:

a. Comisario: el mando, la dirección, la orientación, la coordinación y la inspección, a nivel superior, de los servicios policiales.

b. Inspector jefe: la gestión de las distintas áreas y unidades.

c. Inspector: el mando y la gestión de los grupos policiales.

d. Subinspector: el control operativo y la supervisión de las tareas ejecutivas y los subgrupos policiales.

e. Oficial: las funciones de mando de uno o más funcionarios de la misma escala en los diferentes servicios policiales.

f. Policía: las tareas ejecutivas derivadas del cumplimiento de las funciones policiales.

2. Además de lo establecido en el apartado anterior, los funcionarios de la Policía de Galicia están obligados, en general, a realizar los cometidos que exija la ejecución de los servicios policiales en el marco de las competencias que se tengan asumidas.

Artículo 26. Personal no policial.

1. En la Policía de Galicia existirán las plazas de facultativos y de técnicos, con títulos de los grupos A y B, que se precisen para la cobertura de apoyo del servicio policial dentro de sus respectivas especialidades.

2. También se dispondrá del personal que fuese necesario para llevar a cabo las funciones administrativas y auxiliares de apoyo a la función policial.

3. El personal de los dos apartados anteriores podrá pertenecer, como funcionario, a la Administración de la Comunidad Autónoma de Galicia. En este caso, se integrará en los cuerpos y escalas que establece la Ley de la función pública de Galicia.

\section{Capítulo II ACCESO Y PROMOCIÓN}

Artículo 27. Principios del sistema de selección.

1. Los sistemas de selección para el acceso a las diferentes categorías del Cuerpo de 
la Policía de Galicia se regirán por las bases de la respectiva convocatoria, que habrá de ajustarse a los principios de libre concurrencia, igualdad, mérito y capacidad, así como al de publicidad del proceso selectivo.

2. Las convocatorias se publicarán en el Diario Oficial de Galicia y vinculan a la administración, a los tribunales que evalúen las pruebas selectivas y a quienes tomen parte en las mismas.

3. Las pruebas selectivas para ingresar en las escalas y categorías del Cuerpo de Policía de Galicia serán de carácter teóricopráctico e incluirán pruebas de capacidad física, psicotécnicas, médicas y de conocimientos, tanto generales como específicos, en materias relacionadas con el ejercicio profesional, así como la demostración del conocimiento de la lengua gallega.

Artículo 28. Requisitos de ingreso.

1. Además de estar en posesión de la titulación requerida en cada caso, los requisitos de ingreso en la Policía de Galicia serán los establecidos con carácter general para el ingreso en la función pública gallega y aquellos otros relacionados con el carácter específico de este cuerpo, los cuales se determinarán reglamentariamente.

2. En todo caso, para el ingreso en la Policía de Galicia por el sistema de oposición libre se requerirá una edad no superior a 35 años para la escala básica y a 40 años para la escala ejecutiva. Cuando el ingreso se produzca desde otros cuerpos policiales, la edad máxima será la de 42 años para la escala básica, la de 45 años para la escala ejecutiva y la de 52 años para la de mando y dirección.

Artículo 29. Titulación.

1. Para ingresar en la Policía de Galicia se exige cumplir los requisitos que se establecen en la presente ley y en el resto de la normativa aplicable.

2. De acuerdo con lo establecido en la normativa general en materia de función pública gallega, la titulación exigida para su ingreso será la siguiente:

a. Grupo A: doctor, licenciado, ingeniero, arquitecto o equivalente. b. Grupo B: diplomado universitario, ingeniero técnico, arquitecto técnico, formación profesional de tercer grado o equivalente.

c. Grupo C: bachillerato, formación profesional de segundo grado o equivalente.

Artículo 30. Ingreso en la categoría de policía.

1. El ingreso en la categoría de policía se realiza por el sistema de oposición libre.

2. Dicho sistema requiere, además de superar las pruebas selectivas que establezca la convocatoria, aprobar un curso de formación en la Academia Gallega de Seguridad Pública y superar un periodo de prácticas.

La evaluación del curso de formación y del periodo de prácticas debe restringirse a los méritos y las capacidades profesionales.

3. Una vez se superen las pruebas selectivas, el curso de formación y el periodo de prácticas, los aspirantes serán nombrados funcionarios de carrera de la Comunidad Autónoma de Galicia de la escala y categoría correspondiente.

Artículo 31. Funcionarios en prácticas.

1. Durante el curso de formación y el periodo de prácticas, los aspirantes tendrán la consideración de funcionarios en prácticas. Tal situación conlleva la percepción de una remuneración y la correspondiente cotización a la Seguridad Social.

2. El nombramiento como funcionario de carrera únicamente puede efectuarse una vez se superen el curso de formación y el periodo de prácticas, de acuerdo con lo que se establezca en la convocatoria correspondiente.

3. Con independencia de la prueba de reconocimiento médico que pueda establecer dicha convocatoria, en cualquier momento anterior a ser nombrados funcionarios de carrera, los aspirantes podrán ser sometidos a las pruebas médicas que sean precisas para comprobar su idoneidad, de acuerdo con el cuadro de exclusiones médicas que se determinará reglamentariamente. Si de las pruebas 
practicadas se deduce la existencia de alguna de ellas, el órgano responsable podrá proponer la exclusión de la persona aspirante del proceso selectivo, en cuyo caso corresponde al órgano competente del nombramiento adoptar la resolución que proceda, sin que en ningún caso se tenga derecho a indemnización.

4. No obstante lo dispuesto en el apartado anterior, si la causa de exclusión a que se hace referencia en el apartado anterior ha sobrevenido como consecuencia de lesiones sufridas en el ejercicio de sus cometidos como funcionario en prácticas, el órgano responsable puede proponer su nombramiento como funcionario de carrera al órgano competente. En tal caso, debe asignarse a dicho funcionario un puesto de trabajo adecuado a sus capacidades.

Artículo 32. Acceso a la categoría de oficial.

El acceso a la categoría de oficial se llevará a cabo por la modalidad de promoción interna, mediante concurso-oposición, entre miembros de la Policía de Galicia en situación de servicio activo con un mínimo de dos años de antigüedad en la categoría inmediatamente inferior y que superen en el proceso de selección el curso específico que a estos efectos se impartirá en la Academia Gallega de Seguridad Pública.

Artículo 33. Acceso a la categoría de subinspector.

1. El acceso a la categoría de subinspector se realizará por promoción interna o por oposición libre.

2. El $50 \%$ de las plazas se cubrirán por promoción interna. Dicho sistema se llevará a cabo mediante concurso-oposición entre miembros de la Policía de Galicia en situación de servicio activo con un mínimo de tres años de antigüedad en la categoría inmediatamente inferior que posean la titulación exigida y que superen en el proceso de selección el curso específico que se impartirá en la Academia Gallega de Seguridad Pública.

3. El otro $50 \%$ accederá por el sistema de oposición libre, en el cual se exigirá, además de la superación de las pruebas selectivas que establezca la convocatoria, aprobar un curso de formación en la Academia Gallega de Seguridad Pública y superar un periodo de prácticas.

4. Los aspirantes a la categoría de subinspector que se presenten a la correspondiente prueba selectiva por el turno libre, durante el periodo de prácticas, tendrán la consideración de funcionarios en prácticas, siéndoles de aplicación lo previsto en el artículo 31 de la presente ley.

5. Las convocatorias de plazas de subinspector, sea por turno libre o por promoción interna, pueden establecer que las plazas ofertadas que no se cubran por un sistema se acumularán a las ofertadas en el otro.

Artículo 34. Acceso a la categoría de inspector.

El acceso a la categoría de inspector se realizará mediante concurso-oposición por promoción interna, entre los miembros de la Policía de Galicia en situación de servicio activo que tengan un mínimo de cinco años de antigüedad en la categoría inmediatamente inferior, posean la titulación exigida y superen un curso de formación específico impartido a estos efectos en la Academia Gallega de Seguridad Pública.

Artículo 35. Acceso a la categoría de inspector jefe.

El acceso a la categoría de inspector jefe se realizará por promoción interna, mediante concurso entre miembros de la Policía de Galicia en situación de servicio activo que tengan un mínimo de tres años de antigüedad en la categoría inmediatamente inferior y superen un curso de formación específico impartido a estos efectos en la Academia Gallega de Seguridad Pública.

Artículo 36. Acceso a la categoría de comisario.

Sin perjuicio de las previsiones efectuadas en el artículo 43 de la Ley orgánica 2/1986, de 13 de noviembre, de fuerzas y cuerpos de seguridad, el acceso a la categoría de 
comisario se realizará por promoción interna, mediante concurso, entre miembros de la Policía de Galicia en situación de servicio activo que tengan un mínimo de cinco años de antigüedad en la categoría inmediatamente inferior y superen un curso de formación específico impartido a estos efectos en la Academia Gallega de Seguridad Pública .

Artículo 37. Integración de miembros de otras fuerzas y cuerpos de seguridad.

1. Sin perjuicio de lo dispuesto en los anteriores artículos, cuando se trate de miembros procedentes de otras fuerzas y cuerpos de seguridad, el acceso a las diferentes escalas y categorías se llevará a cabo en la forma que reglamentariamente se determine.

2. Se requerirá, en todo caso, la superación de un curso de adecuación a la Policía de Galicia que a estos efectos se organizará en la Academia Gallega de Seguridad Pública.

\section{Capítulo III FORMACIÓN}

\section{Artículo 38. Formación.}

1. Se promoverán las condiciones más favorables para la adecuada formación profesional, social y humana de los miembros de la Policía de Galicia, de acuerdo con los principios de objetividad, igualdad de oportunidades, mérito y capacidad.

2. La formación y perfeccionamiento de los miembros de la Policía de Galicia se adecuará a los principios de actuación contemplados en el capítulo II del título I de la presente ley, y además:

a. Tendrá carácter profesional y permanente.

b. La Academia Gallega de Seguridad Pública elaborará un plan de carrera profesional para el acceso a las distintas categorías que establece la presente ley.

c. igualmente, la Academia Gallega de Seguridad Pública organizará cursos de formación permanente, de actualización, de especialidades y de promoción. Para impartir las enseñanzas y cursos referidos se promoverá la colaboración institucional de las universidades, del poder judicial, del ministerio fiscal, de las demás fuerzas y cuerpos de seguridad, de las fuerzas armadas y de otras instituciones, centros o establecimientos que específicamente interesen a los referidos fines docentes.

d. Asimismo, la Academia Gallega de Seguridad Pública promoverá la convalidación académica de los estudios que se realicen en el centro docente y convalidará aquellas materias, cursos o titulaciones que hubieran sido superados previamente en otros centros educativos oficiales, de acuerdo con la normativa aplicable y en la forma que se determine reglamentariamente.

\section{Capitulo IV \\ RELACIÓN DE PUESTOS DE TRABAJO Y SU PROVISIÓN}

Artículo 39. Relación de puestos de trabajo.

1. La relación de puestos de trabajo de la Policía de Galicia será la que figure dotada en los presupuestos generales de la Comunidad Autónoma, distribuida en las escalas y categorías que establece el artículo 24 de la presente ley.

2. La mencionada relación, estructurada orgánicamente, incluye la totalidad de plazas de la Policía de Galicia. Corresponde al Consello de la Xunta de Galicia aprobar esta relación, que se publicará en el Diario Oficial de Galicia.

3. Para cada puesto de trabajo la relación incluirá, al menos, la denominación, el nivel, las funciones a desarrollar, las exigencias formativas, los complementos que tengan asignados y la forma de provisión, así como cualquier otra característica significativa del destino.

4. En la relación figurarán los puestos reservados para los miembros de la Policía de Galicia en situación de segunda actividad y la forma de adscripción. 
5. La relación de puestos de trabajo se aprobará de conformidad con el procedimiento establecido en la normativa de la función pública gallega.

Artículo 40. Adscripción.

1. Con carácter general, los puestos serán de adscripción indistinta para todos los componentes del cuerpo pertenecientes a la escala y categoría de que se trate, sin perjuicio de los requisitos específicos que puedan exigir.

2. La relación de puestos de trabajo determinará los puestos que puedan ser cubiertos por funcionarios procedentes de otras fuerzas y cuerpos de seguridad.

Artículo 41. Adscripción para los funcionarios de nuevo ingreso.

El destino de los funcionarios de nuevo ingreso en cada categoría se realizará por el orden de puntuación, de acuerdo con la clasificación obtenida en el proceso selectivo.

Artículo 42. Grado personal.

De conformidad con lo establecido en la Ley de la función pública gallega, cada funcionario de la Policía de Galicia posee un grado personal que corresponde a alguno de los niveles en que se clasifican los puestos de trabajo.

Artículo 43. Permanencia en los puestos.

Los funcionarios adscritos definitivamente a un puesto de trabajo mediante los procedimientos de libre designación o concurso de méritos no podrán tomar parte en otro procedimiento de provisión de puestos de trabajo durante el plazo de dos años.

Artículo 44. Desempeño provisional de funciones.

En los casos de urgencia, si se produjera alguna vacante en un puesto de trabajo de las categorías superiores a la de policía, por parte del jefe del cuerpo puede encomendarse el desempeño provisional de funciones a un funcionario de la Policía de Galicia perteneciente a la categoría inmediatamente inferior. Este desempeño no puede durar más de un año prorrogable por otro. Estos destinos en puestos de trabajo de superior categoría dan derecho a percibir las retribuciones complementarias del puesto a que se accede.

Artículo 45. Permuta.

Podrán efectuarse permutas de puesto de trabajo de igual naturaleza cuando se cumplan por parte de los interesados los requisitos exigibles para el puesto a que se aspira a acceder y los responsables de las unidades de destino de los solicitantes informen favorablemente la petición, correspondiendo su autorización a la jefatura del cuerpo.

\section{Capitulo V \\ CARRERA PROFESIONAL DE LA POLICIAA DE GALICIA}

\section{Artículo 46. Concepto.}

1. La carrera profesional de los funcionarios de la Policía de Galicia se articula mediante la promoción, consistente en la progresión en las diversas categorías que componen la misma o a través de los distintos destinos que integran la relación de puestos de trabajo.

2. La carrera profesional se hará respetando la normativa que la Comunidad Autónoma de Galicia establezca para su funcionariado, con las peculiaridades propias de este cuerpo policial. En todo caso se velará por el estricto cumplimiento del principio de igualdad de oportunidades entre mujeres y hombres.

Artículo 47. Progresión entre categorías profesionales.

La progresión a una categoría o escala superior a la que se posee se efectuará con ocasión de vacantes en las mismas. Periódicamente se publicarán las vacantes existentes en las distintas categorías, salvo en los supuestos de promoción interna, ofreciéndose en convocatoria pública, en la cual podrán participar los funcionarios de la categoría inmediatamente inferior siempre que cumplan los requisitos establecidos en la normativa vigente. 


\section{TÍTULO IV \\ RÉGIMEN ESTATUTARIO}

\section{Capítulo I \\ DERECHOS Y DEBERES}

Artículo 48. Principios generales.

1. Los miembros de la Policía de Galicia tienen los derechos y deberes que les corresponden como funcionarios de la Xunta de Galicia, en el marco de la especificidad de su función, de acuerdo con la legislación vigente.

2. La Xunta de Galicia protegerá a los funcionarios de la Policía de Galicia en el ejercicio de sus funciones y les otorgará la consideración social debida a su jerarquía y a la dignidad del servicio policial.

Artículo 49. Retribuciones.

1. Los funcionarios de la Policía de Galicia tendrán derecho a una remuneración justa, que atenderá a su nivel de formación, el régimen de incompatibilidades, la movilidad por razón de servicio, la dedicación y el riesgo que comporta su misión, así como la especificidad de los horarios de trabajo y su peculiar estructura.

2. Las retribuciones básicas tendrán idéntica cuantía para todos los miembros de un mismo grupo.

3. Las retribuciones complementarias se establecerán teniendo en cuenta los conceptos expuestos en el apartado 1 y dentro de los límites fijados en la legislación vigente.

Artículo 50. Régimen de la Seguridad Social.

Los funcionarios de la Policía de Galicia estarán acogidos al régimen general de la Seguridad Social, sin perjuicio de otros regímenes que les sean de aplicación y que se regirán por su normativa específica. laboral.

Artículo 51. Salud y seguridad Asimismo, tendrán derecho a la promoción de la seguridad y la salud en el desarrollo de su función y a la prevención de riesgos laborales en los términos que establezca la legislación específica para el ámbito de las funciones públicas de policía y seguridad.
Artículo 52. Asistencia jurídica.

1. Los miembros de la Policía de Galicia recibirán asesoramiento jurídico en aquellas situaciones derivadas del servicio en que lo precisen.

2. De acuerdo con la normativa aplicable, la Xunta de Galicia garantizará la defensa jurídica de los funcionarios de la Policía de Galicia en el ejercicio de sus funciones.

Artículo 53. Formación y capacitación profesional permanente.

Los miembros de la Policía de Galicia recibirán una formación y capacitación profesionales permanentes, a fin de garantizar el adecuado cumplimiento de sus funciones, de acuerdo con los principios de objetividad y de igualdad de oportunidades. A estos efectos, puede establecerse la obligatoriedad de la asistencia a determinadas actividades formativas.

Artículo 54. Medios e instalaciones. Los miembros de la Policía de Galicia dispondrán de los medios e instalaciones apropiados para el cumplimiento de sus funciones y para la atención adecuada a la ciudadanía.

Artículo 55. Incompatibilidades. Los miembros de la Policía de Galicia tienen incompatibilidad para el ejercicio de cualquier otra actividad pública o privada, salvo las exceptuadas del régimen general de incompatibilidades. A este respecto, será de aplicación lo dispuesto en la normativa de incompatibilidades del personal al servicio de las administraciones públicas.

Artículo 56. Consumo de drogas, estupefacientes y sustancias psicotrópicas.

1. Los miembros de la Policía de Galicia no podrán consumir bebidas alcohólicas ni cualquier otra droga tóxica, estupefaciente o sustancia psicotrópica mientras estén de servicio o se encuentren en alguna dependencia policial.

Tampoco podrán estar de servicio bajo la influencia de cualquiera de estas sustancias. 
2. Para verificar que un funcionario policial está bajo los efectos del alcohol o de alguna de las sustancias señaladas en el apartado anterior, podrán realizarse pruebas técnicas de comprobación.

3. Los funcionarios que estén bajo tratamiento médico con alguna de las sustancias mencionadas estarán obligados a advertirlo para adecuar el régimen de los servicios que se les asignen.

Artículo 57. Revisiones médicas.

Los miembros de la Policía de Galicia tienen derecho a una revisión médica anual.

Artículo 58. Deber de residencia.

1. Los miembros de la Policía de Galicia podrán residir fuera de la localidad donde trabajan, salvo los casos en que por razón del servicio sea necesario el deber de residencia en la propia localidad.

2. Sin perjuicio de lo que se establece en el apartado 1, se determinará reglamentariamente la distancia máxima en kilómetros, respecto a la localidad de destino, a que están obligados a residir los miembros de la Policía de Galicia.

Artículo 59. Jornada y horario.

1. Los miembros de la Policía de Galicia cumplirán estrictamente la jornada y el horario de trabajo que se determinen por el órgano competente.

2. En situaciones excepcionales, cuando se produzcan hechos o emergencias que así lo exijan, los funcionarios podrán ser requeridos para el servicio fuera de su jornada de trabajo.

3. En caso de que las necesidades del servicio obligaran a prolongar su prestación, tendrán que cumplimentarse las órdenes referidas al respecto, sin perjuicio de la compensación que proceda por el exceso de jornada realizado en la forma que se determine reglamentariamente.

Artículo 60. Permisos, licencias y vacaciones.

El régimen de licencias, permisos y vacaciones se establecerá de acuerdo con lo señalado en la legislación vigente.
Artículo 61. Distinciones y recompensas.

1. Reglamentariamente se regularán las distinciones y recompensas para los miembros de la Policía de Galicia.

2. Todas las distinciones y las recompensas otorgadas a los miembros de la Policía de Galicia constarán en sus expedientes personales, valorándose como mérito en los concursos de provisión de puestos de trabajo. También podrán tenerse en cuenta en los procesos de provisión por el sistema de libre designación.

Artículo 62. Derecho de sindicación.

1. Para la representación, defensa y promoción de sus intereses profesionales, económicos y sociales, los funcionarios de la Policía de Galicia podrán integrarse libremente en las organizaciones sindicales, separarse de ellas y constituir otras organizaciones, de acuerdo con el marco legal aplicable.

2. Las organizaciones sindicales se inscribirán en un registro especial de sindicatos de la Policía de Galicia.

Artículo 63. Limitación del derecho de huelga.

Los funcionarios de la Policía de Galicia, de acuerdo con lo establecido por la Ley orgánica 2/1986, de 13 de marzo, de fuerzas y cuerpos de seguridad, no podrán ejercer en ningún caso el derecho de huelga ni acciones sustitutivas del mismo o concertadas con el fin de alterar el normal funcionamiento de los servicios.

\section{Capitulo II \\ JUBILACIÓN Y SITUACIONES ADMINISTRATIVAS}

Artículo 64. Jubilación.

La jubilación forzosa de los miembros de la Policía de Galicia se declarará de oficio al cumplir el funcionario los 65 años.

Artículo 65. Situaciones administrativas.

1. Los funcionarios del Cuerpo de la Policía de Galicia podrán encontrarse, además de en las situaciones administrativas 
contempladas en la legislación básica de la función pública, en la situación de segunda actividad.

2. Las citadas situaciones se regirán por lo dispuesto en la presente ley y en las normas que la desarrollen. Supletoriamente se aplicará lo dispuesto en el capítulo II del título V de la Ley 4/1988, de 26 de mayo, de la función pública de Galicia.

\section{Capítulo III SEGUNDA ACTIVIDAD}

\section{Artículo 66. Naturaleza.}

La segunda actividad es una situación administrativa especial que tiene como objeto garantizar una adecuada aptitud psicofísica de los integrantes de la Policía de Galicia mientras permanezcan en servicio activo, asegurando la eficacia del servicio.

\section{Artículo 67. Causas.}

1. Se podrá pasar a segunda actividad por:

a. Cumplimiento de las edades que se determinan para cada escala.

b. Disminución de las condiciones psicofísicas para el desempeño de la función policial.

c. Embarazo y lactancia.

2. En situación de segunda actividad se permanecerá hasta el pase a la jubilación o a otra situación que no podrá ser la de servicio activo, salvo que la causa del pase a la situación de segunda actividad hubiera sido por embarazo, lactancia o insuficiencia de las aptitudes psicofísicas y tales circunstancias hayan desaparecido. En el supuesto de disminución de las condiciones psicofísicas deberá ser el tribunal médico a que se refiere el artículo 76 de la presente ley el que aprecie que tal insuficiencia ha desaparecido.

3 . Al personal no policial a que se refiere el artículo 26 no se le aplica la situación de segunda actividad.

Artículo 68. Por razón de edad.

1. El pase a segunda actividad por edad tendrá lugar al cumplirse las siguientes edades: a. Escala de mando y dirección: a los 62 años de edad.

b. Escala ejecutiva: a los 60 años de edad.

c. Escala básica: a los 58 años de edad.

2. Tras oír a la junta de personal, la consejería competente en materia de seguridad podrá motivadamente limitar por cada año natural y categoría el número de funcionarios que puedan acceder a la situación de segunda actividad por razón de edad, prorrogando la permanencia en el servicio activo de quienes, en orden inverso a la fecha en que cumplan la edad, excedan del cupo así fijado.

3. Asimismo, la consejería competente en materia de seguridad podrá aplazar el pase a la situación de segunda actividad, por sucesivos periodos de un año, cuando exista solicitud expresa del interesado, y siempre que medie informe favorable del tribunal médico, constituido según lo establecido en el artículo 76 de la presente ley.

Artículo 69. Por disminución de aptitudes psicofísicas.

1. Pasarán a la situación de segunda actividad, sin la limitación de las edades determinadas en el artículo anterior, aquellos funcionarios de la Policía de Galicia que tengan disminuidas las aptitudes físicas, psíquicas o sensoriales necesarias para el desempeño de la función policial, bien por incapacidad temporal o de otro tipo, y siempre que no constituyan causa de incapacidad permanente. Dicho procedimiento podrá iniciarse de oficio o a solicitud del interesado.

2. La evaluación de la disminución deberá ser dictaminada por el tribunal médico a que se refiere el artículo 76 de la presente ley.

3. Podrá acordarse, de oficio o a solicitud del interesado, el reingreso en el servicio activo en caso de que hayan desaparecido las causas que motivaron la disminución de aptitudes físicas, psíquicas o sensoriales, previo dictamen médico. 
4. En caso de que el pase a la segunda actividad sea motivado por accidente laboral o enfermedad profesional, el funcionario percibirá el $100 \%$ de las retribuciones que venía percibiendo al momento de producirse el hecho causante del referido pase.

Artículo 70. Cuadro de aptitudes. Reglamentariamente se establecerá para cada escala el cuadro de causas de disminución de las aptitudes físicas, psíquicas o sensoriales que originen el pase a la situación de segunda actividad.

Artículo 71. Por embarazo o lactancia.

1. Las funcionarias de la Policía de Galicia podrán pasar a la situación de segunda actividad durante el embarazo, previo dictamen médico que lo acredite.

2. Igualmente, pueden permanecer en esta situación durante el periodo de lactancia siempre que, según el informe facultativo, las condiciones de su puesto habitual de trabajo puedan influir en su estado de salud.

Artículo 72. Razones excepcionales. La persona titular de la consejería competente en materia de seguridad podrá requerir, motivadamente, a los funcionarios de la Policía de Galicia en situación de segunda actividad para el cumplimiento de funciones policiales, cuando concurran razones excepcionales que se determinarán reglamentariamente.

Artículo 73. Puestos de trabajo.

La situación administrativa de segunda actividad se declarará con indicación de destino. A los funcionarios que pasen a dicha situación se les asignarán puestos de trabajo de esta naturaleza bien dentro del mismo cuerpo policial o bien en un puesto de trabajo de la Administración de la Comunidad Autónoma que se corresponda con la categoría que se posea, preferentemente en el área de seguridad y adecuado a su experiencia y capacidad.

Artículo 74. Catálogo de puestos de trabajo.

1. El catálogo de puestos de trabajo de segunda actividad precisará los que pueden ser cubiertos con personal en esta situación.

2. El catálogo determinará para cada puesto la función, el horario, la ubicación, el perfil necesario, la formación adecuada y cualquier otra circunstancia apropiada. Estas definiciones podrán cambiarse y adaptarse en función de las necesidades.

3. El catálogo de puestos de trabajo de segunda actividad se aprobará con la relación de puestos de trabajo de la Policía de Galicia.

Artículo 75. Régimen jurídico.

1. El pase a la situación de segunda actividad no conllevará la pérdida de la condición de agente de la autoridad.

2. Los funcionarios en situación de segunda actividad estarán sujetos a idéntico régimen disciplinario y de incompatibilidades que en el servicio activo, salvo que desempeñen puestos de trabajo distintos a los de la Policía de Galicia, en cuyo caso estarán sometidos al régimen general disciplinario de los funcionarios de la Xunta de Galicia o al específico de aplicación al puesto que ocupen.

3. El tiempo de permanencia en la segunda actividad es computable a los efectos de perfeccionamiento de trienios y de derechos pasivos.

4. En la situación de segunda actividad no se podrá participar en procedimientos de promoción interna o concursos de traslados, salvo cuando se haya accedido por causa de embarazo o lactancia.

Artículo 76. Tribunal médico.

1. Reglamentariamente se determinará la composición de los tribunales médicos que dictaminarán si las afecciones o enfermedades físicas o psíquicas están incursas o no en el cuadro de incompatibilidades médicas para la prestación del servicio ordinario.

2. El tribunal emitirá un dictamen médico y lo dirigirá al órgano competente para su resolución, en el que propondrá el pase a la segunda actividad o que se tramite el correspondiente expediente de incapacidad $\mathrm{o}$, si procede, de jubilación forzosa. 
Artículo 77. Reglamento.

Las circunstancias y condiciones de la situación administrativa de la segunda actividad no contempladas en la presente ley se determinarán reglamentariamente.

\section{Capitulo IV RÉGIMEN DISCIPLINARIO}

Artículo 78. Disposiciones generales.

1. El régimen disciplinario de la Policía de Galicia, sin perjuicio de la observancia de las garantías reconocidas en el ordenamiento jurídico, se inspirará en los principios básicos de actuación que se establecen en el capítulo II del título I de la presente ley.

2. Sin perjuicio de las responsabilidades civiles y penales que pudieran proceder, el régimen disciplinario aplicable a los miembros de la Policía de Galicia será el que se establece en la presente ley y, en su defecto, en la Ley de la función pública de Galicia.

Artículo 79. Ámbito de aplicación.

1. La presente ley es de aplicación a los funcionarios de la Policía de Galicia, cualquiera que sea la situación administrativa en que se encuentren, siempre que la falta cometida sea compatible, en atención a las circunstancias, con dicha situación.

2. Los funcionarios en prácticas se someterán a las normas de régimen disciplinario que se establezcan reglamentariamente.

Artículo 80. Sujetos responsables.

1. Los funcionarios de la Policía de Galicia pueden incurrir en responsabilidad disciplinaria por la comisión de las faltas que se tipifican en el presente capítulo desde el momento de la toma de posesión hasta el de la jubilación o pérdida de la condición de funcionario.

2. Incurrirán en la misma responsabilidad que los autores de una falta los que induzcan a su comisión y los jefes que la toleren.

3. Asimismo, incurrirán en falta de inferior grado los que encubrieran la comisión de una falta muy grave o grave. Debe entenderse por encubrimiento el no dar cuenta al superior jerárquico competente, de forma inmediata y por escrito, de los hechos constitutivos de falta de los que se tenga conocimiento, salvo cuando sea éste el presunto infractor, en cuyo caso la comunicación se efectuará al superior inmediato del mismo.

Artículo 81. Clases de faltas.

Las faltas que pueden cometer los miembros de la Policía de Galicia podrán ser leves, graves y muy graves.

Artículo 82. Faltas muy graves.

Se considerarán faltas muy graves:

a. El incumplimiento del deber de fidelidad a la Constitución y al Estatuto de autonomía en el ejercicio de sus funciones.

b. Haber sido condenado en virtud de sentencia firme a pena privativa de libertad, como autor de una conducta constitutiva de delito doloso, relacionada con el servicio o que cause grave daño a la administración o a los administrados.

c. El acoso moral y el acoso sexual.

d. El abuso de atribuciones que cause grave daño a los ciudadanos, a los subordinados o a la administración, y la práctica de tratos inhumanos, degradantes, discriminatorios o vejatorios a las personas que se encuentren bajo su custodia.

e. La insubordinación individual o colectiva, respecto a las autoridades o mandos de que dependan.

f. La no prestación de auxilio con urgencia, en aquellos hechos o circunstancias graves en que sea obligada su actuación.

g. El abandono del servicio.

h. La publicación o la utilización indebida de secretos declarados oficiales o calificados como tales.

i. La violación del secreto profesional y la falta del debido sigilo respecto a los asuntos que conozcan por razón de su cargo, siempre que perjudique el desarrollo de la labor policial, cause perjuicio a la administración, a los detenidos e investigados o a cualquier otra persona afectada

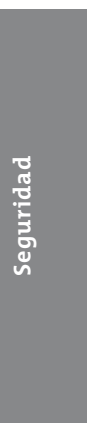


por la investigación policial o se utilice dicho conocimiento en provecho del propio funcionario.

j. La realización de actividades declaradas incompatibles legalmente, cuando las mismas comprometan la imparcialidad o independencia.

k. La participación en huelgas, en acciones sustitutivas de las mismas o en actuaciones concertadas con el fin de alterar el normal funcionamiento de los servicios.

1. Incurrir en falta grave cuando el funcionario hubiera sido sancionado anteriormente, en virtud de resoluciones firmes, por otras tres faltas de carácter grave o muy grave, cometidas en el periodo de un año inmediatamente anterior a la comisión de la nueva infracción.

m. La falta de colaboración manifiesta con los demás miembros de la Policía de Galicia y con los miembros de las fuerzas y cuerpos de seguridad del Estado, cuando resulte perjudicado gravemente el servicio o se deriven consecuencias graves para la seguridad ciudadana.

n. Embriagarse o consumir drogas tóxicas, estupefacientes o sustancias psicotrópicas durante el servicio o siempre que perjudique la prestación del mismo.

ñ. Toda actuación que suponga discriminación por razón de ideología, religión o creencias, situación familiar, pertenencia a etnia o raza, origen nacional, idioma, sexo, orientación sexual, género, enfermedad, discapacidad o cualquier otra condición o circunstancia personal o social.

o. La obstaculización grave al ejercicio de las libertades públicas y derechos sindicales.

p. Asimismo, son faltas muy graves, a los efectos de lo establecido en la Ley orgánica 4/1997, de 4 de agosto, por la que se regula la utilización de videocámaras por las fuerzas y cuerpos de seguridad en lugares públicos:

1. ${ }^{\circ}$ La alteración o manipulación de imágenes y sonidos grabados, siempre y cuando no constituyan delito.
2. ${ }^{\circ}$ La cesión, transmisión y revelación a terceras personas no autorizadas, por cualquier medio y con cualquier ánimo y finalidad, de los soportes originales de las grabaciones o sus copias, de forma íntegra o parcial.

3. ${ }^{\circ}$ La reproducción de imágenes y sonidos grabados con finalidades distintas de las establecidas en la Ley orgánica 4/1997.

4. ${ }^{\circ}$ La utilización de imágenes y sonidos grabados o de los medios técnicos de grabación afectos al servicio para finalidades distintas de las establecidas en la Ley orgánica 4/1997.

q. Cualquier otra conducta no enumerada en los puntos anteriores tipificada como falta muy grave en la legislación general.

Artículo 83. Faltas graves. Son faltas graves:

a. La grave desconsideración con los superiores, compañeros, subordinados o ciudadanos, en el ejercicio de sus funciones o con ocasión de las mismas.

b. La desobediencia a los superiores jerárquicos o responsables del servicio con motivo de las órdenes o instrucciones dadas por aquéllos.

c. La omisión de la obligación de dar cuenta a sus superiores, con la debida diligencia, de todo asunto que requiera su conocimiento o decisión urgentes.

d. La infracción de deberes u obligaciones legalmente establecidos inherentes al cargo o función, cuando se produzcan de manera grave y reiterada.

e. Los actos y conductas que atenten gravemente contra la dignidad de los funcionarios, contra la imagen de la Policía de Galicia y contra el prestigio y la consideración debidos a la Xunta de Galicia.

f. La falta de presentación o puesta a disposición inmediata en la dependencia de destino o en la más próxima en los casos de declaración de los estados de alarma, excepción o sitio, o cuando así se disponga en caso de alteración grave de la seguridad ciudadana. 
g. La tercera falta injustificada de asistencia al servicio en un periodo de tres meses, cuando las dos anteriores hubieran sido objeto de sanción firme por falta leve.

h. No prestar servicio alegando supuesta enfermedad o simulando mayor gravedad de la misma.

i. La falta de rendimiento manifiesta, reiterada y no justificada, que ocasione un grave perjuicio a la ciudadanía o a la eficacia de los servicios.

j. La emisión de informes sobre asuntos de servicio que, sin faltar abiertamente a la verdad, tergiversen la misma, valiéndose de términos ambiguos, confusos o tendenciosos, o la alteren mediante inexactitudes, cuando se cause perjuicio a la administración o a los ciudadanos, siempre que el hecho no constituya delito o falta muy grave.

$\mathrm{k}$. La intervención en un procedimiento administrativo cuando concurra alguna de las causas legales de abstención.

1. No ir provisto en los actos de servicio de la uniformidad reglamentaria cuando su uso sea preceptivo, así como de los distintivos de la categoría o cargo, del arma reglamentaria o de los medios de protección o acción que se determinen, siempre que no medie autorización en contrario.

m. El extravío, la pérdida o la sustracción del arma reglamentaria, siempre que concurra negligencia grave.

n. La utilización del arma en acto de servicio o fuera de él sin causa que lo justifique, creando alarma entre los ciudadanos o grave desprestigio del cuerpo.

ñ. Asistir de uniforme a cualquier manifestación o reunión pública o hacer uso u ostentación del arma reglamentaria y/o de los distintivos de identificación, salvo que se trate de actos de servicio o actos oficiales en que la asistencia con uniforme esté indicada.

o. Causar daños graves en la conservación de locales, material o demás elementos relacionados con el servicio, o dar lugar por negligencia grave al extravío, pérdida o sustracción de éstos. p. Impedir, limitar u obstaculizar a los subordinados en el ejercicio de los derechos que tengan reconocidos, siempre que no constituya falta muy grave.

q. Embriagarse o consumir drogas tóxicas, estupefacientes o sustancias psicotrópicas, en ambos casos con habitualidad o cuando afecte a la imagen del cuerpo o de la función policial.

Se entenderá por habitualidad la existencia acreditada de más de dos episodios de consumo.

r. La negativa a someterse a la realización de las pruebas técnicas tendentes a comprobar que se está bajo la influencia del alcohol o de drogas tóxicas, estupefacientes o sustancias psicotrópicas.

s. Solicitar y obtener cambios de destino mediando cualquier recompensa o ánimo de lucro o falseando las condiciones que lo regulen.

t. La realización de actos o declaraciones que vulneren los límites al derecho de acción sindical señalados en el artículo 19 de la Ley orgánica 2/1986, de 13 de marzo, siempre que se cause perturbación grave en el normal funcionamiento de los servicios.

u. Promover o asistir a encierros en locales de titularidad pública u ocuparlos sin autorización, siempre que cause perturbación grave en el normal funcionamiento de los servicios.

v. Haber sido condenado por sentencia firme como autor de un delito o falta imprudentes cuando afecte al servicio o cause grave daño a la administración o a los ciudadanos.

w. Las infracciones a lo dispuesto en la Ley orgánica 4/1997, de 4 de agosto, no constitutivas de falta muy grave.

$\mathrm{x}$. El incumplimiento de los plazos u otras disposiciones de procedimiento en materia de incompatibilidades, cuando no supongan mantenimiento de una situación de incompatibilidad.

y. El incumplimiento del deber del secreto profesional en lo que se refiere 
a los asuntos conocidos por razón o con ocasión del desempeño de sus funciones que perjudique el desarrollo de la labor policial o a cualquier persona.

z. Las acciones u omisiones tipificadas como faltas muy graves y que, de acuerdo con los criterios que se establecen en el artículo 85 de la presente ley, merezcan la calificación de falta grave.

Artículo 84. Faltas leves.

Son faltas leves:

a. El retraso o negligencia en el cumplimiento de las funciones y órdenes recibidas o la falta de interés en la instrucción o preparación personal para desempeñarlas.

b. La incorrección con los ciudadanos, con otros miembros de la Policía de Galicia o con los miembros de otras fuerzas y cuerpos de seguridad, siempre que no merezca una calificación más grave.

c. La inasistencia al servicio que no constituya falta de mayor gravedad y el incumplimiento de la jornada de trabajo, así como las reiteradas faltas de puntualidad.

d. El mal uso o el descuido en la conservación de los locales, material o demás elementos de los servicios, así como el incumplimiento de las normas dadas en esta materia, cuando no constituya falta más grave.

e. Prescindir del conducto reglamentario para formular cualquier solicitud, reclamación o queja en las relaciones de servicio, así como no tramitar las peticiones o reclamaciones formuladas en debida forma.

f. El descuido en el aseo personal y el incumplimiento de las normas de uniformidad, siempre que no constituya falta más grave.

g. El extravío, la pérdida o la sustracción de los distintivos y credenciales de identificación, siempre que concurra negligencia grave.

h. La ausencia injustificada de cualquier servicio, cuando no merezca calificación más grave.

i. La omisión intencionada del deber de saludo, la no devolución del mismo o el incumplimiento, de cualquier otro modo, de las normas que lo regulan.

j. Cualquier clase de juego que se lleve a cabo en las dependencias policiales, siempre que perjudique la prestación del servicio o menoscabe la imagen policial.

k. La exhibición u ostentación del arma reglamentaria, de los distintivos y credenciales del cargo o de la condición de agente de la autoridad sin causa que lo justifique.

1. Las acciones u omisiones tipificadas como faltas graves y que, de acuerdo con los criterios que se establecen en el artículo 85 de la presente ley, merezcan la calificación de falta leve.

Artículo 85. Criterios de graduación.

Para la determinación de la calificación de una falta como grave o leve, así como para la graduación de las sanciones, se tendrán en cuenta los siguientes criterios:

a. La intencionalidad.

b. La perturbación que puedan producir en el normal funcionamiento de la administración y de los servicios policiales.

c. Los daños y perjuicios o la falta de consideración que puedan implicar para los ciudadanos y subordinados.

d. El quebrantamiento que pueda suponer de los principios de disciplina y jerarquía propios del cuerpo.

e. La falta de consideración para otros miembros de la Policía de Galicia, para las demás fuerzas y cuerpos de seguridad o para los ciudadanos.

f. La reincidencia. Existe reincidencia cuando el funcionario, al cometer la falta, ya hubiera sido anteriormente sancionado en resolución firme por otra falta de mayor gravedad o por dos de gravedad igual o inferior y que no hayan sido canceladas. A los efectos de reincidencia no se computarán los antecedentes disciplinarios cancelados o que debieran serlo.

g. El descrédito y desprestigio para la imagen pública de la institución policial.

h. El historial profesional del funcionario.

i. En general, la trascendencia para la seguridad pública. 
Artículo 86. Sanciones.

1. Las sanciones que podrán imponerse a las faltas anteriormente expuestas serán las siguientes:

a. Por faltas muy graves:

1. ${ }^{\circ}$ Separación del servicio.

2. ${ }^{\circ}$ Suspensión de funciones por más de un año y hasta tres años.

3. ${ }^{\circ}$ Traslado con cambio de residencia.

b. Por faltas graves:

1. ${ }^{\circ}$ Suspensión de funciones desde cinco días hasta un año.

2. Traslado a otro puesto de trabajo dentro de la misma localidad.

c. Por faltas leves:

1. ${ }^{\circ}$ Pérdida de uno a cuatro días de remuneración y suspensión de funciones por igual periodo, que no supondrá la pérdida de antigüedad ni implicará la inmovilización en el escalafón.

$2 .^{\circ}$ Apercibimiento.

2. Las sanciones se inscribirán en los respectivos expedientes personales con indicación de las faltas que las motivaron.

3. Los funcionarios sancionados con traslado con cambio de residencia no podrán obtener nuevo destino por ningún procedimiento en la localidad de la que fueron trasladados en el plazo de uno a dos años.

4. El traslado a otro puesto de trabajo dentro de la misma localidad conlleva la imposibilidad de concursar al mismo puesto en el periodo de seis meses a un año.

5. Los plazos mencionados en los dos apartados anteriores se computarán desde el momento en que se efectúe el traslado.

Artículo 87. Prescripción de las faltas.

1. Las faltas muy graves prescribirán a los dos años desde la fecha de su comisión, las graves al año y las leves al mes.

2. El plazo de prescripción comenzará a contar desde que la falta se hubiera cometido, salvo que la misma se derive de hechos que hayan sido objeto de condena por delito doloso, en cuyo caso el plazo comenzará a contar desde la fecha de la firmeza de la sentencia condenatoria.
3. La prescripción se interrumpirá por la iniciación del procedimiento disciplinario.

4. Cuando se inicie un procedimiento penal contra un funcionario de la Policía de Galicia, la prescripción de las infracciones disciplinarias que de los hechos pudieran derivarse quedará interrumpida por la incoación de aquel procedimiento, aun cuando no se hubiera procedido disciplinariamente. En estos supuestos, el plazo volverá a computarse desde la fecha de la firmeza de la resolución judicial.

Artículo 88. Prescripción de las sanciones.

1. Las sanciones por faltas muy graves prescribirán a los tres años, las impuestas por faltas graves al año y las impuestas por faltas leves al mes.

2. El plazo de prescripción comenzará a contar desde el día siguiente a aquél en que adquiera firmeza la resolución por la que se impone la sanción o desde que se quebrantase su cumplimiento, si hubiese comenzado.

Artículo 89. Cancelación.

1. Las sanciones disciplinarias se anotarán en el registro de personal con indicación de las faltas que las motivan.

2. Transcurridos seis meses desde el cumplimiento de la sanción, si se tratara de faltas leves, o uno y tres años, respectivamente, según se trate de faltas graves o muy graves no sancionadas con separación del servicio, se acordará de oficio la cancelación de aquellas anotaciones siempre que durante aquel tiempo no hubiese sido sancionado el interesado por hechos cometidos en esos mismos periodos. La cancelación producirá el efecto de anular la anotación sin que pueda certificarse sobre la misma, salvo cuando lo soliciten las autoridades competentes para ello, haciéndose constar expresamente la cancelación, y a los únicos efectos de su expediente personal.

Artículo 90. Procedimiento.

1. No se podrán imponer sanciones por faltas graves o muy graves sino en virtud 
de expediente instruido al efecto, cuya tramitación se determinará reglamentariamente y habrá de regirse, en todo caso, por los principios de sumariedad y celeridad, sin que en ningún momento pueda producirse indefensión.

2. La sanción por faltas leves podrá imponerse sin más trámites que la audiencia del interesado.

\section{DISPOSICIÓN ADICIONAL PRIMERA RECURSOS PROVENIENTES DE ACUERDOS CON OTRAS ADMINISTRACIONES}

En la Ley de presupuestos de la Comunidad Autónoma de Galicia figurarán los recursos económicos provenientes de los acuerdos con otras administraciones para el desarrollo, por parte de la Policía de Galicia, de las funciones y servicios que viniesen desarrollando o fuesen competencia de aquéllas.

\section{DISPOSICIÓN ADICIONAL SEGUNDA CORRESPONDENCIA DE CATEGORÍAS}

1. El personal de las fuerzas y cuerpos de seguridad del Estado que se integre en la Policía de Galicia lo hará de acuerdo con las equiparaciones siguientes:

a. Escala de mando y dirección de la Policía de Galicia:

1. Se asimilan a la categoría de comisario las de comisario y comisario principal del Cuerpo Nacional de Policía, y las de comandante, teniente coronel y coronel de la Guardia Civil.

2. ${ }^{\circ}$ Se asimilan a la categoría de inspector jefe la de inspector jefe del Cuerpo Nacional de Policía y la de capitán de la Guardia Civil.

3. ${ }^{\circ}$ Se asimilan a la categoría de inspector la de inspector del Cuerpo Nacional de Policía y las de alférez y teniente de la Guardia Civil.

b. Escala ejecutiva de la Policía de Galicia:

Se asimilan a la categoría de subinspector la de subinspector del Cuerpo Nacional de Policía y las correspondientes a los distintos empleos de la escala de suboficiales de la Guardia Civil.

c. Escala básica de la Policía de Galicia:

1. ${ }^{\circ}$ Se asimilan a la categoría de oficial la de oficial del Cuerpo Nacional de Policía y las de cabo, cabo primero y cabo mayor de la Guardia Civil.

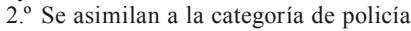
la de policía del Cuerpo Nacional de Policía y la de guardia de la Guardia Civil.

2. En el supuesto de que en la misma categoría de la Policía de Galicia puedan equipararse empleos o categorías distintos de las fuerzas y cuerpos de seguridad del Estado, se tendrá en cuenta la procedencia de los mismos a la hora de su escalafonamiento en el nuevo cuerpo, así como el reconocimiento individual de los derechos adquiridos que procediese.

3. Para la integración de miembros de otras fuerzas o cuerpos de seguridad en la Policía de Galicia se atenderá, con carácter general, a las escalas y categorías en que se hallasen dentro de sus respectivos cuerpos, teniendo en cuenta lo dispuesto en los artículos 24, 28 y 29 de la presente ley, así como la normativa de desarrollo de la misma que pueda afectar.

\section{DISPOSICIÓN ADICIONAL TERCERA ESCALAFÓN}

Los funcionarios integrantes de la Policía de Galicia constituirán el escalafón de dicho cuerpo, ordenados por categorías y, dentro de las mismas, por antigüedad. En dicho escalafón se harán constar los apellidos y nombres, fecha de nacimiento, antigüedad, situación y documento nacional de identidad.

\section{DISPOSICIÓN TRANSITORIA PRIMERA INTEGRACIÓN DE LOS FUNCIONARIOS PERTENECIENTES A LA UNIDAD DEL CUERPO NACIONAL DE POLICÍA ADSCRITA A LA COMUNIDAD AUTÓNOMA DE GALICIA}

En el momento de la entrada en vigor de la presente ley, los miembros de la Unidad del Cuerpo Nacional de Policía adscrita 
a la Comunidad Autónoma de Galicia que se hallasen en la situación de activo y segunda actividad con destino podrán integrarse en las escalas y categorías que les correspondiesen, según la disposición adicional segunda, sin que les sea de aplicación lo dispuesto en el artículo 28 de la presente ley respecto al requisito de la edad y respetándoles los derechos individuales adquiridos, en el momento de la integración, en el Cuerpo Nacional de Policía.

\section{DISPOSICIÓN TRANSITORIA SEGUNDA PROMOCIÓN DE LOS FUNCIONARIOS PERTENECIENTES A LA UNIDAD DEL CUERPO NACIONAL DE POLICÍA ADSCRITA A LA COMUNIDAD AUTÓNOMA DE GALICIA}

1. Los miembros de la Unidad del Cuerpo Nacional de Policía adscrita a la Comunidad Autónoma de Galicia que se hallasen en la situación de activo en la misma en el momento de la entrada en vigor de la presente ley podrán acceder, por la modalidad de concurso de méritos, a la escala o categoría inmediatamente superior, en función de las vacantes que pudieran producirse, siempre que cumplan los requisitos de titulación que, para cada escala y categoría, se contemplan en el artículo 29 de la presente ley.

2. A tales efectos, en el supuesto de carecer de la titulación exigida, podrá dispensárseles de dicho requisito, por esta única vez y sólo a los efectos de facilitar el acceso a la promoción.

\section{DISPOSICIÓN TRANSITORIA TERCERA PROMOCIÓN DE LOS FUNCIONARIOS PERTENECIENTES A OTRAS FUERZAS $Y$ CUERPOS DE SEGURIDAD}

1. Los miembros de otras fuerzas y cuerpos de seguridad que se hubiesen integrado, en virtud de la correspondencia de categorías descrita en la disposición adicional segunda, en el Cuerpo de Policía de Galicia sólo podrán acceder a la escala o categoría inmediatamente superior por la modalidad de promoción interna, siempre que cumplan los requisitos de titulación que, para cada escala y categoría, se contemplan en el artículo 29 de la presente ley.

2. En el supuesto de carecer de la titulación exigida para la categoría a la que opten, podrá dispensárseles en un grado del requisito de titulación exigido, por una sola vez y sólo a los efectos de facilitar el acceso a la promoción, siempre que superen un curso al efecto en la Academia Gallega de Seguridad Pública.

\section{DISPOSICIÓN TRANSITORIA CUARTA PERIODO TRANSITORIO}

En tanto se lleve a cabo el despliegue de la Policía de Galicia y mientras se prolongue, a través de las necesarias reformas legales y estatutarias, el proceso de asunción plena por la Comunidad Autónoma de Galicia de todas las competencias que le atribuye el artículo 15 de la presente ley, las mismas seguirán siendo ejercidas por las fuerzas y cuerpos de seguridad del Estado, en los términos y acuerdos de coordinación que se establezcan con la administración de la que éstos dependen.

\section{DISPOSICIÓN TRANSITORIA QUINTA TRANSFERENCIAS}

Las funciones contempladas en el artículo 15 que se refieran a competencias de titularidad estatal en el momento de la entrada en vigor de la presente ley no serán ejercidas por la Policía de Galicia hasta que no se produzca la previa transferencia o delegación por el procedimiento establecido en el artículo 150.2 de la Constitución.

\section{DISPOSICIÓN DEROGATORIA ÚNICA}

Quedan derogadas todas las disposiciones de igual o inferior rango en lo que se opongan o contradigan lo establecido en la presente ley. 


\section{DISPOSICIÓN FINAL PRIMERA DESARROLLO NORMATIVO}

Se faculta al Consello de la Xunta de Galicia para realizar el desarrollo reglamentario de la presente ley.

\section{DISPOSICIÓN FINAL SEGUNDA ENTRADA EN VIGOR}

La presente ley entrará en vigor a los veinte días de su publicación en el Diario Oficial de Galicia.

\section{LEY 4/2007, DE 20 DE ABRIL, DE COORDINACIÓN DE POLICÍAS LOCALES (DOGA N. ${ }^{\circ} 85,3.5$. $2007)^{502}$}

$(\ldots)^{503}$

\section{TÍTULO I OBJETO Y ÁMBITO DE APLICACIÓN}

\section{Artículo 1. Objeto.}

El objeto de la presente ley es regular la coordinación de las policías locales en el ámbito territorial de la Comunidad Autónoma de Galicia, sin perjuicio de su dependencia de las autoridades municipales, de conformidad con lo dispuesto en la legislación orgánica de fuerzas y cuerpos de seguridad, y con pleno respeto al principio de autonomía municipal.

Artículo 2. Ámbito de aplicación.

1. La presente ley es de aplicación a los cuerpos de Policía Local de los diferentes municipios de la Comunidad Autónoma de Galicia y a su personal.

2. En los municipios donde no exista cuerpo de Policía Local, la coordinación se extenderá al personal que realice funciones propias de auxiliar de Policía Local, que, a partir de la entrada en vigor de la presente ley, pasan a denominarse vigilantes municipales.

\footnotetext{
502 Decreto 243/2008, de 16 de octubre, por el que se desarrolla la Ley 4/2007, de 20 de abril, de coordinación de policias locales.

503 Exposición de motivos omitida.
}

Artículo 3. Formación.

Constituyen objetivos básicos de la coordinación la formación homogénea y el adecuado perfeccionamiento de los miembros de los cuerpos de Policía Local $\mathrm{y}$ de los vigilantes municipales.

\section{TÍTULO II \\ DE LOS CUERPOS DE LA POLICÍA LOCAL}

\section{Capítulo I}

FINALIDAD, NATURALEZA

Y ÁMBITO DE ACTUACIÓN

Artículo 4. Finalidad.

En el ejercicio de las competencias que corresponden a los Ayuntamientos, los cuerpos de Policía Local protegerán el libre ejercicio de los derechos y libertades y contribuirán a garantizar la seguridad ciudadana y la consecución del bienestar social, cooperando con otros agentes sociales, especialmente en los ámbitos preventivo, asistencial y de rehabilitación.

Artículo 5. Naturaleza jurídica y denominación.

1. Los cuerpos de Policía Local son institutos armados de naturaleza civil, con estructura y organización jerarquizada bajo la superior autoridad y dependencia directa del alcalde respectivo, o del concejal en que éste delegue.

2. En los municipios en que existan policías locales, éstos se integrarán en un cuerpo propio y único, con la denominación genérica de cuerpo de Policía Local. Sus dependencias se denominarán Jefatura de la Policía Local.

3. El mando inmediato y operativo de la Policía Local corresponde al jefe del cuerpo.

4. En el ejercicio de sus funciones, los miembros de los cuerpos de Policía Local tienen, a todos los efectos legales, el carácter de agentes de la autoridad.

5. Los policías locales son funcionarios de carrera de los respectivos Ayuntamientos. Queda expresamente prohibida cualquier 
otra relación de prestación de servicios con la Administración local, salvo lo dispuesto para la contratación de auxiliares de Policía Local en los términos contemplados en el artículo 95 de la presente ley.

6. Los Ayuntamientos habrán de ejercer directamente las funciones en el ejercicio de sus competencias en materia de mantenimiento de la seguridad, sin que puedan constituir entidades ni órganos especiales de administración o gestión, ni quepa, en ningún caso, la prestación del servicio mediante sistemas de gestión indirecta.

Artículo 6. Ámbito territorial de actuación.

1. Los cuerpos de Policía Local actuarán en el ámbito territorial de sus municipios. No obstante, sus miembros podrán actuar fuera de su término municipal cuando sean requeridos por la autoridad competente en situaciones de emergencia y previa autorización de los respectivos alcaldes. En estos casos, actuarán bajo la dependencia del alcalde del Ayuntamiento que los requiera, y bajo el mandato del jefe del cuerpo de este municipio, sin perjuicio de las tareas de coordinación que correspondan a la consellería competente en materia de coordinación de policías locales y emergencias.

2. Cuando ejerzan funciones de protección de autoridades de las corporaciones locales, podrán actuar fuera del término municipal según lo dispuesto en la legislación vigente.

3. Eventualmente, cuando por la insuficiencia temporal de los servicios sea necesario reforzar la plantilla de personal del cuerpo de Policía Local de algún Ayuntamiento, su alcalde podrá llegar a acuerdos con otros Ayuntamientos para que miembros de la Policía de estos últimos puedan actuar en el ámbito territorial del solicitante, por tiempo determinado y, si fuera preciso, en régimen de comisión de servicio, aceptado voluntariamente por el funcionario.
4. A los efectos previstos en los apartados anteriores, podrá instarse la colaboración de la consellería competente en materia de seguridad, a la que, en todo caso, se dará cuenta de los acuerdos adoptados por los Ayuntamientos, para su anotación en el Registro de Policías Locales de Galicia.

\section{Capitulo II PRINCIPIOS Y FUNCIONES} ción.

Artículo 7. Principios básicos de actuaSon principios básicos de actuación para los miembros de los cuerpos de Policía Local, de acuerdo con el artículo 5 de la Ley Orgánica 2/1986:

a. Adecuación al ordenamiento jurídico, especialmente:

$1^{\circ}$. Ejercer sus funciones con absoluto respeto a la Constitución, al Estatuto de Autonomía y al resto del ordenamiento jurídico.

$2^{\circ}$. Actuar, en el cumplimiento de sus funciones, con absoluta neutralidad política e imparcialidad y, en consecuencia, sin discriminación alguna por razón de raza, etnia, nacionalidad, ideología, religión o creencias personales, opinión, sexo, orientación sexual, lengua, lugar de vecindad, lugar de nacimiento o cualquier otra condición o circunstancia personal o social.

$3^{\circ}$. Actuar con integridad y dignidad, absteniéndose de todo acto de corrupción y oponiéndose a él resueltamente.

$4^{\circ}$. Sujetarse, en su actuación profesional, a los principios de jerarquía y subordinación. En ningún caso la obediencia debida podrá amparar órdenes que entrañen la ejecución de actos que manifiestamente constituyan delitos o sean contrarios a la Constitución o a las leyes.

$5^{\circ}$. Colaborarán con la Administración de justicia y la auxiliarán en los términos establecidos en la ley.

b. En relación con la sociedad, singularmente:

$1^{\circ}$. Impedir, en el ejercicio de su actuación profesional, cualquier práctica 
abusiva, arbitraria o discriminatoria que entrañe violencia física o moral, con especial atención a las derivadas de las desigualdades por razón de género.

$2^{\circ}$. Observar en todo momento un trato correcto y esmerado en sus relaciones con los ciudadanos, a los cuales procurarán auxiliar y proteger, siempre que las circunstancias lo aconsejen o fuesen requeridos para ello, en especial en todos los supuestos y manifestaciones de violencia de género, y proporcionarles información cumplida, y tan amplia como sea posible, sobre las causas y finalidad de todas sus intervenciones.

$3^{\circ}$. En el ejercicio de sus funciones, actuar con la decisión necesaria y sin demora cuando de ello dependa evitar un daño grave, inmediato o irreparable, rigiéndose, al hacerlo, por los principios de congruencia, oportunidad y proporcionalidad en la utilización de los medios a su alcance.

$4^{\circ}$. Usar armas solamente en las situaciones en que exista un riesgo racionalmente grave para su vida, su integridad física o las de terceras personas, o en aquellas circunstancias que puedan suponer un grave riesgo para la seguridad ciudadana, rigiéndose, al hacerlo, por los principios a que se refiere el apartado 3 de esta letra.

c. En relación con el tratamiento de detenidos, especialmente:

$1^{\circ}$. Los miembros de los cuerpos de la Policía Local de la Comunidad Autónoma de Galicia deberán identificarse debidamente como tales en el momento de efectuar una detención.

$2^{\circ}$. Velarán por la vida y la integridad física de las personas a quienes detuviesen o que se encuentren bajo su custodia, respetando sus derechos, su honor y su dignidad.

$3^{\circ}$. Cumplirán y observarán con la debida diligencia los trámites, plazos y requisitos exigidos por el ordenamiento jurídico, cuando se proceda a la detención de una persona.

d. En cuanto a la dedicación profesional, el deber de realizar sus funciones con total dedicación. Intervendrán siempre, en cualquier tiempo y lugar, estén o no de servicio, en defensa de la ley y la seguridad ciudadana.

e. En relación con el secreto profesional, el deber de guardar riguroso secreto respecto a todas las informaciones que conozcan por razón o con ocasión del desempeño de sus funciones. No estarán obligados a revelar las fuentes de información, salvo que se lo imponga el ejercicio de sus funciones o las disposiciones legales.

f. Respecto a la responsabilidad, serán responsables, personal y directamente, por los actos que en su actuación profesional llevasen a cabo infringiendo o vulnerando las normas legales o reglamentarias y los principios enunciados anteriormente, sin perjuicio de la responsabilidad patrimonial que pueda corresponder a las administraciones públicas de que dependan.

Artículo 8 Funciones de los cuerpos de Policía Local.

1. De acuerdo con lo dispuesto en el artículo 53 de la Ley de Fuerzas y Cuerpos de Seguridad, son funciones de los cuerpos de la Policía Local las que se indican:

a. Proteger a las autoridades de las corporaciones locales y vigilar o custodiar sus edificios e instalaciones.

b. Ordenar, regular, señalizar, denunciar infracciones y dirigir el tráfico en el ámbito de su competencia en el suelo urbano legalmente delimitado, de acuerdo con lo establecido en las normas de tráfico y seguridad viaria.

c. Instruir atestados por accidentes de circulación en el ámbito de su competencia dentro del suelo urbano legalmente delimitado.

d. Policía administrativa, en lo relativo a las ordenanzas, bandos y demás disposiciones municipales dentro del ámbito de su competencia.

e. Participar en las funciones de la Policía judicial, en la forma establecida en la normativa vigente. 
f. La prestación de auxilio, en los casos de accidentes, catástrofe o calamidad pública, participando, en la forma prevista en las leyes, en cuanto a la ejecución de los planes de protección civil.

g. Efectuar diligencias de prevención y cuantas actuaciones tiendan a evitar la comisión de actos delictivos en el marco de colaboración establecido en las juntas de seguridad.

h. Vigilar los espacios públicos y colaborar con las fuerzas y cuerpos de seguridad del Estado y con la Policía de Galicia en la protección de las manifestaciones y el mantenimiento del orden en grandes concentraciones humanas, cuando sean requeridos para ello.

i. Cooperar en la resolución de los conflictos privados cuando sean requeridos para ello.

j. Cualesquiera otras funciones en materia de seguridad pública que, de acuerdo con la legislación vigente, les sean encomendadas.

2. Las actuaciones que practiquen los cuerpos de Policía Local en el ejercicio de las funciones contempladas en los apartados c) y g) deberán ser comunicadas a las fuerzas y cuerpos de seguridad del Estado y a la Policía de Galicia según corresponda, de conformidad con la legislación orgánica de fuerzas y cuerpos de seguridad.

3. En virtud de convenio entre la Xunta de Galicia y los Ayuntamientos, en el marco de las competencias de la Policía de Galicia, los cuerpos de Policía Local también podrán ejercer, dentro de su término municipal, las siguientes funciones:

a. Velar por el cumplimento de las disposiciones y órdenes singulares dictadas por los órganos de la Comunidad Autónoma, con especial atención a las materias relativas a la protección del menor, el medio ambiente, la salud y la mujer, sobre todo en el ámbito de la violencia de género.

b. La vigilancia y protección de personas, órganos, edificios, establecimientos y dependencias de la Comunidad Autónoma y de sus entes instrumentales, garantizando el normal funcionamiento de las instalaciones y la seguridad de los usuarios de los servicios.

c. La inspección de las actividades sometidas a la ordenación y disciplina de la Comunidad Autónoma, denunciando toda actividad ilícita.

d. El uso de la coacción para la ejecución forzosa de los actos o disposiciones de la propia Comunidad Autónoma.

\section{Capítulo III UNIFORMIDAD, ACREDITACIÓN Y MEDIOS TÉCNICOS}

Artículo 9. Uniformidad.

1. La uniformidad será común para todos los cuerpos de Policía Local de Galicia e incorporará preceptivamente el escudo de Galicia, el del Ayuntamiento respectivo y el número de identificación profesional del funcionario.

2. Todos los miembros de los cuerpos de Policía Local vestirán el uniforme reglamentario cuando estén de servicio, salvo en los casos de dispensa previstos en la Ley Orgánica de cuerpos y fuerzas de seguridad y en aquellos casos excepcionales en que por órgano competente se autorice en contrario. En este supuesto deberán identificarse con el documento de acreditación profesional.

3. El uso del uniforme y del material complementario está prohibido cuando se encuentren fuera de servicio, salvo en los casos excepcionales que, legal o reglamentariamente, se establezcan.

4. Reglamentariamente se establecerán las prendas que constituyen el uniforme necesario para el desempeño de las diferentes funciones.

5. Ningún Policía Local uniformado podrá exhibir públicamente otros distintivos que no sean los fijados reglamentariamente.

6. Para ocasiones especiales, cuando sea necesario por motivos de protocolo, 
representación o solemnidad, los miembros de los cuerpos de la Policía Local podrán vestir el uniforme de gala que se determine reglamentariamente.

Artículo 10. Acreditación profesional.

1. La acreditación profesional será común para todos los cuerpos y se establecerá reglamentariamente.

2. Todos los miembros de los cuerpos de Policía Local de Galicia estarán provistos del documento de acreditación profesional y la placa-emblema, que expedirá el Ayuntamiento respectivo, según modelo homologado por la Xunta de Galicia, previo informe de la Comisión de Coordinación de las Policías Locales.

En este documento constará al menos el nombre del Ayuntamiento, el nombre y los apellidos y la fotografía del funcionario, su categoría, el número de identificación profesional, que será el mismo de la placa-emblema, y el número del documento nacional de identidad, firmado por el alcalde respectivo y con el sello del Ayuntamiento.

3. Tendrán la obligación de identificarse ante los ciudadanos o ciudadanas que así lo exijan, en caso de las actuaciones que les afectasen, directa o indirectamente.

Artículo 11. Medios técnicos.

1. Los medios técnicos son los elementos, aparatos y sistemas que los cuerpos de la Policía Local utilizan para poder cumplir con sus obligaciones. Las administraciones locales competentes tienen la obligación de proporcionárselos. Estos medios técnicos serán homogéneos para todos los cuerpos, según se establezca legal y reglamentariamente.

2. Los policías locales, como integrantes de un instituto armado, llevarán el armamento reglamentario que se les asigne, de acuerdo con la normativa vigente en materia de armamento.

3. El alcalde podrá decidir, de forma motivada, los servicios que se presten sin armas, siempre que no conlleven un riesgo racionalmente grave para la vida o la integridad física del funcionario o de terceras personas. No obstante, los servicios en la vía pública y los de custodia se prestarán siempre con armas.

4. A fin de garantizar una adecuada preparación en el uso del arma, los Ayuntamientos promoverán la realización del número anual de prácticas de ejercicios de tiro que reglamentariamente se determine.

5. Los Ayuntamientos habrán de disponer de lugares adecuados para la custodia del armamento asignado, con las condiciones que prevea la normativa aplicable. Los miembros de los cuerpos de Policía Local, bajo su responsabilidad, podrán custodiar el armamento asignado.

6. Los vigilantes municipales y los auxiliares de policía no podrán llevar armas.

\section{TÍTULO III DE LA COORDINACIÓN DE LAS POLICÍAS LOCALES}

\section{Artículo 12. Concepto.}

1. A los efectos de la presente ley, se entiende por coordinación el conjunto de técnicas y medidas que posibiliten la unificación de los criterios de organización y actuación, la formación y perfeccionamiento uniforme del personal y la homogeneización de los recursos técnicos y materiales a su disposición, así como el establecimiento de información recíproca, asesoramiento y colaboración. Dichas técnicas y medidas irán dirigidas a obtener el funcionamiento homogéneo e integrado de los cuerpos de Policía Local de Galicia, en orden a alcanzar una acción conjunta y eficaz en el sistema de seguridad pública.

2. En los Ayuntamientos donde no exista cuerpo de Policía Local, la coordinación se hará extensiva a los vigilantes municipales.

Artículo 13. Funciones en materia de coordinación.

La coordinación de la actuación de las policías locales de Galicia se hará respetando la autonomía local reconocida por la Constitución, así como las competencias estatales en materia de seguridad, y comprenderá el ejercicio de las siguientes funciones: 
a. Determinar las normas marco o criterios generales a que tendrán que ajustarse los reglamentos de las policías locales de Galicia.

b. Establecer la homogeneización en materia de medios técnicos y de los distintivos externos de identificación y uniformidad, respetando en todo caso los emblemas propios de cada entidad local.

c. Propiciar la homogeneización en materia de retribuciones.

d. Fijar los criterios básicos de selección, formación, promoción y movilidad de los miembros de los cuerpos de las policías locales, atendiendo a lo dispuesto en el capítulo I, título II (sobre el acceso al empleo público gallego), de la Ley 7/2004, de 16 de julio, Gallega para la Igualdad de Mujeres y Hombres.

e. Coordinar la formación profesional de los policías locales, a través de la Academia Gallega de Seguridad Pública.

f. Propiciar la homogeneización de la estructura, plantillas de personal, organización y funcionamiento de los cuerpos de la Policía Local.

g. Fijar el régimen jurídico (derechos, deberes y régimen disciplinario) de los miembros de los cuerpos de Policía Local en el marco de la normativa aplicable.

h. Proporcionar a los Ayuntamientos que lo soliciten la información y asesoramiento necesarios en materia de seguridad pública.

i. Disponer los instrumentos y medios materiales que posibiliten un sistema de información recíproca y de actuación conjunta y coordinada, en los términos que reglamentariamente se establezcan.

j. Disponer los medios de información necesarios para garantizar la efectividad de la coordinación, mediante el establecimiento de una red de transmisiones que enlace los diferentes cuerpos de la Policía Local y mediante la creación de un centro de coordinación y de un banco de datos, en los términos que reglamentariamente se establezcan. k. Regular la colaboración eventual entre los diversos Ayuntamientos al objeto de atender sus necesidades en situaciones especiales o extraordinarias.

1. Establecer planes conjuntos de actuación policial en previsión de circunstancias extraordinarias que así lo requieran.

$\mathrm{m}$. Cualesquiera otras que legalmente se les encomienden.

Artículo 14. Órganos de coordinación.

1. Las competencias en materia de coordinación de las policías locales se ejercerán por:

a. El Consello de la Xunta de Galicia.

b. La consejería competente en materia de seguridad.

c. La Comisión de Coordinación de las Policías Locales de Galicia.

2. Sin perjuicio de los órganos citados, podrán constituirse otros con carácter asesor, de preparación o de ejecución de los trabajos que por éstos les sean encomendados.

3. Las funciones a que se refiere la presente ley se realizarán, en todo caso, teniendo en cuenta las normas y procedimientos de colaboración entre las fuerzas y cuerpos de seguridad que se adopten en el seno de los distintos órganos de coordinación, en especial en las juntas locales de seguridad.

Artículo 15. Competencias del Consello de la Xunta de Galicia.

Corresponde al Consello de la Xunta de Galicia, a propuesta de la consellería competente en materia de seguridad, dictar las normas generales de coordinación en el marco de la presente ley, previo informe de la Comisión de Coordinación de las Policías Locales de la Comunidad Autónoma de Galicia.

Artículo 16. Competencias de la consellería competente en materia de seguridad. Corresponde a la consellería competente en materia de seguridad:

a. Establecer las medidas de control y seguimiento necesarias para garantizar que los Ayuntamientos apliquen las normas de coordinación, así como determinar 
el sistema de información que asegure la efectividad de las mismas.

b. Aprobar la programación de los cursos básicos, de promoción interna y de formación que se desarrollen en la Academia Gallega de Seguridad Pública.

c. Prestar a los Ayuntamientos la asistencia necesaria para la elaboración de los planes municipales de seguridad, cuando le sea solicitada por éstos.

Artículo 17. Competencias de la Comisión de Coordinación de las Policías Locales.

1. La Comisión de Coordinación de las Policías Locales, como órgano consultivo y de participación en materia de coordinación, tendrá, entre otras, las siguientes funciones, que tienen carácter no vinculante para los órganos de resolución, excepto en los casos en que la legislación aplicable lo contemple expresamente:

a. Emitir informe sobre los proyectos de disposiciones generales que, en materia de policía local, dicten los distintos órganos de la Xunta de Galicia y las corporaciones locales.

b. Proponer a los órganos competentes en materia de Policía Local de las distintas administraciones públicas la adopción de cuantas medidas estime oportunas para mejorar la prestación de los servicios policiales, la formación y el perfeccionamiento uniforme del personal y la homogeneización de los recursos técnicos y materiales a su disposición.

c. Emitir informe sobre la homogeneización en materia de medios técnicos y distintivos externos de identificación y uniformidad.

d. Emitir informe sobre criterios básicos de selección, formación, promoción y movilidad de los miembros de las policías locales, atendiendo a lo dispuesto en el capítulo I, título II, de la Ley 7/2004.

e. Emitir informes sobre materias de retribución económica y homogeneización de retribuciones. f. Asesorar a la consellería competente en las materias objeto de coordinación de la presente ley, con los informes técnicos que le solicite, sobre la estructura, organización, funcionamiento y medios técnicos de la Policía Local, o sobre cualquier otra materia relacionada.

g. Emitir informe sobre la programación y homologación de los cursos básicos, de promoción interna y de formación que se realicen en la Academia Gallega de Seguridad Pública, a los efectos de la oportuna aprobación por la consellería competente.

h. Emitir informe sobre los planes municipales de seguridad pública.

i. Las demás que le atribuyan las disposiciones vigentes.

2. Los informes a que se refiere el apartado anterior de este artículo no tendrán carácter vinculante para los órganos de resolución, salvo en los casos en que la legislación aplicable lo contemple expresamente.

Artículo 18. Composición de la Comisión de Coordinación.

1. La Comisión de Coordinación de las Policías Locales de Galicia, adscrita a la consellería competente en materia de seguridad, estará constituida por los siguientes miembros:

a. Presidente: El/la conselleiro/a competente en materia de seguridad.

b. Vicepresidente: El/la director/a general con competencia en materia de seguridad.

c. Vocales:

$1^{\circ}$. Cinco representantes de la Xunta de Galicia, designados por el conselleiro competente en materia de seguridad.

$2^{\circ}$. Cinco representantes de los Ayuntamientos de más de 50.000 habitantes.

$3^{\circ}$. Cinco representantes de los Ayuntamientos de menos de 50.000 habitantes.

Los representantes de los Ayuntamientos serán designados por la federación o federaciones de Ayuntamientos gallegos legalmente constituidas.

$4^{\circ}$. Cuatro representantes de los miembros de los cuerpos de las policías locales designados por los sindicatos más representativos 
en el sector de la Administración local en el ámbito de la Comunidad Autónoma gallega.

$5^{\circ}$. Un representante de los miembros de los cuerpos de las policías locales designado por la asociación profesional de jefes de los cuerpos de Policía Local que ostente la mayor representación de ellos.

d. Secretario: Un funcionario de la consejería competente en materia de seguridad, con categoría mínima de jefe de servicio, que actuará con voz pero sin voto.

2. El Presidente de la comisión podrá convocar, con voz y sin voto, a las reuniones de dicha comisión a representantes de otras administraciones públicas, a los efectos de facilitar las acciones de coordinación, así como a técnicos especialistas o asesores.

3 . La condición de los vocales representantes de los Ayuntamientos y de los sindicatos policiales estará ligada a la representatividad que se ostente, perdiéndose al desaparecer ésta, por lo que deberán ser designados nuevamente después de cada proceso electoral, en función de los resultados. Esta circunstancia se notificará, en el plazo de un mes, al Presidente de la comisión, sin perjuicio de que pueda proponerse su sustitución en otro momento y por otras razones.

Artículo 19. Régimen de funcionamiento.

1. La comisión se reunirá preceptivamente, con carácter ordinario, una vez al trimestre, y de forma extraordinaria a petición de un tercio de sus miembros o por disposición del Presidente.

2. El quórum necesario para la constitución válida de la comisión será el de mayoría absoluta de sus miembros en primera convocatoria. En segunda convocatoria, que tendrá lugar media hora después, será suficiente la asistencia de un vocal por cada representación, además del Presidente o vicepresidente (que lo sustituirá, en su caso) y el secretario.

3. Los acuerdos se adoptarán por mayoría de los miembros presentes. Cuando en las votaciones se produzca un empate, decidirá el voto de calidad del Presidente.

4. En el seno de la comisión se podrán constituir grupos técnicos de trabajo con carácter permanente o puntual para un mejor desarrollo de sus funciones.

5. En el primer trimestre de cada año, la comisión elevará a la Xunta de Galicia la memoria de las actividades de coordinación realizadas durante el ejercicio anterior.

6. La Comisión de Coordinación se regirá en su funcionamiento, en lo no previsto por la presente ley, por lo dispuesto en el título II, capítulo II, de la Ley 30/1992, de 26 de noviembre, de régimen jurídico de las administraciones públicas y del procedimiento administrativo común, sobre órganos colegiados.

Artículo 20. Gabinete Técnico.

1. El Gabinete Técnico es el órgano adscrito a la consellería competente en materia de seguridad que intervendrá preceptivamente en la realización de los trabajos de documentación, preparación, asesoramiento, propuesta y demás actividades que se le encomienden por la consellería o por la Comisión de Coordinación.

2. Su composición y régimen de funcionamiento se determinará por orden del conselleiro competente en esta materia, a quien corresponde la facultad de disponer el nombramiento y cese de sus miembros, de conformidad con lo previsto en la normativa aplicable en materia de función pública ${ }^{504}$.

Artículo 21. El Registro de las Policías Locales de Galicia.

1. Como instrumento a disposición de la consellería competente en materia de coordinación de policías locales para garantizar el cumplimento de las funciones de coordinación desarrolladas en la presente ley, se creará el Registro de miembros de los cuerpos de las policías locales de Galicia.

\footnotetext{
504 Orden de 9 de enero de 2008 por la que se regula la composición y el funcionamiento del gabinete técnico en materia de coordinación de las policias locales.
} 
2. En él se inscribirán preceptivamente todos los miembros pertenecientes a los cuerpos de Policía Local y los vigilantes municipales.

3. Reglamentariamente se determinará la información que habrá de figurar en él, referida exclusivamente a los datos profesionales, así como las cautelas necesarias para garantizar la confidencialidad de los datos en los términos que establece la normativa vigente sobre la materia ${ }^{505}$.

\section{TÍTULO IV \\ DE LA CREACIÓN, ESTRUCTURA Y ORGANIZACIÓN}

Artículo 22. Creación del cuerpo de Policía Local.

1. Los Ayuntamientos de la Comunidad Autónoma de Galicia podrán crear cuerpos de Policía Local propios, siempre que lo estimen oportuno en función de sus necesidades, de acuerdo con lo previsto en la Ley Orgánica de Fuerzas y Cuerpos de Seguridad, la Ley Reguladora de las Bases de Régimen Local, la Ley de Administración Local de Galicia, la presente ley y otras disposiciones que sean de aplicación.

2. En los Ayuntamientos de más de 5.000 habitantes la creación de este cuerpo corresponderá al pleno de la corporación. En los Ayuntamientos de población inferior a 5.000, además del acuerdo de la corporación local, será necesario el informe preceptivo de la persona titular de la consellería competente en materia de seguridad.

3. Los municipios que creen el cuerpo de Policía Local, con independencia de otras limitaciones legales, habrán de cumplir las siguientes condiciones mínimas:

a. Disponer de dependencias específicas y adecuadas a sus funciones, medios técnicos idóneos y suficiente dotación presupuestaria.

505 Véase:

- Decreto 105/2008, de 8 de mayo, por el que se crea y regula el Registro de las Policias Locales de Galicia.

- Orden de 27 de enero de 2009, por la que se desarrolla el Decreto 105/2008, de 8 de mayo, por el que se crea y se regula el Registro de Policias Locales de Galicia. b. Disponer de los medios humanos y materiales necesarios para garantizar la prestación de sus funciones de forma adecuada.

Artículo 23. Organización.

La Policía Local de cada Ayuntamiento se integrará en un cuerpo único, sin perjuicio de la organización interna que se adopte por reglamento, ajustándose a lo establecido en la presente ley y a las disposiciones reglamentarias que la desarrollen.

Artículo 24. Escalas y categorías.

1. Los cuerpos de Policía Local de Galicia se estructuran jerárquicamente en las siguientes escalas y categorías:

a. Escala superior, que comprende la categoría de superintendente.

b. Escala técnica, que comprende las categorías de intendente principal e intendente.

c. Escala ejecutiva, que comprende las categorías de inspector principal e inspector.

d. Escala básica, que comprende la categoría de oficial y policía.

2. Cada escala se corresponde a los siguientes grupos de clasificación:

a. A las escalas superior y técnica, grupo A.

b. A la escala ejecutiva, grupo B.

c. A la escala básica, grupo C.

3. La titulación exigible para cada grupo será la establecida en la legislación general sobre función pública y, en particular, la siguiente:

a. Grupo A: Doctor, licenciado, ingeniero, arquitecto o equivalentes.

b. Grupo B: Diplomado universitario, ingeniero técnico, arquitecto técnico o equivalentes.

c. Grupo C: Bachillerato, técnico superior de formación profesional o equivalentes.

\section{Artículo 25. Funciones.}

1. Sin perjuicio de otras funciones que se les atribuyan, de acuerdo con las disposiciones vigentes, corresponderá a los funcionarios de cada escala, con carácter general, las siguientes:

a. Escala superior: La organización, dirección, coordinación y supervisión de las distintas unidades y servicios del cuerpo. 
b. Escala técnica: La responsabilidad inmediata en la planificación y ejecución de los servicios.

c. Escala ejecutiva: El mando operativo y la supervisión de las tareas ejecutivas de las unidades a su cargo.

d. Escala básica: El cumplimiento de las funciones policiales propias del servicio. La realización de funciones planificadas por sus superiores.

2. Corresponderá, en todo caso, al jefe del cuerpo las funciones atribuidas a la escala superior, que deberán adecuarse a las particularidades de organización y dimensionamiento de la plantilla de personal respectiva.

Artículo 26. Subescala facultativa.

1. Los Ayuntamientos podrán crear la subescala facultativa, a la cual corresponderá desempeñar tareas de cobertura $\mathrm{y}$ apoyo a las funciones policiales en las especialidades que se estimen oportunas, según sus peculiaridades propias de organización y funcionamiento.

2. La provisión de estas plazas, en las diferentes categorías señaladas en el párrafo 1 del artículo 24 , se producirá por el sistema de oposición libre, exigiéndose como requisitos de acceso, además de los genéricos para cada categoría, estar en posesión de la titulación académica o profesional exigible en cada caso.

Además, los aspirantes que superen la oposición seguirán un curso en la Academia Gallega de Seguridad Pública, con la duración y contenido que reglamentariamente se determine y, que en todo caso, tendrá por objeto el conocimiento de la estructura, funciones y régimen estatutario de los cuerpos de Policía Local de la Comunidad Autónoma de Galicia, así como la adecuación de los conocimientos propios de la especialidad de que se trate a las necesidades de la función policial.

3. Sin perjuicio de lo dispuesto en el párrafo anterior, en cada convocatoria se reservará hasta un veinticinco por ciento de las plazas convocadas para su provisión por el sistema de concurso-oposición entre los miembros de los cuerpos de la Policía Local de Galicia, siempre que cuenten con la titulación necesaria y con una experiencia de al menos cinco años en el ejercicio de la función policial.

En este caso, los aspirantes que superen el concurso-oposición seguirán un curso en la Academia Gallega de Seguridad Pública, con la duración y contenido que reglamentariamente se determine y que, en todo caso, tendrá por objeto la adecuación de los conocimientos propios de la especialidad de que se trate a las necesidades de la función policial.

Artículo 27. Jefe del cuerpo de Policía Local.

1. El nombramiento del jefe del cuerpo de Policía Local será efectuado por el alcalde por el sistema de libre designación, de acuerdo con los principios de igualdad, mérito y capacidad, previa convocatoria pública en que podrán participar funcionarios de carrera que tengan la máxima categoría de la plantilla de personal del cuerpo de Policía del Ayuntamiento, o entre funcionarios de carrera de los cuerpos de Policía Local de otros Ayuntamientos de la Comunidad Autónoma de Galicia o de la Policía de Galicia, siempre y cuando pertenezcan a una categoría igual a la de la plaza que se va a proceder a cubrir y cumplan los requisitos del puesto de trabajo.

2. El puesto de jefatura ejerce la máxima responsabilidad en la Policía Local y ostenta el mando inmediato sobre todas las unidades, secciones y servicios en que se organiza el cuerpo, bajo la superior autoridad del alcalde o del concejal en quien delegue.

3. Corresponde al Jefe del cuerpo:

a. Transformar en órdenes concretas las directrices recibidas del alcalde o del miembro de la corporación en quien aquél delegue.

b. Dirigir, coordinar y supervisar los servicios operativos del cuerpo, así como las actividades administrativas relacionadas directamente con sus funciones, para asegurar su eficacia. 
c. Evaluar las necesidades de recursos humanos y materiales y formular las correspondientes propuestas.

d. Informar al alcalde, o al cargo en quien éste delegue, del funcionamiento del servicio y del cumplimiento de los objetivos y órdenes recibidas.

e. Cumplir cualquier otra función que le atribuya el reglamento del cuerpo de la Policía Local.

4. En casos de ausencia o enfermedad del funcionario titular, el alcalde podrá sustituirlo por otro funcionario del cuerpo de la misma categoría o, si no lo hay, de la inmediata inferior, atendiendo a los criterios de mérito y capacidad. Esta sustitución será siempre temporal.

5. En caso de vacante, el alcalde cubrirá el puesto de forma inmediata por el procedimiento anterior y, en todo caso, en el plazo máximo de doce meses publicará la convocatoria pública del puesto.

Artículo 28. Creación de categorías.

1. No se podrá crear una categoría sin que existan todas las inferiores y no podrá haber en la estructura de cada escala tres o más puestos de la misma categoría sin que exista la inmediata superior, aunque ésta esté compuesta por un solo integrante.

2. La categoría de superintendente se podrá crear en los Ayuntamientos de población superior a 75.000 habitantes y, asimismo, en los de inferior población si el número de miembros excede de 150 , siendo obligatoria en los Ayuntamientos de más de 150.000 habitantes o que cuenten con más de 200 efectivos en su plantilla de personal.

3. La categoría de intendente principal se podrá crear en los Ayuntamientos de población superior a 50.000 habitantes y, asimismo, en los de inferior población si el número de miembros del cuerpo excede de 100, siendo obligatoria en los Ayuntamientos de más de 75.000 habitantes o que cuenten con más de 150 efectivos en su plantilla de personal.
4. La categoría de intendente se podrá crear en los Ayuntamientos de población superior a 25.000 habitantes y en los de inferior población si el número de miembros del cuerpo excede de 50, siendo obligatoria en los Ayuntamientos con más de 50.000 habitantes o que cuenten con más de 100 efectivos en su plantilla de personal.

5. La categoría de inspector principal se podrá crear en los Ayuntamientos de población superior a 15.000 habitantes y en los de inferior población si el número de miembros del cuerpo excede de 25, siendo obligatoria en los Ayuntamientos con más de 25.000 habitantes o que cuenten con más de 50 efectivos en su plantilla de personal.

6. La categoría de inspector se podrá crear en los Ayuntamientos de población superior a 10.000 habitantes y en los de inferior población si el número de miembros del cuerpo excede de 10 , siendo obligatoria en los Ayuntamientos con más de 15.000 habitantes o que cuenten con más de 25 efectivos en su plantilla de personal.

7. Las categorías de oficial y policía serán obligatorias cuando esté creado el respectivo cuerpo de Policía Local.

Artículo 29. Plantillas de personal.

1. Corresponde a cada Ayuntamiento aprobar la plantilla de personal del respectivo cuerpo de Policía Local, en el cual se integrarán todos los puestos de trabajo correspondientes a cada escala y categorías previstas en la presente ley, con la determinación de los niveles respectivos.

2. La aprobación de las plantillas de personal será comunicada a la consellería competente en materia de seguridad.

Artículo 30. Número mínimo de miembros.

1. El número mínimo de efectivos con que contarán los cuerpos de Policía Local será de dos policías y un oficial.

2. El número máximo de vigilantes municipales que podrán tener los Ayuntamientos que no tengan creado el cuerpo de Policía Local será de dos. 
Artículo 31. Dispensa de requisitos. La consellería competente en materia de seguridad, con carácter excepcional, podrá dispensar de los requisitos mínimos contemplados en los artículos anteriores, en cuanto a la estructura del respectivo cuerpo de Policía Local, a aquellos Ayuntamientos que lo solicitasen y justificasen la imposibilidad de su cumplimento, previo informe de la Comisión de Coordinación de las Policías Locales.

\section{TíTULO V SELECCIÓN, PROMOCIÓN, MOVILIDAD Y FORMACIÓN}

\section{Capítulo I \\ INGRESO, PROMOCIÓN Y MOVILIDAD}

Artículo 32. Principios del sistema de selección.

1. Los sistemas de selección para el acceso a las diferentes categorías de los cuerpos de Policía Local serán los de oposición libre, concurso o concursooposición y se regirán por las bases de la respectiva convocatoria, que, al igual que la provisión de puestos de trabajo, respetarán los principios de libre concurrencia, igualdad, mérito y capacidad, así como el de publicidad del proceso selectivo.

A este respecto será de aplicación lo dispuesto en la Ley 7/2004, de 16 de julio, para Igualdad de Mujeres y Hombres.

2. Las convocatorias se publicarán en el boletín oficial de la provincia y en el Diario Oficial de Galicia, y vinculan a la administración, a los tribunales que evalúen las pruebas selectivas y a los que tomen parte en las mismas.

3. Las pruebas selectivas para ingresar en las escalas y categorías de los cuerpos de la Policía Local de Galicia son de carácter teórico y práctico y pueden incluir pruebas de capacidad física, psicotécnicas, médicas y de conocimientos, que se fijarán en las bases de la convocatoria. Asimismo, deberá demostrarse el conocimiento del idioma gallego.
4. Por vía reglamentaria se fijarán los programas de los temarios para el ingreso en la categoría de policía, los baremos de los concursos de méritos y los programas de los cursos selectivos que se desarrollen en la Academia Gallega de Seguridad Pública.

5. Los Ayuntamientos podrán solicitar a la consellería competente en materia de seguridad la colaboración en la realización de las pruebas de selección para el ingreso, ascenso o promoción a los cuerpos de Policía Local en la forma que reglamentariamente se establezca.

6. Asimismo, la Xunta de Galicia podrá asumir la convocatoria de las plazas vacantes y, en su caso, la formación y el período de prácticas con aquellos Ayuntamientos que así lo acuerden mediante los oportunos convenios de colaboración.

Artículo 33. Requisitos para el ingreso.

1. Además de estar en posesión de la titulación requerida en cada caso, los requisitos de ingreso en los cuerpos de la Policía Local de Galicia serán los establecidos con carácter general para el ingreso en la Administración local y aquellos otros relacionados con el carácter específico de este cuerpo, los cuales se determinarán reglamentariamente.

2. En todo caso, para el ingreso en la categoría de policía se requerirá no haber cumplido los 36 años, salvo cuando el acceso se produzca desde otros cuerpos policiales locales de Galicia, en cuyo caso habrán de faltar más de doce años para pasar a la situación de segunda actividad con destino por razón de edad.

3. Las pruebas selectivas de ingreso en las categorías de policía e inspector serán de carácter teórico y práctico y en las mismas se incluirá, en todo caso, un reconocimiento médico, un examen psicotécnico, pruebas de aptitud física y pruebas de capacitación de conocimientos, tanto generales como específicos, en materias relacionadas con el ejercicio 
profesional, así como la demostración del conocimiento de la lengua gallega.

Artículo 34. Tribunales de selección.

1. Los tribunales de oposición y órganos similares de selección serán designados por el alcalde correspondiente.

2. Estarán constituidos por cinco miembros titulares y cinco suplentes.

3. La totalidad de los vocales deberá poseer un nivel de titulación igual o superior al exigido para el acceso a la categoría de que se trate.

4. Su composición será la siguiente:

a. Presidente: El alcalde o alcaldesa del Ayuntamiento convocante o el concejal o concejala en quien delegue.

b. Tres vocales con conocimientos técnicos designados por el alcalde:

$1^{\circ}$. Uno propuesto por la Academia Gallega de Seguridad Pública, en representación de la Xunta de Galicia.

$2^{\circ}$. Otro propuesto por los sindicatos existentes en la junta de personal del Ayuntamiento.

$3^{\circ}$. El tercer vocal, que habrá de ser técnico en la materia, a propuesta del alcalde.

c. Secretario: Un funcionario del Ayuntamiento convocante con habilitación de carácter nacional.

Artículo 35. Ingreso en la categoría de policía.

1. El ingreso en la categoría de policía se realiza por el sistema de oposición libre.

2. El modo de ingreso por oposición libre requiere, además de la superación de las pruebas selectivas que establezca la convocatoria, aprobar un curso de formación en la Academia Gallega de Seguridad Pública y superar un período de prácticas. La evaluación del curso de formación y el período de prácticas debe restringirse a los méritos y capacidades profesionales.

3. Una vez superadas las pruebas selectivas, el curso de formación y el periodo de prácticas, los aspirantes serán nombrados funcionarios de carrera de la escala y categoría correspondiente.
4. Asimismo, para ser cubiertas mediante concurso, se reservará como mínimo un veinticinco por ciento de las plazas convocadas para funcionarios de otros cuerpos de la Policía Local de la Comunidad Autónoma. Estos funcionarios deberán tener una categoría igual a la de la convocatoria y una antigüedad mínima en ella de cinco años.

Artículo 36. Funcionarios en prácticas.

1. Durante el curso de formación y el período de prácticas, los aspirantes que no procedan de otros cuerpos de seguridad de la Comunidad Autónoma tendrán la consideración de funcionarios en prácticas. Durante este período los aspirantes percibirán las retribuciones que les correspondan de acuerdo con la legislación vigente. El nombramiento como funcionario de carrera se efectuará únicamente tras la superación del curso y el período de prácticas, de acuerdo con lo que se establezca en la correspondiente convocatoria.

2. Con independencia de la prueba de reconocimiento médico que pueda establecer dicha convocatoria, en cualquier momento anterior a ser nombrados funcionarios de carrera los aspirantes podrán ser sometidos a las pruebas médicas que sean precisas para comprobar su idoneidad, de acuerdo con el cuadro de exclusiones médicas que se determinará reglamentariamente. Si de las pruebas practicadas se deduce la existencia de alguna de ellas, el órgano responsable podrá proponer la exclusión de la persona aspirante del proceso selectivo. En dicho caso, corresponde al órgano competente para efectuar el nombramiento adoptar la resolución que proceda, sin que en ningún caso se tenga derecho a indemnización.

3. No obstante lo dispuesto en el apartado anterior, si la causa de exclusión a que se hace referencia en el apartado anterior sobrevino como consecuencia de lesiones sufridas en el ejercicio de sus cometidos como funcionario en prácticas, el órgano 
responsable propondrá su nombramiento como funcionario de carrera al órgano competente. En tal caso, debe asignarse a dicho funcionario un puesto de trabajo adecuado a sus capacidades.

Artículo 37. Acceso a la categoría de oficial.

El acceso a la categoría de oficial se realizará:

a. Por promoción interna, mediante concurso-oposición, entre miembros del cuerpo que tengan un mínimo de tres años de antigüedad en la categoría de policía.

b. Asimismo, para ser cubiertas mediante concurso, se reservará, como mínimo, un veinticinco por ciento de las plazas convocadas para funcionarios de otros cuerpos de la Policía Local de la Comunidad Autónoma. Estos funcionarios deberán tener una categoría igual a la de la convocatoria y una antigüedad mínima en ella de cinco años.

Artículo 38. Acceso a la categoría de inspector.

El acceso a la categoría de inspector se realizará:

a. Por promoción interna, mediante concurso-oposición, entre miembros del cuerpo que tengan un mínimo de tres años de antigüedad en la categoría de oficial.

b. Asimismo, para ser cubiertas mediante concurso, se reservará como mínimo un veinticinco por ciento de las plazas convocadas para funcionarios de otros cuerpos de la Policía Local de la Comunidad Autónoma. Estos funcionarios deberán tener una categoría igual a la de la convocatoria y una antigüedad mínima en ella de cinco años.

Artículo 39. Acceso a la categoría de inspector principal.

El acceso a la categoría de inspector principal se realizará:

a. Por promoción interna, mediante concurso-oposición, entre miembros del cuerpo que tengan un mínimo de tres años de antigüedad en la categoría de inspector.

b. Asimismo, para ser cubiertas mediante concurso, se reservará como mínimo un veinticinco por ciento de las plazas convocadas para funcionarios de otros cuerpos de la Policía Local de la Comunidad Autónoma. Estos funcionarios deberán tener una categoría igual a la de la convocatoria y una antigüedad mínima en ella de cinco años.

Artículo 40. Acceso a la categoría de intendente.

El acceso a la categoría de intendente se realizará:

a. Por promoción interna, mediante concurso-oposición, entre miembros del cuerpo que tengan un mínimo de tres años de antigüedad en la categoría de inspector principal.

b. Asimismo, para ser cubiertas mediante concurso, se reservará como mínimo un veinticinco por ciento de las plazas convocadas para funcionarios de otros cuerpos de la Policía Local de la Comunidad Autónoma. Estos funcionarios deberán tener una categoría igual a la de la convocatoria y una antigüedad mínima en ella de cinco años.

Artículo 41. Acceso a la categoría de intendente principal.

El acceso a la categoría de intendente principal se realizará:

a. Por promoción interna, mediante concurso, entre miembros del cuerpo que tengan un mínimo de tres años de antigüedad en la categoría de intendente.

b. Asimismo, para ser cubiertas mediante concurso, se reservará como mínimo un veinticinco por ciento de las plazas convocadas para funcionarios de otros cuerpos de la Policía Local de la Comunidad Autónoma. Estos funcionarios deberán tener una categoría igual a la de la convocatoria y una antigüedad mínima en ella de cinco años.

Artículo 42. Acceso a la categoría de superintendente.

El acceso a la categoría de superintendente se realizará:

a. Por promoción interna, mediante concurso, entre miembros del cuerpo que 
tengan un mínimo de tres años de antigüedad en la categoría de intendente principal.

b. Asimismo, para ser cubiertas mediante concurso, se reservará como mínimo un veinticinco por ciento de las plazas convocadas para funcionarios de otros cuerpos de la Policía Local de la Comunidad Autónoma. Estos funcionarios deberán tener una categoría igual a la de la convocatoria y una antigüedad mínima en ella de tres años.

Artículo 43. Garantía de la movilidad. Para garantizar el derecho a la movilidad de los miembros de los cuerpos de Policía Local de Galicia, reflejado en los artículos 35 y 37 a 42, cuando no fuese posible cubrir las vacantes con los porcentajes señalados, las fracciones sobrantes se acumularán a la siguiente o siguientes convocatorias.

Artículo 44. Permutas.

Los alcaldes, previo informe de los respectivos jefes de la Policía Local, podrán autorizar la permuta de destinos entre los miembros correspondientes de los cuerpos de Policía Local o agentes de policía en activo que sirvan en diferentes Ayuntamientos, siempre y cuando cumplan los siguientes requisitos:

a. Que ambos sean funcionarios de los cuerpos de Policía Local.

b. Que pertenezcan a la misma escala y categoría.

c. Que tengan diez años ininterrumpidos de servicio activo y con un número de años de servicio que no difiera entre sí en más de diez años.

d. Que falten como mínimo cinco años para cumplir la edad para el pase a la situación de segunda actividad con destino por razón de edad.

e. Que a ninguno de los solicitantes se le esté incoando un expediente disciplinario.

f. No podrá solicitarse una nueva permuta por parte de ninguno de los permutantes hasta que transcurran cinco años desde la obtención de una anterior.

\section{Capitulo II \\ LAFORMACIÓN}

Artículo 45. Formación y capacitación profesional.

1. Los miembros de los cuerpos de la Policía Local de Galicia recibirán una formación y capacitación profesional con carácter permanente que garantice el apropiado cumplimento de sus funciones y asegure el mantenimiento y mejora de sus aptitudes y capacidad profesional, que comprenda necesariamente cursos de formación en igualdad de género y sobre la violencia contra las mujeres.

2. La Academia Gallega de Seguridad Pública elaborará un plan de carrera profesional que incluya los cursos de ingreso, perfeccionamiento, especialización y promoción de los miembros de los cuerpos de la Policía Local de Galicia. En su caso, para conseguir adecuadamente tales objetivos, la academia puede celebrar acuerdos o convenios con instituciones análogas o de otra naturaleza.

3. La Academia Gallega de Seguridad Pública procurará la convalidación, por la administración competente, de los cursos que se impartan en sus centros y convalidará, a su vez, aquellos que hayan sido superados en otros centros oficiales, en la forma que se determine reglamentariamente.

\section{Artículo 46. Cursos.}

1. La duración y contenido de los cursos y programas formativos se determinará reglamentariamente.

2. La asistencia por parte de los miembros de las policías locales a cursos de formación y capacitación profesional habrá de ser autorizada por el alcalde, quien sólo podrá denegar la solicitud de forma motivada y por exigencia del servicio público.

3. Durante su permanencia en la Academia Gallega de Seguridad Pública, los alumnos estarán sujetos a la presente ley y al reglamento de funcionamiento de esta institución. 


\section{TÍTULO VI DEL RÉGIMEN ESTATUTARIO \\ Capítulo I DERECHOS Y DEBERES}

\section{Artículo 47. Principios generales.}

1. Los miembros de los cuerpos de la Policía Local de Galicia y los vigilantes municipales tienen los derechos y deberes que les corresponden como funcionarios de la administración del Ayuntamiento a que pertenezcan, en el marco de la especificidad de su función, de acuerdo con la legislación vigente.

2. Los Ayuntamientos protegerán a los funcionarios de los cuerpos de Policía Local en el ejercicio de sus funciones, otorgándoles la consideración social debida a su jerarquía y a la dignidad del servicio policial.

Artículo 48. Retribuciones.

1. Los funcionarios de los cuerpos de la Policía Local tendrán derecho a una remuneración justa, que comprenderá las retribuciones básicas y las complementarias en el marco de la legislación de la función pública de Galicia.

2. Las retribuciones básicas tendrán idéntica cuantía para todos los miembros de un mismo grupo.

3. Las retribuciones complementarias se fijarán reglamentariamente, dentro de los límites fijados por la legislación vigente, de acuerdo con los siguientes criterios:

a. Nivel de formación.

b. Régimen de incompatibilidades.

c. Movilidad por razón de servicio.

d. Dedicación.

e. Riesgo que conlleva su misión.

f. Especificidad de los horarios de trabajo.

g. Peculiar estructura.

Artículo 49. Seguridad Social.

Los funcionarios de los cuerpos de la Policía Local de la Comunidad Autónoma de Galicia están acogidos al régimen general de la Seguridad Social, sin perjuicio de otros regímenes que les sean de aplicación y que se regirán por su normativa específica.

Artículo 50. Salud y seguridad laboral. Asimismo, tendrán derecho a la promoción de la seguridad y a la salud en el desarrollo de su función y a la prevención de riesgos laborales en los términos que establezca la legislación específica para el ámbito de las funciones públicas de policía y seguridad.

Artículo 51. Asistencia jurídica.

1. Los miembros de los cuerpos de la Policía Local recibirán asesoramiento jurídico en aquellas situaciones derivadas del servicio en que lo necesiten.

2. Asimismo, tendrán derecho a ser representados y defendidos por los profesionales designados por el Ayuntamiento de que dependen, y a cargo del mismo, en todas las actuaciones judiciales en que se les exijan responsabilidades por hechos cometidos en el ejercicio de sus funciones. En ningún caso tendrá derecho a la asistencia jurídica el funcionario que hubiese incurrido en dolo, negligencia grave o abuso de funciones.

Artículo 52. Derechos sindicales.

Para la representación, defensa y promoción de sus intereses profesionales, económicos y sociales, los funcionarios de los cuerpos de la Policía Local de Galicia podrán integrarse libremente en las organizaciones sindicales, separarse de ellas y constituir otras organizaciones, de acuerdo con el marco legal de aplicación.

Artículo 53. Limitación del derecho de huelga.

Los funcionarios de los cuerpos de la Policía Local, de acuerdo con lo establecido por la legislación orgánica de fuerzas y cuerpos de seguridad, no podrán ejercer en ningún caso el derecho de huelga ni acciones sustitutivas de éste o concertadas a fin de alterar el normal funcionamiento de los servicios.

Artículo 54. Deber de residencia.

1. Los miembros de los cuerpos de la Policía Local podrán residir fuera de la 
localidad donde trabajan, exceptuados los casos en que por razón del servicio sea necesario el deber de residencia en la propia localidad.

2. Sin perjuicio de lo que se establece en el apartado 1, se determinará reglamentariamente la distancia máxima en kilómetros, respecto a la localidad de destino, a que están obligados a residir los miembros de los cuerpos de la Policía Local.

Artículo 55. Jornada laboral y horario.

1. Los miembros de los cuerpos de la Policía Local cumplirán estrictamente la jornada y el horario de trabajo que se determinen por el órgano competente.

2. En situaciones excepcionales, cuando se produzcan hechos o emergencias que así lo exijan, los funcionarios podrán ser requeridos para el servicio fuera de su jornada de trabajo.

3 . En caso de que las necesidades extraordinarias del servicio obligaran a prolongar su prestación, tendrán que cumplimentarse las órdenes referidas al respecto, sin perjuicio de la compensación que proceda por el exceso de jornada realizado en la forma que se determine reglamentariamente.

Artículo 56. Revisiones médicas.

Los miembros de los cuerpos de la Policía Local tienen derecho a una revisión médica anual.

Reglamentariamente se determinarán las pruebas médicas que hayan de incluirse en la revisión anual.

Artículo 57. Medios e instalaciones. Los miembros de los cuerpos de la Policía Local dispondrán de los medios e instalaciones apropiados para el cumplimento de sus funciones y para la atención adecuada a la ciudadanía.

Artículo 58. Incompatibilidades.

Los miembros de los cuerpos de la Policía Local no podrán ejercer ninguna otra actividad pública o privada, salvo las exceptuadas en el régimen general de incompatibilidades.

Artículo 59. Consumo de drogas, estupefacientes y sustancias psicotrópicas.

1. Los miembros de los cuerpos de la Policía local no podrán consumir bebidas alcohólicas ni cualquier otra droga tóxica, estupefaciente o sustancia psicotrópica mientras estén de servicio o se encuentren en alguna dependencia policial. Tampoco podrán estar de servicio bajo la influencia de cualquiera de estas sustancias.

2. Para verificar que un funcionario policial está bajo los efectos del alcohol o de alguna de las sustancias señaladas en el apartado anterior, podrán realizarse pruebas técnicas de comprobación. Tales pruebas deberán ser ordenadas de forma expresa por el superior responsable.

3. A fin de adecuar el régimen de los servicios que se les asignen, los funcionarios que estén bajo tratamiento médico con alguna de las sustancias mencionadas estarán obligados a advertirlo, por escrito y con los oportunos informes médicos.

\section{Capítulo II \\ SITUACIONES ADMINISTRATIVAS Y JUBILACIÓN}

Artículo 60. Situaciones administrativas.

1. Los funcionarios de los cuerpos de la Policía local de Galicia podrán encontrarse, además de en las situaciones contempladas en la legislación básica de la función pública, en la situación administrativa de segunda actividad.

2. Dichas situaciones se regirán por lo dispuesto en la presente ley y en las normas que la desarrollen y, supletoriamente, por lo previsto en la legislación vigente en materia de función pública.

Artículo 61. Edad de jubilación.

La jubilación forzosa de los miembros de los cuerpos de la Policía local de Galicia se declarará de oficio al cumplir el funcionario los 65 años de edad.

\section{Capitulo III SEGUNDA ACTIVIDAD}

Artículo 62. Segunda actividad.

La segunda actividad es una situación administrativa especial que tiene como objeto garantizar una adecuada aptitud psicofísica de los integrantes de los cuerpos 
de la Policía local de Galicia en tanto permanezcan en servicio activo, asegurando la eficacia del servicio.

Artículo 63. Causas.

1. Se podrá pasar a la segunda actividad por:

a. Cumplimiento de las edades que se determinan para cada escala.

b. Disminución de las condiciones psicofísicas para el desempeño de la función policial.

c. Embarazo y lactancia.

2. En la situación de segunda actividad se permanecerá hasta el pase a la jubilación o a otra situación que no podrá ser la de servicio activo, salvo que la causa del pase a la situación de segunda actividad fuese por embarazo, lactancia o insuficiencia de las aptitudes psicofísicas y que tales circunstancias hubieran desaparecido. En el supuesto de disminución de las condiciones psicofísicas será el tribunal médico a que se refiere el artículo 73 de la presente ley el que aprecie que tal insuficiencia ha desaparecido.

Artículo 64. Por razón de edad.

1. El pase a la segunda actividad por edad tendrá lugar al cumplirse las siguientes edades:

a. Escala superior y técnica: A los 62 años de edad.

b. Escala ejecutiva: A los 60 años de edad.

c. Escala básica: A los 58 años de edad.

2. Una vez oída la junta de personal, el Ayuntamiento, motivadamente, a fin de optimizar sus recursos, y previo informe a la consellería competente en materia de seguridad, podrá limitar por cada año natural y categoría el número de funcionarios que puedan acceder a la situación de segunda actividad por razón de edad, prorrogando la permanencia en el servicio activo de los que, en el orden inverso a la fecha en que cumplan la edad, excedan del cupo así fijado.

3. Asimismo, el Ayuntamiento, previa comunicación a la consellería competente en materia de seguridad, podrá aplazar el pase a la situación de segunda actividad, por sucesivos períodos de un año, cuando exista solicitud expresa del interesado, y siempre que medie informe favorable del tribunal médico, constituido según lo establecido en el artículo 73 de la presente ley.

Artículo 65. Por disminución de aptitudes psicofísicas.

1. Pasarán a la situación de segunda actividad, sin la limitación de las edades determinadas en el artículo anterior, aquellos funcionarios de los cuerpos de la Policía local que tengan disminuidas las aptitudes físicas, psíquicas o sensoriales necesarias para el desempeño de la función policial, bien por incapacidad temporal o de otro tipo, y siempre que no constituyan causa de incapacidad permanente. Dicho procedimiento podrá iniciarse de oficio o a solicitud del interesado.

2. La evaluación de la disminución habrá de ser dictaminada por el tribunal médico a que se refiere el artículo 73 de la presente ley.

3. Podrá acordarse, de oficio o a solicitud del interesado, el reingreso en el servicio activo en caso de que hubieran desaparecido las causas que motivaron la disminución de aptitudes físicas, psíquicas o sensoriales, previo dictamen médico.

4. En caso de que el pase a la segunda actividad sea motivado por accidente laboral o enfermedad profesional, el funcionario percibirá el cien por cien de las retribuciones que venía percibiendo en el momento de producirse el hecho causante del referido pase.

Artículo 66. Cuadro de aptitudes.

Reglamentariamente se establecerá, para cada escala, el cuadro de causas de disminución de las aptitudes físicas, psíquicas o sensoriales que originen el pase a la situación de segunda actividad.

Artículo 67. Por razón de embarazo o lactancia.

1. Las funcionarias de los cuerpos de Policía local podrán solicitar el pase a la segunda actividad en el destino más acorde 
con la situación de su embarazo, previo informe facultativo que lo acredite.

2. Igualmente pueden permanecer en la segunda actividad durante el período de lactancia, previa solicitud y siempre que, según el informe facultativo, las condiciones de su puesto habitual de trabajo no sean las más adecuadas a su situación.

Artículo 68. Razones excepcionales. El alcalde podrá requerir, motivadamente, dando cuenta al responsable de la consejería en materia de seguridad, a los funcionarios de los cuerpos de la Policía local en situación de segunda actividad para el cumplimiento de funciones policiales, cuando concurran razones excepcionales de seguridad ciudadana que reglamentariamente se determinarán.

Artículo 69. Puestos de trabajo.

La situación administrativa de segunda actividad se declarará con indicación de destino. A los funcionarios que pasen a dicha situación se les asignarán puestos de trabajo de esta naturaleza, bien dentro del mismo cuerpo policial o bien en otro puesto del Ayuntamiento, que se corresponda con la categoría que se tenga, preferentemente en el área de seguridad y adecuado a su experiencia y capacidad.

Artículo 70. Catálogo de puestos de trabajo.

1. El catálogo de puestos de trabajo de segunda actividad precisará los que pueden ser cubiertos con personal en esta situación.

2. El catálogo determinará para cada puesto la función, el horario, la situación, el perfil necesario, la formación adecuada y cualquier otra circunstancia adecuada. Estas definiciones podrán cambiarse y adaptarse en función de las necesidades.

3. El catálogo de puestos de trabajo de segunda actividad se aprobará con la relación de puestos de trabajo del Ayuntamiento.

Artículo 71. Retribuciones en la segunda actividad.

1. El pase a la segunda actividad no supondrá disminución de las retribuciones básicas y complementarias fijas y periódicas.

2. El tiempo de permanencia en la situación de segunda actividad es computable a los efectos de perfeccionamiento de trienios y de derechos pasivos.

Artículo 72. Régimen jurídico.

1. El pase a la situación de segunda actividad no conllevará la pérdida de la condición de agente de la autoridad.

2. Los funcionarios en situación de segunda actividad estarán sujetos a idéntico régimen disciplinario y de incompatibilidad que en el servicio activo, salvo que desempeñen puestos de trabajo distintos a los de los cuerpos de Policía local. En este caso estarán sometidos al régimen general disciplinario de los funcionarios de la Administración local o al específico de aplicación al puesto que ocupen.

3. En la situación de segunda actividad no se podrá participar en procedimientos de promoción interna o concursos de traslados, salvo cuando se hubiera accedido por causa de embarazo o lactancia.

Artículo 73. Tribunal médico.

1. Reglamentariamente se determinará la composición de los tribunales médicos que dictaminarán si las afecciones o enfermedades físicas o psíquicas están incursas o no en el cuadro de incompatibilidades médicas para la prestación del servicio ordinario.

2. El tribunal emitirá un dictamen médico y lo dirigirá al órgano competente para su resolución, en el cual propondrá el pase a la segunda actividad o que se tramite el correspondiente expediente de incapacidad o, si procede, de jubilación forzosa.

\section{Capitulo IV \\ DISTINCIONES Y RECOMPENSAS}

Artículo 74. Distinciones y recompensas.

1. Los miembros de los cuerpos de Policía local de Galicia pueden ser distinguidos o recompensados de acuerdo con lo que se determine reglamentariamente. 
2. Todas las distinciones y las recompensas otorgadas a los miembros de los cuerpos de Policía local de Galicia constarán en sus expedientes personales, valorándose como mérito en los concursos de provisión de puestos de trabajo. También podrán tenerse en cuenta en los procesos de provisión por el sistema de libre designación.

\section{TíTULO VII DEL RÉGIMEN DISCIPLINARIO}

Artículo 75. Disposiciones generales.

1. El régimen disciplinario de los cuerpos de la Policía local, sin perjuicio de la observancia de las garantías reconocidas en el ordenamiento jurídico, se inspirará en los principios básicos de actuación que se establecen en el capítulo II del título II de la presente ley.

2. Sin perjuicio de las responsabilidades civiles y penales que pudieran proceder, el régimen disciplinario aplicable a los miembros de los cuerpos de la Policía local será el que se establece en la presente ley $\mathrm{y}$, en su defecto, en la legislación vigente en materia de función pública.

Artículo 76. Ámbito de aplicación.

1. La presente ley es de aplicación a los funcionarios de los cuerpos de la Policía local, cualquiera que sea la situación administrativa en que se encuentren, siempre que la falta cometida sea compatible, atendidas las circunstancias, con dicha situación.

2. Los funcionarios en prácticas se someterán a las normas de régimen disciplinario que se establezcan reglamentariamente.

Artículo 77. Sujetos responsables.

1. Los funcionarios de los cuerpos de la Policía local pueden incurrir en responsabilidad disciplinaria por la comisión de las faltas que se tipifican en el presente capítulo, desde el momento de la toma de posesión hasta el de la jubilación o pérdida de la condición de funcionario.

2. Incurrirán en la misma responsabilidad que los autores de una falta los que induzcan a su comisión y los jefes que la toleren.
3. Asimismo, incurrirán en falta de inferior grado los que encubriesen la comisión de una falta muy grave o grave. Debe de entenderse por encubrimiento el hecho de no dar cuenta al superior jerárquico competente, de modo inmediato y por escrito, de los hechos constitutivos de falta de los cuales se tenga conocimiento, salvo cuando sea éste el presunto infractor, en cuyo caso la comunicación se efectuará a su superior inmediato.

Artículo 78. Clases de faltas.

Las faltas que pueden cometer los miembros de los cuerpos de la Policía local podrán ser leves, graves y muy graves.

Artículo 79. Faltas muy graves.

Se considerarán faltas muy graves:

a. El incumplimiento del deber de fidelidad a la Constitución y al Estatuto de Autonomía en el ejercicio de sus funciones.

b. Ser condenado, en virtud de sentencia firme, a pena privativa de libertad, como autor de una conducta constitutiva de delito doloso relacionada con el servicio o que cause grave daño a la administración o a los administrados.

c. El acoso moral y el acoso sexual.

d. El abuso de atribuciones que cause grave daño a los ciudadanos, a los subordinados o a la administración, y la práctica de tratos inhumanos, degradantes, discriminatorios o vejatorios a las personas que se encuentren bajo su custodia.

e. La insubordinación individual o colectiva, respecto a las autoridades o mandos de que dependan.

f. La no prestación de auxilio con urgencia en aquellos hechos o circunstancias graves en que sea obligada su actuación.

g. El abandono del servicio.

h. La publicación o la utilización indebida de secretos declarados oficiales o calificados como tales.

i. La violación del secreto profesional y la falta del debido sigilo respecto a los asuntos que conozcan por razón de su cargo, siempre que perjudique el desarrollo de la labor policial, cause perjuicio 
a la administración, a los detenidos e investigados o a cualquier otra persona afectada por la investigación policial o se utilice dicho conocimiento en provecho del propio funcionario.

j. La realización de actividades declaradas incompatibles legalmente, cuando las mismas comprometan la imparcialidad o independencia.

k. La participación en huelgas, en acciones sustitutivas de ellas o en actuaciones concertadas a fin de alterar el normal funcionamiento de los servicios.

1. Incurrir en falta grave cuando el funcionario hubiera sido sancionado anteriormente, en virtud de resoluciones firmes, por otras tres faltas de carácter grave o muy grave, cometidas en el período de un año inmediatamente anterior a la comisión de la nueva infracción.

m. La falta de colaboración manifiesta con los miembros del cuerpo de la Policía local y demás miembros de los cuerpos de Policía local así como con los miembros de las fuerzas y cuerpos de seguridad del Estado, cuando resulte perjudicado gravemente el servicio o se deriven consecuencias graves para la seguridad ciudadana.

n. Embriagarse o consumir drogas tóxicas, estupefacientes o sustancias psicotrópicas durante el servicio o siempre que perjudique su prestación.

ñ. Toda actuación que suponga discriminación por razón de ideología, religión o creencias, situación familiar, pertenencia a etnia o raza, origen nacional, idioma, sexo, orientación sexual, género, enfermedad, discapacidad o cualquier otra condición o circunstancia personal o social.

o. La obstaculización grave al ejercicio de las libertades públicas y derechos sindicales.

p. Asimismo, son faltas muy graves, a los efectos de lo establecido en la Ley Orgánica 4/1997, de 4 de agosto, por la que se regula la utilización de videocámaras por las fuerzas y cuerpos de seguridad en lugares públicos: $1^{\circ}$. La alteración o manipulación de imágenes y sonidos grabados, siempre y cuando no constituyan delito.

$2^{\circ}$. La cesión, transmisión y revelación a terceras personas no autorizadas, por cualquier medio y con cualquier ánimo y finalidad, de los soportes originales de las grabaciones o sus copias, de modo íntegro o parcial.

$3^{\circ}$. La reproducción de imágenes y sonidos grabados con finalidades distintas de las establecidas en la Ley Orgánica 4/1997.

$4^{\circ}$. La utilización de imágenes y sonidos grabados o de los medios técnicos de grabación afectos al servicio para finalidades distintas de las establecidas en la Ley Orgánica 4/1997.

q. Cualquier otra conducta no enumerada en los apartados anteriores tipificada como falta muy grave en la legislación general.

Artículo 80. Faltas graves.

Son faltas graves:

a. La grave desconsideración con los superiores, compañeros, subordinados o ciudadanos, en el ejercicio de sus funciones o con ocasión de las mismas.

b. La desobediencia a los superiores jerárquicos o responsables del servicio con motivo de las órdenes o instrucciones dadas por aquéllos.

c. La omisión de la obligación de dar cuenta a sus superiores con la debida diligencia de todo asunto que requiera su conocimiento o decisión urgentes.

d. La infracción de deberes u obligaciones legalmente establecidos inherentes al cargo o función, cuando se produzcan de manera grave y reiterada.

e. Los actos y conductas que atenten gravemente contra la dignidad de los funcionarios, contra la imagen de los cuerpos de la Policía local y contra el prestigio y la consideración debidos al Ayuntamiento y a la Xunta de Galicia.

f. La falta de presentación o puesta a disposición inmediata en la dependencia 
de destino o en la más próxima en los casos de declaración de los estados de alarma, excepción o sitio, o cuando así se disponga en caso de alteración grave de la seguridad ciudadana.

g. La tercera falta injustificada de asistencia al servicio en un período de tres meses, cuando las dos anteriores hubieran sido objeto de sanción firme por falta leve.

h. No prestar servicio alegando supuesta enfermedad o simulando mayor gravedad de la misma.

i. La falta de rendimiento manifiesta, reiterada y no justificada, que ocasione un grave perjuicio a la ciudadanía o a la eficacia de los servicios.

j. La emisión de informes sobre asuntos de servicio que, sin faltar abiertamente a la verdad, la tergiversen, valiéndose de términos ambiguos, confusos o tendenciosos, o la alteren mediante inexactitudes, cuando se cause perjuicio a la administración o a los ciudadanos, siempre que el hecho no constituya delito o falta muy grave.

$\mathrm{k}$. La intervención en un procedimiento administrativo cuando concurra alguna de las causas legales de abstención.

1. No ir provisto en los actos de servicio de la uniformidad reglamentaria cuando su uso sea preceptivo, así como de los distintivos de la categoría o cargo, del arma reglamentaria o de los medios de protección o acción que se determinen, siempre que no medie autorización en contrario.

m. El extravío, la pérdida o la sustracción del arma reglamentaria, siempre que concurra negligencia grave.

n. La utilización del arma en acto de servicio o fuera de él sin causa que lo justifique, creando alarma entre los ciudadanos o grave desprestigio del cuerpo.

ñ. Asistir a cualquier manifestación o reunión pública de uniforme o hacer uso u ostentación del arma reglamentaria y/o de los distintivos de identificación, salvo que se trate de actos de servicio o actos oficiales en que la asistencia de uniforme esté indicada.

o. Causar daños graves en la conservación de locales, material o demás elementos relacionados con el servicio, o dar lugar, por negligencia grave, al extravío, pérdida o sustracción de éstos.

p. Impedir, limitar u obstaculizar a los subordinados en el ejercicio de los derechos que tengan reconocidos siempre que no constituya falta muy grave.

q. Embriagarse o consumir drogas tóxicas, estupefacientes o sustancias psicotrópicas, en ambos casos con habitualidad o cuando afecte a la imagen del cuerpo o de la función policial.

Se entenderá por habitualidad la existencia acreditada de más de dos episodios de consumo.

r. La negativa a someterse a la realización de las pruebas técnicas tendentes a comprobar que se está bajo la influencia del alcohol o de drogas tóxicas, estupefacientes o sustancias psicotrópicas.

s. Solicitar y obtener cambios de destino mediando cualquier recompensa o ánimo de lucro o falseando las condiciones que lo regulen.

t. La realización de actos o declaraciones que vulneren los límites al derecho de acción sindical señalados en el artículo 19 de la Ley Orgánica 2/1986, de 13 de marzo, siempre que se cause perturbación grave en el normal funcionamiento de los servicios.

u. Promover o asistir a encierros en locales de titularidad pública u ocuparlos sin autorización, siempre que cause perturbación grave en el normal funcionamiento de los servicios.

v. Haber sido condenado por sentencia firme como autor de un delito o falta imprudentes cuando afecte al servicio o cause grave daño a la administración o a los ciudadanos.

w. Las infracciones a lo dispuesto en la Ley Orgánica 4/1997, de 4 de agosto, no constitutivas de falta muy grave. 
x. El incumplimiento de los plazos u otras disposiciones de procedimiento en materia de incompatibilidades, cuando no supongan mantenimiento de una situación de incompatibilidad.

y. El incumplimiento del deber del secreto profesional en lo que se refiere a los asuntos conocidos por razón o con ocasión del desempeño de sus funciones que perjudique el desarrollo de la labor policial o a cualquier persona.

z. Las acciones u omisiones tipificadas como faltas muy graves y que de acuerdo con los criterios que se establecen en el artículo 82 de la presente ley merezcan la calificación de falta grave.

Artículo 81. Faltas leves.

Son faltas leves:

a. El retraso o negligencia en el cumplimiento de las funciones y órdenes recibidas o la falta de interés en la instrucción o preparación personal para desempeñarlas.

b. La incorrección con los ciudadanos, con otros miembros de los cuerpos de la Policía local o con los miembros de otras fuerzas y cuerpos de seguridad, siempre que no merezcan una calificación más grave.

c. La no asistencia al servicio que no constituya falta de mayor gravedad y el incumplimiento de la jornada de trabajo, así como las reiteradas faltas de puntualidad.

d. El mal uso o el descuido en la conservación de los locales, material o demás elementos de los servicios, así como el incumplimiento de las normas dadas en esta materia, cuando no constituyan falta más grave.

e. Prescindir del conducto reglamentario para formular cualquier solicitud, reclamación o queja en las relaciones de servicio, así como no tramitar las peticiones o reclamaciones formuladas en la debida forma.

f. El descuido en el aseo personal y el incumplimiento de las normas de uniformidad, siempre que no constituya falta más grave. g. El extravío, la pérdida o la sustracción de los distintivos y credenciales de identificación, siempre que concurra negligencia grave.

h. La ausencia injustificada de cualquier servicio, cuando no merezca calificación más grave.

i. La omisión intencionada del deber de saludo, la no devolución del mismo o incumplir de cualquier otra manera las normas que lo regulan.

j. Cualquier clase de juego que se lleve a cabo en las dependencias policiales, siempre que perjudique la prestación del servicio o menoscabe la imagen policial.

k. La exhibición u ostentación del arma reglamentaria, de los distintivos y credenciales del cargo o de la condición de agente de la autoridad sin causa que lo justifique.

1. Las acciones u omisiones tipificadas como faltas graves y que, de acuerdo con los criterios que se establecen en el artículo 82 de la presente ley, merezcan la calificación de falta leve.

Artículo 82. Criterios de graduación. Para la determinación de la calificación de una falta como grave o leve, así como para la graduación de las sanciones, se tendrán en cuenta los siguientes criterios:

a. La intencionalidad.

b. La perturbación que pueda producir en el normal funcionamiento de la administración y de los servicios policiales.

c. Los daños y perjuicios o la falta de consideración que pueda implicar para los ciudadanos y subordinados.

d. El quebrantamiento que pueda suponer de los principios de disciplina y jerarquía propios del cuerpo.

e. La falta de consideración para otros miembros de los cuerpos de la Policía local, para las demás fuerzas y cuerpos de seguridad o para los ciudadanos.

f. La reincidencia. Existe reincidencia si el funcionario, al cometer la falta, ya ha sido anteriormente sancionado en resolución firme por otra falta de mayor 
gravedad o por dos de gravedad igual o inferior y que no hayan sido canceladas.

A los efectos de reincidencia no se computarán los antecedentes disciplinarios cancelados o que debieran serlo.

g. El descrédito y desprestigio para la imagen pública de la institución policial.

h. El historial profesional del funcionario.

i. En general, la trascendencia para la seguridad pública.

Artículo 83. Sanciones.

1. Las sanciones que podrán imponerse a las faltas anteriormente expuestas serán las siguientes:

a. Por faltas muy graves:

$1^{\circ}$. Separación del servicio.

$2^{\circ}$. Suspensión de funciones por más de un año y hasta tres años.

b. Por faltas graves:

$1^{\circ}$. Suspensión de funciones desde cinco días hasta un año.

$2^{\circ}$. Inmovilización en la escala por un período no superior a cinco años.

$3^{\circ}$. Traslado a otro puesto de trabajo dentro de la misma localidad.

c. Por faltas leves:

$1^{\circ}$. Pérdida de uno a cuatro días de remuneración y suspensión de funciones por igual período, que no supondrá la pérdida de antigüedad ni implicará la inmovilización en la escala.

\section{$2^{\circ}$. Apercibimiento.}

2. Las sanciones se inscribirán en los respectivos expedientes personales con indicación de las faltas que las han motivado.

Artículo 84. Prescripción de las faltas.

1. Las faltas muy graves prescribirán a los dos años desde la fecha de su comisión, las graves al año y las leves al mes.

2. El plazo de prescripción comenzará a contarse desde que la falta se hubiera cometido, salvo que la misma se derive de hechos que hayan sido objeto de condena por delito doloso; en cuyo caso el plazo comenzará a contar desde la fecha de la firmeza de la sentencia condenatoria.
3. La prescripción se interrumpirá por la iniciación del procedimiento disciplinario.

4. Cuando se inicie un procedimiento penal contra un funcionario de los cuerpos de la Policía local, la prescripción de las infracciones disciplinarias que de los hechos pudiesen derivarse quedará interrumpida por la incoación de aquel procedimiento, aun cuando no se hubiera procedido disciplinariamente. En estos supuestos, el plazo volverá a computarse desde la fecha de la firmeza de la resolución judicial.

Artículo 85. Prescripción de las sanciones.

1. Las sanciones por faltas muy graves prescribirán a los tres años, las impuestas por faltas graves al año y las impuestas por faltas leves al mes.

2. El plazo de prescripción comenzará a contarse desde el día siguiente a aquél en que adquiera firmeza la resolución por la que se impone la sanción o desde que se quebrantase su cumplimiento, si hubiera comenzado.

Artículo 86. Cancelación.

1. Las sanciones disciplinarias se anotarán en el registro de personal con indicación de las faltas que las motivan.

2. Transcurridos seis meses desde el cumplimento de la sanción si se tratase de faltas leves, o uno y tres años, respectivamente, según se trate de faltas graves o muy graves no sancionadas con separación del servicio, se acordará de oficio la cancelación de aquellas anotaciones, siempre que durante aquel tiempo no hubiera sido sancionado el interesado por hechos cometidos en esos mismos períodos.

3. La cancelación producirá el efecto de anular la anotación sin que pueda certificarse sobre ella, salvo cuando lo soliciten las autoridades competentes para ello, haciéndose constar expresamente la cancelación, y a los únicos efectos de su expediente personal.

Artículo 87. Procedimiento.

1. No podrán imponerse sanciones por faltas graves o muy graves sino en virtud

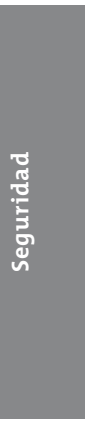


de expediente instruido al efecto, cuya tramitación se determinará reglamentariamente y se regirá, en todo caso, por los principios de sumariedad y celeridad, sin que en ningún momento pueda producirse indefensión.

2. La sanción por faltas leves podrá imponerse sin más trámites que la audiencia del interesado.

\section{TÍTULO VIII VIGILANTES MUNICIPALES $Y$ AUXILIARES DE LA POLICÍA LOCAL}

Artículo 88. Vigilantes municipales.

1. De acuerdo con lo dispuesto en la Ley Orgánica de Fuerzas y Cuerpos de Seguridad, en los Ayuntamientos que no dispongan de cuerpo de Policía local podrán realizarse las funciones de custodia y vigilancia de bienes, servicios e instalaciones con personal funcionario de carrera, que recibirá la denominación de vigilantes municipales.

2. Los Ayuntamientos podrán crear un máximo de dos puestos de trabajo de vigilantes municipales. Si las necesidades del servicio demandasen un número mayor, los Ayuntamientos podrán iniciar la creación del cuerpo de Policía local tal y como se establece en la presente ley.

3. En los Ayuntamientos en que ya exista el cuerpo de Policía local no podrán crearse plazas de vigilantes municipales.

Artículo 89. Funciones.

1. Sin perjuicio de otras que puedan tener asignadas en los respectivos Ayuntamientos, las funciones de carácter policial que podrán desempeñar los vigilantes municipales son las siguientes:

a. Custodiar y vigilar bienes, servicios, instalaciones y dependencias municipales.

b. Ordenar, señalizar y dirigir el tráfico en el suelo urbano legalmente delimitado, de acuerdo con las normas de circulación.

c. Velar por el cumplimiento de las ordenanzas, bandos y demás disposiciones $\mathrm{y}$ actos municipales dentro de su ámbito de competencia. d. Participar en las tareas de auxilio al ciudadano y de protección civil, de acuerdo con lo dispuesto en las leyes.

2. El ejercicio de las funciones de los apartados b) y c) del número 1 habrá de ajustarse a los principios básicos de actuación establecidos en la Ley Orgánica de Fuerzas y Cuerpos de Seguridad, y contemplados en el artículo 7 de la presente ley, ostentando en el ejercicio de sus competencias la condición de agentes de la autoridad.

Artículo 90. Ámbito de actuación.

1. El ámbito de actuación de los vigilantes municipales será el del Ayuntamiento a que pertenezcan, sin perjuicio de lo dispuesto en la legislación vigente en cada caso para los supuestos de catástrofe o calamidad pública.

2. Los Ayuntamientos que sólo dispongan de vigilantes municipales podrán acogerse a lo dispuesto en el artículo 6 de la presente ley, de modo que en fechas determinadas puedan atender las necesidades del servicio de seguridad del Ayuntamiento con la actuación de miembros de las policías locales, o vigilantes municipales, en su caso, de otros Ayuntamientos con los que previamente se hubiese celebrado el convenio oportuno.

Artículo 91. Organización y funcionamiento.

1. Con carácter general, los vigilantes municipales estarán sometidos a las mismas normas de organización y funcionamiento que el resto de funcionarios del Ayuntamiento.

2. Donde exista cuerpo de Policía local $\mathrm{y}$, por tanto, los vigilantes municipales sean una clase a extinguir, dependerán orgánica y funcionalmente del mismo, siéndoles de aplicación las normas comunes de funcionamiento $\mathrm{y}$, asimismo, los deberes y derechos que no sean exclusivos del personal sometido al estatuto policial establecido por el propio reglamento.

Artículo 92. Ingreso.

1. Las plazas de vigilante municipal serán ocupadas por funcionarios de carrera. 
2. La selección se hará por el procedimiento de oposición, siguiendo criterios semejantes a los fijados para los integrantes de los cuerpos de la Policía local, contemplados en el artículo 33 de la presente ley, adaptando las pruebas de conocimientos a la titulación correspondiente, siempre de acuerdo con la normativa aplicable a la selección de los funcionarios de la Administración local.

3. Para el acceso a vigilante municipal se requerirá la certificación de haber superado la enseñanza secundaria obligatoria, título de graduado escolar o equivalente, correspondiente al grupo D de los establecidos en el artículo 25 de la Ley 30/1984, de 2 de agosto, de Medidas para la Reforma de la Función Pública.

4. El acceso a la condición de vigilante municipal requerirá inexcusablemente que los aspirantes realicen y superen previamente un curso de formación programado por la Academia Gallega de Seguridad Pública y adaptado a las características de su función.

Artículo 93. Régimen estatutario. Sin perjuicio de lo dispuesto en la presente ley, los vigilantes municipales se regirán por el estatuto aplicable a los funcionarios de la Administración local.

Artículo 94. Uniformidad y medios técnicos.

1. Los vigilantes municipales actuarán con el uniforme y distintivos propios de su clase, de conformidad con lo que se disponga reglamentariamente por la Xunta de Galicia en desarrollo de la presente ley.

2. En todo caso, la uniformidad de los vigilantes municipales habrá de diferenciarse claramente de la que sea propia de los cuerpos de la Policía local.

3. Los vigilantes municipales no podrán portar armas de fuego.

Artículo 95. Auxiliares de Policía local.

1. En los Ayuntamientos con aumento notorio de población en temporadas determinadas podrá incrementarse transitoriamente su plantilla de personal mediante la contratación de personal con funciones de auxiliar de policía. Dicho incremento no superará el cincuenta por ciento del personal funcionario de la Policía local, no pudiendo tampoco tener una duración de más de cuatro meses en período anual.

2. El establecimiento del personal a que se refiere este apartado requerirá la tramitación por los respectivos Ayuntamientos de un expediente motivado, del cual habrá de darse cuenta a la consellería competente en materia de seguridad de la Xunta de Galicia.

3. Los auxiliares de Policía local desempeñarán las funciones de apoyo y de auxilio a los miembros del cuerpo de Policía local en el marco de lo dispuesto en la legislación de cuerpos y fuerzas de seguridad.

4. La selección se hará siguiendo criterios semejantes a los fijados para los integrantes de los cuerpos de la Policía local, contemplados en el artículo 35 de la presente ley.

5. Para el acceso a auxiliar de la Policía local se requerirá la certificación de haber superado la enseñanza secundaria obligatoria, título de graduado escolar o equivalente, correspondiente al grupo D de los establecidos en el artículo 25 de la Ley 30/1984, de 2 de agosto, de Medidas para la Reforma de la Función Pública.

6. Para poder ejercer estas funciones, los auxiliares tendrán que superar previamente un curso teórico-práctico en la Academia Gallega de Seguridad Pública.

7. En determinados casos, debida y objetivamente justificados a la consellería competente, podrá permitirse la contratación a los Ayuntamientos de un número de auxiliares superior al mencionado en el apartado 1 de este artículo, o por plazo de tiempo superior que no excederá, en todo caso, de los seis meses dentro del año natural.

Artículo 96. Uniformidad.

Para el desempeño de sus funciones, los auxiliares de Policía local deberán vestir el uniforme correspondiente al cuerpo de 
Policía local en que presten temporalmente sus servicios, diferenciándose de aquéllos en las siguientes particularidades:

a. No llevarán placa-emblema ni distintivo alguno en las hombreras y harán constar su condición con la leyenda de "Auxiliar de policía local".

b. Irán provistos de un documento de acreditación semejante al de los miembros de los cuerpos de Policía local, en el cual se sustituirá la categoría de policía por "auxiliar de Policía local", y su número de identificación, dado por el Ayuntamiento, irá precedido de una "A" mayúscula.

\section{DISPOSICIÓN ADICIONAL PRIMERA REINTEGRACIÓN DE CATEGORÍAS DE LOS CUERPOS DE LA POLICÍA LOCAL DE GALICIA}

1. A partir de la entrada en vigor de la presente ley, las anteriores categorías de inspector, subinspector, oficial, suboficial, sargento, cabo y guardia pasarán a integrarse en las siguientes categorías: inspector en la de superintendente, subinspector en la de intendente principal, oficial en la de intendente, suboficial en la de inspector principal, sargento en la de inspector, cabo en la de oficial y guardia en la de policía.

2. Donde no exista cuerpo de Policía local, los auxiliares de Policía local o los funcionarios con funciones semejantes, cualquiera que sea su denominación, pasarán a denominarse vigilantes municipales.

\section{DISPOSICIÓN ADICIONAL SEGUNDA INTEGRACIÓN DE LOS VIGILANTES Y AUXILIARES DE POLICIAA O INTERINOS EN LOS CUERPOS DE POLICÍA LOCAL}

Los vigilantes y auxiliares de policía e interinos, con una antigüedad mínima en estos puestos de tres años continuados en la respectiva entidad local y que en el momento de la entrada en vigor de la presente ley estén prestando servicios en el Ayuntamiento de que se trate, se integrarán en el cuerpo de Policía local ya existente o en el que se cree, previa superación, en un plazo de dos años desde la entrada en vigor de la presente ley y por un máximo de dos convocatorias, de un concurso-oposición con dispensa de los requisitos de edad y estatura. A la titulación exigida en dicho concurso se equipara la superación de un curso específico que a tal efecto impartirá la Academia Gallega de Seguridad Pública.

\section{DISPOSICIÓN TRANSITORIA PRIMERA CLASIFICACIÓN E INTEGRACIÓN DE LOS FUNCIONARIOS DE LA POLICÍA LOCAL}

1. En el plazo de tres años desde la entrada en vigor de la presente ley, los funcionarios de los cuerpos de Policía local de la escala básica, ejecutiva, técnica y superior se entenderán clasificados, únicamente a los efectos retributivos, en los grupos C, B y A, sin que este hecho pueda suponer necesariamente un incremento de gasto público ni modificación del cómputo anual de las retribuciones totales de los funcionarios de esas escalas y categorías.

2. Transcurridos tres años, a contar desde la entrada en vigor de la presente ley, los funcionarios que posean la titulación académica requerida para el acceso a las escalas y categorías en que se les reclasifica quedarán integrados, a todos los efectos, en las mismas. Por el contrario, aquellos que carezcan de la citada titulación académica quedarán integrados, a todos los efectos, en las escalas y categorías en que se les reclasifica, pero en este caso en la situación de "a extinguir", permaneciendo en las mismas hasta que acrediten la obtención de los niveles de titulación académica exigidos en cada caso o superen las actividades formativas que, a los efectos de promoción interna, pudieran establecerse.

3. Los trienios que se hayan perfeccionado en las escalas y categorías que estructuran la Policía local con anterioridad a la entrada en vigor de la Ley de Policía de la Comunidad Autónoma de Galicia se valorarán de acuerdo con el grupo de clasificación a que 
pertenecía el funcionario en el momento de su perfeccionamiento.

4. La clasificación de los funcionarios de la Policía local prevista en la presente disposición se llevará a efecto de modo que no suponga necesariamente incremento en el cómputo conjunto de sus retribuciones. En estos casos percibirán el sueldo base y los trienios correspondientes al nuevo grupo de titulación, pero el exceso sobre el del grupo anterior se deducirá de sus retribuciones complementarias, preferentemente del concepto de productividad, si lo hay, referidas a catorce mensualidades al cómputo anual, de forma que se perciban idénticas remuneraciones globales respecto a la situación anterior.

\section{DISPOSICIÓN TRANSITORIA SEGUNDA PROCEDIMIENTOS SELECTIVOS EN CURSO EN LOS CUERPOS DE POLICIAA LOCAL}

Los procesos de selección convocados con anterioridad a la entrada en vigor de la presente ley se regirán, en cuanto a las titulaciones a exigir para el acceso al cuerpo, por la normativa anterior.

\section{DISPOSICIÓN TRANSITORIA TERCERA SEGUNDA ACTIVIDAD}

Los funcionarios que hayan cumplido, en el momento de la entrada en vigor de la presente ley, la edad mínima establecida en la misma para el pase a la situación de segunda actividad irán accediendo a esta última de manera gradual. Los Ayuntamientos deberán regularizar la situación en el plazo de cinco años, a contar desde la entrada en vigor de la presente ley.

\section{DISPOSICIÓN DEROGATORIA ÚNICA DEROGACIÓN NORMATIVA}

Queda derogada la Ley 3/1992, de 23 de marzo, de coordinación de las policías locales, y todas las disposiciones de igual o inferior rango en lo que se opongan o contradigan lo establecido en la presente ley.

\section{DISPOSICIÓN FINAL PRIMERA DESARROLLO NORMATIVO}

Se faculta al Consello de la Xunta de Galicia para realizar el desarrollo reglamentario de la presente ley.

El decreto de homologación de los distintivos de acreditación profesional y registro de policías locales se publicará en el plazo de seis meses desde la entrada en vigor de la presente ley.

\section{DISPOSICIÓN FINAL SEGUNDA REGLAMENTO DE LA SEGUNDA ACTIVIDAD}

Las circunstancias y condiciones de la situación administrativa de la segunda actividad no contempladas en la presente ley se determinarán reglamentariamente.

\section{DISPOSICIÓN FINAL TERCERA ENTRADA EN VIGOR.}

La presente ley entrará en vigor a los veinte días de su publicación en el "Diario Oficial de Galicia”.

\section{LEY 1/2007, DE 15 DE ENERO, DE LA ACADEMIA GALLEGA DE SEGURIDAD PÚBLICA (DOGA N. $\left.^{\circ} 16,23.1 .2007\right)^{506}$}

\section{$(\ldots)^{507}$}

Artículo 1. Naturaleza jurídica.

1. Se crea la Academia Gallega de Seguridad Pública (AGASP) como organismo autónomo de carácter administrativo adscrito orgánicamente a la consellería competente en materia de interior y justicia.

2. Para el cumplimiento de sus fines la Academia Gallega de Seguridad Pública goza de personalidad jurídica propia, autonomía funcional y plena capacidad de obrar. Dispone de patrimonio propio y se regirá por la presente ley y, de forma supletoria, por las demás normas que

506 Véase Orden de 4 de febrero de 2009 por la que se aprueba el Reglamento de régimen interior de la Academia Gallega de Seguridad Pública (Agasp).

507 Exposición de motivos omitida. 
le sean de aplicación de acuerdo con su naturaleza jurídica.

Artículo 2. Sede.

La sede de la Academia Gallega de Seguridad Pública radica en la localidad pontevedresa de A Estrada, sin perjuicio de la organización de actividades formativas en otras localidades de la Comunidad Autónoma de Galicia.

Artículo 3. Fines.

La Academia Gallega de Seguridad Pública orientará su actuación al:

1. Enriquecimiento del capital humano de los servicios de seguridad pública mediante su capacitación a través de la formación, la innovación y la excelencia.

2. Compromiso de generar y transferir las bases de conocimiento para la mejora de las políticas en materia de seguridad pública.

3. Impulso de la calidad en los servicios de seguridad pública para una mejor atención al ciudadano y mayor satisfacción de sus gestores.

Artículo 4. Funciones formativas. Las funciones formativas de la Academia Gallega de Seguridad Pública son las siguientes:

1. En el ámbito de la formación judicial y penitenciaria y de la seguridad privada: Organizar y realizar en las materias de seguridad pública, en colaboración con el Consejo General del Poder Judicial y los ministerios competentes en materia de justicia e interior, así como con otros organismos, universidades o centros de investigación, actividades dirigidas a la formación de jueces y fiscales, de los funcionarios de instituciones penitenciarias y de los trabajadores de la seguridad privada, a través de la celebración de los oportunos convenios.

2. En el ámbito de la formación policial:

a. Elaborar los programas formativos e impartir los cursos dirigidos al ingreso y promoción interna en las distintas escalas de los cuerpos de la policía de Galicia y de las policías locales, así como su formación continua, perfeccionamiento y especialización. b. Colaborar con las administraciones competentes en la selección del personal de los cuerpos de la policía de Galicia y de las policías locales.

c. Facilitar a los Ayuntamientos los medios de conocimiento e información precisos para una mejor ejecución de los servicios específicos de las policías locales.

3. En el ámbito de la formación de protección civil, bomberos y agentes forestales:

a. Elaborar los programas formativos e impartir los cursos de formación y perfeccionamiento dirigidos a los integrantes de los servicios de protección civil y a los miembros de los cuerpos de bomberos de las entidades locales con las que se formalice el correspondiente convenio de colaboración.

b. Impartir los cursos dirigidos a los agentes forestales.

c. Colaborar con las entidades locales en la selección y formación continua del personal integrante de los cuerpos de bomberos y de protección civil.

d. Facilitar a los Ayuntamientos los medios de conocimiento e información precisos para una mejor ejecución de los servicios específicos de bomberos y protección civil, celebrándose los convenios oportunos.

Artículo 5. Otras funciones.

Son también funciones de la Academia Gallega de Seguridad Pública en las materias que le son propias:

1. Investigar, estudiar y divulgar contenidos, técnicas y documentación, con especial referencia a la realidad gallega.

2. Promover relaciones de intercambio y colaboración con las universidades e instituciones de Galicia, así como con otros centros docentes e investigadores de ámbito autonómico, estatal o internacional.

3. Homologar, cuando proceda, los títulos correspondientes a los cursos de formación impartidos por otras academias, escuelas o centros.

4. Cualesquiera otras que le puedan ser atribuidas por las normas, de conformidad con su naturaleza. 
Artículo 6. Medidas de fomento.

1. Para la consecución de sus fines, la Academia Gallega de Seguridad Pública podrá convocar y otorgar becas, ayudas y premios, así como llevar a cabo otras medidas de fomento dirigidas a favorecer la investigación, facilitar la incorporación de mujeres a los cuerpos de seguridad $\mathrm{y}$ obtener una adecuada formación e innovación de los servicios gallegos de seguridad pública.

2. A los efectos de las disposiciones vigentes, la Academia Gallega de Seguridad Pública tiene el carácter de centro oficial de investigación.

\section{Artículo 7. Órganos.}

1. Los órganos de gobierno y administración de la Academia Gallega de Seguridad Pública son:

a. El Consello Reitor.

b. El/la director/a general.

2. El órgano asesor en materia de formación continua en el campo de la seguridad pública será el Consello Autonómico de Formación Continua para os empregados públicos da seguridade.

Artículo 8. Composición del Conse1lo Reitor.

El Consello Reitor de la Academia Gallega de Seguridad Pública está formado por un Presidente, un vicepresidente, ocho vocales y un secretario.

1. Presidente: La persona titular de la consellería competente en materia de interior y justicia.

2. Vicepresidente: El/la director/a general de la Academia Gallega de Seguridad Pública.

3. Vocales:

a. La persona titular de la dirección general competente en materia de interior.

b. La persona titular de la dirección general competente en materia de protección civil.

c. La persona titular de la dirección de la Escola Galega de Administración Pública. d. Un representante, con categoría al menos de Director general, del departamento competente en materia de menores.

e. Tres vocales designados por la presidencia del Consello Reitor entre personas expertas y de prestigio en materias de seguridad pública.

f. Un representante de los Ayuntamientos de Galicia, designado por la Federación Gallega de Municipios y Provincias.

La condición del vocal representante de los Ayuntamientos estará vinculada a la representatividad poseída, perdiéndose al desaparecer la misma.

4. Secretario: La persona titular de la secretaría general de la Academia Gallega de Seguridad Pública, que actuará además como secretario del Consello Reitor.

Artículo 9. Funciones del Consello Reitor.

1. El Consello Reitor de la Academia Gallega de Seguridad Pública es el órgano colegiado de control, planificación y supervisión general de la actividad del centro.

2. El Consello Reitor debe conocer y aprobar:

a. Las directrices generales de actuación del organismo.

b. El plan anual de actividades.

c. La memoria de las actividades del ejercicio anterior.

d. El reglamento de régimen interior.

e. Los programas mínimos para el ingreso, la formación y la promoción interna a las distintas escalas de los cuerpos de la policía de Galicia y de las policías locales.

f. El anteproyecto del presupuesto anual de la academia y sus cuentas.

3. El Consello Reitor debe conocer y emitir informe sobre:

a. Aquellas normas relativas a las disposiciones y actos que afecten a las funciones que la academia tiene encomendadas en la presente ley.

b. Los asuntos que el Presidente del Consello Reitor o el Director general de la 
Academia Gallega de Seguridad Pública sometan a su consideración.

4. El Consello Reitor debe ser informado de:

a. La estructura orgánica y la plantilla de la academia.

b. Los convenios de colaboración y cooperación suscritos por su Presidente.

c. Los baremos reguladores de las remuneraciones de las actividades docentes en el caso del personal colaborador a que se refiere el artículo $15.2^{\circ}$.

Artículo 10. Funcionamiento del Consello Reitor.

1. El funcionamiento del Consello Reitor se ajustará a lo dispuesto en la Ley de Régimen Jurídico de las Administraciones Públicas y del Procedimiento Administrativo Común, título II, capítulo II, sobre órganos colegiados.

2. El Consello Reitor se reunirá como mínimo una vez cada año, y en cualquier caso siempre que sea convocado por el Presidente o sea solicitado por una tercera parte de sus miembros.

3. El Presidente del Consello Reitor o el Director general de la Academia Gallega de Seguridad Pública podrán convocar a técnicos o especialistas a las reuniones para asesoramiento.

Artículo 11. El/la director/a general. El/la director/a general de la Academia Gallega de Seguridad Pública será nombrado/a por decreto de la Xunta de Galicia, a propuesta de la persona titular de la consellería competente en materia de interior y justicia, entre personas con acreditados conocimientos y experiencia en las materias objeto de la actividad del centro.

Artículo 12. Funciones del director/a general.

Corresponde al director/a general de la Academia Gallega de Seguridad Pública:

1. Ostentar la representación ordinaria del organismo.

2. Ejecutar los acuerdos del Consello Reitor.
3. Elaborar el anteproyecto de presupuesto anual, que será puesto en conocimiento del Consello Reitor.

4. Proponer al Consello Reitor el plan anual de actividades.

5. Elaborar el reglamento de régimen interior.

6. Dirigir la gestión presupuestaria, autorizar y disponer los gastos y ordenar los pagos.

7. Dirigir los servicios administrativos y ejercer la jefatura de personal de la Academia Gallega de Seguridad Pública de Galicia.

8. Preparar la memoria de actividades para someterla al Consello Reitor.

9. Expedir diplomas y certificados.

10. Homologar, cuando proceda, los títulos correspondientes a los cursos de formación impartidos por otras academias, escuelas o centros.

11. Las funciones que pueda delegarle el Consello Reitor o el Presidente del mismo y aquellas otras competencias que, correspondiendo a la Academia Gallega de Seguridad Pública, no se encuentren atribuidas legal o reglamentariamente a otro órgano de ésta.

Artículo 13. El Consello Autonómico de Formación Continua para os empregados públicos da seguridade.

El Consello Autonómico de Formación Continua para os empregados públicos da seguridade actuará como órgano asesor de la academia en materia de formación continua en el campo de la seguridad pública y estará formado por representantes de las administraciones públicas y de los sindicatos y asociaciones de los colectivos mencionados en el artículo 4. Su estructura y régimen de funcionamiento serán determinados por decreto de la Xunta de Galicia a propuesta de la persona titular de la consellería competente en materia de interior y justicia.

Artículo 14. Estructura orgánica.

Para la realización de sus funciones, la Academia Gallega de Seguridad Pública 
tendrá asignadas las unidades organizativas que se determinen por decreto de la Xunta de Galicia a propuesta de la persona titular de la consellería competente en materia de interior y justicia.

Artículo 15. Personal.

1. Los puestos de trabajo de la Academia Gallega de Seguridad Pública serán cubiertos por personal funcionario o laboral de la Comunidad Autónoma de Galicia o, en los casos en que proceda, por personal de otras administraciones públicas, de acuerdo con lo dispuesto en la Ley de la Función Pública de Galicia.

2. Los miembros integrantes del personal docente o investigador que no formen parte de la plantilla de la Academia Gallega de Seguridad Pública tendrán la condición de colaboradores temporales y el derecho a percibir las compensaciones económicas que les correspondan por asistencia, horas lectivas, conferencias, seminarios o trabajos determinados. Estas colaboraciones se regirán por lo dispuesto en la Ley de Contratos de las Administraciones Públicas sobre régimen de contratación para actividades docentes.

3. La Academia Gallega de Seguridad Pública podrá encargar trabajos de investigación, estudios y documentación para el mejor cumplimiento de sus fines, ateniéndose a las normas sobre contratación administrativa del sector público que sean de aplicación.

Artículo 16. Recursos económicos y patrimonio.

1. La Academia Gallega de Seguridad Pública dispondrá, para el cumplimiento de sus fines, de los siguientes recursos:

a. Las cantidades que se le asignen en los presupuestos generales de la Comunidad Autónoma.

b. Los bienes y derechos que constituyan su patrimonio y los rendimientos del mismo.

c. Las subvenciones y otras aportaciones públicas o privadas.

d. Las contraprestaciones derivadas de los convenios en que sea parte. e. Los derechos de matrícula de los cursos, en su caso.

f. Los rendimientos de las publicaciones y cualquier otro servicio retributivo del centro que así se establezca.

2. Tendrán carácter de patrimonio adscrito los bienes que le adscriba la Comunidad Autónoma.

Artículo 17. Régimen de recursos.

1. Los actos administrativos dictados por los órganos de gobierno y administración de la Academia Gallega de Seguridad Pública podrán ser objeto de recurso de alzada ante la persona titular de la consellería competente en materia de interior y justicia. La resolución dictada pondrá fin a la vía administrativa, pudiendo ser objeto de los recursos previstos en la legislación general sobre el procedimiento administrativo y en la legislación sobre la jurisdicción contencioso-administrativa.

2. El recurso extraordinario de revisión será interpuesto ante la persona titular de la consellería competente en materia de interior y justicia, de acuerdo con el procedimiento específico previsto en la Ley de Régimen Jurídico de las Administraciones Públicas y del Procedimiento Administrativo Común.

3. El ejercicio de las acciones civiles y laborales se regirá por las normas específicas, formulándose ante la persona titular de la consellería competente en materia de interior y justicia, que será competente para resolver, sin perjuicio de recabar los informes que estime oportunos a los órganos de la Academia Gallega de Seguridad Pública.

\section{DISPOSICIÓN TRANSITORIA PRIMERA}

La Academia Gallega de Seguridad Pública asumirá el patrimonio, las obligaciones y los derechos presupuestarios, así como los convenios firmados en materia de seguridad pública por el extinto Centro de Estudios Judiciales y Seguridad Pública de Galicia. 
Código de la Administración Gallega

\section{DISPOSICIÓN TRANSITORIA SEGUNDA}

$\mathrm{El}$ personal que figure como dependiente del Centro de Estudios Judiciales y Seguridad Pública de Galicia en la correspondiente relación de puestos de trabajo pasará a depender de la nueva Academia Gallega de Seguridad Pública, conservando sus derechos económicos y administrativos.

\section{DISPOSICIÓN TRANSITORIA TERCERA}

El plan y los cursos de formación elaborados y convocados por el Centro de Estudios Judiciales y Seguridad Pública de Galicia serán asumidos por la nueva Academia Gallega de Seguridad Pública.

\section{DISPOSICIÓN DEROGATORIA}

Queda derogada la Ley 1/2005, de 4 de enero, del Centro de Estudios Judiciales y Seguridad Pública de Galicia, el Decreto $575 / 2005$, de 15 de diciembre, y las demás disposiciones que se opongan a lo dispuesto en la presente ley.

\section{DISPOSICIÓN FINAL PRIMERA}

Se faculta a la Xunta de Galicia para dictar las disposiciones necesarias para el desarrollo y cumplimiento de la presente ley.

\section{DISPOSICIÓN FINAL SEGUNDA}

La presente ley entrará en vigor el día siguiente al de su publicación en el "Diario Oficial de Galicia". 


\section{$\mathrm{XI}$ \\ MEDIOS E INFRAESTRUCTURAS DE TRANSPORTES}

\author{
1. LEY 4/1994, DE 14 DE \\ SEPTIEMBRE, DE CARRETERAS \\ DE GALICIA (DOGA N. ${ }^{\circ} 210$, \\ 31. 10. 1994) \\ $(\ldots)^{508}$

\section{Capitulo I \\ DISPOSICIONES GENERALES}

Sección 1. ${ }^{\mathrm{a}}$

Objeto y definiciones

Artículo 1. Es objeto de la presente ley la regulación de la planificación, proyecto, construcción, conservación, financiación, uso y explotación de las carreteras con itinerario comprendido íntegramente en el territorio de la Comunidad Autónoma de Galicia y que no sean de titularidad del Estado.

Artículo 2. 1. A los efectos de esta ley se consideran carreteras las vías de dominio y uso público proyectadas y construidas fundamentalmente para la circulación de vehículos automóviles, cuyo itinerario no se desarrolle íntegramente en suelo calificado como urbano por el correspondiente instrumento de planeamiento urbanístico, con las excepciones que puedan derivarse de lo dispuesto respecto a las redes arteriales.

2. Por sus características, las carreteras se clasifican en autopistas, autovías, corredores, vías rápidas y carreteras convencionales:

1) Son autopistas las carreteras que están especialmente proyectadas, construidas y señalizadas como tales para la exclusiva circulación de automóviles y que reúnen las siguientes características:

a. No tener acceso a ellas las propiedades contiguas.

508 Exposición de motivos omitida. b. No cruzar a nivel ninguna otra senda, vía, línea de ferrocarril o de tranvía, ni ser cruzadas a nivel por ninguna senda, vía de comunicación o servidumbre de paso.

c. Constar de distintas calzadas para cada sentido de circulación, separadas entre sí, salvo en puntos singulares o con carácter temporal, por una franja de terreno no destinada a la circulación o, en casos excepcionales, por otros medios.

2) Son autovías las carreteras que, no reuniendo todos los requisitos de las autopistas, tienen calzadas separadas para cada sentido de la circulación y limitación de accesos desde las propiedades contiguas.

3) Son corredores las carreteras con limitación de accesos desde las propiedades contiguas, constituidas por una sola calzada, que sean proyectadas con previsión de su futuro desdoblamiento. Las obras de fábrica, en su caso, se realizarán teniendo en cuenta dicha previsión. Los municipios recogerán en sus instrumentos de planeamiento dichos usos futuros ${ }^{509}$.

4) Son vías rápidas las carreteras de una sola calzada y con limitación total de accesos de y a las propiedades contiguas.

5) Son carreteras convencionales las que no reúnen las características propias de las autopistas, autovías, corredores o vías rápidas.

3. Reglamentariamente se establecerán las limitaciones a la circulación en las carreteras de los diferentes tipos de vehículos.

4. Son áreas de servicio las zonas contiguas a las carreteras diseñados expresamente para albergar instalaciones y servicios destinados a la cobertura de las

${ }^{509}$ Art. 2.2.3 modificado por Ley $7 / 2002$, de 27 de diciembre, de medidas fiscales y de régimen administrativo. 
necesidades de la circulación y facilitar la comodidad y seguridad de los usuarios de la carretera, pudiendo incluir estaciones de suministro de carburantes, hoteles, restaurantes, talleres de reparación y otros servicios análogos.

5. Es elemento funcional de una carretera todo terreno o instalación permanentemente afecto a la conservación de la misma o a la explotación del servicio público viario que haya sido adquirido mediante título legítimo por la Administración titular de la carretera o entidad concesionaria de su explotación, en su caso.

Artículo 3. 1. A los efectos de esta ley no tendrán la consideración de carretera, ni se incluirán, por tanto, en las redes de la Comunidad Autónoma, de las provincias o de los municipios:

a. Las vías que componen la red urbana de comunicaciones municipales.

b. Los caminos de servicio cuyos titulares sean el Estado, la Comunidad Autónoma, las entidades locales y demás entidades de derecho público.

c. Los caminos construidos por las personas o entidades privadas con finalidad análoga a los caminos de servicio.

2. Se consideran caminos de servicio los construidos como elementos auxiliares o complementarios de las actividades específicas de sus titulares, a quienes corresponde atender a todos los gastos que ocasione su construcción, reparación y conservación.

Cuando las circunstancias que concurran en los caminos de servicio lo permitan y lo exija el interés general, habrán de abrirse éstos al uso público, según su naturaleza y legislación específica.

Artículo 4. La titularidad de las carreteras de Galicia corresponde a la Comunidad Autónoma o a las entidades locales.

El Consello de la Xunta de Galicia, a propuesta de la consellería competente en materia de carreteras, aprobará por
Decreto la relación de las carreteras de titularidad autonómica ${ }^{510}$.

Las entidades locales aprobarán asimismo la relación de carreteras de titularidad provincial y municipal.

Dichas aprobaciones se harán de acuerdo con los correspondientes planes de carreteras, y podrán modificarse en los siguientes supuestos:

a. Por cambio de titularidad de carreteras, con arreglo a los procedimientos de esta ley.

b. Por construcción de nuevas carreteras.

c. Por variación de trazado en carretera existentes.

Artículo 5. Los cambios de titularidad de carreteras incluidas en las redes dependientes de la Comunidad Autónoma y de las entidades locales habrán de ser aprobados por Decreto de la Xunta de Galicia, a propuesta de la consellería competente en materia de carreteras y previo acuerdo entre las Administraciones afectadas.

\section{Sección 2. ${ }^{\mathrm{a}}$ Competencias}

Artículo 6. Corresponde al Consello de la Xunta de Galicia:

a. Aprobar los planes de carreteras de Galicia y sus modificaciones, en los términos previstos en la presente ley, que serán remitidos para su examen al Parlamento de Galicia.

b. Aprobar la relación y clasificación de las carreteras de titularidad de las entidades locales, en defecto del correspondiente plan.

c. Aprobar la incorporación a la red de titularidad autonómica, en su caso, de los caminos particulares, así como de los caminos de servicio, cuando sean abiertos a uso público con carácter permanentes.

d. Aprobar la incorporación de carreteras o de tramos de ellas de otras redes a la

510 Véase Decreto 308/2003, de 26 de junio, por el que se aprueba la relación de carreteras de titularidad de la Comunidad Autónoma de Galicia. 
red de titularidad autonómica o viceversa, previo acuerdo entre las Administraciones afectadas.

e. Otorgar las concesiones de explotación de nuevas carreteras con itinerario comprendido íntegramente en el territorio de la Comunidad Autónoma de Galicia que no sean de competencia local.

f. Aprobar las redes arteriales y adscribir las vías incluida en ellas a las redes de titularidad autonómica, provincial o municipal, según corresponda.

g. Aprobar la relación de carreteras de Galicia que pertenecen a la categoría de autopistas, autovía, corredor o vía rápida.

h. Las restantes competencias que le encomiende el ordenamiento jurídico vigente.

Artículo 7. Corresponde a la consellería competente en materia de carreteras:

a. Elaborar el plan de carreteras de la Comunidad Autónoma.

b. Elevar al Consello de la Xunta de Galicia los expedientes que hayan de serle sometidos, conforme al artículo anterior.

c. Aprobar los estudios, anteproyectos y proyectos relativos a carreteras de titularidad autonómica.

d. Ejercer las facultades necesarias para la construcción, conservación y explotación de las carreteras de titularidad autonómica.

e. Coordinar los planes provinciales y municipales de carreteras y supervisar su ejecución.

f. Otorgar las concesiones de elementos susceptibles de explotación individualizada en áreas de servicio de carreteras de titularidad autonómica con control de accesos.

g. Aprobar, en el ámbito de sus competencias, la normativa técnica y administrativa para las carreteras de titularidad autonómica, provincial y municipal.

h. Cuantas otras facultades no estén expresamente atribuidas a otros órganos de la Administración en las materias a que se refiere la presente ley.
Artículo 8. Corresponde a las entidades locales el ejercicio de las siguientes competencias:

1. El proyecto, construcción, gestión, explotación, conservación y señalización de los tramos de la red de su titularidad, así como el ejercicio en la misma de las funciones de disciplina viaria, sin perjuicio de los acuerdos que pueda alcanzar con la Xunta de Galicia para el desempeño de estas cuestiones.

2. Las restantes previstas en el ordenamiento jurídico.

\section{Capitulo II RÉGIMEN DE LAS CARRETERAS}

\section{Sección $1 .^{a}$}

Planificación. Estudios y proyectos

Artículo 9. Los planes de carreteras de Galicia habrán de coordinarse entre sí, mediante los procedimientos establecidos en los artículos 11 y 12 de la presente ley, para garantizar la funcionalidad del sistema de comunicaciones y armonizar los intereses públicos afectados.

Corresponde a la consellería competente en materia de carreteras fijar las directrices de coordinación y planificación en materia de carreteras de Galicia, a fin de garantizar la coherencia y funcionalidad del sistema viario de la Comunidad Autónoma.

Artículo 10. 1. Los planes de carreteras comprenderán las previsiones, los objetivos y la programación de actuaciones en las mismas, así como los criterios de revisión del propio plan. En ellos, las carreteras se clasificarán en tres redes: Primaria básica, primaria complementaria y secundaria.

2. La red primaria básica está formada por grandes ejes que, junto con la red de interés general del Estado, vertebran el territorio, lo conectan con la red de carreteras de las Comunidades Autónomas vecinas y relacionan entre sí tanto los grandes centros de población como los principales lugares de actividad económica. 
3. La red primaria complementaria comprende las demás carreteras que conectan con las cabeceras comarcales y con los núcleos de población importantes.

4. La red secundaria comprende todas las carreteras no incluidas en las redes básica y complementaria.

5. Los planes de carreteras incluirán el análisis y diagnóstico de la red existente en el momento de su redacción, las previsiones de la situación de la red de carreteras al final del período de vigencia del plan, la programación de actuaciones y el estudio económico y financiero.

Artículo 11. 1. Para las carreteras que sean de titularidad de las diputaciones, los planes provinciales de carreteras contendrán la clasificación de la red de su titularidad.

2. La elaboración, redacción y aprobación inicial de los planes provinciales a que se refiere el apartado anterior, así como las modificaciones de los mismos, corresponden a las respectivas entidades provinciales. Redactado el plan, y antes de su aprobación inicial por el Pleno de la Diputación, éste se someterá a informe de los Ayuntamientos afectados. Dichos informes habrán de ser evacuados en el plazo de dos meses, y se entenderá que son favorables si no se han emitido en el referido plazo.

La aprobación definitiva de estos planes corresponderá al Consello de la Xunta de Galicia, previo informe de la Consellería competente en materia de carreteras, dándose por producida dicha aprobación por el transcurso de seis meses desde la entrada del expediente en el Registro del Ayuntamiento sin que éste comunique resolución. Las determinaciones del plan se consideran vinculantes a efectos de su inclusión en los programas de inversiones de las Diputaciones.

Artículo 12. 1. Los Ayuntamientos pueden formular planes municipales de carreteras cuando así lo decidan o lo exija la densidad de las redes existentes.
2. La elaboración de los planes municipales, así como las modificaciones de los mismos, corresponden a las respectivas entidades locales y su aprobación inicial a los plenos de las mismas. Después de haberlos aprobado inicialmente, serán sometidos a informe de la Diputación Provincial, que habrá de emitirlo en el plazo de dos meses, y se entenderá que es favorable si no se ha emitido en dicho plazo.

La aprobación definitiva de estos planes corresponderá al Consello de la Xunta de Galicia, previo informe de la consellería competente en materia de carreteras, dándose por producida dicha aprobación por el transcurso de seis meses desde la entrada del expediente completo en el Registro del Ayuntamiento sin que éste comunique resolución.

Artículo 13. 1. Todos los estudios, anteproyectos y proyectos a que hace referencia este capítulo se redactarán con sujeción a las normas técnicas aprobadas por la Administración competente, particularmente en lo que se refiere a la señalización y balizamiento de carreteras, así como a cualquier otro aspecto que se derive del cumplimiento de tratados, convenios, acuerdos y recomendaciones de carácter internacional suscritos por el Estado español.

2. Los proyectos de nuevas carreteras cuyos titulares sean las entidades locales serán aprobados por la corporación correspondiente y sometidos a informe previo con carácter vinculante de la consellería competente en materia de carreteras.

Artículo 14. 1. Los estudios de carreteras que en cada caso requieran la ejecución de una obra se adaptarán a los siguientes tipos establecidos en razón de su finalidad:

a. Estudio de planeamiento. Consiste en la definición de un esquema vial en un determinado año horizonte, así como sus características y dimensiones recomendables, necesidades de suelo y otras 
limitaciones a la vista del planeamiento territorial y de transporte.

b. Estudio previo. Consiste en la recopilación y análisis de los datos necesarios para definir, en líneas generales, las diferentes soluciones de un determinado problema, valorando todos sus efectos.

c. Estudio informativo. Consiste en la definición, en líneas generales, del trazado de la carretera a efectos de que pueda servir de base para el expediente de información pública que pueda incoarse.

d. Anteproyecto. Consiste en el estudio a escala adecuada y en la consiguiente evaluación de las mejores soluciones al problema planteado, de modo que pueda concretarse la solución óptima.

e. Proyecto de construcción. Consiste en el desarrollo completo de la solución óptima, con el detalle necesario para que sea factible su construcción y posterior explotación.

f. Proyecto de trazado. Es la parte del proyecto de construcción que contiene los aspectos geométricos del mismo, así como la definición concreta de los bienes y derechos afectados.

2. Los estudios y proyectos citados constarán de los documentos que reglamentariamente se determinen.

Artículo 15. 1. Cuando se trate de la construcción de una nueva carretera o variante de población no prevista en el planeamiento urbanístico vigente, la Administración titular de la carretera aprobará técnicamente el correspondiente estudio informativo o proyecto de trazado, que habrá de someterse al trámite de información pública durante un plazo de treinta días hábiles, en la forma prevista en la Ley 30/1992, de 26 de noviembre, de Régimen Jurídico de las Administraciones Públicas y del Procedimiento Administrativo Común. Únicamente podrán ser tenidas en cuenta en este trámite las observaciones relativas a las circunstancias que justifiquen la declaración de interés general de la carretera y sobre la concepción global de su trazado.
La aprobación del expediente de información pública corresponde al conselleiro competente en materia de carreteras.

2. Simultáneamente con dicha información pública, habrá de remitirse el estudio o proyecto a la consellería competente en materia de carreteras y a las Administraciones afectadas para que, en el plazo de un mes, examinen si el trazado propuesto es el más adecuado para el interés general y para los intereses de las localidades y provincias afectadas. Transcurrido dicho plazo y un mes más sin que las Administraciones afectadas emitan informe al respecto, se entenderá que están conformes con el estudio o proyecto.

En caso de disconformidad, que necesariamente habrá de ser motivada, el expediente será elevado al Consello de la Xunta de Galicia, que lo aprobará, si procede.

3. La aprobación definitiva del estudio informativo o proyecto de trazado de una nueva carretera o variante de población comportará la modificación o revisión del planeamiento urbanístico existente, que habrá de acomodarse a las determinaciones del estudio en el plazo de un año desde la fecha de dicha aprobación.

Dicha aprobación definitiva comportará la inclusión de la nueva carretera o variante en los instrumentos de planeamiento que se elaboren con posterioridad.

La delimitación del tramo de la carretera que constituye la variante de población corresponde al organismo competente de la Administración titular de la carretera.

4. Acordada la redacción, revisión o modificación de un instrumento de planeamiento que afecte a carreteras, el organismo competente para otorgar su aprobación inicial habrá de enviar, con anterioridad a dicha aprobación, el correspondiente documento a las Administraciones titulares de las carreteras afectadas para que emitan, en el plazo de un mes, y con carácter vinculante, informe comprensivo de las sugerencias que estimen convenientes. 
5. La Administración titular de la carretera someterá los estudios y proyectos que afecten a las actividades de las distintas Consellerías de la Xunta de Galicia a su informe, conforme a lo establecido sobre el particular por las disposiciones vigentes.

Artículo 16. 1. La aprobación de los proyectos de carreteras de titularidad autonómica implicará la declaración de utilidad pública y de la necesidad de ocupación de los bienes y de adquisición de derechos correspondientes a los fines de expropiación, de ocupación temporal o de imposición o modificación de servidumbres.

2. La declaración de utilidad pública y de la necesidad de ocupación incluye también los bienes y derechos comprendidos en el replanteo del proyecto y en las modificaciones de obras que puedan aprobarse posteriormente.

3. A los efectos indicados en los apartados anteriores, los proyectos de carreteras y sus modificaciones habrán de comprender la definición de su trazado y la determinación de los terrenos, construcciones $\mathrm{u}$ otros bienes o derechos que se estimen preciso ocupar o adquirir para la construcción actual o prevista, para la defensa o servicio de aquéllas y para la seguridad de la circulación.

4. La aprobación de un proyecto de construcción o de trazado, en su caso, de una nueva carretera implicará la aplicación a ella de los preceptos relativos al uso y defensa de las carreteras en igual forma que las existentes.

Artículo 17. En los supuestos de actuación sobre travesías existentes que afecten a terrenos situados fuera de la zona de circulación, la Administración titular de la carretera remitirá el proyecto al Ayuntamiento correspondiente para que en el plazo de un mes emita informe sobre él. En caso de no emitir informe en el plazo indicado, se entenderá que no existe objeción alguna al proyecto.

Artículo 18. Los estudios, anteproyectos o proyectos de nuevas carreteras o de variantes de población que hayan de ser sometidos al trámite de información pública habrán de incluir, en todo caso, el correspondiente estudio de impacto ambiental.

\section{Sección 2.}

\section{Artículo 19. Construcción.}

Sólo podrán construirse nuevas carreteras cuando estén previstas en su correspondiente plan.

No obstante, la Consellería de Política Territorial, Obras Públicas e Vivenda podrá, excepcionalmente, realizar actuaciones o ejecutar obras no previstas en el Plan de Carreteras en caso de reconocida urgencia o excepcional interés público, debidamente apreciados por el Consello de la Xunta, debiendo dar cuenta a la Comisión de Economía, Hacienda y Presupuestos del Parlamento de Galicia ${ }^{511}$.

Artículo 20. 1. Las obras de construcción, reparación o conservación de carreteras, por constituir obras públicas de interés general, no están sometidas a los actos de control preventivo municipal a que se refiere el artículo 84.1.b), de la Ley 7/1985, de 2 de abril, Reguladora de las Bases de Régimen Local.

2. La ejecución de dichas obras, siempre que se realice de acuerdo con los proyectos aprobados, únicamente podrá ser suspendida por la autoridad judicial.

\section{Sección 3. ${ }^{\mathrm{a}}$ Financiación}

Artículo 21. 1. La financiación de las actuaciones en la red de carreteras se efectuará mediante las consignaciones que a tal efecto se incluyan en los presupuestos de la Administración titular de ellas, los recursos que provengan de otras Administraciones Públicas y de otras entidades o, excepcionalmente, de particulares.

2. También podrá producirse la financiación mediante contribuciones especiales

511 Art. 19 modificado por Ley 7/2002, de 27 de diciembre, de medidas fiscales y de régimen administrativo. 
en la forma y con los requisitos contenidos en el artículo 22.

3. Las carreteras a construir y explotar en virtud de un contrato de concesión de obras públicas o a través de una sociedad pública autonómica, así como las carreteras a explotar en régimen de gestión indirecta, se financiarán mediante recursos propios de las entidades adjudicatarias, los ajenos que éstas movilicen y las transferencias que pudieran otorgarse ${ }^{512}$.

Artículo 21 bis. 1. A efectos de la presente ley, tendrá la consideración de contrato de concesión de obras públicas aquél en que, siendo su objeto la construcción de carreteras, la contraprestación a favor del concesionario consista en el derecho a explotar la obra y, en su caso, a recibir un precio, siendo su régimen jurídico el establecido en la legislación básica estatal.

2. La utilización de las carreteras construidas y explotadas por los titulares de la concesión dará derecho a percibir de los usuarios las correspondientes tarifas. A estos fines la consellería competente en materia de carreteras determinará los precios máximos las mismas.

3. La Administración titular de la vía podrá establecer en el pliego de cláusulas administrativas particulares la transferencia de fondos públicos, de carácter presupuestario, calculados en función de los usuarios de la infraestructura y de la rentabilidad social producida, tanto por la construcción como por la utilización de la misma.

4. Con la finalidad de determinar las transferencias de fondos públicos, se realizará un estudio de viabilidad en el que habrán de expresarse las hipótesis económicas y se concretará el marco financiero de la concesión ${ }^{513}$.

512 Art. 21.3 modificado por Ley 7/2002, de 27 de diciembre, de medidas fiscales y de régimen administrativo. 513 Art. 21 bis añadido por Ley 7/2002, de 27 de diciembre, de medidas fiscales y de régimen administrativo.
Artículo 22. 1. Podrán imponerse contribuciones especiales cuando de la ejecución de las obras que se realicen para la construcción de carreteras, accesos o vías de servicio resulte la obtención por personas físicas o jurídicas de un beneficio especial, aunque éste no pueda fijarse en una cantidad concreta. El aumento de valor de determinadas fincas a causa de la ejecución de las obras tendrá a estos efectos la consideración de beneficio especial.

2. Serán sujetos pasivos de estas contribuciones especiales aquéllos que se beneficien de modo directo con las carreteras, accesos o vías de servicio y, especialmente, los titulares de las fincas y establecimientos contiguos y los de las urbanizaciones que resulten mejoradas en su comunicación.

3. La base imponible se determinará por el siguiente porcentaje del coste total de las obras, incluido el justiprecio de las expropiaciones, excepto, en cuanto al sujeto pasivo que sea titular del bien expropiado, la parte correspondiente del justiprecio: 100 .

a. Con carácter general, hasta el 25 por b. En vías de servicio, hasta el 50 por 100 .

c. En los accesos de uso particular para determinado número de fincas, urbanizaciones o establecimientos, hasta el 90 por 100 .

4. El importe total de las contribuciones especiales se repartirán entre los sujetos pasivos atendiendo a aquellos criterios objetivos que, según la naturaleza de las obras, construcciones y circunstancias que concurran en aquéllos, se determinen de entre los que figuran a continuación:

a. Superficie de las fincas beneficiadas.

b. Situación, proximidad y accesos a la carretera de las fincas, construcciones, instalaciones, explotaciones o urbanizaciones.

c. Bases imponibles en las contribuciones territoriales de las fincas beneficiadas.

d. Los que determine el Decreto que establezca la contribución especial en 
atención a las circunstancias particulares que concurran en la obra.

5. El Consello de la Xunta de Galicia acordará, mediante Decreto aprobado a propuesta de las consellerías competentes en materia de economía y hacienda y de carreteras, el establecimiento de contribuciones especiales en los supuestos a que se refiere la presente Ley, las cuales sólo podrán referirse a la red de titularidad de la Comunidad Autónoma.

6. En el caso de las entidades locales se estará a lo dispuesto en la legislación de régimen local.

Artículo 23. 1. La Administración Autonómica podrá construir y explotar carreteras mediante sociedades públicas en las que la Administración General participe bien directamente, bien a través de cualquier entidad o sociedad pública autonómica, previa autorización de la correspondiente Ley de Presupuestos.

2. La utilización de las carreteras construidas y explotadas por la sociedad pública dará derecho a percibir de los usuarios las correspondientes tarifas.

3. La Administración titular de la vía podrá realizar transferencias de fondos públicos, de carácter presupuestario, calculados en función de los usuarios de la infraestructura y de la rentabilidad social producida, tanto por la construcción como por la utilización de la misma ${ }^{514}$.

\section{Sección $4 .^{\mathrm{a}}$ Explotación}

Artículo 24. 1. Las carreteras pueden ser explotadas por la Comunidad Autónoma, las entidades locales y los particulares.

2. La Comunidad Autónoma y las entidades locales, como regla general, explotarán directamente las autopistas a su cargo.

En los supuestos de peaje, las tarifas correspondientes a las autopistas de titularidad

514 Art. 23 modificado por Ley 7/2002, de 27 de diciembre, de medidas fiscales y de régimen administrativo. autonómica serán aprobadas por el Consello de la Xunta de Galicia.

Artículo 25. 1. Las carreteras podrán ser explotadas mediante contrato de concesión de obra pública, en régimen de gestión indirecta o a través de una sociedad pública autonómica.

2. Las carreteras en régimen de concesión administrativa se regirán por lo dispuesto en la legislación específica.

3. En el caso de la red de titularidad autonómica, si la explotación de una carretera se efectúa por gestión interesada, por concierto con persona natural o jurídica, por sociedad de economía mixta o por sociedad pública autonómica, corresponde al Consello de la Xunta de Galicia acordar, por Decreto, los términos de la gestión y la constitución de la sociedad ${ }^{515}$.

Artículo 26. 1. Las personas físicas o jurídicas, públicas o privadas, que en aplicación de otros sistemas de gestión diferentes de la concesión resultasen titulares de la explotación de las carreteras podrán gozar de los beneficios fiscales y financieros que para el régimen de concesión disponga la legislación vigente. Tales beneficios están sujetos a los mismos condicionamientos establecidos en el supuesto de que las carreteras sean objeto de concesión administrativa.

2. El contrato de gestión, cualquiera que sea su modalidad, tendrá que determinar el correspondiente régimen jurídico-administrativo y económico-financiero, así como las fórmulas de reparto entre los contratantes o socios, de los beneficios y riesgos de la gestión.

Artículo 27. 1. La explotación de las carreteras comprende las operaciones de conservación y mantenimiento, las actuaciones encaminadas a la defensa de la vía y a su mejor uso, incluyendo las referentes a señalización, estudio y aplicación de la normativa de tráfico y seguridad vial, así

515 Art. 25 modificado por Ley 7/2002, de 27 de diciembre, de medidas fiscales y de régimen administrativo. 
como la ordenación de accesos y uso de las zonas de dominio público, de servidumbre y de afección.

2. La Administración titular de la carretera o, en su caso, la persona física o jurídica titular de su gestión será la única competente para la señalización permanente de la misma fuera de las travesías, debiendo considerarse ilegal, a todos los efectos, toda señalización establecida por cualquier otra persona o entidad sin previa autorización de dicha Administración, salvo en caso de emergencia.

Artículo 28. 1. La Administración titular de la carretera facilitará la existencia de las áreas de servicio necesarias para la seguridad y comodidad del usuario y el buen funcionamiento de la circulación.

2. Reglamentariamente se establecerán las distancias mínimas entre dichas áreas y sus características funcionales, de tal modo que se garantice la prestación de los servicios esenciales, así como la protección del paisaje y de los demás elementos naturales del entorno y la seguridad de la circulación.

3. Las áreas de servicio podrán ser explotadas por cualquiera de los sistemas de gestión de servicios públicos.

Las condiciones para el otorgamiento de concesiones de áreas de servicio se establecerán en un pliego de condiciones generales, que será aprobado por la Consellería competente en materia de carreteras y publicado en el "Diario Oficial de Galicia”.

\section{Capitulo III USO Y DEFENSA DE LAS CARRETERAS \\ Sección $1 .^{\mathrm{a}}$ \\ Limitaciones de la propiedad}

Artículo 29. 1. A los efectos de la presente ley se establece el área de influencia de las carreteras, que está integrada por las siguientes zonas: De dominio público, de servidumbre y de afección.
2. Las obras, instalaciones, edificaciones, cierres y cualquier otra actividad que afecte a terrenos comprendidos en el área de influencia de las carreteras, incluida la plantación de árboles, requerirán, en todo caso, expresa autorización del órgano competente de la Administración titular de la carretera, sin perjuicio de otras competencias concurrentes y de lo dispuesto en el artículo 53 de la presente ley, exceptuándose las labores agrícolas que no supongan una modificación de la configuración del terreno.

3. Las autorizaciones a que se refiere el párrafo anterior se entenderán otorgadas sin perjuicio de tercero, y siempre a precario en la parte en que afecten a la zona de dominio público. El órgano competente de la Administración titular de la carretera establecerá, en su caso, una fianza en metálico para garantizar la ejecución de las obras conforme a las condiciones impuestas, que habrá de depositar la persona o entidad que materialmente las realice.

4. Serán nulas de pleno derecho las licencias y autorizaciones administrativas otorgadas $\sin$ atenerse a lo dispuesto en esta ley.

5. Aprobado el proyecto de construcción o de trazado, en su caso, de una nueva carretera, dichas áreas y zonas quedarán establecidas para ella con igual efecto que para las carreteras existentes.

Artículo 30. 1. Integran la zona de dominio público los terrenos adquiridos por título legítimo por la Administración titular de la carretera para la construcción de la misma y de sus elementos funcionales.

El límite exterior de zona de dominio público no podrá sobrepasar los 15 metros de ancho a cada lado de la explanación en autopistas, autovías, corredores y vías rápidas, y los 10 metros de ancho en el resto de las carreteras, medidos en horizontal y perpendicularmente al eje de la calzada más aproximada, desde la arista exterior de la 
explanación correspondiente a las calzadas previstas y a sus elementos funcionales.

La arista exterior de la explanación es la intersección del talud del desmonte, del terraplén o, en su caso, de los muros de sustentación que la delimitan con el terreno natural.

En los casos especiales de puentes, viaductos, túneles, estructuras u obras similares, podrá fijarse como arista exterior de la explanación la línea de proyección vertical del borde de las obras sobre el terreno. Será, en todo caso, de dominio público, como mínimo, el terreno ocupado por los soportes de la estructura.

2. Sólo podrán realizarse obras, actuaciones o instalaciones en la zona de dominio público de la carretera cuando la prestación de un servicio público de interés general así lo exija, se trate de conexión con ese servicio, de obras imprescindibles para acceder a la carretera o de instalaciones provisionales por plazo fijado, previa autorización del órgano competente de la Administración titular de la carretera. Todo ello sin perjuicio de otras competencias concurrentes y de lo establecido en el artículo 1.

Artículo 31. 1. La zona de circulación de la carretera es la parte de la zona de dominio público constituida por la calzada y sus arcenes.

2. En ningún caso podrán ejecutarse obras, actuaciones o instalaciones que afecten a la zona de circulación de la carretera sin autorización del órgano competente de la Administración titular de la misma.

Artículo 32. 1. La zona de servidumbre de las carreteras consistirá en dos franjas de terreno a ambos lados de las mismas, delimitadas interiormente por la zona de dominio público definida en el artículo 30 y exteriormente por dos líneas paralelas a dicho límite, a una distancia de 17 metros en autopistas, autovías, corredores y vías rápidas, y de dos metros en el resto de las carreteras, medidas desde el límite exterior de la zona de dominio público.

2. En la zona de servidumbre no podrán realizarse obras ni se permitirán más usos que aquellos que sean compatibles con la seguridad vial, previa autorización, en cualquier caso, del órgano competente de la Administración titular de la carretera, sin perjuicio de otras competencias concurrentes y de lo establecido en el artículo 53.

3. En todo caso, el organismo competente de la Administración titular de la carretera podrá utilizar o autorizar la utilización de la zona de servidumbre por razones de interés general o cuando lo requiera el mejor servicio de la carretera.

4. Serán indemnizables la ocupación de la zona de servidumbre y los daños y perjuicios que se causen por su utilización.

Artículo 33. 1. La zona de afección de las carreteras consistirá en dos franjas de terreno a ambos lados de las mismas, delimitadas interiormente por la zona de servidumbre y exteriormente por dos líneas paralelas a las aristas de la explanación, a una distancia de 100 metros en el caso de las autopistas, autovías, corredores y vías rápidas, y de 30 metros en el resto de las carreteras, medidas desde las citadas aristas.

2. Para ejecutar en la zona de afección cualquier tipo de obras o instalaciones fijas o provisionales, cambiar el uso o destino de las mismas y plantar o talar árboles, se requerirá la previa autorización del órgano competente de la Administración titular de la carretera, sin perjuicio de otras competencias concurrentes y de lo establecido en el artículo 53.

Artículo 34. 1. Se prohíbe toda aquella publicidad que sea visible desde las zonas de dominio público de la carretera, salvo en los tramos urbanos, donde la publicidad estará sometida a las ordenanzas municipales, debiendo situarse fuera de 
las zonas de dominio público y no afectar ni interferir las señalizaciones, alumbrado o balizamiento de la carretera, sin que esta prohibición pueda dar, en ningún caso, derecho a indemnización.

Los planeamientos municipales habrán de adaptarse a esta normativa.

2. No se considera publicidad a los efectos de esta ley:

a. La rotulación informativa de las vías.

b. Las indicaciones de orden general que sean de interés para el usuario, tales como información sobre talleres, restaurantes, exposiciones, ferias, celebraciones, etcétera, siempre que no contengan nombres comerciales.

c. Los rótulos y marcas comerciales que se dispongan en el edificio o finca en que se desarrolle la actividad anunciada.

3. En todo caso, para la colocación de cualquier clase de letrero, cartel o reclamo, fuera de las zonas urbanas, será preceptiva la autorización del órgano competente de la Administración titular de la carretera, que atenderá, además, de a lo anteriormente expresado a que las condiciones de forma, tamaño, situación e iluminación no sean perjudiciales para la seguridad de la circulación, para lo que habrán de ajustarse a las características que reglamentariamente se determinen.

Artículo 35. 1. A ambos lados de las carreteras se establece la línea límite de edificación, desde la cual hasta la carretera queda prohibido cualquier tipo de obras de construcción, reconstrucción o ampliación, salvo las que resulten imprescindibles para la mera conservación y mantenimiento de las construcciones existentes, que precisarán autorización del órgano competente de la Administración titular de la carretera.

La línea límite de edificación se sitúa a las distancias que se indican a continuación, medidas horizontalmente a partir de la arista exterior de la explanación correspondiente a las calzadas previstas y a sus elementos funcionales y perpendicularmente al eje de la calzada más próxima:

a. Autopistas, autovías, corredores, vías rápidas y variantes de población: 30 metros.

b. Carreteras de la red primaria básica no incluidas en las categorías anteriores: 12 metros.

c. Carreteras de la red primaria complementaria: 9,5 metros.

d. Resto de las carreteras: Siete metros.

2. Cuando en una carretera de titularidad provincial o municipal las edificaciones sean continuadas, o las características del lugar hagan imposible el respeto de las distancias señaladas en el párrafo anterior, la Administración titular de la carretera, previo informe favorable de la Consejería competente en materia de carreteras, podrá reducir excepcionalmente aquéllas, siempre que quede garantizada una suficiente ordenación de los márgenes de la carretera y el adecuado control de sus accesos.

3. Con carácter excepcional, en los tramos de las carreteras que discurran por zonas urbanas, la consellería competente en materia de carreteras podrá establecer la línea límite de edificación a una distancia distinta a la fijada en el apartado 1 anterior, conforme al procedimiento que reglamentariamente se establezca.

4. Asimismo, el Consello de la Xunta de Galicia, a propuesta de la consellería competente en materia de carreteras y previo informe de las entidades locales afectadas, podrá por razones geográficas o socioeconómicas fijar una línea límite de edificación a una distancia inferior a la establecida con carácter general, de aplicación a determinadas carreteras en zonas o comarcas perfectamente delimitadas.

5. En los lugares en donde la línea límite de edificación, definida con arreglo a lo dispuesto en el apartado 1 del presente artículo, quedase dentro de la zona de servidumbre, la citada línea se hará coincidir con el borde exterior de dicha zona. 
Se exceptúan los casos previstos en los apartados 2, 3 y 4 del presente artículo.

Artículo 36. En el caso de los corredores, el área de influencia y la línea de edificación se fijarán en función de su futuro desdoblamiento.

Artículo 37. Desde el límite exterior de la zona de dominio público hasta la línea límite de edificación, la Administración titular de la carretera podrá proceder a la expropiación de los bienes existentes con arreglo a la normativa vigente, entendiéndose implícita la declaración de utilidad pública y la necesidad de ocupación, siempre que exista previamente un proyecto aprobado de trazado o de construcción, para reparación, ampliación o conservación de la carretera.

Artículo 38. 1. La Administración titular de las carreteras puede limitar los accesos a las mismas y establecer con carácter obligatorio los lugares en que tales accesos puedan construirse.

2. Asimismo queda facultada para reordenar los accesos existentes al objeto de mejorar la explotación de la carretera y la seguridad vial, para lo que podrá expropiar los terrenos necesarios.

3. Cuando los accesos no previstos sean solicitados por los particulares directamente interesados, el órgano competente de la Administración titular de la carretera podrá convenir con éstos la aportación económica procedente, en cada caso, siempre que el acceso sea de interés público o exista imposibilidad de otro tipo de acceso.

4. Las propiedades contiguas no tendrán acceso directo a las nuevas carreteras y variantes de población, conforme a lo que se determine en los correspondientes estudios.

Artículo 39. 1. No se autorizarán cierres en las zonas de dominio público ni en las de servidumbre.

2. Por circunstancias especiales de aprovechamiento agrícola o ganadero, podrán ser autorizados cerramientos diáfanos en las zonas de servidumbre o afección de las carreteras pero no en las de dominio público. Cuando por razón de interés público o por obras de nuevas vías, desdoblamiento de calzada o ensanche de la plataforma de la carretera resulte necesario el retranqueo de cierres de fincas, éstos podrán llevarse a efecto en las mismas condiciones existentes con anterioridad al proyecto de obra, en cuanto a su estructura y distancia de la arista exterior a la plataforma, debiendo quedar, en todo caso, fuera de la zona de dominio público.

No tendrán el derecho de reposición a que se refiere el párrafo anterior aquellos cierres que hayan sido denunciados por haberse construido sin la correspondiente autorización o con incumplimiento de las condiciones de ella.

\section{Sección 2 . $^{\mathrm{a}}$}

\section{Uso de las carreteras}

Artículo 40. La Administración titular de las carreteras, sin perjuicio de lo establecido en otras disposiciones y de las facultades de otros organismos, podrá imponer, en el ámbito de sus competencias, cuando las condiciones, situaciones, exigencias técnicas o seguridad vial de las carreteras lo requieran, limitaciones temporales o permanentes a la circulación en ciertos tramos o partes de las carreteras y señalizar las correspondientes ordenaciones resultantes de la circulación. Le compete igualmente fijar las condiciones de las autorizaciones excepcionales que, según el caso, puedan otorgarse por el órgano competente.

Artículo 41. Las actuaciones públicas o privadas que por sus características propias puedan generar, a juicio de la Administración titular de la carretera, problemas a la circulación o daños a las carreteras habrán de ser sometidas a un estudio de evaluación de su impacto potencial sobre el sistema viario, realizado por su promotor en los términos que reglamentariamente se determinen, y obtener la correspondiente autorización 
administrativa, que contemplará las condiciones que habrán de cumplirse para paliar dicho impacto.

Artículo 42. La Administración titular de las carreteras podrá establecer en puntos estratégicos de la red de carreteras instalaciones para medir la densidad del tráfico y estaciones de pesaje para conocimiento y control de las características de la demanda de tráfico sobre la infraestructura de las carreteras. Las sobrecargas que constituyan infracción serán mencionadas por las autoridades competentes en cada caso.

\section{Sección 3. ${ }^{a}$}

Infracciones y sanciones

Artículo 43. 1. El incumplimiento de las disposiciones de la presente ley tiene la consideración de infracción administrativa. Las infracciones tipificadas en los apartados siguientes de este artículo se clasifican en leves, graves y muy graves.

2. Son infracciones leves:

a. Realizar obras, instalaciones o actuaciones de poca importancia o trascendencia para la carretera en las zonas de dominio público, de servidumbre o de afección de la carretera, llevadas a cabo sin las autorizaciones o licencias requeridas, o incumplir alguna de las prescripciones impuestas en las autorizaciones otorgadas, cuando no puedan ser objeto de legalización posterior.

b. Colocar, verter, arrojar o abandonar dentro de la zona de servidumbre objetos o materiales de cualquier naturaleza que no produzcan daño alguno.

3. Son infracciones graves:

a. Realizar obras, instalaciones o actuaciones no permitidas en las zonas de servidumbre o de afección de la carretera o de poca trascendencia en la zona de dominio público, llevadas a cabo sin las autorizaciones o licencias requeridas o incumplir alguna de las prescripciones impuestas en las autorizaciones otorgadas, cuando no fuese posible su legalización posterior. b. Deteriorar no intencionadamente cualquier elemento de la carretera directamente relacionado con la ordenación, orientación y seguridad de la circulación.

c. Destruir, deteriorar, alterar o modificar cualquier obra o instalación de la carretera o de los elementos funcionales de la misma.

d. Colocar, verter, arrojar o abandonar dentro de la zona de dominio público objetos o materiales de cualquier naturaleza.

e. Realizar en la zona de dominio público cruces aéreos o subterráneos no permitidos, sin la pertinente autorización o sin ajustarse a las condiciones de la autorización otorgada.

f. Colocar carteles informativos en las zonas de dominio público, servidumbre o afección sin autorización del organismo competente de la Administración de la que dependa la carretera.

g. Realizar en el área de influencia de la carretera cualquier obra o actuación que de alguna forma interfiera o modifique las condiciones de desagüe de la carretera y sus obras de fábrica.

h. La reincidencia en faltas leves.

4. Son infracciones muy graves:

a. Realizar obras, instalaciones o actuaciones no permitidas en la zona de dominio público, llevadas a cabo sin las autorizaciones o licencias requeridas, o incumplir alguna de las prescripciones impuestas en las autorizaciones otorgadas, cuando no fuese posible su legalización posterior.

b. Sustraer, añadir o modificar en cualquier forma un elemento o conjunto de elementos permanentes de la carretera o eventualmente autorizados, relacionados con la ordenación o seguridad de la circulación, o alterarlos en cualquier forma que modifique el régimen de la circulación establecido con aquéllos.

c. Destruir, deteriorar, alterar o modificar cualquier obra o instalación de la carretera o de los elementos funcionales 
de la misma cuando las actuaciones afecten a la calzada o a los arcenes.

d. Establecer en la zona de afección instalaciones de cualquier naturaleza o realizar alguna actividad que resulte peligrosa, incómoda o insalubre para los usuarios de la carretera sin adoptar las medidas pertinentes para evitarlo.

e. Dañar o deteriorar la carretera circulando con pesos o cargas que excedan los límites autorizados o por cualquier otro procedimiento.

f. Las calificadas como graves cuando se aprecie reincidencia.

g. Establecer cualquier clase de publicidad en el área de influencia de la carretera.

h. Depositar, verter o abandonar objetos o materiales de cualquier naturaleza en la zona de circulación de la carretera.

Artículo 44. 1. El procedimiento para sancionar las infracciones a los preceptos de esta ley se iniciará de oficio por la Administración titular de la carretera o como consecuencia de denuncia formulada por particulares.

2. En los supuestos en que actos cometidos contra la carretera o sus elementos pudiesen ser constitutivos de delito o falta, la Administración titular de la carretera pasará el tanto de culpa a la autoridad judicial competente y se abstendrá de proseguir el procedimiento sancionador mientras ésta no se pronuncie. La sanción de la autoridad judicial excluirá la imposición de multa administrativa. Si no se estimase la existencia de delito o falta, la Administración podrá proseguir el expediente sancionador en base a los hechos que los tribunales hubiesen considerado probados.

Artículo 45. El órgano competente de la Administración titular de la carretera podrá adoptar las siguientes medidas cuando tenga conocimiento de una posible infracción:

a. Ordenar la paralización inmediata de las obras o usos no autorizados o que no se ajusten a las condiciones impuestas en la autorización.

b. Ordenar la restitución del medio físico a las condiciones anteriores a las actuaciones que puedan constituir infracción, cuando supongan peligro para la circulación.

Artículo 46. Serán responsables de las infracciones:

Por el modo o forma de ejecutar la obra o actuación, su ejecutor material.

Por lo que respecta a la existencia o no de autorización y al cumplimiento o incumplimiento de las condiciones de ella, el promotor o titular de la obra o actuación. En lo relativo a la publicidad será responsable la empresa anunciadora y, subsidiariamente, el propietario de los terrenos en que se instale.

Artículo 47. 1. Las infracciones a que se refiere el artículo 43 serán sancionadas atendiendo a los daños y perjuicios producidos, según el caso, al riesgo creado y a la intencionalidad del causante, con las siguientes multas:

a. Infracciones leves, multa de $25.000 \mathrm{a}$ 250.000 pesetas.

b. Infracciones graves, multa de 50.000 a 1.000.000 de pesetas.

c. Infracciones muy graves, multa de 200.000 a 25.000.000 de pesetas.

2. No obstante lo dispuesto anteriormente, en el supuesto de obras, instalaciones o construcciones, según se trate de infracciones leves, graves o muy graves, la multa impuesta no podrá ser inferior al 5, 10 ó 15 por 100 , respectivamente, del valor de la obra realizada.

3. Cuando las actuaciones que constituyan infracción no puedan ser legalizadas conforme a lo dispuesto en esta ley, la resolución recaída en el expediente sancionador incluirá la obligación del responsable de la infracción de reponer el medio físico al estado anterior a la comisión de la infracción, estableciendo un plazo para su cumplimiento. 
4. Con independencia de las multas previstas en el apartado 1 anterior, y de forma compatible con ellas, los órganos sancionadores, después de haber transcurrido el plazo establecido en la resolución correspondiente sin que el infractor hubiese dado cumplimiento a la obligación de reposición recaída en el expediente sancionador, podrán imponer multas coercitivas conforme a lo establecido en el procedimiento sancionador administrativo general, con el correspondiente requerimiento y apercibimiento previo.

5. La cuantía de cada una de dichas multas no superará el 20 por 100 de la multa fijada por la infracción cometida, y éstas podrán ser reiteradas indefinidamente mientras persistan los efectos de la infracción.

6. En caso de reincidencia en faltas muy graves, la cuantía de la sanción podrá incrementarse hasta un 50 por 100 .

7. Hay reincidencia cuando se cometa una infracción análoga a la que motiva la sanción anterior en el plazo de los dieciocho meses siguientes a la notificación de aquélla. En tal supuesto se requerirá que la primera resolución sancionadora hubiese adquirido firmeza en vía administrativa.

Artículo 48. 1. La imposición de sanciones por infracciones en las carreteras de titularidad autonómica corresponderá:

a. A los Delegados provinciales de la consellería competente en materia de carreteras, para las infracciones leves.

b. Al Director general competente en materia de carreteras, para las infracciones graves.

c. Al conselleiro competente en materia de carretera, para las infracciones muy graves que comporten multa de hasta 5.000 .000 de pesetas.

d. Al Consello de la Xunta de Galicia, a propuesta del mismo conselleiro, para las infracciones muy graves que comporten multa de más de 5.000 .000 de pesetas.

2. La imposición de la sanción correspondiente será independiente de la obligación de restituir el medio físico al estado anterior a la comisión de la infracción, en su caso, así como de la indemnización de los daños y perjuicios causados, con un importe que será fijado por el órgano competente de la Administración de la que dependa la carretera.

3. El plazo de prescripción de las infracciones a que se refiere el artículo 43 será de cinco años para las muy graves, de tres años para las graves y de un año para las leves, a contar desde su total consumación. No obstante, se exigirá la restitución de las cosas y su reposición al estado anterior, cualquiera que sea el tiempo transcurrido.

Artículo 49. 1. La producción de daños a una carretera o a sus elementos funcionales originará la incoación y tramitación del correspondiente expediente administrativo al presunto responsable, a fin de determinar la indemnización de los daños y perjuicios causados, que serán evaluados por el organismo competente de la Administración titular de la carretera.

2. Cuando la reparación de un daño sea urgente para el servicio normal de la carretera y para la seguridad de la circulación, el órgano competente de la Administración titular de la carretera habrá de realizarla inmediatamente, a cargo del causante.

Artículo 50. El importe de toda clase de multas y de los gastos ocasionados por la ejecución subsidiaria de las actuaciones de restitución del medio físico al estado anterior a la comisión de la infracción o por la reparación de daños puede ser exigido por la vía administrativa de apremio.

\section{Capítulo IV \\ TRAVESÍAS Y REDES ARTERIALES}

Artículo 51. Los tramos de carretera que discurran por suelo urbano o estén incluidos en una red arterial se regirán por las disposiciones del presente capítulo y las demás contenidas en esta ley en lo que resulten de aplicación. 
Artículo 52. 1. A los efectos de esta ley se denominará red arterial de una población o grupo de poblaciones el conjunto de tramos de carreteras actuales o previstos que establezcan de forma integrada la continuidad y la conexión de los distintos itinerarios de carreteras, o presten debido acceso a los núcleos de población afectados; será definida por el Consello de la Xunta de Galicia, a propuesta de la consellería competente en materia de carreteras, previo informe del Ayuntamiento o Ayuntamientos afectados.

Después de haber sido definida una red arterial, los Ayuntamientos afectados tendrán la obligación de incluir dicha red en los instrumentos de planeamiento urbanístico que se aprueben en el futuro, así como de modificar los existentes con la misma finalidad en el plazo de un año desde su definición.

2. Se consideran tramos urbanos de carreteras aquéllos que discurran íntegramente por suelo calificado como urbano por el correspondiente instrumento de planeamiento urbanístico.

3. Se considera travesía la parte del tramo urbano en el que existan, al menos en uno de sus márgenes, edificaciones consolidadas en más de las dos terceras partes de su longitud y una trama de calles; debe ser delimitada por mutuo acuerdo de los órganos competentes de la Administración de la que dependa la carretera y del Ayuntamiento o Ayuntamientos afectados, teniendo en cuenta que, a estos efectos, se considera edificación la obra o fábrica construida para habitación o usos análogos, constituyendo un espacio cubierto, delimitado por muros de cierre.

4. A los efectos de esta Ley se considera que en un tramo urbano existe una población, únicamente, cuando en él existe una travesía.

Artículo 53. 1. El otorgamiento de autorizaciones para realizar obras o actividades no ejecutadas por la Administración titular de la carretera que afecten a la zona de circulación de los tramos urbanos o travesías corresponde a la referida Administración, sin perjuicio de otras competencias concurrentes.

2. El otorgamiento de autorizaciones para realizar obras o actividades no ejecutadas por la Administración titular de la carretera en el resto de la zona de dominio público de los tramos urbanos corresponde a los Ayuntamientos, previo informe vinculante de dicha Administración, que habrá de versar sobre los aspectos relativos a disposición de la presente ley o de su Reglamento. Este informe será también preciso en el caso de obras a realizar por el propio Ayuntamiento.

3. En las zonas de servidumbre y afección de los tramos de carretera indicados en el número anterior, las autorizaciones de usos y obras las otorgarán los Ayuntamientos, debiendo atenerse a lo dispuesto en el artículo 35 respecto a la línea límite de edificación.

$\mathrm{Si}$ el instrumento de planeamiento urbanístico vigente no ha sido sometido a informe del órgano competente de la Administración titular de la carretera, en la forma prevista en el artículo 15, habrán de obtener, con carácter previo, el informe vinculante del referido órgano, que habrá de versar sobre disposiciones contenidas en la presente ley o en su Reglamento.

4. En las travesías corresponde a los Ayuntamientos el otorgamiento de toda clase de licencias y autorizaciones sobre actividades a desarrollar en terrenos contiguos en las carreteras situados en las zonas de servidumbre o afección. Los Ayuntamientos podrán señalizar las carreteras en las travesías, previo informe vinculante de la Administración titular de la carretera.

5. Cualquier autorización otorgada sin ajustarse a esta ley, sin los informes previos requeridos o sin ajustarse a ellos será nula. 
6. Las competencias de los Ayuntamientos establecidas por la presente ley para autorizar obras o actuaciones que afectan a tramos urbanos o travesías de carreteras comportan la responsabilidad de los mismos para sancionar las infracciones que puedan cometerse en los ámbitos afectados por dichas competencias, sin perjuicio de la ejecución de sus competencias por el órgano titular de la vía.

Artículo 54. 1. Sin perjuicio de lo dispuesto en el artículo 4, las carreteras autonómicas o provinciales o los tramos determinados de ellas en los que la circulación adquiera características urbanas se entregarán a los Ayuntamientos respectivos. El expediente se promoverá a propuesta del Ayuntamiento o de la Administración titular de la carretera y será resuelto por el Consello de la Xunta de Galicia, a propuesta de la consellería competente en materia de carreteras, previo informe de ambos organismos.

2. No obstante lo dispuesto en el apartado anterior, la Administración titular de la carretera y las entidades locales respectivas podrán convenir lo que estimen procedente para la mejor conservación y funcionalidad de tales vías.

\section{DISPOSICIÓN ADICIONAL}

La Xunta de Galicia, mediante Decreto, podrá actualizar la cuantía de las sanciones previstas en esta ley.

\section{DISPOSICIÓN TRANSITORIA PRIMERA}

En el plazo de un año desde la entrada en vigor de la presente ley habrá de ser retirada cualquier clase de publicidad que contravenga disposiciones de la misma.

\section{DISPOSICIÓN TRANSITORIA SEGUNDA}

En el plazo de dos años desde la entrada en vigor de la presente ley habrán se adaptarse todos los instrumentos de planeamientos urbanísticos a las disposiciones que en la misma se contengan.

\section{DISPOSICIÓN FINAL}

La Xunta de Galicia, a propuesta de la consellería competente en materia de carreteras, aprobará el Reglamento general de ejecución de la presente ley, dentro de los seis meses siguientes a su publicación en el "Diario Oficial de Galicia".

\section{LEY 6/1996, DE 9 DE JULIO, DE COORDINACIÓN DE LOS SERVICIOS DE TRANSPORTES URBANOS E INTERURBANOS POR CARRETERA DE GALICIA (DOGA N. $\left.{ }^{\circ} 141,18.7 .1996\right)^{516}$}

$(\ldots)^{517}$

\section{TÍTULO PRELIMINAR}

Artículo 1. Objeto de la ley.

1. Es objeto de la presente ley la coordinación de los servicios de transporte público urbano de viajeros con los servicios de transporte interurbanos, en los supuestos en que el establecimiento o ampliación de los primeros afectan a los servicios interurbanos previamente establecidos, siempre que se presten íntegramente en el ámbito territorial de la Comunidad Autónoma de Galicia. Se comprenden en el ámbito de aplicación de la ley tanto los servicios permanentes como los temporales y tanto los de uso general como especial.

516 Véase también:

- Decreto 251/1998, de 10 de septiembre, por el que se crea el comité gallego de transporte por carretera y se regula el registro de asociaciones profesionales de transportistas y de empresas de actividades auxiliares y complementarias del transporte con ámbito de actuación en la Comunidad Autónoma gallega.

- Decreto 303/2003, de 19 de junio, por el que se regula la prestación de servicios regulares permanentes de transporte público de viajeros por carretera de uso general, de varios titulares mediante la utilización de un mismo vehículo.

517 Exposición de motivos omitida. 
2. La coordinación a que se refiere esta ley se extenderá también a los servicios cuya ordenación o gestión, total o parcial, delegue el Estado a la Comunidad Autónoma de Galicia.

3. Asimismo es objeto de la presente ley la regulación de situaciones peculiares en la prestación de los servicios de transporte público discrecional interurbano en autotaxi, en los cuales el régimen eminentemente local del transporte necesita ser modulado, a fin de evitar disfunciones en la prestación de dicho transporte mediante autotaxi.

Artículo 2. Definiciones.

A los efectos de esta ley se entenderá por:

a. Transporte público: Aquél que se lleva a cabo por cuenta ajena mediante retribución económica.

b. Transporte de viajeros: Aquél que está dedicado a realizar los desplazamientos de las personas y sus equipajes en vehículos construidos y acondicionados a tal fin.

c. Transporte regular: El que se efectúa dentro de itinerarios preestablecidos y con sujeción a calendarios y horarios prefijados.

d. Transporte regular de uso general: Aquél que va dirigido a satisfacer una demanda general, siendo utilizable por cualquier interesado.

e. Transporte regular de uso especial: Aquél que está destinado a servir, regular y exclusivamente, a un grupo específico de usuarios, tales como escolares, trabajadores, militares o grupos homogéneos similares.

f. Transporte discrecional: Aquél que se lleva a cabo sin sujeción a itinerario, calendario ni horario preestablecido.

g. Transporte permanente: El que se realiza de forma continuada, para atender a necesidades de carácter estable.

h. Transporte temporal: El destinado a atender a tráficos de carácter excepcional o coyuntural y de duración temporalmente limitada, si bien puede darse en los mismos una repetición periódica, tales como los de ferias, mercados, vacaciones u otros similares.

i. Transporte urbano: Aquél que discurre íntegramente por suelo urbano o urbanizable, definido de conformidad con la legislación urbanística de Galicia, o esté dedicado de forma exclusiva a comunicar entre sí núcleos urbanos distintos dentro de un mismo término municipal.

j. Áreas territoriales de prestación conjunta: Son aquellas zonas en que existe interacción o influencia recíproca entre los servicios de transporte.

Artículo 3. Fines y principios.

1. La coordinación de los servicios de transporte público de viajeros servirá para los siguientes fines:

a. Integración en una sola red de los siguientes servicios de transporte público: Urbano, de titularidad municipal, e interurbano, de titularidad de la Comunidad Autónoma de Galicia o gestionado por delegación del Estado.

b. Satisfacción de las necesidades de la comunidad ${ }^{518}$.

c. Establecimiento de los instrumentos de conexión necesarios entre el planeamiento sectorial de transportes y la ordenación territorial, así como, en su caso, de los mecanismos para la fijación de las infraestructuras de transporte.

2. La coordinación de los servicios de transporte público se ajustará a los siguientes principios:

a. Eficacia en la gestión con el mínimo coste económico y social.

b. Autonomía de los Ayuntamientos en la gestión de sus servicios de transporte.

c. Respeto a los derechos de los concesionarios de líneas o zonas de transporte público, de acuerdo con las determinaciones de cada título concesional.

d. Protección de los intereses legítimos de los titulares de autorizaciones de transporte público discrecional.

518 Véase Decreto 80/2005, de 31 de marzo, por el que se regulan los servicios de transporte público a lugares de ocio. 


\section{TÍTULO I \\ DE LA COORDINACIÓN DE COMPETENCIAS ANTE EL ESTABLECIMIENTO O AMPLIACIÓN DE SERVICIOS URBANOSO INTERURBANOS DE TRANSPORTE REGULAR DE VIAJEROS

\author{
Capítulo I \\ DE LA COORDINACIÓN ANTE \\ EL ESTABLECIMIENTO O AMPLIACIÓN \\ DE SERVICIOS URBANOS COLECTIVOS
}

\section{Sección $1 .^{\mathrm{a}}$}

Municipios de hasta 50.000 habitantes

Artículo 4. Ampliación y establecimiento de servicios municipales.

1. En los municipios de hasta 50.000 habitantes, la ampliación o establecimiento de servicios de transporte colectivo urbano, cuando afecten a servicios interurbanos previamente establecidos, se ajustarán a las siguientes reglas:

a. Iniciado el expediente municipal para el establecimiento o ampliación de servicios de transporte colectivo, cuando éste pudiera coincidir con servicios interurbanos ya implantados, y una vez que el proyecto municipal esté suficientemente definido, el Ayuntamiento lo remitirá a la consellería competente por razón de la materia. El proyecto municipal habrá de detallar en todo caso:

El itinerario del nuevo servicio.

La ubicación de las paradas en suelo urbano y urbanizable o núcleo rural, de acuerdo con las previsiones de la legislación urbanística de Galicia.

El número de expediciones del servicio proyectado.

Los tráficos de los servicios regulares permanentes de transporte interurbano que pudieran resultar afectados.

Un estudio de la oferta y demanda de viajeros en el corredor en que se pretenda implantar, prolongar o incrementar el servicio urbano. b. Con el envío del proyecto municipal se suspenderá la tramitación del expediente de establecimiento o ampliación de servicios de transporte urbano, así como el plazo para su resolución.

c. La Dirección General competente de la Xunta de Galicia ordenará la iniciación de un expediente de ampliación de servicios de transporte público interurbano regular de viajeros al objeto de que la misma satisfaga las necesidades demandadas por el Ayuntamiento.

d. En un mismo acto, la Dirección General competente ordenará la práctica de los siguientes trámites: Solicitud de informe a los demás Ayuntamientos de la misma área, notificación de la iniciación del expediente a los concesionarios de transporte interurbano en el área de influencia del Ayuntamiento que pretende el establecimiento o ampliación de sus servicios de transporte urbano, publicación de la resolución por la que se ordena la iniciación del expediente en el "Diario Oficial de Galicia” y exposición pública del proyecto municipal.

e. En las notificaciones y publicación se determinarán el lugar y horario de exhibición al público del proyecto municipal de ampliación de servicios. La exhibición se prolongará por plazo de treinta días naturales. Durante este tiempo podrán formularse las alegaciones oportunas.

f. Los concesionarios de servicios interurbanos coincidentes podrán acordar con la Dirección General competente la asunción, como servicios de transporte interurbano, del proyecto de establecimiento o ampliación de servicios urbanos formulado por el Ayuntamiento con las modificaciones no sustanciales a que hubiese lugar, de acuerdo con el estudio de la oferta y demanda a que se refiere el párrafo siguiente. El contenido del convenio formará parte de la resolución definitiva aprobatoria de la ampliación de 
servicios interurbanos. Sólo por razones sobrevenidas, debidamente motivadas, podrá desatenderse el contenido del convenio o introducirse modificaciones parciales, para un mejor servicio, que en ningún caso entrañen modificaciones sustanciales del proyecto municipal.

g. La resolución definitiva sobre la ampliación de servicios interurbanos corresponderá a la consellería competente. En la resolución favorable a la ampliación se incluirán necesariamente las propuestas municipales sobre itinerarios en núcleo urbano y paradas urbanas, si bien el número de expediciones propuesto por el Ayuntamiento podrá ser corregido por la consellería, atendiendo a un estudio previo de oferta y demanda reales de transporte. La resolución del conselleiro también incluirá necesariamente el contenido del convenio previsto en la letra f). Su inclusión conllevará la modificación o novación de las concesiones incluidas en el mismo. A falta de acuerdo, la consellería competente decidirá también sobre la forma de gestión del servicio de transporte que se amplía.

h. No obstante, cuando a pesar del estudio previo de la oferta y demanda reales del transporte el Ayuntamiento mantenga el número de expediciones de su proyecto, su implantanción quedará condicionada a que el Ayuntamiento garantice el equilibrio económico de las expediciones adicionales que se impongan el concesionario del servicio interurbano.

En ningún caso la consellería aprobará expediciones que sean incompatibles con los principios de organización y funcionamiento del sistema de transportes que se postulan en el artículo 1 de esta ley.

i. Comunicada la resolución de ampliación del servicio interurbano, el Ayuntamiento pondrá fin al expediente municipal de ampliación. No acordada la ampliación del servicio interurbano, el
Ayuntamiento podrá proseguir la tramitación del expediente de establecimiento o ampliación de servicios de transporte urbano.

2. Transcurridos seis meses desde la recepción del proyecto municipal en la consellería competente por razón de la materia sin que hubiese recaído resolución de la misma, cesará la suspensión a que se refiere el párrafo 1.b) de este artículo.

\section{Sección 2. ${ }^{\mathrm{a}}$ \\ Municipios de más de 50.000 habitantes}

\section{Artículo 5. Planes de explotación.}

1. El establecimiento o ampliación de servicios urbanos, cuando afecten a servicios interurbanos previamente establecidos, en áreas de influencia en municipios de más de 50.000 habitantes, se coordinarán a través de los planes de explotación regulados en este capítulo.

2. Cuando existan razones de interés público que así lo aconsejen, y por orden de la consellería competente, podrán incluirse otros municipios en el régimen propio de este capítulo.

Artículo 6. Iniciativa municipal.

1. Los Ayuntamientos, previamente al establecimiento o ampliación de los servicios urbanos de transporte público regular de uso general de viajeros, habrán de redactar un plan de explotación de servicios de transporte público, en adelante plan de explotación.

2. Las asociaciones de transportistas y demás agentes del sector del transporte que solicitaran el establecimiento o ampliación de servicios podrán redactar y proponer al Ayuntamiento, una vez admitido el plan de explotación. El Ayuntamiento, una vez admitido el plan de iniciativa particular, proseguirá su tramitación de acuerdo con lo dispuesto en el artículo 11 de esta ley.

3. El Ayuntamiento redactor del plan de explotación podrá recabar de los Ayuntamientos de su área de influencia 
la información necesaria relativa al transporte público.

4. De la iniciativa municipal respecto a la elaboración del plan de explotación deberá darse cuenta, en el plazo de diez días, a la Dirección General competente.

Artículo 7. Documentación del plan de explotación.

Al plan de explotación habrá de acompañar, en todo caso, la siguiente documentación:

a. Estudio de la oferta y demanda del transporte público de viajeros, tanto regular como discrecional, en el término municipal y su área de influencia, a fin de justificar la insuficiencia del servicio existente para atender adecuadamente a las necesidades de los usuarios.

b. Relación de concesionarios lineales o zonales existentes de servicios regulares, así como de titulares de autorizaciones de transporte regular de uso especial.

c. Estudios de infraestructuras, obras públicas o privadas vinculadas a la prestación de los servicios de transporte público previstas en el plan de explotación.

d. Instrumentos de planeamiento urbanístico del espacio sobre el que va a desarrollarse el servicio de transporte.

e. Memoria sobre la financiación de los distintos servicios de transporte integrados en el plan de explotación.

Artículo 8. Determinaciones vinculantes en la redacción del plan de explotación. El órgano municipal competente ajustará la redacción del plan de explotación a lo dispuesto:

a. En la red de transportes de la Comunidad Autónoma.

b. En los instrumentos de ordenación urbana y territorial.

c. En los planes de infraestructuras.

d. En las normas locales de ordenación del tráfico.

e. En las normas estatales, autonómicas y locales sobre protección del medio ambiente, el paisaje y el patrimonio histórico-artístico.
Artículo 9. Contenido del plan. El plan de explotación habrá de contener:

a. Nuevos itinerarios, calendarios, horarios y expediciones de transporte colectivo urbano o, en su caso, ampliación de los existentes.

b. Determinación de los recorridos coincidentes, total o parcialmente, con los de concesionarios de transporte interurbano.

c. Medidas de coordinación de los servicios urbanos con los interurbanos coincidentes.

d. En su caso, medidas de compensación económica en favor de los concesionarios de transporte interurbano coincidente, de acuerdo con lo dispuesto en el artículo 10. Se entenderá por servicio coincidente aquél que, desarrollándose o no sobre un mismo itinerario, se destine a cubrir los mismos tráficos.

e. Medidas de financiación de los servicios coordinados.

f. Medidas de integración o coordinación de los servicios urbanos e interurbanos.

g. En su caso, módulos objetivos para la distribución de los ingresos por tarifas entre los distintos sujetos prestadores de los servicios de transporte.

h. Programa de ejecución del plan de explotación con arreglo a los instrumentos de planeamiento urbanístico de aplicación.

i. Programa de inspección coordinada de servicios.

j. infraestructuras necesarias para la coordinación de servicios, tales como intercambiadores de transporte o aparcamientos disuasorios.

Artículo 10. Compensación a los concesionarios.

1. Las medidas de compensación económica a que se refiere la letra d) del artículo 9 podrán consistir, entre otras, en las siguientes:

Participación en contratos de gestión interesada de los concesionarios de servicios interurbanos afectados por el establecimiento o ampliación de servicios urbanos. 
Gestión de los nuevos servicios de transporte urbano, previstos en el plan de explotación, mediante concierto con el concesionario del servicio interurbano coincidente.

Participación del concesionario interurbano en sociedad municipal para la gestión de los servicios de transporte público municipal.

Integración de concesionarios interurbanos en cooperativas y posteriormente adjudicación directa de concesiones zonales programadas en el plan de explotación.

Preferencia del concesionario interurbano coincidente en el otorgamiento de las concesiones de servicio municipal incluidas en el plan de explotación.

Cualesquiera otras que garanticen el cumplimiento de los fines y principios del artículo 3 de esta ley.

2. Las medidas de compensación podrán ser objeto de convenio entre el Ayuntamiento y los concesionarios de servicios interurbanos. El Ayuntamiento incluirá el contenido del convenio en la redacción definitiva del plan, teniendo efectos vinculantes para los signatarios.

3. En aquellos supuestos en los cuales no se acuerde el establecimiento de las medidas de compensación reguladas en el punto primero de este artículo podrá procederse al rescate de la concesión interurbana, o de la parte de la misma afectada que sea susceptible de segregación, por parte de la Comunidad Autónoma en beneficio y a cargo de los servicios municipales. Se entenderá que es posible el rescate parcial cuando éste no afecte sustancialmente al equilibrio económico del resto de la concesión.

Artículo 11. Tramitación.

1. Cuando el plan de explotación hubiese alcanzado el suficiente grado de detalle, el Ayuntamiento acordará, en un solo acto de impulso:

a. El anuncio en el "Diario Oficial de Galicia”, así como en uno de los periódicos de mayor circulación en la provincia, de la exposición al público del proyecto del plan de explotación. La exposición pública se prolongará durante treinta días, en el horario que se fije en el anuncio público.

b. La notificación de la exposición pública del proyecto de plan, tanto a las asociaciones de empresarios de transporte de la provincia afectada como a los titulares de concesiones y autorizaciones de transporte regular de uso especial incluidos en su ámbito espacial.

c. La solicitud de informe a otros órganos $\mathrm{u}$ organizaciones jurídico-públicas que ejerzan competencias concurrentes con las del transporte público. En todo caso, el Ayuntamiento recabará informe de la Diputación o diputaciones provinciales afectadas, de la consellería o consellerías competentes en materia de transportes, urbanismo, obras públicas y medio ambiente y del Consello Galego de Transportes.

El informe a que se refiere el presente párrafo será vinculante, salvo el del Consello Galego de Transportes, y habrá de emitirse en el plazo de dos meses, a contar desde la recepción de la solicitud, y transcurrido el mismo sin su emisión se entenderá que éste es favorable.

2. Los informes de los órganos administrativos mencionados se limitarán al ámbito competencial que tienen atribuido y propondrán con detalle las modificaciones necesarias en el plan, a fin de que éste sea compatible con el ejercicio de las competencias que tengan atribuidas.

3. El Ayuntamiento considerará la compatibilidad entre las propuestas de modificación recibidas y la redacción originaria del plan de explotación. Si las propuestas de modificación de otros órganos administrativos fueran incompatibles con el texto del plan, el Ayuntamiento iniciará la redacción de un nuevo plan, que necesariamente incluirá las propuestas de los mencionados informes. Cuando la disconformidad entre los informes de otros órganos administrativos y el texto inicial del plan no sea esencial, el Ayuntamiento 
modificará directamente el plan de explotación en lo que sea necesario.

4. Aprobado inicialmente el plan de explotación por el Pleno del Ayuntamiento, se elevará a la consellería competente por razón de la materia, para su aprobación definitiva.

Artículo 12. Aprobación definitiva.

1. La consellería competente sólo podrá denegar la aprobación definitiva del plan de explotación en los siguientes casos:

a. Defectos en la tramitación del plan. Cuando los defectos sean subsanables, la consellería competente devolverá el plan al Ayuntamiento, detallando los trámites que deben ser cumplidos. Si concurriera junto a un defecto subsanable de procedimiento alguna otra causa de desaprobación mencionada en este artículo, la consellería ordenará la devolución del plan al Ayuntamiento para nueva redacción. Si sólo concurrieran defectos subsanables de tramitación, la consellería competente, una vez subsanados los defectos por el Ayuntamiento, aprobará preceptivamente el plan, al no ser que, como consecuencia directa de la subsanación de trámite, resulte que el plan presenta otra causa de desaprobación. Cuando los defectos de tramitación no fueran subsanables, la Consejería competente denegará la aprobación del plan.

b. Incompatibilidad del plan de explotación con los planes o normas a que se refiere el artículo 8, o con los informes vinculantes enumerados en el artículo 11.1, letra c).

c. Vulneración del equilibrio financiero de las concesiones de servicios interurbanos incluidas en el plan de explotación o sacrificio desproporcionado del interés económico de los titulares de autorizaciones de transporte regular de uso especial, en el ámbito especial coordinado por el plan de explotación.

2. Los proyectos municipales de infraestructuras de transporte incluidas en el plan de explotación sólo vincularán a la consellería competente, en los términos del artículo anterior, en cuanto a su ubicación. La vinculación de la consellería competente comprenderá también el proyecto concreto de infraestructuras cuando en el propio plan de explotación se contemple la financiación municipal de las obras. Aprobado el plan de explotación, los planes generales y demás instrumentos generales de ordenación urbanística habrán de calificar el espacio ocupado por las obras de infraestructura como sistema general de transportes y no podrán incluir determinaciones que supongan una interferencia o perturbación en el ejercicio de las competencias de la Xunta sobre ordenación de los transportes interurbanos y coordinación con los transportes urbanos.

Artículo 13. Actos de ejecución.

Aprobado el plan de explotación, cada Administración dictará las resoluciones necesarias para su ejecución, en el ámbito de su competencia, sin perjuicio de lo establecido en el artículo 14.2 de esta ley.

Artículo 14. Eficacia concentrada.

1. Cuando el plan de explotación incluyera un convenio entre Ayuntamiento y concesionarios, según lo previsto en el artículo 10.2 de esta ley, la resolución favorable de la consellería competente conllevará la modificación o novación de las concesiones de servicios interurbanos incluidas en el convenio.

2. Las obras de infraestructuras incluidas en el plan de explotación tienen el carácter de obras públicas de interés general. Su ejecución no estará sometida a previa autorización de la Junta o licencia municipal, siempre que el proyecto de obras quede suficientemente definido en el plan de explotación aprobado.

Artículo 15. Silencio administrativo.

1. La consellería resolverá sobre la aprobación del plan de explotación en el plazo de siete meses desde la entrada del mismo en el Registro de la consellería. Transcurrido este plazo, el Ayuntamiento podrá iniciar el procedimiento para el 
establecimiento o ampliación de servicios urbanos de transporte colectivo, sin necesidad de seguir el procedimiento establecido en el artículo 6 de la presente ley.

2. La resolución favorable o desfavorable, una vez transcurrido el plazo del párrafo anterior e iniciado el procedimiento municipal de creación o ampliación del servicio, suspenderá éste, pero serán a cargo de la consellería todos los gastos originados al Ayuntamiento o concesionarios como consecuencia del procedimiento iniciado.

La aprobación o denegación tardía de la consellería no paralizará el procedimiento de otorgamiento de concesiones de transporte, una vez publicada la convocatoria.

Artículo 16. Medidas provisionales.

1. Encontrándose en elaboración el plan de explotación, la consellería competente por razón de la materia podrá adoptar, previa audiencia por el plazo de cinco días a los Ayuntamientos y concesionarios afectados, las medidas provisionales necesarias para el cumplimiento de los fines del artículo 3 de esta ley.

2. Las medidas provisionales podrán consistir en la ampliación de las concesiones de servicios interurbanos. Dicha ampliación estará condicionada resolutoriamente a la aprobación del plan de explotación.

\section{CAPÍTULO II INICIATIVA DE LA XUNTA}

Artículo 17. Modificación de servicios interurbanos.

1. La consellería competente por razón de la materia, previo trámite de audiencia al Ayuntamiento, podrá acordar la modificación de las condiciones de prestación de los servicios de transporte interurbano para atender a las necesidades de desplazamiento entre núcleos de población de un mismo término municipal, siempre que éstos no estuvieran atendidos por los servicios urbanos prestados por el Ayuntamiento, todo ello de conformidad con los principios y fines del artículo 3 de la presente ley.
2. De acuerdo con lo establecido en el número anterior, e iniciado el expediente de modificación de servicios interurbanos, los municipios o mancomunidades de los mismos a que se refiere el servicio proyectado no podrán iniciar expedientes de ampliación o establecimiento de servicios urbanos colectivos para atender a los mismos tráficos durante el plazo de siete meses establecido en el punto 5 de este artículo, salvo que en el trámite de audiencia establecido en el punto anterior el Ayuntamiento no acuerde hacerse cargo del servicio.

3. Una vez que el proyecto de servicio interurbano esté suficientemente definido, el Director general competente acordará, en un solo acto de impulso:

a. Recabar informe de los Ayuntamientos a que se refiera el nuevo servicio interurbano. En el informe de los Ayuntamientos se contendrán un mínimo de tres propuestas alternativas de itinerarios y paradas en el tramo de penetración del servicio interurbano sobre suelo urbano y urbanizable. Las propuestas municipales se redactarán de acuerdo con los fines y principios del artículo 3 de esta ley. Transcurridos tres meses sin que se hubiesen formulado dichas propuestas, se continuará la tramitación del expediente.

b. Recabar informe, en todo caso, de la Diputación o diputaciones provinciales afectadas, de la Dirección General de Urbanismo y Calidad Medioambiental, de la Dirección General de Obras Públicas y del Consello Galego de Transportes, que habrá de ser emitido en el plazo de dos meses.

c. Publicar el proyecto de modificación de servicios de transporte en el "Diario Oficial de Galicia", así como en uno de los periódicos de mayor circulación en la provincia. A partir de la publicación se abrirá un plazo de treinta días naturales de exposición pública y alegaciones al proyecto de la Xunta.

d. Notificar el proyecto de modificación de servicios tanto a las federaciones 
y asociaciones de empresarios del transporte como a los titulares de concesiones de transporte interurbano o urbano de la misma área que el servicio proyectado, así como a los titulares de autorizaciones de transporte regular de uso especial.

4. La resolución favorable del conselleiro competente a la modificación del servicio incluirá, en todo caso, itinerario y paradas en el suelo urbano y urbanizable y de núcleos rurales regulados en la legislación del suelo de Galicia, de acuerdo con una de las tres propuestas detalladas en los distintos informes municipales, siempre que éstas se hubiesen formulado en el plazo previsto en el apartado 3.a) de este artículo, así como medidas de garantía del equilibrio económico de los servicios concesionales directamente afectados y del contenido patrimonial de las autorizaciones de transporte regular de uso especial.

5. Transcurridos siete meses desde la fecha de iniciación del expediente de modificación de servicios interurbanos sin que hubiese recaído resolución expresa, el Ayuntamiento podrá proceder a la iniciación de expedientes de establecimiento o ampliación de servicios municipales para atender a los mismos tráficos. A los efectos de este plazo no se computará el tiempo que utilice el Ayuntamiento en la emisión de las propuestas a que se refiere el párrafo 3.a) de este artículo.

Artículo 18. Mejora de la penetración urbana.

La consellería competente podrá acordar la mejora de la penetración de los servicios interurbanos en suelo urbano o urbanizable, de acuerdo con el siguiente procedimiento:

a. El Director general competente requerirá del Ayuntamiento una propuesta de mejora de la penetración del servicio interurbano, con al menos tres soluciones alternativas. Emitida la propuesta municipal, y siempre que ésta sea adecuada a los fines del artículo 3 de esta ley, el Director general competente propondrá al conselleiro la modificación de las concesiones interurbanas de acuerdo con una de las tres soluciones de mejora de penetración propuestas por el Ayuntamiento.

b. Transcurridos tres meses desde el requerimiento de la Dirección General competente sin que se hubiese emitido la propuesta municipal, ésta podrá proponer al Ayuntamiento un proyecto de mejora de la penetración urbana, con al menos tres posibilidades alternativas, todas ellas redactadas con arreglo a los fines y principios del artículo 3 de esta ley. El Ayuntamiento podrá optar por cualquiera de las tres posibilidades alternativas. Realizada la elección, la consellería competente podrá acordar la modificación de las concesiones interurbanas, de acuerdo con la opción escogida por el Ayuntamiento.

c. Transcurridos veinte días desde la fecha de registro municipal de la propuesta de la consellería competente sin que el Ayuntamiento se hubiese pronunciado por alguna de las alternativas, ésta podrá acordar la mejora de la penetración urbana de los servicios interurbanos de acuerdo con cualquiera de las soluciones alternativas previamente sometidas a la elección del Ayuntamiento.

\section{TÍTULO II \\ DE LA COORDINACIÓN DE LOS SERVICIOS DE TRANSPORTE DISCRECIONAL EN AUTOTAXI}

\section{Capítulo único DISPOSICIONES GENERALES}

Artículo 19. Autorizaciones interurbanas.

1. Cuando la demanda de transporte interurbano desde puntos o infraestructuras tales como hospitales, estaciones, puertos, aeropuertos, ferias o mercados no esté suficientemente cubierta con las licencias de autotaxi del municipio en donde se localizan los focos de generación del transporte, el ajuste de la oferta a la demanda se regirá por las siguientes reglas:

a. Constatada en un municipio la insuficiente oferta del transporte interurbano en 
autotaxi, la consellería competente requerirá al Ayuntamiento para que incremente el número de licencias municipales de autotaxi. La constatación a que se refiere este párrafo resultará de expediente administrativo iniciado de oficio e instruido por la Dirección General competente, con informe del Ayuntamiento afectado y audiencia de las asociaciones locales de autotaxi. La consellería comunicará al Ayuntamiento el número preciso de licencias que serían necesarias para atender a la insuficiente oferta de transporte interurbano en autotaxi que resulte del expediente.

b. Transcurridos tres meses desde el requerimiento de la consellería competente, o rechazado expresamente el mismo por el Ayuntamiento, la consellería podrá acordar el otorgamiento de autorizaciones de transporte interurbano en autotaxi, con inicio del servicio en los puntos de generación de transporte.

c. Las autorizaciones de transporte interurbano en autotaxi, a que se refiere el párrafo anterior, se otorgarán bajo condición resolutoria supedita a que se produzca un reequilibrio entre la oferta y la demanda de transporte desde los puntos e infraesctructuras a que hace referencia este número. La constatación de la adecuación entre oferta y demanda resultará de expediente administrativo, no antes de transcurridos dos años desde la resolución del expediente regulado en la letra a) de este número. Las mismas autorizaciones de transporte interurbano podrán otorgarse sometidas a reserva de revocación.

2. En los supuestos en que los servicios se originen en alguno de los centros a que se refiere el número anterior, y siempre que se encuentren situados en más de un término municipal, la regulación del servicio de autotaxis, en lo que afecta exclusivamente a este supuesto, corresponderá a la Dirección General competente, aplicándose en todo caso el régimen tarifario de los servicios interurbanos.
Artículo 20. Servicios interurbanos excepcionales.

1. Excepcionalmente, los titulares de autorizaciones interurbanas de autotaxi podrán iniciar un servicio de transporte en municipio distinto del propio cuando concurran las siguientes circunstancias: Que el contrato para la prestación del servicio tenga lugar en el Ayuntamiento que otorgó la licencia y que el servicio de transporte tenga destino final en el Ayuntamiento que otorgó la licencia.

2. Se entenderá por lugar del contrato aquél en donde el transportista reciba la oferta.

3. El contrato de transporte se convendrá con el usuario del servicio o con mandatario verbal del mismo.

4. La escritura es requisito de forma esencial del contrato. La consellería competente aprobará el modelo oficial del contrato, en donde constarán necesariamente las partes contratantes, precisando si el usuario contrata en nombre propio o por medio de mandatario; el lugar, fecha y hora de la contratación; la hora previsible para el inicio del servicio contratado; y los puntos de inicio y destino del servicio.

5. Cuando el contrato se formalice por mandatario verbal, el usuario dejará constancia escrita de la existencia del mandato antes del inicio del servicio de transporte.

6. El contrato de transporte, que habrá de llevarse en lugar visible del vehículo durante el servicio, estará a disposición de la Inspección de Transportes en cualquier momento de la prestación del citado servicio.

7. Terminado el servicio, el titular de la licencia de autotaxi remitirá copia del contrato al Servicio Provincial de Transportes competente.

8. La recogida de viajeros fuera del ámbito espacial de la licencia de autotaxi, con incumplimiento de lo dispuesto en este artículo, constituirá infracción administrativa muy grave, que será sancionada de acuerdo con la legislación vigente en materia de transportes. Cuando 
la denuncia de infracción por particulares esté acompañada de solicitud de iniciación de expediente sancionador deberá comunicarse al denunciante la iniciación o no del procedimiento. De la imposición de la sanción se dará cuenta al Ayuntamiento que otorgó la licencia. En todo lo no previsto en este artículo, la imposición de la sanción se regirá por los principios y reglas del procedimiento administrativo sancionador establecido en la Ley 16/1987, de 30 de julio, de ordenación de los transportes terrestres, y en su Reglamento de ejecución aprobado por el Real Decreto 1211/1990, así como en lo establecido en el título IX de la Ley estatal común 30/1992, de 26 de noviembre.

9. La acumulación de tres o más infracciones en el período de doce meses determinará la caducidad de la autorización de transporte interurbano, siempre que las sanciones sean definitivas en vía administrativa, y previa declaración expresa de la Dirección General competente. En el procedimiento de declaración de caducidad de la autorización de transporte interurbano se respetarán, en todo caso, las garantías procedimentales del titular de la autorización de transporte interurbano contempladas en el título VI de la Ley estatal común 30/1992, de 26 de noviembre.

10. La Dirección General competente, para garantizar la armónica coordinación de los servicios de autotaxis, podrá establecer limitaciones a la posibilidad de la contratación previa para iniciar el servicio fuera del término municipal en donde esté residenciada la tarjeta del vehículo.

Dichas limitaciones se determinarán con carácter general, para toda Galicia, previo informe de la Sección de Transporte Público de Viajeros en vehículos de menos de nueve plazas, incluido el conductor, del Comité Gallego de Transportes.

Artículo 21. Unificación de tarifas.

1. Toda resolución o convenio para la creación de un área territorial de prestación conjunta incluirá necesariamente la unificación de tarifas para los servicios que se inicien en los puntos de generación de transporte a que se refiere el artículo 19 de esta ley.

2. Los órganos que, con anterioridad a la aprobación de esta ley, establecieron o convinieron la creación de una área territorial de prestación conjunta unificarán las tarifas a que se refiere el párrafo primero en el plazo de tres meses desde la publicación de la presente ley. Transcurrido este plazo, y mientras no tenga lugar la decisión o el convenio de unificación tarifaria, se entenderá por tarifa unificada la más baja de entre las existentes para cada clase de servicio en los distintos municipios de la misma área.

\section{Artículo 22. Servicio nocturno.}

1. Corresponde a cada Ayuntamiento asegurar la prestación de servicios de transporte nocturno interurbano en autotaxi.

2. Constatada la insuficiencia de servicios nocturnos interurbanos en un determinado municipio, la consellería competente, mediante el correspondiente expediente administrativo, requerirá al Ayuntamiento para el cumplimiento de la obligación enunciada en el párrafo primero.

3. Transcurridos tres meses desde la recepción del requerimiento, la consellería competente podrá acordar que los servicios nocturnos sean prestados por los autotaxis de los municipios limítrofes o más próximos, cuando los primeros no permitieran garantizar su prestación. Estas autorizaciones podrán otorgarse bajo condición resolutoria o sometidas a reserva de revocación.

\section{DISPOSICIÓN ADICIONAL}

Lo dispuesto en el título primero de la presente ley, en lo referente al establecimiento o ampliación de servicios urbanos colectivos, será de aplicación además de a los municipios a cualquier entidad local, con competencias en materia de transportes, constituida con anterioridad o posterioridad a la aprobación de esta ley. 


\section{DISPOSICIÓN TRANSITORIA}

Lo dispuesto en la presente ley será inmediatamente de aplicación a todos los procedimientos de ampliación o establecimiento de servicios urbanos que se encuentren en tramitación a la entrada en vigor de la presente ley.

\section{DISPOSICIÓN FINAL PRIMERA}

Se faculta al Consello de la Xunta para que dicte cuantas normas sean precisas para el desarrollo de la presente ley.

\section{DISPOSICIÓN FINAL SEGUNDA}

La presente ley entrará en vigor el día siguiente de su publicación en el "Diario Oficial de Galicia”.

\section{LEY 5/1994, DE 29 DE NOVIEMBRE, DE CREACIÓN DEL ENTE PÚBLICO PUERTOS DE GALICIA (DOGA N. . 243, 20. 12. 1994) $)^{519}$}

\section{$(\ldots)^{520}$ \\ Capítulo I \\ NATURALEZA Y FUNCIONES}

Artículo 1. Naturaleza y personalidad.

1. Se crea en el ámbito de la Comunidad Autónoma de Galicia la entidad de derecho público Puertos de Galicia, que desarrollará y gestionará las funciones y servicios que, en materia de puertos de competencia de la Comunidad Autónoma, le son atribuidos por la presente ley, con sujeción a los principios de la Ley de régimen financiero y presupuestario de Galicia.

2. El ente público tiene personalidad jurídica y patrimonio propios, así como plena capacidad para el cumplimiento de sus fines, sin perjuicio de las relaciones que en esta ley se establecen con la Xunta de Galicia.

519 Véase Decreto 227/1995, de 20 de julio, por el que se aprueba el Reglamento del Ente Público Portos de Galicia, dictado en aplicación y desarrollo de la Ley $5 / 1994$, de 29 de noviembre.

520 Exposición de motivos omitida.
3. El ente público quedará adscrito a la consellería competente en materia de puertos.

Artículo 2. Objeto.

1. Corresponde al Ente Público Portos de Galicia el proyecto, construcción, conservación, mejora, ordenación, administración y explotación de las obras, instalaciones, servicios y actividades portuarias, así como la planificación de las zonas de servicios y sus futuras ampliaciones.

Asumirá igualmente las funciones que, en el ámbito de competencias de la Comunidad Autónoma, puedan serle atribuidas por la Xunta de Galicia en materia de gestión y actuaciones en el dominio público marítimo-terrestre.

2. Sin perjuicio de las competencias que esta ley atribuye en su capítulo III a los órganos superiores de la Administración autónoma gallega, el Ente Público Portos de Galicia dispondrá de las potestades reguladas en la presente ley y de las facultades necesarias para la realización efectiva de sus fines.

3. A los efectos del desarrollo y cumplimiento de dichos fines, el ámbito territorial de cada puerto será el comprendido dentro de los límites de su zona de servicio.

Las aguas de cada puerto serán las adscritas por la Administración del Estado.

Artículo 3. Funciones.

1. Dentro de la esfera de actividades encuadradas en el objeto delimitado en el artículo anterior, Puertos de Galicia gestionará la explotación de las instalaciones portuarias y de los demás bienes adscritos a su patrimonio.

2. Asumirá el fomento global de la actividad económica en el ámbito de los puertos que dependen de la Administración de la Comunidad Autónoma, de las actividades industriales o comerciales directamente relacionadas con el tráfico portuario y el fomento de la investigación y desarrollo tecnológico en materias relacionadas con la explotación y construcción portuarias. 
3. Asimismo podrá realizar con la iniciativa pública o privada cuantas operaciones comerciales e industriales considere convenientes y gestionará todas las obras, instalaciones y servicios, pudiendo celebrar, a estos efectos, cualquier clase de negocios jurídicos.

Artículo 4. Régimen jurídico.

1. Puertos de Galicia se regirá por la presente Ley, que constituye su estatuto, y por las disposiciones que se dicten en su desarrollo. Supletoriamente, y en materia de puertos, será de aplicación la legislación estatal vigente.

2. Sin perjuicio de lo dispuesto en el apartado anterior, en sus relaciones jurídicas externas, adquisiciones patrimoniales y contratación, el ente público estará sujeto al régimen de derecho privado, sin otras excepciones que las previstas en esta ley.

\section{Capítulo II ESTRUCTURA ORGÁNICA}

Artículo 5. Órganos del ente.

Para el desempeño de sus funciones, Puertos de Galicia se estructura en los siguientes órganos:

a. Presidente del Consello de Administración.

b. Consello de Administración.

c. Director.

Artículo 6. El Presidente del Consello de Administración.

1. El Presidente del Consello de Administración es el órgano superior de dirección y gestión del ente público.

2. El Presidente será nombrado por el Consello de la Xunta de Galicia, a propuesta del conselleiro competente en materia de puertos.

3. Compete al Presidente:

a. Ejercer la representación del ente público.

b. Desarrollar y ejecutar las directrices que dicte la Xunta en materia de su competencia.

c. Ejercer la alta dirección del personal del ente público. d. Proponer al Consello de Administración las políticas generales de actuación y gestión del ente, de acuerdo con las directrices y los criterios establecidos al efecto por la Xunta de Galicia.

e. Ejercer la iniciativa en la elaboración de los planes de obras, de instalaciones de los puertos, y de sus ampliaciones, y de los planes especiales de ordenación portuaria.

f. Formular y elevar al Consello de la Xunta, a través de la consellería competente en materia de puertos y a propuesta de la Consellería de Economía e Facenda, los programas generales plurianuales de inversiones y su financiación anual con sus, en su caso, complementarios presupuestos de explotación y capital.

Asimismo le compete formular y elevar al Consello de la Xunta, a través de la consellería competente en materia de puertos, previo informe de la Consellería de Economía e Facenda, el programa anual de actuaciones e inversiones.

g. Acordar la realización de las obras e inversiones, celebrando todos aquellos contratos, actos y negocios jurídicos que sean necesarios para el desarrollo de las funciones del ente y el cumplimiento de sus fines.

h. Acordar las operaciones crediticias a medio y largo plazo que sean necesarias, previo informe de la Consellería de Economía e Facenda.

i. Acordar las operaciones crediticias necesarias para paliar los desequilibrios transitorios de tesorería.

j. Velar por el cumplimiento de los acuerdos del Consello de Administración.

k. Conferir las delegaciones de facultades propias que considere convenientes.

1. Ejercer todas las funciones no atribuidas expresamente a otros órganos del ente público.

Artículo 7. El Consello de Administración.

1. El Consello de Administración es el órgano superior colegiado del ente público. 
2. Estará constituido por su Presidente y el número de vocales que se establezca reglamentariamente, nombrados por el Consello de la Xunta, entre los que, en todo caso, estarán representadas las distintas consellerías que puedan tener intereses en la materia por razones de su competencia, en especial la consellería competente en materia de pesca, así como las entidades locales y los usuarios.

3. Compete al Consello de Administración, en todo caso, el ejercicio de las siguientes facultades:

a. Controlar el cumplimiento de las directrices aprobadas por la Xunta de Galicia.

b. Aprobar las normas de régimen interior del ente público, así como la organización de los servicios administrativos y de los puertos.

c. Aprobar la dotación de personal del ente público y su régimen de retribuciones, previo informe de la Consellería de Economía e Facenda.

d. Elaborar las tarifas por servicios portuarios para su posterior elevación al Consello de la Xunta, a través de la Consellería de Economía e Facenda y a propuesta de la consellería competente en materia de puertos.

e. Proponer a los órganos competentes de la Xunta de Galicia, a través de la consellería competente en materia de puertos, la aprobación de los planes de obras, de instalaciones de los puertos y de sus ampliaciones, así como de los planes especiales de ordenación portuaria.

Cuando se trate de planes de obras o instalaciones portuarias y sus ampliaciones o planes especiales de ordenación portuaria cuyo contenido sea de naturaleza pesquera, previamente a su elevación al órgano competente para su aprobación, se recabará informe de la consellería competente en materia de pesca ${ }^{521}$.

f. Aprobar la gestión anual y el balance, así como la cuenta de resultados y la memoria de cada ejercicio económico.

521 Art. 7.3.e modificado por Ley 3/2002, de 29 de abril, de medidas de régimen fiscal y administrativo. g. Promover y ejercer, dentro del ámbito de su competencia, toda clase de pretensiones, acciones y recursos ante cualquier órgano de la Administración del Estado, de la Comunidad Autónoma y de las administraciones locales, así como ante los Juzgados y Tribunales de Justicia de cualquier grado y jurisdicción, desistir de los formulados o interpuestos y transigir las cuestiones litigiosas, confiriendo al efecto las procuraciones oportunas.

h. Conferir las delegaciones de facultades que juzgue oportunas.

i. Velar por el cumplimiento de la presente ley y de las disposiciones que se dicten para su desarrollo y ejecución.

4. El Consello de Administración designará, a propuesta de su Presidente, un Secretario, que ejercerá las funciones propias del cargo en las empresas mercantiles.

5. Reglamentariamente se determinará el funcionamiento y régimen de adopción de acuerdos del Consello de Administración. En lo no previsto se tendrá en cuenta lo dispuesto en el capítulo II del título II de la Ley 30/1992, de 26 de noviembre, de Régimen Jurídico de las Administraciones Públicas y del Procedimiento Administrativo Común.

Asimismo se podrá prever reglamentariamente la creación de comisiones delegadas del Consello de Administración.

Artículo 8. Juntas territoriales.

Para el estudio de los problemas concretos que afectan a cada fachada marítima, podrá designarse juntas de trabajo, que actuarán con funciones consultivas e informativas. Los miembros de dichas juntas, que serán representantes de los distintos órganos de la Administración y de los sectores de usuarios, serán designados por el Consello de Administración, a propuesta del Presidente del ente.

$\mathrm{Su}$ ámbito territorial de actuación será fijado por el Consello de Administración.

Artículo 9. El Director.

1. El Director es el órgano de gestión del ente público, bajo la directa dependencia del Presidente del Consello de Administración. 
2. Será nombrado por el conselleiro competente en materia de puertos, a propuesta del Presidente de la entidad, entre técnicos de reconocida experiencia ${ }^{522}$.

3. Corresponde al Director, en los términos señalados en el apartado 1 anterior:

a. Dirigir la gestión ordinaria, la inspección del ente y de los puertos y su explotación.

b. Velar por la percepción, contabilización y control de los ingresos derivados de la gestión empresarial.

c. Ejercer cuantas funciones le sean delegadas y, en general, las que resulten inherentes al normal funcionamiento del ente.

\section{Capitulo III RELACIONES CON LA ADMINISTRACIÓN AUTONÓMICA}

Artículo 10. Competencias del Consello de la Xunta.

Compete al Consello de la Xunta el ejercicio de las siguientes funciones:

a. La alta inspección y vigilancia de su funcionamiento, dictando a estos efectos las oportunas directrices.

b. Aprobar los planes de obras e instalaciones, los programas generales de inversiones y su financiación.

c. La alta política en materia de ordenación y coordinación del tráfico y de los transportes portuarios en el ámbito de sus competencias.

d. La designación y la destitución del Presidente y, en su caso, de los vocales del Consello de Administración, así como la fijación de su régimen retributivo.

e. La adopción de medidas especiales en casos de emergencia.

f. Aprobar el proyecto de presupuesto de explotación y capital y el programa de actuaciones, inversiones y financiación, así como, en su caso, los convenios o contratos de programa que proponga el ente.

g. Aprobar las tarifas de los servicios portuarios y por ocupación del dominio

522 Art. 9.2 modificado por Ley 2/1998, de 8 de abril, de medidas tributarias, de régimen presupuestario, función pública, patrimonio, organización y gestión. público portuario adscrito a la Comunidad Autónoma, así como sus modificaciones y revisiones.

h. Adoptar los acuerdos sobre tráfico jurídico del dominio público portuario adscrito al ente, en los casos en que esta facultad le esté reservada por la ley del patrimonio de la Comunidad Autónoma y su Reglamento, y, en especial, en lo relativo a la incorporación de nuevas infraestructuras portuarias.

i. Adscribir las zonas de interés de cultivos marinos en dominio público portuario a la consellería competente en materia de pesca a los efectos del ejercicio de sus competencias en materia de acuicultura.

Se entiende, a los efectos de la presente ley, como zonas de interés de cultivos marinos aquellas zonas de las aguas del dominio público portuario que por sus óptimas condiciones para tal actividad aconsejen una especial protección y así sean declaradas por el Consello de la Xunta de Galicia a propuesta de la consellería competente en materia de pesca ${ }^{523}$.

Artículo 11. Atribuciones de la consellería competente en materia de puertos.

1. Son atribuciones de la consellería competente en materia de puertos:

a. El desempeño de las funciones de inmediata relación de Puertos de Galicia con el Gobierno y con la Administración autonómicos, especialmente a los efectos de actuación de las facultades enumeradas en el artículo anterior.

b. La propuesta de nombramiento y de destitución del Presidente y de los Vocales que reglamentariamente se determinen, así como el nombramiento y la destitución del Director de la entidad.

c. Emitir informe preceptivo sobre los planes, programas generales en materia financiera e infraestructuras, los programas de actuaciones, inversiones y financiación, los presupuestos de explotación y capital $\mathrm{y}$, en general, sobre todas las propuestas,

523 Art. 10.i añadido por Ley 3/2002, de 29 de abril, de medidas de régimen fiscal y administrativo. 
proyectos o documentación que hayan de someterse al examen y aprobación del Consello de la Xunta.

d. Elevar al Consello de la Xunta, previo informe de la Consellería de Economía e Facenda y de las consellerías competentes en materia de industria y comercio y de pesca, la propuesta sobre política de tarifas portuarias.

e. Ejercer en los términos previstos en la legislación vigente las facultades de expropiación forzosa que le sean precisas para el cumplimiento de los fines del ente y promover la entrega de los bienes expropiados a Puertos de Galicia, proponiendo su afectación, en los términos regulados por la Ley del Patrimonio de la Comunidad Autónoma y su Reglamento.

f. Otorgar las concesiones y autorizaciones por ocupación de dominio público adscrito a la Comunidad Autónoma dentro del recinto portuario y aplicar los correspondientes cánones, sin perjuicio de lo dispuesto en el artículo 3.3.

g. Proponer la actualización de la cuantía de las tarifas portuarias de acuerdo con la variación del coste de los servicios, producida por alteraciones en los índices de precios.

Artículo 11 bis. Atribuciones de la consellería competente en materia de pesca.

a. La construcción de lonjas, fábricas de hielo y otras edificaciones del recinto portuario destinadas a actividades pesqueras, acuícolas o marisqueras, debiendo recabar, previamente, de Puertos de Galicia informe preceptivo y vinculante sobre su ubicación.

b. Autorizar la realización de actividades de acuicultura, pesca y marisqueo que tengan lugar en los puertos o en el dominio público portuario, con carácter previo al otorgamiento de las concesiones y autorizaciones para la ocupación de dicho dominio que corresponde a su titular.

c. Emitir, con carácter preceptivo, informe sobre la relación de actuaciones previstas en el programa de infraestructura pesquera del presupuesto general de Puertos de Galicia ${ }^{524}$.

Artículo 12. Competencias de la Consellería de Economía e Facenda.

En lo no previsto expresamente en esta ley es competencia de la Consellería de Economía e Facenda:

a. La alta supervisión de la aplicación por el ente de los planes y programas financieros y de sus presupuestos $\mathrm{y}$, en general, de cuanto concierne al orden financiero de Puertos de Galicia.

b. Presentar al Consello de la Xunta los planes económicos y presupuestarios de Puertos de Galicia y emitir informe sobre su aplicación y liquidación.

c. Presentar las actuaciones que, en materia financiera, tengan que someterse al Consello de la Xunta.

d. El ejercicio de las competencias que, respecto al dominio público portuario, le son atribuidas por la Ley del Patrimonio de la Comunidad Autónoma y su Reglamento.

e. Ejercer todas las demás competencias que la Ley de Régimen Financiero y Presupuestario de Galicia otorga a la Consellería de Economía e Facenda en el ámbito de las empresas públicas.

f. El ejercicio de las atribuciones previstas en la Ley de Tasas, Precios y Exacciones reguladoras de la Comunidad Autónoma de Galicia.

\section{Capitulo IV}

Normas particulares de gestión y explotación empresarial

Artículo 13. Conservación, ampliación y amortización del material y de las instalaciones.

1. Puertos de Galicia adoptará las medidas adecuadas para garantizar que las instalaciones e infraestructuras portuarias o sus servicios y actividades accesorias y complementarias, así como el material confiado a su custodia y explotación, sean construidos, conservados y renovados

524 Art. 11 bis añadido por Ley 3/2002, de 29 de abril, de medidas de régimen fiscal y administrativo. 
conforme a las necesidades del tráfico portuario y al progreso de la técnica.

2. La atribución al ente de la gestión de las instalaciones, servicios o actividades a que se refiere el párrafo anterior comprende el otorgamiento implícito de todas las autorizaciones, permisos o licencias administrativas de competencia de la Administración autonómica que resulten necesarios para las obras de conservación, mantenimiento y reposición de las instalaciones y para las demás actividades auxiliares directamente relacionadas con la explotación portuaria, sin perjuicio de las autorizaciones o de los títulos administrativos propios de la competencia local o estatal cuando resulten exigibles.

Artículo 14. Condiciones generales de contratación.

El ente público elaborará las cláusulas o estipulaciones generales rectoras de su contratación, que aprobará el conselleiro competente en materia de puertos. Los procedimientos tendrán en cuenta, en todo caso, los principios de publicidad y concurrencia, propios de la contratación del sector público.

Artículo 15. Actividad inspectora. Puertos de Galicia ejercerá la inspección de los servicios portuarios, a fin de garantizar su seguridad, su eficacia, el cumplimiento por las empresas explotadoras y por los usuarios de las obligaciones que les correspondan y la observancia de las normas técnicas y comerciales de carácter general a que tenga que sujetarse la gestión y explotación de los bienes, instalaciones o actividades.

\section{Capítulo V HACIENDA Y PATRIMONIO}

Artículo 16. Hacienda.

1. Constituirá la hacienda de Puertos de Galicia el conjunto de sus bienes y derechos.

2. Se incluyen dentro de la hacienda de Puertos de Galicia:

a. La totalidad de los productos de las tarifas por servicios y los cánones que, con arreglo a la legislación sectorial, corresponda percibir a la Comunidad Autónoma por concesiones administrativas y autorizaciones de gestión en el dominio público adscrito a ella.

b. Las dotaciones o subvenciones que se consignen en los presupuestos generales de la Comunidad Autónoma.

c. El importe de las operaciones crediticias que puedan concertar.

d. Las subvenciones de todo tipo que pueda recibir.

e. Los demás ingresos de derecho público o privado que se autoricen en virtud de los presupuestos de la Comunidad Autónoma o de otra Ley del Parlamento de Galicia.

Artículo 17. Patrimonio.

1. Para el desempeño de sus funciones se adscriben a Puertos de Galicia los bienes y derechos que integran el dominio público portuario autonómico a la entrada en vigor de la presente ley, así como los posteriores incorporados al mismo por cualquier título, sin perjuicio de los bienes de dominio público portuario adscritos a la consellería competente en materia de pesca para el ejercicio de sus facultades en acuicultura y ordenación del sector pesquero ${ }^{525}$.

2. La adscripción implica la transferencia al ente público de las facultades de uso, gestión, administración y explotación vinculadas a los fines de éste, sin cambio de titularidad o calificaciones jurídicas de los bienes y derechos cedidos.

3. Cuando los bienes y derechos de dominio público portuario que tuviese adscritos dejen de ser necesarios para el cumplimiento de los fines propios del ente, éstos serán objeto de reversión en la forma prevista en las leyes sectoriales.

4. Puertos de Galicia podrá realizar todo tipo de acto de gestión y aprovechamiento de los bienes demaniales adscritos que estén directamente relacionados con el servicio y tráfico portuario.

525 Art. 17.1 modificado por Ley $3 / 2002$, de 29 de abril, de medidas de régimen fiscal y administrativo. 
El consello de Administración, sin necesidad de previa declaración de desafectación del servicio, podrá acordar el desmantelamiento y, en su caso, la venta de los demás bienes muebles, y aplicará su producto a las atenciones propias del ente.

5. El Consello de la Xunta dictará, previa propuesta de la Consellería de Economía e Facenda e informe de la consellería competente en materia de puertos y de la consellería competente en materia de pesca, las normas para la formación y permanente actualización del inventario de bienes y derechos de Puertos de Galicia, que se ajustarán a las prescripciones de la Ley del Patrimonio de la Comunidad Autónoma y de su Reglamento ${ }^{526}$.

\section{Capítulo VI RÉGIMEN FINANCIERO}

Artículo 18. Equilibrio económicofinanciero y formas de su control.

1. El régimen de control financiero y contabilidad pública, así como el presupuesto de Puertos de Galicia, se ajustarán a lo dispuesto en la materia por la Ley de régimen financiero y presupuestario de Galicia, sin perjuicio de las especialidades contenidas en la presente ley.

2. La gestión de Puertos de Galicia se desarrollará de acuerdo con el principio de equilibrio económico-financiero de la explotación.

A tal efecto presentará anualmente al Consello de la Xunta, a través de la Consellería de Economía e Facenda y a instancia de la consellería competente en materia de puertos, previa elevación a ésta por el Presidente del Consello de Administración, los presupuestos de explotación y capital, así como los correspondientes programas de actuación, inversiones y financiación, y la liquidación, memoria y balance del ejercicio anterior debidamente auditados

526 Art. 17.5 modificado por Ley $3 / 2002$, de 29 de abril, de medidas de régimen fiscal y administrativo. conforme a las reglas usuales de las empresas mercantiles.

3. El Consello de la Xunta determinará anualmente, dentro de los límites autorizados por los presupuestos de la Comunidad Autónoma, el destino de un porcentaje de los beneficios que resulten de la cuenta de explotación a la dotación de un fondo para atender las necesidades de explotación y las de renovación, ampliación y mejora del activo.

4. Se compensará a Puertos de Galicia por los gastos inherentes al cumplimiento de obligaciones de servicio impuestas por la Xunta de Galicia en el ejercicio de sus funciones de alta dirección institucional del ente.

Artículo 19. Tarifas portuarias y otros ingresos de explotación.

Las tarifas, cánones y demás ingresos derivados de la explotación habrán de cubrir, como mínimo, los siguientes gastos:

a. Explotación, conservación y depreciación del material y de las instalaciones portuarias, así como de las infraestructuras que sirvan a sus fines accesorios o complementarios.

b. Los gastos generales que se consideren para cada instalación portuaria o para sus servicios o actividades accesorias o complementarias, dentro del límite máximo que se determine en virtud del decreto aprobado por el Consello de la Xunta.

c. Los impuestos exigibles.

d. Las cargas económicas, administrativas y financieras, incluyendo el reembolso de préstamos derivados de la explotación y el pago de intereses.

Artículo 20. Efectividad de los créditos y de las sanciones.

El ente público podrá utilizar, para la efectividad de los créditos resultantes de la explotación y de las sanciones pecuniarias que impusiese, el procedimiento de apremio en los términos regulados en el Reglamento general de recaudación. 


\section{Capitulo VII PERSONAL}

Artículo 21. Régimen del personal.

1. El personal del Ente Público Portos de Galicia quedará vinculado a él en régimen de derecho laboral, sin perjuicio de lo previsto en las disposiciones transitorias primera y tercera.

2. El personal estará sometido a la legislación laboral y a los preceptos de la Ley de la Función Pública gallega, que le serán de aplicación, excepto en los supuestos previstos expresamente en la ley.

3. El personal de Puertos de Galicia será nombrado por el Consello de Administración dentro de los límites de las relaciones o de las plantillas aprobadas de acuerdo con las previsiones de los presupuestos generales de la Comunidad Autónoma.

4. El ingreso de este personal con carácter fijo en el ente público habrá de realizarse mediante la convocatoria pública de las correspondientes pruebas selectivas, que habrán de tener en cuenta, en todo caso, los principios de méritos y capacidad.

5. El personal funcionario al servicio de la Administración de la Comunidad Autónoma de Galicia podrá entrar a formar parte de Puertos de Galicia a través del procedimiento que reglamentariamente se establezca, integrándose en todo caso en el régimen de derecho laboral y respetándosele su antigüedad.

6. A estos efectos, el ente público recogerá en sus planes económicos y financieros las obligaciones precisas para el respeto de dichos derechos adquiridos.

\section{DISPOSICIÓN ADICIONAL}

1. El Consello de la Xunta podrá autorizar la creación de sociedades mercantiles dependientes del ente público para la gestión empresarial singularizada de actividades portuarias determinadas.

2. El ente público tendrá participación mayoritaria en el capital de las sociedades referidas en el número anterior, a las que se aplicará la legislación autonómica sobre régimen financiero y presupuestario.

\section{DISPOSICIÓN TRANSITORIA PRIMERA}

El personal funcionario que a la entrada en vigor de esta ley estuviese adscrito a los servicios de puertos dependientes de la consellería competente en esta materia podrá solicitar integrarse en la plantilla del ente público sin alteración en su situación administrativa.

\section{DISPOSICIÓN TRANSITORIA SEGUNDA}

El personal laboral que a la entrada en vigor de esta ley estuviese prestando sus servicios en los puertos de competencia de la Comunidad Autónoma de Galicia podrá solicitar intregrarse en Puertos de Galicia, conservando los derechos laborales de todo tipo que tenga reconocidos. $\mathrm{La}$ integración se ajustará a la estructura de la plantilla que en su momento se apruebe.

\section{DISPOSICIÓN TRANSITORIA TERCERA}

Examinadas las solicitudes, los órganos del nuevo ente, a la vista de sus necesidades de personal, según la relación de puestos de trabajo que se apruebe, decidirán sobre dichas solicitudes.

El personal de esta clase que no se integre en Puertos de Galicia tendrá opción a prestar sus servicios en otros órganos de la Administración autonómica.

\section{DISPOSICIÓN TRANSITORIA CUARTA}

El personal interino y el contratado administrativo que a la entrada en vigor de esta ley prestase sus servicios en la Administración portuaria de la consellería competente en materia de puertos podrá, asimismo, ser integrado en Puertos de Galicia, en la forma prevista en la disposición transitoria primera. En todo caso, dicho personal podrá acceder a la condición de funcionario de carrera en los términos establecidos por la Ley de la función pública de Galicia, en las mismas condiciones que el que no ejerciese la opción de integración.

El personal de esta clase que no se integre continuará prestando sus servicios en la Administración autonómica. 


\section{DISPOSICIÓN TRANSITORIA OUUINTA}

La integración en la plantilla del ente público se entenderá sin menoscabo de los derechos adquiridos con anterioridad por el personal que la ejerza.

\section{DISPOSICIÓN DEROGATORIA}

1. A la entrada en vigor de la presente Ley quedarán derogados los Decretos 19/1983, de 17 de enero, y 351/1986, de 2 de octubre, por los que se regulan la estructura y el funcionamiento de la $\mathrm{Co}$ misión de Puertos de Galicia, y los títulos III y IV de la Ley 6/1987, de 12 de julio, del Plan Especial de Puertos de la Comunidad Autónoma de Galicia.

2. Quedarán, asimismo, derogadas todas aquellas disposiciones de igual o inferior categoría que contradigan o sean incompatibles con lo dispuesto en la presente ley.

\section{DISPOSICIÓN FINAL}

La Xunta de Galicia dictará, en el plazo de seis meses a partir del día de la publicación de esta Ley en el "Diario Oficial de Galicia”, el reglamento para su desarrollo y aplicación.

\section{LEY 2/2008, DE 6 DE MAYO, POR LA QUE SE DESARROLLA LA LIBRE PRESTACIÓN DE SERVICIOS DE TRANSPORTE MARÍTIMO DE PERSONAS EN AGUAS INTERIORES DE GALICIA $\left(\text { DOGA N. }^{\circ} 90,6.5 .2008\right)^{527}$}

$$
(\ldots)^{528}
$$

\section{Capítulo I DISPOSICIÓN GENERAL}

Artículo 1. Objeto.

La presente ley tiene por objeto desarrollar la libre prestación de servicios de

527 Véase Decreto 228/2008, de 2 de octubre, sobre la prestación de servicios de transporte maritimo de personas en aguas interiores de Galicia. 528 Preámbulo omitido. transporte marítimo de viajeros y viajeras en aguas interiores de competencia exclusiva de la Comunidad Autónoma de Galicia, por armadores comunitarios que utilicen buques matriculados en un estado miembro de la Unión Europea, naveguen bajo pabellón de dicho estado miembro y cumplan los requisitos necesarios para poder efectuar servicios de cabotaje en el territorio nacional, todo ello con arreglo a lo dispuesto en el Reglamento (CEE) 3577/92, de 7 de diciembre.

\section{Capítulo II \\ REGISTRO DE EMPRESAS OPERADORAS DEL TRANSPORTE MARÍTIMO}

Artículo 2. Creación del registro y obligatoriedad de la inscripción.

1. Se crea en la Comunidad Autónoma de Galicia el Registro de Empresas Operadoras del Transporte Marítimo a fin de compatibilizar la libre prestación de servicios de transporte marítimo de viajeros y viajeras con la utilización de las infraestructuras portuarias, el respeto a los derechos de las personas consumidoras y usuarias, el cumplimiento de la normativa vigente en materia de seguridad marítima y la preservación del medio ambiente natural.

2. Con carácter previo a la realización de servicios de transporte marítimo de viajeros y viajeras por aguas interiores de Galicia será necesaria la inscripción de la empresa operadora y de las condiciones de prestación del servicio en el registro a que se refiere el apartado anterior. En todo caso se inscribirán los recorridos, horarios y periodo de prestación del servicio, los buques y sus características, así como las tarifas y demás condiciones económicas y técnicas que reglamentariamente se establezcan.

3. El registro regulado en el presente artículo quedará adscrito a la consejería competente en materia de transportes.

4. Por vía reglamentaria se establecerá la organización, contenido y régimen de funcionamiento del registro, así como los requisitos y efectos de la inscripción. 


\section{Capitulo III RÉGIMEN SANCIONADOR}

Artículo 3. Concepto y clasificación de las infracciones.

1. Constituyen infracciones administrativas en el ámbito regulado por la presente ley las acciones y omisiones que en la misma se tipifican como tales.

2. Las infracciones se clasificarán en muy graves, graves y leves.

Artículo 4. Infracciones muy graves.

Constituyen infracciones muy graves:

a. La prestación de servicios de transporte marítimo de viajeros y viajeras en aguas interiores de Galicia sin estar inscrito en el Registro de Empresas Operadoras del Transporte Marítimo.

b. La obstrucción de la labor de inspección de la prestación de los servicios a que se refiere la presente ley.

c. La prestación de los servicios a que se refiere la presente ley incumpliendo las limitaciones o condicionantes que reglamentariamente se impongan con relación al transporte a espacios naturales protegidos.

d. La reincidencia en la comisión de infracciones graves. A estos efectos, se considerará reincidencia la comisión en el plazo de un año de dos o más infracciones graves, si así se ha declarado por resolución firme en vía administrativa.

Artículo 5. Infracciones graves.

Tendrán la consideración de infracciones graves:

a. La prestación de servicios de transporte marítimo de viajeros y viajeras en aguas interiores de Galicia en condiciones distintas a las inscritas en el Registro de Empresas Operadoras del Transporte Marítimo.

b. La difusión pública de precios u otras condiciones del servicio de transporte distintas de las que figuran inscritas en el Registro de Empresas Operadoras del Transporte Marítimo.

c. El falseamiento de los datos relativos a las condiciones de prestación del servicio de transporte solicitados por la administración.

d. La reincidencia en la comisión de infracciones leves. A estos efectos, se considerará reincidencia la comisión en el plazo de un año de dos o más infracciones leves, si así se ha declarado por resolución firme en vía administrativa.

Artículo 6. Infracciones leves.

Tendrán la consideración de infracciones leves:

a. La alteración de horarios y el incumplimiento del régimen de utilización de terminales portuarias que figure inscrito en el registro.

b. El retraso en la aportación de los datos que hayan de comunicarse a la administración.

Artículo 7. Sanciones.

1. Las infracciones tipificadas en la presente ley serán sancionadas con:

a. Multa de hasta 300 euros, en caso de infracciones leves.

b. Multa de 301 a 900 euros, en caso de infracciones graves.

c. Multa entre 901 a 6.000 euros, en caso de infracciones muy graves.

2. Sin perjuicio de la agravación de infracciones contemplada en los artículos 4.d) y 5.d) para el caso de reincidencia, la graduación del importe de las sanciones dentro de los límites previstos en el apartado anterior se hará en función de los parámetros siguientes:

a. La incidencia de la infracción con relación al volumen de servicios prestados.

b. El efecto perjudicial para las personas usuarias del servicio.

c. El dolo o culpa del infractor.

Artículo 8. Procedimiento sancionador.

El procedimiento sancionador y la prescripción y caducidad de infracciones y sanciones se regirán por lo dispuesto en el título IX de la Ley 30/1992, de 26 de noviembre, de régimen jurídico de las administraciones públicas y del procedimiento administrativo común; en el Real 
decreto 1398/1993, de 4 de agosto, por el que se aprueba el Reglamento del procedimiento para el ejercicio de la potestad sancionadora, y en la restante normativa de desarrollo.

Artículo 9. Órganos competentes para sancionar.

Los órganos competentes para sancionar serán:

a. El titular de la dirección general con competencia en materia de transportes, para la imposición de las sanciones correspondientes a infracciones muy graves y graves.

b. El titular de la delegación provincial de la consejería competente en materia de transportes que corresponda al lugar de comisión de la infracción, para la imposición de las sanciones correspondientes a infracciones leves.

\section{DISPOSICIÓN ADICIONAL PRIMERA COMPETENCIA DE LA JUNTA ARBITRAL DE TRANSPORTE DE GALICIA}

La Junta Arbitral de Transporte de Galicia conocerá de las reclamaciones de contenido económico derivadas de la prestación de los servicios de transporte por empresas inscritas en el Registro de Empresas Operadoras del Transporte Marítimo, en los términos establecidos en la Ley 16/1987, de 30 de julio, de ordenación de transportes terrestres.

\section{DISPOSICIÓN ADICIONAL SEGUNDA OTRA LEGISLACIÓN DE APLICACIÓN}

Sin perjuicio de lo dispuesto en la presente ley para el Registro de Empresas Operadoras del Transporte Marítimo, será de aplicación la legislación marítima y portuaria. A su vez, a la navegación dentro de los límites del Parque Nacional Marítimo-Terrestre de las Islas Atlánticas de Galicia o por cualquier otro espacio protegido le serán de aplicación las normativas sectoriales de medio ambiente y patrimonio cultural.

\section{DISPOSICIÓN TRANSITORIA ÚNICA INSCRIPCIÓN DE SERVICIOS PREVIO.}

Los servicios de transporte marítimo de viajeros y viajeras en aguas interiores de Galicia que se vinieran prestando con anterioridad a la entrada en vigor de la presente ley se inscribirán en el registro a que se refiere el artículo 2, en los términos que reglamentariamente se establezcan.

\section{DISPOSICIÓN DEROGATORIA ÚNICA}

1. Queda derogada la Ley $4 / 1999$, de 9 de abril, por la que se declara como servicio público de titularidad de la Xunta de Galicia el transporte público marítimo de viajeros en la ría de Vigo.

2. Queda derogado el artículo 24 de la Ley $9 / 2003$, de 23 de diciembre, de medidas tributarias y administrativas.

\section{DISPOSICIÓN FINAL PRIMERA HABILITACIÓN PARA EL DESARROLLO REGLAMENTARIO}

Se habilita al Consello da Xunta para dictar cuantas disposiciones sean necesarias para el desarrollo de lo dispuesto en la presente ley.

\section{DISPOSICIÓN FINAL SEGUNDA ENTRADA EN VIGOR}

1. La presente ley entrará en vigor a los tres meses de su publicación en el Diario Oficial de Galicia.

2. No obstante, lo previsto en la disposición derogatoria única y los preceptos que contengan habilitaciones al Consello da Xunta para dictar reglamentos o disposiciones de desarrollo de la presente ley entrarán en vigor al día siguiente de su publicación en el Diario Oficial de Galicia. 


\section{XII \\ COMUNICACIONES}

\section{LEY 9/1984, DE 11 DE JULIO, DE CREACIÓN DE LA COMPAÑÍA DE RADIO-TELEVISIÓN DE GALICIA (DOGA N. $\left.{ }^{\circ} 148,3.8 .1984\right)$}

$(\ldots)^{529}$

\section{Capitulo I \\ NATURALEZA Y FUNCIONES}

Artículo 1. 1. Se crea en el ámbito de la Comunidad Autónoma de Galicia, con carácter de Entidad de Derecho Público, la Compañía de Radio-Televisión de Galicia, a la cual corresponde la gestión directa de los servicios públicos de radiodifusión y televisión competencia de la Comunidad Autónoma de Galicia, encargo que llevará a cabo en consonancia con lo siguiente:

1) Se atribuye a la Compañía de RadioTelevisión de Galicia la misión de servicio público consistente en la promoción, difusión e impulso de la lengua gallega, así como a la atención a la más amplia audiencia, ofreciendo calidad y la máxima continuidad y cobertura geográfica, social y cultural, propiciando el acceso a los distintos géneros de programaciones y a los eventos institucionales, sociales, culturales y deportivos, dirigéndose a todos los segmentos de público, edades y grupos sociales, y favoreciendo activamente la difusión cultural, intelectual y artística y de los conocimientos cívicos, económicos, sociales, científicos y técnicos mediante toda clase de emisiones en lengua gallega realizadas por dicha Compañía a través de las sociedades "Radio-Televisión de Galicia, Sociedad Anónima", y "'Televisión de Galicia, S. A.”, así como de cualquiera otra que pueda crear en el futuro.

529 Exposición de motivos omitida.
2) Para el desarrollo de las misiones de servicio público encomendadas, actuando bajo el objetivo de rentabilidad social y eficiencia económica, la Compañía de Radio-Televisión de Galicia deberá promover activamente los principios de programación señalados en la presente ley, fomentar la producción audiovisual propia de Galicia, ofrecer programaciones y emisiones que coadyuven a la proyección de cara al exterior de Galicia y de información a las comunidades gallegas del exterior.

3) La Compañía de Radio-Televisión de Galicia promoverá activamente el desarrollo de la sociedad de la información, participando en el progreso tecnológico, utilizando todas las formas y medios de distribución, expresión y lenguaje, así como las nuevas técnicas de producción y de difusión de programas de comunicación audiovisual, y desarrollando nuevos servicios, incluidos los digitales y en línea, susceptibles de enriquecer o completar su oferta de programación, dentro del marco estatutario de Galicia.

2. Las misiones a que se refiere el apartado anterior se entienden sin perjuicio de las competencias que corresponden al Parlamento y al Gobierno de Galicia y de las que, en período electoral, corresponden a las Juntas Electorales ${ }^{530}$.

Artículo 2. La Compañía de RadioTelevisión de Galicia tiene personalidad jurídica propia y plena capacidad para el cumplimiento de sus fines. Se regirá por las normas que se contienen en la presente ley y en las disposiciones que se dicten para desarrollarla. Dichas normas

530 Art. 1 modificado por Ley 3/2002, de 29 de abril, de medidas de régimen fiscal y administrativo. 
integran el derecho propio de Galicia en la materia.

En sus relaciones jurídicas externas, adquisiciones patrimoniales y contratación estará sujeta al régimen de derecho privado $\sin$ otras excepciones que las previstas en esta ley.

\section{Capitulo II ORGANIZACIÓN \\ Sección 1. ${ }^{a}$ Órganos}

Artículo 3. A efectos de funcionamiento, administración y dirección, la Compañía de Radio-Televisión de Galicia se estructurará en los órganos siguientes:

a. Consello de Administración.

b. Consejo asesor de la Compañía y sus sociedades.

c. Director general.

\section{Sección 2.}

\section{Consello de Administración}

Artículo 4. 1. El Consello de Administración se compondrá de doce miembros, elegidos para cada legislatura, por el Parlamento de Galicia, mediante mayoría de dos tercios, entre personas de acreditado prestigio profesional. Una vez nombrado, el Director General asiste a sus reuniones de acuerdo con lo dispuesto en el artículo 10. 4.

2. Las vacantes que se produzcan se cubrirán de acuerdo con el procedimiento establecido en el apartado anterior.

3. El cese de los miembros del Consello de Administración se producirá al final de la legislatura correspondiente, si bien seguirán desempeñando sus funciones hasta que los nuevos tomen posesión de sus cargos.

4. La condición de miembro del Consello de Administración será incompatible con cualquier clase de vinculación directa o indirecta con empresas publicitarias, empresas de producción o distribución de películas cinematográficas o de programas filmados o grabados en magnetoscopio o radiofónicos, casas productoras de discos, cintas magenetofónicas o similares, así como las dedicadas a la provisión o dotación de programas o material a la Compañía y a sus sociedades. También será incompatible con todo tipo de prestación de servicios o relación laboral en activo con la Compañía, con RTVE o con las sociedades de ambos entes.

Artículo 5. La presidencia del Consello de Administración será puramente funcional y se ejercerá de forma rotativa por un período de tres meses por sus miembros. El orden de rotación se determinará teniendo en cuenta la mayor edad. Si durante el transcurso de la legislatura fuese necesario proceder a la sustitución de algún consejero, el sustituto ocupará, a efectos del turno rotatorio en la presidencia, el lugar que le correspondiese al sustituido por su edad.

Artículo 6. 1. Para que el Consello de Administración se entienda válidamente constituido en sesión, será necesaria la presencia de la mayoría absoluta de sus miembros.

2. La adopción de acuerdos se hará por mayoría de miembros presentes, salvo los casos que la presente ley exija una mayoría cualificada.

3. El Consello de Administración se reunirá en sesión ordinaria cuando menos una vez al mes, y también en caso de urgencia a criterio de su Presidente o cuando lo solicite la mayoría absoluta de sus miembros. La convocatoria se hará por escrito e incluirá, en todo caso, el orden del día.

4. No se podrán tratar asuntos distintos de los incluidos en el orden del día, a no ser que medie acuerdo en sentido contrario adoptado por mayoría de dos tercios de los miembros del Consejo.

Artículo 7. 1. Corresponden al Consello de Administración las siguientes competencias:

a. Cuidar del cumplimiento de lo establecido en la presente ley. 
b. Emitir su opinión sobre el nombramiento del Director general.

c. Recibir notificación previa del nombramiento y cese de los directores de la Compañía y de sus sociedades.

d. Aprobar, a propuesta del Director general, el plan de actividades del ente público, que fijará los principios básicos y líneas generales de programación, así como el plan de actuación de sus sociedades.

e. Aprobar la memoria anual relativa al desarrollo de las actividades de la entidad y de sus sociedades.

f. Aprobar con carácter definitivo las plantillas de la Compañía y de sus sociedades, así como sus modificaciones.

g. Aprobar el régimen de retribuciones de la Compañía y de sus sociedades.

h. Aprobar el anteproyecto de presupuestos de la Compañía y de sus sociedades.

i. Informar los proyectos de disposiciones que en materia de publicidad se proponga dictar el Gobierno gallego.

1. Dictar normas reguladoras de emisión de publicidad a través de las sociedades de la Compañía, teniendo en cuenta el control de calidad de la misma, el contenido de los mensajes publicitarios y la adaptación del tiempo de la publicidad a la programación $\mathrm{y}$ a las necesidades de los medios.

11. Determinar semestralmente el porcentaje de horas de programación destinadas a los grupos políticos y sociales significativos, fijando los criterios de distribución entre ellos, en cumplimiento de lo que se establece en el artículo 20 de la Constitución.

$\mathrm{m}$. Determinar anualmente el porcentaje de producción propia que se deberá incluir en la programación de cada medio.

n. Conocer de aquellas cuestiones que, aun no siendo de su competencia, el Director general de la Compañía someta a su consideración.

o. Conocer periódicamente la gestión presupuestaria y emitir su parecer sobre la misma.

2. Estos acuerdos se adoptarán por mayoría simple, a no ser los referidos en los apartados b), d), f), g) y 11), que se adoptarán por mayoría de dos tercios. Con respecto al apartado b), si no se alcanza la mayoría indicada, se entenderá que el Consello de Administración se abstiene de emitir su opinión sobre tal nombramiento, dándose por cumplido el trámite. Por lo que se refiere al apartado d), será suficiente la mayoría absoluta de los miembros del Consello de Administración, una vez que hubiese transcurrido un mes sin recaer acuerdo por mayoría cualificada de dos tercios. En lo que se refiere al apartado h), y en el caso de que no se alcanzase acuerdo por mayoría de dos tercios, el anteproyecto de presupuesto se remitirá a la Xunta en el plazo legal, haciendo constar el sentido del voto de cada uno de los miembros del Consello de Administración.

Artículo 8. El Consello de Administración designará un secretario de actas que, sin voz ni voto, tendrá las funciones que reglamentariamente se le asignen, sin que pueda recaer en persona que forme parte de dicho Consejo.

\section{Sección 3. ${ }^{\mathrm{a}}$ Consejo asesor}

Artículo 9. Las sociedades de la Compañía de Radio-Televisión de Galicia tienen un Consejo asesor, compuesto por los siguientes miembros:

a. Tres Vocales de cada empresa, elegidos por los representantes de los trabajadores, según criterios de proporcionalidad. La representatividad y la proporcionalidad se entienden referidas al grado de implantación de las secciones de los grupos de carácter sindical o independientes en cada empresa dependiente de la Compañía.

b. Tres Vocales representantes de la Administración autonómica, designados por la Xunta de Galicia.

c. Tres Vocales designados, uno, por el Consejo de la Cultura Gallega; uno, por la Universidad, y otro, por los medios de comunicación designado por el Parlamento.

d. Un representante designado por cada una de las Diputaciones provinciales. 
e. El Consejo asesor será convocado cuando menos semestralmente para cada una de las sociedades por el Consello de Administración, y emitirá opinión o dictamen cuando le fuesen expresamente requeridos por éste y, en todo caso, en cuanto a las competencias que sobre programación corresponde al Consello de Administración en los términos del artículo 7 de esta ley.

\section{Sección $4 .^{\mathrm{a}}$ \\ Director general}

Artículo 10. 1. El Director general de la Compañía será el Órgano ejecutivo de la entidad pública y tendrá que ser nombrado por la Xunta, oído el Consello de Administración.

2. Sin perjuicio de las causas de cese establecidas en la presente ley, su mandato coincidirá con la legislatura del Parlamento de Galicia en la que fue nombrado. Cuando su mandato finalice con la legislatura, continuará al frente de su cargo hasta la designación del nuevo Director general.

3. El cargo de Director general estará afectado por las mismas incompatibilidades que las señaladas para los miembros del Consello de Administración. También se considerará causa de incompatibilidad la vinculación con entidades públicas o privadas de medios de comunicación.

4. El Director general asistirá a las reuniones del Consello de Administración con voz y voto, pero carecerá de ellos cuando trate de asuntos que le afecten personalmente.

Artículo 11. Corresponderá al Director general:

a. Cumplir y hacer cumplir lo dispuesto en la presente ley y en las demás normas que regulen la Compañía, así como los acuerdos del Consello de Administración en las materias que sean competencia de este órgano colegiado.

b. Someter a aprobación del Consello de Administración, con la suficiente antelación, el plan anual de trabajo, la memoria económica anual y los anteproyectos de presupuestos de la Compañía y de sus sociedades.

c. Impulsar, orientar, coordinar e inspeccionar los servicios de la Compañía y de sus sociedades y dictar las disposiciones, instrucciones y circulares relativas al funcionamiento de las competencias del Consello de Administración.

d. Actuar como órgano de contratación de la Compañía de Radio-Televisión de Galicia y de sus sociedades.

e. Autorizar los pagos y gastos de la entidad y de sus sociedades, sin perjuicio de que las normas que regulen éstas dispongan la facultad de delegación.

f. Organizar la dirección y nombrar con criterios de profesionalidad al personal directivo de la Compañía y de sus sociedades, notificando con carácter previo los citados nombramientos al Consello de Administración.

g. Ordenar la programación de conformidad con los principios básicos aprobados por el Consello de Administración.

h. Ostentar la representación de la Compañía de Radio-Televisión de Galicia $y$, en consecuencia, comparecer en juicio y en toda clase de actuaciones, confiriendo al efecto los oportunos apoderamientos.

Artículo 12. 1. La Xunta de Galicia podrá cesar al Director general, oído el Consello de Administración, mediante resolución motivada, por alguna de las siguientes causas:

a. Imposibilidad física o enfermedad superior en su duración a seis meses continuos.

b. Incompetencia manifiesta o actuación contraria a los criterios, principios u objetivos a los que se refiere la presente ley.

c. Condena por delito doloso.

2. Asimismo, la Xunta podrá cesar al Director general, a propuesta del Consello de Administración, fundada en algunos de los supuestos anteriores y adoptada por mayoría de dos tercios. 


\section{Comunicaciones}

\section{Capitulo III GESTIÓN \\ Sección $1 .^{a}$ \\ Gestión pública}

Artículo 13. 1. La gestión de los Servicios Públicos de Radiodifusión y Televisión en el ámbito de la Comunidad Autónoma Gallega correspondiente a la Compañía de Radio-Televisión de Galicia se regirá por las disposiciones de la presente ley y normas complementarias que la desarrollen, y se realizará mediante la adscripción de los servicios comunes que reglamentariamente se establezcan.

2. De los recursos y pretensiones que se deduzcan contra los acuerdos que dicten los órganos de gobierno de la Compañía conocerá la jurisdicción que en cada caso corresponda sin necesidad de formular reclamación previa en vía gubernativa.

\section{Sección $2 .^{a}$ Gestión mercantil}

Artículo 14. 1. Las gestiones de los Servicios Públicos de Radiodifusión y Televisión se llevarán a cabo mediante las sociedades públicas con forma de sociedades anónimas que la Compañía de Radio-Televisión de Galicia está facultada para crear. Estas sociedades se regirán por el derecho privado sin más excepciones que las establecidas en la presente ley.

2. El capital de las anteriores sociedades será duplicado en su totalidad, íntegramente suscrito por la Comunidad Autónoma de Galicia, pertenecerá a la Compañía y no podrá ser enajenado, hipotecado, gravado, pignorado ni cedido en forma onerosa o gratuita.

3. Los Directores de las sociedades serán nombrados y separados por el Director general de la Compañía, previa notificación al Consello de Administración, y serán los Administradores únicos. Los Directores de cada sociedad estarán afectados por las mismas incompatibilidades que las previstas para el cargo de Director general en esta ley.
4. Los estatutos de cada sociedad deberán señalar las facultades que en materia de autorización de gasto, ordenación de pagos y contratación corresponden al Administrador único de cada sociedad y las que se reserve el Director general.

5. La adquisición de emisoras privadas de radiodifusión por parte de la Compañía de Radio-Televisión de Galicia quedará condicionada a la subrogación en la titularidad de la concesión administrativa de frecuencia y potencias.

Artículo 15. La Xunta de Galicia, a propuesta del Director general, y de acuerdo con el Consello de Administración de la Compañía, podrá crear sociedades filiales en las áreas de comercialización, producción, comunicación y otras análogas para alcanzar una gestión más eficaz. Estas sociedades filiales que se creen podrán ser de capital íntegramente suscrito y desembolsado por la Comunidad Autónoma y estarán sometidas al régimen jurídico a que se refiere el artículo anterior $\mathrm{y}$ concordantes.

\section{Capitulo IV PROGRAMACIÓN Y CONTROL Sección $1 .^{a}$ Principios de programación}

Artículo 16. Los principios que han de inspirar la programación de los medios gestionados por la Comunidad Autónoma de Galicia son los siguientes:

a. El respeto a la Constitución y al Estatuto de Autonomía de Galicia y a la promoción y difusión de la cultura y lengua gallegas, así como a la defensa de la identidad de la nacionalidad gallega.

b. El respeto a la libertad de expresión, objetividad, veracidad e imparcialidad de las informaciones.

c. La separación entre las informaciones y opiniones, la identificación de quien sustente estas últimas y su libre expresión con los límites del apartado 4 del artículo 20 de la Constitución. 
d. El respeto al pluralismo político, religioso, social, cultural y lingüístico.

e. El respeto al honor, a la fama, a la vida privada de las personas y cuantos derechos y libertades reconoce la Constitución.

f. La protección de la juventud y de la infancia.

g. El respeto a los valores de la igualdad recogidos en el artículo 14 de la Constitución.

\section{Sección 2. ${ }^{a}$ \\ Derecho de antena}

Artículo 17. 1. La ordenación de los espacios de Radiodifusión y Televisión de Galicia se hará de modo que a ellos puedan acceder los grupos políticos y sociales más significativos. Para tal fin, el Consello de Administración, de acuerdo con el Director general, tendrá en cuenta criterios objetivos, como representación parlamentaria, implantación política, sindical, social, cultural y ámbito territorial de actuación.

2. El Gobierno gallego podrá hacer que se emitan, indicando su origen, declaraciones y comunicados oficiales necesarios para el interés público. Por razones de urgencia, apreciadas por el Gobierno, estas declaraciones y comunicados tendrán efecto inmediato.

3. La Xunta de Galicia podrá establecer periódicamente las obligaciones que se deriven de la naturaleza del servicio público de la Compañía de Radio y Televisión de Galicia y, previa consulta al Consello de Administración, hacerlas cumplir.

\section{Sección 3. ${ }^{\mathrm{a}}$}

\section{Derecho de rectificación}

Artículo 18. El derecho de rectificación y su procedimiento se regulará según lo previsto en las normas generales que rigen la materia.

\section{Sección $4 .^{\mathrm{a}}$ \\ Período electoral}

Artículo 19. Durante las campañas electorales se aplicará el régimen especial que establezcan las normas electorales, correspondiendo la aplicación y el control de las mismas a la Xunta electoral competente, que cumplirá su misión a través del Consello de Administración y del Director general de la Compañía.

\section{Sección 5. ${ }^{\mathrm{a}}$ \\ Control parlamentario directo}

Artículo 20. Corresponde al Parlamento de Galicia el control de la actuación de la Compañía de Radio-Televisión de Galicia y de sus Sociedades.

La Comisión Permanente de Control de la Compañía de Radio-Televisión de Galicia y sus Sociedades, constituida de conformidad con lo que disponga el Reglamento de la Cámara, ejercerá el control de la actuación de la Compañía de Radio-Televisión de Galicia y sus Sociedades, de tal modo que no impida el funcionamiento de los medios, velando por el cumplimiento efectivo de la función de servicio público, definida y encomendada a la Compañía de Radio-Televisión de Galicia en el artículo 1, apartado 1, de la presente ley.

A estos efectos, la Compañía de Radio-Televisión de Galicia remitirá, con carácter anual, a dicha Comisión Parlamentaria un informe sobre la ejecución de la función de servicio público encomendada, referido al conjunto de sus actividades, programaciones, servicios y emisiones ${ }^{531}$.

\section{Capitulo V \\ PRESUPUESTO Y FINANCIACIÓN 532}

Artículo 21. El presupuesto de la Compañía de Radio-Televisión de Galicia se ajustará a lo que disponga la ley de Gestión Económica y Financiera Pública de Galicia, sin perjuicio de las especialidades previstas en la presente ley.

Artículo 22. 1. Las Sociedades Gestoras de los Servicios Públicos de

531 Art. 20 modificado por Ley $3 / 2002$, de 29 de abril, de Medidas de Régimen Fiscal y Administrativo.

532 Véase Decreto 480/1990, de 10 de octubre, que regula el control financiero, presupuestario y contable. 
Radiodifusión y de Televisión tendrán presupuestos separados, que se adjuntarán a los generales de la Comunidad Autónoma para su ulterior aprobación por el Parlamento de Galicia.

2. Las Sociedades Filiales creadas al amparo del artículo 15 de la presente ley, estarán sujetas a igual régimen presupuestario.

3. Los presupuestos a que se refieren los anteriores apartados se elaborarán y gestionarán con observancia del principio de equilibrio presupuestario.

4. Sin perjuicio del presupuesto de la Compañía y del separado de cada una de sus sociedades, se establecerá un presupuesto consolidado con la finalidad de evitar déficit de caja y de permitir una cobertura de éstos mediante el superávit de las entidades y sociedades integradas en el presupuesto consolidado.

Por virtud de la presente ley, se autoriza el régimen de minoración de ingresos sobre el presupuesto de la Compañía de RadioTelevisión de Galicia.

Artículo 23. La contabilidad de las sociedades a que se refieren los artículos precedentes se ajustará a las normas que para las sociedades y entidades de capital público se contengan en la Ley de Gestión Económica y Financiera Pública de Galicia.

Artículo 24. 1. El Director general de la Compañía rendirá cuentas periódicamente de la gestión, sometiéndose al control parlamentario a que se refiere el artículo 20 de la presente ley.

2. En los términos que establece la ley reguladora correspondiente, el Consejo de cuentas informará al Parlamento de Galicia de la gestión económica y presupuestaria de la Compañía, de sus sociedades gestoras y de las sociedades filiales que en su caso se creen.

3. El control financiero de la Compañía y de sus sociedades gestoras y filiales se efectuará en todo caso, a través de procedimientos de auditoría, sin sujeción al sistema de intervención previa.

En los demás, se aplicarán las disposiciones que regulen la gestión económica y financiera pública de Galicia.

Artículo 25. 1. La Compañía de Radio-Televisión de Galicia se financiará con cargo a a los presupuestos generales de la Comunidad Autónoma y mediante los ingresos y rendimientos de sus actividades. Las Sociedades Gestoras y las Filiales lo harán mediante subvenciones consignadas en los presupuestos generales de la Comunidad Autónoma, mediante la comercialización y venta de sus productos y, limitadamente, mediante una participación en el mercado de la publicidad.

2. En caso de la televisión habrá que estar, además, a lo señalado en el párrafo tercero de la disposición transitoria sexta del Estatuto de Autonomía para Galicia.

\section{Capítulo VI PATRIMONIO}

Artículo 26. El patrimonio de la Compañía y de las Sociedades de capital íntegramente de la Comunidad Autónoma a las que se refiere la presente ley, tendrá la consideración de dominio público, como patrimonio afecto al servicio público correspondiente y, por lo tanto, gozará en el orden tributario de las exenciones pertinentes.

La titularidad del patrimonio a que se refiere el párrafo anterior se atribuye, en todo caso, a la Administración Autonómica, correspondiendo a la Compañía y a sus Sociedades, en concepto de adscripción de uso, su gestión, conservación y administración para el cumplimiento de sus fines específicos.

Se aplicarán las disposiciones de la Ley de Patrimonio de la Comunidad Autónoma de Galicia en todo lo que se refiere al régimen jurídico de los bienes y derechos patrimoniales o demaniales que le sean cedidos, adscritos o incorporados a su patrimonio independiente. 


\section{Capitulo VII PERSONAL}

Artículo 27. 1. Las relaciones de carácter laboral en la Compañía de RadioTelevisión de Galicia y en sus Sociedades a las que se refiere la presente ley se regularán por lo preceptuado en la legislación laboral, con sujeción al principio de autonomía de las partes.

2. La pertenencia al Consello de Administración o al Consejo asesor regulados en esta ley no dará lugar al nacimiento de derechos de carácter laboral respecto a la Compañía y a sus Sociedades.

3. La situación de los funcionarios que se incorporen a la Compañía o a sus sociedades se regirá por lo que dispongan las normas que, sobre la Función Pública, dicte la Comunidad Autónoma de Galicia, con arreglo a las bases definidas por la legislación estatal.

4. El ingreso con carácter fijo en la Compañía y en sus sociedades sólo se podrá hacer mediante las oportunas pruebas de admisión, establecidas y convocadas por el Director general, de acuerdo con el Consello de Administración y con arreglo a los principios básicos definidos por la legislación estatal.

\section{DISPOSICIÓN TRANSITORIA}

Mientras que no tenga lugar la constitución del Consejo asesor a que se refiere la presente ley, sus funciones las ejercerá el Consejo asesor de Radio y Televisión Española en Galicia.

El Consello de Administración deberá quedar constituido dentro de los treinta días siguientes al de designación de sus miembros.

En todo lo no previsto en esta ley, el Consello de Administración establecerá su régimen de funcionamiento.

\section{DISPOSICIÓN FINAL PRIMERA}

La presente ley entrará en vigor al día siguiente de su publicación en el "Diario Oficial de Galicia".

\section{DISPOSICIÓN FINAL SEGUNDA}

Se faculta a la Xunta de Galicia para dictar las disposiciones reglamentarias que se requieren en desarrollo de la presente ley, sin perjuicio de las facultades reglamentarias autónomas reconocidas en esta ley y las instrucciones y circulares que la Compañía de Radio-Televisión de Galicia pueda dictar para el correcto y coordinado funcionamiento de las sociedades que agrupe.

\section{LEY 10/1983, DEL 9 DE DICIEMBRE, REGULADORA DEL CONSELLO ASESOR DE RTVE EN GALICIA (DOGA N. $\left.^{\circ} 148,3.8 .1984\right)^{533}$}

\section{$(\ldots)^{534}$ \\ Capitulo I ÁMBITO DE APLICACIÓN}

Artículo 1. De acuerdo con lo establecido en el artículo 34.1 del Estatuto de Autonomía para Galicia y en el artículo 14.2 del Estatuto de la Radio y la Televisión, se crea, con esta denominación oficial a todos los efectos, el Consello Asesor de Radio y Televisión Española en Galicia, que se regirá por los preceptos contenidos en esta ley.

\section{Capítulo II FUNCIONES}

Artículo 2. El Consello asesor tiene las siguientes funciones

a. Asesorar al Delegado Territorial de RTVE sobre la propuesta de programación específica y de horario de la Radio y la Televisión en Galicia, que éste habrá de elevar al Director general de Radio y Televisión, de acuerdo con el artículo 15 del Estatuto de la Radio y Televisión. Las recomendaciones del Consello asesor acompañarán, en todo caso, la propuesta que el Delegado Territorial eleve al Director General de RTVE.

b. Estudiar y formular las recomendaciones sobre las necesidades y capacidades

533 Véase Decreto 128/1984, de 19 de julio, Reglamento de organización y funcionamiento del Consello Asesor de RTVE. 534 Exposición de motivos omitida. 


\section{Comunicaciones}

de Galicia para alcanzar la adecuada descentralización de los servicios de radio y televisión y en especial de la Sociedad Estatal de Radio Cadena Española (RCE), conforme a lo establecido en el artículo 14.2 del Estatuto de la Radio y la Televisión

c. Hacer llegar al Consello de Administración de RTVE, a través del delegado territorial, los criterios de asesoramiento que, dentro de su competencia, sean considerados idóneos para que se apliquen en el ámbito de la Comunidad Autónoma los derechos reconocidos en los artículos 8 y 24 del estatuto de RTVE.

d. Conocer con la antelación suficiente para poder formular observaciones los planes anuales de trabajo, los anteproyectos de presupuestos y las memorias anuales de RTVE en Galicia y de sus sociedades.

e. Emitir parecer al Director General de RTVE en lo concerniente al nombramiento del Delegado Territorial de Radio Televisión Española en Galicia

f. Asesorar y asistir directamernte al delegado Territorial de RTVE en todas cuantas cuestiones afecten a la recepción y cobertura en Galicia de los programas que se emitan, así como la financiación de los mismos y, en general, a todas las cuestiones relativas a las competencias propias

g. Informar al Delegado Territorial sobre el cumplimento en la programación de los principios establecidos en el artículo 4 del Estatuto de la Radio y la Televisión, así como la correcta ejecución de las resoluciones y acuerdos a los que se pueda dar lugar la aplicación del apartado a) de este artículo.

h. Emitir pareceres antes del nombramiento de los representantes que correspondan a la Comunidad Autónoma de Galicia en los Consellos Asesores de RNE, RCE y TVE, conforme a lo preceptuado en el artículo 9 del Estatuto de la Radio y la Televisión.

i. Elevar el Consello de Administración de RTVE, a través del Delegado Territorial en Galicia, o con su conocimiento, las recomendacións que estime oportunas en defensa de los intereses de la Comunidad Autónoma.

Artículo 3. El Consello Asesor de RTVE en Galicia informará y asesorará al Delegado Territorial, sin perjuicio de lo establecido en el Estatuto de la Radio y la Televisión sobre:

a. La composición y modificación de las plantillas de personal de RTVE en Galicia.

b. Los criterios de selección de personal, basados en principios de igualdad, capacidad y méritos.

c. Los criterios de adscrición de destino y la regulación de las condiciones de traspaso o traslado de personal, cuando éstas afecten a la plantilla del mismo de RTVE en Galicia.

Artículo 4. El Consello Asesor de RTVE en Galicia adoptará los procedimientos adecuados para conocer el estado de los servicios y será informado de la opinión de los usuarios de RTVE en el ámbito territorial de la Comunidad Autónoma Gallega.

Artículo 5. El Consello asesor, por medio de su Presidente, puede ser informado, por los órganos y personas competentes, de las cuestiones relacionadas con los asuntos sometidos a su consideración y estudio.

Artículo 6. 1. El Consello Asesor de RTVE en Galicia tiene como función específica el estudio y seguimiento de RTVE por lo que se refire a la adecuación al régimen autonómico.

2. Asimismo, elaborará anualmente una memoria que recoja los acuerdos adoptados, la situación de los medios y las actuaciones que el ente público RTVE llevará a cabo en Galicia. Esta memoria será elevada al Parlamento de Galicia, a la Xunta de Galicia y al Delegado Territorial de RTVE.

\section{Capitulo III FINANCIACIÓN}

Artículo 7. 1. El Consello asesor formulará a través del Delegado Territorial de 
RTVE en Galicia y para que se considere su inclusión en el presupuesto del ente público RTVE, la relación de las partidas necesarias para etender su funcionamiento.

2. El presupuesto de la Comunidad Autónoma gallega incluirá las partidas necesarias para cubrir los gastos que no sean financiados por el presupuesto de RTVE.

\section{Capitulo IV COMPOSICIÓN Y FUNCIONAMIENTO}

Artículo 8. 1. El Consello Asesor de RTVE en Galicia constará de trece miembros, designados por el Parlamento de Galicia, teniendo en cuenta la representación de todos los grupos parlamentarios, y nombrados por la Xunta para la Legislatura correspondiente.

La designación se hará en proporción al número de diputados de cada Grupo Parlamentario, según la relación de cocientes y el cómputo de restos de acuerdos con el sistema de mayor medida sobre el total de los miembros del Parlamento.

Una vez acabada la legislatura, el Consello asesor cesante continuará sus funciones hasta que los nuevos miembros tomen posesión del cargo.

2. Si se produjesen vacantes, se cubrirán de acuerdo con lo establecido en el apartado 1 de ese artículo y por el tiempo que quede de mandato.

3. La condición de miembro del Consello asesor es incompatible con cualquiera vinculación directa o indirecta a empresas publicitarias, empresas de producción de programas filmados, radiofónicos o registrados en magnetoscopios, casas discográficas o a cualquiera entidad relacionada con el suministro o dotación de material o de programas de RTVE y sus sociedades. También es incompatible con todo tipo de prestación de servicios o relación laboral en RTVE y sus sociedades.

4. La incompatibilidad de los miembros será apreciada con mayoría absoluta del Parlamento.
Artículo 9. 1. El Consello asesor elegirá de entre sus miembros un Presidente y un vicepresidente por el periodo de un año. Para su elección, cada miembro del Consello asesor escribirá un solo nombre en una papeleta, y salirán elegidos el Presidente y vicepresidente, por orden de voto, de los que obtuviesen mayor número de ellos.

2. ElPresidente ostenta la representación legal del Consello asesor. El vicepresidente lo sustituirá, a todos los efectos, en caso de vacante, ausencia o enfermedad

3. También el Consello asesor elegirá por mayoría un secretario, con las funciones propias del cargo.

Artículo 10. 1. El Consello asesor será convocado por el Presidente, bien a iniciativa propia, o a petición de una tercera parte de sus miembros, o del delegado territorial de RTVE. El Consello asesor habrá, cuando menos con carácter ordinario, de reunirse una vez cada tres meses; las sesiones y reuniones del Consello asesor se efectuarán donde esté el domicilio de la organización territorial de RTVE en Galicia, sin perjuicio de que por propia decisión del Consello se puedan celebrar con carácter circunstancial en cualquier otro lugar de la Comunidad Autónoma.

2. La convocatoria, habrá de hacerse cuando menos, con cuarenta y ocho horas de antelación, salvo por causas excepcionales, y se hará constar el lugar, la fecha, la hora y también el orden del día, que sólo podrá ser modificado por la voluntad de la mayoría de los miembros del Consello.

Artículo 11. 1. El Consello asesor quedará validamente constituído en primera convocatoria cuando estén presentes la mitad más uno de sus miembros, incluyendo el Presidente o quien haga sus funciones. En segunda convocatoria, que tendrá lugar después de veinticuatro horas, quedará válidamente constituido fuere cual fuere el número de asistentes. Cada sesión comezará con la lectura del 
orden del día a cargo del secretario y con la aprobación, si procede, del acta de la sesión anterior.

2. Salvo en los casos establecidos específicamente en esta ley, los acuerdos son tomados por mayoría. En caso de empate, decidirá el voto de quien presida.

Artículo 12. A las sesiones del Consello asesor podrá asistir el Delegado Territorial de RTVE, con voz pero sin voto.

Artículo 13. En tanto no sean aprobadas las partidas presupuestarias a las que hace referencia el artículo 7, se habilitarán los créditos precisos para el funcionamento del Consello asesor.

\section{DISPOSICÓN TRANSITORIA PRIMERA}

El Consello asesor se constituirá en el plazo máximo de un mes a partir de la entrada en vigor de esta ley.

\section{DISPOSICIÓN TRANSITORIA SEGUNDA}

En el plazo máximo de tres meses, a partir de la constitución del Consello asesor, la Xunta de Galicia, a propuesta del propio Consello, aprobará el Reglamento de ejecución y desarrollo de la presente ey.

\section{LEY 6/1999, DE 1 DE SEPTIEMBRE, DEL AUDIOVISUAL DE GALICIA (DOGA N. $\left.{ }^{\circ} 174,8.9 .1999\right)^{535}$}

\section{$(\ldots)^{536}$ \\ Capitulo I \\ DISPOSICIONES GENERALES}

\section{Artículo 1. Objeto de la ley.}

1. La presente ley establece, en el ejercicio de las competencias que son propias a la Comunidad Autónoma, en el ámbito territorial de Galicia, los principios generales y las líneas de acción institucional en el sector audiovisual, así como sus mecanismos de fomento.

535 Véase Decreto $81 / 2005$, de 14 de abril, por el que se regula el régimen jurídico de la gestión del servicio público de televisión digital en la Comunidad Autónoma de Galicia.

536 Exposición de motivos omitida.
2. Es objeto de la presente ley regular la actividad cinematográfica y audiovisual (videograma) y el apoyo a la producción, comercialización y difusión de cine y vídeo gallegos, y en gallego, así como las relaciones de éstos con los otros medios audiovisuales.

3. Los poderes públicos de Galicia reconocen la importancia cultural, económica y social de las actividades cinematográficas y del audiovisual, del papel que pueden desempeñar como creación artística, información, conocimiento e imagen de Galicia, en aras de la consecución de la normalización cultural y lingüística de Galicia, por lo cual los consideran sector estratégico y prioritario.

4. Consecuentemente, los poderes públicos optan por fomentar la actividad cinematográfica y la producción audiovisual gallegas, su comercialización y difusión, asumiendo las competencias de estas actividades en Galicia, asegurando su cumplimiento y coordinando las relaciones entre cine, vídeo y televisión en Galicia y divulgando su conocimiento en el interior y el exterior.

5. A los efectos de la presente ley, se entiende por sector audiovisual el conjunto de actividades que utilizan como cauce de desarrollo y transmisión del mensaje los medios auditivos y visuales.

6. Para los conceptos generales de largometraje, cortometraje, publicitario, comercial o videograma se toman como referencia las normas de transposición de las directivas de la Unión Europea.

Artículo 2. Ámbito de aplicación. La presente ley se aplica al sector audiovisual de Galicia, a aquellas empresas o personas que pretendan realizar actividades audiovisuales, a las que las instituciones de autogobierno de Galicia estimen susceptibles de recibir aportaciones para su fomento y, en general, a los contenidos audiovisuales, cualquiera que sea la tecnología que se utilice para su difusión en el territorio de Galicia. 
Artículo 3. Ejercicio de las competencias propias de la Comunidad Autónoma de Galicia.

1. Corresponde a la Xunta de Galicia, a través de su Gobierno y de la consellería que tenga atribuidas las funciones en la materia objeto de la presente ley, el fomento de todas las actividades relacionadas con la creación, producción, investigación y conservación de obras audiovisuales gallegas, así como la regulación de su difusión dentro de las normas básicas del Estado.

2. Corresponde al Consello de la Xunta de Galicia:

a. La definición de la política general de la Xunta de Galicia en el campo del audiovisual.

b. La aprobación de los reglamentos necesarios para el desarrollo de la presente ley.

c. La coordinación de las actividades de los órganos dependientes de la consellería competente en el audiovisual con las de los restantes departamentos de la Xunta de Galicia, a través de una Comisión, cuya dependencia orgánica, composición y competencias se determinarán reglamentariamente.

3. Corresponde a la consellería competente en el audiovisual, en el ámbito de sus competencias:

a. La propuesta de definición de la política general de la Xunta de Galicia en materia audiovisual.

b. La ejecución de programas y acciones para el desarrollo del sector audiovisual.

c. La elaboración del anteproyecto de presupuestos en materia audiovisual.

d. La elaboración de los proyectos de reglamentos de desarrollo de la presente ley.

e. El control del cumplimiento de la normativa general del audiovisual en el ámbito de la Comunidad Autónoma de Galicia.

Artículo 4. Principios generales de la actividad audiovisual.

Las actividades contempladas en la presente ley se basarán en los siguientes principios:

a. El respeto de los valores y principios que informan la Constitución Española y el Estatuto de Autonomía de Galicia y los derechos y libertades que reconocen y garantizan.

b. La promoción y la difusión de la cultura y normalización de la lengua gallega, así como la defensa de la identidad gallega.

c. El respeto al pluralismo político, religioso, social y cultural.

d. El respeto al honor, a la fama, a la vida privada de las personas, al trabajo, a la creación intelectual y artística y a cuantos otros derechos y libertades personales ampara la Constitución.

e. El respeto y la promoción de los valores de igualdad y no discriminatorios por razón de raza, sexo, nacimiento, religión, opinión y cualquier otra condición o circunstancia, personal o social, contemplados en el artículo 2 de la Declaración universal de los derechos humanos y en el artículo 14 de la Constitución.

f. La protección de la juventud y la infancia, de acuerdo con la regulación de la Ley 25/1994, de 15 de julio, de incorporación de la Directiva 89/552/CEE, y de la Ley Orgánica 1/1996, de 15 de enero, de Protección Jurídica del Menor.

g. La promoción de valores que persigan la igualdad entre el hombre y la mujer y la defensa del respeto a su identidad e imagen.

h. La defensa y preservación del medio ambiente.

i. La promoción de los intereses generales y locales de Galicia, impulsando para ello la participación de las iniciativas gallegas, tanto de carácter local como de ámbito autonómico, al objeto de fomentar, promover y defender la cultura y convivencia, tanto en el ámbito local como en el de Galicia.

Artículo 5. Principios generales de la acción institucional.

1. La Xunta de Galicia reconoce el carácter estratégico y prioritario del sector audiovisual por su importancia cultural, social y económica, como instrumento para la expresión del derecho a la promoción y divulgación de su cultura, 
su historia y su lengua, como datos de autoidentificación.

2. Los poderes públicos de Galicia promoverán las actividades del sector audiovisual gallego, tanto público como privado, mediante mecanismos que fomenten su presencia.

3. Los poderes públicos garantizan y promueven el pluralismo cultural en el audiovisual, potenciando el sector mediante el apoyo a iniciativas educativas, profesionales e industriales.

Artículo 6. Líneas fundamentales de las acciones institucionales.

La Administración de la Comunidad Autónoma de Galicia mantendrá las siguientes líneas fundamentales de actuación en el sector audiovisual:

1. Impulsar la política integral de coordinación del sector audiovisual en Galicia, basada en las siguientes medidas:

a. La coordinación entre los diferentes departamentos de la Xunta de Galicia y organismos dependientes.

b. La coordinación en el conjunto de las administraciones públicas, organizaciones empresariales y profesionales y otras entidades relacionadas con el sector.

c. La adopción de las medidas necesarias para la coordinación de las acciones de la Comunidad en materia audiovisual con las acciones que promuevan el Estado español y la Unión Europea en relación con el sector audiovisual.

2. Favorecer la promoción de la cultura y lengua gallegas dentro y fuera de Galicia, en especial en aquellas zonas en que existan comunidades gallegas en el exterior.

3. Promover la coordinación técnica en el sector audiovisual, facilitando el avance de las nuevas tecnologías.

4. Conservar y potenciar el patrimonio audiovisual de Galicia.

5. Favorecer la competencia y la presencia internacional de las empresas gallegas.

6. Incentivar la producción propia de animación, con ayudas específicas a los establecimientos de producción, y la creación, en particular, por parte de los dibujantes y humoristas gallegos.

7. Estudiar formas de apoyo a los establecimientos técnicos de Galicia que sirvan para desarrollar la actividad cinematográfica y audiovisual, de forma que se cubran las necesidades en este campo y se impulse la producción propia, capacitando en las técnicas apropiadas.

Artículo 7. Comunicaciones de interés público.

Las entidades que presten servicios de difusión de información por radio, televisión $\mathrm{u}$ otros soportes técnológicos en Galicia están obligadas a difundir gratuitamente y con indicación de su origen comunicados o declaraciones por razones de interés público, de acuerdo con lo establecido en la Ley 4/1980, de 10 de enero, por la que se aprueba el Estatuto de la Radio y Televisión, y en la Ley 10/1988, de 3 de mayo, de Televisión Privada.

\section{Capitulo II ACTIVIDADES DE FOMENTO DEL SECTOR AUDIOVISUAL}

Artículo 8. De los objetivos de las actividades de fomento.

Las acciones de fomento del sector audiovisual en Galicia tendrán los siguientes objetivos:

a. Promover un mejor conocimiento de la historia, el arte, la literatura, la música, las producciones culturales y, en general, la realidad social gallega a través de las producciones cinematográficas y audiovisuales.

b. Promover y potenciar la enseñanza del audiovisual y de las nuevas tecnologías interactivas en la práctica docente de la educación.

c. Promover y potenciar la actividad profesional en el sector audiovisual dentro de su territorio.

d. Fomentar la actividad empresarial y la creación de empleo en el sector audiovisual, especialmente de actores y actrices y de técnicos. 
e. Impulsar la producción propia y la coproducción, así como su distribución por cualquiera de los sistemas y cauces de la difusión audiovisual, favoreciendo el desarrollo del sector audiovisual gallego.

f. Promover la investigación y el desarrollo tecnológico en el sector audiovisual.

g. Promover la utilización del idioma gallego mediante su uso en los medios audiovisuales, especialmente apoyando su utilización en salas de exhibición y promoviendo la asistencia a las mismas en municipios de más de 35.000 habitantes.

h. Promover la utilización de los medios audiovisuales entre los ciudadanos discapacitados.

i. Divulgar las obras audiovisuales gallegas en el propio territorio, en el Estado español, en Portugal, en la Unión Europea $\mathrm{y}$ en todos los territorios donde existan comunidades gallegas.

Artículo 9. Potenciación de las acciones institucionales

Del Consorcio Audiovisual de Galicia

1. Para la potenciación institucional de las acciones tendentes al desarrollo del sector audiovisual de Galicia, las administraciones y entidades interesadas convendrán la constitución del Consorcio Audiovisual de Galicia.

2. La consellería competente en materia audiovisual promoverá la constitución de dicho Consorcio, con personalidad jurídica propia y plena capacidad de obrar para el cumplimiento de sus fines.

3. Dicho Consorcio tendrá la condición de entidad de derecho público de carácter interadministrativo y contará con un patrimonio propio.

4. En este Consorcio podrán participar entidades privadas sin ánimo de lucro que persigan los fines de interés público concurrentes con los de las administraciones y entidades públicas consorciadas.

5. El Consorcio se financiará con aportaciones de las entidades que lo constituyan, sin perjuicio de los demás medios económicos que le correspondan con arreglo a su régimen jurídico.
6. El Consorcio promoverá la celebración de convenios de colaboración con fundaciones, asociaciones y empresas que tengan interés en el desarrollo del sector audiovisual gallego. Simultáneamente, promoverá la creación de una oficina del audiovisual ("film comission") para fomentar y facilitar los rodajes en Galicia ${ }^{537}$.

\section{Capítulo III DE LA EXHIBICIÓN}

Artículo 10. Promoción y difusión.

1. La Xunta de Galicia promoverá la difusión de obras audiovisuales gallegas y coproducciones en las salas de exhibición cinematográficas de la Comunidad Autónoma de Galicia, así como en cine clubes, entidades privadas sin ánimo de lucro, asociaciones, centros educativos, hospitales y organismos de asistencia social que oferten sesiones de cine a sus usuarios.

2. La Xunta de Galicia velará porque la producción cinematográfica gallega esté presente en el cupo de exhibiciones de filmes de los Estados miembros de la Unión Europea.

Artículo 11. Ayudas.

A fin de procurar la pervivencia de las salas de exhibición cinematográfica sitas en las zonas rurales o de baja rentabilidad, la Xunta de Galicia fomentará la exhibición de cine mediante ayudas, otorgadas con arreglo a los criterios que se determinen reglamentariamente.

Artículo 12. Calificación e inspección. La Xunta de Galicia adoptará las medidas oportunas para que la exhibición de obras y demás contenidos audiovisuales en los medios de difusión de la Comunidad Autónoma respeten la legislación vigente, ejerciendo funciones de calificación e inspección en coordinación con el Consello Asesor de las Telecomunicaciones y del Audiovisual de Galicia.

537 Véase Decreto 294/2002, de 17 de octubre, por el que se constituye y regula la composición y las funciones del Consorcio audiovisual de Galicia. 


\section{Comunicaciones}

\section{Capitulo IV \\ DEL CONSELLO ASESOR DE LAS TELECOMUNICACIONES Y DEL AUDIOVISUAL DE GALICIA ${ }^{538}$}

Artículo 13. Consello Asesor de las Telecomunicaciones y del Audiovisual de Galicia.

1. El Consello Asesor de las Telecomunicaciones y del Audiovisual se configura como un órgano de integración y participación de las instituciones, empresas, agentes y entidades directamente relacionadas con los referidos sectores, operadores y usuarios, que actuará con carácter consultivo y asesor para la administración y de mediación para el arbitraje y autocontrol entre los que voluntariamente se sometan a estos procedimientos.

2. Asimismo, el consello propiciará funciones de arbitraje y autocontrol en relación con los contenidos de los medios de difusión audiovisuales específicos del ámbito de la Comunidad Autónoma, siempre que lo soliciten las partes.

3. El consello funcionará en pleno, comisión permanente y a través de las comisiones del audiovisual, de usuarios y operadores y del cine de Galicia y, asimismo, de cuantas decida crear el propio consello dentro de sus competencias.

4. El régimen de funcionamiento $\mathrm{y}$ composición del consello se establecerá reglamentariamente procurando la representación de las instituciones, sectores profesionales y empresariales y usuarios relacionados con los servicios de telecomunicaciones y audiovisual.

5. El consello, a través de su comisión permanente, elaborará un informe anual,

538 Véase:

- Decreto 307/1995, de 13 de julio, por el que se crea el Consello Asesor de Telecomunicaciones y Audiovisual de Galicia y se establece su composición y su régimen de funcionamiento.

- Decreto 276/1999, de 21 de octubre, por el que se regula la composición y las funciones del Consello Asesor de Telecomunicaciones y Audiovisual de Galicia.

- Orden de 17 de noviembre de 1999, por la que se aprueba el Reglamento de funcionamiento del Consello Asesor de Telecomunicaciones y Audiovisual de Galicia. de carácter público, sobre la actividad de los respectivos sectores en el ámbito de la Comunidad Autónoma.

6. El Consello Asesor de las Telecomunicaciones y del Audiovisual se encargará de la coordinación y relación con los organismos y entes homólogos del ámbito del Estado y de las otras Comunidades Autónomas, dentro de las materias de su competencia.

Artículo 14. Funciones de arbitraje.

1. El Consello Asesor de las Telecomunicaciones y del Audiovisual ejercerá funciones de arbitraje a fin de garantizar a los usuarios una oferta de servicios competitivos, en los supuestos de situaciones de dominio de mercado que afecten a las relaciones entre los diferentes agentes vinculados a la prestación del servicio de una determinada demarcación en la red de cable, siempre que la cuestión le fuese sometida por los interesados.

2. En el desarrollo de esta función, el Consello Asesor de las Telecomunicaciones y del Audiovisual se ajustará al procedimiento previsto en los artículos 11 y siguientes del Real Decreto 1994/1996, de 6 de septiembre, por el que se aprueba el Reglamento de la Comisión del Mercado de las Telecomunicaciones, y, subsidiariamente, en la Ley estatal 36/1988, de 5 de diciembre, reguladora del Régimen Jurídico del Arbitraje.

3. En todo caso, la sumisión a este arbitraje tendrá para los interesados la eficacia prevista en el artículo 11 de dicha Ley estatal 36/1988, de 5 de diciembre, reguladora del Régimen Jurídico del Arbitraje.

Artículo 15. De las comisiones.

1. Cada una de las comisiones integrará la representación más fidedigna, cualificada y directa de los agentes de cada sector, de la administración y de las partes relacionadas con los productos de los mismos, así como aquella emanada de la propia permanente del Consello asesor.

2. Las comisiones informarán a la consellería competente en la materia sobre las cuestiones que pudiesen afectar a la normativa relacionada con los contenidos 
audiovisuales y la publicidad de cualquiera de los medios de difusión que emiten para la Comunidad Autónoma de Galicia, en relación con el alcance de las propias competencias y el cumplimiento de los derechos fundamentales y la normativa general de aplicación en el sector, con especial atención a la protección de los menores.

3. El Consello asesor propiciará también como tarea inmediata la creación de la Comisión del Cine de Galicia para contribuir al mejor y más directo asesoramiento a la Xunta de Galicia en cuanto a medidas, planes, acciones, programas y proyectos de apoyo e impulso a dicho sector y en lo que se refiera a la creación, producción, realización, distribución, doblaje y exhibición de productos audiovisuales.

4. Las comisiones contribuirán, en colaboración con los operadores implicados, a propiciar fórmulas y vías en favor del uso del gallego en las diferentes redes y medios de difusión audiovisual.

\section{DISPOSICIÓN ADICIONAL PRIMERA}

La Comunidad Autónoma de Galicia ejercerá las competencias que le correspondan según lo que establezcan las leyes estatales en materia de televisión local por ondas terrestres y de telecomunicaciones por cable y las desarrollará regulando expresamente los contenidos audiovisuales que tengan que ser difundidos por cualquier sistema de telecomunicaciones dentro del territorio de la Comunidad Autónoma.

Asimismo, por Decreto del Consello de la Xunta se creará el registro de empresas, asociaciones de profesionales del sector, asociaciones de usuarios y grupos operadores cuyo ámbito de actuación sea la Comunidad Autónoma de Galicia 539 .

\section{DISPOSICIÓN ADICIONAL SEGUNDA}

La Compañía de Radio-Televisión de Galicia y sus sociedades, que tienen personalidad jurídica propia y plena capacidad para el cumplimiento de sus fines, se regirán a través de lo dispuesto en la Ley de Galicia 9/1984, de 11 de julio, de creación de la Compañía de Radio-Televisión de Galicia, respetando lo establecido en el artículo 4 y concordantes de la presente ley.

\section{DISPOSICIÓN ADICIONAL TERCERA}

A propuesta del organismo administrativo competente, las comisiones se encargarán de tratar y estudiar aquellos aspectos de ámbito competencial autonómico referidos a la legislación modificadora de la Ley 25/1994 y, en particular, la incorporación de la Directiva 97/36/CE, de 30 de junio, por la que se modifica la Directiva 89/552/CEE, de 3 de octubre, denominada "Televisión sin fronteras".

\section{DISPOSICIÓN ADICIONAL CUARTA}

El Centro Gallego de las Artes de la Imagen se regirá a través de lo dispuesto en su Decreto de creación y regulación y se dotará de plena capacidad para el cumplimiento de sus fines, respetando lo establecido en el artículo 4 y concordantes de la presente ley.

\section{DISPOSICIÓN DEROGATORIA}

Quedan derogadas todas aquellas disposiciones de igual o menor rango en lo que se opongan o contradigan lo dispuesto en la presente ley.

\section{DISPOSICIÓN FINAL PRIMERA}

Se faculta al Consello de la Xunta para el desarrollo reglamentario de la presente ley.

\section{DISPOSICIÓN FINAL SEGUNDA}

La presente ley entrará en vigor al día siguiente de su publicación en el "Diario Oficial de Galicia”.

539 Véase Decreto 5/2003, de 9 de enero, por el que se crea el registro del sector audiovisual de Galicia. 


\section{LEY $1 / 2006$, DE 5 DE JUNIO, DEL CONSELLO AGRARIO GALEGO (DOGA N. $\left.^{\circ} 113,14.6 .2006\right)^{541}$}

$(\ldots)^{542}$

Artículo 1. Objeto.

1. El objeto de la presente ley es la creación del Consello Agrario Galego como un órgano permanente de participación, asesoramiento, diálogo y consulta de la Administración gallega en materia agraria y desarrollo rural.

2. El Consello Agrario Galego quedará adscrito a la consellería competente en materia de agricultura y desarrollo rural.

Artículo 2. Régimen jurídico.

El Consello Agrario Galego se regirá por lo dispuesto en la presente ley, en su normativa de desarrollo, en su reglamento de régimen interior ${ }^{543}$ y en la Ley 30/1992, de 26 de noviembre, de Régimen Jurídico de las Administraciones Públicas y del Procedimiento Administrativo Común, respecto a los órganos colegiados.

Artículo 3. Funciones.

Son funciones del Consello Agrario Galego:

a. Crear el marco institucional adecuado para favorecer e impulsar la participación

540 Véase:

- Decreto 253/2008, de 30 de octubre, por el que se crea y regula el Registro de Explotaciones Agrarias de Galicia.

- Orden de 22 de enero de 2009 por la que se establecen disposiciones para la gestión del Registro de Explotaciones Agrarias de Galicia, creado por el Decreto 253/2008, de 30 de octubre, y para la calificación y acreditación de las explotaciones agrarias prioritarias.

541 Las referencias al fondo de tierras se entenderán hechas al Banco de Tierras de Galicia (Disposición final segunda Ley 7/2007, de 21 de mayo, de medidas administrativas y tributarias para la conservación de la superficie agraria útil y del Banco de Tierras de Galicia). 542 Exposición de motivos omitida.

543 Véase Orden de 6 de noviembre de 2006 por la que se da publicidad al Reglamento de régimen interior del Consello Agrario Galego. y colaboración de los representantes sindicales del campo en todos aquellos asuntos relativos al sector agrario, así como impulsar el diálogo, la participación y la colaboración entre las instituciones, administraciones y agentes sociales implicados, propiciando el intercambio de información y la búsqueda de acuerdos en aquellos asuntos de mayor relevancia para el sector agroganadero de Galicia.

b. Analizar las políticas que afecten al sector agrario en su conjunto, así como contribuir al seguimiento de los planes y programas de las políticas agrarias que tengan incidencia sobre el medio rural, prestando una especial atención al impacto de género de las medidas adoptadas.

c. Emitir dictámenes sobre la normativa de carácter general del Gobierno y específica de la consellería competente, en las materias de agricultura y desarrollo rural, así como sobre los planes y programas relativos a la política agraria y de desarrollo rural y sobre normativas sectoriales que afecten a las condiciones socioeconómicas de los habitantes del medio rural.

d. Proponer reformas, canalizar recomendaciones y aportar sugerencias respecto a todas aquellas políticas que afecten a las condiciones socioeconómicas de los habitantes del medio rural.

e. Proponer y asesorar a los distintos órganos de la Administración pública gallega sobre las medidas y acciones que se estimen necesarias para mejorar el nivel de renta de las explotaciones agrarias y la calidad de vida de la población dedicada a la actividad agraria, promoviendo la dignificación de las actividades laborales agroganaderas.

f. Realizar informes sectoriales sobre la situación, evolución y perspectivas de los diferentes subsectores agrarios. 
g. Impulsar la participación de las mujeres que se dedican a la actividad agraria, $\mathrm{y}$ en general de las que viven en el medio rural, en todas aquellas cuestiones relativas al sector agrario y al ámbito rural, y fomentar la cooperación con las administraciones competentes en la articulación de políticas de erradicación de las discriminaciones por motivo de género.

h. Aquellas otras que le sean atribuidas por otras disposiciones específicas.

Artículo 4. Composición.

1. El Consello Agrario Galego estará integrado por veinticuatro miembros:

a. Presidente o presidenta: El conselleiro o conselleira competente en materia de agricultura y desarrollo rural.

b. Vicepresidente o vicepresidenta: El secretario o secretaria general de la consellería competente en materia de agricultura y desarrollo rural.

c. Cinco vocales en representación de la consellería competente en materia de agricultura y desarrollo rural.

d. Cinco vocales en representación de las consellerías competentes en materia de bienestar social, medio ambiente, política territorial, industria y sanidad.

e. Doce vocales en representación de las organizaciones agrarias más representativas de Galicia.

2. Actuará como secretario o secretaria del consejo, asistiendo a las sesiones sin voto, un funcionario o funcionaria del servicio técnico jurídico de la consellería competente en materia de agricultura y desarrollo rural, designado por su titular.

Artículo 5. Régimen de funcionamiento.

1. El Pleno del Consello Agrario Galego aprobará, en el plazo de seis meses desde su constitución, y por mayoría absoluta de sus miembros, su reglamento de régimen interior, que contendrá las normas de funcionamiento del consello con arreglo a lo contemplado en la presente ley.

2. El consello actuará en pleno o en comisión permanente. La composición de la comisión permanente se acomodará a la proporcionalidad existente entre los representantes de la administración y de las organizaciones profesionales agrarias representadas en el pleno.

3. Asimismo, podrán crearse aquellas comisiones de trabajo que las circunstancias precisen. La forma de actuación, el número y la composición de las comisiones de trabajo se aprobarán por el pleno.

4. El pleno se reunirá como mínimo en sesión ordinaria cuatro veces al año. Será convocado por el Presidente, a iniciativa propia, a petición de la comisión permanente o a propuesta de la mitad de sus miembros.

5. El pleno se reunirá, como máximo, dos veces al año, en sesión extraordinaria, en casos de urgencia justificada. Será convocado por el Presidente a petición de ocho de sus miembros, en el plazo máximo de siete días desde la solicitud.

6. Para los supuestos de ausencia, enfermedad o cualquier otra causa legal, los miembros del consello serán sustituidos por el competente para el nombramiento de los mismos.

7. La convocatoria, que contendrá el orden del día, será remitida con al menos quince días de antelación a la fecha señalada para la sesión, salvo en casos de urgencia debidamente justificada.

Artículo 6. Nombramiento y mandato.

1. El nombramiento de los vocales y demás integrantes del Consejo Agrario Gallego se realizará por el conselleiro o conselleira competente en materia de agricultura y desarrollo rural, previa designación de los representantes por los titulares de cada consellería y propuesta por las organizaciones profesionales agrarias.

2. El mandato del Presidente o presidenta, del vicepresidente o vicepresidenta y de los vocales que lo sean como consecuencia del cargo que ostentan finalizará cuando dejen de ocupar el cargo del que deriva su nombramiento.

3. El resto de vocales ocupará el cargo durante un máximo de cinco años, siendo 
renovable su mandato por períodos de idéntica duración, sin perjuicio de lo dispuesto para los casos de sustitución y de la posibilidad de suplencia.

4. Además del supuesto especificado en el punto 2 de este artículo, los miembros del Consello Agrario Galego cesarán por renuncia, incapacidad declarada por resolución judicial firme, muerte o declaración de fallecimiento, condena judicial firme que ocasione la inhabilitación o suspensión de empleo o cargo público o por decisión de la autoridad u organización que los hubiera designado.

\section{DISPOSICIÓN ADICIONAL PRIMERA CONSTITUCIÓN DEL CONSELLO AGRARIO GALEGO}

En el plazo máximo de tres meses desde la entrada en vigor de la presente ley se procederá a la constitución del Consello Agrario Galego.

\section{DISPOSICIÓN ADICIONAL SEGUNDA DICTAMEN PRECEPTIVO PARA PROCESOS ELECTORALES}

El Pleno del Consello Agrario Galego, por mayoría absoluta, emitirá dictamen preceptivo y vinculante sobre el procedimiento para regular procesos electorales de cara a establecer la representatividad de las organizaciones profesionales agrarias en el futuro.

\section{DISPOSICIÓN ADICIONAL TERCERA DISOLUCIÓN DE LAS CÁMARAS AGRARIAS PROVINCIALES}

1. A la entrada en vigor de la presente ley quedan disueltas las cámaras agrarias provinciales. En el plazo de tres meses se iniciará el proceso de extinción de las cámaras agrarias provinciales, asumiendo de forma provisional la Consellería del Medio Rural los derechos y las obligaciones de las entidades disueltas.

2. Se faculta a la consellería competente en materia de agricultura y desarrollo rural para dictar o en su caso proponer al
Consello de la Xunta de Galicia las normas necesarias para proceder a la liquidación de los medios personales y materiales de las cámaras agrarias provinciales ${ }^{544}$.

3. La consellería competente en materia de agricultura y desarrollo rural prestará apoyo técnico y jurídico a las cámaras agrarias provinciales en orden a coordinar el proceso de disolución.

\section{DISPOSICIÓN ADICIONAL CUARTA RÉGIMEN DEL PATRIMONIO DE LAS DISUELTAS CÁMARAS AGRARIAS PROVINCIALES}

1. De acuerdo con lo previsto en la Disposición adicional única de la Ley $18 / 2005$, de 30 de septiembre, por la que se deroga la Ley 23/1986, de 24 de diciembre, el patrimonio de las cámaras agrarias provinciales se integrará en el patrimonio de la Comunidad Autónoma de Galicia, quedando adscrito a la consellería competente en materia de agricultura y desarrollo rural para su aplicación a fines de interés agrario en el ámbito territorial de Galicia.

2. El patrimonio procedente de las cámaras agrarias provinciales podrá ser, en todo o parte, desafectado por el Consello de la Xunta de Galicia, previo informe favorable de la consellería competente en materia de agricultura y desarrollo rural, para su posterior cesión a las organizaciones agrarias representadas en el Consello Agrario Galego, siempre que quede garantizada la conservación y aplicación del mismo a los fines y servicios de interés general agrario.

3. Asimismo, con la finalidad prevista en el párrafo anterior, se podrá tener en cuenta el patrimonio de las cámaras agrarias locales que a la fecha de entrada en vigor de la presente ley no hubiera sido cedido ni hubiese revertido a las entidades locales o a las entidades privadas con arreglo a lo dispuesto en la disposición adicional séptima de la Ley 11/1995, de 28 de diciembre, de

544 Véase Decreto 194/2006, de 19 de octubre, por el que se establece el procedimiento de liquidación de los medios materiales de las cámaras agrarias provinciales de Galicia. 
Presupuestos Generales de la Comunidad Autónoma de Galicia para 1996.

\section{DISPOSICIÓN ADICIONAL OUUINTA INTEGRACIÓN DEL PERSONAL PROCEDENTE DE LAS CÁMARAS AGRARIAS PROVINCIALES}

El personal laboral indefinido contratado en régimen de derecho laboral por las cámaras agrarias provinciales tendrá opción de integrarse en las categorías y grupo que corresponda del IV Convenio colectivo único del personal laboral de la Xunta de Galicia. A estos efectos, se tendrán en cuenta las funciones que desempeñaban en las cámaras agrarias provinciales en el momento de su integración y la titulación académica que posean, que habrá de coincidir necesariamente con el nivel de titulación académica que se requiera en cada caso para acceder al grupo del convenio en que se pretenda la integración.

\section{DISPOSICIÓN ADICIONAL SEXTA REFERENCIA EN LA NORMATIVA A LAS CÁMARAS AGRARIAS PROVINCIALES}

Las referencias existentes en la normativa vigente a las cámaras agrarias provinciales, en lo que concierne a emisión de dictámenes preceptivos, consultas o designación de representantes en órganos colegiados de la Administración, se entenderán sustituidas por el Consello Agrario Galego.

\section{DISPOSICIÓN TRANSITORIA ÚNICA REPRESENTATIVIDAD DE LAS ORGANIZACIONES PROFESIONALES AGRARIAS}

A los efectos de lo dispuesto en el apartado e) del artículo 4, y en tanto no sean convocados nuevos procesos electorales, tendrán la consideración de organizaciones profesionales agrarias más representativas aquéllas que concurrieron a las elecciones a cámaras agrarias celebradas el 26 de mayo de 2002 y alcanzaron un porcentaje de votos superior al 15 por 100, distribuyéndose los vocales de forma paritaria entre todas ellas.

\section{DISPOSICIÓN DEROGATORIA ÚNICA DEROGACIÓN NORMATIVA}

Quedan derogadas todas las disposiciones que contravengan lo dispuesto en la presente ley y de manera específica la Ley $1 / 2000$, de 10 de julio, por la que se refunde la normativa en materia de cámaras agrarias.

\section{DISPOSICIÓN FINAL PRIMERA FUNCIONES DE OTROS ÓRGANOS CONSULTIVOS}

Las funciones del Consello Agrario Galego dejarán a salvo las atribuidas al Consello Económico e Social de Galicia por su normativa específica.

\section{DISPOSICIÓN FINAL SEGUNDA FACULTAD DE DESARROLLO}

Se faculta al Consello de la Xunta para dictar las disposiciones necesarias para el desarrollo de la presente ley.

\section{DISPOSICIÓN FINAL TERCERA ENTRADA EN VIGOR}

La presente ley entrará en vigor el día siguiente al de su publicación en el "Diario Oficial de Galicia".

2. LEY 7/1994, DE 29 DE DICIEMBRE, POR LA QUE SE CREA EL INSTITUTO LÁCTEO Y GANADERO DE GALICIA (DOGA N. $\left.{ }^{\circ} 4,5.1 .1995\right)$

$(\ldots)^{545}$

\section{TÍTULO I}

\section{NATURALEZA, FINES Y FUNCIONES}

Artículo 1. 1. En el ámbito de la Comunidad Autónoma de Galicia, y al amparo de su Estatuto de Autonomía, se crea el Instituto Lácteo y Ganadero de Galicia

545 Exposición de motivos omitida. 
(ILGGA) ${ }^{546}$, como organismo autónomo de carácter comercial y financiero, con personalidad jurídica y patrimonio propio.

2. El ILGGA se adscribe a la Consellería de Agricultura, Ganadería y Montes de la Xunta de Galicia.

Artículo 2. 1. Constituye el fin del ILGGA ejecutar la política de la Consellería de Agricultura, Ganadería y Montes de la Xunta de Galicia en lo referente a la aplicación de las medidas de ordenación, fomento, reestructuración y mejora del sector lácteo y ganadero.

2. Para la consecución del citado fin llevará a cabo las siguientes funciones:

a. Informar, asesorar, coordinar y gestionar las operaciones relacionadas con la aplicación de las cantidades de referencia individual para la producción láctea y las relativas a las primas y ayudas contempladas en la reforma de la PAC y medidas de acompañamiento.

b. Incrementar la capacidad de información, tecnificación, formación y gestión de los agentes operativos en el sector lácteo y ganadero.

c. Impulsar la transformación de las explotaciones ganaderas, potenciando el cooperativismo en el sector.

d. Apoyar la modernización y mejora de las industrias de alimentación del ganado, lácteas y cárnicas radicadas en Galicia, promoviendo la implantación de nuevas iniciativas empresariales.

e. Coordinar y apoyar la promoción comercial de los productos lácteos y ganaderos gallegos.

f. Captar sistemas de apoyo y financiación que tengan como objetivo la mejora del sector lácteo y ganadero.

g. Promover, crear y participar, en su caso, en la constitución de sociedades de

546 Por Disposición adicional 5 Ley $7 / 2002$, de 27 de diciembre, de medidas fiscales y de régimen administrativo, pasa a denominarse Fondo Gallego de Garantía Agraria (FOGGA). servicios y comerciales en las que sus fines atiendan a la mejora de la competitividad del sector lácteo y ganadero gallego.

h. Establecer convenios con entidades de derecho público o privado para el mejor ejercicio de sus funciones, en el marco de lo establecido en la presente ley.

i. Todas aquellas acciones que contribuyan a la mejora del sistema productivo agrario y a su desarrollo equilibrado e integrado en el territorio o que le sean encomendadas o sean de su competencia en el ámbito de la presente ley ${ }^{547}$.

\section{TÍTULO II ORGANIZACIÓN}

Artículo 3. Los órganos de dirección del ILGA serán el Consejo de Dirección, el Presidente y el director ${ }^{548}$.

Artículo 4. 1. El Consejo de Dirección estará formado por el Presidente del ILGGA, que lo será también del Consejo, un vicepresidente, su director, cinco vocales y el secretario, que actuará con voz pero sin voto.

2. El vicepresidente será, por razón de su cargo, el Director general de Producción Agropecuaria e Industrias Agroalimentarias.

3. El nombramiento y la destitución del director corresponden al Conselleiro de Agricultura, Gandería e Montes.

4. El nombramiento y la destitución de los vocales corresponden al Conselleiro de Agricultura, Gandería e Montes.

547 Véase:

- Orden de 4 de noviembre de 1997 por la que se determinan los procedimientos administrativos que pasan a ser tramitados por el Instituto Lácteo y Ganadero de Galicia (ILGG).

- Decreto 253/2008, de 30 de octubre, por el que se crea y regula el Registro de Explotaciones Agrarias de Galicia.

- Orden de 22 de enero de 2009 por la que se establecen disposiciones para la gestión del Registro de Explotaciones Agrarias de Galicia, creado por el Decreto $253 / 2008$, de 30 de octubre, y para la calificación y acreditación de las explotaciones agrarias prioritarias. 548 Art. 3 modificado por Ley 9/2003, de 23 de diciembre, de medidas tributarias y administrativas. 
Artículo 5. Corresponden al Consejo de Dirección las más amplias facultades de gobierno y administración del ILGGA $\mathrm{y}$, especialmente, el ejercicio de las siguientes funciones:

a. Establecer las líneas de actuación del ILGGA a través de planes y programas de actuación.

b. Elaborar y aprobar el anteproyecto de presupuestos del Instituto.

c. Aprobar la memoria de actividades del Instituto.

d. Decidir sobre todas las cuestiones relacionadas con la organización, funcionamiento y operaciones que tiene que realizar el ILGGA.

e. Dictar las normas de funcionamiento del propio Consejo.

Artículo 6. El Consejo de Dirección se reunirá, al menos, cuatro veces al año y siempre que lo considere oportuno el Presidente.

Artículo 7. 1. El Presidente del ILGGA será, por razón de su cargo, el Conselleiro de Agricultura, Gandería e Montes.

2. El Presidente representará al ILGGA en toda clase de actos y negocios jurídicos y ejercerá en su nombre acciones y recursos.

3. Corresponde además al Presidente:

a. Ordenar la convocatoria del Consejo, fijar el orden del día, presidir y dirigir las sesiones del mismo.

b. Velar por el cumplimiento de las directrices marcadas por el Consejo de Dirección.

c. Proponer la adopción de las disposiciones reglamentarias necesarias para la organización y funcionamiento del ILGGA.

4. En ausencia del Presidente o por delegación del mismo, el vicepresidente asumirá sus funciones.

Artículo 8. Corresponde al director:

a. Cumplir los acuerdos del Consejo de Dirección. b. Proponer las líneas estratégicas de actuación del ILGGA, el programa anual de actividades y el anteproyecto de presupuestos.

c. Gestionar el ILGGA, elaborar la memoria anual y dar cuenta de su gestión al Consejo de Dirección.

d. Ejercer la dirección administrativa y de personal.

e. Coordinar y controlar el funcionamiento de los servicios y dependencias.

f. Desarrollar las funciones que le sean delegadas por el Presidente o por el Consejo de Dirección.

Artículo 9. (... $)^{549}$.

Artículo 10. Los órganos colegiados del ILGGA adoptarán sus acuerdos, previa deliberación, mediante mayoría simple de sus miembros presentes, siempre que exista quórum. En caso de empate, el voto de calidad del Presidente dirimirá éste.

\section{TÍTULO III}

\section{RECURSOS, RÉGIMEN ECONÓMICO, PERSONAL Y CONTROL}

Artículo 11. Los recursos del ILGGA estarán formados por:

1. Las consignaciones presupuestarias que le sean asignadas en los presupuestos generales de la Comunidad Autónoma de Galicia.

2. Los ingresos que pueda percibir por la prestación de servicios.

3. Las subvenciones o aportaciones voluntarias de entidades e instituciones públicas o privadas, así como de particulares.

4. Las rentas y productos que generen los bienes y valores que constituyen el patrimonio del ILGGA.

5. Los créditos, préstamos y demás operaciones financieras que concierte.

6. Cualesquiera otros recursos que se le puedan atribuir.

549 Art. 9 derogado por Ley 9/2003, de 23 de diciembre, de medidas tributarias y administrativas. 
Artículo 12. El régimen presupuestario, contable y financiero del organismo y de las sociedades, entidades y otras formas asociativas que de él dependan se ajustará a lo dispuesto en la Ley de Régimen Financiero y Presupuestario de Galicia y demás normativa concurrente.

Artículo 13. Reglamentariamente se determinarán la estructura del Instituto y su dotación de personal.

\section{DISPOSICIÓN ADICIONAL PRIMERA}

La Xunta de Galicia dotará al ILGGA de los recursos financieros necesarios para la realización de sus funciones.

\section{DISPOSICIÓN ADICIONAL SEGUNDA}

La Xunta de Galicia habilitará los medios materiales y humanos precisos para garantizar la eficaz realización de las funciones del Instituto.

\section{DISPOSICIÓN ADICIONAL TERCERA}

La Consellería de Agricultura, Ganadería y Montes adaptará su estructura orgánica a la situación resultante de la creación del Instituto Lácteo y Ganadero de Galicia.

\section{DISPOSICIÓN TRANSITORIA ÚNICA}

En tanto no se proceda al nombramiento de director, la dirección del Instituto será asumida por el Director general de Producción Agropecuaria e Industrias Agroalimentarias.

\section{DISPOSICIÓN FINAL PRIMERA}

Se autoriza al Consello de la Xunta a dictar cuantas normas sean precisas para efectuar el desarrollo y la correcta aplicación de esta ley.

\section{DISPOSICIÓN FINAL SEGUNDA}

La presente ley entrará en vigor al día siguiente de su publicación en el "Diario Oficial de Galicia”.

\section{LEY 10/1985, DE 14 DE AGOSTO, DE CONCENTRACIÓN PARCELARIA PARA GALICIA $\left(\text { DOGA N. }{ }^{\circ} 160,22.8 .1985\right)^{550}$}

\section{$(\ldots)^{551}$ TÍTULO I DISPOSICIONES GENERALES 552}

Artículo 1. Es objeto de la presente ley disponer la concentración y ordenación de las fincas rústicas, en orden a promover la constitución y el mantenimiento de las explotaciones con unas dimensiones suficientes y características adecuadas, intentando ampliar su superficie territorial, mantener e incrementar la capacidad productiva del campo, ordenando adecuadamente las explotaciones agrarias, respetando el medio ambiente, intentando reordenar racionalmente los cultivos bajo la perspectiva de la utilidad económica y social, y teniendo en cuenta el objetivo de fijar la población en el medio rural, en base a hacer rentable la actividad productiva. La concentración parcelaria afectará a todas las fincas rústicas, cualquiera que sea su específico destino agrario y la titularidad de su dominio, posesión o disfrute.

El Consello de la Xunta, previo informe preceptivo y consiguiente propuesta de la consellería competente en materia agraria, y teniendo en cuenta los criterios de prioridad de actuaciones previstos en el artículo 4 de la presente ley, acordará, mediante Decreto, el proceso de concentración parcelaria para la zona de que se trate ${ }^{553}$.

Artículo 2. 1. Una vez publicado el decreto de su aprobación, la concentración

550 Las referencias al fondo de tierras se entenderán hechas al Banco de Tierras de Galicia (Disposición final segunda Ley $7 / 2007$, de 21 de mayo, de medidas administrativas y tributarias para la conservación de la superficie agraria útil y del Banco de Tierras de Galicia). 551 Exposición de motivos omitida.

$552 \mathrm{El}$ actual Título I es fruto de la refundición del antiguo Titulo Preliminar y Título I realizado por Ley 12/2001, de 10 de septiembre, de modificación de la Ley de concentración parcelaria para Galicia.

553 Art. 1 modificado por Ley 12/2001, de 10 de septiembre, de modificación de la Ley de concentración parcelaria para Galicia. 
parcelaria será obligatoria para todos los propietarios y titulares de derechos reales o de disfrute de las fincas rústicas comprendidas dentro del área de la concentración.

2. El adquirente, a título oneroso o lucrativo, de fincas afectadas quedará subrogado en todos los derechos y obligaciones del transmitente o causante que se deriven del procedimiento de concentración parcelaria.

3. Las administraciones públicas habrán de comunicar los planes de actuaciones previstas sobre dichas zonas, a fin de que queden debidamente reflejados en el proceso de concentración 554 .

Artículo 3. 1. El Decreto de concentración parcelaria determina no sólo la utilidad pública, sino también la función social de la propiedad con la necesidad de que las tierras cultivables no queden abandonadas, por lo que el titular de un derecho de propiedad rústica de carácter agrario está obligado a:

a. Mantener o conservar la tierra cultivada conforme a su capacidad agrológica y aprovechamiento adecuado de sus recursos, en consonancia con los planes de aprovechamiento de cultivos o forestal recogidos en el acuerdo de concentración.

b. Mantener indivisibles las parcelas de extensión inferior al doble de la indicada como mínima en el acuerdo, con las excepciones reseñadas en el artículo 52.

A este efecto, la Dirección General correspondiente de la consellería competente en materia de agricultura, al aprobar el acuerdo, dictará, oída la Junta Local de zona, resolución motivada, en la que señalará la unidad mínima de cultivo para la zona, que será la suficiente para que las labores fundamentales de su cultivo, utilizando los medios normales y técnicos de producción, puedan llevarse a cabo con un rendimiento satisfactorio, teniendo en cuenta las características socioeconómicas de la agricultura en la comarca o zona,

554 Art. 2.3 modificado por Ley 12/2001, de 10 de septiembre, de modificación de la Ley de concentración parcelaria para Galicia. y que, en ningún caso, será inferior a las unidades mínimas de cultivo establecidas por la Comunidad Autónoma en virtud de lo establecido en el artículo 23 de la Ley estatal, de 4 de julio, de Modernización de las Explotaciones Agrarias.

2. El incumplimiento de estas obligaciones o del plan de ordenación de aprovechamiento de cultivos o forestal, en su caso, así como el cambio de uso de la tierra clasificada como labradío o prado hasta tanto los Ayuntamientos regulen los usos de las tierras concentradas, darán lugar a la imposición de las sanciones que se determinan en la presente ley.

3. Los titulares de fincas concentradas serán responsables de los daños causados en las fincas de los propietarios colindantes que no sean consecuencia del uso normal del inmueble, conforme a las costumbres locales, o por mantener la finca inculta.

El propietario del inmueble afectado por los daños dolosos o culposos tendrá derecho a recibir la indemnización correspondiente por los daños causados, siendo exigible la responsabilidad ante la jurisdicción civil ordinaria ${ }^{555}$.

Artículo 4. 1. En las zonas donde el fraccionamiento de la propiedad rústica y el minifundio agrario constituyan un problema social de carácter estructural y se establezca la prioridad de actuación para garantizar explotaciones rentables y con una clara finalidad social, de estímulo para mantener o incrementar su capacidad productiva, mediante un plan de desarrollo, y producir una reordenación de cultivos y en general del territorio que permita mantener una actividad socioeconómica, se llevará a cabo, previo Decreto acordado por la Xunta de Galicia, a propuesta de la consellería competente en materia de agricultura, la concentración parcelaria por razón de utilidad pública e interés social, con arreglo a lo establecido en la presente ley.

555 Art. 3 modificado por Ley 12/2001, de 10 de septiembre, de modificación de la Ley de concentración parcelaria para Galicia. 
2. Para la declaración de estas zonas tendrán prioridad aquéllas en que se dé alguna de las circunstancias siguientes:

Las zonas que, por su clara vocación agrícola, ganadera o forestal, medida por criterios tales como el número de trabajadores por cuenta propia en el Régimen Especial Agrario o en el Régimen Especial de Autónomos con explotaciones agrarias, así como por el número de explotaciones prioritarias, su situación geográfica o su potencial humano (crecimiento vegetativo), faciliten la estabilización de una población agrícola y su desarrollo socio-económico. El compromiso de titulares de explotaciones, propietarios o cultivadores a quienes pertenezca el 50 por 100 de la superficie a concentrar de constituir cooperativas, siempre que justifiquen de modo racional y fundamentado que la concentración facilitará su consecución.

La existencia de proyectos de obras públicas u otras de interés general, siempre que a través de este procedimiento pueda facilitarse su realización y la distribución más equitativa de sus efectos negativos entre los afectados.

Cualquier otra razón que, suficientemente motivada y documentada en el escrito de petición, demuestre su carácter preferencial ${ }^{556}$.

Artículo 5. 1. La concentración parcelaria tendrá como finalidad la constitución de explotaciones de estructura y dimensiones adecuadas y la reorganización de la propiedad rústica de la tierra dividida y dispersa. A estos efectos, realizando las compensaciones que resulten necesarias, y por los medios que se establecen en la presente ley, se procurará:

a. Situar las nuevas fincas de modo que puedan ser atendidas de la mejor manera desde el lugar donde radique la casa de labor, la vivienda del interesado o su finca más importante.

556 Art. 4 modificado por Ley 12/2001, de 10 de septiembre, de modificación de la Ley de concentración parcelaria para Galicia. b. Que la mayor parte de las explotaciones agrarias constituidas en la zona comprendan una dimensión igual o superior a la unidad mínima de explotación.

c. Determinar a título indicativo el cultivo, la rotación de cultivos y la utilidad o vocación prioritaria de cada explotación resultante.

d. Dar a las nuevas fincas acceso directo a las vías de comunicación, para lo cual se establecerá la red viaria necesaria.

e. Cumplir las reglas o condiciones fundadas en características objetivas de la zona o en criterios realizados por los solicitantes, formulados como condicionantes de la propia solicitud de concentración.

2. A tal fin y para llevar adelante las finalidades de la concentración, se deberá:

a. Adjudicar a cada propietario, en la medida de lo posible, en coto redondo o en el menor número de fincas de reemplazo, una superficie con las menores diferencias en extensión y clase con las que aportó, deducidas las reducciones previstas en el artículo 34 de la presente ley.

b. Adjudicar contiguas, en la medida de lo posible, todas las fincas integradas en una misma explotación, sean llevadas en propiedad, arriendo, aparcería u otras formas de tenencia.

c. Producir la inmatriculación registral de las fincas de reemplazo.

d. Establecer medidas de protección y preservación del paisaje y el medio ambiente.

e. Realizar las obras complementarias necesarias para el aprovechamiento racional de las explotaciones resultantes ${ }^{557}$.

Artículo 5 bis. A los efectos de la presente ley, se entiende por explotación agraria o lugar acasarado el que comprende la casa de labor, edificaciones, dependencias y terrenos, aunque no sean colindantes, así como toda clase de ganado, maquinaria,

557 Art. 5 modificado por Ley 12/2001, de 10 de septiembre, de modificación de la Ley de concentración parcelaria para Galicia. 
aperos de labranza e instalaciones que constituyan una unidad orgánica de explotación agropecuaria y forestal.

Asimismo, se entiende por dimensión económicamente viable de una zona la superficie cultivada por un lugar acasarado, compañía familiar o explotación agraria por debajo de la cual, teniendo en cuenta los cultivos y la producción de la misma, no puede obtenerse la rentabilidad necesaria que permita un nivel de vida digno a una familia media.

Los titulares de explotaciones agrarias a tiempo parcial que obtengan, al menos, un 25 por 100 de sus ingresos procedentes de actividades agrarias tendrán la misma consideración a efectos de la presente ley que los otros propietarios.

Los lotes de reemplazo que se adjudiquen con carácter definitivo a las explotaciones integrados por las tierras en propiedad y las llevadas en diversas formas de tenencia constituirán las nuevas explotaciones agrarias de la zona 558 .

Artículo 6. 1. Los gastos que ocasionen las operaciones de concentración parcelaria, incluidos los de inmatriculación de las fincas resultantes, así como las obras que lleven aparejadas y los ocasionados por el impulso, seguimiento y evaluación posterior, serán satisfechos por la Comunidad Autónoma a través de la consellería competente en materia de agricultura.

2. La consellería competente en materia agraria podrá celebrar, bien directamente o a través de las entidades crediticias, los oportunos Convenios de colaboración para la concesión de préstamos a los participantes en la concentración parcelaria, para aumentar la extensión de las parcelas o explotaciones cuya superficie no alcance la unidad mínima o la dimensión viable, para liberar las cargas y gravámenes de las fincas incluidas en la concentración, para el pago de deudas justificadas, contraídas

558 Art. 5 bis añadido por Ley 12/2001, de 10 de septiembre, de modificación de la Ley de concentración parcelaria para Galicia. como consecuencia de la concentración, y, en general, para cualquier otra finalidad que se relacione directamente con la concentración parcelaria.

3. Se fomentará, mediante ayuda económica y técnica, la agrupación de pequeñas explotaciones o de parcelas colindantes, a efectos de su explotación colectiva en régimen cooperativo.

4. La consellería competente en materia de agricultura podrá incluir entre sus líneas de ayuda subvenciones para aquellos propietarios que, una vez decretada la concentración de una zona y en tanto la transmisión pueda tener acceso al procedimiento, adquieran de otros propietarios tierras sujetas a este proceso, a fin de aumentar el tamaño de sus explotaciones, y siempre que dicha adquisición produzca una disminución en el número de propietarios de la zona. Los mismos derechos corresponderán a los trabajadores agrarios por cuenta ajena que con la adquisición de tierras reduzcan el número de propietarios ${ }^{559}$.

Artículo 7. 1. Cuando, como consecuencia de un proceso de agrupación de explotaciones o aumento de dimensiones de las mismas, los agricultores de una zona concentrada puedan mejorar sustancialmente la estructura de aquélla, la consellería competente en materia de agricultura podrá revisar la concentración.

2. Al existir circunstancias sociales o económicas o de otro tipo que se presenten con acusados caracteres de gravedad, en cualquier fase de la concentración, la consellería competente en materia de agricultura podrá revisar la concentración e incluso retrotraer a la situación primitiva las parcelas, con las compensaciones económicas que procedan, que se determinarán reglamentariamente.

3. En estos casos serán válidos los trabajos ya realizados en cuanto resulten

559 Art. 6 modificado por Ley 12/2001, de 10 de septiembre, de modificación de la Ley de concentración parcelaria para Galicia. 
utilizables para el nuevo procedimiento de concentración parcelaria ${ }^{560}$.

Artículo 8. La delimitación y calificación de los usos del suelo y la utilidad de las parcelas serán definidas al final del proceso de concentración de modo global, teniendo en cuenta los acuerdos de las asambleas de propietarios, los de la Junta Local, los propios planes de ordenación de cultivos y el estudio de viabilidad que se hubiese establecido por una Comisión interdepartamental de las instituciones afectadas, debiendo estar, además, en concordancia con lo dispuesto en la Ley 1/1997, de 24 de marzo, del Suelo de Galicia ${ }^{561}$.

\section{TÍTULO II \\ Capítulo I \\ ÓRGANOS 562} NORMAS ORGÁNICAS

Artículo 9. La ejecución del procedimiento de concentración se llevará a cabo por los siguientes órganos:

a. Por la consellería competente en materia de agricultura, a través de la Dirección general que corresponda, que actuará en cada provincia por medio del adecuado servicio provincial.

b. Por la Junta Local de zona con la colaboración del grupo auxiliar de trabajo ${ }^{563}$.

Artículo 10. 1. Las Juntas Locales de Concentración son órganos colegiados con las competencias recogidas en el artículo 12 y con la siguiente composición:

a. Presidente, con voto de calidad: Un representante de la Consellería competente

560 Art. 7 modificado por Ley 12/2001, de 10 de septiembre, de modificación de la Ley de concentración parcelaria para Galicia.

561 Art. 8 modificado por Ley 12/2001, de 10 de septiembre, de modificación de la Ley de concentración parcelaria para Galicia.

562 Capitulo I del Título II estructurado por Ley $12 / 2001$, de 10 de septiembre, de modificación de la Ley de concentración parcelaria para Galicia.

563 Art. 9 modificado por Ley 12/2001, de 10 de septiembre, de modificación de la Ley de concentración parcelaria para Galicia. en materia de agricultura designado por el titular ${ }^{564}$.

b. Vicepresidentes: El Jefe provincial del Servicio de Estructuras Agrarias y el Alcalde del Ayuntamiento en que más superficie hubiese a concentrar en esa zona.

c. Secretario, con voz y voto: Un funcionario perteneciente al Cuerpo Superior de la Xunta con la condición de Licenciado en Derecho.

d. Vocales: Cuatro representantes de los agricultores de la zona, elegidos libremente en Asamblea convocada al efecto por el Ayuntamiento, de entre todos los afectados, el técnico del Servicio de Estructuras Agrarias encargado de la zona y, en su caso, un técnico agronómico de la empresa que tenga contratados los servicios de asistencia técnica, un Registrador de la propiedad y un Notario y un técnico del Servicio de Extensión Agraria.

Actuarán con voz y sin voto el Alcalde, el técnico del Servicio de Estructuras Agrarias y el técnico agronómico de la empresa ${ }^{565}$.

Artículo 10 bis. Los cuatro representantes de los agricultores que tengan que formar parte de la Junta Local de zona serán elegidos mayoritariamente, con la asistencia, al menos, de la mitad más uno de los propietarios residentes en la zona, en Asamblea convocada previa realización de los trabajos de investigación de la propiedad y presidida por el Alcalde del Ayuntamiento o por el Presidente de la entidad local menor correspondiente, quedando como suplentes los cuatro siguientes en número de votos.

La convocatoria se realizará, al menos, con quince días de antelación a la fecha de celebración, señalando el lugar, día y hora en que se celebrará la Asamblea, y será publicada en un diario de los de mayor tirada de la provincia y en los lugares de costumbre de la parroquia y del Ayuntamiento.

564 Art. 10.1.a modificado por Lei 9/2003, do 23 de decembro, de medidas tributarias e administrativas.

565 Art. 10 modificado por Ley 12/2001, de 10 de septiembre, de modificación de la Ley de concentración parcelaria para Galicia. 
Si no se alcanzase la mayoría en la primera Asamblea, se harán nuevas convocatorias, quedando válidamente constituida la Junta Local cuando estuvieran presentes el 40 por 100 de los propietarios residentes ${ }^{566}$.

Artículo 11. 1. Las Juntas Locales actuarán en Pleno y en Comisión Permanente. Conformará la Comisión Permanente el Presidente y uno de los Vicepresidentes, el Secretario, los técnicos de la Administración y de la empresa y, al menos, tres de los cuatro representantes de los agricultores.

2. En caso de vacante de alguno de los cargos públicos, ocupará provisionalmente el puesto en la junta local la persona que deba asumir legalmente sus funciones y en su día la persona designada o elegida normalmente para el cargo ${ }^{567}$.

3. Si la zona de concentración estuviese comprendida por más de un término municipal, se constituirá la Junta Local en el Ayuntamiento afectado en la mayor extensión.

4. La Junta Local tendrá su domicilio específico en el Ayuntamiento, si bien, a los efectos de celebración de reuniones de trabajo, publicaciones de anuncios e informaciones, podrá utilizarse un local habilitado en la zona para mejor servicio a los afectados. Asimismo, se determinará, al menos, un local por Ayuntamiento para atención al público todos los días hábiles en que estén vigentes fases de exposición pública o de trámites de alegaciones.

Los escritos de alegaciones podrán presentarse en los lugares previstos en la Ley 30/1992, de Régimen Jurídico de las Administraciones Públicas y del Procedimiento Administrativo Común.

Cuando en la ley se mencione la Junta Local, sin otra indicación, se entenderá referida al Pleno.

5. Reglamentariamente se determinará todo lo relativo a la organización, régimen

566 Art. 10 bis modificado por Ley $12 / 2001$, de 10 de septiembre, de modificación de la Ley de concentración parcelaria para Galicia.

567 Art. 11.2 modificado por Ley 9/2003, de 23 de diciembre, de medidas tributarias y administrativas. de incompatibilidades, asistencias, ausencias, dietas y gastos de los miembros de la Junta Local, para lo cual se asignará la correspondiente dotación presupuestaria ${ }^{568}$.

\section{Capítulo II}

\section{COMPETENCIAS DE LAS JUNTAS LOCALES Y GRUPOS AUXILIARES DE TRABAJO}

Artículo 12. 1. Corresponde a la Junta Local de zona:

1.1. En pleno:

a. Aprobar las bases provisionales y definitivas.

b. Procurar la observación de los plazos.

c. Emitir informe sobre el plan de obras y mejoras territoriales, así como sobre los recursos de alzada interpuestos contra las bases definitivas, sobre el acuerdo de concentración parcelaria y sobre los planes de cultivos.

d. Emitir informe, por propia iniciativa, sobre las cuestiones de concentración parcelaria a cualquiera de las unidades $u$ órganos competentes en materia de agricultura, y ser oída en las consultas que se planteen a las mismas.

e. Aquéllas otras que se establezcan en la presente ley.

1.2. En Comisión Permanente:

a. Colaborar en la preparación de las bases provisionales.

b. Estudiar las alegaciones a la encuesta de bases.

c. Preparar las bases definitivas.

d. Asesorar en la redacción del proyecto y estudiar las alegaciones a la encuesta del mismo.

e. Preparar los informes sobre el acuerdo, sobre el plan de obras y mejoras y sobre los planes de cultivos.

2. La Junta Local de zona, en todo caso y sin perjuicio de lo dispuesto en el apartado anterior, colaborará con el órgano competente en materia de concentración parcelaria en todo aquello para lo que sea

568 Art. 11 modificado por Ley 12/2001, de 10 de septiembre, de modificación de la Ley de concentración parcelaria para Galicia. 
requerida, cooperando en los trabajos de investigación de la propiedad, servidumbres o serventías, determinación de cauces y masas de riego, con expresión de los derechos concesionales, aprovechamientos preexistentes, servidumbres y usos consuetudinarios en materia de aguas, solicitudes de reserva o exclusión de parcelas, determinación de las explotaciones agrarias en funcionamiento, delimitación de las zonas que tengan que dedicarse a producción forestal, así como de las zonas para las que se requiera especial protección medioambiental y en cuantas cuestiones de orden práctico contribuyan al mejor conocimiento y concreción de las situaciones de hecho en la zona a concentrar.

3. La Junta Local también colaborará en la determinación de posibles usos agrarios y aprovechamiento del suelo ${ }^{569}$.

Artículo 13. La Junta Local de zona, mediante convocatoria de su Presidente, se constituirá inmediatamente después de publicado el Decreto de concentración parcelaria y se disolverá una vez que se haya declarado la firmeza del acuerdo de concentración ${ }^{570}$.

Artículo 14. 1. En cada zona se creará el grupo auxiliar de trabajo, integrado por agricultores residentes en la misma, que colaborarán tanto con la Comisión Permanente como con los funcionarios del Servicio Provincial correspondiente, colaboración que podrá ser extensiva a los técnicos de la empresa de servicio de asistencia técnica a la que la Administración hubiera contratado los trabajos; en este caso, esta colaboración estará supervisada por los funcionarios directamente responsables de la zona.

2. El grupo auxiliar de trabajo prestará su colaboración y asesorará en todas las fases del proceso para aquello para

569 Art. 12 modificado por Ley 12/2001, de 10 de septiembre, de modificación de la Ley de concentración parcelaria para Galicia.

570 Art. 13 modificado por Ley 12/2001, de 10 de septiembre, de modificación de la Ley de concentración parcelaria para Galicia. lo que sea requerido por la Junta Local o por los funcionarios encargados de la zona, al objeto de contribuir a un mayor conocimiento y concreción de la situación de hecho en la zona, especialmente en los trabajos de clasificación de tierras.

3. El grupo auxiliar de trabajo se elegirá en la misma Asamblea y con los mismos requisitos con que se designen los representantes de los agricultores que tienen que formar parte de la Junta Local de zona. El número de miembros del grupo auxiliar será de 10 a 20 , procurando que estén representadas todas las entidades locales menores de población incluidas en la zona de concentración ${ }^{571}$.

\section{TÍTULO III \\ PROCEDIMIENTO ORDINARIO \\ Capítulo I \\ FASES DEL PROCEDIMIENTO DE CONCENTRACIÓN PARCELARIA 572}

Artículo 15. 1. El procedimiento de concentración parcelaria comprenderá las siguientes fases:

Iniciación.

Estudio de viabilidad con el correspondiente estudio de impacto ambiental y con el plan de desarrollo de la zona a concentrar.

Decreto.

Bases provisionales.

Bases definitivas.

Proyecto de concentración.

Acuerdo de concentración parcelaria.

Acta de reorganización de la propiedad.

2. Cuando alguna de estas fases o parte de las mismas no esté totalmente regulada en la presente ley, se aplicará lo dispuesto en las disposiciones adicionales ${ }^{573}$.

571 Art. 14 modificado por Ley $12 / 2001$, de 10 de septiembre, de modificación de la Ley de concentración parcelaria para Galicia.

572 Rúbrica del Capitulo I del Título III y estructura del mismo fijada por Ley 12/2001, de 10 de septiembre, de modificación de la Ley de concentración parcelaria para Galicia.

573 Art. 15 modificado por Ley 12/2001, de 10 de septiembre, de modificación de la Ley de concentración parcelaria para Galicia. 


\section{Capitulo II \\ BASES DE LA \\ CONCENTRACIÓN PARCELARIA 574}

Artículo 16. 1. El procedimiento de concentración parcelaria podrá iniciarse a petición de, al menos, las dos terceras partes de los propietarios de la zona para la que se solicita la mejora o de la mayoría de los titulares de los lugares acasarados con actividad agraria y que tengan el principal de sus bases territoriales en la zona, de la mayoría de los agricultores de la zona que, como consecuencia de su actividad, estén afiliados al Régimen Especial Agrario de la Seguridad Social o bien al Régimen Especial de Trabajadores Autónomos, en función de su actividad agraria o bien de un número cualquiera de ellos a quienes pertenezca más del 65 por 100 de la superficie a concentrar. Este porcentaje quedará reducido al 50 por 100 cuando quienes soliciten la concentración se comprometan a explotar sus tierras de modo colectivo.

2. Dentro de los sesenta días siguientes a la recepción de la solicitud, el Servicio Provincial competente en materia de concentración parcelaria abrirá información, cursándola a la oficina del Catastro, a los Ayuntamientos afectados o, en su caso, a la Tesorería General de la Seguridad Social para comprobar la realidad de las mayorías invocadas.

Igualmente se invitará a todos los propietarios y titulares de lugares acasarados de la zona no conformes con la concentración para que hagan constar por escrito su oposición. La Dirección general correspondiente apreciará los principios de prueba presentados por los oponentes en función de los criterios establecidos en la presente ley.

3. Asimismo, el Servicio Provincial emitirá informe sobre los criterios de

574 Rúbrica del Capitulo II del Título III y estructura del mismo fijada por Ley $12 / 2001$, de 10 de septiembre, de modificación de la Ley de concentración parcelaria para Galicia. prioridad a que hace referencia el artículo 4 de la presente ley 575 .

Artículo 17. La consellería competente en materia de agricultura podrá, asimismo, iniciar la concentración parcelaria de oficio, procurando su realización en zonas concretas del territorio de la Comunidad Autónoma gallega:

a. Cuando la dispersión parcelaria y el minifundio agrario se presenten con acusados caracteres de gravedad en una zona determinada, de tal modo que la concentración se estime necesaria o muy conveniente.

b. Cuando a través de la consellería se inste por los Ayuntamientos, que harán constar las circunstancias de carácter social y económico que concurran en cada zona.

c. Cuando por causa de construcción, modificación o supresión de vías de ferrocarril, autopistas, caminos o carreteras, cursos fluviales, canales de riego, aeropuertos y otras obras públicas de análogo carácter, predominantemente lineal, se haga necesaria o conveniente la concentración para reorganizar las explotaciones agrarias afectadas, mitigando la discontinuidad o una acusada reducción superficial que la obra pública hubiese causado en las mismas.

d. Cuando por causa de la realización de obras públicas con carácter no predominantemente lineal, tales como construcciones de presas, saneamiento de marismas o terrenos pantanosos, y transformaciones en regadíos y otras, en las cuales la explotación de parcelas se realiza normalmente a gran escala, afectando a un número importante de propietarios, se estime que el procedimiento de concentración pueda compensar los efectos de la expropiación y reordenar las explotaciones que no desaparecen con la ejecución de la gran obra pública.

e. Cuando por causas de la explotación de cotos mineros sea necesaria una

575 Art. 16 modificado por Ley 12/2001, de 10 de septiembre, de modificación de la Ley de concentración parcelaria para Galicia. 
importante cesión de tierras de utilización agraria, de tal modo que se estime que el procedimiento de concentración parcelaria pueda compensar los efectos de la expropiación y paliar el problema social que pudiera derivarse ${ }^{576}$.

Artículo 17 bis. Cuando los peticionarios de la concentración parcelaria en una zona, con su instancia, propusiesen determinadas actuaciones encaminadas a mejorar la concentración parcelaria, fundadas en características objetivas o en criterios generalizados de los solicitantes, versará también sobre las mismas el informe a que hace referencia el artículo 18 de la ley. Si fuese positiva su resolución, se tendrá en cuenta en las bases el proyecto y el acuerdo correspondiente ${ }^{577}$.

Artículo 18. 1. Comprobados los datos a que se refiere la solicitud de la concentración parcelaria de una determinada zona, el Servicio Provincial correspondiente, oída la Administración hidráulica autonómica en el marco de la planificación hidrológica y de la planificación de saneamiento de dicha Administración, procederá a tramitar el expediente, realizando un estudio de viabilidad del estado actual de la zona y de los resultados previsibles como consecuencia de la concentración que permita determinar la funcionalidad de la misma, en el cual, al menos, constarán los siguientes extremos:

a. Grado de división, dispersión y situación jurídica de las parcelas, en relación con las explotaciones agrarias en actividad en la zona.

b. Descripción de los recursos naturales, con referencia especial a las tierras abandonadas o con aprovechamientos inadecuados.

c. Relación de áreas de especial importancia por su valor geológico, paisajístico y ambiental.

576 Art. 17 modificado por Ley $12 / 2001$, de 10 de septiembre, de modificación de la Ley de concentración parcelaria para Galicia.

577 Art. 17 bis modificado por Ley 12/2001, de 10 de septiembre, de modificación de la Ley de concentración parcelaria para Galicia.
Asimismo, se enumerarán los bienes de interés cultural, histórico y/o artístico que puedan resultar afectados por la concentración parcelaria.

d. Valoración de las posibilidades de establecer una nueva ordenación de explotaciones con dimensiones suficientes y estructuras adecuadas a través de la concentración parcelaria.

e. Estudio de evaluación de impacto ambiental de los trabajos inherentes al proceso concentrador.

f. Determinación del grado de aceptación social de las medidas transformadoras previstas.

g. Evaluación económica y financiera de las inversiones necesarias.

h. Superficie y características que en la zona hayan de tener las unidades mínimas de explotación.

i. Descripción de las explotaciones agrarias, teniendo en cuenta las superficies llevadas por cada una de ellas en las distintas formas de tenencia, sus orientaciones productivas y el nivel de viabilidad económica, con posterior agrupación y análisis de su conjunto.

j. Examen detallado y valoración de las proposiciones de reglas o actuaciones de iniciativas propuestas por los peticionarios de concentración como condicionante de la propia solicitud.

k. Aquellos otros que se estimen de suficiente entidad como para ser objeto de valoración objetiva a la hora de decidir el Consello de la Xunta la declaración, mediante Decreto, de la utilidad pública e interés social de la concentración de la zona, así como su urgente ejecución.

2. De forma especial, en el apartado k) se estudia, para su posible incorporación a las bases de concentración, la posibilidad de modificar, ampliar o mejorar la superficie regada con aprovechamiento de nuevas captaciones, el rescate de zonas de monte para terrenos en cultivo y la conveniencia de la plantación y ordenación forestal del monte. 
En este supuesto, el resultado de los estudios se señalará, si procediese, en los planes de base, con las superficies susceptibles de mejora.

3. Cuando la solicitud de la concentración parcelaria incluya, total o parcialmente, terrenos de uso forestal o algún recurso natural que interese mantener o proteger, el Servicio Provincial correspondiente requerirá informe, preceptivo y vinculante, del órgano competente en materia de montes, a los efectos de incluir o no esos terrenos en el perímetro de la zona a concentrar.

Si el informe aludido no se emite en el plazo de dos meses, se entenderá que existe conformidad con la solicitud. En su caso, el informe del órgano competente en materia de montes vendrá acompañado de una relación de montes vecinales en mancomún dentro del perímetro a concentrar, tanto los montes clasificados como los que estén pendientes de clasificación, donde, si es posible, figuren titularidad, superficie, delimitación del perímetro, plano del monte y lindes, así como enumeración y descripción de aquellas masas arboladas y/o espacios que haya que conservar o tengan una especial relevancia, o cualquier otra mención relativa a la conservación y/o fomento de los recursos medioambientales.

El estudio de viabilidad que elabore el Servicio Provincial correspondiente incorporará, además de los extremos reseñados en el punto primero de este artículo, los datos remitidos por el órgano competente en materia de montes ${ }^{578}$.

Artículo 18 bis. Las unidades mínimas de explotación de una zona son las unidades económicas, integradas por la casa campesina, las tierras adscritas a la misma, los elementos de trabajo, el ganado y las instalaciones, de una magnitud que permita, para los principales tipos de cultivos y producciones de la zona, alcanzar

578 Art. 18 modificado por Ley $12 / 2001$, de 10 de septiembre, de modificación de la Ley de concentración parcelaria para Galicia. la renta de referencia a una familia media que la explota de un modo personal y directo ${ }^{579}$.

Artículo 19. Hecho el estudio de viabilidad con el correspondiente estudio de impacto ambiental y el plan de desarrollo, que determinarán la procedencia o no de la concentración parcelaria en la zona, el Decreto representará el inicio oficial del proceso y el compromiso de llevar a efecto las medidas contempladas en el estudio de viabilidad. A partir de su publicación, y contando con todos los datos del estudio de viabilidad, las fases posteriores al Decreto se agilizarán al máximo para que la tardanza en la realización de la concentración no signifique una parálisis de la posibilidad del desarrollo socioeconómico de la zona afectada.

A tal fin, se fijará un tiempo para cada fase, que en el conjunto de las mismas no debería exceder de cinco años ${ }^{580}$.

Artículo 20. Cuando la Xunta de Galicia estimase razones agronómicas y sociales que justifiquen la concentración, dictará Decreto con los siguientes pronunciamientos:

a. Declaración de utilidad pública e interés social y de urgente ejecución de la concentración parcelaria de la zona de que se trate.

b. Determinación del perímetro que se señala en principio como zona a concentrar, con la salvedad expresa de que puede resultar modificado, en definitiva, por las inclusiones/rectificaciones o exclusiones que se acuerden de conformidad con los artículos 23 y siguientes ${ }^{581}$.

Artículo 20 bis. 1. Publicado el Decreto de concentración parcelaria, el Servicio Provincial correspondiente habrá de

579 Art. 18 bis añadido por Ley 12/2001, de 10 de septiembre, de modificación de la Ley de concentración parcelaria para Galicia.

580 Art. 19 modificado por Ley 12/2001, de 10 de septiembre, de modificación de la Ley de concentración parcelaria para Galicia.

581 Art. 20 modificado por Ley 12/2001, de 10 de septiembre, de modificación de la Ley de concentración parcelaria para Galicia. 
comunicar los planes de actuaciones previstas sobre la zona a concentrar al Registro de la Propiedad que corresponda, así como a todos aquellos Departamentos de la Administración autonómica que pudiesen resultar afectados por la concentración, a fin de que, en un plazo máximo de dos meses, quede debidamente reflejada en el expediente de concentración cualquier incidencia que pudiera surgir.

2. La Comisión interdepartamental que anteriormente realizó el estudio de viabilidad emitirá un informe sobre los planes de actuación previstos en la concentración y su afectación a las distintas áreas de ordenación territorial, medio ambiente, patrimonio, etc. 582

Artículo 21. En vigor el Decreto de concentración parcelaria, el Servicio Provincial correspondiente realizará los trabajos precisos en orden a preparar los documentos que permitan establecer las bases provisionales, con los siguientes datos:

a. Indicación de los criterios de ordenación del territorio básicos para la zona, delimitando posibles viales, dotaciones, infraestructuras complementarias y usos previsibles del suelo.

b. Criterios básicos indicativos de ordenación del territorio para la zona que estén previstos por las distintas Administraciones y que hayan sido puestos de manifiesto en la Comisión interdepartamental que elaboró el estudio de viabilidad.

c. Delimitación del perímetro de la zona y subperímetros cultivables y forestales, procurando preservar las masas forestales de especies autóctonas.

d. Propuesta de parcelas excluidas y reservadas.

e. Clasificación de tierras y fijación previa, con carácter general, de los respectivos coeficientes que tengan que servir de base para llevar a cabo las compensaciones que resulten necesarias.

582 Art. 20 bis añadido por Ley 12/2001, de 10 de septiembre, de modificación de la Ley de concentración parcelaria para Galicia. f. Declaración de dominio de las parcelas a favor de quienes las posean en concepto de dueños y determinación de la superficie perteneciente a cada uno de ellos y de la clasificación que corresponda a la citada superficie.

g. Relación de gravámenes, derechos de plantaciones de viñas y otros cultivos leñosos, censos, arrendamientos y demás titularidades y situaciones jurídicas que afecten a la propiedad, posesión o disfrute que hubieran quedado determinadas en el período de investigación.

h. Aprovechamiento de aguas de riego, pozos, manantiales y derechos provenientes de los usos y concesiones de agua.

i. Relación de explotaciones agrarias, lugares acasarados y compañías familiares de la zona, en la que se constatarán los nombres de los titulares y las tierras llevadas en explotaciones, refiriendo superficies, nombres de los propietarios y modos de tenencia.

j. Determinación de la dimensión económicamente viable de las explotaciones agrarias, lugares acasarados y compañías familiares de la zona.

k. Cuando estuviesen incluidas plantaciones agrícolas o tierras de monte con masas forestales, podrá hacerse, además de la clasificación del suelo, también la del vuelo, que se valorará a los efectos de compensación en el proyecto y en el acuerdo.

En este supuesto, la valoración se realizará en base a criterios objetivos y siempre salvaguardando los intereses legítimos de los directamente afectados.

1. Relación de masas forestales autóctonas cuya conservación se proponga, así como de los parajes o entornos de especial interés histórico-arquitectónico o paisajísticos o de cualquier otra área, dentro de la zona de concentración, que por razones de interés general se estime conveniente conservar. De esta relación se dará cuenta a las autoridades u organismos competentes para que, en caso de estimarlo oportuno, se hagan las calificaciones necesarias o 
se adopten las medidas adecuadas para preservarlos de su destrucción.

m. Relación y delimitación de los montes vecinales en mancomún clasificados, así como de los pendientes de clasificación, que existan en la zona ${ }^{583}$.

Artículo 21 bis. 1. La urgente necesidad de aceleración del proceso concentrador precisa de una agilización de los trámites y una remodelación en los métodos de trabajo, manteniendo y aún mejorando el rigor técnico y jurídico en su desarrollo que garantice y facilite el ejercicio de los derechos de los administrados, y para ello la Administración podrá contratar los trabajos preparatorios necesarios a cada fase del proceso de concentración, así como la ejecución de servicios técnicos concretos, a empresas de asistencia técnica. Estas empresas habrán de estar dotadas de personal profesional cualificado, medios informáticos avanzados y especialización contrastada por la experiencia. En todo caso, las empresas contratadas se someterán a la dirección, intervención, seguimiento y control del Servicio de Estructuras Agrarias, encargado de la atención directa a los administrados.

2. En garantía del derecho de los afectados, quedarán excluidos de la contratación los trabajos relativos a la preparación de los recursos ${ }^{584}$.

Artículo 22. Una vez reunidos los datos que permitan establecer las bases provisionales y aprobadas por la Junta Local de zona, se realizará una encuesta relativa a las mismas en el plazo y forma determinados en el artículo 35.

Para dar la máxima difusión a los resultados de los trabajos a que se refiere este artículo, el Servicio Provincial correspondiente remitirá a los interesados una hoja resumen en la que se relacionen:

\footnotetext{
583 Art. 21 modificado por Ley 12/2001, de 10 de septiembre, de modificación de la Ley de concentración parcelaria para Galicia.

584 Art. 21 bis añadido por Ley 12/2001, de 10 de septiembre, de modificación de la Ley de concentración parcelaria para Galicia.
}

Nombre y apellidos del titular, documento nacional de identidad y, en su caso, del cónyuge, estado civil, naturaleza jurídica de los bienes, situación posesoria, cargas y situaciones jurídicas detectadas en el período de investigación, derechos concesionales, aprovechamientos preexistentes, usos consuetudinarios y servidumbres en materia de aguas, número de parcela y polígono, superficie total de cada una y la que corresponda a cada clase, así como explotación, lugar acasarado, compañía familiar o mejorado ("patrucio" con mejora de labrar o poseer) a que pertenezcan.

Se facilitará a los titulares de las explotaciones existentes en la zona unas hojas en las que se relacionen las propiedades que lleven en las distintas formas de tenencia y los propietarios a quienes pertenezca cada finca, con su número de parcela y polígono y la superficie de cada clase y total 585 .

Artículo 23. 1. El perímetro de la zona vendrá delimitado en el Decreto de concentración parcelaria y coincidirá, en principio, con los límites de la parroquia. Cuando por las causas que se expresan en el apartado siguiente el perímetro de la zona haya de ser superior o inferior al de la parroquia, se acompañará al estudio de viabilidad informe suficientemente motivado, emitido por el Servicio Provincial correspondiente, justificativo del perímetro de la zona.

Tanto en las concentraciones gestionadas directamente por la Administración como en las privadas, según el artículo 58, se dará la oportunidad a los propietarios que lo soliciten (con las mayorías que establece la presente ley para abrir los procesos de concentración) de realizar un proceso de permutas previo a la concentración, por un período de seis meses. Finalizado este período, podrá solicitarse una prórroga de igual tiempo, siempre que cuente con el informe favorable de los Servicios agrarios da la consellería competente en materia

585 Art. 22 modificado por Ley 12/2001, de 10 de septiembre, de modificación de la Ley de concentración parcelaria para Galicia. 
de agricultura. Los gastos que ocasionen todas estas labores serán sufragados por la Administración. Ésta delimitará toda carga fiscal o pública para las operaciones de permuta y posterior registro, cuando sea de su competencia.

2. La Dirección general competente en la materia podrá, hasta la declaración de firmeza de las bases definitivas, rectificar el perímetro cuando sea necesario:

a. Por las exigencias del plan de obras y mejoras territoriales.

b. Para adaptarlo a los límites de unidades geográficas naturales.

3. En el perímetro rectificado no podrá incluirse solamente una parte de una parcela, salvo que medie consentimiento de su titular y siempre que la porción restante que no resulte afectada por el procedimiento concentrador sea superior a la unidad mínima de cultivo.

4. El acuerdo de rectificación será objeto de notificación a los propietarios afectados o publicación en la forma prevista en la legislación vigente ${ }^{586}$.

Artículo 24. La condición de bienes comunales y la de vecinales en mano común no será causa de exclusión de las operaciones de concentración parcelaria. A través de ellas se procurará regularizar su contorno y se les dotará de acceso y de las mejoras generales de que sean susceptibles.

De los bienes de dominio público municipal y provincial sólo quedarán exceptuados los que sean de servicio público, salvo que soliciten su inclusión las entidades locales titulares, a cuyo fin serán requeridas por la jefatura provincial de estructuras agrarias en cuanto se aprueben las bases provisionales, para que expresen su voluntad durante el tiempo de duración de la encuesta correspondiente.

Además, se abrirá información sobre estos extremos en la cual se oirá a todos los interesados, a los fines de practicar la determinación correspondiente. Contra

586 Art. 23 modificado por Ley 12/2001, de 10 de septiembre, de modificación de la Ley de concentración parcelaria para Galicia. esa determinación, que no constituye un deslinde en su sentido técnico, podrán los particulares utilizar los recursos pertinentes, sin perjuicio del planteamiento ante los propios organismos o titulares de lo que más convenga a su derecho.

Artículo 25. Con carácter excepcional, por concurrir circunstancias que económica y agrariamente no reporten beneficios a los titulares de la concentración, la Dirección General de Planificación y Desarrollo Agrario, oída la Xunta Local, podrá excluir de la misma aquellos sectores o parcelas sobre las que concurran dichas circunstancias.

Artículo 26. Podrán ser reservadas aquellas parcelas que, por razón de obras o mejoras excepcionales, por servidumbres o serventías, por su especial naturaleza o emplazamiento privilegiado, por su valor extraagrario o por alguna otra circunstancia insólita, a juicio de la Junta Local y con el acuerdo favorable de su Pleno, previo informe del Servicio Provincial correspondiente, no tengan equivalente compensatorio sin perjuicio para su titular. Dichas parcelas se incluirán en las bases, con el indicado carácter, y en los proyectos y acuerdos serán adjudicadas a los mismos propietarios que las aportaron.

Estarán sujetas, en todo caso, a las deducciones por razón de obras inherentes o necesarias de la zona de concentración parcelaria. La aplicación de la cuota de deducción por ajuste de adjudicaciones se fijará por el Pleno de la Junta Local, previo informe del Servicio Provincial que corresponda, en función del grado de coincidencia del lote de reemplazo con la parcela de procedencia ${ }^{587}$.

Artículo 27. 1. Las tierras aportadas a la concentración se agruparán por clases y cultivos, según criterios edafológicos y productivos, asignándose a cada clase un valor relativo, al efecto de llevar a cabo las compensaciones que resulten necesarias.

587 Art. 26 modificado por Ley 12/2001, de 10 de septiembre, de modificación de la Ley de concentración parcelaria para Galicia. 
2. A todas las parcelas se les asignará en bases provisionales el valor que resulte de su clasificación, con arreglo al apartado primero de este artículo.

3. Se valorarán los árboles, tanto de producción forestal como frutales, viñedo, arbustivos o de especial significación, para llevar a cabo las compensaciones que resulten necesarias. Si la Administración decidiese en este proceso de concentración conservar masas forestales por su especial significación, compensará a sus titulares ${ }^{588}$.

Artículo 28. Las aguas utilizadas de forma permanente para el riego de las fincas se reseñarán claramente en los planos de base, con expresión de manantiales y cauces, al objeto de una mejor identificación de las parcelas 589 .

Artículo 29. 1. Redactadas las bases provisionales, la Junta Local procederá a su aprobación y el Servicio Provincial que tiene competencias en materia de concentración parcelaria dispondrá la apertura de un período de encuesta pública para que los afectados por la concentración puedan formular las alegaciones que estimen oportunas, acompañando los documentos en que fundamenten sus derechos.

2. Las alegaciones presentadas serán estudiadas $\mathrm{y}$, en su caso, aprobadas por la Junta Local con las modificaciones que procedan. Esta resolución supone la aprobación de las bases definitivas, que serán remitidas al órgano correspondiente de la consellería competente en materia de agricultura para su publicación en el "Diario Oficial de Galicia", en el Ayuntamiento y en los lugares de costumbre. En los treinta días siguientes a la publicación de las bases definitivas podrá interponerse recurso de alzada ante el conselleiro competente en materia de agricultura, y la Junta Local emitirá informe sobre dichos recursos con

588 Art. 27 modificado por Ley 12/2001, de 10 de septiembre, de modificación de la Ley de concentración parcelaria para Galicia.

589 Art. 28 modificado por Ley 12/2001, de 10 de septiembre, de modificación de la Ley de concentración parcelaria para Galicia. arreglo a lo previsto en el artículo 12 de la presente ley ${ }^{590}$.

\section{Capitulo III ACUERDO DE CONCENTRACIÓN PARCELARIA ${ }^{591}$}

Artículo 30. 1. Firmes las bases, el Servicio Provincial correspondiente, con la colaboración de la Junta Local de zona, procederá a la preparación del proyecto de concentración parcelaria, que constará de un plano, en el que sobre las antiguas parcelas se refleje la nueva distribución de la propiedad, el trazado de los nuevos caminos y viales, la relación de propietarios en la que, con referencia a dicho plano, se indiquen las fincas que en un principio se asignan a cada uno y la relación de explotaciones agrarias y tierras que les corresponden en los distintos modos de tenencia, con enumeración de los dueños de cada lote asignado y de servidumbres prediales que, en su caso, se establezcan según las conveniencias de la nueva ordenación de la propiedad.

2. Al proyecto de concentración parcelaria se incorporará un plan de aprovechamientos de los cultivos adecuado a las características agrológicas de las tierras, de modo que pueda conseguirse un aprovechamiento racional y sostenible de las mismas.

Si la zona de concentración incluyese terrenos de uso forestal o algún recurso natural que interese proteger o mantener, el Servicio Provincial oportuno requerirá del órgano competente en materia de montes la elaboración del correspondiente plan forestal de la zona, que será emitido en un plazo de cuatro meses.

Si transcurren cuatro meses sin la elaboración del referido plan, se entenderá que existe conformidad con las actuaciones

590 Art. 29 modificado por Ley 12/2001, de 10 de septiembre, de modificación de la Ley de concentración parcelaria para Galicia.

591 Rúbrica del Capítulo III del Título III y estructura del mismo fijada por Ley $12 / 2001$, de 10 de septiembre, de modificación de la Ley de concentración parcelaria para Galicia. 
que, a este respecto, realice la consellería competente en materia de agricultura.

3. Cuando sea necesario modificar el sistema de riegos preexistente, se incluirá también en el proyecto de concentración parcelaria un prorrateo de aguas, que habrá de ir acompañado de un plano donde se reflejen las áreas regables y su red de distribución.

4. Serán trasladados a las fincas de reemplazo respectivas aquellos derechos de plantaciones de viñas y otros cultivos leñosos sobre parcelas aportadas a la concentración parcelaria y reconocidos con arreglo a la normativa vigente. Para ello, los titulares de esos derechos, en el período de encuesta del proyecto, formularán por escrito las sugerencias que estimen oportunas sobre dicho traslado.

5. El proyecto de concentración parcelaria se aprobará por el Servicio Provincial competente, previo informe de la Junta Local de zona, siendo sometido a encuesta en la forma y plazos establecidos en el artículo 35592 .

Artículo 31. 1. Se constituirá una masa común de tierras en cada zona que se concentre, que se nutrirá con los sobrantes de las adjudicaciones de los lotes de reemplazo.

2. La finalidad de la masa común de tierras será la corrección de errores manifiestos de los que se deriven perjuicios para las personas afectadas por la concentración. Transcurrido un año desde que el acuerdo de concentración sea firme, los fondos restantes pasarán a integrar el Banco de Tierras de Galicia, sin perjuicio de la adjudicación de fincas integrantes del mismo que se realice por decisión del órgano competente en materia de agricultura, a consecuencia de actas complementarias o de rectificación de la de reorganización de la propiedad.

3. La titularidad de los bienes y derechos que constituyen la masa común

592 Art. 30 modificado por Ley 12/2001, de 10 de septiembre, de modificación de la Ley de concentración parcelaria para Galicia. corresponderá a la Comunidad Autónoma de Galicia durante el año siguiente a la firmeza del acuerdo de concentración. Estos bienes y derechos quedarán adscritos a la consejería competente en materia de agricultura, que estará autorizada a ejercer las funciones dominicales sobre este patrimonio según lo establecido en la legislación patrimonial, salvo cuando estén atribuidas por dicha legislación al Parlamento o Consello de la Xunta de Galicia, sin perjuicio del informe previo de la Consejería de Economía y Hacienda para los actos de disposición sobre bienes inmobles.

La gestión del aprovechamiento y la ordenación y fomento de la producción forestal respecto a los terrenos que estén considerados de uso forestal corresponderán al órgano competente en materia de montes.

4. La Administración autonómica tendrá un plazo de un año para la corrección de errores, a contar desde que el acuerdo de concentración sea firme. Transcurrido dicho plazo, se atribuirá la titularidad de estos bienes y derechos a la sociedad Bantegal, para su incorporación al Banco de Tierras de Galicia, y sin perjuicio de las adjudicaciones de fincas que a consecuencia de rectificaciones se lleven a cabo. La adjudicación de estas fincas realizada a consecuencia de rectificaciones se llevará a cabo por la sociedad Bantegal previa decisión de la dirección general correspondiente de la consejería competente en materia de agricultura, reflejándose en un acta complementaria de la de reorganización de la propiedad e inscribiéndose en el registro a favor de las personas adjudicatarias.

En aras de la protección de la seguridad jurídica y de la salvaguarda de los derechos de los ciudadanos, la consejería competente en materia de agricultura habrá de notificar al registro de la propiedad correspondiente la fecha de la firmeza del acuerdo de concentración, en un plazo 
de quince días hábiles desde que esta se produzca ${ }^{593}$.

Artículo 32. Si durante el procedimiento de concentración se pusiese de manifiesto la necesidad o conveniencia de disponer de determinadas superficies para equipamientos colectivos $\mathrm{u}$ otros fines de interés general, la Junta Local de zona podrá proponer esta utilización con cargo al fondo.

La Dirección general con competencias en la materia, una vez aprobada la propuesta, fijará su titularidad y destino, dándose a esta resolución la oportuna publicidad.

Al redactarse el acta de reorganización, se incluirá a dicho titular como adjudicatario del lote correspondiente ${ }^{594}$.

Artículo 33. 1. Finalizado el período de exposición al público del proyecto de concentración y estudiadas las alegaciones formuladas, así como introducidas las modificaciones que se estimen pertinentes como consecuencia de las mismas, se redactará el acuerdo de concentración, en el cual se determinarán con precisión las fincas de reemplazo, en las que constarán aquellas que queden afectadas por gravámenes y situaciones jurídicas derivadas de las parcelas de procedencia y que se ajustarán estrictamente a las bases definitivas, y en el que se incluirá el plan de aprovechamientos de cultivos o forestal, en su caso, a que hace referencia el artículo 30 de la presente ley.

En la medida en que lo permitan las necesidades de la concentración, se tendrán en cuenta las circunstancias que, aun no habiendo quedado reflejadas en la clasificación de tierras, concurran en el conjunto de las aportaciones de cada participante, así como también el prorrateo de aguas.

2. El órgano competente en materia de montes y medio ambiente verificará que

593 Art. 31 modificado por Ley 7/2007, de 21 de mayo, de medidas administrativas y tributarias para la conservación de la superficie agraria útil y del Banco de Tierras de Galicia.

594 Art. 32 modificado por Ley 12/2001, de 10 de septiembre, de modificación de la Ley de concentración parcelaria para Galicia.

el acuerdo de concentración parcelaria se ajusta al plan forestal elaborado según lo dispuesto en el artículo 30, procediendo, en caso contrario, la consellería competente en materia de agricultura a tomar las medidas pertinentes para que el acuerdo de concentración se ajuste a dicho plan.

3. El acuerdo se aprobará por la Dirección General competente en la materia, previo informe favorable de la Junta Local, siendo notificado en la forma que determina el artículo $36^{595}$.

Artículo 34. Las aportaciones de tierras por los particulares participantes en la concentración parcelaria están sujetas a las deducciones siguientes:

1. Hasta un 3 por 100 para el ajuste de las adjudicaciones de las fincas de reemplazo.

2. Hasta un 6 por 100 para realizar, en beneficio de la zona de concentración parcelaria, las obras precisas a que se refiere el artículo 61, número 2.1.

Dichas deducciones habrán de afectar en la misma proporción a todos los participantes de la concentración, con las excepciones de fincas únicas, con una superficie inferior al doble de la unidad mínima de cultivo, a las que no se aplicará deducción alguna.

En el primero de estos casos, la deducción se llevará a cabo teniendo en cuenta los beneficios que les pueda reportar el proceso de concentración ${ }^{596}$.

\section{Capitulo IV PUBLICACIONES Y COMUNICACIONES 597}

Artículo 35. Las encuestas sobre las bases y el proyecto de concentración, a que se refieren los artículos 22 y 30 y concordantes, se abrirán mediante avisos

595 Art. 33 modificado por Ley 12/2001, de 10 de septiembre, de modificación de la Ley de concentración parcelaria para Galicia.

596 Art. 34 modificado por Ley 12/2001, de 10 de septiembre, de modificación de la Ley de concentración parcelaria para Galicia.

597 Rúbrica del Capitulo IV del Título III y estructura del mismo fijadas por Ley 12/2001, de 10 de septiembre, de modificación de la Ley de concentración parcelaria para Galicia. 
insertos por ocho días en el tablón de anuncios del Ayuntamiento y además en los lugares de costumbre de las parroquias, en los cuales se hará público que estarán expuestos los documentos correspondientes en los plazos que se señalan en este artículo.

La exposición de las bases, del proyecto de concentración parcelaria y de cualquier otro extremo del expediente que la Dirección general competente en la materia decida publicar se realizará simultáneamente en los Ayuntamientos y en uno o varios locales de las parroquias afectadas, designados por la Comisión Permanente de la Junta Local de zona, y en la misma se garantizará el libre acceso de todos los interesados por un mínimo de cuatro horas al día.

Esta exposición se hará por tiempo de veinte días, susceptibles de prórroga por el Servicio Provincial correspondiente, previa petición de la Comisión Permanente de la Junta Local de zona.

Se garantizará en las horas y días que dure la exposición, al menos en un local por Ayuntamiento, la presencia de personal técnico que haya participado en la elaboración para aclarar a los particulares los extremos que sean pertinentes.

Cuando las circunstancias lo aconsejen, a lo largo del proceso de concentración podrá contarse con el apoyo, entre otros, de personal técnico especializado en materia urbanística y sociológica.

Durante estos plazos, los interesados podrán formular, por escrito, debidamente registrado, las observaciones o sugerencias que estimen oportunas, procediéndose a su estudio por un funcionario con los suficientes conocimientos técnicos y otro con la condición de Licenciado en Derecho, perteneciente al Servicio de Concentración Parcelaria, lo que podrá tener como consecuencia las modificaciones pertinentes, que serán reflejadas en las bases definitivas o en el acuerdo de concentración parcelaria, según corresponda.
Las alegaciones se resolverán con la aprobación de las bases o del acuerdo, en los que, en un anexo firmado por los citados funcionarios, se harán constar de manera individualizada las mismas y la solución que se les hubiera dado, siendo notificadas a los interesados 598 .

Artículo 36. Las bases definitivas y el acuerdo de concentración serán notificados a cada uno de los afectados. Cuando éstos sean desconocidos, se ignore el lugar de la notificación o bien intentada la misma no pudiera practicarse, la notificación será sustituida por la publicación del Servicio Provincial correspondiente, mediante aviso inserto por una sola vez en el "Diario Oficial de Galicia" y en el diario de mayor circulación de la provincia, así como por ocho días en el tablón de anuncios del Ayuntamiento y en los lugares habituales de la parroquia, advirtiendo que los documentos estarán expuestos durante treinta días naturales, que comenzarán a contarse desde el día siguiente a la publicación del aviso en el "Diario Oficial de Galicia", y que, dentro del citado plazo, podrá interponerse recurso de alzada ante el conselleiro competente en materia de agricultura ${ }^{599}$.

Artículo 37. Todas las notificaciones y citaciones que tengan que dirigirse a los titulares de explotaciones, propietarios, titulares de derechos reales y situaciones jurídicas y, en general, a las personas afectadas por los trabajos de concentración parcelaria se harán, en todo caso, personalmente al domicilio de los interesados que figure en las bases, sin perjuicio de las que puedan realizarse por medio de edictos y de su inserción en los tablones de anuncios de los Ayuntamientos, en los lugares de

598 Art. 35 modificado por Ley $12 / 2001$, de 10 de septiembre, de modificación de la Ley de concentración parcelaria para Galicia.

599 Art. 36 modificado por Ley 12/2001, de 10 de septiembre, de modificación de la Ley de concentración parcelaria para Galicia.

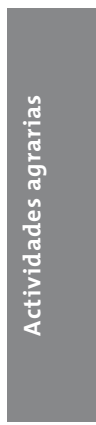


costumbre de la parroquia y en el "Diario Oficial de Galicia”, los cuales surtirán los mismos efectos que las leyes atribuyen a las notificaciones y citaciones ${ }^{600}$.

Artículo 38. Cuando las personas afectadas por la concentración promovieran individualmente reclamaciones o interpusieran recursos, las incidencias de unos y otros se entenderán personalmente con el reclamante o recurrente. A este efecto, habrán de expresar, en el escrito en el que se promueve la reclamación, un domicilio dentro del término municipal de se que trate $y$, en su caso, la persona residente en el mismo a quien tengan que hacerse las notificaciones.

\section{Capitulo V REVISIÓN ${ }^{601}$}

Artículo 39. La revisión de oficio de los actos administrativos dictados en materia de concentración parcelaria se ajustará a lo dispuesto en la legislación sobre procedimiento administrativo.

Artículo 40. Contra las bases definitivas y el acuerdo de concentración parcelaria se podrá interponer recurso de alzada ante el conselleiro de Agricultura, Pesca y Alimentación, dentro del plazo de treinta días, contados en la forma que determina el artículo 36.

Artículo 41. 1. El acuerdo de concentración sólo podrá ser impugnado en alzada si se infringen las formalidades prescritas para su elaboración y publicación, o si no se ajustase a las bases a que se refiere el artículo 21.

2. Los recursos podrán ser interpuestos por los titulares de un derecho subjetivo o de un interés directo, personal y legítimo en el asunto que los motive.

600 Art. 37 modificado por Ley 12/2001, de 10 de septiembre, de modificación de la Ley de concentración parcelaria para Galicia.

601 Rúbrica del Capitulo V del Título III y estructura del mismo fijada por Ley $12 / 2001$, de 10 de septiembre, de modificación de la Ley de concentración parcelaria para Galicia.
3. Durante el término señalado para recurrir, el expediente estará de manifiesto y a disposición de los interesados, para que estos puedan examinarlo y formular, en el mismo escrito en el que interpongan la alzada, las alegaciones que convengan a su derecho.

4. Los recursos de alzada serán preceptivamente informados por la Xunta Local.

Artículo 42. 1. Transcurridos tres meses desde la interposición de un recurso de alzada sin que se notifique su resolución, se entenderá desestimado, y quedará expedita la vía procedente.

Excepcionalmente, y por causas objetivas, podrá acordarse la ampliación del plazo máximo de resolución por otro período no superior a tres meses ${ }^{602}$.

2. La resolución del recurso de alzada será expresa y, en su caso, el plazo para formular el recurso que proceda se contará desde el día siguiente a la notificación de la misma.

Artículo 43. 1. Agotada la vía administrativa, se podrá interponer recurso contencioso-administrativo, que sólo será admisible por vicio sustancial en el procedimiento y por defecto en la apreciación del valor de las fincas, siempre que la diferencia entre el valor de las parcelas aportadas por el recurrente y las recibidas después de la concentración suponga, al menos, perjuicio de la sexta parte del valor de las primeras.

2. El fallo del recurso contenciosoadministrativo se ejecutará en lo posible de forma que no implique perjuicio para la concentración.

\section{Capitulo VI EJECUCIÓN DEL ACUERDO ${ }^{603}$}

Artículo 44. Finalizada la publicación del acuerdo de concentración, y

602 Artículo 42 modificado por la Ley 12/2001, de 10 de septiembre, de modificación de la Ley de concentración parcelaria para Galicia.

603 Rúbrica del Capítulo VI del Título III y estructura del mismo fijada por Ley 12/2001, de 10 de septiembre, de modificación de la Ley de concentración parcelaria para Galicia. 
siempre que el número de recursos presentados y pendientes no exceda del 6 por ciento de los titulares de las explotaciones o no representen los reclamantes más del 10 por ciento de la superficie concentrada, la Dirección General de Planificación y Desarrollo Agrario podrá dar, y los adjudicatarios exigir, la posesión provisional de las nuevas fincas, sin perjuicio de las rectificaciones que procedan como consecuencia de los recursos que prosperen.

Artículo 45. 1. El acuerdo de concentración podrá ejecutarse, previo apercibimiento personal por escrito, mediante compulsión directa sobre aquellos que se resistiesen a permitir la toma de posesión de las fincas de reemplazo, dentro de los términos y en las condiciones previamente anunciadas por la Dirección General, sin perjuicio de las sanciones que pudieran imponerse a quienes no permitan la toma de posesión de las fincas de reemplazo, previa instrucción del oportuno expediente sancionador con arreglo a lo dispuesto en el título VII de la presente ley.

2. Desde que los participantes reciban de la Dirección general la posesión provisional o definitiva de las fincas de reemplazo gozarán, frente a todos, de los medios de defensa establecidos en las leyes ${ }^{604}$.

Artículo 46. Dentro de los sesenta días naturales siguientes a la fecha en que las fincas de reemplazo se pongan a disposición de los participantes para que tomen posesión de las mismas, los interesados podrán reclamar, acompañando dictamen pericial, sobre diferencias superiores al 2 por 100 entre la cabida real de las nuevas fincas y la que conste en el título o expediente de concentración. Si la reclamación fuese estimada, la Dirección general podrá, según las circunstancias, rectificar el acuerdo, compensar al reclamante con cargo al fondo de tierras o, si

604 Art. 45 modificado por Ley 12/2001, de 10 de septiembre, de modificación de la Ley de concentración parcelaria para Galicia. esto último no fuera posible, indemnizarle en metálico ${ }^{605}$.

Artículo 46 bis. 1. Firme el acuerdo de concentración parcelaria a que se refiere el artículo 33, la dirección general correspondiente de la consellería competente en materia de agricultura autorizará el acta de reorganización de la propiedad, en la cual se relacionarán y describirán las fincas resultantes de la concentración, con las circunstancias necesarias para su inscripción en el Registro de la Propiedad, los derechos reales y situaciones jurídicas que hayan sido determinados en el período de investigación y la finca sobre la que hayan de establecerse, así como los nuevos derechos reales que se constituyan en las nuevas fincas de reemplazo.

2. La inscripción de los títulos de concentración en el Registro de la Propiedad se regirá por lo dispuesto en la legislación del Estado en la materia ${ }^{606}$.

\section{Título IV \\ EFECTOS Y CONSERVACIÓN DE LA CONCENTRACIÓN ${ }^{607}$}

Artículo 47. La entrada en vigor del Decreto de concentración parcelaria a que se refiere el artículo 19 faculta al Servicio Provincial correspondiente para realizar las obras que ella misma apruebe, que, en el supuesto de que afecten al dominio público hidráulico y zonas de servidumbre y policía de cauces, habrán de contar con las preceptivas autorizaciones y concesiones a otorgar por la Administración hidráulica autonómica; fijar marcos o señales, convocar reuniones, recabar datos precisos para la ejecución de la concentración y

605 Art. 46 modificado por Ley $12 / 2001$, de 10 de septiembre, de modificación de la Ley de concentración parcelaria para Galicia.

606 Art. 46 bis añadido por Ley 12/2001, de 10 de septiembre, de modificación de la Ley de concentración parcelaria para Galicia.

607 Estructura del Título IV fijada por Ley 12/2001, de 10 de septiembre, de modificación de la Ley de concentración parcelaria para Galicia. 
establecer planes de cultivos y ocupaciones temporales de fincas en tanto se tramita el expediente.

Desde dicha entrada en vigor, cualquier obra o mejora requerirá la previa autorización del referido Servicio, que en caso de no concederla dictará resolución motivada. Los propietarios y cultivadores tendrán la obligación de cuidar y cultivar las fincas, sin que se pueda talar o derribar arbolado, extraer o suprimir plantaciones o realizar actos que puedan disminuir el valor de la parcela sin la previa autorización del Servicio Provincial correspondiente.

Las plantaciones, obras o mejoras realizadas sin autorización no serán tenidas en cuenta a efectos de valoración y clasificación de las parcelas.

Asimismo, obliga a los miembros de la Junta Local a la asistencia a las reuniones que se convoquen y faculta a la Administración para exigir de los afectados por el proceso los datos que sean de interés para el mismo, así como cuanta información se estime necesaria para la redacción de las bases de la zona.

Quienes infrinjan lo anteriormente dispuesto serán sancionados, previa instrucción del oportuno expediente con arreglo a lo dispuesto en el título VII de la presente ley ${ }^{608}$.

Artículo 48. 1. La inclusión de una parcela en la concentración da lugar, mientras dure el procedimiento correspondiente, a la extinción del retracto de colindantes de derecho de permuta forzosa y demás de adquisición que se otorguen por ley para evitar los enclavados o la dispersión parcelaria, salvo que la demanda haya sido interpuesta antes de la inclusión.

2. Sin embargo, si alguna parcela comprendida en la zona fuese después objeto de exclusión, el plazo para interponer la demanda comenzará nuevamente desde el siguiente día en que el titular del derecho

608 Art. 47 modificado por Ley 12/2001, de 10 de septiembre, de modificación de la Ley de concentración parcelaria para Galicia. tuviese o debiese tener conocimiento del acuerdo de exclusión.

Artículo 48 bis. La inclusión de una finca en el plan de aprovechamientos de cultivos o forestal obligará a su titular al estricto cumplimiento del mismo hasta tanto el Ayuntamiento regule los usos de las tierras concentradas ${ }^{609}$.

Artículo 49. Las resoluciones dictadas en el expediente de concentración parcelaria no quedarán en suspenso por las cuestiones judiciales que se planteen entre particulares sobre los derechos afectados por la misma.

Artículo 50. 1. Al objeto de facilitar la disminución del número de propietarios de la zona, una vez publicado el Decreto de concentración parcelaria, el Servicio Provincial correspondiente pondrá a disposición de las personas interesadas en incrementar el tamaño de su explotación un listado elaborado a partir de las notificaciones hechas por aquellos que quieran vender sus parcelas, en su caso.

2. Será potestativo dar efecto en el expediente de concentración a las transmisiones o modificaciones de derechos que se comuniquen después de comenzada la publicación de las bases y hasta la firmeza de las mismas, quedando el adquirente subrogado en el lugar y puesto del anterior, con las limitaciones, deberes y obligaciones que resulten del procedimiento de la concentración.

3. Antes de que sea firme el acuerdo de concentración, los interesados podrán proponer permutas de fincas de reemplazo, que serán aceptadas siempre que, a criterio del Servicio Provincial correspondiente, no haya perjuicio para la concentración, recogiéndose, en tal caso, la situación resultante en el acta de reorganización de la propiedad ${ }^{610}$.

609 Art. 48 bis modificado por Ley $12 / 2001$, de 10 de septiembre, de modificación de la Ley de concentración parcelaria para Galicia.

610 Art. 50 modificado por Ley 12/2001, de 10 de septiembre, de modificación de la Ley de concentración parcelaria para Galicia. 
Artículo 51. Finalizada la concentración, y salvo los supuestos contemplados en las letras b) y c) del artículo siguiente, la división o segregación de una finca rústica no será válida cuando dé lugar a parcelas de extensión inferior a la unidad mínima de cultivo establecida conforme a lo dispuesto en el artículo 3.1.b) y, consecuentemente, no podrá ser objeto de ninguno de los auxilios o beneficios que la consellería competente en materia de agricultura pueda conceder para la mejora de las explotaciones ${ }^{611}$.

Artículo 52. No será válida la división o segregación de fincas de reemplazo, salvo en los siguientes casos:

a. Cuando se trate de disposiciones en favor de propietarios de fincas colindantes, siempre que, como consecuencia de la división o segregación, tanto la finca que se divide o segrega como la colindante, no resulten de extensión inferior a la unidad mínima de cultivo a que se refiere el artículo 3.1.b).

b. $\mathrm{Si}$ es consecuencia del ejercicio del derecho de acceso a la propiedad establecido en la legislación especial de arrendamientos rústicos.

c. Si se produce por causa de expropiación forzosa ${ }^{612}$.

\section{TÍTULO V \\ Capitulo I \\ PROCEDIMIENTOS ESPECIALES Y SIMPLIFICADOS 613}

Artículo 52 bis. Mediante orden del conselleiro competente en materia de agricultura, oída la Junta Local de zona, y por sobrevenir circunstancias excepcionales debidamente justificadas por el Servicio

611 Art. 51 modificado por Ley 12/2001, de 10 de septiembre, de modificación de la Ley de concentración parcelaria para Galicia.

612 Art. 52 modificado por Ley 12/2001, de 10 de septiembre, de modificación de la Ley de concentración parcelaria para Galicia.

613 Estructura del capitulo I del titulo $\mathrm{V}$ fijada por Ley $12 / 2001$, de 10 de septiembre, de modificación de la Ley de concentración parcelaria para Galicia.
Provincial correspondiente, podrá dividirse una zona de concentración en sectores independientes. En este caso, la ejecución y la publicación de los distintos trámites del proceso podrán realizarse en cada sector con independencia de los restantes ${ }^{614}$.

Artículo 53. 1. Acordada la concentración, y siempre que las circunstancias de la zona lo permitan, podrá ser facultada la Dirección General de Planificación y Desarrollo Agrario para que, previo informe de la Junta Local, simplifique el procedimiento ordinario, refundiendo, total o parcialmente, por una parte, las bases provisionales con el proyecto, y, por otra, las bases definitivas con el acuerdo de concentración que, una vez aprobados por los órganos competentes, serán objeto de una única publicación. El proyecto será único y tanto este como las bases provisionales se someterán a la misma encuesta.

2. El procedimiento simplificado al que se refiere el número anterior podrá ser aplicado, bien en zonas de pequeña extensión o de reducido número de explotaciones, o bien en zonas ya concentradas, o en los supuestos especiales previstos en los artículos siguientes.

Artículo 54. 1. Cuando, a consecuencia de cambios experimentados en las explotaciones agrarias o en la infraestructura de una zona ya concentrada, se estime que pueden mejorarse sustancialmente las estructuras mediante una nueva concentración de las mismas, la consellería competente en materia de agricultura queda facultada para promoverla, previo informe del Ayuntamiento o cámara agraria provincial correspondiente, observándose, en cuanto a la solicitud y procedimiento, lo dispuesto en los artículos 14 y siguientes, sin perjuicio de lo dispuesto en el número 2 del artículo anterior.

614 Art. 52 bis añadido por Ley 12/2001, de 10 de septiembre, de modificación de la Ley de concentración parcelaria para Galicia. 
2. La zona objeto de nueva concentración podrá comprender dos o más zonas o parroquias ya concentradas, o parte de las mismas, pudiendo incluirse, si se estimase conveniente, sectores o parcelas anteriormente excluidas ${ }^{615}$.

Artículo 55. Si la concentración se promoviese por existir proyectos de obras públicas u otras de interés general, siempre que a través de este procedimiento pueda facilitarse su realización y la distribución más equitativa de sus efectos entre los implicados, se observarán las normas del procedimiento simplificado referido en el artículo 53, con las siguientes particularidades:

1. La entidad concesionaria de la obra, a instancia de la consellería competente en materia de agricultura, determinará, con referencia a un plano, las parcelas o aquella parte de las mismas que ocupará la obra pública proyectada, con expresión detallada de la superficie.

2. Previo estudio, en el cual se tendrá en cuenta el trazado y la superficie a ocupar por la citada obra pública, la consellería, si procede, realizará la concentración, aprobando el Decreto de concentración parcelaria, en el que se determine el perímetro de la zona y se expresen todos los gastos que la misma origine. La reducción para obtener los terrenos a ocupar por la obra pública no será superior a la quinta parte del perímetro de la zona.

3. La superficie total que ocupará la obra pública se obtendrá por reducción proporcional de las aportaciones de los participantes. Además de esta reducción, se aplicarán las que contempla el artículo 34.

4. La entidad concesionaria valorará, para fijar la indemnización, las parcelas a ocupar, bien por convenios con los afectados o bien por los medios establecidos en la legislación sobre expropiación forzosa. A estos efectos, regirá la clasificación

615 Art. 54 modificado por Ley 12/2001, de 10 de septiembre, de modificación de la Ley de concentración parcelaria para Galicia. prevista en el artículo 27 y demás disposiciones del procedimiento de concentración.

5. En el proyecto se asignará a cada participante el valor que resulte de su aportación, con las reducciones reseñadas en el apartado 3 de este artículo.

6. Una vez conocida, en la encuesta de bases provisionales y proyectos, la valoración indemnizatoria de la entidad concesionaria, los propietarios podrán optar por recibir de inmediato su importe en metálico. En este caso, la superficie de las parcelas indemnizadas se destinará a mitigar la reducción proporcional de las aportaciones reseñadas en el citado apartado 3 de este artículo.

7. La ocupación de los terrenos para la ejecución de la obra pública se llevará a efecto en el acuerdo; no obstante, la entidad concesionaria podrá ocuparlos a partir del momento en que sean aprobadas las bases provisionales. En este caso, se incluirán en las mismas los convenios con los afectados dirigidos a obtener una garantía suficiente en la ejecución de los trabajos de concentración.

8. Las indemnizaciones resultantes de la valoración de la entidad concesionaria se distribuirán entre todos los participantes en proporción a la detracción del valor aportado a la concentración.

9. La superficie ocupada por la obra pública se adjudicará a nombre de la Administración o entidad titular de la misma ${ }^{616}$.

Artículo 56. Si la concentración se promoviese cuando por causas de la explotación de cotos mineros sea necesaria una importante cesión de tierras de utilización agraria, de tal modo que se estime que el procedimiento de concentración parcelaria pueda compensar los efectos de la expropiación y paliar el problema social que pudiera derivarse, se observarán las normas señaladas en los artículos 53 y 55 , con las siguientes particularidades:

616 Art. 55 modificado por Ley 12/2001, de 10 de septiembre, de modificación de la Ley de concentración parcelaria para Galicia. 
La entidad concesionaria, a instancia de la consellería competente en materia de agricultura, determinará con referencia a un plano las parcelas que ocupará el coto minero, con expresión detallada de la superficie, nombre de su propietario, valor fijado a efectos de expropiaciones y número de explotaciones, que desaparecerán por causa del citado coto. Tales datos serán objeto de información pública y, a la vista de su resultado, la consellería promoverá, si procediese, la concentración ${ }^{617}$.

Artículo 56 bis. Cuando se decrete la concentración parcelaria de montes o terrenos repoblados, el Servicio Provincial correspondiente de la consellería competente en materia de agricultura, previamente al conocimiento de un plan de ordenación forestal aplicable a dichos terrenos, podrá proponer la simplificación de alguno de los trámites del procedimiento de concentración y de las obras y mejoras territoriales en caso de que estuviese aprobado un plan de ordenación forestal aplicable a esos terrenos.

La referida simplificación no podrá implicar disminución de garantías, tanto en su ejecución como en los derechos de los titulares afectados.

La propuesta será objeto de información pública por un plazo de treinta días $\mathrm{y}$, a la vista de las alegaciones formuladas, será aceptada o rechazada por la dirección general correspondiente de la consellería competente en materia de agricultura.

El acuerdo de concentración parcelaria de montes llevará anexo su plan forestal, de conformidad con lo establecido en los artículos 30 y 33 de la presente ley, que será obligatorio para todos los titulares afectados, hasta tanto el Ayuntamiento regule los usos de las tierras concentradas 618 .

617 Art. 56 modificado por Ley $12 / 2001$, de 10 de septiembre, de modificación de la Ley de concentración parcelaria para Galicia.

618 Art. 56 bis modificado por Ley 12/2001, de 10 de septiembre, de modificación de la Ley de concentración parcelaria para Galicia.

\section{Capitulo II CONCENTRACIONES DE CARÁCTER PRIVADO ${ }^{619}$}

Artículo 57. Cuando dos o más propietarios titulares de fincas integradas en explotaciones independientes, mediante permuta o por cualquier otro título, agrupen fincas cuya superficie sea, como mínimo, de media hectárea en cultivos intensivos y huerta, 1 hectárea en labradío o prado y 3 hectáreas en monte, los gastos correspondientes al otorgamiento de escrituras, inscripciones registrales y otros legítimos correrán a cargo de la consellería competente en materia de agricultura ${ }^{620}$.

Artículo 58. Cuando un mínimo de tres agricultores con explotaciones individualizadas constituyan una agrupación para la concentración parcelaria de sus fincas rústicas y deseen acogerse a las ventajas que otorga esta ley habrán de reunir las condiciones siguientes:

1. La superficie a concentrar será, como mínimo, de cinco hectáreas en zonas de cultivos intensivos y de huerta y de 30 hectáreas en otros terrenos, siempre que el monte no supere el $30 \%$ de la superficie. Si superase este porcentaje, la superficie será de 75 hectáreas.

2. La superficie constituida por los enclaves de los propietarios ajenos a la agrupación no podrá ser más del $10 \%$ de la superficie a concentrar.

3. La agrupación de propietarios acreditará de modo suficiente el dominio de las tierras correspondientes a cada uno de ellos, delimitará el perímetro de la superficie a concentrar, especificará las cargas y gravámenes de todas y cada una de las fincas y acompañará un plano en el que sobre las parcelas de procedencia se refleje la nueva distribución de la propiedad y la copia del acta de reorganización. Esta

619 Véase Decreto 91/1988, de 7 de abril, que regula la concentración parcelaria de carácter privado.

620 Art. 57 modificado por Ley 12/2001, de 10 de septiembre, de modificación de la Ley de concentración parcelaria para Galicia. 
acta, con las respectivas documentaciones, serán remitidas a la Jefatura Provincial de Estructuras Agrarias, que las verificará y examinará estimándolas como bases definitivas, acuerdo y acta de reorganización.

Artículo 59. La Jefatura Provincial de Estructuras Agrarias remitirá el expediente con la documentación a la que se refiere el artículo 68.3, debidamente informado, a la Consellería de Agricultura, Pesca y Alimentación, que podrá aprobar y conceder los siguientes beneficios:

1. Abono de los gastos ocasionados con motivo del otorgamiento de escrituras, acta de reorganización, inscripciones en el registro de la propiedad, honorarios que devengue el equipo técnico que llevó a cabo los trabajos de concentración, y los de redacción de los proyectos de obras y mejoras previstas en el artículo 63.

2. Realización de todas la obras y mejoras previstas en los proyectos técnicos de la referida concentración.

3. Los demás beneficios previstos en esta ley.

Para el cálculo de los gastos que haya que abonar se tendrán en cuenta los coeficientes medios de gastos e inversiones por hectárea concentrada en el último año.

Artículo 60. Todos los gastos indicados en el artículo anterior, debidamente justificados, tendrán preferencia para su abono en los programas de inversiones a realizar por la dirección general al año siguiente al de la firma del acta de reorganización de la propiedad.

\section{TÍTULO VI OBRAS Y MEJORAS TERRITORIALES}

Artículo 61. 1. Una vez firmes las bases, la Dirección general correspondiente de la consellería con competencias en materia de agricultura, a propuesta del Servicio Provincial y previo conocimiento e informe del Ayuntamiento correspondiente, aprobará un plan de obras y mejoras territoriales, que reflejará todas las actuaciones que como obras anejas a la concentración parcelaria se llevarán a cabo en la zona.

En el supuesto de que el citado plan contemple obras que afecten a competencias de la Administración hidráulica autonómica, el mismo requerirá informe previo favorable de compatibilidad de dichas obras, con la planificación hidrológica de las cuencas de Galicia costa y con el plan de saneamiento de Galicia, que, a su vez, comportará la autorización administrativa correspondiente a cada una de las mismas, que habrá de emitirse en el plazo de cuarenta y cinco días y será aprobado por orden de la consellería competente en materia de agricultura y publicado en el "Diario Oficial de Galicia" y en el tablón de anuncios del Ayuntamiento o Ayuntamientos afectados por el mismo.

Cuando en el citado plan se incluyan obras o mejoras que tengan que ser financiadas con cargo a presupuestos de otras consellerías, su aprobación corresponderá a la Xunta de Galicia, la cual, por Decreto adoptado a propuesta de la misma, señalará expresamente a quien corresponde la financiación y su ejecución.

2. Las obras que realizará la consellería competente en materia de agricultura en las zonas de concentración parcelaria podrán clasificarse en los siguientes grupos:

1) Obras e infraestructuras básicas inherentes al proceso de concentración, incluyendo como tales:

a. Red de caminos rurales, con sus obras de fábrica anejas, saneamiento de tierras, roturación de montes para su destino a cultivo, eliminación de accidentes naturales o artificiales que impidan el cultivo adecuado de los lotes de reemplazo, nivelaciones y otros trabajos de conservación del suelo.

b. Acondicionamiento de regadíos ya existentes, construcción de nuevos que se hayan establecido como necesarios en los estudios de la concentración, canalización de aguas y defensa de márgenes, 
todo ello sin perjuicio de lo dispuesto en el artículo 64.

c. En general, aquellas obras y mejoras que beneficien las condiciones agrarias y ecológicas de la zona o tengan por objeto subsanar defectos de infraestructura.

d. Captación y depuración de aguas y redes de saneamiento.

e. Todas las medidas correctoras que se hayan determinado en el estudio de impacto ambiental.

2. Obras complementarias, entendiéndose aquellas que sin relacionarse directamente con la concentración parcelaria contribuyan a su satisfactorio desarrollo económico y social, redundando en beneficio de todos los agricultores, de algún grupo de los mismos o de alguna explotación comunitaria.

En todo caso, el fin de las obras y mejoras a realizar será de interés agrario o de dotación de equipamientos sociales, o de mejora del hábitat rural, incluyéndose en este grupo las siguientes:

a. Establos, instalaciones para el ganado, implantación de praderas y pastizales, cercados y repoblación forestal en las áreas correspondientes, y ajuste del suelo para el uso de los cultivos siempre que sean los indicados en los estudios de la concentración.

b. Almacenes para maquinaria agrícola, materias primas o productos agrarios, así como instalaciones para industrialización y comercialización de estos productos.

c. Mejora de canales de riego, implantación de diversas técnicas de regadío, investigación y captación de aguas subterráneas y nuevos regadíos.

d. Aprovechamiento comunitario de energías alternativas y electrificación de núcleos rurales con la potencia adecuada a las necesidades.

e. Cualquier otra mejora permanente que redunde en beneficio de todos los agricultores de la zona o de algún grupo de los mismos.

3. El importe de las obras a que se refieren los apartados anteriores se financiará por la Xunta de Galicia a través de la consellería competente en materia de agricultura.
4. Las obras complementarias a que se hace referencia en el apartado 2.2 de este artículo, que no tienen carácter obligatorio, serán proyectadas y ejecutadas por la consellería competente en materia agraria, siendo sufragadas por la misma y estableciéndose reglamentariamente las condiciones y garantías suficientes, a fin de recobrar de los beneficiados directos de las obras y mejoras realizadas el 60 por 100 de su coste, en un plazo no superior a diez años y con la satisfacción anual del importe de los intereses legalmente establecidos para las cantidades a satisfacer.

En su caso, y para general conocimiento de todos los interesados, será objeto de exposición pública el aviso por el que se anuncien la apertura del plazo y las condiciones para que los titulares de explotaciones en la zona puedan presentar la correspondiente solicitud y suscripción de los compromisos que les sean exigibles en garantía del pago de la cuota que les corresponda.

Los vicios ocultos en las obras y mejoras realizadas podrán ser objeto de reclamación en la forma prevista en la legislación vigente ${ }^{621}$.

Artículo 62. 1. A partir de la entrada en vigor del Decreto de concentración parcelaria en el que se declare de utilidad pública e interés social la concentración parcelaria de una zona, la consellería competente en materia de agricultura, en cualquier momento del procedimiento, podrá ocupar temporalmente los terrenos de la misma que sean precisos para dotar a las nuevas fincas de la adecuada red de caminos o para realizar trabajos relacionados con la concentración.

La ocupación temporal de dichos terrenos se regirá, en cuanto a las indemnizaciones que hayan de satisfacerse a los propietarios afectados, por los preceptos de la legislación vigente en materia de expropiación forzosa.

621 Art. 61 modificado por Ley 12/2001, de 10 de septiembre, de modificación de la Ley de concentración parcelaria para Galicia. 
2. Cuando para la realización de la obra y mejora resulte necesaria la expropiación forzosa de terrenos no sujetos a concentración, la consellería podrá utilizar, al expresado fin, el procedimiento urgente que en la legislación vigente en materia de expropiación forzosa se establezca.

Para que la consellería pueda hacer uso de la facultad expropiatoria que le atribuye este artículo será preciso que la necesidad y urgencia de la expropiación se haya expuesto y razonado en el plan de obras y mejoras territoriales o que, si la necesidad ha surgido con posterioridad a tal aprobación, se obtenga de la referida Consejería la autorización correspondiente.

3. Cuando se trate de terrenos sujetos a concentración, sus propietarios no serán indemnizados en metálico, sino que el valor de los mismos se computará en las bases, sin perjuicio de las demás indemnizaciones y garantías que se establezcan en la legislación vigente en materia de expropiación forzosa ${ }^{622}$.

Artículo 63. 1. Los proyectos de las obras a que se refiere el artículo 61.2.1 se ajustarán en su redacción al correspondiente plan de obras y mejoras territoriales y se aprobarán por la Dirección General correspondiente de la consellería competente en materia de agricultura.

Una vez aprobados, deben ser comunicados al Ayuntamiento, siendo objeto de publicación en los lugares de costumbre de las parroquias y en el Ayuntamiento a que pertenezca la zona, para información de los afectados.

La contratación se ajustará a los trámites administrativos previstos en la legislación pertinente.

2. Los proyectos de obras incluidos en el artículo 61.2.2 serán, asimismo, objeto de publicación, a fin de que los agricultores, cooperativas $\mathrm{u}$ otras entidades

622 Art. 62 modificado por Ley 12/2001, de 10 de septiembre, de modificación de la Ley de concentración parcelaria para Galicia. interesadas puedan, con conocimiento de los precios y demás condiciones de la operación, deducir la solicitud correspondiente, asumir el compromiso y prestar las garantías que se señalen ${ }^{623}$.

Artículo 64. 1. El acuerdo de la Dirección general correspondiente de la consellería competente en materia de agricultura de entregar una obra ejecutada por la misma e incluida en sus planes constituye un acto administrativo que, en caso de que la obra no se ajuste a los proyectos correspondientes o no se entregase a quien corresponda, podrá ser recurrido por las personas o entidades que hayan de hacerse cargo de la misma. Dicho acuerdo será inmediatamente ejecutivo, dando lugar al nacimiento de todas las obligaciones dimanantes de la entrega.

2. Dentro de los sesenta días, contados desde el siguiente al de la notificación del acuerdo, podrá interponerse recurso ante la consellería competente en materia de agricultura. La resolución de dicho recurso pondrá fin a la vía administrativa. La notificación será siempre personal cuando la obra haya de ser entregada a una sola persona o entidad.

3. La resolución de los recursos a que se refiere este artículo determinará, si procede, la disminución proporcional del precio o la ejecución de las reformas precisas a expensas de la consellería. Si los defectos de la obra la hacen absolutamente inadecuada para el uso a que se destina, se acordará, a petición del recurrente, la resolución del compromiso asumido por el mismo.

4. Firme el acuerdo, en el momento en que se notifique formalmente a los interesados, se reputará hecha la entrega de las obras y transmitido el dominio ${ }^{624}$.

623 Art. 63 modificado por Ley 12/2001, de 10 de septiembre, de modificación de la Ley de concentración parcelaria para Galicia.

624 Art. 64 modificado por Ley 12/2001, de 10 de septiembre, de modificación de la Ley de concentración parcelaria para Galicia. 
Artículo 64 bis. 1. Podrán ser incluidas en el plan de obras y mejoras territoriales, de acuerdo con lo previsto en el artículo 61 , las obras de competencia de otras consellerías cuya financiación esté prevista en sus presupuestos.

2. La consellería competente en materia de agricultura podrá celebrar convenios con los Ayuntamientos y organismos del Estado para incluir en los planes de obras y mejoras territoriales aquellas que sean de su competencia o le afecten en cuanto a su financiación y beneficien la zona.

3. Para la ejecución de las obras previstas en este artículo podrá establecerse un plan coordinado entre la consellería competente en materia de agricultura y las entidades que colaboren en su ejecución y financiación.

Este plan señalará en el anteproyecto general y por sectores las obras, su enumeración y la relación de las que corresponden a cada organismo o entidad colaboradora, con anotaciones ajustadas al orden y ritmo, tanto de redacción de proyectos como de su ejecución. En este supuesto, la aprobación del plan coordinado corresponde a la Junta ${ }^{625}$.

Artículo 65. 1. La consellería competente en materia de agricultura podrá celebrar Convenios con las Diputaciones, Ayuntamientos y agrupaciones de agricultores al objeto de conseguir una adecuada conservación de las obras de cualquier clase incluidas en sus planes, determinando en los mismos la forma de prestar el servicio y reembolsar los gastos ocasionados.

2. Quienes impidan, destruyan, deterioren o hagan mal uso de cualquier obra o señalización incluida en los planes de concentración parcelaria serán sancionados, previa instrucción del oportuno expediente sancionador, con arreglo a lo dispuesto en el título VII de la presente ley.

625 Art. 64 bis añadido por Ley 12/2001, de 10 de septiembre, de modificación de la Ley de concentración parcelaria para Galicia.
3. Las demás normas relativas a conservación de las obras, según sus diferentes clases, serán dictadas mediante Disposiciones Especiales ${ }^{626}$.

Artículo 66. Las Diputaciones, Ayuntamientos y cualquier otra entidad territorial con personalidad jurídica de ámbito local a las cuales se entregue la propiedad de la red de caminos rurales se comprometerán formalmente a consignar en sus presupuestos los recursos necesarios para su conservación ${ }^{627}$.

Artículo 67. 1. La elaboración de documentos clave en el procedimiento está exclusivamente reservada a la consellería correspondiente (estudio previo, plan de desarrollo, plan de obras y proyecto de concentración), pudiendo ser contratadas con empresas privadas acciones parciales de los mismos.

2. La Administración ejercerá la supervisión y dirección de obra sobre todos los aspectos y acciones del procedimiento.

3. Asimismo, la Junta Local de zona pondrá en conocimiento de la consellería cualquier anomalía que observe para que pueda ser inmediatamente subsanada 628 .

Artículo 68. Transcurridos dos años desde la autorización del acta de reorganización de la propiedad — que supone la finalización del proceso concentrador de que se trate-, la consellería competente en materia agraria deberá realizar una evaluación de la zona de concentración para valorar el grado de consecución de los objetivos fijados, entre otros, el cumplimiento de los planes de aprovechamiento de cultivos, la utilidad económica y social, así como la fijación de población en el medio rural.

626 Art. 65 modificado por Ley 12/2001, de 10 de septiembre, de modificación de la Ley de concentración parcelaria para Galicia.

627 Art. 66 modificado por Ley 12/2001, de 10 de septiembre, de modificación de la Ley de concentración parcelaria para Galicia.

628 Art. 67 modificado por Ley 12/2001, de 10 de septiembre, de modificación de la Ley de concentración parcelaria para Galicia. 
Transcurridos cuatro años desde la autorización del acta a que se refiere el párrafo anterior, se llevará a cabo una nueva evaluación de los resultados alcanzados 629 .

\section{TíTULO VII \\ INFRACCIONES Y SANCIONES ${ }^{630}$}

Artículo 69. 1. Son sancionables las acciones y omisiones que infrinjan lo establecido en la presente ley, sin perjuicio de las responsabilidades exigibles en la vía penal, civil o de otro orden en que pudieran incurrir.

2. Las infracciones a lo establecido en la presente ley se clasifican en leves, graves y muy graves ${ }^{631}$.

Artículo 70. Son infracciones leves:

1. No cuidar o no cultivar las nuevas fincas entregadas.

2. Dificultar los trabajos de investigación y clasificación de tierras.

3. Realizar actos que disminuyan el valor de las parcelas en un valor inferior al 10 por 100 una vez que el Decreto de concentración parcelaria hubiera entrado en vigor.

4. Cualquier otra acción u omisión que suponga incumplimiento de cualquiera de los requisitos establecidos en la presente ley que no esté clasificado como falta grave o muy grave ${ }^{632}$.

Artículo 71. Son infracciones graves:

1. Impedir o dificultar el amojonamiento, la señalización o la realización de las obras que apruebe el Servicio Provincial correspondiente, así como retirar las señales cuando estén instaladas.

629 Art. 68 modificado por Ley 12/2001, de 10 de septiembre, de modificación de la Ley de concentración parcelaria para Galicia.

630 Título VII añadido por Ley 12/2001, de 10 de septiembre, de modificación de la Ley de concentración parcelaria para Galicia.

631 Art. 69 modificado por Ley 12/2001, de 10 de septiembre, de modificación de la Ley de concentración parcelaria para Galicia.

632 Art. 70 modificado por Ley 12/2001, de 10 de septiembre, de modificación de la Ley de concentración parcelaria para Galicia.
2. Realizar, a la entrada en vigor del Decreto de concentración parcelaria, obras o mejoras en las fincas sin la correspondiente autorización.

3. Destruir obras, talar o derribar arbolado, extraer o suprimir plantaciones o cultivos permanentes y esquilmar la tierra y realizar actos que disminuyan el valor de las parcelas en un valor superior al 10 por 100 una vez que el Decreto de concentración parcelaria hubiera entrado en vigor.

4. Impedir al personal encargado de la realización de los trabajos de concentración parcelaria el acceso a las parcelas o fincas para el desarrollo de su función.

5. El deterioro o mal uso de cualquier obra de interés general incluida en los planes de obras y mejoras territoriales.

6. No cultivar las fincas conforme a su capacidad agrológica y aprovechamiento adecuado de sus recursos, el cambio del uso de la tierra clasificada como labradío o prado y el incumplimiento del plan de ordenación de aprovechamiento de cultivos o forestal, conforme establecen los artículos 3 y 30 y concordantes de la presente ley ${ }^{633}$.

Artículo 72. Son infracciones muy graves:

1. Impedir u obstaculizar la toma de posesión de las nuevas fincas de reemplazo.

2. Impedir u obstaculizar la realización de las actuaciones comprendidas en el plan de obras y mejoras territoriales ${ }^{634}$.

Artículo 73. 1. Las infracciones en materia de concentración parcelaria se sancionarán de la siguiente forma:

a. Las infracciones leves con multa de 10.000 a 50.000 pesetas.

b. Las infracciones graves con multa de 50.001 a 250.000 pesetas.

c. Las infracciones muy graves con multa de 250.001 a 500.000 pesetas.

633 Art. 71 añadido por Ley $12 / 2001$, de 10 de septiembre, de modificación de la Ley de concentración parcelaria para Galicia.

634 Art. 72 añadido por Ley 12/2001, de 10 de septiembre, de modificación de la Ley de concentración parcelaria para Galicia. 
2. El Consello de la Xunta, mediante Decreto, podrá proceder a la actualización de los importes de las sanciones contenidas en la presente ley.

3. En todo caso, el infractor deberá reponer la situación alterada a su estado originario, así como indemnizar los daños y perjuicios causados, según se determine en la resolución que ponga fin al expediente sancionador.

4. En los supuestos a que se refiere la Ley 30/1992, de Régimen Jurídico de las Administraciones Públicas y del Procedimiento Administrativo Común, podrán imponerse, previo apercibimiento, multas coercitivas, reiteradas por lapsos de dos meses ${ }^{635}$.

Artículo 74. Los órganos de las consellerías competentes en materia de agricultura y medio ambiente natural a los que corresponde la imposición de sanciones por la comisión de las infracciones contenidas en la presente ley serán los siguientes:

a. A los Delegados provinciales con competencias por razón de la materia, la imposición de sanciones por la comisión de infracciones leves.

b. Al Director general competente por razón de la materia, para las infracciones graves.

c. Al conselleiro competente, por la comisión de infracciones muy graves ${ }^{636}$.

Artículo 75. Las infracciones administrativas a lo establecido en la presente Ley prescribirán, las leves, en el plazo de seis meses, las graves, en el de dos años, y las muy graves, a los tres años ${ }^{637}$.

Artículo 76. Para la instrucción de expedientes y la imposición de sanciones por infracciones a lo establecido en la presente

635 Art. 73 añadido por Ley $12 / 2001$, de 10 de septiembre, de modificación de la Ley de concentración parcelaria para Galicia.

636 Art. 74 añadido por Ley 12/2001, de 10 de septiembre, de modificación de la Ley de concentración parcelaria para Galicia.

637 Art. 75 añadido por Ley 12/2001, de 10 de septiembre, de modificación de la Ley de concentración parcelaria para Galicia. ley se estará a las normas reguladoras del procedimiento sancionador común ${ }^{638}$.

\section{DISPOSICIÓN ADICIONAL PRIMERA}

A efectos de lo establecido en el artículo 25 de la Ley estatal 19/1995, de 4 de julio, de Modernización de las Explotaciones Agrarias, la división o segregación de una finca rústica sólo será válida en los supuestos establecidos en el artículo 52 de la presente ley ${ }^{639}$.

\section{DISPOSICIÓN ADICIONAL SEGUNDA}

Las referencias que efectúa la Ley 10/1985, de 14 de agosto, de Concentración Parcelaria para Galicia, a la consellería competente en materia de agricultura, pesca y alimentación, a la Dirección General de Planificación y Desarrollo Agrario y a la Jefatura Provincial de Estructuras Agrarias se entenderán realizadas a la consellería competente en materia de agricultura y a la Dirección General y Servicios Provinciales correspondientes de la Consejería competente en materia de agricultura ${ }^{640}$.

\section{DISPOSICIÓN ADICIONAL TERCERA}

$$
(\ldots)^{641} \text {. }
$$

\section{DISPOSICIÓN ADICIONAL CUARTA}

$$
(\ldots)^{642} \text {. }
$$

\section{DISPOSICIÓN TRANSITORIA PRIMERA}

1. La consellería competente en materia de agricultura podrá declarar de oficio caducados, a propuesta del correspondiente

638 Art. 76 añadido por Ley 12/2001, de 10 de septiembre, de modificación de la Ley de concentración parcelaria para Galicia.

639 Disposición adicional primera modificada por Ley $12 / 2001$, de 10 de septiembre, de modificación de la Ley de concentración parcelaria para Galicia.

640 Disposición adicional segunda modificada por Ley $12 / 2001$, de 10 de septiembre, de modificación de la Ley de concentración parcelaria para Galicia.

641 Disposición adicional tercera dejada sin contenido por Ley 12/2001, de 10 de septiembre, de modificación de la Ley de concentración parcelaria para Galicia.

642 Disposición adicional cuarta dejada sin contenido por Ley 12/2001, de 10 de septiembre, de modificación de la Ley de concentración parcelaria para Galicia.

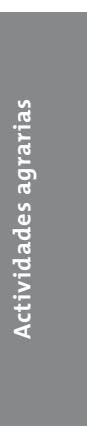


Servicio Provincial y previo informe motivado, aquellos expedientes de concentración parcelaria que a la fecha de entrada en vigor de la presente Ley hayan sido iniciados por Decreto y que después de su publicación han quedado paralizados por cinco o más años sin que, al amparo de los mismos, se hubieran dictado actos administrativos firmes.

2. Respecto a los expedientes de concentración parcelaria que, a la entrada en vigor de la presente ley, hayan sido iniciados por Decreto y que después de su publicación hubieran quedado paralizados por diez o más años y a cuyo amparo se hubiesen realizado actuaciones que hayan conducido a la declaración de firmeza de las bases definitivas o se hubiesen ejecutado otras inversiones por parte de la Administración, podrán ser declarados nulos aquellos actos administrativos que pusiesen fin a la vía administrativa, de conformidad y con los requisitos establecidos en la Ley 30/1992, de Régimen Jurídico de las Administraciones Públicas y del Procedimiento Administrativo Común.

3. En los expedientes de concentración parcelaria administrativamente concluidos, llevados a cabo con anterioridad a los Reales Decretos 2423/1982 y $1124 / 1985$, por los que se traspasan funciones y servicios del Estado a la Comunidad Autónoma de Galicia en materia de reforma y desarrollo agrario, pero en los cuales la reorganización de la propiedad no ha sido aceptada por los interesados, podrán solicitar los mismos una nueva concentración al amparo del artículo 7 de la presente ley, tomando como aportación de los propietarios el valor de las parcelas aportadas del pasado proceso ${ }^{643}$.

\section{DISPOSICIÓN TRANSITORIA SEGUNDA}

En las Juntas Locales ya constituidas con anterioridad a la entrada en vigor de la ley, los Vocales de las extintas cámaras agrarias locales serán sustituidos por

643 Disposición transitoria primera modificada por Ley $12 / 2001$, de 10 de septiembre, de modificación de la Ley de concentración parcelaria para Galicia. dos agricultores de entre los elegidos en reserva para formar parte de dichas Juntas Locales o, en su defecto, de los integrantes de los grupos auxiliares de trabajo a que se refería el artículo 13 de la Ley 10/1985, de 14 de agosto. A estos efectos, se atenderá al orden que figure en las actas de Asamblea a que hacía referencia el artículo 11 de la mencionada Ley.

El Presidente de la extinta cámara agraria local será sustituido por un representante de la cámara agraria provincial, elegido por el Pleno de entre sus miembros ${ }^{644}$.

\section{DISPOSICIÓN TRANSITORIA TERCERA}

A las tierras sobrantes correspondientes a los procedimientos de Concentración Parcelaria realizados desde la entrada en vigor de la Ley 10/1985, de 14 de agosto, de Concentración Parcelaria para Galicia, les será de aplicación lo dispuesto en el artículo 31.3 de la presente ley ${ }^{645}$.

\section{DISPOSICIÓN TRANSITORIA CUARTA}

Las modificaciones que introduce el presente texto legal se aplicarán a los procedimientos en curso, sin retrotraer los trámites, siempre que se acepten por las mayorías establecidas en el artículo 16 de la Ley 10/1985, de 14 de agosto, cuando el procedimiento de concentración parcelaria se hubiera iniciado a petición de los interesados ${ }^{646}$.

\section{DISPOSICIÓN DEROGATORIA ÚNICA}

Quedan derogadas todas las normas de igual o inferior rango en lo que contradigan o se opongan a lo dispuesto en la presente ley ${ }^{647}$.

644 Disposición transitoria segunda modificada por Ley $12 / 2001$, de 10 de septiembre, de modificación de la Ley de concentración parcelaria para Galicia.

645 Disposición transitoria tercera modificada por Ley $12 / 2001$, de 10 de septiembre, de modificación de la Ley de concentración parcelaria para Galicia.

646 Disposición transitoria cuarta modificada por Ley $12 / 2001$, de 10 de septiembre, de modificación de la Ley de concentración parcelaria para Galicia.

647 Disposición derogatoria única modificada por Ley $12 / 2001$, de 10 de septiembre, de modificación de la Ley de concentración parcelaria para Galicia. 


\section{DISPOSICIÓN FINAL ÚNICA}

Se faculta al Consello de la Xunta para dictar cuantas disposiciones de aplicación y desarrollo de la presente ley sean precisas $^{648}$.

\section{LEY 7/2007, DE 21 DE MAYO, DE MEDIDAS ADMINISTRATIVAS $Y$ TRIBUTARIAS PARA LA CONSERVACIÓN DE LA SUPERFICIE AGRARIA ÚTIL Y DEL BANCO DE TIERRAS DE GALICIA (DOGA N. $\left.{ }^{\circ} 104,31.5 .2007\right)$}

\section{$(\ldots)^{649}$ \\ TÍTULO I DISPOSICIONES GENERALES}

\section{Artículo 1. Objeto.}

1. Es objeto de la presente ley regular el uso racional de la superficie agraria útil en la búsqueda de su conservación y evitar su abandono, articulando medidas que favorezcan y dinamicen la oferta y la demanda como las que siguen:

a. Constituir el Banco de Tierras de Galicia, en el que se relacionen todas las fincas rústicas vinculadas a los destinos especificados en el artículo 5.2 de la presente ley.

b. Establecer el régimen jurídico del Banco de Tierras de Galicia.

c. Regular los diferentes procedimientos de incorporación de fincas del Banco de Tierras de Galicia y de cesión de las mismas.

d. Regular el procedimiento para la declaración de fincas incultas o abandonadas que posibilite la realización de prácticas agronómicas de conservación y la preservación del entorno y de las condiciones medioambientales.

648 Disposición final única modificada por Ley $12 / 2001$, de 10 de septiembre, de modificación de la Ley de concentración parcelaria para Galicia.

649 Exposición de motivos omitida. e. Establecer el régimen sancionador correspondiente a las acciones y omisiones descritas en la presente ley.

2. El Bantegal tendrá como función fundamental alcanzar la movilización de las superficies agrarias útiles improductivas, favoreciendo de este modo el redimensionamiento de las explotaciones.

Artículo 2. Ámbito de aplicación.

1. Las disposiciones establecidas en la presente ley serán de aplicación en las zonas de especial interés agrario, entendiendo por tales las fincas con acuerdo de concentración firme posterior a 30 de diciembre de 1992.

Sin perjuicio de lo anterior, también será de aplicación a las restantes fincas incorporadas al Banco de Tierras de Galicia, en el que puede integrarse cualquier finca rústica ubicada en la comunidad autónoma de Galicia, así como a aquellas a que se hace referencia en el artículo 8.2 de la presente ley.

2. También tendrán la condición de zonas de especial interés agrario aquellos ámbitos territoriales que, mediante decreto, determine el Consello de la Xunta al resultar necesarios para conseguir una adecuada gestión del Banco de Tierras de Galicia.

Artículo 3. Definiciones.

A los efectos de la presente ley, se entenderá por:

1. Superficie agraria útil: la totalidad del suelo rústico de protección agropecuaria, según lo establecido en la Ley 9/2002, de ordenación urbanística y protección del medio rural de Galicia, y las zonas de especial interés agrario declaradas por decreto del Consello de la Xunta.

2. Finca rústica: superficie agraria útil delimitada que constituye una heredad o parcela.

3. Barbecho: finca rústica en la que ha habido cultivo en la campaña agrícola anterior y en la presente está en descanso 
sin tener aprovechamiento agroganadero alguno.

4. Posío: finca rústica en la que ha habido cultivo en la campaña agrícola anterior o ha estado a barbecho y en la presente no tiene cultivo agrícola pero tiene aprovechamiento ganadero, normalmente mediante pastoreo.

5. Monte o terreno forestal: todo terreno, excluyendo los anteriores, en el que vegetan especies forestales arbóreas, arbustivas, de matorral o herbáceas, sea espontáneamente o procedan de siembra o plantación, que cumplan o puedan cumplir funciones ambientales, protectoras, productoras, culturales, paisajísticas o recreativas.

Tienen también la consideración de monte o terreno forestal los demás terrenos descritos en el artículo 5 de la Ley 43/2003, de 21 de noviembre, de montes.

6. Explotación agraria: el conjunto de bienes y derechos organizados empresarialmente por su titular en el ejercicio de la actividad agraria, primordialmente con fines de mercado, y que constituye en sí mismo una unidad técnico-económica.

7. Persona titular de la explotación: la persona física o jurídica o, en su caso, la entidad asociativa sin personalidad jurídica propia que ejerce la actividad agraria, organizando los bienes y derechos integrantes de la explotación con criterios empresariales y asumiendo los riesgos y responsabilidades civil, social y fiscal que puedan derivarse de la gestión de la explotación.

8. Persona agricultora profesional: la persona física que, siendo titular de una explotación agraria, obtenga al menos el cincuenta por cien de su renta total de actividades agrarias $\mathrm{u}$ otras actividades complementarias, siempre que la parte de renta procedente directamente de la actividad agraria realizada en su explotación no sea inferior al veinticinco por cien de su renta total y el tiempo de trabajo dedicado a actividades agrarias o complementarias sea superior a la mitad de su tiempo de trabajo total.

A estos efectos, se considerarán actividades complementarias las contempladas con este carácter en el párrafo 2 del artículo $2.5^{\circ}$ de la Ley 19/1995, de 4 de julio, de modernización de las explotaciones agrarias.

9. Persona agricultora a título principal: la persona agricultora profesional que obtenga al menos el cincuenta por cien de su renta total de la actividad agraria ejercida en su explotación y cuyo tiempo de trabajo dedicado a actividades no relacionadas con la explotación sea inferior a la mitad de su tiempo de trabajo total.

10. Persona agricultora joven: la persona que haya cumplido los dieciocho años y no haya cumplido cuarenta años y ejerza o pretenda ejercer la actividad agraria.

11. Zonas de especial interés agrario: las fincas concentradas en los diez años anteriores a la entrada en vigor de la Ley 9/2002, de ordenación urbanística y de protección del medio rural de Galicia, y las que se concentren con posterioridad, siempre que en esos supuestos el acuerdo de concentración sea firme. Tendrán también la consideración de zonas de especial interés agrario aquellas que, mediante decreto, sean declaradas así por el Consello de la Xunta.

\section{TÍTULO II DEL BANCO DE TIERRAS DE GALICIA Y DE SU ÓRGANO DE GESTIÓN \\ Capítulo I \\ DEL BANCO DE TIERRAS DE GALICIA}

Artículo 4. El Banco de Tierras de Galicia.

1. El Banco de Tierras de Galicia es un instrumento en el que figuran inventariadas todas las fincas rústicas vinculadas a los destinos especificados en el artículo 5.2 de la presente ley, independientemente de su titularidad, la cual, según los casos, 
pertenecerá a la Comunidad Autónoma, los particulares y otros cedentes, o a la sociedad Bantegal, cuya creación se contempla en esta ley.

2. Forman parte del Banco de Tierras de Galicia:

a. Las masas comunes y fincas sobrantes de las adjudicaciones de los lotes de reemplazo, una vez transcurrido un año desde que el acuerdo de concentración sea firme, salvo las tierras que tengan otro destino.

b. Las fincas rústicas adquiridas por la sociedad Bantegal, a consecuencia del ejercicio de los derechos de adquisición preferente regulados en la presente ley.

c. Las fincas rústicas o derechos sobre las mismas que estén adscritos al Bantegal.

d. Los bienes o derechos de naturaleza rústica que la Comunidad Autónoma le adscriba conforme a la normativa patrimonial vigente.

e. Las fincas rústicas o explotaciones agrarias, o derechos sobre las mismas, cedidas para su uso y aprovechamiento por cualquier ente público o privado.

f. Las fincas rústicas puestas a disposición de la sociedad Bantegal por sus titulares.

3. Los bienes descritos en las letras a), b) y c) del apartado anterior serán de titularidad de la sociedad Bantegal. En los contemplados en las letras d), e) y f), sean de titularidad pública o privada, tendrá la sociedad Bantegal el derecho de uso y aprovechamiento sobre los mismos.

4. El Bantegal habrá de respetar en sus actuaciones los principios de publicidad, concurrencia y objetividad propios de la contratación administrativa, con arreglo a lo dispuesto en la Ley 10/1996, de 5 de noviembre, de actuación de entes y empresas en las que tenga participación mayoritaria la Xunta de Galicia, así como la restante normativa legal vigente. En todo caso, en los contratos que suscriba con terceros, para la ejecución de los servicios que se le encomienden prestar, se incluirán las cláusulas que resulten pertinentes para la adecuada defensa de los intereses públicos.

Artículo 5. Formalización de actos y destino de los bienes y derechos del Banco de Tierras de Galicia.

1. Todos los actos y contratos que supongan la incorporación en propiedad al Banco de Tierras o la transmisión de la propiedad de bienes del Banco de Tierras de Galicia serán formalizados en escritura pública e inscritos en el registro de la propiedad.

2. Los bienes y derechos incorporados al Banco de Tierras de Galicia tendrán los destinos siguientes:

a. Ampliación de la base territorial de explotaciones existentes y en funcionamiento, así como ampliación y mejora de la base territorial de los proyectos agrarios prioritarios.

b. Primera instalación de personas agricultoras jóvenes.

c. Creación o ampliación de la base territorial de cooperativas agrarias y de explotación comunitaria de la tierra, sociedades agrarias de transformación, sociedades mercantiles y otras asociaciones y entidades legalmente constituidas, siempre que sea para actividades agrarias.

d. Establecimiento de nuevos asentamientos, fundamentalmente en las zonas gravemente afectadas por el envejecimiento de la población o el éxodo rural.

e. Aseguramiento de las condiciones necesarias para facilitar tierra a cuantas personas deseen dedicarse a la agricultura en explotaciones agrarias existentes o de nueva creación.

f. Favorecimiento de las condiciones de las explotaciones dirigidas o explotadas mayoritariamente por mujeres y de la primera instalación de estas.

g. Establecimiento de campos de investigación y experimentación agraria gestionados directamente por la sociedad Bantegal, por la Xunta de Galicia en los términos que se fijen en el correspondiente convenio con la sociedad o para su cesión a entes públicos o privados sin ánimo de lucro que lo soliciten. 
h. Incorporación al patrimonio público por conveniencia medioambiental, declarada por el órgano competente en materia de medio ambiente, o por otros motivos de interés social determinado.

i. Posibilidad de facilitar el acceso a la tierra a las mujeres labradoras que sufren violencia de género y que, a consecuencia de la misma, han tenido que abandonar su casa y sus tierras. El Bantegal deberá dar prioridad a estos expedientes de acceso a las tierras.

Artículo 6. Publicidad de los bienes del Banco de Tierras de Galicia.

La sociedad Bantegal mantendrá una relación permanentemente actualizada, indicando la procedencia de los bienes, la titularidad y su destino actual, de todos aquellos inmuebles y derechos reales que integren el Banco de Tierras de Galicia, a disposición del órgano competente en materia de agricultura y de los interesados que lo soliciten, sometiéndose, en todo caso, a la normativa vigente respecto a la protección de datos.

\section{Capítulo II \\ DE LA SOCIEDAD PÚBLICA BANTEGAL}

Artículo 7. La sociedad pública Bantegal y su régimen jurídico.

1. Se crea la Sociedad Anónima Gestora del Banco de Tierras de Galicia, Bantegal, como una sociedad pública autonómica de las previstas en el artículo 12.1.a) de la Ley de régimen financiero y presupuestario de Galicia, aprobada por el Decreto legislativo $1 / 1999$, de 7 de octubre, y en el artículo 45 de la Ley 3/1985, de 12 de abril, del patrimonio de la Comunidad Autónoma gallega, que ajustará su actuación a lo dispuesto en la legislación de contratos públicos y normativa comunitaria de aplicación.

2. Para el cumplimiento de los fines establecidos en el artículo 5.2 de la presente ley, se atribuye a la sociedad pública Bantegal la titularidad de los bienes inmuebles patrimoniales constituidos por las masas comunes y fincas sobrantes de las adjudicaciones de los lotes de reemplazo que, a fecha de entrada en vigor de la presente ley, figuren en el Inventario del Patrimonio de la Comunidad Autónoma, sin perjuicio de su devolución al patrimonio autonómico en caso de incumplimiento de los fines para los cuales fueron atribuidos o de disolución de la sociedad pública.

Igualmente, las masas comunes y fincas sobrantes de las adjudicaciones de los lotes de reemplazo de aquellas zonas de concentración parcelaria que adquieran firmeza con posterioridad a la entrada en vigor de la presente ley se incorporarán al patrimonio de la sociedad pública Bantegal transcurrido un año desde que adquieran firmeza, sin perjuicio de la adjudicación que de esas fincas se realice, por decisión del órgano competente en materia de agricultura, a consecuencia de actas complementarias o de rectificación de la reorganización de la propiedad posteriores a esa fecha650.

Artículo 8. Funciones.

1. Sin perjuicio de las funciones que el Consello de la Xunta atribuya en sus estatutos, la sociedad Bantegal, como medio propio instrumental y servicio técnico de la Administración de la Comunidad Autónoma, tiene como objetivo principal la gestión de los bienes y derechos incorporados al Banco de Tierras de Galicia, estando obligada a realizar los trabajos que se le encomienden, en las materias que constituyan su objeto social y, especialmente, las que sean urgentes o se le ordenen a consecuencia de situaciones de emergencia.

2. Se encomienda, además, a la sociedad Bantegal la realización de la función de servicio de transmisión mediante arrendamiento respecto a las fincas rústicas procedentes de explotaciones en las que haya cesado anticipadamente la persona titular, sin haber sido cedidas a terceras personas.

650 Decreto 182/2007, de 6 de septiembre, por el que se aprueban los estatutos de la Sociedad Anónima Gestora del Banco de Tierras de Galicia (Bantegal). 
3. Dada su condición de medio propio instrumental y servicio técnico de la Administración de la Comunidad Autónoma de Galicia, las relaciones de la sociedad Bantegal y, en su caso, de sus filiales con aquella tienen naturaleza instrumental y no contractual, por lo que, en consecuencia, son de carácter interno, subordinado y dependiente.

\section{TÍTULO III \\ DEL RÉGIMEN JURÍDICO DE LA INCORPORACIÓN DE BIENES AL BANCO DE TIERRAS DE GALICIA}

\section{Capítulo I \\ DE LOS DERECHOS \\ DE ADQUISICIÓN PREFERENTE}

Artículo 9. Derecho de adquisición preferente.

1. En el marco de la presente ley, la sociedad pública Bantegal disfrutará de un derecho de adquisición preferente, que ejercitará conforme a las normas de derecho privado y que se concretará con arreglo a lo previsto en los artículos siguientes, ante cualquier transmisión a título oneroso o negocio jurídico gratuito inter vivos de fincas rústicas ubicadas en las zonas de especial interés agrario, sin perjuicio de lo establecido en la Ley de derecho civil de Galicia y el Código civil.

2. No habrá lugar al ejercicio de los derechos de tanteo y retracto desarrollados en los artículos 10 y 11 de la presente ley, en las transmisiones gratuitas inter vivos, a favor de personas que tengan la condición de hijos y descendientes, ascendientes o parientes consanguíneos hasta el tercero grado y a favor del cónyuge o persona que estuviera conviviendo con el transmitente en el momento en que se produzca el hecho, en este último caso siempre que se cumplan los requisitos previstos en la disposición adicional tercera de la Ley 2/2006, de 14 de junio, de derecho civil de Galicia, ni en las aportaciones de bienes realizadas por un cónyuge a su sociedad de gananciales.
Tampoco habrá lugar al ejercicio de los referidos derechos en los casos de transmisiones a favor de aquellos que tengan la condición de persona titular de explotación agraria, persona profesional de la agricultura, persona agricultora a título principal o joven. A estos efectos, la acreditación de dichas condiciones será realizada mediante informe del órgano que corresponda de la consejería competente en materia de agricultura.

3. Los derechos de tanteo y retracto contemplados en el presente artículo serán preferentes respecto a cualquier otro derecho de adquisición establecido por la legislación vigente, excepto los retractos de graciosa, el de la persona arrendataria de arrendamientos rústicos, incluidos los históricos, el de lugar acasarado o aparcería y el de personas que tengan la condición de colindantes, coherederos y comuneros, y el de propietarios colindantes que sean titulares de explotaciones prioritarias, en los términos establecidos en la Ley 2/2006, de 14 de junio, de derecho civil de Galicia, en el Código civil y en la Ley 19/1995, de 4 de julio, de modernización de las explotaciones agrarias.

4. Las adquisiciones realizadas por la sociedad Bantegal a consecuencia del derecho de tanteo regulado en el artículo 10 de la presente ley no obstarán el ejercicio de los derechos de retracto por los colindantes, coherederos o comuneros.

5. El ejercicio de estos derechos, así como la renuncia a los mismos, requerirá informe favorable de la consejería competente en materia de agricultura.

6. El precio a abonar en todos los supuestos en que se ejerzan los derechos de adquisición preferente contemplados en la presente ley incluirá, además del precio de la transmisión o, en su caso, la valoración del bien, los costes del contrato y cualquier otro pago legítimo hecho para la transmisión, los costes necesarios y útiles hechos en la cosa transmitida y los impuestos satisfechos a consecuencia de la transmisión. 
Artículo 10. Procedimiento para el ejercicio del derecho de tanteo.

1. Las personas titulares de fincas rústicas ubicadas en zonas de especial interés agrario habrán de notificar a la sociedad Bantegal, por cualquier medio que permita tener constancia de su recepción, la decisión de transmitir las fincas en todo o en parte, o participaciones indivisas sobre las mismas.

2. En dicha notificación se hará constar la descripción y los datos catastrales $\mathrm{y}$, en su caso, registrales del bien que se pretende transmitir, los de identificación y profesión de las personas transmitente y adquiriente, así como el destino que se quiere dar a la finca o explotación y el precio o, en su caso, la valoración del bien y la forma de pago proyectados, si la transmisión fuera onerosa.

Los efectos de tal notificación caducarán a los seis meses siguientes a la misma y toda transmisión realizada transcurrido este plazo se entenderá efectuada sin dicha notificación, a los efectos del ejercicio del derecho de retracto.

3. La sociedad Bantegal podrá ejercitar el derecho de tanteo durante el plazo de treinta días hábiles a partir del siguiente al de la recepción de la notificación, salvo que esta fuera incompleta o defectuosa. En este último caso, la sociedad Bantegal podrá requerir a la persona transmitente los datos incompletos o la subsanación de los defectos, quedando entre tanto en suspenso el plazo señalado.

Antes de que finalice el plazo para el ejercicio del derecho de tanteo, la sociedad Bantegal habrá de comunicar a la persona interesada su renuncia al mismo, en cuyo caso podrá llevarse a cabo inmediatamente la transmisión proyectada. El derecho de tanteo caducará si no se ejercita en el plazo establecido.

Artículo 11. Procedimiento para el ejercicio del derecho de retracto.

1. La sociedad Bantegal podrá ejercitar el derecho de retracto cuando no se le hubiera hecho la notificación contemplada en el artículo precedente, si se hubiera omitido en la misma cualquiera de los requisitos establecidos y no se hubiera atendido al requerimiento hecho por la sociedad Bantegal para su subsanación, se hubiera producido la transmisión después de haber caducado la notificación o antes de que hubiera caducado el derecho de tanteo, así como cuando se hubiera realizado la transmisión en condiciones distintas de las notificadas.

2. Este derecho se ejercitará en el plazo de treinta días hábiles, a contar desde el siguiente al de la notificación de la transmisión efectuada, que la persona adquiriente habrá de realizar, en el plazo de quince días hábiles siguientes a la firma del contrato por el que se realice la transmisión, a la sociedad Bantegal, indicando las condiciones en que se efectuó, mediante entrega de copia del documento en que se hubiera formalizado. Si no se realizara la notificación, el plazo de treinta días hábiles se contará desde que el Bantegal tuviera conocimiento de la transmisión efectuada y de sus condiciones.

3. Si la transmisión se hubiera producido a consecuencia de un procedimiento de ejecución judicial, la persona que resulte adjudicataria vendrá obligada a dar conocimiento de la resolución a su favor a la sociedad Bantegal. En este supuesto el derecho de retracto habrá de ejercitarse en el plazo de quince días hábiles, a contar desde el día siguiente a la recepción de dicha notificación, abonando como precio el fijado judicialmente en el final, sin perjuicio de abonar los demás costes establecidos en el apartado 6 del artículo 9 de la presente ley.

4. El titular de la notaría habrá de notificar a la sociedad Bantegal cualquier transmisión en la que haya intervenido respecto a una finca rústica ubicada en una zona de especial interés agrario. Se hará mediante remisión de copia simple de 
la escritura, en la cual constará la justificación de haber procedido el transmitente a la realización de la notificación contemplada en el artículo 10 de la presente ley, y con los requisitos recogidos en la misma, $\mathrm{o}$, en su caso, la renuncia de la sociedad Bantegal al ejercicio del derecho de tanteo.

Artículo 12. Inscripción registral. No podrán inscribirse en el registro de la propiedad las transmisiones efectuadas sobre las fincas rústicas ubicadas en zonas de especial interés agrario si no se hubiera acreditado la realización de las notificaciones contempladas en los artículos precedentes con los requisitos previstos en los mismos.

\section{Capítulo II \\ DE LA INCORPORACIÓN DE FINCAS RÚSTICAS AL BANCO DE TIERRAS DE GALICIA PARA SU GESTIÓN}

Artículo 13. Cesión temporal de fincas rústicas al Banco de Tierras de Galicia.

1. Las entidades públicas, de acuerdo con su legislación de aplicación, así como los particulares, podrán ceder a la sociedad Bantegal, previa aceptación expresa por parte del órgano correspondiente de la misma, la gestión del uso y aprovechamiento de las fincas rústicas de las que sean titulares ubicadas en zonas de especial interés agrario, para su integración en el Banco de Tierras de Galicia.

2. La cesión de la gestión de una finca rústica a favor del Bantegal conlleva la autorización para que la sociedad ceda su uso y aprovechamiento a terceras personas por un periodo máximo de cinco años, sin perjuicio del consentimiento a que hace referencia el artículo 19.5 de la presente ley.

3. La cesión se realizará mediante contrato suscrito por la persona cedente y el órgano que corresponda de la sociedad Bantegal, donde se determinarán las condiciones, los derechos y obligaciones de las partes, las causas y los efectos de resolución del contrato.
4. El propietario o titular podrá solicitar el rescate de la cesión al Bantegal en cualquier momento, salvo en caso de arrendamiento, en el cual no podrá hacerlo hasta la extinción del mismo. La petición será resuelta en el plazo no superior a un mes.

5. Los bienes transmitidos continuarán, en su caso, inscritos en el registro de la propiedad a nombre de la persona que tenga la condición de propietario.

6. Los propietarios cedentes de fincas al Banco de Tierras de Galicia procederán a poner a disposición del Bantegal, a petición del mismo y a efectos de consulta, todos los documentos que tengan que ver con la propiedad de dichas fincas.

7. El Bantegal no aceptará cesiones gratuitas cuando ello pueda implicar la asunción de gravámenes, cargas o afecciones que excedan del valor de la cesión.

Artículo 14. Efectos de la cesión.

1. La cesión de la gestión del uso y aprovechamiento de las fincas rústicas al Bantegal se entenderá sin perjuicio de que la persona propietaria o titular pueda seguir realizando la explotación de las mismas, así como el cultivo, mejoras y demás actuaciones que considere precisas, y no la exime de efectuar las labores de conservación y mantenimiento, en tanto la sociedad Bantegal no disponga su posterior cesión a terceras personas.

2. Cualquier actuación que afecte de manera singular a las características de la explotación o finca cuya gestión fue cedida y a su valor habrá de ser comunicada a la sociedad Bantegal con una antelación mínima de treinta días naturales, para su conocimiento, salvo supuestos de fuerza mayor u otras circunstancias imprevisibles, que habrán de comunicarse en la mayor brevedad después de su acontecimiento.

3. La sociedad Bantegal podrá establecer una comisión por gastos de gestión no superior al cinco por cien del precio y tipo de la posterior cesión a terceras personas, que será deducida de las liquidaciones efectuadas a la persona titular de la finca rústica. 
4. Si el contrato se resolviera con anterioridad a la cesión a terceras personas del uso y aprovechamiento de la finca rústica, por causas imputables a su propietario, este habrá de abonar a la sociedad Bantegal una comisión por gastos de gestión, sin perjuicio de las indemnizaciones que procedan.

5. No podrá solicitarse la resolución del contrato de cesión de la gestión del uso y aprovechamiento de una finca en caso de vigencia del contrato de cesión firmado con terceras personas.

6. Finalizado el periodo pactado contractualmente, la sociedad Bantegal garantizará para la persona propietaria o titular el rescate de la finca en las mismas condiciones de uso en que se ha entregado.

7. Durante el periodo de la cesión al Bantegal podrán producirse alteraciones de dominio o titularidad de la finca cedida, siempre que lleven implícita la subrogación del pacto contractual con terceras personas.

\section{TÍTULO IV \\ DE LA TRANSMISIÓN DE LOS BIENES INCORPORADOS AL BANCO DE TIERRAS DE GALICIA}

Artículo 15. Regímenes de adjudicación.

1. La sociedad pública Bantegal podrá transmitir los bienes y derechos integrantes del Banco de Tierras de Galicia mediante los regímenes de adjudicación que a continuación se establecen, en función de la titularidad del bien de que se trate:

a. Los bienes y derechos de titularidad de la sociedad pública Bantegal podrán adjudicarse a terceras personas, tanto en propiedad como en régimen de cesión del uso o aprovechamiento, de acuerdo con las condiciones específicas de cada bien, según determine la consejería competente en materia de agricultura a propuesta de la sociedad Bantegal.

b. Los bienes y derechos de titularidad de entes públicos o privados puestos a disposición de la sociedad pública Bantegal sólo pueden cederse a terceras personas para el uso y aprovechamiento de los mismos por tiempo determinado, en régimen de concesión o arrendamiento.

2. Unos y otros quedarán necesariamente vinculados a los fines establecidos en el artículo 5.2 de la presente ley. Será en cualquier caso causa de resolución del contrato el incumplimiento del destino de la finca.

\section{Capitulo I \\ DE LA ENAJENACIÓN DE BIENES Y \\ DERECHOS DE TITULARIDAD DE LA SOCIEDAD BANTEGAL}

Artículo 16. Condiciones generales. La enajenación se hará por el procedimiento de subasta pública o concurrencia, salvo cuando la consejería competente en materia de agricultura, previa solicitud de la sociedad Bantegal, autorice, individual o genéricamente, la adjudicación directa de un bien y derecho, mediante acuerdo motivado en base a los requisitos del artículo 18 de la presente ley.

Artículo 17. Enajenación mediante subasta pública o concurrencia.

1. En los supuestos de adjudicación mediante subasta pública, el pliego de condiciones contendrá, al menos, los límites siguientes:

a. El objeto y su descripción.

b. El precio tipo en función de los valores fijados por el Consello de la Xunta según el informe de la Comisión Técnica de Precios y Valores.

c. La condición de persona titular de explotación agraria, persona profesional de la agricultura, persona agricultora a título principal o joven en los ofertantes, el modo de acreditarla y el destino agrario de las fincas objeto de adjudicación.

d. La obligación de constituir un depósito previo del veinte por cien del precio tipo para poder participar en la subasta y el procedimiento de ingreso.

2. En los supuestos de adjudicación en régimen de concurrencia, el pliego 
de condiciones contendrá, al menos, los extremos siguientes:

a. El objeto y su descripción.

b. El precio tipo en función de los valores fijados por el Consello de la Xunta según el informe de la Comisión Técnica de Precios y Valores.

c. La acreditación o compromiso de destino agrario de los bienes objeto de adjudicación.

d. La obligación de constituir un depósito previo del veinte por cien del precio tipo para poder participar en la subasta y el procedimiento de ingreso.

e. Los criterios de adjudicación, con su ponderación, que, además del precio, habrá de tener en cuenta los factores contemplados en el artículo 5.2 de la presente ley.

3. Los procedimientos a seguir se determinarán reglamentariamente. En todo caso, la celebración de la subasta habrá de anunciarse en el Diario Oficial de Galicia con una antelación mínima de treinta días hábiles.

Artículo 18. Enajenación mediante adjudicación directa.

1. La adjudicación directa de bienes y derechos de titularidad de la sociedad Bantegal habrá de motivarse en la concurrencia, al menos, de alguna de las circunstancias siguientes:

a. Lindes de la finca o fincas, previo ofrecimiento a las personas titulares de todas las fincas colindantes, aplicándose en caso de concurrencia lo establecido en el artículo 1523 del Código civil.

b. Incorporación al patrimonio público de las administraciones por conveniencia medioambiental $\mathrm{u}$ otros motivos de interés social determinado.

c. Acceso a las tierras por parte de mujeres labradoras que sufren violencia y han tenido que abandonar su casa y sus tierras por la violencia de género.

2. El precio de adjudicación directa será fijado en función de los valores determinados por el Consello de la Xunta según el informe de la Comisión Técnica de Precios y Valores.

\section{Capitulo II \\ DE LA CESIÓN A TERCERAS PERSONAS POR TIEMPO DETERMINADO}

Artículo 19. Cesiones de las fincas rústicas a terceras personas.

1. Las fincas rústicas integrantes del Banco de Tierras de Galicia podrán ser cedidas por la sociedad Bantegal a terceras personas para su uso y aprovechamiento, mediante cualquier negocio jurídico válido en derecho, por tiempo determinado.

2. En caso de concurrencia de solicitudes de cesión sobre una misma finca, en los criterios de adjudicación habrán de tenerse en cuenta, con la ponderación que se determine, los factores establecidos en el artículo 5.2 de la presente ley.

3. El contrato de cesión será formalizado por la sociedad Bantegal como cedente y la tercera persona como cesionaria. Las cláusulas del contrato habrán de contener las determinaciones siguientes:

a. El plazo de vigencia de la cesión, que no podrá ser superior a treinta años.

b. Las condiciones de la cesión y las causas y efectos de resolución o caducidad.

c. El precio tipo será establecido por la sociedad Bantegal, no pudiendo ser nunca diferente a los valores que, para ese año, haya establecido el Consello de la Xunta, previo informe de la Comisión Técnica de Precios y Valores, a no ser que exista mutuo acuerdo entre el propietario y el cesionario.

4. La cesión por el Bantegal a terceras personas, así como las sucesivas prórrogas, habrán de ser comunicadas para su conocimiento, en su caso, a la persona titular de la finca con una antelación mínima de un mes antes de la entrada en vigor del contrato suscrito.

5. La cesión por el Bantegal a terceras personas por un periodo superior a cinco años, incluidas las prórrogas o renovaciones, requerirá, en su caso, el consentimiento 
expreso de la persona titular de la finca rústica.

6. La sociedad Bantegal comunicará al registro de la propiedad que corresponda la suscripción del contrato de cesión con terceros, a los efectos de realizar, en su caso, la oportuna inscripción de la cesión y de su plazo.

7. La sociedad Bantegal, con cargo a los presupuestos o por sus propios medios, por la contratación de medios ajenos o por convenios con terceros, podrá realizar labores de acondicionamiento de fincas en los tres meses siguientes al inicio del periodo del contrato de cesión a terceras personas, a petición de estas, y en los tres meses siguientes al término del periodo de ese mismo contrato, a petición de la persona propietaria, para mejorar las condiciones agronómicas de las fincas.

Artículo 20. Garantía de la renta a la persona titular de la finca rústica.

En el caso de las fincas rústicas cedidas para su gestión a la sociedad Bantegal, esta reembolsará periódicamente a la persona titular de la finca rústica el importe que corresponda en concepto de renta por la cesión a terceros, garantizando su percepción con indiferencia del cumplimiento o incumplimiento de la relación contractual por la persona beneficiaria de la cesión, sin perjuicio de la deducción de las comisiones que puedan establecerse.

Artículo 21. Efectos del acceso a la propiedad por parte de la persona beneficiaria de la cesión.

Si en el periodo de vigencia del contrato la persona beneficiaria de la cesión accediera a la propiedad de la finca por algún título, quedará extinguida la relación contractual con la sociedad Bantegal, rescatándose simultáneamente la finca o explotación por la nueva persona titular.

Artículo 22. Causas y procedimiento para la resolución de las cesiones.

1. Las cesiones otorgadas por el Bantegal sobre los bienes integrados en el Banco de Tierras de Galicia podrán ser resueltas previa tramitación de expediente contradictorio, con audiencia de la persona beneficiaria de la cesión, en el que se acredite la existencia de alguna de las causas de resolución previstas en la normativa reguladora del negocio jurídico de que se trate. Serán además causas de resolución:

a. El incumplimiento del destino de la finca especificado en el contrato de entre los contemplados en el artículo 5.2 de la presente ley.

b. La declaración firme en vía administrativa de la finca como inculta, abandonada o en estado de grave abandono.

2. Será competente para la tramitación del expediente la sociedad Bantegal. Antes de la declaración de resolución, se ofrecerá a la persona beneficiaria de la cesión la posibilidad de cumplir sus obligaciones en el plazo que se determine previamente durante la tramitación de dicho expediente contradictorio.

3. En el acuerdo que declare resuelta la cesión, se efectuará la liquidación de la misma con valoración expresa y desglosada de las mejoras útiles y subsistentes realizadas por la persona beneficiaria de la cesión, a los efectos de su pago, con deducción de los daños y perjuicios existentes en la finca, y se fijará el plazo máximo en el cual habrá de proceder al desalojo, que no podrá ser superior a dos meses y comenzará a contar al día siguiente al de la recepción de la notificación si no existe cosecha pendiente y, si existe, al del siguiente a ser recogida.

Artículo 23. Supuestos de subrogación.

1. Los derechos de uso y aprovechamiento sobre fincas rústicas incorporadas al Banco de Tierras son indivisibles.

2. En el supuesto de fallecimiento, jubilación o cese en la actividad agraria de la persona cesionaria, los derechos de uso y aprovechamiento serán transmisibles a favor de las personas siguientes y en el orden que se establece:

a. El cónyuge o persona que estuviera conviviendo con él en el momento en que 
se produzca el hecho; en este último caso siempre y cuando se cumplan los requisitos previstos en la disposición adicional tercera de la Ley 2/2006, de 14 de junio, de derecho civil de Galicia.

b. Los hijos y descendientes, sin perjuicio de la posible sustitución en los casos de los premuertos o renuncias, que tengan dedicación directa y personal a la explotación, con preferencia, si fueran varios, del elegido por él o, en su defecto, por elección mayoritaria entre ellos $\mathrm{y}$, a falta de la misma, por el de mayor edad.

c. Los hijos y descendientes del cónyuge o persona que conviviera con el cesionario, en iguales condiciones del apartado anterior.

d. Las personas trabajadoras de la explotación, por orden de antigüedad.

3. La persona que sea la nueva cesionaria deberá ser mayor de edad o emancipada y reunir o estar en situación de adquirir las condiciones determinantes del contrato, subrogándose en su título, con las mismas condiciones, derechos y obligaciones, previa autorización de la sociedad Bantegal.

4. El plazo para realizar la subrogación será de seis meses desde que se ha producido el hecho causante, correspondiendo el pago de la renta durante dicho plazo a la persona que sea la nueva cesionaria.

\section{Capitulo III PROYECTOS AGRARIOS PRIORITARIOS}

Artículo 24. Proyectos agrarios prioritarios.

1. Podrán ser declarados como proyectos agrarios prioritarios, a efectos de promover la mejora o, en su caso, la dotación de su base territorial productiva, aquellos en que concurra alguna de las características siguientes:

a. Que faciliten la ampliación o implantación de explotaciones con dimensiones y estructuras que favorezcan la creación de empleo, especialmente si es de gente joven y/o mujeres. b. Que impulsen la ampliación o creación de la base territorial de cooperativas u otras asociaciones agrarias.

c Que contribuyan al establecimiento o fijación de la población en las zonas especialmente afectadas por el envejecimiento de la misma.

2. La declaración como prioritario de un proyecto agrario corresponderá al Consello de la Xunta, a propuesta de la consejería competente en materia agraria y/o forestal, cuando el proyecto sea de esa naturaleza.

3. Los proyectos que en virtud de la presente ley se declaren prioritarios tendrán derecho de preferencia para la disponibilidad de las fincas integrantes del Banco de Tierras de Galicia.

\section{TÍTULO V \\ DE LAS MEDIDAS TRIBUTARIAS Y DE FOMENTO}

Artículo 25. Medidas tributarias.

1. Las transmisiones de fincas rústicas del Banco de Tierras de Galicia, mediante su enajenación o cesión a través de los mecanismos previstos en la presente ley, disfrutarán de una deducción en la cuota tributaria del noventa y cinco por cien en el impuesto de transmisiones patrimoniales y actos jurídicos documentados. Este beneficio fiscal será incompatible con cualquier otro que pudiera ser de aplicación a esas transmisiones.

2. La aplicación de dicho beneficio fiscal quedará condicionada al mantenimiento durante un periodo mínimo de cinco años del destino agrario de la finca, salvo en los supuestos de expropiación para la construcción de infraestructuras públicas o de edificación de instalaciones o construcciones asociadas a la explotación agraria.

3. En caso de incumplimiento de dicha condición, el beneficiario deberá ingresar el importe del beneficio disfrutado más los intereses de demora, mediante la presentación de una autoliquidación complementaria en el plazo de treinta días hábiles desde el incumplimiento de la condición.

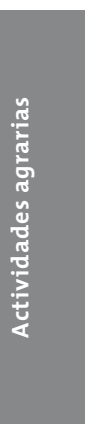


Artículo 26. Ayudas y subvenciones.

1. La consejería competente en materia de agricultura, directamente o por encomienda a la sociedad Bantegal, podrá establecer líneas de ayudas destinadas a la limpieza, puesta en cultivo y mejoras, incluso de carácter permanente, en las fincas cedidas a la sociedad, cuyos beneficiarios podrán ser tanto los cedentes como los cesionarios de las fincas rústicas.

2. También podrá celebrar, directamente o a través de las entidades crediticias, los oportunos convenios de colaboración para la concesión de préstamos o subvenciones a las personas beneficiarias de la cesión de fincas gestionadas por la sociedad Bantegal, sea para su adquisición o sea para la limpieza, puesta en cultivo o mejoras.

\section{TÍTULO VI \\ DE LA COMISIÓN TÉCNICA DE PRECIOS Y VALORES}

Artículo 27. Aprobación de los precios. Los valores de los precios a que se hace referencia en la presente ley serán aprobados por el Consello de la Xunta de Galicia, como valores de referencia máximos para las transacciones que realice la sociedad Bantegal, previo informe de la Comisión Técnica de Precios y Valores, siendo de aplicación obligatoria en las transacciones efectuadas por la sociedad Bantegal.

Artículo 28. Comisión Técnica de Precios y Valores.

1. A los efectos referidos, se crea la Comisión Técnica de Precios y Valores, adscrita a la consejería competente en materia de agricultura, con la composición y funciones que se señalan en la presente ley.

2. Forman parte de la Comisión Técnica de Precios y Valores:

a. Una presidencia, nombrada por la consejería competente en materia de agricultura.

b. Una vocalía nombrada por la consejería competente en materia de economía.

c. Una vocalía nombrada por la consejería competente en materia de ordenación del territorio. d. Una vocalía nombrada por la consejería competente en materia de medio ambiente.

e. Una vocalía nombrada por el organismo representativo de los municipios y provincias gallegas.

f. Una vocalía nombrada por la Gerencia Territorial del Catastro.

g. Una vocalía nombrada por el asociacionismo del cooperativismo agrario gallego.

h. Tres vocalías nombradas por los representantes de las organizaciones profesionales agrarias pertenecientes al Consejo Agrario Gallego.

3. El consejo de administración de la sociedad Bantegal podrá nombrar hasta tres representantes en la Comisión Técnica de Precios y Valores, con derecho a voz pero sin voto.

4. En la secretaría, con derecho a voz pero sin voto, actuará un funcionario o funcionaria de la consejería competente en materia de agricultura.

5. El funcionamiento de la comisión se ajustará a lo dispuesto en la Ley de régimen jurídico de las administraciones públicas y del procedimiento administrativo común, título II, capítulo II, sobre órganos colegiados.

Artículo 29. Informe anual.

1. La Comisión Técnica de Precios y Valores recibirá el informe anual de actividades de la sociedad Bantegal y los informes sobre precios y valores que elaboren los servicios técnicos agrarios de la consejería competente en materia de agricultura y la propia sociedad Bantegal.

2. Por las evidentes diferencias en las distintas zonas del país e incluso por la variabilidad a lo largo del tiempo, la Comisión Técnica de Precios y Valores emitirá un informe anual preceptivo para la fijación por el Consello de la Xunta de los precios a aplicar por la sociedad Bantegal, en el cual constará:

a. El precio tipo que establecerá la sociedad Bantegal en los contratos de 
cesiones y otras transacciones, determinado por zonas geográficas en función de parámetros como productividad, ubicación, configuración geofísica y aquellos otros que técnicamente se consideren.

b. Aquellas otras consideraciones y recomendaciones que estime oportunas respecto a la gestión del Banco de Tierras de Galicia y de su sociedad gestora.

\section{TÍTULO VII \\ DE LAS FINCAS INCULTAS O ABANDONADAS \\ Capitulo I \\ DE LAS CONDICIONES PARA SU DECLARACIÓN}

Artículo 30. Objeto.

Podrán ser declaradas fincas incultas o abandonadas, con las consecuencias que se contemplan en la presente ley y normas que la desarrollen, aquellas que radiquen en las zonas de especial interés agrario $\mathrm{y}$ en las cuales se den las condiciones siguientes:

a. Finca inculta: finca rústica sometida a explotación agraria hasta tiempos recientes sin que en la actualidad se realice práctica laboral alguna ni cultivo alguno sobre la misma, mostrando una cobertura evidente de matorral o sus restos, en el caso de haber ardido, de especies leñosas y arbustivas, con un porcentaje de ocupación superior al cincuenta por cien de extensión superficial y porte medio superior a cincuenta centímetros.

b. Finca abandonada: finca rústica no sometida a ninguna práctica de cultivo o mínimo laboreo, no cultivada ni destinada a pastoreo, ni al mantenimiento de una cubierta vegetal adecuada desde el punto de vista medioambiental, con un porcentaje de ocupación de matorral y sus restos superior al setenta y cinco por cien de extensión superficial y porte medio superior a cincuenta centímetros, así como las plantaciones forestales realizadas en tierras de vocación productiva agraria cuando la cubierta vegetal de sotobosque, de naturaleza herbácea o arbustiva, presente un estado que propicie de forma grave la aparición de incendios.

c. Finca en situación de grave abandono: finca inculta o abandonada que, por su situación, pueda favorecer la aparición y propagación de incendios, fenómenos de erosión y una especial incidencia de malas hierbas, plagas o enfermedades que puedan afectar a las fincas colindantes, o en la que su falta de mantenimiento permita el desarrollo incontrolado de vegetación espontánea invasora que amenace con romper el tradicional equilibrio agroecológico de la finca o zona de cultivo determinada y con afectar por extensión a los campos de cultivo circundantes.

Artículo 31. Excepciones.

No procederá la declaración como finca inculta o abandonada en los supuestos siguientes:

a. Las fincas que estén incorporadas al Banco de Tierras de Galicia, salvo las que la sociedad Bantegal haya cedido a terceras personas.

b. Las que se encuentren en proceso de concentración parcelaria, desde el inicio de las obras de la red de caminos principales hasta transcurridos seis meses desde la toma de posesión.

c. Las fincas que por conveniencia medioambiental, destino cinegético o circunstancias análogas de interés social determinado, declaradas por el órgano que corresponda de la consejería competente en materia de medio ambiente, hagan inviable su explotación agraria, siempre que reciban las apropiadas labores de mantenimiento y no representen riesgo de incendio ni perjuicio a colindantes.

d. Las fincas rústicas en situación de barbecho o posío, siempre que su situación no pueda favorecer fenómenos de erosión o de aparición de incendios, así como invasión de malas hierbas, plagas o enfermedades que representen perjuicio a colindantes.

e. Aquellas sobre las que se realice, a lo menos, agricultura de conservación, 
entendiendo por tal las diversas prácticas agronómicas adaptadas a las condiciones locales dirigidas a alterar lo menos posible la composición, estructura y biodiversidad de los suelos agrícolas, evitando así su posterior erosión y degradación, y que no representen riesgo de incendio ni perjuicio a colindantes.

\section{Capítulo II DEL PROCEDIMIENTO}

Artículo 32. Incoación.

La incoación del expediente de declaración de finca inculta, abandonada o en situación de grave abandono se hará de oficio en la delegación de la consejería competente en materia de agricultura del territorio en donde esté ubicada la finca. Los expedientes de declaración de finca inculta o abandonada serán remitidos desde la respectiva delegación provincial a la dirección general competente en la materia.

Artículo 33. Tramitación.

La tramitación del expediente se regirá por las disposiciones previstas en el título VI de la Ley 30/1992, de 26 de noviembre, de régimen jurídico de las administraciones públicas y del procedimiento administrativo común, respetando en todo caso el trámite de audiencia a los interesados en el procedimiento. En todo caso se dará traslado al órgano competente en materia de medio ambiente para la posible declaración de conveniencia medioambiental a los efectos de la aplicación de la excepción contemplada en el artículo 31.c) de la presente ley.

Artículo 34. Finalización.

1. La declaración de finca inculta, abandonada o en situación de grave abandono se hará por la persona titular de la dirección general competente previo informe de los servicios técnicos de la delegación provincial correspondiente.

2. El procedimiento habrá de ser resuelto y notificado a los interesados en el plazo de seis meses, el cual comenzará a contar desde la fecha de la incoación. Si no fuera notificado en ese plazo se producirá la caducidad del mismo, sin perjuicio de que pueda iniciarse otro expediente si se mantuviera la situación de abandono.

Asimismo, si se constatara por los servicios técnicos que en el curso de la tramitación del expediente cesa la situación de abandono, el órgano competente para resolver el procedimiento podrá declararlo finalizado y ordenar el archivo del expediente.

3. La resolución de la dirección general podrá ser recurrida en alzada ante el consejero competente en materia de agricultura, en la forma y plazo contemplados en los artículos 114 y 115 de la Ley 30/1992, de 26 de noviembre, de régimen jurídico de las administraciones públicas y del procedimiento administrativo común.

Artículo 35. Consecuencias de la declaración de finca inculta, abandonada o en situación de grave abandono.

1. En la resolución que declare estas situaciones se otorgará un plazo, el cual no excederá de treinta días hábiles, para que la persona titular de la finca elija alguna de las opciones siguientes:

a. La realización de una agricultura de conservación, en los términos establecidos en el artículo 31.e) de la presente ley.

b. $\mathrm{Su}$ enajenación, arrendamiento o cualquier otro negocio jurídico válido, a favor de cualquier persona agricultora profesional o joven.

c. Su incorporación al Banco de Tierras de Galicia.

2. Notificada la opción que se pretenda, esta habrá de llevarse a cabo en el plazo de dos meses siguientes a la fecha en que la decisión de la persona interesada haya entrado en el registro del órgano competente.

3. En caso de interposición de recurso de alzada, se entenderá suspendida la ejecutividad de la resolución hasta la resolución del mismo.

Artículo 36. Ausencia de propietario. Si durante la tramitación del expediente se evidenciara la inexistencia de propietario 
conocido, se iniciará el procedimiento legal pertinente para aclarar la propiedad $\mathrm{y}$, en su caso, para la incorporación de la finca al patrimonio público, sin perjuicio de la realización de las actuaciones que posibiliten su incorporación al Banco de Tierras de Galicia.

\section{TíTULO VIII DEL RÉGIMEN SANCIONADOR}

Artículo 37. La actuación inspectora.

1. La consejería competente en materia de agricultura desarrollará actuaciones de control e inspección sobre todas las fincas rústicas ubicadas en zonas de especial interés agrario y respecto a los proyectos agrarios prioritarios, en orden a comprobar su adecuación a las condiciones establecidas en la presente ley y normas que la desarrollen, para garantizar la preservación del entorno y de las condiciones medioambientales.

2. A estos efectos, el personal de esta consejería que desarrolle estas funciones tiene la condición de agente de la autoridad, teniendo los hechos constatados y formalizados por ellos en las correspondientes actas de inspección y denuncia la presunción de veracidad, sin perjuicio de las pruebas que en defensa de los respectivos derechos e intereses puedan aportar los interesados.

Artículo 38. Infracciones administrativas.

Constituye infracción administrativa en materia de abandono cualquier acción u omisión tipificada en la presente ley en lo que respecta a las fincas rústicas ubicadas en zonas de especial interés agrario.

Artículo 39. Tipificación de infracciones.

Las infracciones administrativas en materia de abandono de fincas rústicas se clasifican en leves, graves y muy graves.

1. Se considerarán infracciones de carácter leve:

a. La falta de notificación a la Administración de la opción elegida, con arreglo a lo establecido en el artículo 35.1 de la presente ley, cuando la finca declarada inculta, abandonada o en situación de grave abandono tenga una superficie igual o inferior a una hectárea.

b. El incumplimiento de la realización de la opción elegida en el plazo otorgado, con arreglo a lo previsto en el artículo 35.2 de la presente ley, cuando la finca declarada inculta, abandonada o en situación de grave abandono tenga una superficie igual o inferior a una hectárea.

c. Las acciones y omisiones de las que se deriven daños o perjuicios a fincas colindantes y las que afecten a la integridad o el funcionamiento de bienes y sistemas públicos, en ambos casos por importe inferior a 1.500 euros.

d. El suministro incompleto de información o documentación necesarias para las funciones de inspección y control administrativo.

e. Cualquier otro incumplimiento de las obligaciones establecidas en la presente ley que no esté tipificado como infracción grave o muy grave.

2. Se considerarán infracciones graves:

a. La falta de notificación a la Administración de la opción elegida, con arreglo a lo establecido en el artículo 35.1 de la presente ley, cuando la finca declarada inculta, abandonada o en situación de grave abandono tenga una superficie superior a una hectárea.

b. El incumplimiento de la realización de la opción elegida en el plazo otorgado, con arreglo a lo previsto en el artículo 35.2 de la presente ley, cuando la finca declarada inculta, abandonada o en situación de grave abandono tenga una superficie superior a una hectárea.

c. Las acciones y omisiones de las que se deriven daños o perjuicios a fincas colindantes y las que afecten a la integridad o el funcionamiento de bienes y sistemas públicos, en ambos casos por importe de entre 1.500 y 9.000 euros. 
d. La obstrucción o negativa a suministrar datos o a facilitar las funciones de información, vigilancia o inspección que practique la Administración de la Comunidad Autónoma de Galicia, así como suministrar información inexacta o documentación falsa.

e. El mantenimiento de la finca en situación de inculta, abandono o grave abandono transcurrido un año desde la fecha de la notificación de su declaración.

3. Se considerarán infracciones muy graves:

a. Las acciones y omisiones de las que se deriven daños o perjuicios a fincas colindantes y las que afecten a la integridad o el funcionamiento de bienes y sistemas públicos, en ambos casos por importe superior a 9.000 euros.

b. El mantenimiento de la finca en situación de inculta, abandono o grave abandono transcurridos más de dos años desde la fecha de la notificación de su declaración.

Artículo 40. Sanciones.

1. Las infracciones tipificadas en los apartados del anterior artículo serán sancionadas con las multas siguientes:

a. Infracciones leves: apercibimiento o multa de hasta 300 euros.

b. Infracciones graves: multa entre 301 y 1.000 euros.

c. Infracciones muy graves: multa entre 1.001 y 3.000 euros.

2. El apercibimiento sólo procederá en el supuesto de infracciones leves, siempre y cuando la persona infractora no fuera sancionada con anterioridad por cualquier infracción de las tipificadas en la presente ley.

Artículo 41. Graduación de las sanciones.

1. Para la determinación concreta de la sanción que se imponga, de entre las asignadas a cada tipo de infracción, se tomarán en consideración los criterios siguientes:

a. La existencia de intencionalidad o simple negligencia. b. La reiteración, entendida como la concurrencia de varias irregularidades o infracciones que se sancionen en el mismo procedimiento.

c. La naturaleza de los perjuicios causados.

d. La reincidencia, por comisión en el plazo de dos años de otra infracción de la misma naturaleza, cuando así se hubiera declarado por resolución firme. Este plazo comenzará a contar desde que la resolución haya adquirido firmeza en vía administrativa.

e. La extensión de la superficie de la finca.

2. No obstante lo recogido en el apartado anterior, la cuantía de la sanción podrá aminorarse motivadamente, a juicio del órgano competente para resolver según el tipo de infracción de que se trate, en atención a las circunstancias específicas del caso, entre ellas el reconocimiento y la enmienda de la conducta infractora y la reparación de los daños causados, antes de que se resuelva el correspondiente expediente sancionador, cuando la sanción resulte excesivamente onerosa.

3. Los criterios de graduación recogidos en el apartado 2 no podrán utilizarse para agravar la infracción cuando estén contenidos en la descripción de la conducta infractora o formen parte del propio ilícito administrativo.

4. La propuesta de resolución del expediente y la resolución administrativa que recaiga habrán de explicitar los criterios de graduación de la sanción tenidos en cuenta, de entre los señalados en el apartado 1 del presente artículo. Cuando no se considere relevante a estos efectos ninguna de las circunstancias enumeradas, la sanción se impondrá en la cuantía mínima prevista para cada tipo de infracción.

Artículo 42. Reparación del daño o indemnización.

Con independencia de la sanción que les fuera impuesta, las personas infractoras podrán ser obligadas a reparar el daño 
causado a la administración o, si no fuera posible, a indemnizar los daños y perjuicios. Estos daños se determinarán según criterio técnico debidamente motivado en la resolución sancionadora, que establecerá la forma y plazo en que la reparación habrá de llevarse a cabo o, en su caso, la imposibilidad de la reparación y consiguiente establecimiento de la indemnización. Con relación a los daños causados, las personas afectadas podrán aportar en audiencia y por cuenta propia informe complementario de peritaje de daños.

Artículo 43. Multas coercitivas y ejecución subsidiaria.

1. Si los infractores no hubieran procedido a la reparación o indemnización en la forma y plazo otorgados en la resolución, no hubieran elegido alguna de las opciones contempladas en el artículo 35.1 de la presente ley o no la hubieran ejecutado en los términos establecidos en el apartado 2 del mismo artículo, el órgano que ha dictado la resolución podrá acordar la imposición de multas coercitivas o la ejecución subsidiaria.

2. Las multas coercitivas serán reiteradas por lapsos de tiempo que sean suficientes para cumplir lo ordenado, no pudiendo ser el importe de las mismas superior a 1.000 euros.

3. La ejecución por la administración de la reparación ordenada será por cuenta del infractor.

Artículo 44. Responsabilidad. La responsabilidad de la infracción recaerá sobre:

1. La persona física o jurídica titular del dominio o de otro derecho real de disfrute sobre las fincas, salvo la existencia de cualquier tipo de cesión del derecho de uso o aprovechamiento a favor de una tercera persona.

2. Si existiera, la persona física o jurídica que sea titular de las fincas en régimen de arrendamiento, aparcería o cualquier otro derecho de uso o aprovechamiento análogo, salvo que en el curso del expediente demuestre que las personas arrendadoras o cedentes le impiden el normal desarrollo de los derechos de uso o aprovechamiento de las fincas, en cuyo caso la responsabilidad recaería sobre estas.

3. Los causahabientes de las herencias indivisas y comunidades hereditarias, los representantes de las herencias yacentes, los cotitulares de las sociedades gananciales y comunidades de bienes, los miembros de sociedades civiles y entidades carentes de personalidad jurídica, todos ellos propietarios de fincas rústicas que constituyan una unidad económica o un patrimonio separado, susceptible de imposición, salvo la existencia de cualquier tipo de cesión del derecho de uso o aprovechamiento a favor de una tercera persona. En su caso, las personas copartícipes responderán solidariamente de las sanciones impuestas.

Artículo 45. Órganos sancionadores competentes.

1. El órgano con competencia para incoar el expediente sancionador será la persona titular de la delegación provincial correspondiente de la consejería competente en materia de agricultura del territorio en donde radique la finca, y si existieran varias competentes, la correspondiente a la superficie de la finca de más extensión.

2. Los órganos con competencia para la imposición de las sanciones previstas en la presente ley serán los siguientes:

a. Para sancionar infracciones de carácter leve o grave, la persona titular de la dirección general competente en materia de estructuras agrarias.

b. Para sancionar infracciones de carácter muy grave, la persona titular de la consejería competente en materia de agricultura.

Artículo 46. Duración del procedimiento sancionador.

El plazo máximo para resolver y notificar la resolución expresa que ponga fin al procedimiento será de un año, a contar desde la fecha de inicio del procedimiento administrativo sancionador.

Artículo 47. Prescripción de las infracciones.

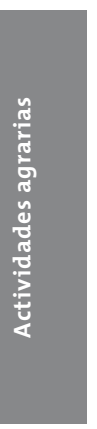


Código de la Administración Gallega

1. Las infracciones leves a que se refiere la presente ley prescribirán al año, las graves a los dos años y las muy graves a los tres años.

2. El término de la prescripción comenzará a contar desde el día en que se haya cometido la infracción, salvo en el supuesto de infracciones continuadas, en el cual el plazo de prescripción comenzará a contar desde el momento de finalización de la actividad, del último acto con el que la infracción se consuma o desde que se ha eliminado la situación ilícita.

3. Interrumpirá la prescripción de la infracción la iniciación, con conocimiento de la persona presunta responsable, del procedimiento sancionador.

\section{DISPOSICIÓN ADICIONAL ÚNICA COMUNICACIÓN DE INSTRUMENTOS DE PLANEAMIENTO URBANÍSTICO}

Aprobado inicialmente un instrumento de planeamiento urbanístico que afecte a fincas rústicas incluidas en las zonas de especial interés agrario o incorporadas al Banco de Tierras de Galicia, a la vez que el trámite de información pública, la Administración municipal deberá solicitar el informe de la consejería competente en materia de agricultura.

\section{DISPOSICIÓN FINAL PRIMERA}

$$
\text { (...) } 651
$$

\section{DISPOSICIÓN FINAL SEGUNDA}

$$
(\ldots)^{652}
$$

\section{DISPOSICIÓN FINAL TERCERA \\ PERIODO TRANSITORIO PARA \\ LA INCOACIÓN DE EXPEDIENTES \\ SANCIONADORES}

La incoación de expedientes sancionadores recogidos en el título VII de la presente ley no podrá iniciarse hasta haber transcurrido un año desde la declaración de zona de especial interés agrario por el Consello de la Xunta o, en su caso, de la declaración de firmeza del acuerdo de concentración parcelaria a que se refiere el artículo 2 de esta ley.

\section{DISPOSICIÓN FINAL CUARTA DESARROLLO REGLAMENTARIO}

Se faculta a la Xunta de Galicia para dictar las disposiciones necesarias para el desarrollo y cumplimiento de la presente ley.

\section{DISPOSICIÓN FINAL OUINTA ENTRADA EN VIGOR}

La presente ley entrará en vigor el día siguiente al de su publicación en el Diario Oficial de Galicia.
651 Disposición final primera contiene modificaciones a Ley $13 / 1989$, de 10 de octubre, de montes vecinales en mano común.
652 Disposición final segunda contiene modificaciones a Ley $12 / 2001$, de 10 de septiembre, de modificación de la Ley de concentración parcelaria para Galicia. 


\section{XIV \\ CAZA, PESCA, GUARDACOSTAS \\ Y CONTROL DEL MEDIO MARINO}

1. LEY 4/1997, DE 25 DE JUNIO,
DE CAZA DE GALICIA
(DOGA N. $\left.^{\circ} 133,11.7 .1997\right)^{653}$

\section{(...) ${ }^{654}$ \\ TÍTULO PRELIMINAR PRINCIPIOS GENERALES}

Artículo 1. Objeto de la ley.

La presente ley tiene por objeto regular el ejercicio de la caza en la Comunidad Autónoma de Galicia, así como el fomento, protección, conservación y ordenado aprovechamiento de las especies cinegéticas.

Artículo 2. Acción de cazar.

Se considera acción de cazar la actividad ejercida por las personas, mediante el uso de armas, artes u otros medios autorizados, para buscar, atraer, perseguir o acosar a los animales que se declaren como piezas de caza, a fin de cobrarlos, apropiarse de ellos o facilitar su captura por un tercero ${ }^{65}$.

Artículo 3. Del cazador.

1. El derecho a cazar corresponde a toda persona mayor de dieciséis años que, habiendo acreditado la aptitud y los conocimientos precisos, esté en posesión de la pertinente licencia de caza y cumpla los demás requisitos exigidos por las leyes y disposiciones de aplicación.

2. Para cazar con armas de fuego será necesario haber alcanzado la mayoría de edad penal o ir acompañado por algún cazador mayor de edad.

Artículo 4. Objeto de la caza.

1. La caza sólo podrá realizarse sobre las especies de la fauna silvestre o asilvestrada declaradas como piezas de caza,

\footnotetext{
653 Véase Decreto 284/2001,d e 11 de octubre, por el que se aprueba el Reglamento de caza de Galicia.

654 Exposición de motivos omitida.

655 Artículo 2 modificado por Ley 6/2006, de 23 de octubre, de modificación de la Ley 4/1997, de 25 de junio, de caza de Galicia.
}

cuyo aprovechamiento cinegético habrá de acomodarse, en todo caso, a las normas que anualmente apruebe la consellería de Agricultura, Gandería e Montes.

2. El ejercicio de la caza se regulará de manera que quede garantizada la conservación de las especies cinegéticas.

Artículo 5. Armas y medios de caza.

1. La tenencia y uso de armas de caza se regulará por lo dispuesto en la legislación especial sobre armas y en la presente ley.

2. Sin perjuicio del cumplimiento de lo dispuesto en otras leyes especiales, para la tenencia y uso de los medios empleados en la práctica de la caza, incluidos los animales domésticos, se estará a lo establecido en la presente ley.

3. Para utilizar medios de caza que precisen autorización especial será necesario estar en posesión del correspondiente permiso.

4. La Consellería de Agricultura, Gandería e Montes podrá establecer normas de homologación y contraste de los medios de caza que precisen autorización especial, al objeto de que tales medios no produzcan efectos distintos de los pretendidos.

\section{Artículo 6. Titularidad.}

Los derechos y obligaciones establecidos en la presente ley, en cuanto se relacionan con los terrenos cinegéticos, corresponderán a los propietarios o, en su caso, a los titulares de otros derechos reales o personales que conlleven el uso y disfrute del aprovechamiento de la caza.

Artículo 7. Competencia en materia de caza.

La planificación, ordenación, fomento, vigilancia y control de la caza corresponde a la Consellería de Agricultura, Gandería e Montes, la cual realizará cuantas actuaciones considere precisas para alcanzar los fines de la presente ley. 


\section{TÍTULO I \\ DE LOS TERRENOS \\ A EFECTOS DE LA CAZA}

\section{Artículo 8. Concepto.}

1. Son terrenos de carácter cinegético los susceptibles de tal aprovechamiento.

2. Se excluyen de esta consideración todos aquéllos que constituyen núcleos urbanos o rurales, villas, jardines, parques destinados al uso público, recintos deportivos, instalaciones fabriles o industriales, carreteras, vías férreas o cualquier otro lugar que sea declarado no cinegético en razón de sus especiales características y en el que el ejercicio de la caza deba estar permanentemente prohibido ${ }^{656}$.

3. Se consideran zonas de seguridad aquéllas en las que deban adoptarse medidas precautorias especiales, con el fin de garantizar la protección de las personas y sus bienes. Con carácter general se prohíbe en las mismas el ejercicio de la caza.

Artículo 9. Clasificación de los terrenos a efectos cinegéticos.

1. Los terrenos de carácter cinegético pueden estar sujetos a un régimen cinegético común o especial.

2. Los terrenos sujetos a régimen cinegético especial pueden pertenecer a alguna de las siguientes categorías: Reservas de caza; refugios de fauna; terrenos cinegéticamente ordenados (Tecor), terrenos cinegético deportivos o explotaciones cinegéticas.

3. Los no comprendidos en alguna de las categorías relacionadas en el párrafo anterior quedarán sujetos al régimen cinegético común, y en los mismos el ejercicio de la caza será libre, sin más limitaciones que las contenidas en la presente ley y disposiciones que la desarrollen.

Los terrenos de régimen cinegético común deberán tener como mínimo una superficie continua de 500 hectáreas para poder practicarse en ellos la caza. Si no alcanzasen dicha superficie, el ejercicio

656 Art. 8.2 modificado por Ley 6/2006, de 23 de octubre, de modificación de la Ley 4/1997, de 25 de junio, de caza de Galicia. de la caza estará prohibido y tendrán la consideración de refugios de fauna.

La gestión de los terrenos de régimen cinegético común será realizada por la Consellería de Agricultura, Gandería e Montes y sus aprovechamientos vendrán determinados por lo que se establezca anualmente en la orden de vedas.

Los terrenos cinegéticos incluidos en espacios naturales protegidos perderán su condición y pasarán a ser refugios de fauna, salvo que la propia declaración o el plan de ordenación de los recursos naturales correspondiente indique otra cosa.

Artículo 10. Señalización.

1. Los titulares de un terreno cinegético especial están obligados a señalizar sus límites, con carteles indicadores de su condición cinegética, conforme a lo que se determine reglamentariamente.

En estos terrenos se prohíbe entrar llevando armas, perros y otros medios dispuestos para cazar sin estar en posesión de autorización o permiso del titular correspondiente.

2. Las zonas de seguridad que se determinen reglamentariamente, así como los refugios de fauna enclavados dentro de otros terrenos de régimen cinegético especial, deberán ser igualmente señalizadas por sus titulares 657 .

Artículo 11. Reservas de caza.

1. Por Decreto podrán ser declaradas reservas de caza aquellas áreas del territorio que, por su situación, condiciones ambientales, vegetación, configuración física o topográfica o cualesquiera otras características, se consideren favorables para la aclimatación, reproducción, conservación, fomento y defensa de especies susceptibles de aprovechamiento cinegético. La declaración de reserva de caza llevará implícita su inclusión en el Registro General de Espacios Naturales de Galicia.

2. El Decreto de creación precisará la composición y funciones de la dirección

657 Véase Orden de 23 de julio de 2002 por la que se regula la señalización en los terrenos cinegéticos. 
técnica y de la junta consultiva y el régimen organizativo de la reserva.

3. La gestión de las reservas de caza corresponde a la Consellería de Agricultura, Gandería e Montes, y el plan de ordenación cinegética incluirá la normativa específica de protección, conservación y recuperación de las poblaciones de determinadas especies, subordinando a esta finalidad el posible aprovechamiento de las especies cinegéticas dentro de las reservas, y fijará el procedimiento de elaboración de los planes anuales de aprovechamiento.

Artículo 12. Refugios de fauna.

1. Cuando por razones biológicas, científicas o educativas sea preciso asegurar la conservación de determinadas especies, la Xunta de Galicia, de oficio o a propuesta de entidades científicas o culturales, públicas o privadas, podrá acordar que determinadas áreas del territorio sean declaradas como refugios de fauna. En estas áreas, la caza estará permanentemente prohibida, sin perjuicio de que por circunstancias especiales, suficientemente justificadas, la Consellería de Agricultura, Gandería e Montes acuerde su autorización para especies determinadas.

2. La administración, control y vigilancia de estos refugios corresponde exclusivamente a la citada consellería, si bien ésta podrá celebrar convenios de colaboración con asociaciones, sociedades o entidades colaboradoras que se comprometan a cumplir el plan de conservación establecido, bajo la supervisión de la misma.

Artículo 13. De los terrenos cinegéticamente ordenados.

1. Se denominan terrenos cinegéticamente ordenados (Tecor) aquellas áreas del territorio gallego susceptibles de aprovechamiento cinegético que hayan sido declaradas y reconocidas como tales por Resolución de la Consellería de Agricultura, Gandería e Montes y en las que la población cinegética ha de estar protegida y fomentada, aprovechándose de forma ordenada.
2. La superficie mínima y continua de los Tecor será de dos mil hectáreas, y la duración de su régimen especial será la del plazo de cesión de los derechos cinegéticos, que en ningún caso será menor de cinco años, ni superará los veinticinco años, a cuyo término se extinguirá el Tecor, salvo que se proceda a su renovación, de acuerdo con lo que se disponga reglamentariamente ${ }^{658}$.

El régimen cinegético especial de los Tecor se mantendrá, no obstante la pérdida de derechos cinegéticos sobre determinados terrenos que lo integren, siempre que la superficie restante no sea inferior a la mínima señalada en el párrafo anterior. Sin perjuicio de lo dispuesto anteriormente, cualquier cambio en la titularidad cinegética de la totalidad o parte de los terrenos comprendidos en el Tecor habrá de ser comunicado a la Administración en el plazo y condiciones previstos reglamentariamente. A fin de fomentar las poblaciones cinegéticas, los Tecor mantendrán como vedado de caza una superficie mínima del 10\% de sus terrenos. Estos vedados de caza deberán mantener los mismos lindes, al menos, durante dos años consecutivos ${ }^{659}$.

3. Los Tecor podrán ser de titularidad pública, societaria o particular, según promuevan su constitución las Administraciones públicas, las sociedades o asociaciones de cazadores legalmente constituidas, las personas físicas u otras jurídicas de carácter particular.

4. La declaración de los terrenos cinegéticos como Tecor lleva inherente a favor de sus titulares la reserva del derecho de caza de todas las especies cinegéticas que

658 Las previsiones relativas a la fijación de un plazo de cesión de los derechos cinegéticos que no superará los veinticinco años, tan sólo serán de aplicación a los Tecor de nueva aprobación, asi como a aquéllos en los que se proceda a la renovación de la cesión. Disposición transitoria única. Ley 6/2006, de 23 de octubre, de modificación de la Ley 4/1997, de 25 de junio, de caza de Galicia.

659 Art. 13.2 modificado por Ley 6/2006, de 23 de octubre, de modificación de la Ley 4/1997, de 25 de junio, de caza de Galicia. 
se encuentren en el mismo y, consecuentemente, la titularidad de los derechos y obligaciones que de conformidad con la presente ley se deriven de dicho aprovechamiento cinegético.

5. Para el ejercicio de la caza en los Tecor será necesario contar con el permiso correspondiente, expedido por el titular del aprovechamiento.

6. En todo caso, los aprovechamientos cinegéticos y las medidas de protección, conservación y fomento de la riqueza cinegética se regularán a través de los correspondientes planes de ordenación y de aprovechamiento cinegético, que habrán de ser aprobados por la Consellería de Agricultura, Gandería e Montes.

Artículo 14. Procedimiento general de declaración de los terrenos cinegéticamente ordenados.

1. A la solicitud de declaración de Tecor habrán de acompañarse los documentos acreditativos de la titularidad cinegética de los terrenos y la especificación de su superficie y sus lindes, así como una memoria con las directrices básicas del plan de ordenación cinegética.

2. El procedimiento de declaración de los Tecor incluirá, en todo caso, un trámite de información pública, por un plazo de dos meses, en el que los propietarios de los terrenos afectados o titulares de otros derechos que conlleven su aprovechamiento cinegético podrán efectuar las alegaciones que estimen pertinentes.

Si se manifestase la negativa a la integración en el Tecor de parte de los terrenos afectados, y la superficie continua de éstos fuese inferior a 500 hectáreas, en los mismos no podrá practicarse la caza y tendrán la consideración de refugios de fauna.

3. En todos los procedimientos de declaración de Tecor deberá recabarse informe del Comité Provincial de Caza correspondiente o, cuando su ámbito territorial comprenda varias provincias, del Comité Gallego de Caza.
4. Una vez iniciado el procedimiento de declaración de los Tecor y acreditado el cumplimiento de lo previsto en los números 1, 2 y 3 del presente artículo, la Consellería de Agricultura, Gandería e Montes otorgará una aprobación provisional para que en el plazo máximo de cuatro meses se adopten las medidas que se señalen en la misma. Si no se adoptasen esas medidas en el citado plazo, quedará sin efecto la aprobación provisional.

5. Durante el citado plazo no podrá realizarse aprovechamiento cinegético alguno.

6. Una vez presentados los planes quinquenales de ordenación cinegética, así como el anual de aprovechamientos, señalizado el perímetro del Tecor y adoptadas cuantas medidas se señalasen en la aprobación provisional, la Consellería de Agricultura, Gandería e Montes podrá declarar constituido el Tecor en el plazo máximo de dos meses. Durante este plazo se mantendrá la prohibición de realizar aprovechamientos cinegéticos.

7. En cualquier momento, aquellos titulares de derechos cinegéticos cuya cesión se presumiese podrán solicitar la segregación de sus terrenos del Tecor.

8. Vencido el plazo de cesión de derechos cinegéticos, los titulares del Tecor podrán iniciar el procedimiento de renovación, según se establezca reglamentariamente.

Este procedimiento habrá de constar al menos de un trámite de información pública y del informe favorable de la Consellería de Agricultura, Gandería e Montes.

Artículo 15. Terrenos cinegéticamente ordenados de carácter autonómico.

1. La Consellería de Agricultura, Gandería e Montes podrá ser titular de Tecor a fin de garantizar el ordenado aprovechamiento de las especies cinegéticas y de favorecer el acceso de los cazadores gallegos a la actividad cinegética.

2. Los Tecor autonómicos se constituirán sobre terrenos de titularidad cinegética de la Comunidad Autónoma o sobre terrenos de aprovechamiento cinegético común. 
3. La gestión de los Tecor autonómicos podrá ser realizada directamente por la Consellería de Agricultura, Gandería e Montes o por medio de sociedades o asociaciones de cazadores a las que se adjudique dicha gestión por el procedimiento que se establezca reglamentariamente.

Artículo 16. Terrenos cinegéticamente ordenados de carácter municipal.

1. Las corporaciones locales podrán solicitar a su favor la declaración de Tecor siempre que acrediten documentalmente al menos la titularidad cinegética del 75 por 100 de los terrenos para los que se solicite dicha declaración y no estén sometidos a otro régimen especial.

2. De conformidad con el número $2 \mathrm{del}$ artículo 14 de la presente ley, se presumirá la cesión de la titularidad del resto de la superficie solicitada, que se incluirá en el Tecor en tanto los propietarios o titulares cinegéticos de los terrenos no manifiesten expresamente y por escrito su negativa a la integración en el correspondiente trámite de información pública.

3. Los Ayuntamientos solicitantes de la declaración a su favor de un determinado territorio como Tecor habrán de acompañar a su solicitud:

a. La cesión de derechos cinegéticos, firmada por sus titulares y con especificación de la superficie del terreno, y el plazo de cesión.

b. El plano de localización a escala suficiente y la especificación de las lindes.

c. La memoria con las directrices básicas del plan de ordenación cinegética.

4. Cuando la extensión del término municipal no comprenda el mínimo de hectáreas necesario para la constitución de un Tecor, dos o más municipios podrán agruparse y solicitarlo mancomunadamente.

5. El aprovechamiento cinegético de los Tecor municipales podrá gestionarse directamente por el Ayuntamiento o bien mediante una sociedad o asociación de cazadores legalmente constituida, a la cual se le ceda o adjudique dicha gestión.
6. Esta cesión de la gestión a una sociedad o asociación de cazadores se realizará de acuerdo con la legislación de régimen local y por plazo no superior al indicado en la resolución de declaración del Tecor.

7. Los pliegos de condiciones de adjudicación de estas cesiones habrán de contener, además de los requisitos exigidos por su legislación específica, prescripciones especiales relativas a:

a. El reconocimiento del derecho que corresponde a todos los propietarios de terrenos susceptibles de aprovechamiento cinegético, para que de acuerdo con los Estatutos de la entidad que lo gestione y los planes de ordenación cinegética en vigor puedan ejercitar la caza dentro del Tecor.

b. La obligación de reservar al menos un 15 por 100 de los permisos diarios para cazadores empadronados con vecindad administrativa en los términos municipales incluidos en el Tecor.

c. La obligación de reservar al menos un 10 por 100 de los permisos diarios a favor de cazadores foráneos.

d. La obligación de reservar un porcentaje de los permisos diarios a favor de los propietarios de terrenos que cediesen su aprovechamiento cinegético a título gratuito.

8. Dichas prescripciones serán de aplicación igualmente en caso de gestión directa por el Ayuntamiento.

9. La entidad que gestione el Tecor será la responsable de su funcionamiento.

Artículo 17. Terrenos cinegéticamente ordenados de carácter societario.

1. Las sociedades o asociaciones de cazadores legalmente constituidas podrán solicitar a su favor la declaración de Tecor siempre que acrediten documentalmente al menos la titularidad cinegética del 75 por 100 de los terrenos para los que se pretenda la declaración.

2. De conformidad con el número 2 del artículo 14 de la presente ley se presumirá la cesión de la titularidad del resto de la superficie solicitada, que se incluirá en el Tecor en 
tanto los propietarios y titulares cinegéticos de los terrenos incluidos en la solicitud no manifiesten expresamente y por escrito su negativa a la integración en el correspondiente trámite de información pública.

3. Las asociaciones o sociedades de cazadores que soliciten la declaración a su favor de un determinado territorio como Tecor societario habrán de acompañar a su solicitud:

a. La cesión de derechos cinegéticos, firmada por sus titulares y con especificación de la superficie del terreno, y el plazo de cesión.

b. Los planos de localización a escala suficiente y la especificación de las lindes.

c. La memoria con las directrices básicas del plan de ordenación cinegética.

d. La documentación acreditativa de la constitución y el legal funcionamiento de la sociedad o asociación.

e. La copia autenticada de los Estatutos en vigor legalmente aprobados.

4. Se reservará un porcentaje de permisos diarios a favor de los propietarios de terrenos incluidos en el Tecor que cediesen su aprovechamiento cinegético a título gratuito, en el momento de la constitución del Tecor, y de acuerdo con lo que establezcan los Estatutos en vigor legalmente aprobados a este respecto.

Artículo 18. Terrenos cinegéticamente ordenados de carácter particular.

1. Las personas físicas o jurídicas que sean titulares de derechos cinegéticos de una superficie continua mínima de 2.000 hectáreas podrán solicitar la declaración de la misma como Tecor de carácter particular.

2. Deberá acreditarse documentalmente la titularidad y cesión de derechos cinegéticos, especificando que se ceden para un Tecor de carácter particular, y el plazo de cesión para la totalidad de la superficie.

3. En la constitución de los Tecor de carácter particular no será de aplicación la presunción de cesión de titularidad cinegética establecida en el número 2 del artículo 14.
Artículo 19. Extinción de los terrenos cinegéticamente ordenados.

El régimen cinegético especial de los Tecor se extinguirá, previa tramitación del correspondiente expediente:

a. Por el incumplimiento de las condiciones, obligaciones, limitaciones o prohibiciones establecidas en la autorización administrativa correspondiente.

b. Por la comisión de infracciones graves o muy graves de conformidad con el número 2 del artículo 61 , siempre que éstas afecten a las condiciones impuestas en las autorizaciones administrativas relativas a la protección y ordenado aprovechamiento de las poblaciones cinegéticas y de los ecosistemas de que forman parte.

c. Por la pérdida de la titularidad cinegética de los terrenos que integren los Tecor cuando no se reúna la superficie mínima señalada en el número 2 del artículo 13.

d. Por el transcurso del plazo de cesión de los terrenos de los derechos cinegéticos cuando no se procediese a su renovación.

Artículo 20. Terrenos cinegético-deportivos.

1. Tendrán la condición de terrenos cinegético deportivos aquellas áreas del territorio en que pueda practicarse la caza de conformidad con la legislación específica que regule las prácticas deportivas.

2. Las sociedades, asociaciones o federaciones de cazadores constituidas al amparo de la legislación del deporte podrán solicitar la declaración de terreno cinegético-deportivo, para practicar en el mismo la caza con un exclusivo carácter deportivo, exento de cualquier ánimo de lucro. En ningún caso la actividad o sus resultados podrán ser objeto de venta o comercialización.

3. Los solicitantes deberán acreditar la titularidad cinegética con arreglo a lo establecido en el artículo 18 de la presente ley y disponer de terrenos continuos cuya superficie mínima y máxima sea de 50 y 250 hectáreas respectivamente. La gestión de estos terrenos se realizará directamente por la entidad titular, que 
informará periódicamente a la Consellería de Agricultura, Gandería e Montes del calendario de pruebas, modalidades y cualesquiera otros requisitos que se determinen reglamentariamente.

Artículo 21. Terrenos dedicados a las explotaciones cinegéticas.

1. Las personas físicas o jurídicas que sean titulares cinegéticos de terrenos en coto redondo, con las superficies mínimas exigidas en cada caso, podrán solicitar autorización para dedicarlos a explotación cinegética, a fin de destinarlos a la producción de piezas de caza o a la explotación comercial de la actividad cinegética.

2. Las explotaciones constituidas sobre terrenos cinegéticos dedicados a la producción y venta de piezas vivas estarán sujetas, en cuanto a los requisitos de autorización, funcionamiento y control, al régimen establecido para las granjas cinegéticas. Su régimen fiscal será el mismo que el de las explotaciones agropecuarias.

3. En las explotaciones cinegéticas de carácter comercial, que habrán de constituirse como empresas mercantiles, podrá ejercitarse la caza sobre animales procedentes de granjas cinegéticas o de otros establecimientos autorizados, tales como parques de vuelo, cercados de aclimatación, biotopos, etc., de conformidad con los planes establecidos y previamente aprobados por la Consellería de Medio Ambiente y Desarrollo Sostenible.

La superficie mínima para poder autorizar este tipo de explotaciones es de cincuenta hectáreas, si se dedican a caza menor, y de cien hectáreas cuando el objeto de la explotación sea la caza mayor.

Los titulares de estas explotaciones habrán de señalizarlas con arreglo a la normativa reglamentaria, que a tal efecto se dicte, y, en todo caso, están obligados a señalizar los terrenos que se encuentren dentro del perímetro de la explotación y de los que no se disponga de autorización expresa de sus titulares, para su aprovechamiento cinegético.
Para autorizar una explotación cinegética comercial es imprescindible contar con la titularidad cinegética de la totalidad de los terrenos, en superficie continua, sobre los que pretende constituirse. Cuando estas autorizaciones afecten a espacios naturales protegidos, el promotor habrá de presentar un proyecto a efectos de que el órgano ambiental decida en cada caso, conforme a lo previsto en el artículo 1.2 de la Ley $6 / 2001$, de 8 de mayo, de modificación del Real Decreto legislativo 1302/1986, de 28 de junio, de Evaluación de Impacto Ambiental, de forma motivada y pública y conforme a los criterios del anexo III de este real decreto, si estos proyectos han de someterse o no a una evaluación de impacto ambiental.

Por vía reglamentaria se determinarán las condiciones en las que esta actividad pueda desarrollarse, y en especial las referentes a controles genéticos y sanitarios, requisitos para realizar las sueltas, época y frecuencia de éstas, marcado de las piezas, modalidades de caza, requisitos para su transporte y cuantas otras se consideren pertinentes ${ }^{660}$.

Artículo 22. Obligaciones de los titulares.

Son deberes de los titulares del aprovechamiento de terrenos sujetos a régimen especial:

a. Cumplir las condiciones establecidas en las resoluciones de declaración.

b. Ajustarse al plan de ordenación cinegética y a los planes anuales de aprovechamientos, de obligado cumplimiento una vez aprobados por la Consellería de Agricultura, Gandería e Montes.

c. Dotar a dichos terrenos de la vigilancia y señalización prevista de acuerdo con dichos planes.

d. Colaborar con la Administración pública en la protección y fomento de la fauna cinegética, suministrando los datos

660 Art. 21.3 modificado por Ley 6/2006, de 23 de octubre, de modificación de la Ley 4/1997, de 25 de junio, de caza de Galicia. 
estadísticos solicitados, realizando los controles sobre las especies susceptibles de captura y adoptando las medidas sanitarias establecidas.

e. Responder de la organización y correcta ejecución de las actividades cinegéticas que lleven a cabo.

f. Solicitar con la suficiente antelación la celebración de monterías, acechos y ojeos, y velar para que se cumplan las condiciones impuestas en la autorización.

g. Cualesquiera otros establecidos o que se establezcan por la Consellería de Agricultura, Gandería e Montes.

Artículo 23. Indemnizaciones por daños.

1. En accidentes de tráfico ocasionados por el atropello de especies cinegéticas los daños personales y patrimoniales se atendrán a lo dispuesto en la normativa estatal en materia de seguridad vial existente al respecto.

2. Los titulares de aprovechamientos cinegéticos de terrenos sujetos a régimen cinegético especial responderán en los demás casos de los daños ocasionados por las especies cinegéticas.

La Consellería de Medio Ambiente y Desarrollo Sostenible, previa instrucción del correspondiente expediente de valoración, indemnizará los daños efectivamente producidos por las especies cinegéticas de los terrenos cinegéticos de aprovechamiento común, de los Tecor autonómicos de su Administración, de las reservas de caza, de los refugios de fauna y de cualquier otro terreno cuya administración y gestión le correspondan ${ }^{661}$.

Artículo 24. Incumplimientos.

Ante el incumplimiento de las condiciones, obligaciones, limitaciones o prohibiciones establecidas en las autorizaciones para el aprovechamiento o explotación de terrenos sujetos a régimen cinegético especial, la Consellería de Agricultura, Gandería e

661 Art. 23 modificado por Ley 6/2006, de 23 de octubre, de modificación de la Ley 4/1997, de 25 de junio, de caza de Galicia.
Montes, previa audiencia de los titulares de los derechos cinegéticos, podrá suspender cautelarmente el ejercicio de la caza en los mismos o iniciar expediente de anulación de la declaración sin perjuicio de la imposición de las sanciones que les correspondan.

Artículo 25. Descripción de las zonas de seguridad.

1. A los efectos de lo establecido en el artículo 8.3 de la presente ley, se considerarán zonas de seguridad:

a. Los márgenes y zonas de servidumbre que se encuentren cercados de las vías y caminos de uso público y las vías férreas.

b. Las aguas públicas, incluidos sus cauces y márgenes, en una franja de cinco metros del límite de las mayores crecidas ordinarias.

c. Los perímetros de los núcleos urbanos y rurales y de otras zonas habitadas.

d. Los perímetros de las villas, edificios habitables aislados, jardines y parques públicos, áreas recreativas, zonas de acampada, recintos deportivos y cualquier otro lugar que por sus características sea declarado como tal en razón de lo previsto en el artículo 8.3.

2. No obstante lo previsto en el apartado anterior, la Consellería de Medio Ambiente y Desarrollo Sostenible, previa petición de los titulares cinegéticos interesados, podrá autorizar la caza en las vías y caminos de uso público, así como en los cauces y márgenes de los ríos, arroyos y canales que atraviesen terrenos cinegéticos o constituyan el límite entre los mismos. En las resoluciones que se dicten al efecto, si son afirmativas, se fijarán las condiciones aplicables en cada caso para ejercitar la caza bajo la responsabilidad de los titulares de la autorización.

3. Cualquier persona física o jurídica, pública o privada, podrá solicitar, fundadamente, a la Consellería de Medio Ambiente y Desarrollo Sostenible la declaración como zona de seguridad de un determinado 
lugar cuando concurran las circunstancias previstas en el artículo 8.3. Dichas zonas, en caso de ser así declaradas, deberán ser señaladas por el promotor conforme se determine reglamentariamente 662 .

Artículo 25 bis. La caza en las zonas de seguridad.

1. Queda prohibido circular con armas de caza cargadas y usarlas en el interior de los núcleos urbanos y rurales y en otras zonas habitadas hasta el límite que alcancen las últimas edificaciones o instalaciones habitables, ampliado en una franja de cien metros en todas las direcciones.

2. En caso de villas, edificios habitables aislados, recintos deportivos, jardines y parques destinados al uso público, áreas recreativas y zonas de acampada, el límite de la prohibición a que se refiere el apartado anterior será el de los propios terrenos donde se encuentren ubicados, ampliado en una franja de cien metros en todas las direcciones.

3. Se prohíbe circular con armas de caza cargadas y usarlas en el caso de autopistas, autovías, vías rápidas, corredores, carreteras nacionales, autonómicas y locales, en una franja de cincuenta metros de ancho a ambos lados de la zona de seguridad. En ningún caso se podrá disparar en dirección a otros caminos de uso público o vías férreas.

En los márgenes de las vías no incluidas en el párrafo anterior, si las condiciones de las mismas permiten el ejercicio seguro de la caza, se podrá cazar o situar los puestos para los zapeos, ganchos o monterías.

En los senderos y caminos rurales poco transitados, destinados al paso a pie y al uso agrícola o forestal, se podrá cazar siempre que las condiciones de seguridad lo permitan ${ }^{663}$.

662 Art. 25 modificado por Ley 6/2006, de 23 de octubre, de modificación de la Ley $4 / 1997$, de 25 de junio, de caza de Galicia.

663 Art. 25 bis añadido por Ley 6/2006, de 23 de octubre, de modificación de la Ley 4/1997, de 25 de junio, de caza de Galicia.
Artículo 26. Terrenos cercados.

1. Son terrenos cercados, a los efectos de la presente ley, aquellos que se encuentren rodeados materialmente por muros, cercas o vallados, construidos con el fin de impedir o prohibir el acceso a las personas o a animales ajenos o para evitar la salida de los propios.

2. En los terrenos cercados no acogidos a régimen cinegético especial, la caza estará permanentemente prohibida.

3. En estos terrenos la Consellería de Agricultura, Gandería e Montes podrá acordar las medidas que considere precisas dirigidas a reducir la caza existente, cuando razones técnicas o sanitarias lo aconsejen, así como autorizar la penetración en los mismos de sus agentes, para vigilar el cumplimiento de la ley.

\section{TÍTULO II}

\section{DE LAS ESPECIES CINEGÉTICAS Y LA PROPIEDAD DE LAS PIEZAS DE CAZA} ticas.

Artículo 27. De las especies cinegé-

1. Son especies cinegéticas las declaradas reglamentariamente objeto de caza.

2. A efectos de planificación y ordenación de los aprovechamientos cinegéticos, las especies de caza se clasificarán en dos grandes grupos: Especies de caza mayor y especies de caza menor.

3. Con la misma finalidad, dentro de las especies de caza menor se distinguirán las migratorias de las que no lo son, y de manera diferenciada las aves acuáticas.

4. Asimismo se considerarán separadamente las especies cinegéticas predadoras que puedan ejercer sensibles efectos sobre las restantes especies objeto de la caza.

Artículo 28. De la propiedad de las piezas de caza.

1. Serán propiedad del cazador las piezas que hubiese capturado, vivas o muertas, mediante el ejercicio de la caza, siempre que ésta sea realizada conforme a las prescripciones establecidas en la presente ley o normativa que la desarrolle. 
2. El cazador que hiera una pieza en terreno donde le sea permitido cazar tiene derecho a cobrarla aunque entre o caiga en terreno distinto. Cuando éste estuviese cercado, necesitará permiso del titular o de su representante para penetrar en el mismo, y si le fuese negado tendrá derecho a que se le entregue la pieza herida o muerta si fuese hallada y pudiese ser aprehendida.

3. En terrenos abiertos sometidos a régimen cinegético especial, y para piezas de caza menor, no será necesario el permiso a que se refiere el párrafo anterior, cuando el cazador entre a cobrar la pieza solo, sin armas ni perro.

4. Cuando uno o varios cazadores levantasen y persiguiesen una pieza de caza, cualquier otro cazador deberá abstenerse, en tanto dure la persecución, de abatir o intentar abatir dicha pieza.

5. Se entenderá que una pieza de caza es perseguida cuando el cazador que la levantó, con o sin ayuda de perro u otros medios, vaya en su seguimiento y tenga una razonable posibilidad de cobrarla.

6. Cuando haya duda respecto a la propiedad de las piezas de caza, se aplicarán los usos y costumbres del lugar. En su defecto, la propiedad corresponderá al cazador que le hubiese dado muerte, cuando se trate de caza menor, y al autor de la primera sangre, cuando se trate de caza mayor.

\section{TÍTULO III DE LA PROTECCIÓN, CONSERVACIÓN Y APROVECHAMIENTO DE LA CAZA}

\section{Capitulo I DE LA PROTECCIÓN}

Artículo 29. De las medidas de protección.

1. Cuando razones técnicas o sanitarias lo aconsejen, la consellería podrá acordar en cualquier momento medidas generales o particulares que corrijan situaciones anómalas o excepcionales.

2. Cuando las personas, los cultivos, la ganadería, la caza, los bienes o las instalaciones sean perjudicados por la fauna silvestre cinegética, la Consellería de Agricultura, Gandería e Montes, a instancia de parte, podrá autorizar a sus dueños para que adopten, dentro de ellas, medidas extraordinarias de control o acometer ella misma las acciones preventivas necesarias para evitar que dichos daños se repitan.

Artículo 30. Del estado sanitario de las especies cinegéticas.

1. La Administración autonómica velará por el estado sanitario de las especies cinegéticas y adoptará las medidas necesarias para prevenir, detectar, comprobar, diagnosticar y eliminar cualquier brote $o$ foco infeccioso en la fauna silvestre.

2. Los cazadores, los titulares de terrenos cinegéticos en régimen especial y, en general, cualquier persona que tenga conocimiento o sospecha de alguna anomalía en el comportamiento de los animales que pudiese hacer presumir la existencia de enfermedad contagiosa o de intoxicación deberán comunicarlo de inmediato a las autoridades o a sus agentes.

3. Las inspecciones sanitarias se realizarán en la forma y condiciones que reglamentariamente se determinen.

Artículo 31. De las repoblaciones cinegéticas.

1. Las sueltas de especímenes de especies cinegéticas exigirán la autorización previa de la Consellería de Agricultura, Gandería e Montes en todo tipo de terrenos sometidos a régimen cinegético especial. En los terrenos de aprovechamiento cinegético común, refugios de fauna y terrenos no cinegéticos, dichas repoblaciones solamente podrán ser realizadas directamente por la Consellería de Agricultura, Gandería e Montes.

2. A los efectos de lo establecido en el punto anterior, los especímenes deberán proceder de una granja cinegética o una explotación cinegética autorizada, con garantías sanitarias.

3. Cuando provengan de capturas en terrenos abiertos deberán acreditar su procedencia y la legalidad de su captura y, en cualquier caso, su correcto estado sanitario. 


\section{Capitulo II DE LA CONSERVACIÓN}

Artículo 32. Procedimientos masivos y no selectivos de caza.

1. Quedan prohibidas la tenencia y utilización de todos los procedimientos de caza masivos o no selectivos, así como aquellos que pudiesen causar localmente la desaparición de una especie cinegética $o$ indirectamente de una especie incluida en alguno de los catálogos de especies amenazadas, o alterar significativamente la estabilidad de sus poblaciones y de los ecosistemas de que forman parte.

2. Por razones de control de población y en circunstancias o condiciones excepcionales, podrá ser autorizada por la Consellería de Agricultura, Gandería e Montes la utilización de algunos de estos medios.

Artículo 33. Medios y métodos prohibidos.

Reglamentariamente se establecerán los medios y métodos prohibidos para la caza.

Artículo 34. De otras prohibiciones.

1. Queda prohibido:

1) Cazar en época de veda.

2) Cazar fuera del período comprendido entre una hora antes de la salida del sol y una hora después de su ocaso, salvo en las modalidades de caza nocturna expresamente autorizadas.

3) Cazar en tiempo y lugares en que, como consecuencia de incendios, epizootias, envenenamientos, inundaciones, sequías u otras causas, los animales se ven privados de sus hábitats y facultades normales de defensa y obligados a concentrarse en determinados lugares.

4) Cazar en días de nieve, cuando ésta cubra de forma continua el suelo o cuando por causa de la misma queden reducidas las posibilidades de defensa de las piezas de caza. Esta prohibición no será de aplicación a la caza mayor de alta montaña ni a determinadas especies de aves migratorias ni a otras especies cinegéticas a las que la existencia de nieve no reduzca sus posibilidades de defensa en las condiciones que reglamentariamente se fijen.

5) Cazar cuando por circunstancias meteorológicas y cualquier otra circunstancia esté reducida la visibilidad, de forma que puedan producirse peligros para las personas o sus bienes.

6) Cazar sirviéndose de animales o de cualquier vehículo como medio de ocultación.

7) Cazar en línea de retranca, tanto que se trate de caza mayor como menor.

8) Cazar en refugios de fauna, en terrenos vedados temporal o permanentemente en razón a planes cinegéticos legalmente aprobados o en estaciones biológicas o zoológicas, salvo que se esté en posesión de un permiso especial.

9) Entrar en terrenos sometidos a reglamentación cinegética especial debidamente señalizados, sin el oportuno permiso, llevando armas, perros o artes dispuestas para cazar.

10) Cazar combinando la acción de dos o más grupos de cazadores o haciendo uso de medios que persigan el cansancio o agotamiento de las piezas, salvo en los casos de batidas y monterías debidamente autorizadas.

11) Cazar al ojeo sin autorización expresa.

12) Portar armas de caza desenfundadas o dispuestas para su uso cuando se circule por el campo en época de veda.

13) Cazar con armas de fuego quienes carezcan de los requisitos exigidos para ello o no dispongan de los oportunos permisos.

14) Disparar con ninguna clase de armas los ojeadores, batidores, secretarios o podenqueros que asistan en calidad de tales a ojeos, batidas o monterías.

15) Cazar sin estar provisto de la documentación preceptiva o sin llevarla consigo.

16) Cazar, tener o transportar especies no cinegéticas o piezas de caza cuya edad o sexo, siempre que sean notorios, no concuerden o no cumplan los requisitos legalmente permitidos. 
17) Cazar con reclamo de perdiz, incumpliendo las disposiciones que regulen esta modalidad.

18) Destruir vivares y nidos, así como la recogida de crías o huevos y su circulación y venta.

19) Cualquier práctica que tienda a chantear, atraer o espantar la caza existente en terrenos ajenos.

20) Usar o poseer sin autorización animales, útiles, artes o productos aplicables a la captura o atracción de piezas de caza a que se refiere el artículo anterior.

21) Poseer en cautividad individuos de especies cinegéticas de caza mayor sin la oportuna autorización.

22) Disparar a las palomas en los bebederos habituales o a menos de 1.000 metros de un palomar autorizado, siempre que su localización esté debidamente señalada. Asimismo, disparar a las palomas mensajeras y a las deportivas o buchonas que ostenten marcas reglamentarias.

23) Emplear o poseer postas o balas explosivas, así como cualquier tipo de proyectil en el que se hayan producido manipulaciones.

24) Cazar con arma larga rayada, salvo que expresamente se autorice, o emplear cartuchos de bala o postas para especies de caza menor o utilizar municiones de perdigones o postas para la caza mayor ${ }^{664}$.

25) Cazar en terrenos que carezcan de plan de ordenación cinegética o de plan de aprovechamiento cinegético anual y que tengan la obligación legal de tenerlos.

26) Cazar con pistola y armas de aire u otros gases comprimidos.

27) Cazar con armas que disparen en ráfagas o con armas automáticas o semiautomáticas provistas de cargador que pueda contener más de dos cartuchos, así como con las dotadas de silenciador, visor para el disparo nocturno o munición no autorizada.

664 Art. 34.1.24 modificado por Ley 6/2006, de 23 de octubre, de modificación de la Ley 4/1997, de 25 de junio, de caza de Galicia.
28) Cualesquiera otros sistemas establecidos o que se establezcan, en disposiciones legales o reglamentarias.

29) Cazar bajo la influencia de estupefacientes, alcohol, sustancias psicotrópicas o cualquier otra droga que altere sensiblemente las facultades normales del cazador o su capacidad de reacción ${ }^{665}$.

2. La Consellería de Agricultura, Gandería e Montes, de oficio o a petición de organismos o instituciones públicas o privadas o de un particular, podrá acordar, por medio de una resolución motivada, el empleo de cualquiera de los medios, modos o formas prohibidos en el presente artículo o el anterior.

3. En este caso, la autorización que se conceda será por plazo determinado, personal e intransferible, fijará las condiciones para su utilización y responsabilizará expresamente al titular de la autorización, solicitándole, si se considera pertinente, la oportuna fianza.

Artículo 35. Aves de cetrería y hurones.

La posesión de aves de cetrería y hurones exigirá una especial autorización. Su tenencia se ajustará a las normas que le sean de aplicación y a lo que se disponga por vía reglamentaria.

Artículo 35 bis. Taxidermia.

Por vía reglamentaria se regulará la actividad de la taxidermia, en la que se contemplará, en todo caso, la obligación de llevar un libro registro donde conste la procedencia del animal y la obligación de abstenerse de recibir y preparar la pieza que no venga acompañada de la documentación y los precintos acreditativos de su origen 666 .

Artículo 36. Limitaciones por razones de cultivos y en masas de agua.

1. En las huertas, viñedos, campos de frutales, cultivos de regadío y montes

665 Art. 34.1.29 añadido por Ley 6/2006, de 23 de octubre, de modificación de la Ley 4/1997, de 25 de junio, de caza de Galicia.

666 Art. 35 bis añadido por Ley 6/2006, de 23 de octubre, de modificación de la Ley 4/1997, de 25 de junio, de caza de Galicia. 
de repoblación reciente, la Consellería de Agricultura, Gandería e Montes podrá condicionar o prohibir el ejercicio de la caza durante determinadas épocas.

2. La consellería establecerá igualmente de forma reglamentaria el aprovechamiento cinegético de las masas de agua cuyas características aconsejan aplicar un régimen especial, previo informe de los organismos con competencia sobre las mismas.

Artículo 37. Conservación de hábitats.

1. A fin de conservar, preservar y mejorar el hábitat natural de las diferentes especies cinegéticas, la Xunta de Galicia podrá acordar las oportunas medidas de ayuda para el logro de dicho objetivo y cuantas otras de carácter limitativo, correctoras o restauradoras persigan idéntica finalidad.

2. La Consellería de Agricultura, Gandería e Montes podrá declarar determinadas áreas o hábitats como zonas de especial interés cinegético. Estas áreas estarán sometidas a un régimen especial de gestión cinegética que fomente y garantice la conservación de los hábitats y del patrimonio genético. Las actuaciones públicas o privadas que puedan alterar las condiciones del medio, afectando a las especies cinegéticas en dichas áreas, deberán contar con un informe previo de la Consellería de Agricultura, Gandería e Montes.

3. Previa notificación y audiencia a los titulares de los derechos cinegéticos, la Consellería de Agricultura, Gandería e Montes, en los terrenos de régimen cinegético especial, podrá vedar toda o parte de su superficie, vedar una determinada especie o reducir el período hábil de caza, cuando así lo aconsejen circunstancias especiales para la protección de la fauna o la flora.

Artículo 38. Caza con fines científicos.

1. La Consejería de Agricultura, Ganadería y Montes podrá autorizar, condicionadamente, para fines científicos o de investigación, la caza de especies cinegéticas en cualquier época del año así como la utilización de medios y métodos prohibidos con carácter general.

2. Estas autorizaciones serán personales e intransferibles y por plazo determinado a favor de personal cualificado, y requerirán informe previo favorable de la institución directamente relacionada con la actividad investigadora del peticionario.

Artículo 39. Anillamiento y marcado.

1. La Consellería de Agricultura, Gandería e Montes podrá dictar normas para la práctica del anillamiento o marcado de especies cinegéticas sin perjuicio de lo que establezcan otras disposiciones al respecto.

2. Quienes hallen o capturen alguna pieza portadora de anillas o marcas utilizadas para la identificación de animales deberán comunicarlo a la consellería haciendo llegar a la misma aquellas señales y datos sobre el lugar y tiempo de la aprehensión.

Artículo 40. De los perros y la caza.

1. Los dueños de perros utilizados para la práctica de la caza quedarán obligados a cumplir las prescripciones generales que sobre tenencia, matriculación y vacunación dicten las autoridades competentes, de conformidad con la Ley 1/1993, de 13 de abril, de Protección de Animales Domésticos y Salvajes en Cautividad.

2. El tránsito de perros sueltos por terrenos cinegéticos o su empleo en el ejercicio de la caza se acomodará a los preceptos que se dicten reglamentariamente.

3. En todo caso el dueño de estos animales evitará que vaguen sin control, tanto en terrenos cinegéticos como en las zonas de seguridad, evitando daños o molestias a las piezas de caza, las crías o sus huevos, y responderá de los daños que aquéllos ocasionen.

4. Los perros utilizados para la práctica de la caza deberán ir provistos de la identificación que se determine reglamentariamente. Para el empleo de rehalas será necesario estar en posesión de licencia especial.

5. A fin de que los perros de caza puedan ser adiestrados y entrenados, en los 
planes de ordenación cinegética se fijarán los lugares, épocas y condiciones en que podrá llevarse a cabo el adiestramiento.

6. En la Consellería de Agricultura, Gandería e Montes se abrirá un libro-registro de razas caninas de caza existentes en la Comunidad Autónoma.

Artículo 41. Modalidades de caza.

1. Las modalidades de caza que pueden practicarse, así como los requisitos para llevar a cabo las mismas, las normas de seguridad de personas y bienes y las medidas de protección de la fauna silvestre no cinegética que deban adoptarse en las cacerías se establecerán por vía reglamentaria. De la misma forma se reglamentará el procedimiento de caza en puestos fijos, combinado con la acción de batidores, ojeadores y perros.

2. Las normas que con carácter general se dicten para regular esta materia se complementarán con los planes cinegéticos aprobados para los terrenos en que se realicen.

3. La celebración de monterías, batidas, ganchos, recechos, esperas nocturnas y ojeos requerirá autorización previa de la Consellería de Agricultura, Gandería e Montes, a la que habrán de ajustarse. La misma obligación incumbe a los titulares cinegéticos de terrenos sujetos a régimen especial para realizar cualquiera de las modalidades de caza descritas en el párrafo anterior, en caso de batidas por daños.

Los titulares cinegéticos de los terrenos, los organizadores de cacerías y los participantes en las mismas serán directamente responsables del cumplimiento de dichas disposiciones.

\section{Capítulo III DEL APROVECHAMIENTO}

Artículo 42. De los períodos hábiles de caza.

La Consellería de Agricultura, Gandería e Montes, oído el Comité Gallego de Caza, publicará anualmente, con la suficiente antelación, una orden en la que se determinarán las limitaciones y épocas hábiles de caza de las distintas especies, así como los regímenes especiales necesarios y la normativa de aplicación en los terrenos de régimen cinegético común.

Artículo 43. Ordenación del aprovechamiento cinegético.

1. Los titulares de aprovechamientos cinegéticos sujetos a régimen especial deberán presentar obligatoriamente un plan quinquenal de ordenación cinegética redactado por técnico competente, que una vez aprobado por la Consellería de Agricultura, Gandería e Montes constituirá norma de obligado cumplimiento a partir de la que se desarrollará ordenadamente la actividad cinegética, dentro del marco de los períodos hábiles generales.

2. Los planes de aprovechamiento, de vigencia anual, serán aprobados por la Consellería de Agricultura, Gandería e Montes y contendrán las especies cazables, cupos de capturas, períodos, número de jornadas de caza, número de cazadores diarios, zonas de aplicación y modalidades de caza y cualesquiera otras cuestiones relacionadas, con el ejercicio de la caza.

Artículo 44. Planes de ordenación y aprovechamientos cinegéticos.

1. Los planes de ordenación cinegética incluirán los datos del estado cinegético, dentro del que han de figurar, al menos, la definición y descripción de las unidades de gestión e inventariación y la estimación de parámetros poblacionales como abundancia y productividad de las especies objeto del aprovechamiento, así como una evaluación de la capacidad de carga del hábitat.

2. Se incluirá asimismo:

a. El establecimiento de los objetivos de la ordenación, de acuerdo con la información recogida en la fase de inventario.

b. La estimación de la extracción sostenible en función de la evolución prevista de las poblaciones.

c. La zonificación del área, un sistema de seguimiento de la propia planificación y una previsión de mecanismos correctores. 
d. También figurarán articuladas en el tiempo las acciones de conservación de las especies cinegéticas, así como, en su caso, de otras especies silvestres.

e. Las acciones y modalidades complementarias articuladas en el espacio y tiempo, como el adiestramiento de perros, la suelta-captura y otras similares.

f. Cualesquiera otros aspectos que reglamentariamente se determinen.

3. Los planes de aprovechamientos cinegéticos de vigencia anual se realizarán en base al plan de ordenación cinegética y a las tablas de capturas de años anteriores.

4. Si se comprobase que un plan de ordenación o aprovechamiento aprobado contiene datos falsos o se está aplicando indebidamente, previa incoación del oportuno expediente sancionador, podrá ser anulado o suspendida cautelarmente la actividad cinegética, sin perjuicio de que la Consellería de Agricultura, Gandería e Montes emprenda las demás acciones que correspondan contra el titular del Tecor y contra quienes suscriban el plan, en su caso.

5. Al final de cada temporada de caza, y antes de la fecha que reglamentariamente se establezca, los titulares de los aprovechamientos cinegéticos comunicarán a la Consellería de Agricultura, Gandería e Montes los datos que sobre la misma les requiera.

\section{TÍTULO IV DE LOS REQUISITOS PARA CAZAR}

\section{Artículo 45. Requisitos generales.}

1. Para poder practicar la caza es preciso:

a. Ser titular de una licencia de caza en vigor.

b. Tener concertado un contrato de seguro de responsabilidad civil del cazador.

c. Estar en posesión de un documento oficial de identificación.

d. En caso de utilizar armas, poseer el correspondiente permiso así como la guía de pertenencia, con arreglo a la normativa que regula esta materia. e. No estar inhabilitado por sentencia firme para la obtención de licencia de caza o no estar sancionado por resolución administrativa que implique la imposibilidad de obtener la licencia por un período determinado.

f. Cualesquiera otros permisos o autorizaciones que por razón del lugar, los métodos o las especies fuesen exigidos por la ley o normativa de aplicación.

2. Estos documentos deberá llevarlos consigo el cazador durante el ejercicio de esta actividad.

3. Los menores de edad deben ir acompañados de algún cazador mayor de edad, para poder cazar con armas.

4. Los cazadores que sean sorprendidos cazando con síntomas de encontrarse bajo la influencia de estupefacientes, alcohol, sustancias psicotrópicas o cualquier otra droga deberán someterse a las pruebas de detección, cuando sean requeridos para ello por los agentes o miembros de los cuerpos y fuerzas de seguridad del Estado y por el personal de las escalas de agentes forestales y agentes facultativos medioambientales de la Xunta de Galicia. Por vía reglamentaria se determinarán el procedimiento, las diligencias a llevar a cabo y, en general, las reglas a que deberá ajustarse esta actuación ${ }^{67}$.

Artículo 46. Licencias.

1. La licencia de caza es un documento personal e intransferible, expedido por la Consellería de Agricultura, Gandería e Montes a quien, no estando inhabilitado para obtenerla, acredite la aptitud y conocimientos precisos y reúna los requisitos legales necesarios.

2. El menor de edad no emancipado que haya cumplido dieciséis años necesitará autorización escrita de la persona que legalmente lo represente para obtener la licencia de caza.

667 Art. 45.4 añadido por Ley 6/2006, de 23 de octubre, de modificación de la Ley 4/1997, de 25 de junio, de caza de Galicia. 
3. La validez de las licencias podrá ser de uno o varios años a partir de la fecha de su expedición, y éstas se clasifican en:

Licencias de clase A, que autorizan para el ejercicio de la caza con armas de fuego.

Licencias de clase B, que autorizan para el ejercicio de la caza con otros medios o procedimientos permitidos, distintos de los anteriores.

Licencias de clase $\mathrm{C}$, que autorizan la tenencia o utilización de medios o procedimientos especiales.

4. Reglamentariamente se determinarán los requisitos y condiciones para la obtención de la licencia de caza, así como las pruebas de aptitud que habrán de superar quienes pretendan obtener por primera vez dicha licencia ${ }^{668}$.

Artículo 47. De las personas inhabilitadas para obtener la licencia.

No podrán obtener la licencia ni tendrán derecho a renovación:

a.Quienes no reúnan las condiciones $\mathrm{y}$ requisitos que se establecen para su obtención.

b. Los inhabilitados para obtenerla en virtud de sentencia firme.

c. Los infractores de la presente ley o normas que la desarrollen a quienes por resolución administrativa firme recaída en el expediente sancionador instruido al efecto se les haya impuesto la sanción de inhabilitación o retirada de licencia.

d. Los infractores de la presente ley o normas que la desarrollen que no acrediten documentalmente el cumplimiento de la sanción impuesta por resolución firme, recaída en el expediente instruido.

Artículo 48. Anulación y suspensión de licencias.

1. La licencia de caza podrá ser anulada o suspendida por tiempo determinado, como consecuencia de expediente sancionador, en los supuestos establecidos en la presente ley.

668 Orden de 1 de junio de 2007 por la que se regula el examen del cazador en la Comunidad Autónoma de Galicia.
En estos casos, el titular de la licencia deberá entregar el documento acreditativo y abstenerse de solicitar una nueva, en tanto dure la inhabilitación.

2. Cautelarmente, la Consellería de Agricultura, Gandería e Montes podrá suspender la licencia al incoarse un expediente sancionador por falta grave o muy grave.

\section{TíTULO V DE LA VIGILANCIA Y CUIDADO DE LA CAZA}

Artículo 49. De la vigilancia de la actividad cinegética.

1. La vigilancia de la actividad cinegética y el cumplimiento de los preceptos de la presente ley serán desempeñados por los agentes forestales de la Consellería de Agricultura, Gandería e Montes y por los demás cuerpos e instituciones de la Administración que, con carácter general, tengan encomendadas funciones de custodia de los recursos naturales.

2. En el ejercicio de sus funciones, los agentes forestales tendrán la consideración de agentes de la autoridad y como tales podrán ocupar y retener, cuando proceda, las piezas cobradas y los medios de caza empleados.

3. Las autoridades y sus agentes con competencia en materia cinegética, cuando actúen en el ejercicio de sus funciones de vigilancia, inspección y control, podrán, previa identificación, acceder a todo tipo de terreno, instalaciones y vehículos relacionados con la actividad cinegética.

Artículo 50. Guardas de campo de caza.

1. La Consellería de Agricultura, Gandería e Montes podrá otorgar el título de guarda de campo de caza a las personas que cumplan los requisitos que se establezcan reglamentariamente, al objeto de colaborar en el cumplimiento de lo dispuesto en la presente ley con los agentes forestales y con los demás cuerpos e instituciones 
de la Administración que, con carácter general, tengan encomendadas funciones de custodia de los recursos naturales. A estos efectos tendrán la consideración de agentes de la autoridad.

2. Los terrenos cinegéticos ordenados dispondrán de un servicio de vigilancia.

Los miembros de los servicios de vigilancia estarán obligados a denunciar, en un plazo máximo de cuarenta y ocho horas, todos aquellos hechos que se produzcan en la demarcación que tengan asignada y que presumiblemente constituyan infracciones a la presente ley, así como a colaborar con los agentes de la autoridad en materia cinegética, para lo cual deberán poseer el título de guardas de campo de caza.

3. Los guardas de campo de caza deberán portar uniforme y los distintivos de su cargo, así como la documentación que los identifique como tales.

\section{TÍTULO VI DE LAS ENTIDADES COLABORADORAS Y ÓRGANOS CONSULTIVOS}

Artículo 51. De las entidades colaboradoras.

Se considerarán entidades colaboradoras las que realicen acciones en favor de la riqueza cinegética, la conservación de las especies y su hábitat y su ordenado aprovechamiento, además o indistintamente de las que les correspondan, en su caso, como titulares de terrenos de régimen cinegético especial.

Serán declaradas por la Consellería de Agricultura, Gandería y Montes.

Reglamentariamente se determinarán los requisitos necesarios para la obtención de la condición de entidad colaboradora, así como sus beneficios y obligaciones.

Artículo 52. De los órganos consultivos y asesores.

1. La función de asesoramiento a la Administración y de representación de las organizaciones de cazadores y otros grupos vinculados a la caza en la gestión cinegética se realizará a través del Comité Gallego de Caza y los comités provinciales de caza.

2. Ambos comités emitirán informe preceptivo en su respectivo ámbito territorial sobre las propuestas de órdenes generales de vedas, los expedientes de declaración de los Tecor y cualquier otra cuestión de interés cinegético.

3. La composición de los comités de caza incluirá a representantes de las federaciones, sociedades colaboradoras y asociaciones de cazadores, en el ámbito territorial de su competencia, así como de las instituciones dedicadas a la investigación y de las organizaciones cuyo fin sea la conservación de la naturaleza y de los intereses socioeconómicos relacionados con la actividad cinegética.

4. Reglamentariamente se determinarán la composición y funciones del Comité Gallego de Caza y de los comités provinciales de caza.

Artículo 53. La Comisión de Homologación de Trofeos de Caza.

1. La Comisión de Homologación de Trofeos de Caza es un órgano adscrito a la Consellería de Agricultura, Gandería e Montes cuya función principal es la homologación de los trofeos de caza, conforme a las fórmulas y baremos establecidos por los organismos nacionales e internacionales.

2. Su composición y régimen de funcionamiento se determinará reglamentariamente.

\section{TÍTULO VII \\ DE LAS GRANJAS CINEGÉTICAS}

Artículo 54. Granjas cinegéticas.

1. Las granjas cinegéticas tienen la consideración de explotaciones ganaderas, conforme prevén la Ley 8/2003, de 24 de abril, de Sanidad Animal, y el Real Decreto $479 / 2004$, de 26 de marzo, por el que se establece y regula el Registro General de Explotaciones Ganaderas.

2. La autorización y el registro de las granjas cinegéticas en el Registro General 
de Explotaciones Ganaderas corresponderá a la Consellería del Medio Rural, sin perjuicio de la necesidad de informe previo y favorable al mencionado registro de la Consellería de Medio Ambiente y Desarrollo Sostenible.

3. La Consellería del Medio Rural pondrá en conocimiento de la Consellería de Medio Ambiente y Desarrollo Sostenible el registro de las granjas cinegéticas en el Registro General de Explotaciones Ganaderas, a los efectos del ejercicio de las facultades de control en la actividad cinegética correspondientes a la Consellería de Medio Ambiente y Desarrollo Sostenible. En este sentido se remitirá, junto con la notificación del registro de la granja, una copia íntegra del expediente ${ }^{669}$.

\section{TÍTULO VIII DEL RÉGIMEN FISCAL}

Artículo 55. Matrículas.

La Consellería de Agricultura, Gandería e Montes expedirá la matrícula anual acreditativa de la condición cinegética de los terrenos sujetos a régimen cinegético especial.

La tasa anual se fijará atendiendo a la calificación otorgada al terreno en la autorización, en proporción al número de hectáreas y al grupo en que se incluya, de conformidad con la normativa autonómica reglamentadora de tasas, precios y exacciones reguladoras.

En lo que se refiere a las bonificaciones, reglamentariamente se determinará el porcentaje y las condiciones de las mismas, y se tendrá en cuenta, en todo caso, la superficie dedicada a refugio de fauna, el número de permisos autorizados para cazadores ajenos, o propietarios de terrenos no socios, el número de socios y el tipo de Tecor.

Las explotaciones cinegéticas de carácter comercial, así como las granjas cinegéticas, estarán sujetas al régimen fiscal de las explotaciones mercantiles.

669 Art. 54 modificado por Ley 6/2006, de 23 de octubre, de modificación de la Ley 4/1997, de 25 de junio, de caza de Galicia.
Asimismo no se contabilizará a efectos de la tasa de la matrícula anual la superficie en hectáreas que se dediquen a vedado de caza al menos durante dos años.

\section{TÍTULO IX \\ DE LAS INFRACCIONES Y SANCIONES \\ Capitulo \\ DE LAS INFRACCIONES}

Artículo 56. Concepto y clases de infracciones administrativas.

1. Las acciones u omisiones que infrinjan lo establecido en la presente ley darán lugar a responsabilidad de naturaleza administrativa, sin perjuicio de la exigible en la vía penal o civil.

2. A los efectos de la presente ley, las infracciones se clasifican en leves, graves y muy graves.

Artículo 57. De las infracciones leves. Son infracciones leves:

1. Cazar siendo menor de dieciséis años.

2. Cazar con armas de fuego sin haber alcanzado la mayoría de edad cuando se haga a más de 50 metros del cazador mayor de edad encargado de la vigilancia del menor o cuando no se cumplan sus indicaciones.

3 . No vigilar eficazmente las actividades cinegéticas del menor que utilice armas de fuego el cazador mayor de edad encargado de esa vigilancia.

4. No llevar consigo durante el ejercicio de la caza la documentación preceptiva, aun siendo titular de la misma.

5. Abatir o intentar abatir una pieza que haya sido levantada y sea perseguida por otro u otros cazadores y sus perros.

6. Practicar la caza a caballo cuando no se disponga de autorización para ello.

7. Cazar palomas en sus bebederos habituales o a menos de 1.000 metros de un palomar agroindustrial debidamente señalizado.

8. Establecer palomares agroindustriales sin autorización.

9. Cazar palomas mensajeras, deportivas o buchonas que ostenten las marcas establecidas al efecto. 
10. No impedir en época hábil que los perros propios vaguen sin control por terrenos cinegéticos.

11. Transitar con perros sin la debida diligencia para evitar molestias a las piezas de caza, las crías o sus huevos.

12. No ejercer la debida vigilancia sobre los perros pastores de ganado para evitar que causen perjuicios o molestias a las piezas de caza.

13. Incumplir las normas que regulen el adiestramiento de perros en las zonas que se establezcan al efecto.

14. No cumplir las normas sobre caza en caminos y aguas públicas que atraviesen o linden con terrenos sometidos a régimen cinegético especial, o cazar en estos lugares sin el debido permiso.

15. Incumplir las normas que se establezcan sobre la actividad cinegética en relación con determinados terrenos por razón de cultivos o repoblaciones forestales.

16. Cualquier práctica que tienda a chantear, atraer o espantar la caza en terrenos ajenos o zonas protegidas.

17. Infringir lo dispuesto respecto a la entrega y cobro de piezas de caza heridas o muertas que entren en terrenos cinegéticos de otra titularidad, cuando el peticionario de acceso acredite que la pieza fue herida en terreno donde le estaba permitido cazar.

18. Entrar con armas o perros en terrenos abiertos sometidos a régimen cinegético especial, para cobrar una pieza de caza menor herida fuera de él, siempre que se encuentre en lugar visible desde la linde.

19. Infringir las limitaciones o prohibiciones que regulen el ejercicio de la caza en terrenos sometidos a régimen cinegético especial, cuando el infractor esté en posesión del correspondiente permiso para ejercitar la caza en los mismos.

20. Incumplir lo que se establezca reglamentariamente sobre la caza de aves migratorias.

21. Contravenir las disposiciones sobre la caza de aves acuáticas desde puestos fijos y sobre perros de persecución o cetrería.
22. Practicar la caza con armas o cualquier otro medio o arte los auxiliares de los cazadores que asistan en tal calidad.

23. Estar en posesión de armas o municiones no permitidas para la modalidad de caza que se esté practicando.

24. Solicitar la licencia de caza estando inhabilitado para obtenerla por resolución firme, en tanto dure la inhabilitación o esté pendiente de pago alguna sanción firme.

25. Poseer sin autorización o identificación lazos, trampas, cepos, costillas, perchas, nasas o alares, arbolillo, varetas, rametas, barracas o paranys, artefactos que requieran para su uso el funcionamiento de mallas, redes abatibles, redes niebla o verticales o redes cañón, todo tipo de medios que impliquen el uso de liga, hurones y postas, entendiendo por tales aquellos proyectiles múltiples cuyo peso sea igual o superior a 2,5 gramos.

26. Poseer, con fines de caza, aparatos electrocutantes o paralizantes, cebos, gases o sustancias venenosas, paralizantes, tranquilizantes, atrayentes o repelentes, productos para crear rastros de olor, explosivos, anzuelos y alambres.

27. Anillar o marcar piezas de caza sin la debida autorización, o no remitir a la Administración las anillas o marcas oficiales que posean las piezas abatidas.

28. Incumplir las condiciones que se fijen en las autorizaciones para celebrar batidas.

29. Incumplir la obligación de dar cuenta del resultado de las cacerías.

30. Incumplir los cazadores las limitaciones contenidas en el plan de ordenación cinegética oficialmente aprobado, salvo que estuviese tipificado como infracción específica de mayor gravedad en la presente ley.

31. No cumplir las disposiciones específicas dictadas o cursadas a los titulares de terrenos sujetos a régimen cinegético especial sobre su funcionamiento.

32. Transportar caza muerta sin cumplir las disposiciones que la reglamenten o no 
cumplir con los requisitos que, al efecto, se establezcan.

33. Transportar en vehículos motorizados armas desenfundadas y listas para su uso, aunque no estuviesen cargadas, en época hábil.

34. Estar en posesión, en épocas de veda, de piezas de caza menor muertas cuya procedencia no pueda justificarse suficientemente.

35. En general, incumplir los requisitos, obligaciones, limitaciones o prohibiciones establecidas en la presente ley, cuando no sea constitutivo de infracción grave o muy grave.

Artículo 58. De las infracciones graves.

Son infracciones graves:

1. Cazar o portar medios dispuestos para la caza sin autorización o sin cumplir los requisitos establecidos en tiempo de veda, épocas, horas, lugares o circunstancias prohibidas.

2. Cazar no siendo titular de licencia o estando inhabilitado para ello.

3. Falsear los datos en la solicitud de la licencia de caza.

4. Cazar con redes o artefactos que requieran para su uso el funcionamiento de mallas, redes abatibles, redes niebla o verticales o redes cañón.

5. Cazar utilizando alguno de los procedimientos o instrumentos relacionados en los números 25 y 26 del artículo anterior, así como cualquier otro medio masivo o no selectivo.

6. Utilizar animales vivos, muertos o naturalizados, como reclamo, sin autorización expresa o en contra de las disposiciones establecidas en la misma.

7. Aprovechar de manera abusiva y desordenada las especies naturales existentes en terrenos sujetos a régimen cinegético especial o incumplir los planes de ordenación y aprovechamiento aprobados. $\mathrm{La}$ sanción podrá llevar aparejada la suspensión o revocación de dicho régimen especial.
8. Impedir a la autoridad o a sus agentes el acceso a terrenos sujetos a régimen cinegético especial o no mostrar su documentación, así como impedir o resistirse a su inspección.

9. Incumplir los titulares de terrenos sujetos a régimen especial cualquiera de las condiciones impuestas en la autorización. La sanción puede llevar aparejada su anulación.

10. No señalizar debidamente los terrenos cinegéticos sometidos a régimen cinegético especial. La sanción puede llevar aparejada la suspensión de la autorización.

11. Comercializar, introducir, soltar o transportar ejemplares de caza vivos o muertos o huevos de especies cinegéticas incumpliendo los requisitos previstos en la normativa vigente.

12. Explotar industrialmente la caza sin autorización o incumplir las condiciones fijadas en la misma.

13. Cazar, comercializar, poseer o transportar piezas de caza, vivas o muertas, cualquiera que sea su edad o sexo, en caso de que sean notorios, cuando no concuerden con los legalmente permitidos.

14. Negarse a la inspección por los agentes de la autoridad de morrales, cestos, sacos, armas u otros aparatos o medios, cuando sean requeridos para ello.

15. Obstruir las labores de investigación del paradero de piezas de caza ilegalmente cobradas.

16. Negarse a mostrar la documentación pertinente para el ejercicio de la caza a los agentes forestales o a otros agentes de la autoridad que lo requieran.

17. Infringir las normas específicas de la orden general de vedas y demás disposiciones concordantes respecto al ejercicio de la caza en terrenos cinegéticos.

18. Infringir las limitaciones y prohibiciones que reglamenten el ejercicio de la caza en terrenos sometidos a un régimen cinegético especial cuando el infractor no esté en posesión del correspondiente permiso para ejercitar la caza en los mismos. 
19. No declarar los titulares o gestores de terrenos sometidos a un régimen cinegético especial las epizootias o envenenamientos que afecten a la fauna existente en los mismos, o incumplir las medidas que se dicten para su prevención o erradicación.

20. Poseer piezas de caza mayor, viva o muerta, cuya procedencia no pueda acreditarse debidamente.

21. Alterar los precintos y marcas reglamentarios.

22. Cerrar o cercar terrenos con fines cinegéticos sin autorización o sin cumplir los requisitos establecidos en la misma, así como dañar o alterar los que estén autorizados.

23. Cazar con armas de fuego sin cumplir las medidas de seguridad que reglamentariamente se especifiquen.

24. Cazar en línea de retranca haciendo uso de armas de fuego, tanto si se trata de caza mayor como de caza menor.

25. Cazar con armas que disparen en ráfagas o con armas automáticas o semiautomáticas provistas de cargador que pueda contener más de dos cartuchos, así como con las dotadas de silenciador, visor para el disparo nocturno o munición no autorizada.

26. Abrir portillos en cercas o vallados o construir artificios, trampas, barreras o cualquier otro dispositivo que sirva o pueda servir para beneficiarse de la caza, así como destruir o dañar las instalaciones destinadas a la protección y fomento de la caza.

27. Cazar en terrenos sometidos a régimen cinegético especial o terrenos cercados, aun cuando no se hubiese cobrado pieza alguna, sin estar en posesión del correspondiente permiso.

28. Portar armas de caza desenfundadas, sin la oportuna autorización, cuando se transite por el campo en época de veda.

29. Cazar con armas o medios que precisen de autorización especial sin estar en posesión del correspondiente permiso.

30. Celebrar monterías, batidas y ojeos sin la oportuna autorización.

31. Cazar sin tener contratado el seguro obligatorio del cazador o tenerlo caducado.
32. Destruir, alterar o cambiar las señales indicadoras de la condición cinegética de un terreno.

33. Hacer uso indebido de armas rayadas o escopetas de caza en zonas de seguridad o proximidades.

34. Atribuirse indebidamente la titularidad de terrenos sometidos a régimen cinegético especial.

35. Destruir vivares, zonas de cría o espacios de reunión habitual de las especies de la fauna silvestre, tanto cinegética como no cinegética.

36. Arrendar o ceder a título oneroso o gratuito las autorizaciones para el aprovechamiento cinegético de terrenos sometidos a régimen cinegético especial. La sanción llevará aparejada la anulación de la autorización.

37. Cazar fuera del período comprendido entre una hora antes de la salida del sol y una hora después de su ocaso salvo autorización expresa.

38. Cazar cuando por circunstancias meteorológicas o cualquier otra circunstancia esté reducida la visibilidad, de forma que puedan producirse peligros para las personas o sus bienes.

39. Cazar sirviéndose de animales o vehículos como medio de ocultación.

40. Entrar con armas u otras artes autorizadas en terreno cercado, o con prohibición permanente de cazar, no acogido a otro régimen cinegético especial, cuando existan en sus accesos señales o carteles que prohíban la caza en su interior.

41. Incumplir la obligación establecida para los talleres de taxidermia, en el artículo 35 bis, de llevar un libro registro donde conste la procedencia del animal y la obligación de abstenerse de recibir y preparar la pieza que no venga acompañada de la documentación y los precintos acreditativos de su origen ${ }^{670}$.

670 Art. 58.41 añadido por Ley 6/2006, de 23 de octubre, de modificación de la Ley 4/1997, de 25 de junio, de caza de Galicia. 
Artículo 59. De las infracciones muy graves.

Son infracciones muy graves:

1. Cazar en refugios de fauna o reservas de caza o en aquellas zonas de los espacios naturales protegidos donde el ejercicio de la caza estuviese expresamente prohibido sin estar en posesión de una especial autorización, aunque no se haya cobrado pieza alguna.

2. Soltar especies exóticas o animales infectados.

3. Usar explosivos, venenos u otras sustancias tóxicas con el fin de cazar o eliminar especies animales.

4. Falsear intencionadamente los datos para la obtención de autorizaciones y concesiones o para la inscripción en los registros correspondientes.

5. Cazar sirviéndose o aprovechándose del fuego o de sus efectos.

6. Envenenar terrenos cuando pueda ocasionar daños a las personas, animales domésticos o fauna silvestre.

7. Agredir o adoptar actitudes amenazantes con los agentes de la autoridad cuando se encuentren en el ejercicio de sus funciones.

8. Transportar en vehículos motorizados, embarcaciones o aeronaves armas desenfundadas y listas para su uso, aunque no estuviesen cargadas, en época de veda, en horas no hábiles o en zonas vedadas.

9. Instalar cierres electrificados con fines cinegéticos.

10. Destruir los nidales o áreas de cría de las especies cinegéticas.

11. Cazar bajo la influencia de estupefacientes, alcohol, sustancias psicotrópicas o cualquier otra droga que altere sensiblemente las facultades normales del cazador o su capacidad de reacción cuando así lo acrediten las pruebas previstas, o negarse a realizar las correspondientes pruebas para su detección requeridas por los agentes de la autoridad 671 .

671 Art. 59.11 modificado por Ley 6/2006, de 23 de octubre, de modificación de la Ley 4/1997, de 25 de junio, de caza de Galicia.
12. Cazar empleando faros, linternas, espejos y otras fuentes luminosas artificiales, desde aeronaves de cualquier tipo, vehículos motorizados o embarcaciones en movimiento.

Artículo 60. De la prescripción de las infracciones.

1. Las infracciones previstas en la presente ley prescribirán: A los seis meses las leves, al año las graves a los dos años las muy graves.

2. El plazo de prescripción comenzará a contarse desde el día en que la infracción se hubiese cometido.

En las infracciones derivadas de una actividad continuada, la fecha inicial del cómputo será la de finalización de la actividad o la del último acto en que la infracción se consume.

3. Se interrumpirá la prescripción a la iniciación, con conocimiento del interesado, del procedimiento sancionador.

\section{Capitulo II DE LAS SANCIONES}

Artículo 61. Sanciones aplicables.

1. Las infracciones tipificadas en la presente ley podrán ser sancionadas por las autoridades competentes con las sanciones siguientes:

a. Multa de 10.000 a 100.000 pesetas para las infracciones leves.

Multa de 100.001 a 1.000 .000 de pesetas para las infracciones graves y retirada de la licencia de caza e inhabilitación para obtenerla de un año y un día a cinco años. Multa de 1.000 .001 a 5.000 .000 de pesetas para las infracciones muy graves y retirada de la licencia de caza e inhabilitación para obtenerla de cinco años y un día a diez años.

b. Suspensión de la actividad cinegética o inhabilitación para ser titular de terrenos sometidos a régimen cinegético especial de uno a cinco años de acuerdo con la gravedad de la infracción.

2. En los supuestos de infracciones graves o muy graves, la sanción llevará 
aparejada, en su caso, la suspensión o anulación de la actividad cinegética.

Dicha suspensión o anulación podrá consistir en la declaración de vedado temporal, anulación del régimen especial de los terrenos o de la declaración de la granja cinegética, inhabilitación temporal para comercializar piezas de caza o clausura de instalaciones, tratándose de granjas cinegéticas, de hasta cinco años.

3. El importe de las multas a que hace referencia el número 1 de este artículo podrá ser actualizado por decreto de la Xunta de Galicia teniendo en cuenta las variaciones del índice de precios al consumo.

4. En las sanciones graves o muy graves que afecten a un Tecor en su conjunto, deberá solicitarse informe del Comité Gallego de Caza.

Artículo 62. Criterios para la graduación de las sanciones.

Para la graduación de las sanciones se tendrán en cuenta los siguientes criterios:

a. La intencionalidad.

b. La trascendencia social y el perjuicio causado a los recursos cinegéticos, a las especies incluidas en cualquiera de los catálogos de especies amenazadas o a los hábitats.

c. La situación de riesgo creada para las personas o los bienes.

d. El ánimo de lucro y el beneficio obtenido.

e. La naturaleza y volumen de los medios ilícitos empleados.

f. La reincidencia o reiteración en un período de un año. Si se apreciase esta circunstancia el importe de la multa podrá incrementarse en un 50 por 100.

g. En el caso de concurrencia de dos o más infracciones, se impondrá la sanción correspondiente a la de mayor gravedad.

Artículo 63. De la retirada de armas y otros medios de caza.

1. El agente denunciante procederá a la retirada de las armas y de su correspondiente guía sólo en aquellos casos en que fuesen utilizadas para cometer la presunta infracción, por disparo directo, muerte de animales no cazables o disposición de uso en lugar o tiempo no autorizados. En todo caso se dará recibo en que conste la clase, marca, número y puesto de la Guardia Civil donde quedará depositada.

2. El uso o tenencia durante el ejercicio de la caza de armas o medios no autorizados dará lugar a su retirada por el agente denunciante. Las armas serán depositadas en el puesto de la Guardia Civil más próximo a donde se produjesen los hechos denunciados.

3. La negativa a la entrega del arma o medios, cuando el presunto infractor sea requerido para ello, podrá dar lugar a denuncia ante el Juzgado competente a los efectos previstos en la legislación penal y se tendrá como circunstancia agravante en el procedimiento administrativo sancionador.

4. Las armas o medios retirados, si son de lícita tenencia y utilización conforme a esta ley, serán devueltos por algunos de los siguientes procedimientos:

a. De forma gratuita, cuando la resolución recaída en el expediente fuese absolutoria o se proceda al sobreseimiento del mismo.

b. Gratuitamente, por disposición expresa del instructor del expediente, en el supuesto de infracción leve, una vez tipificada por éste la infracción, previa solicitud de devolución por el interesado y siempre que el mismo no tenga pendiente de pago sanciones por infracciones de la presente ley.

c. Previo rescate en la cuantía establecida, cuando se hagan efectivas las sanciones e indemnizaciones impuestas en los supuestos de infracción grave o muy grave. No obstante, el instructor del expediente podrá acordar, una vez dictada la propuesta de sanción, la devolución del arma si el presunto infractor presenta aval bancario que garantice el importe total de la sanción e indemnización propuestas. 
d. En el supuesto de ocupación de perros utilizados como medio de captura o acoso de animales, aquéllos quedarán en depósito del denunciado, que deberá abonar una cantidad en concepto de rescate.

e. A las armas decomisadas se les dará el destino establecido en la legislación del Estado en la materia. Los demás medios materiales no rescatados serán enajenados o destruidos.

Artículo 64. Indemnizaciones y multas coercitivas.

1. Las sanciones serán compatibles con la exigencia al infractor de la reposición de la situación alterada por el mismo a su estado originario, así como con la indemnización por los daños y perjuicios causados.

2. Para lograr el cumplimiento de las resoluciones adoptadas, y de conformidad con lo dispuesto en el artículo 99 de la Ley de Régimen Jurídico de las Administraciones Públicas y del Procedimiento Administrativo Común, podrán imponerse multas reiteradas por lapsos de tiempo no inferiores a quince días, cuyo importe no excederá en cada caso de 500.000 pesetas.

Artículo 65. Decomisos.

1. Toda infracción administrativa grave o muy grave, en materia de caza, llevará consigo el decomiso de la caza, viva o muerta, que fuese ocupada al infractor, así como de cuantas artes, medios o animales, vivos o muertos, que de forma ilícita sirviesen para cometer el hecho. A los bienes ocupados se les dará el destino que se señale reglamentariamente.

2. Tratándose de perros u otros animales vivos cuya tenencia estuviese autorizada, éstos quedarán en depósito del denunciado, y el decomiso será sustituido por el abono de la cantidad que se determine reglamentariamente.

3. La caza viva decomisada será puesta en libertad siempre que fuese posible. La caza muerta útil para el consumo será entregada en un centro benéfico. En caso de la existencia de trofeos, éstos serán puestos a disposición de la autoridad cinegética competente. En cualquier caso, el agente denunciante expedirá recibo de lo decomisado al denunciado, en el que constará su destino y puesta a disposición de la autoridad correspondiente.

\section{Capitulo III DEL PROCEDIMIENTO Y COMPETENCIA}

Artículo 66. Del expediente sancionador y su caducidad.

1. Para imponer las sanciones previstas en la presente ley, será precisa la incoación e instrucción del correspondiente expediente sancionador de acuerdo con lo previsto en la normativa vigente.

2. Iniciado el expediente, el órgano que ordenase su incoación podrá acordar la adopción de medidas cautelares para evitar la continuidad de la infracción o el agravamiento de los daños. Dichas medidas habrán de ser proporcionales a la naturaleza y gravedad de la infracción.

3. El acuerdo de incoación del expediente sancionador, que se debe remitir a la persona o personas presuntamente responsables, tendrá que contener como mínimo:

a. Los hechos constatados, destacando los relevantes a efectos de la tipificación de la infracción y graduación de la sanción.

b. La infracción presuntamente cometida, con expresión del precepto vulnerado.

c. La propuesta de sanción, su graduación y cuantificación.

d. La indemnización que proceda por los daños y perjuicios, en su caso.

e. Las sanciones accesorias que procedan.

f. El destino de las armas, medios o piezas ocupadas o decomisadas.

Artículo 67. De la presunción de existencia de delito o falta.

1. Cuando de las características de la infracción que motivó el expediente pudiese presumirse la existencia de un delito o falta sancionable penalmente, se dará traslado de la denuncia y actuaciones practicadas a la autoridad judicial, suspendiéndose la 
actuación administrativa en tanto la autoridad judicial no se pronuncie.

2. Si no se estimase la existencia de delito o falta, se continuará el expediente administrativo hasta su resolución definitiva, en base, en su caso, a los hechos que la jurisdicción penal haya considerado probados.

3. La tramitación de las diligencias penales interrumpirá la prescripción de las infracciones.

Artículo 68. De la competencia para la imposición de sanciones.

La competencia para la imposición de las sanciones a que se refiere la presente ley corresponderá:

a. A los Delegados provinciales de la Consellería de Agricultura, Gandería e Montes, en las infracciones calificadas como leves.

b. Al Director general de Montes y Medio Ambiente Natural, en las infracciones calificadas como graves.

c. Al Conselleiro de Agricultura, Gandería e Montes, en las infracciones calificadas como muy graves.

Artículo 69. Ejecutividad de las resoluciones.

1. Contra las resoluciones sancionadoras podrán interponerse los recursos previstos en la legislación vigente.

2. La resolución sancionadora será ejecutiva cuando sea firme en vía administrativa.

Artículo 70. De las denuncias de los agentes de la autoridad.

En los procedimientos sancionadores que se instruyan con ocasión de infracciones tipificadas en la presente ley, las denuncias formuladas por los agentes de la autoridad que presenciasen los hechos, acompañadas de los elementos probatorios disponibles, y previa ratificación en caso de ser negados por el infractor, constituirán base suficiente, salvo prueba en contrario, para adoptar la resolución que proceda.

Artículo 71. De la prescripción de las sanciones.

1. Las sanciones previstas en la presente ley prescribirán: Al año las impuestas por infracciones leves, a los dos años las impuestas por infracciones graves y a los tres años las que se impongan por infracciones muy graves.

2. El plazo de prescripción comenzará a contarse desde el día siguiente a aquel en que adquiera firmeza la resolución por la que se imponga la sanción.

3. Interrumpirá la prescripción la iniciación, con conocimiento del interesado, del procedimiento de ejecución.

\section{TíTULO X DEL REGISTRO DE INFRACTORES DE CAZA}

Artículo 72. Creación del Registro de Infractores de Caza.

1. Se crea en la Comunidad Autónoma de Galicia el Registro de Infractores de Caza, en el que se inscribirán de oficio todos aquellos infractores que fuesen sancionados por resolución firme, en expediente incoado como consecuencia del ejercicio de la actividad cinegética.

2. Las inscripciones y variaciones que se produzcan en los asientos del Registro serán remitidas al Registro Nacional de Infractores de Caza y Pesca.

\section{DISPOSICIÓN ADICIONAL PRIMERA}

La Consellería de Agricultura, Gandería e Montes, oído el Comité Gallego de Caza, establecerá periódicamente los baremos de valoración de las piezas de caza a efectos indemnizatorios.

\section{DISPOSICIÓN ADICIONAL SEGUNDA}

Las autorizaciones a que se refieren los artículos 33, 34, 35 y 41 de la presente ley se entenderán denegadas si transcurrido el plazo de un mes desde la presentación de la solicitud correspondiente no recayó resolución expresa.

Para las restantes peticiones se estará a lo dispuesto en la Ley de Régimen Jurídico de las Administraciones Públicas y del Procedimiento Administrativo Común. 


\section{DISPOSICIÓN ADICIONAL TERCERA}

A los efectos de lo dispuesto en la presente ley, tendrán la consideración de reserva de caza los terrenos de la Comunidad Autónoma de Galicia integrados en la reserva nacional de caza de Os Ancares, sin perjuicio de su legislación específica. La reserva nacional de caza de Os Ancares, en cuanto a los terrenos comprendidos dentro de la Comunidad Autónoma de Galicia, quedará sujeta a las disposiciones de la presente ley.

\section{DISPOSICIÓN ADICIONAL CUARTA}

Los Tecor situados en espacios naturales protegidos se regirán por la normativa específica que regule dichos espacios.

\section{DISPOSICIÓN TRANSITORIA PRIMERA}

Los cazadores que acrediten haber estado en posesión de la licencia de caza, expedida en cualquier Comunidad Autónoma española, en alguno de los últimos cinco años, a contar desde la fecha de entrada en vigor de la presente ley, podrán obtener la licencia de caza en la Comunidad Autónoma de Galicia sin necesidad de realizar las pruebas de aptitud previstas en el artículo 46.4 .

\section{DISPOSICIÓN TRANSITORIA SEGUNDA}

1. Los cotos de caza de titularidad de sociedades o asociaciones de cazadores que estén legalmente constituidas a la entrada en vigor de la presente ley, cuya superficie sea superior a 2.000 hectáreas, dispondrán de un plazo de cuatro años para solicitar su transformación en Tecor. A dicho fin, dentro del referido plazo, deberán presentar la solicitud de transformación, acompañada de una memoria explicativa de la situación actual del coto de caza, copia autenticada de los Estatutos en vigor de la entidad titular, relación de los socios, composición de la Junta Directiva, un plano a escala 1:25.000 de los terrenos que comprende y un plan de ordenación cinegética, que deberá ser aprobado por la Consellería de Agricultura, Gandería e Montes.

2. Las mismas condiciones para su transformación serán de aplicación a aquellos cotos que, a pesar de su carácter societario, figuren a nombre de una persona física o jurídica, en cuyo caso habrá de justificarse suficientemente en la memoria la razón de tal anomalía y precisar expresamente cuál es la entidad a la que realmente corresponde la titularidad. $\mathrm{Si}$ no se hiciese así, el coto se considerará como coto privado y su titular deberá acreditar formalmente, en la forma prevista en el artículo 18 de la presente ley, la titularidad cinegética de todas y cada una de las fincas que lo integran, para su transformación en Tecor particular.

3. Los cotos existentes en la actualidad que pertenezcan a sociedades o asociaciones de cazadores, pero cuya superficie no alcance las 2.000 hectáreas, podrán fusionarse con otro u otros colindantes, para constituir un Tecor, incorporarse a otro ya existente, siempre que exista colindancia, u obtener la superficie necesaria por ampliación del primitivo coto sobre terrenos de régimen cinegético común.

En los dos primeros casos bastará con el acuerdo legalmente adoptado por las entidades que pretendan fusionarse o integrarse, que deberán acompañar a la solicitud de transformación los documentos de constitución de la sociedad resultante de la fusión o integración y los demás señalados en el párrafo 1 precedente.

Si el aumento de superficie se consigue por ampliación sobre terrenos que actualmente son de aprovechamiento común, la titularidad de los mismos deberá acreditarse en la forma prevista en el artículo 17 de la presente ley.

4. En los casos en que los procedimientos descritos en el punto 3 no sean posibles, podrán constituirse Tecor 
societarios con titularidad compartida por un máximo de tres sociedades o asociaciones de cazadores.

Cada sociedad podrá aprovechar de modo exclusivo la superficie correspondiente a su coto de caza original, de acuerdo con el plan de ordenación cinegética único, que regulará los aprovechamientos cinegéticos del Tecor.

La superficie mínima de los Tecor societarios de titularidad compartida será de 2.000 hectáreas continuas.

En caso de no haber linde que posibilite la titularidad compartida, podrán constituirse Tecor a partir de cotos de caza que no alcancen la superficie mínima prevista en la presente ley mediante la adhesión al plan de ordenación cinegética de otro Tecor.

La Consellería de Agricultura, Gandería e Montes comunicará a dichos cotos de caza a qué plan de ordenación de Tecor colindante habrán de adherirse.

A estos efectos, los titulares de un Tecor estarán obligados a facilitar a los titulares de dichos cotos de caza las normas y directrices básicas de su plan de ordenación cinegética a fin de redactar los correspondientes planes de aprovechamiento.

5. La no presentación de la solicitud de transformación en el referido plazo de cuatro años a partir de la fecha de entrada en vigor de la presente ley producirá automáticamente la caducidad del coto de caza y los terrenos pasarán a la condición de terrenos de régimen cinegético común.

Si la documentación para su transformación se presentase en los seis últimos meses de plazo, mientras el plan de ordenación cinegética no fuese aprobado, los terrenos tendrán la consideración de Tecor provisional, no permitiéndose el ejercicio de la caza en los mismos.

\section{DISPOSICIÓN TRANSITORIA TERCERA}

1. Los propietarios o titulares cinegéticos que individualmente o mediante asociación voluntaria hubiesen solicitado cotos privados de caza que se encuentren legalmente constituidos a la entrada en vigor de la presente ley, cuya superficie sea siempre igual o superior a 2.000 hectáreas, podrán solicitar su transformación en Tecor particular, y dentro del plazo de cuatro años acreditarán que siguen conservando la titularidad de conformidad con lo establecido en el artículo 18 de esta ley.

2. Cuando los cotos existentes no alcancen la superficie mínima exigida, podrán seguir con igual régimen durante el referido plazo de cuatro años. Transcurrido ese plazo, pasarán a la condición de terrenos de régimen cinegético común, salvo que con anterioridad se integren con otros terrenos colindantes para constituir un Tecor compartido, se incorporen a otro Tecor ya constituido o soliciten y obtengan la transformación de dichos terrenos en una explotación cinegética de acuerdo con las disposiciones que reglamenten esta figura.

\section{DISPOSICIÓN TRANSITORIA CUARTA}

1. Los terrenos sometidos a régimen de caza controlada, siempre que estén adjudicados a una sociedad de cazadores colaboradora, mantendrán este régimen hasta el vencimiento del plazo de adjudicación. Si no estuviesen adjudicados a alguna sociedad, se extinguirán automáticamente a la entrada en vigor de la presente ley.

2. Vencido el plazo de adjudicación o extinguido el régimen por la causa referida en el punto anterior, los terrenos afectados pasarán a la condición de terrenos de régimen cinegético común, salvo que con anterioridad se inicie la declaración de otra figura de las recogidas en la presente ley.

\section{DISPOSICIÓN TRANSITORIA QUUINTA}

Los cotos locales de caza que estén legalmente constituidos en la actualidad dispondrán de un plazo de cuatro años para solicitar su transformación en cualquiera de las figuras cinegéticas previstas en la presente ley y de acuerdo con las establecidas para cada caso. 


\section{DISPOSICIÓN TRANSITORIA SEXTA}

Las explotaciones cinegéticas y granjas cinegéticas actualmente existentes dispondrán del plazo de un año, desde la fecha de entrada en vigor de la presente ley, para adaptarse a lo exigido en la misma, pero en su actividad comercial habrán de observar lo previsto en esta ley desde el momento de su entrada en vigor.

\section{DISPOSICIÓN TRANSITORIA SÉPTIMA}

Los expedientes sancionadores en trámite en el momento de la entrada en vigor de la presente ley se regirán por la legislación de aplicación en el momento en que se cometió la infracción, salvo que sea más favorable al infractor la aplicación de ésta.

\section{DISPOSICIÓN DEROGATORIA}

Quedan derogadas cuantas disposiciones de igual o inferior rango se opongan o contradigan lo dispuesto en la presente ley.

\section{DISPOSICIÓN FINAL}

La presente ley entrará en vigor a los tres meses a contar a partir del día siguiente al de su publicación en el "Diario Oficial de Galicia".

\section{LEY $11 / 2008$, DE 3 DE DICIEMBRE, DE PESCA DE GALICIA (DOGA 243. 16.12.2008)}

$(\ldots)^{672}$

\section{TÍTULO I \\ DE LAS DISPOSICIONES GENERALES}

\section{Artículo 1. Objeto.}

La presente ley tiene por objeto la regulación, en el ámbito de las competencias de la Comunidad Autónoma de Galicia, de las siguientes materias:

1. La adopción de medidas de conservación, protección y regeneración de los recursos marinos vivos.

672 Preámbulo omitido.
2. El ejercicio de la pesca, el marisqueo y la acuicultura marina.

3. La ordenación del sector pesquero gallego.

4. La ordenación, adecuación y mejora de la flota pesquera gallega.

5. La comercialización, manipulación, transformación y conservación de los productos pesqueros.

6. La formación, investigación y desarrollo tecnológico en materia marítimopesquera.

7. La inspección y control de las materias contempladas en este artículo.

8. El régimen sancionador de las materias contempladas en este artículo.

Artículo 2. Finalidad.

La política pesquera gallega tiene por finalidad la viabilidad duradera del sector pesquero, marisquero y acuícola gallego, garantizando la mejora de las condiciones de vida y trabajo de las personas que se dedican a estas actividades mediante la explotación sostenible, equilibrada y responsable de los recursos basada en un asesoramiento científico sólido y teniendo en cuenta los aspectos medioambientales, económicos y sociales.

En particular, la regulación de las materias contempladas en la presente ley persigue como fines:

1. Proteger, conservar y regenerar los recursos marinos y sus ecosistemas.

2. Garantizar una explotación responsable, equilibrada y sostenible de los recursos marinos, asegurando que la actividad extractiva sea proporcional a la capacidad de producción de las especies marinas.

3. Impulsar el desarrollo y la ordenación responsable de la acuicultura marina.

4. Potenciar el empleo, los ingresos y el nivel de vida de las personas profesionales del sector, así como la seguridad de las mismas en el desarrollo de su actividad, teniendo en cuenta la integración de la perspectiva de género en la aplicación del principio de igualdad. Asimismo, se fomentará el acceso y 
la promoción de la presencia e incorporación de las mujeres en los sectores de actividad y profesiones en que estén infrarrepresentadas, especialmente en los de las actividades extractivas a bordo.

5. Fomentar la vertebración del sector pesquero gallego, así como su participación en los procedimientos para la toma de decisiones sobre las políticas pesqueras.

6 . Fomentar la renovación, modernización y mejora de las estructuras pesqueras, marisqueras y acuícolas en el marco de los recursos existentes.

7. Desarrollar y mejorar los procesos de comercialización y transformación de los productos pesqueros, así como fomentar el ejercicio de un comercio responsable que garantice la calidad, trazabilidad e identificación de los productos.

8. Potenciar la investigación, el desarrollo tecnológico y la innovación en la pesca, el marisqueo y la acuicultura, así como fomentar la cooperación entre los científicos y el sector.

9. Fomentar la formación y capacitación profesional del sector pesquero, marisquero y acuícola.

10.Promover la pesca marítima de recreo como actividad de ocio en armonía con la pesca marítima profesional, así como las actividades turísticas, deportivas o de conocimiento relacionadas con el medio marino, en la procura de la diversificación económica del sector.

Artículo 3. Ámbito de aplicación.

Las disposiciones de la presente ley, en función de las materias objeto de su regulación, tendrán el siguiente ámbito de aplicación territorial:

1. Las relativas al ejercicio de la actividad pesquera, tanto profesional como de recreo, así como las relacionadas con la conservación, protección, gestión, regeneración y explotación de los recursos marinos vivos, serán de aplicación en las aguas marítimas competencia de Galicia.

2. Las relativas al ejercicio del marisqueo serán de aplicación en la zona marítimo-terrestre, las aguas marítimas interiores, el mar territorial y la zona económica exclusiva correspondiente al litoral de Galicia.

3. Las relativas al ejercicio de la acuicultura marina serán de aplicación a todas las actividades acuícolas que se desarrollen en tierra, la zona marítimo-terrestre, las aguas marítimas interiores, el mar territorial y la zona económica exclusiva correspondiente al litoral de Galicia.

4. Las relativas a la ordenación del sector pesquero gallego, a la ordenación de las estructuras, a mercados, comercialización, manipulación, transformación y conservación de los productos pesqueros, así como las relativas a la formación, investigación y desarrollo tecnológico serán de aplicación en todo el territorio de Galicia.

5. Las relativas a los regímenes de control, inspección, infracciones y sanciones se aplicarán en el ámbito territorial que corresponda según el objeto material de que se trate, de los señalados en los números del 1 al 4 anteriores.

Artículo 4. Definiciones.

A efectos de la presente ley, se establecen las definiciones siguientes:

1. Acondicionamiento marino: preparación de zonas delimitadas en el litoral para favorecer la protección, reproducción y desarrollo de los recursos marinos, utilizando obras o instalaciones que favorezcan dicha finalidad.

2. Arrecifes artificiales: artefactos que se instalan en el medio marino a fin de favorecer la regeneración, atracción, concentración, desarrollo o protección de los recursos marinos, y aquellos que doten al medio marino de ejemplares de peces y crustáceos, por regeneración natural del medio, facilitando e incrementando la productividad.

3. Banco natural: lugar o zona geográfica en donde de forma natural se concentran una o varias especies susceptibles de explotación con individuos en las diversas fases de desarrollo. 
4. Capacidad de pesca: facultad de un buque o grupo de buques para capturar especies de interés pesquero. Puede cuantificarse a partir de dos tipos de indicadores principales: las características del buque y las características de las artes de pesca.

5. Cultivo marino extensivo: actividad de acuicultura ejercida en la zona marítima o marítimo-terrestre que, por medios técnicos, permite la cría de especies marinas sin aporte de alimento y con una mínima intervención humana.

6. Cultivo marino semiextensivo: actividad de acuicultura ejercida en la zona marítima o marítimo-terrestre que, por medios técnicos, permite la cría de especies marinas sin aporte de alimento y con intervención humana en diversas fases del proceso de cría o engorde.

7. Esfuerzo pesquero: el producto de la capacidad pesquera y del tiempo de actividad de pesca en una zona determinada. El esfuerzo pesquero se expresa en GT por día o en $\mathrm{kW}$ por día.

8. Establecimientos auxiliares: son aquellos establecimientos que tienen como función principal la depuración, expedición, almacenamiento, mantenimiento, clasificación y regulación comercial de los productos pesqueros, con la finalidad de posibilitar la llegada de los mismos a las consumidoras y consumidores en las condiciones higiénico-sanitarias que la ley demanda.

9. Establecimientos de cultivos marinos: son los establecimientos que se dedican a la realización de actividades de acuicultura marina en cualquiera o todas sus fases de explotación, cría, cultivo o reproducción.

10. Lonja: instalaciones ubicadas en los puertos gallegos en las que habrán de realizarse las actividades de exposición y primera venta de los productos pesqueros frescos, así como las actividades de control del proceso de comercialización en origen.

11. Planes experimentales: medidas reguladoras de la actividad pesquera aplicadas en un periodo de tiempo determinado y cuyo objeto son nuevas especies, nuevas artes, modificación de las existentes o nuevas medidas de gestión.

12. Planes de recuperación: medidas reguladoras de la actividad pesquera aplicadas en un periodo de tiempo determinado para especies fuera de límites biológicos de seguridad. En los planes de recuperación se fijarán plazos y objetivos para garantizar la recuperación de las poblaciones.

13. Planes de gestión anuales o plurianuales: medidas reguladoras de la actividad pesquera aplicadas en un periodo de tiempo determinado y dirigidas a especies que se encuentren dentro de los límites biológicos de seguridad. Estos planes podrán incluir limitaciones de capturas, capacidad y esfuerzo pesquero, así como medidas técnicas y de otra clase adaptadas a las circunstancias.

14. Primera venta: se entiende por primera venta aquella transacción comercial que se realiza por primera vez dentro del territorio de la Unión Europea y en la que se acredite documentalmente el precio del producto, conforme a la normativa sobre comercialización e identificación.

15. Productos pesqueros: productos que tengan su origen en la pesca extractiva, el marisqueo o la acuicultura.

16. Productores de base: se entiende por productores de base a aquellas personas que tengan otorgada habilitación administrativa para la extracción de los recursos pesqueros mediante la pesca y/o el marisqueo o para ejercer la acuicultura.

17. Recursos específicos: se consideran recursos específicos aquellas especies marisqueras que por sus características biológicas, su técnica de extracción o las especificidades de su comercialización requieren un sistema de gestión que atienda a estas particularidades.

18. Repoblaciones marinas: suelta deliberada al medio natural de organismos marinos producidos en criadero y semillero, con distintos fines, entre los 
cuales se incluyen la recuperación de stocks sobreexplotados o extinguidos, el incremento de la producción pesquera de distintas especies y la siembra de ejemplares en áreas marinas para su cultivo.

19. Reservas marinas: son aquellas zonas de especial interés para la preservación y regeneración de los recursos marinos por su condición de áreas de reproducción, desove, cría o engorde de especies de interés pesquero o marisquero.

20. Sector: parte de la economía que incluye todas las actividades de extracción, cultivo, producción, manipulación, transformación y comercialización de los productos de la pesca, el marisqueo y la acuicultura.

21. Semicultivo marino: la actividad ejercida sobre un banco natural o una parte del mismo que, por medios técnicos o científicos, logra aumentar su producción con relación a la que se obtendría en el banco en condiciones naturales.

22. Títulos administrativos habilitantes: son aquellos documentos que se otorgan a las personas físicas o jurídicas y que las habilitan para la ocupación, instalación, puesta en funcionamiento y explotación de los establecimientos de cultivos marinos o para el ejercicio de la actividad pesquera, marisquera y acuícola.

Artículo 5. Preferencia de las organizaciones de productores de base.

Las autorizaciones y concesiones se otorgarán con carácter preferente a los productores de base o a las organizaciones de productores de base, en cualesquiera de sus formas asociativas.

\section{TíTULO II DE LA CONSERVACIÓN Y GESTIÓN DE LOS RECURSOS PESQUEROS Y MARISQUEROS \\ Capítulo I CONSERVACIÓN Y GESTIÓN}

Artículo 6. Objetivos.

La política de la Administración de la Comunidad Autónoma de Galicia tendrá como objetivos con relación a la conservación y gestión de los recursos pesqueros y marisqueros, entre otros, los de:

1. El establecimiento y regulación de medidas dirigidas a la conservación, gestión y explotación responsable, racional y sostenible de los recursos marinos vivos.

2. La adopción de medidas tendentes a promover el ejercicio de una actividad pesquera y marisquera respetuosa con el medio ambiente, así como la protección de los recursos pesqueros y marisqueros de otras actividades que tengan incidencia sobre los mismos.

3. La adopción de medidas destinadas a una mejor utilización de especies poco aprovechadas, subproductos y residuos.

4. El fomento de la participación del sector de la pesca y marisqueo en la adopción de medidas de conservación.

5. El fomento de mejoras en el acceso y explotación de los recursos marinos vivos.

Artículo 7. Medidas de conservación y gestión.

1. A fin de asegurar los objetivos de política pesquera de Galicia señalados en el artículo 2, la Xunta de Galicia, a propuesta de la consejería competente en materia de pesca, podrá adoptar, entre otras, las siguientes medidas de conservación y gestión de la pesca y el marisqueo:

a. La regulación de artes, aparejos y útiles permitidos, así como sus características técnicas, y del modo de empleo de los mismos para el ejercicio de la pesca y el marisqueo. La pesca y el marisqueo sólo podrán ejercerse con artes, aparejos y útiles expresamente autorizados.

b. La regulación de los derechos y deberes que puedan afectar a la gestión de los recursos marinos vivos.

2. Asimismo, y con la misma finalidad, corresponde a la consejería competente en materia de pesca la adopción de las medidas siguientes:

a. Planes de gestión anuales o plurianuales para las especies que se encuentren 
dentro de los límites biológicos de seguridad. Estos planes podrán incluir limitaciones de capturas, capacidad y esfuerzo pesquero, medidas técnicas y de otra clase adaptadas a las circunstancias.

b. Planes de recuperación de carácter plurianual, para las especies fuera de los límites biológicos de seguridad. En los planes de recuperación se fijarán plazos y objetivos para garantizar la recuperación de las poblaciones.

c. Medidas excepcionales para supuestos de amenazas graves para los recursos o el ecosistema, al objeto de que surtan efecto inmediatamente.

d. Regulación directa del esfuerzo de pesca y marisqueo limitando la capacidad de pesca o el tiempo de actividad, incluyendo el cierre de la pesca o el marisqueo.

e. Planes experimentales para nuevas especies, nuevas artes, modificación de las existentes o nuevas medidas de gestión.

f. Regulación indirecta del esfuerzo de pesca y marisqueo limitando el volumen de capturas.

g. Fijación de tallas, pesos mínimos u otras medidas de conservación de las especies. Las especies de talla o peso inferior al reglamentado no podrán retenerse a bordo o en tierra, transbordarse, desembarcarse, ni depositarse, debiendo devolverse al mar inmediatamente después de la captura, salvo norma específica en contra.

h. Establecimiento de vedas temporales o zonales para determinadas especies así como de los fondos autorizados.

i. Establecimiento de los parámetros de evaluación de los proyectos presentados por las diferentes organizaciones, que determinen la concesión de ayudas, formalizadas a través de convenios o contratos administrativos.

Artículo 8. Clasificación de las zonas de producción.

La consejería competente en materia de pesca clasificará las zonas de producción de moluscos bivalvos y otros organismos procedentes de la pesca, el marisqueo y la acuicultura en función de la calidad de las aguas.

Determinará las medidas necesarias para la comercialización de los productos extraídos según la clasificación de la zona de producción, y en concreto:

a. El control de las condiciones oceanográficas, la biogeoquímica marina y las poblaciones fitoplanctónicas, de las biotoxinas marinas, la contaminación química y la contaminación microbiológica, tanto en lo referente a los organismos como a las zonas de producción.

b. Las actuaciones relacionadas con el conocimiento y control de las patologías de los organismos marinos sometidos a explotación comercial mediante la pesca, el marisqueo y la acuicultura.

c. Decretar la apertura y cierre del ejercicio de la actividad pesquera, de marisqueo y acuicultura en función del resultado de los controles que se realicen sobre la calidad de las aguas y los productos, en aplicación de la normativa vigente.

\section{Capitulo II PROTECCIÓN Y REGENERACIÓN}

Artículo 9. Medidas de protección y regeneración.

La Xunta de Galicia, a propuesta de la consejería competente en materia de pesca, establecerá áreas marinas pesqueras protegidas con la finalidad de preservar el medio en el que se desarrollan los recursos marinos. Las áreas pueden ser calificadas como:

a. De acondicionamiento marino.

b. De repoblación marina.

c. Reservas marinas.

Artículo 10. Áreas de acondicionamiento marino.

Se entiende por áreas de acondicionamiento marino las zonas delimitadas en el litoral para favorecer la protección, reproducción y desarrollo de los recursos marinos. En estas zonas podrán realizarse obras e instalaciones que favorezcan esta finalidad, entre las cuales pueden figurar los arrecifes artificiales. 
La declaración de área de acondicionamiento marino se hará en conformidad con la legislación vigente en materia de ocupación del dominio público marítimo-terrestre, estableciéndose en la misma las medidas de protección de la zona respecto al ejercicio o prohibición, en su caso, de la actividad pesquera, así como de cualquier otra actividad que pueda perjudicar su finalidad.

Artículo 11. Áreas de repoblación marina.

A fin de favorecer la regeneración de especies podrán declararse áreas de repoblación marina para realizar liberaciones controladas de especies en cualquier fase de su ciclo vital. La declaración de área de repoblación marina requerirá previamente la realización de aquellos estudios e informes de carácter científico que garanticen su idoneidad.

En estas áreas se establecerán normas especiales para el ejercicio de la actividad pesquera, así como de todas aquellas actividades que puedan afectar a la efectividad de esta medida regeneradora.

Artículo 12. Reservas marinas.

1. Se consideran reservas marinas aquellas zonas de especial interés para la preservación y regeneración de los recursos marinos y los ecosistemas marinos que los sustentan, por su condición de áreas de reproducción, desove, cría o engorde de especies de interés pesquero o marisquero.

2. En la norma de declaración se determinará el régimen de funcionamiento de las reservas así como las actividades permitidas y las limitaciones o prohibiciones de usos en la reserva.

Artículo 13. Otras medidas de protección.

1. A efectos de proteger y conservar los recursos pesqueros, marisqueros y de acuicultura, así como para el mantenimiento de la calidad de las aguas, se requerirá informe preceptivo de la consejería competente en materia de pesca en los casos siguientes: a. Obra o instalaciones, desmontables o no, que se pretendan emplazar en zona marítima o marítimo-terrestre.

b. Extracción de áridos y otros materiales en zona marítima o marítimo-terrestre.

c. Regeneración de playas.

d. Vertidos al mar.

e. Cualesquier otras actividades que, sin obras o instalaciones, puedan afectar a los recursos o actividades pesqueras, marisqueras y de acuicultura o a la calidad de las aguas.

2. Reglamentariamente se adoptarán las medidas necesarias de prevención y control sanitario y medioambiental, para la protección de los recursos marinos.

\section{TÍTULO III DE LA PESCA MARÍTIMA}

\section{Capitulo I \\ PESCA MARÍTIMA PROFESIONAL}

Artículo 14. Definición.

Se entiende por pesca marítima profesional el ejercicio de la actividad extractiva, dirigida a la explotación comercial de especies piscícolas, utilizando artes, aparejos, útiles o equipos propios de la pesca. Se incluye en esta definición la captura de especies de crustáceos, moluscos y otros invertebrados marinos con artes no específicas para estas especies.

Artículo 15. Objetivos.

La política de la Administración de la Comunidad Autónoma de Galicia tendrá, en materia de pesca marítima, entre otros, los objetivos siguientes:

1. La regulación de las condiciones de acceso a los recursos marinos vivos en condiciones de igualdad.

2. La regulación de las condiciones del ejercicio de la pesca marítima profesional y el marisqueo.

3. La mejora de las condiciones de trabajo en la explotación de los recursos marinos vivos. 
Artículo 16. Buques de pesca autorizados.

Para el ejercicio de la pesca profesional y del marisqueo a flote sólo podrán emplearse embarcaciones incluidas en el Censo de flota pesquera operativa y en el Registro de buques pesqueros de Galicia.

Artículo 17. Censos por modalidades. La consejería competente en materia de pesca podrá establecer censos por modalidades, pesquerías y caladeros, así como dictar las normas para la inclusión de los buques en uno o más censos conforme al procedimiento y criterios que se establezcan, entre los que habrá de tenerse en cuenta la habitualidad en la pesquería así como la idoneidad de los buques y demás condiciones técnicas de los mismos.

Artículo 18. Licencia de pesca profesional.

1. El ejercicio de la pesca marítima profesional requerirá estar en posesión de una licencia, sin perjuicio de lo dispuesto en la normativa vigente para el ejercicio de la pesca en aguas exteriores.

2. La licencia, de carácter intransferible, es un documento inherente al buque y contendrá, como mínimo, los datos siguientes:

a. La identificación y características técnicas del buque.

b. La identificación de su titular.

c. La modalidad de pesca: artes, aparejos y útiles autorizados.

d. El caladero o zona de pesca autorizada.

e. Cualquier otra información relativa a la actividad.

f. En caso de primera licencia se incluirán además las bajas aportadas y el puerto base.

3. Las licencias se otorgarán por la consejería competente en materia de pesca por tiempo ilimitado.

4. La modificación o modernización de los elementos propios del buque o la variación de los datos que constan en la licencia conllevará la solicitud de una nueva licencia, en las condiciones y plazos que se determinen reglamentariamente, sin perjuicio de la emisión de los informes y autorizaciones que se establezcan.

5. En el supuesto de transmisión de la titularidad del buque, la nueva persona propietaria habrá de comunicarlo a la consejería competente en materia de pesca a efectos de la subrogación en el uso de la licencia, siempre y cuando la embarcación mantenga como base un puerto de la comunidad autónoma de Galicia.

Artículo 19. Permiso de pesca especial.

1. Cuando las características especiales de una pesquería aconsejen limitaciones del esfuerzo pesquero o medidas especiales de conservación de los recursos pesqueros, la consejería competente en materia de pesca podrá establecer que el ejercicio de la actividad extractiva esté condicionado a la previa concesión de un permiso de pesca especial.

2. Dicho permiso, complementario de la licencia de pesca, tendrá carácter temporal y permitirá faenar al buque en una zona determinada y para una actividad de pesca concreta.

3. La consejería competente en materia de pesca otorgará los permisos de pesca especiales, que habrán de contener, como mínimo, la información siguiente:

La identificación del buque.

Las zonas, especies y artes de pesca autorizadas.

Las condiciones para el ejercicio de la actividad.

El periodo de validez.

Artículo 20. Acceso de buques de otras comunidades autónomas.

La consejería competente en materia de pesca podrá conceder permisos de pesca especiales a buques de otras comunidades autónomas, que los habiliten para el ejercicio de la pesca en aguas de la Comunidad Autónoma de Galicia, en función del estado de los recursos y de los acuerdos de reciprocidad que con este motivo se establezcan entre las comunidades autónomas. 
Artículo 21. Cambio temporal de modalidad.

La consejería competente en materia de pesca podrá autorizar temporalmente a los buques cambio de modalidad distinta de la establecida en la licencia en función del estado de los recursos.

\section{Capitulo II PESCA MARITIMA DE RECREO}

Artículo 22. Definición.

Se entiende por pesca marítima de recreo la que se realiza por entretenimiento, deporte o afición, sin ánimo de lucro.

Sus capturas no podrán ser objeto de venta ni transacción.

Artículo 23. Modalidades.

Se establecen las siguientes modalidades de pesca recreativa:

a. Pesca desde embarcación de la séptima lista del Registro de matrícula de buques.

b. Pesca desde tierra en superficie.

c. Pesca submarina.

d. Pesca desde embarcación de la sexta lista del Registro de matrícula de buques, incluidas las distintas modalidades de pesca de alquiler.

Artículo 24. Licencias y autorizaciones de pesca de recreo.

1. El ejercicio de la pesca marítima de recreo, en cualquiera de sus modalidades, requerirá estar en posesión de las correspondientes licencias, en los términos que reglamentariamente se determinen.

2. Las licencias se expedirán por la consejería competente en materia de pesca, directamente o por aquellas instituciones $\mathrm{u}$ organizaciones con las que se firmen los correspondientes acuerdos o convenios de colaboración o cooperación.

3. Los concursos, campeonatos y competiciones de pesca marítima de recreo necesitarán autorización de la consejería competente en materia de pesca, que regulará en cada caso sus condiciones.

Artículo 25. Validez de licencias de otras comunidades autónomas y otros estados miembros de la Unión Europea.
Los permisos o licencias que habilitan para la pesca marítima de recreo expedidos por la Administración del Estado, otros estados miembros de la Unión Europea u otras comunidades autónomas tendrán plena vigencia en aguas de Galicia, sin perjuicio de que las personas titulares de los mismos tengan la obligación de cumplir las disposiciones autonómicas que regulan la pesca de recreo.

Artículo 26. Condiciones de ejercicio.

1. Serán de aplicación a la pesca marítima de recreo las medidas de protección y conservación de los recursos pesqueros establecidos para la pesca marítima profesional.

2. No obstante lo anterior, la Xunta de Galicia, a propuesta de la consejería competente en materia de pesca, podrá establecer medidas específicas para la pesca recreativa en razón a la protección y conservación de los recursos pesqueros, a fin de que la misma no interfiera o perjudique a la actividad pesquera profesional.

\section{TÍTULO IV DEL MARISQUEO}

\section{Capítulo I \\ DISPOSICIONES GENERALES}

Artículo 27. Definición.

Se entiende por marisqueo el ejercicio de la actividad extractiva, desarrollada a pie o desde embarcación, en la zona marítima o marítimo-terrestre dirigida de modo exclusivo y con artes selectivas y específicas a la captura de una o varias especies de moluscos, crustáceos, tunicados, equinodermos y otros invertebrados marinos, con fines de comercialización.

Artículo 28. Objetivos.

La política de la Administración de la Comunidad Autónoma de Galicia en materia de marisqueo tendrá, entre otros, los objetivos siguientes:

1. La regulación de las condiciones de acceso a la actividad marisquera y a los 
recursos marinos vivos en condiciones de igualdad.

2. La regulación de las condiciones del ejercicio del marisqueo.

3. La mejora de las condiciones de trabajo en la explotación de los recursos marinos vivos.

4. La procura de que las explotaciones marisqueras sean sostenibles y económicamente rentables.

\section{Capitulo II \\ ZONAS DE EXPLOTACIÓN MARISOUERA}

Artículo 29. Clasificación de las zonas de explotación marisquera.

Las zonas de explotación marisquera se clasifican en:

a. Zonas de libre marisqueo: bancos naturales cuya explotación no está sujeta a una autorización o concesión administrativa. La consejería competente determinará periódicamente las zonas de libre marisqueo, previa consulta con las organizaciones del sector.

b. Zonas de autorización marisquera: bancos naturales o porciones de ellos cuya explotación se otorga en uso privativo normal a título precario para su explotación en régimen de exclusividad.

c. Zonas de concesión marisquera: bancos naturales o porciones de ellos cuya explotación se otorga en uso privativo anormal que implique el derecho a ocupación, uso o disfrute en régimen temporal.

Artículo 30. Otorgamiento de autorizaciones y concesiones.

1. El otorgamiento de las autorizaciones y concesiones corresponde a la consejería competente en materia de marisqueo, previo el informe sobre la ocupación del dominio público marítimo o marítimo-terrestre previsto en la legislación de costas.

2. La resolución que disponga el otorgamiento de la autorización o concesión de actividad expresará quien ostente su titularidad, el tipo de establecimiento, las especies autorizadas, la zona, la duración, las causas de extinción del título habilitante y las condiciones técnicas y administrativas en que se autoriza la actividad.

Artículo 31. Garantías de la explotación.

1. Cuando las personas titulares de las autorizaciones y concesiones sean organizaciones de productores de base, estas habrán de garantizar el acceso a la explotación de los recursos marinos de las personas asociadas de las mismas que reúnan los requisitos legales para realizar tal actividad. 2. La explotación de los recursos marinos mediante las autorizaciones y concesiones otorgadas a las organizaciones de productores de base habrá de permitir el desarrollo de proyectos de común interés, partiendo de opciones eficientes, desde el punto de vista financiero, económico y social.

Artículo 32. Objeto de las concesiones y autorizaciones para la explotación de bancos naturales.

1. Cuando la explotación de un banco natural sea susceptible de mejora significativa, la consejería competente en materia de marisqueo podrá otorgar una autorización o concesión para la explotación de zonas de marisqueo, delimitando su superficie.

2. Las autorizaciones se otorgarán al objeto de realizar una explotación controlada de un banco natural mediante la realización de labores de semicultivo.

3. Las concesiones se otorgarán al objeto de realizar una explotación controlada de un banco natural mediante la realización de labores de cultivo extensivo o semiextensivo. Estas concesiones se regirán por lo dispuesto en el título $\mathrm{V}$, capítulo II, de la presente ley.

4. La consejería competente promoverá el acceso a la titularidad de autorizaciones y concesiones de las cooperativas integradas mayoritariamente por mujeres.

Artículo 33. Otorgamiento de las autorizaciones.

1. Las autorizaciones se otorgarán preferentemente a las entidades de interés colectivo. 
2. En su otorgamiento se tendrán en cuenta los derechos de otras personas que regularmente hayan venido explotando la zona objeto de la autorización.

3. Las entidades y personas físicas solicitantes habrán de disponer de una dirección técnica y gestora de la explotación, cuyo nivel de cualificación se determinará reglamentariamente.

Artículo 34. Extensión de las autorizaciones.

La extensión de las autorizaciones tendrá que guardar proporción con el número de personas que realicen o pretendan realizar la actividad autorizada, en directa relación con el estado de los recursos objeto de la explotación y el sostenimiento económico de los mismos.

Artículo 35. Señalización de los límites de la autorización.

Los límites de las áreas de explotación autorizadas, definidos por la consejería competente, han de estar señalizados o balizados de forma totalmente visible, con elementos que no supongan peligro para la navegación, siendo el establecimiento y mantenimiento de las señales responsabilidad de los titulares de la autorización.

Artículo 36. Prohibiciones.

Las autorizaciones no podrán ser transmisibles ni enajenables por ningún título, sin perjuicio de lo dispuesto en la legislación vigente en materia de cooperativas, ni se permitirá la construcción de instalaciones no desmontables en las áreas de explotación.

Artículo 37. Condiciones y duración de las autorizaciones de explotación de bancos naturales.

1. Sin perjuicio de lo que reglamentariamente se establezca, las autorizaciones de marisqueo en la zona marítima o zona marítimo-terrestre estarán limitadas a la duración y delimitación especial que en las mismas se especifique, no otorgando ni consolidando a sus beneficiarios derecho alguno o preferencia en lo sucesivo.

2. Las autorizaciones tendrán una vigencia máxima de cinco años, pudiendo prorrogarse por periodos iguales al autorizado, hasta un máximo de treinta años.

3. Las autorizaciones se otorgarán a título de precario, no dando su extinción derecho a indemnización alguna.

Artículo 38. Extinción de las autorizaciones de explotación de bancos naturales.

1. Las autorizaciones reguladas en el presente capítulo podrán extinguirse, previa audiencia de la persona titular de las mismas en el correspondiente procedimiento, por las causas siguientes:

a. Por vencimiento del plazo de vigencia de la autorización, sin haber solicitado u obtenido prórroga.

b. Por el incumplimiento de las cláusulas de la autorización.

c. Por la renuncia expresa de la persona titular.

d. Por razones de utilidad pública que conlleven la pérdida de la disponibilidad de los terrenos para la actividad marisque$\mathrm{ra}, \sin$ perjuicio de las indemnizaciones que correspondan.

e. Por abandono de la explotación o cese de la actividad por un periodo de seis meses consecutivos, salvo causas de fuerza mayor.

f. Por infrautilización en la explotación de la totalidad o alguna de las zonas autorizadas, salvo causas de fuerza mayor.

2. Extinguida la autorización, será obligación de la última persona titular reponer la zona a su estado natural anterior a la autorización así como cualquier alteración provocada en el medio, siendo a su cargo el coste de esas operaciones, que habrán de realizarse conforme a las instrucciones emanadas de la consejería competente en materia de protección del medio ambiente. Excepcionalmente, la consejería competente en materia de marisqueo podrá proponer, según se determine reglamentariamente, el mantenimiento de la zona en las condiciones existentes en el momento de la declaración de extinción para dedicarla a investigación, actividades 
culturales y de conocimiento de las actividades acuícolas o cualesquier otras de interés público.

\section{Capitulo III \\ EJERCICIO DEL MARISOUEO}

Artículo 39. Licencia de marisqueo.

1. El ejercicio del marisqueo en zonas de autorización marisquera o de libre marisqueo requerirá estar en posesión de una licencia.

2. Se establecen los siguientes tipos de licencia:

a. Licencia para marisqueo a pie.

b. Licencia para marisqueo a flote.

3. La Xunta de Galicia, a propuesta de la consejería competente en materia de marisqueo, establecerá los requisitos para la obtención, renovación, pérdida o suspensión de la licencia.

4. Las condiciones para la utilización de embarcaciones de la lista cuarta en el ejercicio del marisqueo serán establecidas reglamentariamente.

Artículo 40. Licencia de marisqueo a pie.

1. La licencia de marisqueo a pie será expedida a nombre de una persona física a título individual e intransferible. Para su obtención se requerirá tener la cualificación profesional correspondiente.

2. Se otorgará por un periodo de cinco años, renovable por iguales periodos.

3. La licencia contendrá, como mínimo, la información siguiente:

a. El nombre de la persona titular y DNI.

b. Las zonas y especies autorizadas.

c. Cualquier otra información relativa a la actividad.

d. La validez de la licencia.

Artículo 41. Licencia de marisqueo a flote.

1. La licencia de marisqueo a flote se expedirá a nombre del buque, por un periodo de cinco años, renovable por iguales periodos.

2. La modificación o modernización de los elementos del buque o la variación de los datos que constan en la licencia conllevará la solicitud de una nueva licencia, en las condiciones y plazos que se determinen reglamentariamente, sin perjuicio de la emisión de los informes y autorizaciones que se establezca.

3. En el supuesto de transmisión de la titularidad del buque, la nueva persona propietaria habrá de comunicarlo a la consejería competente en materia de marisqueo a efectos de la subrogación en el uso de la licencia, siempre y cuando la embarcación mantenga como base un puerto de la Comunidad Autónoma de Galicia.

4. El contenido mínimo de la licencia habrá de recoger los aspectos siguientes:

a. La identificación y características técnicas del buque.

b. La identificación de su titular.

c. El puerto base.

d. La modalidad de marisqueo: artes, aparejos y útiles autorizados.

e. La zona de marisqueo autorizada.

f. La validez de la licencia.

g. En caso de primera licencia, se incluirán además las bajas aportadas.

5. Para ejercer el marisqueo a flote sólo podrán emplearse embarcaciones incluidas en el Censo de flota pesquera operativa y en el Registro de buques pesqueros de Galicia.

Artículo 42. Explotación de los recursos específicos.

1. La explotación de los recursos específicos requerirá estar en posesión de la correspondiente modalidad de licencia para marisqueo y participar en un plan de gestión o recuperación.

2. En caso de que para la extracción de recursos específicos se empleen técnicas de buceo, será necesario que los buceadores y buceadoras estén en posesión de la titulación adecuada a los medios empleados.

Artículo 43. Recogida de algas y argazos.

1. La recogida de algas podrá ser realizada por personas recolectoras o empresas. En caso de recogida por 
personas recolectoras, estas habrán de estar debidamente autorizadas y requerirá la presentación de un plan de gestión por la organización de productores de base a la que pertenezcan. En caso de recogida por entidades de carácter económico, estas habrán de presentar un plan de gestión, pudiendo ser realizada la recogida por su personal o sus socios o socias.

2. La recogida de argazos o algas muertas no requiere licencia, pudiendo recogerse en la forma y condiciones que reglamentariamente se determinen.

\section{TÍTULO V \\ DE LA ACUICULTURA MARINA Capitulo I DISPOSICIONES GENERALES}

Artículo 44. Definición.

Se entiende por acuicultura marina la cría o cultivo de organismos acuáticos con técnicas encaminadas a aumentar la producción de los organismos en cuestión por encima de las capacidades naturales del medio; estos organismos serán, a lo largo de toda la fase de cría o cultivo y hasta el momento de su recogida, propiedad de personas físicas o jurídicas.

La actividad de acuicultura podrá realizarse en la zona terrestre, en la zona marítimo-terrestre o en la zona marítima, en instalaciones fijas, flotantes o a medias aguas.

Artículo 45. Objetivo.

El objetivo de la acuicultura marina será conseguir el óptimo aprovechamiento del potencial productivo de la acuicultura, respetando el medio ambiente y aumentando y promoviendo la competitividad, así como la mejora de las condiciones de vida y trabajo de las personas que se dedican a esta actividad y la contribución al desarrollo socioeconómico de las comunidades costeras.

Artículo 46. Atribuciones.

Para el fomento y desarrollo de la acuicultura marina, corresponden a la Xunta de Galicia, a propuesta de la consejería competente en materia de acuicultura, las atribuciones siguientes:

a. La aprobación de declaración de zonas de interés para cultivos marinos.

b. La ordenación de las actividades de la acuicultura mediante los instrumentos y medidas que reglamentariamente se determinen.

c. La regulación de las condiciones de los establecimientos de cultivos marinos y auxiliares.

Asimismo, corresponden a la consejería competente en materia de acuicultura las atribuciones siguientes:

a. El otorgamiento de los títulos habilitantes para el ejercicio de la actividad de acuicultura.

b. La regulación y determinación de las especies autorizadas y prohibidas para su cultivo en Galicia o en determinadas zonas.

c. La inspección y control de los establecimientos de cultivos marinos y auxiliares, tanto con relación a sus instalaciones como a sus métodos, condiciones técnicas, de producción y a las especies existentes en los mismos.

Artículo 47. Títulos administrativos habilitantes.

1. El ejercicio por toda persona física o jurídica de la actividad de cultivos marinos en cualquier tipo de establecimiento requiere un título administrativo habilitante previo otorgado por la consejería competente en materia de acuicultura, sin perjuicio de los permisos, licencias y autorizaciones que corresponda otorgar a otros organismos en el ejercicio de sus competencias.

2. A efectos de la presente ley, se consideran títulos administrativos habilitantes aquellos que se otorgan a las personas físicas o jurídicas para la instalación, puesta en funcionamiento y explotación de los establecimientos de cultivos marinos y auxiliares.

3. Los títulos administrativos habilitantes para el ejercicio de la acuicultura adoptarán alguna de las modalidades siguientes: 
a. Concesión de actividad.

b. Permiso de actividad.

4. Los establecimientos de cultivos marinos y auxiliares que precisen ocupar para su instalación, puesta en funcionamiento y explotación terrenos de dominio público marítimo o marítimo-terrestre precisarán de la concesión de actividad que otorgará la consejería competente en materia de acuicultura, conforme al procedimiento que reglamentariamente se establezca, previo informe preceptivo y vinculante de la Administración del Estado sobre la ocupación del dominio público.

5. Los establecimientos de cultivos marinos y auxiliares en zona terrestre requerirán el permiso de actividad en todo caso.

\section{Capitulo II \\ CONCESIONES DE ACTIVIDAD EN ZONA MARÍTIMO-TERRESTRE}

Artículo 48. Objeto.

Para el desarrollo de la actividad de acuicultura en zonas marítimo-terrestres, la consejería competente podrá otorgar una concesión para la explotación en exclusiva de esas zonas a personas físicas o jurídicas.

Artículo 49. Supuestos de concesión.

1. La consejería competente en materia de acuicultura podrá otorgar concesiones para desarrollar actividades acuícolas en la zona marítimo-terrestre, siempre que se justifique que este sistema de explotación es mejor en la producción de recursos.

2. En los supuestos de que la concesión tenga por objeto exclusivo la explotación de bancos naturales que conlleven la realización de labores de cultivo marino extensivo o semiextensivo, se requerirá la presentación, entre los demás requisitos que reglamentariamente se establezcan, de un plan de viabilidad que garantice una explotación eficaz y racional y acredite la autosuficiencia económica.

Artículo 50. Contenido de la concesión.

1. La resolución que disponga el otorgamiento de la concesión expresará la persona titular, el tipo de establecimiento, las especies autorizadas, la zona, la duración y las causas de caducidad, extinción y revocación de la concesión, así como las condiciones técnicas y administrativas en que se autoriza la actividad.

2. Las modificaciones o reformas de un proyecto autorizado, así como cualquier modificación de las condiciones establecidas, requerirán autorización de la consejería competente en materia de acuicultura en la forma que reglamentariamente se determine.

3. La extensión de las concesiones tendrá que guardar proporción con el espacio necesario para el ejercicio de la actividad autorizada.

4. Dentro del terreno de la concesión podrán establecerse áreas para el almacenamiento de semilla, la regulación comercial y otras actividades relacionadas con la explotación.

Artículo 51. Obligaciones de la persona titular de la concesión.

1. Las concesiones otorgadas al amparo del presente capítulo obligan a quien ostente su titularidad, entre otras obligaciones que reglamentariamente puedan establecerse, a:

a. Instalar y mantener los dispositivos de ayudas a la navegación marítima de las instalaciones otorgadas en régimen de concesión.

Si las instalaciones se encuentran ubicadas en polígonos o en otros instrumentos de ordenación de la actividad acuícola marina, la instalación y mantenimiento se realizará por la consejería competente en materia de acuicultura, corriendo los gastos a cargo de todas las personas concesionarias del polígono. En el supuesto de que las instalaciones estuvieran ubicadas fuera de estos espacios, corresponderá a la persona titular de la concesión la instalación y mantenimiento de los dispositivos de ayudas a la navegación conforme a la normativa vigente.

b. Mantener en buen estado el dominio público marítimo-terrestre y las obras e 
instalaciones que componen el establecimiento de cultivos marinos y auxiliares.

c. Establecer las medidas correctoras que puedan minimizar el impacto ambiental y el impacto sobre el patrimonio histórico de la actividad acuícola, así como a desaguar en las condiciones sanitarias necesarias para garantizar la calidad de las aguas.

d. Pagar el correspondiente canon por ocupación del dominio público.

e. Constituir un seguro que garantice posibles daños a terceros.

2. En la zona marítimo-terrestre no se permitirá otro tipo de obras que las imprescindibles para el funcionamiento de la explotación. Las tuberías de toma de agua y desagüe deberán ir bajo tierra.

3. En caso de que existan áreas manifiestamente infrautilizadas dentro de una concesión, la consejería competente podrá declarar la revocación de la misma en dichas áreas. Se entiende por áreas manifiestamente infrautilizadas aquellas que, salvo causa de fuerza mayor, no produzcan unos rendimientos y valores de producción determinados reglamentariamente.

Artículo 52. Criterios de otorgamiento de las concesiones.

1. Las concesiones serán otorgadas previo procedimiento, el cual estará presidido por los principios de objetividad, equidad, publicidad, concurrencia y transparencia.

2. Las concesiones, en igualdad de condiciones, serán otorgadas preferentemente a los proyectos presentados por las entidades asociativas de profesionales de la pesca, el marisqueo y la acuicultura del ámbito territorial afectado por la concesión.

3. El baremo que regirá en el procedimiento de otorgamiento valorará, preferentemente, los criterios siguientes:

a. Haber sido titular de una concesión de actividad para el ejercicio de la acuicultura marina en la zona marítimo-terrestre.

b. Haber ejercido habitualmente la explotación de una concesión de acuicultura marina en la zona marítimo-terrestre. c. La experiencia en el desarrollo de actividades de acuicultura en la zona marítimo-terrestre por parte de los particulares y empresas solicitantes.

d. La adecuación a los criterios técnicos, sanitarios y ambientales que se determinen.

Artículo 53. Duración.

Las concesiones se otorgarán por un periodo máximo de diez años, prorrogables por periodos de diez si se demuestra la rentabilidad y el buen uso de la explotación, hasta un máximo de treinta años, a petición de la persona concesionaria y con una antelación mínima de tres meses al vencimiento de la concesión.

Artículo 54. Transmisión de la concesión.

1. Los establecimientos amparados por la concesión podrán ser enajenados o cedidos juntamente con esta en cualquier momento del periodo de vigencia de la misma, siendo necesarias para su transmisión o cesión la autorización previa de la consejería competente en materia de acuicultura y la comprobación de que la nueva persona titular cumple los requisitos contenidos en la presente ley.

2. Los establecimientos amparados por concesiones otorgadas conforme a la presente ley se considerarán indivisibles, cualquiera que sea su dimensión y capacidad.

Artículo 55. Extinción de la concesión.

1. Las concesiones reguladas en el presente capítulo podrán extinguirse, previa audiencia de la persona titular de las mismas en el correspondiente procedimiento, por las causas siguientes:

a. Por vencimiento del plazo de vigencia de la concesión, sin haber solicitado u obtenido prórroga. En estos supuestos será necesaria la declaración expresa de extinción de la concesión.

b. Por el incumplimiento de las cláusulas de la concesión.

c. Por la renuncia expresa de la persona titular. 
d. Por razones de utilidad pública que conlleven la pérdida de la disponibilidad de las áreas en que se desarrolla la actividad acuícola, sin perjuicio de las indemnizaciones que correspondan.

e. Por el cese de la actividad del cultivo por un periodo superior a dos años, salvo causa justificada.

f. Por vencimiento del plazo establecido para la puesta en explotación, salvo causa de fuerza mayor.

g. Por daños ecológicos notorios, peligros para la salud pública o para la navegación u otros riesgos de análoga trascendencia, debidos al establecimiento o a su funcionamiento anormal.

h. Por el incumplimiento reiterado de las normas de extracción, regulación y comercialización.

i. Por haber efectuado el cambio de titularidad del establecimiento sin la previa autorización de la consejería competente en materia de acuicultura.

j. Por el alquiler del establecimiento de cultivos marinos a terceras personas.

k. Por la utilización de las instalaciones para la comisión de ilícitos penales, siempre que tales hechos hayan sido declarados probados por resolución penal firme.

1. Por la no remisión de los datos estadísticos a que obliga la legislación vigente, tras haber incumplido dos requerimientos.

$\mathrm{m}$. Por el incumplimiento manifiesto de los objetivos de rentabilidad previstos en el proyecto de instalación o en la solicitud de prórroga, cuando hubiera sido imputable a la persona titular del establecimiento.

n. Por las causas recogidas para la extinción en la legislación que regula la ocupación del dominio público marítimo-terrestre.

2. Extinguida la concesión, será obligación de la última persona titular reponer la zona a su estado natural anterior a la concesión así como cualquier alteración provocada en el medio, siendo a su cargo el coste de esas operaciones, que habrán de realizarse conforme a las instrucciones emanadas de la consejería competente en materia de protección del medio ambiente. Excepcionalmente, la consejería competente en materia de acuicultura podrá proponer, según se determine reglamentariamente, el mantenimiento de las obras e instalaciones para dedicarlas a la investigación, actividades culturales y de conocimiento de las actividades acuícolas o cualesquier otras de interés público.

Artículo 56. Concesiones experimentales.

Con carácter experimental, y nunca por un periodo superior a los tres años, podrá otorgarse una concesión experimental en la zona marítimo-terrestre para la realización de proyectos de investigación o proyectos que introduzcan innovaciones sustanciales en la explotación, artefactos y especies, en las condiciones que reglamentariamente se establezcan.

Las personas titulares de la concesión experimental están obligadas a cumplir los requisitos que reglamentariamente se establezcan y, en todo caso, habrán de presentar a la consejería competente en materia de acuicultura una memoria sobre el resultado de su actividad en los plazos que se determinen.

\section{Capítulo III \\ CONCESIONES DE ACTIVIDAD EN LA ZONA MARITIMA}

Artículo 57. Objeto.

Para el desarrollo de la acuicultura en zona marítima, la consejería competente en materia de acuicultura podrá otorgar una concesión de actividad a personas físicas o jurídicas.

Artículo 58. Objetivo.

Las concesiones de actividad tendrán como objetivo la instalación de bateas, líneas de cultivo o jaulas a fin de conseguir el óptimo aprovechamiento del potencial productivo de la zona marítima. Reglamentariamente podrá determinarse otro tipo de instalaciones que se podrán emplazar en esta zona. 
Artículo 59. Contenido de la concesión.

1. La resolución que disponga el otorgamiento de la concesión expresará la persona titular, el tipo de establecimiento, las especies autorizadas, la zona, la duración, las causas de caducidad, extinción y revocación de la concesión y las condiciones técnicas y administrativas en que se autoriza la actividad.

2. .Las modificaciones o reformas a un proyecto autorizado, así como cualquier modificación de las condiciones establecidas, requerirán autorización de la consejería competente en materia de acuicultura en la forma que reglamentariamente se determine.

3. La superficie de ocupación de la zona marítima contemplada en la concesión tendrá que guardar proporción con el espacio necesario para el ejercicio de la actividad autorizada.

Artículo 60. Obligaciones de la persona titular de la concesión.

1. Las concesiones otorgadas al amparo del presente capítulo obligan a quien ostente su titularidad, entre otras obligaciones que reglamentariamente puedan establecerse, a:

a. Instalar y mantener los dispositivos de ayudas a la navegación marítima de las instalaciones otorgadas en régimen de concesión.

$\mathrm{Si}$ las instalaciones se encuentran ubicadas en polígonos o en otros instrumentos de ordenación de la actividad acuícola marina, la instalación y mantenimiento se realizará por la consejería competente en materia de acuicultura, corriendo los gastos a cargo de todas las personas concesionarias del polígono. En el supuesto de que las instalaciones estuvieran ubicadas fuera de estos espacios, corresponderá a la persona titular de la concesión la instalación y mantenimiento de los dispositivos de ayudas a la navegación conforme a la normativa vigente.

b. Mantener en buen estado el dominio público marítimo, así como las instalaciones que componen el establecimiento de cultivos marinos.

c. Establecer las medidas correctoras que puedan minimizar el impacto ambiental y el impacto sobre el patrimonio histórico de la actividad acuícola.

d. Pagar el correspondiente canon por ocupación del dominio público.

e. Constituir un seguro que garantice posibles daños a terceros.

2. En caso de que existan instalaciones manifiestamente infrautilizadas objeto de una concesión, la consejería competente en materia de acuicultura podrá declarar la revocación de la misma. Reglamentariamente se determinarán los criterios y causas para declarar una instalación como manifiestamente infrautilizada.

Artículo 61. Duración de la concesión. Las concesiones se otorgarán por un periodo máximo de diez años, prorrogables por periodos de diez años, hasta un máximo de treinta años, a petición de la persona concesionaria.

Artículo 62. Criterios de otorgamiento de las concesiones.

1. Las concesiones de actividad serán otorgadas previo procedimiento de concurso público, el cual estará presidido por los principios de objetividad, equidad, publicidad, concurrencia y transparencia.

2. La consejería competente en materia de acuicultura, previo informe de las organizaciones representativas del correspondiente subsector de la acuicultura marina, convocará concurso público para el otorgamiento de las concesiones de actividad contempladas en el presente capítulo.

3. En el supuesto de extinción de concesiones de actividad, la consejería competente en materia de acuicultura convocará el concurso público para la misma especie de cultivo que tenía por objeto la concesión extinta.

4. El baremo que regirá en el concurso valorará preferentemente los criterios siguientes: 
a. Haber sido titular de una concesión para el ejercicio de la acuicultura marina en zona marítima en el mismo subsector de actividad de las concesiones para cuyo otorgamiento se convoca el concurso.

b. Haber ejercido habitualmente la explotación de una concesión de acuicultura marina en zona marítima en el mismo subsector de actividad de las concesiones para cuyo otorgamiento se convoca el concurso.

c. La experiencia en el desarrollo de actividades de acuicultura en la zona marítima por parte de los particulares y empresas solicitantes en el mismo subsector de actividad de las concesiones para cuyo otorgamiento se convoca el concurso.

d. La adecuación a los criterios técnicos, sanitarios y ambientales que se determinen.

El procedimiento de concesión mediante concurso público será determinado a través del correspondiente desarrollo reglamentario.

Artículo 63. Transmisión de la concesión.

1. Las instalaciones amparadas por la concesión podrán ser enajenadas o cedidas juntamente con esta en cualquier momento del periodo de vigencia de la misma, siendo necesaria para la transmisión o cesión la autorización previa de la consejería competente en materia de acuicultura, en conformidad con lo que reglamentariamente se establezca.

2. Los establecimientos amparados por concesiones otorgadas conforme a la presente ley se considerarán indivisibles, cualquier que sea su dimensión y capacidad.

3. Se permite la transmisión mortis causa de las concesiones. En los supuestos de transmisión por actos inter vivos, habrá de favorecerse la integración económica y social del sector.

Artículo 64. Extinción de la concesión.

1. Las concesiones reguladas en el presente capítulo podrán extinguirse, previa audiencia de la persona titular de las mismas en el correspondiente procedimiento, por las causas siguientes:

a. Por vencimiento del plazo de vigencia de la concesión, sin haber solicitado u obtenido prórroga. En estos supuestos será necesaria la declaración expresa de extinción de la concesión.

b. Por el incumplimiento de las cláusulas de la concesión.

c. Por la renuncia expresa de la persona titular.

d. Por razones de utilidad pública que conlleven la pérdida de la disponibilidad de las áreas en que se desarrolla la actividad acuícola, sin perjuicio de las indemnizaciones que correspondan.

e. Por el cese de la actividad del cultivo por un periodo superior a dos años, salvo causa justificada.

f. Por vencimiento del plazo establecido para la puesta en explotación, salvo causa de fuerza mayor.

g. Por daños ecológicos notorios, peligros para la salud pública o para la navegación u otros riesgos de análoga trascendencia, debidos al establecimiento o a su funcionamiento anormal.

h. Por el incumplimiento reiterado de las normas de extracción, regulación y comercialización.

i. Por haber efectuado el cambio de titularidad del establecimiento sin la previa autorización de la consejería competente en materia de acuicultura.

j. Por el alquiler del establecimiento de cultivos marinos a terceras personas.

k. Por la utilización de las instalaciones para la comisión de ilícitos penales, siempre que tales hechos hayan sido declarados probados por resolución penal firme.

1. Por la no remisión de los datos estadísticos a que obliga la legislación vigente, tras haber incumplido dos requerimientos.

$\mathrm{m}$. Por el incumplimiento manifiesto de los objetivos de rentabilidad previstos en el proyecto de instalación o en la solicitud de prórroga, cuando hubiera sido imputable a la persona titular del establecimiento. 
n. Por las causas recogidas para la extinción en la legislación que regula la ocupación del dominio público marítimo-terrestre.

2. Extinguida la concesión, será obligación de la última persona titular reponer la zona a su estado natural anterior a la concesión así como cualquier alteración provocada en el medio, siendo a su cargo el coste de esas operaciones, que habrán de realizarse conforme a las instrucciones emanadas de la consejería competente en materia de protección del medio ambiente. Excepcionalmente, la consejería competente en materia de acuicultura podrá proponer, según se determine reglamentariamente, el mantenimiento de las instalaciones para dedicarlas a la investigación, actividades culturales y de conocimiento de las actividades acuícolas o cualesquier otras de interés público.

Artículo 65. Concesiones experimentales.

Con carácter experimental, y nunca por un periodo superior a los tres años, podrá otorgarse una concesión experimental en la zona marítima para la realización de proyectos de investigación o proyectos que introduzcan innovaciones sustanciales en la explotación, artefactos y especies, en las condiciones que reglamentariamente se establezcan.

\section{Capítulo IV PERMISO DE ACTIVIDAD}

Artículo 66. Objeto.

1. Para el desarrollo de la actividad de acuicultura en zona terrestre, la consejería competente en materia de acuicultura podrá otorgar un permiso de actividad a personas físicas o entidades públicas o privadas.

2. Los establecimientos de acuicultura y auxiliares emplazados en la zona terrestre y en propiedades privadas requerirán el oportuno permiso de actividad, sin perjuicio de los demás permisos, licencias y autorizaciones que corresponda otorgar a otros organismos en el ejercicio de sus competencias.
3. En el supuesto de que estos establecimientos precisen de la correspondiente concesión de actividad, el permiso de actividad se integrará en la resolución de la concesión, tramitándose de acuerdo con lo dispuesto en los capítulos precedentes del presente título.

4. En caso de que las instalaciones que cuenten con un permiso de actividad sean manifiestamente infrautilizadas, la consejería competente en materia de acuicultura podrá declarar su revocación. Reglamentariamente se determinarán los criterios y causas para declarar una instalación como manifiestamente infrautilizada.

Artículo 67. Contenido del permiso.

1. La resolución que disponga el otorgamiento del permiso de actividad expresará la persona titular, el tipo de establecimiento, las especies autorizadas, la zona, la duración, las causas de caducidad, extinción y revocación de la concesión y las condiciones técnicas y administrativas en que se autoriza la actividad.

2. Las modificaciones o reformas a un proyecto autorizado, así como cualquier modificación de las condiciones establecidas, requerirán autorización de la consejería competente en materia de acuicultura en la forma que reglamentariamente se determine.

3. Dentro del terreno en donde se sitúa la instalación podrán establecerse áreas para el almacenamiento de semilla, la regulación comercial y otras actividades relacionadas con la explotación.

Artículo 68. Obligaciones de la persona titular del permiso.

Los permisos otorgados al amparo del presente título obligan a quien ostente su titularidad, entre otras obligaciones que reglamentariamente puedan establecerse, a:

a. Mantener en buen estado las obras e instalaciones que componen el establecimiento de cultivos marinos y auxiliares.

b. Establecer las medidas correctoras que puedan minimizar el impacto ambiental y el impacto sobre el patrimonio histórico de la 
actividad acuícola, así como a desaguar en las condiciones sanitarias necesarias para garantizar la calidad de las aguas.

c. Constituir un seguro que garantice posibles daños a terceros, agresiones al medio ambiente o pérdidas por circunstancias extraordinarias en las propias instalaciones.

Artículo 69. Duración.

Los permisos de actividad para el establecimiento de cultivos marinos y auxiliares que se emplacen en terrenos de titularidad privada tendrán carácter indefinido.

Artículo 70. Transmisión.

1. Los establecimientos amparados por el permiso de actividad podrán ser enajenados o cedidos juntamente con este en cualquier momento del periodo de vigencia del mismo, siendo necesaria para su transmisión o cesión la autorización previa de la consejería competente en materia de acuicultura.

2. Los establecimientos amparados por permisos otorgados conforme a la presente ley se considerarán indivisibles, cualquiera que sea su dimensión y capacidad.

Artículo 71. Extinción del permiso de actividad.

1. El permiso de actividad regulado en el presente capítulo podrá extinguirse, previa audiencia de la persona titular del mismo en el correspondiente procedimiento, por las causas siguientes:

a. Por el incumplimiento de las cláusulas del permiso de actividad.

b. Por la renuncia expresa de la persona titular.

c. Por el cese de la actividad del cultivo por un periodo superior a dos años, salvo causa justificada.

d. Por vencimiento del plazo establecido para la puesta en explotación, salvo causa de fuerza mayor.

e. Por daños ecológicos notorios, peligros para la salud pública o para la navegación $\mathrm{u}$ otros riesgos de análoga trascendencia, debidos al establecimiento o a su funcionamiento anormal. f. Por el incumplimiento de forma reiterada de las normas de extracción, regulación y comercialización.

g. Por haber efectuado el cambio de titularidad del establecimiento sin la previa autorización de la consejería competente en materia de acuicultura.

h. Por el alquiler del establecimiento de cultivos marinos o auxiliar a terceras personas.

i. Por la utilización de las instalaciones para la comisión de ilícitos penales, siempre que tales hechos hayan sido declarados probados por resolución penal firme.

j. Por la no remisión de los datos estadísticos a que obliga la legislación vigente, tras haber incumplido dos requerimientos.

$\mathrm{k}$. Por el incumplimiento manifiesto de los objetivos de rentabilidad previstos en el proyecto de instalación o en la solicitud de prórroga, cuando hubiera sido imputable a la persona titular del establecimiento.

Artículo 72. Permisos de actividad experimentales.

Excepcionalmente podrán autorizarse permisos temporales para la realización de proyectos de investigación o experimentales de nuevos cultivos. Reglamentariamente se establecerán las condiciones y supuestos de autorización de estos permisos temporales, que en ningún caso podrán ser superiores a los tres años.

\section{TÍTULO VI DE LA FLOTA PESQUERA GALLEGA}

Artículo 73. Definición.

Se entiende por flota pesquera gallega al conjunto de embarcaciones dedicadas a labores de pesca extractiva, embarcaciones auxiliares de pesca y de acuicultura y embarcaciones que se dediquen al marisqueo a flote, tengan su puerto base en Galicia y se encuentren inscritas en el Registro de buques pesqueros de Galicia y en el Censo de flota pesquera operativa.

Artículo 74. Objetivos.

La política de la Administración de la Comunidad Autónoma de Galicia tendrá 
como objetivos con relación a la flota pesquera gallega:

1. El mantenimiento y modernización de la flota pesquera.

2. La consecución y mantenimiento de unos niveles de seguridad acordes con el nivel de desarrollo tecnológico existente.

3. La mejora continuada de las condiciones de vida y trabajo a bordo, adoptando las medidas necesarias para que no exista discriminación efectiva en el acceso al empleo a bordo.

4. La consecución de los niveles de equipamiento a bordo que garanticen la igualdad de oportunidades por razón de género.

5. La garantía de un aprovechamiento sostenible de los recursos, especialmente en cuanto al mantenimiento de poblaciones viables de las especies objeto de captura, y la minoración de los impactos negativos de las diferentes artes sobre otras poblaciones de especies marinas y sobre el medio marino.

6. La mejora continuada de la competitividad a través de la eficacia en la explotación de los recursos y la optimización de los costes de operación.

7. La mejora de la calidad de las producciones.

8. El fomento de la implantación de convenios colectivos en la relación laboral de los trabajadores y trabajadoras de la flota pesquera gallega.

Artículo 75. Puerto base.

Se entiende por puerto base aquel desde el cual el buque desarrolla la mayor parte de sus actividades de inicio de las mareas, despacho y comercialización de las capturas dentro del territorio de Galicia.

Si el buque pesca fuera del caladero nacional, el puerto base será aquel con el que mantenga una vinculación socioeconómica destacable dentro del territorio de Galicia.

Corresponde a la consejería competente en materia de pesca autorizar el establecimiento y cambio de puerto base de las embarcaciones de acuerdo con la legislación básica del Estado.

Artículo 76. Autorización de construcción.

Corresponde a la consejería competente en materia de pesca la autorización para la construcción de nuevas embarcaciones que vayan a dedicarse al ejercicio de la pesca profesional, al marisqueo o a auxiliar de acuicultura con puerto base en Galicia, con arreglo a lo establecido en la normativa estatal.

Las autorizaciones para nuevas construcciones se ajustarán a las posibilidades reales de pesca y en las condiciones que reglamentariamente se determinen, en la procura de contar con una flota moderna y mejorar las condiciones de seguridad, habitabilidad, higiene a bordo, perfeccionamiento de los procesos de extracción, transformación, manipulación y conservación de los productos de la actividad pesquera o marisquera, y se tendrá en cuenta, especialmente en las medidas de fomento, lo señalado en el artículo $74^{\circ} .3$ de la presente ley.

Artículo 77. Modernización y reconversión.

Corresponde a la consejería competente en materia de pesca la autorización de las obras de modernización y reconversión de los buques de pesca con puerto base en Galicia y en las condiciones que reglamentariamente se determinen conforme a la normativa vigente.

Estas obras tendrán como finalidad la modificación de las condiciones técnicas de los buques, en la procura de mejorar las condiciones de seguridad, habitabilidad, higiene a bordo, perfeccionamiento de los procesos de extracción, transformación, manipulación y conservación de los productos de la actividad pesquera o marisquera, habida cuenta, especialmente en las medidas de fomento, de lo señalado en el artículo $74^{\circ} .3$ de la presente ley. 


\section{TíTULO VII \\ DE LOS AGENTES DEL SECTOR PESQUERO GALLEGO}

Artículo 78. Entidades representativas del sector pesquero.

Las cofradías de pescadores, las organizaciones de productores, las cooperativas del mar, las asociaciones de profesionales del sector, las organizaciones sindicales de profesionales del sector, las asociaciones de pesca marítima y náutica de recreo y demás entidades asociativas jurídicamente reconocidas y constituidas por profesionales del sector tendrán la consideración de entidades representativas a efectos de su colaboración en la toma de decisiones que puedan afectar a los intereses que representan.

Artículo 79. Las cofradías de pescadores.

1. Las cofradías de pescadores son corporaciones de derecho público, sin ánimo de lucro, dotadas con personalidad jurídica y capacidad de obrar para el cumplimiento de sus fines.

2. Las cofradías actúan como órganos de consulta y colaboración de la Administración de la Comunidad Autónoma de Galicia.

Artículo 80. Miembros de las cofradías.

Podrán ser miembros de las cofradías las personas armadoras y propietarias de las embarcaciones de pesca, los trabajadores y trabajadoras del sector pesquero extractivo y las personas poseedoras de un título administrativo habilitante para el ejercicio del marisqueo.

Las personas armadoras o propietarias de más de una embarcación con diferentes puertos base podrán asociarse a más de una cofradía de pescadores. En este caso, solamente se podrá ser miembro de los órganos representativos de una de las cofradías a las que se pertenezca.

Reglamentariamente se determinará el número mínimo de personas socias por cofradía.
Artículo 81. Funciones de las cofradías de pescadores.

Son funciones de las cofradías de pescadores:

a. Actuar como órgano de consulta de la consejería competente y ejercer las funciones que se les encomienden en el ámbito de sus respectivas competencias.

b. Prestar servicios a sus miembros y representar y defender sus intereses.

c. Administrar los recursos propios de su patrimonio.

Artículo 82. Formas de asociación de las cofradías.

Las cofradías podrán asociarse entre sí en cualquiera de las formas asociativas contempladas en la legislación vigente, siempre y cuando reúnan las condiciones, requisitos o exigencias establecidos en la normativa que les sea de aplicación.

Artículo 83. Estatutos.

Las cofradías se regirán en su funcionamiento por la normativa que le sea de aplicación, por sus estatutos, que serán elaborados y aprobados por su junta general, y por la aplicación de principios democráticos en su funcionamiento.

Los estatutos habrán de regular, al menos, los aspectos siguientes:

a. La denominación de la cofradía.

b. El domicilio social.

c. Los derechos y deberes de las personas socias.

d. La estructura y funcionamiento de los órganos representativos.

e. El régimen electoral.

f. El régimen económico, recursos y patrimonio.

g. El destino del patrimonio en caso de fusión o disolución.

h. El ámbito territorial, cuya validez se limita para la determinación de las personas que pueden asociarse a la misma y residan en ese ámbito territorial, excepto en el supuesto contemplado en el artículo 80 , párrafo segundo.

Artículo 84. Órganos representativos.

1. Son órganos de las cofradías de pescadores la junta general, el cabildo y el patrón o la patrona mayor. 
2. Estos órganos tendrán carácter representativo y serán elegidos de entre los miembros de la cofradía de pescadores mediante sufragio libre, igual y secreto.

3. El mandato de los cargos electos para los órganos representativos de las cofradías tendrá una duración de cuatro años, pudiendo ser reelegidos por periodos de igual duración.

4. Reglamentariamente se determinará el número mínimo de miembros de los órganos representativos.

Artículo 85. Junta general.

La junta general estará integrada por el mismo número de personas trabajadoras y empresarias en representación de los distintos sectores de la cofradía de pescadores y ejercerá las funciones que le encomienden sus estatutos.

Su composición habrá de respetar las disposiciones legales vigentes en materia de igualdad entre el hombre y la mujer.

Artículo 86. Cabildo.

El cabildo estará integrado por el mismo número de personas trabajadoras y empresarias en representación de los distintos sectores de la cofradía de pescadores y ejercerá las funciones que le encomienden sus estatutos, y entre ellas las de gestión y administración ordinaria de la misma.

Su composición habrá de respetar las disposiciones legales vigentes en materia de igualdad entre el hombre y la mujer.

Artículo 87. Patrón o patrona mayor. El patrón o la patrona mayor será elegido o elegida de entre y por los miembros de la junta general, ejerciendo la función de dirección de la cofradía y aquellas otras funciones que le encomienden sus estatutos.

Artículo 88. Fusión y disolución de cofradías.

La fusión de cofradías requerirá el voto favorable de la mayoría absoluta de los miembros de las juntas generales respectivas.

La disolución de cofradías se producirá por el acuerdo favorable de las tres cuartas partes de las personas socias de la cofradía o acuerdo del Consejo de la Xunta en caso de inviabilidad económica, por carecer del número mínimo de personas socias establecido o por la imposibilidad de constituir la junta general o comisión gestora de la cofradía.

Reglamentariamente se determinarán las consecuencias que produzcan la fusión o disolución de cofradías.

Artículo 89. Federaciones de cofradías. Existe una federación provincial de cofradías en cada una de las provincias costeras de Galicia, en las que pueden integrarse las cofradías de pescadores de sus respectivos ámbitos territoriales.

Existe una federación gallega de cofradías de pescadores, en la que pueden integrarse las cofradías de pescadores de Galicia. Reglamentariamente se determinarán sus órganos, régimen de funcionamiento y funciones.

Artículo 90. Organizaciones de productores.

Las organizaciones de productores son entidades reconocidas oficialmente, constituidas a iniciativa de las personas productoras a fin de garantizar el ejercicio racional de la pesca, el marisqueo y la acuicultura y la mejora de las condiciones de venta de su producción.

Artículo 91. Reconocimiento.

Constituida válidamente una asociación de productores, para obtener el reconocimiento oficial de organización de productores, sus miembros deberán tener principalmente su domicilio social y su producción en Galicia, en los porcentajes y términos establecidos en la normativa vigente en esta materia.

Reglamentariamente se establecerán las condiciones y requisitos para acceder y conservar el reconocimiento de organización de productores.

Este reconocimiento podrá retirarse cuando se incumplan los requisitos que determinaron su otorgamiento, cuando se incumplan las normas que le son de aplicación, cuando se incumpla lo reglamentado 
para su funcionamiento o cuando no se realice actividad alguna en el plazo de dos años consecutivos.

Artículo 92. Cooperativas del sector del mar.

Las cooperativas del sector del mar se regularán por la normativa vigente en materia de cooperativas.

La consejería competente en materia de pesca tendrá como objetivos, entre otros, con relación a las cooperativas del sector del mar:

a. Promover la constitución de cooperativas de explotación de los recursos marinos integradas por productores de base, en cuya composición habrán de respetarse las disposiciones legales en materia de igualdad entre el hombre y la mujer.

b. Promover la constitución de cooperativas de productores de base integradas mayoritariamente por mujeres.

c. Impulsar el funcionamiento y la participación de las cooperativas del sector del mar.

Artículo 93. Entidades asociativas. Las asociaciones de armadores, las agrupaciones de productores de base y demás entidades asociativas jurídicamente reconocidas y vinculadas a la explotación y comercialización de los recursos pesqueros, marisqueros y acuícolas, así como las organizaciones náuticas deportivas, tendrán la consideración de entidades representativas a efectos de su colaboración en la toma de decisiones que puedan afectar a los intereses que representan.

Artículo 94. Organizaciones sindicales. Tendrán la consideración de agentes del sector las organizaciones sindicales más representativas, según la legislación de aplicación, en el ámbito pesquero, promoviéndose su participación y colaboración en la aplicación de los objetivos establecidos en la presente ley.

Artículo 95. Consejo Gallego de Pesca.

1. El Consejo Gallego de Pesca es un órgano colegiado, consultivo $\mathrm{y}$ asesor de la Xunta de Galicia en los asuntos de pesca, marisqueo y acuicultura con incidencia en el sector gallego que depende de la consejería competente en materia de política pesquera.

2. Reglamentariamente se desarrollará la composición, funciones y régimen de funcionamiento del mismo.

En el Consejo Gallego de Pesca estarán representados, entre otros, todos los agentes del sector pesquero gallego.

Sus funciones son, entre otras, las siguientes:

a. Colaborar con la consejería competente en la elaboración de la planificación pesquera y la programación de estudios sobre distintas actividades.

b. Estudiar y proponer las reformas que considere precisas en la reglamentación pesquera que puedan influir en el ordenamiento del sector pesquero gallego.

c. Analizar y proponer las reglamentaciones que, en materia pesquera, se consideren precisas.

d. Realizar consultas a otros organismos e instituciones.

e. Emitir informes y dictámenes en todos los casos en que así lo disponga el propio consejo, así como en aquellos otros que así lo solicite la consejería competente en materia de pesca.

f. Emitir dictámenes sobre anteproyectos de ley y proyectos normativos en materia de pesca, marisqueo y acuicultura.

TÍTULO VIII
DE LA COMERCIALIZACIÓN,
TRANSFORMACIÓN Y PROMOCIÓN
DE LOS PRODUCTOS DE LA PESCA,
EL MARISQUEO Y LA ACUICULTURA

\section{Capítulo I LA COMERCIALIZACIÓN}

Artículo 96. Comercialización.

1. Se entiende por comercialización en origen, en cuanto afecta a la ordenación del sector pesquero, el proceso seguido por los productos pesqueros, transformados 
o no, que comprende todas o alguna de las actividades siguientes:

a. El desembarque de los productos en un puerto del litoral de la Comunidad Autónoma de Galicia o su introducción en el territorio de la comunidad autónoma sin haberse efectuado su primera venta.

b. El transporte de los productos hasta la lonja pesquera o centro autorizado.

c. La primera venta de los productos en las lonjas pesqueras o centros autorizados.

2. Se entiende por comercialización en destino el proceso seguido por los productos pesqueros desde que se ha realizado la primera venta de los mismos hasta su consumo final y que comprende todas o alguna de las actividades siguientes:

a. El transporte y distribución.

b. El almacenamiento, manipulación, transformación y envasado.

c. La exposición y venta en mercados y establecimientos autorizados, incluida la que se realiza en los establecimientos de restauración.

Artículo 97. Objetivos.

La política de la Administración de la Comunidad Autónoma de Galicia tendrá como objetivos con relación a la comercialización, transformación y promoción de los productos pesqueros:

a. La mejora de las condiciones de trabajo y la incorporación de medidas a favor de la efectividad del principio de igualdad con arreglo a lo dispuesto en la Ley $2 / 2007$, de 28 de marzo, del trabajo en igualdad de las mujeres de Galicia.

b. La mejora de los canales de comercialización y distribución de los productos.

c. La adopción de medidas destinadas a conseguir una mejora de las condiciones higiénicas y de salud pública de los productos.

d. La promoción de la producción de productos de alta calidad para mercados altamente especializados.

e. La adopción de medidas tendentes a promover el ejercicio de una actividad comercializadora y transformadora respetuosa con el medio ambiente. f. Una mejor utilización de especies poco aprovechadas, subprodutos y residuos.

g. El fomento de la producción o comercialización de nuevos productos, la aplicación de nuevas tecnologías o el desarrollo de métodos innovadores de producción.

h. El fomento de la comercialización de productos procedentes esencialmente de los desembarques locales y de la acuicultura.

i. El fomento de la participación activa de los productores de base en los canales de comercialización.

Artículo 98. Transporte anterior a la primera venta.

Los productos pesqueros frescos que vayan a ser objeto de su primera venta a través de una lonja o centro autorizado de un puerto distinto al del desembarque, así como los productos congelados o transformados a bordo que vayan a ser transportados antes de su primera venta, deberán ir acompañados, desde la salida del recinto portuario hasta que se produzca esa primera venta, de la documentación que se establezca reglamentariamente, entre la que habrá de constar, en todo caso, las cantidades transportadas de cada especie, el origen del envío y el lugar de destino de los productos.

Artículo 99. Primera venta.

La primera venta se realizará a través de las lonjas pesqueras de los puertos ubicados en la comunidad autónoma o centros autorizados.

Reglamentariamente podrá excepcionarse la obligación anterior para determinado tipo de capturas y modalidades de pesca.

Reglamentariamente se establecerán las condiciones y establecimientos autorizados para llevar a cabo la primera venta de productos congelados o transformados.

Artículo 100. Trazabilidad.

A lo largo de todo el proceso de comercialización, los productos pesqueros habrán de estar correctamente identificados y cumplir la normativa vigente en materia de comercialización. 


\section{Artículo 101. Comunicación de} datos.

Las personas titulares de los establecimientos autorizados para la comercialización en origen de los productos pesqueros habrán de remitir a la consejería competente la información referida a los datos de primera venta de los productos, en los términos que reglamentariamente se establezca.

En las lonjas no explotadas en régimen de concesión administrativa, el suministro de los datos de primera venta corresponderá a las personas consignatarias-vendedoras autorizadas por las distintas administraciones.

Artículo 102. Prohibiciones.

1. Queda prohibida la tenencia, transporte, tránsito, almacenamiento, transformación, exposición y venta de productos pesqueros de cualquier origen o procedencia que estuvieran en veda o fueran de talla o peso inferior al reglamentado en el ámbito internacional, comunitario, estatal o autonómico, excepto aquellos productos destinados a siembra o cría para resiembra, en las condiciones que reglamentariamente se determinen.

2. Queda prohibida la venta de cría de mejillón y de mejillón de desdoble, excepto para su instalación en bateas ubicadas en aguas competencia de Galicia.

3. No se permitirá en el territorio de Galicia ninguna fase del proceso de comercialización, transformación, conservación o elaboración de productos pesqueros procedentes de países no comunitarios cuando no conste documentalmente que hayan sido introducidos por un puesto de inspección fronteriza autorizado o un puerto designado en el que hubieran sido sometidos a los controles reglamentarios.

4. Los productos procedentes de estos países sometidos a las normas comunes de comercialización habrán de estar presentados en embalajes con las indicaciones claramente visibles y perfectamente legibles que establece la normativa comunitaria en cuanto al país de origen y a las normas establecidas para el etiquetado de estos productos.

\section{Capitulo II \\ LA TRANSFORMACIÓN}

Artículo 103. Transformación.

Se entiende por transformación de los productos pesqueros el conjunto de operaciones que modifican las características físicas o químicas de los productos, con el objetivo de prepararlos para su comercialización.

La transformación de los productos de la pesca, el marisqueo y la acuicultura comprende las operaciones de preparación, tratamiento y conservación.

Artículo 104. Fomento de la transformación.

Las medidas de fomento de las operaciones de transformación de los productos pesqueros, puestas en práctica por la consejería competente en materia de pesca, serán dirigidas preferentemente a:

a. La diversificación de los productos.

b. La mejora de la calidad.

c. La innovación tecnológica.

d. El aprovechamiento de los recursos excedentarios o infrautilizados.

e. El desarrollo de las profesiones con la colaboración del sector.

f. El aprovechamiento de los subproductos.

g. La adopción de medidas tendentes a promover el ejercicio de una actividad comercializadora respetuosa con el medio ambiente.

h. La puesta en valor de los productos pesqueros.

\section{Capítulo III \\ LA PROMOCIÓN}

Artículo 105. Promoción.

Las acciones de promoción de los productos pesqueros, desarrolladas por la consejería competente en materia de pesca, serán dirigidas preferentemente a:

a. Favorecer el consumo de productos excedentarios o infrautilizados.

b. Facilitar la comercialización de productos tradicionales y artesanales. 
c. Contribuir a la adaptación entre la oferta y la demanda.

d. Divulgar el conocimiento de las producciones autóctonas.

e. Impulsar el desarrollo de los distintivos de calidad u origen.

f. Contribuir a una adecuada información al consumidor acerca de las características de los productos.

g. La proyección internacional de los productos pesqueros gallegos.

\section{TÍTULO IX \\ DEL DESARROLLO SOSTENIBLE DE LAS ZONAS DE PESCA}

\section{Capítulo I \\ LA AGENCIA DE DESARROLLO SOSTENIBLE DE LAS ZONAS DE PESCA}

Artículo 106. Creación.

En el ámbito de Galicia se autorizará la creación de la Agencia de Desarrollo Sostenible de las Zonas de Pesca como agencia pública cuya constitución, funcionamiento y desarrollo estará a lo establecido en la disposición adicional quinta del texto refundido de la Ley de régimen financiero y presupuestario de Galicia, aprobado por Decreto legislativo 1/1999, de 7 de octubre.

La creación de la agencia se producirá con la aprobación de sus estatutos por decreto del Consejo de la Xunta a propuesta de la Consejería de Economía y Hacienda, previa iniciativa de la consejería competente en materia de pesca.

Artículo 107. Agencia pública.

La agencia será una entidad instrumental de derecho público, dotada de personalidad jurídica pública, patrimonio propio y autonomía en su gestión, facultada para ejercer potestades administrativas en el marco del cumplimiento de los programas correspondientes a las políticas públicas de pesca.

La agencia será el instrumento básico de actuación de la Xunta de Galicia en el fomento y coordinación del desarrollo de las zonas costeras gallegas en el ámbito de las competencias de la consejería competente en materia de pesca, para mejorar las condiciones de vida de las personas profesionales del sector y de las poblaciones costeras.

Artículo 108. Régimen jurídico.

La Agencia de Desarrollo Sostenible de las Zonas de Pesca se regirá por la presente ley, por lo establecido en la disposición adicional quinta del texto refundido de la Ley de régimen financiero y presupuestario de Galicia, aprobado por Decreto legislativo 1/1999, de 7 de octubre, por sus propios estatutos y demás normas de aplicación.

En sus actividades de contratación se aplicará la Ley 30/2007, de 30 de octubre, de contratos en el sector público, o la norma que la sustituya.

La agencia se adscribirá a la consejería competente en materia de pesca.

Artículo 109. Fines de la Agencia de Desarrollo Sostenible de las Zonas de Pesca.

La agencia, que llevará a cabo sus actividades al objeto de fijar población y generar empleo y riqueza en las poblaciones costeras, en conformidad con el principio de igualdad e integrando en éste la perspectiva de género, tiene por finalidad, entre otras, las de:

a. Elaborar estrategias y planes integrados de coordinación de actuaciones de diversa naturaleza en las zonas costeras, en el ámbito de las competencias que tiene atribuidas la consejería competente en materia de pesca.

b. Difundir las políticas y medidas de desarrollo costero aplicables en cada momento.

c. Dinamizar y coordinar los grupos de acción costera vinculados a la política de desarrollo de la pesca, el marisqueo y la acuicultura, con independencia de sus fuentes de financiación y de su localización.

d. Impulsar la formación, por parte de los agentes socioeconómicos de las zonas costeras, de iniciativas y programas de desarrollo y diversificación de la actividad pesquera, marisquera y acuícola. 
Artículo 110. Recursos de la agencia. Los recursos económicos estarán constituidos por:

1. Las transferencias consignadas en los presupuestos generales de la Xunta.

2. Los ingresos propios que perciban como contraprestación por las actividades que puedan realizar, en virtud de contratos, convenios o disposición legal, para otras entidades públicas o privadas o personas físicas.

3. La enajenación de los bienes y valores que constituyan su patrimonio de acuerdo con la legislación patrimonial de la comunidad autónoma.

4. El rendimiento procedente de sus bienes y valores.

5. Las aportaciones voluntarias, donaciones, herencias y legados y demás aportaciones a título gratuito de entidades privadas y particulares.

6. Los ingresos recibidos de personas físicas y jurídicas a consecuencia de patrocinio de actividades o instalaciones.

7. Los demás ingresos de derecho público o privado que esté autorizada a percibir.

8. Cualesquier otros recursos que se le puedan atribuir conforme a las disposiciones en vigor.

Artículo 111. Régimen de personal. Sin perjuicio de lo establecido para el personal directivo, el personal de la agencia podrá estar constituido por:

a. El personal que se incorpore a la agencia desde la Administración pública gallega por los procedimientos que se desarrollen conforme a la normativa vigente.

b. El personal contratado en régimen de derecho laboral seleccionado por la agencia mediante las correspondientes pruebas selectivas convocadas al efecto conforme a la normativa vigente.

El personal contemplado en la letra a) mantendrá la condición de funcionario conforme a la normativa vigente.

\section{Capítulo II \\ TURISMO MARINERO}

Artículo 112. Definición.

Se entiende por turismo marinero las actividades desarrolladas por los colectivos de profesionales del mar, mediante contraprestación económica, orientadas a la valorización y difusión de su trabajo en el medio marino así como de las costumbres, tradiciones, patrimonio y cultura marinera.

En todo caso, estas actividades serán complementarias a las actividades propias de los colectivos de profesionales del mar.

A efectos del presente artículo, tendrán la consideración de profesionales del mar las personas que desarrollen una actividad de pesca, marisqueo o acuicultura.

Artículo 113. Actividades.

Tendrán la consideración de actividades de turismo marinero, entre otras, las de:

a. Pesca turismo: actividades desarrolladas a bordo de embarcaciones pesqueras por parte de los profesionales del mar dirigidas al conocimiento, valorización y difusión de su trabajo en el medio marino.

b. Rutas guiadas: actividades dirigidas al conocimiento del medio en que se desarrollan las actividades profesionales en playas, puertos y villas marineras, guiadas por profesionales del mar.

c. Ictiturismo y casas de turismo marinero: actividades dirigidas al alojamiento en casas titularidad de profesionales del mar.

d. Gastronomía: actividades dirigidas a la promoción y puesta en valor del consumo de los productos de la pesca, el marisqueo y la acuicultura.

Reglamentariamente se establecerán las condiciones para el ejercicio de las actividades contempladas en el presente artículo, sin perjuicio de la obligación de contar con las preceptivas autorizaciones turísticas, la inscripción en el Registro de empresas y actividades turísticas de la Comunidad Autónoma de Galicia y, en su caso, la habilitación de guía de turismo 
especializado, con arreglo a la normativa dictada por la consejería competente en materia de turismo.

\section{TÍTULO X \\ DE LA INVESTIGACIÓN, DESARROLLO TECNOLÓGICO E INNOVACIÓN}

Artículo 114. Objetivos.

La política de la Administración de la Comunidad Autónoma de Galicia tendrá como objetivos con relación a la investigación, desarrollo tecnológico e innovación, entre otros:

a. El aprovechamiento de los recursos marinos en el marco de los objetivos de desarrollo sostenible.

b. La adopción de medidas dirigidas a disponer de la información y fundamentos científicos suficientes que sustenten y guíen las acciones políticas y las conductas de los agentes económicos y sociales.

c. La realización de programas destinados a incentivar el avance de la investigación relativa al medio marino y el desarrollo económico y social en el marco de la sostenibilidad.

d. La innovación tecnológica y el avance en las técnicas de gestión y en la regulación de los mercados.

e. La realización de programas destinados a promover el avance y la transferencia de tecnología en todas las actividades relacionadas con el medio marino.

f. El mejor conocimiento del estado de los recursos marinos vivos y de su relación con el medio, así como de las condiciones y estado de ese medio marino.

g. La realización de programas de $\mathrm{I}+\mathrm{D}+\mathrm{I}$ destinados a la mejora de la seguridad y condiciones de trabajo de las personas del sector y de los medios empleados para el ejercicio de las actividades pesqueras, marisqueras y de acuicultura.

h. El traslado y transferencia a la sociedad de la información de los resultados de la investigación, el desarrollo tecnológico y la innovación.
Artículo 115. Acciones de apoyo.

La consejería competente en materia de pesca promoverá y adoptará medidas para fomentar y realizar investigaciones científicas y desarrollar tecnologías adecuadas en el apoyo de la conservación y ordenación de los recursos marinos vivos, en los diferentes ámbitos de explotación y comercializaciones, mediante:

a. La definición de programas estratégicos y líneas de actuación prioritarias, que se llevarán a cabo, preferentemente, en los centros de investigación dependientes de la consejería.

b. La financiación y ejecución de proyectos dentro de los programas aprobados por la consejería competente.

c. La promoción de la cooperación entre las administraciones públicas y los agentes económicos y sociales, en particular las entidades asociativas del sector, y los centros de investigación.

d. El impulso de acuerdos de colaboración con entidades o centros de investigación susceptibles de desarrollar y trabajar en líneas de investigación de interés para nuestra comunidad.

e. El desarrollo de la formación específica de personal técnico e investigador sobre el medio marino, los recursos y la acuicultura.

f. La difusión de datos y resultados de la investigación.

Artículo 116. Colaboración del sector.

Los agentes del sector pesquero prestarán su colaboración para el cumplimiento de los objetivos de investigación, innovación y desarrollo tecnológico, facilitando las actuaciones correspondientes a bordo de los buques, en los puertos y centros de venta, y aportando la información y medios necesarios.

La consejería competente en materia de pesca tendrá en consideración las propuestas del sector para el desarrollo de estrategias sectoriales de liderazgo y competitividad. 


\section{TÍTULO XI \\ DE LA FORMACIÓN MARÍTIMO-PESQUERA}

Artículo 117. Actuaciones.

La consejería competente en materia de pesca realizará las actuaciones necesarias para el fomento de la formación, capacitación y reciclaje de las personas profesionales de los distintos sectores así como la de aquellas personas que puedan demandar dicha prestación formativa, y en particular:

a. La programación, planificación, ejecución y seguimiento de las enseñanzas regladas de formación marítimo-pesquera, marisquera y acuícola en el ámbito de la Comunidad Autónoma gallega, en coordinación con los departamentos competentes en la materia y dentro de la programación general del sistema educativo gallego.

b. La programación, planificación, ejecución y seguimiento de las enseñanzas no regladas de formación marítimo-pesquera, marisquera, acuícola y de buceo profesional en el ámbito de Galicia, en coordinación con los departamentos competentes en la materia y dentro de la programación general del sistema educativo gallego y de formación profesional para el empleo.

c. La promoción de todo tipo de actividades formativas mediante la colaboración, cooperación y coordinación entre organismos y entidades competentes en materia de pesca, educación y seguridad en el trabajo.

d. La dotación de los medios materiales y humanos necesarios y adecuados para el desarrollo, seguimiento y ejecución de los programas y medidas que se aprueben.

e. La dirección, inspección y supervisión de los centros de enseñanza que imparten las materias reguladas en el presente título.

Artículo 118. Objetivos.

1. Las actuaciones contempladas en el presente título se adaptarán a las necesidades formativas y de reciclaje demandadas por el sector pesquero, marisquero y acuícola, teniendo como objetivo:

a. Regular la formación, capacitación y reciclaje profesional en materia marítimopesquera dentro del ámbito competencial de la Comunidad Autónoma gallega, dirigida tanto a las personas profesionales de los distintos sectores como a aquellas personas que demanden dicha prestación formativa, así como establecer métodos necesarios e indispensables para el desarrollo, seguridad, modernización y mejora de los sectores de la pesca, el marisqueo, la acuicultura y el buceo profesional.

b. Dictar normas de desarrollo de la legislación básica del Estado sobre condiciones y requisitos para la obtención y expedición de las titulaciones y tarjetas y demás acreditaciones de carácter profesional que sean de su competencia.

c. Dictar normativa sobre condiciones y requisitos para la obtención de certificados y titulaciones.

d. Dictar las normas de desarrollo para la homologación de aquellas titulaciones o acreditaciones obtenidas o expedidas por otras administraciones.

2. Habida cuenta de lo establecido por el artículo $22.2^{\circ}$ a) de la Ley $7 / 2004$, de 16 de julio, para la igualdad de mujeres y hombres, y el artículo 31.3 de la Ley $2 / 2007$, de 28 de marzo, del trabajo en igualdad de las mujeres de Galicia, por los órganos competentes de la Administración de la Comunidad Autónoma de Galicia se adoptarán medidas de acción positiva que favorezcan el acceso efectivo de las mujeres a los estudios oficiales, reglados y de cualquier otra naturaleza, y a las actividades de formación, perfeccionamiento y de reciclaje profesional, conducentes a las titulaciones y capacitaciones académicas y profesionales que permitan la inserción y promoción laboral en el sector de la pesca, en tanto se registre infrarrepresentación de las mujeres en la proporción señalada en el artículo 37.2 de la Ley 7/2004, de 16 de julio. 


\section{TÍTULO XII \\ DE LA INSPECCIÓN, CONTROL, SALVAMENTO MARÍTIMO Y LUCHA CONTRA LA CONTAMINACIÓN}

\author{
Capítulo I \\ OBJETIVOS
}

Artículo 119. Objetivos.

El objetivo del régimen de inspección, control, salvamento marítimo y lucha contra la contaminación es garantizar el cumplimiento de la legislación vigente en materia de pesca, marisqueo y acuicultura, vigilar e inspeccionar las actividades incluidas en el ámbito de aplicación de la presente ley, prever y realizar todas aquellas actuaciones necesarias para la protección de los recursos marinos en todas sus fases, desde la captura o producción hasta la fase final de la comercialización, apoyar a la flota pesquera gallega, prestar servicios de búsqueda, rescate y salvamento marítimo y prever y luchar contra la contaminación del medio marino.

\section{Capítulo II \\ INSPECCIÓN Y CONTROL}

Artículo 120. Inspección y vigilancia pesqueras.

Las actuaciones contempladas en el artículo anterior serán llevadas a cabo por medio de los miembros del Servicio de Inspección y Vigilancia Pesquera, quienes tendrán la consideración de agentes de la autoridad en el desempeño de sus funciones.

El Servicio de Inspección y Vigilancia Pesquera contará con las siguientes escalas de funcionarios, pertenecientes a la Administración especial de la Xunta de Galicia:

a. Escala técnica del Servicio de Inspección y Vigilancia Pesquera, grupo A.1.

b. Escala ejecutiva del Servicio de Inspección y Vigilancia Pesquera, grupo A.2.

c. Escala de agentes del Servicio de Inspección y Vigilancia Pesquera, grupo C.1.

Dentro de esta escala se creará la especialidad de patrones y mecánicos, la cual se desarrollará reglamentariamente.
Los miembros del Servicio de Inspección y Vigilancia Pesquera colaborarán y auxiliarán, cuando sea necesario, en las acciones de salvamento marítimo y de lucha contra la contaminación conforme a los planes de contingencias y de lucha contra la contaminación marítima accidental.

Artículo 121. Identificación e indumentaria.

El personal perteneciente a las escalas del Servicio de Inspección y Vigilancia Pesquera irá perfectamente identificado, provisto del correspondiente carné y placa acreditativa y con el uniforme reglamentariamente determinado, excepto en aquellas actuaciones en que sea preciso garantizar el secreto de la operación.

Los medios de la consejería competente en materia de pesca empleados en el ejercicio de las funciones del personal de las escalas del Servicio de Inspección y Vigilancia Pesquera irán debidamente identificados, excepto en aquellos supuestos que reglamentariamente se determinen.

Artículo 122. Funciones de los miembros de Inspección y Vigilancia Pesquera.

1. La función inspectora tendrá entre otras funciones las de:

a. Velar por el cumplimiento de la legalidad vigente en las fases de producción, extracción, manipulación, distribución y comercialización de los productos pesqueros, marisqueros y acuícolas, mediante el control de las actividades pesqueras. En los supuestos de ordenación del sector, esta función comenzará desde el momento de la descarga o desembarque de las capturas, y en materia de comercialización de productos de la pesca, independientemente de su origen, después de la primera comercialización en las lonjas de los puertos o desde la primera comercialización cuando los productos no se vendan por primera vez en dichas lonjas.

b. El ejercicio de las funciones administrativas de investigación, realización de actuaciones de obtención de información, 
comprobación de los datos exigidos para la obtención de beneficios, incentivos, ayudas y subvenciones en materias de la consejería competente en materia de pesca.

c. Información y formación a los administrados con motivo de las actuaciones inspectoras sobre sus derechos y obligaciones y las demás funciones que se establezcan en otras disposiciones o que se encomienden a las autoridades competentes.

2. Funciones de vigilancia y control:

a. Todas aquellas actuaciones de vigilancia y prevención dirigidas a adoptar medidas de preservación del medio marino, en la zona del litoral de Galicia.

b. Vigilancia, defensa y control de los recursos marinos de Galicia.

c. Vigilar y prever la contaminación marina, participando y colaborando en las tareas de eliminación de productos contaminantes.

d. Apoyo y colaboración entre los miembros de las distintas escalas.

e. Dentro de sus competencias, coordinar los sistemas de vigilancia privada de las cofradías de pescadores de Galicia.

3. En el ejercicio de sus funciones, podrán inspeccionar embarcaciones, vehículos, establecimientos de acuicultura en tierra o mar, lonjas o centros de venta, industrias transformadoras, transportes, establecimientos comerciales y de hostelería, instalaciones portuarias, especialmente los que funcionen sin las autorizaciones preceptivas, sin perjuicio de las competencias de otras consejerías, administraciones u organismos públicos.

4. Las funciones de los miembros de las escalas del Servicio de Inspección y Vigilancia Pesquera se desarrollarán por tierra, mar o aire, utilizando los medios de que disponga la consejería competente en materia de pesca. Excepcionalmente, y siempre y cuando las circunstancias operativas relacionadas con el salvamento marítimo y de lucha contra la contaminación marina así lo aconsejen, podrán desarrollar sus funciones en medios de otros organismos públicos o privados.
Artículo 123. Responsables del sector. Las personas responsables de los buques pesqueros, vehículos, productos, empresas o instalaciones objeto de inspección prestarán a los agentes intervinientes su colaboración para la realización de la función inspectora. La falta de dicha colaboración o la obstrucción, en su caso, al ejercicio de la citada función será sancionada conforme a lo dispuesto en la presente ley.

\section{Capítulo III \\ SALVAMENTO MARÍTIMO Y LUCHA CONTRA LA CONTAMINACIÓN}

Artículo 124. Cooperación.

La Xunta de Galicia podrá establecer acuerdos y convenios con otras administraciones o entidades para el mejor ejercicio de la función inspectora.

Artículo 125. Salvamento marítimo y lucha contra la contaminación

Corresponde a la consejería competente en materia de pesca la prestación de los servicios de búsqueda, rescate y salvamento marítimo, así como de prevención y lucha contra la contaminación del medio marino.

\section{TíTULO XIII DE LOS REGISTROS}

Artículo 126. Registros.

1. La consejería competente en materia de pesca establecerá en el ámbito de sus competencias, entre otros, los registros públicos siguientes:

a. Registro de buques pesqueros de Galicia.

b. Registro de autorizaciones y concesiones marisqueras.

c. Registro de licencias de pesca marítima de recreo.

d. Registro de empresas de transformación, conservación y comercialización.

e. Registro de infracciones y sanciones.

f. Registro de entidades representativas del sector pesquero.

g. Registro de ayudas públicas al sector pesquero. 
h. Registro de titulaciones, acreditaciones, certificaciones y cualificaciones profesionales.

i. Registro de establecimientos de acuicultura.

j. Registro de actividades de turismo marinero.

2. Reglamentariamente se establecerá el régimen de acceso, inscripción y funcionamiento de cada uno de los registros.

\section{TÍTULO XIV \\ DEL RÉGIMEN SANCIONADOR}

\section{Capítulo I \\ DISPOSICIONES GENERALES}

Artículo 127. Objeto.

El presente título tiene por objeto regular el ejercicio de la potestad sancionadora en materia de pesca marítima, marisqueo, acuicultura, ordenación del sector pesquero y de la actividad comercial de los productos de la pesca, así como los relativos a las actividades náuticas de recreo y las subacuáticas profesionales en el ámbito de las competencias de Galicia.

Asimismo, este título tiene por objeto regular el ejercicio de la potestad sancionadora en materia de vertidos y de aquellas acciones $u$ omisiones de cualquier naturaleza que incidan sobre la calidad de los recursos marinos, excepto los supuestos contemplados en la Ley $8 / 2001$, de 2 de agosto, de protección de calidad de las aguas de las rías de Galicia y de ordenación del servicio público de depuración de aguas residuales urbanas.

Artículo 128. Potestad sancionadora. La potestad sancionadora en las materias objeto de la presente ley corresponderá ejercerla a la consejería competente, que la ejercerá con arreglo a esta ley y a lo dispuesto en la Ley 30/1992, de 26 de noviembre, de régimen jurídico de las administraciones públicas y del procedimiento administrativo común, y demás disposiciones de aplicación en esta materia.
Artículo 129. Responsabilidad.

1. Serán responsables de las infracciones tipificadas en la presente ley las personas físicas o jurídicas que las cometan, aun cuando estén integradas en asociaciones temporales de empresas, agrupaciones o comunidades de bienes.

2. Cuando la infracción sea imputable a varias personas y no sea posible determinar el grado de participación de cada una, responderán solidariamente:

a. En los casos de infracciones cometidas en materia de pesca y marisqueo, las personas propietarias de embarcaciones, personas armadoras, personas fletadoras, capitanes o capitanas y patrones o patronas.

b. En los casos de infracciones cometidas en materia de acuicultura, las personas titulares de establecimientos de cultivos marinos y auxiliares.

c. En los casos de infracciones cometidas en el transporte de productos de la pesca, el marisqueo y la acuicultura, las personas titulares de empresas de transporte.

d. Las personas titulares de entidades gestoras de las lonjas pesqueras y centros de venta respecto a la identificación de las especies así como a la exposición y venta de productos vedados y de talla o peso inferiores a los reglamentarios.

e. En los casos de infracciones cometidas en la comercialización de los productos de la pesca, el marisqueo y la acuicultura, las personas titulares de empresas comercializadoras o transformadoras de dichos productos.

f. Las personas titulares de empresas de hostelería que ofrezcan al consumo productos vedados o de talla o peso inferior al reglamentario.

g. Los titulares de las escuelas náutico-deportivas, centros de inmersión y academias náutico-deportivas, respecto a las infracciones que afecten a dichas actividades.

h. En el caso de infracciones cometidas en materia de vertidos en el mar, 
las personas titulares de los buques y, en su caso, de las empresas e industrias que hubieran efectuado los vertidos contaminantes, excepto los supuestos previstos en la Ley 8/2001, de 2 de agosto, de protección de calidad de las aguas de las rías de Galicia y de ordenación del servicio público de depuración de aguas residuales urbanas.

i. En el caso de obras de construcción que incidan directamente sobre el medio marino, las personas titulares de las empresas constructoras y, en su caso, las administraciones públicas promotoras de las mismas, excepto los supuestos previstos en la Ley 8/2001, de 2 de agosto, de protección de calidad de las aguas de las rías de Galicia y de ordenación del servicio público de depuración de aguas residuales urbanas.

j. En el caso de infracciones cometidas por las entidades asociativas del sector, los miembros de los órganos de gobierno.

3. De las infracciones cometidas por los menores de edad no emancipados serán responsables sus padres y madres o personas tutoras.

Artículo 130. Concurrencia de responsabilidades.

1. La responsabilidad por las acciones u omisiones tipificadas en la presente ley es de naturaleza administrativa y no excluye la de otro orden a que hubiera lugar.

2. Las sanciones que se impongan a distintos sujetos a consecuencia de una misma infracción tendrán entre sí carácter independiente, excepto en los supuestos de responsabilidad solidaria regulados en la presente ley.

3. El órgano competente podrá aplazar la resolución del procedimiento si se acreditara que se está siguiendo un procedimiento por los mismos hechos e infracciones distintas ante los órganos comunitarios europeos. La suspensión se alzará cuando aquéllos dictaran resolución firme. Si impusieran sanción los órganos comunitarios, el órgano competente para resolver habrá de tenerla en cuenta a los efectos de graduar la que, en su caso, deba imponer, pudiendo compensarla, sin perjuicio de declarar la comisión de la infracción.

Artículo 131. Vinculación con el orden jurisdiccional penitenciario.

No podrán sancionarse los hechos que hayan sido sancionados penal o administrativamente en los casos en que se aprecie identidad de sujeto, hecho y fundamento. En cualquier momento del procedimiento sancionador en que los órganos competentes juzguen que los hechos también pueden ser constitutivos de ilícito penal, se lo comunicarán al Ministerio Fiscal, solicitándole testimonio sobre las actuaciones practicadas respecto a la comunicación.

En estos supuestos, así como cuando los órganos competentes tengan conocimiento de que se está desarrollando un proceso penal sobre los mismos hechos, solicitarán del órgano judicial comunicación sobre las actuaciones adoptadas.

Si se considera que existe identidad de sujeto, hecho y fundamento entre la infracción administrativa y la infracción penal que pudiera corresponder, el órgano competente para la tramitación acordará su suspensión hasta que recaiga resolución judicial, notificándoselo a la persona interesada.

En todo caso, los hechos declarados probados por resolución penal firme vinculan a los órganos administrativos respecto a los procedimientos sancionadores que se sustancien.

Artículo 132. Extinción de la responsabilidad.

La responsabilidad derivada de la comisión de infracciones en la presente ley se extinguirá:

a. Por el fallecimiento de la persona física sancionada.

b. Por el cumplimiento de la sanción impuesta.

c. Por la prescripción de la infracción.

d. Por la prescripción de la sanción. 
Artículo 133. Prescripción de infracciones y sanciones.

1. Las infracciones administrativas previstas en la presente ley prescribirán: en el plazo de tres años las muy graves, en el de dos años las graves y en el de seis meses las leves.

2. Las sanciones impuestas por la comisión de infracciones muy graves prescribirán a los tres años, en tanto que las impuestas por graves o leves lo harán a los dos años y al año respectivamente.

3. Para el cómputo de los plazos de prescripción de infracciones y sanciones se estará a lo dispuesto en el artículo $132.2^{\circ}$ y $3^{\circ}$ de la Ley 30/1992, de 26 de noviembre, de régimen jurídico de las administraciones públicas y del procedimiento administrativo común.

4. La declaración de prescripción de la infracción o de la sanción conllevará el archivo de las actuaciones y la notificación a las personas interesadas.

\section{Capítulo II \\ INFRACCIONES ADMINISTRATIVAS}

Artículo 134. Infracciones administrativas.

Constituye infracción administrativa en materia de pesca marítima, marisqueo, acuicultura, actividades náuticas de recreo y subacuáticas profesionales y de ordenación del sector y comercialización de los productos pesqueros toda acción u omisión tipificada como tal en la presente ley.

Constituyen también infracción administrativa los vertidos $\mathrm{u}$ otras acciones $\mathrm{u}$ omisiones de cualquier naturaleza que, incidiendo en la calidad de los recursos marinos, se sitúen en el ámbito de las competencias autonómicas, excepto en aquellos supuestos regulados por la normativa sectorial o específica en la materia.

Artículo 135. Tipos de infracciones. Las infracciones administrativas se clasifican en leves, graves y muy graves.

Artículo 136. Infracciones leves.

Se consideran infracciones leves las siguientes:
A. En materia de cooperación con las autoridades:

1. Las faltas de respeto a las autoridades de vigilancia o inspección cometidas con ocasión del ejercicio de sus funciones.

2. La falta de auxilio a las autoridades de vigilancia e inspección sin justificación cuando se sea requerido en el caso de acciones que afecten o causen perjuicios a los recursos marinos.

3. La falta de colaboración de las entidades representativas del sector con la administración en el cumplimiento de los requerimientos de documentación, plazos y trámites a realizar, cuando se esté obligado a prestar colaboración según la legislación vigente.

B. En materia de pesca profesional y marisqueo:

1. No llevar consigo o no exhibir la licencia o documentación que se establezca reglamentariamente sobre la actividad pesquera o marisquera.

No obstante lo anterior, se quedará exento de responsabilidad si en el plazo máximo de veinticuatro horas se presenta ante la autoridad competente la documentación requerida.

2. El incumplimiento de las normas de los planes de gestión aprobados por la consejería competente.

3. El incumplimiento de las disposiciones reglamentarias sobre autorizaciones o concesiones marisqueras o de las condiciones contenidas en dicha autorización o concesión.

4. No tener reglamentariamente identificadas y balizadas las artes, aparejos o útiles de pesca, así como utilizar boyas o balizas que no cumplan la normativa vigente.

5. El incumplimiento de la obligación de llevar visibles, en la forma prevista por la legislación vigente, el folio y la matrícula de la embarcación o cualquier otro distintivo, o impedir su visualización cuando dificulte el ejercicio de la actividad inspectora. 
C. En materia de acuicultura:

1. El mantenimiento en condiciones diferentes a las reglamentariamente establecidas de las placas identificativas de los viveros de cultivos marinos.

2. El incumplimiento de las normas relativas a la autorización administrativa así como de las condiciones establecidas en dicha autorización necesaria para la transferencia de los establecimientos de cultivos marinos y auxiliares.

3. El no envío de los informes establecidos en la declaración de impacto ambiental.

D. En materia de pesca recreativa:

1. No llevar en el momento de la práctica de la pesca recreativa la correspondiente licencia que habilita para ejercer dicha actividad o no exhibirla al ser requerido para ello.

No obstante lo anterior, se quedará exento de responsabilidad si en el plazo máximo de veinticuatro horas se presenta ante la autoridad competente la documentación requerida.

2. El incumplimiento de las condiciones de acceso en las zonas definidas como reservadas o prohibidas para la pesca recreativa sin la preceptiva notificación o autorización previa de la consejería competente.

3. El ejercicio de la pesca recreativa con incumplimiento de las distancias mínimas establecidas en la normativa vigente.

4. El incumplimiento de la obligación de llevar visibles, en la forma prevista por la legislación vigente, el folio y la matrícula de la embarcación o cualquier otro distintivo, o impedir su visualización cuando dificulte el ejercicio de la actividad inspectora.

E. En materia de actividades náuticas de recreo y subacuáticas profesionales:

1. El incumplimiento por parte de las escuelas de navegación de recreo de las obligaciones exigidas reglamentariamente en materia de información y reclamaciones.

2. La realización de intervenciones subacuáticas hiperbáricas sin portar la tarjeta de buceo profesional o el libro diario sin actualizar o indebidamente diligenciado.

No obstante lo anterior, se quedará exento de responsabilidad si en el plazo máximo de veinticuatro horas se presenta ante la autoridad competente la documentación requerida.

F. En materia de ordenación del sector:

1. El incumplimiento de las preceptivas obligaciones de información a las administraciones públicas o su comunicación incumpliendo los plazos o condiciones de las mismas, cuando no esté tipificada como infracción grave o muy grave.

2. Cargar en cualquier medio de transporte productos pesqueros fuera de los lugares o puertos autorizados al efecto.

G. En materia de comercialización de los productos pesqueros:

La colocación en los circuitos comerciales de productos del mar que incumplan parcial o erróneamente las normas de etiquetado, presentación o publicidad en las diversas fases de comercialización, incluidos el transporte y distribución hasta el consumidor final.

H. En materia de documentos de registro:

1. La anotación incorrecta en los documentos de registro.

2. El incumplimiento de la obligación de entrega del documento de registro en los plazos establecidos en la normativa vigente.

I. Las acciones $\mathrm{u}$ omisiones que supongan el incumplimiento de las obligaciones establecidas en la legislación pesquera comunitaria o previstas en los tratados o convenios internacionales suscritos por la Unión Europea que afecten a la actividad pesquera y no supongan infracción grave o muy grave.

Artículo 137. Infracciones graves. Se consideran infracciones graves las siguientes:

A. En materia de cooperación con las autoridades:

1. La obstrucción de las labores de inspección. 
2. El incumplimiento de las normas electorales y de los requerimientos efectuados en el proceso electoral por la Administración pesquera a las cofradías de pescadores.

3. El impedimento de obtención de muestras por parte de quien ostente la titularidad de establecimientos marinos o auxiliares dirigidas al control sanitario.

B. En materia de pesca profesional y marisqueo:

1. La comisión de la tercera infracción leve en esta materia dentro de un periodo de dos años.

Relativas al ejercicio de la actividad:

2. El ejercicio de la actividad extractiva $\sin$ la licencia.

3. La utilización para la captura de especies marinas de equipos de respiración autónoma u otro tipo de equipos submarinos no autorizados.

4. La infracción de las normas relativas a los topes de captura reglamentariamente establecidos.

5. El ejercicio de la actividad extractiva en fondos o zonas prohibidas o no autorizadas.

6. No respetar los días u horarios establecidos para la actividad extractiva.

7. Realizar faenas de pesca sin encender ninguna de las luces reglamentarias o encender luces diferentes de las que corresponden al tipo de pesca que se realice.

8. El incumplimiento de la obligación de respetar distancias mínimas para buques y artes establecidas en la normativa vigente, a fin de entorpecer las actividades pesqueras.

9. La obtención de las licencias en base a documentos, datos o informes falsos.

10. Impedir u obstaculizar indebidamente la actividad pesquera o marisquera.

11. La realización de actividades de pesca o marisqueo sin disponer de un seguro reglamentariamente establecido.

12. Manipular la matrícula de la embarcación, cuando dificulte el ejercicio de la actividad inspectora.

\section{Relativas a las especies:}

13. La captura de especies de talla o peso inferior al establecido, según los límites y condiciones que se fijen reglamentariamente.

14. La captura de especies en época vedada, según los límites que se fijen reglamentariamente.

15. La introducción de especies o individuos en aguas del litoral de Galicia sin cumplir con los requisitos que reglamentariamente se determinen.

16. La no comunicación a la consejería competente, en el plazo que reglamentariamente se determine, de mortalidades anómalas producidas.

\section{Relativas a las artes:}

17. El uso o mera posesión, cuando no se justifique razonablemente su aplicación a menesteres distintos de la pesca o el marisqueo, de artes, aparejos o instrumentos prohibidos o con medidas antirreglamentarias.

18. La posesión en la embarcación de artes de pesca en mayor número del autorizado reglamentariamente.

19. El uso o tenencia a bordo de artes, aparejos o útiles de pesca o marisqueo distintos a los autorizados en la licencia, o no anotar dicha actividad en la forma que reglamentariamente se establezca, salvo casos puntualmente autorizados.

Relativas a los medios de control:

20. La alteración de los datos o circunstancias que figuren en la correspondiente licencia.

21. No cubrir el diario de pesca, la declaración de desembarque o libro de capturas u otros documentos necesarios que acompañen los productos de la pesca, el marisqueo o la acuicultura hasta los puntos de venta o comercialización, o hacerlo alterando los datos relativos a las capturas o al esfuerzo de pesca, infringiendo la normativa en vigor, así como no llevar a bordo el citado diario.

C. En materia de acuicultura:

1. La comisión de la tercera infracción leve en esta materia en un periodo de dos años. 
2. La alteración de las características o el incumplimiento de las condiciones establecidas en el correspondiente título administrativo que habilita para la explotación de establecimientos de cultivos marinos o auxiliares.

3. El incumplimiento de las normas de producción y venta de las especies marinas que se encuentren en los establecimientos de cultivos marinos y auxiliares.

4. El incumplimiento de las normas que regulan la autorización administrativa así como de las condiciones establecidas en dicha autorización para cambio de sistema de los viveros de cultivos marinos.

5. La instalación o explotación de expositores o centros reguladores de crustáceos sin contar con la oportuna autorización administrativa.

6. La ausencia de los elementos identificativos de los viveros de cultivos marinos o la inclusión en los mismos de datos no reales.

7. La explotación de un vivero de cultivos marinos o de establecimientos de explotación de recursos marinos vivos sin disponer del seguro reglamentariamente establecido.

8. El incumplimiento de las normas que regulan la autorización administrativa así como de las condiciones establecidas en dicha autorización para el traslado de especies entre viveros.

9. El incumplimiento de las normas relativas a la autorización así como de las condiciones establecidas en dicha autorización para la extracción de semilla de mejillón.

10. La introducción de especies o individuos en establecimientos de cultivos marinos o auxiliares sin cumplir los requisitos que reglamentariamente se determinen.

D. En materia de pesca recreativa:

1. La comisión de una tercera infracción leve en esta materia en un periodo de dos años.

2. El ejercicio de la pesca recreativa sin la preceptiva licencia.
3. La tenencia a bordo o el empleo para la captura de especies marinas de útiles prohibidos reglamentariamente.

4. La pesca marítima de recreo incumpliendo los días y horarios reglamentariamente establecidos.

5. La pesca recreativa en fondos prohibidos o en zonas o épocas vedadas, así como de especies no permitidas.

6. La captura de especies de talla o peso inferior al establecido reglamentariamente.

7. El incumplimiento de los topes de captura reglamentariamente establecidos en la pesca marítima de recreo.

8. La comercialización de las especies capturadas en el ejercicio de la pesca marítima de recreo.

9. La captura de especies marinas con equipos de respiración autónomos, semiautónomos o cualquier otro sistema que permita la respiración en inmersión o mediante la utilización de artefactos hidrodeslizantes o vehículos similares.

10. El empleo de luces artificiales de superficie o sumergidas o de cualquier otro medio que sirva de atracción o concentración artificial de las especies que vayan a capturarse.

11. La falta del balizamiento reglamentario establecido.

E. En materia de actividades náuticas de recreo y subacuáticas profesionales:

1. La comisión de una tercera infracción leve en esta materia en un periodo de dos años.

2. La realización de prácticas por las escuelas de navegación de recreo con instructores con titulación insuficiente para el nivel correspondiente.

3. No mantener actualizados y en vigor los seguros obligatorios exigidos a la escuela.

4. La alteración de datos y el deficiente mantenimiento o custodia, por parte de la persona obligada a ello, del libro de registro de prácticas.

5. La alteración o refrendo como jefe de equipo de las anotaciones del libro diario de buceo con datos falsos. 
6. Realizar actividades subacuáticas hiperbáricas sin la autorización expedida por la consejería competente o con incumplimiento de dicha autorización.

7. El uso de la tarjeta de buceo profesional fuera de su periodo de vigencia.

8. La realización de actividades subacuáticas hiperbáricas con el libro diario fuera del periodo de vigencia.

9. El incumplimiento por parte de las escuelas de navegación de recreo de los requisitos para su reconocimiento.

F. En materia de ordenación del sector:

1. La comisión de una tercera infracción leve en esta materia en un periodo de dos años.

2. Toda omisión o falseamiento grave de datos sobre la producción o venta de productos obtenidos en la actividad pesquera, marisquera o de acuicultura, cuando sea obligada su presentación ante la consejería competente.

3. La no aplicación, el falseamiento y la desviación de la aplicación de todo tipo de ayudas y subvenciones que perciban las personas beneficiarias con cargo a los presupuestos de la consejería competente, siempre que no se califique de infracción grave, conforme a los criterios reglamentarios de graduación, sin perjuicio del reintegro de la ayuda en los términos establecidos en la normativa del régimen financiero.

4. La realización de operaciones de construcción o modernización de buques pesqueros al margen o con incumplimiento de las preceptivas autorizaciones de los departamentos de la Xunta de Galicia en el ámbito de sus competencias.

5. El ejercicio de actividades profesionales pesqueras sin estar en posesión de la titulación que acredite la capacitación y formación profesional marítimo-pesquera.

6. El incumplimiento de la normativa vigente relativa a la potencia de los motores u otros parámetros establecidos para embarcaciones.

7. La entrada o salida del puerto fuera del horario establecido para el ejercicio de la actividad pesquera, debiéndose en este supuesto tener en cuenta el tiempo que reglamentariamente se determine como necesario y razonable para llegar a la zona o caladero en donde se ejercerá la actividad pesquera, salvo supuestos de estado de necesidad, fuerza mayor o convenio entre la administración y los particulares afectados del sector, todo ello sin perjuicio de las competencias concurrentes en la materia.

8. El incumplimiento de los descansos de pesca establecidos.

9. El desembarque, carga o descarga de especies y productos pesqueros en condiciones distintas de las establecidas legalmente.

10. El cambio de la base del buque pesquero sin haber obtenido previamente la correspondiente autorización administrativa o su utilización incorrecta, salvo en los casos de fuerza mayor o debido al retraso o paralización injustificada por parte de los organismos administrativos encargados del expediente de cambio de base.

11. El transporte de productos procedentes de la pesca, el marisqueo o la acuicultura sin la correspondiente documentación exigida en la normativa vigente.

12. La tenencia, consignación, almacenamiento, transporte, exposición y primera venta, en cualesquiera de las formas previstas legalmente, de productos pesqueros prohibidos o de talla o peso antirreglamentario.

G. En materia de comercialización de los productos pesqueros:

1. La comisión de una tercera infracción leve en esta materia en un periodo de dos años.

2. La realización de actividades de compraventa de productos pesqueros en lugar o forma no autorizados legalmente o con incumplimiento de los requisitos exigidos, así como la no expedición de la nota de venta, la inclusión de datos falsos en la misma o la no especificación exigida legalmente. 
3. El transporte de productos procedentes de la pesca, el marisqueo o la acuicultura sin la correspondiente documentación exigida en la normativa vigente.

4. La identificación incorrecta en las cajas o embalajes de las especies contenidas.

5. La comercialización de especies pesqueras con incumplimiento de la normativa sobre categorías de frescura y calibrado o sin contar con las autorizaciones necesarias o en condiciones distintas de las establecidas en dichas autorizaciones.

6. La tenencia, consignación, transporte, tránsito, almacenamiento, transformación, exposición y venta, en cualesquiera de las formas previstas legalmente, de productos pesqueros prohibidos o de talla o peso inferior al reglamentario.

7. La comercialización de productos de la pesca y el marisqueo de cualquier origen o procedencia cuya talla o peso sea inferior al reglamentario de cada modalidad, o su modo de obtención no fuera conforme a la normativa internacional, comunitaria, estatal y autonómica de aplicación en la materia, o incumplan la normativa sanitaria que en cada momento se establezca.

8. La comercialización de productos de acuicultura incumpliendo los tamaños comerciales que reglamentariamente se establezcan.

9. La negativa injustificada por las entidades gestoras de las lonjas o centros de venta a prestar los servicios necesarios para la primera venta y comercialización.

10. La colocación en circuitos comerciales de productos del mar sin ninguno de los datos obligados exigidos por la normativa de etiquetado, presentación y publicidad de los productos del mar en las diversas fases de comercialización, incluidos el transporte y la distribución de los mismos hasta el consumidor final.

H. En materia de conservación del medio marino:

1. Cualquier actuación de conservación y regeneración de recursos pesqueros en zonas marinas costeras sin la correspondiente autorización administrativa, siempre que dicho supuesto no esté regulado por la normativa sectorial o específica sobre la materia.

2. Cualquier actuación o variación de las características del medio marino, tanto en la zona marítima como marítimoterrestre o del borde litoral, que no cumpla las normas de protección ambiental aprobadas, cuando esta actuación no esté regulada por la normativa medioambiental o específica sobre la materia.

3. El incumplimiento de las medidas correctoras o compensatorias o del programa de vigilancia ambiental, así como de las disposiciones contenidas en la declaración de impacto ambiental.

I. En materia de documento de registro: La alteración o falseamiento de los datos del documento de registro.

Artículo 138. Infracciones muy graves. Se consideran infracciones muy graves las siguientes:

A. En materia de cooperación con las autoridades:

1. La resistencia o desobediencia grave a las autoridades de vigilancia o inspección impidiendo el ejercicio de la misma, así como la violencia ejercida sobre los citados agentes en el cumplimiento de sus funciones.

2. La comisión de tres infracciones graves en el mismo periodo electoral por una misma comisión electoral o cofradía.

B. En materia de pesca profesional y marisqueo:

1. La comisión de una tercera infracción grave en esta materia en un periodo de dos años.

Relativas al ejercicio de la actividad:

2. El empleo de armas o sustancias venenosas, corrosivas, explosivas, paralizantes, soporíferas o contaminantes en las labores de pesca o marisqueo, y su tenencia o transporte.

3. La explotación de recursos marinos en bancos naturales sin contar con la preceptiva autorización administrativa.

4. Ejercer faenas de pesca profesional sin estar incluido en los censos establecidos reglamentariamente. 
Relativas a las artes:

5. El empleo en faenas de pesca o marisqueo de artes o métodos de arrastre, salvo en los casos reglamentados.

Relativas a las especies:

6. La extracción, posesión, transporte o comercialización de especies marinas procedentes de zonas de producción cerradas por motivos de seguridad alimentaria y/o higiénico-sanitarios.

7. La introducción en aguas del litoral de la Comunidad Autónoma gallega, sin cumplir los requisitos que reglamentariamente se determinen, de especies o individuos alóctonos o de aquellos cuya introducción ponga en peligro la clasificación sanitaria del lugar en donde se efectúe.

C. En materia de acuicultura:

1. La comisión de una tercera infracción grave en esta materia en un periodo de dos años.

2. La instalación o explotación de establecimientos de cultivos marinos y auxiliares, con excepción de los expositores y centros reguladores de crustáceos, sin contar con el preceptivo título administrativo habilitante.

3. La obtención de concesiones, autorizaciones o permisos de actividad basándose en documentos, datos o información falsos.

4. El exceso de capacidad autorizada para el cultivo por exceso de cuerdas o de longitud de las mismas.

D. En materia de pesca recreativa:

1. La comisión de una tercera infracción grave en esta materia en un periodo de dos años.

2. La alteración de los datos o circunstancias que figuren en la correspondiente licencia de pesca recreativa, así como el uso fraudulento de la misma.

3. La obtención de la licencia de pesca recreativa en base a documentos, datos o información falsos.

4. El uso de sustancias venenosas, narcóticas, explosivas o contaminantes.

E. En materia de actividades náuticas de recreo y subacuáticas profesionales:
1. La comisión de una tercera infracción grave en esta materia en un periodo de dos años.

2. La expedición por las escuelas de navegación de recreo de certificados de prácticas sin la realización total o parcial de los programas correspondientes o su denegación injustificada a personas que las hubieran realizado.

3. Practicar el buceo careciendo de título para el mismo o sin la titulación adecuada al nivel de exposición hiperbárica de la intervención, así como alterar los datos o circunstancias que figuren en la tarjeta o libro diario de buceo o en la autorización para la realización de las actividades.

4. La alteración de los datos con falsedad o de las circunstancias que figuren en la correspondiente tarjeta de buceo profesional o en el libro diario de buceo así como el uso fraudulento de los mismos.

5. Aportar documentos, datos o información falsos para obtener cualquier título o autorización.

F. En materia de ordenación del sector y comercialización de los productos pesqueros:

1. La comisión de una tercera infracción grave en esta materia en un periodo de dos años.

2. La obtención de subvenciones, préstamos y en general cualquier tipo de ayuda en base a datos falsos, así como destinarlas a fines distintos de los previstos, sin perjuicio del reintegro de la ayuda en los términos de la normativa del régimen financiero.

3. La obtención de las autorizaciones necesarias en base a documentos o informaciones falsos.

G. En materia de conservación del medio marino:

1. Las actividades que perjudiquen, alteren o destruyan reservas de pesca o zonas de especial interés pesquero.

2. Verter al mar organismos, sustancias o productos que por sus características biológicas o químicas causen perjuicio 
a los recursos marinos, excepto los supuestos previstos en la Ley 8/2001, de 2 de agosto, de protección de calidad de las aguas de las rías de Galicia y de ordenación del servicio público de depuración de aguas residuales urbanas.

3. Cualquier actuación ejercida sobre el medio marino, el medio marítimo-terrestre o el borde litoral que cause efectos nocivos sobre los recursos pesqueros, marisqueros y acuícolas cambiando sus características, excepto los supuestos previstos en la Ley $8 / 2001$, de 2 de agosto, de protección de calidad de las aguas de las rías de Galicia y de ordenación del servicio público de depuración de aguas residuales urbanas.

4. El incumplimiento de lo establecido en la declaración de impacto ambiental cuando dicho incumplimiento cause un grave perjuicio para el sector pesquero, marisquero o acuícola.

\section{Capitulo III SANCIONES}

Artículo 139. Clases de sanciones.

1. Las sanciones que pueden aplicarse por la comisión de las infracciones previstas en la presente ley son las siguientes:

a. Apercibimiento.

b. Multa.

c. Inhabilitación para el ejercicio o desarrollo de actividades pesqueras, marisqueras, de buceo profesional o de formación náutica de recreo durante un periodo no superior a cinco años.

d. Suspensión, retirada o no renovación de las autorizaciones durante un periodo no superior a cinco años.

e. Imposibilidad de ser beneficiario o beneficiaria durante un plazo no superior a cinco años de préstamos, subvenciones o ayudas públicas convocadas por la Administración autonómica en las materias reguladas en la presente ley.

f. Decomiso de los aparejos, artes, útiles, instrumentos, embarcaciones o equipos de todo género empleados para la comisión de alguno de los hechos tipificados como infracción en la presente ley, o de los productos o bienes obtenidos.

g. La clausura temporal de un establecimiento de cultivos marinos y auxiliares, sin perjuicio de la declaración de caducidad, en su caso, del correspondiente título administrativo habilitante.

h. La suspensión de la actividad o actuación que suponga una infracción en materia de conservación del medio marino hasta que se adopten las medidas que garanticen su cese.

i. La intervención de la cofradía para garantizar el desarrollo del proceso electoral conforme a la legislación vigente en materia electoral.

2. Estas sanciones serán acumulables de acuerdo con lo establecido en la presente ley.

3. El órgano sancionador podrá acordar la imposición de multas coercitivas, con arreglo a lo dispuesto en el artículo 99 de la Ley 30/1992, de 26 de noviembre, de régimen jurídico de las administraciones públicas y del procedimiento administrativo común, una vez transcurridos los plazos señalados en el requerimiento correspondiente.

La cuantía de cada una de dichas multas no superará el veinte por ciento de la multa fijada por la infracción correspondiente.

4. Cuando se hubiera utilizado el buque o embarcación para efectuar el transporte de drogas tóxicas, estupefacientes, sustancias psicotrópicas, transporte ilegal de inmigrantes o para cualquier otra actividad constitutiva de delito y se hubiera determinado por resolución judicial firme la responsabilidad de los autores, estos quedarán inhabilitados para el ejercicio o desarrollo de las actividades pesqueras durante un periodo de diez años.

5. Conjuntamente con la sanción que se imponga, podrá acordarse la recuperación, restitución y subsanación por la persona infractora y a su cargo de los efectos causados por su acción o actuación. 
Artículo 140. Criterios de graduación.

1. La determinación de las sanciones se efectuará de acuerdo con las circunstancias siguientes:

a. El grado de negligencia o intencionalidad de la persona infractora.

b. La reincidencia de las infracciones cometidas.

c. La reiteración.

d. La índole o trascendencia de los perjuicios causados al medio, a los recursos marinos o a terceros.

e. El beneficio obtenido en la comisión de la infracción.

f. El precio en lonja o de mercado de las especies capturadas, cultivadas, transportadas o comercializadas.

2. Se considera circunstancia atenuante proceder a subsanar la infracción cometida en el plazo que se señalara en el correspondiente requerimiento.

Artículo 141. Reincidencia y reiteración.

1. Existirá reincidencia cuando en el plazo de un año se cometa más de una infracción del mismo tipo y calificación, siempre que haya sido así declarado por resolución firme.

2. Existirá reiteración cuando se dé el supuesto reglado en el apartado anterior y no exista resolución firme.

Artículo 142. Sanciones en materia de cooperación con las autoridades.

1. Las infracciones reguladas en la presente ley en materia de cooperación con las autoridades se sancionarán, según su carácter, conforme a los criterios siguientes:

a. Las infracciones leves serán sancionadas con apercibimiento o multa de 60 a 300 euros.

b. Las infracciones graves, con multa de 301 a 6.000 euros.

c. Las infracciones muy graves, con multa de 6.001 a 60.000 euros.

2. Las infracciones graves y muy graves previstas en el apartado 1, además de con la multa correspondiente, podrán ser sancionadas con la sanción accesoria recogida en el artículo $139.1^{\circ}$, letra i), por un periodo máximo hasta que finalice el proceso electoral.

Artículo 143. Sanciones en materia de pesca profesional y marisqueo.

1. Las infracciones reguladas en la presente ley en materia de pesca profesional y marisqueo se sancionarán, según su carácter, conforme a los criterios siguientes:

a. Las infracciones leves serán sancionadas con apercibimiento o multa de 30 a 150 euros.

b. Las infracciones graves, con multa de 151 a 30.000 euros.

c. Las infracciones muy graves, con multa de 30.001 a 150.000 euros.

2. Las infracciones graves y muy graves, además de con la multa correspondiente, podrán ser sancionadas con una o varias de las sanciones accesorias recogidas en el artículo $139.1^{\circ}$, letras c), d) y e), por un periodo máximo de tres años para el caso de las infracciones graves y de cinco años en el caso de las muy graves, y en la letra $f$ ).

Artículo 144. Sanciones en materia de acuicultura.

1. Las infracciones reguladas en la presente ley en materia de cultivos marinos se sancionarán, según su carácter, conforme a los criterios siguientes:

a. Las infracciones leves serán sancionadas con apercibimiento o multa de 60 a 300 euros.

b. Las infracciones graves, con multa de 301 a 60.000 euros.

c. Las infracciones muy graves, con multa de 60.001 a 300.000 euros.

2 . Las infracciones graves o muy graves, además de con las multas correspondientes, podrán ser sancionadas con una o varias sanciones accesorias recogidas en el artículo $139.1^{\circ}$, letras d), e) y g), por un periodo máximo de tres años para el caso de las infracciones graves y de cinco años en el caso de las muy graves. 
Artículo 145. Sanciones en materia de pesca recreativa.

1. Las infracciones reguladas en la presente ley en materia de pesca recreativa se sancionarán, según su carácter, conforme a los criterios siguientes:

a. Las infracciones leves serán sancionadas con apercibimiento o multa de 30 a 150 euros.

b. Las infracciones graves, con multa de 151 a 3.000 euros.

c. Las infracciones muy graves, con multa de 3.001 a 18.000 euros.

2. Las infracciones graves o muy graves, además de con la multa correspondiente, podrán ser sancionadas con una o varias sanciones accesorias recogidas en el artículo $139.1^{\circ}$, letra d), por un periodo máximo de tres años para el caso de las infracciones graves y de cinco años en el caso de las muy graves, y en la letra f).

Artículo 146. Sanciones en materia de actividades náuticas de recreo y subacuáticas profesionales.

1. Las infracciones reguladas en la presente ley en materia de actividades náuticas y subacuáticas de recreo se sancionarán, según su carácter, conforme a los criterios siguientes:

a. Las infracciones leves serán sancionadas con apercibimiento o multa de 30 a 150 euros.

b. Las infracciones graves, con multa de 151 a 6.000 euros.

c. Las infracciones muy graves, con multa de 6.001 a 60.000 euros.

2. Las infracciones graves y muy graves, además de con la multa correspondiente, podrán ser sancionadas con una o varias de las sanciones accesorias recogidas en el artículo $139.1^{\circ}$, letras c), d) y e), por un periodo máximo de tres años para el caso de las infracciones graves y de cinco años en el caso de las muy graves.

Artículo 147. Sanciones en materia de ordenación del sector.

1. Las infracciones reguladas en la presente ley en materia de ordenación del sector se sancionarán, según su carácter, conforme a los criterios siguientes:

a. Las infracciones leves serán sancionadas con apercibimiento o multa de 60 a 300 euros.

b. Las infracciones graves, con multa de 301 a 60.000 euros.

c. Las infracciones muy graves, con multa de 60.001 a 300.000 euros.

2. Las infracciones graves, además de con la multa correspondiente, podrán ser sancionadas con una o varias de las sanciones accesorias siguientes en función de las circunstancias concurrentes:

a. Decomiso de los productos o bienes obtenidos ilegalmente, las infracciones previstas en el artículo 137.F), números 8, 9, 11 y 12 .

b. Suspensión, retirada o no renovación de las autorizaciones durante un periodo no superior a cinco años, las infracciones previstas en el artículo 137.F), números 2, 3, 4, 6 y 12 .

c. Inhabilitación para el ejercicio o desarrollo de actividades pesqueras durante un periodo no superior a cinco años, las infracciones previstas en el artículo 137. F), números 4, 5, 7 y 10.

d. Imposibilidad de obtención durante el plazo no superior a cinco años de préstamos, subvenciones o ayudas públicas, las infracciones previstas en el artículo 137. F), números 2 y 3 .

3. Las infracciones muy graves, además de con la multa correspondiente, podrán ser sancionadas, en función de las circunstancias concurrentes, con una o varias de las sanciones accesorias siguientes:

a. Suspensión, retirada o no renovación de las autorizaciones durante un periodo no superior a cinco años, las infracciones previstas en el artículo 138.F), número 3.

b. Inhabilitación para el ejercicio o desarrollo de actividades durante un periodo no superior a cinco años, las infracciones previstas en el artículo 138.F), número 3.

c. Imposibilidad de obtención de ayudas, préstamos o subvenciones públicas 
durante un plazo máximo de cinco años, la infracción prevista en el artículo 138.F), número 2.

Artículo 148. Sanciones en materia de comercialización de los productos pesqueros.

1. Las infracciones reguladas en la presente ley en materia de comercialización de los productos pesqueros se sancionarán, según su carácter, conforme a los criterios siguientes:

a. Las infracciones leves serán sancionadas con apercibimiento o multa de 60 a 300 euros.

b. Las infracciones graves, con multa de 301 a 60.000 euros.

c. Las infracciones muy graves, con multa de 60.001 a 300.000 euros.

2. Las infracciones graves, además de con la multa correspondiente, podrán ser sancionadas con una o varias de las sanciones accesorias siguientes en función de las circunstancias concurrentes:

a. Decomiso de los productos o bienes obtenidos ilegalmente, las infracciones previstas en el artículo 137.G), números 3 , 4, 5, 6, 7, 8 y 10 .

b. Suspensión, retirada o no renovación de las autorizaciones durante un periodo no superior a cinco años, las infracciones previstas en el artículo 137.G), números 4, $5,6,7$ y 8 .

c. Inhabilitación para el ejercicio o desarrollo de actividades pesqueras durante un periodo no superior a cinco años, las infracciones previstas en el artículo 137. G), número 5 .

d. Imposibilidad de obtención durante el plazo no superior a cinco años de préstamos, subvenciones o ayudas públicas, las infracciones previstas en el artículo 137. G), número 7 .

3. Las infracciones muy graves, además de con la multa correspondiente, podrán ser sancionadas, en función de las circunstancias concurrentes, con una o varias de las sanciones accesorias siguientes:

a. Suspensión, retirada o no renovación de las autorizaciones durante un periodo no superior a cinco años, las infracciones previstas en el artículo 138.F), número 3.

b. Inhabilitación para el ejercicio o desarrollo de actividades durante un periodo no superior a cinco años, las infracciones previstas en el artículo 138.F), número 3.

c. Imposibilidad de obtención de ayudas, préstamos o subvenciones públicas durante un plazo máximo de cinco años, la infracción prevista en el artículo 138.F), número 2.

Artículo 149. Sanciones en materia de conservación del medio marino.

1. Las infracciones reguladas en la presente ley en materia de conservación del medio marino se sancionarán, según su carácter, conforme a los criterios siguientes:

a. Las infracciones graves, con multa de 301 a 60.000 euros.

b. Las infracciones muy graves, con multa de 60.001 a 300.000 euros.

2. Las infracciones previstas en este artículo, además de con la multa correspondiente, podrán ser sancionadas con las sanciones accesorias siguientes:

a. La imposibilidad de obtención de ayudas, préstamos o subvenciones públicas durante un plazo máximo de cinco años.

b. La recuperación, restitución y subsanación por el infractor y a su cargo de los efectos causados por su actuación.

c. La suspensión de la actividad o actuación que suponga una infracción en materia de conservación del medio marino hasta que se adopten las medidas que garanticen su cese.

3. Cuando el infractor no realice las actuaciones previstas en las letras b) y c) del apartado 2 de este artículo, se procederá a la ejecución subsidiaria de acuerdo con lo previsto en la Ley 30/1992, de 26 de noviembre.

Artículo 150. Sanciones en materia de documentos de registro.

1. Las infracciones reguladas en la presente ley en materia de seguridad alimentaria se sancionarán, según su carácter, conforme a los criterios siguientes: 
a. Las infracciones leves serán sancionadas con apercibimiento o multa de 60 a 300 euros.

b. Las infracciones graves, con multa de 301 a 60.000 euros.

2. Las infracciones graves, además de con la multa correspondiente, podrán ser sancionadas en función de las circunstancias concurrentes con una o varias de las sanciones accesorias previstas en el artículo 139.1, letras d), e), f) y g).

Artículo 151. Suspensión condicional y remisión de la sanción.

1. En las sanciones en materias reguladas en la presente ley, una vez sea firme en vía administrativa, la persona infractora podrá solicitar en el plazo de un mes, contado desde la firmeza, la suspensión condicional de la ejecución de la sanción impuesta.

Para ello habrá de presentar escrito debidamente motivado, dirigido a la persona titular de la consejería competente en materia de pesca, marisqueo y acuicultura, en el que manifieste el compromiso de atenerse a las condiciones que para su otorgamiento se establezcan, a fin de garantizar, durante el plazo de suspensión, un comportamiento de respeto de la normativa reguladora de la actividad pesquera.

La presentación de la solicitud determinará la suspensión automática de la ejecución de la sanción hasta la resolución del expediente sobre la suspensión condicional.

El plazo de suspensión condicional será de seis a nueve meses para las faltas leves y de nueve a dieciséis meses para las faltas graves y muy graves en su caso, atendiendo en ambos casos a las circunstancias de la infracción cometida.

2. Serán requisitos para solicitar la suspensión condicional:

a. Que la persona infractora no hubiera sido sancionada en los últimos tres años, ni tener abierto un procedimiento sancionador por comisión de infracción regulada en la presente ley.

b. Que la cuantía de la sanción impuesta no exceda de 30.000 euros.
3. A efectos de la resolución de suspensión condicional de la ejecución, se concederá audiencia a la persona interesada y podrán recabarse informes de las entidades asociativas del sector afectado y de otros organismos públicos interesados. Podrán, asimismo, recabarse todos aquellos informes que se juzguen convenientes para resolver sobre la suspensión condicional.

Una vez acreditado el cumplimiento de los requisitos establecidos, la persona titular de la consejería competente podrá resolver la concesión o denegación de la suspensión condicional de la ejecución de la sanción en el plazo máximo de seis meses, a contar desde que la solicitud hubiera entrado en el registro de la consejería.

4. La resolución denegatoria de la suspensión condicional, debidamente motivada, será notificada a la persona interesada, procediéndose a continuar la tramitación de la ejecución de la sanción impuesta. Asimismo, la resolución favorable, debidamente motivada, será notificada a las personas interesadas y expresará las condiciones en que se llevará a cabo, así como que la misma suspende los plazos de prescripción de la sanción establecida en la presente ley. Las personas interesadas podrán entender desestimada por silencio administrativo su solicitud.

5. Las condiciones de obligado respeto por la persona infractora, durante el periodo de suspensión, incluirán en todo caso:

a. No cometer infracción alguna de las tipificadas en esta ley.

b. Cumplir debidamente las medidas cautelares impuestas y mantenidas, en su caso.

6. Si la persona interesada, durante el plazo de suspensión fijado, incumpliera las obligaciones o condiciones impuestas o fuera sancionada por otras infracciones pesqueras, el órgano competente, previa audiencia de aquella, revocará la suspensión condicional de la ejecución de la infracción y se continuará la tramitación de la ejecución de la sanción impuesta. 
7. Una vez cumplido el tiempo establecido en la suspensión, si la persona infractora, a la vista de los informes que puedan ser requeridos al efecto, cumplió las condiciones establecidas y no fue sancionada por otras infracciones pesqueras, la persona titular de la consejería competente acordará la remisión de la sanción impuesta siempre que la resolución administrativa sancionadora sea firme y no hubiera recaído sentencia judicial.

\section{Capitulo IV PROCEDIMIENTO SANCIONADOR}

Artículo 152. Procedimiento sancionador.

La imposición de sanciones tipificadas en la presente ley se ajustará al procedimiento sancionador regulado en este título y, subsidiariamente, a lo establecido en la Ley 30/1992, de 26 de noviembre, de régimen jurídico de las administraciones públicas y del procedimiento administrativo común, y demás disposiciones aplicables.

Reglamentariamente podrá aprobarse un procedimiento simplificado o abreviado.

Artículo 153. Órganos competentes.

1. La competencia para acordar la iniciación del procedimiento sancionador corresponderá a la persona titular de la delegación territorial de la consejería competente en materia de pesca.

2. Será competente para la instrucción del procedimiento el funcionario o funcionaria designado por la persona titular de la delegación territorial.

3. La competencia para la imposición de sanciones corresponderá:

a. A las personas titulares de la delegación territorial del ámbito en el que se hubiera cometido la infracción, en los casos de infracciones sancionadas con multas de cuantía inferior a 15.000 euros.

b. A las personas titulares de las direcciones generales en el ámbito de sus competencias, en los casos de infracciones sancionadas con multas de cuantía comprendida entre 15.000 y 60.000 euros. c. A la persona titular del departamento de la consejería competente en materia de pesca, en los casos de infracciones sancionadas con una multa de cuantía superior a la señalada en la letra anterior de este apartado.

4. La competencia para la imposición de las sanciones accesorias corresponderá al mismo órgano al que competa la imposición de la sanción principal.

Artículo 154. Plazo de tramitación.

1. El plazo para tramitar, resolver y notificar la resolución sancionadora será de un año, a computar desde la adopción del acuerdo de iniciación del procedimiento sancionador.

2. Transcurrido dicho plazo, habida cuenta de las posibles interrupciones de su cómputo por causas imputables a las personas interesadas o por la suspensión del procedimiento, se declarará la caducidad de las actuaciones.

Artículo 155. Actas de inspección.

1. Las actas de inspección redactadas por el personal funcionario de la Inspección Pesquera tendrán la condición de documento público y gozarán de eficacia probatoria respecto a los hechos en las mismas denunciados, sin perjuicio de las pruebas que en defensa de los respectivos derechos e intereses puedan señalar o aportar las personas interesadas.

2. Las actas deberán expresar los hechos y circunstancias relacionados con la presunta infracción, los medios técnicos empleados desde tierra, embarcaciones o aeronaves para su comprobación y los datos que identifiquen a las personas o entidades que intervengan en la infracción detectada, así como las medidas cautelares adoptadas con arreglo a lo establecido en el artículo $156.4^{\circ}$ de la presente ley. Siempre que sea posible, se adjuntará al acta el material gráfico o cualquier otro elemento objetivo que acredite la presunta infracción.

3. Una copia del acta será entregada a la presunta persona infractora en el mismo acto de levantamiento. Si ello no fuera posible, se harán constar las circunstancias 
que lo impidieron, y se entregará posteriormente al notificarse la incoación del procedimiento.

4. Cuando en el ejercicio de sus funciones de asesoramiento el personal funcionario de Inspección Pesquera detecte deficiencias o simples inobservancias de la normativa fácilmente subsanables, sustituirá el acta a que se refiere el apartado primero del presente artículo por un acta de advertencia, en la cual, sin dar lugar a la incoación de un procedimiento sancionador, se harán constar:

a. Las deficiencias o inobservancias detectadas.

b. Las advertencias o medidas correctoras propuestas y el plazo de subsanación.

Artículo 156. Medidas cautelares.

1. Para asegurar la eficacia de la resolución que pudiera recaer y el buen fin del procedimiento, evitar el mantenimiento de los efectos de la infracción y garantizar la protección de los recursos marítimo-pesqueros y demás intereses generales, podrán adoptarse las medidas cautelares siguientes:

a. Incautación de los productos de la pesca, marisqueo y acuicultura, debiendo definir el acuerdo la descripción de lo incautado.

b. Incautación de artes, aparejos, útiles de pesca y marisqueo, vehículos, embarcaciones, equipos $\mathrm{u}$ otros accesorios que hayan sido empleados en la comisión de infracciones tipificadas en la presente ley como graves o muy graves, debiendo definir el acuerdo la descripción de lo incautado.

c. Constitución de fianza.

d. Cierre temporal de las instalaciones y establecimientos.

e. Suspensión temporal de los títulos administrativos habilitantes.

f. Retención temporal de la tarjeta profesional náutico-pesquera que habilita para el ejercicio de la profesión de capitán o capitana, o patrón o patrona, en un buque pesquero.

g. Suspensión temporal de la actividad o actuación que suponga una infracción en materia de conservación del medio marino hasta que se adopten las medidas que garanticen su cese.

2. La adopción de estas medidas se realizará motivadamente y basándose en un juicio de razonabilidad, eligiendo aquella que menos dañe la situación jurídica del administrado. En todo caso, se respetará el principio de proporcionalidad de la medida que va a adoptarse con los objetivos que se pretenda garantizar en cada caso concreto.

3. Las medidas cautelares podrán ser adoptadas, una vez iniciado el procedimiento sancionador, por la persona titular de la delegación territorial de la consejería competente. Durante su tramitación, podrán ser alzadas o modificadas en virtud de circunstancias sobrevenidas o que no han podido ser tenidas en cuenta en el momento de su adopción.

4. Antes de iniciarse el procedimiento, cuando resulte necesario por razones de urgencia o necesidad, el personal funcionario de Inspección Pesquera podrá adoptar verbalmente las medidas cautelares previstas en el apartado 1, letras a) y b), de este artículo; dando razón de su proceder en la correspondiente acta. En defecto de esta, habrá de reflejarse el oportuno acuerdo y su motivación por escrito con la mayor brevedad posible, y en todo caso en un plazo no superior a cinco días, dando traslado del mismo a las personas interesadas y a la delegación territorial. Las medidas cautelares deberán ser confirmadas, modificadas o levantadas en el acuerdo de iniciación del procedimiento, que habrá de efectuarse dentro de los quince días siguientes a su adopción.

En todo caso, dichas medidas cautelares quedarán sin efecto si no se iniciara el procedimiento en dicho plazo o cuando el acuerdo de iniciación no contuviera un pronunciamiento expreso acerca de las mismas.

5. Las medidas cautelares adoptadas se extinguirán con la eficacia de la resolución administrativa que ponga fin al procedimiento sancionador. 
Artículo 157. Destino de los productos y bienes incautados.

1. El destino de los productos incautados será el siguiente:

a. Se devolverán al medio del que han sido extraídas las especies procedentes de la pesca, el marisqueo y la acuicultura que tuvieran posibilidades de sobrevivir.

b. Si las especies estuvieran muertas, habida cuenta de su volumen y condiciones higiénico-sanitarias, su destino podrá ser alguno de los siguientes:

Subasta pública, siempre que se trate de especies no vedadas o de tamaño o peso reglamentario, consignándose su importe a lo que resulte del expediente.

Entrega, para su consumo, a un centro benéfico.

Destrucción, en la forma que reglamentariamente se establezca.

2. Las artes, aparejos, útiles de pesca $\mathrm{y}$ marisqueo, equipos $\mathrm{u}$ otros accesorios antirreglamentarios incautados serán destruidos.

3. Las artes, aparejos, útiles de pesca y marisqueo, vehículos, embarcaciones, equipos u otros accesorios reglamentarios incautados serán liberados previa constitución de fianza, cuya cuantía será fijada por la persona titular de la delegación territorial de la consejería competente, no pudiendo exceder la misma del importe de la sanción que pudiera corresponder por la infracción o infracciones cometidas.

4. El importe de los gastos derivados de la adopción de las medidas anteriormente descritas se exigirá a la persona imputada si en la resolución del expediente se apreciara la comisión de la infracción.

5. Si en la resolución del procedimiento sancionador no se apreciara la comisión de la infracción, se acordará la devolución de los productos o bienes incautados o, en su caso, su valor. Si la persona interesada no se hiciera cargo de los mismos en el plazo de seis meses desde que hubiera sido requerida para ello, se presumirá su abandono, y la consejería competente habrá de decidir su destino, una vez agotada la vía administrativa.

6. Si en la resolución del procedimiento sancionador se apreciara la comisión de infracción, los objetos incautados que no fueran susceptibles de un uso lícito serán destruidos. Si su uso fuera lícito y siempre que en la resolución sancionadora no se estableciera su decomiso como sanción accesoria o medida cautelar para asegurar la eficacia de la sanción en tanto no sea ejecutiva, se acordará la devolución de los mismos. Si la persona interesada no se hiciera cargo de los mismos en el plazo de seis meses desde que hubiera sido requerida para ello, se presumirá su abandono, procediendo la consejería competente a su venta en subasta pública, a su entrega a entidades sin ánimo de lucro o de carácter benéfico o a su destrucción.

7. De todas estas actuaciones se dejará constancia en acta.

Artículo 158. Reconocimiento de responsabilidad.

1. Cuando la sanción que pudiera imponerse en el procedimiento sancionador tuviera carácter pecuniario y se hubiera fijado su cuantía, sea en el acuerdo de iniciación, sea en la propuesta de resolución, el reconocimiento de responsabilidad y la conformidad con la misma por el presunto responsable en cualquier momento anterior a la resolución determinará la finalización del procedimiento.

En este caso, la resolución del procedimiento sancionador recogerá una reducción del treinta por ciento sobre el importe de la sanción propuesta, siempre que el abono de la misma se efectúe en periodo voluntario.

2. Lo dispuesto en el apartado anterior no será de aplicación cuando la persona infractora incurra en el supuesto de reincidencia contemplado en la presente ley. 


\section{Capítulo V \\ LUCHA CONTRA LA PESCA ILEGAL DE LOS BUOUES CON ABANDERAMIENTO DE CONVENIENCIA}

Artículo 159. Abanderamiento de conveniencia.

1. Los países y territorios a los que se atribuye la calificación de abanderamiento de conveniencia serán los calificados por la Unión Europea, el Estado español o las organizaciones regionales de ordenación pesquera (ORP) como no cooperantes en su área de regulación, de acuerdo con los criterios establecidos por dichas administraciones u organizaciones.

2. Los buques apátridas o sin nacionalidad tendrán, en todo caso, la consideración de buques con abanderamiento de conveniencia.

3. Queda prohibido el desembarque, transporte y comercialización de capturas procedentes de buques identificados por la Unión Europea, el Estado español o las organizaciones regionales de ordenación pesquera por llevar a cabo actividades de pesca ilegal o contrarias a las medidas de conservación y gestión en su área de regulación, aplicándose en estos casos el régimen sancionador vigente sobre la materia.

\section{DISPOSICIÓN ADICIONAL PRIMERA EXTINCIÓN DEL INTECMAR}

A la entrada en vigor de la presente ley, se extinguirá el Instituto Tecnológico para el Control del Medio Marino de Galicia (Intecmar) como un ente de derecho público, siendo sus funciones asumidas por la unidad que se determine en el decreto de estructura orgánica de la consejería competente.

Los bienes y derechos de que sea titular el Intecmar se adscribirán a la consejería competente en materia de pesca, en la forma establecida en la legislación patrimonial.

El personal que a la entrada en vigor de la presente ley preste servicios como personal propio del Intecmar pasará a ser personal de la Xunta de Galicia, adscrito a la unidad que se determine en el decreto de estructura orgánica de la consejería competente en materia de pesca.

Reglamentariamente se fijará el procedimiento y condiciones en que se hará efectiva la integración de dicho personal como personal de la Xunta de Galicia.

\section{DISPOSICIÓN ADICIONAL SEGUNDA ELECCIONES EN LAS COFRADÍAS DE PESCADORES DE GALICIA}

La consejería competente en materia de pesca procederá a la convocatoria de elecciones para todas las cofradías de pescadores y sus federaciones.

En la primera convocatoria, y de manera excepcional, la duración del mandato de los órganos de gobierno de las cofradías se extenderá o acortará a la fecha de convocatoria, unificándose el calendario electoral a partir de la misma para todas las cofradías de Galicia.

\section{DISPOSICIÓN ADICIONAL TERCERA INFRACCIONES COMETIDAS EN EL ÁMBITO TERRITORIAL DE LA PROVINCIA DE OURENSE}

Los procedimientos sancionadores que se inicien por infracciones tipificadas en la presente ley cometidas en el ámbito territorial de la provincia de Ourense se tramitarán en la delegación territorial en Pontevedra.

\section{DISPOSICIÓN ADICIONAL CUARTA INSPECCIÓN DE LOS CENTROS DE FORMACIÓN ADSCRITOS A LA CONSEJERÍA COMPETENTE EN MATERIA DE PESCA}

La consejería competente en materia de pesca habilitará personal perteneciente a las escalas de profesores numerarios y de maestros de taller de institutos politécnicos marítimo-pesqueros para la realización de las funciones de inspección de los centros de formación adscritos al departamento, para velar por el funcionamiento general de los centros y el cumplimiento de las obligaciones inherentes a cada uno de los miembros de la comunidad educativa. 


\section{DISPOSICIÓN ADICIONAL OUUINTA AGENTES DE LA AUTORIDAD}

Tendrán la condición de agentes de la autoridad los funcionarios y funcionarias de otras escalas, adscritos a la consejería competente en materia de pesca, que tengan atribuidas funciones de control del cumplimiento de la legislación vigente en materia de seguridad alimentaria, sanidad animal y medio ambiente, atribuyéndoles para el ejercicio de estas funciones lo establecido en los artículos 121, 122 y 123.

\section{DISPOSICIÓN ADICIONAL SEXTA \\ CAMBIO DE DENOMINACIÓN DEL SERVICIO DE GUARDACOSTAS DE GALICIA}

El Servicio de Guardacostas de Galicia existente hasta la entrada en vigor de la presente ley pasa a denominarse Servicio de Inspección y Vigilancia Pesquera, contando con las escalas de funcionarios contempladas en el artículo 120 de la presente ley y debiendo desarrollar las funciones contenidas en su artículo 122.

De acuerdo con lo anterior:

a. La escala técnica del Servicio de Guardacostas de Galicia, grupo A, pasa a denominarse escala técnica del Servicio de Inspección y Vigilancia Pesquera, grupo A.1, de la que forma parte todo el personal funcionario que a la entrada en vigor de la presente ley esté integrado en aquella.

b. La escala ejecutiva del Servicio de Guardacostas de Galicia, grupo B, pasa a denominarse escala ejecutiva del Servicio de Inspección y Vigilancia Pesquera, grupo A.2, de la que forma parte todo el personal funcionario que a la entrada en vigor de la presente ley esté integrado en aquella.

c. La escala de agentes del Servicio de Guardacostas de Galicia, grupo C, pasa a denominarse escala de agentes del Servicio de Inspección y Vigilancia Pesquera, grupo C.1, de la que forma parte todo el personal funcionario que a la entrada en vigor de la presente ley esté integrado en aquella.

\section{DISPOSICIÓN ADICIONAL SÉPTIMA AGENTES DEL SERVICIO DE INSPECCIÓN Y VIGILANCIA PESOUERA}

La consejería competente adoptará las medidas necesarias para que el personal funcionario perteneciente a la escala de agentes del Servicio de Inspección y Vigilancia Pesquera, grupo C.1, pueda obtener la titulación de técnico superior.

\section{DISPOSICIÓN ADICIONAL OCTAVA \\ DEL PERSONAL FUNCIONARIO DE \\ LA ESCALA BÁSICA DE VIGILANCIA PESOUERA, GRUPO D}

El personal funcionario del grupo $\mathrm{D}$ de la escala básica de vigilancia pesquera contemplado en la disposición transitoria segunda de la Ley 2/2004, de 21 de abril, por la que se crea el Servicio de Guardacostas de Galicia, que a la fecha de la entrada en vigor de la presente ley aún no hubiera optado a la integración prevista en dicha disposición, mantendrá su derecho a integrarse en la escala de agentes del Servicio de Inspección y Vigilancia Pesquera, grupo C.1, expirando el plazo para ejercer tal derecho el 31 de diciembre de 2011 y siempre que dentro del citado plazo acrediten estar en posesión de la titulación requerida.

Asimismo, y dentro del mismo plazo, mantendrá el derecho a obtener un puesto de trabajo reservado al cuerpo auxiliar de Administración general de la Xunta de Galicia, grupo D.

\section{DISPOSICIÓN ADICIONAL NOVENA DE LA INTEGRACIÓN DE FUNCIONARIOS EN EL SERVICIO DE INSPECCIÓN Y VIGILANCIA PESOUERA}

El personal funcionario perteneciente a los cuerpos de administración especial que, con posterioridad a la entrada en vigor de la Ley $2 / 2004$, de 21 de abril, por la que se creó el Servicio de Guardacostas de Galicia, hubiera obtenido por alguno de los sistemas de provisión previstos en la normativa vigente un puesto de trabajo 
adscrito a dicho servicio y que a la entrada en vigor de la presente ley continúe prestando en el mismo sus servicios quedará integrado en la escala del Servicio de Inspección y Vigilancia Pesquera correspondiente a su grado funcional de pertenencia.

\section{DISPOSICIÓN ADICIONAL DÉCIMA VIGENCIA DE DETERMINADAS DISPOSICIONES REGLAMENTARIAS APLICABLES AL SERVICIO DE INSPECCIÓN Y VIGILANCIA PESOUERA}

En todo lo que no se opongan a la presente ley, siguen vigentes el Decreto $157 / 2005$, de 26 de mayo, sobre ordenación y funcionamiento del Servicio de Guardacostas de Galicia; la Orden de 2 de mayo de 2006 por la que se establece el régimen de prestación de servicios, horarios, vacaciones, licencias y permisos y compensaciones económicas para percibir por el personal del Servicio de Guardacostas de Galicia, y la Orden de 20 de marzo de 2007 por la que se establecen los distintivos de identificación y uniformidad de los miembros del Servicio de Guardacostas de Galicia.

A estos efectos, y con arreglo a lo dispuesto en la disposición adicional sexta de la presente ley, todas las referencias al Servicio de Guardacostas de Galicia contenidas en dichas normas reglamentarias se entienden hechas al Servicio de Inspección y Vigilancia Pesquera. En consecuencia, son aplicables a las escalas técnica, ejecutiva y de agentes de este último servicio las disposiciones que en las citadas normas se refieren, respectivamente, a las escalas técnica, ejecutiva y de agentes del Servicio de Guardacostas de Galicia.

\section{DISPOSICIÓN ADICIONAL UNDÉCIMA EMBARCACIONES AUXILIARES DE ACUICULTURA}

Para el acceso a las actividades de recolección de cría de mejillón se podrá emitir un permiso temporal para embarcaciones de acuicultura o auxiliares de acuicultura.

\section{DISPOSICIÓN ADICIONAL DUODÉCIMA SEGUROS EN EL EJERCICIO DE LAS ACTIVIDADES DE PESCA, MARISOUEO Y ACUICULTURA}

Las personas físicas o jurídicas que realicen actividades de pesca profesional, marisqueo o acuicultura tendrán que constituir un seguro que garantice la cobertura de posibles daños a terceros.

La consejería competente en materia de pesca, marisqueo y acuicultura promoverá la cultura del seguro en el sector, fomentando iniciativas que potencien o introduzcan la suscripción de seguros de producción o cualquier otra naturaleza dirigidos a la cobertura de contingencias extraordinarias en el ejercicio de la actividad pesquera, marisquera y acuícola.

\section{DISPOSICIÓN ADICIONAL DECIMOTERCERA ADSCRIPCIÓN DEL DOMINIO PÚBLICO MARÍTIMO}

En el supuesto de adscripción del dominio público marítimo a la Comunidad Autónoma de Galicia para el desarrollo de actividades acuícolas, corresponderá a la consejería competente en materia de acuicultura regular el ejercicio de la actividad en los espacios adscritos, adecuando los títulos administrativos habilitantes al contenido de lo dispuesto en la presente ley y en la legislación reguladora del dominio público marítimo-terrestre.

\section{DISPOSICIÓN TRANSITORIA PRIMERA PROCEDIMIENTOS EN TRAMITACIÓN Y APLICACIÓN DE LA LEGISLACIÓN MÁS FAVORABLE}

Los procedimientos sancionadores iniciados con anterioridad a la entrada en vigor de la presente ley se seguirán tramitando hasta su resolución final conforme a la normativa de aplicación en el momento de su iniciación, sin perjuicio 
Caza, pesca, guardacostas y...

de la retroactividad de esta ley en cuanto sea más favorable para la presunta persona infractora.

\section{DISPOSICIÓN TRANSITORIA SEGUNDA COFRADIAAS DE PESCADORES Y SUS FEDERACIONES}

A la entrada en vigor de la presente ley, se reconocen como cofradías de pescadores y federaciones las existentes, con el ámbito territorial y estatutos que tengan aprobados, sin que sea posible el reconocimiento o creación de más cofradías de pescadores, excepto la creación de aquellas cofradías que, existentes a la entrada en vigor de esta ley, fueran disueltas por cualquier de los motivos legalmente contemplados y siempre en conformidad con lo que se disponga reglamentariamente.

\section{DISPOSICIÓN TRANSITORIA TERCERA CONSEJO GALLEGO DE PESCA}

A la entrada en vigor de la presente ley, el Consejo Gallego de Pesca permanecerá con las funciones y composición que se determina en la disposición reglamentaria vigente.

\section{DISPOSICIÓN TRANSITORIA CUARTA CONCESIONES, AUTORIZACIONES Y PERMISOS DE ACTIVIDAD}

A la entrada en vigor de la presente ley, las concesiones, autorizaciones y permisos de actividad seguirán vigentes en las condiciones y plazos por los que han sido concedidos o autorizados.

\section{DISPOSICIÓN TRANSITORIA QUUINTA PERMISOS DE EXPLOTACIÓN}

A la entrada en vigor de la presente ley, seguirán vigentes, en las condiciones y plazos por los que han sido otorgados, los permisos de explotación hasta que se otorguen nuevos permisos de pesca o licencias, conforme a la presente ley y normativa de desarrollo.

\section{DISPOSICIÓN TRANSITORIA SEXTA PERMISOS DE EXPLOTACIÓN DE MARISOUEO A PIE CON EMBARCACIÓN AUXILIAR}

A la entrada en vigor de la presente ley, a las personas titulares de permiso de explotación de marisqueo a pie con embarcación auxiliar se les otorgará una licencia de marisqueo a flote, en las condiciones que reglamentariamente se definan.

\section{DISPOSICIÓN TRANSITORIA SÉPTIMA. REVISIÓN DE LAS AUTORIZACIONES Y CONCESIONES MARISOUERAS.}

A la entrada en vigor de la presente ley, y en el plazo máximo de cinco años, se procederá a la revisión de las autorizaciones y concesiones marisqueras.

\section{DISPOSICIÓN DEROGATORIA ÚNICA DEROGACIÓN NORMATIVA}

Quedan derogadas cuantas disposiciones de igual o inferior rango se opongan a lo establecido en la presente ley, y expresamente:

a. La Ley 6/1993, de 11 de mayo, de pesca de Galicia.

b. La Ley 9/1993, de 8 de julio, de cofradías de pescadores de Galicia.

c. La Ley $2 / 2004$, de 21 de abril, por la que se crea el Servicio de Guardacostas de Galicia.

d. La Ley 3/2004, de 7 de junio, de creación del Instituto Tecnológico para el Control del Medio Marino de Galicia.

e. La Ley $8 / 2004$, de 30 de julio, de protección, control, infracciones y sanciones en materia marítimo-pesquera de Galicia.

\section{DISPOSICIÓN FINAL PRIMERA MODIFICACIÓN DE LA LEY 6/2003, DE 9 DE DICIEMBRE, DE TASAS, PRECIOS Y EXACCIONES REGULADORAS DE LA COMUNIDAD AUTÓNOMA DE GALICIA}

\section{$(\ldots)^{673}$}

673 Disposición final primera contiene modificaciones a los anexos de Ley 6/2003, de 9 de diciembre, de Tasas, Precios y Exacciones Reguladoras de la Comunidad Autónoma de Galicia. 


\section{DISPOSICIÓN FINAL SEGUNDA ACTUALIZACIÓN DE SANCIONES}

Las cuantías económicas de las sanciones previstas en la presente ley habrán de actualizarse a través de la correspondiente norma reglamentaria conforme al índice de precios al consumo o sistema que lo sustituya.

\section{DISPOSICIÓN FINAL TERCERA DESARROLLO REGLAMENTARIO}

Se faculta a la Xunta de Galicia para dictar cuantas disposiciones reglamentarias resulten necesarias para el desarrollo y aplicación de la presente ley.

\section{DISPOSICIÓN FINAL CUARTA ENTRADA EN VIGOR}

La presente ley entrará en vigor a los doce meses de su publicación en el Diario Oficial de Galicia.

A la entrada en vigor de la presente ley, seguirán vigentes aquellas disposiciones que no han sido derogadas expresamente en aquellos artículos que no contradigan lo dispuesto en esta ley.

Lo dispuesto en el primer párrafo de la presente disposición no será de aplicación al capítulo I del título IX de la presente ley, referido a la Agencia de Desarrollo Sostenible de las Zonas de Pesca, que entrará en vigor al día siguiente de su publicación, ni a la disposición adicional octava, que entrará en vigor a los seis meses de la publicación de la presente ley ${ }^{674}$.

\section{LEY 7/1992, DE 24 DE JULIO, DE PESCA FLUVIAL \\ (DOGA N. ${ }^{\circ} 151$, DE 5. 8. 1992) ${ }^{675}$}

$$
\text { (...) } 676
$$

674 Disposición final cuarta modificada por Ley $1 / 2009$, de 15 de junio, de modificación de la Ley $11 / 2008$, de 3 de diciembre, de pesca de Galicia.

675 Véase Decreto 130/1997, de 14 de mayo, por el que se aprueba el Reglamento de ordenación de la pesca fluvial y de los ecosistemas acuáticos continentales. 676 Exposición de motivos omitida.

\section{TÍTULO I OBJETO DE LA LEY}

Artículo 1. Objeto de la ley.

1. La presente ley tiene por objeto la regulación de la conservación, el fomento y el ordenado aprovechamiento de las poblaciones piscícolas y de otros seres vivos que habitan en las aguas continentales de la Comunidad Autónoma de Galicia.

2. A los efectos de esta ley, se consideran aguas continentales las de los ríos, arroyos, regatos, embalses, lagunas y marismas.

La Xunta de Galicia establecerá las zonas de desembocadura la forma en que cada consellería ejercerá sus competencias para que la presente ley y las que afecten a las especies marinas se cumplan.

\section{TíTULO II APROVECHAMIENTOS \\ Capítulo I \\ LICENCIAS, REGIMENES ESPECIALES, PERMISOS Y MATRÍCULAS}

Artículo 2. Licencias y permisos para pesca.

1. El derecho de pescar corresponde a todas las personas, sin más limitaciones que las contenidas en la presente ley y las derivadas de la conservación y el fomento de la riqueza piscícola.

2. Licencias. Para poder pescar en las aguas continentales gallegas es imprescindible estar en posesión de una licencia, que tendrá carácter personal e intransferible.

3. Permisos. Cuando el tramo en el que se desee pescar se encuentre acotado o sometido a un régimen especial de pesca, además de la licencia, se requerirá estar en posesión del oportuno permiso para pescar.

4. Las licencias y permisos para pescar serán expedidos por la Consellería de Agricultura, Ganadería y Montes.

Los requisitos para la obtención de licencias y permisos serán determinados reglamentariamente.

Artículo 3. Debido a sus especiales características, y en orden a una mejor 
regulación de la pesca, determinadas masas de agua podrán ser acotadas de forma temporal o permanente como: Coto de pesca, coto de pesca intensiva y coto de pesca sin muerte, entre otros.

Artículo 4. Embarcaciones.

Sólo podrán utilizarse para la pesca embarcaciones y artefactos flotantes inscritos y matriculados para este fin y que cumplan las condiciones fijadas por las normas que dearrolla esta ley.

\section{Capítulo II CONCESIONES}

Artículo 5. Concesiones.

La Consellería de Agricultura, Ganadería y Montes podrán otorgar concesiones de aprovechamientos piscícolas a las asociaciones o Sociedades de pescadores de carácter no lucrativo, con fines de fomento o especial proteción de la pesca, que les facilitarán el acceso a las mismas a los pescadores ribereños. Las concesiones recaerán sobre tramos concretos de ríos, embalses y lagunas, en las condiciones que se determinen reglamentariamente.

Estas concesiones no darán otros derechos sobre las aguas, cauces y márgenes de masa de agua que el exclusivo de pescar en la forma y épocas preceptuadas en la presente ley, y con las limitaciones específicas que se establezcan en cada pliego de condiciones. Las Entidades concesionarias se encargarán del cuidado, la conservación, la promoción y la gestión de los recursos piscícolas.

Asimismo, y con el fin de fomentar el turismo, podrán otorgarse concesiones en tramos de embalses y lagunas a empresas que se encargarán, además del cuidado y la conservación del bien objeto de la concesión, de su promoción y de la gestión de los recursos piscícolas del mismo. Estas concesiones requerirán para su otorgamiento el informe favorable de la Secretaría General para el Turismo, que estudiará sus condiciones y velará por su cumplimiento. También, y con el mismo fin, y mediante el sistema de concurso, podrán otorgarse lotes de permisos en zonas acotadas destinadas a Entidades de promoción o Empresas turísticas.

La Consellería de Agricultura, Ganadería y Montes y la Secretaría General para el Turismo determinarán los cotos con reservas de permisos, que en todo caso no podrán superar el 10 por 100 de los disponibles.

Artículo 6. Entidades colaboradoras. Se consideran Entidades colaboradoras las que realicen actividades o inversiones en favor de la riqueza piscícola de las aguas continentales gallegas, así como en la mejora de la calidad del medio ambiente de dicha aguas y que tengan reconocido tal carácter.

La condición de Entidad colaboradora llevará anexo el cumplimiento de las obligaciones y el disfrute de los beneficios que para tal colaboración establezca la Consellería de Agricultura, Ganadería y Montes, de conformidad con la legislación vigente. Las Entidades colaboradoras deberán inscribirse en el registro que a tal efecto se establezca.

La determinación de los requisitos necesarios para la obtención de la condición de Entidad colaboradora se establecerá reglamentariamente.

Artículo 7. En cada una de las provincias y para el conjunto de la Comunidad Autónoma existirá un Comité de Pesca Fluvial con funciones asesoras a la Administración, y del cual formarán parte, además de miembros de la misma, representantes de las asociaciones relacionadas con la pesca y conservación de la naturaleza.

\section{TÍTULO III CONSERVACIÓN Y FOMENTO DE LA RIQUEZA PISCÍCOLA}

\section{Capitulo I RESTRICCIONES AL APROVECHAMIENTO PISCICOLA}

Artículo 8. La Consellería de Agricultura, Ganadería y Montes establecerá los períodos hábiles de pesca para las distintas 
especies y demás seres vivos que habitan las aguas continentales de Galicia, adoptando las medidas excepcionales y los regímenes especiales que se estimen pertinentes.

En caso de extremo empobrecimiento de los recursos vivos de las aguas, o cuando circunstancias excepcionales lo aconsejen, la Consellería de Agricultura, Ganadería y Montes, oído el Comité Gallego de Pesca Fluvial, podrá acordar las medidas que estime pertinentes, incluso la veda absoluta en aquellas masas de agua que juzgue oportuno o, en su caso, la pesca sin muerte como única modalidad autorizada.

Siempre que en una masa de agua exista varias especies y alguna de ellas esté vedada, la veda se extenderá en esa masa o todas las especies que se capturen con la misma modalidad o cebo, salvo autorización expresa de la Consellería de Agricultura, Ganadería y Montes, que será públicada en el "Diario Oficial de Galicia".

Artículo 9. Restricciones temporales. La Consellería de Agricultura, Ganadería y Montes podrá prohibir temporalmente el empleo de cualquier arte o modalidad de pesca, en toda o en parte de las aguas continentales de la Comunidad Autónoma, cuando existan razones hidrobiológicas que así lo aconsejen. Esta prohibición habrá de publicarse en el "Diario Oficial de Galicia" con expresión de su motivación y la duración de la misma.

Artículo 10. Transporte y comercialización de la pesca fluvial.

1. Queda prohibida la comercialización de cualquier especie de salmónidos no procedentes de centros de producción autorizados en toda época, sea cual fuere el sistema de captura.

2. Para poseer y transportar reos o salmones y para comercializar cualquier tipo de salmónido será condición indispensable que vayan provistos de la documentación que acredite su procedencia legal. A los ejemplares del reo y de salmón pescados al amparo de esta ley se les facilitará la documentación acreditativa de su origen.
3. Las autoridades competentes podrán ordenar la inspección de locales públicos al objeto de hacer las comprobaciones oportunas sobre posesión de guías, documentos de compra y cualquier otro acreditativo de aquellos extremos, quedando los titulares de dichos locales obligados a facilitar las inspecciones.

Artículo 11. Cañas de pescar y útiles auxiliares.

En las aguas continentales de la Comunidad Autónoma de Galicia, cada pescador sólo podrá utilizar el número de cañas y los útiles auxiliares que se detallen en las oportunas disposiciones reglamentarias.

Artículo 12. Autorizaciones especiales. Para fines científicos, de repoblación o para evitar su muerte, la Consellería de Agricultura, Ganadería y Montes podrá utilizar la pesca y el transporte de especies acuícolas de sus huevos en toda época del año haciendo uso de cualquiera de los métodos de captura previstos en la presente ley, debiendo en todo caso quedar fijadas las condiciones de expedición de estas autorizaciones especiales.

\section{Capítulo II FOMENTO DE LAS POBLACIONES ICTÍCOLAS}

Artículo 13. La Consellería de Agricultura, Ganadería y Montes promoverá la realización de los estudios hidrológicos precisos de las aguas continentales de la Comunidad Autónoma, así como la investigación, dedicando especial atención a los ríos habitados por salmón o reo, y adaptará sus actuaciones para el fomento de la riqueza ictícola a las conclusiones y resultados de dichos estudios y programas de investigación.

Artículo 14. Frezaderos.

La Consellería de Agricultura, Ganadería y Montes procederá a la delimitación y señalización de los frezaderos, prohibiendo cualquier alteración de los mismos, salvo las que realice la propia consellería 
o autorice con la finalidad de protegerlos, conservarlos y mejorarlos.

Cuando la Consellería de Agricultura, Ganadería y Montes estime que el baño $\mathrm{u}$ otras actividades puedan suponer el deterioro del frezadero, podrá adoptar las medidas precisas para la protección y conservación del mismo, señalizando, a tal efecto, las respectivas zonas donde se prohibiesen estas actividades.

Artículo 15. Repoblaciones piscícolas. Solamente podrán realizar repoblaciones o sueltas de especímenes piscícolas en las aguas continentales los organismos dependientes de la consellería de Agricultura, Gandería e Montes o aquellos a los que ésta autorice expresamente.

Las entidades que tengan la concesión para el aprovechamiento de alguna masa de agua continental podrán, en su caso, solicitar la realización directa de repoblaciones piscícolas en las aguas objeto de la concesión, si bien las especies, tipos o variedades y métodos empleados requerirán la aprobación previa de la consellería para garantizar su idoneidad. Dicha aprobación incluirá las condiciones y formas de ejecutar su repoblación.

Artículo 16. Repoblaciones de vegetación en márgenes y álveos.

A todos los efectos, se declara de interés general y la conservación de las formaciones vegetales, así como la repoblación arbórea y arbustiva en las márgenes de los ríos y arroyos con especies ripícolas o de riberas, respetando las servidumbres legales.

Para el aprovechamiento y utilización de cualquier tipo de vegetación en las riberas de los ríos y aguas, y por su incidencia sobre las poblaciones piscícolas, será necesaria la previa autorización de la Consellería de Agricultura, Ganadería y Montes.

Artículo 17. Instalaciones.

1. La Consellería de Agricultura, Ganadería y Montes fomentará la construcción de piscifactorías, estaciones de captura, frezaderos artificiales, canales de alevinaje, laboratorios ictiogénicos y demás instalaciones que sirvan para incrementar la riqueza piscícola de las aguas continentales de Galicia. Asimismo, podrá autorizar trabajos y construcciones financiados por personas físicas o jurídicas que sirvan para contribuir a la conservación y fomento de esta riqueza.

2. Las piscifactorías $u$ otras instalaciones industriales autorizadas, con fines comerciales o de repoblación piscícola, podrán producir especies piscícolas siempre que reúnan los requisitos legalmente exigidos y estén en posesión de los permisos establecidos en la legislación vigente.

Los proyectos deberán estar firmados por técnico competente y definirán los caudales necesarios, los sistemas de producción y las características de funcionamiento de la instalación.

La autorización para el funcionamiento de las piscifactorías o instalaciones industriales será concedida para cada proyecto por la Consellería de Agricultura, Ganadería y Montes, sin perjuicio del otorgamiento de la correspondiente concesión por parte de la Administración hidráulica competente.

3. Las industrias e instalaciones que produzcan, transporten, almacenen, traten, recuperen o eliminen residuos tóxicos o que puedan poner en peligro la biocenosis de las masas de agua de la Comunidad Autónoma vendrán obligadas a acatar las instrucciones impartidas por la Consellería competente y a facilitar la labor inspectora, al objeto de evitar o reducir aquel peligro, sin perjuicio de lo dispuesto en la legislación medio ambiental.

\section{Capitulo III MEDIDAS PROTECTORAS}

Artículo 18. Ordenación de los aprovechamientos piscícolas.

La Consellería de Agricultura, Ganadería y Montes promoverá la ordenación adecuada de los aprovechamientos piscícolas a través de planes técnicos, que deberán comprender, como mínimo, la descripción de las características de las 
aguas y los problemas que afectan a las comunidades piscícolas, su cuantificación y las posibilidades de potenciarlas y las medidas tendentes a mejorar su estado, períodos de veda y topes de captura aconsejables, período de revisión y mecanismo de revisión.

Estos planes técnicos serán preceptivos en aguas habitadas por salmón y reo, en todas aquellas que la Consellería considere de interés piscícola y en aquellas masas de agua que sean objeto de su concesión.

Su aprobación se publicará en el "Diario Oficial de Galicia".

Artículo 19. Protección de los recursos piscícolas.

El Consello de la Xunta de Galicia, a propuesta de la Consellería de Agricultura, Ganadería y Montes, podrá declarar determinados tramos de ríos como de "especial interés para la riqueza piscícola", fijando las medidas adecuadas para su protección, conservación, mantenimiento y mejora, que deberán ser, como mínimo, la elaboración del plan técnico y la relación de actuaciones que hayan de llevarse a cabo para proteger y mejorar los recursos piscícolas, así como la fijación de veda o de una determinada modalidad de pesca que no suponga peligro para las especies de interés.

Artículo 20. Dimensiones mínimas

1. Deberán devolverse inmediatamente al agua todos los ejemplares capturados que no superen las dimensiones mínimas que reglamentariamente establezca la Consellería de Agricultura, Ganadería y Montes.

2. Se entenderá por longitud, en los peces, la distancia existente desde la extremidad anterior de la cabeza hasta el punto medio de la parte posterior de la aleta caudal o cola extendida y, para el cangrejo, la comprendida entre el ojo y la extremidad de la cola también extendida.

Queda prohibida la pesca, posesión, circulación, comercialización y consumo de los ejemplares que no alcancen las dimensiones mínimas establecidas, excepto en el caso de la anguila, que estará admitida en su estado de angula.

Artículo 21. Obstáculos naturales. La Consellería de Agricultura, Ganadería y Montes podrá acordar la eliminación de los obstáculos naturales o su modificación para facilitar la circulación de los peces a lo largo de los cursos de agua competencia de la Comunidad Autónoma, especialmente en los ríos salmoneros y de reos, y cuando ello no sea posible, el empleo de los medios sustitutivos que aseguren el ciclo biológico de la riqueza piscícola en los distintos tramos del río.

Artículo 22. Aprovechamientos hidráulicos.

Las concesiones de aprovechamiento hidráulico habrán en todo tiempo de respetar el caudal ecológico necesario para facilitar el normal desarrollo de las poblaciones piscícolas.

En los procedimientos que se sustancien para su determinación por el organismo de cuenca competente, habrán de recabarse los informes necesarios para la Consellería de Agricultura, Ganadería y Montes.

Toda variación del caudal del curso fluvial motivada por cualquier tipo de aprovechamiento hidráulico habrá de hacerse paulatinamente.

Se establecerá en la zona de influencia de caída de presas, embalses y aprovechamientos hidráulicos la obligatoriedad de instalar señales acústicas o luminosas que advierten suficientemente sobre la apertura de compuertas o el incremento de caudales fluviales por medios artificiales.

Artículo 23. Pasos y escalas.

Las solicitudes y proyectos de todas las presas, diques o canales que se pretendan construir en las masas acuícolas al objeto de facilitar las migraciones periódicas de los peces a lo largo de los cursos fluviales deberán presentar:

a. El estudio de evaluación del impacto ambiental, en su caso.

b. La previsión de la pertinente escala, paso, esclusa o cualquier otro dispositivo 
que permita su remonte para especies migratorias.

c. El mantenimiento en todo tiempo del caudal ecológico que habrá de verter por la escala o por el paso necesario para asegurar el movimiento natural de las especies. Los organismos hidráulicos no autorizarán las obras o trabajos a realizar en las masas de agua de la Comunidad Autónoma de Galicia que incumplan lo anteriormente establecido, excepto que justifiquen adecuadamente la imposibilidad de su realización, debiendo solicitar informe previo a la Consellería de Agricultura, Ganadería y Montes.

En las presas y diques levantados con anterioridad a esta ley o en los de nueva construcción donde no sea posible construir un dispositivo de remonte se establecerán otras alternativas.

Artículo 24. Contaminación de las aguas.

Queda prohibido alterar la condición natural de las aguas con cualquier tipo de producto contaminante que dañe los ecosistemas fluviales, en especial la fauna piscícola, considerándose como tal todo aquel que produzca una alteración lesiva de las condiciones físicas, químicas o biológicas de las masas de aguas continentales.

Si no hubiese posibilidad de armonizar los intereses piscícolas con los de los concesionarios de aprovechamientos hidráulicos, industrias y explotaciones que por su interés público deban ser preferentes, los dueños y concesionarios quedarán obligados a acatar las disposiciones que dicte la Xunta de Galicia para conseguir que los vertidos no sobrepasen los parámetros establecidos por la CEE para los ríos de salmónidos, sin perjuicio de lo dispuesto en la legislación medio ambiental.

Artículo 25. Alteración de fondos y márgenes.

1. Se precisará informe preceptivo de la Consellería de Agricultura, Ganadería y Montes para modificar la vegetación de las orillas y márgenes, siempre que ésta afecte a la zona de servidumbre de las aguas públicas.

En el caso de que el informe señale una incidencia negativa de esta modificación sobre las poblaciones piscícolas la ecología de las aguas, el organismo de cuenca deberá adoptar o proponer al titular del aprovechamiento las condiciones necesarias para evitar el impacto negativo.

2. Se prohíbe modificar los cauces y desviar el curso natural de las aguas públicas sin contar con el informe pertinente de la Consellería de Agricultura, Ganadería y Montes, independientemente de los otros que sean precisos.

3. Queda prohibido desviar el curso natural de las aguas, embalses y pantanos, de los cauces de derivación y de los canales de navegación y riego para el aprovechamiento de su pesca sin el correspondiente informe de la Consellería de Agricultura, Ganadería y Montes.

4. Cualquier concesión de extracción de áridos de los ríos habrá de contar con un informe de la Consellería de Agricultura, Ganadería y Montes, en el que se especifique que dicha extracción no supone peligro u obstáculo alguno para el remonte, freza o vida de la fauna ictícola.

Artículo 26. Rejillas y otros dispositivos de control.

En toda obra de toma de agua, así como a la salida de los canales de fábricas, molinos o turbinas, deberá existir un dispositivo que impida el acceso de la población ictícola a dichas corrientes de derivación o aporte. Los dueños o concesionarios están obligados a su colocación y mantenimiento en buen estado. La Consellería de Agricultura, Ganadería y Montes fijará el emplazamiento, dimensiones, características, sistemas de precintado y control y épocas del año en que debe permanecer operativo.

Artículo 27. Agotamiento de masas de agua.

Siempre que un particular o una entidad concesionaria de un aprovechamiento hidráulico vaya a proceder a la anulación o 
vaciado de una masa de agua en la que exista población ictícola, habrá de comunicarlo con una antelación mínima de un mes al órgano competente, que deberá notificarlo inmediatamente a la Consellería de Agricultura, Ganadería y Montes para que ésta establezca las medidas que habrán de adoptarse al objeto de proteger la citada población.

Los gastos derivados de la toma de medidas necesarias para evitar mortandad de peces o riesgos para la riqueza piscícola correrán por cuenta del concesionario, que igualmente será responsable de los daños y perjuicios ocasionados.

\section{TÍTULO IV \\ EL CONTROL Y LA POLICÍA DE AGUAS CONTINENTALES}

Artículo 28. Agentes de la Guardería. Sin perjuicio de lo establecido en la legislación vigente, y no obstante las demás misiones que desempeñen, los agentes de la Guardería dependiente de la Consellería de Agricultura, Ganadería y Montes se encargarán específicamente de velar por el cumplimiento de los preceptos establecidos en esta ley y de denunciar las infracciones que contra la misma se produzcan, teniendo, a tales efectos, la consideración de agentes de la autoridad.

Artículo 29. Vigilantes jurados de pesca fluvial.

La Consellería de Agricultura, Ganadería y Montes podrá otorgar el título de Vigilante Jurado de Pesca Fluvial a las personas que cumplan los requisitos que reglamentariamente se establezcan, al objeto de colaborar en el cumplimiento de lo dispuesto en esta ley con los agentes de la Guardería, con la Policía Autonómica y, en su caso, con las Fuerzas de Seguridad del Estado o de cualquier otro cuerpo que tenga funciones de policía y custodia de los recursos piscícolas y de sus hábitats. A estos efectos, tendrán la consideración de agentes de la autoridad.

\section{TÍTULO V \\ PROHIBICIONES, INFRACCIONES, SANCIONES Y PROCEDIMIENTO SANCIONADOR

\author{
Capítulo I \\ PROHIBICIONES
}

Artículo 30. Prohibiciones en beneficio de la pesca.

Queda prohibido en todas las aguas continentales de la Comunidad Autónoma gallega:

1. Pescar con caña $u$ otras artes en épocas de veda.

2. El empleo con fines de pesca de:

a. Cualquier material explosivo o sustancia que al contacto con el agua produzca explosión.

b. Toda sustancia venenosa para la población ictícola o desoxigenadora de las aguas.

c. La energía eléctrica.

3. Apalear las aguas, arrojar piedras o espantar de cualquier modo los peces para obligarlos a huir en dirección de las artes propias o para que no caigan en las ajenas, así como cebar las aguas para atraer los peces a las artes propias.

4. Pescar, con cualquier tipo de arte, en los canales de derivación o de riego.

5. Pescar a mano, con arma de fuego, golpear las piedras que sirvan de refugio a los peces, así como la práctica de la pesca subacuática.

6. Reducir arbitrariamente el caudal de las aguas, alterar los cauces y destruir la vegetación acuática o de ribera.

7. La pesca de salmones y de reos durante su descenso al mar una vez realizada la freza.

8. Deteriorar, inutilizar o trasladar sin autorización de la Consellería de Agricultura, Ganadería y Montes los aparatos de incubación artificial que estén instalados en las aguas continentales. Destruir los frezaderos, enturbiar las aguas o arrojar materias que los perjudiquen.

9. Pescar salmones o reos en las rías y aguas marítimas interiores competencia de la Comunidad Autónoma. 
10. Pescar durante la costera del salmón y reo en las entradas de los ríos o en las zonas de paso de éstos.

11. Hacer seguimiento de los desplazamientos de salmones y reos por cualquier sistema o instalar medios que los detecten, salvo cuando se cuente con autorización expresa de la Consellería de Agricultura, Ganadería y Montes.

12. Emplear cualquier otro procedimiento de pesca que sea declarado nocivo por dicha Consellería.

Artículo 31. Obstáculos, instrumentos, artes y aparatos prohibidos.

1. Queda prohibida la construcción o colocación de cualquier tipo de obstáculo, permanente o transitorio, que sirva para encaminar la pesca para su captura.

No obstante, podrán seguir utilizándose las pesqueras existentes en la actualidad, previa autorización específica e individual de la Consellería de Agricultura, Ganadería y Montes, en la que se describirán las condiciones técnicas de su utilización.

2. En aguas continentales de la Comunidad Autónoma gallega no podrá utilizarse ningún tipo de red o artefacto de malla, excepto las nasas utilizadas en la pesca de anguilas y lampreas, sin que en ningún caso se pueda superar el número de diez por pescador. Reglamentariamente se determinarán las formas y dimensiones que habrán de tener estas nasas, así como la distancia de la orilla a la que podrán colocarse, pudiendo restringir o incluso prohibir temporalmente su uso.

Cuando en algún curso fluvial existan razones que así lo aconsejen, la Consellería de Agricultura, Ganadería y Montes podrá autorizar el uso de redes o artefactos de malla durante períodos determinados y en tramos concretos. En los embalses que se hallen invadidos por especies no salmónidas y en los que su control o aprovechamiento comercial sea deseable podrá autorizar la pesca con red.

También se permitirá, para la pesca del cangrejo, la utilización de reteles y lamparillas, en el número que se establezca, que nunca será superior a diez por pescador.

3. Queda prohibida la pesca durante la noche, excepto para lamprea, angulas y anguilas, en aquellos lugares en donde lo autorice la Consellería de Agricultura, Ganadería y Montes. Se entiende por pesca nocturna la que se practica en el período comprendido entre una hora después de la puesta de sol y una hora antes de la salida. Las artes empleadas en estos casos sólo serán aptas para la pesca de las especies citadas.

4. Se prohíbe el uso de artefactos luminosos con fines de pesca, excepto para la anguila y la lamprea, que deberán contar con una autorización especial para cada temporada de pesca.

5. No se permitirá para pescar la utilización de aparatos punzantes, excepto en la pesca de la lamprea desde pontones y previa autorización de la Consellería de Agricultura, Ganadería y Montes. Asimismo, no podrán utilizarse artes de tirón y ancla, cualquiera que sea su forma.

6. Queda prohibido el uso de cordelillos, sedales durmientes y palangres.

7. Se prohíbe pescar con cualquier clase de artes fijas, como garlitos, butrones $\mathrm{y}$, especialmente, con las llamadas "de parada" para truchas, aunque no se sujeten a estacas, caneiros o empalizadas.

\section{Capitulo II INFRACCIONES Y SANCIONES}

Artículo 32. Clasificación. Las infracciones a los preceptos de la presente ley se clasifican en leves, menos graves, graves y muy graves.

Artículo 33. Infracciones leves. Tendrán la consideración de infracciones leves y serán sancionadas con multa de hasta 50.000 pesetas las siguientes:

1. Pescar siendo titular de una licencia válida de pesca cuando no se lleve consigo ésta y un documento acreditativo de su identidad. 
2. Pescar en un tramo acotado, siendo titular del permiso reglamentario, cuando no se lleve consigo dicho permiso.

3. No guardar las distancias establecidas reglamentariamente durante la práctica de la actividad pesquera.

4. Pescar con más cañas de las permitidas o con útiles auxiliares no autorizados reglamentariamente.

5. Pescar entorpeciendo o molestando a otros pescadores cuando estuviesen previamente pescando.

6. No guardar, respecto a otros pescadores, mediando requerimiento previo, una distancia de 40 metros cuando se pesca con ova, 30 metros con cola de rata o 10 metros con otras modalidades de pesca.

7. Dejar transcurrir más de media hora sin ceder su puesto o pozo a un pescador de salmón que lo hubiese requerido para hacerlo, si al transcurrir dicho plazo no se hubiese trabado un ejemplar.

8. Bañarse, navegar con lanchas o embarcaciones de recreo o realizar actividades expresamente prohibidas entorpeciendo la práctica de las actividades regladas por esta ley en los lugares donde el desarrollo de tales actividades haya sido declarado y señalado como preferente.

9. No respetar las limitaciones de número, peso o tamaño fijadas por la Consellería de Agricultura, Ganadería y Montes para las capturas o las prescripciones especiales dictadas por la misma para determinados tramos o masas de agua.

10. Descomponer los fondos o lechos de ríos sin afectar a zonas de cría y reproducción de la fauna acuícola.

Artículo 34. Infracciones menos graves.

Tendrán la consideración de infracciones menos graves y serán sancionadas con multa comprendida entre 50.001 y 500.000 pesetas e inhabilitación para obtener la licencia de pesca durante un año las siguientes:

1. Pescar sin licencia.

2. Emplear para la embarcación o aparatos flotantes legales que no estén provistos en la matrícula expedida por la Consellería de Agricultura, Ganadería y Montes.

3. Utilizar, para extraer o sacar del agua salmones o reos legalmente pescados, ganchos u otros elementos punzantes que produzcan heridas en los peces.

4. Tener en las márgenes, riberas u orillas del río redes o artefactos de uso prohibido y productos tóxicos o explosivos cuando no se justifique razonadamente su aplicación a menesteres distintos de la pesca.

5. Pescar cangrejos con artes no permitidas o empleando a la vez cada pescador más reteles, lamparillas o arañas de los que la Consellería de Agricultura, Ganadería y Montes determine.

6. Pescar con caña u otras artes autorizadas en zonas o lugares vedados o donde esté prohibido hacerlo.

7. Pescar con caña en ríos salmoneros y de reos de modo que el pescador o el cebo se sitúen a menos de 50 metros del pie de las presas, excepto las sumergidas, o de las entradas y salidas de las escalas o pasos, o en los canales de restitución de agua de instalaciones legalmente autorizadas, a excepción de la pesca con mosca ortodoxa a menos de 20 metros.

8. Pescar con caña u otras artes autorizadas en época de veda.

9. Pescar haciendo uso de luces que faciliten la captura de las especies, excepto para la pesca de la anguila y la lamprea.

10. Pescar en tramos acotados sin estar en posesión del permiso reglamentario.

11. Pescar a mano.

12. $(\ldots)^{677}$

13. Remover o perturbar las aguas con ánimo de espantar los peces y facilitar su captura.

14. Emplear cebos de uso no permitido o cebar las aguas con fines de pesca, excepto en las zonas en que ello haya sido autorizado por la Consellería de Agricultura, Ganadería y Montes.

677 Art. 34.12 sin contenido por Corrección de errores de la Ley 7/1992, de 24 de julio, de pesca fluvial. 
15. No restituir inmediatamente a las aguas los pintos de salmón capturados, estuviesen o no con vida, o cualquier pez que no haya sido capturado por la simple mordedura del cebo, sino de la trabazón del anzuelo en cualquier parte del cuerpo de éste.

16. No respetar las prescripciones contenidas en las concesiones o autorizaciones otorgadas por las autoridades competentes, en las materias propias de esta ley.

17. Emplear para la pesca de anguilas y lampreas más nasas de las autorizadas por pescador.

18. La tenencia, transporte o comercio de salmones y reos pescados en su retorno hacia el mar después del desove.

19. La transgresión de las obligaciones derivadas de lo dispuesto en el artículo 27 de esta ley.

20. Negarse a mostrar el contenido de los cestos, morrales o recipientes, así como los aparejos empleados para la pesca cuando sea requerido por agentes de la autoridad competentes en policía, control y vigilancia de las aguas y la fauna acuícola.

21. Descomponer los fondos o lechos de los ríos afectando a zonas de cría y reproducción de la fauna acuícola.

22. Talar, destruir o modificar de forma significativa la vegetación acuícola y de ribera sin autorización, sin perjuicio de lo que establezca la legislación especial.

23. Extraer gravas, gravillas, arenas y otros áridos de los cauces sin cumplir las condiciones que, a efectos piscícolas, se señalen en la concesión otorgada por el organismo competente, siempre que no afecte a frezaderos.

24. Arrojar o verter a las aguas o en sus inmediaciones basura, inmundicias, desperdicios o cualquier otra sustancia similar a las anteriores, siempre que las mismas sean susceptibles de causar daños a los seres acuáticos, sin perjuicio de lo dispuesto en la legislación medio ambiental.

25 . La tenencia, transporte o comercialización de especies acuícolas, excepto salmónidos, de tamaño menor al reglamentario, o de tamaño legal en época cuya pesca esté vedada o prohibida su comercialización, o que no vayan amparados por las guías, precintos o señales reglamentarios.

26. Entorpecer la inspección de barcas, vehículos, molinos, fábricas, lonjas y demás dependencias no destinadas a viviendas a los agentes de la autoridad competente en policía, control y vigilancia de las aguas y la fauna acuícola, cuando se sospeche fundamentalmente la existencia de medios o sustancias prohibidas o especies que por su tamaño, época o cualquier otra circunstancia tengan prohibida su posesión.

27. Entorpecer las servidumbres de paso por las riberas y márgenes establecidas en beneficio o para el uso de los pescadores.

28. Practicar la pesca con gafas subacuáticas.

29. Colocarse de vigía durante la costera del salmón y reo para registrar y avisar su paso con fines de pesca o valerse de otros medios para seguir los desplazamientos de los mismos, así como vigilar la presencia o movimiento de los agentes de la autoridad para facilitar la pesca fraudulenta practicada por otros pescadores.

30. Entorpecer el buen funcionamiento de las escalas o pasos de peces.

31. No conservar en buen estado las rejillas instaladas a fin de proteger la riqueza piscícola, cuando de ello se derive el no cumplimiento de su función, o quitar los precintos colocados en las mismas por la Consellería de Agricultura, Ganadería y Montes.

32. No mantener en perfecto estado de conservación las obras realizadas por los concesionarios a instancia de la Administración cuando estas obras hubiesen sido ejecutadas con el fin de armonizar los intereses hidráulicos y piscícolas.

33. Colocar en las presas tablas u otros materiales con el fin de alterar el nivel de las aguas o el caudal del río, a menos 
que haya una autorización para hacerlo otorgada por organismo competente.

34. Derribar, dañar o cambiar de lugar los hitos o mojones indicadores de deslindes de jurisdicciones, competencia o propiedad, así como los carteles de tramos acotados, vedados, zonas de baño, frezaderos y otras señales colocadas por la Consellería de Agricultura, Ganadería y Montes o por otro organismo autorizado.

35. Poner en funcionamiento viveros, criaderos o centros de piscicultura o astacicultura sin la debida autorización de la Consellería de Agricultura, Ganadería y Montes.

Artículo 35. Infracciones graves.

Tendrán la consideración de infracciones graves y serán sancionadas con multa comprendida entre 500.001 y 5.000 .000 de pesetas e inhabilitación para obtener la licencia de pesca durante un período de un año y un día a tres años las siguientes:

1. Pesca en el interior de las escalas o pasos de peces.

2. Practicar la pesca con redes en aguas continentales sin estar en posesión de la correspondiente autorización concedida por la Consellería de Agricultura, Ganadería y Montes.

3. Pescar con redes en las inmediaciones de las desembocaduras de los ríos salmoneros o de reos, o en los lugares de paso de éstos en las épocas prohibidas por la Consellería de Agricultura, Ganadería y Montes o la de Pesca, Marisqueo y Acuicultura.

4. Pescar dentro de los límites de las rías y aguas marítimas interiores de la Comunidad Autónoma de Galicia salmón o reo.

5. Pescar utilizando artefactos o instrumentos de uso prohibido, tales como cordelillos, sedales durmientes, tridentes, arpones, fisga (salvo autorización para lamprea), saetas, grampines, fitoras, bingo, pesca subacuática, armas de fuego o de aire comprimido y embarcaciones no permitidas.

6. Pescar utilizando peces vivos como cebo, cuando la especie que sirve de cebo no estuviese presente de forma natural en la masa de agua donde se está pescando.

7. Destruir o alterar frezaderos debidamente señalizados.

8. Pescar ejemplares por persona no autorizada en las estaciones de la captura, piscifactorías, canales de alevinaje u otros análogos.

9. Provocar el enturbamiento en las aguas continentales mediante la incorporación o remoción de áridos, arcillas, escombros, limos, residuos orgánicos o industriales o cualquier otra clase de sustancia que altere sus condiciones de habitabilidad piscícola, con daño para esta riqueza, sin la correspondiente autorización.

10. La formación de escombreras en lugares que por su proximidad a las aguas o cauces sean susceptibles de ser arrastradas por éstas o llevadas por la lluvia, con el consiguiente daño para la población ictícola, salvo que reúnan las debidas garantías para impedir que se produzcan daños a la riqueza piscícola y hubiesen sido autorizadas por el órgano hidráulico en la cuenca correspondiente.

11. Construir barreras de piedras $u$ otros materiales, estacadas, empalizadas, atajos, cañeras, cañizales o pesqueras con fines directos o indirectos de pesca, así como colocar en los ríos artefactos designados a este fin, salvo los autorizados por la Consellería de Agricultura, Ganadería y Montes.

12. No cumplir las condiciones fijadas por la Consellería de Agricultura, Ganadería y Montes para la defensa, conservación o fomento de la riqueza piscícola, cuando aquéllas hayan sido determinadas mediante acto que hubiese adquirido carácter de firmeza.

13. No instalar las rejillas reglamentarias en los canales, acequias y presas de derivación o desagüe y similares.

14. La tenencia, transporte y almacenamiento de salmón o reo sin los precintos y guías preceptivos. 
15. La comercialización de toda especie de salmónidos en cualquier época del año, cuando no procedan de centros industriales o cuando, procediendo de éstos, no vayan debidamente identificados de forma que permitan su control de procedencia.

16. La resistencia o negativa a facilitar las inspecciones en locales públicos o por cualquier agente de la autoridad al objeto de efectuar las comprobaciones oportunas sobre las posibles infracciones al artículo 10.3 de esta ley.

17. Pescar cuando medie resolución firme que inhabilite al interesado para la obtención de este documento.

18. Introducir en las aguas continentales y transportar con estos fines huevos o ejemplares de peces o cangrejos de otros países o Comunidades Autónomas sin autorización expresa de la Consellería de Agricultura, Ganadería y Montes. Dar entrada en la Comunidad Autónoma a huevos o ejemplares de peces, cangrejos y otros seres vivos piscícolas sin la correspondiente autorización y control sanitario de la Consellería de Agricultura, Ganadería y Montes.

19. Pescar durante las horas que esté prohibido hacerlo.

\section{0. (...) ${ }^{678}$}

Artículo 36. Infracciones muy graves. Tendrán la consideración de infracciones muy graves y serán sancionadas con multa comprendida entre 5.000 .001 y 50.000 .000 de pesetas y la inhabilitación para la obtención de licencia de pesca durante un período de tres años y un día a diez años las siguientes:

1. Pescar haciendo uso de energía eléctrica, productos tóxicos o desoxigenantes, naturales o artificiales, y explosivos o sustancias que al contacto con el agua hagan explosión, salvo autorización expresa de la Consellería de Agricultura, Ganadería y Montes.

678 Art. 35.20 sin contenido por Corrección de errores de la Ley $7 / 1992$, de 24 de julio, de pesca fluvial.
2. La no observancia de lo establecido en el artículo 23 de la presente ley, referente a los pasos y escalas.

3. La inobservancia de los caudales ecológicos legalmente determinados, salvo autorización expresa.

4. El vertido y depósito incontrolado de residuos tóxicos y peligrosos para la fauna acuícola en las márgenes y cauces.

5. La obstrucción a la inspección y control sobre la producción, transporte, almacenamiento, tratamiento, recuperación y eliminación de residuos tóxicos y peligrosos que tengan o puedan tener incidencias sobre la calidad de las aguas y biocenosis de los cursos fluviales y masas de aguas de la Comunidad Autónoma.

6. El falseamiento de cualquier dato referido a las operaciones de producción y gestión de residuos tóxicos y peligrosos, así como la negativa a suministrar la información solicitada por la Administración pública competente.

7. Agotar o disminuir notablemente el volumen de agua de los embalses y canales, así como la circulante por el lecho de los ríos sin autorización, o el incumplimiento de las condiciones que a estos efectos se hubiesen fijado cuando del mismo se deriven daños a la riqueza piscícola.

8. Alterar el caudal de un cauce fluvial sin cumplir lo establecido en el párrafo tercero del artículo 22.

9. Repoblar o introducir en aguas continentales especies acuícolas sin la autorización de la Consellería de Agricultura, Ganadería y Montes.

10. Instalar o trasladar, sin permiso de la Consellería de Agricultura, Ganadería y Montes y de las entidades o particulares autorizados para hacerlo, las piscifactorías, estaciones de captura, aparatos de incubación artificial, capturaderos u otros análogos, así como su daño o perjuicio.

Artículo 37. Sanciones a explotaciones industriales.

En el caso concreto de explotación o construcción de viveros o centros de piscicultura 
o de instalaciones destinadas en general a alguna de las actividades a que se refiere esta ley sin la debida autorización de la Consellería de Agricultura, Ganadería y Montes, la sanción llevará siempre aparejada la suspensión de las actividades y, en su caso, el cierre definitivo de la instalación si no reuniese los requisitos para ser autorizada, así como la obligación de reponer a su estado inicial los cauces y masas acuícolas afectados.

Artículo 38. Gradación de las sanciones.

1. Serán circunstancias a tener en cuenta para la gradación de las sanciones a imponer en las distintas clases de infracciones:

a. La intencionalidad.

b. El daño producido a la riqueza piscícola o a su hábitat.

c. La reiteración o reincidencia.

d. La agrupación u organización para cometer la infracción.

e. El beneficio económico perseguido.

f. La irreversibilidad del daño en el bien protegido.

2. Si un solo hecho constituye dos o más infracciones administrativas se impondrá la sanción que corresponda a la mayor gravedad.

\section{Capítulo III PROCEDIMIENTO SANCIONADOR}

Artículo 39. Competencia.

Corresponde a la Consellería de Agricultura, Ganadería y Montes el conocimiento y resolución de los expedientes instruidos por infracciones de los preceptos objeto de esta ley.

Artículo 40. Procedimiento sancionador.

1. El procedimiento sancionador se ajustará a la Ley de Procedimiento Administrativo, con las especialidades contempladas en la presente ley.

2. La iniciación e instrucción de los expedientes sancionadores corresponde a las delegaciones provinciales de la Consellería de Agricultura, Gandería e Montes.
3. La resolución de los citados expedientes corresponderá:

a. En el supuesto de infracciones leves y menos graves, al delegado provincial de la Consellería de Agricultura, Gandería e Montes.

b. En el supuesto de infracciones graves, al Director general de Montes y Medio Ambiente Natural.

c. En el supuesto de infracciones muy graves, al Conselleiro de Agricultura, Gandería e Montes.

4. La resolución de estos expedientes, además de la sanción que en su caso proceda, llevará aparejadas las medidas que se fijen para minorar o solventar sus efectos negativos.

5. Cuando las acciones $\mathrm{u}$ omisiones objeto de la infracción puedan ser constitutivas de delitos o faltas, el órgano competente dará traslado de los hechos a la autoridad judicial.

En este caso, si se hubiese incoado expediente administrativo, éste quedará en suspenso en tanto no recaiga resolución judicial y la misma adquiera firmeza.

Si la autoridad judicial correspondiente resolviese que las acciones u omisiones no constituyen delito o falta, se alzará la suspensión del expediente administrativo, continuándose el procedimiento hasta su resolución.

La tramitación de las diligencias judiciales interrumpirá la prescripción de las infracciones, acciones y responsabilidades.

\section{Artículo 41. Recursos.}

Contra las resoluciones dictadas por las autoridades facultadas para sancionar podrán interponerse los recursos establecidos en la Ley de Procedimiento Administrativo. La resolución del conselleiro pondrá fin a la vía administrativa.

Artículo 42. Multas coercitivas.

Cuando los infractores viniesen obligados a reparar personalmente el daño o a no efectuar una actividad en beneficio del bien jurídico protegido e incumpliesen dicha obligación, podrán ser objeto de 
reiteradas multas coercitivas hasta conseguir su cumplimiento.

La primera imposición de la multa cabrá cuando hubiese transcurrido el plazo fijado en la resolución administrativa para la satisfacción de la obligación. Aquélla se repetirá cada vez que transcurra un plazo similar sin haberse efectuado la reparación o abstención.

La cuantía de las multas coercitivas será un tercio de la sanción pecuniaria impuesta con motivo de la infracción.

Artículo 43. Prescripción.

Las infracciones a los preceptos de esta ley prescribirán, las leves y menos graves a los seis meses, y las graves y muy graves a los doce meses, a contar desde la fecha de su comisión, si antes de transcurrir dicho plazo no se ha notificado al presunto infractor la incoación del expediente sancionador o si, habiéndose iniciado éste, se produjese la paralización de las actuaciones por tiempo superior a dichos plazos.

Las responsabilidades derivadas de la infracción de esta ley prescriben a los dos años, a contar a partir de la fecha en que la sanción sea firme.

\section{Capitulo IV \\ INDEMNIZACIONES Y DECOMISOS}

\section{Artículo 44. Indemnizaciones.}

1. Las sanciones serán compatibles con la exigencia al infractor de la indemnización correspondiente por los daños y perjuicios que se hayan causado a la riqueza ictícola y al medio que la sustenta.

2. El órgano competente precederá a la valoración en cada caso de los daños y perjuicios causados por la infracción, teniendo en cuenta para la valoración de los perjuicios el potencial productivo de la masa de agua.

3. En caso de que la infracción afecte a un coto que sea explotado por un organismo, sociedad o particular distinto de la Administración, deberá abonarse al mismo la indemnización por daños y perjuicios.
4. El importe de las indemnizaciones habrá de destinarse a mejoras para paliar los daños ocasionados a la masa fluvial.

Artículo 45. Ocupación de piezas.

Si al hacer la ocupación las piezas tuviesen posibilidades de sobrevivir, el agente denunciante las devolverá a su medio, a ser posible ante testigos, levantándose acta, que se adjuntará al expediente sancionador.

Cuando las piezas ocupadas estén muertas o no tengan posibilidad de sobrevivir, éstas se entregarán mediante recibo, que se adjuntará a la denuncia, a un centro benéfico y en su defecto a la Alcaldía que corresponda, con idéntico fin.

Artículo 46. Decomisos.

1. Sin perjuicio de las responsabilidades establecidas en esta ley, podrán caer en decomiso todos los aparejos, artes, útiles, instrumentos, sustancias y embarcaciones empleados para la comisión de alguno de los hechos tipificados como infracciones menos graves, graves o muy graves de esta ley.

2. Cuando su uso esté declarado como ilícito, serán destruidos, levantándose la correspondiente acta y si su uso fuese lícito se depositarán en las dependencias de la Consellería de Agricultura, Ganadería y Montes para su devolución o rescate o para su cesión en pública subasta, de acuerdo con la resolución del expediente sancionador. Las cuantías económicas obtenidas por la cesión de las artes, aparejos o medios empleados de forma ilícita serán destinadas por la Administración a la mejora de la riqueza piscícola.

\section{DISPOSICIÓN ADICIONAL}

En lo que atañe al tramo internacional del río Miño esta ley será de aplicación mientras no se oponga a lo dispuesto en el Canje de Notas de 22 de junio de 1968, celebrado entre el Ministerio español de Asuntos Exteriores y la Embajada de Portugal en Madrid.

\section{DISPOSICIÓN TRANSITORIA PRIMERA}

Los expedientes sancionadores ya iniciados al amparo de la legislación anterior 
Código de la Administración Gallega

continuarán tramitándose por la misma hasta su resolución.

DISPOSICIÓN TRANSITORIA SEGUNDA

Las licencias y permisos de pesca expedidos con anterioridad a la entrada en vigor de la presente ley mantendrán su validez hasta el fin de su período de caducidad.

\section{DISPOSICIÓN TRANSITORIA TERCERA}

Se establece un plazo de seis meses, ampliable en supuestos justificados, a contar desde la entrada en vigor de esta ley, para la adaptación de las instalaciones, instrumentos y otros mecanismos a las disposiciones que supongan una innovación respecto a la legislación anterior.

\section{DISPOSICIÓN TRANSITORIA CUARTA}

En tanto el órgano competente no determine el caudal ecológico, se entenderá por tal el 10 por 100 del caudal medio anual.

\section{DISPOSICIÓN FINAL PRIMERA}

Se faculta al Conselleiro de la Xunta para que, mediante Decreto, actualice las cuantías de las sanciones previstas en la presente ley, de acuerdo con la evolución del índice de precios al consumo.

\section{DISPOSICIÓN FINAL SEGUNDA}

En lo no previsto en esta ley y con carácter supletorio se aplicará lo dispuesto en la Ley de Pesca Fluvial de 20 de febrero de 1942 y en el Reglamento para su aplicación.

\section{DISPOSICIÓN FINAL TERCERA}

Se autoriza al Consello de la Xunta para dictar cuantas disposiciones sean necesarias para el dearrollo y aplicación de la presente ley.

\section{DISPOSICIÓN FINAL CUARTA}

La presente ley entrará en vigor a los tres meses de su publicación en el "Diario Oficial de Galicia”. 


\section{XV \\ PROTECCIÓN DE CONSUMIDORES Y USUARIOS}

\section{LEY 8/1994, DE 30 DE DICIEMBRE, DE CREACIÓN DEL INSTITUTO GALEGO DE CONSUMO $\left({ }^{2} \text { DOGA N. }{ }^{\circ} 9,13.1 .1995\right)^{679}$}

$(\ldots)^{680}$

Artículo 1. 1. Se crea el Instituto Galego de Consumo como organismo autónomo de carácter adscrito orgánicamente a la consellería que tenga las competencias en materia de consumo.

2. El Instituto Galego de Consumo es una entidad de derecho público con personalidad jurídica y patrimonio propio, que actúa con plena autonomía funcional para el cumplimiento de sus fines y que se regirá por la presente ley, por la normativa autonómica que le sea de aplicación y por la reguladora de las entidades autónomas.

Artículo 2. El Instituto Galego de Consumo tendrá su sede en Santiago de Compostela, y podrá crear oficinas y desarrollar sus actividades en otras localidades de Galicia.

Artículo 3. El Instituto tendrá los siguientes fines:

a. Orientar, formar e informar a los consumidores y usuarios sobre sus derechos y la forma de ejercer los y de difundir su conocimiento, a fin de que sean tenidos en cuenta y respetados por todos aquellos que intervengan en el mercado y por aquéllos a los que pueda afectar directa o indirectamente en relación con los bienes y servicios.

b. Potenciar el establecimiento y desarrollo de las organizaciones de consumidores y usuarios y asesorarlas técnicamente.

679 Véase Decreto 329/1995, de 21 de diciembre, que desarrolla la Ley $8 / 1994$, de 30 de diciembre, de creación del Instituto Galego de Consumo.

680 Exposición de motivos omitida. c. Promover y llevar a cabo los estudios que permitan una adecuada prognosis de la problemática del consumo, así como llevar a cabo ensayos comparativos, análisis de laboratorio y, en general, todos los procedimientos técnicos que se precisen para el mejor conocimiento de los bienes, productos y servicios que se oferten al consumidor y usuario.

d. Elaborar y difundir información para facilitar a los consumidores y usuarios la elección, con criterios de racionalidad, de los bienes, productos y servicios genéricos más adecuados a sus necesidades.

e. Impulsar la formación del ciudadano, como consumidor y usuario, proponiendo a los organismos competentes la adopción de programas de educación para el consumo en los distintos grados de la enseñanza y realizar las actuaciones necesarias para asegurar que dicha formación sea permanente.

f. Asesorar a la Xunta de Galicia en el desarrollo de la normativa de todos aquellos aspectos que afecten o puedan afectar a los consumidores y usuarios, promoviendo la elaboración de normas para su defensa, aportando la información necesaria a este fin.

g. Cooperar con las administraciones públicas, atendiendo de forma especial a las oficinas municipales de información al consumidor, y con aquellas otras entidades de similar ámbito competencial, por suponer el servicio más próximo al ciudadano, y coordinar sus actuaciones con las de los Ayuntamientos.

h. Asesorar técnicamente a las oficinas de información al consumidor y usuario de la Administración local y colaborar con las mismas. 
i. Poner en conocimiento de los organismos competentes de la Administración propuestas e iniciativas en relación con las funciones y competencias del Instituto.

j. Ejercer los demás fines que se le encomienden, en su función de protección del consumidor y usuario.

Artículo 4681. Los órganos de gobierno del Instituto Galego de Consumo son:

a. El Consejo de Dirección.

b. El Presidente.

Artículo 5. 1. El Consejo de Dirección estará constituido por un Presidente y por Vocales representantes de la Administración Autonómica, de la Administración local, de las organizaciones representantes de los consumidores y usuarios y de las cámaras de comercio, en la forma y número que reglamentariamente se determinen.

2. El Presidente del Instituto Galego de Consumo será designado por el conselleiro competente en materia de consumo.

3. Los Vocales serán designados por el conselleiro que tenga las competencias en materia de consumo, a propuesta de los órganos o entidades que representen.

4. El Consejo de Dirección contará, además, con un Secretario, con voz y sin voto, que redactará y custodiará las actas y que se encargará del despacho de los asuntos del mismo, con el visto bueno del Presidente.

Artículo 6. 1. Serán funciones del Consejo de Dirección:

a. Aprobar el reglamento de régimen interior.

b. Aprobar las líneas generales de actuación del Instituto.

c. Aprobar los planes y programas de actuación.

d. Autorizar la celebración de convenios para la aplicación de los programas.

e. Formular propuestas y recomendaciones sobre cuestiones de consumo en relación con otros organismos y entidades.

681 Véase Decreto 192/2005, de 23 de junio, por el que se establece la estructura orgánica del Instituto Galego de Consumo. f. Aprobar los anteproyectos de presupuestos y elevarlos a la consellería que tenga las competencias en materia de consumo.

g. Aprobar las cuentas y la memoria anual.

2. El Consejo de Dirección podrá delegar las funciones previstas en los apartados c), d) y e) del número anterior en una Comisión ejecutiva, que se constituirá en los términos que reglamentariamente se determinen.

Artículo 7. Serán funciones del Presidente del Instituto Galego de Consumo:

a. Representar al Instituto.

b. Presidir y convocar el Consejo de Dirección.

c. Dirigir el Instituto y hacer cumplir y ejecutar los acuerdos del Consejo de Dirección.

d. Impulsar y supervisar las actuaciones del organismo y de sus comisiones y ponencias.

e. Atender y canalizar las propuestas y peticiones de las organizaciones de consumidores y usuarios y velar por su adecuada tramitación.

f. Ordenar los pagos.

g. Proponer al Consejo de Dirección los planes generales y los programas de actuaciones, así como los convenios de colaboración y cooperación que sea preciso establecer con otros organismos y entidades.

h. Ejercer la dirección superior de personal.

i. Ejercer cualesquiera otras funciones, no reservadas expresamente a otros órganos de la Junta, en materia propia del Instituto.

Artículo 8. 1. A propuesta del Presidente, el Consejo de Dirección del Instituto Galego de Consumo designará a un Gerente que tendrá las siguientes funciones:

a. Dirigir la administración y el personal del Instituto.

b. Administrar y gestionar los recursos económicos.

c. Elaborar los anteproyectos de los presupuestos, las cuentas y la memoria anual de las actividades del Instituto. 
d. Las demás funciones que le delegue el Presidente y encargue el Consejo de Dirección.

2. El gerente asistirá a las reuniones del Consejo de Dirección con voz pero sin voto.

Artículo 9. Para el cumplimiento de sus fines, el Instituto Galego de Consumo dispondrá de los siguientes medios económicos:

1. Recursos ordinarios:

1) Las cantidades que se le asignen en los presupuestos de la Comunidad Autónoma.

2) Los bienes y valores que constituyen su propio patrimonio y los rendimientos del mismo.

2. Recursos ordinarios:

1) Las subvenciones oficiales y las aportaciones o contribuciones de otros organismos, entidades o particulares.

2) Las contraprestaciones que pueda percibir de convenios que celebre y por las actividades del Instituto.

3) Los ingresos percibidos en concepto de tasas y precios públicos o privados.

4) El rendimiento de publicaciones, estudios, cursos y otras actividades atribuidas al Instituto.

3. Otros ingresos ordinarios y/o extraordinarios que el Instituto esté autorizando a percibir, con arreglo a las disposiciones vigentes.

Artículo 10. El presupuesto para el desarrollo del Instituto Galego de Consumo se elaborará anualmente con sujeción a lo preceptuado en la materia para los organismos autónomos administrativos por la Ley 11/1992, de 7 de octubre, de régimen financiero y presupuestario de Galicia, y las demás normas que la complementen o desarrollen.

Artículo 11. 1. El Instituto habrá de estructurarse adecuadamente para atender, como mínimo a las siguientes áreas operativas:

a. Estudios y asistencia técnica y jurídica. b. Orientación, información, formación y educación de los consumidores y usuarios.

c. Documentación, publicaciones y difusión.

d. Administración y registro de entidades.

e. Relaciones con organismos y entidades.

2. El Instituto podrá crear, en su seno, por acuerdo del Consejo de Dirección, comisiones y ponencias que tengan como finalidad el estudio de las cuestiones relacionadas con la producción, distribución y prestación de servicios a los consumidores y usuarios, y éstas estarán integradas por representantes de la Administración, de los sectores correspondientes y de las organizaciones representantes de los consumidores y usuarios.

\section{DISPOSICIÓN DEROGATORIA ÚNICA}

Quedan derogadas todas aquellas disposiciones de igual o inferior rango que se opongan a lo dispuesto en la presente ley.

\section{DISPOSICIÓN FINAL PRIMERA}

El Consello de la Xunta de Galicia adoptará cuantas disposiciones sean necesarias para la aplicación y desarrollo de la presente ley.

\section{DISPOSICIÓN FINAL SEGUNDA}

Esta ley entrará en vigor al día siguiente de su publicación en el "Diario Oficial de Galicia".

\section{LEY 11/2004, DE 19 DE NOVIEMBRE, DE INSPECCIÓN DE CONSUMO DE GALICIA (DOGA N. $\left.{ }^{\circ} 235,2.12 .2004\right)$}

\section{$(\ldots)^{682}$}

Artículo 1. Objeto.

La presente ley tiene por objeto la regulación de la inspección en materia de consumo en la Comunidad Autónoma de Galicia.

682 Exposición de motivos omitida. 
Artículo 2. Funciones de la Inspección de Consumo.

Corresponden a la Inspección de Consumo las siguientes funciones:

1. Vigilar, verificar y constatar el cumplimiento de la normativa que pueda afectar, directa o indirectamente, a los derechos de los consumidores y usuarios en la comercialización de productos y prestación de servicios que tengan como destinatarios finales a los consumidores y usuarios.

2. Investigar y comprobar los hechos de los que tenga conocimiento la administración en materia de consumo, por presuntas infracciones o irregularidades en materia de defensa del consumidor y usuario.

3. Informar a las empresas, durante la realización de sus actuaciones, sobre las exigencias, cumplimiento y aplicación de la normativa vigente en materia de protección y defensa de los derechos de los consumidores y usuarios, así como facilitar a los consumidores y usuarios la información que precisen para el adecuado ejercicio de sus derechos, divulgando el sistema arbitral de consumo.

4. Realizar actuaciones de mediación en aquellos casos en que a través de este medio puedan solucionarse los posibles conflictos que puedan surgir entre empresarios y consumidores y usuarios.

5. Elaborar los informes que requiera su actividad, así como los recabados por los órganos competentes en materia de arbitraje de consumo o potestad sancionadora, y los que, en su caso, le sean requeridos por otros órganos de la Administración de la Comunidad Autónoma.

6. Estudiar, preparar y ejecutar las campañas de inspección, así como cualquier otra actuación preparatoria para la correcta ejecución de sus funciones.

7. Ejecutar las acciones derivadas del sistema de intercambio rápido de información relativo a la seguridad de los productos industriales.
8. Ejecutar las órdenes dictadas por las autoridades competentes en materia de consumo en el ámbito de la inspección de consumo.

9. Cualquier otra que se establezca en el desarrollo reglamentario de la presente ley.

Artículo 3. Obligaciones ante la Inspección de Consumo.

1. A fin de salvaguardar los derechos de los consumidores y usuarios, las personas físicas o jurídicas, asociaciones o entidades que de cualquier forma intervengan en la producción o comercialización de bienes o servicios estarán obligadas, por requerimiento de los órganos competentes en materia de consumo o de los funcionarios de la Inspección de Consumo:

A suministrar toda clase de información y datos, incluidos los de carácter personal, sobre instalaciones, productos, servicios, transacciones comerciales o contratos de prestación de servicios, permitiendo la directa comprobación de los funcionarios de la Inspección de Consumo.

A exhibir la documentación que sirva de justificación de las transacciones efectuadas o contrataciones realizadas, de los precios y márgenes aplicados y de los conceptos en que se desglosan los mismos.

A facilitar copia o reproducción de la referida documentación, incluida aquella que contenga datos de carácter personal.

A permitir que se practique la oportuna toma de muestras de los productos o mercancías que elaboren, distribuyan o comercialicen o que se practique cualquier otro tipo de control o ensayo sobre productos o bienes en cualquier fase de elaboración, envasado o comercialización.

Y, en general, a consentir la realización de las visitas de inspección y a dar toda clase de facilidades para ello.

2. En la inspección de los productos objeto de venta o de la prestación de servicios, el compareciente habrá de justificar, en el momento de la inspección, el cumplimiento 
de los requisitos exigidos por la legislación vigente para su venta o prestación.

3. La falsedad, así como la constancia en dichos documentos de datos inexactos o incompletos, se considerará infracción en materia de consumo, sin perjuicio de que, si se observase la posible existencia de delito o falta, se pase el tanto de culpa a los tribunales de justicia.

4. La carencia de toda o parte de la documentación reglamentaria exigida, su defectuosa llevanza o la negativa a suministrarla, cuando afecte fundamentalmente a la determinación de los hechos imputados o a la calificación de los mismos, se estimará como presunción de infracción, salvo prueba en contrario.

5. Sólo podrán requerirse datos de carácter personal cuando los mismos sean imprescindibles para el cumplimiento de las funciones de la Inspección de Consumo.

Artículo 4. Colaboración con la Inspección de Consumo.

A fin de salvaguardar los derechos de los consumidores y usuarios, y dentro de las funciones de la Inspección de Consumo, las empresas con participación pública, organizaciones empresariales y corporativas, así como las organizaciones de consumidores y usuarios, prestarán cuando sean requeridas para ello cualquier información que les soliciten los correspondientes servicios de inspección, incluidos datos de carácter personal, a los que será de aplicación lo establecido en el apartado 5 del artículo anterior. El incumplimiento de esta obligación supondrá infracción en materia de consumo.

Artículo 5. Escalas de la Inspección de Consumo.

1. La actividad inspectora en materia de consumo será realizada por los funcionarios de la Inspección de Consumo, que se estructura en las siguientes escalas que se crean a través de la presente ley:

a. Escala de inspectoras e inspectores de consumo, perteneciente al cuerpo de gestión, grupo B, de la Xunta de Galicia, y b. Escala de subinspectoras y subinspectores de consumo, perteneciente al cuerpo administrativo de la Xunta de Galicia, grupo C.

Para el ingreso en estas escalas se exigirá estar en posesión de la titulación correspondiente al grupo a que pertenece cada una, de acuerdo con la normativa de función pública.

2. Corresponde a los inspectores de consumo la dirección y ejecución de las acciones dirigidas al cumplimiento de las funciones establecidas en el artículo 2 de la presente ley.

3. Corresponde a los subinspectores de consumo la prestación de apoyo a las labores encomendadas a los inspectores de consumo.

4. El acceso a estas escalas será a través de cualquiera de los sistemas de acceso previstos en la normativa de función pública.

5. Las funcionarias y los funcionarios de la Inspección de Consumo se integran dentro del Instituto Galego de Consumo creado por la Ley 8/1994, de 30 de diciembre, con dependencia orgánica de dicho instituto y con la dependencia funcional establecida reglamentariamente.

Artículo 6. Habilitación de funcionarios para la realización de funciones de inspección de consumo.

En caso de necesidad del servicio o por la naturaleza de la inspección, el Presidente del Instituto Galego de Consumo podrá habilitar funcionarios pertenecientes al grupo B como inspectores de consumo y funcionarios del grupo $\mathrm{C}$ como subinspectores de consumo.

Estas habilitaciones podrán ser para un caso concreto o por un período de tiempo que en ningún caso podrá ser superior a seis meses continuados y siempre cumpliendo con las garantías de profesionalidad y especialización para el caso.

Deberá procederse a ajustar la plantilla de personal cuando, realizada una habilitación, 
el objeto de la misma ponga de manifiesto una necesidad continua y permanente, con el fin de atender a esta.

Artículo 7. Carácter y colaboración del funcionariado de la Inspección de Consumo.

1. Los funcionarios de la Inspección de Consumo, en el ejercicio de sus funciones, tendrán el carácter de autoridad y, para el desarrollo de sus funciones, podrán recabar la ayuda que resulte precisa de cualquier otra autoridad o de sus agentes, que deberán prestársela, incluidos los pertenecientes a los cuerpos y fuerzas de seguridad del Estado de acuerdo con su normativa específica.

2. Asimismo, los funcionarios de la Inspección de Consumo deberán colaborar con otros departamentos de la Xunta de Galicia u otras administraciones, de acuerdo con lo establecido en la Ley de Régimen Jurídico de las Administraciones Públicas y del Procedimiento Administrativo Común, en la verificación de los requisitos de comercialización o prestación de servicios destinados a los consumidores y usuarios.

3. En la planificación de las actuaciones de la Inspección de Consumo se actuará, en la medida de lo posible, en coordinación con otras inspecciones de cualquier administración pública, especialmente con las de la Administración local.

Artículo 8. Forma de realización de las actuaciones inspectoras.

1. En el ejercicio de sus funciones, el funcionariado de la Inspección de Consumo estará obligado a identificarse como tal y, cuando le sea solicitado, exhibir las credenciales de su condición.

2. Lo dispuesto en el punto anterior, en lo relativo al carácter previo de la identificación, no será de aplicación en aquellos casos en que la finalidad de la inspección pueda frustrarse por tal motivo.

Sólo podrá actuarse de la forma establecida en el párrafo anterior siempre que las labores de inspección se realicen en lugares de acceso público y se determinen, por escrito, las causas que justifiquen tal actuación.

3. Las actuaciones de la Inspección de Consumo se practicarán en la forma que resulte más cómoda para aquellas personas con quienes hayan de realizarse y compatible, en la medida de lo posible, con sus obligaciones laborales o profesionales.

Artículo 9. Visitas de inspección.

1. El funcionariado de la Inspección de Consumo podrá en cualquier momento realizar visitas a las empresas, actividades y establecimientos dedicados a la comercialización de productos o a la prestación de servicios para la práctica de cualquiera de las actuaciones referentes a sus labores. A estos efectos, el funcionariado de la Inspección de Consumo tendrá la facultad de acceder libremente y sin notificación previa, en cualquier momento, a las instalaciones, locales o dependencias, previa acreditación de su condición, sin perjuicio de lo dispuesto en el apartado 2 del artículo 8 de la presente ley.

2. El funcionariado de la Inspección de Consumo durante la visita podrá ir acompañado del jefe de servicio o de los técnicos especialistas en la materia correspondiente, en aquellos casos en que se estime conveniente.

3. Durante la visita los funcionarios de la Inspección de Consumo podrán:

a. Inspeccionar los productos objeto de venta, el local y sus dependencias, realizando las verificaciones y comprobaciones que procedan.

b. Exigir la presentación de documentación, libros y registros que tengan relación con el objeto de la investigación, a fin de examinarlos y obtener las copias o reproducciones necesarias, incluidos aquellos que contengan datos de carácter personal.

c. Solicitar declaración, datos o antecedentes del titular, responsable o representante de la empresa o actividad y recabar información de los empleados o clientes sobre 
cuestiones relacionadas con el objeto de la inspección, incluidos datos de carácter personal.

d. Realizar mediciones y tomar muestras o fotografías, así como practicar cualquier otra prueba por los medios legales permitidos.

3. Llevar a cabo cuantas actuaciones sean precisas en razón del cumplimiento de las funciones de inspección que desarrollan.

Artículo 10. Citaciones.

1. El funcionariado de la Inspección de Consumo podrá efectuar citaciones a fin de que las personas titulares de empresas, actividades o establecimientos, o sus representantes legales, se personen en el lugar donde se encuentre el domicilio de la empresa, donde se realice la venta de los productos o la prestación de los servicios o en las oficinas del Instituto Galego de Consumo a los efectos de facilitar el desarrollo de la labor inspectora y aportar la documentación precisa y cuanta información o datos sean necesarios, incluida aquella con datos de carácter personal.

2. Estas citaciones podrán realizarse igualmente a cualquier consumidor o usuario, siempre que sea absolutamente imprescindible para la actividad inspectora.

3. En las citaciones se hará constar el lugar, fecha, hora y objeto de la comparecencia, procurando la mínima perturbación de las obligaciones laborales y profesionales de las personas citadas, que podrán acudir acompañadas de asesores identificados.

Artículo 11. Requerimientos.

1. El funcionariado de la Inspección de Consumo, en el ejercicio de las funciones que tiene reconocidas, está facultado para requerir la presentación o remisión de documentos, el suministro de datos, incluso de carácter personal, de acuerdo con lo dispuesto en los apartados 1 y $5 \mathrm{del}$ artículo 3, o la ejecución de las actuaciones necesarias para el esclarecimiento de los hechos objeto de la actividad inspectora. $\mathrm{Su}$ incumplimiento se entenderá como obstrucción a la inspección o negativa a facilitar la información requerida por ellos, sin perjuicio de lo establecido en el apartado 4 del artículo 3 de la presente ley.

2. Cuando de la inspección realizada resultasen simples inobservancias de exigencias o requisitos fácilmente subsanables, de las que no se deriven daños o perjuicios inmediatos para los consumidores o usuarios, la inspección podrá formular al titular o representante del establecimiento o servicio los requerimientos que estime oportunos, a fin de lograr su efectiva adecuación a la normativa vigente.

En este caso, el requerimiento recogerá las anomalías, irregularidades o deficiencias apreciadas con la indicación, en su caso, del plazo para su subsanación.

Artículo 12. Documentación de la actuación inspectora.

1. Las actuaciones del funcionariado de la Inspección de Consumo se documentarán en comunicaciones, diligencias, informes y actas. Los requisitos específicos de estos documentos, sin perjuicio de lo establecido en la presente ley, son los determinados reglamentariamente.

2. Las diligencias son los documentos que redacta el funcionariado de la Inspección de Consumo en el curso del procedimiento inspector para hacer constar cualquier hecho, circunstancia o manifestación con relevancia para la inspección.

La diligencia será válida con la firma únicamente del personal actuante en aquellos casos en que no se requiera la presencia de un compareciente o ésta no sea posible, o bien cuando su presencia pueda frustrar la acción inspectora.

3. Las actas de inspección son documentos que redactan los funcionarios de la Inspección de Consumo en los que se recoge el resultado de la función inspectora de vigilancia y verificación del cumplimiento de las disposiciones y normativa de protección y defensa de los derechos de 
los consumidores y usuarios durante las visitas de inspección y en las que deben figurar, como mínimo, la fecha, hora y lugar de la inspección, la identificación de los funcionarios actuantes, el motivo de la inspección, la ubicación del establecimiento o actividad inspeccionada y la referencia a los hechos constatados.

4. Las diligencias y las actas de inspección tienen naturaleza de documento público y tendrán valor probatorio de los hechos que motiven su formalización, salvo que se acredite lo contrario.

Artículo 13. Ratificación de las actuaciones.

El superior jerárquico o los instructores de los procedimientos podrán solicitar de los funcionarios de la Inspección de Consumo intervinientes la ratificación de las actas o diligencias formalizadas por estos.

\section{DISPOSICIÓN TRANSITORIA PRIMERA}

Las funcionarias y los funcionarios pertenecientes al cuerpo de gestión de la Xunta de Galicia, grupo B, que a la entrada en vigor de la presente ley desempeñen puestos con carácter definitivo con funciones de inspección de consumo, y así figuren en la vigente relación de puestos de trabajo, podrán integrarse en la escala de inspectores de consumo manteniendo su localidad de destino, o mantener su situación actual de acuerdo con lo establecido en la disposición transitoria tercera. A tales efectos deberán presentar escrito de opción en el plazo de quince días hábiles desde la fecha de la entrada en vigor de la presente ley.

\section{DISPOSICIÓN TRANSITORIA SEGUNDA}

Las funcionarias y los funcionarios pertenecientes al cuerpo administrativo de la Xunta de Galicia, grupo C, que a la entrada en vigor de la presente ley desempeñen puestos con carácter definitivo con funciones de inspección de consumo, y así figuren en la vigente relación de puestos de trabajo, podrán integrarse en la escala de subinspectores de consumo manteniendo su localidad de destino, o mantener su situación actual de acuerdo con lo establecido en la disposición transitoria tercera. A tales efectos deberán presentar escrito de opción en el plazo de quince días hábiles desde la fecha de entrada en vigor de la presente ley.

\section{DISPOSICIÓN TRANSITORIA TERCERA}

El personal de la Xunta de Galicia que a la entrada en vigor de la presente ley desempeñe puestos con carácter definitivo con funciones de inspección de consumo seguirá desempeñando dichas funciones en la forma y condiciones previstas en esta ley.

Los puestos de trabajo que ocupen los funcionarios o funcionarias que no se integren en las escalas de inspectores y subinspectores de consumo, una vez que queden vacantes, se recalificarán para ser incorporados a una de estas dos escalas.

\section{DISPOSICIÓN DEROGATORIA PRIMERA}

Queda derogado el artículo 13 de la Ley 3/2002, de 29 de abril, de Medidas de Régimen Fiscal y Administrativo.

\section{DISPOSICIÓN DEROGATORIA SEGUNDA}

Quedan derogadas todas las disposiciones de igual o inferior rango que se opongan a lo establecido en la presente ley.

\section{DISPOSICIÓN FINAL PRIMERA}

Se autoriza a la Xunta de Galicia para proceder al desarrollo reglamentario de la presente ley.

\section{DISPOSICIÓN FINAL SEGUNDA}

La presente ley entrará en vigor a los veinte días de su publicación en el "Diario Oficial de Galicia”. 


\section{LEY 12/1984, DE 28 DE DICIEMBRE, DEL ESTATUTO GALLEGO DEL CONSUMIDOR Y USUARIO (DOGA N.․ 23, 1. 2. 2005)}

$(\ldots)^{683}$

\section{TÍTULO I PRINCIPIOS GENERALES}

Artículo 1. Conforme a lo previsto en el art. 30, apartado I, párrafo cuarto, del Estatuto de Autonomía, la presente ley tiene por objeto establecer los principios y normas básicas a que debe atenerse la defensa de los derechos e intereses de los consumidores y usuarios en el ámbito de la Comunidad Autónoma 684.

Artículo 2. Se entiende por consumidores y usuarios, a los efectos de esta ley, todas las personas físicas o jurídicas que adquieran, utilicen o disfruten de bienes, muebles, inmuebles y semovientes, medios, productos o servicios y actividades, cualquiera que sea la naturaleza, pública o privada, individual o colectiva, de quien lo produce o interviene, directa o indirectamente, en su comercialización, siempre que su destino final sea para su uso personal, familiar o colectivo.

Artículo 3. Son derechos de los consumidores y usuarios:

a. El derecho a la protección de la salud y seguridad y del medio ambiente adecuado.

b. El derecho a la protección de sus intereses económicos y sociales ${ }^{685}$.

c. El derecho a la información y educación en materia de uso y consumo.

d. El derecho a crear sus propias organizaciones en orden a la representación y defensa de sus intereses, y a que éstas

683 Exposición de motivos omitida.

684 Véase FJ. 2 y 3 STC 62/1991, de 22 de marzo, en el Recurso de Inconstitucionalidad 376/1985 y Conflicto Positivo de Competencia 763/1985 (acumulados).

685 Véase Decreto 139/1999, de 7 de mayo, por el que se regula la actividad de prestación a domicilio de servicios de mantenimiento, reparación y reforma. sean consultadas en materias que les afecten ${ }^{686}$.

e. El derecho a la protección jurídica, administrativa y técnica y a la reparación de daños y perjuicios ${ }^{687}$.

Artículo 4. Se otorgará una protección prioritaria y rigurosa a los derechos de los consumidores y usuarios, en relación con la adquisición y disfrute de aquellos productos y servicios de consumo y uso común ordinario o generalizado, y especialmente a los de rápido consumo y perecederos.

\section{TÍTULO II \\ DERECHOS DEL CONSUMIDOR}

\section{Capítulo I \\ DERECHO A LA PROTECCIÓN DE LA SALUD Y SEGURIDAD}

Artículo 5. Los bienes, medios, productos, servicios y actividades ofertados en el mercado deben ser suministrados o prestados de modo que, en condiciones razonables y previsibles, no lleven consigo riesgos que puedan eliminar o reducir las condiciones de seguridad para la vida y la salud de los consumidores y usuarios. En otro caso, y a través de procedimientos eficaces, deberán ser retirados del mercado los bienes, medios y productos, o suspendidos los servicios y actividades susceptibles de generar tales riesgos.

Artículo 6. Cualquier riesgo previsible que pudiera provenir de la normal utilización de bienes y servicios, en atención a su naturaleza y a las eventuales circunstancias personales que puedan concurrir en su destinatario, habrá de ser puesto en conocimiento previo de los consumidores 686 Véase:

- Decreto 127/1998, de 23 de abril, por el que se crea el Consello Galego de Consumidores e Usuarios.

- Orden de 25 de mayo de 2000 por la que se ratifica el Reglamento de organización y funcionamiento interno del Consello Galego de Consumidores e Usuarios y se ordena su publicación en el "Diario Oficial de Galicia". 687 Véase Ley 12/1984, de 28 de diciembre, del Estatuto Galego do Consumidor e Usuario. 
y usuarios por los medios apropiados y en forma clara y visible.

Artículo 7. En el etiquetado, presentación y publicidad de los productos alimenticios y bebidas puestos a disposición de los consumidores deberán observarse las normas comunes o las específicas de cada producto, $\mathrm{y}$, en particular, se facilitará una correcta información al consumidor sobre los ingredientes, aditivos, fecha de producción y caducidad, modo de empleo, conservación, número del registro sanitario de alimentos o cualquier otra circunstancia que pueda afectar a la salud y seguridad.

Con objeto de mantener los alimentos y bebidas en condiciones idóneas para su consumo, se adoptarán, asimismo, las medidas necesarias para evitar la alteración o contaminación que, para tales productos, pudiese provenir de falta de higiene en su manipulación, de envasado defectuoso o de inadecuadas condiciones de transporte, conservación o comercialización.

Se regularán los casos, modalidades y condiciones en que se podrá efectuar la venta ambulante de bebidas y alimentos.

Artículo 8. En relación con los productos farmacéuticos, la Administración gallega, con la necesaria colaboración de los organismos encargados de la protección y defensa de los consumidores y usuarios, adoptará las medidas necesarias para el estricto cumplimiento de la normativa vigente, en atención a su particular incidencia sobre las condiciones de seguridad para la vida y la salud de las personas. Del mismo modo se arbitrarán las medidas oportunas en orden a evitar los riesgos que para la salud de los consumidores pudiese representar el uso inadecuado de los productos zoo y fitosanitarios.

Los cosméticos y detergentes habrán de ajustarse a la normativa vigente, en particular en lo que se refiere a su composición, envasado y etiquetado, con objeto de garantizar su inocuidad y prevenir los riesgos derivados de su uso inadecuado.
Los fertilizantes, insecticidas, fungicidas, herbicidas y todos los artículos que lleven en su composición sustancias tóxicas, cáusticas, corrosivas o abrasivas deberán ir envasados con las debidas garantías, y en el etiquetado mismo se deberá suministrar al usuario una correcta y clara información sobre los riesgos que comportan su manipulación y su empleo, así como las adecuadas prevenciones y los pertinentes tratamientos en casos de urgencia por posibles descuidos, con una correcta, clara y visible información.

Respecto a los productos enumerados en el párrafo anterior, se establecerán normas rigurosas para evitar que, en su almacenaje, transporte o venta, se pueda producir contaminación de artículos alimentarios o confusión en el consumidor por similitud externa o proximidad de los productos en los establecimientos de expedición.

Artículo 9. Se adoptarán las medidas oportunas en orden a que los productos manufacturados que puedan generar un riesgo para la salud y seguridad física de las personas, sean sometidos a controles rigurosos y eficaces en su proceso de fabricación, transporte y comercialización, prestando a este respecto la debida atención a los servicios de reparación y mantenimiento.

Artículo 10. El Gobierno Gallego, anualmente, llevará a cabo la confección de una relación de productos, bienes y servicios considerados de primera necesidad, atribuyéndose esta condición a aquellos que por ser de uso o consumo común, ordinario o generalizado, y, por lo tanto, afectar a amplios sectores de la población, necesitan de un control más intenso y continuado ${ }^{688}$.

Artículo 11. Quien pretenda adquirir, utilizar o disfrutar de una vivienda para su uso particular, familiar o colectivo, tendrá derecho a obtener del que la ofrece en el mercado una información

688 Véase Decreto 53/1985, de 21 de marzo, de productos, bienes y servicios de primera necesidad o uso común, ordinario o generalizado. 
veraz sobre las características constructivas, calidades de material e instalaciones de todo tipo, incluso aquellas que conlleven un ahorro energético, condiciones higiénico-sanitarias, y todas aquellas circunstancias que puedan repercutir en la salud y seguridad de las personas y en la calidad de vida.

En todo caso, se observará la prohibición de utilizar en la construcción de viviendas en locales de uso público materiales y demás elementos susceptibles de generar riesgos para la salud y seguridad de las personas ${ }^{689}$.

Artículo 12. Los poderes públicos, conforme a la normativa vigente, y en atención al interés general de los consumidores y usuarios, velarán por la seguridad, calidad y salubridad de los transportes y locales de uso público, ejerciendo de una forma rigurosa y eficaz las funciones de control, inspección y sanción, en su caso, que tienen atribuidas para asegurar el cumplimiento de aquellas condiciones.

La prescripción contenida en el párrafo anterior se ejercerá con especial rigor e intensidad respecto de los transportes y locales destinados al uso y servicios de menores en edad escolar.

Artículo 13. Los poderes públicos, ya sea directamente a través de los propios órganos de la Administración, o bien en colaboración con las organizaciones y asociaciones de consumidores y usuarios, organizarán campañas informativas, así como actuaciones programadas de control de calidad, especialmente en relación con los productos y servicios de uso o consumo común, ordinario o generalizado, y con los que reflejen una mayor incidencia en los estudios estadísticos y epidemiológicos, dirigidas, entre otros objetivos, a:

1. Prevenir los riesgos que se pudiesen derivar del uso inadecuado de productos o

689 Véase Decreto 42/2009, de 21 de enero, por el que se regula la certificación energética de edificios de nueva construcción en la Comunidad Autónoma de Galicia. servicios eventualmente peligrosos, fundamentalmente en los que puedan afectar en mayor grado a la salud y seguridad de las personas.

2. Evitar los fraudes o adulteraciones de que puedan ser objeto los productos en su proceso de fabricación y comercialización.

3. Impedir las situaciones de indefensión o inferioridad en que se puedan encontrar los usuarios y consumidores, tanto en la contratación como durante el desarrollo del contrato y en su genérica posición jurídica de usuarios de un servicio público.

4. Proteger y vigilar de un modo especial los productos con denominación de origen.

Artículo 14. La Administración de la Comunidad Autónoma de Galicia, a través de los órganos encargados de la aplicación y control de la normativa que garantice el derecho a la protección de la salud y seguridad de los consumidores, publicará anualmente una Memoria detallada de sus actividades, indicando los resultados de los controles efectuados y presentando como anexos los fundamentos de sus decisiones.

\section{Capitulo II}

DERECHO A LA PROTECCIÓN DE LOS INTERESES ECONÓMICOS Y SOCIALES DE LOS CONSUMIDORES Y USUARIOS

Artículo 15. Sin perjuicio de lo que establezcan las normas civiles y mercantiles en la materia, y otras disposiciones de carácter general o las específicas de cada producto o servicio, y en atención al interés general de los consumidores y usuarios, deberán ser respetados y defendidos los legítimos intereses económicos y sociales en los términos establecidos en esta ley y disposiciones complementarias.

Artículo 16. La publicidad en general de los productos, servicios o actividades ofrecidas en el mercado se ajustará a su verdadera naturaleza, características, condiciones, utilidad o finalidad. Cualquier

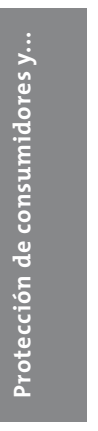


manifestación publicitaria engañosa que atente contra los legítimos intereses de los consumidores o usuarios será considerada como fraude y podrá ser objeto de sanción administrativa. Las asociaciones de consumidores y usuarios estarán legitimadas para iniciar e intervenir en los oportunos procedimientos administrativos.

Artículo 17. Aquellos métodos de venta que limiten, dificulten o restrinjan la libertad de elección, así como la voluntad de contratar en perjuicio de los consumidores y usuarios, serán debidamente reglamentados. En especial, se protegerá a los consumidores y usuarios con las correspondientes reglamentaciones específicas, frente a los perjuicios que se pudiesen derivar de las ventas ambulantes, a domicilio, por correspondencia, mediante saldos y liquidaciones, o de las que incluyan la concesión de un premio, la participación en un sorteo, concurso y cualquier clase de prima y en todas aquellas que de algún modo puedan redundar en detrimento de la libertad de elección, de la comprobación de calidad o de la voluntad de contratar de los consumidores y usuarios 690 .

Artículo 18. Conforme a la normativa general vigente en la materia, los consumidores y usuarios serán protegidos frente a las eventuales cláusulas abusivas contenidas en los contratos tipo o de adhesión establecidas de una forma unilateral por quien ofrece en el mercado bienes o servicios, incluidos los que faciliten las administraciones públicas y las entidades y empresas de ellas dependientes. $(\ldots)^{691}$

Artículo 19. Se adoptarán todas las medidas precisas y oportunas para la defensa de la calidad de los bienes y servicios ofre-

690 Véase FJ. 4 STC 62/1991, de 22 de marzo, en el Recurso de Inconstitucionalidad 376/1985 y Conflicto Positivo de Competencia 763/1985 (acumulados).

691 Art. 18, excepto párrafo primero, declarado inconstitucional por FJ. 4 STC 62/1991, de 22 de marzo, en el Recurso de Inconstitucionalidad 376/1985 y Conflicto Positivo de Competencia 763/1985 (acumulados). cidos en el mercado y el mantenimiento de la transparencia en los precios.

A este respecto, los bienes y servicios puestos a la venta se ajustarán a sus propias normas de calidad, y en general se exigirá de los mismos que sean ajustados a la finalidad que puede motivar su adquisición, conforme a las expectativas razonables que se deriven de su descripción, precio y otras circunstancias.

Asimismo, para mantener la transparencia de los precios en el mercado, se exigirá absoluta precisión en el precio de la adquisición, ya sea al contado o aplazado, y, al mismo tiempo, se garantizará la exactitud en el peso y en la medida ${ }^{692}$.

Artículo 20. Respecto a los bienes de naturaleza duradera, se adoptarán dentro de la normativa vigente las medidas que conduzcan a lograr los siguientes objetivos:

a. Entrega, por el fabricante o vendedor, de una garantía que, formalizada por escrito, expresará necesariamente:

1. El garante.

2. El beneficiario de la garantía.

3. El objeto o contenido de la garantía.

4. El plazo de duración de la garantía, durante el cual el beneficiario de la misma tendrá derecho, como mínimo, a la reparación totalmente gratuita de los vicios o defectos originarios y de los daños y perjuicios por ellos ocasionados, así como la sustitución del objeto adquirido por otro de idénticas características o a la devolución del precio pagado en los presupuestos en que la reparación efectuada no hubiese sido satisfactoria y el bien no tuviese las condiciones óptimas para cumplir el uso a que estuviese destinado.

5. Una información precisa que le permita diferenciar con claridad los servicios postventa debidos por el vendedor o fabricante en concepto de garantía contractual de los que tienen que ser costeados a su cargo.

692 Véase FJ. 4 STC 62/1991, de 22 de marzo, en el Recurso de Inconstitucionalidad 376/1985 y Conflicto Positivo de Competencia 763/1985 (acumulados). 
b. Adecuado servicio técnico y existencia de repuestos durante el período ordinario de duración según los casos. En todo caso, los poderes públicos velarán por las condiciones de los servicios postventa ${ }^{693}$.

Artículo 21. (...) ${ }^{694}$

\section{Capítulo III \\ DERECHO A LA INFORMACIÓN Y EDUCACIÓN}

Artículo 22. Los consumidores y usuarios tienen derecho a recibir una información veraz, completa, objetiva y eficaz sobre las características esenciales de los bienes y servicios puestos a su disposición en el mercado, con las indicaciones para su correcto uso o consumo y las advertencias

$693 \mathrm{El}$ art. 20 debe considerarse constitucional interpretado en el sentido que establece el FJ. 4 STC 62/1991, de 22 de marzo, en el Recurso de Inconstitucionalidad 376/1985 y Conflicto Positivo de Competencia 763/1985 (acumulados): "El apartado a) del art. 20 impugnado, reproduce el apartado $2 .^{\circ}$ del art. 11 de la Ley estatal 26/1984 con un contenido casi idéntico pero con distinta ordenación, en cuanto a la regulación del contenido de la garantia que deberá entregar el fabricante o vendedor de bienes de naturaleza duradera. Únicamente difieren en cuanto la norma estatal lo impone como deber y la norma autonómica, en su primer párrafo, lo establece como "objetivos" para los que "se adoptarán dentro de la normativa vigente las medidas" para lograrlos; y por otra parte, en su punto 5 la Ley gallega añade que la garantía debe contener información que distinga los servicios postventa debidos al vendedor o fabricante en concepto de garantia contractual de los que deban ser costeados a cargo del comprador.

Aunque el Letrado de la Junta admite de plano que el precepto impugnado cae dentro de la esfera de la competencia estatal sobre el derecho contractual, sin que ello, no obstante, se allane a la pretensión en el suplico de su escrito de contestación a la demanda, la cuestión no puede zanjarse sin más en favor de la pretensión del Gobierno. Pues, si bien resulta incontrovertible que la preceptuación de la formalización de una garantía para los bienes duraderos y la determinación de su contenido mínimo es materia incluida dentro de los derechos y obligaciones contractuales, y por tanto de titularidad estatal, lo cierto es que el primer párrafo del art. 20, no impugnado, de la ley gallega no impone una obligación a los fabricantes o vendedores con un correlativo derecho de los compradores, lo que si hace, por supuesto, la norma estatal al prescribir que "el productor o suministrador deberá entregar una garantía...", sino que se limita a señalar que "se adoptarán dentro de la normativa vigente las medidas que conduzcan a lograr los siguientes sobre riesgos previsibles, de tal forma que puedan realizar una elección consciente y racional entre los diversos bienes y servicios concurrentes y utilizarlos de una manera segura y satisfactoria ${ }^{695}$.

Artículo 23. Para garantizar el derecho de los consumidores y usuarios a una correcta información sobre los diversos bienes y servicios que se ofrecen en el mercado, la Administración de la Comunidad Autónoma de Galicia exigirá el estricto cumplimiento de la normativa vigente, común o específica de cada producto o servicio, relativa a la fabricación, composición y etiquetado, presentación y publicidad de los productos y servicios puestos a la venta.

Se arbitrarán las medidas oportunas para que la información sobre bienes y servicios,

objetivos". Entendida la remisión a la legislación vigente como referencia a la legislación estatal en materia contractual, imponiendo a los poderes públicos gallegos la obligación de hacerla efectiva a través de su actuación y adoptando medidas adecuadas para ello, el precepto se inserta dentro de la competencia autonómica para hacer efectiva, conforme al mandato constitucional, la protección del consumidor.

Por consiguiente, el precepto impugnado, en la medida en que viene a enunciar como "objetivos" los mandatos contenidos en la norma estatal no invade la competencia del Estado.

A idéntica conclusión hay que llegar con respecto a la declaración contenida en el número cinco del art. 20, siempre que se efectúe una interpretación adecuada de la norma, de conformidad con los titulos competenciales en conflicto. En efecto, aun cuando dicha prescripción no constituya una transcripción de la normativa estatal, la previsión de medidas administrativas, tendentes a asegurar el cumplimiento por el vendedor de su deber de información con respecto al comprador del servicio posventa cubierto por la garantia, es una materia que se enmarca dentro de la "defensa del consumidor" cuya competencia pertenece en exclusiva a la Comunidad Gallega. En la medida, pues, de que no se trata aqui de consagrar una nueva obligación civil o mercantil, sino tan solo de facultar a la C.A. a que pueda arbitrar la actividad de policia que estime conveniente para obtener el cumplimiento de tal deber de información, ningún reproche de inconstitucionalidad cabe efectuar a la citada norma".

694 Art. 21 declarado inconstitucional por STC 62/1991, de 22 de marzo, en el Recurso de Inconstitucionalidad 376/1985 y Conflicto Positivo de Competencia $763 / 1985$ (acumulados).

695 Véase FJ. 4 STC 62/1991, de 22 de marzo, en el Recurso de Inconstitucionalidad 376/1985 y Conflicto Positivo de Competencia 763/1985 (acumulados). 
contenida en el etiquetado, facilitada en los establecimientos mercantiles, o difundida mediante anuncios publicitarios, sea rigurosamente veraz y objetiva $\mathrm{y}$, particularmente, sobre los siguientes extremos: Origen empresarial y procedencia geográfica, naturaleza y composición; calidad, cantidad y categoría comercial; condiciones de idoneidad para el consumo $\mathrm{y}$ advertencias sobre riesgos previsibles; condiciones de los servicios, precios y demás características relevantes.

En todo caso, la Administración de la Comunidad Autónoma fomentará la oportuna información sobre el modo de utilización, las contraindicaciones y las garantías de los productos.

A estos efectos, y en el ámbito de la Comunidad Autónoma Gallega, se propiciará el empleo del gallego ${ }^{696}$.

Artículo 24. Con el fin de facilitar a los consumidores y usuarios la información precisa para el adecuado ejercicio de los derechos que esta ley les reconoce y, en general, atender a la defensa y protección de sus legítimos intereses, la Administración de la Comunidad Autónoma de Galicia promoverá, fomentará y, en su caso, habilitará o apoyará la creación de oficinas y servicios de información al consumidor y usuario, ya sean de titularidad pública, ya dependan de una organización o asociación de consumidores.

En las Oficinas de Información no estará permitida la publicidad expresa o encubierta.

Artículo 25. Con la finalidad de conseguir que el consumidor o usuario pueda efectuar una elección racional entre los diversos productos y servicios puestos a su disposición en el mercado, el Gobierno Gallego instrumentará las medidas precisas para el desarrollo de las siguientes actuaciones:

a. La utilización de etiquetas voluntarias informativas.

b. El otorgamiento, por una Entidad pública o privada, de certificados de calidad

696 Véase Decreto 185/1994, de 16 de junio, regula la utilización del idioma gallego en los productos y en la información al consumidor y usuario. o denominación de origen que acrediten la adecuación del producto o servicio o determinadas normas de calidad.

c. La realización de ensayos o pruebas comparativas entre los productos y servicios concurrentes.

Artículo 26. Los poderes públicos promoverán la educación y la formación permanente de los consumidores o usuarios con la finalidad de que puedan conseguir y desarrollar un comportamiento en libertad y responsabilidad en el mercado de bienes y servicios, y lleguen a conocer sus derechos y deberes y la forma de ejercerlos adecuadamente.

Para lograr estos fines, el Gobierno Gallego adoptará las medidas oportunas en orden a que se dé acogida en el sistema educativo a las enseñanzas en materia de consumo.

Se promoverá asimismo la información y educación de los consumidores o usuarios a través de los medios de comunicación social de titularidad pública, facilitando el acceso a ellos a las asociaciones de consumidores y usuarios y a grupos o entidades interesadas. Asimismo se llevarán a cabo campañas informativas con la finalidad de conseguir que el usuario de servicios alcance los conocimientos adecuados sobre sus peculiaridades.

\section{Capítulo IV DERECHO DE REPRESENTACIÓN, CONSULTA Y PARTICIPACIÓN}

Artículo 27. Los consumidores y usuarios tienen derecho a constituirse en organizaciones y asociaciones para hacer efectiva una adecuada representación y defensa de sus intereses.

Las asociaciones de consumidores y usuarios, en su estructura interna y en la adopción de sus acuerdos, se regirán por un sistema democrático. Asimismo, y con el fin de conseguir una mayor representatividad y alcanzar una mayor eficacia en el desempeño de sus funciones, podrán integrarse en agrupaciones o federaciones. El Gobierno Gallego adoptará las medidas precisas para promover el asociacionismo 
y dar adecuada y eficaz participación a las asociaciones de consumidores y usuarios ${ }^{697}$.

Artículo 28. A los efectos de la presente ley, serán reconocidas como organizaciones de consumidores y usuarios aquellas que, estando legalmente constituidas, tengan como finalidad primordial la defensa información y educación de los mismos y estén inscritas en el Registro correspondiente. También se considerarán organizaciones de consumidores y usuarios las entidades constituidas por los mismos con arreglo a la legislación cooperativa que entre sus fines figure, necesariamente, la educación y formación de sus socios, y están obligados a constituir un fondo con tal objeto, según su legislación específica.

Artículo 29. El Gobierno Gallego establecerá los cauces adecuados para que las organizaciones o asociaciones de consumidores y usuarios sean consultados en cuantos temas puedan afectar directamente al interés de los consumidores y usuarios.

Las asociaciones de consumidores y usuarios se consultarán en los términos del art. 130, apartado 4 de la Ley de Procedimiento Administrativo, en la elaboración de todas aquellas disposiciones de carácter general que afecten directamente a los consumidores y usuarios, siempre que razones de urgencia o interés general no aconsejen lo contrario.

El Gobierno Gallego, por razones de interés general, promoverá la colaboración entre organizaciones de consumidores y empresarios.

\section{Capítulo V}

DERECHO A LA PROTECCIÓN JURÍDICA, ADMINISTRATIVA Y TÉCNICA Y REPARACIÓN DE DAÑOS Y PERJUICIOS

Artículo 30. De acuerdo con lo establecido en la legislación general del Estado en

697 Véase:

- Decreto 127/1998, de 23 de abril, por el que se crea el Consello Galego de Consumidores e Usuarios.

- Orden de 25 de mayo de 2000 por la que se ratifica el Reglamento de organización y funcionamiento interno del Consello Galego de Consumidores e Usuarios y se ordena su publicación en el "Diario Oficial de Galicia". materia de garantías y responsabilidades, los consumidores y usuarios tendrán derecho a una eficaz protección jurídica, administrativa y técnica ordenada a la prevención o reparación de los daños y perjuicios que puedan sufrir como consecuencia de la adquisición, uso o disfrute de los bienes y servicios que se ponen a su disposición en el mercado.

Artículo 31. Se creará una comisión consultiva, que tendrá que ser consultada en la adopción de aquellas disposiciones que afecten directa o indirectamente a la protección y defensa de los consumidores y usuarios, y velará por la correcta aplicación de la normativa vigente en esta materia. En esta comisión tendrán que estar adecuadamente representadas las asociaciones que tengan como objetivo la defensa de los consumidores y usuarios y las organizaciones o entidades vinculadas a intereses profesionales o empresariales, así como los órganos de la Administración gallega que desarrollen competencias en esta materia. (... $)^{698}$

\section{TÍTULO III GRUPOS DE PROTECCIÓN ESPECIAL}

Artículo 32. 1. Los niños, mujeres en estado de gestación, ancianos, disminuidos físicos y psíquicos y, en general, aquellos consumidores o usuarios que, de una forma individual o colectiva, se encuentren en una situación de inferioridad o indefensión, deberán recibir una protección especial en lo referente al consumo o utilización de los bienes o servicios puestos a su disposición en el mercado.

2. Los órganos y servicios de la Administración Autónoma Gallega que tengan atribuidas competencias en materia de consumo adoptarán las siguientes medidas en relación con los bienes o servicios destinados a ser consumidos o utilizados por aquellas personas:

698 Párrafo segundo del art. 31 declarado inconstitucional por FJ. 5 STC 62/1991, de 22 de marzo, en el Recurso de Inconstitucionalidad 376/1985 y Conflicto Positivo de Competencia 763/1985 (acumulados). 
a. En el etiquetado, presentación y publicidad de aquellos bienes o servicios se proporcionará una correcta información, así como las advertencias precisas, por medios claros y notorios, acerca de los riesgos que para la salud y seguridad física de sus destinatarios se pudiesen derivar de un uso normal o de un previsible mal uso.

b. Se instrumentarán los controles necesarios para verificar el estricto cumplimiento de las condiciones de seguridad exigidas legalmente, en orden a garantizar un uso o disfrute sin riesgos de aquellos bienes o servicios.

Artículo 33. En los medios de comunicación social de carácter público o que reciban alguna subvención o ayuda con cargo a los fondos públicos, los mensajes dirigidos a los niños a través de los anuncios publicitarios, programas, espectáculos o publicaciones deben reunir las siguientes condiciones:

a. Evitar la manipulación psíquica de los niños, con el fin de no interferir en el adecuado desarrollo de su personalidad.

b. Evitar la incitación a la violencia o a la realización de actos delictivos.

c. No sugerir hábitos de consumo de bebidas alcohólicas, tabaco o cualquier otro producto que pueda originar efectos nocivos para la salud o que generen dependencia.

d. Que sus contenidos no sean contrarios a la moral pública y ofendan sentimientos éticos o religiosos.

Artículo 34. El Gobierno Gallego establecerá la normativa adecuada para que los ancianos y disminuidos físicos no se vean discriminados, por razones de inferioridad o indefensión, en los diferentes aspectos de la vida social que afecten al uso o disfrute de los bienes y servicios que se pongan a su disposición en el mercado. En particular, se adoptarán las medidas oportunas para facilitarles la utilización de los transportes y servicios públicos y el acceso a los locales de uso público.

\section{DISPOSICIÓN FINAL PRIMERA}

La incoación, trámite y resolución de los expedientes sancionadores que se deriven de la presente ley y de otras disposiciones que se dicten en su desarrollo, así como la finalización de los mismos en la vía administrativa, corresponderá a los órganos competentes de la Comunidad Autónoma que tengan asumidas reglamentariamente tales facultades.

En lo que afecta a la calificación de infracciones, tipo de sanciones y, en su caso, cuantía de las mismas, será de aplicación el régimen general que rige para el Estado.

\section{DISPOSICIÓN FINAL SEGUNDA}

El Gobierno Gallego promoverá oportunamente la creación de laboratorios que tengan por objeto efectuar ensayos, controles y análisis, en la medida en que cuente con medios para su realización o, en otro caso, por medio de la colaboración con otras entidades y organismos capaces de prestar la asistencia técnica adecuada; todo ello con objeto de facilitar una información útil a los consumidores o de contribuir a la mejora de la calidad de los productos, así como proporcionar los informes precisos a los órganos de la Administración encargados del ejercicio de la potestad sancionadora en materia de consumo, pudiendo emitir las certificaciones correspondientes.

\section{DISPOSICIÓN FINAL TERCERA}

El Gobierno Gallego presentará anualmente ante la Comisión correspondiente del Parlamento Autónomo una Memoria de las actividades que desarrolle en el ámbito del consumo.

\section{DISPOSICIÓN FINAL CUARTA}

El Gobierno Gallego podrá dictar cuantas disposiciones legales sean precisas para el desarrollo normativo de la presente ley.

\section{DISPOSICIÓN FINAL QUUINTA}

La presente ley entrará en vigor al día siguiente de su publicación en el "Diario Oficial de Galicia”. 


\section{XVI \\ SERVICIOS SOCIALES, SANIDAD \\ Y VIOLENCIA DE GÉNERO}

\section{LEY 9/1991, DE 2 DE OCTUBRE, DE MEDIDAS BÁSICAS PARA LA INSERCIÓN SOCIAL (DOGA N. $\left.{ }^{\circ} 191,3.10 .1991\right)$ \\ (...) ${ }^{699}$ \\ Título preliminar}

Artículo 1. La presente ley tiene por objeto la creación y desarrollo de un conjunto coordinado de medidas orientadas a la lucha contra la pobreza en la Comunidad Autónoma de Galicia y a la reinserción social y/o laboral de las personas afectadas por las diferentes formas de exclusión y marginación social.

Artículo 2. El plan de lucha contra la pobreza incorpora al sistema de servicios sociales de la Comunidad Autónoma de Galicia los siguientes programas:

a. Renta de integración social de Galicia.

b. Ayudas para situaciones de emergencia social.

c. Programas de desarrollo integral comunitario.

Artículo 3. La renta de integración social de Galicia y las ayudas para situaciones de emergencia social se configuran como derechos reconocibles a toda persona que reúna los requisitos y condiciones exigidos en la presente ley y según los preceptos contenidos en la misma.

Artículo 4. El desarrollo y aplicación de la presente ley corresponderán a los órganos competentes de la administración autonómica en colaboración con los Ayuntamientos, con arreglo a lo dispuesto en los artículos siguientes.

Artículo 5. Corresponde a la consellería competente en materia de servicios sociales el ejercicio de las siguientes funciones:

a. La elaboración de las normas de desarrollo de la presente ley.

699 Exposición de motivos omitida. b. El control y evaluación general de la aplicación de las medidas contempladas en la presente ley, sin perjuicio de lo establecido en el capítulo octavo del título primero.

c. La concesión, modificación, suspensión, extinción, denegación y pago de la renta de integración social de Galicia y de las ayudas para situaciones de emergencia social.

d. La propuesta de los programas a incluir en el anteproyecto de los presupuestos generales de la Comunidad Autónoma de Galicia.

e. La potenciación de la red de servicios sociales de atención primaria precisos para la eficaz aplicación de las medidas de inserción regulada en la presente ley, sin perjuicio de lo establecido en el artículo siguiente.

f. La elaboración de los estudios de pobreza, de las causas de la misma y de su localización social y territorial, así como de las consecuencias, que permitan la realización de un mapa de pobreza en Galicia y su actualización.

g. La propuesta de convenios con otras Comunidades Autónomas que permitan el mantenimiento de derechos adquiridos o en curso de adquisición por beneficiarios vecinos de las respectivas Comunidades Autónomas en virtud del principio de reciprocidad 700 .

Artículo 6. Corresponde a los Ayuntamientos de la Comunidad Autónoma de Galicia el ejercicio de las siguientes funciones:

a. En cooperación con la Xunta de Galicia, las Diputaciones Provinciales y los órganos competentes de la Administración General del Estado, implantar y desarrollar los servicios sociales de atención

700 Art. 5 modificado por Ley 1/1999, de 5 de febrero, por la que se modifica la Ley 9/1991, de 2 de octubre, de medidas básicas para la inserción social. 
primaria precisos para la aplicación de lo dispuesto en la presente ley, de acuerdo con la legislación vigente en la materia.

b. Cooperar con la Xunta de Galicia en la aplicación de la presente ley en los términos establecidos en la misma.

c. Mejorar con cargo a los presupuestos las ayudas para situaciones de emergencia social, de acuerdo con las condiciones establecidas en el título segundo, sin perjuicio de que puedan celebrar convenios con la Xunta de Galicia a fin de asumir la gestión única de las mismas, previa transferencia de los créditos que les correspondan 701 .

\section{TÍTULO I \\ DE LA RENTA DE INTEGRACIÓN SOCIAL DE GALICIA ${ }^{702}$ \\ Capitulo I \\ DISPOSICIONES GENERALES}

Artículo 7. 1. La renta de integración social de Galicia se configura como una prestación social destinada a garantizar recursos económicos de subsistencia a quienes carezcan de ellos, así como a alcanzar su autonomía e integración normalizada mediante un proyecto personalizado de inserción.

2. La renta de integración social de Galicia, en cuanto a prestación económica, tendrá carácter alimenticio, personal y no transmisible, no pudiendo ser objeto de embargo o retención ni darse en garantía de obligaciones. Asimismo, tendrá carácter subsidiario y complementario de cualquier otro ingreso o prestación de acuerdo con lo establecido en los artículos 12 y 14 de la presente ley.

3. Los proyectos de inserción estarán constituidos por un conjunto coordinado y programado de acciones que tendrá como objetivo la mejora de la integración

701 Art. 6 modificado por Ley 1/1999, de 5 de febrero, por la que se modifica la Ley 9/1991, de 2 de octubre, de medidas básicas para la inserción social.

702 Véase Decreto 374/1991, de 24 de octubre, desarroIla la Ley de 2 de octubre de 1991, de medidas básicas para la inserción social, en lo relativo a la renta de integración social. personal, familiar o social, así como, en su caso, la incorporación del beneficiario al sistema laboral.

4. En todo caso, la aceptación y el cumplimiento de las acciones contenidas en los proyectos de inserción por el beneficiario serán condición necesaria para la percepción de la prestación económica.

Artículo 8. 1. Los perceptores de pensiones o ayudas de carácter público, contributivas o no contributivas, sólo tendrán derecho, siempre que cumplan todos los requisitos establecidos en el capítulo siguiente, a la incorporación a los proyectos de inserción, sin perjuicio de lo establecido en el artículo 13.3 de la presente ley.

2. No obstante, tendrán también derecho al subsidio básico y al complemento variable aquéllos que por tener cargas familiares tuviesen derecho a prestaciones de protección a la familia, de acuerdo con la legislación en vigor en los términos establecidos en el artículo 14.

3. Igualmente podrán acceder al proyecto de inserción quienes, pudiendo obtener las prestaciones señaladas en el número 1 del presente artículo, no hubiesen ejercitado las acciones pertinentes para su reconocimiento ${ }^{703}$.

\section{Capitulo II DE LOS BENEFICIARIOS}

Artículo 9. 1. Podrán ser beneficiarias de la renta de integración social de Galicia, en las condiciones previstas en la presente ley, aquellas personas que reúnan los siguientes requisitos:

$1^{\circ}$. Tener residencia efectiva y estar empadronadas en cualquiera de los Ayuntamientos de la Comunidad Autónoma gallega por lo menos durante el año inmediatamente anterior a la formulación de la solicitud.

703 Art. 8 modificado por Ley 1/1999, de 5 de febrero, por la que se modifica la Ley 9/1991, de 2 de octubre, de medidas básicas para la inserción social. 
Quedan eximidas del cumplimiento de este requisito de un año:

a. Aquellas personas que, procedentes de otras Comunidades Autónomas del Estado español, sean beneficiarias del salario social en la Comunidad Autónoma de la que proceden, siempre que en la legislación de la Comunidad de la que proceden se recoja la reciprocidad.

b. Las víctimas de violencia doméstica que cambian su domicilio por motivos de seguridad.

c. Las personas emigrantes gallegas, en los términos señalados en el artículo 3 del Estatuto de Autonomía para Galicia, cuando hubieran fijado su residencia en el territorio de la Comunidad Autónoma. Al mismo tiempo, aquellas personas nacidas en Galicia que residiendo en otras Comunidades Autónomas vuelvan a fijar su residencia en el territorio de la Comunidad Autónoma gallega.

Los ciudadanos y ciudadanas de estados no miembros de la Unión Europea precisarán, además, acreditar la residencia legal en España en el momento de la formulación de la solicitud.

$2^{\circ}$. Tener constituida una unidad de convivencia independiente, vinculada económicamente a la persona solicitante.

$3^{\circ}$. Tener una edad comprendida entre los veinticinco y los sesenta y cinco años. No obstante, también podrán ser beneficiarias:

a. Las personas menores de veinticinco años que, reuniendo el resto de los requisitos de ese artículo, tengan menores a su cargo.

b. Las personas mayores de dieciocho años que, teniendo reconocida la condición de minusvalía, no tengan derecho a prestación o ayuda de igual o análoga naturaleza.

c. Las personas mayores de dieciocho años que, antes de alcanzar la mayoría de edad, estuvieran tuteladas por la Xunta de Galicia e internadas en centros de protección de menores o en acogimiento familiar.

d. Las personas mayores de dieciocho años en situación de orfandad absoluta que, reuniendo los demás requisitos de este artículo, no tengan derecho a otras prestaciones o ayudas de análoga naturaleza.

4. ${ }^{\circ}$ Disponer de unos recursos inferiores a la cuantía de la prestación económica de la renta de integración social de Galicia que les correspondería considerando su situación económica y familiar de acuerdo con el artículo 12 de la presente ley.

5. ${ }^{\circ}$ Que no existan personas legalmente obligadas y con posibilidad real de prestarles alimentos de acuerdo con la legislación civil. A juicio del órgano de resolución, se podrán eximir de este requisito aquellos solicitantes de los que se prevea que la obligación de alimentos no se pueda hacer efectiva por malos tratos, relaciones familiares deterioradas o inexistentes, de las cuales exista constancia en el expediente. No obstante, se considera que no tienen la obligación de prestar alimentos los parientes que, en atención a las circunstancias socioeconómicas concurrentes, no pueden hacer frente o atender las necesidades básicas de la unidad familiar solicitante sin desatender las propias necesidades o las de los familiares a su cargo. Las circunstancias constarán claramente en el informe social correspondiente.

2. A los efectos de lo dispuesto en este artículo, se entiende por residencia efectiva aquélla que habite el solicitante por tiempo superior a seis meses en un período de doce ${ }^{704}$.

Artículo 10. 1. Únicamente se concederá una renta de integración social de Galicia por unidad de convivencia independiente.

2. A los efectos previstos en la presente ley, se considerará unidad de convivencia independiente a las personas que vivan solas, y, en su caso, al conjunto de personas que convivan en el mismo marco físico y se encuentren vinculadas con el solicitante por matrimonio o cualquier otra forma de relación estable análoga a la conyugal, por

704 Art. 9 modificado por Ley 16/2004, de 29 de diciembre, por la que se modifica la Ley 9/1991, de 2 de octubre, de medidas básicas para la inserción social. 
adopción o acogimiento o por parentesco de consanguinidad o afinidad hasta el cuarto y segundo grado respectivamente.

3. No obstante lo anterior, cuando en una unidad de convivencia existan personas con menores a su cargo, se considerará que constituyen una unidad de convivencia independiente.

4. La unidad de convivencia independiente beneficiaria no perderá esta condición cuando por causa de fuerza mayor, accidente o desahucio se vea obligada a residir con otra.

5. Reglamentariamente se determinarán los supuestos del marco físico de residencia colectiva que puedan ser considerados unidad de convivencia independiente a los efectos de este artículo 705 .

\section{Capitulo III DE LAS PRESTACIONES}

\section{Sección $1 .^{\mathrm{a}}$}

Prestaciones económicas

Artículo 11. La prestación económica de la renta de integración social de Galicia estaráintegrada porun subsidio básico, en los supuestos contemplados en los dos artículos siguientes, por un complemento variable en función de los miembros que componen la unidad de convivencia independiente y por un complemento de inserción ${ }^{706}$.

Artículo 12. 1. La cuantía del subsidio básico será equivalente al $75 \%$ del importe mensual del indicador público de renta de efectos múltiples, fijado en la legislación específica que resulte de aplicación, sin perjuicio de lo señalado en los apartados 3 y 4 de este artículo.

2. La cuantía del complemento variable, en función del número de miembros de la unidad de convivencia independiente, será la siguiente:

El $12 \%$ del importe mensual del indicador público de renta de efectos múltiples por el primer miembro adicional.

\footnotetext{
705 Art. 10 modificado por Ley $1 / 1999$, de 5 de febrero, por la que se modifica la Ley 9/1991, de 2 de octubre, de medidas básicas para la inserción social.

706 Art. 11 modificado por Ley 16/2004, de 29 de diciembre, por la que se modifica la Ley 9/1991, de 2 de octubre, de medidas básicas para la inserción social.
}

El 10\% del importe mensual del indicador público de renta de efectos múltiples por el segundo miembro adicional.

El 8\% del importe mensual del indicador público de renta de efectos múltiples por cada uno de los restantes miembros adicionales.

3. Los beneficiarios y beneficiarias que, por aplicación de lo previsto en la letra g) del apartado 1 del artículo 32 de la presente ley, se mantengan en la percepción de la prestación después de cuatro años sólo tendrán derecho al subsidio básico con una cuantía mensual equivalente al importe mensual de la pensión no contributiva individual, fijada en la legislación específica que resulte de aplicación, sin derecho a la percepción del complemento variable señalado en el apartado anterior y sin perjuicio de lo señalado en el artículo 13 de la presente ley. Salvo la diferente cuantía en la prestación económica, estos beneficiarios y beneficiarias tendrán los mismos derechos y obligaciones que el resto de las personas perceptoras y estarán sometidos a la revisión anual de la prestación prevista en el artículo 22.2 de la presente ley, pudiendo añadirse reglamentariamente términos específicos y complementarios en los que se deba realizar dicha evaluación anual de este colectivo.

4. Las cuantías señaladas en el apartado anterior también serán las que corresponde abonar a los beneficiarios y beneficiarias que se reincorporen al programa en los términos señalados en la letra c) del apartado 2 del artículo 32 de la presente ley.

5. El importe que percibirá cada persona beneficiaria estará constituido por la diferencia entre la cuantía mensual de la renta de integración social de Galicia, que con arreglo a este artículo le correspondiera, y la de los recursos económicos de que disponga, computados de conformidad con el artículo 14, y en ningún caso podrá superar el límite del $125 \%$ del importe mensual del indicador público de renta de efectos múltiples.

Ello no obstante, se denegará la prestación económica de la renta de integración social de Galicia cuando las características, 
valoración, posibilidad de explotación o venta de los bienes muebles o inmuebles sobre los que se ostente un derecho de propiedad, posesión, usufructo u otro de análoga naturaleza real indiquen la existencia de medios suficientes para la subsistencia de los miembros de la unidad de convivencia ${ }^{707}$.

Artículo 13. 1. La cuantía del complemento de inserción, que en los correspondientes proyectos se pueda establecer, será determinada en función de sus especiales características, dedicación y gastos que implique.

2. El importe de este complemento no se computará a efectos de la determinación del tope máximo a que se refiere el apartado 5 del artículo anterior.

3. Se podrá beneficiar de este complemento toda persona que, no siendo perceptora de la renta de integración social de Galicia, esté incorporada a un proyecto de inserción dentro de los programas elaborados para este fin ${ }^{708}$.

Artículo 14. 1. A los efectos previstos en la presente ley, se entenderán como recursos económicos de los que dispone la unidad de convivencia independiente los siguientes:

a. El total de ingresos que perciba en el momento de la solicitud la persona solicitante o las personas que constituyan la unidad de convivencia en concepto de retribuciones, rentas, prestaciones, ayudas, subsidios o por cualesquiera otros conceptos.

b. Las cantidades percibidas en concepto de pago único, depósitos bancarios, cuentas corrientes o de ahorro, así como los bienes muebles o inmuebles sobre los que se ostente un derecho de propiedad, posesión, usufructo o cualesquiera otros de análoga naturaleza, con la salvedad de la vivienda destinada a su uso, siempre que su valoración catastral no supere

707 Art. 12 modificado por Ley 16/2004, de 29 de diciembre, por la que se modifica la Ley 9/1991, de 2 de octubre, de medidas básicas para la inserción social. 708 Art. 13 modificado por Ley 16/2004, de 29 de diciembre, por la que se modifica la Ley 9/1991, de 2 de octubre, de medidas básicas para la inserción social. quince anualidades del indicador público de renta de efectos múltiples vigente.

2. En todo caso, no se considerarán los ingresos irregulares que únicamente resulten un complemento de supervivencia ni tampoco los ingresos de carácter finalista dirigidos a la formación reglada y profesional o a paliar situaciones de emergencia social.

3. Tampoco serán computables las prestaciones familiares por hijo a cargo mayor de diceciocho años con una minusvalía igual o superior al $65 \%$ generadas por las personas integrantes de la unidad de convivencia ${ }^{709}$.

4. A los efectos previstos en la presente ley, en los casos de violencia de género no se considera al agresor miembro integrante de la unidad familiar de la solicitante, por lo que sus rentas individuales no se computan como recursos económicos de la unidad de convivencia ${ }^{710}$.

Artículo 15. El beneficiario tendrá derecho a percibir la prestación económica de la renta de integración social de Galicia desde el día primero del mes siguiente a aquél en que se dicte la resolución.

La resolución concediendo o denegando la solicitud habrá de dictarse en el plazo máximo de tres meses a contar a partir del día de registro de la petición inicial. Transcurridos tres meses sin haberse dictado la resolución, se otorgará la prestación provisionalmente, en tanto no se resuelva definitivamente la solicitud, siempre que la demora no se deba a causa imputable al solicitante y a la solicitud se adjuntasen los documentos a que hace referencia el punto 1 del artículo 24 de la presente ley ${ }^{711}$.

709 Art. 14 modificado por Ley 16/2004, de 29 de diciembre, por la que se modifica la Ley $9 / 1991$, de 2 de octubre, de medidas básicas para la inserción social. 710 Art. 14.4 añadido por Ley 11/2007, de 27 de julio, gallega para la prevención y el tratamiento integral de la violencia de género.

711 Art. 15 modificado por Ley 1/1999, de 5 de febrero, por la que se modifica la Ley 9/1991, de 2 de octubre, de medidas básicas para la inserción social. 
Artículo 16. El pago de las prestaciones económicas se realizará al solicitante por mensualidades vencidas en la forma que reglamentariamente se establezca.

\section{Sección 2. ${ }^{\text {a }}$}

\section{Proyecto de inserción}

Artículo 17. 1. El proyecto de inserción será elaborado partiendo de las necesidades y características de cada caso, de tal forma que procure la autonomía personal, familiar y económica del beneficiario y logre su integración social y/o laboral.

2. Por cada unidad de convivencia independiente destinataria de la renta de integración social de Galicia habrá de elaborarse al menos un proyecto de inserción. Serán beneficiarias del mismo la persona o personas mayores de edad que a juicio de los servicios sociales de atención primaria $\mathrm{o}$, en su caso, del órgano de resolución estén en mejor disposición y aptitud para lograr la integración que se pretende ${ }^{712}$.

Artículo 18. 1. Todo proyecto de inserción para alcanzar su finalidad habrá de integrar acciones de la siguiente naturaleza:

a. Acciones que procuren la rehabilitación personal y familiar.

b. Acciones que procuren la integración en el medio social.

c. Acciones de motivación laboral, orientación profesional y formación ocupacional.

d. Actividades de interés colectivo y social en entidades públicas o privadas, sin menoscabo de sus derechos laborales, así como en los diversos programas de colaboración con otras administraciones públicas y entidades sin ánimo de lucro, para la realización de obras y servicios de interés general o social, y en los programas mixtos de formación y empleo.

e. Actividades orientadas hacia el trabajo autónomo o cualquiera de las formas de economía social.

712 Art. 17 modificado por Ley 1/1999, de 5 de febrero, por la que se modifica la Ley 9/1991, de 2 de octubre, de medidas básicas para la inserción social. f. Acciones tendentes a la plena incorporación al trabajo mediante la formalización del correspondiente contrato laboral.

2. En el supuesto de que los proyectos de inserción incluyan alguna de las medidas previstas en las letras c), d) y f) del apartado anterior, la persona beneficiaria quedará obligada a inscribirse como demandante de empleo en la correspondiente oficina del servicio público de empleo.

3. En aquellos casos en que así se considere, el proyecto de inserción podrá estar integrado exclusivamente por las acciones que se deban realizar para el cuidado del hogar, la atención a menores o mayores dependientes o cualquier otra dedicación solidaria.

4. En cualquier caso, el proyecto de inserción se diseñará con criterios rigurosos de programación, con determinación de objetivos, plazos, medios y actividades que permitan la posterior evaluación de los efectos reales de aplicación de la renta de integración social de Galicia en cada caso ${ }^{713}$.

Artículo 19. Con la finalidad de incentivar la incorporación de los beneficiarios y beneficiarias de la renta de integración social de Galicia al mercado de trabajo, la Xunta de Galicia primará, especialmente, a las personas integrantes de dicho colectivo, a través de los incentivos tanto para la contratación por cuenta ajena como para el autoempleo y economía social, dándoles el máximo nivel de ayuda que, en cada momento, permita la normativa vigente ${ }^{714}$.

Artículo 20. Los beneficiarios y beneficiarias de la renta de integración social de Galicia también tendrán prioridad para participar en los programas de colaboración con otras administraciones públicas y entidades sin ánimo de lucro, para la realización de obras y servicios de interés

713 Art. 18 modificado por Ley $16 / 2004$, de 29 de diciembre, por la que se modifica la Ley 9/1991, de 2 de octubre, de medidas básicas para la inserción social. 714 Art. 19 modificado por Ley $16 / 2004$, de 29 de diciembre, por la que se modifica la Ley 9/1991, de 2 de octubre, de medidas básicas para la inserción social. 
general o social, así como para su participación en programas mixtos de formación y empleo ${ }^{715}$.

Artículo 21. Sin perjuicio de lo establecido en los artículos anteriores, la Xunta de Galicia, a través de la consellería competente en materia de servicios sociales, para la ejecución de los proyectos de inserción descritos en esta sección, podrá firmar convenios de colaboración con asociaciones o entidades de iniciativa social, así como los organismos públicos y privados que considere oportunos.

\section{Sección $3 .^{a}$}

\section{Duración de las prestaciones}

Artículo 22. 1. La renta de integración social de Galicia será otorgada al beneficiario en tanto subsistan las causas que motivaron su concesión.

2. La revisión de las condiciones de su otorgamiento y la evaluación de los resultados alcanzados se efectuarán cada doce meses. La resolución decidirá sobre la renovación, modificación o extinción, sin perjuicio de lo establecido en los artículos 23 y 32 de la presente ley.

3 . La prestación se entenderá prorrogada en defecto de resolución expresa ${ }^{716}$.

\section{Capítulo IV \\ DE LAS OBLIGACIONES DE LOS BENEFICIARIOS}

Artículo 23. Los beneficiarios de la renta de integración social de Galicia quedan obligados a:

1. Destinar el importe de la prestación al fin para el que se concede.

2. Participar en las acciones o actividades que se determinen de acuerdo con el beneficiario dentro del proyecto de inserción.

3. Escolarizar a los menores a su cargo que estén en edad escolar obligatoria,

715 Art. 20 modificado por Ley 16/2004, de 29 de diciembre, por la que se modifica la Ley 9/1991, de 2 de octubre, de medidas básicas para la inserción social.

716 Art. 22 modificado por Ley 1/1999, de 5 de febrero, por la que se modifica la Ley 9/1991, de 2 de octubre, de medidas básicas para la inserción social. garantizando su asistencia al centro de enseñanza que corresponda.

Dicha asistencia se acreditará debidamente.

4. No ejercer la mendicidad ni la prostitución, ni inducir o compeler a la práctica de cualquiera de ellas a ningún miembro de la unidad de convivencia.

5. Comunicar las variaciones sobrevenidas que, de conformidad con la presente ley, pudiesen dar lugar a la modificación, suspensión o extinción de la prestación.

6. Ejercitar cuando el órgano competente para la resolución lo estime conveniente, a la vista de los informes obrantes en el expediente y en el plazo que se establezca en la correspondiente resolución, cualquier derecho económico que pudiese corresponderles según la legislación vigente.

7. Cuantas otras obligaciones se deriven del objeto y finalidad de la renta de integración social de Galicia ${ }^{717}$.

\section{Capitulo V DE LA TRAMITACIÓN}

Artículo 24. 1. El reconocimiento de la renta de integración social de Galicia se realizará previa solicitud de la persona interesada, mediante la presentación en su Ayuntamiento del modelo normalizado por la consellería competente, al cual habrá de adjuntar los documentos necesarios para justificar el cumplimiento de los requisitos establecidos en el artículo 9 y aquellos otros que se pudieran determinar reglamentariamente.

2. Para el cómputo de los recursos económicos de la unidad de convivencia, la instancia normalizada de solicitud incluirá una declaración jurada en la que los peticionarios y peticionarias harán constar todos los recursos de que disponga la unidad de convivencia.

3. En la instancia normalizada a que se refiere el apartado anterior, la persona solicitante

717 Art. 23 modificado por Ley 1/1999, de 5 de febrero, por la que se modifica la Ley 9/1991, de 2 de octubre, de medidas básicas para la inserción social. 
hará constar que autoriza al órgano de resolución para recabar la información adicional que considere necesaria para la adecuada estimación de los ingresos o recursos económicos de la unidad de convivencia, y en general para completar el expediente, dirigiéndose a los órganos públicos o privados competentes, ya sea a través del acceso directo a bases de datos por medios informáticos o cursando el correspondiente oficio.

4. Las entidades locales, a través de los equipos técnicos de los servicios sociales de atención primaria municipales correspondientes, elaborarán un informe social en el que se valore la procedencia, o no, de la aplicación de la renta de integración social de Galicia, así como, en su caso, la propuesta de un proyecto de inserción, de conformidad con lo dispuesto en la presente ley.

5. El informe señalado en el apartado anterior destacará el perfil sociológico y una valoración sobre las posibilidades de inserción social y/o laboral, indicando, en este último supuesto, qué centros o instituciones adecuados existen en el entorno de la persona beneficiaria. Asimismo, destacará cuantos datos se estimen pertinentes para poner de manifiesto: la existencia de una unidad de convivencia independiente; el número de personas que conviven, junto con la información sobre minusvalía que pueda afectar a alguno de sus miembros; y la descripción del hogar y de la posible existencia de personas o familiares con obligación legal y posibilidad real de prestación de alimentos.

6. La propuesta del proyecto de inserción habrá de contar con el asentimiento de la persona interesada o, en caso contrario, con las razones invocadas por la misma para su rechazo.

7. El municipio de residencia, en el plazo de un mes desde la recepción de la solicitud, remitirá los informes, la propuesta de resolución y la restante documentación necesaria para poder continuar la tramitación del expediente a la Delegación Provincial de la consellería competente en materia de servicios sociales, para su calificación y posterior resolución. De no remitirse en el plazo señalado, dado el carácter determinante para la resolución del procedimiento, sin perjuicio de la responsabilidad en que incurre el responsable de la demora, quedará interrumpido el plazo para resolver el expediente, con arreglo a lo previsto en le artículo 83.3 de la Ley 30/1992, de 26 de noviembre, de Régimen Jurídico de las Administraciones Públicas y del Procedimiento Administrativo Común.

8. Las delegaciones provinciales de la consellería competente en materia de servicios sociales resolverán las solicitudes remitidas por los Ayuntamientos en el plazo máximo de un mes desde su recepción.

9. Excepcionalmente, en aquellos casos en que la situación de la persona beneficiaria lo haga imprescindible, podrá realizar la solicitud a su nombre el propio Ayuntamiento; sin embargo, no se resolverá favorablemente el expediente mientras la persona interesada no asuma el proyecto de inserción social y/o laboral que, a propuesta de los servicios sociales de atención primaria, sea aprobado por el órgano de resolución de la renta de integración social de Galicia ${ }^{718}$.

10. Cuando la persona beneficiaria de la renta de integración social de Galicia posea la condición de víctima de violencia de género, la concesión de la renta se tramitará por un procedimiento abreviado y su abono efectivo se efectuará en el plazo máximo de un mes desde la solicitud ${ }^{719}$.

Artículo 25. Tanto a nivel autonómico como en cada Delegación Provincial de la consellería competente en materia de servicios sociales se constituirán con carácter permanente unidades técnicoadministrativas de apoyo al órgano de resolución con la composición y funciones que reglamentariamente se determinen ${ }^{720}$.

718 Art. 24 modificado por Ley 16/2004, de 29 de diciembre, por la que se modifica la Ley 9/1991, de 2 de octubre, de medidas básicas para la inserción social. 719 Art. 24.10 añadido por Ley 11/2007, de 27 de julio, gallega para la prevención y el tratamiento integral de la violencia de género.

720 Art. 25 modificado por Ley 1/1999, de 5 de febrero, por la que se modifica la Ley 9/1991, de 2 de octubre, de medidas básicas para la inserción social. 
Artículo 26. (... $)^{721}$

Artículo 27. Los órganos competentes para la resolución podrán comprobar, a través de los organismos públicos y privados correspondientes, la veracidad de los datos obrantes en el expediente ${ }^{722}$.

Artículo 28. Se garantiza la confidencialidad de los datos obtenidos en la tramitación de los expedientes, de conformidad con la legislación vigente.

\section{Capítulo VI \\ DE LA CONCESIÓN PROVISIONAL, MODIFICACIÓN, SUSPENSIÓN Y EXTINCIÓN}

Artículo 29. 1. Cuando el órgano competente imponga al beneficiario o a cualquiera de los miembros de la unidad de convivencia independiente la obligación señalada en el artículo 23.6 de la presente ley, habrá de informarles sobre los derechos que les asistan y los trámites necesarios para la interposición de la correspondiente demanda o ejecución de sentencia.

2. En el supuesto de que la demanda prospere, por el órgano competente se dictará la oportuna resolución modificando o extinguiendo, en su caso, el derecho a la renta. Al mismo tiempo el beneficiario, a partir de la ejecución de la sentencia, vendrá obligado a devolver una cuantía igual a la obtenida hasta el límite de la prestación económica de la renta de integración social de Galicia que viniese percibiendo. No obstante, podrá acordarse el pago aplazado o incluso la condonación de esta obligación, en función de las circunstancias económicas concurrentes en la persona beneficiaria ${ }^{723}$.

Artículo 30. La modificación sobrevenida del número de miembros de la unidad de convivencia o de los recursos económicos que sirvieron de base para

721 Art. 26 suprimido por Ley 1/1999, de 5 de febrero, por la que se modifica la Ley $9 / 1991$, de 2 de octubre, de medidas básicas para la inserción social.

722 Art. 27 modificado por Ley 1/1999, de 5 de febrero, por la que se modifica la Ley 9/1991, de 2 de octubre, de medidas básicas para la inserción social.

723 Art. 29 modificado por Ley 1/1999, de 5 de febrero, por la que se modifica la Ley 9/1991, de 2 de octubre, de medidas básicas para la inserción social. el cálculo de la prestación económica de la renta de integración social de Galicia dará lugar a la minoración o aumento que proceda a partir del mes siguiente a aquél en que tenga lugar. La comunicación de tales circunstancias se hará a través de los servicios sociales de atención primaria correspondientes ${ }^{724}$.

Artículo 31. La percepción de la prestación económica de la renta de integración social de Galicia se suspenderá por las siguientes causas:

1. Cuando los recursos económicos, computados de acuerdo con el artículo 14 , superen, en cómputo mensual, por un período inferior a seis meses, la prestación económica de la renta de integración social de Galicia correspondiente en cada caso, se suspenderá su abono, y se reiniciará, a instancia de la persona beneficiaria, cuando decaigan las circunstancias que motivaron dicha suspensión, con la salvedad de que en este supuesto podrá continuar la persona beneficiaria percibiendo el complemento de inserción, en función de las acciones desarrolladas en el proyecto de inserción.

2. Igualmente, será causa de suspensión la imposibilidad sobrevenida, por parte de la persona beneficiaria, de cumplir las obligaciones asumidas, o la declaración legal de incapacidad. En este supuesto, en función de las circunstancias concurrentes, durante un plazo máximo de seis meses se podrá acordar el abono de la prestación a otro miembro de la unidad de convivencia, modificando, si procede, su cuantía mientras subsistan las citadas causas ${ }^{725}$.

Artículo 32. 1. El derecho a las prestaciones de la renta de integración social de Galicia se extingue por:

a. La pérdida de alguno de los requisitos exigidos para su reconocimiento, sin

\footnotetext{
724 Art. 30 modificado por Ley 1/1999, de 5 de febrero, por la que se modifica la Ley 9/1991, de 2 de octubre, de medidas básicas para la inserción social.

725 Art. 31 modificado por Ley 16/2004, de 29 de diciembre, por la que se modifica la Ley 9/1991, de 2 de octubre, de medidas básicas para la inserción social.
} 
perjuicio de lo establecido en el apartado 1 del artículo anterior. Con carácter previo a dictarse la resolución de extinción, se tramitará por el órgano de resolución el correspondiente procedimiento de revisión, con audiencia de la persona interesada, pudiendo acordarse, al disponer el inicio de dicho procedimiento, la suspensión cautelar del abono de la prestación cuando exista una presunción fundada de que la persona beneficiaria perdió su derecho a la misma.

b. El fallecimiento de la persona beneficiaria, supuesto en que será de aplicación lo dispuesto en el punto 2 del artículo 31 , mientras tramite una nueva solicitud otro miembro de la unidad de convivencia independiente.

c. El incumplimiento de las obligaciones previstas en el artículo 23 de la presente ley por causas imputables a la persona beneficiaria.

d. El mantenimiento de las causas que dieron lugar a la suspensión previstas en el artículo 31.

e. La ocultación o falseamiento de los datos o cualquier otra actuación fraudulenta dirigida a obtener o conservar la prestación económica, sin perjuicio de lo dispuesto en el vigente código penal.

f. El traslado de la residencia efectiva a un municipio que no esté comprendido en el territorio de la Comunidad Autónoma de Galicia, salvo que se produzca la circunstancia señalada en el artículo 5.g) de la presente ley.

g. El transcurso de cuatro años consecutivos en su percepción, excepto que, a juicio del órgano de resolución y previo informe de los servicios sociales de atención primaria del municipio de residencia de la persona beneficiaria, fuera necesario mantener a ésta en la percepción de la prestación por su situación de exclusión social y/o desestructuración familiar de su unidad de convivencia, especialmente cuando existan menores en la misma.
2. La extinción del derecho a la renta de integración social de Galicia implicará las siguientes consecuencias:

a. Cuando la extinción se lleve a cabo por la causa señalada en el artículo 32.1.e) de la presente ley, se devolverán las cantidades indebidamente percibidas por la persona beneficiaria. Dichas cantidades habrán de ser reintegradas o serán objeto de compensación en caso de que se reconozca un nuevo derecho a la renta de integración social de Galicia en los términos que señale el órgano de resolución.

b. Cuando la extinción se produzca por el incumplimiento de las obligaciones establecidas en los apartados 1, 2, 3 y 4 del artículo 23 o por las causas establecidas en las letras e) o g) del artículo 32.1, no se reconocerá a ningún miembro de la unidad de convivencia un nuevo derecho a la renta de integración social de Galicia hasta que transcurra un año desde la fecha de la resolución de extinción, salvo que se constituya una nueva unidad de convivencia por un miembro no responsable del incumplimiento.

c. Cuando la extinción se produzca por la percepción de la renta durante cuatro años consecutivos, se podrá solicitar una nueva renta si durante el año siguiente a la resolución de extinción concurrieran circunstancias excepcionales que agraven la situación de exclusión social de la persona interesada o la situación de desestructuración social y familiar de la unidad de convivencia, debidamente acreditadas por los servicios sociales de atención primaria de su Ayuntamiento ${ }^{726}$.

\section{Capítulo VII DE LA IMPUGNACIÓN}

Artículo 33. Contra las resoluciones dictadas por los delegados o delegadas

726 Art. 32 modificado por Ley 16/2004, de 29 de diciembre, por la que se modifica la Ley 9/1991, de 2 de octubre, de medidas básicas para la inserción social. 
provinciales se podrá interponer, en el plazo de un mes, recurso de alzada ante el titular de la consellería competente en materia de servicios sociales ${ }^{727}$.

Artículo 34. El recurso se podrá interponer ante el órgano que dictara la resolución o ante el órgano competente para resolverlo, con arreglo a lo previsto en el artículo 114 de la Ley 30/1992, de 26 de noviembre, de Régimen Jurídico de las Administraciones Públicas y del Procedimiento Administrativo Común, según redacción dada por la Ley 4/1999728.

Artículo 35. 1. Si la resolución fuera estimatoria del recurso, los efectos económicos de éste se retrotraerán a la fecha de resolución inicial denegatoria, en los términos fijados por el artículo 15 de la presente ley.

2. La resolución del recurso de alzada pondrá fin a la vía administrativa ${ }^{729}$.

\section{Capitulo VIII \\ DE LOS ÓRGANOS DE CONTROL Y SEGUIMIENTO}

Artículo 36. Como órganos superiores de control y seguimiento de la aplicación de la renta de integración social de Galicia se constituye una Mesa en cada provincia y otra a nivel autonómico ${ }^{730}$.

Artículo 37. 1. En cada una de las provincias de la Comunidad Autónoma, presidida por el Delegado provincial de la consellería competente en materia de servicios sociales, se constituirá una Mesa integrada por:

Siete representantes de la Administración Autonómica.

727 Art. 33 modificado por Ley 16/2004, de 29 de diciembre, por la que se modifica la Ley 9/1991, de 2 de octubre, de medidas básicas para la inserción social.

728 Art. 34 modificado por Ley 16/2004, de 29 de diciembre, por la que se modifica la Ley 9/1991, de 2 de octubre, de medidas básicas para la inserción social. 729 Art. 35 modificado por Ley 16/2004, de 29 de diciembre, por la que se modifica la Ley 9/1991, de 2 de octubre, de medidas básicas para la inserción social.

730 Art. 36 modificado por Ley 1/1999, de 5 de febrero, por la que se modifica la Ley 9/1991, de 2 de octubre, de medidas básicas para la inserción social.
Siete representantes de las centrales sindicales más representativas a nivel autonómico. Siete representantes de las organizaciones empresariales en el mismo ámbito.

Dos representantes de los Ayuntamientos de la Comunidad Autónoma.

Reglamentariamente se determinará la forma de designación de los representantes de los Ayuntamientos y la periodicidad de las reuniones, aportándoles la Administración los datos globales que se deriven de la aplicación del programa.

2. Serán funciones de las Mesas el control y seguimiento estadístico, tanto de los procesos de concesión de la renta de integración social de Galicia como de la correcta aplicación de las medidas de fomento de empleo que vinculadas a los proyectos de inserción se consideran en la presente ley.

3. A las reuniones de las Mesas podrán asistir, a petición de cualquiera de las partes, representantes de las asociaciones y otras entidades de iniciativa social colaboradoras del programa, que participarán en las mismas con voz pero sin voto.

Las actas de las sesiones que celebren estas Mesas serán remitidas a la Mesa Autonómica a que se refiere el artículo siguiente ${ }^{731}$.

Artículo 38. 1. A nivel autonómico se constituirá una Mesa presidida por el titular de la consellería competente en materia de servicios sociales o persona en la que delegue, con igual representación y sistema de designación que las Mesas Provinciales, la cual se reunirá con periodicidad trimestral.

2. Serán funciones de esta Mesa el control y evaluación global de los resultados de la ejecución del programa, así como la formulación de observaciones y propuestas de modificación que ayuden a mejorarlo.

3. A las reuniones de esta Mesa podrán asistir, a petición de cualquiera de las partes,

731 Art. 37 modificado por Ley 1/1999, de 5 de febrero, por la que se modifica la Ley 9/1991, de 2 de octubre, de medidas básicas para la inserción social. 
representantes de las asociaciones y otras entidades de iniciativa social colaboradoras en el programa, que participarán en las mismas con voz pero sin voto, en aquellos temas directamente relacionados con sus actividades.

4. La Administración Autonómica facilitará a esta Mesa la documentación necesaria, así como las actas de las sesiones que celebren las Mesas Provinciales de Control y Seguimiento.

5. Deberá ser oída la Mesa con anterioridad a la aprobación de la documentación necesaria, así como de las actas de las sesiones que celebren las Mesas Provinciales de Control y Seguimiento.

6. La Mesa elaborará sus propias normas de funcionamiento ${ }^{732}$.

Artículo 39. Los acuerdos de estas Mesas serán adoptados por mayoría absoluta de los miembros presentes, dirimiendo los empates el voto de calidad del Presidente.

Artículo 40. Las citadas Mesas tendrán un Secretario, con voz pero sin voto, que será designado por el Delegado provincial o por el conselleiro, según proceda, de entre los funcionarios adscritos a su consellería.

\section{TÍTULO II \\ DE LAS AYUDAS PARA SITUACIONES DE EMERGENCIA SOCIAL ${ }^{733}$}

\section{Capitulo I \\ OBJETO Y NATURALEZA}

Artículo 41. 1. El objeto del presente título es el establecimiento de ayudas económicas de pago único, destinadas a paliar necesidades extraordinarias y urgentes de personas afectadas por situaciones de emergencia.

2. Las ayudas para situaciones de emergencia social se constituyen como

732 Art. 38 modificado por Ley 1/1999, de 5 de febrero, por la que se modifica la Ley 9/1991, de 2 de octubre, de medidas básicas para la inserción social.

733 Véase Decreto $375 / 1991$, de 24 de octubre, por el que se desarrolla la Ley $9 / 1991$, de 3 de octubre, gallega de medidas básicas para la inserción social, en lo relativo a las ayudas para situaciones de emergencia social. el segundo programa dentro del conjunto coordinado de medidas consideradas en el título preliminar de la presente ley ${ }^{734}$.

Artículo 42. 1. Estas ayudas tendrán carácter finalista y serán incompatibles con cualquier otra prestación pública que pudiese corresponder al beneficiario para la misma finalidad.

2. No obstante, podrán ser complementarias, en los casos en que se considere oportuno, en virtud de la gravedad de la situación socioeconómica y familiar reflejada en los informes pertinentes ${ }^{735}$.

\section{Capítulo II DE LOS REOUISITOS}

Artículo 43. Podrán ser beneficiarias de estas ayudas las personas que, encontrándose en las situaciones a que hace referencia el artículo 41, reúnan los requisitos siguientes:

a. Ser mayor de edad.

b. Estar empadronada y tener residencia efectiva en cualquiera de los municipios de la Comunidad Autónoma Gallega.

c. No disponer de ingresos suficientes para afrontar los gastos derivados de la situación de emergencia ${ }^{736}$.

Artículo 44. A los efectos de lo previsto en el presente título se consideran situaciones de emergencia social aquéllas que originen gastos extraordinarios para cubrir necesidades específicas de carácter básico y urgente no cubiertas por los diferentes sistemas de protección ${ }^{737}$.

Artículo 45. 1. Se consideran ingresos insuficientes, a los efectos de la aplicación de esta medida, aquéllos que,

734 Art. 41 modificado por Ley 1/1999, de 5 de febrero por la que se modifica la Ley 9/1991, de 2 de octubre, de medidas básicas para la inserción social.

735 Art. 42 modificado por Ley 1/1999, de 5 de febrero, por la que se modifica la Ley 9/1991, de 2 de octubre, de medidas básicas para la inserción social.

736 Art. 43 modificado por Ley 1/1999, de 5 de febrero, por la que se modifica la Ley $9 / 1991$, de 2 de octubre, de medidas básicas para la inserción social.

737 Art. 44 modificado por Ley $1 / 1999$, de 5 de febrero, por la que se modifica la Ley 9/1991, de 2 de octubre, de medidas básicas para la inserción social. 
obtenidos por los miembros de la unidad de convivencia independiente en concepto de rentas, retribuciones, pensiones o por cualquier otro título, salvo los de carácter finalista que estén dirigidos a la formación reglada o se perciban como complemento de inserción, no sean superiores al 125 por 100 del importe del subsidio básico más el complemento familiar de la renta de integración social de Galicia que, según lo dispuesto en el artículo 12, puntos 1 y 2 de la presente ley, les corresponderían en cómputo mensual.

2. No podrá concederse esta ayuda cuando los solicitantes o cualquier miembro de la unidad de convivencia independiente sean propietarios o usufructuarios de bienes muebles o inmuebles que, por sus características, valoración, posibilidad de venta o cualquier forma de explotación, indiquen, de forma notoria, la existencia de medios materiales suficientes para atender a los gastos objeto de estas ayudas ${ }^{738}$.

\section{Capitulo III DE LA CUANTÍA}

Artículo 46. 1. La cuantía de las ayudas se establecerá para cada caso concreto en función de las circunstancias y las previsiones de los gastos que ocasionen la situación de emergencia, no pudiendo en caso alguno superar la cuantía anual del salario mínimo interprofesional.

2. Reglamentariamente serán establecidas las normas que posibiliten la determinación de la cuantía de la ayuda de emergencia social para cada caso concreto.

3. En ningún caso podrá concederse más de una ayuda para situación de emergencia social por unidad de convivencia al año ${ }^{739}$.

\footnotetext{
738 Art. 45 modificado por Ley $1 / 1999$, de 5 de febrero, por la que se modifica la Ley 9/1991, de 2 de octubre, de medidas básicas para la inserción social.

739 Art. 46 modificado por Ley 1/1999, de 5 de febrero, por la que se modifica la Ley 9/1991, de 2 de octubre, de medidas básicas para la inserción social.
}

\section{Capitulo IV DE LA TRAMITACIÓN}

Artículo 47. 1. La tramitación de las ayudas será iniciada por el interesado mediante presentación de solicitud, en instancia normalizada, en su Ayuntamiento de residencia, junto con los documentos acreditativos de la veracidad de los datos alegados.

2. Sin perjuicio de lo señalado en el apartado anterior, el interesado habrá de adjuntar a la solicitud:

a. El presupuesto de los gastos para los que solicita la ayuda.

b. La justificación de otras subvenciones o ayudas concedidas por el mismo concepto, o declaración jurada de no percibirlas.

3. Será elaborado, previa visita domiciliaria, un informe por los servicios comunitarios en el que, en la medida de lo posible, se constate:

a. La veracidad de las circunstancias alegadas por el solicitante como originadoras de la situación de emergencia.

b. La situación de necesidad que determine la incapacidad económica.

c. La adecuación y proporcionalidad entre lo solicitado y la necesidad descrita.

d. La condición de habitual de la vivienda.

Artículo 48. Corresponde a los Ayuntamientos, a través de los servicios sociales de atención primaria, la recepción, instrucción, propuesta de resolución y traslado del expediente a la Delegación Provincial correspondiente, así como el seguimiento y control de las ayudas concedidas ${ }^{740}$.

Artículo 49. Corresponde a las Delegaciones Provinciales de la consellería competente en materia de servicios sociales resolver en el plazo de un mes sobre la concesión o denegación de ayuda, así como sobre su cuantía, una vez remitida la totalidad de cuantos documentos integran el oportuno expediente por parte del Ayuntamiento de 740 Art. 48 modificado por Ley 1/1999, de 5 de febrero, por la que se modifica la Ley 9/1991, de 2 de octubre, de medidas básicas para la inserción social. 
procedencia, sin perjuicio de lo establecido en el artículo 6.c) de la presente ley ${ }^{741}$.

Artículo 50. 1. Las ayudas para situaciones de emergencia social reguladas en la presente ley se podrán abonar anticipadamente, en pago total o fraccionado, en los porcentajes que estime procedente el órgano de resolución atendiendo a las circunstancias de cada caso, debiendo el beneficiario o beneficiaria justificar el gasto subvencionado conforme a los requisitos que se establezcan reglamentariamente.

2. Sin perjuicio de lo señalado en el apartado anterior, la Xunta de Galicia se reserva para sí la facultad de efectuar el pago de la ayuda directamente, y en nombre del beneficiario o beneficiaria, a la persona, entidad o empresa que realice la prestación o el servicio a favor de éstos, en aquellos casos en que lo considere conveniente el órgano de resolución, a fin de garantizar su aplicación finalista.

3. En todo caso, la resolución de concesión de la ayuda de emergencia social podrá ser revocada en el supuesto de que no se realicen las obras presupuestadas o no se destine la misma para el fin solicitado.

4. Estas obras habrán de estar concluidas en el plazo de un año, a contar a partir del momento de la comunicación de la resolución, salvo en circunstancias excepcionales que hicieran necesario la concesión de una prórroga ${ }^{742}$.

\section{Capítulo V DE LA IMPUGNACIÓN}

Artículo 51. En materia de recursos habrá que estar a lo dispuesto en los artículos 33 y siguientes de la presente ley para la renta de integración social de Galicia ${ }^{743}$.

741 Art. 49 modificado por Ley $1 / 1999$, de 5 de febrero, por la que se modifica la Ley 9/1991, de 2 de octubre, de medidas básicas para la inserción social.

742 Art. 50 modificado por Ley 16/2004, de 29 de diciembre, por la que se modifica la Ley 9/1991, de 2 de octubre, de medidas básicas para la inserción social.

743 Art. 51 modificado por Ley 1/1999, de 5 de febrero, por la que se modifica la Ley $9 / 1991$, de 2 de octubre, de medidas básicas para la inserción social.

\section{TÍTULO III \\ PROGRAMAS DE DESARROLLO INTEGRAL COMUNITARIO \\ Capítulo I \\ OBJETO}

Artículo 52. El presente título tiene por objeto el establecimiento de las bases de una actuación integrada y multisectorial de los diversos departamentos de la Xunta de Galicia, tendente a eliminar las bolsas de pobreza urbana o rural existentes en el territorio de esta Comunidad Autónoma, así como crear las condiciones necesarias para evitar la aparición de las distintas formas de marginación social.

\section{Capítulo II \\ COMISIÓN INTERDEPARTAMENTAL DE SERVICIOS SOCIALES E INCLUSIÓN SOCIAL ${ }^{744}$}

\section{Artículo 53.}

$(\ldots)^{745}$

Artículo 54. Son funciones básicas de la Comisión Interdepartamental de Servicios Sociales e Inclusión Social ${ }^{746}$ :

1. La elaboración y elevación de propuestas al consello de la Xunta de Galicia sobre medidas generales que favorezcan la remoción de cuantos obstáculos impidan o dificulten la integración social de las personas más desfavorecidas, pudiendo diseñar, a tal fin, medidas concretas de discriminación positiva, tales como:

a. La preferencia de los beneficiarios de la renta de integración social de Galicia para el acceso a las ayudas públicas dirigidas a satisfacer necesidades básicas: vivienda, alimentación, transporte y otras.

b. La preferencia de los beneficiarios de la renta de integración social de Galicia para el acceso a los servicios públicos gestionados

\footnotetext{
744 Rúbrica del Capitulo II del Título III modificada por Ley $13 / 2008$, de 3 de diciembre, de servicios sociales de Galicia.

745 Art. 53 derogado por Ley 13/2008, de 3 de diciembre, de servicios sociales de Galicia.

746 Primer párrafo del art. 54 modificado por Ley 13/2008, de 3 de diciembre, de Servicios Sociales de Galicia.
} 
por la Xunta de Galicia, dentro de los diferentes subsistemas de bienestar social.

c. El establecimiento de una línea de ayudas tendentes a prevenir la marginación de las personas internadas en centros de menores cuando cumplan la mayoría de edad.

d. La preferencia en el acceso al aprovechamiento de parcelas agrícolas procedentes de un banco de tierras que, en su día, pueda crear la consellería competente en la materia.

e. La preferencia en el acceso a las viviendas que, en su día, pueda destinar la consellería competente a dotar el programa de inserción social.

2. El estudio y la aprobación previa, en su caso, de programas integrados, locales o comarcales, de erradicación de la pobreza, que puedan proponer las diversas instancias del sistema público de servicios sociales o las asociaciones y otras entidades de iniciativa social, para su elevación al Consello de la Xunta de Galicia.

3. La estimación de los gastos que generen las medidas propuestas, así como su distribución entre las distintas Consellerías implicadas y la elevación al Consello de la Xunta de Galicia de la propuesta de inclusión de éstos en el proyecto de presupuestos para el ejercicio correspondiente.

4. La evaluación de las medidas adoptadas, el seguimiento de su aplicación y la propuesta de las modificaciones oportunas tendentes a su mejora o a su perfeccionamiento.

5. Recabar de los órganos competentes de la Xunta de Galicia cuanta información sea precisa para el desempeño de sus funciones.

6. Cuantas otras de análoga naturaleza le pueda atribuir el Consello de la Xunta de Galicia.

Artículo 55.

$(\ldots)^{747}$

Artículo 56.

$(\ldots)^{748}$

747 Art. 55 derogado por Ley 13/2008, de 3 de diciembre, de servicios sociales de Galicia.

748 Art. 56 derogado por Ley 13/2008, de 3 de diciembre, de servicios sociales de Galicia.
Artículo 57. 1. Se crean a nivel comarcal equipos técnicos de desarrollo integral comunitario, dependientes orgánicamente de la consellería competente en materia de servicios sociales, que tendrán por objeto la puesta en práctica de proyectos comarcales y locales de dinamización socioeconómica, con un marcado carácter de prevención de la pobreza, en los que se hagan efectivas las decisiones adoptadas en la Comisión Interdepartamental de Lucha contra la Pobreza.

2. Serán funciones básicas de estos equipos, entre otras, las siguientes:

a. El análisis de las causas de la marginación y del subdesarrollo socioeconómico en las bolsas de pobreza y áreas deprimidas, así como de las circunstancias que determinan los perfiles sociales y culturales de los colectivos que sufren la marginación de su comarca.

b. La elaboración y ejecución de proyectos integrales de actuación, técnicamente homologados y operativos, de carácter interdepartamental, interadministrativo y comunitario, orientados a la promoción e inserción social de los marginados.

c. La coordinación para la puesta en práctica de esos proyectos de la administración local y autonómica, de los diferentes sistemas públicos de bienestar social y de las instituciones y entidades de iniciativa social con presencia activa en la comarca, constituyendo, si procede, una coordinadora comarcal de inserción social.

d. La elevación a la comisión interdepartamental de lucha contra la pobreza de cuantas propuestas de actuación sobre medidas operativas se consideren necesarias para apoyar los proyectos integrales de actuación.

e. Cuantas otras se consideren oportunas y procedentes para la prevención de la marginación e inserción social de los socialmente excluidos, en el ámbito comarcal, dentro de los objetivos que marca esta ley. 
3. La composición, distribución y dotación de estos equipos técnicos será determinada reglamentariamente.

\section{DISPOSICIÓN ADICIONAL PRIMERA}

Los presupuestos generales de la Comunidad Autónoma incluirán las partidas necesarias para la financiación de los programas contemplados en la presente ley ${ }^{74}$.

\section{DISPOSICIÓN ADICIONAL SEGUNDA}

La Xunta de Galicia informará anualmente al Parlamento de Galicia sobre el desarrollo de la presente ley en el seno de la comisión correspondiente ${ }^{750}$.

\section{DISPOSICIÓN ADICIONAL TERCERA}

Se autoriza a la Xunta de Galicia a publicar un texto refundido de la Ley 9/1991, de 2 de octubre, de medidas básicas para la inserción social, al objeto de recoger las modificaciones establecidas por disposiciones legislativas posteriores ${ }^{751}$.

\section{DISPOSICIÓN TRANSITORIA PRIMERA}

1. Se autoriza a la Xunta de Galicia, durante los dos primeros ejercicios presupuestarios de aplicación de la presente ley, a adoptar medidas para acomodar la ejecución del programa a las limitaciones presupuestarias, estableciendo una relación en la concesión según los siguientes criterios y en el orden que se indica:

a. Inaplicación del régimen de concesión provisional previsto en el artículo 29. 1 de la presente ley.

749 Disposición adicional primera modificada por Ley $16 / 2004$, de 29 de diciembre, por la que se modifica la Ley 9/1991, de 2 de octubre, de medidas básicas para la inserción social.

750 Disposición adicional segunda modificada por Ley 1/1999, de 5 de febrero, por la que se modifica la Ley 9/1991, de 2 de octubre, de medidas básicas para la inserción social.

751 Disposición adicional tercera modificada por Ley $16 / 2004$, de 29 de diciembre, por la que se modifica la Ley $9 / 1991$, de 2 de octubre, de medidas básicas para la inserción social. b. Preferencia de los solicitantes que dispongan de un hogar independiente sobre los que estén acogidos en otro hogar.

c. Preferencia de los solicitantes con mayor número de cargas familiares sobre los restantes.

2. Asimismo, la Xunta de Galicia podrá, cuando las disponibilidades presupuestarias lo permitan, reducir el nivel de exigencia en los requisitos establecidos en el artículo 9.1.a a de la presente ley a los efectos de la concesión de las prestaciones económicas de la renta de integración social de Galicia, sin el límite temporal establecido en el apartado 1.

\section{DISPOSICIÓN TRANSITORIA SEGUNDA}

Al objeto de determinar con la mayor precisión posible el ámbito sociológico de aplicación de las medidas de inserción social que se regulan en la presente ley, la Xunta de Galicia elaborará, durante el año siguiente a su entrada en vigor, un estudio sobre la pobreza, de conformidad con lo establecido en el artículo 5.f. De las conclusiones de este estudio se derivará la determinación del crédito presupuestario ajustado que ponga fin al régimen transitorio de los dos primeros años.

\section{DISPOSICIÓN TRANSITORIA TERCERA}

Los diferentes órganos de control y seguimiento previstos en la presente ley se constituirán en un plazo de tres meses a partir de su entrada en vigor.

\section{DISPOSICIÓN DEROGATORIA}

Quedanderogadas cuantas disposiciones de igual o inferior categoría contradigan lo dispuesto en la presente ley, y en especial los artículos 5, 6, 7, 8, 9, 10 y 11 del Decreto $131 / 1989$, de 29 de junio, por el que se regulan los servicios sociales comunitarios.

\section{DISPOSICIÓN FINAL PRIMERA}

Se autoriza a la Xunta de Galicia para dictar las disposiciones necesarias para el 
desarrollo y aplicación de esta disposición legal.

\section{DISPOSICIÓN FINAL SEGUNDA}

La presente Ley entrará en vigor al día siguiente de su publicación en el "Diario Oficial de Galicia”.

\section{LEY 13/2008, DE 3 DE DICIEMBRE, DE SERVICIOS SOCIALES DE GALICIA (DOGA} 245. 18.12.2008)

$(\ldots)^{752}$

\section{TÍTULO PRELIMINAR DISPOSICIONES GENERALES}

Artículo 1. Objeto de la ley.

1. La presente ley tiene por objeto estructurar y regular, como servicio público, los servicios sociales en Galicia para la construcción del sistema gallego de bienestar.

2. Mediante la presente ley los poderes públicos gallegos garantizan como derecho reconocible y exigible el derecho de las personas a los servicios sociales que les correspondan en función de la valoración objetiva de sus necesidades, a fin de posibilitar que su libertad e igualdad sean reales y efectivas, removiendo los obstáculos que impiden o dificultan su plenitud y facilitando la participación de todas y todos en la vida política, económica, cultural y social.

3. Asimismo, constituye el objeto de la presente ley posibilitar la coordinación del sistema gallego de servicios sociales con los demás elementos del sistema gallego de bienestar y con las políticas públicas sectoriales que incidan sectorial o transversalmente en la mejora del bienestar de la ciudadanía gallega.

Artículo 2. Sistema gallego de servicios sociales.

1. A los efectos de la presente ley, se entiende por servicios sociales el conjunto

752 Preámbulo omitido. coordinado de prestaciones, programas y equipamientos destinados a garantizar la igualdad de oportunidades en el acceso a la calidad de vida y a la participación social de toda la población gallega, mediante intervenciones que permitan el logro de los objetivos expresados en el artículo siguiente.

2. Integra el sistema gallego de servicios sociales el conjunto de servicios, programas y prestaciones, tanto de titularidad pública como de titularidad privada, acreditados y concertados por la administración en los términos establecidos en la presente ley.

3. Los poderes públicos fomentarán, asimismo, en el ámbito de los servicios sociales, el desarrollo de actuaciones solidarias por entidades de iniciativa social siempre que se ajusten a los requisitos de autorización, calidad y complementariedad establecidos en la presente ley y las normas que la desarrollen.

4. Las entidades de naturaleza privada y carácter mercantil podrán prestar servicios sociales de acuerdo con lo establecido en la presente ley y, en particular, en lo que se refiere a su registro, autorización, inspección y control.

Artículo 3. Objetivos del sistema gallego de servicios sociales.

Son objetivos del sistema gallego de servicios sociales los siguientes:

a. Facilitar alternativas, recursos e itinerarios de integración social a aquellas personas que se encuentran en situación o en riesgo de exclusión social.

b. Garantizar la vida independiente y la autonomía personal de las personas en situación de dependencia integrando, a estos efectos, el catálogo de prestaciones del sistema para la autonomía y atención a la dependencia.

c. Dar protección y oportunidades sociales y educativas a menores de edad y a aquellas otras personas que se encuentren en situación de conflicto o de desamparo. 
d. Prevenir la aparición de cualquier situación de dependencia, exclusión, desigualdad o desprotección a las que hacen referencia los objetivos anteriores.

e. Proporcionar oportunidades y recursos que garanticen la igualdad entre mujeres y hombres y posibiliten la conciliación entre la vida personal, familiar y laboral.

f. Facilitar la ejecución de políticas públicas de anticipación a una sociedad multicultural emergente, favoreciendo la integración y socialización normalizada de inmigrantes, emigrantes retornados y minorías étnicas.

g. Promover y dinamizar la participación comunitaria, el asociacionismo solidario, la ayuda mutua y la implicación de la ciudadanía en la puesta en marcha de iniciativas de prevención y mejora de la cohesión social.

h. Facilitar la aplicación efectiva en sus servicios y programas de políticas transversales que incidan en la eliminación de todo tipo de discriminación selectiva y exclusión social.

i. Garantizar el apoyo a las familias como marco de referencia en el que se desarrollan las personas ${ }^{753}$.

j. Sensibilizar, informar y promover valores de solidaridad e integración en la sociedad gallega.

k. Promover y garantizar el derecho universal de la ciudadanía gallega al acceso a los servicios sociales, garantizando la suficiencia presupuestaria que asegure su efectividad.

Artículo 4. Principios generales de los servicios sociales.

El sistema gallego de servicios sociales se regirá por los principios de:

a. Universalidad: el sistema está abierto a toda la ciudadanía, en los términos establecidos en el artículo $5 .^{\circ}$ de la presente ley, tanto en el ámbito preventivo como en el de la intervención social, con carácter gratuito en su acceso,

753 Decreto 9/2009, de 15 de enero, por el que se regulan los puntos de encuentro familiar en Galicia. estableciendo el tipo de intervención en función de las situaciones concretas y las necesidades valoradas. Este principio no excluye la posibilidad de que, para la prestación de determinados servicios, se requieran aportaciones económicas de las personas usuarias. Estas aportaciones se determinarán, en todo caso, atendiendo a criterios de progresividad.

b. Prevención: las políticas de servicios sociales enfocarán sus actuaciones a prevenir y superar las causas que originen las necesidades sociales, dando la debida prioridad a las acciones preventivas y al enfoque comunitario de las intervenciones sociales.

c. Responsabilidad pública: los poderes públicos garantizarán el derecho subjetivo, universal y exigible a los servicios sociales con criterios de igualdad y equidad, mediante la disponibilidad de servicios sociales públicos a través de la regulación y aportación de los medios humanos, técnicos y financieros y de los centros necesarios.

Igualmente, dentro de la planificación general de los servicios sociales, los poderes públicos regularán, fomentarán y supervisarán a los demás servicios cuyos titulares sean las entidades privadas de iniciativa social. Asimismo, las entidades privadas de carácter mercantil podrán complementar la red de recursos de titularidad pública.

d. Igualdad: toda la ciudadanía gallega tendrá derecho a los servicios sociales sin que en ningún caso se pueda producir discriminación por razones de raza, sexo, orientación sexual, estado civil, edad, discapacidad, ideología, creencia o cualquier otra circunstancia de carácter social o personal.

No obstante, los poderes públicos de Galicia integrarán en sus criterios de planificación y actuación la perspectiva de género y de acción positiva y podrán adoptar, en consecuencia, medidas que refuercen la posición de los sectores que sufren discriminación en orden a la consecución de una efectiva igualdad de oportunidades. 
e. Equidad y equilibrio territorial: en el desarrollo de la red de centros y servicios se tendrá en cuenta la necesidad de compensar los desequilibrios territoriales, garantizando el acceso al sistema de las gallegas y gallegos que residan en áreas sociales con altas tasas de envejecimiento y dispersión, mediante una oferta equitativa y equilibrada de servicios en todo el territorio.

f. Solidaridad: los poderes públicos fomentarán la solidaridad como valor inspirador de las relaciones entre las personas y los grupos sociales e impulsarán la implicación ciudadana en la superación de las condiciones que provoquen situaciones de marginación. Se dará prioridad a las acciones encaminadas al logro y consolidación de formas organizadas y estables de solidaridad.

g. Acción integral y personalizada: las intervenciones de los servicios sociales con las personas y su entorno serán abordadas con profesionalidad, de forma individual mediante la evaluación integral y personalizada de las necesidades, con respeto de sus derechos y, en especial, de su dignidad e intimidad.

h. Autonomía personal y vida independiente: es obligación de los poderes públicos facilitar los medios necesarios para que las personas dispongan de las condiciones más convenientes y los apoyos necesarios para desarrollar sus proyectos vitales, dentro de la unidad de convivencia que deseen, según la naturaleza de los servicios, su idoneidad y las condiciones de utilización de los mismos y siempre con respeto a la libre decisión de las personas.

i. Participación: los poderes públicos promoverán la participación de las personas usuarias, familiares, de los grupos sociales y entidades representativas de las personas o colectivos a los que van destinados los servicios, de las entidades del tercer sector y de los agentes sociales, tanto en su planificación como en su diseño y seguimiento. La participación se promoverá a través de las vías y mecanismos que establezca la normativa, y, en cualquier caso, deberán estar inspirados en criterios democráticos, de calidad y eficacia en la prestación de los servicios.

j. Integración y normalización: en el desarrollo de los servicios sociales deberá tenderse al mantenimiento de las personas en su entorno personal, social y familiar, procurando su inserción social y sin menoscabo del derecho a la diferencia.

k. Globalidad: la intervención de los servicios sociales se procurará realizar con una perspectiva global y de conjunto, favoreciendo la actuación transversal y coordinada y evitando la fragmentación derivada de la complejidad de las problemáticas sociales y la distribución competencial.

1. Descentralización y proximidad: la intervención desde los servicios sociales, siempre que su naturaleza lo permita, responderá a criterios de descentralización y desconcentración, de manera que su gestión se lleve a cabo de modo preferente por los órganos administrativos más próximos a la ciudadanía.

Lo anterior no podrá suponer, en ningún caso, una disminución en la garantía de igualdad de servicios y prestaciones a la población en el territorio de Galicia.

m. Coordinación: se promoverá la creación y desarrollo de instrumentos y mecanismos de relación interadministrativa que garanticen una actuación coordinada en el campo del bienestar social y la igualdad, tanto por parte de los diferentes departamentos del Gobierno gallego que desarrollen políticas públicas que incidan en el bienestar social como por el resto de administraciones públicas y entidades integradas en el sistema, sean de carácter público o privado.

n. Economía, eficacia y eficiencia: la gestión de los servicios sociales se realizará con criterios de economía, eficiencia y eficacia. En este sentido, la actuación administrativa en esta materia empleará 
los instrumentos idóneos para cada intervención, de forma que los objetivos y estándares de calidad se consigan con independencia de la titularidad de la gestión, mediante un uso racional de recursos públicos.

Sin perjuicio de lo anterior, deberán aplicarse en la valoración de la eficacia social criterios correctores que tengan en consideración la complejidad de los procesos de recuperación, normalización e inclusión social de las personas y grupos.

ñ. Planificación: se implantarán los mecanismos de planificación que permitan una mejora de la eficacia, objetividad y transparencia en la toma de decisiones. La planificación, en cualquier caso, partirá de las demandas y necesidades objetivas de la ciudadanía. Con independencia de la diversidad de las condiciones de las distintas áreas sociales, se garantizará una calidad de servicio equiparable en la totalidad del territorio de Galicia.

o. Evaluación y calidad: se establecerán sistemas de evaluación que garanticen la calidad y acreditación de los servicios sociales tomando como referente el concepto de calidad de vida de las personas.

Artículo 5. Titulares del derecho de acceso a los servicios sociales.

1. Tendrán derecho de acceso al sistema gallego de servicios sociales las ciudadanas y ciudadanos de los estados miembros de la Unión Europea empadronados en un ayuntamiento de Galicia, que tendrán derecho a participar en los diferentes programas, servicios y prestaciones del sistema en función de la valoración objetiva de sus necesidades.

2. Las personas extranjeras empadronadas en cualquier ayuntamiento de Galicia podrán acceder al sistema gallego de servicios sociales de acuerdo con lo establecido en la legislación vigente y, en su caso, tratados y convenios internacionales que resulten de aplicación.

3. Además, tendrán derecho a las prestaciones y servicios regulados en la presente ley todas aquellas personas que, sin estar en los supuestos anteriores, se encontraran en estado de necesidad o en situación de emergencia social o humanitaria.

4. Las gallegas y gallegos residentes fuera de Galicia y su descendencia tendrán derecho a las prestaciones reguladas en la presente ley cuando, al tener necesidad de atención, les sirva de medio para su retorno definitivo, en los términos que reglamentariamente se establezcan.

Artículo 6. Derechos de las personas en relación con los servicios sociales.

1. El respeto de la dignidad de la persona, de su autonomía e intimidad y de su bienestar orientará la actuación pública y la actividad de las personas profesionales y entidades gestoras de servicios sociales.

2 . Se reconoce el derecho a los servicios sociales, como derecho subjetivo, cuando se trate de servicios y prestaciones esenciales reconocidos como tales en la presente ley.

3. Asimismo, todas las personas, en tanto que usuarias o usuarios de los servicios sociales, tendrán los siguientes derechos con relación al sistema gallego de servicios sociales:

a. A utilizar el sistema de servicios sociales en condiciones de igualdad y $\sin$ discriminación por razón de nacimiento, raza, sexo, orientación sexual, estado civil, edad, situación familiar, discapacidad, ideología, creencia, opinión o cualquier otra circunstancia personal, económica o social.

b. A recibir un trato acorde a la dignidad de la persona y al respeto de los derechos y libertades fundamentales, tanto por parte del personal como de las personas implicadas en el centro, programa o servicio.

c. A una intervención individualizada acorde con sus necesidades específicas, así como a que se les asista en los trámites necesarios de cara a su acceso a la atención social, sanitaria, educativa, cultural $\mathrm{y}$, en general, a todas las necesidades personales que sean precisas para conseguir su desarrollo integral. 
d. A recibir información de manera ágil, suficiente y veraz, y en términos comprensibles, sobre los recursos y prestaciones del sistema gallego de servicios sociales.

e. A tener asignada una persona profesional de referencia que actúe como interlocutora principal y que asegure la coherencia y la globalidad en el proceso de intervención social.

f. A la confidencialidad, sigilo y respeto en relación a sus datos personales e información que sea conocida por los servicios sociales en razón de la intervención profesional, sin perjuicio del posible acceso a los mismos en el ejercicio de una acción inspectora, de conformidad con la legislación vigente en materia de protección de datos de carácter personal.

g. A acceder a su expediente personal y a obtener copia del mismo.

h. A elegir libremente, dentro de la capacidad de oferta del sistema y previa valoración técnica, el tipo de medidas o de recursos adecuados para su caso.

i. A rechazar la oferta de participación en servicios o programas que les oferte el sistema, o, en su caso, a que su consentimiento, libre y expreso, sea requerido para el ingreso en un centro o participación en un programa, sin perjuicio del cumplimiento debido de las resoluciones judiciales cuando esté limitada su capacidad de obrar.

j. A recibir una tarjeta social de carácter personal e intransferible que las acredite como titulares del derecho de acceso a los servicios sociales.

k. A la calidad de los servicios y prestaciones recibidas, pudiendo presentar sugerencias y reclamaciones.

1. A dar instrucciones previas respecto a la asistencia o cuidados que se les puedan administrar, al objeto de hacer frente a situaciones futuras en cuyas circunstancias no sean capaces de expresarlas personalmente.

$\mathrm{m}$. Al respeto a los derechos lingüísticos da las personas usuarias, garantizando, en todo caso, el desarrollo por parte del sistema gallego de servicios sociales de su actividad desde la práctica de una oferta positiva del idioma gallego.

n. A los demás derechos que, en materia de servicios sociales, estén reconocidos en la presente ley y el resto del ordenamiento jurídico.

Artículo 7. Deberes de las personas con relación a los servicios sociales.

Las personas usuarias de los servicios sociales tendrán los siguientes deberes:

a. Cumplir las normas, requisitos y procedimientos para el acceso al sistema gallego de servicios sociales, facilitando información precisa y veraz sobre las circunstancias determinantes para su utilización y comunicando las variaciones que experimenten las mismas.

b. Comunicar al personal de referencia cualquier cambio significativo de circunstancias que pudiera implicar la interrupción o modificación sustancial de la intervención propuesta por los servicios sociales.

c. Colaborar con el personal encargado de prestarles la atención necesaria, acudiendo a las entrevistas con los mismos y siguiendo los programas y orientaciones que les prescriban.

d. Mantener una actitud positiva de colaboración con las personas profesionales de los servicios sociales, participando activamente en el proceso que genere la intervención social en la que sean destinatarias.

e. Participar de manera activa en su proceso de mejora, autonomía personal e inserción social.

f. Destinar las prestaciones recibidas al fin para el que fueron concedidas.

g. Contribuir a la financiación del coste de los servicios con arreglo a la normativa vigente.

h. Cuando utilicen las instalaciones o residan en un centro, observar los reglamentos de régimen interior y normas de funcionamiento o convivencia. 


\section{TÍTULO I \\ DEL SISTEMA GALLEGO DE SERVICIOS SOCIALES}

\section{Capítulo I \\ DE LA ESTRUCTURA DEL SISTEMA}

Artículo 8. Estructura básica de los servicios sociales.

1. El sistema gallego de servicios sociales se estructura en forma de red, conforme a dos niveles de actuación:

a. Servicios sociales comunitarios, que comprenden, a su vez, dos modalidades: servicios sociales comunitarios básicos y servicios sociales comunitarios específicos.

b. Servicios sociales especializados.

2. Cada nivel de actuación contará con los equipamientos y las personas profesionales y equipos técnicos interdisciplinares que se determinen reglamentariamente.

Artículo 9. De los servicios sociales comunitarios.

1. Los servicios sociales comunitarios, de carácter predominantemente local, están referenciados a un territorio y población determinados y constituyen el acceso normalizado y el primer nivel de intervención del sistema gallego de servicios sociales.

2. Los servicios sociales comunitarios se configuran como servicios de carácter integrador, constituyéndose en la principal instancia del sistema para el desarrollo de intervenciones de carácter preventivo, de atención integral a personas y familias y de incorporación social y laboral.

3. Los servicios sociales comunitarios estarán coordinados mediante protocolos y sistemas de derivación, información y colaboración con los servicios sociales especializados, así como con otros servicios para el bienestar que operen en el mismo territorio, especialmente con los de salud, educación, cultura, empleo, vivienda, migraciones y, en su caso, desarrollo rural, a fin de favorecer una intervención integral con las personas.
Artículo 10. De los servicios sociales comunitarios básicos.

1. Los servicios sociales comunitarios básicos tienen un carácter local, abierto y polivalente y constituyen la vía normal de acceso al sistema de servicios sociales, garantizando la universalidad del sistema y su cercanía a las personas usuarias y a los ámbitos familiar y social.

2. Los servicios sociales comunitarios básicos se desarrollarán desde los centros de servicios sociales polivalentes por medio de equipos interdisciplinares y con la estructura organizativa que se establezca por la administración titular del servicio, sin perjuicio de los requisitos y dotaciones mínimas que reglamentariamente se determinen.

Artículo 11. Funciones de los servicios sociales comunitarios básicos.

1. Son funciones de los servicios sociales comunitarios básicos las siguientes:

a. El estudio y diagnóstico social de la comunidad, que implica la detección y análisis de necesidades y demandas, explícitas e implícitas, en su ámbito de intervención.

b. La elaboración de un plan de intervención comunitario acorde con las necesidades detectadas o anticipadas en el diagnóstico social.

c. La identificación de grupos de población vulnerables y la detección precoz de situaciones de riesgo para el desarrollo de actuaciones de carácter preventivo y de promoción social.

d. La atención de las situaciones individuales, la información en relación a las demandas presentadas, el diagnóstico y valoración técnica previa y la consecuente intervención en el caso, que incluirá, cuando sea conveniente, la derivación hacia el recurso idóneo dentro del sistema gallego de servicios sociales o a otros sistemas de bienestar o la asistencia en los trámites necesarios para acceder a otros recursos.

e. La participación en la gestión de las prestaciones económicas y el seguimiento 
de los correspondientes proyectos personalizados de intervención en los términos establecidos en la normativa específica en materia de inclusión social.

f. La gestión del servicio de ayuda en el hogar, así como la participación en la gestión de las prestaciones destinadas a garantizar la autonomía personal y la atención a la dependencia, en los términos establecidos en la normativa que resulte de aplicación ${ }^{754}$.

g. La información, orientación y asesoramiento a toda la población, facilitando su acceso a los recursos sociales.

h. El fomento de la participación activa de la ciudadanía mediante estrategias socioeducativas que impulsen la solidaridad y la cooperación social organizada.

2. Las funciones de los servicios sociales comunitarios básicos previstas en el apartado anterior se desarrollarán reglamentariamente.

Artículo 12. De los servicios sociales comunitarios específicos.

1. Sin perjuicio de la orientación polivalente y preventiva del nivel de actuación comunitaria, los servicios sociales comunitarios específicos desarrollarán programas y gestionarán centros orientados a colectivos con problemáticas identificadas y singulares, procurando su normalización y reincorporación social o como espacio de tránsito a un servicio especializado.

2. Los servicios sociales comunitarios específicos, atendiendo a criterios de equidad territorial y rentabilidad social, podrán tener un carácter comarcal, de acuerdo con la planificación y ordenación del sistema gallego de servicios sociales regulada en el título IV de la presente ley.

Artículo 13. Funciones de los servicios sociales comunitarios específicos.

Los servicios sociales comunitarios específicos tendrán como función el desarrollo de:

a. Programas y actividades para prevenir la exclusión de grupos vulnerables de

754 Orden de 22 de enero de 2009 por la que se regula el servicio de ayuda a domicilio. características homogéneas y facilitar su inserción y normalización social.

b. La atención directa a colectivos con déficits de autonomía o en riesgo de exclusión que se desarrolle a través de programas en medio abierto, en centros de carácter no residencial o de carácter residencial temporal.

c. La gestión de equipamientos comunitarios para sectores de población con necesidades específicas que posibiliten en su ámbito el logro de los objetivos recogidos en el artículo $3 .^{\circ}$ de la presente ley, en el marco del Plan estratégico de servicios sociales.

Artículo 14. De los servicios sociales especializados.

1. Los servicios sociales especializados están referenciados a un sector de población o a una necesidad determinada que demandan una mayor especialización técnica, una especial intensidad en la intervención o una base territorial de intervención de carácter supramunicipal.

2. En la planificación estratégica regulada en el título IV de la presente ley se establecerán los centros y servicios a los que se atribuye esta calificación.

Artículo 15. Funciones de los servicios sociales especializados.

Los servicios sociales especializados tendrán las siguientes funciones:

a. Valorar, diagnosticar e intervenir ante situaciones que requieran una alta especialización técnica $\mathrm{y}$, normalmente, interdisciplinar.

b. Gestionar centros y programas especializados.

c. Promover medidas de reinserción en su ámbito de actuación y desarrollar medidas de rehabilitación social orientadas a normalizar las condiciones de vida de las personas usuarias.

d. Prestar colaboración y asesoramiento técnico a los servicios sociales comunitarios, así como revertir a este nivel de actuación los casos en los que ya no sea preciso una intervención especializada. 
Artículo 16. Continuidad de los niveles de actuación social.

1. La relación entre servicios sociales comunitarios y servicios sociales especializados responderá a criterios de complementariedad, de acción coordinada para la consecución de objetivos comunes o de actuación conjunta, con la finalidad de conseguir la continuidad y complementariedad de las intervenciones que se deban aplicar desde los distintos niveles de actuación.

2. Existirá un único expediente social básico en el ámbito de los servicios sociales comunitarios, en el que quedarán recogidas todas las intervenciones y servicios prestados a la persona usuaria en los diferentes niveles de actuación del sistema gallego de servicios sociales.

3. A los efectos de lo establecido en el apartado anterior, los servicios sociales especializados incorporarán protocolos de retorno de la información a los servicios sociales comunitarios que aseguren la actualización de la información en el expediente social básico.

4. Reglamentariamente, se establecerán los procedimientos de recogida y tratamiento de información de las personas usuarias del sistema, garantizando, en todo caso, la confidencialidad de los datos de carácter personal.

Artículo 17. Tarjeta social gallega.

1. Todas las personas con derecho de acceso a los servicios sociales, de conformidad con el artículo $5 .^{\circ}$, puntos 1 y 2 , de la presente ley, dispondrán de una tarjeta social gallega que las identificará como titulares del derecho de acceso a los servicios sociales.

2. La tarjeta social gallega facilitará la continuidad y coherencia del itinerario de intervención social y deberá garantizar la homogeneidad de la información existente en la red de servicios sociales de cada persona usuaria.

3. En esta tarjeta figurará el centro y la persona profesional de referencia para su titular.
4. Reglamentariamente, se establecerán las medidas oportunas para la implantación progresiva y generalizada de esta tarjeta.

\section{Capitulo II \\ DEL CATÁLOGO DE SERVICIOS SOCIALES}

Artículo 18. Definición.

1. El Catálogo de servicios sociales está integrado por el conjunto de intervenciones, programas, servicios y prestaciones que a continuación se relacionan:

a. Intervenciones o servicios de carácter técnico-profesional.

b. Servicios y actuaciones de naturaleza material o tecnológica.

c. Prestaciones económicas orientadas a satisfacer necesidades pecuniarias valoradas de los individuos o familias y a estimular su incorporación social y laboral.

d. Programas de intervención comunitaria que constituirán un instrumento de prevención e inserción social que reforzarán la eficacia de las prestaciones esenciales y normalizadoras del sistema.

2. Las intervenciones, programas, servicios y prestaciones desarrolladas en el punto anterior podrán ser:

a. Esenciales: que se configuran como derecho exigible y estarán garantizadas para aquellas personas que cumplan las condiciones establecidas de acuerdo con la valoración técnica de su situación.

b. Normalizadoras: que estarán incluidas en la oferta habitual en función de las disponibilidades presupuestarias y en régimen de concurrencia.

3. El reconocimiento efectivo del derecho a una intervención, programa, servicio o prestación de carácter esencial corresponderá a la administración titular y prestadora de los mismos, conforme al título VII de la presente ley. En caso de las prestaciones incluidas en el Catálogo del sistema para la autonomía y atención a la dependencia, su reconocimiento se efectuará por la Administración autonómica. 
4. Con independencia de la clasificación de las intervenciones, programas, servicios y prestaciones, se garantizará el acceso al sistema gallego de servicios sociales, con carácter gratuito, de las personas con insuficiencia de recursos económicos, sin perjuicio del establecimiento, con carácter general, de un sistema progresivo de participación en la financiación de acuerdo con lo establecido en el artículo $56 .^{\circ}$ En cualquier caso, se habrá de asegurar la disponibilidad de un mínimo vital de libre disposición para las personas usuarias.

5. Reglamentariamente, se desarrollará y actualizará el catálogo a instancias del departamento competente en materia de servicios sociales.

Artículo 19. Intervenciones o servicios de carácter técnico-profesional.

1. Tienen la consideración de intervenciones o servicios de carácter técnico-profesional los actos profesionales realizados para:

a. La información, orientación, asesoramiento y acompañamiento a las personas, familias o grupos.

b. La valoración y diagnóstico social de las demandas de la ciudadanía.

c. La intervención social, biopsicosocial, sociológica o socioeducativa que favorezca la adquisición o recuperación de funciones y habilidades personales y sociales de cara a la mejora de la autonomía, de la convivencia social y familiar y de la inclusión social.

2. Todas las intervenciones y servicios consignados en este artículo serán esenciales, de conformidad con el artículo $18 .^{\circ}$

Artículo 20. Servicios y actuaciones de naturaleza material o tecnológica.

1. Tendrán la consideración de servicios y actuaciones de naturaleza material o tecnológica los siguientes:

a. La protección social de las personas, con capacidad de obrar limitada, que se encuentren en situación de conflicto o desamparo. b. La atención residencial, que comporta alojamiento, continuado o temporal, sustitutivo del hogar.

c. La atención diurna, que ofrece cuidados personales y actividades de promoción y prevención que no requieran el ingreso en un centro residencial.

d. La ayuda en el hogar, consistente en ofrecer un conjunto de atenciones a personas o familias en su propio domicilio, para facilitar su desarrollo y permanencia en su entorno habitual.

e. La teleasistencia social y otros servicios de carácter tecnológico, que procuren la permanencia de las personas usuarias en su medio habitual.

f. El apoyo a la movilidad personal, en los términos previstos en la normativa reguladora del servicio gallego de apoyo a la movilidad personal para personas con discapacidad y/o dependientes.

g. La manutención, ya sea en locales de atención colectiva o en el propio domicilio de la persona usuaria.

h. Las ayudas técnicas e instrumentales, que permitan mantener la autonomía de la persona para desenvolverse en su medio.

i. El servicio de asistente personal.

j. Cualquier otro servicio o actuación no previsto en la presente ley que se considere necesario para garantizar una adecuada atención social.

2. Los servicios y actuaciones descritos en el apartado a) tendrán carácter esencial. También tendrán carácter esencial los servicios y actuaciones establecidos en las letras b), c), d) y e), previa correspondiente valoración técnica cuando se trate de personas con déficit de autonomía personal incluidas en el sistema de atención a la dependencia.

3. Las demás prestaciones tendrán la consideración de normalizadoras, sin perjuicio de la ampliación del conjunto de prestaciones de carácter esencial.

Artículo 21. Prestaciones económicas.

1. Son prestaciones económicas del sistema gallego de servicios sociales las

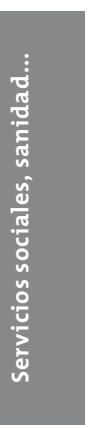


aportaciones en dinero, de carácter periódico o de pago único, que tienen como finalidad, entre otras, apoyar el cuidado de menores, paliar situaciones transitorias de necesidad, garantizar mínimos de subsistencia y reforzar procesos de integración familiar e inclusión social, así como garantizar el cuidado de personas con limitaciones en su autonomía personal en el marco de la Ley 39/2006, de 14 de diciembre, de promoción de la autonomía personal y atención a las personas en situación de dependencia.

2. Tienen la consideración de prestaciones económicas del sistema gallego de servicios sociales las siguientes:

a. Las rentas de inclusión social.

b. Las ayudas de emergencia y necesidad social.

c. Las ayudas económicas a particulares para el fomento del acogimiento familiar de menores de edad, de mayores y de personas con discapacidad.

d. Los cheques-servicio.

e. La libranza vinculada a la adquisición de servicios de atención a personas en situación de dependencia.

f. La libranza para cuidados en el entorno familiar de personas en situación de dependencia.

g. Las prestaciones para cuidados en el entorno familiar de menores de tres años con grave discapacidad.

h. La libranza para la asistencia personal de las personas afectadas por una situación de gran dependencia.

i. Las prestaciones económicas dirigidas a las mujeres víctimas de violencia de género.

j. Las ayudas económicas de análoga o similar naturaleza y finalidad que las anteriores.

3. Las prestaciones expresadas en las letras a), b), e), f), g) y h) del punto anterior tendrán la consideración de esenciales y serán exigibles en los términos de su norma reguladora.
Artículo 22. Programas de intervención comunitaria.

Los programas de intervención comunitaria se elaborarán a partir del diagnóstico social de una comunidad definida, favoreciendo la cooperación con los otros servicios de bienestar social existentes en su ámbito de actuación, y con la implicación de la ciudadanía, a fin de incidir en la superación de las situaciones detectadas, mediante la elaboración y desarrollo de actuaciones con una perspectiva preventiva y de inclusión social.

\section{Capítulo III \\ DEL EQUIPO PROFESIONAL DE LOS SERVICIOS SOCIALES}

Artículo 23. Disposiciones generales.

1. La intervención profesional en los servicios sociales tendrá como norma general un carácter interdisciplinario en la búsqueda de una atención integral.

2. De forma reglamentaria, se fijarán las titulaciones y calificaciones profesionales y los prorrateos de cobertura de los equipos de trabajo que actúen en los servicios sociales, de conformidad con la distribución y tipología de áreas sociales contempladas en el planeamiento estratégico, con arreglo al título IV de la presente ley. Asimismo, se tendrán en cuenta los objetivos y características particulares de cada centro, las personas usuarias, sus servicios o programas, de manera que se asegure una adecuada calidad de servicio y de trato profesional a las personas destinatarias.

3. De manera particular, se asegurará en las áreas sociales rurales y de alta dispersión una oferta de servicios profesionales semejante a la que exista en el resto del territorio.

Artículo 24. Profesional de referencia.

1. A cada persona titular del derecho de acceso al sistema gallego de servicios sociales se le asignará una persona 
profesional de referencia en el ámbito de los servicios sociales comunitarios correspondientes, con la finalidad de dar coherencia al itinerario de intervenciones y garantizar el acceso a los diferentes servicios y prestaciones que necesite la persona o, en su caso, su familia.

2. La persona profesional de referencia será preferentemente una trabajadora o trabajador social de la red pública de servicios sociales, sin perjuicio de las titulaciones o especialidades de quien gestione el caso o actúe como responsable de la intervención o programa.

3. La persona profesional de referencia tendrá a su cargo el expediente social básico al que hace referencia el artículo 16. 2 de la presente ley.

4. De acuerdo con las disponibilidades del sistema, la persona usuaria podrá solicitar motivadamente el cambio de profesional de referencia, de entre los existentes en su área.

5. Las funciones de la persona profesional de referencia se desarrollarán reglamentariamente.

Artículo 25. Estabilidad laboral y calidad del empleo de las personas profesionales de los servicios sociales y políticas de igualdad.

1. Las administraciones públicas promoverán la calidad en el empleo y la estabilidad laboral de las personas profesionales de servicios sociales, evitando situaciones de precariedad, como medio de lograr la calidad y permanencia de la oferta pública de servicios sociales.

2. A tal efecto, se considerará la estabilidad del empleo de las personas profesionales de servicios sociales como criterio evaluable en el acceso a la financiación pública por parte de las entidades prestadoras de servicios sociales. Igualmente, será criterio evaluable la adopción de medidas a favor de la efectividad del principio de igualdad en los términos establecidos en la normativa reguladora del trabajo en igualdad de las mujeres de Galicia.
3. Asimismo, las administraciones públicas fomentarán la mejora de las condiciones laborales y la implantación de medidas a favor de la efectividad del principio de igualdad, en particular, de aquellas tendentes a la conciliación de la vida familiar y laboral.

\section{Capítulo IV \\ FORMACIÓN E INVESTIGACIÓN EN SERVICIOS SOCIALES}

Artículo 26. Fomento de la formación e investigación.

1. Las administraciones competentes, Xunta de Galicia y entidades locales adoptarán las medidas necesarias para el fomento de la realización de actividades y programas dirigidos a la formación y mejora de las capacidades del personal profesional de los servicios sociales y cuidadores, así como para la investigación y mejora tecnológica en esta materia.

2. La Xunta de Galicia podrá crear centros y organismos especializados en esta materia y actuar de forma coordinada con las universidades gallegas y centros de formación e investigación.

Artículo 27. Formación permanente.

1. La formación permanente en materia de servicios sociales tendrá como finalidad la ampliación de los conocimientos, teóricos o prácticos, y estará orientada al desarrollo de habilidades en la atención directa a las personas usuarias y a cuantas otras materias incidan en la mejora de la calificación de los profesionales a fin de dar respuesta a las necesidades y demandas de la población.

2. La formación permanente tendrá como destinatario todo el personal profesional del sistema gallego de servicios sociales.

3. La formación podrá ser desarrollada directamente por la Administración autonómica o bien a través de convenios de colaboración con otras entidades. 
Artículo 28. Investigación e innovación tecnológica.

1. Las administraciones públicas habrán de garantizar la necesaria innovación tecnológica a fin de lograr la mayor eficiencia en la prestación de los diferentes servicios.

2. Las administraciones públicas fomentarán la realización de estudios e investigaciones sobre las necesidades emergentes de atención social, sobre los factores que inciden en la demanda y sobre la evaluación de los elementos organizativos y de gestión del sistema.

\section{TÍTULO II \\ DE LA PRESTACIÓN DE LOS SERVICIOS SOCIALES}

\section{Capitulo I DISPOSICIONES GENERALES}

Artículo 29. Formas de prestación de los servicios sociales.

1. Los servicios sociales se prestarán por las administraciones públicas gallegas directamente o, de manera indirecta, a través de las diversas modalidades de contratación de la gestión de servicios públicos establecidas en la normativa reguladora de los contratos del sector público, especialmente mediante la modalidad de concierto.

2. Las personas físicas y jurídicas privadas, de iniciativa social o de carácter mercantil, podrán actuar como entidades prestadoras de servicios sociales y, en consecuencia, crear centros de servicios sociales, así como gestionar programas y prestaciones de esta naturaleza, de conformidad con lo establecido en el presente título.

El ejercicio de este derecho queda sujeto a un régimen de registro y autorización previa con arreglo a lo establecido en el título VIII de la presente ley y requerirá, en todo caso, el cumplimiento de los requisitos de calidad y demás condiciones que establezca la normativa reguladora de los servicios sociales de Galicia.

\section{Capitulo II \\ LA PARTICIPACIÓN DE LA INICIATIVA SOCIAL Y DE ENTIDADES PRIVADAS DE CARÁCTER MERCANTIL EN LA PRESTACIÓN DE LOS SERVICIOS SOCIALES}

Artículo 30. Iniciativa social.

A los efectos de la presente ley, las entidades de iniciativa social son aquellas organizaciones o instituciones no gubernamentales que gestionan centros o desarrollan actuaciones y programas de servicios sociales sin ánimo de lucro.

No obstará para la consideración de carencia de ánimo de lucro el hecho de que dichas entidades perciban contraprestación de las personas usuarias, siempre y cuando del análisis de sus cuentas anuales se deduzca la no obtención de beneficio.

Artículo 31. Fomento de la iniciativa social.

1. El cumplimiento de los fines de las entidades de iniciativa social se promoverá mediante el otorgamiento de subvenciones, que se concederán atendiendo al interés social de los distintos servicios y proyectos, a su complementariedad con la oferta pública de servicios sociales, a la calidad y carácter innovador de las prestaciones y servicios ofertados, a la eficiencia en el empleo de los fondos públicos y a su adecuación a los objetivos fijados por la planificación autonómica en materia de servicios sociales.

2. En los términos establecidos en la normativa reguladora de las subvenciones $\mathrm{y}$, sin perjuicio de la aplicación ordinaria del régimen abierto de concurrencia competitiva en la gestión de las subvenciones, por razones de interés público, debidamente justificadas, se podrán suscribir convenios singulares con entidades de iniciativa social debidamente autorizadas para la prestación de servicios sociales cuando por razones humanitarias o de emergencia social, o bien cuando por la singularidad de las características de la entidad, la especificidad de los servicios que presta o la especial 
vulnerabilidad de las personas usuarias, no sea posible o conveniente promover la concurrencia pública.

Estos convenios podrán tener carácter plurianual en aras a garantizar un marco estable que favorezca y facilite la mejor prestación de los servicios, planes y programas, sin perjuicio de su posible resolución anticipada por incumplimiento, por inexistencia sobrevenida de las razones especiales que lo justificaron o cualquier otra causa establecida reglamentariamente o en el propio convenio.

Artículo 32. Iniciativa mercantil.

1. Son entidades de iniciativa mercantil las personas y entidades privadas con ánimo de lucro que presten servicios sociales.

2. Las administraciones públicas competentes podrán contratar con entidades mercantiles debidamente autorizadas la prestación de servicios sociales a personas usuarias del sistema.

3. La participación de estas entidades en la ejecución de las políticas sociales se realizará desde la aplicación del principio de complementariedad respecto a la gestión pública y su materialización se producirá en la forma y con las condiciones que se prevean en los correspondientes planes y programas de servicios sociales.

Artículo 33. Fomento de previsiones de índole social en la contratación pública.

1. Los pliegos de condiciones administrativas particulares de las licitaciones que convoquen las administraciones públicas de Galicia en materia de gestión de servicios sociales podrán señalar la preferencia en la adjudicación de los contratos a las proposiciones presentadas por empresas públicas o privadas que en el momento de acreditar su solvencia técnica tengan en su plantilla un número de trabajadoras y trabajadores con discapacidad superior al 2 por 100 , siempre que dichas proposiciones igualen en sus términos a las más ventajosas desde el punto de vista de los criterios que sirvan de base para la adjudicación.
En los supuestos de empate, se podrá reconocer la preferencia en la adjudicación a la persona licitadora que disponga de un mayor porcentaje de trabajadoras y trabajadores fijos con discapacidad en su plantilla.

2. En los términos previstos en la normativa de contratación pública, los pliegos de cláusulas que rijan la contratación de servicios sociales pueden dar preferencia en la adjudicación de contratos, en igualdad de condiciones con las que sean económicamente más ventajosas, a las proposiciones presentadas por empresas dedicadas específicamente a la promoción e inserción laboral de personas en situación de exclusión social. Igualmente, resultarán de aplicación los criterios establecidos en la Ley 2/2007, de 28 de marzo, del trabajo en igualdad de las mujeres de Galicia.

3. En la misma forma y condiciones, se podrá establecer tal preferencia en la adjudicación de los contratos relativos a prestaciones de carácter social o asistencial para las proposiciones presentadas por entidades sin ánimo de lucro, con personalidad jurídica, siempre que su finalidad o actividad tenga una relación directa con el objeto del contrato en los términos previstos en la normativa de contratación pública.

4. De conformidad con la legislación de aplicación, se impulsará el establecimiento de áreas reservadas para centros especiales de empleo en el ámbito de contratación de las administraciones públicas.

\section{Capitulo III AGENCIA GALLEGA DE SERVICIOS SOCIALES}

Artículo 34. Creación y naturaleza.

1. Se autoriza a la Xunta de Galicia para la creación de la Agencia Gallega de Servicios Sociales, como entidad instrumental de derecho público, dotada de personalidad jurídica, patrimonio propio 
y autonomía en su gestión, facultada para ejercer potestades administrativas en el marco del cumplimiento de los programas correspondientes a las políticas públicas de servicios sociales.

2. La Agencia Gallega de Servicios Sociales se adscribirá al departamento de la Xunta de Galicia con competencias en materia de servicios sociales.

Artículo 35. Régimen jurídico.

1. La creación de la Agencia Gallega de Servicios Sociales se producirá con la aprobación de su estatuto por decreto del Consejo de la Xunta de Galicia, a propuesta de la Consejería de Economía y Hacienda, previa iniciativa del departamento de la Administración autonómica con competencias en materia de servicios sociales.

2. La constitución y funcionamiento de la Agencia Gallega de Servicios Sociales se regirá por lo establecido en la presente ley, en la disposición adicional quinta del texto refundido de la Ley de régimen financiero y presupuestario de Galicia, aprobado mediante Decreto legislativo $1 / 1999$, de 7 de octubre, en su respectivo estatuto y en las demás normas que resulten de aplicación.

3. En sus actividades de contratación, la Agencia Gallega de Servicios Sociales se regirá por lo dispuesto en la Ley $30 / 2007$, de 30 de octubre, de contratos del sector público.

Artículo 36. Funciones.

Serán funciones de la Agencia Gallega de Servicios Sociales las siguientes:

a. Conseguir un aprovechamiento óptimo y la racionalización en el empleo de los recursos dedicados a los servicios sociales, asegurando el mayor nivel de eficacia y eficiencia en la gestión y prestación de los mismos.

b. Velar por la plena efectividad del principio de responsabilidad pública en la prestación de los servicios sociales.

c. Gestionar equipamientos, prestaciones económicas, programas y servicios sociales de competencia autonómica. d. Coordinar el ejercicio de las actuaciones públicas y privadas en materia de servicios sociales, promoviendo el establecimiento de convenios, conciertos o cualesquiera otras fórmulas de coordinación o cooperación que permitan una utilización óptima y racional de los recursos.

Artículo 37. Recursos.

La Agencia Gallega de Servicios Sociales se financiará con los siguientes recursos:

a. Las transferencias consignadas en los presupuestos generales de la Xunta de Galicia.

b. Los ingresos propios que perciba como contraprestación por las actividades que puede realizar, en virtud de contratos, convenios o disposición legal, para otras entidades públicas, privadas o personas físicas.

c. La enajenación de los bienes y valores que constituyan su patrimonio, de acuerdo con lo establecido en la legislación patrimonial de la comunidad autónoma.

d. El rendimiento procedente de sus bienes y valores.

e. Las aportaciones voluntarias, donaciones, herencias y legados y demás aportaciones a título gratuito de entidades privadas y particulares.

f. Los ingresos recibidos de personas físicas y jurídicas como consecuencia de patrocinio de actividades o instalaciones.

g. Los demás ingresos de derecho público o privado que esté autorizada a percibir.

h. Cualesquiera otros recursos que se le puedan atribuir conforme a las disposiciones vigentes.

Artículo 38. Régimen de personal.

1. Sin perjuicio de lo establecido para el personal directivo en la normativa que resulte de aplicación en materia de función pública, el personal al servicio de la Agencia Gallega de Servicios Sociales podrá estar constituido por personal funcionario, laboral y estatutario.

2. El personal que, con observación de los procedimientos establecidos en la normativa vigente, se incorpore a la agencia 
desde la administración pública gallega mantendrá la condición de personal funcionario, estatutario o laboral de origen, de acuerdo con la legislación de aplicación.

3. La agencia podrá contratar a personal en régimen de derecho laboral mediante las correspondientes pruebas selectivas convocadas al efecto y en las que se garantizará el cumplimiento de los principios de publicidad, igualdad, mérito y capacidad.

Artículo 39. Régimen financiero y presupuestario.

En materia de régimen financiero y presupuestario la Agencia Gallega de Servicios Sociales se regirá por lo dispuesto en el texto refundido de la Ley de régimen financiero y presupuestario de Galicia, aprobado por Decreto legislativo 1/1999, de 7 de octubre.

\section{TÍTULO III ÓRGANOS CONSULTIVOS Y DE PARTICIPACIÓN}

Artículo 40. Consejo Gallego de Bienestar Social.

1. El Consejo Gallego de Bienestar Social es el órgano superior consultivo y de participación del sistema gallego de servicios sociales y está adscrito al departamento de la Xunta de Galicia competente en la materia.

2. El Consejo Gallego de Bienestar Social, presidido por la persona titular del departamento de la Xunta de Galicia competente en materia de servicios sociales, estará compuesto, en la forma, número y proporción que reglamentariamente se determinen, por representantes de:

a. La Xunta de Galicia.

b. Las entidades locales, a través de la Federación Gallega de Municipios y Provincias.

c. Las organizaciones empresariales, centrales sindicales y organizaciones profesionales agrarias más representativas a nivel gallego.

d. Las entidades prestadoras de servicios sociales. e. Las asociaciones de personas usuarias de servicios sociales.

f. Las universidades gallegas.

g. Los colegios profesionales representativos de las disciplinas directamente relacionadas con los servicios sociales.

3. Son funciones del Consejo Gallego de Bienestar Social:

a. Evaluar las políticas de servicios sociales.

b. Informar los proyectos de planificación y programación y la normativa en materia de servicios sociales.

c. Emitir dictámenes, a instancias del Parlamento de Galicia, en el campo de los servicios sociales.

d. Conocer de la gestión de los servicios sociales.

e. Fomentar la participación de la sociedad y de las administraciones públicas.

f. El seguimiento estadístico, tanto de los procesos de concesión de la renta de integración social de Galicia como de la correcta aplicación de las medidas de fomento del empleo que, vinculadas a los proyectos de inserción, se contemplen en la Ley gallega de medidas básicas para la inserción social, sin perjuicio de las competencias del Instituto Gallego de Estadística.

g. La evaluación global de los resultados de la ejecución de los programas de inserción social contemplados en la Ley gallega de medidas básicas para la inserción social, así como el planteamiento de observaciones y propuestas de modificación que ayuden a mejorarlos.

h. Elaborar y/o modificar su reglamento de régimen interior.

i. Cualquier otra que le pueda ser reglamentariamente atribuida.

4. El consejo podrá crear comisiones y grupos de trabajo específicos, con carácter sectorial o por áreas de gestión, al objeto de dinamizar su funcionamiento y dotarlo de mayor operatividad.

5. Sin perjuicio de lo establecido en el punto anterior, cuando se trate de materias que afecten o incidan directamente en el

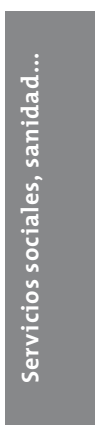


ámbito local, se creará una Comisión en la que participarán la Xunta de Galicia y las entidades locales, así como aquellas entidades que pudieran resultar afectadas por las materias a tratar.

6. La presidencia del consejo, atendiendo a la índole de las materias a tratar, podrá invitar a participar en las sesiones a personas de reconocido prestigio en el campo de los servicios sociales o áreas afines.

7. En las funciones a desarrollar por el Consejo Gallego de Bienestar Social se tendrá en cuenta la adopción, entre otros, de los necesarios enfoques y perspectivas de género. El reglamento establecerá la forma de designación de las personas integrantes del consejo, de manera que se procure en este órgano una composición de género equilibrada según lo previsto en la Ley 7/2004, de 16 de julio, para la igualdad de mujeres y hombres en la Comunidad Autónoma de Galicia, y en la Ley orgánica 3/2007, de 22 de marzo, para la igualdad efectiva de mujeres y hombres.

Artículo 41. Del Observatorio Gallego de Servicios Sociales.

1. En el seno del Consejo Gallego de Bienestar Social se creará el Observatorio Gallego de Servicios Sociales, que tendrá como objetivo establecer un sistema de información permanente sobre la situación de los servicios sociales en Galicia, proporcionando una visión global de la realidad de los mismos, y teniendo en cuenta, entre otras, la perspectiva de género.

2. Con carácter anual, presentará informes de coyuntura social, en los que se reflejen las principales variables sociales y se formulen propuestas y recomendaciones tendentes a promover el desarrollo de las políticas sociales en Galicia.

3. Reglamentariamente, se desarrollará su composición y régimen de funcionamiento.

Artículo 42. Mesa Gallega de Servicios Sociales.

1. La Mesa Gallega de Servicios Sociales es el órgano específico de participación institucional de los agentes sociales para el diseño de las políticas públicas en el ámbito de los servicios sociales.

2. La Mesa Gallega de Servicios Sociales será presidida por la persona titular del departamento de la Xunta de Galicia con competencias en materia de servicios sociales o persona en quien delegue, y se reunirá con una periodicidad anual.

3. La Mesa Gallega de Servicios Sociales estará integrada por representantes de las organizaciones sindicales y empresariales intersectoriales gallegas más representativas. La designación de las personas representantes de dichas organizaciones se realizará por la persona titular del departamento de la Xunta de Galicia competente en materia de servicios sociales, de conformidad con las propuestas formuladas por estas organizaciones a través de sus órganos de dirección competentes y siempre teniendo en cuenta que la designación ha de ser de tantos representantes como sindicatos más representativos de carácter intersectorial de ámbito gallego existan, sin que se pueda producir exclusión alguna.

4. Reglamentariamente, se desarrollarán las funciones de la Mesa Gallega de Servicios Sociales, entre las que figurarán, como mínimo, las siguientes:

a. Conocer los anteproyectos de ley o los proyectos de normas reglamentarias.

b. Recibir información sobre la planificación estratégica del sistema gallego de servicios sociales.

c. Proponer directrices y líneas generales de actuación.

d. Proponer la adopción de iniciativas legislativas o actuaciones concretas.

5. La mesa elaborará sus propias normas de funcionamiento con respeto, en su composición, al principio de paridad, procurando una presencia equilibrada de mujeres y hombres.

Artículo 43. Participación ciudadana y de las personas usuarias de servicios sociales. 
1. Las administraciones públicas competentes en materia de servicios sociales garantizarán la participación ciudadana en el sistema gallego de servicios sociales mediante el establecimiento, por vía reglamentaria, de sistemas de consulta y debate abiertos a toda la ciudadanía y, de manera particular, a las personas usuarias y sectores directamente afectados.

2. En la formulación de los instrumentos de planificación y gestión de los servicios sociales contemplados en la presente ley se establecerán mecanismos y procesos específicos de participación que podrán tener un ámbito territorial o sectorial.

\section{TÍTULO IV \\ PLANIFICACIÓN DEL SISTEMA GALLEGO DE SERVICIOS SOCIALES}

Artículo 44. De las áreas sociales.

1. La unidad territorial de referencia para la planificación de los servicios sociales será el área social que, definida atendiendo a indicadores sociales, económicos y demográficos, facilite una distribución equilibrada de los recursos, de manera que se garantice la igualdad de oportunidades en el acceso a los servicios sociales para toda la ciudadanía, con independencia de su lugar de residencia.

2. Reglamentariamente, se aprobará el Mapa gallego de servicios sociales, en el que se definirán las áreas sociales y se establecerán los criterios de dotación de centros y de servicios en el territorio de Galicia.

Artículo 45. Plan estratégico de servicios sociales.

1. El departamento de la Xunta de Galicia con competencias en materia de servicios sociales elaborará cada seis años un Plan estratégico de servicios sociales que se formulará en función de las necesidades sociales presentes y emergentes de la ciudadanía gallega, garantizando, en todo caso, la participación de las entidades locales.

2. El Plan estratégico de servicios sociales deberá ser aprobado por el Consejo de la Xunta de Galicia.
Artículo 46. Finalidad y contenido básico del Plan estratégico de servicios sociales.

1. La finalidad del Plan estratégico será la de desarrollar y concretar los objetivos del sistema gallego de servicios sociales definidos en la presente ley, así como la de priorizar el establecimiento de medidas, servicios y recursos que permitan conseguirlos.

2. El Plan estratégico tomará como punto de partida el Mapa gallego de servicios sociales con la definición de las áreas sociales sobre las que se vertebrará el sistema gallego de servicios sociales e identificará el tipo de centros y servicios en relación a la estructura del sistema y distribución competencial que se establecen en la presente ley.

3. El Plan estratégico contendrá criterios de calidad y los mecanismos de seguimiento y control e irá acompañado de una memoria económica.

Artículo 47. Planes y programas sectoriales del Plan estratégico de servicios sociales.

1. El Plan estratégico de servicios sociales podrá ser complementado y desarrollado en forma de planes y programas sectoriales.

2. Los planes y programas desarrollarán, cada uno en el ámbito que le es propio, los siguientes aspectos:

a. El análisis de las necesidades y de la demanda social que motiva el plan.

b. La definición de los objetivos de cobertura y el establecimiento de periodos temporales indicativos para su consecución.

c. La tipificación y distribución territorial de los recursos necesarios para el logro de los objetivos previstos.

d. Los criterios y mecanismos indicados para el seguimiento, aplicación y evaluación del plan.

e. La previsión de medidas generales para la coordinación interadministrativa e interdepartamental.

f. Cuantos otros aspectos se consideren precisos para conseguir una planificación

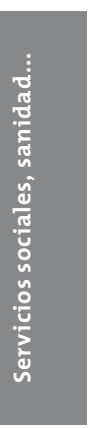


objetiva y adecuada a las necesidades de servicios sociales.

3. En el proceso de elaboración de los planes y programas sectoriales participarán las entidades representativas de los sectores implicados y las entidades locales.

Artículo 48. Planificación de ámbito local.

Los ayuntamientos podrán elaborar su propia planificación que, en el marco de la planificación estratégica, la completen en su propio ámbito territorial, a través de los planes y programas de servicios sociales municipales.

\section{TÍTULO V \\ DE LA CALIDAD DEL SISTEMA GALLEGO DE SERVICIOS SOCIALES} les.

Artículo 49. Disposiciones genera-

1. La calidad del sistema gallego de servicios sociales constituye un principio general del mismo, así como un derecho de las personas usuarias.

2. Las exigencias de calidad afectarán por igual a todo el sistema, tanto de iniciativa pública como privada concertada.

3. El sistema de calidad tendrá siempre como referente el nivel de satisfacción de las necesidades de las personas en relación a los servicios sociales.

Artículo 50. Establecimiento de criterios de calidad del sistema gallego de servicios sociales.

Los criterios y normas de calidad se definirán sobre los siguientes objetivos generales:

a. La elaboración de normas y estándares de calidad propios del sistema gallego de servicios sociales.

b. El establecimiento de sistemas de información homogéneos que posibiliten la actuación integrada y la coordinación del sistema gallego de servicios sociales.

c. El seguimiento y evaluación permanente, orientando el sistema de calidad a la mejora continuada del mismo.
Artículo 51. Plan de calidad.

1. El departamento de la Administración autonómica con competencias en materia de servicios sociales elaborará un Plan de calidad del sistema que defina los objetivos esenciales, indicadores y estándares de referencia, así como los mecanismos de seguimiento y control oportunos.

2. El Plan de calidad fijará medidas concretas para el desarrollo de un sistema documental único del sistema gallego de servicios sociales.

3. El Plan de calidad debe incluir, en todo caso, las siguientes previsiones:

a. La definición de los objetivos de calidad que se establezcan.

b. Los instrumentos y sistemas de mejora globales o sectoriales.

c. Los estudios de opinión y los resultados de los procedimientos de participación de las personas usuarias y sus familias.

d. Los requisitos de calidad exigibles a las actividades y prestaciones sociales correspondientes a la red de atención pública de servicios sociales.

e. Los recursos y dotaciones suficientes que garanticen la oferta de las prestaciones y servicios adecuados, en las condiciones y características que se establezcan en el Catálogo de servicios.

f. Una memoria económica.

\section{TÍTULO VI DE LA FINANCIACIÓN DE LOS SERVICIOS SOCIALES}

Artículo 52. Fuentes de financiación.

La financiación del sistema gallego de servicios sociales se efectuará mediante:

a. Los presupuestos generales de la comunidad autónoma.

b. Los presupuestos de las entidades locales.

c. Los precios públicos correspondientes.

d. Cualquier otra aportación pública o privada destinada a fines de servicios sociales, de acuerdo con lo establecido en la normativa que resulte de aplicación. 
Artículo 53. Financiación por la Comunidad Autónoma de Galicia.

1. El Parlamento de Galicia aprobará anualmente en los presupuestos generales las cantidades necesarias para hacer frente al cumplimiento de los gastos derivados del ejercicio de las competencias de la Xunta de Galicia en materia de servicios sociales, así como a la participación en la financiación de servicios, programas y prestaciones del sistema.

2. La atribución a las entidades locales de competencias de titularidad autonómica en materia de servicios sociales deberá ir acompañada de la transferencia de los medios económicos, materiales y personales que resulten necesarios para el adecuado ejercicio de las mismas.

3. La Xunta de Galicia habrá de contribuir al desarrollo, mejora y sostenimiento de las actividades realizadas por entidades de iniciativa social.

Artículo 54. Financiación por las entidades locales.

1. Los ayuntamientos tendrán que consignar en sus presupuestos las cantidades necesarias para la creación, mantenimiento, gestión y desarrollo de los servicios sociales de su competencia, con arreglo al título VII de la presente ley.

2. El nivel de esfuerzo presupuestario de los ayuntamientos para la prestación de los servicios sociales de su competencia podrá constituir un criterio de valoración para el acceso a la financiación por parte del Gobierno gallego, que, en todo caso, deberá tener en cuenta el principio de equidad y equilibrio territorial.

Artículo 55. Colaboración financiera.

1. La colaboración financiera entre las administraciones públicas se llevará a cabo mediante convenios o cualquier otra fórmula regulada, quedando condicionada al cumplimiento de los objetivos fijados en el marco de la planificación y programación autonómica y local, así como a una preceptiva fiscalización.
2. Las administraciones públicas podrán igualmente conceder subvenciones o suscribir convenios de colaboración con las entidades de carácter público o privado que presten servicios sociales, debiendo garantizarse, en todo caso, el cumplimiento de la normativa vigente en materia de autorización de centros, programas y servicios sociales.

Artículo 56. Aportaciones de las personas usuarias.

1. Se acordará, de ser el caso, la aportación de las personas usuarias a la financiación de los servicios sociales mediante el establecimiento de un sistema de precios públicos, sin perjuicio de la aplicación de criterios de progresividad.

2. La administración, para determinar la participación de las personas usuarias en la financiación del sistema, tendrá en cuenta, en los baremos que reglamentariamente se establezcan, la naturaleza del servicio, el coste de referencia y la capacidad económica de la persona usuaria, especialmente, su nivel de renta y el sector de población a quien se dirija la prestación del servicio.

3. La determinación de las aportaciones se ha de fundamentar en los principios de equidad, solidaridad y redistribución. La Xunta de Galicia debe establecer y regular un sistema de bonificaciones para la participación en las prestaciones garantizadas, a fin de atender a situaciones de insuficiencia de recursos de las personas usuarias. Las bonificaciones se deben establecer en función del nivel de renta personal y de las obligaciones económicas respecto a las personas que la usuaria o usuario tenga a su cargo.

4. Reglamentariamente, se podrán establecer fórmulas alternativas de financiación para aquellas personas que, careciendo de recursos suficientes para el pago ordinario de los precios públicos referidos, dispongan de un patrimonio personal que se pueda afectar al pago de los mismos.

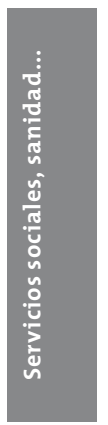


5. En ningún caso se podrá privar a una persona ni excluirla de la prestación de servicios sociales financiados total o parcialmente con fondos públicos por el hecho de no disponer de recursos económicos o resultar éstos insuficientes.

6. La calidad de los servicios y la prioridad en su prestación no podrá depender o quedar condicionada a la realización de aportaciones económicas de las personas usuarias.

Artículo 57. Participación de las entidades privadas en la financiación de los servicios sociales.

1. Las administraciones públicas facilitarán la participación de entidades privadas que acrediten estar al día de las obligaciones legales que les afecten en la financiación de los servicios sociales.

2. Reglamentariamente, se desarrollarán actuaciones que posibiliten el patrocinio y el ejercicio de la responsabilidad social corporativa de las entidades privadas para el desarrollo de los servicios sociales de Galicia.

\section{TÍTULO VII \\ DE LA ATRIBUCIÓN \\ DE COMPETENCIAS}

\section{Capitulo I \\ DISPOSICIONES GENERALES}

Artículo 58. Criterios generales.

1. Las competencias en materia de servicios sociales corresponderán a la Administración de la Comunidad Autónoma de Galicia y a las corporaciones locales de Galicia, así como, en su caso, a las demás entidades públicas previstas en el Estatuto de autonomía de Galicia o establecidas en la presente ley.

2. Las competencias que la presente ley atribuye a la Xunta de Galicia podrán ser objeto de delegación y transferencia, de conformidad con lo previsto en la normativa vigente en la materia.

3. La Xunta de Galicia, conforme a lo dispuesto en la legislación de régimen local, podrá adoptar las medidas necesarias para garantizar las prestaciones esenciales que correspondan a la ciudadanía cuando se produzca el incumplimiento por parte de una corporación local de sus deberes en relación a la presente ley.

\section{Capítulo II COMPETENCIAS DE LAS ADMINISTRACIONES PÚBLICAS}

Artículo 59. Competencias de la Xunta de Galicia.

Son competencias de la Xunta de Galicia las siguientes:

a. El establecimiento del marco normativo en materia de servicios sociales.

b. La planificación y programación general de los servicios sociales en el ámbito territorial de Galicia mediante la elaboración del Plan estratégico de servicios sociales y los planes y programas sectoriales.

c. El Registro Único de Entidades Prestadoras de Servicios Sociales.

d. La autorización y acreditación de centros, servicios y programas sociales, así como su tipificación y la reglamentación de los requisitos mínimos, tanto generales como específicos, que necesariamente han de cumplir.

e. La formación e investigación en el campo de los servicios sociales.

f. El asesoramiento y asistencia técnica a las entidades e instituciones que participen en la prestación de los servicios sociales a fin de que su actuación se adecue a lo dispuesto en la presente ley y a su normativa de desarrollo.

g. El diseño, creación, gestión y coordinación de un sistema de información estadística de los servicios sociales, así como su mantenimiento y actualización.

h. La supervisión y evaluación de la calidad en la prestación de los servicios sociales estableciendo mecanismos de control objetivo y continuo de los mismos. 
i. La creación, mantenimiento y gestión de los servicios sociales especializados, así como de los centros y programas de los servicios sociales comunitarios específicos que, por su naturaleza, ámbito supramunicipal u otras circunstancias, debidamente justificadas en el marco del Plan estratégico de servicios sociales, asuma la Xunta de Galicia.

j. La valoración técnica de las situaciones que determinen el reconocimiento del derecho a los servicios y prestaciones esenciales de carácter material o económico.

k. La concesión de las prestaciones o ayudas económicas destinadas a personas físicas, sin perjuicio de la colaboración de los entes locales cuando así se establezca en su normativa específica.

1. La gestión de subvenciones y otras ayudas públicas que conceda a centros y entidades prestadoras de servicios sociales.

$\mathrm{m}$. El ejercicio de las potestades inspectora y sancionadora.

n. Cualquier otra que se le atribuya por la normativa vigente, así como aquellas otras que siendo necesarias para el desarrollo y ejecución de la política de servicios sociales no estén expresamente atribuidas a otra Administración pública.

Artículo 60. Competencias de los ayuntamientos.

1. De conformidad con lo previsto en la presente ley y en la legislación de aplicación sobre régimen local, corresponden a los ayuntamientos, en el marco de la planificación y ordenación general del sistema gallego de servicios sociales, las siguientes competencias:

a. La creación, gestión y mantenimiento de los servicios sociales comunitarios básicos.

b. La creación, gestión y mantenimiento de los servicios sociales comunitarios específicos, sin perjuicio de lo establecido en el artículo $59 .^{\circ}$ i). c. La colaboración en el fomento de los servicios sociales prestados por entidades de iniciativa social, así como la promoción de mecanismos de coordinación de las actuaciones realizadas por las mismas, evitando en lo posible la duplicidad e infrautilización de los equipamientos sociales.

d. La promoción y realización de estudios e investigaciones sobre la problemática de los servicios sociales en el ámbito local y la divulgación de los resultados obtenidos en los mismos.

e. La detección y análisis de las necesidades y de la problemática social existente en su ámbito territorial.

f. La elaboración de planes y programas de servicios sociales en su ámbito territorial, de conformidad con lo previsto en el artículo $48^{\circ}$ de la presente ley.

g. La participación, como entidad colaboradora, en la gestión de las prestaciones económicas y, en su caso, en las subvenciones concedidas por la Xunta de Galicia, en los términos legalmente establecidos.

h. El fomento y promoción de la solidaridad y de la participación de la sociedad civil en la prevención e intervención social en el ámbito local.

i. La creación, regulación e impulso de mecanismos de participación local en el ámbito de los servicios sociales.

j. La coordinación de los servicios sociales con los restantes servicios municipales y de las restantes administraciones en el desarrollo de los planes y programas de intervención comunitaria, facilitando la participación de las entidades sociales y la implicación de la ciudadanía en el proceso.

k. Cuantas otras les estén atribuidas o les sean delegadas, de acuerdo con la legislación vigente.

2. Estas competencias se ejercerán por los ayuntamientos, por sí mismos o asociados, o a través de las fórmulas de 
colaboración interadministrativa, a fin de alcanzar una mayor eficacia y rentabilidad social de los recursos disponibles.

Artículo 61. De los servicios sociales mínimos garantizados por los ayuntamientos.

1. De cara a garantizar una oferta pública de servicios sociales a todas las personas, con independencia de su residencia, todos los ayuntamientos de Galicia asegurarán, como mínimo, la prestación de servicios sociales comunitarios básicos de titularidad municipal.

2. Si la prestación de estos servicios mínimos resultara imposible o de muy difícil cumplimiento, se podrá solicitar su dispensa, siguiendo el procedimiento establecido en la Ley 5/1997, de 22 de julio, de Administración local de Galicia.

Artículo 62. De las actividades municipales complementarias de otras administraciones públicas.

Para la mejor atención de las necesidades sociales de su ámbito territorial, y una vez garantizada la prestación de los servicios sociales comunitarios básicos y demás competencias enumeradas en el artículo $60{ }^{\circ}$, los ayuntamientos de Galicia podrán crear, gestionar y mantener servicios sociales especializados, en coordinación con la Xunta de Galicia y de acuerdo con el Catálogo de servicios sociales y la planificación correspondiente.

Artículo 63. Competencias de las diputaciones provinciales.

Las diputaciones provinciales, de conformidad con lo previsto en la normativa de régimen local, proporcionarán asistencia económica, técnica y jurídica a los ayuntamientos en la ejecución de sus competencias en materia de servicios sociales, especialmente en la prestación de servicios sociales comunitarios básicos por aquellos ayuntamientos con menos de veinte mil habitantes.
Artículo 64. De la colaboración interadministrativa.

1. La Xunta de Galicia promoverá una efectiva coordinación y cooperación con los ayuntamientos a fin de asegurar la calidad y una cobertura equilibrada de los servicios sociales en todo el territorio, especialmente en lo que atañe a la creación y mantenimiento de servicios sociales comunitarios específicos.

2. Además, a los efectos de lo previsto en el apartado anterior, la Xunta de Galicia promoverá fórmulas de cooperación interadministrativa de naturaleza consorcial.

Artículo 65. Comisión Interdepartamental de Servicios Sociales e Inclusión Social.

1. Se crea la Comisión Interdepartamental de Servicios Sociales e Inclusión Social como órgano de coordinación de las actuaciones de los diferentes departamentos de la Xunta de Galicia que incidan en la mejora del bienestar de la ciudadanía gallega, a los efectos del desarrollo de la presente ley.

2. Serán funciones de la Comisión Interdepartamental de Servicios Sociales e Inclusión Social las siguientes:

a. Garantizar el intercambio de información, la coherencia y la complementariedad de las actividades de los departamentos de la Xunta de Galicia en los ámbitos del bienestar y la inclusión social.

b. Informar el Plan estratégico de servicios sociales, así como los planes y programas que desarrollen el mismo.

c. Cualquier otra función que le venga atribuida mediante disposición legal o reglamentaria.

3. En el ejercicio de sus funciones, la Comisión tendrá en cuenta la perspectiva de género.

4. Reglamentariamente, se desarrollarán su composición y régimen de funcionamiento. 


\section{TÍTULO VIII}

DE LOS MECANISMOS DE CONTROL Y GARANTÍA PÚBLICA DEL SISTEMA GALLEGO DE SERVICIOS SOCIALES

\section{Capítulo I \\ RÉGIMEN DE REGISTRO, AUTORIZACIÓN ADMINISTRATIVA Y ACREDITACIÓN DE ENTIDADES, CENTROS, SERVICIOS O PROGRAMAS}

Artículo 66. Entidades prestadoras, centros y programas de servicios sociales.

1. Tendrá la consideración de entidad prestadora de servicios sociales toda persona física o jurídica, legalmente reconocida como tal, que sea titular o gestora de centros sociales y/o desarrolle programas o servicios sociales en las áreas de actuación señaladas en la normativa de aplicación.

2. Son entidades prestadoras:

a. La Administración autonómica.

b. Las entidades locales.

c. Las entidades de iniciativa social.

d. Las entidades de iniciativa mercantil.

3. Tendrán la consideración de centros de servicios sociales todos aquellos equipamientos reglamentariamente tipificados en los que se desarrollen de un modo estable y continuado servicios, programas y actividades de servicios sociales en las distintas áreas sociales.

4. Tendrán la consideración de programas de servicios sociales el conjunto articulado de objetivos, acciones y servicios dotados presupuestariamente y que cuenten con los recursos humanos y materiales adecuados para llevarlos a cabo, y por medio de los cuales se procuren soluciones a las necesidades sociales.

Artículo 67. Registro.

1. Las entidades prestadoras de servicios sociales titulares de centros, así como las que presten servicios, programas o colaboren en la gestión de servicios sociales, habrán de estar inscritas, con carácter previo al inicio de sus actividades, en el Registro Único de Entidades Prestadoras de Servicios Sociales, que estará adscrito al departamento de la Xunta de Galicia con competencias en materia de inspección de servicios sociales.

2. Reglamentariamente, se desarrollarán las condiciones y procedimientos para la inscripción y cancelación de la inscripción de las entidades y sus centros, servicios y programas. La duración máxima de estos procedimientos será de tres meses. Una vez transcurrido dicho plazo sin que se dicte resolución administrativa, las solicitudes se entenderán desestimadas por silencio administrativo.

Artículo 68. Régimen de autorización administrativa en materia de servicios sociales.

1. Los centros, servicios y programas de titularidad pública y privada que desarrollen sus actividades en Galicia precisarán de la correspondiente autorización del departamento de la Xunta de Galicia competente en materia de autorización de servicios sociales, para su creación o construcción, inicio de actividades, modificación sustancial y cese de actividades, sin perjuicio de otras autorizaciones o licencias exigibles de acuerdo con la legislación vigente.

2. Reglamentariamente, se desarrollarán las condiciones y procedimientos para la obtención, revocación y suspensión de las autorizaciones. Los procedimientos administrativos para la tramitación de las diferentes autorizaciones tendrán una duración máxima de seis meses. Una vez transcurrido dicho plazo sin que se hubiera dictado resolución administrativa, las solicitudes se entenderán desestimadas por silencio administrativo en los procedimientos relativos a la obtención de las diferentes autorizaciones, produciéndose la caducidad en los procedimientos relativos a la suspensión y revocación de las autorizaciones administrativas.

3. Cuando la creación o construcción, la modificación sustancial o el inicio de 
actividades de un centro, servicio o programa de servicios sociales se realice sin la preceptiva autorización administrativa, de conformidad con lo previsto en la presente ley y en su normativa de desarrollo, el departamento de la Xunta de Galicia con competencias en materia de autorización de servicios sociales dispondrá la clausura del centro o la suspensión inmediata de las actividades, previa tramitación del correspondiente procedimiento en los términos que reglamentariamente se establezcan, con audiencia, en todo caso, de la persona interesada.

Artículo 69. Régimen de acreditación en materia de servicios sociales.

1. Los centros, servicios o programas autorizados podrán ser acreditados por el departamento de la Xunta de Galicia con competencias en materia de autorización de servicios sociales, con los efectos que reglamentariamente se determinen, cuando se constate el cumplimiento de los criterios específicos y estándares de calidad que a tal efecto se establezcan para los diferentes tipos de prestación y personas destinatarias.

2. Reglamentariamente, se desarrollará el procedimiento para la concesión, renovación, revocación o suspensión de la acreditación. Estos procedimientos tendrán una duración máxima de seis meses. Una vez transcurrido dicho plazo sin que se hubiera dictado resolución administrativa, las solicitudes se entenderán desestimadas por silencio administrativo en los procedimientos relativos a la concesión y renovación de la acreditación, produciéndose la caducidad en los procedimientos relativos a su revocación y suspensión.

3. La acreditación se podrá tener en cuenta en los contratos que se liciten por las administraciones públicas en materia de servicios sociales, así como para la obtención de subvenciones o percepción de cualquier otro tipo de ayuda pública.

Artículo 70. Incumplimientos.

$\mathrm{El}$ incumplimiento del régimen de registro de entidades y del régimen de autorización administrativa de entidades, centros, servicios o programas condicionará el otorgamiento o el pago de subvenciones, así como la obtención de cualquier tipo de financiación por parte de la Xunta de Galicia en relación a la entidad, centro, servicio o programa de que se trate.

\section{Capitulo II DE LA INSPECCIÓN}

Artículo 71 Función inspectora.

1. La Administración autonómica ejercerá sus facultades inspectoras sobre las entidades, centros, servicios y programas, tanto públicos como privados, a través del departamento de la Xunta de Galicia competente en materia de inspección de servicios sociales, a fin de verificar el estricto cumplimiento de la normativa de aplicación en esta materia, de forma que se garanticen los derechos de las personas usuarias y se procure la mejora continua de la calidad en los servicios sociales que se presten a los ciudadanos en el territorio de Galicia.

2. A los efectos de un eficaz desarrollo de la función inspectora, cuando se detecte la posible existencia de una infracción en materia sanitaria, laboral, industrial o de otra naturaleza, el departamento de la Xunta de Galicia con competencias en materia de inspección de servicios sociales dará el oportuno traslado a la autoridad competente, pudiendo solicitar, cuando sea necesario, la debida colaboración de otras unidades de inspección de otros órganos, administraciones e instituciones públicas de conformidad con la normativa vigente.

3. El ejercicio de la función inspectora en materia de servicios sociales se realizará sin perjuicio de la labor inspectora que en virtud de la normativa sectorial corresponda a otras autoridades de la Administración general del Estado, autonómica o local.

Artículo 72. Personal inspector.

1. La inspección de servicios sociales habrá de ser ejercida por personal 
funcionario nombrado al efecto y con la calificación necesaria para el desarrollo del puesto.

2. El personal inspector de servicios sociales ostenta en el ejercicio de sus funciones la condición de autoridad pública y actuará con plena independencia, objetividad e imparcialidad. Habrá de estar provisto del correspondiente documento acreditativo.

3. El personal inspector habrá de guardar sigilo profesional respeto a los asuntos que conozca por razón de su cargo, función y actuaciones. Igualmente, habrá de respetar la confidencialidad de los datos personales que afecten a la intimidad de las personas usuarias, así como de las personas directamente relacionadas con el servicio. ción.

Artículo 73. Funciones de la inspec-

Son funciones de la inspección de servicios sociales las siguientes:

a. Verificar el cumplimiento de los requisitos y condiciones exigibles para la obtención de las preceptivas autorizaciones administrativas y para la acreditación de las entidades, centros, servicios y programas sociales.

b. Velar por el respeto de los derechos de las personas usuarias de los servicios sociales.

c. Controlar el cumplimiento de la normativa vigente y el nivel de calidad de los servicios sociales que se presten en el territorio de Galicia, pudiendo formular propuestas de mejora en la calidad de los servicios sociales.

d. Asesorar, en el ejercicio de las actuaciones de inspección, a las entidades prestadoras de servicios sociales titulares o gestoras de centros, programas o servicios y a las personas usuarias o sus representantes legales sobre sus respectivos derechos y deberes y sobre la forma de cumplir las disposiciones vigentes sobre la materia.

e. Informar sobre el destino y adecuada utilización de las subvenciones y ayudas públicas percibidas por personas físicas o jurídicas en materia de servicios sociales, así como sobre cualquier otra ayuda económica articulada a través de convenios, contratos u otras figuras establecidas en la normativa vigente.

f. Recibir e investigar quejas y reclamaciones.

g. Emitir informes, proponer la iniciación de expedientes sancionadores, proponer la adopción de medidas cautelares, proponer la clausura de centros, la suspensión de sus actividades y la revocación y suspensión de las autorizaciones y acreditaciones concedidas.

h. Todas aquellas funciones que le encomiende la presente ley o su normativa de desarrollo.

Artículo 74. Obligaciones de las entidades.

Las entidades prestadoras de servicios sociales titulares o gestoras de centros o que desarrollen servicios o programas sociales habrán de aportar, a requerimiento de la inspección, toda la documentación relativa a cualquier aspecto de su actividad, estando obligadas a permitir el acceso a las instalaciones, a facilitar la información, documentos, libros, soportes informáticos y demás datos que les sean requeridos, así como a prestar toda la colaboración que resulte necesaria a los efectos de facilitar al personal inspector su labor de comprobación del cumplimiento de la normativa vigente.

Artículo 75. Desarrollo de la función inspectora.

1. El personal inspector podrá, en ejercicio de sus funciones:

a. Acceder libremente, sin previa notificación y en cualquier momento, a todos los centros de servicios sociales, sede de las entidades o instalaciones de referencia del servicio o programa.

b. Efectuar toda clase de actividades y de comprobaciones materiales, de documentales y de análisis de la calidad, así como realizar todas las investigaciones 
que estime adecuadas en el cumplimiento de sus funciones.

c. Elaborar informes en las materias objeto de la inspección de servicios sociales.

d. El personal inspector podrá, sin necesidad de visita, requerir de las entidades titulares o gestoras de centros o que desarrollen programas o servicios sociales la aportación de los datos necesarios, así como solicitarles la documentación precisa y, en su caso, los informes oportunos.

e. Emplazar, en las oficinas de la administración, a las personas responsables de las entidades, centros, servicios, programas o actividades que considere oportunas a los efectos de la investigación, haciendo constar el lugar, fecha, hora y motivo de la citación, expresando, a su vez, los efectos de no atender a la misma.

f. Entrevistar con carácter privado a las personas usuarias, familiares y personal trabajador de los centros, servicios o programas sociales.

g. Solicitar la emisión de informes o dictámenes y el auxilio de otros órganos o autoridades.

h. Realizar todas aquellas funciones que le sean atribuidas por la normativa vigente en la materia.

2. Efectuadas las comprobaciones oportunas se extenderá la correspondiente acta de inspección. Los hechos recogidos en las correspondientes actas de inspección disfrutarán de valor probatorio, sin perjuicio de las pruebas que en defensa de los respectivos derechos o intereses puedan señalar o aportar los propios administrados.

3. Cuando en el decurso de la actuación inspectora se aprecie, razonablemente, la existencia de una situación de riesgo inminente o perjuicio grave para las personas usuarias, se podrá proponer al órgano competente la adopción de las medidas cautelares oportunas durante el tiempo que persista el riesgo que las justificó, de conformidad con lo previsto en la Ley 30/1992, de 26 de noviembre, de régimen jurídico de las administraciones públicas y del procedimiento administrativo común.

Con carácter previo a su adopción, se dará audiencia a la entidad responsable, salvo que la situación de urgencia o de riesgo haga necesaria su ejecución inmediata.

\section{TÍTULO IX \\ DE LAS INFRACCIONES Y SANCIONES}

\section{Capítulo I \\ DISPOSICIONES GENERALES}

Artículo 76. Régimen de infracciones y sanciones.

1. Las infracciones en materia de servicios sociales serán objeto de las sanciones administrativas correspondientes, que serán impuestas por los órganos competentes de la Administración autonómica, previa instrucción del oportuno expediente y $\sin$ perjuicio de las responsabilidades penales, laborales o de otro orden que pudieran concurrir.

2. Sin perjuicio del régimen de infracciones y sanciones previsto en el presente título, resultará de aplicación la regulación contenida en el título III de la Ley 39/2006, de 14 de diciembre, de promoción de la autonomía personal y atención a las personas en situación de dependencia, con las especialidades previstas en la presente ley.

Artículo 77. Sujetos responsables y concurrencia con otras responsabilidades.

1. Son responsables de las infracciones las personas físicas o jurídicas titulares o gestoras de los centros, servicios o programas sociales que incurran en las acciones $u$ omisiones tipificadas en el presente título.

2. En caso de que los hechos imputados pudieran ser constitutivos de ilícito penal, se pondrán en conocimiento del ministerio fiscal o del órgano judicial competente, suspendiéndose por el instructor la tramitación del procedimiento sancionador hasta que adquiera firmeza la resolución que ponga fin al procedimiento judicial. La comunicación al órgano judicial o al ministerio fiscal o el inicio de actuaciones por parte de éstos no afecta al cumplimiento inmediato de las 
medidas cautelares adoptadas en los casos de riesgo grave para la seguridad o salud de las personas usuarias.

Artículo 78. Prescripción de infracciones y sanciones.

1. Las infracciones cometidas prescribirán transcurridos uno, tres o cuatro años desde la fecha de su comisión, según se calificaran como leves, graves o muy graves. En el supuesto de que la infracción tenga carácter continuado en el tiempo, el referido plazo de prescripción comenzará a contar desde la fecha en la que tuviera lugar la completa finalización de la actividad infractora.

2. Las sanciones prescribirán transcurridos uno, cuatro y cinco años desde su imposición firme en la vía administrativa según se califiquen como leves, graves o muy graves.

\section{Capítulo II DE LAS INFRACCIONES}

Artículo 79. De las infracciones administrativas en materia de servicios sociales.

1. Constituyen infracciones administrativas en materia de servicios sociales las acciones y omisiones de los sujetos responsables tipificadas y sancionadas en la presente ley.

2. Las infracciones en materia de servicios sociales se clasifican en leves, graves y muy graves, de conformidad con lo establecido en el presente título.

3. Se entiende por reincidencia, a los efectos de la presente ley, la comisión de una infracción una vez que el sujeto hubiera sido sancionado, mediante resolución administrativa firme, por esa misma infracción o por otra de gravedad igual o mayor o por dos o más infracciones de gravedad inferior, durante los dos últimos años.

Artículo 80. Infracciones leves. Son infracciones leves:

a. Las irregularidades de carácter formal en el cumplimiento de la normativa vigente en materia de servicios sociales. b. Las deficiencias estructurales o de acabado en los locales e instalaciones, en el mobiliario o los enseres, así como en su funcionamiento, sin que de ello se derive un riesgo para las personas usuarias.

c. La falta de limpieza que no comporte riesgo para las personas usuarias.

d. La no comunicación previa de cualquiera de las obras, reformas o mejoras realizadas en los centros.

e. No cumplir la normativa vigente y las obligaciones establecidas respecto al debido seguimiento y evaluación periódica de las personas usuarias de centros, programas y servicios, siempre que no comporte un perjuicio grave para la persona usuaria.

Artículo 81. Infracciones graves.

Son infracciones graves:

a. El inicio, modificación sustancial o cese de actividades de un centro, servicio o programa careciendo de la autorización administrativa correspondiente.

b. El incumplimiento de las obligaciones relativas a la seguridad de las instalaciones del centro.

c. No prestar el tratamiento técnico propio de la finalidad específica del centro, servicio o programa, según las normas sobre autorización y acreditación.

d. La falta de limpieza o de higiene que comporte riesgo para las personas usuarias.

e. El incumplimiento del deber de sigilo y confidencialidad en relación a la información obtenida en el ejercicio de sus funciones.

f. Desatender a las necesidades básicas de atención o de evaluación y seguimiento de las personas usuarias, de acuerdo con los requerimientos de su plan individual de atención.

g. No contar con el personal suficiente y/o con la titulación exigida, de acuerdo con el tipo de actividad y número de personas atendidas en el centro, servicio o programa. 
h. No comunicar a la autoridad judicial o administrativa competente, cuando sea exigible, el ingreso o salida de los centros de servicios sociales de las personas usuarias, o no dar inmediata cuenta, en caso de incapacidad sobrevenida de algún residente, a la autoridad judicial por parte de la dirección del centro.

i. La realización de actividades lucrativas, o encubrir el ánimo de lucro, en centros o servicios definidos como sin ánimo de lucro o que se presentan como tales ante la administración y la sociedad.

j. Las irregularidades en la administración, custodia y manejo de fondos y bienes de las personas usuarias de los centros de servicios sociales por parte de las personas responsables de su dirección, administración y demás personal del centro o servicio.

k. La obstrucción a la labor inspectora. Se consideran obstrucción a la labor inspectora las acciones y omisiones que impidan, obstaculicen, dificulten o retrasen la labor inspectora, así como las omisiones o retrasos injustificados del cumplimiento de las obligaciones de información, comunicación o comparecencia y el suministro de informaciones falsas, y también la desatención injustificada de los requerimientos exigidos por la inspección.

1. Incumplir o falsear sus obligaciones formales y la alteración no autorizada del régimen de precios de los servicios prestados.

$\mathrm{m}$. Superar el límite de ocupación, con respecto a las plazas autorizadas, de personas usuarias o camas por habitación e instalar camas o similares en espacios inadecuados y no autorizados previamente como dormitorios.

n. La realización de publicidad engañosa en relación a la denominación de la entidad, centro o programa o en relación a los servicios prestados o actividades realizadas.

ñ. La reincidencia en la comisión de infracciones leves.
Artículo 82. Infracciones muy graves. Son infracciones muy graves:

a. Proporcionar a las personas usuarias tratos degradantes, discriminatorios o incompatibles con su dignidad, así como la realización de actuaciones que supongan violación, restricción o impedimento injustificado de sus derechos fundamentales y libertades públicas.

b. Prestar servicios sociales de forma clandestina, es decir, tratando de ocultar o enmascarar la verdadera naturaleza de las actividades que se desarrollan, al objeto de eludir la aplicación de la normativa vigente en materia de servicios sociales.

c. Obstruir la labor inspectora de servicios sociales, mostrando resistencia reiterada, coacción, amenazas, violencia o cualquier otra forma de presión ejercida sobre el personal inspector, las personas usuarias o el personal trabajador.

d. La reincidencia en la comisión de infracciones graves.

e. Las infracciones tipificadas como graves en el artículo anterior cuando su comisión provoque daños o perjuicios de difícil o imposible reparación para las personas usuarias de servicios sociales, o cause un importante deterioro o perjuicio social.

\section{Capítulo III DE LAS SANCIONES}

\section{Artículo 83. Sanciones.}

1. Las infracciones en materia de servicios sociales se sancionarán de la forma siguiente:

a. Infracciones leves:

Multa de hasta 3.000 euros, en los siguientes grados:

Mínimo: hasta 1.000 euros.

Medio: de 1.001 euros a 2.000 euros.

Máximo: de 2.001 euros a 3.000 euros.

b. Infracciones graves:

Multa de 3.001 euros hasta 15.000 euros, en los siguientes grados:

Mínimo: de 3.001 euros a 7.000 euros.

Medio: de 7.001 euros a 11.000 euros.

Máximo: de 11.001 euros a 15.000 euros. 
c. Infracciones muy graves:

Multa de 15.001 euros hasta 60.000 euros, en los siguientes grados:

Mínimo: de 15.001 euros a 30.000 euros.

Medio: de 30.001 euros a 45.000 euros.

Máximo: de 45.001 euros a 60.000 euros.

2. En cualquier caso, las sanciones graves y muy graves podrán llevar como accesorias las siguientes:

a. Prohibición de acceder a la financiación pública de la Xunta de Galicia durante un periodo de entre uno y cinco años, en relación al centro, servicio o programa sancionado.

b. Inhabilitación para el desarrollo de funciones o actividades similares hasta un plazo máximo de cinco años.

c. La suspensión de la actividad o el cierre temporal, total o parcial, por un periodo máximo de cinco años.

d. El cese definitivo del servicio o programa o el cierre definitivo del centro, ya sea total o parcial.

3. Cuando el beneficio económico que resulte de la comisión de una infracción tipificada en la presente ley sea superior a la sanción pecuniaria que corresponda, ésta se podrá incrementar en la cuantía equivalente al beneficio obtenido.

4. En caso de que la infracción cometida se derive del incumplimiento de la normativa vigente en materia de precios, la resolución sancionatoria podrá incluir un pronunciamiento sobre la procedencia de indemnizar a las personas usuarias por una cuantía equivalente al importe de las cantidades percibidas indebidamente. ciones.

Artículo 84. Graduación de las san-

Para la graduación de las sanciones en materia de servicios sociales se atenderá a las circunstancias siguientes:

a. La gravedad del riesgo o peligro generado para las personas usuarias de los servicios sociales.

b. Los perjuicios físicos, morales y materiales ocasionados, así como su permanencia o transitoriedad. c. El número de personas usuarias afectadas por la infracción.

d. La trascendencia social de los hechos.

e. El grado de culpabilidad o intencionalidad de la persona responsable.

f. La existencia de fraude o connivencia para la comisión de la infracción.

g. El beneficio económico obtenido o la cifra de negocios de la empresa titular del establecimiento o centro infractor.

h. El incumplimiento de advertencias previas formuladas por las autoridades competentes.

i. La reincidencia.

j. La acreditación de la enmienda de los hechos que motivaron la iniciación del procedimiento sancionador con carácter previo a que se dicte la oportuna resolución.

Artículo 85. Destino del importe de las sanciones.

1. La persona sancionada, a criterio del órgano sancionador, podrá destinar el importe de las sanciones de carácter económico directamente a la mejora de los servicios que presta. En este caso, habrá de acreditar que enmendó todas las infracciones objeto de sanción antes de que se dicte la resolución sancionadora.

2. La Xunta de Galicia habrá de destinar los ingresos derivados de la imposición de sanciones establecidas en la presente ley a la mejora de la calidad y a la cobertura de los servicios sociales.

\section{Capitulo IV DEL PROCEDIMIENTO SANCIONADOR}

Artículo 86. Del procedimiento sancionador.

El procedimiento sancionador de las infracciones tipificadas en la presente ley se ajustará a lo previsto en el título IX de la Ley 30/1992, de 26 de noviembre, de régimen jurídico de las administraciones públicas y del procedimiento administrativo común, y a lo establecido en el Real decreto 1398/1993, de 4 de agosto, por el que se aprobó el Reglamento del 
procedimiento para el ejercicio de la potestad sancionadora.

Artículo 87. Medidas provisionales.

1. El órgano competente para iniciar o resolver el procedimiento podrá adoptar las medidas provisionales necesarias para asegurar la eficacia de la resolución final que pueda recaer, de conformidad con lo previsto en la Ley 30/1992, de 26 de noviembre, de régimen jurídico de las administraciones públicas y del procedimiento administrativo común.

2. Las medidas provisionales podrán consistir en:

a. El cierre o suspensión temporal, total o parcial, del centro y de las actividades del centro, servicio o programa.

b. La prohibición de aceptación de nuevas personas usuarias.

c. La suspensión del procedimiento de pago de las subvenciones y ayudas concedidas.

d. La suspensión de la acreditación.

e. Cualquier otra que se considere idónea y proporcionada a la naturaleza y gravedad de la presunta infracción.

Artículo 88. Resolución e imposición de sanciones.

1. La resolución que ponga fin al procedimiento sancionador será motivada y resolverá todas las cuestiones pertinentes suscitadas en el expediente.

2. Los órganos competentes para la imposición de las sanciones a que se refiere la presente ley serán:

a. La persona titular de la delegación provincial del departamento de la Xunta de Galicia competente en materia de servicios sociales, en caso de sanciones por comisión de infracciones leves.

b. La persona titular del centro directivo de la Administración autonómica competente en materia de inspección de centros, servicios y programas, en caso de sanciones por comisión de infracciones graves.

c. La persona titular del departamento de la Xunta de Galicia competente en materia de servicios sociales, en caso de sanciones por comisión de infracciones muy graves.

d. En caso de que en un mismo supuesto concurran sanciones de diferente naturaleza, la imposición de todas ellas corresponderá a la autoridad que imponga las de mayor gravedad.

3. No obstante lo establecido en el apartado 2 del presente artículo, cuando las sanciones lleven aparejado el cierre, temporal o definitivo, del establecimiento, así como la inhabilitación para el desarrollo de funciones o actividades similares, el órgano competente para su imposición será el Consejo de la Xunta de Galicia.

\section{TÍTULO $\mathrm{X}$ RÉGIMEN SANCIONADOR DE LAS PERSONAS USUARIAS DE LOS SERVICIOS SOCIALES}

\section{Capítulo I \\ DISPOSICIONES GENERALES}

Artículo 89. Régimen de infracciones y sanciones de las personas usuarias de servicios sociales.

1. Las conductas de las personas usuarias de centros, programas o servicios sociales públicos, cuando se puedan calificar como constitutivas de las infracciones tipificadas en el presente título, podrán ser objeto de las sanciones establecidas en el mismo.

2. Sin perjuicio del régimen de infracciones y sanciones previsto en el presente título, resultará de aplicación la regulación contenida en el título III de la Ley 39/2006, de 14 de diciembre, de promoción de la autonomía personal y atención a las personas en situación de dependencia, con las especialidades previstas en la presente ley.

Artículo 90. Sujetos responsables y concurrencia de responsabilidades.

Podrán ser responsables de estas infracciones las personas físicas usuarias de centros, programas o servicios sociales de carácter público cuando incurran en las acciones u omisiones tipificadas en el presente título, sin perjuicio de las responsabilidades de otro tipo que pudieran concurrir. 
Artículo 91. Prescripción de infracciones y sanciones.

1. Las infracciones cometidas prescribirán transcurridos uno, tres o cuatro años desde la fecha de su comisión, según se calificaran como leves, graves o muy graves. En el supuesto de que la infracción tenga carácter continuado en el tiempo, el referido plazo de prescripción comenzará a contar desde la fecha en la que tuviera lugar la completa finalización de la actividad infractora.

2. Las sanciones prescribirán transcurridos uno, cuatro y cinco años desde su imposición firme en la vía administrativa, según se califiquen como leves, graves o muy graves.

\section{Capítulo II \\ DE LAS INFRACCIONES DEL RÉGIMEN SANCIONADOR DE LAS PERSONAS USUARIAS DE LOS SERVICIOS SOCIALES}

Artículo 92. De las infracciones de las personas usuarias de los servicios sociales.

1. Constituyen infracciones del régimen sancionador de las personas usuarias de los servicios sociales las acciones y omisiones de los sujetos responsables tipificadas y sancionadas en el presente título.

2 . Las infracciones en materia de servicios sociales previstas en el presente título se clasifican en leves, graves y muy graves.

3. Se entiende por reincidencia, a los efectos de la presente ley, la comisión de una infracción una vez el sujeto hubiera sido sancionado, mediante resolución administrativa firme, por esa misma infracción o por otra de gravedad igual o mayor o por dos o más infracciones de gravedad inferior, durante los dos últimos años.

Artículo 93. Infracciones leves.

Se considerarán infracciones leves cualquier incumplimiento del reglamento de régimen interior o de las normas de funcionamiento que, por la naturaleza o gravedad, no se tipifiquen como graves o muy graves.
Artículo 94. Infracciones graves. Tendrán la consideración de infracciones graves:

a. No facilitar a la entidad u órgano de la administración los datos que se le requieran o falsear datos o no comunicar la alteración de las circunstancias o requisitos que determinen el otorgamiento o la continuidad de la prestación.

b. El incumplimiento del reglamento de régimen interior o de las normas de funcionamiento cuando ocasionen perjuicios notorios en la prestación del servicio o produzcan daños o perjuicios graves a otras personas usuarias o al personal trabajador.

c. La reincidencia en la comisión de infracciones leves.

Artículo 95. Infracciones muy graves. Tendrán la consideración de infracciones muy graves:

a. Provocar desórdenes y alteraciones muy graves en el servicio que hagan imposible la continuidad de la prestación.

b. La agresión física, acoso o maltrato hacia el personal del centro, programa o servicio, al resto de personas usuarias o las personas visitantes.

c. Ocasionar daños o sustraer bienes del centro, de otras personas usuarias, del personal trabajador o, en su caso, de las personas visitantes.

d. La falta injustificada de pago.

e. La reincidencia en la comisión de infracciones graves.

\section{Capitulo III \\ DE LAS SANCIONES APLICABLES \\ A LAS PERSONAS USUARIAS DE LOS SERVICIOS SOCIALES}

Artículo 96. Sanciones.

Las infracciones se sancionarán de la forma siguiente:

a. Infracciones leves:

Apercibimiento público.

Suspensión de los derechos de participación de las personas usuarias o restricción 
en la participación en algunas actividades, por un periodo no superior a quince días.

b. Infracciones graves:

Suspensión de los derechos de participación de las personas usuarias o restricción en la participación en algunas de las actividades, por un periodo no superior a seis meses.

Suspensión temporal de la prestación del servicio, por un periodo no superior a tres meses.

c. Infracciones muy graves:

Suspensión temporal de la prestación del servicio, por un periodo no superior a seis meses.

Inhabilitación para el acceso y/o percepción de ayudas o subvenciones públicas, por un periodo no superior a seis meses.

Traslado temporal o definitivo a otro centro o servicio.

Revocación de la adjudicación de la plaza pública, temporal o definitivamente.

Revocación de la adjudicación de la plaza pública con inhabilitación para el acceso a cualquier otro centro de la red asistencial de la Xunta de Galicia.

\section{Capitulo IV \\ PROCEDIMIENTO SANCIONADOR}

Artículo 97. Del procedimiento sancionador.

1. En caso de infracciones leves y graves la iniciación del expediente corresponderá a la persona titular de la dirección del centro o, en su caso, a la persona titular de la jefatura de servicio de la delegación provincial del departamento de la Xunta de Galicia competente en materia de servicios sociales. La instrucción se realizará por personal funcionario de la delegación provincial designado al efecto, siendo competente para la resolución del expediente la delegada o delegado provincial.

2. En casos de infracciones muy graves la iniciación del expediente corresponderá a la persona titular de la jefatura de servicio competente por razón de la materia de los servicios centrales de la Administración autonómica. La instrucción corresponderá al personal funcionario designado al efecto. A la vista del expediente remitido y previa audiencia de la persona presuntamente infractora, se emitirá una propuesta de resolución que será notificada a la persona interesada. La resolución del procedimiento corresponderá a la persona titular del centro directivo de la Administración autonómica competente en materia de inspección de servicios sociales.

Contra dicha resolución, que no pone fin a la vía administrativa, se podrán interponer los recursos administrativos previstos en la Ley 30/1992, de 26 de noviembre, de régimen jurídico de las administraciones públicas y del procedimiento administrativo común.

3. En lo no previsto en la presente norma se atenderá a la regulación del procedimiento sancionador del título IX de la Ley 30/1992, de 26 de noviembre, de régimen jurídico de las administraciones públicas y del procedimiento administrativo común, y a lo establecido en el Real decreto 1398/1993, de 4 de agosto, por el que se aprobó el Reglamento del procedimiento para el ejercicio de la potestad sancionadora.

\section{DISPOSICIÓN ADICIONAL PRIMERA HABILITACIÓN PARA LA DOTACIÓN DE MEDIOS MATERIALES}

Se faculta al Consejo de la Xunta de Galicia para que, dentro del ejercicio presupuestario en el que entre en vigor la presente ley, y previo informe de la Consejería de Economía y Hacienda, habilite los créditos necesarios para la dotación de los medios materiales precisos a la Agencia Gallega de Servicios Sociales para su puesta en funcionamiento y el cumplimiento de sus funciones. 


\section{DISPOSICIÓN ADICIONAL SEGUNDA EL CONSORCIO GALLEGO DE SERVICIOS DE IGUALDAD Y BIENESTAR}

1. En cumplimiento de lo previsto en el artículo $64^{\circ}$ de la presente ley, el Consorcio Gallego de Servicios de Igualdad y Bienestar promoverá la coordinación y cooperación efectiva con los ayuntamientos gallegos a fin de asegurar una cobertura equilibrada de los servicios sociales en todo el territorio de Galicia.

2. El Consorcio Gallego de Servicios de Igualdad y Bienestar se regirá por los estatutos que figuran como anexo al convenio de colaboración entre la Xunta de Galicia, a través de la Vicepresidencia de la Igualdad y del Bienestar, y los ayuntamientos de Portas, Taboadela, Vilamarín, Boimorto, Carnota, As Neves, Outes, Xove, Cerdedo, Allariz, A Illa de Arousa, Laza, Ribadeo y Carballeda de Avia, y que fueron objeto de publicación en el Diario Oficial de Galicia de 7 de julio de 2006, mediante Resolución de 4 de julio de 2006 de la Secretaría General y de Relaciones Institucionales, sin perjuicio de su posible modificación y adaptación a la presente ley con arreglo al procedimiento establecido en los mismos, que atenderá a criterios de calidad en las prestaciones y el empleo.

\section{DISPOSICIÓN ADICIONAL TERCERA MARCO TEMPORAL DE CUMPLIMIENTO DE OBJETIVOS Y OBLIGACIONES}

Los objetivos y/u obligaciones establecidos en la presente ley se llevarán a efecto en el plazo máximo de seis años desde su entrada en vigor. La ley de presupuestos generales de cada ejercicio determinará las cuantías destinadas por la Xunta de Galicia para la financiación de los servicios, programas y prestaciones previstos en la presente ley y en el Plan estratégico de servicios sociales, sin perjuicio de los fondos destinados por otras administraciones públicas a la financiación de los servicios sociales de su competencia.

\section{DISPOSICIÓN ADICIONAL CUARTA ÓRGANOS CONSULTIVOS Y DE PARTICIPACIÓN}

1. La Xunta de Galicia promoverá la constitución del Consejo Gallego de Bienestar Social, que vendrá a sustituir al Consejo Gallego de Servicios Sociales, en un plazo no superior a nueve meses desde la entrada en vigor de la presente ley.

2. Igualmente, y en el plazo máximo de un año desde la entrada en vigor de la presente ley, la Xunta de Galicia deberá proceder a la constitución de la Mesa Gallega de Servicios Sociales.

\section{DISPOSICIÓN ADICIONAL OUINTA COMISIÓN INTERDEPARTAMENTAL DE SERVICIOS SOCIALES E INCLUSIÓN SOCIAL}

La Xunta de Galicia procederá, en el plazo máximo de un año desde la entrada en vigor de la presente ley, a la constitución de la Comisión Interdepartamental de Servicios Sociales e Inclusión Social, que asumirá, además de las funciones previstas en el artículo 65 de la presente ley, las funciones establecidas en el artículo 54 de la Ley 9/1991, de 2 de octubre, de medidas básicas para la integración social.

\section{DISPOSICIÓN ADICIONAL SEXTA SENTIDO DEL SILENCIO ADMINISTRATIVO EN EL PROCEDIMIENTO PARA EL RECONOCIMIENTO DE LA SITUACIÓN DE DEPENDENCIA Y DEL DERECHO A LAS PRESTACIONES DEL SISTEMA PARA LA AUTONOMÍA Y ATENCIÓN A LA DEPENDENCIA EN LA COMUNIDAD AUTÓNOMA DE GALICIA}

En los procedimientos de reconocimiento de la situación de dependencia y del derecho a las prestaciones del sistema para la autonomía y atención a la dependencia en la Comunidad Autónoma de Galicia, una vez transcurridos seis meses desde la entrada de la solicitud en el registro del órgano competente para su tramitación 
sin que recaiga resolución expresa, dicha solicitud se entenderá desestimada.

\section{DISPOSICIÓN ADICIONAL SÉPTIMA REFERENCIAS NORMATIVAS A LOS SERVICIOS SOCIALES DE ATENCIÓN PRIMARIA}

Las referencias previstas en la normativa vigente a los servicios sociales de atención primaria se entenderán efectuadas, de conformidad con las previsiones contenidas en la presente ley, a los servicios sociales comunitarios.

\section{DISPOSICIÓN ADICIONAL OCTAVA} MODIFICACIÓN DE LA LEY 9/1991, DE 2 DE OCTUBRE, DE MEDIDAS BÁSICAS PARA LA INSERCIÓN SOCIAL $(\ldots)^{755}$

\section{DISPOSICIÓN TRANSITORIA PRIMERA PROCEDIMIENTOS EN TRAMITACIÓN Y APLICACIÓN DE LA LEGISLACIÓN MÁS FAVORABLE}

Los procedimientos iniciados con anterioridad a la entrada en vigor de la presente ley se seguirán tramitando hasta su resolución final conforme a la normativa de aplicación en el momento de su iniciación, sin perjuicio de que en los procedimientos sancionadores se pueda aplicar la retroactividad de la presente ley en cuanto sea más favorable para el presunto infractor.

\section{DISPOSICIÓN TRANSITORIA SEGUNDA MEDIDAS DE ADAPTACIÓN REGLAMENTARIA}

En tanto no se lleve a cabo el desarrollo reglamentario previsto en los artículos $67 .^{\circ}, 68 .^{\circ}$ y $69 .^{\circ}$ de la presente ley, resultará de aplicación, en todo lo que no se oponga a lo previsto en la misma, lo dispuesto en el Decreto 291/1995, de 3 de noviembre, por el que se desarrolla la Ley 4/1993, de 14 de

755 Disposición adicional octava contiene modificaciones a la Ley 9/1991, do 2 de octubre, de medidas básicas para la inserción social. abril, de servicios sociales, en lo relativo al Registro de Entidades Prestadoras de Servicios Sociales, en la Orden de 5 de febrero de 1996 por la que se desarrolla el citado decreto y en el Decreto 143/2007, de 12 de julio, que regula el régimen de autorización y acreditación de los programas y centros de servicios sociales.

\section{DISPOSICIÓN TRANSITORIA TERCERA COMISIÓN INTERDEPARTAMENTAL DE LUCHA CONTRA LA POBREZA}

En tanto no se proceda a la constitución de la Comisión Interdepartamental de Servicios Sociales e Inclusión Social en los términos previstos en el artículo $65^{\circ}$ y en la disposición adicional quinta de la presente ley, continuarán en vigor las normas reguladoras de la Comisión Interdepartamental de Lucha contra la Pobreza.

\section{DISPOSICIÓN DEROGATORIA ÚNICA. EXPRESA Y GENÉRICA.}

Quedan derogadas las siguientes disposiciones:

a. La Ley 4/1993, de 14 de abril, de servicios sociales.

b. Los artículos 53, 55 y 56 de la Ley 9/1991, de 2 de octubre, de medidas básicas para la inserción social.

c. Todas las normas de igual o inferior rango que contradigan o se opongan a lo establecido en la presente ley.

\section{DISPOSICIÓN FINAL PRIMERA REVISIÓN DE LA LEY 9/1991, DE 2 DE OCTUBRE, DE MEDIDAS BÁSICAS PARA LA INSERCIÓN SOCIAL}

En el plazo máximo de un año desde la entrada en vigor de la presente ley, y considerando los principios informadores de la misma, la Xunta de Galicia procederá a la revisión de la regulación legal de la renta de integración social de Galicia establecida en la Ley 9/1991, de 2 de octubre, de medidas básicas para la inserción social, elaborando un nuevo proyecto de ley para su remisión al Parlamento de Galicia. 


\section{DISPOSICIÓN FINAL SEGUNDA APROBACIÓN DEL CATÁLOGO DE SERVICIOS SOCIALES}

En el plazo máximo de un año desde la entrada en vigor de la presente ley, el Consejo de la Xunta de Galicia, a propuesta del departamento con competencias de servicios sociales, deberá proceder a la aprobación del Catálogo de servicios sociales.

\section{DISPOSICIÓN FINAL TERCERA HABILITACIÓN NORMATIVA}

Se faculta a la Xunta de Galicia para dictar cuantas disposiciones reglamentarias sean necesarias para el adecuado desarrollo de la presente ley.

\section{DISPOSICIÓN FINAL CUARTA ENTRADA EN VIGOR}

La presente ley entrará en vigor a los tres meses de su publicación en el «Diario Oficial de Galicia».

\section{LEY 8/2008, DE 10 DE JULIO, DE SALUD DE GALICIA (DOGA 143. 24.7 .2008$)^{756}$ \\ $(\ldots)^{757}$}

\section{TÍTULO PRELIMINAR OBJETO, ALCANCE Y DEFINICIONES}

\section{Artículo 1. Objeto.}

La presente ley tiene por objeto la regulación general de todas las acciones que permitan hacer efectivo, en el ámbito territorial de la Comunidad Autónoma de Galicia, el derecho constitucional a la protección de la salud en el marco de las competencias que le atribuye el Estatuto de autonomía, mediante la ordenación del Sistema de Salud de Galicia, que

756 Véase:

- Decreto 206/2008, de 28 de agosto, de receta electrónica

- Decreto 12/2009, de 8 de enero, por el que se regula la autorización de centros, servicios y establecimientos sanitarios

757 Preámbulo omitido. comprende los sectores sanitarios público y privado, y la regulación del Sistema Público de Salud de Galicia y de los derechos y deberes sanitarios de la ciudadanía gallega, así como de los instrumentos que garantizan su cumplimiento.

Artículo 2. Alcance.

La presente ley comprende los ámbitos siguientes:

1. La definición y garantía de los derechos y obligaciones de la ciudadanía en el ámbito sanitario, en concordancia y desarrollo de lo previsto en la Ley 14/1986, general de sanidad, y en las leyes de ámbito estatal que desarrollan ésta.

2. La ordenación del Sistema Público de Salud de Galicia.

3. La planificación sanitaria del Sistema Público de Salud de Galicia y la definición de las actuaciones e intervenciones públicas en materia de salud.

4. La ordenación de las prestaciones y servicios sanitarios que configuran el derecho a la protección de la salud y a la atención sanitaria en el ámbito territorial de Galicia.

5. La ordenación y regulación del Servicio Gallego de Salud.

6. La regulación general de las competencias sanitarias de las diferentes administraciones públicas de Galicia, de las actuaciones de la Xunta de Galicia con relación a la Unión Europea y de las relaciones de cooperación con el Estado, otras comunidades autónomas y las comunidades gallegas en el exterior en materia sanitaria.

7. El establecimiento y la regulación de la colaboración del sector sanitario privado con el Sistema Público de Salud de Galicia como complemento que contribuye a hacer efectivo el derecho constitucional a la protección de la salud y a la atención sanitaria en el ámbito de la Comunidad Autónoma de Galicia.

8. La formación e investigación en el ámbito de la sanidad.

9. La coordinación de la prestación de los servicios sociosanitarios. 
Artículo 3. Definiciones.

A los efectos de la presente ley se entiende por:

1. Acción intersectorial: la acción en que el sector sanitario y otro relevante sector de la economía o de otro sector público o privado colaboran o interactúan para conseguir objetivos de salud.

2. Acreditación sanitaria: el conjunto de procedimientos y criterios que, superando los requisitos técnicos y las condiciones mínimas exigidas para la autorización sanitaria, hayan de cumplir los centros, servicios y establecimientos sanitarios, en cuanto a mejorar y reconocer la calidad de los mismos y de sus prestaciones. La acreditación será requisito para la suscripción de contratos de servicios sanitarios en los supuestos determinados reglamentariamente.

3. Actividad sanitaria: cualquier resolución, intervención, servicio, prestación o actuación cuyo objetivo principal sea la salud de las personas.

4. Atención sanitaria: cualquier tipo de servicio recibido de forma individual y proporcionado por profesionales sanitarios con impacto en el estado de salud. Es sinónimo de asistencia sanitaria. Toda referencia al ámbito «asistencial» que se hace a lo largo de la presente ley se entiende referida a la asistencia sanitaria.

5. Autoridad sanitaria: el órgano de la administración pública que tiene asignadas por la legislación vigente competencias o funciones de ordenación, regulación, inspección, control o sanción en el ámbito sanitario o de la salud.

6. Autorización sanitaria: la resolución administrativa que, según los requerimientos que se establezcan, faculta a un centro, servicio o establecimiento sanitario para su instalación, funcionamiento, modificación de sus actividades sanitarias o, en su caso, su cierre.

7. Cartera de servicios: el conjunto de técnicas, tecnologías o procedimientos, entendiendo por tales cada uno de los métodos, actividades y recursos basados en el conocimiento y la experimentación científica, mediante los que se hacen efectivas las prestaciones sanitarias.

8. Catálogo de prestaciones sanitarias: los servicios o conjunto de servicios preventivos, diagnósticos, terapéuticos, rehabilitadores y de promoción y mantenimiento de la salud de la ciudadanía cuyo objeto es garantizar las condiciones básicas y comunes para una atención integral, continuada y en el nivel adecuado de atención.

9. Centro sanitario: el conjunto organizado de medios técnicos e instalaciones en que profesionales capacitados, por su titulación oficial o habilitación profesional, realizan básicamente actividades sanitarias a fin de mejorar la salud de las personas.

10. Establecimiento sanitario: el conjunto organizado de medios técnicos e instalaciones en que profesionales capacitados, por su titulación oficial o habilitación profesional, realizan básicamente actividades sanitarias de dispensación de medicamentos o de adaptación individual de productos sanitarios.

11. Función de producción/provisión de servicios: las actividades que permiten la producción y oferta de servicios sanitarios.

12. Intervención sanitaria: una actividad o conjunto de actividades que intentan, modificando un proceso, el curso de acción o la secuencia de eventos, mejorar el resultado esperado en salud, referido siempre a un aspecto previamente determinado.

13. Paciente: la persona que requiere asistencia sanitaria y está sometida a cuidados profesionales para el mantenimiento o la recuperación de su salud.

14. Sanidad: el conjunto de servicios públicos ordenados para preservar la salud del común de los habitantes de un territorio administrativo. Sinónimo de sistema sanitario o sistema de salud cuando éste sea definido como público.

15. Salud pública: el conjunto de iniciativas, actividades y servicios organizados por las administraciones públicas para mejorar la salud de la población mediante 
intervenciones colectivas o sociales. Las intervenciones colectivas o sociales son aquéllas cuyo objetivo es la identificación y modificación, en su caso, de los factores protectores y de riesgo para la salud que evitan o condicionan la aparición de morbilidad, mortalidad prematura y discapacidad.

16. Salud: el estado de la persona que le permite realizar las funciones vitales y sociales propias de su edad, adaptarse y superar dificultades de forma socialmente aceptable y personalmente satisfactoria. Este concepto incluye, por tanto, los aspectos físicos, psíquicos y sociales.

17. Sector privado de atención sanitaria: el conjunto de actividades y agentes económicos cuyas características homogéneas son la elaboración y prestación de productos y servicios sanitarios y cuya titularidad es privada.

18. Servicios sanitarios: cualquier servicio que pueda contribuir a mejorar la salud o a diagnosticar, tratar o rehabilitar a una persona, y no necesariamente limitado a servicios médicos o servicios de atención sanitaria. Se entienden también como organizaciones destinadas a vigilar y proteger la salud de la ciudadanía.

19. Sistema de Salud de Galicia: el conjunto de recursos, actividades, servicios y prestaciones, públicos y privados, cuya finalidad es la promoción y protección de la salud, la prevención de la enfermedad, la asistencia sanitaria, la rehabilitación y la reinserción social, todo ello bajo una perspectiva de asistencia sanitaria integral y funcionalmente articulada.

20. Sistema Público de Salud de Galicia: el conjunto de recursos, medios organizativos, actividades, servicios y prestaciones públicas cuya finalidad es la promoción y protección de la salud, la prevención de la enfermedad, la asistencia sanitaria, la rehabilitación y la reinserción social, todo ello bajo una perspectiva de asistencia sanitaria integral y funcionalmente articulada.
21. Sostenibilidad: la capacidad de responder a las necesidades presentes sin comprometer la posibilidad de responder a las necesidades futuras.

22. Usuario/Usuaria: la persona que utiliza los servicios sanitarios.

\section{TÍTULO I \\ DE LOS DERECHOS Y DEBERES SANITARIOS DE LA CIUDADANÍA \\ Capitulo I \\ DISPOSICIONES GENERALES}

Artículo 4. Titulares del derecho a la protección de la salud y a la atención sanitaria.

1. El derecho a la protección de la salud y a la atención sanitaria con cargo a fondos públicos en el ámbito de la Comunidad $\mathrm{Au}$ tónoma de Galicia y de cobertura universal se garantiza a todas las personas que residan en los municipios de esta comunidad autónoma. A los transeúntes en el territorio de la comunidad se les garantizarán en la forma y condiciones que establezca la legislación vigente, el derecho comunitario y europeo y los convenios nacionales o internacionales que resulten de aplicación, así como a todos los gallegos y gallegas de origen o ascendencia que, residiendo fuera de Galicia, se vean amparados por los convenios al efecto, en la manera y condiciones establecidas en los mismos.

2. Igualmente, se garantiza la protección de la salud y la atención sanitaria con cargo a fondos públicos a las personas menores y las mujeres gestantes no incluidas en el apartado 1 del presente artículo.

3. Además, se garantiza a todas las personas la atención sanitaria en situación de urgencia y emergencia.

4. Este derecho se garantiza con pleno respeto a su personalidad, dignidad e intimidad, sin ninguna discriminación por razón de raza, sexo, religión, opinión, idioma, ideología o cualquier otra condición o circunstancia personal o social. 


\section{Capitulo II DERECHOS SANITARIOS}

Artículo 5. Derechos sanitarios. Los titulares del derecho a la protección de la salud y a la asistencia sanitaria disfrutarán de los derechos sanitarios que se recogen en el presente capítulo, sin perjuicio de la aplicación y reconocimiento de los definidos en la Ley 14/1986, general de sanidad, así como en otras leyes sanitarias de ámbito estatal que sean de aplicación.

Artículo 6. Derechos relacionados con la integridad e intimidad de la persona.

Serán derechos sanitarios relacionados con la integridad e intimidad de la persona los siguientes:

1. Derecho a la integridad física y psíquica.

2. Derecho al máximo respeto posible de la intimidad de la persona, en todos los centros, servicios y establecimientos sometidos a la presente ley, en la prestación de actividades sanitarias tales como exploraciones, cuidados o actividades de higiene.

3 . Derecho a que se reduzca la presencia de profesionales, estudiantes e investigadores, o de otros usuarios, que no colaboren directamente en la realización de tales atenciones, cuando así sea expresamente solicitado.

4. Derecho a no ser grabada mediante fotografías, vídeos u otros medios que permitan su identificación como destinatarios de servicios sanitarios, excepto que la persona afectada, una vez que le sean explicados claramente los motivos de su realización y el ámbito de difusión, preste autorización expresa para ello.

Artículo 7. Derechos relacionados con el acompañamiento del o la paciente.

1. Serán derechos relacionados con el acompañamiento del o la paciente los siguientes:

1. Derecho a ser acompañado o acompañada, al menos, por una persona que mantenga vínculos familiares o de hecho con el o la paciente o una persona de su confianza.
2. Derecho de toda mujer a que se le facilite el acceso al proceso del parto a aquella persona designada por ella al efecto.

3. Derecho de las personas menores a estar acompañadas por sus padres, tutores o guardadores.

4. Derecho de las personas incapacitadas a estar acompañadas por los responsables legales de su guarda y protección.

2. Los derechos anteriormente citados se limitarán, e incluso se exceptuarán, en los casos en que esas presencias sean desaconsejadas o incompatibles con la prestación sanitaria conforme a criterios clínicos. En todo caso, esas circunstancias serán explicadas a los afectados y afectadas de manera comprensible.

Artículo 8. Derechos relacionados con la autonomía de decisión.

Serán derechos relacionados con la autonomía de decisión los siguientes:

1. Derecho a que se solicite consentimiento informado en los términos establecidos en la Ley $3 / 2001$, de 28 de mayo, y en la Ley $3 / 2005$, de 7 de marzo, de modificación de la anterior. Se entenderá por consentimiento informado el prestado libre y voluntariamente por la persona afectada para toda actuación en el ámbito de su salud y una vez que, recibida la información adecuada, hubiera valorado las opciones propias del caso. El consentimiento será verbal, por regla general, prestándose por escrito en los casos de intervenciones quirúrgicas, procedimientos diagnósticos y terapéuticos invasores y, en general, en la aplicación de procedimientos que supongan riesgos o inconvenientes de notoria y previsible repercusión negativa sobre la salud del o la paciente.

2. Derecho a la libre elección entre las opciones que le presente el responsable médico de su caso y a rechazar el tratamiento, excepto en los casos señalados en ésta u otras leyes, debiendo para ello solicitar y firmar el alta voluntaria. Si no lo hiciera así, corresponderá darle el alta a la dirección del centro. Todo esto 
sin perjuicio de que el o la paciente pueda recibir otros tratamientos alternativos, curativos o paliativos y sanitarios.

3. Derecho a otorgar el consentimiento por sustitución y a manifestar sus instrucciones previas al amparo de lo establecido en la Ley $3 / 2001$, de 28 de mayo, y en la Ley $3 / 2005$, de 7 de marzo, de modificación de la anterior, y disposiciones concordantes.

4. Derecho a elegir médico general y pediatra de entre los que presten sus servicios en la zona sanitaria de su lugar de residencia en conformidad con las normas reglamentarias que resulten de aplicación.

5. Derecho a una segunda opinión médica con el objetivo de fortalecer la relación médico-paciente y complementar las posibilidades de la atención sanitaria.

6. Derecho a disponer de los tejidos y muestras biológicas que provienen de biopsias o extracciones en su proceso asistencial, con la finalidad de conseguir una segunda opinión médica y garantizar la continuidad asistencial.

7. Derecho a rechazar aquellas acciones preventivas que se propongan, para situaciones que no impliquen riesgos a terceros, sin perjuicio de lo dispuesto en la normativa sanitaria de aplicación.

8. Derecho a rechazar la participación en procedimientos experimentales como alternativa terapéutica para su proceso asistencial.

9. Derecho a rechazar el uso o conservación, fuera de su proceso asistencial, de sus tejidos y muestras biológicas que provengan de biopsias, extracciones o nacimientos $\mathrm{y}$, por tanto, derecho a que se proceda a su eliminación como residuo sanitario.

Artículo 9. Derechos relacionados con la confidencialidad e información.

1. El derecho a la confidencialidad se concreta en:

a. Derecho a la confidencialidad sobre su estado de salud, de sus datos referidos a creencias, religión, ideología, vida sexual, origen racial o étnica, malos tratos $\mathrm{y}$ otros datos especialmente protegidos. En todo caso, el grado de confidencialidad, entendido como la identificación del destinatario y el contenido de la información que puede suministrarse, será decidido por el o la paciente, excepto en los casos en que legalmente se contemple el deber de información.

b. Derecho a la confidencialidad de la información de su genoma y que éste no pueda ser utilizado para ninguna forma de discriminación.

Los datos personales a que se refiere este apartado 1 se someterán al régimen de protección establecido en la Ley orgánica 15/1999, de 13 de diciembre, de protección de datos de carácter personal.

2. El derecho a la información en su proceso asistencial se concreta en:

a. Derecho a conocer, con motivo de cualquier actuación en el ámbito de su salud, toda la información disponible sobre la misma, salvo en los supuestos exceptuados por la ley. La información, como regla general, se proporcionará verbalmente, dejando constancia en la historia clínica, y comprenderá, como mínimo, la finalidad y naturaleza de cada intervención, sus riesgos y consecuencias. La información clínica será verdadera y se comunicará al o a la paciente de forma comprensible y adecuada a sus necesidades como ayuda para tomar decisiones de acuerdo con su propia y libre voluntad.

b. Derecho a renunciar a recibir información.

c. Derecho a ser informado o informada y advertido o advertida acerca de si los procedimientos de pronóstico, diagnóstico y terapéuticos aplicados van a ser empleados en un proyecto docente o de investigación, lo que en ningún caso podrá comportar peligro adicional para su salud. En todo caso, será imprescindible el consentimiento previo por escrito del o la paciente y la aceptación por parte del profesional sanitario y de la dirección del correspondiente centro sanitario. 
d. Derecho a solicitar y a obtener información comprensible y adecuada sobre el coste de las prestaciones y servicios de salud recibidos.

e. Derecho a conocer los requisitos de uso de las prestaciones y servicios de salud en relación a su proceso asistencial.

3. El derecho a la información sobre sus derechos, deberes, servicios y programas del Sistema Público de Salud de Galicia se concreta en:

a. Derecho a ser informado o informada de los planes, programas y acciones que se están desarrollando en el Sistema Público de Salud de Galicia, de forma comprensible y mediante los mejores cauces.

b. Derecho a disponer en todos los centros, servicios y establecimientos sanitarios del sistema público de una carta de derechos y deberes, y a que ésta sea facilitada como marco de relación entre el centro sanitario y sus usuarios y usuarias.

c. Derecho a conocer la cartera de servicios como marco de compromiso entre el centro sanitario y sus usuarios y usuarias.

4. Derecho a ser informado o informada por la autoridad sanitaria de los problemas de salud que le afecten y sobre los riesgos sanitarios para su salud, mediante información difundida en términos comprensibles, veraces y adecuados.

5. Derecho a recibir información epidemiológica ante un riesgo grave y probado para la salud pública.

6. Derecho a la utilización de nuevas tecnologías de la información y comunicación para potenciar la interacción electrónica entre la ciudadanía y el Sistema Público de Salud.

7. Para garantizar la confidencialidad de los datos relativos al o la paciente, mediante una norma legal se regulará el personal que pueda acceder a los datos del o la paciente.

8. Para garantizar la mejor información sobre la historia clínica del o la paciente, teniendo en cuenta las nuevas tecnologías, los datos de la misma estarán disponibles en tres idiomas (gallego, castellano e inglés), haciendo para ello las adaptaciones técnicas necesarias.

Artículo 10. Derechos relacionados con la documentación sanitaria.

Son derechos relacionados con la documentación sanitaria:

1. Derecho del o la paciente a que quede constancia por escrito o en soporte técnico apropiado de todo su proceso y que al finalizar el episodio asistencial se le entregue el informe de alta hospitalaria, de interconsulta de atención especializada $\mathrm{y}$ de urgencias.

2. Derecho a acceder a su historia clínica y a obtener los informes y resultados de las exploraciones que sobre su estado de salud o enfermedad se incluyan en la misma, así como una copia de dichos documentos, de acuerdo con lo establecido en la Ley 3/2001, de 28 de mayo, del consentimiento informado y de la historia clínica de los pacientes, y disposiciones concordantes.

3. Derecho a que se le faciliten los informes o certificaciones acreditativos de su estado de salud. Éstos serán gratuitos, cuando así lo establezca una disposición legal o reglamentaria.

Artículo 11. Derechos relacionados con las sugerencias y reclamaciones.

Son derechos relacionados con las sugerencias y reclamaciones:

1. Derecho a emplear los procedimientos ágiles y efectivos de sugerencias y reclamaciones, así como a recibir respuesta por escrito en los plazos establecidos reglamentariamente.

2. Derecho al libre acceso al vicevaledor o vicevaledora del paciente.

3. Se desarrollarán las medidas necesarias para que todos los centros, servicios y establecimientos sanitarios y sociosanitarios tengan permanentemente a disposición de los usuarios y usuarias formularios de sugerencias y reclamaciones, estando al mismo tiempo habilitados cauces en la web institucional. 
Artículo 12. Derechos relacionados con la prestación de servicios sanitarios por parte del Sistema Público de Salud de Galicia.

Son derechos relacionados con la prestación de servicios sanitarios:

1. Derecho a la humanización de la asistencia sanitaria evidenciada en la calidad humana de la prestación de los servicios sanitarios y a la incorporación de los adelantos científicos a la misma, que habrá de ser adecuada a los valores, creencias y culturas de la ciudadanía.

2. Derecho a obtener una garantía de demoras máximas, de modo que determinadas prestaciones sanitarias financiadas públicamente les sean dispensadas en unos plazos previamente definidos y conocidos.

3. Derecho a obtener los medicamentos y productos sanitarios que se consideren necesarios para promover, conservar o restablecer su salud.

4. Derecho a la utilización de las ventajas de las nuevas tecnologías genómicas dentro del marco legal vigente.

5. Derecho a la asignación de personal facultativo, quien será su interlocutor principal con el equipo asistencial, y, en su caso, del personal de enfermería responsable del seguimiento y plan de cuidados. En el caso de ausencia, las personas sustitutas asumirán tal responsabilidad.

6. Derecho a la educación sanitaria y a la información adecuada que propicien la adopción de hábitos y estilos de vida saludables.

7. Derecho a medidas de protección de la salud frente a riesgos ambientales y laborales, generales o específicos.

8. Derecho a medidas de prevención de la enfermedad de probada efectividad y seguridad.

9. Derecho a la continuidad asistencial, a la coordinación y a la integración de las funciones asistenciales de la atención primaria y especializada.

10. Derecho a conocer e identificar, de forma rápida y clara, el personal que le presta asistencia sanitaria. Para la eficacia de este derecho, el personal que preste dicha asistencia llevará siempre visible su tarjeta identificativa.

11. Derecho de las mujeres en los periodos de embarazo, lactación y menopausia a disponer de programas específicos.

12. Derecho de las mujeres que sufren o hayan sufrido violencia de género a la atención sanitaria, incluido el derecho a asistencia psicológica gratuita y al seguimiento de la evolución de su estado de salud, hasta su total restablecimiento. Se tratará, en todo caso, de servicios gratuitos y accesibles con carácter prioritario, que garanticen la privacidad e intimidad de las mujeres.

13. Derecho de las mujeres a la interrupción voluntaria del embarazo, en todos los supuestos contemplados por la normativa vigente de aplicación.

14. Derecho a que los servicios y actividades sanitarias o asistenciales que el Sistema Público de Salud de Galicia contrate con el sector privado de asistencia sanitaria se ajusten a los mismos parámetros, estándares, derechos o criterios de actuación exigibles para los del propio Sistema Público de Salud de Galicia.

Artículo 13. Derechos relacionados con la participación.

La ciudadanía de la Comunidad Autónoma de Galicia tendrá derecho a participar, en los términos establecidos en la presente ley, en la gestión del Sistema Público de Salud de Galicia, a través de los órganos de participación comunitaria.

Artículo 14. Derechos relacionados con grupos especiales.

1. Las personas menores, las mayores dependientes, las enfermas mentales y terminales, las enfermas que padecen enfermedades crónicas y discapacitantes, los y las pacientes diagnosticados de enfermedades raras o de baja incidencia en la población y las personas pertenecientes a grupos de riesgo, en tanto que colectivos que deben ser objeto de especial atención 
por las administraciones sanitarias competentes, tienen derecho a actuaciones y/o programas sanitarios específicos y preferentes, los cuales se ejecutarán a través de los centros, servicios y establecimientos del Sistema Público de Salud de Galicia.

2. Las personas enfermas mentales, además de los derechos señalados en los apartados anteriores, disfrutan de los derechos siguientes:

a. En los ingresos voluntarios, si desapareciera la plenitud de facultades durante el internamiento, a que la dirección del centro solicite la correspondiente ratificación judicial para su continuación, en los términos establecidos en el artículo 763 de la Ley de enjuiciamiento civil.

b. En los ingresos forzosos, el derecho a que se reexamine periódicamente la necesidad del internamiento, en los términos del precepto a que se refiere la letra anterior.

c. La personas enfermas mentales menores de edad tienen derecho al internamiento en centros o unidades de salud mental infanto-juvenil.

3. A las personas enfermas terminales, además de los derechos señalados en el apartado 1, se les reconocen los derechos siguientes:

a. Al rechazo de tratamientos de soporte vital que prolonguen sin necesidad su sufrimiento.

b. Al adecuado tratamiento del dolor y cuidados paliativos.

c. A la posibilidad de decidir la presencia de personas con las que mantenga vínculos familiares o de hecho en los procesos que requieran hospitalización.

4. Las personas menores y las dependientes que vivan o padezcan situaciones de violencia de género tendrán derecho a asistencia psicológica gratuita, que comprenderá medidas de apoyo psicosocial específicas y adaptadas a sus características y necesidades.

5. A las personas con discapacidad les será de aplicación lo previsto en el artículo 25, apartados b), c), d) y f), de la
Convención de derechos de las personas con discapacidad, ratificada por España el 30 de marzo de 2007.

6. Accesibilidad universal. Conforme a lo previsto en la Ley 51/2003, de 2 de diciembre, de igualdad de oportunidades, no discriminación y accesibilidad universal de las personas con discapacidad, así como en el artículo 9 de la Convención de la Organización de las Naciones Unidas-ONU, se garantiza el acceso de las personas con discapacidad, en igualdad de condiciones con las demás, a las instalaciones y servicios sanitarios, de acuerdo con los principios de normalización, accesibilidad universal, diseño para todos y transversalidad.

\section{Capitulo III DEBERES SANITARIOS}

Artículo 15. Deberes.

La ciudadanía, en relación con las instituciones y organismos del Sistema Público de Salud de Galicia, tiene los deberes y obligaciones individuales siguientes:

1. Cumplir las prescripciones generales de naturaleza sanitaria comunes a toda la población, así como las específicas determinadas por los servicios sanitarios.

2. Mantener el debido respeto al personal que presta sus servicios en el ámbito del sistema público.

3. Cuidar las instalaciones y colaborar en el mantenimiento de la habitabilidad de las instituciones sanitarias.

4. Usar adecuadamente los recursos, servicios y prestaciones ofrecidas por el sistema sanitario.

5. Mantener la debida observancia de las normas establecidas en cada centro.

6. Firmar los documentos de alta voluntaria cuando no desee la continuidad del tratamiento que se le dispensa. No obstante, el hecho de no aceptarla no determinará el alta inmediata cuando existan otros tratamientos alternativos, curativos o paliativos y el o la paciente desee recibirlos. En este último caso, tal 
situación habrá de quedar debidamente documentada después de la información correspondiente.

7. Cooperar con las autoridades sanitarias en la protección de la salud y la prevención de las enfermedades.

8. Facilitar información veraz de los datos de filiación, identificación y del estado de salud que sean necesarios en su proceso asistencial o sean solicitados por razones de interés general debidamente motivadas.

9. Aceptar el alta cuando hubiera terminado su proceso asistencial, cuando se hubiera comprobado que la situación clínica del o la paciente no mejoraría prolongando su estancia o cuando la complejidad del proceso aconseje su traslado a un centro de referencia.

10. Cumplir las normas y procedimientos de uso y acceso a los derechos que se le otorguen a través de la presente ley.

11. Comunicar al sistema sanitario, a la mayor brevedad posible, la no utilización por cualquier causa de un servicio programado previamente.

12. También estarán sujetos a los deberes establecidos en los apartados 1, 2, 3, 4, 5, 7 y 10 las personas familiares o acompañantes de los usuarios y usuarias del sistema sanitario.

\section{Capitulo IV}

\section{GARANTÍA DE LOS DERECHOS Y DEBERES SANITARIOS}

Artículo 16. Garantías normativas y de organización.

1. El Estatuto del o la paciente, entendido como el conjunto de derechos y deberes relatados en los artículos precedentes, se definirá y concretará mediante normas e instrumentos jurídicos que regulen su alcance, desarrollo y contenido.

2. Las actuaciones que se adopten en desarrollo del estatuto jurídico del o la paciente irán dirigidas a:

a. Disponer de los cauces de información suficientes, adecuados y comprensibles sobre los derechos, deberes y garantías sanitarias.

b. Velar por el efectivo cumplimiento de los derechos, deberes y garantías sanitarias según dispongan las leyes, normas y reglamentos que los desarrollen, garantizando además la eliminación de cualquier tipo de desigualdad.

c. Adoptar las medidas organizativas, de gestión y de comunicación que fomenten la satisfacción de la ciudadanía respecto a un sistema sanitario orientado a ella.

d. Establecer mecanismos de arbitraje y conciliación.

3. Las infracciones por violaciones de estos derechos y el incumplimiento de los deberes estarán sometidos al régimen sancionador previsto en la presente ley, sin perjuicio de la responsabilidad de cualquier orden en que pudiera incurrir su autor o autora según la legislación vigente.

4. Todos los centros, servicios y establecimientos y su personal sometidos a la presente ley tienen la obligación de adoptar las medidas oportunas para garantizar los derechos reconocidos en la misma. Los poderes públicos de Galicia velarán por su adecuado cumplimiento.

5. Las autoridades sanitarias proporcionarán información pública de cada área sobre indicadores de calidad de los servicios, coberturas de programa, listas de espera y eficiencia de los procesos del Sistema Público de Salud de Galicia.

Artículo 17. Garantías de sostenibilidad.

El desarrollo normativo y organizativo de los derechos sanitarios tendrá en cuenta los principios de:

a. Optimización de la eficiencia en costes de todos sus niveles orgánicos y asistenciales.

b. Sostenibilidad financiera del sistema sanitario en su conjunto y de manera integral, teniendo en cuenta aspectos como la dispersión, el envejecimiento y la comorbilidad de la población. 


\section{Capitulo V \\ DE LA DEFENSA Y PROMOCIÓN DE LOS DERECHOS DE LOS USUARIOS Y USUARIAS DEL SISTEMA PÚBLICO DE SALUD DE GALICIA}

Artículo 18. Objeto y naturaleza.

Las atribuciones del Valedor do Pobo con relación a la Administración sanitaria serán ejercidas a través de uno de sus vicevaledores o vicevaledoras designado o designada por aquél.

La persona designada tendrá la consideración de vicevaledor o vicevaledora del paciente, teniendo atribuida la defensa y promoción de los derechos e intereses de los usuarios y usuarias del Sistema Público de Salud de Galicia, bajo la supervisión del Valedor do Pobo.

Artículo 19. Ámbito de actuación.

Las actuaciones del vicevaledor o vicevaledora del paciente, como dependiente del Valedor do Pobo, tendrán como ámbito el territorio de la Comunidad Autónoma de Galicia.

Habida cuenta el peso de la emigración en nuestra comunidad autónoma, el ámbito de actuación del vicevaledor o vicevaledora del paciente comprenderá también a aquellos centros sanitarios e instituciones que tengan una relación contractual o de convenio con la Xunta de Galicia, aunque se encuentren fuera de la comunidad.

Artículo 20. Actuaciones.

1. En el ejercicio de sus atribuciones el Valedor do Pobo, directamente o a través del vicevaledor o vicevaledora del paciente, podrá iniciar y proseguir de oficio, o a petición de parte, cualquier investigación que conduzca al esclarecimiento de los actos y resoluciones de la administración relacionados con los servicios sanitarios y sociosanitarios.

2. Podrá dirigir sugerencias o reclamaciones, en ese aspecto, a la oficina del Valedor do Pobo, directamente o a través del vicevaledor o vicevaledora del paciente, toda persona natural o jurídica que invoque un interés legítimo con relación a situaciones de lesión de los derechos de los pacientes reconocidos en la presente ley.

3. Se excluye de lo dispuesto en el apartado anterior a la autoridad administrativa en asuntos de su competencia, excepto cuando ejerza como responsable directo de una persona menor de edad o incapacitada legalmente en su condición de usuaria.

Artículo 21. Facultades.

El valedor o valedora do pobo, sea directamente o sea a través del vicevaledor o vicevaledora del paciente, tendrá acceso directo a cualquier centro sanitario o de carácter administrativo de la comunidad autónoma y, con sujeción a la normativa de protección de datos, a cualquiera de sus archivos y registros.

\section{Capítulo VI PARTICIPACIÓN SOCIAL}

Artículo 22. Aspectos generales.

1. Con arreglo a lo establecido en los artículos 9.2 y 129.1 de la Constitución española y en los artículos 5 y 53 de la Ley 14/1986, general de sanidad, así como en el artículo 13 de la presente ley, la ciudadanía de la Comunidad Autónoma gallega tiene el derecho a participar, a través de los órganos de participación comunitaria, en la gestión del Sistema Público de Salud de Galicia, en las cuestiones que afecten directamente a la calidad de vida o al bienestar general y, en concreto, en la formulación de la política sanitaria y el control de su ejecución.

2. La participación en la formulación de la política sanitaria y en el control de su ejecución constituye un derecho de la ciudadanía y de la sociedad en general, un valor social y un instrumento de cooperación e información en el ámbito del Sistema Público de Salud de Galicia, para la mejora de la salud y el bienestar de la ciudadanía.

3. Las distintas organizaciones que componen el Sistema Público de Salud 
de Galicia deberán incorporar sistemáticamente la visión y percepción de la sociedad en la elaboración de normativas, políticas y planes de actuación sanitaria.

4. El derecho de participación supone la responsabilidad en su ejercicio y obliga a actuar con lealtad al interés general, al bien público y a la promoción del bienestar social.

Artículo 23. Órganos y fórmulas de participación social.

1. La presente ley prevé como órgano de participación comunitaria el Consejo Gallego de Salud y, en el ámbito de cada área sanitaria, los consejos de salud de área.

2. Estos órganos desarrollarán funciones consultivas y de asesoramiento en el planteamiento de planes y objetivos generales en el ámbito territorial respectivo, así como en el seguimiento y evaluación de los resultados de ejecución.

3. La presente ley prevé otras fórmulas de participación social e individual tales como las comisiones de participación ciudadana y el voluntariado.

4. Los miembros de los órganos de participación tendrán derecho a la información relativa a las materias sobre las que tengan competencia, con acceso y consulta, en cualquier momento y en un tiempo razonable, de datos o documentos disponibles por la administración de la que dependa el órgano consultivo.

Artículo 24. Consejo Gallego de Salud.

1. El Consejo Gallego de Salud es el principal órgano colegiado de participación comunitaria en el Sistema Público de Salud de Galicia al que corresponde el asesoramiento a la Consellería de Sanidad de la Xunta en la formulación de la política sanitaria y el control de su ejecución.

2. La persona titular de la presidencia del Consejo Gallego de Salud es la titular de la Consellería de Sanidad.

3. El Consejo Gallego de Salud se compone de los vocales siguientes: a. Seis vocales en representación de la Administración sanitaria de la Xunta, designados por la persona titular de la Consellería de Sanidad.

b. Doce vocales en representación de la ciudadanía, a través de las entidades locales.

c. Nueve vocales en representación de las organizaciones sindicales más representativas de la Comunidad Autónoma de Galicia.

d. Nueve vocales en representación de las organizaciones empresariales más representativas de la Comunidad Autónoma de Galicia.

e. Cuatro vocales en representación de las organizaciones de consumidores y usuarios.

f. Seis vocales en representación de los colegios profesionales sanitarios.

g. Dos vocales en representación de las reales academias radicadas en Galicia y cuyos fines se relacionen directamente con las ciencias de la salud.

h. Un representante por cada una de las universidades públicas.

i. Cuatro vocales en representación de las asociaciones de pacientes y familiares más representativas.

j. Dos representantes de las asociaciones vecinales gallegas.

4. Por decreto de la Xunta de Galicia se determinarán los sistemas de asignación de representantes de entre las distintas organizaciones y entidades representadas en el Consejo Gallego de Salud, así como los mecanismos para su designación, y las normas generales de organización y funcionamiento. La representación de las organizaciones sindicales y empresariales se fijará tomando en consideración los criterios señalados en el artículo 28 de la presente ley.

5. Los miembros del Consejo Gallego de Salud son nombrados y separados del cargo por la persona titular de la Consellería de Sanidad, a propuesta de cada una de las representaciones que lo componen. 
El nombramiento se hará por un periodo máximo de cuatro años, sin perjuicio de que las personas interesadas puedan ser reelegidas sucesivamente, siempre que cuenten con la representación requerida.

6. Son funciones del Consejo Gallego de Salud:

a. Conocer las directrices de la política sanitaria de Galicia aprobadas por el Consejo de la Xunta y su evaluación.

b. Conocer y emitir informe sobre el anteproyecto del Plan de salud y ser informado de su evaluación.

c. Conocer y ser informado de los contratos de servicios sanitarios, conciertos y programas de subvenciones así como de la evaluación del informe del seguimiento relativo a los mismos.

d. Conocer y emitir informe sobre el anteproyecto de memoria anual del Sistema Público de Salud de Galicia.

e. Conocer y ser informado del proyecto de presupuesto de la Consellería de Sanidad y del Servicio Gallego de Salud.

f. Conocer e informar de las prestaciones sanitarias y de la cartera de servicios del Sistema Público de Salud de Galicia.

g. Proponer aquellas medidas de carácter sanitario que contribuyan a elevar el nivel de salud de la población.

h. Emitir, a solicitud de la Administración sanitaria de la Xunta o a iniciativa propia, informes o dictámenes en materia de legislación y política sanitaria general.

i. Elaborar y aprobar su reglamento de funcionamiento interno.

7. En la composición de este órgano se procurará una composición paritaria de mujeres y hombres.

Artículo 25. Participación territorial. Los consejos de salud de área.

1. Los consejos de salud de área son los órganos colegiados de naturaleza consultiva a través de los cuales se articula la participación comunitaria en el terreno de las áreas sanitarias.

2. Los consejos de salud de área están integrados por la representación de las entidades y organizaciones siguientes: a. Entidades locales comprendidas en el área sanitaria.

b. Agrupaciones o federaciones de asociaciones vecinales con actuación en el ámbito del área sanitaria.

c. Organizaciones empresariales intersectoriales más representativas de la Comunidad Autónoma de Galicia.

d. Organizaciones sindicales más representativas de la Comunidad Autónoma de Galicia.

e. El director o directora del área sanitaria correspondiente, los gerentes de los dispositivos, centros y establecimientos del Servicio Gallego de Salud comprendidos en el área sanitaria y, en su caso, los representantes de los equipos directivos de los citados dispositivos, centros y establecimientos.

f. La persona responsable del área de salud pública.

g. Un representante de la Conselljería de Sanidad.

h. Asociaciones de pacientes.

3. Por orden de la persona titular de la Consellería de Sanidad se determinarán la composición de los consejos de salud de área y los sistemas de asignación de representantes de entre las distintas organizaciones y entidades representadas en su seno, así como los mecanismos para su designación.

4. Los miembros de los consejos de salud de área son nombrados y separados del cargo por la persona titular de la Consellería de Sanidad, a propuesta de cada una de las representaciones que lo componen. El nombramiento se hará por un periodo máximo de cuatro años, sin perjuicio de que las personas interesadas puedan ser reelegidas sucesivamente, siempre que cuenten con la representación requerida.

5. Son funciones de los consejos de salud de área, en el ámbito del área sanitaria respectiva:

a. Proponer a los órganos de dirección del área aquellas medidas de carácter sanitario que contribuyan a elevar el nivel de salud de la población. 
b. Conocer y emitir informe sobre el anteproyecto del Plan de salud o documento estratégico del área sanitaria y ser informados de su evaluación.

c. Conocer la memoria anual del área sanitaria, a los efectos del seguimiento, y la evaluación de la gestión.

d. Conocer y ser informados de los contratos de servicios sanitarios, conciertos y programas de subvención hechos en el área.

e. Proponer medidas dirigidas a mejorar la gestión sanitaria.

6. Por orden de la persona titular de la Consellería de Sanidad se establecerán las normas generales de organización y funcionamiento de los consejos de salud de área.

7. En la composición de estos órganos se procurará una composición paritaria de mujeres y hombres.

Artículo 26. Otras formas de participación social: las comisiones de participación ciudadana.

1. Por orden de la persona titular de la Consellería de Sanidad podrán establecerse órganos de participación comunitaria a otros niveles territoriales y funcionales del Sistema Público de Salud de Galicia con la finalidad de asesorar a los correspondientes órganos directivos e implicar a las organizaciones sociales y ciudadanas en el objetivo de conseguir mayores niveles de salud.

2. Corresponde a la persona titular de la Consellería de Sanidad, mediante orden, regular la composición y establecer las normas generales de organización y funcionamiento de los órganos a que se refiere el apartado anterior.

3. Estos órganos de participación podrán incluir, además del personal y de los representantes de equipo directivo que se considere, entre otros, representantes de los colegios profesionales sanitarios, sociedades científicas, asociaciones, entidades locales y consumidores y usuarios, así como personas físicas y jurídicas de reconocido prestigio en el campo de las ciencias de la salud.
4. En la composición de estos órganos se procurará una composición paritaria de mujeres y hombres.

Artículo 27. Del voluntariado.

1. Sin perjuicio de lo dispuesto en la Ley $3 / 2000$, de 22 de diciembre, de voluntariado social de Galicia, y en la Ley 3/2003, de 19 de junio, de cooperación para el desarrollo, o en otras normas sectoriales, en el ámbito estrictamente sanitario podrá reconocerse la colaboración desinteresada, individual o colectiva, dentro del Sistema Sanitario Público de Salud de Galicia, entendida como la expresión de un compromiso libre y altruista con la sociedad, que se desarrolla individualmente o dentro del marco de aquellas organizaciones sociales cuyo objetivo sea la mejora de la calidad de vida, que no tengan afán de lucro y que estén integradas principalmente por voluntarios y voluntarias o cooperantes.

2. El departamento de la Xunta de Galicia competente en materia de voluntariado facilitará la colaboración y cooperación con el Sistema Público de Salud de Galicia, habilitando los cauces necesarios para que las aportaciones desinteresadas, individuales o colectivas, puedan ser efectivas.

3. Se excluye de aquella colaboración y cooperación el ejercicio de funciones o tareas propias de los empleados públicos.

4. La colaboración de las organizaciones de voluntarios y voluntarias o cooperantes con las organizaciones sanitarias adscritas o vinculadas a la Consellería de Sanidad podrá instrumentarse, en su caso, a través de convenios, conciertos, programas de subvenciones, etc., de conformidad con la naturaleza de la colaboración que pretenda establecerse. Ninguna colaboración, individual o colectiva, implicará relación laboral con la Administración sanitaria.

5. Reglamentariamente se establecerán los supuestos y condiciones bajo los que el personal que preste servicios en el Sistema Público de Salud de Galicia podrá prestar servicios como voluntario o cooperante, de conformidad con la normativa vigente.

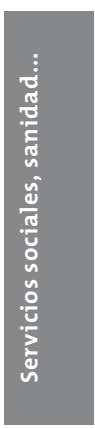




\section{Capítulo VII \\ PARTICIPACIÓN INSTITUCIONAL DE LAS ORGANIZACIONES SINDICALES Y EMPRESARIALES MÁS REPRESENTATIVAS DE GALICIA}

Artículo 28. Foro de Participación Institucional de Sanidad.

1. Conforme a lo establecido en la normativa vigente en materia de participación institucional de las organizaciones sindicales y empresariales, el Foro de Participación Institucional de Sanidad se configura como el marco de la participación institucional de las organizaciones sindicales y empresariales intersectoriales gallegas más representativas.

2. A los efectos de lo que se dispone en la presente ley, se entiende por participación institucional el ejercicio de tareas y actividades de promoción y defensa en el seno de la Administración autonómica, sus organismos y empresas públicas de los intereses generales, comunes, sectoriales e intersectoriales que corresponden a todos los trabajadores y trabajadoras y a los empresarios y empresarias.

3. El Foro de Participación Institucional de Sanidad estará conformado, bajo el criterio de proporcionalidad en relación a su representatividad, por las organizaciones sindicales y empresariales intersectoriales más representativas en el ámbito de Galicia, junto con representantes de la Administración sanitaria gallega. Será, por tanto, tripartito y paritario.

4. Son organizaciones más representativas en el ámbito de Galicia, a los efectos de lo que se dispone en la presente ley, las que tengan dicha condición con arreglo a lo dispuesto en los artículos 6.2.a) y 7.1 de la Ley orgánica 11/1985, de 2 de agosto, de libertad sindical, y en la disposición adicional sexta del Real decreto legislativo $1 / 1995$, de 24 de marzo, por el que se aprueba el texto refundido de la Ley del Estatuto de los trabajadores.

5. La designación de las personas representantes se realizará en conformidad con las propuestas formuladas por el órgano de dirección de las organizaciones representadas en el Foro de Participación Institucional de Sanidad, procurando una composición paritaria de mujeres y hombres.

Artículo 29. Derechos y deberes en el ejercicio de la participación institucional.

1. La representación de las organizaciones integrantes del Foro de Participación Institucional de Sanidad llevará a cabo sus tareas de participación institucional de acuerdo con los principios de buena fe negociadora y de confianza legítima.

2. Son funciones del Foro de Participación Institucional de Sanidad:

a. Conocer, con carácter previo, los anteproyectos de ley o los proyectos de normas reglamentarias de desarrollo de normas legales, con relación a las materias de ámbito sanitario.

b. Emitir dictamen con carácter previo sobre los proyectos de normas reglamentarias de desarrollo de la participación social.

c. Recibir información sobre los planes, programas y actuaciones desarrolladas sobre materias de naturaleza sanitaria.

d. Proponer y participar en la elaboración de criterios, directrices y líneas generales de actuación con relación a materias de naturaleza sanitaria.

e. Proponer a la Consellería de Sanidad la adopción de iniciativas legislativas en actuaciones concretas que estimen convenientes en las materias objeto de participación.

3. En su cometido, las personas que ejerzan funciones de participación institucional en el Foro de Participación Institucional de Sanidad tienen los deberes siguientes:

a. Asistir a las reuniones del Foro de Participación Institucional de Sanidad como órgano de participación institucional en el que las organizaciones sindicales y empresariales a las que pertenezcan tengan legalmente reconocida su presencia.

b. Custodiar los documentos a los que se tenga acceso con motivo del ejercicio del derecho de participación institucional. 
c. Guardar la confidencialidad debida sobre las deliberaciones producidas en el seno del Foro de Participación Institucional de Sanidad y no utilizar la información obtenida en sus reuniones, habiendo sido declarada reservada, para fines diferentes de los que se someten a consideración.

\section{TÍTULO II DEL SISTEMA PÚBLICO DE SALUD DE GALICIA \\ Capítulo I \\ DISPOSICIONES GENERALES}

Artículo 30. Sistema Público de Salud de Galicia.

1. El Sistema Público de Salud de Galicia es parte integrante del Sistema Nacional de Salud, sin perjuicio de las competencias y funciones que sobre el primero corresponden a la Comunidad Autónoma de Galicia de conformidad con las leyes.

2. No se incluyen dentro del Sistema Público de Salud de Galicia las actividades o servicios que sean prestados con recursos no públicos.

Artículo 31. Dirección del Sistema Público de Salud de Galicia.

Corresponde a la Consellería competente en materia de sanidad, sin perjuicio de las competencias atribuidas al Consejo de la Xunta de Galicia, la dirección del Sistema Público de Salud de Galicia, teniendo como principales funciones de carácter estratégico las siguientes:

1. Las intervenciones que supongan ejercicio de autoridad necesarias para garantizar la tutela general de la salud.

2. La ordenación de las relaciones con las personas en el sistema de salud y las prestaciones sanitarias de cobertura pública.

3. La fijación de objetivos de mejora de la salud, de garantía de derechos sanitarios y de sostenibilidad financiera del sistema.

4. La delimitación de los dispositivos de medios de titularidad pública o adscritos al sistema, según las necesidades de salud de la población.
5. La ampliación, cuando proceda, del catálogo de prestaciones básicas ofrecidas por el Sistema Nacional de Salud.

\section{Capitulo II \\ LOS PRINCIPIOS RECTORES DE SU FUNCIONAMIENTO}

Artículo 32. Principios rectores del Sistema Público de Salud de Galicia.

Conforman el Sistema Público de Salud de Galicia los principios siguientes:

1. La universalidad del derecho a los servicios y prestaciones de cobertura pública.

2. La orientación hacia la ciudadanía y la participación social y comunitaria en la formulación de políticas sanitarias, así como del control de sus actuaciones.

3. La concepción integral de la salud, que incluye la promoción de la salud, la protección frente a situaciones y circunstancias que suponen riesgo para la salud, en particular la protección frente a los riesgos medioambientales, la prevención de la enfermedad y la asistencia sanitaria, así como la rehabilitación e integración social, desde la perspectiva de la asistencia sanitaria.

4. La promoción de la equidad y del equilibrio territorial en el acceso y la prestación de los servicios sanitarios. La promoción de la superación de las desigualdades sociales en salud.

5. La adecuación de las prestaciones sanitarias a las necesidades de salud de la población.

6. La promoción del interés individual, familiar y social por la salud y el Sistema Público de Salud de Galicia, potenciando la solidaridad y educación sanitaria.

7. La información sobre las formas de vida saludables, los recursos y los servicios existentes.

8. La promoción del uso racional del Sistema Público de Salud de Galicia.

9. La cooperación intersectorial como elemento de cohesión de las políticas de todos los sectores con responsabilidades sobre la salud. 
10. La integración funcional de todos los recursos sanitarios públicos, apostando por fórmulas colaborativas en lugar de fórmulas competitivas.

11. La calidad de los servicios y mejora continua, con un énfasis especial en la calidad de la atención clínica y de la organización de los servicios, en una atención personalizada y humanizada, y de la docencia como estrategia de garantía de calidad.

12. La seguridad, efectividad y eficiencia en el desarrollo de las actuaciones, las cuales habrán de basarse en la evidencia científica disponible y los valores éticos, sociales y culturales.

13. La acreditación y evaluación continua de los servicios sanitarios prestados en la comunidad autónoma.

14. La participación e implicación de profesionales en el sistema sanitario.

15. La descentralización, desconcentración y autonomía en la gestión de los servicios sanitarios.

16. La eficacia, efectividad y eficiencia en la gestión del Sistema Público de Salud de Galicia.

17. La promoción de la investigación básica y clínica en el ámbito de las ciencias de la salud con un carácter traslacional a la práctica clínica.

18. La coordinación de los recursos sanitarios, sociosanitarios y de salud laboral.

19. La búsqueda de su suficiencia financiera y de medios.

\section{Capítulo III LAS INTERVENCIONES PÚBLICAS OUE GARANTIZAN LOS DERECHOS Y DEBERES DE LA CIUDADANÍA}

Artículo 33. Autoridad sanitaria.

1. Dentro de sus respectivas competencias, tienen la condición de autoridad sanitaria el Consejo de la Xunta de Galicia, la persona titular de la Consellería de Sanidad, las personas titulares de los órganos y las personas responsables de las unidades que reglamentariamente se determinen, así como los alcaldes y alcaldesas. Se reconoce el carácter de autoridad sanitaria, en el desempeño de sus funciones, al personal que lleve a cabo la función de inspección sanitaria.

2. Corresponderá a los titulares de los órganos citados establecer las intervenciones públicas necesarias para garantizar los derechos y deberes sanitarios de la ciudadanía.

Artículo 34. Intervenciones públicas sobre actividades, centros y bienes.

Las intervenciones públicas que podrán ejercer las autoridades sanitarias competentes sobre las actividades públicas y privadas que, directa o indirectamente, puedan tener consecuencias para la salud son:

1. Establecer un registro único de profesionales del Sistema de Salud de Galicia, el cual será desarrollado reglamentariamente siguiendo la clasificación establecida en la Ley de ordenación de las profesiones sanitarias.

2. Establecer sistemas de información y registro sobre patologías, peligros $\mathrm{y}$ riesgos para la salud o poblaciones específicas.

3. Establecer las exigencias de autorizaciones por razones sanitarias a empresas, productos y actividades.

4. Establecer prohibiciones y requisitos mínimos para el uso y tráfico de bienes y productos, cuando supongan un perjuicio o amenaza para la salud mediante normativa.

5. Establecer las exigencias de las autorizaciones de los centros sanitarios de la comunidad autónoma.

6. Establecer, controlar e inspeccionar las condiciones higiénico-sanitarias, de funcionamiento y desarrollo de actividades que puedan tener repercusión sobre la salud de las personas.

7. Controlar la publicidad y propaganda de productos y actividades que puedan tener incidencia sobre la salud, a fin de ajustarla a criterios de veracidad y evitar lo que pueda constituir un perjuicio para ésta.

8. Controlar e inspeccionar el funcionamiento de las entidades, instalaciones y 
actividades que tengan su funcionamiento regulado sanitariamente.

9. Controlar la actividad asistencial prestada a través de mutualidades y compañías aseguradoras, vinculadas al principio de universalidad de las prestaciones.

10. Tomar muestras y analizar los productos o componentes de la producción que puedan tener repercusión sobre la salud de la población.

11. Exigir certificaciones o dictamen sanitario de productos antes de su entrada en el mercado.

12. Adoptar las medidas preventivas que se consideren pertinentes en caso de que exista o se sospeche razonablemente la existencia de un riesgo inminente y extraordinario para la salud. A tal efecto, la Administración sanitaria podrá proceder a la incautación o inmobilización de productos, la suspensión del ejercicio de actividades, el cierre de empresas o de sus instalaciones, la intervención de medios materiales y personales y cuantas otras medidas se consideren sanitariamente justificadas. La duración de las medidas a que se refiere este apartado se fijará para cada caso, sin perjuicio de las prórrogas sucesivas acordadas por resoluciones motivadas, no excediendo de lo que exija la situación de riesgo extraordinario que las ha justificado.

13. Incoar un expediente sancionador en los casos que sean reconocidos como faltas tipificadas en la legislación vigente.

14. Cualquier otra intervención conducente a establecer normativamente los requisitos y condiciones que, desde el punto de vista sanitario, han de reunir todos los centros, actividades y bienes que puedan suponer un riesgo para la salud, así como vigilar, controlar e inspeccionar, de la forma establecida en las correspondientes normas, su cumplimiento.

Artículo 35. Intervenciones públicas sanitarias en materia de salud laboral.

1. La Xunta de Galicia promoverá actuaciones en materia sanitaria referentes a la salud laboral, en el marco de lo dispuesto en la Ley 14/1986, general de sanidad, y en la Ley 31/1995, de 8 de noviembre, de prevención de riesgos laborales.

2. La Consellería de Sanidad, los organismos y las entidades dependientes de ella, en el ámbito de sus competencias, desarrollarán la prevención, protección, promoción y mejora de la salud integral de sus trabajadores y trabajadoras.

3. Sin perjuicio de las competencias atribuidas a las restantes administraciones públicas de Galicia, y en coordinación con ellas, corresponde a la Consellería de Sanidad en materia de salud laboral el ejercicio de las funciones siguientes:

a. El desarrollo en la Comunidad Autónoma de Galicia de los sistemas de información sanitaria ordenados a determinar la morbilidad y mortalidad por patologías profesionales, de manera integrada con el resto de sistemas de información y vigilancia epidemiológica.

b. La elaboración y aprobación de los protocolos de vigilancia sanitaria específica según los riesgos para la detección precoz de problemas de salud que puedan afectar a los trabajadores y trabajadoras en el desarrollo de sus tareas.

c. La promoción de la información, formación y participación de los trabajadores y empresarios en los planes, programas y actuaciones sanitarias en el ámbito de la salud laboral.

d. La realización de estudios epidemiológicos para la identificación y prevención de patologías que, con carácter general, puedan verse producidas o agravadas por las condiciones de trabajo.

e. La inspección, supervisión y registro de los servicios de prevención autorizados o que soliciten autorización para su reconocimiento como tales en el ámbito de la Comunidad Autónoma de Galicia, en lo que alcanza a los aspectos sanitarios.

f. La supervisión de la formación que, en el terreno de prevención y promoción de la salud laboral, haya de recibir el personal 
sanitario de los servicios de prevención autorizados.

g. Todas aquellas funciones que la normativa vigente le encomiende en materia de accidentes de trabajo, enfermedades profesionales, entidades colaboradoras de la Seguridad Social, mutuas aseguradoras, incapacidad temporal y servicios de prevención de riesgos laborales, promoviendo la mejora en la vigilancia y control de la salud de los trabajadores y trabajadoras, incluyendo la prescripción en la asistencia médico-farmacéutica derivada de contingencias profesionales a través del personal sanitario de los servicios de prevención, actividad que tendrá, en todo caso, carácter voluntario tanto para los trabajadores como para las empresas.

h. Cualquier otra función que pueda serle encomendada por el Consejo de la Xunta.

Artículo 36. De las limitaciones impuestas en las intervenciones públicas sobre actividades.

Las limitaciones impuestas dentro de las intervenciones públicas especificadas en los artículos anteriores seguirán los principios siguientes:

a. Preferencia de la colaboración voluntaria con las autoridades sanitarias.

b. Minimización de la incidencia sobre la libre circulación de personas y bienes, la libertad de empresa y cualquier otro derecho.

c. Prohibición de ordenar medidas obligatorias que supongan riesgo para la vida.

d. Proporcionalidad a los fines que en cada caso se persigan.

Artículo 37. De la inspección sanitaria.

1. El personal que lleve a cabo funciones de inspección en el ámbito sanitario, en el ejercicio de las funciones inspectoras que reglamentariamente se determinen, tendrá carácter de autoridad sanitaria.

2. El personal al servicio de la Administración sanitaria que actúe en el ejercicio de las funciones de inspección, y acreditando su identidad, estará autorizado para:

a. Entrar libremente y sin previa notificación, en cualquier momento, en todo centro, servicio o establecimiento sujeto a la presente ley.

b. Proceder a las pruebas, investigaciones o exámenes necesarios para comprobar el cumplimiento de la presente ley y de las normas que se dicten para su desarrollo.

c. Tomar o sacar muestras, a fin de comprobar el cumplimiento de lo previsto en la legislación sanitaria vigente.

d. Realizar cuantas actuaciones sean necesarias para el cumplimiento de las funciones de inspección que ejerzan.

e. Ante situaciones de riesgo grave e inmediato para la salud, los inspectores e inspectoras deberán comunicar inmediatamente a la autoridad sanitaria competente la situación detectada y adoptar las medidas cautelares de emergencia definidas por la autoridad sanitaria competente.

3. Los hechos constatados por funcionarios o funcionarias a los que se les reconoce la condición de autoridad y que se formalicen en documento público con observancia de los requisitos legales pertinentes tendrán valor probatorio, sin perjuicio de las pruebas que en defensa de los respectivos derechos o intereses puedan señalar o aportar los propios ciudadanos, conforme al artículo $137.3 .^{\circ}$ de la Ley $30 / 1992$, de 26 de noviembre, de régimen jurídico de las administraciones públicas y del procedimiento administrativo común.

Artículo 38. Intervenciones públicas sobre individuos.

Las autoridades sanitarias podrán llevar a cabo las siguientes intervenciones públicas en los supuestos de riesgos para la salud de terceras personas:

1. Medidas de reconocimiento, diagnóstico, tratamiento, hospitalización o control cuando se aprecien indicios racionales que permitan suponer la existencia de peligro para la salud de la población debido a la situación sanitaria concreta de 
una persona o grupo de personas o por las condiciones sanitarias en que se desarrolle una actividad.

2. A fin de controlar las enfermedades transmisibles, además de realizar las acciones preventivas generales, podrán adoptar las medidas oportunas para el control de las personas enfermas, de las que estén o hayan estado en contacto con ellas y del medio inmediato, así como las que se consideren necesarias en caso de riesgo de carácter transmisible.

\section{Capitulo IV INFRACCIONES Y SANCIONES}

Artículo 39. Concepto y procedimiento.

1. Son infracciones sanitarias las acciones $\mathrm{u}$ omisiones tipificadas en la presente ley y en las leyes estatales y autonómicas que les sean de aplicación en esta materia.

2. Las infracciones serán objeto, previa incoación del oportuno expediente, de las sanciones administrativas establecidas en el presente título, sin perjuicio de la responsabilidad civil, penal o de otro orden que pudiera concurrir.

3. En cualquier momento del procedimiento sancionador en que el órgano instructor considere que las infracciones pudieran ser constitutivas de delito, la administración pasará el tanto de culpa a la jurisdicción competente, absteniéndose de seguir el procedimiento sancionador mientras la autoridad jurisdiccional no dicte resolución judicial firme. Si no se estimara la existencia de delito, la administración continuará el expediente sancionador, tomando como base los hechos que los tribunales hubieran considerado probados.

4. Igualmente, si el órgano competente para resolver el procedimiento sancionador tuviera conocimiento de la instrucción de causa penal ante los tribunales de justicia y estimara que existe identidad de sujeto, hecho y fundamento entre la infracción administrativa y la infracción penal que pudiera concurrir, acordará la suspensión del procedimiento hasta que recaiga resolución judicial firme.

5. Las medidas administrativas que se hayan adoptado para salvaguardar la salud y seguridad de las personas se mantendrán hasta que la autoridad judicial se pronuncie respecto a ellas o bien cese la necesidad de las mismas.

6. En ningún caso se impondrá una doble sanción por los mismos hechos y en función de los mismos intereses públicos protegidos, sin embargo habrán de exigirse las demás responsabilidades que se deduzcan de otros hechos o infracciones concurrentes.

7. No tendrán carácter de sanción la clausura o cierre de establecimientos, instalaciones o servicios que no cuenten con las autorizaciones o registros sanitarios preceptivos, o la suspensión de su funcionamiento hasta que se rectifiquen los defectos o se cumplan los requisitos exigidos por razones de sanidad, higiene o seguridad, ni la retirada del mercado, cautelar o definitiva, de productos o servicios por las mismas razones.

Artículo 40. Calificación de las infracciones.

Las infracciones se califican como leves, graves y muy graves, atendiendo a los criterios de riesgo para la salud, la cuantía del eventual beneficio obtenido, el grado de intencionalidad, la gravedad de la alteración sanitaria y social producida, la generalización de la infracción y la reincidencia.

Artículo 41. Infracciones leves.

Sin perjuicio de las que se establezcan por otras leyes especiales, se tipifican como infracciones sanitarias leves las siguientes:

a. Las simples irregularidades en el cumplimiento de la normativa sanitaria vigente, sin trascendencia directa para la salud, que no se encuentren expresamente recogidas en esta relación.

b. El incumplimiento simple del deber de colaboración con las autoridades sanitarias 
para la elaboración de los registros y documentos de información sanitaria establecidos legal o reglamentariamente.

c. La negativa a informar a las personas que se dirijan a los servicios sanitarios sobre los derechos y obligaciones que les afectan, en los términos establecidos en la presente ley.

d. La emisión o difusión al público de anuncios publicitarios o propaganda comercial por cualquier medio, con repercusión directa sobre la salud humana o a fin de promover la contratación de bienes o servicios sanitarios, sin disponer de la correspondiente autorización administrativo-sanitaria.

e. La obstrucción de la labor inspectora mediante cualquier acción u omisión que la perturbe o retrase.

f. La identificación falsa o contraria al principio de veracidad en cuanto a los méritos, experiencia o capacidad técnica del personal sanitario en su actividad profesional y en sus relaciones asistenciales con la población, salvo cuando merezca ser calificada como grave o muy grave.

g. El incumplimiento, por simple negligencia, de los requisitos, obligaciones o prohibiciones establecidas en la normativa sanitaria, así como cualquier otro comportamiento, a título de imprudencia o inobservancia, siempre que se produzca alteración o riesgo sanitario y éste sea de escasa incidencia.

h. Aquellas infracciones que, al amparo de los criterios previstos en el presente artículo, merezcan la calificación de leves o no proceda la calificación de las mismas como faltas graves o muy graves.

Artículo 42. Infracciones graves.

Sin perjuicio de las que se establezcan por otras leyes especiales, se tipifican como infracciones sanitarias graves las siguientes:

a. El ejercicio o desarrollo de actividades sin la correspondiente autorización o registro sanitario preceptivo, o transcurrido su plazo de vigencia, así como la modificación no autorizada por la autoridad competente de las expresas condiciones técnicas o estructurales sobre las cuales se hubiera otorgado la autorización correspondiente.

b. La creación, modificación o supresión de centros, servicios o establecimientos sanitarios sin obtener las autorizaciones administrativas correspondientes, conforme a la normativa que sea de aplicación, así como el incumplimiento de las normas relativas al registro y acreditación de los mismos.

c. El incumplimiento de los requerimientos específicos y de las medidas cautelares o definitivas que formulen las autoridades sanitarias, siempre y cuando se produzcan por primera vez y no concurra daño grave para la salud de las personas.

d. La negativa a suministrar datos, facilitar información o prestar colaboración a las autoridades sanitarias o a sus agentes en el desarrollo de las labores de inspección o control sanitarios e investigaciones epidemiológicas de brotes o situaciones de especial riesgo para la salud de la población.

e. El incumplimiento, por negligencia grave, de los requisitos, condiciones, obligaciones o prohibiciones establecidas en la vigente legislación en materia sanitaria, así como cualquier otro comportamiento que suponga imprudencia grave, siempre y cuando ocasionen alteración o riesgo sanitario, aunque sean de escasa entidad. $\mathrm{Y}$ el mismo incumplimiento y comportamiento cuando, cometidos por negligencia simple, produzcan riesgo o alteración sanitaria grave. A los efectos de este apartado, constituirá un supuesto de negligencia la omisión del deber de control o la falta de los controles o precauciones exigibles en la actividad, servicio o instalación de que se trate.

f. La promoción o venta para uso alimentario o la utilización o posesión de aditivos o sustancias extrañas de uso no autorizado por la normativa vigente en la elaboración del producto alimenticio o alimentario de que se trate, cuando no 
produzcan riesgos graves y directos para la salud de los consumidores.

g. La elaboración, distribución, suministro o venta de preparados alimenticios, cuando su presentación induzca a confusión sobre sus verdaderas características sanitarias o nutricionales, y el uso de sellos o identificaciones falsas en cualquiera de las actuaciones citadas.

h. El dificultar o impedir el disfrute de los derechos reconocidos en la presente ley a los usuarios y usuarias del sistema sanitario, ya sea en el terreno de los servicios sanitarios o sociosanitarios públicos o privados.

i. La comisión por negligencia de las conductas tipificadas como infracción muy grave, cuando el riesgo o la alteración sanitaria producida sea de escasa entidad.

j. La reincidencia en la comisión de infracciones leves en los últimos tres meses.

$\mathrm{k}$. Las actuaciones tipificadas en el artículo $41 .^{\circ}$ que, a tenor del grado de concurrencia de los elementos a que se refiere el artículo $40 .^{\circ}$, merezcan la calificación de faltas graves o no proceda la calificación de las mismas como faltas leves o muy graves.

1. Las actuaciones que en razón a su expresa calificación en la normativa especial sanitaria aplicable en cada caso merezcan la tipificación de faltas graves o no proceda la calificación de las mismas como faltas leves o muy graves.

$\mathrm{m}$. El incumplimiento por parte del personal que en virtud de sus funciones deba tener acceso a la información relacionada con el estado individual de salud del deber de garantizar la confidencialidad e intimidad de las personas.

n. Las faltas leves que sean concurrentes con otras infracciones sanitarias leves o pudieran servir para facilitarlas o encubrirlas.

Artículo 43. Infracciones muy graves. Sin perjuicio de las que se establezcan por otras leyes especiales, se tipifican como infracciones sanitarias muy graves las siguientes:

a. El incumplimiento de las medidas cautelares o definitivas que adopten las autoridades sanitarias competentes, cuando se produzcan de manera reiterada o cuando concurra daño grave para la salud de las personas.

b. La resistencia, coacción, amenaza o represalia, desacato o cualquier otra forma de presión ejercida sobre las autoridades sanitarias o sus agentes.

c. El incumplimiento consciente y deliberado de los requisitos, obligaciones o prohibiciones establecidas en la normativa sanitaria, o cualquier comportamiento doloso, siempre y cuando ocasionen alteración, daños o riesgo sanitario grave.

d. La preparación, distribución, suministro, venta de alimentos, bebidas o productos relacionados directa o indirectamente con la alimentación humana que contengan gérmenes, sustancias químicas o radiactivas, toxinas o parásitos capaces de producir o transmitir enfermedades al hombre.

e. La promoción o venta para uso alimentario o la utilización o posesión de aditivos o sustancias extrañas de uso no autorizado por la normativa vigente en la elaboración o conservación del producto alimenticio o alimentario de que se trate, cuando produzca riesgos graves y directos para la salud de los consumidores.

f. El desvío para consumo humano de productos no aptos para ello o destinados específicamente para otros usos.

g. La alteración o falsificación de los documentos de registro y transporte de los productos destinados al consumo humano, cuando tales modificaciones supongan o puedan suponer un riesgo para la salud.

h. La reincidencia en la comisión de faltas graves en los últimos cinco años.

i. Las actuaciones tipificadas en los artículos 41 y 42 que, a tenor del grado de concurrencia de los elementos a que se refiere el artículo 40, merezcan la calificación 
de faltas muy graves o no proceda su calificación como faltas leves o graves.

j. Las actuaciones que en razón a su expresa calificación en la normativa especial sanitaria aplicable en cada caso merezcan la tipificación de faltas muy graves o no proceda la calificación de las mismas como faltas leves o graves.

k. Las faltas graves que sean concurrentes con otras infracciones sanitarias graves o sirvieran para facilitar o encubrir su comisión.

1. El incumplimiento reiterado de los requerimientos específicos que formulen las autoridades sanitarias.

m. La negativa absoluta a facilitar información o prestar colaboración a los servicios de inspección y control.

Artículo 44. Sanciones.

1. Las infracciones serán sancionadas guardando la debida adecuación entre la gravedad del hecho constitutivo de la infracción y la sanción aplicada, estableciéndose una graduación de ésta de mínimo, medio y máximo para cada nivel de calificación, en función del fraude o connivencia, el incumplimiento de las advertencias previas, el número de personas afectadas, los perjuicios causados, los beneficios obtenidos a causa de la infracción y la permanencia y transitoriedad de los riesgos.

2. Las infracciones sanitarias tipificadas en los artículos 41, 42 y 43 serán sancionadas con multas, conforme a la graduación siguiente:

a. Infracciones leves:

Grado mínimo: Hasta 601,01 euros.

Grado medio: De 601,02 a 1.803,04 euros.

Grado máximo: De 1.803,05 a 3.005,06 euros.

b. Infracciones graves:

Grado mínimo: De 3.005,07 a 6.010,12 euros.

Grado medio: De $6.010,13$ a $10.517,71$

euros.

Grado máximo: De 10.517,72 a 15.025,30 euros.

c. Infracciones muy graves:
Grado mínimo: De 15.025,31 a 120.202,42 euros.

Grado medio: De 120.202,43 a 360.607,26 euros.

Grado máximo: De 360.607,27 a 601.012,11 euros.

Las cantidades expresadas pueden excederse hasta alcanzar el quíntuplo del valor de los productos o servicios objeto de la infracción.

3. Sin perjuicio de la multa que proceda con arreglo a lo previsto en el apartado 2 anterior, y a los efectos de evitar que la comisión de infracciones resulte más beneficiosa para la persona que comete la infracción que el cumplimiento de las normas infringidas, la sanción económica que en su caso se imponga podrá ser incrementada con la cuantía del beneficio ilícito obtenido.

4. En los supuestos de infracciones muy graves, el Consejo de la Xunta podrá acordar como sanción accesoria el cierre temporal del establecimiento, instalación o servicio por un plazo máximo de cinco años, todo ello con los efectos laborales que determina la legislación aplicable en esta materia.

5. La autoridad a la que corresponda resolver el expediente podrá acordar, junto con la sanción correspondiente, el decomiso de bienes o productos deteriorados, caducados, no autorizados o que por cualquier otra causa puedan entrañar riesgo para la salud o seguridad de las personas, siendo por cuenta de quien cometa la infracción los gastos que origine su intervención, depósito, decomiso, transporte o destrucción.

6. Las cuantías señaladas en el apartado 2 podrán ser actualizadas periódicamente a través de la oportuna disposición legal, teniendo en cuenta la variación de los índices de precios para el consumo.

Artículo 45. Competencia para la imposición de sanciones.

1. Los órganos de la Administración de la comunidad autónoma competentes para 
la imposición de las sanciones previstas en la presente ley son los siguientes:

a. Los órganos de la Consellería de Sanidad y del Servicio Gallego de Salud, en su caso, hasta 120.202,42 euros, en los términos que se establezcan reglamentariamente.

b. El Consejo de la Xunta, desde $120.202,43$ euros.

2. Los ayuntamientos de la comunidad autónoma, al amparo de sus respectivas ordenanzas municipales, podrán sancionar las infracciones previstas en la presente ley, siempre que dichas infracciones afecten a las áreas de responsabilidad mínima sobre las cuales ejercen competencias de control sanitario.

3. A los efectos del apartado anterior, deberá comunicarse a la Consellería de Sanidad la ordenanza municipal por la que se acuerda ejercer dicha potestad sancionadora, así como los expedientes sancionadores incoados a su amparo y las resoluciones definitivas que recaigan, en su caso. Cuando por la naturaleza y gravedad de la infracción tenga que superarse la cuantía máxima establecida en el apartado 1.a), la entidad local correspondiente remitirá a la Consellería de Sanidad las actuaciones que constan en el expediente, debidamente tramitado, adjunto con la propuesta de sanción. La Consellería de Sanidad comunicará a la entidad local correspondiente la sanción recaída, así como las restantes actuaciones que se deriven de su intervención.

4. La Administración de la Comunidad Autónoma de Galicia podrá actuar en sustitución de los ayuntamientos en los supuestos y con los requisitos contemplados en la legislación de régimen local.

Artículo 46. Medidas cautelares.

Una vez iniciado el procedimiento sancionador, el órgano competente para resolver podrá adoptar, previa audiencia de la persona interesada y mediante acuerdo motivado, las medidas cautelares que resulten necesarias para asegurar el cumplimiento de la resolución que pudiera recaer, así como el cumplimiento de la legalidad y la salvaguarda de la salud. Tales medidas, entre otras, podrán ser:

a. La suspensión total o parcial de la actividad.

b. La clausura de centros, servicios, establecimientos o instalaciones.

c. La exigencia de fianza.

Artículo 47. Prescripción y caducidad.

1. Las infracciones y sanciones tipificadas en la presente ley como leves prescriben al año, las graves a los dos años y las muy graves a los cinco años.

2. La prescripción de las infracciones comenzará a computarse desde el día en que se hubiera cometido la infracción y se interrumpirá con la iniciación del procedimiento sancionador, con conocimiento de la persona interesada. Además, el plazo de prescripción de las sanciones comenzará a contar desde el día siguiente a aquél en que adquiera firmeza la resolución por la que se impone la sanción.

3. La acción para perseguir las infracciones caducará si, conocida por la administración competente la existencia de una infracción y terminadas las diligencias dirigidas al esclarecimiento de los hechos, hubieran transcurrido seis meses sin que la autoridad competente hubiera ordenado incoar el oportuno procedimiento. A tal efecto, si hubiere toma de muestras, las actuaciones de la inspección se entenderán finalizadas después de practicado el análisis inicial.

\section{Capitulo V \\ PRESTACIONES SANITARIAS DEL SISTEMA PÚBLICO DE SALUD DE GALICIA}

Artículo 48. Prestaciones sanitarias. Las distintas prestaciones de salud que constituyen el catálogo de prestaciones sanitarias, tal como se define en el artículo 3.8 de la presente ley, comprenden las prestaciones de salud pública, de atención primaria, de atención especializada, de 
atención sociosanitaria en los términos del artículo 53.2, de atención de urgencias, farmacéutica, de atención ortoprotésica, de productos dietéticos y de transporte sanitario.

Artículo 49. Salud pública.

Sin perjuicio de lo dispuesto en el artículo 11 de la Ley de cohesión y calidad del Sistema Nacional de Salud, la prestación de salud pública comprende:

a. La medición del nivel de salud de la población y la identificación de los problemas y riesgos para la salud.

b. La investigación de las causas o determinantes de los problemas de salud que afectan a la población a través del establecimiento de los registros y análisis de datos que, respetando la normativa en materia de protección de datos personales, permitan analizar y conocer las situaciones que tienen influencias sobre la salud, incluyendo el ámbito laboral. En los registros que se elaboren, se tendrán en cuenta especialmente los casos de violencia de género, maltrato infantil y cualquier otra manifestación de violencia, incluyendo en las encuestas de salud indicadores sobre esta materia.

c. Los estudios epidemiológicos necesarios para orientar con mayor eficacia la prevención de riesgos para la salud, así como la planificación y evaluación sanitaria.

d. La prevención y control de las enfermedades transmisibles.

e. El establecimiento de estándares de producción y medidas de protección de la salud frente a riesgos medioambientales, como los derivados de productos alimenticios, del uso de productos químicos, de agentes físicos, de la contaminación atmosférica, del uso de las zonas de baño, de la gestión y tratamiento de desechos y aguas residuales, de las aguas de consumo y de la sanidad mortuoria, entre otros.

f. El establecimiento de estándares y medidas de promoción de estilos de vida saludables y de prevención, en especial los de carácter intersectorial. g. La comunicación a la población de la información sobre su salud y de los determinantes principales que le afectan. La promoción de la cultura sanitaria entre la población.

h. El establecimiento de sistemas de farmacovigilancia.

i. La promoción de los estándares sanitarios de producción de bienes y servicios y de estilos de vida, a través de la educación para la salud y otras actividades.

j. La verificación del cumplimiento de los estándares sanitarios definidos.

$\mathrm{k}$. Las actuaciones necesarias para fomentar y verificar la corrección de las desviaciones de los estándares sanitarios definidos.

1. El fomento de la formación e investigación científica en materia de salud pública.

$\mathrm{m}$. El control sanitario y la prevención de los riesgos para la salud derivados de las sustancias susceptibles de generar dependencia.

n. El establecimiento y difusión de guías de actuación preventiva para profesionales y la población frente a problemas comunitarios de salud.

o. La prevención de los riesgos para la salud en casos de catástrofes medioambientales.

p. Estudios epidemiológicos precisos para conocer, prevenir y planificar la asistencia en relación a los discapacitados.

q. Cualquier otra acción ordenada a mejorar la salud de la población.

Artículo 50. Atención primaria.

1. La atención primaria constituye el primer nivel de acceso ordinario de la población al Sistema Público de Salud de Galicia y se caracteriza por un enfoque global e integrado de la atención y la salud y por asumir un papel orientador y de canalización de la asistencia requerida por el o la paciente en cualquier punto del sistema sanitario.

2. Sin perjuicio de lo dispuesto en el artículo 12 de la Ley de cohesión y calidad 
del Sistema Nacional de Salud la atención primaria incluirá entre su catálogo de servicios las funciones y modalidades de atención sanitaria siguientes:

a. La indicación o prescripción y la realización, en su caso, de procedimientos diagnósticos y terapéuticos.

b. Las actividades programadas en materia de vigilancia e información, así como la promoción y protección de la salud y la prevención de la enfermedad.

c. Las atenciones y servicios específicos relativos a programas integrales de atención a grupos específicos de población: atención a la mujer y a los ancianos, así como los referidos en el artículo $14 .^{\circ} \mathrm{de}$ la presente ley.

d. La atención ordinaria y continuada de las urgencias.

e. La rehabilitación básica.

f. La atención paliativa a enfermos terminales.

g. La atención pediátrica.

h. La atención a la salud bucodental.

i. La atención a la salud mental, en coordinación con los servicios de atención especializada.

j. El trabajo social con los usuarios y usuarias, en coordinación con el sistema de servicios sociales.

k. La participación en la docencia, la formación continuada y la investigación, en su ámbito de actuación.

1. La realización de las prestaciones sociosanitarias que se corresponden a este nivel de asistencia, en coordinación con el sistema de servicios sociales.

m. Cualesquier otras funciones o modalidades asistenciales que se le encomienden, así como los restantes servicios y prestaciones facilitados en cada momento por el Sistema Nacional de Salud en lo que se refiere a este ámbito de la atención sanitaria.

3. Las actuaciones de atención primaria se desarrollarán en los centros de salud o en otros periféricos que de los mismos dependan, en los puntos de atención continuada, así como en los domicilios de los enfermos, en los centros que presten servicios sociosanitarios o en cualquier otro lugar que se determine reglamentariamente. Estas actividades podrán ser desarrolladas en régimen de:

a. Consultas a demanda o programadas en los centros sanitarios de atención primaria.

b. Atención de urgencias de atención primaria.

c. Atención a domicilio.

4. En función de los medios técnicos y profesionales y del conocimiento disponible en cada momento, la atención primaria dispondrá progresivamente del acceso a la realización de técnicas, a la información clínica y a los medios técnicos disponibles en atención especializada en la medida en que sean necesarios para garantizar la continuidad asistencial a través del mejor seguimiento y/o resolución de los procesos clínicos completos de sus pacientes.

Artículo 51. Atención especializada.

1. La atención especializada es el nivel de asistencia que, una vez superadas las posibilidades de diagnóstico y tratamiento de la atención primaria, se caracteriza por una alta intensidad de los cuidados requeridos o por la especificidad del conocimiento y/o la tecnología que los y las pacientes precisan para su adecuada atención sanitaria.

2. Sin perjuicio de lo dispuesto en el artículo 13 de la Ley de cohesión y calidad del Sistema Nacional de Salud, la atención especializada comprenderá las funciones siguientes:

a. La indicación o prescripción y la realización, en su caso, de procedimientos diagnósticos y terapéuticos.

b. Las atenciones de salud mental y la asistencia psiquiátrica y psicológica.

c. La atención a las urgencias hospitalarias.

d. La atención paliativa a enfermos terminales.

e. La rehabilitación en pacientes con déficit funcional recuperable. 
f. La educación para la salud y la prevención de enfermedades en su ámbito de actuación, así como la participación en los sistemas de vigilancia e información.

g. La participación en la docencia, la formación continuada y la investigación.

h. La realización de las prestaciones sociosanitarias que se corresponden a este nivel de asistencia, en coordinación con el sistema de servicios sociales que se determine, así como la búsqueda de alternativas para el alta hospitalaria.

i. Cualesquier otras funciones o modalidades asistenciales que se le encomienden, así como los restantes servicios y prestaciones facilitados en cada momento por el Sistema Nacional de Salud en lo que se refiere a este ámbito de la atención sanitaria.

j. La participación en las acciones de coordinación, producción de documentación clínica y consultoría con los centros de atención primaria a través de los procedimientos que se determinen.

3. La atención especializada será prestada por los hospitales o complejos hospitalarios. El hospital, junto a los centros de especialidades adscritos al mismo, constituye la estructura sanitaria responsable de la asistencia especializada programada y urgente a la población de su ámbito de influencia. Estas actividades podrán ser desarrolladas en régimen de:

a. Consultas externas.

b. Hospital de día.

c. Ambulatorio de procedimientos quirúrgicos menores y de cirugía mayor.

d. Hospitalización para los procesos médicos, quirúrgicos, pediátricos u obstétricos que así lo requieren.

e. Hospitalización a domicilio.

4. La atención especializada se prestará, siempre que las condiciones del o la paciente lo permitan, en consultas externas y en hospital de día.

Artículo 52. Atención a urgencias y emergencias.

1. Todo el Sistema Público de Salud de Galicia prestará la atención continuada y de las urgencias a través de sus dispositivos asistenciales.

2. En situaciones de emergencia originadas por catástrofes o accidentes en cualquier lugar de Galicia, el Sistema Público de Salud de Galicia facilitará, a través de sus dispositivos asistenciales, la asistencia sanitaria in situ, el traslado de personas afectadas y la asistencia en los centros más apropiados.

3. La atención de urgencia se presta al paciente en los casos en que su situación clínica obliga a una atención sanitaria inmediata. Se dispensará tanto en centros sanitarios como fuera de los mismos, incluyendo el domicilio del paciente, durante las veinticuatro horas del día, mediante la atención médica y de enfermería.

4. Ante situaciones de crisis, alerta o alarma de salud pública, el Sistema Público de Salud de Galicia responderá con mecanismos y acciones precisas que garanticen la protección de la salud de la población.

Artículo 53. Atención sociosanitaria.

1. A los efectos de la presente ley, se considera atención sociosanitaria el conjunto de cuidados sanitarios y de aquellos otros que correspondan dentro del sistema de servicios sociales establecido en su normativa específica, destinados a aquellos enfermos, generalmente crónicos, que por sus especiales características pueden beneficiarse de la atención simultánea y sinérgica de los servicios sanitarios y sociales para aumentar su autonomía, paliar sus limitaciones o sufrimientos y facilitar su reinserción social.

2. En el terreno sanitario la atención sociosanitaria comprenderá:

a. Los cuidados sanitarios de larga duración.

b. La atención sanitaria a la convalecencia.

c. La rehabilitación en pacientes con déficit funcional recuperable.

3. La continuidad del servicio será garantizada por los servicios sanitarios y sociales a través de la adecuada coordinación entre 
las administraciones públicas correspondientes, así como entre los departamentos competentes en materia de sanidad y en materia de servicios sociales de la Xunta de Galicia.

Artículo 54. Prestaciones farmacéuticas.

1. La prestación farmacéutica comprende los medicamentos y productos sanitarios y el conjunto de actuaciones encaminadas a que los y las pacientes los reciban de forma adecuada a sus necesidades, en las dosis precisas según sus requerimientos individuales, durante el periodo de tiempo apropiado y con el menor coste posible para ellos y la comunidad.

2. La Administración sanitaria de la Xunta garantizará la prescripción y dispensación de medicamentos en el Sistema Público de Salud de Galicia en los términos previstos en la legislación vigente.

3. La política autonómica en relación a la prestación farmacéutica promoverá el desarrollo de programas orientados a racionalizar el empleo de los recursos farmacoterapéuticos en los servicios sanitarios y en la prestación sociosanitaria, con criterios de efectividad, seguridad y coste. Del mismo modo, impulsará programas y actividades de información y formación dirigidos a los profesionales sanitarios, así como a la ciudadanía en general.

Artículo 55. Prestaciones ortoprotésicas.

1. La prestación ortoprotésica consiste en la utilización de productos sanitarios implantables o no, cuya finalidad es sustituir total o parcialmente una estructura corporal o bien modificar, corregir o facilitar su función.

2. Sin perjuicio de lo dispuesto en el artículo 11 de la Ley de cohesión y calidad del Sistema Nacional de Salud, la prestación ortoprotésica incluye las prestaciones siguientes:

a. Las prótesis quirúrgicas fijas y su oportuna renovación. b. Las prótesis ortopédicas permanentes o temporales (prótesis externas) y su oportuna renovación.

c. Los vehículos para personas con discapacidad cuya invalidez así lo aconseje.

3. Esta prestación será facilitada por los servicios de salud o dará lugar a ayudas económicas, en los casos y de acuerdo con las normas que reglamentariamente sean fijadas por las administraciones sanitarias competentes.

4. La prescripción será realizada por los facultativos especialistas y/o médicos de atención primaria en la materia correspondiente a la clínica que justifique la prescripción y se ajustará a lo establecido en el catálogo autorizado por la Administración sanitaria, siguiéndose para su prestación el procedimiento regulado por la Administración sanitaria.

5. Las modificaciones del catálogo o la prescripción de productos ortoprotésicos no incluidos en el mismo requerirán la aprobación por la Consellería de Sanidad.

Artículo 56. Transporte sanitario.

1. La prestación del transporte sanitario, que deberá ser accesible a las personas con discapacidad, comprende el transporte especial de personas accidentadas o enfermas cuando concurra una situación de urgencia que implique riesgo vital o daño irreparable para la salud de la gente afectada, o exista una imposibilidad física u otras causas clínicas que impidan o incapaciten para la utilización de transporte ordinario para desplazarse a un centro sanitario o a su domicilio después de recibir atención sanitaria.

2. La prescripción corresponderá al facultativo que preste asistencia y/o a la inspección de servicios sanitarios, siguiéndose para su prestación el procedimiento regulado por la Administración sanitaria.

Artículo 57. Productos dietéticos.

1. La prestación de productos dietéticos comprende la dispensación de los tratamientos dietoterápicos a las personas que padezcan determinados trastornos 
metabólicos congénitos y la nutrición enteral domiciliaria para pacientes a los que no es posible cubrir sus necesidades nutricionales, a causa de su situación clínica, con alimentos de uso ordinario.

2. La prescripción corresponderá al facultativo que preste asistencia, obedeciendo su indicación sólo a causas clínicas y siguiéndose para su prestación el procedimiento regulado por la Administración sanitaria.

Artículo 58. Prestaciones complementarias.

1. Son prestaciones complementarias todas aquéllas que suponen un elemento adicional y necesario para la consecución de una asistencia completa y adecuada.

2. La prescripción corresponderá al facultativo que preste asistencia, obedeciendo su indicación sólo a causas clínicas y siguiéndose para su prestación el procedimiento regulado por la Administración sanitaria.

En todo caso se tendrá en cuenta la disposición adicional duodécima de la Ley 29/2006, de 26 de julio, sobre garantías y uso racional de los medicamentos.

Artículo 59. Prestaciones y servicios sanitarios financiados públicamente.

1. La Comunidad Autónoma de Galicia asegura, como mínimo, a todas las personas a que se refiere el artículo 4 de la presente ley las prestaciones y los servicios de salud individual o colectiva facilitados en cada momento por el Sistema Nacional de Salud, así como la garantía de poder acceder, mediante financiación pública, a las prestaciones o técnicas terapéuticas que, estando reconocidas por el Sistema Nacional de Salud, no se realizan en la comunidad autónoma gallega y puedan resultar beneficiosas para el o la paciente al haber sido prescritas por profesionales del Sistema Público de Salud.

2. La inclusión de nuevas prestaciones y servicios sanitarios financiados públicamente requerirá la aprobación del Consejo de la Xunta, a propuesta de la Consellería de Sanidad y previo sometimiento de los mismos a un proceso de evaluación tecnológica con relación a su seguridad, eficacia, efectividad, eficiencia, impacto desde el punto de vista económico y desde el punto de vista ético y de su contribución al bienestar individual y social, debiendo garantizarse en todo caso la financiación correspondiente.

3. Serán beneficiarios de las nuevas prestaciones que se incluyan en la financiación pública, a tenor de lo previsto en el apartado anterior, los beneficiarios definidos en el artículo $4 .^{\circ}$ de la presente ley.

Artículo 60. Cartera de servicios.

1. La cartera de servicios del Sistema Público de Salud de Galicia será definida por la Consellería de Sanidad después de un proceso de identificación y selección con relación a las necesidades de salud y a los criterios científicos utilizados en la evaluación de tecnologías sanitarias. El procedimiento de su actualización será definido reglamentariamente.

2. Para garantizar la equidad y accesibilidad a una adecuada atención sanitaria, el Servicio Gallego de Salud, dentro de la cartera de servicios aprobada, establecerá la de cada centro o establecimiento del Sistema Público de Salud de Galicia, conforme al procedimiento que reglamentariamente se determine.

\section{Capitulo VI \\ PLANIFICACIÓN DEL SISTEMA PÚBLICO DE SALUD DE GALICIA: LAS DIRECTRICES DE POLÍTICA SANITARIA DE GALICIA Y EL PLAN DE SALUD DE GALICIA}

Artículo 61. Objeto y ámbito de las directrices de política sanitaria de Galicia.

1. Las directrices de política sanitaria de Galicia serán el principal instrumento de planificación y dirección del Sistema Público de Salud de Galicia, que establecerá el plan de mejora del sistema y ordenará todos los proyectos y acciones de mejora organizativa respecto a cumplir los objetivos de salud definidos en el Plan 
de salud, siendo, por tanto, un instrumento complementario de éste.

2. Las directrices de política sanitaria de Galicia identificarán aquellos puntos fuertes, debilidades estructurales y organizativas y áreas de mejora del sistema que incidan más sobre la consecución de los objetivos de salud definidos en el Plan de salud y definirán el conjunto de proyectos y acciones orientados a la mejora organizativa y a la efectividad de los cambios estructurales necesarios en el Sistema Público de Salud de Galicia.

Artículo 62. Contenido de las directrices de política sanitaria de Galicia.

Las directrices de política sanitaria de Galicia contendrán, al menos, los aspectos siguientes:

1. La identificación de los puntos fuertes y debilidades del Sistema Público de Salud de Galicia.

2. La identificación de las áreas de mejora del Sistema Público de Salud de Galicia y su priorización.

3. La visión, valores y ejes estratégicos de la política sanitaria gallega.

4. Los objetivos de gestión del Sistema Público de Salud de Galicia.

5. Las estrategias para la consecución de los objetivos mencionados en el apartado anterior.

6. Los planes, programas, proyectos o acciones necesarias para desarrollar las estrategias elegidas.

7. La vigencia del documento estratégico.

8. El sistema de seguimiento y evaluación de las directrices de política sanitaria de Galicia.

Artículo 63. Tramitación de las directrices de política sanitaria de Galicia.

1. La elaboración de las directrices de política sanitaria de Galicia corresponde a la Consellería de Sanidad.

2. La Consellería de Sanidad presentará el proyecto de las directrices de política sanitaria de Galicia al Consejo Gallego de Salud. Además, informará a este órgano del resultado de su evaluación.
3. La Consellería de Sanidad elevará las directrices de política sanitaria de Galicia al Consejo de la Xunta de Galicia para su aprobación.

4. Una vez aprobadas esas directrices de política sanitaria de Galicia serán presentadas en el Parlamento de Galicia por la persona titular de la Consellería de Sanidad.

5. Anualmente será remitido al Parlamento de Galicia un informe con la evaluación de los objetivos contenidos en las directrices de política sanitaria de Galicia.

Artículo 64. Objeto y ámbito del Plan de salud.

1. En el marco de los criterios generales de la planificación sanitaria, el Plan de salud de Galicia es el instrumento técnico superior de planificación y dirección del Sistema Público de Salud de Galicia, que, integrando los planes o estrategias de salud de las áreas sanitarias, condiciona todas las acciones orientadas a conseguir el mejor estado de salud posible, el cumplimiento de los derechos reconocidos en la presente ley, de acuerdo con los principios que inspiran el Sistema Público de Salud de Galicia.

2. El Plan de salud identificará aquellos problemas de salud que estén incidiendo más sobre la salud de los gallegos y gallegas y definirá el conjunto de acciones dirigidas a la consecución ordenada de los fines propuestos, mediante proyectos y planes de actuación.

3. En sus contenidos y objetivos, el Plan de salud de Galicia habrá de incluir las políticas públicas de carácter intersectorial que tengan relación con los principales determinantes de la salud de la población de Galicia.

4. Con carácter previo a su elaboración habrá de realizarse el diagnóstico de situación del estado de salud de la comunidad y de las áreas sanitarias en que esté ordenada, identificando las patologías que más influyan en los indicadores del estado de salud. 
Se añadirán, asimismo, medidas específicas para la prevención, detección, atención e intervenciones en los casos de violencia de género, incluyendo disposiciones que permitan evaluar el impacto y los efectos de la violencia en la salud de las mujeres.

Artículo 65. Formulación y contenido del Plan de salud.

Una vez seleccionados los problemas a abordar, y en lo referente a la formulación y elaboración del contenido del plan se deberá:

1. Definir los objetivos a alcanzar en cada problema o grupo de problemas de salud.

2. Definir las estrategias, planes, proyectos y acciones a llevar a cabo para modificar los factores identificados como responsables de los problemas. Estas estrategias y acciones tendrán presente:

a. El conocimiento científico y los valores éticos, sociales y culturales.

b. Los recursos disponibles.

c. Los principios rectores del Sistema Público de Salud de Galicia.

d. Las políticas de igualdad de género en el sistema sanitario.

e. Las políticas de responsabilidad social corporativa.

3. Definir el sistema de gestión y seguimiento de las estrategias, planes, proyectos y acciones definidas.

4. Indicar su plazo de vigencia.

5. Definir el sistema de evaluación del plan y comunicación, atendiendo a los criterios siguientes:

a. El Plan de salud se someterá a un proceso de evaluación continua, debiendo elaborarse a mitad del periodo de su vigencia un informe de evaluación del dicho plan.

b. Corresponde a la Consellería de Sanidad la elaboración, difusión, seguimiento, vigilancia y evaluación del cumplimiento del Plan de salud.

Artículo 66. Tramitación del Plan de salud.

1. La elaboración del Plan de salud corresponde a la Consellería de Sanidad.
2. La Consellería de Sanidad presentará el anteproyecto del Plan de salud al Consejo Gallego de Salud, informándolo del resultado de su evaluación.

3. La Consellería de Sanidad trasladará el Plan de salud al Consejo de la Xunta de Galicia para su aprobación.

4. Una vez aprobado será enviado y presentado por la Consellería de Sanidad en el Parlamento de Galicia para su conocimiento y toma en consideración.

5. Una vez conocido por el Parlamento de Galicia será remitido al Ministerio de Sanidad.

6. El informe de evaluación de los objetivos contenidos en el Plan de salud, elaborado a mitad del periodo de su vigencia, será remitido al Parlamento de Galicia para su conocimiento.

\section{Capítulo VII ORDENACIÓN TERRITORIAL DEL SISTEMA PÚBLICO DE SALUD DE GALICIA}

Artículo 67. Ordenación territorial.

El Sistema Público de Salud de Galicia se estructura territorialmente en áreas y zonas sanitarias articuladas en el Mapa sanitario de Galicia, el cual será definido reglamentariamente.

Artículo 68. Las áreas sanitarias.

1. Las áreas sanitarias constituyen la demarcación territorial equivalente a las áreas de salud contempladas en el artículo 56 de la Ley 14/1986, de 25 de abril, general de sanidad.

2. El ámbito geográfico de cada una de las áreas sanitarias se determinará por decreto del Consejo de la Xunta a propuesta de la Consellería de Sanidad, en función de las necesidades sanitarias de la comunidad autónoma y teniendo en cuenta factores geográficos, socioeconómicos, demográficos, laborales, de dotación de vías y medios de comunicación y los criterios y directrices de ordenación y de desarrollo territorial establecidos por la Xunta de Galicia. 
3. Corresponde a las áreas sanitarias la gestión integrada de los recursos sanitarios asistenciales públicos de su ámbito territorial, así como de las prestaciones y programas sanitarios que éstas desarrollen.

4. La estructura y funciones de los órganos de dirección y gestión de las áreas sanitarias y de los dispositivos sanitarios dependientes de las mismas, en su caso, se determinarán reglamentariamente, tomando en consideración lo reflejado en el artículo $25^{\circ}$ de la presente ley.

Artículo 69. Las zonas sanitarias.

1. Las zonas sanitarias son divisiones funcionales de las áreas y constituyen las unidades elementales de prestación de los servicios sanitarios. Estas zonas facilitan la gestión en las áreas de salud y representan los territorios básicos de actuación de las diferentes unidades que prestan servicios sanitarios.

2. La delimitación de las zonas sanitarias tendrá carácter funcional, conforme a criterios funcionales de índole geográfica, demográfica, epidemiológica y de accesibilidad, teniendo en cuenta, en todo caso, las necesidades sanitarias de la población.

3. Los municipios cuya población sea superior a los 50.000 habitantes (o menos si así fuera considerado adecuado funcionalmente) habrán de dividirse en zonas básicas a efectos de adscripción a las unidades y servicios de atención primaria.

Artículo 70. Otros dispositivos territoriales sanitarios.

1. En las provincias podrán establecerse actividades y servicios sanitarios no asistenciales que darán cobertura a las diferentes áreas sanitarias.

2. Cuando se considere necesario podrán establecerse oficinas y servicios dependientes de las estructuras periféricas o de los servicios centrales de la Consellería, distribuidos territorialmente dentro de las áreas sanitarias.

3. Estas actividades y servicios sanitarios no asistenciales habrán de coordinarse con los equipos directivos de las áreas sanitarias.

\section{Capítulo VIII SISTEMA DE INFORMACIÓN DE SALUD Y EVALUACIÓN DEL SISTEMA DE SALUD DE GALICIA}

Artículo 71. Sistema de Información de Salud de Galicia.

1. La Consellería de Sanidad creará el Sistema de Información de Salud de Galicia, con los objetivos de disponer de una herramienta útil para la realización de la planificación sanitaria, la verificación del cumplimiento del Estatuto del y la paciente y la realización de la evaluación de la calidad de los servicios y prestaciones sanitarias.

2. La Consellería de Sanidad es la responsable del Sistema de Información de Salud de Galicia y garantizará su funcionamiento continuo, el cumplimiento de la legislación vigente en materia de protección de la información y la utilización de estándares internacionales.

3. Se creará el Centro de Servicios de Tecnologías y Sistemas de Información del Sistema Público de Galicia como centro operativo de la Consellería de Sanidad que actuará en coordinación con otros servicios y centros de información de la Xunta de Galicia. Su estructura, funciones, recursos y régimen de personal serán definidos reglamentariamente, previo informe del Consejo Gallego de Salud.

Artículo 72. Evaluación del Sistema de Salud de Galicia.

Serán objeto de evaluación, seguimiento o intervención por parte de la autoridad sanitaria competente:

a. El nivel de adecuación y calidad de las prestaciones sanitarias.

b. El grado de cumplimiento de los derechos reconocidos por la presente ley.

c. El cumplimiento por parte de la población de las obligaciones respecto a los servicios sanitarios contenidos en la presente ley.

d. El cumplimiento en los centros y organismos del Sistema Público de Salud de 
Galicia de la legislación vigente, en materia de salud laboral, accidentes de trabajo, enfermedades profesionales y situaciones de incapacidad e invalidez.

e. El desarrollo de las políticas y programas sanitarios.

f. Los servicios y actividades sanitarias o asistenciales que el Sistema Público de Salud de Galicia contrate con el sector privado de asistencia sanitaria, de modo que se ajusten a los mismos parámetros, estándares, derechos o criterios de actuación exigibles para los del propio Sistema Público de Salud de Galicia.

g. En general, toda la actividad sanitaria del personal, centros, servicios y establecimientos sanitarios de la Comunidad Autónoma respecto al cumplimiento de las normas sanitarias vigentes.

\section{Capitulo IX \\ FINANCIACIÓN DEL SISTEMA PÚBLICO DE SALUD DE GALICIA}

Artículo 73. Financiación.

1. El Sistema Público de Salud de Galicia se financiará con criterios de autonomía, equidad, racionalidad, sostenibilidad, solidaridad y suficiencia presupuestaria con cargo a:

a. Los recursos que le correspondan por la participación de la Comunidad Autónoma en los presupuestos del Estado afectos a los servicios y prestaciones sanitarias.

b. Los rendimientos obtenidos por los tributos cedidos total o parcialmente por el Estado a la Comunidad Autónoma con los fines anteriores.

c. Los recursos que le sean asignados a cuenta de los presupuestos de la Comunidad Autónoma.

2. Asimismo, constituyen fuentes de financiación del Sistema Público de Salud de Galicia:

a. Las contribuciones que hayan de realizar las corporaciones locales con cargo a su presupuesto.

b. Los rendimientos de los bienes y derechos propios y de los que tengan adscritos, de acuerdo con lo previsto en la normativa patrimonial de referencia.

c. Las subvenciones, donaciones y contribuciones voluntarias de entidades y particulares.

d. Los ingresos comunes y extraordinarios que esté autorizado a percibir, a tenor de las disposiciones vigentes y de los convenios interadministrativos que pudieran suscribirse para la atención sanitaria, así como cualquier otro recurso que pudiera ser atribuido o asignado.

e. Otros ingresos públicos recogidos en la Ley 14/1986, general de sanidad, así como cualquier otro recurso que pudiera asignarse para la atención sanitaria.

\section{Capitulo $\mathrm{X}$ CONTRATO DE SERVICIOS SANITARIOS}

Artículo 74. El contrato de servicios sanitarios.

1. El contrato de servicios sanitarios es el instrumento mediante el cual se ordenan las relaciones entre la Consellería de Sanidad y los diferentes proveedores de servicios sanitarios, financiados públicamente, para la consecución de los objetivos del Sistema Público de Salud de Galicia.

2. Del mismo modo, es el instrumento mediante el cual se ordenan las relaciones entre el Servicio Gallego de Salud y las organizaciones, centros, servicios y establecimientos, públicos y privados, para la consecución de los objetivos asistenciales fijados.

3. El contrato de servicios sanitarios revestirá la forma de protocolos internos de actividad-financiación, contratos, contratosprograma, conciertos, convenios, acuerdos u otros instrumentos de colaboración.

4. Reglamentariamente se establecerán los supuestos en que la suscripción de un contrato de servicios sanitarios requiera la acreditación sanitaria previa.

5. Motivadamente, y por razones de interés público, urgencia vital o por necesidades urgentes de asistencia sanitaria, la Consellería de Sanidad podrá 
establecer, mediante resolución, excepciones al requisito de previa acreditación sanitaria. Con el mismo carácter de excepcionalidad podrá autorizarse el uso de servicios sanitarios no concertados.

6. Los servicios y actividades sanitarias o asistenciales que el Sistema Público de Salud de Galicia contrate con el sector privado de asistencia sanitaria habrán de ajustarse a los mismos parámetros, estándares, derechos o criterios de actuación exigibles para los del propio Sistema Público de Salud de Galicia.

\section{TÍTULO III \\ DE LAS COMPETENCIAS DEL SISTEMA PÚBLICO DE SALUD DE GALICIA}

\section{Capítulo I \\ LA ADMINISTRACIÓN AUTONÓMICA}

Artículo 75. Consejo de la Xunta de Galicia.

Corresponde al Consejo de la Xunta de Galicia el ejercicio de las competencias siguientes:

a. El establecimiento de las directrices de la política de protección de la salud de la Comunidad Autónoma de Galicia.

b. La aprobación del Plan de salud de Galicia.

c. La aprobación de las directrices de política sanitaria de la Xunta de Galicia.

d. La aprobación de la ordenación territorial del Sistema Público de Salud de Galicia.

e. La aprobación de la estructura orgánica de la Consellería de Sanidad y del Servicio Gallego de Salud.

f. La aprobación del proyecto de presupuesto de la Consellería de Sanidad y del Servicio Gallego de Salud.

g. El nombramiento y cese de los altos cargos de la Administración pública sanitaria de la Xunta de Galicia.

h. La autorización para la constitución o participación de la Xunta de Galicia o del Servicio Gallego de Salud en entidades de nueva creación o ya existentes que actúen en el ámbito sanitario o sociosanitario, de acuerdo con lo establecido en la legislación financiera y presupuestaria, así como patrimonial de la comunidad autónoma.

i. La autorización de la suscripción de convenios con la Administración general del Estado y con otras comunidades autónomas.

j. La aprobación de las normas de autorización y acreditación que han de cumplir los centros, servicios y establecimientos a los efectos de la prestación de servicios sanitarios en Galicia.

k. La aprobación de nuevas prestaciones, entendidas en el sentido de lo señalado en el capítulo $\mathrm{V}$ del título II de la presente norma.

1. Los acuerdos de creación de hospitales públicos en Galicia.

$\mathrm{m}$. Las restantes competencias que le atribuye la normativa vigente.

Artículo 76. Consellería de Sanidad. Corresponde a la Consellería de Sanidad el ejercicio de las competencias siguientes:

a. La evaluación, en términos de salud y actividad, del funcionamiento del Sistema Público de Salud de Galicia.

b. La elaboración, desarrollo y coordinación de la ejecución de las directrices de la política sanitaria de la Comunidad Autónoma de Galicia.

c. La elaboración del proyecto del Plan de salud de Galicia y su remisión al Consejo de la Xunta de Galicia.

d. La definición y establecimiento de los objetivos relativos a los derechos de la ciudadanía y su comunicación y garantía.

e. La planificación de la ordenación territorial del Sistema Público de Salud de Galicia.

f. La propuesta sobre incorporación de nuevas prestaciones en el Sistema Público de Salud de Galicia, así como la actualización de la cartera de servicios.

g. La planificación estratégica de la política de recursos humanos conjunta del Sistema Público de Salud de Galicia, sin perjuicio del ejercicio de planificación que cada organización especializada haya de realizar. 
h. El nombramiento y cese del personal directivo de la Consellería de Sanidad y los de los entes, organismos y/o instrumentos de gestión a ella adscritos, en tanto que titular de su presidencia.

i. La aprobación del anteproyecto de presupuesto del Servicio Gallego de Salud y de los correspondientes a otras entidades con personalidad jurídica propia adscritas a la Consellería.

j. La propuesta de los módulos económicos para la prestación de servicios propios y la aprobación de los concertados.

k. La articulación y gestión del registro único de profesionales señalado en el artículo $34 .^{\circ}$ de la presente ley.

1. La autorización para la creación, modificación, traslado y supresión o cierre de centros, servicios y establecimientos sanitarios. Su registro y catalogación.

m. La confección de los estándares de calidad y la determinación de los criterios y mecanismos de autorización y acreditación de los centros, servicios y establecimientos sanitarios, y la remisión de los mismos al Consejo de la Xunta para su aprobación.

n. La inspección sanitaria en su ámbito competencial.

o. El ejercicio de la potestad disciplinaria en relación al personal con destino en la Consellería de Sanidad y en el Servicio Gallego de Salud, con excepción de la sanción de separación del servicio, y sin perjuicio de las competencias que en esta materia tenga atribuidas la persona titular de la Consellería competente en materia de administración pública.

p. El ejercicio de la potestad sancionadora sobre los centros, servicios y establecimientos sanitarios, salvo la imposición de sanciones pecuniarias atribuidas al Consejo de la Xunta con arreglo a lo establecido en el artículo 45 de la presente ley.

q. La vigilancia y control de la publicidad susceptible de repercutir positiva o negativamente sobre la salud de las personas. r. Los registros, autorizaciones sanitarias obligatorias e inspecciones de cualquier tipo de instalaciones, establecimientos, servicios, actividades y productos, directa o indirectamente relacionados con la salud de la población, sin perjuicio de las competencias de otras Consellerías y de las corporaciones locales.

s. La definición, comunicación y establecimiento de objetivos y garantías de cumplimiento de los criterios de gestión incorporados en la prestación de servicios sanitarios.

t. La planificación, generación, puesta a disposición y evaluación de los recursos necesarios para la prestación de servicios sanitarios dentro del Sistema Público de Salud de Galicia.

u. La provisión directa de servicios sanitarios.

v. Las restantes competencias que le atribuye la normativa vigente, sin perjuicio de las competencias de otros departamentos o administraciones.

Artículo 77. Instrumentos de gestión de la Consellería de Sanidad y de los organismos dependientes de la misma.

1. Para el ejercicio de sus competencias, la Consellería de Sanidad y los organismos dependientes de la misma podrán:

a. Desarrollarlas directamente o a través de organismos autónomos, entes públicos de carácter institucional o agencias públicas vinculadas orgánicamente al Servicio Gallego de Salud o a la Consellería de Sanidad y con el objetivo posible de crear estructuras específicas vinculadas a criterios técnicos o territoriales para gestiones especializadas (emergencias, transfusión, aprovisionamientos, evaluación de tecnologías, desarrollo de tecnologías de la información, docencia, investigación o para evaluación de sistemas de promoción profesional).

La relación entre dichas entidades, como medio propio instrumental y servicio técnico de la administración, con la Consellería de Sanidad o el Servicio Gallego de Salud se regulará, tanto para la prestación de 
servicios sanitarios como de otros incluidos en su objeto social o finalidad, a través de los instrumentos contemplados en el artículo 74 , los cuales permitirán vincular el funcionamiento de aquéllas y su financiación con los criterios de planificación de la Consellería o del Servicio Gallego de Salud y con las necesidades de los usuarios y usuarias.

b. Delegar funciones en el Servicio Gallego de Salud u otros organismos o entidades adscritos a la Consellería de Sanidad.

c. Establecer encomiendas de gestión, acuerdos, convenios o contratos -cualquiera que sea su tipología y modalidadcon entidades públicas o privadas.

d. Participar en cualquier otra entidad pública o privada, cuando así convenga a la gestión y ejecución de las competencias asignadas.

2. Corresponde al Foro de Participación Institucional de Sanidad y al Consejo Gallego de Salud conocer y emitir informe sobre los expedientes de autorización de la constitución o participación de la comunidad autónoma en los organismos y entidades de nueva creación o ya existentes a que se refiere el apartado anterior.

3. Corresponde al Consejo de la Xunta autorizar la constitución o participación de la comunidad autónoma en los organismos y entidades de nueva creación o ya existentes a que se refiere el apartado 1 del presente artículo, de acuerdo con lo establecido en la legislación financiera y presupuestaria así como patrimonial de la comunidad autónoma.

Artículo 78. Consejo Asesor del Sistema Público de Salud de Galicia.

1. El Consejo Asesor del Sistema Público de Salud de Galicia es el órgano no colegiado superior de consulta y asesoramiento de la Consellería de Sanidad.

2. El Consejo Asesor del Sistema Público de Salud de Galicia estará integrado mayoritariamente por profesionales del mismo. La composición, en su caso, y las normas generales de organización y funcionamiento del consejo se determinarán por orden de la persona titular de la Consellería de Sanidad.

3. El Consejo Asesor del Sistema Público de Salud de Galicia contará con una secretaría permanente, que lo coordinará y le prestará soporte técnico y logístico.

4. El nombramiento de las personas que formen parte del Consejo Asesor del Sistema Público de Salud de Galicia será, en todo caso, a título individual, procurándose una composición paritaria de mujeres y hombres. Dicho nombramiento podrá hacerse con carácter temporal, en tanto duren las funciones de asesoramiento asignadas a la persona titular del mismo, o bien con carácter permanente, comportando en este caso la disponibilidad de la persona nombrada para prestar cometidos de asesoramiento cuando le sean requeridos.

5. La persona titular de la Consellería de Sanidad podrá designar asesores sectoriales en materias específicas relacionadas con la asistencia y organización sanitarias, la salud pública, la docencia e investigación en las ciencias de la salud y, en general, en cualquier otra materia de interés sanitario respecto a la cual resulte conveniente solicitar asesoramiento especializado.

Artículo 79. Organizaciones, entidades y centros públicos proveedores de servicios sanitarios.

Corresponde a las organizaciones, entidades o centros públicos proveedores de servicios sanitarios las funciones siguientes:

1. La planificación, disposición, distribución y gestión de los recursos técnicos, humanos y económicos precisos para cumplir con la prestación de las actividades acordadas con la Consellería.

2. La articulación, en su caso, de las áreas de gestión clínica y la garantía en la aplicación de las guías de práctica clínica, vías clínicas, y planes y programas en su área de responsabilidad. 
3. La celebración de contratos de servicios sanitarios con terceros.

\section{Capitulo II LA ADMINISTRACIÓN LOCAL}

Artículo 80. Competencias de la Administración local.

1. Las entidades locales participarán en el Sistema Público de Salud de Galicia en los términos previstos en la presente ley y disposiciones que la desarrollen, en la Ley general de sanidad y demás legislación específica.

2. Las entidades locales ejercerán las competencias que en materia sanitaria les atribuye la legislación de régimen local y las restantes que les confiere el ordenamiento jurídico.

3. Los municipios, sin perjuicio de las competencias de las demás administraciones públicas, tendrán con relación al obligado cumplimiento de las normas y planes sanitarios las siguientes obligaciones derivadas de sus competencias:

a. La prestación de los servicios mínimos obligatorios determinados en la legislación de régimen local en lo referente a los servicios de salud y a los regulados en la presente ley.

b. El control sanitario del medio natural, $y$, en especial, la contaminación atmosférica, ruidos y vibraciones, abastecimiento y saneamiento de aguas, residuos urbanos.

c. El control sanitario de industrias, actividades, servicios y transportes que impacten en la salud de su ciudadanía.

d. El control sanitario de edificios y lugares de vivienda y convivencia humana, especialmente de los centros de alimentación, peluquerías, saunas y centros de higiene personal, hoteles y centros residenciales, escuelas, campamentos turísticos y áreas de actividad física, deportiva y de recreo.

e. El control sanitario de la distribución y suministro de alimentos, bebidas y demás productos relacionados con el uso o consumo humano, así como de los medios para su transporte que estén dirigidos a los ciudadanos y ciudadanas del municipio.

f. El control sanitario de los cementerios y policía sanitaria mortuoria.

g. El desarrollo de programas de promoción de la salud, educación sanitaria y protección de grupos sociales con riesgos específicos que se prevean en los planes de salud.

h. La participación en órganos de dirección y/o participación de las organizaciones públicas de salud en la forma que reglamentariamente se determine.

i. La colaboración, en los términos en que se acuerde en cada caso, en la construcción, reforma y/o equipación de centros y servicios sanitarios.

4. Además, los municipios podrán realizar actividades complementarias de las que sean propias de otras administraciones públicas en las materias objeto de la presente ley, en los términos establecidos en la legislación reguladora del régimen local.

5. Igualmente, los municipios podrán prestar los servicios relacionados con las materias objeto de la presente ley que se deriven de las competencias que en los mismos delegue la Xunta de Galicia al amparo de la legislación de régimen local y en aplicación del Plan de acción local de Galicia.

6. Para el desarrollo de las funciones relacionadas en los apartados anteriores, los municipios solicitarán el apoyo técnico del personal y los medios de las áreas sanitarias en que se encuentren comprendidos. El personal sanitario de la Consellería de Sanidad, del Servicio Gallego de Salud u otras organizaciones públicas proveedoras de servicios que presta apoyo a los municipios tendrá, a estos efectos, la consideración de personal al servicio de éstos, con sus obligadas consecuencias en cuanto al régimen de recursos y responsabilidades personales y patrimoniales.

7. La elaboración y desarrollo de la normativa municipal en las materias objeto de la presente ley incluirá su conocimiento previo por parte de la Consellería de Sanidad, 
a favor de la efectiva coordinación y eficacia administrativa.

8. Los planes sanitarios generales de Galicia se pondrán en conocimiento de las entidades locales de Galicia, a través de sus organizaciones representativas. Los planes especiales se remitirán a los municipios a los que afecten.

9. Para un mejor cumplimiento de los fines de la presente ley las entidades locales podrán establecer convenios con la Administración sanitaria autonómica.

Artículo 81. Delegación de competencias en la Administración local.

1. Sin perjuicio de lo establecido en los artículos anteriores, las entidades locales podrán asumir competencias delegadas por la Consellería de Sanidad, siempre y cuando acrediten poder ejecutar plenamente las funciones que en materia de salud les asigne como competencia propia la legislación vigente y obtengan la pertinente acreditación para la delegación de tales competencias en la forma que reglamentariamente se determine.

2. Las competencias a que se refiere el apartado anterior sólo podrán ser delegadas, de acuerdo con los principios de autonomía municipal y responsabilidad financiera, cuando las entidades locales asuman los resultados económicos de su gestión.

\section{TÍTULO IV \\ DE LAS RELACIONES DEL SISTEMA PÚBLICO DE SALUD DE GALICIA CON LA UNIÓN EUROPEA, LA ADMINISTRACIÓN GENERAL DEL ESTADO Y OTRAS COMUNIDADES AUTÓNOMAS \\ Capítulo I \\ DE LA RELACIÓN CON OTROS PAÍSES, INSTITUCIONES INTERNACIONALES SANITARIAS Y LA UNIÓN EUROPEA}

Artículo 82. Relación con otros países e instituciones internacionales sanitarias.

1. El Gobierno de Galicia, a través de la Consellería de Sanidad, realizará las actividades de colaboración sanitaria con otros países e instituciones internacionales sanitarias con el objetivo de lograr un impacto en la salud de la población, sin perjuicio de lo dispuesto en el artículo $38 .^{\circ}$ 1 de la Ley 14/1986, de 25 de abril, general de sanidad.

2. Del mismo modo, podrá formalizar acuerdos de colaboración sanitaria con autoridades sanitarias de otros países a los efectos de garantizarles la adecuada prestación sanitaria a las comunidades gallegas asentadas en el exterior.

3. Estas líneas de colaboración podrán ser recogidas en acuerdos o convenios que serán tramitados siguiendo la normativa vigente en esta materia.

Artículo 83. Actuación de la Xunta con la Unión Europea.

1. En las materias objeto de la presente ley, corresponde a la Xunta de Galicia la transposición, desarrollo y ejecución de la normativa comunitaria en aquellos ámbitos que sean propios de su competencia al amparo de lo previsto en la Constitución y el Estatuto de autonomía de Galicia.

2. La Xunta de Galicia participará de modo efectivo en el proceso de formación de la voluntad del Estado español en lo referente a la adopción de decisiones y la emisión de actos normativos por los órganos de la Comunidad Europea que afecten a las materias objeto de la presente ley, en los términos previstos en las leyes y convenios que se establezcan con la Administración del Estado.

\section{Capítulo II DE LAS RELACIONES CON LA ADMINISTRACIÓN DEL ESTADO}

Artículo 84. De las relaciones de cooperación con la Administración del Estado.

1. En las materias objeto de la presente ley, la Xunta de Galicia participará de modo efectivo en el ejercicio de las competencias que de acuerdo con el bloque de la constitucionalidad corresponden al 
Estado, en los términos que establecen las leyes y los convenios que se suscriban con éste, y, en particular, por lo que se refiere al establecimiento de las bases, la coordinación general de la sanidad y el alta inspección, todo ello sin perjuicio de lo previsto en el apartado 4 del presente artículo. Esta participación se dirigirá a la consecución de una coordinación, integración y aprovechamiento de las actividades y actuaciones que desarrolla cada comunidad autónoma en materia sanitaria, a fin de mejorar la salud de toda la población.

2. En defecto de leyes estatales que garanticen la efectiva participación a que se refiere el apartado anterior o al objeto de completar las previsiones que al respecto se contienen en las mismas, el Consejo de Gobierno de la Xunta de Galicia promoverá con la indicada finalidad la celebración de los oportunos convenios con la Administración del Estado conforme a lo previsto en la Ley 30/1992, de 26 de noviembre, de régimen jurídico de las administraciones públicas y del procedimiento administrativo común, y disposiciones concordantes.

3. Igualmente, en defecto de leyes estatales que así lo establezcan, la Xunta de Galicia promoverá la celebración de los oportunos convenios con la Administración del Estado, así como la adopción de cuantas medidas sean precisas para hacer efectiva la participación de aquélla en los órganos de gobierno de los organismos y entidades dependientes de la Administración general del Estado, cualquiera que sea su naturaleza jurídica, que desarrollen su actividad en las materias objeto de la presente ley.

4. Por razones de eficacia, la Xunta de Galicia promoverá la celebración de los oportunos convenios con la Administración general del Estado a fin de encomendar a los órganos de la comunidad u organismos o entidades de ella dependientes, en el ámbito territorial de Galicia, la prestación de los servicios y el desempeño de las competencias ejecutivas y de inspección y control que en materia sanitaria corresponden al Estado de acuerdo con el bloque de la constitucionalidad, todo ello sin perjuicio de su eventual transferencia o delegación a esta comunidad.

5. La Xunta de Galicia podrá acordar la realización de planes y programas conjuntos de actuación con la Administración general del Estado para el logro de objetivos comunes en las materias objeto de la presente ley, conforme a lo previsto en la Ley 30/1992, de 26 de noviembre, de régimen jurídico de las administraciones públicas y del procedimiento administrativo común, y disposiciones concordantes.

\section{Capítulo III \\ DE LAS RELACIONES CON OTRAS COMUNIDADES AUTÓNOMAS Y LAS COMUNIDADES GALLEGAS EN EL EXTERIOR EN MATERIA SANITARIA}

Artículo 85. De las relaciones de cooperación con otras comunidades autónomas.

1. La Xunta de Galicia podrá establecer relaciones de cooperación con otras comunidades autónomas para la consecución de objetivos comunes en las materias objeto de la presente ley mediante cualquiera de las fórmulas admitidas en derecho y, en su caso, mediante la celebración de los oportunos convenios de colaboración y acuerdos de cooperación, que se tramitarán con arreglo a lo establecido en los artículos 145.2. ${ }^{\circ}$ de la Constitución, 35 del Estatuto de autonomía de Galicia y $4.8 .^{\circ}$ de la Ley 1/1983, de 22 de febrero, reguladora de la Xunta y de su Presidencia.

2. Además, podrá acordar la realización de planes y programas conjuntos de actuación con otras comunidades autónomas para el logro de objetivos de interés común, en especial de carácter territorial con relación a la protección de la salud y la provisión de los servicios sanitarios y sociosanitarios en áreas limítrofes y de carácter sectorial con relación a la atención de determinadas patologías o ámbitos de 
la asistencia en concreto $\mathrm{y} / \mathrm{o}$ colectivos necesitados de especial protección.

Artículo 86. De las relaciones de cooperación con las comunidades gallegas en el exterior.

1. La Xunta de Galicia podrá firmar acuerdos de colaboración y cooperación con las comunidades gallegas asentadas en el exterior en el marco previsto en el Estatuto de autonomía.

2. Los convenios y acuerdos de colaboración y cooperación podrán consistir en la adopción de fórmulas de gestión directa o indirecta de los centros asistenciales pertenecientes a las comunidades gallegas y en el reconocimiento, de acuerdo con el principio de reciprocidad, a la prestación de asistencia sanitaria a sus miembros en desplazamientos temporales a la comunidad autónoma.

\section{TÍTULO V \\ DEL SECTOR PRIVADO DE ATENCIÓN SANITARIA Y SUS RELACIONES CON EL SISTEMA PÚBLICO DE SALUD DE GALICIA}

Artículo 87. Autorización y acreditación de centros.

Todos los centros, servicios y establecimientos sanitarios de titularidad privada que presten servicios en la comunidad autónoma deberán ser autorizados siguiendo la regulación establecida. Reglamentariamente se determinarán los supuestos en que habrán de contar con la acreditación correspondiente.

Artículo 88. Complementariedad y subsidariedad del sector sanitario privado.

1. Para la consecución de los objetivos y principios rectores del Sistema Público de Salud de Galicia se reconoce la importancia del sector privado de atención sanitaria como complementario y subsidiario a toda su actividad.

2. Para la cooperación del sector privado de atención sanitaria con el Sistema Público de Salud de Galicia, y sin perjuicio de lo dispuesto expresamente en la presente ley, el Plan de salud de Galicia determinará además las acciones que durante su vigencia sean susceptibles de una acción conjunta.

Artículo 89. Mecanismo de relación con el Sistema Público de Salud de Galicia.

1. La colaboración del sector privado de atención sanitaria con el Sistema Público de Salud de Galicia se instrumentará a través de las diferentes fórmulas de contratos de servicios definidas en el artículo 74 de la presente ley.

2. Los contratos de servicios se realizarán en igualdad de condiciones de eficacia, eficiencia y calidad, teniendo en cuenta los principios de subsidiariedad, complementariedad y optimización, la adecuada coordinación en la utilización de recursos públicos y privados y las necesidades de atención sanitaria.

3. Las entidades y organizaciones sin ánimo de lucro tendrán consideración preferente para la celebración de contratos de servicios, en los términos expresados en el apartado anterior.

Artículo 90. Gestión de los contratos de servicios con el sector privado de atención sanitaria.

1. Para la realización de contratos de servicios con la Consellería de Sanidad u organismos dependientes de la misma y con el Servicio Gallego de Salud, las entidades e instituciones deberán reunir los requisitos establecidos en los reglamentos vigentes.

2. No podrán realizarse contratos de servicios con aquellas entidades e instituciones en que presten su actividad profesionales con funciones directivas en el Sistema Público de Salud de Galicia.

3. No podrán contratarse servicios a entidades e instituciones privadas cuando éstos sean realizados por personal vinculado laboralmente al Sistema Público de Salud de Galicia, aunque se encuentre en situación legal de compatibilidad.

4. Los contratos cumplirán las especificaciones que reglamentariamente se 
determinen y, con arreglo a lo dispuesto en el artículo 74.6 de la presente ley, la prestación de estos servicios se hará con sujeción al sistema de garantías de los derechos y deberes sanitarios contemplados en la presente ley.

Artículo 91. Garantía de los derechos en el sector sanitario privado.

1. Los centros y establecimientos sanitarios privados, para poder prestar servicios sanitarios a sus usuarios y usuarias, deberán cumplir todas las exigencias normativas en materia de protección de salud que sean de aplicación.

2. Respetando el peculiar régimen económico de cada centro sanitario, los derechos contemplados en los artículos $5,6,7,8,9$ y 10 de la presente ley serán garantizados por los centros y establecimientos sanitarios privados. Igualmente cumplirán con aquellos otros derechos recogidos en la normativa vigente y cuyo alcance incluya a los centros y establecimientos sanitarios privados.

3. Para la actividad que presten en régimen de concierto con el Sistema Público de Salud de Galicia, se estará a lo dispuesto en los artículos 12, 13 y 74.6 de la presente ley.

\section{TÍTULO VI \\ DEL SERVICIO GALLEGO DE SALUD}

\section{Capitulo I \\ PRINCIPIOS GENERALES}

Artículo 92. Naturaleza.

1. Para el adecuado desarrollo de las competencias que en el ámbito sanitario corresponden a la Comunidad Autónoma de Galicia se configura el Servicio Gallego de Salud, creado por la Ley $1 / 1989$, como un organismo autónomo de naturaleza administrativa, dotado de personalidad jurídica propia y plena capacidad para el cumplimiento de sus fines.

2. El Servicio Gallego de Salud está adscrito a la Consellería de Sanidad, que ejercerá sobre él las facultades de dirección, vigilancia y tutela y, en particular, el ejercicio de las potestades reglamentarias y de organización que le atribuyen la presente ley y las restantes disposiciones que sean de aplicación.

3. El Servicio Gallego de Salud se regirá por lo establecido en la presente ley y normas dictadas en su desarrollo y por las restantes disposiciones que le sean de aplicación. En materia de contratación, el servicio se rige por lo recogido en la legislación sobre contratos de las administraciones públicas. La contratación de servicios sanitarios se regirá por sus normas específicas.

4. El Servicio Gallego de Salud y la totalidad de entidades adscritas al mismo disfrutan de la reserva de nombres y de los beneficios, exenciones y franquicias de cualquier clase y naturaleza que las leyes atribuyen a la Xunta de Galicia y a las entidades públicas encargadas de la gestión de la Seguridad Social.

5. El objetivo del Servicio Gallego de Salud es la provisión de los servicios y prestaciones de atención sanitaria individual de cobertura pública en el ámbito de la Comunidad Autónoma de Galicia, dentro del marco básico de financiación del Sistema Público de Salud de Galicia, garantizando los derechos sanitarios reconocidos en la presente ley.

Artículo 93. Centros y servicios.

1. Integran el Servicio Gallego de Salud los centros, servicios y establecimientos sanitarios y administrativos creados por la Administración de la Xunta de Galicia o procedentes de transferencias, así como las entidades sanitarias de naturaleza pública que se le adscriban.

2. Se integrarán, de la manera que reglamentariamente se determine y tras su liquidación, en el Servicio Gallego de Salud o adscritas a la Consellería de Sanidad, según el artículo 77.1.a) de la presente ley, las fundaciones públicas sanitarias y las sociedades públicas sanitarias, ambas de carácter asistencial. 
Artículo 94. Funciones.

Para la consecución de su objetivo, el Servicio Gallego de Salud desarrolla, bajo la supervisión y control de la Consellería de Sanidad, las funciones siguientes:

a. La prestación directa de asistencia sanitaria en sus propios centros, servicios y establecimientos o en los adscritos al servicio.

b. El desarrollo de los programas de actuación sanitaria.

c. El gobierno, dirección y gestión de los centros, servicios y establecimientos sanitarios propios o adscritos al Servicio Gallego de Salud.

d. La planificación, coordinación y gestión de los recursos humanos, materiales y financieros asignados al servicio para el cumplimiento de sus fines.

e. La introducción de nuevas técnicas y procedimientos diagnósticos y terapéuticos, previa evaluación de los mismos en términos de eficacia, seguridad, coste e impacto desde el punto de vista bioético.

f. La promoción de la docencia e investigación en ciencias de la salud en el ámbito de los centros, servicios y establecimientos sanitarios asistenciales.

g. El establecimiento de la cartera de servicios que presta cada uno de los centros, servicios y establecimientos sanitarios asistenciales propios o adscritos, con arreglo a lo previsto en el artículo $60 .^{\circ}$ de la presente ley.

h. La gestión de la cartera de servicios a que se refiere el apartado anterior.

i. El desarrollo de programas de calidad y mejora de la práctica clínica y de mejora de gestión.

j. La gestión de las prestaciones farmacéuticas y complementarias que corresponda en el ámbito de sus competencias.

k. La celebración de contratos de servicios sanitarios con organizaciones, centros, servicios y establecimientos, públicos y privados, para la consecución de los objetivos asistenciales fijados.
1. La aprobación de los planes, programas, directrices y criterios de actuación a que han de someterse los centros, servicios y establecimientos incluidos en el Servicio Gallego de Salud, así como el ejercicio de la supervisión y control respecto a éstos.

m. La elaboración, desarrollo y evaluación de los programas sanitarios del Servicio Gallego de Salud.

n. La definición, comunicación y establecimiento de objetivos y garantías de los criterios de gestión de los servicios sanitarios que preste el Servicio Gallego de Salud.

o. La definición, planificación y compra de actividades sanitarias que desarrolle el Servicio Gallego de Salud en cumplimiento de sus fines.

p. La planificación, generación, puesta a disposición y evaluación de los recursos que precise en cumplimiento de sus fines.

q. El establecimiento, gestión y actualización de los acuerdos, convenios y contratos, cualquiera que sea su tipología y modalidad, con terceras entidades titulares de centros, servicios y establecimientos sanitarios.

Artículo 95. Instrumentos de prestación de servicios sanitarios del Servicio Gallego de Salud.

El Servicio Gallego de Salud podrá utilizar los instrumentos de gestión contemplados en el artículo 74 .

\section{Capitulo II ORGANIZACIÓN} ción.

Artículo 96. Órganos de administra-

1. Será presidente o presidenta del Servicio Gallego de Salud la persona titular de la Consellería de Sanidad.

2. El Servicio Gallego de Salud dispondrá de un consejo de dirección que será presidido por la persona titular de la Consellería de Sanidad o un alto cargo designado por ésta como director-gerente.

3. Tendrá los órganos directivos que reglamentariamente se determine. 


\section{Código de la Administración Gallega}

4. La estructura orgánica del Servicio Gallego de Salud, tanto en su nivel central como periférico, se determinará reglamentariamente, según las necesidades asistenciales de la ciudadanía en cada territorio y atendiendo a los principios de eficacia, eficiencia, simplicidad, transparencia y cercanía. En todo caso, habrá de tenerse en cuenta la ordenación territorial del Sistema Público de Salud de Galicia vigente en cada momento. Se definirán también los órganos unipersonales mínimos de dirección propios.

\section{Capítulo III ORGANIZACIÓN DE SERVICIOS. CENTROS SANITARIOS. ORGANIZACIÓN Y GESTIÓN}

Artículo 97. Instrumentos de organización y gestión.

1. La modernización del sistema requiere la introducción de modelos de gestión que dinamicen el servicio público y garanticen un marco de innovación tecnológica adecuado, a fin de obtener la mayor rentabilidad social.

2. Se introducirán fórmulas organizativas con una visión horizontal e integradora de los procesos asistenciales y se adoptarán las medidas que fomenten la coordinación, colaboración y cooperación.

3. Estas fórmulas organizativas tenderán a superar la compartimentación existente, especialmente en los hospitales, y la relación primaria-especializada fruto de la progresiva especialización y de la fragmentación del trabajo, haciendo compatible éste con una atención horizontal de las necesidades asistenciales de los y las pacientes y facilitando una mayor autonomía de gestión de los centros y establecimientos sanitarios.

4. Todo instrumento de organización y gestión se articulará bajo el principio básico de garantía de la participación real y efectiva de los profesionales en la gestión del centro y/o área sanitaria.

\section{Capitulo IV RÉGIMEN JURÍDICO}

Artículo 98. Régimen jurídico de los actos.

El régimen jurídico de los actos emanados de los órganos de dirección y gestión del Servicio Gallego de Salud será el establecido en la Ley 30/1992, de 26 de noviembre, de régimen jurídico de las administraciones públicas y del procedimiento administrativo común, y en la normativa de organización y funcionamiento de la Administración de la comunidad autónoma.

\section{Capítulo V MEDIOS MATERIALES Y RÉGIMEN PATRIMONIAL}

Artículo 99. Medios materiales.

El Servicio Gallego de Salud contará con los medios materiales precisos para el cumplimiento de los fines que la presente ley le atribuye.

Artículo 100. Patrimonio.

1. Constituye el patrimonio propio del Servicio Gallego de Salud todos los bienes y derechos que le pertenezcan a la entrada en vigor de la presente ley o que adquiera o reciba en el futuro por cualquier título.

2. Constituye el patrimonio adscrito al Servicio Gallego de Salud:

a. Los bienes y derechos del patrimonio de la comunidad autónoma afectos a servicios de asistencia sanitaria que tenga adscritos o que se le adscriban.

b. Los bienes y derechos de toda índole afectos a los servicios de asistencia sanitaria del sistema de Seguridad Social transferidos a la Xunta de Galicia, con pleno respeto a lo previsto en la disposición adicional séptima de la Ley general de sanidad.

c. Los bienes y derechos de las entidades locales que se le adscriban.

d. Cualesquier otros bienes y derechos adquiridos por otro título jurídico. 
Artículo 101. Régimen jurídico del patrimonio.

1. El régimen jurídico del patrimonio del Servicio Gallego de Salud se regirá por lo establecido en la presente ley y, en su defecto, por lo dispuesto en la normativa reguladora del patrimonio de la Comunidad Autónoma de Galicia, debiendo ajustarse a los principios siguientes:

a. El Servicio Gallego de Salud tiene plena capacidad para adquirir y poseer bienes y derechos por los medios establecidos en el ordenamiento jurídico, así como para ejercer las acciones y recursos que procedan para la defensa y tutela de su patrimonio.

b. Son bienes de dominio público del Servicio Gallego de Salud los afectos a la prestación directa de servicios públicos propios del organismo y los inmuebles de su propiedad en que se alojen sus unidades y entidades dependientes de su administración, y como tal disfrutan de los beneficios tributarios que les sean de aplicación.

c. Se aplicará el régimen jurídico demanial a los derechos reales del Servicio Gallego de Salud en los que concurran las circunstancias descritas en el apartado anterior.

d. La declaración de utilidad pública se entiende implícita en toda expropiación relativa a obras y servicios que sean competencia del Servicio Gallego de Salud para el cumplimiento de las funciones y la consecución de los fines fijados por la ley.

2. El Servicio Gallego de Salud podrá adquirir por sí mismo bienes inmuebles y derechos a título gratuito previa autorización del Consejo de la Xunta. Las adquisiciones gratuitas de bienes muebles podrá hacerlas directamente sin necesidad de autorización previa, dejando constancia en el expediente de la conveniencia de la adquisición.

3. El Servicio Gallego de Salud podrá arrendar directamente los inmuebles que sean necesarios para el desarrollo de sus funciones, debiendo publicar el anuncio y la adjudicación en el Diario Oficial de Galicia. No obstante, se exceptuará la publicación del anuncio en aquellos casos en que se acredite que basándose en las peculiaridades del bien haya de arrendarse un inmueble determinado.

4. El Servicio Gallego de Salud podrá disponer de los bienes y derechos que le pertenezcan en propiedad y que no sean necesarios para el ejercicio de sus funciones.

5. Podrán cederse los bienes muebles propiedad del organismo a terceros en el marco de relaciones de colaboración y para fines de interés sanitario. También podrán cederse con fines benéficos bienes muebles de los que no se prevea su utilización.

Artículo 102. Inventario.

El Servicio Gallego de Salud llevará un inventario de los bienes y derechos que integran su patrimonio a los efectos de conocer en todo momento la naturaleza y calificación de los mismos, así como su situación, uso y destino.

\section{Capitulo VI RÉGIMEN FINANCIERO, PRESUPUESTARIO Y CONTABLE}

Artículo 103. Régimen financiero.

El Servicio Gallego de Salud se financiará con los recursos que le sean asignados con cargo a los presupuestos de la Comunidad Autónoma de Galicia, entre los cuales podrán figurar los siguientes:

a. Los destinados por la comunidad autónoma a la financiación de los servicios sanitarios de la Seguridad Social por la aplicación de lo establecido en la Ley 21/2001, de 27 de diciembre, por la que se regulan las medidas fiscales y administrativas del nuevo sistema de financiación de las comunidades autónomas de régimen común y ciudades con estatuto de autonomía.

b. La parte que, en razón a las funciones conferidas, pueda corresponderle por la participación de la Xunta de Galicia 
en los recursos destinados a financiar la gestión de los servicios sanitarios.

c. Las aportaciones que hayan de realizar las entidades locales con cargo a sus presupuestos, en su caso.

d. Los productos y rentas de toda índole procedentes de los bienes y derechos que integran su patrimonio, propio o adscrito.

e. Los ingresos ordinarios y extraordinarios que legal o convencionalmente esté autorizado a percibir y, en particular, los ingresos procedentes de la prestación de servicios sanitarios cuando existan terceros obligados al pago y los procedentes de acuerdos con entidades aseguradoras de asistencia sanitaria o con otras comunidades autónomas.

f. Las subvenciones, donaciones y cualquier otra aportación voluntaria de entidades y particulares.

g. Cualesquier otros recursos que puedan serle atribuidos o asignados.

Artículo 104. Presupuesto.

El presupuesto del Servicio Gallego de Salud ha de orientarse de acuerdo con las previsiones contenidas en el Plan de salud de Galicia y en las directrices de política sanitaria de la comunidad autónoma, ha de incluirse en los presupuestos de la Xunta de forma diferenciada y se regirá por las disposiciones del Decreto legislativo 1/1999, de 7 de octubre, por el que se aprueba el texto refundido de la Ley de régimen financiero y presupuestario de Galicia.

Artículo 105. Contabilidad.

El Servicio Gallego de Salud estará sometido al régimen de contabilidad pública en los términos que se establecen en el Decreto legislativo 1/1999, de 7 de octubre, por el que se aprueba el texto refundido de la Ley de régimen financiero y presupuestario de Galicia, y disposiciones concordantes.

Artículo 106. Régimen de control. La Intervención General de la Xunta de Galicia ejercerá sus funciones en el ámbito del Servicio Gallego de Salud, en los términos que establece el Decreto legislativo 1/1999, de 7 de octubre, por el que se aprueba el texto refundido de la Ley de régimen financiero y presupuestario de Galicia, y demás disposiciones que resulten de aplicación.

\section{TÍTULO VII \\ DE LA ORGANIZACIÓN DE LA SALUD PÚBLICA EN EL SISTEMA PÚBLICO DE SALUD DE GALICIA}

Artículo 107. La organización de la salud pública.

Para el adecuado desarrollo de las competencias que en el ámbito sanitario corresponden a la Comunidad Autónoma de Galicia y para la provisión de los servicios y prestaciones de salud pública de cobertura pública en el ámbito de la Comunidad Autónoma de Galicia, la Consellería de Sanidad se dotará de la estructura organizativa y de gestión que mejor permita el adecuado desarrollo de las funciones siguientes:

a. La prestación directa de servicios de salud pública en sus propios centros, servicios y establecimientos o en los adscritos a ella.

b. El desarrollo de los programas de actuación sanitaria.

c. El gobierno, dirección y gestión de los centros y servicios propios o adscritos.

d. La coordinación y gestión de los recursos humanos, materiales y financieros que le sean asignados para el cumplimiento de sus fines.

e. La promoción de la docencia e investigación en salud pública.

f. El desarrollo de programas de calidad y mejora de la salud pública y de mejora de gestión.

g. La celebración de contratos de servicios sanitarios con organizaciones, centros, servicios y establecimientos, para la consecución de los objetivos fijados con la Consellería de Sanidad. 


\section{TÍTULO VIII \\ DE LOS EMPLEADOS Y EMPLEADAS PÚBLICOS DE LA SALUD DEL SISTEMA PÚBLICO DE SALUD DE GALICIA}

\section{Capítulo I \\ ÁMBITO Y RÉGIMEN JURÍDICO}

Artículo 108. Empleado público de la salud.

1. A los efectos de la presente ley son empleados públicos de la salud del Sistema Público de Salud de Galicia aquéllos que prestan servicios en las instituciones y estructuras de titularidad de la Comunidad Autónoma de Galicia dentro del ámbito competencial de la Consellería de Sanidad y de los organismos de ella dependientes.

2. Integran el colectivo de empleados públicos de la salud del Sistema Público de Salud de Galicia a que se refiere el apartado anterior:

a. El personal estatutario de la Comunidad Autónoma de Galicia que presta servicios en las instituciones, órganos, unidades o estructuras del Sistema Público de Salud de Galicia.

b. El personal funcionario perteneciente a los diferentes cuerpos, generales o especiales, de la Administración estatal o de sus organismos autónomos que preste servicios en las instituciones, órganos, unidades o estructuras del Sistema Público de Salud de Galicia.

c. El personal transferido, cualquiera que sea el régimen jurídico de dependencia, laboral, funcionario o estatutario, de otras administraciones públicas con ocasión del traspaso y/o la asunción de las competencias, medios y servicios en materia de asistencia sanitaria.

d. El personal que preste servicios en las entidades de titularidad pública, con personalidad jurídica propia, que estén adscritas a la Consellería de Sanidad.

3. Los funcionarios que, por aplicación de lo dispuesto en la Ley 17/1989, de 23 de octubre, de creación de escalas del personal sanitario al servicio de la comunidad autónoma, estén adscritos a la Consellería de Sanidad se integrarán en el colectivo de empleados públicos de la salud del Sistema Sanitario de Galicia, sin perjuicio de que por la naturaleza jurídica de su vínculo se mantengan sometidos en cuanto a sus condiciones laborales y retributivas al régimen jurídico funcionarial, en tanto no se integren en el régimen estatutario con arreglo a lo previsto en el artículo 112.5.

Artículo 109. Régimen jurídico del empleado público y empleada pública de la salud.

1. Con carácter general, el régimen jurídico de los empleados públicos de salud del Sistema Público de Salud de Galicia, a que se refiere el artículo 108, será el correspondiente a la relación funcionarial del personal estatutario.

2. El régimen jurídico de los empleados públicos de salud del Sistema Público de Salud de Galicia, a que se refiere el artículo $1088^{\circ}$, se regirá por las disposiciones que le sean de aplicación, atendiendo a la naturaleza jurídica de su vínculo.

3. Se desarrollará por ley el Estatuto jurídico de los empleados o empleadas públicos de salud de Galicia.

Artículo 110. Interrelaciones entre los distintos regímenes de personal.

1. Con la finalidad de conseguir la mejor utilización de los recursos humanos de la Administración gallega, se determinarán los supuestos, efectos y condiciones en que el personal del Sistema Público de Salud de Galicia pueda pasar a prestar servicios en puestos de trabajo de otros ámbitos de la Administración de la Xunta de Galicia. A tal efecto se suscribirán los oportunos convenios de colaboración entre los órganos competentes atendiendo estrictamente a condiciones de reciprocidad.

2. El personal del Sistema Público de Salud de Galicia que pase a prestar servicios en puestos de trabajo de las unidades y servicios de la Administración sanitaria, de distinto régimen jurídico al de su 
pertenencia, tendrá derecho a percibir las retribuciones correspondientes al puesto de trabajo que desempeñe efectivamente y los complementos personales que tenga asignados en su régimen originario.

3. La relación de empleo de los funcionarios sanitarios locales tendrá la consideración de una única prestación de servicios a todos los efectos, sin perjuicio del ejercicio voluntario de la opción de integración en el nuevo modelo de atención primaria.

4. El régimen jurídico de los profesionales que desempeñen plazas vinculadas, a las que se refiere el artículo 105 de la Ley general de sanidad, será el establecido por la legislación vigente en correlación con el nombramiento o nombramientos que dieron lugar a la vinculación de los puestos de trabajo. El régimen de derechos y deberes se colegirá de la aplicación de la normativa vigente para el personal estatutario y el profesorado universitario que sea compatible con el ejercicio de las funciones inherentes a cada uno de los puestos de trabajo desempeñados por el profesional.

\section{Capítulo II PLANIFICACIÓN Y ORDENACIÓN DE LOS RECURSOS HUMANOS}

Artículo 111. Principios y criterios generales de ordenación.

Junto a los fundamentos generales de actuación incorporados a la presente ley y de aquéllos que son propios del Estatuto general de los empleados públicos y del Estatuto marco del persoal estatutario de los servicios de salud, la ordenación del personal de la salud se inspirará en los principios y criterios siguientes:

a. Garantía de servicio a la ciudadanía.

b. Mejora de la relación entre el personal de la salud y el usuario y/o usuaria del sistema sanitario.

c. Modernización del servicio a través de sus profesionales.

d. Igualdad de género y no discriminación. e. Transparencia en la gestión.

f. Objetividad, responsabilidad e imparcialidad en el desempeño de las funciones.

g. Dedicación prioritaria al servicio público.

h. Estabilidad del empleo.

i. Participación del personal de la salud en el mejora de la organización sanitaria de la que forma parte.

j. Cooperación interprofesional y trabajo en equipo.

k. Evaluación del desempeño.

1. La negociación colectiva.

Artículo 112. Planificación de recursos humanos.

1. La planificación del personal se realizará teniendo en cuenta las necesidades reales del servicio, con la finalidad de dar cumplimiento a los derechos de la ciudadanía previstos por las normas en materia de salud.

2. La planificación de los recursos humanos tenderá a un apropiado dimensionamiento para la adecuación entre los recursos disponibles y las necesidades de la población, en orden a promover la eficacia y eficiencia del servicio sanitario público y mejorar la calidad asistencial y atención a los usuarios y usuarias del Sistema Público de Salud de Galicia.

3. Podrán realizarse planes globales de ordenación de recursos humanos en los que se recojan los objetivos y las bases generales de planificación, en materias relevantes en la gestión de los recursos humanos, con vigencia máxima de cuatro años. Pueden realizarse también planes parciales relativos a materias concretas de personal y planes de vigencia inferior.

4. Los planes de ordenación de recursos humanos serán aprobados por la Consellería de Sanidad u órgano que se determine reglamentariamente, previa negociación con los representantes del personal e informe favorable de la Consellería de Economía y Hacienda.

5. Al objeto de homogeneizar las relaciones de empleo del personal que preste 
sus servicios en el Sistema Público de Salud de Galicia y de mejorar la eficacia en la gestión, la Administración sanitaria pública gallega promoverá las medidas a fin de establecer procedimientos para la integración directa y voluntaria del personal en la condición de personal estatutario, con las especialidades que procedan por las peculiaridades de las instituciones, centros y servicios y de las diferentes agrupaciones de personal.

6. Asimismo, la Administración sanitaria gallega podrá establecer procedimientos para la integración directa del personal temporal o interino en la condición de estatutario temporal.

Artículo 113. Clasificación del personal.

1. La ordenación del personal se realizará según su dependencia orgánica y régimen jurídico de pertenencia y conforme a los criterios de clasificación determinados por la normativa vigente, atendiendo a la función desarrollada, al nivel de titulación exigido para el ingreso y al nombramiento. Podrá realizarse la clasificación del personal por categorías y áreas funcionales atendiendo a las competencias técnicas y capacidades comunes del grupo de titulación. En la clasificación del personal podrán tenerse en cuenta criterios que propugnen el trabajo en equipo y faciliten la realización de los procesos asistenciales o administrativos auxiliares.

2. En la búsqueda de la mejora de la eficacia de los servicios y de la adaptación del desarrollo del trabajo a la organización de la prestación asistencial y a la evolución de las tecnologías, el ámbito funcional de cada categoría de personal se corresponde con el conjunto de aptitudes y capacidades que derivan de la titulación académica exigida para el ingreso, de la formación y del estado actual del conocimiento y de los medios técnicos.

3. Por orden de la Consellería de Sanidad podrán determinarse los puestos de trabajo cuya provisión podrá ser realizada por personal estatutario de diversas categorías de la misma o similar área funcional, mediante los sistemas que se determinen reglamentariamente. Su determinación se realizará después de la negociación colectiva previa.

$\mathrm{Si}$ dichos puestos están incluidos tanto en la relación de puestos de trabajo de la Consellería de Sanidad como del Servicio Gallego de Salud, la Consellería de Sanidad propondrá dicha modificación para que, siguiendo los cauces reglamentarios, sea aprobada, en su caso, por el Consejo de la Xunta de Galicia.

4. La creación, modificación y supresión de categorías estatutarias se realizará por decreto del Consejo de la Xunta.

5. Podrá acordarse la integración del personal fijo de las categorías que se declaren a extinguir en otras categorías en función de las necesidades organizativas o asistenciales en los ámbitos que se determinen reglamentariamente.

Artículo 114. Estructura de los puestos de trabajo.

1. Sin perjuicio de lo que establece la normativa básica de función pública para los colectivos que le afectan, el instrumento técnico de ordenación del personal del Sistema Público de Salud de Galicia es la plantilla de personal, recogida en el anexo de personal de las correspondientes leyes de presupuestos de la comunidad autónoma. La totalidad de los puestos de trabajo de carácter estructural del Sistema Público de Salud de Galicia, con independencia de su régimen jurídico o retributivo, estarán consignados en ella, desglosados en el terreno de la categoría profesional.

2. La plantilla del Sistema Público de Salud de Galicia constituye la expresión cifrada, contable y sistemática de los efectivos que, como máximo, pueden prestar servicios con carácter estructural tanto en su organización central y periférica como en sus instituciones, centros y servicios con sujeción a las dotaciones económicas consignadas en las correspondientes leyes 
de presupuestos generales de la Comunidad Autónoma de Galicia, y sin perjuicio de las contrataciones o nombramientos de carácter temporal para el mantenimiento de la continuidad de los servicios o para atender a necesidades de carácter no permanente que puedan realizarse con cargo a los créditos existentes para esta finalidad.

3. Corresponde a la Consellería de Sanidad la gestión y modificación de las plantillas de personal con las limitaciones establecidas en las disposiciones presupuestarias en vigor.

4. El Consejo de la Xunta, dentro del respeto a la normativa presupuestaria y de función pública, podrá determinar otros instrumentos organizativos de los puestos de trabajo o modificar los existentes, en los niveles central y periférico, estableciendo un sistema de agrupamiento $\mathrm{y}$ enumeración de puestos o plazas orientado a mejorar la calidad, eficacia y eficiencia de los servicios.

5. Dichos instrumentos se establecerán atendiendo a las características de las instituciones, órganos, centros y servicios y a las peculiaridades de las diferentes agrupaciones de personal.

\section{Capitulo III SELECCIÓN, PROVISIÓN Y PROMOCIÓN INTERNA}

Artículo 115. Selección y provisión de plazas.

1. La provisión de plazas y puestos de trabajo en el Sistema Público de Salud de Galicia se realizará a través de los procedimientos de selección, promoción interna, movilidad, reingreso al servicio activo y libre designación.

2. La selección del personal del Sistema Público de Salud de Galicia se realizará conforme a los sistemas establecidos por la normativa básica vigente y la autonómica de desarrollo.

3. La oferta de empleo público del Sistema Público de Salud de Galicia tendrá al menos una periodicidad bianual.
4. Cuando en los procedimientos de acceso exista la fase de concurso podrán tenerse en cuenta, entre otros méritos y en la medida que se determine reglamentariamente y en las correspondientes convocatorias, la experiencia en la actividad sanitaria, la actualización de la formación, la investigación y la docencia, relacionada con el puesto de trabajo al que se accede, con sistemas selectivos adecuados a los puestos a cubrir y la titulación o formación de acceso.

5. En el acceso a la Administración sanitaria podrá requerirse la acreditación del manejo básico de herramientas informáticas en todas las categorías profesionales del sector sanitario, así como el manejo de nuevas tecnologías o técnicas sanitarias.

6. Por razones organizativas y de exigencia en la calificación profesional, la Administración sanitaria podrá establecer los requisitos de calificación, trayectoria y experiencia profesional para poder optar a los destinos que se determinen. Asimismo, las convocatorias de los procesos de movilidad podrán valorar preferentemente el desempeño de puestos de trabajo en destinos especiales, atendiendo a las específicas condiciones de dificultad, aislamiento o carga de trabajo.

7. El personal que desempeñe los puestos de trabajo abiertos a distintas categorías tendrá la obligación de desempeñar las funciones inherentes a ese puesto sin perjuicio de la categoría a que pertenezca como personal estatutario fijo. Estos puestos en ningún caso podrán ser ofertados al personal de nuevo ingreso que no pertenezca a su categoría originaria.

8. Sin perjuicio del puesto de trabajo cuya titularidad acredite el profesional y del ámbito determinado en su nombramiento, los profesionales del Sistema Público de Salud de Galicia se considerarán adscritos al área de salud donde radique su destino.

9. La Administración sanitaria podrá trasladar, temporal o definitivamente, su personal, cuando existan razones de 
imperiosa necesidad de la organización sanitaria, variando la adscripción de los puestos de trabajo de los que sean titulares, con pleno derecho al mantenimiento de sus retribuciones y al abono de las indemnizaciones establecidas reglamentariamente. El cambio de la adscripción definitiva de los puestos de trabajo se realizará previa consulta a las organizaciones representadas en la mesa sectorial. Cuando la variación de la adscripción de los puestos se incardine en el seno de un plan de ordenación de recursos humanos se llevará a cabo previa negociación en la mesa correspondiente.

10. La administración establecerá medidas de movilidad del personal, tendentes a la protección de las víctimas de violencia de género y a favorecer la conciliación de la vida personal y familiar y la protección de la salud laboral. A tal efecto, podrá suscribir convenios de colaboración con otras administraciones públicas.

11. Los procesos de movilidad en el área habrán de ser negociados por los órganos de representación de personal en esos ámbitos, con las bases que sean determinadas por la mesa de negociación del personal de la salud.

12. El acceso y permanencia en determinados centros sanitarios caracterizados por su distancia, aislamiento o dimensión podrán ser incentivados y valorados específicamente en los sistemas de provisión, de carrera, de acceso a la formación y de condiciones de trabajo, a través de los mecanismos que se determinen mediante la negociación colectiva.

13. Se determinarán reglamentariamente en atención a las funciones que tengan que desarrollar los puestos de trabajo, que podrán ser cubiertos mediante el sistema de libre designación.

Artículo 116. Promoción interna.

1. La Administración sanitaria podrá realizar convocatorias específicas para la promoción interna de los profesionales que favorezcan su acceso a otras categorías profesionales del mismo o superior grupo de clasificación.

2. Las convocatorias podrán contemplar la exención de una o más pruebas para los y las aspirantes que accedan por este turno y procedan de categorías de la misma área funcional que las plazas a proveer, siempre que dichas pruebas guarden relación con las funciones anteriormente desarrolladas.

3. La promoción interna entre categorías de grupo de nivel de titulación y/o especialidad idéntico y de la misma área funcional podrá realizarse por los sistemas que se determinen. En el turno de promoción interna podrá reservarse una cuota de la oferta para el acceso de aspirantes por la promoción interna horizontal de la misma área funcional y grupo de titulación. Para el caso de que la selección se produzca por el sistema de concurso de méritos las convocatorias podrán contemplar puntuaciones mínimas por debajo de las cuales no podrá accederse a la categoría objeto de la convocatoria.

\section{Capítulo IV RETRIBUCIONES Y JORNADA}

Artículo 117. Retribuciones y jornada.

1. El personal del Sistema Público de Salud de Galicia percibirá sus retribuciones de acuerdo con el régimen jurídico que rija su relación de empleo y dentro de los límites que anualmente fija la Ley de presupuestos de la Comunidad Autónoma.

La Administración sanitaria podrá establecer, previo informe favorable emitido por la Consellería de Economía y Hacienda, un modelo retributivo orientado a la calidad del servicio, la incentivación de la actividad, la motivación de los profesionales, la consideración singular de actuaciones concretas en el ámbito sanitario y la consecución de los objetivos planificados, previa negociación en la mesa sectorial.

2. La jornada laboral del personal del Sistema Público de Salud será determinada, previa negociación en la correspondiente 
mesa sectorial, teniendo en cuenta las específicas cargas de trabajo y la penosidad que supone la necesaria prestación de servicios continuados y permanentes por parte de los centros sanitarios.

\section{Capitulo V CARRERA PROFESIONAL}

Artículo 118. Carrera profesional.

1. Se establecerán mecanismos de carrera profesional articulados en un sistema de grados para el personal estatutario y, de acuerdo con su normativa básica, para el resto del personal del Sistema Público de Salud de Galicia, de forma que se posibilite la promoción del personal y el cumplimiento de los objetivos de la organización.

Los sistemas de carrera se basarán en el reconocimiento del desarrollo profesional en cuanto al cumplimiento de los objetivos de la organización, conocimientos y experiencia profesional en la Administración sanitaria.

2. El sistema de carrera profesional de las personas licenciadas y diplomadas sanitarias se basará en los criterios generales de desarrollo profesional recogidos en la normativa de ordenación de las profesiones sanitarias, adaptados a las características del Sistema Público de Salud de Galicia y, en su caso, a las de los propios centros.

Cuando así proceda en atención a los objetivos de la organización, podrá otorgarse especial reconocimiento a la prestación de servicios en centros comarcales con dificultades para la provisión de plazas de especialistas, así como a determinadas actividades formativas, docentes y de investigación.

3. El grado de carrera reconocido al personal fijo se retribuirá mediante el complemento de carrera establecido para el correspondiente grado y categoría. Este complemento se percibirá en todo caso en la situación de servicio activo en la correspondiente categoría o durante el desempeño de puestos o cargos en el ámbito de la Administración sanitaria.

\section{Capitulo VI \\ SALUD LABORAL}

Artículo 119. Salud laboral.

La Administración sanitaria, en el marco de la legislación general en materia de salud laboral y prevención de riesgos laborales, adoptará las medidas oportunas para la protección de la salud de los trabajadores y trabajadoras del sector sanitario público a través de órganos dedicados en exclusiva a esta función.

Se establecerán medidas de coordinación que obliguen a participar a las unidades de los centros y órganos cuando en razón a la materia tenga relevancia su cooperación en la protección de la salud laboral y la prevención de riesgos laborales en el sector.

\section{Capítulo VII \\ MESA DE NEGOCIACIÓN DEL EMPLEADO PÚBLICO DE LA SALUD DEL SISTEMA PÚBLICO DE SALUD DE GALICIA}

Artículo 120. Mesa de negociación del empleado público de la salud del Sistema Público de Salud de Galicia.

Con arreglo a lo que establezca la normativa básica sobre los derechos de participación en la determinación de las condiciones de trabajo y de representación del personal, podrá promoverse la constitución de una mesa sectorial para el ámbito del Sistema Público de Salud de Galicia con las competencias que se determinen.

Las unidades electorales, a los efectos de la constitución de las juntas de personal, serán las áreas sanitarias del Sistema Público de Salud de Galicia.

\section{Capitulo VIII FUNCIÓN DIRECTIVA}

Artículo 121. Función directiva.

1. Es personal directivo aquél que desempeña funciones directivas profesionales en el Sistema Público de Salud de Galicia.

2. Se consideran funciones directivas las funciones de gobierno, dirección, gerencia y gestión del Sistema Público de Salud de Galicia en sus niveles central y 
periférico. La Administración sanitaria determinará qué puestos de trabajo están reservados a la función directiva.

3. El personal directivo estará sujeto a evaluación según criterios de eficacia y eficiencia, responsabilidad por su gestión y control de resultados en relación a los objetivos que se le fijen.

4. Los puestos de trabajo del personal directivo se entenderán como de especial dedicación y serán incompatibles con cualquier otra actividad pública o privada.

5. La Consellería de Sanidad o el órgano que se determine reglamentariamente establecerá los criterios y la cuantía para la remuneración del desempeño de cargos directivos, previo informe favorable de la Consellería de Economía y Hacienda.

6. La selección del personal directivo se regirá por los principios de mérito, capacidad, idoneidad y publicidad.

7. La designación del personal directivo será realizada por el órgano competente en conformidad con la legislación vigente, mediante nombramiento de libre designación, si el personal fuera nombrado funcionario o estatutario fijo, o contrato de alta dirección, para el caso de personal que no acredite dicha condición. En todo caso, si la función directiva a desarrollar implica la participación directa o indirecta en el ejercicio de las potestades públicas o en la salvaguarda de los intereses generales de la comunidad autónoma y de las administraciones públicas, el profesional habrá de acreditar la condición de funcionario de carrera o estatutario fijo.

8. El personal funcionario o estatutario que acceda al desempeño de puestos directivos será declarado en su puesto de origen en la situación administrativa de servicios especiales conforme al Decreto legislativo 1/2008, de 13 de marzo, por el que se aprueba el texto refundido de la Ley de la función pública de Galicia, y a la Ley 55/2003, del Estatuto marco del personal estatutario de los servicios de salud. El desempeño de los servicios prestados en los citados puestos será computado para los procesos de selección y provisión como prestados en la plaza de origen, así como a los efectos de trienios y determinación del grado de desarrollo profesional.

9. El ejercicio de la función directiva no impedirá la participación en el sistema de desarrollo profesional, ni el disfrute de los derechos de carácter económico y/o profesional inherentes al grado acreditado.

10. Las condiciones de trabajo del personal directivo no serán objeto de negociación colectiva.

\section{Capitulo IX \\ GARANTÍAS DE MODERNIZACIÓN Y PRESTACIÓN DE LA ASISTENCIA}

Artículo 122. Nuevas tecnologías.

1. Como exigencia de la ineludible necesidad de incorporar los resultados del desarrollo tecnológico en beneficio de los usuarios y usuarias y pacientes, el personal deberá adaptarse y utilizar las nuevas tecnologías y nuevas habilidades en el desempeño de los puestos de trabajo.

2. Todo el personal de las unidades en que se establezcan nuevas tecnologías como herramienta necesaria para la modernización del sector sanitario estará obligado a adaptarse y utilizarlas cuando sea necesario para la prestación del servicio.

3. La Administración sanitaria realizará las acciones formativas necesarias para la adaptación de los trabajadores y trabajadoras que requieran el uso de nuevas tecnologías o nuevas habilidades en el desempeño de su puesto de trabajo.

Artículo 123. Evaluación del desempeño.

1. La Administración sanitaria establecerá los sistemas y mecanismos que permitan evaluar el desempeño del trabajo por los profesionales en la consecución de los objetivos de la organización, la implicación en el servicio y el nivel de satisfacción de los usuarios y usuarias.

2. En los procedimientos y determinación de la evaluación del desempeño regirán 
los principios de igualdad, publicidad, ponderación adecuada y transparencia.

3. La Administración sanitaria determinará los efectos que tendrá la evaluación del desempeño en la carrera profesional, movilidad, retribuciones complementarias vinculadas a la productividad o cumplimiento de los objetivos.

Artículo 124. Prestaciones en diferentes centros.

Los profesionales podrán prestar servicios conjuntos en dos o más centros, aun cuando mantengan su vinculación a uno solo de ellos, cuando se mantengan alianzas estratégicas o proyectos de gestión compartida entre distintos establecimientos sanitarios, o así lo demanden necesidades urgentes e inaplazables para garantizar la asistencia sanitaria en todas las áreas del Sistema Público de Salud de Galicia. A estos efectos podrán expedirse nombramientos o dictarse órdenes de servicios específicos vinculados a los citados proyectos o a la cobertura de las necesidades asistenciales.

\section{TÍTULO IX DE LA DOCENCIA E INVESTIGACIÓN}

\section{Capitulo I DOCENCIA Y FORMACIÓN}

Artículo 125. Principios generales.

1. La Xunta de Galicia velará por la coordinación entre los sistemas sanitario, educativo e investigador de Galicia, a fin de conseguir una mayor adecuación de la formación de los profesionales a las necesidades de salud de la población.

2. El Sistema Público de Salud de Galicia estará en disposición de ser aprovechado para la docencia de pregrado y de posgrado, conforme a lo previsto en la Ley 14/1986, de 25 de abril, general de sanidad, y normativa reguladora de las profesiones sanitarias; a este efecto se establecerán los convenios de colaboración oportunos.

3. La Consellería de Sanidad promoverá la formación continuada de los profesionales del Sistema Público de Salud de Galicia, con el objetivo de adecuar sus conocimientos y habilidades a sus necesidades. En todos los planes de formación del personal existirá un módulo sobre la igualdad entre hombres y mujeres, haciendo en el mismo especial referencia a la violencia de género.

4. La Consellería de Sanidad garantizará un sistema autonómico de acreditación de la formación continuada de las profesiones sanitarias, integrado dentro del sistema estatal, a fin de velar por la calidad de las actividades de formación continuada realizadas por agentes públicos o privados.

5. Las organizaciones sindicales participarán en la programación y ejecución del Plan de formación continuada del personal de las instituciones sanitarias del Servicio Gallego de Salud.

Artículo 126. Colaboración en materia de educación y sanidad.

1. Las autoridades públicas competentes en educación y sanidad establecerán el régimen de colaboración entre las universidades y las instituciones sanitarias en que han de impartirse enseñanzas universitarias, a los efectos de garantizar la docencia práctica de medicina, enfermería y otras enseñanzas que así lo exigieran, mediante los oportunos convenios.

2. Las universidades deberán contar, al menos, con un hospital y tres centros de atención primaria para el ejercicio docente e investigador, concertados según lo establecido por las disposiciones vigentes.

3. Los centros de formación profesional de la rama sanitaria contarán con centros asistenciales concertados, según las necesidades de las distintas especialidades y de acuerdo con las necesidades organizativas del Sistema Público de Salud de Galicia.

4. Las Consellerías competentes en materia de educación y sanidad promoverán la revisión y mejora continuada de los programas docentes de las enseñanzas relacionadas con las ciencias de la salud, al objeto de conseguir la mejor adecuación de la formación de los profesionales y las necesidades del Sistema Público de Salud de Galicia. 


\section{Capítulo II \\ ESCUELA GALLEGA DE LA ADMINISTRACIÓN SANITARIA}

Artículo 127. Objeto.

Para el adecuado desarrollo de las competencias que en el ámbito sanitario corresponden a la Comunidad Autónoma de Galicia y para la coordinación, financiación y gestión de la docencia, la formación en administración, gestión y calidad sanitaria, técnica y clínica, en el ámbito de la Comunidad Autónoma de Galicia se creará la Escuela Gallega de la Administración Sanitaria, que dirigirá su actividad a los profesionales de la sanidad gallega y demás interesados en el desarrollo sanitario de Galicia, como un organismo dotado de personalidad jurídica propia y plena capacidad para el cumplimiento de sus fines.

Artículo 128. Funciones.

La Escuela Gallega de la Administración Sanitaria ajustará su actividad a los fines de interés general y a la ejecución de las directrices de política sanitaria de Galicia, desarrollando, entre otras, las funciones siguientes:

a. La programación y ejecución de los programas de docencia y formación, derivados de la estrategia definida por la Consellería de Sanidad.

b. La programación y financiación de actuaciones, becas y ayudas a la formación.

c. La edición, realización y difusión de estudios y trabajos de carácter científico y de toda clase de publicaciones.

d. El asesoramiento que le sea solicitado por cualquier entidad o institución dependiente de las administraciones públicas sanitarias de Galicia, así como por parte de otras entidades públicas o privadas.

Artículo 129. Órganos de administración.

1. Será presidente o presidenta de la Escuela Gallega de la Administración Sanitaria la persona titular de la Consellería de Sanidad.

2. La Escuela Gallega de la Administración Sanitaria dispondrá de un consejo de dirección que será presidido por la persona titular de la Consellería de Sanidad o un alto cargo designado por ésta como director-gerente.

3. Tendrá los órganos directivos que reglamentariamente se determine.

4. En la conformación de sus órganos se procurará una composición paritaria de hombres y mujeres.

5. La estructura orgánica de la Escuela Gallega de la Administración Sanitaria, tanto en su nivel central como periférico, se determinará reglamentariamente, atendiendo a los principios de eficacia, eficiencia, simplicidad, transparencia y cercanía. En todo caso, habrá de tenerse en cuenta la ordenación territorial del Sistema Público de Salud de Galicia vigente en cada momento.

Artículo 130. Financiación.

1. La Escuela Gallega de la Administración Sanitaria se financia con los recursos siguientes:

a. Las aportaciones consignadas en los presupuestos generales de la comunidad autónoma.

b. Las aportaciones de las universidades y otros centros docentes que colaboren con ella.

c. Las aportaciones procedentes de entidades e instituciones con las que se suscriban acuerdos o convenios.

d. Los derechos de inscripción a los cursos y a cualquier otra actividad que realice, así como la venta de publicaciones.

e. Los rendimientos de su patrimonio.

f. Las donaciones o cualquier otra aportación voluntaria.

g. Los créditos y préstamos que le sean concedidos, de acuerdo con lo establecido en el texto refundido de la Ley de régimen financiero y presupuestario de Galicia, así como en las leyes anuales de presupuestos.

2. La actividad realizada por la Escuela Gallega de la Administración Sanitaria para la Consellería de Sanidad se regulará a través de los convenios oportunos, en los cuales se fijarán las directrices de actuación, los objetivos que se pretendan y los recursos asignados para ello. 


\section{Capitulo III}

DE LA INVESTIGACIÓN BIOMÉDICA EN EL SISTEMA PÚBLICO DE SALUD DE GALICIA

Artículo 131. Principios generales.

1. La Administración sanitaria promoverá la investigación biosanitaria como un instrumento para la mejora de la salud de la población habida cuenta de las prioridades marcadas por el Plan gallego de investigación, desarrollo e innovación tecnológica y el Plan de salud. Todos los centros y servicios sanitarios estarán en disposición de favorecer y desarrollar la investigación.

2. Las autoridades públicas competentes en investigación y sanidad establecerán el régimen de colaboración con el Sistema Público de Salud de Galicia.

3. Se establecerán los mecanismos de coordinación del Plan gallego de investigación y desarrollo en materia sanitaria con el Plan gallego de I+ D+I.

4. La Administración sanitaria impulsará, en coordinación con la Consellería competente en materia de $\mathrm{I}+\mathrm{D}+\mathrm{I}$, y desarrollará los mecanismos de cooperación, colaboración y articulación de redes tendentes a favorecer que el sector sanitario se convierta en uno de los motores de desarrollo económico de Galicia en términos de actividad productiva, generación de empleo de calidad, incremento de la productividad y aportación al PIB gallego.

\section{Capítulo IV INSTITUTO GALLEGO DE INVESTIGACIÓN SANITARIA}

\section{Artículo 132. Objeto.}

Para el adecuado desarrollo de las competencias que en el ámbito sanitario corresponden a la Comunidad Autónoma de Galicia y para el fomento, coordinación y financiación de la investigación en biomedicina y ciencias de la salud del Sistema Público de Salud de Galicia se creará, conforme a la normativa vigente en el momento del desarrollo normativo correspondiente, el Instituto Gallego de Investigación Sanitaria como un organismo dotado de personalidad jurídica propia y plena capacidad para el cumplimiento de sus fines.

\section{Artículo 133. Funciones.}

El Instituto Gallego de Investigación Sanitaria ajustará su actividad a los fines de interés general y a la ejecución de las directrices de política sanitaria de Galicia, desarrollando, con carácter general y entre otras, las funciones siguientes:

a. Fomentar la investigación sanitaria de calidad en las instituciones sanitarias.

b. Ejecutar los programas derivados de las prioridades de investigación sanitaria de la comunidad autónoma, definidas por la Consellería de Sanidad en coordinación con la Consellería competente en materia de $\mathrm{I}+\mathrm{D}+\mathrm{I}$.

c. Potenciar la investigación coordinada y multicéntrica.

d. Facilitar la difusión de la actividad investigadora.

e. Evaluar las investigaciones realizadas en el campo de las ciencias de la salud.

f. Evaluar las tecnologías sanitarias y los sistemas organizativos en los que se desarrolla la atención sanitaria, de acuerdo con criterios de seguridad, eficacia, efectividad y eficiencia teniendo en cuenta valores éticos, clínicos, económicos y sociales.

g. Desarrollar estudios específicos de evaluación de técnicas o procedimientos de los que no se cuenta con suficiente información sobre su efectividad en la práctica clínica de un entorno sanitario determinado.

Artículo 134. Órganos de administración.

1. Será presidente o presidenta del Instituto Gallego de Investigación Sanitaria la persona titular de la Consellería de Sanidad.

2. El Instituto Gallego de Investigación Sanitaria dispondrá de un consejo de dirección que será presidido por la persona 
titular de la Consellería de Sanidad o un alto cargo designado por ésta como director-gerente.

3. Tendrá los órganos directivos que reglamentariamente se determine.

4. En la conformación de sus órganos se procurará una composición paritaria de hombres y mujeres.

5. La estructura orgánica del Instituto Gallego de Investigación Sanitaria, tanto en su nivel central como periférico, se determinará reglamentariamente, atendiendo a los principios de eficacia, eficiencia, simplicidad, transparencia y cercanía. En todo caso, habrá de tenerse en cuenta la ordenación territorial del Sistema Público de Salud de Galicia vigente en cada momento.

Artículo 135. Financiación.

1. El Instituto Gallego de Investigación Sanitaria se financia con los recursos siguientes:

a. Las aportaciones consignadas en los presupuestos generales de la comunidad autónoma.

b. Las aportaciones de los fondos comunes de investigación sanitaria y otros centros de investigación que colaboren con él.

c. Las aportaciones procedentes de entidades e instituciones con las que se suscriban acuerdos o convenios.

d. Los rendimientos de su patrimonio.

e. Las donaciones o cualquier otra aportación voluntaria.

f. Los créditos y préstamos que le sean concedidos, de acuerdo con lo establecido en el texto refundido de la Ley de régimen financiero y presupuestario de Galicia, así como en las leyes anuales de presupuestos.

2. La actividad realizada por el Instituto Gallego de Investigación Sanitaria para la Consellería de Sanidad se regulará a través de los convenios oportunos, en los cuales se fijarán las directrices de actuación, los objetivos que se pretendan y los recursos asignados para ello.

\section{TÍTULO X \\ DE LA COORDINACIÓN INTERDEPARTAMENTAL DE LA ATENCIÓN SOCIOSANITARIA}

Artículo 136. Principios generales.

1. La consecución de una sociedad gallega de avanzada calidad de vida, donde todas las personas tengan derecho al bienestar y a vivir su vida con plenitud, salud y madurez, de acuerdo con sus decisiones, precisa unos servicios sociosanitarios adecuados y de calidad.

2. Como parte de los servicios de bienestar, la atención sociosanitaria deberá cubrir las diferentes necesidades de las personas bajo criterios de igualdad, equidad, accesibilidad, universalidad y complementariedad en la acción de las diferentes administraciones.

3. En este sentido la Consellería de Sanidad promoverá la cooperación y coordinación con el Sistema Gallego de Servicios Sociales, para que la atención a las circunstancias y necesidades sociales y las acciones de prevención y asistencia sanitaria se complementen de forma adecuada. Igualmente, fomentará actuaciones integrales sociales y sanitarias ante aquellas circunstancias de dependencia, cronicidad, discapacidad u otras en que la cooperación de los dos sistemas conlleve ventajas sociales y asistenciales.

Artículo 137. Instrumento de coordinación.

1. A fin de garantizar una adecuada, efectiva y eficiente coordinación institucional se crea la Comisión Interdepartamental de Coordinación de la Atención Sociosanitaria de Galicia.

2. La Comisión Interdepartamental de Coordinación de la Atención Sociosanitaria de Galicia estará integrada al menos por:

a. La persona titular de la Consellería con competencias en materia de sanidad.

b. La persona titular del departamento de la Xunta de Galicia con competencias en la planificación y ordenación del Sistema Gallego de Servicios Sociales. 
c. La persona titular de la Secretaría General de la Consellería de Sanidad.

d. Las personas titulares de la(s) secretaría(s) general(es) de la(s) Consellería(s) con competencias en materia de bienestar social.

e. Dos personas representantes del Servicio Gallego de Salud.

f. Una persona representante de cada una de las diferentes áreas de la Administración de la Xunta de Galicia con competencias en el ámbito sociosanitario.

g. Una persona representante de la Consellería de Economía y Hacienda.

3. Por decreto de la Xunta de Galicia se determinarán los sistemas de asignación de representantes en la comisión, así como los mecanismos para la designación de los mismos.

4. Son funciones de la Comisión Interdepartamental de Coordinación de Atención Sociosanitaria de Galicia:

a. Orientar las directrices de la política sociosanitaria de Galicia.

b. Coordinar las diferentes administraciones y organizaciones que participan en la atención sociosanitaria.

c. Proporcionar la información que permita el funcionamiento en red de los centros y entidades dedicadas a la atención sociosanitaria.

d. Colaborar en la resolución de los problemas que se identifican en Galicia dentro de la atención sociosanitaria.

e. Coordinar los diferentes recursos para conseguir la eficiencia en la prestación de servicios sociosanitarios.

f. Elaborar su reglamento de funcionamiento.

5. Por orden conjunta de las Consellerías competentes en materia de sanidad y bienestar social se establecerán las normas generales de organización y funcionamiento de la comisión interdepartamental.

6. Por decreto de la Xunta de Galicia y a propuesta de la Comisión Interdepartamental de Coordinación de la Atención Sociosanitaria de Galicia se establecerán los mecanismos e instrumentos de coordinación de la atención sociosanitaria a nivel territorial en las áreas sanitarias. En estos instrumentos de coordinación se garantizará una adecuada representación de los poderes públicos locales con competencias en la materia.

\section{DISPOSICIÓN ADICIONAL ÚNICA FUNDACIÓN PÚBLICA DE LA ESCUELA GALLEGA DE ADMINISTRACIÓN SANITARIA}

La Fundación Pública de la Escuela Gallega de Administración Sanitaria se integrará en la estructura de la Escuela Gallega de la Administración Sanitaria cuando se proceda a la creación de ésta, con arreglo a lo previsto en el artículo 127 de la presente ley.

\section{DISPOSICIÓN TRANSITORIA PRIMERA DESARROLLO DE LA ESTRUCTURA DE LA CONSELLERÍA Y DEL SERVICIO GALLEGO DE SALUD}

En el plazo de seis meses, a contar a partir de la entrada en vigor de la presente ley, se aprobarán las normas reglamentarias que resulten necesarias para adaptar la estructura orgánica de la Consellería de Sanidad y del Servicio Gallego de Salud a lo establecido en la misma, manteniéndose en tanto vigentes las normas de estructura y delegación de competencias vigentes en la fecha de entrada en vigor de la presente ley.

\section{DISPOSICIÓN TRANSITORIA SEGUNDA ÁREAS SANITARIAS}

1. En tanto no se establezca la estructura de las áreas sanitarias correspondientes se mantendrán las estructuras de las direcciones provinciales, bajo la dependencia del secretario general del Sergas, con las funciones siguientes:

a. La evaluación, seguimiento y control de los planes y actuaciones del Sergas.

b. La dirección de la gestión de los servicios de la dirección provincial y el ejercicio de la supervisión y seguimiento 
de sus actividades, asumiendo la plena representatividad de los mismos.

c. Las informaciones previas e instrucciones de expedientes disciplinarios del personal estatutario no facultativo, en los términos previstos en la normativa reguladora.

d. La recepción, tramitación $y$, en su caso, resolución de cuantas denuncias, quejas, recursos y reclamaciones se produzcan en su ámbito funcional.

e. La coordinación de aquellas cuestiones que afecten a más de un centro o institución sanitaria, así como la relación entre los hospitales y servicios de atención primaria.

f. La gestión del personal de la propia dirección provincial y la evaluación, seguimiento y control de la gestión del personal de todos los centros de gasto e instituciones sanitarias de su ámbito territorial.

g. La gestión económica de la propia dirección provincial y la evaluación, seguimiento y control de la gestión de los centros de gasto e instituciones, así como la gestión económica de las prestaciones sanitarias.

h. Cualquier otra función, competencia administrativa o atribución que las leyes y demás disposiciones generales les confieran o les sean delegadas por la autoridad competente.

2. Sin perjuicio de lo anterior, el consejero o consejera de Sanidad y el presidente o presidenta del Servicio Gallego de Salud podrá delegar en los gerentes de atención primaria y especializada funciones relacionadas con sus correspondientes ámbitos de actuación.

\section{DISPOSICIÓN DEROGATORIA ÚNICA}

Quedan derogadas cuantas disposiciones de igual o inferior rango se opongan a lo dispuesto en la presente ley, en particular, la Ley $7 / 2003$, de 9 de diciembre, de ordenación sanitaria de Galicia; la Ley 5/1983, de 30 de junio, de sanidad escolar, y el Decreto $44 / 1985$, de 29 de marzo, por el que se aprueba el Reglamento de sanidad escolar.
DISPOSICIÓN FINAL PRIMERA MODIFICACIÓN DEL ARTÍCULO 8 DE LA LEY 6/1984, DE 5 DE JUNIO, DEL VALEDOR DO POBO

$(\ldots)^{758}$

\section{DISPOSICIÓN FINAL SEGUNDA DESARROLLO REGLAMENTARIO DE LA LEY}

Sin perjuicio de lo previsto en las disposiciones adicionales y transitorias de la presente ley, se autoriza al Consejo de la Xunta para que apruebe los reglamentos que sean necesarios para la aplicación y desarrollo de la presente ley.

\section{DISPOSICIÓN FINAL TERCERA ENTRADA EN VIGOR DE LA LEY}

La presente ley entrará en vigor dos meses después de su publicación en el «Diario Oficial de Galicia».

4. LEY 3/2001, DE 28 DE MAYO, REGULADORA DEL CONSENTIMIENTO INFORMADO Y DE LA HISTORIA CLIINICA DE LOS PACIENTES (DOGA N. $^{\circ} 111$, 8. 6. 2001) 759

\section{$(\ldots)^{760}$ \\ TítULO I OBJETO Y ÁMBITO DE APLICACIÓN}

Artículo 1. Objeto.

1. La presente ley tiene por objeto regular el consentimiento informado de los pacientes así como su historia clínica, garantizando el acceso de aquéllos a la información contenida en la misma.

2. Los pacientes tendrán los derechos y obligaciones previstos en la presente ley, en la Ley 4/1986, de 25 de abril, General de Sanidad, en la Ley 41/2002, de 14 de noviembre, básica reguladora de la autonomía del paciente y de derechos y obligaciones en materia de información y

758 Disposición derradeira primera contiene modificaciones a la Ley 6/1984, do 5 de junio, de Valedor de Pobo.

759 Véase Decreto 29/2009, de 5 de febrero, por el que se regula el uso y acceso a la historia clínica electrónica. 760 Exposición de motivos omitida. 
documentación clínica, y demás disposiciones que sean de aplicación ${ }^{761}$.

Artículo 2. Ámbito de aplicación.

La presente ley será de aplicación a todo tipo de asistencia sanitaria que se preste en la Comunidad Autónoma de Galicia en los centros y establecimientos sanitarios públicos o privados, sean o no concertados con el Servizo Galego de Saúde.

\section{TíTULO II DEL CONSENTIMIENTO INFORMADO}

Artículo 3. Definición.

1. A los efectos de la presente ley, se entiende por consentimiento informado el prestado libre y voluntariamente por el afectado para toda actuación en el ámbito de su salud y una vez que, recibida la información adecuada, hubiera valorado las opciones propias del caso. El consentimiento será verbal, por regla general, y se prestará por escrito en los casos de intervención quirúrgica, procedimientos diagnósticos y terapéuticos invasores, y, en general, en la aplicación de procedimientos que supongan riesgos o inconvenientes de notoria y previsible repercusión negativa sobre la salud del paciente.

2. La prestación del consentimiento informado es un derecho del paciente y su obtención un deber del médico.

3. El paciente tiene derecho a decidir libremente, tras recibir la información adecuada, entre las opciones clínicas disponibles. Asimismo, tiene derecho a negarse al tratamiento, salvo en los casos determinados en la ley. Su negativa al tratamiento constará por escrito ${ }^{762}$.

Artículo 4. Prestación del consentimiento.

El consentimiento deberá recabarse por el médico designado por el centro sanitario

761 Art. 1 modificado por Ley 3/2005, de 7 de marzo, de modificación de la Ley $3 / 2001$, de 28 de mayo, reguladora del consentimiento informado y de la historia clinica de los pacientes.

762 Art. 3 modificado por Ley 3/2005, de 7 de marzo, de modificación de la Ley $3 / 2001$, de 28 de mayo, reguladora del consentimiento informado y de la historia clinica de los pacientes. para la atención del paciente o por el que practique la intervención diagnóstica o terapéutica del propio paciente.

El paciente tendrá también derecho a que se tome en consideración su voluntad, expresada con anticipación ante el personal facultativo del centro sanitario cuando no se encuentre en situación de manifestarla en el momento de la intervención y conste por escrito debidamente firmada.

Artículo 5. Instrucciones previas.

1. Por el documento de instrucciones previas, una persona mayor de edad, capaz y libre, manifiesta anticipadamente su voluntad, a fin de que ésta sea cumplida en el momento en que llegue a situaciones en las que por las circunstancias no sea capaz de expresarla personalmente, sobre los cuidados y el tratamiento de su salud, o, una vez llegado el fallecimiento, sobre el destino de su cuerpo o de los órganos del mismo. El otorgante del documento puede designar, además un representante para que, llegado el caso, sirva como interlocutor suyo con el médico o el equipo sanitario para procurar el cumplimiento de las instrucciones previas.

2. Tendrá que haber constancia fehaciente de que este documento está otorgado en las condiciones expuestas en el apartado anterior. A estos efectos, la declaración de instrucciones previas deberá formalizarse mediante alguno de los procedimientos siguientes:

a. Ante Notario. En este supuesto no será necesaria la presencia de testigos.

b. Ante tres testigos mayores de edad y con plena capacidad de obrar, de los cuales dos, como mínimo, no podrán tener relación de parentesco hasta el segundo grado ni estar vinculados por relación patrimonial con el otorgante.

3. No serán aplicadas las instrucciones previas contrarias al ordenamiento jurídico, a la "lex artis", ni las que no se correspondan con el supuesto de hecho que el interesado tenga previsto en el momento de manifestarlas. En la historia 
clínica del paciente quedará constancia razonada de las anotaciones relacionadas con estas previsiones.

4. Cuando existan instrucciones previas, la persona que las otorga, sus familiares o su representante harán llegar el documento que las contenga al centro sanitario donde la persona esté hospitalizada. Este documento de voluntades anticipadas será incorporado a la historia clínica del paciente.

5. Las instrucciones previas podrán revocarse libremente en cualquier momento dejando constancia por escrito.

6. A fin de garantizar la eficacia, en el ámbito de la Comunidad Autónoma, de las instrucciones previas manifestadas por los pacientes, y formalizadas documentalmente, con arreglo a lo dispuesto en este artículo, se creará un Registro Autonómico de Instrucciones Previas, adscrito a la Consellería de Sanidade, que se regirá por las normas que reglamentariamente se determinen 763764 .

Artículo 6. Otorgamiento del consentimiento por sustitución.

1. Son situaciones de otorgamiento del consentimiento por sustitución las siguientes:

a. Cuando el paciente esté circunstancialmente incapacitado para tomar decisiones, por criterio del médico responsable de la asistencia, el derecho corresponderá a sus familiares o a las personas vinculadas de hecho a él.

En caso de familiares, se dará preferencia al cónyuge o, en su caso, a quien tenga la condición legal de pareja de hecho. En su defecto, a los familiares de grado más próximo y dentro del mismo grado a los que ejerzan de cuidadores o, a falta de éstos, a los de mayor edad.

b. Cuando el paciente sea un incapacitado legal, el derecho corresponde a su

763 Art. 5 modificado por Ley $3 / 2005$, de 7 de marzo, de modificación de la Ley $3 / 2001$, de 28 de mayo, reguladora del consentimiento informado y de la historia clínica de los pacientes.

764 Decreto 259/2007, de 13 de diciembre, por el que se crea el Registro gallego de instrucciones previas sobre cuidados y tratamiento de la salud. representante legal, que habrá de acreditar de forma clara e inequívoca, en virtud de la correspondiente sentencia de incapacitación, que está legalmente habilitado para tomar decisiones que afecten a la persona del incapaz.

Asimismo, cuando a criterio del médico responsable, el incapacitado reúne suficientes condiciones de madurez, le facilitará la información adecuada a su capacidad. La opinión de éste será tomada en consideración como un factor que será tanto más determinante en función de su capacidad.

c. Cuando el paciente menor de edad no sea capaz intelectual ni emocionalmente de comprender el alcance de la intervención, en este caso, el consentimiento lo dará el representante legal del menor después de haber escuchado su opinión si tiene doce años cumplidos. Cuando se trate menores no incapaces ni incapacitados, pero emancipados o con dieciséis años cumplidos, no cabe prestar el consentimiento por sustitución. Sin embargo, en caso de actuación de grave riesgo, según el criterio del facultativo, los padres serán informados y su opinión será tenida en cuenta para la toma de la decisión correspondiente.

d. En caso de que la decisión del representante legal sea contraria a los intereses del menor o incapacitado, habrán de ponerse los hechos en conocimiento de la autoridad competente en virtud de lo dispuesto en la legislación civil.

2. La interrupción voluntaria del embarazo, la práctica de ensayos clínicos y la práctica de técnicas de reproducción humana asistida se rigen por lo establecido con carácter general sobre la mayoría de edad y por las disposiciones especiales de aplicación.

3. La representación del consentimiento por sustitución será adecuada a las circunstancias y proporcionada a las necesidades que es preciso atender,siempre a favor del paciente y con respeto a su dignidad personal. El paciente participará en la medida

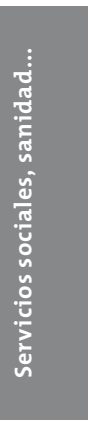


de lo posible en la toma de decisiones a lo largo de su proceso sanitario ${ }^{765}$.

Artículo 7. Restricción de la información en interés del paciente.

El derecho a la información sanitaria de los pacientes puede limitarse por la existencia acreditada de un estado de necesidad terapéutica. Se entiende por tal la facultad del médico para actuar profesionalmente sin informar antes al paciente, cuando por razones objetivas el conocimiento de su propia situación puede perjudicar su salud de modo grave. Llegado este caso, el médico dejará constancia razonada de las circunstancias en la historia clínica y comunicará su decisión a las personas vinculadas al paciente por razones familiares o de hecho, con arreglo a lo establecido en el apartado 1.a) del artículo 6 de la presente ley ${ }^{766}$.

Artículo 8. Características de la información previa al consentimiento.

1. El titular del derecho a la información es el paciente. También serán informadas las personas vinculadas a él, por razones familiares o de hecho, en la medida en que el paciente lo permita de forma expresa o tácita.

2. La información será verdadera, comprensible, adecuada a las necesidades del paciente, continuada, razonable y suficiente 767.

3. La información se facilitará con la antelación suficiente para que el paciente pueda reflexionar y decidir libremente.

4. La información será objetiva, específica y adecuada al procedimiento, evitando los aspectos alarmistas que puedan incidir negativamente en el paciente.

\footnotetext{
765 Art. 6 modificado por Ley 3/2005, de 7 de marzo, de modificación de la Ley $3 / 2001$, de 28 de mayo, reguladora del consentimiento informado y de la historia clinica de los pacientes.

766 Art. 7 modificado por Ley $3 / 2005$, de 7 de marzo de modificación de la Ley $3 / 2001$, de 28 de mayo, reguladora del consentimiento informado y de la historia clinica de los pacientes.

767 Art. 8.1 y 8.2 modificados por Ley $3 / 2005$, de 7 de marzo, de modificación de la Ley $3 / 2001$, de 28 de mayo, reguladora del consentimiento informado y de la historia clinica de los pacientes.
}

5. En caso de que deba constar por escrito, la información previa habrá de incluir: Identificación y descripción del procedimiento.

Objetivo del mismo.

Beneficios que se esperan alcanzar.

Alternativas razonables a dicho procedimiento.

Consecuencias previsibles de su realización. Consecuencias de la no realización del procedimiento.

Riesgos frecuentes.

Riesgos poco frecuentes, cuando sean de especial gravedad y estén asociados al procedimiento de acuerdo con el estado de la ciencia.

Riesgos personalizados de acuerdo con la situación clínica del paciente.

Contraindicaciones ${ }^{768}$.

Artículo 9. Responsabilidad de información previa al consentimiento.

El médico responsable del paciente le garantiza el cumplimiento de su derecho a la información. Los profesionales que lo atiendan durante el proceso asistencial o que le apliquen una técnica o un procedimiento concreto también serán responsables de informarlo ${ }^{769}$.

Artículo 10. Contenido del documento formulario.

1. El documento de consentimiento informado, además de la información del procedimiento diagnóstico o terapéutico a que se refiere el artículo anterior, y sin perjuicio de la posibilidad de adjuntar anexos y otros datos de carácter general, habrá de contener los siguientes datos mínimos 770: Identificación del centro.

768 Art. 8.5 modificado por Ley $3 / 2005$, de 7 de marzo, de modificación de la Ley $3 / 2001$, de 28 de mayo, reguladora del consentimiento informado y de la historia clínica de los pacientes.

769 Art. 9 modificado por Ley 3/2005, de 7 de marzo, de modificación de la Ley $3 / 2001$, de 28 de mayo, reguladora del consentimiento informado y de la historia clínica de los pacientes.

770 Art. 10.1 modificado por Ley 3/2005, de 7 de marzo, de modificación de la Ley $3 / 2001$, de 28 de mayo, reguladora del consentimiento informado y de la historia clínica de los pacientes. 
Identificación del procedimiento.

Identificación del paciente, representante legal, familiar o allegado que presta el consentimiento.

Identificación del médico que informa.

Consentimiento del paciente o del familiar, allegado o representante legal que autoriza. Declaración del paciente de que conoce que el consentimiento puede ser revocado en cualquier momento sin expresión de la causa de la revocación.

Lugar y fecha.

Firmas del médico, paciente, familiar, representante legal o persona a él allegada.

2. En el documento de consentimiento informado quedará constancia de que el paciente o la persona destinataria de la información recibe una copia de dicho documento y de que comprendió adecuadamente la información.

Artículo 11. Excepción y límites del consentimiento informado.

1. La renuncia del paciente a recibir información está limitada por el interés de la salud del propio paciente, de terceros, de la colectividad y de las exigencias terapéuticas del caso. Cuando el paciente manifieste expresamente su deseo de no ser informado, se respetará su voluntad haciendo constar su renuncia documentalmente, sin perjuicio de obtener el consentimiento previo para la intervención.

2. Los facultativos podrán llevar a cabo las intervenciones clínicas indispensables a favor de la salud del paciente, sin necesidad de contar con su consentimiento, en los siguientes casos:

a. Cuando existe riesgo para la salud pública a causa de razones sanitarias establecidas por la ley y así se declare expresamente por acuerdo del delegado provincial de la Consellería de Sanidade o del Director general de Salud Pública si afectara a más de una provincia. En todo caso, una vez adoptadas las medidas pertinentes, de conformidad con lo establecido en la Ley Orgánica 3/1986, de 14 de abril, de medidas especiales en materia de salud pública, se comunicarán a la autoridad judicial en el plazo máximo de veinticuatro horas siempre que dispongan el internamiento obligatorio de personas.

b. Cuando existe riesgo inmediato grave para la integridad física y psíquica del paciente y no es posible obtener la autorización, consultando, cuando las circunstancias lo permitan, a sus familiares o a las personas vinculadas de hecho a él 771 .

Artículo 12. Comisión de Consentimiento Informado.

1. A los efectos previstos en la presente ley, se constituirá, dependiendo de la Consellería de Sanidade e Servizos Sociais, la Comisión de Consentimiento Informado, a la que corresponderán las siguientes funciones:

a. Revisión, actualización y publicación periódica de una guía de formularios de referencia recomendados de consentimento informado.

b. Conocimiento de la implantación de los formularios de referencia de consentimiento informado.

c. Prestación del asesoramiento necesario a los órganos de la Consellería de Sanidade e Servizos Sociais y del Servizo Galego de Saúde en las materias relacionadas con sus funciones.

d. Valoración, selección y expurgación de la documentación clínica.

e. Todas aquellas que le atribuyan normas de carácter legal o reglamentario.

2. La composición de la Comisión de Consentimiento Informado será determinada por Decreto de la Xunta de Galicia.

3. La Comisión de Consentimiento Informado se reunirá, al menos, dos veces al año y siempre que la convoque su Presidente. Corresponde a la propia Comisión la elaboración y aprobación de su reglamento de funcionamiento interno, rigiéndose, en todo lo no previsto en él, por lo dispuesto en el capítulo II del título I de la Ley 30/1992, de 26 de noviembre, del Régimen

771 Art. 11 modificado por Ley 3/2005, de 7 de marzo, de modificación de la Ley $3 / 2001$, de 28 de mayo, reguladora del consentimiento informado y de la historia clinica de los pacientes. 
Jurídico de las Administraciones Públicas y del Procedimiento Administrativo Común, relativo a los órganos colegiados 772 .

\section{TíTULO III DE LA HISTORIA CLÍNICA}

Artículo 13. Definición.

La historia clínica es el conjunto de documentos en los que se contienen los datos, las valoraciones y las informaciones de cualquier tipo sobre la situación y la evolución clínica de los pacientes a lo largo de su proceso asistencial, así como la identificación de los médicos y demás profesionales que intervinieron en éste ${ }^{773}$.

Artículo 14. Soporte.

En la historia clínica podrán ser usados cualquiera de los soportes documentales adecuados para su utilización, siempre y cuando garanticen su autenticidad, integridad, seguridad y conservación.

En todo caso, el uso de dichos soportes se atendrá a lo dispuesto en la normativa sobre tratamiento automatizado de datos de carácter personal.

Artículo 15. Ámbito territorial.

La historia clínica deberá ser única por paciente, al menos en cada complejo hospitalario, hospital o centro sanitario.

Dicha historia clínica acumulará toda la información clínica generada en cada episodio asistencial e integrará los diferentes episodios del paciente.

Artículo 16. Contenido.

La historia clínica contendrá suficiente información para identificar al paciente y documentar su proceso de atención sanitaria. A tal efecto, incluirá, al menos:

a. Datos suficientes para la adecuada identificación del paciente.

b. Médico o profesional responsable.

c. Datos que identifiquen el proceso de atención sanitaria.

772 Véase Decreto 247/2002, de 18 de julio, por el que se determina la constitución, composición y funciones de la Comisión de Consentimiento Informado.

773 Art. 13 modificado por Ley $3 / 2005$, de 7 de marzo, de modificación de la Ley $3 / 2001$, de 28 de mayo, reguladora del consentimiento informado y de la historia clinica de los pacientes. d. Datos relativos al proceso, que incluirán, como mínimo:

1. Anamnesis y exploración física.

2. Órdenes médicas.

3. Hoja de evolución y de planificación de cuidados de enfermería.

4. Evolución clínica.

5. Informe sobre los procedimientos diagnósticos o terapéuticos e interconsultas realizadas.

6. Informe de alta del episodio de atención $u$ hoja de problemas en atención primaria.

7. Documento de consentimiento informado.

8. Documento firmado de alta volun$\operatorname{taria}^{774}$.

Artículo 17. Requisitos.

1. La elaboración de la historia clínica, en los aspectos relacionados con la asistencia directa al paciente, será responsabilidad de los profesionales que intervienen en la misma.

2. Las historias clínicas deberán ser claramente legibles, evitándose, en lo posible, la utilización de símbolos y abreviaturas, y estarán normalizadas en cuanto a su estructura lógica, de conformidad con lo que se disponga reglamentariamente. Cualquier información incorporada a la historia clínica habrá de ser datada y firmada de manera que se identifique claramente el personal que la realice ${ }^{775}$.

Artículo 18. Propiedad y custodia.

1. Las historias clínicas son documentos confidenciales propiedad de las Administración sanitaria o entidad titular del centro sanitario cuando el médico trabaje por cuenta y bajo la dependencia de una institución sanitaria.

En caso contrario, la propiedad corresponde al médico que realiza la atención sanitaria.

774 Art. 16 modificado por Ley 3/2005, de 7 de marzo, de modificación de la Ley $3 / 2001$, de 28 de mayo, reguladora del consentimiento informado y de la historia clínica de los pacientes.

775 Art. 17 modificado por Ley 3/2005, de 7 de marzo, de modificación de la Ley $3 / 2001$, de 28 de mayo, reguladora del consentimiento informado y de la historia clínica de los pacientes. 
2. La entidad o facultativo propietario es responsable de la custodia de las historias clínicas y habrá de adoptar todas las medidas precisas para garantizar la confidencialidad de los datos o de la información contenida en las mismas.

Asimismo, toda persona que en el ejercicio de sus funciones o competencias tenga conocimiento de los datos e informaciones contenidas en la historia clínica tendrá la obligación de reserva y sigilo respecto de los mismos.

\section{Artículo 19. Acceso.}

1. El paciente tiene el derecho de acceso a la documentación de la historia clínica y a obtener copia de los datos que figuran en la misma. Los centros sanitarios regularán el procedimiento que garantice la observancia de estos derechos.

Este derecho de acceso podrá ejercitarse por representación debidamente acreditada.

2. En los supuestos de procedimientos administrativos de exigencia de responsabilidad patrimonial o en las denuncias previas a la formalización de un litigio sobre la asistencia sanitaria se permitirá que el paciente tenga acceso directo a la historia clínica, en la forma y con los requisitos que se regulen legal o reglamentariamente.

También tendrán acceso a la historia clínica los órganos competentes para tramitar y resolver los procedimientos de responsabilidad patrimonial por el funcionamiento de la Administración sanitaria, así como la inspección sanitaria en el ejercicio de sus funciones.

3. El acceso a la historia clínica con fines judiciales, epidemiológicos, de salud pública, de investigación o de docencia se rige por lo dispuesto en la Ley Orgánica 15/1999, de 13 de diciembre, de Protección de Datos de Carácter Personal, en la Ley 14/1986, de 25 de abril, General de Sanidad, y demás normas de aplicación en cada caso. $\mathrm{El}$ acceso a la historia clínica con estos fines obliga a preservar los datos de identificación personal del paciente, separados de los de carácter clínico-asistencial, de modo que como regla general quede asegurado el anonimato, salvo que el propio paciente hubiera dado su consentimiento para no separarlos. Se exceptúan los supuestos de investigación de la autoridad judicial en los que se considere imprescindible la unificación de los datos identificativos con los clínico-asistenciales, en los cuales se estará a lo que dispongan los jueces y tribunales en el proceso correspondiente. El acceso a los datos y documentos de la historia clínica queda limitado estrictamente a los fines específicos en cada caso.

4. El derecho al acceso del paciente a la documentación de la historia clínica no puede ejercitarse en perjuicio del derecho de terceras personas a la confidencialidad de los datos que constan en ella recogidos en interés terapéutico del paciente, ni en perjuicio del derecho de los profesionales participantes en su elaboración, los cuales pueden oponer al derecho de acceso la reserva de sus anotaciones subjetivas.

5. El acceso por otras personas distintas al paciente a la información contenida en la historia clínica habrá de estar justificado por la atención sanitaria del mismo.

En todo caso, el personal de administración y gestión de los centros sanitarios sólo puede acceder a los datos de la historia clínica relacionados con sus propias funciones.

6. Los centros sanitarios y los facultativos de ejercicio individual sólo facilitarán el acceso a la historia clínica de los pacientes fallecidos a las personas vinculadas a él, por razones familiares o de hecho, salvo que el fallecido lo hubiera prohibido expresamente y así se acredite.

En cualquier caso, el acceso de un tercero a la historia clínica motivado por un riesgo para su salud se limitará a los datos pertinentes. No se facilitará información que afecte a la intimidad del fallecido ni a las anotaciones subjetivas de los profesionales, ni que perjudiquen a terceros.

Cualquier otra razón de carácter excepcional habrá de responder a un interés legítimo susceptible de protección y estar convenientemente motivada. 
7. El personal sanitario debidamente acreditado que ejerza funciones de inspección, evaluación, acreditación y planificación tiene acceso a las historias clínicas en el cumplimiento de sus funciones de comprobación de la calidad de la asistencia, del respeto de los derechos del paciente o de cualquier otra obligación del centro en relación con los pacientes y usuarios o la propia Administración sanitaria.

8. En todos los casos quedará plenamente garantizado el derecho del paciente a su intimidad personal y familiar, por lo que el personal que acceda a esta información guardará el correspondiente secreto profesional ${ }^{776}$.

Artículo 20. Conservación.

1. La historia clínica habrá de conservarse en condiciones que garanticen la preservación de la información asistencial que contiene, aunque no se mantenga en el soporte original en el cual se ha generado, con las cautelas que se establezcan reglamentariamente para evitar la manipulación de datos cuando no se mantenga dicho soporte original.

2. Se conservará indefinidamente la siguiente información:

Informes de alta.

Hojas de consentimiento informado.

Hojas de alta voluntaria.

Informes quirúrgicos y/o registro de parto. Informes de anestesia.

Informes de exploraciones complementarias.

Informes de necropsia.

Hoja de evolución y de planificación de cuidados de enfermería.

Otros informes médicos Cualquier otra información que se considere relevante a efectos asistenciales, preventivos, epidemiológicos o de investigación.

La información de aquellas historias clínicas cuya conservación sea procedente por razones judiciales.

$\overline{776}$ Art. 19 modificado por Ley $3 / 2005$, de 7 de marzo, de modificación de la Ley $3 / 2001$, de 28 de mayo, reguladora del consentimiento informado y de la historia clinica de los pacientes.
3. El resto de la información se conservará, como mínimo, hasta que transcurran cinco años desde la última asistencia prestada al paciente o desde su fallecimiento.

Artículo 21. Régimen sancionador. Sin perjuicio de las exigencias que se pudiesen derivar en los ámbitos de la responsabilidad civil y penal, o de la responsabilidad profesional o estatutaria, en su caso, será de aplicación a las infracciones a lo dispuesto en la presente normativa el régimen sancionador previsto en el capítulo VI del título I de la Ley 14/1986, de 25 de abril, General de Sanidad, y en el título VII de la Ley Orgánica 15/1999, de 13 de diciembre, de Protección de Datos de Carácter Personal.

\section{DISPOSICIÓN ADICIONAL PRIMERA}

La Administración sanitaria realizará las inspecciones oportunas a los efectos de garantizar y comprobar que los centros e instituciones sanitarias y el personal a su servicio cumplen las obligaciones establecidas en la presente ley.

\section{DISPOSICIÓN ADICIONAL SEGUNDA}

La Consellería de Sanidade e Servizos Sociais procederá a agilizar los procedimientos de aprobación de los formularios de referencia de consentimiento informado para que puedan ser utilizados progresivamente en los centros asistenciales del Servizo Galego de Saúde y en los centros concertados con éste.

\section{DISPOSICIÓN ADICIONAL TERCERA}

El Servizo Galego de Saúde adoptará las medidas adecuadas tendentes a la informatización progresiva de las historias clínicas, garantizando la integración de la información relativa a cada paciente con independencia del soporte en que se encuentre.

\section{DISPOSICIÓN FINAL PRIMERA}

La Consellería de Sanidade e Servizos Sociais dictará las disposiciones necesarias para el desarrollo y ejecución de la presente ley. 


\section{DISPOSICIÓN FINAL SEGUNDA}

La presente ley entrará en vigor al mes siguiente al de su publicación en el "Diario Oficial de Galicia”.

5. LEY 5/1999, DE 21 DE MAYO, DE ORDENACIÓN FARMACÉUTICA (DOGA N. ${ }^{\circ} 99,26.5$. 1999) 777

\section{$(\ldots))^{778}$ \\ TÍTULO I DISPOSICIONES GENERALES}

Artículo 1. Objeto y ámbito de aplicación de la ley.

Corresponde a la Comunidad Autónoma de Galicia, en desarrollo de lo previsto en los artículos 28.8 y 33 del Estatuto de Autonomía, y es el objeto de la presente Ley, ordenar y regular en su ámbito territorial la atención farmacéutica.

\section{TÍTULO II \\ LA ATENCIÓN FARMACÉUTICA \\ Capítulo I \\ DISPOSICIONES GENERALES}

Artículo 2. Atención farmacéutica.

1. La atención farmacéutica es un servicio de interés público que garantiza el acceso de los ciudadanos a los medicamentos y productos sanitarios y que contribuye a hacer un uso racional y eficiente de los mismos, tanto en los distintos niveles de asistencia sanitaria como en el campo de la salud pública.

2. Las actividades que constituyen la atención farmacéutica, encaminadas a la correcta conservación, custodia, distribución y dispensación de los medicamentos, se harán bajo la responsabilidad y supervisión de un farmacéutico en los

\section{Véase:}

- Decreto 244/2003, de 24 de abril, de homologación sanitaria de recetas oficiales para la prestación farmacéutica - Orden de 8 de febrero de 2007 de autorización a las oficinas de farmacia para llevar el libro recetario oficial por medios informáticos.

- Decreto 206/2008, de 28 de agosto, de receta electrónica.

778 Exposición de motivos omitida. establecimientos y servicios señalados en la presente ley.

3. La Administración garantizará que la atención farmacéutica se preste en todos los niveles del sistema de salud de modo coordinado e integrado y ofrezca a la población una asistencia eficaz, completa y eficiente.

Artículo 3. Establecimientos y servicios de atención farmacéutica.

A los efectos de la presente ley, son establecimientos y servicios de atención farmacéutica los siguientes:

1. De dispensación:

a. Las oficinas de farmacia.

b. Los botiquines de medicamentos y productos sanitarios.

c. Los servicios de farmacia de atención primaria, los de los hospitales, los de los centros de asistencia social que presten asistencia sanitaria específica y los de los establecimientos psiquiátricos.

d. Los depósitos de medicamentos y productos sanitarios.

2. De distribución:

a. Los centros de distribución de medicamentos y productos sanitarios.

b. Las unidades de dosificación de medicamentos.

La distribución y dispensación de medicamentos veterinarios se realizará mediante los correspondientes servicios farmacéuticos en los establecimientos y servicios que se determinan en el artículo 49 de la presente ley.

Artículo 4. Dispensación de medicamentos.

1. La dispensación de medicamentos sólo podrá hacerse en los establecimientos previstos a tal fin en el artículo 3, en las condiciones establecidas para su autorización.

2. Queda prohibida la venta ambulante de medicamentos destinados al uso humano o al uso veterinario.

3. Las oficinas de farmacia, en las condiciones que previamente se regulen, podrán dispensar a través de correo o servicios de mensajería, propios o ajenos, 
los medicamentos que, por circunstancias especiales, requieran periódicamente los enfermos crónicos, cuya prescripción esté garantizada por receta médica y exista una dispensación previa en esa oficina de farmacia de ese mismo medicamento ${ }^{779}$.

Artículo 5. Derechos de los ciudadanos.

En la atención farmacéutica en Galicia se reconocen los siguientes derechos, además de los contemplados en la Ley 14/1986, de 25 de abril, General de Sanidad, y en la Ley 25/1990, de 20 de diciembre, del medicamento:

a. Elegir libremente la oficina de farmacia.

b. Recibir la prestación farmacéutica precisa.

c. Obtener del farmacéutico la información que se solicite del medicamento, sea de carácter técnico o económico, con claridad y por escrito si así lo solicita.

d. Recibir atención farmacéutica con la mayor privacidad posible y confidencialidad.

e. Conocer y tener acceso a los datos contenidos en su historia farmacoterapéutica en los centros de atención primaria.

Artículo 6. Objeción de conciencia.

La Administración sanitaria garantizará que el derecho a la objeción de conciencia del profesional farmacéutico no limite o condicione el derecho a la salud de los ciudadanos. Cuando se produzca tal circunstancia, la Consellería de Sanidade e Servizos Sociais podrá adoptar medidas excepcionales que, preservando el derecho a la objeción de conciencia, garanticen el derecho a la salud del ciudadano.

\section{Capitulo II \\ AUTORIZACIÓN DE NUEVOS ESTABLECIMIENTOS O SERVICIOS DE ATENCIÓN FARMACÉUTICA}

\section{Artículo 7. Autorización.}

1. Los establecimientos y servicios regulados por la presente ley estarán sujetos a

779 Véase FJ. 6 y 7 STC 152/2003, de 17 de julio de 2003. Recurso de inconstitucionalidad 3537/99. autorización administrativa previa para su apertura y funcionamiento, ampliación, modificación, traslado, transmisión y cierre.

2. La Consellería de Sanidade e Servizos Sociais es el órgano competente para la tramitación de los expedientes de autorización a que se refiere el punto 1 de este artículo, así como de cualquier procedimiento de los previstos en esta ley que sea competencia de la Comunidad Autónoma de Galicia. Lo anterior se entiende sin perjuicio de lo dispuesto en el artículo 49 para los centros de distribución y dispensación de medicamentos veterinarios.

3. Los procedimientos de autorización se ajustarán a lo dispuesto en la presente Ley y en la Ley 30/1992, de régimen jurídico de las administraciones públicas y del procedimiento administrativo común.

4. Transcurrido el plazo reglamentariamente fijado para la resolución de las solicitudes de autorización a que se refiere el número 1 de este artículo así como de las solicitudes de autorización de nuevas oficinas de farmacia sin haber recaído resolución expresa, éstas se entenderán desestimadas.

5. Previamente a la apertura y funcionamiento, traslado o modificación de las instalaciones, la autoridad sanitaria comprobará que se cumplen todos los requisitos establecidos, levantándose acta de inspección.

6. Los establecimientos y servicios regulados por la presente ley estarán sujetos al registro y catalogación y a la elaboración y remisión a la autoridad sanitaria de las informaciones que les sean requeridas.

Igualmente, estarán sujetos al cumplimiento de las obligaciones derivadas del principio de solidaridad e integración sanitaria, en casos de emergencia o de peligro para la salud pública 780 .

780 Véase Decreto 443/2003, de 11 de diciembre, de regulación de las actividades de elaboración y control de calidad de fórmulas magistrales y preparados oficinales. 


\section{Capitulo III LA ATENCIÓN FARMACÉUTICA EN LA ATENCIÓN PRIMARIA}

\section{Sección $1 .^{\mathrm{a}}$}

Las oficinas de farmacia

Artículo 8. Definición y funciones. La oficina de farmacia es un establecimiento sanitario de interés público, integrado en la atención primaria, cuya propiedad y titularidad pertenece a uno o más farmacéuticos, quienes bajo su responsabilidad dirigen y supervisan las siguientes funciones:

1. La adquisición, conservación y custodia de medicamentos y productos sanitarios.

2. La dispensación de medicamentos y productos sanitarios, de acuerdo con la prescripción médica o veterinaria, o según las orientaciones técnico-farmacéuticas para aquéllos cuya dispensación esté autorizada $\sin$ receta.

3. La elaboración de fórmulas magistrales y preparados oficinales, de acuerdo con las normas de correcta fabricación.

4. La información sobre medicamentos, que siempre ha de ser dada por un farmacéutico, incidiendo en aspectos que favorezcan una mejor utilización.

5. La colaboración en el seguimiento individualizado de la terapéutica medicamentosa a fin de evaluar su efectividad y los fracasos por incumplimiento terapéutico, así como de detectar las reacciones adversas y notificárselas a los organismos de farmacovigilancia.

6. La vigilancia, control y custodia de las recetas médicas dispensadas, hasta su caducidad o hasta su facturación a entidades.

7. La colaboración en el uso racional de los medicamentos y en la prevención de su utilización abusiva, así como en la protección y promoción de la salud y educación sanitaria.

8. La realización de análisis clínicos y otras funciones profesionales o sanitarias que, por estar contempladas en normas específicas, pueda desarrollar el farmacéutico con arreglo a su titulación y especialidad.

9. La participación en estudios de utilización de medicamentos, así como en estudios epidemiológicos.

10. La colaboración en programas de salud pública y drogodependencias, establecidos por la autoridad sanitaria.

11. La colaboración con las medidas que establezca la autoridad sanitaria, tendentes a la racionalización del gasto en medicamentos.

12. La cooperación en la docencia para la obtención del título de licenciado en farmacia de acuerdo con las universidades y la normativa estatal al respecto.

13. Cualesquiera otras que se establezcan legal o reglamentariamente.

Artículo 9. Medicamentos de uso veterinario.

En relación con los medicamentos veterinarios, las oficinas de farmacia ejercerán las funciones señaladas en el artículo 49 de la presente ley.

Artículo 10. Titularidad de las oficinas de farmacia.

1. Sólo los farmacéuticos podrán ser propietarios y titulares de las oficinas de farmacia. Cada farmacéutico solamente podrá ser propietario y titular o copropietario y cotitular de una única oficina de farmacia. La condición de copropietario conlleva necesariamente la adquisición de la condición de cotitular y viceversa.

2. Farmacéutico titular es el que ha obtenido la autorización para la apertura, instalación y mantenimiento de una oficina de farmacia, y bajo cuya responsabilidad se ejercen en la misma las funciones descritas en el artículo 8. Deberá también acreditar la propiedad o los derechos de naturaleza real o personal que legitimen la utilización del local para la instalación de la oficina de farmacia.

Artículo 11. Presencia e identificación del farmacéutico.

1. La presencia y actuación profesional del farmacéutico en la oficina de farmacia 
es requisito inexcusable para llevar a cabo las funciones establecidas en el artículo 8 de la presente ley; en la Ley 14/1986, de 25 de abril, General de Sanidad; en la Ley 25/1990, de 20 de diciembre, del Medicamento, y demás normativa de aplicación. La colaboración de farmacéuticos adjuntos, técnicos o auxiliares de farmacia y demás personal no excusa la responsabilidad del farmacéutico titular o cotitular de la oficina de farmacia, sin perjuicio de las responsabilidades administrativas, civiles y penales que pudieran derivarse en cada caso.

2. Los farmacéuticos que presten servicios en la oficina de farmacia llevarán el distintivo que les identifique como técnicos responsables de la actuación farmacéutica.

3. El resto del personal que preste su servicio en la oficina de farmacia deberá ir igualmente provisto del distintivo que le identifique.

Artículo 12. Farmacéutico regente.

1. En los casos de fallecimiento, incapacidad permanente no parcial, incapacitación judicial o declaración judicial de ausencia del farmacéutico titular, la Consellería de Sanidade e Servizos Sociais podrá autorizar, por un tiempo limitado, el nombramiento de un farmacéutico regente, quien asumirá las mismas funciones, responsabilidades e incompatibilidades profesionales que las señaladas para el titular, sin perjuicio de las responsabilidades administrativas, civiles y penales que pudieran derivarse en cada caso.

2. La solicitud de designación de regente o, en su caso, de cierre de la oficina de farmacia deberá formularse en el plazo máximo de veinte días desde la declaración de jubilación, incapacidad permanente no parcial, incapacitación judicial o declaración judicial de ausencia.

Si entre tanto la oficina de farmacia permaneciera abierta, deberá estar atendida por un farmacéutico sustituto.
3. De no producirse la solicitud a que se refiere el punto anterior, se procederá de oficio a iniciar el expediente de cierre de la oficina de farmacia.

4. La regencia tendrá una duración máxima de cinco años, salvo en la transmisión "mortis causa".

Artículo 13. Farmacéutico sustituto.

1. Cuando el titular o regente haya de ausentarse por circunstancias excepcionales y temporales debidamente justificadas, como vacaciones, enfermedad, deficiencias físicas y psíquicas transitorias, estudios relacionados con la profesión, cargos públicos, deberes militares y otras circunstancias análogas que impidan el desarrollo de sus funciones, la Consellería de Sanidade e Servizos Sociais podrá autorizar el nombramiento de un farmacéutico sustituto del titular o regente.

2. El farmacéutico sustituto tendrá las mismas funciones, responsabilidades e incompatibilidades profesionales que el titular o regente, sin perjuicio de las responsabilidades administrativas, civiles y penales que pudieran derivarse en cada caso.

3. La solicitud de designación de farmacéutico sustituto deberá formularse a partir del momento en que se conozca o produzca la circunstancia que obliga a la desatención de la farmacia por el titular o regente, sin que en caso alguno se supere el plazo de cinco días.

En todo caso, si no hay farmacéutico responsable adjunto, la farmacia permanecerá cerrada hasta la incorporación del farmacéutico sustituto.

Artículo 14. Farmacéutico adjunto, personal técnico y auxiliar de farmacia.

1. Tanto los titulares como los regentes y sustitutos podrán contar con la asistencia de farmacéuticos adjuntos, técnicos y auxiliares de farmacia, cuya adecuada formación será responsabilidad del farmacéutico titular o regente.

2. Reglamentariamente se determinarán los casos en que, por razón de edad del 
titular, regente o sustituto, o atendiendo al volumen y diversidad de las funciones de la oficina de farmacia, o al horario ampliado en que haya decidido ejercer, sea necesaria la presencia de farmacéuticos adjuntos. En el supuesto de que el aumento de actividad provenga de las funciones a que se refiere el punto $8 \mathrm{del}$ artículo 8 de la presente ley, podrá contemplarse como alternativa a la designación de un farmacéutico adjunto la de otro profesional sanitario titulado competente para el ejercicio de dichas funciones.

3. En los casos de ausencia de carácter ocasional no permanente, debidos al cumplimiento de deberes profesionales o inexcusables de carácter personal o público, que impidan la presencia del titular, cotitular, sustituto o regente, un farmacéutico adjunto podrá asumir las funciones determinadas en el artículo 8, siempre que el período de tiempo sea inferior a cinco días, siendo el responsable, en todo caso, el titular de la oficina de farmacia o, en su caso, el regente, sin perjuicio de las responsabilidades administrativas, civiles y penales que pudieran derivarse en cada caso.

Artículo 15. Nombramiento de regente, sustituto y adjunto.

La autorización del nombramiento de regente, sustituto y adjunto se concederá por la Consellería de Sanidade e Servizos Sociais previa comprobación de que el designado por el titular, herederos o representante legal cumple con las condiciones exigidas en la presente ley y con aquellas otras que reglamentariamente se determinen.

Artículo 16. Acceso y dependencias de la oficina de farmacia.

1. Las oficinas de farmacia tendrán acceso directo, libre y permanente a la vía pública, exento de barreras arquitectónicas. Los locales e instalaciones reunirán las condiciones higiénico-sanitarias precisas para el servicio farmacéutico.
2. Las oficinas de farmacia que se autoricen a partir de la entrada en vigor de la presente ley dispondrán de una superficie útil mínima de setenta metros cuadrados. Las oficinas de farmacia contarán con las siguientes zonas:

a. De atención al usuario.

b. De recepción, revisión y almacenamiento de medicamentos y productos sanitarios.

c. De laboratorio para la elaboración de fórmulas magistrales y preparados oficinales.

d. De toma de muestras, en caso de realizar análisis clínicos.

e. De atención individualizada.

f. De descanso para las guardias.

g. Aseo para uso del personal de la oficina de farmacia.

3. Las oficinas de farmacia deberán contar con un equipamiento informático adecuado para el desarrollo de sus funciones y con otros medios técnicos y materiales que reglamentariamente se determinen.

Artículo 17. Horarios y servicio de guardia.

1. Las oficinas de farmacia funcionan en régimen de libertad y flexibilidad de horarios y jornadas. Sin perjuicio de ello, la Consellería de Sanidade e Servizos Sociais, para garantizar a la población la atención farmacéutica permanente, establecerá reglamentariamente, oídos los colegios oficiales de farmacéuticos, los horarios mínimos de atención al público.

2. La atención farmacéutica prestada por los profesionales farmacéuticos, con la colaboración del personal técnico o auxiliar en las oficinas de farmacia, será continuada. A tal efecto, permanecerán abiertas al público al menos durante el horario mínimo que se fije por la autoridad sanitaria.

Fuera de dicho horario, la atención farmacéutica estará garantizada en régimen de servicio de urgencia, atendida mediante un sistema de turnos propuesto por el colegio oficial de farmacéuticos en cada 
provincia y autorizado por la Consellería de Sanidade e Servizos Sociais.

El servicio de urgencias se realizará, en cualquier caso, con presencia física del farmacéutico.

3. La información sobre las oficinas de farmacia en servicio de urgencias o con horario ampliado figurará en todas las establecidas en la zona farmacéutica, en lugar visible desde el exterior.

4. Las oficinas de farmacia pueden cesar temporalmente sus actividades durante el período de vacaciones siempre y cuando queden debidamente cubiertas las necesidades de atención farmacéutica durante las veinticuatro horas del día. Corresponde a los colegios oficiales de farmacéuticos proponer a la Consellería de Sanidade e Servizos Sociais los turnos de vacaciones entre las farmacias interesadas en disfrutarlas.

Permanecerán abiertas, al menos, el 50 por 100 de las oficinas de farmacia de cada zona farmacéutica ${ }^{781}$.

Artículo 18. Planificación de las oficinas de farmacia ${ }^{782}$.

1. Dada su condición de establecimientos sanitarios de interés público y en orden a garantizar una atención farmacéutica conveniente, oportuna y eficiente, la autorización de nuevas oficinas de farmacia estará sometida a planificación por la Consellería de Sanidade e Servizos Sociais.

2. Se toman como base de planificación las unidades básicas de atención primaria, que, a los efectos de la presente ley, se corresponden con las demarcaciones municipales en las que se ordena el territorio de la Comunidad Autónoma gallega, creándose las zonas farmacéuticas, que se clasifican en:

a. Zona farmacéutica urbana: Municipios con más de 30.000 habitantes.

781 Véase Decreto 342/1999, de 16 de diciembre, sobre horarios, turnos de urgencia y vacaciones de las oficinas de farmacia.

782 Véase Decreto 146/2001, de 7 de junio, sobre planificación, apertura, traslado, cierre y transmisión de oficinas de farmacia. b. Zona farmacéutica semiurbana: Municipios con un número de habitantes comprendido entre 10.000 y 30.000 .

c. Zona farmacéutica rural: Municipios de población con menos de 10.000 habitantes.

3. No obstante la anterior planificación farmacéutica establecida, y al objeto de garantizar las necesidades de atención farmacéutica que se requieran, teniendo en cuenta las diferentes características geográficas, demográficas, turísticas y sanitarias, por la Xunta de Galicia podrá acordarse la declaración de determinadas zonas farmacéuticas como especiales.

4. Se establecen los siguientes módulos para la apertura de nuevas oficinas de farmacia:

a. Zonas farmacéuticas urbanas: Una por cada 2.800 habitantes empadronados, salvo que se rebase esa proporción en 1.500 habitantes, supuesto en el cual podrá establecerse una nueva oficina de farmacia.

b. Zonas farmacéuticas semiurbanas: Una por cada 2.500 habitantes empadronados, salvo que se rebase esa proporción en 1.500 habitantes, supuesto en el cual podrá establecerse una nueva oficina de farmacia.

c. Zonas farmacéuticas rurales: Una por cada 2.000 habitantes empadronados, salvo que se rebase esa proporción en 1.500 habitantes, supuesto en el cual podrá establecerse una nueva oficina de farmacia.

5. En cada municipio podrá haber, al menos, una oficina de farmacia.

6. Sin perjuicio de la aplicación de los módulos poblacionales establecidos en el punto 4 de este artículo, podrá autorizarse la apertura de una nueva oficina de farmacia en las entidades colectivas de población que carezcan de oficina de farmacia y la más cercana esté a una distancia superior a cuatrocientos metros, de acuerdo con lo fijado por el Instituto Nacional de Estadística, con un número de habitantes de 2.000 o superior. 
7. Corresponderá a la Consellería de Sanidade e Servizos Sociais fijar la delimitación territorial concreta en que puedan establecerse las nuevas oficinas de farmacia, dentro de cada zona farmacéutica.

8. Para el cómputo de habitantes se tendrá en cuenta la población que conste en la última revisión del padrón municipal vigente en el momento de iniciarse el expediente de apertura.

9. El establecimiento de una oficina de farmacia, sea por razón de nueva instalación o traslado, no podrá hacerse a una distancia inferior a doscientos cincuenta metros de otras oficinas de farmacia o de un centro público de asistencia sanitaria.

Artículo 19. Autorización de la oficina de farmacia ${ }^{783}$.

1. El procedimiento de autorización de nuevas oficinas de farmacia se ajustará a lo dispuesto en la presente ley, a las normas generales de procedimiento administrativo y a lo que se establezca reglamentariamente en esta materia.

2. El procedimiento podrá iniciarse:

a. A instancia de un farmacéutico interesado.

b. A petición de los Ayuntamientos.

c. A petición de los colegios oficiales de farmacéuticos.

d. De oficio por la Consellería de Sanidade e Servizos Sociais.

3. La Consellería de Sanidade e Servizos Sociais conocerá, tramitará y resolverá los procedimientos de autorización de nuevas oficinas de farmacia.

4. La autorización de oficinas de farmacia se otorgará por concurso público, con arreglo al baremo y procedimiento que reglamentariamente se establezca, y en el que necesariamente habrá que tener en cuenta la experiencia profesional, los méritos académicos, la formación posgraduada, el conocimiento de la lengua gallega, las

783 Véase Decreto 146/2001, de 7 de junio, sobre planificación, apertura, traslado, cierre y transmisión de oficinas de farmacia. medidas de fomento, mantenimiento y creación de empleo y cualquier otro que se determine, estableciendo, en todo caso, un baremo equilibrado.

5. En ningún caso pueden solicitar la adjudicación de una nueva oficina de farmacia los titulares de una oficina de farmacia instalada en la misma zona farmacéutica en la que se pretenda abrir la nueva ${ }^{784}$.

6. La autorización de una nueva oficina de farmacia se otorgará al farmacéutico que resulte con mayor puntuación entre todos los solicitantes según el baremo reglamentario.

7. La adjudicación por resolución firme en la vía administrativa a un farmacéutico titular de una oficina de farmacia de otra de nueva apertura determinará automáticamente la pérdida de la autorización de la primera, aún en caso de renuncia a la nueva oficina adjudicada.

No obstante, en caso de que se recurriera la resolución de adjudicación en vía jurisdiccional, la oficina de farmacia perdida no entrará en concurso hasta haber recaído sentencia firme. Si dicha sentencia anulase la adjudicación efectuada en vía administrativa, la antigua oficina de farmacia se adjudicará directamente a quien fuera su titular.

Artículo 20. Caducidad de la autorización.

1. Las autorizaciones de funcionamiento de oficinas de farmacia caducarán al cumplir el farmacéutico a cuyo nombre se extienda la autorización 70 años de edad. En este caso, con un mes de antelación a que se produzca la caducidad, habrá de comunicar esta circunstancia a la delegación provincial de la Consellería de Sanidade correspondiente para proceder al cierre. De no comunicarlo, se iniciará expediente de cierre, sin perjuicio de las responsabilidades previstas en el artículo 56.b.1 a que pudiera dar lugar de no hacerlo.

784 Art. 19.5 modificado por Ley 7/2006, de 1 de diciembre, de modificación de la Ley 5/1999, de 21 de mayo, de ordenación farmacéutica.

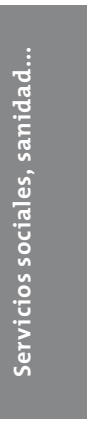


Sin embargo, no se procederá al cierre cuando el titular hubiese ejercitado su derecho de transmisión de acuerdo con lo dispuesto en la presente ley 785786 .

2. Asimismo, dichas autorizaciones caducarán en caso de fallecimiento, incapacidad permanente no parcial, incapacitación judicial o declaración judicial de ausencia del farmacéutico titular, sin perjuicio de las previsiones de los artículos 12 y 23 de la presente ley.

3. En caso de cotitularidad, la caducidad de la autorización de uno de los cotitulares conlleva extender la autorización a otro u otros cotitulares, proporcionalmente, en su caso, a la totalidad de la oficina de farmacia, siempre que no se hubiese producido con anterioridad la transmisión, tanto "inter vivos" como "mortis causa", de la cuota de cotitularidad correspondiente de la oficina de farmacia.

4. En aquellas oficinas de farmacia en que se verifique el incumplimiento de la obligación de dispensación de medicación que les sea solicitada por los ciudadanos, en las condiciones legal y reglamentariamente establecidas, la Consellería de Sanidade podrá proceder a la revocación de la autorización por un período de cinco años ${ }^{787}$.

Artículo 21. Traslado de las oficinas de farmacia ${ }^{788}$.

1. Sólo se autorizará el traslado de las oficinas de farmacia dentro de la misma zona farmacéutica y en las condiciones que reglamentariamente se determinen.

\footnotetext{
785 Véase FJ. 5 STC 152/2003, de 17 de julio de 2003. Recurso de inconstitucionalidad 3537/99.

786 Téngase en cuenta que lo "dispuesto en el artículo 20.1 no será de aplicación a los titulares de las oficinas de farmacia autorizadas con anterioridad a la entrada en vigor de la presente ley de modificación hasta que transcurra un plazo de cinco años desde su entrada en vigor". Disposición transitoria única de la Ley $4 / 2005$, de 17 de marzo, de modificación de la Ley 5/1999, de 21 de mayo, de ordenación farmacéutica.

787 Art. 20 modificado por Ley 4/2005, de 17 de marzo, de modificación de la Ley 5/1999, de 21 de mayo, de ordenación farmacéutica.

788 Véase Decreto $146 / 2001$, de 7 de junio, sobre planificación, apertura, traslado, cierre y transmisión de oficinas de farmacia.
}

2. Los traslados de oficinas de farmacia estarán sujetos al procedimiento de autorización administrativa, así como a las condiciones y requisitos que reglamentariamente se fijen. Los traslados podrán ser voluntarios o forzosos. Estos últimos pueden ser definitivos o provisionales.

a. Son traslados forzosos, y tienen carácter definitivo, aquéllos en los que la prestación del servicio de una oficina de farmacia no pueda continuar en el local en que está instalada y no exista posibilidad de retorno al mismo, bien por las condiciones físicas de las instalaciones o bien porque el titular pierda la disponibilidad jurídica de dicho local.

b. Son traslados forzosos provisionales los que se produzcan por obras, derrumbe o demolición del edificio y que supongan el cierre temporal de la oficina de farmacia en su asentamiento, autorizándose con carácter transitorio su funcionamiento en otras instalaciones, con el compromiso y la obligación del titular a que la oficina de farmacia retorne a su primitivo local en el plazo que reglamentariamente se determine. Habiendo transcurrido el plazo otorgado sin que la oficina de farmacia haya retornado a su lugar, se procederá al cierre del local donde se hubiera instalado provisionalmente. Podrá regularse un procedimiento de autorización de urgencia para traslados provisionales.

c. Son traslados voluntarios todos los demás que se produzcan a instancia del titular de la oficina de farmacia ${ }^{789}$.

3. La nueva situación de la oficina de farmacia en los traslados voluntarios y forzosos definitivos respetará las condiciones señaladas en el punto 9 del artículo 18 de la presente ley. En los traslados forzosos provisionales con obligación de retorno, las distancias mínimas a que se

789 Art. 21.2 modificado por Ley $4 / 2005$, de 17 de marzo, de modificación de la Ley 5/1999, de 21 de mayo, de ordenación farmacéutica. 
refiere el artículo 18.9 se reducen a ciento veinticinco metros 790 .

4. La Consellería de Sanidade e Servizos Sociais velará porque la población afectada por el cierre temporal tenga la atención farmacéutica debida.

Artículo 22. Cierre voluntario ${ }^{791}$.

1. Será preceptiva la autorización administrativa para proceder al cierre voluntario definitivo de una oficina de farmacia.

2. La autoridad sanitaria, oídos los colegios oficiales de farmacéuticos, podrá autorizar excepcionalmente el cierre temporal de la oficina de farmacia durante un período máximo de dos años, siempre que las que permanezcan abiertas presten la suficiente y adecuada atención farmacéutica.

3. Dicho plazo no será de aplicación a los cierres forzosos por sanción administrativa o inhabilitación profesional o penal, o de cualquier otra índole que afecte al titular.

Artículo 23. Transmisión "inter vi$\operatorname{vos} " 792$.

1. La transmisión de oficinas de farmacia, mediante actos "inter vivos", sea total o parcial, estará sujeta al procedimiento de autorización administrativa, a las condiciones $\mathrm{y}$ a los requisitos que reglamentariamente se establezcan.

2. La transmisión de una oficina de farmacia a favor de otro farmacéutico sólo podrá llevarse a cabo cuando lleve abierta al público un mínimo de tres años, salvo en los supuestos de fallecimiento, jubilación, declaración judicial de ausencia, incapacitación física o jurídica del farmacéutico titular o de uno de los titulares de la oficina de farmacia, en los que bastará que la oficina esté abierta al público en la fecha de producción de estas circunstancias.

790 Art. 21.3 modificado por Ley 4/2005, de 17 de marzo, de modificación de la Ley 5/1999, de 21 de mayo, de ordenación farmacéutica.

791 Véase Decreto 146/2001, de 7 de junio, sobre planificación, apertura, traslado, cierre y transmisión de oficinas de farmacia

792 Véase Decreto 146/2001, de 7 de junio, sobre planificación, apertura, traslado, cierre y transmisión de oficinas de farmacia.
3. En caso de cotitularidad, en la transmisión onerosa tendrán derecho de adquisición preferente el farmacéutico cotitular o, en su caso, los farmacéuticos cotitulares proporcionalmente a sus cuotas de participación.

El plazo y demás condiciones para el ejercicio de este derecho se establecerán reglamentariamente ${ }^{793} 794$.

Artículo 24. Transmisión "mortis causa" 795 .

1. En caso de fallecimiento del farmacéutico titular de la oficina de farmacia, los herederos habrán de comunicar a la autoridad sanitaria su voluntad de continuar o cerrar definitivamente la oficina de farmacia.

Dicha comunicación se formulará en el plazo máximo de veinte días, debiendo acompañarse de la propuesta de designación de regente. De no hacerse en este tiempo y modo, la Administración sanitaria iniciará de oficio el expediente de cierre de la oficina de farmacia ${ }^{796}$.

2. En el supuesto de transmisión "mortis causa", el cotitular podrá ejercitar su derecho de adquisición preferente, salvo en el supuesto de que la transmisión se produzca a favor del cónyuge o cualquiera de los herederos en primer grado que, en el momento del fallecimiento del cotitular, sea licenciado en farmacia o esté cursando estudios de farmacia, siempre que finalice los mismos en el plazo de cinco años de acuerdo con lo dispuesto en el artículo 24.4797 .

793 Véase FJ. 4 152/2003, de 17 de julio de 2003. Recurso de inconstitucionalidad 3537/99. En dicha sentencia se declaraba inconstitucional el antiguo art. 26.

794 Art. 23 modificado por Ley 4/2005, de 17 de marzo, de modificación de la Ley 5/1999, de 21 de mayo, de ordenación farmacéutica.

795 Véase Decreto 146/2001, de 7 de junio, sobre planificación, apertura, traslado, cierre y transmisión de oficinas de farmacia

796 Art. 24.1 modificado por Ley 4/2005, de 17 de marzo, de modificación de la Ley 5/1999, de 21 de mayo, de ordenación farmacéutica.

797 Art. 24.2 modificado por Ley 4/2005, de 17 de marzo, de modificación de la Ley 5/1999, de 21 de mayo, de ordenación farmacéutica.

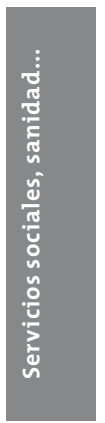


3. En el supuesto de fallecimiento del farmacéutico titular, podrán continuar con la oficina de farmacia el cónyuge o alguno de los herederos en primer grado, siempre que sean farmacéuticos y cumplan los requisitos exigidos.

4. Igualmente podrán continuar con la oficina de farmacia el cónyuge o cualquiera de los herederos en primer grado que al tiempo del fallecimiento del titular estén cursando estudios de farmacia, siempre que los finalicen en el plazo de cinco años. Durante este tiempo la oficina de farmacia estará atendida por un farmacéutico regente.

Artículo 25. Limitaciones a la transmisión.

1. Las oficinas de farmacia no podrán transmitirse desde el momento en que su titular haya presentado solicitud de autorización de apertura de otra farmacia. Esta limitación se mantendrá en tanto no se agote la vía administrativa en la resolución del expediente de apertura, extendiéndose, en su caso, hasta que no se resuelva con carácter definitivo en la vía jurisdiccional 798 .

2. Cuando el titular de una oficina de farmacia obtenga la autorización firme de apertura de una nueva oficina de farmacia, la autorización primera caducará automáticamente, así como el derecho de transmisión de la misma ${ }^{799}$.

3. La caducidad de una autorización y el consiguiente cierre de la oficina de farmacia no afectarán al régimen legal aplicable a los locales, instalaciones y enseres, de conformidad con lo dispuesto en la legislación civil.

4. En los casos de cierre forzoso de una oficina de farmacia por sanción administrativa o inhabilitación profesional o penal

\footnotetext{
798 Art. 25.1 modificado por Ley 4/2005, de 17 de marzo, de modificación de la Ley 5/1999, de 21 de mayo, de ordenación farmacéutica.

799 Art. 25.2 modificado por Ley 4/2005, de 17 de marzo, de modificación de la Ley 5/1999, de 21 de mayo, de ordenación farmacéutica.
}

o de cualquier otra índole de su titular, éste no podrá transmitir dicha oficina de farmacia durante el tiempo en que la misma permanezca clausurada.

\section{Sección 2. ${ }^{\mathrm{a}}$ \\ Los botiquines ${ }^{800}$}

\section{Artículo 26. Disposiciones genera-} les.

1. En las parroquias o núcleos de población y lugares en donde no pueda instalarse una oficina de farmacia porque no se cumplan los requisitos exigidos por la presente ley, y se den circunstancias de lejanía, difícil comunicación con la oficina de farmacia más cercana, altas concentraciones de población temporales o cuando concurran situaciones de emergencia que lo hagan aconsejable, podrá autorizarse la apertura de un botiquín.

2. El botiquín estará vinculado a la oficina de farmacia más cercana entre las existentes en el mismo municipio, y en caso de renuncia podría asumirlo otra oficina de farmacia del mismo municipio, y en último lugar podrá ser asumido por la oficina de farmacia más cercana de otro municipio, siempre que ésta lo acepte.

El botiquín estará bajo la responsabilidad del farmacéutico titular, que asegurará la cobertura de la asistencia farmacéutica de acuerdo con las necesidades para las cuales fue establecido el botiquín, así como del correcto almacenaje, custodia y conservación de los medicamentos y productos sanitarios.

3. Los botiquines de urgencia de medicamentos veterinarios podrán estar vinculados, además de lo establecido en el apartado anterior de este artículo, a cualquier otro establecimiento o servicio de dispensación de medicamentos veterinarios autorizado.

4. La dispensación de medicamentos al público será realizada por un farmacéutico,

800 Véase Orden de 20 de noviembre de 2001 por la que se establecen los requisitos y el procedimiento de autorización de los botiquines. 
con la colaboración, en su caso, de un técnico o auxiliar de farmacia. En circunstancias excepcionales, la Consellería de Sanidade e Servizos Sociais podrá autorizar que dicha función pueda ser realizada por personal no farmacéutico expresamente autorizado.

5. La Consellería de Sanidade e Servizos Sociais establecerá los requisitos y condiciones para la instalación de botiquines, el procedimiento de autorización y el régimen de funcionamiento, así como su clausura o cierre.

6. La transmisión de una oficina de farmacia que posea un botiquín vinculado implica automáticamente la transmisión del mismo.

7. En caso de cierre definitivo de una oficina de farmacia o establecimiento debidamente autorizado que posea un botiquín vinculado, automáticamente se cerrará el mismo. La Administración sanitaria, posteriormente, adjudicará éste a la oficina de farmacia más cercana del mismo municipio o, en último término, a la oficina de farmacia o establecimiento debidamente autorizado más cercano de otro municipio.

\section{Sección 3. ${ }^{\mathrm{a}}$}

Los servicios de farmacia en las estructuras de atención primaria ${ }^{801}$

Artículo 27. Disposición general. De acuerdo con el artículo 103 de la Ley 14/1986, de 25 de abril, General de Sanidad, en el nivel de atención primaria se prestará, a través de servicios de farmacia, la atención farmacéutica necesaria para que el equipo multidisciplinario de atención a la salud disponga de los medios terapéuticos necesarios para su aplicación dentro de dichas instituciones y los que exijan una particular vigilancia, supervisión y control del equipo multidisciplinario.

801 Véase Decreto 176/2001, de 12 de julio, sobre creación, apertura y funcionamiento de los servicios de farmacia y depósitos de medicamentos en las estructuras de atención primaria.
Artículo 28. Condiciones y requisitos.

1. Se establecerán reglamentariamente los requisitos para la creación y funcionamiento de los servicios de farmacia en las estructuras de atención primaria, así como las condiciones materiales y técnicas con que tendrán que contar.

2. Podrán constituirse depósitos de medicamentos en los centros de salud y estructuras de atención primaria para su utilización dentro de las mismas, bajo la responsabilidad de un servicio de farmacia hospitalario o un servicio de farmacia de atención primaria, con la presencia de un farmacéutico, que contará con la colaboración del personal técnico o auxiliar, en su caso, y demás personal que precise, según el volumen de dispensación.

3. La Consellería de Sanidade e Servizos Sociais podrá constituir depósitos de medicamentos en estructuras del sistema sanitario público, bajo la responsabilidad de un farmacéutico, que contará con la colaboración del personal técnico o auxiliar que se establezca reglamentariamente para uso interno en la red de atención primaria.

Artículo 29. Funciones de los servicios de farmacia de atención primaria.

Son funciones de los servicios de farmacia de atención primaria:

a. Adquirir, custodiar, conservar y dispensar los medicamentos y elaborar, según las normas de correcta fabricación, las fórmulas magistrales y preparados oficinales a aplicar en los centros de atención primaria o los que exijan una particular supervisión y control del equipo multidisciplinario. Dichas funciones serán realizadas por el farmacéutico responsable del servicio o bajo su dirección y responsabilidad, de acuerdo con la prescripción médica.

b. Promover la elaboración, actualización y difusión de la guía farmacoterapéutica de su área y el seguimiento de su aplicación.

c. Colaborar en que la utilización de los recursos disponibles para la atención farmacéutica sea eficiente. 
d. Asesorar al personal sanitario y a los órganos de gestión del área en materia de medicamentos y productos sanitarios, así como en aquellas otras actuaciones que puedan ser necesarias.

e. Realizar la historia farmacoterapéutica de los pacientes del centro.

f. Colaborar en la evaluación del uso y efectividad de medicamentos de utilización en patologías de especial control.

g. Colaborar con el sistema de farmacovigilancia en la detección de los posibles efectos adversos de los medicamentos.

h. Colaborar en los programas que se establezcan en su área sobre el uso racional del medicamento.

i. Participar en la implantación, desarrollo y seguimiento de protocolos terapéuticos a fin de conseguir una farmacoterapia segura y eficiente.

j. Realizar trabajos de investigación en el ámbito del medicamento y productos sanitarios, participar en los ensayos clínicos y conservar y dispensar los fármacos y productos sanitarios en fase de investigación clínica.

k. Coordinar las oficinas de farmacia con los servicios de farmacia de los hospitales, con arreglo a lo dispuesto en los artículos 87.d) y 91.g) de la Ley 25/1990, de 20 de diciembre, del Medicamento.

Artículo 30. Recursos materiales y humanos.

Las funciones recogidas en el artículo anterior serán realizadas bajo la responsabilidad de un farmacéutico, el cual contará con medios materiales y personales suficientes para su desempeño.

\section{Capitulo IV \\ LA ATENCIÓN FARMACÉUTICA EN LOS HOSPITALES, CENTROS DE ASISTENCIA SOCIAL Y PSIQQUIÁTRICOS}

Artículo 31. Disposiciones generales.

1. La atención farmacéutica en los centros hospitalarios, centros de asistencia social y psiquiátricos se llevará a cabo a través de los servicios de farmacia y los depósitos de medicamentos. En ellos, los farmacéuticos desarrollarán las funciones que les encomienda la presente ley, prestando un servicio integrado con otras actividades de la atención hospitalaria, sociosanitaria o psiquiátrica.

2. Será obligatorio el establecimiento de un servicio de farmacia en:

a. Todos los hospitales que tengan cincuenta o más camas.

b. Los centros de asistencia social que tengan cincuenta camas o más en régimen de asistidos.

c. Los demás hospitales y centros de asistencia social cuyas características y actividad asistencial impliquen una especial cualificación en la utilización de medicamentos y productos sanitarios, y que se determinen reglamentariamente.

3. Reglamentariamente se determinarán las condiciones que obliguen a la creación de un servicio de farmacia en centros psiquiátricos.

Artículo 32. Funciones de los servicios de farmacia de hospitales y centros de asistencia social.

Son funciones de los servicios de farmacia de hospitales y centros de asistencia social:

1. Participar, a través de la Comisión de Farmacia y Terapéutica, en el proceso multidisciplinario de la selección de medicamentos y productos sanitarios precisos para la correcta atención farmacéutica, bajo criterios de seguridad, calidad y coste/efectividad, recogidos en la guía farmacoterapéutica de obligada edición y difusión, la cual habrá de actualizarse periódicamente.

2. Asumir la responsabilidad técnica de la gestión del servicio, así como la adquisición con criterios de eficiencia, calidad, correcta conservación, control y dispensación de los medicamentos para uso del propio hospital.

3. Proponer a la dirección del centro las normas internas para la correcta 
conservación, disponibilidad, accesibilidad y reposición de los medicamentos en depósito en las unidades de enfermería.

4. Elaborar, de acuerdo con las normas de correcta fabricación, fórmulas magistrales y preparados oficinales y su posterior dispensación individualizada.

5. Establecer un sistema de dispensación de medicamentos que favorezca la atención farmacéutica individualizada y permita un seguimiento integrado de la terapéutica del paciente.

6. Solicitar a las entidades debidamente autorizadas por el órgano competente la elaboración o control de aquellos medicamentos necesarios para la atención farmacéutica a pacientes concretos, que no pueden ser elaborados por el servicio de farmacia y no están disponibles.

7. Disponer de un sistema de información de medicamentos para el personal sanitario del centro, así como propiciar la formación adecuada del personal adscrito al servicio.

8. Colaborar en el establecimiento de un sistema de seguimiento y control del uso individualizado de los medicamentos, a fin de detectar sus posibles efectos adversos y notificárselos al sistema de farmacovigilancia.

9. Participar en la implantación, desarrollo y seguimiento de protocolos terapéuticos, a fin de conseguir la farmacoterapia más segura y eficiente y promover el uso racional del medicamento en el hospital y su área de influencia.

10. Formar parte de las comisiones del centro y preceptivamente de la de Farmacia y Terapéutica para la selección y evaluación científica de los medicamentos y productos sanitarios.

11. Llevar a cabo trabajos de investigación en el ámbito del medicamento y de los productos sanitarios y participar en los ensayos clínicos, así como la custodia y dispensación de los productos en fase de investigación clínica.
12. Promover la eficiencia en la gestión del servicio farmacéutico.

13. Colaborar con la atención primaria en los casos en que se determine por la Administración sanitaria.

14. Colaborar en la formación pre y posgrado de los profesionales sanitarios.

15. Realizar actividades de farmacocinética clínica, encaminadas a la individualización posológica en función de parámetros farmacocinéticos.

Artículo 33. Recursos materiales.

1. El servicio de farmacia deberá disponer de una superficie adecuada en relación con el número de pacientes atendidos.

2. El servicio de farmacia de hospitales contará con un área diferenciada de atención a pacientes externos, para preservar la confidencialidad y privacidad.

Artículo 34. Recursos humanos.

1. Los hospitales con cincuenta o más camas y los centros de asistencia social que tengan cincuenta camas o más en régimen de asistidos contarán con un servicio de farmacia, bajo la titularidad y responsabilidad de un farmacéutico especialista en farmacia hospitalaria.

2. Dependiendo del volumen, actividades y tipo de centro, se establecerá reglamentariamente el número de farmacéuticos adicionales, técnicos o auxiliares en farmacia, personal administrativo y subalterno necesarios para desarrollar con normalidad el funcionamiento del servicio.

3. Todos los farmacéuticos que ejerzan su actividad en los servicios de farmacia hospitalaria y centros de asistencia social en régimen de asistidos estarán en posesión del título de especialista en farmacia hospitalaria.

Artículo 35. Depósitos de medicamentos y productos sanitarios.

1. Los centros hospitalarios, centros de asistencia social que presten asistencia sanitaria específica y psiquiátricos que no cuenten con un servicio de farmacia y que no estén obligados a tenerlo dispondrán de un depósito, que estará vinculado a

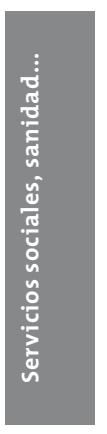


un servicio de farmacia del área sanitaria y bajo la responsabilidad del jefe del servicio, en el caso de los hospitales del sector público, y a una oficina de farmacia establecida en la misma zona farmacéutica o a un servicio de farmacia, en el supuesto de que se trate de un hospital del sector privado.

2. El depósito será atendido por un farmacéutico vinculado al servicio de farmacia o, en su caso, a la oficina de farmacia que con la colaboración del personal técnico o auxiliar de farmacia necesario realizará las funciones siguientes:

a. Garantizar la correcta conservación, custodia y dispensación de medicamentos y productos sanitarios para su aplicación dentro del centro.

b. Asegurar un sistema eficaz y seguro de dispensación de medicamentos y productos sanitarios en el centro, con la implantación de medidas que contribuyan a garantizar su correcta administración.

c. Establecer las normas de acceso al depósito para el personal previamente autorizado.

d. Informar al personal sanitario del centroyalos propios pacientes en materia de medicamentos, así como realizar estudios de utilización de medicamentos.

e. Colaborar con la Comisión de Farmacia y Terapéutica y los comités éticos de investigación clínica, así como con otras comisiones del centro hospitalario de referencia en las que sus conocimientos puedan ser útiles.

f. Garantizar las existencias necesarias para que la dispensación de medicamentos quede cubierta las veinticuatro horas del día.

Artículo 36. Localización de los servicios y depósitos.

Tanto los servicios de farmacia como los depósitos de medicamentos y productos sanitarios, referidos en el capítulo IV de la presente ley, deberán disponer de una localización y superficie adecuada y una buena comunicación dentro del centro.

\section{TÍTULO III LA DISTRIBUCIÓN}

Artículo 37. Centros de distribución.

1. La distribución de medicamentos y productos sanitarios para el suministro a los establecimientos y servicios farmacéuticos de dispensación se llevará a cabo a través de los centros de distribución de medicamentos y productos sanitarios.

2. Los centros distribuidores dispondrán del personal, equipos, instalaciones y locales necesarios para garantizar la identidad y calidad de los medicamentos, así como el almacenamiento seguro y eficaz y la conservación, custodia y distribución de los mismos de conformidad con la Ley 25/1990, de 20 de diciembre, del Medicamento, y normas de desarrollo.

Artículo 38. Director técnico.

Los centros de distribución contarán con un director técnico farmacéutico, que será responsable de las actividades técnico-sanitarias que se desarrollen en los mismos, $\mathrm{y}$, según el volumen de actividad, con farmacéuticos adjuntos.

Artículo 39. Autorizaciones.

La Consellería de Sanidade e Servizos Sociais autorizará el nombramiento del director técnico, así como la creación, funcionamiento, modificación, traslado o supresión de los centros de distribución domiciliados en Galicia, mediante los procedimientos que se determinen reglamentariamente y previa comprobación de que reúnen los requisitos técnico-sanitarios exigidos.

Artículo 40. Funciones del director técnico.

Son funciones del director técnico de los centros de distribución las siguientes:

a. Custodiar la documentación técnica relativa a la autorización y funcionamiento del centro de distribución.

b. Establecer los protocolos de los análisis que, de forma obligatoria, han de realizarse en el centro.

c. Vigilar y controlar los procedimientos propios del centro y analizar la calidad 
y pureza de los productos que se adquieran a granel.

d. Protocolizar y comprobar el cumplimiento de las normas establecidas de calidad y de garantía aplicables a la recepción, envasado, etiquetado y distribución al detalle de los productos que se adquieran a granel.

e. Garantizar la aplicación y el cumplimiento de las normas legalmente establecidas y de buena práctica en la distribución.

f. Adoptar las medidas para el inmediato cumplimiento de los planes de alerta, inmovilización o suspensión temporal de medicamentos y productos sanitarios establecidas por la autoridad sanitaria.

g. Asegurar la legitimidad de origen de los medicamentos y productos sanitarios y de cualquier otro producto que el centro distribuya.

h. Supervisar el cumplimiento de la legislación sobre estupefacientes y psicótropos.

Artículo 41. Exigencias de funcionamiento.

1. Los centros de distribución dispondrán, en todo momento, de existencias de medicamentos, sustancias medicinales y demás productos farmacéuticos que sean suficientes y adecuados para el abastecimiento de las farmacias a las que provean de modo habitual.

2. Los centros de distribución estarán obligados a cumplir los servicios de guardia que establezca la Consellería de Sanidade e Servizos Sociais.

Artículo 42. Unidades de dosificación de medicamentos.

A los efectos de la presente ley, se consideran unidades de dosificación de medicamentos los establecimientos que, debidamente autorizados por el órgano competente y bajo la responsabilidad, supervisión y control de un director técnico farmacéutico, lleven a cabo, previa prescripción médica individualizada, la dosificación de medicamentos para su distribución a los establecimientos y servicios autorizados de dispensación de atención primaria, hospitales, centros de asistencia social y psiquiátricos, garantizando la aplicación y el cumplimiento de las normas de buena práctica en la dosificación y distribución.

Artículo 43. Autorizaciones.

La Consellería de Sanidade e Servizos Sociais establecerá reglamentariamente los requisitos exigidos para la autorización de apertura, acreditación, requisitos técnicos de funcionamiento y recursos materiales y humanos de las unidades de dosificación de medicamentos.

\section{TÍTULO IV \\ UNIDADES DE RADIOFARMACIA 802}

Artículo 44. Disposición general.

Los radiofármacos de uso humano, en su calidad de medicamentos, se ajustarán a la normativa que los regule.

La preparación extemporánea de radiofármacos se realizará en unidades de radiofarmacia previstas en el artículo siguiente y dirigidas por un especialista en radiofarmacia ${ }^{803}$.

Artículo 45. Clasificación de las unidades de radiofarmacia.

Las unidades de radiofarmacia podrán ser de dos tipos:

a. Unidades de radiofarmacia de tipo I. Podrán realizar procedimientos de preparación de dosis individuales de radiofármacos a punto para ser utilizados, de preparación de radiofármacos a partir de generadores y equipos reactivos y de producción de radiofármacos obtenidos a partir de muestras autólogas del propio paciente.

b. Unidades de radiofarmacia de tipo II. Son aquellas que pueden estar instaladas en locales independientes de los servicios o centros asistenciales y realizar todas las

802 Rúbrica del Título IV modificada por Ley 4/2005, de 17 de marzo, de modificación de la Ley 5/1999, de 21 de mayo, de ordenación farmacéutica. 803 Segundo párrafo del art. 44 modificado por Ley 4/2005, de 17 de marzo, de modificación de la Ley 5/1999, de 21 de mayo, de ordenación farmacéutica. 
operaciones de elaboración de preparaciones extemporáneas de radiofármacos contempladas en su regulación específica y su suministro a otros servicios o centros de radiofarmacia o de medicina nuclear. Asimismo, podrán efectuar funciones de investigación y docencia relacionadas con la radiofarmacia y de asesoramiento sobre procedimientos técnicos y de calidad a las unidades de tipo I 804805 .

Artículo 46. Autorización.

La autorización para la apertura, acreditación y cierre de las unidades de radiofarmacia corresponde a la Consellería de Sanidade e Servizos Sociais, que establecerá reglamentariamente los procedimientos oportunos, pudiendo establecer, asimismo, los controles de calidad e inspecciones que considere necesarios. Todo ello sin perjuicio de las competencias que correspondan a otros organismos según la normativa vigente ${ }^{806}$.

Artículo 47. Dotación de personal. Las unidades de radiofarmacia estarán dotadas, como mínimo, del siguiente personal:

a. Unidades de radiofarmacia de tipo I: Un especialista en radiofarmacia, que será responsable de la preparación y producción de radiofármacos de la unidad, y un técnico cualificado encargado de las tareas de preparación.

b. Unidades de radiofarmacia de tipo II: Un especialista en radiofarmacia, que será responsable de la preparación y control de radiofármacos y de los técnicos debidamente cualificados dedicados a las funciones básicas de la unidad, bajo la supervisión del facultativo responsable.

Todo el personal facultativo y técnico deberá estar capacitado como supervisor $\mathrm{u}$ operador de instalaciones radiactivas.

\footnotetext{
804 Véase FJ. 8-9 STC 152/2003, de 17 de julio de 2003. Recurso de inconstitucionalidad 3537/99.

805 Art. 45 modificado por Ley 4/2005, de 17 de marzo, de modificación de la Ley 5/1999, de 21 de mayo, de ordenación farmacéutica.

806 Véase FJ. 10 STC 152/2003, de 17 de julio de 2003. Recurso de inconstitucionalidad 3537/99.
}

Artículo 48. Adquisición y dispensación.

La adquisición y dispensación de radiofármacos elaborados en las unidades de radiofarmacia no integradas en servicios de farmacia es responsabilidad del servicio de farmacia del centro donde se vayan a utilizar.

\section{TÍTULO V \\ LA DISTRIBUCIÓN Y DISPENSACIÓN DE MEDICAMENTOS VETERINARIOS}

Artículo 49. Distribución y dispensación de medicamentos veterinarios.

1. La distribución y dispensación de medicamentos veterinarios se llevará a cabo en los establecimientos y servicios $\mathrm{y}$ en las condiciones reglamentadas en el artículo 50 de la Ley 25/1990, del Medicamento, y demás normativa estatal básica, en lo dispuesto en la presente Ley de Ordenación Farmacéutica y en lo que reglamentariamente pueda determinarse en esta Comunidad Autónoma.

2. Para facilitar la distribución de los medicamentos veterinarios desde los laboratorios fabricantes y entidades importadoras a los establecimientos y servicios de dispensación autorizados, podrá utilizarse la mediación de los centros de distribución de medicamentos veterinarios.

Los laboratorios preparadores de medicamentos veterinarios podrán disponer de depósitos reguladores para facilitar el suministro exclusivamente al por mayor de los productos propios.

3. La dispensación al público de los medicamentos prefabricados, especialidades farmacéuticas, fórmulas magistrales y preparados oficinales veterinarios se realizarán exclusivamente por:

a. Las oficinas de farmacia legalmente establecidas, que además serán las únicas autorizadas para la elaboración de fórmulas magistrales y preparados oficinales.

b. Las entidades y agrupaciones ganaderas para el uso exclusivo de sus miembros, autorizadas en las condiciones que se 
establezcan en base a la realización de programas zoosanitarios y que cuenten con servicios farmacéuticos y veterinarios.

c. Los establecimientos comerciales detallistas autorizados en las condiciones que se establezcan, siempre que cuenten con servicios farmacéuticos responsables de la custodia, suministro y control de utilización de estos medicamentos.

d. Los botiquines de medicamentos veterinarios que, por razones de urgencia o lejanía de oficinas de farmacia y demás establecimientos y servicios de dispensación de medicamentos veterinarios, legalmente se autoricen.

4. Las entidades o agrupaciones ganaderas habrán de contar con un número de farmacéuticos, técnicos o auxiliares adecuado al número de centros de dispensación de medicamentos, en las condiciones que reglamentariamente se establezcan, así como con programas zoosanitarios aprobados por el órgano competente de la Comunidad Autónoma.

5. Los establecimientos comerciales detallistas autorizados habrán de contar con servicios farmacéuticos, que serán responsables de la custodia, suministro y control de utilización de los medicamentos veterinarios.

Estos establecimientos y los del apartado anterior deberán estar identificados con la leyenda "Productos zoosanitarios".

6. El veterinario en ejercicio clínico podrá disponer de existencias de medicamentos veterinarios para su utilización en casos urgentes, de lejanía de los establecimientos y servicios de dispensación, o que precisen por imposición legal su aplicación directa por el veterinario o bajo su dirección y control, siempre que no implique actividad comercial. Estos medicamentos serán adquiridos a través de cualquier establecimiento y servicio de dispensación autorizado.

7. Los establecimientos y servicios de distribución y dispensación exclusiva de medicamentos veterinarios requerirán autorización previa de la Consellería de Agricultura, Ganadería y Política Agroalimentaria, previo informe de la Consellería de Sanidade e Servizos Sociais.

La autorización de las oficinas de farmacia en que se dispensen medicamentos veterinarios se regirá por lo dispuesto en el artículo 7 de la presente ley.

Los centros que distribuyan medicamentos tanto de uso humano como de uso veterinario serán autorizados por la Consellería de Sanidade e Servizos Sociais, previo informe favorable de la Consellería de Agricultura, Ganadería y Política Agroalimentaria.

\section{TÍTULO VI}

\section{LOS PROFESIONALES FARMACÉUTICOS}

Artículo 50. Formación continuada. La Consellería de Sanidade e Servizos Sociais, en colaboración con las universidades, colegios oficiales de farmacéuticos y otras organizaciones interesadas, impulsará la formación continuada de los farmacéuticos y personal auxiliar de los establecimientos y servicios de atención farmacéutica a fin de ofrecer una prestación actualizada, útil y eficiente a los ciudadanos.

Artículo 51. Incompatibilidades.

1. Además de las incompatibilidades de régimen general, el ejercicio profesional farmacéutico en los establecimientos y servicios de atención farmacéutica regulados en la presente Ley es incompatible con la existencia de cualquier clase de intereses económicos, directos e indirectos, en la fabricación de medicamentos y productos sanitarios.

2. El ejercicio profesional del farmacéutico en la oficina de farmacia, en cualquiera de sus modalidades, es incompatible con:

a. La práctica profesional en el resto de los establecimientos y servicios de atención farmacéutica, salvo en los botiquines de medicamentos.

b. El ejercicio clínico de la medicina, la odontología y la veterinaria.

c. Toda actividad que impida la presencia física del farmacéutico en el horario de atención al público. 
d. La prestación de servicios retribuidos en cualquier administración pública, salvo en los supuestos previstos en la legislación específica.

\section{TÍTULO VII \\ LA PRODUCCIÓN DE LOS MEDICAMENTOS, LA INSPECCIÓN DE LOS ENSAYOS CLÍNICOS Y LA FARMACOVIGILANCIA}

Artículo 52. Disposiciones generales. La Consellería de Sanidade e Servizos Sociais, de conformidad con las competencias transferidas, verificará:

a. Que los laboratorios farmacéuticos realicen los controles exigidos.

b. Los programas de control de calidad de los medicamentos.

c. Que el transporte de los medicamentos hasta su destino se realice cumpliendo las obligaciones impuestas en la autorización de los laboratorios farmacéuticos.

d. Que los ensayos clínicos se lleven a cabo de acuerdo con la normativa vigente.

e. Que se promueva el desarrollo de programas de farmacovigilancia.

Artículo 53. Acción inspectora.

A la Consellería de Sanidade e Servizos Sociais le corresponde la inspección y el cumplimiento de la legislación sobre medicamentos y productos sanitarios. A estos efectos, la autoridad sanitaria tendrá acceso a:

a. Los servicios de producción y control de los laboratorios farmacéuticos.

b. La documentación justificativa de los plazos, condiciones y desarrollo de los ensayos clínicos.

\section{TÍTULO VIII PUBLICIDAD Y PROMOCIÓN DE LOS MEDICAMENTOS 807}

Artículo 54. Disposiciones generales.

1. La Consellería de Sanidade e Servizos Sociais adoptará las medidas oportunas

807 Véase Decreto 107/2008, de 15 de mayo, por el que se regula la señalización, información y publicidad de las oficinas de farmacia. para garantizar que la información, promoción y publicidad de los medicamentos y productos sanitarios, destinadas a los profesionales de la salud o a la población en general, se ajusten a criterios de veracidad, evitando inducir a una utilización incorrecta o a un sobreconsumo.

2. Corresponde a la Consellería de Sanidade e Servizos Sociais la autorización de cualquier publicidad de especialidades farmacéuticas que se difunda específicamente en el ámbito de la Comunidad Autónoma gallega. Reglamentariamente se fijará el procedimiento para obtener tal autorización.

3. La Consellería de Sanidade e Servizos Sociais velará porque la promoción de medicamentos y especialidades farmacéuticas dirigida a profesionales sanitarios en el territorio de la Comunidad gallega esté de acuerdo con los datos contenidos en su ficha técnica.

4. La autoridad sanitaria tendrá acceso, a efectos de inspección, a todos los medios de información y promoción utilizados para la publicidad de medicamentos, ya sean escritos, audiovisuales, informáticos o de cualquier otra naturaleza. El material informativo deberá tener carácter científico e ir dirigido exclusivamente a profesionales sanitarios.

\section{TÍTULO IX RÉGIMEN SANCIONADOR}

Artículo 55. Disposición general. Las infracciones contempladas en la presente ley serán objeto de las correspondientes sanciones administrativas, previa instrucción del oportuno expediente, sin perjuicio de las responsabilidades civiles, penales o de otro orden que puedan concurrir.

Artículo 56. Infracciones.

Constituirán faltas administrativas, y serán sancionadas en los términos previstos en el artículo siguiente, las infracciones que a continuación se tipifican:

a. Infracciones leves:

1. La modificación por parte del titular de la autorización de cualquiera de las 
condiciones en base a las cuales se otorgó la misma.

2. No aportar las entidades o personas responsables los datos que estén obligados a suministrar por razones sanitarias, técnicas, económicas, administrativas y financieras.

3. La falta de un ejemplar de la Real Farmacopea Española y del formulario nacional en los establecimientos obligados a ello.

4. No contar las entidades de distribución y dispensación con las existencias adecuadas de medicamentos para la normal prestación de sus actividades o servicios, así como no disponer de las existencias mínimas establecidas.

5. No disponer de existencias mínimas de medicamentos para supuestos de emergencia o catástrofe, en los casos que resulte obligado.

6. Dificultar la labor inspectora mediante cualquier acción u omisión que perturbe o retrase la misma.

7. Dispensar medicamentos transcurrido el plazo de validez de la receta.

8. No ir provisto el personal que presta servicios en la oficina de farmacia del distintivo que acredita su identificación en los términos reglamentariamente establecidos.

9. Realizar la sustitución de una especialidad farmacéutica, en los casos en que ésta sea posible, incumpliendo los requisitos establecidos al efecto.

10. Realizar publicidad de fórmulas magistrales o preparados oficinales.

11. El incumplimiento del deber de colaborar con la Administración sanitaria en la evaluación y control de medicamentos.

12. No ajustar los precios de las especialidades farmacéuticas a lo determinado por la Administración.

13. El ofrecimiento directo o indirecto de cualquier tipo de incentivo, primas $\mathrm{u}$ obsequios efectuados por quienes tengan intereses directos o indirectos en la producción, fabricación y comercialización de medicamentos a los profesionales sanitarios implicados en el ciclo de prescripción, dispensación y administración,o a sus parientes y personas de su convivencia.

14. Los incumplimientos horarios o de la información de los turnos de guardia en las oficinas de farmacia.

15. El incumplimiento de los requisitos, obligaciones o prohibiciones establecidas en la presente ley y disposiciones que la desarrollan, que, en razón de los criterios contemplados en este artículo, merezcan la calificación de leves o no proceda su calificación como faltas graves o muy graves.

b. Infracciones graves:

1. La elaboración, distribución y dispensación de medicamentos por personas físicas o jurídicas que no cuenten con la preceptiva autorización.

2. No realizar en la elaboración, fabricación, importación, exportación y distribución de medicamentos los controles de calidad exigidos en la legislación sanitaria o efectuar los procesos de fabricación o control mediante procedimientos no validados.

3. El funcionamiento de una entidad dedicada a la elaboración, fabricación y distribución de medicamentos sin que exista designado y en actividad un director técnico, así como el resto del personal exigido en cada caso.

4. El funcionamiento de servicios farmacéuticos, oficinas de farmacia, explotaciones ganaderas, establecimientos detallistas y botiquines autorizados sin la presencia y actuación profesional del farmacéutico responsable.

5. Incumplir el director técnico y demás personal las obligaciones que competen a sus cargos.

6. Impedir la actuación de los inspectores, debidamente acreditados, en los centros en que se elaboren, fabriquen, distribuyan y dispensen medicamentos.

7. La preparación de fórmulas magistrales y preparados oficinales que incumplan los requisitos legales establecidos. 
8. Distribuir o conservar los medicamentos sin observar las condiciones exigidas, así como poner a la venta medicamentos alterados, en malas condiciones $o$, cuando se haya señalado, pasado el plazo de validez.

9. Utilizar en personas o en animales de abasto algún producto en fase de investigación sin haber recaído previamente la declaración que lo califique como tal.

10. Realizar ensayos clínicos sin la previa autorización administrativa.

11. El incumplimiento por parte de fabricantes, importadores y titulares de las autorizaciones de medicamentos de la obligación de comunicar a las autoridades sanitarias los efectos adversos de los medicamentos.

12. El incumplimiento por el personal sanitario del deber de farmacovigilancia.

13. La preparación individualizada de vacunas y alérgenos en establecimientos distintos de los autorizados.

14. Dispensar medicamentos en establecimientos distintos a los autorizados.

15. La negativa a dispensar medicamentos sin causa justificada así como la dispensación sin receta de medicamentos sometidos a esta modalidad de prescripción.

16. La sustitución en la dispensación de especialidades farmacéuticas contraviniendo lo dispuesto en el artículo 90 de la Ley 25/1990, de 20 de diciembre, del Medicamento.

17. Cualquier acto u omisión encaminados a coartar la libertad del usuario en la elección de la oficina de farmacia.

18. El incumplimiento por parte del personal sanitario del deber de garantizar la confidencialidad e intimidad de los pacientes en la tramitación de las recetas y órdenes médicas.

19. Realizar promoción, información o publicidad de medicamentos no autorizados o sin ajustarse a las condiciones establecidas en la autorización de comercialización, a lo dispuesto en la presente ley y a la legislación general sobre publicidad.
20. La actuación de los profesionales sanitarios implicados en el ciclo de prescripción, dispensación y administración, siempre que estén en ejercicio con las funciones de delegados de visita médica, representantes, comisionistas o agentes informadores de los laboratorios de especialidades farmacéuticas.

21. El incumplimiento de los servicios de guardia y urgencia.

22. La ausencia en la plantilla del personal obligatorio de acuerdo con la normativa vigente.

23. La reincidencia en la comisión de infracciones leves, así como la comisión de alguna de las infracciones calificadas como leves cuando concurran de forma grave las circunstancias de riesgo para la salud, cuantía del beneficio ilícitamente obtenido, grado de intencionalidad o grado de perjuicio social.

c. Infracciones muy graves:

1. La elaboración, distribución y dispensación de productos o preparados que se presentasen como medicamentos sin estar legalmente reconocidos.

2. La puesta en el mercado de medicamentos sin haber obtenido la preceptiva autorización sanitaria.

3. La importación y exportación de sangre, fluidos, glándulas y tejidos humanos y de sus componentes y derivados sin la previa autorización.

4. El incumplimiento de las medidas cautelares y definitivas sobre medicamentos que las autoridades sanitarias competentes acuerden por causa grave de salud pública.

5. La reincidencia en la comisión de faltas graves en los últimos cinco años.

6. Realizar ensayos clínicos sin ajustarse al contenido de los protocolos sobre la base de los cuales se hayan otorgado las autorizaciones, o bien sin contar con el consentimiento de la persona sujeto del mismo o, en su caso, de su representante, o el incumplimiento sustancial del deber 
de información sobre el ensayo clínico en el que participa como sujeto.

7. La preparación de remedios secretos.

8. El ofrecimiento de primas, obsequios, premios, concursos o similares como métodos vinculados a la promoción o venta al público de los productos regulados en la Ley 25/1990, de 20 de diciembre, del Medicamento.

9. El incumplimiento de la normativa vigente en materia de incompatibilidades.

10. La reincidencia en la comisión de infracciones graves, así como la comisión de tales infracciones, cuando concurran de forma grave las circunstancias de riesgo para la salud, cuantía del beneficio ilícitamente obtenido, grado de intencionalidad o grado de perjuicio social.

Artículo 57. Sanciones.

1. Las infracciones señaladas en la presente ley serán sancionadas, de conformidad con lo establecido en el artículo 56, aplicando una graduación mínima, media y máxima a cada nivel de infracción en función de la negligencia e intencionalidad, grado de connivencia, incumplimiento de las advertencias previas, cifra de negocios de la entidad, perjuicio causado y número de personas afectadas, beneficios obtenidos con la infracción, duración de los riesgos generados y tipo de establecimiento o servicio en el que se ha cometido la infracción:

a. Infracciones leves:

Grado mínimo: Hasta 100.000 pesetas.

Grado medio: De 100.001 a 300.000 pesetas. Grado máximo: De 300.001 a 500.000 pesetas.

b. Infracciones graves:

Grado mínimo: De 500.001 a 1.150 .000 pesetas.

Grado medio: De 1.150.001 a 1.800 .000 pesetas.

Grado máximo: De 1.800 .001 a 2.500 .000 pesetas.

c. Infracciones muy graves:

Grado mínimo: De 2.500.001 a 35.000.000 de pesetas.
Grado medio: De 35.000.001 a 67.500.000 pesetas.

Grado máximo: De 67.500.001 a 100.000.000 de pesetas. Esta cantidad podrá sobrepasar hasta cinco veces el valor de los productos o servicios objeto de la infracción.

La cuantía económica de estas sanciones podrá ser objeto de actualización por acuerdo del Consello de la Xunta de Galicia.

2. En caso de infracciones muy graves, podrá sancionarse con el cierre del establecimiento, por tiempo de hasta cinco años.

Artículo 58. Expedientes sancionadores.

La tramitación de los expedientes administrativos sancionadores será competencia de la inspección sanitaria, sin perjuicio de las competencias que en materia de medicamentos veterinarios tiene atribuidas la Consellería de Agricultura, Ganadería y Política Agroalimentaria.

Artículo 59. Competencia sancionadora.

Reglamentariamente se determinarán los órganos competentes para la imposición de las sanciones a que se refiere el artículo 57 de la presente ley, sin perjuicio de las competencias que en materia de medicamentos veterinarios tiene atribuidas la Consellería de Agricultura, Ganadería y Política Agroalimentaria.

Artículo 60. Medidas cautelares.

1. No tendrá la consideración de sanción la clausura o cierre de los establecimientos, centros y servicios que no dispongan de las preceptivas autorizaciones o registros o de cuya actuación se derive riesgo para la salud de la población, así como la suspensión del funcionamiento o la prohibición de las actividades que se lleven a cabo, hasta que se subsanen los defectos o se cumplan los requisitos establecidos. La adopción de tales medidas corresponderá al órgano que reglamentariamente se determine.

2. Asimismo, si como consecuencia de la acción inspectora se apreciase razonablemente la existencia de un riesgo para la salud o seguridad de las personas, el

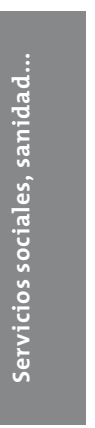


órgano de la Consellería de Sanidade e Servizos Sociais que reglamentariamente se determine podrá adoptar cautelarmente las medidas a que hacen referencia los artículos 26 y 31.2 de la Ley 14/1986, de 25 de abril, General de Sanidad.

Artículo 61. Prescripciones.

1. Las infracciones a que se refiere la presente Ley calificadas como leves prescribirán al año; las calificadas como graves, a los dos años, y las calificadas como muy graves, a los cinco años. El plazo de prescripción empezará a contar desde el día en que se haya cometido la infracción y se interrumpirá desde el momento en que el procedimiento se dirija contra el presunto infractor.

2. Asimismo, las sanciones impuestas calificadas como leves prescribirán al año; las calificadas como graves, a los dos años, y las calificadas como muy graves, a los cinco años. El plazo de prescripción comenzará a contar desde el día siguiente a aquél en que adquiriese firmeza la resolución imponiendo la sanción.

\section{DISPOSICIÓN ADICIONAL PRIMERA}

A efectos de instrumentar la colaboración entre las oficinas de farmacia y la Administración sanitaria, prevista en el articulado de la presente ley, podrán suscribirse convenios de colaboración con la corporación farmacéutica.

\section{DISPOSICIÓN ADICIONAL SEGUNDA}

La Xunta de Galicia procederá a establecer, en el plazo de un año, la normativa adecuada para reestructurar el cuerpo de farmacéuticos titulares 808 .

\section{DISPOSICIÓN ADICIONAL TERCERA}

Reglamentariamente se establecerán los requisitos y las funciones de los depósitos de medicamentos en los centros penitenciarios.

808 Véase Decreto 202/2005, de 7 de julio, por el que se crea la clase de farmacéuticos inspectores de salud pública.

\section{DISPOSICIÓN TRANSITORIA PRIMERA}

Hasta la entrada en vigor del correspondiente desarrollo reglamentario de la presente ley, será de aplicación la normativa vigente en cuanto no se oponga a la misma.

\section{DISPOSICIÓN TRANSITORIA SEGUNDA}

Los expedientes de autorización de nuevas oficinas de farmacia iniciados antes de la entrada en vigor de la presente ley se tramitarán con arreglo a la normativa vigente en el momento de la solicitud.

\section{DISPOSICIÓN TRANSITORIA TERCERA}

A las oficinas de farmacia que se adjudiquen como consecuencia de la resolución del concurso público actualmente en trámite les será de aplicación lo dispuesto en los números 6 y 7 del artículo 19 y en el número 1 del artículo 23 de la presente ley.

\section{DISPOSICIÓN TRANSITORIA CUARTA}

Los farmacéuticos sin especialidad de farmacia hospitalaria que a la entrada en vigor de la presente Ley desempeñen su labor profesional en los servicios de farmacia hospitalaria permanecerán en el desempeño de sus funciones en tanto mantengan su relación laboral con aquellos centros.

\section{DISPOSICIÓN TRANSITORIA QUUINTA}

En tanto no se determinen reglamentariamente los órganos competentes para la imposición de las sanciones a que se refiere el artículo 59 de la presente ley, la potestad sancionadora será ejercida por aquéllos que la tienen atribuida a su entrada en vigor.

\section{DISPOSICIÓN TRANSITORIA SEXTA}

En los baremos que se apliquen en los concursos públicos determinados en el artículo 19.4 de la presente ley para el acceso a la titularidad de las oficinas de farmacia se valorarán, prioritaria y preferentemente, las solicitudes que primero hubieran 
iniciado el expediente de apertura al amparo del artículo 3.1.b) del Real Decreto $909 / 1978$, de 14 de abril, siempre que concurran las siguientes circunstancias:

a. Que la delimitación territorial concreta de la nueva oficina de farmacia, a que se refiere el artículo 18.7 de la presente ley, esté comprendida mayoritariamente en el territorio del núcleo de población para el que hubiera sido solicitada la autorización al amparo de la normativa anterior.

b. Que la denegación administrativa de la solicitud hubiera sido recurrida en vía contencioso-administrativa y el recurso esté pendiente de resolución.

c. Que el solicitante hubiera sido el primero en interponer el recurso contencioso-administrativo.

\section{DISPOSICIÓN FINAL PRIMERA}

Se autoriza a la Xunta de Galicia para que dicte las disposiciones necesarias para el desarrollo y aplicación de la presente ley.

\section{DISPOSICIÓN FINAL SEGUNDA}

La presente ley entrará en vigor al mes de su publicación en el "Diario Oficial de Galicia", sin perjuicio de lo dispuesto en sus disposiciones transitorias.

\section{LEY 11/2007, DE 27 DE JULIO, GALLEGA PARA LA PREVENCIÓN Y EL TRATAMIENTO INTEGRAL DE LA VIOLENCIA DE GÉNERO (DOGA N. ${ }^{\circ} 152$, 7. 8. 2007)}

$$
(. .)^{809}
$$

\section{TÍTULO PRELIMINAR DISPOSICIONES GENERALES}

Artículo 1. Objeto.

1. Constituye el objeto de la presente ley la adopción en Galicia de medidas integrales para la sensibilización, prevención

809 Preámbulo omitido. y tratamiento de la violencia de género, así como la protección y apoyo a las mujeres que la sufren.

2. A los efectos de la presente ley, se entiende por violencia de género cualquier acto violento o agresión, basados en una situación de desigualdad en el marco de un sistema de relaciones de dominación de los hombres sobre las mujeres que tenga o pueda tener como consecuencia un daño físico, sexual o psicológico, incluidas las amenazas de tales actos y la coacción o privación arbitraria de la libertad, tanto si ocurren en el ámbito público como en la vida familiar o privada.

Artículo 2. Ámbito de aplicación.

Las medidas contempladas en la presente ley serán de aplicación a todas las mujeres que vivan, residan o trabajen en Galicia y que se encuentren en una situación de violencia de género, así como a sus hijas e hijos y a otras personas dependientes de ellas, víctimas directas e indirectas.

Artículo 3. Formas de violencia de género.

A los efectos de la presente ley, se consideran formas de violencia de género, fundamentalmente, las siguientes:

a. Violencia física, que incluye cualquier acto de fuerza contra el cuerpo de la mujer, con resultado o riesgo de producir lesión física o daño, ejercida por quien sea o haya sido su cónyuge o por quien esté o haya estado ligado a ella por análoga relación de afectividad, aun sin convivencia. Igualmente, tendrán la consideración de actos de violencia física contra la mujer los ejercidos por hombres de su entorno familiar o de su entorno social y/o laboral.

b. Violencia psicológica, que incluye toda conducta, verbal o no verbal, que produzca en la mujer desvalorización o sufrimiento, a través de amenazas, humillaciones o vejaciones, exigencia de obediencia o sumisión, coerción, insultos, aislamiento, culpabilización o limitaciones de su ámbito de libertad, ejercida por quien sea o haya sido su cónyuge o por quien esté 
o haya estado ligado a ella por análoga relación de afectividad, aun sin convivencia. Igualmente, tendrán la consideración de actos de violencia psicológica contra la mujer los ejercidos por hombres de su entorno familiar o de su entorno social y/o laboral.

c. Violencia económica, que incluye la privación intencionada, y no justificada legalmente, de recursos para el bienestar físico o psicológico de la mujer y de sus hijas e hijos o la discriminación en la disposición de los recursos compartidos en el ámbito de la convivencia de pareja.

d. Violencia sexualy abusos sexuales, que incluyen cualquier acto de naturaleza sexual forzada por el agresor o no consentida por la mujer, abarcando la imposición, mediante la fuerza o con intimidación, de relaciones sexuales no consentidas, y el abuso sexual, con independencia de que el agresor guarde o no relación conyugal, de pareja, afectiva o de parentesco con la víctima.

e. Acoso sexual, que incluye aquellas conductas consistentes en la solicitud de favores de naturaleza sexual, para sí o para una tercera persona, prevaliéndose el sujeto activo de una situación de superioridad laboral, docente o análoga, con el anuncio expreso o tácito a la mujer de causarle un mal relacionado con las expectativas que la víctima tenga en el ámbito de dicha relación, o bajo la promesa de una recompensa o premio en el ámbito de la misma.

f. El tráfico de mujeres y niñas con fines de explotación, cualquiera que fuera la relación que una a la víctima con el agresor y el medio utilizado.

g. Cualquier otra forma de violencia recogida en los tratados internacionales que lesione o sea susceptible de lesionar la dignidad, la integridad o la libertad de las mujeres.

Artículo 4. Principios generales.

Los principios generales que orientan el contenido de la presente ley son:

1. Consideración de la violencia de género como una forma extrema de desigualdad, incidiendo una parte importante de la ley en la prevención de la violencia a través de la sensibilización, la investigación y la formación en materia de igualdad.

2. Carácter integral. La presente ley tiene un carácter integral, implicando de forma coordinada a las diferentes instancias y administraciones que tienen un papel destacado en la prevención y tratamiento de la violencia de género. Las medidas previstas tienen en cuenta la totalidad de daños que las mujeres sufren como consecuencia de la violencia de género, asegurando un acceso rápido, transparente y eficaz a los servicios y recursos.

3. Perspectiva de género. En la totalidad de las actuaciones previstas en la presente ley se implementará la perspectiva de género, basada en el análisis de los roles de género tradicionalmente impuestos, que sitúan a la violencia como un mecanismo de control hacia la mujer.

4. Victimización secundaria. Todas las acciones que las administraciones públicas realicen contra la violencia de género evitarán la victimización secundaria de las mujeres y no reproducirán o perpetuarán los estereotipos sobre las mujeres y la violencia de género, debiendo garantizar la especialización de los colectivos profesionales que intervienen en el proceso. Las administraciones públicas procurarán en todo momento que las mujeres tengan garantizada su integridad psicológica y su autonomía social y económica a través de los recursos adecuados.

5. Cooperación y coordinación. Los poderes públicos gallegos intensificarán las acciones para la cooperación y coordinación interinstitucional de los recursos e instrumentos contra la violencia de género, promoviendo la colaboración y la participación de las asociaciones de mujeres, así como de las entidades y organizaciones de la sociedad civil. Los ayuntamientos como administración más próxima a la ciudadanía participarán en el desarrollo de la presente ley, habilitándose 
por parte de la administración gallega los recursos necesarios a tal fin.

6. Equidad territorial. En el desarrollo de la red de recursos y servicios de prevención, atención, apoyo, tratamiento y protección de la violencia de género se tendrá en cuenta la necesidad de compensar los desequilibrios territoriales, garantizando su acceso a la totalidad de las mujeres, especialmente a las que viven en el ámbito rural.

Artículo 5. Acreditación de la situación de violencia de género.

A los efectos de la presente ley, la situación de violencia se acreditará por cualquiera de las siguientes formas:

a. Certificación de la orden de protección o de la medida cautelar, o testimonio o copia autentificada por la secretaria o el secretario judicial de la propia orden de protección o de la medida cautelar.

b. Sentencia de cualquier orden jurisdiccional que declare que la mujer sufrió violencia en cualquiera de las modalidades definidas en la presente ley.

c. Certificación y/o informe de los servicios sociales y/o sanitarios de la Administración pública autonómica o local.

d. Certificación de los servicios de acogida de la Administración pública autonómica o local.

e. Informe del ministerio fiscal que indique la existencia de indicios de violencia.

f. Informe de la Inspección de Trabajo y de la Seguridad Social.

g. Cualesquiera otras que se establezcan reglamentariamente.

\section{TÍTULO I \\ PREVENCIÓN DE LA VIOLENCIA DE GÉNERO}

\section{Capítulo I \\ MEDIDAS DE SENSIBILIZACIÓN CONTRA LA VIOLENCIA DE GÉNERO}

Artículo 6. Diseño, elaboración y difusión de campañas.

1. El departamento competente en materia de igualdad, en coordinación con los restantes departamentos de la Xunta de Galicia, pondrá en marcha, de forma periódica, campañas de información y sensibilización que tengan como objetivo mudar los estereotipos sexistas y que incidan en el rechazo social sobre todas las formas de violencia de género. Las campañas tendrán especial divulgación en los medios de comunicación de titularidad pública, en los centros escolares, educativos, sociales, sanitarios, laborales, culturales y deportivos.

2. Las campañas que se desarrollen dedicarán atención específica a la sensibilización y a la formación de la población juvenil en la prevención e identificación de actitudes que constituyan actos de violencia de género. Asimismo, las campañas harán posible su accesibilidad a las mujeres con más dificultades para acercarse a los recursos e información. Las campañas se harán en un formato accesible y comprensible a las personas con diversidad funcional, utilizando el lenguaje de signos u otras modalidades de comunicación.

Se diseñarán campañas específicas que tengan en cuenta las circunstancias que dificultan a las mujeres del ámbito rural el acceso a la información, colaborando en el desarrollo de las mismas con las asociaciones de mujeres rurales.

3. Asimismo, la Xunta de Galicia pondrá en marcha los acuerdos necesarios con otras administraciones públicas para garantizar la difusión de las campañas de sensibilización entre los centros dependientes de la Administración local, de la Administración de justicia y entre las Fuerzas y Cuerpos de Seguridad del Estado y la Policía Local.

4. Igualmente, la Xunta de Galicia llevará a cabo acciones de sensibilización dirigidas a la población masculina, incidiendo en la necesidad de promover una sociedad más igualitaria entre mujeres y hombres.

5. Las campañas de información y sensibilización contra la violencia de género serán evaluadas regularmente. 
Artículo 7. Fomento del movimiento asociativo.

1. El departamento competente en materia de igualdad establecerá anualmente un plan de ayudas económicas destinadas a las asociaciones de mujeres con sede en Galicia, para el desarrollo de actividades que promuevan la prevención, protección, asistencia y acompañamiento a las mujeres que sufren violencia de género.

2. El departamento competente en materia de igualdad establecerá ayudas económicas destinadas a que el movimiento asociativo en Galicia desarrolle actividades que promuevan la prevención y la erradicación de la violencia de género.

Artículo 8. Actividades culturales y artísticas.

La Administración de la Xunta de Galicia impulsará todo tipo de manifestaciones culturales y artísticas que potencien aspectos recogidos en la presente ley, en las que se propongan estrategias o espacios dirigidos a sensibilizar a la sociedad en la prevención y tratamiento de la violencia de género.

Artículo 9. Tratamiento de la información.

1. La Xunta de Galicia, a través de los departamentos competentes en el ámbito de la comunicación, garantizará que los medios de comunicación de titularidad pública, especialmente la Compañía de Radio-Televisión de Galicia y aquellos otros en los que participe o que financie no emitan en su programación imágenes o contenidos que resulten contrarios a la finalidad y espíritu de la presente ley y de la Ley $7 / 2004$, de 16 de julio, gallega para la igualdad de mujeres y hombres, teniendo especial cuidado en el tratamiento gráfico de la información.

2. Igualmente, la Xunta de Galicia velará para que en los medios de comunicación de Galicia se ofrezca un tratamiento adecuado de las noticias sobre violencia de género, y promoverá que cuando se difundan noticias relativas a la violencia de género se agreguen pautas informativas de los recursos de prevención, asistencia y protección existentes en Galicia y que guarden relación con el hecho difundido. Asimismo, se promoverá que las informaciones relativas a la violencia sobre la mujer velen por el derecho a la intimidad de las víctimas y de sus hijas e hijos.

3. El departamento competente en materia de igualdad elaborará y difundirá un manual de estilo dirigido a que las y los profesionales de los medios de comunicación impriman el tratamiento mediático adecuado a las informaciones relacionadas con la violencia de género. La compañía de Radio-Televisión de Galicia asumirá como propio el citado manual de estilo.

Artículo 10. Convenios de autorregulación.

La Xunta de Galicia promoverá acuerdos y convenios de autorregulación en todos los medios de comunicación social, acercando los criterios orientadores que sirvan como pauta de actuación sobre como tratar la violencia de género y la imagen de las mujeres. Estas normas de autorregulación tendrán carácter de códigos deontológicos o de contenido ético.

Artículo 11. Contenidos y publicidad en relación con la violencia de género.

1. En los medios de comunicación social que actúen en el ámbito de Galicia se evitará la realización y difusión de contenidos y anuncios publicitarios que mediante su tratamiento o puesta en escena justifiquen, banalicen o inciten a la violencia de género, o en los que se contengan, tácita o implícitamente, mensajes misóginos o que atenten contra la dignidad de las mujeres.

2. La publicidad institucional y la publicidad dinámica en Galicia respetarán las disposiciones establecidas sobre publicidad y velarán especialmente por el respeto a los principios especificados en el punto 1 de este artículo.

3. La Xunta de Galicia podrá ejercer ante los tribunales la acción de cesación de la publicidad ilícita por utilizar de forma 
vejatoria o discriminatoria la imagen de las mujeres.

\section{Capítulo II}

MEDIDAS DE INVESTIGACIÓN Y

DE FORMACIÓN EN MATERIA DE VIOLENCIA DE GÉNERO

Artículo 12. Potenciación de la investigación sobre la violencia de género.

1. La Xunta de Galicia, a través del departamento competente en materia de igualdad, en colaboración con los restantes departamentos de la Administración autonómica, potenciará en las universidades gallegas y en otros entes, espacios u organismos, la investigación sobre las causas y consecuencias de la violencia de género, así como sobre los medios necesarios para evitarla, el grado de sensibilización de la sociedad ante la misma y los medios necesarios para su tratamiento. En este sentido se articularán medidas de apoyo a la elaboración de tesis doctorales y cátedras específicas que versen sobre el estudio de la violencia contra las mujeres y los principios que inspiran la presente ley.

2. Igualmente, la Xunta de Galicia difundirá el resultado de los estudios e investigaciones que se consideren de interés. La difusión se realizará de forma universal y gratuita, y tendrá en cuenta la utilización de las tecnologías de la información y la comunicación.

Artículo 13. Registros administrativos.

La Xunta de Galicia garantizará la existencia de registros administrativos para unificar y actualizar los datos sobre la situación de las mujeres que sufren violencia de género en Galicia, así como sobre la situación de las niñas y niños que en su ámbito familiar conviven con este tipo de situaciones, según lo establecido en la Ley orgánica 15/1999, de 13 de diciembre, de protección de datos de carácter personal.

Artículo 14. Formación en las universidades.

Las administraciones educativas y universidades, en el ámbito de sus competencias, asegurarán que en la totalidad de los estudios conducentes a la obtención de títulos universitarios en disciplinas que habiliten para el ejercicio de profesiones que tengan relación directa con la violencia de género se incorporen contenidos relacionados con la comprensión de esta violencia, dirigidos a la capacitación para la prevención, detección precoz, intervención y/o apoyo a las mujeres que la sufren.

Artículo 15. Formación de la totalidad de las y los profesionales.

1. La Xunta de Galicia garantizará, en los términos que se establezcan reglamentariamente, y promoverá, mediante los instrumentos necesarios, la formación en igualdad de todas y todos los profesionales que trabajan en ámbitos relacionados directa o indirectamente con la violencia de género, y en especial de las y los profesionales de la sanidad, de los servicios sociales, educativos, de las Fuerzas y Cuerpos de Seguridad y de las operadoras y los operadores jurídicos.

2. A estos efectos, el departamento competente y todos aquellos organismos y entidades que imparten formación velarán para que en la formación inicial y en sus programas formativos se incorporen módulos específicos de prevención, atención, asistencia y/o tratamiento de situaciones de violencia de género.

3. La Xunta de Galicia, a través del departamento competente en materia de de igualdad, diseñará programas específicos de formación en materia de violencia de género y los pondrá a disposición de cualquier ente, organismo o departamento, y de la sociedad en general, para su aplicación en las diversas acciones formativas.

\section{Capítulo III \\ MEDIDAS EN EL ÁMBITO EDUCATIVO}

Artículo 16. Actitudes.

La Administración educativa gallega, en colaboración con el departamento

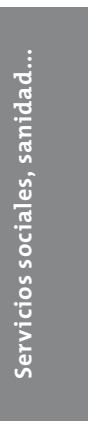


competente en materia de igualdad, impulsará la realización de actividades dirigidas a la comunidad escolar para la prevención de comportamientos y actitudes sexistas y de la violencia de género, destinadas a ahondar en las estrategias para el análisis y resolución de los conflictos, así como en el aprendizaje de la convivencia basada en el respeto a todas las personas, garantizando y fomentando actitudes, valores y capacidades que contribuyan a un pleno desarrollo en igualdad.

Artículo 17. Escolarización inmediata en caso de violencia de género.

La Xunta de Galicia asegurará la escolarización inmediata de las niñas y los niños que se vean afectados por cambios de centro derivados de situaciones de violencia de género. Asimismo, facilitará que los centros educativos presten una atención especial a dicho alumnado.

Artículo 18. Edición y adaptación de materiales.

1. El departamento competente en materia de igualdad y el departamento competente en materia de educación velarán para que, en el ámbito de sus competencias, no se utilicen materiales educativos y libros de texto que incluyan contenidos que vulneren el principio de igualdad.

Con el mismo fin se revisarán y adaptarán las materias del ámbito educativo no reglado.

2. El departamento de la Xunta de Galicia competente en materia de igualdad y el departamento de la Xunta de Galicia competente en materia de educación desarrollarán y difundirán proyectos y materiales didácticos actualizados, dirigidos a todos los niveles educativos, que contengan pautas de conducta que transmitan valores de respeto e igualdad, de forma que se favorezca la prevención de actitudes y situaciones violentas.

Artículo 19. Revisión y adaptación del currículo educativo.

El departamento de la Xunta de Galicia competente en materia de educación, al objeto de garantizar la igualdad real entre mujeres y hombres, velará para que se garantice la perspectiva de género en los contenidos, procedimientos, actitudes y valores que conforman el currículo en todos los niveles educativos.

En todo caso, los currículos de los distintos niveles, etapas, ciclos, grados y modalidades del sistema educativo se adaptarán a lo dispuesto en el artículo 9 de la Ley $7 / 2004$, de 16 de julio, gallega para la igualdad de mujeres y hombres.

Se promoverá la inclusión de contenidos relacionados con la educación para la paz y la no violencia y el fomento del principio de igualdad en los programa de educación para personas adultas.

Artículo 20. Planes de acción tutorial.

Los planes de acción tutorial de todos los niveles educativos incluirán apartados específicos destinados a potenciar modificaciones en los modelos masculino y femenino, así como una orientación de estudios y profesiones basada en las aptitudes y capacidades de las personas y no en estereotipos sexistas.

Artículo 21. Proyectos educativos y curriculares de centro.

Los proyectos educativos de centro incorporarán la perspectiva de género en su elaboración y desarrollo. Los proyectos curriculares propiciarán medidas de coeducación en los contenidos, las actitudes y los procedimientos.

Artículo 22. Consejos escolares y Consejo Escolar de Galicia.

1. La Administración educativa gallega, en el ámbito de sus competencias, adoptará las medidas necesarias para garantizar que los consejos escolares de los centros impulsen medidas educativas que promuevan la igualdad real entre mujeres y hombres, la coeducación y la prevención de la violencia de género en el centro educativo.

2. Se garantizará la representación y participación en el Consejo Escolar de Galicia del órgano de la Administración 
autonómica que ostente la competencia en materia de igualdad.

3. El Consejo Escolar de Galicia, en colaboración con el departamento de la Xunta de Galicia competente en materia de igualdad, elaborará un informe anual sobre la situación de la coeducación y prevención de la violencia de género en los centros educativos de Galicia.

Artículo 23. Inspección educativa.

Los servicios de inspección educativa del departamento de la Xunta de Galicia competente en materia de educación velarán por el cumplimiento y aplicación de todos los principios recogidos en este capítulo en el sistema educativo, destinados a fomentar la igualdad real entre mujeres y hombres.

\section{TÍTULO II}

\section{PROTECCIÓN Y ASISTENCIA FRENTE} A LA VIOLENCIA DE GÉNERO

\section{Capítulo I \\ MEDIDAS EN EL ÁMBITO SANITARIO Y PSICOLÓGICO}

Artículo 24. Derecho a la atención sanitaria.

1. Los servicios públicos de salud garantizarán a las mujeres que sufren o hayan sufrido cualquier tipo de violencia de género que recoge la presente ley el derecho a la atención sanitaria y al seguimiento de la evolución de su estado de salud, hasta su total restablecimiento, en lo concerniente a la sintomatología o las secuelas derivadas de la situación de violencia sufrida.

2. En estos supuestos, los servicios serán gratuitos y accesibles con carácter preferente, en su caso, para todas las mujeres que sufran o hayan sufrido violencia de género, garantizando la privacidad y la intimidad de las mujeres y respetando las decisiones que ellas tomen.

3. Los planes de salud de la Xunta de Galicia, y en especial el Plan de atención integral a la salud de las mujeres, preverán en su redacción inicial o en sus revisiones periódicas medidas específicas para la prevención, detección, atención e intervención en los casos de violencia de género. Asimismo, en dichos planes se implementarán disposiciones específicas que contribuyan a evaluar el impacto y los efectos de la violencia de género sobre la salud de las mujeres.

4. Asimismo, se establecerán en todas las medidas anteriores actuaciones y protocolos sanitarios específicos para la detección, intervención y apoyo de situaciones de violencia contra las mujeres con discapacidad o en situación de vulnerabilidad.

Artículo 25. Atención psicológica.

1. La asistencia psicológica inmediata será considerada como un servicio de atención primaria, en coordinación con la atención especializada en las áreas sanitarias, y deberá procurar la desaparición de la sintomatología presentada y la total rehabilitación psicológica para conseguir una recuperación integral de las mujeres, aportándoles mecanismos que promocionen su autonomía y les impidan verse de nuevo envueltas en relaciones de maltrato.

2. Se reconoce el derecho a la asistencia psicológica gratuita para las mujeres que sufran violencia de género, que comprenderá la atención inicial y el seguimiento durante todo el proceso terapéutico. Se considerarán prioritarias las intervenciones con mujeres que se encuentren en una situación de violencia y presenten problemas de salud mental, dependencia de sustancias adictivas $y / u$ otras patologías que requieran un tratamiento psicológico específico.

3. Se reconoce el derecho a la asistencia psicológica gratuita para las y los menores y para otras personas dependientes que vivan o padezcan situaciones de violencia de género, que comprenderá medidas de apoyo psicosocial específicas y adaptadas a sus características y necesidades.

4. La Xunta de Galicia desarrollará programas de atención psicológica gratuita 
destinados a hombres con problemas de violencia machista.

Artículo 26. Protocolo de actuación.

1. El departamento de la Xunta de Galicia competente en el ámbito sanitario elaborará, en los términos que se establezcan reglamentariamente, un protocolo que contemple pautas uniformes de actuación sanitaria. Asimismo, elaborará los procedimientos de coordinación de las distintas instancias que intervienen de forma específica en la atención sanitaria de las mujeres que sufren violencia de género, en colaboración con el departamento de la Xunta de Galicia competente en materia de igualdad.

2. Se diseñarán medidas para la detección precoz de la violencia de género entre las mujeres y sus hijas e hijos menores de edad y se establecerá un cuestionario para la detección precoz de la violencia de género en la atención primaria y un parte de lesiones único y universal para todos los centros sanitarios de Galicia, que será de obligado cumplimiento para todas y todos los profesionales.

\section{Artículo 27. Registro de casos.}

1. El departamento de la Xunta de Galicia competente en el ámbito sanitario implantará un sistema de registro de casos de violencia de género en los servicios sanitarios, que permita dimensionar el problema, y del que facilitará información periódica al departamento de la Xunta de Galicia competente en materia de igualdad, según lo establecido en la Ley orgánica 15/1999, de 13 de diciembre, de protección de datos de carácter personal.

2. En las encuestas de salud se incluirán indicadores sobre la violencia de género.

\section{Capítulo II MEDIDAS EN EL ÁMBITO JUDICIAL}

\section{Artículo 28. Atención jurídica.}

1. Las mujeres en situación de violencia de género tienen derecho a recibir toda la información jurídica relacionada con la situación de violencia. El Servicio de

Atención 24 horas, previsto en el artículo 51 de la presente ley, garantizará, en todo caso, la atención jurídica permanente, todos los días y horas del año, en casos de violencia de género.

2. El servicio de orientación jurídica de los colegios profesionales de la abogacía de Galicia garantizará una información y atención jurídica especializada en materia de violencia de género. Las personas profesionales que presten estos servicios habrán de efectuar cursos de formación específica en materia de violencia contra las mujeres como requisito para su adscripción a esos servicios.

Artículo 29. Asistencia letrada.

1. Las mujeres en situación de violencia de género tendrán derecho a la asistencia jurídica gratuita en la forma establecida en la Ley 1/1996, de 10 de enero, de asistencia jurídica gratuita, modificada por la Ley 16/2005, de 18 de julio, y por la Ley orgánica 1/2004, de 28 de diciembre, de medidas de protección integral contra la violencia de género.

2. A efectos de lo previsto en el artículo 3.3 de la Ley 1/1996, de 10 de enero, de asistencia jurídica gratuita, los medios económicos de las mujeres que acrediten por cualquiera de los medios previstos en el artículo 5 de la presente ley que se encuentran en situación de violencia de género serán valorados individualmente, con los límites establecidos en la legislación aplicable.

3. La totalidad de los colegios profesionales de la abogacía de Galicia dispondrán de un turno de oficio en materia de violencia de género, debiendo superarse, para el acceso al mismo, los cursos de formación o perfeccionamiento que se establezcan. Igualmente, adoptarán las medidas necesarias para la designación urgente de letrada o letrado de oficio en los procedimientos que se sigan por violencia de género, tal y como recoge la legislación vigente en la materia a nivel estatal. 
4. La Xunta de Galicia, a través del departamento competente en materia de justicia, garantizará que las abogadas o abogados, y si procede procuradoras o procuradores, que asistan a las mujeres víctimas de violencia de género posean formación especializada en esta materia.

Artículo 30. Ejercicio de la acción popular.

1. La Administración de la Xunta de Galicia podrá ejercer la acción popular, en los procedimientos penales por violencia de género, en la forma y condiciones establecidas por la legislación procesal.

2. El ejercicio de la acción popular por parte de la Administración de la Xunta de Galicia no se llevará a cabo en caso de negativa expresa por parte de la mujer víctima de violencia de género o, en su caso, de quien ostente su representación legal.

Artículo 31. Personación de la Xunta de Galicia en los procedimientos penales iniciados por causas de violencia de género.

1. En los casos en que proceda, la Xunta de Galicia podrá acordar su personamiento en los procedimientos penales instados por causa de violencia de género, en calidad de parte perjudicada civilmente, de conformidad con lo establecido en el artículo 110 de la Ley de enjuiciamiento criminal.

2. La representación y defensa en juicio corresponderá a la Xunta de Galicia, sin perjuicio de que las mencionadas funciones de representación y defensa en juicio puedan ser encomendadas a uno o a más profesionales de la abogacía colegiados en ejercicio, con arreglo a la normativa reguladora de los servicios jurídicos de la Administración autonómica, de acuerdo con lo previsto en el artículo 447 de la Ley orgánica del poder judicial.

Artículo 32. Intervención de la administración.

1. El departamento competente en materia de menores, cuando tenga conocimiento de una situación en la que las y los menores convivan en situaciones de violencia de género, intervendrá según lo dispuesto en la Ley 3/1997, de 9 de junio, gallega de la familia, la infancia y la adolescencia, y su normativa de desarrollo, para evaluar y realizar un seguimiento de la situación de las y los menores.

2. Cuando el departamento competente en materia de menores aprecie que cualquier menor, como consecuencia de una situación de violencia de género, se encuentra en una situación de desamparo, según lo establecido en la legislación vigente, declarará dicha situación y asumirá la tutela, acordando la medida de protección que proceda.

\section{Capitulo III \\ OTRAS MEDIDAS DE APOYO Y PROTECCIÓN}

Artículo 33. Diseño e implantación de dispositivos de alarma.

1. La Xunta de Galicia, a través del departamento competente en materia de políticas de igualdad, coordinará la implantación de los diversos dispositivos de alarma que en su territorio se pongan a disposición de las mujeres que sufren violencia de género, y tenderá a unificarlos.

2. Igualmente, la Xunta de Galicia, a través de los departamentos competentes en materia de políticas de igualdad, de justicia, de interior, de protección civil y de investigación, innovación y desarrollo diseñará e implantará sistemas especiales de protección para las mujeres que estando en una situación de riesgo los necesiten.

Artículo 34. Programas de intervención con hombres en relación con la violencia de género.

1. La Xunta de Galicia, a través de los departamentos competentes en materia de igualdad y justicia, facilitará, a aquellos agresores que lo soliciten, la incorporación a programas específicos de reeducación. Para ello, podrán suscribirse convenios de colaboración con otras administraciones públicas y organismos competentes, con capacidad y experiencia en la materia. 
2. Los programas de reeducación social comprenderán tratamiento psicológico, mecanismos de readaptación, resocialización, rehabilitación y otros procedimientos técnicos aconsejables. Dichos programas se desarrollarán según criterios de calidad que garanticen una intervención profesionalizada en la que se incluya la perspectiva de género.

\section{Capitulo IV \\ MEDIDAS EN EL ÁMBITO DE LA FORMACIÓN Y EL EMPLEO}

Artículo 35. Medidas específicas en el ámbito de la formación y el empleo.

1. Con el fin de favorecer la integración sociolaboral de las mujeres que sufren violencia de género, la Xunta de Galicia adoptará las siguientes medidas:

a. El establecimiento de las mujeres que sufren violencia de género como colectivo preferente en la totalidad de la normativa autonómica relativa al establecimiento de ayudas y subvenciones a las empresas para la contratación de personal.

b. El establecimiento de un régimen de ayudas y subvenciones específico para las empresas que contraten a mujeres que sufren violencia de género, estableciendo medidas y acciones para fomentar su contratación con carácter estable.

c. El establecimiento de un régimen de ayudas y subvenciones para las mujeres que sufren violencia de género cuando decidan constituirse como trabajadoras autónomas. En este caso, se establecerán también ayudas para garantizar apoyo y seguimiento tutorial personalizado de su proyecto.

d. El establecimiento de un régimen de ayudas y subvenciones para el fomento del empleo de las mujeres que sufren violencia de género a través de los programas de cooperación en el ámbito de colaboración con las entidades locales y los órganos y organismos de las administraciones públicas distintas de la local, universidades y entidades sin ánimo de lucro. e. La integración preferente de las mujeres que sufren violencia de género en todos los programas de formación profesional, ocupacional y continua, y de inserción laboral que se pongan en marcha desde la Xunta de Galicia. Los cursos de formación profesional ocupacional habrán de contemplar ayudas económicas para las mujeres que sufren violencia de género, según las condiciones que reglamentariamente se establezcan.

2. El Servicio Público de Empleo de Galicia garantizará en todos los procedimientos de selección que se efectúen a través de las oficinas de empleo la preferencia de las mujeres que sufran violencia de género, siempre y cuando cumplan la totalidad de los requisitos establecidos en las ofertas de empleo.

3. Las competencias de la Xunta de Galicia en materia de prevención de riesgos para proteger la seguridad y la salud en el trabajo integrarán activamente entre sus objetivos y sus actuaciones el principio de igualdad de trato entre mujeres y hombres, investigando la influencia de la violencia de género en la aparición o en el agravamiento de enfermedades profesionales o en la causa de accidentes de trabajo.

Artículo 36. Planes de igualdad en las empresas.

1. Los planes de igualdad de las empresas fijarán objetivos y actuaciones concretas y especificarán indicadores de buenas prácticas encaminadas a mejorar la situación de las mujeres que sufren violencia de género, en los ámbitos de la selección, contratación, promoción profesional, prevención de la violencia y conciliación de la vida personal, familiar y profesional.

2. Las convocatorias de ayudas para el establecimiento de planes de igualdad en las empresas tendrán en cuenta, como criterios preferenciales a los efectos de establecer las ayudas y las cuantías de las mismas, la existencia de medidas de apoyo a la inserción, permanencia y promoción 
laboral de las mujeres en general y de las que sufren violencia de género en particular.

3. La Xunta de Galicia convocará líneas de ayudas dirigidas a las empresas que asuman acciones de responsabilidad social cuando estas acciones se refieran a la implantación de medidas económicas, comerciales, laborales, sindicales o asistenciales, con la finalidad de mejorar la situación de las mujeres en general, y de las que sufren violencia de género en particular.

Artículo 37. Obligación de confidencialidad en el ámbito laboral.

El empresariado, la representación sindical, los organismos competentes en materia de empleo y las entidades formadoras están obligadas a guardar confidencialidad sobre las circunstancias personales de la mujer que sufrió o sufre violencia de género, según lo establecido en la Ley orgánica 15/1999, de 13 de diciembre, de protección de datos de carácter personal.

\section{Capitulo V MEDIDAS DE CARÁCTER ECONÓMICO}

Artículo 38. Valoración de rentas.

Con el fin de favorecer la autonomía de las mujeres que estén en situación de violencia de género, y a los efectos del derecho a percibir la renta de integración social de Galicia y las otras ayudas económicas previstas en la presente ley, quedan excluidos del cómputo de las rentas los ingresos del agresor.

Artículo 39. Prestaciones periódicas.

1. La Xunta de Galicia, a través del departamento competente en materia de igualdad, establecerá una prestación económica dirigida a las mujeres que sufren violencia de género. Dicha prestación tendrá en cuenta la situación socioeconómica de las mujeres e irá dirigida a posibilitar su autonomía e independencia económica respecto a su agresor, y a intentar ayudarle a romper con la situación de violencia.
2. Esta prestación se abonará periódicamente, previa acreditación de la situación de violencia de género por cualquiera de las formas previstas en el artículo 5 de la presente ley, siendo el departamento competente en materia de igualdad el encargado de regular las bases de convocatoria y las cuantías de las ayudas, dentro de los límites presupuestarios de cada anualidad.

Artículo 40. Otras prestaciones.

La Xunta de Galicia, a través del departamento competente en materia de igualdad, regulará las bases de la convocatoria y tramitará las ayudas de pago que se definan en la legislación estatal, según lo dispuesto en la Ley orgánica 1/2004, de 28 de diciembre, de medidas de protección integral contra la violencia de género.

Artículo 41. Procedimiento abreviado para la percepción de la renta de integración social de Galicia.

1. La Xunta de Galicia establecerá un procedimiento abreviado para la tramitación, concesión y abono de la renta de integración social de Galicia (Risga) para las mujeres que sufran violencia de género y cumplan los requisitos legales para su percepción. A estos efectos, el reconocimiento del derecho a la prestación y su abono efectivo se efectuará en el plazo máximo de un mes desde la solicitud formulada por la interesada ante los servicios sociales correspondientes.

2. Las mujeres acogidas en recursos de carácter residencial tienen derecho a percibir la renta de integración social de Galicia (Risga) aun cuando su manutención básica sea cubierta por estos centros, siempre que se cumplan el resto de requisitos exigidos para su obtención.

Artículo 42. Ayudas escolares.

Para la concesión de ayudas escolares, la Administración educativa gallega, así como la Administración local, ponderarán como factor cualificado la situación de violencia de género en el entorno familiar 
de las y los menores, especialmente para ayudas en materias de gastos escolares, de transporte, de comedor y de actividades extraescolares.

Artículo 43. Fondo Gallego de Garantía de Indemnizaciones.

1. La Xunta de Galicia concederá indemnizaciones, que se abonarán por una sola vez, en la cuantía que reglamentariamente se establezca, a favor de las mujeres que sufren violencia de género y/o las y los menores o personas dependientes afectadas que residan en Galicia y que no puedan percibir las indemnizaciones que les correspondan por los daños y perjuicios causados, y que resultarán fijadas mediante sentencia judicial dictada por juzgados y tribunales con sede en el territorio gallego.

2. Estas indemnizaciones se abonarán cuando exista constatación judicial de incumplimiento del deber de satisfacerlas por insolvencia económica y este incumplimiento conlleve una situación de precariedad económica, de acuerdo con los límites y condiciones que se fijen reglamentariamente.

3. Las indemnizaciones comenzarán a concederse, en los supuestos que proceda, en el plazo máximo de un año a partir de la entrada en vigor de la presente ley. Con este fin, la correspondiente ley anual de presupuestos habilitará una partida específica.

Artículo 44. Derecho de acceso a la vivienda.

La Xunta de Galicia, a través del departamento competente en materia de vivienda y en coordinación con el departamento competente en materia de igualdad, garantizará, en los términos que se establezcan reglamentariamente, el derecho a una vivienda a las mujeres que sufran o hayan sufrido violencia de género y se encuentren en una situación de precariedad económica. Podrán beneficiarse tanto de las medidas para el acceso a una vivienda en propiedad como en régimen de alquiler.

Artículo 45. Acceso prioritario a las viviendas de promoción pública.

En la adjudicación de las promociones públicas de viviendas se dará prioridad a las necesidades de las mujeres que sufran violencia de género y se encuentren en una situación de precariedad económica.

Asimismo, podrá reservarse un número de viviendas adaptadas para mujeres que sufran violencia de género con movilidad reducida de carácter permanente.

Artículo 46. Equipamientos sociales especializados.

Las mujeres mayores y las mujeres afectadas de diversidad funcional que sufran violencia de género, así como las personas de ellas dependientes, se considerarán colectivos preferentes para acceder a los equipamientos sociales especializados, en especial residencias para personas mayores y centros de día.

\section{TíTULO III DE LA ORGANIZACIÓN DEL SISTEMA DE PROTECCIÓN Y ASISTENCIA INTEGRAL ESPECIALIZADA FRENTE A LA VIOLENCIA DE GÉNERO}

\section{Artículo 47. Criterios básicos.}

1. Los centros y servicios que conforman los recursos de asistencia integral a las mujeres que sufren violencia de género tienen como finalidad básica aportar ayuda y asistencia directa a las mujeres y las personas de ellas dependientes, y apoyarlas en la búsqueda de soluciones de los conflictos que se derivan de la violencia.

2. La Xunta de Galicia, a través del departamento competente en materia de igualdad, garantizará que en la totalidad de los centros y servicios que conforman los recursos de asistencia integral el trabajo se realice desde una perspectiva de género. 
3. Se garantizará que las mujeres con discapacidad que sufran una situación de violencia de género tengan acceso integral a la información sobre sus derechos y a los recursos existentes, ofertando la información en formato accesible y comprensible.

Artículo 48. Red gallega de acogida.

1. Los centros de acogida son recursos especializados residenciales y temporales que ofrecen acogida, atención y recuperación a las mujeres que sufren violencia de género y a las y los menores a su cargo que requieren un espacio de protección debido a la situación de indefensión o riesgo causada por la violencia de género.

2. Pueden ser titulares del derecho de acceso a los centros de acogida las mujeres que acrediten mediante cualquiera de los medios establecidos en el artículo $5 \mathrm{su}$ situación de violencia de género.

3. Los centros de acogida estarán atendidos por equipos multidisciplinares y garantizarán un tratamiento integral de atención y/o de recuperación, que abarque aspectos psicológicos, educativos, sociolaborales y jurídicos y favorezca la normalización de la situación personal de las mujeres, de su unidad familiar y la superación de los efectos de la violencia.

4. Las normas y requisitos específicos a los que tendrán que ajustarse los centros de acogida se establecerán reglamentariamente.

Artículo 49. Creación del Centro de Recuperación Integral para Mujeres que Sufren Violencia de Género.

1. La Xunta de Galicia, a través del departamento competente en materia de igualdad, garantizará la creación de un Centro de Recuperación Integral para Mujeres que Sufren Violencia de Género.

2. El Centro de Recuperación Integral para Mujeres que Sufren Violencia de Género desarrollará un modelo de atención integral, basado en un sistema coordinado de servicios, recursos y medidas de carácter social, laboral y económico.
3. El Centro de Recuperación Integral actuará como centro coordinador de la red gallega de acogida.

Artículo 50. Red de información a las mujeres.

1. La Xunta de Galicia, a través del departamento competente en materia de igualdad, y en colaboración con las entidades locales, garantizará la existencia de una red de información a las mujeres, distribuida de forma uniforme por el territorio gallego.

2. La red de información a las mujeres desarrollará acciones de carácter preventivo y de sensibilización. Asimismo, facilitará información, orientación, derivación y seguimiento a las mujeres que sufren violencia de género.

3. La red de información a las mujeres funcionará en estrecha colaboración con los servicios sociales, sanitarios y de orientación escolar, así como con los servicios de urgencia y de seguridad ciudadana para la detección y prevención de situaciones de violencia de género.

Artículo 51. Servicio de Atención 24 horas.

1. El Servicio de Atención 24 horas, dependiente del departamento competente en materia de igualdad, ofrecerá atención e información integral sobre los recursos públicos y privados al alcance de las mujeres en situaciones de violencia de género.

2. Serán funciones del Servicio de Atención 24 horas:

a. Escuchar las demandas de las mujeres e informar sobre las medidas a adoptar y los recursos disponibles.

b. Proporcionar asistencia adecuada frente a situaciones de vulnerabilidad emocional y psicológica.

c. Prestar asistencia y, en su caso, derivar al recurso más adecuado.

d. Colaborar y coordinarse con la red de información a las mujeres, con los servicios de acogida temporal y con todos los servicios de urgencia en los casos necesarios. 
El Servicio de Atención 24 horas funcionará todas las horas del día y todos los días del año.

3. Las mujeres podrán acceder al Servicio de Atención 24 horas sin necesidad de aportar ningún tipo de acreditación de su situación de violencia de género, conservando asimismo su anonimato, sin necesidad de facilitar sus datos de identificación personal.

Artículo 52. Punto de Coordinación de las Órdenes de Protección.

1. El Punto de Coordinación de las Órdenes de Protección dependiente del departamento competente en materia de igualdad es el encargado de recibir la comunicación de la totalidad de las órdenes de protección que se dicten en el territorio de Galicia.

2. A estos efectos, el Punto de Coordinación de las Órdenes de Protección llevará a cabo un seguimiento individualizado de cada caso, poniéndose en comunicación con las mujeres que posean una orden de protección, con la finalidad de facilitarles cuanta información demanden y articular una actuación ordenada de los servicios asistenciales y de protección.

Artículo 53. Puntos de encuentro familiar.

1. El departamento competente en materia de igualdad garantizará la existencia de puntos de encuentro familiar, como un servicio que facilita y preserva la relación entre las y los menores y las personas de sus familias en situaciones de crisis, y que permite y garantiza la seguridad y el bienestar de las niñas y los niños y facilita el cumplimiento del régimen de visitas.

2. La prestación de este servicio debe ser neutral y su carácter transitorio. Los puntos de encuentro familiar contarán con personal cualificado para el seguimiento de la evolución de las relaciones de las niñas y los niños con sus familias.

3. Las normas y requisitos específicos a los que tendrán que ajustarse los puntos de encuentro familiar se establecerán reglamentariamente.

Artículo 54. Creación de oficinas de atención a las víctimas de los delitos.

1. La Xunta de Galicia, a través del departamento competente en el área de justicia, garantizará la creación de oficinas de atención a las víctimas del delito, distribuidas de forma equilibrada en el territorio gallego, dotadas de personal cualificado, con la finalidad, entre otras, de ofrecer a las mujeres que sufren violencia de género información y apoyo para que puedan ejercer los derechos que les reconoce la legislación vigente.

2. Los departamentos de la Xunta de Galicia competentes en las áreas de justicia e de igualdad se coordinarán para la planificación conjunta de procedimientos y para la formación y actualización permanente del personal técnico de las oficinas en la atención, asistencia y tratamiento de las mujeres que sufren violencia de género.

Artículo 55. Titularidad y gestión de los servicios.

1. Los servicios del sistema de protección y asistencia integral serán de titularidad pública, municipal o autonómica, correspondiéndole su coordinación y supervisión a la Administración de la Xunta de Galicia a través del departamento competente en materia de políticas de igualdad. Dichos servicios adecuarán sus reglamentos de régimen interno a lo dispuesto en la presente ley, así como a las demás disposiciones que establezca la Xunta de Galicia.

2. La Xunta de Galicia garantizará un desarrollo territorialmente equilibrado del sistema de protección y asistencia integral de las mujeres que sufren violencia de género.

3. Con el fin de garantizar una protección y asistencia adecuada a las mujeres que sufren violencia de género, la Xunta de Galicia podrá establecer fórmulas de 
colaboración con entidades privadas sin fin de lucro.

Artículo 56. Confidencialidad de la información.

Las administraciones públicas titulares del sistema de protección y asistencia integral a las mujeres que sufren violencia de género garantizarán, en todo caso, la confidencialidad de la información que traten por razón de sus funciones, según lo establecido en la Ley orgánica 15/1999, de 13 de diciembre, de protección de datos de carácter personal.

\section{DISPOSICIÓN ADICIONAL PRIMERA}

$$
(\ldots)^{810}
$$

\section{DISPOSICIÓN ADICIONAL SEGUNDA ACUERDOS INTERINSTITUCIONALES E INSTRUMENTOS DE COLABORACIÓN}

1. El Gobierno de la Xunta de Galicia impulsará la formalización y actualización de acuerdos interinstitucionales de coordinación entre las diversas instancias y administraciones públicas con competencias en la materia objeto de la presente ley, que sirvan de cauce de actuación y colaboración para conseguir, en los ámbitos policial, sanitario, social, judicial, laboral, educativo y de investigación, una atención y asistencia integral y coordinada a las mujeres que sufren violencia de género.

2. Sin perjuicio de lo establecido en el apartado anterior, la Xunta de Galicia habilitará los instrumentos de colaboración necesarios para la prevención y tratamiento de la violencia de género.

\section{DISPOSICIÓN ADICIONAL TERCERA COMPETENCIAS EN MATERIA DE VIOLENCIA DE GÉNERO DE LA POLICÍA DE GALICIA}

De conformidad con lo dispuesto en la disposición transitoria quinta de la Ley 8/2007, de 13 de junio, de Policía de Galicia,

810 Contiene modificaciones a Ley $4 / 2001$, de 31 de mayo, reguladora de la mediación familiar. el Gobierno gallego llevará a cabo las gestiones y actuaciones necesarias para que se dé prioridad a la transferencia o delegación de las competencias en materia de protección y asistencia a las mujeres víctimas de violencia de género.

\section{DISPOSICIÓN ADICIONAL CUARTA INFORMACIÓN AL PARLAMENTO DE GALICIA}

El Gobierno de la Xunta de Galicia remitirá al Parlamento de Galicia, con carácter anual, un informe sobre la situación de la violencia de género en Galicia, que contará con las aportaciones de todos los departamentos implicados en la prevención y tratamiento de la violencia de género

\section{DISPOSICIÓN ADICIONAL QUINTA CREACIÓN DEL CONSEJO GALLEGO DE LAS MUJERES}

1. Se crea el Consejo Gallego de las Mujeres como órgano colegiado e institucional de Galicia, de carácter consultivo, de participación y asesoramiento en materia de políticas de igualdad, que tendrá, entre otras, la función de colaborar con el Gobierno de la Xunta de Galicia en el desarrollo de la aplicación de la presente ley, dado que es necesario reconocer la importante labor desempeñada por muchas asociaciones de mujeres en la lucha contra la violencia de género, así como establecer vías estables de interlocución entre la Administración gallega y el entramado asociativo de mujeres que busquen el mayor consenso posible en el diseño de políticas contra la violencia machista.

2. Su naturaleza, fines, composición y adscripción se establecerán reglamentariamente.

\section{DISPOSICIÓN ADICIONAL SEXTA CREACIÓN DEL OBSERVATORIO GALLEGO DE LA VIOLENCIA DE GÉNERO}

1. Se creará el Observatorio Gallego de la Violencia de Género como órgano colegiado e institucional de Galicia, encargado

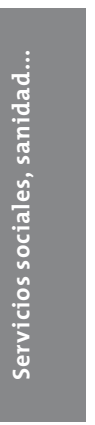


del estudio, evaluación y seguimiento de las políticas contra la violencia de género que se desarrollen en Galicia.

2. Su naturaleza, fines, composición y adscripción se establecerán reglamentariamente.

\section{DISPOSICIÓN ADICIONAL SÉPTIMA CREACIÓN DE LA COMISIÓN INTERDEPARTAMENTAL DE IGUALDAD}

1. Se creará la Comisión Interdepartamental de Igualdad como órgano colegiado e institucional de Galicia, a la que corresponderán, entre otras, las funciones de seguimiento de la aplicación de la presente ley y de los correspondientes planes para la igualdad de oportunidades y de lucha contra la violencia de género.

Igualmente, será objeto de esta comisión adaptar el plan de etapas de aplicación de la presente ley a las cuantías presupuestarias anuales consignadas para su desarrollo en las leyes de presupuestos de cada ejercicio.

2. Las restantes funciones, régimen de funcionamiento, composición y adscripción se establecerán reglamentariamente.

\section{DISPOSICIÓN ADICIONAL OCTAVA INFORMES SOBRE EL GRADO DE DESARROLLO Y REPERCUSIONES ECONÓMICAS DE LA PRESENTE LEY}

Para la correcta aplicación de las medidas contempladas en la presente ley las consejerías competentes en esta materia elaborarán informes sobre el grado de desarrollo de la misma, así como sobre sus repercusiones económicas, que serán presentados en la Comisión Interdepartamental de Igualdad.

\section{DISPOSICIÓN ADICIONAL NOVENA}

$$
(\ldots)^{811}
$$

\section{DISPOSICIÓN ADICIONAL DÉCIMA DOTACIÓN PRESUPUESTARIA}

La Xunta de Galicia dotará anualmente los presupuestos necesarios para poner en práctica las medidas que se desarrollen en cumplimiento de la presente ley.

\section{DISPOSICIÓN DEROGATORIA ÚNICA}

Quedanderogadas cuantas disposiciones de igual o inferior categoría contradigan lo dispuesto en la presente ley, y en especial los artículos 19 y 20 de la Ley 7/2004, de 16 de julio, gallega para la igualdad de mujeres y hombres.

\section{DISPOSICIÓN FINAL PRIMERA HABILITACIÓN NORMATIVA}

Se faculta a la Xunta de Galicia para dictar cuantas disposiciones sean necesarias para la aplicación y desarrollo de la presente ley.

\section{DISPOSICIÓN FINAL SEGUNDA ENTRADA EN VIGOR}

La presente ley entrará en vigor al día siguiente al de su publicación en el Diario Oficial de Galicia.

811 Contiene modificaciones a Ley 9/1991, de 2 de octubre, gallega de medidas básicas para la inserción social. 


\section{XVII \\ EDUCACIÓN, CULTURA, INVESTIGACIÓN, DEPORTES Y TURISMO}

1. LEY 14/1989, DE 11 DE OCTUBRE,
DE BIBLIOTECAS 812813
(DOGA N. $\left.{ }^{\circ} 204,24.10 .1989\right)$

(...) 814

\section{TÍTULO I \\ CONCEPTO, ÁMBITO Y \\ FUNCIONES DE LAS BIBLIOTECAS PÚBLICAS DE GALICIA}

Artículo 1. A efectos de la presente ley, se entiende por biblioteca pública en Galicia un centro cultural en el que se reúne un conjunto organizado de libros, publicaciones periódicas, registros sonoros y audiovisuales, o cualquier otro soporte de conservación y reproducción de textos, ubicado en determinados recintos fijos o móviles para su utilización por el público, cuya finalidad es contribuir con los medios técnicos y personal adecuado, esencialmente, al ejercicio del derecho de la cultura e información, a la difusión y fomento de la lectura, al enriquecimiento del tiempo libre y promoción y difusión de la lengua y de la cultura gallegas.

2. La Xunta de Galicia deberá fomentar la creación de las bibliotecas que requieran las necesidades sociales y culturales

\footnotetext{
812 Véase sobre libros y lectura:

- Ley 17/2006, de 27 de diciembre, del libro y de la lectura de Galicia.

- Decreto 43/2001, de 1 de febrero, de refundición de la normativa en materia del depósito legal.

- Decreto 178/2007, de 13 de septiembre, por el que se regula la composición y funcionamiento del Consejo Asesor del Libro.

- Decreto 342/2009, de 18 de junio, por el que se crea el Registro Administrativo de Librerias de Galicia y se regula su organización y funcionamiento.

813 Véase Orden de 11 de junio de 2007 por la que se regula el reconocimiento de biblioteca de especial interés para Galicia.

814 Exposición de motivos omitida.
}

específicas de Galicia, debiendo procurar la conservación y mejora de las bibliotecas existentes.

3. Los poderes públicos de Galicia arbitrarán las fórmulas necesarias para crear y mantener un adecuado sistema bibliotecario que preste un servicio gratuito. Podrán, no obstante, correr a cargo del usuario aquellos servicios que generen gastos o trabajos especiales.

Artículo 2. 1. Quedan comprendidas en el ámbito de esta ley:

a. Las bibliotecas de titularidad y uso público, que son las creadas y mantenidas por organismos públicos, salvo las de titularidad estatal y sin perjuicio de lo previsto en la disposición final tercera.

b. Las bibliotecas de titularidad privada y uso público con un régimen de funcionamiento establecido de acuerdo con los organismos competentes de la Xunta de Galicia, en virtud de convenio y en razón del interés público de estas bibliotecas.

c. Las bibliotecas privadas que, me-

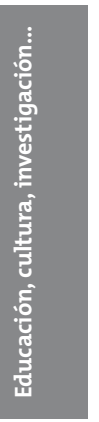
diante convenio entre la Xunta de Galicia y los propietarios, puedan ser accesibles a un uso público especializado.

2. Las bibliotecas citadas en el apartado anterior se someterán a la inspección, tutela y coordinación, según proceda, de la Xunta de Galicia, la cual habrá de adoptar las medidas necesarias para asegura su correcto funcionamiento. Los fondos de las bibliotecas a las que se refiere la presente ley forman una unidad de gestión al servicio de la comunidad gallega. En consecuencia deberá mantenerse un servicio de préstamo interbibliotecario, al servicio del lector, entre las bibliotecas a las que se refiere esta ley. 
Artículo 3. 1. Son funciones de las bibliotecas de Galicia:

a. Ofrecer al público un conjunto organizado de fondos bibliográficos y audiovisuales que permitan la formación cultural y la atención de las necesidades de información de los ciudadanos.

b. Conservar y enriquecer el patrimonio bibliográfico.

c. Fomentar el uso y cooperación mediante el intercambio de información, adquisiciones y préstamos.

d. Fomentar la cooperación interbibliotecaria mediante el intercambio de información, la coordinación de adquisiciones y los préstamos.

2. La Xunta de Galicia habrá de establecer y mantener actualizado un registro de bibliotecas que presten servicio público en Galicia, así como de sus fondos y servicios. Asimismo, clasificará las bibliotecas según la población servida, los servicios con los que cuenten y la importancia de sus fondos.

\section{TÍTULO II ORGANIZACIÓN Y FUNCIONAMIENTO DEL SISTEMA BIBLIOTECARIO EN GALICIA}

Artículo 4. El sistema bibliotecario de Galicia queda constituido del siguiente modo:

a. Órganos: Los servicios bibliotecarios dependientes de la Consellería de Cultura e Deportes, el Consello de Bibliotecas y los Centros Territoriais de Bibliotecas.

b. Centros bibliotecarios: El Centro Superior Bibliográfico de Galicia y otros centros bibliotecarios que entren en el ámbito de la presente ley.

Artículo 5. 1. La Xunta de Galicia, a través de su Consellería de Cultura e Deportes, se ocupará del estudio de la planificación de la programación de las necesidades, del informe, apoyo e inspección técnica, de la propuesta de distribución de créditos y de la coordinación del funcionamiento de las bibliotecas que se integren en el sistema.
2. La Xunta de Galicia establecerá las normas reguladoras de la estructura y funcionamiento del sistema bibliotecario, así como los reglamentos por los que habrán de regirse los organismos y los centros bibliotecarios mencionados en el artículo 4 .

Artículo 6. 1. El Consello de Bibliotecas es un órgano consultivo y asesor de la Xunta de Galicia en materias relacionadas con el sistema bibliotecario.

2. El Consello de Bibliotecas estará presidido por el Conselleiro de Cultura y Deportes, siendo su vicepresidente el Director general de Cultura.

Formarán parte del mismo, en calidad de vocales natos, el subdirector general del Libro y Bibliotecas y el director del Centro Superior Bibliográfico de Galicia.

Serán también vocales:

a. Cuatro miembros designados por la Comisión 4. ${ }^{\circ}$, Educación y Cultura del Parlamento de Galicia, entre personas de reconocido prestigio en el ámbito cultural.

b. Un miembro designado por el Conse1lo da Cultura Galega.

Actuará como Secretario del Consello de Bibliotecas, con voz y con voto, el titular del Servicio de Bibliotecas de la Consellería de Cultura e Deportes.

Los miembros señalados en los apartados a) y b) tendrán un mandato no superior al de la legislatura en la que fuesen nombrados y podrán ser reelegidos.

3. Serán funciones del Consello:

a. Actuar como órgano de información, consulta y asesoramiento del sistema bibliotecario de Galicia.

b. Conocer el programa de actuación y distribución de fondos económicos destinados al sistema bibliotecario.

c. Conocer e informar, en su caso, el programa anual de mejora, ampliación y coordinación de los Centros Bibliotecarios de Galicia.

d. Propondrá la creación de bibliotecas en aquellos ámbitos donde sea necesario para el cumplimiento de los fines propuestos en la presente ley. 
e. En general, cualesquiera otras funciones que le asigne la normativa vigente.

4. El Consello de Bibliotecas se reunirá, en sesión ordinaria, al menos una vez cada seis meses, siendo convocado por el Presidente con diez días de antelación. En la convocatoria se precisará el orden del día, lugar y fecha de celebración. El Consejo quedará válidamente constituido cuando concurra la mayoría de sus componentes en primera convocatoria y con cualquier número de asistentes en segunda convocatoria. Los acuerdos se tomarán por mayoría de votos, dirimiendo los empates el voto del Presidente.

El Consello podrá ser convocado por el Presidente, en sesión extraordinaria, cuando lo estime conveniente o bien a petición de la mitad más uno de sus componentes, con los mismos requisitos de convocatoria, constitución y adopción de acuerdos establecidos para las sesiones ordinarias.

Artículo 7. 1. Los Centros Territoriales de Bibliotecas son órganos de orientación y coordinación del funcionamiento de la red bibliotecaria.

2. Los Centros Territoriales de Bibliotecas estarán presididos por el delegado de la Consellería de cultura e Deportes, siendo su vicepresidente el Jefe de Área de Cultura de la Delegación.

Los vocales serán los siguientes:

Dos bibliotecarios en representación de los bibliotecarios de las bibliotecas públicas municipales.

Dos representantes de los Ayuntamientos que cuenten con biblioteca pública.

Un representante de las Asociaciones Profesionales más representativas del sector.

El Director de la Biblioteca Pública Provincial. Un representante de la Diputación Provincial.

Actuará como secretario, con voz y con voto, un funcionario, técnico de bibliotecas designado por el delegado de Cultura y Deportes.

3. Serán funciones de los Centros Territoriales de Bibliotecas: a. Orientar y fomentar el desarrollo de las bibliotecas dentro de su ámbito.

b. Coordinar el funcionamiento de las bibliotecas de la red.

c. Conocer y aprobar los presupuestos anuales de bibliotecas de la red, de acuerdo con lo establecido en el artículo 16.2 de esta ley.

d. Repartir los fondos procedentes de las aportaciones de Xunta de Galicia y de otros organismos entre las Bibliotecas de la Red Provincial según los criterios que los propios Centros establecerán de acuerdo con las directrices generales del Consello de Bibliotecas y de la Xunta de Galicia.

e. Servir de apoyo técnico a las bibliotecas.

4. Los Centros Territoriales de Bibliotecas se reunirán al menos una vez por trimestre en los términos previstos en el artículo 6.4 para el Consello de Bibliotecas.

Artículo 8. El Centro Superior Bibliográfico de Galicia tendrá como funciones propias, sin perjuicio de las que se le puedan atribuir por otras disposiciones, las siguientes:

a. Recoger, conservar y difundir el patrimonio bibliográfico de Galicia y toda la producción impresa, sonora, audiovisual e informática que se realice en Galicia.

A tal fin recibirá, al menos, un ejemplar de las obras sujetas a depósito legal.

El Centro Superior Bibliográfico de Galicia tendrá preferencia en caso de reasentamientos o de depósitos de fondos procedentes de otras bibliotecas.

También reunirá y conservará toda la producción impresa, sonora, audiovisual e informática en gallego y en otras lenguas, realizada fuera de Galicia pero referente a ésta o de especial interés para Galicia.

b. Ejercer las competencias de la Xunta de Galicia en materia de gestión del depósito legal y de registro de la propiedad intelectual.

c. Elaborar y difundir la información bibliográfica sobre la producción editorial gallega, actual y retrospectiva. 
d. Elaborar y ser depositario del Catálogo Colectivo de Galicia.

e. El Centro Superior Bibliográfico de Galicia deberá contar con un sistema de consulta de su Catálogo general, que sea accesible, de modo eficaz, desde los distintos Centros bibliotecarios del sistema.

f. Establecer relaciones de colaboración e intercambio con otros sistemas bibliotecarios nacionales y extranjeros.

g. La Consellería de Cultura e Deportes determinará la composición, funcionamiento y dotaciones materiales y personales de este Centro.

Artículo 9. 1. La Xunta de Galicia establecerá Convenios con los Ayuntamientos y otros Organismos públicos y privados para crear y mantener servicios bibliotecarios y bibliotecas públicas suficientes de acuerdo con la normativa vigente.

A estos efectos podrá establecer Convenios con los Ayuntamientos para que todos los núcleos de población de más de 2.000 habitantes cuenten con una biblioteca abierta al público, que podrá ser la del Colegio Público o la de otros entes de carácter público.

Aquellos núcleos con menor volumen de habitantes estarán atendidos por un subsistema de bibliotecas móviles o Agencias de Lectura.

2. La Xunta de Galicia velará para que en las ciudades de más de 50.000 habitantes se establezcan redes bibliotecarias, que contarán con una biblioteca nodal que coordinará y dará soporte a los diversos puntos de servicio de la ciudad, así como para que no haya ninguna comarca sin una biblioteca pública como mínimo.

3. La Xunta de Galicia podrá ubicar en ámbitos menores tantas bibliotecas como sea necesario para actuar como cabeceras de redes comarcales, mancomunidades, urbanas, parroquiales o de cualquier otro tipo. Sin perjuicio de que se puedan crear Centros hemerográficos o hemerotecas de carácter específico general, la Xunta de Galicia deberá velar para que en cada comarca exista una biblioteca, como mínimo, que cuente con un servicio que se encargue de la recogida, clasificación y conservación de todo el material hemerográfico publicado en el correspondiente ámbito geográfico.

4. La Xunta de Galicia estimulará la coordinación entre bibliotecas de los municipios de una comarca en orden a una mejor optimización de los recursos.

\section{TÍTULO III \\ DE LOS SERVICIOS BIBLIOTECARIOS, DE LA COLABORACIÓN Y LA COOPERACIÓN INTERBIBLIOTECARIAS}

Artículo 10. 1. La Xunta de Galicia velará para que los servicios bibliotecarios, en su conjunto, puedan atender adecuadamente a grupos específicos de usuarios.

2. La Xunta de Galicia establecerá las normas por las que se fijarán los servicios que prestarán las bibliotecas y las características y calificación del personal, los locales, los fondos bibliográficos y los horarios de apertura al público.

3. Las bibliotecas públicas reunirán las condiciones necesarias en cuanto a locales e instalaciones, y dispondrán de fondos, servicios y personal de acuerdo con la población a la que tienen que servir. Habrán de contar, al menos, con los siguientes servicios y secciones:

Lectura en sala.

Préstamo a domicilio.

Publicaciones periódicas.

Sección infantil y juvenil.

Sección local.

Información.

4. Las agencias de lectura habrán de contar, al menos, con los siguientes servicios y secciones:

Préstamo a domicilio.

Sección infantil y juvenil.

Información.

5. Las bibliotecas móviles contarán con los servicios de información y préstamo a domicilio. 
Artículo 11. La Xunta de Galicia deberá establecer Convenios de colaboración en el ámbito bibliotecario con las Universidades gallegas. Asimismo, podrá establecer convenios de colaboración con otros organismos y entidades de carácter público o privado.

Artículo 12. 1. Las bibliotecas escolares son parte integrante y fundamental de las actividades pedagógicas de los Centros docentes.

2. Las Consellerías de Cultura y Deportes y Educación y Ordenación Universitaria deberán establecer convenios de colaboración a fin de que las bibliotecas de los Centros públicos de enseñanza no universitaria puedan ser disfrutadas por la comunidad escolar.

3. A estos efectos se tendrá en cuenta la autonomía de gestión de los Consejos Escolares.

Artículo 13. Mientras no se perjudique el normal desarrollo de las funciones que les son propias, las bibliotecas podrán ejercer otras actividades de carácter estrictamente cultural, siempre que cuenten con las instalaciones adecuadas. Cuando la dirección de la biblioteca ceda las instalaciones de la misma para la organización de actividades culturales, sus promotores deberán aportar los medios personales y materiales necesarios para su instalación y desarrollo.

Artículo 14. Sin perjuicio de sus funciones propias, todas las bibliotecas tienen la obligación de proporcionar los datos estadísticos y de participar en las actividades de cooperación interbibliotecaria que la Consellería de Cultura e Deportes determine.

\section{TÍTULO IV DEL PERSONAL Y DE LA FINANCIACIÓN}

Artículo 15. 1. Las bibliotecas contarán con personal con la cualificación y nivel técnico que exijan las diversas funciones que se van a desempeñar, de acuerdo con la reglamentación que se establezca.

2. A través de cursos, seminarios, reuniones y otros medios que se estimen convenientes se procurará la formación permanente del personal bibliotecario en ejercicio.

3. La Xunta de Galicia establecerá los requisitos de acceso a las plazas que convoquen las distintas entidades adscritas al sistema bibliotecario de Galicia en los términos que se determinan en la Ley 4/1988, de 26 de mayo, de la Función Pública de Galicia. En cuanto al personal de la Administración local, se estará a lo dispuesto en el art. 3.2 de la citada ley.

Artículo 16. 1. En el presupuesto de la Xunta de Galicia se consignarán las partidas destinadas a la creación, mantenimiento y mejora de las bibliotecas integrantes del sistema.

2. Los titulares de las bibliotecas a que hace referencia en el apartado 1.a), del artículo 2 de esta ley, salvo cuando se trate de organismos dependientes de la Xunta de Galicia, y los titulares de las bibliotecas de uso público a que se refiere el apartado 1.b), del mismo artículo deberán consignar en sus presupuestos ordinarios las partidas destinadas al funcionamiento de las citadas bibliotecas, incluyendo, en todo caso, los emolumentos del personal, los gastos corrientes y los gastos en dotación bibliográfica. De estos presupuestos se dará cuenta a los organismos competentes de la Xunta de Galicia.

\section{DISPOSICIÓN TRANSITORIA}

Las bibliotecas ya existentes, afectadas por la presente ley, se ajustarán a ella en el plazo de dos años a partir de la entrada en vigor de su desarrollo reglamentario.

\section{DISPOSICIÓN FINAL PRIMERA}

La Xunta de Galicia procederá al desarrollo reglamentario de la presente ley. 


\section{DISPOSICIÓN FINAL SEGUNDA}

Se autoriza a la Consellería de Cultura e Deportes a dictar las disposiciones ordinarias sobres condiciones técnicas de instalaciones y utilización de las bibliotecas de uso público ${ }^{815}$.

\section{DISPOSICIÓN FINAL TERCERA}

Las bibliotecas de titularidad estatal radicadas en Galicia, cuando sean transferidas a la Comunidad Autónoma gallega, se incardinarán en el sistema bibliotecario de Galicia de acuerdo con los términos convenidos en la Administración del Estado.

\section{DISPOSICIÓN FINAL CUARTA}

Los titulares de las bibliotecas integradas en el sistema podrán establecer normas internas para el funcionamiento de las mismas, que serán sometidas a la aprobación de la Consellería de Cultura e Deportes, previo informe, en su caso, del Consello de Bibliotecas.

\section{DISPOSICIÓN FINAL QUUINTA}

Quedan derogadas todas las disposiciones, cualquiera que sea su rango, que se opongan, total o parcialmente a lo dispuesto en la presente ley.

\section{DISPOSICIÓN FINAL SEXTA}

Esta ley entrará en vigor al día siguiente de su publicación en el "Diario Oficial de Galicia".

\section{DISPOSICIÓN FINAL SÉPTIMA}

La Xunta de Galicia, en el plazo de un año, presentará ante el Parlamento, para su aprobación, un plan de desarrollo del sistema bibliotecario de Galicia, en el que figurará la planificación temporal, de inversiones, medios y personas para la implantación del referido sistema.

815 Véase art. 7 Decreto 24/1995, de 20 de enero, por el que se regulan los centros bibliotecarios fijos.
2. LEY 1/2003, DE 9 DE MAYO, DE LOS CONSELLOS SOCIAIS DO SISTEMA UNIVERSITARIO DE GALICIA (DOGA N. $\left.^{\circ} 104,30.5 .2003\right)^{816}$

$(\ldots)^{817}$

\section{Capitulo I \\ DEFINICIÓN, FUNCIONES Y COMPETENCIAS DEL CONSELLO SOCIAL}

Artículo 1. Objeto y ámbito de aplicación de la ley.

La presente ley tiene por objeto la regulación del Consello Social de cada una de las universidades públicas que integran el sistema universitario de Galicia.

Artículo 2. Definición y funciones del Consello Social.

1. El Consello Social es el órgano de participación de la sociedad gallega en las universidades comprendidas en el artículo anterior que impulsa la colaboración entre las mismas y aquélla mediante la satisfacción por las universidades de las necesidades de su entorno, contribuyendo eficazmente al desarrollo social, profesional, económico, tecnológico y cultural de Galicia, a la mejora de la calidad del servicio público de la educación superior universitaria y a la obtención de los recursos precisos para procurar su suficiencia económica y financiera.

2. Para el cumplimiento de estas funciones, el Consello Social tendrá las competencias determinadas en la presente ley y cualesquiera otras que le reconozca la normativa vigente.

Artículo 3. Competencias de relación entre la universidad y la sociedad.

816 Véase:

- Ley 3/1986, de 18 de diciembre, Normas Reguladores de los Consejos Escolares.

- Decreto 44/1988, de 11 de noviembre, desarrolla Ley 18 de diciembre de 1986, de normas reguladoras de los consejos escolares.

- Decreto 87/1992, de 26 de marzo, Reglamento de Régimen Interno del Consejo Escolar de Galicia.

817 Exposición de motivos omitida. 
Corresponden al Consello Social las siguientes competencias de relación entre la universidad y la sociedad:

a. Promover el conocimiento mutuo entre la universidad y la sociedad, favoreciendo y organizando eventos que difundan en ésta la labor universitaria y transmitiendo a aquélla las aspiraciones de las fuerzas sociales de Galicia.

b. Fomentar la colaboración de la sociedad en la financiación de la enseñanza y de la investigación de la universidad, contribuyendo a la captación de recursos económicos externos.

c. Aprobar, con carácter anual, una memoria de sus actividades, que remitirá al Parlamento de Galicia y a la consellería competente en materia universitaria.

d. Realizar estudios sobre materias de su competencia, y, en particular, sobre la adecuación de la oferta de titulaciones y el contenido de los planes de estudios de la universidad a las necesidades sociales, sobre el rendimiento académico del alumnado y la inserción laboral de los titulados universitarios, sobre la investigación desarrollada en la universidad y la transferencia a la sociedad de los resultados de la misma y sobre cualquier otra cuestión propuesta por la consellería competente en materia universitaria, de acuerdo con las funciones propias de este órgano.

e. Impulsar aquellas actuaciones que permitan un mayor acercamiento de los estudiantes universitarios a las demandas del mercado laboral, y, en especial, la celebración de convenios entre la universidad y otras entidades públicas y privadas orientadas a completar la formación de los alumnos y titulados de la universidad y facilitar el acceso de los mismos al mundo profesional.

f. Estimular la actividad investigadora de la universidad, especialmente en lo relativo a su vinculación con los sectores productivos, apoyando los proyectos de investigación y desarrollo compartidos entre la universidad, las empresas y el tejido social, así como las políticas de transferencia y difusión de los resultados obtenidos en las investigaciones universitarias.

g. Favorecer las actividades orientadas a completar la formación científica, cultural y humanística de los universitarios, apoyando sus manifestaciones en el seno de la universidad y asegurando su extensión al conjunto de la sociedad gallega.

h. Otorgar, en su caso, premios, distinciones y reconocimientos en el ámbito de sus competencias.

Artículo 4. Competencias de carácter económico, financiero y patrimonial.

Corresponden al Consello Social las siguientes competencias de carácter económico, financiero y patrimonial:

a. Supervisar las actividades de carácter económico de la universidad.

b. Aprobar, a propuesta del Consello de Goberno, la programación plurianual de la universidad, así como realizar su seguimiento.

c. Aprobar, a propuesta del Consello de Goberno, el presupuesto de la universidad.

Los órganos responsables de la ejecución del presupuesto deberán informar al Consello Social del estado de ejecución en las condiciones que determine su Reglamento de organización y funcionamiento.

d. Aprobar, con carácter previo a su rendición ante el órgano de fiscalización de la Comunidad Autónoma, las cuentas anuales de la universidad y de las sociedades, fundaciones u otras entidades en cuyo capital o fondo patrimonial equivalente tenga participación mayoritaria la universidad, cualquiera que sea la forma jurídica que adopten las mismas, pudiendo el Consello Social acordar motivadamente la realización de auditorías externas.

e. Fijar los precios de las enseñanzas propias, de los cursos de especialización y los referentes a las demás actividades autorizadas por las universidades, así como informar en materia de precios públicos 
de los estudios universitarios oficiales, dentro de los límites que establezca el Consejo de Coordinación Universitaria.

f. Aprobar, con carácter previo a su remisión a la Xunta de Galicia para su autorización, las propuestas de operaciones de endeudamiento.

g. Informar sobre la plantilla y la relación de puestos de trabajo del personal docente e investigador de la universidad, especificando la totalidad de sus costes, sus modificaciones y los gastos que suponen, así como informar, con carácter previo a su celebración, sobre los convenios colectivos del personal docente e investigador contratado por la universidad.

h. Acordar, a propuesta del Consejo de Gobierno de la universidad y dentro de los límites fijados por la Comunidad Autónoma, la asignación singular e individual de retribuciones adicionales ligadas a méritos individuales docentes, investigadores y de gestión a miembros del personal docente e investigador de la universidad, previa valoración de los mismos por la Agencia para la Calidad del Sistema Universitario de Galicia o, en su caso, por la Agencia Nacional de Evaluación de la Calidad y Acreditación, o por cualquier otro órgano de evaluación que determinen leyes de otras Comunidades Autónomas, siempre que exista previo convenio o concierto con la Comunidad Autónoma gallega. El Consello Social podrá recabar informe de los centros a que pertenezca o esté adscrito el profesorado afectado por tales acuerdos, al objeto de motivar su decisión ${ }^{818}$.

i. Informar sobre la plantilla y la relación de puestos de trabajo del personal de administración y servicios de la universidad, sus modificaciones y los gastos que suponen, especificando la totalidad de sus costes, así como informar, con carácter previo a su formalización, sobre los convenios colectivos del personal de

818 Véase Decreto 55/2004, de 4 de marzo, por el que se establecen las retribuciones adicionales ligadas a méritos individuales docentes, investigadores y de gestión del profesorado universitario. administración y servicios en régimen laboral de la universidad.

k. Aprobar, a propuesta del Consejo de Gobierno, los reglamentos internos que regulan la gestión contractual y patrimonial de la universidad.

1. Ser informado de los contratos o convenios en que la universidad sea parte y de aquellos que se celebren al amparo del artículo 83 de la Ley Orgánica 6/2001, de 21 de diciembre, de Universidades.

$\mathrm{m}$. Aprobar, con carácter previo a su realización, los actos de disposición sobre bienes inmuebles y muebles de extraordinario valor de la universidad y la desafectación de sus bienes de dominio público. A tal efecto las universidades contarán con un inventario, que habrán de remitir al Consello Social de acuerdo con lo que se estipule en su reglamento de régimen interno.

n. Aprobar, a propuesta del Consejo de Gobierno, la aceptación por la universidad de herencias, donaciones o legados.

ñ. Informar sobre la creación o adscripción de colegios mayores y residencias universitarias.

o. Aprobar la creación, modificación sustancial o extinción de las sociedades, fundaciones u otras entidades en cuyo capital o fondo patrimonial tenga participación la universidad, cualquiera que sea la forma jurídica que adopten, así como su integración en las mismas.

Artículo 5. Competencias de supervisión de las actividades universitarias y relativas a la actividad del Consello Social. Corresponden al Consello Social las siguientes competencias de gestión universitaria y relativas a su propia actividad:

a. Supervisar el rendimiento y calidad de los servicios universitarios, formulando, en su caso, sugerencias y propuestas al Consejo de Gobierno de la universidad, orientadas a promover la excelencia de la enseñanza, investigación, gestión y servicios.

b. Solicitar, en su caso, de las administraciones públicas la realización de informes e inspecciones de los servicios 
que presta la universidad, especialmente los de enseñanza, investigación, gestión y servicios, oído el Consejo de Gobierno.

c. Proponer motivadamente a la Xunta de Galicia, previo informe del Consejo de Gobierno de la universidad, la implantación y supresión de enseñanzas conducentes a la obtención de títulos universitarios de carácter oficial y validez en todo el territorio nacional. En caso de que la iniciativa partiera de la Comunidad Autónoma, deberá contar con el acuerdo del Consello Social.

d. Proponer motivadamente a la Xunta de Galicia, previo informe del Consejo de Gobierno de la universidad, la creación, modificación o supresión de facultades, escuelas técnicas o politécnicas superiores y escuelas universitarias o escuelas universitarias politécnicas. En caso de que la iniciativa partiera de la Comunidad Autónoma, deberá contar con el acuerdo del Consello Social.

e. Proponer a la Xunta de Galicia, previo informe del Consejo de Gobierno de la universidad y antes de su celebración, la aprobación de los convenios de adscripción o de los convenios o acuerdos de desadscripción a la universidad de centros docentes para impartir estudios conducentes a la obtención de títulos de carácter oficial y validez en todo el territorio nacional.

f. Proponer a la Xunta de Galicia, previo informe del Consejo de Gobierno de la universidad, la creación o supresión de institutos universitarios de investigación.

En caso de que la iniciativa partiera de la Comunidad Autónoma, deberá contar con el acuerdo del Consello Social.

g. Proponer a la Xunta de Galicia, previo informe del Consejo de Gobierno de la universidad y antes de su celebración, la aprobación de los convenios de adscripción o de los convenios o acuerdos de desadscripción a la universidad de instituciones o centros de investigación como institutos universitarios de investigación.
En caso de que la iniciativa partiera de la Comunidad Autónoma, deberá contar con el acuerdo del Consello Social.

h. Proponer motivadamente, para su posterior aprobación por la Xunta de Galicia, la creación, modificación o supresión en el extranjero de centros dependientes de la universidad para la impartición de enseñanzas conducentes a la obtención de títulos de carácter oficial y validez en todo el territorio nacional, así como la impartición en centros dependientes de la universidad de enseñanzas conducentes a la obtención de títulos extranjeros de educación superior universitaria.

i. Acordar, con el rector, en los términos previstos en la Ley Orgánica de Universidades, el nombramiento del gerente.

$\mathrm{k}$. Informar sobre los procedimientos que establezca la universidad para la admisión de estudiantes.

1. Aprobar, previo informe del Consello de Coordinación Universitaria, las normas que regulen el progreso y permanencia de los estudiantes en la universidad.

$\mathrm{m}$. Promover, al objeto de que nadie quede excluido del estudio en la universidad por razones económicas, las bases de la política de becas, ayudas y créditos para el estudio y la investigación que, en su caso, otorgue la universidad con cargo a sus presupuestos, así como proponer a las restantes administraciones competentes la adopción de medidas con relación a sus políticas de becas, ayudas y créditos a los estudiantes universitarios.

n. Designar, de entre sus miembros pertenecientes a la representación social, los representantes del Consello Social en las entidades e instituciones que corresponda, $\mathrm{y}$, en particular, los tres representantes del órgano en el Consejo de Gobierno de la universidad.

ñ. Proponer el cese de alguno de sus miembros a la autoridad, entidad o institución que lo hubiera designado, previa declaración de su situación de incompatibilidad o incumplimiento grave o reiterado de sus obligaciones. 
o. Informar a la Xunta de Galicia sobre el régimen de retribuciones o indemnizaciones de sus miembros, con arreglo a lo dispuesto en el artículo 11.2.f) de la presente ley.

p. Acordar la constitución de comisiones temporales.

q. Aprobar y modificar su Reglamento de organización y funcionamiento, de acuerdo con lo establecido en el artículo 22.

Artículo 6. Relaciones de cooperación. En ejercicio de sus funciones, el Consello Social, a través de su Presidente, podrá solicitar la colaboración de personas físicas y jurídicas, pertenecientes o no al ámbito universitario, así como conseguir la información que precise de todos los órganos de la universidad, de la Agencia para la Calidad del Sistema Universitario de Galicia y de la Agencia Nacional de Evaluación de la Calidad y Acreditación. En el ámbito de sus competencias, podrá mantener relaciones de colaboración con otras instituciones y organismos estatales o extranjeros.

\section{Capitulo II \\ MIEMBROS DEL CONSELLO SOCIAL}

Artículo 7. Composición del Conse1lo Social.

1. El Consello Social está integrado por un máximo de veintiocho miembros, a designar conforme a lo dispuesto en los apartados siguientes.

2. Son miembros natos del Consello Social el rector de la universidad, el secretario general y el gerente de la universidad.

Asimismo, serán miembros del Consello Social un profesor, un estudiante y un representante del personal de administración y servicios, elegidos por el Consejo de Gobierno de la universidad de entre sus miembros en la forma que determinen sus estatutos. En todo caso, los nombramientos serán publicados en el "Diario Oficial de Galicia".

3. La representación de los intereses sociales en el Consello Social corresponde a personalidades de la vida cultural, profesional, económica, laboral o social, de acuerdo con la siguiente distribución:

a. El Presidente del Consello Social, designado con arreglo a lo dispuesto en el artículo 17.1.

b. Seis miembros designados por el Parlamento de Galicia.

c. Seis miembros designados por la Xunta de Galicia.

d. Dos miembros designados por los sindicatos más representativos en el territorio de la Comunidad Autónoma de Galicia.

e. Cuatro miembros designados por las organizaciones empresariales más representativas de los sectores estratégicos de la economía gallega, en el área de influencia de la universidad.

f. Un miembro designado por las corporaciones de los municipios en que se ubican los campus.

4. El Presidente del Consello Social será nombrado por decreto del Presidente de la Xunta de Galicia. Los restantes acuerdos de designación de miembros del Consello Social serán comunicados al conselleiro competente en materia universitaria, quien procederá a su nombramiento mediante orden de su consellería. El decreto y órdenes de nombramiento deberán publicarse en el "Diario Oficial de Galicia".

5. La condición de miembro del Consello Social se adquiere una vez cumplidos los requisitos de designación, nombramiento y publicación en el "Diario Oficial de Galicia”, surtiendo efectos a partir de esa fecha.

Artículo 8. Incompatibilidades.

Los miembros del Consello Social estarán sujetos al régimen previsto en la vigente Ley de Incompatibilidades y demás normas reguladoras.

Artículo 9. Duración del mandato.

1. La duración del mandato de los miembros del Consello Social señalados en el párrafo segundo del artículo 7.2 será establecida por los estatutos de la universidad. 
2. La duración del mandato de los miembros del Consello Social señalados en el artículo 7.3 será de cuatro años, renovable por una sola vez.

Artículo 10. Cese y sustitución.

1. Los miembros del Consello Social cesarán:

a. Por expiración del período de mandato. No obstante, continuarán en sus funciones hasta la toma de posesión de los nuevos miembros.

b. Por renuncia, incapacidad declarada por resolución judicial firme, muerte o declaración de fallecimiento.

La renuncia habrá de presentarse por escrito a la autoridad, entidad o institución designante y al Presidente del Consello Social, quien se la comunicará a la consellería competente en materia universitaria, y se publicará en el "Diario Oficial de Galicia”, fecha desde la que surtirá efectos.

c. Por condena judicial firme que ocasione la inhabilitación o suspensión de empleo o cargo público.

d. Por decisión de la autoridad, entidad o institución que lo hubiera designado, en los casos contemplados en el artículo 12 .

2. Las vacantes que se produzcan antes de la finalización del mandato habrán de cubrirse por la autoridad, entidad o institución correspondiente en el plazo máximo de tres meses. Si no se comunicara el acuerdo de designación dentro del anterior plazo al conselleiro competente en materia universitaria, el puesto permanecerá vacante hasta la finalización del correspondiente mandato.

En todo caso, el miembro sustituto se entenderá nombrado por el período que reste del anterior mandato.

Artículo 11. Derechos.

1. Los miembros del Consello Social desarrollarán sus competencias velando por los intereses generales de la institución universitaria.

Desempeñarán sus cargos personalmente, sin que puedan delegar sus competencias ni su voto en ningún caso.
2. Además de los que corresponden a los integrantes de un órgano colegiado y de los que pueda reconocerles el Reglamento de organización y funcionamiento y la restante normativa vigente, los miembros del Conse1lo Social tienen los siguientes derechos:

a. Presentar mociones o sugerencias para la deliberación y adopción de acuerdos o recomendaciones por el Pleno o para su estudio en una comisión.

b. Recibir, con una antelación razonable, la convocatoria, la cual contendrá el orden del día de las sesiones ordinarias y extraordinarias.

c. Asistir con voz a las sesiones de los órganos de que formen parte, ejercer su derecho de voto y formular votos particulares.

d. Ser informados de cuanto acontezca en el Consello Social y que interese para su buen funcionamiento.

e. Conseguir, a través del Presidente del Consello Social, cuanta información, datos o documentos consideren necesarios para el ejercicio de sus funciones.

f. Percibir las retribuciones o indemnizaciones que apruebe la Xunta de Galicia, previo informe de los consejos sociales de las universidades comprendidas en el artículo 1. En todo caso, los órganos unipersonales a que se refiere el artículo 13 sólo percibirán dietas y gastos locomoción en ejercicio de sus cargos.

Artículo 12. Deberes.

Además de los que pueda establecer el Reglamento de organización y funcionamiento y la restante normativa vigente, los miembros del Consello Social tienen los siguientes deberes:

a. Asistir a las sesiones del Pleno y a las de las comisiones de que formen parte.

b. Ejecutar cuantos cometidos les sean encomendados por razón de sus cargos.

c. Poner en conocimiento del consejo cualquier información que pueda afectar a las actuaciones o competencias del consejo.

d. Guardar secreto sobre las deliberaciones internas, así como sobre las materias 
y actuaciones que expresamente se declaren reservadas.

e. Observar en todo momento la normativa de incompatibilidades.

El Reglamento de organización y funcionamiento establecerá un procedimiento para que, en caso de que algún miembro incumpliera grave o reiteradamente sus obligaciones, el pleno proponga razonadamente su cese a la autoridad, entidad o institución que lo hubiera designado.

\section{Capítulo III \\ ORGANIZACIÓN Y FUNCIONAMIENTO DEL CONSELLO SOCIAL}

Artículo 13. Estructura interna.

1. El Consello Social se estructura en órganos colegiados y unipersonales.

2. Son órganos colegiados el Pleno y, en su caso, la Comisión Ejecutiva y las demás comisiones que establezca el Reglamento de organización y funcionamiento o que el Pleno acuerde constituir.

3. Son órganos unipersonales la presidencia, la secretaría y, en su caso, una o varias vicepresidencias, de acuerdo con lo que disponga el Reglamento de organización y funcionamiento.

Artículo 14. Pleno.

El Pleno del Consello Social es su máximo órgano de gobierno y está integrado por todos sus miembros.

Ejerce con carácter indelegable la competencia decisoria en las materias a que se refieren los artículos 3.c) y h), 4, salvo las letras a), g), i), 1) y n), y 5, salvo las letras a), h), k) y o), todos ellos de la presente ley, así como las restantes que tenga reconocidas el Consello Social en tanto no se encuentren encomendadas a otros órganos del mismo.

Artículo 15. Periodicidad de las sesiones.

El Pleno del Consello Social se reunirá con carácter ordinario al menos cuatro veces al año, y podrá hacerlo con carácter extraordinario cuando así lo acuerde el Presidente o lo soliciten por escrito seis de sus miembros o el rector de la universidad. En el escrito de solicitud se harán constar, como mínimo, los motivos de la sesión extraordinaria y los asuntos que se deseen incluir en la orden del día, debiendo el Presidente convocar al pleno en el plazo máximo de siete días hábiles desde la recepción de la solicitud.

Artículo 16. Comisiones.

1. El Reglamento de organización y funcionamiento puede contemplar la existencia de una comisión ejecutiva, a la que corresponde la dirección ordinaria del Consello Social, y cuantas comisiones permanentes se juzguen necesarias para el cumplimiento de las funciones del órgano. El reglamento determinará también el procedimiento para la constitución por el Pleno de comisiones temporales.

2. La función de las comisiones consistirá en estudiar, deliberar y proponer al pleno la adopción de decisiones sobre materias que les fueran atribuidas por el Reglamento de organización y funcionamiento o por el acuerdo de constitución. No obstante, gozarán de capacidad decisoria en aquellos asuntos de su competencia que determine expresamente el reglamento o su acuerdo de constitución o bien por delegación del Pleno, en todo caso en materias susceptibles de la misma.

3. El Pleno podrá, en todo momento, reclamar para sí el conocimiento de cualquier asunto que estuviera examinándose en una comisión.

Artículo 17. Presidencia.

1. El Presidente del Consello Social será designado por el Presidente de la Xunta de Galicia, entre personalidades de la vida cultural, profesional, económica, laboral y social no pertenecientes a la comunidad universitaria, a propuesta del conselleiro competente en materia universitaria, previa comunicación al rector de la universidad.

2. Su mandato es de cuatro años, renovable por una sola vez, siéndole de aplicación lo dispuesto en el artículo 10.

3. Ejerce, en el pleno y en todas las comisiones, las competencias propias de 
la presidencia de un órgano colegiado, con voto de calidad en caso de empate, y aquellas que le encomiendan la presente ley, el Reglamento de organización y funcionamiento y la restante normativa vigente.

Artículo 18. Vicepresidencia.

El Reglamento de organización y funcionamiento podrá contemplar la existencia de uno o varios vicepresidentes, designados entre los miembros a que se refiere el artículo 7.3, que, por el orden que se establezca en el mismo, sustituirán al Presidente en caso de vacante, ausencia, enfermedad u otra causa legal. En su defecto, será suplido por el miembro del Consello Social que, al poder ser legalmente Presidente, goce de mayor antigüedad en el órgano. Si existieran dos o más miembros con la misma antigüedad ejercerá las funciones de la presidencia el de mayor edad.

Artículo 19. Secretaría.

1. El secretario del Consello Social será designado y cesado por decisión de su Presidente. Si la designación recayese en una persona que no fuera miembro del Consello Social, actuará con voz pero sin voto.

2. Ejerce, en el Pleno y en todas las comisiones, las competencias propias de la secretaría de un órgano colegiado y aquellas que le encomiendan la presente ley, el Reglamento de organización y funcionamiento del Consello Social y la restante normativa vigente.

Artículo 20. Sesiones.

1. Las sesiones del Pleno y de las comisiones podrán ser ordinarias y extraordinarias. De acuerdo con lo establecido en la presente ley, el Reglamento de organización y funcionamiento determinará el número y periodicidad de las sesiones ordinarias, con un mínimo de cuatro al año, así como los requisitos y procedimiento para la convocatoria de las extraordinarias.

2. El quórum para la válida constitución de los órganos colegiados del Consello Social, así como para la deliberación y adopción de decisiones en su seno, será de la mitad más uno del número de miembros del órgano con derecho a voto.
3. Adoptarán sus decisiones por mayoría simple de votos, salvo en aquellas materias para las cuales el Reglamento de organización y funcionamiento la eleve. El reglamento también establecerá los tipos y formalidades de las votaciones.

No podrá ser objeto de deliberación o decisión asunto alguno que no figure incluido en el orden del día, salvo que estén presentes todos los miembros del órgano colegiado y sea declarada la urgencia del asunto por voto favorable de la mayoría absoluta.

4. La presidencia del Consello Social, a iniciativa propia o, en su caso, a instancia de la Comisión Ejecutiva, puede invitar a asistir a las sesiones de los órganos colegiados, con voz y sin voto, a personas expertas y miembros de la comunidad universitaria, de acuerdo con la naturaleza de los asuntos a tratar.

Podrá también solicitar la comparecencia ante el Pleno o las comisiones de los miembros del Consejo de Dirección de la universidad del personal o alumnado de la misma, o de representantes de cualquier entidad o institución pública o privada.

Artículo 21. Régimen jurídico de las decisiones del Consello Social.

1. Las decisiones que tome el Pleno del Consello Social en materias de su competencia, o las comisiones por delegación del mismo, adoptarán la forma de acuerdos, que agotan la vía administrativa y son impugnables directamente ante la jurisdicción contencioso-administrativa, sin perjuicio de la previa interposición de un recurso potestativo de reposición. No obstante, las tomadas por las comisiones en ejercicio de competencias propias podrán recurrirse en alzada ante el Pleno del consejo en los términos establecidos por la legislación básica del procedimiento administrativo común.

En los demás casos, las decisiones del consejo adoptarán la forma de recomendaciones y no tendrán carácter vinculante.

2. Los acuerdos adoptados por el Consello Social poseen ejecutividad inmediata. 
$\mathrm{Su}$ secretario, con el visto bueno de su Presidente, remitirá inmediatamente una certificación de los acuerdos al rectorado, así como a cuantos órganos, servicios y dependencias de la universidad guarden relación competencial con los asuntos aprobados.

Deberán notificar a los interesados conforme a la normativa vigente y se publicarán en el "Diario Oficial de Galicia" con carácter previo a su entrada en vigor cuando así lo decida el órgano del Consello Social que los aprobara o lo determine el Reglamento de organización y funcionamiento.

3. Aquellos acuerdos del Consello Social, que hayan de serle elevados a los órganos de la Comunidad Autónoma de Galicia, se cursarán a través de la consellería competente en materia universitaria.

Artículo 22. Reglamento de organización y funcionamiento.

1. El Consello Social elaborará, con sujeción a lo dispuesto en la presente ley, y elevará para su publicación en el "Diario Oficial de Galicia” su Reglamento de organización y funcionamiento, que entrará en vigor el día siguiente a la publicación.

Transcurridos tres meses desde la elevación del reglamento sin que recayera resolución expresa, se entenderá aprobado, debiendo proceder el Presidente del Consello Social a su publicación en el "Diario Oficial de Galicia".

Lo dispuesto en los párrafos anteriores se observará también para sus modificaciones.

2. En todo aquello que no esté específicamente regulado en la presente ley y en el Reglamento de organización y funcionamiento será de aplicación la normativa reguladora de los órganos colegiados.

\section{Capitulo IV MEDIOS ECONÓMICOS, MATERIALES Y PERSONALES AL SERVICIO DEL CONSELLO SOCIAL}

Artículo 23. Presupuesto.

El Consello Social elaborará su partida específica, que figurará dentro de los presupuestos de la universidad, y en la misma se garantizará en todo caso la suficiencia de los recursos asignados para el cumplimiento de sus funciones.

Artículo 24. Medios materiales y personales.

El Consello Social se valdrá del personal de administración y servicios adecuado para su funcionamiento, obligándose la universidad a garantizar lo dispuesto en el artículo 14.4 de la Ley Orgánica de Universidades.

\section{DISPOSICIÓN ADICIONAL ÚNICA}

Consejos sociales de universidades de nueva creación.

Lo dispuesto en el apartado primero de las disposiciones transitorias primera y segunda será de aplicación, con las oportunas adaptaciones, a los consejos sociales de universidades de nueva creación, y el plazo de tres meses establecido en la disposición transitoria primera se computará desde la aprobación de los estatutos de la universidad.

\section{DISPOSICIÓN TRANSITORIA PRIMERA DESIGNACIÓN Y NOMBRAMIENTO DE LOS NUEVOS MIEMBROS}

1. En el plazo máximo de tres meses desde la entrada en vigor de la presente ley, las autoridades, entidades e instituciones señaladas en el artículo 7.3 deberán comunicar a la Consellería de Educación y Ordenación Universitaria sus representantes en los consejos sociales, con arreglo a las condiciones previstas en el artículo 7. En el mismo plazo deberán hacerlo también las juntas de gobierno o, en su caso, los consejos de gobierno de las universidades de Santiago de Compostela, A Coruña y Vigo, que designarán de entre sus miembros a sus representantes en el Consello Social, de acuerdo con lo que dispongan sus propios estatutos o, si no estuvieran los mismos adaptados a las previsiones de la Ley Orgánica 6/2001, de 21 de diciembre, de Universidades, mediante 
el procedimiento que apruebe al efecto la respectiva junta o consejo de gobierno.

Recibidas las comunicaciones a que se refieren los párrafos anteriores, se procederá a la renovación de los consejos sociales mediante el nombramiento de sus nuevos miembros, según lo dispuesto en el artículo 7.

2. En tanto no se produzca la renovación de los consejos sociales, continuarán en funciones los actuales miembros.

\section{DISPOSICIÓN TRANSITORIA SEGUNDA APROBACIÓN DE LOS NUEVOS REGLAMENTOS}

1. Los consejos sociales de las universidades de Santiago de Compostela, A Coruña y Vigo, en el plazo máximo de tres meses desde su completa renovación, con arreglo a lo dispuesto en la disposición transitoria primera, elaborarán y elevarán, para su publicación en el "Diario Oficial de Galicia", sus respectivos reglamentos de organización y funcionamiento, de acuerdo con lo establecido en el artículo 21.

2. En tanto no se produzca la aprobación de los nuevos reglamentos, mantendrán su vigencia los actuales en cuanto no se opongan a lo dispuesto en la presente ley.

\section{DISPOSICIÓN DEROGATORIA ÚNICA DEROGACIÓN NORMATIVA}

Quedan derogados el título primero y las disposiciones adicionales, transitoria y finales de la Ley 5/1987, de 27 de mayo, del Consello Social de la Universidad y el Consejo Universitario de Galicia, así como cuantas disposiciones de igual o inferior rango se opongan a lo establecido en la presente ley.

\section{DISPOSICIÓN FINAL PRIMERA HABILITACIÓN NORMATIVA}

El Consello de la Xunta, en el ámbito de sus competencias, podrá dictar las disposiciones necesarias para el desarrollo y ejecución de la presente ley.

\section{DISPOSICIÓN FINAL SEGUNDA ENTRADA EN VIGOR}

La presente ley entrará en vigor el día siguiente a su publicación en el "Diario Oficial de Galicia”.

\section{LEY 7/2001, DE 2 DE JULIO, DE CONTROL EN MATERIA DE CREACIÓN Y RECONOCIMIENTO DE UNIVERSIDADES, CENTROS UNIVERSITARIOS Y AUTORIZACIÓN DE ESTUDIOS EN LA COMUNIDAD AUTÓNOMA DE GALICIA (DOGA N. $\left.{ }^{\circ} 136,13.7 .2001\right)$}

$(\ldots)^{819}$

\section{Capitulo I \\ DISPOSICIONES GENERALES}

Artículo 1. Objeto de la ley.

1. La presente ley tiene por objeto tipificar las infracciones y sanciones en materia de creación y reconocimiento de universidades, centros universitarios y autorización de estudios en la Comunidad Autónoma de Galicia, así como establecer el procedimiento sancionador aplicable.

2. Las infracciones cometidas en este ámbito serán sancionadas en la vía administrativa de acuerdo con las normas del procedimiento sancionador, con sujeción a la presente ley y a las normas reglamentarias que la desarrollen.

3. Cuando los hechos cometidos o la omisión de actos debidos puedan ser constitutivos de ilícito penal, la Consellería de Educación e Ordenación Universitaria los pondrá en conocimiento de las autoridades competentes, absteniéndose de resolver en tanto las mismas no dicten sentencia firme o resolución que ponga fin al procedimiento, sin perjuicio del ejercicio de las acciones civiles que correspondan.

Artículo 2. Sujetos responsables administrativamente.

1. Serán sujetos responsables administrativamente de las infracciones en

819 Exposición de motivos omitida. 
materia de creación y reconocimiento de universidades, centros universitarios y autorización de estudios en la Comunidad Autónoma de Galicia las personas físicas y jurídicas que incurran en las acciones $u$ omisiones tipificadas como infracciones en la presente ley.

2. Cuando el incumplimiento de las obligaciones impuestas por el ordenamiento jurídico así como de las tipificadas como infracciones en la presente ley sea atribuible a varias personas físicas o jurídicas, responderán de forma solidaria de las infracciones que, en su caso, se cometan y de las sanciones que se impongan.

3. Los titulares de empresas o entidades promotoras serán responsables administrativamente de las infracciones cometidas por cualquier persona afecta a las mismas, sin perjuicio de las acciones que pudieran ejercerse en derecho sobre las personas que hayan cometido la infracción para el resarcimiento que corresponda.

4. Quienes ejerzan en la entidad cargos de administración o dirección serán responsables de las infracciones cuando las mismas sean imputables a su conducta dolosa o negligente.

\section{Capitulo II INSPECCIÓN DE ESTUDIOS UNIVERSITARIOS}

Artículo 3. Inspección de estudios universitarios.

1. La Consellería de Educación y Ordenación Universitaria ejercerá la inspección de las universidades, centros universitarios, centros adscritos y centros extranjeros que desarrollen su actividad en el ámbito territorial propio de competencia de la Administración gallega.

2. Al amparo de lo dispuesto en el artículo 20 de la Ley 4/1988, de 26 de mayo, de la función pública de Galicia, dentro del cuerpo superior de la Administración de la Xunta, grupo A, se crea la escala de inspección de estudios universitarios.
3. La escala de inspección de estudios universitarios dependerá funcionalmente de la consellería correspondiente.

4. Las funciones de la escala de inspección serán ejercidas por los inspectores de estudios universitarios.

5. Para el acceso a dicha escala será imprescindible estar en posesión de cualquiera de las titulaciones requeridas para el ingreso en el cuerpo superior de la Administración de la Xunta de Galicia.

6. Los inspectores tienen el carácter de agentes de la autoridad y gozarán como tal de la protección y facultades que a estos efectos les concede la legislación vigente. En el ejercicio de su actividad, estarán dotados de la correspondiente acreditación, que exhibirán en el ejercicio de sus funciones.

7. Los actos o hechos constatados en la inspección se reflejarán en un acta normalizada en el modo que se determine reglamentariamente. Las actas de inspección que levanten tendrán presunción de veracidad, sin perjuicio de prueba en contrario de las admitidas en derecho.

8. Las funciones de la escala de inspección de estudios universitarios serán las siguientes:

a. La comprobación y el control del cumplimiento de las disposiciones y normativa vigente en materia de estudios universitarios.

b. La emisión de los informes técnicos que le solicite la Administración universitaria autonómica.

c. El asesoramiento a la Dirección General de Universidades en las materias relacionadas con el ámbito de la presente ley.

d. Cualesquiera otras funciones que se establezcan por vía reglamentaria.

9. Se desarrollará por decreto la organización y funcionamiento de la escala de inspección de estudios universitarios.

Artículo 4. Obligaciones de los administrados.

1. Las universidades, los representantes o titulares de las empresas o entidades 
promotoras o, en su defecto, sus empleados debidamente autorizados están obligados a facilitar a los funcionarios de la Consellería de Educación y Ordenación Universitaria el acceso a las dependencias e instalaciones de la entidad para el examen de documentos, libros y registros que estén relacionados con su actividad.

2. Si no estuviese presente el titular o representante autorizado, dejarán a la persona que esté presente requerimiento, advirtiendo que en el plazo de veinticuatro horas se procederá a realizar la inspección, que habrá de ser facilitada por cualquier persona relacionada con la entidad presente en ese momento.

3. Están también obligados a facilitar la obtención de copias o reproducciones de la documentación a que hace referencia el apartado 1 de este artículo.

4. Si a requerimiento de la administración se aporta algún documento, éste irá firmado por una persona con facultad de representar a la empresa o entidad promotora.

5. Los estudiantes que se matriculen en estudios autorizados en la Comunidad Autónoma pero no homologados en España firmarán una declaración explícita de conocimiento de esa condición.

\section{Capítulo III \\ DE LA TIPIFICACIÓN Y CALIFICACIÓN DE LAS INFRACCIONES}

Artículo 5. Infracciones.

1. Son infracciones en materia de estudios universitarios las acciones y omisiones tipificadas en la presente ley.

2. Las infracciones administrativas a la normativa en materia de estudios universitarios en la Comunidad Autónoma de Galicia se califican como muy graves, graves y leves, en función de la naturaleza de la contravención, de su trascendencia y repercusión y, en su caso, de la reincidencia en las mismas conductas sancionables.

3. La Consellería de Educación y Ordenación Universitaria, cuando compruebe, en el ejercicio de sus funciones, la existencia de posibles infracciones administrativas en materias competencia de otros órganos administrativos, les dará cuenta de las mismas, a los efectos pertinentes. Igualmente, las posibles infracciones en materia de creación y reconocimiento de universidades, centros universitarios y autorización de estudios en la Comunidad Autónoma de Galicia detectadas por otros órganos de la Xunta de Galicia, actuando en el ámbito de sus competencias, serán comunicadas a la Dirección General de Universidades, la cual actuará en el ámbito de sus competencias.

4. Se desarrollarán por decreto las infracciones contempladas en la presente ley.

Artículo 6. Infracciones muy graves. Tendrán la consideración de infracciones de carácter muy grave:

a. La impartición, sin la preceptiva autorización, de estudios universitarios en la Comunidad Autónoma de Galicia.

b. La puesta en funcionamiento o el cese de las actividades de un centro o universidad sin haber obtenido previamente la autorización administrativa pertinente.

c. La publicidad engañosa respecto a la existencia de autorización para la impartición de estudios universitarios o a las condiciones de la misma.

d. El incumplimiento por parte de las universidades, posteriormente al inicio de sus actividades, de la normativa aplicable.

e. El incumplimiento por parte de los centros extranjeros autorizados de las condiciones generales aplicables.

f. La falta de veracidad en la memoria justificativa de los anexos del Decreto 259/1994 que hubiese sido determinante en la concesión de la autorización.

g. El incumplimiento de los índices de calidad establecidos en el anexo IV del Decreto 259/1994 en lo referente al personal docente y a los espacios docentes e investigadores.

h. Acoger en las instalaciones autorizadas para enseñanzas de distinto nivel estudios de nivel universitario. 
i. Sin perjuicio de las actuaciones que la universidad pública o privada pueda llevar a cabo frente a la entidad que actúa en su nombre sin autorización, dicha actuación podrá ser sancionada por la Administración educativa si resulta incardinada en alguna de las demás conductas tipificadas al no contar con la autorización correspondiente.

j. El impedimento, la obstrucción o la dificultad planteada para el ejercicio de las funciones de inspección y seguimiento por los servicios de inspección de estudios universitarios de la Xunta de Galicia de la actividad de los centros.

k. La reincidencia en las infracciones graves.

1. Las acciones y omisiones contempladas en el apartado siguiente, siempre que el incumplimiento o los perjuicios fuesen muy graves.

Artículo 7. Infracciones graves. Tendrán la consideración de infracciones de carácter grave:

a. La extralimitación de la autorización concedida.

b. El incumplimiento de los índices de calidad establecidos en el anexo IV del Decreto 259/1994 en lo referente al personal de administración y servicios y a los espacios y servicios comunes.

c. La inexistencia de los servicios comunes exigidos en el anexo IV del Decreto 259/1994.

d. La utilización por personas físicas o jurídicas, en el ámbito de la Comunidad Autónoma de Galicia, de denominaciones cuyo significado pueda inducir a confusión con los centros y enseñanzas conducentes a la obtención de títulos universitarios oficiales.

e. La omisión, en la publicidad y en las certificaciones que expida la entidad promotora respecto a estudios no homologados, aunque autorizados y cursados en Galicia, de la indicación de si tienen o no el carácter y la validez oficial que reconoce la Ley Orgánica de Reforma Universitaria.

f. La reincidencia en las infracciones leves.

g. Las acciones y omisiones contempladas en el apartado siguiente, siempre que el incumplimiento o los perjuicios fuesen graves.

Artículo 8. Infracciones leves. Tendrán la consideración de infracciones de carácter leve:

a. La impartición de estudios universitarios sin la autorización que para la puesta en funcionamiento debe expedir la administración, una vez que consten en el expediente todos los informes favorables y estando pendiente de publicación la norma que lo autorice.

b. Cualesquiera otras infracciones en materia de estudios universitarios que no tengan la consideración de graves o muy graves.

\section{Capítulo IV LAS SANCIONES}

Artículo 9. Determinación de las sanciones.

Las infracciones a que se refiere la presente ley darán lugar a la imposición de las sanciones contempladas en este capítulo.

Artículo 10. Sanciones.

1. Las infracciones establecidas en los artículos anteriores serán sancionadas:

a. Las infracciones muy graves, con multa de 25 a 75 millones de pesetas.

b. Las infracciones graves, con multa de 5 a 25 millones de pesetas.

c. Las infracciones leves, con apercibimiento por escrito o multa de hasta 5 millones de pesetas.

2. En cualquier caso, las infracciones graves y muy graves podrán llevar aparejadas como accesorias las siguientes sanciones:

a. El cierre total o parcial de las instalaciones.

b. La revocación de la autorización y/o la suspensión de la actividad cuando la infracción suponga un notorio perjuicio para el sistema universitario de Galicia o daños irreparables a los alumnos. 
c. La inhabilitación total o parcial para el desarrollo de funciones y actividades similares.

3. En caso de infracciones graves y muy graves, independientemente de las sanciones impuestas, el órgano sancionador podrá proponer a la autoridad correspondiente:

a. La inhabilitación de la empresa sancionada para contratar con la Xunta de Galicia.

b. La supresión, cancelación o suspensión total o parcial de las ayudas oficiales, tales como créditos, subvenciones u otras que tuviese reconocidas o que solicitase la empresa sancionada.

4. En su caso, cuando estén en tramitación de la preceptiva normativa, no se considerará sanción el cierre de las instalaciones o la suspensión de la actividad.

Artículo 11. Graduación de la sanción.

1. En la graduación de la sanción se tendrán en cuenta, entre otros, los perjuicios ocasionados a los alumnos, la naturaleza de la infracción y de la disposición infringida, el beneficio ilícito obtenido, la trascendencia social de la infracción, la negligencia, la existencia de intencionalidad, el incumplimiento de los requerimientos efectuados por la administración, la reincidencia y las repercusiones negativas que tuviese para el sistema universitario de Galicia.

2. En ningún caso podrá obtenerse un beneficio derivado de las infracciones contempladas en la presente ley, siendo la sanción, en todo caso, equivalente al menos al beneficio obtenido, con una cuantía máxima no superior a lo dispuesto en el artículo 10 .

3. Las responsabilidades administrativas que se deriven del procedimiento sancionador regulado en la presente ley serán compatibles con la exigencia al infractor de la reposición a su estado originario de la situación alterada por el mismo, así como con la indemnización por los daños y perjuicios causados.

Dicha indemnización se determinará por el órgano competente para la imposición de la sanción, debiendo en este caso comunicárselo al infractor para su satisfacción en el plazo de tres meses. En caso de no realizar el pago, quedará expedita la vía judicial.

4. Se tendrá en cuenta, como atenuante para la fijación de la sanción, que antes de la resolución definitiva del expediente incoado se subsanen satisfactoriamente las actuaciones que han dado lugar al comienzo del mismo.

Artículo 12. Reincidencia.

1. A los efectos de la presente ley, se entiende por reincidencia la comisión de una infracción de idéntica naturaleza, tipificación o calificación a la que motivó la sanción anterior en un plazo de cinco años en caso de las muy graves, de tres años en caso de las graves y de un año en caso de las leves, a contar a partir de la notificación de la misma. En tal supuesto se requerirá que la primera resolución sancionadora hubiese adquirido firmeza en vía administrativa.

2. En los supuestos de reincidencia, podrá elevarse la cuantía de la sanción que resulte hasta el doble de la que corresponda.

Artículo 13. Publicidad de las sanciones.

Las sanciones por cuantía igual o superior a los cinco millones de pesetas, así como aquellas que supongan la clausura de las instalaciones, la revocación de la autorización, cualquier tipo de inhabilitación, la supresión, cancelación o suspensión de ayudas oficiales o la suspensión de la actividad, habrán de ser publicadas en el Diario Oficial de Galicia.

Artículo 14. Prescripción de las infracciones.

1. Las infracciones a que se refiere la presente ley prescribirán: las leves, al año; las graves, a los tres años y las muy graves, a los cinco años.

2. El plazo de prescripción de las infracciones comenzará a contarse desde el día en que la administración tenga conocimiento de las mismas. Este plazo se interrumpirá mediante el inicio, con 
conocimiento del interesado, del procedimiento sancionador.

De la misma forma, se reanudará si el expediente sancionador permaneciese paralizado más de un mes por causa no imputable al infractor.

Artículo 15. Prescripción de las sanciones.

1. Las sanciones que contempla esta ley prescribirán: las impuestas por infracción leve, al año; las impuestas por infracción grave, a los tres años, y las impuestas por infracción muy grave, a los cinco años.

2. El plazo de prescripción de las sanciones empezará a contar desde el día siguiente a aquél en que adquiera firmeza la resolución por la que se impone la sanción. Este plazo se interrumpirá mediante el inicio, con conocimiento del interesado, del procedimiento de ejecución, volviendo a reanudarse si permaneciese paralizado más de un mes por causa no imputable al infractor.

Artículo 16. Concurrencia de infracciones y sanciones.

1. Si en un mismo expediente sancionador concurriesen infracciones de la misma naturaleza, cada una de las mismas podrá ser objeto de la correspondiente sanción.

2. No podrán sancionarse los hechos que hubiesen sido sancionados penal o administrativamente en los casos en que se aprecie identidad del sujeto, hecho y fundamento.

Artículo 17. Recursos.

Contra las resoluciones y demás actos adoptados al amparo de la presente ley podrán interponerse los recursos establecidos en la Ley 30/1992, de 26 de noviembre, de Régimen Jurídico de las Administraciones Públicas y del Procedimiento Administrativo Común.

\section{Capitulo V DEL PROCEDIMIENTO SANCIONADOR}

Artículo 18. Procedimiento sancionador.

1. La tramitación de los expedientes sancionadores se ajustará a lo establecido en la Ley 30/1992, de 26 de noviembre, de Régimen Jurídico de las Administraciones Públicas y del Procedimiento Administrativo Común, y se incoará mediante:

\section{a. Denuncia.}

b. Iniciativa del Director general de Universidades o de los servicios de inspección.

c. Orden superior.

d. Petición razonada de otros órganos.

2. Previamente a la incoación del expediente, cualquiera de los órganos competentes en la iniciación o resolución de los procedimientos podrá ordenar que se efectúen diligencias preliminares o trámites de información reservada para investigar los hechos.

3. En caso de apreciarse una situación de riesgo inminente o perjuicio grave para los usuarios, podrán adoptarse medidas provisionalísimas consistentes en el cierre del centro donde se imparte la docencia o en la suspensión de la actividad ejercida, sin perjuicio de las acciones legales de que puedan ser responsables las personas físicas o jurídicas titulares de las mismas. Una vez tomada una medida provisionalísima por parte de la Administración universitaria, deberá procederse en un plazo de un mes a la iniciación de un procedimiento sancionador. Una vez iniciado el procedimiento, el Director general de Universidades procederá a la confirmación, modificación o levantamiento de estas medidas, sin perjuicio de que puedan ser alzadas o modificadas durante la tramitación del procedimiento en virtud de circunstancias sobrevenidas o que no pudieron ser tenidas en cuenta en el momento de su adopción.

4. Iniciado, en su caso, el oportuno expediente, el Director general de Universidades deberá nombrar a un instructor y secretario, a quien se dará traslado inmediato del expediente.

5. El instructor notificará al interesado la apertura del procedimiento sancionador, acompañando copia del expediente con el nombramiento de instructor y secretario. 
6. El instructor ordenará y efectuará las pruebas y actuaciones que sean necesarias para aclarar totalmente los hechos y determinar posibles responsabilidades administrativas. La fase probatoria será oral o escrita, según determine el instructor, para la mejor y más ágil resolución del expediente.

a. En caso de vista oral, en la misma notificación se comunicará a los interesados la fecha de su celebración, que será dentro del plazo de diez días hábiles a partir de la notificación.

b. En caso de procedimiento escrito, en la misma notificación se dará al interesado un plazo de diez días hábiles para que presente las alegaciones que estime oportunas.

7. El interesado, en el procedimiento, podrá proponer la prueba de que intente valerse para la defensa de su derecho. En todo caso, la administración apreciará la prueba realizada en el expediente sancionador y valorará el resultado de la misma en su conjunto.

8. A la vista de lo actuado, el instructor formulará el oportuno pliego de cargos, que será notificado al inculpado para que, en el término de diez días desde su recepción, formule las alegaciones que estime pertinentes.

Transcurrido ese plazo, haya o no alegaciones, el instructor remitirá la propuesta de resolución definitiva a quien competa la sanción en función de su cuantía para que resuelva de forma inmediata.

9. Si presumiese que los hechos investigados pudieran constituir delito, se dará cuenta a la autoridad judicial, suspendiendo las actuaciones hasta que exista resolución judicial, sin perjuicio de adoptar las medidas cautelares oportunas.

Artículo 19. Órganos competentes para la imposición de las sanciones.

1. La competencia para la clausura de las instalaciones y la revocación de la autorización corresponde al Consello de la Xunta de Galicia, a propuesta del Conselleiro de Educación y Ordenación Universitaria.
2. La competencia para suspender la actividad corresponde al Conselleiro de Educación y Ordenación Universitaria, a propuesta del Director general de Universidades.

3. La competencia para la imposición de la sanción en caso de una infracción muy grave corresponde al Conselleiro de Educación y Ordenación Universitaria.

4. La competencia para la imposición de la sanción en caso de una infracción leve o grave corresponde al Director general de Universidades.

Artículo 20. Multas coercitivas.

1. La ejecución de las resoluciones recaídas en los expedientes sancionadores podrá realizarse mediante la aplicación de las medidas de ejecución subsidiaria establecidas en la Ley 30/1992, de 26 de noviembre, de Régimen Jurídico de las Administraciones Públicas y del Procedimiento Administrativo Común, sin perjuicio de lo dispuesto en este artículo.

2. Los órganos competentes para la imposición de las sanciones establecidas en la presente ley podrán imponer multas coercitivas, de un $10 \%$ más sobre la cuantía de la sanción, por cada día que pase sin atender a la comunicación cuando la misma se refiere al cese de la actividad infractora.

3. Las multas coercitivas serán independientes de las sanciones que puedan imponerse como consecuencia de un expediente sancionador y compatibles con las mismas.

Artículo 21. Caducidad del procedimiento.

El procedimiento sancionador caducará a los tres meses de su paralización, entendiéndose que así ocurre cuando no se hubiese llevado a cabo en este plazo ninguna notificación de actuación o diligencia, sin perjuicio de que el instructor del expediente pueda acordar un plazo mayor, mediante resolución debidamente motivada y notificada al interesado, cuando la naturaleza o circunstancias de la actuación o diligencia en curso lo justifique. 


\section{DISPOSICIÓN FINAL PRIMERA}

Se faculta al Consello de la Xunta de Galicia para que mediante decreto actualice las cuantías de las sanciones contempladas en la presente ley. La elevación porcentual nunca podrá superar la experimentada por el índice general de precios al consumo en la Comunidad Autónoma de Galicia.

\section{DISPOSICIÓN FINAL SEGUNDA}

Se faculta al Consello de la Xunta de Galicia para dictar las disposiciones que resulten necesarias para la aplicación, desarrollo y ejecución de la presente ley.

\section{DISPOSICIÓN FINAL TERCERA}

La presente ley entrará en vigor el día siguiente al de su publicación en el "Diario Oficial de Galicia”.

\section{LEY 2/2003, DE 22 DE MAYO, DEL CONSELLO GALEGO DE UNIVERSIDADES DOGA N. $\left.{ }^{\circ} 106,3.6 .2003\right)$} (...) ${ }^{820}$

\section{Capítulo preliminar COORDINACIÓN UNIVERSITARIA Y SUS FINES}

Artículo 1. Objeto y marco normativo de la ley.

La presente ley tiene por objeto el desarrollo de las funciones de coordinación universitaria que corresponden a la Comunidad Autónoma de Galicia respecto a las universidades públicas y privadas de su competencia, en el marco establecido por el artículo 27.10.o de la Constitución, el artículo 31 del Estatuto de autonomía de Galicia, la Ley Orgánica 6/2001, de 21 de diciembre, de universidades, sus disposiciones de desarrollo y las competencias que corresponden al Consello de Coordinación Universitaria, así como

820 Exposición de motivos omitida. a los demás órganos de la universidad, en virtud de la autonomía de la misma.

Artículo 2. Coordinación y cooperación interuniversitaria.

1. Las tareas de coordinación de las universidades, comprendidas en el artículo anterior, corresponden a la consellería competente en materia universitaria, la cual contará, para su desarrollo, con el asesoramiento institucional del Consello Galego de Universidades.

2. A fin de facilitar el cumplimiento de dichas tareas, las instituciones universitarias deberán facilitarse entre sí cuanta información precisen para el desarrollo de sus respectivas competencias, así como proporcionársela también a la consellería competente en materia universitaria en el ejercicio de las suyas propias.

Artículo 3. Fines de la coordinación universitaria.

La coordinación universitaria persigue las finalidades siguientes:

a. La planificación universitaria en la Comunidad Autónoma de Galicia, orientada a la mejora de la calidad de la docencia, investigación y gestión universitarias, con pleno respeto a la autonomía universitaria.

b. El conocimiento mutuo, consultas recíprocas e intercambio de información entre las universidades gallegas en todas las esferas de su actividad, así como entre las mismas y la Xunta de Galicia a través de la consellería competente en materia universitaria, en especial con relación a aquellas intervenciones que hayan de acometerse conjuntamente o afecten a más de una universidad.

c. La fijación de directrices y criterios comunes respecto a:

La creación y reconocimiento de nuevas universidades. La creación, adscripción, desadscripción, modificación o supresión de centros universitarios e institutos universitarios de investigación. La implantación y supresión de enseñanzas conducentes a 
la obtención de títulos universitarios de carácter oficial y validez en todo el territorio estatal. El estatuto de su personal contratado y la asignación de retribuciones adicionales al personal docente e investigador de las mismas. Los precios de las enseñanzas propias y estudios oficiales. La política de becas, ayudas y créditos para el estudio y la investigación. En general, cuantas materias sean de interés común de las universidades.

d. La promoción y realización de actividades y estudios conjuntos en el ámbito de la docencia, el estudio, la investigación, la gestión y la extensión universitarias.

e. El establecimiento y seguimiento de programas conjuntos de actuación en alguno de los ámbitos señalados en la letra anterior.

f. La promoción de la cooperación entre las universidades gallegas, las restantes administraciones públicas y otras instituciones universitarias estatales o extranjeras para la ejecución de proyectos de interés general, intercambios de personal y puesta en común de recursos para emprender acciones conjuntas en los ámbitos ya señalados.

\section{Capitulo I \\ DEFINICIÓN, ADSCRIPCIÓN Y COMPETENCIAS DEL CONSELLO GALEGO DE UNIVERSIDADES}

Artículo 4. Definición y adscripción del Consello Galego de Universidades.

1. El Consello Galego de Universidades es el órgano colegiado de consulta y asesoramiento de la consellería competente en materia universitaria para el desarrollo de la política de coordinación y planificación del sistema universitario de Galicia.

2. Este consejo estará adscrito orgánicamente a esa consellería, la cual sufragará los costes derivados de su funcionamiento con cargo a sus presupuestos.
Artículo 5. Competencias del Conse1lo Galego de Universidades.

Corresponden al Consello Galego de Universidades las competencias siguientes:

a. Asesorar al conselleiro competente en materia universitaria en aquellas cuestiones que decida someter a su consideración, formulándole cuantas recomendaciones considere oportunas para el desarrollo de la política universitaria y del sistema universitario de Galicia.

b. Conocer e informar sobre los proyectos de disposiciones normativas en materia universitaria, así como sobre la programación y financiación por la Xunta de Galicia de las universidades de competencia autonómica.

c. Facilitar el conocimiento mutuo, las consultas recíprocas y el intercambio de información entre las universidades gallegas en todas sus esferas de actividad, así como entre las mismas y la Xunta de Galicia, en especial con relación a aquellas intervenciones que hayan de acometerse conjuntamente o afecten a más de una universidad.

d. Realizar estudios y programas conjuntos de actuación, estudios sobre materias de su competencia y, en particular, sobre las necesidades y problemas del sistema universitario de Galicia.

e. Informar sobre las propuestas de creación de universidades públicas y de reconocimiento de universidades privadas en el territorio de la Comunidad Autónoma de Galicia.

f. Informar sobre las propuestas de creación, modificación o supresión de facultades, escuelas técnicas o politécnicas superiores y escuelas universitarias o escuelas universitarias politécnicas.

g. Informar sobre las propuestas de convenios de adscripción o convenios o acuerdos de desadscripción a la universidad de centros docentes para impartir estudios conducentes a la obtención de 
títulos de carácter oficial y validez en todo el territorio estatal.

h. Informar sobre las propuestas de creación o supresión de institutos universitarios de investigación.

i. Informar sobre las propuestas de convenios de adscripción o convenios o acuerdos de desadscripción a las universidades, tanto de instituciones o centros de investigación como de institutos universitarios de investigación.

j. Informar sobre las propuestas de implantación y supresión de enseñanzas conducentes a la obtención de títulos universitarios de carácter oficial y validez en todo el territorio nacional.

k. Conocer los nuevos planes de estudios de las enseñanzas impartidas por las universidades gallegas así como las modificaciones de los mismos, una vez homologados por el Consello de Coordinación Universitaria.

1. Informar sobre las propuestas de organización conjunta de estudios entre universidades.

m. Informar sobre las propuestas de creación, modificación o supresión en el extranjero de centros dependientes de una universidad gallega para la impartición de enseñanzas conducentes a la obtención de títulos de carácter oficial y validez en todo el territorio estatal, así como sobre las de impartición en centros ubicados en el territorio de la Comunidad Autónoma de Galicia de enseñanzas conducentes a la obtención de títulos extranjeros de educación superior universitaria.

n. Informar sobre los convenios de colaboración en materia universitaria con otras Comunidades Autónomas y regiones o países extranjeros.

ñ. Promover la cooperación entre las universidades gallegas, las restantes administraciones públicas y otras instituciones universitarias estatales o extranjeras para la organización conjunta de actividades y enseñanzas, especialmente en el ámbito del tercer ciclo y doctorado o conducentes a la obtención de diplomas y títulos propios de las universidades.

o. Informar sobre las propuestas de evaluaciones y mejora de la calidad de los servicios universitarios.

p. Informar sobre los procedimientos para la admisión de estudiantes que establezcan las universidades.

q. Informar sobre las normas que regulen el progreso y la permanencia de los estudiantes en las universidades.

r. Informar sobre la racionalización de las enseñanzas, servicios y actividades universitarias existentes en Galicia, especialmente mediante el intercambio de personal, instrumentos e infraestructuras de investigación existentes o de futura adquisición, fondos bibliográficos y datos informáticos.

s. Informar sobre los precios públicos de las enseñanzas propias y estudios oficiales.

t. Informar sobre los criterios y directrices de becas, ayudas y créditos para el estudio y la investigación.

u. Informar sobre el Plan gallego de I+D.

v. Informar sobre la memoria anual presentada por las universidades gallegas.

Artículo 6. Relaciones de cooperación. En desarrollo de sus competencias, el Consello Galego de Universidades, a través de su Presidente, podrá requerir la colaboración de personas físicas y jurídicas así como solicitar la información que precise de todos los órganos de la universidad y de la Agencia para la Calidad del Sistema Universitario de Galicia.

\section{Capitulo II \\ MIEMBROS DEL CONSELLO GALEGO DE UNIVERSIDADES}

Artículo 7. Composición del Consello Galego de Universidades.

1. El Consello Galego de Universidades está integrado por los siguientes miembros:

a. El Conselleiro competente en materia universitaria.

b. El Director general competente en materia universitaria. 
c. El Secretario general, o Director general, competente en materia de investigación y desarrollo.

d. Los Rectores de las universidades, comprendidas en el artículo 1.

e. Los Presidentes de los consejos sociales de las universidades, comprendidas en el artículo 1.

f. Cinco miembros designados por la comisión del Parlamento de Galicia competente en materia universitaria, en proporción a su representación en el Pleno del Parlamento.

g. La persona que ocupe la dirección de la Agencia para la Calidad del Sistema Universitario de Galicia.

2. El nombramiento y cese en los cargos a que se refieren las letras a), b), c), d) y e) del apartado anterior determinará automáticamente la adquisición y pérdida de la condición de miembro del Consello Galego de Universidades.

Los acuerdos de designación de los miembros elegidos por el Parlamento de Galicia serán comunicados inmediatamente al conselleiro competente en materia universitaria, quien procederá a nombrarlos mediante orden de su consellería, que se publicará en el "Diario Oficial de Galicia" y surtirá efectos a partir de esta fecha.

Artículo 8. Estatuto jurídico de sus miembros.

1. La duración del mandato de los miembros del Consello Galego de Universidades de designación parlamentaria será de cuatro años, y permanecerán en funciones desde la expiración de dicho período hasta la toma de posesión de los nuevos miembros.

2. Cesarán por renuncia, incapacidad declarada por resolución judicial firme, muerte o declaración de fallecimiento o condena judicial firme que comporte la inhabilitación o suspensión de empleo o cargo público. La renuncia habrá de presentarse por escrito al Presidente de la comisión parlamentaria competente en materia universitaria, quien se la comunicará inmediatamente al conselleiro competente en materia universitaria para su publicación en el "Diario Oficial de Galicia", y surtiendo efectos a partir de esta fecha.

Las vacantes que se produzcan entre los miembros elegidos por el Parlamento antes de la finalización de su mandato habrán de cubrirse por el mismo procedimiento empleado para su designación en el plazo máximo de tres meses, y se entenderá nombrado el miembro sustituto por el período que reste del anterior mandato, sin perjuicio de lo dispuesto en el párrafo anterior.

3. Los miembros del Consello Galego de Universidades percibirán únicamente las indemnizaciones que, de acuerdo con la legislación vigente, les correspondan por razón de servicio.

\section{Capítulo III ORGANIZACIÓN Y \\ FUNCIONAMIENTO DEL CONSELLO GALEGO DE UNIVERSIDADES}

Artículo 9. Estructura interna.

1. El Consello Galego de Universidades se estructura en órganos colegiados y unipersonales.

2. Son órganos colegiados el Pleno, la Comisión de Titulaciones y Centros, la Comisión de Financiación e Inversiones y las demás comisiones que el Pleno acuerde constituir.

3. Son órganos unipersonales la presidencia, la vicepresidencia y la secretaría.

Artículo 10. Pleno.

1. El Pleno del Consello Galego de Universidades, integrado por todos sus miembros, ejerce las competencias que le atribuye el reglamento interno y las restantes que tenga reconocidas el Consejo, en tanto no estén encomendadas a otros órganos del mismo.

2. Se reunirá con carácter ordinario al menos una vez por trimestre, y podrá hacerlo con carácter extraordinario cuando así lo acuerde el Presidente o lo soliciten por escrito la mayoría de sus miembros. En el escrito de solicitud habrán de constar los 
motivos de la sesión extraordinaria y los asuntos que se deseen incluir en el orden del día, debiendo el Presidente convocar a Pleno en el plazo máximo de catorce días hábiles desde la recepción de la solicitud.

3. Podrán ser incluidos puntos en el orden del día de las sesiones ordinarias del Pleno del Consejo previa de petición de una cuarta parte de sus miembros.

Artículo 11. Comisiones.

1. El Pleno designará de entre sus miembros a los integrantes de la Comisión de Titulaciones y Centros y de la Comisión de Financiación e Inversiones, en las cuales estarán representados adecuadamente los miembros de designación administrativa, universitaria y parlamentaria. En todo caso, los rectores formarán parte de la primera de las mismas y los Presidentes de los consejos sociales de la segunda.

El reglamento interno podrá contemplar cuantas comisiones permanentes se juzguen necesarias para el desarrollo de las competencias del órgano y determinará el procedimiento para la constitución por el Pleno de comisiones temporales.

2. La función de las comisiones consistirá en estudiar, deliberar y proponer al Pleno la adopción de acuerdos sobre materias que les fueran atribuidas por el reglamento interno o el acuerdo de constitución.

\section{Artículo 12. Presidencia.}

1. El Presidente del Consello Galego de Universidades es el conselleiro competente en materia universitaria.

2. Ejerce, en el pleno y en todas las comisiones, las competencias propias de la presidencia de un órgano colegiado, con voto de calidad en caso de empate, y aquéllas que le encomiendan la presente ley, el reglamento interno y la restante normativa vigente.

Artículo 13. Vicepresidencia.

El Vicepresidente es el Director general competente en materia universitaria, quien sustituirá al Presidente por delegación expresa del mismo, así como en caso de vacante, ausencia, enfermedad u otra causa legal.

\section{Artículo 14. Secretaría.}

1. El secretario del Consello Galego de Universidades será designado y cesado por su Presidente entre funcionarios del grupo A. Si la designación recayese en una persona que no fuera miembro del Consello Galego de Universidades, actuará con voz y $\sin$ voto.

2. Ejerce, en el Pleno y en todas las comisiones, las competencias propias de la secretaría de un órgano colegiado y aquéllas que le encomiende el reglamento interno y la restante normativa vigente.

En el ejercicio de sus funciones, así como para la guarda y custodia de la documentación, la secretaría podrá contar con un órgano de apoyo.

\section{Artículo 15. Sesiones.}

1. Las sesiones del Pleno y de las comisiones no serán públicas, pudiendo ser ordinarias y extraordinarias.

De acuerdo con lo establecido en la presente ley, el reglamento interno determinará el número y periodicidad de las sesiones ordinarias y requisitos y procedimiento para la convocatoria de las extraordinarias.

2. El quórum para la válida constitución de los órganos colegiados del Consello Galego de Universidades, así como para la deliberación y adopción de decisiones en su seno, será de la mitad más uno del número de miembros del órgano con derecho a voto, debiendo encontrarse entre ellos el Presidente y el secretario, o quienes los sustituyan.

No podrá ser objeto de deliberación o decisión asunto alguno que no figure incluido en el orden del día, salvo que estén presentes todos los miembros del órgano colegiado y sea declarada la urgencia del asunto por el voto favorable de la mayoría absoluta.

3. Las decisiones se adoptarán por mayoría simple de votos, salvo en aquellas materias para las que el reglamento interno 
la eleve. Los rectores de las universidades privadas solamente tendrán derecho de voto en asuntos que específicamente afecten a las mismas.

El reglamento también establecerá los tipos y formalidades de las votaciones.

4. La presidencia del Consello Galego de Universidades puede invitar a asistir a las sesiones de los órganos colegiados, con voz y sin voto, a personas expertas, miembros de las comunidades universitarias y representantes de cualquier entidad o institución pública o privada, de acuerdo con la naturaleza de los asuntos a tratar.

Artículo 16. Carácter de los acuerdos. Los acuerdos que adopten los órganos del Consello Galego de Universidades no tendrán carácter vinculante, dada su naturaleza consultiva y de asesoramiento. El Consejo deberá ser informado de las disposiciones y resoluciones relativas a los asuntos que hubiera informado o hubiera conocido previamente.

Artículo 17. Reglamento interno.

1. El Consello Galego de Universidades elaborará, con arreglo a lo dispuesto en la presente ley, y elevará para su aprobación por la Xunta de Galicia su reglamento interno.

Lo dispuesto en el párrafo anterior se observará también para las modificaciones del mismo.

2. En todo aquello que no esté específicamente regulado en la presente ley y en el reglamento interno será de aplicación la normativa reguladora de los órganos colegiados de las administraciones públicas.

\section{DISPOSICIÓN TRANSITORIA PRIMERA CONSTITUCIÓN DEL CONSELLO GALEGO DE UNIVERSIDADES}

1. En el plazo máximo de tres meses desde la entrada en vigor de la presente ley, se procederá a la constitución del Consello Galego de Universidades conforme a lo establecido en la presente ley.
2. El actual Consello Universitario de Galicia continuará con sus funciones mientras no se cumpla lo previsto en el párrafo anterior.

\section{DISPOSICIÓN TRANSITORIA SEGUNDA APROBACIÓN DEL REGLAMENTO INTERNO}

El Consello Galego de Universidades, en el plazo máximo de tres meses desde su constitución, elaborará y elevará para su aprobación su reglamento interno, de acuerdo con lo establecido en el artículo 17.

\section{DISPOSICIÓN DEROGATORIA ÚNICA DEROGACIÓN NORMATIVA}

Queda derogado el título segundo de la Ley 5/1987, de 27 de mayo, del Consello Social de la Universidad y el Consello Universitario de Galicia, el Decreto 240/1992, de 30 de julio, por el que se aprueba el Reglamento del Consello Universitario de Galicia, así como cuantas disposiciones de igual o inferior rango se opongan a lo establecido en la presente ley.

\section{DISPOSICIÓN FINAL PRIMERA TÍTULO COMPETENCIAL}

La presente ley se aprueba en desarrollo de la competencia plena que posee la Comunidad Autónoma de Galicia para la regulación y administración de la enseñanza en toda su extensión, niveles y grados, modalidades y especialidades, y de lo establecido en el artículo 2.5.o de la Ley Orgánica 6/2001, de 21 de diciembre, de Universidades, que asigna a las Comunidades Autónomas las tareas de coordinación de las universidades de su competencia.

\section{DISPOSICIÓN FINAL SEGUNDA HABILITACIÓN NORMATIVA}

Se autoriza a la Xunta de Galicia a dictar las disposiciones que resulten necesarias para la aplicación, desarrollo y ejecución de la presente ley. 


\section{LEY 11/1989, DE 20 DE JULIO, DE ORDENACIÓN DEL SISTEMA UNIVERSITARIO DE GALICIA (DOGA N. ${ }^{\circ} 156,16.8 .1989$ )}

$(\ldots)^{821}$

Artículo 1. 1. La presente ley desarrolla el Sistema Universitario de Galicia.

2. Es objeto de esta ley establecer las bases de ordenación territorial, funcional y financiera del Sistema Univesitario de Galicia, así como los criterios para la implantación de nuevas titulaciones y la creación de los correspondiente centros, teniendo en cuenta las características y exigencias demográficas, cientifico-educativas, socioeconómicas y socioculturales de la sociedad gallega.

Artículo 2. Dentro de los objetivos y finalidades propios del Sistema Universitario de Galicia, se tendrá especialmente en cuenta:

1. La formación y capacitación de ciudadanos en el plano cientifico-técnico y en el correlativo plano profesional.

2. El favorecer una movilidad social ascendente en el seno de la sociedad gallega.

3. La creación y difusión de la innovación científica y técnica ${ }^{82}$.

4. La irradiación de la cultura y la promoción del desarrollo cultural de Galicia a través de la dimensión universitaria.

5. La promoción del gallego, lengua propia de Galicia, como idioma vehicular en la enseñanza superior, la investigación científica y la creatividad artística y cultural.

Artículo 3. 1. Se crean por esta ley la Universidad de Vigo y la Universidad de A Coruña.

2. El Sistema Universitario de Galicia estará constituido por la Universidad de Santiago de Compostela, la Universidad de A Coruña y la Universidad de Vigo.

821 Exposición de motivos omitida.

822 Véase Decreto 185/2008, de 31 de julio, por el que se crea el Observatorio de Ciencia y Tecnologia Universitario de Galicia (0ctuga) y se determinan sus funciones, composición y funcionamiento.
3. Se encomienda a las tres universidades el servicio público de la enseñanza superior en Galicia, mediante el ejercicio de la docencia, el estudio, la investigación y la creación de conocimiento.

Artículo 4. Cada Universidad goza de personalidad jurídica y patrimonio propio, rigiéndose por la presente ley, por la legislación autonómica y estatal aplicable y por sus respectivos estatutos.

Artículo 5. La Universidad de Santiago de Compostela, ciudad donde seguirá radicando su sede, contará además con el campus de Lugo. La Universidad de Vigo tendrá su sede en esta ciudad, incluyendo los campus de Pontevedra y de Ourense. La Universidad de A Coruña tendrá su sede en la ciudad del mismo nombre, integrándose en ella el campus de Ferrol.

Artículo 6. Cada campus habrá de tener o, en otro caso, ser dotado de un mínimo de dos centros con rango de facultad o escuela técnica superior.

Se estructurará a su vez internamente teniendo en cuenta el criterio de complementariedad interdisciplinar dentro de cada gran área de conocimiento científico y técnico.

Cada campus contará con unos mínimos cualitativos y cuantitativos en dotación docente, de administración y servicios, de infraestructura en edificios y de equipamiento en servicios complementarios a la docencia e investigación y en servicios comunitarios.

Artículo 7. Sin perjuicio de los nuevos centros que pueden crearse, las nuevas universidades contarán inicialmente con aquellos en donde se ubican en la actualidad las facultades, escuelas técnicas superiores, colegios universitarios, escuelas universitarias, así como las instalaciones complementarias situadas en los campus de A Coruña, Ferrol, Vigo, Pontevedra y Ourense, pertenecientes a la Universidad de Santiago, segregándose de la misma. 
Artículo 8. El repertorio de titulaciones del Sistema Universitario de Galicia atenderá al principio de complitud, en cuya virtud debe tender a abarcar e incorporar la totalidad del repertorio de titulaciones existentes, por área de conocimiento, en el estado actual de la ciencia y la técnica.

Sólo excepcionalmente se podrá dejar de aplicar ese principio, de forma individualizada, en atención a la desmesurada distorsión que implique en la asignación de los recursos humanos y financieros $\mathrm{u}$ obstáculos insolubres para su cobertura con el nivel de calidad cientifico-docente razonablemente exigible ${ }^{823}$.

Artículo 9. La creación y localización de nuevas titulaciones y centros y, en definitiva, la ordenación del Sistema Universitario de Galicia, seguirá una programación que atienda a la demanda universitaria y la disponibilidad de los recursos económicos y docentes necesarios, ajustándose a los siguientes criterios.

a. Cubrir las necesidades de titulados para el desarrollo económico, cultural, científico y técnico de Galicia.

b. Acercar la oferta a la demanda y a las previsiones de puestos de trabajo.

c. Subsanar los desequilibrios existentes en los actuales campus.

d. Alcanzar la especialización de los campus, aunque manteniendo la coexistencia de enseñanzas técnicas y de humanidades.

e. Evitar la multiplicidad de titulaciones en la Comunidad Autónoma, salvo cuando coincidan la demanda real de estudiantes y la necesidad social de titulados.

823 Véase:

- Decreto 259/1994, de 29 de julio, por el que se establece el procedimiento para la creación y reconocimiento de universidades, centros universitarios y autorización de estudios en la Comunidad Autónoma de Galicia.

- Resolución de 7 de julio de 2006, de la Dirección General de Ordenación y Calidad del Sistema Universitario de Galicia, por la que se dispone la publicación de instrucciones sobre el procedimiento de autorización para la implantación de estudios universitarios oficiales de postgrado conducentes al titulo de máster y doctor. f. Agrupar las titulaciones por grandes áreas científicas para favorecer la consolidación de unidades departamentales y lograr un más fácil aprovechamiento de los recursos infraestructurales y la generación de sólidas líneas de investigación.

g. Transformar positivamente los actuales colegios universitarios, incardinando este proceso en la expansión general de la oferta.

Artículo 10. Los estudiantes podrán acceder a cualquiera de las universidades de la Comunidad Autónoma, siempre que reúnan los requisitos académicos necesarios, aplicándose el procedimiento conocido como distrito único.

Artículo 11. 1. La coordinación y planificación del Sistema Universitario de Galicia, constituido por las tres universidades, corresponderá a la Consellería de Educación y Ordenación Universitaria. A estos efectos, habrá de contar con el Consello Universitario de Galicia como órgano de asesoramiento y consulta, según lo dispuesto en el artículo 10 de la Ley 5/1987, de 27 de mayo.

2. $(\ldots)^{824}$

Serán funciones del Consello Universitario Galego las siguientes:

a. Facilitar el intercambio de información y las consultas recíprocas entre las universidades de Galicia sobre todas sus áreas de actividad.

b. Elaborar programas conjuntos de actuación que conciernan a problemas y necesidades del Sistema Universitario de Galicia y potenciar equipos interuniversitarios para desempeñar esta labor.

c. Informar las propuestas de creación de nuevas universidades y de creación, modificación o supresión de centros, titulaciones universitarias e institutos de investigación.

d. Conocer los nuevos planes de estudios de las diferentes titulaciones y enseñanzas impartidas por las universidades y sus modificaciones.

824 El Art. 11.2 contiene modificaciones a la Ley 5/1987, de 27 de mayo. 
e. Proponer la organización conjunta de estudios entre las universidades, especialmente en lo que se refiere a terceros ciclos, estudios de postgrado y titulaciones que no tengan carácter oficial en el Estado.

f. Informar las normas de acceso y permanencia de los alumnos en las universidades y las relativas a las responsabilidades de los estudiantes en lo que se refiere al cumplimiento de las obligaciones académicas.

g. Conocer las solicitudes de las subvenciones globales ordinarias y extraordinarias que forman parte de los ingresos en los presupuestos de las universidades e informar los programas de inversiones en el sistema universitario de Galicia hechos directamente por la Comunidad Autónoma.

h. Garantizar la racionalización de los estudios, servicios y actividades universitarias existentes en Galicia, especialmente en lo referente al intercambio flexible del profesorado, infraestructura de investigación existente o de futura adquisición, intercambio de los fondos bibliográficos y de datos informáticos, creación de servicios conjuntos de publicaciones universitarias y otras de interés común.

i. Elaborar programas de extensión universitaria, así como de formación y actualización del profesorado.

j. Asesorar a la Consellería de Educación e Ordenación Universitaria en todas las cuestiones que le sean requeridas.

\section{DISPOSICIÓN ADICIONAL PRIMERA}

La Xunta de Galicia dictará las oportunas disposiciones para la segregación de los centros de la Universidad de Santiago a los que se refiere el artículo 7 y la correspondiente integración de los mismos en las nuevas universidades.

Esta segregación, que se establecerá mediante un Decreto de la Xunta de Galicia, previos los trámites oportunos ante el Consello Social de la Universidad de Santiago, tendrá lugar con todos sus medios materiales y humanos. En particular, el personal a ellos adscrito pasará a prestar servicio en la universidad en la que tales centros se integren, respetándosele los derechos que posea en el momento de la segregación.

El equipamiento y pleno desarrollo de las actividades docentes y de investigación de los centros segregados se hará con cargo al plan de financiación de las universidades contemplado en la Disposición adicional cuarta de esta ley.

\section{DISPOSICIÓN ADICIONAL SEGUNDA}

Las nuevas universidades darán comienzo a sus actividades académicas después de producirse la integración efectiva de los centros segregados de la Universidad de Santiago, o la creación de otros nuevos en su caso, y la constitución de los órganos de Gobierno previstos en la disposición transitoria primera.

\section{DISPOSICIÓN ADICIONAL TERCERA}

La Xunta de Galicia, previa aprobación del Plan de financiación de las universidades al que se hace referencia en la disposición adicional cuarta, adoptará las medidas oportunas para la extinción de los colegios universitarios y su transformación en facultades, escuelas técnicas superiores, escuelas universitarias u otros centros de enseñanza superior.

\section{DISPOSICIÓN ADICIONAL CUARTA}

1. La Xunta de Galicia habrá de presentar al parlamento el Plan de financiación de las universidades de Galicia, en el que figurarán, como mínimo, los siguientes aspectos:

a. Transferencias corrientes a las universidades.

b. Inversiones reales previstas para la construcción de nuevos centros, institutos de investigación, bibliotecas, residencias y otras instalaciones y servicios. 
c. Gastos correspondientes a la dotación y formación del profesorado.

d. Las transferencias de capital para gastos de investigación, de acuerdo con lo previsto en la Ley 8/1988, de 18 de julio, del Plan General de Investigación Científica y Técnica de Galicia.

e. Gastos de becas para estudiantes.

2. Los presupuestos de la Comunidad Autónoma para el período 1990/96 contemplarán los gastos previstos en el plan.

3. Se autoriza al Gobierno gallego a asumir los créditos o emitir deuda pública precisos para garantizar el cumplimiento del plan.

\section{DISPOSICIÓN TRANSITORIA PRIMERA}

Se crean los siguientes órganos en las nuevas universidades para el desarrollo de las funciones de gobierno y administración necesarias para el comienzo de sus actividades:

a. La Comisión de Gobierno, a la que corresponderán las funciones organizativas y de gobierno en el ámbito académico. Estará compuesta por cinco miembros, nombrados por la Consellería de Educación e Ordenación Universitaria, debiendo tener cuatro de ellos la condición de profesor numerario de la universidad, con destino actual en alguno de los centros radicados en el área territorial correspondiente a la nueva universidad. El quinto miembro será el gerente de la universidad, que habrá de tener la condición de funcionario.

La Xunta de Galicia, a propuesta del Conselleiro de Educación e Ordenación Universitaria, nombrará al Rector de la Universidad, que presidirá la Comisión de Gobierno. La citada Comisión se estructurará funcionalmente en dos vicerrectores, un secretario general y el gerente.

b. El Consello Económico, que desempeñará las funciones de carácter económico y financiero atribuidas por la legislación vigente al Consello Social. Estará compuesto por seis miembros, siendo su Presidente y dos de los mismos nombrados por la Xunta de Galicia, dos por el Parlamento de Galicia y uno por la respectiva Comisión de Gobierno.

\section{DISPOSICIÓN TRANSITORIA SEGUNDA}

En el plazo máximo de tres meses, a partir de la entrada en vigor de la presente ley, la Xunta de Galicia procederá a la designación de los rectores y de los miembros de las Comisiones de Gobierno de las nuevas universidades. En el mismo plazo adoptará las medidas necesarias para la constitución de los respectivos Consellos Económicos.

\section{DISPOSICIÓN TRANSITORIA TERCERA}

El Consello Universitario habrá de constituirse en el plazo de seis meses, a partir de la entrada en vigor de la presente ley. Los Presidentes de los Consellos Económicos ocuparán el lugar previsto en la Ley 5/1987, de 27 de mayo, para los Presidentes de los Consejos Sociales.

\section{DISPOSICIÓN TRANSITORIA CUARTA}

En el plazo máximo de tres meses, desde su constitución, cada Comisión de Gobierno elaborará y someterá a aprobación de la Xunta de Galicia su Reglamento de régimen interno y las normas estatutarias provisionales, por las que se regirán las nuevas universidades en tanto no se aprueben sus estatutos.

\section{DISPOSICIÓN TRANSITORIA QUINTA}

En el plazo de dos años, a partir de la entrada en vigor de esta ley, las nuevas universidades procederán a la elección del respectivo claustro universitario constituyente. Este claustro elegirá al Rector y, en el plazo máximo de seis meses, desde su constitución, elaborará los estatutos y los someterá a aprobación de la Xunta de Galicia. 
Si transcurrido el plazo fijado en el párrafo anterior no se hubiesen sometido los estatutos a la mencionada aprobación, la Xunta de Galicia determinará la normativa singular reguladora de la actividad universitaria hasta la aprobación de los mismos.

En tanto no se aprueben los estatutos de las nuevas universidades, la Xunta de Galicia ejercerá las competencias que la legislación atribuye a las universidades, sin perjuicio de las que correspondan a las respectivas Comisiones de Gobierno y a los Consellos Económicos, así como de las que figuren en las normas estatutarias provisionales ${ }^{825}$.

\section{DISPOSICIÓN TRANSITORIA SEXTA}

Inmediatamente después de la elección del claustro se procederá a la constitución de los correspondientes Consellos sociais, que se integrarán de acuerdo con lo previsto en la Ley 5/1987, de 27 de mayo, del Consello Social y del Consello Universitario de Galicia, de conformidad con lo establecido en esta ley.

\section{DISPOSICIÓN TRANSITORIA SÉPTIMA}

En tanto no se constituya el Consello Universitario de Galicia, el Gobierno nombrará una comisión de titulaciones, a fin de dar cumplimiento a lo previsto en el artículo 9 de la presente ley.

\section{DISPOSICIÓN TRANSITORIA OCTAVA}

El Gobierno habrá de aprobar el plan de financiación en el plazo de veinte días desde la publicación de esta ley, a efectos de dar cumplimiento a lo dispuesto en la disposición adicional cuarta.

\section{DISPOSICIÓN FINAL PRIMERA}

Se autoriza a la Xunta de Galicia a dictar cuantas disposiciones considere necesarias para la aplicación y desarrollo de la presente ley.

825 Véase Decreto 217/1989, de 19 de octubre, desarroIla la Disposición transitoria quinta de la Ley de 20 de julio de 1989, de ordenación del sistema universitario de Galicia.

\section{DISPOSICIÓN FINAL SEGUNDA}

Esta ley entrará en vigor a partir de su publicación en el "Diario Oficial de Galicia”.

\section{LEY 8/1983, DE 8 DE JULIO, DEL CONSELLO DA CULTURA GALEGA}

(DOGA N. $\left.{ }^{\circ} 146,1.8 .1984\right)^{826827}$

\section{(...) ${ }^{828}$ \\ TÍTULO PRELIMINAR}

Artículo 1. Con la finalidad de defender y promocionar los valores culturales del pueblo gallego, conforme a lo previsto en el artículo 32 del Estatuto

826 Véase respecto a espectáculos públicos y actividades recreativas:

- Decreto 292/2004, de 18 de noviembre, por el que se aprueba el catálogo de espectáculos públicos y actividades recreativas de la Comunidad Autónoma de Galicia.

- Decreto 309/2003, de 11 de julio, por el que se determina el procedimiento aplicable para el ejercicio de la potestad sancionadora en establecimientos y espectáculos públicos.

Véase respecto a las academias de Galicia:

- Decreto 392/2003, de 23 de octubre, por el que se regula el ejercicio por la Comunidad Autónoma de Galicia de las competencias en materia de Academias de Galicia.

- Orden de 8 de abril de 2005 por la que se desarrolla el Decreto 392/2003, de 23 de octubre, en lo referente a la creación de las academias de Galicia y su registro general y el procedimiento de inscripción de las mismas.

Véase sobre archivos y patrimonio documental:

- Decreto 307/1989, de 23 de noviembre, que regula el sistema de archivos y el patrimonio documental de Galicia.

Véase sobre museos:

- Decreto 314/1986, de 16 de octubre, regulación del sistema público de museos.

Véase también:

- Decreto 210/1989, de 5 de octubre, de creación del Centro Galego de Artes da Imaxe.

- Decreto 326/1996, de 26 de julio, de reglamentación del Centro Galego de Arte Contemporánea.

- Decreto 279/2008, de 11 de diciembre, por el que se crea y regula el Consejo Gallego de Enseñanzas Artisticas Superiores.

827 Véase Decreto 162/2008, de 10 de julio, por el que se aprueba el reglamento de organización y funcionamiento del Consejo de la Cultura Gallega.

828 Exposición de motivos omitida. 
de Autonomía de Galicia, se constituye el Consello da Cultura Galega, con carácter, composición, competencias y funcionamiento que se establecen en la presente ley.

Artículo 2. El Consello da Cultura Galega es un órgano con personalidad jurídica propia y plena capacidad para el cumplimiento de sus fines.

\section{TÍTULO I \\ DE LA COMPOSICIÓN DEL CONSEJO}

Artículo 3. 1. La composición del Consello da Cultura Galega se estructurará de esta forma:

a. El Presidente, que será elegido por el Consejo en votación secreta, y nombrado por decreto de la Xunta de Galicia.

b. El vicepresidente o vicepresidentes, que serán elegidos por el Consejo en votación secreta entre sus miembros.

c. El secretario, que será elegido en votación secreta entre sus miembros.

d. El Conselleiro de Cultura.

e. Los representantes de las entidades siguientes, por designación de las mismas: Un representante de la Real Academia Galega.

Un representante de la Academia de Xurisprudencia e Lexislación de Galicia.

Dos representantes de la Universidad gallega, elegidos entre sus profesores.

Un representante del Instituto Padre Sarmiento de Estudos Galegos.

Un representante del Seminario de Estudos Galegos.

Un representante da Academia das Ciencias.

Un representante del Instituto da Lingua Galega.

Un representante del Instituto de Estudos Xacobeos.

Un representante de los museos de Galicia. Un representante del "Padroado Rosalía de Castro".

Dos representantes de las fundaciones culturales de interés gallego, elegidos en votación secreta por el Consejo. f. Personalidades destacadas en los campos de la cultura, elegidas por el Consejo en votación secreta en número de diez.

2. El Consejo podrá invitar a representantes de centros de investigación, medios de comunicación social, asociaciones culturales o profesionales y otras instituciones gallegas, para ser oídas o para participar en las ponencias.

3. El Consejo podrá incorporar nuevas entidades, para ello ser preciso abrir una información en la que se justifique la conveniencia de la incorporación. La incorporación requerirá la mayoría absoluta de los miembros del Consejo.

Artículo 4. El Presidente de la Xunta de Galicia ejercerá la presidencia de honor del Consello da Cultura Galega.

Artículo 5. El mandato de los miembros del Consejo no será superior a cuatro años. Los representantes adscritos en los párrafos e) y f) del artículo 3 serán renovados por mitades cada dos años, pudiendo ser reelegidos.

Los miembros del Consejo a que se refieren el apartado e) del mismo artículo, perderá la condición de tales en el momento en que decida sustituirlos la entidad que los hubiere designado.

\section{TíTULO II COMPETENCIAS}

Artículo 6. Compete al Consello da Cultura Galega:

a. Analizar cuantas cuestiones se refieran al patrimonio cultural y fomentar la lengua y la cultura gallegas.

b. Investigar y valorar las necesidades culturales del pueblo gallego.

c. Organizar actuaciones culturales adecuadas a los fines del Consejo dentro o fuera de Galicia.

d. Asesorar y consultar a los poderes de la Comunidad Autónoma en lo que juzgue preciso para la defensa y promoción de los valores culturales del pueblo gallego.

e. Elevar a los poderes de la Comunidad Autónoma informes y propuestas a favor 
de la defensa y promoción de los valores culturales del pueblo gallego.

\section{TíTULO III DEL FUNCIONAMIENTO}

Artículo 7. El Consejo funcionará en pleno y a través de la ejecutiva, de la que formarán parte, por lo menos, el Presidente, un vicepresidente y el secretario; asimismo, podrá funcionar en ponencias, comisiones técnicas, fijas o circunstanciales, y en secciones.

Artículo 8. El pleno se reunirá por lo menos una vez cada trimestre y siempre que el Presidente lo convoque.

Las reuniones plenarias serán convocadas y presididas por el Presidente.

Artículo 9. 1. Las deliberaciones y acuerdos del Consejo en pleno requieren la presencia de la mitad mas uno de sus miembros, incluidos necesariamente el Presidente y el secretario. Dado el carácter del Consejo no se admiten votos delegados.

2. Los acuerdos se adoptarán por mayoría de votos de los asistentes. El Presidente decidirá, con su voto de calidad, los empates.

\section{TíTULO IV FINANCIACIÓN}

Artículo 10. El Consello da Cultura Galega, de acuerdo con la Xunta de Galicia, elaborará su presupuesto, que figurará como un unidad orgánica dentro de los presupuestos generales de la Comunidad Autónoma.

A su Presidente, de conformidad con la ejecutiva, le corresponde desarrollar la estructura presupuestaria del Consejo.

\section{DISPOSICIÓN TRANSITORIA}

En el plazo de un mes a partir de la entrada en vigor de la presente ley, el Consello da Cultura Galega será constituido provisionalmente, bajo la presidencia del Conselleiro de Cultura, por los miembros que hubieran sido designados de acuerdo con el apartado e) del artículo 3 , que en el plazo de un mes procederán a elegir las personalidades que forman parte del apartado f) del artículo 3.

En el mes siguiente al día en el que se produzca la elección a que se refiere el apartado anterior, se procederá a la constitución formal del Consello bajo la presidencia de honor del Presidente de la Xunta de Galicia.

\section{DISPOSICIÓN FINAL PRIMERA}

Previa consulta al Consello da Cultura Galega, el Gobierno de Galicia queda facultado para el desarrollo reglamentario de la presente ley.

\section{DISPOSICIÓN FINAL SEGUNDA}

Esta ley entrará en vigor a los veinte días de su publicación en el "Diario Oficial de Galicia”.

\section{LEY 3/1983, DE 15 DE JUNIO, DE NORMALIZACIÓN LINGÜÍSTICA (DOGA N. $\left.{ }^{\circ} 84,14.7 .1983\right)^{829}$}

\section{(... ${ }^{830}$ \\ TíTULO I DE LOS DERECHOS LINGÜÍSTICOS EN GALICIA}

Artículo 1. El gallego es la lengua propia de Galicia.

Todos los gallegos tienen (...) ${ }^{831}$ el derecho de usarlo.

Artículo 2. Los poderes públicos de Galicia garantizaran el uso normal del gallego y del castellano, lenguas oficiales de la Comunidad Autónoma.

Artículo 3. Los poderes públicos de Galicia adoptarán las medidas oportunas para que nadie sea discriminado por razón de lengua.

829 Véase:

- Decreto 267/2002, de 13 de junio, por el que se regula la habilitación profesional para la traducción y la interpretación jurada de otras lenguas al gallego, y viceversa.

- Orden de 11 de noviembre de 1998 por la que se declaran las equivalencias entre distintos cursos y pruebas de lengua gallega.

830 Exposición de motivos omitida.

831 El inciso "el deber de conocerlo", contenido en la redacción original del art. 1 ha sido declarado inconstitucional por FJ. 2 STC 84/1986, de 26 de junio de 1986. 
Los ciudadanos podrán dirigirse a los jueces y tribunales para obtener la protección judicial del derecho a emplear su lengua.

\section{TÍTULO II \\ DEL USO OFICIAL DEL GALLEGO}

Artículo 4. 1. El gallego, como lengua propia de Galicia, es lengua oficial de las instituciones de la Comunidad Autónoma, de su Administración, de la Administración local y de las entidades públicas dependientes de la Comunidad Autónoma.

2. También lo es el castellano como lengua oficial del Estado.

Artículo 5. Las leyes de Galicia, los decretos legislativos, las disposiciones normativas y las resoluciones oficiales de la administración pública gallega se publicarán en gallego y castellano en el "Diario Oficial de Galicia".

Artículo 6. 1. Los ciudadanos tienen derecho al uso del gallego, oralmente y por escrito, en sus relaciones con la Administración pública en el ámbito territorial de la Comunidad Autónoma.

2. Las actuaciones administrativas en Galicia serán validas y producirán sus efectos cualquiera que sea la lengua oficial empleada.

3. Los poderes públicos de Galicia promoverán el uso normal de la lengua gallega, oralmente y por escrito, en sus relaciones con los ciudadanos.

4. La Xunta dictará las disposiciones necesarias para la normalización progresiva del uso del gallego. Las corporaciones locales deberán hacerlo de acuerdo con las normas recogidas en esta ley.

Artículo 7. 1. En el ámbito territorial de Galicia, los ciudadanos podrán utilizar cualquiera de las dos lenguas oficiales en las relaciones con la Administración de justicia ${ }^{832}$.

2. Las actuaciones judiciales en Galicia serán válidas y producirán sus efectos cualquiera que sea la lengua oficial

832 Véase FJ. 3 STC 84/1986, de 26 de junio de 1986. empleada. En todo caso, la parte o interesado tendrá derecho a que se le entere o notifique en la lengua oficial que elija ${ }^{833}$.

3. La Xunta de Galicia promoverá, de acuerdo con los órganos correspondientes, la progresiva normalización del uso del gallego en la Administración de justicia.

Artículo 8. Los documentos públicos otorgados en Galicia se podrán redactar en gallego o castellano. De no haber acuerdo entre las partes, se emplearan ambas lenguas.

Artículo 9. 1. En los registros públicos dependientes de la Administración autonómica, los asentamientos se harán en la lengua oficial en que este redactado el documento o se haga la manifestación. Si el documento es bilingüe, se inscribirá en la lengua que indique quien lo presenta en el registro. En los registros públicos no dependientes de la Comunidad Autónoma, la Xunta de Galicia promoverá, de acuerdo con los órganos competentes, el uso normal del gallego.

2. Las certificaciones literales se expedirán en la lengua en la que se efectuase la inscripción reproducida. Cuando no sea transcripción literal del asentamiento, se empleará la lengua oficial interesada por el solicitante.

3. En el caso de documentos inscritos en doble versión lingüística se pueden obtener certificaciones en cualquiera de las versiones, a voluntad del solicitante.

Artículo 10. 1. Los topónimos de Galicia tendrán como única forma oficial la gallega.

2. Corresponde a la Xunta de Galicia la determinación de los nombres oficiales de los municipios, de los territorios, de los núcleos de población, de las vías de comunicación interurbanas y de los topónimos de Galicia. El nombre de las vías urbanas será determinado por el Ayuntamiento correspondiente.

3. Estas denominaciones son las legales a todos los efectos y la rotulación tendrá

833 Véase FJ. 3 STC 84/1986, de 26/06/1986. 
que concordar con ellas. La Xunta de Galicia reglamentará la normalización de la rotulación pública respetando en todos los casos las normas internacionales que suscriba el Estado ${ }^{834}$.

Artículo 11. 1. A fin de hacer efectivos los derechos reconocidos en el presente título, los poderes autonómicos promoverán la progresiva capacitación en el uso del gallego del personal afecto a la Administración pública y a las empresas de carácter público en Galicia.

2. En las pruebas selectivas que se realicen para el acceso a las plazas de la administración autónoma y local se considerará, entre otros méritos, el grado de conocimiento de las lenguas oficiales, que se ponderará para cada nivel profesional ${ }^{835}$.

3. En las resoluciones de los concursos y oposiciones para proveer los puestos de magistrados, jueces, secretarios judiciales, fiscales y todos los funcionarios al servicio de la Administración de justicia, así como notarios, registradores de la propiedad y mercantiles, será mérito preferente el conocimiento del idioma gallego.

\section{TÍTULO III DEL USO DEL GALLEGO EN LA ENSEÑANZA}

Artículo 12. 1. El gallego, como lengua propia de Galicia, es también lengua oficial en la enseñanza en todos los niveles educativos.

2. La Xunta de Galicia reglamentará la normalización del uso de las lenguas oficiales en la enseñanza, de acuerdo con las disposiciones de la presente ley ${ }^{836}$.

Artículo 13. 1. Los niños tienen derecho a recibir la primera enseñanza en su lengua materna.

834 Véase Decreto 132/1984, Toponimia, Procedimiento para la fijación o recuperación de la toponimia gallega. 835 Decreto $103 / 2008$, do 8 de maio, polo que se regula o coñecemento do galego nos procedementos para a provisión de postos de traballo reservados a funcionarios/as con habilitación de carácter estatal no ámbito territorial da Comunidade Autónoma de Galicia.

836 Véase Decreto $124 / 2007$, de 28 de junio, por el que se regula el uso y la promoción del gallego en el sistema educativo.
El gobierno gallego arbitrará las medidas necesarias para hacer efectivo este derecho.

2. Las autoridades educativas de la Comunidad Autónoma arbitrarán las medidas encaminadas a promover el uso progresivo del gallego en la enseñanza.

3. Los alumnos no podrán ser separados en centros diferentes por razón de la lengua. También se evitará, a no ser que con carácter excepcional las necesidades pedagógicas así lo aconsejasen, la separación en aulas diferentes.

Artículo 14. 1. La lengua gallega es materia de estudio obligatorio en todos los niveles educativos no universitarios.

Se garantizará el uso efectivo de este derecho en todos los centros públicos y privados.

2. El gobierno gallego regulará las circunstancias excepcionales en que un alumno puede ser dispensado del estudio obligatorio de la lengua gallega. Ningún alumno podrá ser dispensado de esta obligación si hubiese cursado sin interrupción sus estudios en Galicia.

3. Las autoridades educativas de la Comunidad Autónoma garantizarán que al final de los ciclos en que la enseñanza del gallego es obligatoria, los alumnos conozcan éste, en sus niveles oral y escrito, en igualdad con el castellano.

Artículo 15. 1. Los profesores y los alumnos en el nivel universitario tienen el derecho a emplear, oralmente y por escrito, la lengua oficial de su preferencia.

2. El gobierno gallego y las autoridades universitarias arbitrarán las medidas oportunas para hacer normal el uso del gallego en la enseñanza universitaria.

3. Las autoridades educativas adoptarán las medidas oportunas a fin de que la lengua no constituya obstáculo para hacer efectivo el derecho que tienen los alumnos a recibir conocimientos.

Artículo 16. 1. En los cursos especiales de educación de adultos y en los cursos de enseñanza especializada en los 
que se enseñe la disciplina de lengua, es preceptiva la enseñanza del gallego.

En los centros de enseñanza especializada dependientes de la Xunta de Galicia se establecerá la enseñanza de la lengua gallega en los casos en que su estudio no tenga carácter obligatorio.

2. En los centros de educación especial para alumnos con deficiencias físicas o mentales para el aprendizaje, se empleará como lengua instrumental aquella que, teniendo en cuenta las circunstancias familiares y sociales de cada alumno, mejor contribuya a su desarrollo.

Artículo 17. 1. En las escuelas universitarias y demás centros de formación del profesorado será obligatorio el estudio de la lengua gallega. Los alumnos de estos centros deberán adquirir la capacitación necesaria para hacer efectivos los derechos que se amparan en la presente ley.

2. Las autoridades educativas promoverán el conocimiento del gallego por parte de los profesores de los niveles no incluidos en el párrafo anterior, a fin de garantizar la progresiva normalización del uso de la lengua gallega en la enseñanza.

\section{TÍTULO IV}

\section{DEL USO DEL GALLEGO EN LOS MEDIOS DE COMUNICACIÓN}

Artículo 18. El gallego será la lengua usual en las emisoras de radio y televisión y en los demás medios de comunicación social sometidos a gestión o competencia de las instituciones de la Comunidad Autónoma.

Artículo 19. El gobierno gallego prestará apoyo económico y material a los medios de comunicación no incluidos en el artículo anterior que empleen el gallego de una forma habitual y progresiva.

Artículo 20. Serán obligaciones de la Xunta de Galicia:

1. Fomentar la producción, el doblaje, la subtitulación y la exhibición de películas $\mathrm{y}$ otros medios audiovisuales en lengua gallega.

2. Estimular las manifestaciones culturales, representaciones teatrales y los espectáculos hechos en lengua gallega.

3. Contribuir al fomento del libro en gallego, con medidas que potencien la producción editorial y su difusión.

\section{TÍTULO V DEL GALLEGO EXTERIOR}

Artículo 21. 1. El gobierno gallego hará uso de los recursos que le confieren la Constitución Española y el Estatuto de Autonomía para que los emigrantes gallegos puedan disponer de servicios culturales y lingüísticos en lengua gallega.

2. Asimismo hará uso de lo previsto en el art. 35 del Estatuto de Autonomía a fin de proteger la lengua gallega hablada en territorios limítrofes con la Comunidad Autónoma.

\section{TÍTULO VI \\ DE LA ADMINISTRACIÓN AUTONÓMICA Y LA FUNCIÓN NORMALIZADORA}

Artículo 22. El gobierno gallego asumirá la dirección técnica y el seguimiento del proceso de normalización de la lengua gallega; asesorará a la administración y a los particulares, y coordinará los servicios encaminados a conseguir los objetivos de la presente ley.

Artículo 23. El gobierno gallego establecerá un plan destinado a resaltar la importancia de la lengua como patrimonio histórico de la comunidad y a poner de manifiesto la responsabilidad y los deberes que ésta tiene respecto de su conservación, protección y transmisión.

Artículo 24. 1. La Escola galega de Administración Pública se encargará de la formación de los funcionarios a fin de que puedan usar el gallego en los términos establecidos por la presente ley. 
2. El dominio de las lenguas gallega y castellana será condición necesaria para obtener el diploma de la Escola Galega de Administración Pública.

Artículo 25. El gobierno gallego y las corporaciones locales dentro de su ámbito fomentarán la normalización del uso del gallego en las actividades mercantiles, publicitarias, culturales, asociativas, deportivas y otras. Con esta finalidad y por actos singulares, se podrán otorgar reducciones o exenciones de las obligaciones fiscales 837 .

\section{DISPOSICIÓN ADICIONAL}

En las cuestiones relativas a la normativa, actualización y uso correcto de la lengua gallega, se estimará como criterio de autoridad el establecido por la Real Academia Galega ${ }^{838}$.

Esta normativa será revisada en función del proceso de normalización del uso del gallego.

\section{DISPOSICIÓN FINAL}

La presente ley entrará en vigor al día siguiente de su publicación en el "Diario Oficial de Galicia”.

8. LEY 11/1997, DE 22 DE AGOSTO, GENERAL DEL DEPORTE DE GALICIA (DOGA N. $\left.^{\circ} 170,4.9 .1997\right)^{839}$

\section{$(\ldots)^{840}$ \\ TÍTULO I \\ OBJETO Y PRINCIPIOS GENERALES}

Artículo 1. La finalidad de la presente ley es la ordenación, promoción y coordinación de la actividad deportiva en Galicia con arreglo a la competencia

837 Véase Decreto 185/1994, de 16 de junio, por el que se regula la utilización del idioma gallego en los productos de información al consumidor y usuario. 838 Véase Decreto 173/1982, de 17 de noviembre, sobre uso y enseñanza de la lengua gallega.

839 Véase sobre el Consello de Deporte de Galicia, Decreto 102/2005, de 28 de abril, por el que se crea el Consello del Deporte de Galicia.

840 Exposición de motivos omitida. exclusiva en la materia atribuida a la Comunidad Autónoma en el artículo 27.22 de su Estatuto de Autonomía.

Conforme a dicha finalidad, la presente ley tiene por objeto el fomento, implantación y divulgación de la actividad deportiva en $\mathrm{Ga}$ licia, a todos los niveles, como un medio de lograr el derecho de todo ciudadano, sin ninguna discriminación, al ejercicio y desarrollo de sus facultades físicas e intelectuales mediante el libre acceso a la práctica del deporte.

Artículo 2. Los poderes públicos de la Comunidad Autónoma garantizarán el libre acceso de todo ciudadano, en igualdad de condiciones y oportunidades, al conocimiento y a la práctica de la actividad deportiva con arreglo a los principios inspiradores de la presente ley y de las normas reguladoras de las respectivas actividades. La actividad deportiva se desarrollará conforme a los principios de libertad, igualdad y participación democrática.

Artículo 3. 1. La Administración autonómica promoverá el deporte de mera actividad o participación procurando su realización tanto de manera individual como asociada.

2. La Administración de la Comunidad Autónoma promoverá adecuadamente las prácticas deportivas especiales, considerándose como tales, a los efectos de la presente ley, la actividad deportiva desarrollada por personas en las cuales concurran circunstancias especiales por razón de edad, condición física, psíquica o situación personal que exijan de la Administración pública una consideración y atención diferenciada del resto de los practicantes de la actividad deportiva para facilitar su plena integración social.

3. La Administración de la Comunidad Autónoma fomentará los deportes autóctonos tradicionales de Galicia.

4. La Administración de la Comunidad Autónoma promoverá el deporte 
de competición, en colaboración con las federaciones deportivas.

5. La Administración autonómica colaborará con la Administración del Estado y las federaciones correspondientes en la preparación y apoyo técnico, científico y médico a los deportistas de alto nivel de la Comunidad Autónoma, procurará la compatibilidad de su intensa dedicación al deporte con otras situaciones de trabajo o estudio y favorecerá su plena integración profesional al finalizar su etapa de deportistas de alto nivel.

Artículo 4. 1. La Administración autonómica divulgará los beneficios inherentes a la práctica deportiva.

2. Asimismo, la Administración autonómica procurará la formación de dirigentes, técnicos y voluntarios en la promoción y organización de la actividad deportiva.

3. La Administración autonómica colaborará con las universidades gallegas y otras entidades públicas y privadas para promover, impulsar y coordinar la investigación científica y el desarrollo tecnológico del deporte.

Artículo 5. 1. La Administración autonómica promocionará la enseñanza y la práctica de la actividad deportiva en la edad escolar.

2. Todos los centros docentes, públicos o privados, deberán disponer de instalaciones deportivas para atender la práctica de la actividad deportiva, en la forma que se determine reglamentariamente.

Artículo 6. 1. La Administración deportiva de la Comunidad Autónoma fomentará la construcción y óptima utilización de las instalaciones deportivas, potenciando el carácter polivalente de las mismas para la obtención de la máxima rentabilidad social y posibilitando la práctica generalizada de la actividad deportiva.

2. La Administración deportiva de la Comunidad Autónoma planificará y ejecutará, directamente o en colaboración con otras administraciones, la construcción de instalaciones deportivas propias o la mejora de las ya existentes en el territorio de Galicia, y deberá ser informada de la construcción o mejora en las de otra titularidad.

3. La Administración deportiva de la Comunidad Autónoma determinará los requisitos técnicos de las instalaciones, asegurando el cumplimiento de la normativa específica para la accesibilidad, de modo que no dificulte la libre circulación de personas con minusvalía física o en edad avanzada. Asimismo deberán proyectarse y construirse de modo que se impidan o limiten al máximo las posibles acciones de violencia, de acuerdo con la legislación vigente y los convenios internacionales.

Artículo 7. 1. La Administración deportiva de la Comunidad Autónoma velará por la incorporación en los instrumentos de ordenación urbanística de las reservas de espacios necesarios para el desarrollo y la práctica de la actividad deportiva.

2. Promocionará la protección y respeto al medio natural, concebido también como un espacio para el ocio y la práctica de la actividad física.

Artículo 8. La Administración autonómica procurará las condiciones necesarias para aplicar las máximas ventajas fiscales en el ámbito de la Comunidad Autónoma a las entidades que realicen actividades de promoción deportiva.

\section{TÍTULO II}

\section{DE LAS COMPETENCIAS DE LAS} ADMINISTRACIONES PÚBLICAS

\section{Capítulo I \\ COMPETENCIAS DE LA COMUNIDAD AUTÓNOMA}

Artículo 9. A los efectos de la presente ley, se entiende por Administración deportiva los órganos de la Comunidad Autónoma de Galicia competentes en materia de deporte. Corresponderá a la Administración deportiva de la Comunidad 
Autónoma el ejercicio de las facultades que le vienen reconocidas en el Estatuto de Autonomía y las funciones previstas en la presente ley, así como la coordinación y cooperación con la Administración del Estado y las corporaciones locales en materia deportiva.

Para el mejor ejercicio de sus competencias, la Administración autonómica podrá celebrar convenios de colaboración con las demás administraciones públicas y entidades públicas y privadas vinculadas a la actividad deportiva.

Artículo 10. Será competencia exclusiva de la Administración autonómica la autorización y, en su caso, denegación motivada de la constitución de las asociaciones deportivas a que se refiere el título III de la presente ley, así como la aprobación de los estatutos y reglamentos de las mismas.

Será competencia exclusiva de la Administración deportiva de Galicia la formulación de los programas de carácter general en materia deportiva de ámbito gallego a los que deberán atenerse las demás administraciones y entes públicos y privados en sus actuaciones en la materia, sin perjuicio de las competencias propias de los mismos.

Será también competencia exclusiva de la Administración autonómica el reconocimiento de modalidades deportivas.

Artículo 11. 1. Será competencia de la Administración autonómica:

a. Autorizar la realización de actividades deportivas y la celebración de competiciones que afecten a las competencias propias de las federaciones deportivas gallegas en el ámbito de la Comunidad Autónoma. También será competencia suya la calificación de las competiciones oficiales y la denominación de "campeonato gallego", "copa de Galicia" o expresiones de contenido similar.

Las competiciones o actividades de las federaciones deportivas gallegas se entenderán autorizadas por inscripción de las mismas en el Registro correspondiente, salvo prohibición expresa, que deberá ser motivada.

b. Efectuar convocatorias de ámbito autonómico para otorgar premios, distinciones o ayudas a la realización de actividades promotoras del deporte encaminadas a mejorar la presencia del deporte gallego en las distintas competiciones o manifestaciones deportivas.

c. Conceder las subvenciones económicas que procedan, sin perjuicio de las que establezcan otras administraciones públicas, a las federaciones y demás asociaciones deportivas, garantizando a través de las oportunas inspecciones que la actuación de las mismas se ajuste a los fines previstos en la presente ley y controlando y evaluando la ejecución de los programas subvencionados.

d. Promover la cobertura asistencial y fijar los requisitos de carácter médico-deportivo que deberán ser observados por las federaciones deportivas gallegas para el otorgamiento de licencias a sus deportistas, promoviendo la adecuada protección asistencial mediante convenios entre las federaciones con las entidades mutualistas o con las instituciones sanitarias gallegas que garanticen la asistencia sanitaria de los practicantes con independencia del deporte que realicen.

e. Adoptar las medidas de prevención, control y represión del uso de sustancias prohibidas y métodos no reglamentarios, destinados a aumentar artificialmente la capacidad física de los deportistas o a modificar los resultados de las competiciones.

f. Aplicar las medidas necesarias para evitar la violencia en el deporte ${ }^{841}$.

En los apartados e) y f) colaborará con la Administración del Estado, sin perjuicio del desarrollo reglamentario correspondiente.

841 Véase Decreto 116/2004, de 27 de mayo, por el que se crea la Comisión Gallega para la Prevención de la Violencia en el Deporte. 
2. Será competencia de la Administración deportiva de Galicia determinar la formación y acreditación necesaria para dirigir o entrenar a deportistas o equipos que participen en competiciones oficiales en el ámbito de Galicia, sin menoscabo de lo dispuesto en la legislación del Estado en materia de su competencia.

\section{Capítulo II \\ Sección $1 .^{\mathrm{a}}$ \\ Provincias} COMPETENCIAS DE LOS ENTES LOCALES

Artículo 12. Corresponde a las Diputaciones Provinciales en el ámbito de su territorio:

1. Fomentar, promover y difundir la actividad deportiva en su ámbito territorial, facilitando al máximo la realización de actividades deportivas, en coordinación con los programas generales de la Comunidad Autónoma.

2. Participar en la elaboración y ejecución de los programas generales de la Administración deportiva autonómica cuyo objeto sea la construcción y mejora de las instalaciones deportivas de uso público.

3. Coordinar dentro del programa general de la Administración autonómica la utilización de las instalaciones deportivas públicas de titularidad provincial.

4. Ejercer cuantas funciones y competencias les estén atribuidas en virtud de la normativa estatal, de la presente ley y de las normas que la desarrollan, así como todas las que les puedan ser transferidas o delegadas, dentro de los programas generales aprobados por la Administración autonómica.

5. Ejecutar, en su caso, por delegación los programas generales que en la materia objeto de la presente ley apruebe la Administración autonómica correspondiente a su ámbito territorial.

6. Colaborar con los Ayuntamientos en la promoción y fomento de la actividad deportiva, en especial en el deporte en edad escolar.
7. Cualesquiera otras actuaciones que redunden en beneficio del desarrollo deportivo local, comarcal o provincial.

\section{Sección 2 . $^{\text {a }}$ Ayuntamientos}

Artículo 13. Corresponde a los Ayuntamientos en su respectivo término municipal:

1. Fomentar y promocionar la actividad deportiva en su territorio respectivo, en los términos de la legislación vigente y de la presente ley.

2. Autorizar, de conformidad con los requisitos generales, la realización de actividades deportivas fuera de las instalaciones deportivas y en el patrimonio público municipal.

3. Promover y tutelar y, en su caso, ejecutar en el ámbito de su competencia los programas generales del deporte en edad escolar de la Administración autonómica, mediante la colaboración con la misma, así como con otros entes locales, federaciones deportivas gallegas $u$ otras asociaciones deportivas.

4. Construir instalaciones deportivas de carácter comunitario de conformidad con el Plan general de instalaciones y equipamientos deportivos, velar por la plena utilización de las existentes en su término, procurando la participación de las asociaciones deportivas de su ámbito municipal en la optimización del uso de las mismas, y cuidar sus condiciones de higiene y seguridad.

5. Llevar un censo actualizado de instalaciones deportivas en su término.

6 . Velar para que en los planes de ordenación urbanística se establezcan las reservas de espacios y calificaciones de zonas para la práctica del deporte y la instalación de equipamientos deportivos en los instrumentos de ordenación urbanística.

7. Cooperar con otros entes públicos o privados para llevar a cabo el cumplimiento de los programas generales que establezca la Administración autonómica $\mathrm{y}$, en general, el cumplimiento de las finalidades contempladas en la ley. 
8. Fomentar la creación de asociaciones deportivas, especialmente en los centros de enseñanza, barrios y centros de trabajo.

9. Cualesquiera otras facultades atribuidas legal o reglamentariamente que contribuyan a los fines u objetivos de la presente ley.

\section{Capitulo III DISPOSICIONES COMUNES}

Artículo 14. Las entidades locales mencionadas en este título coordinarán sus actividades en materia deportiva con las de las asociaciones deportivas gallegas al objeto de no interferir la actividad de las mismas en los programas generales aprobados por la Administración autonómica.

\section{TÍTULO III SUJETOS DE LA ACTIVIDAD DEPORTIVA}

\section{Capítulo I DEPORTISTA}

Artículo 15. 1. Tendrá la consideración de deportista, a los efectos de la presente ley, toda persona que practique alguna modalidad deportiva aun cuando no participe en competiciones o no forme parte de una asociación deportiva.

2. Se promoverá y facilitará la integración de todas las personas que practiquen la actividad deportiva en las asociaciones recogidas en la presente ley para una mayor efectividad de los programas de fomento y desarrollo del deporte y para la mejor asistencia y protección de los deportistas.

3. Tendrán la consideración de deportistas de alto nivel aquellos deportistas que figuren en las relaciones a que se refiere el artículo 46.3 .

Artículo 16. 1. Los deportistas podrán ser aficionados o profesionales. A su vez los deportistas aficionados podrán ser federados o no.

2. Los deportistas federados dispondrán de la licencia federativa otorgada por la correspondiente federación deportiva gallega. Los no federados que se inscriban obtendrán la correspondiente licencia acreditativa de su condición del Registro de Asociaciones Deportivas y Deportistas de Galicia. La expedición de la licencia tendrá carácter reglado, no pudiendo denegarse cuando el solicitante reúna los requisitos establecidos.

3. Las ligas profesionales deberán estar integradas por deportistas profesionales.

\section{Capítulo II ASOCIACIONES DEPORTIVAS}

\section{Sección $1 .^{\mathrm{a}}$}

Disposiciones comunes

Artículo 17. 1. A los efectos de la presente ley, las asociaciones deportivas se clasifican en clubes deportivos, agrupaciones deportivas escolares, federaciones deportivas gallegas y, en su caso, sociedades anónimas deportivas, ligas profesionales y entidades de fomento deportivo.

2. Las asociaciones deportivas incluirán en sus actividades programas de asistencia y protección a los deportistas integrados en las mismas o que intervengan en actividades organizadas por aquéllas.

Artículo 18. Para garantizar el cumplimiento de los objetivos de las asociaciones deportivas gallegas, la Administración autonómica podrá llevar a cabo las siguientes actuaciones:

a. Inspeccionar los libros y documentos de las asociaciones en la forma y supuestos que se establezcan reglamentariamente, al objeto de garantizar el cumplimiento de las funciones que se les encomiendan en la presente ley.

b. Convocar a sus órganos colegiados a instancia de parte interesada cuando éstos no hubiesen sido estatutariamente convocados por los órganos de gobierno de las asociaciones.

c. Convocar las elecciones para constituir los órganos de gobierno de las asociaciones al final del mandato de cada uno de los mismos, en la forma que se determine 
estatutariamente, si no hubiesen sido oportunamente convocadas.

d. Suspender o anular los acuerdos adoptados por los órganos de gobierno de las asociaciones deportivas que sean contrarios a las disposiciones de la presente ley, así como a sus disposiciones de desarrollo o a sus propios estatutos y reglamentos.

Artículo 19. Todas las asociaciones deportivas constituidas al amparo de lo dispuesto en la presente ley deberán llevar una contabilidad susceptible de justificar la exactitud de los resultados de las operaciones económicas realizadas.

Las asociaciones deportivas de Galicia están acogidas al régimen de presupuesto y patrimonio propios y deben someter anualmente su contabilidad y su estado económico a una auditoría o verificación contable, en los casos en que así lo disponga la Administración Autonómica.

No podrán aprobar presupuestos deficitarios sin la autorización expresa de la Administración Autonómica.

Artículo 20. Las asociaciones deportivas de Galicia aplicarán sus recursos al cumplimiento de sus fines, de acuerdo con lo establecido en sus estatutos, y en especial:

a. Podrán fomentar manifestaciones de carácter físico-deportivo y organizar actividades o competiciones deportivas dirigidas al público en general. Los beneficios económicos, si los hubiese, se destinarán al desarrollo de su objeto social.

b. Podrán gravar y enajenar bienes, muebles o inmuebles, y tomar dinero a préstamo, siempre y cuando dichos actos no comprometan de modo irreversible el patrimonio de la entidad ni la actividad que constituye su objeto.

c. Podrán ejercer complementariamente actividades comerciales, industriales, profesionales o de servicios a condición de que los posibles beneficios se apliquen al fomento de la actividad deportiva. En ningún caso podrán repartir beneficios entre sus miembros.
Artículo 21. Las asociaciones deportivas constituidas al amparo de la presente ley adaptarán su actuación y funcionamiento a las disposiciones normativas de aplicación. La ausencia de este requisito determinará la cancelación de la inscripción registral. Al objeto de facilitar el cumplimiento de esta exigencia, la Administración Autonómica procurará a las asociaciones deportivas inscritas el asesoramiento jurídico necesario.

\section{Sección 2. ${ }^{\mathrm{a}}$ Clubes deportivos}

Artículo 22. Son clubes deportivos, a los efectos de la presente ley, las asociaciones privadas con personalidad jurídica y capacidad de obrar, integradas por personas físicas, cuyo objeto exclusivo o principal sea la práctica de una o varias modalidades deportivas por los asociados, así como la participación en actividades y competiciones oficiales.

Artículo 23. 1. Para la constitución de un club deportivo, sus fundadores habrán de solicitar la ratificación de los estatutos, e inscribir en el Registro de Asociaciones Deportivas y Deportistas de Galicia el acta fundacional y los estatutos. El acta fundacional deberá ser otorgada, al menos, por cinco personas físicas con capacidad de obrar y deberá hacer constar la voluntad de éstas de constituir un club deportivo y la aprobación de sus Estatutos.

Los clubes que intervengan en competiciones oficiales de ámbito autonómico, estatal o internacional deberán protocolizar ante notario el acta fundacional y los estatutos.

2. Los clubes elaborarán y aprobarán sus estatutos, que se formularán con arreglo a los principios de representatividad y participación. La organización interna de los mismos deberá ser democrática.

3. Los clubes deportivos se regirán en lo que se refiere a su constitución, organización y funcionamiento por la presente ley, las disposiciones que la desarrollan y sus estatutos y reglamentos. Con carácter 
supletorio, serán de aplicación a los clubes los estatutos y reglamentos de la federación gallega a la que estuviesen adscritos.

4. Los clubes deportivos que adquieran el derecho a participar en competiciones de carácter profesional y ámbito gallego deberán transformarse en sociedades anónimas deportivas.

Artículo 24. Para participar en competiciones de carácter oficial, los clubes deberán afiliarse a las federaciones deportivas gallegas correspondientes.

Las federaciones deportivas gallegas exigirán a los clubes que deseen afiliarse a ellas su inscripción previa en el Registro de Asociaciones Deportivas y Deportistas de Galicia, sin perjuicio de los demás requisitos que federativamente les correspondan.

Artículo 25. Los Estatutos de los clubes deportivos deberán contener como mínimo las siguientes menciones:

a. Denominación, actividad deportiva que constituya su objeto y domicilio del club, que tendrá que estar radicado en Galicia.

b. Nombres, DNI y domicilio de los fundadores.

c. Requisitos y procedimiento de adquisición y pérdida de la condición de socios y derechos y deberes de los mismos.

d. Órganos de gobierno y representación, y su régimen de elección, funcionamiento y cese, que deberá ajustarse a principios democráticos. Los clubes habrán de contar necesariamente con los siguientes órganos: Presidente y asamblea general, los cuales, independientemente de las funciones estatutarias que se les asignen. deberán tener las competencias que se establezcan en las normas de desarrollo de la presente ley.

e. Régimen de adopción de acuerdos y medios para su impugnación. Necesariamente deberá hacerse mención de la posibilidad de impugnar los acuerdos ante los órganos competentes de las federaciones y ante el Comité Gallego de Justicia Deportiva.

f. Régimen de responsabilidad de los directivos y de los socios. En cualquier caso, los directivos responderán frente a los socios, el club o terceros por culpa o negligencia grave.

g. Régimen documental, que deberá contener registro de socios, libro de actas y libros contables.

h. Régimen disciplinario.

i. Régimen económico-financiero y patrimonial.

j. Procedimiento de reforma de sus estatutos.

k. Procedimiento de disolución y destino de los bienes, que en todo caso se aplicarán a fines análogos de carácter deportivo.

Artículo 26. Cuando entidades públicas o privadas pretendan desarrollar entre sus actividades el fomento y la práctica de la actividad deportiva, podrán acceder al Registro de Asociaciones Deportivas y Deportistas de Galicia y gozar de los derechos y beneficios deportivos reservados a los mismos mediante el cumplimiento de los requisitos documentales exigidos para los clubes deportivos en este título, con las siguientes modificaciones:

a. Estatutos propios o certificación de la entidad de la que dependan que acrediten su naturaleza jurídica o, en su caso, la indicación del acuerdo de su creación.

b. Nombre de la persona física que ejercerá dentro de los mismos las funciones que para los Presidentes de clubes deportivos se establezcan en la presente ley y en sus normas reglamentarias.

c. Régimen de presupuesto propio.

A los efectos de la presente ley tendrán la consideración de clubes las entidades indicadas.

\section{Sección $3 .^{a}$ \\ Agrupaciones deportivas escolares}

Artículo 27. 1. Son agrupaciones deportivas escolares las asociaciones deportivas formadas por personas físicas o jurídicas, públicas o privadas, dedicadas exclusivamente a la actividad deportiva en edad escolar.

2. Las agrupaciones deportivas escolares tendrán personalidad jurídica y 
capacidad de obrar para el cumplimiento de sus funciones.

3. El ámbito territorial y las normas de constitución, composición, funcionamiento y régimen jurídico se determinarán reglamentariamente y deberán estar inspiradas en los principios de representación y democracia; en todo caso, coordinarán su actuación con las federaciones deportivas gallegas correspondientes a la modalidad deportiva de que se trate.

4. Les será de aplicación con carácter general el régimen de constitución, organización y funcionamiento establecido en la presente ley para los clubes deportivos, con las siguientes particularidades:

a. Su objeto deberá referirse a la actividad del deporte en edad escolar.

b. Su ámbito territorial podrá comprender uno o varios municipios.

c. Podrán formar parte de las mismas los centros escolares, asociaciones de padres de alumnos, Ayuntamientos, diputaciones, federaciones deportivas gallegas, clubes deportivos y otros colectivos interesados.

\section{Sección $4 .^{\text {a }}$}

\section{Federaciones deportivas gallegas}

Artículo 28. 1. Las federaciones deportivas gallegas son entidades privadas con personalidad jurídica propia y plena capacidad de obrar, cuyo ámbito de actuación se extiende al territorio de la Comunidad Autónoma de Galicia, en el desarrollo de las competencias que les son propias. Están integradas por clubes, deportistas, técnicos, jueces, árbitros y otros colectivos interesados estatutariamente establecidos que promueven, practican o contribuyen al desarrollo de una misma modalidad o especialidad deportiva.

2. Se reserva expresamente la denominación de federación deportiva gallega para las asociaciones reguladas en esta sección.

3. Las federaciones deportivas gallegas ejercen, además de sus propias atribuciones, por delegación funciones públicas de carácter administrativo, actuando en tal caso como agentes colaboradores de la Comunidad Autónoma gallega.

4. También podrán realizar actividades no incompatibles con su objeto social de carácter industrial, comercial o de servicios y destinar sus bienes o recursos a los mismos objetivos y sin que en ningún caso puedan repartirse beneficios entre sus miembros.

Artículo 29. Sólo podrá reconocerse en el ámbito territorial de la Comunidad Autónoma una federación deportiva gallega por cada modalidad deportiva, para cuya constitución se requiere la existencia y práctica habitual y previa de dicha modalidad que no esté ya asumida por una federación deportiva gallega.

Se exceptúan de lo dispuesto en el párrafo anterior las federaciones deportivas de disminuidos físicos, psíquicos o sensoriales, que podrán tener carácter polideportivo.

Las federaciones españolas deberán ser representadas por las federaciones deportivas gallegas en el ámbito territorial de la Comunidad Autónoma de Galicia al objeto de obtener el reconocimiento, apoyo y protección de las autoridades y organismos públicos en Galicia, en los términos establecidos en la presente ley.

Las federaciones deportivas gallegas, a efectos de su participación en actividades o competiciones deportivas de ámbito estatal o internacional, deberán formar parte de las federaciones deportivas españolas correspondientes a su actividad, por medio de los oportunos acuerdos, y les serán de aplicación las normas y reglamentos de las federaciones deportivas españolas o internacionales cuando actúen en competiciones ofciales de carácter estatal o internacional.

Artículo 30. 1. Las federaciones deportivas gallegas regularán su estructura y funcionamiento de acuerdo con los principios de representación y participación democrática y se regirán por la presente ley, sus normas de desarrollo, sus propios Estatutos y reglamentos debidamente aprobados y las demás disposiciones legales o federativas que resulten de aplicación. 
2. Las federaciones deportivas gallegas tendrán la consideración de entidades de utilidad pública en los términos establecidos en la legislación.

Artículo 31. 1. Corresponde a la Administración deportiva de Galicia autorizar y revocar la constitución de las federaciones deportivas gallegas y la aprobación de sus estatutos y reglamentos.

2. La constitución de una nueva federación deportiva podrá producirse:

a. Por creación "ex novo".

b. Por segregación de otra.

c. Por fusión de dos o más preexistentes.

3. Para la constitución de una nueva federación deportiva se requerirá la autorización de la Administración, que la concederá o denegará motivadamente en base a los siguientes criterios:

a. Interés general de la actividad.

b. Suficiente implantación en Galicia.

c. Existencia de la modalidad deportiva oficialmente reconocida.

d. Viabilidad económica de la nueva federación.

4. a. Para la constitución de una nueva federación deportiva "ex novo", la iniciativa podrá corresponder a representantes de como mínimo treinta clubes deportivos con domicilio social al menos en tres provincias gallegas, constituidos en Junta Promotora, justificando los requisitos a que se refiere el apartado anterior y la no inclusión de la práctica deportiva correspondiente en ninguna de las federaciones existentes. Esta propuesta tendrá el carácter de acta fundacional y deberá otorgarse ante Notario.

b. En el caso de constitución de una nueva federación por segregación de otra será necesario el informe de la federación de la que se pretende la segregación y contar con actividades deportivas que tengan implantación e identidad suficientes para convertirse en modalidad deportiva autónoma. c. En el caso de constitución de una nueva federación por fusión de otras será necesario el acuerdo de las federaciones fusionadas.

5. En todo caso, para la constitución de una federación será necesario contar con estatutos ajustados a la normativa legal e inscribirse en el Registro de Asociaciones Deportivas y Deportistas de Galicia. Esta inscripción será condición previa y necesaria para la integración de la federación deportiva gallega de que se trate en la federación española correspondiente.

6. Los estatutos de las federaciones deportivas gallegas y sus modificaciones se publicarán en el "Diario Oficial de Galicia”, previa aprobación de los mismos por la Administración deportiva gallega en el plazo máximo de dos meses. Las demás normas reglamentarias que rigen el funcionamiento de la federación se depositarán en la Administración deportiva de Galicia.

7. El reconocimiento de una federación deportiva gallega por la Administración deportiva de Galicia confiere a la misma la representación de esa modalidad deportiva en todos los ámbitos.

8. La revocación de la autorización de las federaciones deportivas gallegas corresponderá a la Administración deportiva de Galicia por la desaparición de los motivos que dieron lugar a su autorización e inscripción.

Artículo 32. Corresponderán a las federaciones deportivas gallegas como competencia exclusiva en su respectiva modalidad deportiva las siguientes funciones:

a. Elaborar los programas de promoción general de su modalidad deportiva en el ámbito de la Comunidad Autónoma.

b. Elaborar las normas técnicas de su modalidad deportiva y dirigir y regular las actividades propias de la misma.

c. Desarrollar programas de especialización de su modalidad deportiva.

d. Diseñar, elaborar y ejecutar los planes de preparación de los deportistas de alto nivel en su respectiva modalidad deportiva 
y las listas de los mismos en colaboración con la Administración deportiva de Galicia y, en su caso, la federación española correspondiente.

e. Colaborar con la Administración Autonómica y cooperar con las correspondientes federaciones deportivas españolas, en su caso, en la formación de técnicos deportivos de su especialidad.

f. Organizar y dirigir las competiciones de carácter oficial que se desarrollen en su ámbito territorial, de acuerdo con las normas y reglamentos autonómicos, nacionales e internacionales que sean de aplicación.

Expedirán, a estos efectos, las correspondientes licencias deportivas.

g. Ejercer la potestad disciplinaria en los términos establecidos en la presente ley y en sus normas de desarrollo, así como en sus propios estatutos y reglamentos.

h. Resolver en vía de recurso las impugnaciones contra los acuerdos de los órganos de los clubes deportivos que dependan de las mismas.

i. Ejercer el control de las subvenciones oficiales que se asignen a los clubes deportivos que dependan de las mismas en la forma que reglamentariamente se determine.

j. Designar a los deportistas de su modalidad que integrarán la selección gallega, para la cual los clubes deberán poner a disposición de la federación a los deportistas elegidos.

k. Representar a Galicia en actividades y competiciones deportivas de carácter estatal o supraestatal organizando las selecciones autonómicas.

1. Colaborar con la Administración deportiva de Galicia, entes locales y agrupaciones deportivas escolares en la organización y desarrollo de los programas generales del deporte en edad escolar.

m. Ejecutar las resoluciones del Comité Gallego de Justicia Deportiva.

n.Colaborar con la Administración deportiva de Galicia y otros órganos competentes de la Administración Autonómica en la prevención, control y represión del uso de sustancias y grupos farmacológicos prohibidos en el deporte y en la prevención y control de la violencia en el deporte.

ñ. Podrán, además de sus propias atribuciones, ejecutar por delegación de la Administración autonómica programas de promoción de su modalidad deportiva.

o. Aquellas otras funciones que pueda encomendarles la Administración deportiva de la Comunidad Autónoma.

Artículo 33. A fin de garantizar el cumplimiento efectivo de las funciones atribuidas a las federaciones deportivas gallegas, la Administración deportiva de Galicia podrá llevar a cabo las siguientes actuaciones:

1. Suspender motivadamente, de forma cautelar y provisional, al Presidente o a los miembros de los órganos federativos, cuando se incoe contra ellos expediente disciplinario por presuntas infracciones muy graves y susceptibles de sanción tipificadas como tales en la presente ley o estén incursos en procedimiento penal que conlleve privación de libertad.

2. En los casos de notoria inactividad o abandono de funciones por parte de una federación o de sus órganos que suponga incumplimiento grave de sus deberes legales o estatutarios, la Administración deportiva de Galicia podrá asumir las funciones de la federación para que se restaure el funcionamiento legal y regular de la misma. A tales efectos, si fuese necesario, se nombrará una comisión gestora y se convocarán elecciones. De no ser posible su nombramiento o no alcanzar su finalidad, se disolverá la federación y se cancelará la inscripción registral.

Artículo 34. Los estatutos de las federaciones deportivas gallegas deberán contener y regular, al menos, las siguientes materias:

a. La denominación de la federación.

b. El domicilio, que deberá fijarse dentro del territorio de Galicia. 
c. La modalidad y especialidades deportivas cuyo desarrollo específico se atienda.

d. Los requisitos de afiliación y los derechos y deberes de los afiliados.

e. La estructura territorial, que podrá ser mediante delegaciones de ámbito comarcal o cualquier otro.

f. La composición, funcionamiento y competencia de los órganos de gobierno y representación.

g. El procedimiento de elección del Presidente, de la Asamblea general y de la Comisión delegada de la federación ${ }^{842}$.

h. Las causas de cese de los órganos de gobierno y representación, entre las cuales se incluirá la moción de censura al Presidente, que será constructiva.

i. El régimen de adopción de acuerdos y su impugnación.

j. El régimen documental de la federación, que comprenderá, como mínimo, el libro-registro de clubes deportivos y, en su caso, deportistas, el libro de actas de los órganos de gobierno y representación, los libros de contabilidad y el libro inventario de bienes muebles e inmuebles, todos ellos debidamente diligenciados por el Registro de Asociaciones Deportivas y Deportistas de Galicia.

k. El régimen económico-financiero, que deberá precisar el carácter, procedencia, administración y destino de todos sus recursos.

1. El régimen disciplinario.

$\mathrm{m}$. El procedimiento para la reforma de sus estatutos, que deberán ser aprobados por la Administración deportiva de Galicia.

n. Las causas de extinción o disolución de la federación, así como el destino al que haya que aplicar su patrimonio en tales supuestos.

Artículo 35. 1. Son órganos de gobierno y representación la Asamblea general y el Presidente. En la Asamblea general de-

842 Véase Orden de 3 de abril de 2006 por la que se establecen los criterios para la elaboración de reglamentos y realización de los procesos electorales en las federaciones deportivas gallegas. berá constituirse una Comisión delegada de asistencia a la misma. Los estatutos podrán contemplar otros órganos complementarios de gobierno para asistir al Presidente.

2. La Asamblea general es el máximo órgano de representación y gobierno. En ella estarán representados los diferentes estamentos deportivos que componen la federación. La determinación de los miembros de cada estamento que forman parte de la Asamblea general se hará en base a una elección. mediante sufragio libre, igual, directo y secreto por y entre los integrantes mayores de edad de cada colectivo.

3. La Asamblea general elegirá entre sus miembros a la Comisión delegada.

4. El Presidente es el órgano ejecutivo de la federación, ostenta la representación legal y preside los órganos de representación y gobierno ejecutando los acuerdos de los mismos.

Será elegido mediante sufragio libre, igual y secreto por y entre los miembros de la Asamblea general.

En ningún caso podrá ser al mismo tiempo Presidente de otra federación y de un club.

5. Los demás órganos y comités que puedan crearse, de acuerdo con los estatutos y normas que les sean de aplicación, serán designados y removidos libremente por el Presidente de la federación.

6. El mandato de los miembros de la Asamblea general y del Presidente es de cuatro años, renovándose en los años en que se celebren los juegos olímpicos de invierno.

Artículo 36. En caso de disolución de una federación, su patrimonio tendrá el destino que se determinase en sus Estatutos. En lo no previsto en los mismos la Administración deportiva de Galicia le dará el destino que corresponda.

\section{Sección $5 .^{\mathrm{a}}$}

\section{Ligas profesionales y sociedades anónimas deportivas}

Artículo 37. 1. Los clubes deportivos de una misma modalidad podrán constituir ligas-profesionales integradas exclusiva y 
obligatoriamente por todos los clubes participantes en ellas. Deberán ser autorizadas por la Administración Autonómica.

2. Los clubes deportivos integrantes de una liga profesional deberán adoptar la forma jurídica de sociedad anónima deportiva, en los términos establecidos en la legislación vigente.

3. Las ligas profesionales tendrán personalidad jurídica propia y gozarán de autonomía para su organización interna y funcionamiento y podrán celebrar convenios con la federación deportiva gallega correspondiente. Su constitución, organización y funcionamiento se establecerán reglamentariamente.

4. La constitución, estatutos y reglamentos de las ligas profesionales serán aprobados por la Administración Autonómica.

Artículo 38. Serán competencias de las ligas profesionales:

a. Organizar sus propias competiciones.

b. Desempeñar respecto de sus asociados las funciones de control, tutela y supervisión, así como las establecidas en la presente ley y disposiciones de desarrollo.

c. Ejercer la potestad disciplinaria en los términos previstos en la presente ley y en sus normas de desarrollo, estatutos y reglamentos.

Artículo 39. 1. Las sociedades anónimas deportivas constituidas de conformidad con la Ley 10/1990, de 15 de octubre, del Deporte, y con domicilio social dentro del ámbito territorial de la Comunidad Autónoma de Galicia podrán gozar, en su caso, de los beneficios específicos derivados de la presente ley y de sus normas de desarrollo, previo acceso de las mismas al Registro de Asociaciones Deportivas y Deportistas de Galicia mediante su adscripción al censo correspondiente del mencionado Registro.

2. Las sociedades anónimas deportivas con domicilio social en la Comunidad Autónoma de Galicia que participen en competiciones oficiales no profesionales tendrán la consideración de clubes deportivos a los efectos de participación en los órganos de las federaciones deportivas gallegas.

3. Reglamentariamente se determinará el procedimiento de adscripción y la documentación necesaria para que ésta pueda realizarse.

\section{Sección $6 .^{\mathrm{a}}$ \\ Entidades de fomento deportivo}

Artículo 40. 1. Son entidades de fomento deportivo de ámbito autonómico las asociaciones constituidas por personas físicas cuya finalidad exclusiva sea la promoción y organización de actividades deportivas con fines lúdicos, formativos, recreativos o sociales, y que en ningún caso entren en concurrencia con la actividad propia de las federaciones deportivas gallegas.

2. Para proceder a su reconocimiento se requerirá que no tengan finalidad de lucro, un número no menor de 6.000 asociados, funcionamiento interno democrático $\mathrm{y}$ que la adhesión de los miembros sea enteramente libre, y deberán ser plenamente independientes de cualquier organización política sindical, económica o religiosa.

\section{Capítulo III REGISTRO DE ASOCIACIONES DEPORTIVAS Y DEPORTISTAS DE GALICIA}

Artículo 41. 1. Se crea el Registro de Asociaciones Deportivas y Deportistas de Galicia adscrito a la Administración deportiva de Galicia cuyo objeto es la inscripción de las asociaciones deportivas y de los deportistas regulados en la presente ley.

2. En caso de asociaciones deportivas, la inscripción afectará a los datos y actos que reglamentariamente se determinen y, en todo caso, comprenderá:

a. El acta de constitución.

b. Los estatutos.

c. Los órganos directivos, los promotores y los representantes legales.

d. En todo caso deberán inscribirse las licencias expedidas por las federaciones a los deportistas integrantes de las mismas. 
Artículo 42. 1. La organización, régimen interno y funcionamiento del Registro de Asociaciones Deportivas y Deportistas de Galicia se determinará por vía reglamentaria.

2. El Registro se estructurará en diferentes secciones para las diferentes clases de asociaciones y deportistas, con arreglo a lo que se determine reglamentariamente.

3. Los deportistas no federados podrán solicitar la licencia correspondiente al Registro de Asociaciones Deportivas y Deportistas de Galicia en la forma que reglamentariamente se determine.

4. La inscripción en el Registro de Asociaciones Deportivas y Deportistas de Galicia de las asociaciones deportivas y entidades reguladas en la Ley determinará su reconocimiento legal y es un requisito indispensable para optar a las ayudas, subvenciones y asesoramiento de la Administración autonómica, así como para la participación en las competiciones oficiales.

5. La inscripción en el Registro de Asociaciones Deportivas y Deportistas de Galicia no convalidará los actos que sean nulos ni los datos que sean incorrectos de acuerdo con las leyes.

Artículo 43. 1. El nombre y los símbolos de las asociaciones inscritas gozarán de protección registral. El Registro dará fe de los datos que se contienen en el mismo. Estas garantías se entienden referidas al ámbito de la práctica deportiva sin perjuicio de los derechos establecidos en las leyes generales.

2. Las asociaciones deportivas no podrán utilizar una denominación idéntica a la de otras ya registradas o que pueda inducir a confusión, ni podrán usar los símbolos o emblemas de otras entidades y asociaciones.

\section{Capitulo IV \\ AYUDAS Y SUBVENCIONES A LAS ASOCIACIONES DEPORTIVAS}

Artículo 44. La Administración autonómica podrá disponer los sistemas de ayudas económicas a las asociaciones deportivas, estableciendo los mecanismos de control precisos para la efectiva aplicación de aquéllas para el fin para el que fueron concedidas.

Artículo 45. Para la concesión de las ayudas y subvenciones a que se refiere este capítulo se tendrán en cuenta la calificación deportiva obtenida por los destinatarios o solicitantes de las mismas, la clase de competición en la que hubiesen intervenido o pretendan intervenir, el número de participantes, el material deportivo de utilización necesaria, las personas necesarias para su organización y cuantos otros aspectos se determinen en las normas reglamentarias.

\section{TÍTULO IV ACTIVIDAD DEPORTIVA}

\section{Capítulo I DISPOSICIÓN GENERAL}

Artículo 46. 1. Se considera actividad deportiva a los efectos de la presente ley la práctica de las modalidades deportivas realizadas por cualquiera de las personas o miembros de las asociaciones a que se refiere el título III.

2. Todos los deportistas que realicen actividad deportiva en el ámbito de la Comunidad Autónoma de Galicia en los términos de la presente ley gozarán de la protección y asistencia de los órganos correspondientes de la Administración autonómica, y singularmente de la asistencia médico-sanitaria en caso de lesión o accidente deportivo, a través del sistema de sanidad pública o, en su caso, mediante los oportunos convenios con entidades privadas.

Las asociaciones deportivas no podrán exigir cantidad alguna en concepto de derechos de formación o retención ni cualquier otro tipo de compensación económica por los deportistas menores de dieciséis años.

3. La Comunidad Autónoma de Galicia coordinará su actuación con la Administración deportiva del Estado para la promoción y apoyo al deporte de alto nivel en el ámbito territorial que le es propio, estableciendo programas de preparación 
conjuntos para coordinar la asignación de beneficios y ayudas.

Además de las medidas que, en coordinación con las demás administraciones públicas, se adopten para la mejor protección y asistencia de los deportistas de alto nivel, se considerará dicha calificación como mérito evaluable tanto para las pruebas de selección para plazas relacionadas con la actividad deportiva correspondiente como en los concursos para la provisión de puestos de trabajo relacionados con aquella actividad, siempre que en ambos casos esté prevista la valoración de méritos específicos.

Independientemente de la clasificación general de deportistas de alto nivel y de las medidas que se establecen en la legislación del Estado, la Comunidad Autónoma de Galicia podrá realizar una calificación propia de deportistas de alto nivel, de acuerdo con las federaciones deportivas gallegas, a efectos del ámbito gallego, y que será publicada en el "Diario Oficial de Galicia”, a los que les serán de aplicación los beneficios que se establecerán reglamentariamente ${ }^{843}$.

4. La Comunidad Autónoma de Galicia establecerá los mecanismos necesarios de colaboración entre los distintos órganos de la Comunidad y la Administración local para facilitar la realización efectiva del deporte a la población, en especial a la de edad escolar, coordinando a tal efecto la actuación de los órganos con competencias en deporte, educación, sanidad y obras públicas.

\section{Capítulo II ACTIVIDAD DEPORTIVA COMPETITIVA}

\section{Sección $1 .^{a}$}

Competiciones

Artículo 47. Las competiciones deportivas que se celebren en territorio de Galicia se clasifican:

843 Véase:

- Decreto 6/2004, de 8 de enero, por el que se regula la cualificación de los deportistas gallegos de alto nivel y los programas de beneficios dirigidos a éstos. a. Por su ámbito territorial, en internacionales, estatales, interautonómicas, autonómicas, provinciales, comarcales y locales.

b. Por su naturaleza, en oficiales y no oficiales. Las oficiales pueden ser de carácter profesional o no profesional.

Artículo 48. 1. Para que una competición tenga el carácter de oficial en el ámbito autonómico deberá ser calificada como tal por la Administración deportiva de Galicia. Se entenderá concedida la correspondiente calificación a las competiciones organizadas por las federaciones deportivas gallegas, en el ámbito de su competencia, salvo denegación expresa, que deberá ser motivada.

2. Será necesario estar en posesión de la correspondiente licencia deportiva expedida por la federación deportiva gallega correspondiente para participar en las competiciones de carácter oficial organizadas por la misma. En otro caso será necesario estar en posesión de la licencia deportiva expedida por el Registro de Asociaciones Deportivas y Deportistas de Galicia.

Artículo 49. Las competiciones de carácter profesional deberán ser calificadas como tales por la Administración deportiva de Galicia. Tal calificación deberá contener, asimismo, las condiciones de uso de las instalaciones deportivas de titularidad pública, que serán fijadas reglamentariamente.

Artículo 50. 1. La organización de las competiciones oficiales de ámbito autonómico de una determinada modalidad deportiva corresponderá exclusivamente a las federaciones deportivas gallegas, que tendrán derecho preferente para tal fin al uso de las instalaciones deportivas públicas autonómicas, en las condiciones que se establezcan reglamentariamente, sin perjuicio de lo establecido en el artículo 60.3.

2. En caso de no existir federación deportiva gallega a la que estuviese atribuida dicha modalidad deportiva, o bien de 
que aquélla no organizase competiciones para determinadas categorías, la organización podrá corresponder a otra de las asociaciones previstas en la ley o a la Administración deportiva de Galicia.

\section{Sección 2. ${ }^{\mathrm{a}}$}

\section{Actividad de entrenamiento}

Artículo 51. La actividad de entrenamiento consiste en los ejercicios sistemáticos y regulares de preparación física y técnica para el logro de una mayor eficiencia en la práctica de diversas especialidades deportivas, con la finalidad de participar en competiciones deportivas de carácter oficial.

Esta actividad será objeto de atención preferente, aunque subordinada a la de competición con relación al uso de instalaciones deportivas.

\section{Capitulo III ACTIVIDAD DEPORTIVA NO COMPETITIVA}

Artículo 52. La Administración autonómica, en colaboración con las diferentes administraciones locales y entidades y asociaciones deportivas, promoverá el deporte como hábito de salud y facilitará la actividad deportiva libre y espontánea ofreciendo el máximo de opciones al mayor número de personas para poder ocupar adecuadamente el tiempo libre.

Consecuentemente, a los efectos de la presente ley, se entenderá la actividad deportiva no competitiva como la realizada por personas de manera individual o colectiva con la única finalidad de lograr una mayor calidad de vida y bienestar social.

\section{TÍTULO V}

\section{INSTALACIONES DEPORTIVAS}

\section{Capítulo I}

REGISTRO DE INSTALACIONES

Y EQUIPAMIENTOS DEPORTIVOS DE GALICIA

Artículo 53. Se crea el Registro de Instalaciones y Equipamientos Deportivos de Galicia, cuya finalidad será incluir y controlar los espacios naturales de uso deportivo, las instalaciones y los equipamientos deportivos en la Comunidad Autónoma y facilitar la elaboración de los planes generales de instalaciones y equipamientos deportivos.

Artículo 54. 1. La Administración deportiva de la Comunidad Autónoma, con la colaboración de los Ayuntamientos, diputaciones y asociaciones deportivas, realizará un censo detallado de las infraestructuras deportivas de Galicia A estos efectos se entenderá como infraestructura deportiva todo espacio abierto o cerrado, con independencia de su ubicación, dotado de las condiciones suficientes para la práctica de una actividad deportiva. El censo se plasmará en el Registro de Instalaciones y Equipamientos Deportivos de Galicia.

2. A estos efectos, tanto los entes públicos como las asociaciones deportivas y las entidades privadas titulares de instalaciones de uso público de la Comunidad Autónoma de Galicia deberán facilitar a la Administración deportiva autonómica todos los datos necesarios para la elaboración y actualización del censo.

Artículo 55. Los datos de las infraestructuras que se incluyen en el censo reflejarán, al menos:

La ubicación territorial.

La titularidad de las mismas.

El estado de conservación y los servicios con que cuentan.

El aforo y la accesibilidad para personas disminuidas.

Las modalidades deportivas que puedan desarrollarse.

\section{Capitulo II \\ PLAN GENERAL DE INSTALACIONES Y EOUIPAMIENTOS DEPORTIVOS}

Artículo 56. 1. Al objeto de garantizar una adecuada utilización de los recursos que las administraciones públicas destinen a la promoción del deporte, se elaborará el Plan general de instalaciones y equipamientos deportivos de Galicia. 
2. Corresponde a la Administración Autonómica la redacción y aprobación de dicho plan. La aprobación llevará implícita la declaración de utilidad pública o interés social de las obras y la necesidad de ocupación de los bienes y derechos necesarios para llevar a cabo su ejecución, a los efectos de expropiación forzosa o imposición de servidumbres.

3. Dicho plan determinará los criterios generales de actuación y la ubicación geográfica de las instalaciones y equipamientos deportivos de interés general o federativo, establecerá las determinaciones y la tipología técnica de los mismos y señalará las etapas necesarias para su ejecución.

4. Con arreglo al título I de la presente ley, este plan establecerá como acción preferente dotar a todos los municipios de, al menos, las instalaciones deportivas más elementales, procurando ubicarlas en los centros de enseñanza o en sus proximidades.

Artículo 57. 1. Las entidades locales, clubes, federaciones gallegas y otros organismos públicos $\mathrm{y}$ privados, vinculados a la actividad deportiva, deberán facilitar a la Administración Autonómica la documentación e información pertinentes para la redacción del Plan general de instalaciones y equipamientos deportivos de Galicia.

2. Los clubes, federaciones gallegas $\mathrm{u}$ otros organismos públicos y privados, vinculados a la actividad deportiva, participarán en su elaboración y velarán por su cumplimiento en la forma que se determine reglamentariamente.

3. En cuanto a las entidades locales, se aplicará lo dispuesto en el artículo 59 de la presente ley.

Artículo 58. Las determinaciones del Plan general de instalaciones y equipamientos deportivos de Galicia se concretarán en:

a. Los estudios y planes de información y estimaciones de los recursos disponibles.

b. La memoria explicativa del plan con la definición de las actuaciones prioritarias en relación con los objetivos perseguidos y las necesidades territoriales.

c. El estudio económico y financiero de la valoración de las actuaciones territoriales prioritarias y de las de carácter ordinario.

d. Los planes y normas técnicas que definan y regulen las actuaciones.

e. Las características técnicas y requisitos de idoneidad de las instalaciones.

f. El censo de las instalaciones y de los equipamientos deportivos.

g. Las garantías de protección ambiental y paisajística de los terrenos y ubicación elegidos.

h. Los mecanismos de evaluación de la ejecución anual del plan.

Artículo 59. 1. La Administración Autonómica redactará el Plan general de instalaciones y equipamientos deportivos de Galicia con el informe previo de las entidades locales cuando el territorio de éstas se vea afectado por sus previsiones del plan, creándose a tal fin para dicho territorio una Comisión Paritaria compuesta por miembros de la Administración autonómica y de las administraciones locales.

2. La ejecución del Plan general de instalaciones y equipamientos deportivos deberá ser previamente aprobada por el Pleno de las corporaciones locales en la parte que les afecta, facilitando éstas a tal fin los terrenos y la financiación necesarios que, de acuerdo con el Plan, les corresponda.

\section{Capitulo III REQUUISITOS DE LAS INSTALACIONES}

Artículo 60. 1. Compete a la Administración autonómica efectuar el seguimiento y control de la ejecución de los proyectos de instalaciones deportivas subvencionadas por ella, a fin de garantizar el cumplimiento de los programas de actuación aprobados.

2. Las instalaciones deportivas deberán cumplir las disposiciones reguladoras de los siguientes aspectos:

a. Tipología de las instalaciones.

b. Características técnicas, condiciones y dimensiones. 
c. Higiene y seguridad y prevención de acciones violentas.

d. Acceso y utilización por las personas con minusvalía.

Los Ayuntamientos velarán por el cumplimiento de la citada normativa en todas las instalaciones de uso público que estén en su término municipal. Su cumplimiento se comprobará en el acto de concesión de la licencia de obras o de su actividad, que no podrá otorgarse si infringiese lo dispuesto en la normativa de referencia. Una vez otorgadas dichas licencias, se inscribirán en el censo municipal y se comunicarán al Registro de Instalaciones y Equipamientos Deportivos de Galicia para su inclusión en el censo autonómico.

3. Las instalaciones de los centros docentes públicos se proyectarán de forma que se favorezca su utilización deportiva polivalente y deberán ser puestas a disposición de los municipios, asociaciones deportivas y deportistas, respetando en todo caso el normal desarrollo de las actividades docentes.

Artículo 61. 1. Las instalaciones en cuya financiación y planificación participe la Administración autonómica incluidas en el Plan general de instalaciones y equipamientos deportivos deberán utilizarse de forma que se favorezca su uso deportivo polivalente en coordinación con las asociaciones deportivas que tengan una actividad relacionada con el uso de las instalaciones.

2. Los titulares de estas instalaciones deberán permitir el uso de las mismas a la Comunidad Autónoma para hacer posible la práctica general de la actividad deportiva, en la forma que se determine reglamentariamente.

\section{TÍTULO VI FORMACIÓN E INVESTIGACIÓN DEPORTIVA}

Artículo 62. 1. Para el desarrollo de la formación de técnicos deportivos, la
Administración autonómica colaborará con la Administración del Estado en las materias que le corresponden a éste como competencia exclusiva. Sin perjuicio de lo anterior, la Administración autonómica elaborará los programas de las enseñanzas de técnicos de acuerdo con las competencias que corresponden a la Comunidad Autónoma.

2. La Administración autonómica establecerá programas de formación y perfeccionamiento de técnicos en materia deportiva en colaboración con las federaciones deportivas gallegas.

3. Estos programas de formación y perfeccionamiento podrán ser realizados directamente por la Administración deportiva de Galicia o bien ser adjudicada la realización de los mismos a la Escuela Gallega del Deporte o a entidades privadas en la forma que se establezca reglamentariamente.

Artículo 63. La Escuela Gallega del Deporte, adscrita a la Administración deportiva de Galicia, será el centro rector de las enseñanzas deportivas en el ámbito de Galicia y también el centro de documentación deportiva. Su estructura, organización y funcionamiento se determinarán reglamentariamente.

Será competencia de la Administración Autonómica de Galicia la regulación, dentro del ámbito de la presente Ley, de las titulaciones del ámbito deportivo de Galicia, estableciendo los programas, niveles y régimen de acceso que corresponda para cada una. Expedirá las titulaciones correspondientes, sin perjuicio de los acuerdos a que pudiese llegarse con las federaciones deportivas gallegas para sus modalidades deportivas propias.

Artículo 64. Las asociaciones deportivas y demás organismos referidos en este título colaborarán con la Administración autonómica en la formación y cualificación de jueces o árbitros, técnicos y entrenadores de cada una de las respectivas modalidades 
deportivas, celebrando, a tal efecto, los cursos de formación y capacitación necesarios.

\section{TíTULO VII \\ DE LA JUSTICIA DEPORTIVA}

Artículo 65. En el marco de la presente ley, la justicia deportiva se extiende a:

a. Cuestiones disciplinarias, entendiendo por tales:

Infracciones de las reglas de juego o competición.

Acceso a la competición.

Infracciones de las normas generales de conducta deportiva establecidas en la presente ley, en las normas que la desarrollan y en los estatutos o reglamentos de las asociaciones deportivas.

Concesión de licencias.

b. La impugnación de los actos y acuerdos que en materia electoral adopten las asociaciones deportivas.

c. La impugnación de los actos y acuerdos de los órganos de gobierno y representación de las asociaciones deportivas.

Artículo 66. 1. Se entiende por infracciones de las reglas del juego o de la competición a los efectos de la presente ley las acciones u omisiones que durante el curso del juego o de la competición vulneren, impidan o perturben su normal desarrollo.

2. Son infracciones de las normas generales de conducta deportiva las acciones $\mathrm{u}$ omisiones que supongan un quebrantamiento por parte de cualquiera de las personas sujetas al ámbito de aplicación de la presente ley de cualquier norma de aplicación en el deporte no incluida en el apartado anterior o de los principios generales de la conducta deportiva.

3. Independientemente de lo anterior, se consideran expresamente comprendidos en el ámbito de la justicia deportiva los acuerdos o actos adoptados o realizados por los órganos de gobierno de las asociaciones deportivas que supongan vulneración de las normas o de los acuerdos de aplicación o infracción de lo dispuesto en la ley o en sus normas de desarrollo.

Artículo 67. 1. Se crea el Comité Galego de Xustiza Deportiva como órgano supremo de la justicia deportiva en el ámbito territorial de la Comunidad Autónoma gallega, adscrito a la Administración deportiva de Galicia, que, actuando con total independencia, decide en última instancia en vía administrativa las cuestiones de su competencia. Sus resoluciones serán directamente impugnables ante el órgano competente de la jurisdicción contencioso-administrativa.

2. El Comité Galego de Xustiza Deportiva conocerá de las materias a que se refiere el artículo 65 de la presente ley. Estará integrado por un Presidente y cuatro vocales, todos ellos Licenciados en Derecho. Tres de ellos serán designados por la Administración deportiva de Galicia y los otros dos por las federaciones deportivas gallegas, por un período de cuatro años, a través del procedimiento que se establecerá reglamentariamente. De entre ellos se elegirá al Presidente. Estará asistido por un secretario, que tendrá la condición de funcionario.

3. Son de la competencia del Comité Galego de Xustiza Deportiva el conocimiento y la resolución de los recursos interpuestos contra los actos y acuerdos de los órganos de gobierno de los clubes y federaciones deportivas gallegas en los supuestos, formas y términos que se determinen reglamentariamente.

4. También tendrá competencia para resolver respecto a cualquier otra acción u omisión que por su trascendencia en la actividad deportiva considere oportuno tratar la Administración deportiva de Galicia ${ }^{844}$.

Artículo 68. 1. Se entiende por potestad disciplinaria la facultad de investigar

844 Véase Decreto 198/1998, de 25 de junio, por el que se constituye el Comité Galego de Xustiza Deportiva y se establece el procedimiento de designación de sus miembros. 
y, en su caso, imponer sanciones a los sujetos que intervengan en la organización deportiva con ocasión de infracciones de las reglas de juego o competición y de las normas generales deportivas.

2. El ejercicio de la potestad disciplinaria deportiva corresponderá:

a. A los jueces o árbitros, durante el desarrollo de los encuentros o pruebas, con sujeción a las reglas establecidas en los reglamentos de cada modalidad deportiva.

b. A los clubes deportivos y asociaciones deportivas, sobre sus socios o asociados, deportistas, técnicos, directivos y administradores, de acuerdo con lo establecido en sus estatutos.

c. A las federaciones deportivas de Galicia, sobre todas las personas que forman parte de su estructura orgánica, comprendiéndose a estos efectos los clubes deportivos y sus deportistas, técnicos y directivos, los jueces y árbitros $\mathrm{y}$, en general, todas aquellas personas y entidades que, en condición de federados, desarrollen la modalidad deportiva correspondiente en el ámbito de la Comunidad Autónoma.

d. A las ligas profesionales de carácter autonómico, sobre las sociedades deportivas que participan en competiciones oficiales de carácter profesional y sobre sus directivos o administradores.

e. Al Comité Galego de Xustiza Deportiva, sobre la mismas personas y entidades que las federaciones deportivas gallegas, sobre éstas mismas y sus directivos y sobre las ligas profesionales.

Artículo 69. Se faculta a las federaciones deportivas gallegas y a los clubes deportivos y demás asociaciones para que determinen reglamentariamente las infracciones y sanciones que han de aplicar a consecuencia de la vulneración de las reglas de juego o competición y de las normas generales de la conducta deportiva. Dichos reglamentos incluirán, en todo caso:

a. La tipificación de las infracciones, de conformidad con las peculiaridades de la modalidad deportiva en cuestión, y también las sanciones correspondientes a cada una de las mismas.

b. La determinación de las circunstancias atenuantes y agravantes de la responsabilidad y los requisitos por los que ésta se extingue o prescribe.

c. La calificación de las infracciones, señalando las muy graves, graves y leves y estableciendo los criterios de diferenciación $\mathrm{y}$, en todo caso, los de proporcionalidad de la sanción aplicable.

d. La prohibición de la doble sanción por los mismos hechos.

e. La aplicación de los efectos retroactivos favorables.

f. La prohibición de sancionar por infracciones no tipificadas en el momento de su comisión.

g. La obligación de conceder audiencia al interesado.

h. Los distintos procedimientos de tramitación e imposición, en su caso, de sanciones.

i. El sistema de recursos contra las sanciones impuestas, en el que tendrá que mencionarse expresamente el recurso al Comité Galego de Xustiza Deportiva contra las resoluciones de los órganos disciplinarios federativos.

Artículo 70. 1. Los estatutos de las asociaciones deportivas clasificarán las infracciones en muy graves, graves y leves, aplicando las sanciones correspondientes en función de las mismas. Reglamentariamente se determinarán las infracciones y sanciones que con carácter mínimo deberán constar en cada uno de los grupos mencionados.

2. En todo caso, se considerarán infracciones muy graves las siguientes:

a. Las actuaciones dirigidas a predeteminar, mediante precio, intimidación o simple acuerdo o decisión, el resultado de una prueba o competición.

b. Los comportamientos, actitudes y gestos agresivos y antideportivos de los 
jugadores, cuando se dirijan al árbitro, a otros jugadores o al público.

c. Los quebrantamientos de sanciones impuestas.

d. La manipulación o alteración, ya sea personalmente o a través de persona interpuesta, del material o equipamiento deportivo en contra de las reglas técnicas de cada deporte cuando puedan alterar la seguridad de la prueba o competición o pongan en peligro la integridad de las personas.

e. La utilización, incitación o favorecimiento del uso de sustancias o fármacos prohibidos y la negativa a someterse a los controles de los mismos establecidos reglamentariamente.

f. La alineación indebida y la incomparecencia o retirada injustificada de las pruebas, encuentros o competiciones.

g. La participación en pruebas o competiciones no autorizadas por la Administración deportiva de Galicia.

h. La no ejecución de las resoluciones del Comité Galego de Xustiza Deportiva.

i. El incumplimiento de acuerdos de la Asamblea general y de los reglamentos federativos.

j. La no convocatoria de los órganos de gobierno de las federaciones deportivas gallegas en los plazos y condiciones legales.

k. La incorrecta utilización de los fondos privados o de las subvenciones, créditos, avales y demás ayudas de carácter público.

1. La organización de actividades distintas a las competiciones oficiales sin la preceptiva autorización de la Administración deportiva de Galicia.

m. La denegación injustificada de la licencia.

n. El incumplimiento de los convenios celebrados con la Administración deportiva de Galicia.

ñ. La reiteración de faltas graves.

De las infracciones a que se refieren los apartados g), h), i), j), k), 1), m) y n) podrá ser responsable el Presidente de la federación, sin perjuicio de las responsabilidades en que pudiesen incurrir otras personas físicas integrantes de los órganos federativos.

3. Se considerarán infracciones graves las siguientes:

a. El incumplimiento de órdenes e instrucciones emanadas de los órganos deportivos competentes.

b. Actuar de forma pública y notoria contra la dignidad y decoro propios de la actividad deportiva.

c. El incumplimiento de las reglas de administración y gestión del presupuesto y patrimonio.

d. La reiteración de faltas leves.

De las infracciones a que se refieren los apartados a) y c) podrá ser responsable el Presidente de la federación, sin perjuicio de las responsabilidades en que pudiesen incurrir otras personas físicas integrantes de los órganos federativos.

4. Se considerarán infracciones leves las siguientes:

a. Las conductas contrarias a las normas deportivas que no estén incursas en la calificación de muy graves o graves.

b. La incorrección con el público, compañeros y subordinados.

c. La adopción de una actitud pasiva

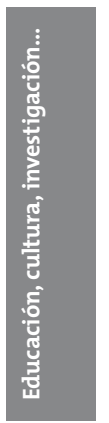
en el cumplimiento de las órdenes e instrucciones recibidas de jueces, árbitros y autoridades deportivas en el ejercicio de sus funciones.

Artículo 71. 1. Por la comisión de faltas muy graves se impondrán las siguientes sanciones:

a. Multa en cuantía no superior a 100.000 pesetas. Las multa solamente podrán imponerse a las asociaciones deportivas.

b. Pérdida de puntos o puestos de clasificación.

c. Pérdida de ascenso de categoría o división.

d. Clausura del recinto deportivo por un período máximo de una temporada. 
e. Suspensión o privación de la licencia federativa o de la habilitación para ocupar cargos en una organización deportiva por un plazo máximo de cinco años.

f. Suspensión o privación de la licencia federativa o de la habilitación para ocupar cargos en la organización deportiva a perpetuidad. Esta sanción sólo podrá acordarse, de modo excepcional, por la reincidencia en infracciones de extrema gravedad.

g. Inhabilitación por un período de dos a cuatro años, cuando las infracciones hubiesen sido cometidas por directivos.

h. Destitución del cargo, cuando las infracciones hubiesen sido cometidas por los directivos.

2. Por la comisión de faltas graves se impondrán las siguientes sanciones:

a. Amonestación pública.

b. Multa en cuantía no superior a 50.000 pesetas. La sanción de multa solamente podrá imponerse a las asociaciones deportivas.

c. Clausura del recinto deportivo hasta un máximo de cuatro encuentros o tres meses.

d. Suspensión de los derechos de asociado hasta un máximo de un año.

e. Suspensión o privación de la licencia federativa o habilitación equivalente e inhabilitación para ocupar cargos de un mes a dos años.

3. Por la comisión de faltas leves se impondrán las siguientes sanciones:

a. Apercibimiento.

b. Inhabilitación para ocupar cargos o suspensión de hasta un mes, o de uno a tres encuentros o pruebas.

Los clubes deportivos y restantes asociaciones previstas en la presente ley podrán establecer un sistema de infracciones y sanciones que deberá atenerse a lo dispuesto en ella. En caso de ausencia de tal regulación les será de aplicación lo establecido en la federación a la que estuviesen adscritos.

Artículo 72. 1. Para imponer sanciones por cualquier tipo de infracción será preceptiva la instrucción de un expediente, de acuerdo con el procedimiento que se establezca reglamentariamente, en el cual necesariamente se dará audiencia al interesado.

2. Los procedimientos disciplinarios tendrán las siguientes condiciones mínimas:

a. Notificación al interesado de la iniciación del expediente con expresión de los cargos que se le imputan. En los casos de infracción de las reglas de juego, esta notificación podrá hacerse a través del acta del partido o de la competición.

b. Plazo para proponer y practicar prueba.

c. Audiencia al interesado al término de la instrucción, con la posibilidad de alegación por parte de éste y de aportación de documentos.

d. Notificación personal o pública al interesado de la resolución dictada.

e. Recursos que procedan, indicando si agotan o no la vía federativa y, en este último caso, indicación expresa de recurso y plazo ante el Comité Galego de Xustiza Deportiva.

3. En todo caso las normas de procedimiento deberán garantizar el normal desarrollo del juego o competición y deberán interpretarse y aplicarse en tal sentido.

Artículo 73. 1. Serán consideradas como circunstancias atenuantes la de arrepentimiento espontáneo y la provocación suficiente inmediatamente anterior a la comisión de la infracción.

2. Serán consideradas como circunstancias agravantes de la responsabilidad la reincidencia, el precio y el perjuicio económico ocasionado.

3. Los órganos sancionadores podrán, en el ejercicio de su función, aplicar la sanción en el grado que consideren adecuado, teniendo en cuenta la naturaleza de los hechos, la personalidad del responsable, las consecuencias de la infracción y la 
concurrencia de circunstancias atenuantes o agravantes.

Artículo 74. 1. La responsabilidad disciplinaria se extingue:

a. Por el cumplimiento de la sanción.

b. Por el fallecimiento del inculpado.

c. Por disolución del club o federación deportiva sancionados.

d. Por prescripción de las infracciones o sanciones.

2. Las infracciones leves prescribirán al mes, las graves al año y las muy graves a los tres años.

3. Eltérminodeprescripcióncomienza a contar el día en que se cometieron los hechos y se interrumpe en el momento en que se acuerda iniciar el procedimiento sancionador, pero se reanuda si el expediente permaneciese paralizado durante un mes por causa no imputable al infractor.

4. Las sanciones prescribirán a los tres años, al año o al mes, según se trate de las que correspondan a infracciones muy graves, graves o leves, y el plazo de prescripción comienza a contar desde el día siguiente a aquél en que adquiera firmeza la resolución por la cual se impuso o desde que se quebrantase su cumplimiento, si éste ya comenzó.

\section{DISPOSICIÓN TRANSITORIA PRIMERA}

En cuanto no se elabore el Plan general de instalaciones y equipamientos deportivos de Galicia, las entidades locales notificarán a la Administración Autonómica sus previsiones de inversión en instalaciones y equipamientos.

\section{DISPOSICIÓN TRANSITORIA SEGUNDA}

Las asociaciones deportivas adaptarán sus Estatutos y reglamentos a lo dispuesto en la presente ley, en cuanto fuese necesario, en el plazo de un año, a partir de su entrada en vigor.

\section{DISPOSICIÓN TRANSITORIA TERCERA}

El Comité Galego de Xustiza Deportiva se constituirá en el plazo máximo de seis meses a partir de la fecha de entrada en vigor de la presente ley.

\section{DISPOSICIÓN TRANSITORIA CUARTA}

Las entidades deportivas inscritas en el Registro de Clubes, Federaciones y Entidades Deportivas de Galicia, creado por el Decreto 82/1983, de 21 de abril, deberán adaptarse a las disposiciones y en los plazos y formas que se determine reglamentariamente, a efectos de su inclusión en el Registro de Asociaciones Deportivas y Deportistas previsto en la presente ley.

\section{DISPOSICIÓN DEROGATORIA}

Quedan derogadas cuantas disposiciones de igual o inferior categoría se opogan a lo dispuesto en la presente ley.

No obstante lo anterior, mientras no se promulguen las disposiciones reglamentarias a que se refiere la disposición final primera, continuarán en vigor las disposiciones reglamentarias que sean compatibles con lo dispuesto en la presente ley.

\section{DISPOSICIÓN FINAL PRIMERA}

Se faculta al Consello de la Xunta de Galicia para dictar las disposiciones reglamentarias previstas en la presente ley y las que sean precisas para su desarrollo.

\section{DISPOSICIÓN FINAL SEGUNDA}

Se autoriza al Consello de la Xunta de Galicia para modificar la cuantía económica de las sanciones a que se refiere el artículo 71 de la presente ley.

\section{DISPOSICIÓN FINAL TERCERA}

La presente ley entrará en vigor el día siguiente al de su publicación en el "Diario Oficial de Galicia”. 


\section{LEY $14 / 2008$, DE 3 DE DICIEMBRE, DE TURISMO DE GALICIA (DOGA 246. 19.12.2008) \\ $(\ldots)^{845}$ \\ TÍTULO I \\ DISPOSICIONES GENERALES}

Artículo 1. Objeto y fines.

1. Esta ley tiene por objeto la ordenación del sector turístico gallego, así como el establecimiento de los principios básicos en materia de planificación, promoción y fomento del turismo.

2. La Administración autonómica acomodará sus actuaciones a la consecución de los siguientes fines:

a. La promoción y el estímulo de un sector turístico gallego competitivo y de calidad.

b. La promoción de la cooperación interterritorial.

c. El impulso de la desestacionalización y diversificación de la oferta turística.

d. El establecimiento de estándares que garanticen la sostenibilidad del desarrollo turístico y la conservación y difusión del patrimonio de Galicia.

e. El fomento de la autorregulación del sector turístico.

f. El impulso del turismo como medio de desarrollo de los valores propios de la cultura y de la identidad gallegas.

g. La garantía y la protección de los derechos de las usuarias y de los usuarios turísticos y la información y concienciación sobre sus deberes.

h. La erradicación de la clandestinidad y de la competencia desleal.

i. El impulso de la profesionalización del sector, con la mejora de la formación de los recursos humanos; en particular, en el uso de las nuevas tecnologías y en las competencias lingüísticas.

j. El impulso de los programas de investigación y desarrollo turístico $(\mathrm{I}+\mathrm{D}+\mathrm{T})$

845 Exposición de motivos omitida. que faciliten la incorporación de las empresas turísticas gallegas a la sociedad del conocimiento.

k. La promoción de la comercialización de los recursos y de las empresas turísticas dentro y fuera de nuestro país, para facilitar su acceso a nuevos mercados internacionales, en especial allí donde radiquen comunidades gallegas en el exterior.

1. La promoción de Galicia como marca turística de calidad, con la garantía de su tratamiento unitario en la difusión interior y exterior de los recursos del país.

m. El estímulo a los procesos de cooperación y asociacionismo entre las empresas y entre profesionales de los distintos sectores turísticos.

n. Fomentar la actividad turística para conseguir el equilibrio territorial entre las distintas zonas de Galicia.

Artículo 2. Ámbito de aplicación.

Las disposiciones de esta ley se aplicarán a los siguientes sujetos:

a. Administraciones, organismos y empresas públicas vinculadas al sector turístico.

b. Empresas turísticas.

c. Profesionales turísticos.

d. Cualquier actividad, empresarial y no empresarial, que preste servicios relacionados con el turismo y que sea calificada por la Administración turística con tal carácter.

e. Usuarias y usuarios turísticos.

\section{TÍTULO II ORGANIZACIÓN Y COMPETENCIAS DE LA ADMINISTRACIÓN TURÍSTICA GALLEGA}

Artículo 3. Administraciones públicas competentes en materia de turismo.

1. A los efectos de la presente ley, tienen la consideración de administraciones competentes en materia de turismo las siguientes:

a. La Administración de la Xunta de Galicia.

b. Los ayuntamientos. 
c. Las entidades locales supramunicipales.

d. Los organismos autónomos y las entidades de derecho público constituidos por cualquiera de las administraciones indicadas, o adscritos a las mismas, para el ejercicio de las competencias que afecten al sector turístico.

2. Las competencias de las administraciones turísticas mencionadas en el apartado 1 , siempre que no supongan el ejercicio de autoridad pública, podrán ejercerse a través de sociedades mercantiles públicas o recurriendo a otras fórmulas de derecho privado, conforme a lo establecido por la legislación aplicable en cada caso.

Artículo 4. Competencias de la Administración de la Xunta de Galicia.

1. Le corresponden a la Administración de la Xunta de Galicia, entre otras, las siguientes atribuciones:

a. La ejecución y actuación de las medidas de ordenación y promoción del turismo determinadas por la presente ley.

b. La protección y preservación de los recursos turísticos existentes y el fomento de la creación o la creación directa de nuevos recursos turísticos.

c. La promoción y protección de la imagen de Galicia como marca turística.

d. La declaración de recursos de interés turístico general, la declaración de ayuntamientos turísticos, la declaración de territorios de preferente actuación turística y la creación y definición de denominaciones geoturísticas.

e. La potenciación de la enseñanza de turismo y de la formación y perfeccionamiento de las profesionales y de los profesionales del sector.

f. El ejercicio de las potestades administrativas de planificación, programación, fomento, inspección y sanción previstas en la presente ley, de forma exclusiva o en colaboración con otras administraciones.

g. El sostenimiento del Registro de Establecimientos y Actividades Turísticas de Galicia. h. La elaboración de estadísticas turísticas y estudios relacionados con la materia, de acuerdo con lo dispuesto en la Ley 9/1988, de 19 de julio, de estadística de Galicia.

i. La elaboración y aprobación de los planes precisos para la determinación y priorización de los objetivos que haya que alcanzar para el desarrollo turístico de Galicia.

j. El ejercicio de potestades administrativas vinculadas a la protección de las empresas turísticas legalmente constituidas y a la defensa de su actividad frente al intrusismo.

2. Las atribuciones especificadas en el apartado 1 serán ejercidas por la consejería competente en cada caso, bajo la dirección y coordinación de la Xunta de Galicia.

Artículo 5. Competencias municipales.

Corresponden a los ayuntamientos, sin perjuicio de las competencias establecidas por la legislación de régimen local, las siguientes atribuciones:

a. La promoción y protección de los recursos turísticos de interés local y general.

b. La declaración de los recursos turísticos de interés local y, si procede, la iniciativa para que sean declarados recursos de interés turístico general.

c. La promoción de la concesión de denominaciones geoturísticas y de la declaración de interés turístico de lugares, bienes y servicios situados dentro de su territorio.

d. La colaboración con la Administración de la Comunidad Autónoma, instrumentada a través de fórmulas cooperativas adecuadas como la consorcial.

e. La participación en el proceso de elaboración de planes de ordenación, promoción o inspección turística de Galicia.

f. El ejercicio de las competencias turísticas que les delegue o les asigne la Administración de la Xunta, de acuerdo con lo establecido por la legislación de régimen local.

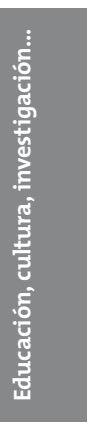


Artículo 6. Competencias de las entidades locales supramunicipales.

1. Corresponden a las entidades locales supramunicipales, sin perjuicio de las competencias establecidas por la legislación de régimen local, las siguientes atribuciones:

a. La promoción de los recursos y de las marcas turísticas de su ámbito territorial, en coordinación con todos los entes locales afectados.

b. El asesoramiento y apoyo técnico a los entes locales de su ámbito territorial en cualquier aspecto que mejore su competitividad turística.

c. La articulación, coordinación y fomento de las estrategias de promoción derivadas del ámbito privado del sector turístico.

d. La participación en la formulación de los instrumentos de planificación turística.

2. Las entidades locales supramunicipales ejercerán sus competencias turísticas en coordinación con el departamento de la Xunta competente en materia de turismo y con las demás administraciones turísticas de su ámbito territorial.

Artículo 7. Consejo Regulador del Turismo de Galicia.

1. El Consejo Regulador del Turismo de Galicia es un órgano consultivo de la consejería competente en materia de turismo encargado de colaborar con los órganos ejecutivos de ésta para garantizar el cumplimiento de la normativa aplicable en materia de turismo, así como en la ordenación, fomento y control de la calidad de los establecimientos y servicios del sector.

2. En particular, le corresponde:

a. Velar por que las clasificaciones de los establecimientos turísticos se adecuen a la realidad económica y social y a los niveles de calidad exigibles. A estos efectos, el consejo le propondrá a la consejería competente la creación, modificación o supresión de tipos de establecimientos turísticos o de modalidades o grupos dentro de los ya existentes. b. Favorecer el desarrollo de una oferta turística gallega de calidad, mediante la elaboración de la reglamentación de marcas turísticas de calidad.

c. Informar las normas y planes que se elaboren en materia turística.

d. Proponer cuantas iniciativas considere pertinentes en el ámbito de sus competencias.

e. Ejercer cuantas funciones le atribuya la Administración turística de Galicia.

3. El Consejo Regulador del Turismo de Galicia estará integrado por una presidenta o un presidente, que se elegirá de entre sus miembros, y un número máximo de 12 vocales que representarán a las administraciones públicas con competencias en materia turística y a las asociaciones más representativas del sector turístico.

Las o los vocales se elegirán por un período de cuatro años, y pueden ser reelegidos. Las o los vocales deberán estar vinculados a los sectores que representan, bien directamente o bien por ser cargos directivos de sociedades que se dediquen a las actividades que representan.

4. El régimen de elección de los miembros del consejo, así como el funcionamiento interno y las funciones correspondientes a cada uno, serán objeto de desarrollo reglamentario. Se procurará en este órgano la composición de género equilibrada según lo previsto en la Ley 7/2004, para la igualdad de mujeres y hombres en la Comunidad Autónoma de Galicia y en la Ley orgánica 3/2007, de 22 de marzo, para la igualdad efectiva de mujeres y hombres.

Artículo 8. Red Gallega de Oficinas de Turismo.

1. Son oficinas de turismo aquellas dependencias de titularidad pública o privada abiertas al público en general en las que se facilite orientación, asistencia e información turística.

2. Con el fin de fomentar la imagen de Galicia como marca turística y proporcionar una información veraz, completa 
y homogénea adecuada a las necesidades de las personas visitantes, se crea la Red Gallega de Oficinas de Turismo, integrada por las oficinas de turismo de titularidad de la Xunta de Galicia y aquellas otras de titularidad pública o privada que se integren voluntariamente en ella.

3. Se establecerán por reglamento las funciones, los servicios, el régimen horario mínimo, la identidad de imagen de la red y los demás requisitos que deban cumplir las oficinas integradas en la Red Gallega de Oficinas de Turismo, y las ventajas o prestaciones de la Administración turística de la Xunta de Galicia a las que pueden acceder, así como el procedimiento para solicitar la adhesión voluntaria a la red.

Artículo 9. Comunidades gallegas en el exterior.

1. Con el fin de complementar la actuación de la Administración de la Comunidad Autónoma gallega en el exterior en materia turística, que se lleva a cabo a través de las delegaciones de la Xunta en el exterior, se podrán suscribir acuerdos con las entidades representativas de las comunidades gallegas en el exterior, al considerarlas como un vehículo preferente de promoción turística fuera de nuestras fronteras.

2. La Xunta garantizará a estas comunidades y a las federaciones, uniones y confederaciones en que se agrupen el acceso a la información sobre las disposiciones y la actividad de sus órganos en materia de turismo, y promoverá la colaboración de éstas con la Administración de la Comunidad Autónoma de Galicia, de acuerdo con la legislación aplicable en la materia, para reforzar la presencia en el exterior de la Comunidad Autónoma, prestar los servicios que se les encomienden en el ámbito de la promoción turística de Galicia y, en su caso, percibir las ayudas públicas fijadas por la Xunta.

La Administración autonómica colaborará con estas comunidades y con las uniones, federaciones y confederaciones en que se agrupen, les garantizará el acceso a la información sobre las disposiciones y la actividad de sus órganos en materia de turismo y establecerá, en su caso, ayudas públicas dirigidas a ellas.

\section{TÍTULO III \\ DERECHOS Y OBLIGACIONES DE LA USUARIA O USUARIO TURÍSTICO}

Artículo 10. Concepto de usuaria o usuario turístico.

Son las personas físicas o jurídicas que disfrutan algún servicio o bien turístico o que los utilizan como destinatarios finales.

Artículo 11. Derechos de las usuarias y de los usuarios turísticos.

Las usuarias y los usuarios turísticos gozarán de los derechos que a continuación se enumeran, con independencia de otros reconocidos por la normativa general.

1. Derecho de información.

a. La usuaria o usuario turístico tiene derecho a recibir información comprensible, veraz, objetiva y completa sobre las características y el precio de los bienes y servicios que se le ofrecen antes de contratarlos. Dicha información será vinculante para el oferente en los términos establecidos en la legislación protectora de las consumidoras y consumidores.

b. La persona usuaria de servicios turísticos tiene derecho a obtener de la otra parte contratante todos los documentos que acrediten los términos de la contratación, así como las facturas emitidas, cuando sean legalmente exigibles.

c. La persona usuaria de servicios turísticos tiene derecho a exigir que, en un lugar de fácil visibilidad, se exhiban públicamente los distintivos acreditativos de la clasificación del establecimiento, el aforo y cualquier otra variable de actividad, así como los símbolos de calidad normalizados.

d. Toda información engañosa, incluso la publicitaria, dará a la usuaria o al usuario turístico el derecho a recibir la prestación o servicio turístico en las condiciones acordadas o anunciadas, o bien a una 
indemnización por los daños y perjuicios ocasionados.

2. Derecho a la calidad de los bienes y servicios adquiridos.

La usuaria o usuario turístico tiene derecho a la calidad del servicio, de acuerdo con el tipo de establecimiento y publicidad efectuada y en los términos previstos en el artículo 16.

3. Derecho a la seguridad.

a. La usuaria o usuario turístico tiene derecho a la seguridad de su persona y de sus bienes, de acuerdo con lo establecido en la legislación vigente.

b. La usuaria o usuario turístico tiene derecho a ser informado por la empresaria o el empresario turístico de cualquier riesgo previsible que pudiera derivarse del uso normal de las instalaciones y servicios, teniendo en cuenta su naturaleza y las circunstancias personales que puedan concurrir en la persona usuaria.

4. Derecho a la tranquilidad e intimidad. La usuaria o usuario turístico tiene derecho a la tranquilidad e intimidad de acuerdo con las características del establecimiento de que se trate y del entorno en el que éste se encuentre.

5. Derecho a formular quejas y reclamaciones.

a. La usuaria o usuario turístico tiene derecho a formular quejas y reclamaciones de acuerdo con lo establecido en la presente ley. Las empresas turísticas están obligadas a tener en sus establecimientos hojas de reclamaciones facilitadas por la Administración turística. Su existencia deberá ser anunciada de forma visible e inequívoca y deberán ser entregadas a los clientes cuando estos las soliciten $\mathrm{y}$, de ser el caso, previo pago de los servicios prestados. Las características y el procedimiento para la tramitación de las hojas de reclamaciones se determinarán reglamentariamente.

b. La usuaria o usuario turístico, de acuerdo con lo establecido por la legislación aplicable, podrá solicitar la intervención de los órganos arbitrales, los cuales están obligados a llevar a cabo todas las actuaciones pertinentes para dar respuesta a su solicitud.

6. Derecho a no sufrir discriminación en el acceso a los establecimientos de las empresas turísticas por razones de discapacidad, raza, lugar de procedencia, sexo, opción sexual, religión, opinión o cualquier otra circunstancia personal o social, de acuerdo con lo que se establece en la normativa de espectáculos públicos.

Artículo 12. Derechos de las usuarias y de los usuarios turísticos ante la Administración turística.

1. La usuaria o usuario turístico tiene derecho a obtener, de la Administración pública competente, información objetiva, veraz y completa sobre los distintos aspectos de la oferta turística y de los servicios comprendidos en ella, de acuerdo con lo establecido en la legislación vigente.

2. La usuaria o usuario turístico tiene derecho a que la Administración pública competente garantice la efectividad de todos los derechos inherentes a su condición, y a que procure la máxima eficacia en la atención y tramitación de sus quejas y reclamaciones.

3. La usuaria o usuario turístico podrá presentar las quejas y reclamaciones dirigidas a la Administración turística competente en las siguientes entidades:

a. En el establecimiento turístico de que se trate.

b. En las oficinas de información turística de la Red Gallega de Oficinas de Turismo.

c. En los registros de la Administración turística competente.

d. En cualquiera de los registros habilitados por el artículo 38 de la Ley 30/1992, de 26 de noviembre, reguladora del régimen jurídico de las administraciones públicas y del procedimiento administrativo común.

Artículo 13. Obligaciones de las usuarias y de los usuarios turísticos.

1. En el disfrute de los servicios contratados la usuaria o el usuario turístico deberá: 
a. Respetar el entorno social, cultural y el medio ambiente.

b. Pagar el precio de los servicios contratados en el lugar, tiempo y forma pactados, sin que la presentación de una queja o reclamación sea causa de exención.

c. Cumplir las prescripciones y reglas particulares de los lugares objeto de visita y de las empresas prestadoras del servicio turístico de que se trate, siempre que no sean contrarias a lo establecido en la legislación vigente.

d. Observar las normas usuales de educación, higiene, convivencia social $\mathrm{y}$ respeto a las personas, instituciones y costumbres de los lugares.

e. Respetar la dignidad y libertad sexual de las personas con las que se relacione.

2. Las usuarias y los usuarios turísticos, en el disfrute de las actividades turísticas, no podrán dañar ni alterar los servicios y recursos turísticos, y, en su caso, serán responsables de los daños que hubiesen causado.

\section{TÍTULO IV \\ DE LA ORDENACIÓN GENERAL DE LA ACTIVIDAD TURÍSTICA}

Artículo 14. Recursos de interés turístico.

1. Son recursos de interés turístico todos los bienes materiales e inmateriales y las manifestaciones de la realidad física, social, histórica y cultural que puedan generar o incrementar de manera directa o indirecta los flujos turísticos con repercusiones económicas para Galicia.

2. Tienen la consideración de recursos de interés turístico general aquellos que poseen la capacidad de generar flujos turísticos que contribuyen a reforzar la imagen de Galicia como marca turística global. En todo caso, tendrán este carácter los bienes culturales protegidos por la Administración autonómica o por organismos internacionales o estatales.

3. Tienen la consideración de recursos de interés turístico local aquellos que, aunque poseen la capacidad de generar flujos turísticos, no pueden ser clasificados como recursos de interés turístico general.

4. La declaración de un recurso como de interés turístico general o local se hará de acuerdo con el procedimiento que se establezca reglamentariamente y conllevará necesariamente su ordenación, promoción y protección, así como la previsión de los recursos precisos para este fin. En el caso de los recursos de interés turístico local corresponderá a los municipios afectados su declaración, previo informe favorable de la Xunta de Galicia.

5. Corresponde a la Administración de la Xunta de Galicia la competencia para inventariar los recursos de interés turístico de Galicia. Con este fin se creará un registro de recursos de interés turístico de carácter público que llevará la consejería competente en materia de turismo.

Artículo 15. Territorios de preferente actuación turística.

1. Los territorios que por sus especiales características demanden una actuación específica y singular de las administraciones turísticas, con el fin de garantizar la ejecución de una política turística común y especial, podrán ser declarados territorios de preferente actuación turística.

2. El procedimiento para la declaración podrá iniciarse a solicitud del ayuntamiento o de los ayuntamientos interesados mediante acuerdo de las respectivas corporaciones, o de oficio por la consejería competente en materia de turismo, en cuyo caso se les dará audiencia a los ayuntamientos afectados.

3. La declaración como territorio de preferente actuación turística se hará por el Consello de la Xunta de Galicia, a propuesta de la consejería competente en materia de turismo, por el procedimiento que se establezca reglamentariamente.

4. Para que un territorio sea declarado de preferente actuación turística será preciso que en él concurran las siguientes circunstancias: 
a. Que pueda ser susceptible de la ejecución de una política turística común.

b. Que disponga de recursos turísticos de interés general.

c. Que el planeamiento urbanístico prevea el suelo preciso para la dotación de los equipamientos turísticos necesarios para la ejecución de las políticas turísticas que se formulen.

d. Quesu declaración no sea incompatible con otros usos más dignos de protección.

5. La declaración como territorio de preferente actuación turística conllevará la aprobación de un plan de actuación integral sobre éste, que se formalizará a través de los oportunos mecanismos de cooperación interadministrativa entre la consejería competente en materia de turismo, las entidades locales afectadas y las asociaciones y organismos correspondientes. En todo caso, se garantizará la participación del Consejo Regulador del Turismo.

6. El plan de actuación integral tendrá como mínimo el siguiente contenido:

a. La catalogación de los recursos de interés turístico existentes.

b. Las propuestas de reforma del planeamiento urbanístico precisas para la dotación de los equipamientos turísticos.

c. La concreción de los usos turísticos previstos para el desarrollo del plan.

d. Los recursos económicos precisos para su desarrollo y líneas de ayuda para ayuntamientos y empresas privadas.

e. Los plazos de ejecución de los programas de actuación turística previstos en el mismo.

f. Las medidas necesarias para garantizar la adecuada protección de los recursos culturales y patrimoniales existentes.

g. Las previsiones organizativas precisas para su desarrollo.

7. En los territorios de preferente actuación turística se preverán programas específicos de protección medioambiental de las zonas turísticas a fin de lograr, entre otros, los siguientes objetivos: a. Evitar la degradación o destrucción del medio natural y procurar su correcto aprovechamiento.

b. Potenciar conductas responsables ecológicamente en todos los agentes que intervienen en el sector del turismo.

c. Preservar los recursos naturales no renovables, con la reducción de su consumo en lo posible, así como evitar su contaminación.

d. Acomodar el desarrollo turístico al entorno físico, al espacio y a la estética, siendo respetuosos con la historia y cultura de cada zona.

e. Garantizar el equilibrio del medio natural en la utilización de los servicios turísticos.

8. Asimismo, se desarrollarán programas para la preservación y restauración de las zonas culturales con valor histórico que, por sus singulares circunstancias de interés monumental, histórico o artístico, permitan el empleo de estos valores como incentivo para la promoción y el incremento de la demanda turística, con la garantía de la protección prevista en la Ley del patrimonio cultural de Galicia.

9. La elaboración y aprobación de la planificación turística se basará en la necesidad de garantizar la coherencia entre las determinaciones que los instrumentos de ordenación turística contuvieron, en relación al planeamiento territorial y urbanización, en aquellos aspectos que deban ser reglamentados en ambos marcos de planificación. En especial, se tendrá en cuenta en lo que afecta a la redacción de programas de protección para la conservación y valorización del patrimonio histórico y artístico, bellezas naturales, sistemas medioambientales, salud pública $\mathrm{y}$, en general, para la mejora de los medios urbanos, rurales y naturales.

Artículo 16. De la calidad turística. La Administración turística gallega velará por una elevación de la calidad de los servicios, lo que se concretará, entre otras, en las siguientes acciones: 
a. Corregir las deficiencias de infraestructura, instalaciones y equipamientos turísticos.

b. Conseguir un trato adecuado en la prestación de los servicios turísticos y hosteleros.

c. Facilitar una mayor profesionalización de las personas que trabajen en el sector, así como su acceso a una formación continua.

d. Apoyar la implantación de sistemas y controles de calidad.

e. Elaborar manuales de calidad, así como diseñar, difundir e incorporar distintivos y marcas de calidad.

f. En general, cualquier acción pública o de apoyo de la iniciativa privada dirigida a obtener la excelencia en la prestación de las actividades turísticas.

Artículo 17. Galicia como marca turística.

1. En la promoción de los recursos turísticos se impulsará la proyección interior y exterior de Galicia como marca turística global y de calidad que integra y respeta las demás marcas turísticas gallegas.

2. La Administración de la Xunta de Galicia promocionará la imagen de Galicia como marca turística en los mercados que considere adecuados. En esta actividad podrán colaborar las entidades municipales y supramunicipales y debe reflejarse la pluralidad de la oferta turística del país.

3. En el ejercicio de las funciones de coordinación que le corresponden y en los términos establecidos por la legislación de régimen local, la Administración de la Comunidad Autónoma podrá declarar obligatoria la inclusión del nombre «Galicia» y de los logotipos y lemas que se establezcan en las campañas de promoción impulsadas por las entidades locales gallegas.

4. La Administración de la Comunidad Autónoma podrá declarar obligatoria la inclusión del nombre "Galicia», y de los logotipos y lemas que se establezcan, en las campañas de promoción impulsadas por empresas y asociaciones turísticas llevadas a cabo con fondos públicos.
Artículo 18. Marcas turísticas de calidad.

Corresponde al Consejo Regulador del Turismo la elaboración de la propuesta de reglamento, que deberá ser aprobado por decreto de la Xunta, en el que se determinen los requisitos y el procedimiento para la obtención de las marcas turísticas de calidad. Asimismo, le corresponde al Consejo Regulador del Turismo la revisión periódica de los criterios para la obtención de dichas marcas.

Artículo 19. Otras denominaciones geoturísticas.

1. La Xunta de Galicia, oídos los ayuntamientos afectados, podrá definir, crear y otorgar denominaciones geoturísticas a itinerarios turísticos o rurales, a áreas concretas y a determinadas localidades, términos municipales o comarcas que presenten especiales características que así lo aconsejen para la promoción y ordenación de la actividad turística.

2. Las denominaciones geoturísticas podrán ser utilizadas tanto por entidades públicas como privadas para la promoción turística de las zonas o de los itinerarios a los que aquéllas se refieran.

3. En la consejería competente en materia de turismo existirá un Registro de Denominaciones Geoturísticas de Galicia, de naturaleza administrativa y carácter público, en el que se inscribirán en los términos que reglamentariamente se establezcan las denominaciones geoturísticas que otorgue la Xunta de Galicia.

Artículo 20. Ayuntamientos turísticos.

1. El Consello de la Xunta, a propuesta del departamento competente en materia de turismo, podrá declarar ayuntamientos turísticos a aquellos que cumplan como mínimo una de las siguientes condiciones:

a. Que el promedio ponderado anual de población turística sea superior al $25 \%$ del número de vecinos y que el número de plazas de alojamiento turístico y de plazas de segunda residencia sea superior al $50 \%$ del número de vecinos. 
b. Que el término municipal incluya un área territorial que tenga la calificación de recurso de interés turístico.

c. Que acrediten contar, dentro de su territorio, con algún evento o servicio turístico susceptible de producir una atracción turística que genere una cantidad de visitantes cinco veces superior a su población.

2. Sin perjuicio de los servicios mínimos que se establezcan con carácter general y de las competencias que le correspondan a otras administraciones públicas, los ayuntamientos turísticos deben prestar los siguientes servicios:

a. La protección de la salubridad pública y de la higiene en todo el término municipal, incluidas playas y costas.

b. La protección civil y la seguridad ciudadana.

c. La promoción y protección de los recursos turísticos del término municipal.

d. La señalización turística y la de información general.

e. La atención y la orientación a las usuarias y usuarios turísticos, mediante una oficina de información adherida a la Red de Oficinas de Turismo de Galicia.

f. La puesta a disposición de las usuarias y usuarios turísticos de un servicio de acceso a internet, de utilización momentánea, en la oficina de información turística o en otros puntos de consulta abiertos al público.

g. Las funciones ambientales que les correspondan de acuerdo con la normativa sectorial.

Los municipios turísticos deben prestar, además de los arriba indicados, los servicios mínimos que correspondan al volumen de población resultante de sumar el número de residentes con el promedio ponderado anual de población turística. También pueden establecer, de acuerdo con la legislación de régimen local, y en función de sus necesidades, otros servicios complementarios que puedan prestar temporalmente, o con varias intensidades, en función de la afluencia turística.

3. De acuerdo con lo establecido en la legislación de haciendas locales, los ayuntamientos turísticos pueden establecer tributos o recargos específicos.

4. Los ayuntamientos turísticos y los sujetos turísticos que prestan en ellos sus servicios deben ser objeto de atención preferente en los siguientes ámbitos:

a. En la elaboración de los planes y programas turísticos de las administraciones turísticas supramunicipales y de la Administración turística de la Xunta de Galicia.

b. En las líneas y medidas de fomento económico establecidas por la Administración de la Xunta y por las diputaciones.

c. En la declaración de áreas o ámbitos de interés turístico en los que queden incluidos.

d. En las actividades de la Administración de la Xunta dirigidas a la promoción interior y exterior del turismo y al fomento de la imagen de Galicia como oferta o marca turística global.

e. En las políticas de implantación o de mejora de infraestructuras y servicios que incidan notoriamente en el turismo y sean impulsadas por los distintos departamentos de la Administración de la Xunta.

5. La pérdida de la condición de ayuntamiento turístico se producirá:

a. Si lo solicita el ayuntamiento interesado.

b. Si dejan de darse las circunstancias que lo motivaron.

c. Si el ayuntamiento no presta los servicios mínimos inherentes a la condición de ayuntamiento turístico.

6. Será objeto de desarrollo reglamentario el procedimiento para la aprobación de la declaración de ayuntamiento turístico, así como para la pérdida de tal condición, que en los supuestos b) y c) del apartado anterior incluirá la audiencia al ayuntamiento afectado. 


\section{TÍTULO V \\ DE LA ORDENACIÓN DE LAS EMPRESAS TURÍSTICAS}

\section{Capitulo I \\ DE LOS DERECHOS Y OBLIGACIONES DE LAS EMPRESAS TURISTICAS}

Artículo 21. Concepto.

Son empresas turísticas las personas físicas o jurídicas que, de manera habitual y con ánimo de lucro, prestan servicios en el ámbito de la actividad turística.

Artículo 22. Derechos de las empresarias y de los empresarios turísticos.

Las empresarias y los empresarios turísticos gozarán de los derechos que a continuación se enumeran, con independencia de otros reconocidos por la normativa general:

a. El derecho a que se incluya información sobre sus establecimientos y su oferta de actividades en los catálogos, directorios y guías, cualquiera que sea su soporte, de la Administración general de la Xunta de Galicia y, en los términos que estas establezcan, de las demás administraciones turísticas.

b. El derecho a incorporarse a las actividades de promoción turística que lleven a cabo las administraciones públicas, en las condiciones que ellas fijen.

c. El derecho a solicitar las ayudas, subvenciones e incentivos para el desarrollo del sector promovidos por las administraciones públicas.

d. El derecho a participar, a través de sus asociaciones, en el proceso de adopción de decisiones públicas en relación con el turismo y en los órganos colegiados representativos de sus intereses previstos en esta ley.

e. El derecho a impulsar, a través de sus asociaciones, el desarrollo y la ejecución de programas de cooperación pública, privada y social de interés general para el sector turístico.

f. El derecho a proponer, a través de sus asociaciones, la realización de estudios, investigaciones y publicaciones que contribuyan a la mejora del desarrollo de la empresa turística en la comunidad autónoma.

g. El derecho a proponer, a través de sus asociaciones, cualquier otra acción no citada anteriormente que pueda contribuir al fomento y desarrollo turístico.

Artículo 23. Obligaciones de las empresarias y de los empresarios turísticos. Las empresarias y los empresarios turísticos estarán obligados a:

a. Contar con las autorizaciones previstas en esta ley.

b. Prestar los servicios a los que estén obligados en función de la clasificación de sus empresas y establecimientos turísticos, en las condiciones ofertadas o pactadas con las usuarias y con los usuarios turísticos, de conformidad con lo dispuesto en la presente ley y en los reglamentos que se dicten al efecto.

c. Velar por el buen estado general de las dependencias y del mantenimiento de las instalaciones y servicios del establecimiento y garantizarles un trato correcto a las clientas y clientes.

d. Informar previamente con objetividad y veracidad a las turistas y los turistas sobre el régimen de servicios que se ofertan en el establecimiento, sus condiciones de prestación y su precio y forma de pago, así como proporcionar a las usuarias y usuarios turísticos los demás datos e informaciones que establezca la normativa turística.

e. Comunicar al órgano competente, antes de su aplicación, los precios de los servicios ofertados y exhibirlos en un lugar visible y de modo legible con indicación clara de la inclusión del impuesto sobre el valor añadido, junto con el distintivo correspondiente a la clasificación del establecimiento.

f. Tener a disposición de las usuarias y usuarios turísticos hojas de reclamaciones turísticas, y entregar un ejemplar cuando se lo soliciten.

g. Facturar detalladamente los servicios de conformidad con los precios ofertados o pactados. 
h. Disponer de los libros y demás documentos que sean exigidos por la legislación vigente.

i. Garantizar la accesibilidad y la adaptación de las instalaciones de los establecimientos a las personas discapacitadas según lo dispuesto en el ordenamiento jurídico.

j. No discriminar a las usuarias y usuarios turísticos por razón de raza, lugar de procedencia, sexo, opción sexual, religión, opinión o cualquier otra circunstancia personal o social.

k. Proporcionar a las administraciones públicas la información y la documentación necesarias para el ejercicio de sus atribuciones legalmente reconocidas.

1. Suscribir los seguros de responsabilidad profesional obligatorios exigidos por los reglamentos de desarrollo de esta ley.

m. Colaborar en la protección de los recursos de interés turístico.

n. Mantener vigentes y debidamente actualizados el capital social, las fianzas y los seguros a los que obliga la normativa turística.

\section{Capitulo II \\ ASPECTOS BÁSICOS PARA EL DESARROLLO DE LA ACTIVIDAD TURÍSTICA}

Artículo 24. Libertad de empresa.

El ejercicio de la actividad turística empresarial es libre, sin otras limitaciones que las establecidas por la presente ley y las demás normas aplicables, bajo la forma de empresaria o empresario individual o colectivo, de conformidad con la legislación civil y mercantil.

Artículo 25. Protección de los derechos de las personas en la actividad turística.

La configuración y divulgación de los paquetes turísticos o la prestación de otros servicios turísticos por parte de empresas y actividades turísticas no podrán contener como elemento de reclamo la explotación sexual de las personas o cualquier otro aspecto que afecte a su dignidad, de conformidad con lo previsto en el Código ético mundial para el turismo, y cuidarán especialmente la utilización no sexista del lenguaje y/o de las imágenes en la publicidad de las acciones subvencionadas, especialmente en internet.

Artículo 26. Protección del patrimonio histórico-artístico, natural y cultural de Galicia.

Las actividades turísticas respetarán, conservarán y difundirán las costumbres y tradiciones gallegas y su riqueza cultural, preservarán su patrimonio histórico-artístico y natural y procurarán la armonía con otros sectores productivos.

Artículo 27. Intrusismo profesional. La realización o publicidad por cualquier medio de difusión de las actividades de las empresas turísticas sin estar en posesión de la autorización preceptiva tendrá la consideración de intrusismo profesional y se sancionarán administrativamente de conformidad con lo previsto en esta ley.

\section{Capitulo III \\ REOUISITOS GENERALES DE LAS EMPRESAS TURÍSTICAS}

Artículo 28. Autorización turística.

1. Las empresas turísticas, con anterioridad al inicio de sus actividades, deberán solicitar de la Administración turística competente la correspondiente autorización para su ejercicio y para la clasificación, en su caso, de los establecimientos. La mencionada autorización es independiente de otras que deban ser concedidas por otros órganos, en virtud de sus respectivas competencias. Para la concesión de la autorización turística es imprescindible la previa obtención de la licencia municipal de apertura, en caso de que esta proceda.

2. Las empresas turísticas también podrán obtener la pertinente autorización para la realización de cualquier tipo de modificación o reforma esencial que afecte a las condiciones en que se otorgó la autorización y clasificación inicial, así como en los casos en los que se produzcan 
cambios en el uso turístico o en la titularidad del establecimiento.

3. El plazo de resolución de las solicitudes de autorización mencionadas en los apartados anteriores será de tres meses, contados desde su entrada en el registro del órgano competente para su tramitación. Si transcurrido el mencionado plazo no tuvo lugar la notificación de una resolución expresa, la persona interesada podrá entender desestimada su solicitud.

4. Las empresas de alojamiento turístico que proyecten la construcción o modificación de un establecimiento turístico deberán, antes de iniciar cualquier tipo de obra y con anterioridad a la obtención de la correspondiente licencia municipal de obras, solicitar de la Administración turística informe relativo al cumplimiento de los requisitos mínimos de infraestructura y servicios, que será emitido en el plazo máximo de dos meses. Potestativamente podrán solicitar este informe las restantes empresas turísticas.

5. Las autorizaciones y clasificaciones otorgadas podrán ser modificadas o revocadas cuando se incumplan o desaparezcan las circunstancias que motivaron su concesión o sobrevengan otras que, de existir en aquel momento, justificaran su denegación.

Artículo 29. Registro de Empresas y Actividades Turísticas de la Comunidad Autónoma de Galicia.

1. El Registro de Empresas y Actividades Turísticas tiene como objeto fundamental elaborar y tener a disposición un censo de las empresas y actividades turísticas reglamentadas por la Comunidad Autónoma de Galicia, así como de aquellas otras que sean consideradas por la Administración turística de conveniente inscripción, debido a su incidencia turística, aun cuando no le ataña su reglamentación a dicha administración, siempre que ejerzan su actividad en el ámbito territorial de la Comunidad Autónoma de Galicia y soliciten la inscripción.
2. El Registro de Empresas y Actividades Turísticas es un registro público, de naturaleza administrativa, custodiado y gestionado por la Administración turística de la Comunidad Autónoma de Galicia.

3. La Administración turística de la Comunidad Autónoma de Galicia velará por su buen funcionamiento, y le corresponderá la clasificación de la documentación que esté bajo su custodia, así como la expedición de las certificaciones que se soliciten.

Artículo 30. Inscripción en el Registro de Empresas y Actividades Turísticas.

1. La inscripción será obligatoria para las empresas turísticas y sus establecimientos, para las entidades turísticas no empresariales y para aquellas actividades turísticas que estén reglamentadas. En este caso será precisa la obtención previa de la correspondiente autorización de la Administración turística.

Potestativamente, podrán inscribirse en el registro otras actividades que por sus servicios, instalaciones o interés para el turismo se consideren relevantes para ser incluidas en la oferta turística.

En todo caso, la inscripción en el Registro de Empresas y Actividades Turísticas será requisito imprescindible para poder acceder a ayudas y subvenciones en materia de turismo.

2. Las empresas que cesen en su actividad turística deberán notificarlo, en el plazo de diez días, a la Administración turística, y solicitar al efecto su baja.

La Administración turística revocará, previa audiencia a las personas interesadas, las autorizaciones otorgadas a aquellas empresas y actividades turísticas que incumplan el deber establecido en el párrafo anterior, y procederá a continuación a la cancelación de su inscripción en el Registro de Empresas y Actividades Turísticas.

3. Reglamentariamente se fijarán las normas de organización y funcionamiento del registro, el procedimiento y contenido de las inscripciones, así como su forma de acreditación. 
Artículo 31. Régimen, comunicación y publicidad de precios.

1. Los precios de todos los alojamientos turísticos y de los establecimientos de restauración tienen carácter de libres, y pueden fijarse y modificarse por las empresas a lo largo del año sin más obligación que notificarlos y sellarlos ante la Administración turística. El sellado también lo podrán realizar las asociaciones empresariales del sector turístico debidamente autorizadas.

2. Reglamentariamente se establecerán las normas sobre facturación, publicidad de precios, régimen de reservas, cesión y anulación de servicios turísticos y las indemnizaciones a que puedan dar lugar.

\section{Capitulo IV \\ DE LAS EMPRESAS DE ALOJAMIENTO TURÍSTICO}

\section{Artículo 32. Concepto.}

1. Son empresas de alojamiento turístico aquellas, de titularidad pública o privada, que desde un establecimiento abierto al público se dedican, de manera profesional, habitual y mediante contraprestación económica, a proporcionar hospedaje de forma temporal a las personas, con o $\sin$ prestación de otros servicios.

2. Quedan excluidas del ámbito de aplicación de la presente ley las actividades de alojamiento que tengan fines institucionales, sociales, asistenciales, laborales, educacionales o que se lleven a cabo en el marco de programas de la Administración dirigidos a la infancia y juventud, a la tercera edad, a las mujeres o a los colectivos en situación de necesidad o exclusión social o a víctimas de violencia de género.

Artículo 33. Modalidades de la actividad de alojamiento.

El ejercicio de la actividad turística de alojamiento solamente se podrá llevar a cabo previa obtención de autorización y/o de la clasificación del establecimiento en alguna de las siguientes modalidades:

a. Establecimientos hoteleros.

b. Apartamentos y viviendas turísticas. c. Campamentos de turismo.

d. Establecimientos de turismo rural.

e. Albergues turísticos.

f. Cualquier otra que se fije reglamentariamente.

Artículo 34. Establecimientos hoteleros. Concepto y clasificación.

1. Tendrán la consideración de establecimientos hoteleros los establecimientos turísticos situados en uno o en varios edificios próximos, o en parte de ellos, que estén dedicados a dar hospedaje, con ánimo de lucro, al público en general.

2. Se dividirán en los siguientes grupos:

a. Hoteles.

b. Residencias turísticas.

3. Tendrán la calificación de hoteles aquellos establecimientos que ofrezcan alojamiento, con o sin comedor y otros servicios complementarios, ocupen la totalidad de uno o varios edificios o una parte independizada de ellos, cuyas dependencias constituyan una explotación homogénea, con entradas, escaleras y ascensores de uso exclusivo, y que reúnan los requisitos técnicos mínimos en función de su categoría que se determinen reglamentariamente.

Los hoteles se clasificarán en cinco categorías identificadas por estrellas, con arreglo a las condiciones establecidas reglamentariamente, según, entre otros criterios, los servicios ofertados, el confort, el equipamiento de las habitaciones, las condiciones de las instalaciones comunes, los servicios complementarios y el personal de servicio.

4. Tendrán la calificación de residencias turísticas aquellos establecimientos que ofrezcan alojamiento con o sin comedor y otros servicios complementarios y tengan una estructura y unas características que les impidan conseguir los requisitos y condiciones exigidos para los hoteles. Las residencias turísticas estarán sometidas a los requisitos técnicos mínimos que en función de su categoría se fijen reglamentariamente. 
Artículo 35. Apartamentos y viviendas turísticas.

1. Tienen la condición de apartamentos turísticos los bloques o conjuntos de apartamentos, las casas, bungaloes, y otras edificaciones semejantes, que oferten alojamiento turístico, profesional y habitualmente, mediante contraprestación económica.

2. También se incluirá dentro de esta categoría la cesión por motivos vacacionales o turísticos, mediante contraprestación económica, de unidades aisladas de apartamentos, bungaloes o viviendas unifamiliares. En todo caso, el alojamiento comprenderá el piso completo o la vivienda unifamiliar, no habitaciones sueltas; y queda prohibido expresamente el alojamiento en viviendas particulares.

3. Las modalidades de apartamentos y viviendas turísticas, así como los requisitos que sirvan de criterios para su clasificación, se fijarán por vía reglamentaria.

Artículo 36. Campamentos de turismo.

1. Se entiende por campamento de turismo el establecimiento turístico que ocupa un espacio de terreno debidamente delimitado y dotado de las instalaciones y servicios que reglamentariamente se establezcan que esté destinado a facilitar, mediante contraprestación económica, la estancia temporal en tiendas de campaña, remolques habitables, caravanas o cualquier elemento semejante fácilmente transportable, así como en cabañas de madera y construcciones fijas destinadas al alojamiento temporal, siempre que se trate de edificaciones independientes o adosadas de planta baja, que la superficie que ocupen no supere el límite establecido reglamentariamente y que sean explotadas por la misma o el mismo titular del campamento.

2. Asimismo, podrán construirse elementos fijos, de planta baja únicamente, que tengan por objeto satisfacer necesidades colectivas de las personas acampadas, tales como la recepción, el supermercado, el restaurante o bar, los bloques de servicios higiénicos y las oficinas, y las dedicadas exclusivamente al personal de servicio. Este tipo de construcciones no podrá exceder del porcentaje de superficie total del campamento que se fije reglamentariamente.

3. Quedan fuera del ámbito de aplicación de la presente ley los campamentos juveniles, albergues, centros y colonias de vacaciones escolares, así como toda clase de acampadas que estén reguladas por sus normas específicas.

4. Se fijarán reglamentariamente las categorías y los requisitos que sirvan de criterios para su clasificación.

Artículo 37. Establecimientos de turismo rural.

1. Son considerados establecimientos de turismo rural aquellas edificaciones ubicadas en el medio rural que, por sus especiales características de construcción, emplazamiento y tipicidad, prestan servicios de alojamiento turístico mediante contraprestación económica. Estos establecimientos podrán estar situados en suelo de núcleo rural, en asentamientos tradicionales de menos de 500 habitantes cuyo suelo esté clasificado como suelo urbano o en suelo rústico. En cualquier caso, será de aplicación lo previsto en la normativa urbanística e instrumentos de planeamiento urbanístico en vigor.

2. Los establecimientos de turismo rural se clasifican en las siguientes modalidades:

a. Hoteles rurales.

b. Casas grandes y pazos.

c. Casas rurales.

d. Otros fijados reglamentariamente.

3. Con independencia de la modalidad de alojamiento de turismo rural adoptada, la especialidad de agroturismo será aplicable a los establecimientos que estén integrados en explotaciones agrarias, ganaderas o forestales que, juntamente al hospedaje, oferten servicios generados por la propia explotación. 
4. Por vía reglamentaria se fijarán las condiciones precisas para que un establecimiento sea clasificado en cada una de las modalidades indicadas en el apartado segundo, así como el número máximo de plazas de alojamiento.

Dentro de cada una de las modalidades indicadas podrán establecerse especialidades atendiendo a características como el emplazamiento en zonas determinadas, la tipología arquitectónica, la antigüedad de la edificación originaria, la obligación de la persona titular de residir en la propia explotación agraria o en la comarca, o el número máximo de habitantes de los núcleos de población, con la consideración de su carácter rural, la actividad agroturística u otras análogas.

Artículo 38. Hoteles rurales.

Son hoteles rurales los establecimientos hoteleros que cumplan los requisitos establecidos en el artículo 34 y que además reúnan las condiciones fijadas en el artículo 37 para ser considerados establecimientos de turismo rural.

Artículo 39. Casas grandes y pazos. Son casas grandes y pazos los establecimientos de turismo rural situados en pazos, castillos, monasterios, casas grandes, casas rectorales o inmuebles tradicionales de singulares características o valor arquitectónico.

Artículo 40. Casas rurales.

Son casas rurales los establecimientos de turismo rural situados en viviendas autónomas e independientes, con las características propias de la arquitectura tradicional gallega de la zona, en las que se proporcione mediante precio el servicio de alojamiento y, eventualmente, otros servicios complementarios.

Artículo 41. Modalidades de alojamiento.

La prestación de alojamiento turístico en las casas grandes, pazos y casas rurales se ajustará a algunas de las siguientes modalidades: a. Contratación individualizada de habitaciones dentro de la propia vivienda unifamiliar, con desayuno incluido.

b. Contratación de un grupo independiente de habitaciones o apartamentos.

c. Contratación integrada del inmueble para uso exclusivo del contratante, en condiciones, equipo, instalaciones y servicios que permitan su inmediata utilización. En los casos en que la persona titular no gestione directamente el alojamiento, deberá designar una persona encargada que facilite el alojamiento y resuelva cuantas incidencias puedan surgir con las usuarias y usuarios.

Artículo 42. Albergues turísticos. Son albergues turísticos los establecimientos que, en los términos previstos reglamentariamente, ofrezcan al público en general, de manera habitual, profesional y mediante precio, el servicio de alojamiento por plaza en habitaciones de capacidad múltiple.

\section{Capítulo V \\ DE LAS EMPRESAS DE RESTAURACIÓN}

Artículo 43. Empresas de restauración.

1. Son empresas de restauración las dedicadas de forma habitual y profesional a suministrar en establecimientos, fijos o provisionales, abiertos al público en general, comidas y bebidas para ser consumidas en el propio local o en otro lugar.

2. Quedan fuera del ámbito de aplicación de esta ley:

a. Aquellas empresas que presten servicio de comida y bebida con carácter gratuito o sin ánimo de lucro.

b. Las empresas que sirvan comidas y bebidas a contingentes particulares, siempre que no estén abiertas al público en general,

c. Los servicios de restauración en alojamientos hoteleros, siempre que su explotación no sea independiente del alojamiento y no esté abierta al público en general. 
d. Las empresas que sirvan comidas y bebidas a domicilio en lo que a la prestación de este servicio domiciliario se refiere.

e. Las empresas que presten este servicio en medios de transporte públicos.

f. Las empresas que sirvan comidas y bebidas a través de máquinas expendedoras.

g. Las empresas que sirvan comidas y bebidas de manera ambulante, es decir, fuera de un establecimiento comercial, en puestos o instalaciones desmontables, así como en vehículos.

3. Las empresas de restauración se clasifican en los siguientes grupos:

a. Restaurantes.

b. Bares.

c. Cafeterías.

d. Furanchos.

4. Reglamentariamente se definirán cada uno de los grupos y categorías de los establecimientos de restauración.

\section{Capitulo VI}

\section{DE LAS EMPRESAS DE INTERMEDIACIÓN}

Artículo 44. Concepto.

Son empresas de intermediación turística las dedicadas profesional y comercialmente al ejercicio de actividades de información, mediación y organización de servicios turísticos, con la posibilidad de que utilicen medios propios para llevarlas a cabo.

Artículo 45. Clasificación.

1. Las empresas de intermediación se clasifican en:

a. Agencias de viaje.

b. Centrales de reservas.

2. Reglamentariamente se fijarán los requisitos que deben cumplir las empresas para integrarse en cada categoría, y se pondrá especial atención en las entidades que prestan este tipo de servicios a través de internet.

\section{Capitulo VII \\ DE LOS COMPLEJOS TURÍSTICOS}

Artículo 46. Complejos turísticos vacacionales.

1. Se entiende por complejos turísticos vacacionales aquellos establecimientos que, además de prestar alojamiento en una o en varias de las modalidades previstas en esta ley, complementan su oferta con actividades turísticas de servicios complementarios de las previstas en el título VI.

2. Reglamentariamente se establecerán los requisitos y categorías de los complejos turísticos.

3. Los complejos turísticos de vacaciones se denominarán «ciudades de vacaciones» cuando cumplan las condiciones que, a estos efectos, se prevean reglamentariamente.

\section{TÍTULO VI \\ DE LA ORDENACIÓN DE LAS \\ EMPRESAS Y ACTIVIDADES DE SERVICIOS COMPLEMENTARIOS}

Artículo 47. Concepto y requisitos.

1. Son empresas o actividades turísticas de servicios complementarios aquellas consideradas por la Administración como de interés para el turismo o directamente relacionadas con él, tales como:

a. Empresas dedicadas a espectáculos y actividades recreativas de acuerdo con la normativa vigente en la materia.

b. Actividades de aventura o naturaleza.

c. Actividades deportivas en locales, en recintos o en espacios abiertos, especialmente campos de golf y actividades náuticas.

d. Empresas de transporte turístico o de alquiler de vehículos.

e. Empresas o actividades dedicadas a la valorización del patrimonio históricoartístico y cultural.

f. Empresas dedicadas a la organización de congresos y ferias de muestras.

g. Spas y parques acuáticos.

h. Empresas de oferta cultural combinada.

2. La realización de estas actividades podrá comunicarse a la Administración turística a efectos de su inscripción en el correspondiente registro.

3. La constancia registral de esta actividad no suplirá las autorizaciones sectoriales que resulten preceptivas en cada caso, si bien será precisa para su consideración 
como empresas o actividades turísticas a todos los efectos, incluyendo el derecho a percibir ayudas y subvenciones de la Administración turística de la Comunidad Autónoma de Galicia.

4. Reglamentariamente pueden fijarse los requisitos exigidos para el desarrollo de estas actividades.

Artículo 48. Balnearios y centros de talasoterapia.

Las empresas a las que hace referencia la Ley 5/1995, de 7 de junio, de regulación de las aguas minerales, termales, de manantial y de los establecimientos balnearios de la Comunidad Autónoma de Galicia, así como los centros de talasoterapia que dispongan de instalaciones complementarias turísticas, tendrán la consideración de empresas y actividades de servicios complementarios y estarán sujetas a las disposiciones de esta ley en todo lo relativo al ejercicio de sus actividades turísticas en dichas instalaciones.

\section{TÍTULO VII DE LAS PROFESIONES TURÍSTICAS}

Artículo 49. Concepto.

Se consideran profesiones turísticas las relativas a la prestación, de manera habitual y retribuida, de servicios específicos directamente relacionados con el sector en las empresas turísticas $\mathrm{y}$, en particular, las tendentes a procurar el descubrimiento, conservación, promoción, información, conocimiento y disfrute de los recursos turísticos.

Artículo 50. De las guías y de los guías de turismo.

1. La actividad profesional de la guía o del guía de turismo tendrá por objeto la prestación, de manera habitual y retribuida, de servicios de asistencia, acompañamiento e información en materia cultural, artística, histórica y geográfica a las turistas y a los turistas en sus visitas a museos y demás bienes integrantes del patrimonio cultural y nacional de Galicia situado en el ámbito territorial de la Comunidad Autónoma.
2. Se determinarán reglamentariamente las condiciones de acceso, ámbito de actuación y demás requisitos precisos para el ejercicio de la profesión de guía.

\section{TÍTULO VIII \\ PROMOCIÓN Y FOMENTO DEL TURISMO \\ Capitulo I \\ DISPOSICIONES GENERALES}

Artículo 51. Competencias y principios de actuación.

1. Corresponde a la Xunta de Galicia la promoción y el fomento interior y exterior del turismo de Galicia, sin perjuicio de las competencias de las entidades locales y de las del Estado.

2. La promoción de la oferta turística de Galicia, con la coordinación de las acciones y con el fomento de las actividades del sector turístico gallego, se realizará a través del centro directivo correspondiente de la consejería competente en materia de turismo, del Consejo Regulador del Turismo y de las empresas públicas Turgalicia, S.A. y Xacobeo, S.A., o entidades que las sustituyan en la promoción de la oferta turística. Reglamentariamente se determinarán los requisitos para que otras entidades públicas o privadas puedan colaborar en el ejercicio de esta función pública.

3. Las actuaciones en materia de promoción y fomento del turismo de Galicia se regirán por los principios de eficacia y economía de medios, y se buscará la máxima coordinación y colaboración entre las administraciones públicas con competencias en el ámbito turístico y entre ellas y el sector privado.

\section{Capitulo II \\ MEDIDAS DE PROMOCIÓN Y FOMENTO}

Artículo 52. Medidas de promoción turística.

1. La Xunta de Galicia adoptará en materia de promoción del turismo las medidas más adecuadas para potenciar 
y promocionar la imagen de calidad de Galicia como destino turístico.

2. Las actuaciones promocionales comprenderán:

a. El diseño y la ejecución de campañas de promoción turística de Galicia.

b. La participación en ferias y certámenes relacionados con el sector turístico.

c. La utilización de las nuevas tecnologías, especialmente de internet.

d. La concertación de acciones conjuntas de promoción turística con otras comunidades autónomas, con la Administración general del Estado y con las administraciones de otros estados, en especial con la República Portuguesa en el marco de la eurorregión Galicia-Norte de Portugal.

Artículo 53. Fiestas de interés turístico nacional de Galicia.

La Xunta de Galicia podrá declarar fiestas de interés turístico nacional de Galicia aquellas manifestaciones que supongan una valorización de la cultura y de las tradiciones populares y que tengan una especial importancia como atractivo turístico. Esta declaración se hará según se determine reglamentariamente en función de la antigüedad, singularidad o arraigo del acontecimiento.

Artículo 54. Fomento del turismo.

1. La Administración turística de la Comunidad Autónoma elaborará programas para potenciar la oferta turística gallega, a través de medidas de fomento que permitan conseguir, entre otros, los siguientes objetivos:

a. Impulsar el turismo como medio de desarrollo de los valores propios de la cultura y de la identidad gallegas, mediante la puesta en valor del patrimonio turístico gallego, con la revitalización de las costumbres, fiestas, tradiciones populares y demás recursos turísticos, la restauración del patrimonio histórico, artístico y cultural y con la preservación y potenciación del medio natural. A estos efectos, la Administración turística otorgará preferencia a los proyectos y acciones en aquellos municipios que adopten medidas tendentes a la conservación, potenciación y puesta en valor de su patrimonio cultural y natural.

b. Diversificar la oferta turística, con el impulso de su segmentación mediante el apoyo al desarrollo:

1. ${ }^{\circ}$ Del turismo rural y de interior, como sectores turísticos alternativos de calidad, con el fomento de la rehabilitación y conservación de la riqueza histórico-artística del ámbito rural y también de sus atractivos medioambientales.

2. ${ }^{\circ}$ Del turismo de costa, al aprovechar la cantidad y pluralidad de la oferta turística gallega vinculada a este sector y con el fomento de la preservación de la calidad de las aguas y playas gallegas, así como del paisaje y del medio litoral.

3. ${ }^{\circ}$ Del turismo cultural, con el aprovechamiento de la importante riqueza histórica y cultural de Galicia y con el fomento de su conservación y puesta en valor.

4. ${ }^{\circ}$ Del turismo de convenciones y congresos.

$5 .^{\circ}$ Del turismo náutico.

$6{ }^{\circ}$ Del turismo termal en establecimientos balnearios.

7. ${ }^{\circ}$ Del turismo activo vinculado con todo tipo de actividades deportivas y de contacto con la naturaleza.

$8 .^{\circ}$ Del turismo gastronómico.

$9{ }^{\circ}$ De cualquier otro segmento emergente en el marco de la continua evolución y de los cambios del mercado turístico.

c. Modernizar y profesionalizar el sector turístico y sus infraestructuras, para estimular y mejorar la calidad y la competitividad de la oferta turística, mediante las siguientes acciones:

1. ${ }^{\circ}$ Impulsar las agrupaciones de empresas y las actuaciones empresariales conjuntas que posibiliten la mejora de la productividad mediante la reducción de costes, prestación de servicios en común u otras acciones análogas.

2. ${ }^{\circ}$ Apoyar la modernización y la mejora de las infraestructuras de las empresas a 
través de la renovación y dotación de sus instalaciones, introducción de nuevos equipos o relevo de los ya obsoletos e implantación de servicios complementarios en sus ofertas turísticas, así como el fomento de la elevación de la categoría de los establecimientos turísticos.

$3{ }^{\circ}$ Incentivar el crecimiento selectivo y cualitativo de la oferta turística, y adecuarla a la demanda del mercado como medida para mejorar su competitividad.

4. ${ }^{\circ}$ Contribuir a la realización de actividades consistentes en la elaboración de estudios, publicaciones e investigaciones sobre el sector turístico que promuevan su innovación.

$5 .^{\circ}$ Potenciar las actuaciones de las entidades locales en materia de turismo relativas a la dotación de infraestructuras, equipamientos o servicios de interés turístico, así como a la promoción de sus recursos turísticos. Asimismo, se impulsará la agrupación de esfuerzos de los ayuntamientos que permitan configurar territorios con una oferta turística complementaria e integrada.

2. Se promoverán especialmente los programas de iniciativa pública o privada tendentes a proteger el medio natural de las zonas turísticas y a garantizar la sostenibilidad del desarrollo turístico, así como los que favorezcan la desestacionalización de la oferta turística.

Artículo 55. Ayudas y subvenciones.

1. La Administración turística podrá, de acuerdo con la normativa aplicable, establecer líneas de ayuda y otorgar subvenciones a las empresas turísticas, a las entidades locales y a otras entidades y asociaciones como medidas para estimular la realización de las acciones fijadas en los programas de promoción y fomento del turismo.

2. La concesión de subvenciones a todo tipo de entidades para la recuperación, restauración y rehabilitación de bienes de interés turístico, sean culturales, históricos, arqueológicos, artísticos o de otro tipo, que puedan producir flujos turísticos llevará siempre aparejada la exigencia inexcusable de asegurar el acceso a ellos de las usuarias y los usuarios en las condiciones que se determinen, expresada bien en la disposición normativa que anuncie dichas subvenciones o bien a través del correspondiente convenio de colaboración.

3. La concesión de las ayudas y subvenciones previstas en el presente artículo respetará los principios de publicidad, concurrencia y objetividad, así como las normas generales sobre la libre competencia y el derecho de la Unión Europea. De acuerdo con lo dispuesto por el artículo $14.11{ }^{\circ}$ de la Ley orgánica $3 / 2007$, de 22 de marzo, para la igualdad efectiva de mujeres y hombres, así como por el artículo $18.2 .^{\circ}$ de la Ley 7/2004, de 16 de julio, para la igualdad de mujeres y hombres en la Comunidad Autónoma de Galicia, se tendrá en cuenta la utilización no sexista del lenguaje y/o de las imágenes en la publicidad de las acciones subvencionadas, especialmente en internet.

4. Se podrá establecer en las bases que rijan la concesión de subvenciones por los órganos y entes de la Administración de la Xunta de Galicia la previsión de acciones positivas en el sentido del artículo 11 de la Ley orgánica $3 / 2007$, de 22 de marzo, para la igualdad efectiva de mujeres y hombres, y del artículo 4 de la Ley 7/2004, de 16 de julio, para la igualdad de mujeres y hombres en la Comunidad Autónoma de Galicia, en tanto se produzcan las condiciones y circunstancias previstas en estas normas.

Artículo 56. Fomento de los estudios turísticos.

1. La Administración turística propiciará la unificación de criterios en la programación de los estudios de formación reglada y ocupacional del sector turístico y promoverá el acceso a la formación continua de las trabajadoras y trabajadores ocupados del sector. Asimismo, apoyará la formación turística destinada a la adquisición de nuevos conocimientos y tecnologías y la formación de formadores. 
2. La Administración turística impulsará la suscripción de acuerdos y convenios con las universidades para la elaboración de programas y planes de estudios en materia turística.

\section{TÍTULO IX DISCIPLINA TURÍSTICA Capítulo I INSPECCIÓN TURÍSTICA}

Artículo 57. Ámbito de actuación de la Inspección turística.

1. Corresponde a las inspectoras y a los inspectores de turismo la verificación y el control del cumplimiento de las obligaciones impuestas por esta ley y demás normativa turística aplicable.

2. Con el fin de garantizar una adecuada planificación de la actividad inspectora y la consecución de los objetivos de calidad y excelencia de la actividad turística, anualmente la consejería competente en materia de turismo aprobará un plan de inspección turística.

3. En el plan de inspección se establecerán los objetivos de la actuación inspectora, los establecimientos objeto de inspección y su ámbito geográfico y temporal.

Artículo 58. Escala de inspección turística.

1. Para el ejercicio de las actividades de inspección turística se crea, dentro del cuerpo superior de administración de la Xunta de Galicia, grupo A, la escala de inspección turística. Para el ingreso en esta escala se exigirá estar en posesión de cualquiera de las titulaciones que habilitan para el acceso al grupo A.

2. La estructura, dependencia y funcionamiento orgánico de la escala de inspección turística serán establecidos reglamentariamente. Al mismo tiempo, se determinará reglamentariamente la relación que deberá existir entre el número de inspectoras e inspectores y las zonas objeto de inspección, al efecto de fijar el número de plazas con que contará la escala, que, en todo caso, debe ser suficiente para garantizar un control eficaz y eficiente de la actividad turística.

Artículo 59. Funciones de la Inspección turística.

Son funciones de la Inspección turística:

a. La vigilancia y la comprobación del cumplimiento de la normativa vigente en materia de turismo y, en particular, de la existencia de las infraestructuras y la dotación de los servicios obligatorios exigidos por aquélla.

b. La investigación de los hechos que puedan ser constitutivos de infracción administrativa de acuerdo con lo previsto en la presente ley.

c. El asesoramiento a los sujetos que desarrollan actividades turísticas sobre el cumplimiento y la aplicación de la normativa vigente.

d. La emisión de los informes técnicos que le solicite la Administración turística, y preceptivamente en los siguientes casos:

$1{ }^{\circ}$ En la apertura y clasificación de nuevos establecimientos e instalaciones turísticas y en las demás autorizaciones necesarias para el funcionamiento de las empresas turísticas, así como para las modificaciones, cambios de actividad y reclasificaciones.

2. ${ }^{\circ}$ En el control de la ejecución de las actividades subvencionadas y en la vigilancia del cumplimiento de las condiciones requeridas o de los convenios firmados que motivaron la concesión de subvenciones por parte de la Administración turística.

3. ${ }^{\circ}$ En el estado de las infraestructuras turísticas.

e. Todas aquellas otras funciones que reglamentariamente se le atribuyan dentro de su ámbito de actuación definido por esta ley.

Artículo 60. Facultades de las inspectoras y de los inspectores de turismo.

1. Las inspectoras y los inspectores de turismo tendrán la consideración de agentes de la autoridad, con las facultades 
y la protección que les confiere la normativa vigente.

2. El personal inspector estará provisto de una acreditación con la que se identificará en el desempeño de sus funciones.

3. Cuando lo consideren preciso para el ejercicio de sus funciones, las inspectoras e inspectores de turismo podrán solicitar el apoyo, concurso, auxilio y protección que necesiten de otras administraciones públicas.

4. Para el ejercicio de sus funciones, las inspectoras y los inspectores de turismo podrán:

a. Efectuar visitas de comprobación en cualquier momento.

b. Examinar la documentación de los sujetos que desarrollan actividades turísticas y que esté relacionada con dichas actividades.

c. Realizar citaciones a estos sujetos o a quien los represente, en las que constará la fecha, lugar, hora y objeto de la comparecencia, así como los efectos de no atenderlas.

Artículo 61. Deberes de las titulares y los titulares de actividades turísticas y del personal a su servicio.

1. Las titulares y los titulares de actividades turísticas, quien los represente legalmente y el personal empleado debidamente autorizado, o, en su defecto, las personas que se encuentren al frente de la actividad en el momento de una inspección, tienen el deber de facilitarles a las inspectoras e inspectores de turismo el acceso a las dependencias e instalaciones, el examen de los documentos, libros y registros preceptivos relacionados con la actividad turística y la obtención de copias o reproducciones de esta documentación, así como la comprobación de cuantos datos sean precisos para los fines de la inspección.

2. En los establecimientos donde se realice una actividad turística deberá existir un libro de visitas de la Inspección turística a disposición de las inspectoras e inspectores de turismo, con las características que reglamentariamente se determinen, en el que se reflejarán las inspecciones que se lleven a cabo y sus circunstancias.

3. $\mathrm{Si}$ por requerimiento de la Administración turística se tuviera que presentar algún documento, se extenderá la correspondiente diligencia de entrega, que deberá ser firmada por persona con facultad para representar a la titular o al titular del documento.

Artículo 62. Deberes del personal de los servicios de la Inspección turística.

1. El personal de los servicios de la Inspección turística deberá guardar secreto y sigilo profesional sobre el objeto de sus funciones.

2. En el ejercicio de sus funciones, la Inspección turística guardará con las administradas y los administrados la mayor consideración y cortesía, y los informará de sus derechos y de sus deberes, así como de la conducta que deben seguir en sus relaciones con la Administración turística, para facilitarles el cumplimiento de sus obligaciones.

Artículo 63. Coordinación interadministrativa.

1. La Inspección turística pondrá en conocimiento de los órganos administrativos correspondientes las deficiencias y posibles infracciones detectadas en el curso de sus actuaciones que incidan en el ámbito competencial de otros departamentos o administraciones públicas.

2. Las deficiencias y posibles infracciones en materia turística detectadas por las inspectoras y los inspectores o por el personal funcionario de otros servicios de la Xunta de Galicia o de las entidades locales serán comunicadas a la Administración turística, que actuará en el ámbito de sus competencias.

Artículo 64. Documentación de la actuación inspectora.

1. Todas las actuaciones de la Inspección turística se documentarán en actas, diligencias, comunicaciones e informes. 
2. Las actas y diligencias extendidas por la Inspección turística tienen la naturaleza de documentos públicos $\mathrm{y}$, si reúnen los requisitos establecidos por esta ley y sus disposiciones de desarrollo, constituirán prueba suficiente de los hechos que motiven su formalización, sin perjuicio de las pruebas que en defensa de los respectivos derechos o intereses puedan señalar o aportar las personas interesadas.

Artículo 65. Actas de inspección y de infracción.

1. Los resultados de la función inspectora de vigilancia y comprobación del cumplimiento de la normativa turística vigente serán recogidos en el acta de inspección correspondiente, en la que se consignarán, además de los datos identificativos del sujeto y la actividad inspeccionada, la referencia expresa de los hechos constatados y cuantas circunstancias contribuyan a su mejor determinación y valoración.

2. El acta de inspección será levantada en presencia de la persona titular de la actividad, de quien la represente o, en su caso, de cualquier persona dependiente de aquélla. De no haber persona ante la cual se pueda levantar el acta, se hará constar esta circunstancia por diligencia y se repetirá la inspección en momento distinto.

3. Cuando la Inspección turística estime que los hechos o comportamientos que dieron lugar a la inspección pueden ser constitutivos de infracción administrativa, se deberá hacer constar en un acta de infracción, en la que se describirán los hechos y los preceptos normativos que se consideren vulnerados.

4. Las personas interesadas, o quien las represente, podrán efectuar cuantas alegaciones o aclaraciones estimen convenientes para su defensa, que se reflejarán en el acta correspondiente.

5. Las actas tendrán que ser firmadas por la inspectora o inspector actuante y por la persona titular de la actividad, o por quien la represente o, en su defecto, por la persona que en ese momento esté al frente de la actividad. Si las personas mencionadas se negaran a firmar el acta, la inspectora o el inspector hará constar esta circunstancia, así como los motivos manifestados, si los hubiera, mediante la oportuna diligencia.

6. La firma del acta levantada acreditará el conocimiento de su contenido y en ningún caso implicará su aceptación.

7. El acta de infracción se extenderá al efecto de iniciación del expediente sancionador oportuno, de acuerdo con lo establecido en el artículo $82 .^{\circ}$ de la presente ley, y en el mismo acto se entregará una copia de ella a la persona titular de la actividad, o quien la represente. Si la persona inspeccionada rehusara la copia del acta, la inspectora o el inspector lo hará constar mediante diligencia, así como los motivos de la negativa, si los hubiera.

8. La entrega de la copia del acta o la negativa a recibirla, documentada mediante la correspondiente diligencia, se considerará como notificación del resultado de la inspección y abrirá un plazo de diez días para que la persona inspeccionada formule las alegaciones que estime procedentes.

Artículo 66. Cierre de establecimientos y suspensión de actividades.

1. Si mediante la correspondiente inspección se constatara el desarrollo de una actividad turística sin contar con la preceptiva autorización administrativa, la Inspección turística comunicará esta circunstancia al órgano competente para el otorgamiento de dicho título, al efecto de que este adopte, previa audiencia a la persona interesada, la medida del cierre del establecimiento o de la suspensión de la actividad. La medida podrá levantarse provisionalmente cuando se inicie la tramitación del procedimiento para obtener el preceptivo título administrativo habilitante.

2. Si mediante la correspondiente inspección se constatara el desarrollo de una actividad turística de modo que se produzca un grave riesgo para la salud o la seguridad de las consumidoras y consumidores 
o de las usuarias y usuarios, la Inspección turística adoptará con carácter urgente la medida de cierre del establecimiento o de suspensión de la actividad, y dará traslado del expediente al órgano competente para la tutela del interés público afectado.

Estas medidas provisionales deberán ser confirmadas, modificadas o levantadas en el acuerdo de iniciación del procedimiento, que deberá de efectuarse en los quince días siguientes a su adopción, y que podrá ser objeto del recurso que proceda. Las citadas medidas quedarán sin efecto si el procedimiento no se inicia en ese plazo o cuando el acuerdo de iniciación no contenga un pronunciamiento expreso acerca de ellas.

3. Las medidas previstas en este artículo se refieren a la normativa turística y son independientes de las consecuencias sancionadoras que, de acuerdo con la presente ley y otras que sean de aplicación, puedan seguirse de los hechos que las motivaron.

\section{Capitulo II RÉGIMEN SANCIONADOR Sección primera Disposiciones generales}

Artículo 67. Sujetos responsables.

1. Serán responsables administrativamente de las infracciones en materia de turismo las personas físicas y jurídicas que realicen actividades comprendidas en el ámbito de aplicación de la presente ley a las que les sean imputables las acciones $\mathrm{u}$ omisiones tipificadas en ella como infracciones.

2. Las titulares y los titulares de actividades turísticas serán responsables administrativamente de las infracciones cometidas por el personal afecto a su servicio cuando no se le pueda imputar directamente a éste la responsabilidad por la acción u omisión cometida.

3. Cuando el cumplimiento de las obligaciones previstas en la norma infringida les corresponda a varias personas conjuntamente, responderán éstas de forma solidaria de las infracciones cometidas y de las sanciones que se impongan.
Artículo 68. Concurrencia de regímenes sancionadores.

1. No se podrán sancionar los hechos que hubieran sido sancionados penal o administrativamente, en los casos en los que se aprecie identidad de sujeto, hecho y fundamento.

2. Si de la investigación de los hechos constitutivos de las infracciones tipificadas en la presente ley se obtuvieran indicios de que estos pudieran constituir delito o falta, se paralizará el procedimiento y se dará cuenta al Ministerio Fiscal, sin perjuicio de la adopción de las medidas provisionales oportunas.

\section{Sección segunda Infracciones}

Artículo 69. Infracciones leves. Se consideran infracciones administrativas de carácter leve:

a. Incumplir las obligaciones formales expresamente impuestas por la presente ley y sus disposiciones de desarrollo y, en particular:

$1 .^{\circ}$ No disponer materialmente de los documentos exigidos por la normativa turística para el ejercicio de las actividades, así como no observar en dicha documentación las condiciones exigidas.

$2 .^{\circ}$ Incumplir el deber de exhibir los distintivos, los carteles, la lista de precios y la documentación exigida por la normativa turística, así como exhibirlos sin las formalidades requeridas.

$3 .^{\circ}$ No comunicar a la Administración turística los cambios de titularidad de las actividades, los precios y aquellas alteraciones en el ejercicio de las actividades que no requieran autorización expresa, así como hacerlo fuera de los plazos establecidos.

4. ${ }^{\circ}$ Expedir sin los requisitos exigidos por la normativa turística las facturas o los justificantes de cobro por los servicios prestados, así como no conservar los correspondientes duplicados durante el tiempo establecido reglamentariamente.

5 . $^{\circ}$ No disponer de hojas de reclamaciones turísticas. 
6. ${ }^{\circ}$ Las acciones $\mathrm{u}$ omisiones que, en lo que atañe a la labor inspectora, impliquen un mero retraso en el cumplimiento de las obligaciones de comunicación e información.

b. Las deficiencias en la prestación de los servicios debidos en los términos contratados, cuando no causen un grave perjuicio a la clienta o cliente.

c. No poseer personal habilitado legalmente para el ejercicio de un puesto de trabajo, cuando así lo exija la normativa turística aplicable.

d. Las deficiencias en la atención y en el trato a la clientela por parte del personal de la empresa o del establecimiento cuando no constituyan infracción grave o muy grave, incluidas las que supongan una vulneración de su derecho a la tranquilidad de acuerdo con las características del establecimiento de que se trate y del entorno en el que este se encuentre.

e. Las deficiencias en las condiciones de funcionamiento y limpieza de los locales, instalaciones, mobiliario y equipamiento y la falta de decoro de los establecimientos, fachadas y cercanías del inmueble que formen parte de la explotación.

f. Las deficiencias en las dependencias o instalaciones destinadas al personal del establecimiento.

g. Permitir la venta ambulante ilegal de objetos en el establecimiento.

h. Cualquier otro incumplimiento de las obligaciones expresamente impuestas por esta ley que no esté tipificado como infracción grave o muy grave.

Artículo 70. Infracciones graves.

Se consideran infracciones administrativas de carácter grave:

a. Realizar actividades turísticas sin el título administrativo habilitante exigido por la normativa turística aplicable.

b. Incumplir o alterar las circunstancias que motivaron el otorgamiento del título administrativo habilitante para el ejercicio de la correspondiente actividad.

c. Utilizar denominaciones, rótulos o distintivos diferentes a los que correspondan según la normativa turística. d. Efectuar modificaciones de la estructura, capacidad o características de los establecimientos sin la previa autorización de la Administración turística cuando esta sea preceptiva.

e. Carecer de las dependencias o instalaciones para las trabajadoras y los trabajadores exigidas por la normativa vigente.

f. Obstruir la inspección o negarse a facilitar la información requerida por las inspectoras e inspectores.

g. Usar marcas o denominaciones geoturísticas que no correspondan o incumplan las condiciones reglamentariamente establecidas.

h. Efectuar cambios sustanciales o no cumplir en la prestación de los servicios respecto del lugar, tiempo, precio y demás condiciones acordadas en los contratos.

i. No prestar o prestar deficientemente los servicios debidos, siempre que cause un grave perjuicio a la clienta o cliente.

j. No expedir factura o justificante de pago por los servicios prestados en aquellos establecimientos en los que reglamentariamente se exija y cuando, en todo caso, la clienta o el cliente lo solicite, así como la facturación de conceptos no incluidos en los servicios prestados.

k. Percibir precios superiores a los exhibidos o notificados a la clienta o al cliente o percibir precios por servicios que, en virtud de la normativa turística, no sean susceptibles de cobro.

1. Tratar incorrectamente a la clientela en los supuestos manifiestamente ofensivos.

$\mathrm{m}$. Reservar plazas en número superior al de las disponibles.

n. Informar o hacer publicidad de los bienes o servicios de forma que se induzca a error o confusión en la persona consumidora o en la usuaria o usuario turístico.

ñ. Negarse o resistirse a facilitar las hojas de reclamaciones en el momento de ser solicitadas, incluso si la reclamación se fundamenta en la denegación de acceso al local o en que no se presta el servicio solicitado. 
o. Prohibir el libre acceso y expulsar a las clientas o clientes del establecimiento, en concordancia con la normativa vigente en materia de espectáculos públicos, cuando esto sea injustificado de acuerdo con la presente ley.

p. Contratar con empresas y establecimientos que no posean el preceptivo título administrativo habilitante turístico para el ejercicio de su actividad.

q. Vender o alquilar parcelas en los campamentos de turismo.

r. Reincidir en la comisión de faltas leves.

Artículo 71. Infracciones muy graves. Se consideran infracciones administrativas de carácter muy grave:

a. Utilizar las ayudas económicas otorgadas por la Administración turística para fines distintos de aquellos para los que fueron concedidas.

b. Ofrecer o prestar servicios turísticos que contengan como elemento de reclamo aspectos que vulneren los derechos fundamentales o las libertades públicas.

c. Vulnerar el derecho a la intimidad de las clientas y clientes.

d. Reincidir en la comisión de faltas graves.

Artículo 72. Reincidencia.

De acuerdo con lo previsto en la legislación del procedimiento administrativo común, se entiende por reincidencia la comisión de una infracción de la misma naturaleza respecto de la que motivó la sanción anterior en el plazo del año siguiente a la notificación de esta. En todo caso, se requerirá que la primera resolución hubiese adquirido firmeza en la vía administrativa.

Artículo 73. Prescripción de las infracciones.

1. Las infracciones tipificadas en la presente ley prescribirán en los siguientes plazos:

a. Las infracciones de carácter leve, al año.

b. Las infracciones de carácter grave, a los dos años. c. Las infracciones de carácter muy grave, a los tres años.

2. El plazo de prescripción de las infracciones comenzará a contarse desde el día en el que la infracción se hubiese cometido, o desde el día en el que cesase la conducta infractora, si esta tuviera carácter continuado en el tiempo.

Interrumpirá la prescripción la iniciación, con conocimiento formal de la persona interesada, del procedimiento sancionador, y se reanudará el plazo de prescripción si el expediente sancionador estuviera paralizado durante más de un mes por causa no imputable a la presunta o presunto responsable.

\section{Sección tercera Sanciones}

Artículo 74. Determinación de las sanciones.

1. Las infracciones tipificadas en la presente ley tendrán las siguientes sanciones:

a. Las infracciones leves, el apercibimiento o multa de hasta 900 euros. El grado mínimo de esta multa abarca hasta 300 euros; el grado medio, de 301 a 600 euros; y el grado máximo, de 601 a 900 euros.

b. Las infracciones graves, la multa de 901 hasta 9.000 euros. El grado mínimo de esta multa abarca de 901 a 3.600 euros; el grado medio, de 3.601 a 6.300 euros; y el grado máximo, de 6.301 a 9.000 euros.

c. Las infracciones muy graves, la multa de 9.001 hasta 90.000 euros. El grado mínimo de esta multa abarca de 9.001 a 36.000 euros; el grado medio, de 36.001 a 63.000 euros; y el grado máximo, de 63.001 a 90.000 euros.

Las cuantías de las sanciones de multa podrán ser actualizadas periódicamente por el Consello de la Xunta, pero en ningún caso la elevación porcentual que se fije en dicha actualización podrá superar la experimentada por el índice general de precios al consumo en la Comunidad Autónoma de Galicia desde la entrada en vigor de esta ley o desde la anterior revisión de las cuantías. 
2. Además, se podrán imponer las siguientes sanciones accesorias a las multas:

a. La suspensión de la actividad turística o del ejercicio profesional.

En caso de que se produzca reiteración de infracciones graves y cuando la comisión de una infracción cualificada como grave suponga un notorio perjuicio para la imagen turística de Galicia, un desprestigio de la profesión turística o un daño irreparable para la usuaria o el usuario, se podrá imponer una sanción de hasta seis meses de suspensión de la actividad o del ejercicio profesional.

En caso de que se produzcan infracciones muy graves, la sanción de suspensión podrá ser de seis meses y un día a un año.

b. La clausura definitiva del establecimiento o revocación del título administrativo habilitante para el ejercicio de la actividad.

Se podrá acordar la imposición de esta sanción en las infracciones muy graves que supongan un notorio perjuicio para la imagen turística de Galicia, un desprestigio evidente para la profesión o un daño irreparable para las usuarias y usuarios.

c. La pérdida de la posibilidad de obtener subvenciones y otras ayudas económicas de la Administración durante un plazo de hasta cinco años.

Esta sanción se impondrá como accesoria a la de multa en la infracción muy grave consistente en utilizar las ayudas económicas otorgadas por la Administración turística para fines distintos de aquellos para los que fueron concedidas, sin perjuicio de la obligación de reintegro de las ayudas recibidas.

Artículo 75. Graduación de las sanciones.

1. Para la graduación de las sanciones se considerarán especialmente los siguientes criterios:

a. La existencia de intencionalidad de la persona infractora.

b. La categoría de la empresa turística.

c. La reiteración en las conductas infractoras. d. El incumplimiento de los plazos y requisitos concedidos para la corrección de las deficiencias detectadas por las inspectoras e inspectores de turismo.

e. La corrección voluntaria, antes o durante la tramitación del procedimiento, de las deficiencias detectadas y de los daños y perjuicios causados.

f. Los perjuicios causados a los particulares.

g. El beneficio ilícito obtenido.

h. La trascendencia social de la infracción.

i. Las repercusiones negativas para el sector turístico y la imagen turística de Galicia.

2. De conformidad con los criterios establecidos en el apartado anterior, las sanciones de multa se podrán imponer en sus grados mínimo, medio o máximo. Asimismo, cuando la comisión de la infracción suponga un resultado más beneficioso para la persona infractora que el cumplimiento de la norma vulnerada, se considerará esta circunstancia como agravante para la imposición de la sanción de multa en su grado máximo.

Artículo 76. Publicidad de las sanciones.

Las sanciones por infracciones muy graves y las sanciones por infracciones graves que comporten la suspensión de la actividad turística o del ejercicio profesional serán publicadas en el Diario Oficial de Galicia.

Artículo 77. Inscripción de las sanciones.

Las sanciones administrativas impuestas por las infracciones tipificadas en la presente ley se anotarán en el libro-registro de sanciones.

Artículo 78. Prescripción de las sanciones.

1. Las sanciones previstas en esta ley prescribirán:

a. Las impuestas por infracciones leves, al año.

b. Las impuestas por infracciones graves, a los dos años. 
c. Las impuestas por infracciones muy graves, a los tres años.

2. El plazo de prescripción de las sanciones comenzará a contarse desde el día siguiente a aquel en el que adquiera firmeza la resolución por la que se impone la sanción.

Interrumpirá la prescripción la iniciación, con conocimiento formal de la interesada o del interesado, del procedimiento de ejecución, y volverá a transcurrir el plazo si aquél está paralizado durante más de un mes por causa no imputable a la persona infractora.

Artículo 79. Órganos competentes para la imposición de sanciones.

1. La competencia para imponer las sanciones previstas en la presente ley corresponde:

a. En las infracciones leves, a las delegadas o los delegados provinciales de la consejería competente en materia de turismo.

b. En las infracciones graves, a la persona titular del órgano directivo correspondiente en la consejería competente en materia de turismo.

c. En las infracciones muy graves, a la persona titular de la consejería competente en materia de turismo.

2. En caso de que las sanciones de multa se acompañen de las accesorias de suspensión de la actividad turística o del ejercicio profesional o de clausura definitiva del establecimiento o revocación del título administrativo habilitante para el ejercicio de la actividad, la competencia sancionadora corresponderá:

a. En las infracciones graves, a la persona titular de la consejería competente en materia de turismo.

b. En las infracciones muy graves, al Consello de la Xunta, a propuesta de la persona titular de la consejería competente en materia de turismo.

\section{Sección cuarta}

\section{Procedimiento sancionador}

Artículo 80. Regulación del procedimiento sancionador.

En todo lo que no esté previsto en la presente ley y en sus disposiciones de desarrollo, la tramitación del procedimiento sancionador se ajustará a los principios y al procedimiento establecidos con carácter general en la normativa autonómica gallega sobre el ejercicio de la potestad sancionadora $\mathrm{y}$, en defecto de la misma, en la normativa estatal sobre la materia.

Artículo 81. Conciliación y subsanación.

1. Previa o simultáneamente a la tramitación del procedimiento sancionador, el órgano competente para su incoación ofrecerá a la presunta persona infractora la posibilidad de reparar los perjuicios causados o de corregir las irregularidades administrativas en las que hubiera incurrido.

2. La conciliación voluntaria para la reparación de los perjuicios causados a las consumidoras y consumidores o a las usuarias y usuarios por parte de las personas titulares de actividades turísticas sólo se podrá intentar en aquellos supuestos en los que prime un interés privado y éste sea cuantificable.

Producirá los mismos efectos que la conciliación voluntaria el sometimiento de las partes al sistema arbitral de consumo o a los procedimientos arbitrales que la Administración turística pueda instituir al amparo de lo previsto en esta ley.

3. La subsanación de las irregularidades administrativas sólo será admisible cuando lo permita la entidad de la infracción y del perjuicio que la misma hubiese producido.

4. La conciliación y la subsanación plena comportarán el archivo de las actuaciones o la atenuación de las sanciones, atendiendo a la naturaleza y gravedad de los perjuicios causados. La subsanación parcial únicamente podrá dar lugar a la atenuación de las sanciones.

5. La tramitación de los procedimientos de conciliación y la subsanación interrumpirán la prescripción de las infracciones y el cómputo del plazo para resolver los procedimientos sancionadores. 
Artículo 82. Incoación del procedimiento sancionador.

1. El procedimiento sancionador por infracciones tipificadas en la presente ley se iniciará de oficio, por acuerdo del órgano competente adoptado:

a. Por propia iniciativa.

b. Por acta de infracción levantada por la Inspección turística.

c. Por orden superior.

d. Por comunicación de la autoridad o del órgano administrativo que tenga conocimiento de la posible infracción.

e. Por denuncia formulada por organizaciones profesionales del sector turístico, organizaciones de consumidoras y consumidores y usuarias y usuarios o particulares. A estos efectos, las hojas de reclamaciones tendrán la consideración de denuncia formal.

2. La competencia para la incoación del procedimiento sancionador corresponderá a las delegadas y delegados provinciales de la consejería competente en materia de turismo.

3. Previamente a la incoación del procedimiento sancionador, el órgano competente para ésta podrá acordar la realización de cuantas actuaciones sean necesarias con el objeto de determinar con carácter preliminar si concurren circunstancias que justifiquen su iniciación.

4. El acuerdo de incoación se comunicará a la instructora o al instructor, con traslado de cuantas actuaciones se hubieran realizado, y se notificará al denunciante y a las personas interesadas en el procedimiento.

5. Tendrán la condición de personas interesadas en los procedimientos sancionadores por infracciones tipificadas en esta ley, además de las presuntas o presuntos responsables de las infracciones, las personas directamente perjudicadas por las mismas.

Artículo 83. Medidas provisionales.

1. En cualquier momento del procedimiento sancionador, el órgano competente para resolver podrá acordar la adopción de las medidas de carácter provisional que resulten necesarias para asegurar la eficacia de la resolución final, evitar el mantenimiento de los efectos de la infracción y proteger las exigencias de los intereses generales.

2. En particular, si los hechos que provocaron la incoación del procedimiento sancionador consistieran en el desarrollo de una actividad turística sin contar con el preceptivo título administrativo habilitante, o en incumplir requisitos normativamente establecidos de modo que se produzca un grave riesgo para las consumidoras y consumidores o usuarias y usuarios, se adoptará como medida provisional, en ambos casos, el cierre del establecimiento o la suspensión de la actividad, de no haberse acordado ya la medida antes de la iniciación del expediente en los términos previstos por esta ley.

Artículo 84. Resolución del procedimiento sancionador.

1. El plazo máximo en el que debe notificarse la resolución del procedimiento sancionador será de un año desde la fecha del acuerdo de incoación. De transcurrir dicho plazo sin que se notificara la correspondiente resolución, se producirá la caducidad del procedimiento en los términos y con los efectos previstos en la legislación del procedimiento administrativo común.

2. Si las conductas sancionadas hubieran causado daños o perjuicios a la Administración, la resolución del procedimiento podrá imponer a la persona infractora la reposición a su estado originario de la situación alterada por la infracción y la indemnización por los daños y perjuicios causados.

3. Si la sanción viniera motivada por la falta de adecuación de la actividad o del establecimiento a los requisitos establecidos por la normativa vigente, la resolución sancionadora incluirá un requerimiento, con expresión de plazo suficiente para su cumplimiento, para que la persona sancionada lleve a cabo las actuaciones necesarias para regularizar la situación de 
la actividad o del establecimiento del que es titular.

Artículo 85. Ejecución de las resoluciones sancionadoras.

1. La ejecución de las resoluciones sancionadoras, una vez que pongan fin a la vía administrativa, corresponderá al órgano competente para la incoación de procedimiento.

2. En los casos en los que la resolución sancionadora incluya un requerimiento para que la persona sancionada lleve a cabo las actuaciones necesarias para regularizar la situación de la actividad o del establecimiento del que es titular, el órgano competente para la ejecución podrá imponer a aquélla multas coercitivas de un $10 \%$ de la cuantía de la sanción máxima fijada para la infracción cometida por cada día que pase desde el vencimiento del plazo otorgado para el cumplimiento del requerimiento sin que se realizaran las actuaciones ordenadas.

\section{TÍTULO X DEL ARBITRAJE}

Artículo 86. Arbitraje.

1. Mediante el arbitraje las personas físicas y jurídicas podrán someter voluntaria y expresamente a la decisión de una $o$ varias personas que ejerzan esa función arbitral la resolución de los conflictos que puedan surgir en relación con las materias reguladas en esta ley.

2. La Administración turística de la Xunta de Galicia podrá crear mecanismos de mediación, de conformidad con lo establecido en la legislación vigente sobre la materia.

\section{DISPOSICIÓN ADICIONAL PRIMERA CONSEJO REGULADOR DEL TURISMO}

En el plazo de un año a partir de la entrada en vigor de esta ley se constituirá el Consejo Regulador del Turismo.

En tanto no se cree el Consejo Regulador del Turismo, sus funciones serán asumidas por el Consejo Gallego de Turismo previsto en la Ley 9/1997, de 21 de agosto, de ordenación y promoción del turismo de Galicia.

\section{DISPOSICIÓN ADICIONAL SEGUNDA AYUNTAMIENTOS TURÍSTICOS}

Los ayuntamientos que a la entrada en vigor de esta ley hubieran conseguido la calificación de ayuntamientos turísticos la mantendrán, siempre y cuando cumplan los requisitos previstos en la misma.

\section{DISPOSICIÓN ADICIONAL TERCERA FIESTAS DE INTERÉS TURÍSTICO NACIONAL DE GALICIA}

Las fiestas que a la entrada en vigor de esta ley hubiesen alcanzado la declaración de fiesta de interés turístico gallego tendrán la consideración de fiestas de interés turístico nacional de Galicia siempre que sigan cumpliendo los requisitos que dieron lugar a dicha declaración.

\section{DISPOSICIÓN ADICIONAL CUARTA TRABAJO EN IGUALDAD}

La Administración turística colaborará con los departamentos de la Administración de la Xunta de Galicia competentes en materia de trabajo e igualdad, y con cualquier otro de las administraciones públicas competentes en estas materias, en el desarrollo de las actuaciones conducentes a la detección y a la erradicación de situaciones de economía sumergida y/o de irregularidades en el sector de la hostelería, de acuerdo con lo dispuesto por el artículo $36.2 .^{\circ}$ y por el apartado 8 del anexo de la Ley $2 / 2007$, de 28 de marzo, del trabajo en igualdad de las mujeres en Galicia.

\section{DISPOSICIÓN ADICIONAL OUINTA ESCALA DE INSPECCIÓN TURÍSTICA}

A partir de la entrada en vigor de la presente ley, la escala técnica de inspección turística creada por la Ley 9/1997, de 21 de agosto, de ordenación y promoción del turismo de Galicia, será una escala a extinguir. La Xunta de Galicia regulará por decreto las condiciones y el procedimiento de 
acceso del personal de la actual escala técnica de inspección turística a la nueva escala de inspección turística creada por el artículo 58 de esta ley.

\section{DISPOSICIÓN TRANSITORIA PRIMERA ADAPTACIÓN DE LOS ESTABLECIMIENTOS TURISTICOS A LAS NUEVAS CATEGORIAS}

En tanto no se desarrolle reglamentariamente lo dispuesto en la presente ley, será de aplicación a las empresas y actividades turísticas la normativa actualmente vigente.

\section{DISPOSICIÓN TRANSITORIA SEGUNDA PROCEDIMIENTOS SANCIONADORES \\ INICIADOS ANTES DE LA ENTRADA EN VIGOR DE LA PRESENTE LEY}

Los procedimientos sancionadores iniciados antes de la entrada en vigor de la presente ley se tramitarán y se resolverán de acuerdo a lo establecido en la Ley del Parlamento de Galicia 9/1997, de 21 de agosto, de ordenación y promoción del turismo en Galicia, y en sus disposiciones de desarrollo.

\section{DISPOSICIÓN TRANSITORIA TERCERA}

El personal de la Xunta de Galicia que a la entrada en vigor de esta ley desempeñe puestos con carácter definitivo y con funciones de inspección turística seguirá desempeñando dichas funciones en la forma y condiciones previstas en esta ley.

\section{DISPOSICIÓN DEROGATORIA ÚNICA}

Queda derogada la Ley 9/1997, de 21 de agosto, de ordenación y promoción del turismo en Galicia, así como cuantas disposiciones de igual e inferior rango se opongan a lo dispuesto en la presente ley.

\section{DISPOSICIÓN FINAL PRIMERA HABILITACIÓN PARA EL DESARROLLO REGLAMENTARIO}

Se autoriza al Gobierno para dictar cuantas disposiciones de aplicación y desarrollo de esta ley sean precisas.
En el plazo de dos años desde su entrada en vigor se aprobarán la totalidad de los desarrollos reglamentarios previstos en esta ley.

\section{DISPOSICIÓN FINAL SEGUNDA ENTRADA EN VIGOR}

Esta ley entrará en vigor al mes de su publicación en el Diario Oficial de Galicia.

\section{LEY 4/2008, DE 23 DE MAYO, DE CREACIÓN DE LA AGENCIA GALLEGA DE LAS INDUSTRIAS CULTURALES (DOGA N. $\left.{ }^{\circ} 111,10.6 .2008\right)$$$
(\ldots)^{846}
$$ \\ TÍTULO I DISPOSICIONES GENERALES}

Artículo 1. Naturaleza y adscripción.

1. Se crea, en el ámbito de la Comunidad Autónoma gallega, la Agencia Gallega de las Industrias Culturales (Agadic).

2. La Agadic es una agencia pública autonómica de las reguladas en la disposición adicional quinta del Decreto legislativo $1 / 1999$, de 7 de octubre, por el que se aprueba el texto refundido de la Ley de régimen financiero y presupuestario de Galicia, con personalidad jurídica propia, patrimonio propio y autonomía en su gestión, facultada para ejercer potestades administrativas en el ámbito de sus funciones.

3. La Agadic se adscribe a la consellería con competencias en materia de cultura de la Xunta de Galicia.

Artículo 2. Régimen jurídico.

1. La Agadic se rige por la presente ley, por el texto refundido de la Ley de régimen financiero y presupuestario de Galicia y, en su marco, por su estatuto.

2. La Agadic está sometida al derecho público en la formación de la voluntad de sus órganos, en el ejercicio de las potestades administrativas que tiene atribuidas y en aquellos aspectos que de acuerdo con la legislación

846 Exposición de motivos omitida. 
general administrativa o presupuestaria haya de someter a derecho público.

3. El estatuto de la Agadic será aprobado y modificado por decreto del Consello de la Xunta, a propuesta de la persona titular de la consellería con competencia en materia de economía y hacienda, previa iniciativa de la consellería competente en materia de cultura.

Artículo 3. Objeto y ámbito.

1. La Agadic tiene por objeto el impulso y la consolidación del tejido empresarial en el sector cultural gallego, cooperando en la aportación de factores productivos, en el fomento de la oferta de bienes y servicios y en la asignación de ingresos suficientes y estables.

2. A los efectos de lo establecido en la presente ley, son empresas culturales privadas las organizaciones constituidas bajo cualquiera de las formas mercantiles reconocidas por la legislación vigente que se dediquen con carácter principal a la producción, distribución o comercialización de productos culturales incorporados en cualquier clase de soporte, de espectáculos en vivo y de factores de producción exclusivamente destinados al mercado cultural.

Artículo 4. Fines.

Son fines de la Agadic:

a. Garantizar el progreso de la cultura gallega, y especialmente la normalización y el impulso del idioma gallego como medio para proteger y fomentar la identidad cultural de Galicia, el desarrollo social, el crecimiento económico y el diálogo intercultural en condiciones de igualdad y respeto con identidades diferentes en un contexto globalizado.

b. Impulsar la participación, consolidación y cooperación de las empresas y profesionales en la producción, creación, conservación, difusión y comercialización del patrimonio cultural gallego, en un mercado dinámico, sostenible y plural que fomente la participación ciudadana y remueva los obstáculos geográficos, físicos, educativos, sociales o económicos que pueden dificultar el acceso a la cultura, especialmente de los colectivos menos favorecidos.

c. Fomentar la demanda de productos culturales en la sociedad gallega al objeto de promover la orientación al mercado de las empresas, mejorar la viabilidad de sus proyectos, aportar recursos propios y aumentar el peso relativo del sector en el sistema productivo gallego.

d. Potenciar los programas de investigación y desarrollo cultural, mejorando la calidad y diferenciación de los productos, la agilidad en el servicio prestado y la creación de valor añadido en la economía digital.

e. Estrechar la coordinación entre las administraciones públicas con competencias en la materia y los agentes privados, de acuerdo con los principios de subsidiariedad y complementariedad, para aprovechar las sinergias, incrementar la posibilidad de financiación y conseguir una mayor calidad y eficiencia en la acción cultural.

f. Favorecer la creación y producción artística y cultural de las mujeres y su difusión, adoptando medidas de acción positiva destinadas a combatir la discriminación directa, indirecta o estructural de género.

\section{Artículo 5. Funciones.}

1. En consonancia con sus objetivos y fines, la Agadic ejercerá las siguientes funciones:

a. Impulsar la creación y el desarrollo de empresas que produzcan bienes y servicios culturales, prestando especial atención a las industrias culturales que generen mecanismos de producción eficientes y que suministren en el mercado bienes culturales de amplio consumo.

b. Favorecer los productos que difundan la lengua, la cultura y las tradiciones propias de Galicia como elemento singularizador en el mercado, y los que aporten a la cultura gallega innovaciones creativas y ofertas de calidad de nuevas estéticas y lenguajes artísticos. 
c. Promover la distribución y comercialización de los productos culturales dentro y fuera de nuestro país, fomentando la captación de públicos y facilitando el acceso de la cultura gallega a nuevos mercados internacionales. Para ello podrán establecer marcas de referencia y campañas publicitarias que refuercen el posicionamiento de Galicia y de los productos culturales gallegos en el mercado interior y exterior.

d. Contribuir a la mejora en la preparación y cualificación artística, técnica y empresarial de los recursos humanos, impulsando planes formativos acordes con las necesidades profesionales de las empresas del sector, en especial en la formación de personal cualificado para su administración y gestión y en el diseño, acceso y empleo de las nuevas tecnologías.

e. Estimular la creación, avivar el talento y la capacitación e incitar al reconocimiento social y económico de artistas y autores y autoras, en cuanto suministradores de recursos inmateriales en el proceso de producción. También apoyará la colaboración entre empresas y creadores y creadoras como instrumento necesario para el impulso y asentamiento del sector cultural.

f. Fomentar la creación, el mantenimiento y la utilización de infraestructuras y equipamientos por parte de los agentes culturales, en especial el impulso de centros que faciliten el acceso a la cultura de los ciudadanos y ciudadanas de los núcleos pequeños, y el estímulo de la mejora y modernización tecnológica.

g. Impulsar, a través del Igape, la presencia de las empresas culturales en los mercados financieros en condiciones ventajosas, con programas de préstamos públicos o actuando como intermediaria entre los productores culturales y las entidades financieras privadas, en especial para poder afrontar grandes proyectos desde la iniciativa privada. h. Impulsar la cooperación y el asociacionismo entre los trabajadores y trabajadoras y las empresas de los distintos sectores culturales, así como las medidas del sector profesional gallego para aumentar su presencia y competitividad en los mercados culturales, en especial en el apoyo a las exportaciones de bienes y servicios culturales gallegos.

i. Adoptar programas que potencien las sinergias entre el desarrollo empresarial de las actividades culturales y otros fines públicos como la protección del patrimonio natural, material e inmaterial, la contribución al desarrollo territorial y el fomento de la educación, el empleo, la integración social, el turismo y la investigación.

j. Hacer estudios y planes estratégicos sobre el sector cultural, así como difundir la información sobre los recursos destinados a las empresas culturales en cualquier ámbito.

k. Cualesquiera otras iniciativas y acciones dirigidas a la consecución de sus fines.

2. La Agadic podrá, para el logro de sus objetivos, celebrar convenios con instituciones públicas y privadas, realizar actividades comerciales e industriales, incluso mediante la participación en consorcios o sociedades, conceder subvenciones y establecer cualquier otra iniciativa y acción tendente a la consecución de los objetivos que se le atribuyen.

3. Corresponden a la Agadic el control y la evaluación del nivel de eficacia y eficiencia alcanzado con las medidas adoptadas y de los efectos de sus políticas, así como el control externo del empleo de sus ayudas por los receptores. La Agadic coordinará sus operaciones estadísticas propias con la que desarrolle la consellería competente en materia de cultura, en los términos previstos en las normas reguladoras de la actividad estadística de la Xunta de Galicia. 


\section{TÍTULO II ORGANIZACIÓN}

Artículo 6. Estructura.

1. La Agadic se estructura en los órganos de gobierno y asesoramiento contemplados en la presente ley y en los órganos complementarios que se determinen en su estatuto.

2. La designación de sus titulares y miembros procurará la paridad entre hombre y mujer.

\section{Capítulo I \\ ÓRGANOS DE GOBIERNOY ASESORAMIENTO}

Artículo 7. Órganos de gobierno.

Son órganos de gobierno de la Agadic el consejo de dirección y la dirección.

Artículo 8. Consejo de dirección.

1. El consejo de dirección es el órgano de gobierno colegiado de la Agadic.

2. El consejo de dirección es presidido por la persona titular de la consellería con competencias en materia de cultura. Estará integrado por la persona titular de la dirección general competente en materia de creación y difusión cultural, por la persona titular de la subdirección competente en materia de creación y difusión cultural, por la persona titular de la dirección de la Agadic, por un o una representante de la Consellería de Innovación e Industria con rango de director o directora general y por un o una representante de la Consellería de Economía y Hacienda con rango de director o directora general.

3. Corresponden al consejo de dirección las siguientes atribuciones:

a. Aprobar el proyecto de estatuto y de sus modificaciones y las normas de régimen interior de la Agadic y, en su caso, de los centros adscritos a la misma, a propuesta del director o directora.

b. Aprobar el anteproyecto de presupuestos anuales y la contracción de obligaciones de carácter plurianual. c. Aprobar las cuentas anuales y, en su caso, la distribución del resultado del ejercicio, de acuerdo con la legislación presupuestaria.

d. Aprobar el plan anual de actividades y su memoria explicativa.

e. Aprobar la memoria anual sobre la actuación y la gestión de la Agadic.

f. Seguir la ejecución de los presupuestos y del plan anual de actividades.

g. Controlar la gestión de la dirección y exigirle las responsabilidades que procedan.

h. Aprobar las dotaciones presupuestarias y el régimen retributivo del personal de la Agadic, de acuerdo con las previsiones presupuestarias y la legalidad vigente.

i. La determinación de los criterios de selección del personal, así como la aprobación de la relación de puestos de trabajo, en los términos previstos en la legislación de función pública.

j. La resolución de los recursos administrativos contra actos de los órganos de la Agadic, así como de las reclamaciones previas a las vías civil y laboral. Asimismo, resolverá los procedimientos de responsabilidad patrimonial.

k. Las demás competencias que se determinen, en su caso, en el estatuto de la Agadic.

4. Los acuerdos del consejo de dirección pondrán fin a la vía administrativa.

5. La presidencia del consejo de dirección tendrá las siguientes competencias:

a. Ostentar la representación de la Agadic.

b. Convocar las reuniones del consejo de dirección, de acuerdo con lo establecido en el estatuto.

c. Presidir y dirigir las deliberaciones del consejo de dirección.

d. Firmar los convenios con otras entidades públicas o privadas que sean necesarios para el cumplimiento de los objetivos de la Agadic.

e. Personarse en juicio y en toda clase de actuaciones, pudiendo otorgar, en su caso, poderes para pleitos. 
f. Las demás competencias que se determinen, en su caso, en el estatuto de la Agadic.

\section{Artículo 9. Dirección.}

1. La dirección es el órgano ejecutivo de la Agadic, correspondiéndole la gestión ordinaria de la misma.

2. La dirección será nombrada por el Consello de la Xunta, a propuesta de la persona titular de la consellería competente en materia de cultura, entre las personas que reúnan las cualificaciones necesarias para el cargo, según determine el estatuto de la Agadic.

3. Corresponden al director o directora las siguientes atribuciones:

a. Elaborar el proyecto de estatuto de la Agadic y sus modificaciones, y las normas de régimen interior de la Agadic y, en su caso, de los centros y unidades adscritos a la misma.

b. Elaborar el proyecto de plan anual de actividades de la Agadic y su memoria explicativa.

c. Elaborar la memoria anual sobre la actuación y la gestión de la Agadic.

d. Elaborar el anteproyecto de los presupuestos de la Agadic.

e. Impulsar, orientar, coordinar e inspeccionar los servicios, centros y unidades de la Agadic y dictar las disposiciones, instrucciones y circulares relativas al funcionamiento de los mismos.

f. Ejecutar los presupuestos y el plan anual de actividades de la Agadic.

g. Autorizar los pagos y los gastos de la Agadic y de los centros y unidades de producción, dentro de la normativa vigente.

h. Ejercer la jefatura del personal de la Agadic.

i. Proponer al consejo de dirección el nombramiento, de acuerdo con los criterios de profesionalidad, mérito y capacidad, del personal directivo de la Agadic.

j. La propuesta de resolución de los recursos administrativos contra los actos de los órganos de la Agadic y las reclamaciones previas a las vías civil y laboral.
Asimismo, instruirá los procedimientos de responsabilidad patrimonial.

k. Ejecutar los acuerdos del consejo de dirección y ejercer las funciones que éste le delegue.

1. Las demás competencias que se determinen, en su caso, en el estatuto de la Agadic.

m. Las demás competencias que no estén atribuidas por la presente ley o por el estatuto a otros órganos.

4. La dirección está sujeta, en el desarrollo de sus cometidos, a evaluación con arreglo a los criterios de eficacia, eficiencia y cumplimiento de la legalidad, responsabilidad por su gestión y control de resultados en relación con los objetivos que le hayan sido fijados.

5. La dirección percibe una parte de su retribución como incentivo de rendimiento, mediante el complemento correspondiente que valore la productividad, de acuerdo con los criterios y porcentajes que se establezcan por el consejo de dirección.

Artículo 10. Consejo asesor.

1. El Consejo Asesor de la Agadic, presidido por la persona titular de la consellería competente en materia de cultura o persona en que delegue, es el órgano encargado del estudio, deliberación y propuesta en las materias competencia de la Agadic.

2. En particular, corresponde al consejo:

a. Emitir informe sobre la planificación anual de actividades.

b. Emitir informe sobre la memoria referente a la actuación y gestión de la agencia.

c. Emitir informe sobre los anteproyectos de presupuestos.

d. Emitir informe sobre la aprobación de las cuentas de la agencia.

e. Emitir informe sobre el proyecto de estatuto.

f. Elevar a los órganos de gobierno de la Agadic las propuestas que estime convenientes en el ámbito de actuación de la misma. 
3. El estatuto de la agencia establecerá la composición y el régimen de funcionamiento del Consejo Asesor de la Agadic. En todo caso, se procurará la paridad de género y se garantizará la presencia de los representantes de las administraciones públicas con competencias en materia cultural, así como de las asociaciones empresariales y profesionales más representativas del ámbito de la cultura gallega.

\section{Capitulo II ORGANIZACIÓN ADMINISTRATIVA}

Artículo 11. Departamentos.

1. La Agadic se estructurará en los departamentos que establezca su estatuto.

2. En todo caso, existirá un departamento de gestión que desarrollará las funciones de gestión de los recursos humanos, de gestión económico-financiera y de recopilación y difusión de conocimiento y documentación en las materias competencia de la Agadic.

3. La organización, las funciones y el régimen interno de los diferentes departamentos se regirán por lo establecido en el estatuto y demás normas complementarias.

Artículo 12. Coordinadores/as.

1. Al frente de cada departamento estará un coordinador o coordinadora, que dependerá directamente de la dirección.

2. Los coordinadores y coordinadoras tendrán la consideración de personal directivo y tendrán las funciones y potestades que les atribuya el estatuto.

\section{TÍTULO III RÉGIMEN DE PERSONAL}

Artículo 13. Personal de la Agadic.

1. Sin perjuicio del personal directivo contemplado en el artículo 16, el personal al servicio de la Agadic está constituido por:

a. El personal que esté ocupando puestos de trabajo en servicios que se integren en la Agadic. b. El personal que se incorpore a la Agadic desde cualquier administración pública por los correspondientes procedimientos de provisión de puestos de trabajo contemplados en la presente ley.

c. El personal seleccionado por la Agadic, mediante pruebas selectivas convocadas al efecto en los términos establecidos en la presente ley.

2. El personal a que se refieren las letras a) y b) del apartado anterior mantiene la condición de personal funcionario, estatutario o laboral de origen, de acuerdo con la legislación aplicable.

3. El personal funcionario y estatutario se rige por la normativa reguladora de la función pública gallega, con las especialidades contempladas en la presente ley y las que, con arreglo a la misma, se establezcan en el estatuto.

El personal laboral se rige por las disposiciones que le sean de aplicación de la normativa reguladora de la función pública gallega, por el Estatuto de los trabajadores, por el Convenio colectivo único del personal laboral de la Xunta de Galicia y por el resto de la normativa laboral de aplicación.

Artículo 14. Procedimientos de selección.

1. La Agadic seleccionará su personal laboral a través de los órganos y procedimientos establecidos en su estatuto y en la restante legislación de función pública que sea de aplicación.

2. La selección de este personal se realizará mediante convocatoria pública y de acuerdo con los principios de igualdad, mérito y capacidad, así como de acceso al empleo público de las personas con discapacidad.

Artículo 15. Ordenación de puestos de trabajo.

La Agadic dispondrá de su relación de puestos de trabajo. La relación será elaborada por la dirección, y propuesta por el consejo de dirección para su aprobación ulterior, 
con arreglo a los trámites previstos en la legislación general de función pública.

Artículo 16. Personal directivo.

1. Constituyen el personal directivo de la Agadic las personas coordinadoras de los diferentes departamentos. No obstante, el estatuto podrá determinar que otros puestos de trabajo puedan ser ocupados por personal directivo en atención a la especial responsabilidad, competencia técnica y relevancia de los cometidos asignados a las mismas.

2. El personal directivo de la Agadic es nombrado y cesado por el consejo de dirección, a propuesta del director o directora, en atención a criterios de competencia profesional y experiencia entre personas con titulación superior, mediante procedimiento que garantice el respeto a los principios de mérito, capacidad, concurrencia y publicidad.

El proceso de provisión se realizará por órganos de selección especializados que formularán propuesta motivada a la dirección de la agencia, incluyendo a tres personas candidatas para cada puesto a cubrir.

Cuando el personal directivo de la Agadic ostente la condición de funcionario/a permanecerá en la situación de servicios especiales en su respectivo cuerpo o escala o en la que corresponda con arreglo a la legislación laboral si se tratara de personal de este carácter.

3. El personal directivo está sujeto, en el desarrollo de sus cometidos, a evaluación con arreglo a los criterios de eficacia, eficiencia y cumplimiento de la legalidad, responsabilidad por su gestión y control de resultados en relación con los objetivos que le hayan sido fijados.

4. El personal directivo percibe una parte de su retribución como incentivo de rendimiento, mediante el complemento correspondiente que valore la productividad, de acuerdo con los criterios y porcentajes que se establezcan por el consejo de dirección.

\section{TÍTULO IV \\ RÉGIMEN ECONÓMICO Y FINANCIERO}

\section{Capitulo I \\ RÉGIMEN ECONÓMICO-PATRIMONIAL}

Artículo 17. Régimen económico y financiero.

Dentro del marco básico previsto por la disposición adicional quinta del texto refundido de la Ley de régimen financiero y presupuestario de Galicia, el régimen económico y financiero de la Agadic será desarrollado por el estatuto.

Artículo 18. Patrimonio.

1. La Agadic tiene, para el cumplimiento de sus fines, un patrimonio propio, distinto del de la Xunta de Galicia, integrado por el conjunto de bienes y derechos de los que sea titular.

2. La gestión y administración de los bienes y derechos propios, así como de aquéllos del patrimonio de la Xunta de Galicia que se le adscriban para el cumplimiento de sus fines, será ejercida de acuerdo con lo señalado en el estatuto, con sujeción, en todo caso, a lo establecido para los organismos públicos en la legislación, estatal y autonómica, de patrimonio de las administraciones públicas.

\section{DISPOSICIÓN TRANSITORIA PRIMERA INSTITUTO GALLEGO DE LAS ARTES ESCÉNICAS Y MUSICALES}

La Agadic sucederá al Instituto Gallego de las Artes Escénicas y Musicales en el ejercicio de las funciones que desarrolla y quedará subrogada en la totalidad de los bienes, derechos y obligaciones afectos o constitutivos en virtud de las mencionadas funciones.

El personal que preste sus servicios en el IGAEM pasará a prestarlos en la Agadic sin alteración alguna de sus condiciones laborales.

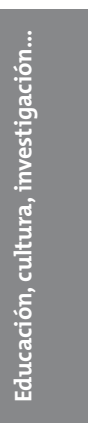


Código de la Administración Gallega

DISPOSICIÓN TRANSITORIA SEGUNDA CENTROS DE PRODUCCIÓN, ARCHIVO, INFORMACIÓN E INVESTIGACIÓN CULTURAL DEPENDIENTES DEL IGAEM

Quedan provisionalmente adscritos a la Agadic los centros de producción, archivo, información e investigación cultural dependientes del IGAEM, en tanto no se cree un ente específico para la gestión y coordinación de los centros de producción cultural de titularidad pública.

\section{DISPOSICIÓN TRANSITORIA TERCERA REESTRUCTURACIÓN ORGÁNICA DE LA DIRECCIÓN GENERAL DE CREACIÓN Y DIFUSIÓN CULTURAL}

Tras la entrada en vigor de la presente ley, el Consello de la Xunta, a propuesta de la consellería competente en materia de cultura, aprobará la reestructuración orgánica de la Dirección General de Creación y Difusión Cultural, suprimiendo o refundiendo las unidades afectadas por las competencias y funciones que asume la Agadic.

\section{DISPOSICIÓN DEROGATORIA PRIMERA DEROGACIÓN DE LA LEY 4/1989}

Queda derogada la Ley 4/1989, de 21 de abril, de creación del Instituto Gallego de las Artes Escénicas y Musicales, así como su modificación por la Ley 2/1991, de 14 de enero.

\section{DISPOSICIÓN DEROGATORIA SEGUNDA DEROGACIÓN NORMATIVA}

Quedan asimismo derogadas cuantas disposiciones de igual o inferior rango se opongan a lo dispuesto en la presente ley.

\section{DISPOSICIÓN FINAL PRIMERA DESARROLLO NORMATIVO}

El Consello de la Xunta de Galicia y la consellería con competencias en materia de cultura, en el ámbito de sus competencias, adoptarán cuantas disposiciones sean necesarias para la aplicación y el desarrollo de la presente ley.

\section{DISPOSICIÓN FINAL SEGUNDA ENTRADA EN VIGOR}

La presente ley entrará en vigor al día siguiente de su publicación en el Diario Oficial de Galicia. 


\section{XVIII \\ EMERGENCIAS}

1. LEY 5/2007, DE 7 DE MAYO, DE EMERGENCIAS DE GALICIA (DOGA N. ${ }^{\circ} 94,16.5 .2007$

\section{(...) 847 \\ TÍTULO PRELIMINAR DISPOSICIONES GENERALES}

Artículo 1. Objeto y ámbito de aplicación.

1. La presente ley regula el sistema integrado de protección civil y emergencias en Galicia, dirigido a adoptar medidas preventivas que eviten situaciones de riesgo, a actuar en caso de riesgo ordinario y a proteger la integridad de las personas y los bienes de titularidad pública o privada y el medio ambiente de daños en situaciones de emergencia o grave riesgo provocados por catástrofes, calamidades, accidentes y otras situaciones o contingencias análogas.

2. La protección civil es un servicio público esencial. En su organización, funcionamiento y ejecución participan las distintas Administraciones públicas de Galicia, así como la ciudadanía mediante la colaboración voluntaria o en cumplimiento de los deberes que establece la presente ley.

3. A los efectos de la presente ley, se entiende por emergencia una situación sobrevenida, de carácter inesperado, que afecta en menor o mayor grado a la seguridad de las personas, de los bienes o del medio ambiente.

4. La presente ley es de aplicación en todo el territorio de Galicia y para todas las situaciones de emergencia.

Artículo 2. Principios generales.

1. Las Administraciones públicas de Galicia, en cumplimiento de los fines

847 Exposición de motivos omitida. de la presente ley y en el ámbito de sus respectivas competencias, garantizan la existencia de un sistema integrado de protección civil y emergencias, basado en los principios de coordinación, solidaridad, participación, subsidiariedad, colaboración, responsabilidad pública y privada y lealtad institucional, promoviendo la asistencia y socorro mutuos con otras Comunidades Autónomas y en el ámbito transfronterizo.

2. La protección civil se desarrollará de acuerdo con los criterios de profesionalidad, autoprotección, prevención, continuidad y celeridad en la acción pública, transparencia e información.

Artículo 3. Objetivos.

La actuación de las Administraciones públicas de la Comunidad Autónoma gallega en materia de protección civil y emergencias tendrá como objetivos los que se especifican en los ámbitos siguientes:

1. Gestión de riesgos:

a. Identificar, analizar y evaluar de manera permanente los riesgos existentes en el territorio.

b. Prevenir los riesgos existentes mediante el conjunto de actuaciones encaminadas a la disminución de los mismos y la adopción de medidas necesarias para su detección y posibles soluciones.

c. Planificar la acción pública y privada ante las situaciones de riesgo, previniendo una estructura operativa y de mando unificadas, los medios necesarios y los protocolos de actuación precisos para asegurar la integridad de las personas y de los bienes.

2. Gestión de emergencias:

a. La canalización unificada de las incidencias y alertas que se produzcan a través del número único europeo de emergencias 112 .

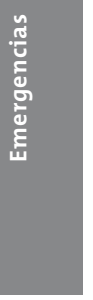


b. La gestión, entendida como la aplicación y adecuación de los planes establecidos a las características singulares de las emergencias que se produzcan, a través de protocolos específicos y la movilización de los medios y recursos disponibles o que estén previstos incorporar para la más adecuada resolución de la emergencia.

3. Gestión de la rehabilitación mediante la restauración de los servicios esenciales y la recuperación de la situación de normalidad tras la emergencia.

4. Gestión de la formación e información:

a. La adecuada formación, preparación y coordinación de las personas que intervienen de forma profesional o voluntaria en la gestión de riesgos y emergencias.

b. La formación de una ciudadanía responsable que colabore en la prevención y gestión de riesgos y la información públicas a las personas y colectivos que puedan verse afectados por emergencias.

\section{TíTULO I DERECHOS Y DEBERES}

Artículo 4. Derecho a la protección e información y obligaciones de las Administraciones públicas.

1. Los ciudadanos tienen derecho a:

a. Una actuación preventiva de los poderes públicos, una respuesta eficaz ante los riesgos y una adecuada protección de su integridad, de los bienes y del entorno.

b. Ser informados de los riesgos que puedan afectarles y de las consecuencias de los mismos que sean previsibles, así como de los medios de que dispone la Comunidad Autónoma de Galicia para hacerles frente.

c. Participar y ser escuchados en los procesos de elaboración de los planes de protección civil.

2. Las Administraciones públicas gallegas, en sus respectivos ámbitos de competencia, tienen la obligación de proporcionar información e impartir instrucciones claras y precisas a aquellas personas que puedan verse afectadas por situaciones de grave riesgo, sobre las medidas de seguridad que han de adoptar y la conducta que han de seguir en caso de emergencia. Se fomentarán campañas de información y divulgativas.

Artículo 5. Derecho y deber de colaboración.

1. Los ciudadanos y ciudadanas tienen el derecho de colaborar en las tareas de protección civil, y los mayores de edad el deber de colaborar, conforme a lo establecido en los planes y demás instrumentos de planificación contemplados en la presente ley y según las instrucciones de las autoridades de protección civil.

2. El deber de colaboración implica también la participación de los ciudadanos en los simulacros programados por las autoridades de protección civil. Este deber afectará de manera especial a las entidades públicas o privadas cuya actividad esté relacionada con la prevención, atención, socorro y seguridad de las personas y sus bienes.

3. La colaboración regular con las autoridades de protección civil se realizará a través de las organizaciones del voluntariado de protección civil, de la Cruz Roja Española y de otras entidades existentes o que puedan crearse en el desarrollo de la presente ley.

4. Las ciudadanas y ciudadanos podrán colaborar también de forma ocasional con los servicios de emergencia, principalmente a través de convenios de colaboración que, a fin de facilitar esa participación, suscriba la Xunta con entidades públicas o privadas.

Artículo 6. Derecho de restablecimiento.

Se reconoce el derecho de los ciudadanos afectados por una catástrofe o calamidad a la restauración de los servicios esenciales, la rehabilitación de las zonas afectadas por los siniestros y el retorno a la normalidad en los términos establecidos por el artículo 31 . 
Artículo 7. Deber de comunicación y cumplimiento de órdenes.

1. Todo ciudadano y ciudadana que tengan conocimiento de actividades o circunstancias que puedan generar situaciones de emergencia deberán comunicárselo al organismo competente en materia de protección civil.

2. Las personas, empresas y entidades deberán adoptar comportamientos responsables que eviten la producción de riesgos y asumir las medidas de autoprotección que reglamentariamente se establezcan.

3. En caso de emergencia los ciudadanos deberán cumplir las órdenes e instrucciones, generales o particulares, que sean dictadas por las autoridades competentes.

Artículo 8. Prestaciones personales y reales.

1. Una vez activado un plan de protección civil o en las situaciones de riesgo o emergencia declarada, la autoridad de protección civil competente podrá ordenar a los ciudadanos la prestación de servicios personales, de acción u omisión, siempre de forma proporcionada a la situación de necesidad y a la capacidad de cada individuo.

2. Esta prestación personal tendrá carácter obligatorio y no dará derecho a indemnización, a salvo de las lesiones producidas respecto de cualquiera de los bienes o derechos del prestador derivadas de la prestación, con arreglo a lo establecido en el sistema de responsabilidad patrimonial de las Administraciones públicas.

3. En caso de activación de un plan de protección civil, siempre que la emergencia lo haga necesario y teniendo siempre presente el principio de proporcionalidad, la autoridad de protección civil podrá ordenar la requisa, destrucción, intervención y ocupación temporal y transitoria de los bienes de los ciudadanos, incluidos combustibles, locales, industrias y otros establecimientos y medios de transporte que se precisen para afrontar la emergencia. Los ciudadanos que sufran daños y perjuicios en sus bienes, a causa de estas actuaciones, podrán ser indemnizados de acuerdo con lo estipulado por la legislación vigente.

Artículo 9. Medios de comunicación social.

1. Los medios de comunicación social, tanto de titularidad pública como privada, tienen la obligación de colaborar, de forma gratuita, con las autoridades de protección civil competentes en las situaciones de emergencia colectiva.

2. Esta colaboración se concreta en el deber de emitir, transmitir, publicar y difundir, de manera inmediata, prioritaria y destacada, si así se les requiere, la información, avisos, órdenes e instrucciones dictadas por las autoridades competentes y dirigidas a la población. En todo caso, será necesaria la identificación de la autoridad emisora del mensaje.

\section{TíTULO II \\ ORGANIZACIÓN ADMINISTRATIVA Y COMPETENCIAS}

\section{Capítulo I NIVELES DE ACTUACIÓN}

Artículo 10. Distribución de las responsabilidades públicas en materia de protección civil y gestión de emergencias.

En el sistema integrado de protección civil y emergencias de Galicia, y sin perjuicio de las competencias del Estado, corresponde a:

a. La Xunta de Galicia, la superior coordinación y dirección de la protección civil, la gestión de los servicios que se considere necesario prestar de forma unitaria para todo el territorio gallego y la gestión de las emergencias que superen los medios de respuesta de que disponen las entidades locales.

b. Los órganos de gobierno de los entes provinciales, la garantía del cumplimiento por los municipios de sus deberes en este ámbito. 
c. Los municipios y entidades locales supramunicipales, en su caso, la prestación de los servicios de protección civil y la actuación inicial ante cualquier situación de emergencia que se detecte, con las previsiones del artículo 331.1 de la Ley 5/1997, de Administración local de Galicia.

\section{Capítulo II \\ COMPETENCIAS DE \\ LA XUNTA DE GALICIA}

Artículo 11. El Consello de la Xunta.

1. El Consello de la Xunta es el órgano superior de dirección y coordinación de la protección civil y de la gestión de emergencias de la Comunidad Autónoma de Galicia.

2. Corresponde al Consello de la Xunta:

a. Aprobar las disposiciones de carácter general en materia de protección civil y gestión de emergencias.

b. Aprobar el Plan territorial de protección civil de Galicia y los planes especiales.

c. Aprobar el mapa y el catálogo de riesgos de Galicia.

d. Fijar las directrices de la política de prevención y autoprotección.

e. Declarar la situación de emergencia de interés gallego, cuando la situación de peligro, por su especial extensión o intensidad particularmente grave, lo requiera.

f. Establecer las líneas de cooperación en materia de protección civil con la Administración general del Estado y con las demás administraciones públicas de Galicia.

g. Ejercer la potestad de reemplazo de las entidades locales en los casos y términos contemplados en la presente ley, especialmente en el artículo 28.

h. Ejercer la potestad sancionadora en los términos establecidos en la presente ley.

i. Las demás funciones que le otorgue la legislación vigente.

Artículo 12. La persona titular de la presidencia de la Xunta.

1. En tanto autoridad superior de dirección y coordinación de la Xunta, a la persona titular de la presidencia de la Xunta le corresponde:

a. Ejercer el mandoúnico de los servicios de intervención frente a las emergencias en los casos contemplados en la presente ley.

b. Promover las fórmulas de cooperación transrregional y transfronteriza que resulten precisas para la prevención de los riesgos y la gestión de las emergencias comunes en estos ámbitos.

c. Promover, cuando fuera preciso, a través de la persona titular de la Delegación del Gobierno, el concurso de las Fuerzas Armadas y de los Cuerpos y Fuerzas de Seguridad del Estado en el campo de la prevención de los riesgos y la gestión de las emergencias.

2. La persona titular de la presidencia de la Xunta de Galicia podrá, por razones funcionales, operativas u organizativas, delegar expresamente alguna de estas atribuciones.

Artículo 13. La persona titular de la consellería competente en materia de protección civil y gestión de emergencias.

La persona titular de la consellería de la Xunta de Galicia que tenga atribuida la competencia en materia de protección civil y gestión de emergencias es el órgano responsable de la política de protección civil y gestión de emergencias de Galicia, $y$, como tal, le corresponde:

a. Proponer al Consello de la Xunta la declaración de situación de emergencia de interés gallego.

b. Proponer al Consello de la Xunta, para su aprobación, el Plan territorial de protección civil de Galicia, los planes especiales, el mapa y el catálogo de riesgos y cuantas disposiciones de carácter general se requieran en materia de protección civil y gestión de emergencias.

c. Proponer a la persona titular de la presidencia de la Xunta de Galicia las iniciativas que sean precisas para garantizar la prevención de los riesgos y la gestión de las emergencias comunes en los ámbitos transregional y transfronterizo. 
d. Proponer a la persona titular de la presidencia de la Xunta las iniciativas relativas al sistema estatal de protección civil y al sistema integrado de protección civil y emergencias de Galicia y aquellas otras en el ámbito de la asistencia mutua bilateral entre comunidades autónomas o internacionales en las materias de la presente ley.

e. Adoptar las decisiones que correspondan en cuanto a la revisión de los planes a que se refiere el artículo 34 de la presente ley.

f. Aprobar los catálogos de medios y recursos ${ }^{848}$.

g. Aprobar las directrices de actuación de la Axencia Galega de Emerxencias y ejercer las demás atribuciones derivadas de la adscripción orgánica de la misma a la consellería competente.

h. Requerir de las demás administraciones públicas, entidades públicas o privadas y de los particulares la colaboración necesaria para el cumplimiento de las obligaciones establecidas en la presente ley y resolver, en su caso, sobre la ejecución subsidiaria de las medidas de autoprotección, contemplada en el artículo 42.2 de la presente ley.

i. Coordinar las actuaciones de la Xunta de Galicia con otras administraciones públicas en materia de protección civil y gestión de emergencias.

j. Coordinar entre sí los servicios públicos y privados que hayan de intervenir en situaciones de emergencia.

k. Proponer al Consello de la Xunta el reemplazo de las entidades locales en los casos y términos contemplados en la presente ley y, especialmente, en el artículo 28.

1. Ejercer la potestad de reconocimiento público de las actuaciones meritorias

848 Véase Orden de 20 de marzo de 2009 por la que se aprueba el Catálogo de medios y recursos de la Comunidad Autónoma de Galicia disponibles para la protección civil. de ciudadanos, entidades, organismos y profesionales.

m. Ejercer la potestad sancionadora en los términos establecidos en la presente ley.

n. Promover la formación en materias de protección civil y gestión de emergencias, contribuyendo a consolidar una cultura social de colaboración institucional y ciudadana.

Artículo 14. Las personas titulares de las delegaciones provinciales del departamento competente en materia de protección civil y gestión de emergencias. A las personas titulares de las delegaciones provinciales de la consellería competente en materia de protección civil y gestión de emergencias les corresponde activar los planes públicos de protección civil en su provincia, dirigir la gestión de las emergencias y ejercer la potestad sancionadora en los casos y términos establecidos en la presente ley.

Artículo 15. Las demás consellerías de la Xunta de Galicia.

La protección civil incumbe a todas las consellerías de la Xunta de Galicia, así como a los organismos vinculados o dependientes de las mismas. En especial, y en su ámbito de competencias, corresponde a cada una de ellas:

a. Realizar las funciones de previsión, evaluación y prevención de los riesgos susceptibles de generar emergencias de protección civil.

b. Participar en la elaboración de los planes de protección civil e integrar en los mismos los recursos y servicios propios.

c. Potenciar los servicios y medios necesarios para mejorar la operatividad de los planes de protección civil.

d. Poner a disposición de la autoridad que ejerza las funciones de dirección y coordinación de cada emergencia los medios y recursos disponibles de su titularidad.

e. Realizar los trabajos de rehabilitación que les son propios e impulsar, dentro de su ámbito competencial, los que correspondan 
a otras administraciones públicas o al sector privado.

f. Tomar las iniciativas que consideren necesarias para la mejor gestión de los riesgos y de las emergencias de su ámbito competencial para garantizar la seguridad integral de las personas, de los bienes y del medio ambiente que les estén confiados, incluyendo la posible incorporación al número europeo de emergencias, en los términos que reglamentariamente se establezcan, dentro del marco de coordinación establecido en la presente ley.

g. Colaborar con el titular de la consellería competente en materia de protección civil y emergencias en la garantía del cumplimiento de las obligaciones atribuidas a la Xunta en el artículo 10.a) de la presente ley.

\section{Capítulo III LA AXENCIA GALEGA DE EMERXENCIAS ${ }^{849}$}

Artículo 16. Naturaleza.

1. Se crea la Axencia Galega de Emerxencias, como entidad instrumental de la Xunta de Galicia, para el estudio y ejecución de la política autonómica en materia de protección civil y gestión de emergencias, en los términos establecidos en la presente ley.

2. La Axencia Galega de Emerxencias tiene la naturaleza de entidad de derecho público con personalidad jurídica propia conforme al artículo 12.1.b) del texto refundido de la Ley de Régimen Financiero y Presupuestario de Galicia, aprobado por el Decreto legislativo 1/1999, de 7 de octubre, y estará dotada de patrimonio propio y plena capacidad para el cumplimiento de sus fines.

Artículo 17. Régimen jurídico y adscripción.

1. En el marco de lo dispuesto por la presente ley y su estatuto, la Axencia

849 Véase Decreto 292/2008, de 30 de diciembre, por el que se establece la estructura orgánica de la Agencia Gallega de Emergencias.
Galega de Emerxencias ajustará su actividad al ordenamiento jurídico privado, salvo cuando ejercite potestades administrativas. El personal podrá ser contratado en régimen de derecho laboral o ser funcionario, o asimilado al servicio de la Administración de la Xunta de Galicia adscrito a la agencia, en los términos previstos por la Ley 10/1996, de 5 de noviembre, de Actuación de Entes y Empresas en las que tiene participación mayoritaria la Xunta de Galicia.

2. Por decreto del Consello de la Xunta se aprobará el estatuto de la Axencia Galega de Emerxencias, en el cual se determinará su organización, régimen jurídico y funciones, en desarrollo de lo contemplado en la presente ley ${ }^{850}$.

3. La Axencia Galega de Emerxencias se adscribe funcionalmente a la consellería competente en materia de protección civil y gestión de emergencias, correspondiendo a la persona titular de la misma el ejercicio de las facultades derivadas de tal adscripción.

\section{Artículo 18. Funciones}

Corresponde a la Axencia Galega de Emerxencias:

a. Gestionar el Centro de Atención de Emergencias 112 Galicia y prestar materialmente la asistencia requerida por los ciudadanos y ciudadanas a través del mismo, o dar traslado, según se establezca reglamentariamente, de aquellas que corresponda atender a otros organismos competentes en la materia.

b. Gestionar los helicópteros de emergencias del 112 y todos los otros medios y recursos operativos que puedan incorporarse a la agencia.

c. Analizar los riesgos e identificarlos y localizarlos en el territorio en orden a elaborar el mapa y catálogo de riesgos de Galicia, así como los catálogos de medios y recursos y el catálogo de servicios.

850 Decreto 223/2007, de 5 de diciembre, por el que se aprueba el estatuto de la Agencia Gallega de Emergencias. 
d. Desarrollar programas en materia de protección civil y gestión de riesgos y de emergencias con arreglo a las directrices emanadas de la Xunta de Galicia y establecer los medios para fomentar actuaciones que contribuyan a la prevención de riesgos, a la atenuación de sus efectos $\mathrm{y}$, en general, a la toma de conciencia y sensibilización de los ciudadanos de la importancia de protección civil.

e. Llevar a cabo los estudios necesarios para la elaboración del Plan territorial de protección civil de Galicia, de los planes especiales y de las líneas directrices para la elaboración de los planes territoriales que correspondan.

f. Evaluar y calificar el riesgo cuando le sea comunicada una situación de emergencia de las que pueden dar lugar a la activación de un plan público de protección civil.

g. Poner a disposición de los órganos competentes de la Xunta de Galicia los medios a su disposición para la gestión de las emergencias de interés gallego bajo la superior dirección de la persona titular de la presidencia de la Xunta o de la persona titular de la consellería en que ésta delegue, y de aquellas otras emergencias que los planes especiales o territoriales determinen.

h. Estudiar las actuaciones necesarias para el restablecimiento de los servicios esenciales para la comunidad y la restauración, la rehabilitación y el retorno a la normalidad en los casos de catástrofe o calamidad.

i. Fomentar, en colaboración con la consellería competente en materia de voluntariado, la vinculación voluntaria y desinteresada de los ciudadanos a las actividades de protección civil.

j. Las demás funciones que en el ámbito de la protección civil y la gestión de emergencias se determinen en su estatuto.

Artículo 19. Órganos.

Los órganos de gobierno y administración de la Axencia Galega de Emerxencias son:

a. El Consello Reitor.

b. La presidencia.

c. La vicepresidencia.

d. La gerencia.
Artículo 20. Composición del Consello Reitor.

El Consello Reitor de la Axencia Galega de Emerxencias está formado por una presidencia, una vicepresidencia, la gerencia, dieciséis vocalías y una secretaría.

1. Presidencia: La persona titular de la consellería competente en materia de protección civil y gestión de emergencias.

2. Vicepresidencia: La persona titular del órgano directivo de la consellería de la Xunta de Galicia competente en materia de protección civil y gestión de emergencias que designe la persona titular de la misma.

3. Gerencia: El/la gerente de la Axencia Galega de Emerxencias.

4. Vocalías:

a. La persona titular de la secretaría general de la consellería competente en materia de protección civil y gestión de emergencias.

b. La persona titular de la dirección general competente en materia de interior.

c. Un representante, con categoría al menos de Director general, de la consellería competente en materia de voluntariado.

d. Un representante, con categoría al menos de Director general, de la consellería competente en materia de urbanismo y transportes.

e. Un representante, con categoría al menos de Director general, de la consellería competente en materia de montes e incendios forestales.

f. Un representante, con categoría al menos de Director general, de la consellería competente en materia de sanidad.

g. Un representante, con categoría al menos de Director general, de la consellería competente en materia de pesca y asuntos marítimos.

h. Un representante, con categoría al menos de Director general, de la consellería competente en materia de medio ambiente.

i. Tres vocales designados por la presidencia del Consello Reitor entre personas expertas y de prestigio en materia de emergencias. 
j. Cuatro representantes de los municipios de Galicia, designados por la Federación Gallega de Municipios y Provincias.

La condición del vocal representante de los municipios estará vinculada a la representatividad ostentada, perdiéndose al desaparecer la misma.

k. Un representante de la Administración del Estado, nombrado por la persona titular de la Delegación del Gobierno en Galicia.

Los vocales serán nombrados y removidos por el Consello de la Xunta a propuesta de la persona titular de la consellería competente en materia de protección civil y gestión de emergencias.

5. Secretaría: La persona titular de la Secretaría General de la Axencia Galega de Emerxencias.

Artículo 21. Funciones del Consello Reitor.

1. El Consello Reitor de la Axencia Galega de Emerxencias es el órgano colegiado de control, planificación y supervisión general de la actividad del centro.

2. El Consello Reitor ha de conocer y aprobar:

a. Las directrices generales de actuación del organismo.

b. El plan anual de actividades.

c. La memoria de las actividades del ejercicio anterior.

d. El reglamento de régimen interior.

e. El anteproyecto del presupuesto anual de la agencia y sus cuentas.

3. El Consello Reitor ha de conocer e informar:

a. Aquellas normas relativas a las disposiciones y actos que afecten a las funciones que la agencia tiene encomendadas en la presente ley.

b. Los asuntos que la persona titular de la presidencia del Consello Reitor o el/la gerente de la Axencia Galega de Emerxencias sometan a su consideración.

4. El Consello Reitor ha de ser informado de:

a. La estructura orgánica y la plantilla de la agencia. b. Los convenios de colaboración y cooperación suscritos por la persona titular de la presidencia.

Artículo 22. Funcionamiento del Consello Reitor.

1. El funcionamiento del Consejo Reitor se ajustará a lo dispuesto en la Ley de Régimen Jurídico de las Administraciones Públicas y del Procedimiento Administrativo Común, título II, capítulo II, sobre órganos colegiados.

2. El Consejo Reitor se reunirá, como mínimo, una vez cada año y, en cualquier caso, siempre que sea convocado por la persona titular de la presidencia o sea solicitado por una tercera parte de sus miembros.

3. La persona titular de la presidencia del Consello Reitor o el/la gerente de la Axencia Galega de Emerxencias podrá convocar a personas técnicas o especialistas a las reuniones para asesoramiento.

Artículo 23. El/la gerente.

1. La presidencia de la Axencia Galega de Emerxencias corresponderá, en razón a su cargo, a la persona titular de la consellería de la Xunta de Galicia competente en materia de protección civil y gestión de emergencias.

2. La vicepresidencia de la Axencia Galega de Emerxencias corresponderá a la persona titular del órgano directivo de la consellería de la Xunta de Galicia competente en materia de protección civil y gestión de emergencias que designe la persona titular de esta última consellería. Corresponderá a dicha persona la resolución de los recursos que puedan interponerse respecto a las actuaciones de la agencia, agotando la vía administrativa.

3. La gerencia es el órgano ejecutivo de la Axencia Galega de Emerxencias, compitiéndole la gestión ordinaria de la misma. La persona titular de la gerencia será nombrada y removida por el Consello Reitor, a propuesta de la persona titular de la presidencia, siendo su cargo incompatible con cualquier otra actividad pública o privada. 
Artículo 24. Estructura orgánica. Para la realización de sus funciones, la Axencia Galega de Emerxencias tendrá asignadas las unidades organizativas que se determinen por decreto de la Xunta de Galicia a propuesta de la consellería competente en materia de protección civil.

Artículo 25. Recursos económicos y patrimonio.

1. La Axencia Galega de Emerxencias dispondrá, para el cumplimiento de sus fines, de los recursos siguientes:

a. Las cantidades que se le asignen en los presupuestos generales de la Comunidad Autónoma.

b. Los bienes y derechos que constituyan su patrimonio y los rendimientos del mismo.

c. Las subvenciones y otras aportaciones públicas o privadas.

d. Las contraprestaciones derivadas de los convenios en que sea parte.

e. Los rendimientos de las publicaciones y cualesquiera otros servicios retributivos del centro que así se establezcan.

2. Tendrán carácter de patrimonio adscrito los bienes que le adscriba la Comunidad Autónoma.

\section{Capitulo IV COMPETENCIAS DE LAS ENTIDADES LOCALES}

Artículo 26. Las provincias. Los órganos de gobierno provinciales ejercerán sus competencias en materia de protección civil y gestión de emergencias con arreglo a lo contemplado en la presente ley, en la legislación gallega de régimen local y la normativa estatal de aplicación. Corresponde a estos:

a. Elaborar los inventarios de riesgos y de recursos de su respectiva provincia.

b. Facilitar la asistencia técnica y financiera a los municipios de la provincia para la elaboración y ejecución de los planes de emergencia.

c. Poner a disposición de la autoridad que ejerza las funciones de dirección y coordinación de cada emergencia los medios y recursos disponibles de su titularidad que figuren en los planes correspondientes cuando que les sean requeridos.

d. Garantizar la prestación del servicio de protección civil y gestión de emergencias, incluidos los servicios contra incendios y de salvamento, en aquellos municipios que no cuenten con servicios propios, por no resultar obligados o haber obtenido dispensa de los mismos ${ }^{851}$.

Artículo 27. Los municipios.

1. Sin perjuicio de la competencia general en materia de protección civil y gestión de emergencias que el artículo 10 de la presente ley atribuye a todos los municipios, corresponde a los municipios de más de 20.000 habitantes:

a. Crear el servicio municipal de protección civil y gestión de emergencias.

b. Crear los servicios de prevención, extinción de incendios y salvamento con arreglo a lo establecido en la legislación de régimen local y de protección civil.

c. Elaborar y aprobar el plan de emergencia municipal, los planes de actuación municipales y, en general, cualesquiera otros instrumentos de planificación de protección civil en el ámbito municipal.

d. Colaborar en la recogida y transmisión a la Axencia Galega de Emerxencias de datos e información relevantes para la protección civil.

e. Elaborar los inventarios de riesgos y el catálogo de recursos municipales en situaciones de emergencia.

f. Poner a disposición de la autoridad que ejerza las funciones de dirección y coordinación de cada emergencia los medios y recursos disponibles de su titularidad que figuren en los planes correspondientes o que les fueran requeridos.

g. Fomentar los programas municipales de previsión y prevención, promoviendo campañas y programas de sensibilización

851 Véase Decreto 19/2009, de 5 de febrero, por el que se aprueba la constitución del Consorcio Provincial de Lugo para la Prestación del Servicio contra Incendios y Salvamento. 
a la población, divulgando los medios de autoprotección y realizando prácticas y simulacros de protección civil.

h. Promover, en colaboración con la consellería de la Administración autonómica competente en materia de voluntariado, la creación de organizaciones del voluntariado de protección civil.

2. La persona titular de la alcaldía es la autoridad municipal superior de protección civil y gestión de emergencias.

En particular, en los municipios que dispongan de servicios propios de protección civil y gestión de emergencias, corresponde a la persona titular de la alcaldía:

a. Elaborar y mantener el catálogo de medios y recursos movilizables para la protección civil en el municipio.

b. Activar los planes de protección civil de ámbito municipal, declarar su desactivación y comunicar a la persona titular de la consellería con competencia en materia de protección civil la activación y desactivación de dichos planes a través de la Axencia Galega de Emerxencias.

c. Solicitar del Consello de la Xunta, a través de la persona titular de la consellería competente en materia de protección civil y gestión de emergencias, la declaración de la situación de emergencia de interés gallego en los casos contemplados en la presente ley.

d. Ejercer la dirección, mando superior, coordinación e inspección de todos los servicios y recursos afectados al plan municipal activado y de las actuaciones que se realicen.

e. Constituir el centro de coordinación de operaciones local y ejercer la dirección superior del mismo.

f. Requerir de las entidades privadas y particulares la necesaria colaboración para el cumplimiento de las obligaciones establecidas en la presente ley.

g. Realizar las actividades de inspección previstas en la presente ley.

h. Ejercer la potestad sancionadora en los términos establecidos en la presente ley.
Artículo 28. Potestad de reemplazo.

1. La Xunta de Galicia podrá proceder al reemplazo de las entidades locales cuando éstas incumplan, de manera reiterada, cualquiera de las obligaciones que la presente ley les impone:

a. Aprobar los correspondientes planes de protección civil.

b. Modificar los planes aprobados, si la modificación es condición para su homologación o viene exigida por circunstancias sobrevenidas o por la modificación de los planes superiores en que se integren.

c. Activar el correspondiente plan de protección civil, si se produjeran los presupuestos para ello.

d. Poner a disposición de la autoridad que ejerza las funciones de dirección y coordinación de cada emergencia los medios y recursos disponibles de su titularidad que figuren en los planes correspondientes o que les fueran requeridos.

e. Cumplir las obligaciones derivadas del apartado e) del artículo 26.

2. El reemplazo habrá de ir precedido de un requerimiento del titular del departamento competente en materia de protección civil y gestión de emergencias. Transcurrido un mes desde dicho requerimiento sin que se haya llevado a cabo la actuación requerida o no se hayan justificado los motivos de la inactividad, la persona titular de la consellería, oída la Comisión Galega de Protección Civil, propondría al Consello de la Xunta de Galicia, a través del consejero competente en la materia, la declaración de su incumplimiento y, producida, en su caso, ésta, adoptaría las resoluciones de ejecución subsidiaria que fueran precisas, a costa de la entidad local obligada.

3. No será necesario dejar transcurrir el plazo de un mes desde la comunicación del requerimiento cuando la actuación requerida sea urgente y la no realización de la misma pudiera poner en peligro a personas, bienes o el medio ambiente, o suponer una agravación de la situación de riesgo. 


\section{Capitulo V}

Órganos de coordinación y cooperación interadministrativa

Artículo 29. La Comisión Galega de Protección Civil.

1. La Comisión Galega de Protección Civil es el órgano colegiado de coordinación y cooperación de las administraciones públicas en Galicia en materia de protección civil, adscrito a la consellería de la Xunta de Galicia competente en materia de protección civil y gestión de emergencias.

2. Reglamentariamente se determinará la composición, organización y funcionamiento de la Comisión Galega de Protección Civil, en la cual estarán representadas la Administración de la Xunta de Galicia, la Administración general del Estado, las entidades locales de Galicia, los servicios de emergencia y las organizaciones del voluntariado de protección civil.

3. Corresponde a la Comisión Galega de Protección Civil:

a. Informar el Plan territorial de protección civil de Galicia y los planes especiales.

b. Informar el mapa de riesgos, el catálogo de riesgos y los catálogos de medios y recursos.

c. Homologar los planes de protección civil de ámbito inferior a la Comunidad Autónoma e informar los planes especiales de protección civil de ámbito de la Comunidad Autónoma, así como los planes de autoprotección que se indiquen en la normativa vigente.

d. Informar las normas técnicas y proyectos de normas reglamentarias sobre protección civil y gestión de emergencias.

e. Informar los procedimientos de operativos de protección civil y de gestión de emergencias.

f. Proponer medidas preventivas y de protección civil ante los órganos competentes de las diferentes administraciones públicas.

g. Las demás funciones que reglamentariamente se determinen.

4. La Comisión Galega de Protección Civil contará con una comisión técnica de carácter permanente, con la composición que se determine reglamentariamente, como órgano de estudio y propuesta para la preparación de sus decisiones y la adopción por delegación de aquellas que la comisión determine. Asimismo, podrá crear grupos de trabajo temporales, integrados por miembros de la misma y otras personas técnicas, para el estudio e informe de aspectos concretos relacionados con sus funciones.

5. La Comisión Galega de Protección Civil y sus órganos de trabajo, para el ejercicio de sus funciones, podrán solicitar información de cualquier persona física o jurídica, así como de las organizaciones de voluntarios de protección civil y de los servicios de emergencias de Galicia, y solicitar el asesoramiento de especialistas.

Artículo 30. Las Xuntas Locais de Protección Civil.

1. Los municipios podrán crear, como órgano asesor en materia de protección civil y gestión de emergencias en el ámbito local, las Xuntas Locais de Protección Civil, cuya composición y modo de funcionamiento se determinará reglamentariamente, sin perjuicio de las competencias municipales en materia de protección civil.

2. Corresponde a las Xuntas Locais de Protección Civil, como órganos asesores de protección civil y gestión de emergencias en el ámbito local:

a. Proponer la elaboración del plan de emergencias municipal o supramunicipal de acuerdo con los riesgos del municipio.

b. Informar, con carácter previo a su aprobación, sobre los planes de protección civil elaborados.

c. Supervisar el desarrollo, implantación, revisión y realización de simulacros y actualización de los planes.

d. Promover y supervisar el cumplimiento de las medidas de prevención establecidas en el plan de emergencias municipal o supramunicipal.

e. Promover las campañas de formación e información ciudadana, así como 
el adestramiento de aquellos sectores de la población que se considere necesario, conforme a los riesgos que les afecten.

f. Analizar y evaluar el desarrollo del plan de emergencias municipal o supramunicipal una vez concluida la situación de emergencia y proponer las correcciones necesarias en el mismo.

g. Promover e impulsar las medidas que considere necesarias en el ámbito de la protección civil.

h. Informar y proponer las previsiones económicas y de infraestructuras que sean necesarias para el desarrollo de sus competencias.

i. Las demás funciones que reglamentariamente se determinen.

\section{TÍTULO III LA ACCIÓN PÚBLICA DE PROTECCIÓN CIVIL Y EMERGENCIA \\ Capítulo I PLANIFICACIÓN}

Artículo 31. Clases de planes.

1. Los planes públicos de protección civil se definen como el marco orgánico y funcional de las autoridades, órganos y organismos, así como la identificación y evaluación de riesgos y los mecanismos de movilización de los medios materiales y personales, tanto públicos como privados, necesarios para la protección de la integridad física de las personas, los bienes y el patrimonio colectivo y medioambiental ante situaciones de emergencia colectiva. En el marco de la normativa vigente en materia de protección civil, dichos planes pueden ser territoriales y especiales. Se realizarán planes de protección en los casos contemplados en la Norma básica de autoprotección.

2. Los planes de protección civil territoriales prevén, con carácter general, las emergencias que puedan producirse en el respectivo ámbito. Los niveles de planificación son el conjunto de Galicia, los municipios de más de 20.000 habitantes y el ámbito supramunicipal.
3. Los planes especiales establecen las medidas necesarias para afrontar emergencias que por su naturaleza requieran unos métodos científicos o técnicos adecuados para su evaluación y tratamiento. Son objeto de planes especiales, en los ámbitos territoriales que sean precisos, las emergencias producidas por inundaciones, movimientos sísmicos, riesgos químicos, transporte de mercancías peligrosas, incendios forestales y todas aquellas otras que se determinen por parte de los órganos competentes. Los planes especiales de ámbito municipal o supramunicipal se integrarán en los planes de protección civil correspondientes.

Artículo 32. Contenido.

Los planes de protección civil, en el marco de la normativa vigente en materia de protección civil, se elaborarán siguiendo una estructura homogénea para su adecuada integración y habrán de incluir, necesariamente, previsiones sobre:

a. Identificación del territorio, población y bienes de interés relevante afectados por el plan.

b. Análisis de los riesgos.

c. Medidas de prevención de los riesgos existentes y actuaciones de los servicios operativos de emergencia.

d. Centro de coordinación operativa con designación del/la director/a del plan y del responsable de comunicación.

e. Servicios que componen los grupos operativos.

f. Inventario de medios y recursos disponibles.

g. Niveles de aplicación del plan, procedimiento de activación y de relación con planes de otros niveles.

h. Programa de implantación, mantenimiento, actualización y simulacros de los planes.

i. Financiación.

Artículo 33. Procedimiento de aprobación y publicación.

1. El Plan territorial de protección civil de Galicia será aprobado por el Consello 
de la Xunta, a propuesta de la persona titular de la consellería competente en materia de protección civil y de gestión de emergencias, previa consulta a los departamentos de la Xunta de Galicia y organismos afectados. Los planes municipales serán aprobados por los plenos de los Ayuntamientos, previa información pública e informe, en su caso, de la Junta Local de Protección Civil. Todos los planes serán homologados por la Comisión Galega de Protección Civil.

2. Corresponde al Consello de la Xunta, previo informe de la Comisión Galega de Protección Civil, la aprobación de los planes especiales, previa consulta a las entidades locales y entidades que reglamentariamente se establezcan. Las entidades locales afectadas por los planes especiales deberán incorporarlos en sus planes.

3. Todos los planes de emergencias han de ser objeto de publicación en los diarios oficiales pertinentes. Las administraciones dispondrán de ejemplares de los planes aprobados para su consulta pública y promoverán la publicación electrónica de los mismos.

Artículo 34. Adaptación y revisión. Los planes han de ser adaptados a los cambios de circunstancias y revisados periódicamente. Todos los planes han de ser revisados cada cuatro años por el mismo procedimiento de aprobación y homologación iniciales. Periódicamente se realizarán simulacros que permitirán contrastar la adaptación de los planes a los posibles riesgos.

Artículo 35. Activación de los planes.

1. Detectada una situación de emergencia, la Axencia Galega de Emerxencias, a través del Centro de Atención de Emergencias 112 Galicia, previa evaluación y calificación del riesgo, establecerá el procedimiento de actuación pertinente.

2. Corresponde a la autoridad local, en su término municipal, la responsabilidad de la adopción de las medidas inmediatas necesarias para afrontarla, sin perjuicio del auxilio de las diputaciones provinciales.
3. Cuando la naturaleza o extensión del riesgo o la necesidad de servicios o recursos excedan de los previstos en su correspondiente plan, la autoridad competente de la dirección del plan de nivel superior activará el plan territorial más amplio conforme a las necesidades de la emergencia, asumiendo la dirección y coordinación de las actuaciones la autoridad que ejerza tales funciones en el plan territorial más amplio.

4. En todo caso, los órganos autonómicos competentes asumirán la dirección y coordinación cuando se disponga la activación del Plan territorial de emergencias de Galicia o de un plan especial, o cuando sea declarada la situación de emergencia de interés gallego.

5. Procedimiento formal de activación de un plan: Ante una situación de emergencia que requiera la activación de un plan, el director del plan pertinente activará formalmente el plan que corresponda, comunicando esta situación a la Axencia Galega de Emerxencias a través del Centro de Atención a las Emergencias 112 Galicia. La activación del plan implicará, en todo caso:

a. La constitución del centro de coordinación operativo del plan y, en su caso, del centro de control operativo integrado.

b. El enlace con el puesto de mando avanzado.

c. La movilización inmediata de los diversos grupos operativos.

d. La información a la población y la comunicación de las instrucciones pertinentes.

6. La desactivación de un plan de protección civil será declarada formalmente por su director, una vez superada totalmente la situación de emergencia, comunicando esta situación a la Axencia Galega de Emerxencias a través del Centro de Atención a las Emergencias 112 Galicia.

Artículo 36. Declaración de emergencias de interés gallego.

1. Cuando la situación de peligro o los daños ocurridos sean, por su especial extensión o intensidad, particularmente graves, el Consello de la Xunta, a solicitud 
de la persona titular de la consellería competente en materia de protección civil, podrá acordar la declaración de emergencia de interés gallego.

2. La declaración de emergencia de interés gallego supondrá la asunción por la persona titular de la presidencia de la Xunta o persona titular de la consellería en quien delegue de la dirección de todas las actividades de la emergencia. A tal fin estará asistido por un gabinete de crisis formado por aquellos miembros del Consello de la Xunta implicados en la emergencia, además de la persona titular del departamento competente en materia de protección civil.

3. La gestión de la emergencia de interés gallego corresponderá a la Axencia Galega de Emerxencias, sin perjuicio de la incorporación de medios de otros órganos o entes administrativos. La declaración podrá implicar la reorganización funcional de los servicios administrativos y las modificaciones presupuestarias precisas para afrontar la emergencia.

\section{Capitulo II LA GESTIÓN DE RIESGOS ORDINARIOS}

Artículo 37. Gestión de riesgos ordinarios.

1. Organización de la gestión:

a. Cuando la emergencia afecte al territorio de un único municipio y los medios de que este disponga sean suficientes para la atención de la emergencia, la Axencia Galega de Emerxencias, a través del Centro de Atención a las Emergencias 112 Galicia, limitará su cometido a calificar el riesgo, movilizar los medios y realizar el seguimiento y cierre de la misma.

b. En caso de que la emergencia afecte a más de un municipio o los recursos de éste no fueran suficientes, la Axencia Galega de Emerxencias, a través del Centro de Atención a las Emergencias 112 Galicia, movilizará los medios necesarios y solicitará de la autoridad competente en materia de protección civil y emergencias la activación del plan correspondiente si fuera necesario.

c. En caso de emergencias de interés gallego, se actuará con arreglo a lo dispuesto en el artículo 36.

2. El Centro de Atención a las Emergencias 112 Galicia tiene por objeto atender las llamadas realizadas por los ciudadanos ante situaciones de emergencia, darles el tratamiento correspondiente a las mismas y dirigirlas a los centros de atención de los servicios públicos que habrán de prestar la asistencia objeto de la llamada.

El Centro de Atención a las Emergencias 112 Galicia non comprenderá la prestación material de la asistencia requerida.

\section{Capítulo III RESTABLECIMIENTO}

Artículo 38. Restablecimiento.

1. Las administraciones públicas, dentro de sus respectivas competencias, restablecerán los servicios esenciales para la comunidad afectada por una catástrofe o calamidad.

2. El Consello de la Xunta, a propuesta de la persona titular de la consellería de la Xunta de Galicia competente en materia de protección civil, aprobará un reglamento sobre los criterios a seguir, en su caso, para la concesión de ayudas o subvenciones en atención a las necesidades derivadas de situaciones de emergencia de naturaleza catastrófica. Estas ayudas tendrán carácter subsidiario y complementario de cualquier otro sistema de cobertura de daños, público o privado, estatal o internacional, del que puedan ser beneficiarios los afectados.

3. Las administraciones públicas colaborarán, de forma recíproca, en las tareas de restauración, rehabilitación y retorno a la normalidad. La Xunta de Galicia y las diputaciones provinciales prestarán asistencia a los municipios y entidades locales supramunicipales que hayan asumido la competencia de protección civil y gestión de emergencias para la elaboración 
y ejecución de planes de recuperación, para lo cual podrán firmar convenios de colaboración. Se adoptarán las medidas presupuestarias precisas para realizar las actuaciones de restauración, rehabilitación y retorno a la normalidad.

4. Las empresas de servicios públicos o de interés general, tanto públicas como privadas, procederán al restablecimiento de sus servicios, cuando sean afectados por una situación de catástrofe o calamidad, a la mayor celeridad posible.

\section{TíTULO IV LAS MEDIDAS DE AUTOPROTECCIÓN PRIVADA}

Artículo 39. Obligación de autoprotección.

1. Las personas, empresas y, en general, entidades y organismos que realizan actividades que pueden generar situaciones de grave riesgo colectivo, catástrofe o calamidad, así como los centros e instalaciones públicos y privados que puedan resultar afectados de forma especialmente grave por situaciones de este carácter, están obligados a adoptar medidas de autoprotección y a mantener los medios personales y materiales necesarios para afrontar situaciones de riesgo y emergencia, además de lo señalado en el artículo 20 de la Ley 31/1995, de 8 de noviembre, de prevención de riesgos laborales, y normativa específica, y en los artículos 8 y 40 de la Ley 9/2004, de 10 de agosto, de Seguridad Industrial de Galicia.

2. La Xunta determinará por reglamento el catálogo de actividades y los tipos de centros a que se refiere el apartado anterior, así como las medidas mínimas que han de adoptarse en cada caso, de acuerdo con las directrices básicas de autoprotección establecidas en la legislación vigente.

Artículo 40. Autoprotección en los centros educativos.

1. Se considera centro docente o educativo, a los efectos de la presente norma, aquel en que se lleven a cabo actividades de formación presencial de personas tales como:

a. Guarderías.

b. Escuelas de educación infantil.

c. Centros de educación primaria, secundaria obligatoria, bachillerato, formación profesional, enseñanza de régimen especial y centros de educación especial.

d. Universidades.

e. Academias, cualquiera que sea el tipo de enseñanza que impartan.

f. Otros centros asimilados a los mencionados.

2. En los diferentes ciclos educativos es necesario programar actividades de información, prevención y divulgación en materia de protección civil, para lo cual habrá de realizarse, al menos una vez al año, un simulacro de evacuación, de acuerdo con las previsiones del plan de autoprotección correspondiente.

3. Estos programas se elaborarán en colaboración con las autoridades con competencia en la materia de educación, elaborando los mecanismos necesarios para su cumplimiento.

4. Los planes de autoprotección en los centros educativos habrán de ser aprobados por su titular.

Artículo 41. Catálogo de actividades de riesgo y planes de autoprotección.

1. La Xunta de Galicia, previa audiencia de las personas, empresas y entidades que puedan verse afectadas o de sus organizaciones representativas, determinará, mediante reglamento, un catálogo autonómico complementario de actividades y tipos de centros a los cuales se les exijan medidas de autoprotección de acuerdo con las directrices básicas de autoprotección establecidas en la legislación vigente.

2. Los citados planes de autoprotección comprenderán, al menos, los aspectos contemplados en la Norma básica de autoprotección. 
Artículo 42. Actividad administrativa de apoyo y control de las medidas de autoprotección.

1. La Xunta de Galicia promoverá la formación de organizaciones de autoprotección entre las personas, entidades y empresas, facilitándoles asesoramiento técnico y asistencia. Éstas comunicarán a las autoridades de protección civil los planes y medidas de autoprotección adoptados y sus modificaciones.

2. Las administraciones públicas, en el ámbito de sus respectivas competencias en materia de protección civil y gestión de emergencias, podrán proceder de oficio a la ejecución subsidiaria de las medidas de autoprotección, prevención y seguridad en caso de incumplimiento por el obligado, en conformidad con lo previsto en la legislación de procedimiento administrativo, sin perjuicio de las infracciones penales o administrativas en que pueda haber incurrido y, en su caso, de la exigencia del pago de los costes de las intervenciones públicas.

\section{TÍTULO V EL PERSONAL}

Artículo 43. El personal del sistema integrado de protección civil y emergencias de Galicia.

1. El sistema integrado de protección civil y emergencias de Galicia estará formado tanto por personal de carácter profesional como por voluntarios. La dirección y coordinación de las actividades reguladas en la presente ley corresponderá al personal profesional.

2. El personal profesional es aquel que desempeña su actividad mediante vínculo laboral con alguno de los servicios relacionados con la gestión de riesgos y de emergencias, con independencia del régimen jurídico de gestión de los mismos.

3. El personal voluntario es aquel que, libre y desinteresadamente, se incorpora a entidades $\mathrm{u}$ organizaciones públicas o privadas sin ánimo de lucro, las cuales tienen como fin la protección de las personas, los bienes y el medio ambiente en situaciones definidas en la presente ley como situaciones de gestión de riesgos y de emergencias.

Artículo 44. La organización del personal. Los grupos operativos.

1. El personal del sistema integrado de protección civil y emergencias en Galicia se organizará, para el desarrollo de las funciones contempladas en la presente ley, en grupos operativos que habrán de estar previstos en los correspondientes planes públicos de protección civil.

2. Cada grupo operativo estará conformado por el personal profesional y voluntario que por su formación y actividad ordinaria esté específicamente preparado y equipado para el desarrollo de las actividades contempladas en la presente ley. Los planes deberán prever el número mínimo de personas y equipamiento que han de integrar cada grupo para asegurar el correcto desarrollo de las tareas que tienen atribuidas.

3. En la conformación de los grupos operativos se respetará, dentro de lo posible, la estructura organizativa propia de los mismos, pero garantizándose, en todo caso, un mando operativo único profesional en las intervenciones que así lo requieran.

Artículo 45. La relación jurídica de los miembros de los grupos operativos.

1. La participación del personal profesional y voluntario en los grupos operativos se llevará a cabo por medio de la organización en que se integre cada uno. La actividad desarrollada al amparo de la presente ley no generará vínculo contractual de tipo alguno con la administración gestora del riesgo o emergencia.

2. El personal profesional será retribuido o indemnizado por los servicios prestados al amparo de la presente ley en conformidad con lo que establezcan las normas reguladoras de su estatuto 
jurídico. El personal voluntario prestará los servicios regulados en la presente ley de manera voluntaria, altruista y gratuita, sin perjuicio de las indemnizaciones que puedan establecerse.

3. Los miembros de los grupos operativos tendrán derecho a la cobertura de un seguro de accidentes, enfermedad, invalidez y muerte y, en su caso, de responsabilidad civil, además de alojamiento, manutención y transporte, tanto durante los períodos de formación y prácticas como durante las misiones a desarrollar al amparo de la presente ley.

4. Los miembros de los grupos operativos tienen la obligación de participar en las actividades previstas en los correspondientes planes y en los simulacros que se lleven a cabo.

Artículo 46. La formación y acreditación del personal del sistema integrado de protección civil y emergencias de Galicia.

1. Los miembros de los grupos operativos tienen la obligación de realizar las actividades de formación y capacitación precisas para al ejercicio de sus funciones.

2. La Xunta de Galicia, por sí misma o de acuerdo con las entidades locales y organismos públicos y privados interesados, establecerá un sistema de formación que asegure la capacitación profesional del personal del sistema integrado de protección civil y emergencias y la acreditación de los directores de puesto de mando avanzado.

Esta formación será continuada por medio de cursos que incluirán una parte de ejercicios de adestramiento y coordinación y que formarán parte de un diseño curricular de gestión de riesgos y de emergencias, en los términos que reglamentariamente se determine.

La Xunta de Galicia promoverá la formación homogénea del personal de los servicios contra incendios y salvamento de Galicia según la estructura que se determine en el Plan director de los servicios contra incendios y salvamento, habida cuenta de la cualificación profesional del Instituto
Nacional de Cualificaciones en lo relativo al módulo de la formación profesional de extinción de incendios y salvamento.

3. El personal voluntario deberá seguir un curso de formación básica, organizado u homologado por la Xunta de Galicia, a fin de obtener la acreditación precisa para el ejercicio de su función. La superación de dicho curso dará derecho a la obtención de un carné de personal voluntario del sistema integrado de protección civil y de gestión de riesgos y de emergencias de Galicia y a emplear los distintivos e insignias que se establezcan reglamentariamente.

Artículo 47. El personal colaborador no permanente.

1. Será personal colaborador aquellas personas o entidades que de forma ocasional o temporal participen en el desarrollo de alguna de las actividades contempladas en la presente ley, se integren o no en los grupos operativos.

2. La Xunta de Galicia podrá suscribir convenios de colaboración con entidades, públicas o privadas, a fin de facilitar la participación del personal colaborador en las actividades de gestión de riesgos y de emergencias y en las actividades formativas del personal.

3. La colaboración ocasional con los servicios de emergencia no generará vínculo contractual o laboral alguno con los mismos, sin perjuicio de las indemnizaciones que puedan establecerse.

Artículo 48. Voluntariado de protección civil y emergencias.

1. El personal voluntario del sistema integrado de protección civil y emergencias de Galicia podrá agruparse, de acuerdo con la normativa autonómica en materia de voluntariado, en asociaciones cuya finalidad social será la colaboración desinteresada en la protección de las personas, los bienes y el medio ambiente en situaciones definidas en la presente ley como situaciones de gestión de riesgos y de emergencias.

2. Las entidades de voluntariado de protección civil habrán de estar a lo dispuesto 
en la Ley 3/2000, de 22 de diciembre, de Voluntariado de Galicia, y habrán de inscribirse en el Registro de entidades de acción voluntaria adscrita a la consellería de la Xunta de Galicia competente en materia de voluntariado. Igualmente, habrán de inscribirse en un registro especial que se llevará en el departamento de la Xunta de Galicia competente en materia de protección civil y gestión de emergencias. En todo caso, este último registro deberá funcionar de manera coordinada con el Registro de entidades de acción voluntaria adscrito al departamento de la Xunta de Galicia competente en materia de voluntariado.

3. Reglamentariamente se fijarán los requisitos precisos para inscribirse en el Registro de asociaciones de protección civil y de emergencias, así como los derechos, obligaciones y distintivos de sus miembros, en la materia específica de protección civil y emergencias.

4. Las autoridades competentes en materia de protección civil y emergencias, en coordinación con la consellería de la Administración autonómica competente en materia de voluntariado, promoverán la creación, desarrollo y equipamiento de las organizaciones del voluntariado de protección civil en los términos que se establezcan reglamentariamente.

\section{TÍTULO VI \\ FINANCIACIÓN}

Artículo 49. Recursos financieros del sistema integrado de protección civil y emergencias de Galicia.

El sistema integrado de protección civil y emergencias de Galicia se financiará mediante la aplicación de los recursos siguientes:

a. Las dotaciones previstas a este fin en los presupuestos de:

- Los municipios de más de 20.000 habitantes.

- Las diputaciones provinciales para actividades propias o para atender las que correspondan a los municipios de menos de 20.000 habitantes.

- La Comunidad Autónoma. b. Los fondos provenientes de las aseguradoras que cubran riesgos personales o de bienes y los que por razones de ayuda y urgente necesidad puedan ser devengados por las administraciones públicas.

c. Las contribuciones especiales.

d. Las tasas por la prestación de servicios.

e. El producto de las sanciones pecuniarias impuestas en aplicación de la presente ley.

f. Las subvenciones y otros ingresos de derecho público.

g. Las donaciones, herencias y legados y cualesquiera otros ingresos de derecho privado.

\section{TÍTULO VII \\ RÉGIMEN SANCIONADOR EN MATERIA DE PROTECCIÓN CIVIL Y GESTIÓN DE EMERGENCIAS}

\section{Capítulo I \\ INFRACCIONES Y SANCIONES}

\section{Sección 1. ${ }^{\mathrm{a}}$ \\ Infracciones}

Artículo 50. Infracciones muy graves.

1. Constituyen infracciones muy graves las conductas siguientes:

a. No adoptar medidas de autoprotección o no mantener los medios personales y materiales necesarios para afrontar situaciones de riesgo y emergencia.

b. No adoptar o revisar los planes de autoprotección preceptivos.

c. Impedir la inspección del estado de las medidas y de los medios de autoprotección por la autoridad competente.

d. Realizar llamadas al Centro de Atención de Emergencias 112 Galicia comunicando avisos falsos, siempre que tales avisos den lugar a la movilización de recursos o a que la ocupación de la línea por las mismas incida negativamente en la prestación del servicio.

e. Negarse los medios de comunicación social a emitir, transmitir, publicar y difundir, de manera inmediata, prioritaria y destacada, si así se les requirió, la información, avisos, órdenes e instrucciones 
dictadas por las autoridades competentes y dirigidas a la población.

f. Impedir la destrucción, intervención u ocupación temporal y transitoria de los bienes y medios de transporte, cuando sea ordenada por la autoridad competente de protección civil con arreglo a lo establecido en la presente ley.

g. No respetar las órdenes o instrucciones dictadas por la autoridad de protección civil en situaciones de activación de un plan o emergencia declarada.

h. Negarse, sin causa justificada, a realizar las prestaciones personales ordenadas por la autoridad de protección civil de conformidad con la presente ley en situaciones de activación de un plan o emergencia declarada.

2. Constituyen también infracciones muy graves en materia de protección civil y gestión de emergencias la comisión de dos infracciones graves cuando sean cometidas por una persona o entidad sancionada con carácter firme en los tres años anteriores a aquel en que se cometieron los hechos constitutivos de la última infracción grave.

Artículo 51. Infracciones graves.

1. Constituyen infracciones graves las conductas siguientes:

a. Obstaculizar, sin llegar a impedir, la inspección del estado de las medidas y de los medios de autoprotección por la autoridad competente de protección civil.

b. No comunicar a las autoridades competentes de protección civil cualquier circunstancia o incidente que pueda generar situaciones de emergencia.

c. No participar, en caso de emergencia, salvo causa debidamente justificada, en las actividades previstas en los correspondientes planes el personal voluntario de los grupos operativos.

d. Obstaculizar, sin llegar a impedir, la destrucción, intervención u ocupación temporal y transitoria de los bienes y medios de transporte, cuando sea ordenada por la autoridad competente de protección civil con arreglo a lo establecido en la presente ley.

e. Obstaculizar el cumplimiento de las órdenes e instrucciones emanadas de las autoridades de protección civil en situaciones de activación de un plan o emergencia declarada.

2. Constituyen también infracciones graves en materia de protección civil y gestión de emergencias la comisión de dos infracciones leves cuando sean cometidas por una persona o entidad sancionada con carácter firme en el año anterior a aquel en que se cometió la infracción leve.

3. También pueden constituir infracciones graves en materia de protección civil y gestión de emergencias las conductas constitutivas de infracciones muy graves previstas en el apartado primero del artículo anterior cuando por su naturaleza y las circunstancias concurrentes no deban ser calificadas como muy graves.

Artículo 52. Infracciones leves.

1. Constituyen infracciones leves las conductas siguientes:

a. Realizar llamadas injustificadas al Centro de Atención de Emergencias 112 Galicia.

b. No seguir o no respetar las medidas e instrucciones dispuestas por la autoridad de protección civil y gestión de emergencias cuando se hagan simulacros.

2. También pueden constituir infracciones leves en materia de protección civil y gestión de emergencias las conductas constitutivas de infracciones graves previstas en el apartado primero del artículo anterior cuando por su naturaleza y las circunstancias concurrentes no deban ser calificadas como graves.

\section{Sección 2. ${ }^{a}$ \\ Sanciones}

Artículo 53. Sanciones pecuniarias.

1. Las infracciones muy graves se sancionarán con multa de 15.001 hasta 600.000 euros.

2. Las infracciones graves se sancionarán con multas de 1.001 hasta 15.000 euros. 
3. Las infracciones leves se sancionarán con multas de 60 hasta 1.000 euros.

Artículo 54. Graduación y actualización de la cuantía de las sanciones.

1. La cuantía de las sanciones ha de graduarse atendiendo a las circunstancias siguientes:

a. La gravedad del hecho constitutivo de la infracción, habida cuenta de su trascendencia económica o social, la incidencia en la seguridad, el riesgo objetivo causado a bienes y personas y los daños y perjuicios producidos.

b. La culpabilidad presente en la concreta actuación infractora, habida cuenta de la intencionalidad, la reiteración, la reincidencia, la realización de actos para dificultar o impedir su descubrimiento, la actitud del interesado en la reparación del daño causado evitando un perjuicio mayor, así como la subsanación, durante la tramitación del procedimiento, de las anomalías que han dado lugar a su incoación.

c. La situación socioeconómica del infractor, habida cuenta de la capacidad económica del mismo.

Artículo 55. Sanciones no pecuniarias.

1. Las infracciones graves y muy graves cometidas por los miembros voluntarios de los grupos operativos se sancionarán con la baja forzosa en el sistema integrado de protección civil y emergencias en la condición de voluntario, y la prohibición de su reincorporación al mismo en esa condición durante un plazo de cinco años en los casos de falta muy grave y de tres años en los casos de falta grave.

2. Las infracciones leves cometidas por los miembros voluntarios de los grupos operativos se sancionarán con la suspensión, de entre uno y seis meses, de su participación en el sistema integrado de protección civil en la condición de voluntario.

Artículo 56. Responsabilidad por daños o perjuicios.

1. Las sanciones que correspondan a las infracciones tipificadas en la presente ley se impondrán con independencia de la obligación de indemnizar por los daños y perjuicios a las personas, bienes e instalaciones.

2. En particular, si la comisión de la infracción ocasionara daños o perjuicios a la administración pública, el infractor, además de la sanción que corresponda en función de la gravedad de la infracción cometida, estará obligado a reintegrar la cuantía económica de los costes originados a la Administración pública.

\section{Capítulo II \\ PROCEDIMIENTO SANCIONADOR}

Artículo 57. Competencia sancionadora.

1. La potestad sancionadora corresponde a los municipios y a la Administración autonómica, en los términos establecidos en este artículo.

2. La competencia para imponer las sanciones corresponde a:

a. Las personas titulares de las alcaldías o las personas titulares de las delegaciones provinciales de la consellería de la Xunta de Galicia competente en materia de protección civil y gestión de emergencias, de acuerdo con el ámbito del plan o de la emergencia afectada por la conducta constitutiva de infracción, en el caso de infracciones leves.

b. La persona titular de la consellería competente en materia de protección civil y gestión de emergencias en el caso de infracciones graves.

c. El Consello de la Xunta de Galicia en el caso de infracciones muy graves.

Artículo 58. Medidas provisionales.

1. Cuando concurran circunstancias graves que afecten a la seguridad de las personas o de los bienes, podrá acordarse cautelarmente la clausura inmediata de establecimientos, el precintado de instalaciones o la suspensión de actividades.

2. Estas medidas podrán ser adoptadas, mediante resolución motivada, por las autoridades de protección civil tanto en el 
acuerdo de iniciación del procedimiento como durante su instrucción.

3. Excepcionalmente, en los supuestos de grave riesgo o peligro inminente para las personas o bienes, dichas medidas podrán ser adoptadas por las autoridades de protección civil antes de la iniciación del procedimiento.

En este supuesto, las medidas provisionales deberán ser confirmadas, modificadas o levantadas en el acuerdo de iniciación del procedimiento, que habrá de efectuarse dentro de los quince días siguientes a su adopción y podrá ser recurrido procedentemente. En todo caso, las citadas medidas quedarán sin efecto si no se inicia el procedimiento en dicho plazo o cuando el acuerdo de iniciación no contenga un pronunciamiento expreso sobre las mismas.

Artículo 59. Normativa de aplicación al procedimiento sancionador.

En la tramitación de las infracciones y en la imposición de las sanciones contempladas en la presente ley se observarán los principios del título IX de la Ley 30/1992, de 26 de noviembre, de Régimen Jurídico y del Procedimiento Administrativo Común, aplicándose lo dispuesto en este capítulo y, en todo lo no previsto en el mismo, la normativa gallega sobre el ejercicio de la potestad sancionadora.

\section{DISPOSICIÓN ADICIONAL PRIMERA RECONOCIMIENTO DE ACTIVIDADES DEL VOLUNTARIADO}

La experiencia, debidamente justificada, desarrollada durante un período mínimo de un año en organizaciones de voluntariado que realicen actividades relacionadas con la protección civil o la gestión de emergencias podrá ser considerada como mérito para acceder a los servicios profesionales de protección civil, extinción de incendios o cualesquiera otros relacionados con la gestión de emergencias, sin perjuicio de los principios de igualdad, mérito, capacidad y publicidad y de lo dispuesto en la Ley 4/988, de 26 de mayo.

\section{DISPOSICIÓN ADICIONAL SEGUNDA}

$$
\text { (...) })^{852}
$$

\section{DISPOSICIÓN ADICIONAL TERCERA SERVICIOS DE PREVENCIÓN Y EXTINCIÓN DE INCENDIOS Y DE SALVAMENTO}

1. La Xunta de Galicia, a través de la consellería competente en materia de emergencias y protección civil, impulsará las acciones necesarias para homogeneizar en el plazo de tres años las prestaciones y condiciones de trabajo en todo el territorio de Galicia de los servicios de prevención y extinción de incendios y de salvamento a que se refiere el segundo párrafo del apartado 2 de este artículo.

2. La Xunta de Galicia procederá, en el plazo de seis meses desde su puesta en funcionamiento, a la elaboración de un plan director de los servicios contra incendios y de salvamento que definirá el modelo de reordenación territorial y la estructura operativa de los mismos.

En este sentido, la Xunta impulsará la creación de los consorcios provinciales en cuya gestión y financiación participen las diputaciones y los municipios de más de 20.000 habitantes que no tengan parque propio y la propia Xunta de Galicia.

3. En el plazo de un año desde la aprobación de la presente ley, la Xunta de Galicia, mediante propuesta de la consellería competente en la materia, promoverá la elaboración de un reglamento del bombero profesional y del voluntariado.

\section{DISPOSICIÓN ADICIONAL CUARTA FINANCIACIÓN DE LOS SERVICIOS CONTRA INCENDIOS Y DE SALVAMENTO}

La financiación de los servicios contra incendios y de salvamento se realizará por las distintas administraciones en los términos establecidos en la presente ley y según el porcentaje de participación en los consorcios que se determine. A este efecto,

852 Contiene modificaciones a la Ley 6/2003, de 9 de diciembre, de tasas, precios y exacciones reguladoras de la Comunidad Autónoma de Galicia. 
las entidades que lo integren aportarán la cantidad proporcional correspondiente conforme a la evaluación objetiva de los factores de riesgo y de la frecuencia de servicios demandados por cada uno de los municipios, la cual se actualizará periódicamente.

\section{DISPOSICIÓN ADICIONAL QUUNTA INTEGRACIÓN DEL ANÁLISIS DÉ RIESGOS EN LA PLANIFICACIÓN URBANÍSTICA}

La legislación urbanística y de ordenación del territorio en Galicia tendrá en cuenta los planes territoriales y especiales y las medidas de prevención de riesgos y de reducción de impacto de eventuales catástrofes.

A este fin, dentro de la tramitación de los planes urbanísticos, en su momento procedimental, el órgano competente en materia de protección civil solicitará, cuando lo considere necesario, especialmente cuando se identifiquen riesgos de orden hidrológico, geotécnico, de incendios o cualesquiera otros que afecten a la seguridad de las personas, un informe de la Comisión Galega de Protección Civil, para evitar situaciones de riesgo colectivo derivado de la ordenación del territorio.

\section{DISPOSICIÓN ADICIONAL SEXTA COMPETENCIA DE LAS ÁREAS METROPOLITANAS Y ENTIDADES SUPRAMUNICIPALES}

Por ley del Parlamento de Galicia se determinará, en su caso, la competencia de las áreas metropolitanas y otras entidades supramunicipales en materia de protección civil y gestión de emergencias.

DISPOSICIÓN TRANSITORIA PRIMERA APROBACIÓN DEL DECRETO DE AYUDAS PARA LAS NECESIDADES DERIVADAS DE SITUACIONES DE EMERGENCIA Y DEL CATÁLOGO DE RECURSOS DE PROTECCIÓN CIVIL Y ACTUALIZACIÓN O APROBACIÓN DE PLANES

La consellería de la Xunta de Galicia competente en materia de protección civil remitirá, en el plazo de nueve meses a partir de la entrada en vigor de la presente ley, para su aprobación en el Consello de la Xunta, un decreto de ayudas para las necesidades derivadas de situaciones de emergencia o de naturaleza catastrófica.

La consellería de la Xunta de Galicia competente en materia de protección civil habrá de aprobar, en el plazo de un año a partir de la entrada en vigor de la presente ley, un catálogo de todos los recursos disponibles para la protección civil. A tal efecto podrá requerir información a los demás departamentos y entes autonómicos, a los entes locales y a las empresas y organizaciones privadas.

En el plazo máximo de un año la Xunta de Galicia actualizará los planes vigentes hasta el momento.

Los municipios habrán de actualizar o, en su caso, elaborar los planes de nivel municipal en el plazo de un año a partir de la terminación de la actualización del Plan territorial de protección de Galicia. En tanto no sean remitidos para su aprobación u homologación, los municipios no podrán ser beneficiarios de ayudas públicas en materia de protección civil.

\section{DISPOSICIÓN TRANSITORIA SEGUNDA HOMOLOGACIÓN DE LA FORMACIÓN DE LOS SERVICIOS DE PROTECCIÓN CIVIL Y SERVICIOS CONTRA INCENDIOS Y DE SALVAMENTO}

La consellería de la Xunta de Galicia competente en materia de protección civil habrá de aprobar, en el plazo de un año a partir de la entrada en vigor de la presente ley, un sistema de homologación de la formación de los servicios de protección civil y de los servicios contra incendios y de salvamento, en el cual se valorará la experiencia demostrable y la formación ya adquirida.

\section{DISPOSICIÓN TRANSITORIA TERCERA CONSTITUCIÓN DE LOS CONSORCIOS Y ENTIDADES LOCALES DE COOPERACIÓN}

Los consorcios y demás entidades locales de cooperación contemplados en la presente 
ley se constituirán en el plazo de tres años a partir de la entrada en vigor de la misma.

\section{DISPOSICIÓN DEROGATORIA}

Quedan derogadas todas las normas de igual o inferior rango que se opongan a lo previsto en la presente ley.

\section{DISPOSICIÓN FINAL PRIMERA \\ DESARROLLO REGLAMENTARIO}

Se autoriza al Consello de la Xunta para dictar las disposiciones de aplicación y desarrollo de la presente ley.

\section{DISPOSICIÓN TRANSITORIA SEGUNDA ENTRADA EN VIGOR}

La presente ley entrará en vigor a los veinte días de su publicación en el "Diario Oficial de Galicia”. 


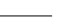




\section{Índice de Consellerías}

\section{NORMAS COMUNES}

1. Ley Orgánica 1/1981, de 6 de abril, del Estatuto de Autonomía para Galicia (I.1).

2. Ley Orgánica 16/1995, de 27 de diciembre, de Transferencia de Competencias a la Comunidad Autónoma Gallega (I.2).

3. Ley Orgánica 6/1999, de 6 de abril, de Transferencia de Competencias a la Comunidad Autónoma de Galicia (I.3).

\section{PRESIDENCIA}

1. Ley $1 / 1983$, de 22 de febrero, reguladora de la Xunta y su presidencia (II.1).

2. Ley 6/1999, de 1 de septiembre, de Audiovisual de Galicia (XII.3).

3. Ley 9/1984, de 11 de julio, de Creación de Compañía de Radio-Televisión de Galicia (XII.1).

4. Ley 10/1983, de 9 de diciembre, reguladora del Consello Asesor de RTVE en Galicia (XII.2).

5. Ley 11/2007, de 27 de julio, Gallega para la prevención y/o Tratamiento Integral da Violencia de Género (XVI.6).

6. Ley 11/1997, de 22 de agosto, General de Deportes de Galicia (XVII.8).

7. Ley 9/1995, de 10 de noviembre, del Consello Consultivo de Galicia (II.4).

\section{CONSELLERIAA DE PRESIDENCIA, ADMINISTRACIÓNS PÚBLICAS E XUSTIZA}

1. Ley 9/1996, de 18 de octubre, de Incompatibilidades de los Miembros de la Xunta de Galicia y Altos Cargos de la Administración Autónomica (II.2).

2. Ley $4 / 2002$, de 25 de junio, del Estatuto de Capitalidad de la Ciudad de Santiago de Compostela (II.6).

3. Ley 5/1997, de 22 de julio, de Administración Local de Galicia (III.1).

4. Ley 7/1996, de 10 de julio, de Desarrollo Comarcal (III.2).

5. Ley 4/2004, de 28 de junio, para la aplicación a los Municipios de Ferrol, Lugo, Ourense, Pontevedra y Santiago de Compostela del Régimen de Organización de los Municipios de Gran Población (III.3).

6. Ley 11/1983, de 29 de diciembre, de Actuación Intensiva en las Parroquias Rurales (III.4).

7. Ley $6 / 2001$, de 29 de junio, de adecuación de la normativa de la Comunidad Autónoma de Galicia a la Ley 4/1999, de 13 de enero, de moficación de la Ley 30/1992, de 26 de noviembre, de Regimen Jurídico de las Administraciones Públicas y del Procedimiento Administrativo Común (IV.1).

8. Ley 4/2006, de 30 de junio, de Transparencia y de Buenas Prácticas en la Administración Pública Gallega (IV.2).

9. Ley 6/1984, de 5 de junio, del Valedor do Pobo de Galicia (II.5). 


\section{I Índice de Consellerías}

10. Ley 4/1987, de 27 de mayo, de creación de la Escola Galega de Administracion Pública (IV.4).

11. Ley 12/2006, de 1 de diciembre, de Fundaciones de Interés Gallego (VI.3).

12. Ley $8 / 2007$, de 13 de junio, de Policía de Galicia (X.1).

13. Ley $4 / 2007$, de 20 de abril, de Coordinación de Policias Locales (X.II).

14. Ley $1 / 2007$, de 15 de enero, de Academia Galega de Seguridade Pública (X.III).

15. Ley 5/2007, do 7 de mayo, de Emergencias de Galicia (XVIII.1).

\section{CONSELLERÍA DE FACENDA}

1. Decreto Legislativo $1 / 1999$, do 7 de octubre, por el que se aprueba el texto refundido de la Ley del Régimen Financiero y Presupuestario de Galicia (V.1).

2. Ley 6/2003, de 9 de diciembre, de Tasas, Precios y Exacciones Reguladoras de la Comunidad Autónoma de Galicia (V.3).

3. Ley $12 / 1995$, de 29 de diciembre, de Impuesto sobre la Contaminación Atmosférica (V.2).

4. Ley 13/1991, de 9 de diciembre, de Tasas, Precios y Exacciones Reguladoras de la Comunidad Autónoma de Galicia (V.4).

5. Ley 9/2007, de 13 de junio, de Subvenciones de Galicia (V.5).

6. Ley 9/2008, do 28 de julio, Gallega de Medidas Tributarias en relación con el Impuesto sobre Sucesiones y Donaciones (V.6).

7. Ley 15/2008, de 19 de diciembre, de Impuesto sobre el Daño Medioambiental causado por determinados Usos y Aprovechamientos del Auga Embalsada (V.7).

8. Ley 3/1985, de 12 de abril, de Patrimonio de la Comunidad Autónoma Gallega (VII.1).

9. Decreto Legislativo $1 / 2005$, de 10 de marzo, por el que se aprueba el texto refundido de las Leyes 7/1985, de 14 de julio, y 4/1996, de 31 de mayo, de Cajas de Ahorros de Galicia (VI.1).

10. Ley 6/2004, de 12 de julio, Reguladora de los Órganos de Defensa de la Competencia de la Comunidad Autónoma de Galicia (VI.5).

11. Ley 6/1985, de 24 de junio, del Consello de Contas (II.9).

12. Ley 10/1996, de 5 de noviembre, de Actuación de Entes y Empresas en las que tienen participación mayoritaria la Xunta de Galicia, en materia de personal y contratación.

13. Decreto Legislativo $1 / 2008$, de 13 de marzo, por el que se aprueba el Texto Refundido de la Ley de la Función Pública de Galicia (IV.3).

\section{CONSELLERÍA DE MEDIO AMBIENTE, TERRITORIO E INFRAESTRUTURAS}

1. Ley $1 / 1995$, de 2 de enero, de Protección Ambiental de Galicia (IX.1).

2. Ley 8/2002, de 18 de diciembre, de Protección del Ambiente Atmosférico de Galicia (IX.2).

3. Ley 7/1997, de 11 de agosto, de Protección contra la Contaminación Atmosférica (IX.3).

4. Ley 10/2008, de 3 de noviembre, de Residuos de Galicia (IX.4). 


\section{Índice de Consellerías}

5. Ley $8 / 2001$, de 2 de agosto, de Protección de la Calidad de las Aguas de las Rías de Galicia y de Ordenación del Servicio Público de Depuración de Aguas Residuales Urbanas (IX.6).

6. Ley 12/1995, de 29 de diciembre, del Imposto sobre la Contaminación Atmosférica (V.2).

7. Ley 5/1995, de 7 de junio, de Regulación de las Aguas Minerales, Termales, de Manantial y de los Establecimientos Balnearios de la Comunidad Autónoma de Galicia (IX.7).

8. Ley $5 / 2006$, de 30 de junio, para la Protección, la Conservación y la mejora de los Ríos Gallegos (IX.8).

9. Ley 7/2008, de 7 de xulio, de Protección del Paisaje de Galicia (IX.9).

10. Ley 8/1993, de 23 de junio, Reguladora de la Administración Hidráulica de Galicia (VII.3).

11. Ley $4 / 1994$, de 14 de septiembre, de las Carreteras de Galicia (XI.1).

12. Ley 6/1996, de 9 de julio, de Coordinación de los Servicios de Transporte Urbanos e Interurbanos por Carreteras de Galicia (XI.2).

13. Ley 5/1994, de 29 de noviembre, de Creación del Ente Público Puertos de Galicia (XI.3).

14. Ley $2 / 2008$, de 6 de mayo, por la que se desarrolla la Libre Prestación de Servicios de Transporte Marítimo de Personas en Aguas Interiores de Galicia (XI.4).

15. Ley 10/1995, de 23 de noviembre, de Ordenación del Territorio de Galicia (VIII.1).

16. Ley 9/2002, de 30 de diciembre, de Ordenación Urbanística y Protección del Medio Rural de Galicia (VIII.2).

17. Ley 6/2007, de 11 de mayo, de Medidas Urgentes en materia de Ordenación del Territorio y del Litoral de Galicia (XVI.3).

18. Ley $18 / 2008$, de 29 de diciembre, de Vivienda de Galicia (VIII.4).

19. Ley $3 / 1988$, de 27 de abril, de Creación del Instituto Galego da Vivenda e Solo (VIII.5).

20. Ley 8/1997, de 20 de agosto, de Accesibilidad y Supresión de Barreras en la Comunidad Autónoma de Galicia (VIII.6)

21. Ley $6 / 2008$, de 19 de junio, de Medidas Urgentes en materia de Vivienda y Suelo, por la que se modifica la Ley 9/2002, de 30 de diciembre, de Ordenación Urbanística y Protección del Medio Rural de Galicia (VIII.7).

22. Ley 15/2008, de 19 de diciembre, del Impuesto sobre el Dano Medioambiental causado por determinados Usos y Aprovechamientos del Agua Embalsada (V.7).

\section{CONSELLERÍA DE ECONOMÍA E INDUSTRIA}

1. Ley $3 / 2008$, de 23 de mayo, de Ordenación de la Minería de Galicia (VII.7).

2. Ley 5/1992, de 10 de junio, de Creación del Instituto Galego de Promoción Económica (VI.2). 


\section{I Índice de Consellerías}

3. Ley $5 / 2004$, de 8 de julio, de Cámaras Oficiales de Comercio, Industria y navegación de Galicia (II.8).

4. Ley 8/1994, de 30 de diciembre, de Creación del Instituto Galego de Consumo (XV.1).

5. Ley 11/2004, de 19 de noviembre, de Inspección de Consumo de Galicia (XV.2).

6. Ley $12 / 1984$, de 28 de diciembre, del Estatuto Gallego del Consumidor y Usuario (XV.3).

7. Ley 3/1999, de 11 de marzo, de Creación del Instituto Enerxético de Galicia (VII.4).

8. Ley 6/1999, de 1 de septiembre, del Audiovisual de Galicia (XII.3).

\section{CONSELLERÍA DE EDUCACIÓN E ORDENACIÓN UNIVERSITARIA}

1. Ley $1 / 2003$, de 9 de mayo, de los Consellos Sociais do Sistema Universitario de Galicia (XVII.2).

2. Ley $7 / 2001$, de 2 de julio, de Control en materia de Creación y Reconocimiento de Universidades, Centros Universitarios y Autorización de Estudios en la Comunidad Autónoma (XVII.3).

3. Ley $2 / 2003$, de 22 de mayo, del Consello Galego de Universidades (XVII.4).

4. Ley 11/1989, de 20 de julio, de Ordenación del Sistema Universitario de Galicia (XVII.5).

5. Ley 3/1983, de 15 de junio, de Normalización Lingüística (XVII.7).

\section{CONSELLERÍA DE SANIDADE}

1. Ley $8 / 2008$, de 10 de julio, de Salud de Galicia (XVI.3).

2. Ley $3 / 2001$, de 28 de mayo, reguladora del Consentimento Informado y de la Historia Clínica de los Pacientes (XVI.4).

3. Ley 5/1999, de 21 de mayo, de Ordenación Farmacéutica (XVI.5).

\section{CONSELLERÍA DE CULTURA E TURISMO}

1. Ley 14/1989, de 11 de octubre, de Bibliotecas (XVII.1).

2. Ley $8 / 1983$, de 8 de julio, del Consello da Cultura Galega (XVII.6).

3. Ley 4/2008, de 23 de mayo, de Creación de Agencia Gallega de las Industrias Culturales.

4. Ley 14/2008, de 3 de diciembre, de Turismo de Galicia (XVII.9).

5. Ley 8/1995, de 30 de octubre, do Patrimonio Cultural de Galicia (VII.5).

6. Ley 3/1996, de 10 de mayo, de Protección de los Caminos de Santiago (VII.6).

\section{CONSELLERÍA DE TRABALLO E BENESTAR}

1. Ley 9/1991, de 2 de octubre, Gallega de Medidas Básicas para la inserción social (XVI.1).

2. Ley $13 / 2008$, de 3 de diciembre, de Servicios Sociales de Galicia (XVI.2).

3. Ley $6 / 1995$, de 28 de julio, por la que se crea el Consello Económico e Social de Galicia (II.3). 


\section{Índice de Consellerías}

\section{CONSELLERÍA DO MEDIO RURAL}

1. Ley $1 / 2006$, de 5 de junio, del Consello Agrario Galego (XIII.1).

2. Ley $7 / 1994$, de 29 de diciembre, por la que se crea el Instituto Lácteo e Gandeiro de Galicia (XIII.2).

3. Ley 10/1985, de 14 de agosto, de Concentración Parcelaria (XIII.3).

4. Ley $7 / 2007$, de 21 de mayo, de Medidas Administrativas y Tributarias para la Conservación de la Superficie Agraria Útil y del Banco de Tierras de Galicia (XIII.4).

5. Ley 3/1989, do 10 de octubre, de Montes Vecinales en Man Común (VII.2).

6. Ley 9/2001, do 21 de agosto, de Conservación de la Naturaleza (IX.5).

7. Ley 4/1997, do 25 de junio, de Caza de Galicia (XIV.1)

\section{CONSELLERIAA DO MAR}

1. Ley $11 / 2008$, do 3 de diciembre, de Pesca de Galicia (XIV.2).

2. Ley 7/1992, do 24 de julio, de Pesca Fluvial (XIV.3). 


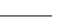




\section{ÍNDICE DE CONCEPTOS}

\section{Academia Galega}

de Seguridade Pública

Consello Autonómico de Formación Continua para los empleados públicos de la seguridad: X.3: art. 13

Consello Reitor: X.3: arts. 8-10

Director general: X.3: arts. 11-12

Estructura orgánica: X.3: art. 14

Fines: X.3: art. 3

Funciones: X.3: arts. 4-5

Medidas de fomento: X.3: art. 6

Naturaleza jurídica: X.3: art. 1

Órganos: X.3: art. 7

Personal: X.3: art. 15

Recursos económicos y patrimonio: X.3: art. 16

Régimen de recursos: X.3: art. 17

Sede: X.3: art. 2

\section{ACCESIBILIDAD Y SUPRESIÓN DE BARRERAS}

Ámbito de aplicación: VIII.6: art. 2

Características de las urbanizaciones: VIII.6: arts. 5-8

Características del mobiliario urbano: VIII.6: arts. 10-12

Características de los elementos de urbanización: VIII.6: art. 9

Consello Galego para a Promoción da Accesibilidade e a Supresión de Barreiras: VIII.6: art. 44

Definiciones: VIII.6: art. 3

Edificios de titularidad privada y uso residencial: VIII.6: art. 22

Edificios de titularidad pública y uso residencial: VIII.6: art 23

Edificios de uso público: VIII.6: arts. 13-21

Fondo para la supresión de barreras: VIII.6: arts. 30-32
Licencias y autorizaciones: VIII.6: art. 33

Medidas de control: VIII.6: arts. 33-35

Medidas de fomento: VIII.6: arts. 30-32

Niveles de accesibilidad: VIII.6: art. 4

Objeto: VIII.6: art. 1

Régimen sancionador: VIII.6: arts. 36-43

Reserva de viviendas para personas con limitaciones: VIII.6: arts. 24-25

Sistemas de comunicación y señalización: VIII.6: art. 29

Tarjetas de accesibilidad: VIII.6: arts. 27-28 Transportes de uso público: VIII.6: art. 26 Visado de proyectos técnicos: VIII.6: art. 34

\section{Actos ADMINISTRATIVOS}

Revisión: competencia: IV.1: art. 3

\section{Administración de la Comunidad Autónoma de Galicia}

Personalidad jurídica única: II.1: art. 36.1

Principios rectores de su actuación: II.1: art. 36.2

\section{Administración HidráUlica DE GALICIA}

Canon de saneamiento: VII.3: arts. 33-42

Competencias: VII.3: arts. 3-4

Cuencas hidrográficas comprendidas íntegramente dentro del territorio de Galicia: VII.3: art. 5

Demarcaciones hidrográficas: VII.3: art. 6 Empresa pública de Obras y Servicios Hidráulicos: VII.3: disposición adicional primera

Normas de procedimiento administrativo: VII.3: arts. 27-32

Organismo autónomo Augas de Galicia: véase la voz "Augas de Galicia" Órganos: VII.3: art. 2

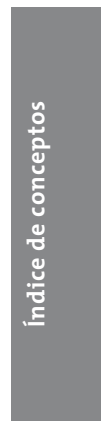




\section{Agencia Gallega de LAS INDUSTRIAS CULTURALES}

Consello asesor: XVII.10: art. 10

Consello de Dirección: XVII.10: art. 8

Departamentos: XVII.10: arts. 11-12

Dirección: XVII.10: art. 9

Fines: XVII.10: art. 4

Funciones: XVII.10: art. 5

Naturaleza y adscripción: XVII.10: art. 1

Objeto y ámbito: XVII.10: art. 3

Organización: XVII.10: arts. 6-12

Régimen de personal: XVII.10: arts. 13-16

Régimen económico-profesional: XVII.10: art. 17-18

Régimen jurídico: XVII.10: art. 2

\section{Agencias públicas de Galica}

Agencias públicas autonómicas: V.1: disposición adicional quinta

\section{AGRUPACIONES DE MUNICIPIOS}

Agrupaciones forzosas: III.1: arts. 168-170

Agrupaciones voluntarias: III.1: arts. $165-167$

\section{Aguas minerales, termales Y DE MANANTIAL}

Clasificación: IX.7: art. 2

Competencias administrativas: IX.7: art. 25

Condiciones generales del aprovechamiento: IX.7: arts. 13-21

Declaración de la condición de mineral o termal de las aguas y reconocimiento del derecho a la utilización de tales denominaciones: IX.7: arts. 3-7

Informes de los órganos consultivos: IX.7: disposición adicional primera

Infracciones y sanciones: IX.7: arts. 26-29

Junta Asesora: IX.7: arts. 23-24

Normativa subsidiaria: IX.7: disposición adicional cuarta

Reconocimiento del derecho a la utilización de la denominación agua de manantial: IX.7: arts. 8-12

\section{ÁreAs METROPOLITANAS}

Comisión de Gobierno: III.1: arts. 126-127

Competencias: III.1: art. 133

Consideración como entidades locales no territoriales: III.1: art. 2

Consello Metropolitano: III.1: arts. 124-125

Creación: III.1: arts. 120-122

Delegado da Xunta de Galicia na área metropolitana: III.1: art. 130

Director general: III.1: arts. 128-129

Hacienda: III.1: art. 134

Organización: III.1: art. 123

Órganos complementarios: III.1: arts. 131-132

\section{Audiovisual de Galicia}

Actividades de fomento del sector audiovisual: XII.3: arts. 8-9

Ámbito de aplicación: XII.3: art. 2

Comunicaciones de interés público: XII.3: art. 8

Consello Asesor das Telecomunicacións e do Audiovisual de Galicia: XII.3: arts. $13-15$

Ejercicio de las competencias propias de la Comunidad de Galicia: XII.3: art. 3

Exhibición: XII.3: arts. 10-12

Líneas fundamentales de las acciones institucionales: XII.3: art. 6

Objeto: XII.3: art. 1

Principios generales de la acción institucional: XII.3: art. 5

Principios generales de la actividad audiovisual: XII.3: art. 4

\section{Augas de Galicia}

Competencias: VII.3: art. 7.2

Comisiones de desembalse: VII.3: art. 20

Disposiciones generales: VII.3: arts. 7-10

Junta de Gobierno: VII.3: arts. 13-18

Juntas de explotación: VII.3: art. 19

Naturaleza y adscripción: VII.3: art. 7.1

Órganos de gestión: VII.3: arts. 19-21

Patrimonio y régimen financiero: VII.3: arts. $22-26$ 
Personalidad jurídica y capacidad de obrar: VII.3: art. 8

Presidente: VII.3: arts. 11-12

\section{AYUdAS Y SUBVENCIONES}

Infracciones, sanciones y régimen de responsabilidad: V.1: art. 79

Régimen general: V.1: art. 78

\section{Banco de Tierras de Galicia (BANTEGAL)}

Ayudas y subvenciones: XIII.4: art. 26

Cesión a terceras personas por tiempo determinado: XIII.4: arts. 19-23

Comisión Técnica de precios y valores: XIII.4: arts. 27-29

Composición: XIII.4: art. 4.2

Comunicación de instrumentos de planeamiento urbanístico: XIII.4: disposición adicional única

Condiciones para la declaración de fincas incultas o abandonadas: XIII.4: arts. 30-31

Derecho de adquisición preferente de la sociedad BANTEGAL: XIII.4: arts. 9-12

Desarrollo reglamentario: XIII.4: disposición final cuarta

Destino de los bienes y derechos incorporados: XIII.4: art. 5.2

Enajenación de bienes y derechos de titularidad de la sociedad BANTEGAL: XIII.4: arts. 16-18

Fincas incultas o abandonadas: XIII.4: arts. 30-36

Formalización de actos: XIII.4: art. 5.1

Función: XIII.4: art. 1.2

Funciones de la sociedad

BANTEGAL: XIII.4: art. 8

Incorporación de fincas rústicas al

BANTEGAL para su gestión: XIII.4: arts. 13-14

Medidas tributarias: XIII.4: art. 25

Naturaleza: XIII.4: art. 4.1

Principio de actuación: XIII.4: art. 4.3
Procedimiento de declaración de fincas incultas o abandonadas: XIII.4: arts. 32-36

Proyectos agrarios prioritarios: XIII.4: art. 24

Publicidad de sus bienes incorporados: XIII.4: art. 6

Régimen sancionador: XIII.4: art. 37-47 y disposición final tercera

Sociedad Anónima Gestora del Banco de Tierras de Galicia y su régimen jurídico: XIII.4: art. 7

Trasmisión de los bienes incorporados al BANTEGAL: XIII.4: art. 15

\section{Bandera de Galicia}

I.1: art. 6.1

\section{BIBLIOTECAS PÚBLICAS}

Actividades culturales: XVII.1: art. 13

Concepto: XVII.1: art. 1

Convenios de colaboración: XVII.1: arts. 11-12

Cooperación interbibliotecaria: XVII.1: art. 14

Financiación: XVII.1: art. 16

Funciones: XVII.1: art. 1

Organización y funcionamiento del sistema bibliotecario de Galicia: XVII.1: arts. 4-9

Personal: XVII.1: art. 15

Servicios bibliotecarios: XVII.1: art. 10

\section{CAJAS DE AHORROS}

Acción de gobierno: VI.1: art. 5

Apertura de oficinas: VI.1: art. 60

Asamblea general: VI.1: arts. 24-34

Autorización: VI.1: art. 9

Comisión de control: VI.1: arts. 42-43

Concepto: VI.1: art. 2

Consejeros generales: VI.1: arts. 26-30

Consejo de Administración: VI.1: arts. 35-41

Contenido mínimo de la escritura fundacional: VI.1: art. 11 


\section{I Índice de conceptos}

Contenido mínimo de los estatutos: VI.1: art. 12

Creación: VI.1: art. 10

Cuotas participativas: VI.1: art. 18

Director general: VI.1: arts. 44-46

Disolución: VI.1: arts. 55-56

Doble dimensión de las cajas: VI.1: art. 6

Emisión de cuotas y financiación subordinado: VI.1: art. 17

Federación Gallega de Cajas de Ahorros: VI.1: arts. 98-100

Financiación subordinada: VI.1: art. 20

Fondo de estabilización: VI.1: art. 19

Fondo fundacional: VI.1: art. 14

Fundación: VI.1: art. 8

Fusión: VI.1: arts. 50-54

Impugnación de acuerdos: VI.1: art. 47

Intervención pública, principios generales: VI.1: arts. 59-61

Libro de actas: VI.1: art. 48

Liquidación: VI.1: arts. 57-58

Mecansimos de control: VI.1: arts. 81-84

Naturaleza de las aportaciones: VI.1: art. 16

Obligación de información: VI.1: arts. 79-80

Obra benéfico social: VI.1: arts. 74-78

Organización democrática: VI.1: art. 7

Órganos de Gobierno, criterios comunes: VI.1: arts. 21-23

Período transitorio: VI.1: art. 13

Política crediticia: VI.1: arts. 72-73

Protección al cliente: VI.1: arts. 69-71

Régimen sancionador: VI.1: arts. 85-97

Registro de altos cargos: VI.1: art. 23

Registro de Cajas de Ahorros: VI.1: art. 4

Reserva de denominación: VI.1: art. 3

Responsabilidad de los vocales del Consejo de Administración: VI.1: art. 49

Situación de déficit patrimonial: VI.1: art. 15

Solvencia: VI.1: arts. 62-65

Transparencia de mercado: VI.1: arts. 66-68

\section{Cámaras Agrarias Provinciales}

Disolución: XIII.1: disposición adicional segunda-disposición adicional sexta
Cámaras Oficiales de Comercio, Industria y NaVegación de Galicia

Ámbito territorial: II.8: art. 7

Censo electoral: II.8: arts. 30-31

Comité ejecutivo: II.8: arts. 16-18

Contabilidad y presupuesto: II.8: art. 44

Consello Galego de Cámaras: II.8: arts. 49-56

Convocatoria de elecciones: II.8: art. 32

Creación de delegaciones: II.8: art. 12

Deber de información y emisión de informes: II.8: art. 60

Delegación de funciones y encomiendas de gestión: II.8: art. 5

Derecho de sufragio activo: II.8: art. 28

Derecho de sufragio pasivo: II.8: art. 29

Disolución de Cámaras: II.8: art. 9

Finalidad: II.8: art. 3

Financiación: II.8: art. 38

Funcionamiento de los órganos de gobierno durante el período electoral: II.8: art. 37

Funciones: II.8: art. 4

Junta electoral: II.8: art. 33

Modificación de demarcaciones: II.8: art. 10

Naturaleza jurídica: II.8: art. 2

Normas comunes para los procedimientos de creación, disolución y modificación de las demarcaciones camerales: II.8: art. 11

Operaciones especiales: II.8: art. 45

Personal de alta dirección: II.8: art. 25

Personal, régimen jurídico: II.8: art. 23

Pleno: II.8: arts. 14 y 15

Presidencia: II.8: arts. 19-21

Proceso electoral: II.8: arts. 33-35

Reclamaciones y recursos: II.8: art. 59

Recurso cameral: II.8: arts. 39-43

Régimen jurídico: II.8: art. 57

Régimen presupuestario: II.8: art. 46-48

Reglamento de régimen interior: II.8: arts. 26-27

Requisitos y supuestos de creación de Cámaras: II.8: art. 8

Secretaría General: II.8: art. 24

y disposición transitoria 2 
Servicios mínimos obligatorios: II.8: art. 6

Suspensión y disolución de los órganos de gobierno de las cámaras: II.8: art. 61

Tutela: II.8: art. 58

Vicepresidencias: art. 22

Voto por correspondencia: art. 36

\section{Camino de Santiago}

Comité Asesor do Camiño de Santiago: VII.6: art. 30

Conservación y protección: VII.6: art. 8-19

Definición: VII.6: art. 1

Delimitación: VII.6: art. 5-6

Deslinde: VII.6: art. 7

Infracciones y sanciones: VII.6: arts. 20-25

Naturaleza: VII.6: arts. 2-4

Promoción: VII.6: arts. 26-29

\section{Carreteras de Galicia}

Áreas de servicio: XI.1: art. 28

Clasificación: XI.1: art. 2

Competencias: XI.1: arts. 6-8

Construcción: XI.1: arts. 19-20

Definición: XI.1: arts. 2-3

Estudios y proyectos: XI.1: arts. 13-18

Explotación: XI.1: art. 24-28

Financiación: XI.1: arts. 21-23

Infracciones y sanciones: XI.1: arts. 43-50 y disposición adicional

Limitaciones de la propiedad: XI.1: art. 29-39

Planificación: XI.1: arts. 9-12

Titularidad: XI.1: arts. 4-5

Travesías y redes arteriales: XI.1: arts. 51-54

Uso de las carreteras: XI.1: arts. 40-42

\section{Caza de Galicia}

Acción de cazar: XIV.1: art. 2

Anillamiento y marcado: XIV.1: art. 39

Aprovechamiento: XIV.1: arts. 42-44

Armas y medios de caza: XIV.1: art. 5

Aves de cetrería y hurones: XIV.1: art. 35

Caza con fines científicos: XIV.1: art. 38

Cazador: XIV.1: art. 3
Clasificación de los terrenos a efectos cinegéticos: XIV.1: art. 9

Competencia en materia de caza: XIV.1: art. 7

Comisión de Homologación de Trofeos de Caza: XIV.1: art. 53

Concepto de terreno de carácter cinegético: XIV.1: art. 8

Conservación: XIV.1: arts. 32-41

Decomisos: XIV.1: art. 65

Entidades colaboradoras y órganos consultivos: XIV.1: arts. 51-53

Especies cinegéticas: XIV.1: art. 27

Estado sanitario de las especies cinegéticas: XIV.1: art. 30

Granjas cinegéticas: XIV.1: art. 54

Guardas de campo de caza: XIV.1: art. 50

Infracciones y sanciones: XIV.1: arts. 56-72

Licencias: XIV.1: arts. 46-48

Medidas de protección: XIV.1: art. 29

Objeto de la caza: XIV.1: art. 4

Obligaciones de los titulares del aprovechamiento de terrenos sujetos a régimen especial: XIV.1: arts. 22-24

Períodos hábiles de caza: XIV.1: art. 42

Perros: XIV.1: art. 40

Poblaciones cinegéticas: XIV.1: art. 31

Procedimiento sancionador: XIV.1: arts. 66-71

Propiedad de las piezas de caza: XIV.1: art. 28

Refugios de fauna: XIV.1: art. 12

Régimen fiscal: XIV.1: art. 55

Registro de Infractores de Caza: XIV.1: art. 72

Requisitos para cazar: XIV.1: arts. 45-48

Reservas de caza: XIV.1: art. 11

Retirada de armas y otros medios de caza: XIV.1: art. 63

Señalización: XIV.1: art. 10

Taxidermia: XIV.1: art. 35 bis

Terrenos cercados: XIV.1: art. 26

Terrenos cinegéticamente ordenados

(Tecor): XIV.1: arts. 13-19

Terrenos cinégetico-deportivos: XIV.1: art. 20 


\section{Índice de conceptos}

Terrenos dedicados a las explotaciones cinégeticas: XIV.1: art. 21

Titularidad de derechos y obligaciones: XIV.1: art. 6

Vigilancia y cuidado de la caza: XIV.1: arts. 49-50

Zonas de seguridad: XIV.1: arts. 8.3 y $25-25$ bis

\section{Colegios Profesionales}

Colaboración con la Administración: II.7: art. 7

Consejos Gallegos de Colegios Profesionales: II.7: arts. 23-29

Constitución: II.7: art. 11

Denominación: II.7: art. 13

Deontología profesional: II.7: art. 10

Disposiciones comunes a Colegios y Consejos Gallegos de Colegios profesionales: II.7: arts. 30-32

Ejercicios de profesiones colegiadas: II.7: art. 2

Estatutos: II.7: arts. 16-18

Estructura interna: II.7: art. 5

Fines: II.7: art. 8

Funciones: II.7: art. 9

Fusión: II.7: art. 14

Naturaleza jurídica: II.7: art. 4

Organización: II.7: art. 19-22

Personalidad jurídica: II.7: art. 12

Profesionales al servicio de la

Administración: II.7: art. 3

Régimen de funcionamiento: II.7: art. 5

Registro de Colegios profesionales y de Consejos Gallegos de Colegios profesionais: II.7: art. 33

Relaciones con la Administración autonómica: II.7: art. 6

Segregación: II.7: art. 15

\section{ComARCA}

Desarrollo comarcal: III.2

Posibilidad de reconocimiento como entidad local: I.1: art. 40. 1

\section{Comisión Galega} de Cooperación Local

III.1: arts. 188-192 y disposición adicional primera

\section{Competencias de la Comunidad Autónoma de Galicia}

Atribución de competencias a la Comunidad Autónoma de Galicia: I.1: art. 27 a 36 .

Régimen jurídico de las competencias de la Comunidad Autónoma de Galicia: I.1: art. 37 y art. 38 .

Transferencia de competencias de titularidad estatal a la Comunidad Autónoma Gallega: I.2 y I.3

\section{CONCENTRACIÓN PARCELARIA}

Acuerdo de concentración parcelaria: XIII.3: art. 30-34

Ámbito: XIII.3: art. 1

Bases de la concentración parcelaria: XIII.3: arts. 16-29

Concentración parcelaria de carácter privado: XIII.3: arts. 57-60

Definición de explotación agraria o lugar acasarado: XIII.3: art. 5 bis

Definición de dimensión económicamente viable de una zona: XIII.3: art. 5 bis

Delimitación y calificación de los usos del suelo y la utilidad de las parcelas: XIII.3: art. 8

Disposiciones generales: XIII.3: arts. 1-8

Efectos y conservación de la concentración: XIII.3: arts. 47-52

Ejecución del acuerdo: XIII.3: arts. $44-46$ bis

Fases de procedimientos de concentración parcelaria: XIII.3: art. 15

Fines: XIII.3: art. 5

Gastos y medidas de apoyo económico: art. 5

Infracciones y sanciones: XIII.3: arts. 69-76

Objeto: XIII.3: art. 1

Obligatoriedad: XIII.3: art. 2 
Obras y mejoras territoriales: XIII.3: art. 61-68

Órganos: XIII.3: arts. 9-14

Procedimientos especiales y simplificados: XIII.3: arts. 52 bis-56 bis

Publicaciones y comunicaciones: XIII.3: art. 35-38

Recursos administrativos: XIII.3: arts. 40-42

Recurso contenciosoadministrativo: XIII.3: art. 43

Revisión de la concentración: XIII.3: art. 7

Revisión de oficio: XIII.3: art. 39

Utilidad pública y función social de la propiedad: XIII.3: art. 3

\section{Condición Política de GALlego}

I.1: art. 3

\section{Consello Asesor de RTVE en Galicia}

Composición: XII.2: arts. 8-9

Financiación: XII.2: art. 7

Funcionamiento: XII.2: arts. 10-12

Funciones: XII.2: arts. 2-6

\section{Consello Agrario Galego}

Composición: XIII.1: art. 4

Dictamen preceptivo para procesos electorales: XIII.1: disposición adicional segunda

Funciones: XIII.1: art. 3

Naturaleza: XIII.1: art. 1

Nombramiento y mandato de sus integrantes: XIII.1: art. 6

Régimen de funcionamiento: XIII.1: art. 5

Régimen jurídico: XIII.1: art. 2

\section{Consello Consultivo de Galicia}

Autonomía: II.4: art. 2

Competencias: II.4: arts. 11-14

Consultas y dictámenes: II.4: art. 3

Designación del secretario: II.4: art. 5.2

Elección del Presidente: II.4: arts. 5.1 y 10.1
Funciones: II.4: arts. 15-17

Incompatibilidades: II.4: art. 9

Miembros natos: II.4: art. $4-4$ bis

Naturaleza: II.4: art. 1.1

Número de miembros y nombramiento: II.4: art. 4

Pérdida de la condición de consejero: II.4: arts. 6 y 7

Personal: II.4: arts. 21-23

Procedimiento: II.4: arts. 18-20

Sede: II.4: art. 1.2

Suspensión en funciones de los conselleiros: II.4: art. 8

Sustituciones del Presidente: II.4: art. 10.2

Vacantes: II.4: art. 7

\section{Consello da Cultura Galega}

Competencias: XVII.6: art. 6

Composición: XVII.6: art. 3

Creación: XVII.6: art. 1

Finalidad: XVII.6: art. 1

Financiación: XVII.6: art. 10

Funcionamiento: XVII.6: arts. 7-9

Mandato de sus miembros: XVII.6: art. 5

Personalidad jurídica y capacidad para el ejercicio de sus fines: XVII.6: art. 2

Presidencia de honor: XVII.6: art. 4

\section{Consello de Contas de Galicia}

Abstención y recusación: II.9: art. 14

Ámbito de actuación: II.9: art. 2

Aplicación subsidiaria Ley Orgánica del

Tribunal de Contas: II.9: disposición adicional primera

Comisionados: II.9: art. art. 18

Comisión de Goberno: II.9: art. 9

Competencia: II.9: art. 1.1

Conselleiro Maior: II.9: art. 8

Conselleiros: II.9: art. 12

Creación: I.1: art. 53.2

Cuentadantes: II.9: art. 26

Deber de colaboración: II.9: art. 23

Dependencia del Parlamento: II.9: art. 1.2

Documentación: II.9: art. 19

Enjuiciamiento: II.9: art. 5 
Fiscalización: II.9: art. 4

Incompatibilidades: art. 13

Medios de apremio: II.9: arts. 27 y 28

Memoria anual: II.9: art. 20

Órganos: II.9: art. 6

Pérdida de la condición de miembro: II.9: art. 16

Personal al servicio del Consello, régimen general: II.9: art. 17

Pleno: II.9: art. 7

Presentación de cuentas: II.9: art. 25

Procedimiento para el ejercicio de la función fiscalizadora: II.9: art. 24

Régimen interior: II.9: art. 3

Relaciones con el Parlamento: II.9: arts. 21-22

Responsabilidad: II.9: art. 15

Secciones: II.9: art. 10

Secretaría general: II.9: art. 11

\section{Consello de la Xunta de Galicia}

Certificación y fe de sus acuerdos: II.1: art. 6

Funcionamiento: II.1: art. 7

Normas internas: II.1: art. 9

Principios rectores: II.1: art. 5

\section{Consello Económico \\ E Social de Galicia}

Comisiones Sectoriales: II.3: art. 15

Comisión Permanente: II.3: art. 14

Composición y designación: II.3: art. 7

Contratación: II.3: art. 23

Control y contabilidad: II.3: art. 24

Creación: II.3: art. 1

Denominación: II.3: art. 1

Duración del mandato: II.3: art. 9

Facultad de información: II.3: art. 6

Finalidad: II.3: art. 2

Financiación: II.3: art. 22

Funciones: II.3: art. 5

Gabinete Técnico: II.3: art. 18

Incompatibilidades: art. 11

Naturaleza jurídica: II.3: art. 3

Nombramientos: II.3: art. 8
Órgano del Consejo: II.3: art. 12

Patrimonio: II.3: art. 25.

Pérdida de la condición de miembro: II.3: art. 10

Personal: II.3: art. 21

Pleno: II.3: art. 13

Presidente: II.3: art. 16

Publicidad de las sesiones y trabajos del Consejo: II.3: art. 19

Reglamento: II.3: art. 20

Secretario general: II.3: art. 17

Sede: II.3: art. 4

\section{Consello Galego de Universidades}

Adscripción: XVII.4: art. 4

Carácter de los acuerdos: XVII.4: art. 16

Comisiones: XVII.4: art. 11

Competencias: XVII.4: art. 5

Composición: XVII.4: art. 7

Coordinación y cooperación universitaria: XVII.4: art. 2

Definición: XVII.4: art. 4

Estatuto jurídico de sus miembros: XVII.4: art. 8

Estructura interna: XVII.4: art. 9

Fines de la coordinación universitaria: XVII.4: art. 3

Marco normativo: XVII.4: art. 1

Objeto: XVII.4: art. 1

Pleno: XVII.4: art. 10

Presidencia: XVII.4: art. 12

Reglamento interno: XVII.4: art. 17

Relaciones de cooperación: XVII.4: art. 6

Secretaría: XVII.4: art. 14

Sesiones: XVII.4: art. 15

Vicepresidencia: XVII.4: art. 13

\section{Consellos Sociais do Sistema UnIVERSITARIO DE GALICIA}

Cese y sustitución: XVII.2: art. 10

Comisiones: XVII.2: art. 16

Competencias: XVII.2: arts. 3-5

Composición del Consejo Social: XVII.2: art. 7

Deberes: XVII.2: art. 12

Definición: XVII.2: art. 2 
Derechos: XVII.2: art. 11

Duración del mandato: XVII.2: art. 9

Estructura interna: XVII.2: art. 13

Funciones: XVII.2: art. 2

Incompatibilidades: XVII.2: art. 8

Medios personales y materiales: XVII.2: art. 24

Periocidad de las sesiones: XVII.2: art. 15

Pleno: XVII.2: art. 14

Presidencia: XVII.2: art. 17

Presupuesto: XVII.2: art. 23

Regimen Jurídico de las decisiones del

Consejo Social: XVII.2: art. 21

Reglamento de Organización y

Funcionamiento: XVII.2: art. 22

Relaciones de cooperación: XVII.2: art. 6

Secretaría: XVII.2: art. 19

Sesiones: XVII.2: art. 20

Vicepresidencia: XVII.2: art. 18

\section{Conselleiros de la Xunta de Galicia}

Atribuciones: II.1: art. 34

Cese: II.1: art. 27 y 29

Incompatibilidades: II.1: art. 31

Inmunidad: II.1: art. 32

Juramento: II.1: art. 28

Nombramiento: II.1: art. 27

\section{Consentimiento InFORMADO}

Ámbito de aplicación: XVI.4: art. 2

Características de la información previa al consentimiento: XVI.4: art. 8

Comisión del consentimiento informado: XVI.4: art. 12

Contenido del documento formulario: XVI.4: art. 10

Definición: XVI.4: art. 3

Excepción y límites del consentimiento informado: XVI.4: art. 11

Instrucciones previas: XVI.4: art. 5

Otorgamiento del consentimiento por sustitución: XVI.4: art. 6

Prestación de consentimiento: XVI.4: art. 4

Responsabilidad de información previa al consentimiento: XVI.4: art. 9
Restricción de la información en interés del paciente: XVI.4: art. 7

\section{Conservación dE LA nATURALEZA}

Ámbito de aplicación: IX.5: disposición adicional segunda

Catalogación de especies: IX.5: arts. 48-52

Catálogo Gallego de Árboles Singulares: IX.5: art. 52

Catálogo Gallego de Especies

Amenazadas: IX.5: art. 49

Categorías de espacios naturales protegidos: IX.5: art. 9

Centros de recuperación de fauna: IX.5: art. 58

Clasificación de instrumentos de planificación de espacios naturales protegidos: IX.5: art. 31

Compatibilidad de la declaración de espacio natural protegido con la declaración de bien de interés cultural: IX.5: disposición adicional octava

Deberes de conservación: IX.5: art. 3

Denominaciones de espacios naturales: IX.5: art. 19

Descalificación de espacios naturales protegidos: IX.5: disposición adicional séptima

Duración máxima de los procedimientos: IX.5: disposición adicional sexta

Efectos de la declaración de espacios naturales protegidos: IX.5: arts. 26-30

Espacio natural de interés local: IX.5: art. 17

Espacio privado de interés natural: IX.5: art. 18

Fauna y flora, disposiciones generales: IX.5: arts. 44-47

Fauna silvestre: IX.5: arts. 56-58

Flora silvestre: IX.5: arts. 59-60

Gestión de espacios naturales protegidos: IX.5: arts. 41-43

Humedal protegido: IX.5: art. 14 


\section{I Índice de conceptos}

Infracciones y sanciones: IX.5: arts. 61-74 y disposición adicional quinta

Inspección: IX.5: disposición adicional tercera y disposición adicional novena

Monumento natural: IX.5: art. 13

Objeto: IX.5: art. 1

Paisaje protegido: art. 15

Parque: IX.5: art. 12

Planeamiento de los recursos naturales: IX.5: arts. 4-7

Planes de conservación: IX.5: arts. 37-40

Planes de ordenación de los recursos naturales: IX.5: art. 32

Planes rectores de uso y gestión: IX.5: arts. 33-36

Principios inspiradores: IX.5: art. 2

Procedimiento de declaración de espacios naturales protegidos: IX.5: arts. 20-24

Procedimiento sancionador: IX.5: arts. 71-74 y disposición adicional sexta

Protección de la fauna y flora silvestres, disposiciones generales: IX.5: arts. 53-55

Protección preventiva en la declaración de espacios naturales protegidos: IX.5: art. 25

Red gallega de espacios protegidos: IX.5: art. 10

Régimen de los espacios naturales protegidos: IX.5: arts. $8-10$

Reserva natural: IX.5: art. 11

Taxidermia y herborización: IX.5: art. 55

Zona de especial protección de los valores naturales: IX.5: art. 16

\section{Consorcios locales}

Consideración como entidades locales no territoriales: III.1: art. 2

\section{ContABILIDAD}

Competencias de la Consellería de Economía e Facenda: V.1: art. 110

Cuentadantes: V.1: art. 114

Forma y plazos: V.1: art. 115

Funciones como centro gestor: V.1: art. 112 Funciones de la Intervención General como centro directivo: V.1: art. 111
Publicidad e información: V.1: art. 117

Régimen: V.1: art. 109

Sociedades públicas, entes y

organismos: V.1: art. 116

Soporte documental: V.1: art. 113

Control en MATERIA de CREACIÓN Y RECONOCIMIENTO DE UNIVERSIDADES, Centros Universitarios y

AUTORIZACIÓN DE ESTUDIOS EN LA

Comunidad Autónoma de Galicia

Infracciones y sanciones: XVII.2: arts. 5-21 y disposición final primera

Inspección de estudios universitarios: XVII.2: arts. 3-4

Objeto: XVII.3: art. 1

Procedimiento sancionador: XVII.2: arts. $18-21$

Sujetos responsables administrativamente: XVII.2: art. 2

Control INTERNo DE LA ACTIVIDAD ECONÓMICA Y FINANCIERA

Ámbito de aplicación del control financiero: V.1: art. 106

Aspectos generales: V.1: arts. 93-94

Auditorías y clases: V.1: art. 104

Documentación y plazo de la función interventora: V.1: art. 98

Fases de la función interventora: V.1: art. 95

Finalidad y principios del control financiero: V.1: art. 103

Iniciación y desarrollo del control financiero: V.1: art. 105

Intervención limitada: V.1: art. 97

Omisiones en la función interventora: V.1: art. 102

Plan anual de auditorías: V.1: art. 107

Principios de la función interventora: V.1: art. 96

Reparos y reclamaciones en la función interventora: V.1: arts. 99-101

Resultado e informes del control financiero: V.1: art. 108 


\section{Convenios urbanísticos}

Celebración y perfeccionamiento: VIII.2: art. 237

Concepto, alcance y naturaleza: VIII.2: art. 233

Convenios urbanísticos de planeamiento: VIII.2: art. 235

Convenios urbanísticos para la ejecución del planeamiento: VIII.2: art. 236

Objeto: VIII.2: art. 234

\section{Coordinación de LOS SERVICIOS}

DE TRANSPORTES URBANOS E

\section{INTERURBANOS POR CARRETERA}

Coordinación de competencias ante el establecimiento o ampliación de servicios urbanos o interurbanos de transporte regular de viajeros: XI.2: arts. 4-18

Coordinación de los servicios de transporte discrecional en autotaxi: XI.2: arts. 19-22

Definiciones: XI.2: art. 2

Fines: XI.2: art. 3

Objeto: XI.2: art. 1

Principios: XI.2: art. 3

\section{Cuenta general de la comunidad}

Documentación: V.1: art. 118

Formación: V.1: art. 119

Organismos autónomos: V.1: art. 120

Revisión y aprobación: V.1: art. 121

\section{Cuestión de CONFIANZA}

II.1: art. 47

\section{Delegación LEGisLativa}

II.1: arts. 53-57

\section{DePORTE}

Actividad deportiva: XVII.8: arts. 46-52 Actividad deportiva no competitiva: XVII.8: art. 52 Actividades de entrenamiento: XVII.8: art. 51
Agrupaciones deportivas escolares: XVII.8: art. 27

Asociaciones deportivas: XVII.8: arts. 17-21

Ayudas y subvenciones a las asociaciones deportivas: XVII.8: arts. 44-45

Clubs deportivos: XVII.8: arts. 22-26

Competencias: XVII.8: arts. 9-14

Competiciones: XVII.8: arts. 47-50

Deportista: XVII.8: arts. 15-16

Entidades de fomento deportivo: XVII.8: art. 40

Federaciones deportivas gallegas: XVII.8: art. 28-36

Formación e investigación deportiva: XVII.8: arts. 62-64

Instalaciones deportivas: XVII.8: arts. 53-61 Justicia Deportiva: XVII.8: arts. 65-74 Ligas profesionales: XVII.8: arts. 37-38

Objeto: XVII.8: art. 1

Plan General de Instalaciones y Equipamientos Deportivos: XVII.8: arts. 56-59

Principios: XVII.8: art. 2

Promoción por la Administración: XVII.8: art. 3-8

Registro de Asociaciones Deportivas y Deportistas de Galicia: XVII.8: arts. 41-43

Registro de Instalaciones y Equipamientos Deportivos de Galicia: XVII.8: arts. 53-55

Sociedades anónimas deportivas: XVII.8: art. 39

\section{Desarrollo comarcal}

Ámbito de aplicación: III.2: art. 3

Comisión de Comarcalización: III.2: art. 23

Consello Comarcal: III.2: art. 22

Eficacia del Plan de Desarrollo

Comarcal: III.2: arts. 16-19

Fines: III.2: art. 2

Gabinete de Planificación y Desarrollo Territorial: III.2: art. 21

Instrumentos de planificación: III.2: arts. 7-15 
Órganos de planificación, coordinación, gestión y promoción: III.2: arts. 20-23

Mapa comarcal de Galicia: III.2: arts. 27-33

Plan de desarrollo comarcal: III.2: arts. 4-6

\section{DEUdA PÚBLICA}

Emisión: I.1: art. 47 y 48

Reserva de ley: I.1: art. 51

\section{EJECUCIÓN DE LOS PLANES DE ORDENACIÓN}

Actuaciones aisladas: VIII.2: art. 124

Aprovechamiento tipo: VIII.2: arts. 113-114

Áreas de reparto: VIII.2: arts. 111-112

Cargas de urbanización: VIII.2: art. 135

Clases de sistemas de actuación: VIII.2: art. 126

Competencias: VIII.2: art. 108

Cumplimiento de las previsiones de urbanización establecidas: VIII.2: art. 128

Distribución justa de cargas y beneficios: VIII.2: art. 131

Ejecución y conservación de obras de urbanización: VIII.2: art. 110

Elección del sistema de actuación: VIII.2: art. 127

Finalidad: VIII.2: art. 107

Gastos de urbanización: VIII.2: art. 132

Instrumentos de ejecución de los planes en suelo de núcleo rural: VIII.2: arts. 171-173

Justiprecio: VIII.2: art. 142

Obtención de terrenos de sistemas generales y de dotaciones públicas: VIII.2: arts. 165-170

Operaciones de reorganización de la propiedad en suelo urbano consolidado: VIII.2: art. 122

Polígonos con aprovechamiento real inferior al susceptible de apropiación: VIII.2: art. 130

Polígonos con exceso de aprovechamiento real: VIII.2: art. 129

Polígonos de ejecución: VIII.2: art. 123

Presupuestos de la ejecución: VIII.2: art. 109
Principios y criterios de la equidistribución: VIII.2: arts. 115-121

Régimen de contratación de las obras de urbanización: VIII.2: art. 133

Reparcelación voluntaria: VIII.2: art. 139

Reserva de terrenos para gastos de urbanización: VIII.2: art. 136

Sistema de cesión de viales: VIII.2: arts. $171-172$

Sistema de compensación: VIII.2: arts. $154-160$

Sistema de concesión de obra urbanizadora: VIII.2: arts. 161-164

Sistema de concierto: VIII.2: arts. 150-153

Sistema de expropiación: VIII.2: arts. 140-149

Sistemas de cooperación: VIII.2: arts. 134-139

Sociedades mercantiles para la ejecución del planeamiento: VIII.2: art. 125

Tasación conjunta: VIII.2: art. 143-144

\section{EMERGENCIAS}

Axencia Galega de Emerxencias: XVIII.1: arts. 16-25

Ámbito de aplicación: XVIII.1: art. 1

Comisión Galega de Protección Civil: XVIII.1: art. 29

Competencias: XVIII.1: arts. 11-28 y disposición adicional sexta

Derechos y deberes: XVIII.1: arts. 4-9

Financiación: XVIII.1: art. 49

Gestión de los riesgos ordinarios: XVIII.1: art. 37

Infracciones y sanciones: XVIII.1: arts. 50-59

Xuntas Locais de Protección Civil: XVIII.1: art. 30

Medidas de autoprotección privada: XVIII.1: arts. 39-42

Niveles de actuación: XVIII.1: art. 10

Objetivos: XVIII.1: art. 3

Objeto: XVIII.1: art. 1

Personal: XVIII.1: arts. 43-48 y disposición adicional primera

Planificación: XVIII.1: arts. 31-36

Principios generales: XVIII.1: art. 2 
Procedimiento sancionador: XVIII.1: arts. 57-59

Reestablecimiento: XVIII.1: art. 38

Servicios de prevención de incendios y de salvamento: XVIII.1: disposición adicional tercera y disposicón adicional cuarta

\section{Empleo Público de Galicia}

Acceso a la función pública: IV.3: arts. 32-43

Adscripción de puestos de trabajo: IV.3: art. 28-31

Adquisición de la condición de funcionario: IV.3: art. 47

Carrera administrativa: IV.3: arts. 63-68

Clases de personal: IV.3: art. 5

Comisión de Persoal: IV.3: art. 20

Comisión de servizos de carácter forzoso: IV.3: art. 53

Consello Galego da Función Pública: IV.3: arts. 18-19

Cuerpos de personal funcionario: IV.3: arts. 21-23 y disposición adicional primera

Derecho de huelga: IV.3: art. 77

Excedencia forzosa: IV.3: art. 58

Excedencia voluntaria: IV.3: art. 57

Expectativa de destino: IV.3: art. 59

Funcionarios transferidos del Estado:

IV.3: disposición adicional segunda

Jubilación forzosa: IV.3: art. 49

Jubilación voluntaria: IV.3: art. 50

Licencias: IV.3: art. 74

Movilidad del personal funcionario: IV.3: arts. 44-46

Objeto y ámbito de aplicación de la ley: IV.3: arts. 1-4

Órganos de la función pública: IV.3: arts. 12-20

Perdida de la condición de funcionario: IV.3: arts. 48-50

Permisos: IV.3: art. 76

Personal eventual IV.3: arts. 7 y 9

Personal funcionario: definición: IV.3: art. 6
Personal interino: IV.3: arts. 8, 9 y 11

Personal laboral: IV.3: art. 10

Personas discapacitadas: IV.3: disposición adicional séptima y disposición adicional octava

Planes de empleo: IV.3: art. 31

Régimen retributivo: IV.3: arts. 69-73 y disposición transitoria quinta

Registro de personal: IV.3: arts. 24-26

Relaciones de puestos de trabajo: IV.3: art. 27

Seguridad social: IV.3: arts. 78-79

Servicio activo: IV.3: art. 52

Servicios en otras administraciones públicas: IV.3: art. 56

Servicios especiales: IV.3: art. 54-55

Situaciones administrativas: IV.3: arts. 51-62

Suspensión de funciones: IV.3: art. 60

Vacaciones: IV.3: art. 75

\section{EMPRESAS PÚBLICAS}

Constitución: I.1: art. 55.2

\section{Ente Público Portos de Galicia}

Actividad inspectora: XI.3: art. 15

Condiciones generales de la contratación: XI.3: art. 14

Consello de Administración: XI.3: art. 7

Conservación, ampliación y amortización del material y de las instalaciones: XI.3: art. 13

Director: XI.3: art. 9

Estructura orgánica: XI.3: arts. 5-9

Funciones: XI.3: art. 3

Hacienda: XI.3: art. 16 Juntas territoriales: XI.3: art. 8

Naturaleza: XI.3: art. 1.1

Objeto: XI.3: art. 2

Patrimonio: XI.3: art. 17

Personal: XI.3: art. 21

Personalidad jurídica propia: XI.3: art. 1.2

Presidente del Consello de

Administración: XI.3: art. 6

Régimen financiero: XI.3: arts. 18-20 


\section{I Índice de conceptos}

Régimen jurídico: XI.3: art. 4

Relaciones con la Administración autonómica: XI.3: arts. 10-12

Sociedades mercantiles dependientes del ente público: XI.3: disposición adicional

\section{ENTIDADES Locales}

Acceso al empleo público local: III.1: art. 233

Actividades relativas a la contratación: III.1: art. 317-328

Adquisición y enajenación de sus bienes: III.1: arts. 270-279

Asociaciones de vecinos: III.1: arts. 255-256

Bienes, disposiciones comunes: III.1: arts. 263-269

Competencias: III.1: art. 8

Colaboración, cooperación y auxilio: III.1: arts. 193-204

Comisión de Heráldica: III.1: arts. 260-261

Concesión administrativa: III.1: art. 303

Consideración de no territoriales: III.1: art. 2

Consideración de territoriales: III.1: art. 1

Consultas populares: III.1: art. 257

Contratación, disposiciones generales: III.1: arts. 310-316

Coordinación: III.1: art. 205-209

Delegación: III.1: arts. 182-185

Derecho de acceso a la información de sus miembros: III.1: art. 226

Derecho de petición de los ciudadanos: III.1: art. 254

Derecho-obligación de sus miembros de acudir al pleno: III.1: art. 228

Encomienda de gestión: III.1: art. 186

Entidades locales menores: véase la voz "entidades locales menores"

Estatuto de sus miembros: III.1: arts. 221-230

Fomento: III.1: art. 294

Formación personal funcionario: III.1: art. 237

Funcionarios con habilitación de carácter nacional: III.1: arts. 238-241
Funcionarios de carrera distintos a los de habilitación de carácter nacional: III.1: arts. 242-248

Gestión interesada: III.1: art. 304

Hacienda de las Entidades Locales: véase la voz "Hacienda de las Entidades Locales"

Impugnación de actos y acuerdos y ejercicio de acciones: III.1: arts. 210-220

Incompatibilidades de sus miembros: III.1: art. 230

Información a los ciudadanos: III.1: arts. 251 y 252

Infracciones y sanciones: III.1: art. 287

Iniciativa en la actividad económica: III.1: art. 309

Licencias: III.1: art. 288

Medios de intervención en la actividad de los ciudadanos: III.1: art. 286

"Municipios", véase la voz "municipios"

Obligación de reserva de sus miembros: III.1: art. 227

Obras: III.1: arts. 290-293

Participación ciudadana: III.1: arts. 251 y $253-254$

Pérdida de la condición de miembro: III.1: art. 223

Personal, disposiciones generales: III.1: arts. 231-237

Personal eventual: III.1: art. 250

Personal laboral: III.1: arts. 235 y 249

Plantilla y relaciones de puestos de trabajo: III.1: art. 232

Potestades: III.1: art. 6

Potestades y prerrogativas respecto a sus bienes: III.1: arts. 280-285

Principios que rigen su actuación: III.1: art. 5

Provincias: véase la voz "provincias"

Régimen de funcionamiento: III.1: arts. 210-215

Régimen jurídico: III.1: art. 4.1

Reserva de funciones públicas al personal funcionario: III.1: art. 234

Responsabilidad de sus miembros: III.1: art. 229

Retribución de personal funcionario: III.1: art. 236 
Retribución de sus miembros: III.1: art. 225

Servicios especiales: III.1: art. 224

Servicios locales: III.1: arts. 295-309

Símbolos: III.1: arts. 258-262

Suspensión de sus miembros: III.1: art. 222

Tipos de personal: III.1: art. 231

Transferencias de competencias de la Comunidad Autónoma en las Entidades Locales: III.1: arts. 179-181

Transferencia y delegación de competencias de la Comunidad Autónoma en las Entidades Locales y de la encomienda de gestión, disposiciones generales: III.1: arts. 171-178.

Uso del gallego: III.1: art. 7

\section{ENTIDADES LOCALES MENORES}

Competencias: III.1: art. 163

Consideración como entidades locales no territoriales: III.1: art. 2

Disolución: III.1: art. 156

Hacienda: III.1: art. 164

Órganización: III.1: arts. 158-162

Procedimiento de constitución: III.1: arts. 154-156

Procedimiento de disolución: III.1: art. 157

Requisitos para su constitución: III.1: art. 153

\section{Escola Galega de}

\section{Administracion Pública}

Curso de selección o formación de los aspirantes al ingreso en la función publica: IV.3: art. 43

Expedición del Diploma de Directivo: IV.3: art. 29

Fines: IV.4: art. 3

Formación de funcionarios a fin de que puedan hacer uso de la lengua gallega: XVII.7: art. 24.1

Formación de funcionarios de la Administración local: III.1: art. 237

Formación y perfeccionamiento del personal encargado de la gestión económica de las Entidades Locales: III.1: art. 116
Medios económicos: IV.4: art. 12

Naturaleza jurídica: IV.4: art. 1

Órganos: IV.4: arts. 5-10

Personal: IV.4: art. 11

Sede: IV.4: art. 2

Selección y formación de los funcionarios con habilitación nacional: III.1: art. 239

\section{Escudo de Galicia}

I.1: art. 6.2

\section{ESTABLECIMIENTOS BALNEARIOS}

Competencias administrativas: IX.7: art. 25

Definición: IX.7: art. 22

Informes de los órganos consultivos: IX.7: disposición adicional primera

Infracciones y sanciones: IX.7: arts. 26-29

Junta Asesora: IX.7: arts. 23-24

Normativa subsidiaria: IX.7: disposición adicional cuarta

\section{EstATUTO DE AUTONOMÍA}

Reforma: I.1: art. 56 y 57

\section{ESTATUTO DE CAPITALIDAD DE LA Comunidad Autónoma}

Áreas de servicio: II.6: art. 9

Atribución de la capitalidad a

Santiago de Compostela: II.6: art. 2

Autonomía municipal: II.6: art. 10

Cartas de servicios: II.6: art. 14

Competencias: II.6: art.11

Consejo de la Capitalidad: II.6: arts. 16-20

Financiación: II.6: art. 28

Idioma: II.6: art. 6

Incorporación de medios técnicos a las relaciones del Ayuntamiento con los ciudadanos: II.6: art. 13

Información a los ciudadanos: II.6: art. 12 Órganos de la corporación: II.6: art. 8

Patrimonio histórico-artístico: II.6: art. 22

Principios generales que rigen el Gobierno municipal: II.6: art. 7 


\section{Índice de conceptos}

Relaciones entre el Consejo de la Capitalidad y el Consorcio de la Ciudad de Santiago de Compostela: II.6: art. 27

Relaciones interadministrativas: II.6: art. 15 Régimen jurídico especial: II.6: arts. 3 y 5 Seguridad pública: II.6: art. 24

Servicios y actuaciones metropolitanas: II.6: art. 21

Símbolos: II.6: art. 3

Término municipal: II.6: art. 4

Territorio y urbanismo: II.6: art. 23

Transporte: II.6: art. 25

Turismo: II.6: art. 26

\section{Ex-Conselleiros de la Xunta}

Consejeros natos: II.4: art. $4-4$ bis y 17.4

Derechos: art. 27.2

\section{Ex-Presidentes de la Xunta}

Derechos: II.1: art. 11.7

\section{EX-Vicepresidentes de LA XuntA}

Derechos: II.1: art. 27.2

\section{Fin dE LA VÍA ADMINISTRATIVA}

IV.1: art. 4

\section{FundACIONES DE INTERÉS GALLEGo}

Aprobación y presentación de las cuentas: VI.3: art. 38

Auditoría: VI.3: art. 37

Autocontratación: VI.3: art. 40

Capacidad para fundar: VI.3: art. 9

Causas y formas de extinción: VI.3: art. 44

Concepto: VI.3: art. 2

Consello Superior de Fundacións da Comunidade Autónoma de Galicia: VI.3: arts. 56-57

Contabilidad: VI.3: art. 36

Denominación: VI.3: art. 6

Destino de los bienes en caso de extinción: VI.3: art. 45

Destino de los ingresos de la fundación: VI.3: art. 35
Domicilio: VI.3: art. 7

Dotación de la fundación: VI.3: art. 13

Enajenación y gravamen: VI.3: art. 29

Escisión: VI.3: art. 43

Escritura de constitución: VI.3: art. 11

Estatutos: VI.3: art. 12

Financiación: VI.3: art. 33

Fines y beneficiarios: VI.3: art. 4

Funcionamiento: VI.3: art. 32

Fundaciones del sector público de Galicia: VI.3: arts. 58-63

Fundaciones en proceso de formación: VI.3: art. 14

Fundaciones extranjeras: VI.3: art. 8

Fusión: VI.3: art. 42

Gestión de la fundación: VI.3: art. 25

Herencia y donaciones: VI.3: art. 30

Liquidación: VI.3: art. 46

Modalidades de constitución: VI.3: art. 10

Modificación de los estatutos: VI.3: art. 41

Obtención de ingresos: VI.3: art. 34

Patrimonio: VI.3: arts. 26-28

Patronato: VI.3: arts. 15-24

Personalidad jurídica: VI.3: art. 5

Plan de actuación: VI.3: art. 39

Principios de actuación de la fundación: VI.3: art. 31

Protectorado: VI.3: arts. 47-51

Régimen jurídico: VI.3: art. 3

Registro de Fundaciones de Interés Gallego: VI.3: arts. 52-55

\section{Hacienda de la Comunidad Autónoma de GaLicia}

Administración de los recursos: V.1: art. 16

Aplicación presupuestaria: V.1: art. 36

Autorización del endeudamiento: V.1: art. 29.2

Autorización de la emisión o contracción: V.1: art. 33

Beneficios de la deuda pública: V.1: art. 38

Cesión de tributos estatales: I.1: disposición adicional 1

Competencia: V.1: arts. 6 y 9

Competencia en deuda pública: V.1: art. 37 
Composición: I.1: art. 44; V.1: art. 1

Contabilización: V.1: art. 34

Control: V.1: art. 4

Convenios: V.1: art. 13.1

Criterios y fines: V.1: art. 2

Denominación de las operaciones de endeudamiento: V.1: art. 29.1

Destino de las operaciones de endeudamiento: V.1: art. 30

Destino de los recursos: V.1: art. 15

Deuda de tesorería: V.1: art. 31

Disoponibilidad de bienes y derechos: V.1: art. 18

Endeudamiento: V.1: art. 28

Garantías: V.1: art. 19

Garantías por avales: V.1: arts. 40-45

Gestión de los tributos: V.1: art. 17

Importe máximo de las operaciones de endeudamiento: V.1: art. 32

Inembargabilidad: V.1: art. 25

Integridad de la Hacienda: V.1: art. 22

Intereses de demora: V.1: art. 21

Intereses de las obligaciones de la

Comunidad: V.1: art. 26

Materias propias: V.1: art. 1.2

Nacimiento y exigibilidad de las obligaciones: V.1: art. 24

Normativa reguladora: V.1: art. 3

Organismos autónomos: V.1: art. 11

Prerrogativas: V.1: art. 10

Prescripción: V.1: art. 23

Prescripción de las obligaciones: V.1: art. 27

Prescripción en la deuda pública: V.1: art. 39

Principios presupuestarios: V.1: art. 4.1

Recursos: V.1: art. 14

Reglamentos generales de los tributos propios: I.1: art. 52

Reglamentos para gestionar tributos estatales cedidos: I.1: art. 52

Reserva legal: I.1: art. 51; V.1: art. 5

Sociedades públicas autonómicas: V.1: art. 12

Suscripción y transmisión de la deuda pública: V.1: art. 35
Suspensión del procedimiento de apremio: V.1: art. 20

Transferencias de competencias: V.1: art. 13.2

\section{Hacienda de los Entes Locales}

Elementos que la componen: III.1: art. 331

Fondo de cooperación local: III.1: art. 332

Participación en los ingresos estatales: I.1: art. 49

Tributos propios: I.1: art. 49

Tutela financiera: I.1: art. 49; III.1: art. 330

\section{Himno de Galicia}

I.1: art. 6.2

\section{HISTORIA CLÍNICA}

Acceso: XVI.4: art. 19

Ámbito de aplicación: XVI.4: art. 2

Ámbito territorial: XVI.4: art. 15

Conservación: XVI.4: art. 20

Contenido: XVI.4: art. 16

Definición: XVI.4: art. 13

Informatización: XVI.4: disposición adicional tercera

Objeto: XVI.4: art. 1

Propiedad y custodia: XVI.4: art. 18

Régimen sancionador: XVI.4: art. 21

Requisitos: XVI.4: art. 17

Soporte de la historia clínica: XVI.4: art. 14

\section{IMPUESTO DE SUCESIONES}

\section{Y DONACIONES}

Adquisiciones lucrativas entre vivos: V.6: arts. 13-20

Adquisiciones por causa de muerte: V.6: arts. 1-12

Aplicación de la normativa sobre gestión del impuesto: V.6: disposición transitoria primera

Base de las reducciones: V.6: arts. 12 y 20

Cuota tributaria: V.6: art. 22

Deducción en cuota por solicitud de valoraciones previas: V.6: disposición adicional tercera 


\section{I Índice de conceptos}

Deducción para adquisiciones mortis causa por sujetos pasivos del grupo I: V.6: art. 23

Deducción por parentesco: V.6: art. 24

Deuda tributaria: V.6: arts. 21-24

Incompatibilidad de reducciones: V.6: arts. 4,9 y 17

Plazo de mantenimiento de las adquisiciones: V.6: disposición transitoria segunda

Reducciones por parentesco: V.6: art. 1

Reducción por adquisición de vivienda habitual: V.6: art. 7

Reducción por discapacidad: V.6: art. 2

Reducción por la adquisición de bienes y derechos afectos a una actividad económica y de participaciones en entidades: V.6: arts. 5, 13 y 15

Reducción por la adquisición de bienes y derechos afectos a una actividad económica, de participaciones en entidades y de explotaciones agrarias en los pactos sucesorios: V.6: art. 15

Reducción por la adquisición de dinero destinado a la adquisición de una vivienda habitual en Galicia: V.6: art. 16

Reducción por la adquisición de explotaciones agrarias y de elementos afectos: V.6: arts. 6, 14 y 15

Reducción por la adquisición de fincas rústicas incluidas en la Red gallega de espacios protegidos: V.6: art. 8

Reducción por la adquisición de las indemnizaciones del síndrome tóxico y por actos de terrorismo: V.6: art. 3

Requisito de mantenimiento e incumplimiento de requisitos: V.6: arts. 10 y 18

Solicitud de las reducciones: V.6: arts. 11 y 19

Solicitud de valoraciones previas: V.6: disposición adicional segunda

Tarifa: V.6: art. 21

Tratamiento fiscal de las uniones estables de pareja: V.6: art. 25

Valoración previa de bienes inmuebles: V.6: disposición adicional primera
IMPUESTO SOBRE EL DAÑO

MEDIOAMBIENTAL CAUSADO

POR DETERMINADOS USOS

Y APROVECHAMIENTOS

DEL AGUA EMBALSADA

Afectación de la recaudación: V.7: art. 4 Ámbito de aplicación: V.7: art. 3

Autoliquidación: V.7: art. 14

Base imponible: V.7: art. 10

Cuota tributaria: V.7: art. 11

Declaración inicial: V.7: art. 13

Finalidad del impuesto: V.7: art. 1

Gestión del tributo: V.7: arts. 12-21

Hecho imponible: V.7: art. 6

Liquidaciones provisionales: V.7: art. 17

Naturaleza y objeto: V.7: art. 2

Normativa de aplicación: V.7: art. 5

Órganos competentes: V.7: art. 20

Órganos de colaboración: V.7: art. 21

Periodo impositivo y devengo: V.7: art. 8

Potestad sancionadora: V.7: art. 18

Revisión: V.7: art. 19

Sujeto pasivo: V.7: art. 9

Supuestos de no sujeción: V.7: art. 7

Tipo de gravamen: V.7: art. 11

\section{IMPUESTO SOBRE}

\section{LA CONTAMINACIÓN ATMOSFÉRICA}

Afectación de los ingresos: V.2: art. 4

Ámbito del tributo: V.2: art. 3

Base imponible: V.2: art. 8

Determinación de la base imponible: V.2: art. 10

Determinación de oficio: V.2: art. 11

Devengo: V.2: art. 11

Fin del tributo: V.2: art. 1

Foco emisor: V.2: art. 9

Hecho imponible: V.2: art. 6

Infracciones y sanciones: V.2: art. 17

Liquidación e ingreso: V.2: art. 15

Normas de gestión: V.2: art. 14

Normativa de aplicación: V.2: art. 2

Órganos competentes: V.2: art. 5

Reclamaciones: V.2: art. 16

Sujeto pasivo: V.2: art. 7

Tarifa impositiva: V.2: art. 12 
INCOMPATIBILIDADES DE LOS MIEMBROS de la Xunta y de los altos cargos DE LA Administración Autonómica

Ámbito de aplicación: II.2: art. 2

Compatibilidad con actividades privadas: II.2: art. 7

Compatibilidad con actividades públicas: II.2: art. 4

Compatibilidad con cargos representativos: II.2: art. 6 .

Compatibilidad con el ejercicio de la docencia: II.2: art. 5

Información al Parlamento de Galicia: II.2: art. 12

Obligaciones de los altos cargos: II.2: arts. 8 y 9 .

Órganos de gestión: II.2: art. 11

Régimen de actividades: principios generales: II.2: art. 3

Régimen de responsabilidades: II.2: arts. 13-19.

Registros: II.2: art. 10

\section{INSERCIÓN SOCIAL}

Ayudas para situaciones de emergencia social: XVI.1: arts. 3 y 41

Beneficiarios de renta de integración social: XVI.1: arts. 9-10

Comisión Interdepartamental de Servicios Sociales e Inclusión Social: XVI.1: arts. 54-57

Competencias: XVI.1: arts. 4-6

Concesión provisional, modificación, suspensión y extinción de la renta de integración social: XVI.1: arts. 29-32

Cuantía de las ayudas para situaciones de emergencia social: XVI.1: arts. 46

Impugnación de la renta de integración social: XVI.1: arts. 33-35

Impugnación de las ayudas para situaciones de emergencia social: XVI.1: art. 51

Obligaciones de los beneficiarios de la renta de integración social: XVI.1: art. 23

Órganos de control y seguimiento: XVI.1: arts. 36-40

Prestaciones de la renta de integración social: XVI.1: arts. 11-22
Programas: XVI.1: art. 2

Programas de desarrollo integral comunitario, objeto: XVI.1: art. 52

Renta de integración social: XVI.1: arts. 3, 7-40

Requisitos de las ayudas para situaciones de emergencia social: XVI.1: arts. 43-45

Tramitación de las ayudas para situaciones de emergencia social: XVI.1: arts. 47-50

Tramitación de la renta de integración social: XVI.1: art. $24-28$

\section{InSPECCIÓn DE CONSUMO}

Carácter y colaboración del funcionariado de Inspección de Consumo: XV.2: art. 7

Citaciones: XV.2: art. 10

Colaboración con la Inspección de Consumo: XV.2: art. 4

Documentación de la actuación inspectora: XV.2: art. 12

Escalas de la Inspección de Consumo: XV.2: art. 5

Forma de realización de las actuaciones inspectoras: XV.2: art. 8

Funciones: XV.2: art. 2

Habilitación de funcionarios para la realización de funciones de Inspección de Consumo: XV.2: art. 6

Obligaciones ante la Inspección de Consumo: XV.2: art. 3

Ratificación de las actuaciones: XV.2: art. 13

Requerimientos: XV.2: art. 11

Visitas de inspección: XV.2: art. 9

\section{Instituto Enerxético de Galicia}

Actuaciones: VII.4: art. 5

Adscripción: VII.4: art. 1.3

Autonomía funcional: VII.4: art. 3

Consejo Asesor: VII.4: art. 9

Consejo de Administración: VII.4: art. 7

Creación: VII.4: art. 1.1

Director: VII.4: art. 8

Fines: VII.4: art. 2

Funciones: VII.4: art. 4

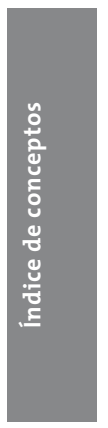


Naturaleza: VII.4: art. 1.1

Normas reguladoras: VII.4: art. 1.2

Órganos de gobierno: VII.4: art. 6

Personal: VII.4: art. 13

Programa: VII.4: art. 11

Recursos: VII.4: art. 10

Régimen financiero y presupuestario: VII.4: art. 12

Transformación, modificación, liquidación o extinción: VII.4: disposición adicional única

\section{Instituto Galego de Consumo}

Adscripción: XV.1: art. 1

Áreas operativas: XV.1: art. 11

Creación: XV.1: art. 1

Fines: XV.1: art. 3

Medios económicos: XV.1: art. 9

Naturaleza: XV.1: art. 1

Órganos: XV.1: arts. 4-8

Presupuestos: XV.1: art. 10

Sede: XV.1: art. 2

\section{Instituto Galego da Vivenda e Solo}

Adscripción de funcionarios: VIII.5: art. 12

Aprobación de la estructura orgánica: VIII.5: art. 12

Competencia del Consello de la Xunta: VIII.5: art. 6

Consello do Instituto: VIII.5: arts. 8-10

Contratación y ejecución de obras y servicios: VIII.5: art. 15

Creación: VIII.5: art. 1

Director general: VIII.5: arts. 11

Estructura orgánica: VIII.5: art. 7

Facultades: VIII.5: art. 5

Funciones: VIII.5: arts. 3-4

Medios económicos: VIII.5: art. 13

Personalidad jurídica y capacidad de obrar: VIII.5: art. 2

Recursos: VIII.5: art. 16

Régimen económico, financiero y presupuestario: VIII.5: art. 14

\section{Instituto Galego}

\section{de Promoción Económica}

Adscripción: VI.2: art. 2

Autorización de la transformación, modificación, liquidación o extinción del IGAPE: VI.2: disposición adicional primera

Consejo Asesor: VI.2: art. 13

Consignación inicial: VI.2: disposición adicional segunda

Consello de Dirección: VI.2: arts. 8-10

Control de eficiacia: VI.2: art. 18

Director: VI.2: art. 12

Facultades y medios para el cumplimiento de sus fines: VI.2: arts. 5-6

Fines: VI.2: art. 3

Funciones: VI.2: art. 4

Naturaleza: VI.2: art. 1

Organización: VI.2: arts. 7-13

Personal: VI.2: art. 17

Presidente: VI.2: art. 11

Programa de actividades: VI.2: art. 15

Recursos: VI.2: art. 14

Régimen financiero, contable y presupuestario: VI.2: art. 16

\section{INSTITUTO LÁCTEO E}

\section{Gandeiro de Galicia}

Adscripción: XIII.2: art. 1.2

Consello de Dirección: XIII.2: arts. 4-6

Director: XIII.2: art. 8

Fines: XIII.2: art. 2.1

Funciones: XIII.2: art. 2.2

Naturaleza: XIII.2: art. 1.1

Órganos: XIII.2: arts. 3-10

Personal: XIII.2: art. 13 y disposición adicional segunda

Presidente: XIII.2: art. 7

Recursos: XIII.2: art. 11

Régimen económico y presupuestario: XIII.2: art. 12 y disposición adicional primera 


\section{INSTRUMENTOS DE INTERVENCIÓN EN EL MERCADO DEL SUELO}

Derecho de superficie: VIII.2: art. 178

Derecho de tanteo y retracto: VIII.2: art. 179-187

Patrimonios públicos de suelo: VIII.2: arts. $174-177$

\section{INSTRUMENTOS REGULADORES}

Concepto: V.3: art. 54

Establecimiento de instrumentos reguladores: V.3: art. 55

Reclamacione y recursos: V.3: art. 56

INTERVENCIÓN EN LA EDIFICACIÓN Y USO

DEL SUELO Y DISCIPLINA URBANISTICA

Deber de conservación y ruina: VIII.2: arts. 199-201

Fomento de la edificación: VIII.2: arts. $188-193$

Fomento de la conservación y rehabilitación de las edificaciones tradicionales: VIII.2: arts. 202-203

Infracciones y sanciones: VIII.2: arts. 216-223 y disposición adicional quinta

Inspección urbanística: VIII.2: art. 208

Licencias: VIII.2: arts. 194-198

Licencias en suelo urbano no consolidado: VIII.3: disposición adicional primera

Parcelaciones: VIII.2: arts. 204-207

Protección de la legalidad urbanística: VIII.2: arts. 209-215

\section{LENGUA GALLEGA}

Conocimiento de la lengua gallega en las pruebas selectivas para acceder al empleo público: IV.3: art. 35

Idioma oficial en Galicia: I.1: art. 5.

Uso por las entidades locales: III.1: art. 7

\section{LIBRE PRESTACIÓN DE SERVICIOS}

DE TRANSPORTE MARITIMO DE PERSONAS EN AGUAS INTERIORES

Competencia de la Junta Arbitral de Transportes de Galicia: XI.4: disposición adicional primera

Inscripción de servicios previos: XI.4: disposición transitoria única
Régimen sancionador: XI.4: arts. 3-9

Registro de empresas operadoras del

Transporte Marítimo: XI.4: art. 2

\section{Mancomunidades de MUNicipios}

Asistencia de la Xunta: III.1: art. 136

Competencias: III.1: art. 147

Consideración como entidades locales no territoriales: III.1: art. 2

Consorcios locales: III.1: arts. 149-152

Derecho a asociarse en mancomunidad: III.1: art. 135.1

Hacienda: III.1: art. 148

Objeto: III.1: art. 135.2

Organización: III.1: arts. 145-146

Procedimiento de constitución de las mancomunidades de municipios: III.1: arts. $138-142$

Procedimiento para la modificación de estatutos o la disolución de la mancomunidad: III.1: arts. 143-144

\section{Moción de CEnSURA:}

II.1: arts. 45 y 46

\section{Montes Vecinales en MANO COMÚN}

Aprovechamientos: VII.2: arts. 21-23

Asamblea general: VII.2: art. 14

Clasificación: VII.2: arts. 9-13

Definición: VII.2: art. 1

Estatutos: VII.2: art. 16 y 18

Indivisibilidad, inalienabilidad, imprescriptibilidad e inembargabilidad: VII.2: art. 2

Inventario general de montes en mano común: VII.2: disposición adicional quinta

Junta Provisional: VII.2: art. 19

Junta Rectora: VII.2: art. 15

Jurado Provincial de Clasificación de Montes Vecinales: VII.2: art. 10

Monte vecinal en estado de grave abandono o degradación: VII.2: arts. 28-30 y disposición transitoria tercera

Organización de la Comunidad vecinal: VII.2: arts. 14-20 
Plan de aprovechamiento de montes vecinales en mano común: VII.2: disposicón adicional sexta

Propiedad: VII.2: art. 3

Protección y gestión cautelar: VII.2: arts. $24-30$

Régimen jurídico: VII.2: arts. 4-8

Registro General del Montes Vecinales: VII.2: art. 26

\section{Municipio}

Actividades complementarias de otras Administraciones Públicas: III.1: art. 86

Alcalde: III.1: art. 61

Alcalde de barrio: III.1: art. 73

Alteraciones de los términos municipales: III.1: arts. 12-14

Ayuntamiento: III.1: art. 59

Cambio de denominación y capitalidad del municipio: III.1: arts. 48-51

Comisiones de Estudio, Informe o Consulta: III.1: art. 68

Comisión de Gobierno: III.1: art. 65

Comisión Especial de Contas: III.1: art. 67

Comisión Galega de Delimitación Territorial: III.1: arts. 15-17

Competencias propias: III.1: art. 80

Consideración como entidad local territorial: III.1: art. 1

Demarcación, deslinde y amojonamiento: III.1: arts. 40-47

Derechos y deberes de los vecinos: III.1: arts. 57-58

Elementos: III.1: art. 10.3

Fusión: III.1: arts. 18-20

Grupos políticos: III.1: arts. 74-79

Incorporación de municipios: III.1: arts. 21-23

Municipios de gran población: aplicación a los municipios de Lugo, Ferrol, Ourense, Pontevedra y Santiago de Compostela: III.3

Municipios histórico-artísticos: III.1: arts. 93-94

Municipios industriales: III.1: arts. 95-97
Municipios pesqueros: III.1: arts. 98-99

Municipios rurales: III.1: art. 100

Municipios turísticos: III.1: arts. 90-92

Naturaleza: III.1: art. 10.1

Organización: III.1: art. 59

Órganos territoriales para la gestión municipal desconcentrada y de participación ciudadana: III.1: arts. 69-72

Padrón municipal: III.1: arts. 52-56

Personalidad jurídica: III.1: art. 10.2

Pleno: III.1: art. 64

Población: III.1: art. 52

Procedimiento común para la alteración de los términos municipales: III.1: arts. 31-39

Regímenes municipales especiales: III.1: arts. 88-89

Segregación-agregación: III.1: arts. 28-30

Segregación para la creación de municios independientes: III.1: arts. 24-27

Servicios mínimos: III.1: arts. 81-85

Tenientes de alcalde: III.1: arts. 62-63

Territorio: III.1: art. 11

Transferencia y delegación de competencias de la Comunidad Autónoma en los municipios y de la encomienda de gestión: III.1: art. 87

\section{Museos}

Acceso: VII.5: art. 73

Colección visitable: VII.5: art. 68

Creación y reglamentación: VII.5: art. 69

Definición: VII.5: art. 67

Funciones: VII.5: art. 67

Instrumentos y medios: VII.5: art. 72

Red de museos: VII.5: art. 71

Reproducciones: VII.5: art. 74

Sistema Galego de Museos: VII.5: art. 70

\section{NORMALIZACIÓN LINGÜÍSTICA}

Administración autonómica y función normalizadora: XVII.7: arts. 22-25

Derechos lingüísticos: XVII.7: arts. 1-3

Gallego en el exterior: XVII.7: art. 21 
Uso correcto de la lengua gallega: XVII.7: disposición adicional

Uso del gallego en la enseñanza: XVII.7: arts. 12-17

Uso del gallego en los medios de comunicación: XVII.7: arts. 18-20

Uso oficial del gallego: XVII.7: arts. 4-11

\section{Ordenación de la Minería}

Ámbito de aplicación de la ley: VII.7: art. 2

Concurso de derechos mineros: VII.7: art. 35

Concellos mineiros: VII.7: art. 45

Consello da Minaría de Galicia: VII.7: arts. 6-8

Contenido de los derechos mineros: VII.7: arts. 28-34

Derechos mineros: VII.7: arts. 15-38

Expedientes de regularización no resueltos: : VII.7: disposición transitoria única

Fianza ambiental: VII.7: disposición adicional cuarta

Fomento de la minería: VII.7: art. 39-41

Incentivos económicos: VII.7: arts. 42-44

Inspección minera: VII.7: arts. 46-49 y disposición adicional tercera.

Organización administrativa y competencias: VII.7: arts. 4-10 y disposición adicional primera

Planificación de la minería: VII.7: arts. 11-14

Principios: VII.7: art. 3

Procedimiento de otorgamiento de los derechos minero: VII.7: arts. 17-27

Régimen sancionador: VII.7: arts. 50-64

Rexistro de Solicitudes de Dereitos

Mineiros: VII.7: art. 10

Rexistro Mineiro de Galicia: VII.7: art. 9

\section{ORdenACIÓN DEL TERRITORIO}

Contenido: VIII.1: art. 2

Directrices de ordenación del territorio: VIII.1: art. 6-11
Evaluación ambiental estratégica de instrumentos de ordenación del territorio y de planeamiento urbanístico: VIII.3: arts. 5-8

Instituto de Estudios del Territorio: VIII.1: art. 31; VIII.3: arts. 9-16

Instrumentos: VIII.1: arts. 4-5 bis

Objetivos: VIII.1: art. 3

Plan de ordenación del litoral: VIII.3: art. 2

Planes de ordenación del medio

físico: VIII.1: arts. 26-30

Planes territoriales integrados: VIII.1: arts. 12-15

Planes y proyectos sectoriales: VIII.1: arts. 22-25

Programas coordinados de actuación: VIII.1: arts. 16-21

\section{ORdenación FARMACÉUTICA}

Ámbito de aplicación: XVI.5: art. 1

Atención farmacéutica: XVI.5: art. 2

Atención farmacéutica en los hospitales, centros de asistencia social y psiquiatrícos: XVI.5: art. 31-36

Autorización de nuevos establecimientos o servicios de atención farmacéutica: XVI.5: art. 7

Botiquines: XVI.5: art. 26

Depósitos de medicamentos de los centros penitenciarios: XVI.5: disposición adicional tercera

Derechos de los ciudadanos: XVI.5: art. 5

Dispensación de medicamentos: XVI.5: art. 4

Distribución: XVI.5: arts. 37-43

Distribución y dispensación de medicamentos veterinarios: XVI.5: art. 49

Establecimientos y servicios de atención farmacéutica: XVI.5: art. 3

Objeción de conciencia: XVI.5: art. 6

Objeto: XVI.5: art. 1

Oficinas de farmacia: XVI.5: arts. 8-25

Producción de los medicamentos, inspección de los ensayos clínicos y farmacovigilancia: XVI.5: arts. 52-53 
Profesionales farmacéuticos: XVI.5: arts. 50-51

Publicidad y promoción de medicamentos: XVI.5: art. 54

Régimen sancionador: XVI.5: arts. 55-61

Servicios de farmacia en las oficinas de atención primaria: XVI.5: arts. 27-30

Unidades de radiofarmacia: XVI.5: arts. 44-48

\section{Ordenación urbanística}

Acción pública: VIII.2: disposición adicional cuarta

Actividad urbanística: VIII.2: art. 2

Actuaciones públicas en municipios sin planeamiento: VIII.2: disposición adicional primera

Adaptaciones al ambiente: VIII.2: art. 104

Axencia de Protección da Legalidade

Urbanística: VIII.2: art. 226 y

disposición adicional sexta

Altura de las edificaciones: VIII.2: art. 105

Ámbito de la competencia urbanística: VIII.2: art. 3

Convenios urbanísticos: véase la voz "Convenios urbanísticos"

Dirección de la actividad urbanística: VIII.2: art. 5

Ejecución de los planes de ordenación: véase la voz "ejecución de los planes de actuación"

Evaluación ambiental estratégica de instrumentos de ordenación del territorio y de planeamiento urbanístico: VIII.3: arts. 5-8

Fines de la actividad urbanística: VIII.2: art. 4

Instrumentos de intervención en el mercado del suelo: véase la voz "instrumentos de intervención en el mercado del suelo".

Intervención en la edificación y uso del suelo y disciplina urbanística: véase la voz "intervención en la edificción y uso del suelo y disciplina urbanística

Jurado de Expropiación de

Galicia: VIII.2: art. 232
Organización: VIII.2: arts. 224-232

Planeamiento urbanístico: véase la voz "planeamiento urbanístico"

Protección de las vías de circulación: VIII.2: art. 106

Régimen urbanístico del suelo: véase la voz "régimen urbanístico del suelo"

Reglas de interpretación del planeamiento urbanístico: VIII.2: art. 6

Suspensión de nuevos desarrollos urbanísticos en la zona del litoral: VIII.3: arts. 3-4

\section{Órganos Gallegos DE DEFENSA DE LA COMPETENCIA}

Convenios de colaboración: VI.5: art. 19

Deber de secreto: VI.5: art. 21

Normas de procedimiento: VI.5: art. 15

Publicación en el "Diario Oficial de Galicia”: VI.5: art. 17

Recursos: VI.5: art. 16

Relaciones con las Administraciones Públicas: VI.5: art. 20

Representación en la Xunta Consultiva en materia de conflictos: VI.5: art. 18

Servizo Galego de Defensa da Competencia: véase voz "Servizo Galego de Defensa da Competencia"

Tribunal Galego de Defensa da Competencia: véase voz "Tribunal Galego de Defensa da Competencia"

\section{PAISAJE}

Ámbito de aplicación: IX.9: art. 4

Catálogos de paisaje: IX.9: art. 9 y disposición transitoria segunda

Definiciones: IX.9: art. 3

Directrices de paisaje: IX.9: art. 10

Estudios de impacto e integración paisajística: IX.9: art. 11

Instrumentos de organización, sensibilización y concertación de las políticas de paisaje: IX.9: art. 13

Instrumentos para la protección, gestión y ordenación del paisaje: IX.9: arts. 8-12 
Objeto de la Ley de Protección del Paisaje Bienes arqueológicos de dominio de Galicia: IX.9: art. 1

Observatorio Gallego del Paisaje: IX.9: art. 13

Planes de acción del paisaje en áreas protegidas: IX.9: art. 12

Políticas de paisaje: IX.9: arts. 5-7

Principios inspiradores de la Ley de Protección del Paisaje de Galicia: IX.9: art. 2

\section{Parlamento de Galicia}

Constitución: I.1: art. 11.1

Disolución: II.1: art. 24

Elección: I.1: art. 11

Elección del primer Parlamento de Galicia: I.1: disposición transitoria 1

Funcionamiento: I.1: art. 12

Funciones: I.1: art. 10.1; II.1: arts. 24-26

Incompatibilidad de sus miembros: I.1: art. 11.5

Inviolabilidad: I.1: art. 10.2

Inviolabilidad de sus miembros: I.1: art. 11.3

Mociones, interpelaciones y preguntas a los miembros del la Xunta: II.1: art. 52

No sujeción a mandato imperativo de sus miembros: art. 11.7

Órganos: I.1: art. 12

Procedimiento legislativo: I.1: art. 13

Relaciones con la Xunta: II.1: arts. 45-57

\section{Parroouias}

Actuación intensiva en las parroquías rurales: III.4

Autonomía para la gestión de sus intereses patrimoniales: III.1: art. 1.2

Consideración como entidades locales territoriales: III.1: art. 1.2

Juntas parroquiales: III.4: art. 9

Posibilidad de reconocimiento de personalidad jurídica: I.1: art. 40.3

\section{PATRIMONIO CULTURAL}

Acceso: VII.5: art. 26 público: VII.5: art. 56

Bienes de Interés cultural: VII.5: arts. 8-16

Catalogación de los bienes: VII.5: arts. 17-21

Colaboración de la Iglesia católica: VII.5: art. 5

Colaboración de las Corporaciones Locales: VII.5: art. 4

Comercio: VII.5: art. 29

Competencia: VII.5: art. 2

Composición: VII.5: art. 1

Deber de conservar: VII.5: art. 25

Derecho a premio: VII.5: art. 60

Derechos de tanteo y retracto: VII.5: art. 27

Escrituras públicas: VII.5: art. 28

Expropiación: VII.5: art. 31

Hallazgos casuales: VII.5: art. 59

Impacto o efecto ambiental: VII.5: art. 32

Intervenciones arqueológicas por obras en conjuntos históricos, zonas arqueológicas o yacimientos catalogados o inventariados: VII.5: art. 63

Inventario General: VII.5: arts. 22-23 y disposición adicional segunda

Limitaciones a la transmisión: VII.5: art. 30

Medidas de fomento: VII.5: arts. 83-88

Museos: Véase la voz "museos"

Órganos asesores y consultivos: VII.5: art. 7

Patrimonio arqueológico, definición: VII.5: art. 55

Patrimonio bibliográfico: VII.5: art. 75

Patrimonio documental y archivos: VII.5: art. 76-82

Patrimonio etnográfico: VII.5: arts. 64-66

Particulares: VII.5: art. 3

Protección general: VII.5: art. 24

Protección de los bienes catalogados: VII.5: arts. 52-53

Protección de los bienes de interés cultural: VII.5: arts. 33-51

Protección de los bienes inventariados: VII.5: art. 54

Proyección exterior: VII.5: art. 6

Actividades arqueológicas: VII.5: art. 57 Red de archivos: VII.5: art. 79 
Régimen de los conjuntos históricos: VII.5: arts. 45-47

Régimen de los monumentos: VII.5: arts. 43-44

Régimen sancionador: VII.5: arts. 89-99 y disposición adicional quinta

Registro de Bienes de Interés Cultural de Galicia: VII.5: art. 14

Requisitos y autorización para realizar y dirigir las actividades arqueológicas: VII.5: art. 61

Responsabilidad en la dirección y destino de los hallazgos arqueológicos: VII.5: art. 62

Sistema de arquivos de Galicia: VII.5: art. 78

Urgencias arqueológicas: VII.5: art. 58

Vigilancia e inspección: VII.5: disposición adicional séptima

\section{Patrimonio de la Comunidad Autónoma de Galicia}

Actividad empresarial del sector público de Galicia: VII.1: arts. 44-47

Adscripción de bienes y derechos demaniales a entidades públicas u organismos autónomos dependientes de la Administración de la Comunidad Autónoma: VII.1: art. 13

Adquisición: VII.1: arts. 16-23

Afectación al uso general o a la prestación de los servicios públicos: VII.1: arts. 9-12

Bienes de dominio público: VII.1: art. 3

Bienes patrimoniales: VII.1: art. 4

Clasificación de los bienes y derechos que lo integran: VII.1: art. 2

Competencia: VII.1: art. 7

Composición: I.1: art. 43.1; VII.1: art. 1

Deslinde: VII.1: arts. 72-76

Enajenación y cesión de bienes inmuebles: VII.1: arts. 24-33

Enajenación y cesión de bienes muebles: VII.1: arts. 34-37
Explotación de los bienes patrimoniales: VII.1: arts. 60-68

Formas de utilización de los bienes demaniales: VII.1: arts. 48-59

Inalienabilidad, imprescriptibilidad e inembargabilidad: VII.1: art. 8 y 77

Incripción o anotación registral en registros públicos: VII.1: art. 79

Inventario General del Patrimonio: VII.1: art. 78

Licencia, permiso o concesión administrativa: VII.1: art. 15

Normativa reguladora: VII.1: art. 5

Propiedades incoroporales: VII.1: arts. 38-39

Recuperación de la posesión: VII.1: arts. 69-71

Responsabilidad: VII.1: arts. 80-82

Sucesión entre organismos públicos: VII.1: art. 14

Títulos representativos del capital o deuda emitida por sociedades y empresas: VII.1: arts. 40-43

Tráfico de los bienes y derechos que lo componen: VII.1: art. 6

\section{Pesca}

Abanderamiento de conveniencia: XIV.2: art. 159

Acceso de buques de otras comunidades autónomas: XIV.2: art. 20

Acuicultura marina: XIV.2: arts. 44-66

Agencia de desarrollo sostenible de las zonas de pesca: XIV.2: arts. 106-111

Agentes del Sector Pesquero Gallego: XIV.2: arts. 78

Ámbito de aplicación: XIV.2: art. 3

Áreas de acondicionamiento marino: XIV.2: art. 10

Áreas de repoblación marina: XIV.2: art. 11

Autorización de construcción: XIV.2: art. 76

Cambio temporal de modalidad: XIV.2: art. 21 
Censos por modalidades: XIV.2: art. 17

Clasificación de las zonas de producción: XIV.2: art. 8

Cofradías de pescadores: XIV.2: arts. 79-89, disposición adicional segunda y disposición transitoria segunda

Comercialización de los productos de la pesca, el marisqueo y la acuicultura: XIV.2: arts. 96-102

Comercialización, transformación y promoción de los productos de la pesca, el marisqueo y la acuicultura: XIV.2: arts. 96-105

Concesiones de actividad en la zona marítima: XIV.2: arts. 57-65

Concesiones de actividad en zonas marítimo-terrestres: XIV.2: arts. 48-56

Consejo Gallego de Pesca: XIV.2: art. 95 $\mathrm{y}$ disposición transitoria tercera

Conservación y gestión de los productos pesqueros y marisqueros: XIV.2: arts. 6-13

Cooperativas del sector del mar: XIV.2: art. 92

Definiciones: XIV.2: art. 4

Desarrollo sostenible de las zonas de pesca: XIV.2: arts. 106-113

Ejercicio del marisqueo: XIV.2: arts. 39-43

Embarcaciones auxiliares de acuicultura: XIV.2: disposición adicional undécima

Entidades representativas del sector pesquero: XIV.2: art. 78-95

Federación de Cofradías: XIV.2: art. 89 y disposición transitoria segunda

Finalidad de la Ley de Pesca: XIV.2: art. 2

Flota pesquera: XIV.2: arts. 73-77

Formación martítimo pesquera: XIV.2: arts. $117-118$

Inspección, control, salvamento marítimo y lucha contra la contaminación: XIV.2: arts. 119-

Inspección y control: XIV.2: arts. 120-123
INTECMAR: XIV.2: Disposición adicional primera

Investigación, desarrollo tecnológico e innovación: XIV.2: arts. 114-116

Licencia de Marisqueo: XIV.2: art. 39

Licencia de Marisqueo a flote: XIV.2: art. 41

Licencia de Marisqueo a pie: XIV.2: art. 40

Licencia de Pesca Profesional: XIV.2: art. 18

Marisqueo: XIV.2: arts. 27-43

Objeto de la Ley de Pesca: XIV.2: art. 1

Organizaciones de productores: XIV.2: arts. 90-91

Permiso de actividad: XIV.2: arts. 66-72

Permisos de explotación: XIV.2: disposición transitoria quinta

Permisos de explotación de marisqueo a pie con embarcación auxiliar: XIV.2: disposición transitoria sexta

Permiso de pesca especial: XIV.2: art. 19

Pesca Marítima: XIV.2: arts. 14-26

Pesca Marítima de recreo: XIV.2: arts. 22-26

Pesca Marítima profesional: XIV.2: arts. 14-21

Preferencia de las organizaciones de productores de base: XIV.2: art. 5

Primera venta: XIV.2: art. 99

Promoción de los productos de la pesca, el marisqueo y la acuicultura: XIV.2: art. 105

Protección y regeneración: XIV.2: arts. 9-13

Puerto base: XIV.2: art. 75

Recogida de algas y argazos: XIV.2: art. 43

Régimen sancionador: XIV.2: arts. 127158 y disposición final segunda

Registros: XIV.2: art. 126

Reservas marinas: XIV.2: art. 12

Salvamento marino y lucha contra la contaminación: XIV.2: arts. 124-125

Servicio de Guardacostas de Galicia: XIV.2: disposición adicional sexta 


\section{I Índice de conceptos}

Servicio de Inspección y Vigilancia

Pesquera: XIV.2: disposición adicional sexta a disposición adicional décima

Transformación de los productos de la pesca, el marisqueo y la acuicultura: XIV.2: arts. 103-104

Transporte anterior a la primera venta: XIV.2: art. 98

Turismo marinero: XIV.2: arts. 112-113

Zonas de explotación marisquera: XIV.2: arts. 29-38

\section{Pesca fluvial}

Concesiones: XIV.3: arts. 5-7

Control y policía de aguas continentales: XIV.3: arts. 28-29

Embarcaciones: XIV.3: art. 4

Fomento de las poblaciones ictícolas: XIV.3: arts. 13-17

Frezaderos: XIV.3: art. 14

Indemnizaciones y decomisos: XIV.3: arts. 44-46

Infracciones y sanciones: XIV.3: arts. 32-46

Licencias, regímenes especiales, permisos y matrículas: XIV.3: arts. 2-4

Medidas protectoras de la riqueza piscícola: XIV.3: arts. 18-27

Objeto: XIV.3: art. 1

Procedimiento sancionador: XIV.3: arts. 39-43

Prohibiciones: XIV.3: arts. 30-31

Restricciones al aprovechamiento piscícola: XIV.3: arts. 8-12

Tramo internacional del río Miño: XIV.3: disposición adicional primera

\section{Planeamiento urbanístico}

Alteración del planeamiento: VIII.2: art. 93

Calidad de vida y cohesión social: VIII.2: art. 47

Catálogos: VIII.2: art. 75

Competencia para la aprobación definitiva: VIII.2: art. 89

División del suelo urbano y urbanizable: VIII.2: art. 49
Efectos de la aprobación de los planes: VIII.2: arts. 97-103

Elaboración del plan: VIII.2: art. 76

Elaboración del planeamiento: VIII.2: art. 84

Estudios de detalle: VIII.2: art. 73

Formulación de las normas subsidiarias y complementarias de planeamiento: VIII.2: art. 80

Formulación del planeamiento de desarrollo: VIII.2: art. 83

Formulación del planeamiento general: VIII.2: art. 81

Instrumentos de ordenación: VIII.2: art. 45

Límites de sostenibilidad: VIII.2: art. 46

Modificaciones de los planes: VIII.2: art. 94

Modifiación de los planes en suelo rústico: VIII.2: art. 95

Normas de calidad urbana: VIII.2: art. 48

Normas técnicas del planeamiento: VIII.2: art. 50

Normas subsidiarias y complementarias del planeamiento: VIII.2: art. 51

Ordenación urbanística que afecta a varios municipios: VIII.2: art. 82

Planeamiento de desarrollo: VIII.2: arts. 62-75

Planes de iniciativa particular: VIII.2: art. 74

Planes especiales: VIII.2: arts. 68-72

Planes de iniciativa particular: VIII.2: art. 79

Planes de sectorización: VIII.2: arts. 66-67

Planes parciales: VIII.2: arts. 63-65

Plan general de ordenación municipal: VIII.2: arts. 52-61

Plazos para la aprobación definitiva de instrumentos de planeamiento de desarrollo de iniciativa particular: VIII.2: art. 90

Propuestas de planeamiento: VIII.2: art. 78 Suspensión de licencias: VIII.2: art. 77

Suspensión del planeamiento: VIII.2: art. 96

Tramitación del planeamiento: VIII.2: art. 85

Vigencia de los planes: VIII.2: art. 92 


\section{Policía de Galicia}

Acatamiento a la Constitución y al Estatuto de Autonomía de Galicia: X.2: art. 6

Acceso y promoción: X.2: arts. 27-37

Adscripción a puestos de trabajo: X.1: arts. 40-41

Ámbito de actuación: X.2: art. 2

Asistencia jurídica: X.2: art. 52

Carrera profesional: X.2: arts. 46-47

Centro de elaboración y proceso de datos para el servicio policial: X.2: art. 19

Comisión Gallega de Seguridad: X.2: art. 21

Consejo de la Policía de Galicia: X.2: art. 20

Consumo de drogas, estupefacientes y sustancias psicotrópicas: X.2: art. 56

Convenios de colaboración con las entidades locales: X.2: art. 16

Correspondencia de categorías: X.2: Disposición adicional segunda

Deber de residencia: X.2: art. 58

Derecho de sindicación: X.2: art. 62

Derechos y deberes de sus miembros: X.2: arts. 48-63

Desempeño provisional de funciones: X.2: art. 44

Distinciones y recompensas: X.2: art. 61

Escalafón: X.2: Disposición adicional tercera

Escalas y categorías: X.2: art. 24

Formación y capacitación profesional: X.2: art. 38 y 53

Funciones: X.2: art. 15

Funciones de sus miembros: X.2: art. 25

Gabinete de Iniciativas Ciudadanas para la Optimización del Servicio Policial: X.2: art. 22

Grado personal: X.2: art. 42

Incompatibilidades: X.2: art. 55

Integración y promoción de los funcionarios pertenecientes a la unidad del Cuerpo Nacional de Policía adscrita a la Comunidad Autónoma de Galicia y otras fuerzas y cuerpos de seguridad: X.2: disosición transitoria primera-disposición transitoria tercera
Jornada y horario: X.2: art. 59

Jubilación: X.2: art. 64

Junta de Seguridad de Galicia: X.2: art. 18

Limitación del derecho de huelga: X.2: art. 63

Medios e instalaciones: X.2: art. 54

Misión: X.2: art. 5

Naturaleza: X.2: art. 3

Órganos consultivos: X.2: arts. 20-21

Órganos de coordinación: X.2: arts. 18-19

Órganos de dirección: X.2: art. 17

Órganos de participación ciudadana: X.2: art. 22

Permanencia en los puestos: X.2: art. 43

Permisos, licencias y vacaciones: X.2: art. 60

Permuta: X.2: art. 45

Personal no policial: X.2: art. 26

Principios de actuación: X.2: arts. 8-14

Recursos provinientes de acuerdos con otras Administraciones Públicas: X.2:

Disposición adicional Primera

Régimen de la Seguridad Social: X.2: art. 50

Régimen disciplinario: X.2: arts. 78-90

Régimen funcionarial: disposiciones generales: X.2: arts. 23-26

Régimen jurídico: X.2: art. 7

Relación de puestos de trabajo: X.2: art. 39

Retribuciones: X.2: art. 49

Revisiones médicas: X.2: art. 57

Salud y seguridad laboral: X.2: art. 51

Segunda actividad: X.2: arts. 66-77

Situaciones administrativas: X.2: arts. $65-77$

Uso de armas y uniforme: X.2: art. 4

\section{Policías locales}

Academia Galega de Seguridade Pública: véase la voz "Academia Galega de Seguridade Pública"

Acceso a la categoría de inspector: X.1: art. 38 


\section{I Índice de conceptos}

Acceso a la categoría de inspector principal: X.1: art. 39

Acceso a la categoría de intendente: X.1: art. 40

Acceso a la categoría de intendente principal: X.1: art. 41

Acceso a la categoría de oficial: X.1: art. 37

Acceso a la categoría de superintendente: X.1: art. 42

Acreditación profesional: X.1: art. 10

Ámbito de aplicación: X.1: art. 2

Ámbito territorial de actuación de los cuerpos: X.1: art. 6

Auxiliares de Policía Local: X.1: arts. 95-96

Coordinación: X.1: arts. 12-21

Creación de categorías: X.1: art. 28

Creación del cuerpo de policía local: X.1: art. 22

Denominación: X.1: art. 5

Derechos y deberes: X.1: art. 47-59

Dispensa de requisitos de los cuerpos: X.1: art. 31

Distinciones y recompensas: X.1: art. 74

Edad de jubilación: X.1: art. 61

Escalas y categorías: X.1: art. 24

Finalidad de los cuerpos: X.1: art. 4

Funcionario en prácticas: X.1: art. 36

Funciones de los cuerpos de policía local: X.1: art. 8

Formación: X.1: arts. 3 y 45 y 46

Garantía de movilidad: X.1: art. 43

Incompatibilidades: X.1: art. 58

Ingreso en la categoría de policías: X.1: art. 35

Integración de los vigilantes y auxiliares de policía o interinos en los cuerpos de Policía Local: X.1: disposición adicional segunda

Jefe del Cuerpo de Policía Local: X.1: art. 27

Jornada laboral y horario: X.1: art. 55

Medios técnicos: X.1: art. 11

Naturaleza jurídica: X.1: art. 5

Número mínimo de miembros de los cuerpos: X.1: art. 30

Objeto: X.1: art. 1
Organización: X.1: art. 23

Permutas: X.1: art. 44

Plantillas de personal: X.1: art. 29

Principios básicos de actuación: X.1: art. 6

Principios del sistema de selección: X.1: art. 32

Régimen disciplinario: X.1: arts. 75-87

Registro de policías locales: X.1: art. 21

Reintegración de categorías de los cuerpos de la Policía Local de Galicia: X.1: disposición adicional primera

Requisitos para el ingreso: X.1: art. 33

Retribuciones: X.1: art. 48

Segunda actividad: X.1: arts. 62-73

Situaciones administrativas: X.1: art. 60

Subescala facultativa: X.1: art. 26

Tribunal de selección: X.1: art. 34

Uniformidad: X.1: art. 9

Vigilantes municipales: X.1: arts. 88-94

\section{PRECIOS PRIVADOS}

Concepto: V.3: art. 50

Fijación: V.3: art. 51

Gestión: V.3: art. 52

Régimen jurídico: V.3: art. 53

\section{Precios públicos}

Concepto: V.3: art. 43

Cuantía de los precios públicos: V.3: art. 46

Fijación de precios públicos: V.3: art. 47

Gestión: V.3: art. 48

Normativa aplicable: V.3: art. 44

Obligados al pago: V.3: art. 45

Reclamaciones y recursos: V.3: art. 49

\section{Presidente de la Xunta}

Cese: II.1: art. 21 y 29

Derechos: II.1: art. 11

Elección: I.1: art. 15; II.1: art. 15-18

Estatuto: I.1: art. 16.4

Funciones: I.1: art. 16.4

Incompatibilidades: II.1: art. 12

Inmunidad: I.1: art. 18; II.1: art. 14

Juramento: II.1: art. 20

Nombramiento: I.1: art. 15.2 
Presidente en funciones: II.1: art. 23

Representación suprema de la Comunidad

Autónoma de Galicia y ordinaria del

Estado: II.1: art. 10

Responsabilidad política ante el

Parlamento: I.1 art. 16.4; II.1: art. 13

Sustitución en el cargo: II.1: art. 22

Toma de posesión: II.1: art. 19

\section{Presupuestos de las}

Diputaciones Provinciales

V.1: art. 53

\section{Presupuestos de los \\ ORGANISMOS AUTÓNOMOS}

V.1: art. 82

\section{Presupuestos generales \\ DE LA Comunidad Autónoma}

Anticipos de tesorería: V.1: art. 63

Anulación de créditos: V.1: art. 59

Aprobación: I.1: art. 53; V.1: art. 46

Autorización de créditos: V.1: art. 56

Autorización de gasto: V.1: art. 72

Competencias de las consellerías: V.1: art. 50

Competencias del Consello de la Xunta: art. 65

Concepto: V.1: art. 46

Contenido: V.1: art. 48

Créditos ampliables: V.1: art. 64

Créditos extraordinarios y suplementos: 62

Derechos y obligaciones

reconocidas: V.1: art. 55

Ejercicio presupuestario: V.1: art. 47

Elaboración: I.1: art. 53; V.1: art. 51

Estructura: V.1: art. 49

Facultades de la Consellería de Economía e Facenda: V.1: art. 66

Facultades de los conselleiros: V.1: art. 67

Fases del gasto: V.1: art. 73

Gastos plurianuales: V.1: art. 58

Generación de créditos: V.1: art. 69

Incorporaciones: V.1: art. 71
Limitaciones: V.1: art. 68

Liquidación: V.1: art. 80

Normativa aplicable: V.1: art. 61

Nulidad de obligaciones: V.1: art. 57

Ordenación general de los pagos: V.1: art. 74

Pagos a justificar: V.1: art. 77

Plan de disposición: V.1: art. 75

Prórroga: V.1: art. 54

Regulación de obligaciones: V.1: art. 60

Remanentes de tesorería: V.1: art. 81

Remisión al Parlamento: V.1: art. 52

Reposición: V.1: art. 70

\section{Prevención Y tRatamiento INTEGRaL DE LA VIOLENCIA DE GÉNERO}

Acreditación de la situación de violencia de genero: XVI.6: art. 5

Acuerdos interinstitucionales y acuerdos de colaboración: XVI.6: disposición adicional segunda

Ámbito de aplicación de la Ley: XVI.6: art. 2

Centro de Recuperación Integral para Mujeres que Sufren Violencia de Género: XVI.6: art. 49

Comisión Interdepartamental de igualdad: XVI.6: disposición adicional séptima

Competencias en materia de violencia de genero de la policía de Galicia: XVI.6: disposiicón adicional tercera

Consejo Gallego de Mujeres: XVI.6: disposición adicional quinta

Creación de oficinas de atención a las víctimas de los delitos: XVI.6: art. 54

Definición de violencia de genero: XVI.6: art. 1.2

Diseño e implantación de dispositivos de alarma: XVI.6: art. 33

Formas de violencia de genero: XVI.6: art. 3 


\section{I Índice de conceptos}

Información al Parlamento de

Galicia: XVI.6: disposición adicional cuarta

Medidas de carácter económico: XVI.6: arts. 38-45

Medidas de formación y organización en materia de violencia de genero: XVI.6: arts. $12-15$

Medidas de sensibilización contra la violencia de genero: XVI.6: arts. 6-11

Medidas en el ámbito educativo: XVI.6: arts. 16-23

Medidas en el ámbito judicial: XVI.6: art. 28-32

Medidas en el ámbito de la formación y el empleo: XVI.6: arts. 35-37

Medidas en el ámbito sanitario y psicológico: XVI.6: arts. 24-27

Observatorio Gallego de Violencia de Genera: XVI.6: disposición adicional sexta

Organización del sistema de protección y asistencia integral especializada frente a la violencia de género: XVI.6: arts. 47-56

Principios generales: XVI.6: art. 4

Procedimiento abreviado de concesión de la renta de integración social: XVI.1: art. 24.10

Programas de intervención con hombres en relación a la violencia de genero: XVI.6: art. 34

Punto de coordinación de ordenes de protección: XVI.6: art. 52

Puntos de encuentro familiar: XVI.6: art. 53

Red de información de mujeres: XVI.6: art. 50

Red gallega de acogida: XVI.6: art 48

Rentas individuales del conyuge agresor de la unidad de convivencia: XVI.1: art. 14.4

Servicio de atención 24 horas: XVI.6: art. 51

\section{Procedimiento administrativo}

Normativa aplicable a los procedimientos que carecen de regulación específica: IV.1: disposición adicional segunda

Plazo máximo para resolver: IV.1: art. 1; IV.1: anexo 1

Registro del órgano competente para tramitar la solicitud: IV.1: disposición adicional primera

Silencio administrativo: IV.1: art. 2; IV.1: anexo 2

\section{Programas de SOCIEDADES PÚBliCAS}

V.1: arts. 83-86

\section{PROTECCIÓN AMBIENTAL}

Administración ambiental: IX.1: art. 27

Ámbito de protección: IX.1: art. 4

Aplicación de técnicas y medidas de defensa a actividades que ya se estén realizando: IX.1: art. 6

Autorización: IX.1: art. 5 y disposición adicional cuarta

Clasificación del grado de protección: IX.1: art. 5

Conexión con los elementos de planeamiento: IX.1: art. 21

Consello Galego de Medio Ambiente: IX.1: art. 28

Conservación de la naturaleza: véase la voz "conservación de la naturaleza"

Ecoetiqueta: IX.1: art. 26

Educación ambiental: IX.1: art. 22

Evaluación de efectos ambientales: IX.1: arts. 10-12

Evaluación de impacto ambiental: IX.1: arts. 7-9

Evaluación de incidencia ambiental: IX.1: arts. 13-19

Información y participación ambiental: IX.1: art. 24

Infracciones y sanciones: IX.1: arts. 33-49 y disposición adicional segunda

Inspección y vigilancia: IX.1: arts. 29-32

Investigación: IX.1: art. 23 
Mandato general: IX.1: art. 3

Objetivos: IX.1: art. 2

Pacto ambiental: IX.1: art. 25

Principios: IX.1: art. 2

Procedimiento sancionador: IX.1: arts. 41 y 43-49

Protección de la calidad de las aguas de las rías de Galicia: véase la voz: "protección de la calidad de las aguas de las rías de Galicia.

Protección contra la contaminación acústica: véase la voz "protección contra la contaminación acústica"Protección del ambiente atmosférico: véase la voz "protección del ambiente atmosférico".

Protección, conservación y mejora de los ríos gallegos: véase la voz "protección, conservación y mejora de los ríos gallegos"

Régimen de registros, catálogos e inventarios: IX.1: art. 20

Residuos sólidos urbanos: véase la voz "residuos sólidos urbanos"

Servicio público de depuración de aguas residuales urbanas: véase la voz "servicio público de depuración de aguas residuales urbanas"

Suspensión de actividades no autorizadas: IX.1: art. 40

\section{PROTECCIÓN, CONSERVACIÓN}

Y MEJORA DE LOS RÍOS GALLEGOS

Ámbito de aplicación: IX.8: disposición adicional segunda

Capacitación técnica del personal de la Administración: IX.8: art. 7

Educación ambiental: IX.8: art. 7

Gestión del uso del agua: IX.8: art. 5

Participación ciudadana en las políticas del agua: IX.8: art. 6

Planificación hidrológica: IX.8: arts. 2-3

Principios generales: IX.8: art. 1

Protección integral de los ecosistemas fluviales: IX.8: art. 4

Red de vigilancia y control del estado ecológico de los ríos: IX.8: art. 3

\section{Protección CONTRA LA}

\section{CONTAMINACIÓN ACÚSTICA}

Actividades varias: IX.3: art. 7

Ámbito: IX.3: art. 2

Auditorías: IX.3: arts. 21-22

Autorizaciones: IX.3: disposición adicional tercera

Competencia administrativa: IX.3: art. 3

Edificación: IX.3: art. 6

Infracciones y sanciones: IX.3: arts. 12-20

Inspección y vigilancia: IX.3: art. 9-11

Normativa subsidiaria: IX.3: art. 8

Objeto: IX.3: art. 1

Régimen jurídico de las actividades susceptibles de producir ruido y vibraciones, normas generales: IX.3: art. 4

Relaciones interadministrativas y de auxilio: IX.3: arts. 23-25

Tráfico: IX.3: art. 5

\section{Protección de CONSUMIDORES \\ Y USUARIOS}

Definición de consumidores y usuarios: XV.3: art. 2

Derecho a la información y la educación: XV.3: arts. 22-26

Derecho a la protección de la salud y la seguridad: XV.3: arts. 4-14

Derecho a la protección de los intereses económicos y sociales de los consumidores y usuarios: XV.3: arts. 15-20

Derecho a la protección jurídica, administrativa y técnica y reparación de daños y perjuicios: XV.3: arts. 30-31

Derechos de consumidores y usuarios: XV.3: arts. 3-31

Derecho de representación, consulta y participación: XV.3: arts. 27-29

Expedientes sancionadores: XV.3: disposición final primera

Grupos de protección especial: XV.3: arts. 32-34

Inspección de consumo: véase la voz "Inspección de consumo"

Instituto Galego de Consumo: véase la voz "Instituto Galego de Consumo" 


\section{Protección de LA CALIDAD de LAS AGUAS DE LAS RÍAS DE GALICIA}

Ámbito: IX.6: art. 1

Aplicación de las técnicas de protección ambiental al planeamiento urbanístico y a las actividades en funcionamiento: IX.6: art. 5

Infracciones y sanciones: IX.6: arts. 11 y $13-14$

Objetivos de calidad de las aguas: IX.6: art. 3

Objeto: IX.6: art. 1

Ría de Ribadeo: disposición adicional tercera

Vertidos de aguas residuales industriales: IX.6: art. 4

Vertidos de residuos: IX.6: art. 2

\section{PROTECCIÓN DEL}

\section{AMBIENTE ATMOSFÉRICO}

Ámbito de aplicación: IX.2: art. 4

Control de la contaminación atmosférica producida por actividades industriales: IX.2: arts. 19-22

Control de la contaminación atmosférica urbana y de la derivada del transporte: IX.2: arts. 23-24

Definiciones: IX.2: art. 5

Fondo de protección del ambiente atmosférico de Galicia: IX.2: art. 26

Funciones de las Administraciones públicas de Galicia: IX.2: arts. 37-38

Información y participación en la gestión del ambiente atmosférico: IX.2: arts. 33-36

Infracciones y sanciones: IX.2: arts. 44-52

Inspección: IX.2: arts. 42-43

Instrumentos económicos y de apoyo financiero para el fomento de la calidad del aire: IX.2: arts. 25-29

Instrumentos horizontales de apoyo para el fomento de la calidad del aire: IX.2: arts. 30-31

Inventario de las fuentes de emisión: IX.2: art. 17
Líneas de actuación: IX.2: art. 2

Medidas para el mantenimiento y la mejora de la calidad del aire: IX.2: arts. 13-16

Normativa subsidiaria: IX.2: disposición adicional primera

Objeto: IX.2: art. 1

Obligaciones generales para los titulares de actividades potencialmente contaminantes: IX.2: art. 18

Planificación territorial y sectorial: IX.2: art. 32

Parámetros de la calidad del aire: IX.2: arts. 6-7

Principios: IX.2: art. 3

Régimen de recursos: IX.2: arts. 53-54

Relaciones interadministrativas: IX.2: arts. 39-41

Vigilancia y evaluación de la calidad del aire: IX.2: arts. 8-12

\section{Provincia}

Asistencia económica financiera: art. 114

Asistencia en materia de formación y perfeccionamiento en general: III.1: art. 116

Asistencia jurídica: III.1: art. 113

Asistencia técnica: III.1: art. 115

Carácter de entidad local de carácter territorial: III.1: art. 1

Comisión de Gobierno: III.1: art. 108

Competencias propias: III.1: art. 109

Coordinación de los servicios municipales entre sí para garantizar la prestación integral y adecuada de los servicios públicos en todo el territorio de la provincia: III.1: arts. 110-112

Fomento y de la administración de los intereses peculiares de la provincia: III.1: art. 118

Naturaleza: III.1: art. 101.1

Organización: III.1: arts. 103-104

Pleno: III.1: art. 107

Personalidad jurídica propia: III.1: art. 101.1 
Presidente de la Diputación: III.1: art. 105

Prestación de servicios de carácter municipal: III.1: art. 117

Principios rectores: III.1: art. 101.2

Territorio: III.1: art. 102

Transferencia y delegación de competencias de la Comunidad Autónoma en las provincias y de la encomienda de gestión: III.1: art. 119

Vicepresidente: III.1: art. 106

\section{Radio-Televisión de Galicia}

Consello Asesor: XII.1: art. 9

Consello de Administración: XII.1: arts. 4-8

Control parlamentario directo: XII.1: art. 20

Derecho de antena: XII.1: art. 17

Derecho de rectificación: XII.1: art. 18

Director general: XII.1: arts. 10-12

Funciones: XII.1: art. 1

Gestión mercantil: XII.1: arts. 14-15

Gestión pública: XII.1: art. 13

Naturaleza: XII.1: art. 1

Órganos: XII.1: art. 3

Patrimonio: XII.1: art. 26

Período electoral: XII.1: art. 19

Personal: XII.1: art. 27

Personalidad jurídica y capacidad: XII.1: art. 2

Presupuesto y financiación: XII.1: arts. 21-25

Principios de programación: XII.1: art. 16

Régimen jurídico: XII.1: art. 2;

XII.3: disposición adicional segunda

RECLAMACIÓN PREVIA A LA VÍA JUDICIAL

IV.1: art. 6

\section{RECONOCIMIENTO DE GALLEGUIDAD DE Comunidades Gallegas ASENTADAS FUERA DE GALICIA}

I.1: art. 7

\section{RÉGIMEN FINANCIERO Y} PRESUPUESTARIO, RESPONSABILIDAD

Diligencias previas: V.1: art. 126

Ejecución: V.1: art. 125
Instrucción y resolución: V.1: art. 124

Sujetos responsables: V.1: art. 122

Tipificación de las infracciones: V.1: art. 123

\section{RÉGIMEN URBANíSTICO DEL SUELO}

Aprovechamiento urbanístico de los propietarios de suelo urbanizable: VIII.2: art. 23

Aprovechamiento urbanístico de los propietarios de suelo urbano: VIII.2: art. 18

Clasificación del suelo: VIII.2: arts. 10-16

Condiciones de edificación en los núcleos rurales: VIII.2: art. 29

Condiciones de edificación en el suelo rústico: VIII.2: arts. 42-44

Condiciones de uso de los terrenos incluidos en núcleos rurales: VIII.2: arts. 25-28

Condiciones de uso del suelo rústico: VIII.2: arts. 33-40

Deberes de los propietarios de suelo urbanizable: VIII.2: art. 22

Deberes de los propietarios de suelo urbano consolidado: VIII.2: art. 19

Deberes de los propietario de suelo urbano no consolidado: VIII.2: art. 20

Deberes de uso, conservación y rehabilitación: VIII.2: art. 9

Derechos de los propietarios de suelo urbano: VIII.2: art. 17

Núcleos rurales afectados por la legislació de costas: VIII.2: disposición adicional tercera

Núcleos rurales, derechos y deberes: VIII.2: art. 24

Procedimiento para el otorgamiento de autorizaciones en suelo rústico: VIII.2: art. 41

Régimen de la propiedad: VIII.2: art. 7

Régimen del suelo en los municipios sin planeamiento: VIII.2: disposición adicional segunda

Régimen del suelo rústico: VIII.2: art. 31-32 


\section{I Índice de conceptos}

Régimen del suelo urbanizable: VIII.2: art. 21

Solares: VIII.2: art. 16

Subrogación real: VIII.2: art. 8

Suelo de núcleo rural: VIII.2: art. 13

Suelo rústico: VIII.2: art. 15

Suelo urbanizable: VIII.2: art. 14

Suelo urbano: VIII.2: arts. 11-12

\section{REGISTRO DE ENTIDADES LOCALES}

III.1: art. 3

\section{Reglamentos}

Inderogabilidad singular: II.1: art. 42

Invalidez: II.1: art. 40

Orden jerárquico: II.1: art. 39

Participación en su elaboración: IV.2: art. 9

Prohibición de establecer, tributos o sanciones: II.1: art. 41

Tipos: II.1: art. 37

\section{Residuos}

Acción de las Administraciones Públicas: IX.IV: arts. 11-15

Ámbito de aplicación de la Ley de Residuos: IX.IV: art. 3

Competencias: IX.IV: arts. 5-9

Contaminación y degradación del suelo: IX.IV: arts. 42-49

Declaración de suelo contaminado: IX. IV: arts. 42-43

Definiciones: IX.IV: art. 4

Espacios degradados: IX.IV: arts. 48-49

Expropiación: IX.IV: arts. 40-41

Fomento: IX.IV: arts. 50-51

Formación y concienciación: IX.IV: art. 15

Garantías financieras de las actividades sometidas a autorización: IX.IV: art. 28

Inspección, vigilancia y control: IX.IV: arts. $52-57$

Medidas Económicas y Financieras: IX. IV: arts. 28-29
Objetivos de la Ley de Residuos: IX. IV: art. 2

Objeto de la Ley de Residuos: IX.IV: art. 1

Optimización en la eliminación: IX.IV: art. 14

Planificación autonómica: IX.IV: arts. $18-23$

Planificación de las entidades locales: IX.IV: arts. 24-27

Planificación en materia de residuos: IX. IV: arts. 16-27

Prevención de residuos: IX.IV: art. 12

Puesta en el mercado de productos que con su uso se convierten en residuos: IX.IV: arts. 30-36

Régimen de Intervención administrativa: IX.IV: arts. 37-39

Régimen sancionador: IX.IV: arts. 58-80

Residuos de establecimientos sanitarios: IX.IV: disposición adicional primera

Sistemas integrados de gestión: IX.IV: art. 32

Sociedad Gallega del Medio Ambiente: IX.IV: art. 10

Suelos contaminados: IX.IV: arts. 42-47

Valorización: IX.IV: art. 13

\section{RESPONSABILIDAD PATRIMONIAL} DE LA ADMINISTRACIÓN

IV.1: art. 5

\section{SALud}

Alcance de la Ley de Salud de Galicia: XVI.3: art. 2

Áreas sanitarias: XVI.3: art. $68 \mathrm{y}$ disposición transitoria segunda

Atención a urgencias y emergencias: XVI.3: art. 52

Atención especializada: XVI.3: art. 51

Atención primaria: XVI.3: art. 50

Atención sociosanitaria: XVI.3: art. 53 
Carrera profesional: XVI.3: art. 118

Cartera de servicios: XVI.3: art. 60

Centros y servicios del Servicio Gallego de Salud: 93

Comisiones de Participación Ciudadana: XVI.3: art. 26

Competencias: XVI.3: arts. 75-81

Consejo Asesor del Sistema Público de Salud de Galicia: XVI.3: art. 78

Consejo Gallego de Salud: XVI.3: art. 24

Consejos de Salud de Área: XVI.3: art. 25

Contrato de servicios sanitarios: XVI.3: art. 74

Coordinación interdepartamental de la atención sociosanitaria: XVI.3: arts. 136-137

Deberes sanitarios: XVI.3: art. 15

Defensa y promoción de los derechos de los usuarios y usuarias del sistema público de salud de Galicia: XVI.3: arts. 18-21

Definiciones: XVI.3: art. 3

Derechos relacionados con el acompañamiento de el o la paciente: XVI.3: art. 7

Derechos relacionados con la autonomía de decisión: XVI.3: art. 8

Derechos relacionados con la confidencialidad e información: XVI.3: art. 9

Derechos relacionados con la documentación sanitaria: XVI.3: art. 10

Derechos relacionados con grupos especiales: XVI.3: art. 14

Derechos relacionados con la integridad e intimidad de la persona: XVI.3: art. 6

Derechos relacionados con la participación: XVI.3: art. 13

Derechos relacionados con la prestación de servicios sanitarios por parte del Sistema Público de Salud de Galicia: XVI.3: art. 12

Derechos relacionados con sugerencias y reclamaciones: XVI.3: art. 11
Derechos sanitarios: XVI.3: arts. 5-14

Derechos y deberes sanitarios de los ciudadanos: XVI.3: arts. 4-21

Directrices de política sanitaria: XVI.3: arts. 61-63

Docencia e investigación: XVI.3: arts. 125-135

Empleados y empleadas públicas de la Salud: XVI.3: art. 108

Escuela Gallega de Administración Sanitaria: XVI.3: art. 127-130 y Disposición Adicional única

Evaluación del Sistema de Salud de Galicia: XVI.3: art. 72

Financiación del Sistema Público de Salud: XVI.3: art. 73

Función directiva: XVI.3: art. 121

Funciones del Servicio Gallego de Salud: XVI.3: art. 94

Foro de participación institucional de Sanidad: XVI.3: art. 28

Garantía de los derechos y deberes sanitarios: XVI.3: arts. 16-17

Garantías de modernización y prestación de la asistencia: XVI.3:

arts. 122-124

Infracciones y sanciones: XVI.3: art. 39-47

Inspección sanitaria: XVI.3: art. 37

Instrumentos de prestación de servicios sanitarios del Servicio Gallego de Salud: XVI.3: art. 95

Instituto Gallego de Investigación Sanitaria: XVI.3: arts. 132-135

Intervenciones públicas que garantizan los derechos y deberes de la ciudadanía: XVI.3: arts. 33-38

Investigación biomédica: XVI.3: art. 131

Medios materiales y régimen patrimonial del Servicio Gallego de Salud: XVI.3: arts. 99-102

Mesa de negociación del empleado público de la salud del Sistema Público de Salud de Galicia: XVI.3: art. 120 
Naturaleza del Servicio Gallego de Salud: XVI.3: art. 92

Objeto de la Ley de Salud de Galicia: XVI.3: art. 1

Ordenación territorial del Sistema Público de Salud de Galicia: XVI.3: arts. 67-70

Organización de la Salud Pública en el Sistema Público de Salud de Galicia: XVI.3: art. 107

Organización del Servicio Gallego de Salud: XVI.3: art. 96

Organización de servicios del Servicio Gallego de Salud: XVI.3: art. 97

Participación institucional de las organizaciones sindicales y empresariales más representativas de Galicia: XVI.3: arts. 28-29

Participación social: XVI.3: arts. 22-27

Plan de salud: XVI.3: arts. 64-66

Planificación del sistema público de salud de Galicia: XVI.3: arts. 61-66

Planificación y ordenación de los recursos humanos: XVI.3: arts. 111-114

Prestaciones complementarias: XVI.3: art. 58

Prestaciones farmacéuticas: XVI.3: art. 54

Prestaciones ortoprotésicas: XVI.3: art. 55

Prestaciones sanitarias del sistema público de salud de Galicia: XVI.3: arts. 48-60

Prestaciones y servicios sanitarios financiados públicamente: XVI.3: art. 59

Principios rectores del sistema público de salud: XVI.3: art. 32

Productos dietéticos: XVI.3: art. 57

Promoción interna: XVI.3: art. 116

Régimen jurídico de los actos del Servicio Gallego de Salud: XVI.3: art. 98

Régimen financiero, presupuestario y contable del Servicio Gallego de Salud: XVI.3: arts. 103-106
Relaciones del Sistema Público de Salud de Galicia con la Unión Europea, la Administración General del Estado y otras comunidades autónomas: XVI.3: arts. 82-86

Retribuciones y jornada: XVI.3: art. 117

Salud laboral: XVI.3: art. 119

Sector privado de atención sanitaria: XVI.3: arts. 87-91

Selección y provisión de plazas: XVI.3: art. 115

Servicio Gallego de Salud: XVI.3: arts. 92-106

Sistema de información de salud de Galicia: XVI.3: art. 71

Sistema público de Salud de Galicia: XVI.3: arts. $30-81$

Titulares del derecho a la protección de la salud y a la atención sanitaria: XVI.3: art. 4

Transporte sanitario: XVI.3: art. 56

Voluntariado: XVI.3: art. 27

Zonas sanitarias: XVI.3: art. 69

\section{Sede dE LAS}

INSTITUCIONES AUTONÓMICAS

\section{I.1: art. 8}

\section{Servicio público de depuración}

DE AGUAS RESIDUALES URBANAS

Administración gestora del servicio: IX.6: art. 8

Competencias de las Entidades Locales: IX.6: art. 7

Declaración de interés general de la Comunidad Autónoma: IX.6: art. 6

Financiación del servicio: IX.6: art. 9

Infracciones y sanciones: IX.6: arts. 12-14

Regulación del servicio: IX.6: art. 10

\section{Servicios sociales}

Agencia Gallega de Servicios Sociales: XVI.2: arts. 34-39

Áreas sociales: XVI.2: art. 44

Calidad: XVI.2: arts. 49-51 
Catálogo de servicios sociales: XVI.2: arts. 18-22 y disposición final segunda

Comisión Interdepartamental de Lucha contra la Pobreza: XVI.2: disposición transitoria tercera

Comisión Interdepartamental de Servicios Sociales e Inclusión Social: XVI.2: art. 65 y disposición adicional quinta

Competencias: XVI.2: arts. 58-65

Consejo Gallego de Bienestar Social: XVI.2: art. 40

Consorcio Gallego de Servicios de Igualdad y Bienestar: XVI.2: disposición adicional segunda

Continuación de los niveles de actuación social: XVI.2: art. 16

Deberes de las personas en relación con los servicios sociales: XVI.2: art. 7

Derechos de las personas en relación con los servicios sociales: XVI.2: art. 6

Equipo profesional de los servicios sociales: XVI.2: arts. 23-25

Estructura básica del sistema de servicios sociales: XVI.2: art. 8

Estructura del sistema de servicios sociales: XVI.2: arts. 8-17

Financiación: XVI.2: arts. 52-57

Formación e investigación en servicios sociales: XVI.2: arts. 26-28

Inspección: XVI.2: arts. 71-75

Intervenciones o servicios de carácter técnico profesional: XVI.2: art. 19

Mecanismos de control y garantía pública del sistema gallego de servicios sociales: XVI.2: arts. 66-75

Mesa Gallega de Servicios Sociales: XVI.2: art. 42

Objeto de la Ley de servicios sociales: XVI.2: art. 1

Observatorio Gallego de Servicios Sociales: XVI.2: art. 41

Órganos consultivos y de participación: XVI.2: arts. 40-43 y disposición adicional cuarta
Participación ciudadana y de las personas usuarias de servicios sociales: XVI.2: art. 43

Participación de la iniciativa social y de entidades privadas de carácter mercantil en la prestación de los servicios sociales: XVI.2: arts. 30-33

Plan de calidad: XVI.2: art. 51

Plan Estratégico de Servicios Sociales: XVI.2: arts. 45-47

Planificación del ámbito local: XVI.2: art. 48

Planificación del Sistema Gallego de Servicios Sociales: XVI.2: arts. 44-48

Prestación de los servicios sociales: XVI.2: arts. 29-39

Prestaciones económicas: XVI.2: art. 21

Principios generales: XVI.2: art. 4

Profesional de referencia: XVI.2: art. 24-25

Programas de intervención comunitaria: XVI.2: art. 22

Reconocimiento de la situación de dependencia y del derecho a las prestaciones del sistema para la autonomía y atención a la dependencia en la Comunidad Autónoma de Galicia: XVI.2: disposición adicional sexta

Régimen de registro, autorización administrativa y acreditación de entidades, centros, servicios o programas: XVI.2: arts. 66-70

Régimen sancionador: XVI.2: arts. $76-88$

Régimen sancionador de las personas usuarias de los servicios sociales: XVI.2: arts. 89-97

Servicios sociales comunitarios: XVI.2: arts. 9-13

Servicios sociales especializados: XVI.2: arts. $14-15$ 
Servicios sociales comunitarios básicos: XVI.2: arts. 10-11

Servicios sociales comunitarios específicos: XVI.2: arts. 12-13

Servicios sociales mínimos garantizados por los ayuntamientos: XVI.2: art. 62

Servicios y actuaciones de naturaleza material o tecnológica: XVI.2: art. 20

Sistema Gallego de servicios sociales: XVI.2: arts. 2-3 y 8-28

Tarjeta Social Gallega: XVI.2: art. 17

Titulares del derecho de acceso a los servicios sociales: XVI.2: art. 5

\section{Servizo Galego de Defensa DA COMPETENCIA}

Deber de colaboración: VI.5: art. 13

Funciones: VI.5: art. 12

Funciones de investigación e inspección: VI.5: art. 13

Naturaleza: VI.5: art. 11

Registro Gallego de Defensa de la Competencia: VI.5: art. 14

\section{Sistema Universitario de Galicia}

Consello Galego de Universidades: véase voz "Consello Galego de Universidades"

Consellos Sociais do Sistema Universitario de Galicia: véase voz "Consellos Sociais do Sistema Universitario de Galicia"

Control en materia de creación y reconocimiento de Universidades, Centros Universitarios y autorización de estudios en la Comunidad Autónoma de Galicia: véase voz "control en materia de creación y reconocimiento de Universidades, Centros Universitarios y autorización de estudios en la Comunidad Autónoma de Galicia"

Coordinación y planificación: XVII.5: art. 11

Creación y localización de nuevas titulaciones y centros: XVII.5: art. 9

Derecho de acceso de los estudiantes: XVII.5: art. 10
Finalidades: XVII.5: art. 2

Objeto: XVII.5: art. 1

Personalidad jurídica y capacidad de las Universidades. XVII.5: art. 4

Repertorio de titulaciones: XVII.5: art. 8

Requisitos de los campus: XVII.5: art. 6

Universidades que lo componen: XVII.5: art. 3 y 5

\section{SubVenciones}

Actividad de patrocinio: V.5: disposición adicional cuarta

Actualización de las cuentas previstas en la Ley de Subvenciones de Galicia: V.5: disposición adicional séptima

Adaptación de procedimientos: V.5: disposición adicional primera

Ámbito de aplicación de la Ley de Subvenciones de Galicia: V.5: arts. 3-4

Autorización para la regulación de procedimientos en materia de subvenciones por medios telemáticos: V.5: disposición adicional octava

Ayudas en especie: V.5: disposición adicional tercera

Bases reguladoras de la concesión de subvenciones: V.5: art. 14

Beneficiarios: V.5: art. 8

Comprobación de subvenciones: V.5: art. 30

Concepto: V.5: art. 2

Control financiero de subvenciones: V.5: arts. 41-49

Convenio de colaboración con entidades colaboradoras: V.5: art. 13

Entidades colaboradoras: V.5: art. 9

Exoneración de la presentación de los justificantes de acreditación de obligaciones tributarias, con la seguridad social y deudas con la administración de la comunidad autónoma: V.5: disposición transitoria tercera

Financiación de las actividades subvencionadas: V.5: art. 17 


\section{Índice de conceptos}

Gastos subvencionables: V.5: art. 29

IGAPE: V.5: disposición transitoria segunda

Infracciones y sanciones: V.5: arts. 50-68

Justificación de las subvenciones: V.5: art. 28

Obligaciones de los beneficiarios: V.5: art. 11

Obligaciones de las entidades colaboradoras: V.5: art. 12

Órganos competentes para su concesión: V.5: art. 7

Principios generales: V.5: art. 5

Procedimiento de aprobación del gasto y pago: V.5: art. 31

Procedimiento de concesión: V.5: arts. 19-26

Procedimiento de concesión directa: V.5: art. 26

Procedimiento de concesión en régimen de concurrencia competitiva: V.5: arts. 20-25

Procedimiento de control financiero: V.5: art. 47

Procedimiento de gestión presupuestaria: V.5: art. 31

Procedimiento de gestión y justificación de subvenciones: V.5: arts. 27-30

Procedimiento de reintegro: V.5: arts. 37-40

Publicidad de las subvenciones concedidas: V.5: art. 15

Régimen de garantías: V.5: art. 18

Régimen especial de las ayudas en materia de cooperación exterior: V.5: disposición adicional segunda

Régimen transitorio de los procedimientos: V.5: disposición transitoria primera

Registro Público de Ayudas, Subvenciones y convenios: V.5: disposición adicional sexta

Registro Público de subvenciones: V.5: art. 16

Reintegro de subvenciones: V.5: arts. $32-40$
Requisitos para el otorgamiento de subvenciones: V.5: art. 6

Requisitos para obtener la condición de benificiario o entidad colaboradora: V.5: art. 10

Subcontratación de las actividades subvencionadas por los beneficiarios: V.5: art. 27

Universidades: V.5: disposición adicional quinta

\section{TASAS}

Clases de tasas: V.3: art. 13

Concepto: V.3: art. 7

Cuota tributaria: V.3: art. 15

Devengo: V.3: art. 14

Gestión: V.3: art. 17

Normativa aplicable: V.3: art. 8

Pago: V.3: art. 16

Prescripción: V.3: art. 20

Principio de capacidad económica: V.3: art. 10

Principio de equivalencia: V.3: art. 11

Reclamaciones y recursos: V.3: art. 19

Régimen sancionador: V.3: art. 20

Reserva de ley: V.3: art. 9

Responsables: V.3: art. 18

Revisión y reducción de las tarifas:

V.3: disposición adicional segunda

Supuestos de no sujeción: V.3: art. 12

Tasa por servicios administrativos: V.3: arts. $21-25$

Tasa por servicios profesionales: V.3: arts. 26-32

Tasas por utilización privativa, ocupación o aprovechamiento especial del dominio público de la Comunidad Autónoma de Galicia: V.3: arts. 38-42

Tasa sobre la venta de bienes: V.3: arts. 33-37

\section{TASAS, PRECIOS Y}

\section{EXACCIONES REGULADORAS}

Ámbito de aplicación: V.3: art. 3

Normativa aplicable: V.3: art. 6 


\section{Índice de conceptos}

Régimen presupuestario y aplicación obligatoria: V.3: art. 4

Responsabilidades: V.3: art. 5

Tipos de instrumentos: V.3: art. 2

\section{TESORERÍA}

Concepto: V.1: art. 87

Ingresos y medios de pago: V.1: art. 91

Flujos financieros: V.1: art. 92

Funciones: V.1: art. 88

Situación de los fondos de la Comunidad Autónoma: V.1: art. 89

Situación de los fondos de los organismos autónomos: V.1: art. 90

\section{TRANSPARENCIA Y BUENAS PRÁCTICAS DE LA AdMINISTRACIÓN}

Actividad de fomento: IV.2: art. 13

Ámbito de aplicación: IV.2: art. 1

Cartas de servicios: IV.2: art. 6

Concesiones de servicios públicos: IV.2: art. 12

Contratos públicos: IV.2: art. 10

Convenios de colaboración: IV.2: art. 11

Derecho a la información de los ciudadanos: IV.2: art. 4

Derecho a la información de los interesados en el procedimiento: IV.2: art. 5

Medios electrónicos, informáticos y telemáticos: IV.2: art. 8

Miembros del Gobierno y Altos Cargos de la Adminitración: IV.2: arts. 14-18

Participación en la elaboración de disposiciones de carácter general: IV.2: art. 9

Principios generales: IV.2: art. 2

Publicidad de la programación anual y plurianual: IV.2: art. 7

\section{Tribunal ECONómico}

Administrativo de la Comunidad Autónoma de Galicia

Véase la voz "Xunta Superior de Facenda"

\section{Tribunal Galego de Defensa DA Competencia}

Adscripción: VI.5: art. 1.2

Causas de cese y suspensión en el ejercicio del cargo de sus miembros: VI.5: art. 5

Composición: VI.5: art. 4

Fines: VI.5: art. 2

Funcionamiento: VI.5: art. 7

Funciones: VI.5: art. 3

Naturaleza jurídica: VI.5: art. 1

Personal y contratación: VI.5: art. 10

Presidente: VI.5: art. 6

Recursos: VI.5: art. 8

Régimen presupuestario y contable: VI.5: art. 9

\section{TURISMO}

Albergues turísticos: XVII.9: art. 42

Ámbito de aplicación de la Ley de

Turismo: XVII.9: art. 2

Apartamientos y viviendas turísticas: XVII.9: art. 35

Arbitraje: XVII.9: art. 86

Aspectos básicos para el desarrollo de la actividad turística: XVII.9: arts. 24-27

Autorización turística: XVII.9: art. 28

Ayuntamientos turísticos: XVII.9: art. 20 y disposición adicional segunda

Balnearios y centros de talasoterapia: XVII.9: art. 48

Calidad turística: XVII.9: art. 16

Campamentos de turismo: XVII.9: art. 36

Casas grandes y pazos: XVII.9: art. 39

Casas rurales: XVII.9: art. 40

Competencias: XVII.9: arts. 3-9

Complejos turísticos: XVII.9: art. 46

Consejo Regulador de Turismo: XVII.9: art. 7 y disposición adicional primera

Denominaciones geoturísticas: XVII.9: art. 19

Derechos y obligaciones de las empresas turísticas: XVII.9: arts. 21-23 


\section{Índice de conceptos}

Derechos y obligaciones de la usuaria o usuario turístico: XVII.9:

arts. 10-12

Empresas de alojamiento

turístico: XVII.9: arts. 32-42

Empresas de intermediación: XVII.9: arts. 44-45

Empresas de restauración: XVII.9: arts. 43

Establecimientos de turismo rural: XVII.9: art. 37

Establecimientos hoteleros: XVII.9: art. 34

Fiestas de interés turístico nacional: XVII.9: art. 53 y disposición adicional tercera

Galicia como marca turística: XVII.9: art. 17

Guías de Turismo: XVII.9: art. 50

Hoteles rurales: XVII.9: art. 38

Inspección turística: XVII.9: arts. 57-66

Marcas turísticas de calidad: XVII.9: art. 18

Objeto y fines de la Ley de Turismo: XVII.9: art. 1

Ordenación de empresas turísticas: XVII.9: arts. 21-46

Ordenación de las empresas y actividades de servicios complementarios: XVII.9: arts. 47-48

Ordenación general de la actividad turística: XVII.9: arts. 14-20

Precios: XVII.9: art. 31

Profesiones turísticas: XVII.9: arts. 49-50

Promoción y fomento del turismo: XVII.9: arts. 51-56

Recursos turísticos: XVII.9: art. 14

Red Gallega de Oficinas de Turismo: XVII.9: art. 8

Régimen sancionador: XVII.9: arts. 67-85

Registro de Empresas y Actividades Turísticas de la Comunidad Autónoma de Galicia: XVII.9: arts. 29-30
Requisitos generales de las empresas turísticas: XVII.9: art. 28

Territorios de preferente actuación turística: XVII.9: art. 15

\section{VAledor do Pobo}

Atribuciones: II.5: arts. 13, 14 y 16

Autonomía y prerrogativas para el ejercicio de sus funciones: II.5: art. 6

Carácter: II.5: art. 1

Cese: II.5: art. 5

Creación: I.1: art. 14

Deber de colaboración: II.5: arts. 26-27

Dotación económica: II.5: art. 12

Elección: II.5: arts. 2 y 3

Gastos causados a particulares: II.5: art. 28 Incompatibilidades: II.5: art. 7

Informes al Parlamento: II.5: arts. 36-37

No interrupción de su actividad por disolución del Parlamento, estado de alarma, sitio o excepción: II.5: art. 15

Notificaciones: II.5: arts. 34 y 35

Personal: II.5: arts. 10 y 11

Relaciones con el Defensor del Pueblo y Comisionados de Parlamentos de otras Comunidades Autónomas: II.5: arts. 38-40

Relaciones con el Parlamento: II.5: art. 4

Resoluciones: II.5: arts. 29-33

Toma de posesión: II.5: art. 3.3

Tramitación de la investigación: II.5: art. 23-25

Tramitación de quejas: II.5: arts. 17-22

Vicevaledores: arts. 8, 9 y 11

\section{VICEPRESIDENTES}

Atribuciones: II.1: art. 33

Cese: II.1: art. 27 y 29

Incompatibilidades: II.1: art. 31

Inmunidad: II.1: art. 32 


\section{Índice de conceptos}

Juramento: II.1: art. 28

Nombramiento: II.1: art. 27

\section{ViVIENDA}

Acceso a la vivienda de las mujeres víctimas de violencia de genero: VIII.4: disposición transitoria cuarta

Actuaciones previas: VIII.4: art. 16

Agentes de control de calidad: VIII.4: art. 12

Arbitraje: VIII.4: art. 105

Arrendamiento de viviendas: VIII.4: arts. 100-104

Calidad de las edificaciones: VIII.4: arts. 11-12 y disposición final segunda

Calificación de las viviendas protegidas: VIII.4: arts. 41-45

Concepto de vivienda protegida: VIII.4: arts. 33-36

Declaración de obra nueva: VIII.4: art. 22

Depósito de las fianzas de los arrendamientos de vivienda: VIII.4: arts. 102-104

Derecho a la vivienda: VIII.4: arts. 1-5

Descalificación: VIII.4: disposición final primera

Ejecución de la obra: VIII.4: art. 18

Emigrantes: VIII.4: disposición adicional cuarta

Fases del proyecto de edificación: VIII.4: arts. 14-22

Fomento de la calidad, la innovación y la accesibilidad: VIII.4: arts. 80-82

Fomento del acceso a la vivienda en régimen de alquiler: VIII.4: arts. 76-79

Fondo social de vivienda: VIII.4: art. 9

Información en la oferta de arrendamiento: VIII.4: arts. 89-90

Información en la oferta de venta: VIII.4: arts. 86-88

Inspección: VIII.4: arts. 106-107

Libro del edificio: VIII.4: arts. 23-24
Licencia de primera ocupación: VIII.4: art. 20 y disposición adicional tercera

Licencia urbanística: VIII.4: art. 17

Modos de acceso a la vivienda protegida: VIII.4: arts. 51-60

Observatorio de la vivienda de Galicia: VIII.4: disposición adicional sexta

Organización y competencias: VIII.4: arts. 6-8

Personas beneficiarias de viviendas protegidas: VIII.4: arts. 46-49

Planeamiento urbanístico: VIII.4: disposición adicional primera

Políticas de fomento del acceso a la vivienda: VIII.4: arts. 68-75

Procedimientos de calificación antes de entrada en vigor de la nueva Ley de la vivienda: VIII.4: disposición transitoria tercera

Proceso de edificación, disposiciones generales: VIII.4: arts. 10-24

Promoción de vivienda protegida: VIII.4: arts. 37-40

Protección de los adquirentes y arrendatarios de vivienda: VIII.4: arts. 83-105

Proyecto: VIII.4: art. 15

Publicidad en la oferta de venta: VIII.4: arts. 83-85

Recepción de la obra ejecutada: VIII.4: art. 19

Régimen sancionador: VIII.4: arts. 108-119, disposición adicional quinta y disposición transitoria primera

Registro de agentes de la edificación: VIII.4: art. 13

Registro único de demandantes de vivienda: VIII.4: art. 50

Requisitos para el arrendamiento: VIII.4: arts. 100-101

Servicios: VIII.4: art. 21

Utilización de la vivienda: VIII.4: arts. 25-32

Utilización y disposición de las viviendas protegidas: VIII.4: arts. 61-67

Venta de viviendas en proyecto o construcción: VIII.4: arts. 91-99 


\section{Índice de conceptos}

\section{Xunta de Galicia}

Cese: I.1 art. 17.2

Composición: I.1: art. 16; II.1: art. 2

Continuación en funciones: I.1: art. 17.2

Detención y responsabilidad de sus miembros: I.1: art. 18

Estatuto personal de sus miembros: I.1: art. 16

Funcionamiento: II.2: arts. 5-9

Funciones: II.1: art. 4

Organización: I.1: art. 16

Posibilidad de crear Comisiones Delegadas: II.1:art. 8

Posibilidad de delegación de funciones por parte de sus miembros: II.1: art. 43 y 44

Posibilidad de sus miembros de nombrar y cesar personal eventual: II.1: art. 35
Relaciones con el Parlamento: II.1: arts. 45-57

Remuneraciones y gastos de representación de sus miembros: II.1: art. 30

Responsabilidad política ante el Parlamento: I.1: art. 17.1. II.1: art. 3

Xunta en funciones: II.1: art. 29

\section{Xunta Superior de Facenda}

Cambio de denominación: V.3: disposición adicional primera

Creación: V.4: disposición adicional primera

Funciones: V.4: disposición adicional primera 


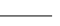




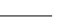




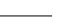

